\title{
جامعَة الأزهنح
}

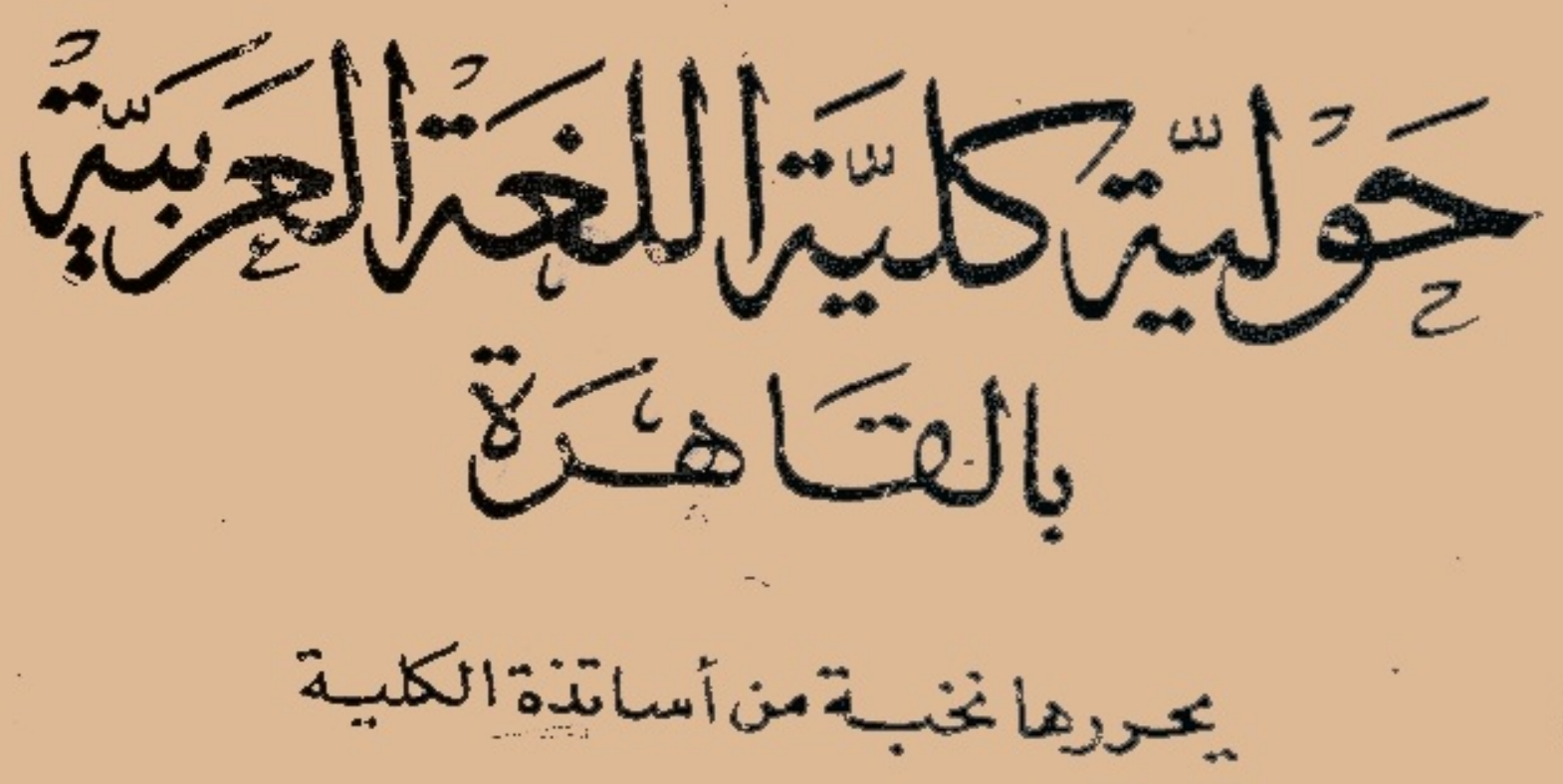

\section{المدد r}

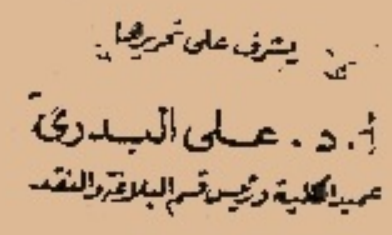

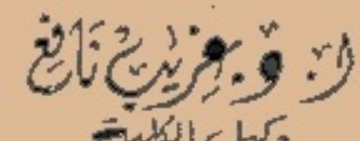





$\infty$

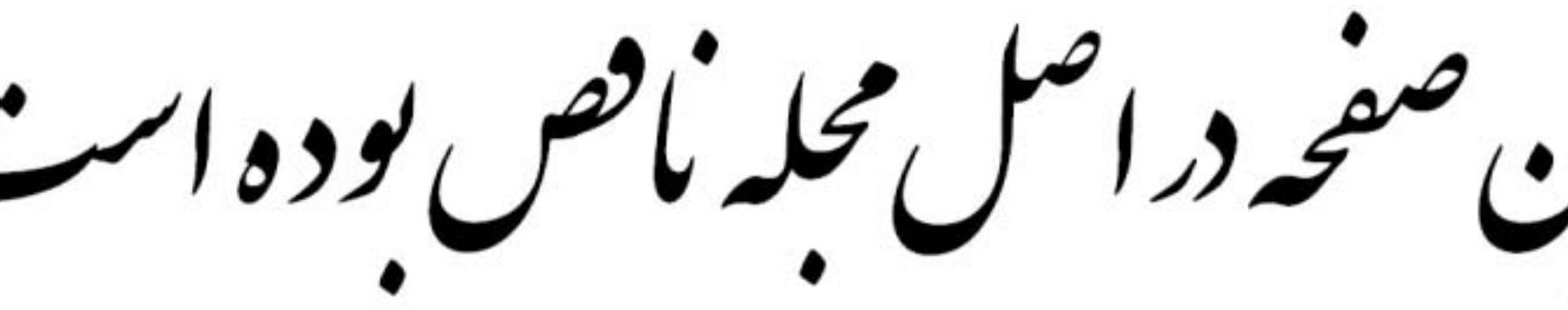




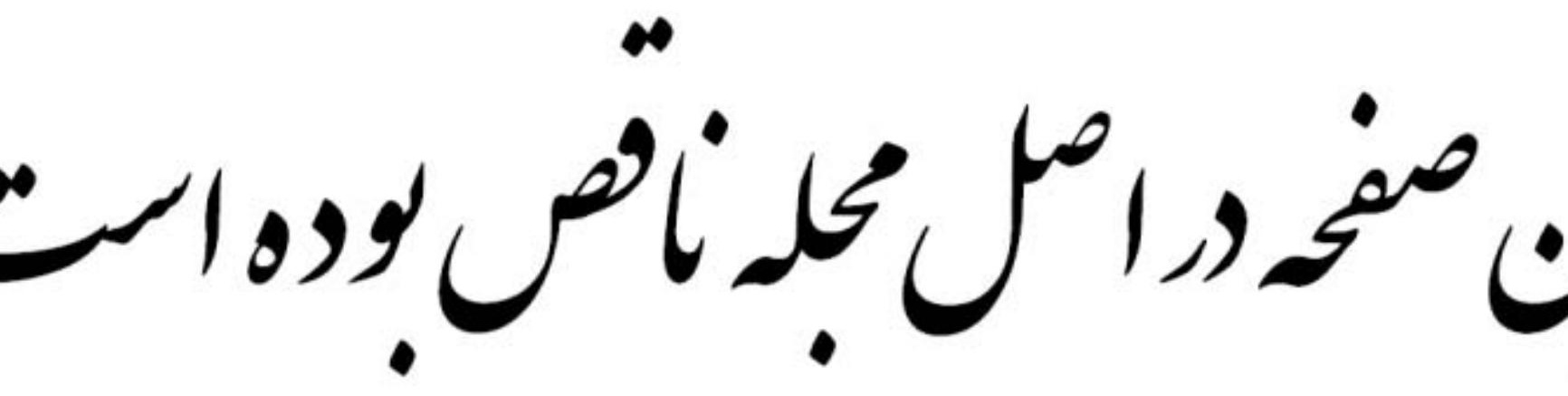




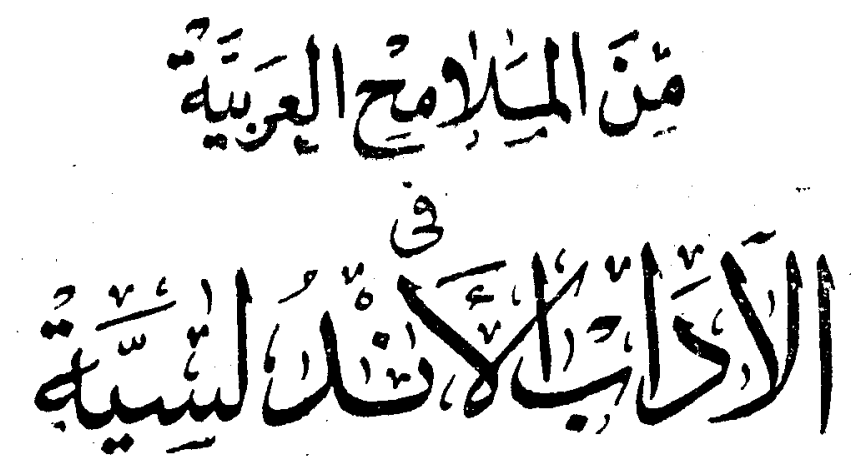

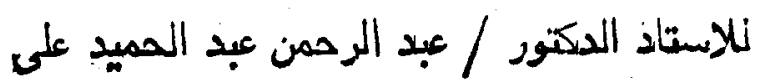

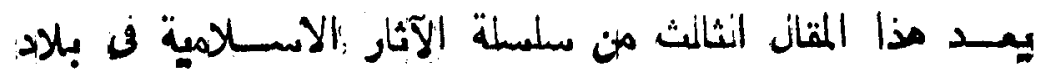

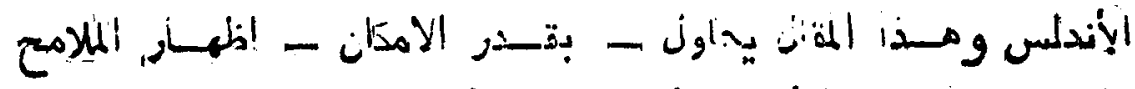

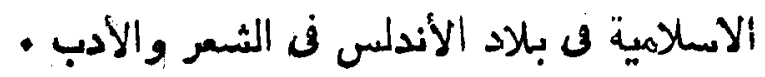

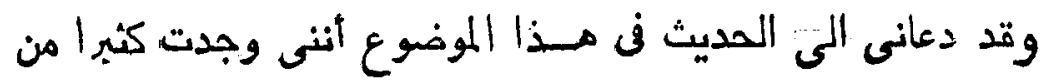

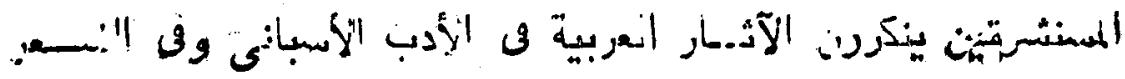

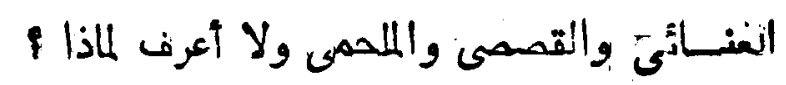

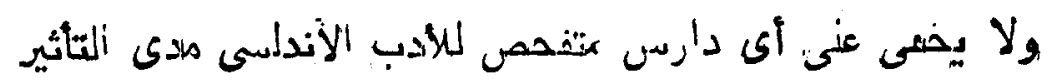

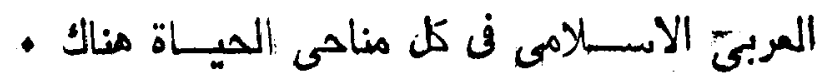

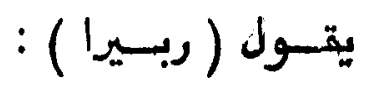

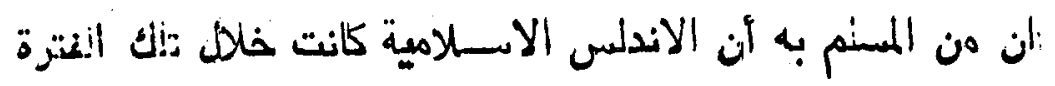

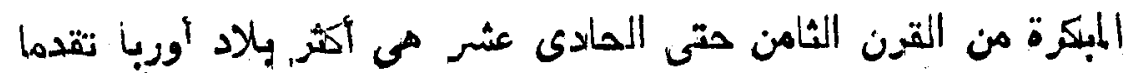

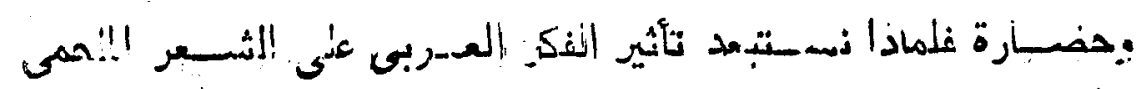

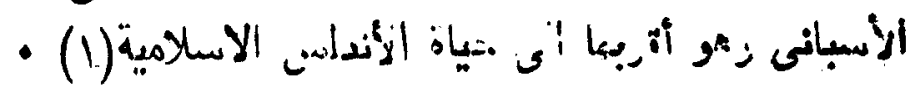

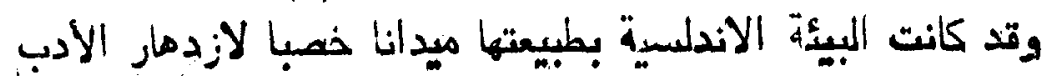

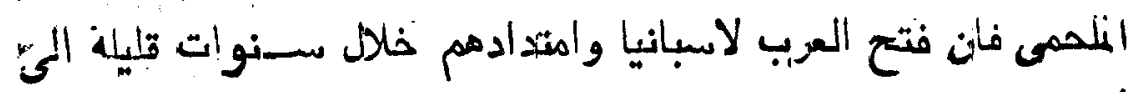

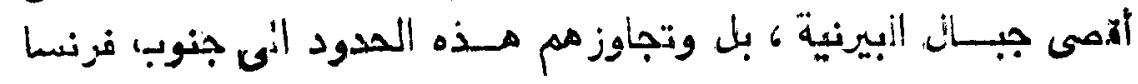

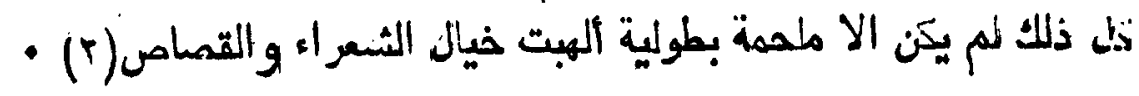

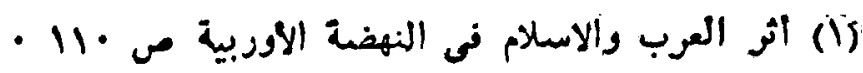

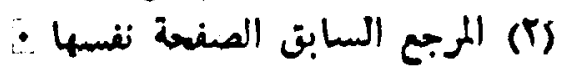




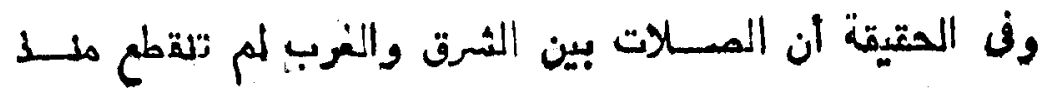

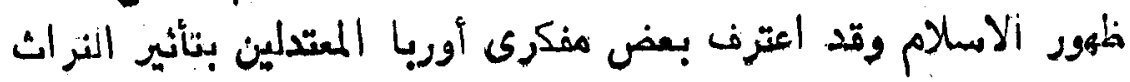

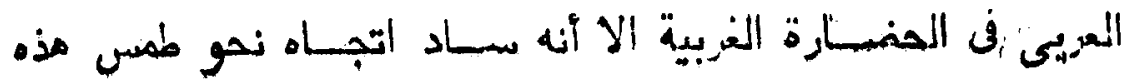

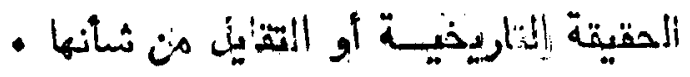

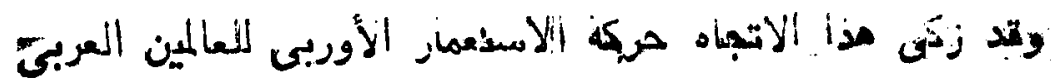

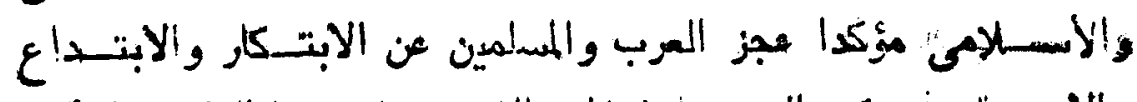

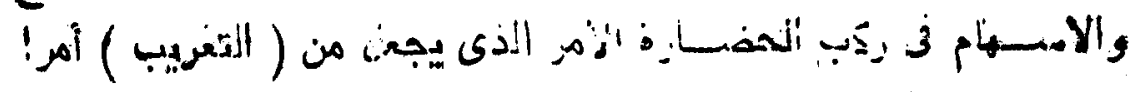

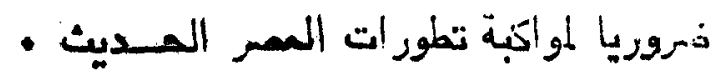

ولعل من أحسد الأسباب الأخرى أن المسلمين والعرب ذاتهم أو

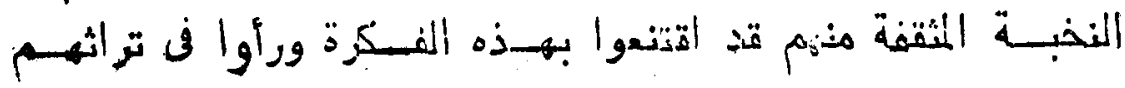

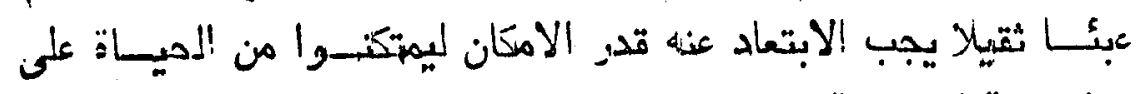

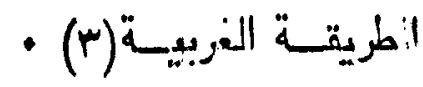

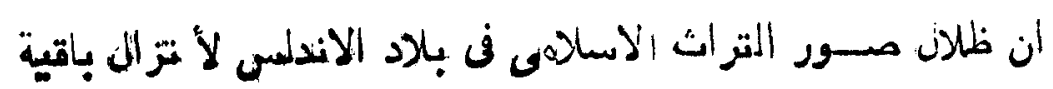

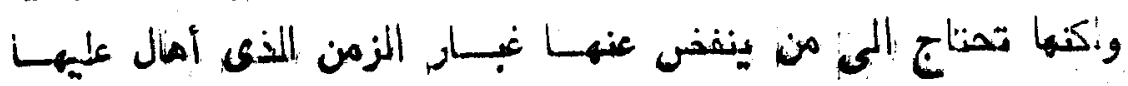

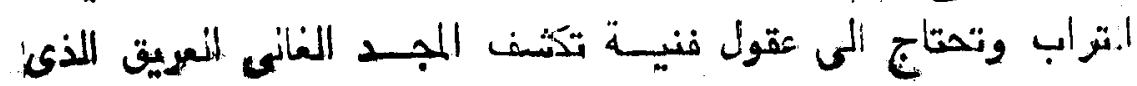

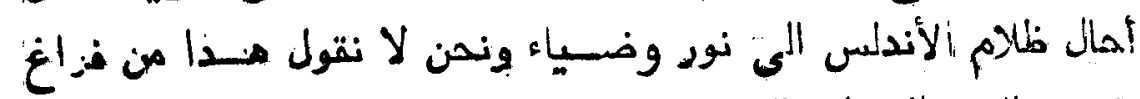

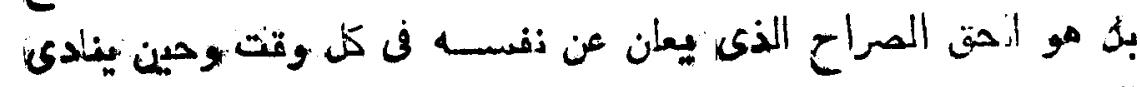

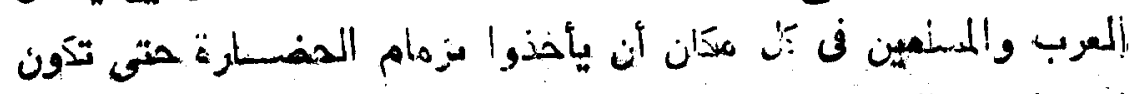

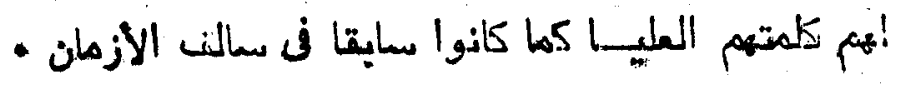

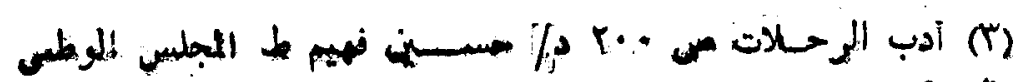
للثقافة بالكويت آدي 


\section{i}

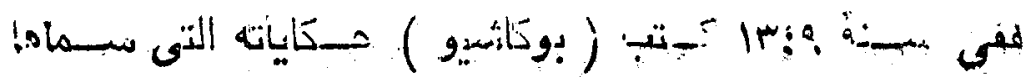

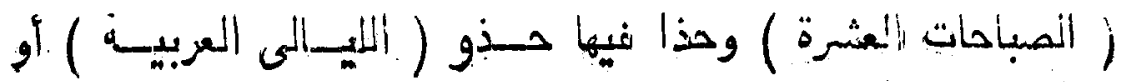

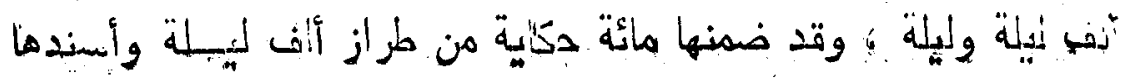

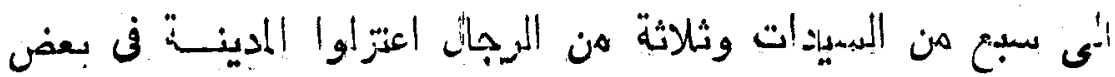

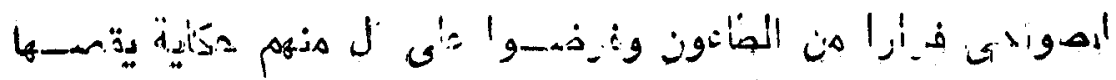

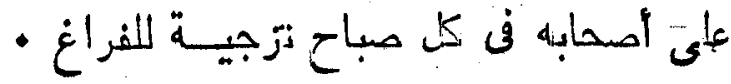

وقد ملات هـذه المكايات أقبطار أوربة واقتبس منها (شتكبيير)

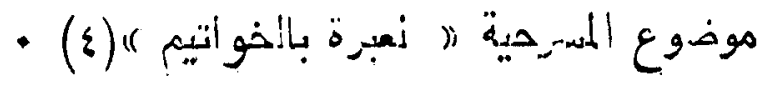

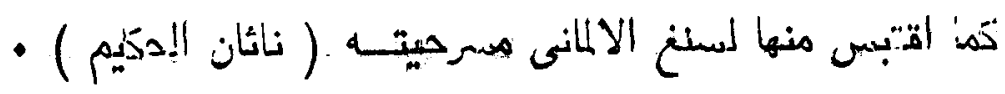

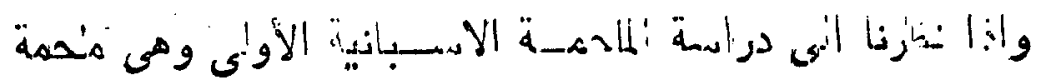

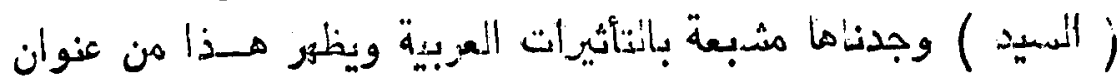

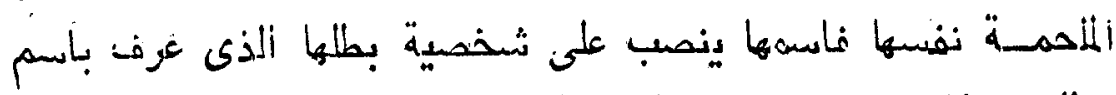

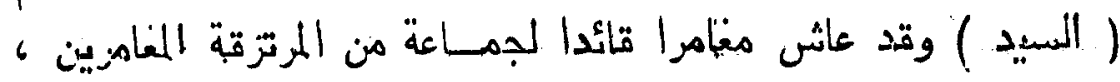

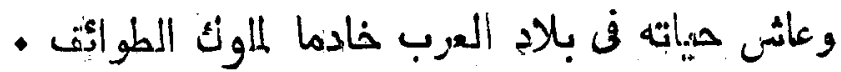

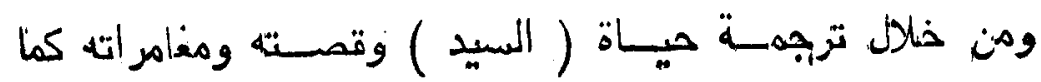

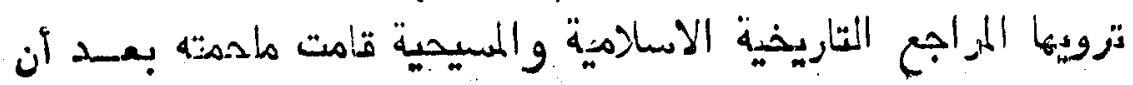

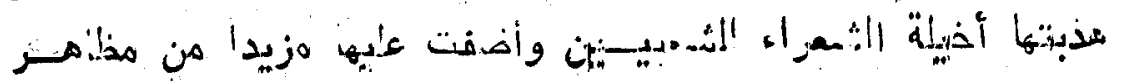

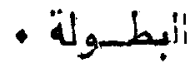

ولهيـذا نان باكورة اللأدب الملحهى الأسبانى التى تروى نئا قصة

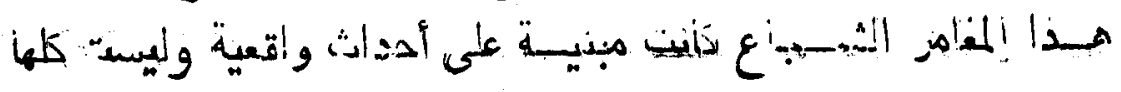
من نسبي الخيهلة

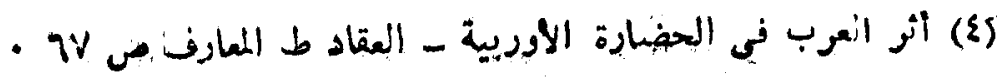




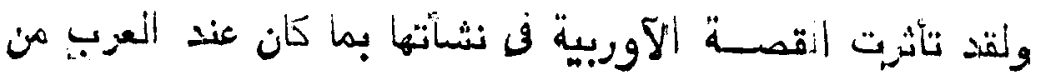

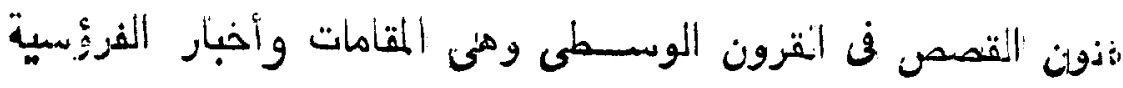

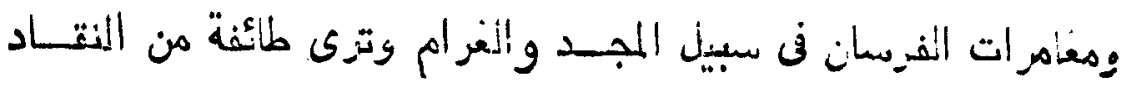

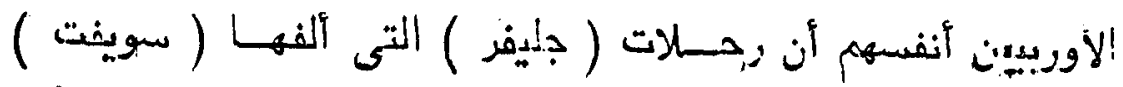

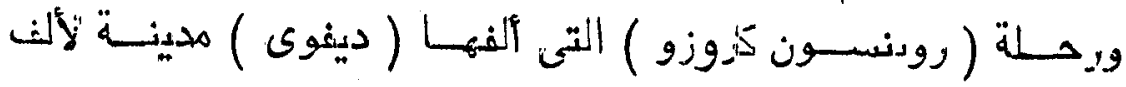

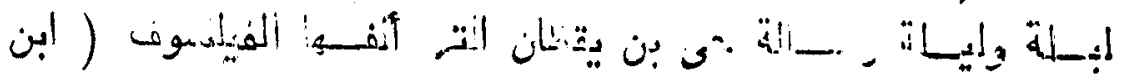
- مفيـال )

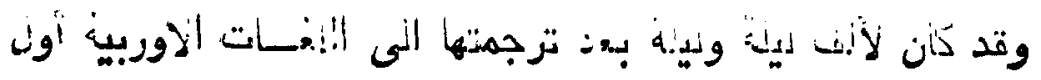

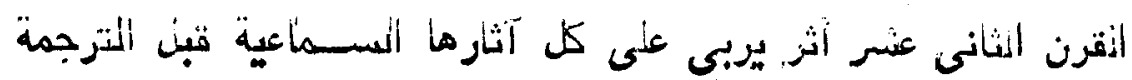

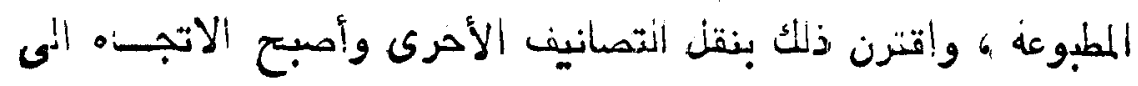

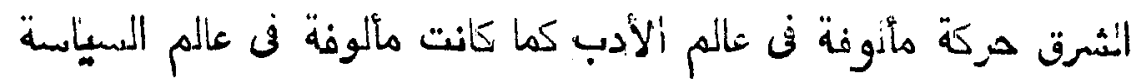

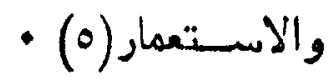

ولسنا بص-دد جمع كل التأثيرا تالتى أحدثت أثرها في الأدب

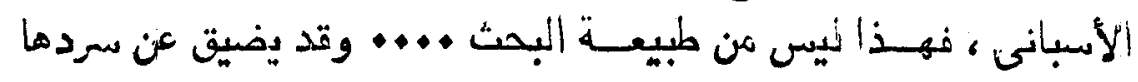

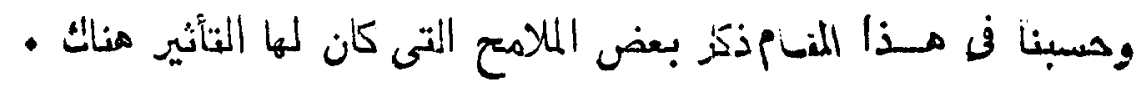

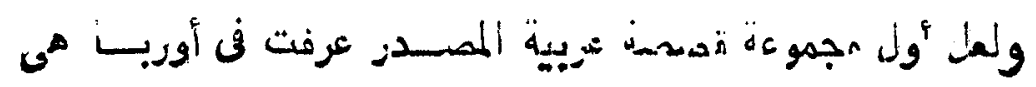

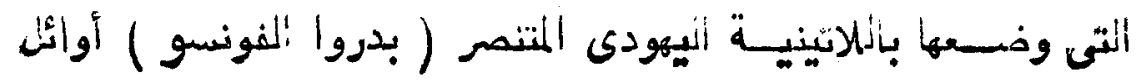

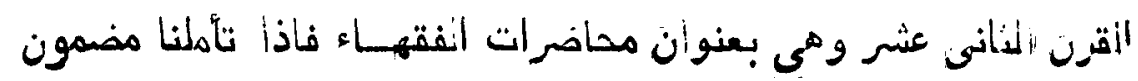

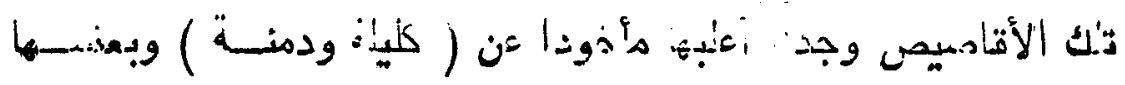

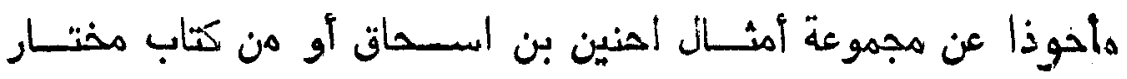

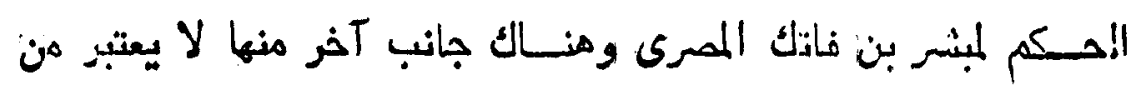

(0) أثر العرب فى الحضارة الأوربية / الكقاد ص V ط المعارف م 
Ti.

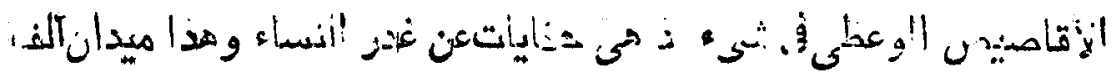

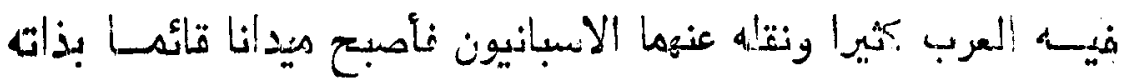

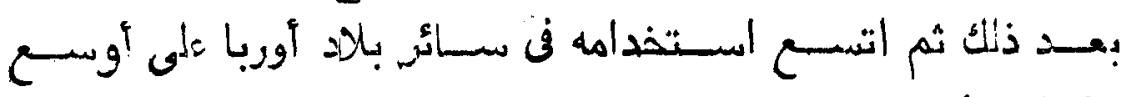
نطـاق (y) نداق وتد كثرت مداولات تقلنيد (كَّليلة ودمنة ) سـواء فن الاطلار النعام

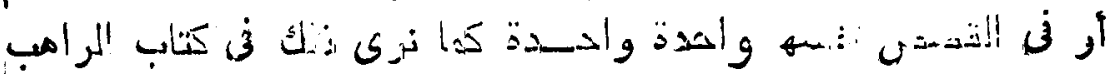

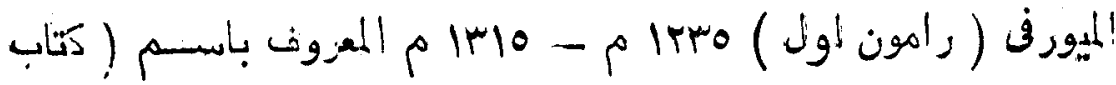

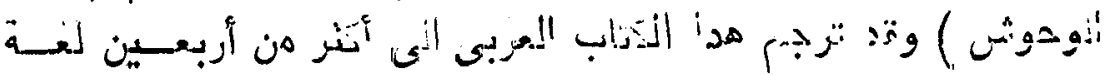

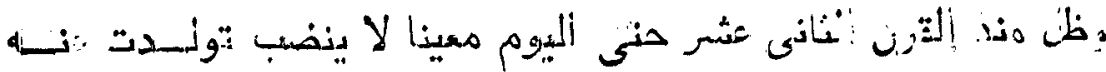

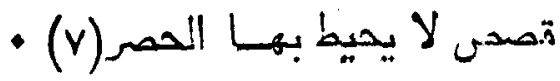

وتعتبر ( قد.أ ألسن:-ند ) من أشهر ا:قصد الاسهامية أنتى كان

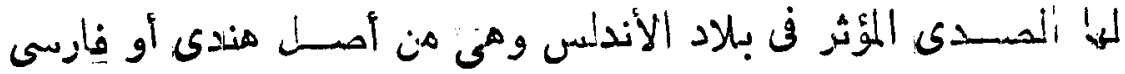

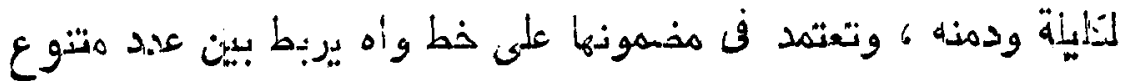

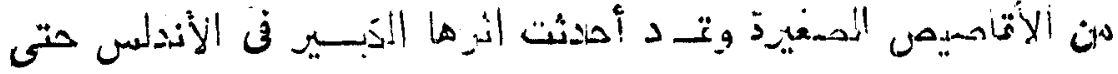

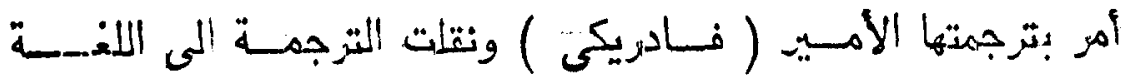

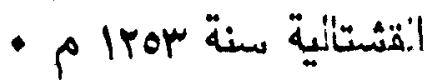

وكان عن جُرأه ذيوع هده القصص أن زأينا انراهب الأسـبانى

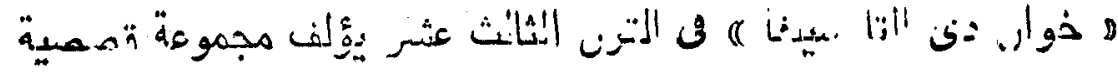

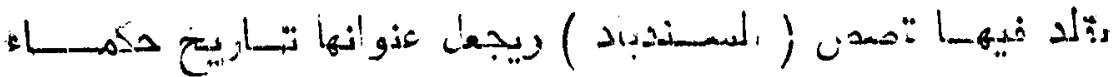

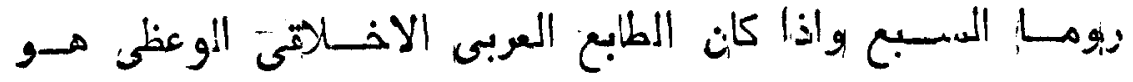

(T) أثو العوب والاسلام فى النهفة الأوربية ص 70 . 


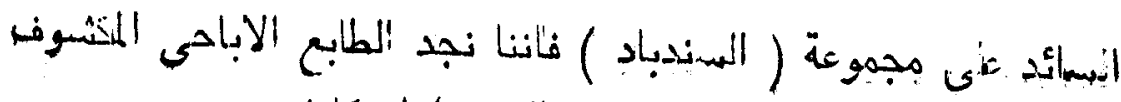

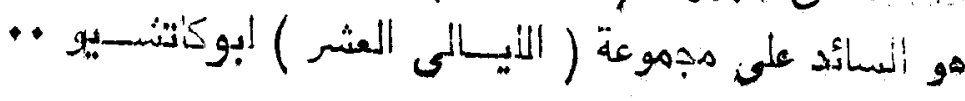

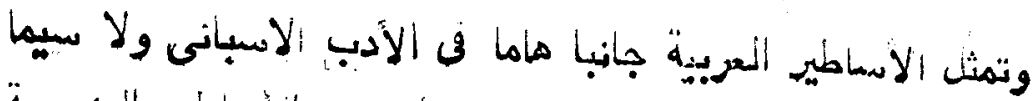

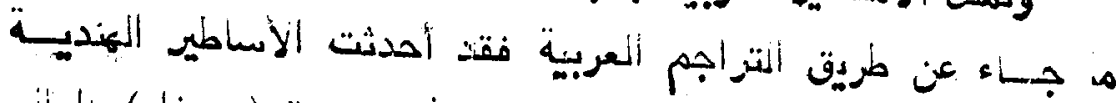

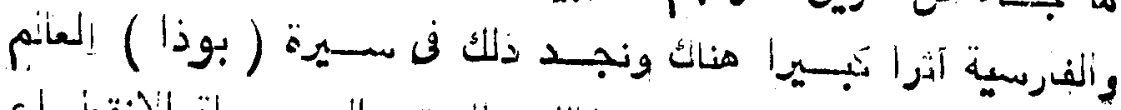

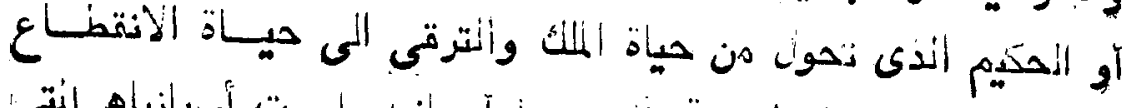

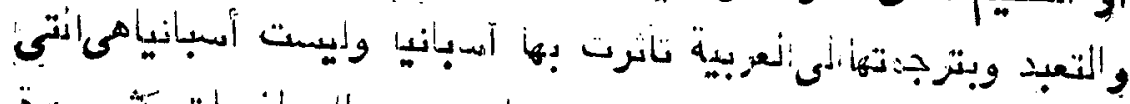

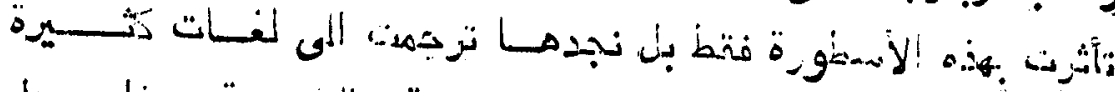

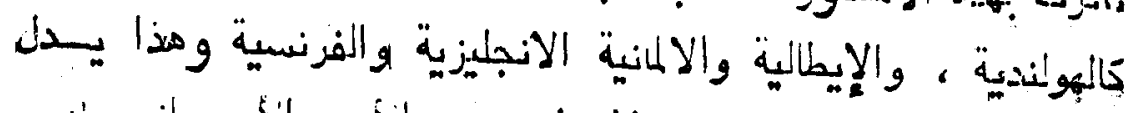
\%

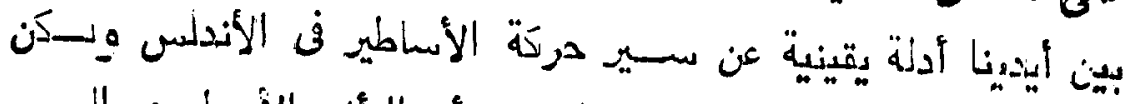

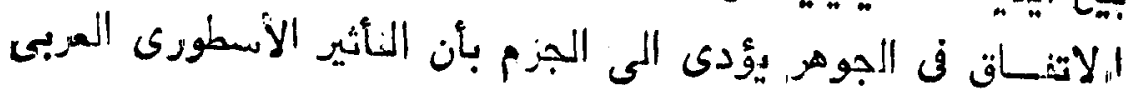

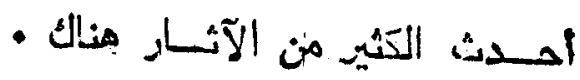

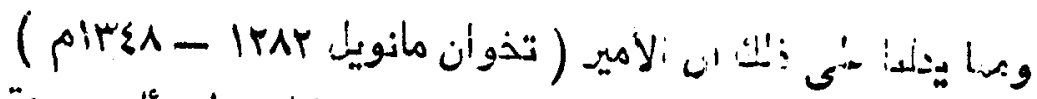

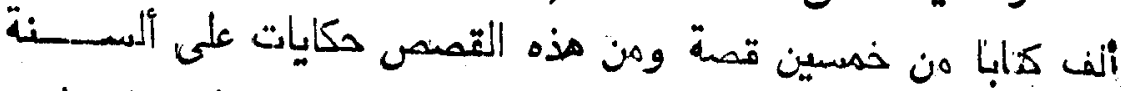

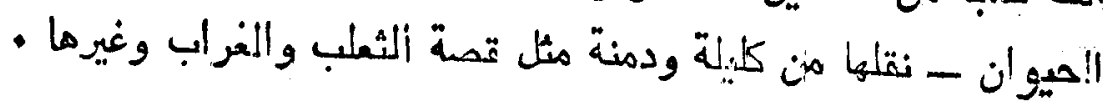

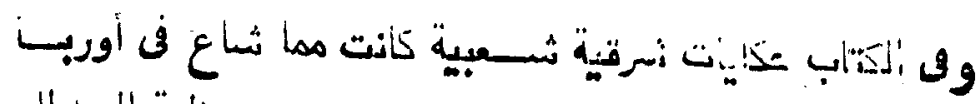

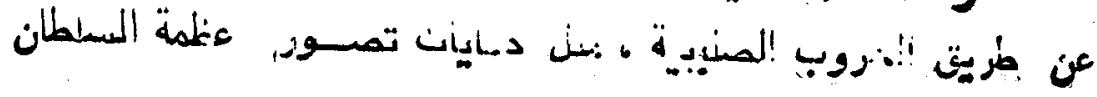

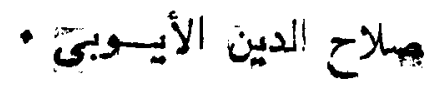

ومن المكايات أيضا قصة ( المعتمدا بن عبــاد ) و اعتماد الرميكية

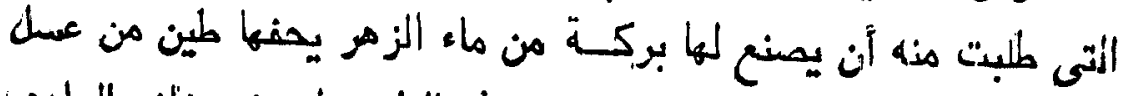

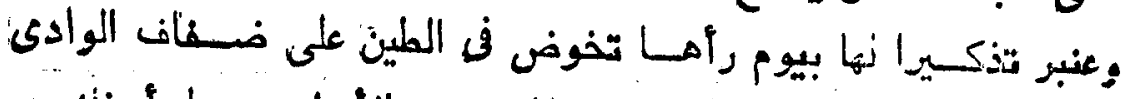

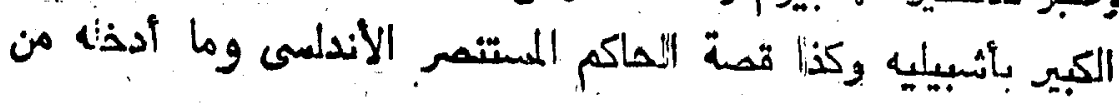


تعديلات على بعض الآلات الموسيقية وكذا قصــة الزاهد الاندلسى

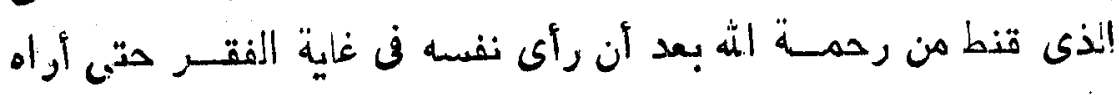

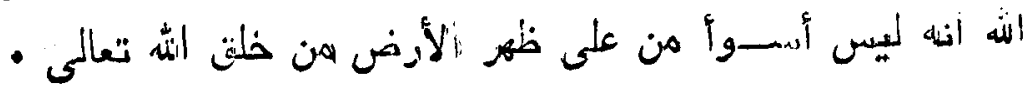

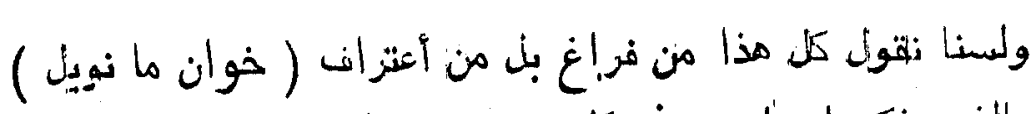

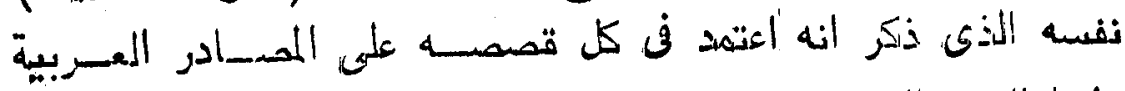

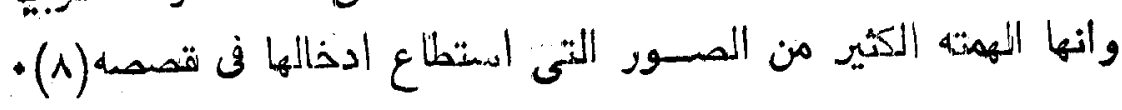

وهناك فن آخر اشتهر في بلاد الثرق وأثر تأثبرا كبيرا أيضــان

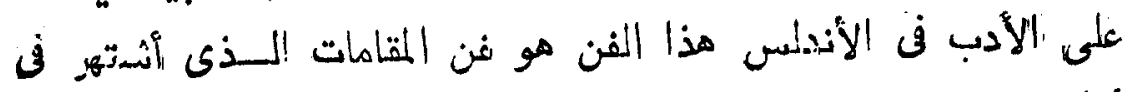

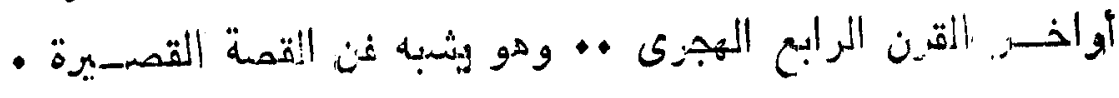

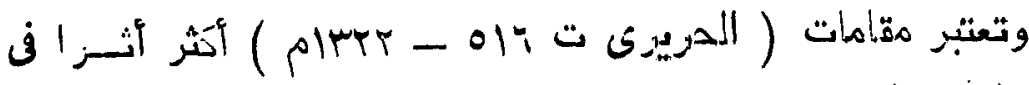

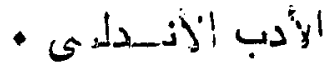

فلقد عارضسها الكثير من الادباء ومن أثهرهم ( أبو سطاهر محمد

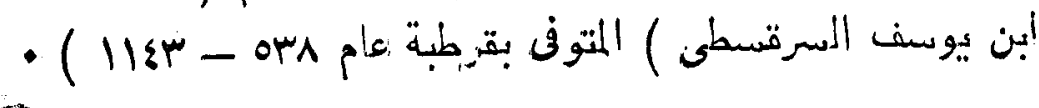
فقاد عمل خدسين مقامة ولا زالت منها نسخــة في أسسـتاهبوأ

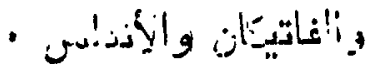

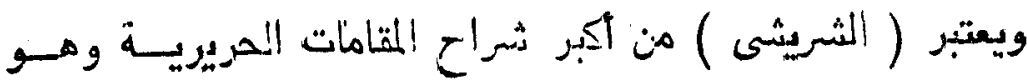

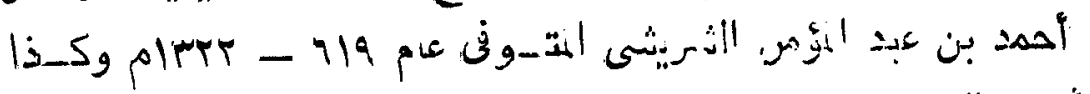
الأديب العالم ( لمنسان اللزين بن الخطيب ) هن أحسن الأدباء الذين

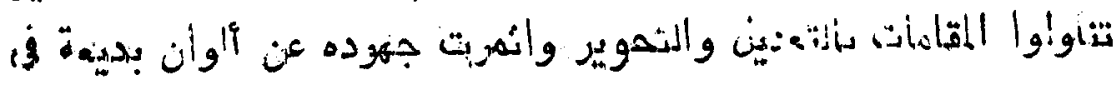
ن 0 :

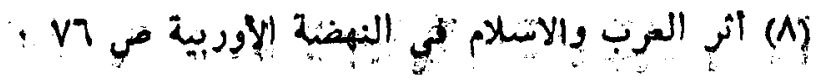




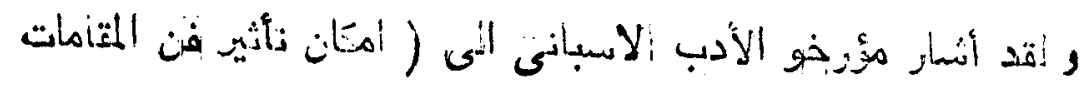

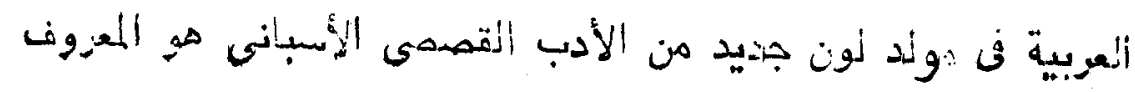

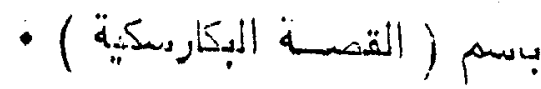

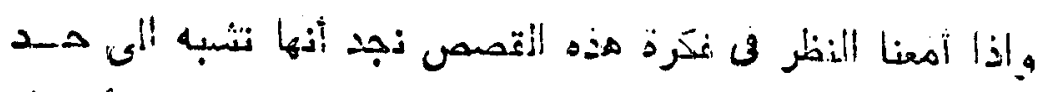

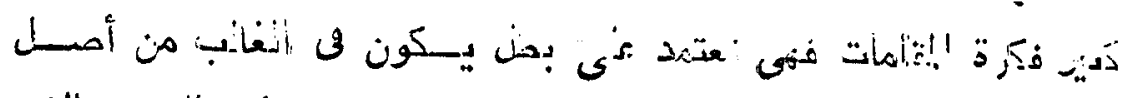

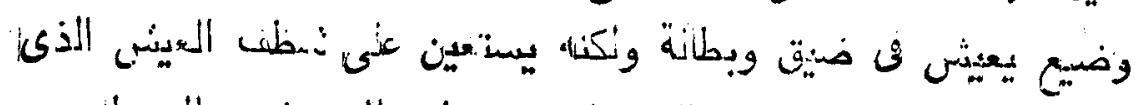

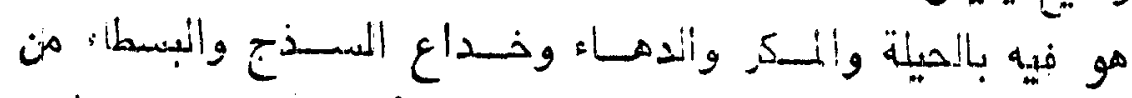

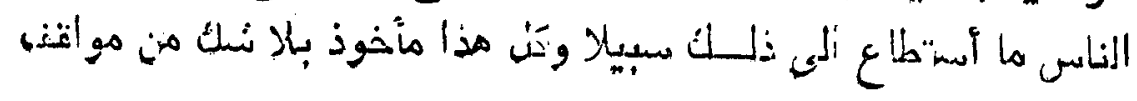

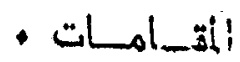

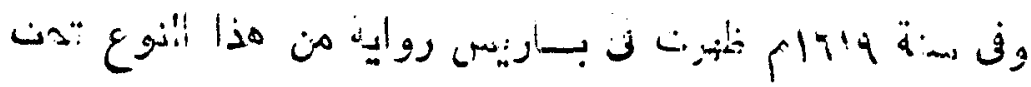

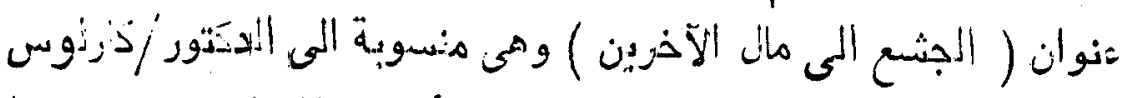

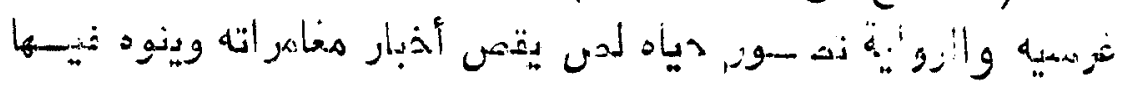

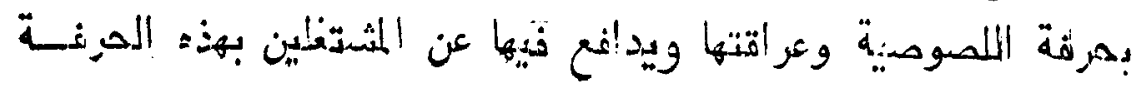

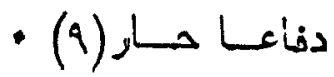

ولا ننسى زنحن في هذا الفتام ما أحدثته التصص الوعظاية من تأثين

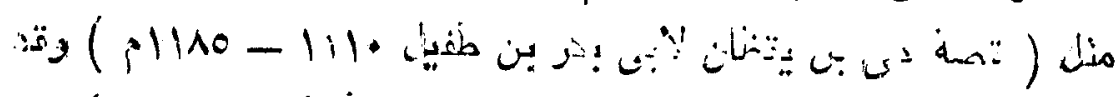

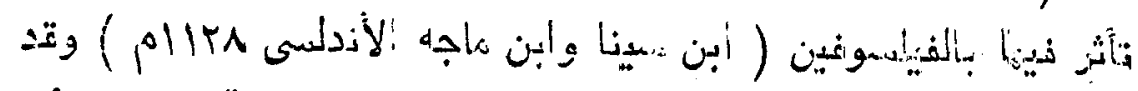

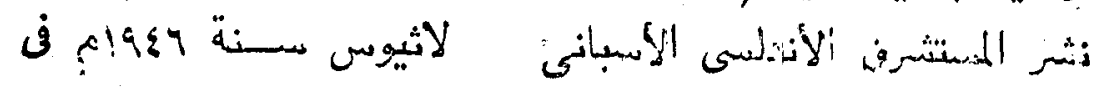

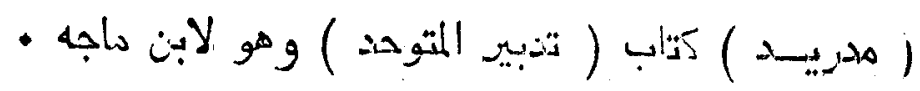

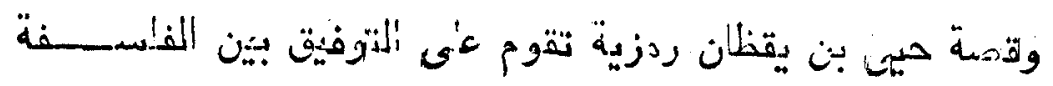

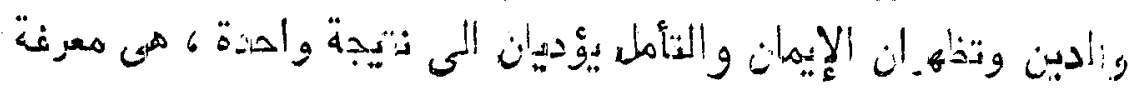

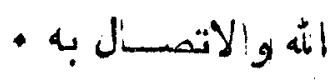

أثر العرب والاسلام فى النهضة الأوربية ص AV - 


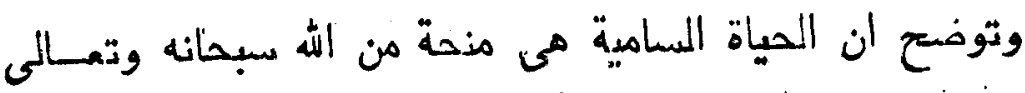

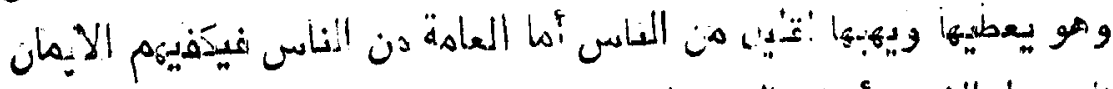

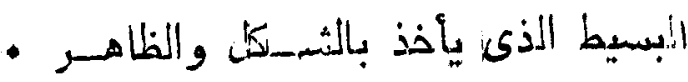

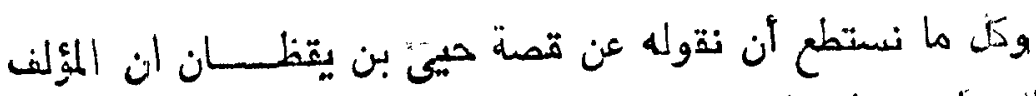

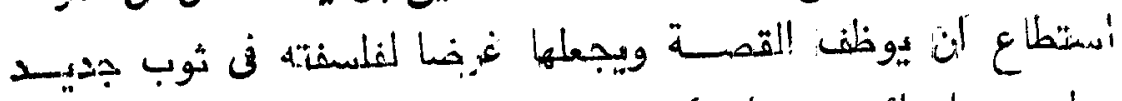

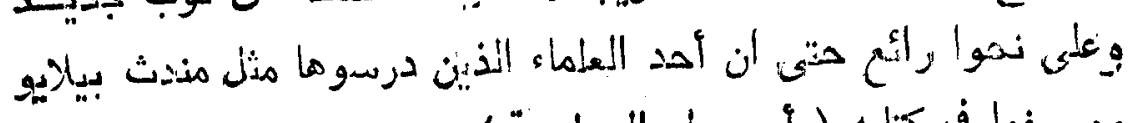

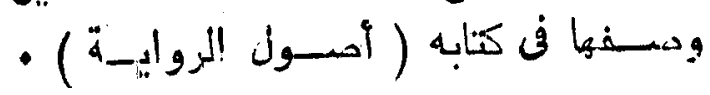

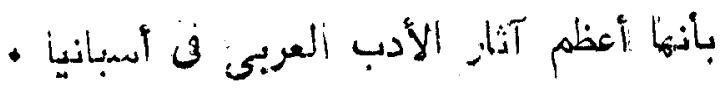

وتد ذذاع صدى هذه القصة وأثرت تأثيرا كبيرا في أدباء أسبانيا

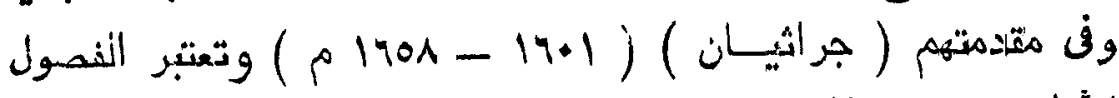

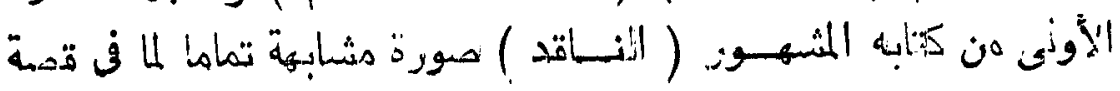

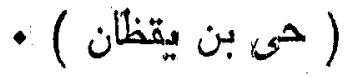

فجرائيان أخذ مفسون القصة ونحوأها ووضعها في كتابه يقون

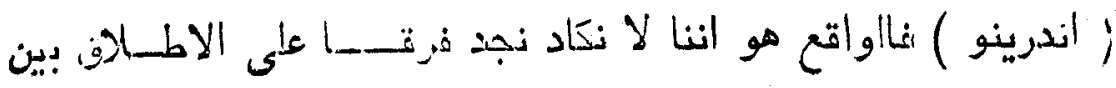

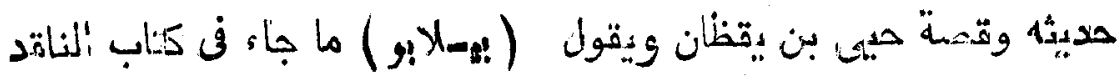

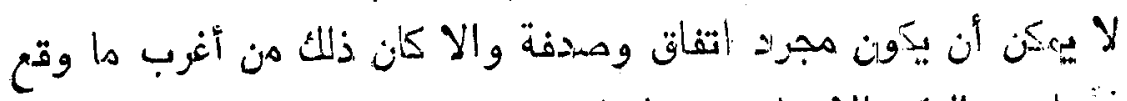

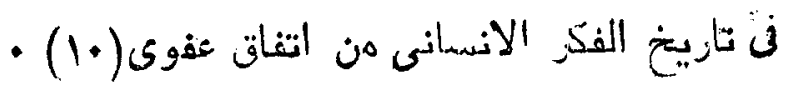

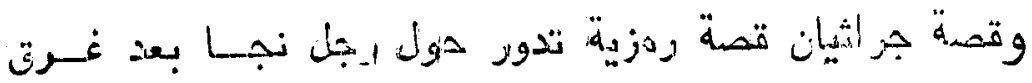

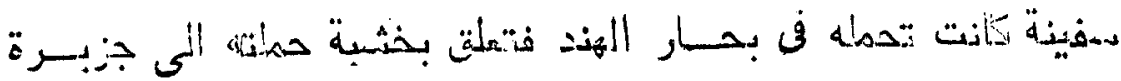

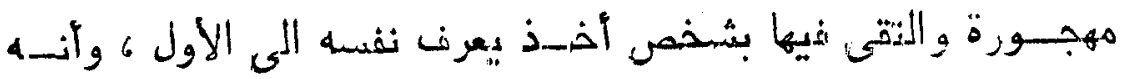

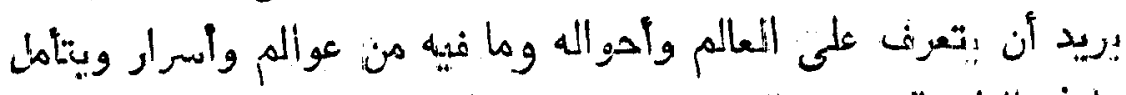

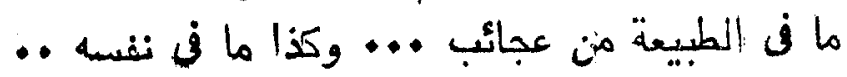

- 91 1.) 


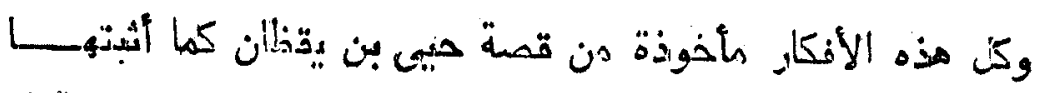

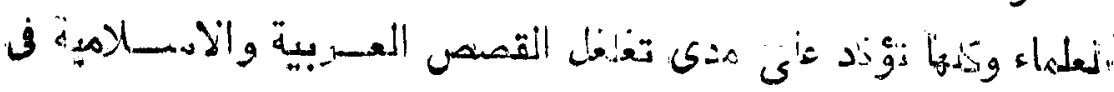

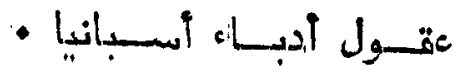

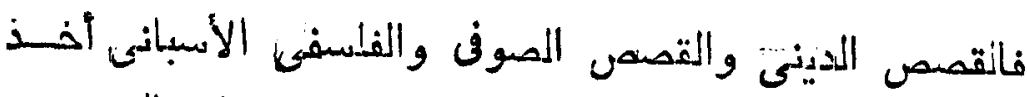

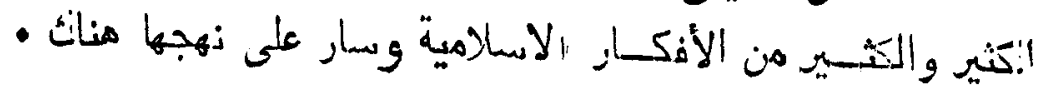

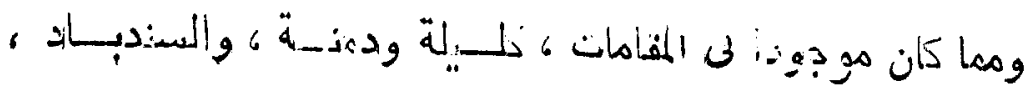

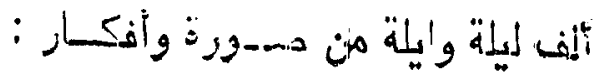

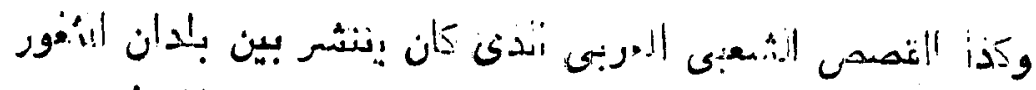

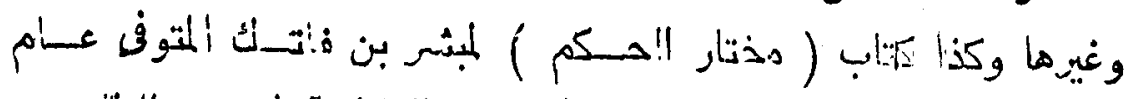

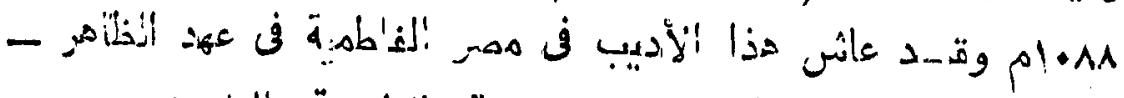

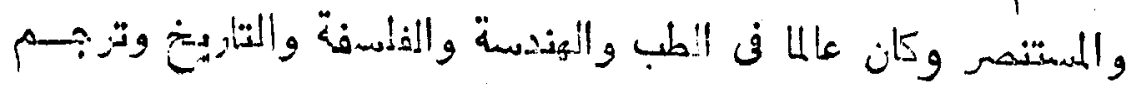

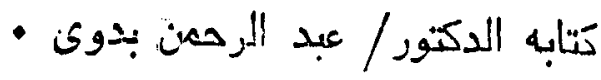

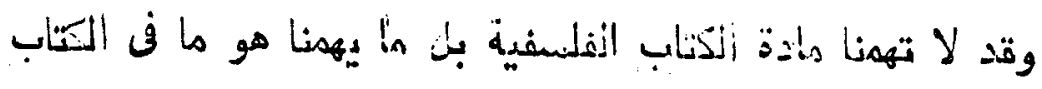

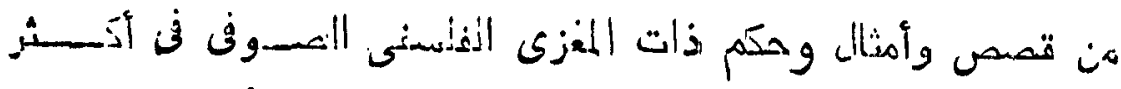

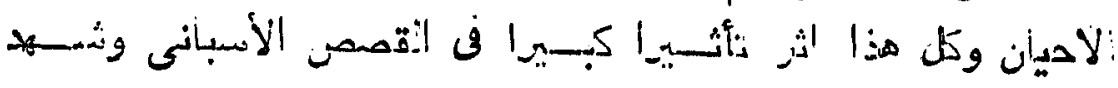

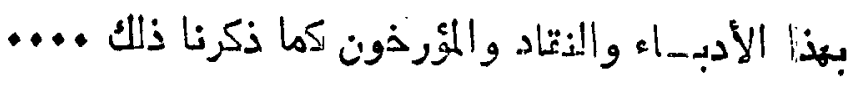

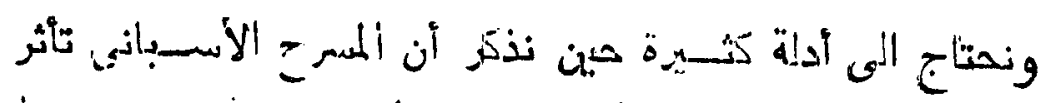

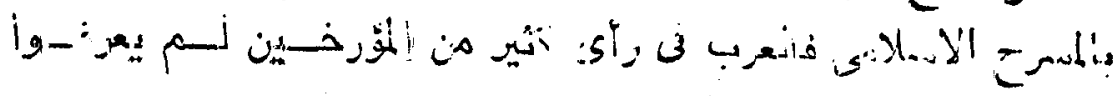

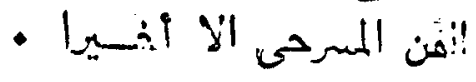

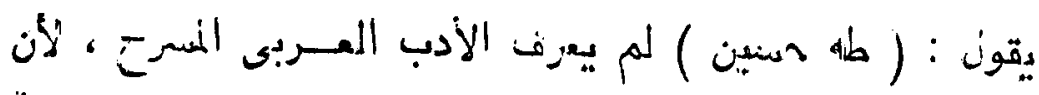

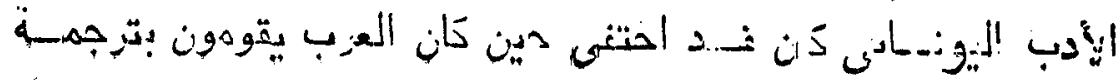

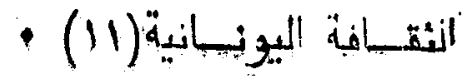

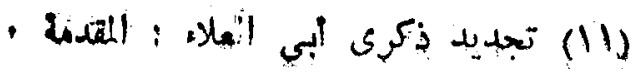


iv

\section{ويقول هنريش بيسكر الالمنىى(IT) :}

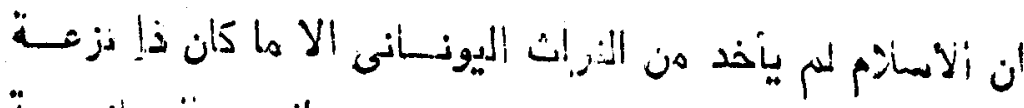

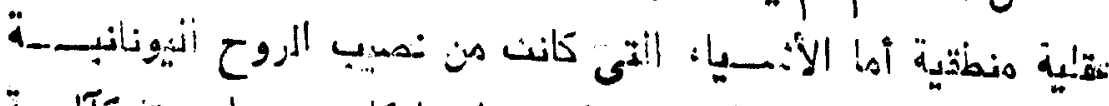

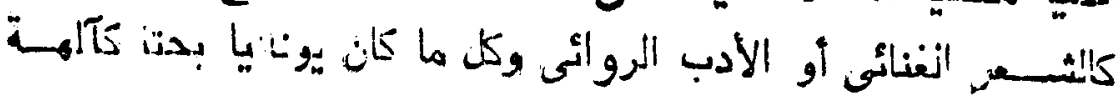

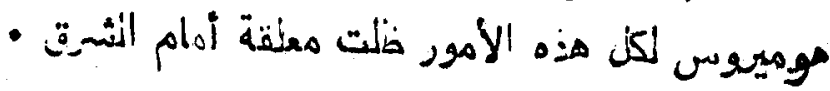

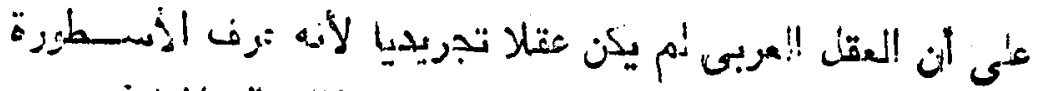

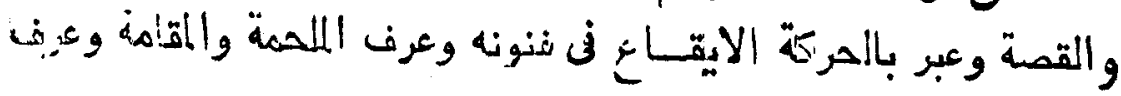

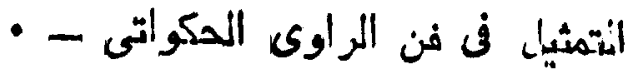

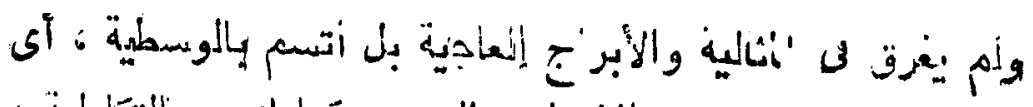

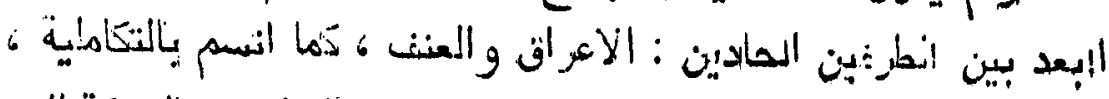

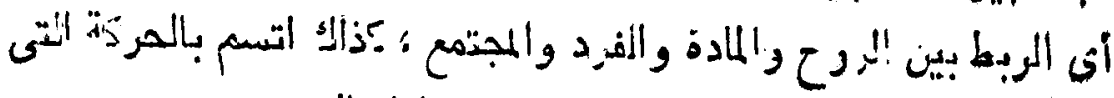

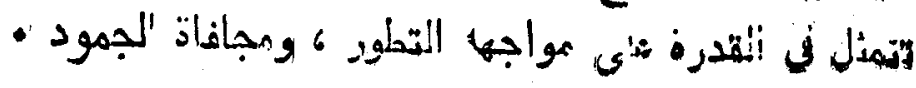

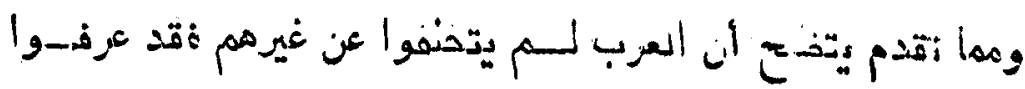

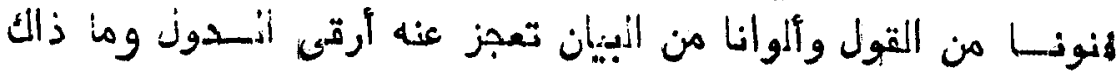

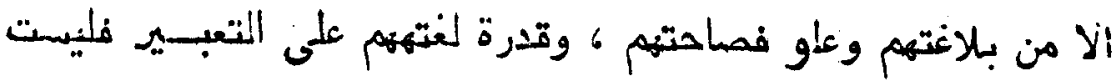

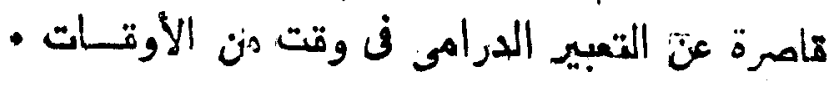

ومن يبحث فن الأدب العربي يجد أمامه الملاولات ومى المبلقنت.

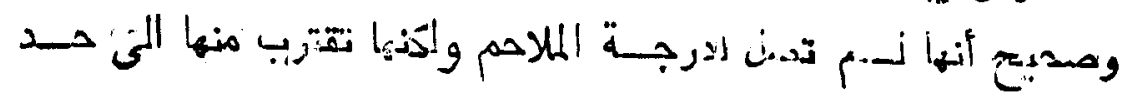

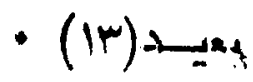

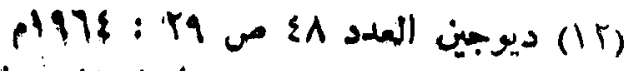

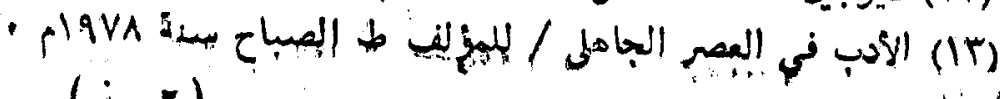
$(j-r)$ 


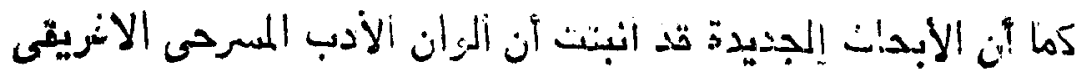

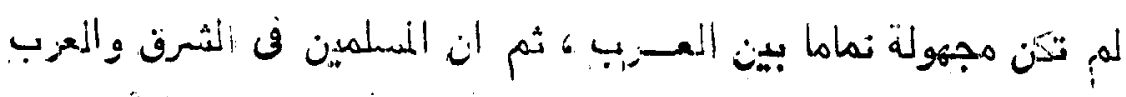

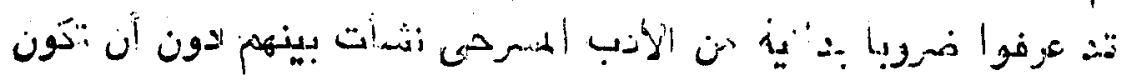

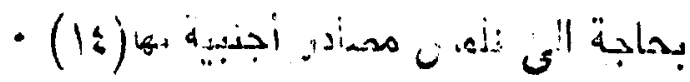

على أنن المسرح الدينى قد انتشر في بعض بذدان العالم العربيَ

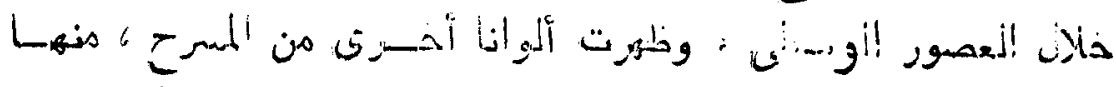

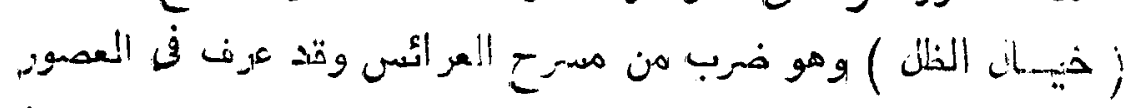

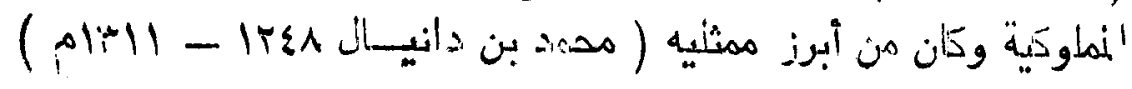
:

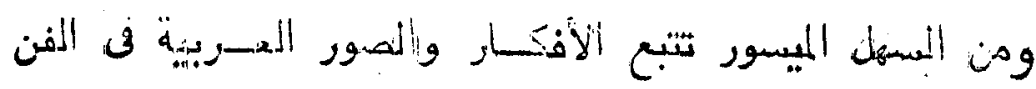

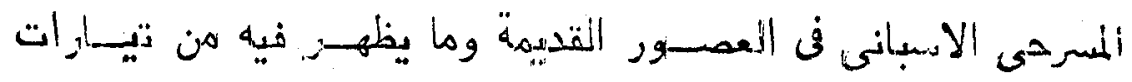

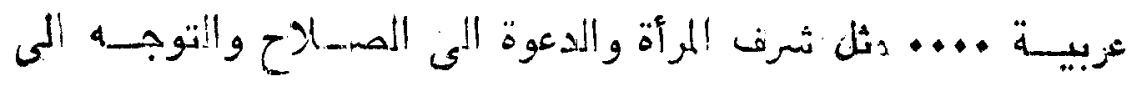

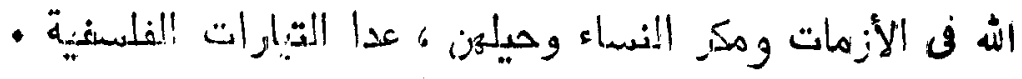

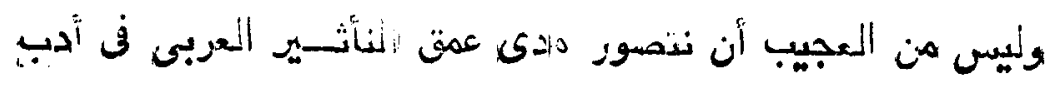

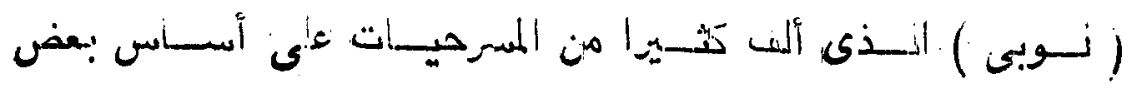

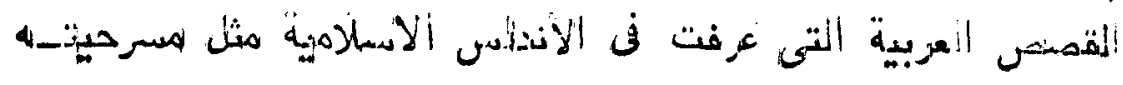

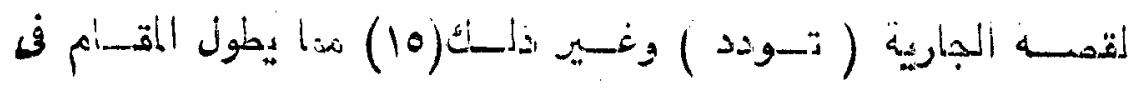

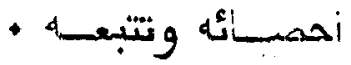

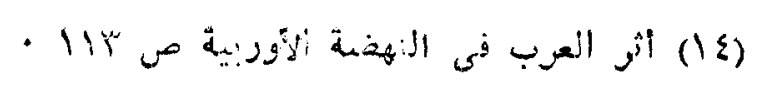

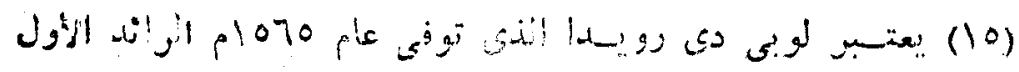

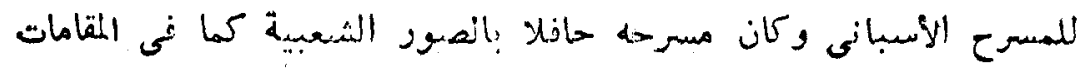

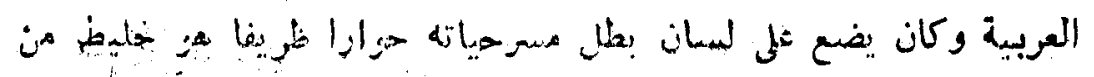

العوبية والأسبانيح

تئي سودي مولينا 


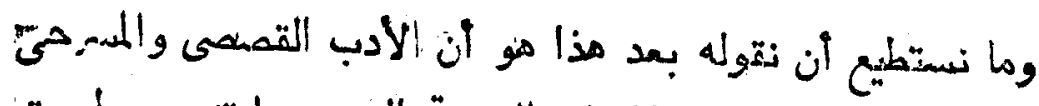

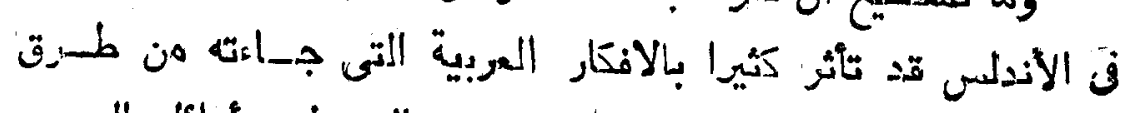

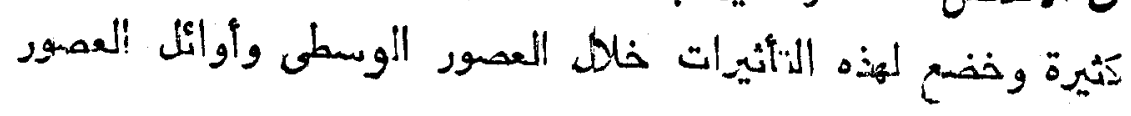
الحسيدة ايثة

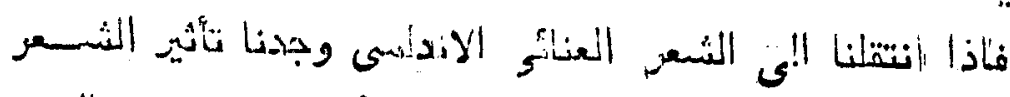

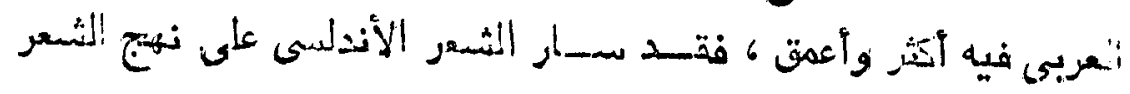

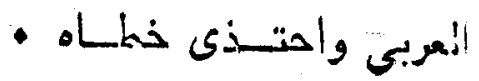

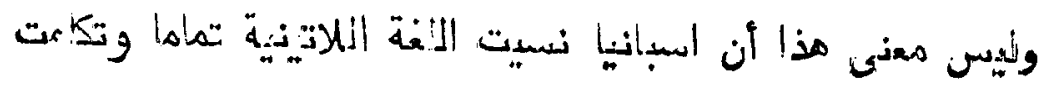

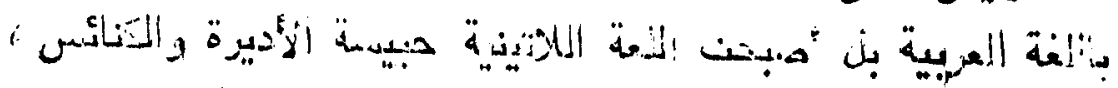

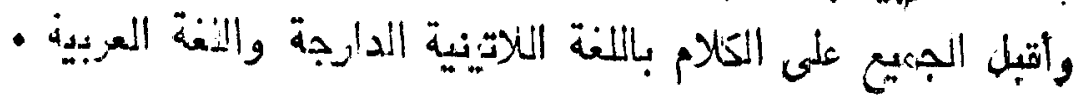

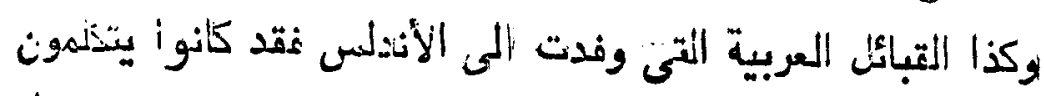

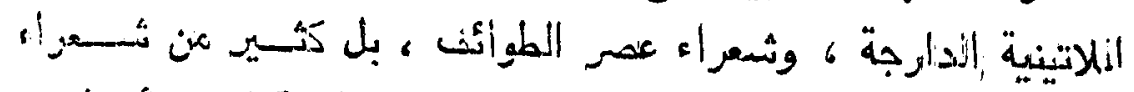

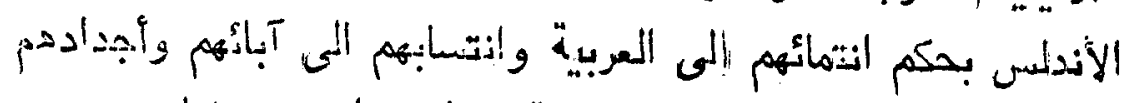

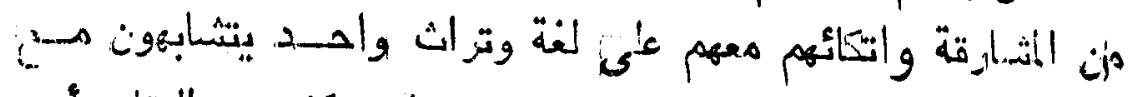

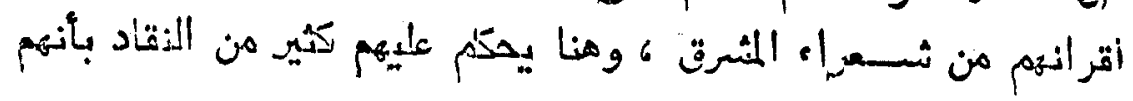

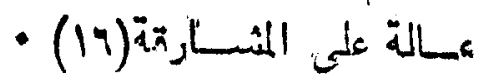

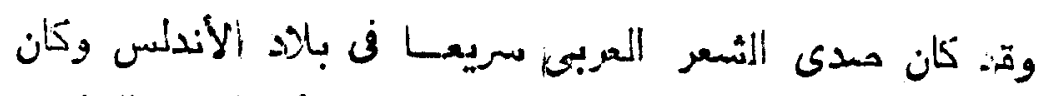

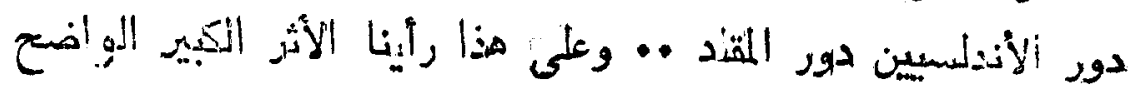
-

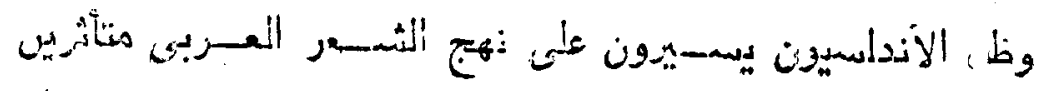

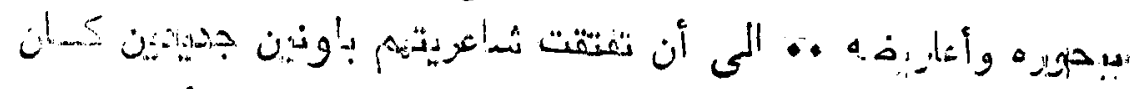

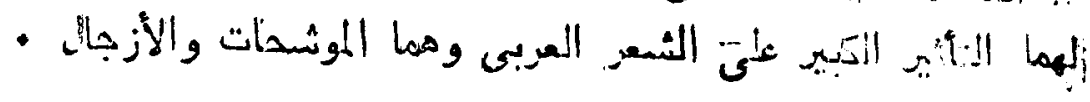

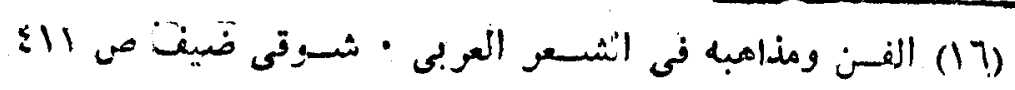

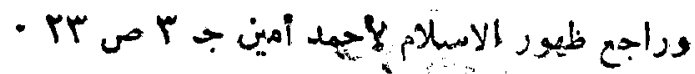


يقول ابن بسـام صاهب كتاب الذخيرة ( وأول من صنغ أوزان

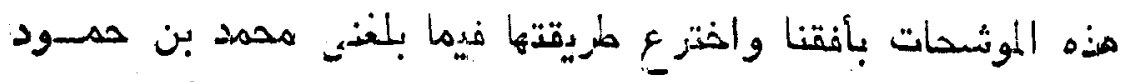

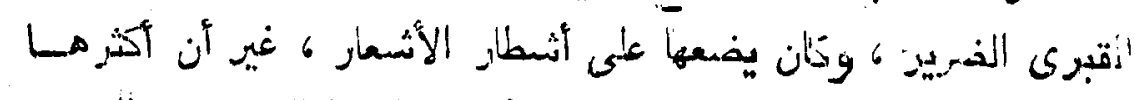

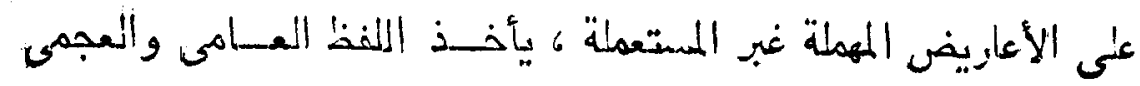

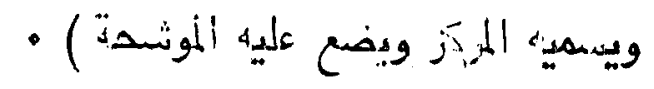

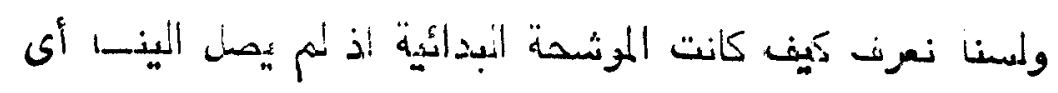

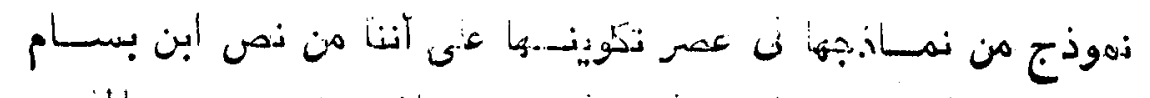

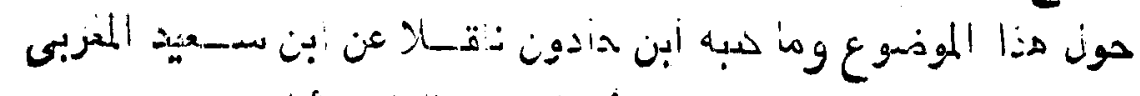

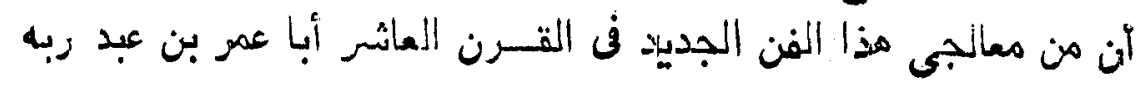

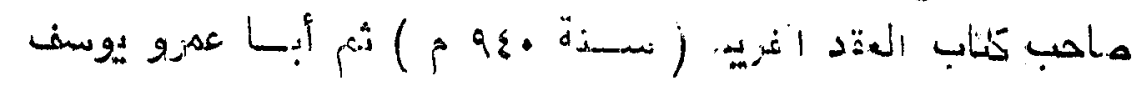

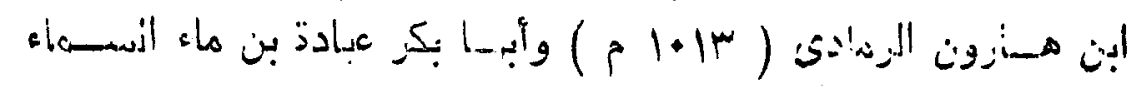

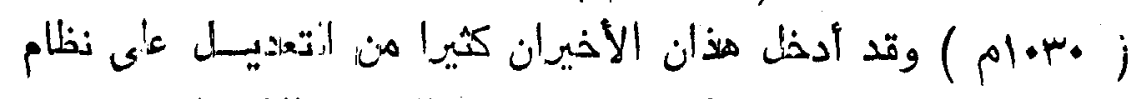

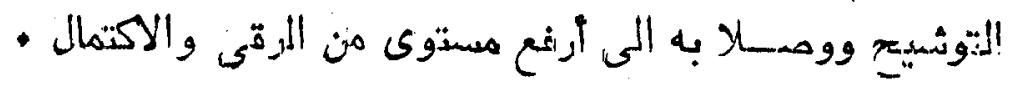

وقد أففانا ( ابن خـلدون ) عن تطور فن النتوشيح فـ مقدمته

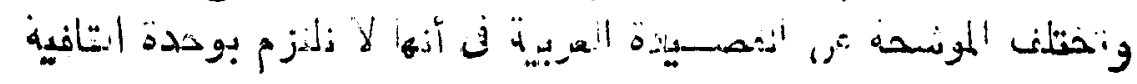

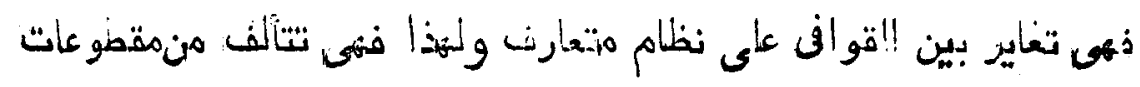

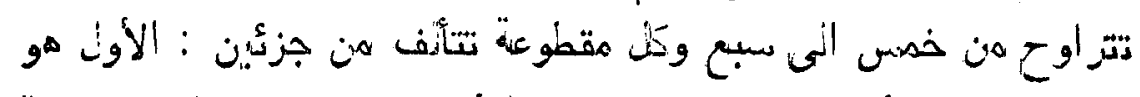

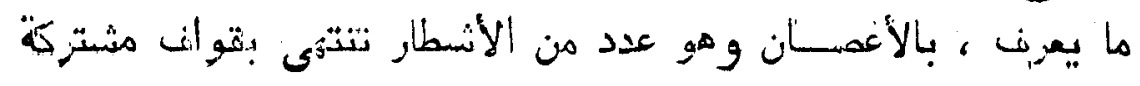

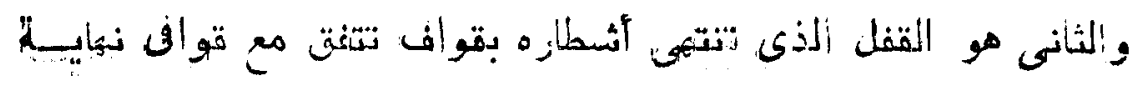

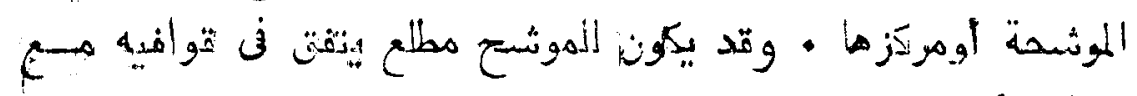

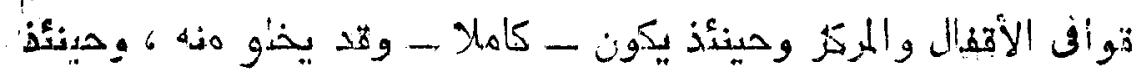

$$
\text { • }
$$

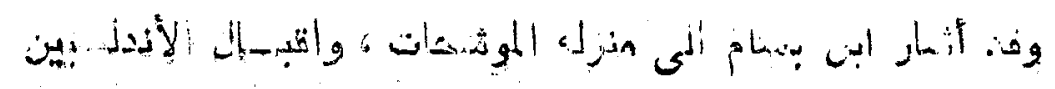

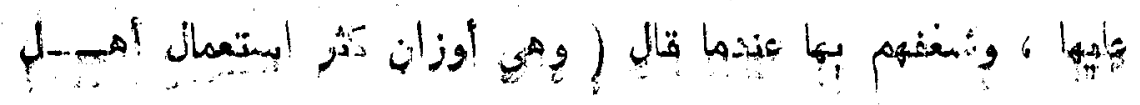




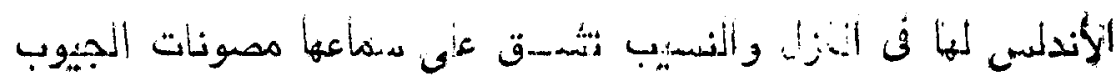

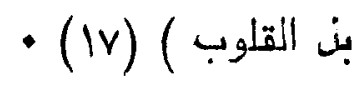

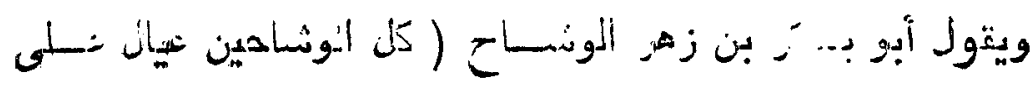

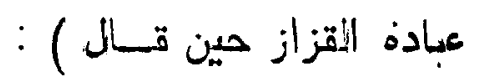

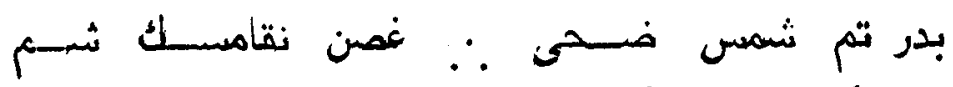

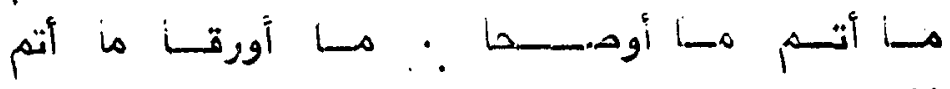

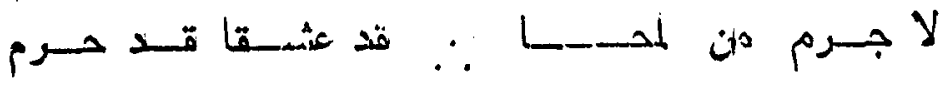

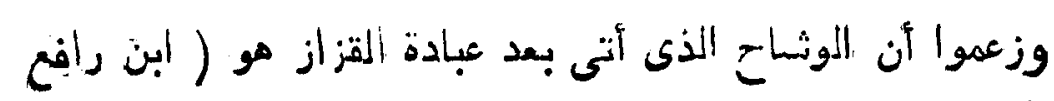

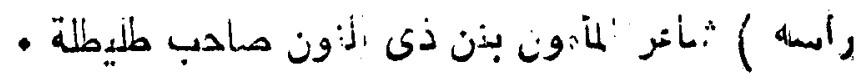

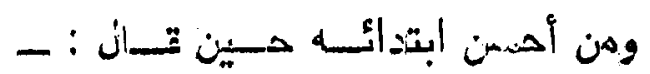

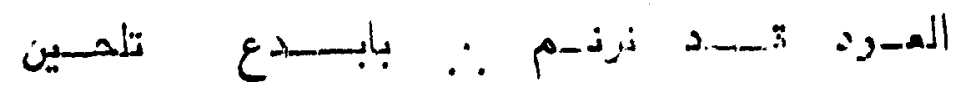

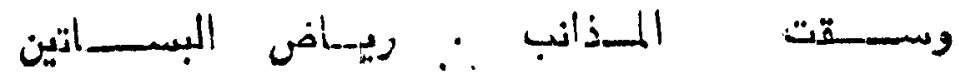

$$
\text { وانتهى - بالخرجة - دين تسان - وست }
$$

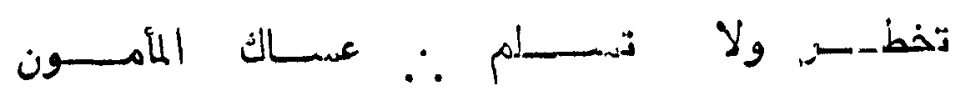

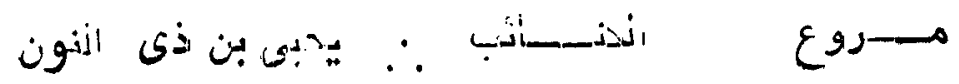

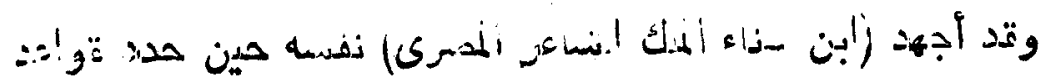

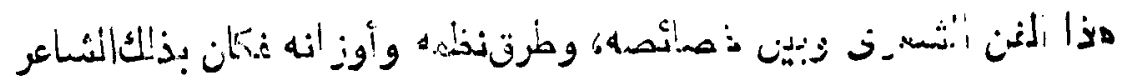

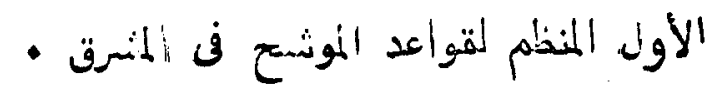

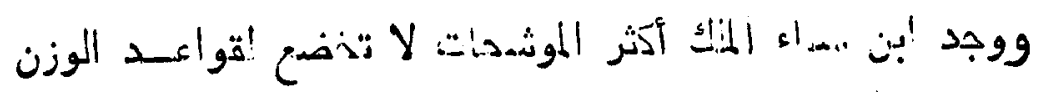

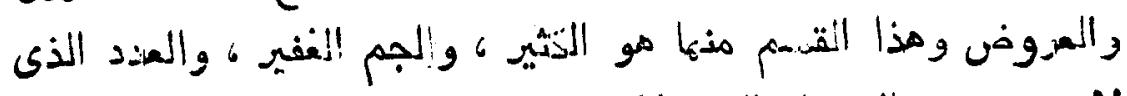

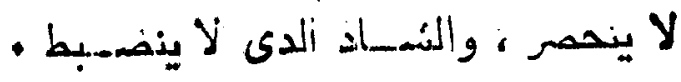

(IV) 


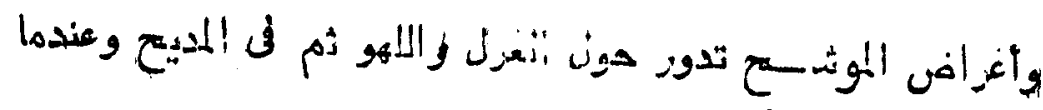

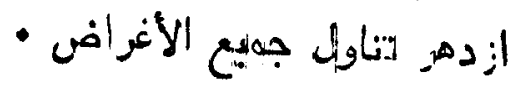

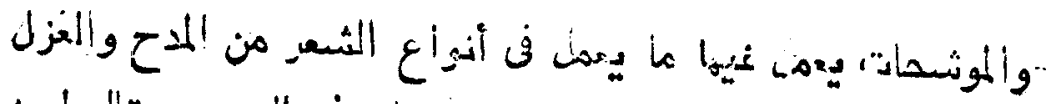

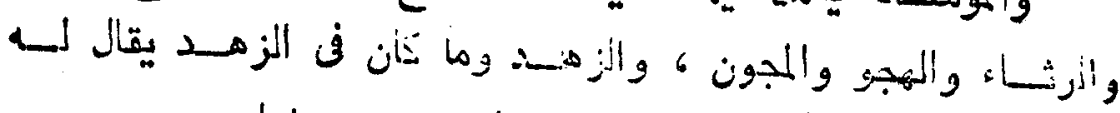

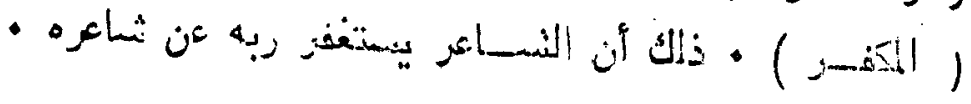

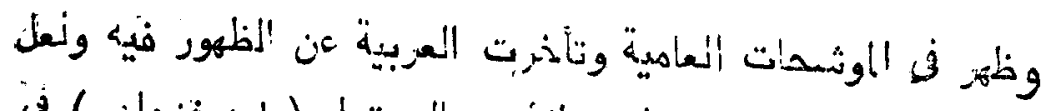

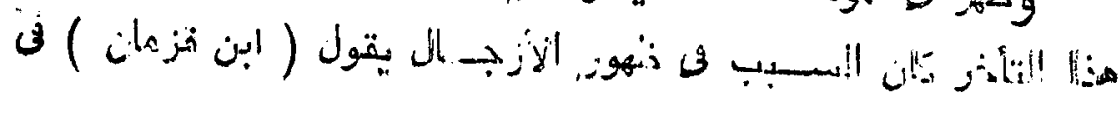

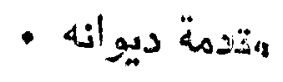

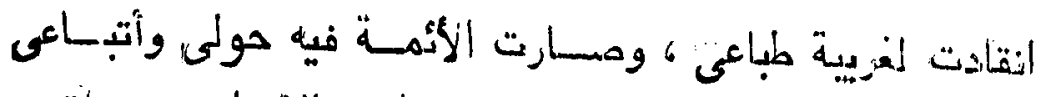

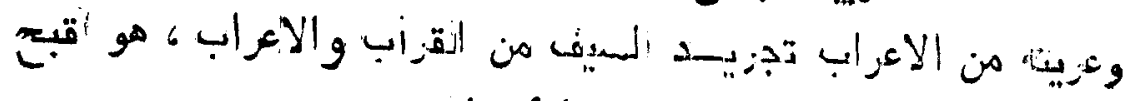

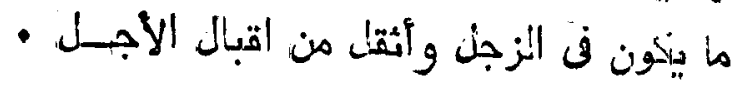

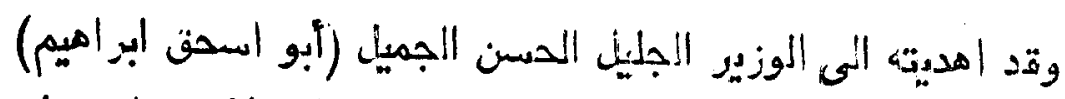

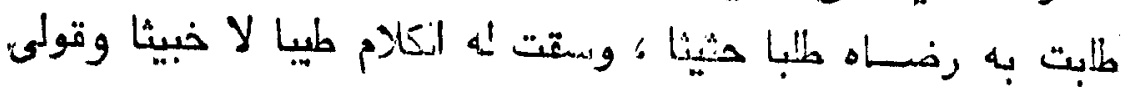

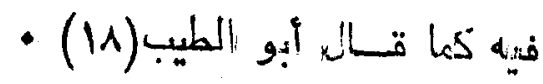

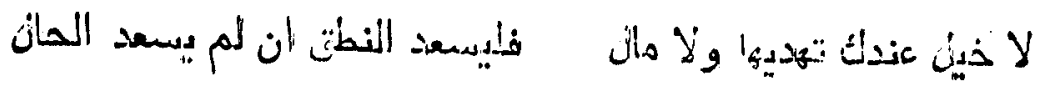

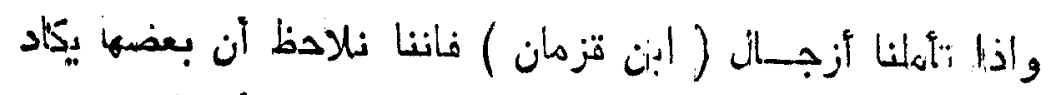

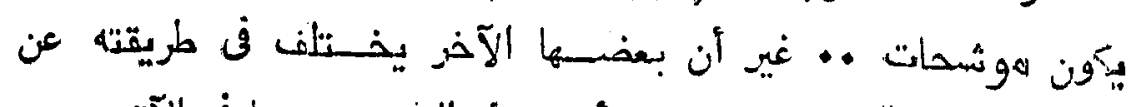

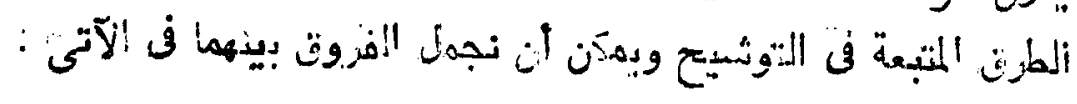

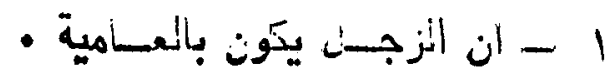

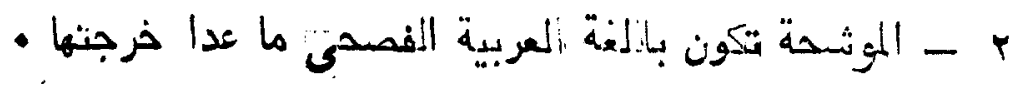




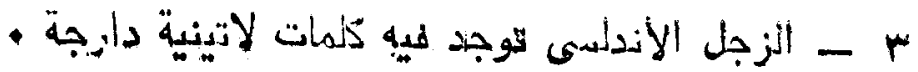

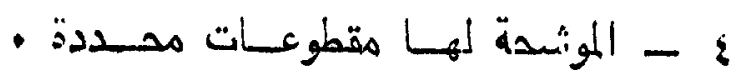

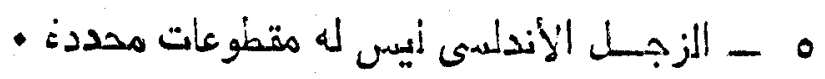

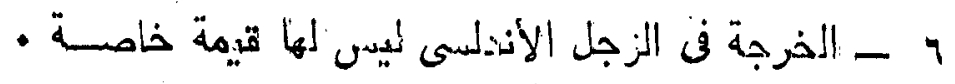

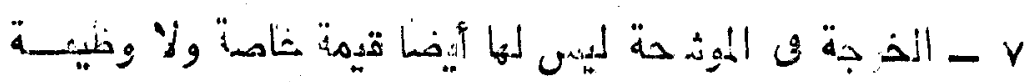

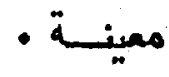

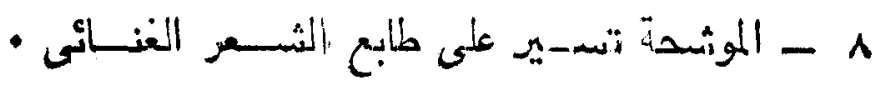

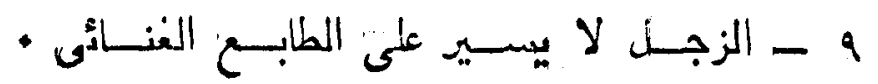

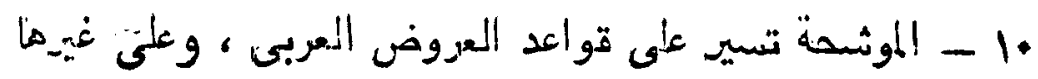

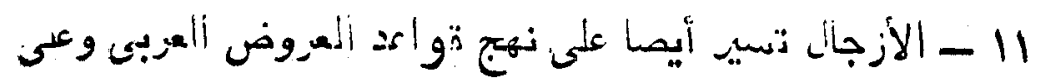

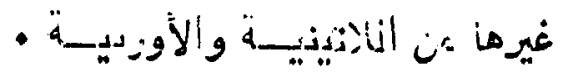

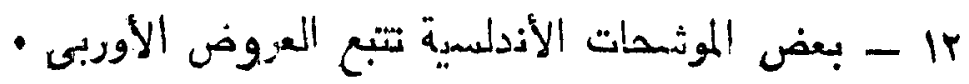

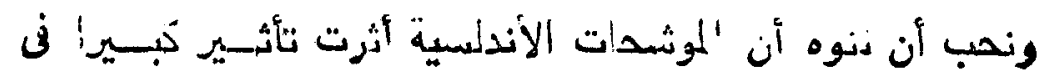

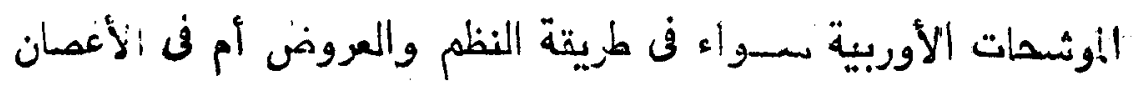

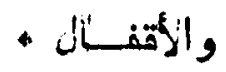

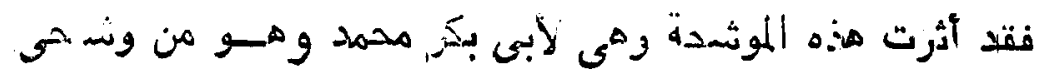

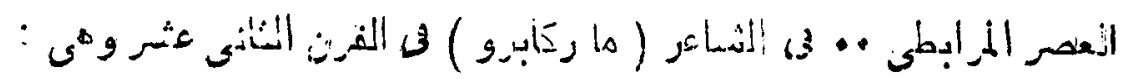

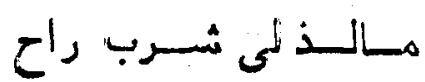

عسنى ريساض الأقساح

لــولا هضــيم الوشتيـاح

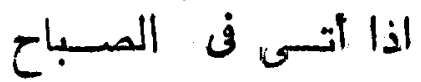

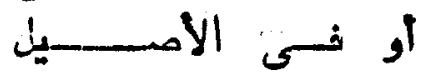

يتــــــ 


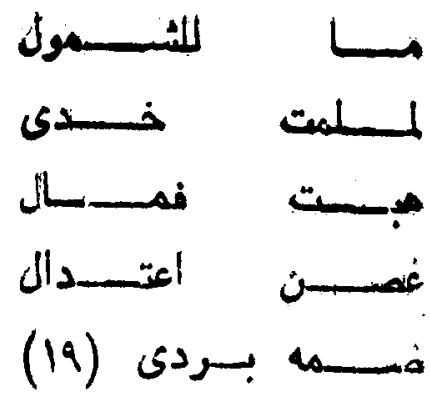

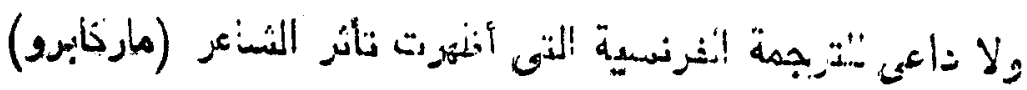

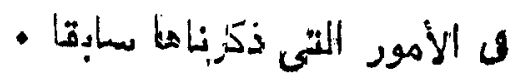

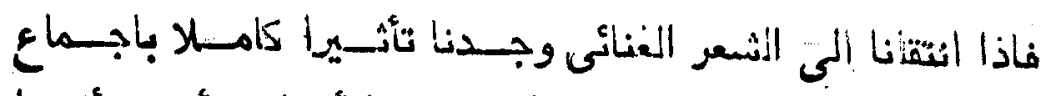

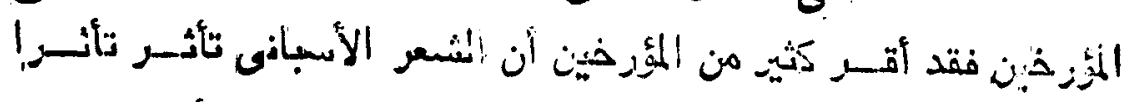

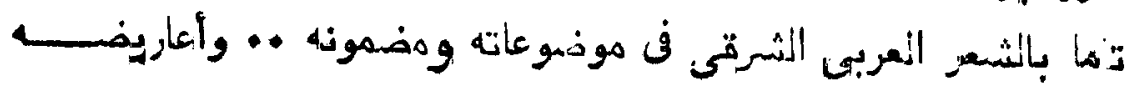

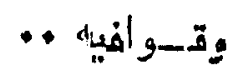

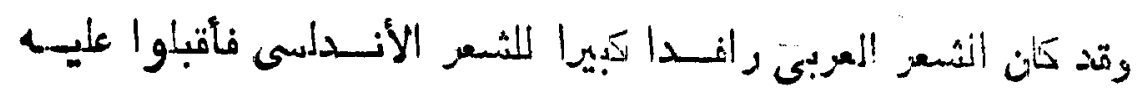

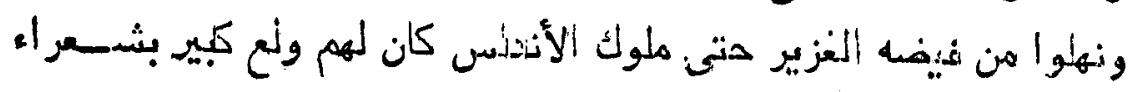

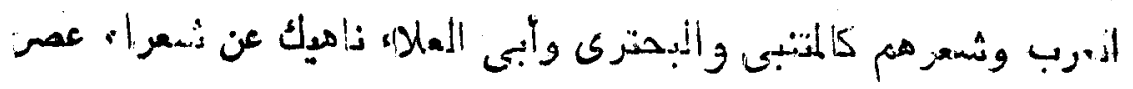

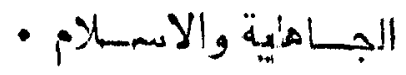

وتذ كان المعتمد بن عباد معجبا بشسر المتببى فقائه بيتا من شسعره

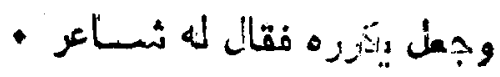

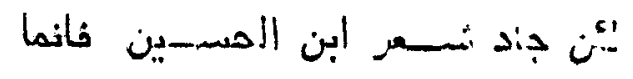

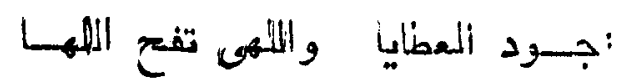

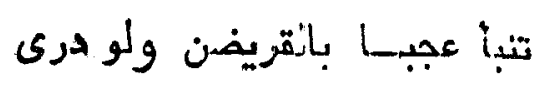

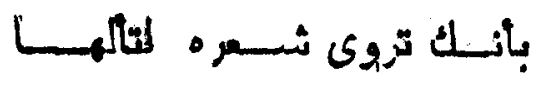

(19) اثو العرب والاسلام فى النهفة الأوربية ص \&ه - 
18

وأُهـارون الرشهـيد أبيـات مشهــورة هى : ملك الثـلاث الآنسات عنانى تركي

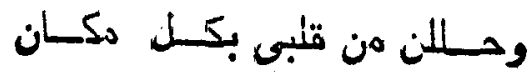

مالب تطاوعنى البري- وهية كلهبا

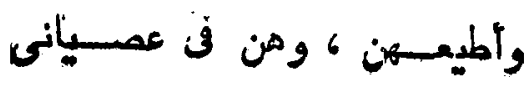

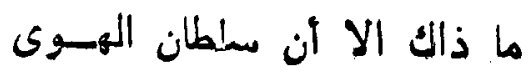

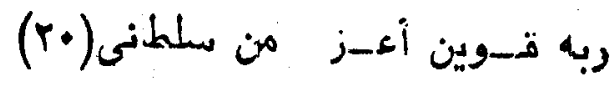

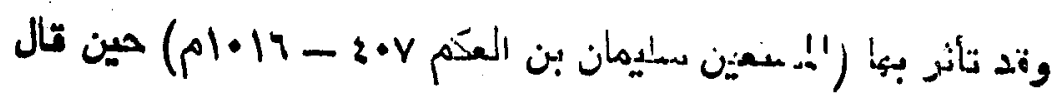

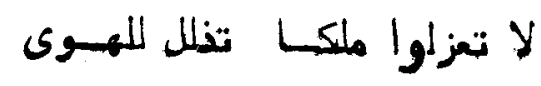

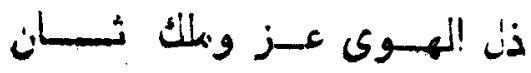

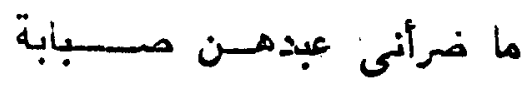

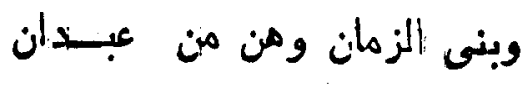

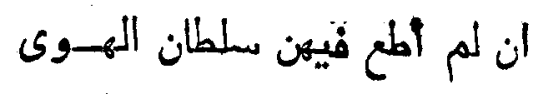

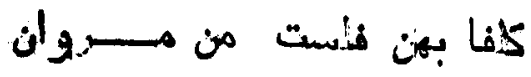

وبقول جهيل بنينة فل المصر الأموى :

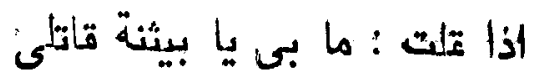

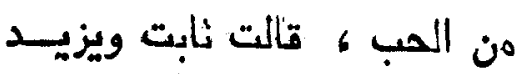

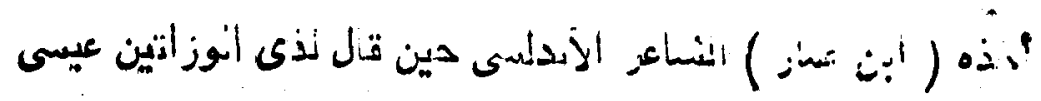

أبن ابـون :

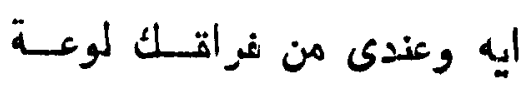

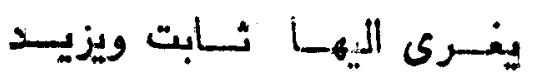

• (r.) الحلة السيراه بـ r مص 
بم التعسلا، لا أهـل ولا وطن

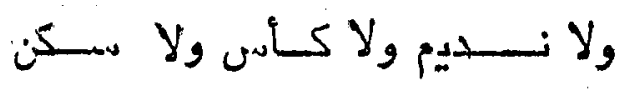

اخذه الثُاعر ( ابن زيسدون ) نقان :

هل تذكرون غزيبــا عـاده شُهن

من ذكركم وجفا أجنفنانه الوسن

وابن خفاجه الأنلالدى يقون فى قمسـيدته :

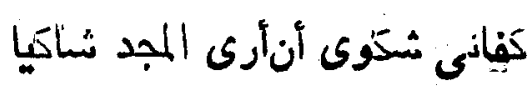

وحسب الرزايا أن ترإنى باكيـا سيا

وهذا البيت اخذه من المتنبى حين قال :

كلى بلك داء أن ترى الموت ثافيا

وحسب المنايــا أن يكن أمانيـا

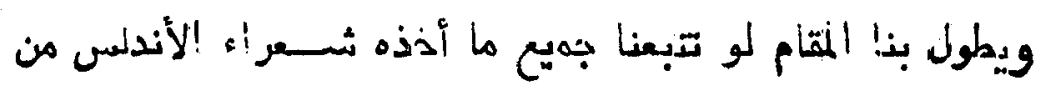

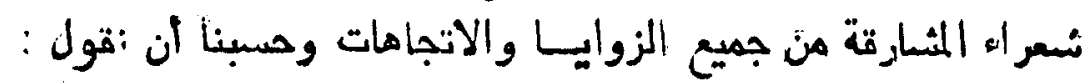

اني شعراء الأندلس أخذوا هن ثشعراء المشارقة افتتاح القهــائد

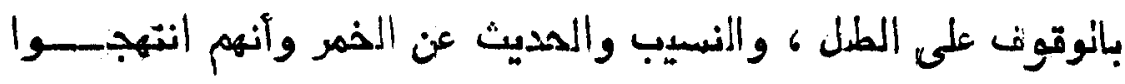

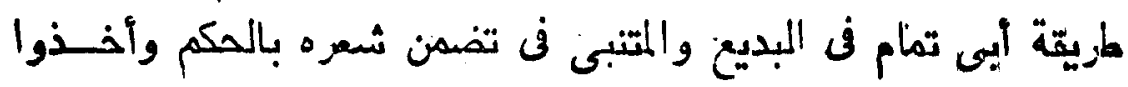

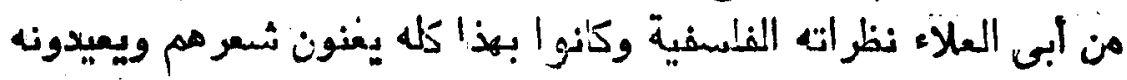

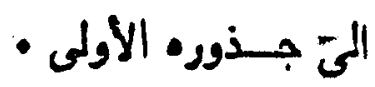

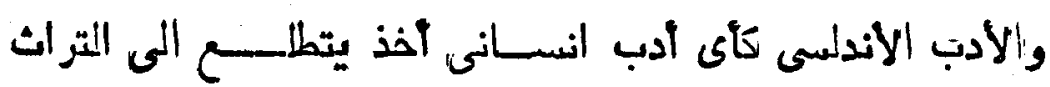

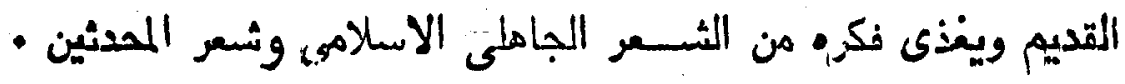


Fv

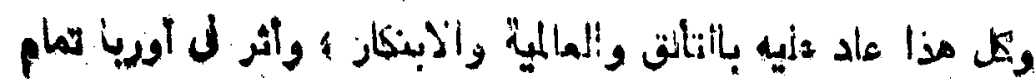

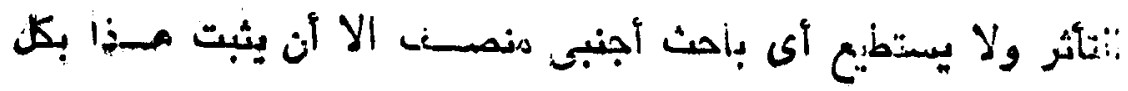

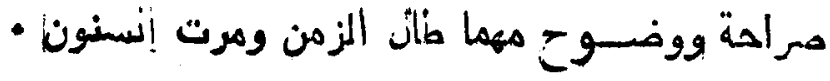

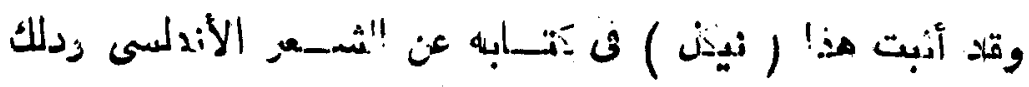

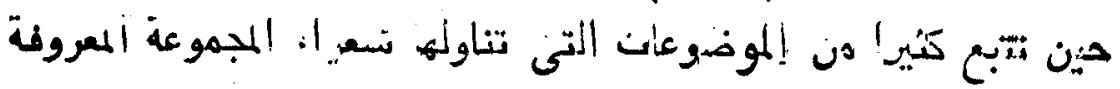

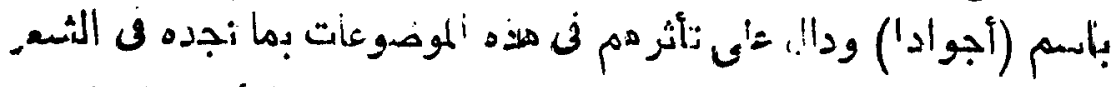

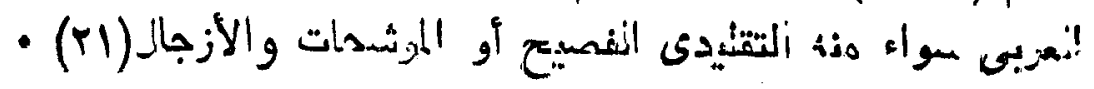

• · · (TI) 


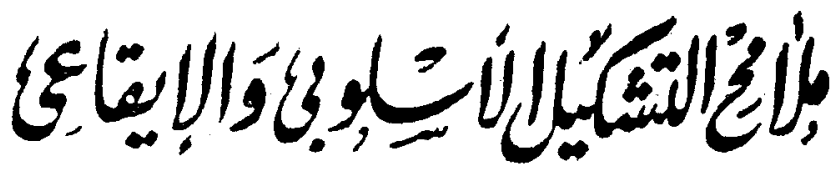

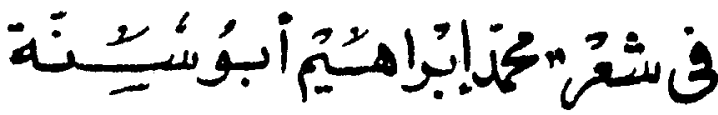

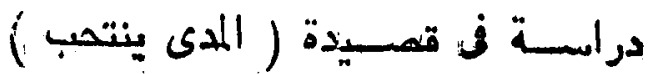 بتمنم}

ا.د / صـابير عبــد إلدايم

وكيـل الكليــا

\section{(1)}

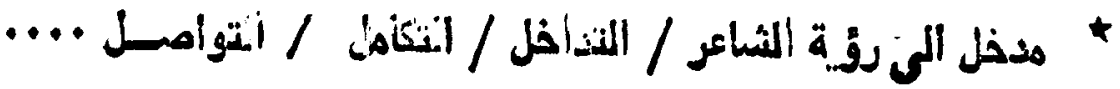

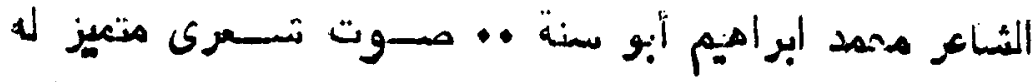

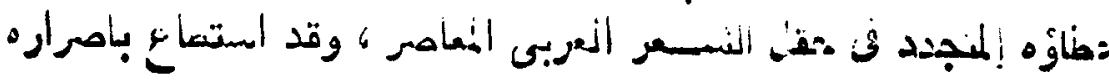

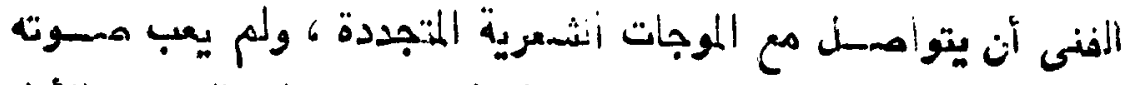

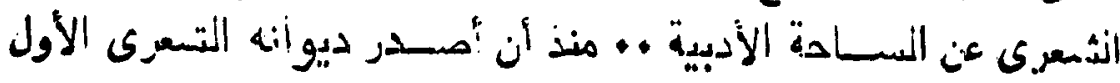

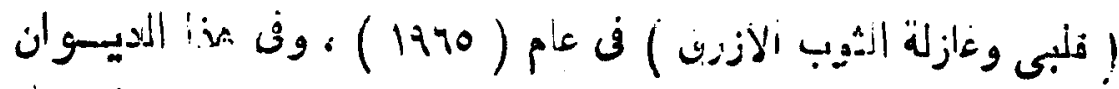

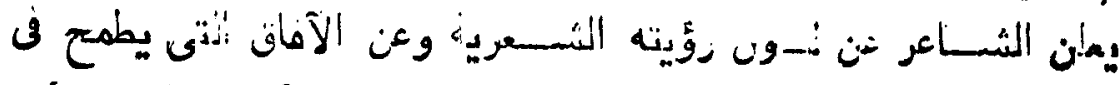

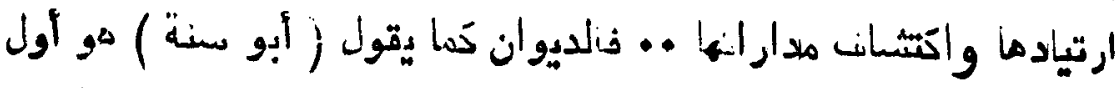

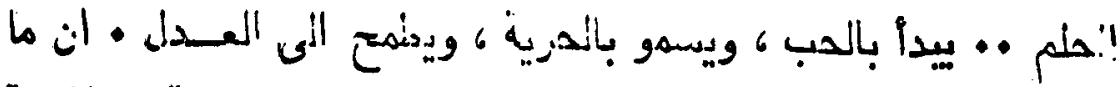

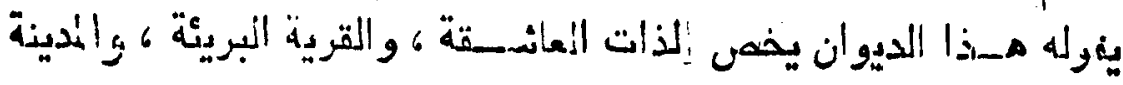

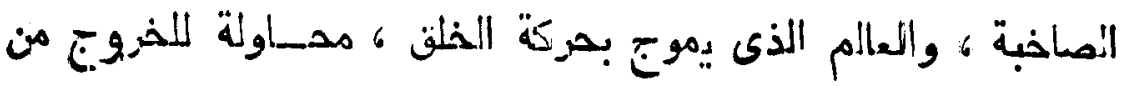

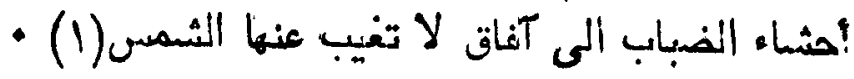

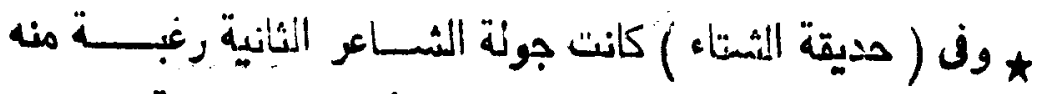

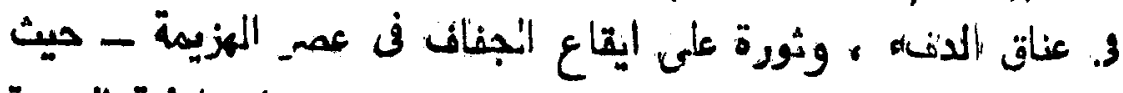

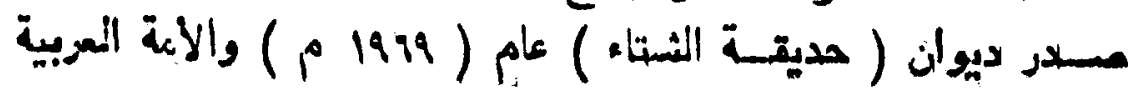




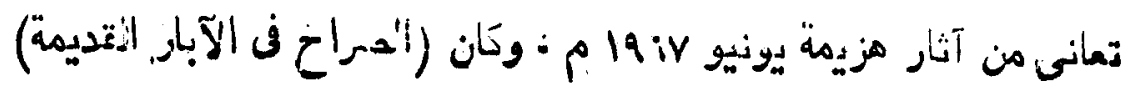

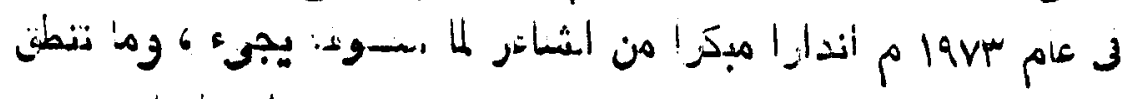

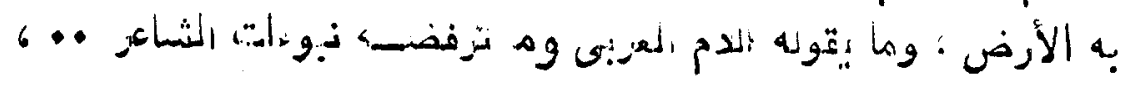

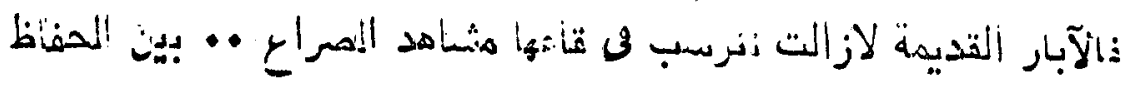

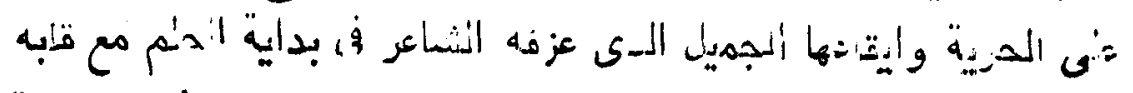

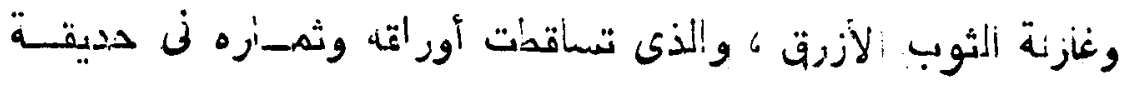

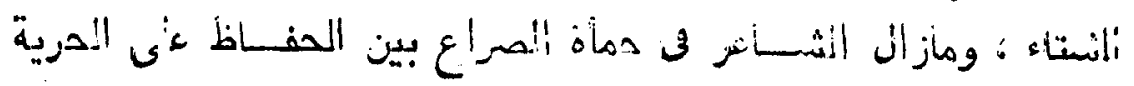

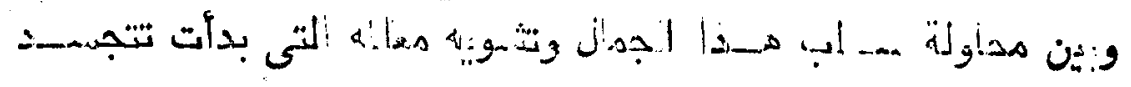

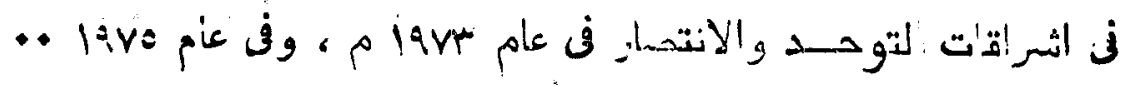

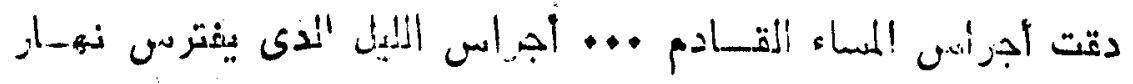

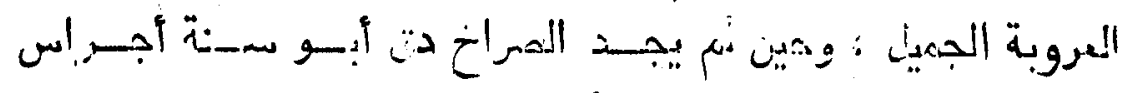

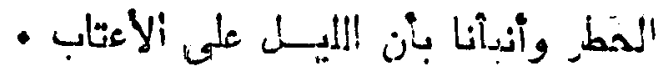

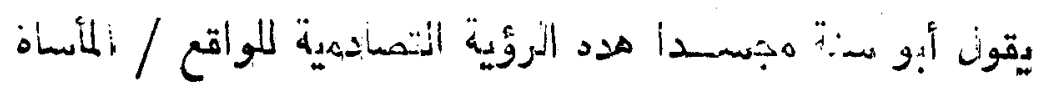

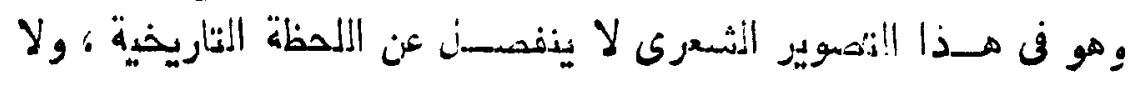

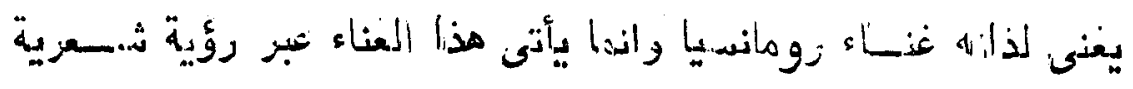

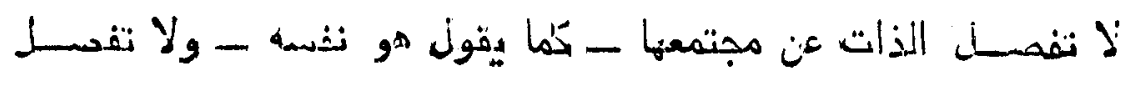

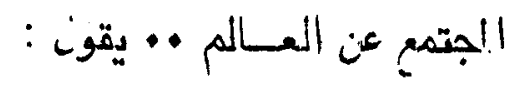

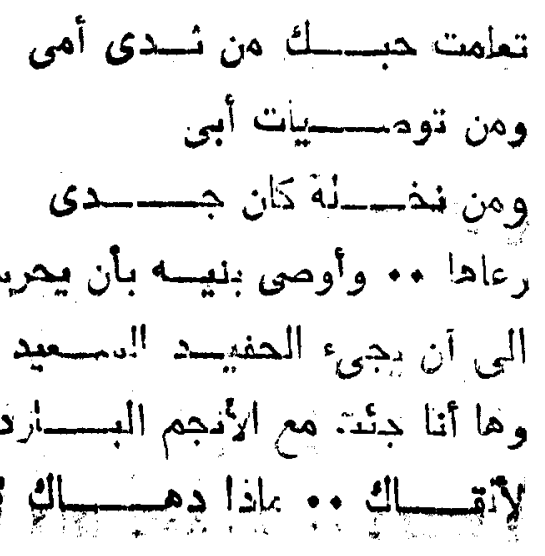




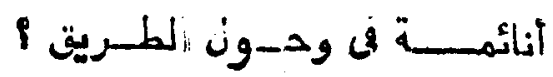

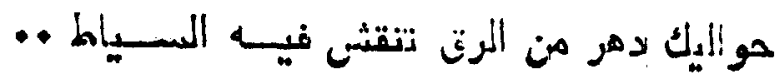

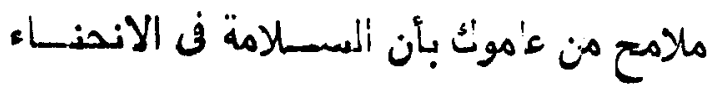

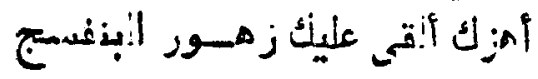

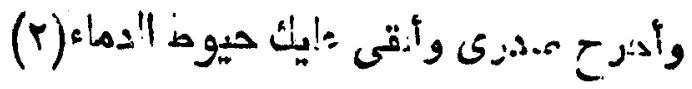

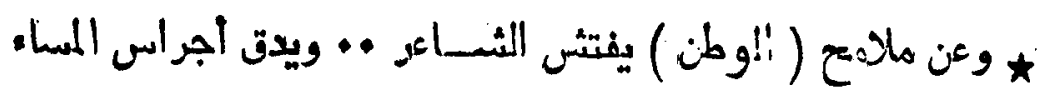

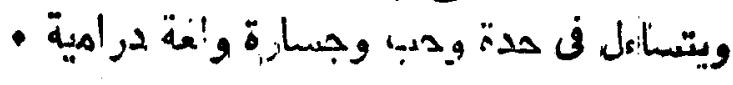

أنثزى سيكون هو الوطن

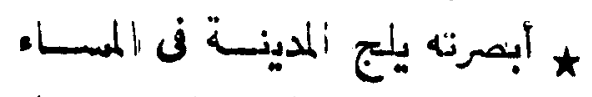

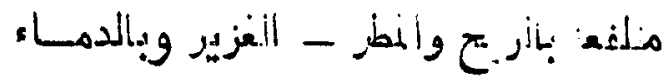

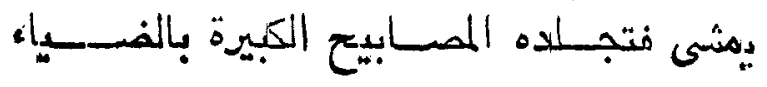

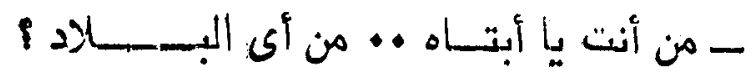

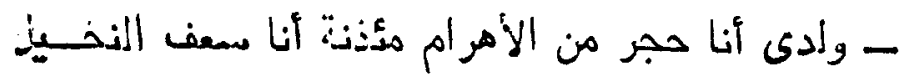

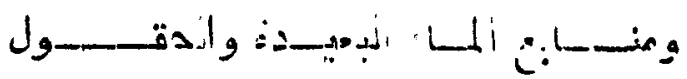

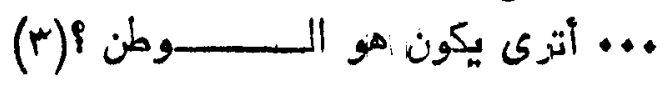

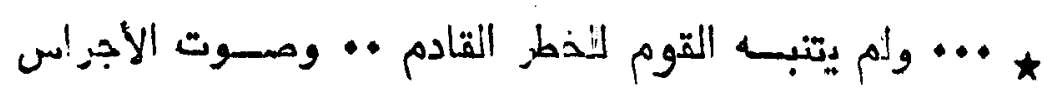

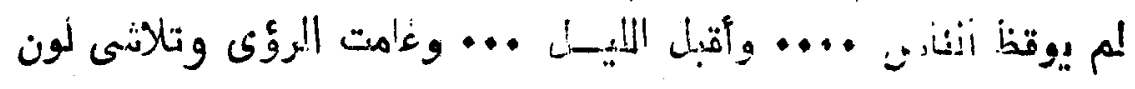

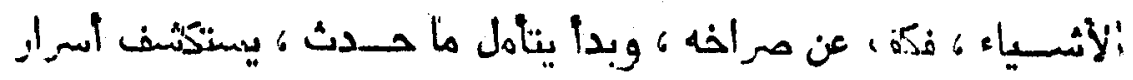

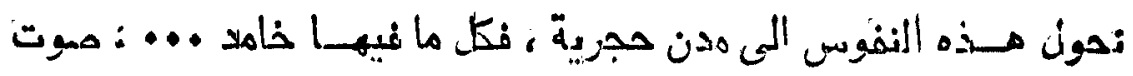

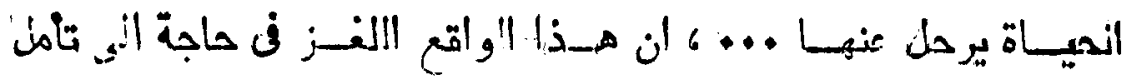

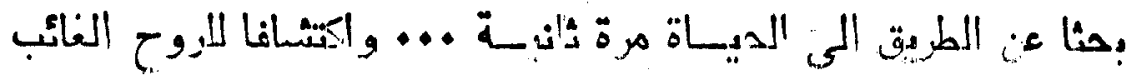

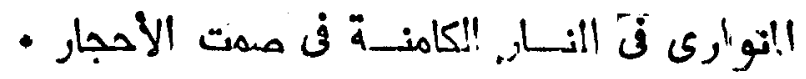

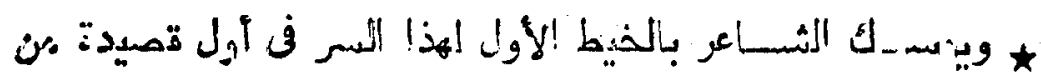

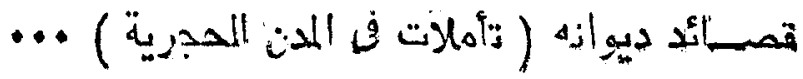




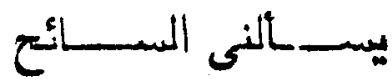

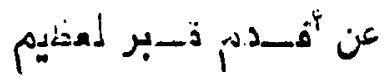

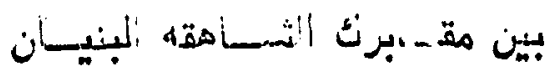

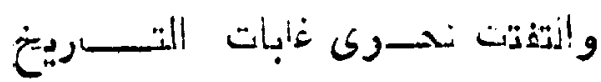

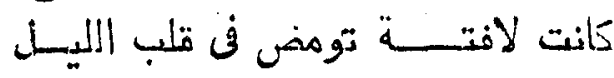

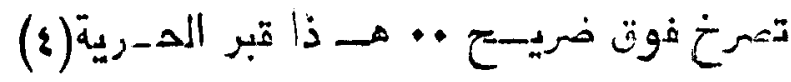

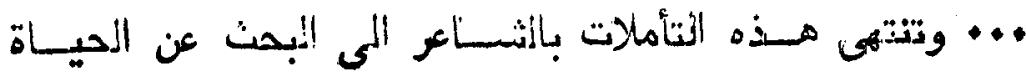

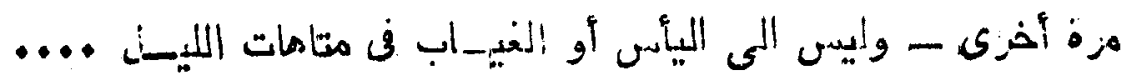

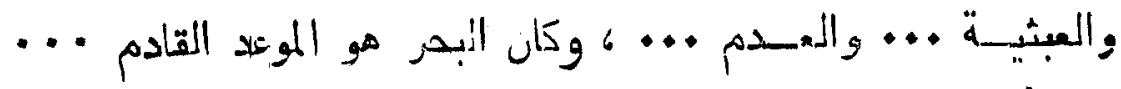

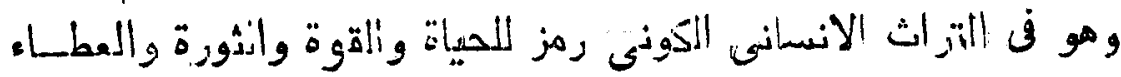
والنتحدى

ولم تخمسد نيزان أنشسوواق المنهساعر الى الخلاص : والبحث عن

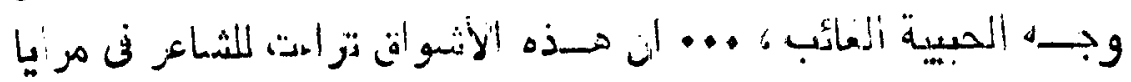

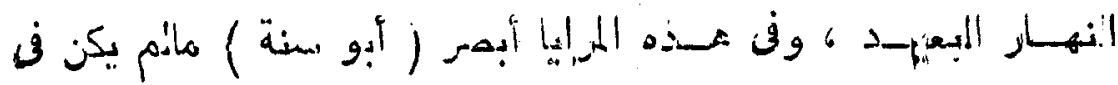

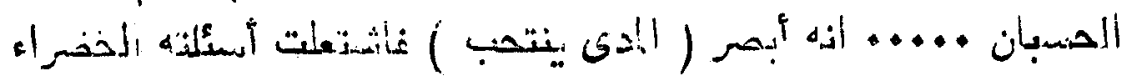

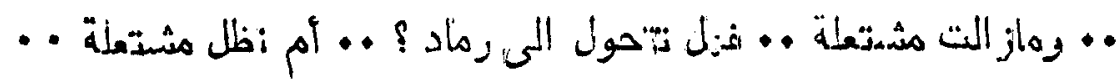

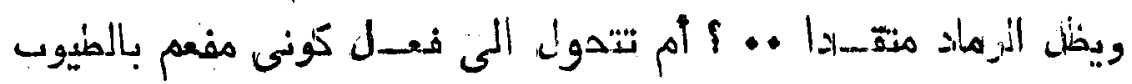

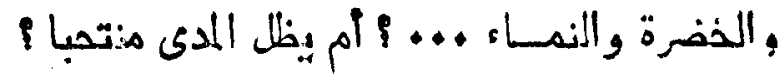

:

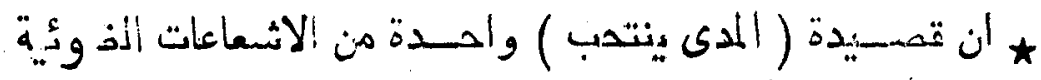

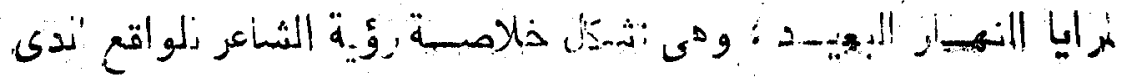

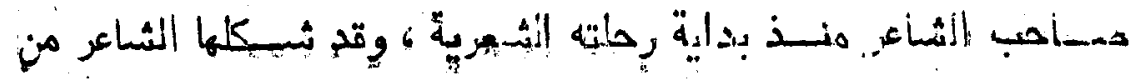

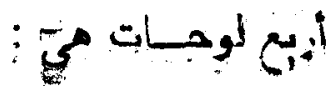




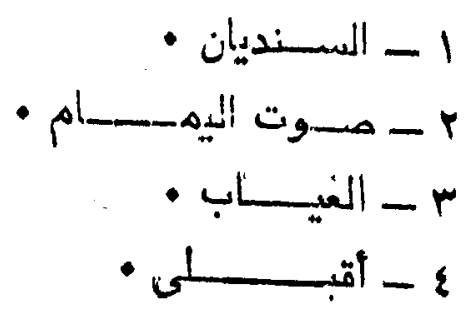

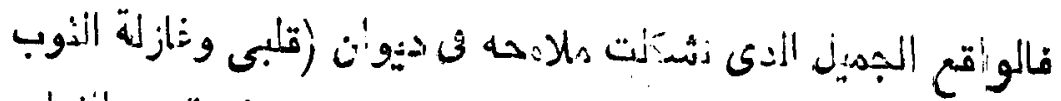

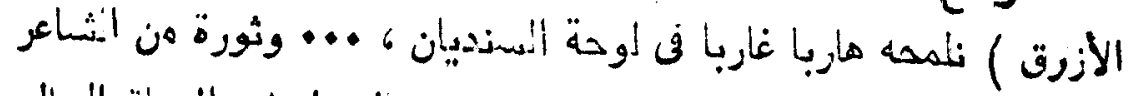

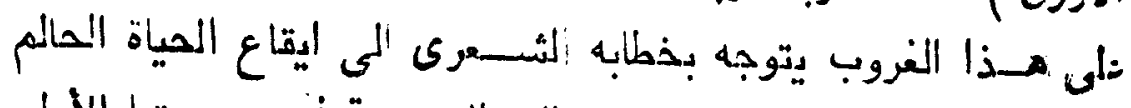

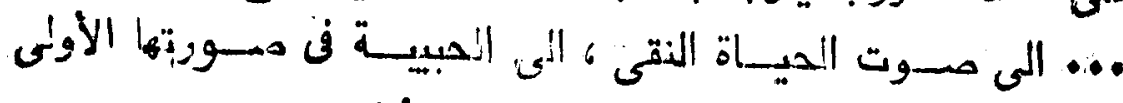

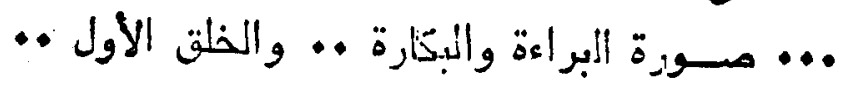

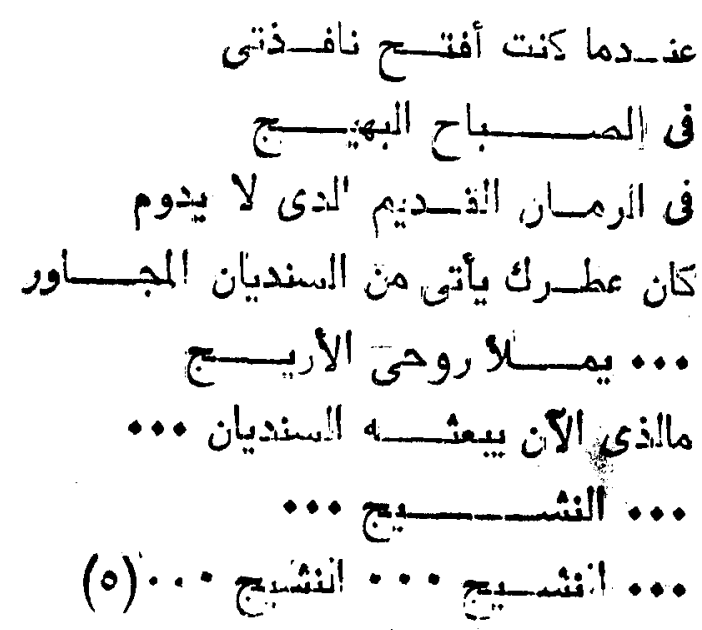

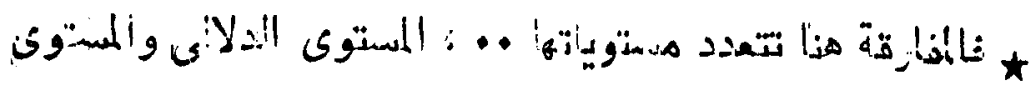

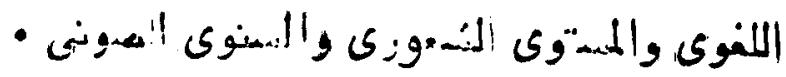

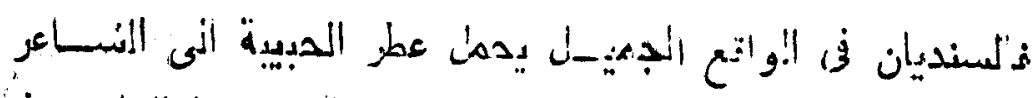

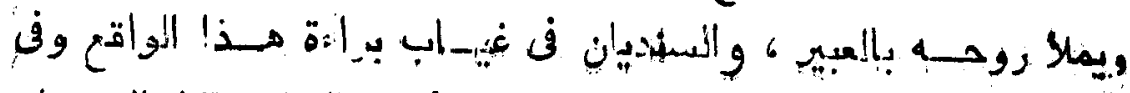

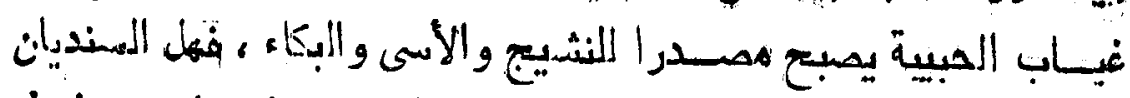

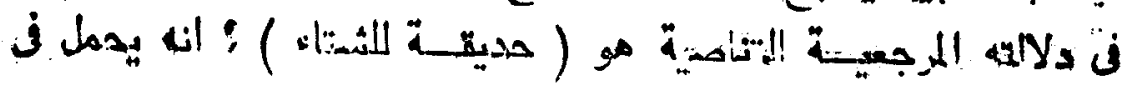

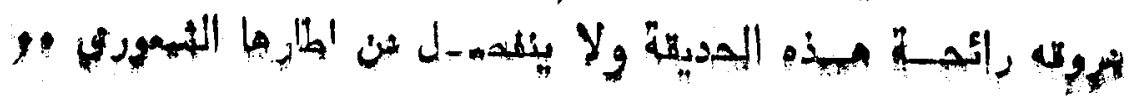




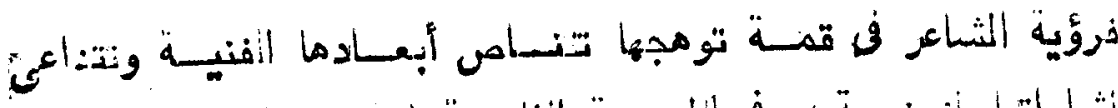

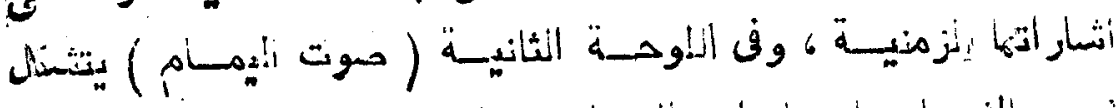

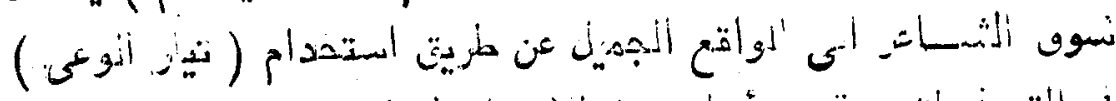

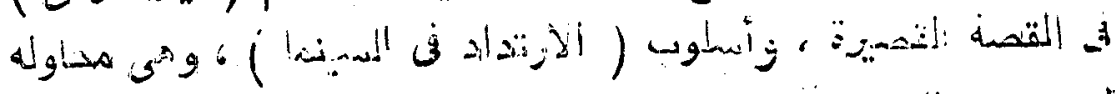

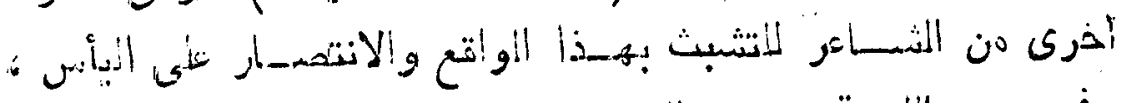

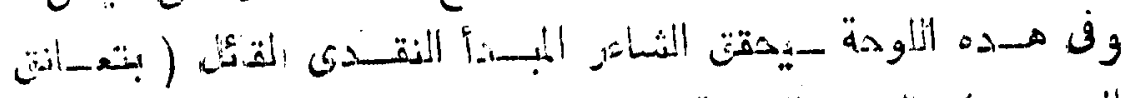

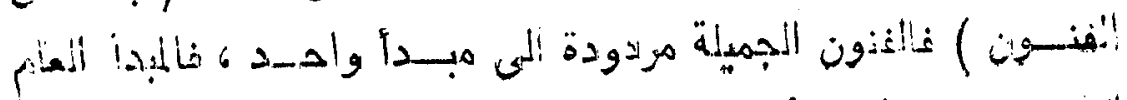

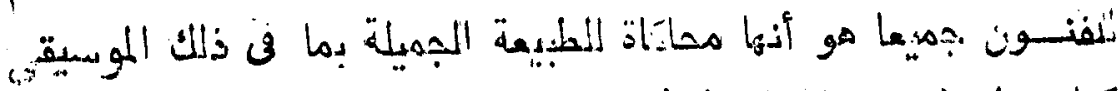

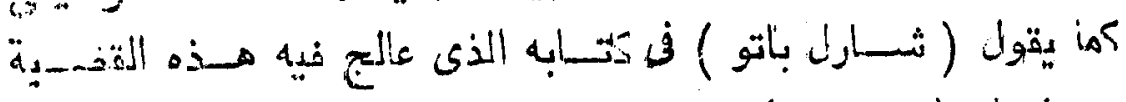

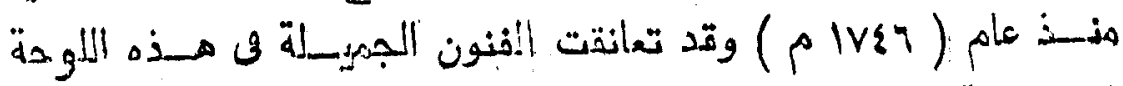

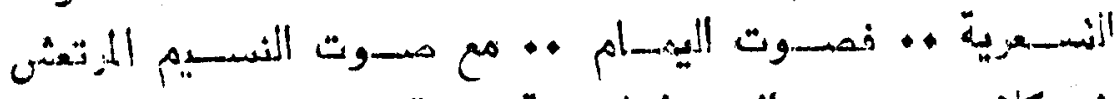

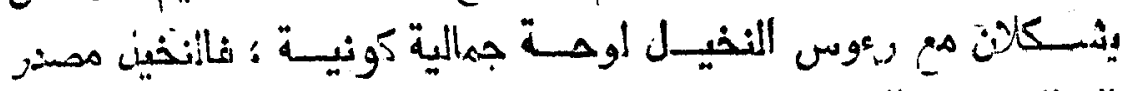

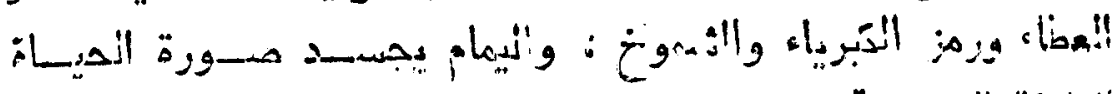

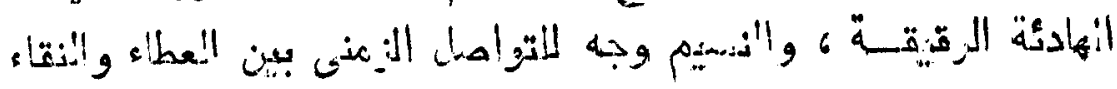

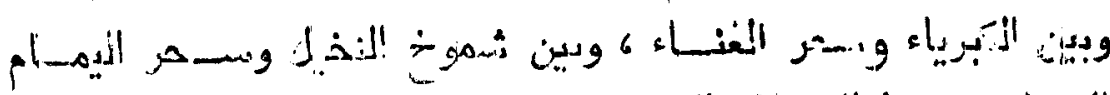

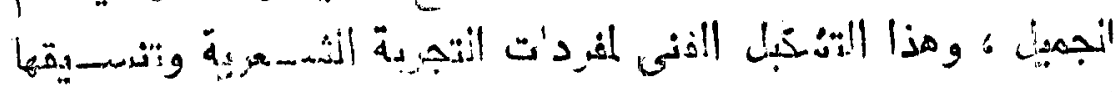

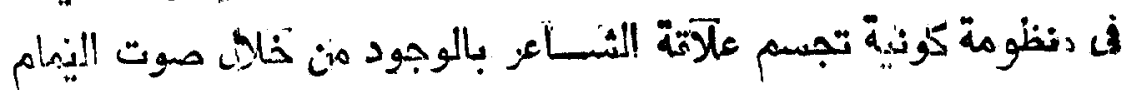

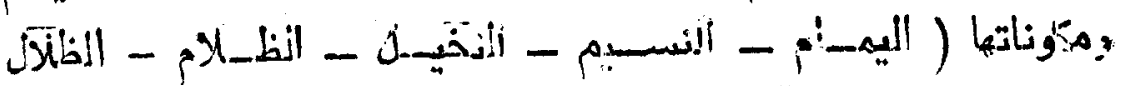

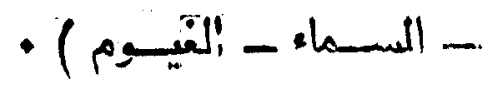

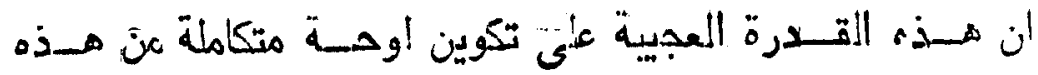

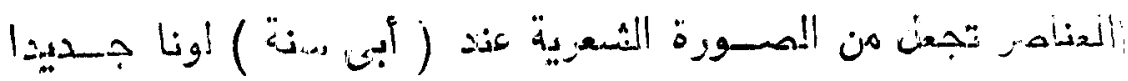

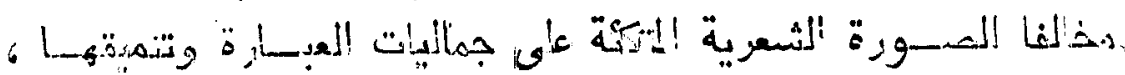

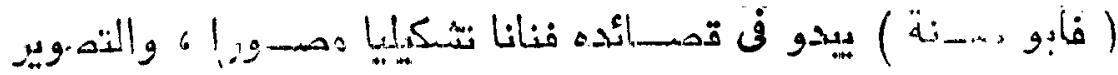

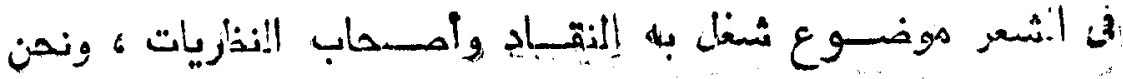
(j-r) 


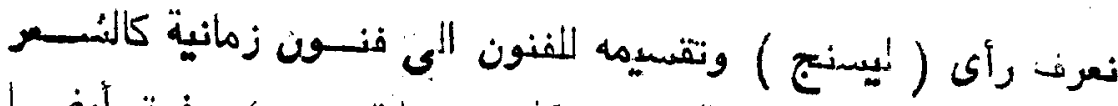

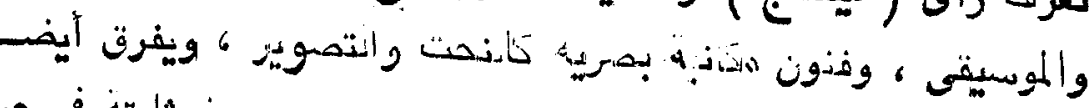

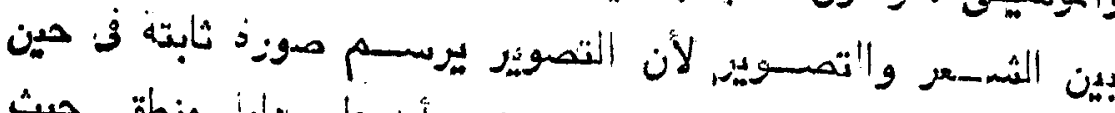

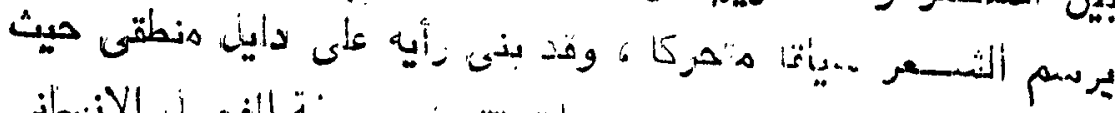

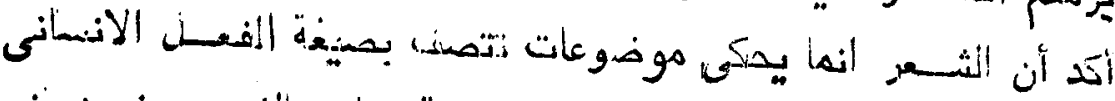

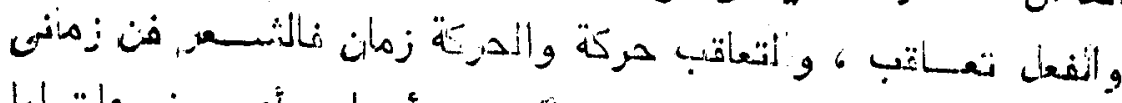

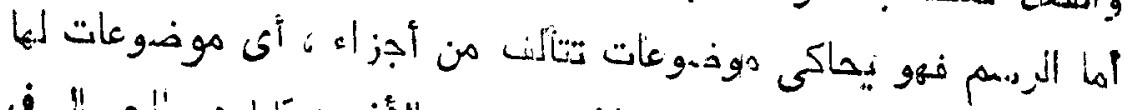

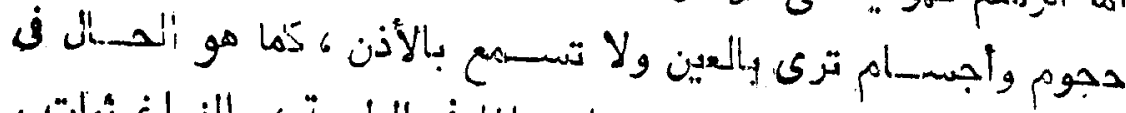

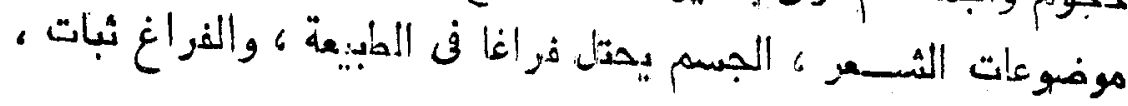

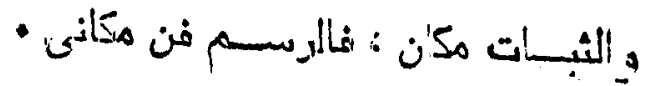

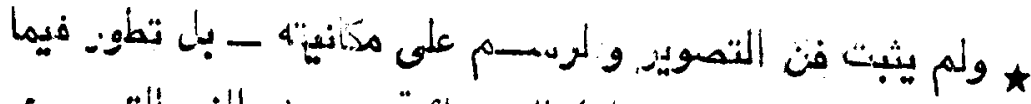

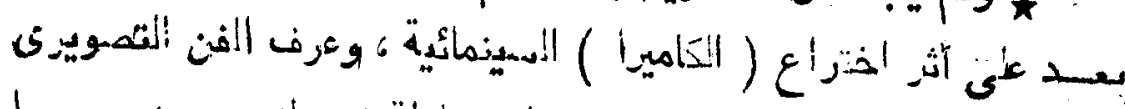

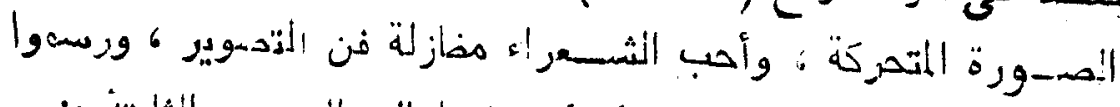

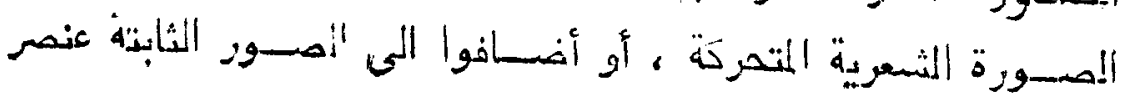

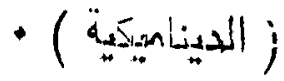

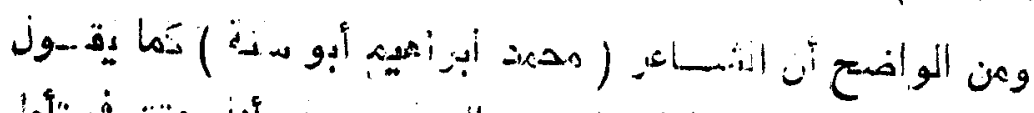

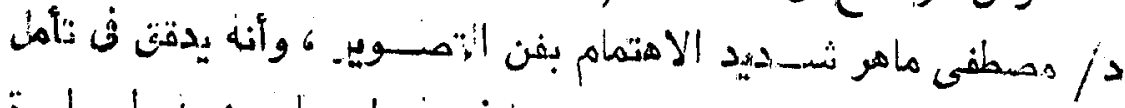

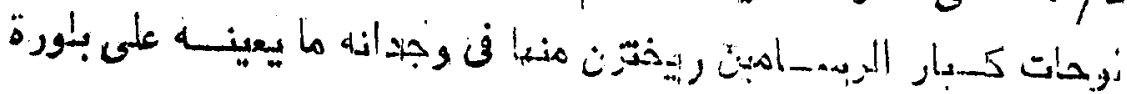

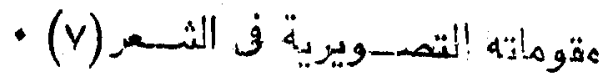

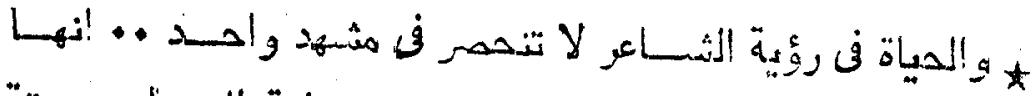

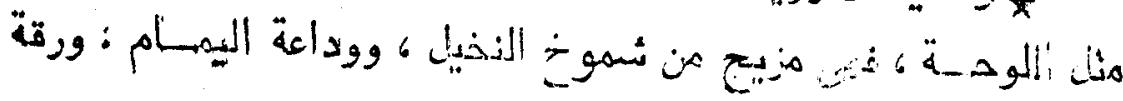
- pil

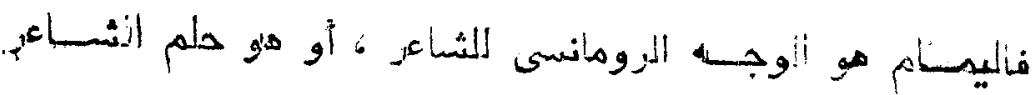

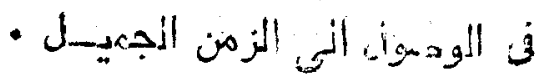


كنت أعثــــق هـذا أليمسام الإيتيم ...

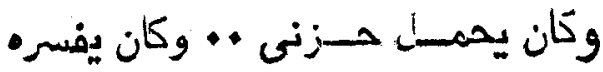

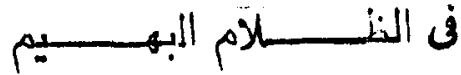

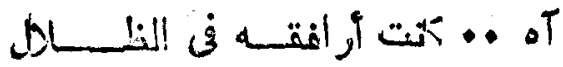

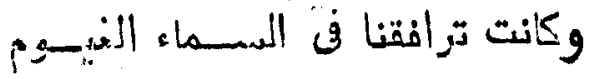

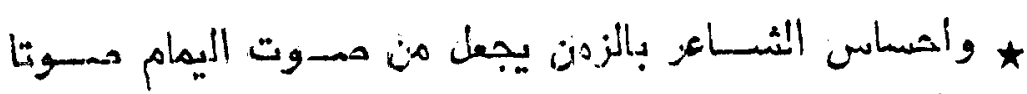

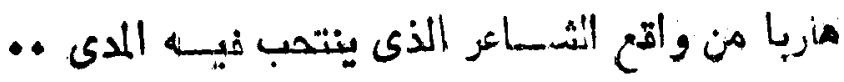

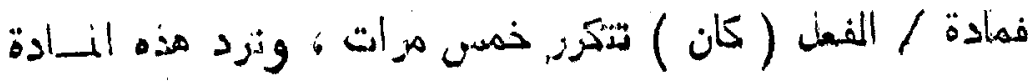

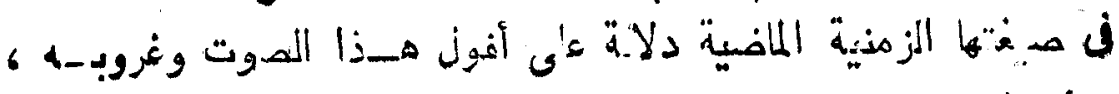

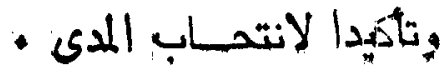

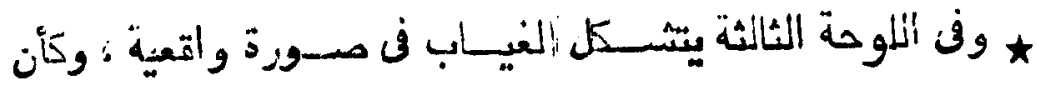

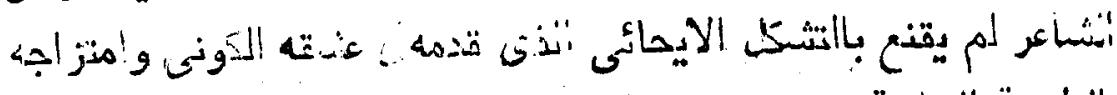

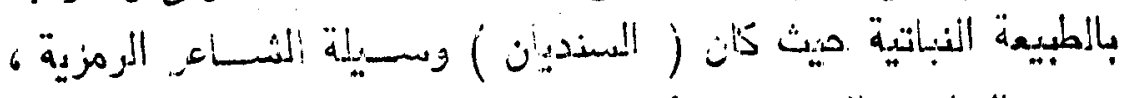

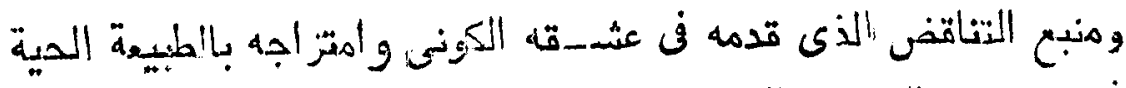

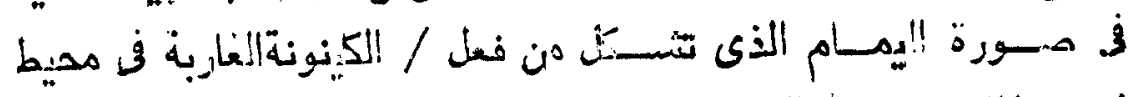

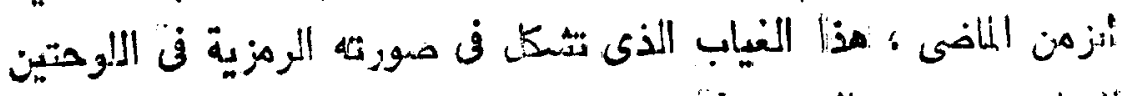

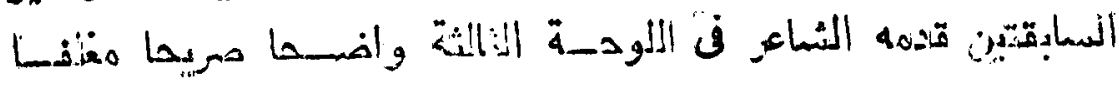

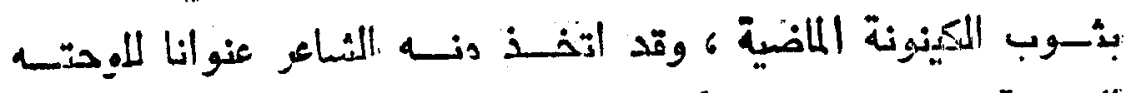

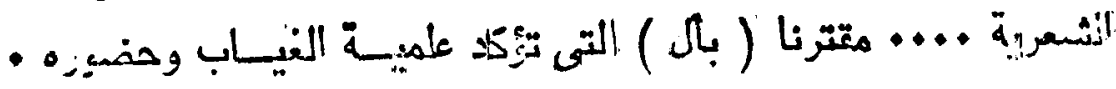

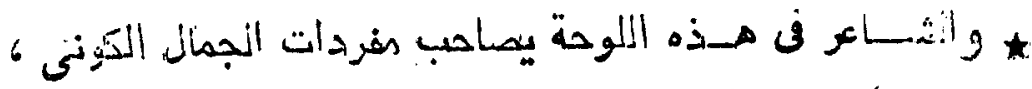

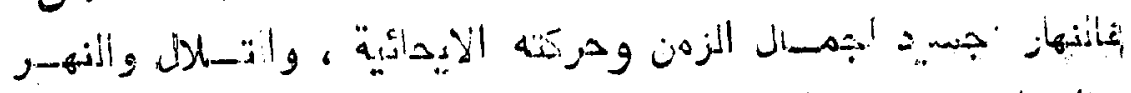

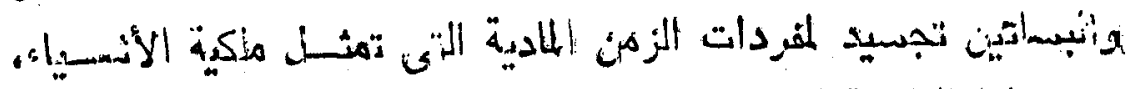

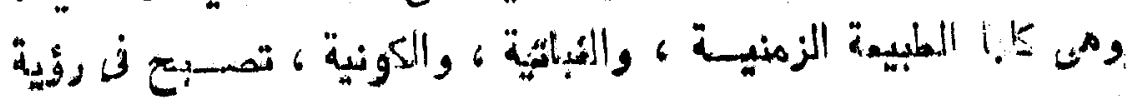




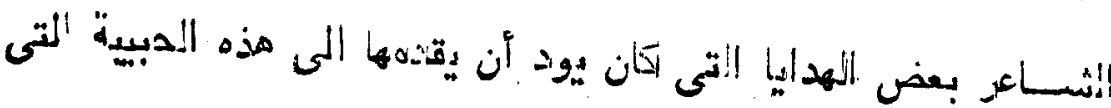

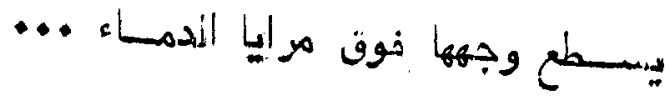

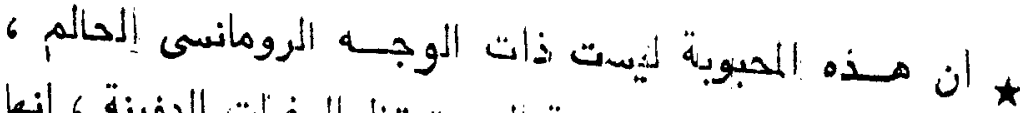

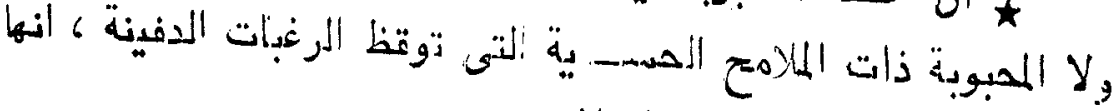

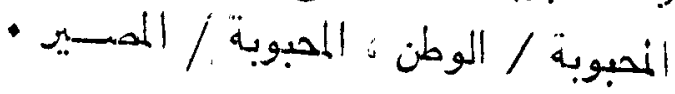

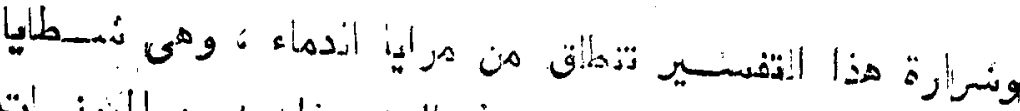

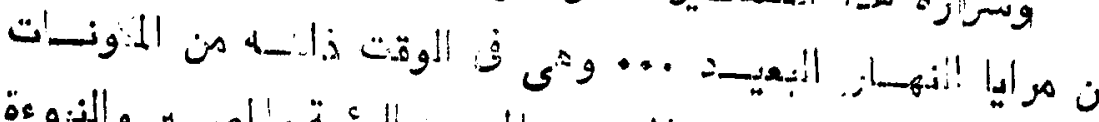

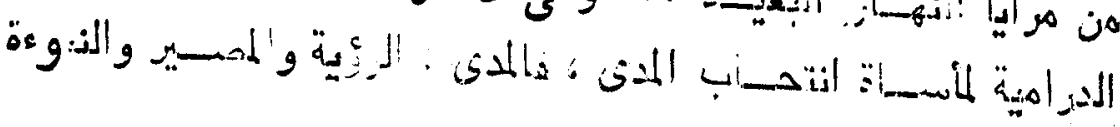

$$
\text { •.... }
$$

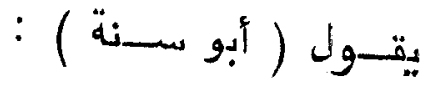

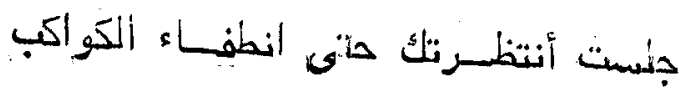

$$
\begin{aligned}
& \text { مها جئت }
\end{aligned}
$$

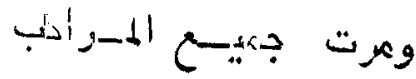

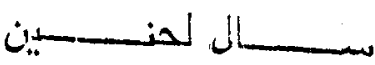

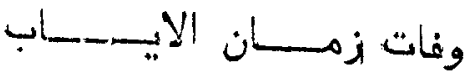

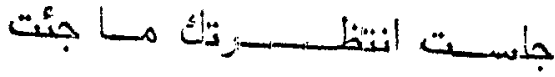

$$
\begin{aligned}
& \text { ج }
\end{aligned}
$$

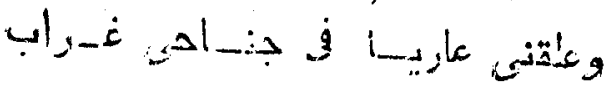

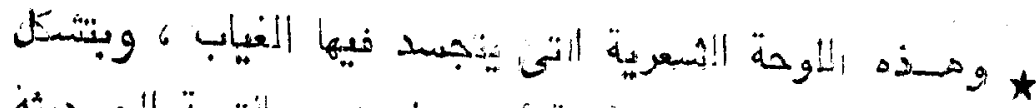

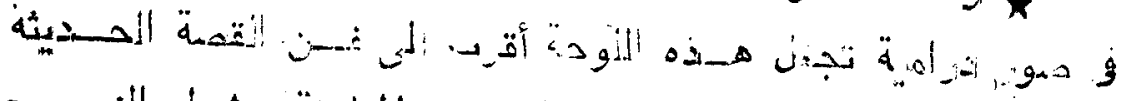

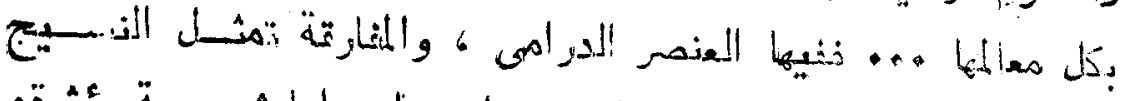

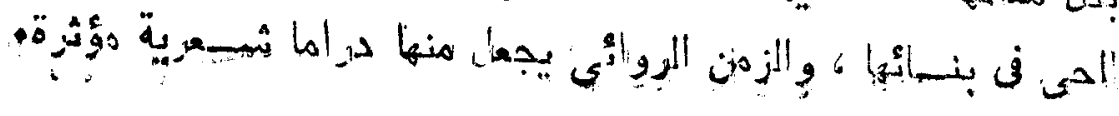




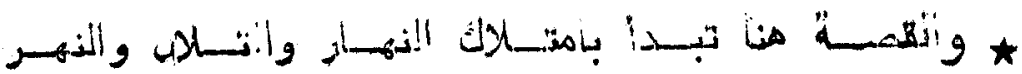

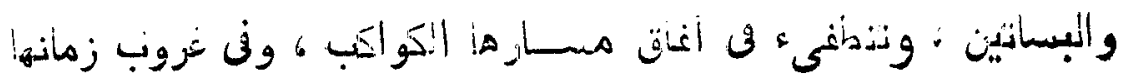

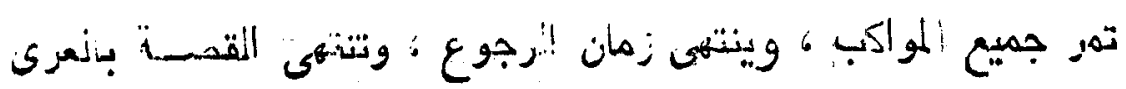

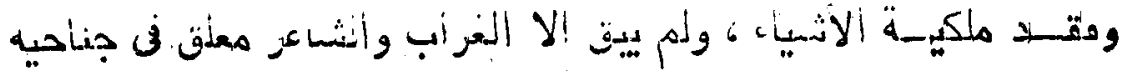

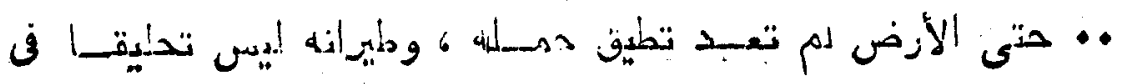

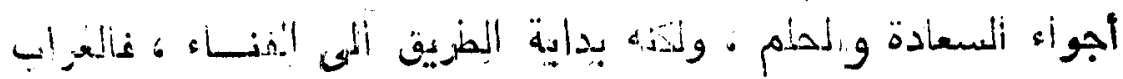

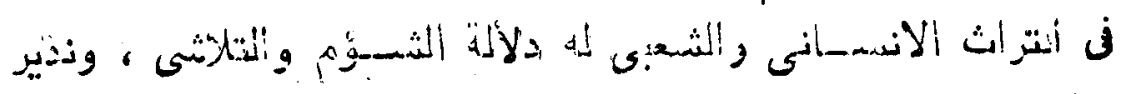

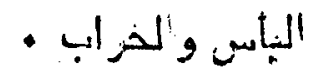

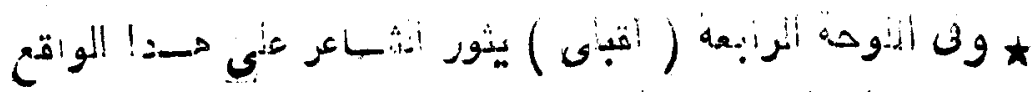

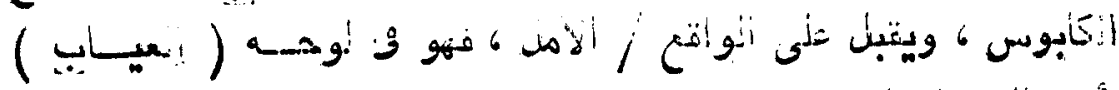

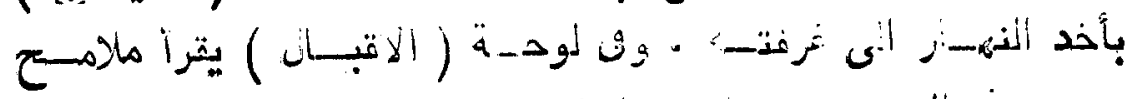

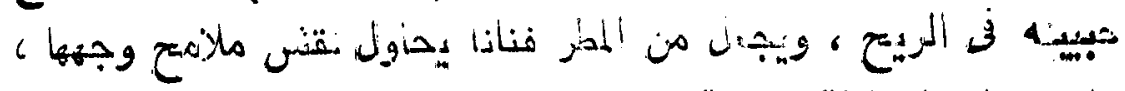

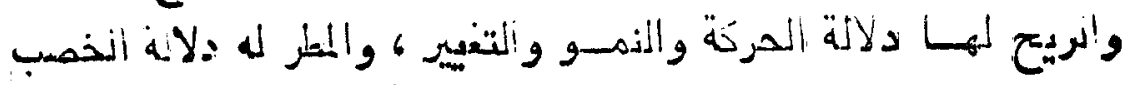

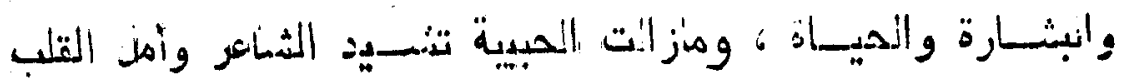

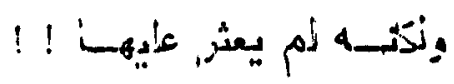

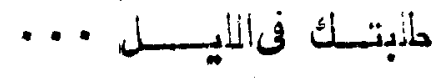

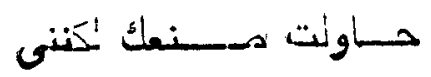

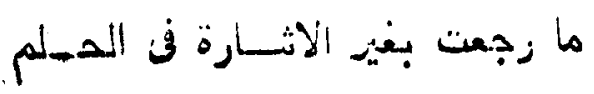

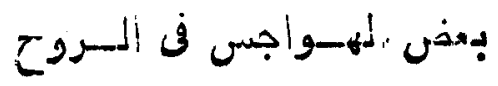

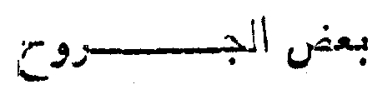

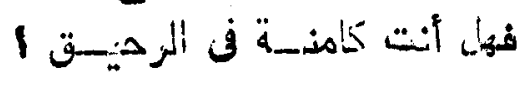

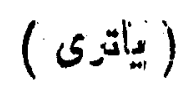

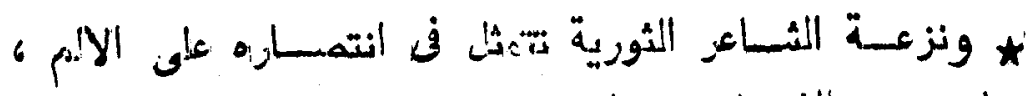

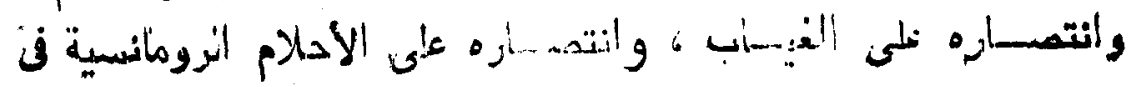




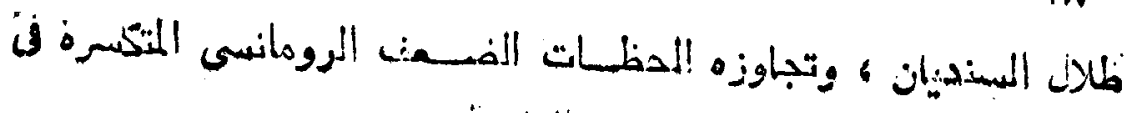

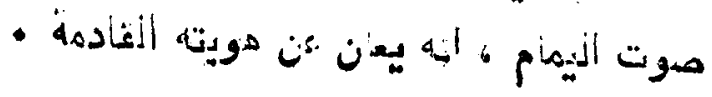

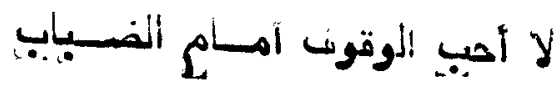

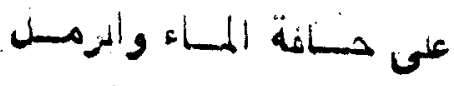

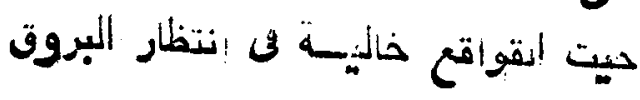

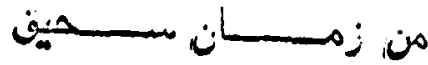

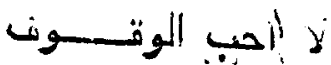
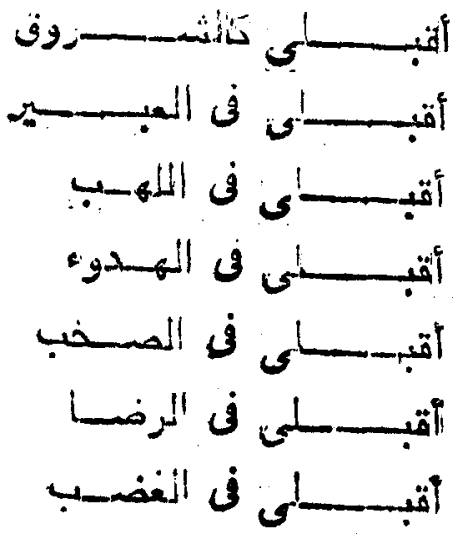

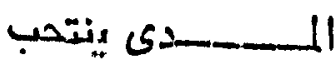

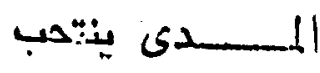

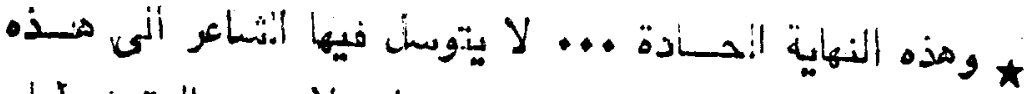

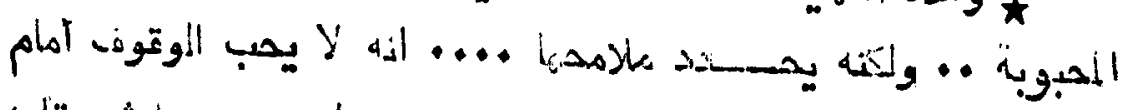

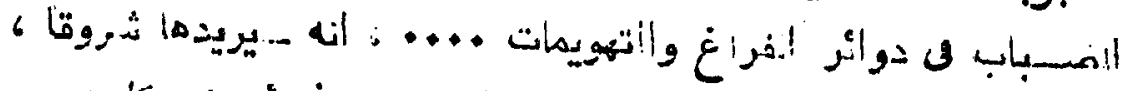

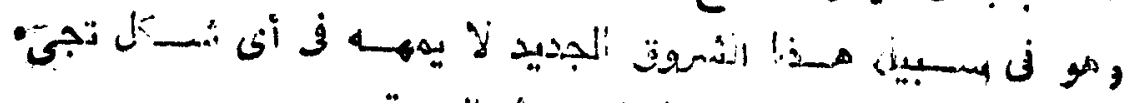

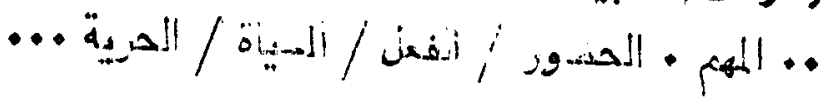

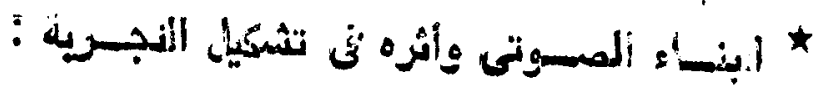

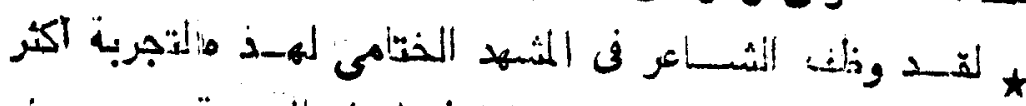

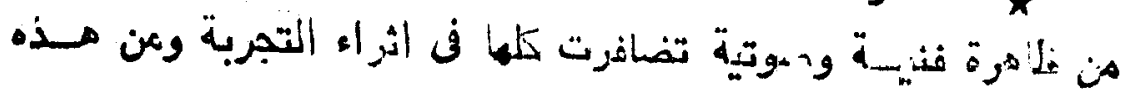




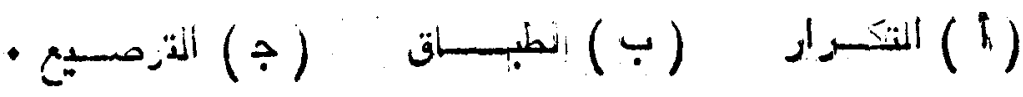

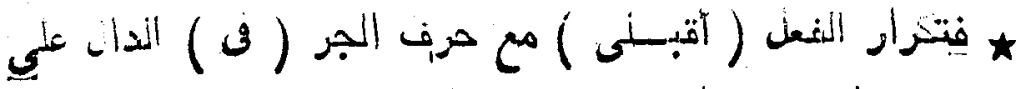

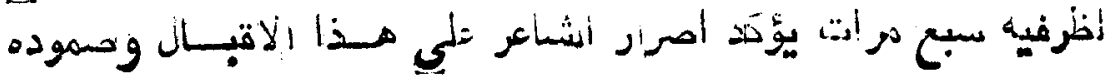

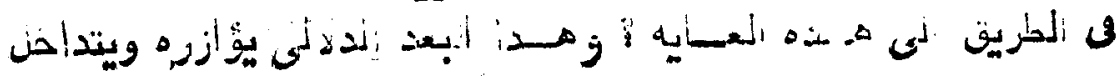

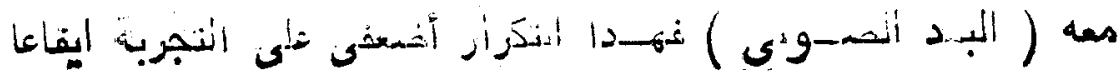

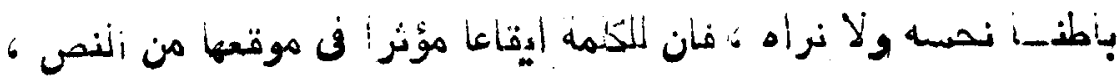

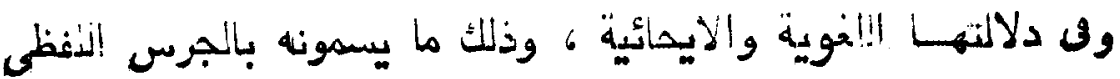

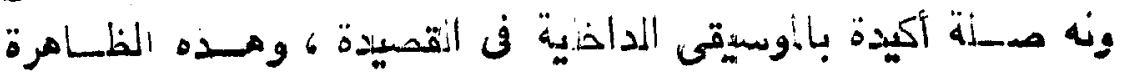

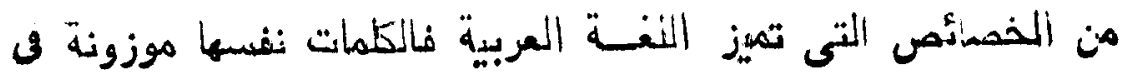

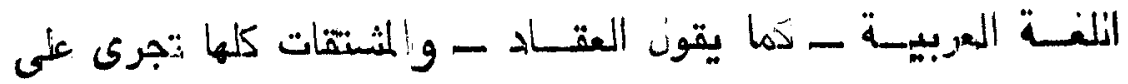

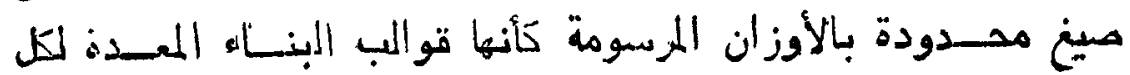

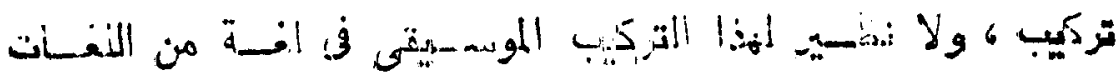

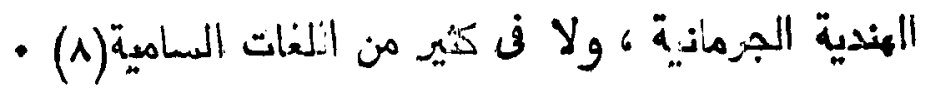

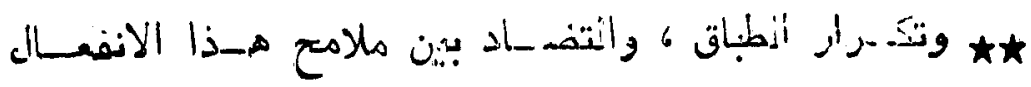

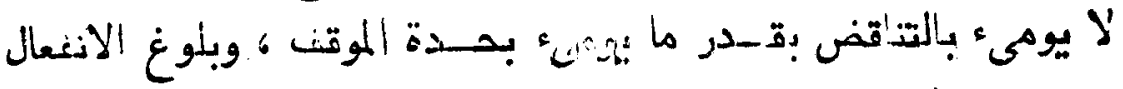

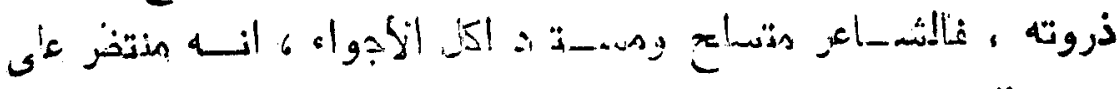
مـد المسكين

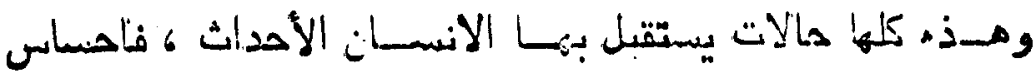

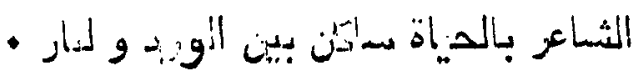

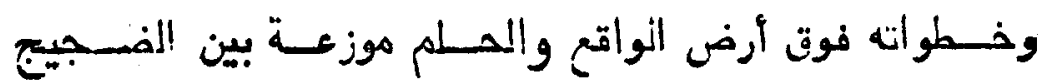

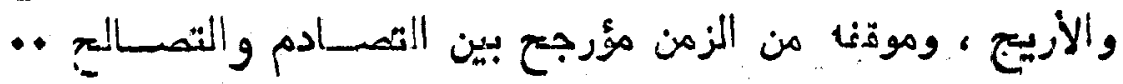

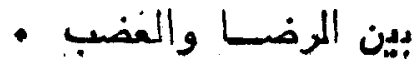




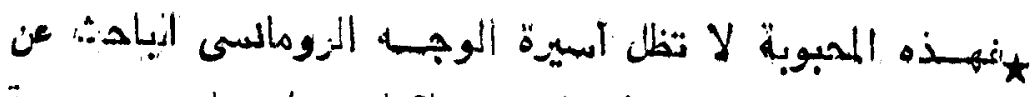

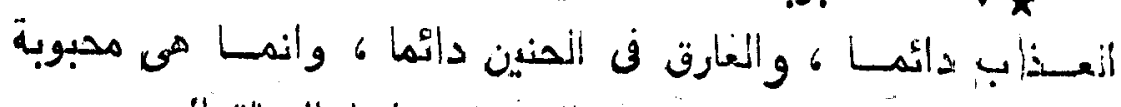

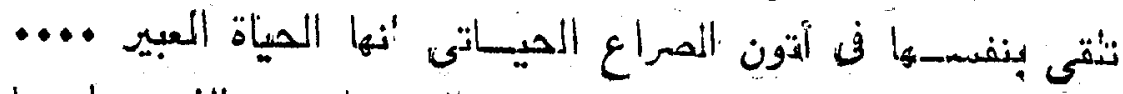

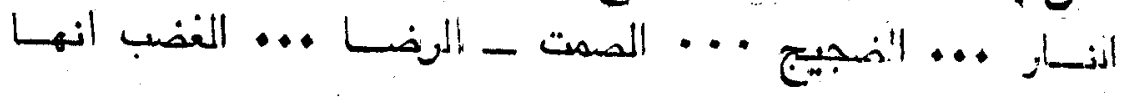
-!

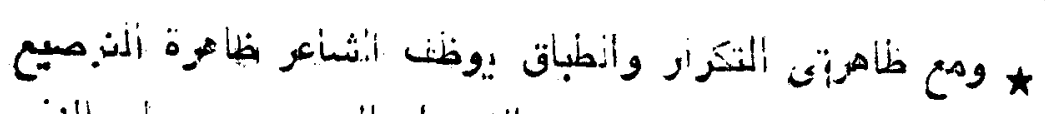

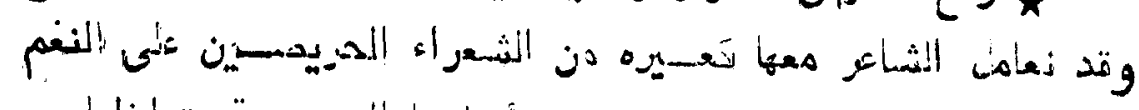

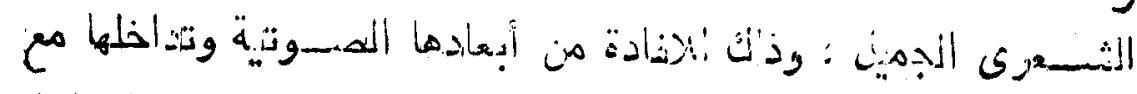

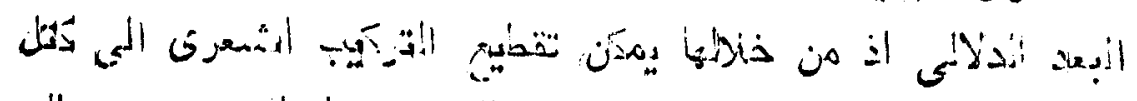

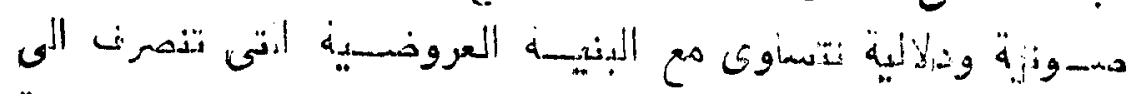

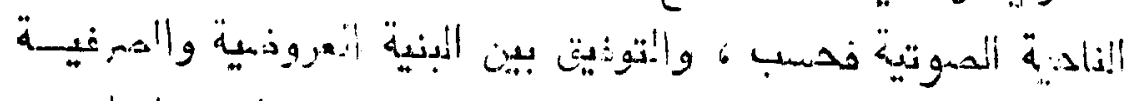

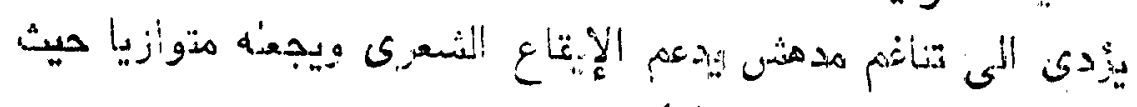

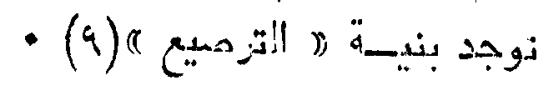

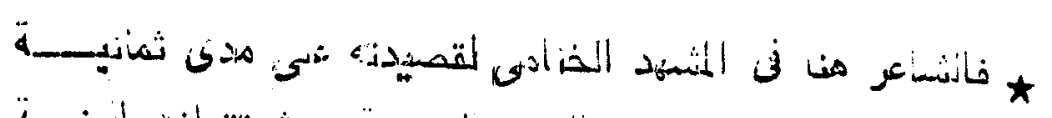

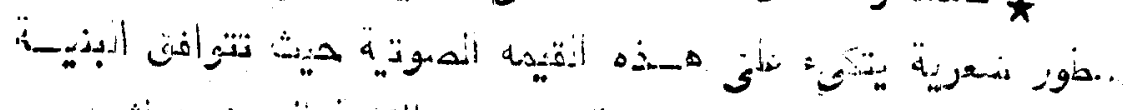

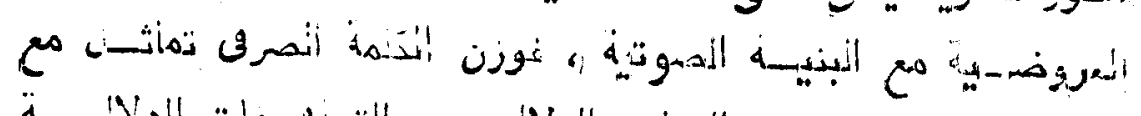

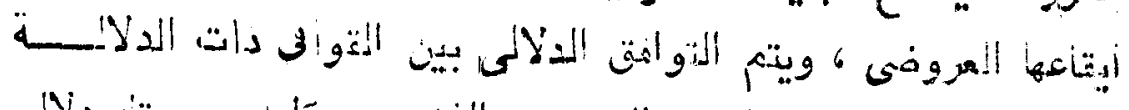

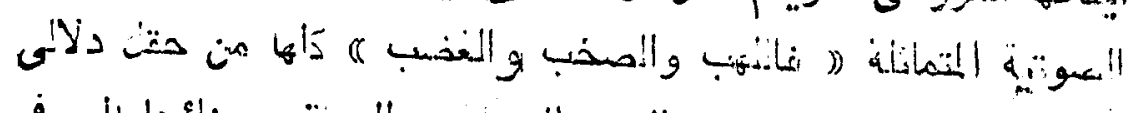

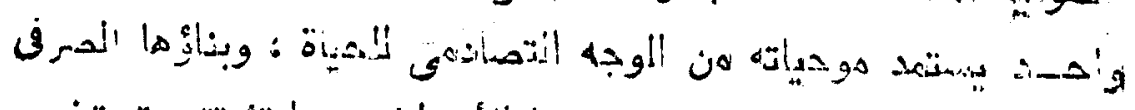

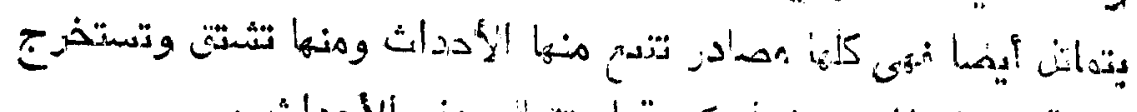

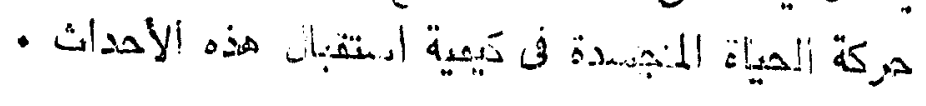

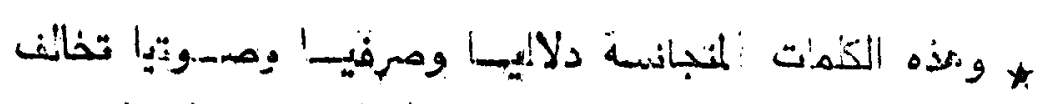

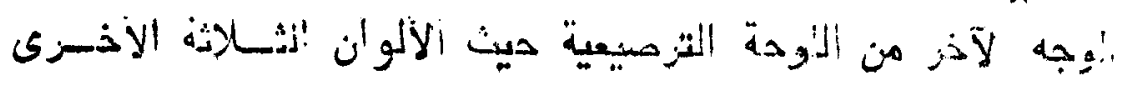




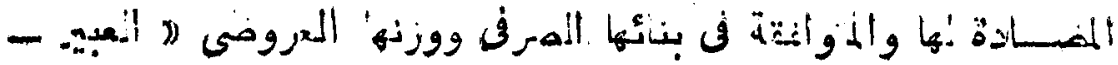

$$
\text { - } \mathbb{1}
$$

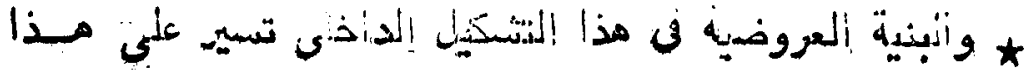

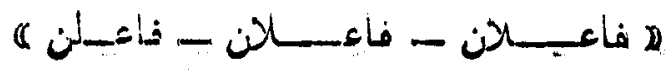

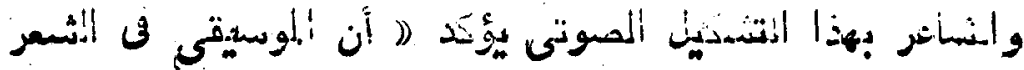

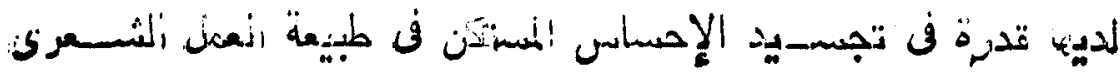

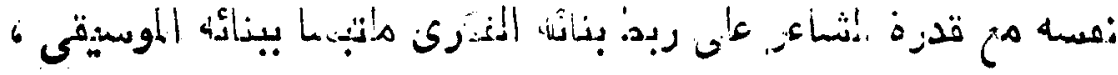

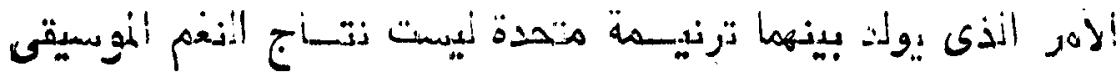

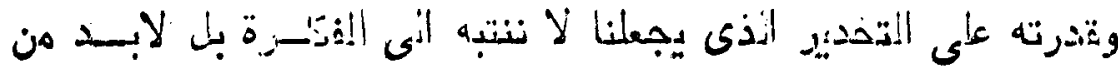

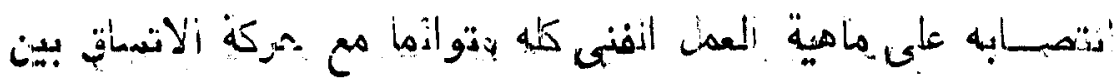

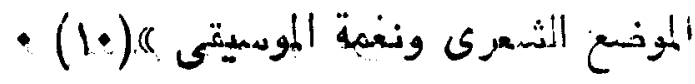

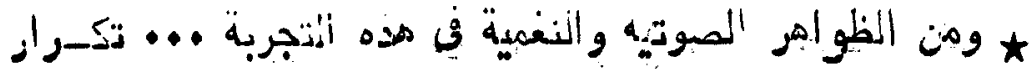

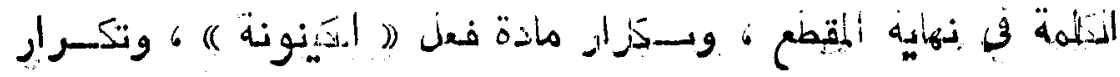
بمضن المجلما بعينها ؛ وذلك يمان عن حرص الشاعر على عنصر التآنيه.

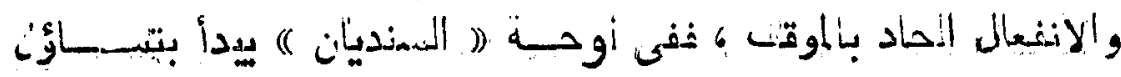

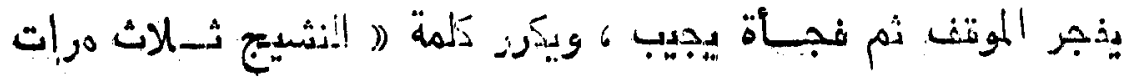

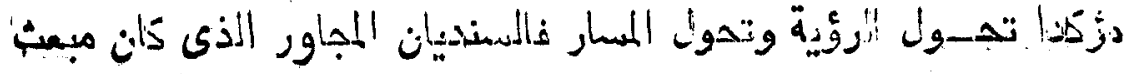
- ألعطز هو ألآن مبعبث النشئيج

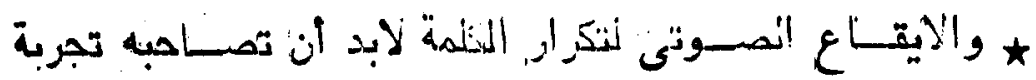

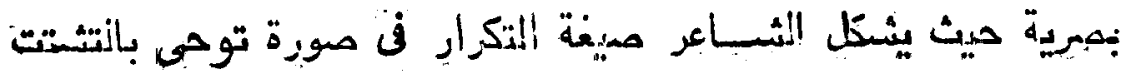

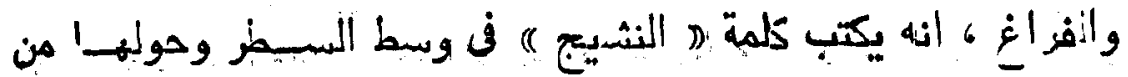

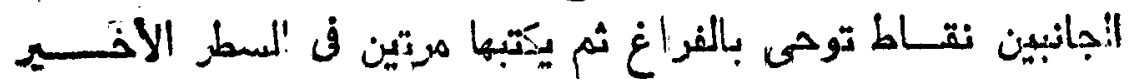




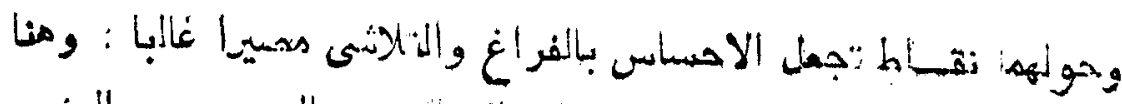

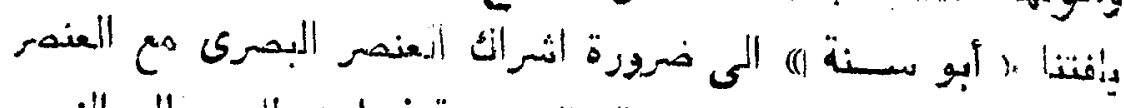

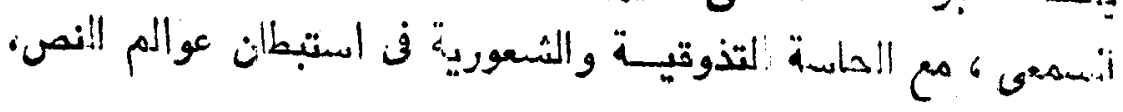

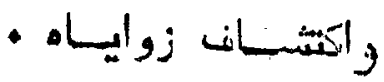

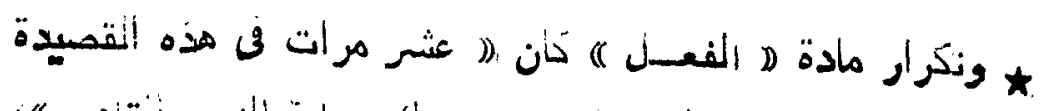

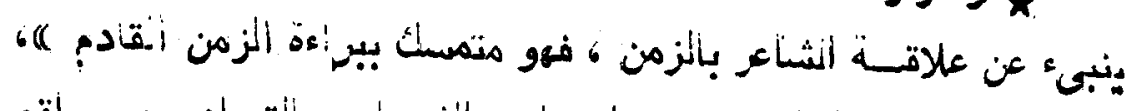

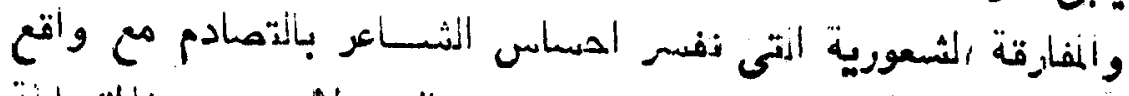

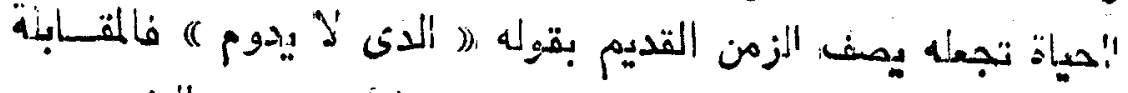

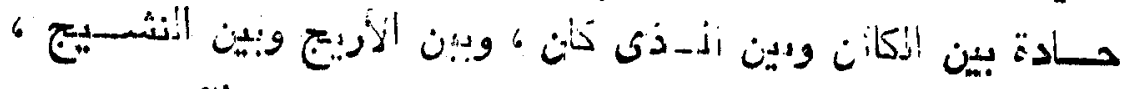

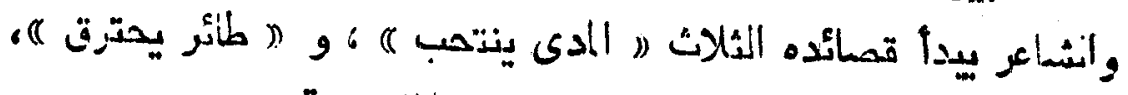

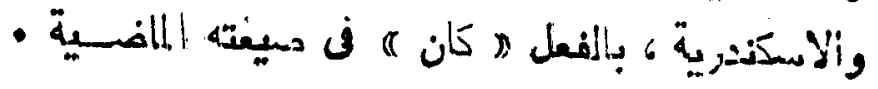

ويتثرد مذا الفعى نفسه فن قصسيدة لا طائر يحترق ه عشر مرأت،

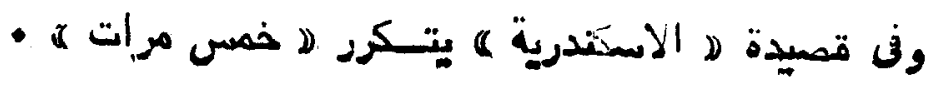

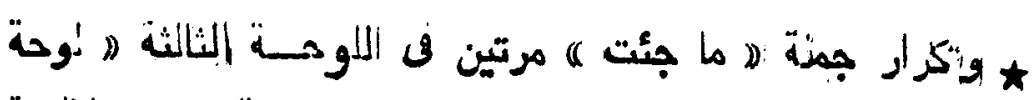

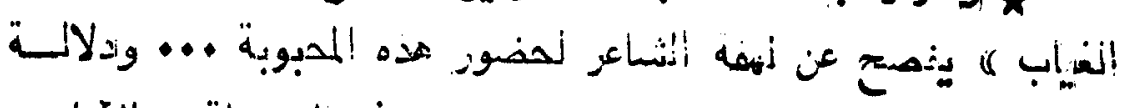

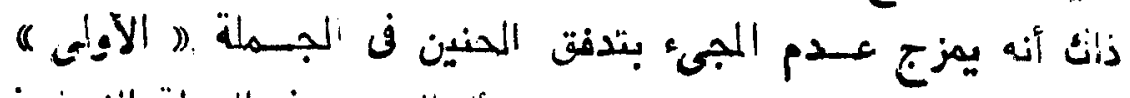

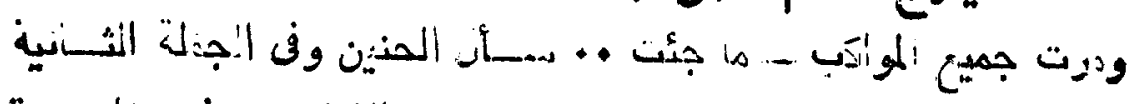

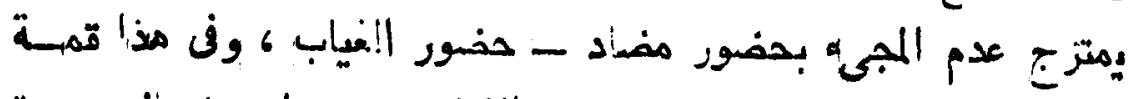

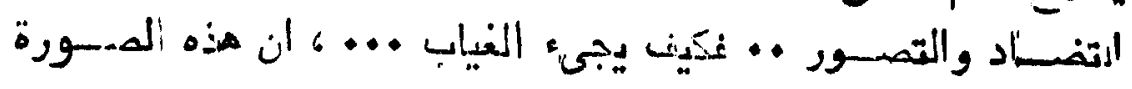

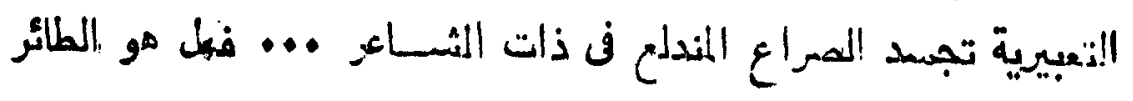

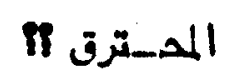

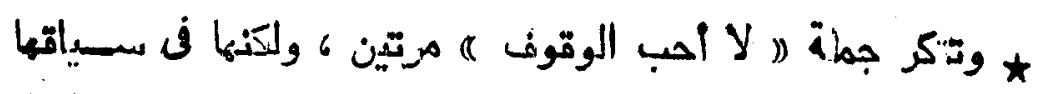

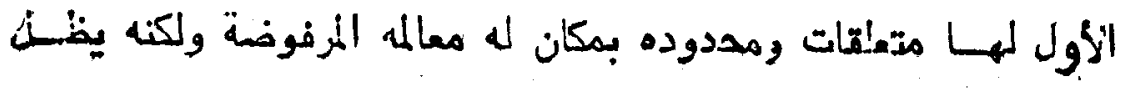




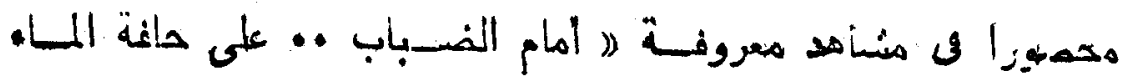

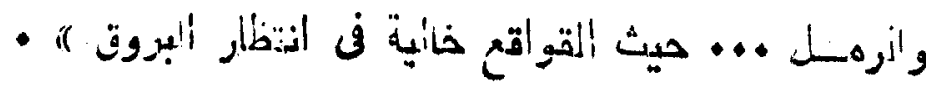

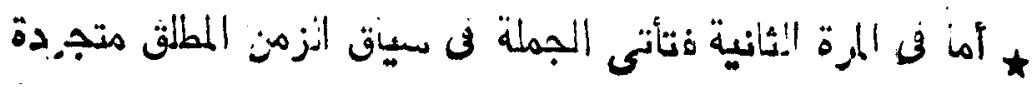

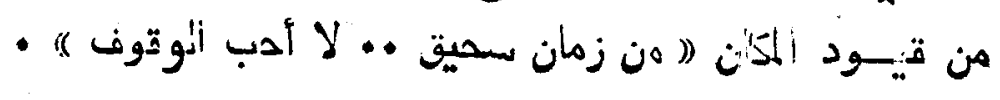

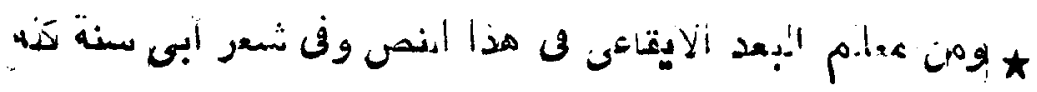

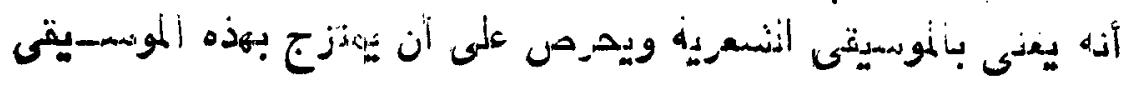

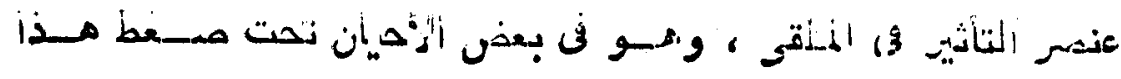

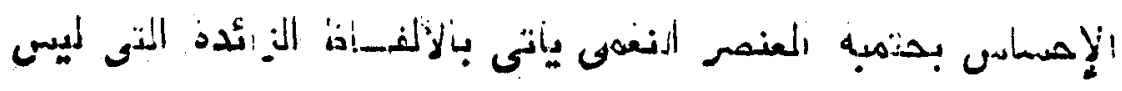

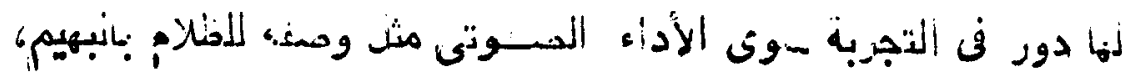

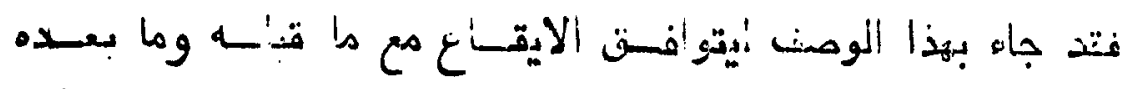

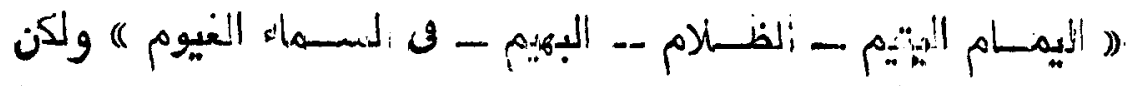

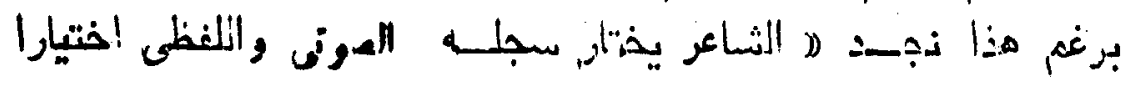

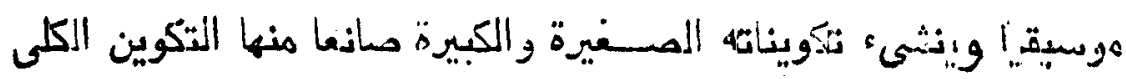

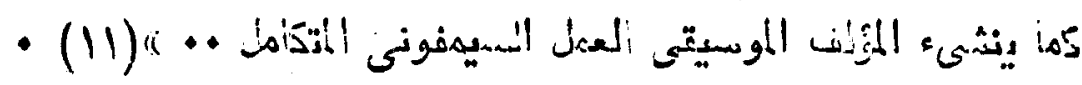

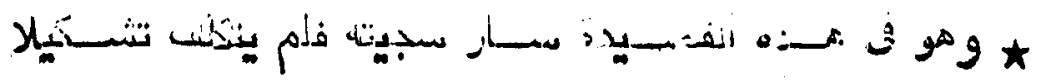

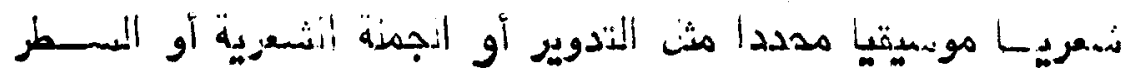

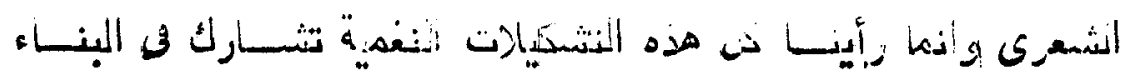

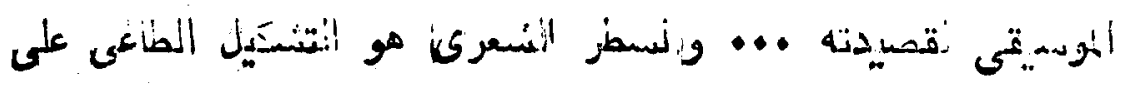

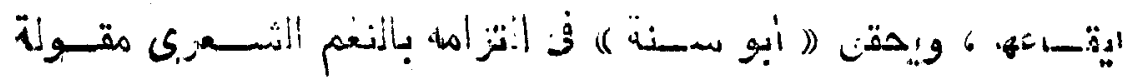

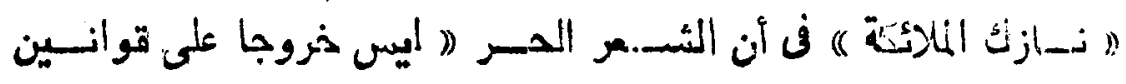

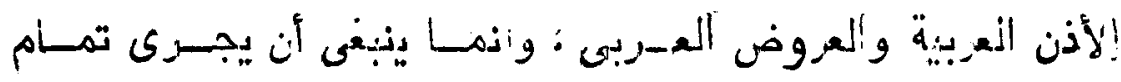

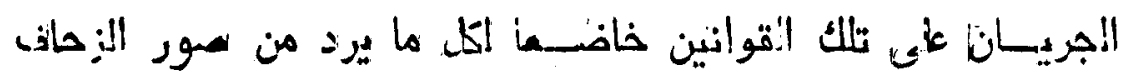

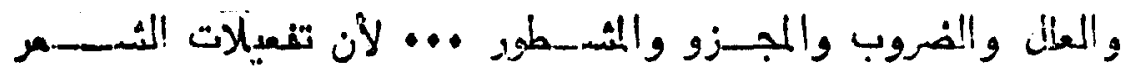

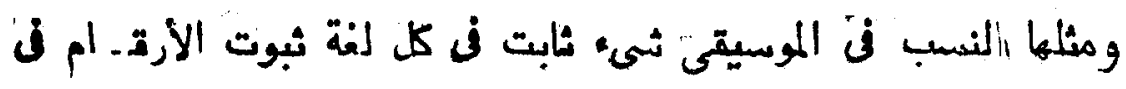




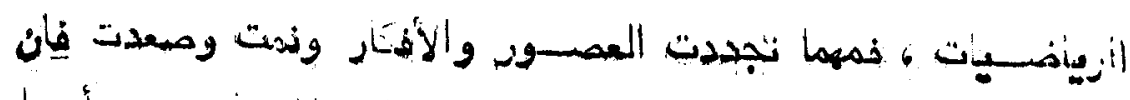

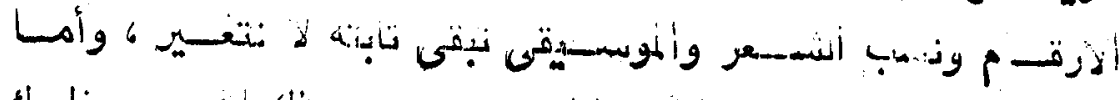

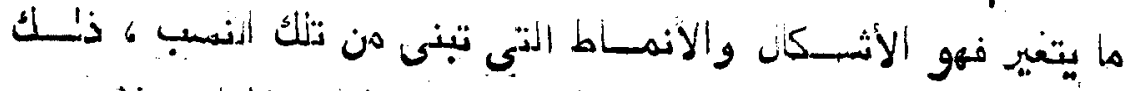

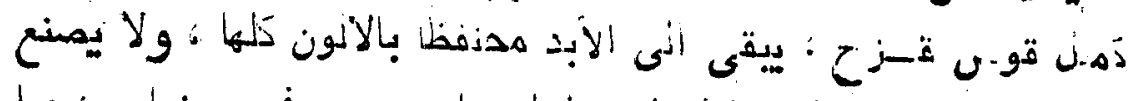

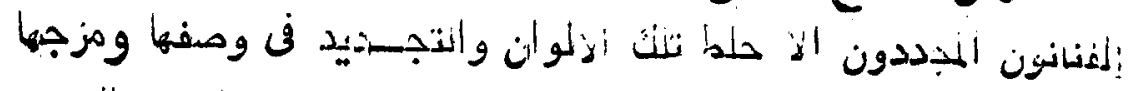

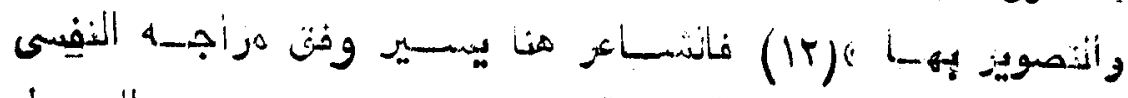

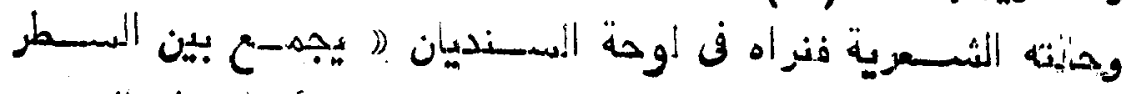

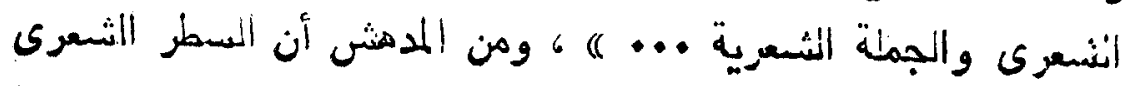

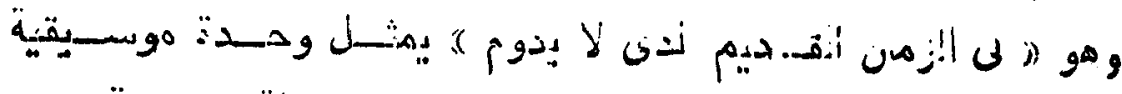

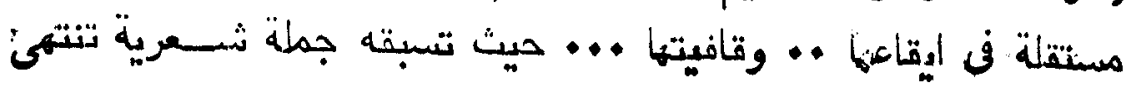

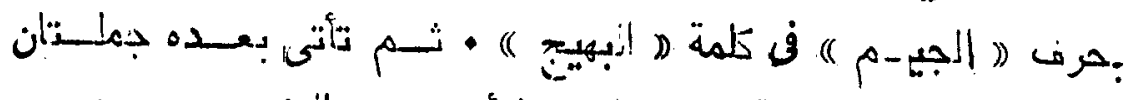

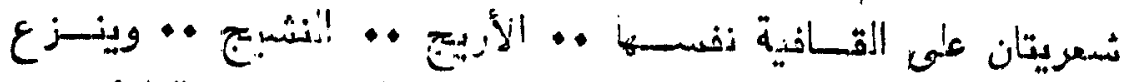

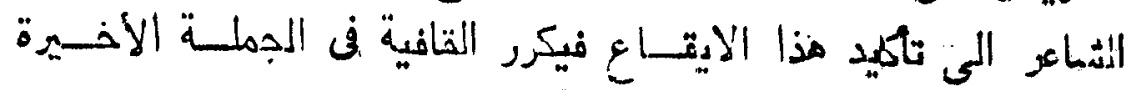

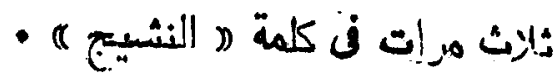

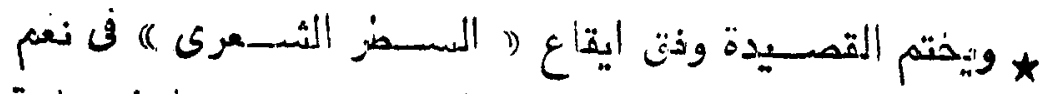

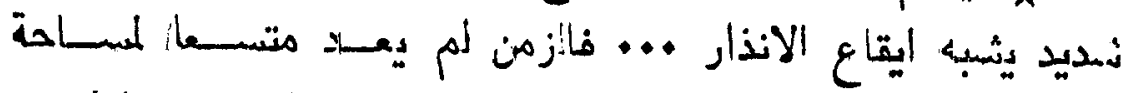

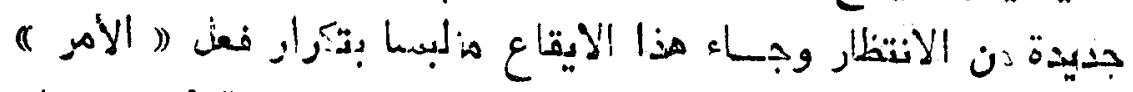

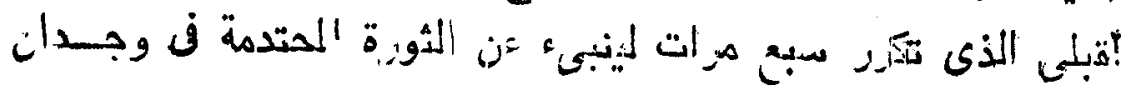

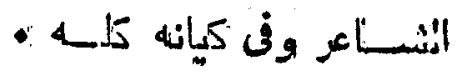

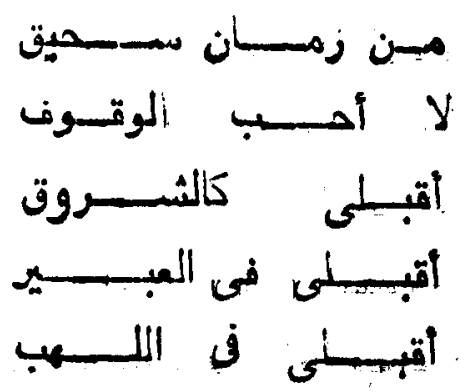




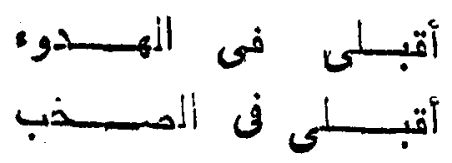

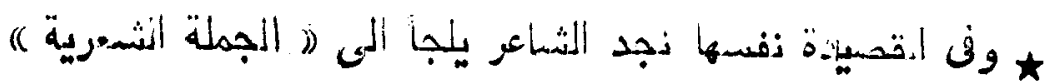

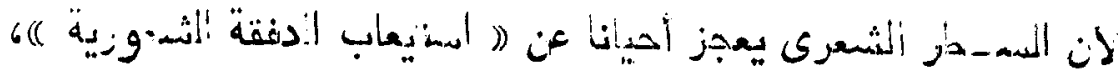

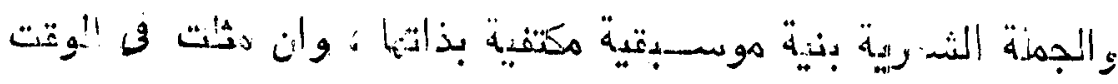

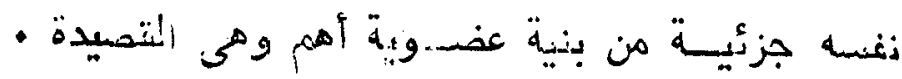

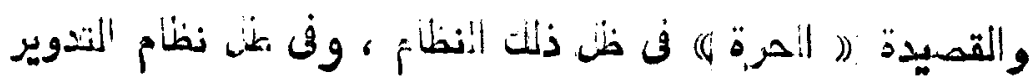

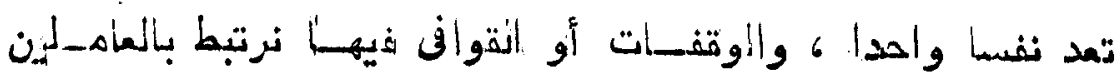

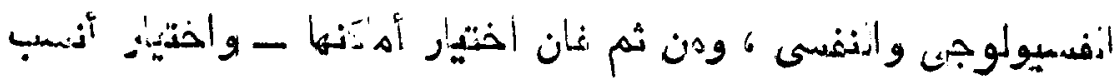

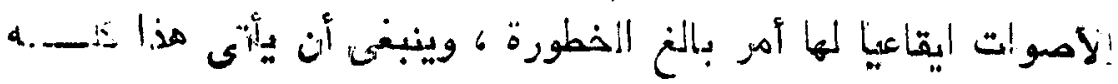

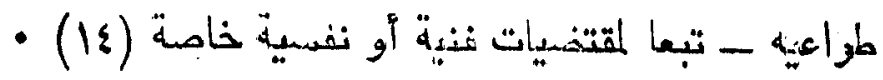

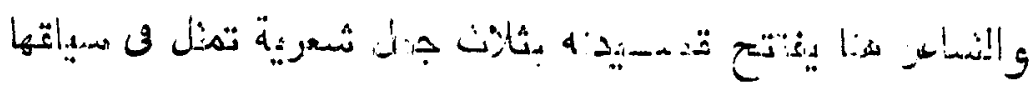

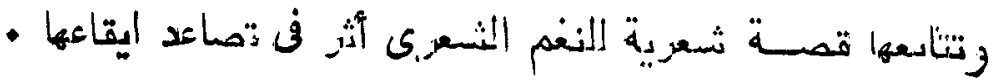

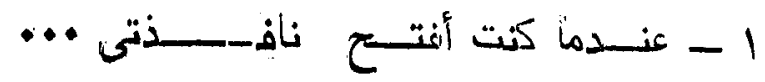

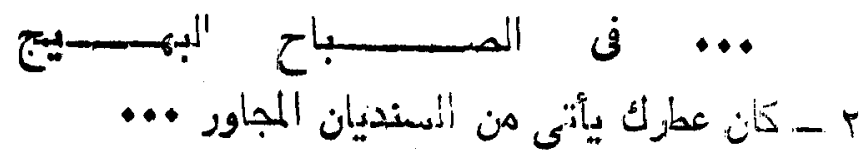

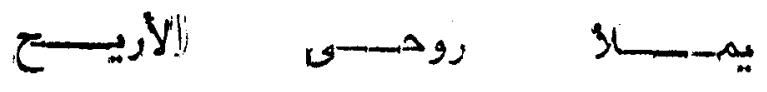

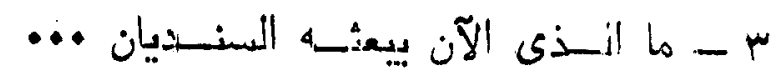

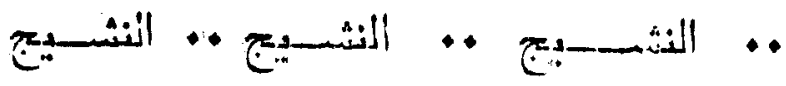

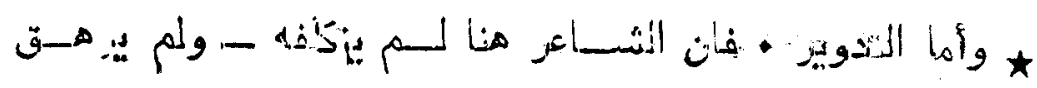

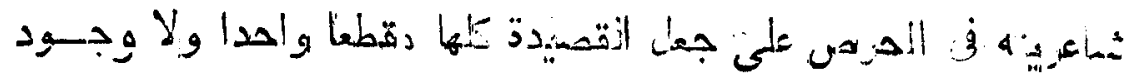

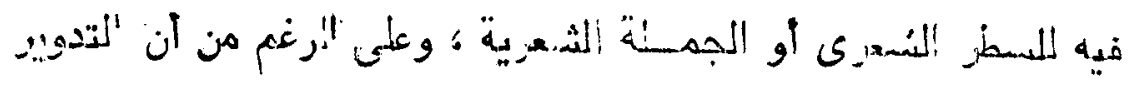

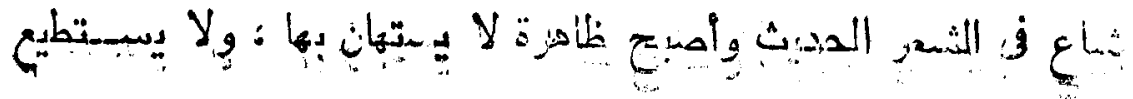




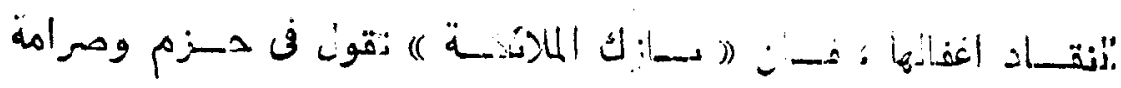

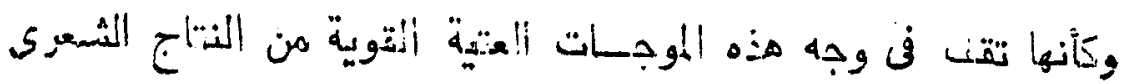

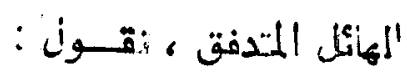

)

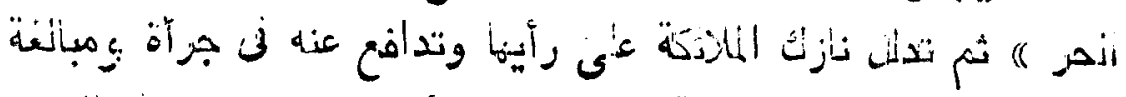

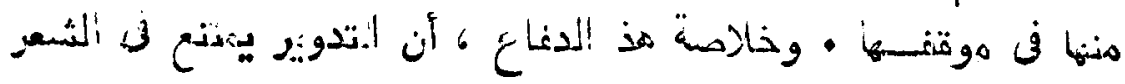

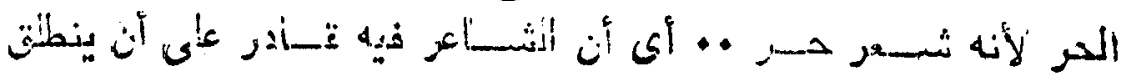

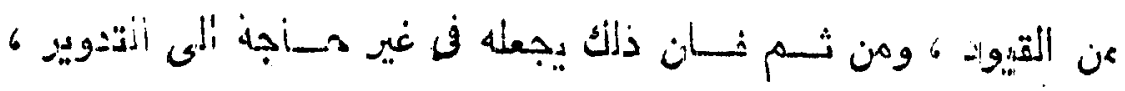

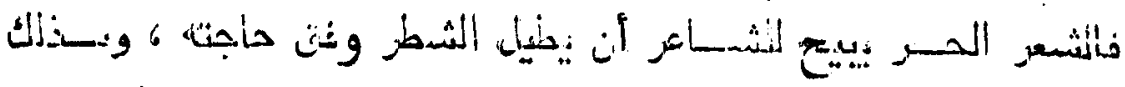

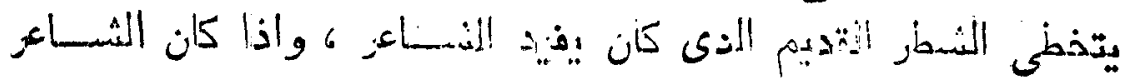

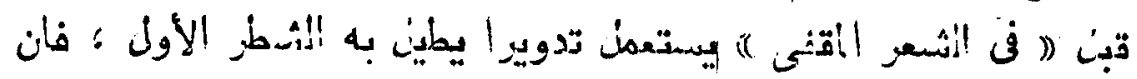

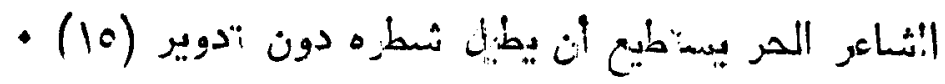

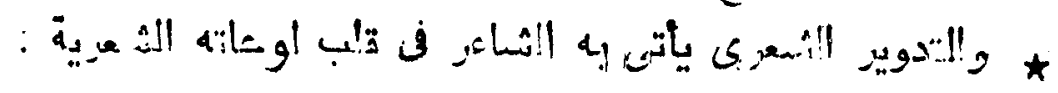

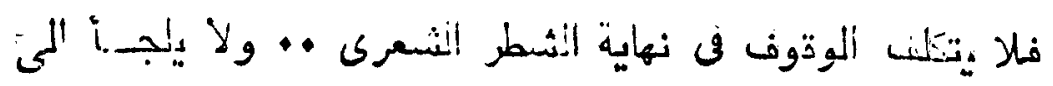

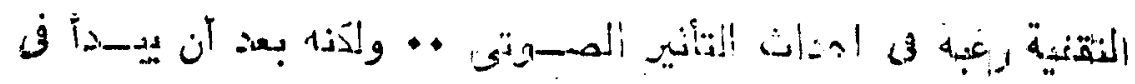

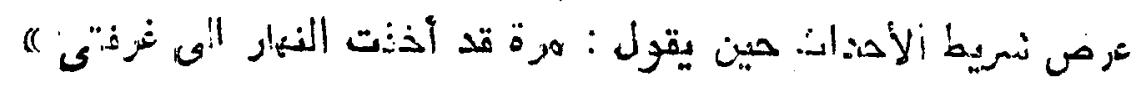

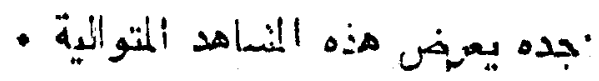

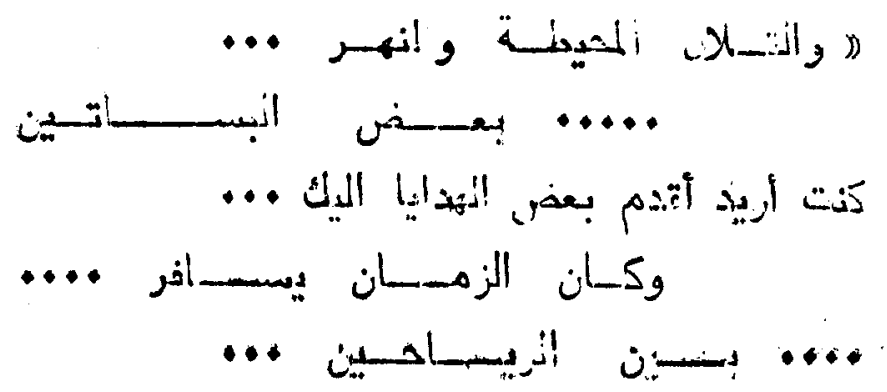

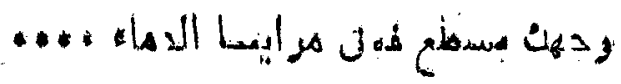




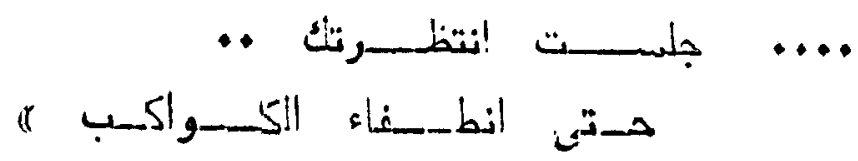

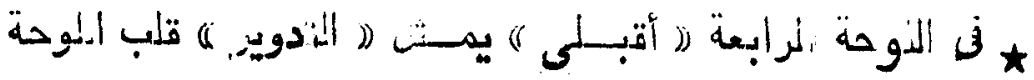

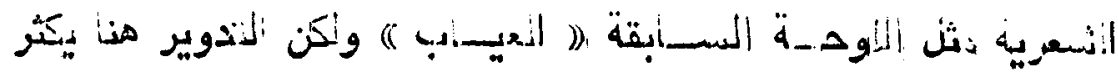

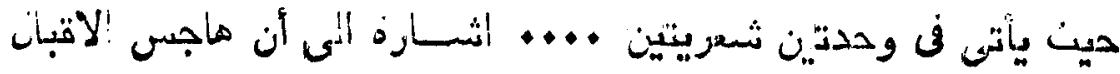

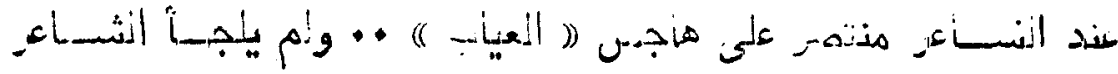

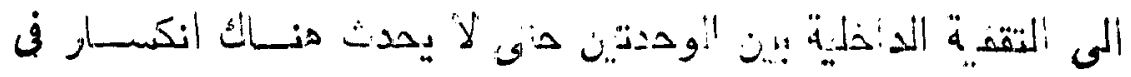

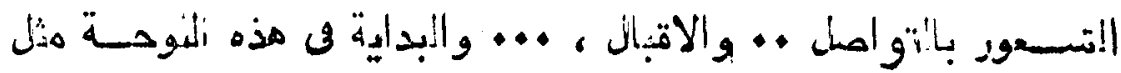

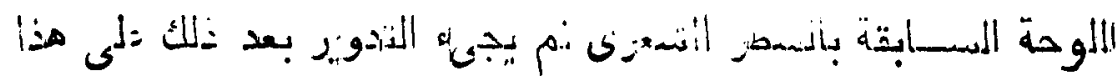

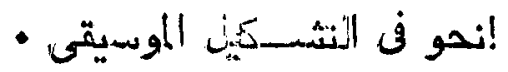

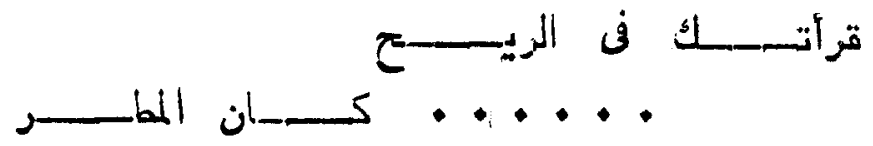

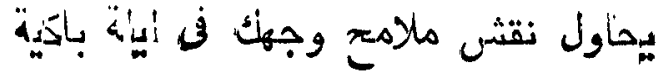

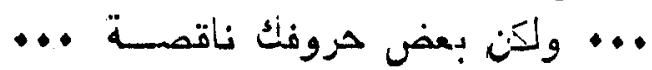

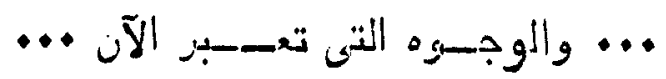

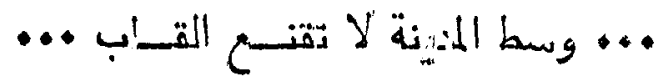

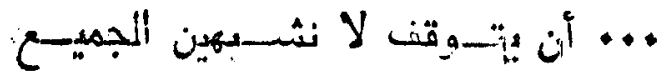

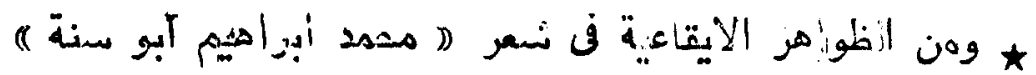

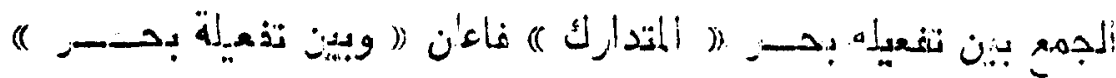

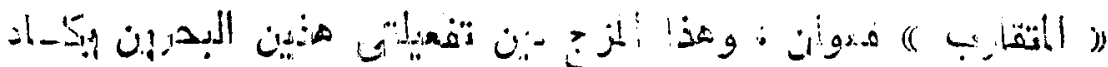

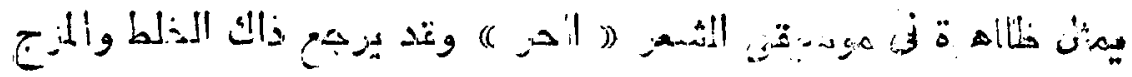

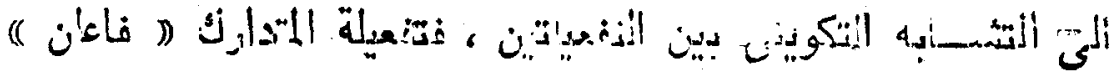

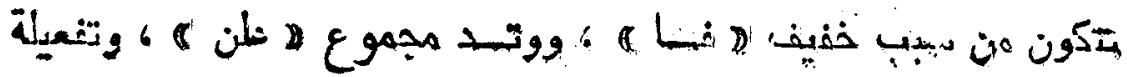




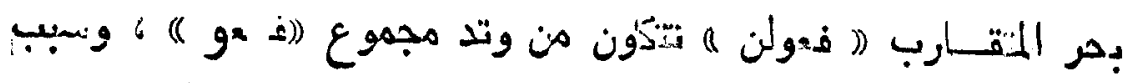

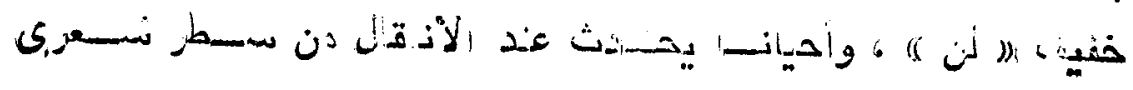

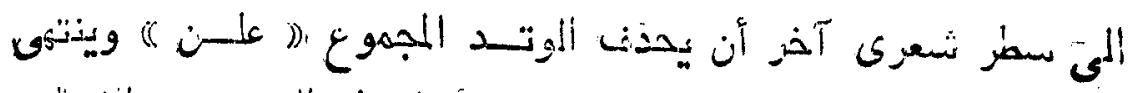

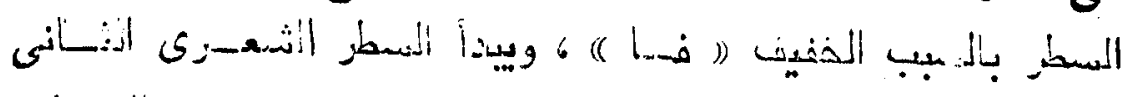

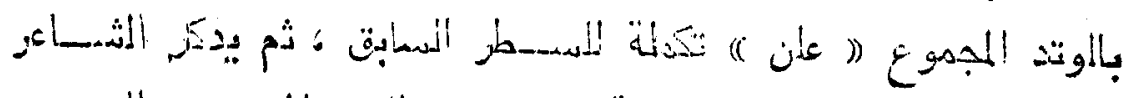

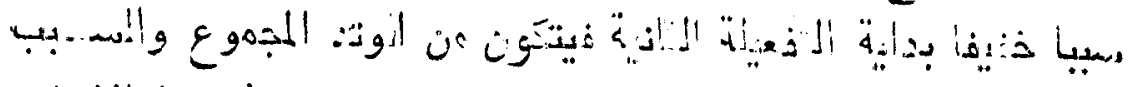

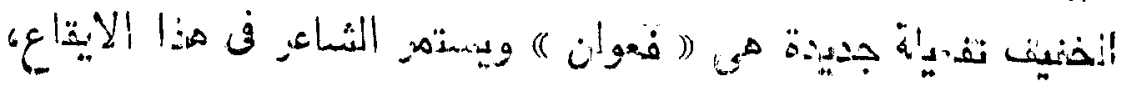

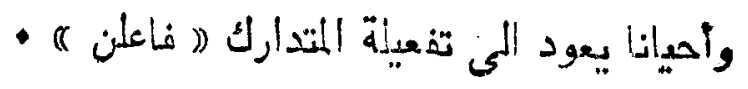

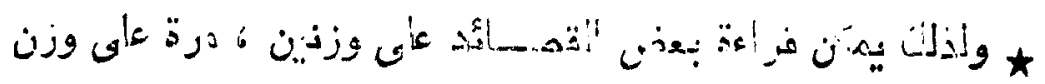

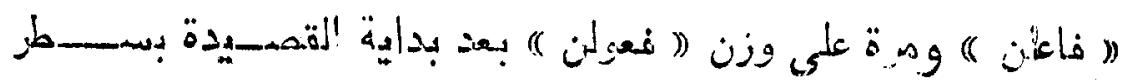

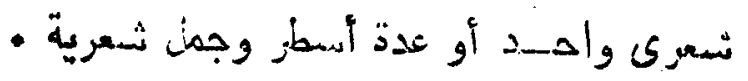

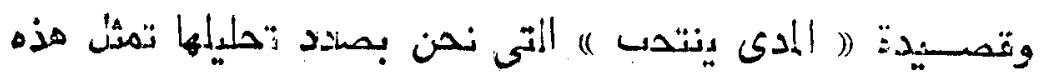

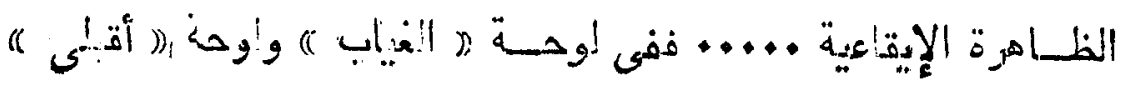

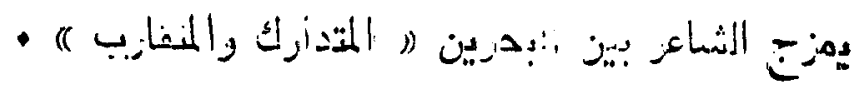

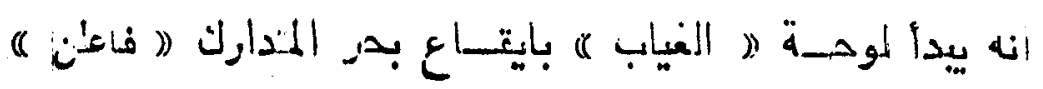

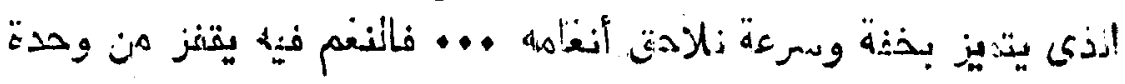

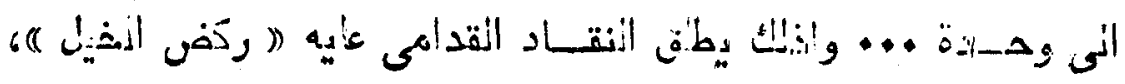

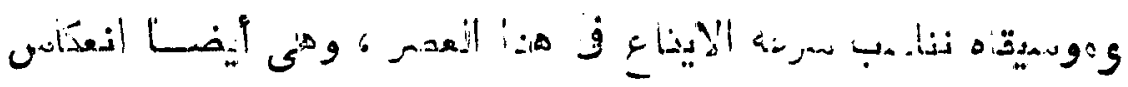

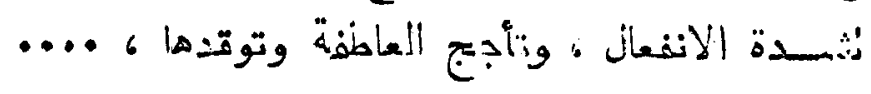

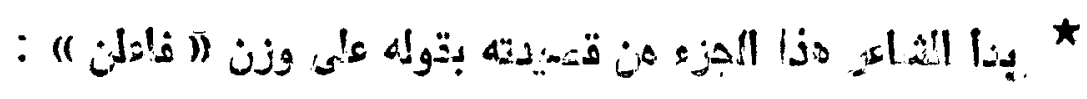

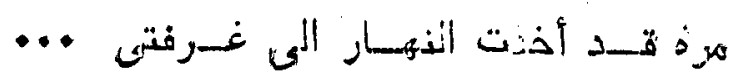

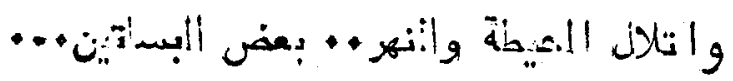

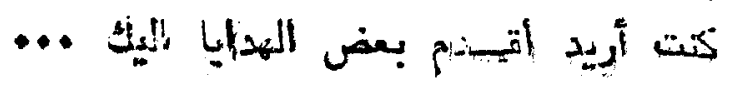




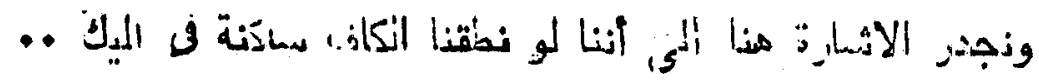

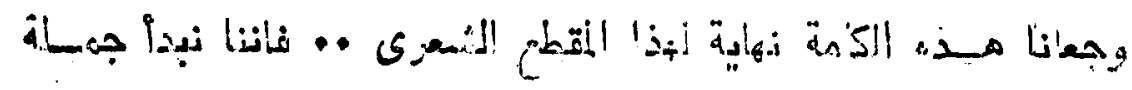
-

$$
\begin{aligned}
& \text { وكان الزمان يبسافر بسين الريساحين • }
\end{aligned}
$$

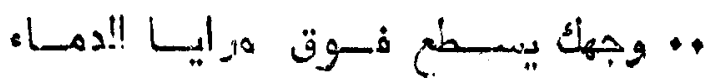

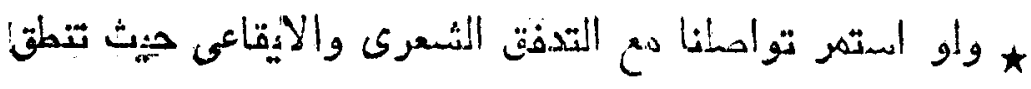

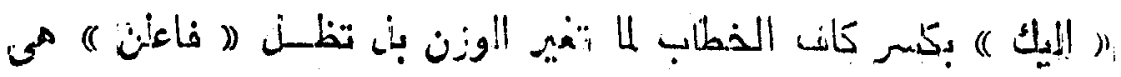

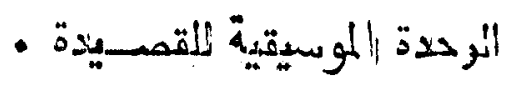

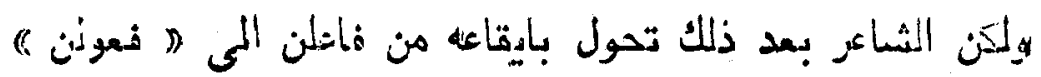

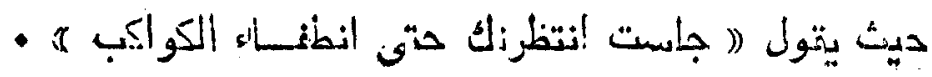

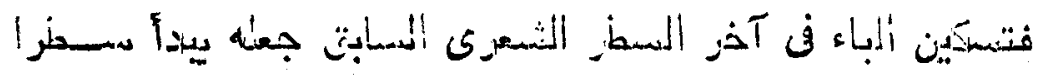

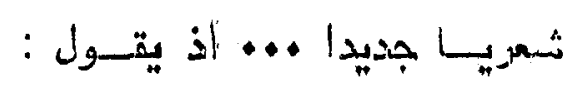

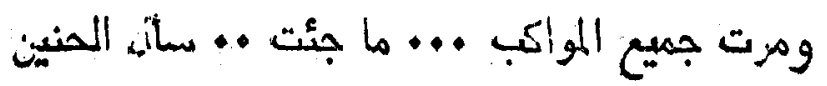

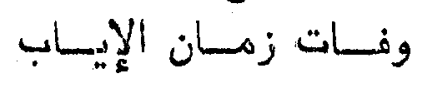

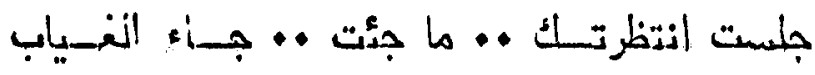

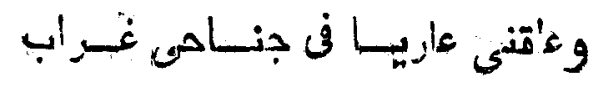

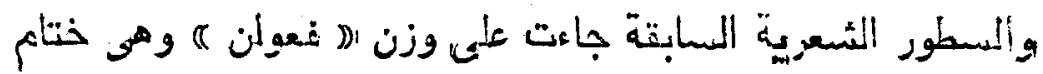

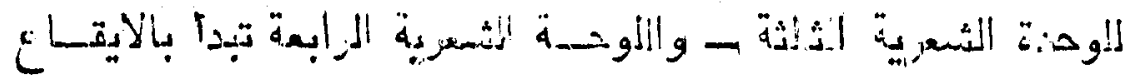

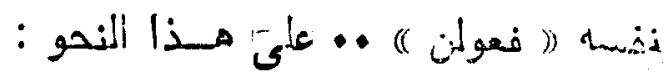

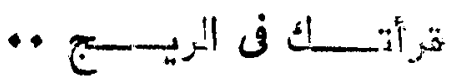

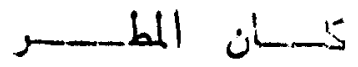

يحاون نقتس ملامح وجيله في ليلة باكية

$(;-1)$ 


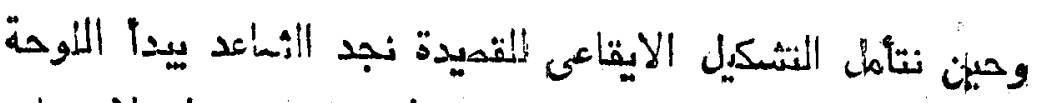

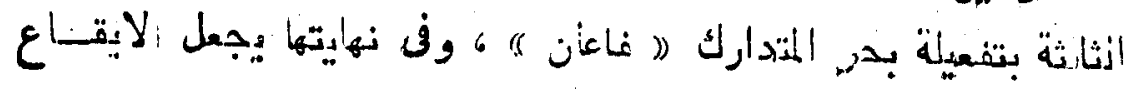

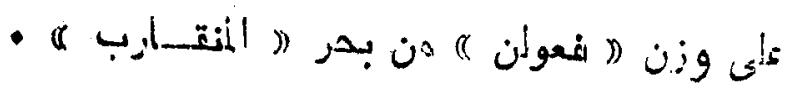

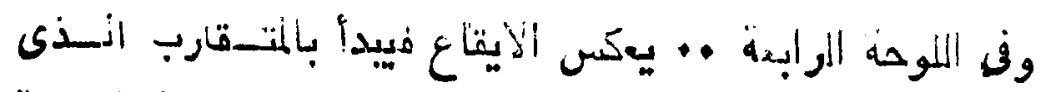

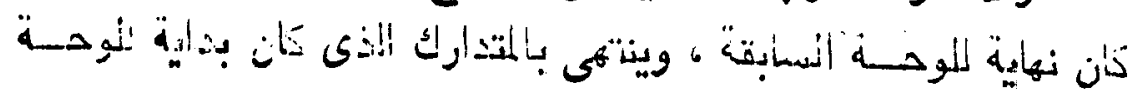

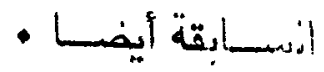

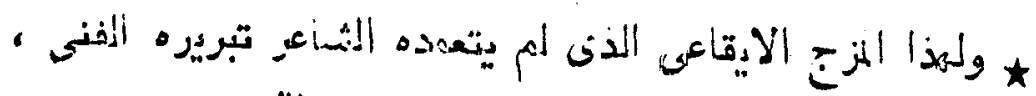

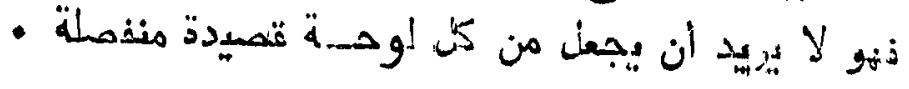

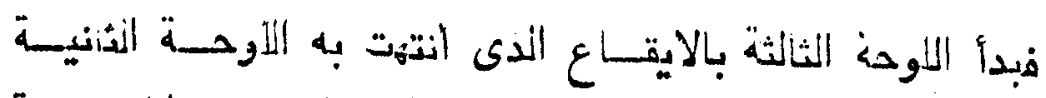

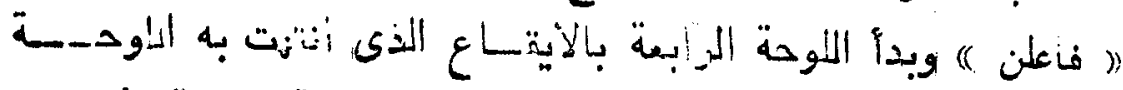

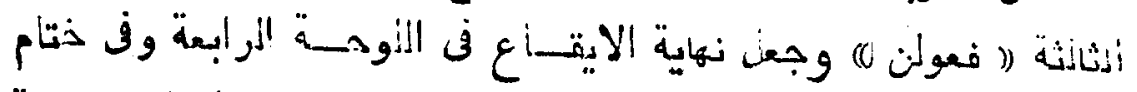

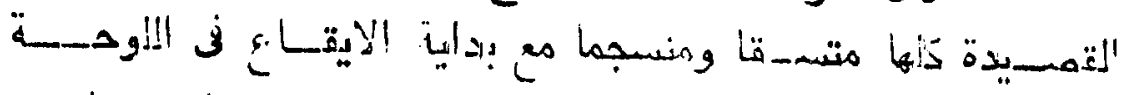

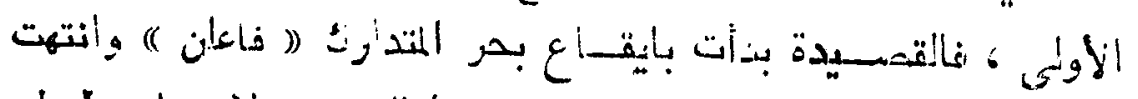

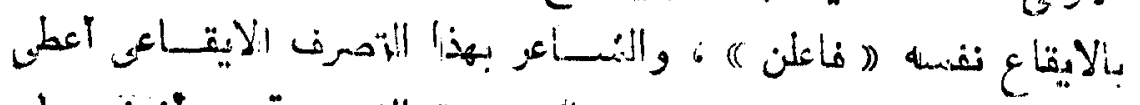

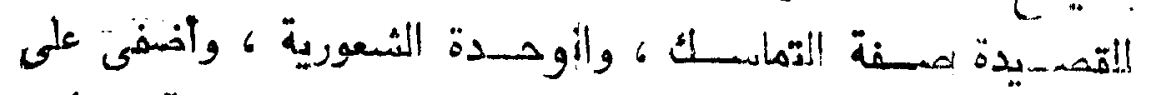

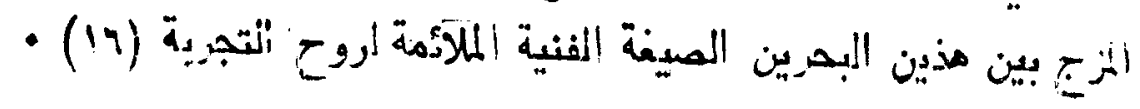

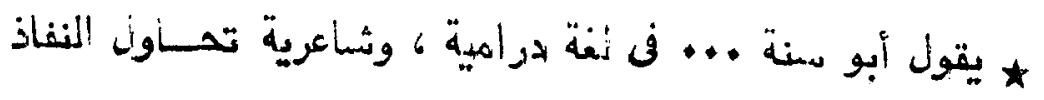

$$
\text { المى لب الأثشياء }
$$

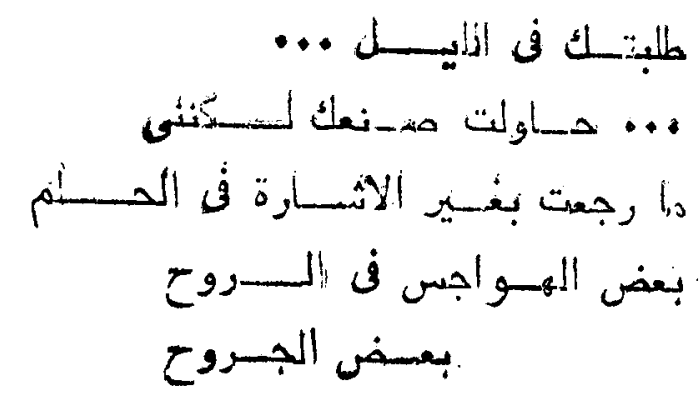


ol

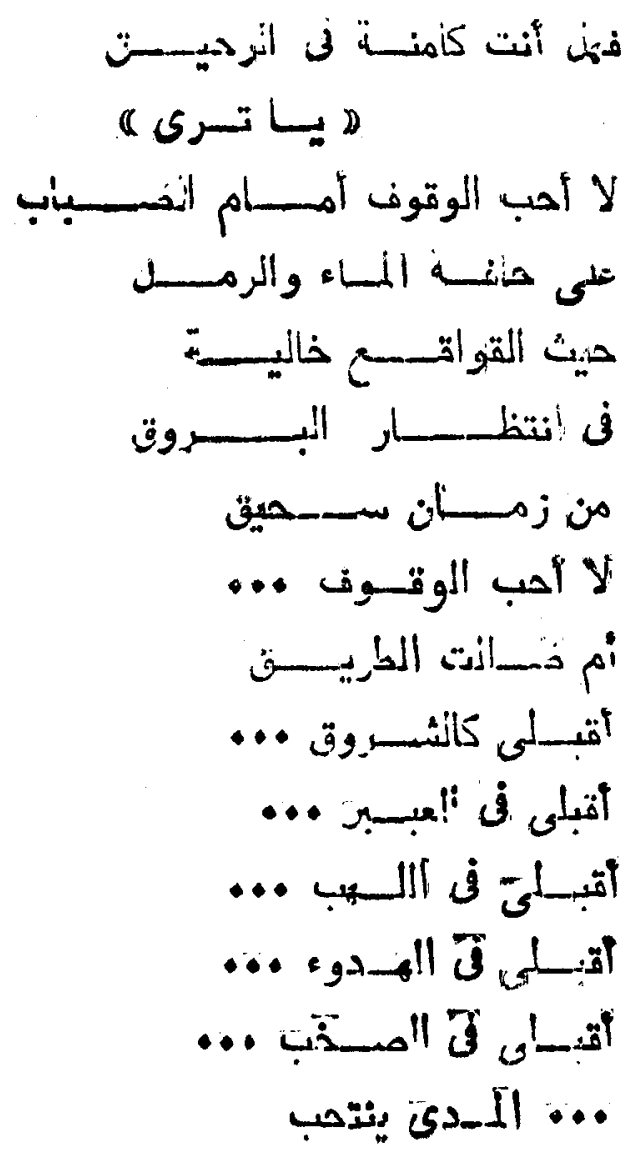




\section{الهـوامش : (الهـ}

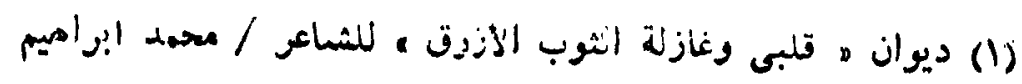

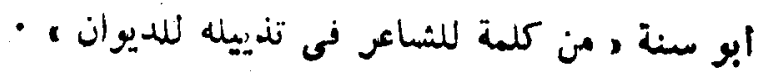

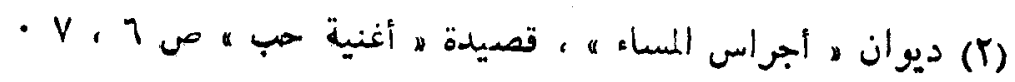

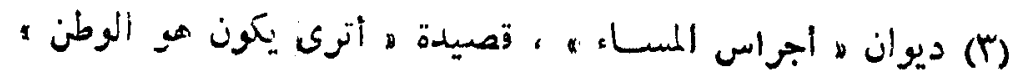

ص م

(ع) ديوان ه تأملات فى المدن الحجرية " قصديدة ه مشاهدأت دامية فى

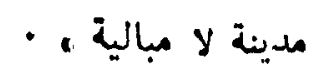

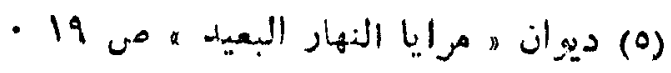

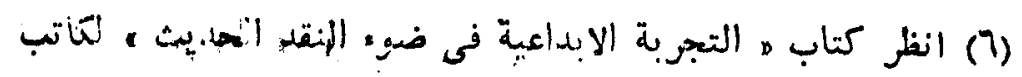

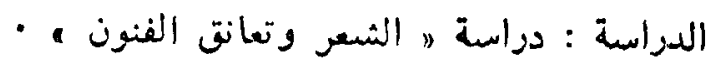

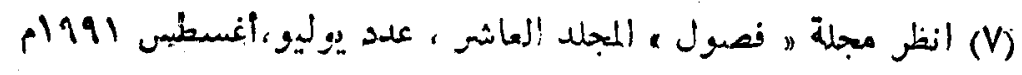

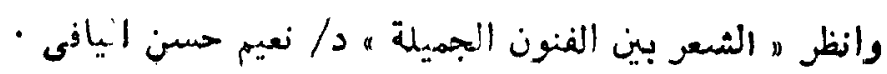

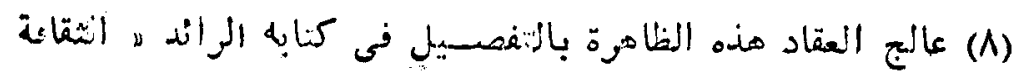

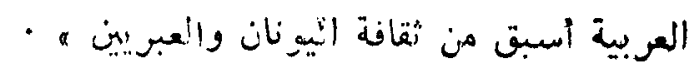

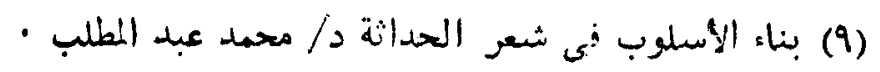

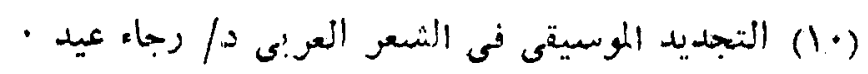

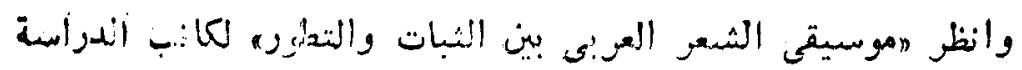

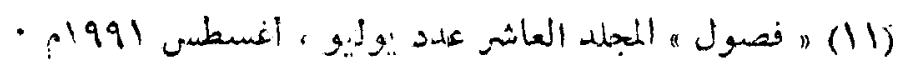

-

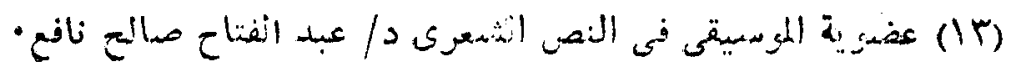

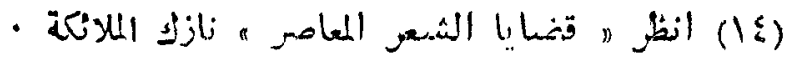

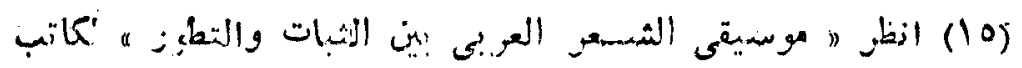

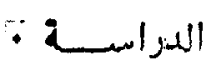

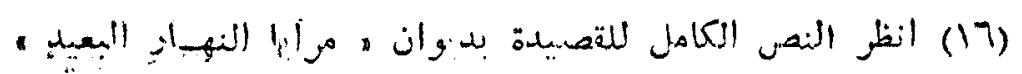

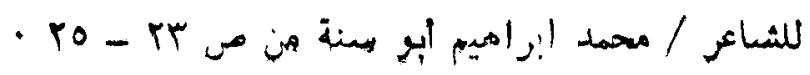




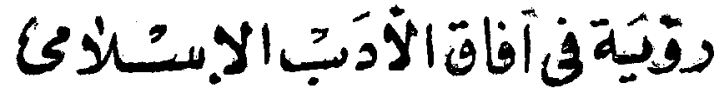

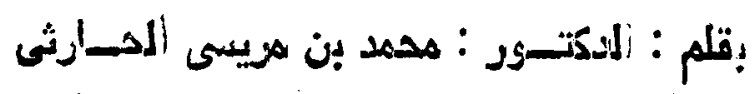

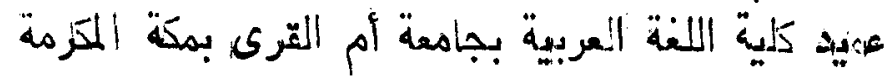

\section{$\star \star$}

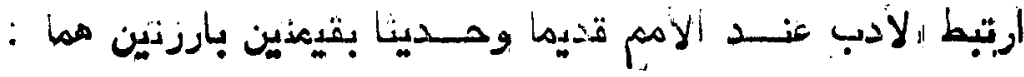

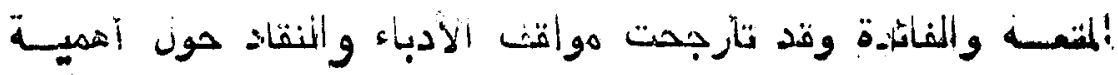

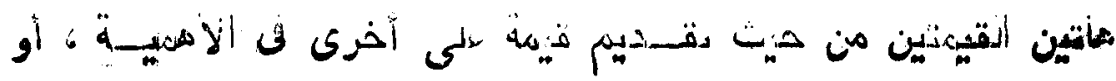

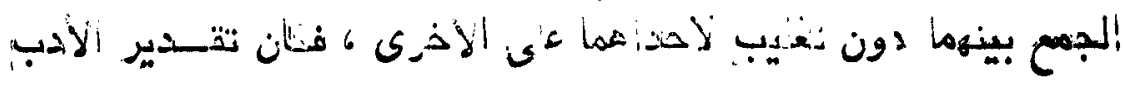

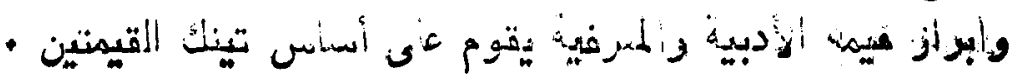

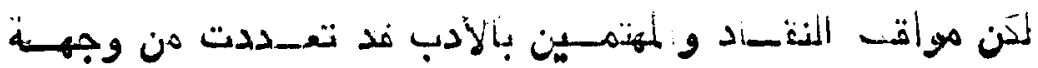

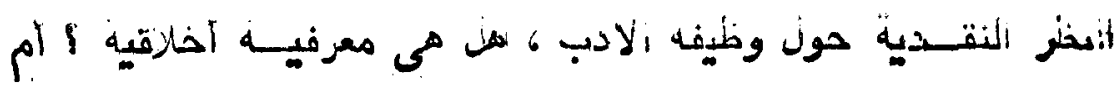

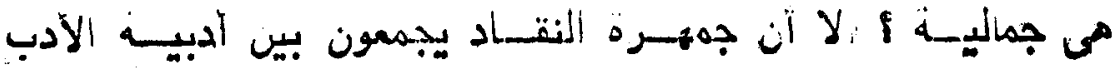

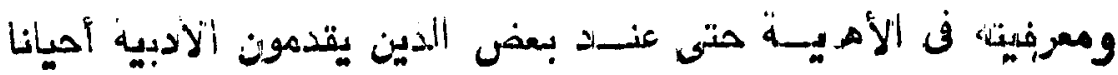

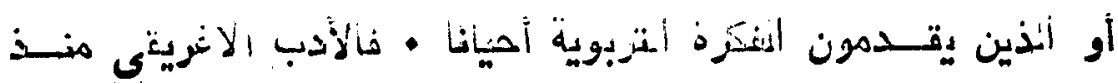

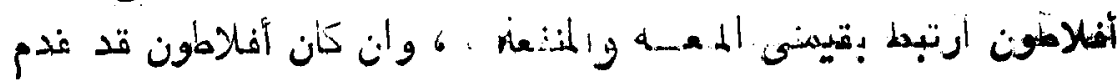

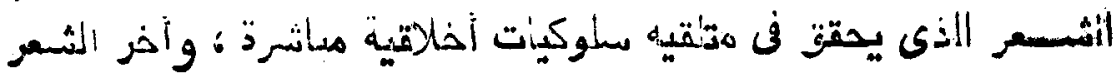

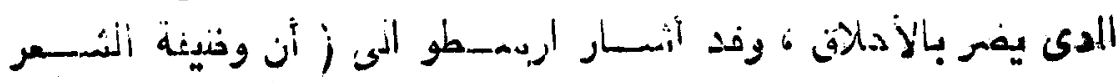

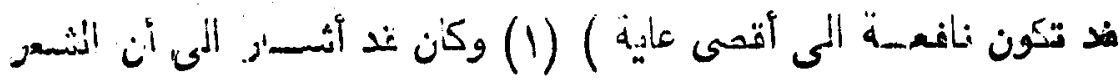

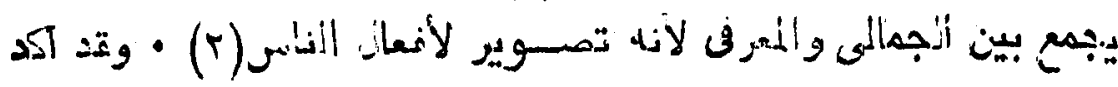

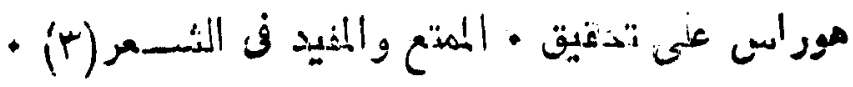

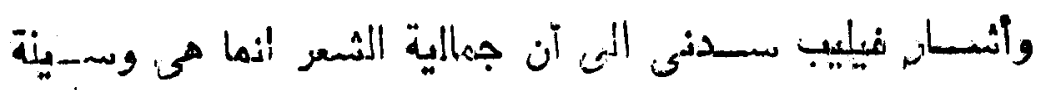

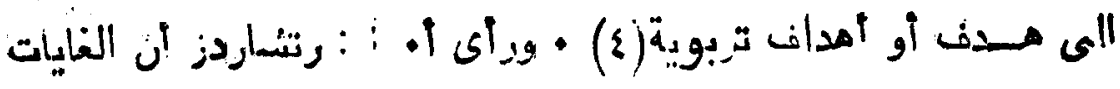




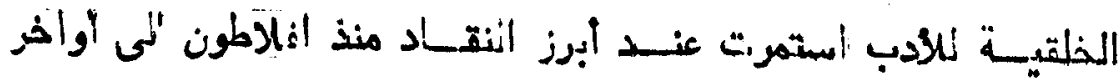

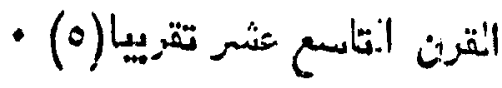

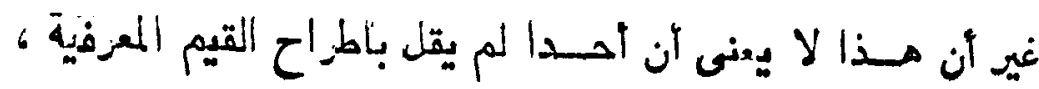

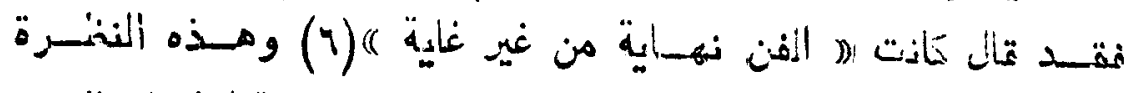

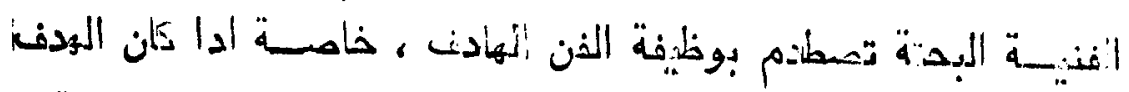

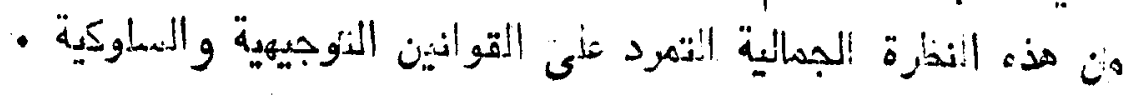

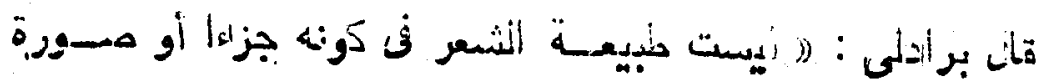

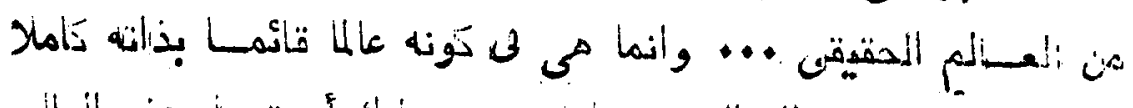

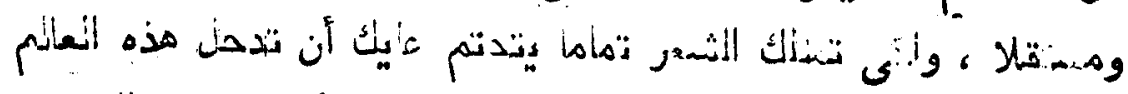

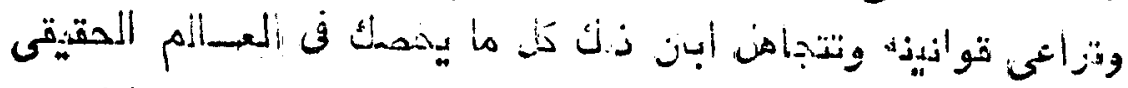

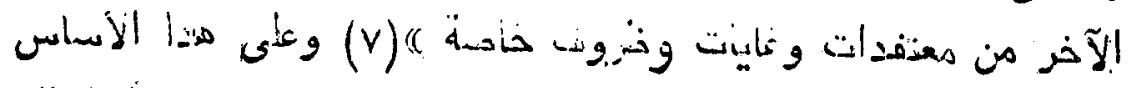

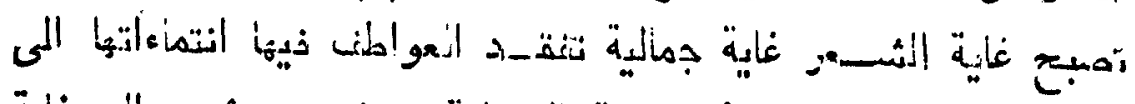

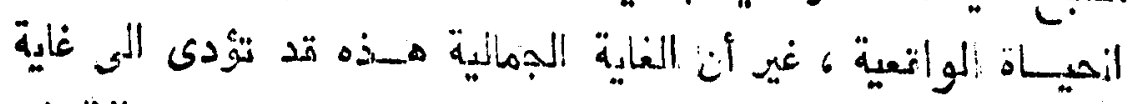

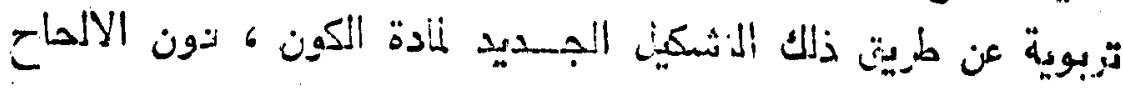

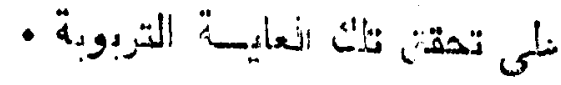

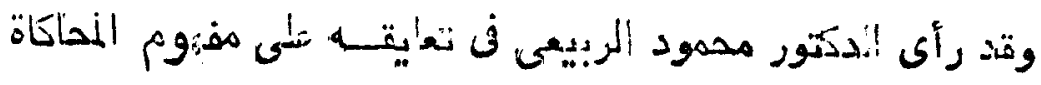

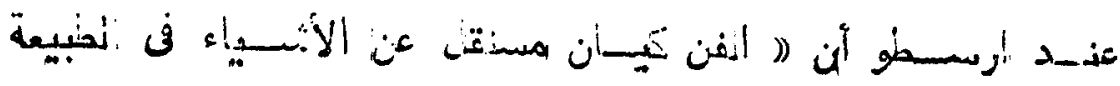

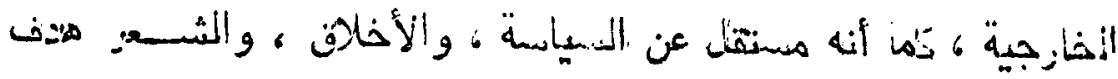

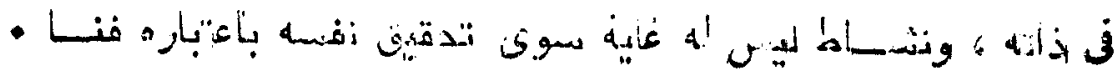

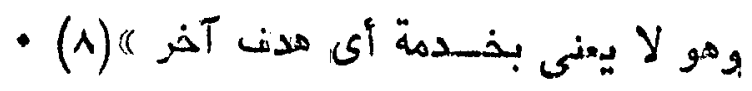

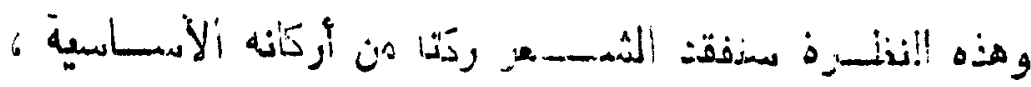

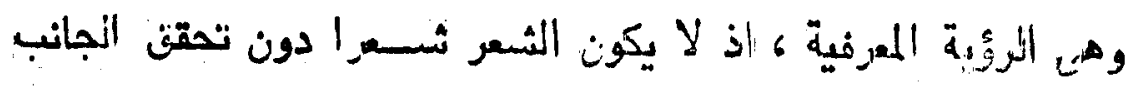




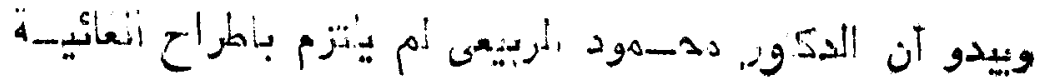

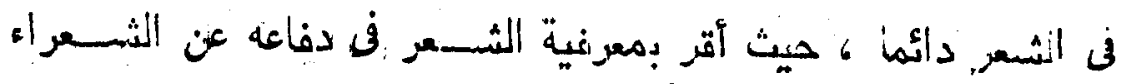

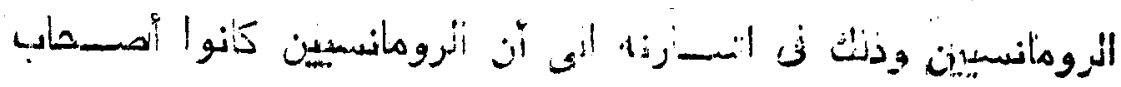

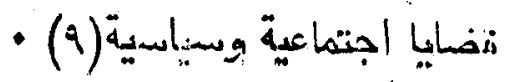

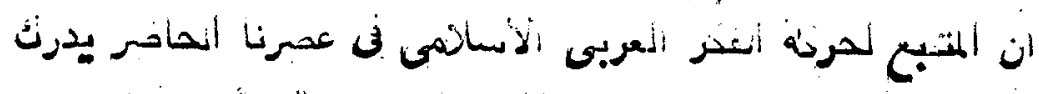

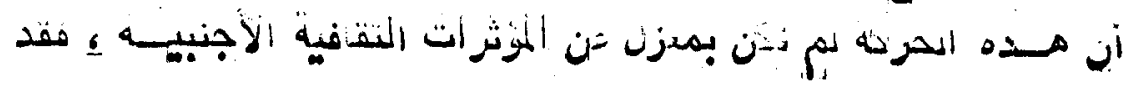

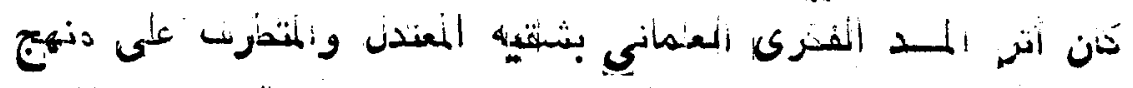

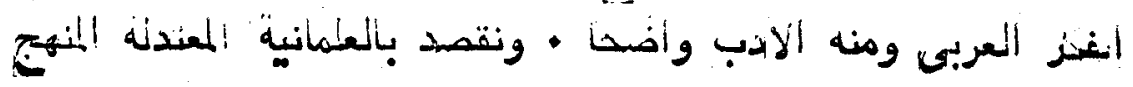

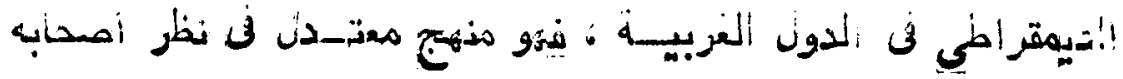

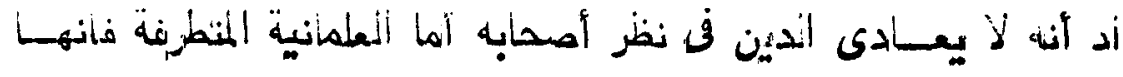

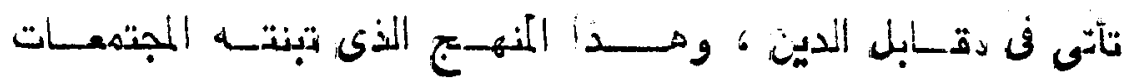

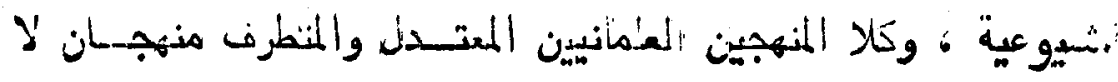

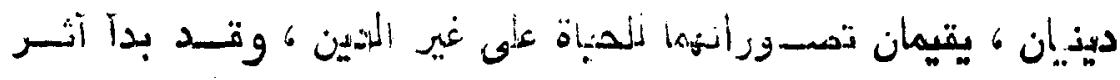

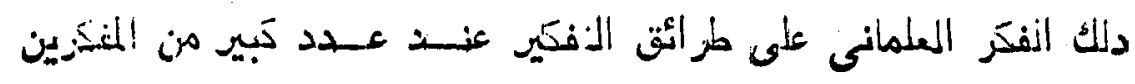

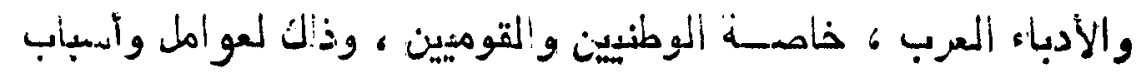

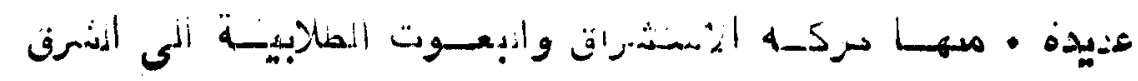

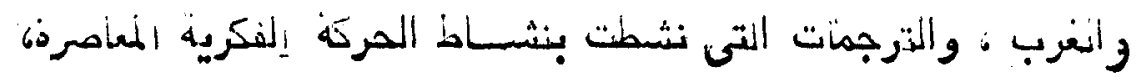

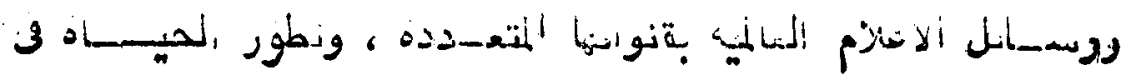

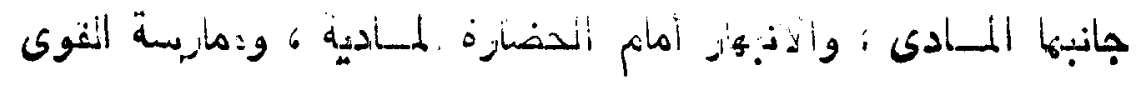

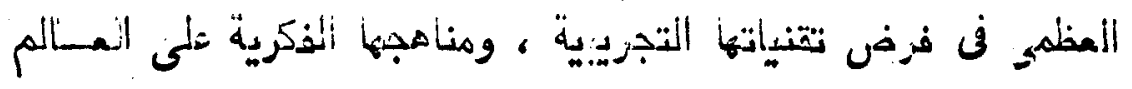

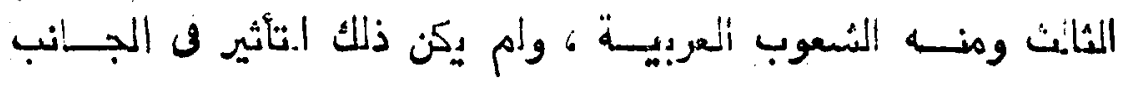

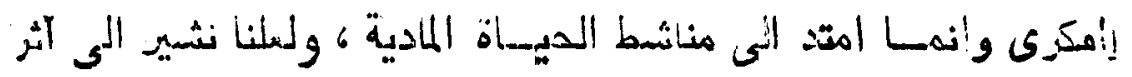

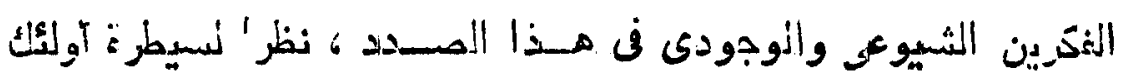

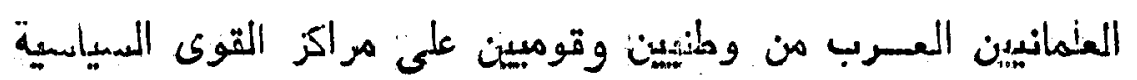

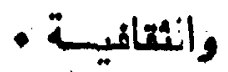




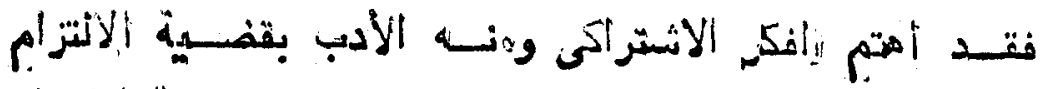

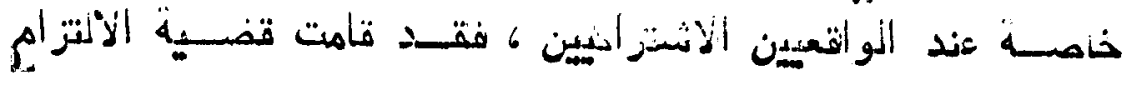

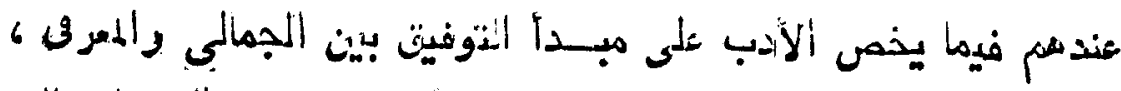

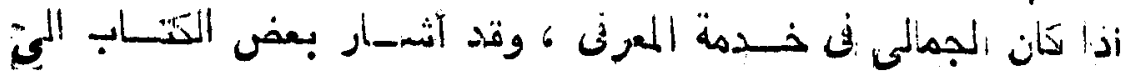

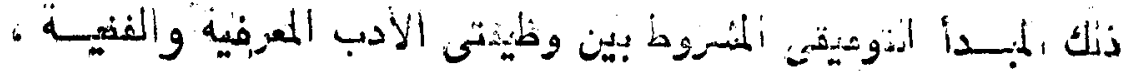

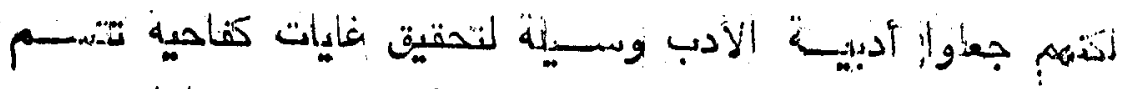

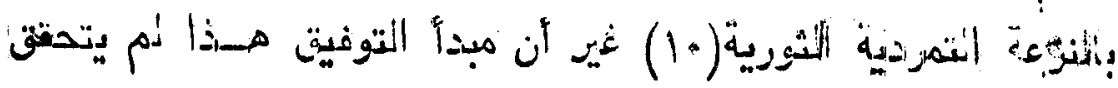

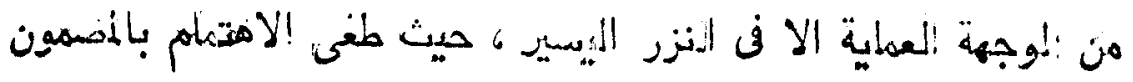

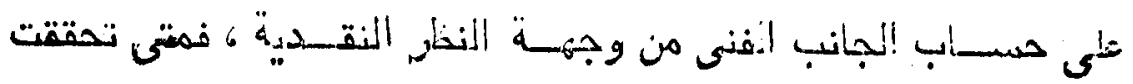

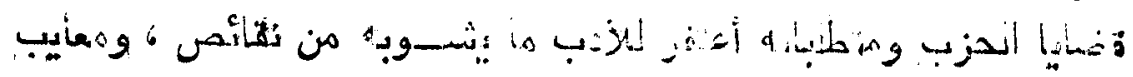

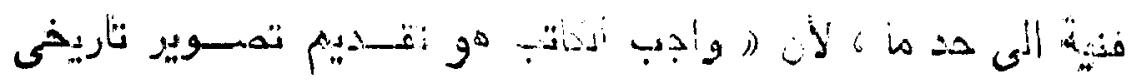

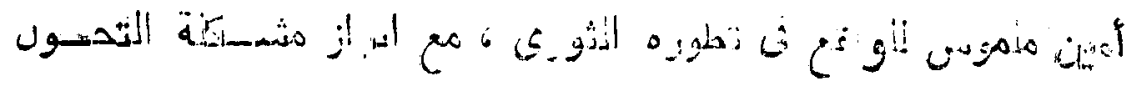

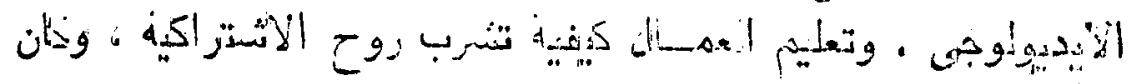

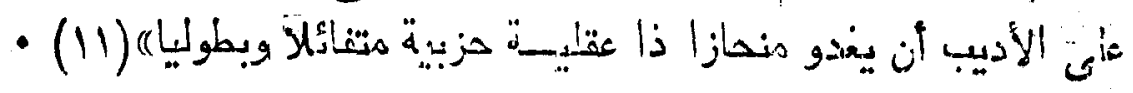

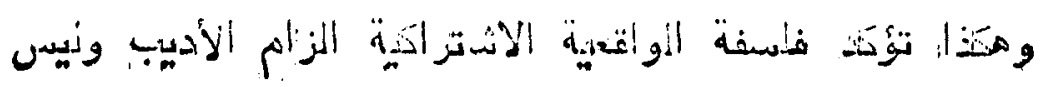

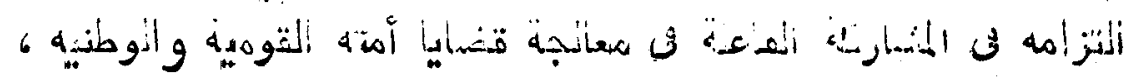

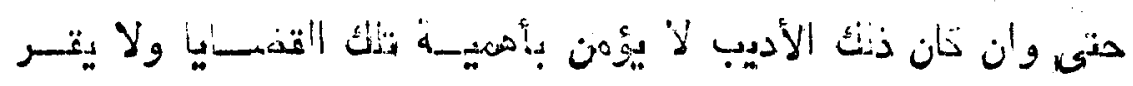

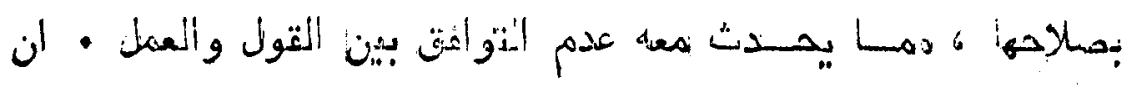

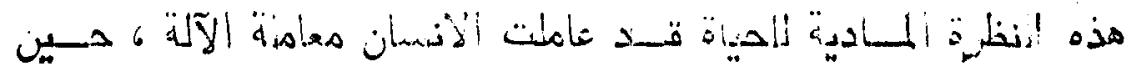

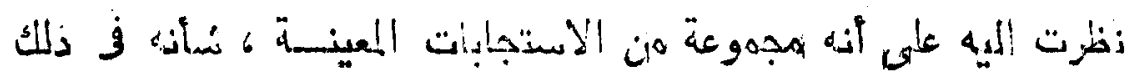

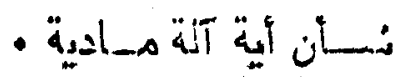

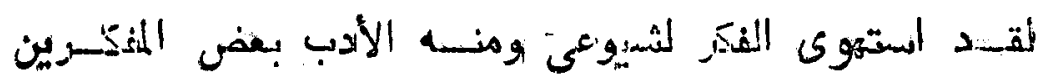

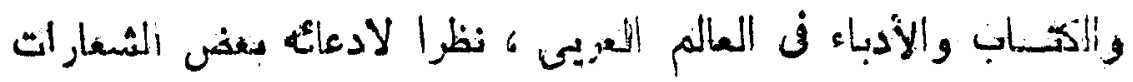

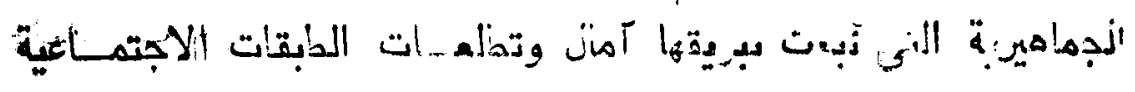




\section{ov}

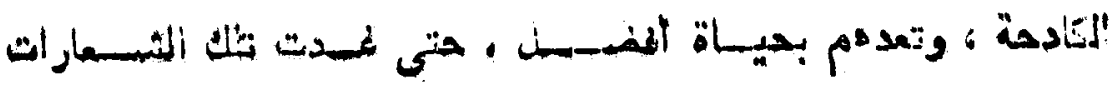

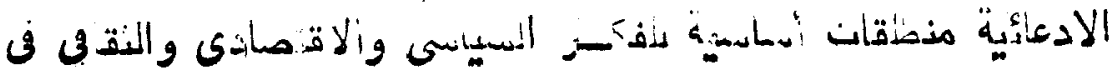

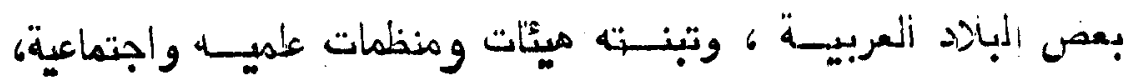

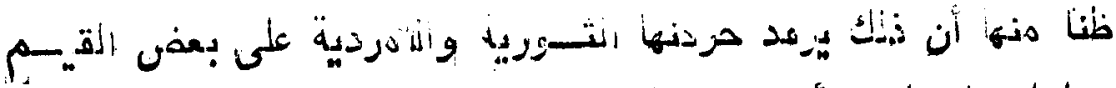

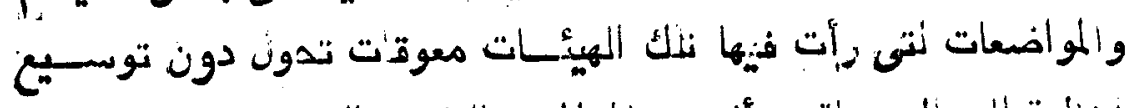

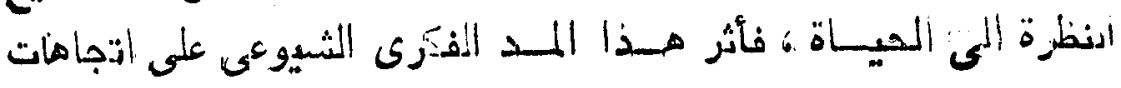

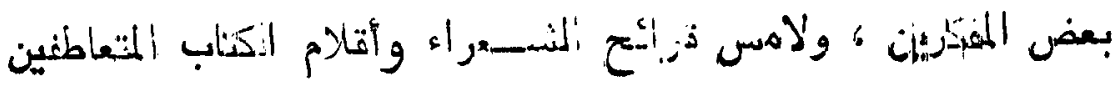

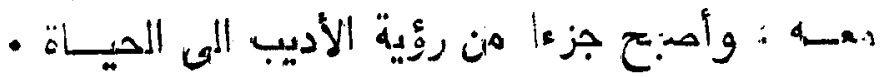

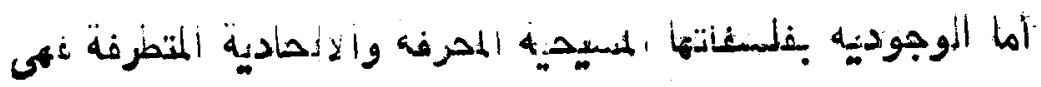

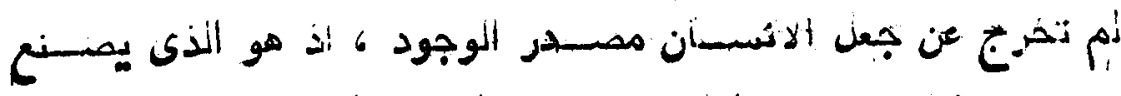

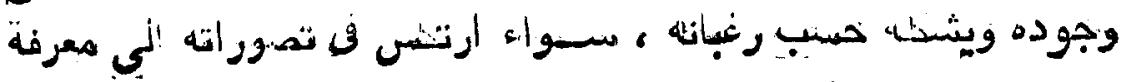

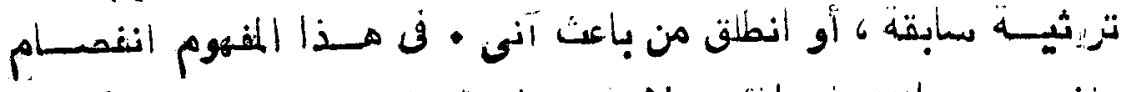

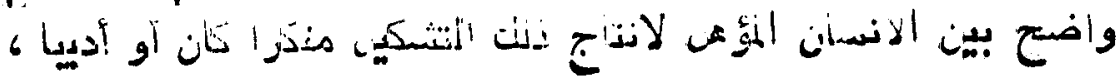

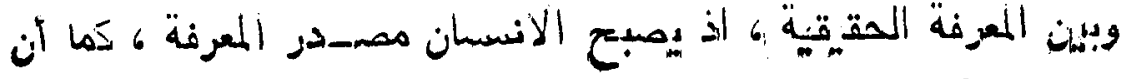

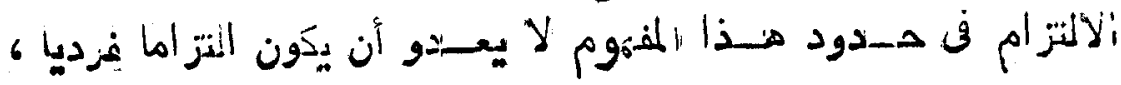

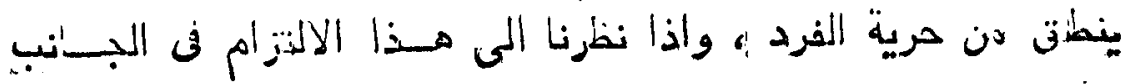

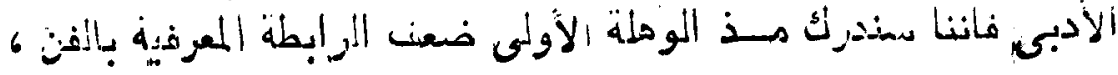

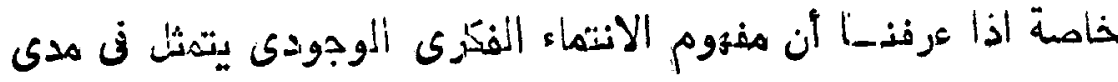

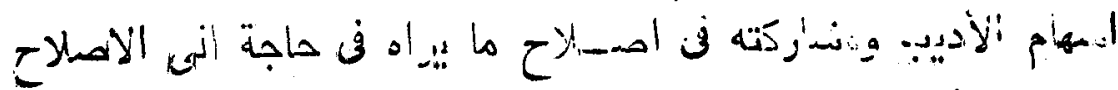

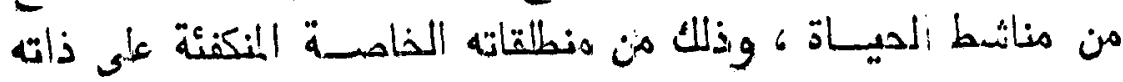

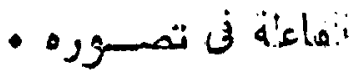

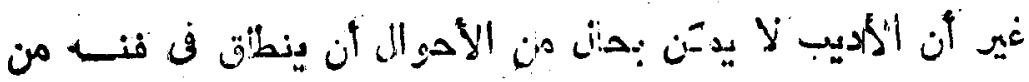

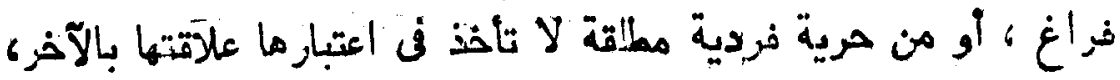




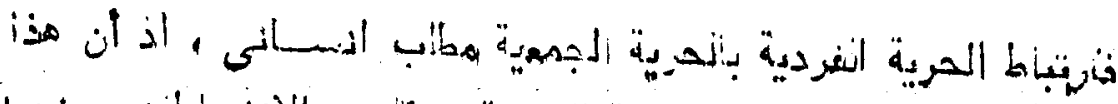

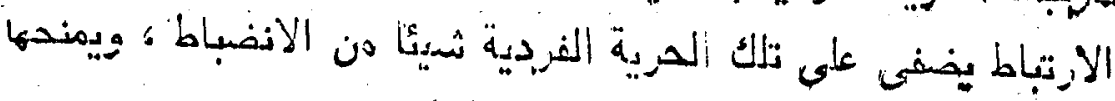

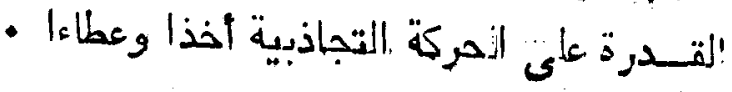

كما أن الخلفية المعرفية لنانديب لها علاقة استمد الدية واستزفادية

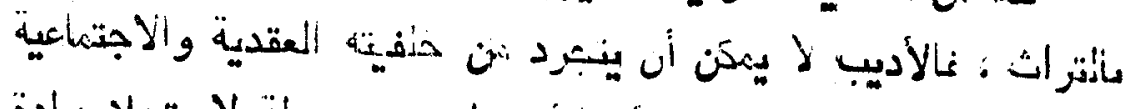

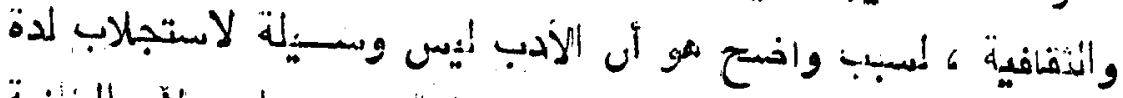

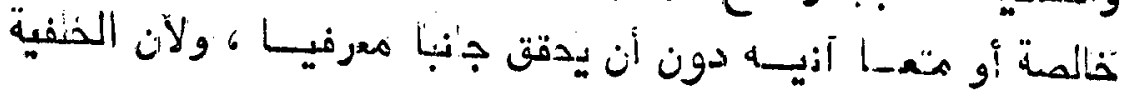

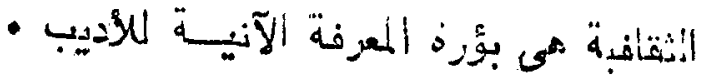

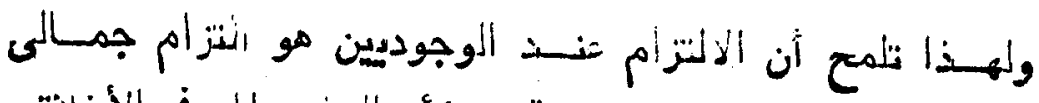

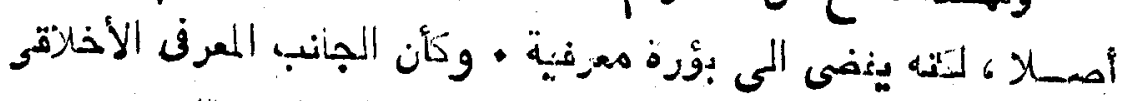

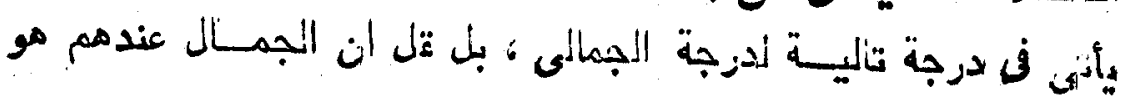

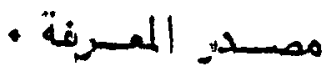

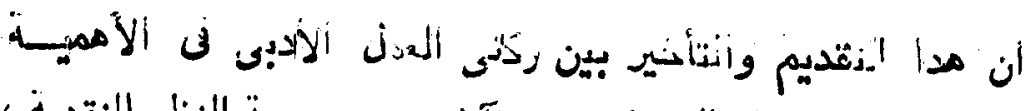

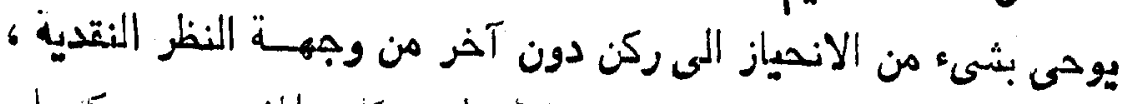

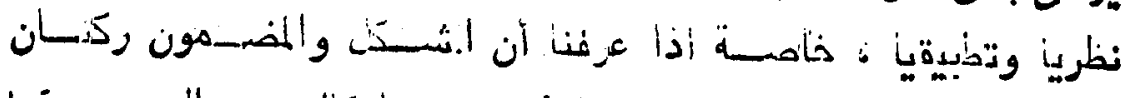

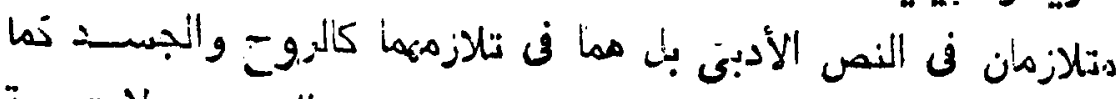

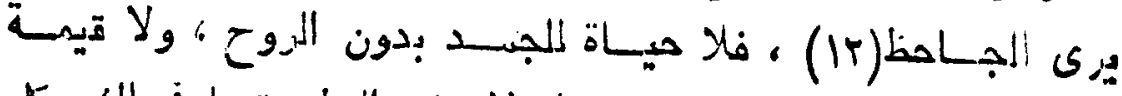

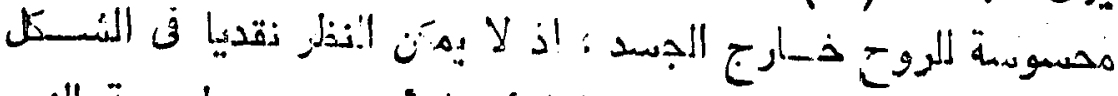

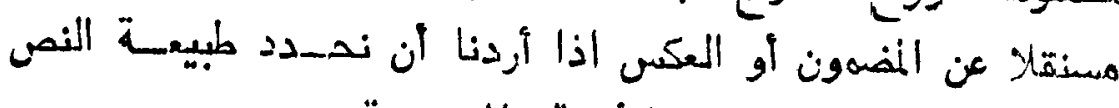

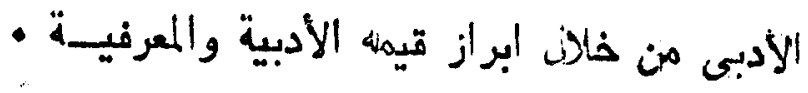

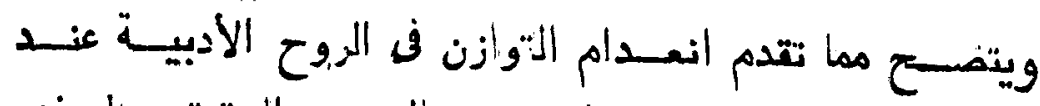

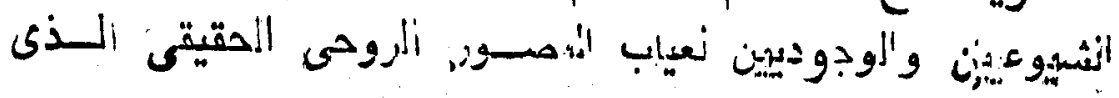

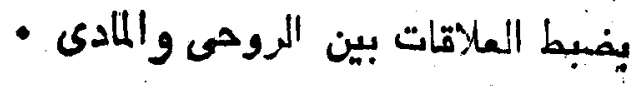




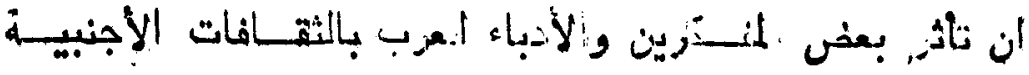

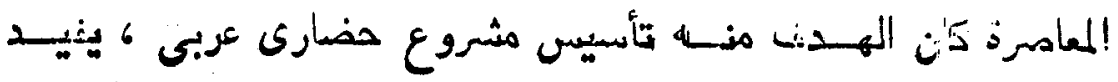

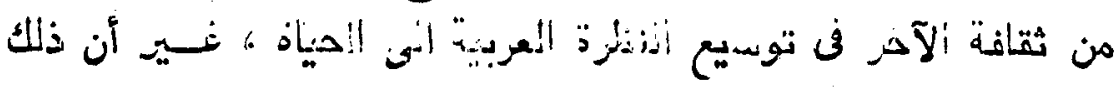

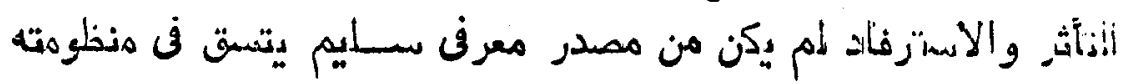

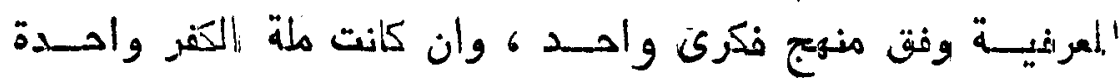

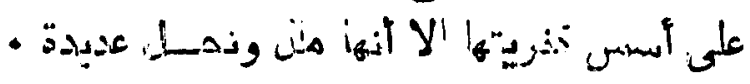

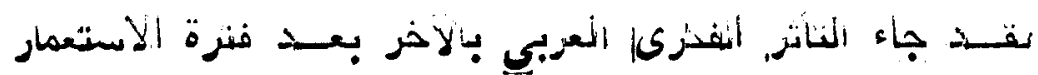

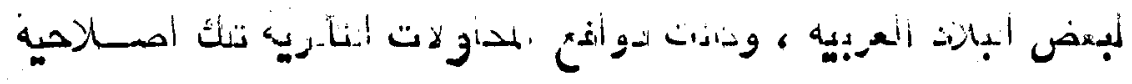

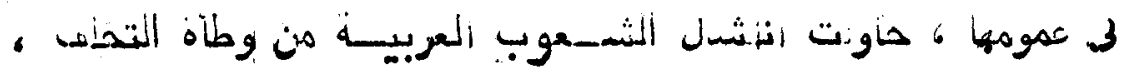

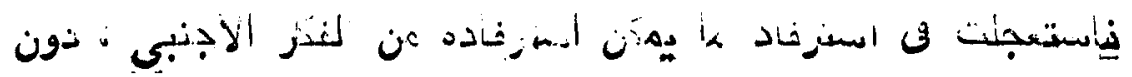

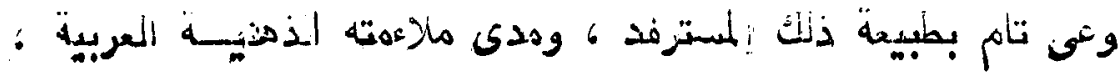

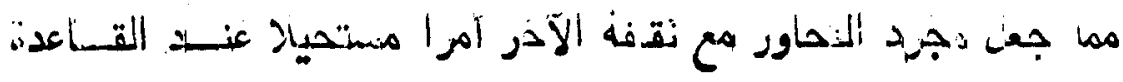

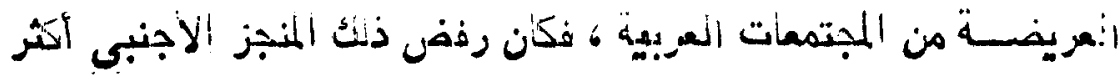

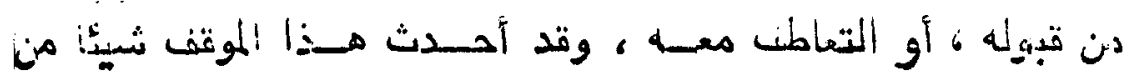

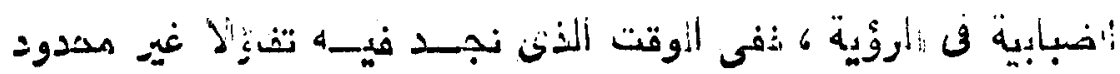

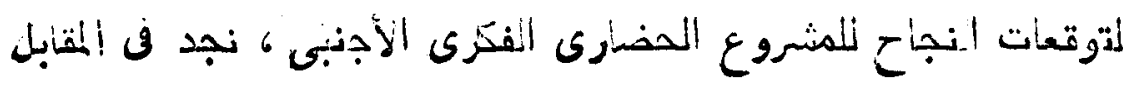

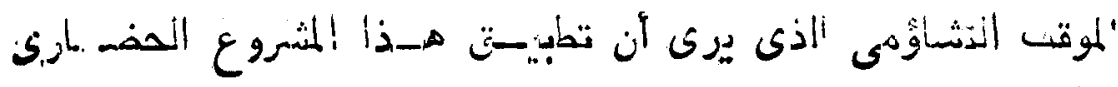

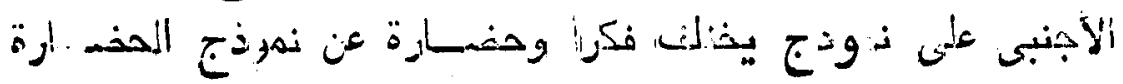

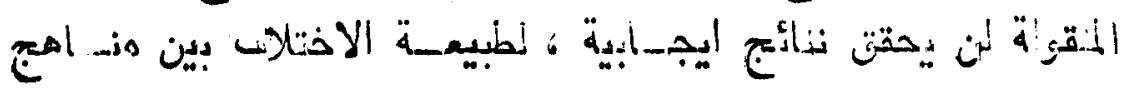

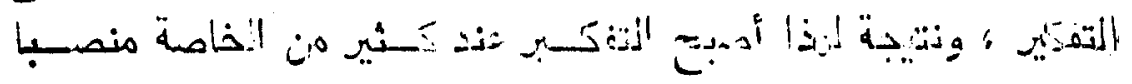

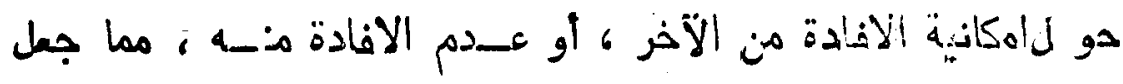

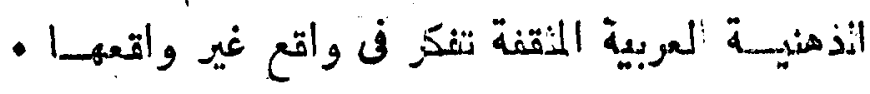

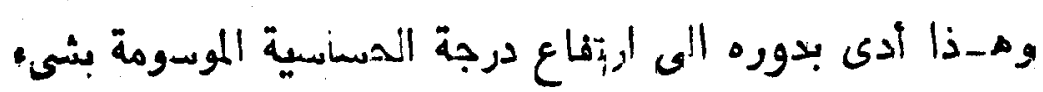

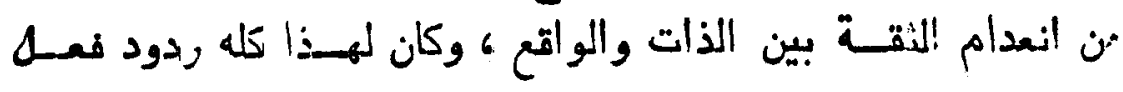




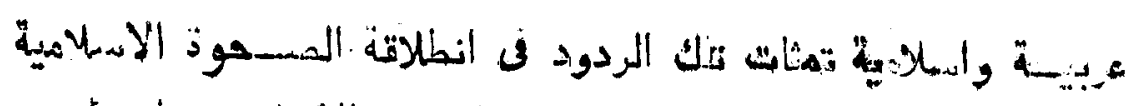

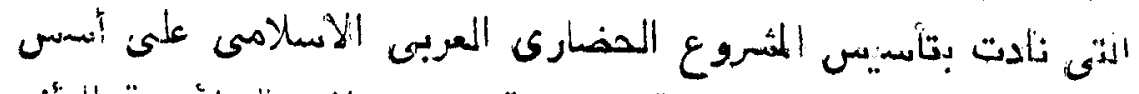

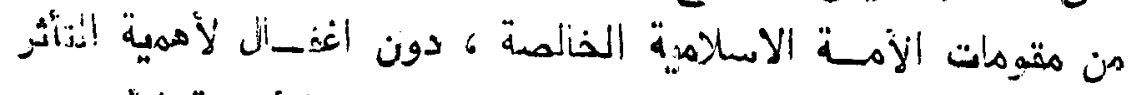

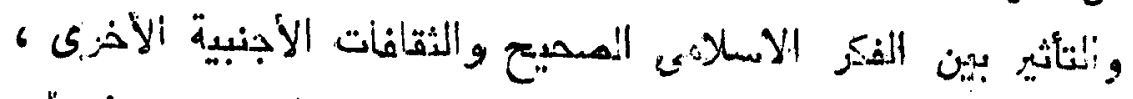

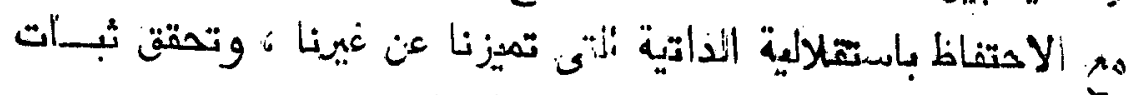

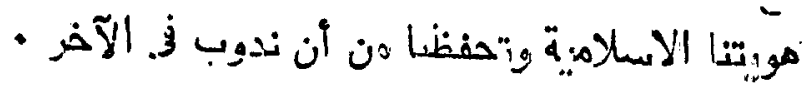

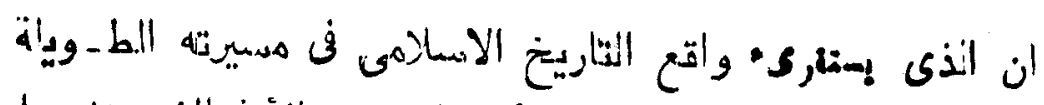

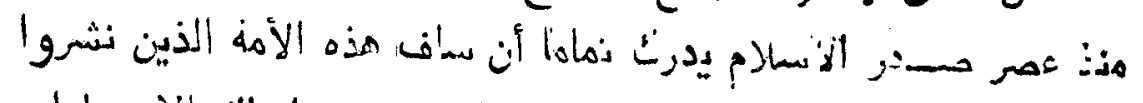

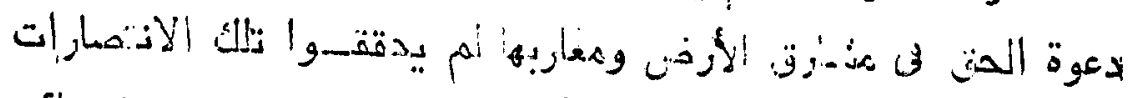

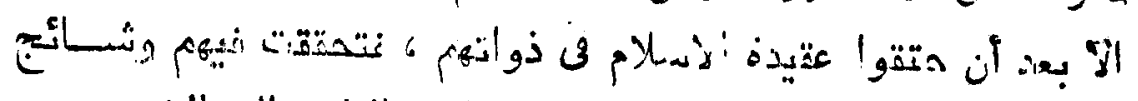

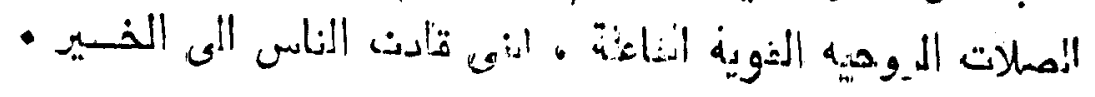

ولو أردنا أن نكمسف عن مؤشرات الصـدوة الاسلامية في عصرنا

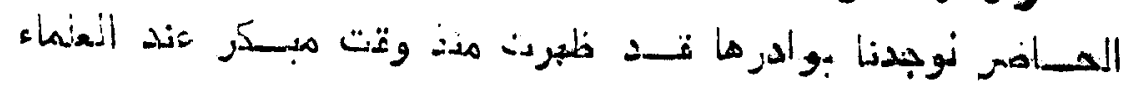

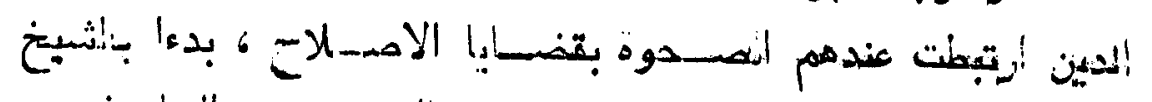

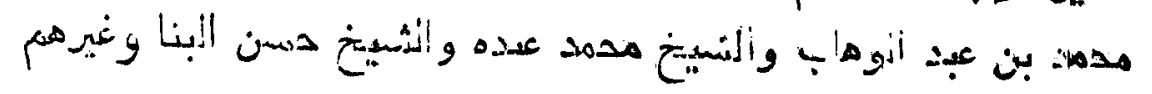

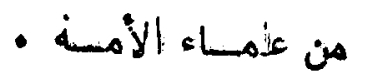

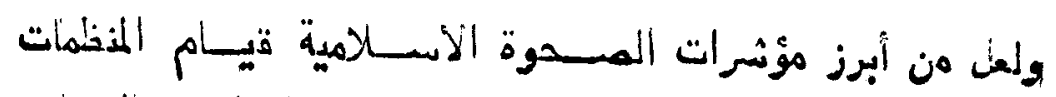

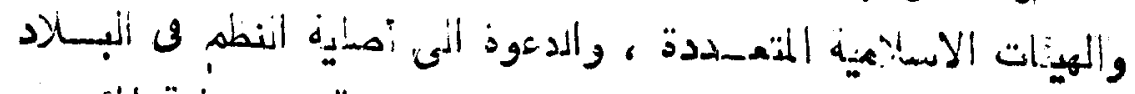

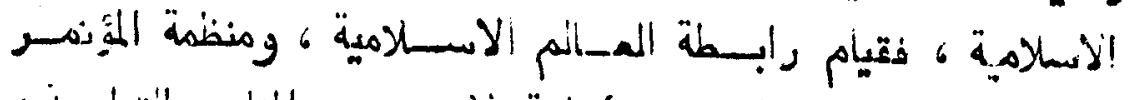

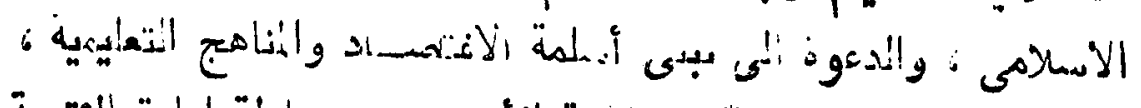

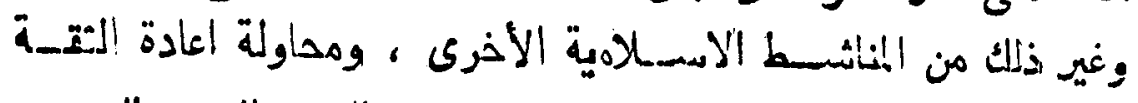

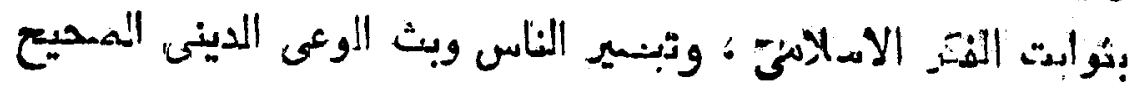




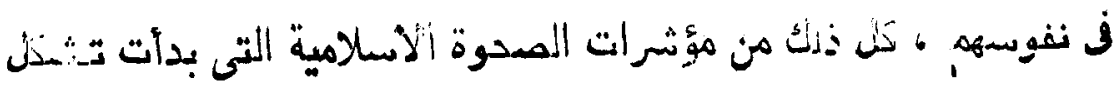

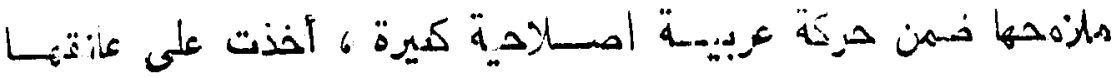

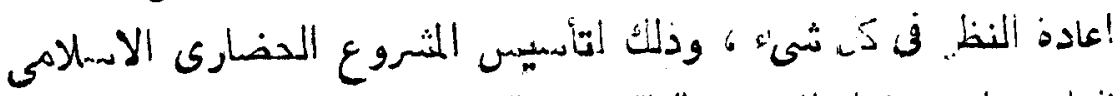

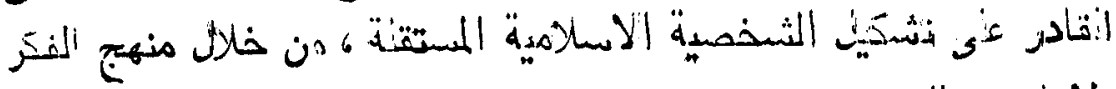

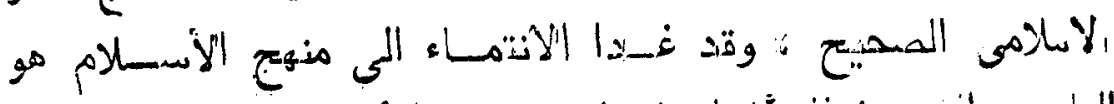

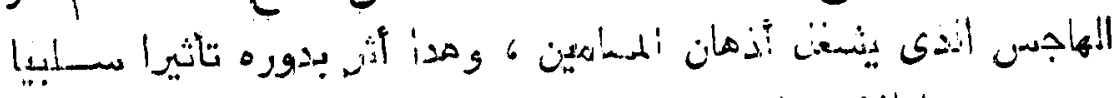

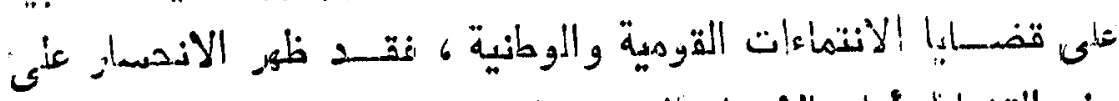

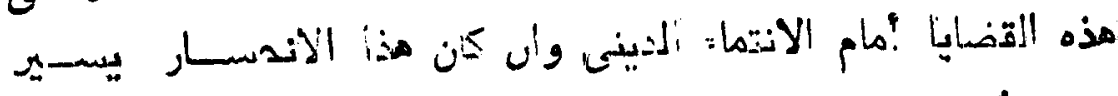

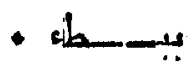

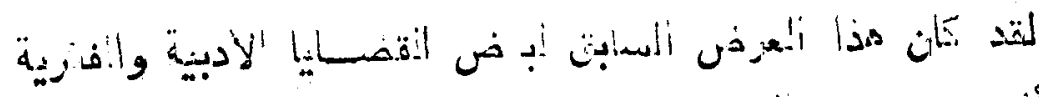

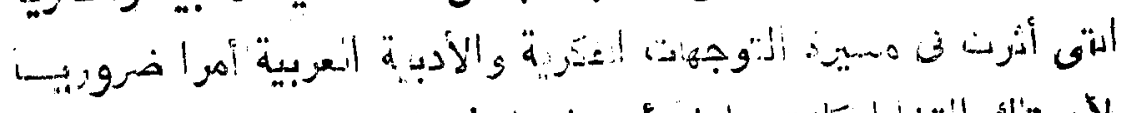

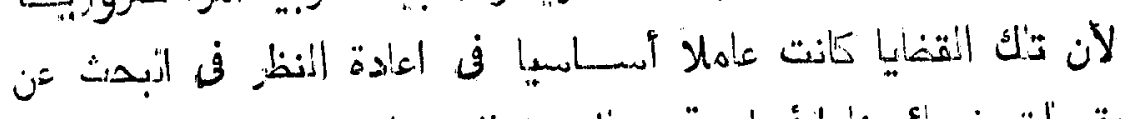

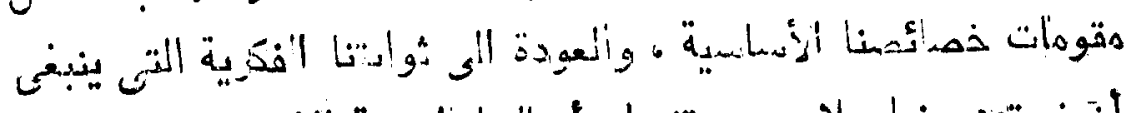

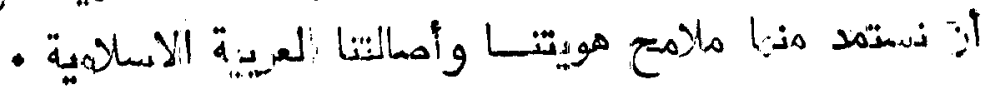

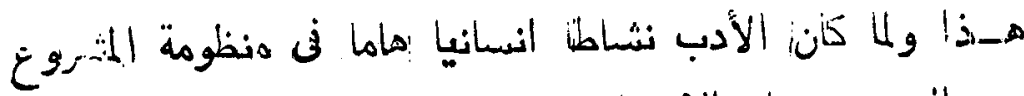

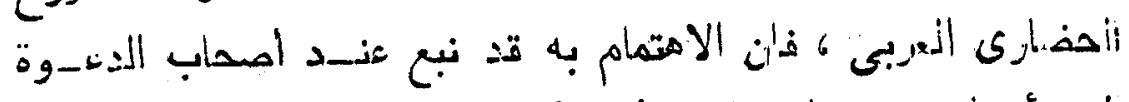

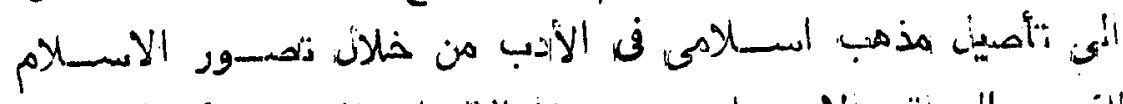

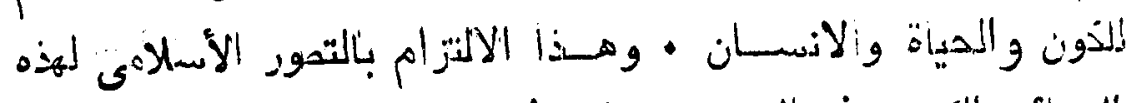

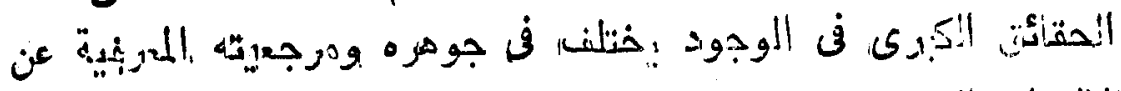

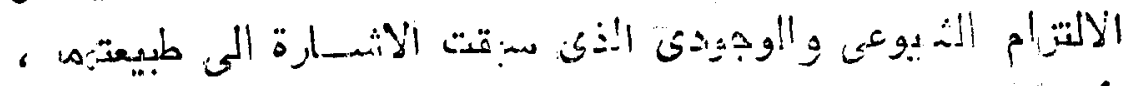

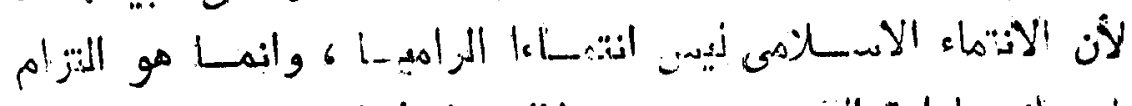

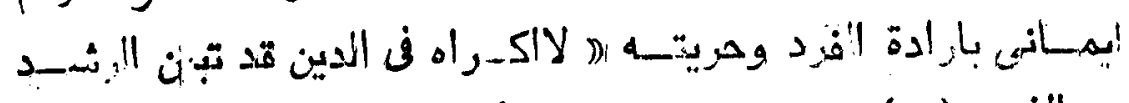

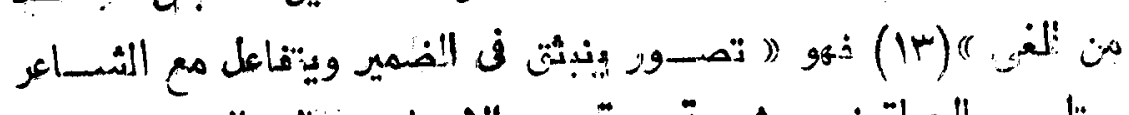

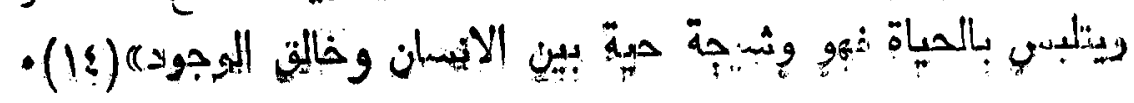




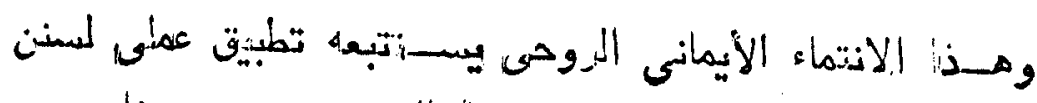

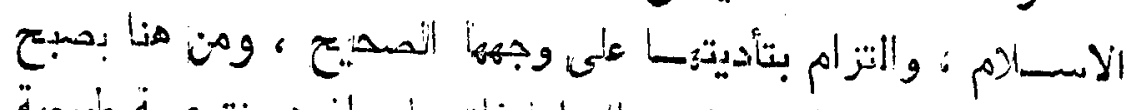

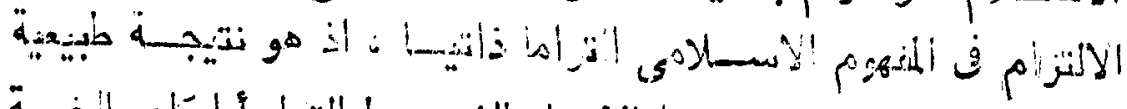

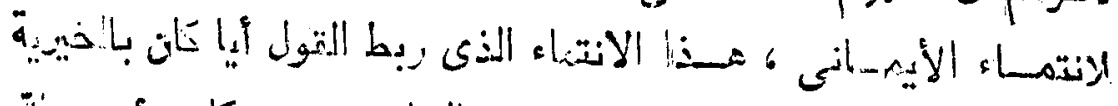

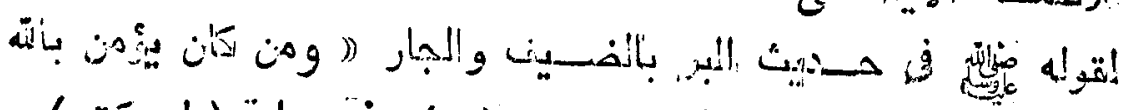

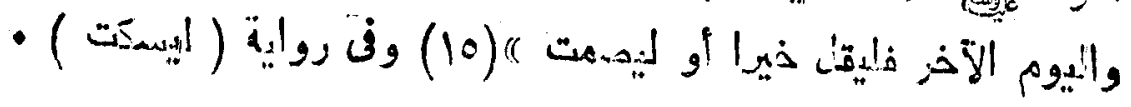

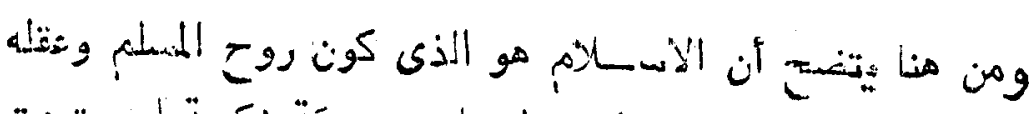

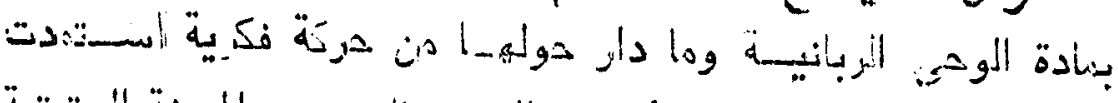

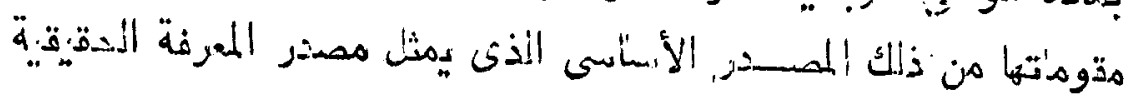

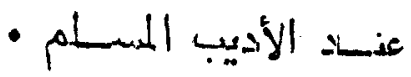

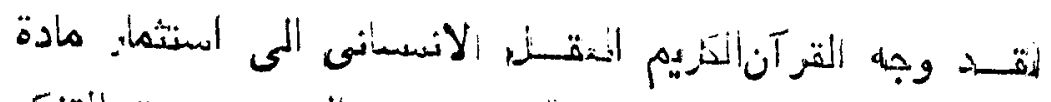

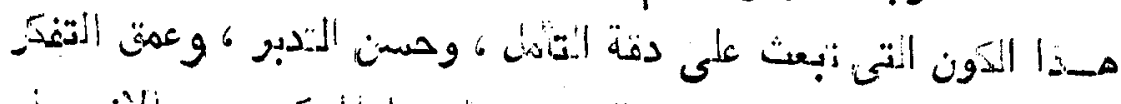

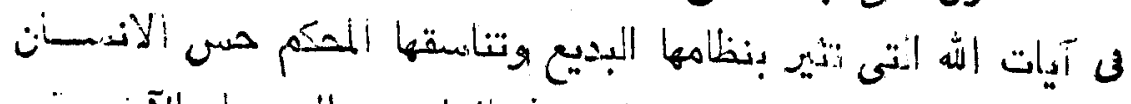

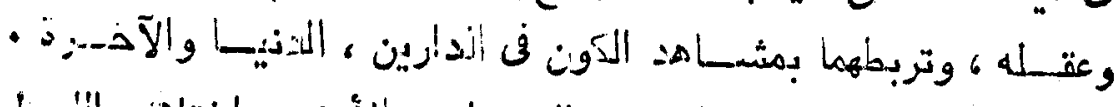

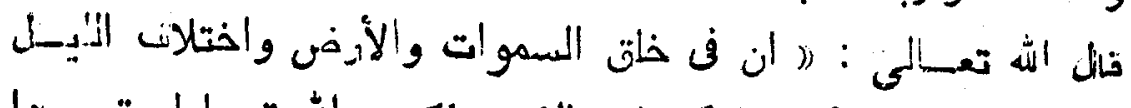

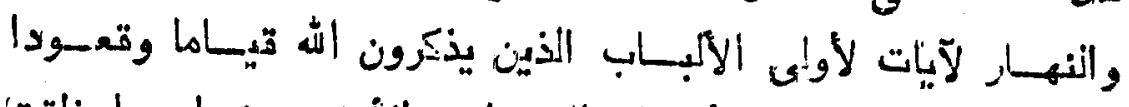

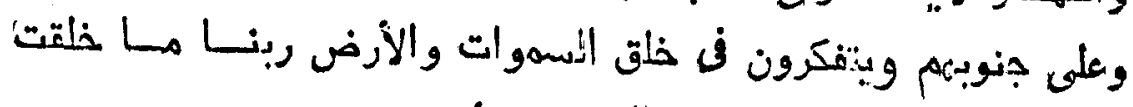

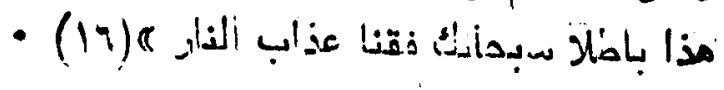

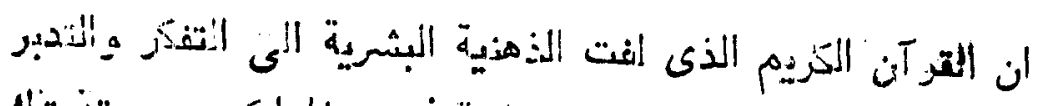

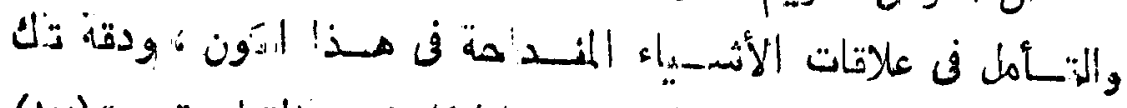

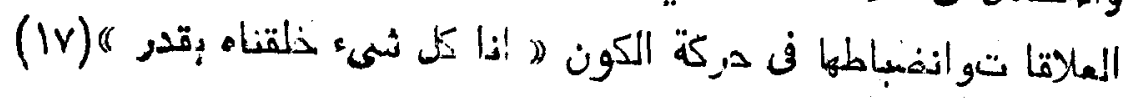

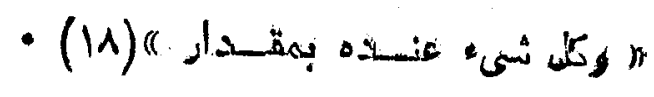




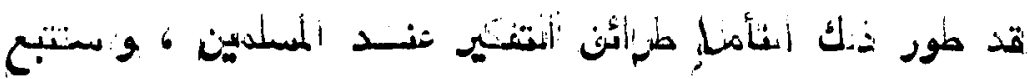

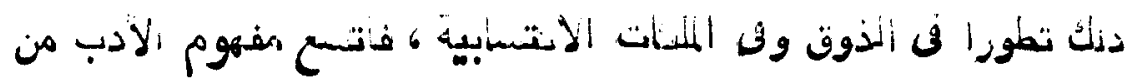

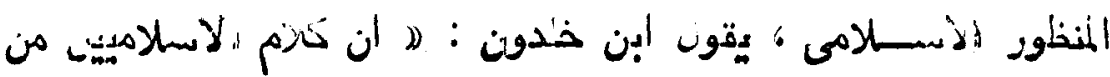

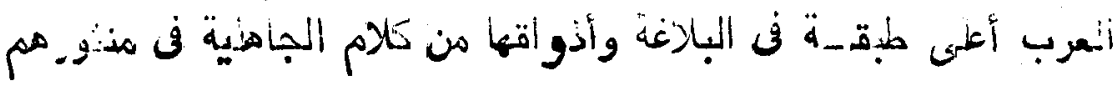

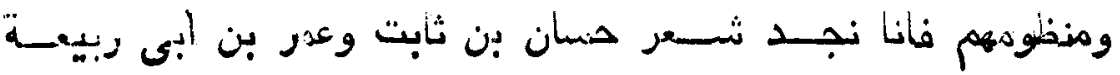

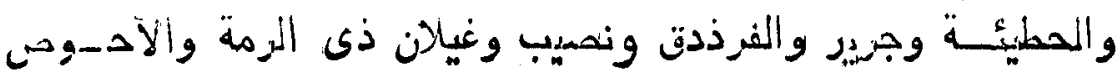

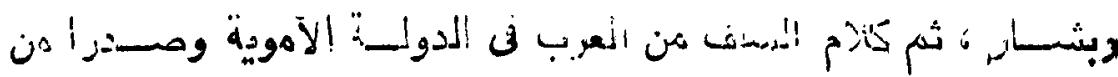

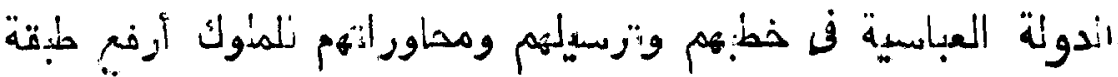

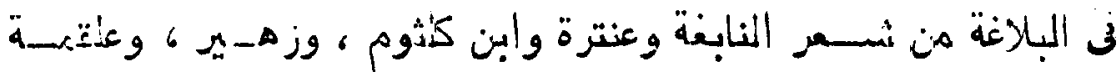

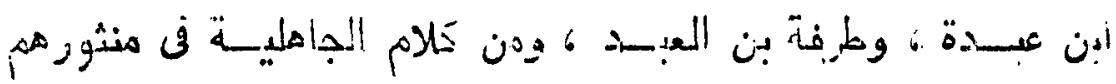

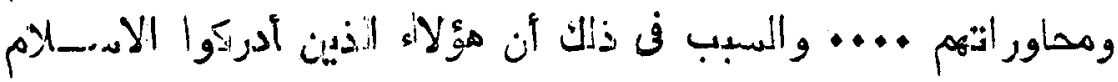

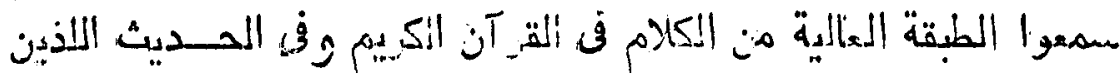

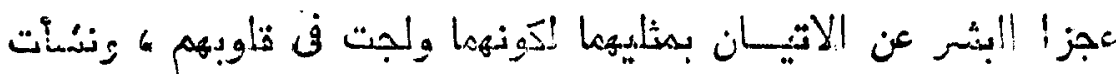

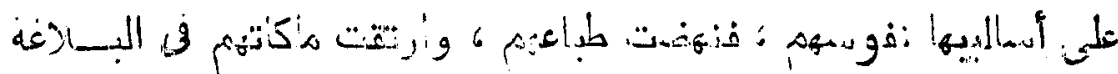

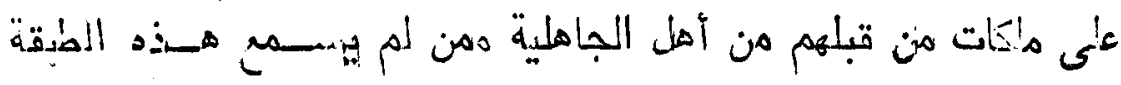

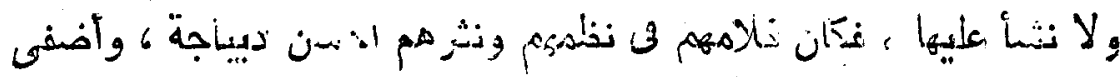

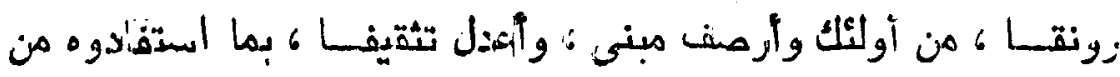

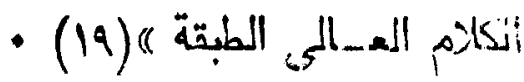

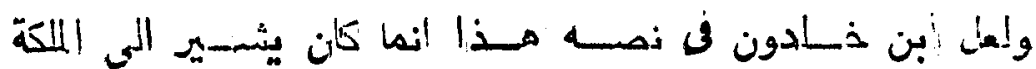

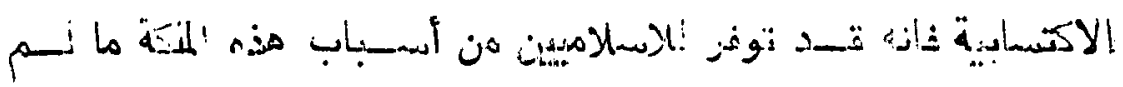

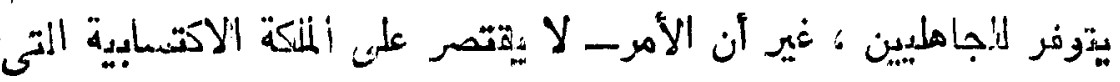

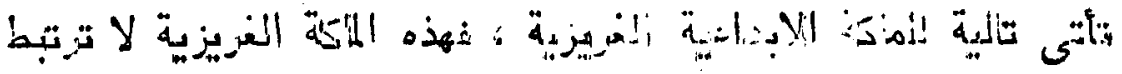

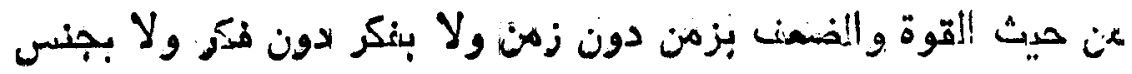
• 


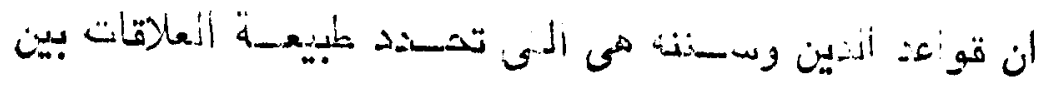

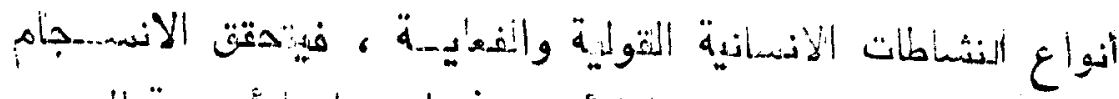

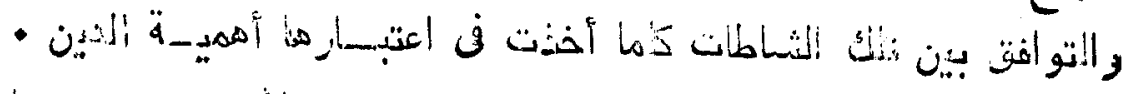

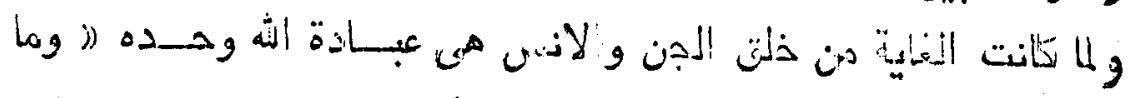

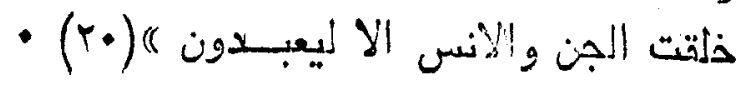

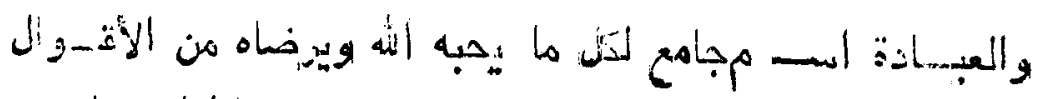

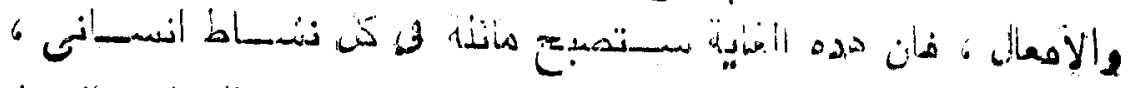

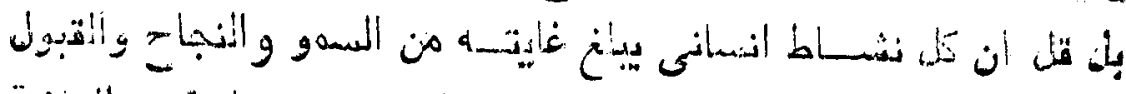

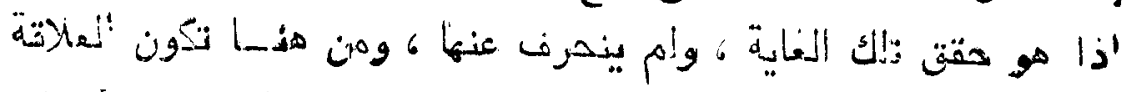

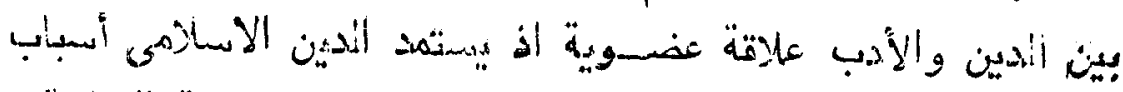

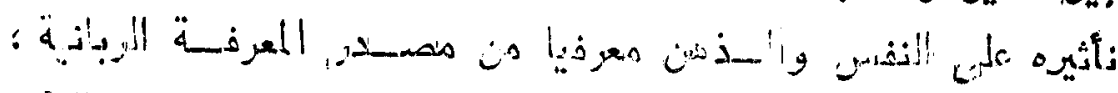

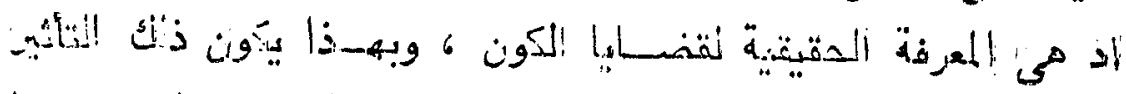

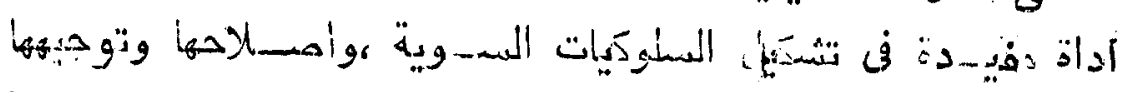

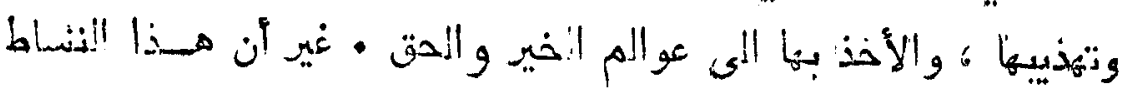

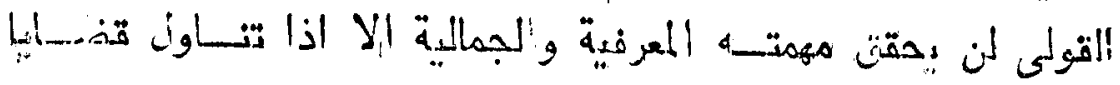

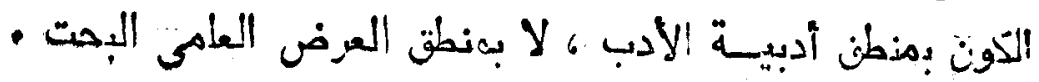

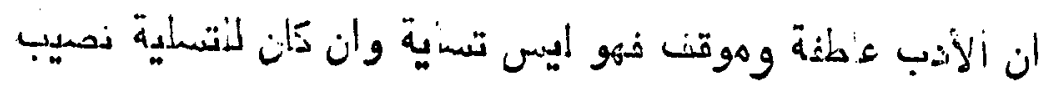

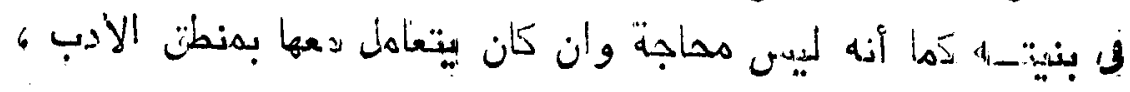

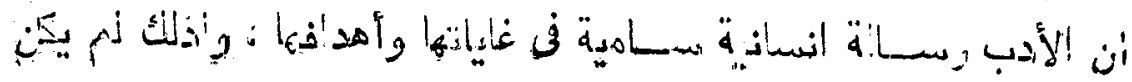

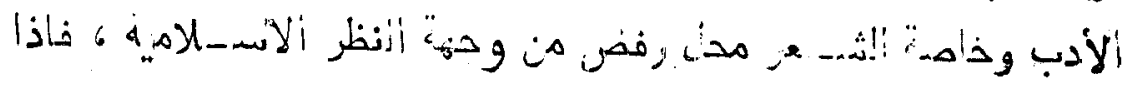

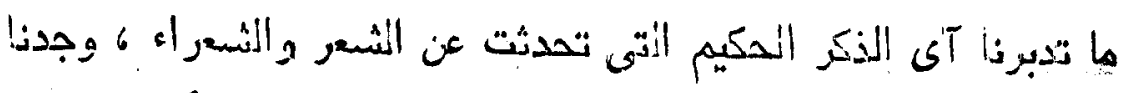

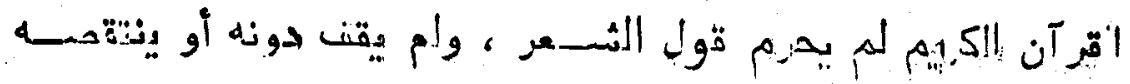

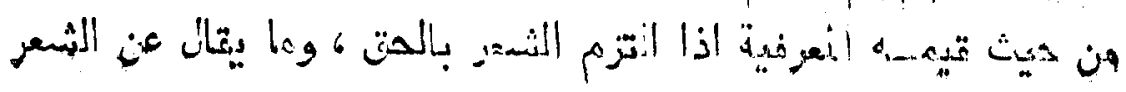




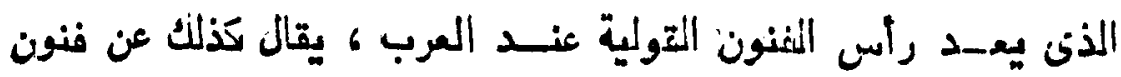

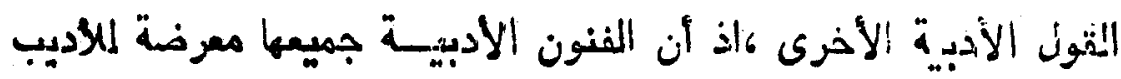

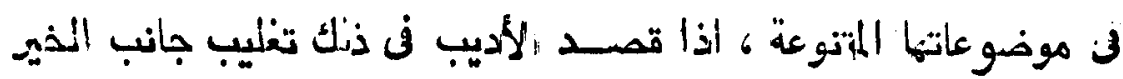

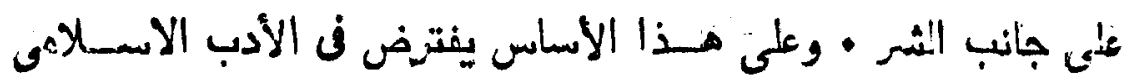

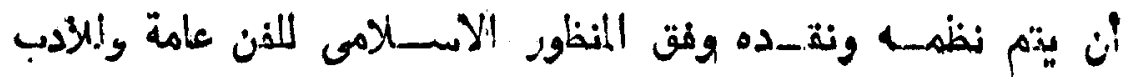

خامـة . نام

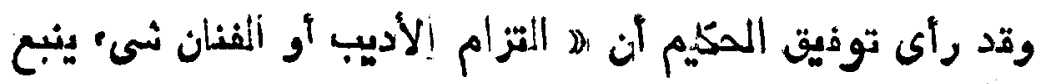

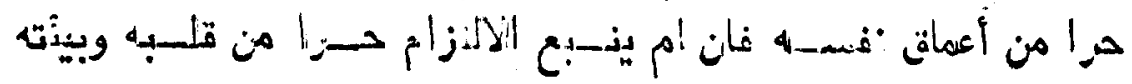

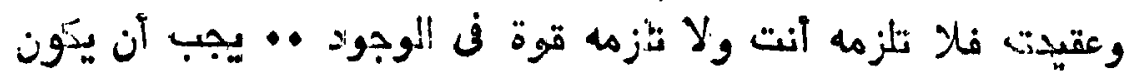

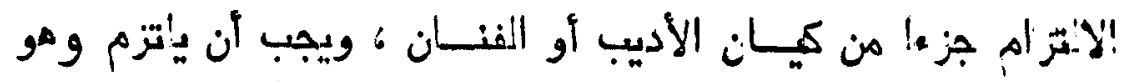

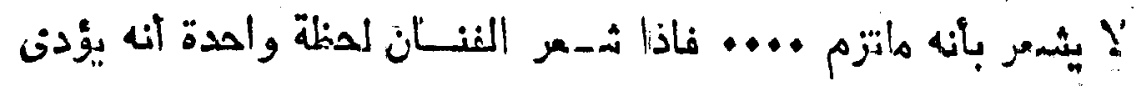

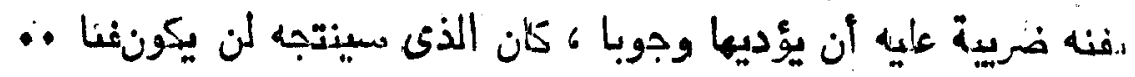

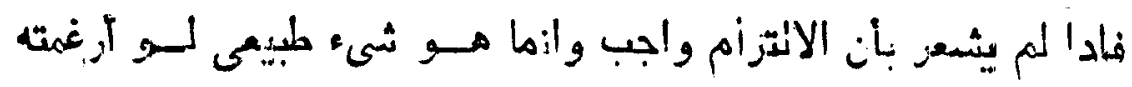

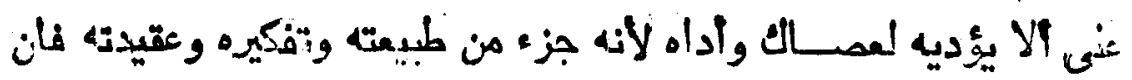

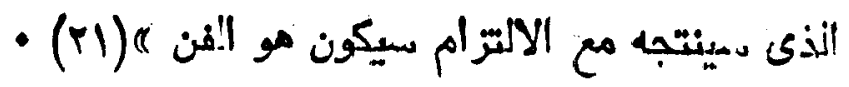

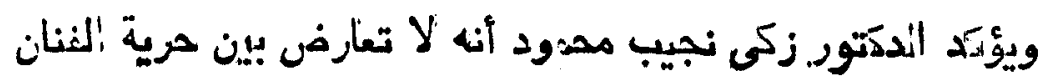

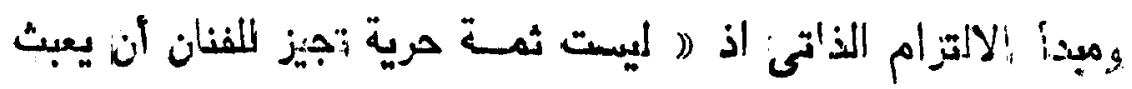

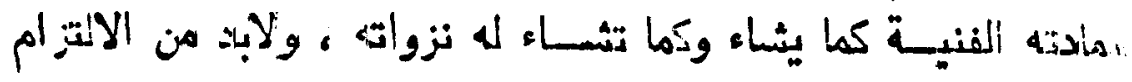

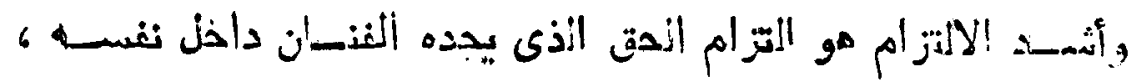

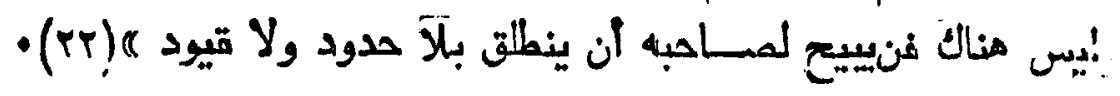

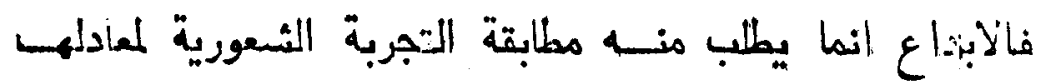

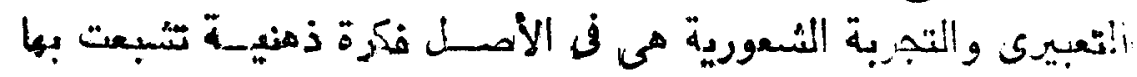

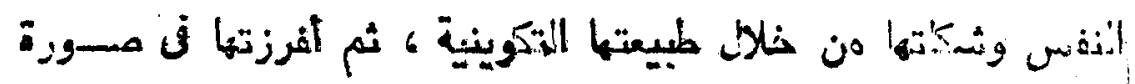
(j-e) 
تعبيرية مؤثرة كانت نك ألصسورة أو نغير مؤثرة ، والنفس هى بؤرة

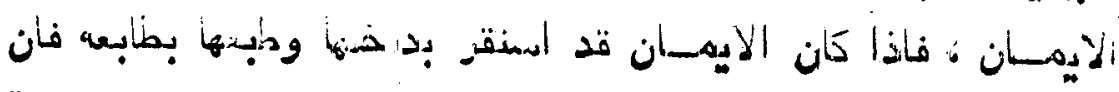

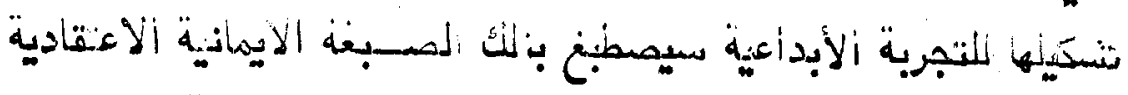

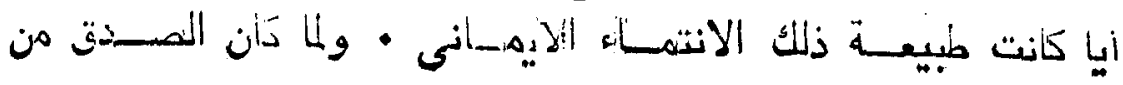

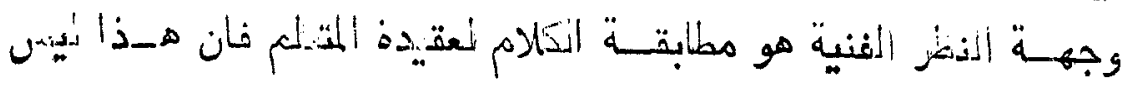

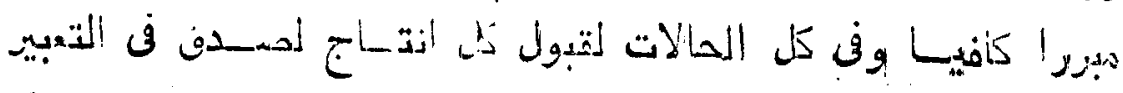

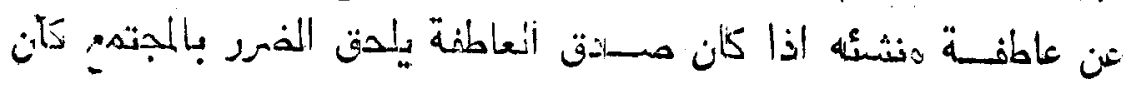

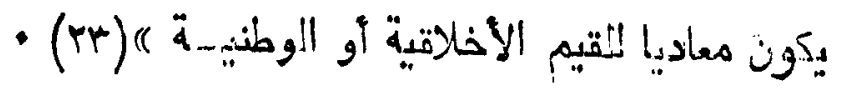

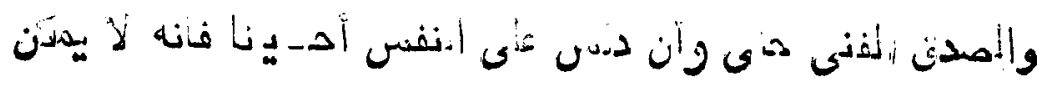

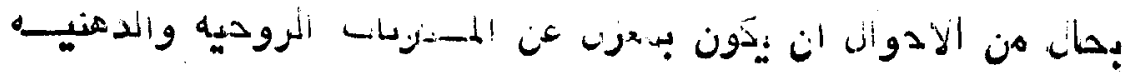

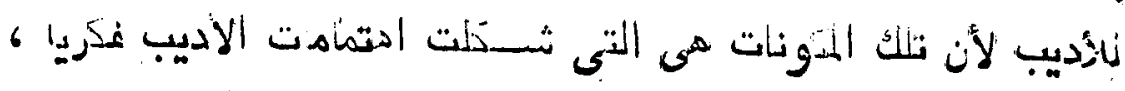

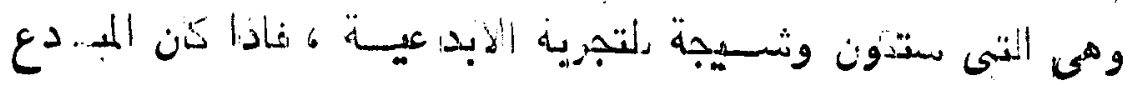

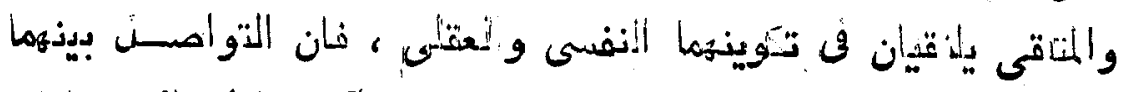

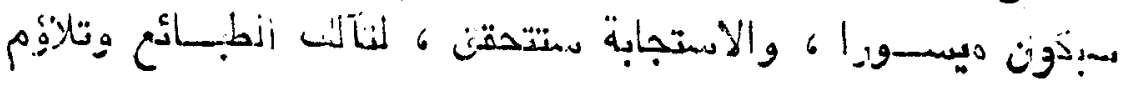

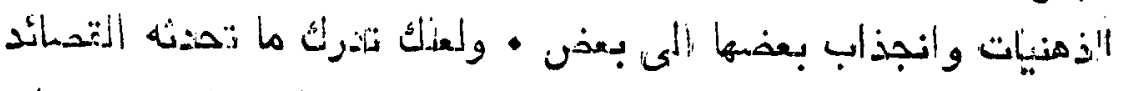

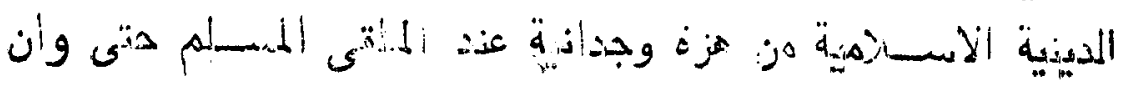

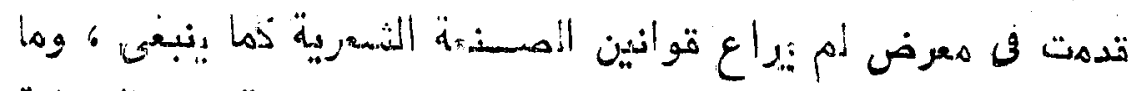

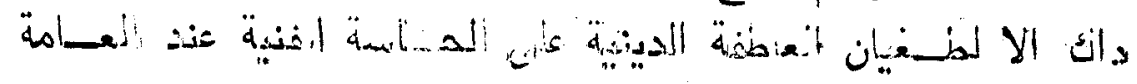

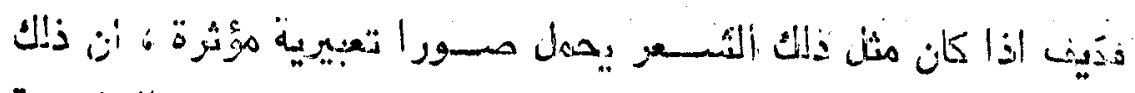

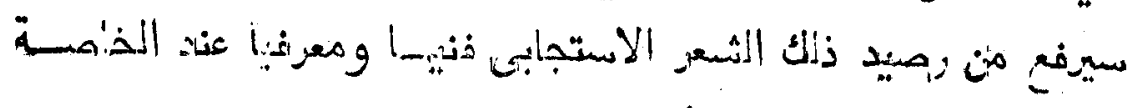

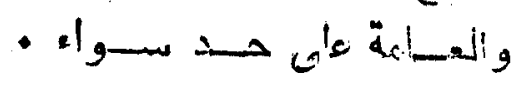

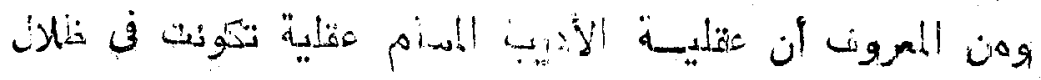

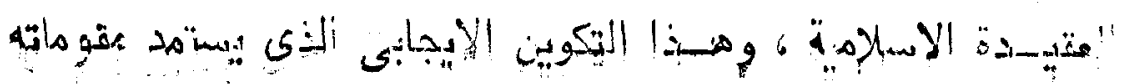




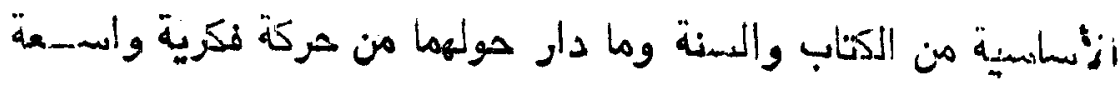

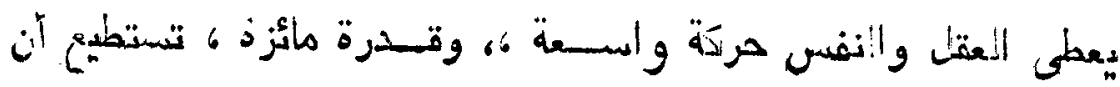

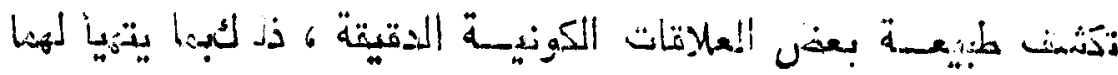

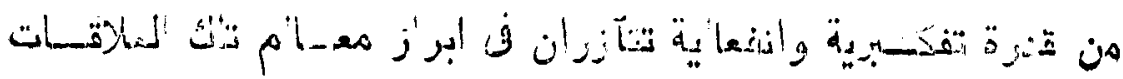

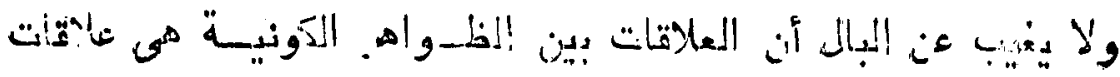

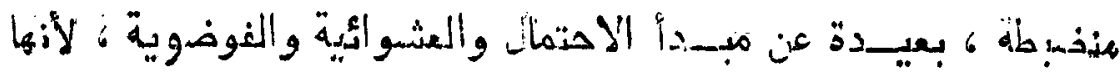

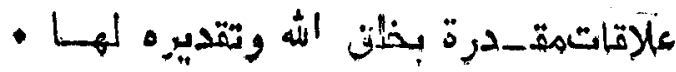

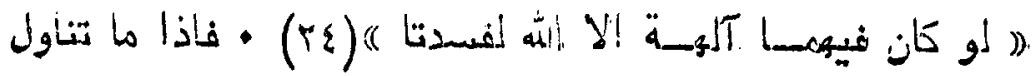

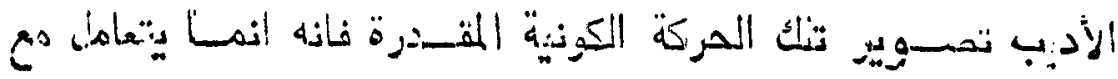

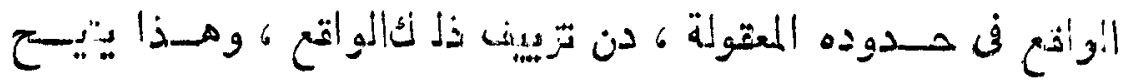

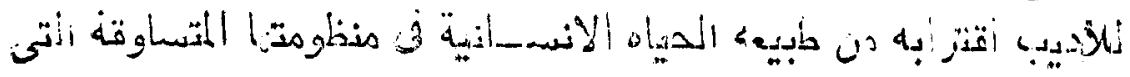

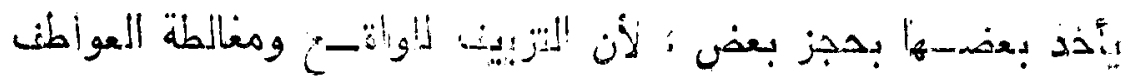

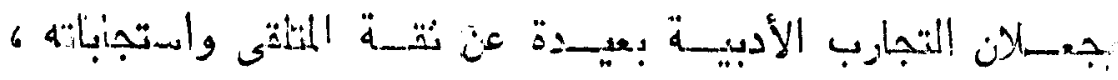

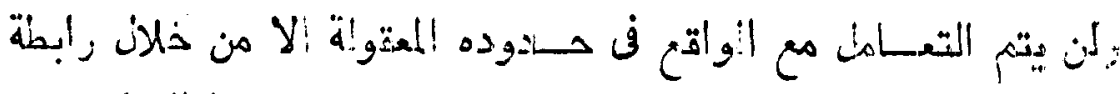

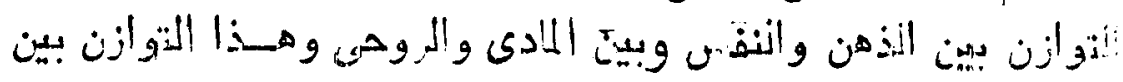

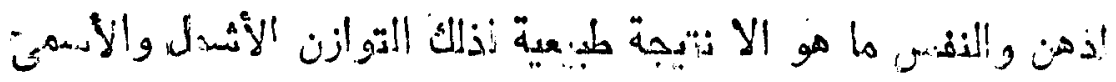

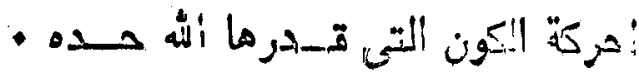

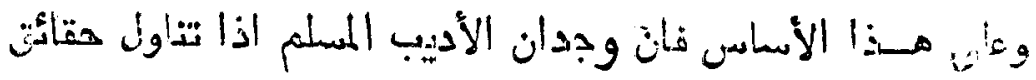

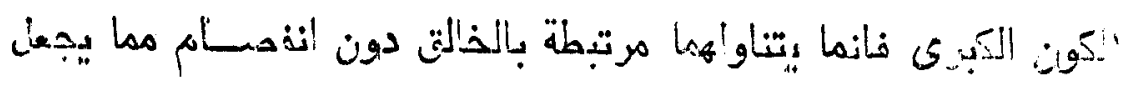

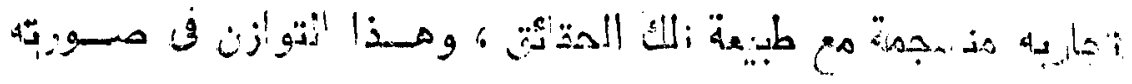

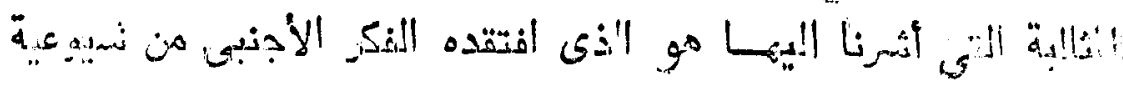

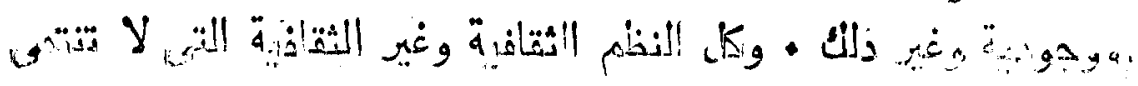

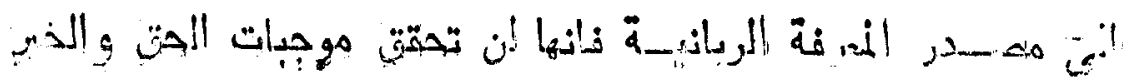

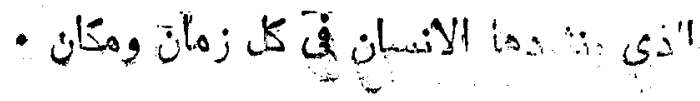


واذا كانت الفضيلة فى صورتها الربانية الثهولية هى النبع الذى الذي

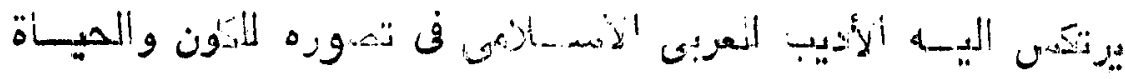

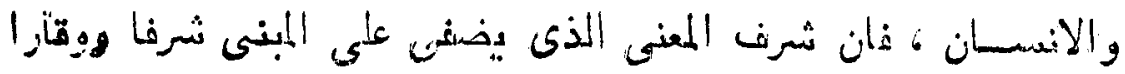

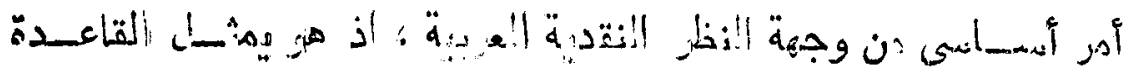

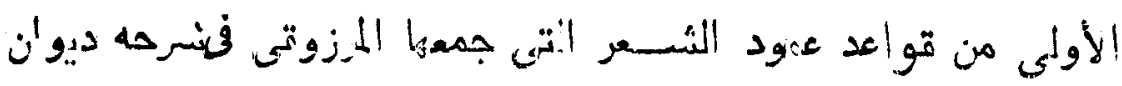

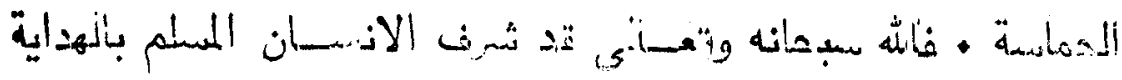

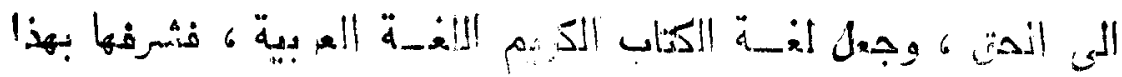

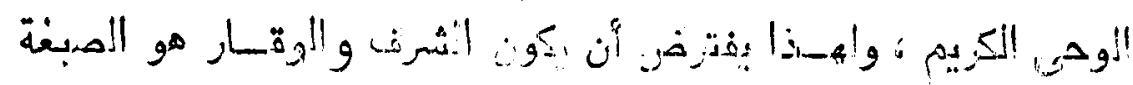

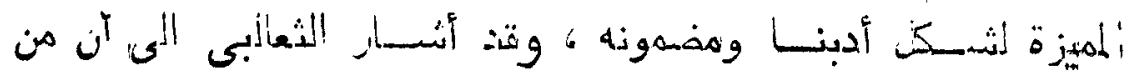

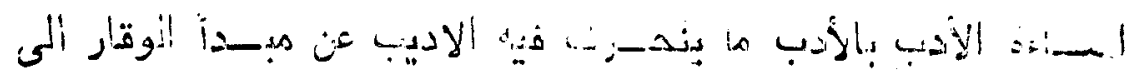

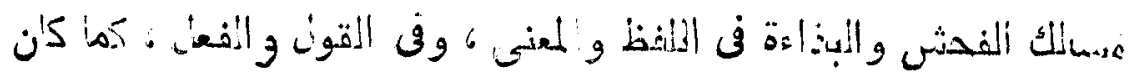

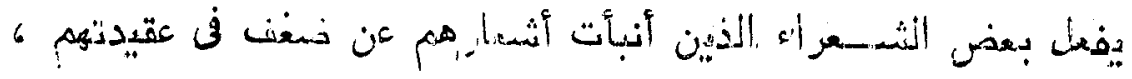

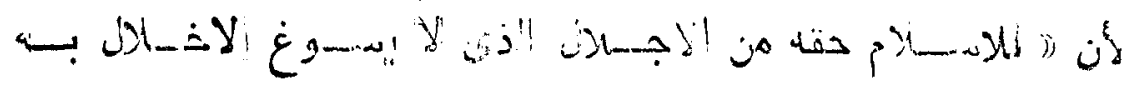

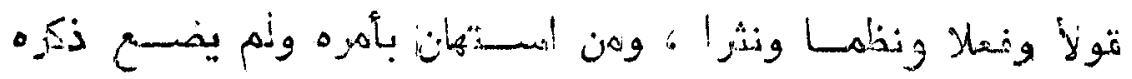

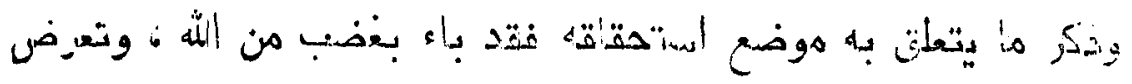

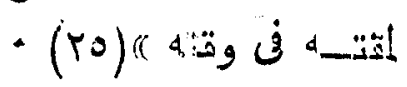

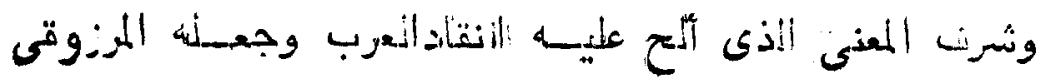

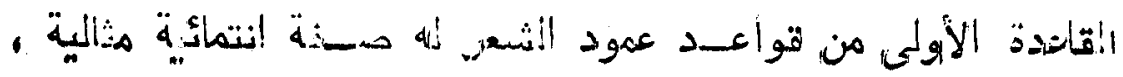

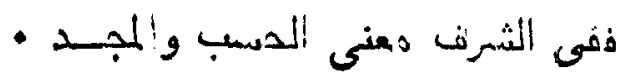

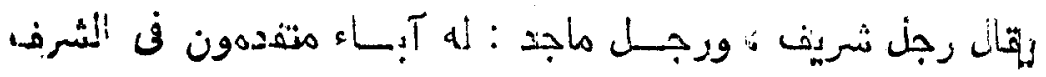

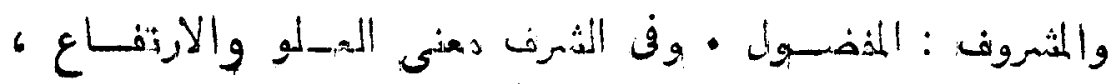

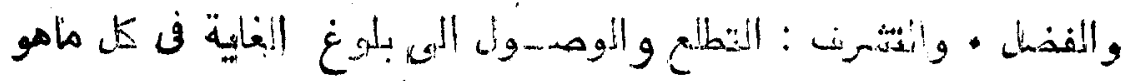

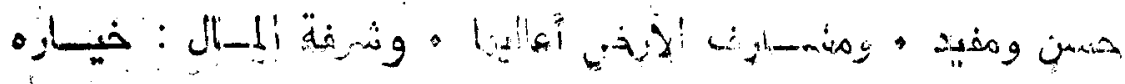




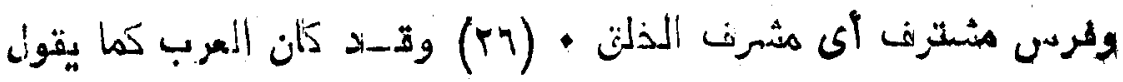

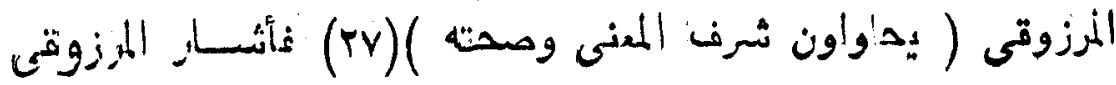

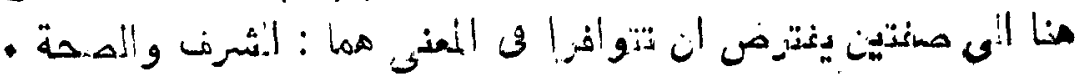

ولم يوذسح قصده من المعنى النشريت • فنل نمان يلمح المى المعنى

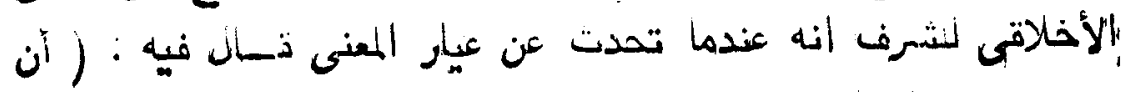

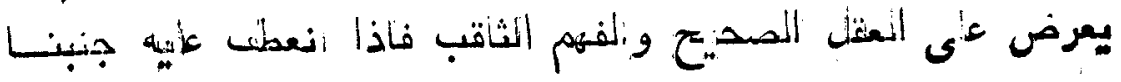

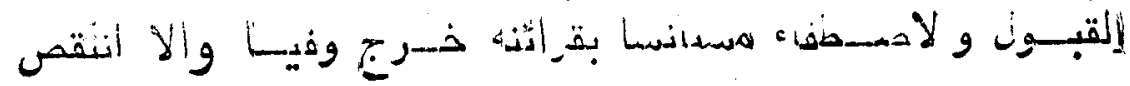

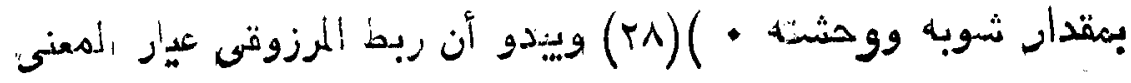

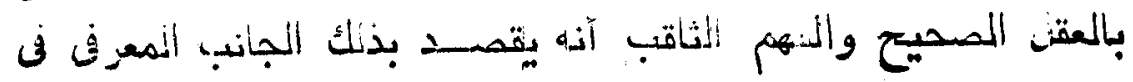

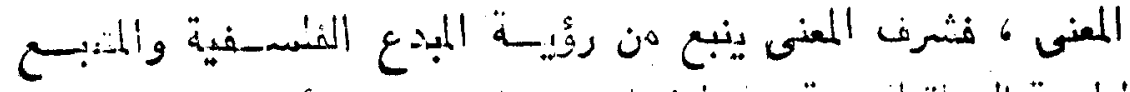

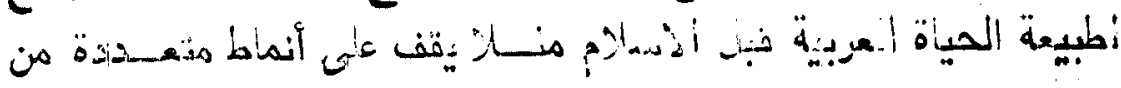

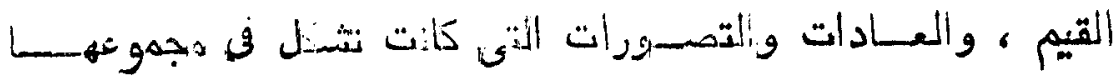

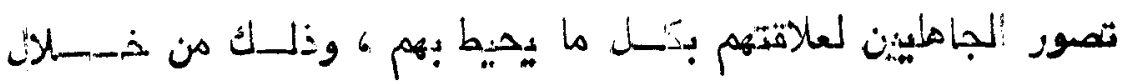

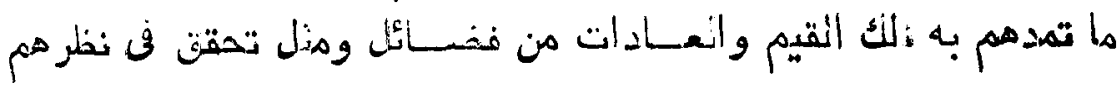

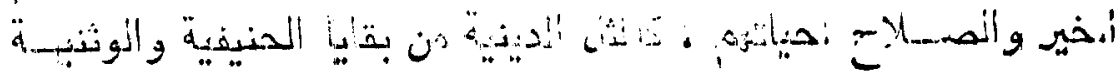

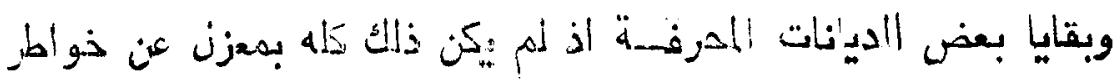

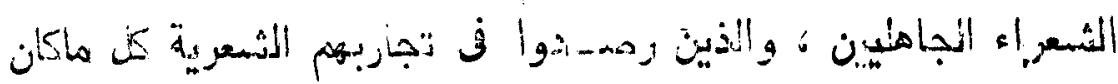

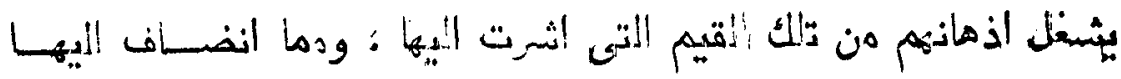

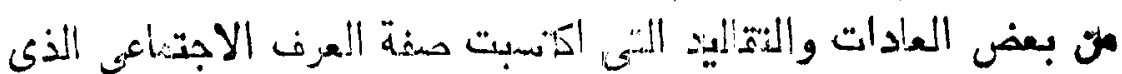

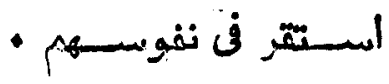

وقد غددت تلك النعات من الفضائل ، ومن مجموعة المسوكيات

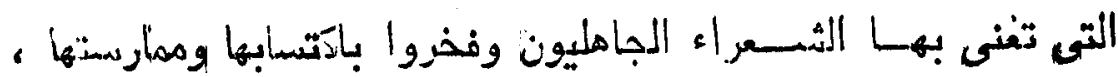

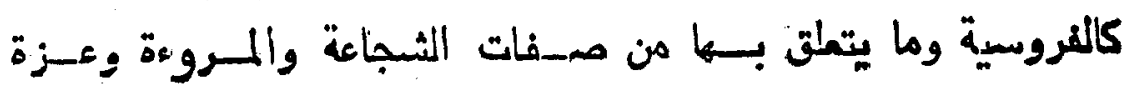




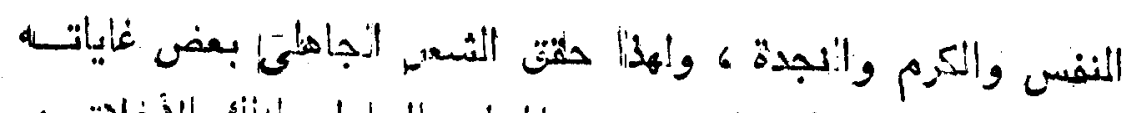

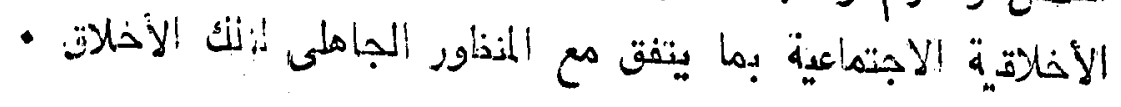

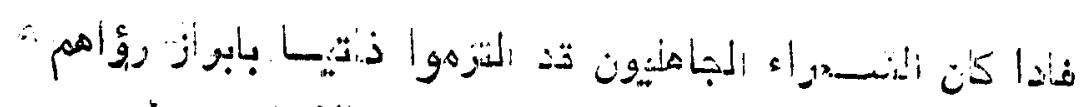

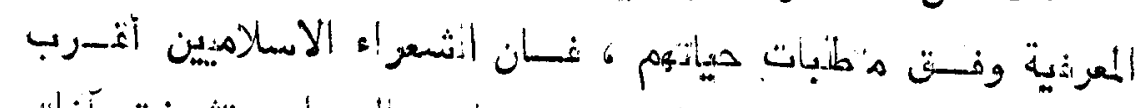

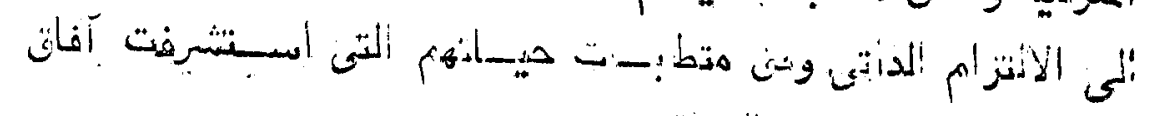

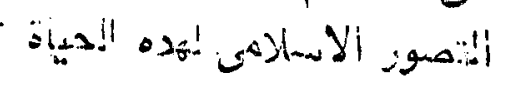

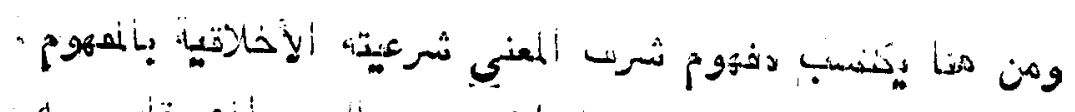

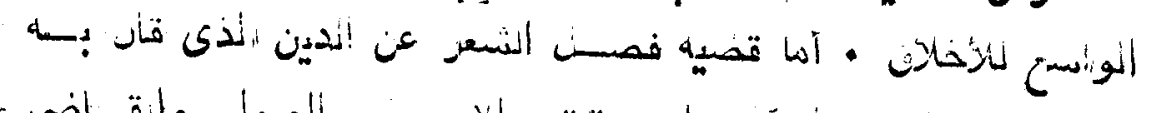

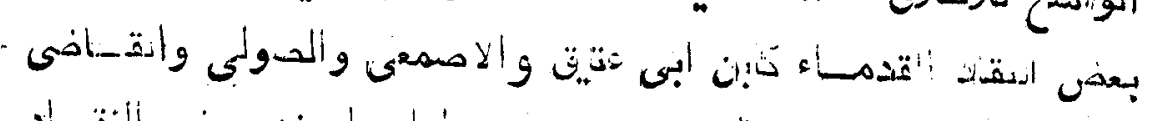

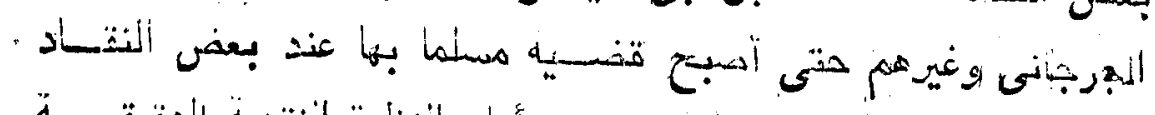

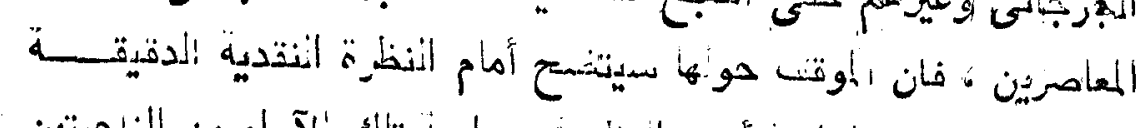

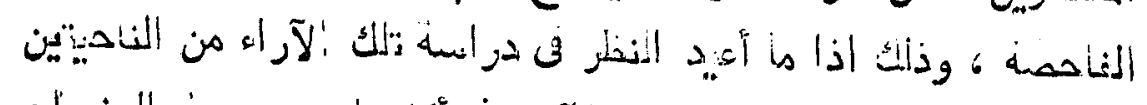

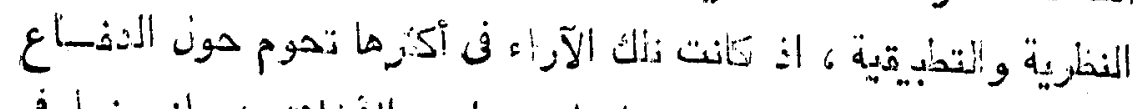

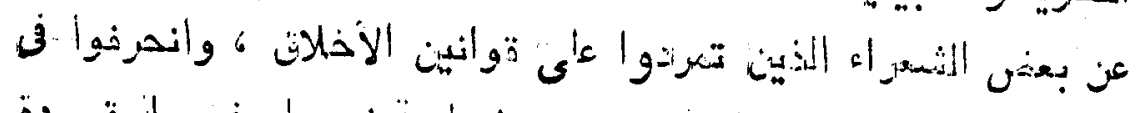

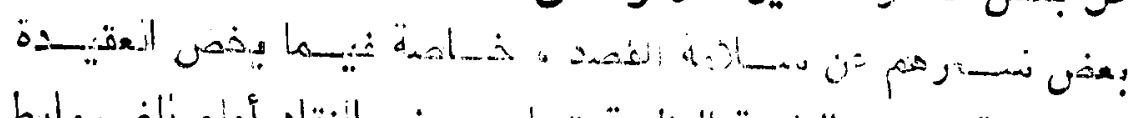

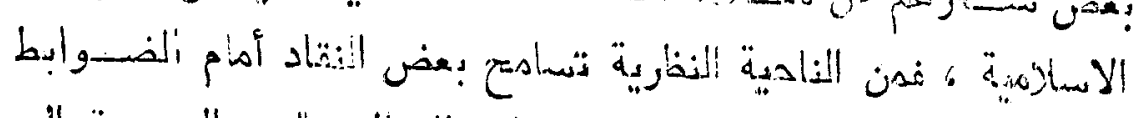

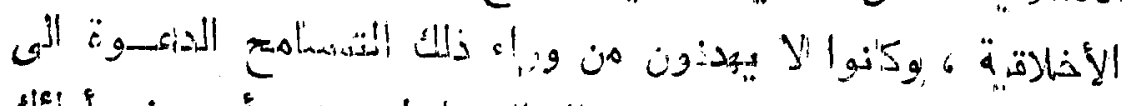

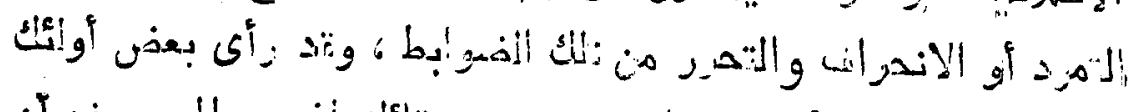

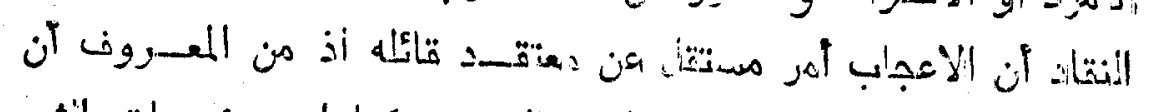

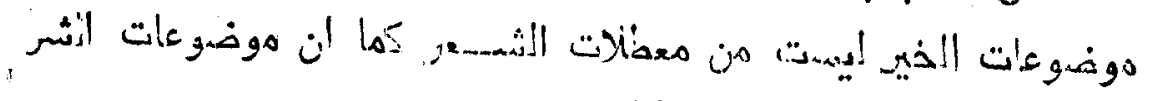

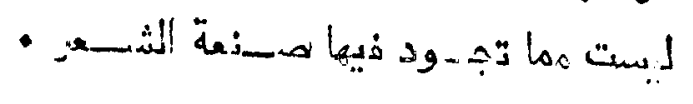

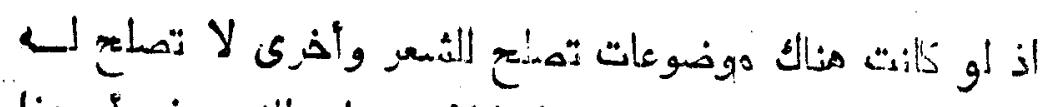

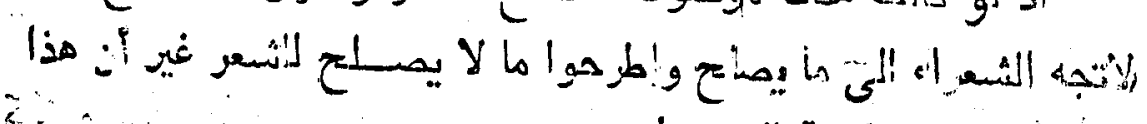

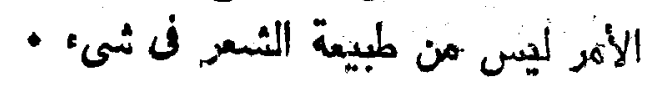




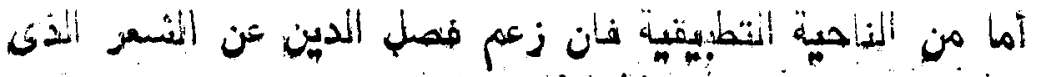

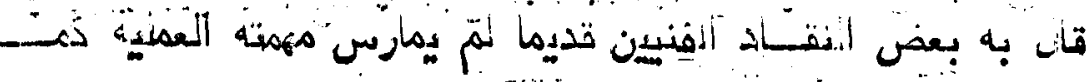

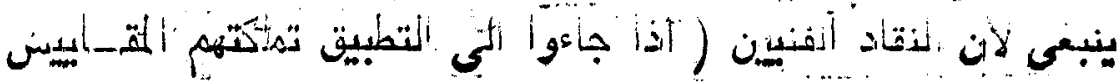

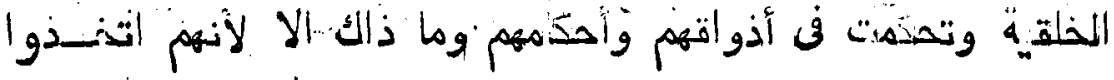

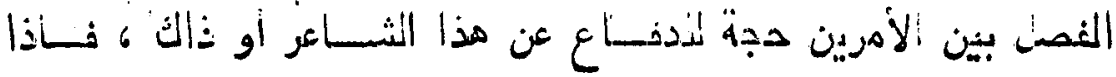

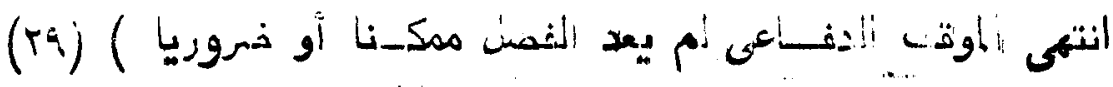

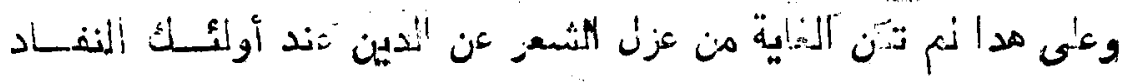

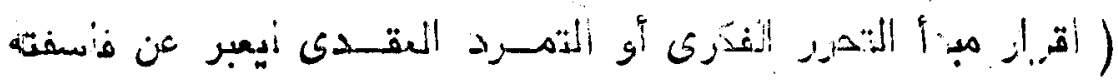

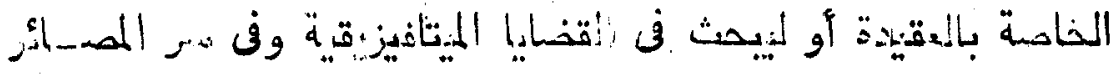

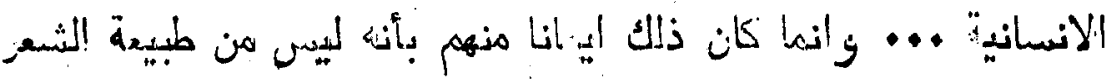

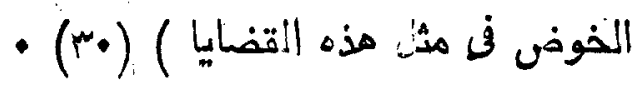

ونمن نتقف مع الكنتور محمد غنيمى هذل في أن النغاية من فصل

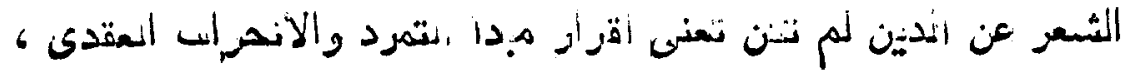

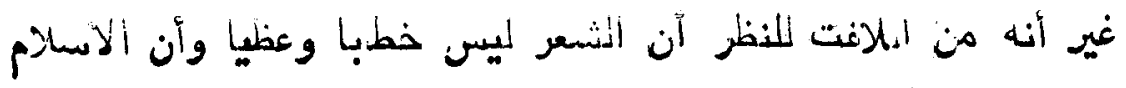

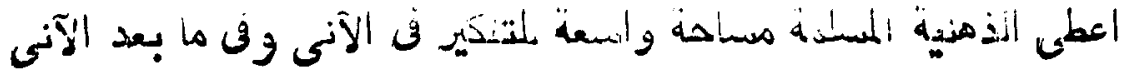

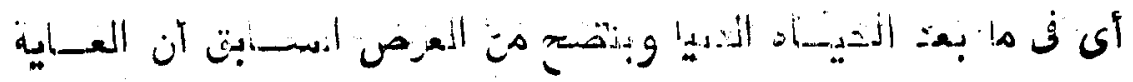

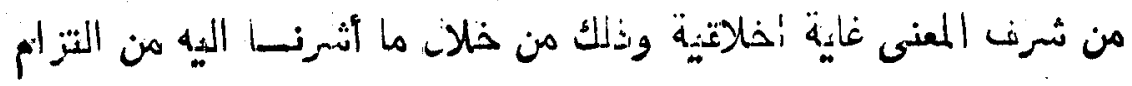

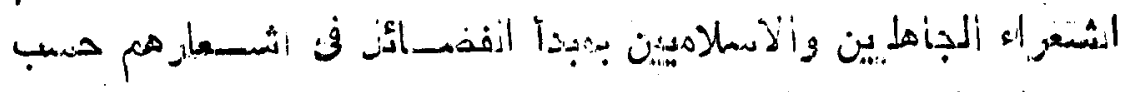

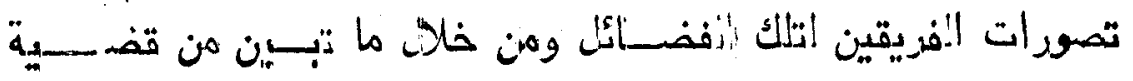

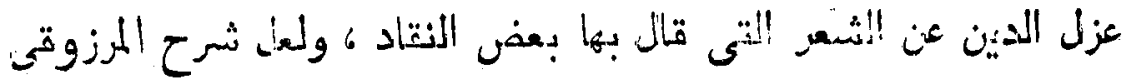

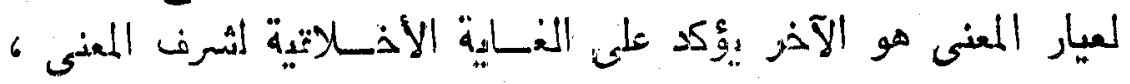

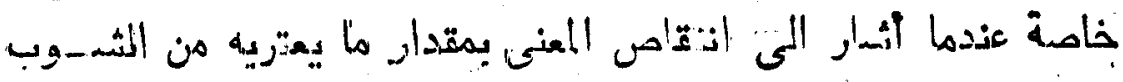

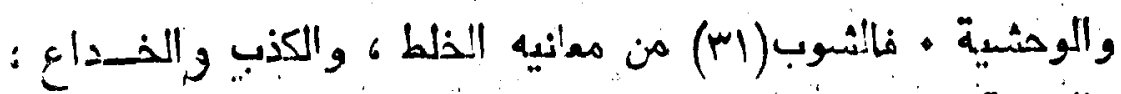

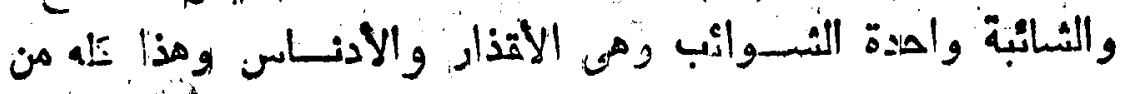




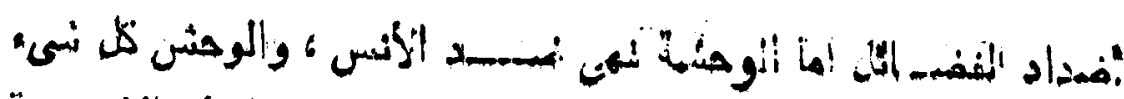

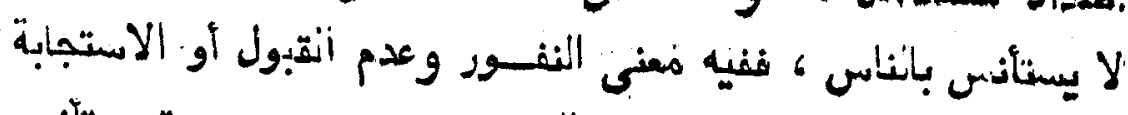

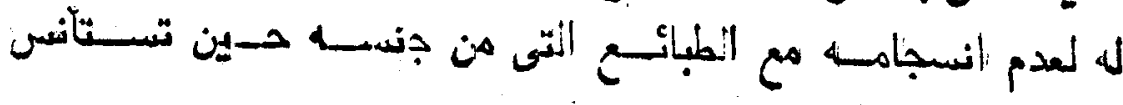

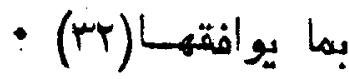

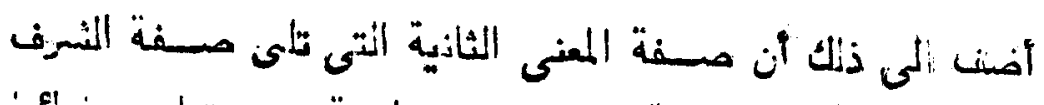

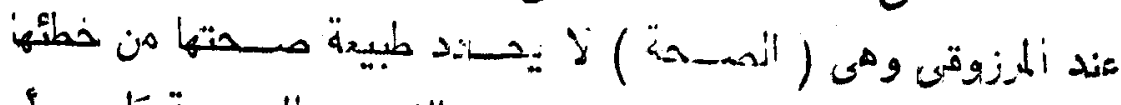

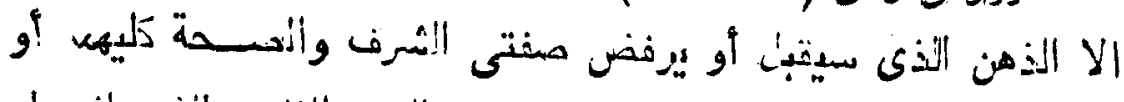

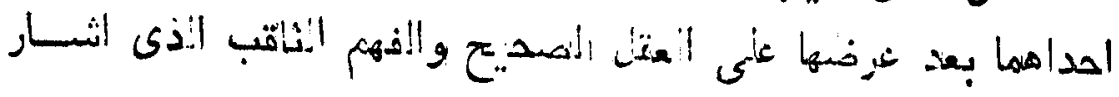

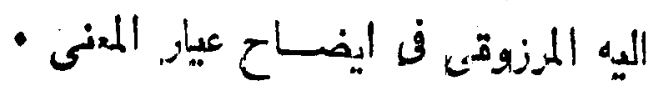

بعد مذا التوضيتح لمفهوم شرف المنىى هن تطلبه في المسـنمة

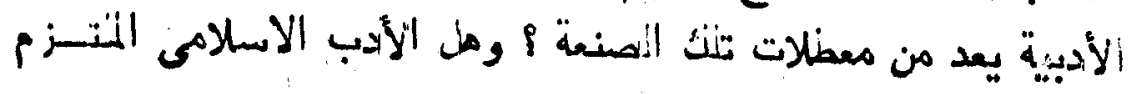

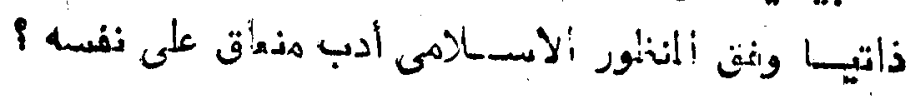

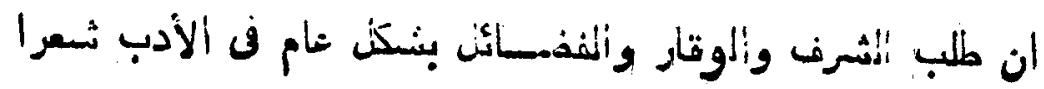

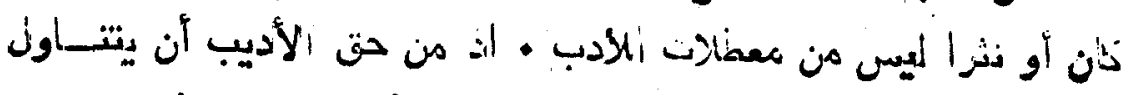

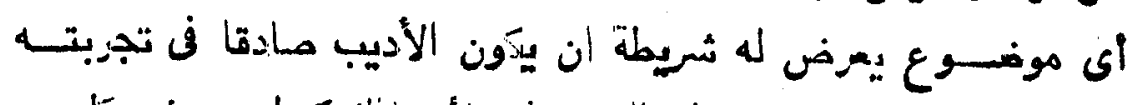

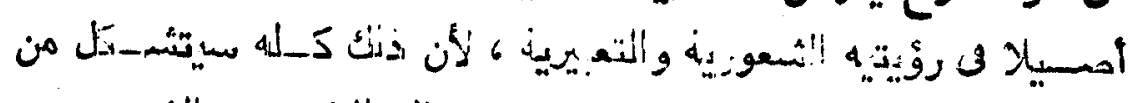

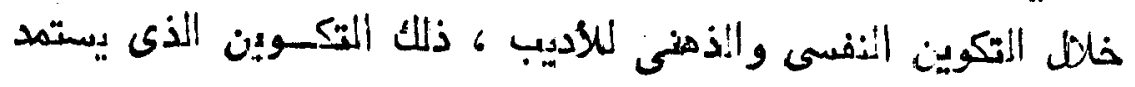

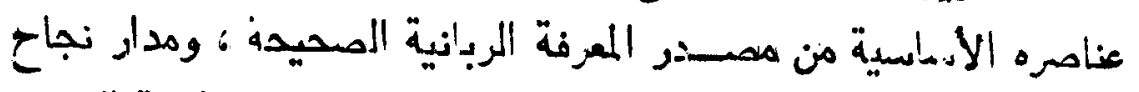

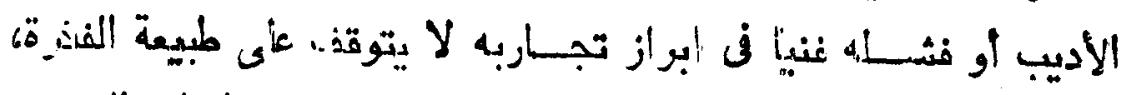

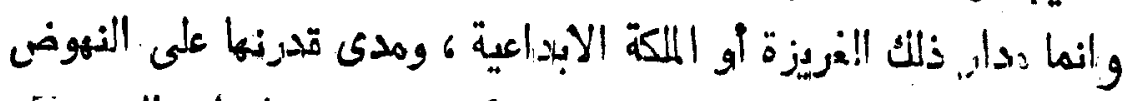

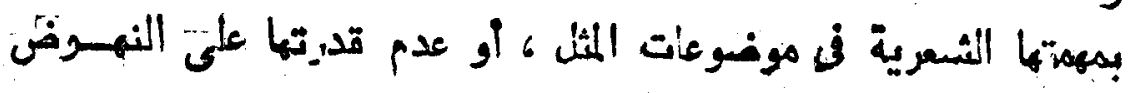

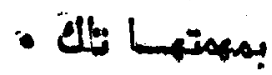




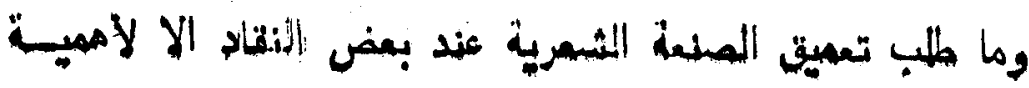

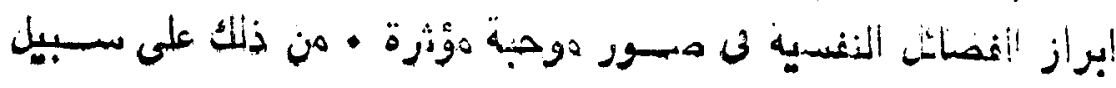

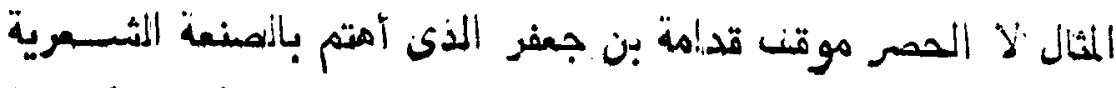

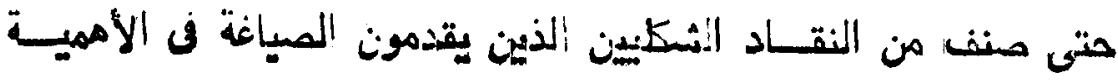

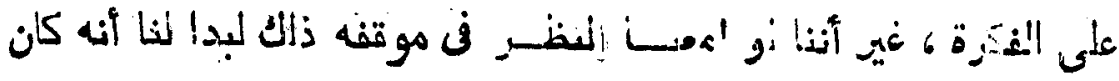

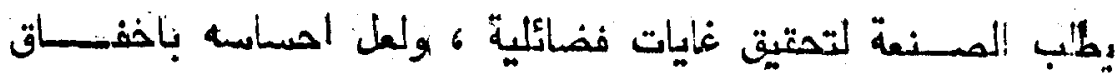

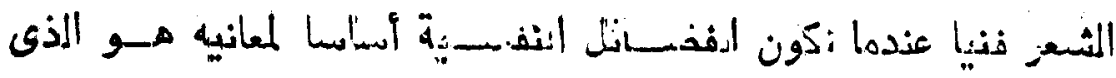

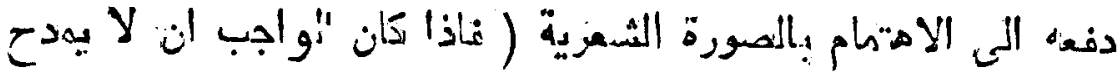

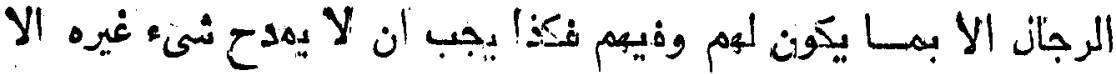

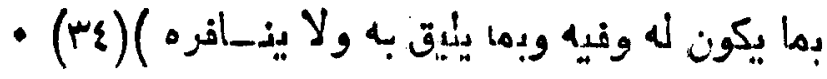

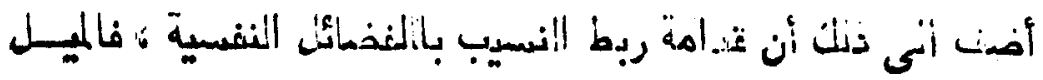

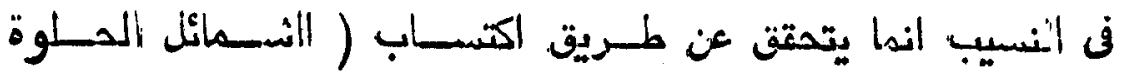

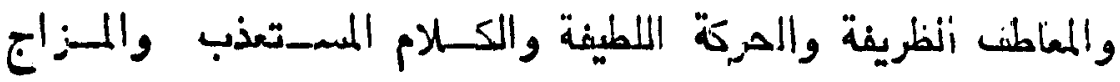

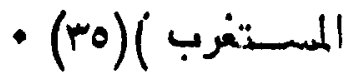

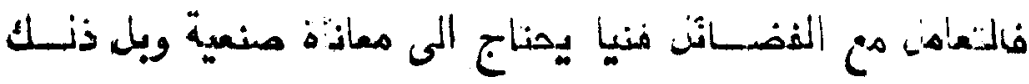

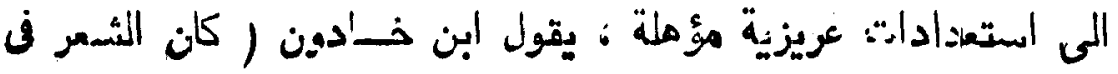

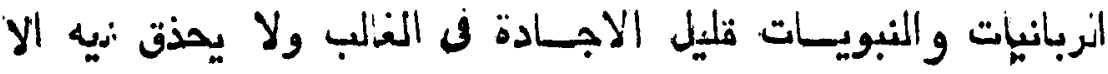

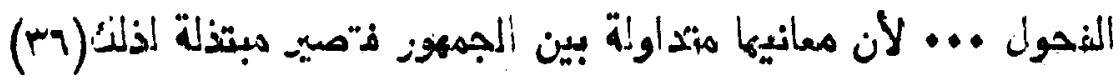

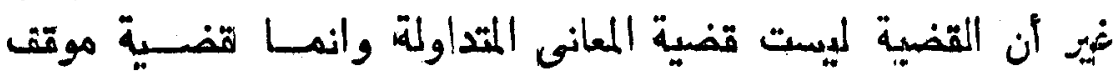

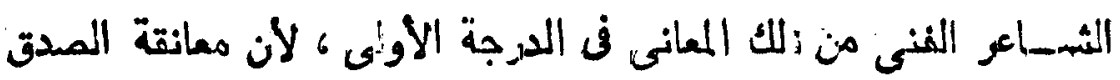

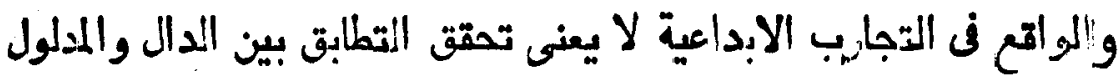

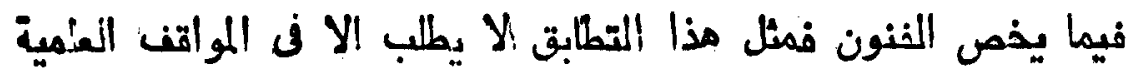

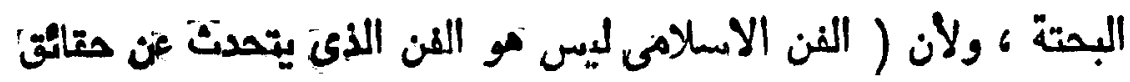




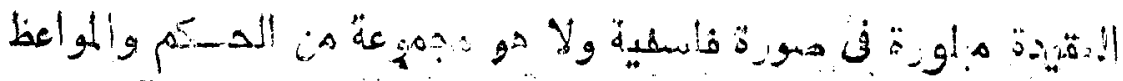

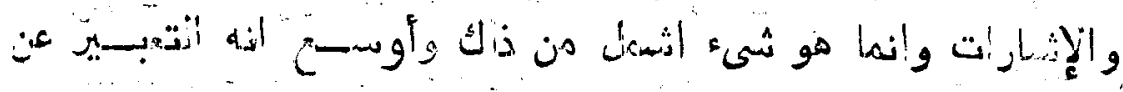

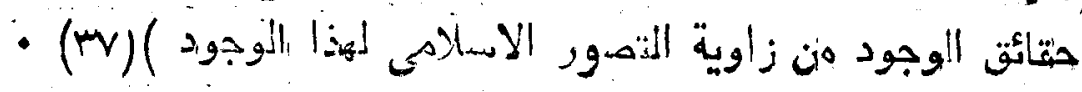

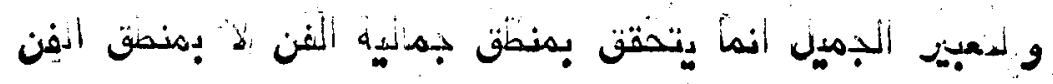

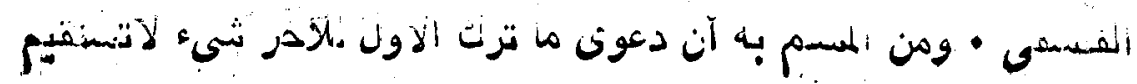

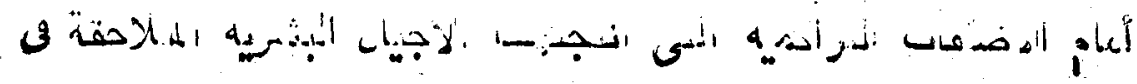

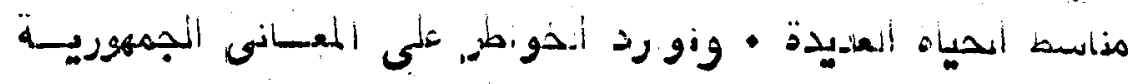

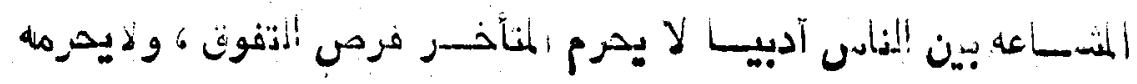

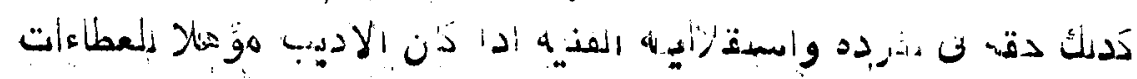

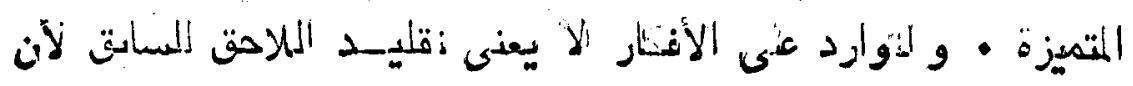

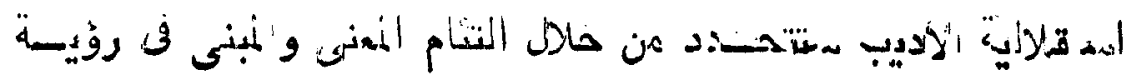

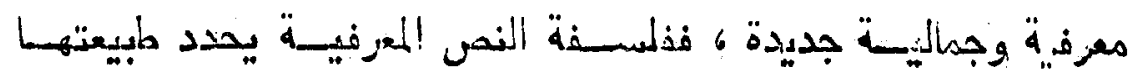

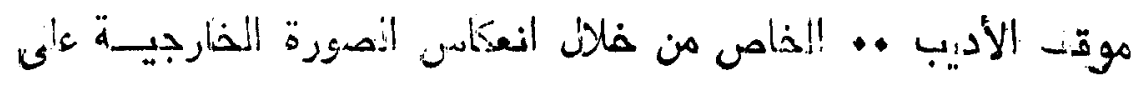

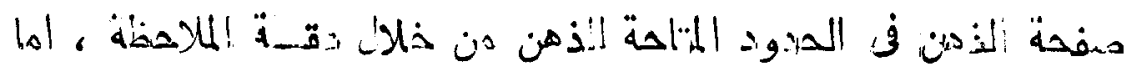

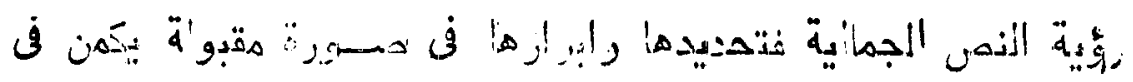

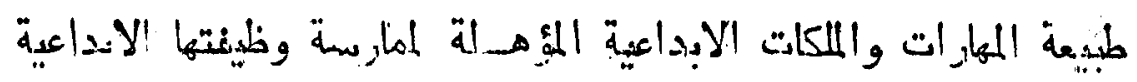
باتنتـداو

\section{فذنة ما قصرت ملكًات الأديب الغريزية والاكتسابية عن مدارسة}

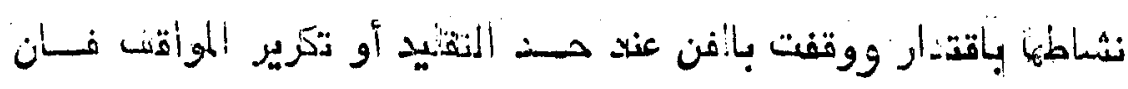

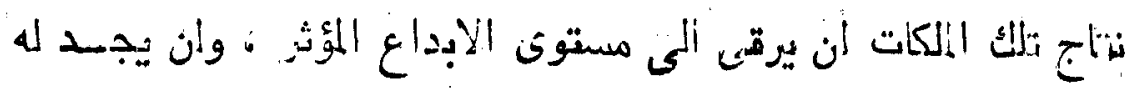

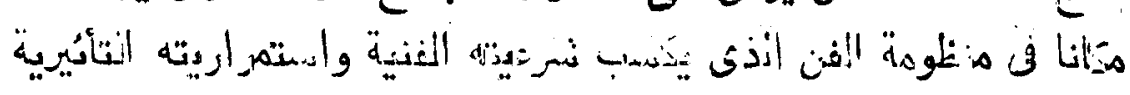

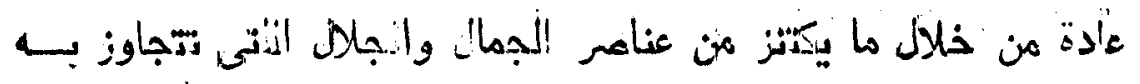

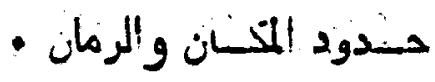




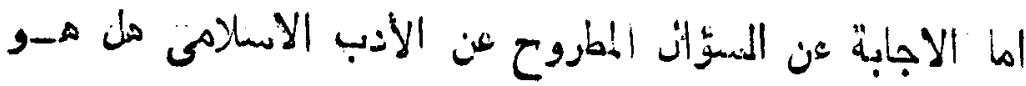

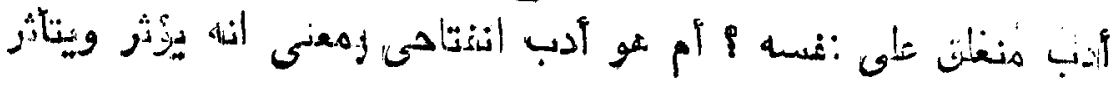

- أئسذ ويعطى

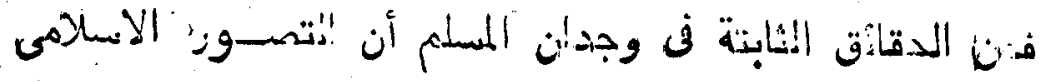

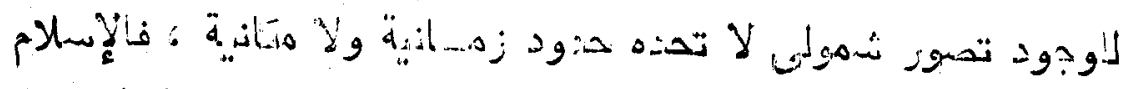

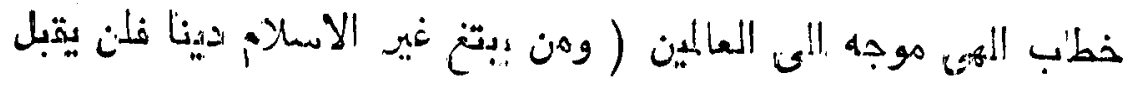

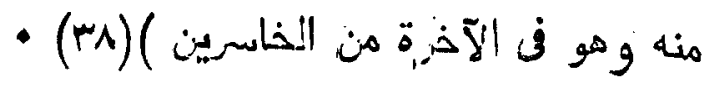

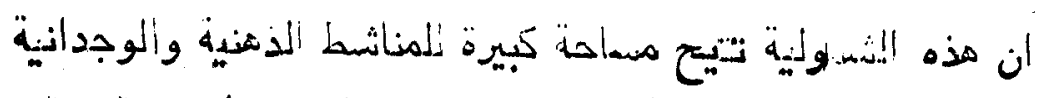

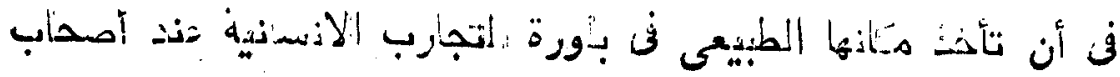

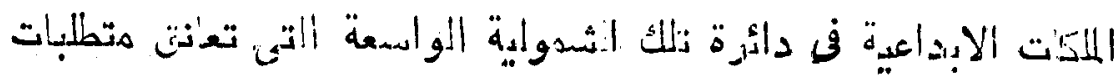

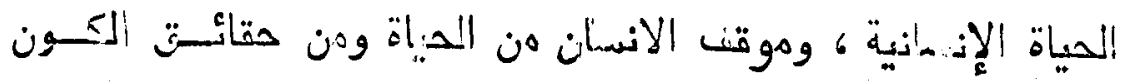

الكبــى

والآفاتق المزهية التى يتحركن في دائرتها الادب ألاسلامى أَفاق

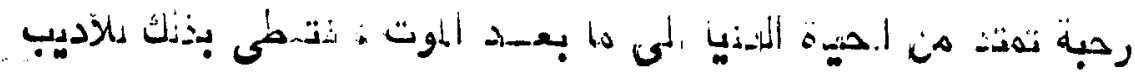

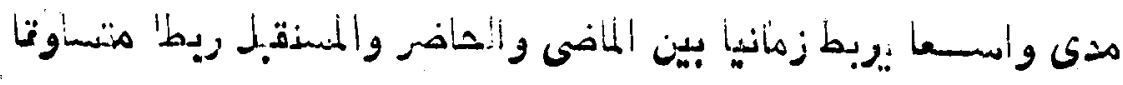

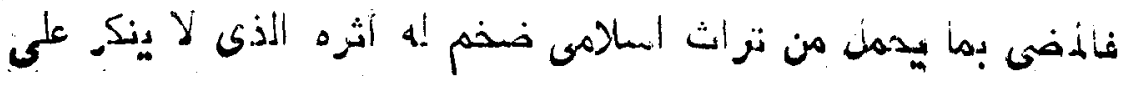

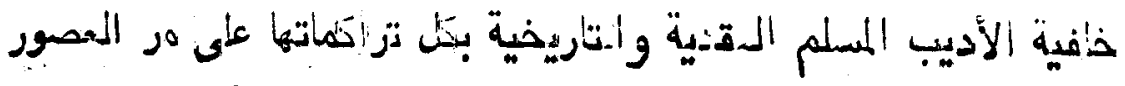

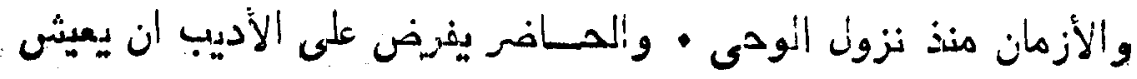

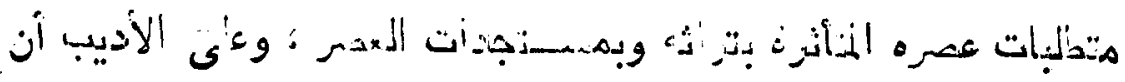

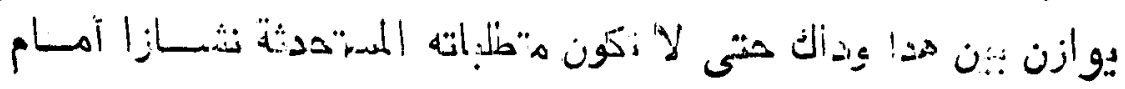

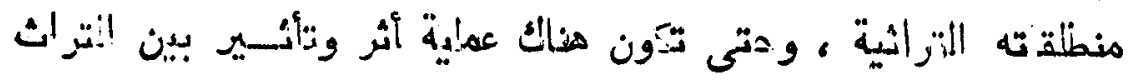

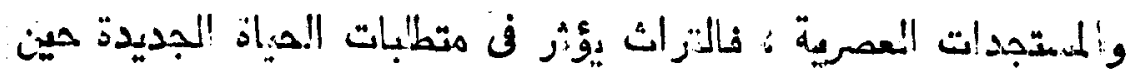

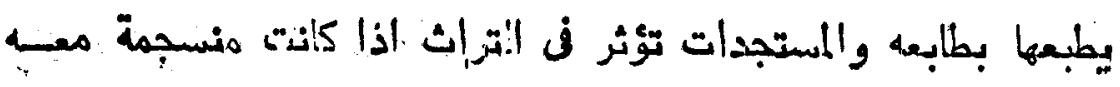




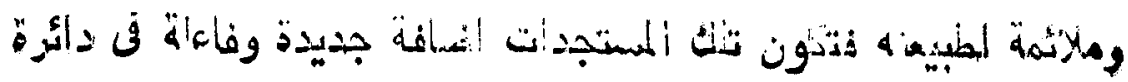

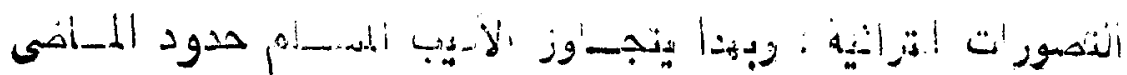

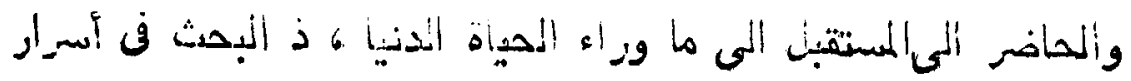

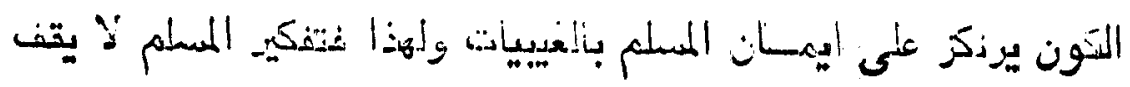

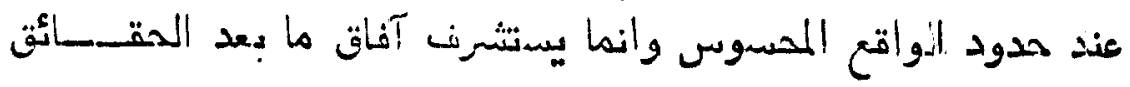

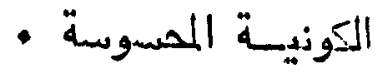

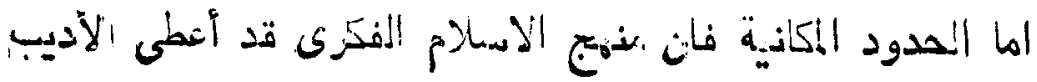

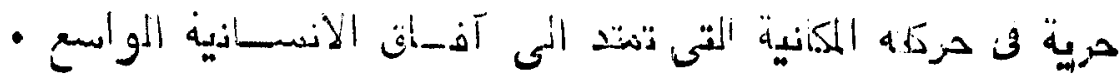

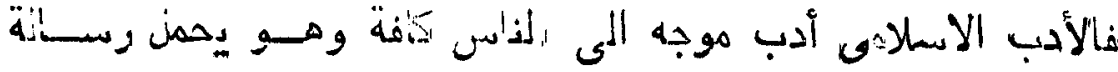

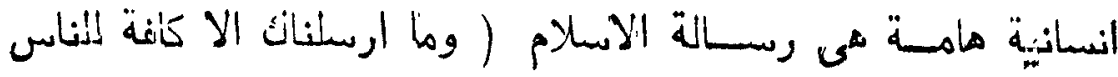

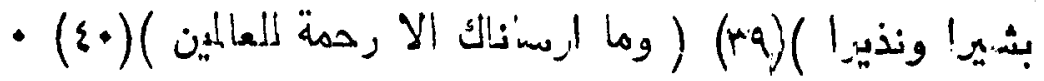

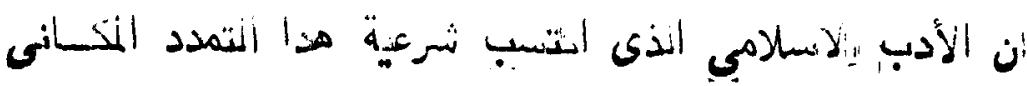

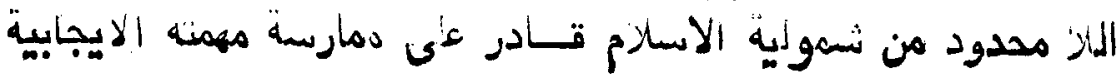

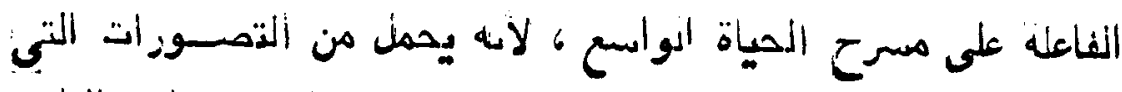

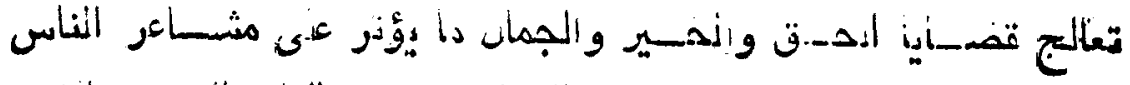

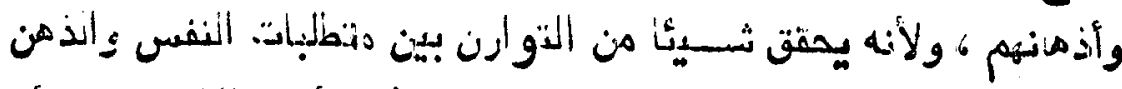

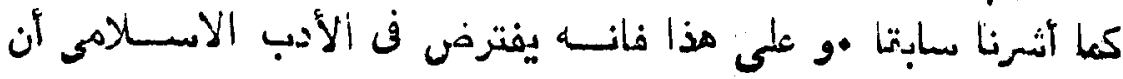

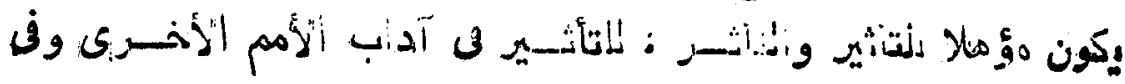

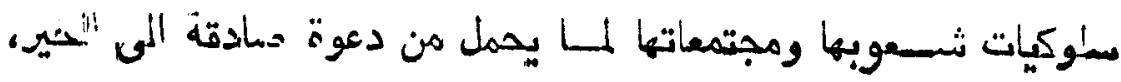

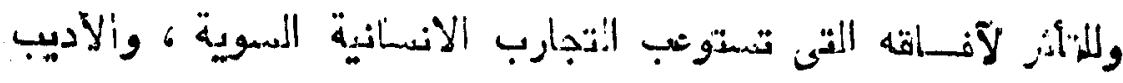

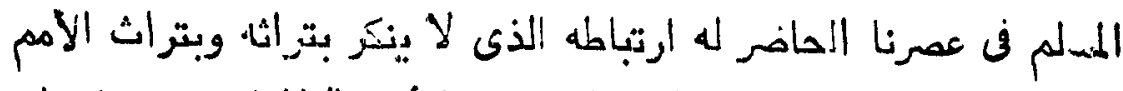

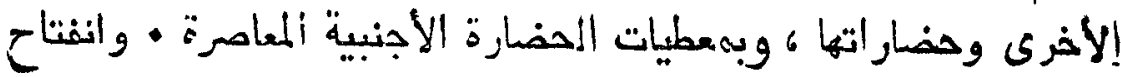

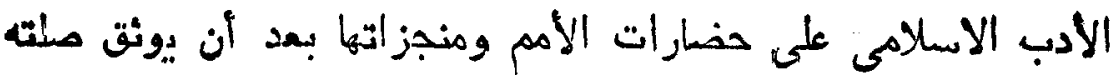

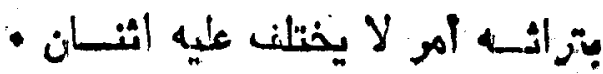




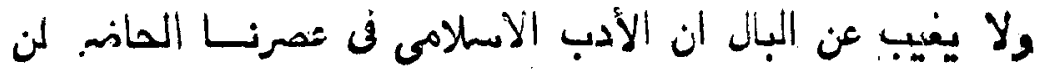

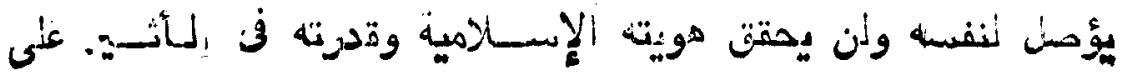

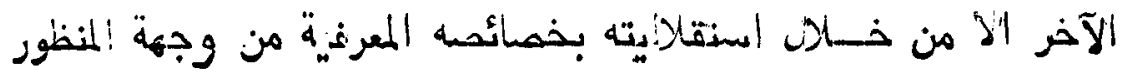

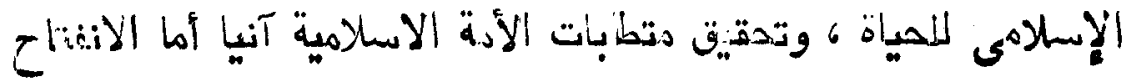

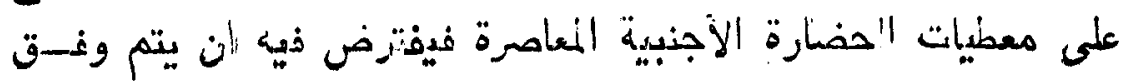

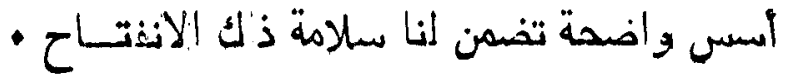

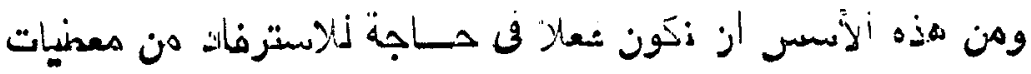

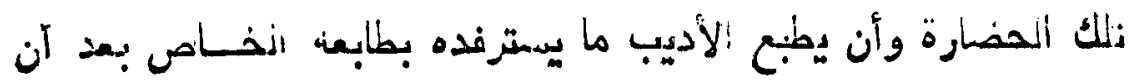

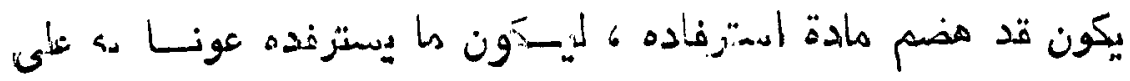

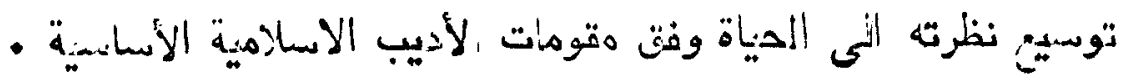

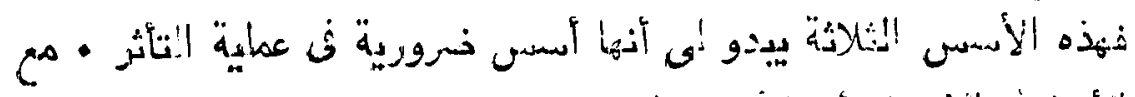

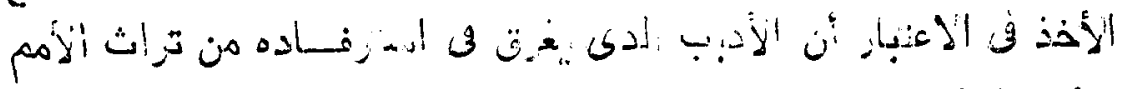

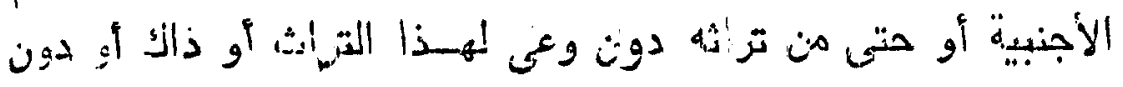

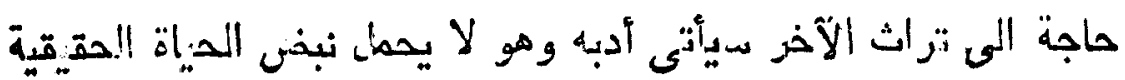

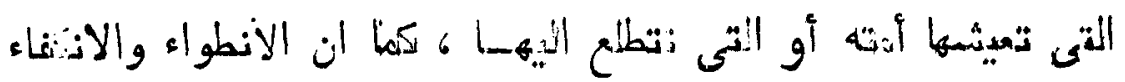

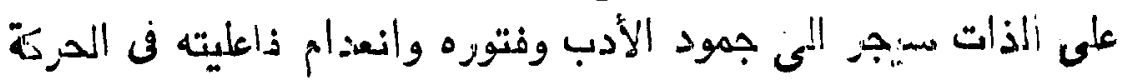

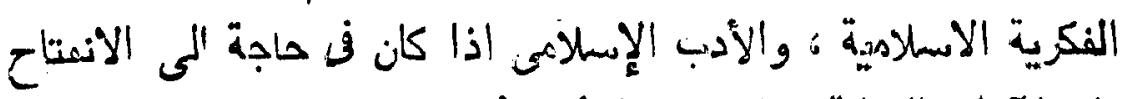

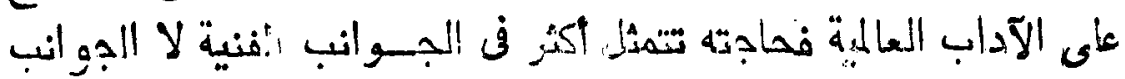

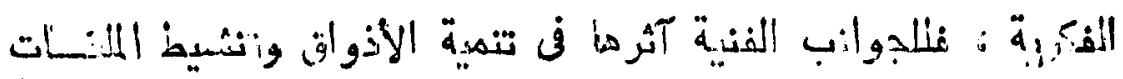

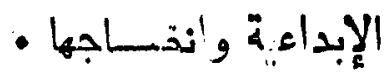

غير أن كل نثاط انسانى ينشته الحق والحير ان يجد النظزيهق

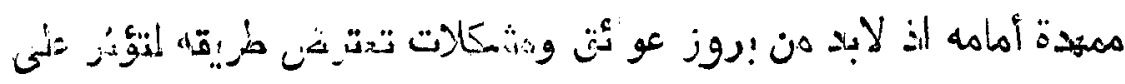

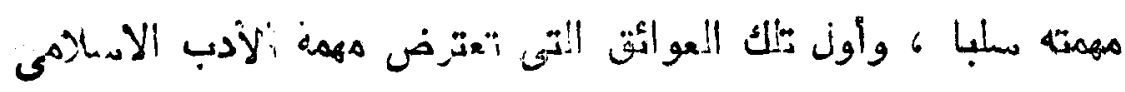

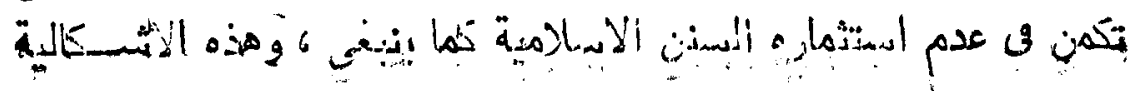




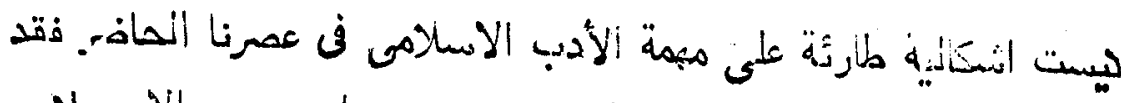

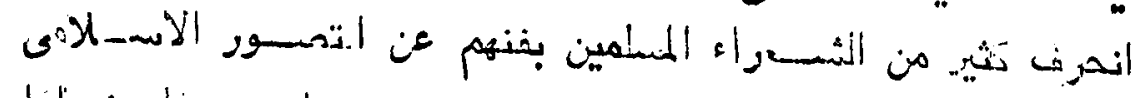

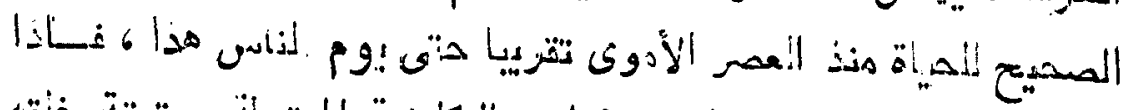

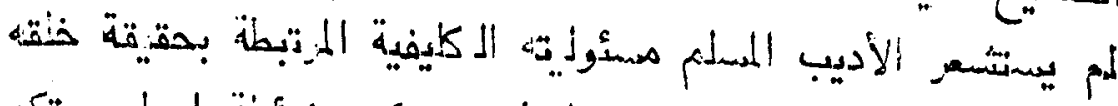

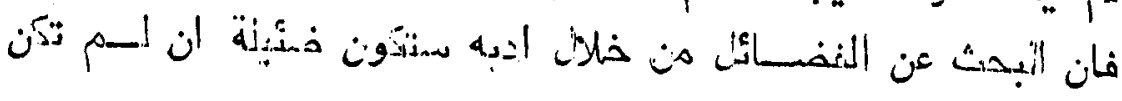

معدومة كان

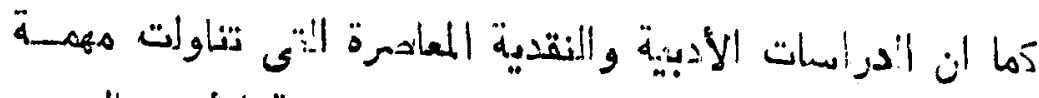

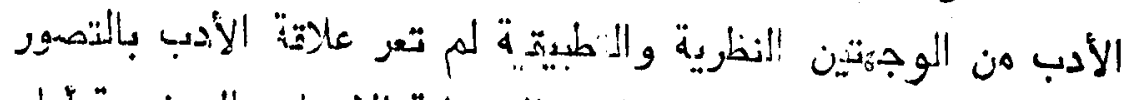

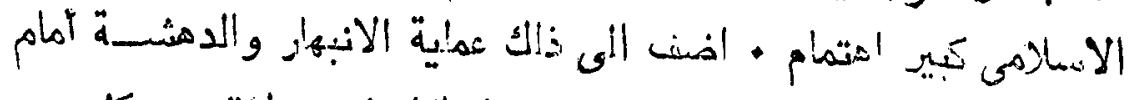

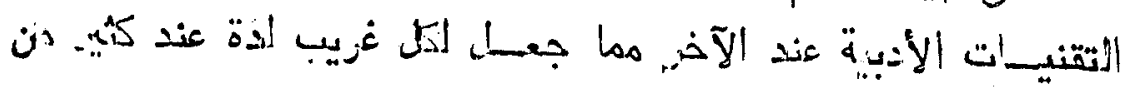

- ادبائنــا

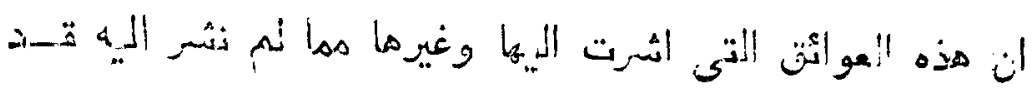

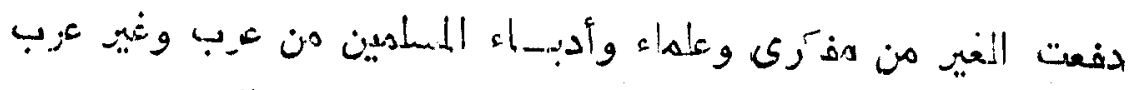

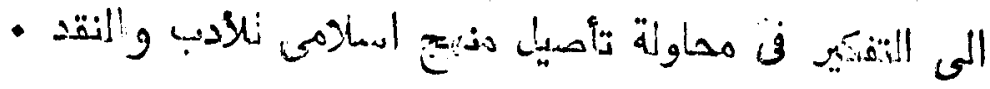

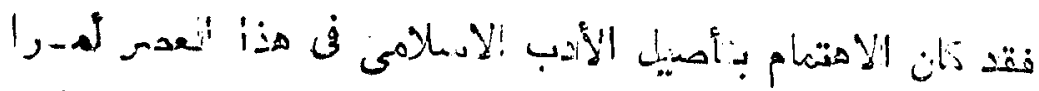

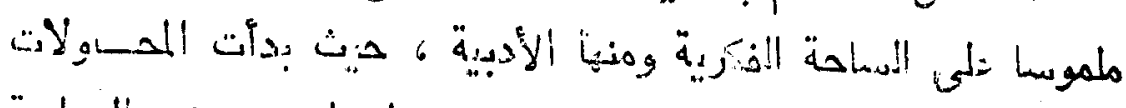

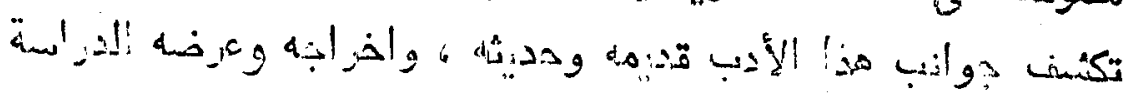

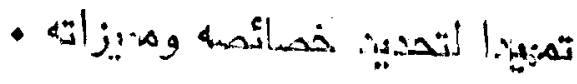

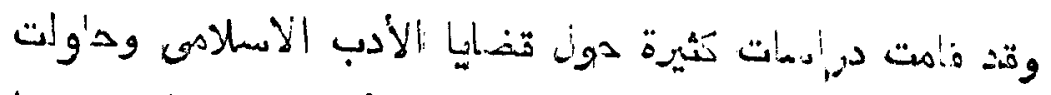

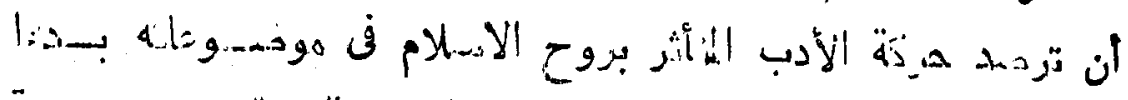

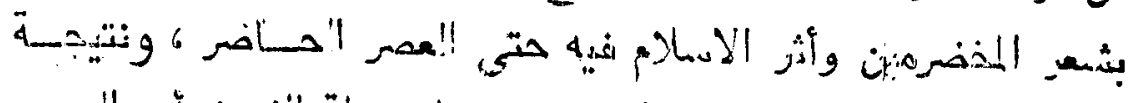

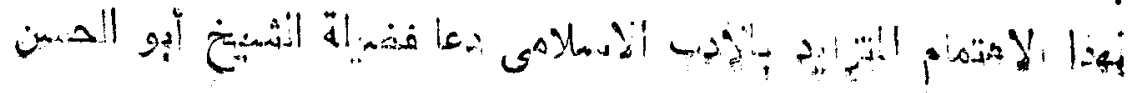




\section{va}

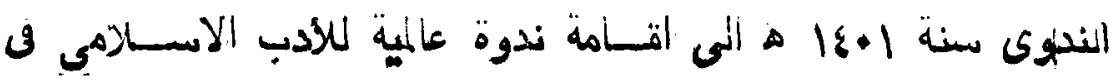

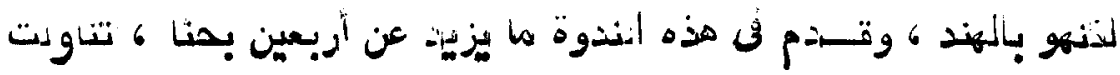

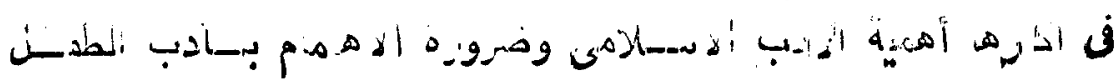

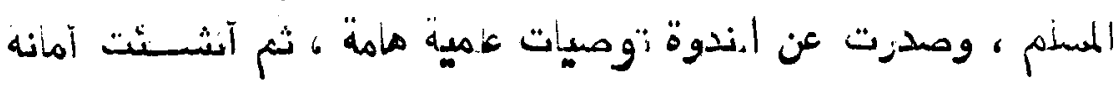

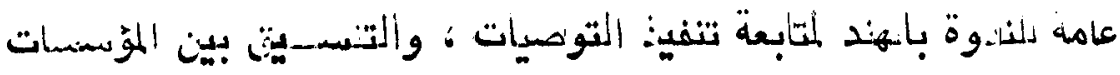

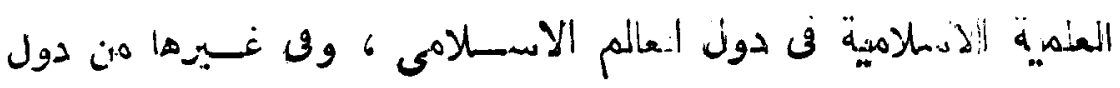

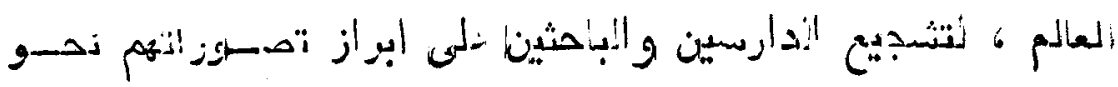

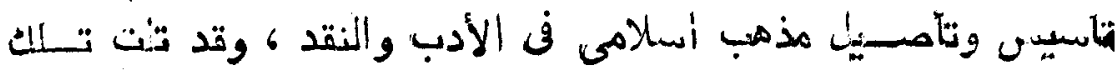

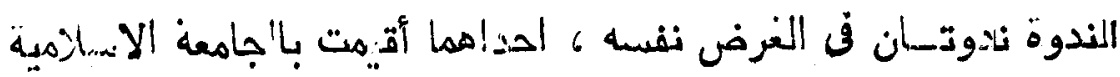

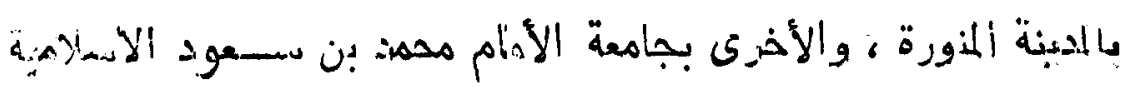

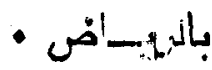

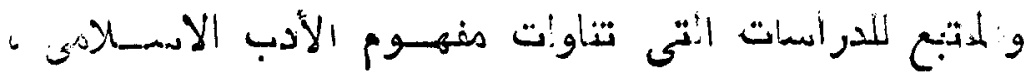

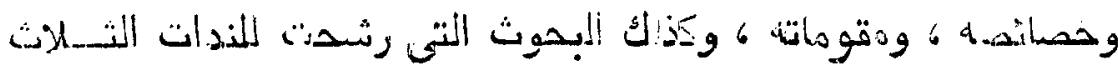

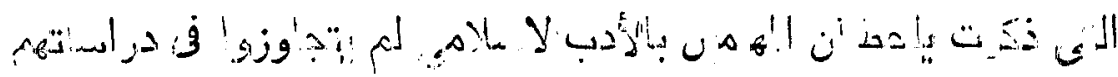

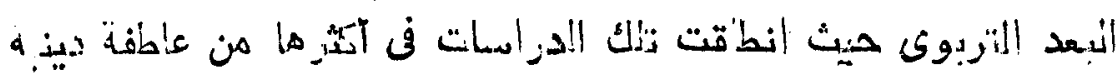

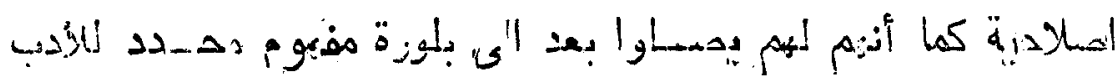

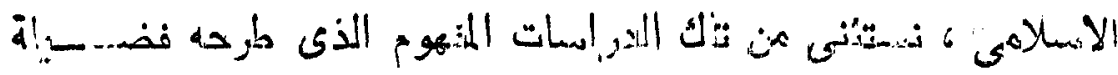

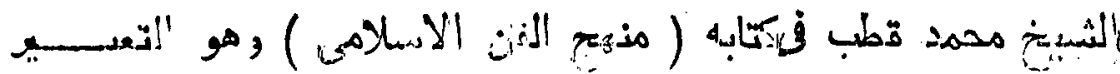

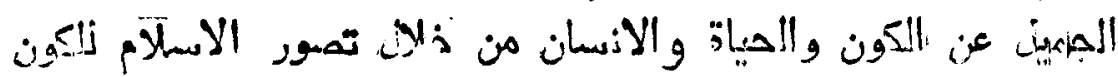

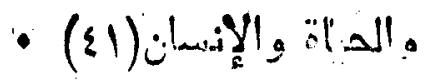

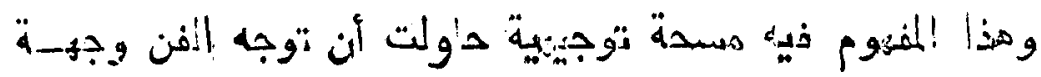

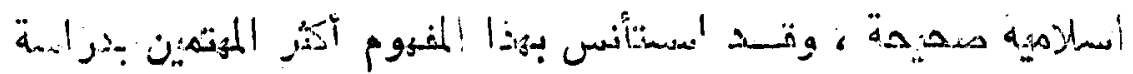

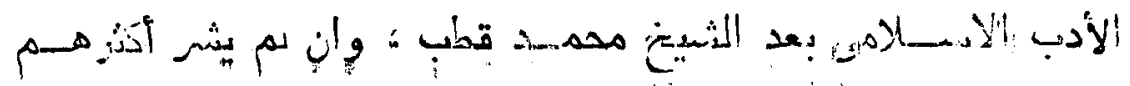
إن 


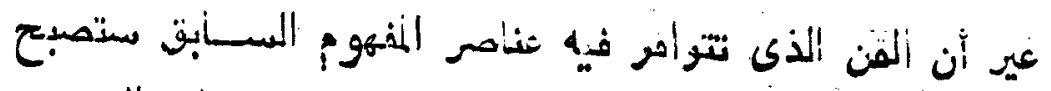

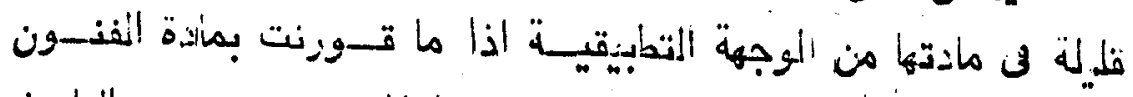

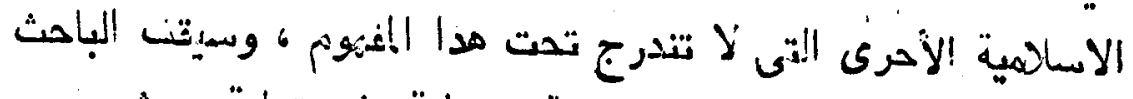

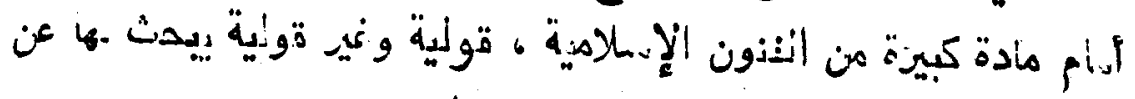

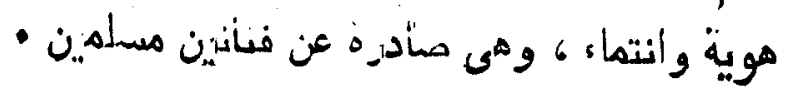

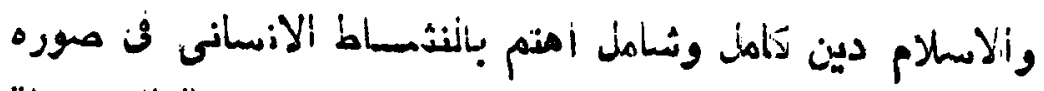

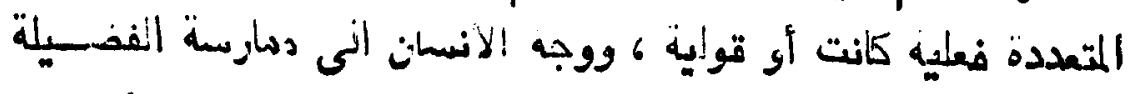

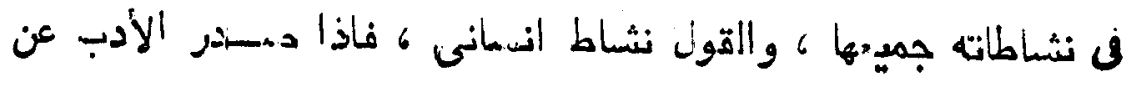

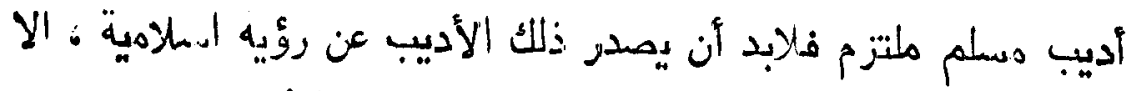

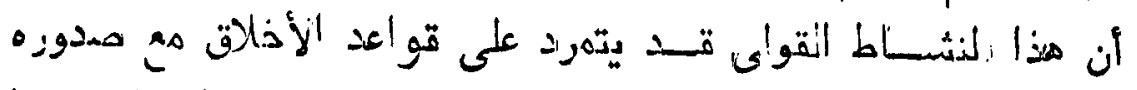

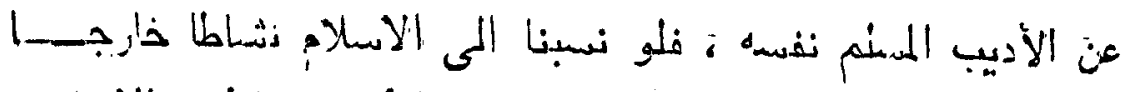

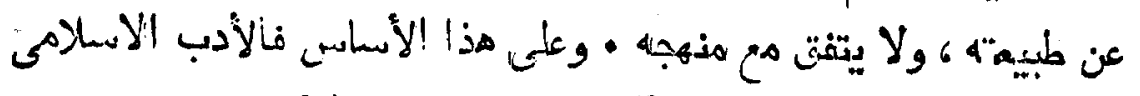

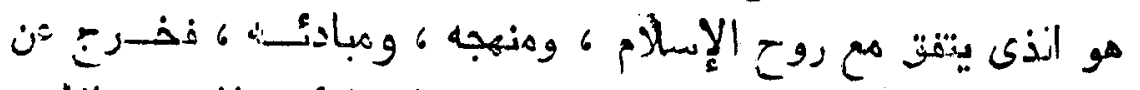

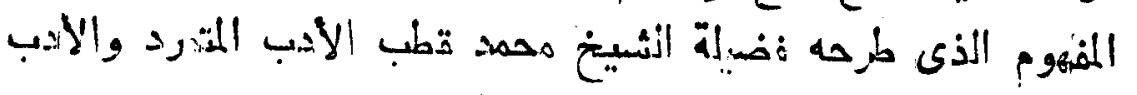

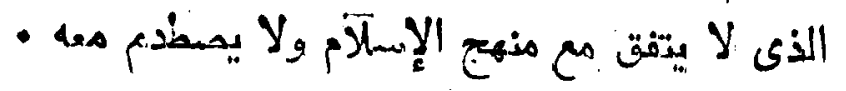

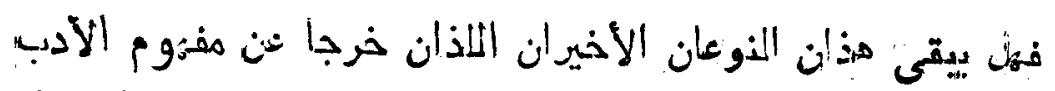

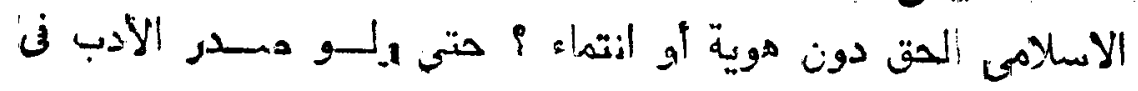

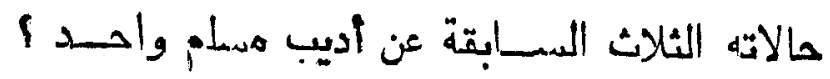

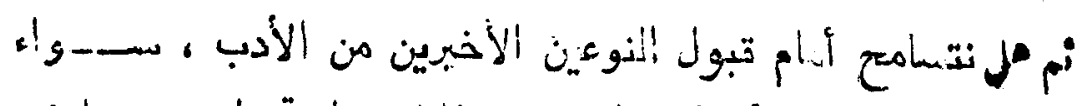

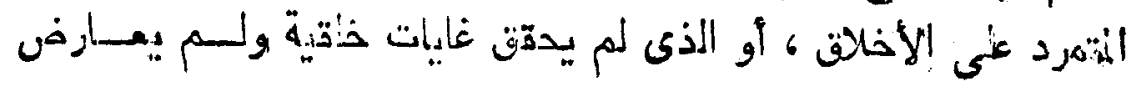

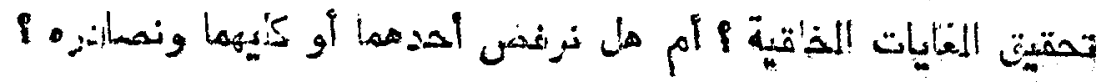


لكل اختلافت المهتمين بدراسة الأدب الأنطلامس حون الإجوبسة

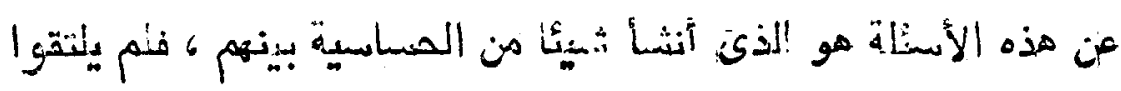

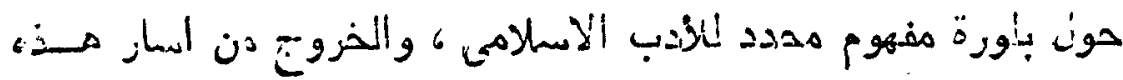

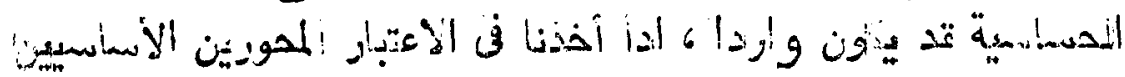

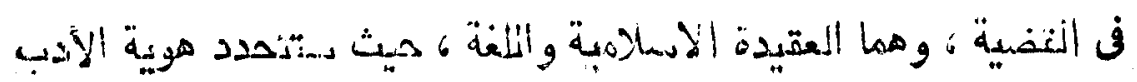

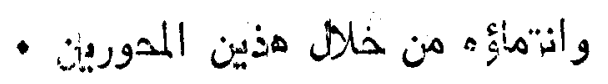

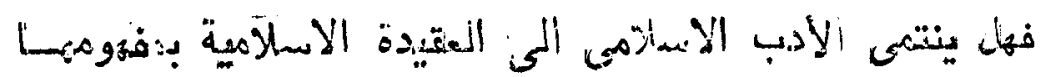

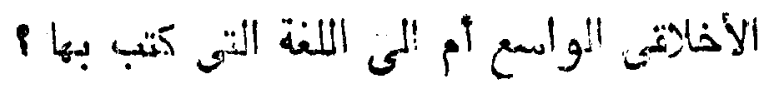

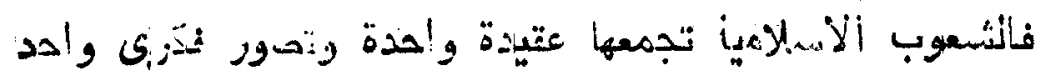

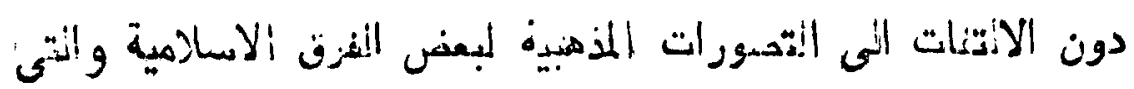

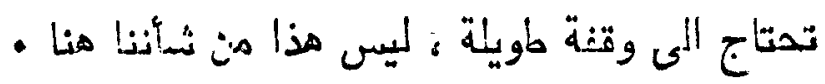

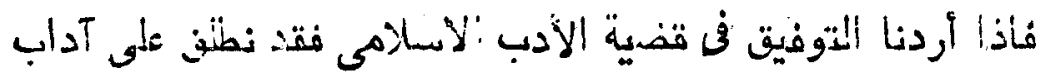

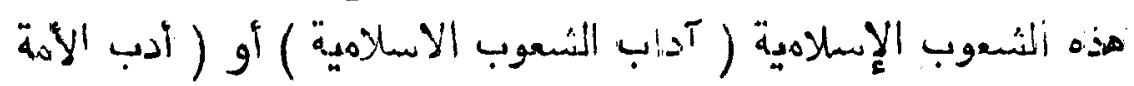

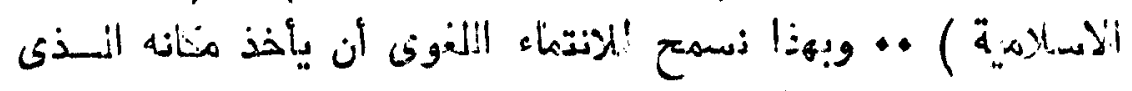

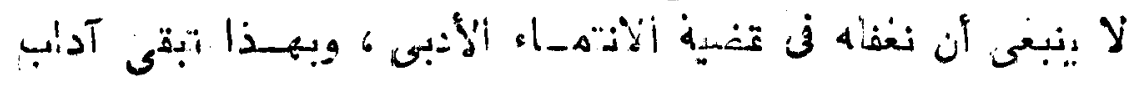

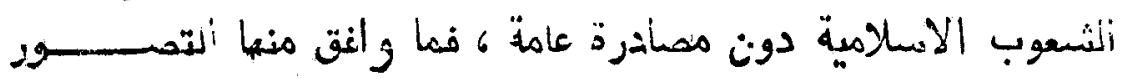

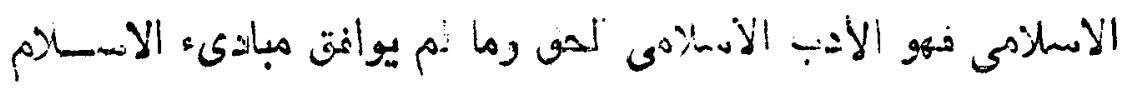

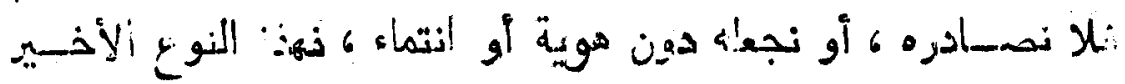

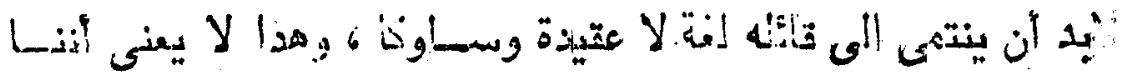

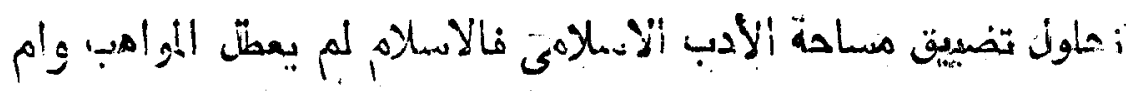

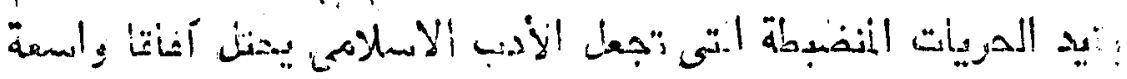

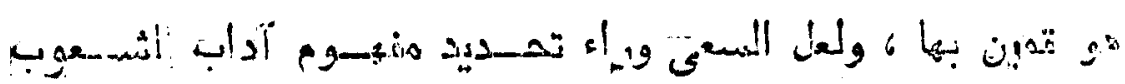

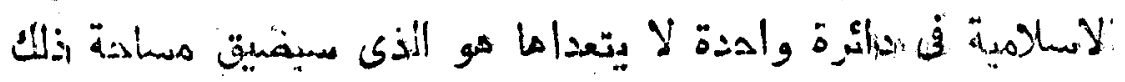

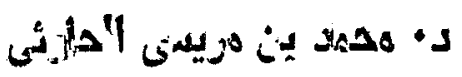

$$
\begin{aligned}
& +4 \\
& \text { مكسة المترة } \\
& (; 7-6)
\end{aligned}
$$




\section{مصسادر ومراجع البحث}

ا. - ـ كرمبى • لاسـل آبر • قواعد النقد الادبى • ترجمة محمد عزض

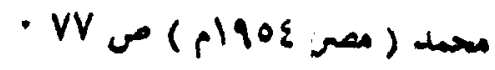

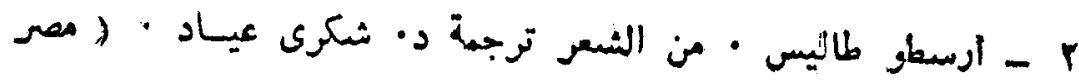
- r p p pat

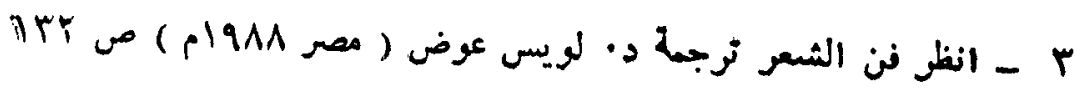

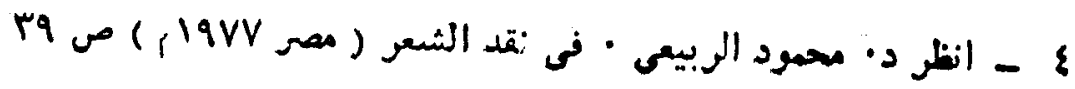

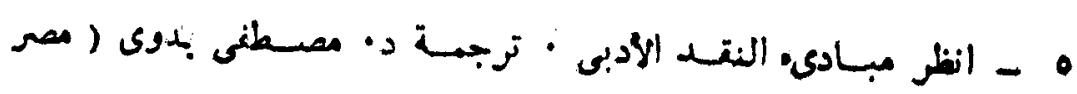
- IIV p p p pr

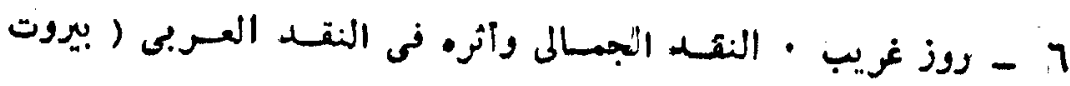
- $7 \varepsilon$ ( plqor

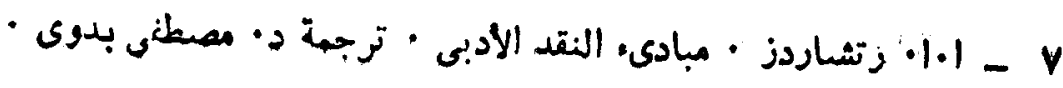
صن Iro

A - فى نقد الثره م

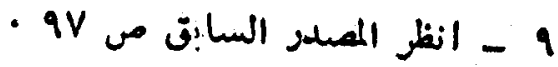

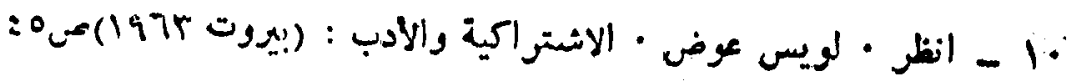

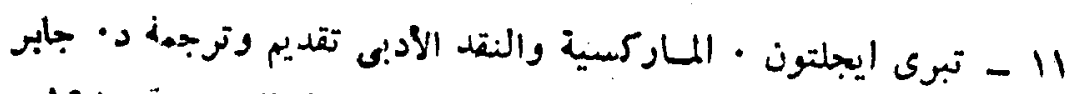

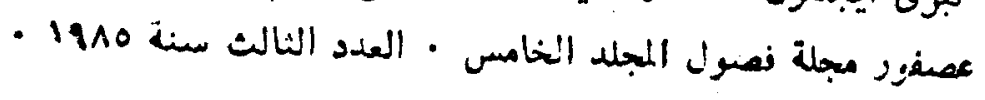
- rr

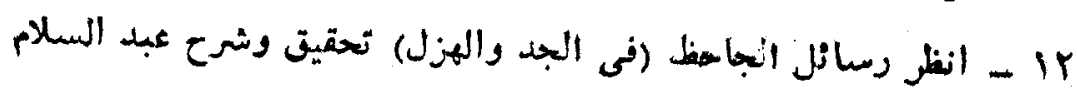

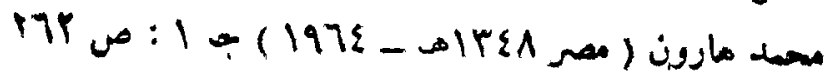

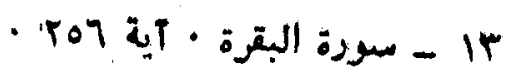

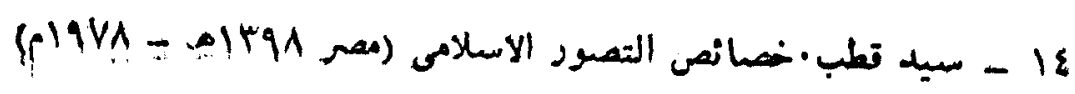


10 - ابن الأثير الجزرى · جامع الاجمول فى الحاديث الرسول · نهقيق

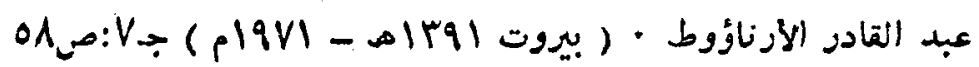

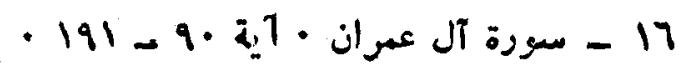

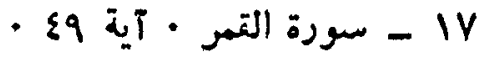

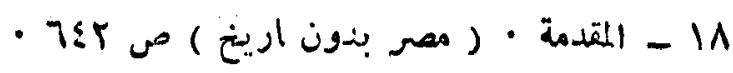

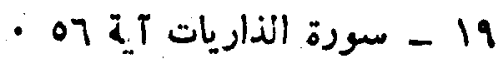

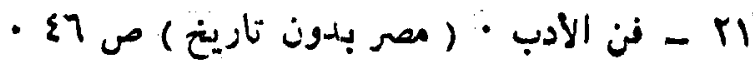

$-r r$

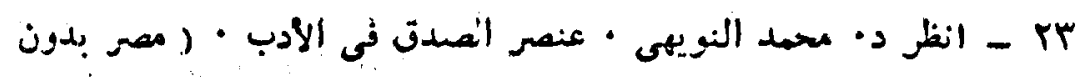

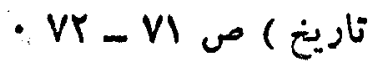

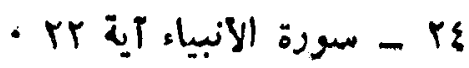

هب - يتيهة الدهز • تحقيق : محمد محيى الدين عبد الحمبد ( بيروت

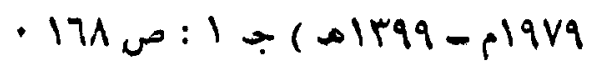

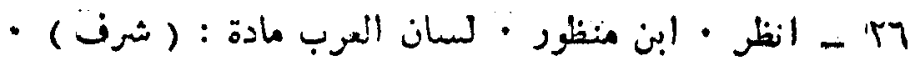

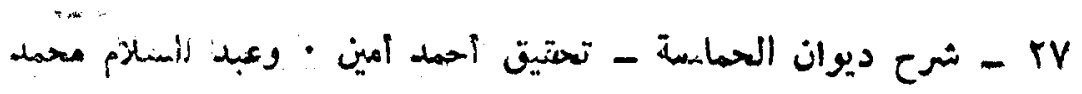

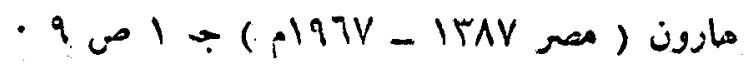

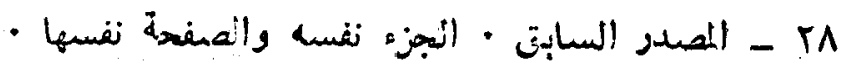

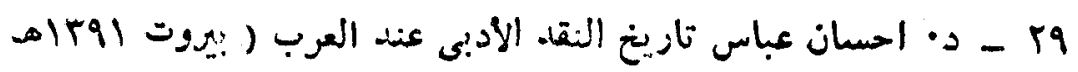
- (

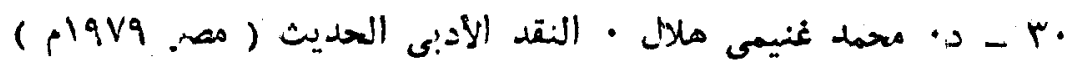
- MIT-MIO

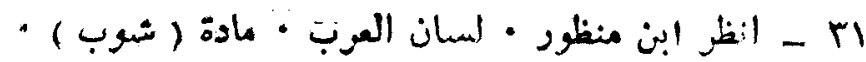

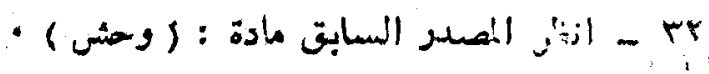




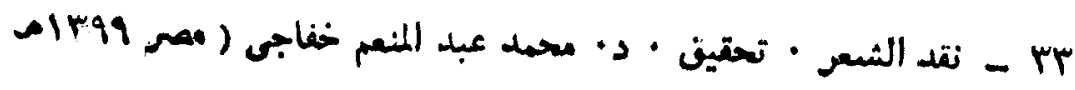

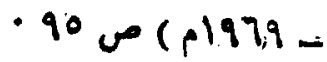

E - انظر المملد السابق ص

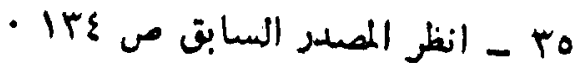

- Irv

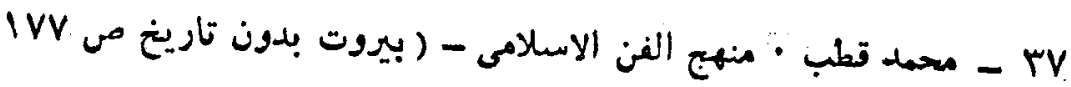

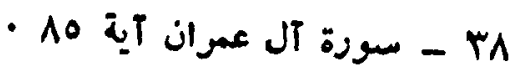

- rA

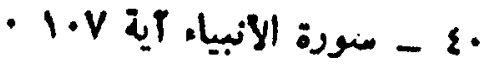

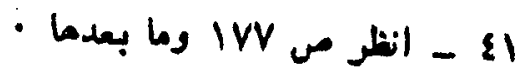




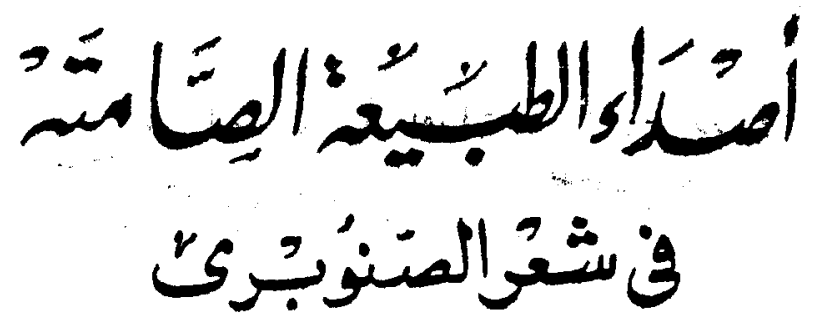

اللدتّود/حسن الميد خفسر الفرباوى

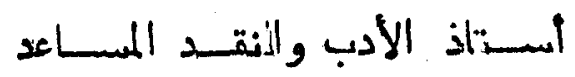

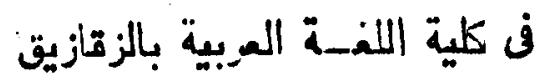

البربيمـة والانعـان:

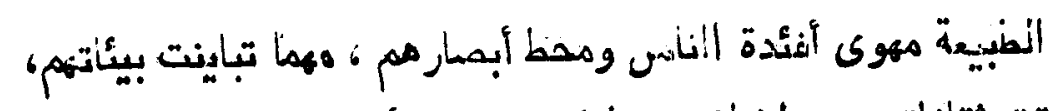

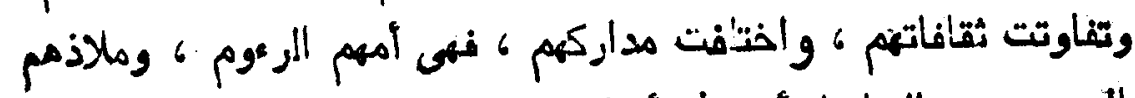

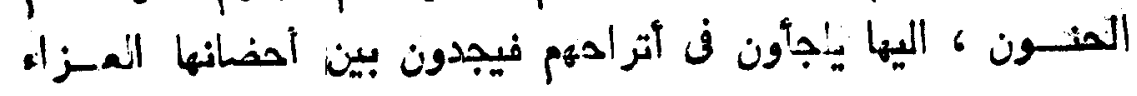

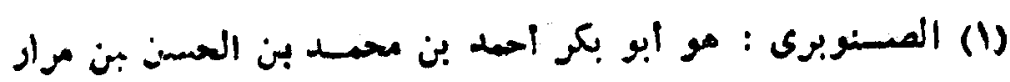

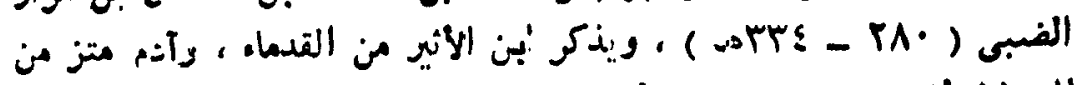

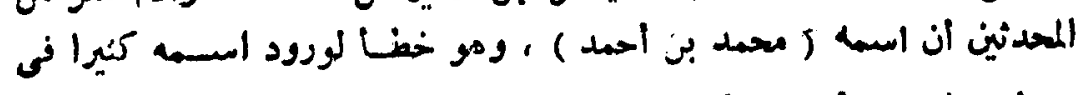

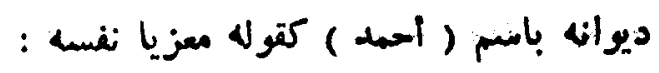

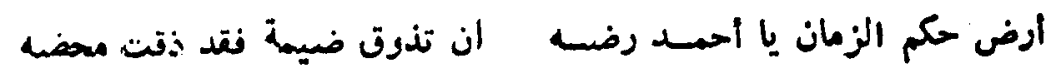

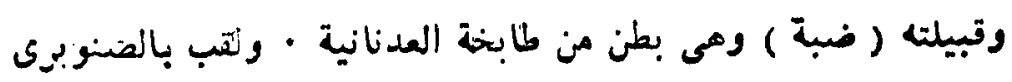

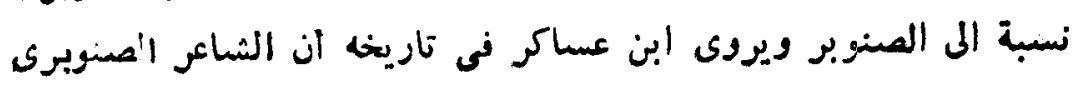

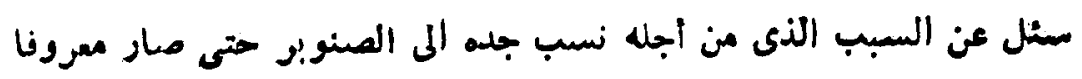

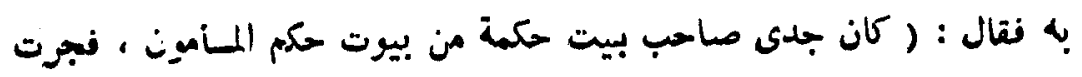

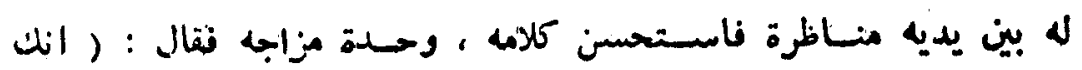

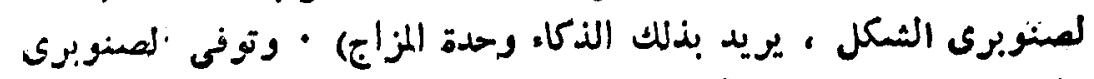

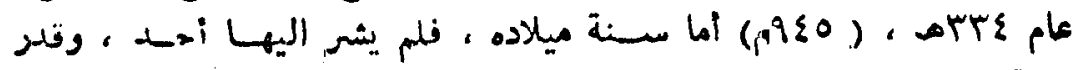

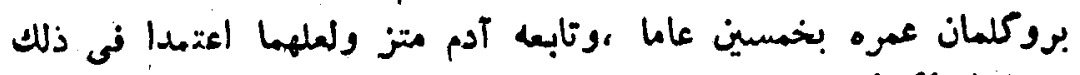

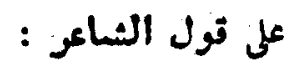

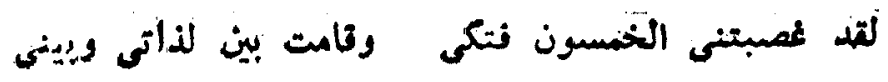




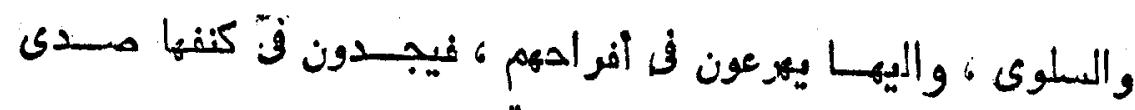

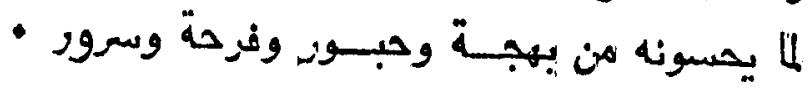

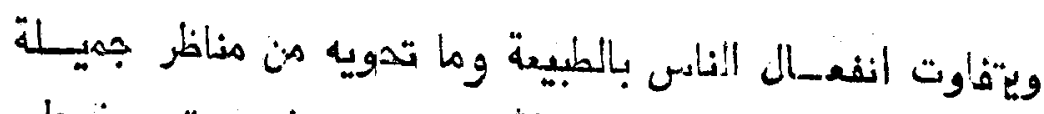

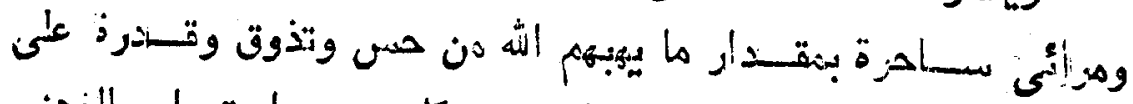

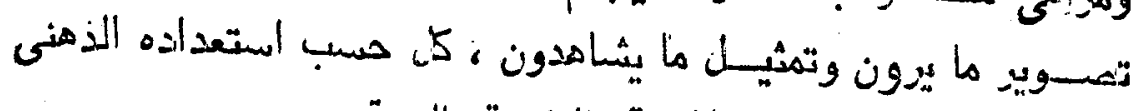

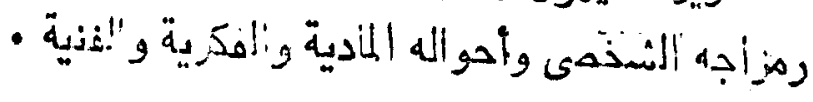

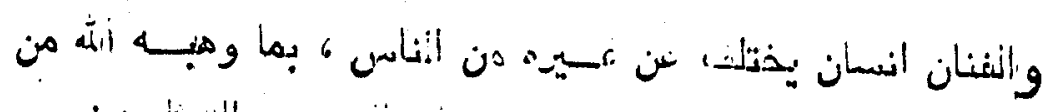

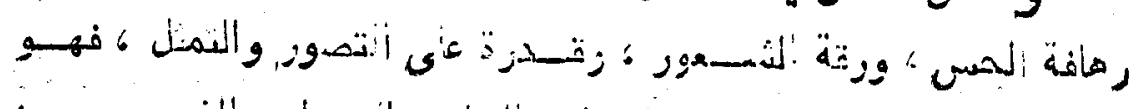

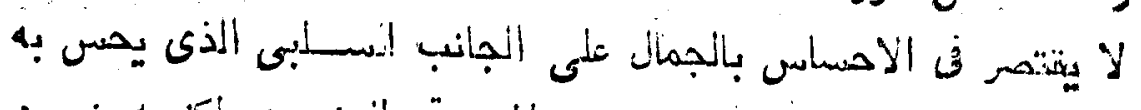

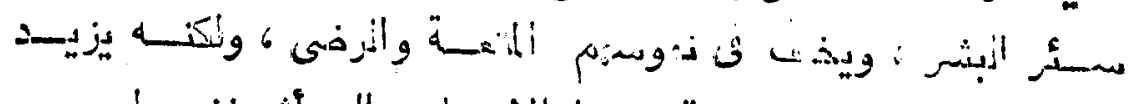

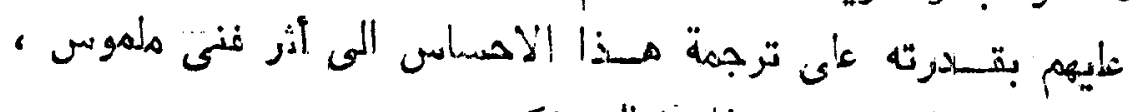

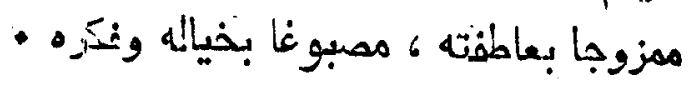

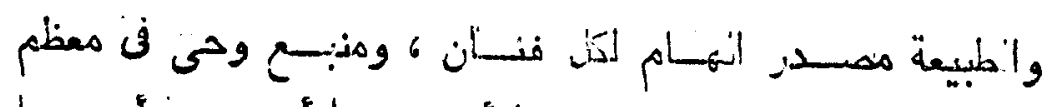

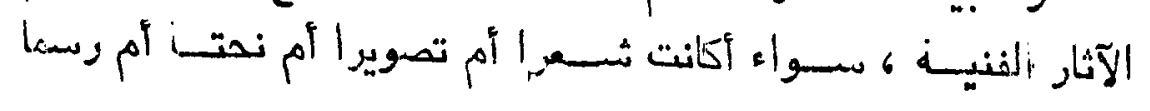

ولمن المتصسفح نديوانه يجده الثـاد الى أنه تجـاوز الخهسين عاما

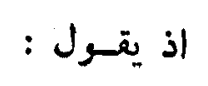

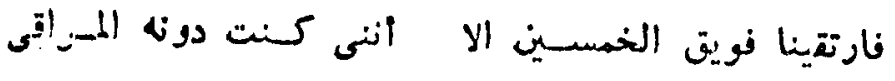

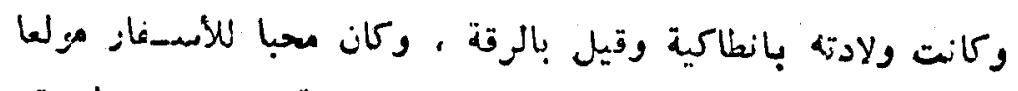

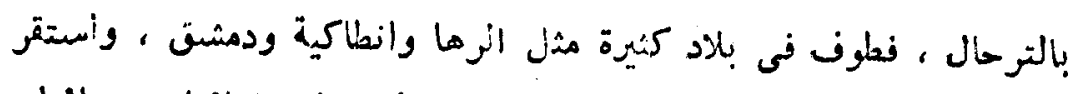

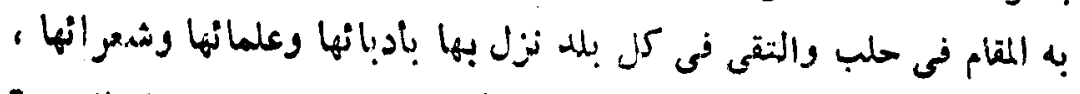

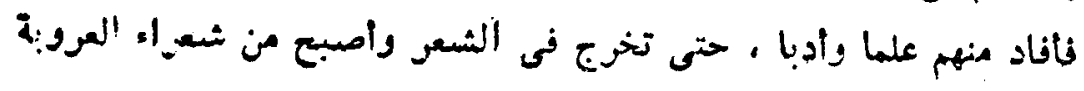

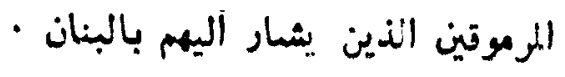




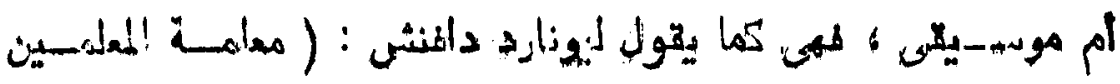

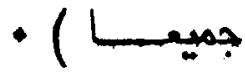

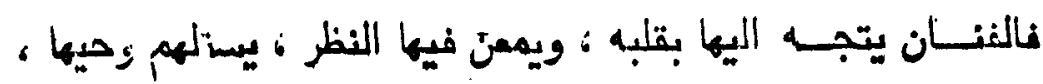

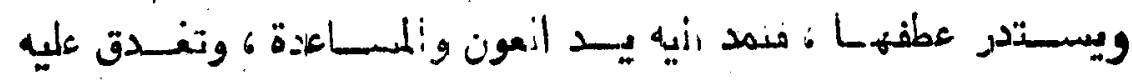

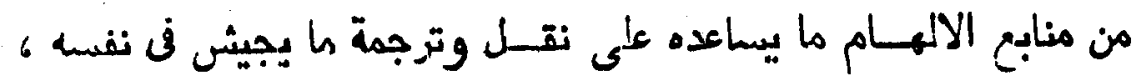

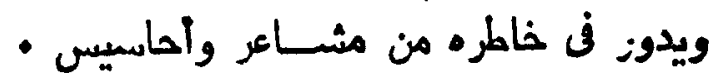

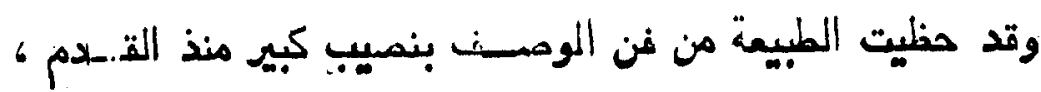

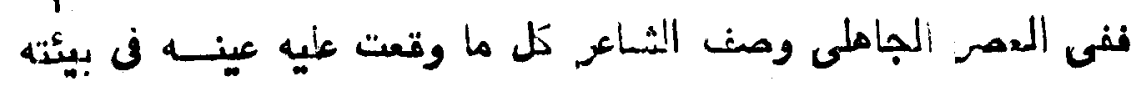

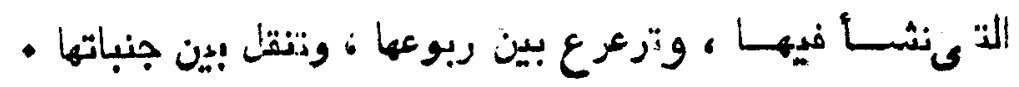

وصف الليـل وطوله تعبيرا عن مهومه وأحزانه ؛ ووصف البرق

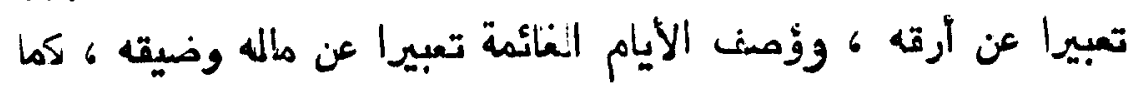

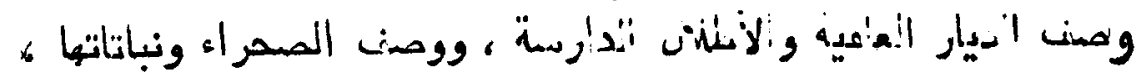

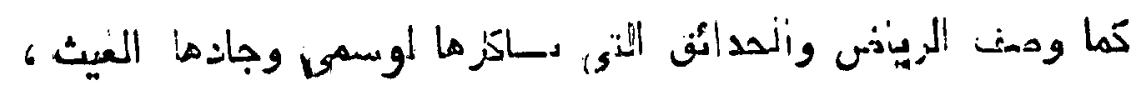

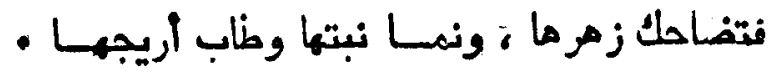

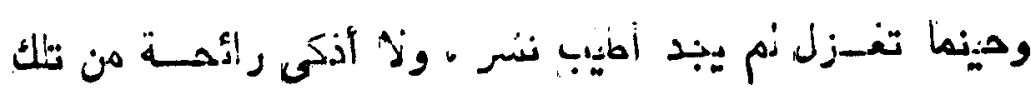

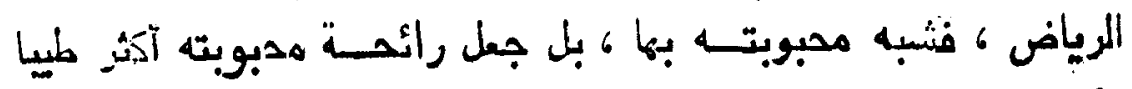

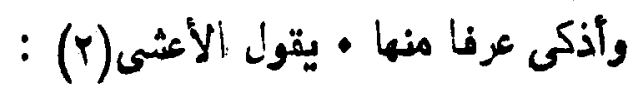

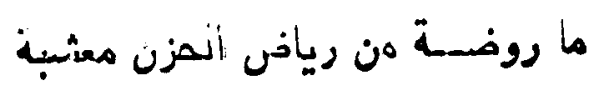

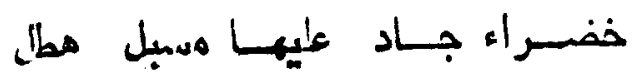
يضـاحك الشمس منها كوكب ثشسرق

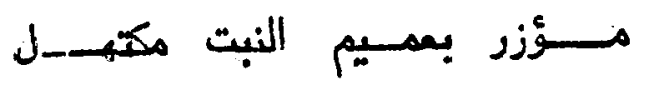

(T) ديوان الاعثى ص 180 . 


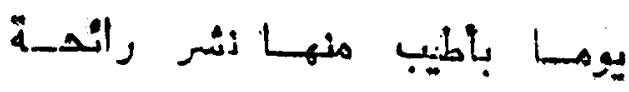

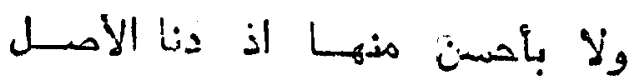

وحين وصف الثشاعر الجاهلى الطبيعة كان هــادقا فم التزجهـة

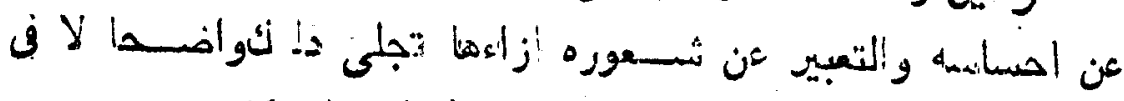

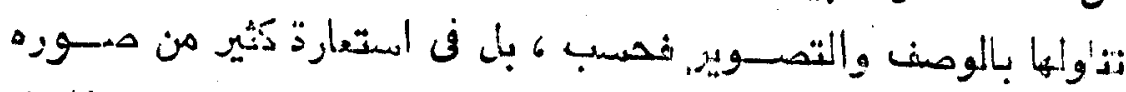

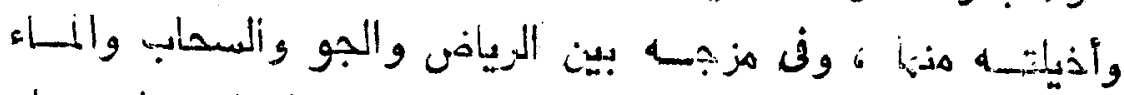

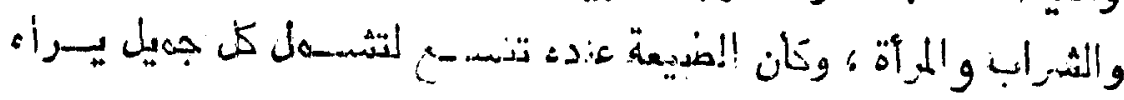

-

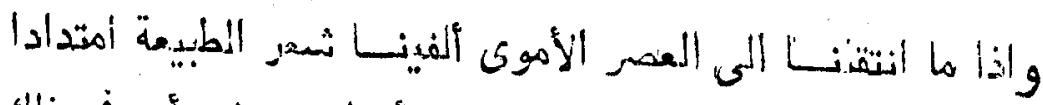

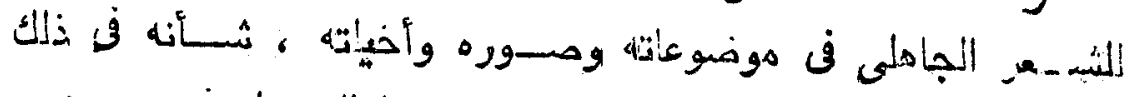

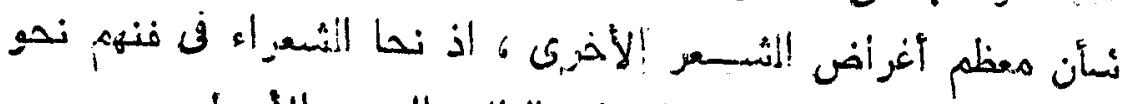

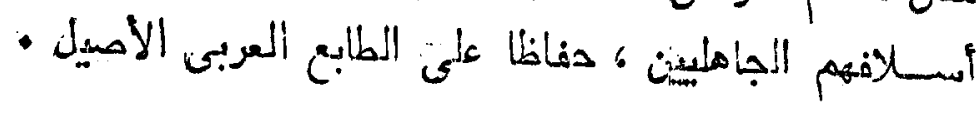

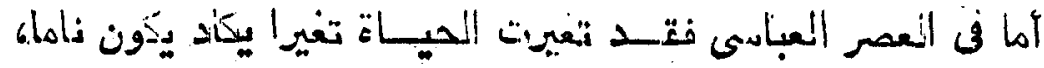

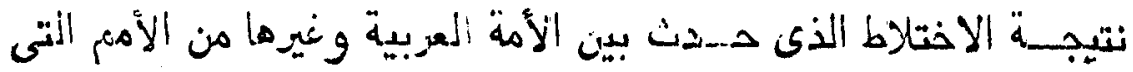

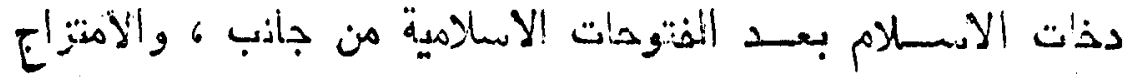

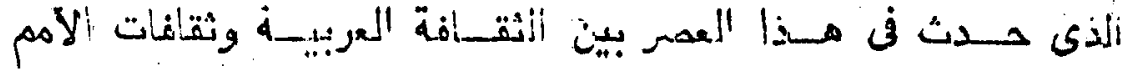

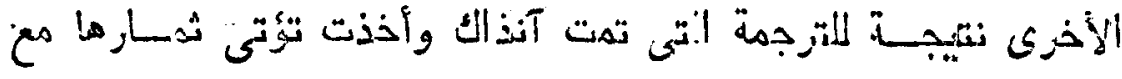

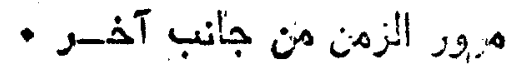

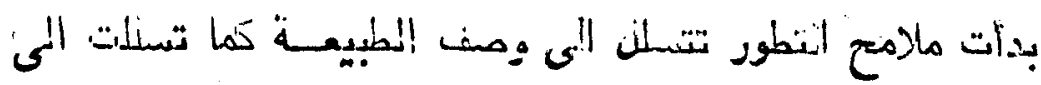

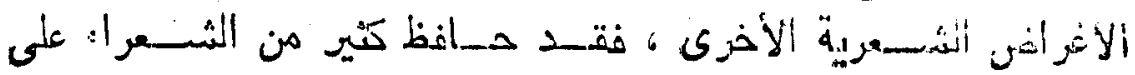

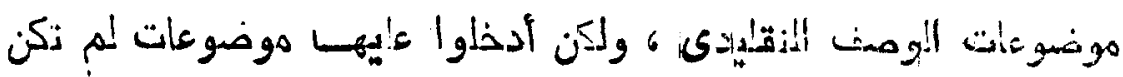

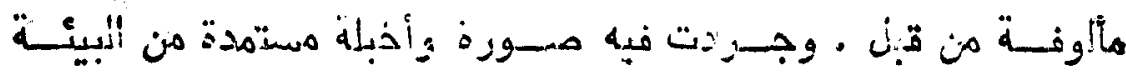

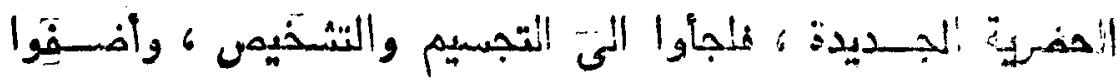




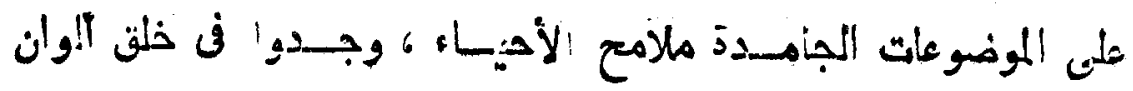

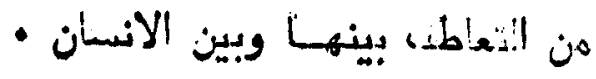

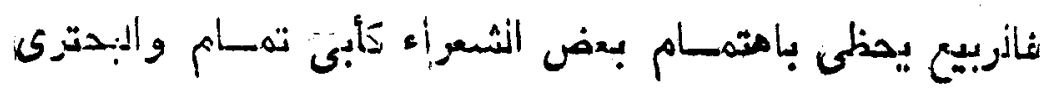

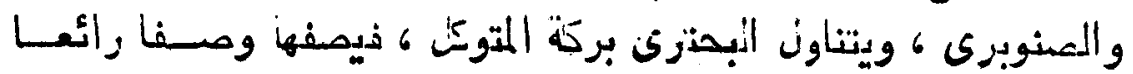

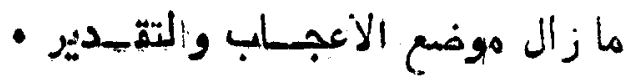

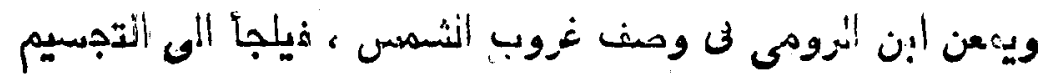

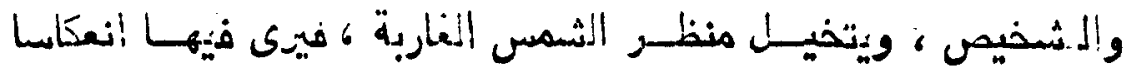

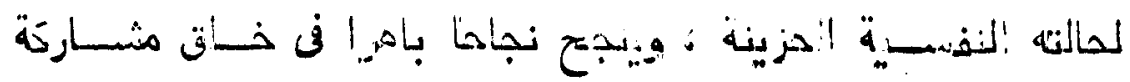

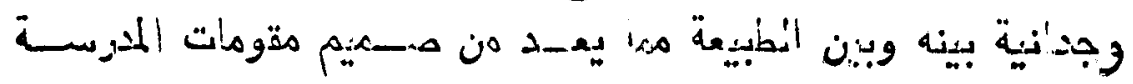

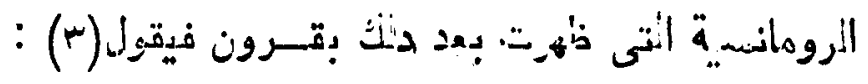

اذا ارنقت شمس الأصسيا ونفضست

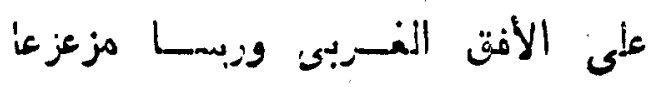

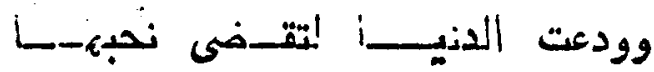

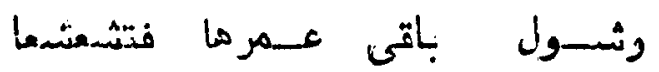

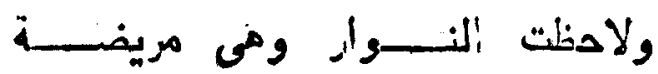

وقد وضعت خـدا ألى الأرض أذضرعا

كا لاحضت عـواده عسين مهدنف وهن

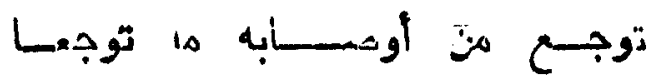

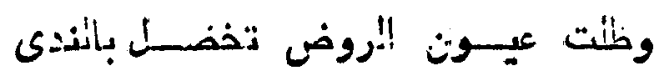

كما اغرورقت عين الثمجئى لتدمعا

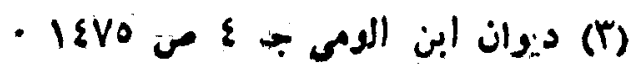




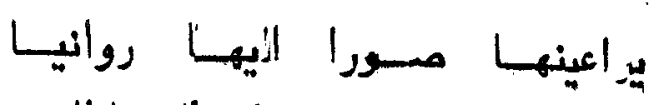

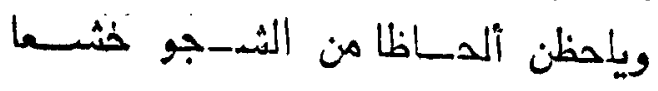

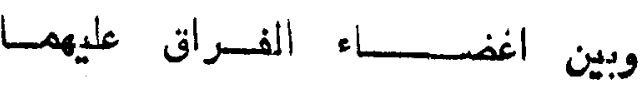

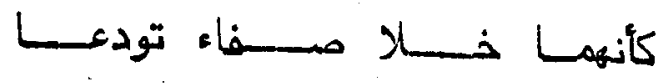

وقد ضربت فن خضرة اللروض صفرة

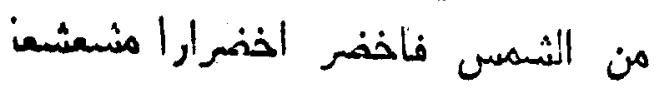

وأذكى نبسيم الروض ريعسان ظله

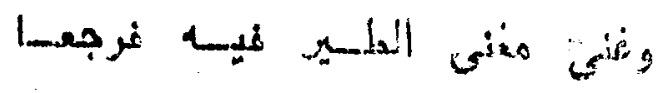

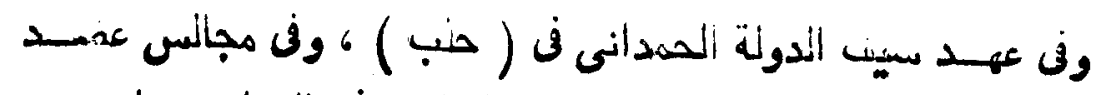

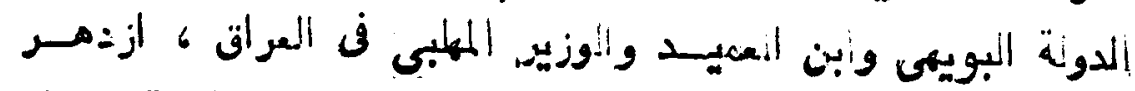

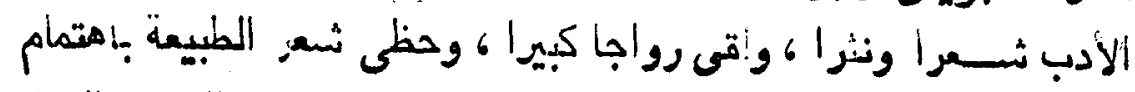

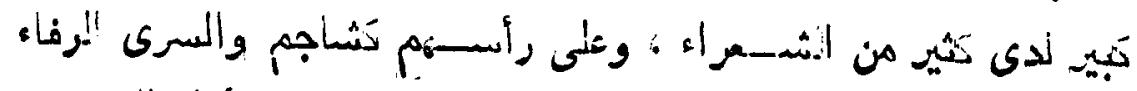

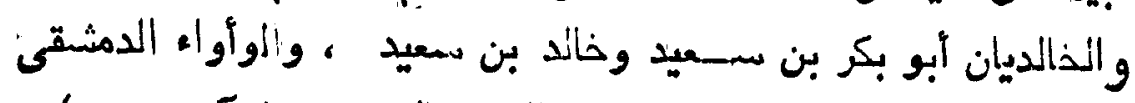

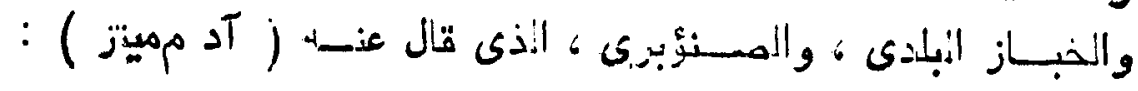

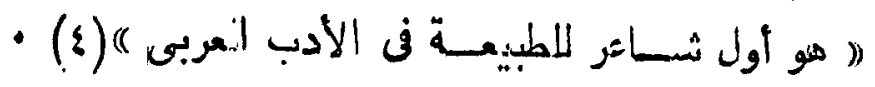

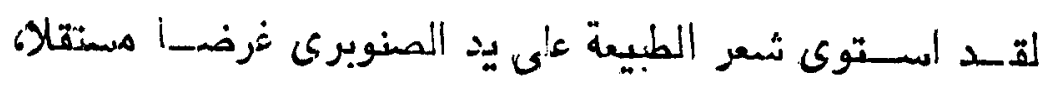

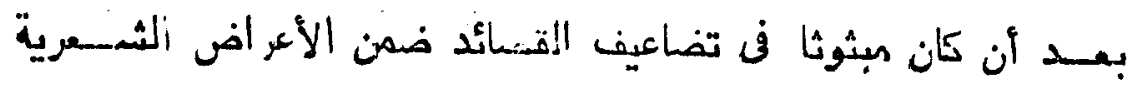

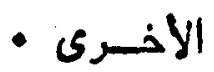

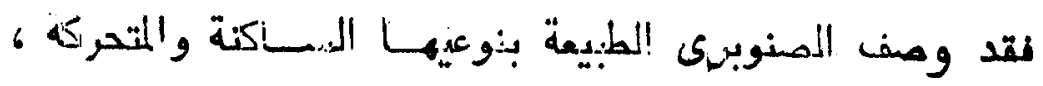

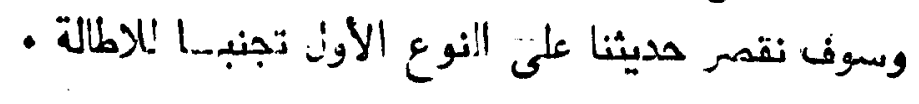
$\ldots$

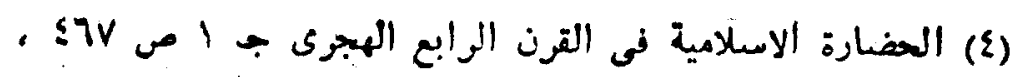

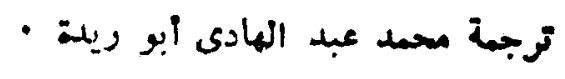




\section{مشفـاهد المبيعسة في شهـمره}

$$
\text { : } 1
$$

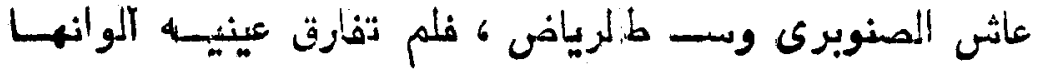

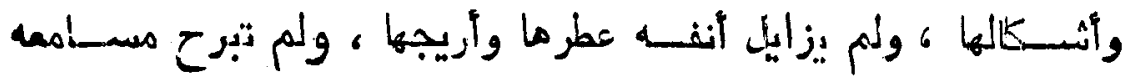

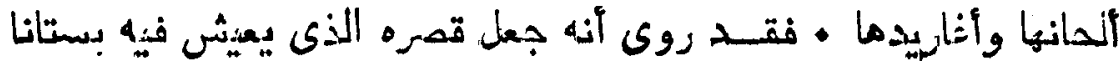

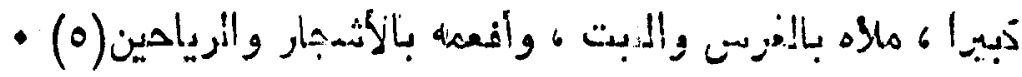

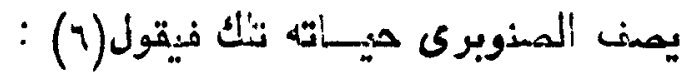
تم تأمل ان شسئت أحواضى سطحى تـر تلك الجنســان في الأهسواض

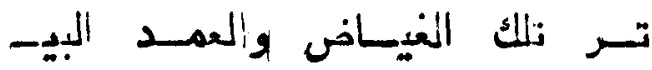

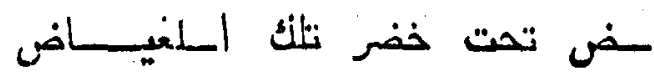

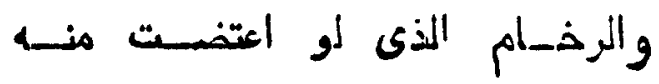

هـرث ريث هـا كنت بالمعتـانه

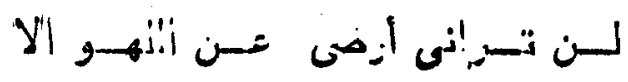

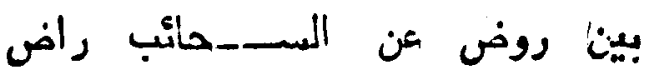

بين حمدر وبين بيض تحسار النـ

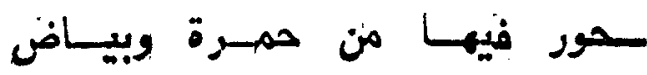

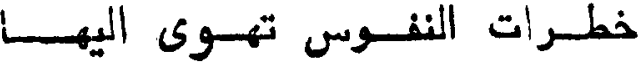

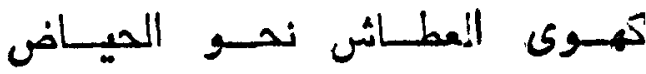

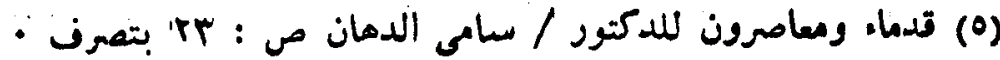
ديوان المنوبرى م : •مץ. 


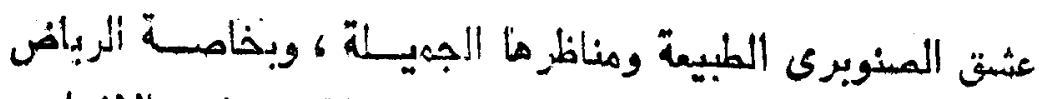

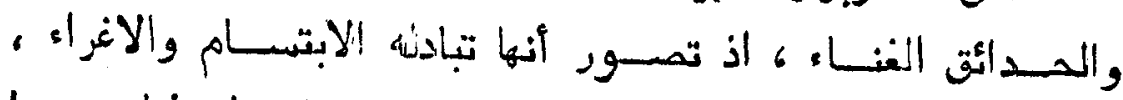

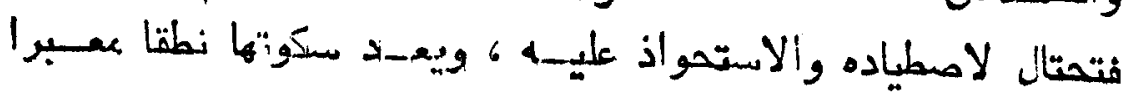

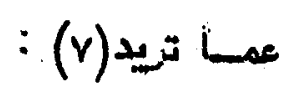

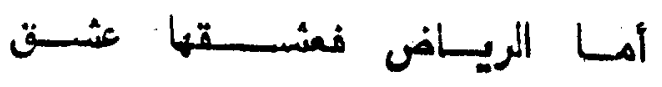

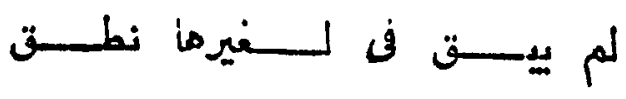
زمهر انريساض اذا هم ابتتسمت

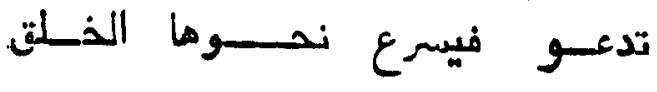

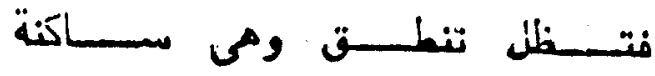

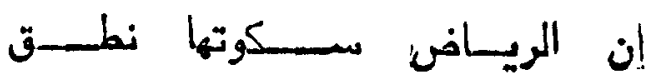

ويحلق المنوبرى بخياله ، فيجلى الطبيمسة الجديلة ورياضسها

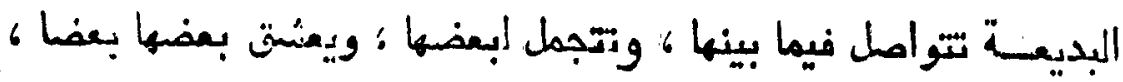

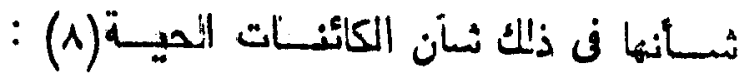

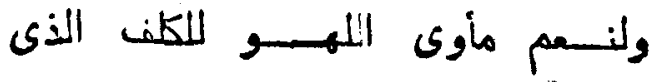

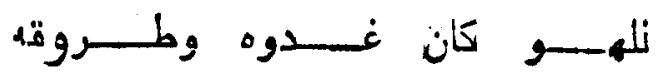

روض عهــلدناه تمسـوغ بطسونه

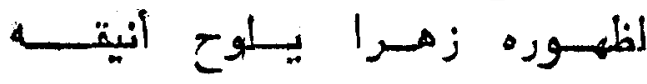

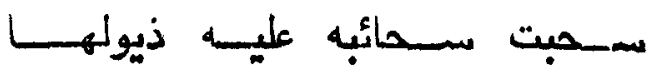

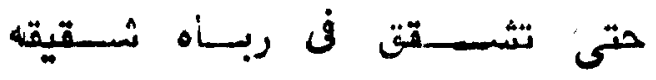

(V) المرجع السابق ص : •r)

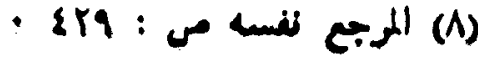




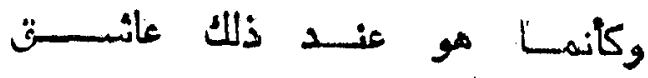

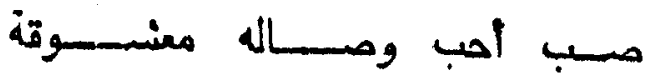

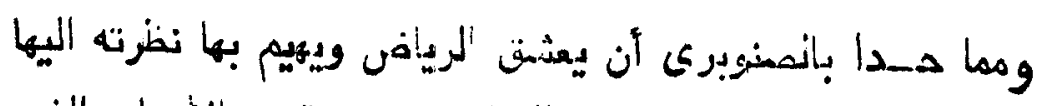

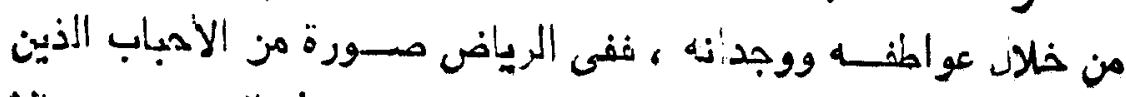

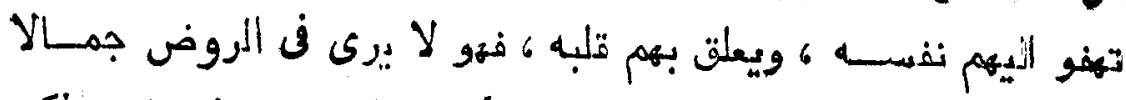

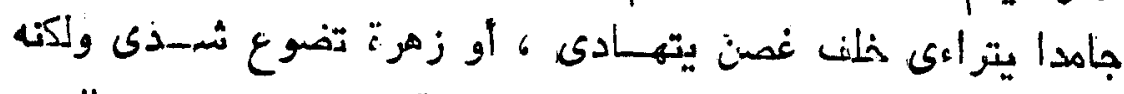

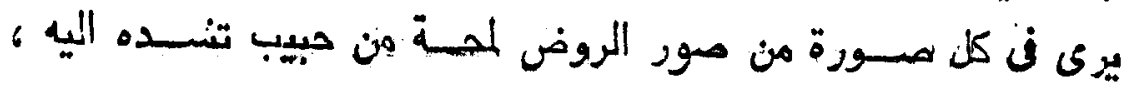

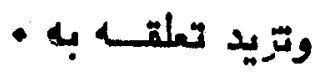

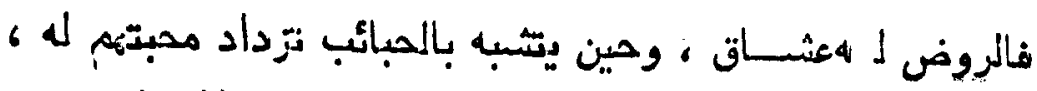

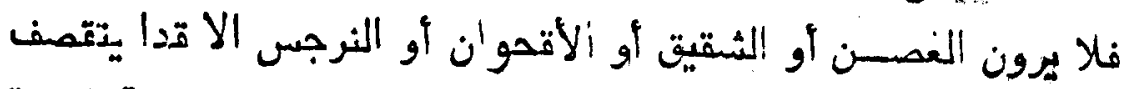

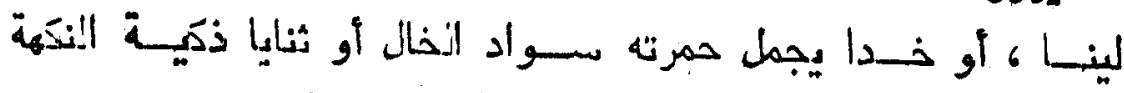
أو عدوذا تصبى حين تسارق انغمز خشية الرقباء(9) :

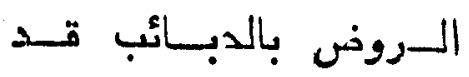

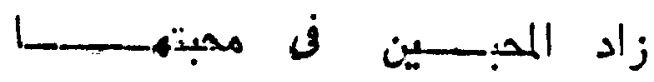

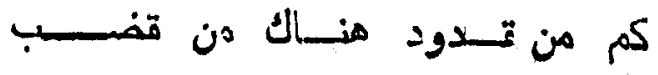

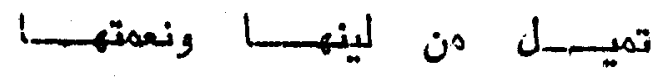

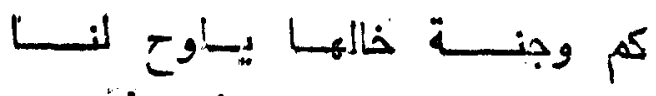

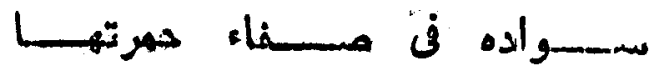

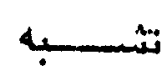




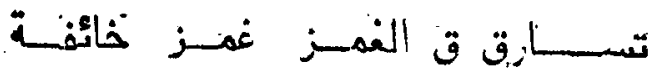

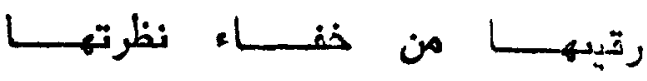

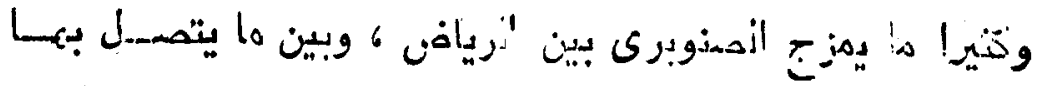

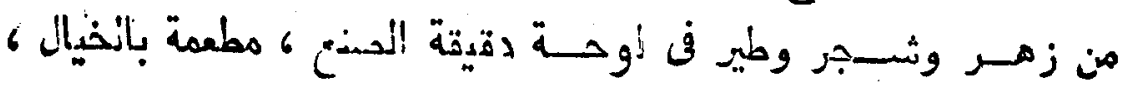

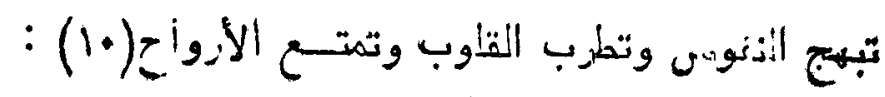

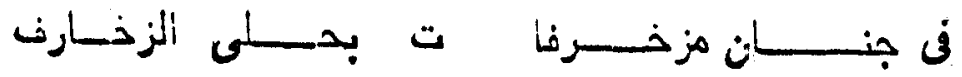

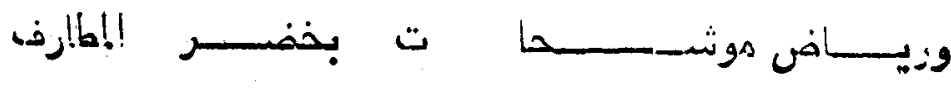

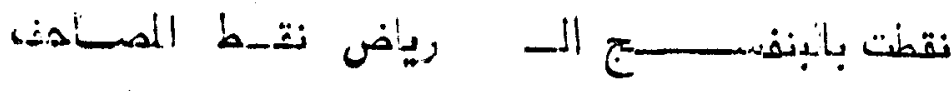

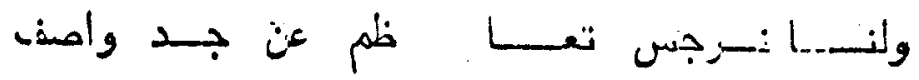

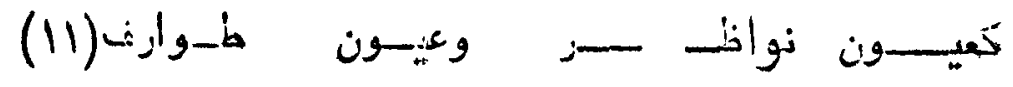

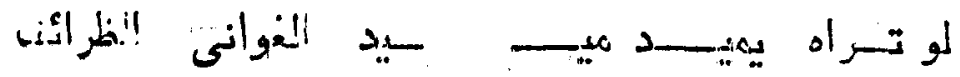

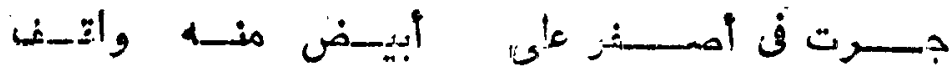

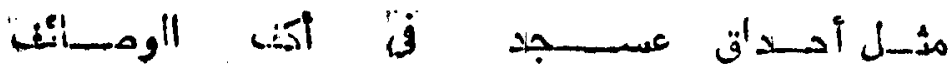

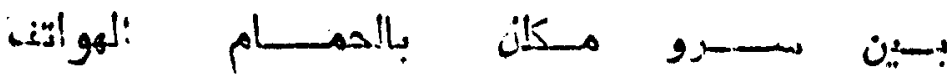

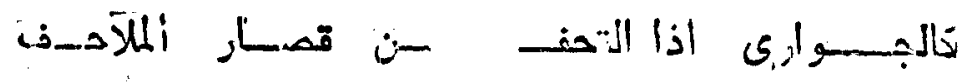

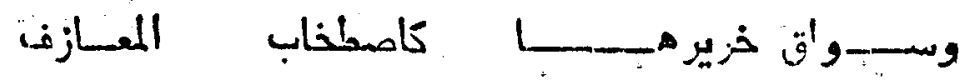

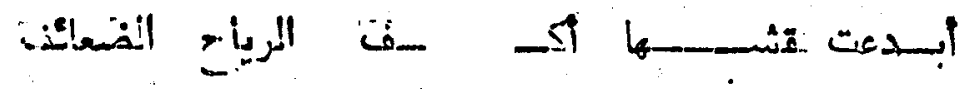

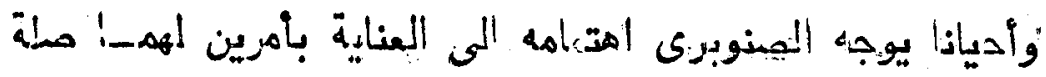

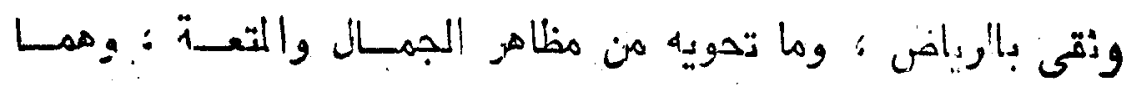

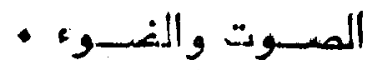

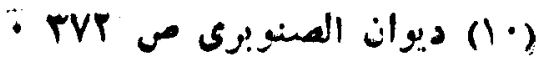

|ll) الميون الطوارف : المنكسرة تنثرا - 


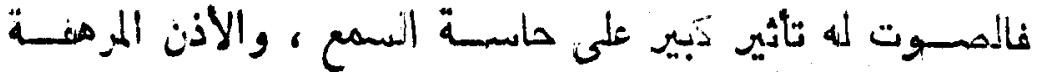

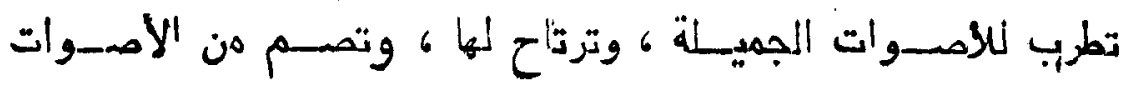

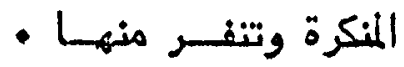

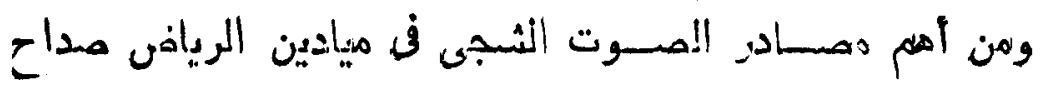

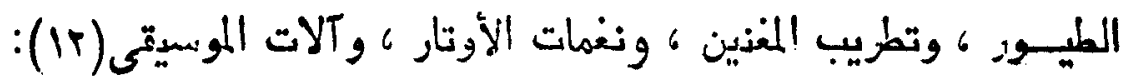

$$
\text { فن روضـا زهرت بألنبت قد شينت }
$$

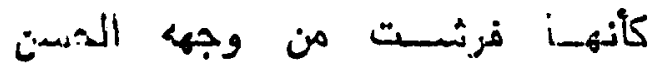

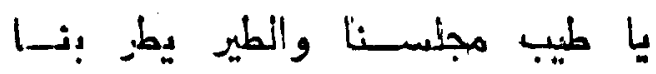

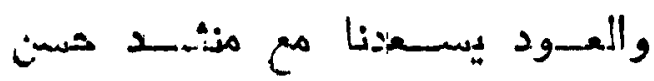

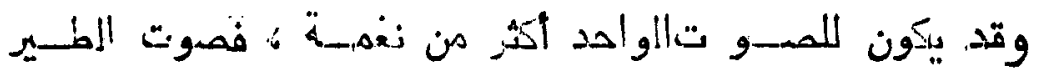

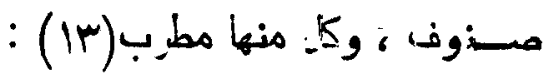

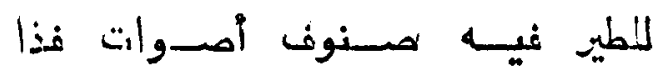

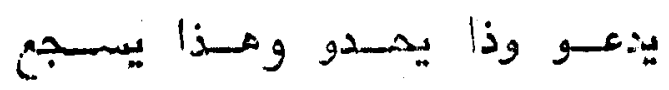

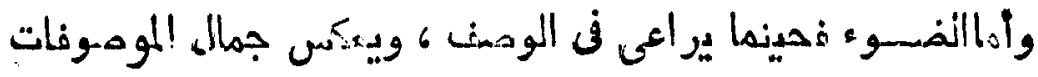

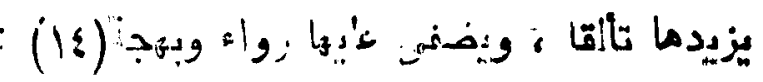

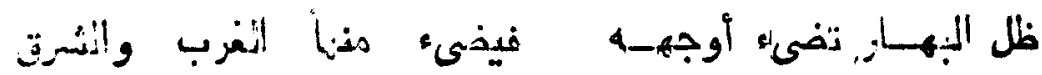

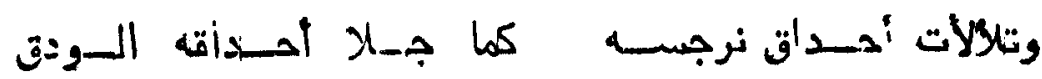

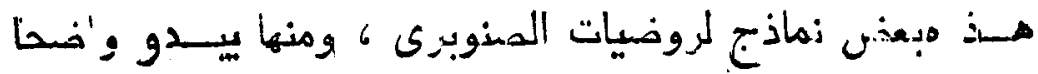

(IT) تكملة الديوان ص : (IT)

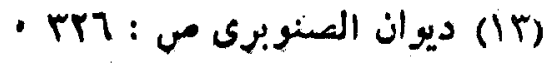

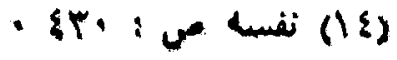




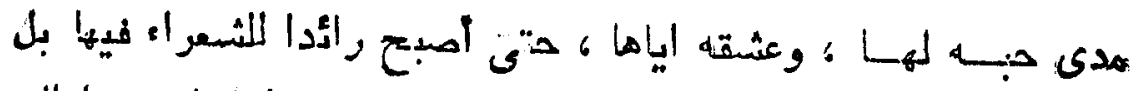

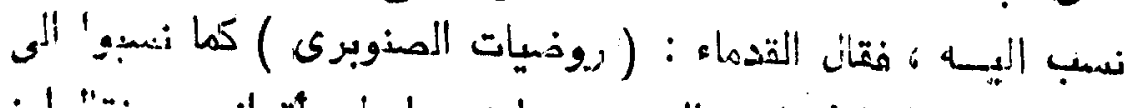

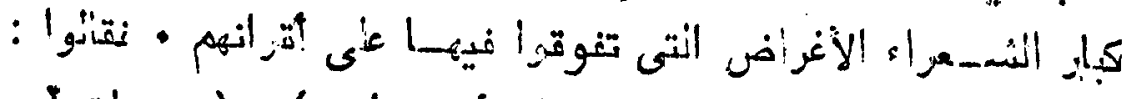

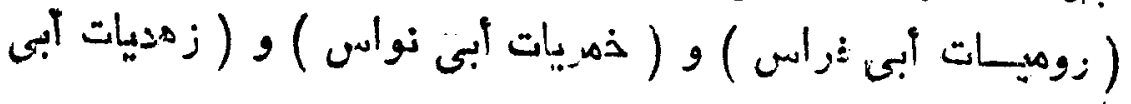
- العتاهيـة )

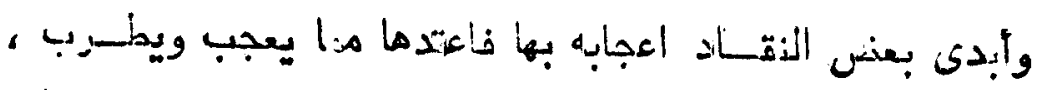

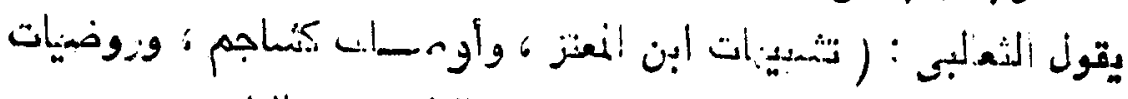

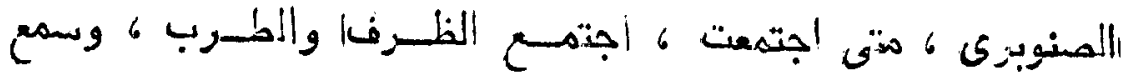

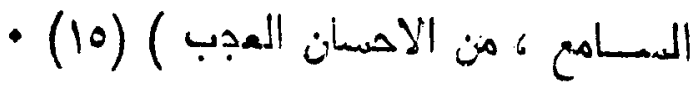

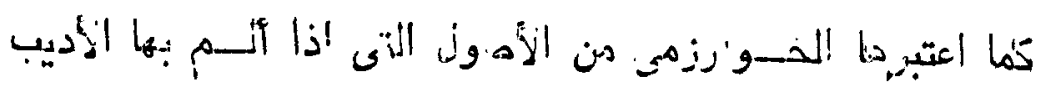

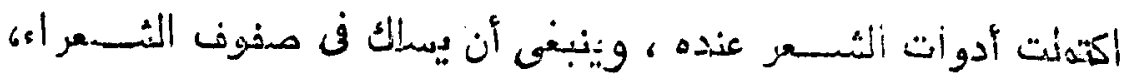

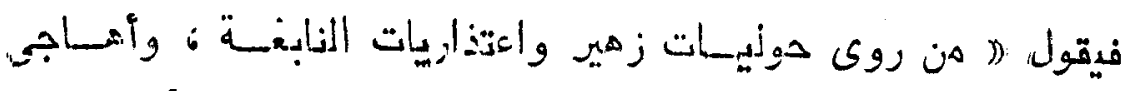

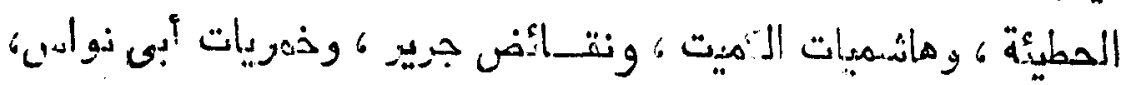

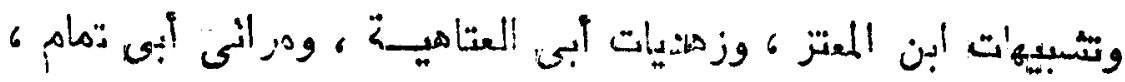

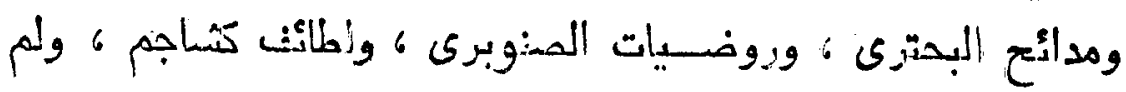

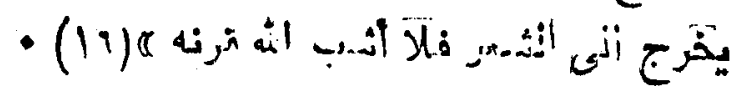

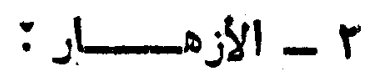

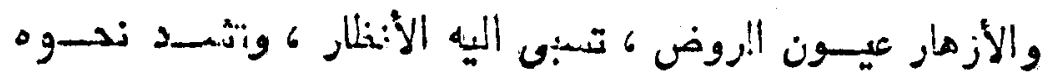

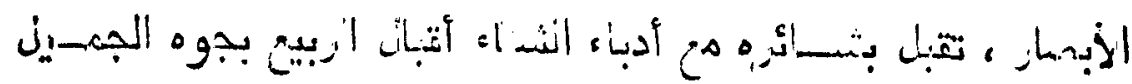

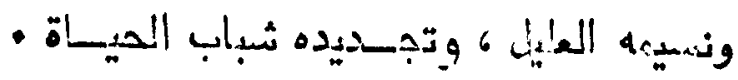

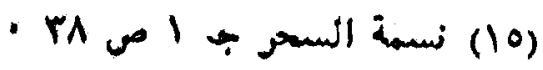

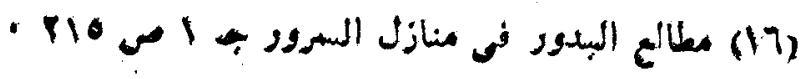




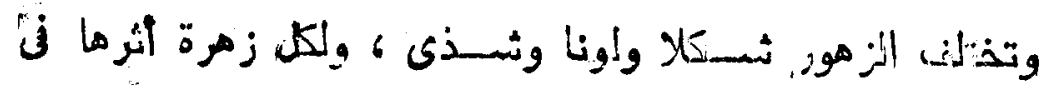

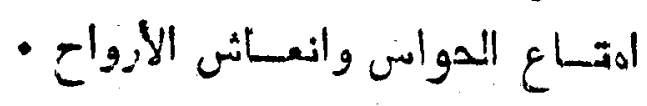

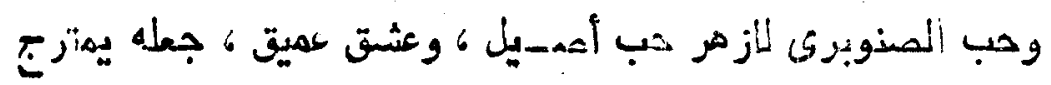

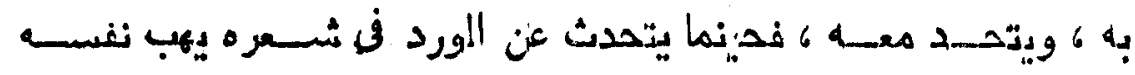

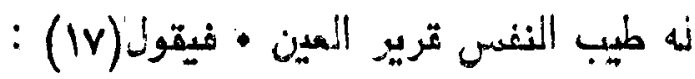

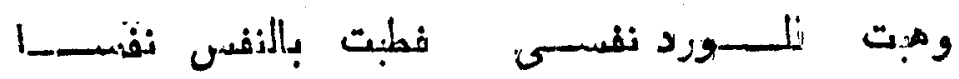

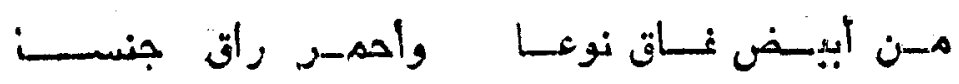

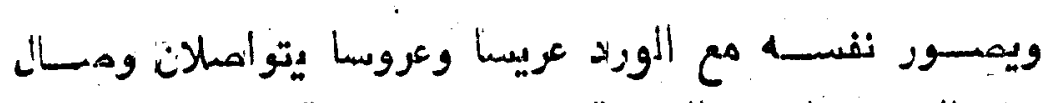

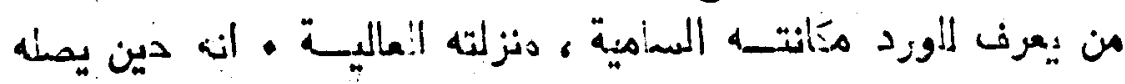

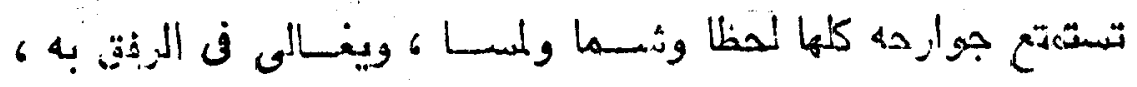

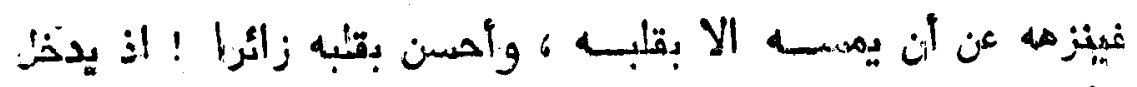

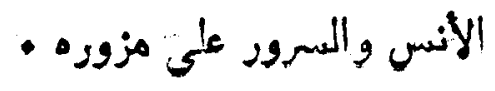

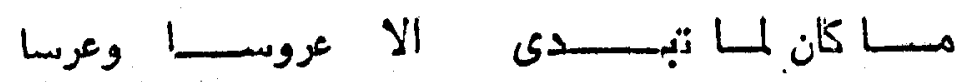

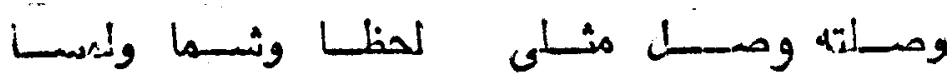

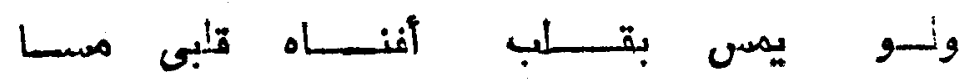

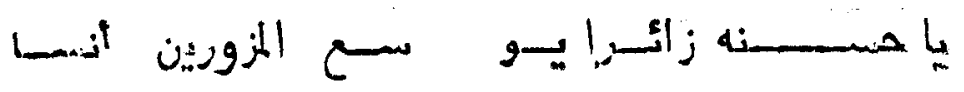

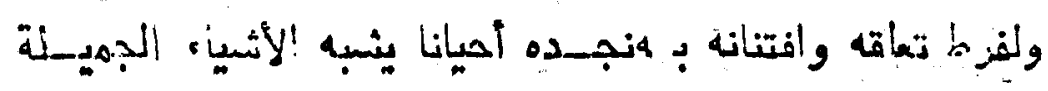

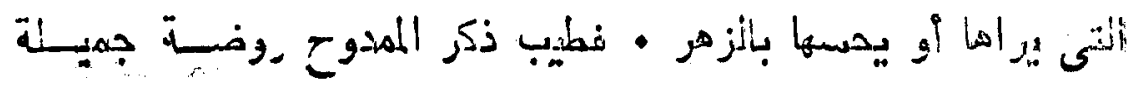

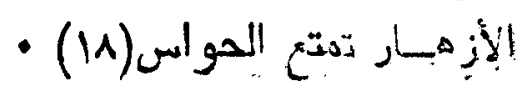

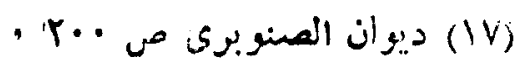
- V9 نقيه (IN)

$(j v-i)$ 


\section{ف}

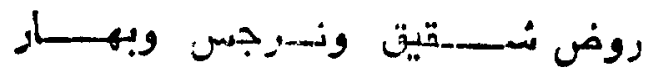

والهـديث الجميلن دقطي حسنا كأزاهي الزهـدر(19) :

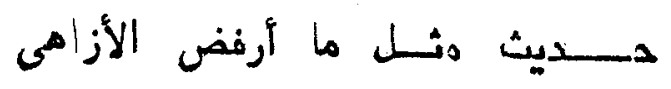

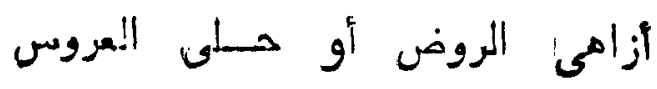

واذزهو البيديع يستدعى مجالس الثئب والطرب(•r) :

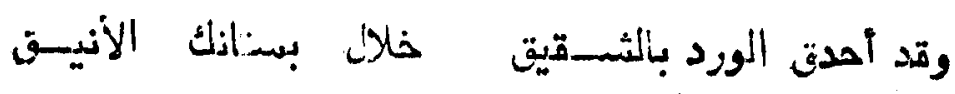

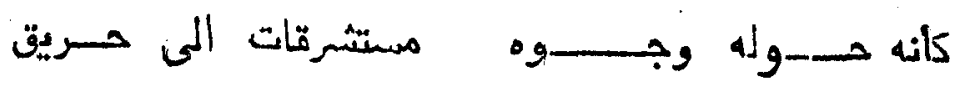
هانسرب عائ ذا الشقيق كأسا

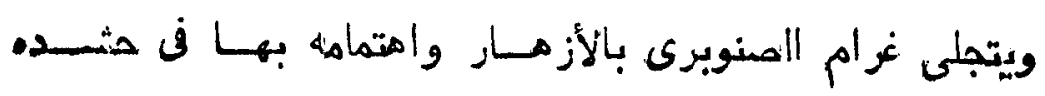

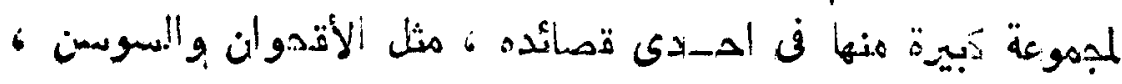

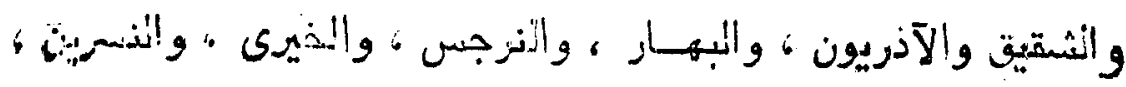

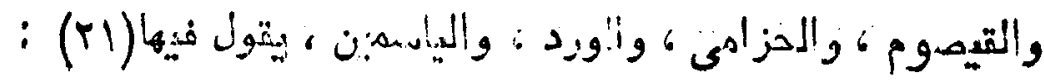

يا نديسهى أهسا نحن الى إقصس

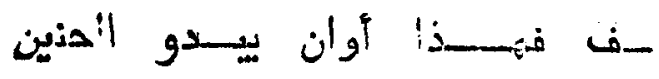

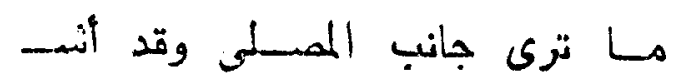

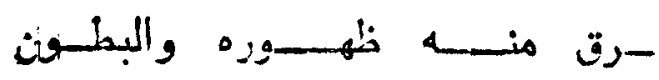

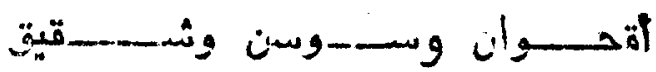

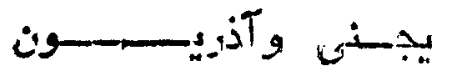

- (19)

- EY : : تمبه

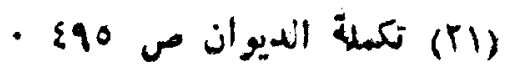




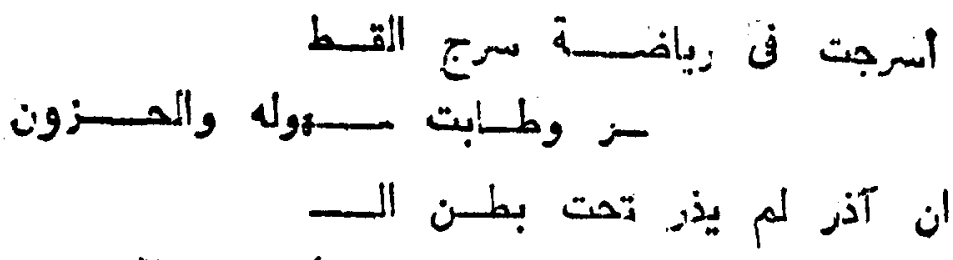

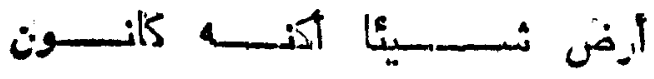

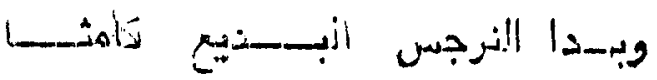

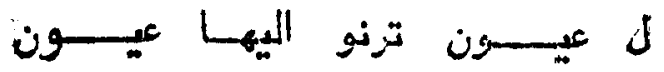

ما تزى جانب الهنى وتسـ أشسـر

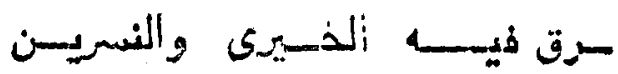

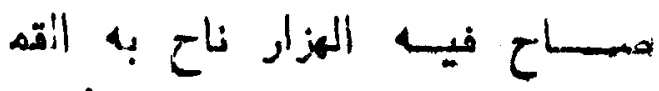

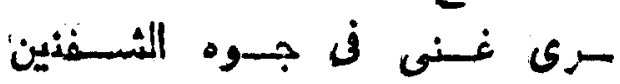

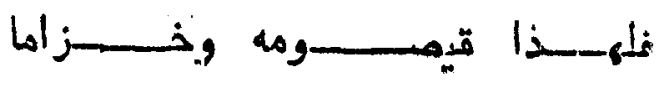

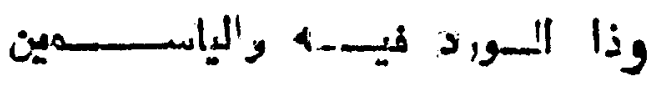

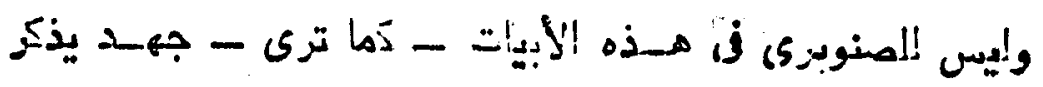

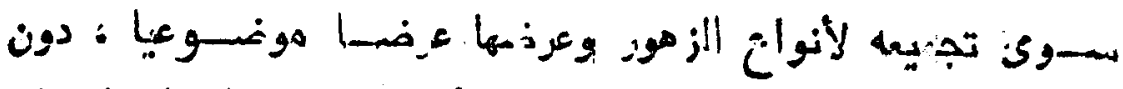

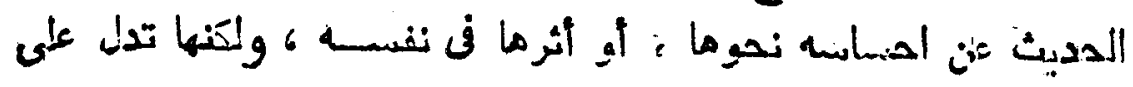
مدى الهتمامه بها وحصره لأدئأفها

وأولغ الهمنوبرى بأنواع خاصسـة هن الزهود 6 فأعطاها الهتماما

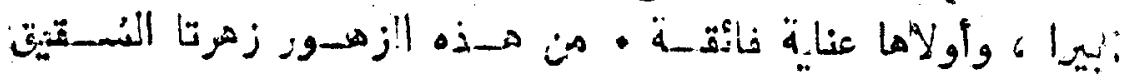

- و النرجس

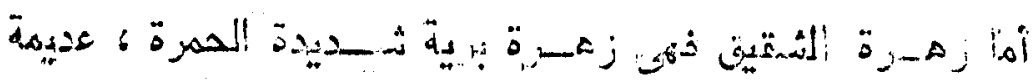

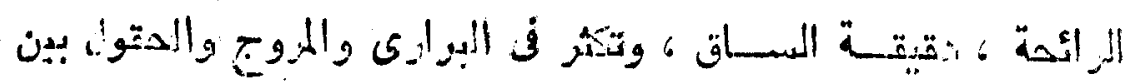

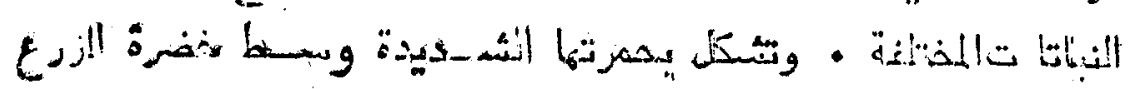

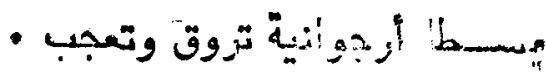




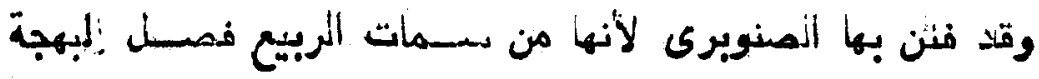

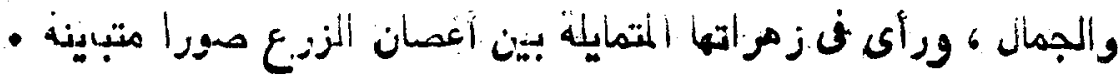

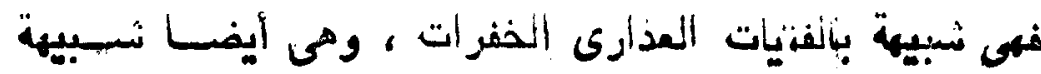

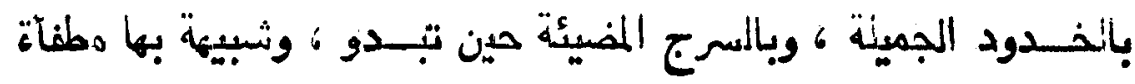

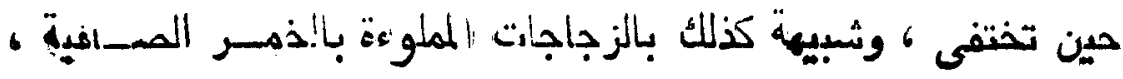

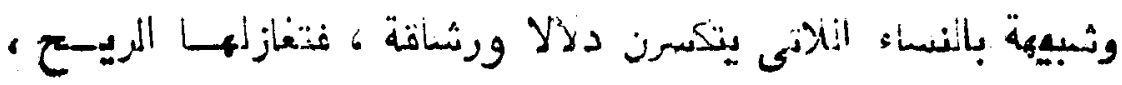

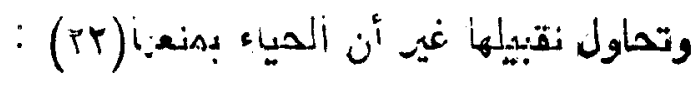

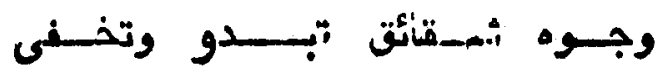

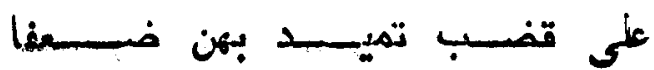

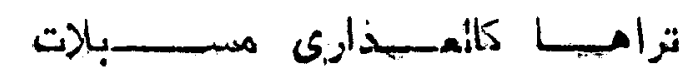

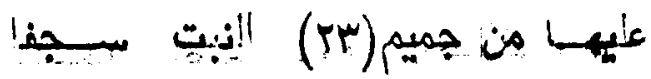

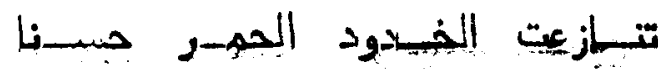

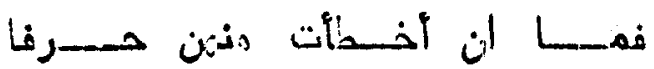

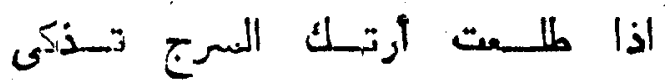

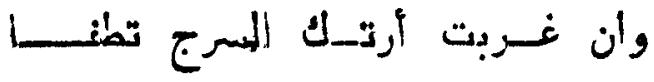

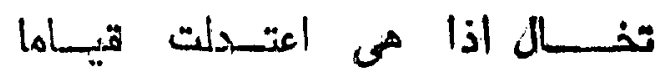

زجـاجات ملّن الخمسر صـــــــا

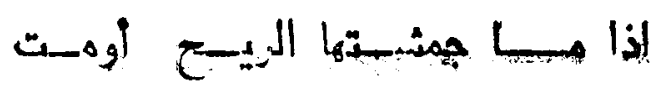

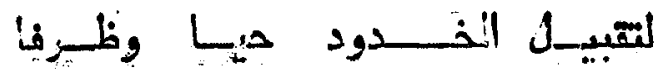

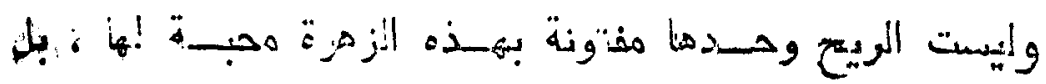

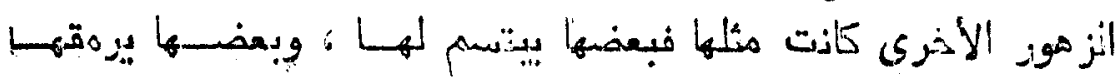

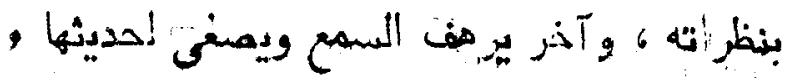

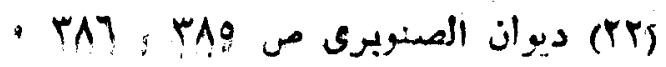

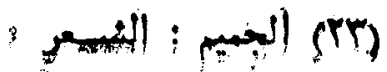




\section{$\because !$}

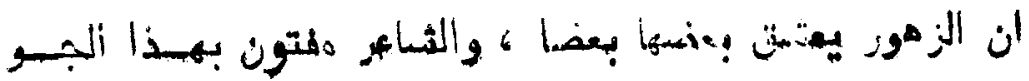

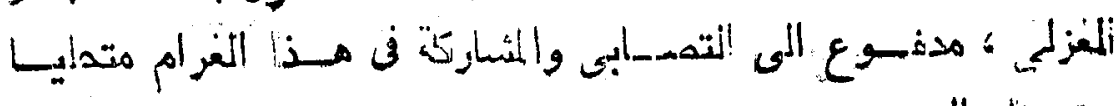

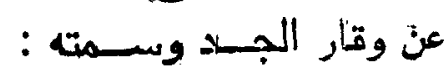

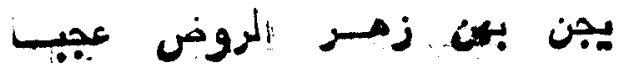

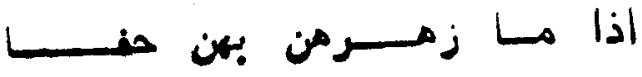

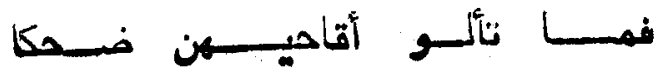

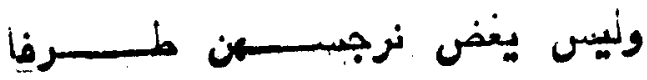

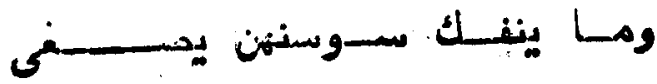

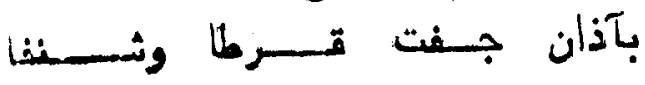

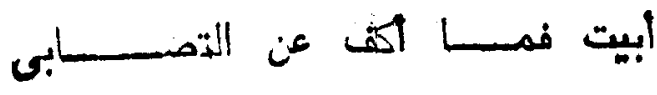

بهن وكيف يحســن أن أكنـ

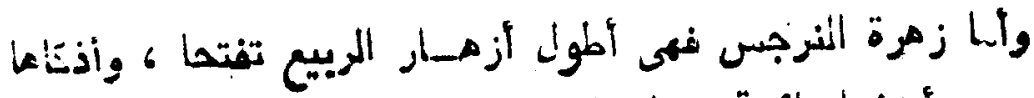

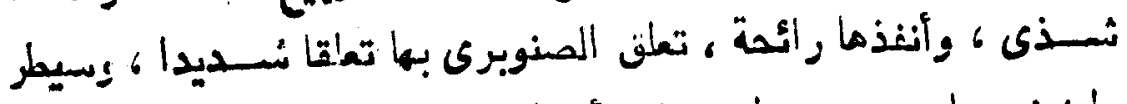

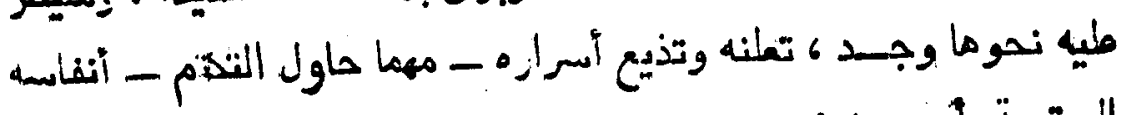

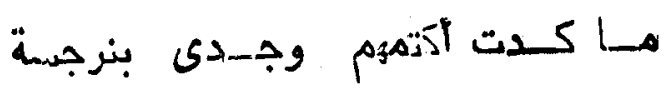

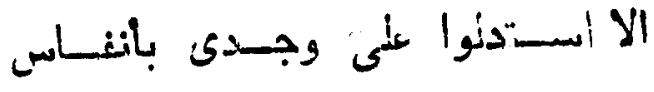

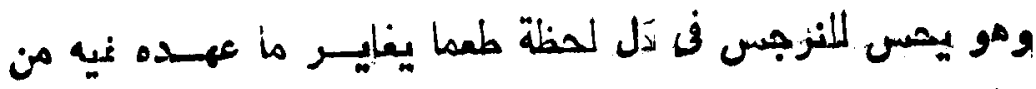

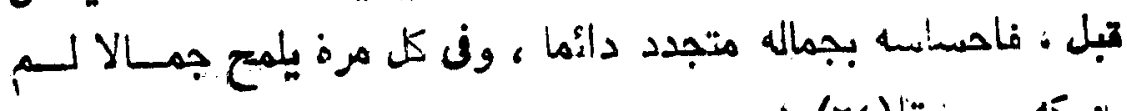

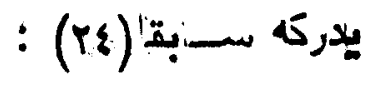

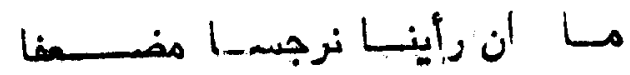

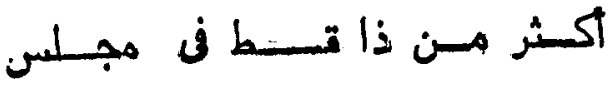

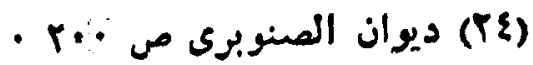




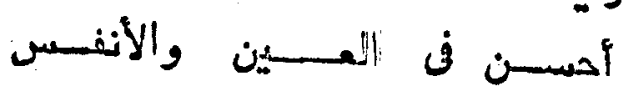

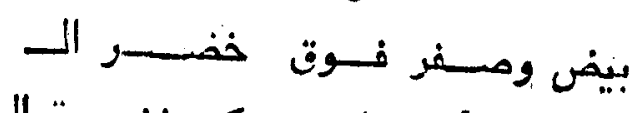

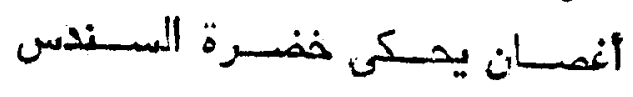

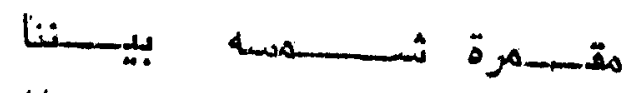

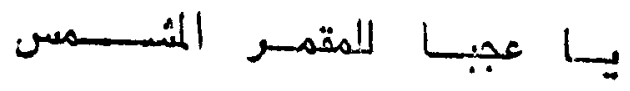

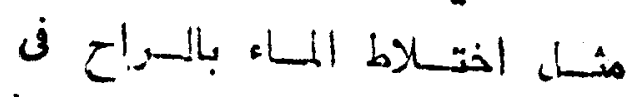

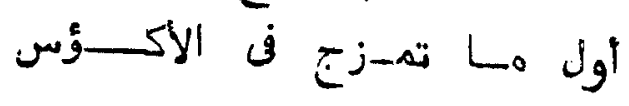

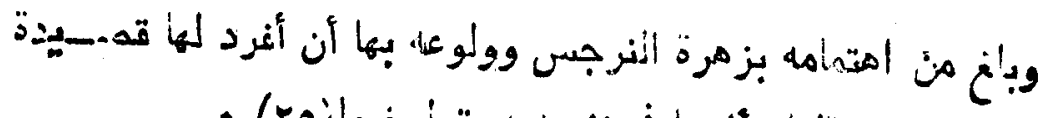

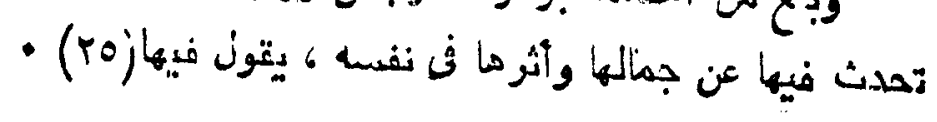

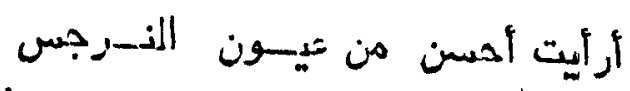

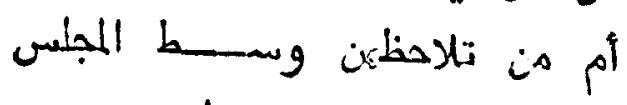

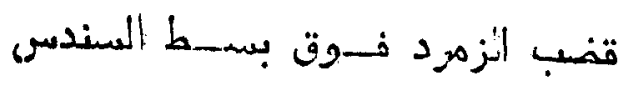

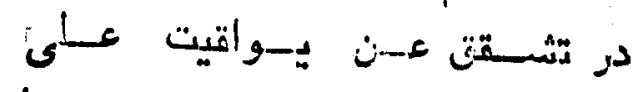

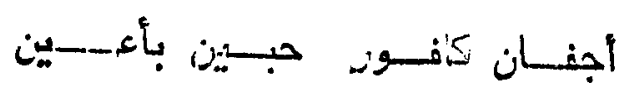

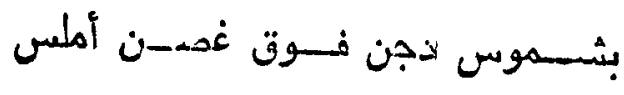

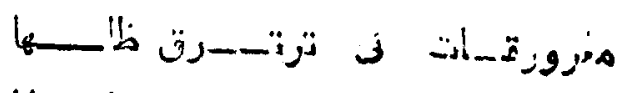

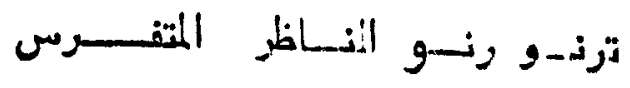

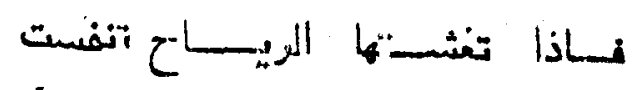

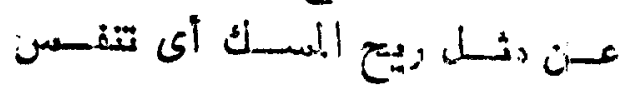

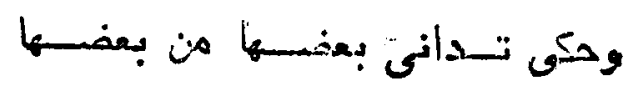

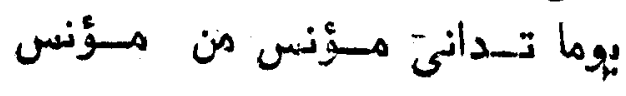

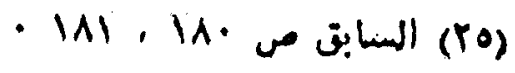




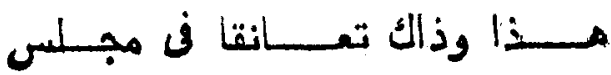

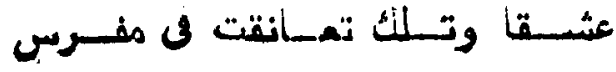

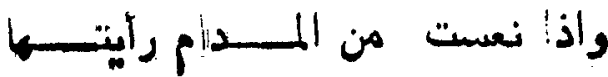

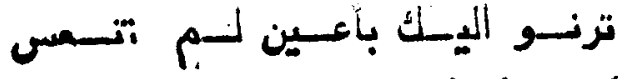

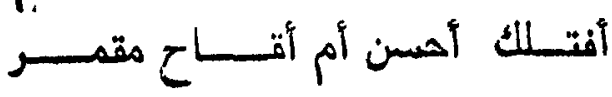

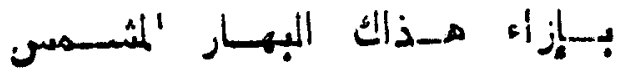

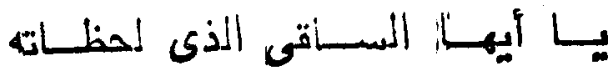

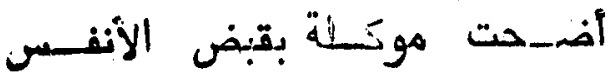

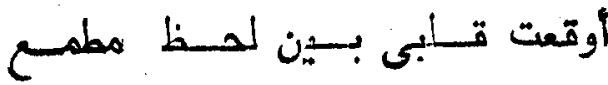

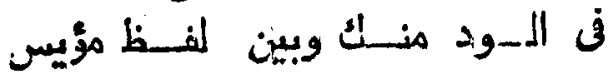

فقد شخص زهرة النرجس 6 وأبرزما في صور، محبية من النهيوبة

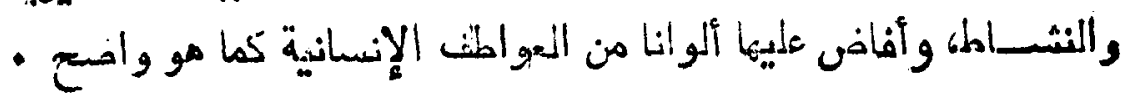

غنى إلصنوبرى للأز هلر. أشعارا رقيقة ؛ ورسم لها صورا مبتكرة

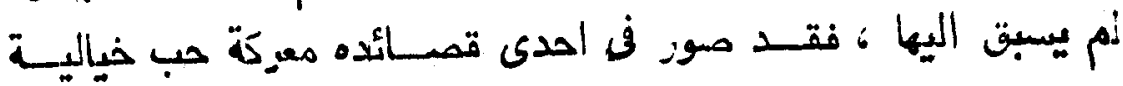

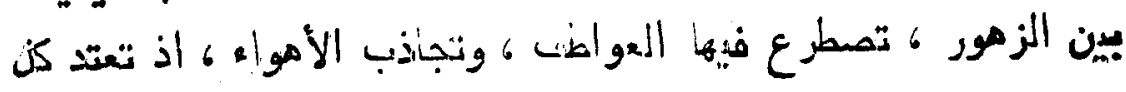

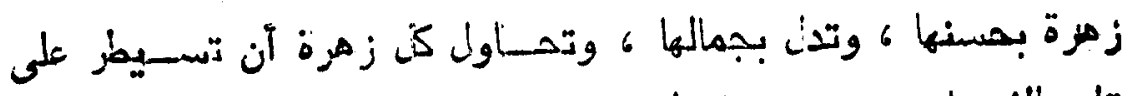

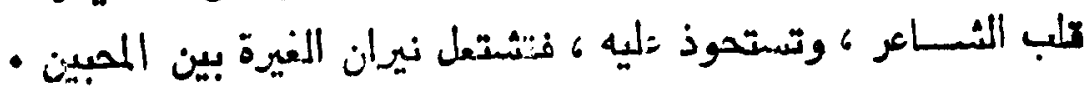

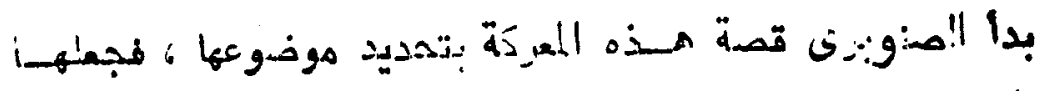

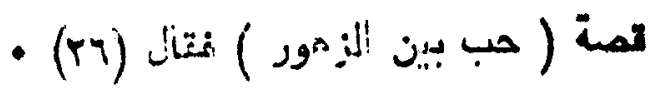

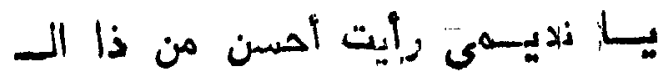

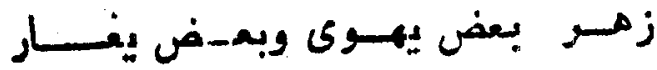

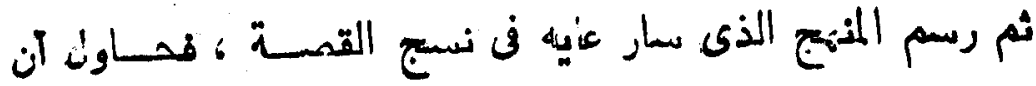

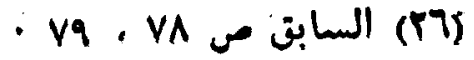




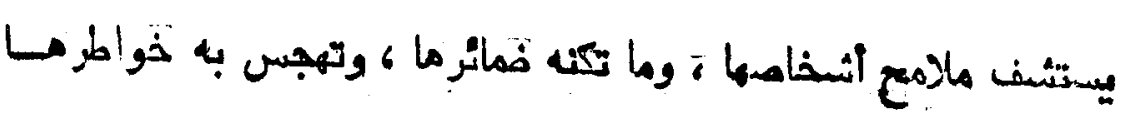
: فتمسال

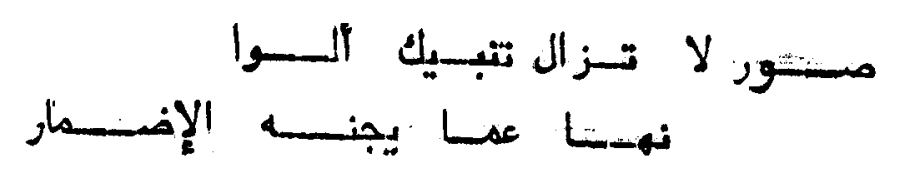

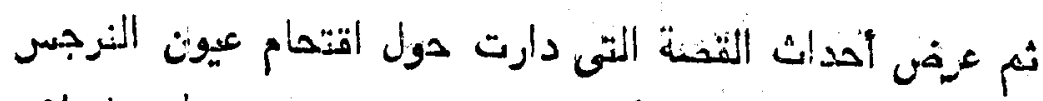

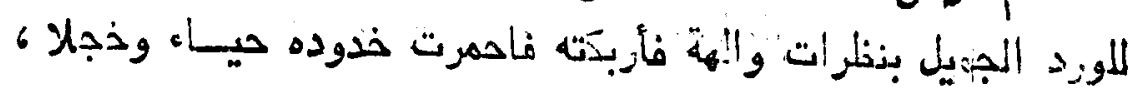

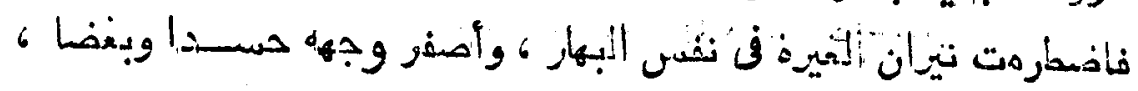

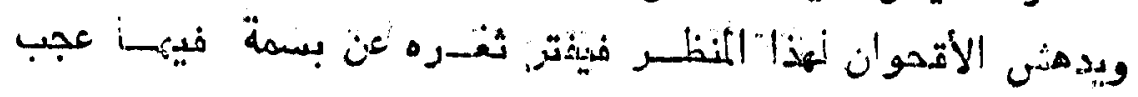

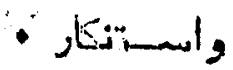

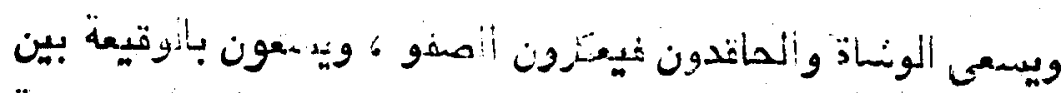

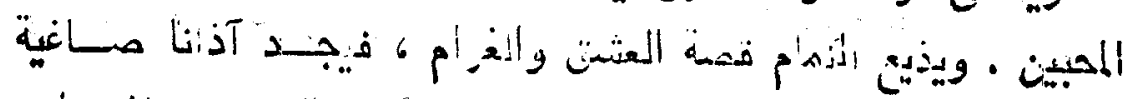

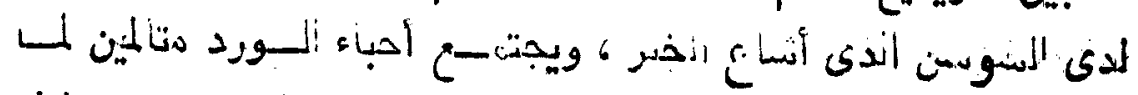

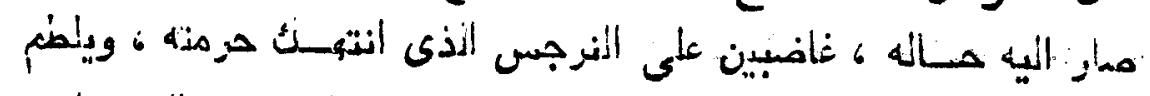

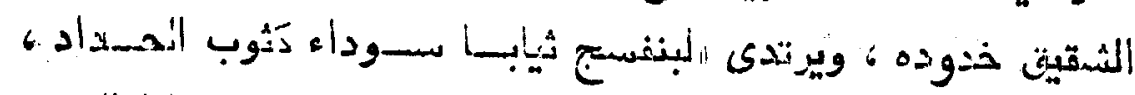

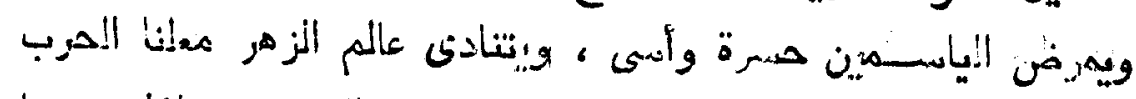

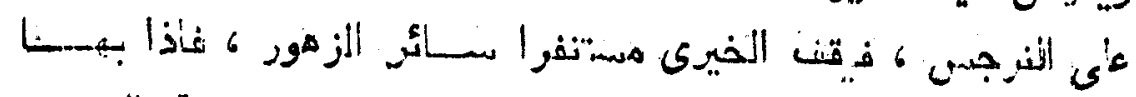

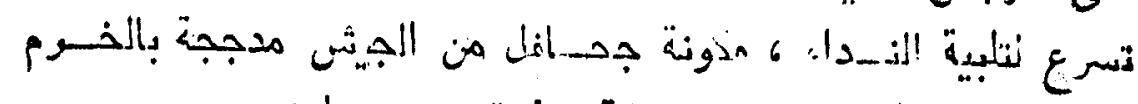

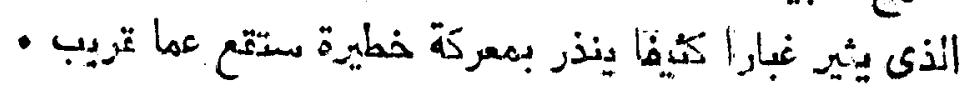

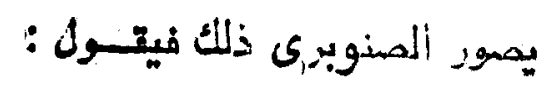

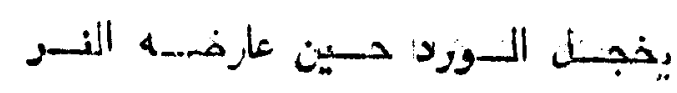

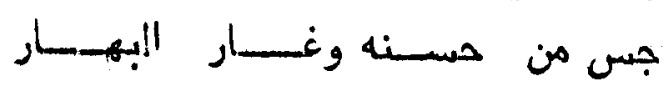

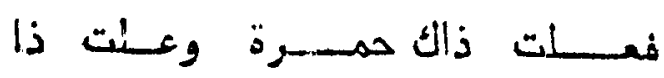

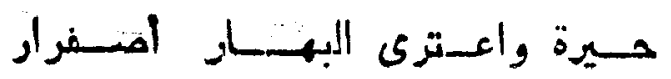




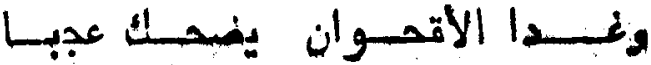

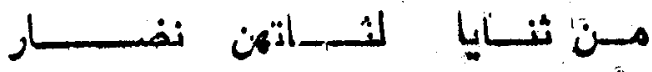

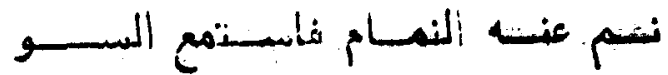

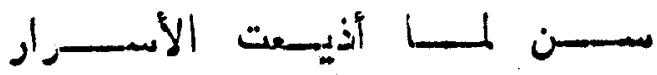

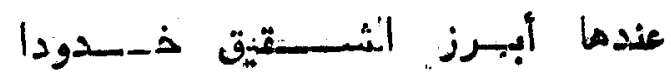

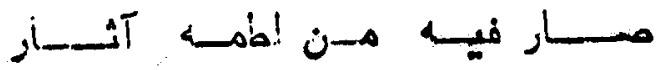

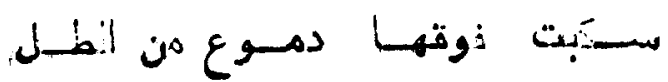

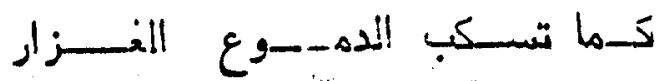

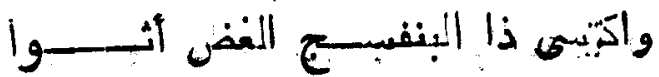

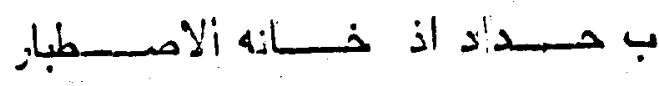

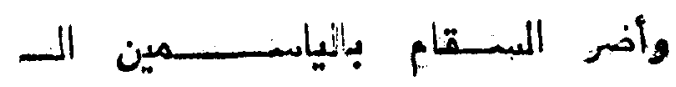

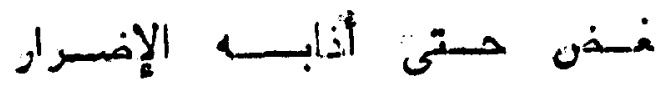

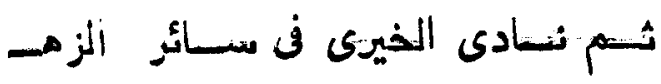

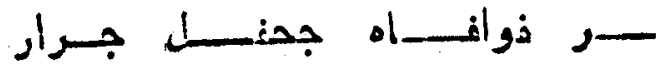

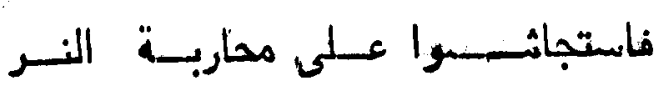

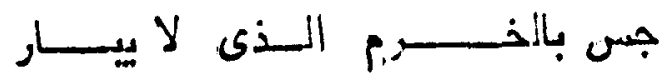

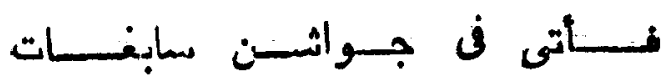

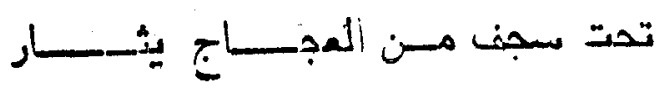

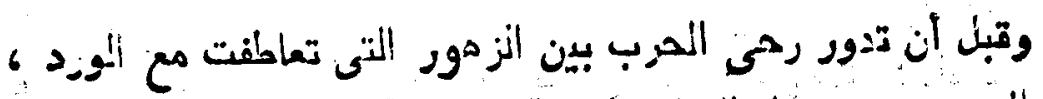

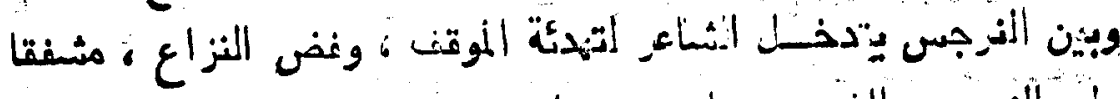

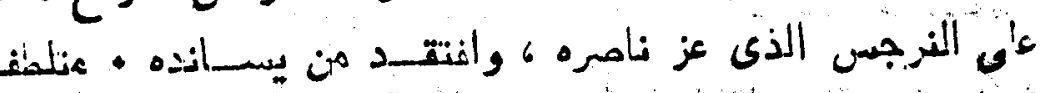

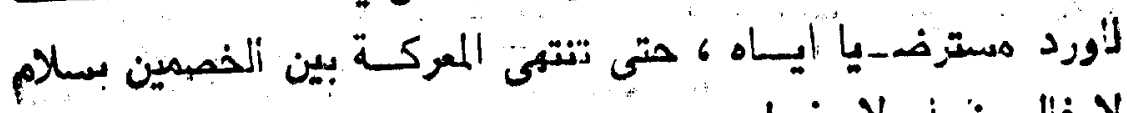

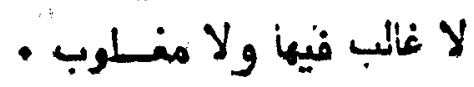




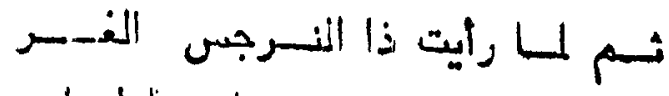

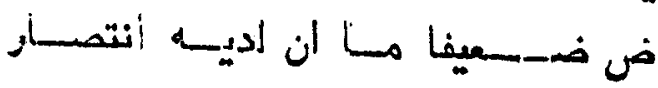

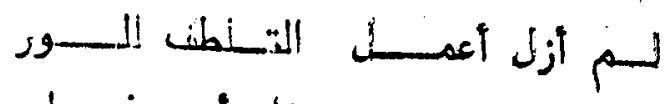

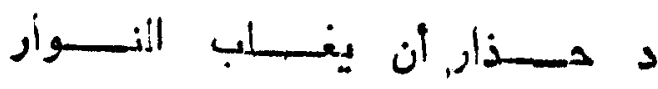

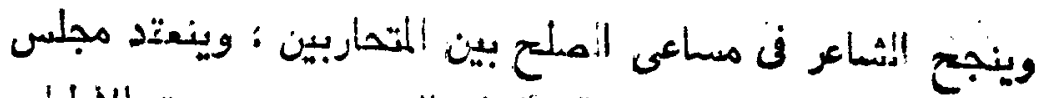

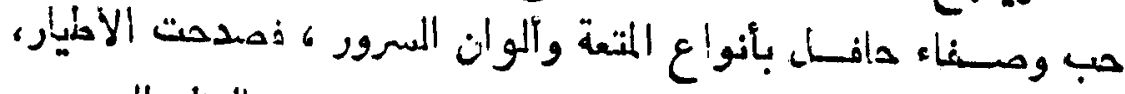

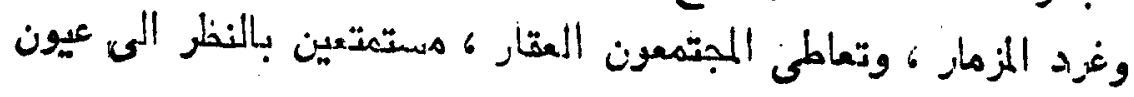

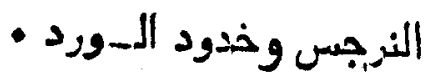

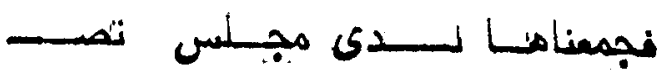

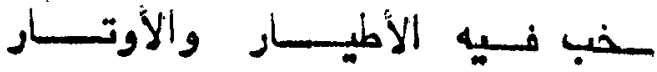

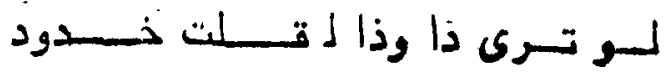

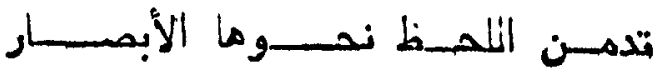

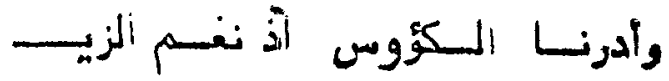

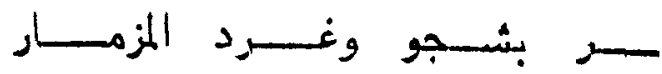

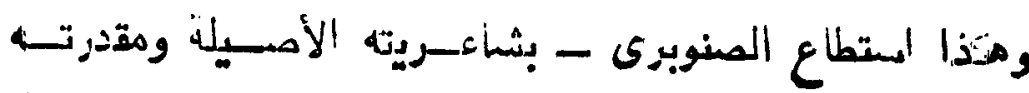

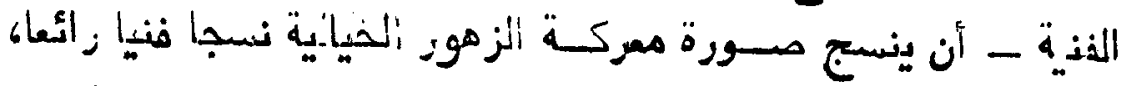

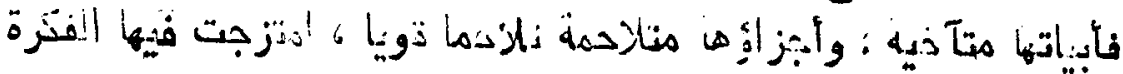

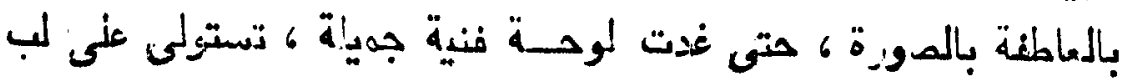

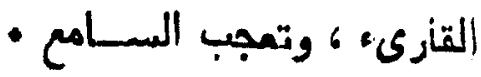

ومها يرفع من ثشأن هذه المصورة ، ويسمو بمكانتها ، أنهـا، ذات

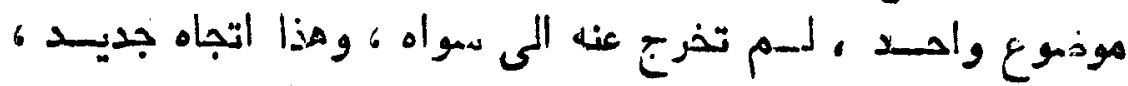

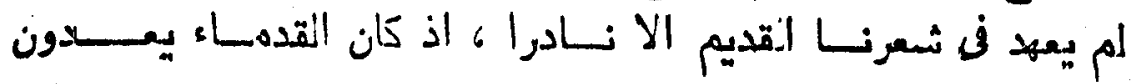

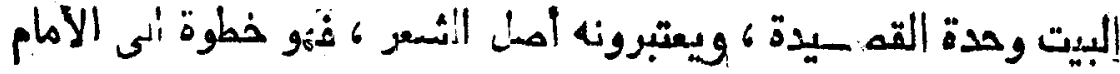

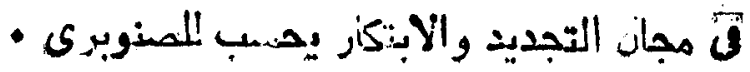




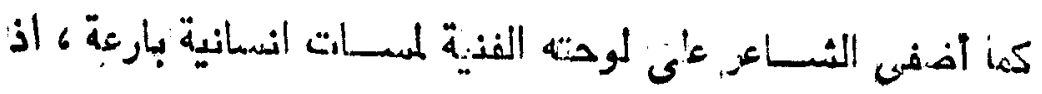

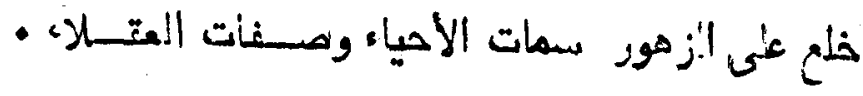

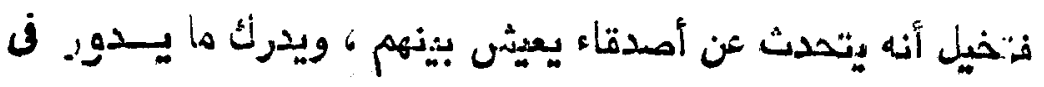

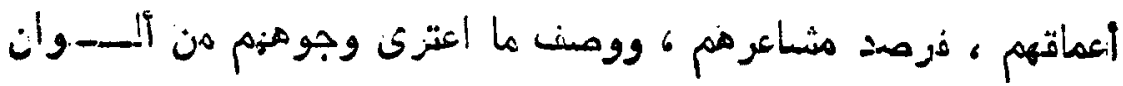

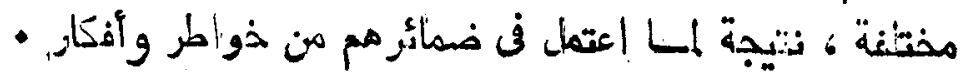

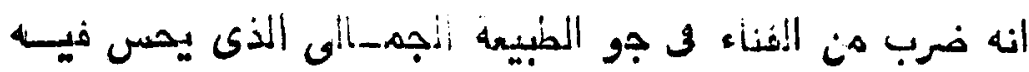

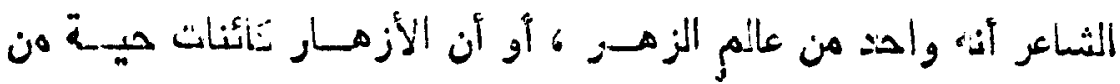

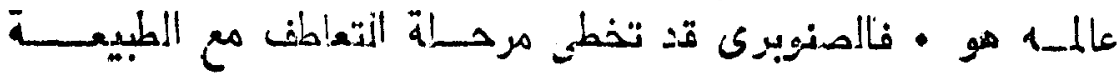

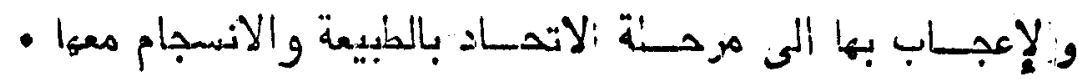
ونى قصسيدة, أخرى يّ"حدث عن شسقائق النعسهان والنـرجس

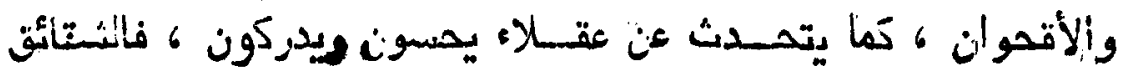

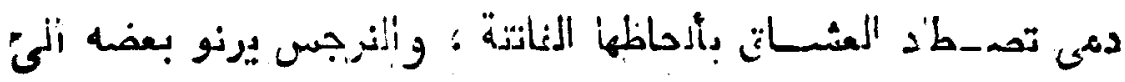

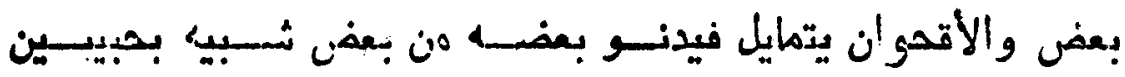

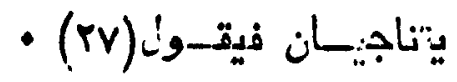

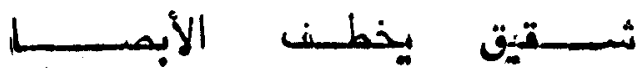

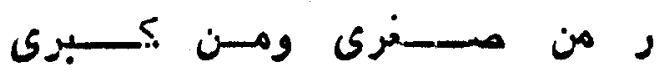
دمسى بتندسـن من بالألح

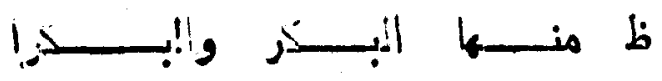

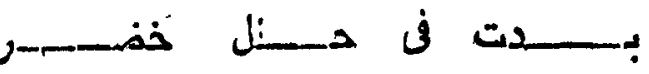

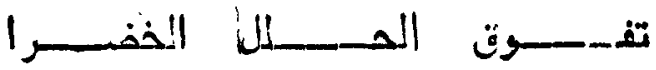

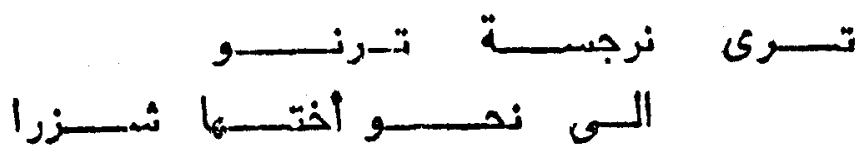




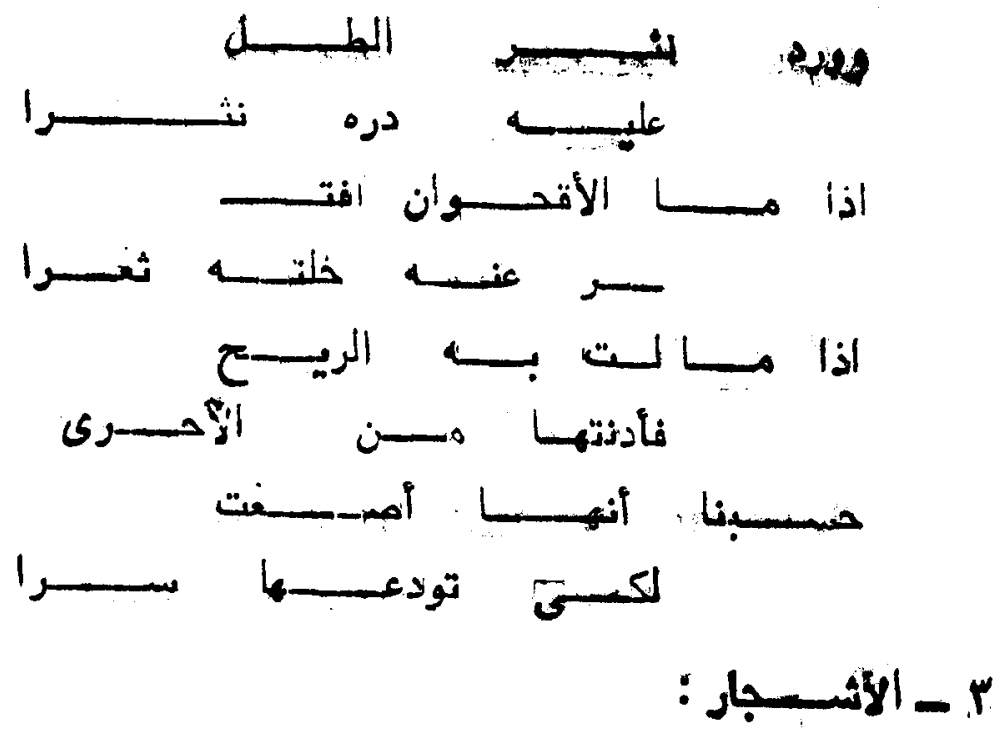

وكان للأُشجار صدى فن نفس المهنوبرى ، إذ هى تتراءى أهـام

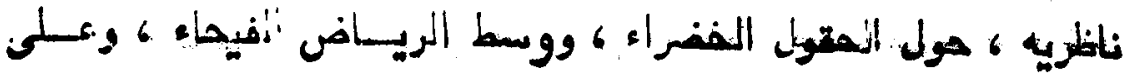

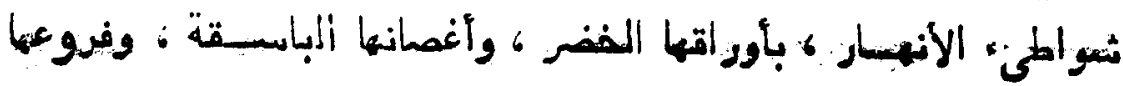

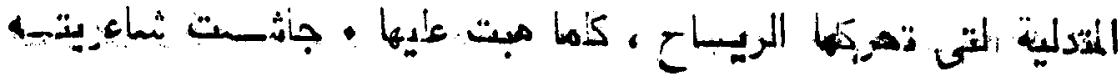

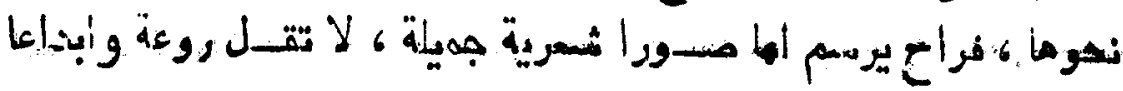

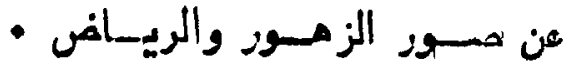

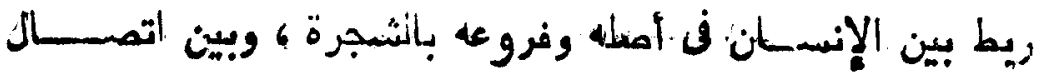

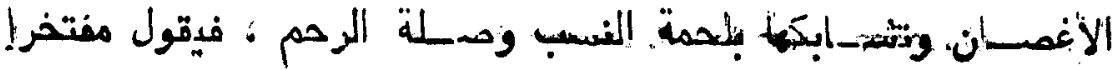

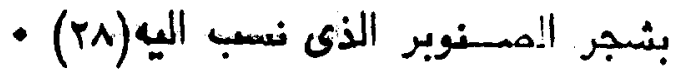

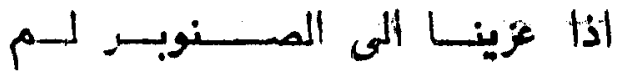

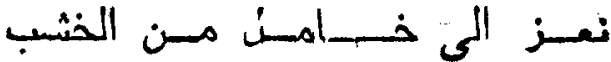

$$
\text { لا بـن الى باسـ-ق الفهروع عـــاليا }
$$

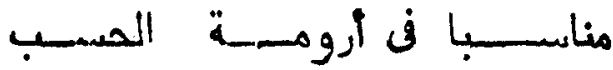

• تكملة الديوان م (YA) 


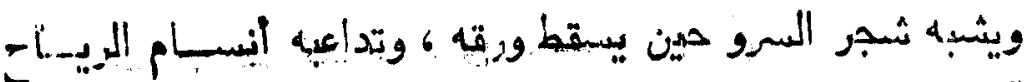

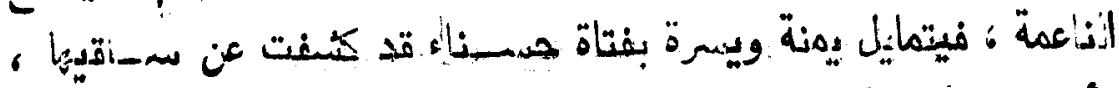

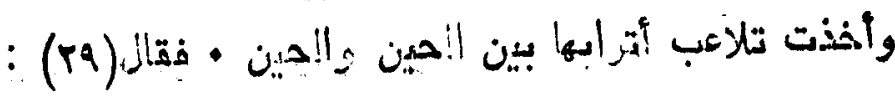

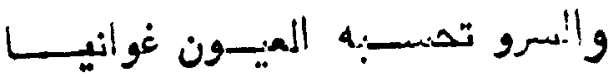

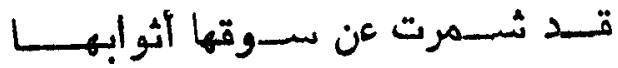

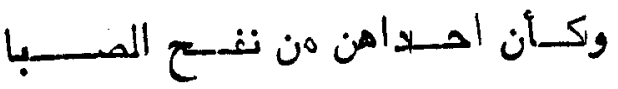

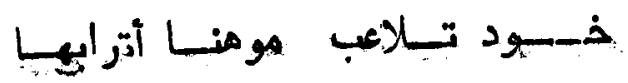

وهن أرق ما قاله فن الثمجر قميدته النتى عزى بها شجرة (الندب)

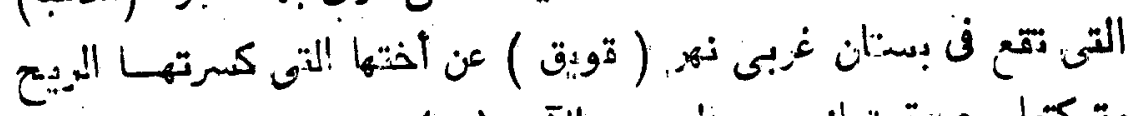

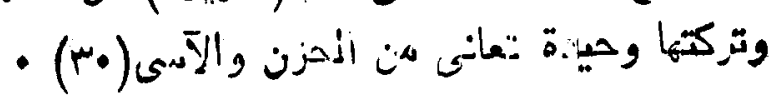

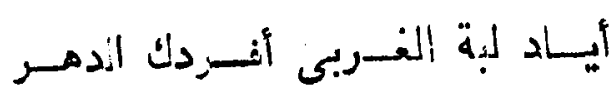

سقى المدلب دلب الفغرب من إجلنك ألقطر

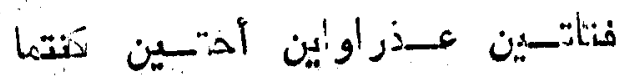

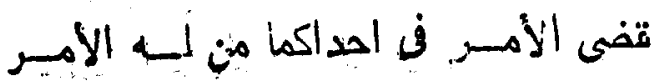

ثم يعتد مشاركة وجدانية بينه ربين مذه الشجرة • فقد فتد هو

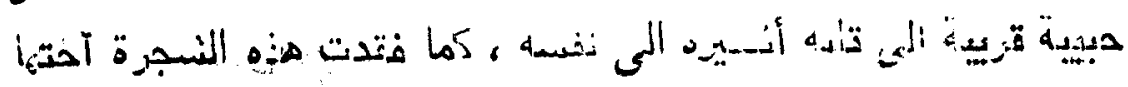

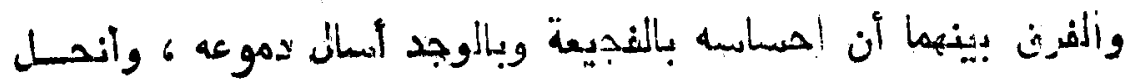

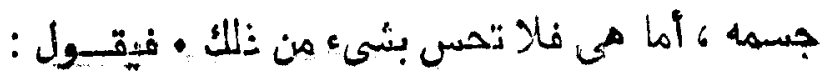

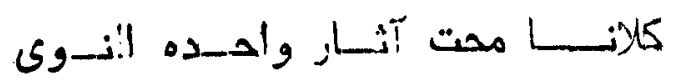

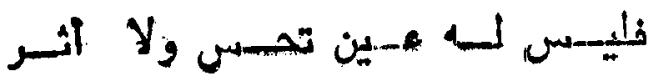

:

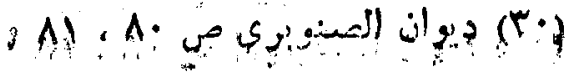




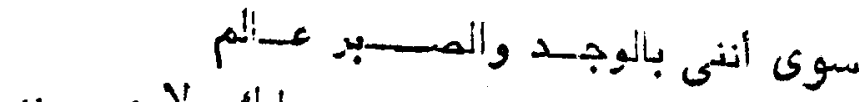

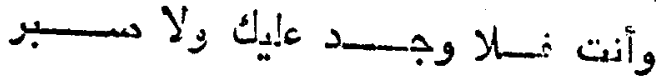

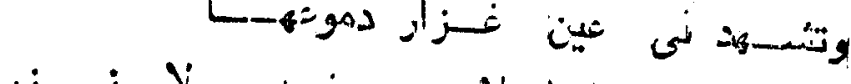

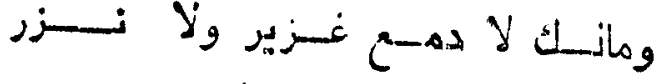

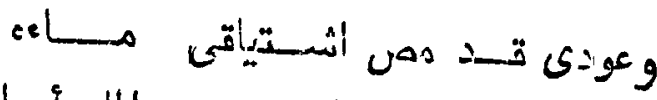

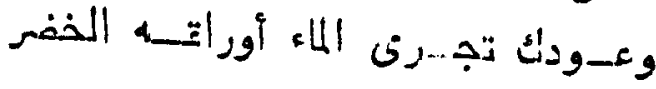

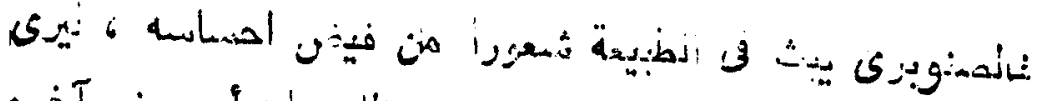

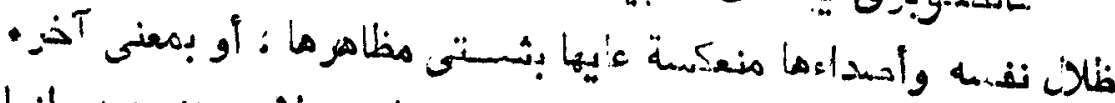

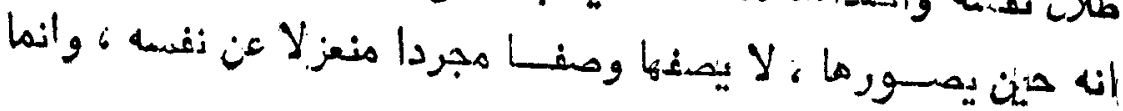

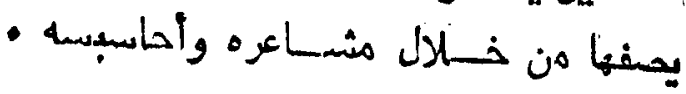

\section{8}

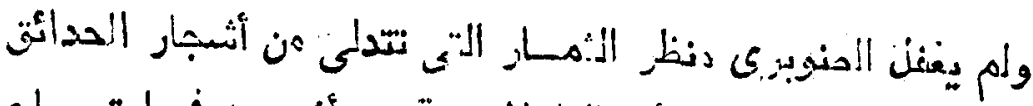

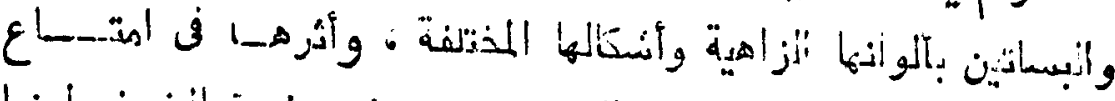

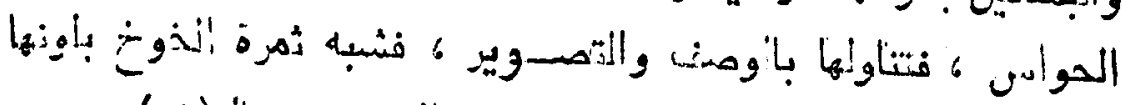

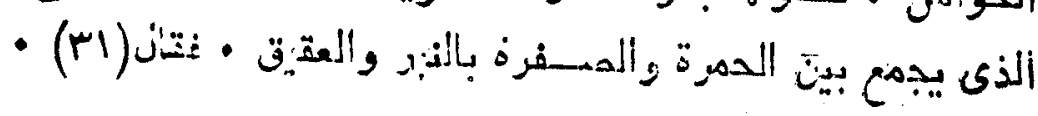

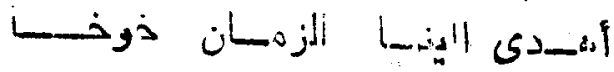

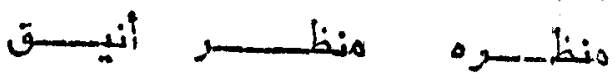

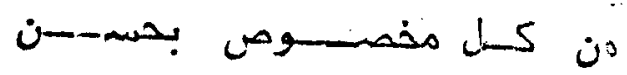

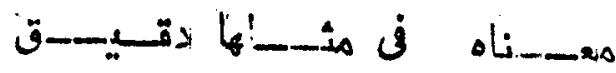

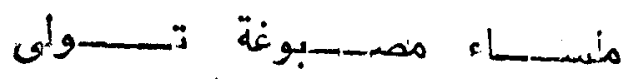

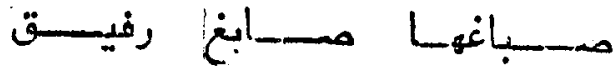

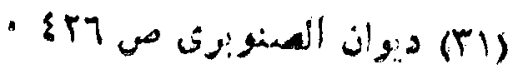




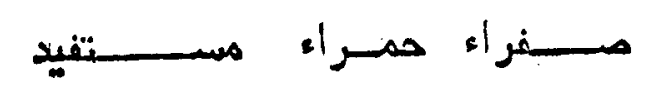

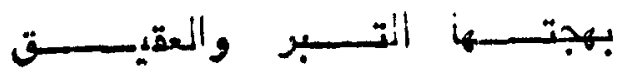

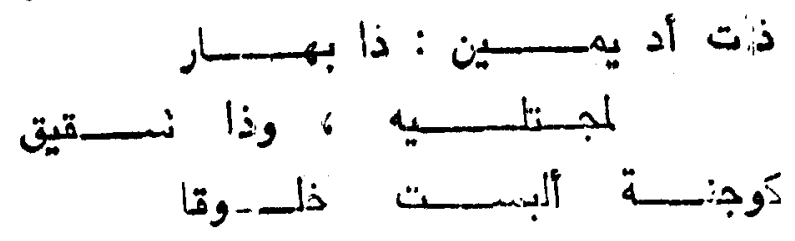

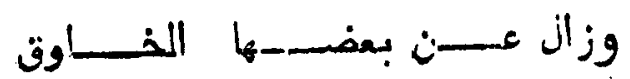

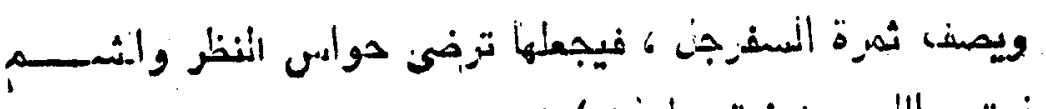

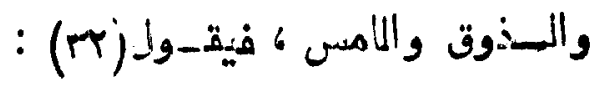

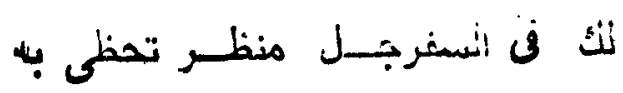

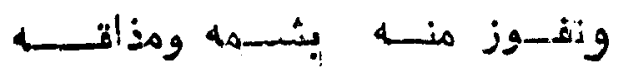

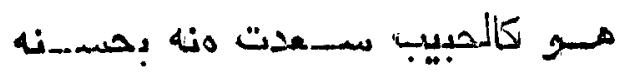

أis

يـكى اذا ألذهب إلمهـفى أونهـ

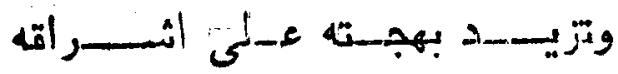

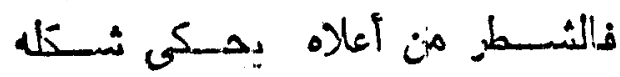

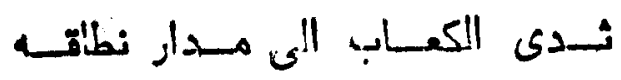

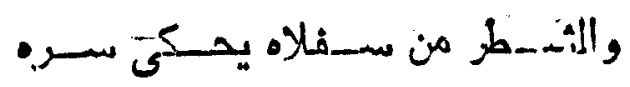

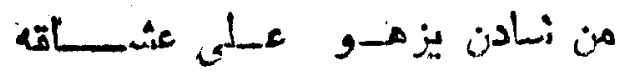

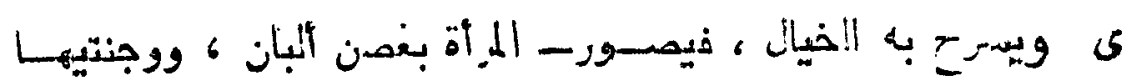

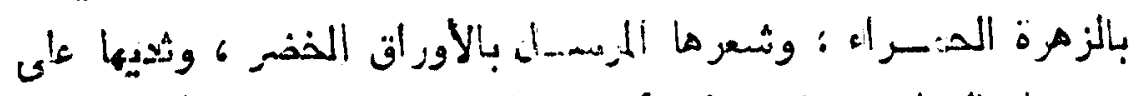

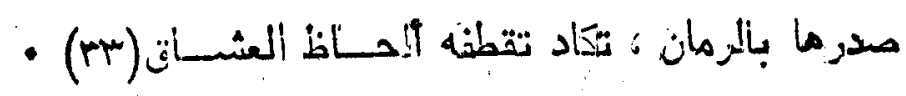

-

• EFV ديو (TrT) 


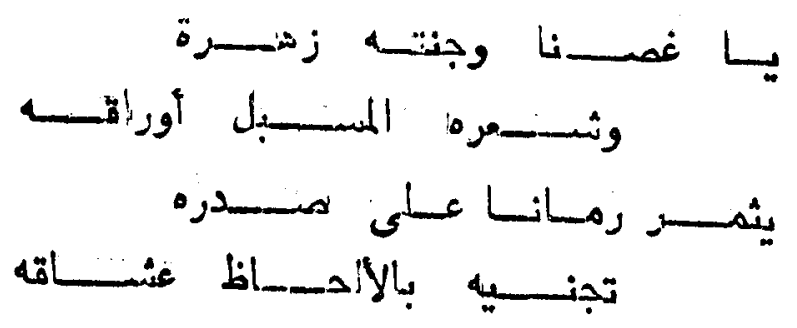

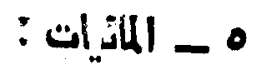

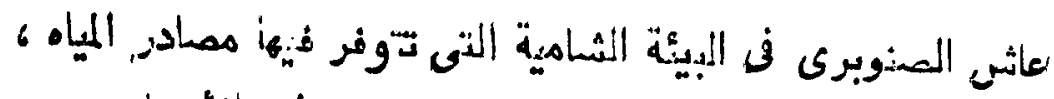

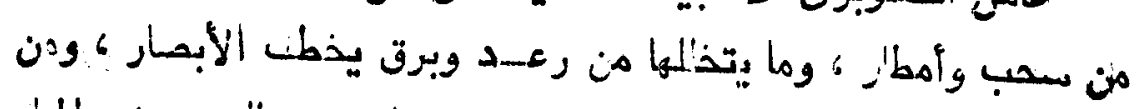

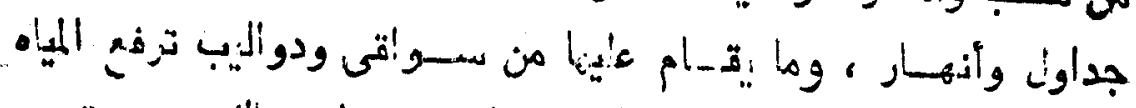

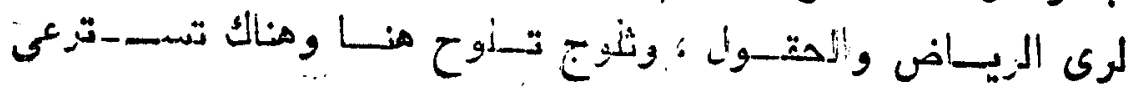

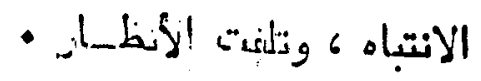

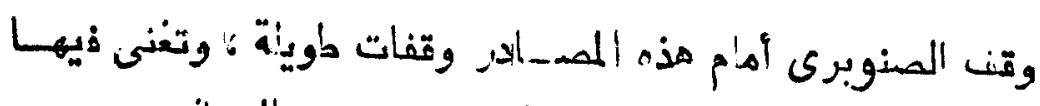

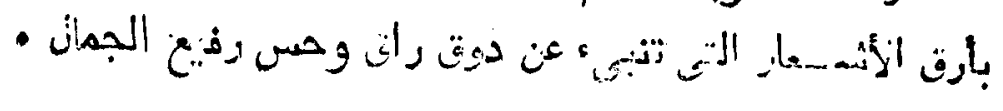

\section{المسـداب والمطــ}

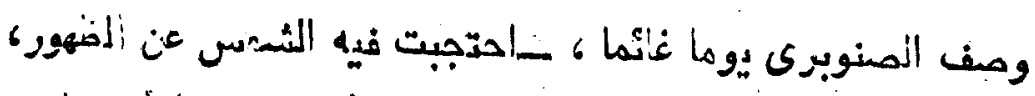

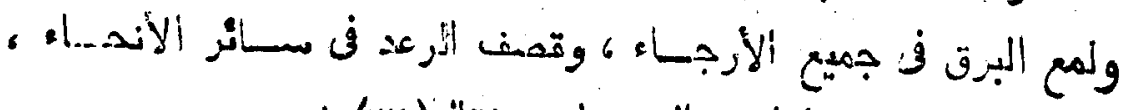

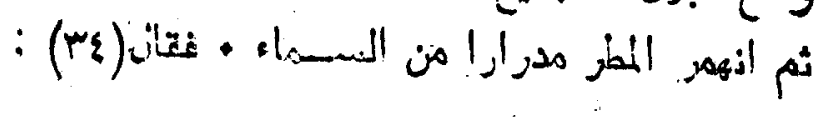

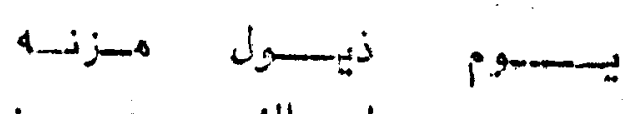

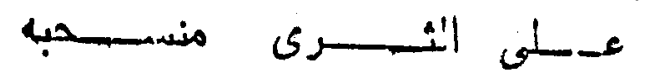

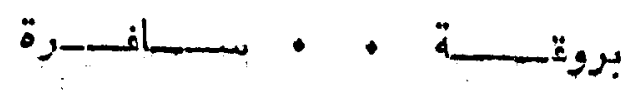

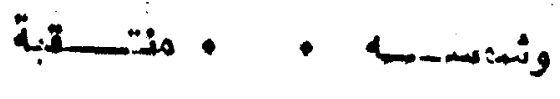

- 
iir

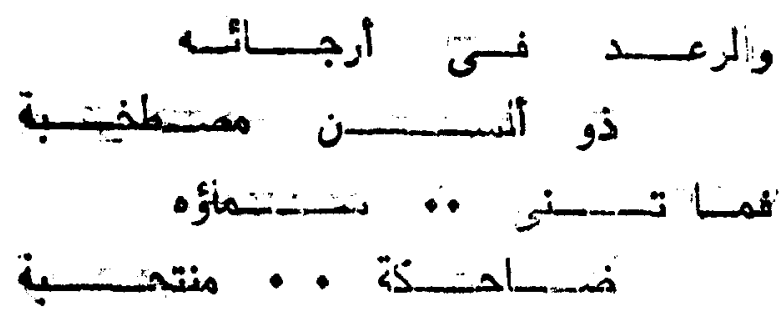

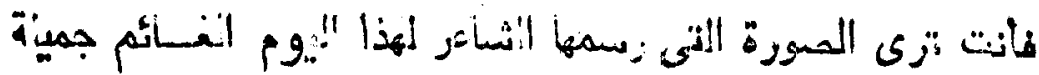

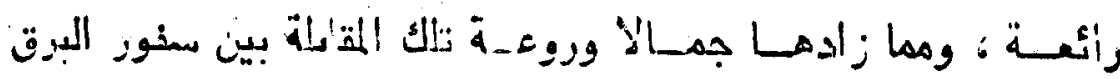

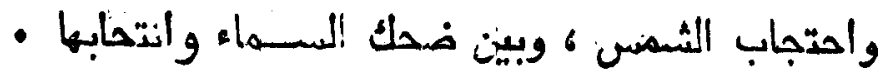

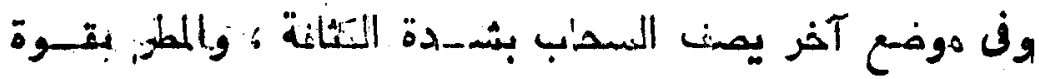

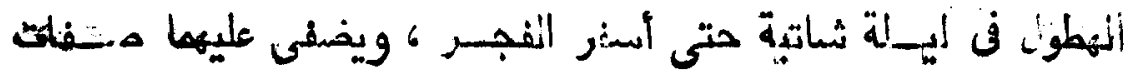

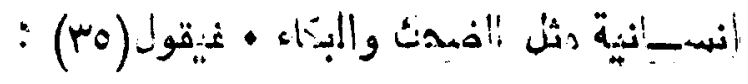

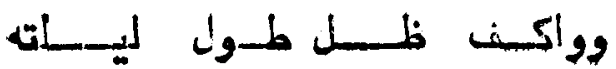

يعطسـ

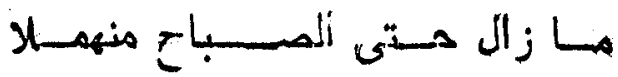

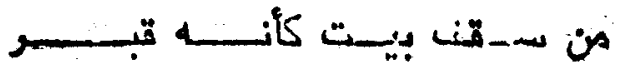

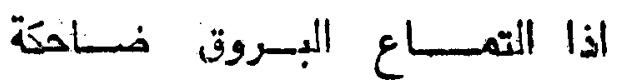

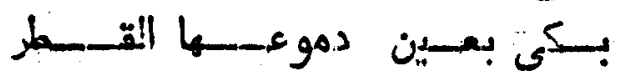

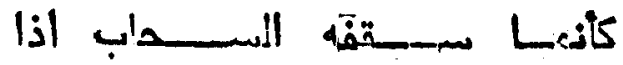

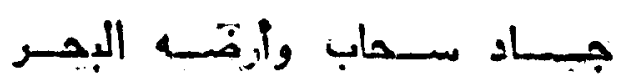

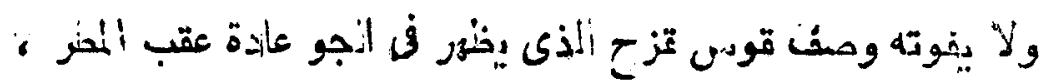

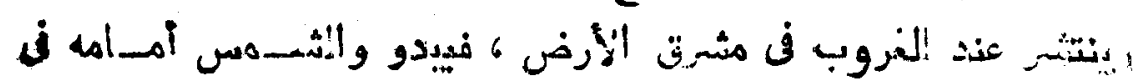

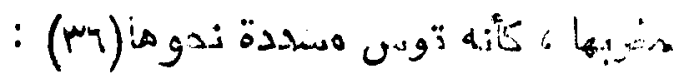

-

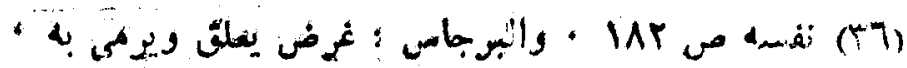

$\left(\sum x+4\right)$ 


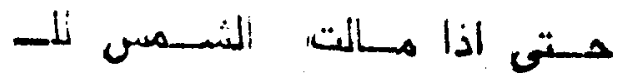

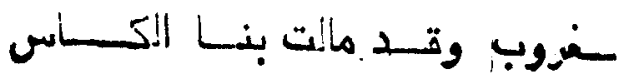

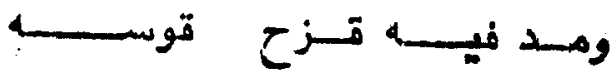

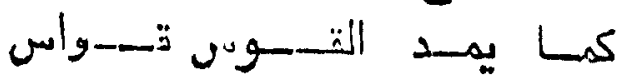

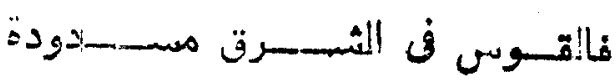

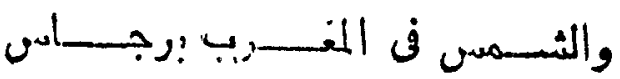

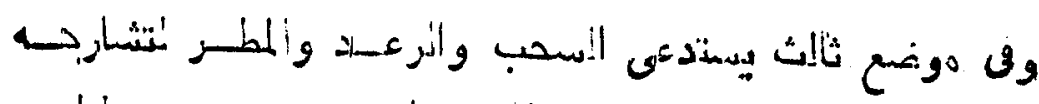

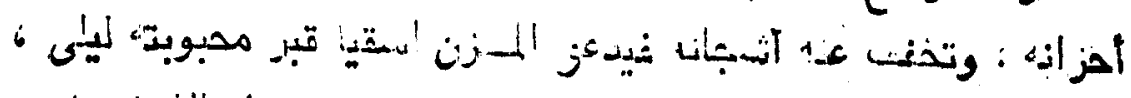

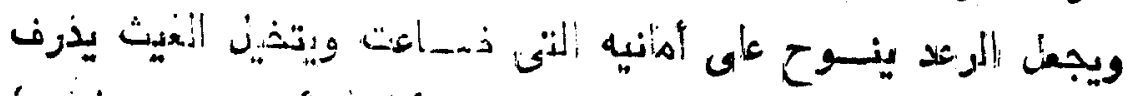

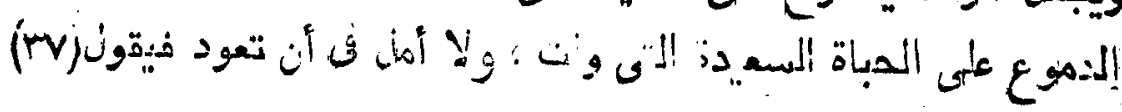

سـقتت ذا انبـــــاب م-زن بعسد هزن

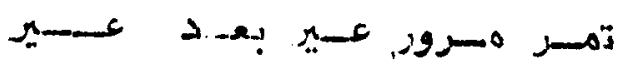

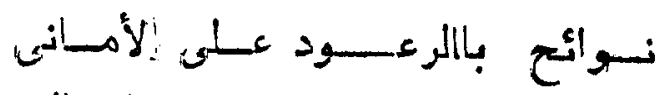

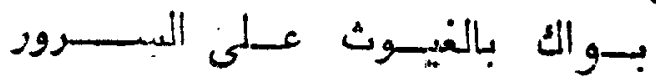

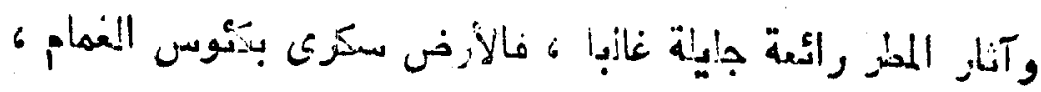

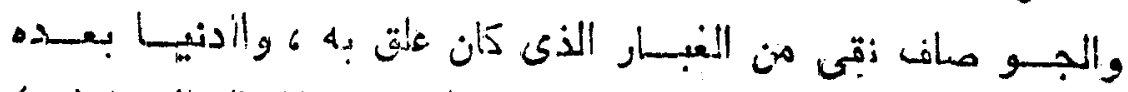

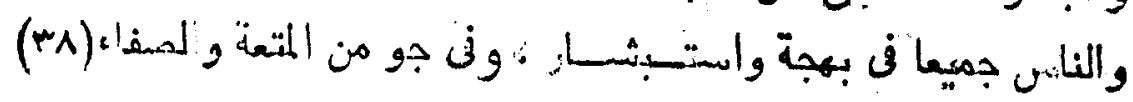

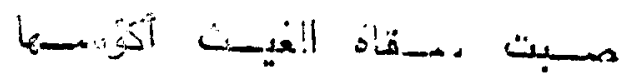

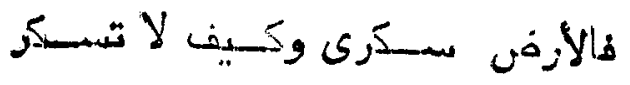

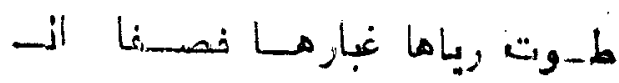

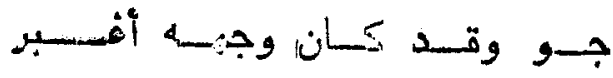

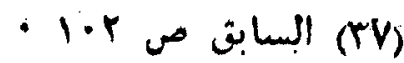

- 19 (rA) 


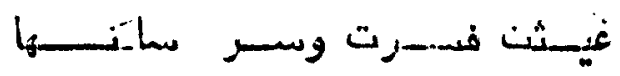

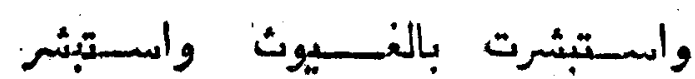

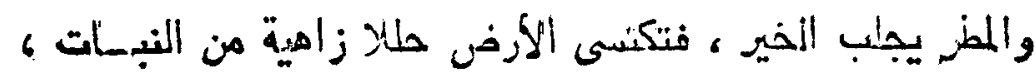

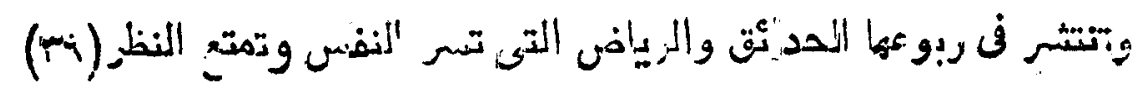

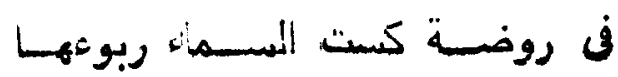

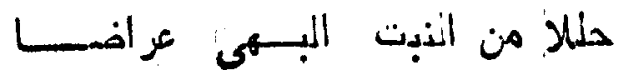

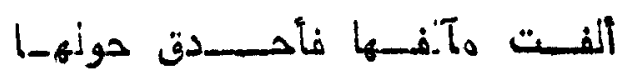

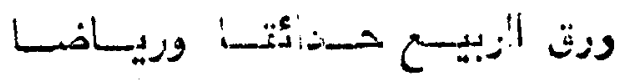

وسرت سوارى المـزن في جن جنباتهـا

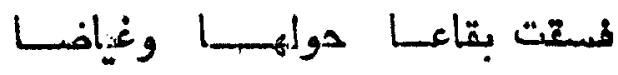

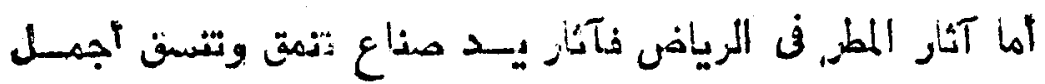

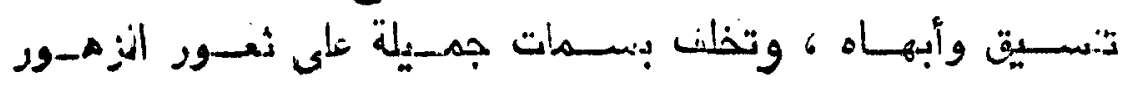

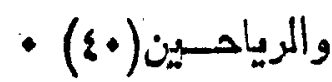

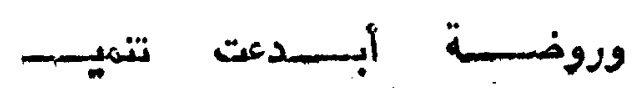

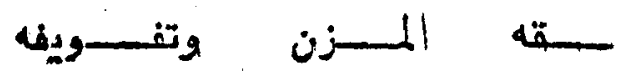

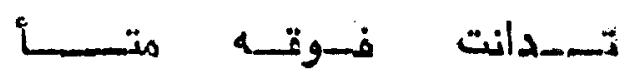

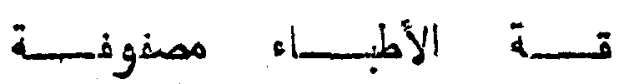

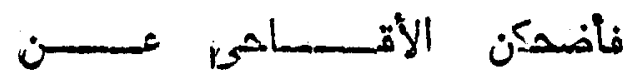

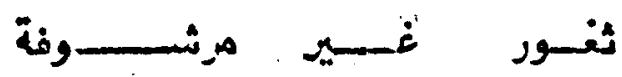

$: j-1$

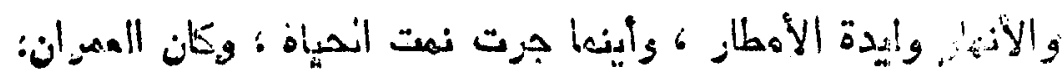

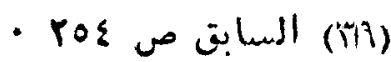

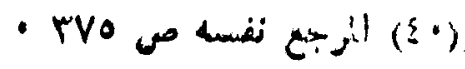




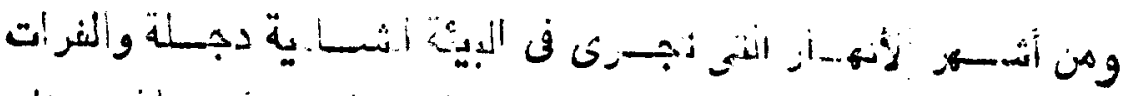

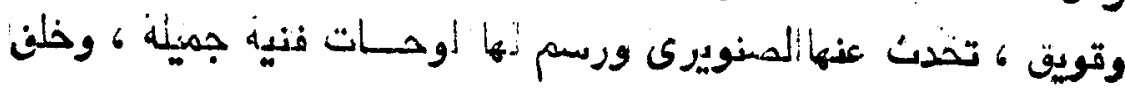

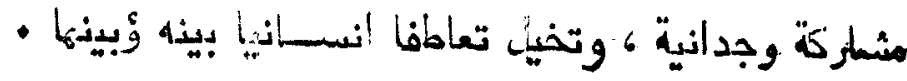

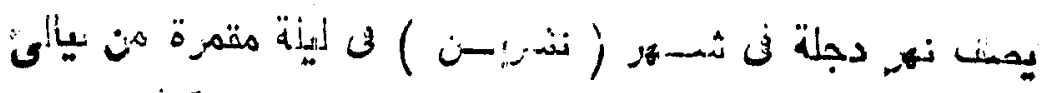

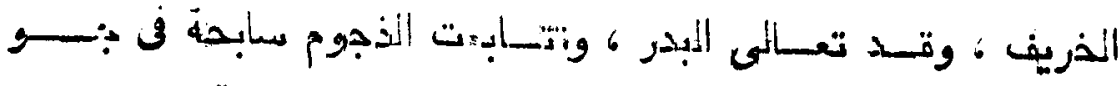

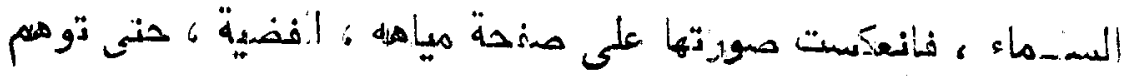

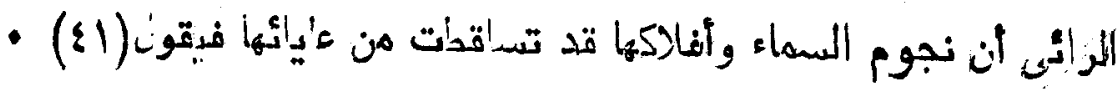

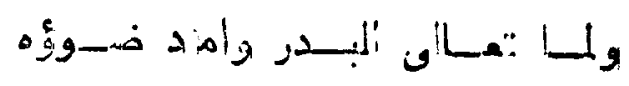

بدجـله في تنشرين بألطـول والعرض.

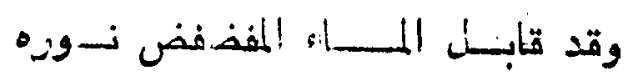

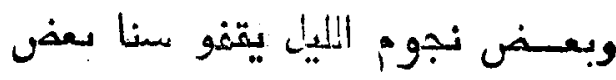

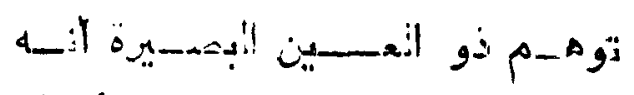

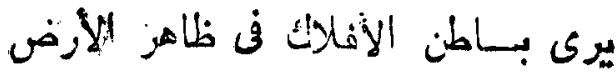

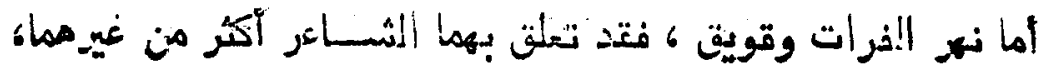

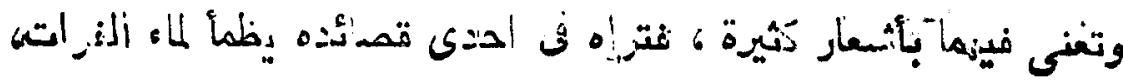

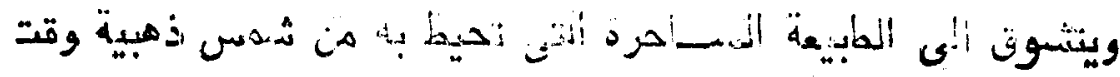

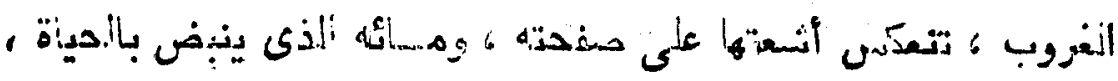

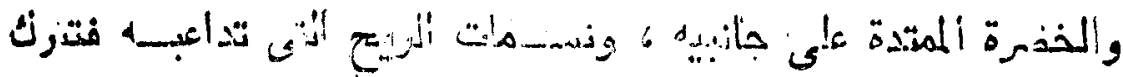

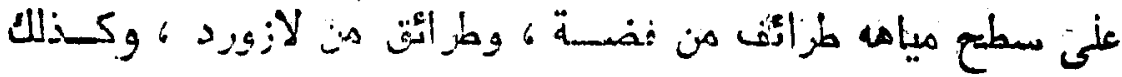

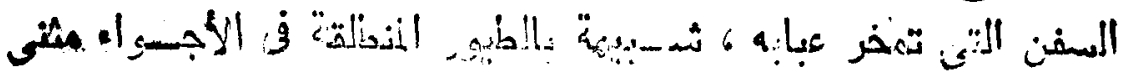

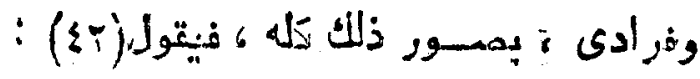

- sar sor - EVI نفسه ص (ET) 


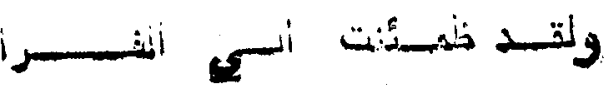

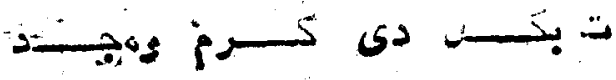

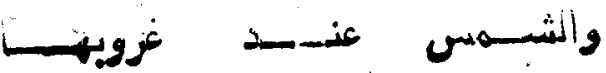

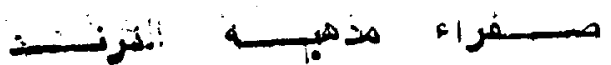

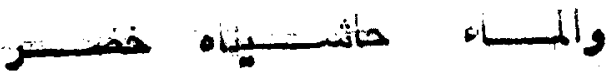

ر'أوأن مستس

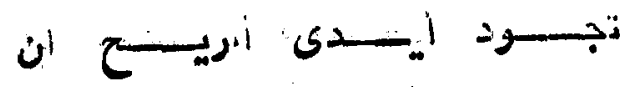

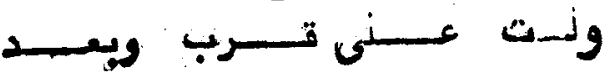

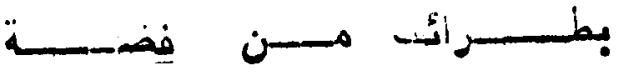

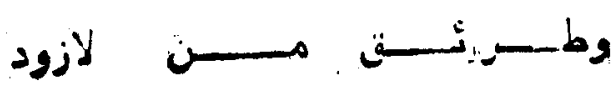

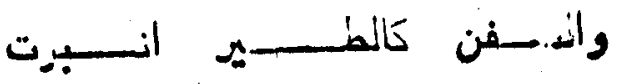

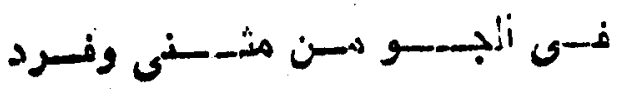

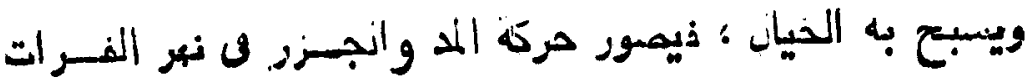

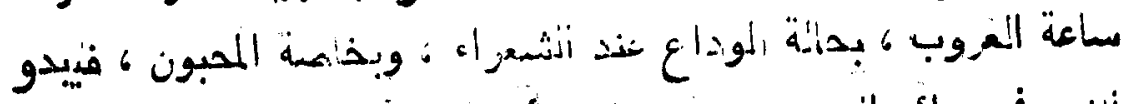

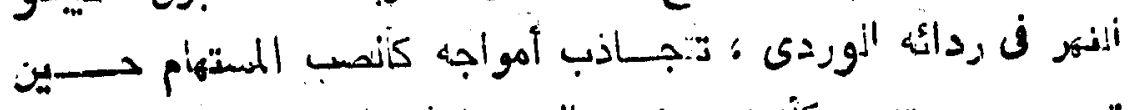

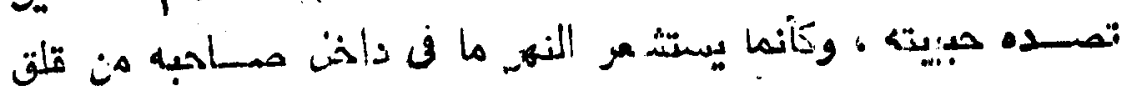

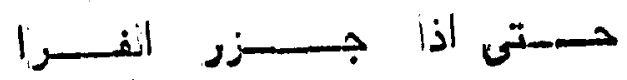

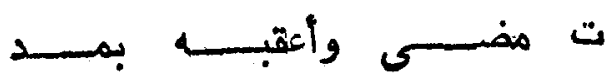

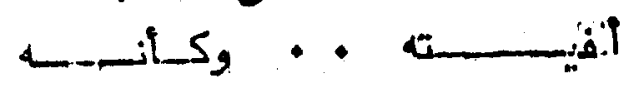

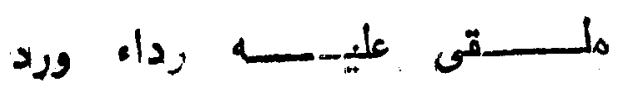

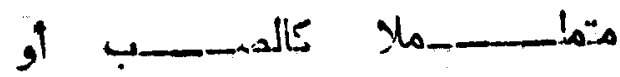

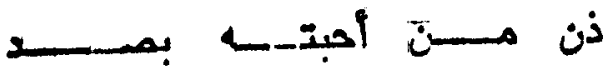

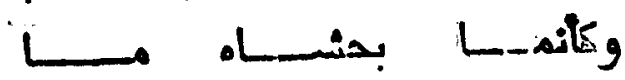

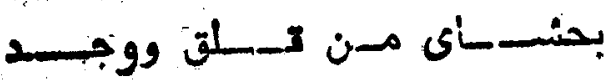




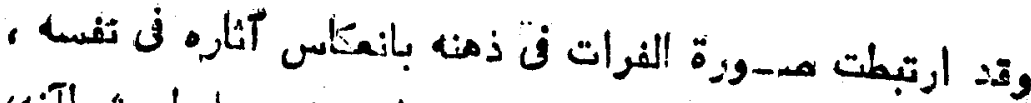

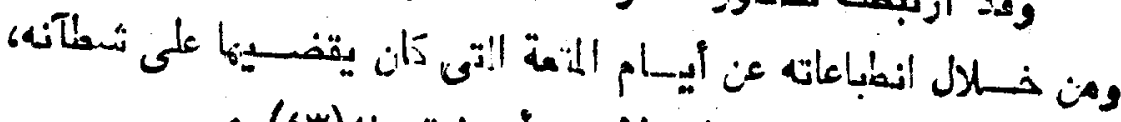

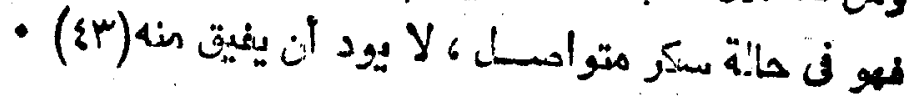

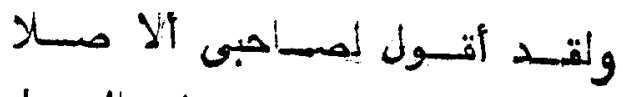

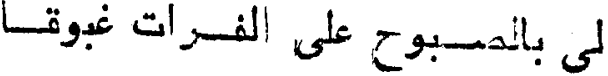

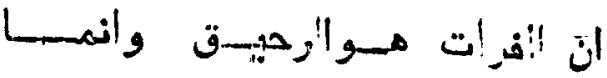

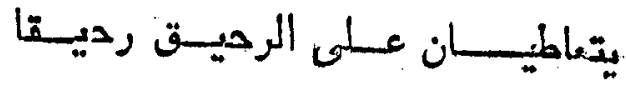

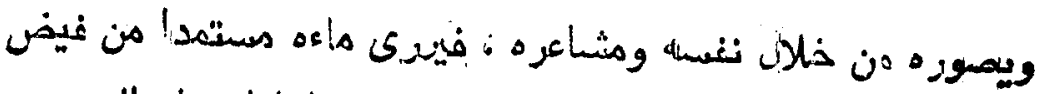

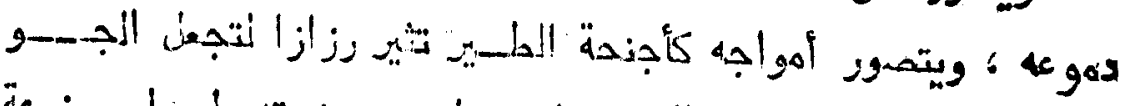

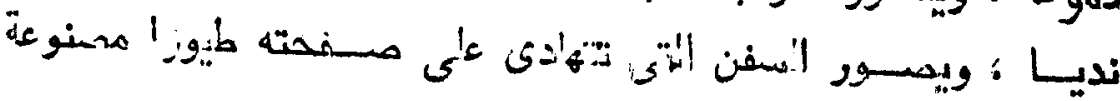

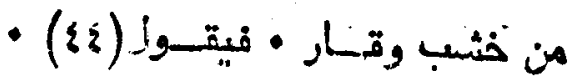

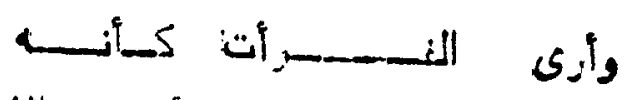

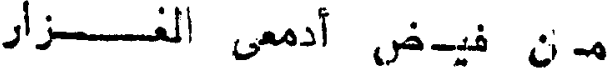

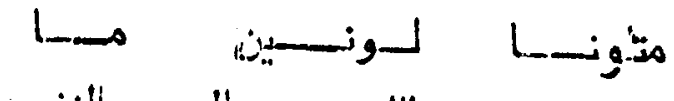

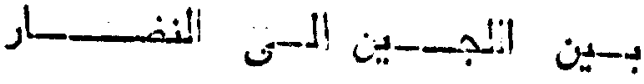

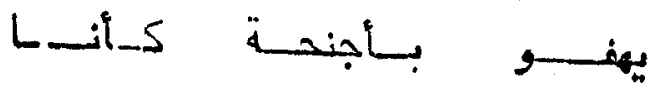

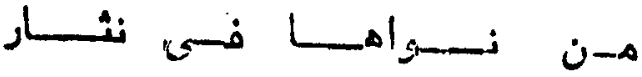

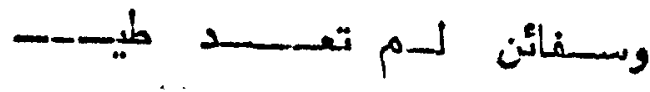

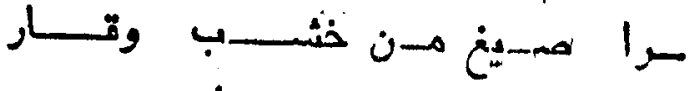

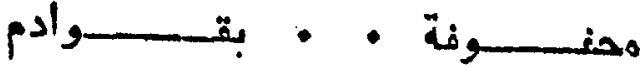

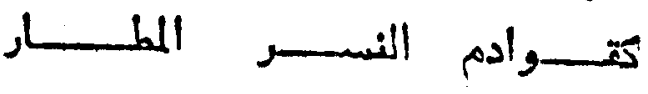

-

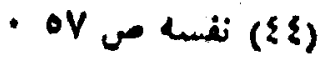




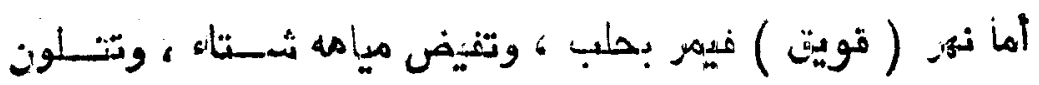

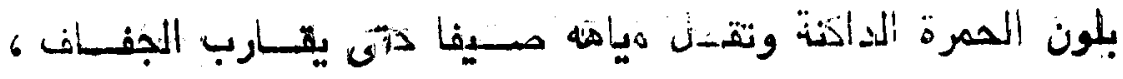

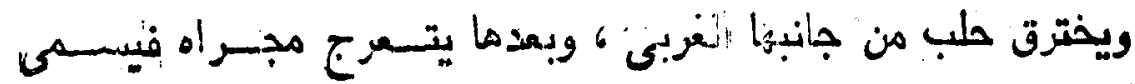

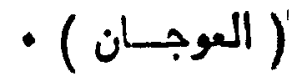

وقد حظى هذا النزر بحب الثشاعر أتثر من غيره ك فهو لديه قنيــة

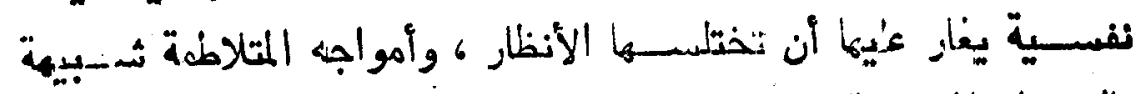

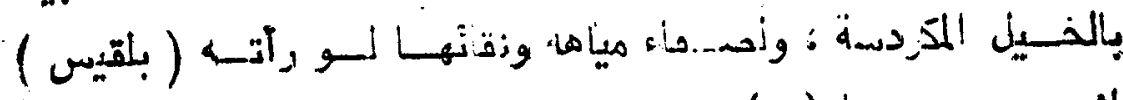

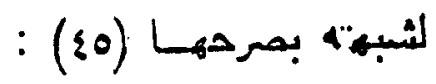

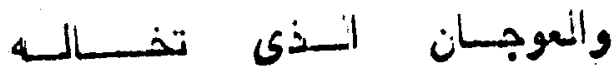

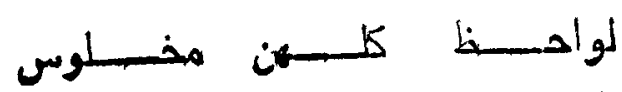

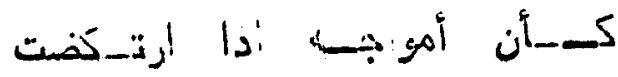

ن

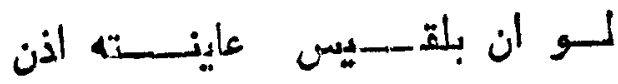

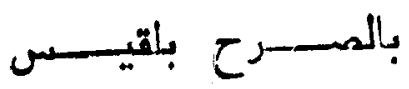

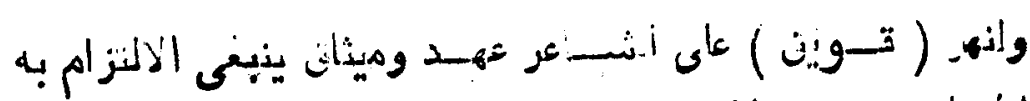

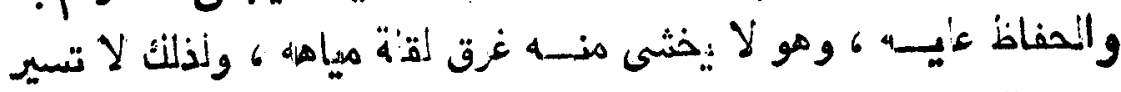

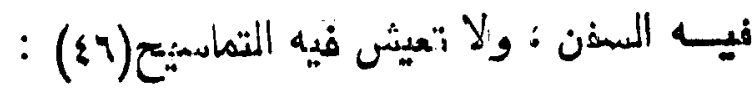

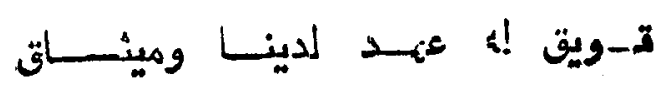

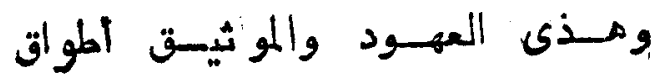

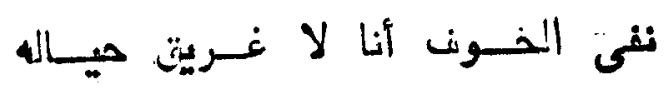

فنحن على أمسن وذا الامهـن الرزاق

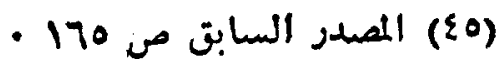




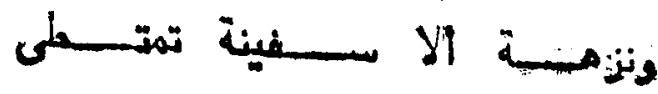

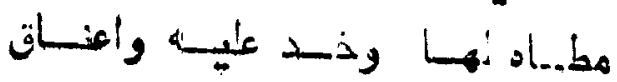

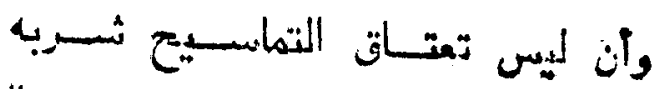

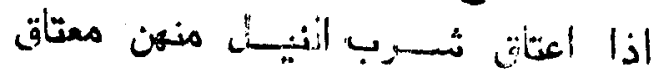

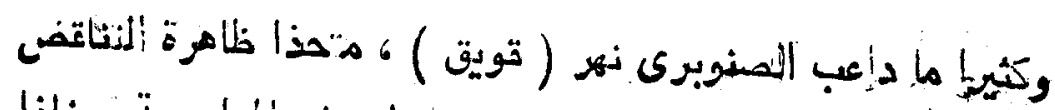

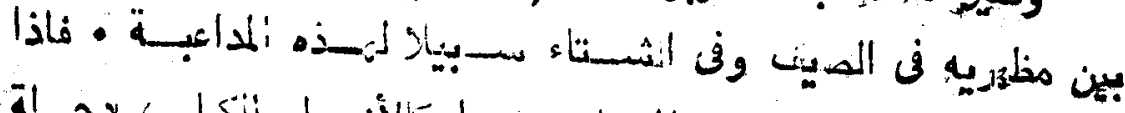

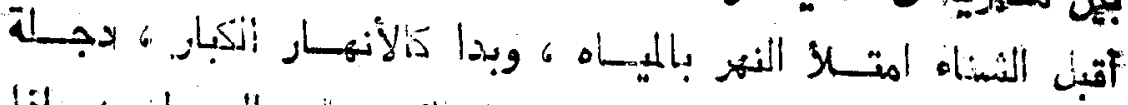

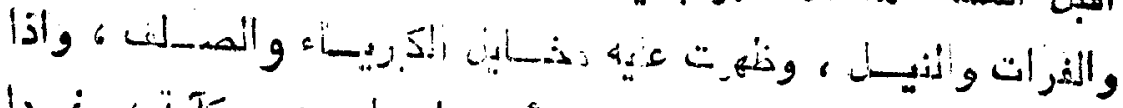

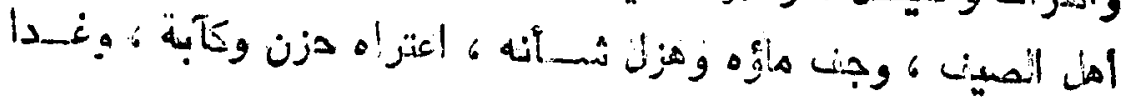

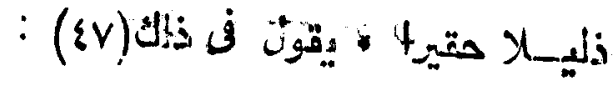

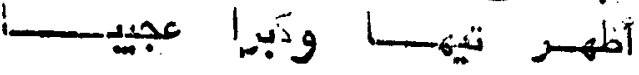

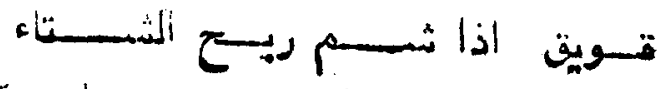

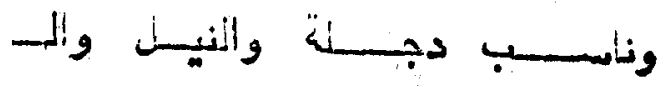

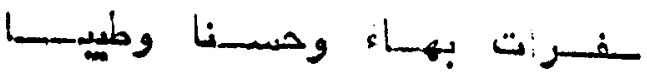

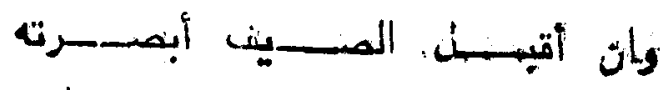

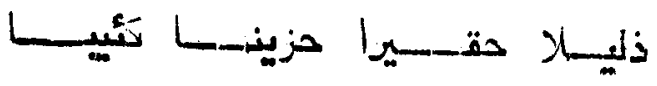

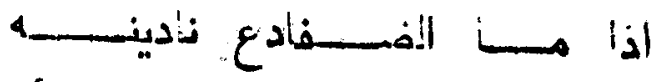

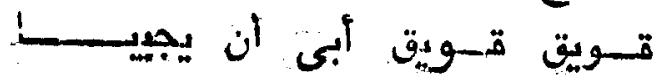

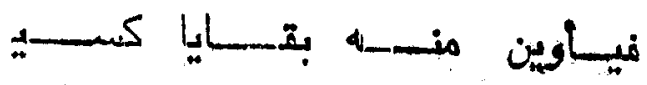

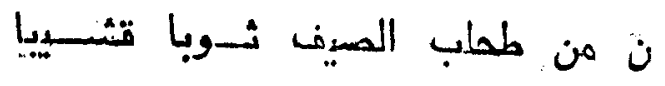

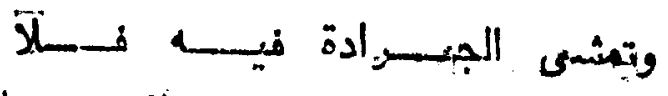

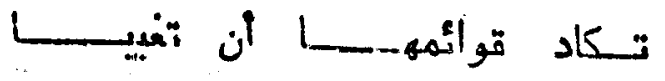

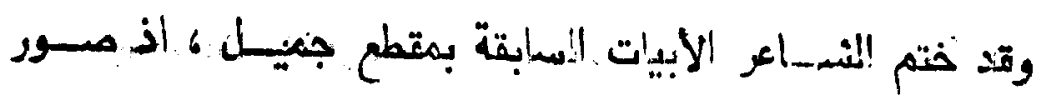

- ع01 تكملة الديوان صل 


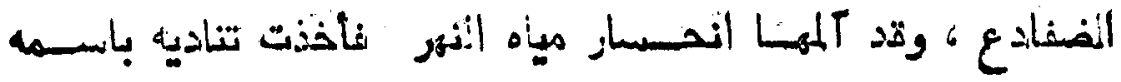

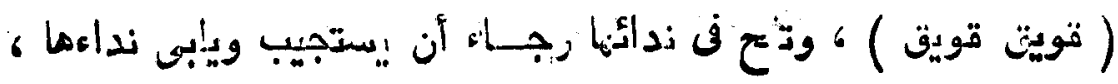

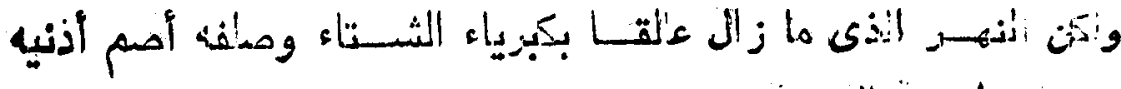

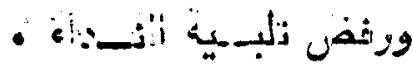

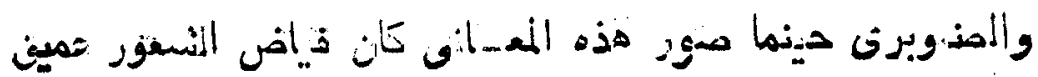

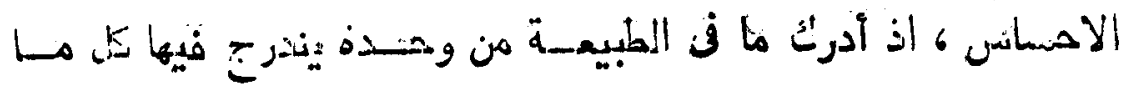

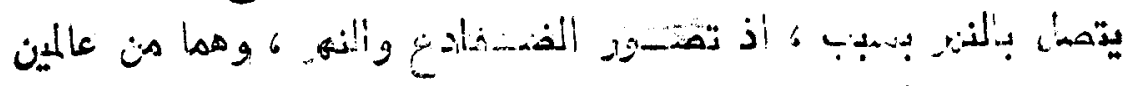

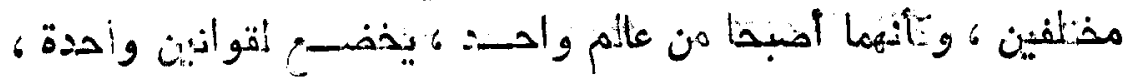

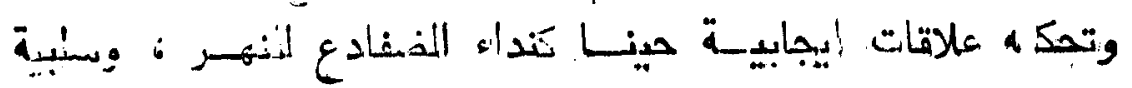

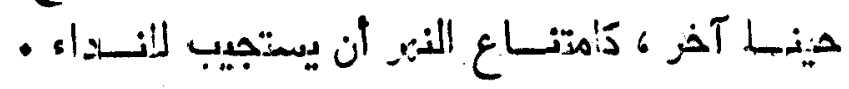

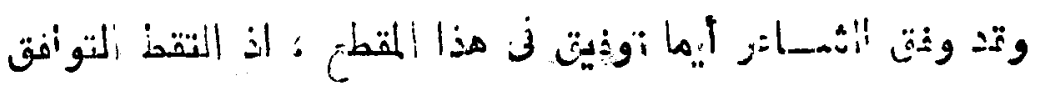

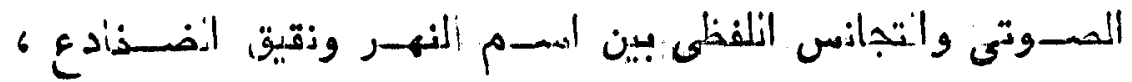

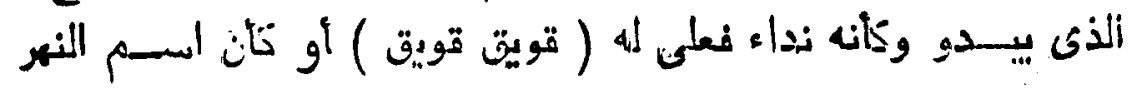

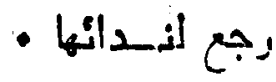

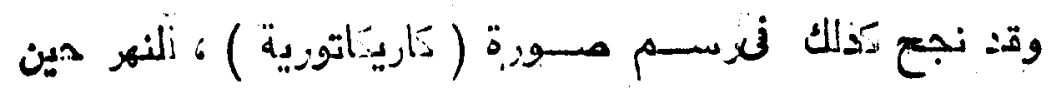

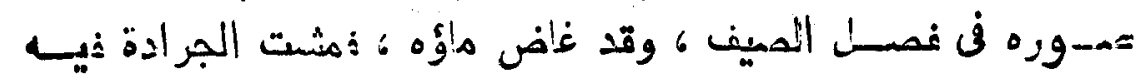

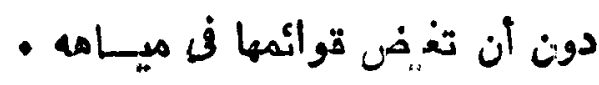

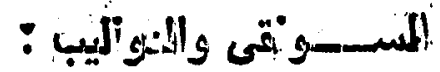

ولمم يفغل إنصتوبرى ها يتمنـل بالميساه بسبب 6 فنتاول السوراقى والدواليب التى كانت نتــام على شـوراطىء الأنهار وحافات الآبار

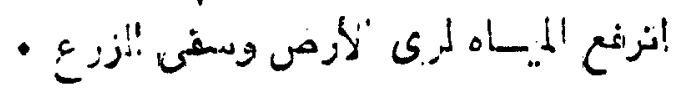

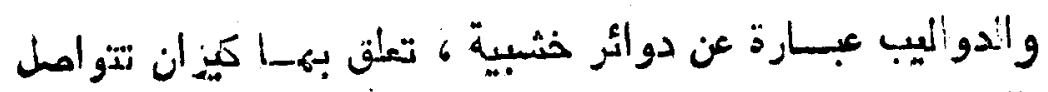

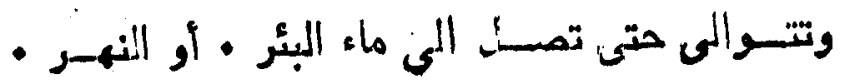




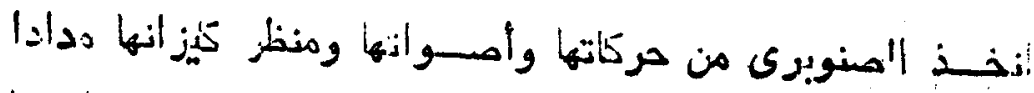

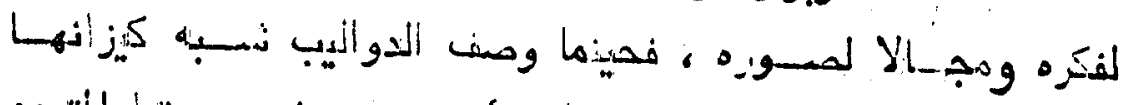

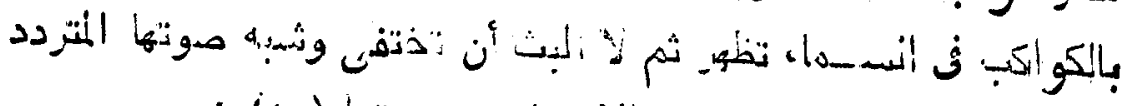

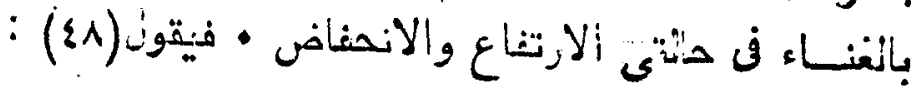

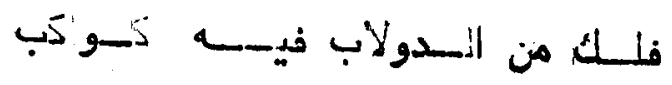

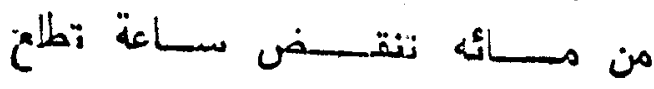

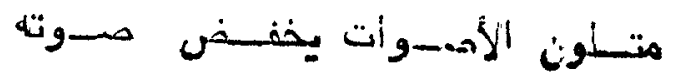

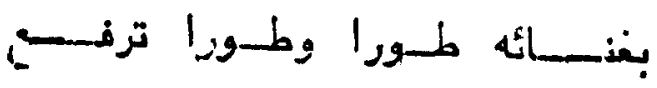

ثم يدقق :لنظر ويمعن الفكر فن طبيعة الصسـوت ، فيراه هادئا هينا

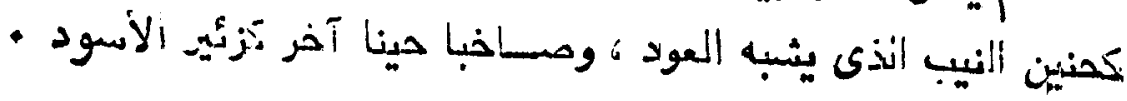

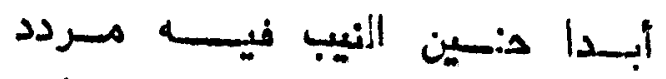

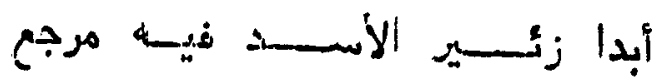

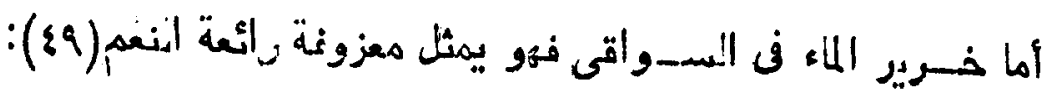

ijenl

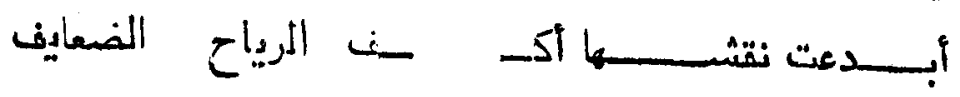

$$
\text { : I }
$$

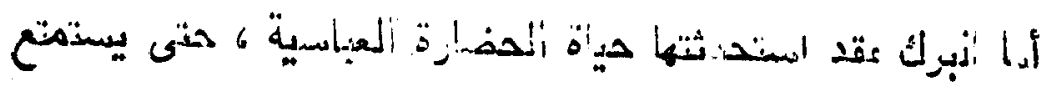

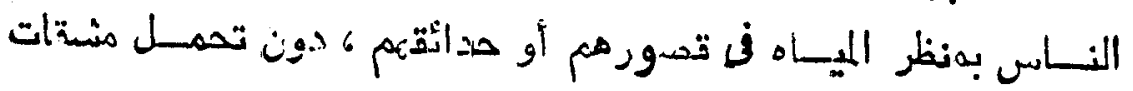

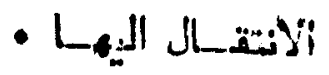

-

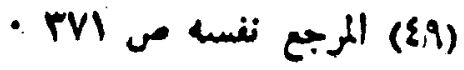




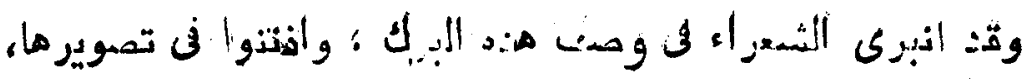

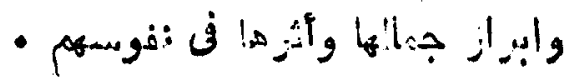

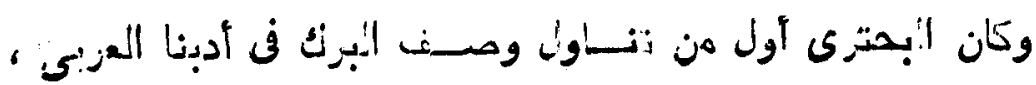

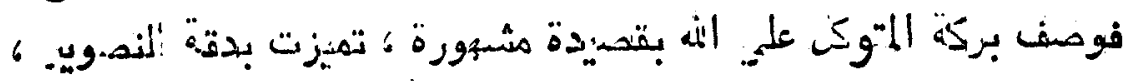

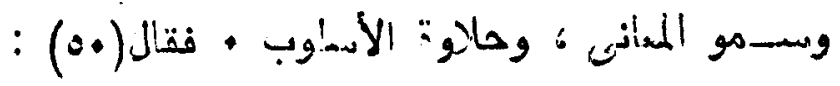

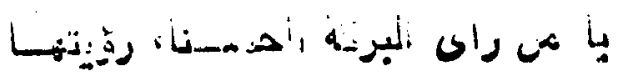

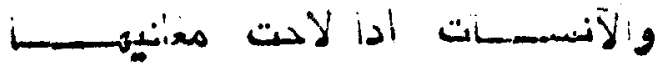

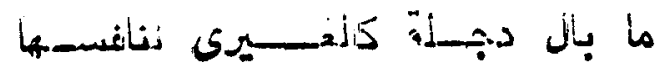

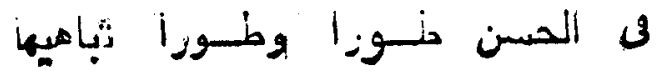

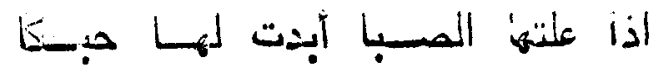

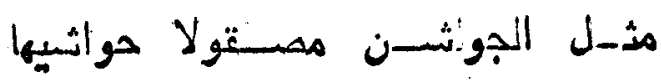

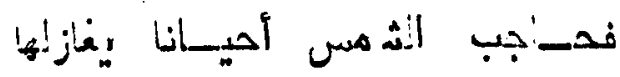

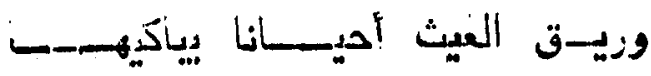

اذا !'نجــوم تزاءت في جوانبهـ

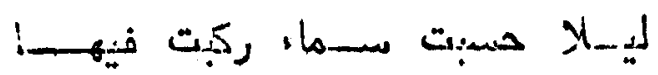

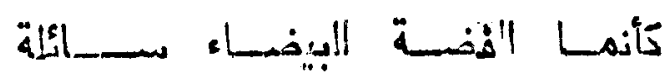

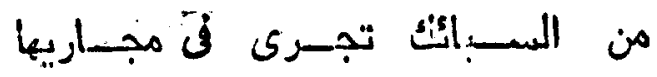

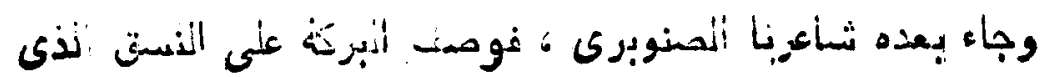

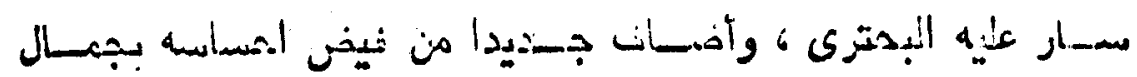

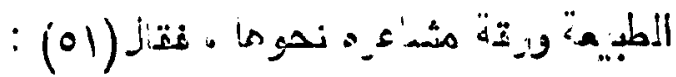

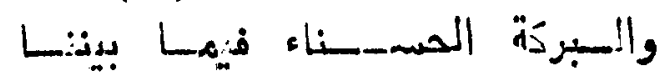

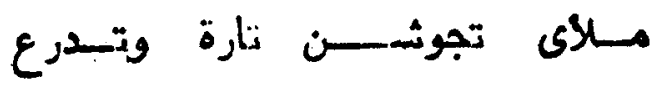

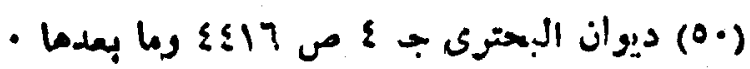

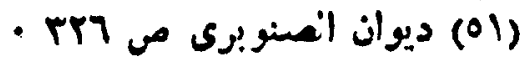




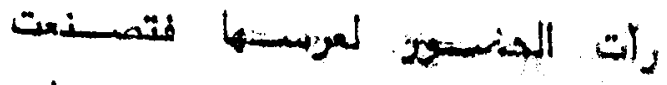

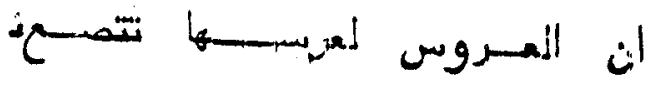

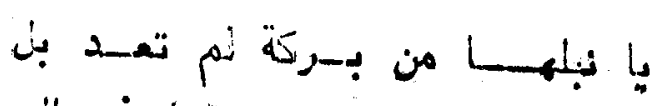

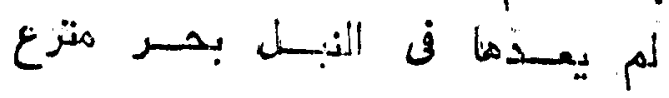

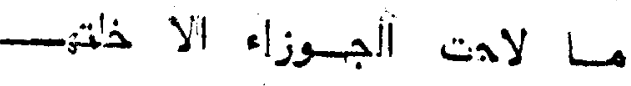

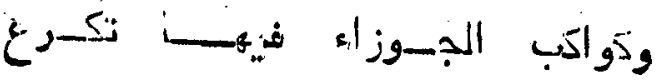

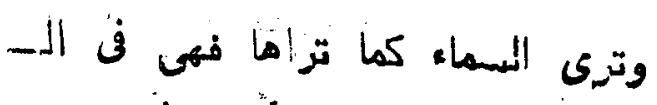

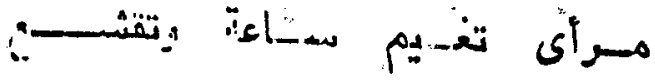

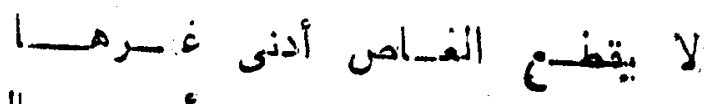

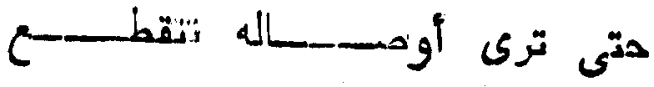

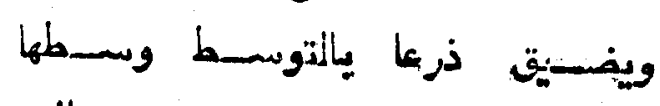

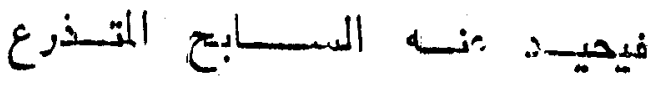

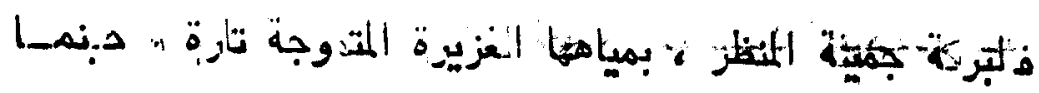

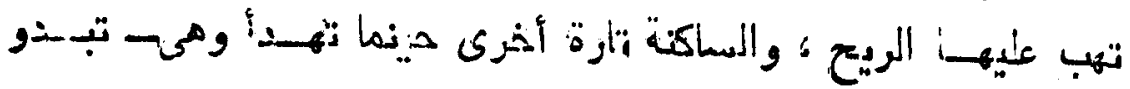

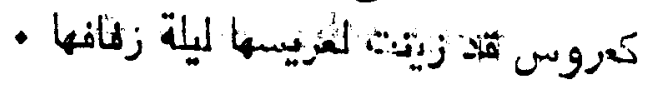

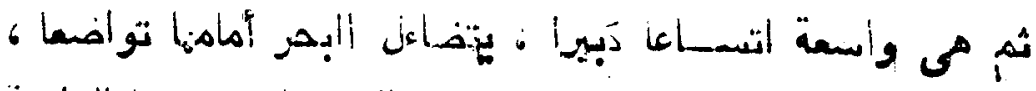

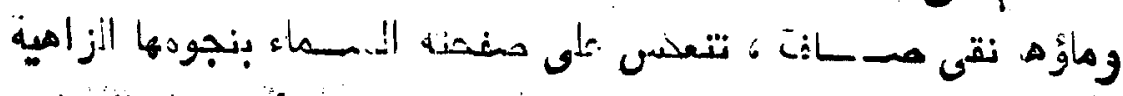

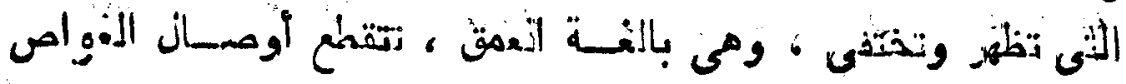

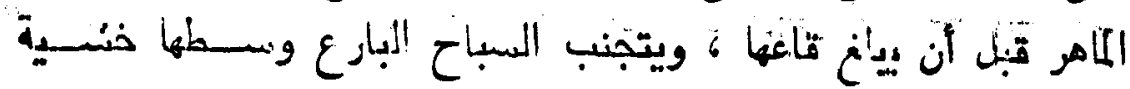

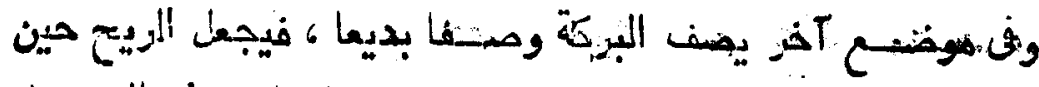

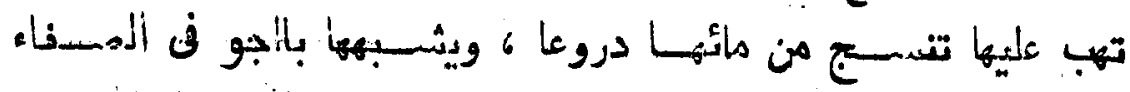

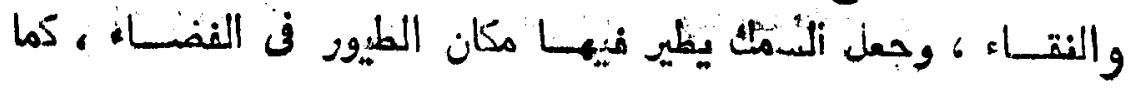


شبه المزمور على دافتها بانجوم في كبد السماء ، فيقول(or) :

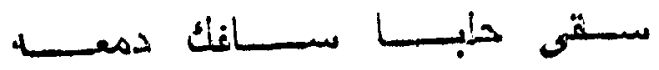

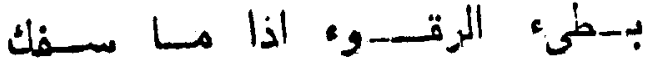

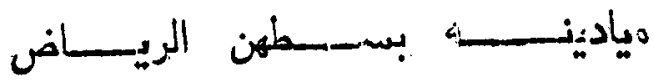

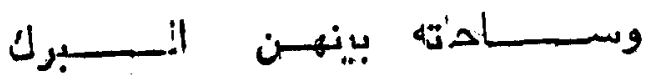

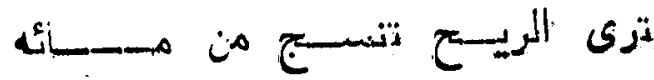

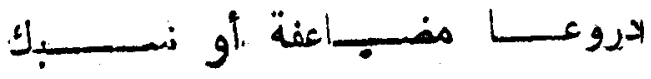

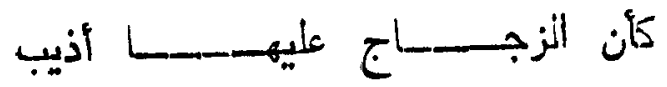

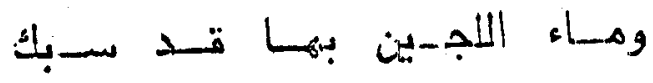

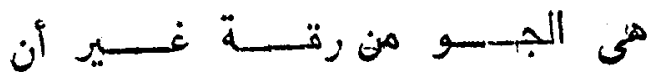

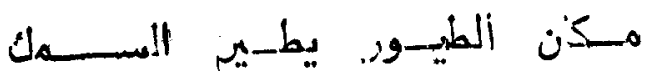

وت-د

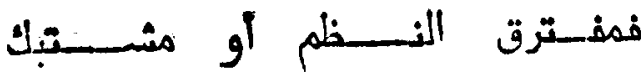

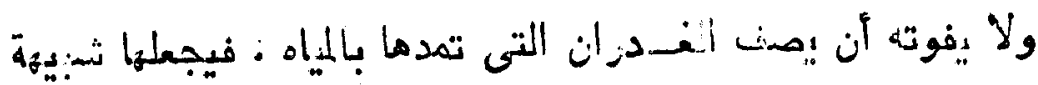

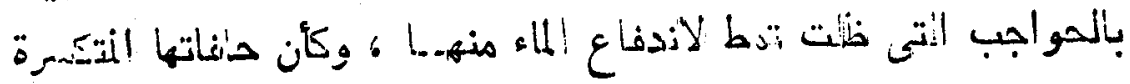

مسسروك حيـات

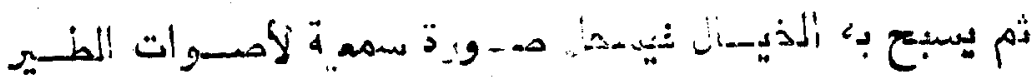

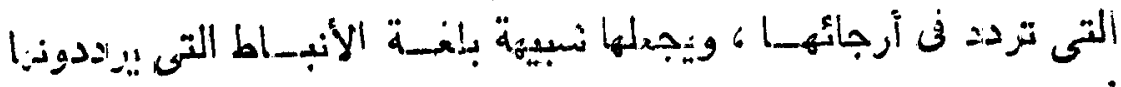

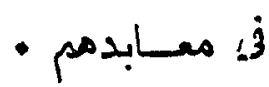

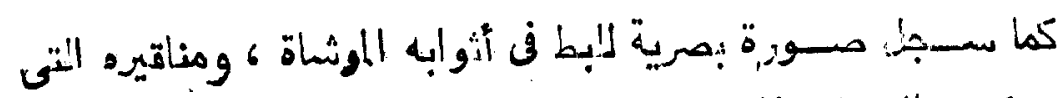

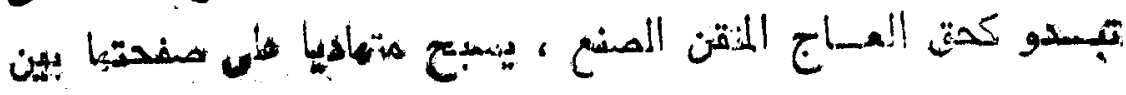

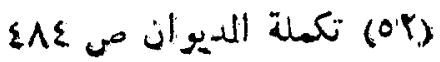




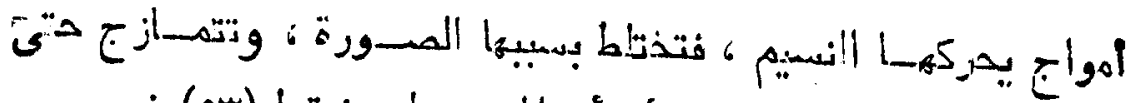

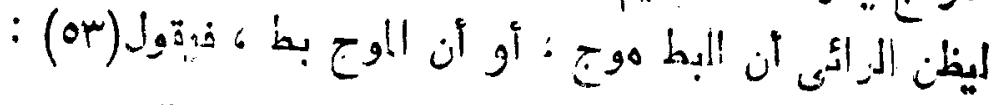

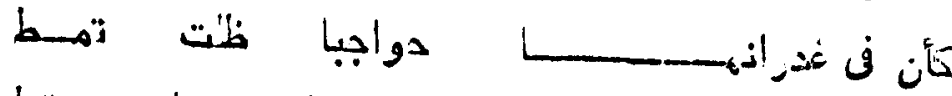

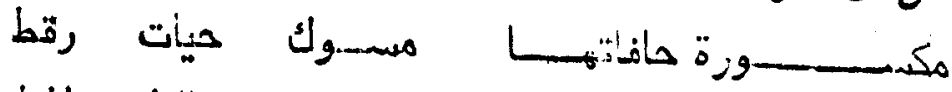

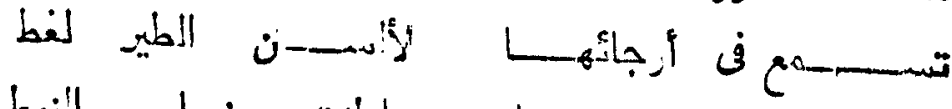

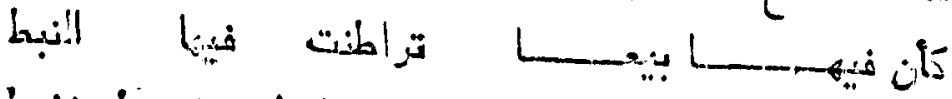

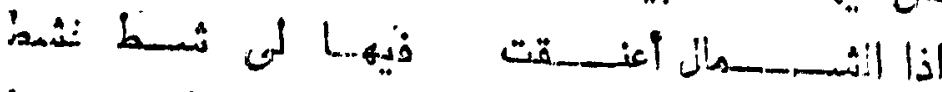

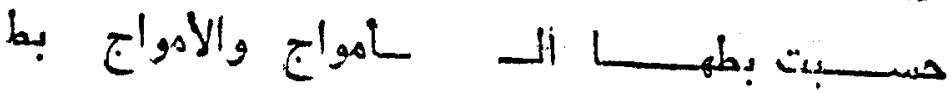

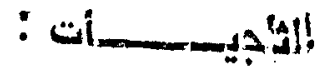

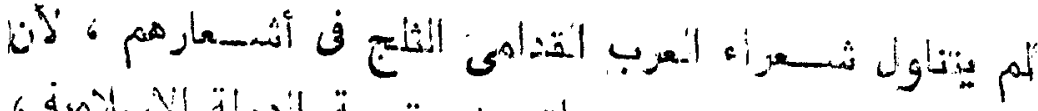

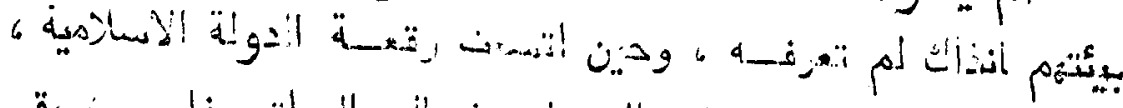

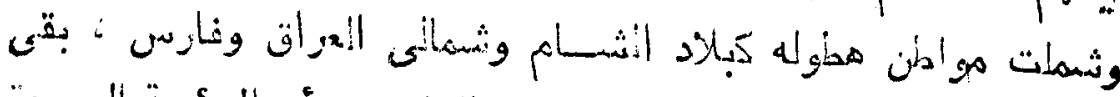

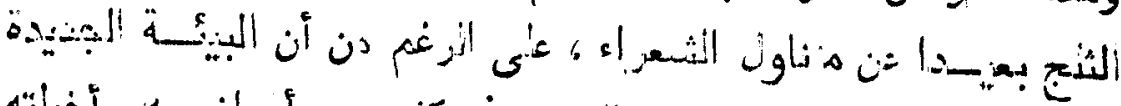

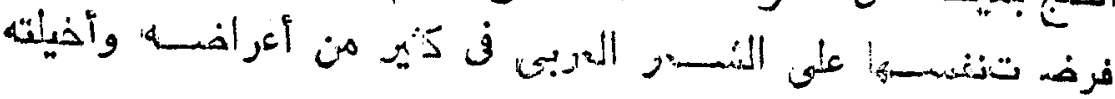

- aمانيـ

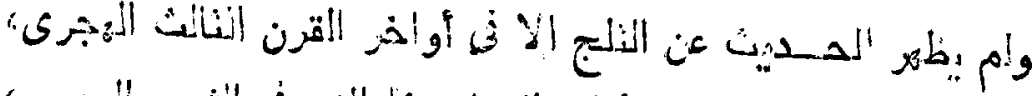

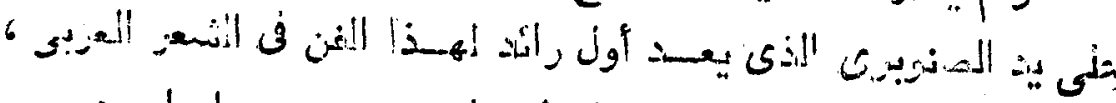

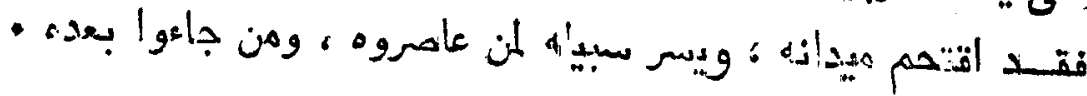

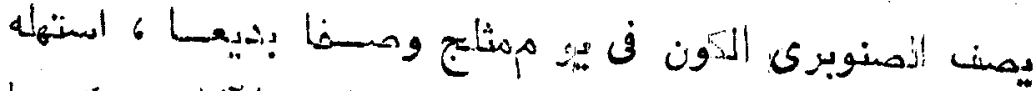

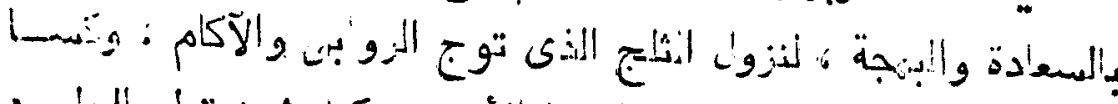

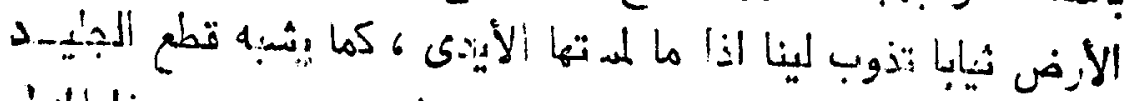

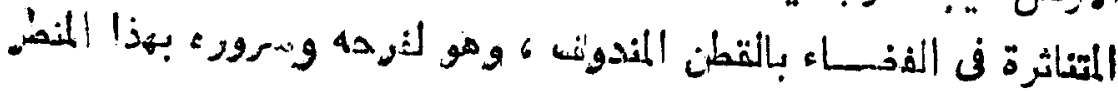

، ra 
IrV

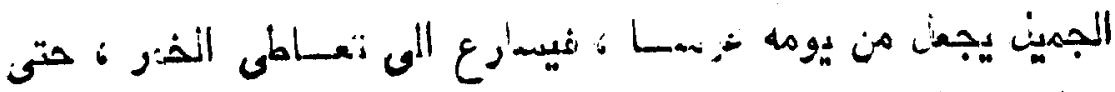

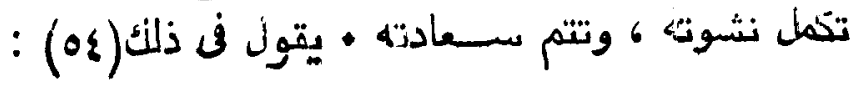

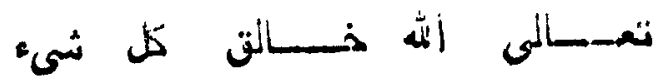

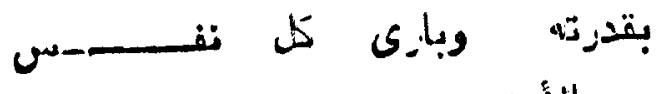

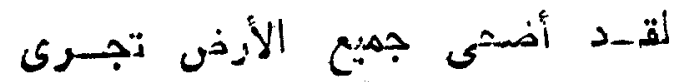

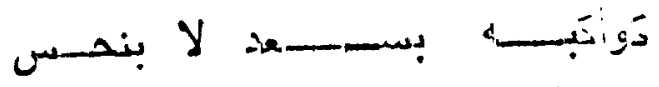

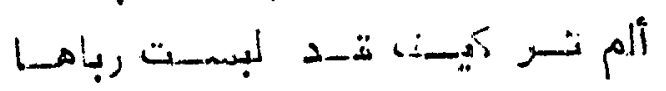

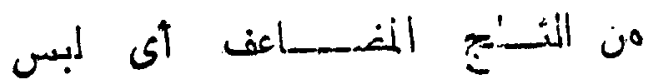

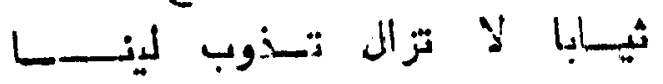

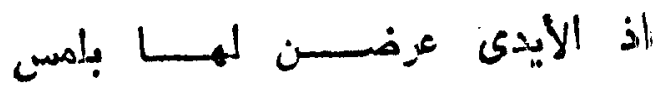

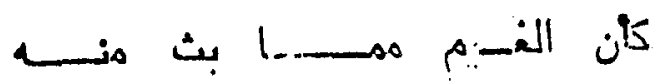

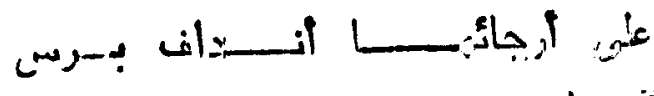

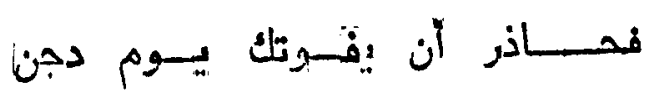

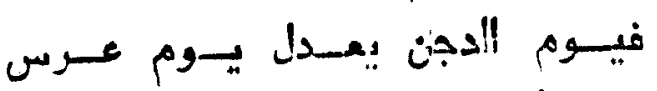

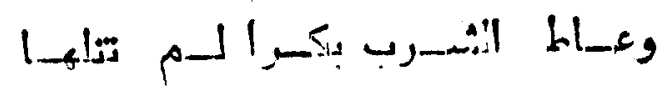

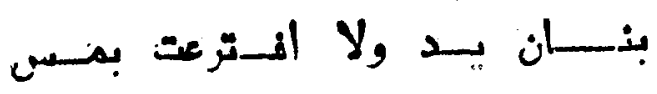

وفى :تطوثة أخرى يؤلن الصنوبرى بين التخمادات ك ويجمع بين

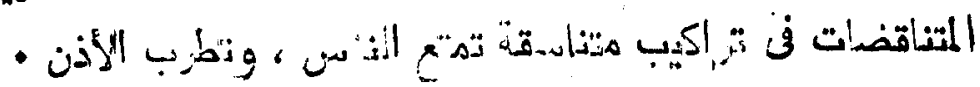

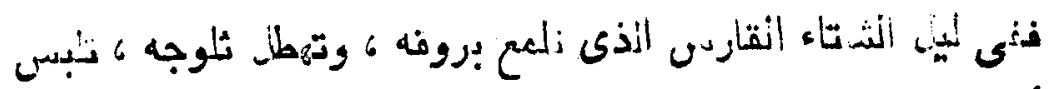

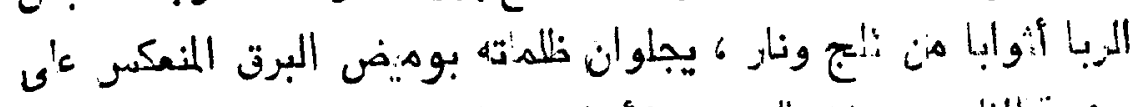

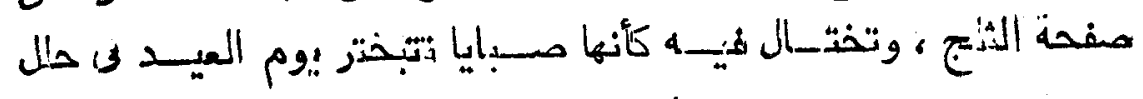

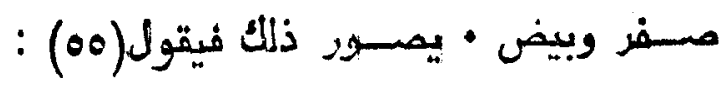

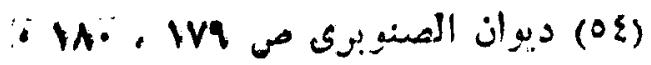




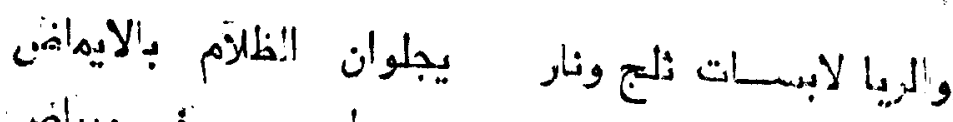

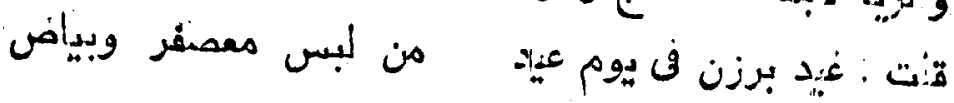

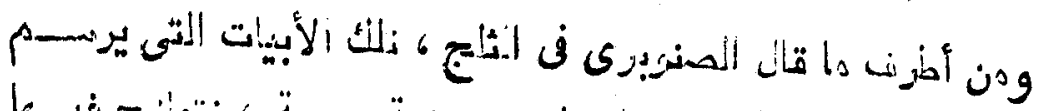

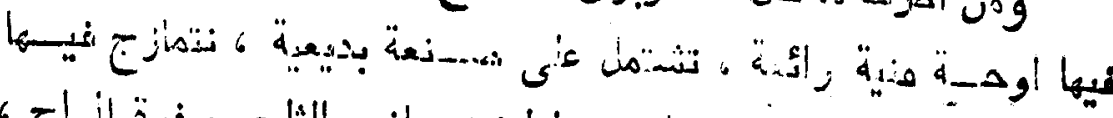

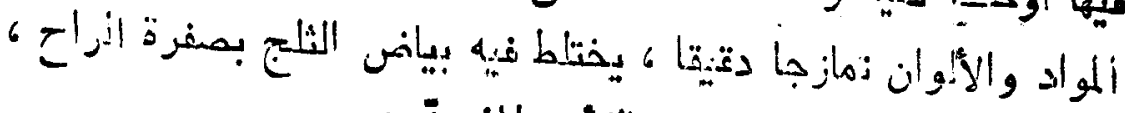

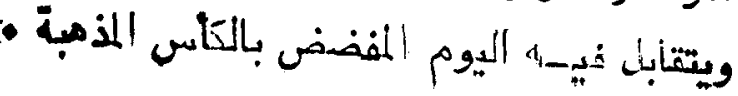

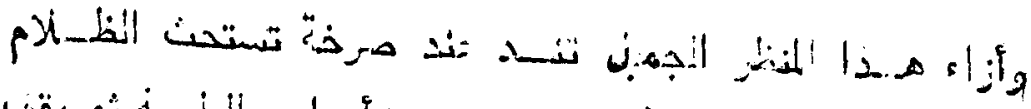

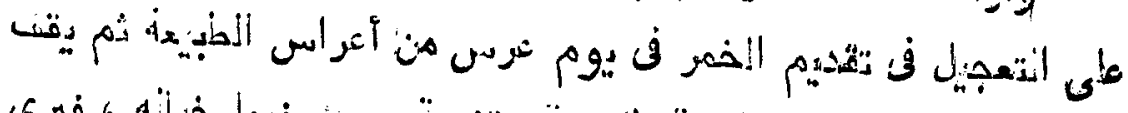

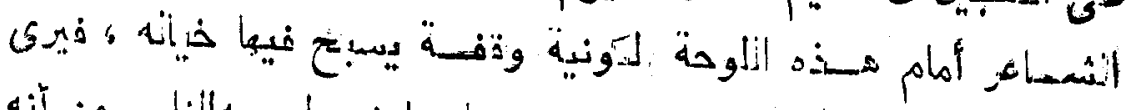

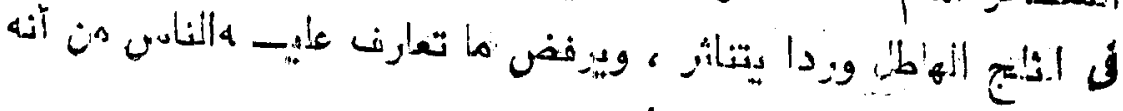

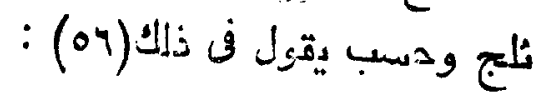

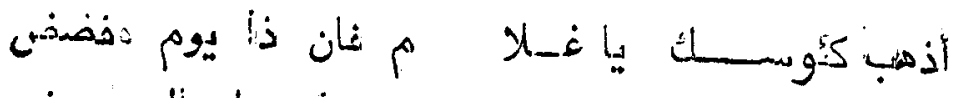

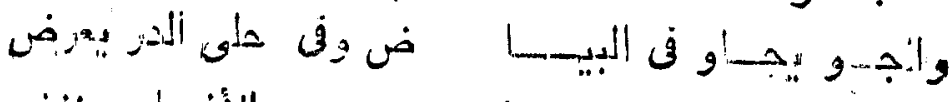

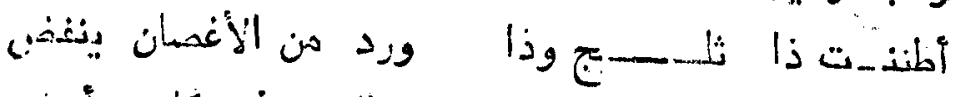

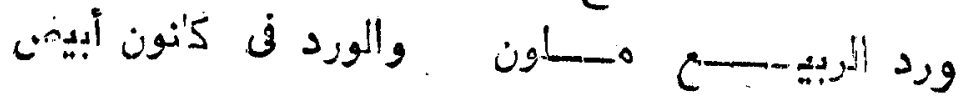

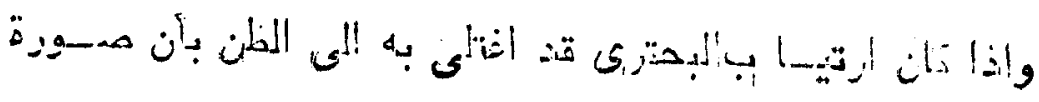

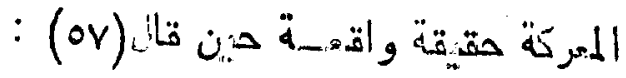

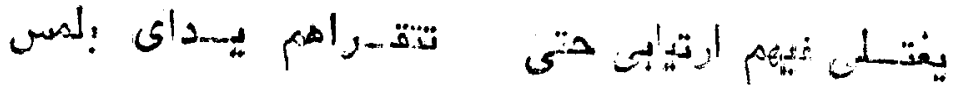

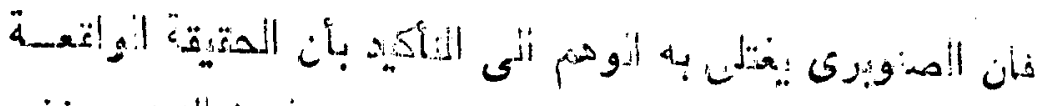

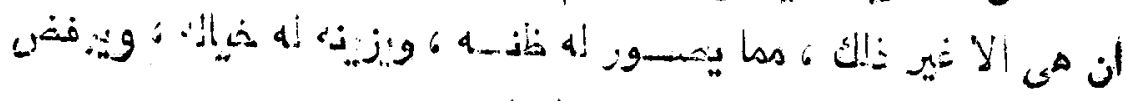

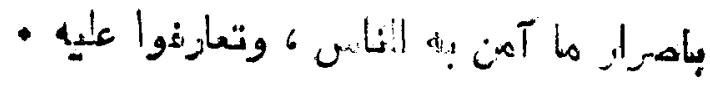

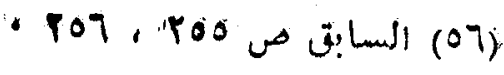

- llov sov) 


\section{Nir}

ولو تبعنا ثلميات الصنوبرى لطال بذــا المتـام ة ودسبينا مها

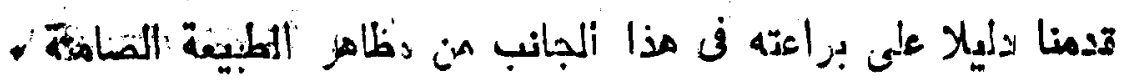

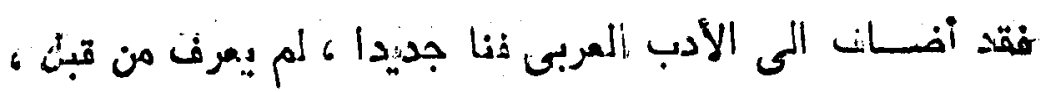

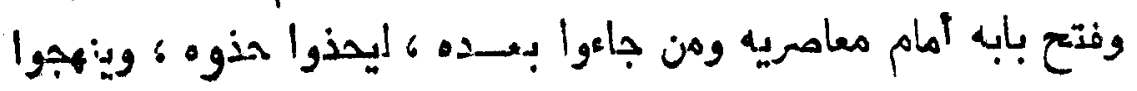
نهجـ

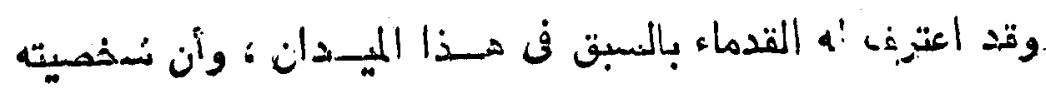

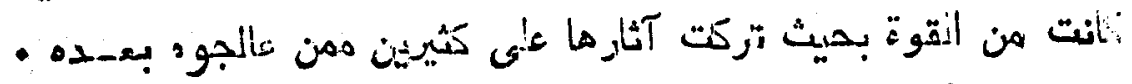

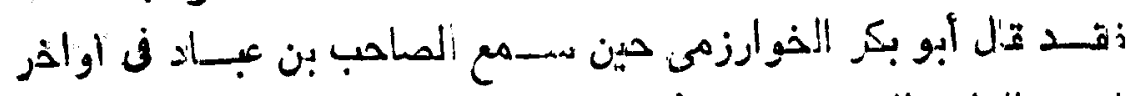

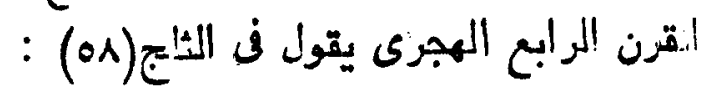

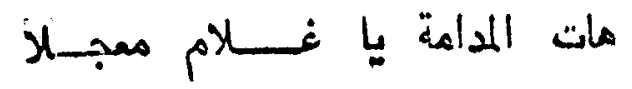

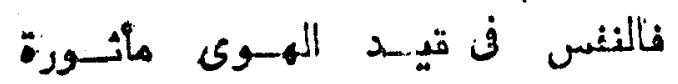

$$
\text { أو مســا تسرى كانسون ينسـثر دره فئس }
$$

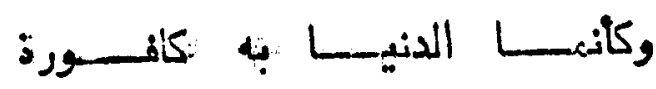

ان هـذ موأمثالها من الثلجيات كلما عيسان على تول المنوبيرى :

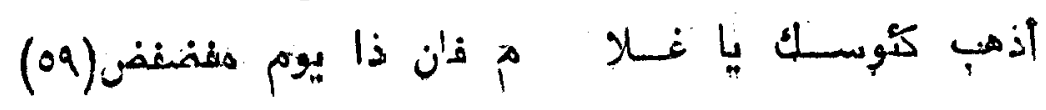

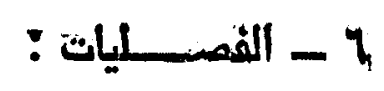

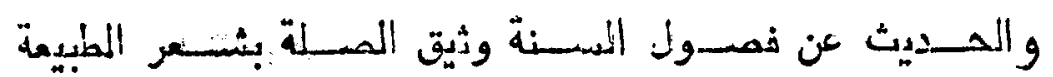

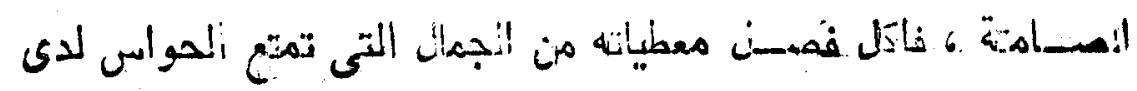

وإتمد :تول الثبعراء قديهن الفصول تناولا محسدودا ، إذ تحثثوا

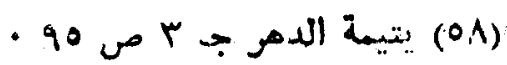

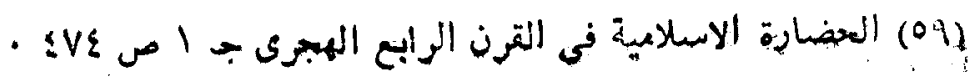

$$
\begin{aligned}
& (j q-p)
\end{aligned}
$$


عنها فن بعض جزئياتها ، حسبما أتيح لهم من مواهب عقليـة ؛ وثقافة

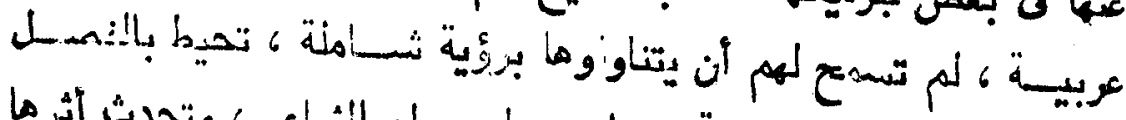

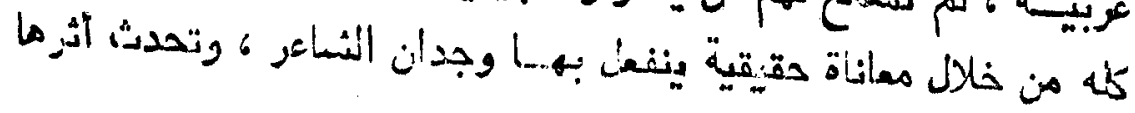

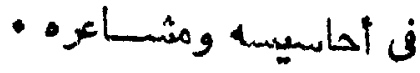

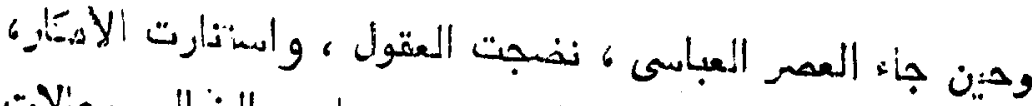

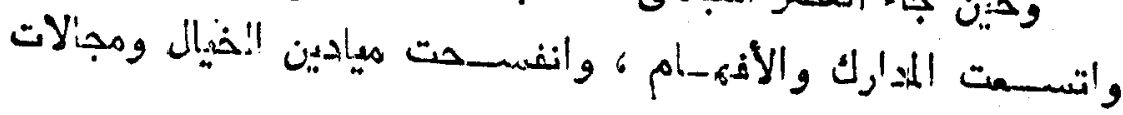

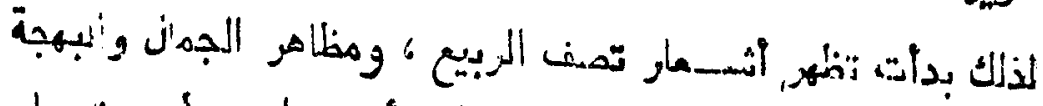

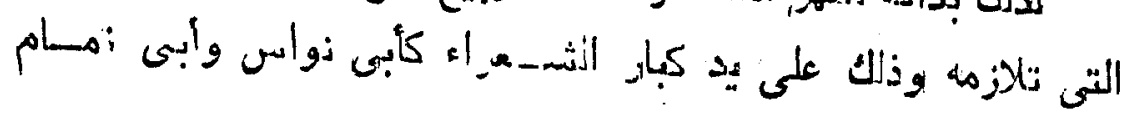

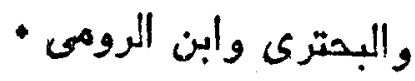

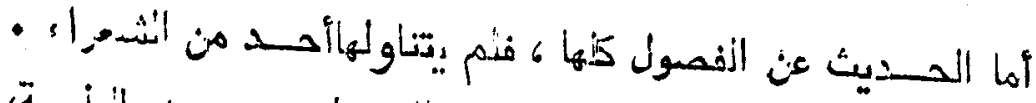

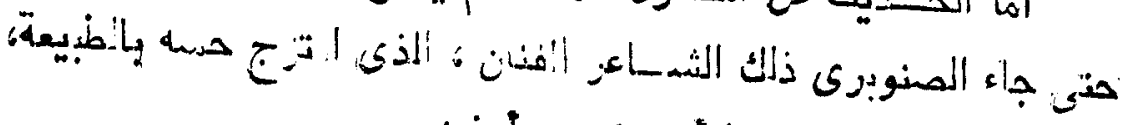

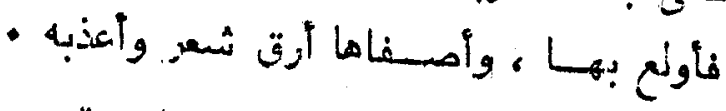

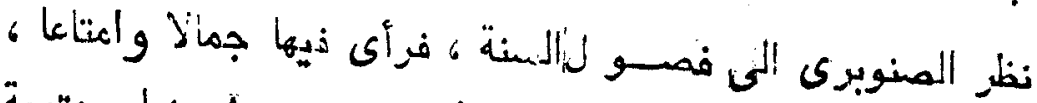

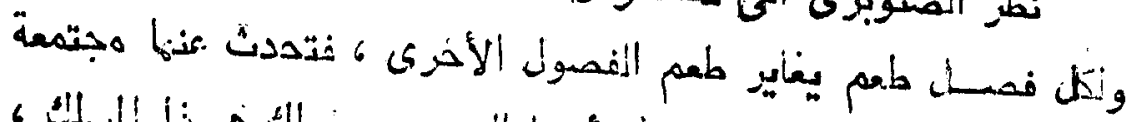

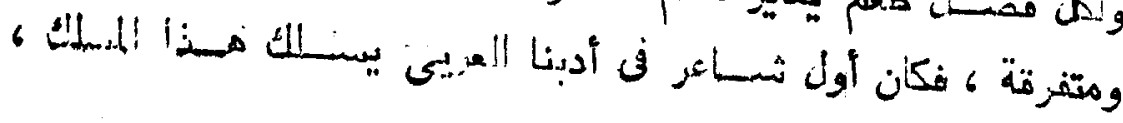

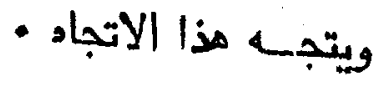

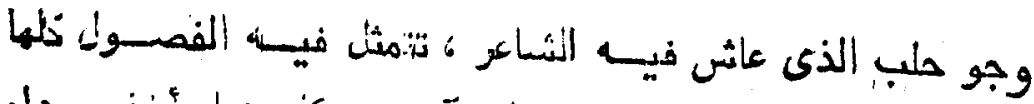

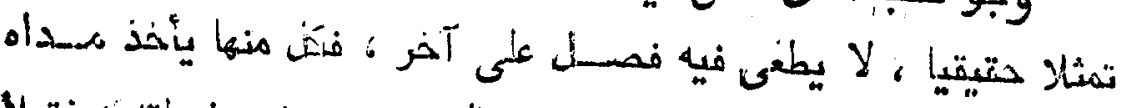

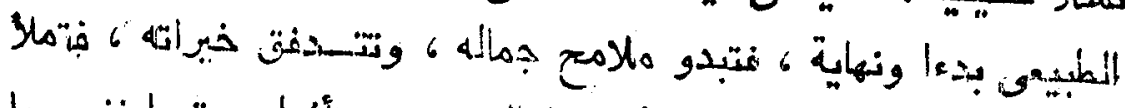

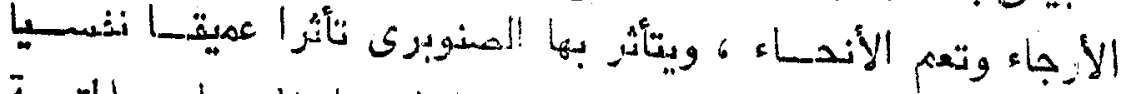

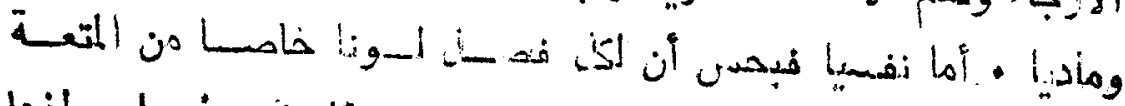

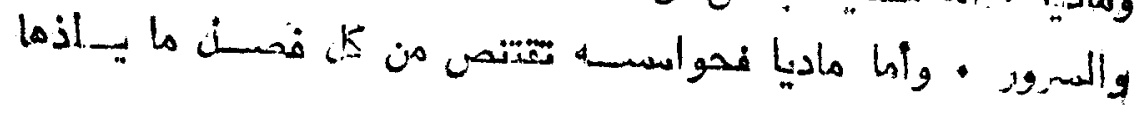




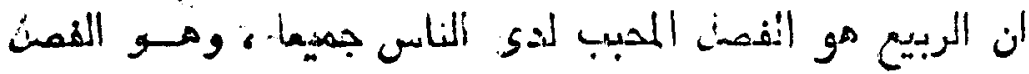

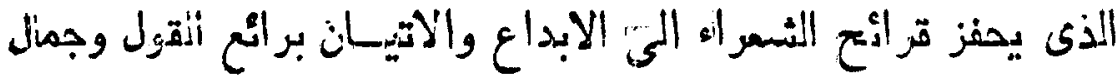

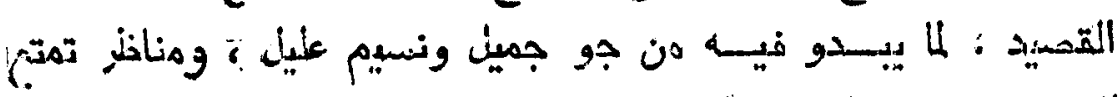

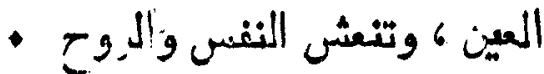

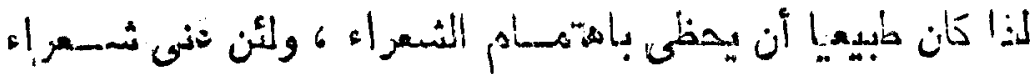

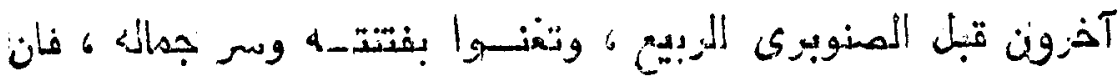

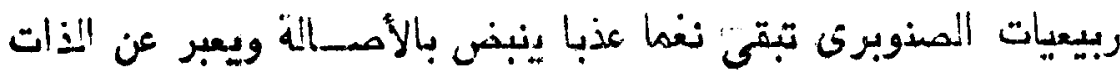

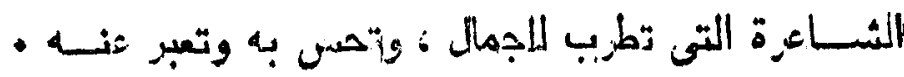

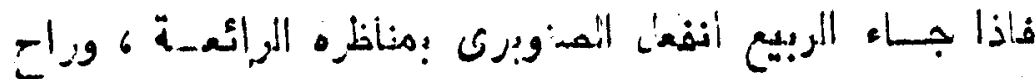

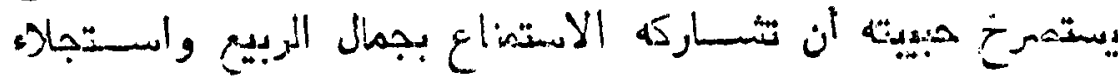

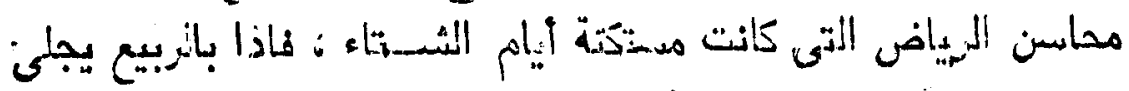

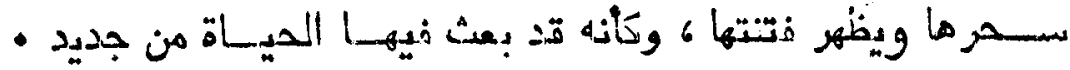

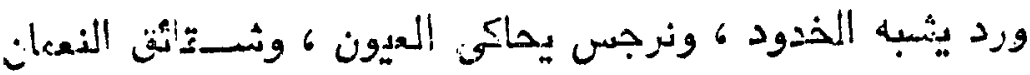

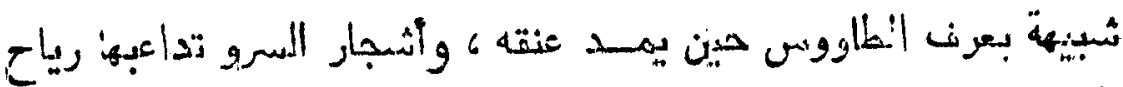

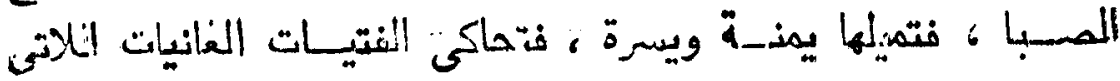

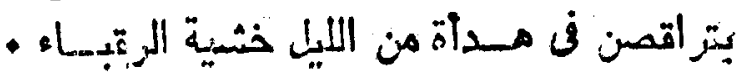

ثم ينتلى به الاعجاب بهـذه الرياذن المساصرة ، فيجعلها حرما

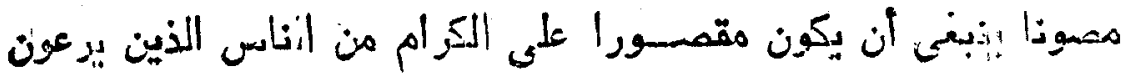

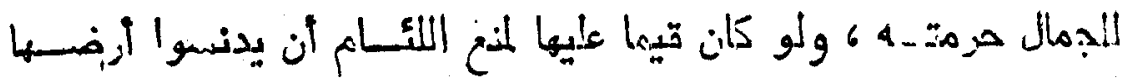

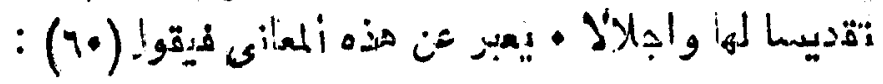

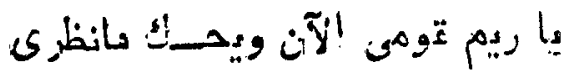

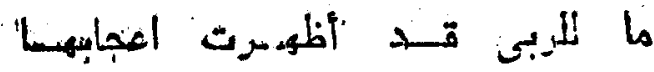




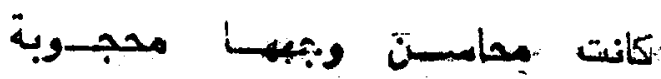

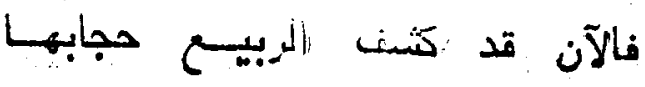

$$
\text { ورد بــا يحسكي المهـود ونرجس فيس }
$$

يحـكن انعيـون اذا رأت أحبابهن

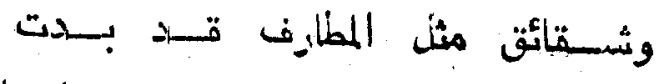

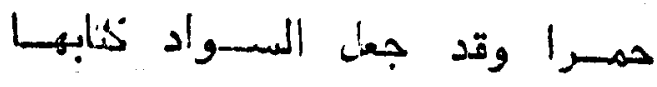

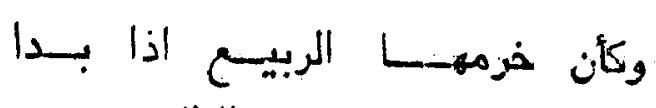

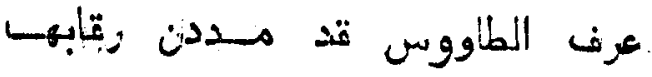

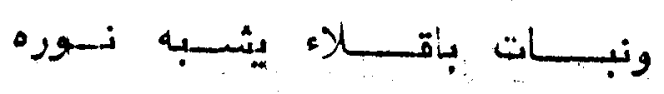

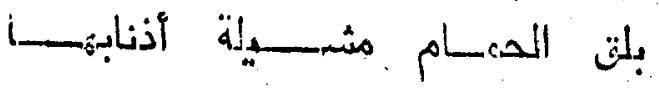

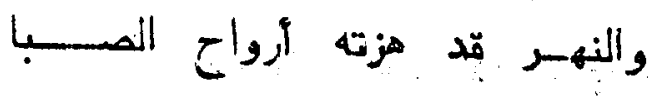

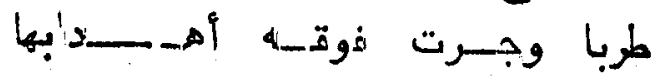

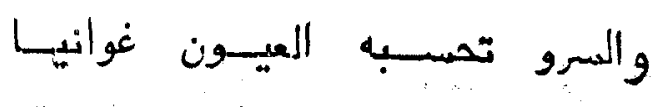

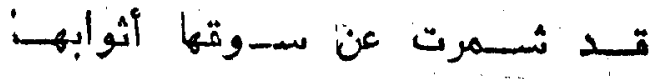

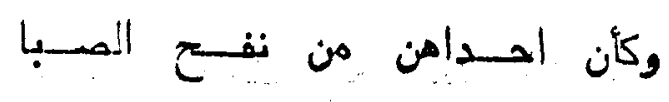

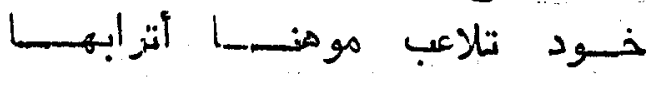

لو كنت أمسليك للزيساض مســي!نة

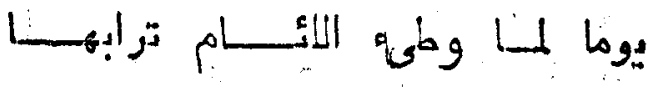

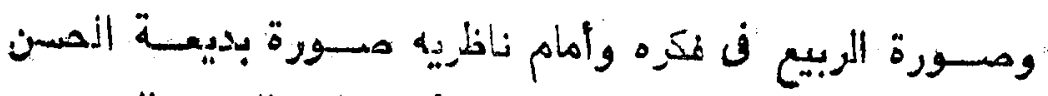

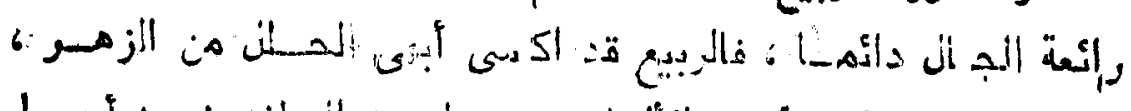

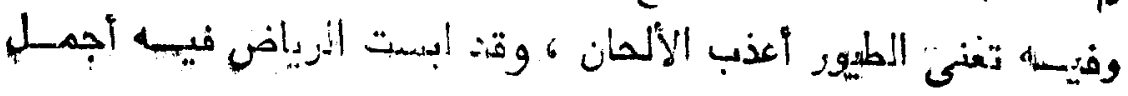

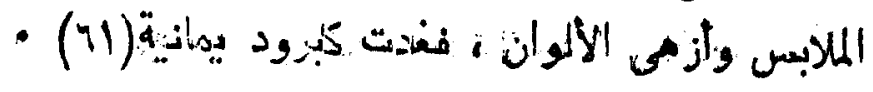

+ \&qv السابتي مي 
Irt

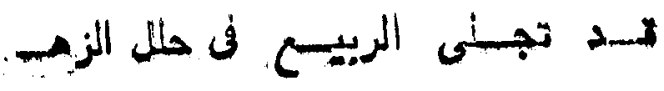

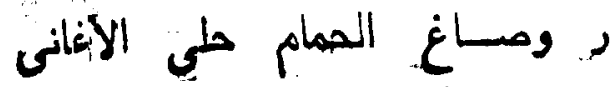

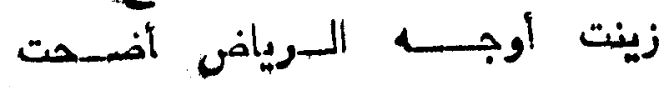

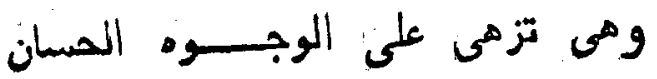

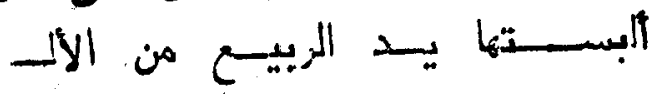

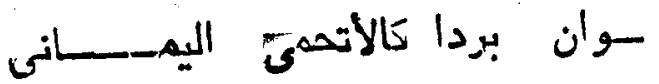

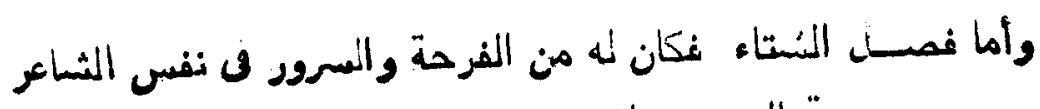

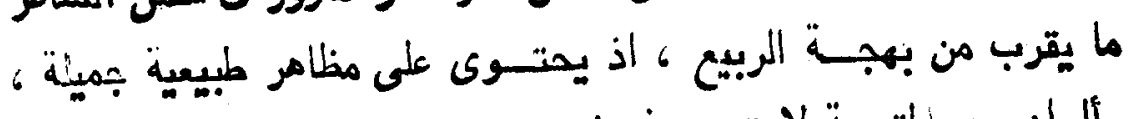

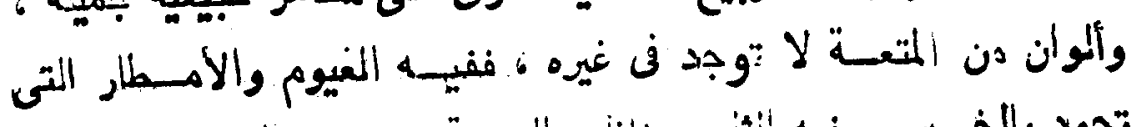

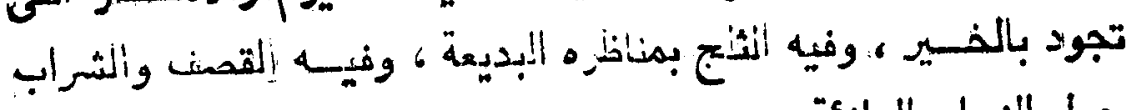

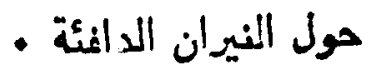

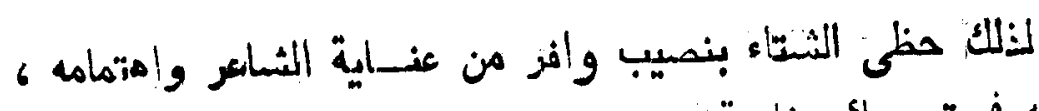

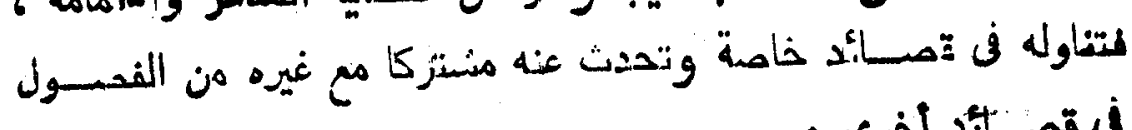

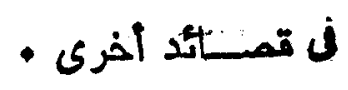

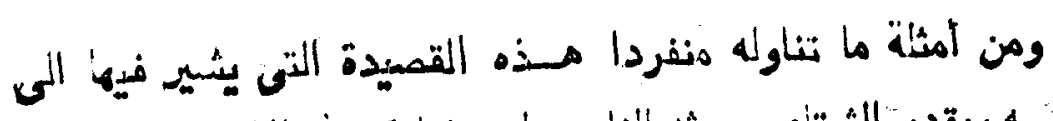

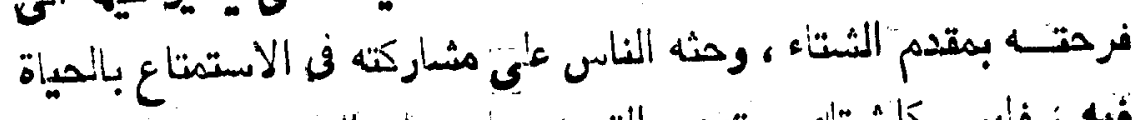

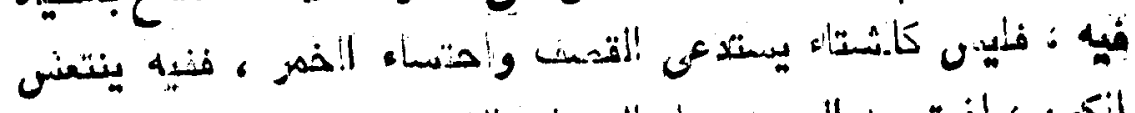

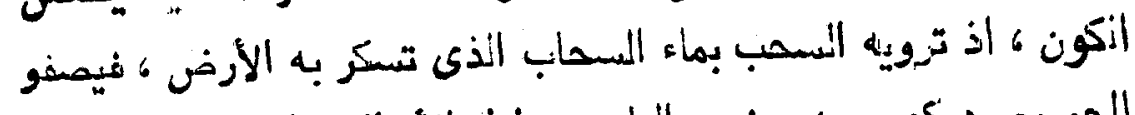

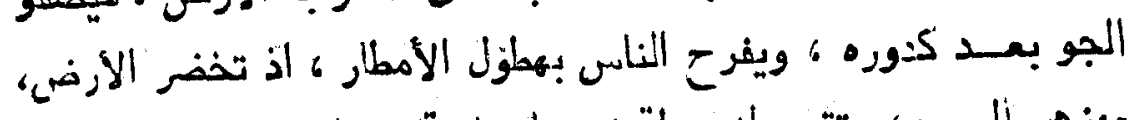

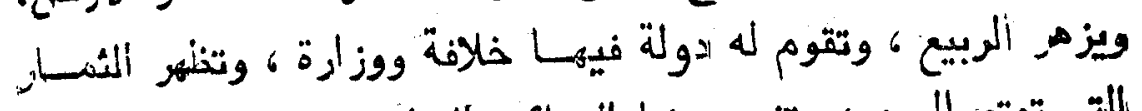

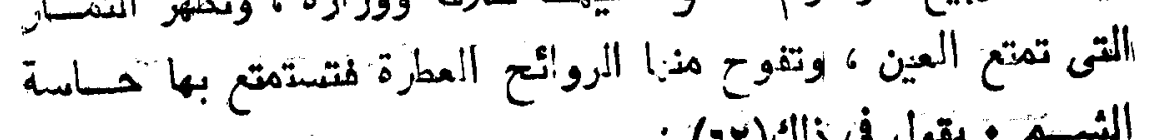

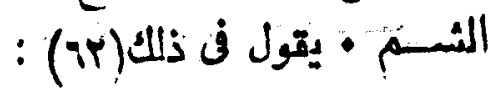

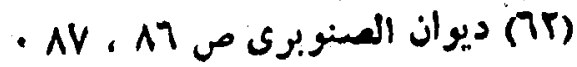




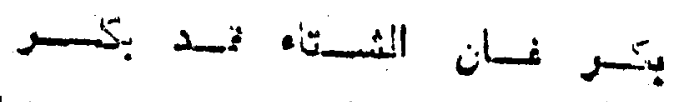

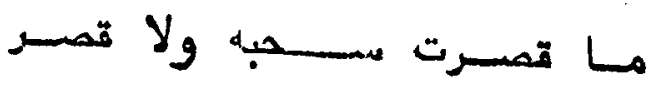

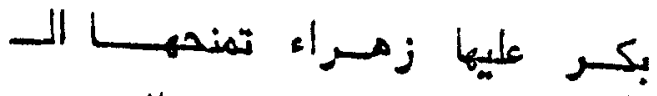

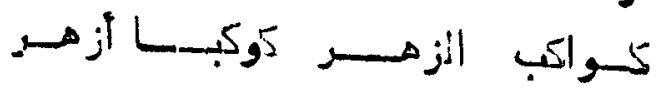

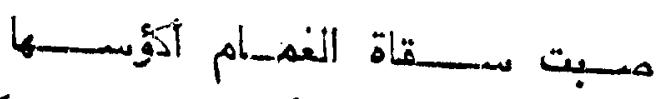

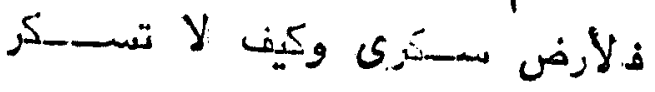

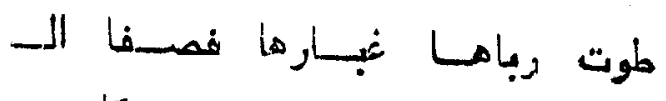

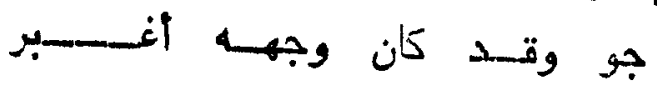

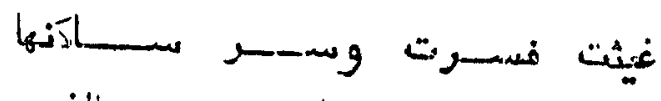

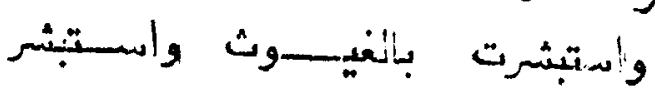

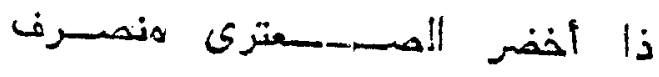

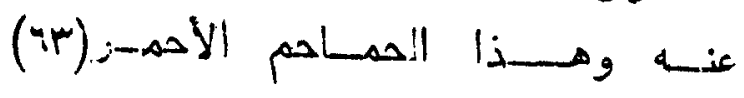

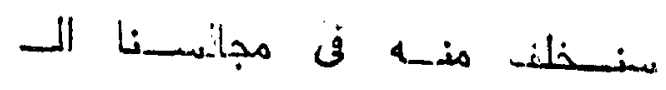

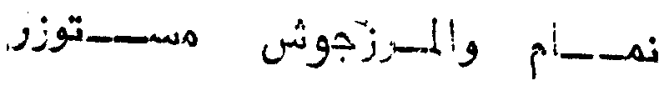

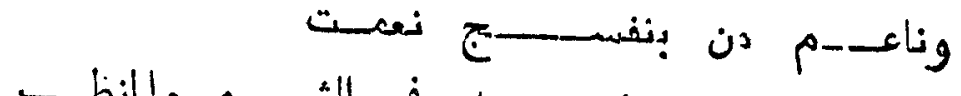

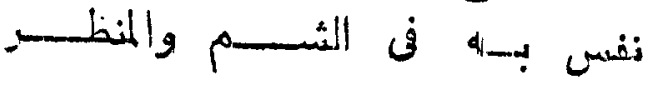

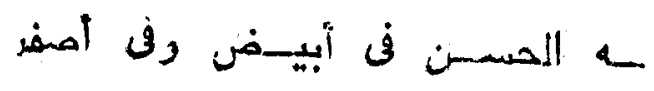

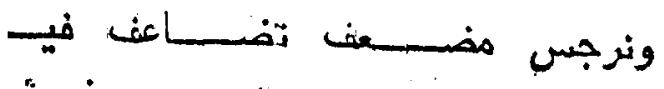

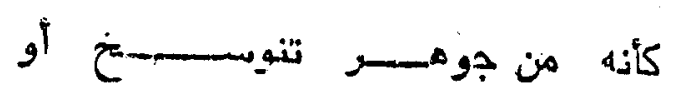

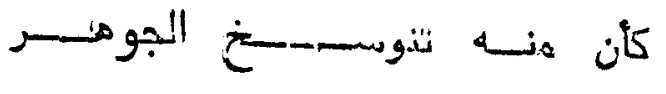

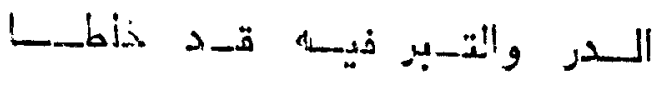

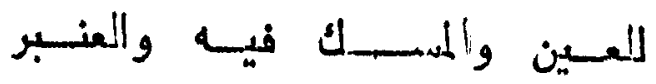

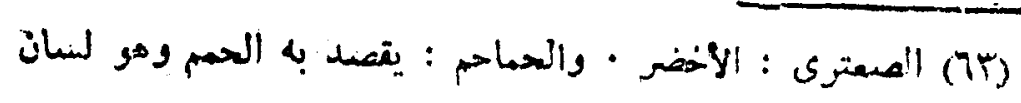

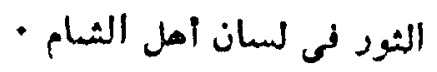


Iro

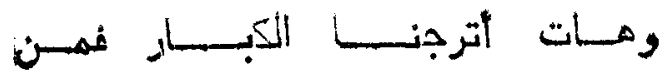

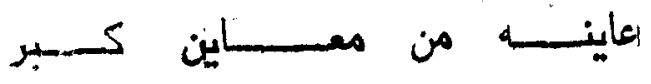

$$
\text { وهـات تنإحنسـا لاسـذى مهـو مسن }
$$

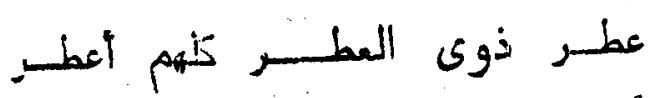

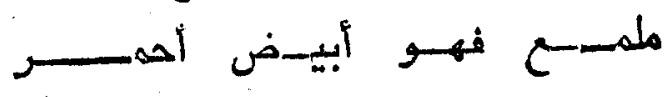

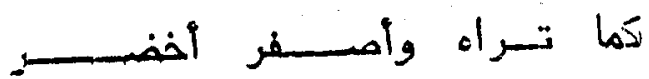

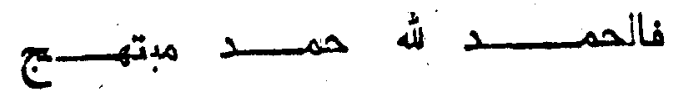

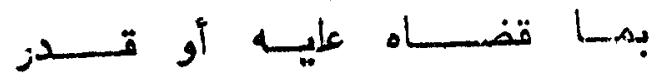

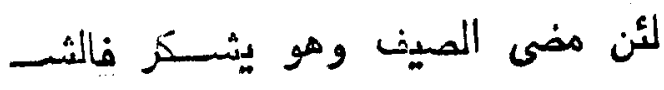

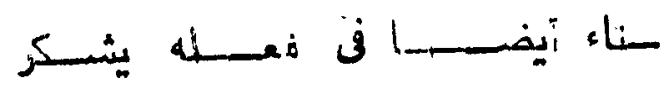

وتتفح فن هـذه القصيدة ( وحسدة ألموضوع ) وهي سمة يارزة

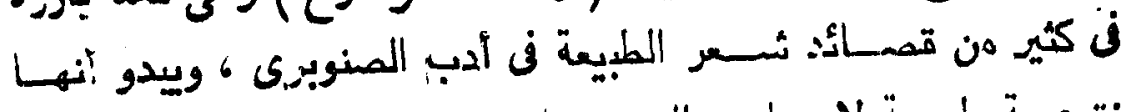

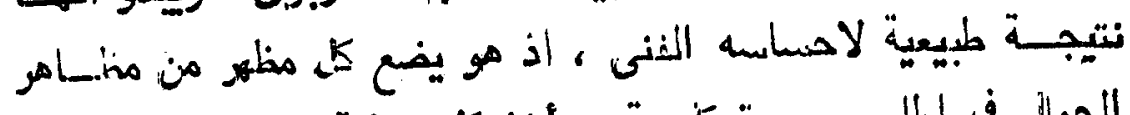

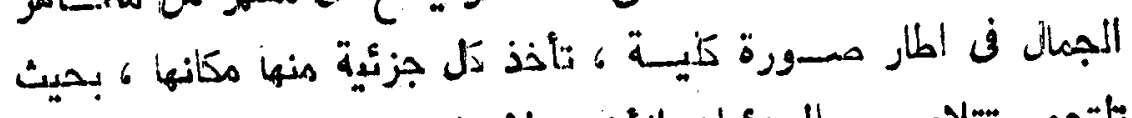

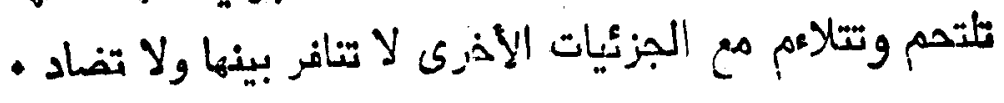

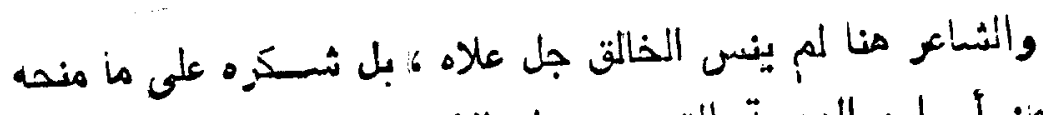

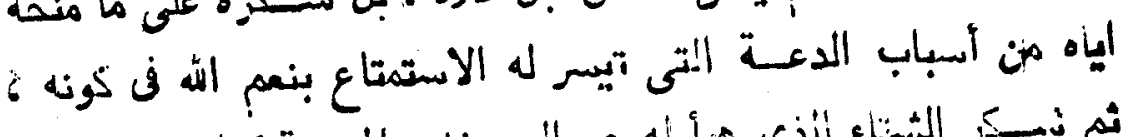

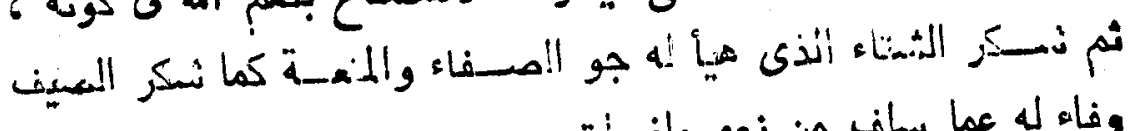

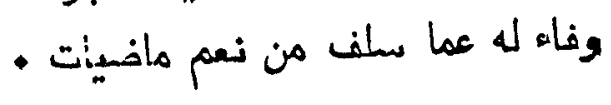

والنار من مستلزمات إلشتاء ومتط'باته ، وحولها تنعقــد مجانس

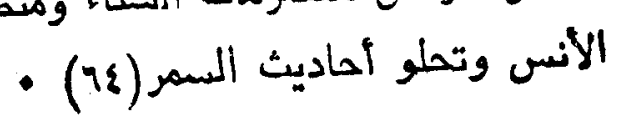

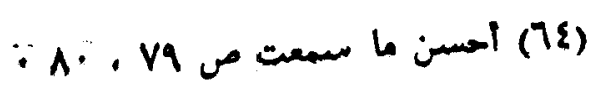




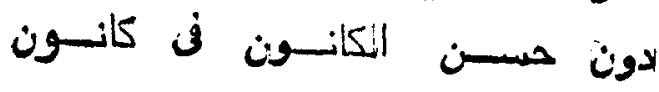

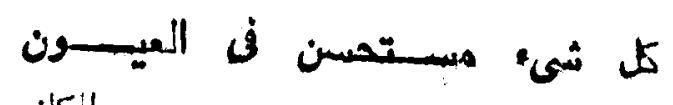

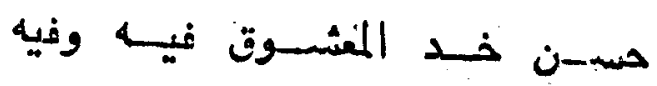

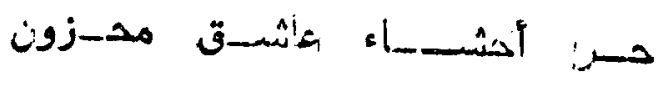

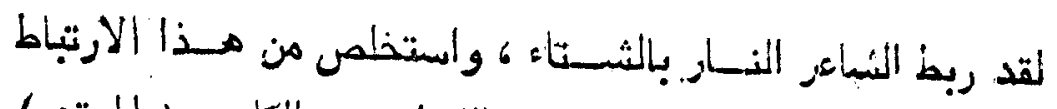

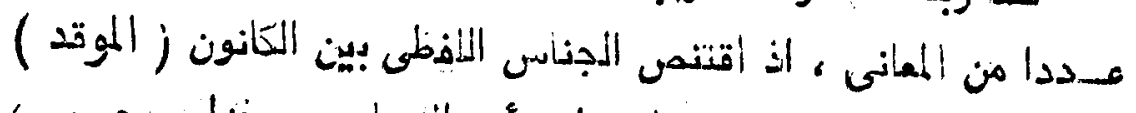

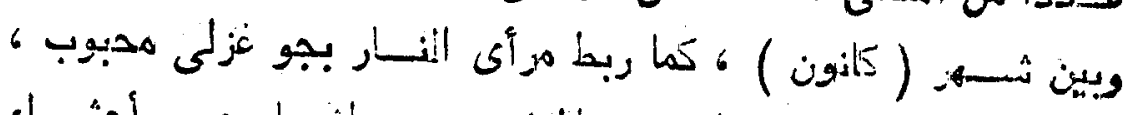

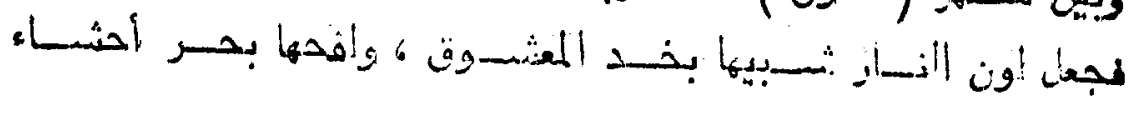

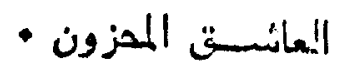

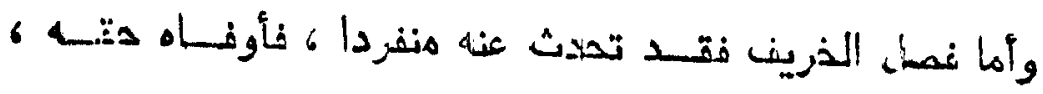

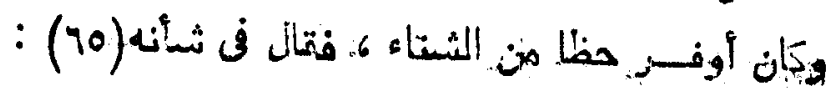

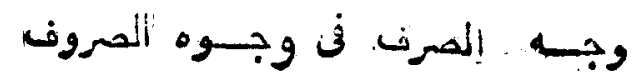

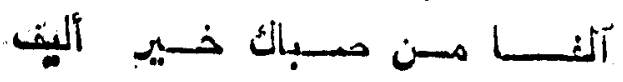

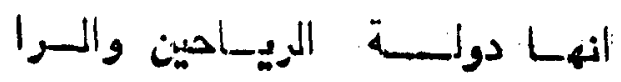

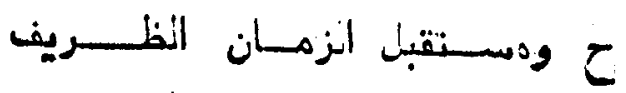

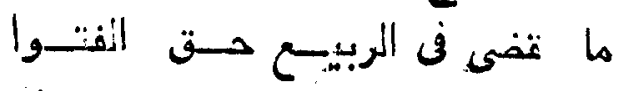

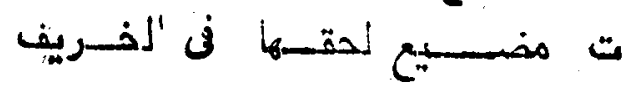

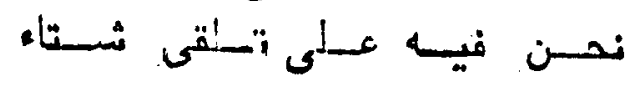

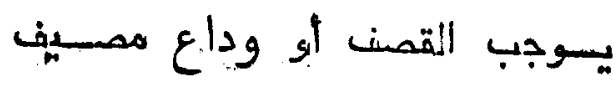

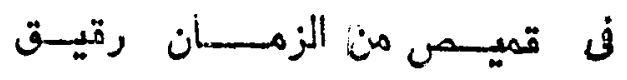

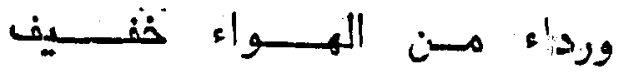

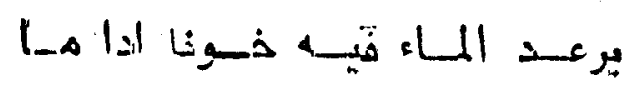

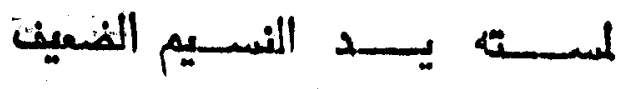

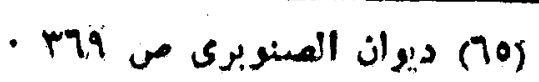




\section{Irv}

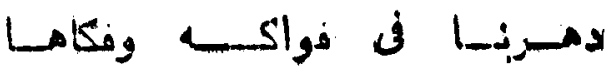

ت حسنان الصــنون والتصــنه

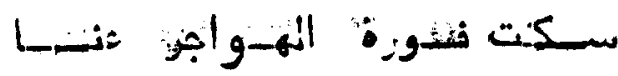

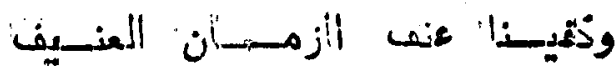

وتخلى الفضــاء من ســوسن البـ

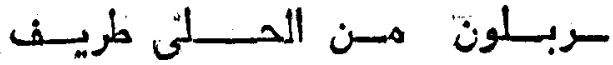

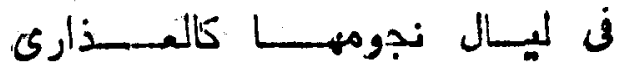

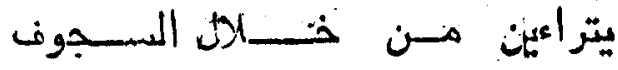

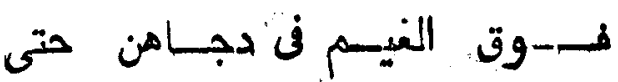

هــو فــوق البــرود في" إلتهـويف

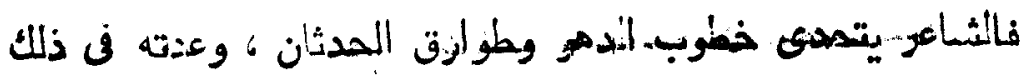

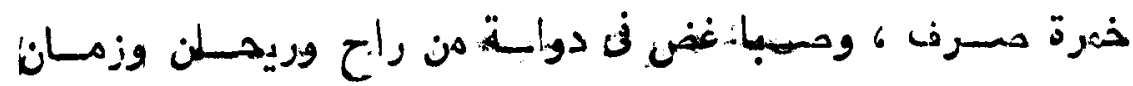

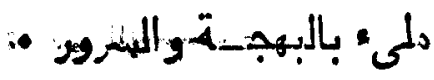

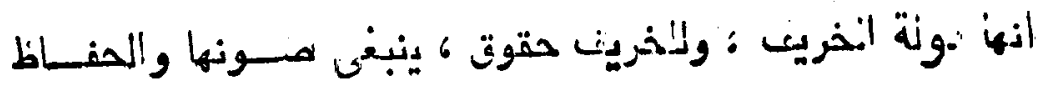

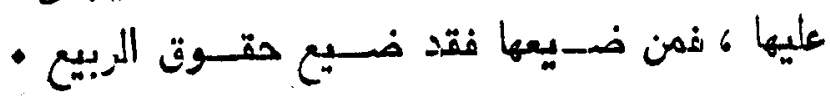

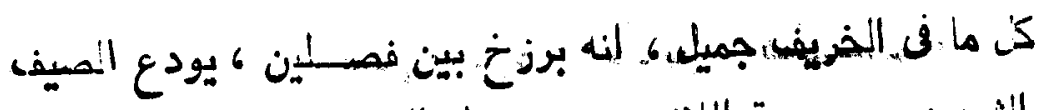

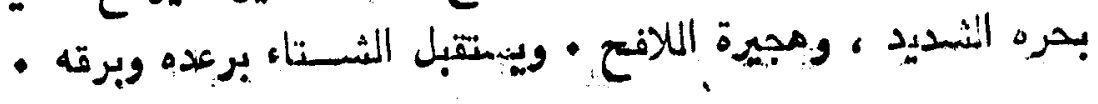

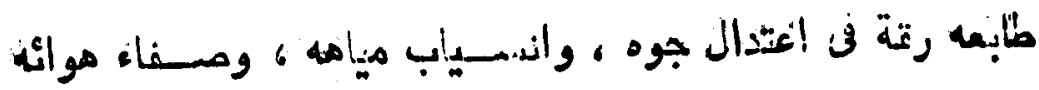

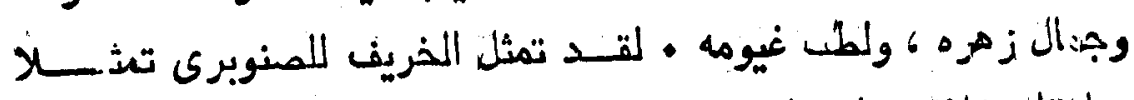

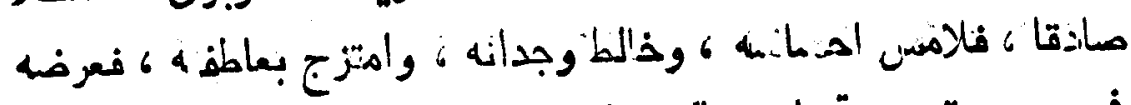

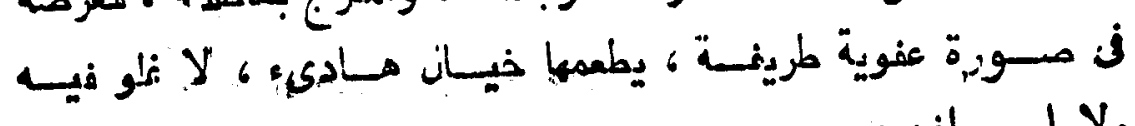

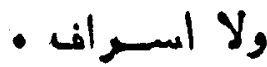




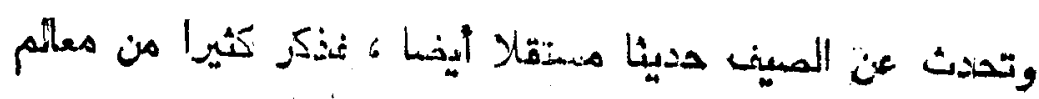

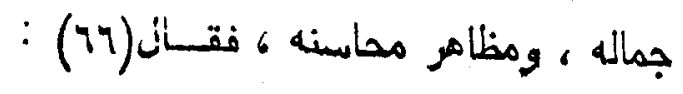

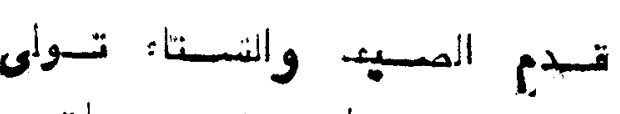

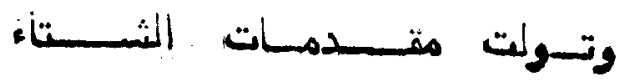

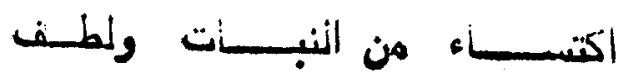

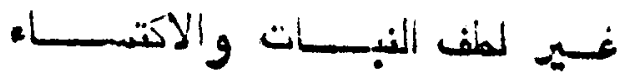

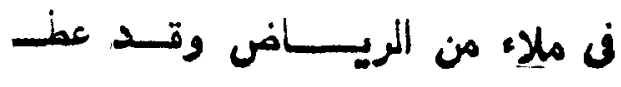

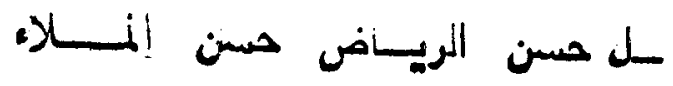

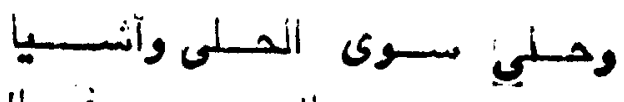

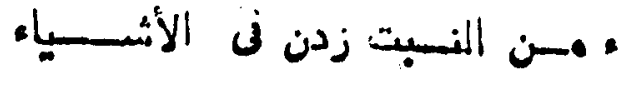

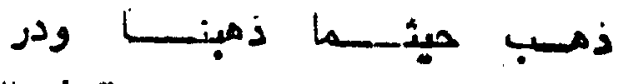

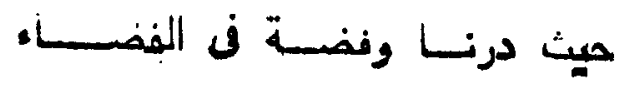

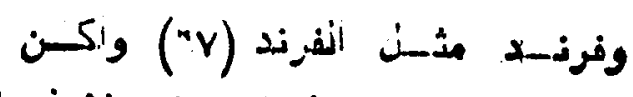

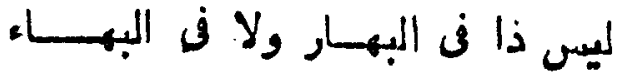

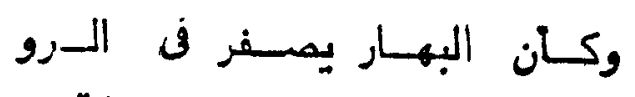

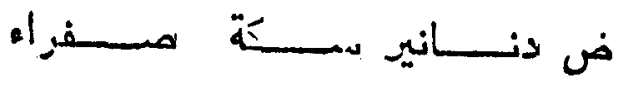

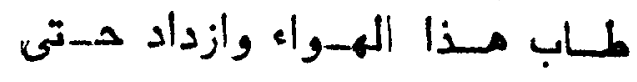

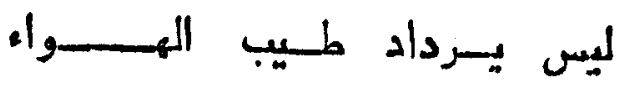

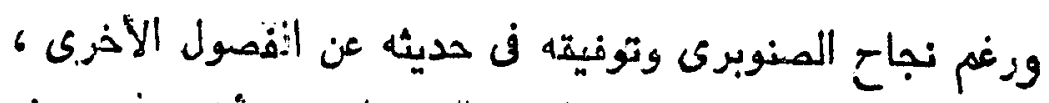

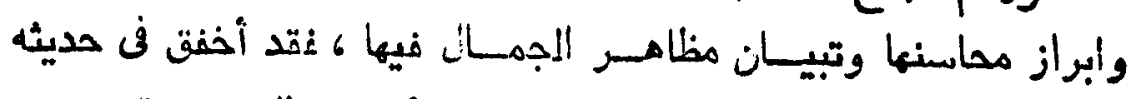

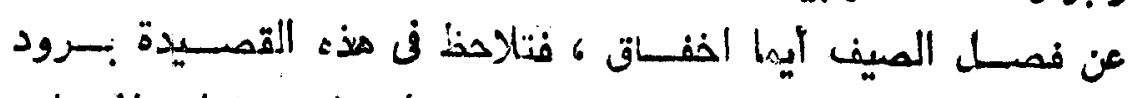

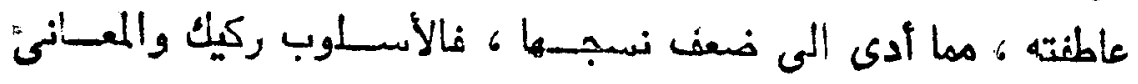

-

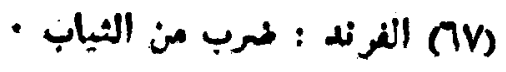




\section{Ir9}

هزيلة لا جـدة فئها ولا ابتّار ك نفضسلا عن رداءة عرضها ج وجاول

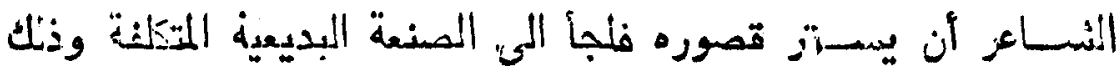

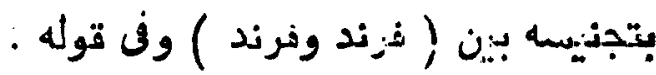

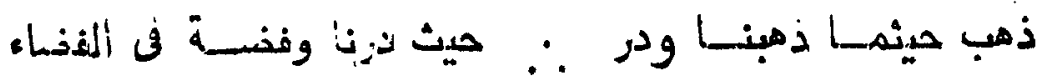

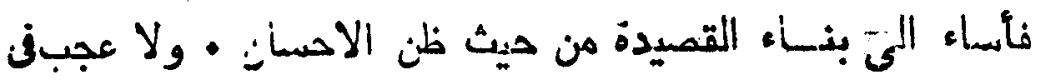

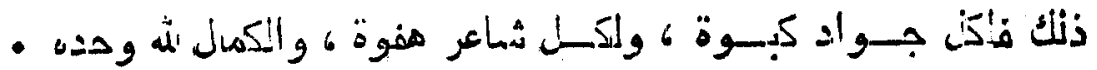

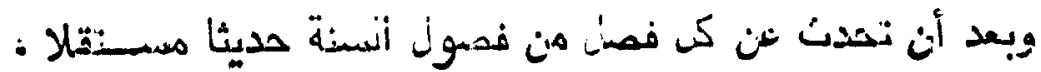

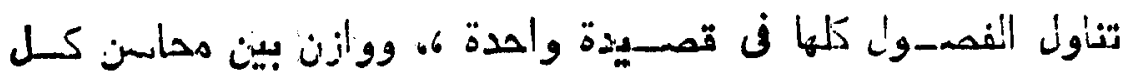

- منهـا ومسيساوئه

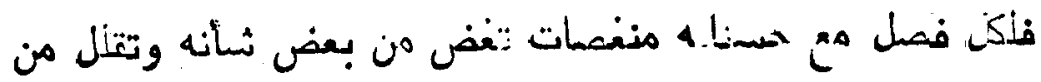

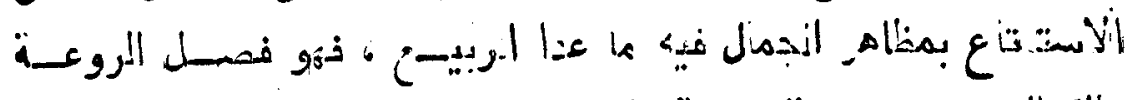

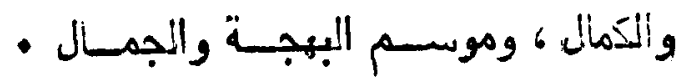

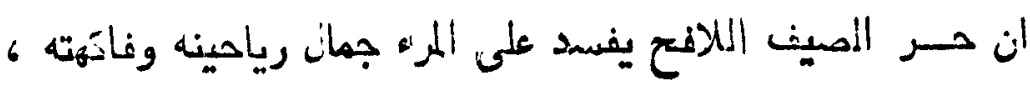

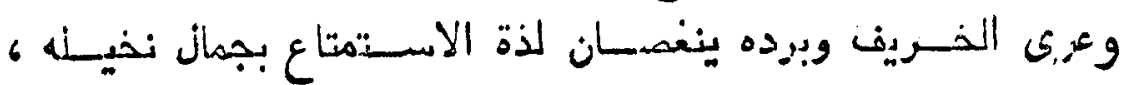

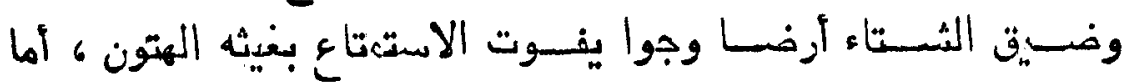

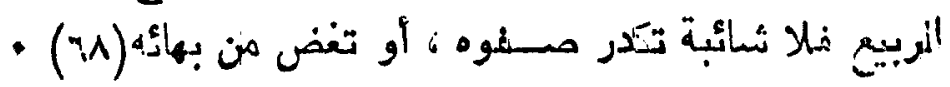
ان كان فن الصسيف ريحسان وفاكهة

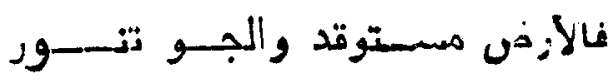

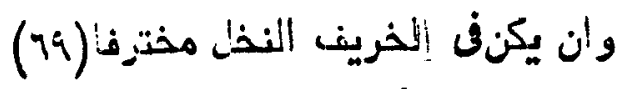

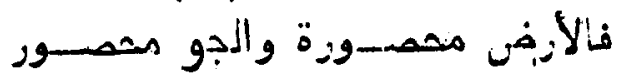

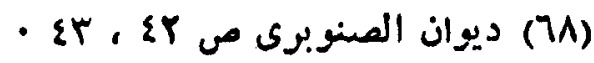

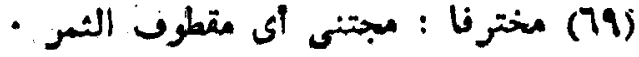




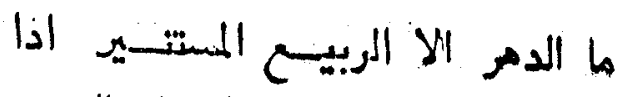

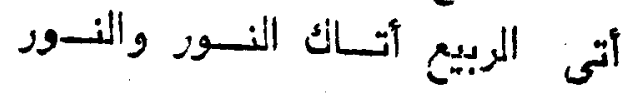

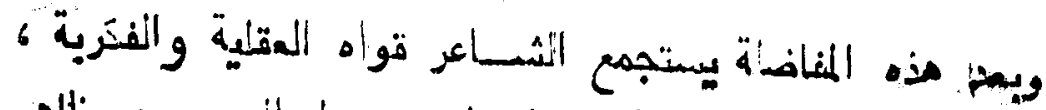

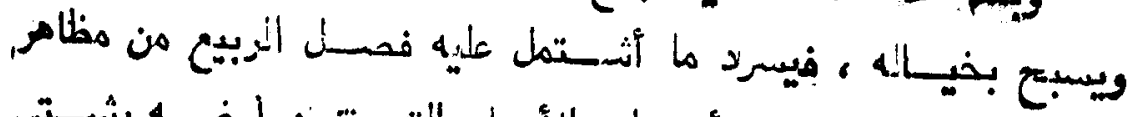

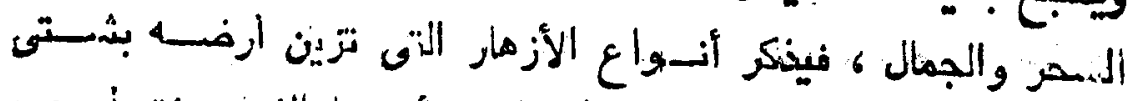

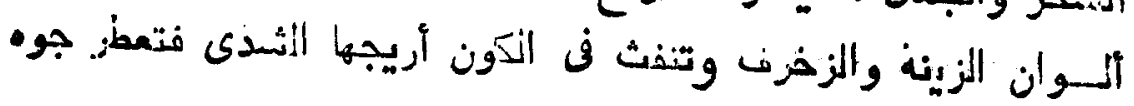

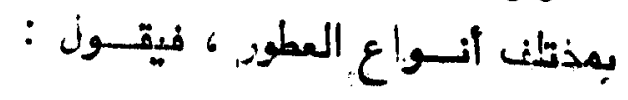

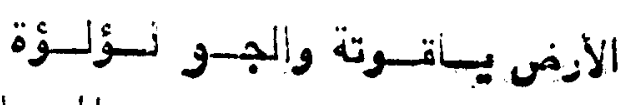

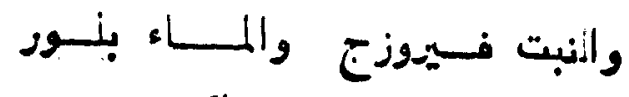

ما يعـدم اننبت كأسـا هن سمـائبه

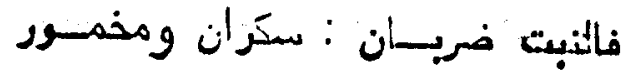

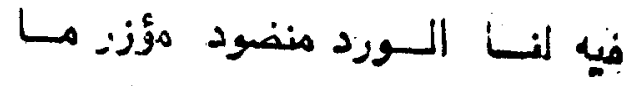

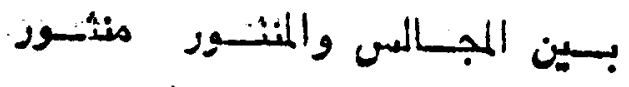

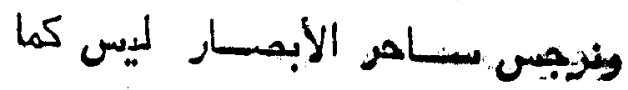

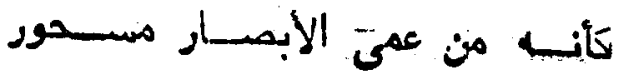

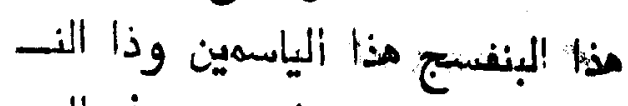

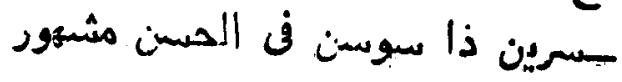

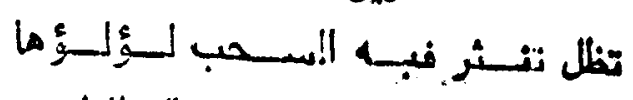

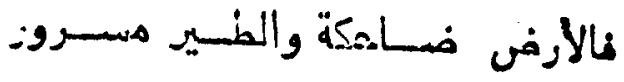

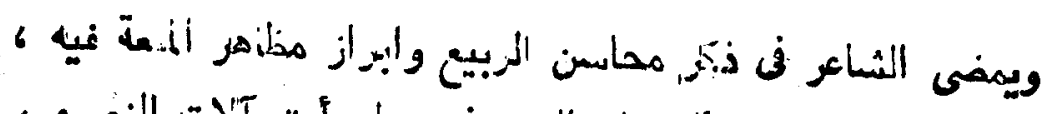

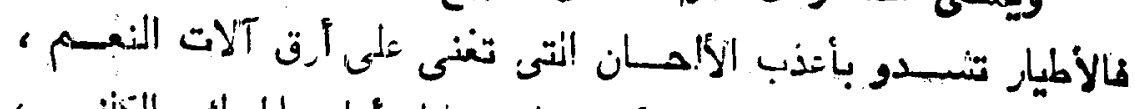

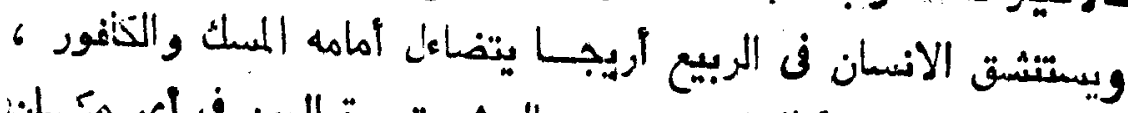

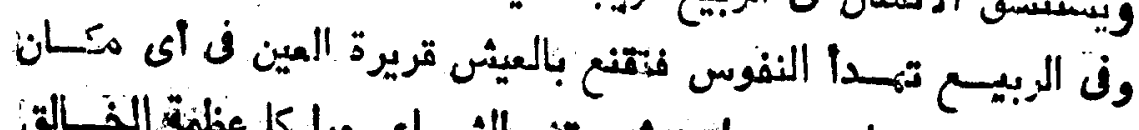

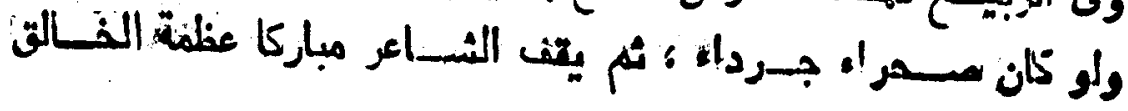




\section{(2)}

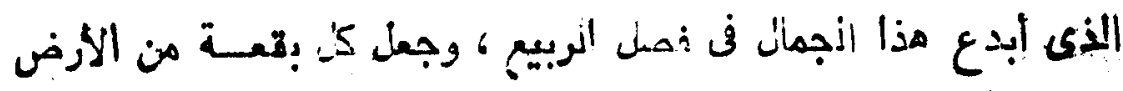

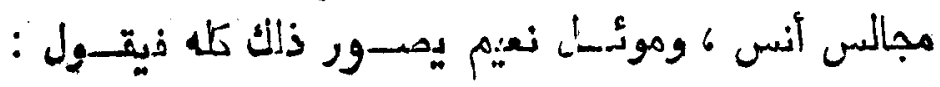

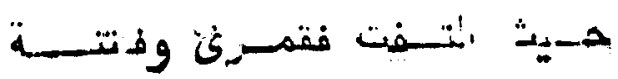

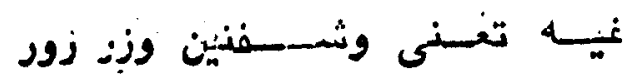

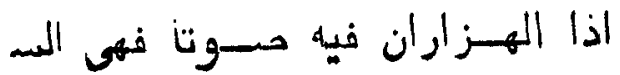

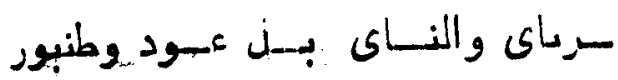

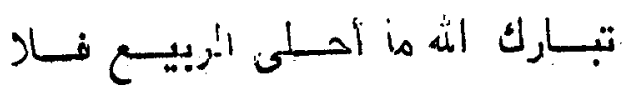

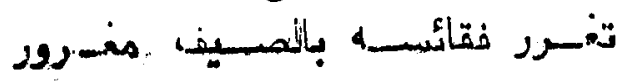

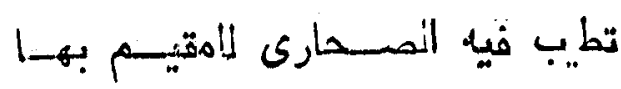

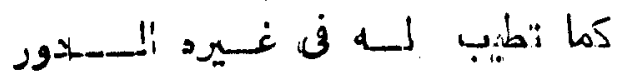

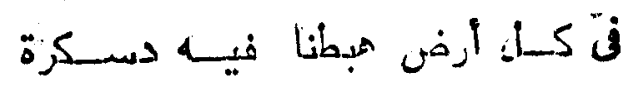

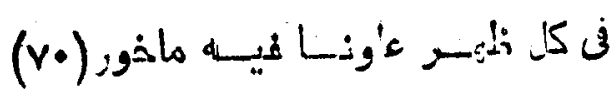

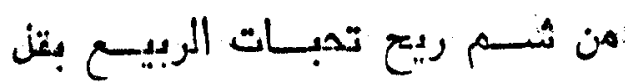

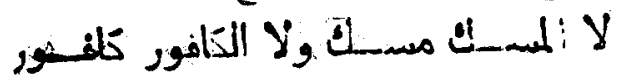

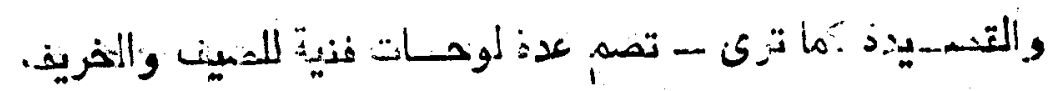

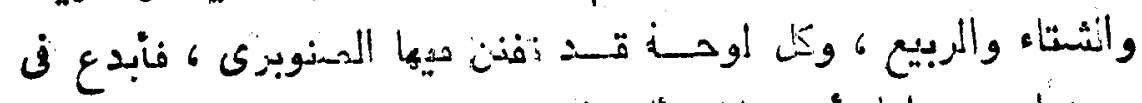

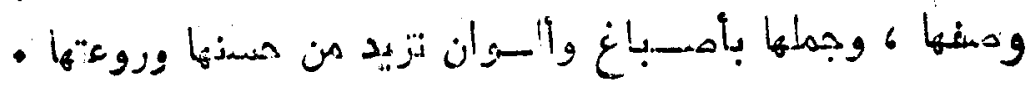

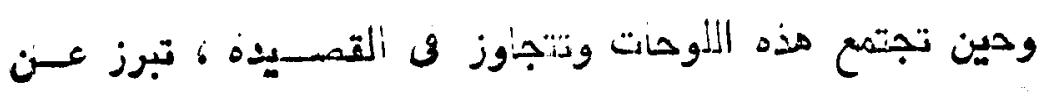

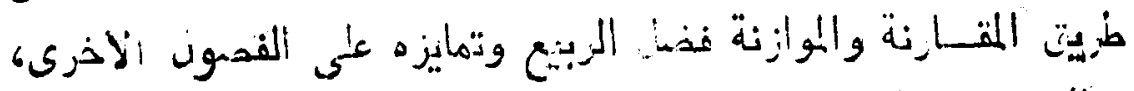

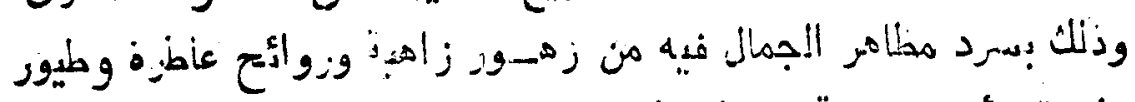

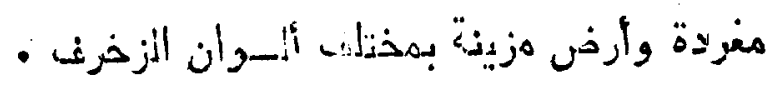

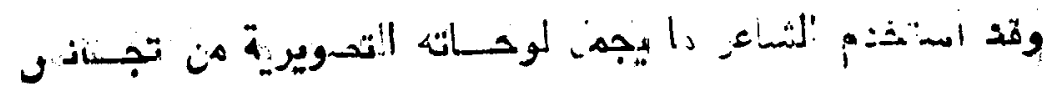

: 


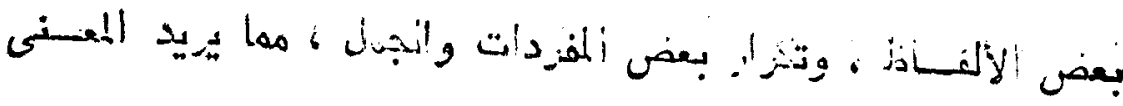

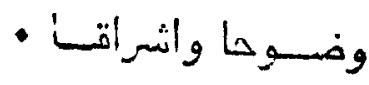

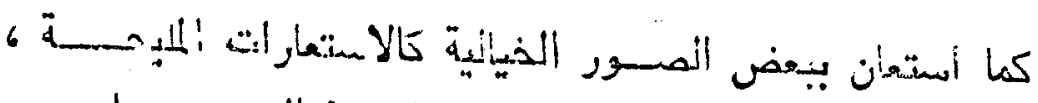

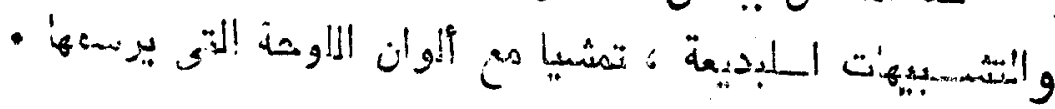

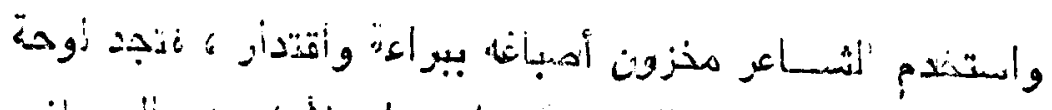

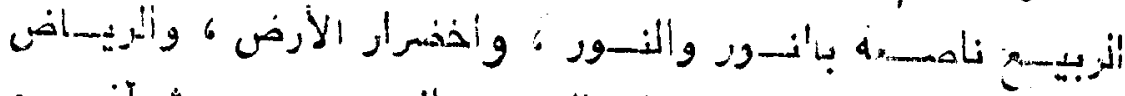

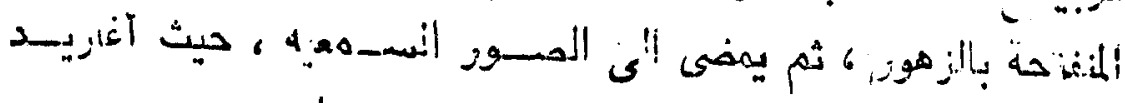

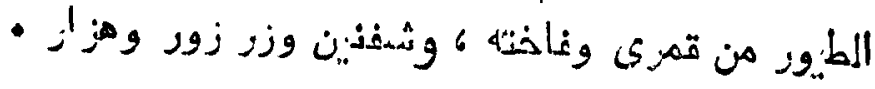

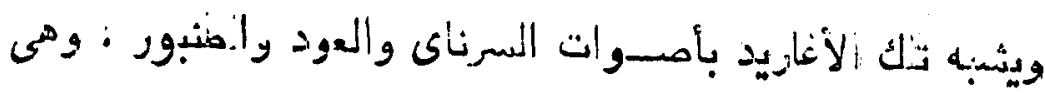

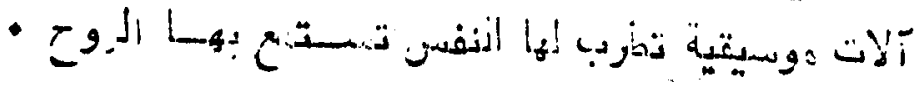

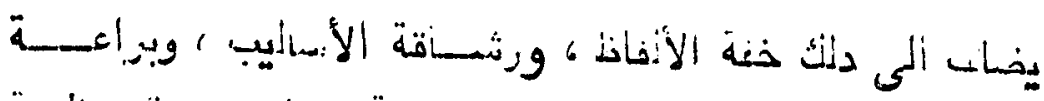

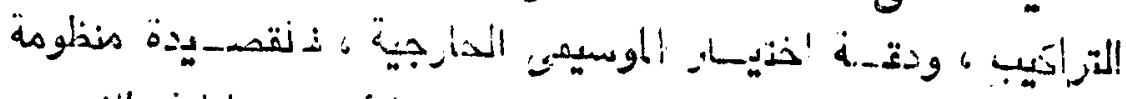

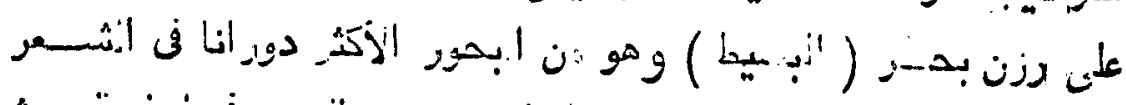

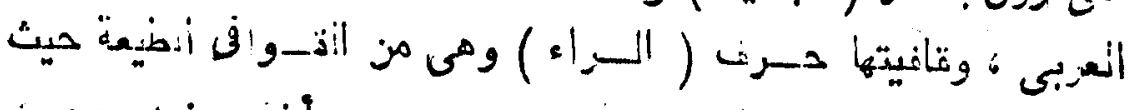

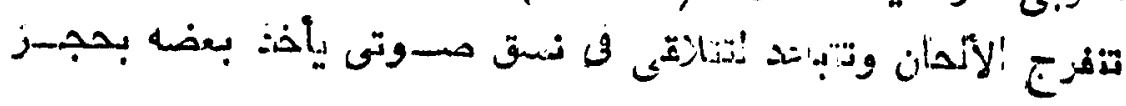

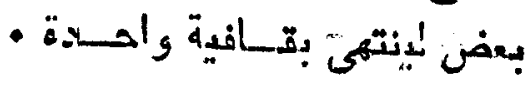

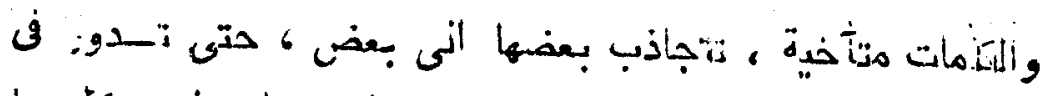

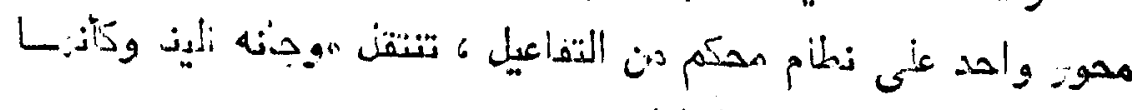

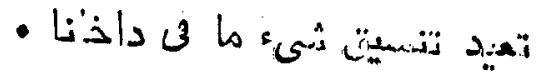

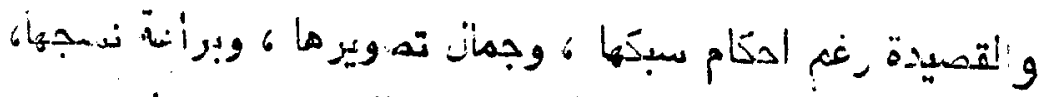

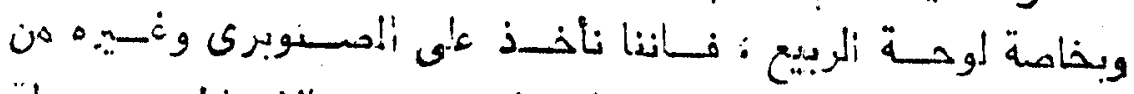

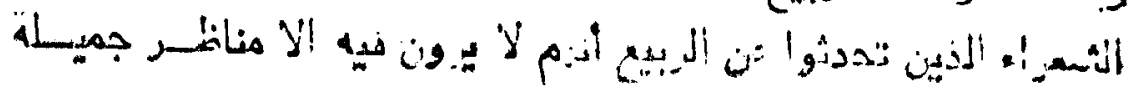


تمتع الحواس فحسب ، ألموانــا زامية تسر أمعين ، وروأتح عطسرة

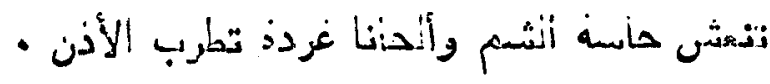

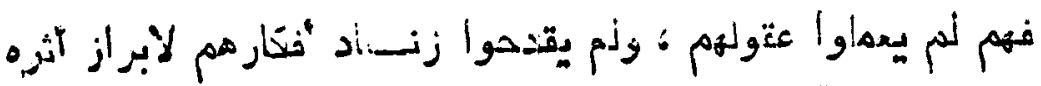

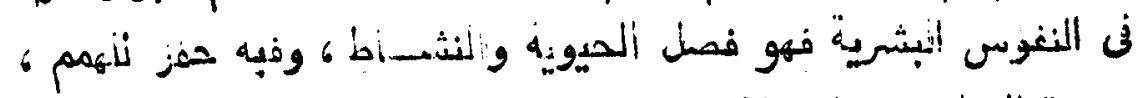

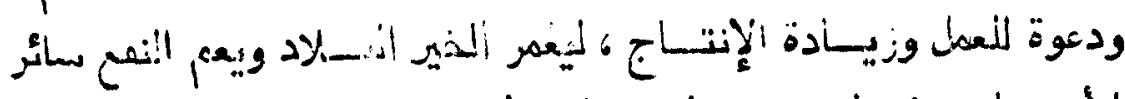

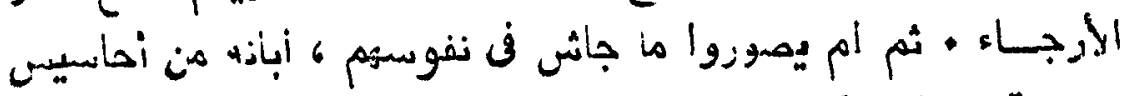

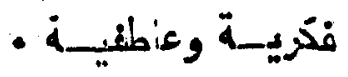

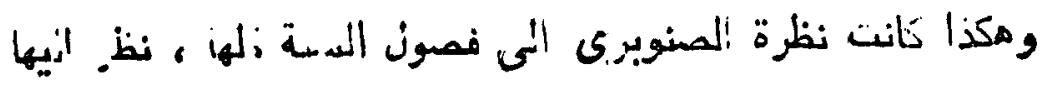

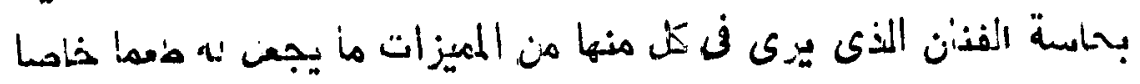

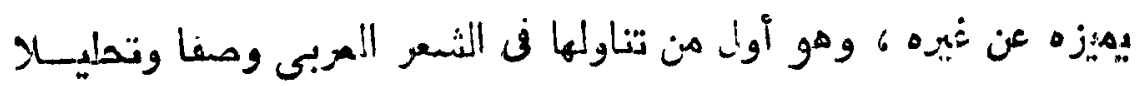

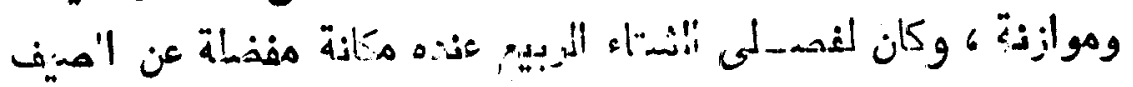

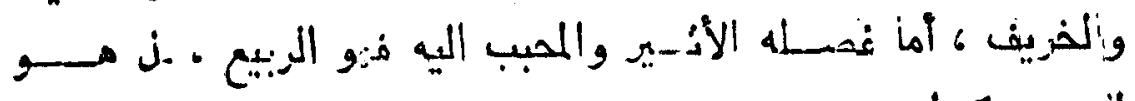

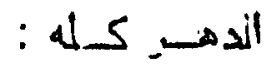

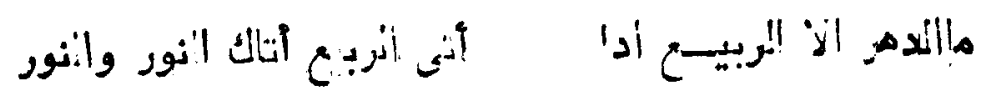




\section{ذــاتمــة}

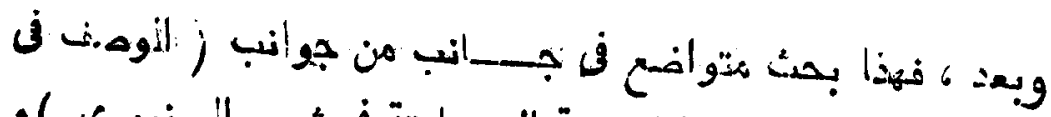

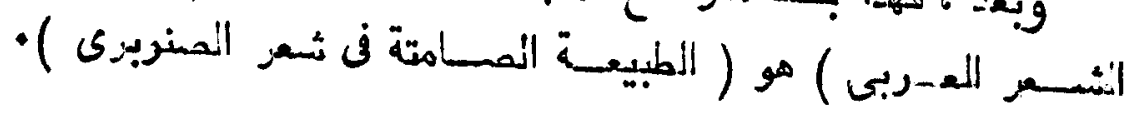

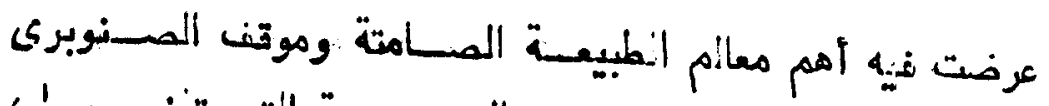

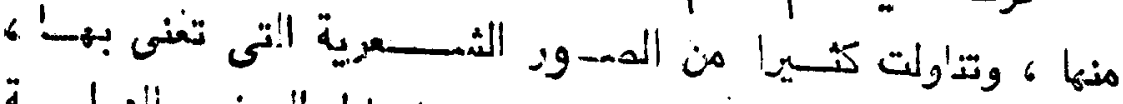

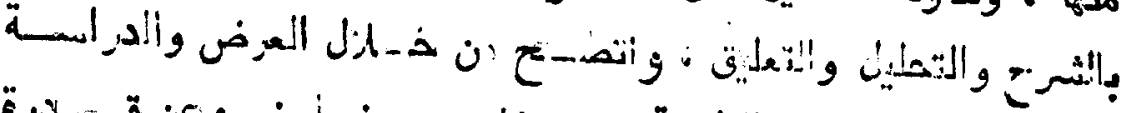

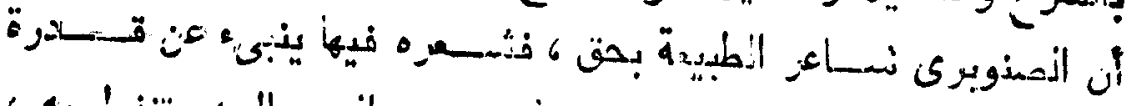

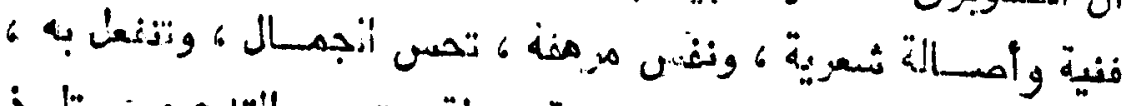

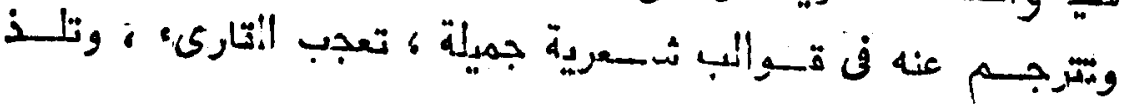

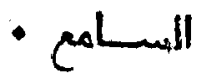

وكان له في عزأ المجال تجديدات ه:تيكرة لم يسبق إليها ومى :

\section{1 - وحسدة الموضسوع :}

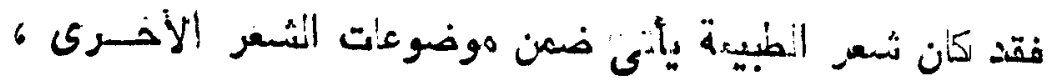

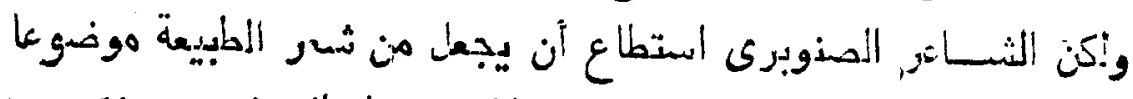

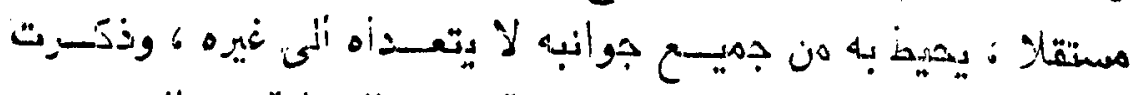

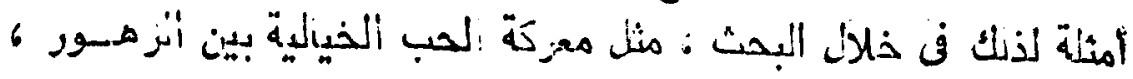

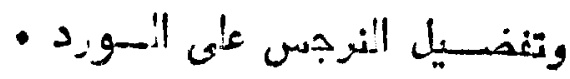
r ا

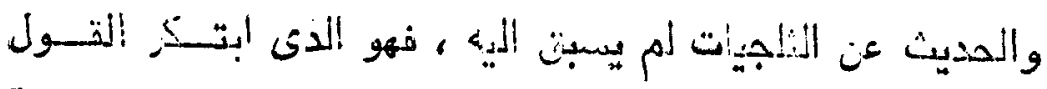

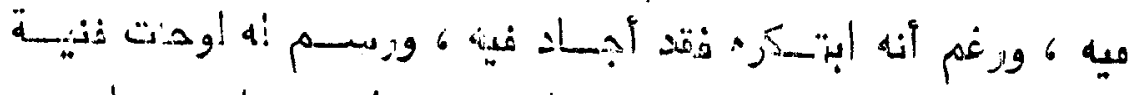

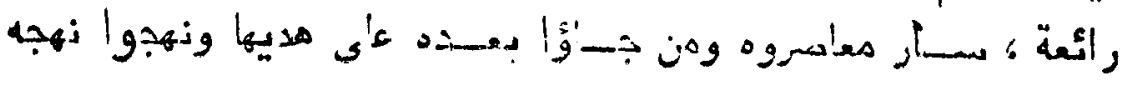




\section{r - الحـديث عن الفنهسول، :}

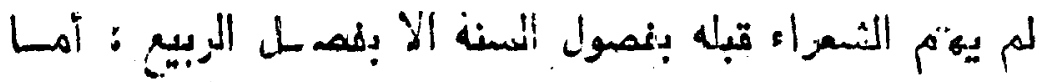

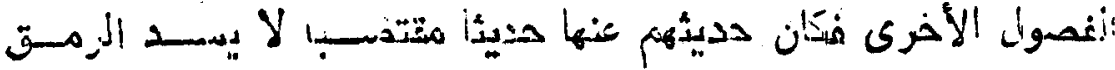

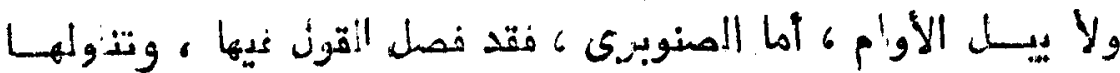

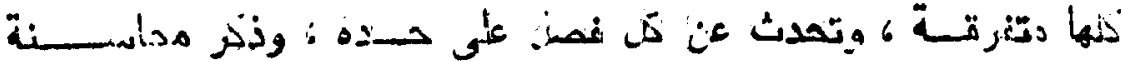

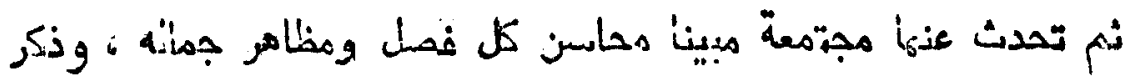

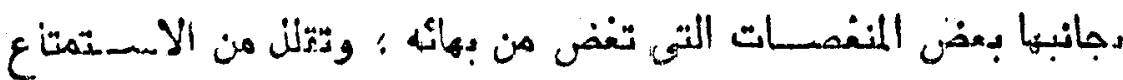

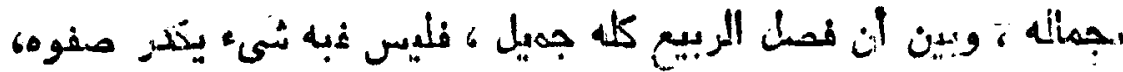

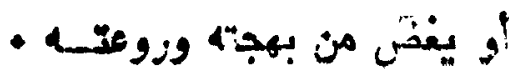

وكان الربيعاته مـذاق خاد ، بفيق ربيعيات هن عامروه رمن

سبسـبقوه

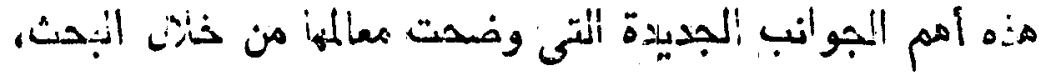

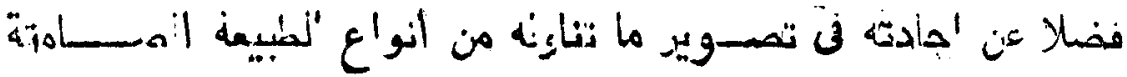
- الأخــرى

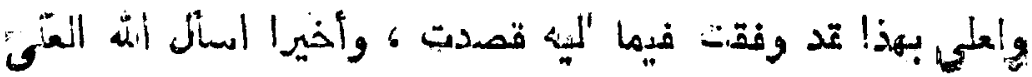

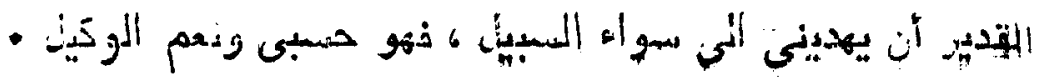

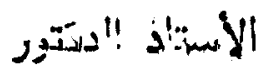

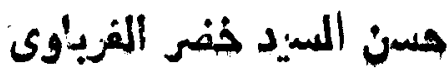

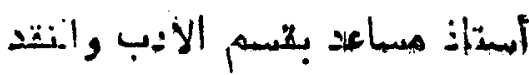

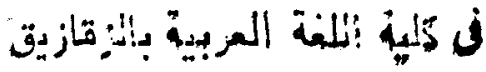
$(j 1 \cdot-p)$ 
11

امر المراجسـا

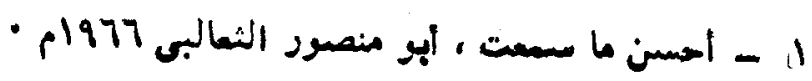

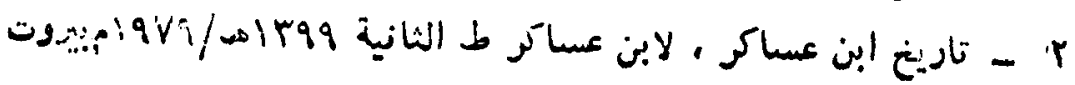

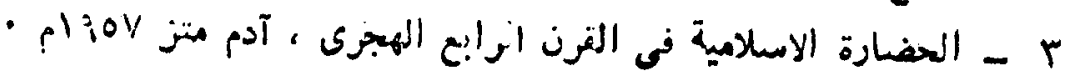

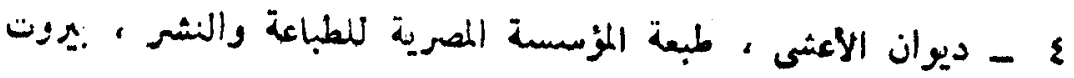

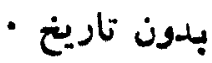

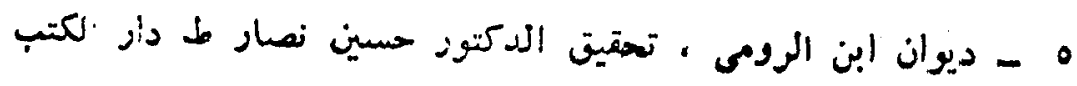

- plqrr

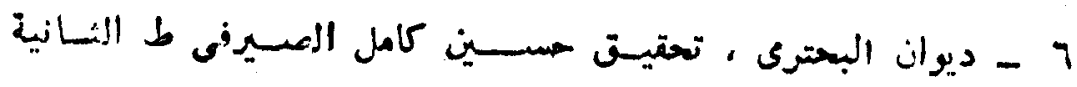

دار العـارف - دان

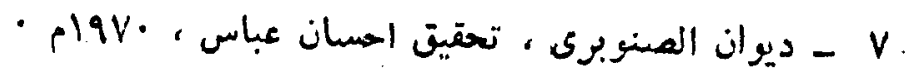

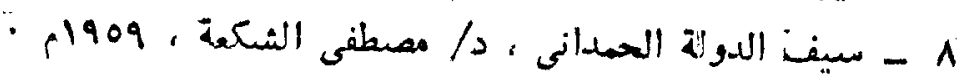

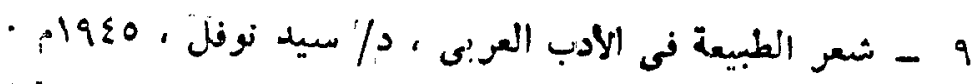

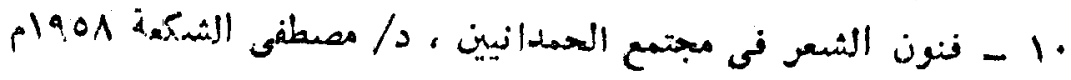

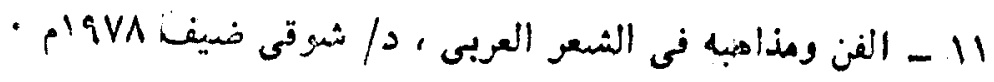

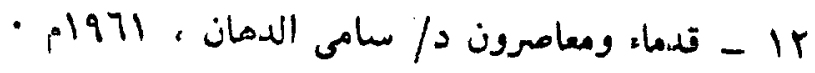

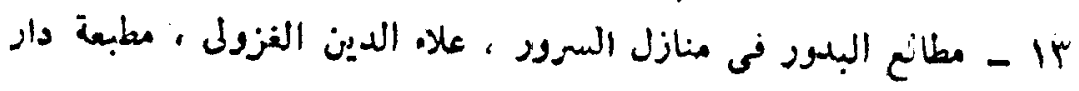

- الوطن بلدون تاريخ فيدرو فئر

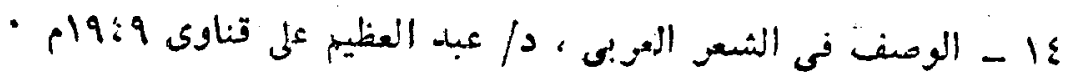

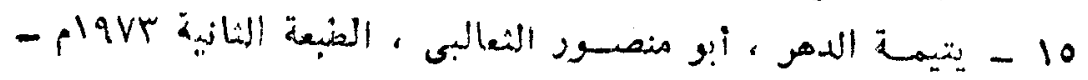

- 


\section{ابتـالزونقا}

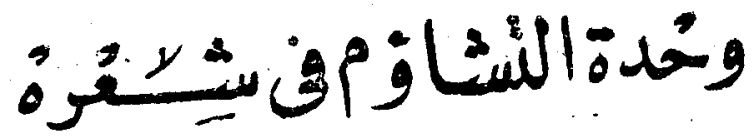

دكتو: : الحسينى مدمد ابزاهيم ا:فقى

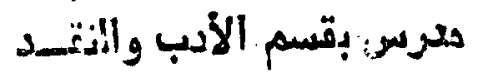

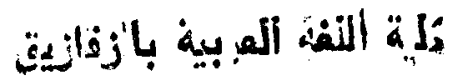

$$
\text { أفعنّ الأول - هياة ابن المومى (") : }
$$

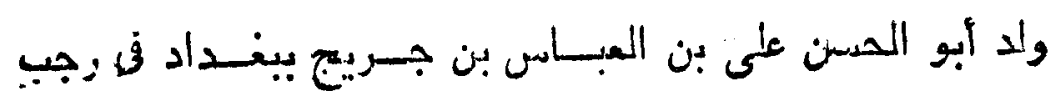

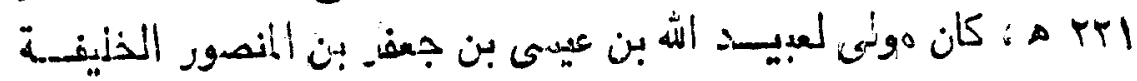

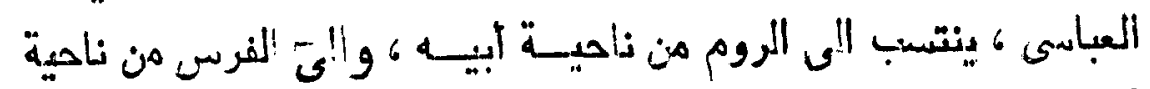

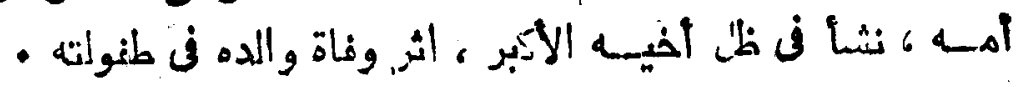

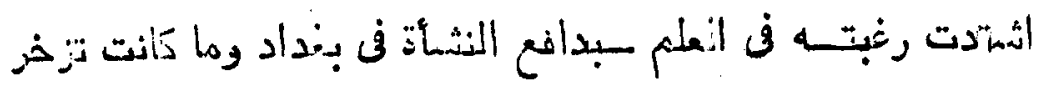

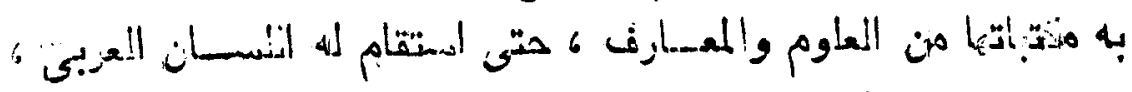

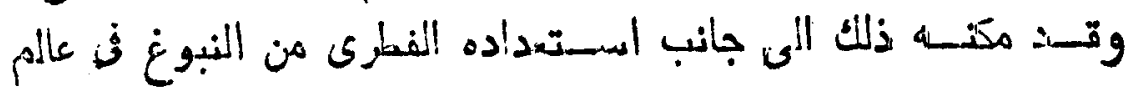

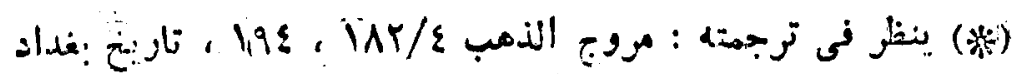

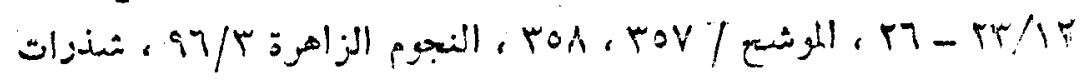

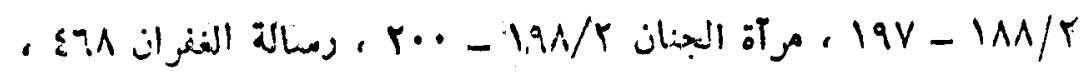

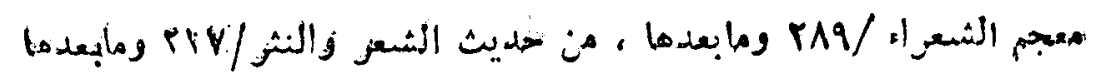

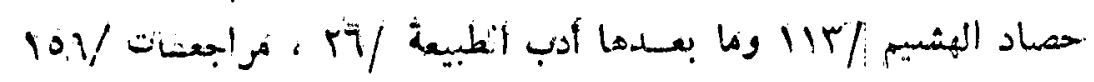

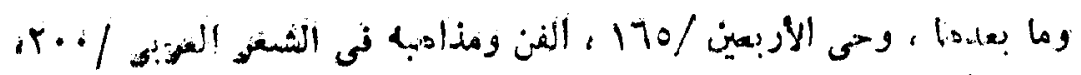

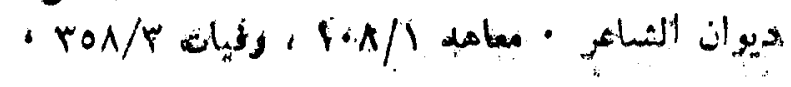




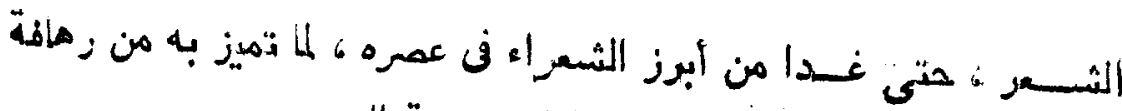

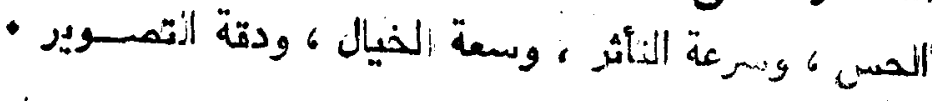

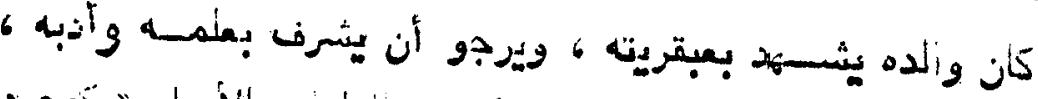

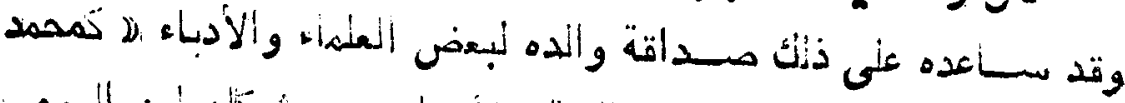

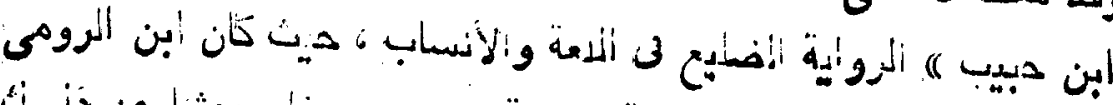

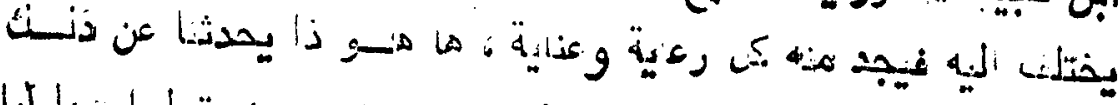

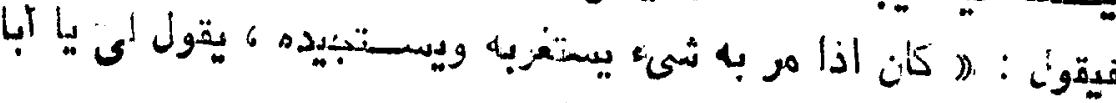

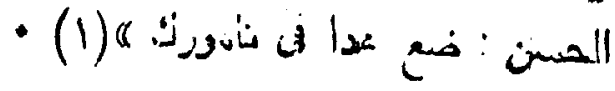

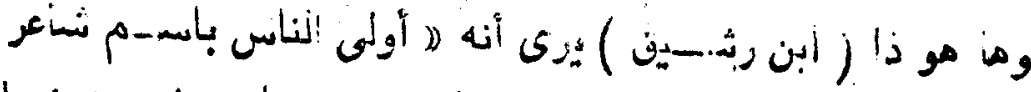

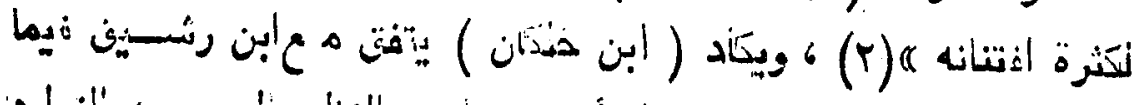

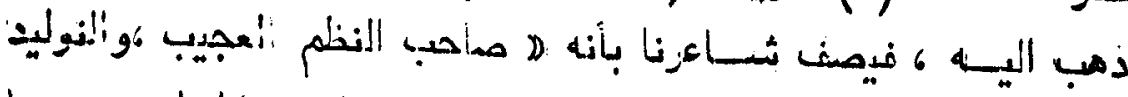

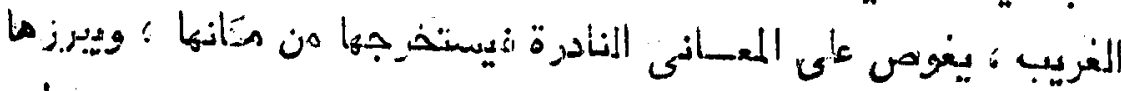

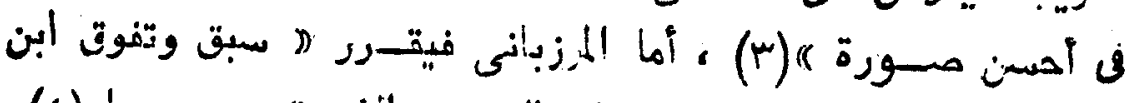

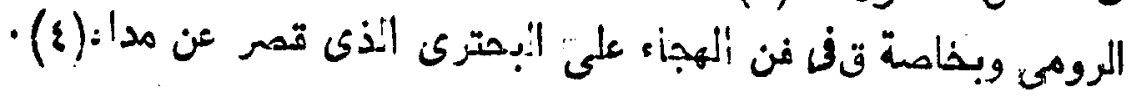

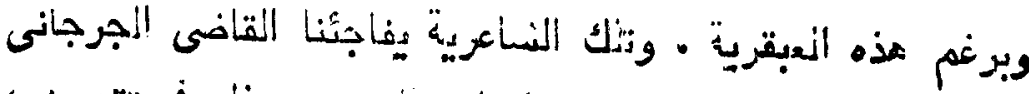

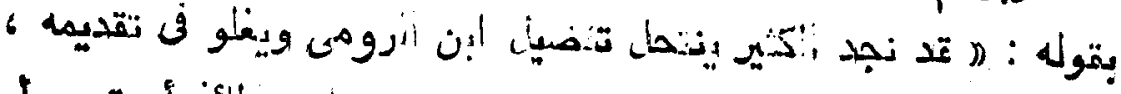

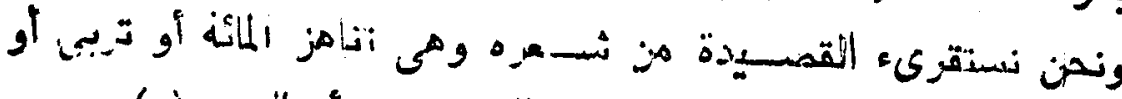

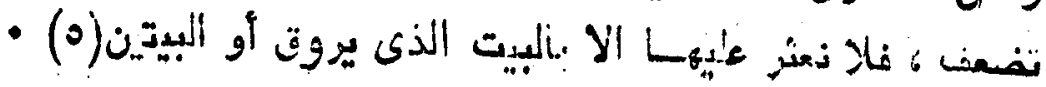

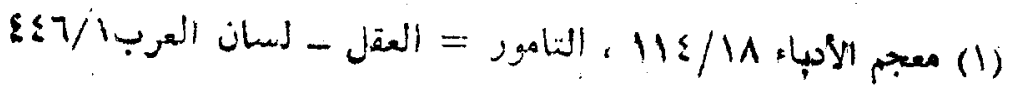

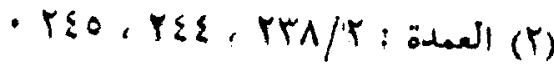

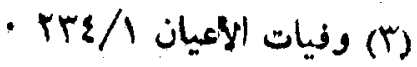

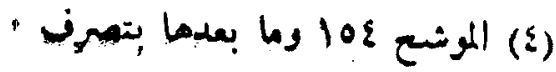

, 


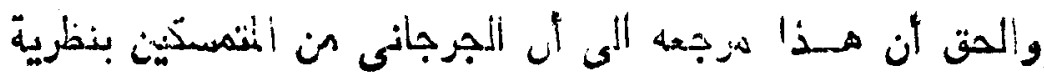

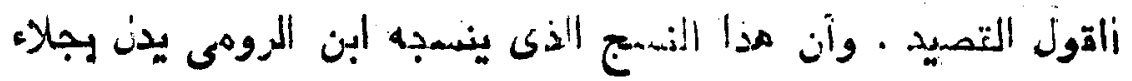

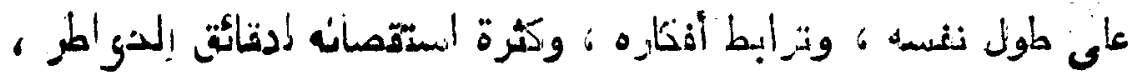

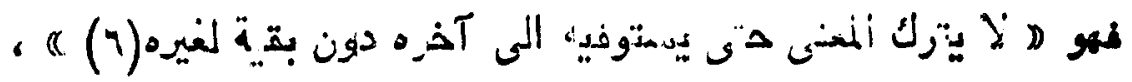

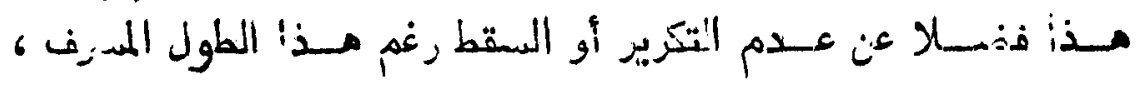

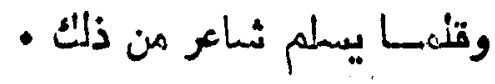

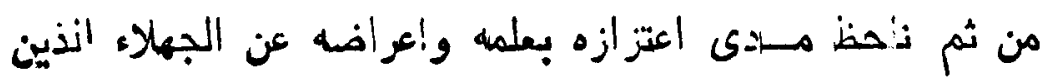

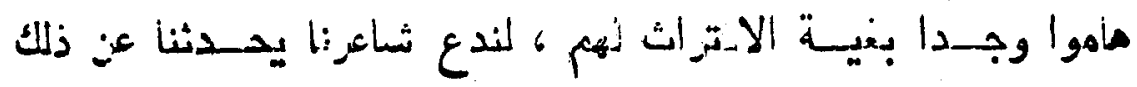

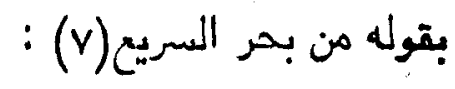

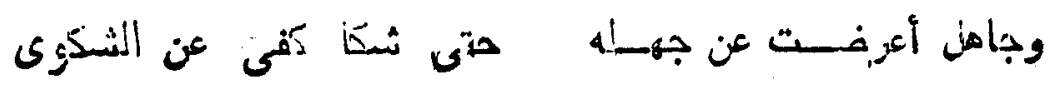

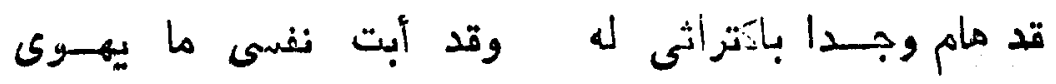

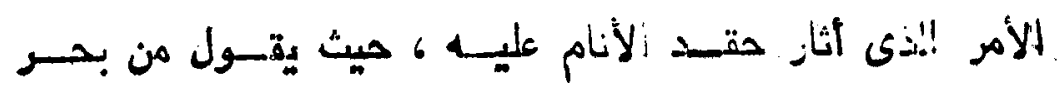
الخفين(1) : (1)

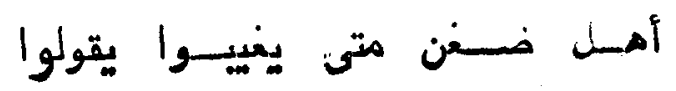

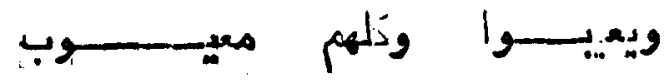

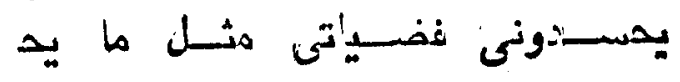

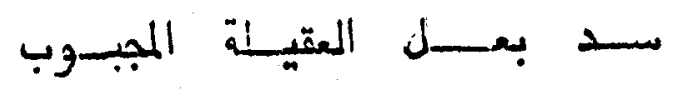

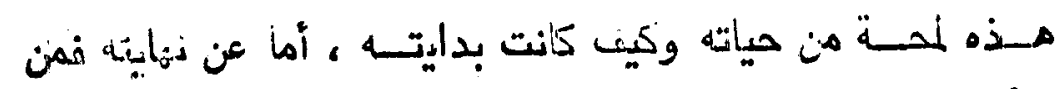

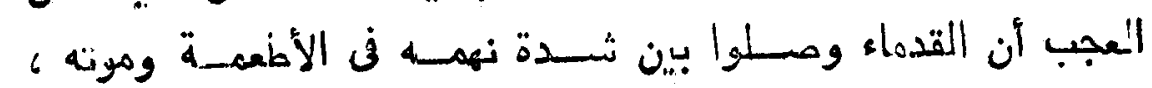

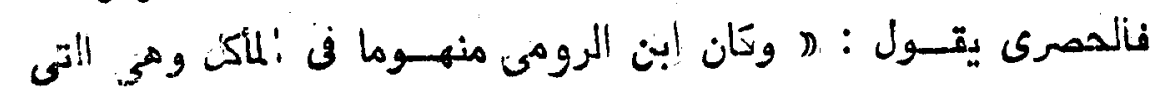

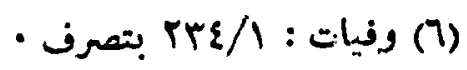

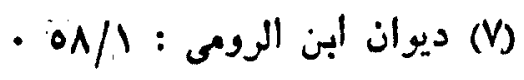

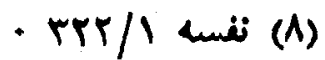




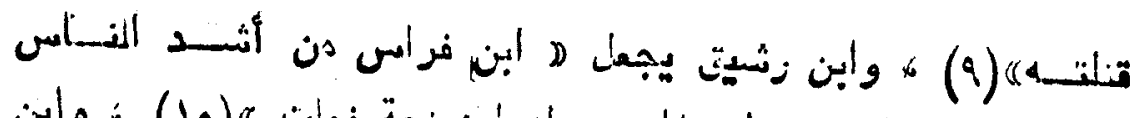

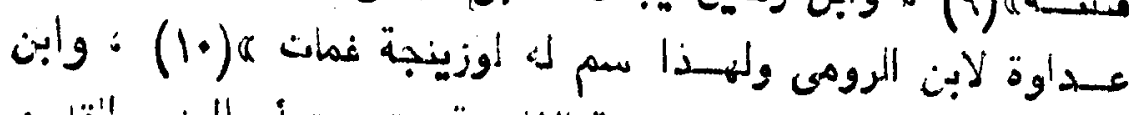

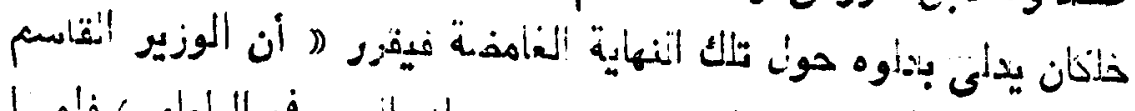

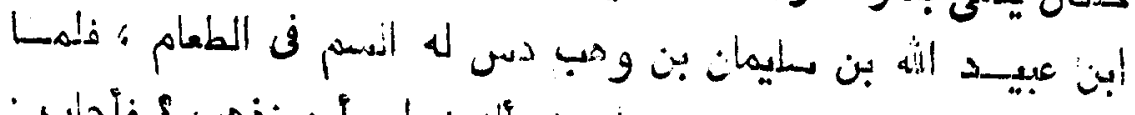

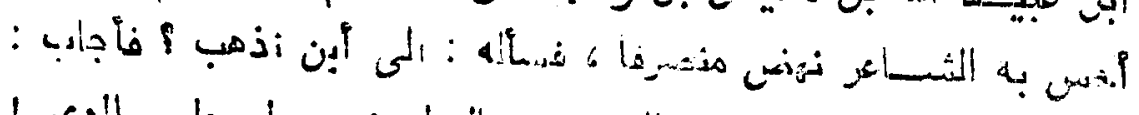

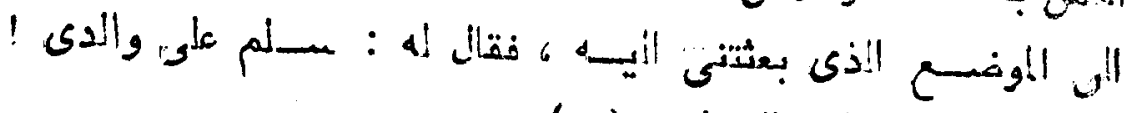

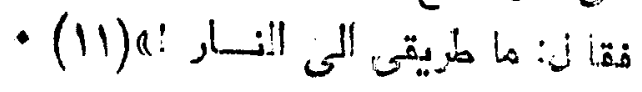

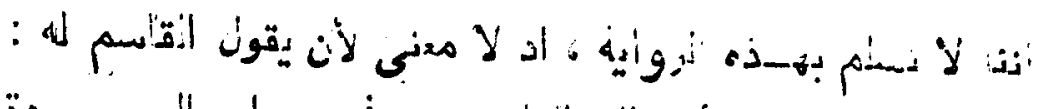

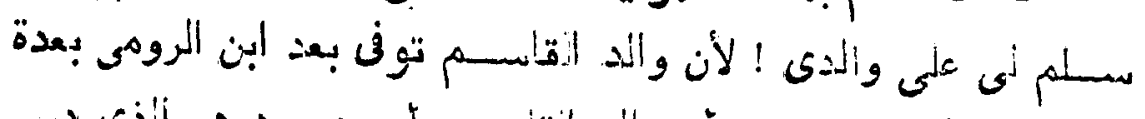

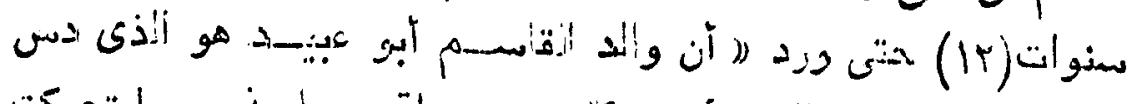

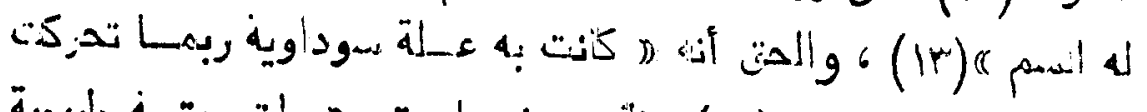

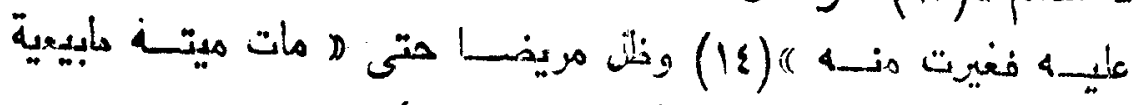

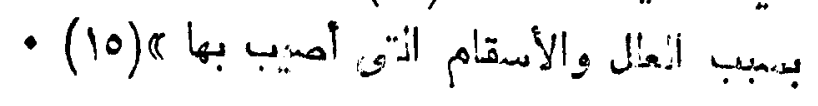
ومها يـضـد هـذا أثمعاره في المرمق الأذير من حياته كتـواه

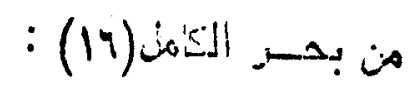

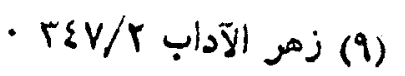

• $V Y / 1$ (1) (1) (1) (1) •

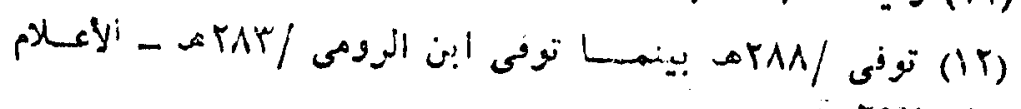
- TqV. IAE/s

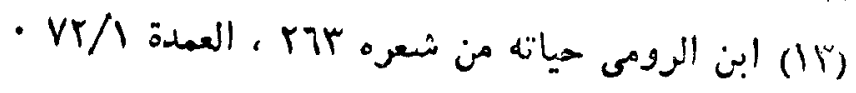

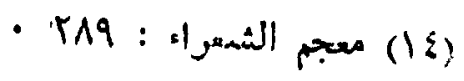

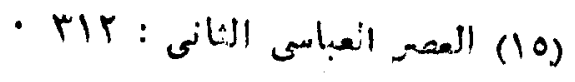

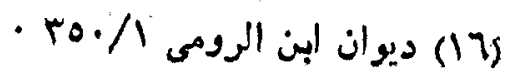




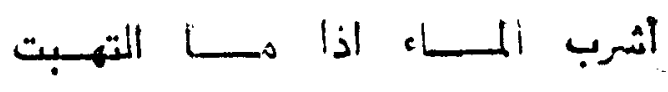

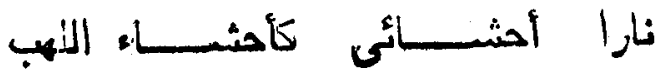

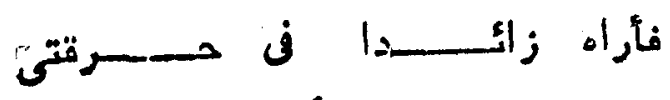

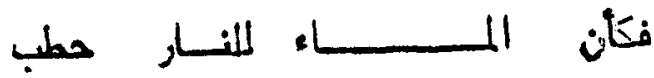

ونَقوله هن بحر الخفيت (IV) :

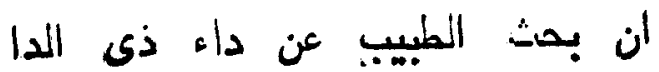

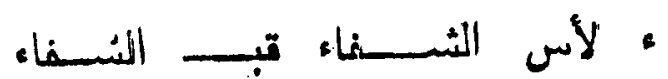

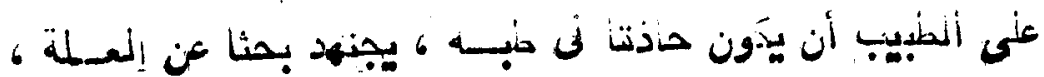

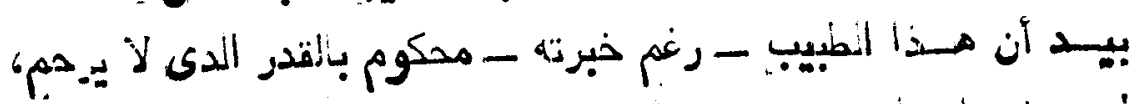

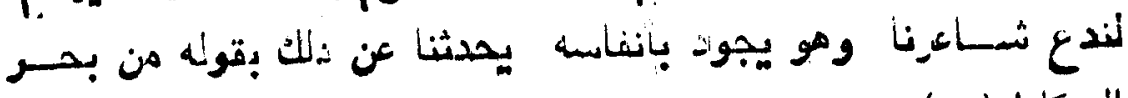

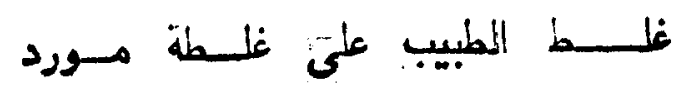

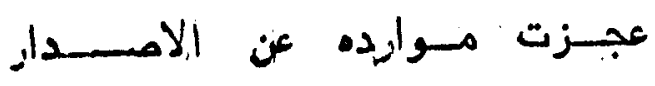

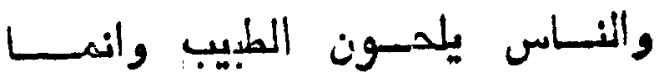

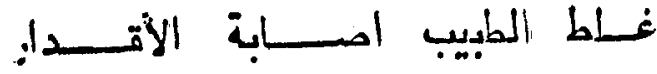

\section{الأنمسل الثهانى}

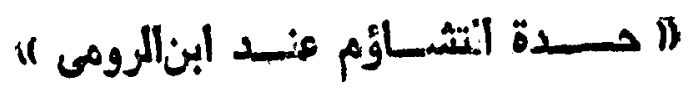

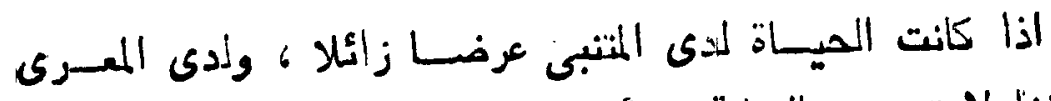

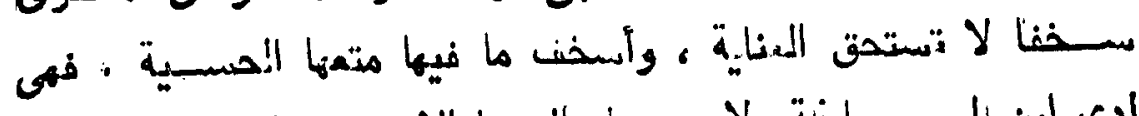

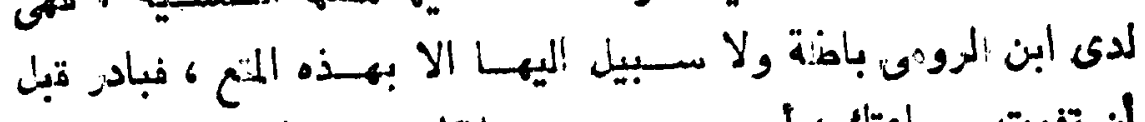

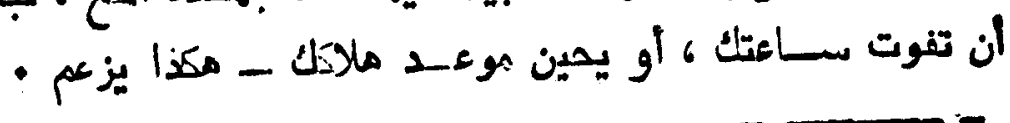

- 70// السابق (IV)

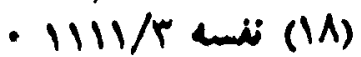




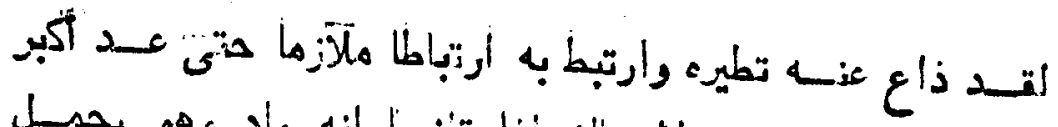

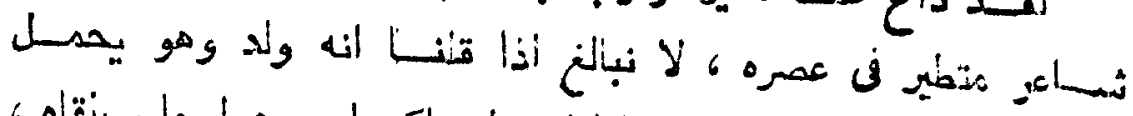

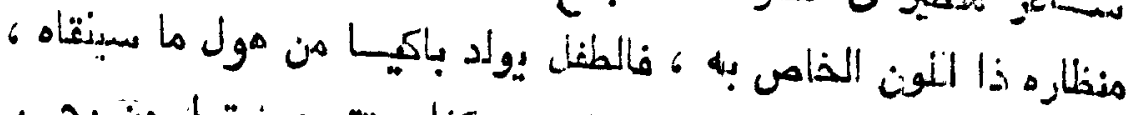

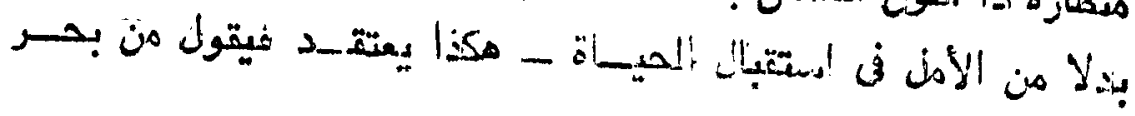

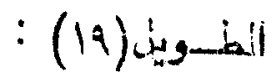

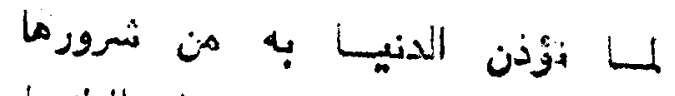

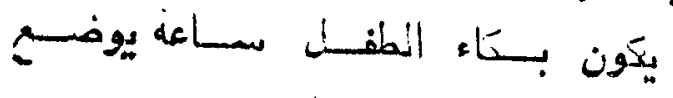

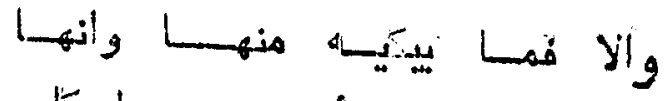

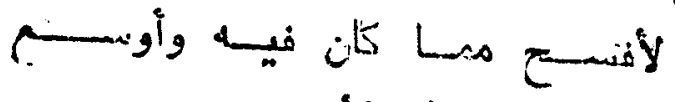

أذا أبصر إلدنيـا اسمستـانل كأنه

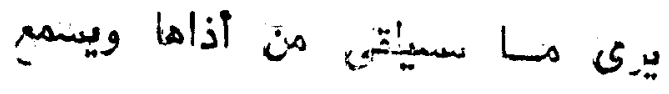

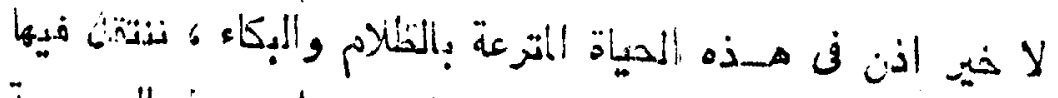

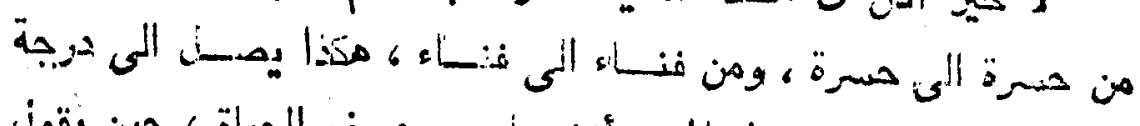

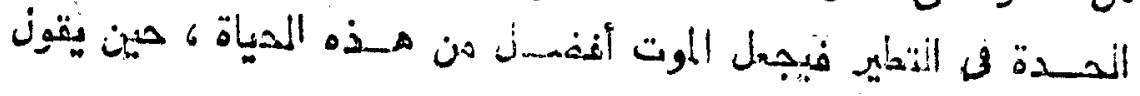

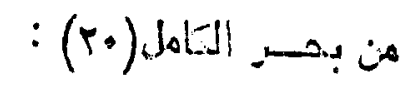

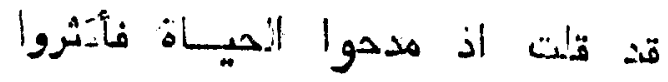

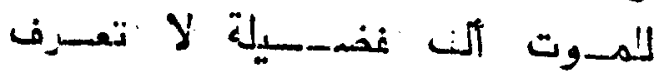

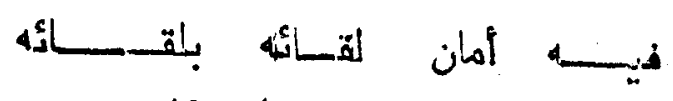

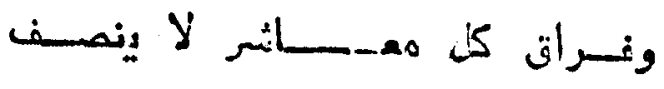

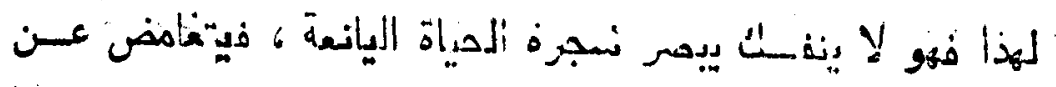

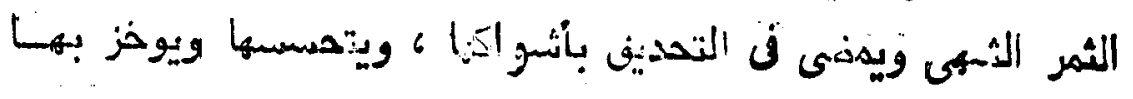

- 1001\% \& (19) المصدر السابق (19)

• 17ro/s المصد (r.) 


\section{I.r}

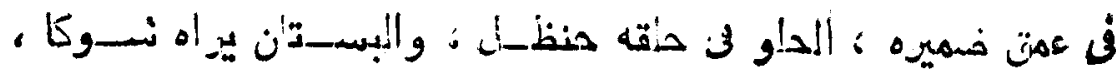

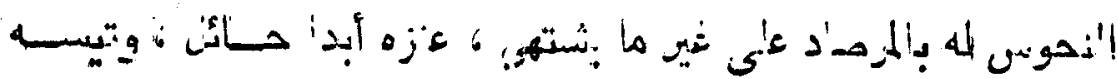

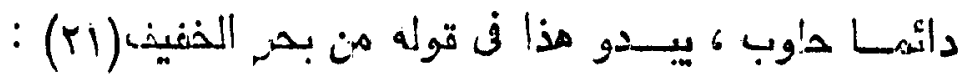

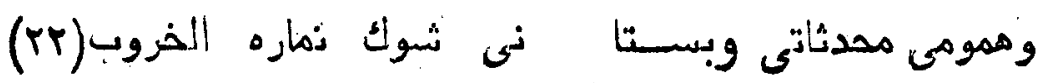

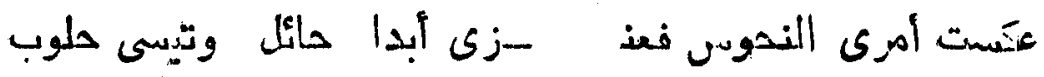

ومن ثم لا غرو أن يلفــ القنوط من جهيع الأتطنا. ويستولئ: عليه

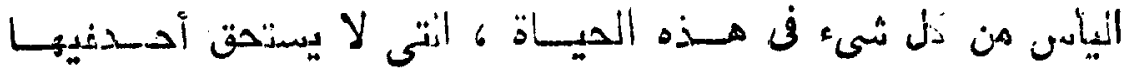

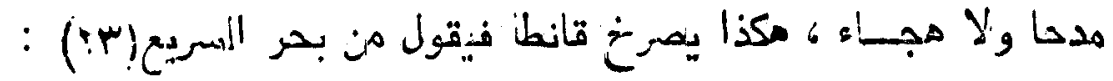

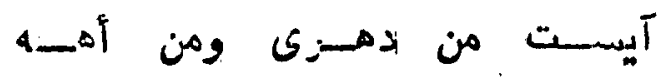

$$
\begin{aligned}
& \text { فليس فهيس هم أهن }
\end{aligned}
$$

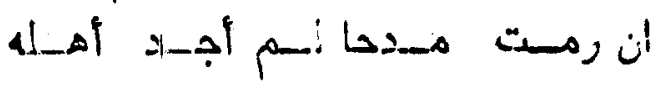

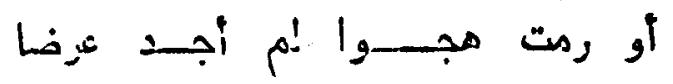

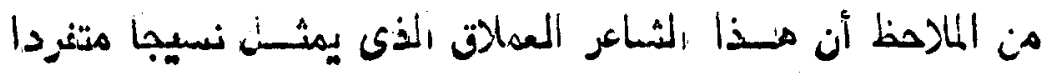

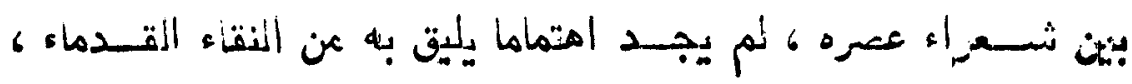

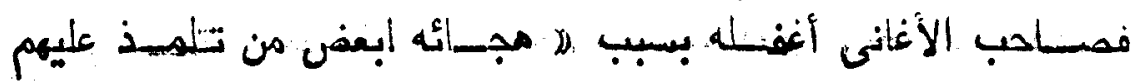

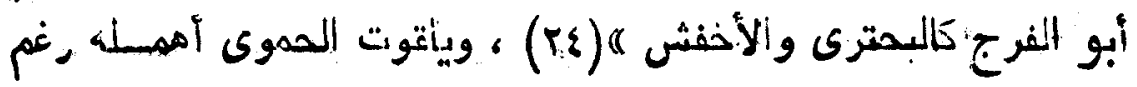

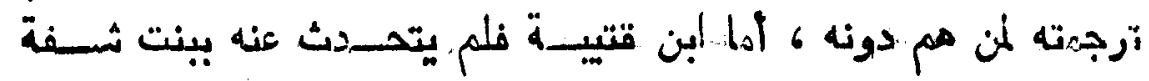

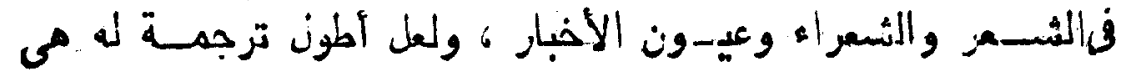

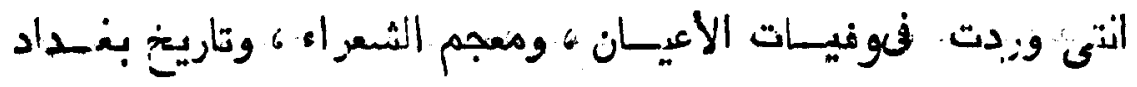

$$
\text { : rrr/l السابت (Yr) }
$$

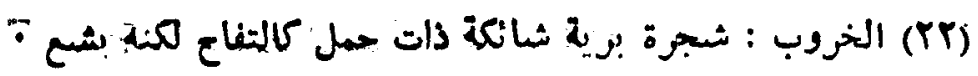

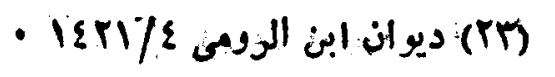

( ) 


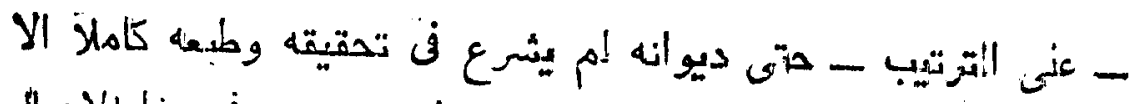

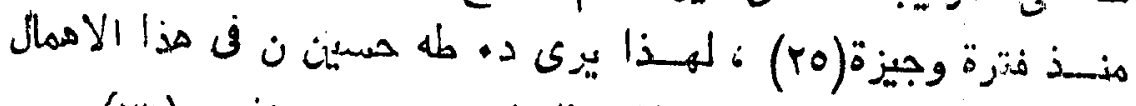

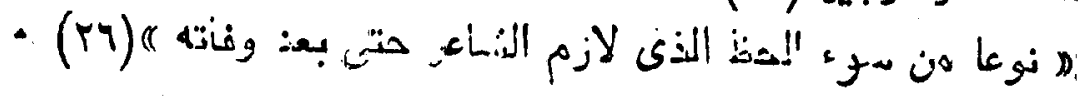

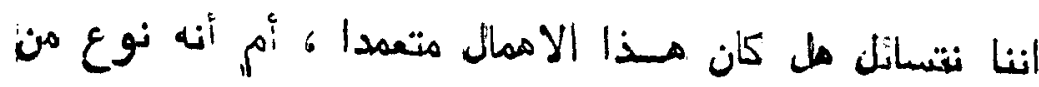

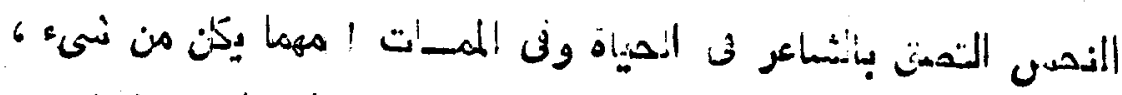

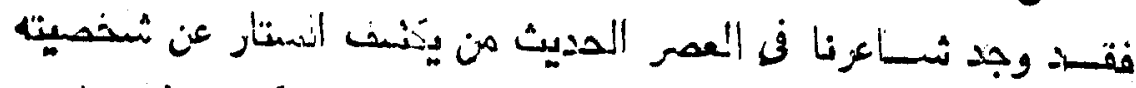

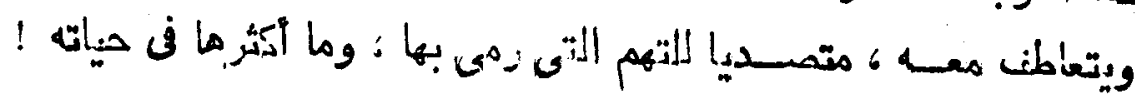

لهـذذا كنه لـم يجذ ابن الرومى أنيســا يرنى لحاله ، ويواسيه

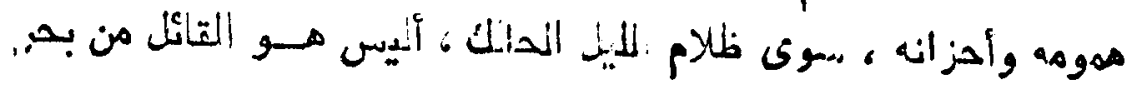

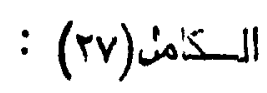

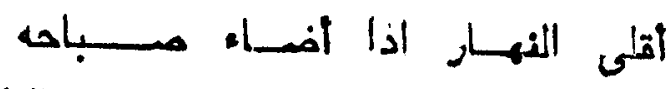

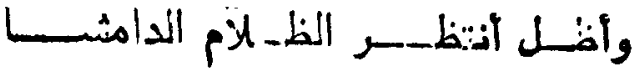

هالصبح يشمت بى فيقبل ضيساحكا

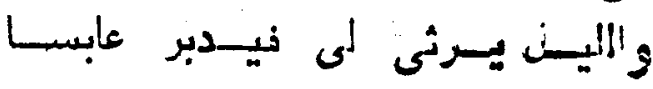

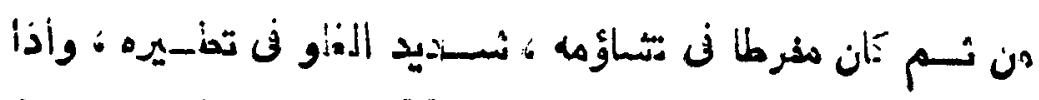

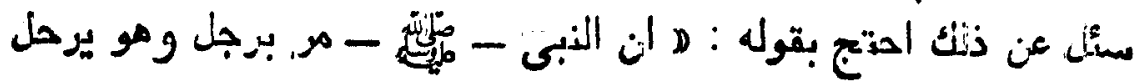

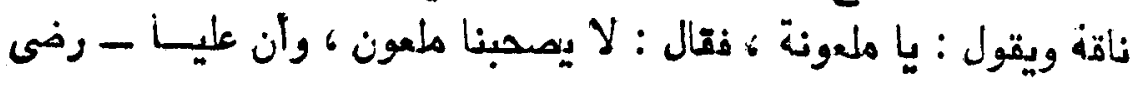

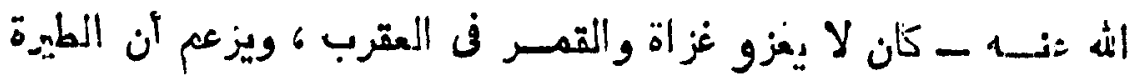

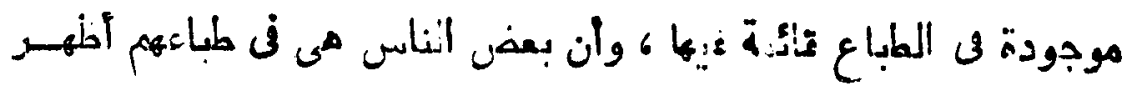

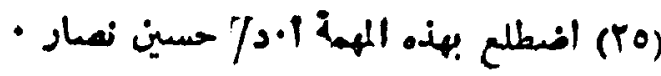

- Irr :

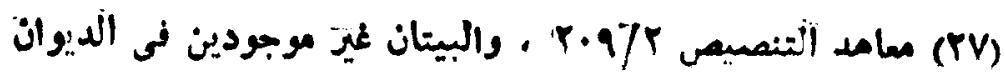


منها في ب:ض ك، وأن الأكثر فى الناس اذا لقى ما يكرهه ثقال : على وجه

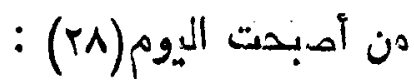

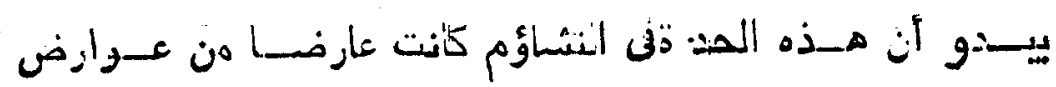

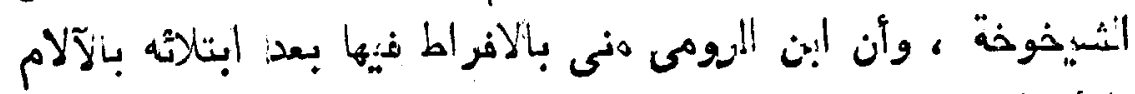

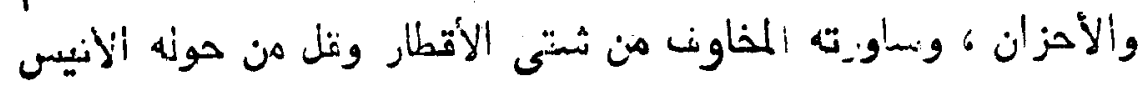
والرني-ق

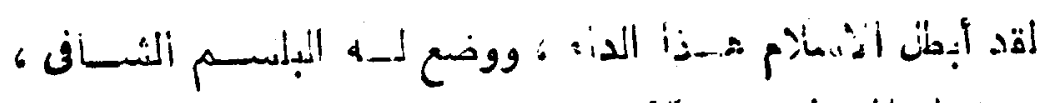

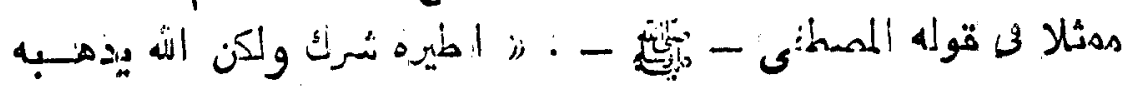

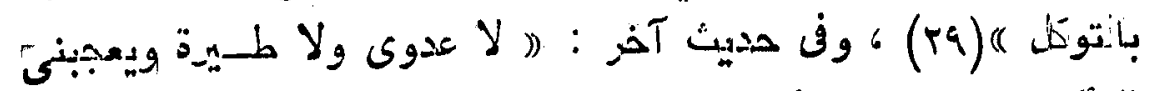

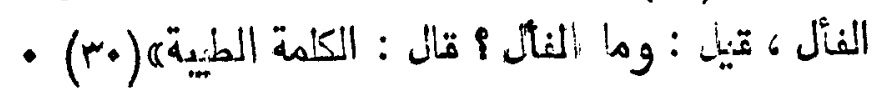

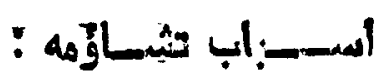

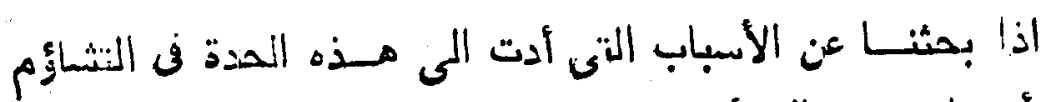

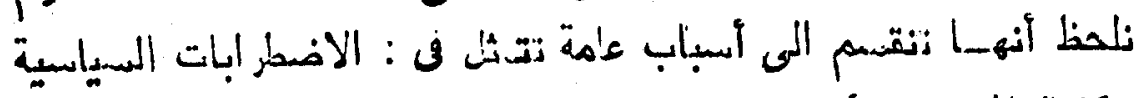

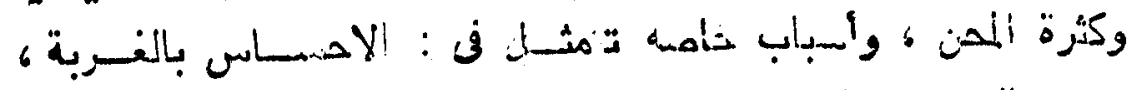

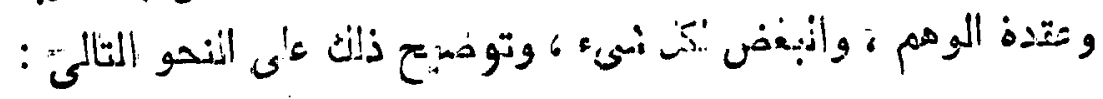

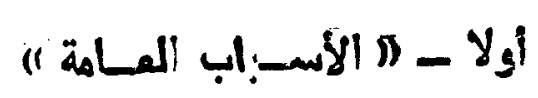

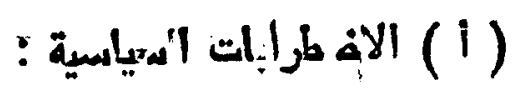

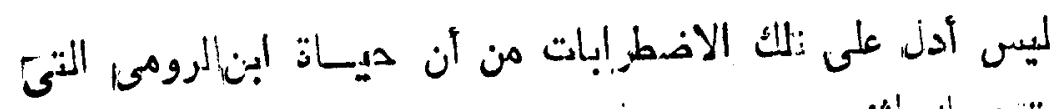

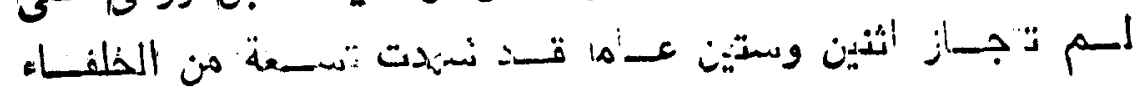

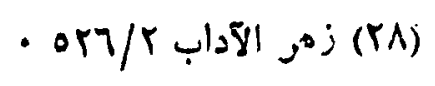

- rINTIS : : (r.9)

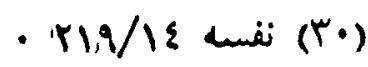




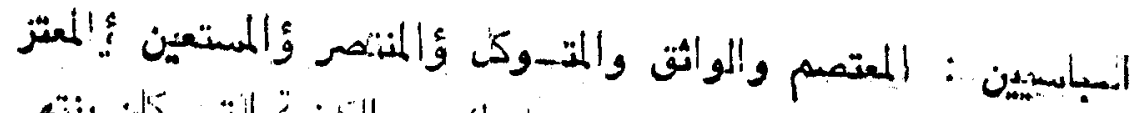

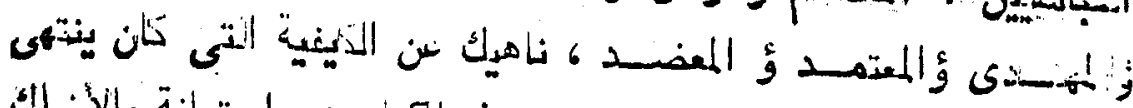

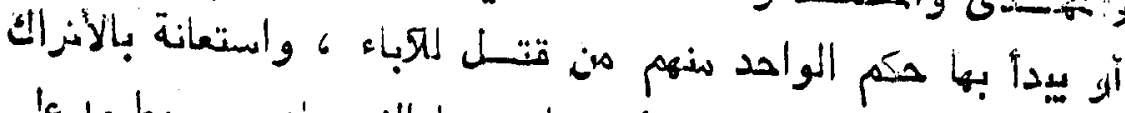

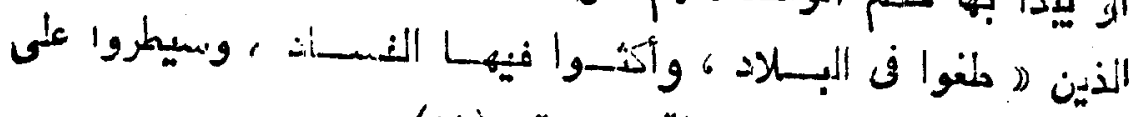

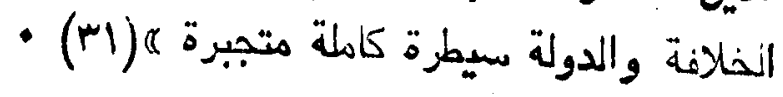

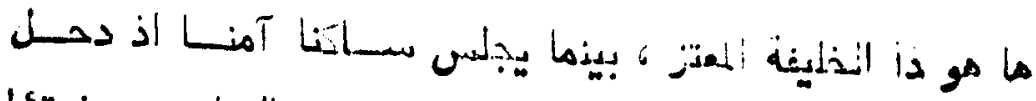

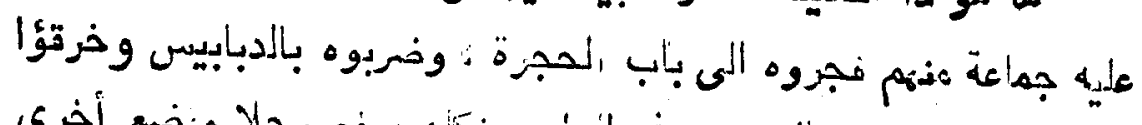

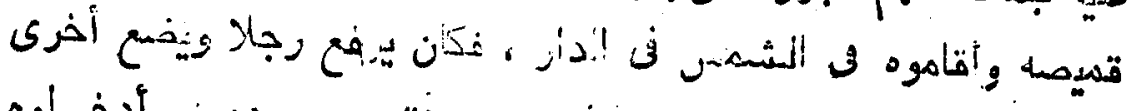

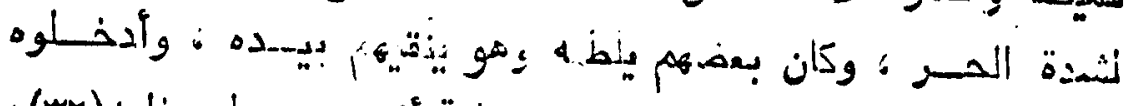

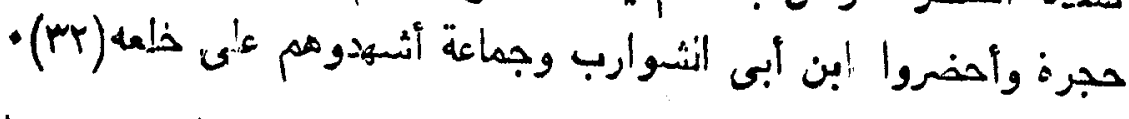

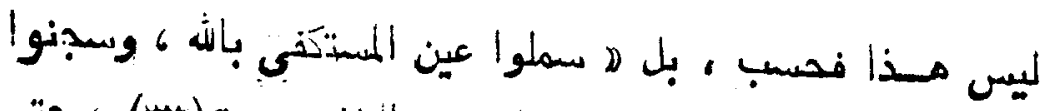

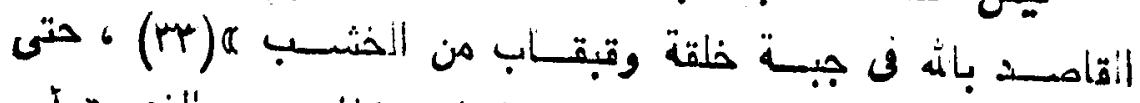

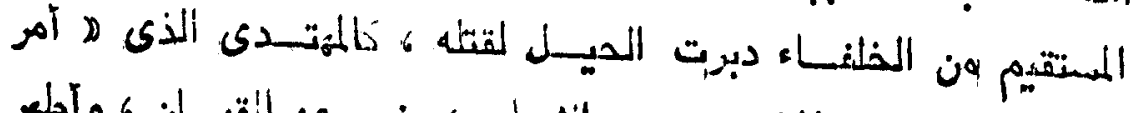

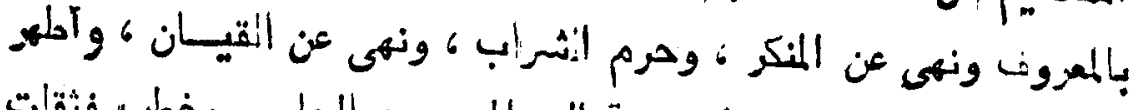

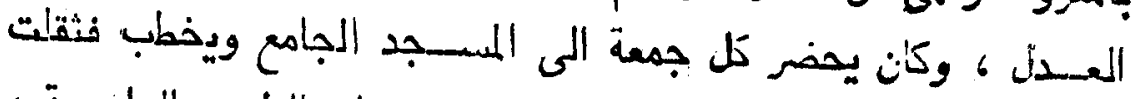

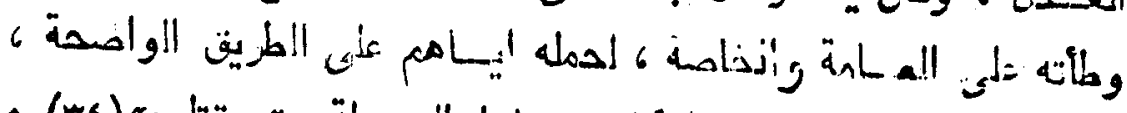

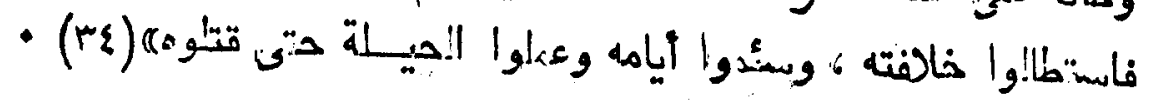

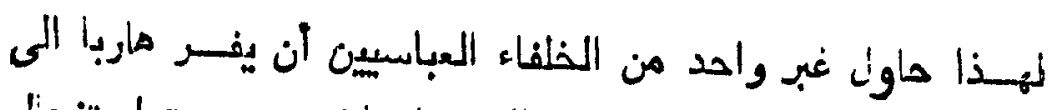

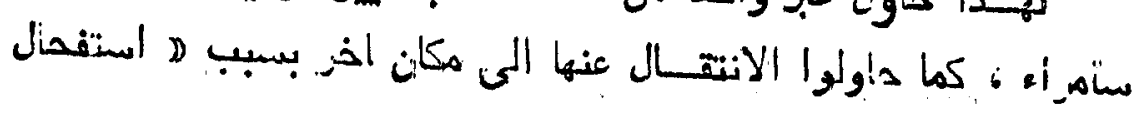

(rIT) الخلانة والدولة في العصر العباسى rو وما بعدها •

(

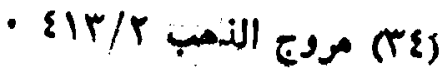




\section{lov}

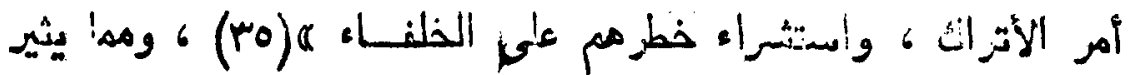

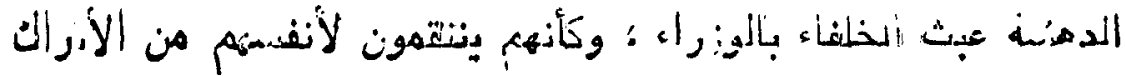

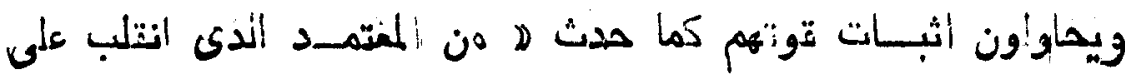

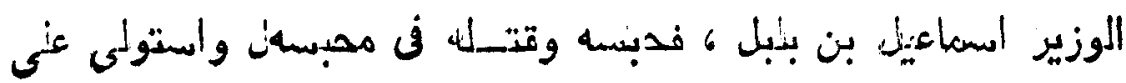

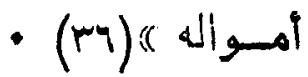

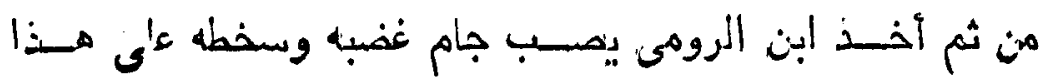

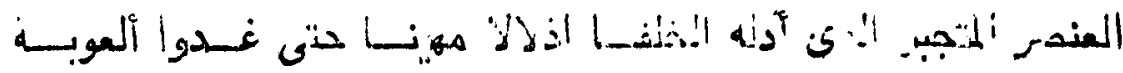

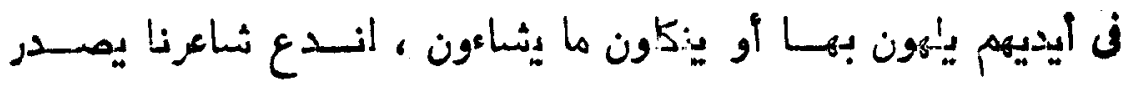

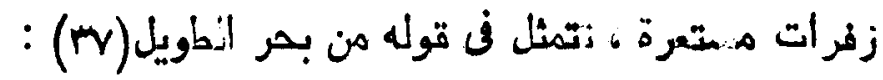

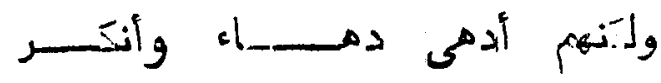

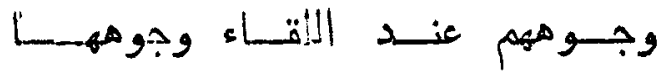

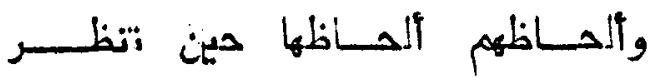

$$
\text { هم هن ، لولا الريستم وحساومهم }
$$

لهم منظلــ منهـا مهيب ومخفـبر

$$
\text { المئ أن قال : }
$$

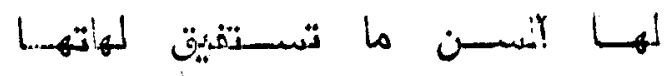

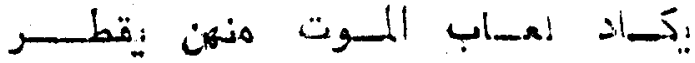

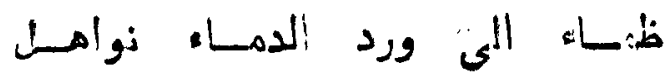

لهـا مسورد هن غير مأتاه نصـد:

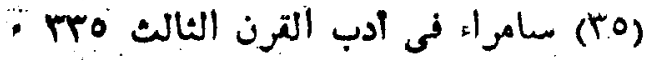

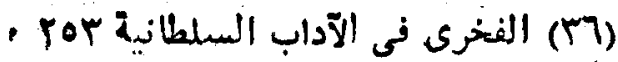

- 


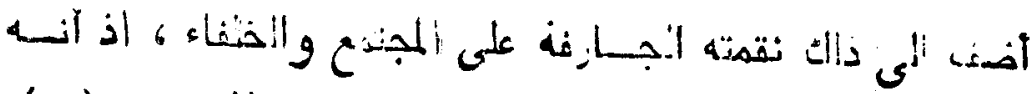

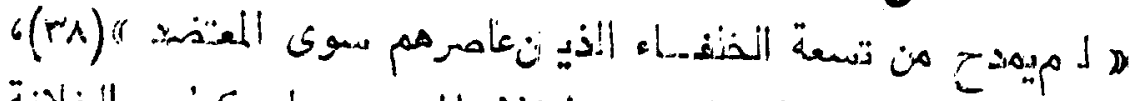

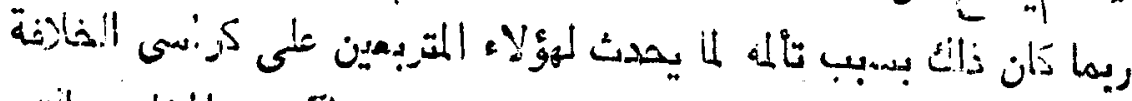

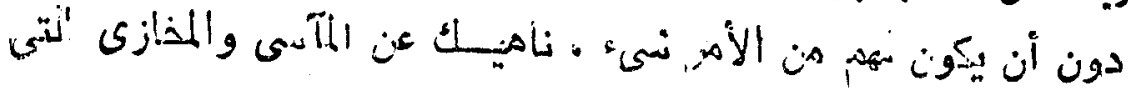

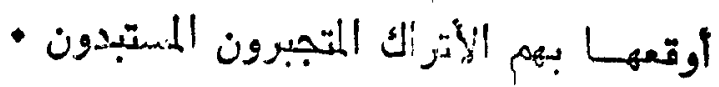

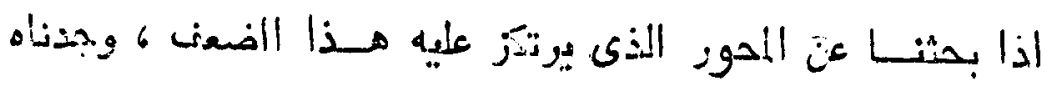

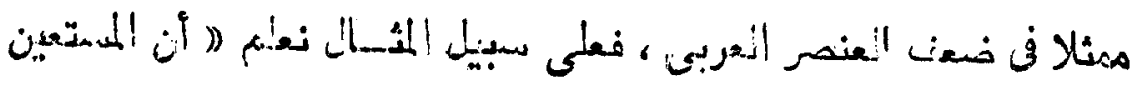

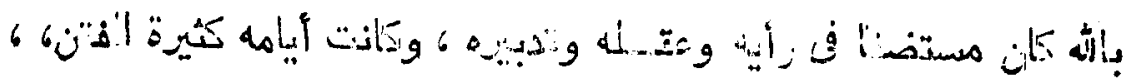

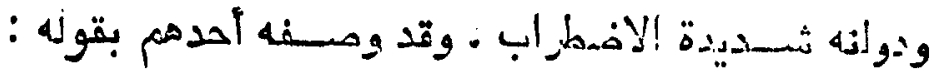

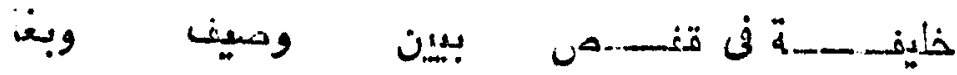

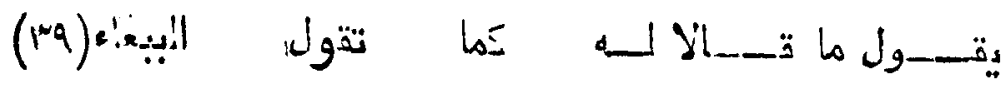

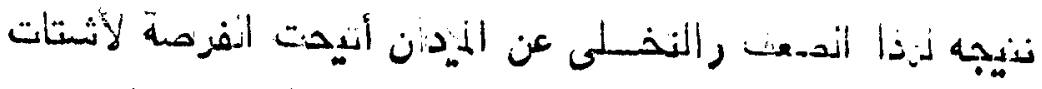

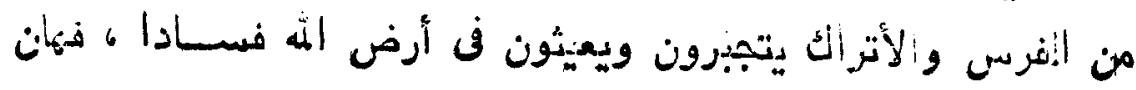

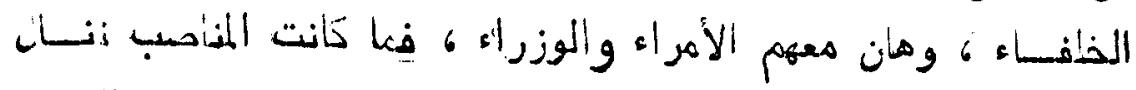

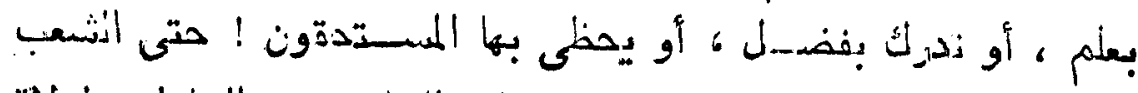

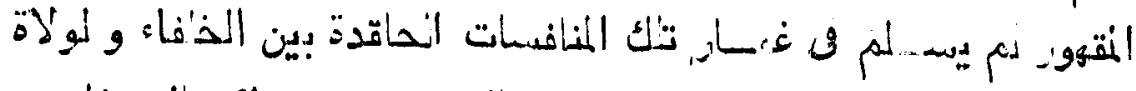

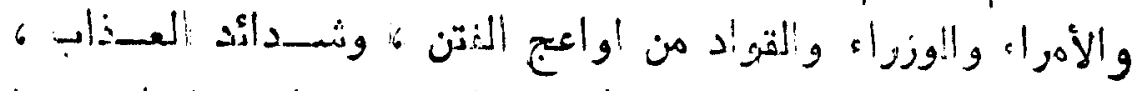

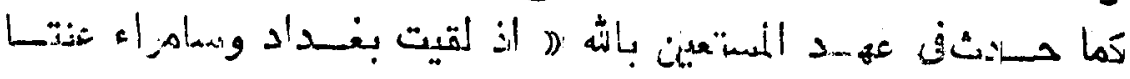

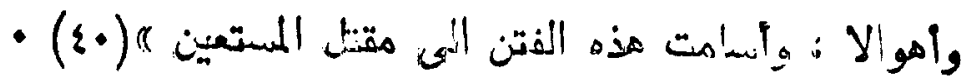

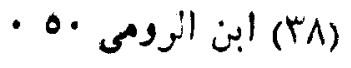

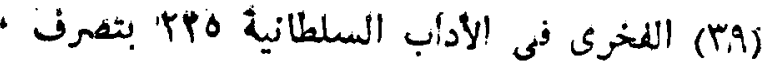

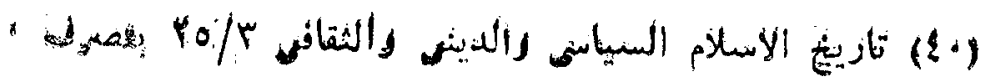


104

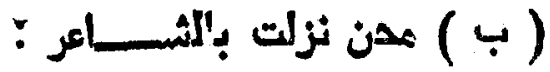

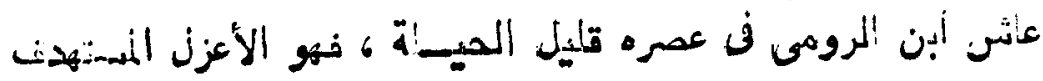

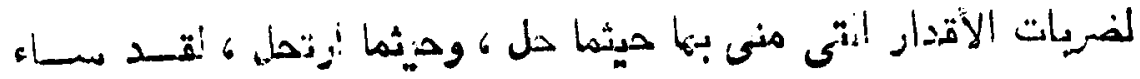

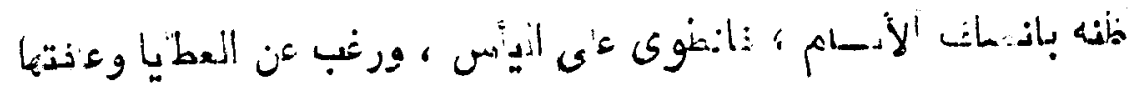

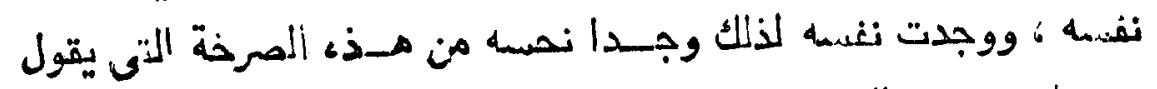

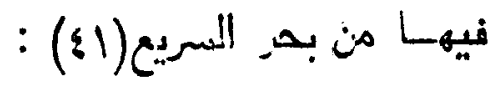

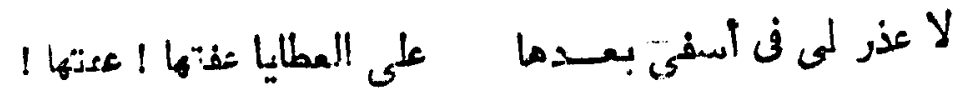

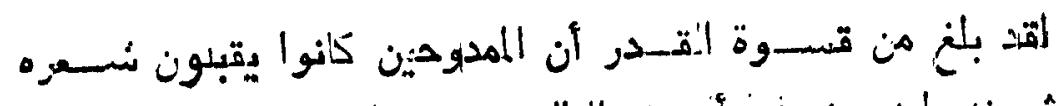

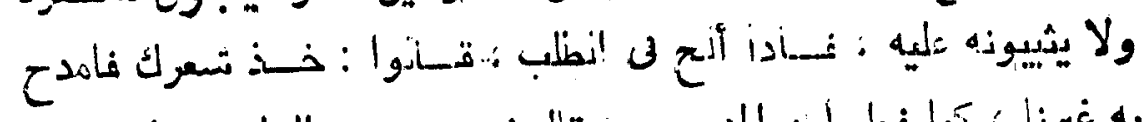

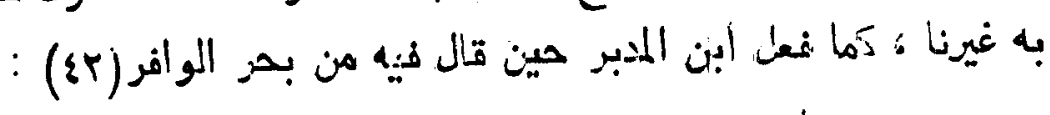

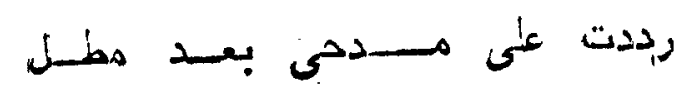

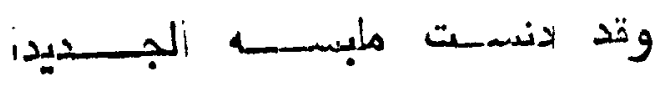

$$
\text { وتنتت : امسـدح }
$$

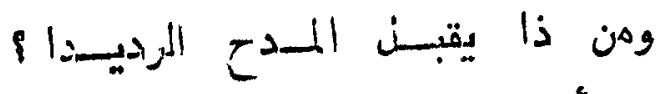

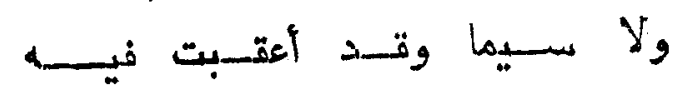

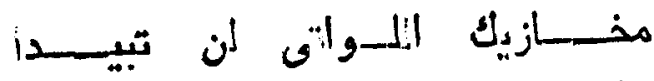

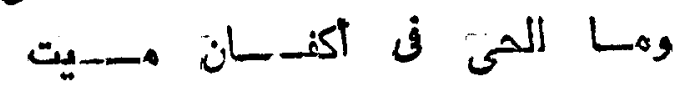

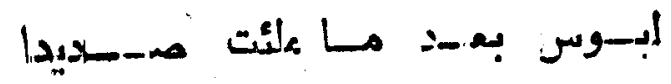

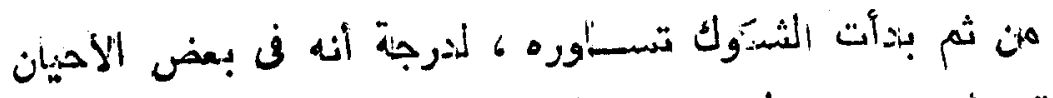

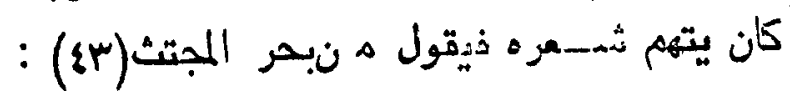

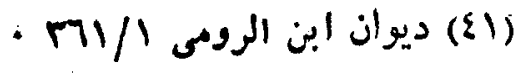

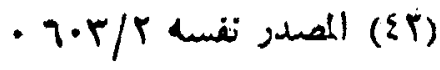

• $Y \cdot r / 1$ (2) 


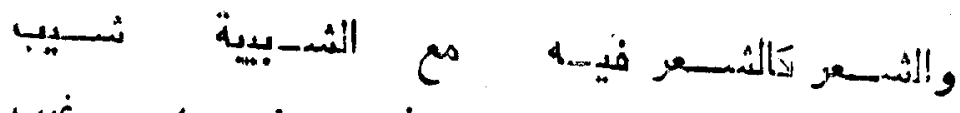

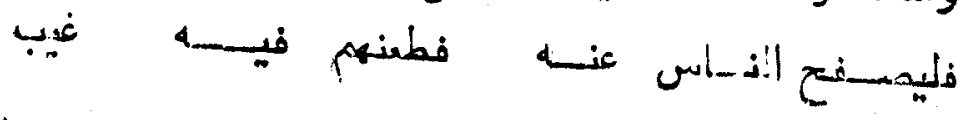

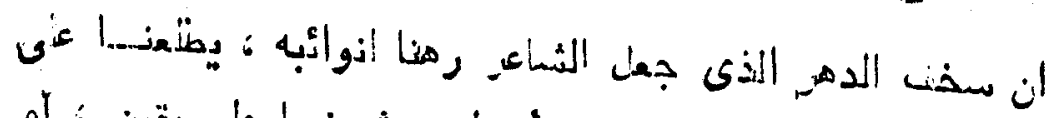

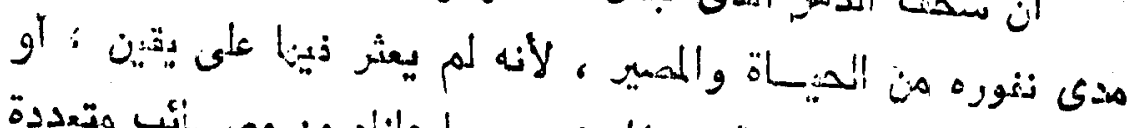

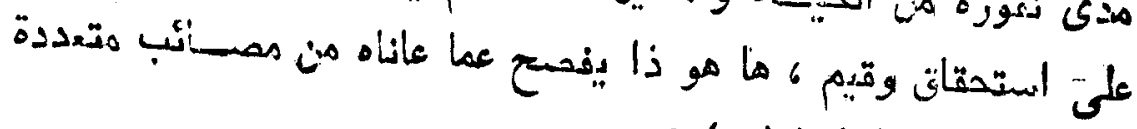

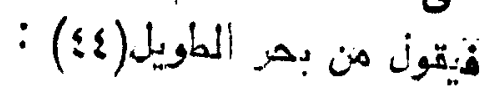

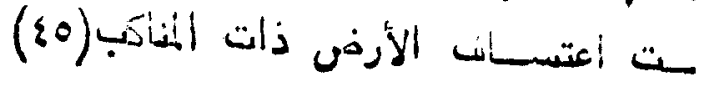

ودن نذبـة لافيتها بعد نئبة رهبه

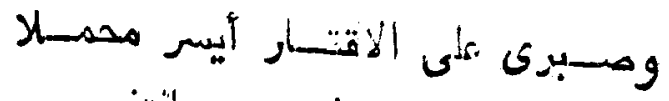

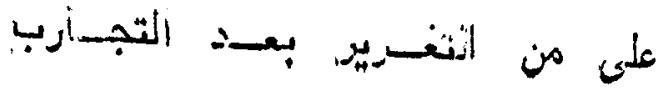

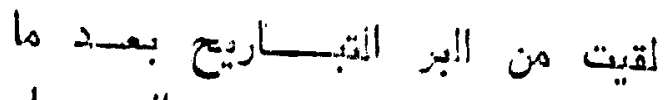

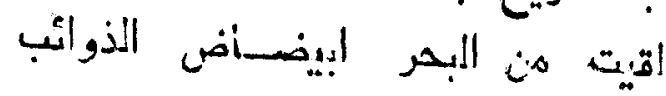

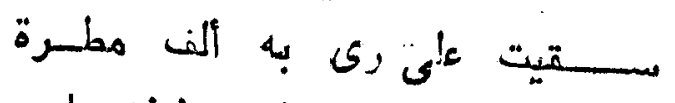

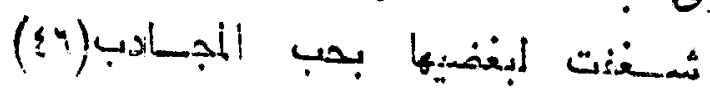

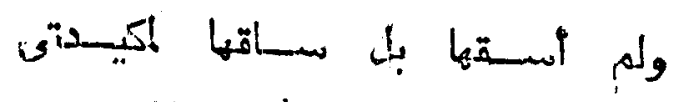

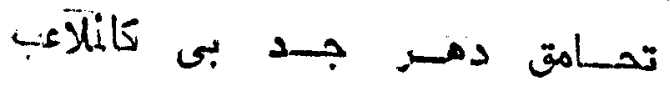

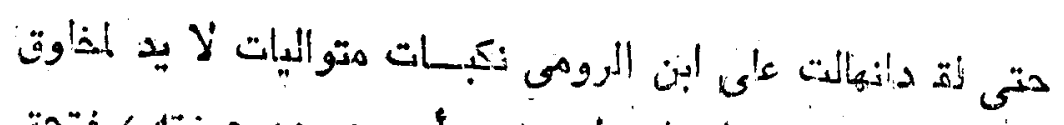

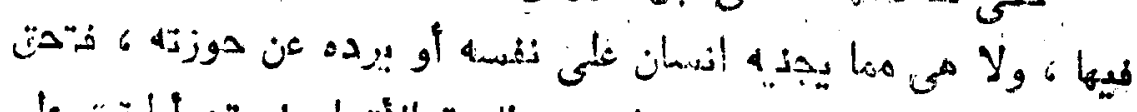

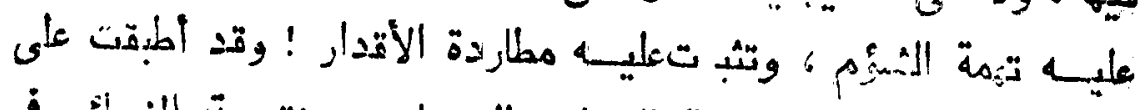

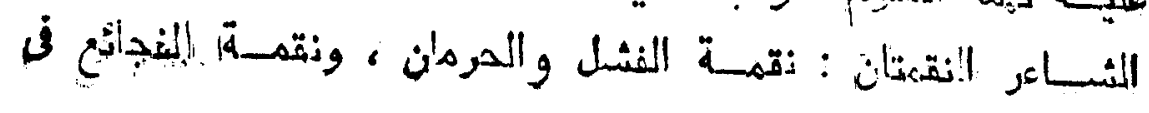

\section{- $r\{\%$ / الس}

•

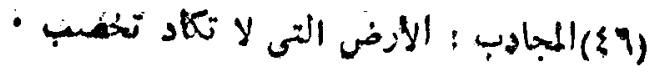


17

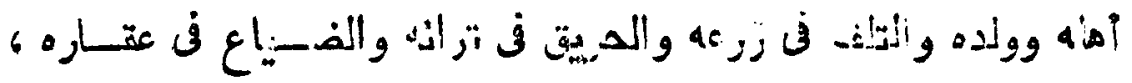

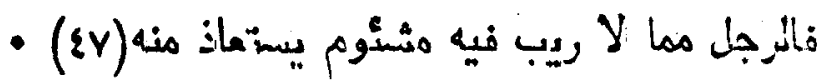

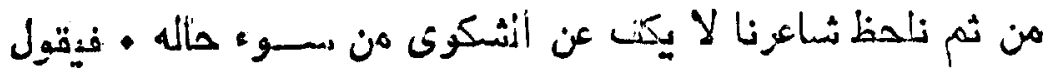

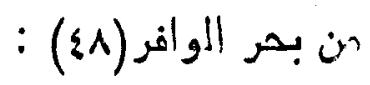

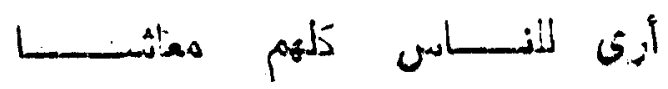

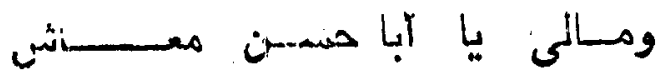

ولى مسولى يسريث دمس ومسانما غيرى

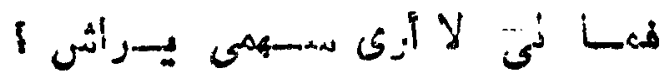

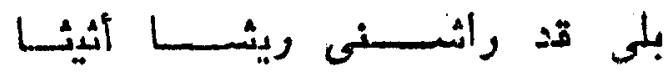

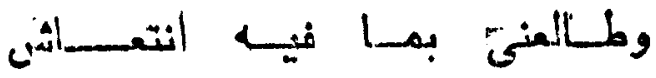

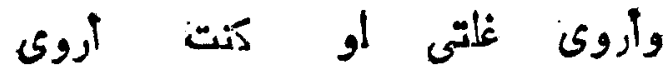

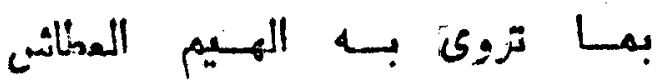

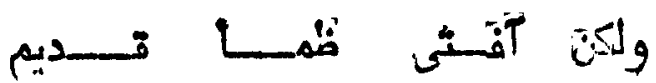

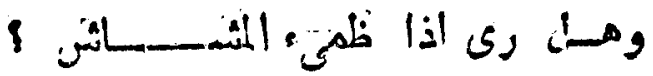

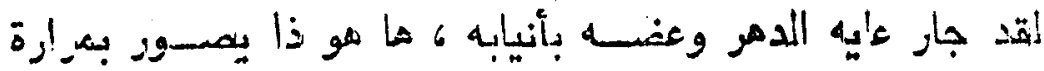

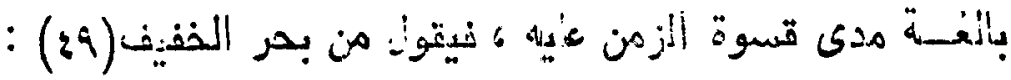

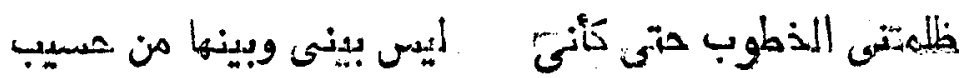

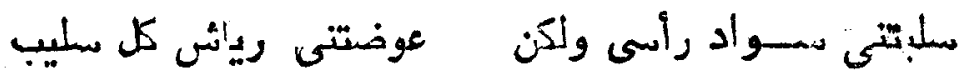

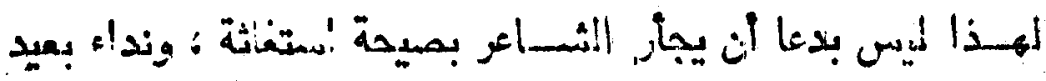

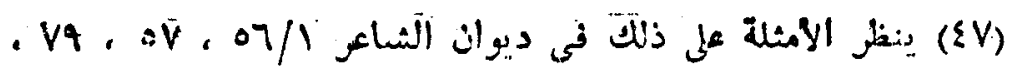

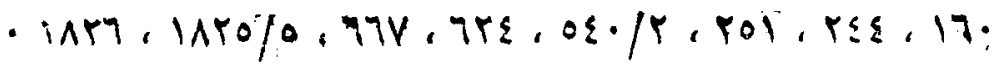

- Ir\&o/r :

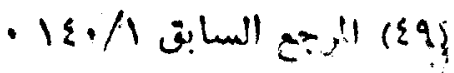

$(511-1)$ 


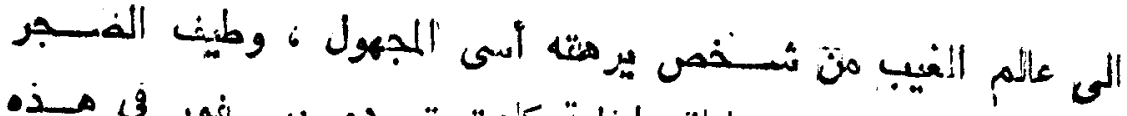

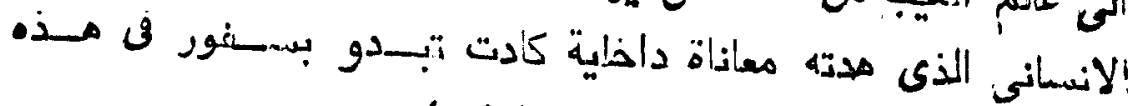

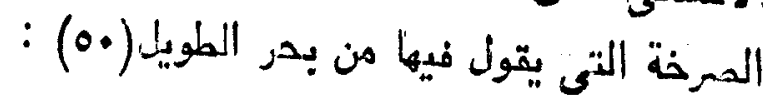

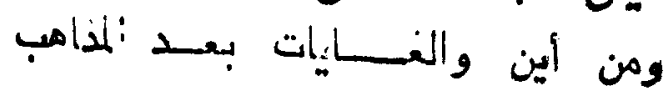

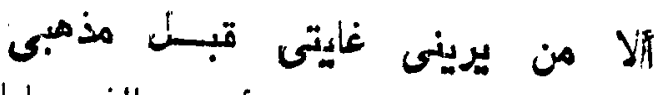

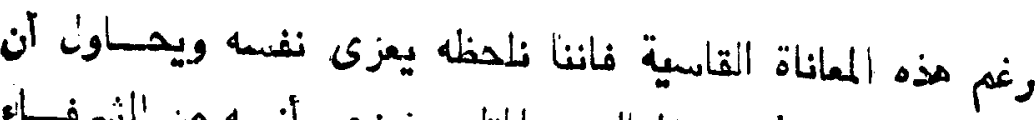

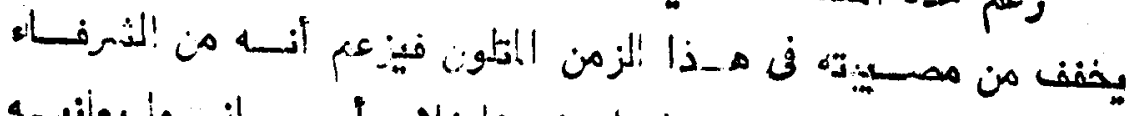

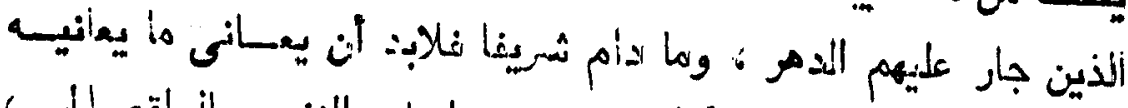

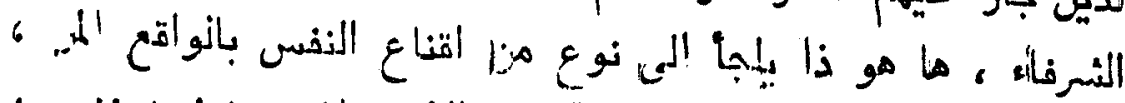

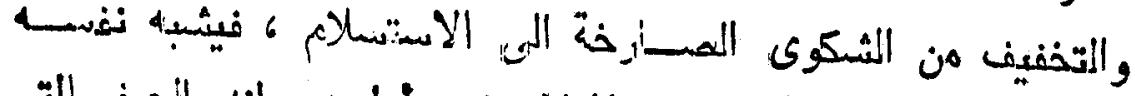

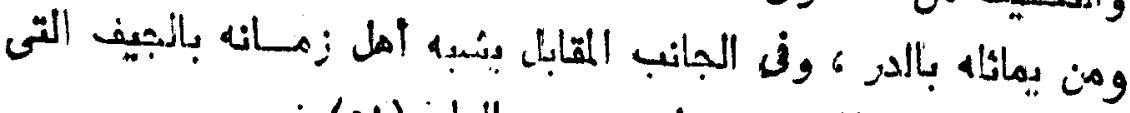

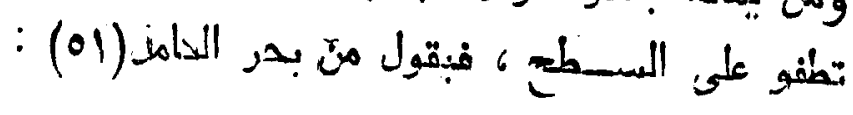

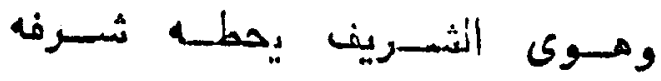
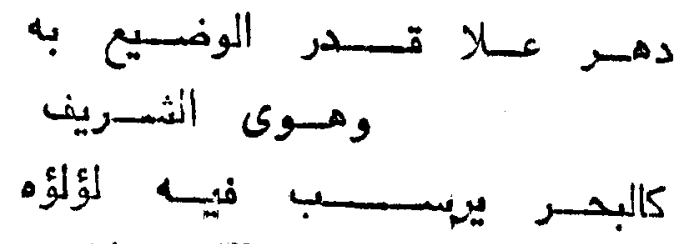

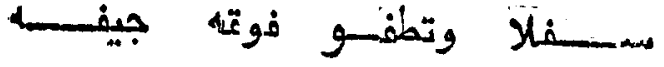

لا هناص أذن هن. الصيز ، فهم الملانغ هن خدوب الدهر آتى لا مهرب

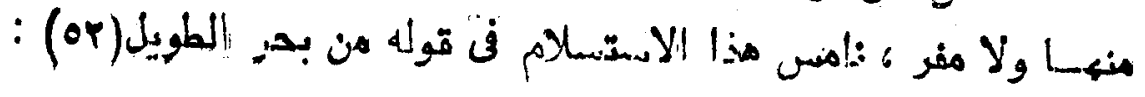

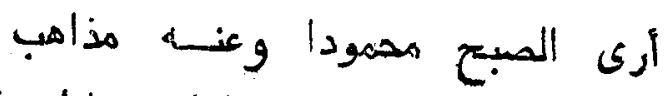

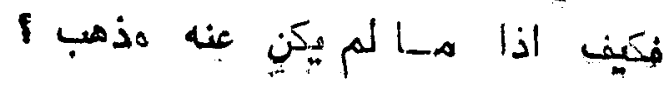

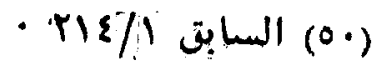

- loVI/\& نفس (01)

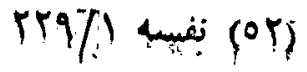


17

هنــاك يحق الصبر والمــبر واجب

ومها كان منــــ كالضرورة أوجب وائ

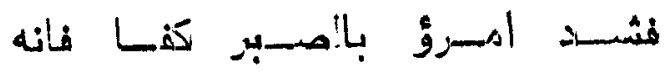

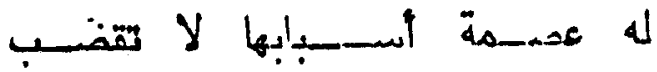

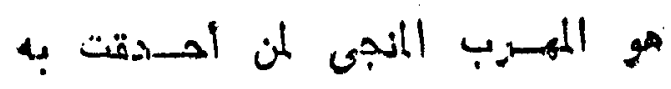

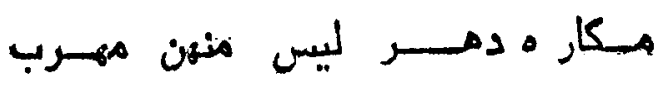

بجانب الصمبر مذه لدعوى لاطراح الهموم ، والإقبال على ما يدخل

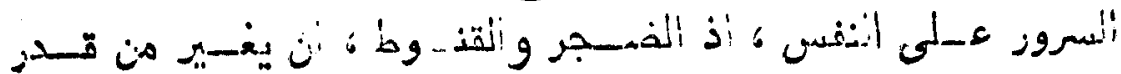

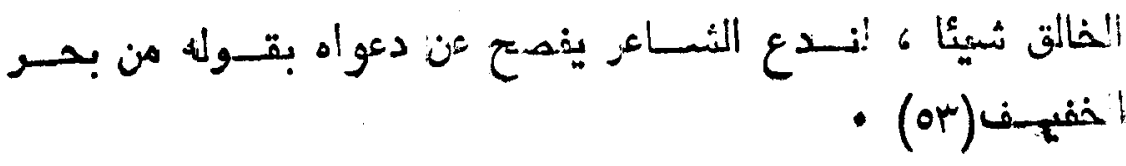

$$
\text { لاح شــيبيَ فـــربهت أمسرح غيه }
$$

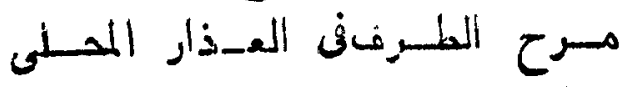

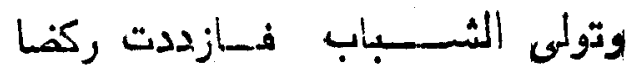

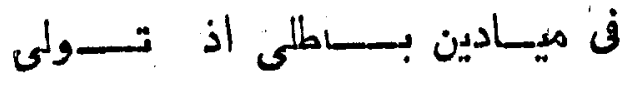

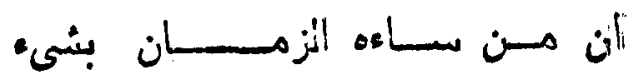

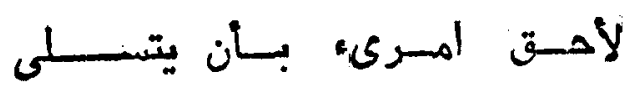

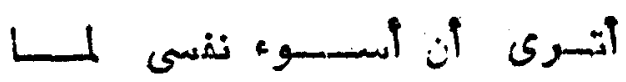

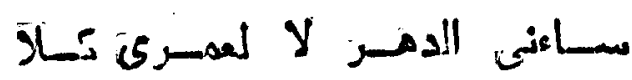

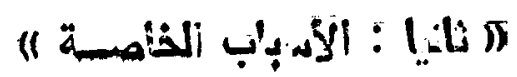

$$
\text { : }
$$

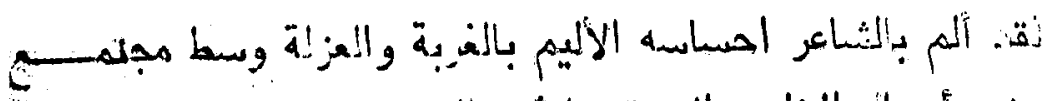

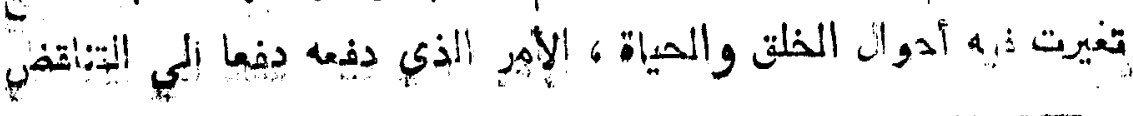

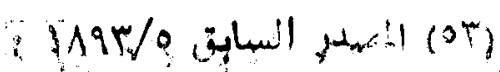




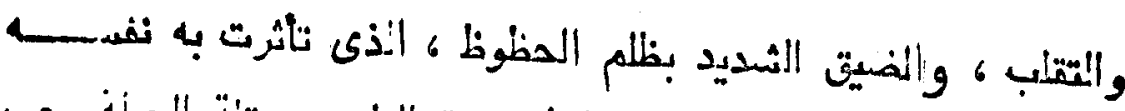

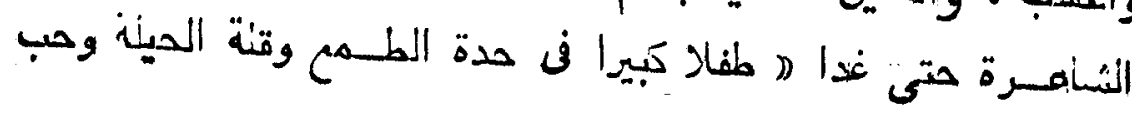
- النفس ه ! (0)

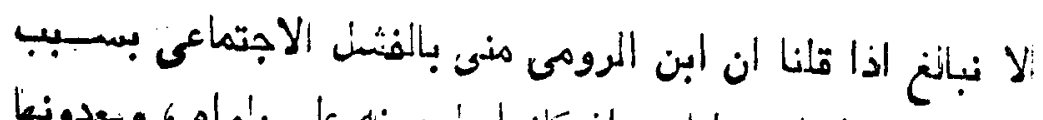

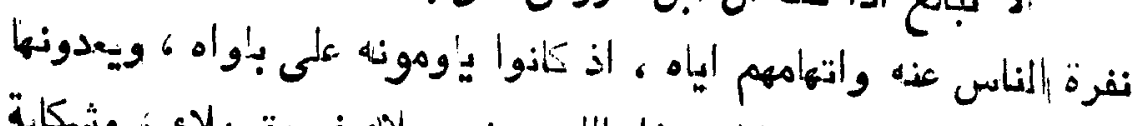

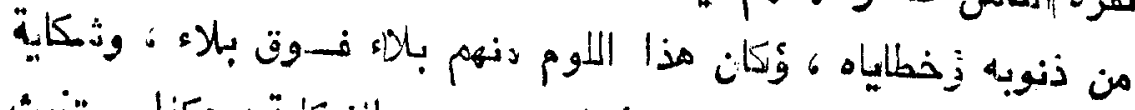

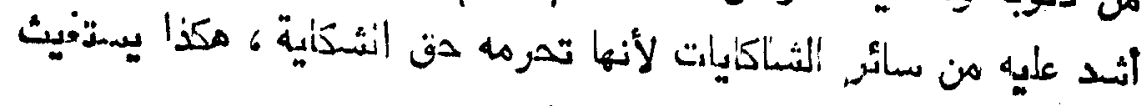

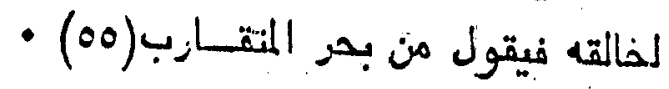

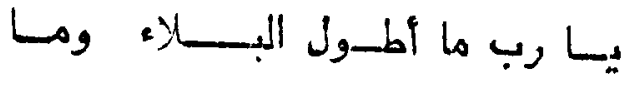

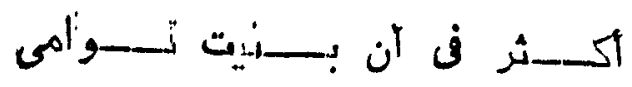

$$
\begin{aligned}
& \text { يلومنى النساس ان حسزهت وهـا }
\end{aligned}
$$

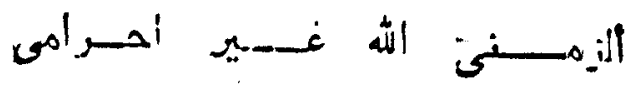

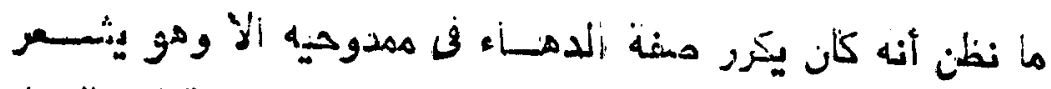

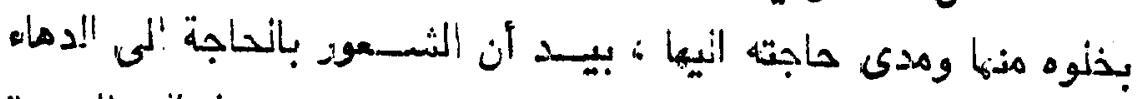

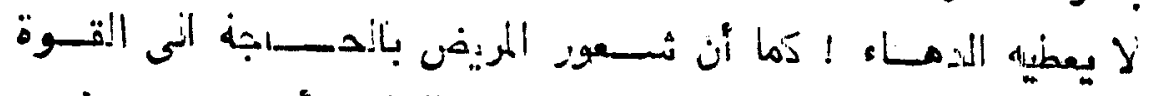

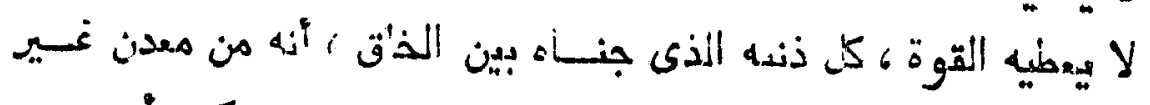

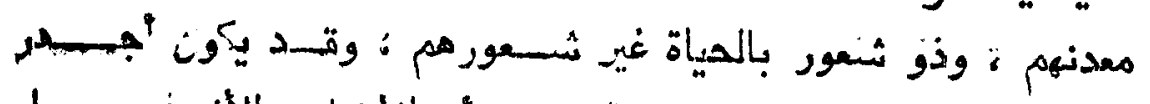

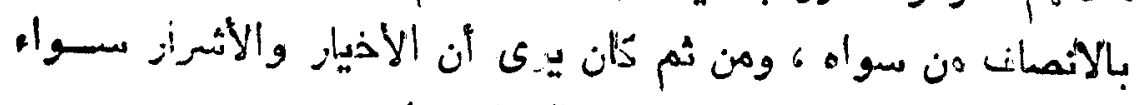

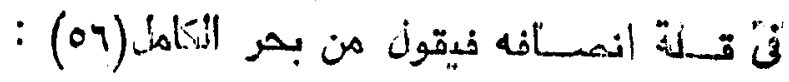

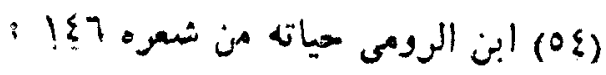

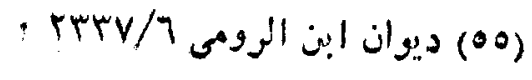

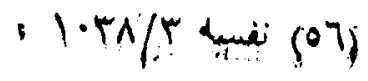




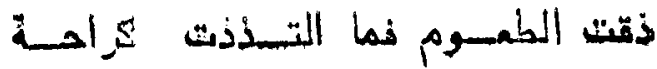

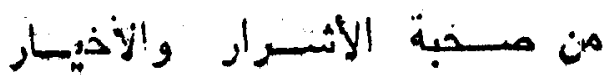

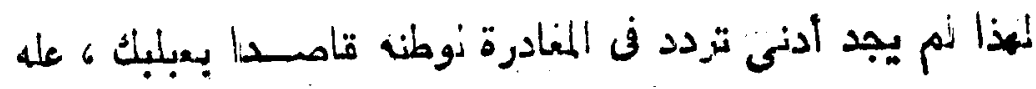

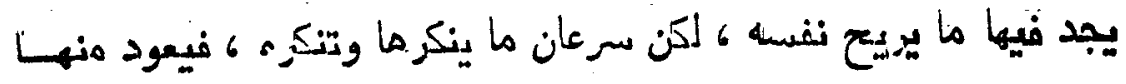

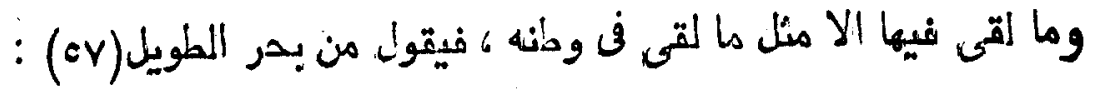

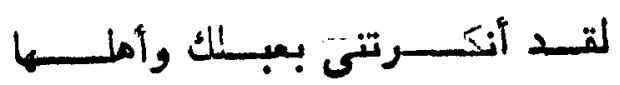

بـل الأزض بل بغداد صامبة التبـلـل

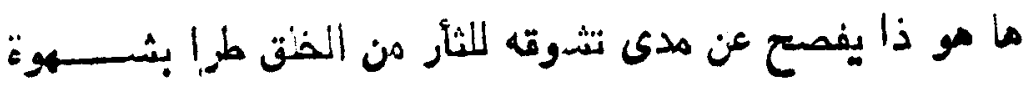

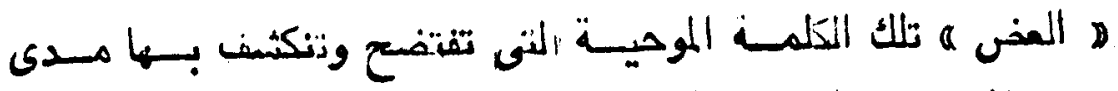

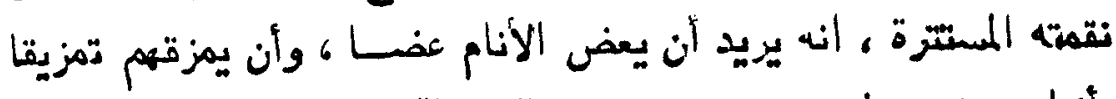

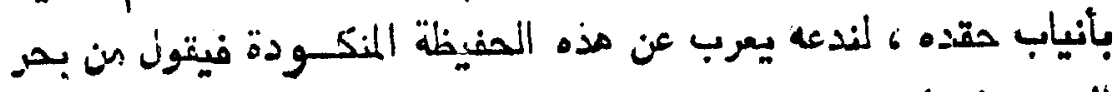
المفيف (ON)

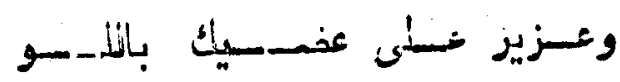

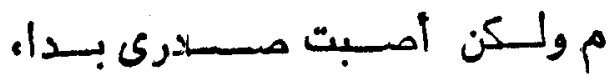

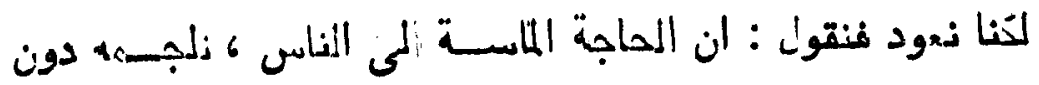

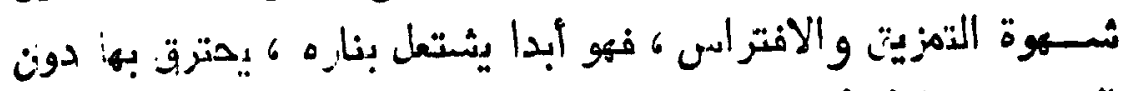

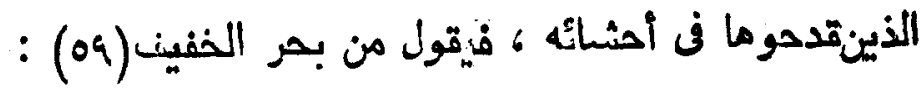

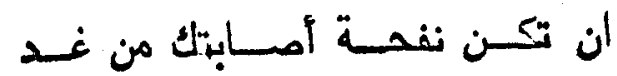

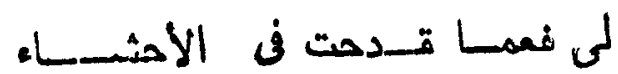

$$
\begin{aligned}
& \text { • r.r/0 المصدر السابق (OV) } \\
& \text { - VI/ نفس (OAS) } \\
& \text { - VI/I نفس (09) }
\end{aligned}
$$




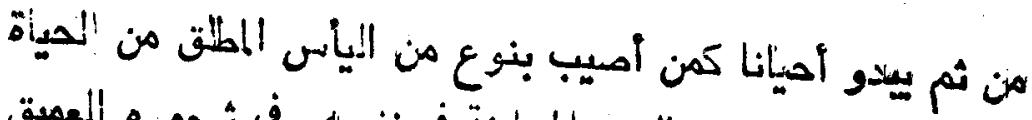

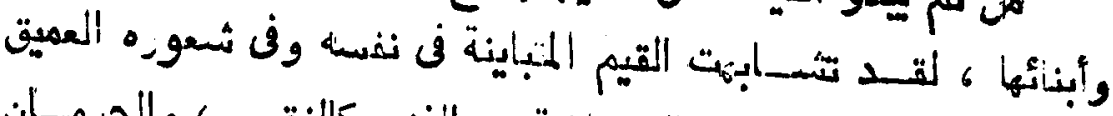

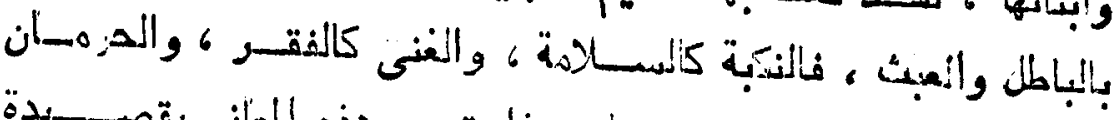

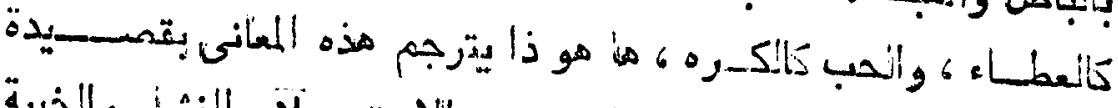

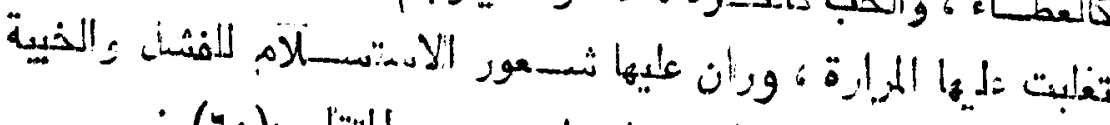

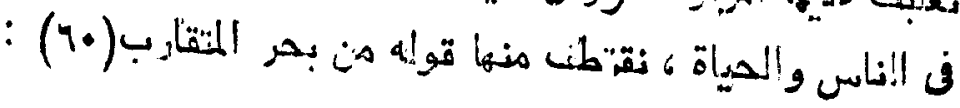

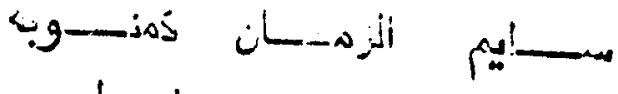

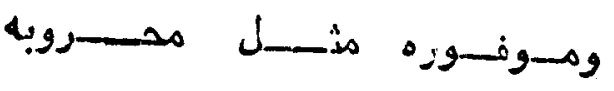

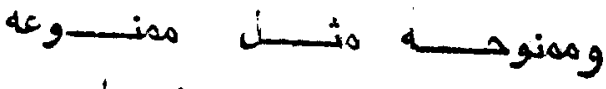

ومذستسو

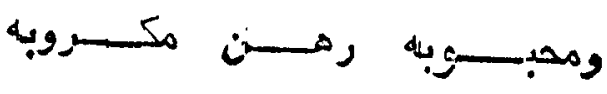

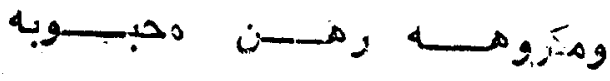

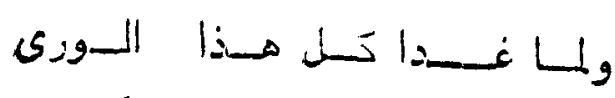

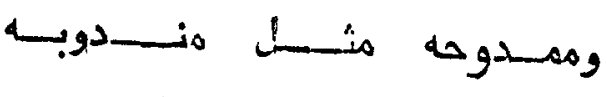

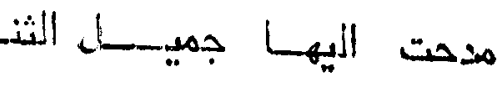

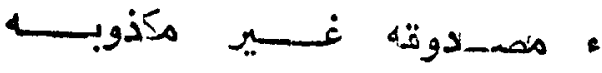

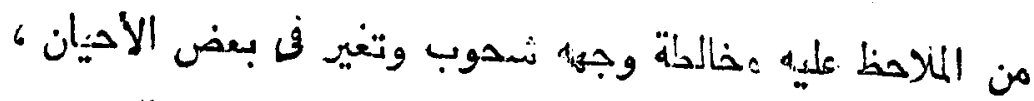

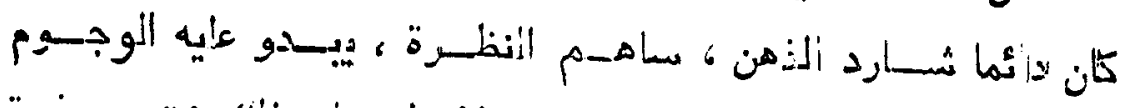

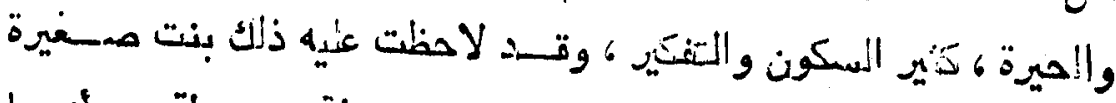

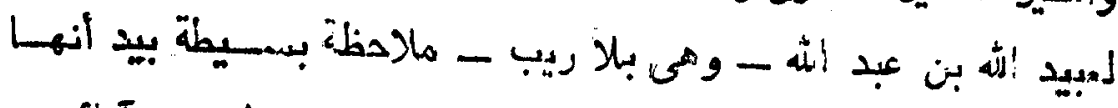

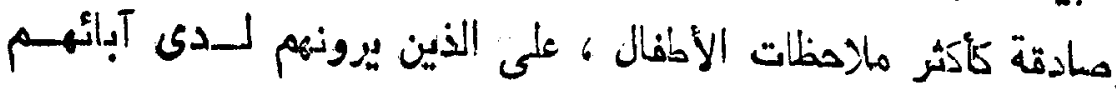




\section{IV}

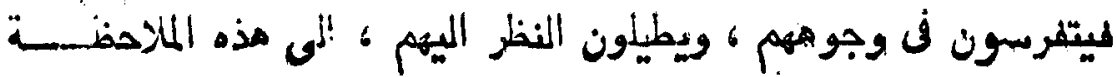
يد:ثنا عن نفيس فيقول فن بحسي الكسامل (11) :

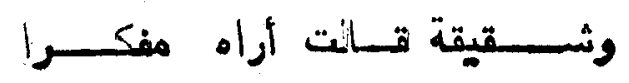

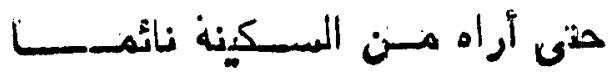

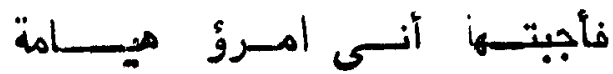

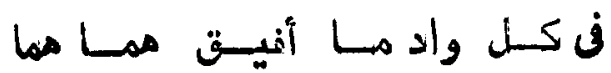

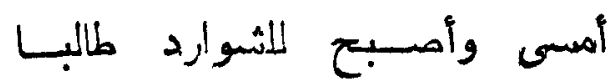
بهواجسى هـولن الأوابسـ حائهــا

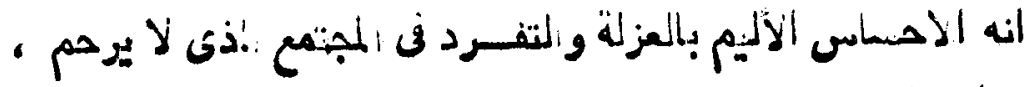

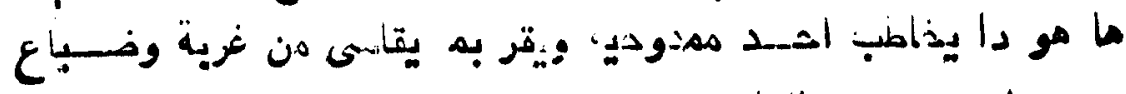

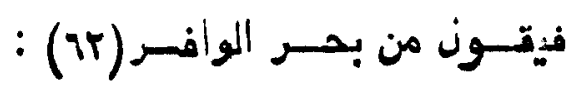

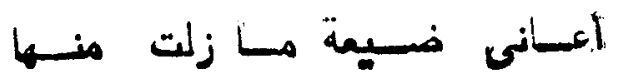

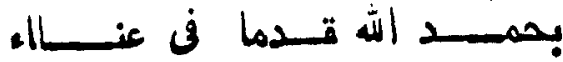

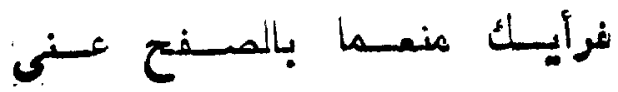

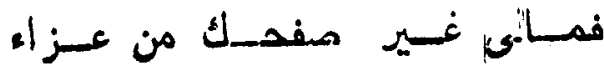

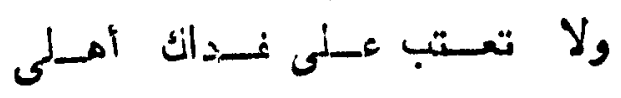

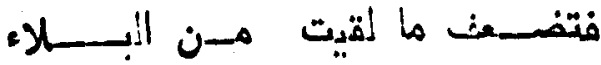

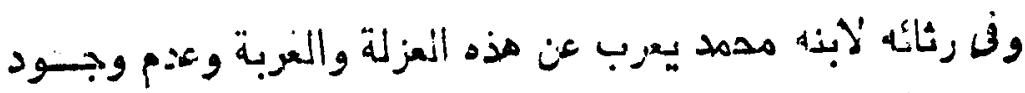

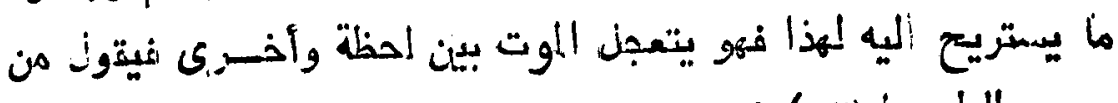

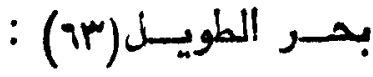

- rirt/o (7)

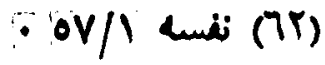

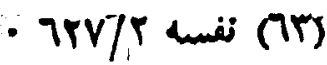




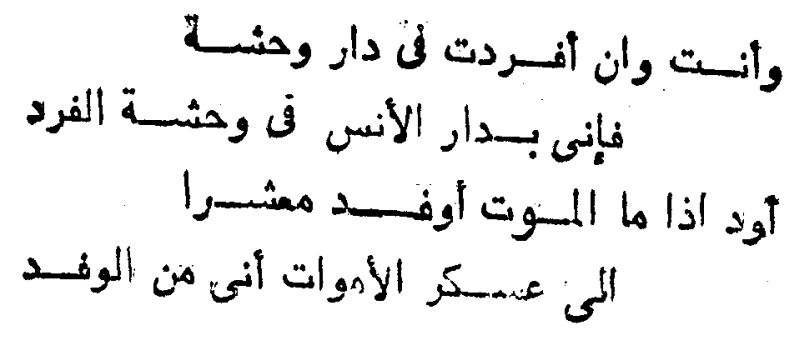

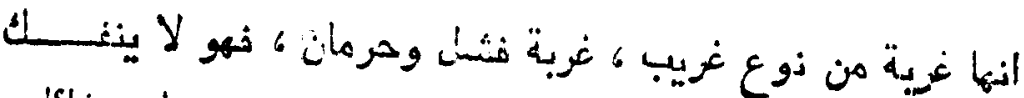

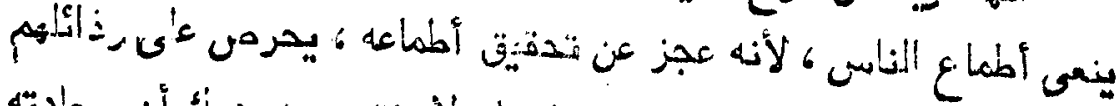

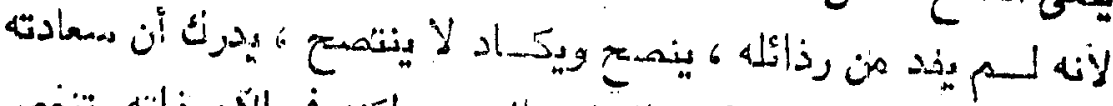

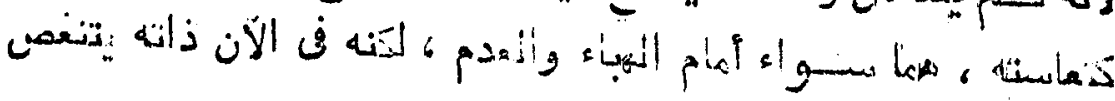

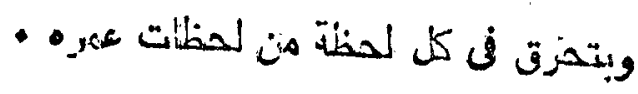

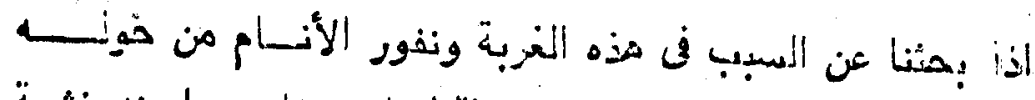

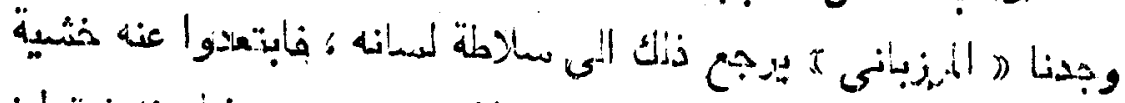

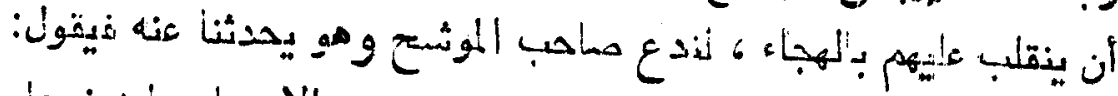

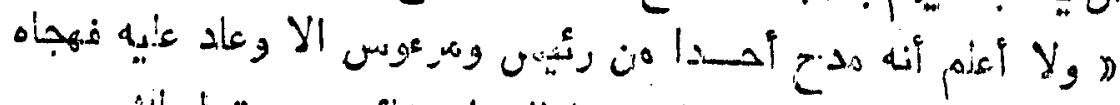

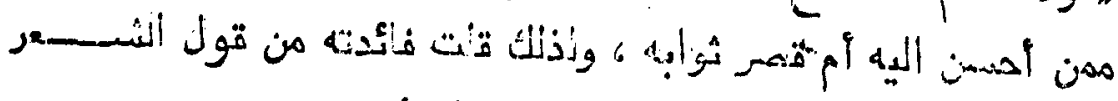

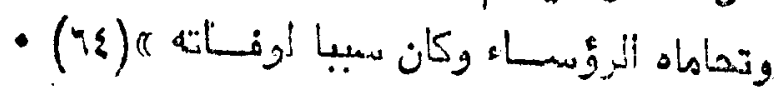

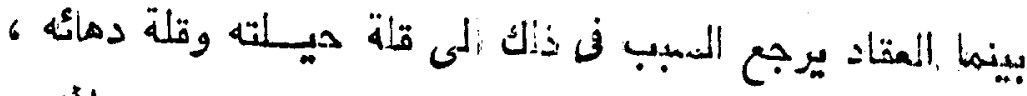

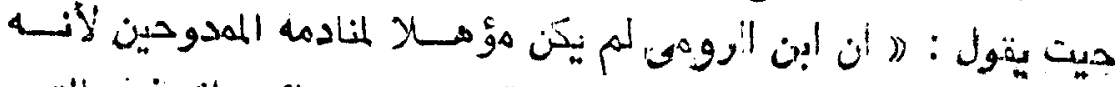

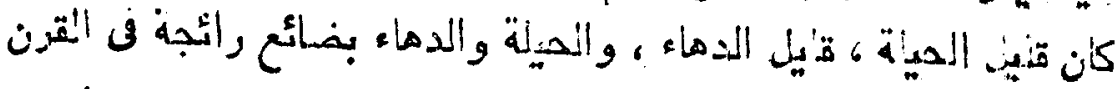

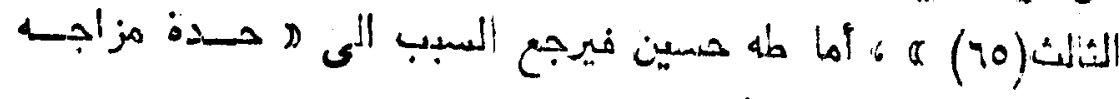

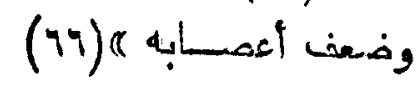

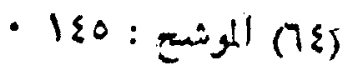

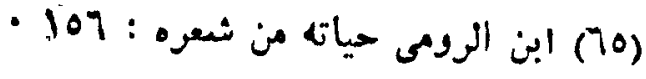

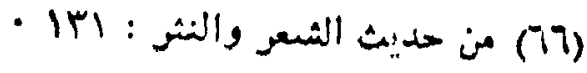




\section{9}

والتمقيق يرى أن المبب في هذه الغربة نتيجة لنفوز الناس من وناس

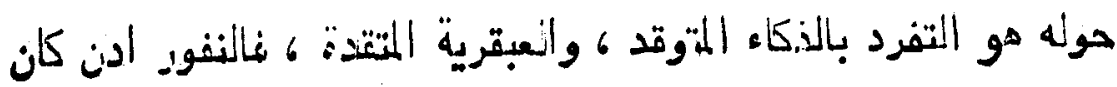

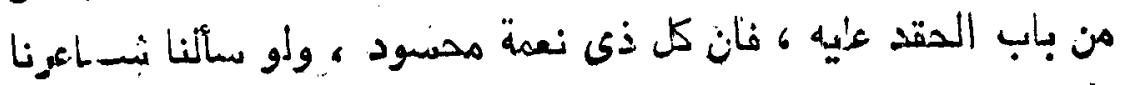

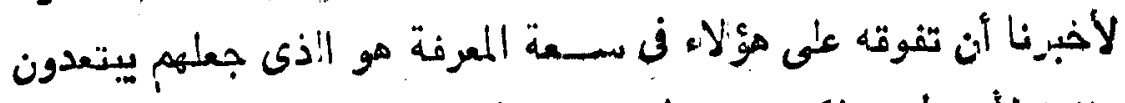

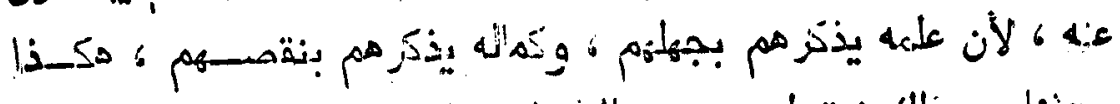

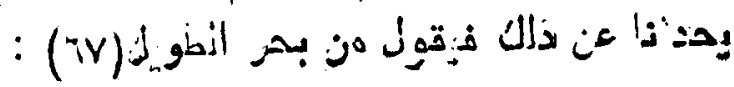

رأى القوم لى فضـالا يعاديه نقصهم

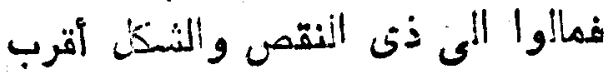

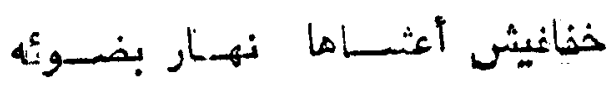

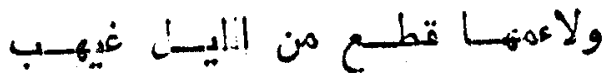

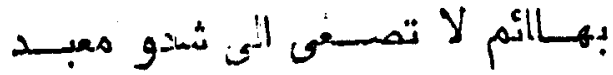

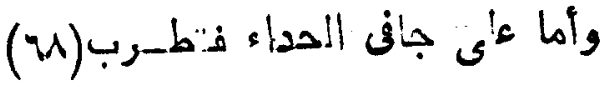

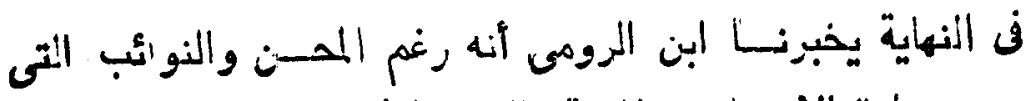

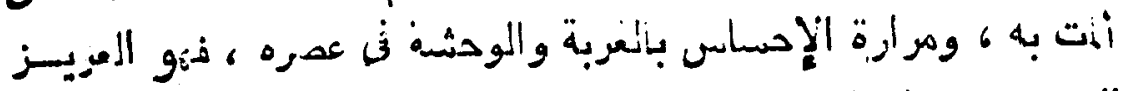

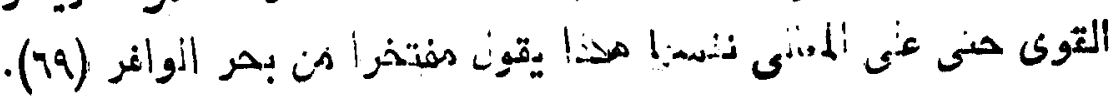
وائست دتــــارعا جيثـمســا ولكسن

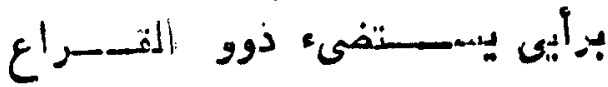

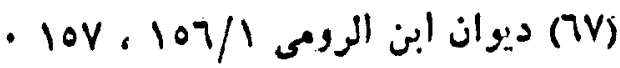

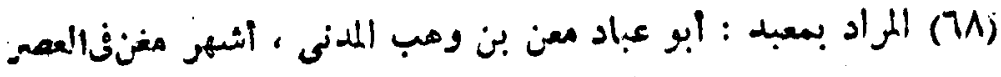

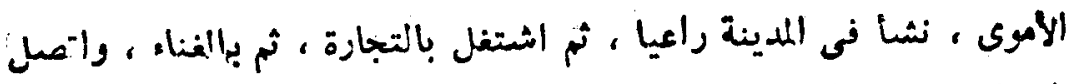

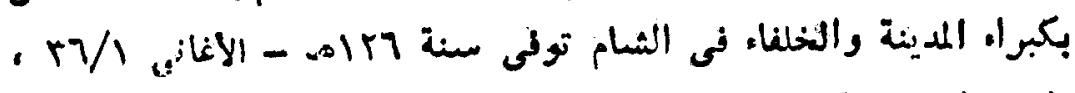

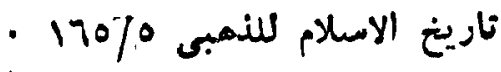

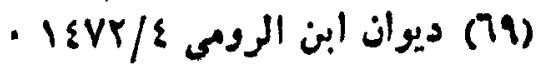




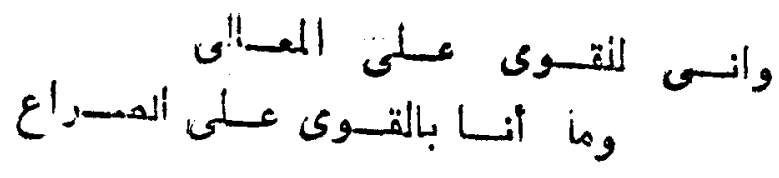

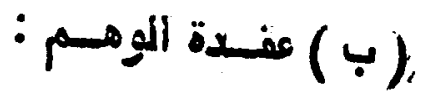

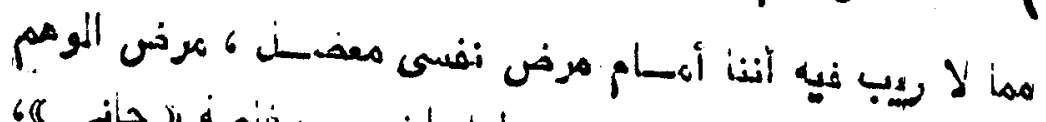

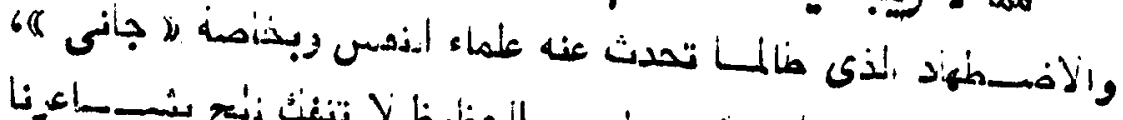

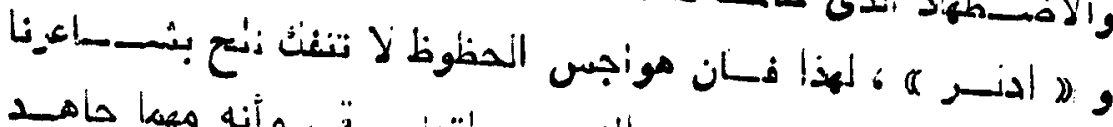

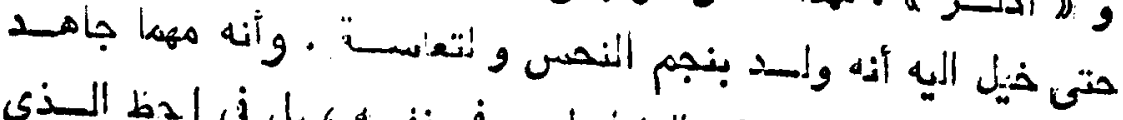

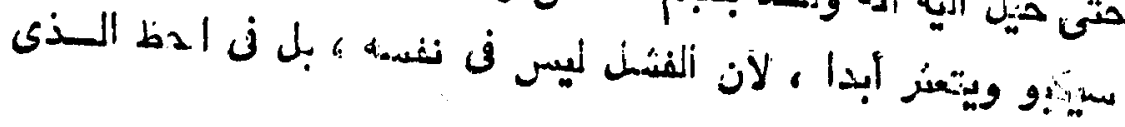

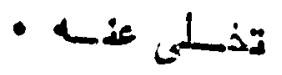

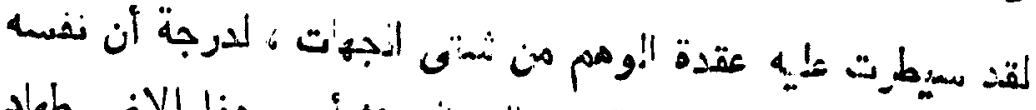

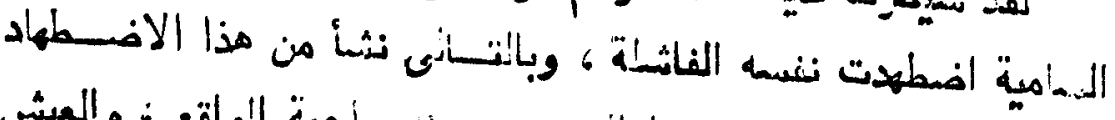

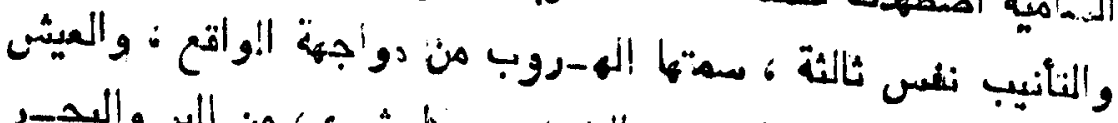

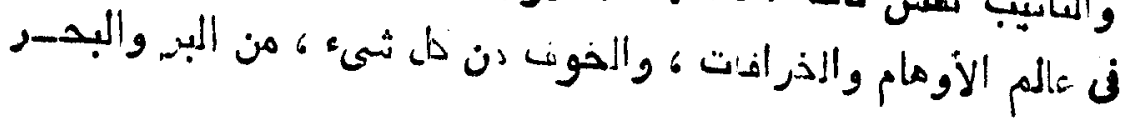

$$
\text { • }
$$

أما عن البر نها هو ذا يتصدى لوجه واحهد من وجوه الحياة 6

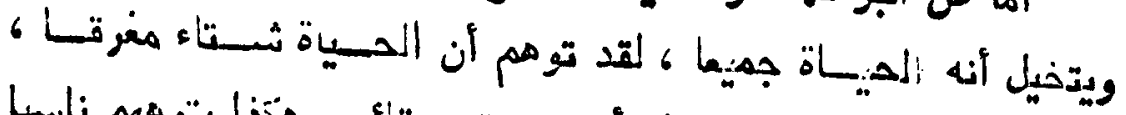

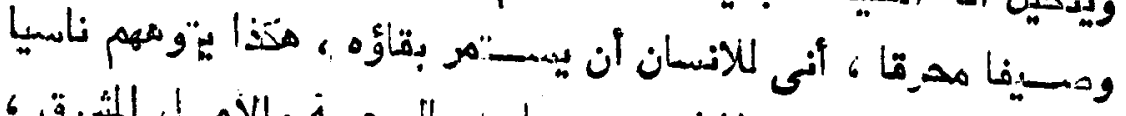

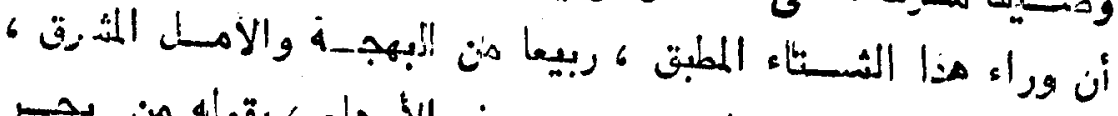

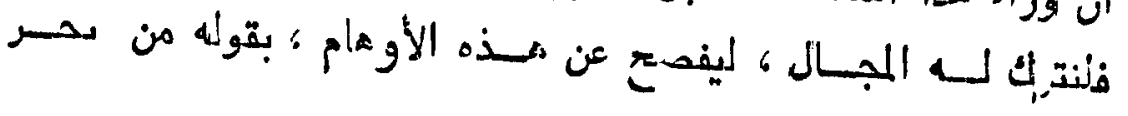

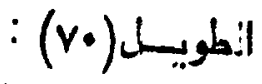

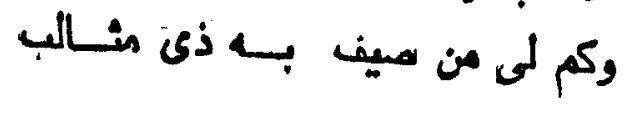

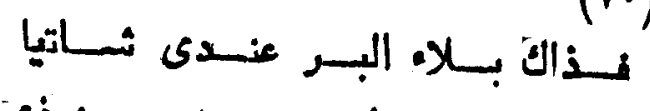$$
\text { - Profi (V.) }
$$ 


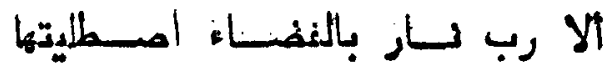

$$
\begin{aligned}
& \text { هن المنح يودى نفحها بالحواجب(v) }
\end{aligned}
$$

وأما Fن البحر فقد تومهاه جيثا هن الموت يذانيه ويتحفز اليه ،

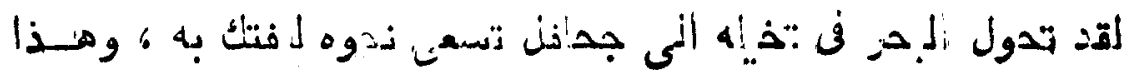

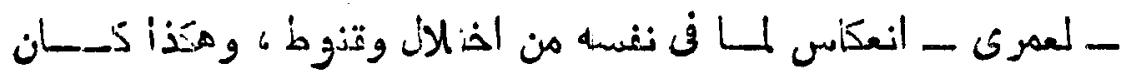
تودهه لزلبحر حيث يقول دن بحر الطويل(vr) :

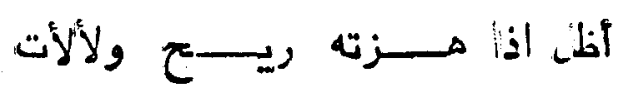

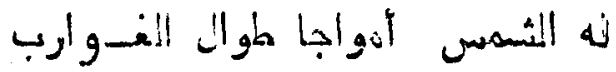

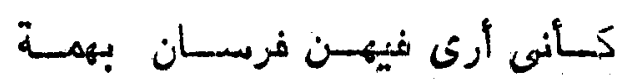

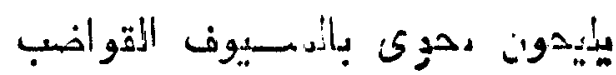

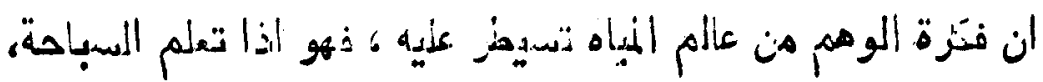

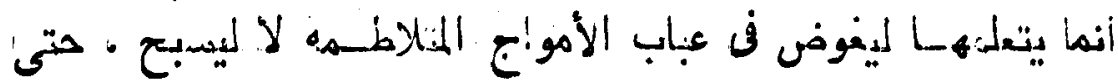

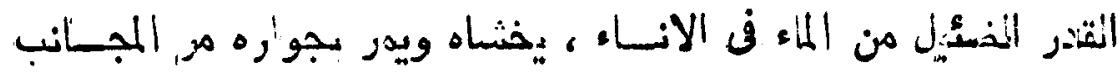

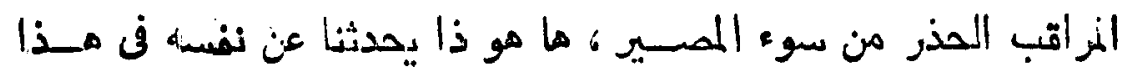

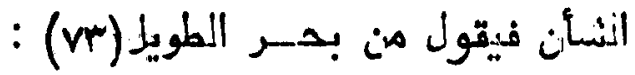

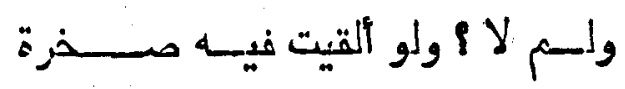

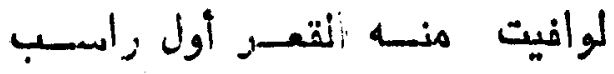

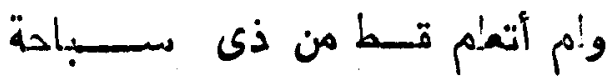

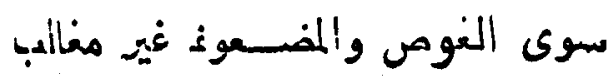

• الضع : حرارة الشمس (VI)

- rIT/L ديوان ابن الرومئ (VT)

- rIT/S نفس (VT) 


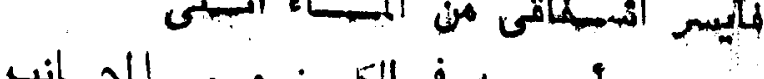

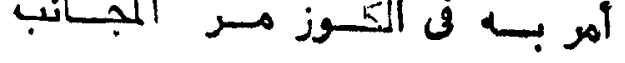

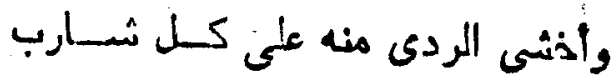

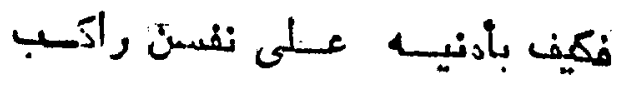

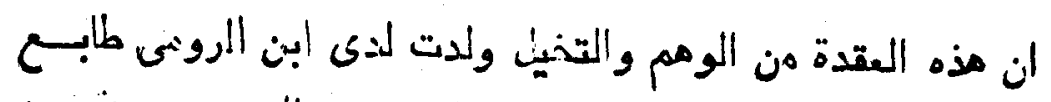

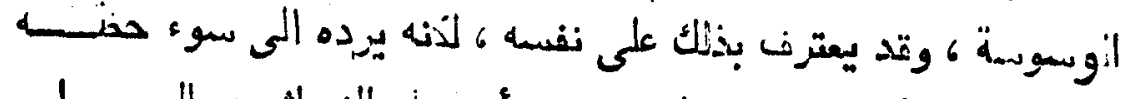

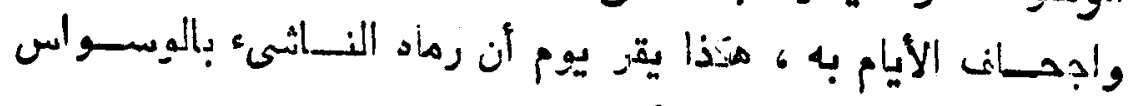

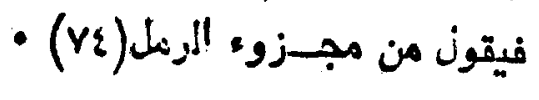

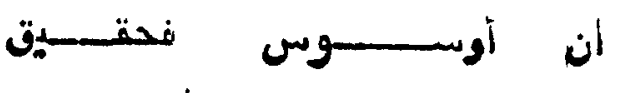

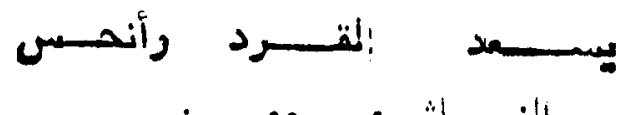

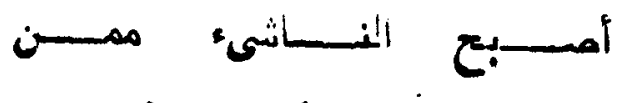

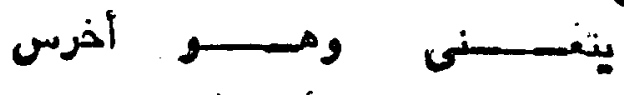

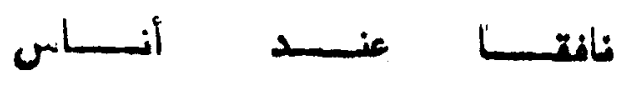

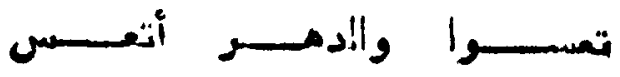

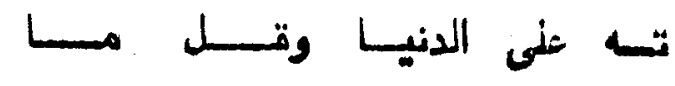

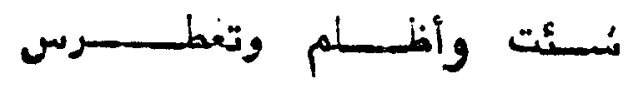

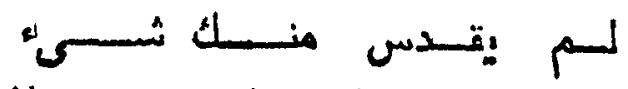

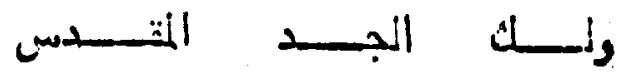

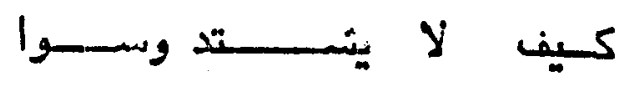

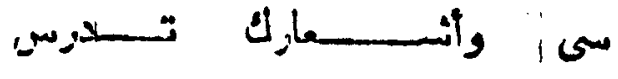

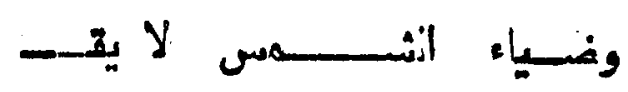

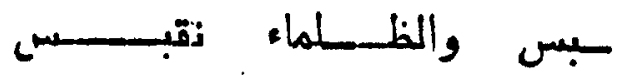

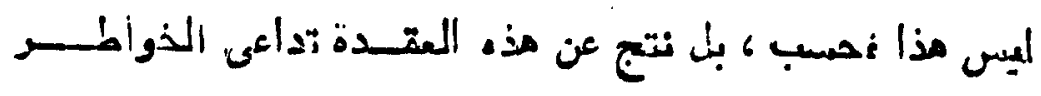

$\therefore$ المسدر السابق (VI) 


\section{IV}

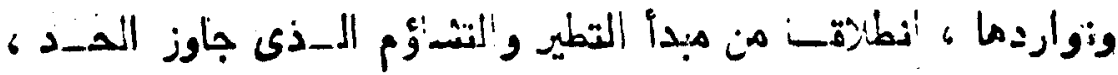

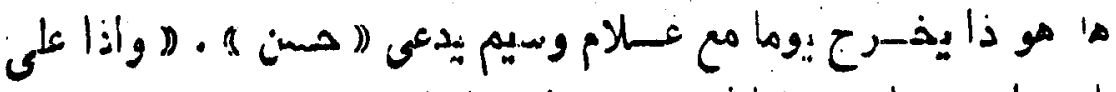

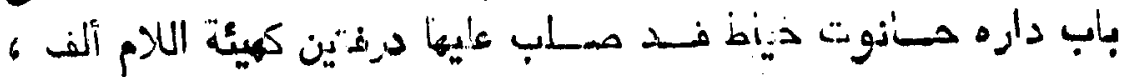

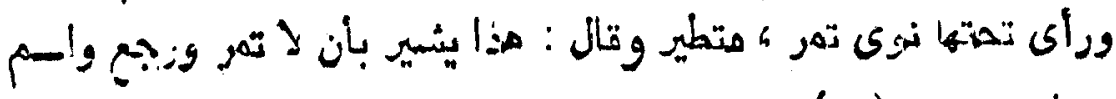

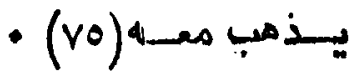

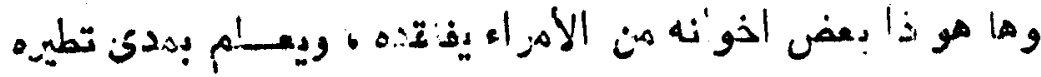

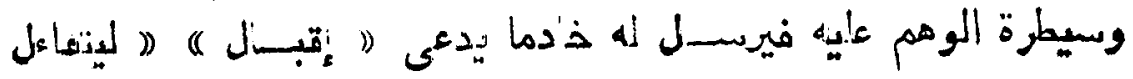

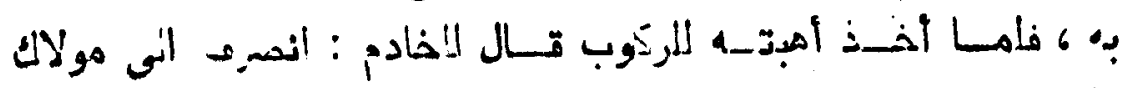

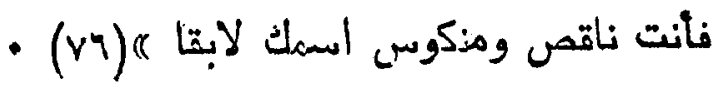

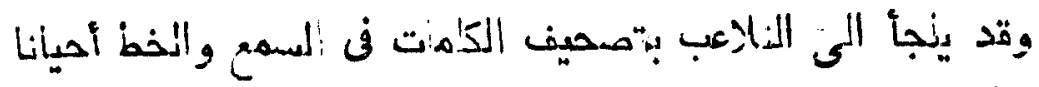

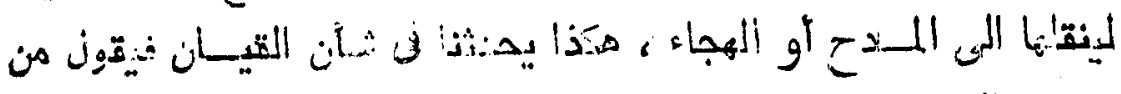
: بحسر السريع(w)

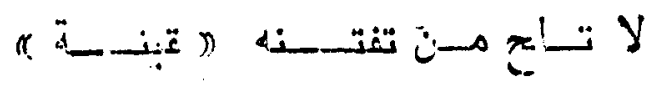

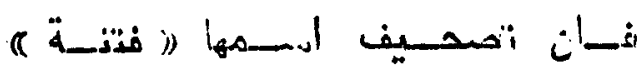

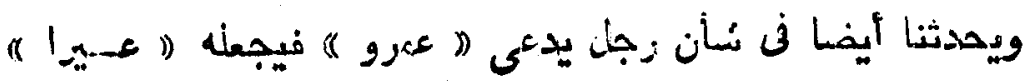

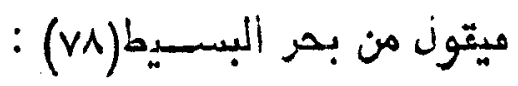

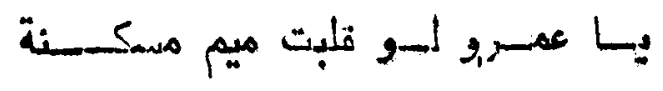

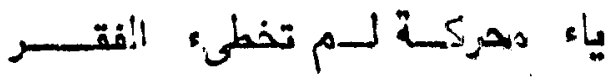

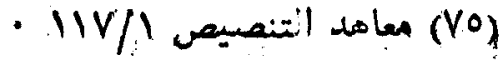

$$
\begin{aligned}
& \text { - 79/1 إلعمد (V) }
\end{aligned}
$$

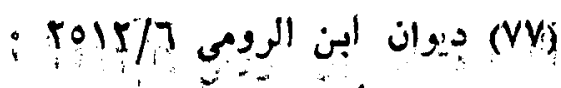

$$
\begin{aligned}
& \text { : ن نفيس }
\end{aligned}
$$




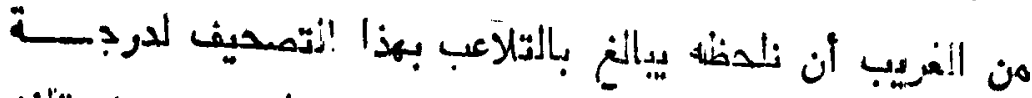

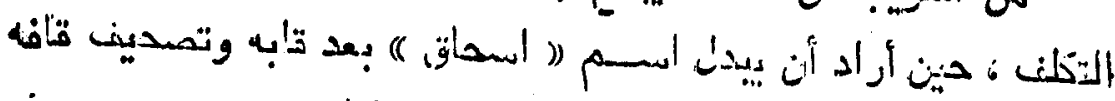

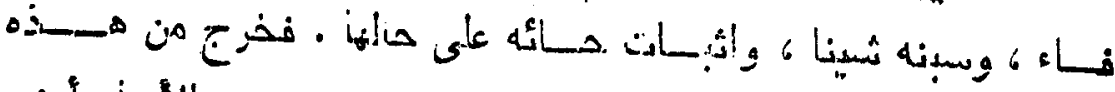

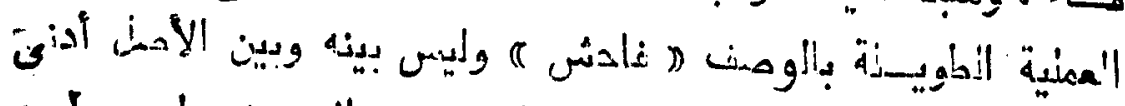

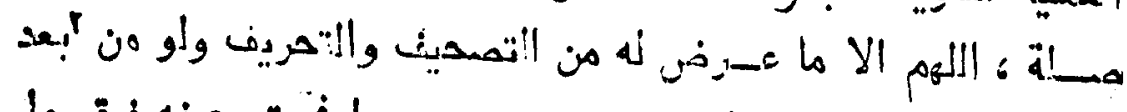

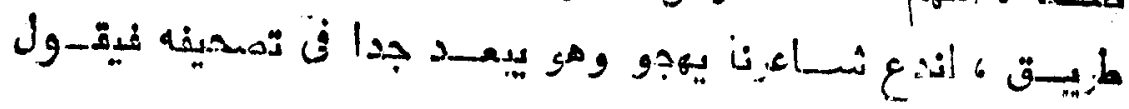
: (va) من مجسزوء الرهاع

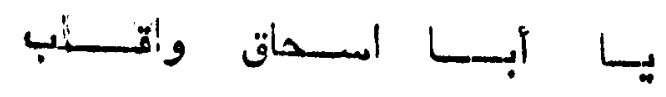

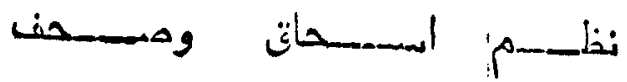

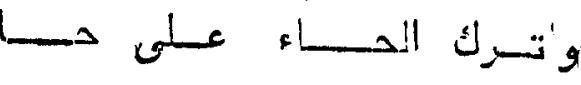

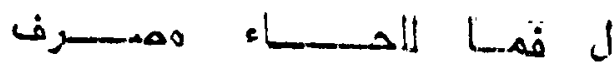

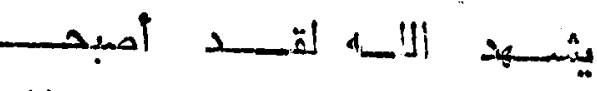

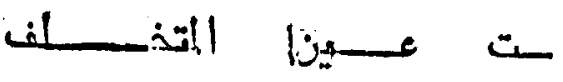

:

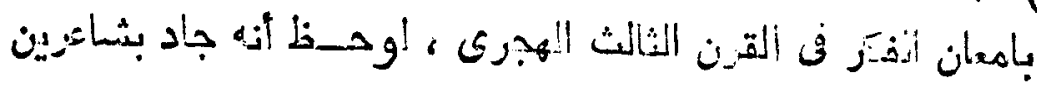

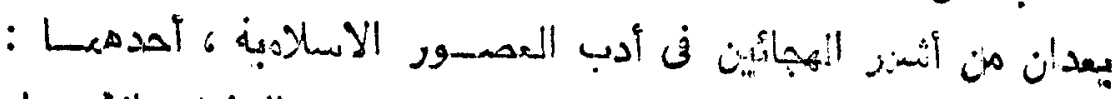

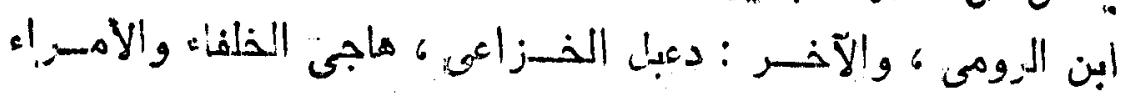

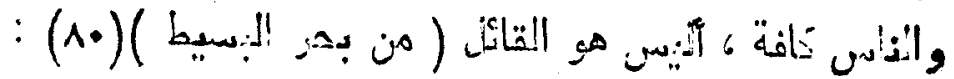

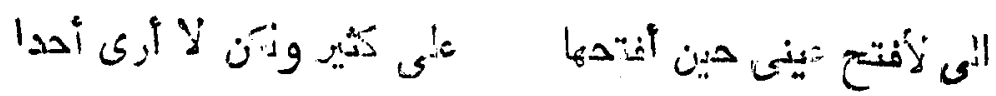

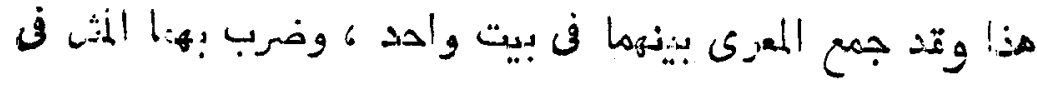

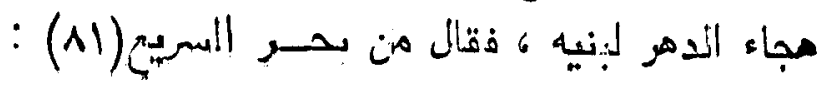

- lo7r/\& المصدر السابق (V9)

- IVY :

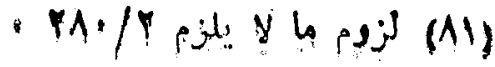




\section{IVo}

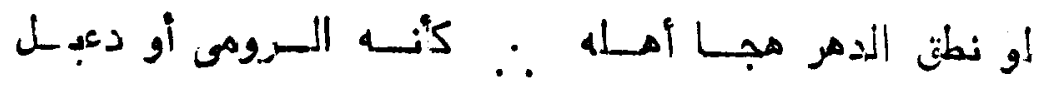

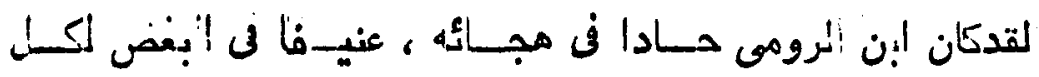

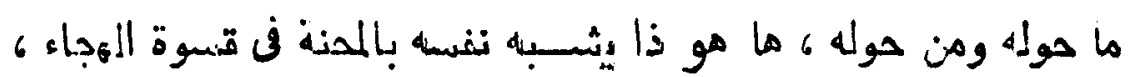

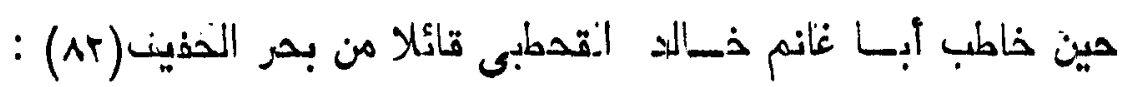

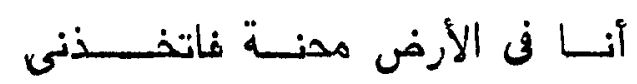

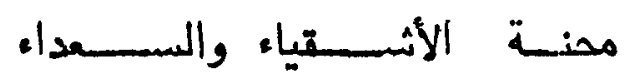

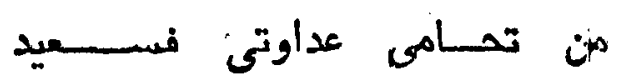

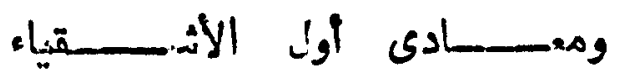

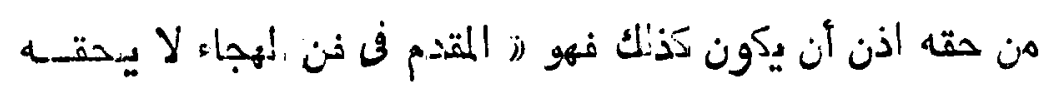

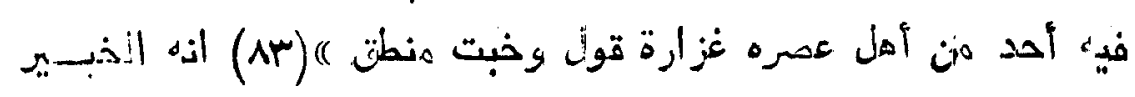

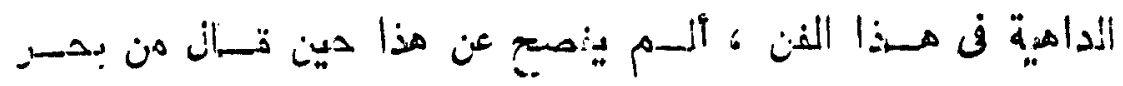
: الكـامل (1)

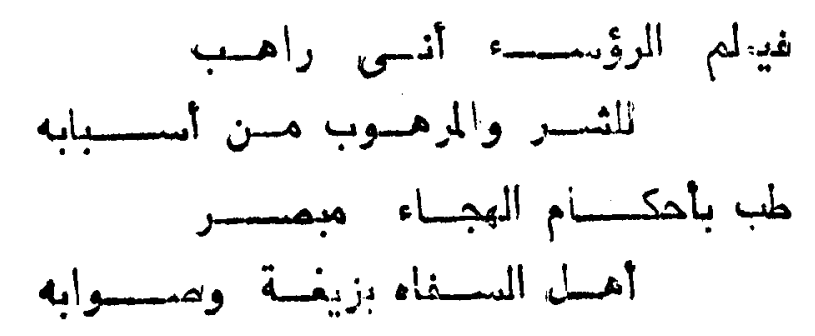

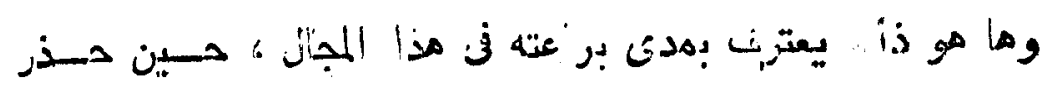

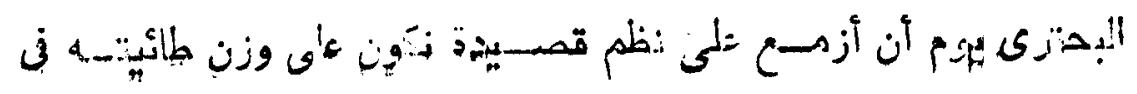

$$
\begin{aligned}
& \text { : (AT) } \\
& \text { : }
\end{aligned}
$$

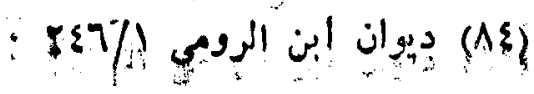




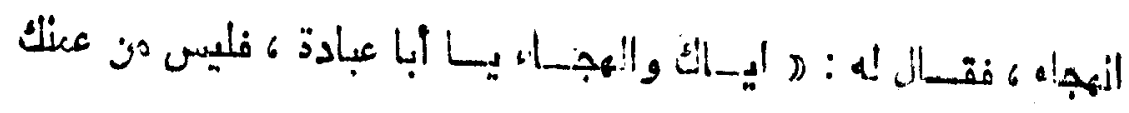

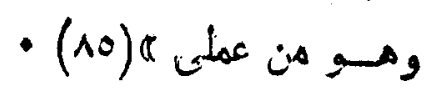

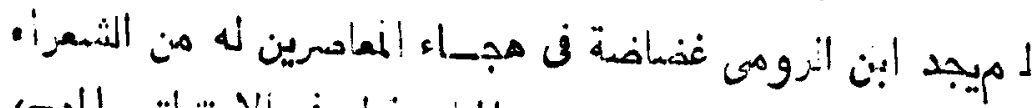

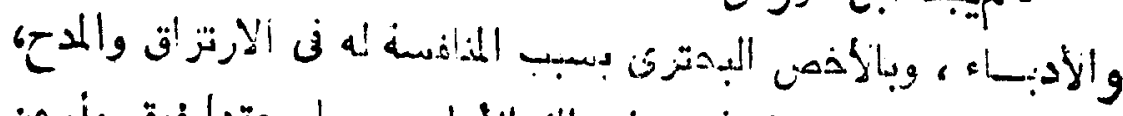

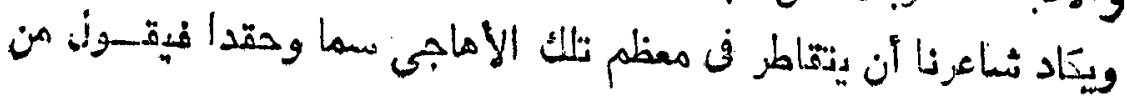

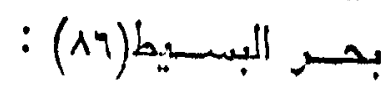

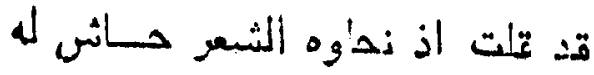

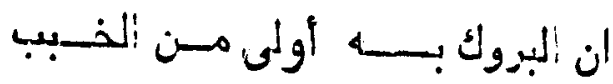

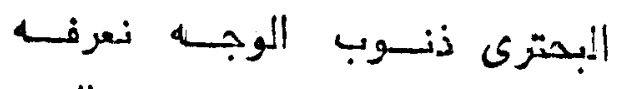

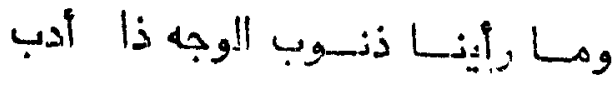

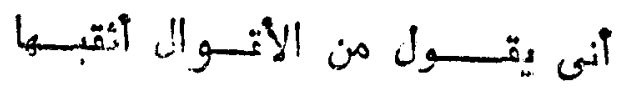

is

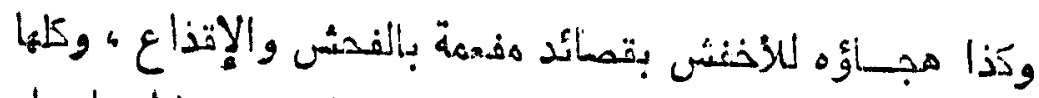

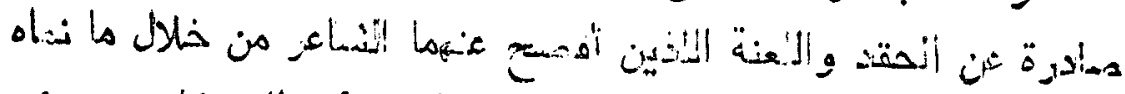

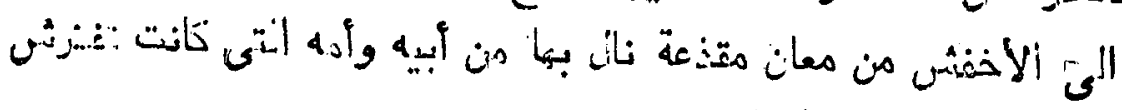

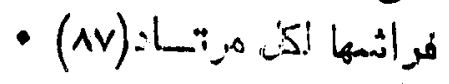

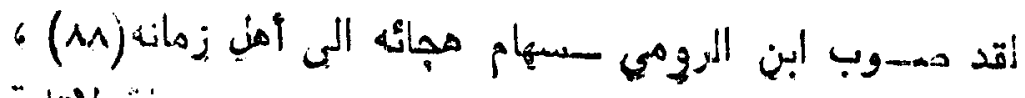

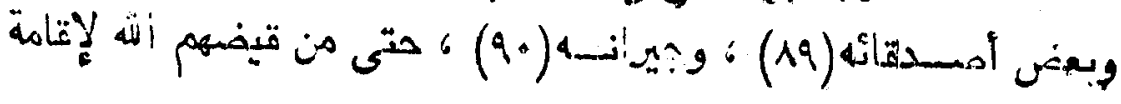

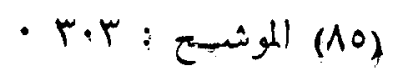

• rV./ /

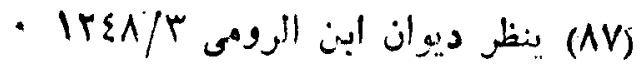

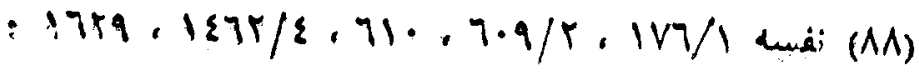

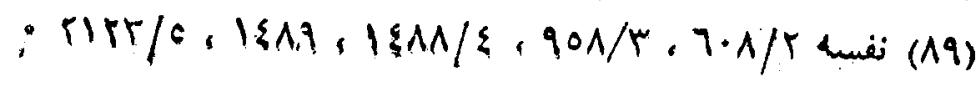

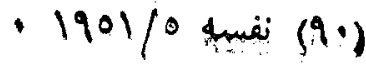




\section{IvV}

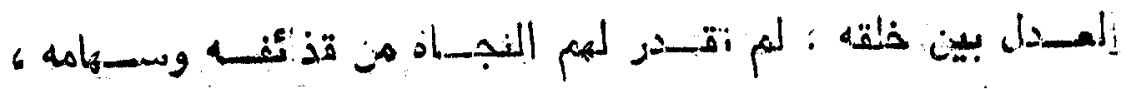

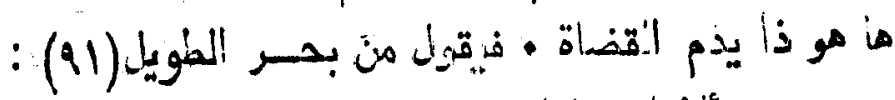

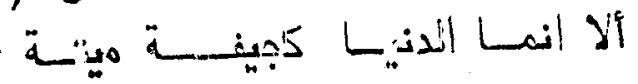

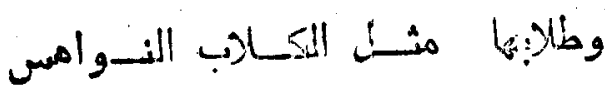

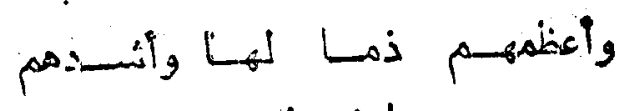

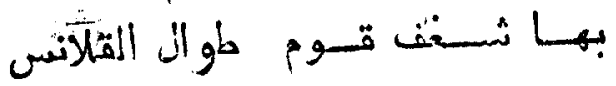

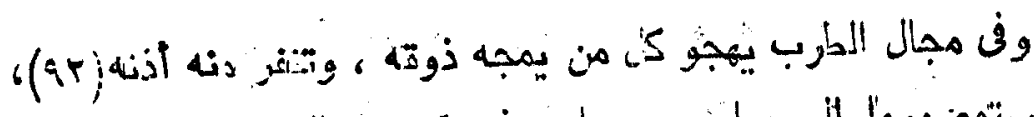

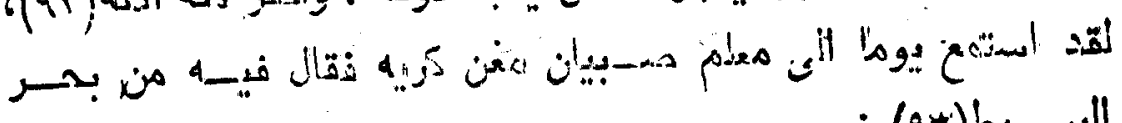

$$
\text { : البســـإ) }
$$

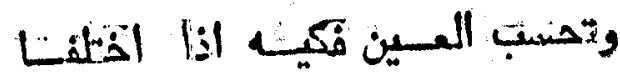

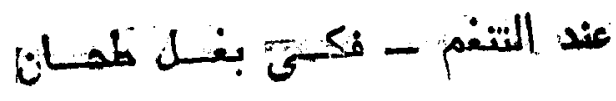

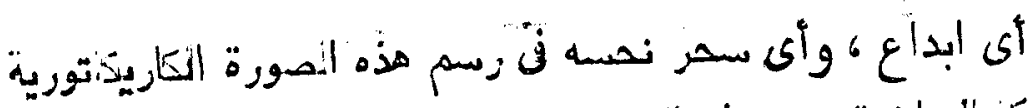

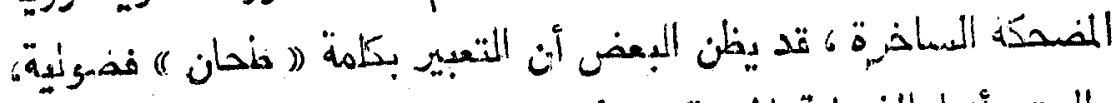

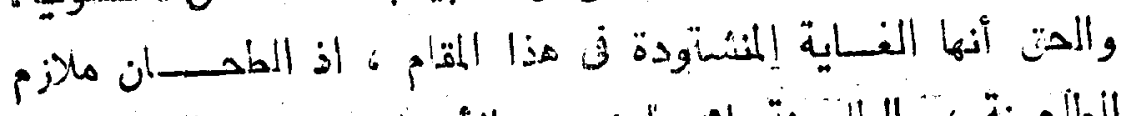

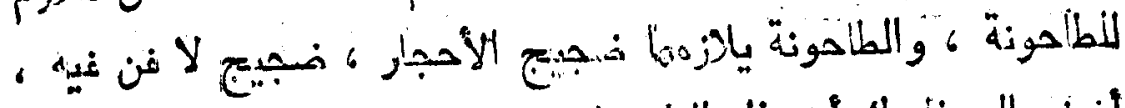

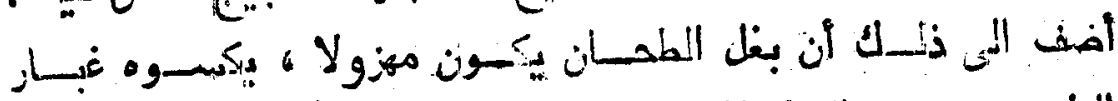

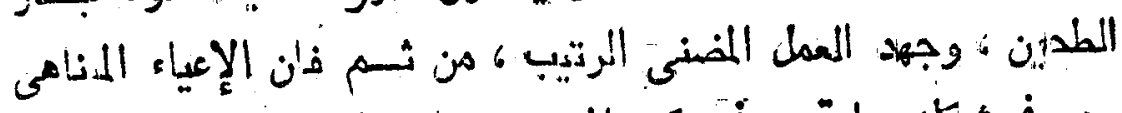

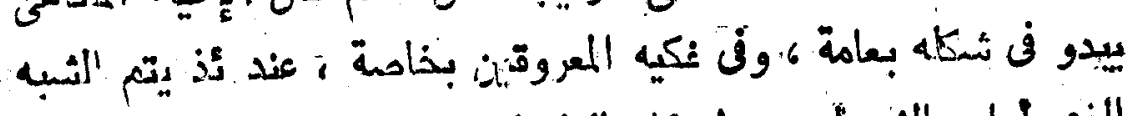

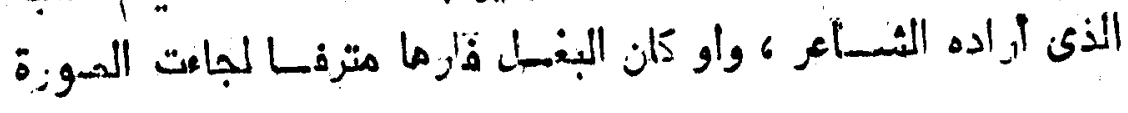

$$
\text { - }
$$

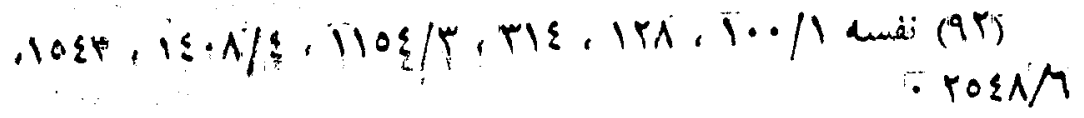

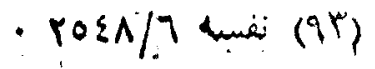

$$
(j \text { j r p }
$$




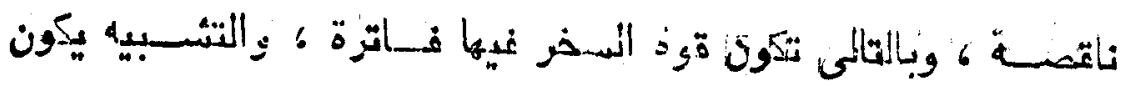

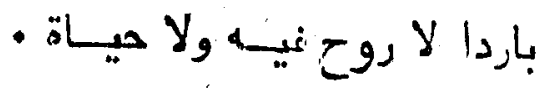

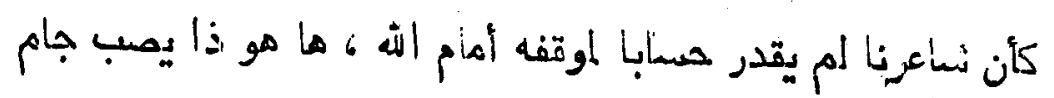

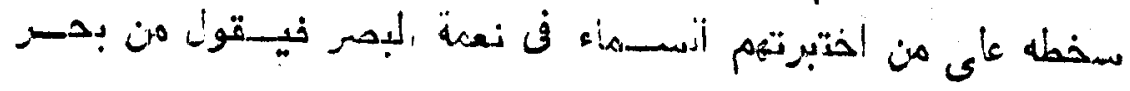

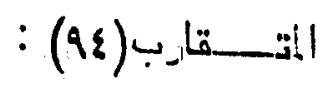

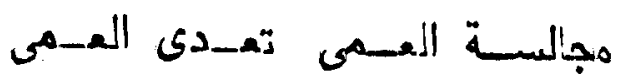

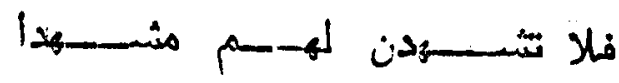

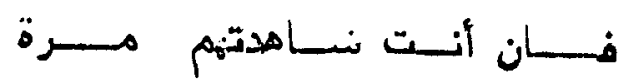

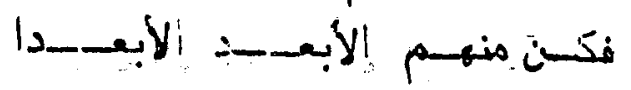

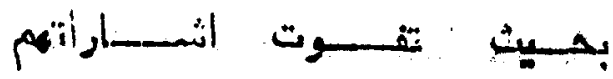

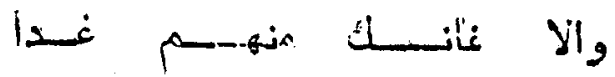

ويقول في آذز هن بحر الففيف(90) :

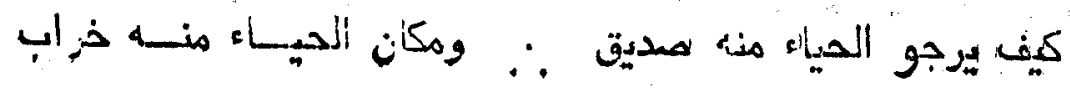

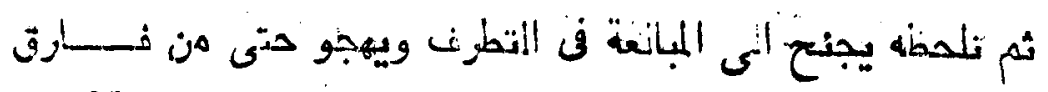

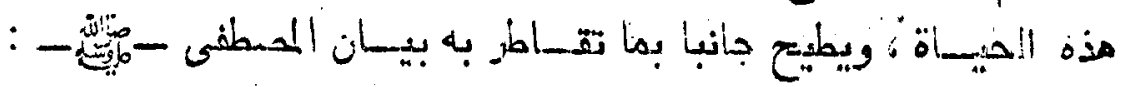

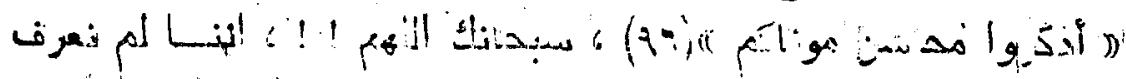

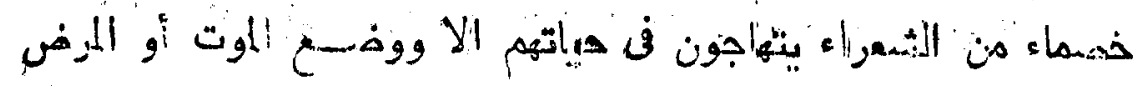

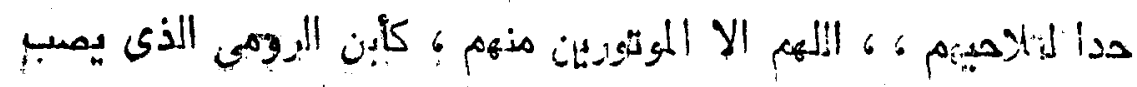

$$
\begin{aligned}
& \text { - } 79.7 \% \text { (95) السابت } \\
& \text { - ro. }
\end{aligned}
$$

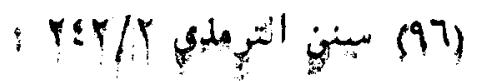




\section{ivs}

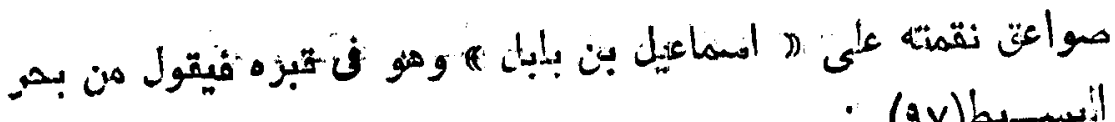

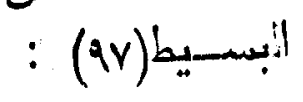

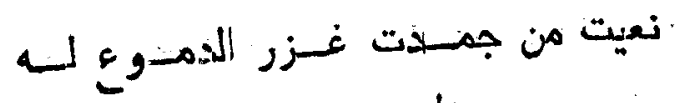

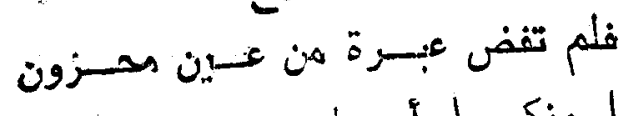

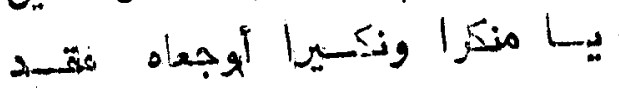

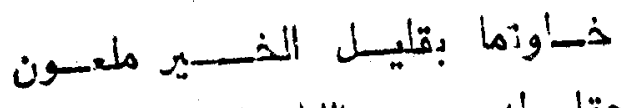

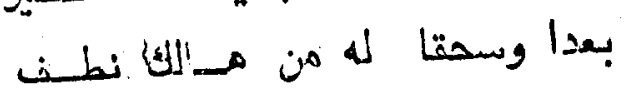

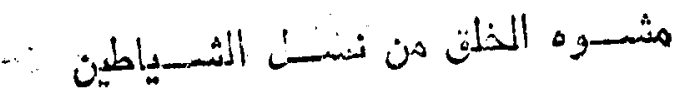

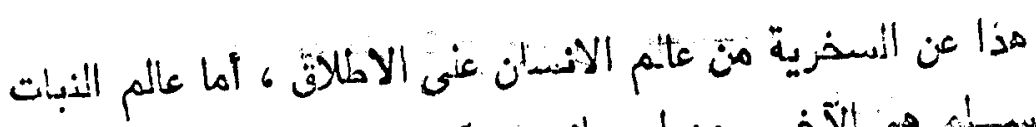

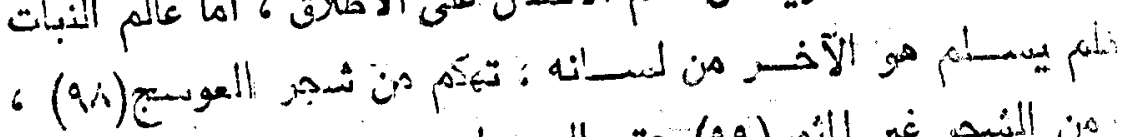

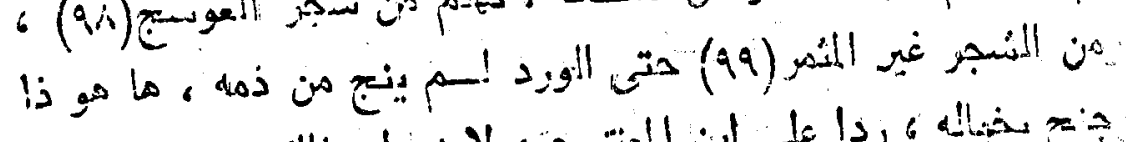

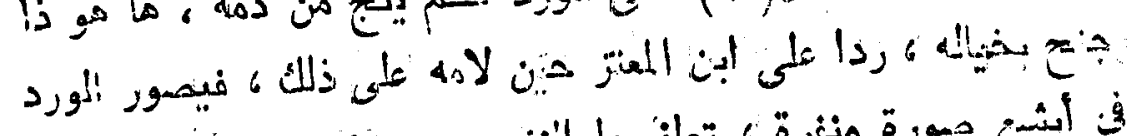

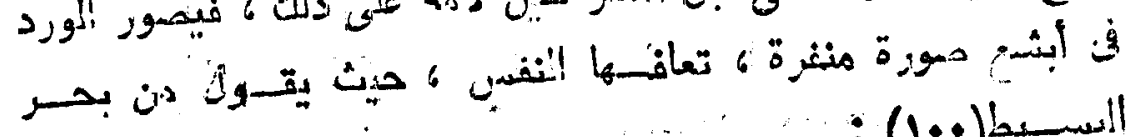

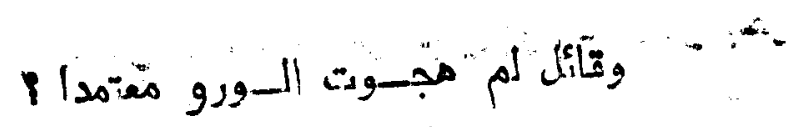

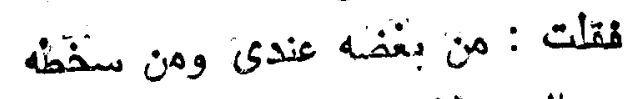

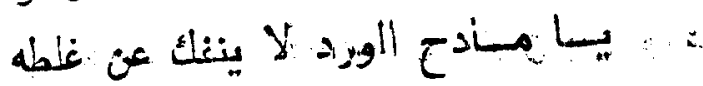

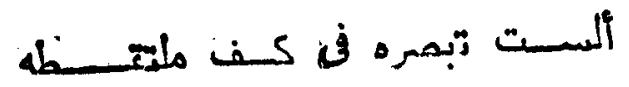

$$
\begin{aligned}
& \text { - } \\
& \text { - } 11 r / 1 \text { L is (9.1) } \\
& \text { - rqr/l is (1.9) } \\
& \text { - Isor/s aren (1) }
\end{aligned}
$$




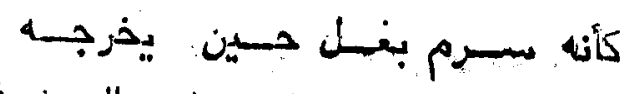
عند الريساث وباقى الروث فى وسطه

لم ينس شاعرنا بعد أن سفر مبي غيره أن يدهيخر أخيرا من نغسه

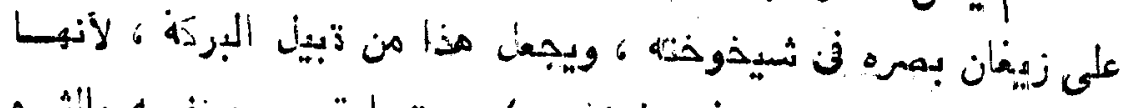

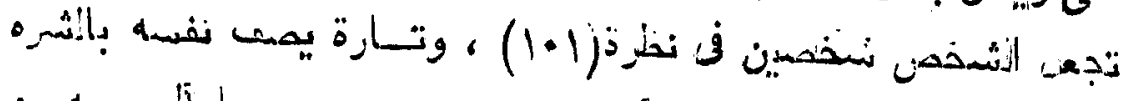

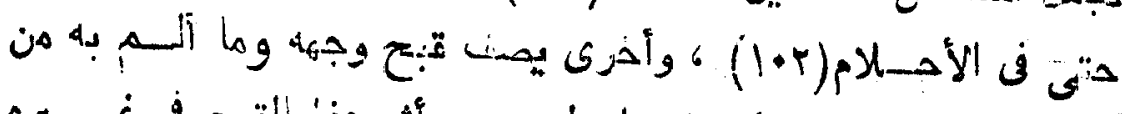

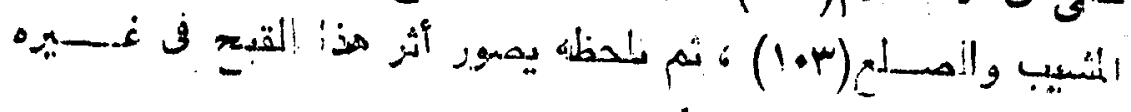

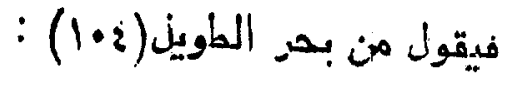

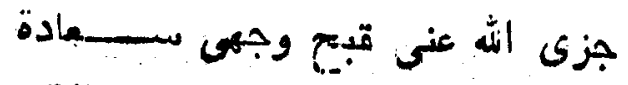

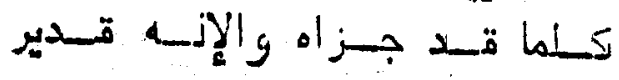

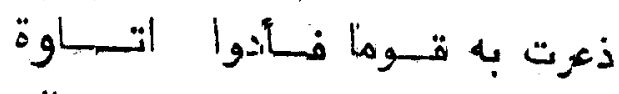

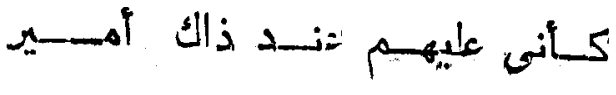

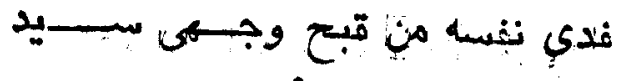

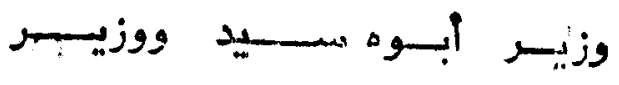

$$
\begin{aligned}
& \text { : }
\end{aligned}
$$

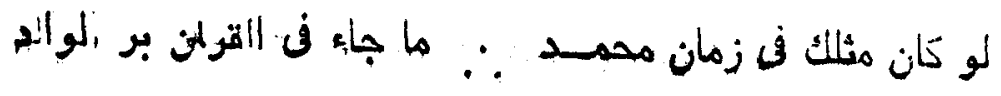

$$
\begin{aligned}
& \text { • }
\end{aligned}
$$

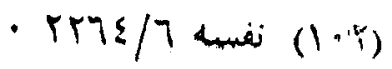

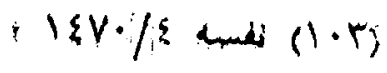

$$
\begin{aligned}
& \text { 1.9r/T نغ (1. (1. ) }
\end{aligned}
$$

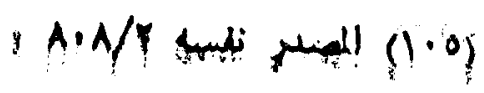




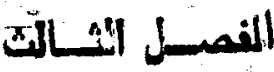

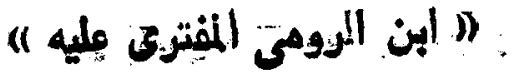

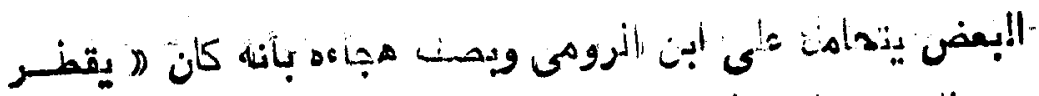

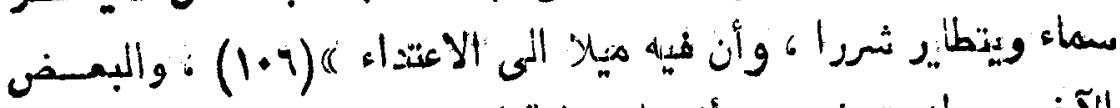

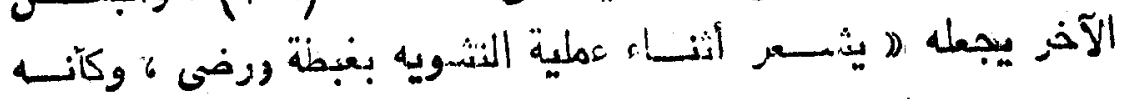

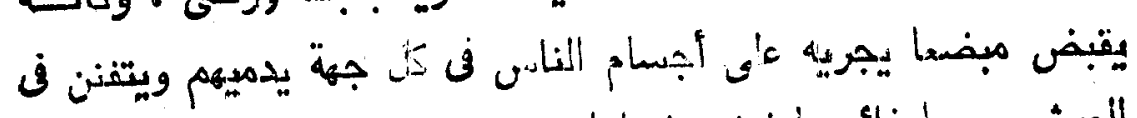

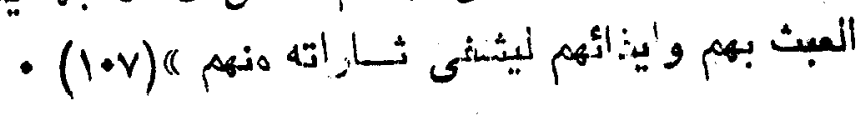

والحتق أن هجأهد بعامة ، وما يخدثى الدياء بخاصة 6 ليس ذيه

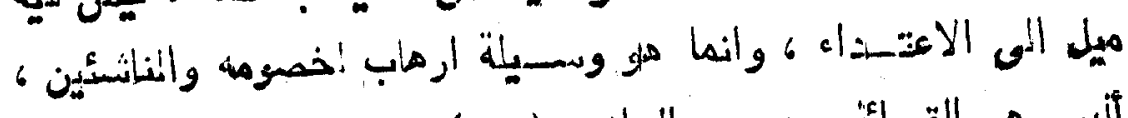

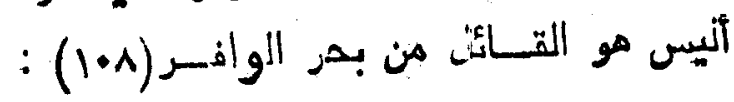

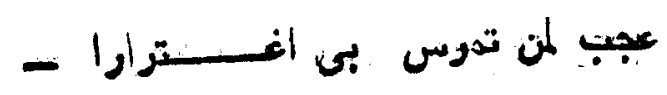

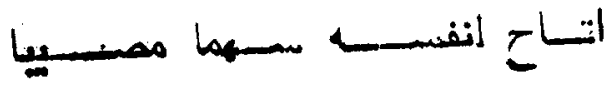

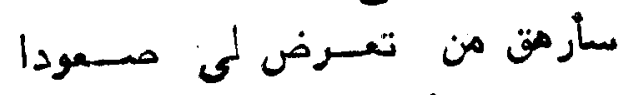

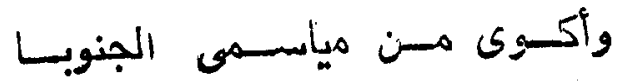

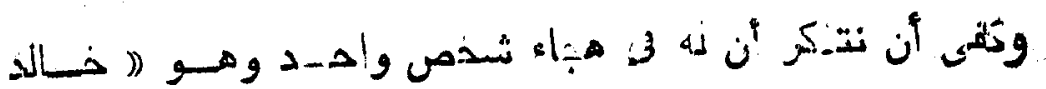

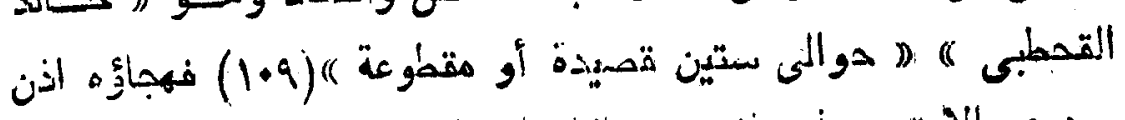

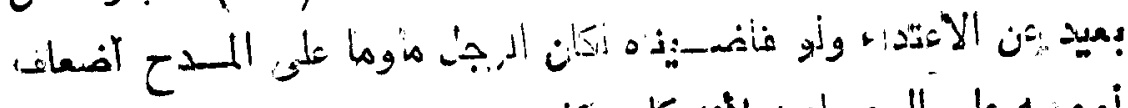

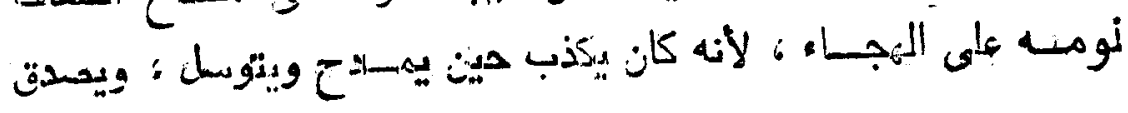

$$
\text { (1) }
$$

•

$$
\begin{aligned}
& \text { • }
\end{aligned}
$$

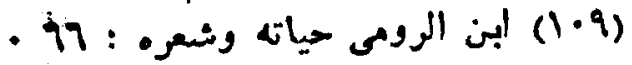




\section{MP}

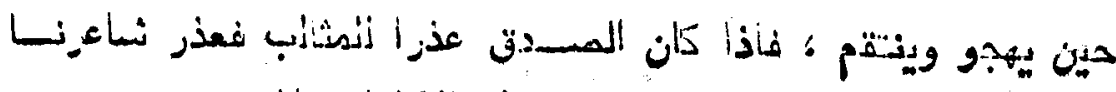

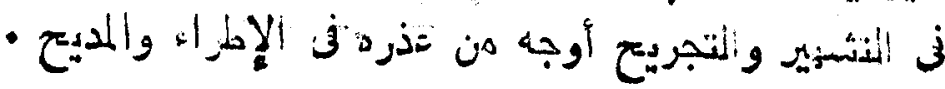

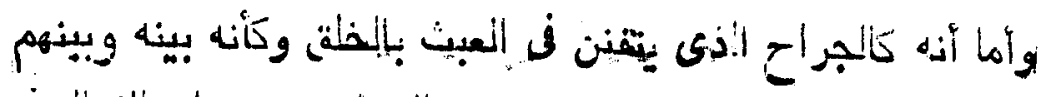

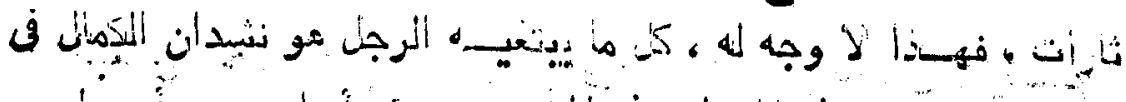

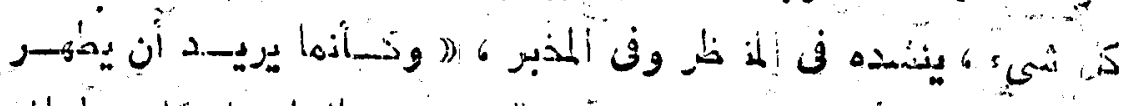

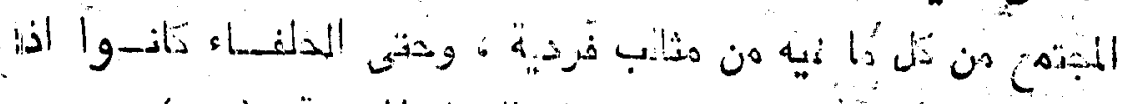

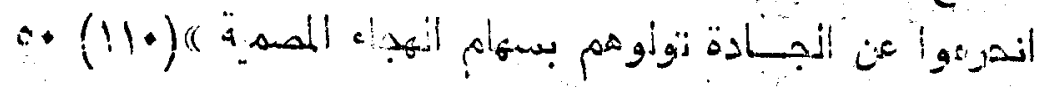

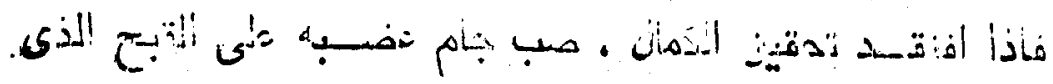

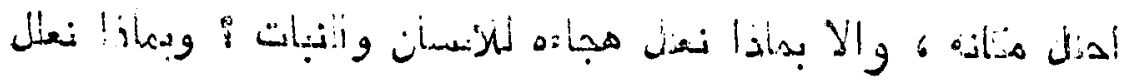

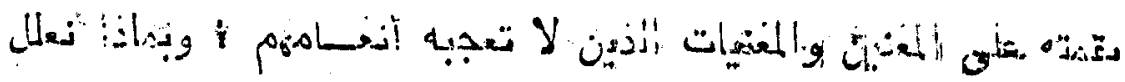

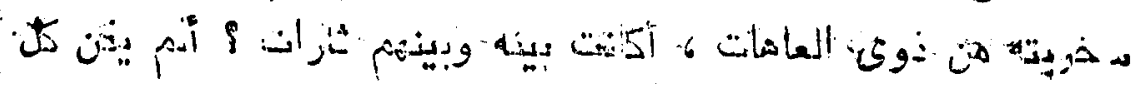

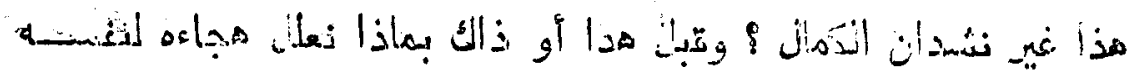

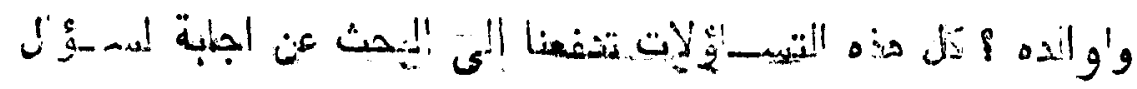

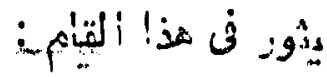

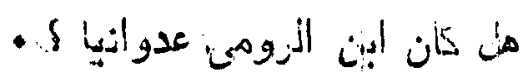

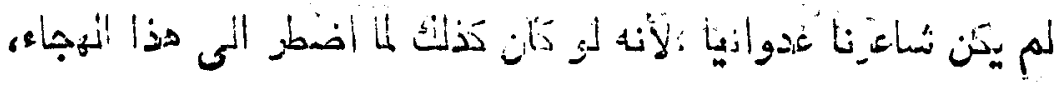

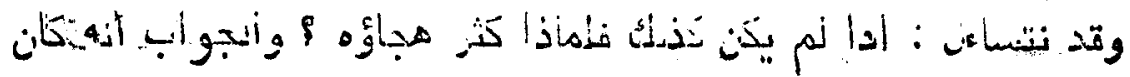

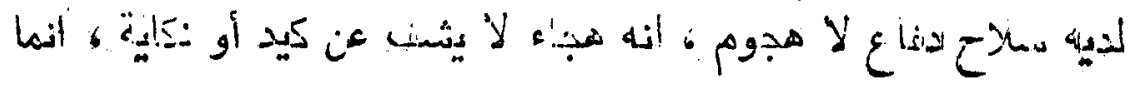

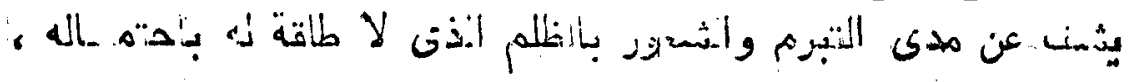

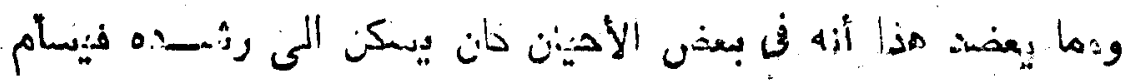

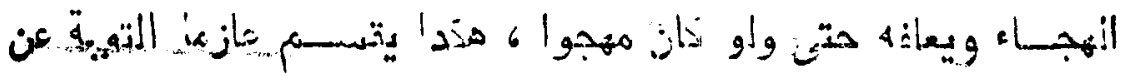

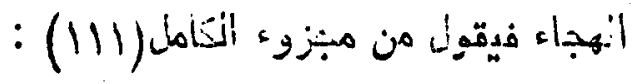

71 )

• roog/7 (111) 
IA

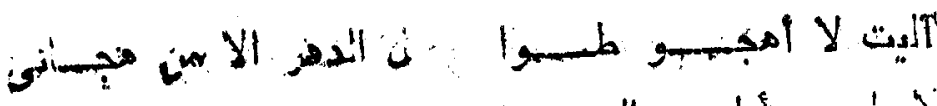

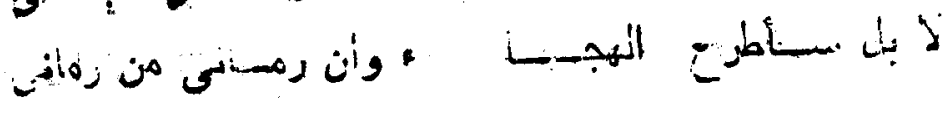

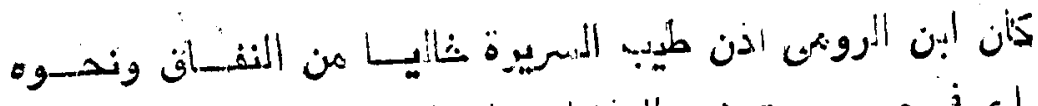

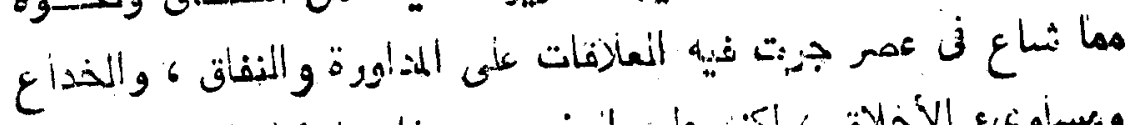

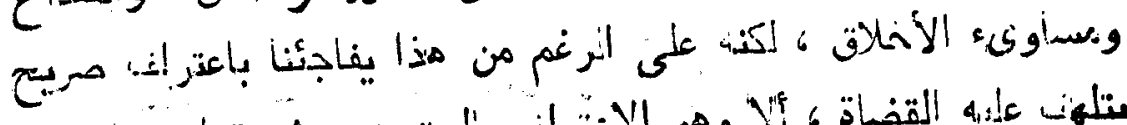

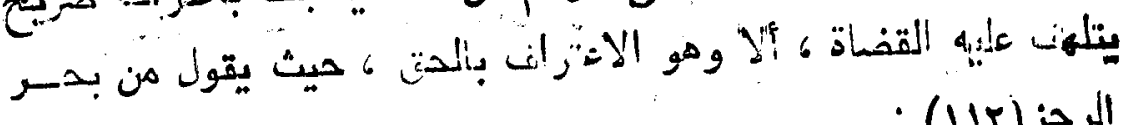

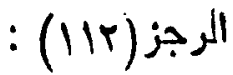

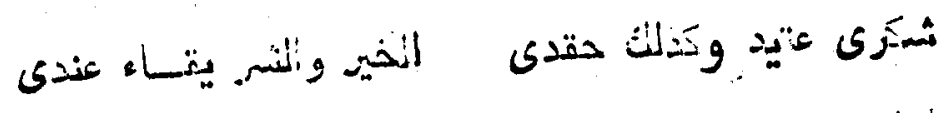

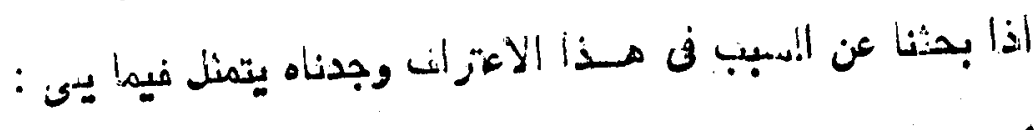

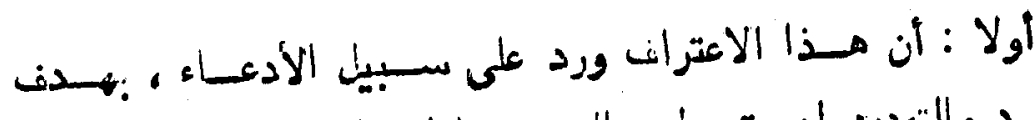

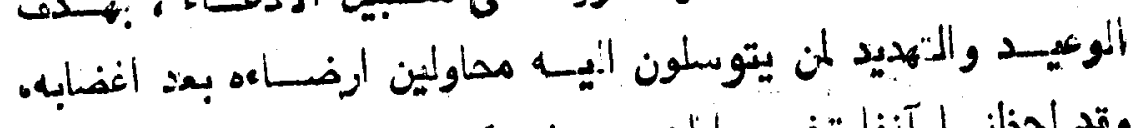

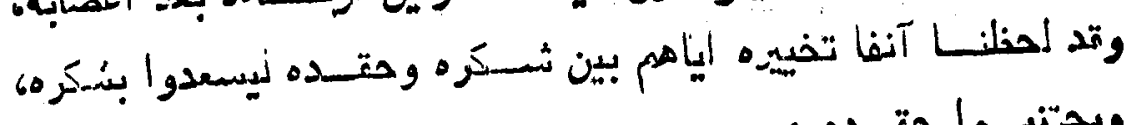

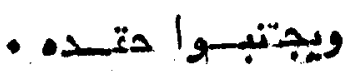

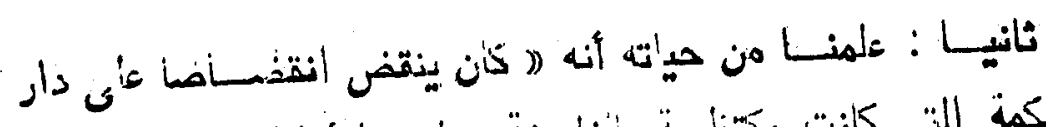

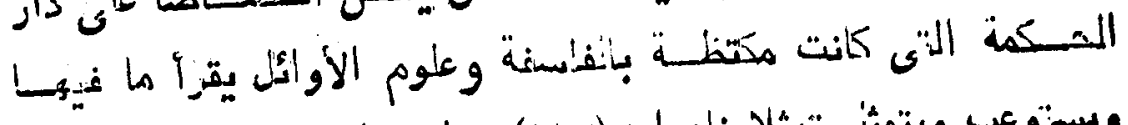

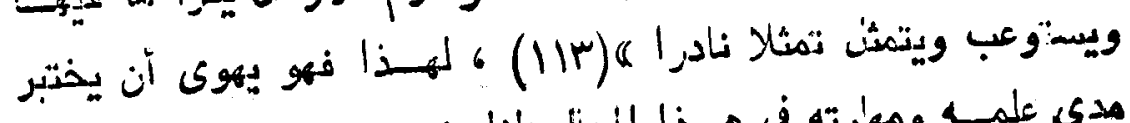

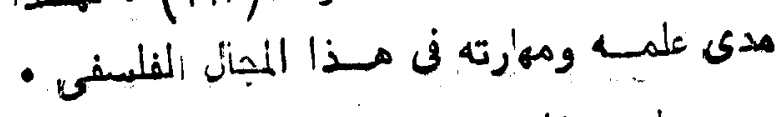

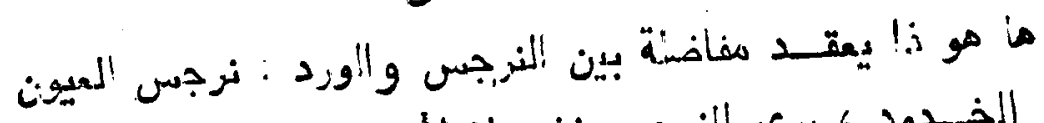

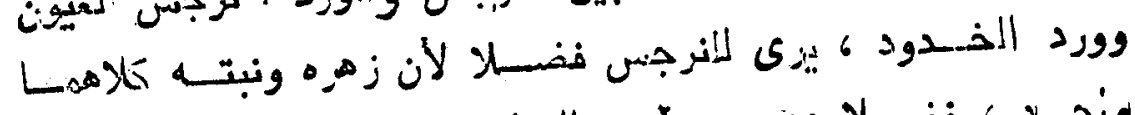

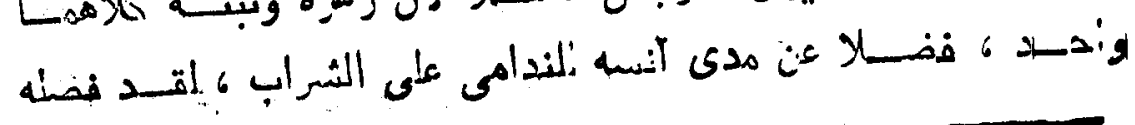

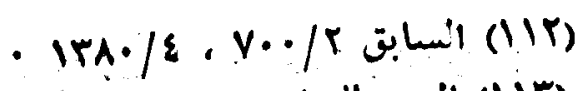

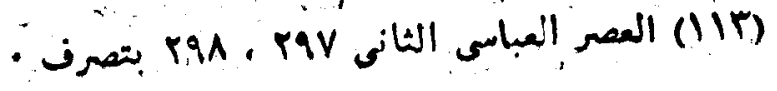




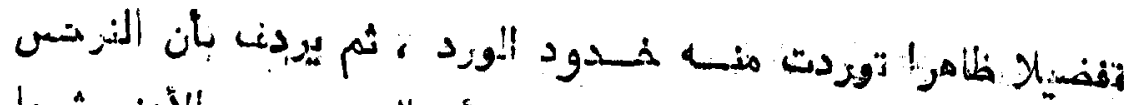

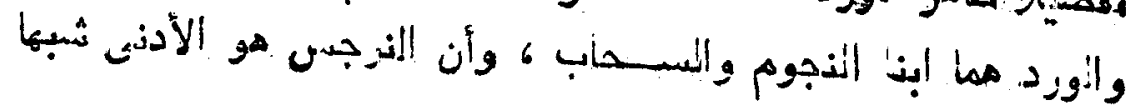

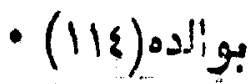

توما نلحفنه يمبدح الفقد فيقون من بحر الطويل/110) :

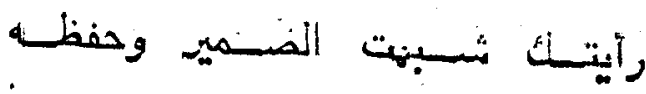

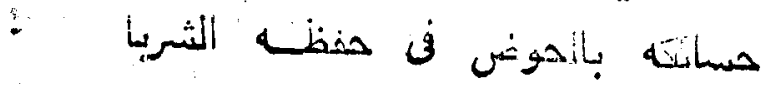

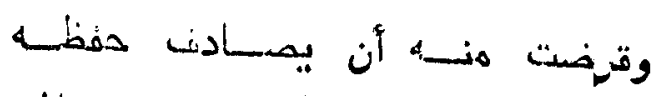

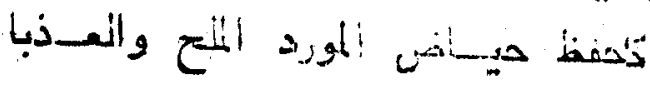

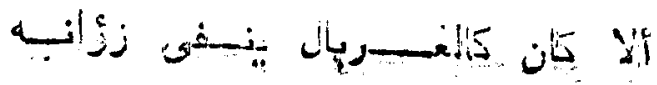

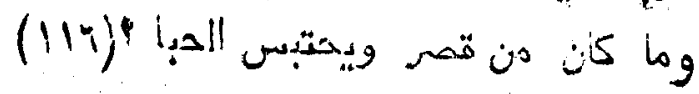

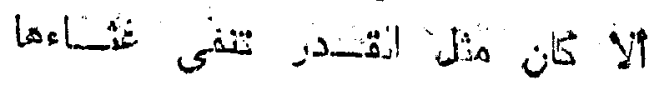

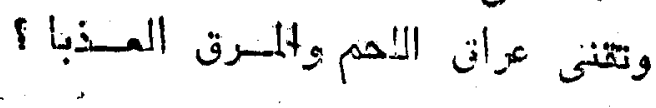

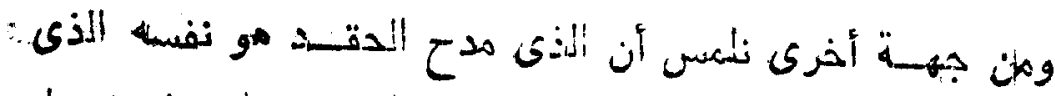

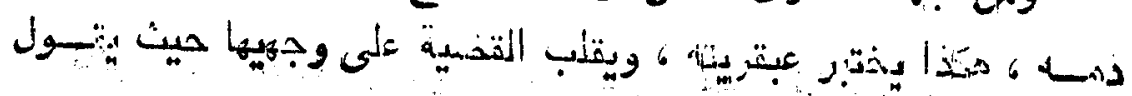

:")

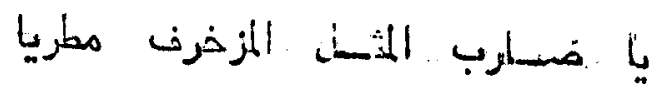

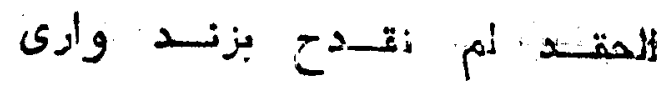

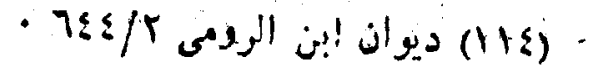

- INVjI: illo)

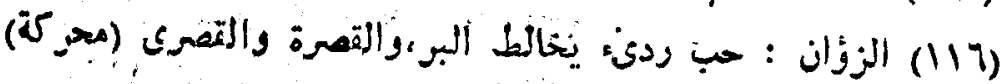

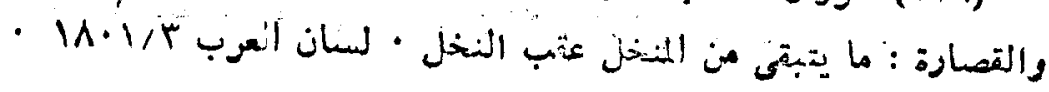


Nis

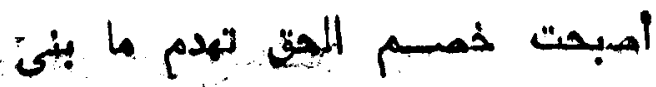

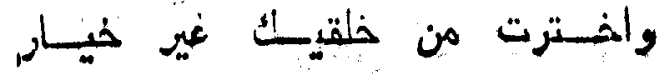

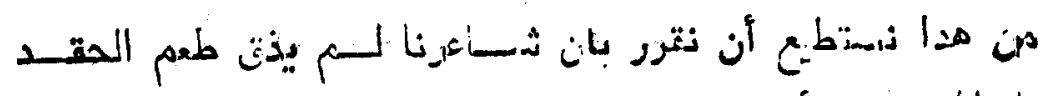

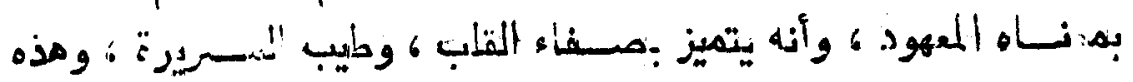

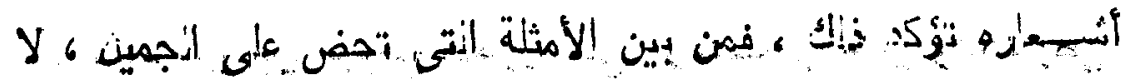

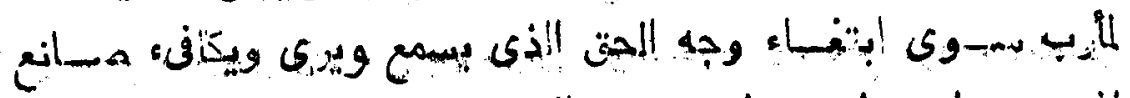

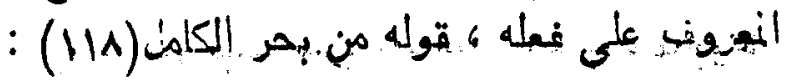

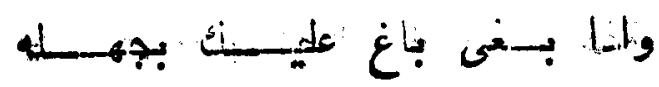

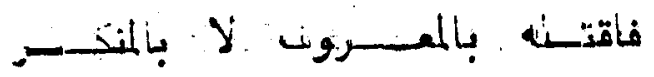

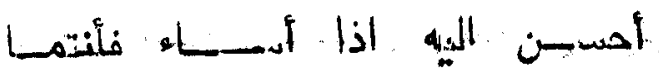

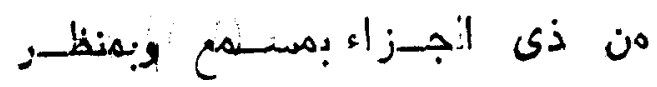

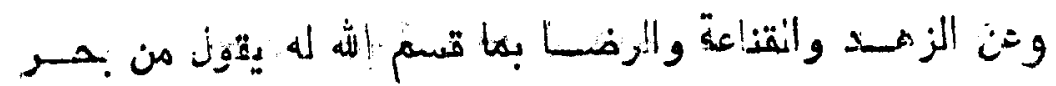

: الرجه-ز (119)

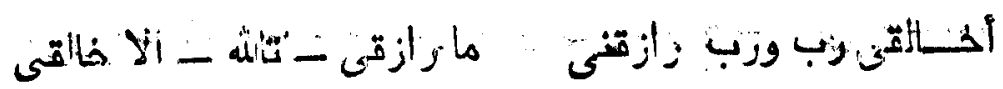

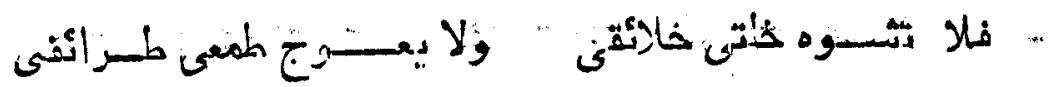

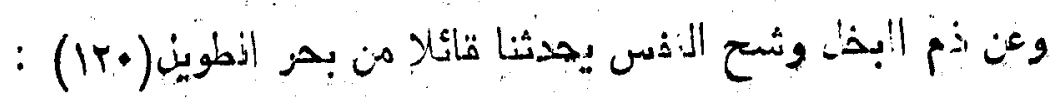

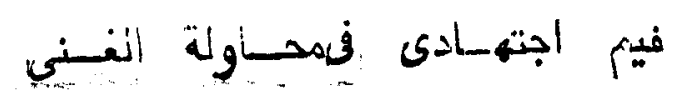

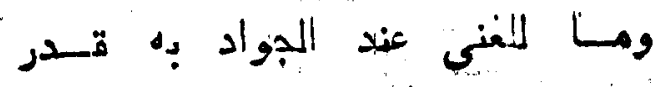

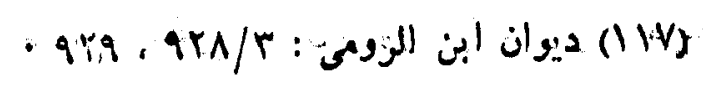

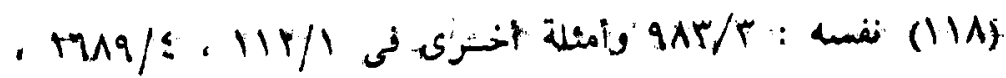

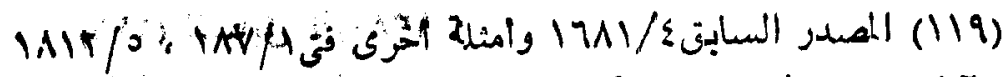

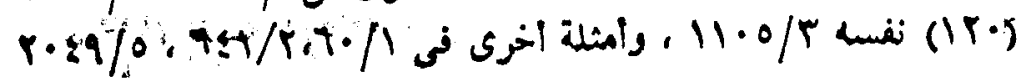




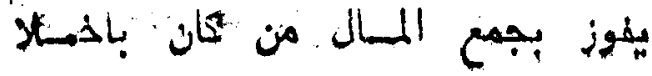

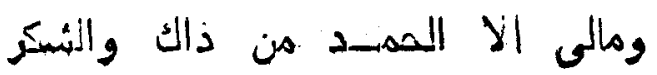

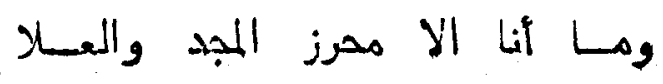

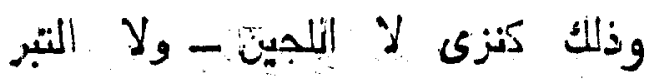

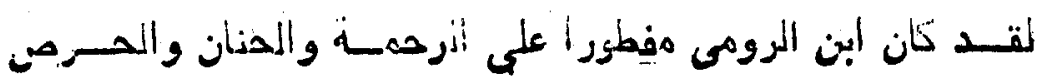

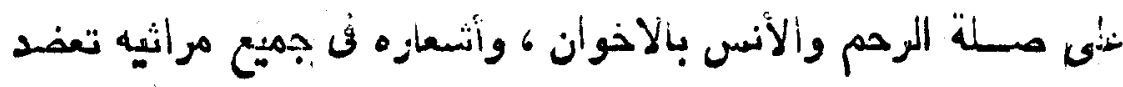

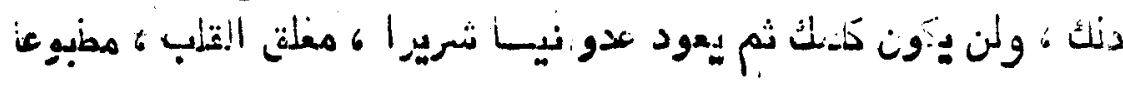

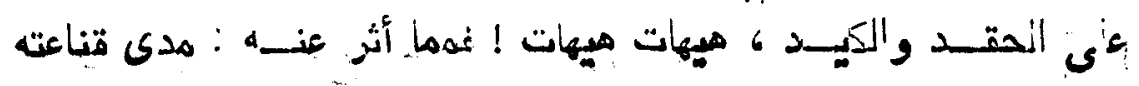

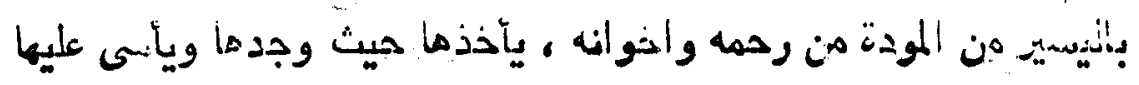

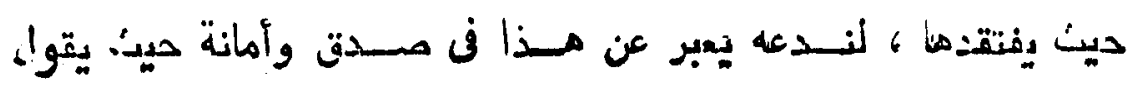

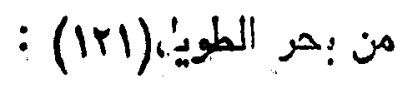

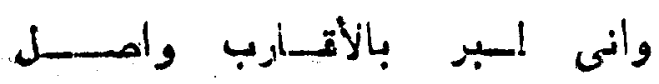

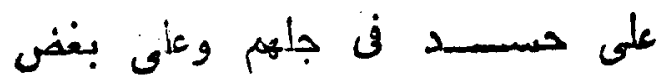

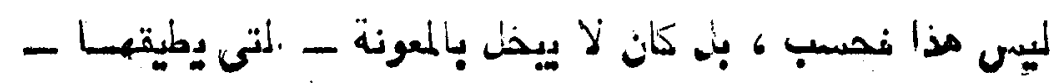

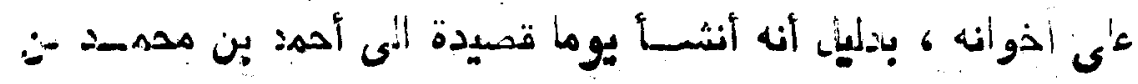

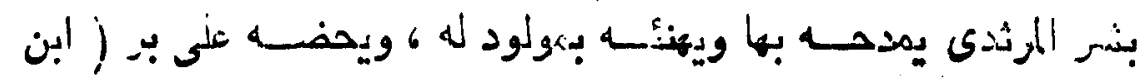

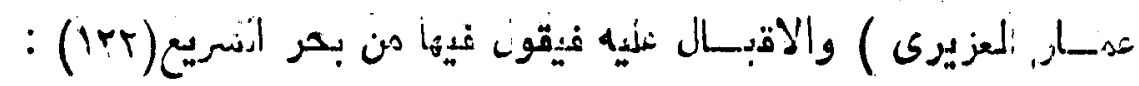

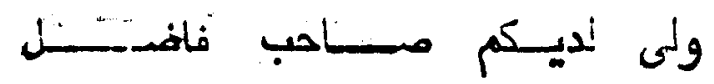

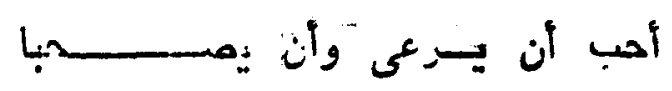

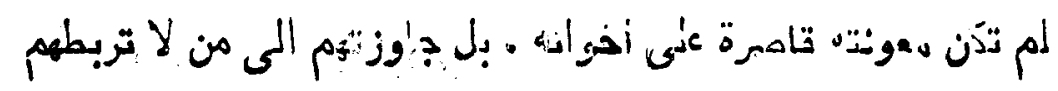

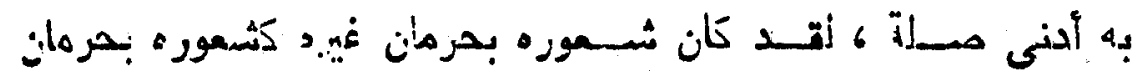

• IrA•/2 السابق (IFI)

- rrop/l (Irr). 


\section{IAV}

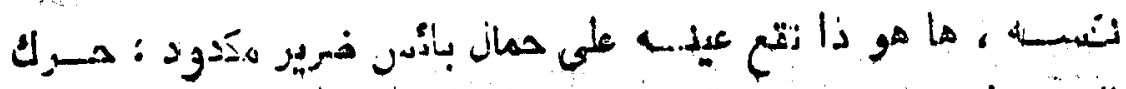

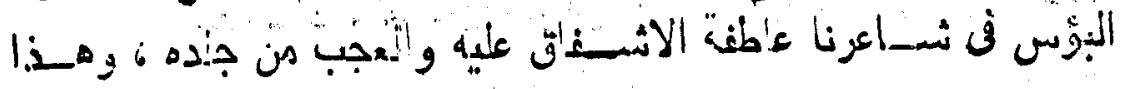

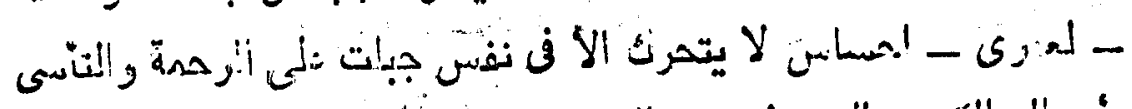

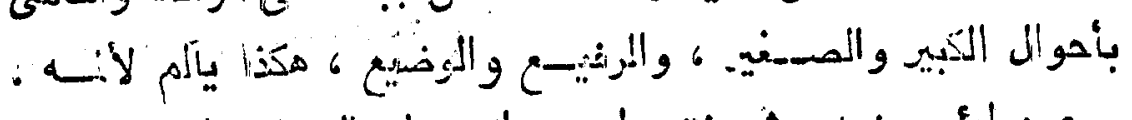

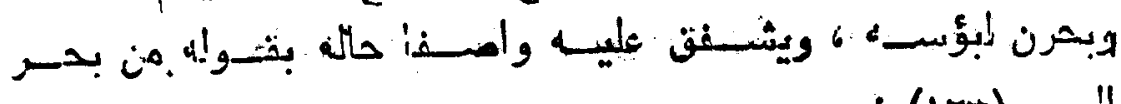
: (Irr)

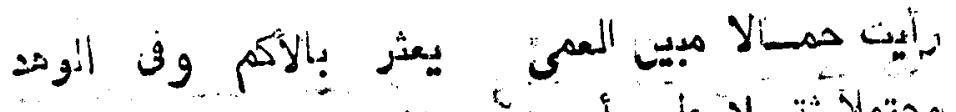

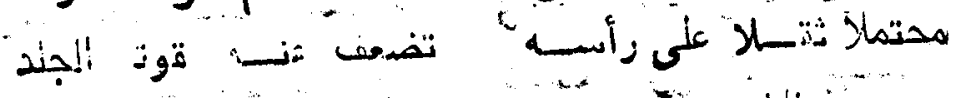

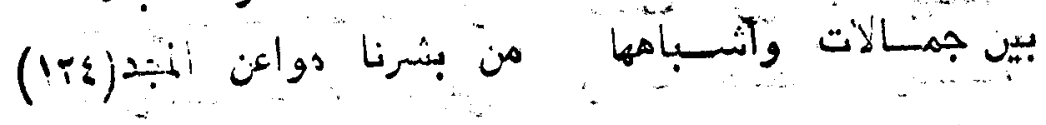
أنز أن قا!

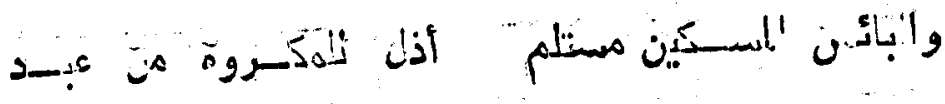

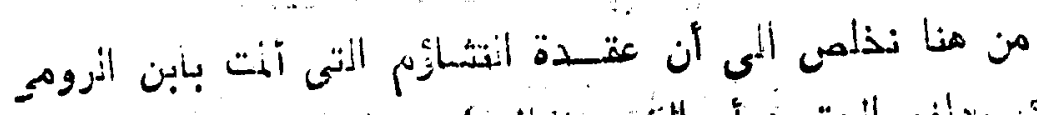

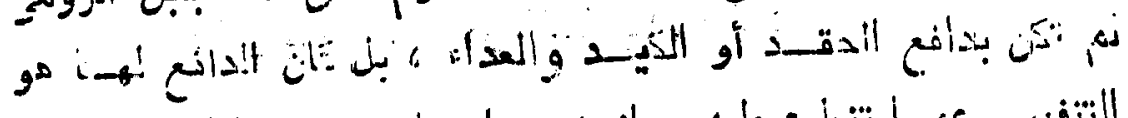

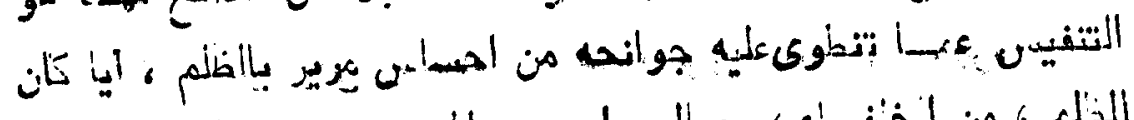

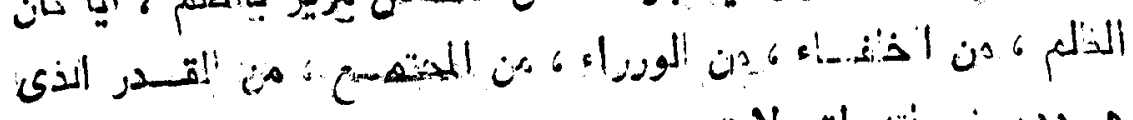

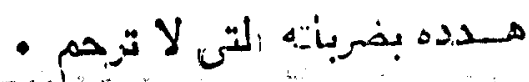

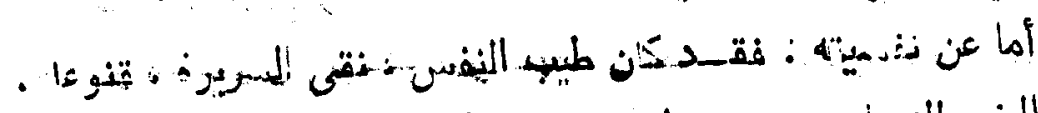

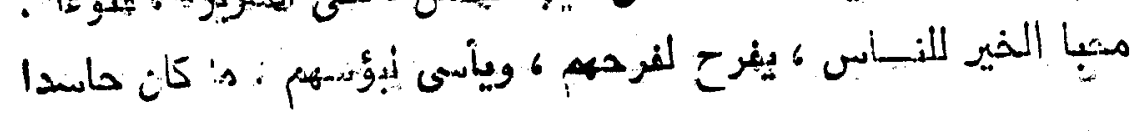

$$
\text { • }
$$

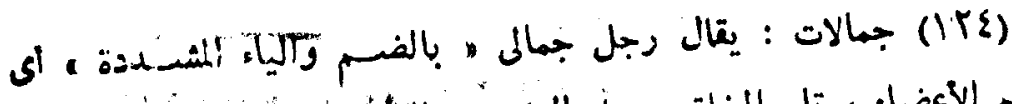

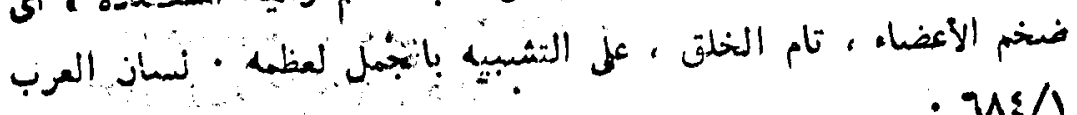


IM

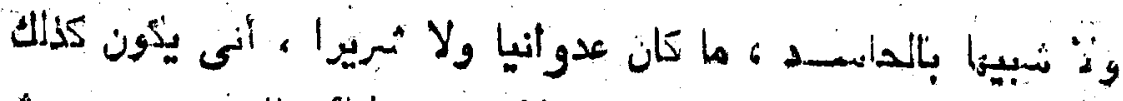

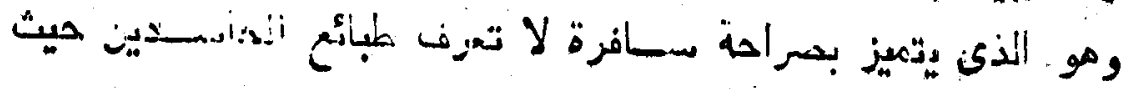

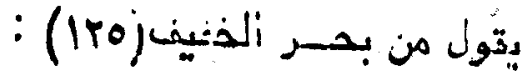

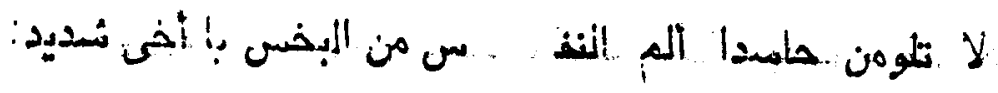

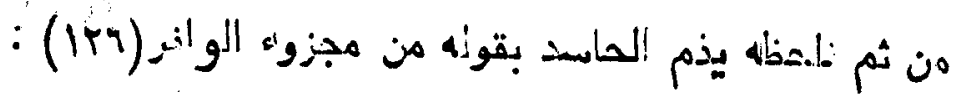

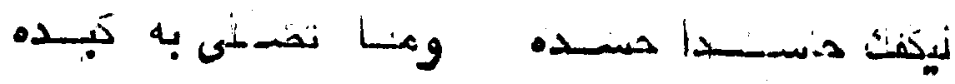

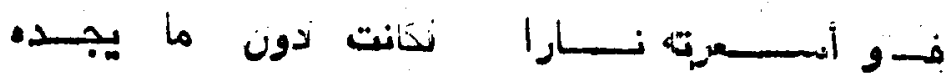

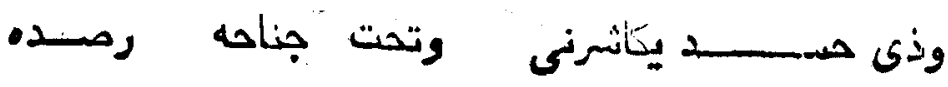

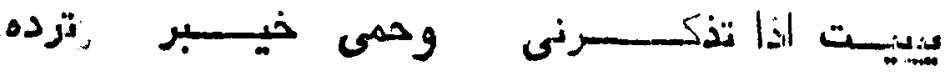

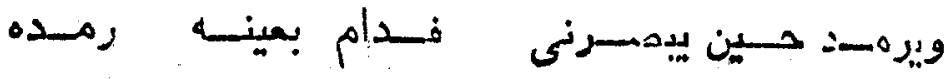

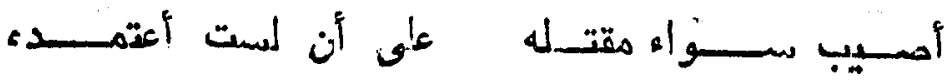
ويذم المنافق بقوله من بحر المتقارب(Irv) :

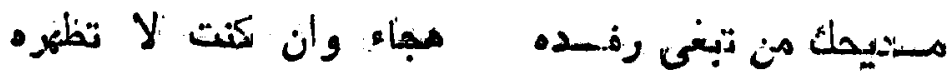

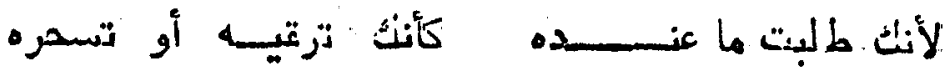

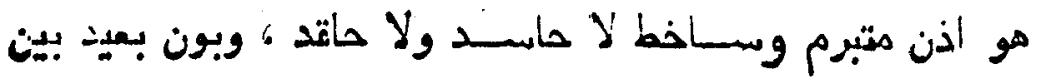

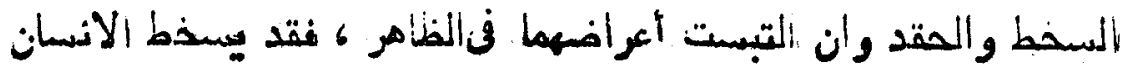
متبرما ضجبرا من كن ما يحيسط به بسبب الأتعـدار وضرباتها : اكن.

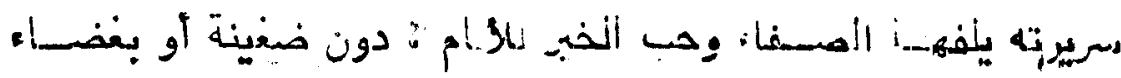

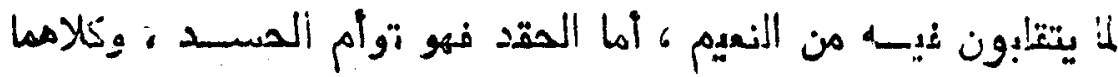

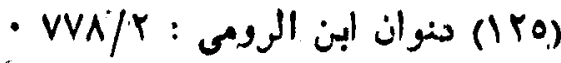

$$
\begin{aligned}
& \text { - TVo, TVE/R S (IYT) }
\end{aligned}
$$

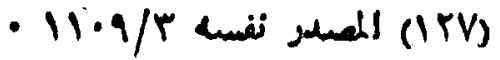




\section{4}

يعنى تهنى زولـ النعهـلة ممن أذنم الخالق عليه عداء وبنضا ، وكر اهية

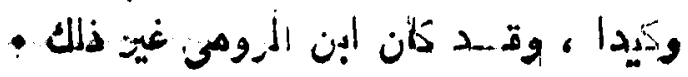

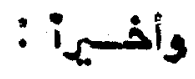

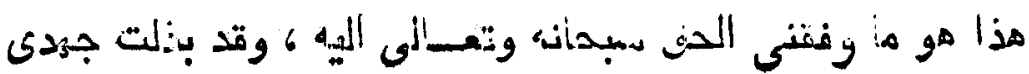

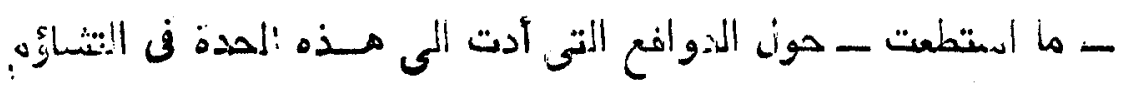

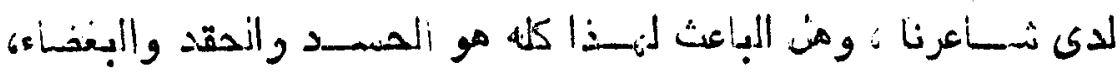

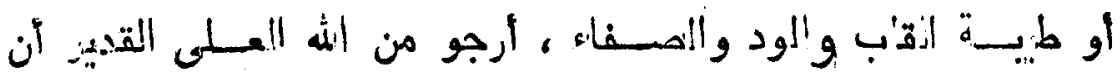

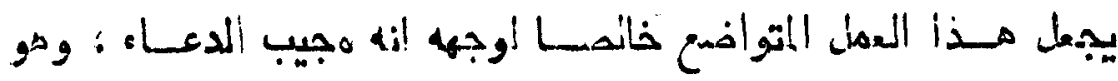

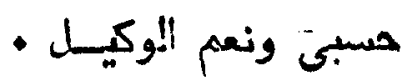

$$
\begin{aligned}
& \text { دكت }
\end{aligned}
$$

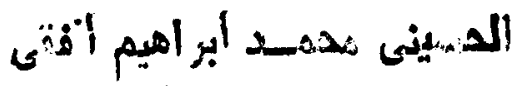

$$
\begin{aligned}
& \text { م:رس بقدم الأدب والانتــد } \\
& \text { كلية اللمنه المزبية بالزتازيق وتيق }
\end{aligned}
$$




\section{ثبت المهمسـادر}

1

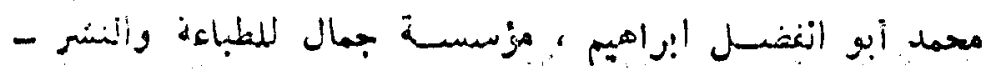

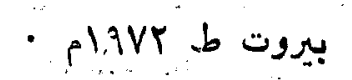

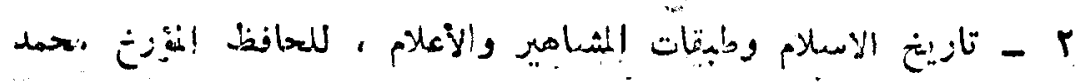

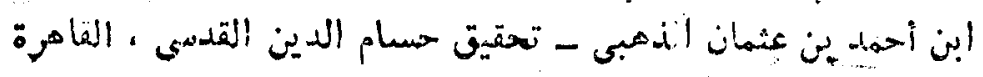

$$
\therefore \text { igvo b }
$$

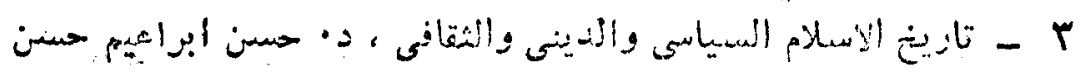

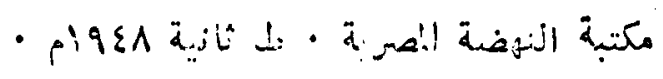

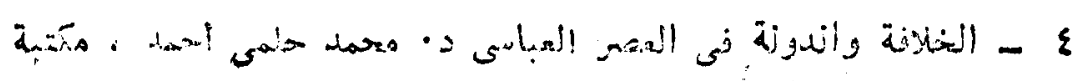

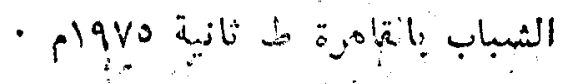

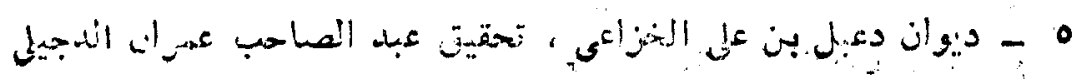

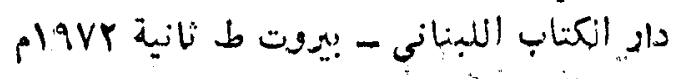

7

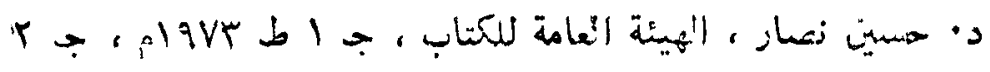

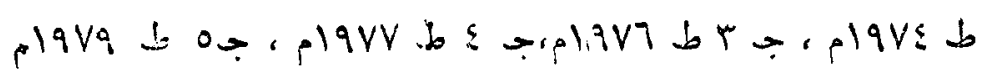

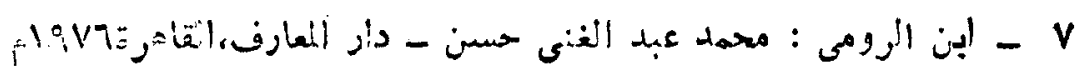

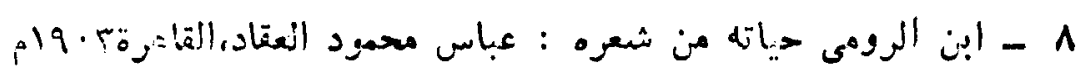

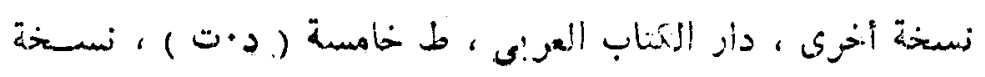

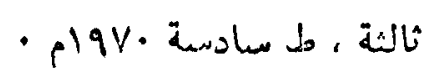

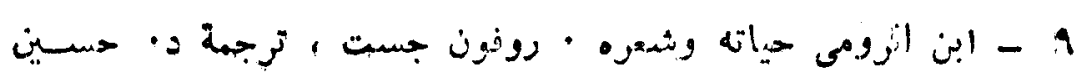

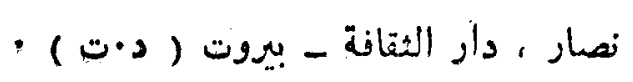

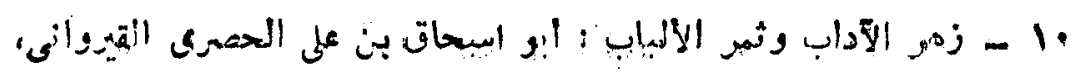

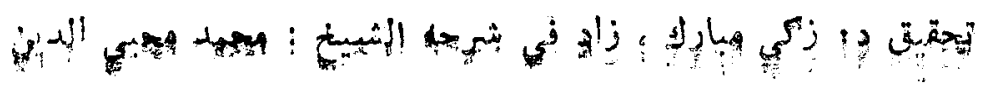




\section{(a)}

عبد الحميد ، نشر مكتبة المحتسب - عمان ، دار الجيل - بيروت

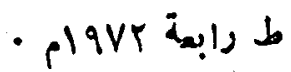

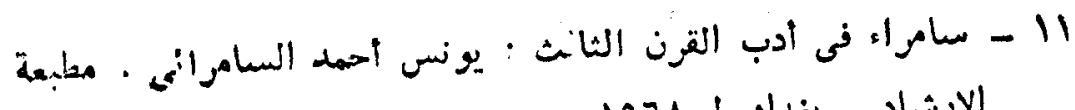

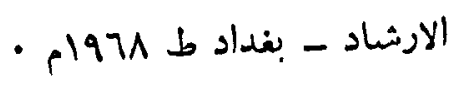

r ا - سنن الترمذى وهو الجامع الصحيح للامام الحافظ أبى عيسى

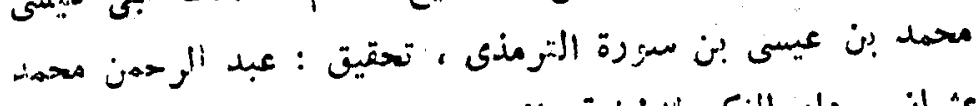

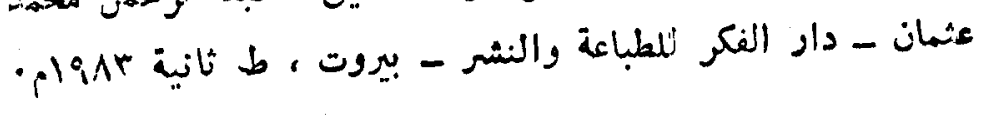

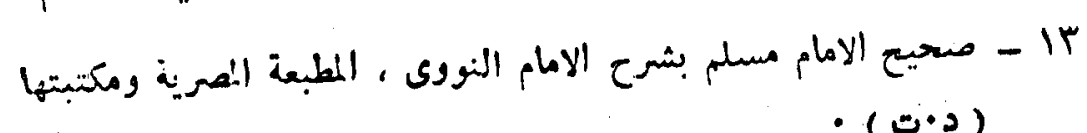
- $(\infty+3)$

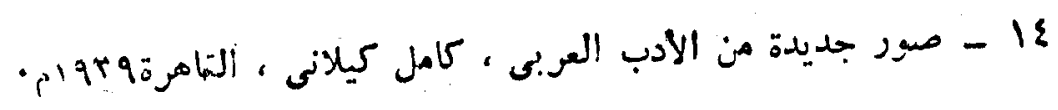

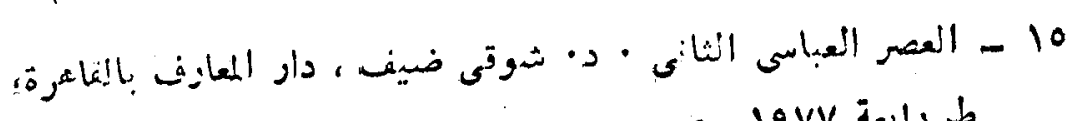

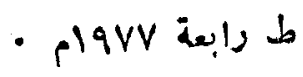

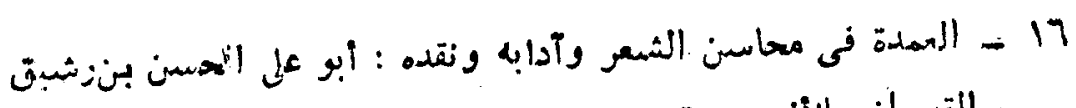

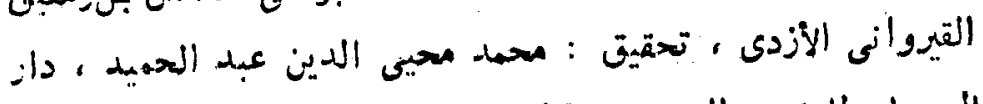

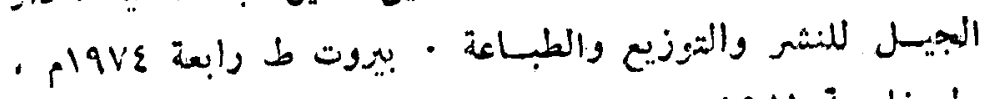

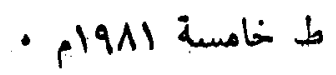

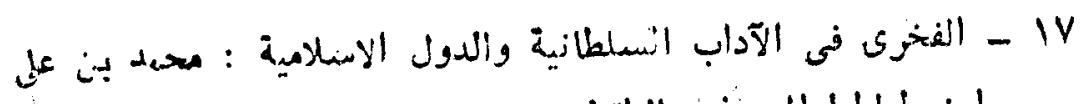

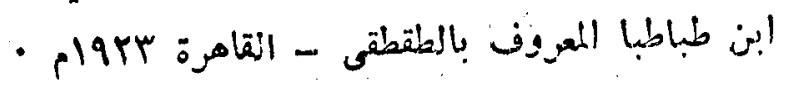

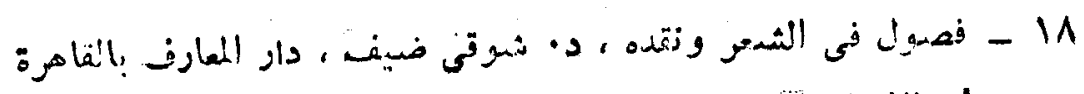
p plavl

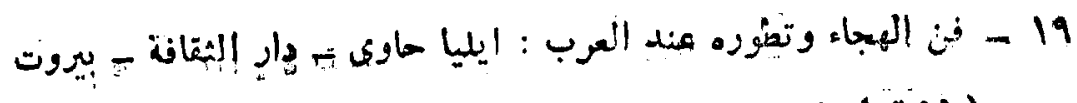

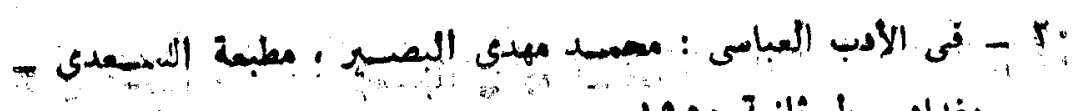

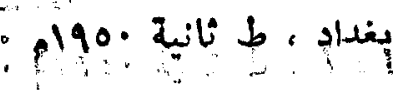




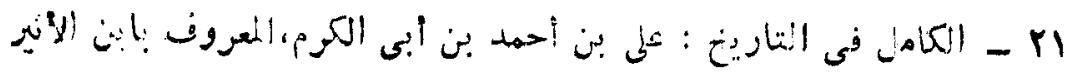

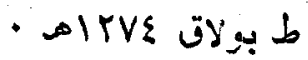

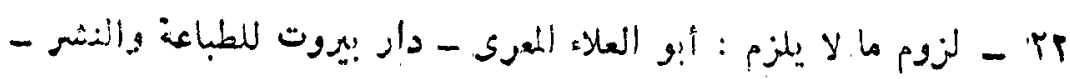

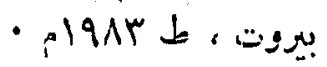

rا - لسان أعرب : جمال الدين بن منظير ، تهقيق : عبد ائه على انكبير

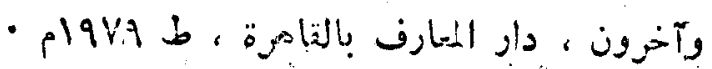

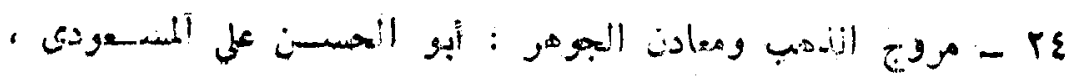

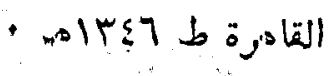

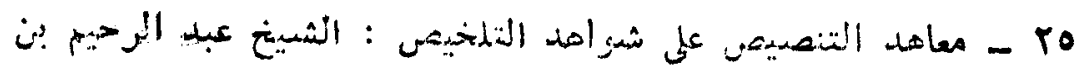

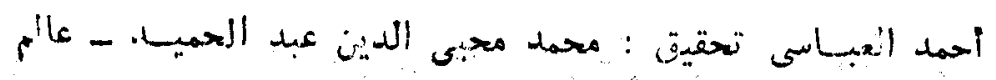

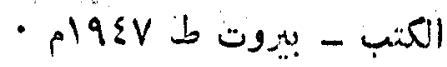

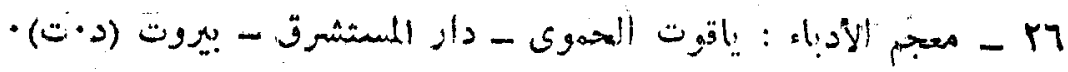

- PV

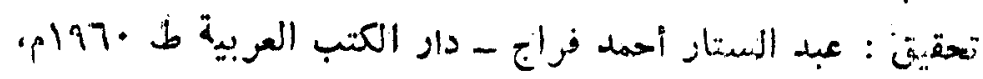

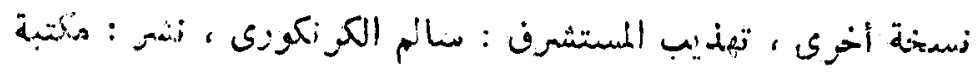

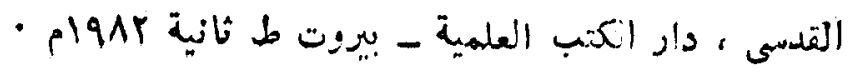

T1 - من حديث انشعر والنثر : طه هسين - دار المعازف بالقاهرة ،

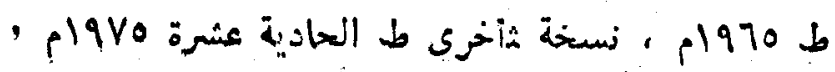

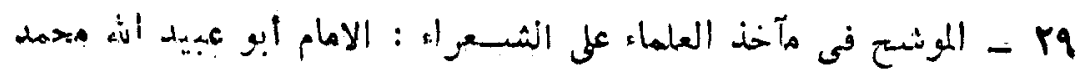

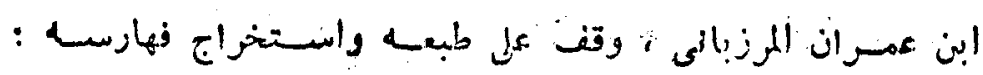

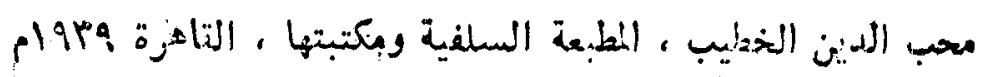

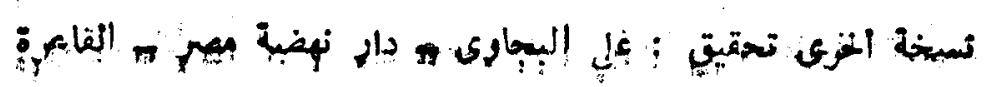
ip plage t 


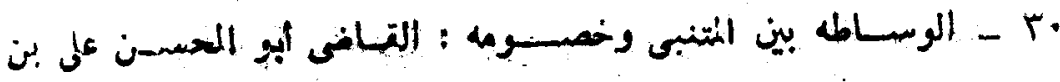

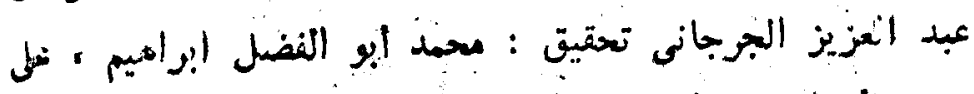

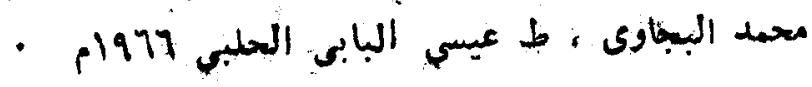

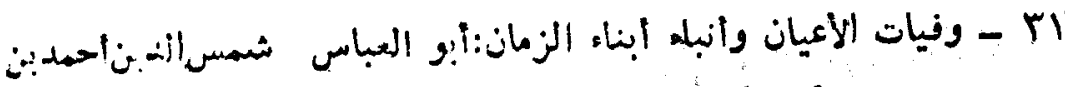

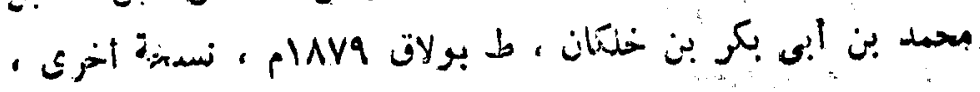

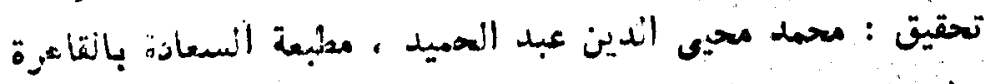

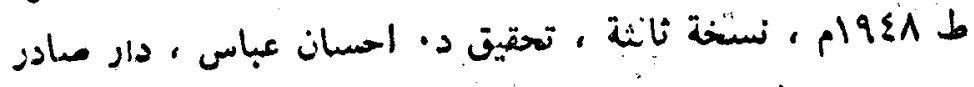
- ميروت ، ط ل

ذكموز ألحسميني معمد ابي اهبم

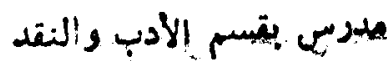

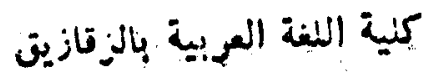




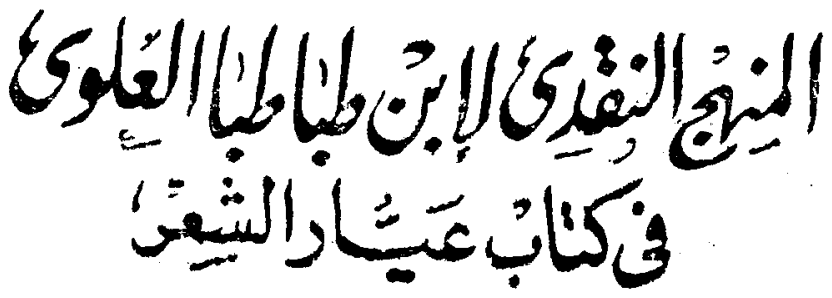

د/ عاطف =بد الإنيف ألسيد

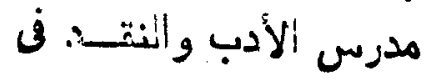

كايه النغة النعربية بالزتنزيق

الفعـل التول

\section{ابن طباط ! أنيبـا وناقـــا :}

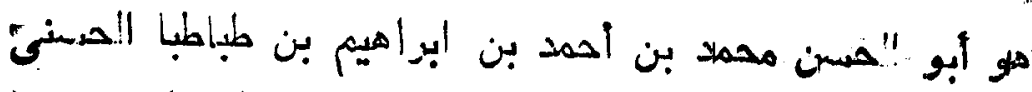

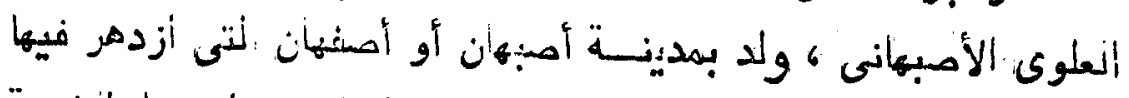

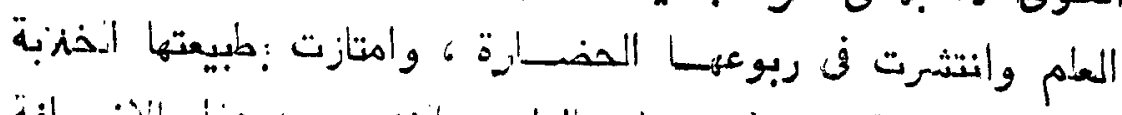

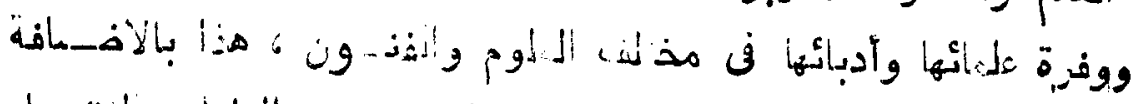

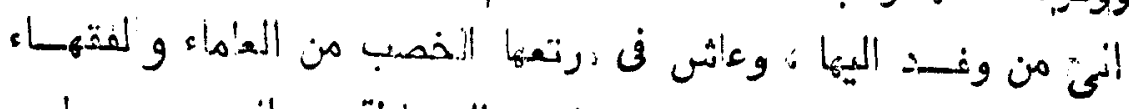

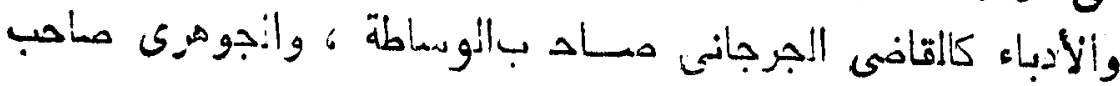

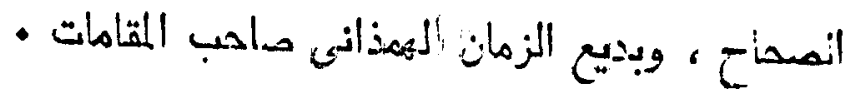

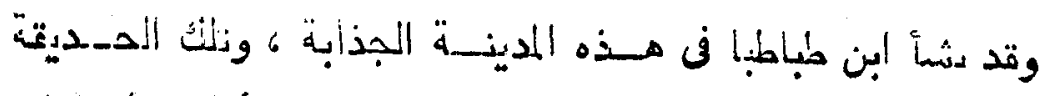

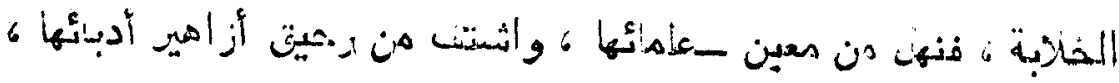

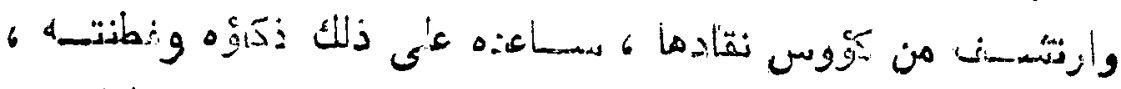

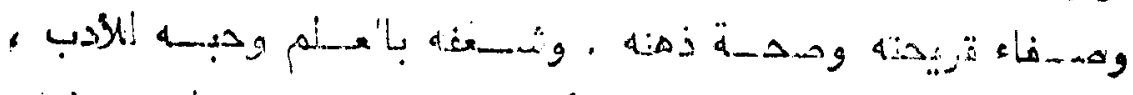

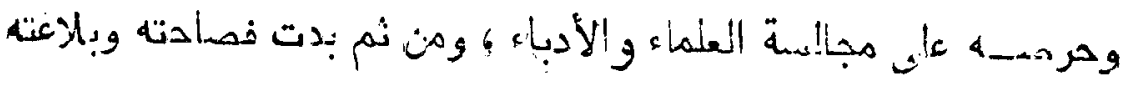

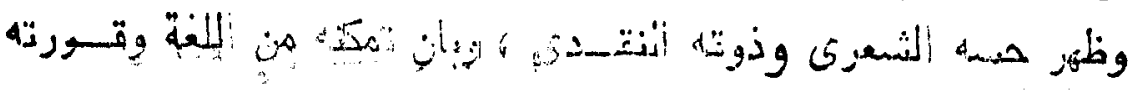

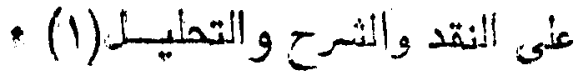

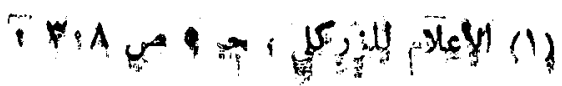




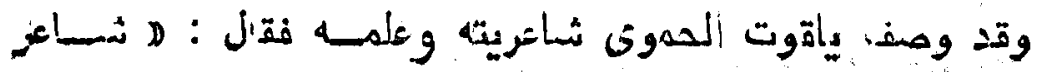

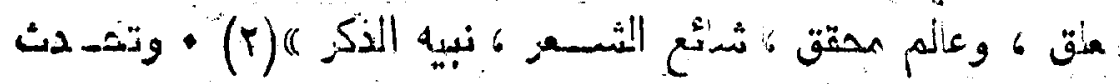

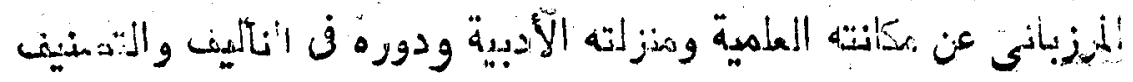

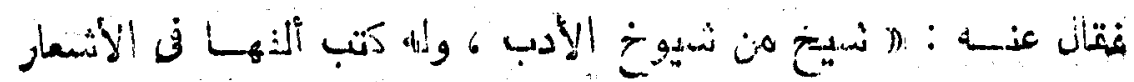

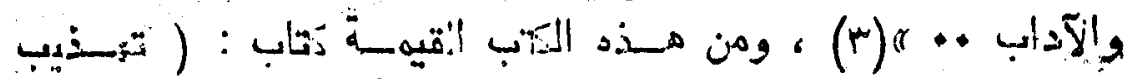

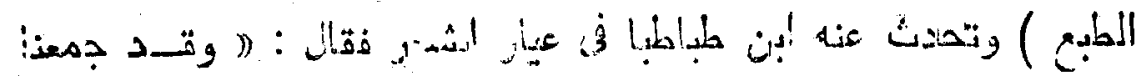

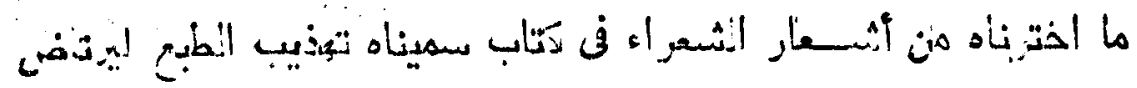

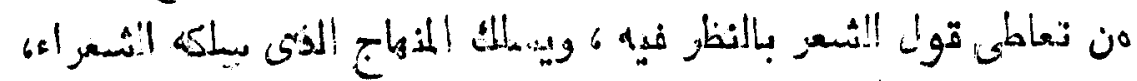

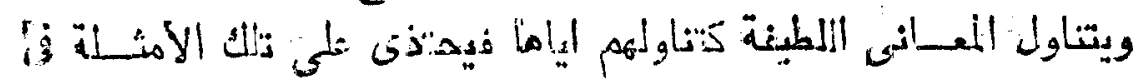

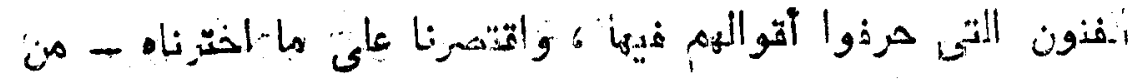

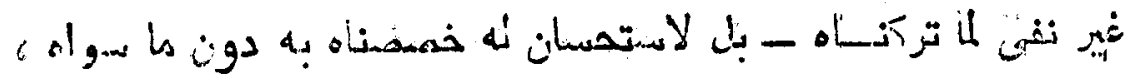

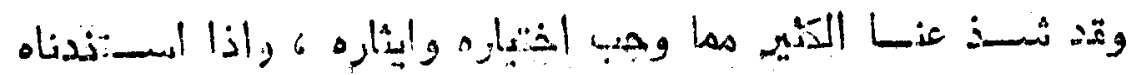

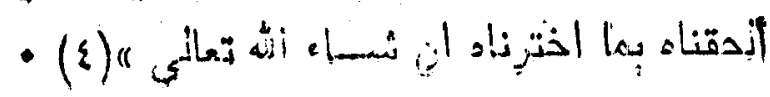

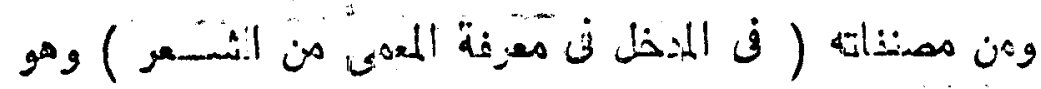

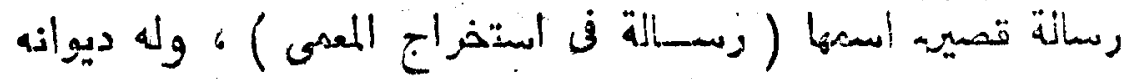

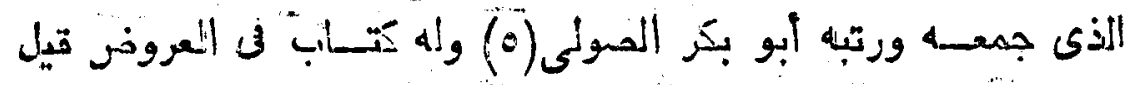

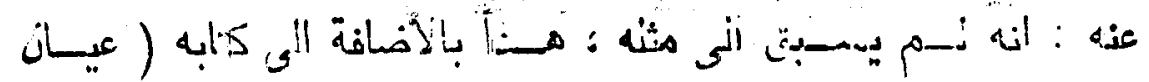

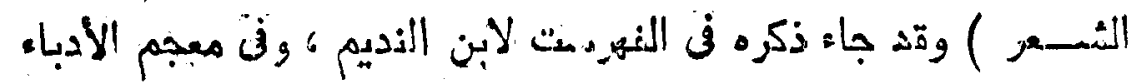

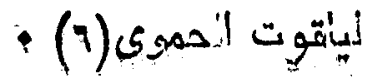

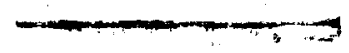

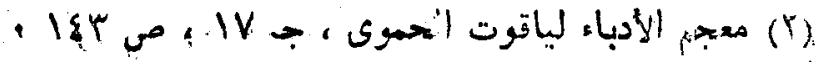

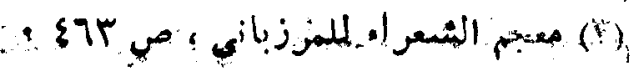

$$
\begin{aligned}
& \text { - 1) }
\end{aligned}
$$

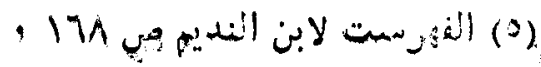

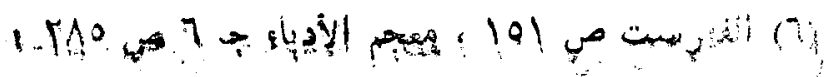




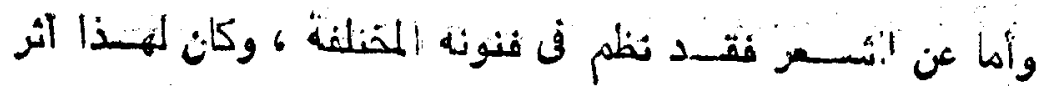

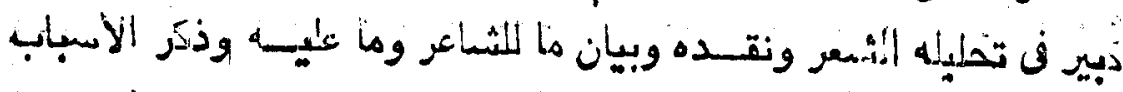

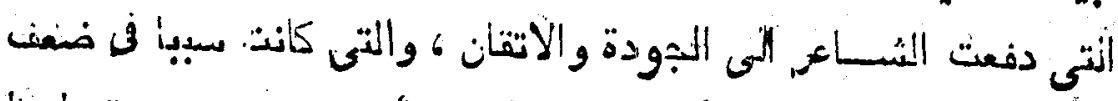

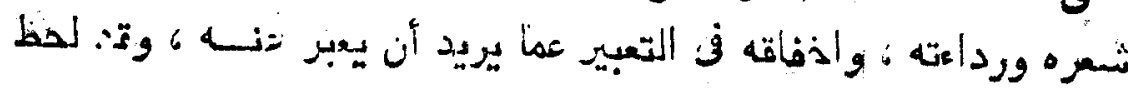

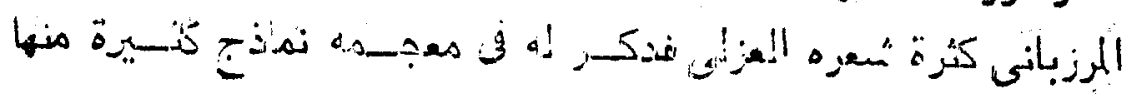

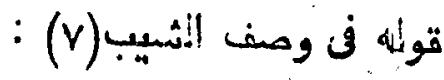

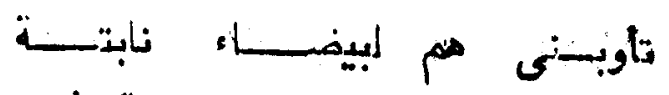

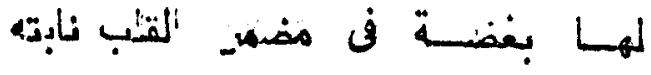

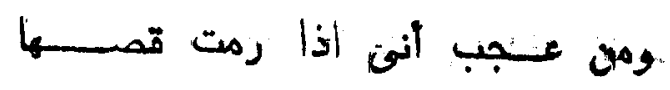

قمخت شسواها وهمي تفحك شماهته

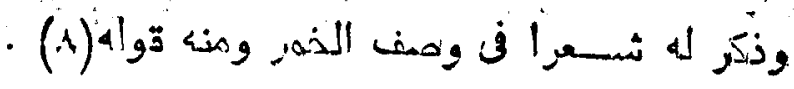

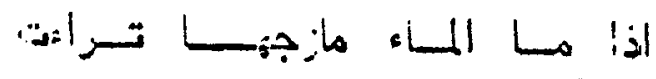

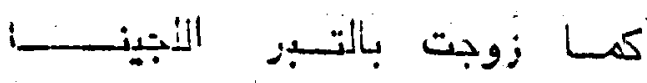

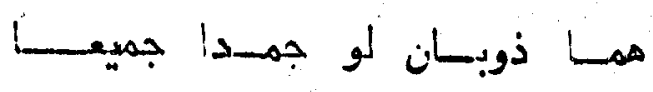

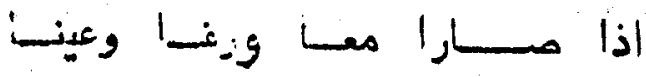

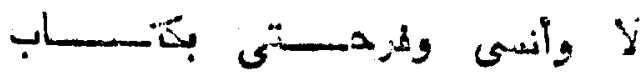

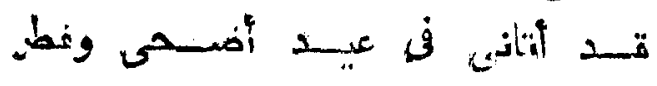

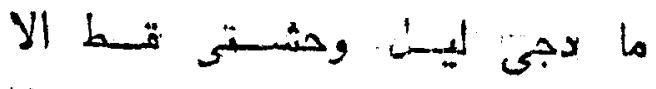

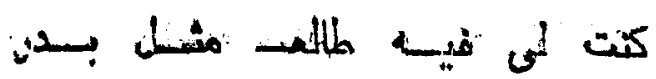

- (A.V) 


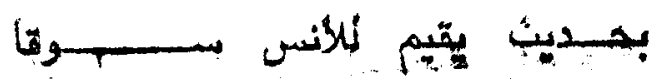

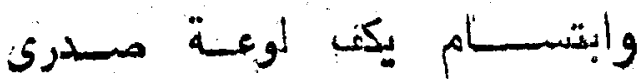

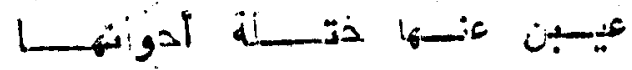

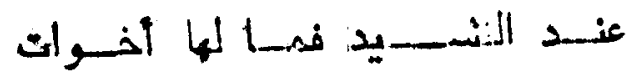

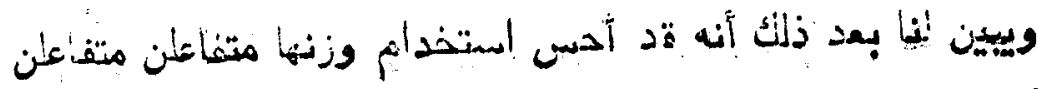

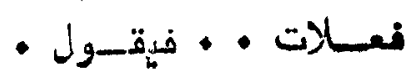

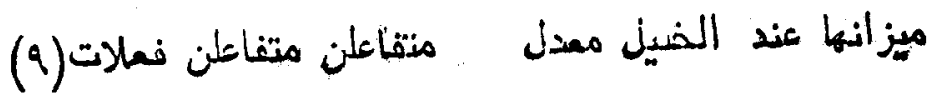

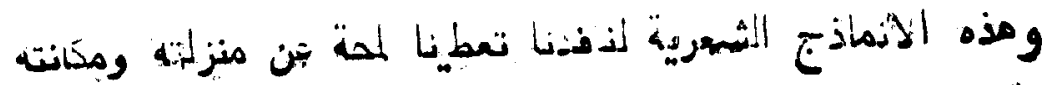

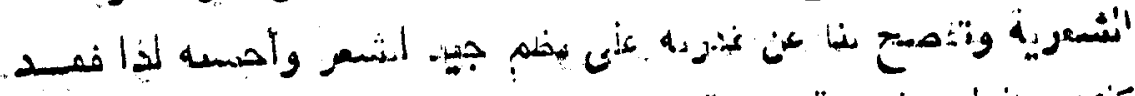

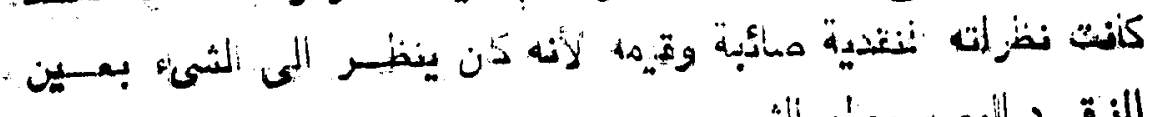

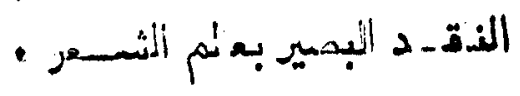

$$
\begin{aligned}
& \text { ونه بمسئ انقــلم }
\end{aligned}
$$

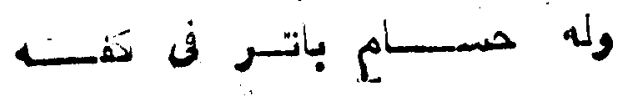

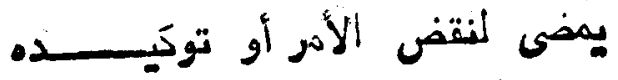

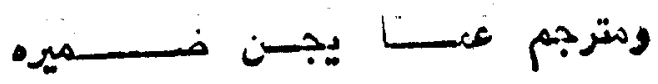

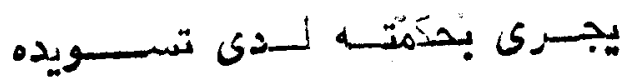

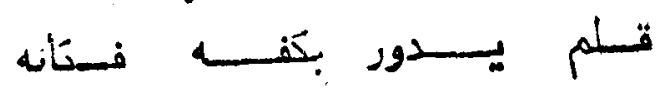

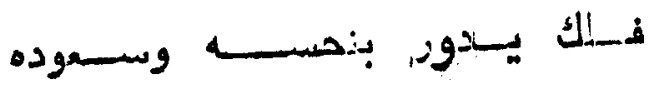

$$
\text { وله فن ومستف الفهـيد : }
$$

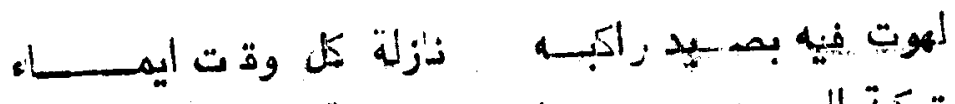

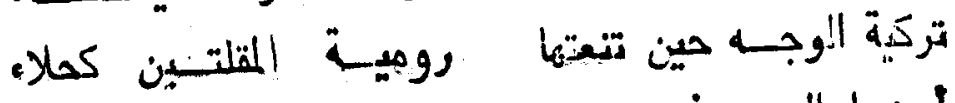

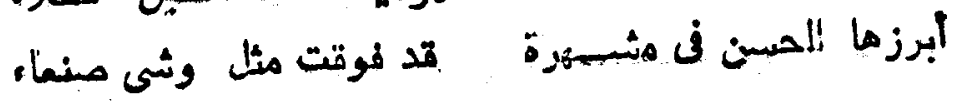

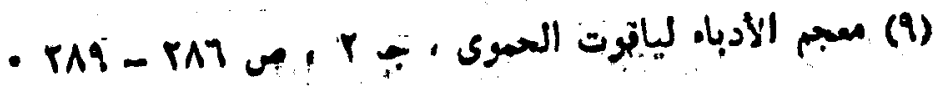




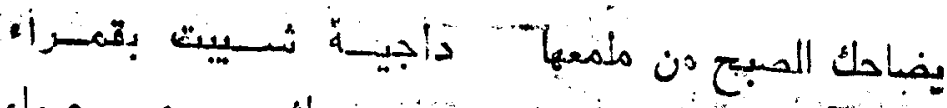

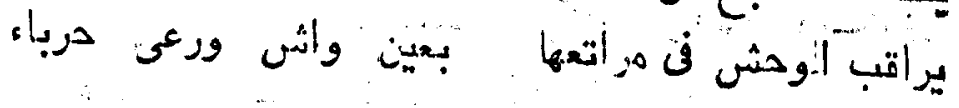

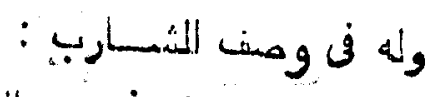

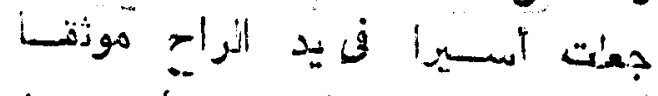

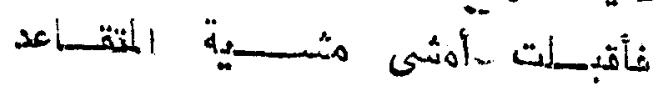
a.e.

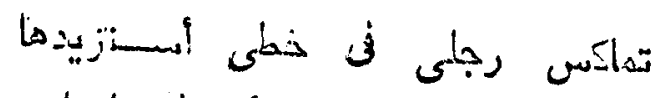

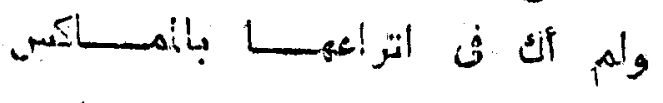

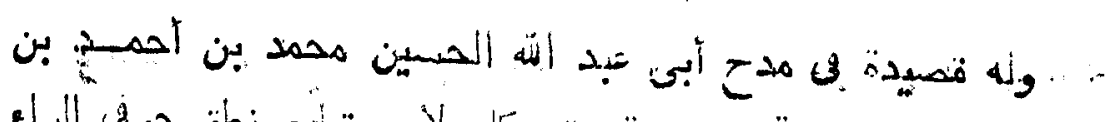

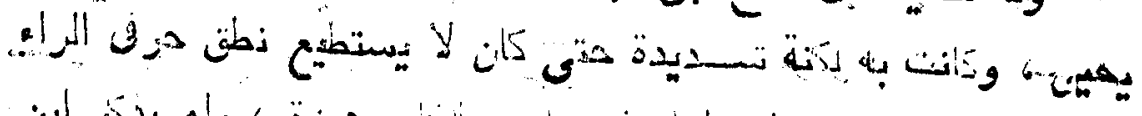

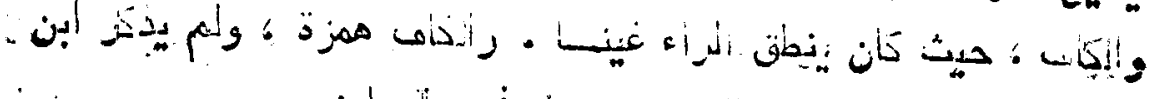

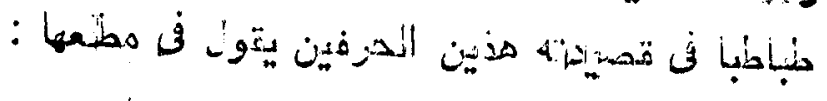
:

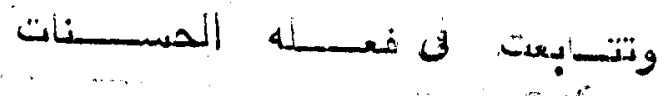

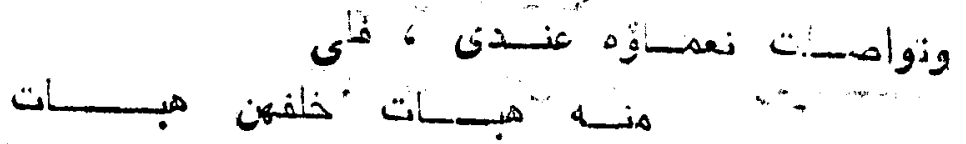

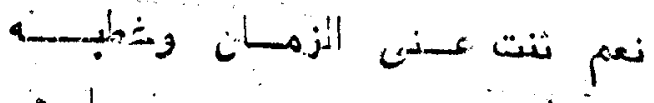

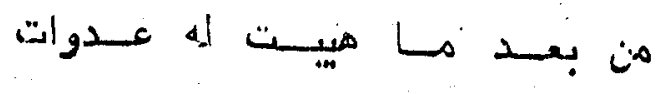
فأنلت

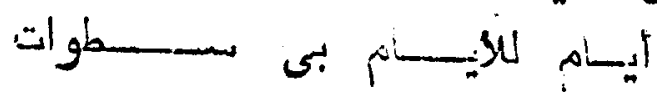

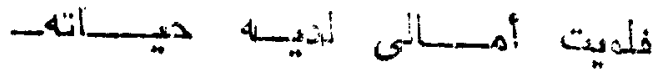

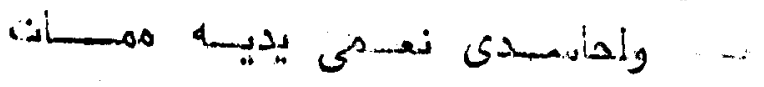

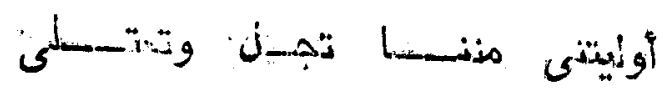

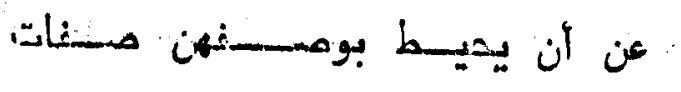

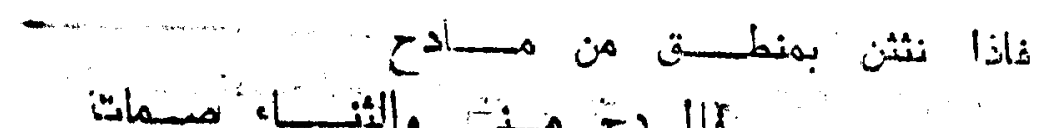

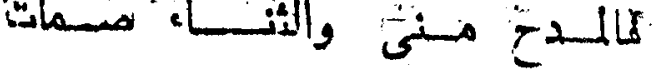


194

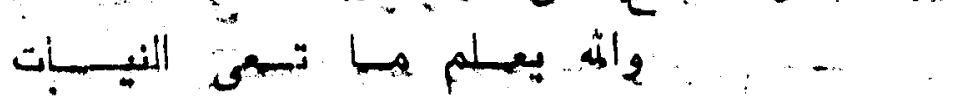

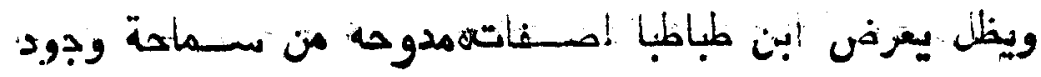

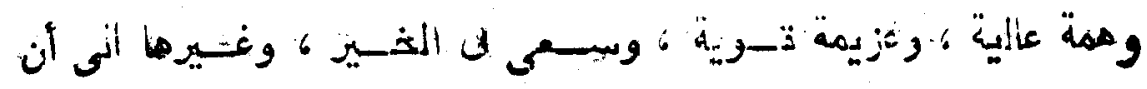

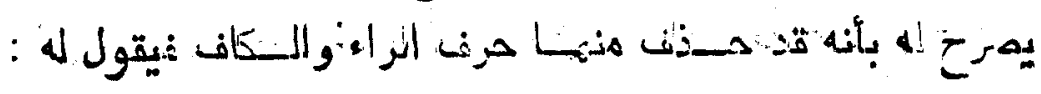

$$
\text { خـذهنا الإغـداة أبا الصسن قمسيدة }
$$

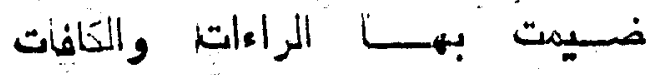

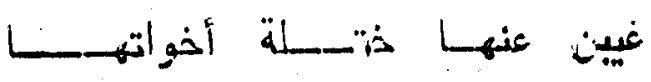

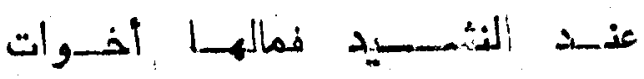

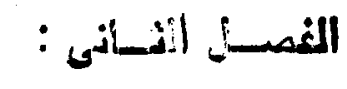

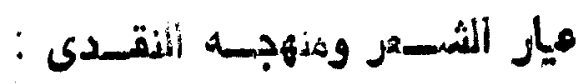

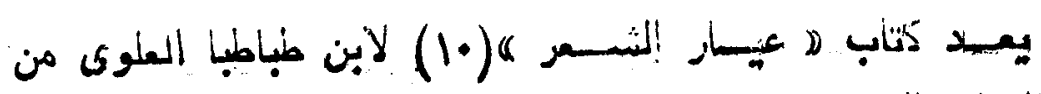

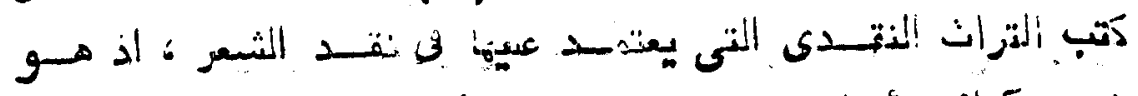

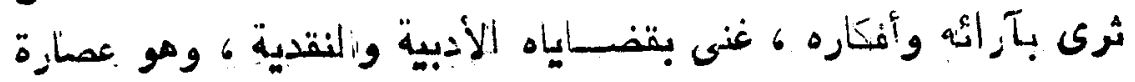

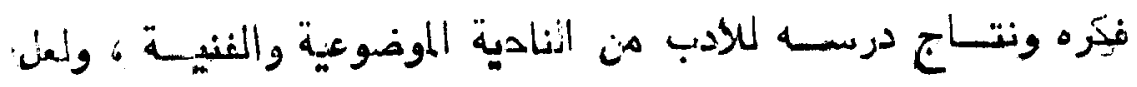

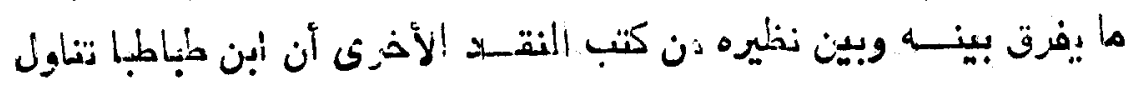

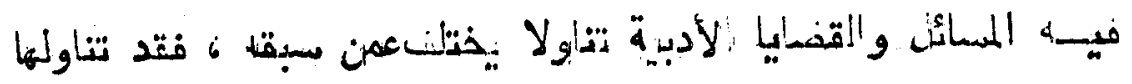

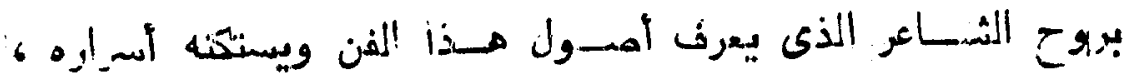

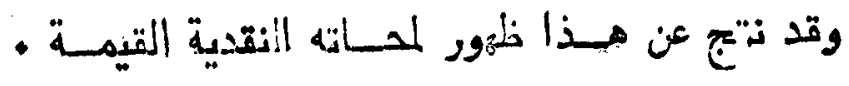

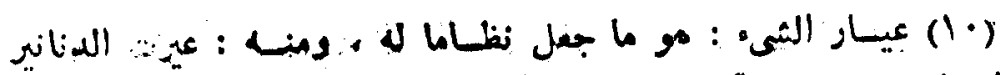

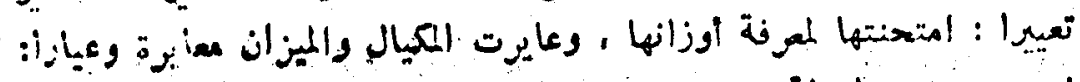

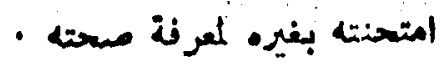




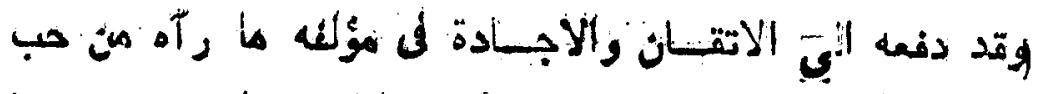

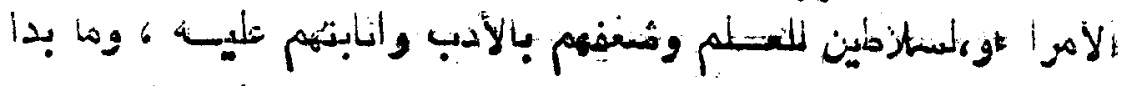

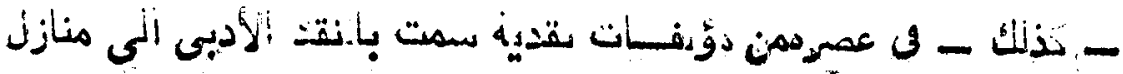

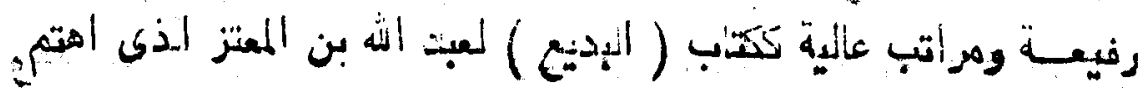

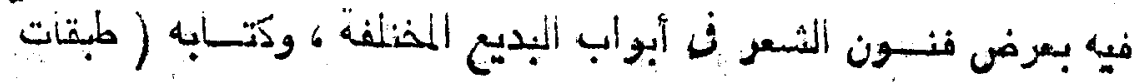

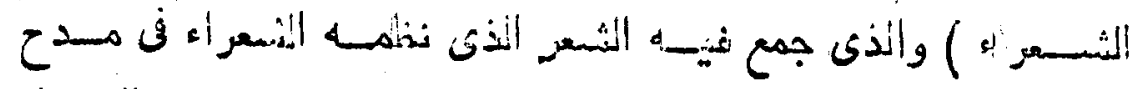

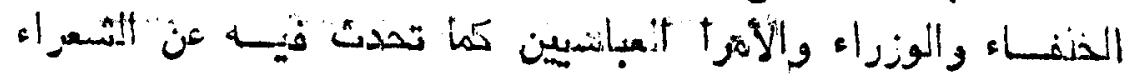

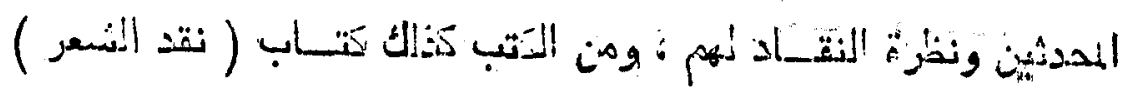

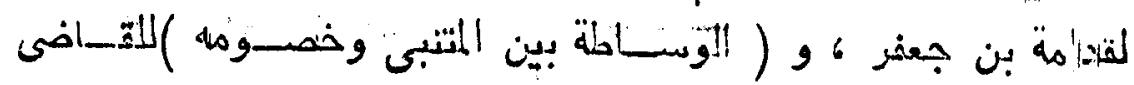

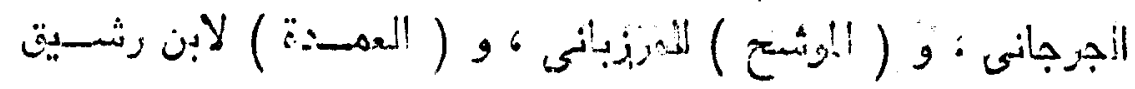

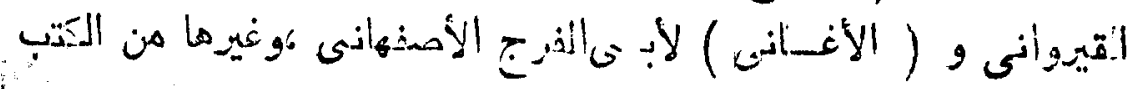

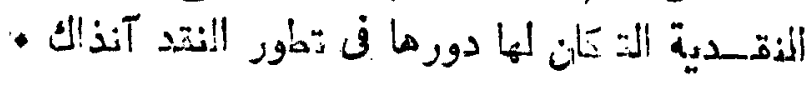

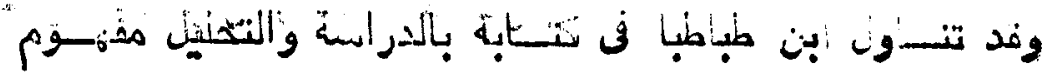

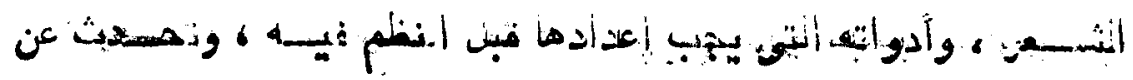

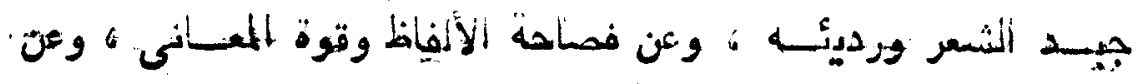

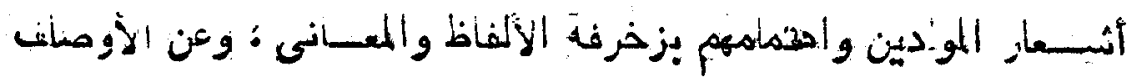

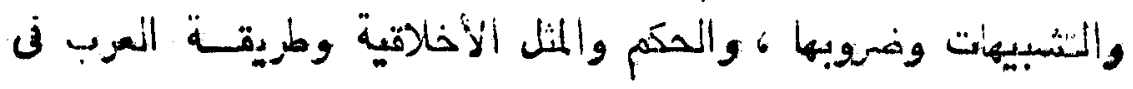

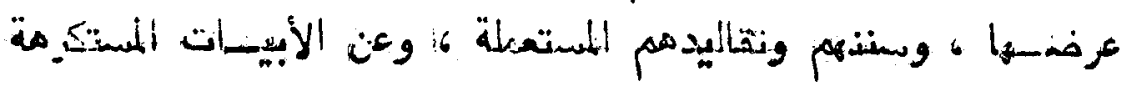

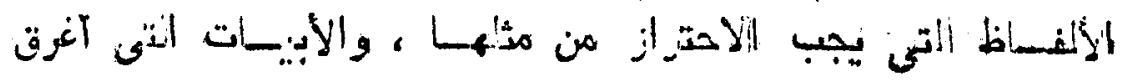

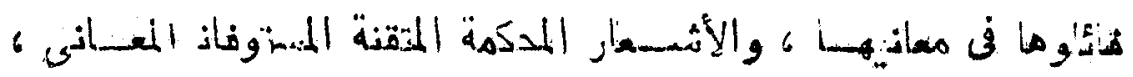

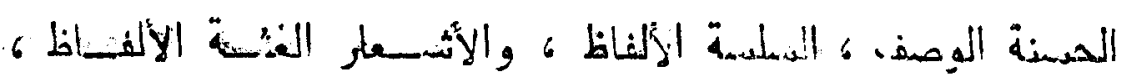

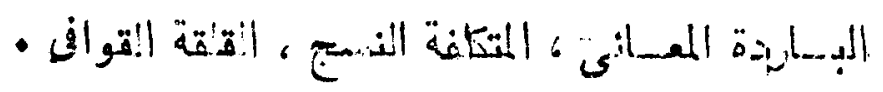

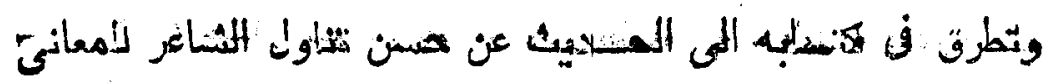

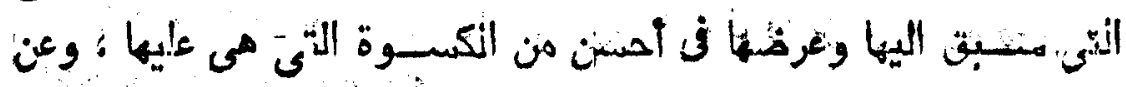




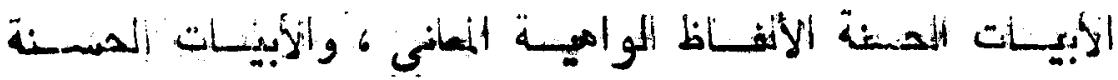

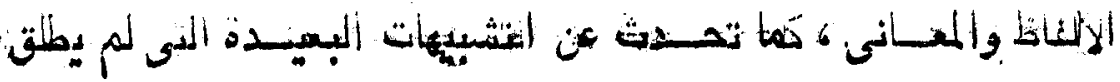

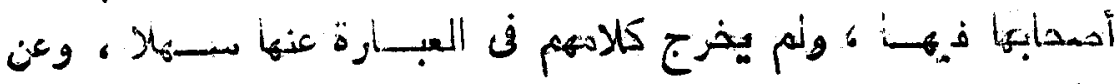

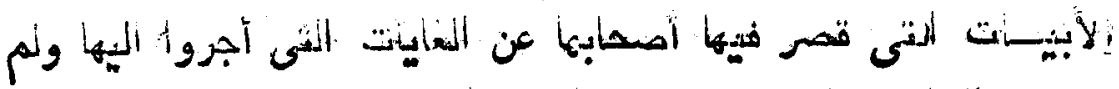

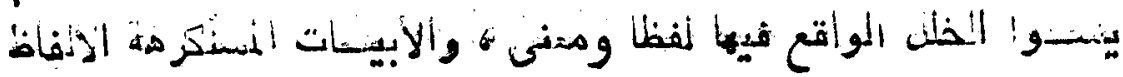

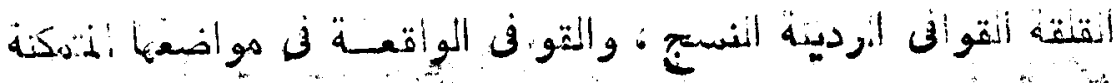

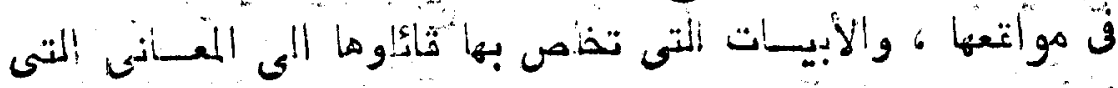

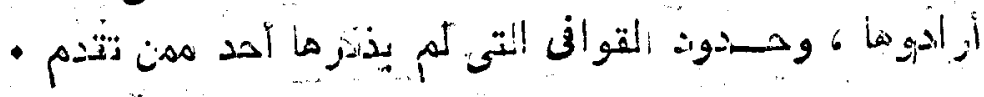

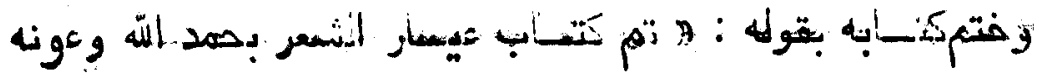

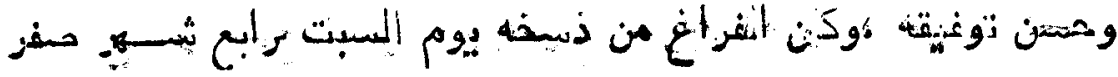

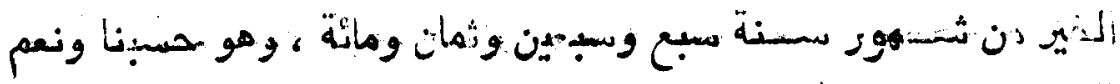

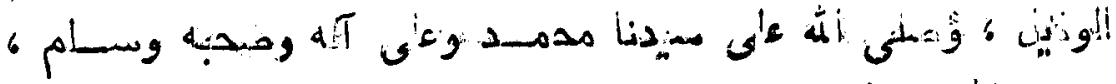

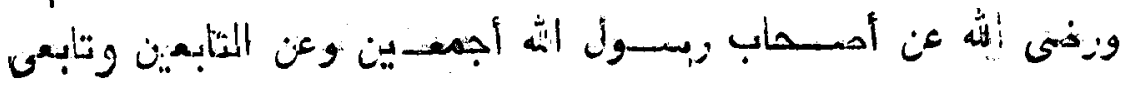

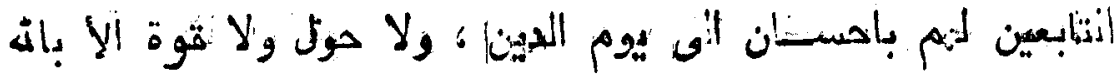

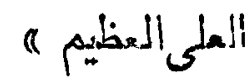

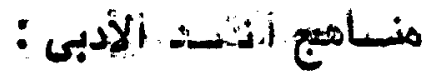

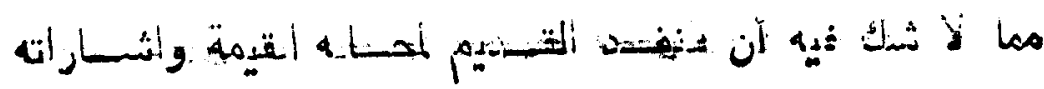

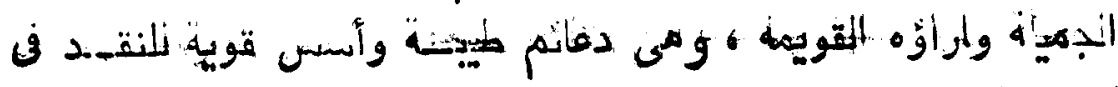

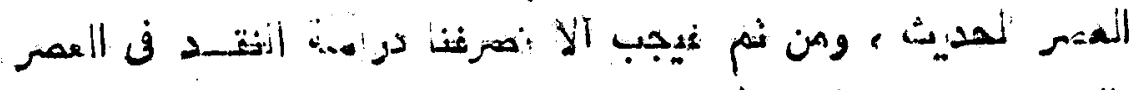

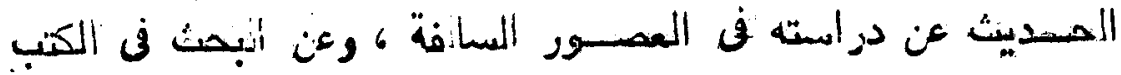

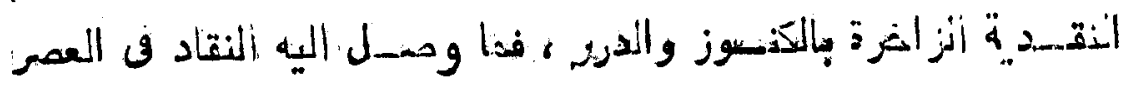

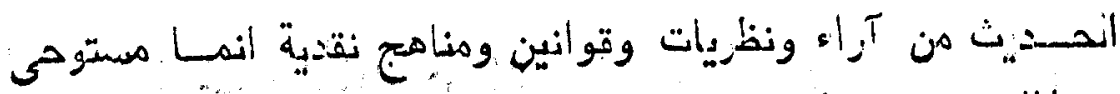

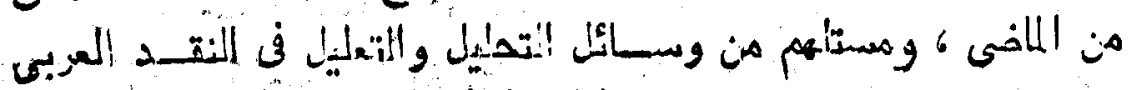

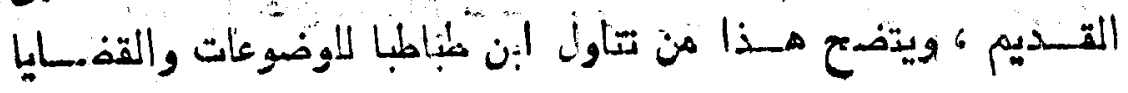




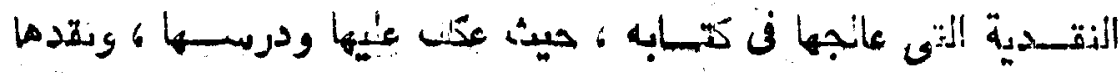

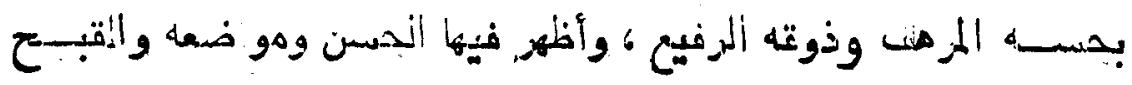

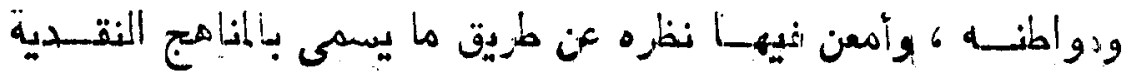

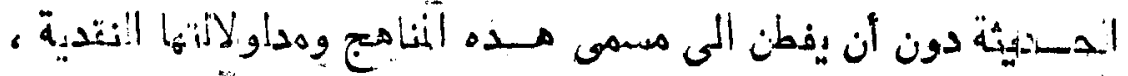

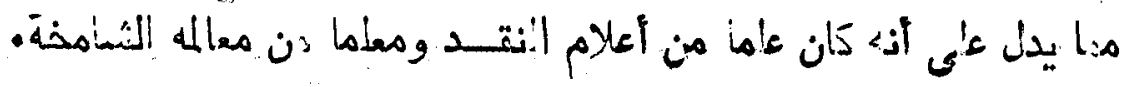

وقبل أن نهـدد المنهج النقـدى لابن طباطبا له كَّـابه ينبنى

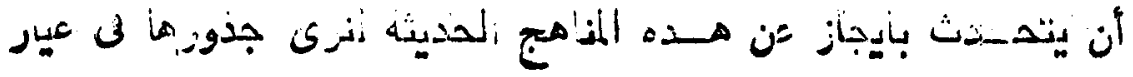

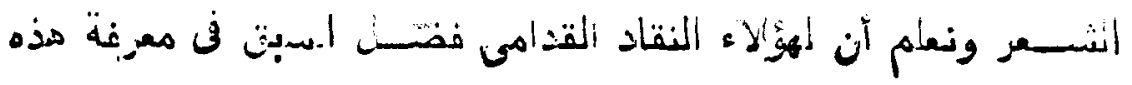

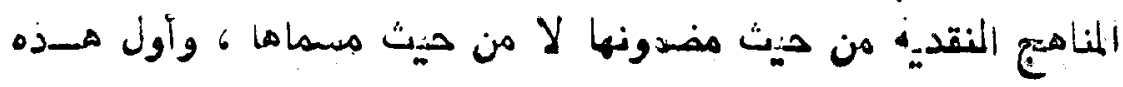

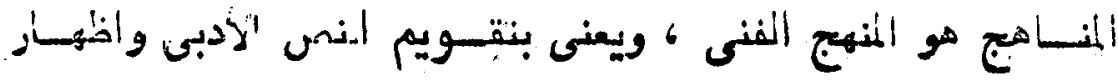

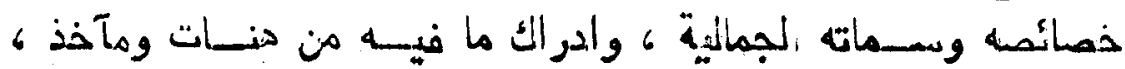

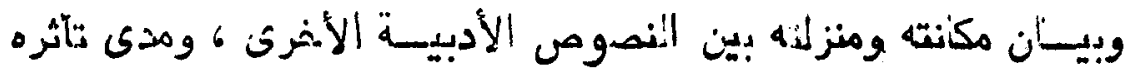

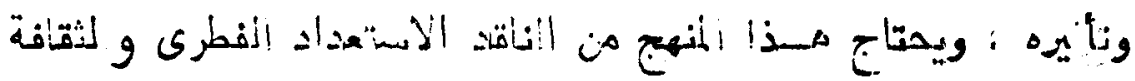

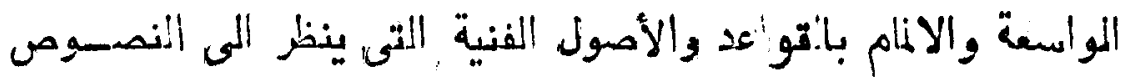

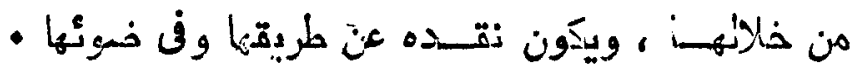

وثانى هـذه المناهج هو المنهج التتاريخىب6 ويعنى.بدراسة تأثر

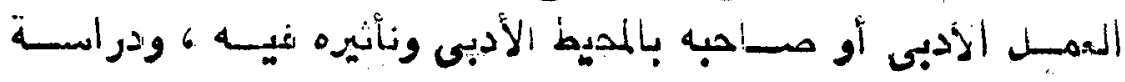

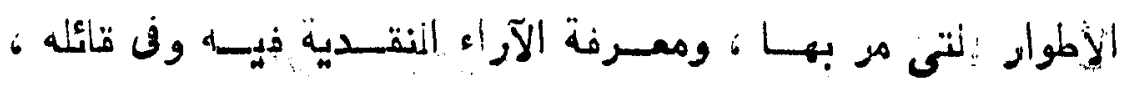

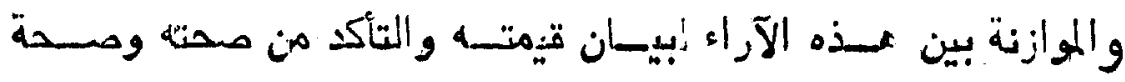

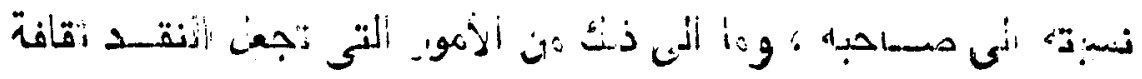

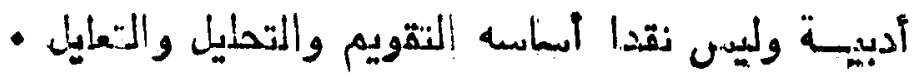

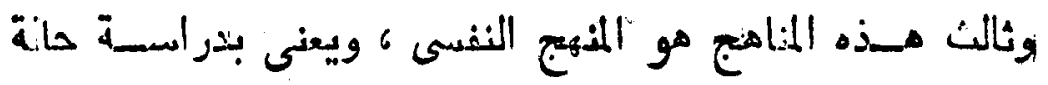

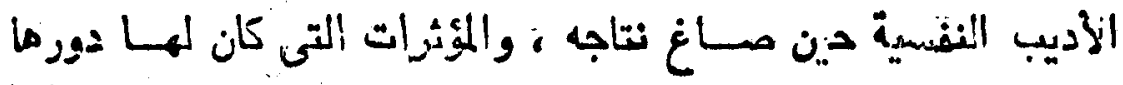




\section{r.r}

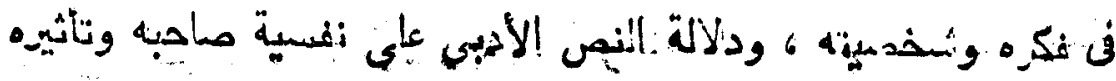
-

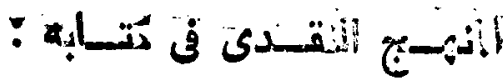

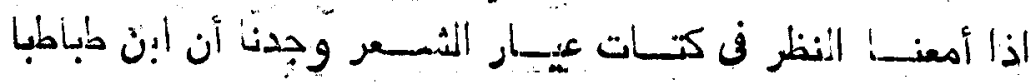

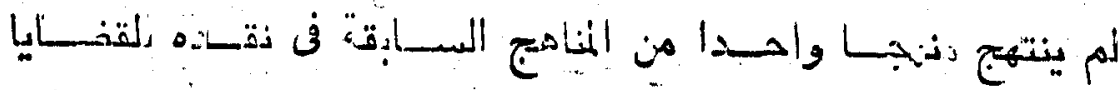

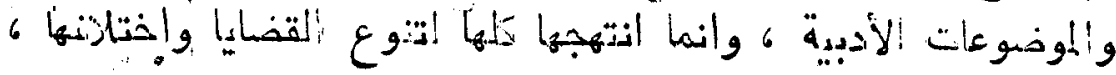

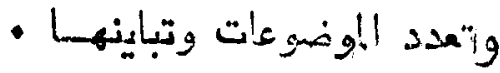

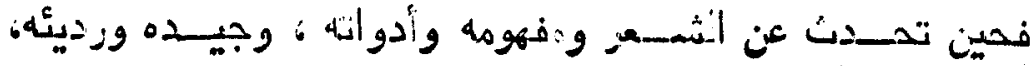

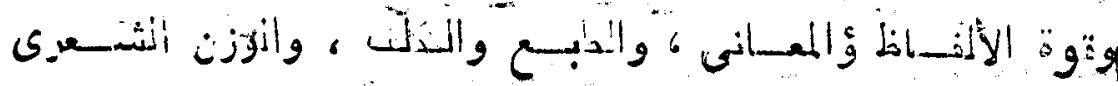

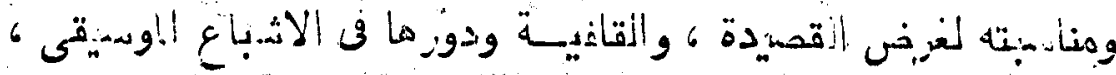

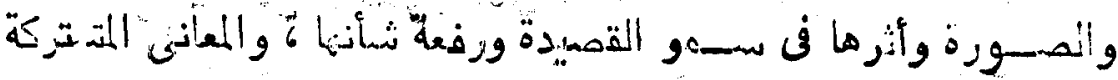

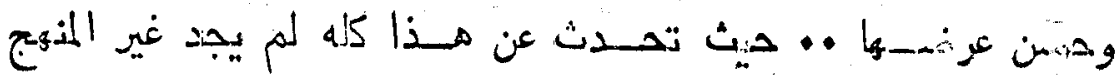

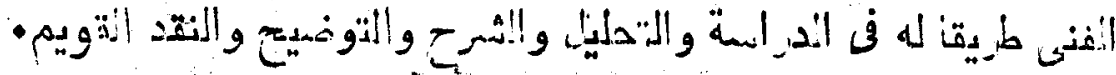

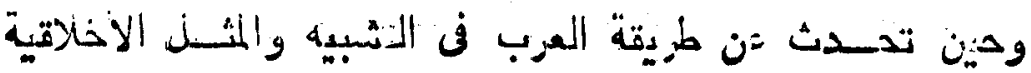

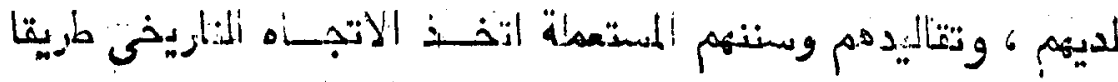

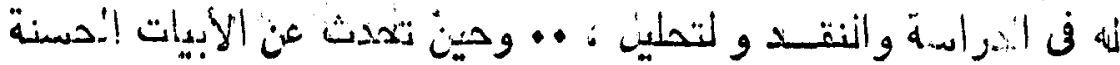

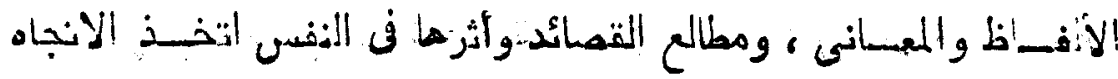

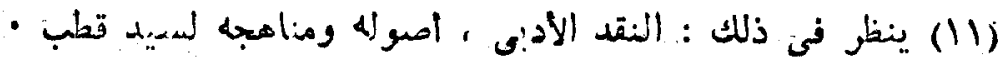

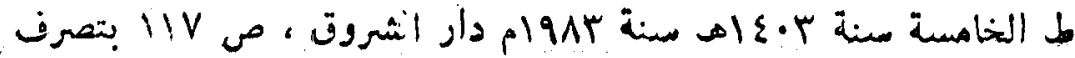

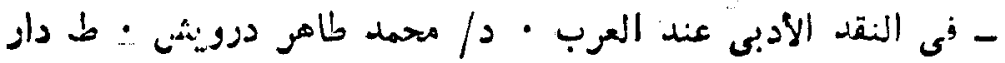

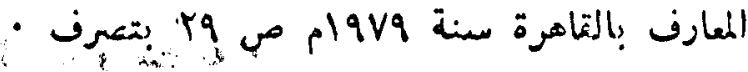

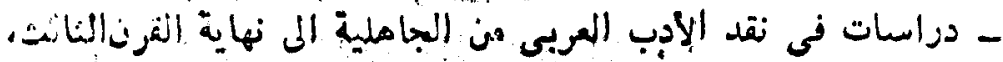

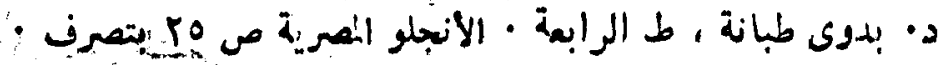




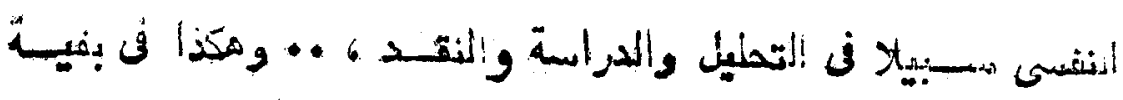

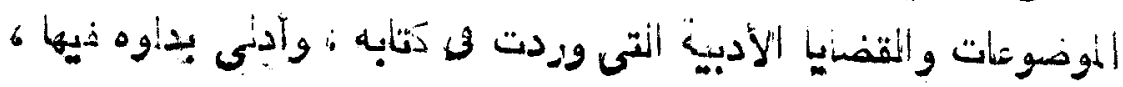

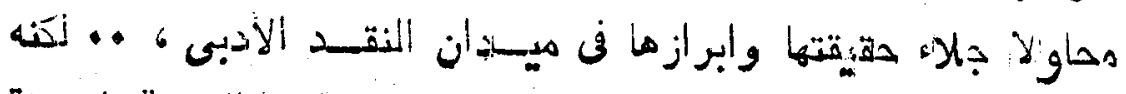

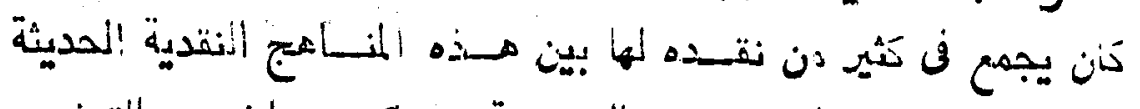

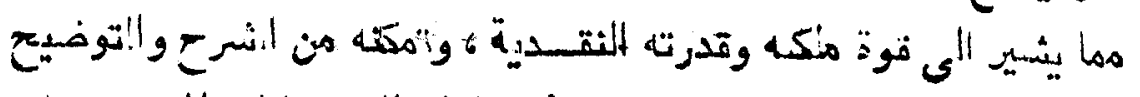

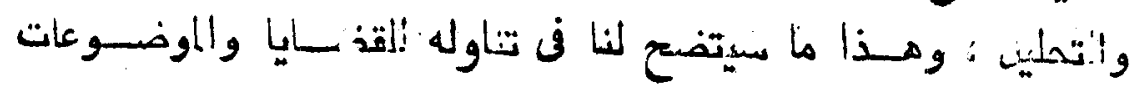

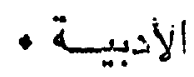

\section{أولا - هـدت المنعج الفنى فى كتـابه :}

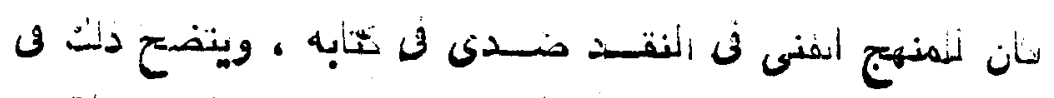

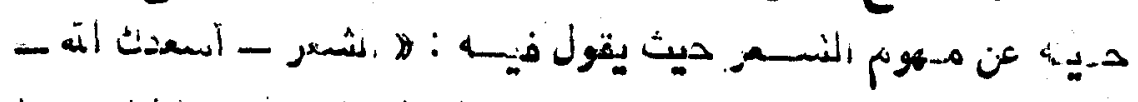

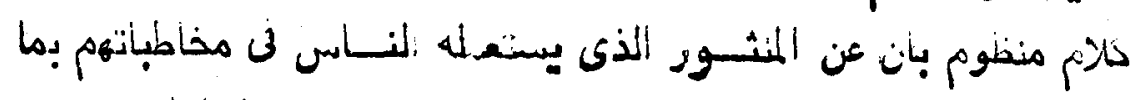

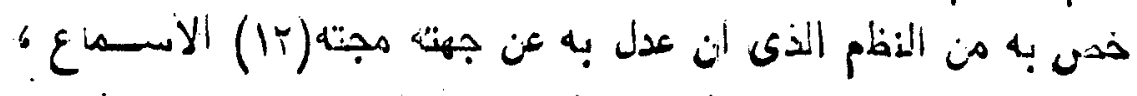

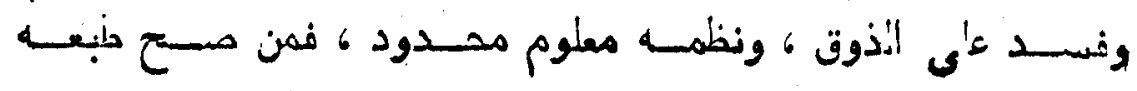

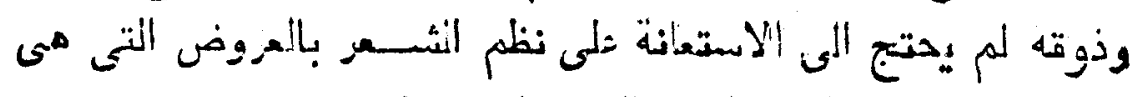

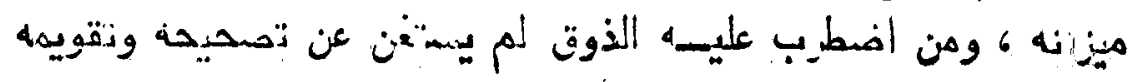

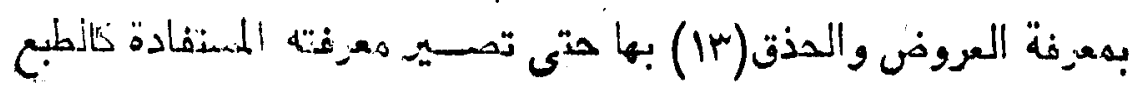

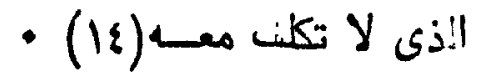

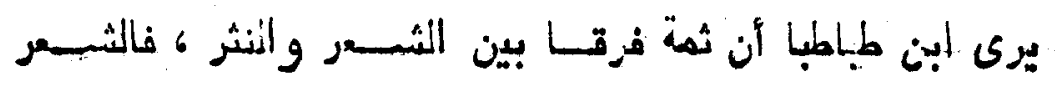

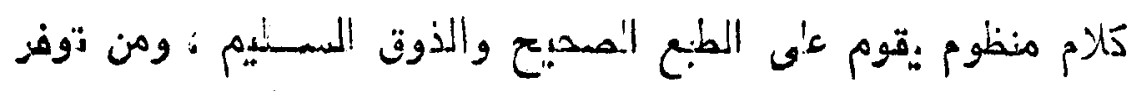

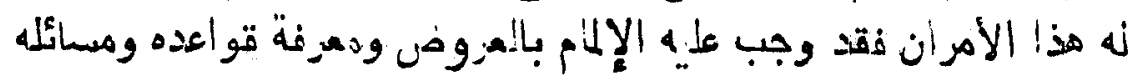

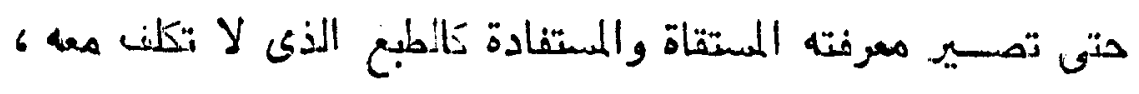

-

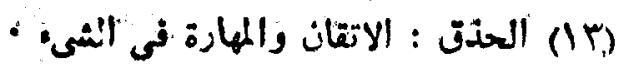

(\$) عيار الثعر الاتثان 
وليس هن شـاك في أن مذه التظرة لابن طبطبا في منهوم الشعر وتمييزه

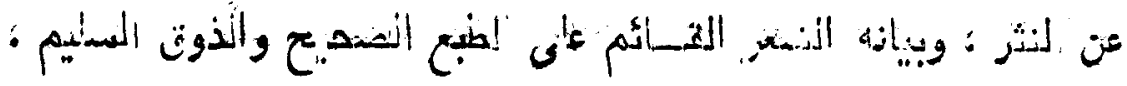

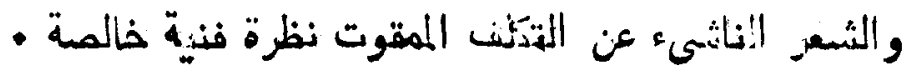

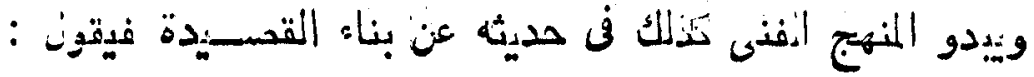

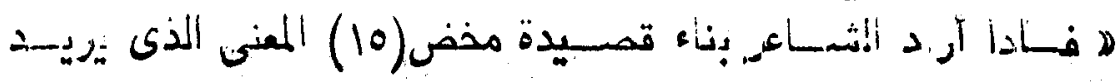

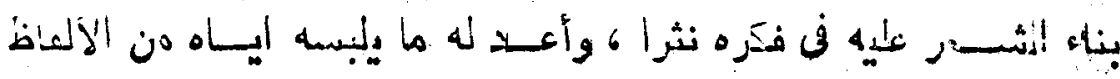

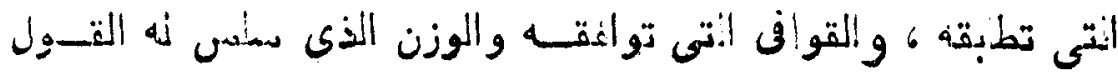

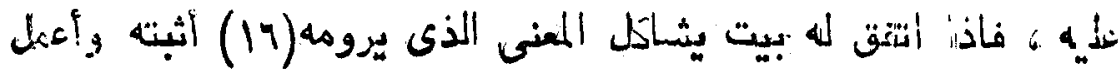

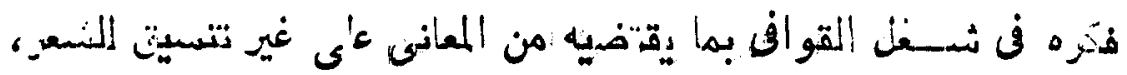

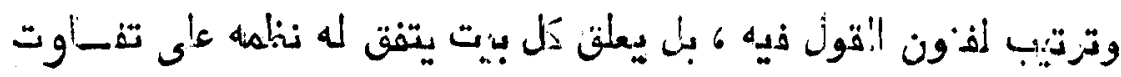

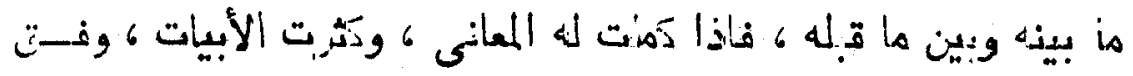

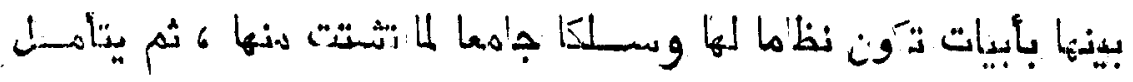

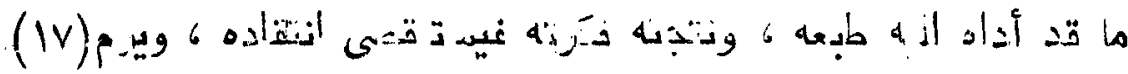

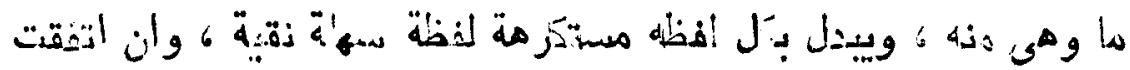

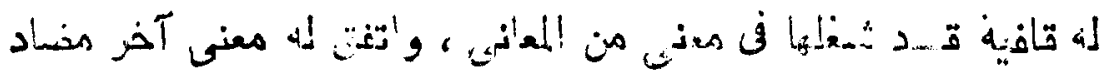

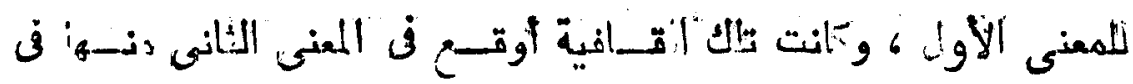

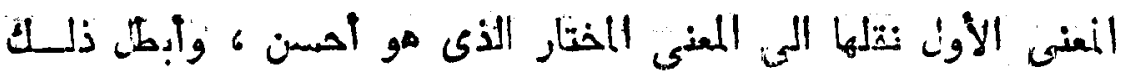

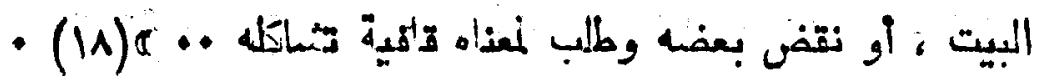

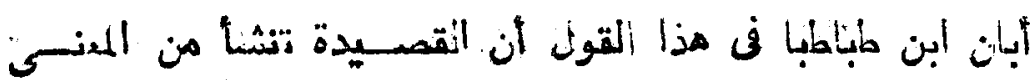

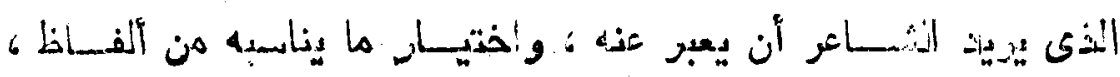

$$
\begin{aligned}
& \text { (10) مخض : تحرك فى فكرو }
\end{aligned}
$$

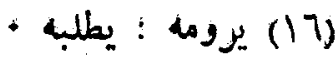

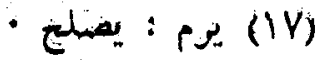

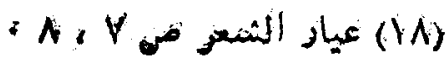




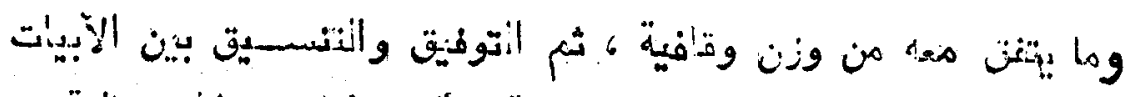

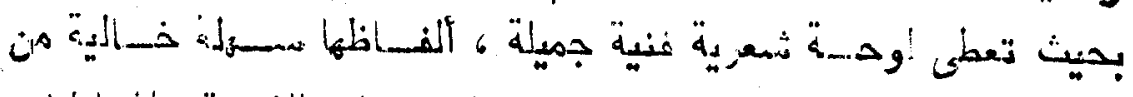

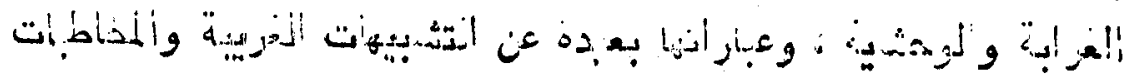

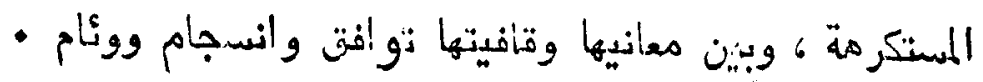

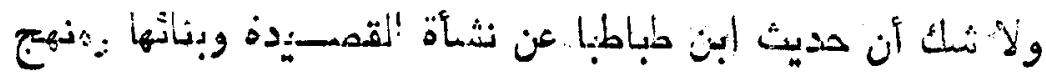

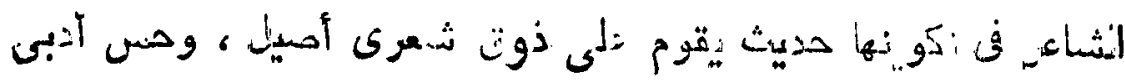

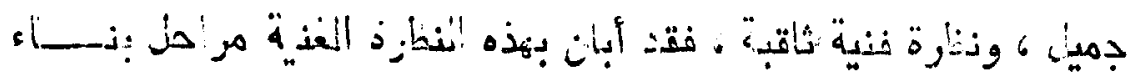

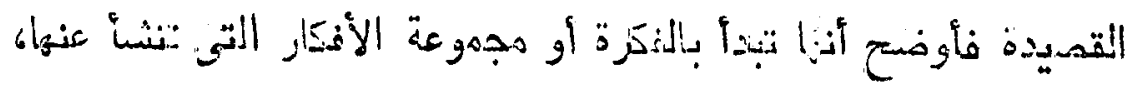

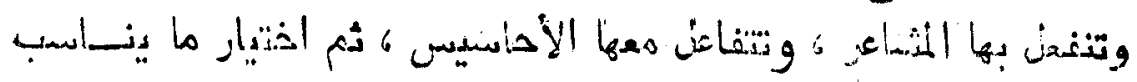

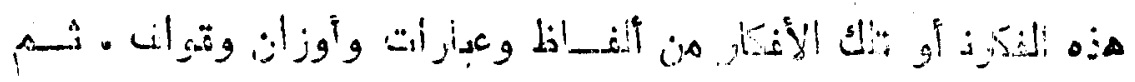

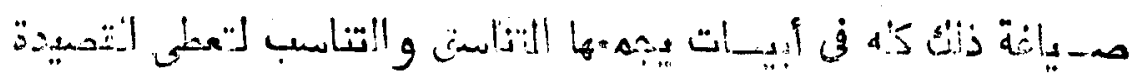

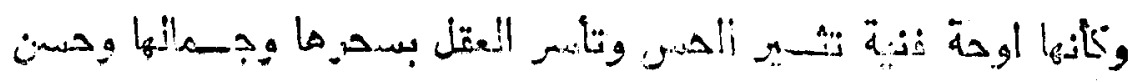

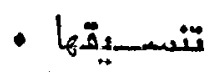

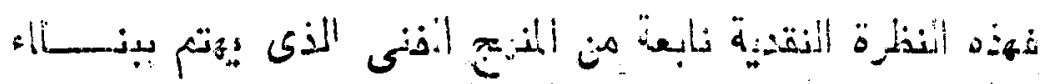

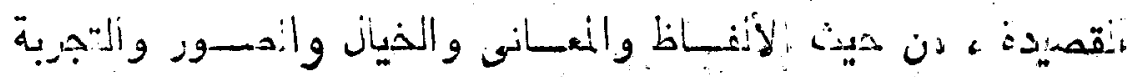

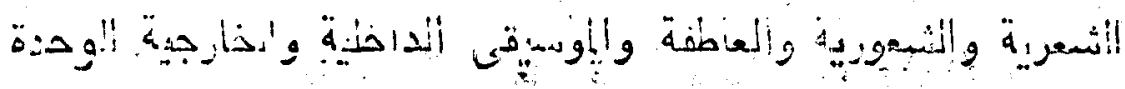

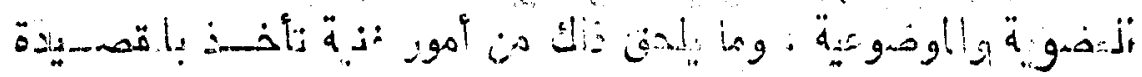

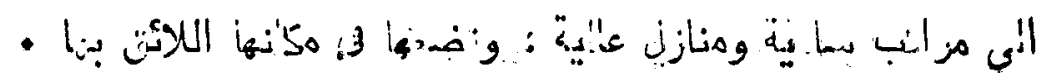

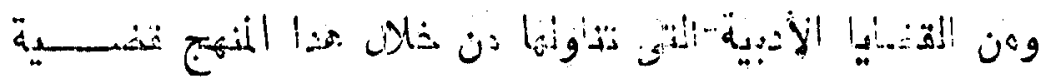

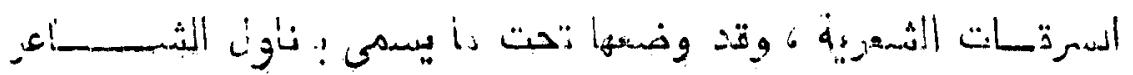

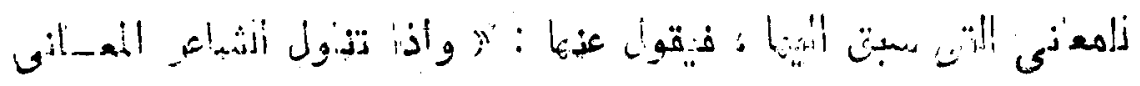

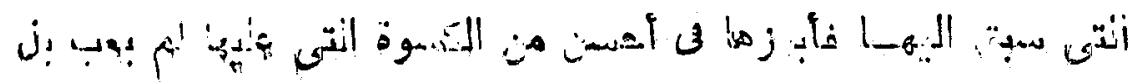

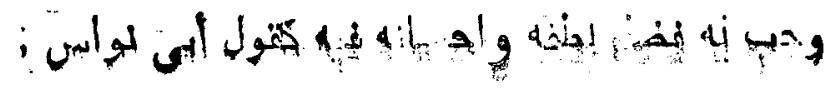




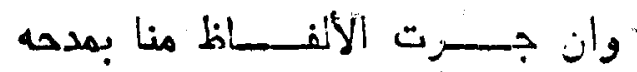

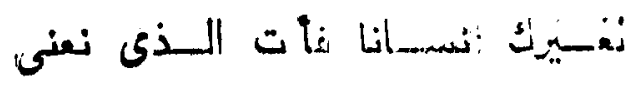

$$
\text { أخذه هن :لأحود هيث دقوبا : }
$$

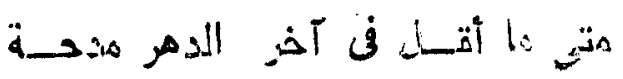

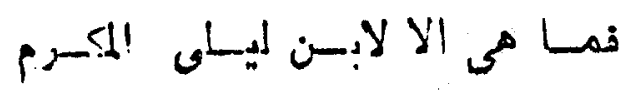

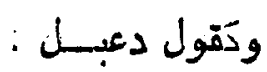

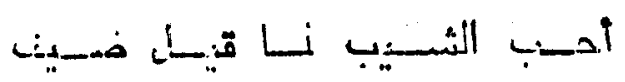

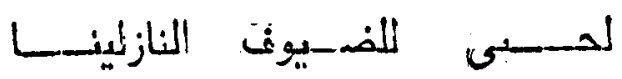

$$
\text { أخذه دن قون الأمهـوص حيث يقول : }
$$

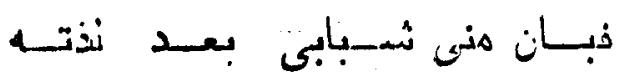

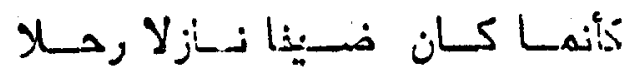

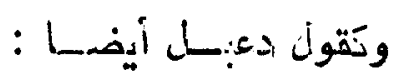

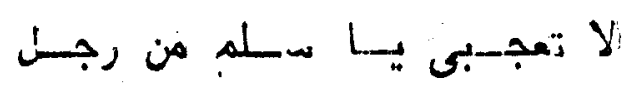

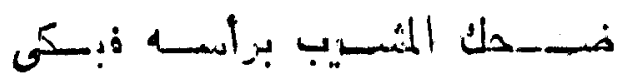

أنذه مين قولى الحس:ن بن مطير

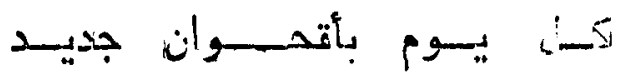

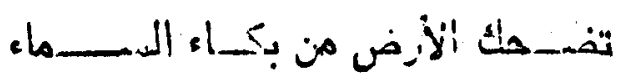

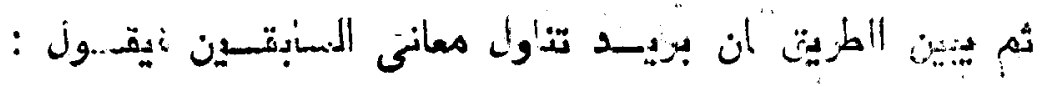

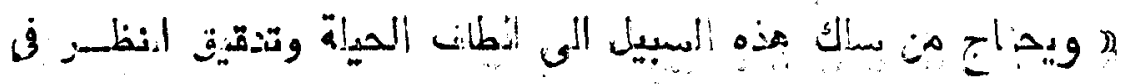

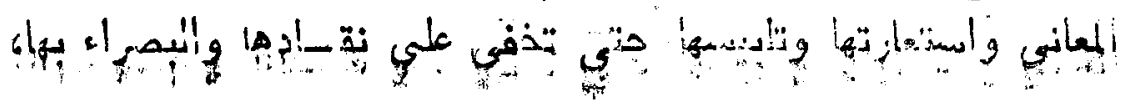




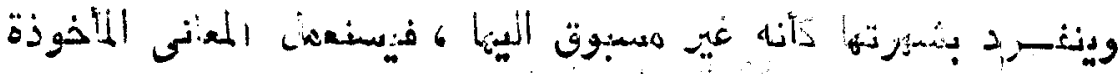

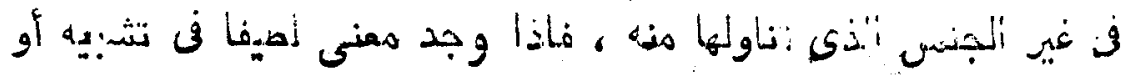

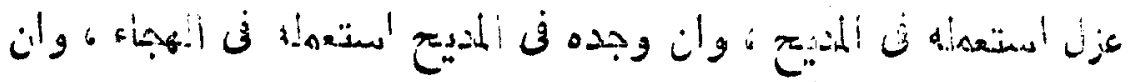

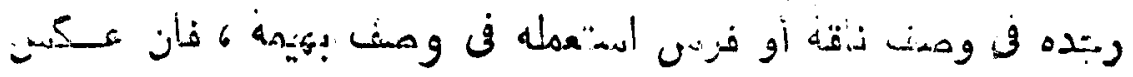

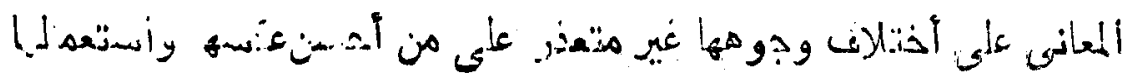

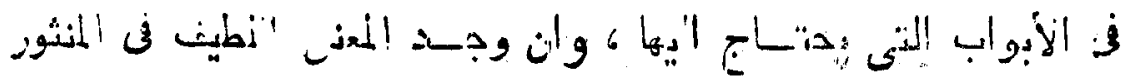

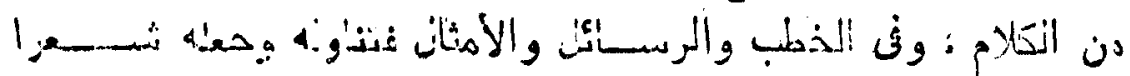

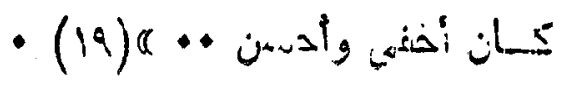

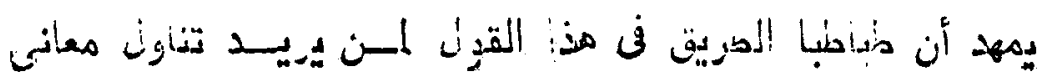

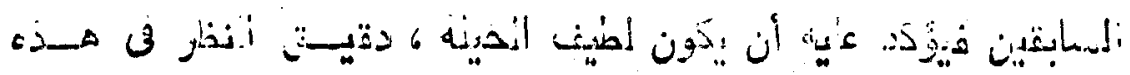

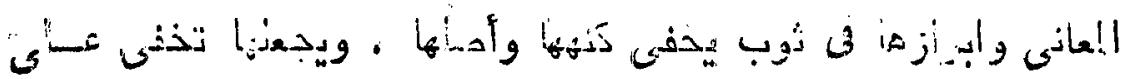

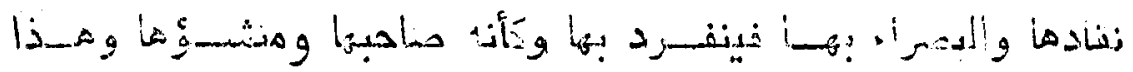

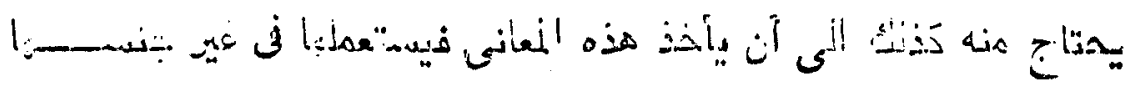

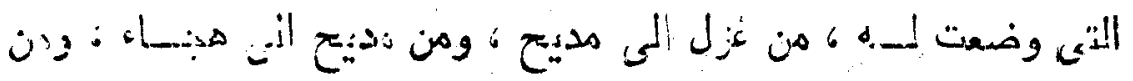

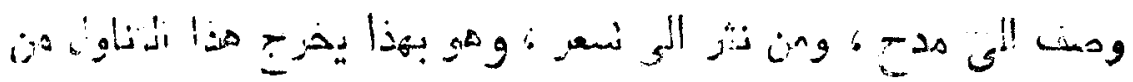

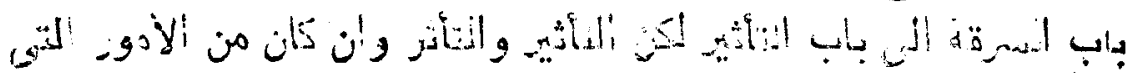

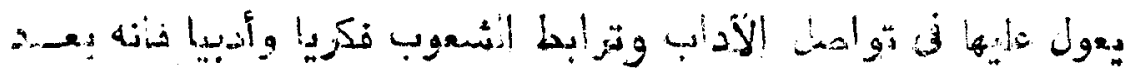

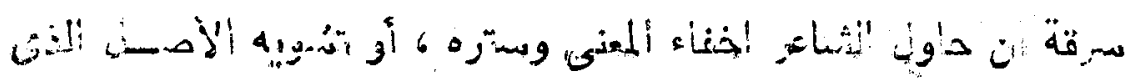

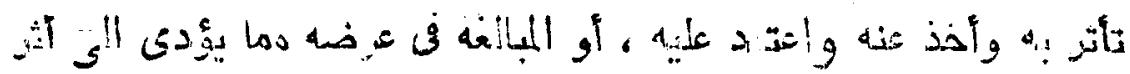

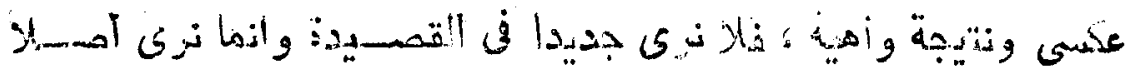

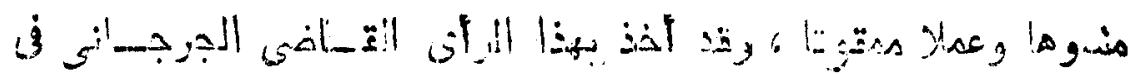

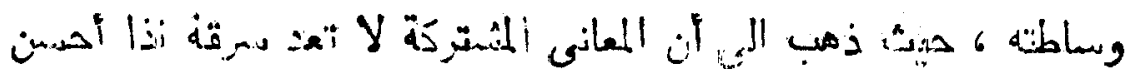

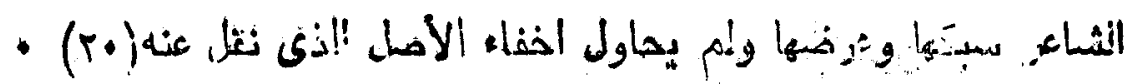




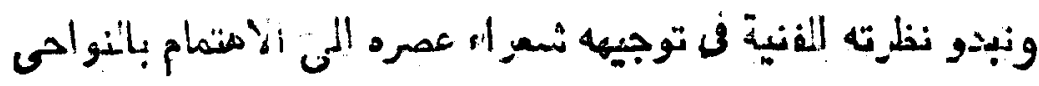

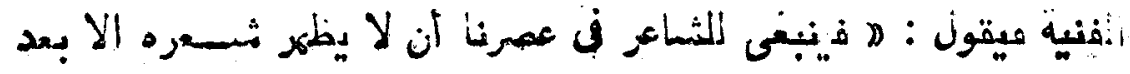

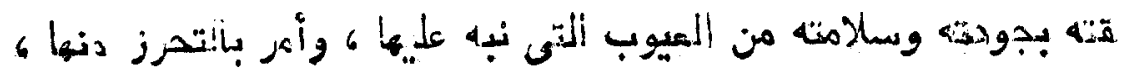

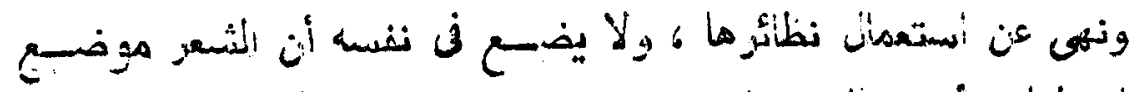

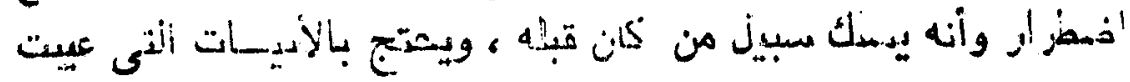

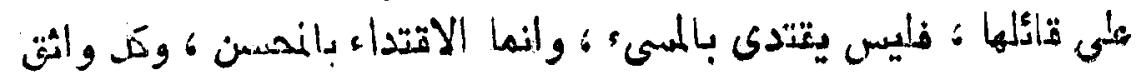

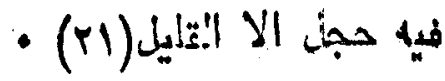

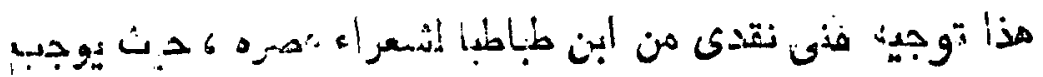

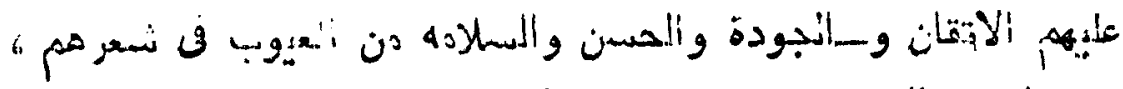

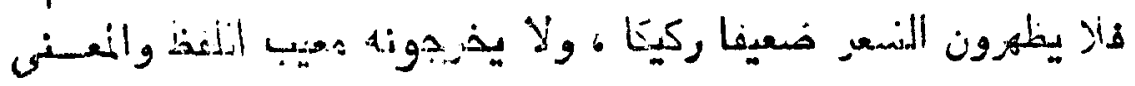

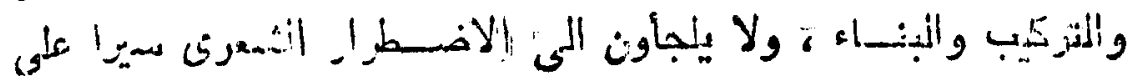

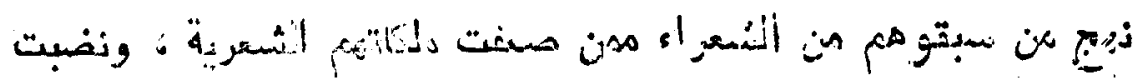

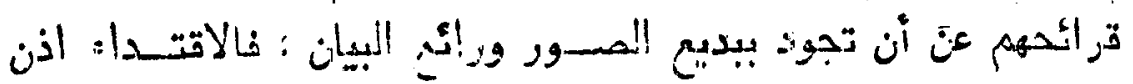

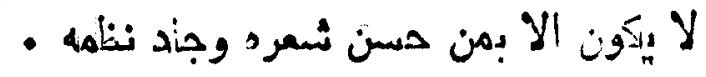

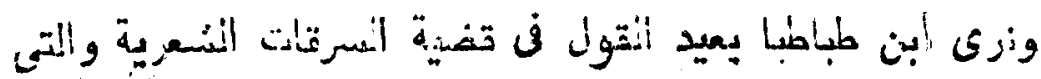

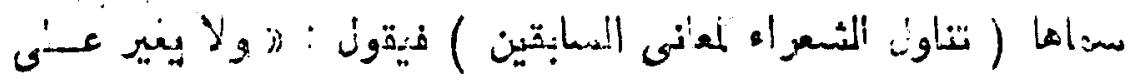

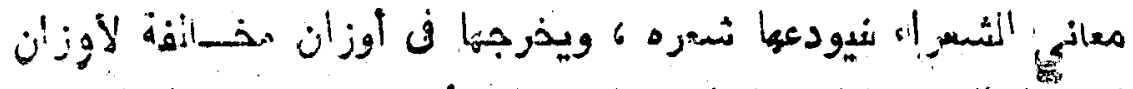

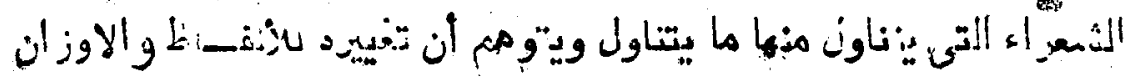

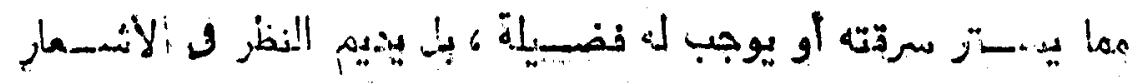

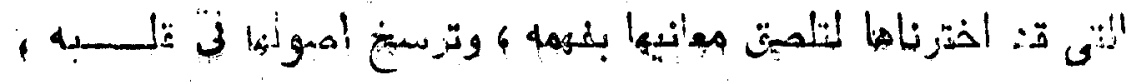

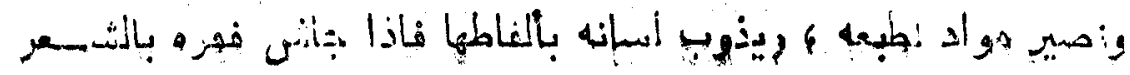

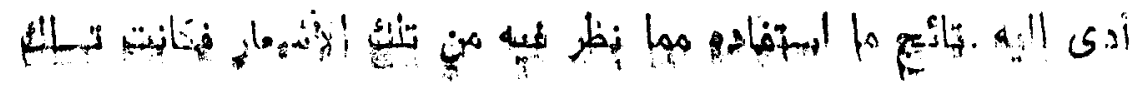

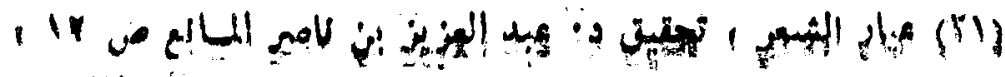

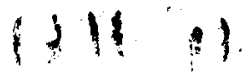




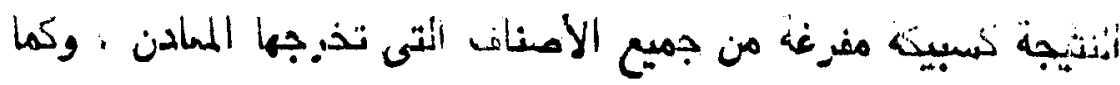

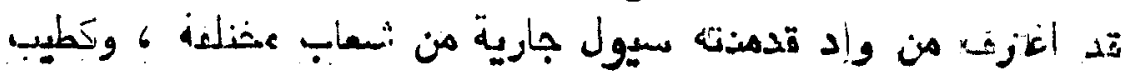

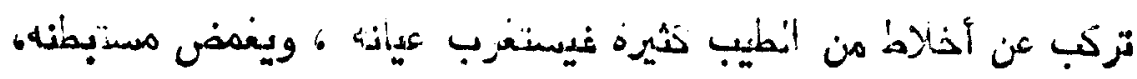

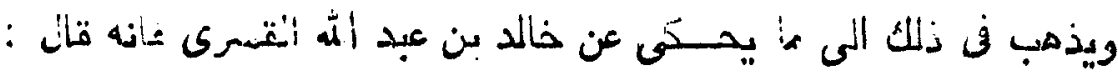

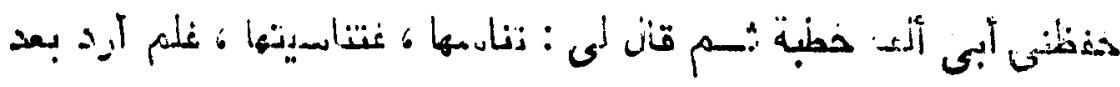

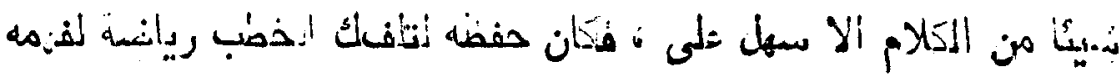

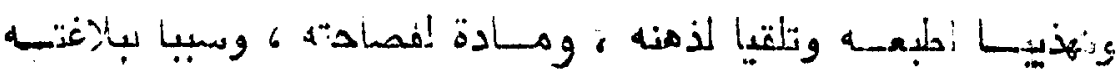

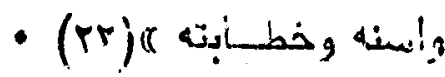

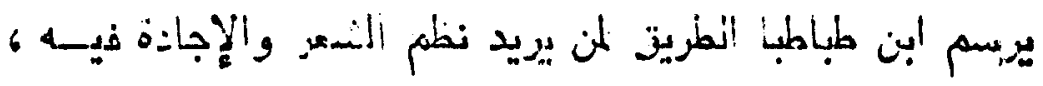

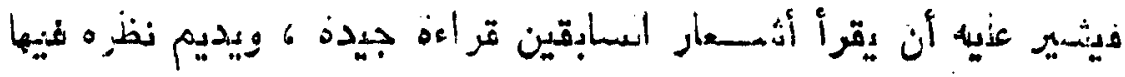

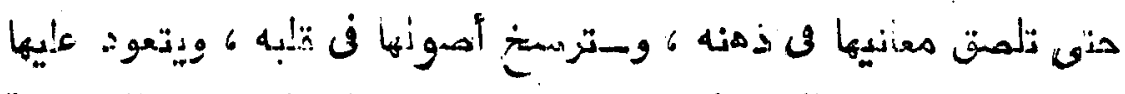

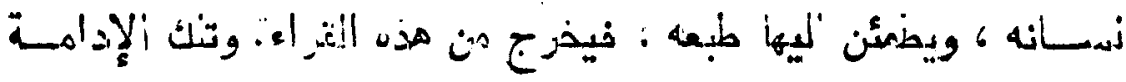

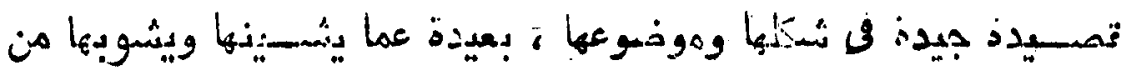

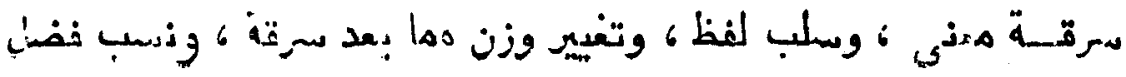

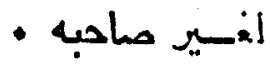

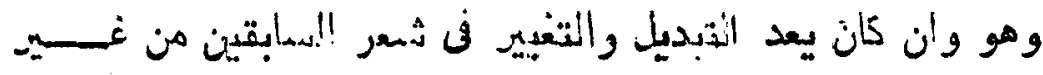

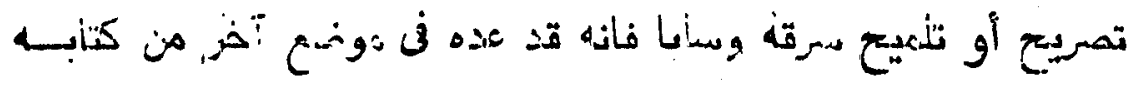

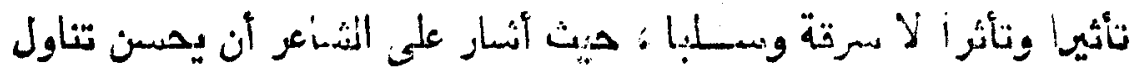

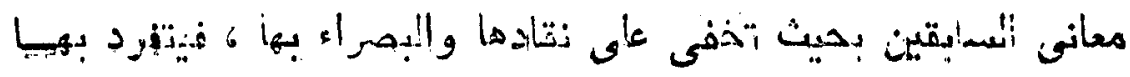

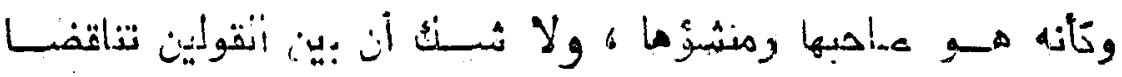

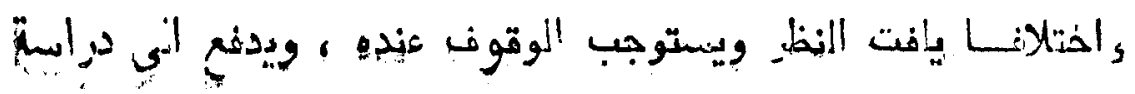

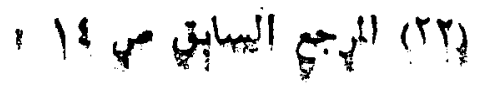


Pi

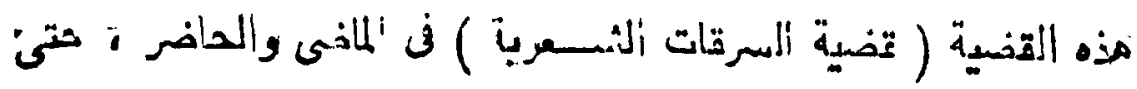

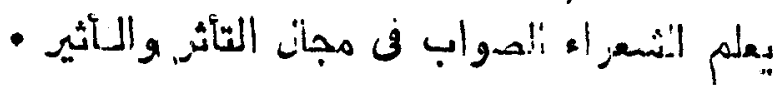

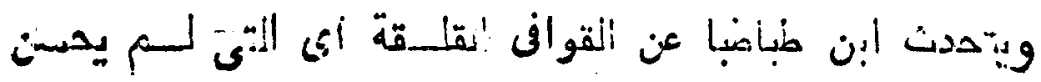

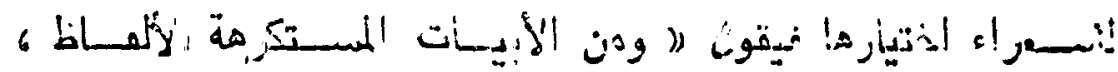

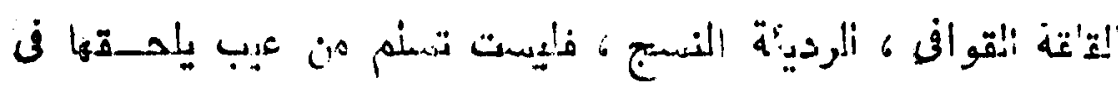

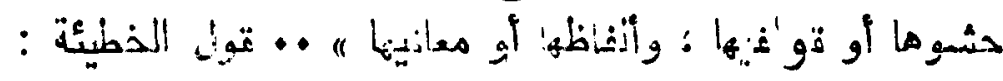

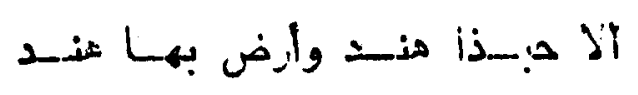

وهنس أتى هن دونيـا النائي وأبعد

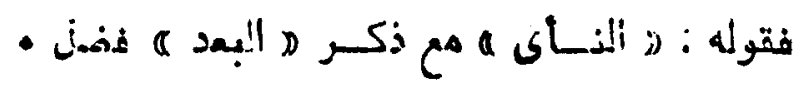
زَتَتسول الأعثى :

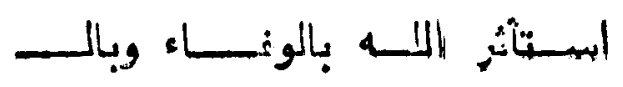

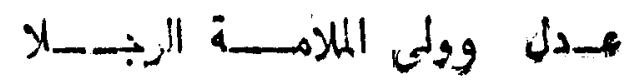
أيراد : الإنسسان :

ودَتــول الحطيئهة: :

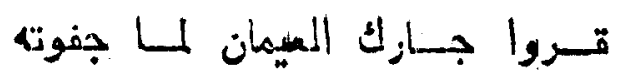

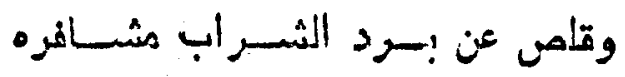

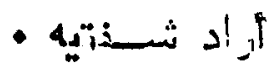

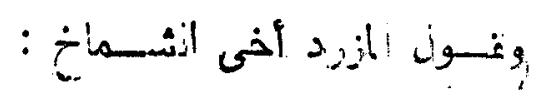

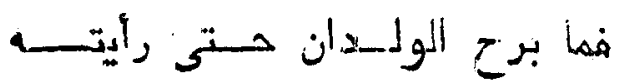

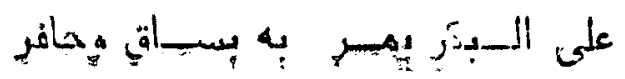

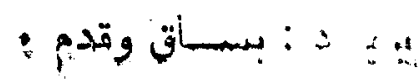


وتكسفى أني-وم المأسوين وتــــ

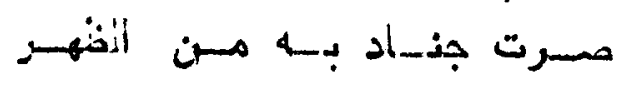

أرإد بالظهز : حسر ألظهيرة

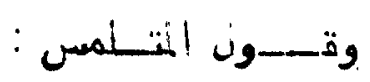

أن تسـلكى سبل المومساة منجسيدة

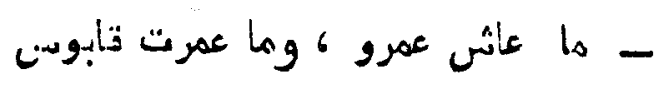

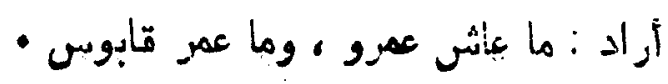

وتـــــــ : من

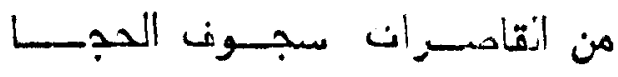

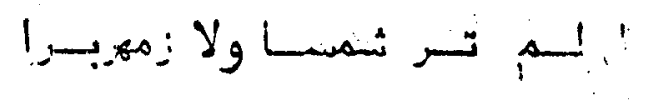

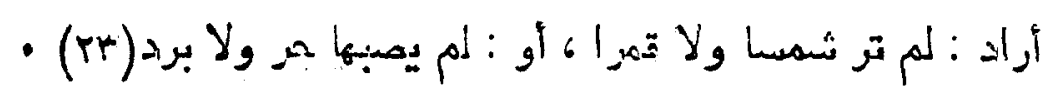

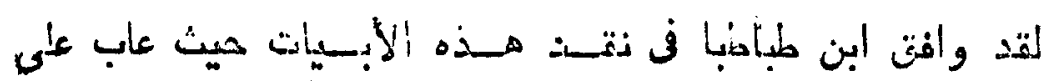

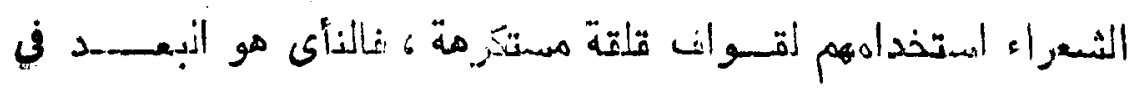

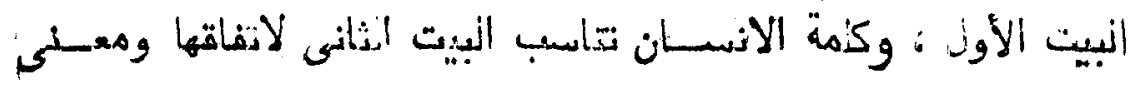

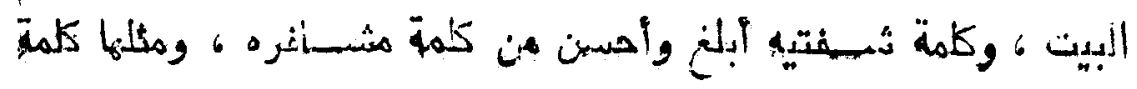

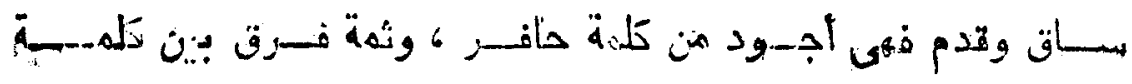

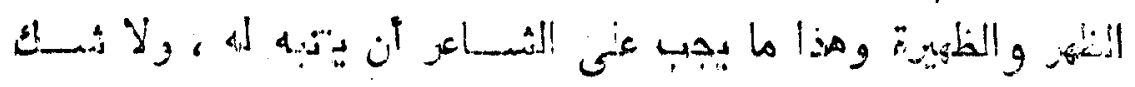

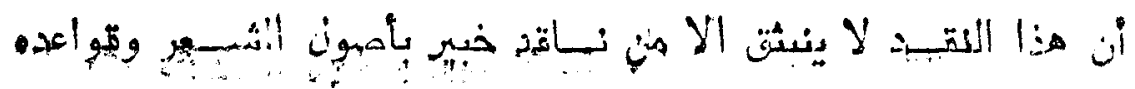

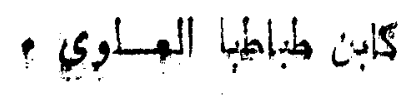

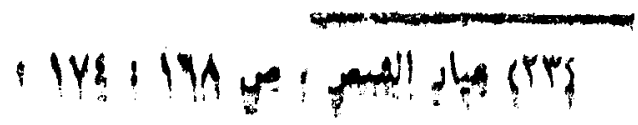




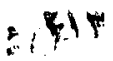

وبم"ضم المنهج الفنى كتلله لدى بن طباطبا في حديثه عن حسدود

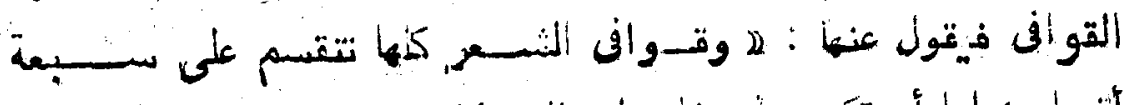

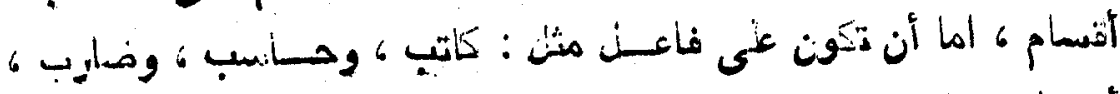

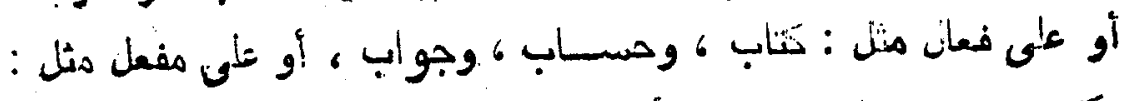

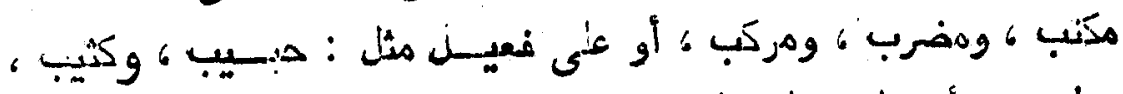

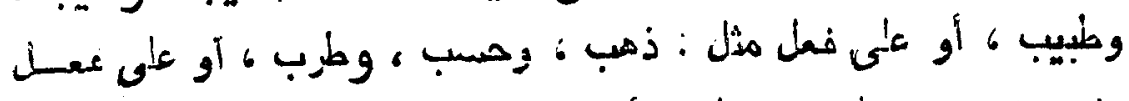

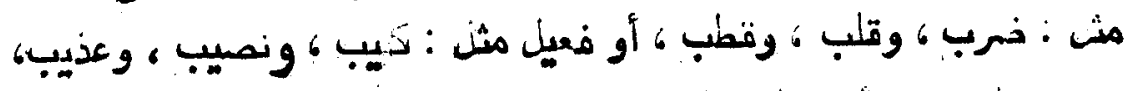

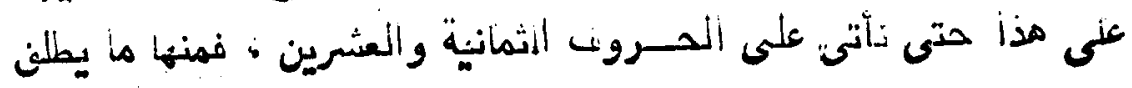

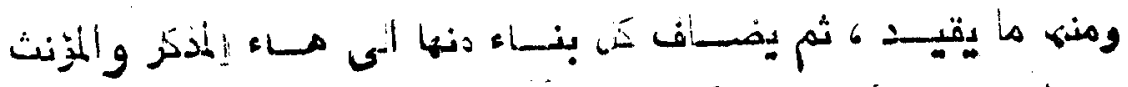

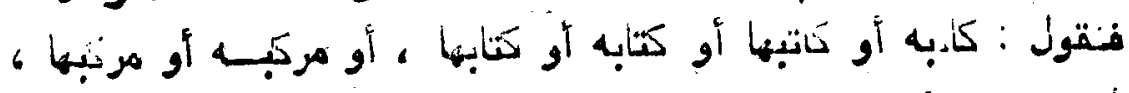

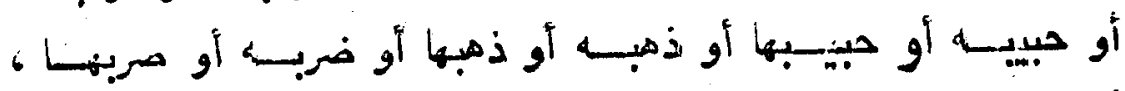

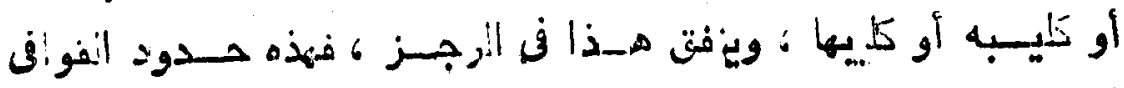

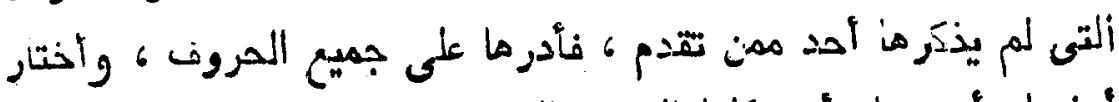

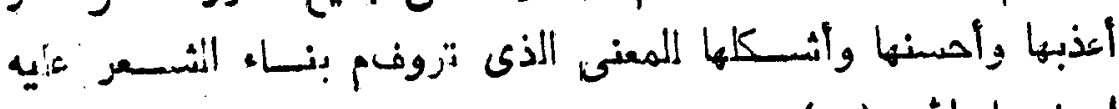

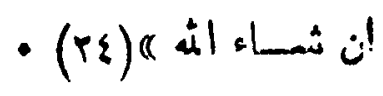

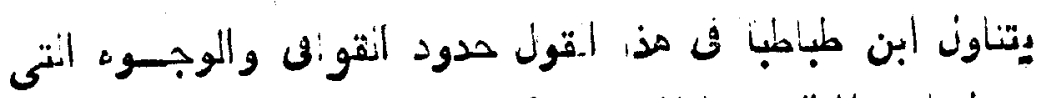

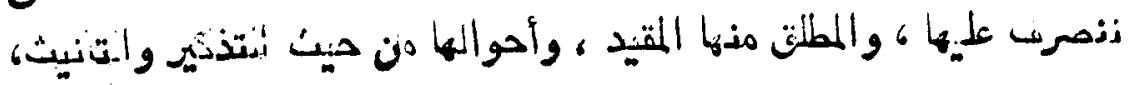

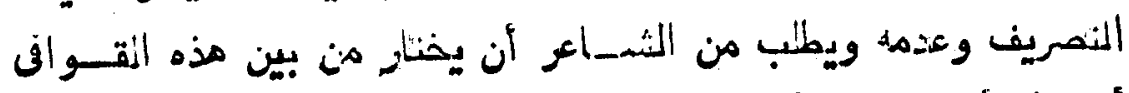

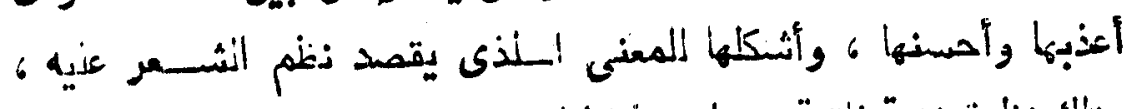

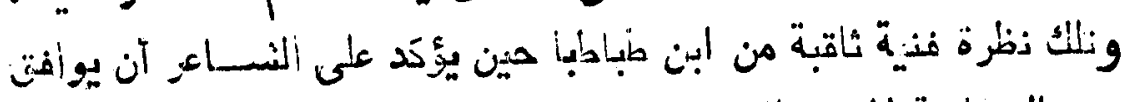

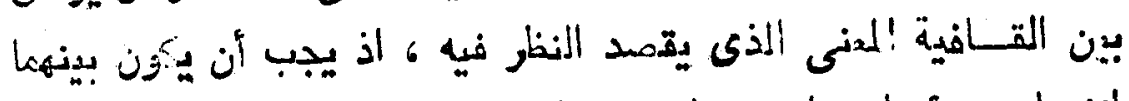

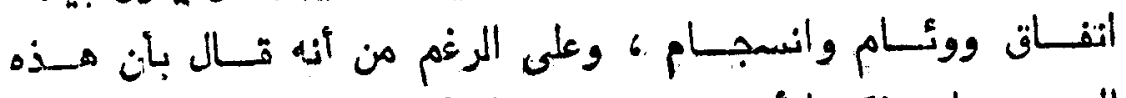

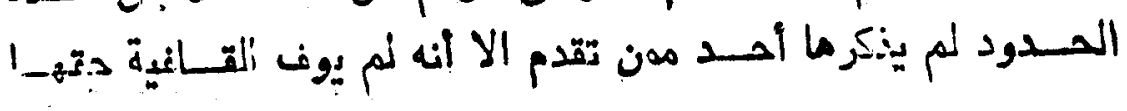




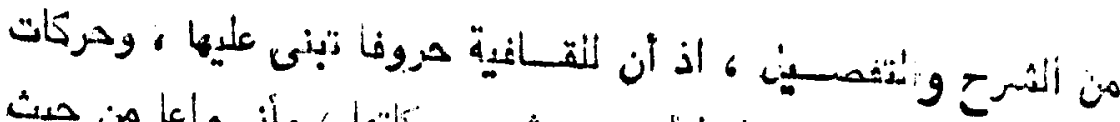

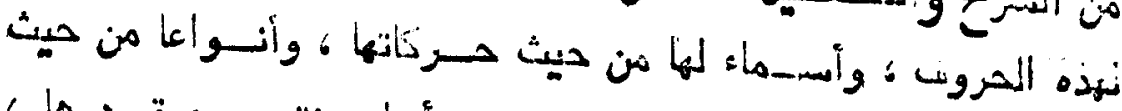

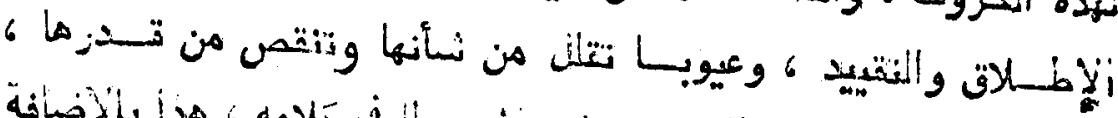

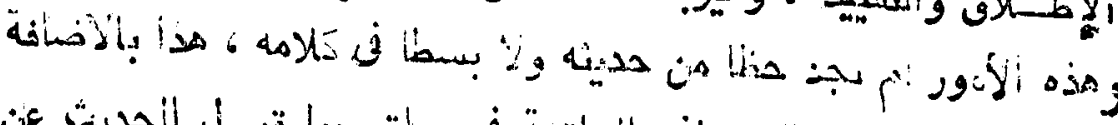

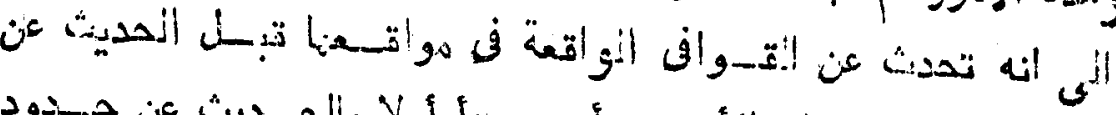

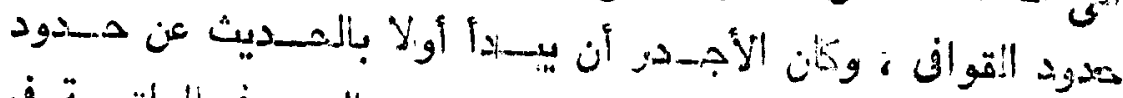

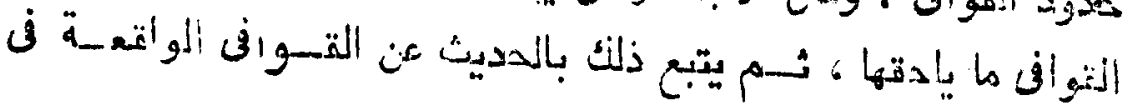

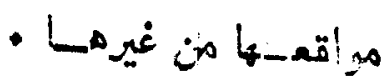

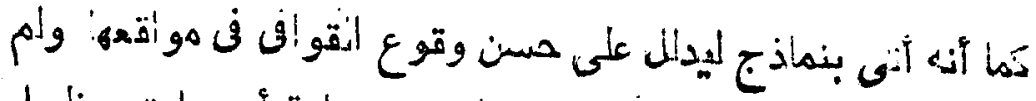

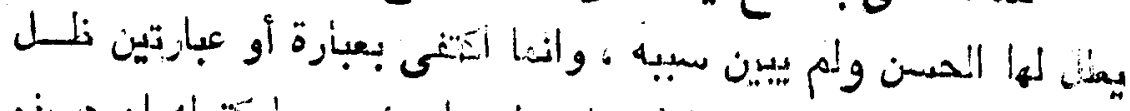

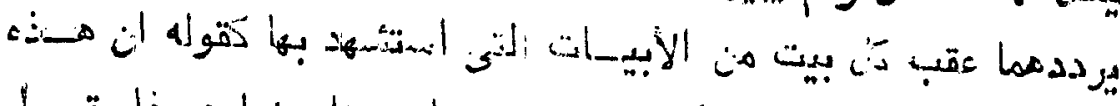

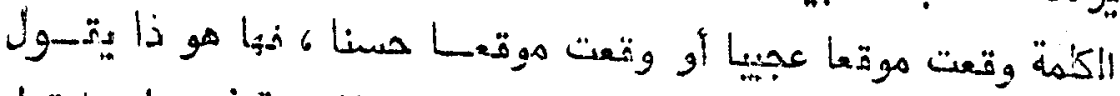

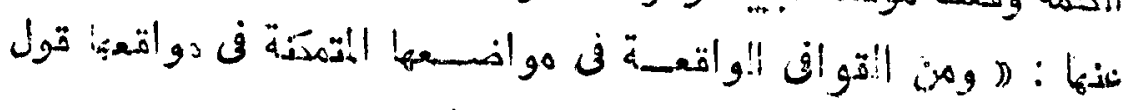

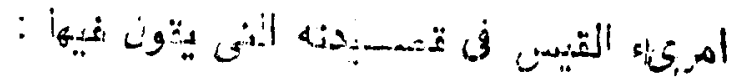

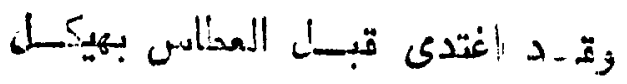

آرأi : ألإنس :

شديد مشسـنك الجنب فعسم ألمنطق

:

بعثنـا ربئيسا قبـن ذلـك مخمهـا

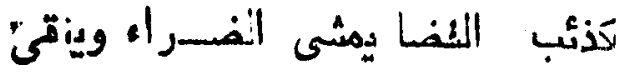

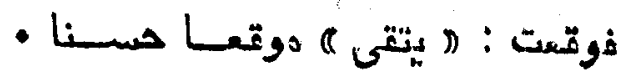




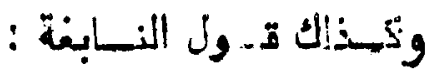

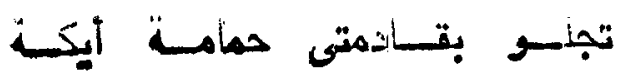

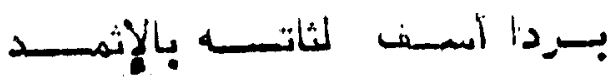

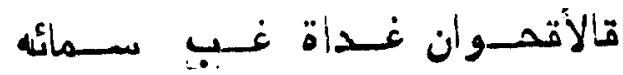

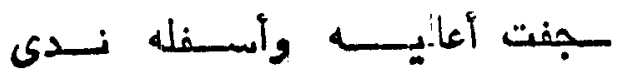

زعم الهمام بـأن فاهـا بـــأرد

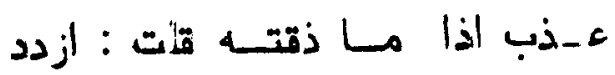

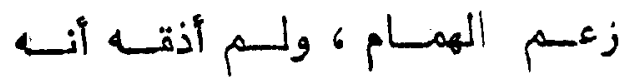

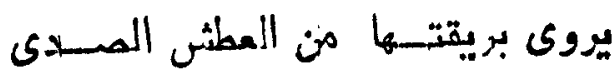

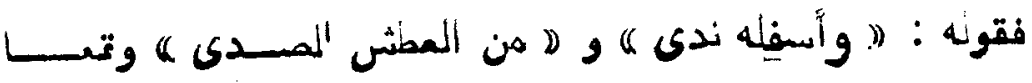

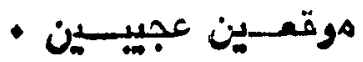

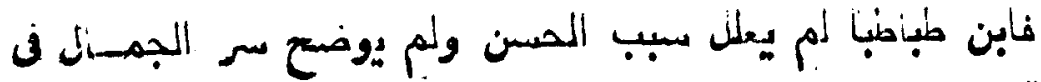

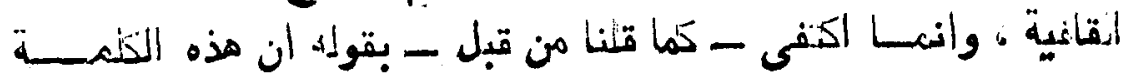

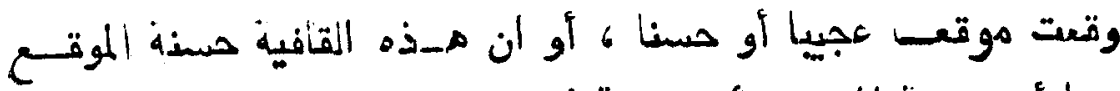

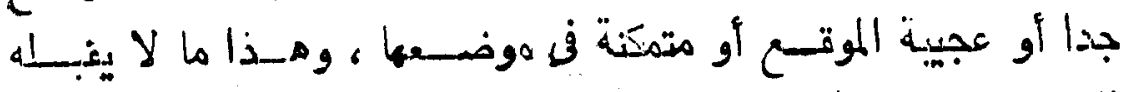

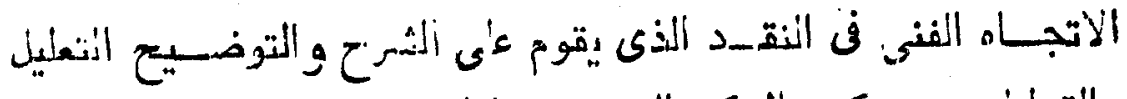

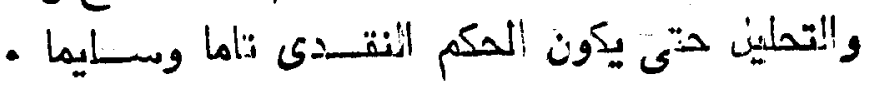

ثانيـا - هـدى النهج أفنى و'لناريذّى قى كتابه :

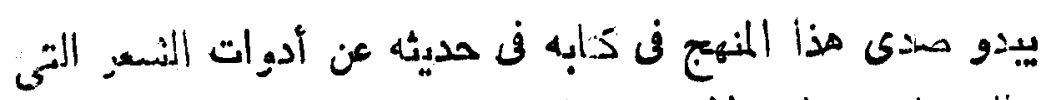

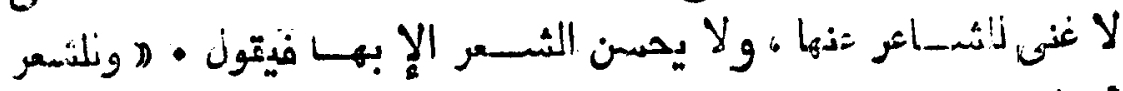

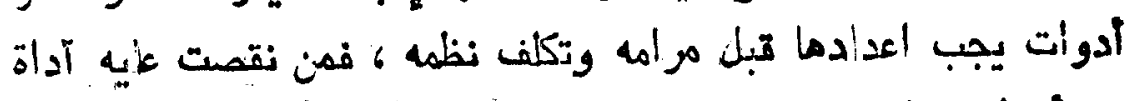

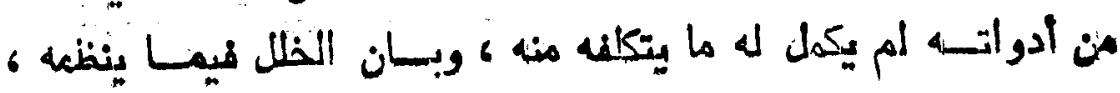




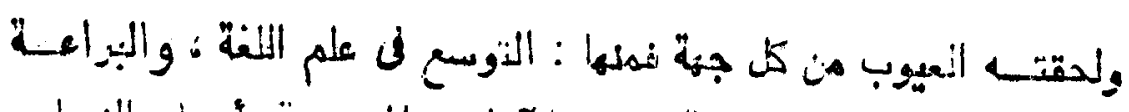

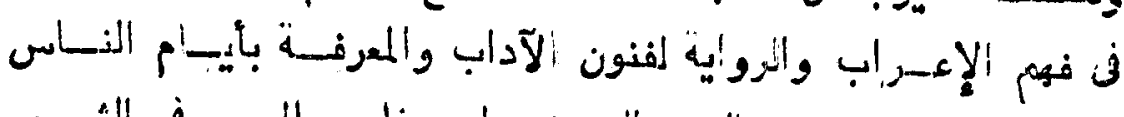

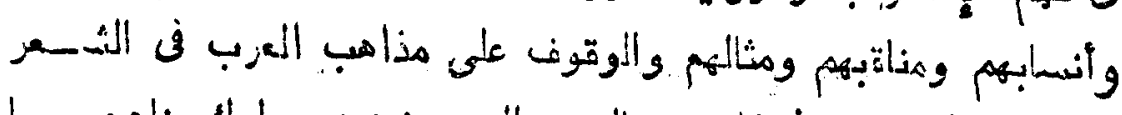

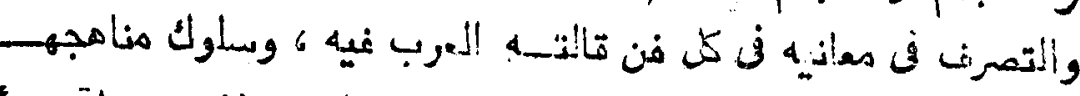

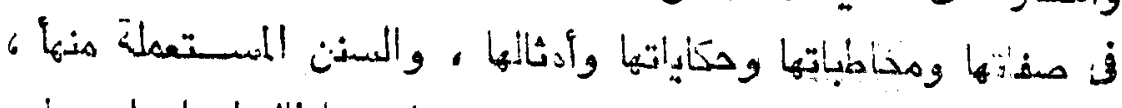

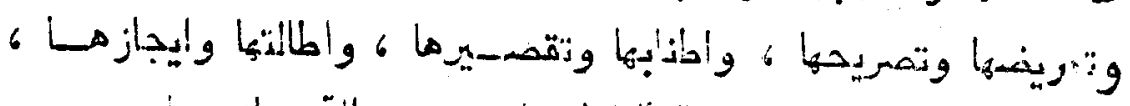

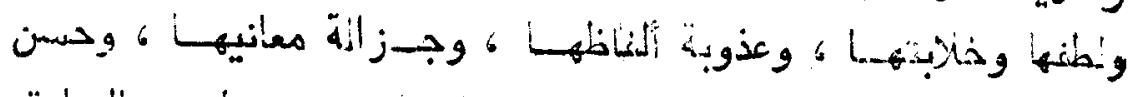

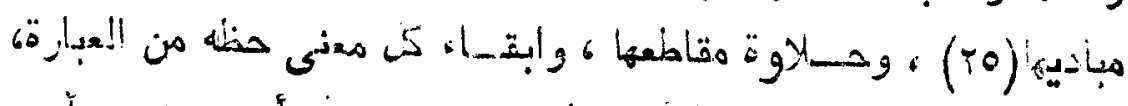

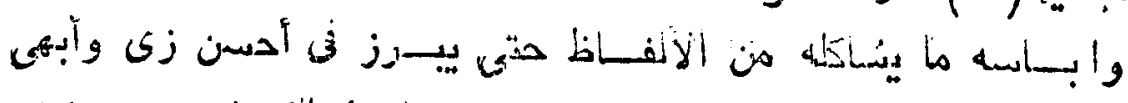

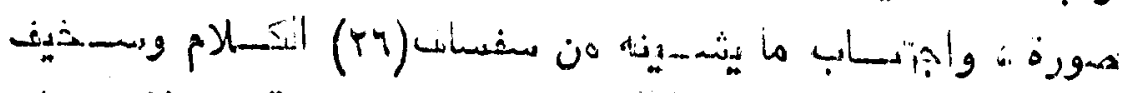

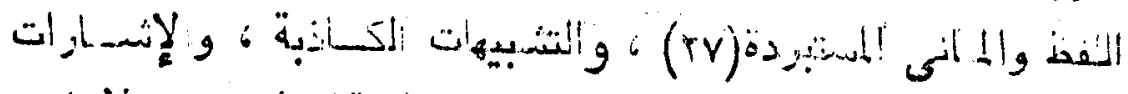

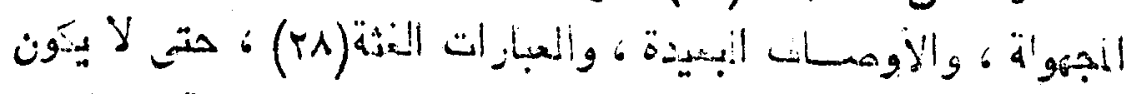

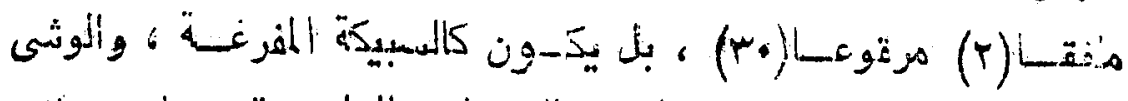

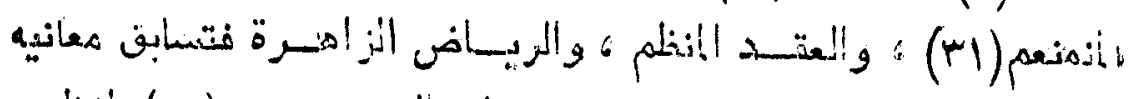

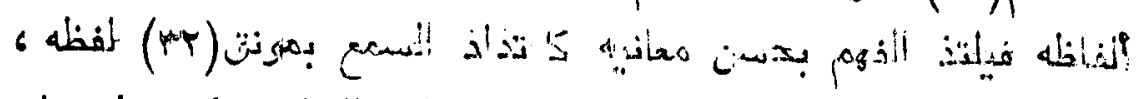

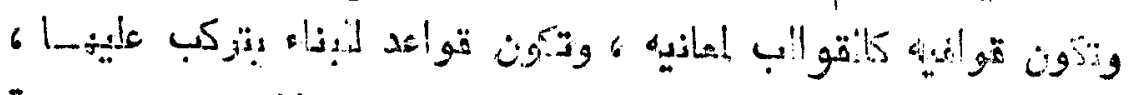

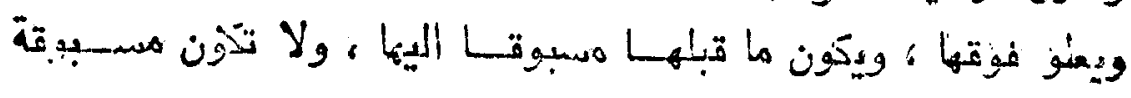

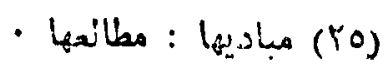

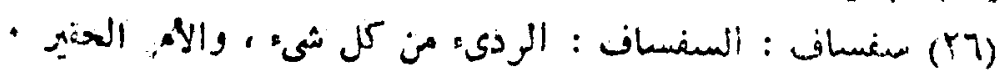

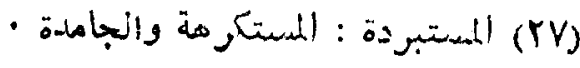

$$
\begin{aligned}
& \text { - النفاسنة (YA) }
\end{aligned}
$$

•

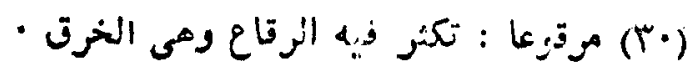

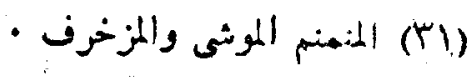

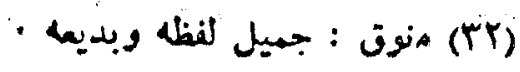




\section{Iir}

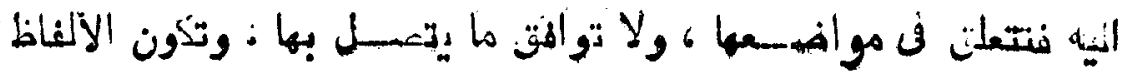

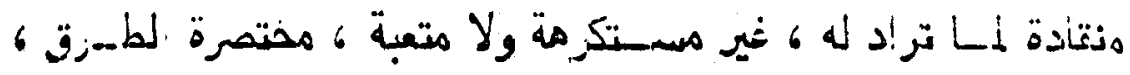

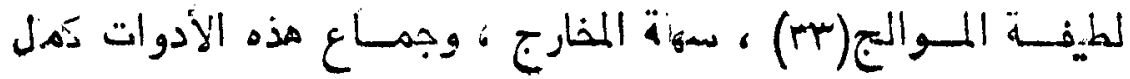

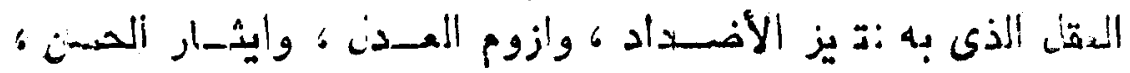

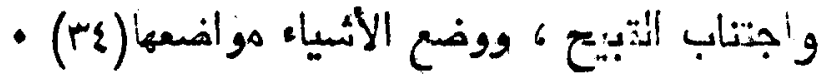

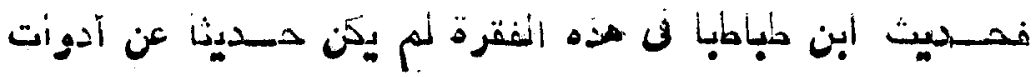

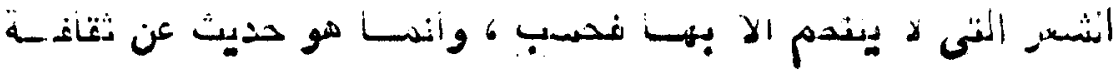

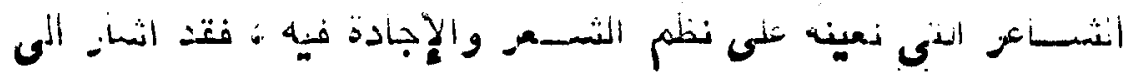

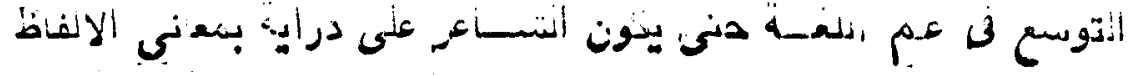

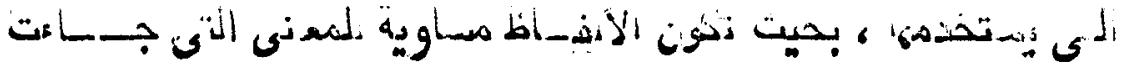

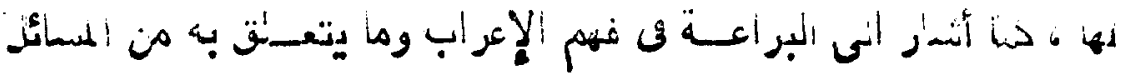

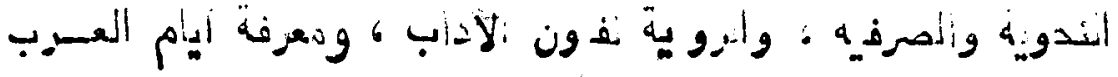

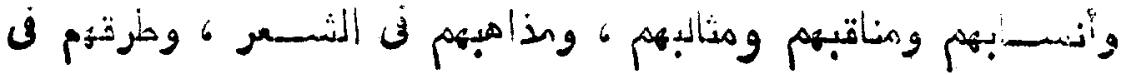

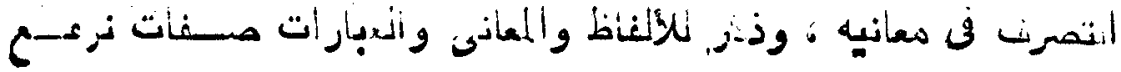

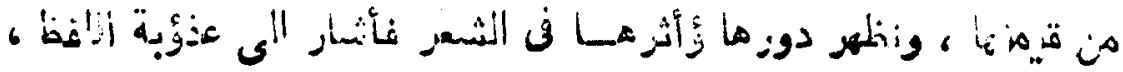

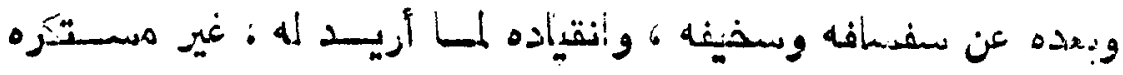

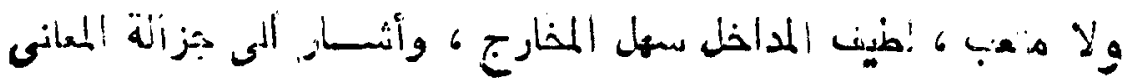

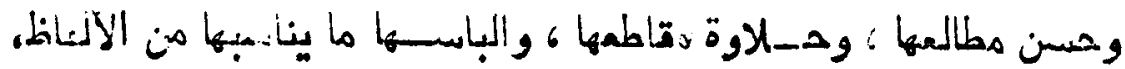

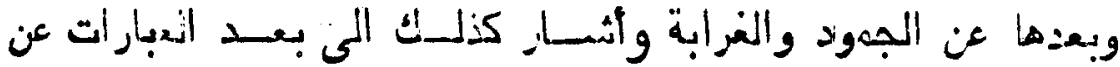

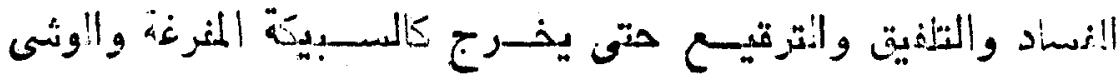
المزخرف والعد_د المنظم والريـاض الز اهرة ، كما أنتسار :لى الالمام

- (r)

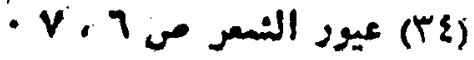




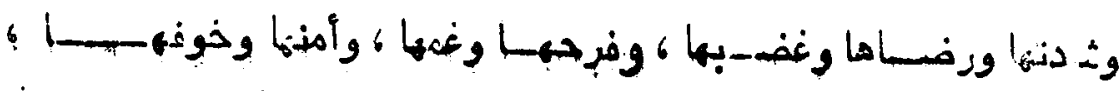

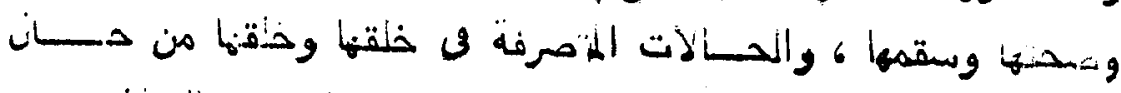

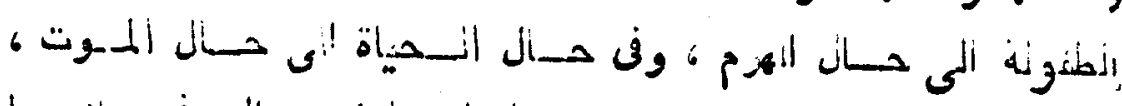

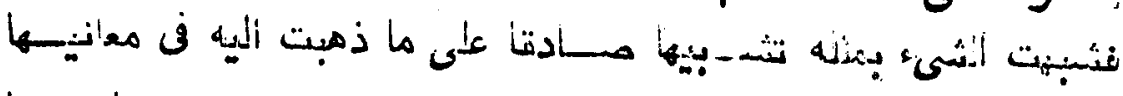

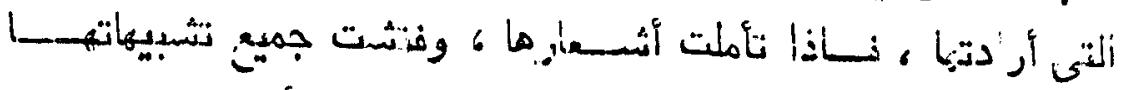

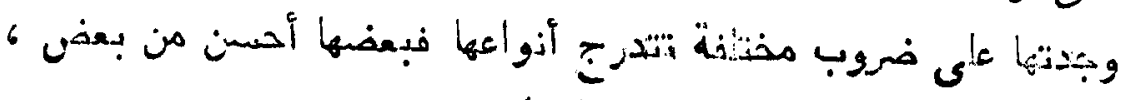

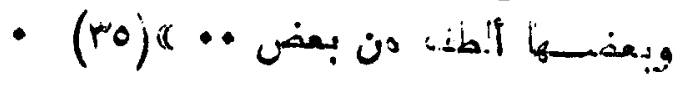

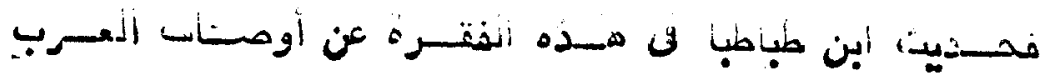

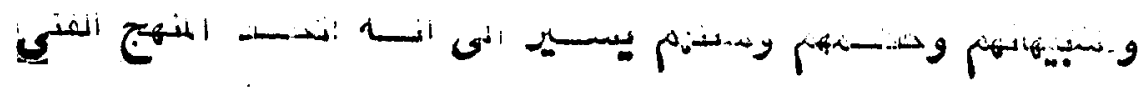

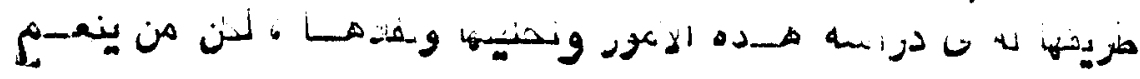

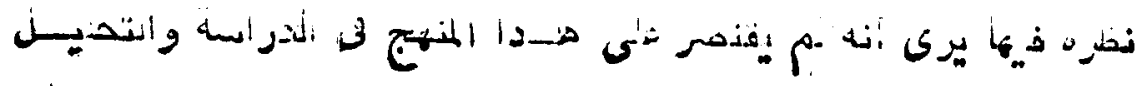

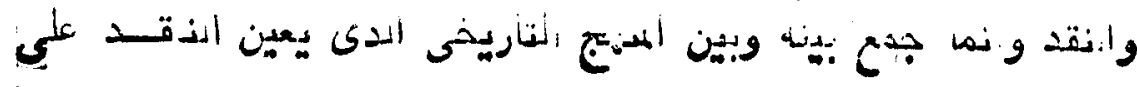

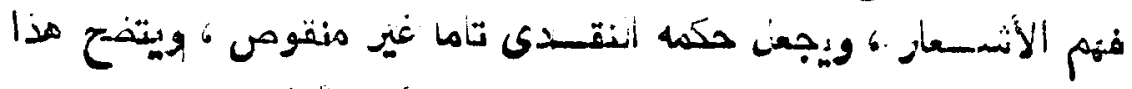

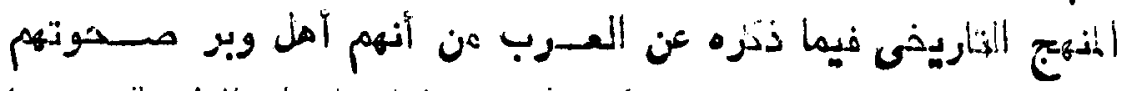

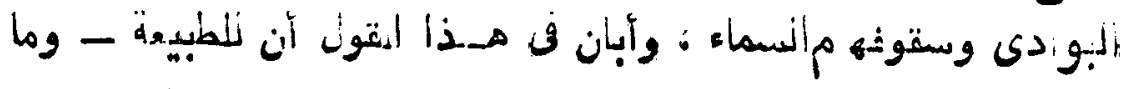

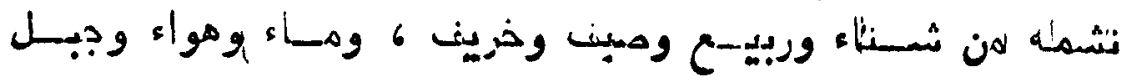

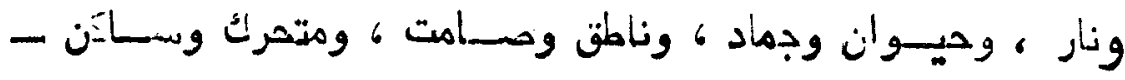

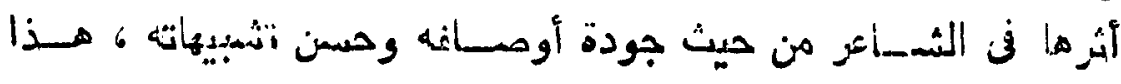

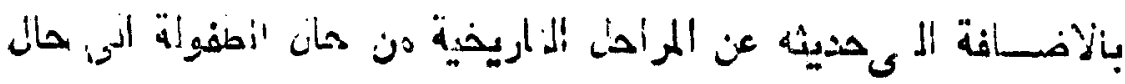

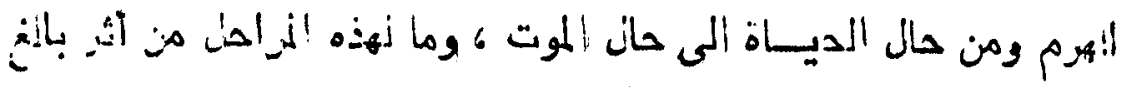

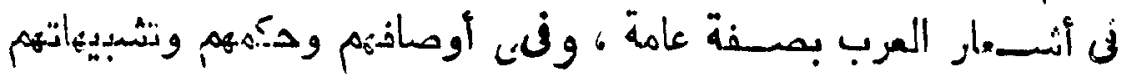

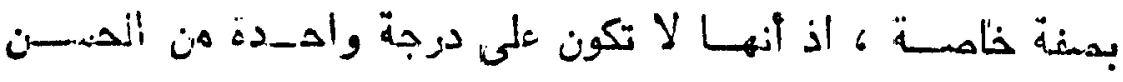

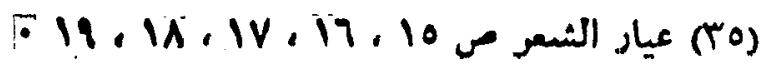




\section{9}

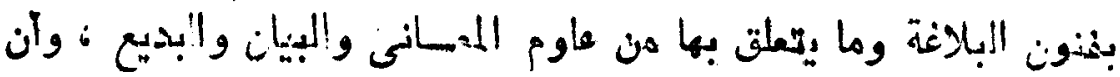

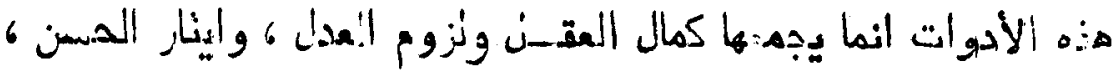

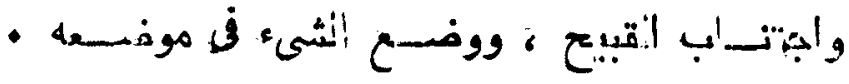

ودما لا ثيك ذيه أن رأى أبن طبنطبا في هذه الأدو'ت وما يأدقها

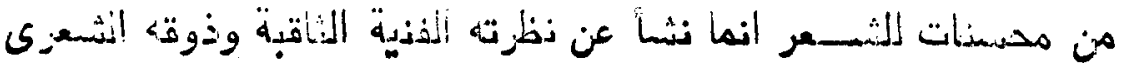

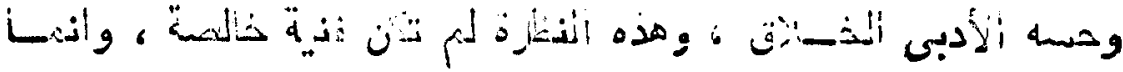

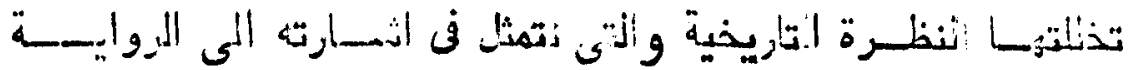

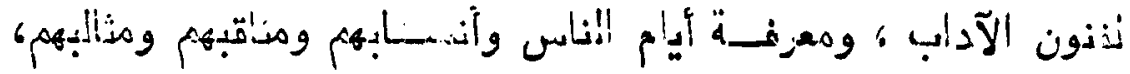

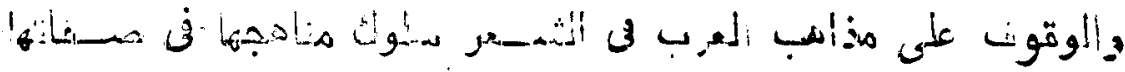

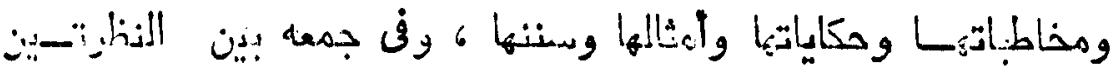

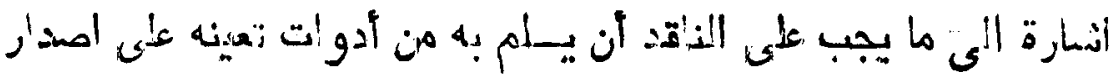

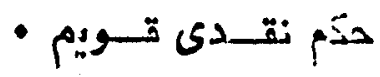

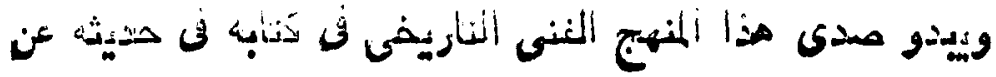

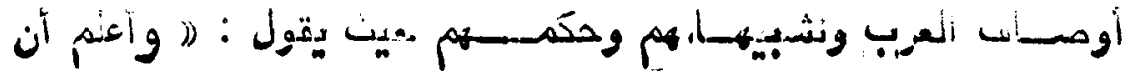

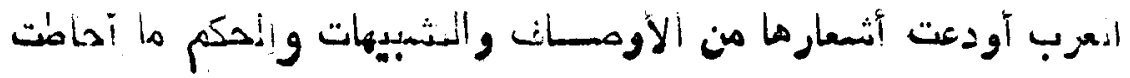

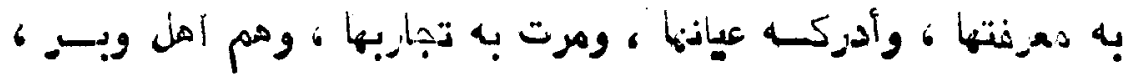

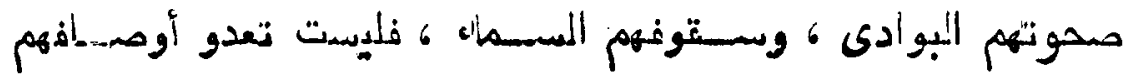

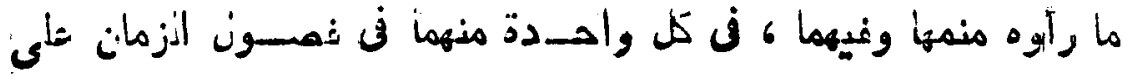

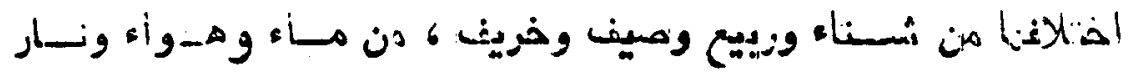

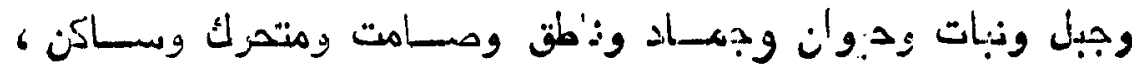

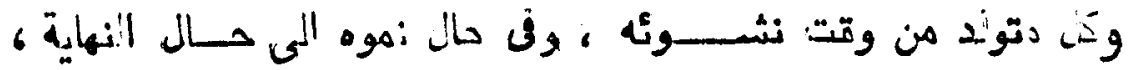

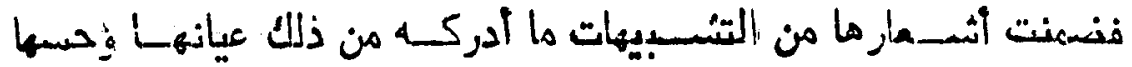

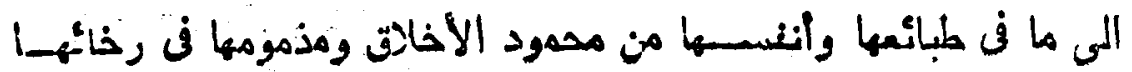




\section{PY.}

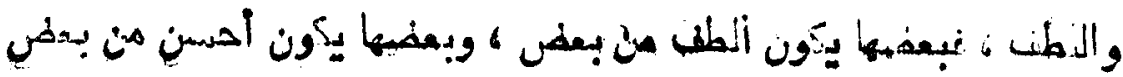

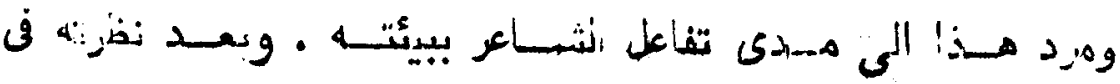

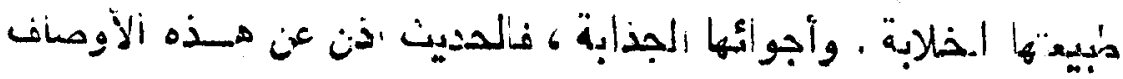

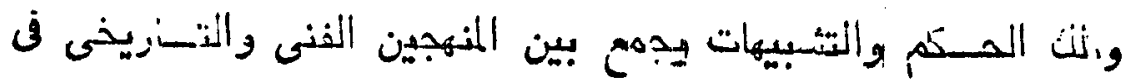

- ن.jil

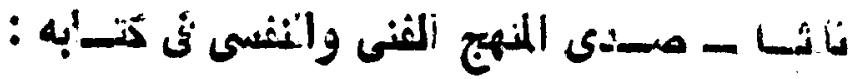

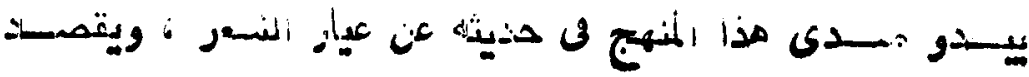

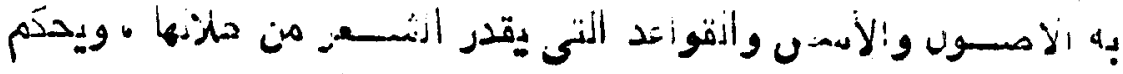

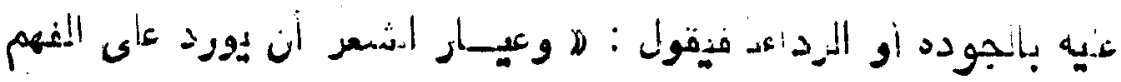

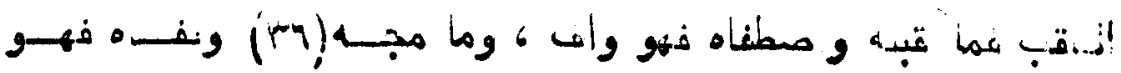

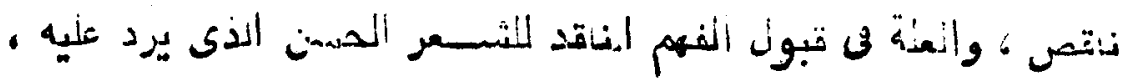

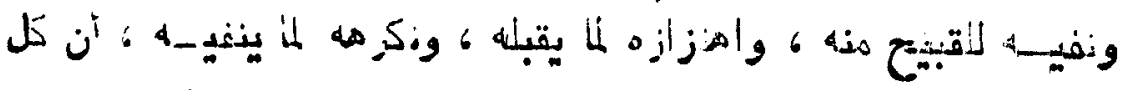

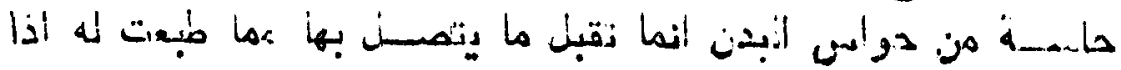

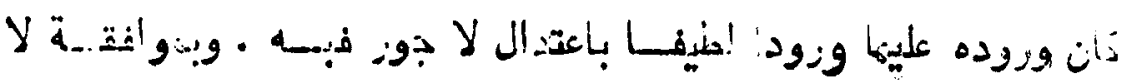

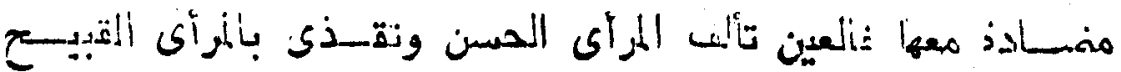

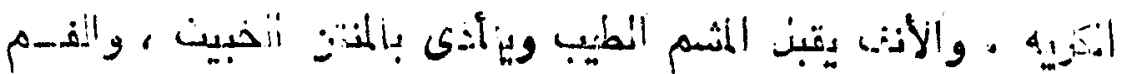

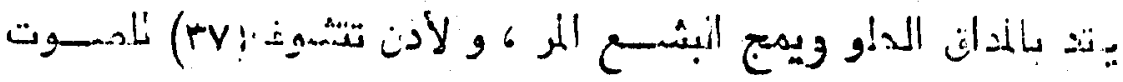

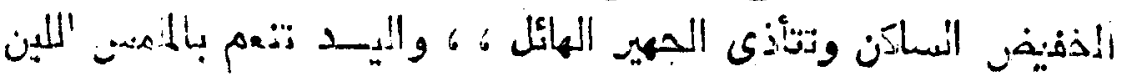

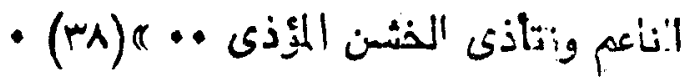

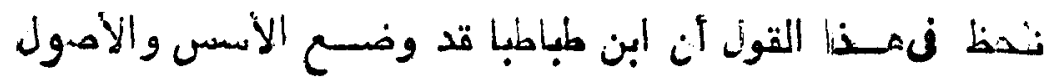

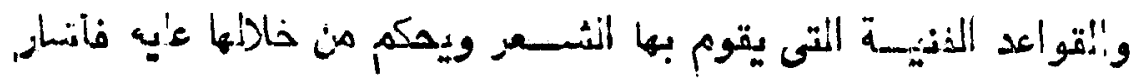

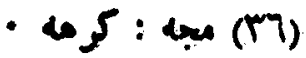

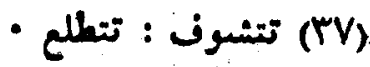

- II مئ (MA) 


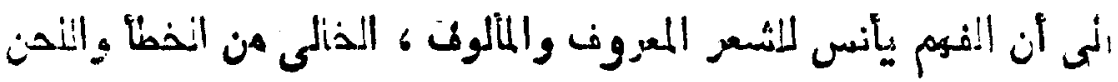

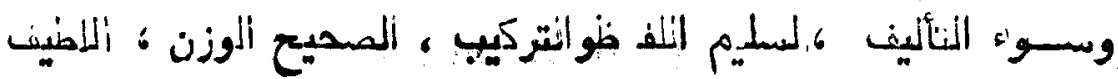

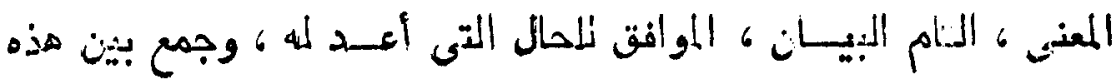

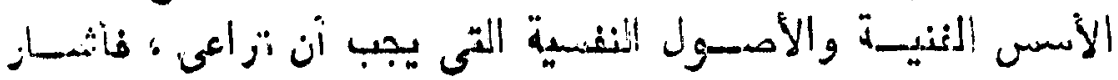

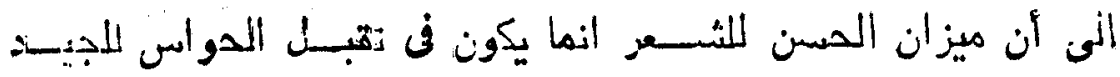

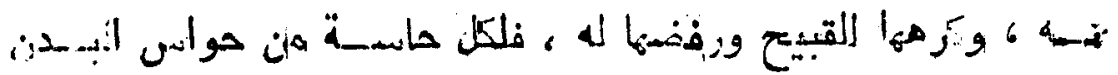

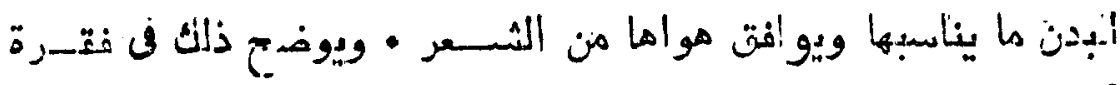

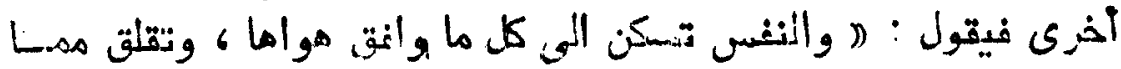

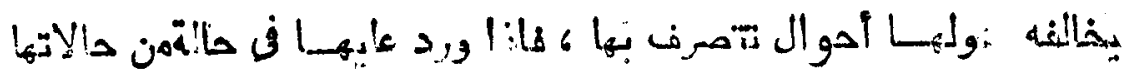

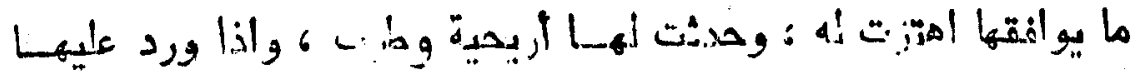

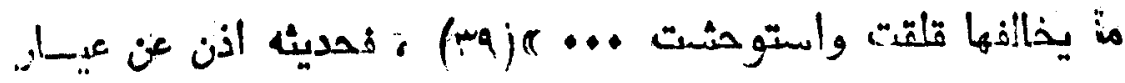

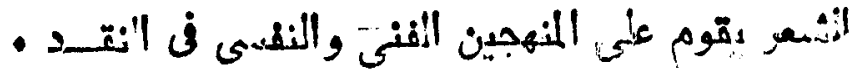

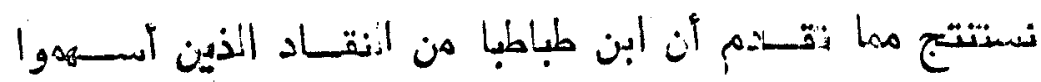

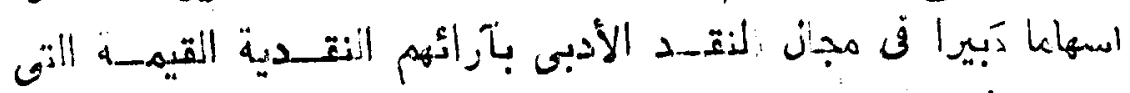

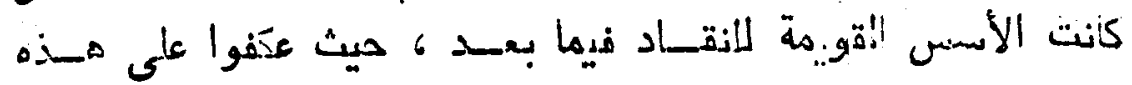

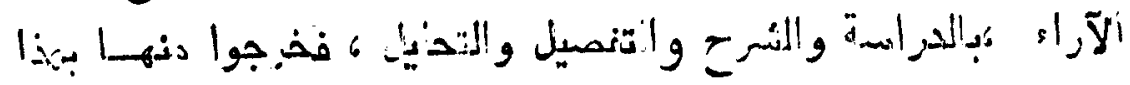

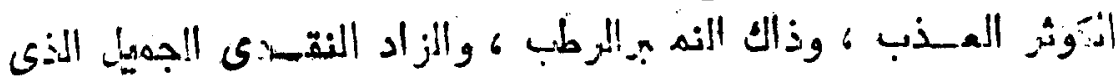

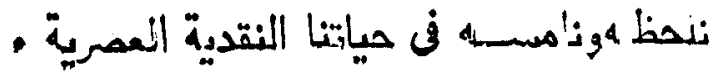

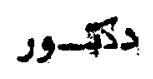

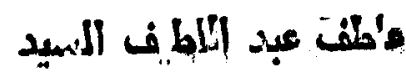

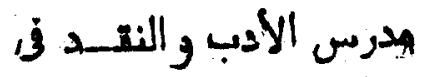

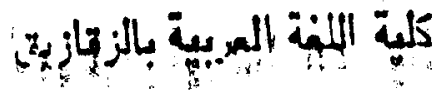


rrr

ثبت المصسادر والمراجع

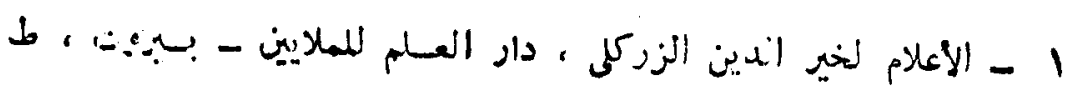

-

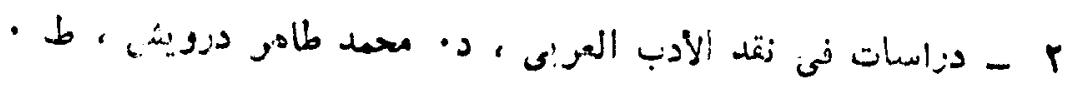

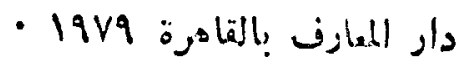

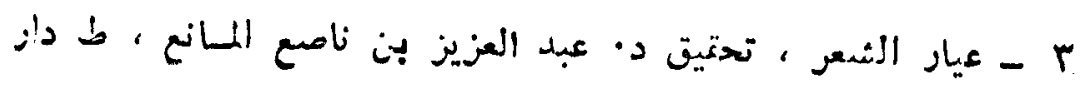

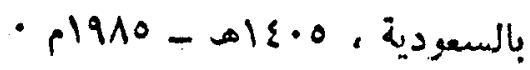

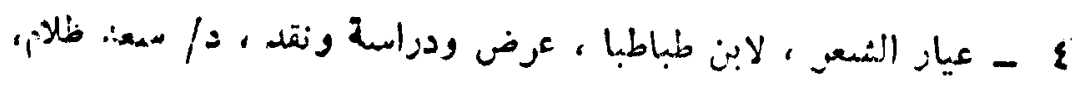

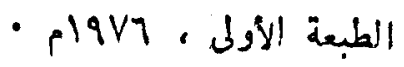

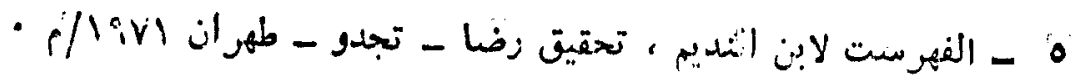

1 - 1

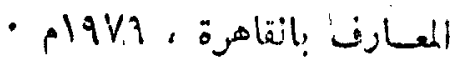

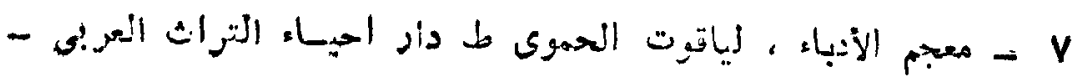

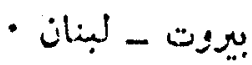

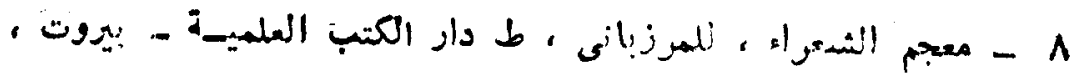

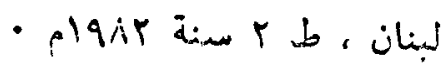

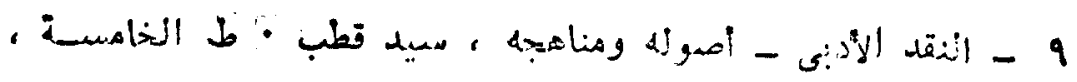

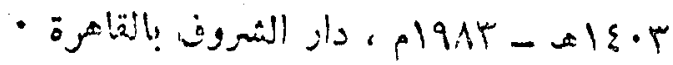

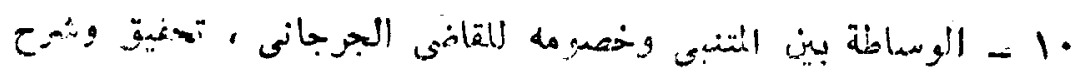

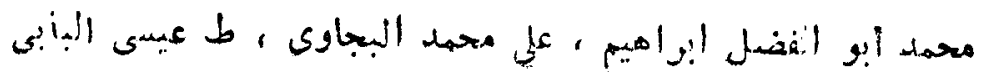

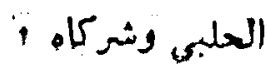




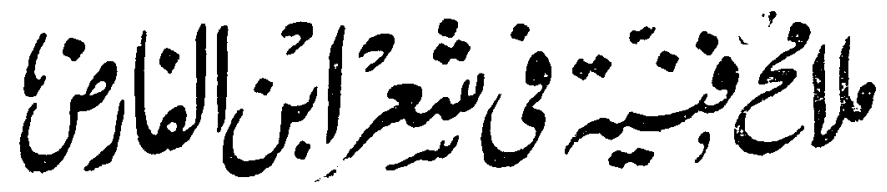 \\ دكتיـور}

رمذان: :وسف مدمز هده2 سلئيان

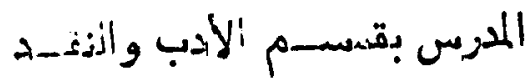

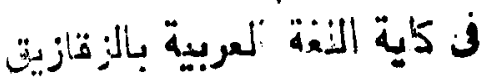

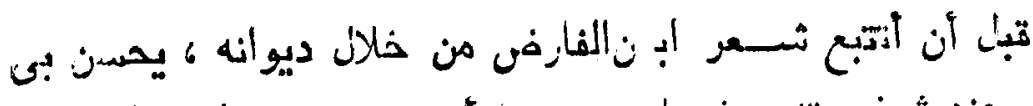

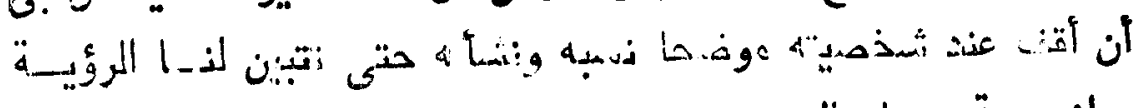

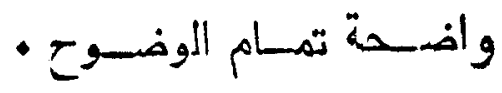

:

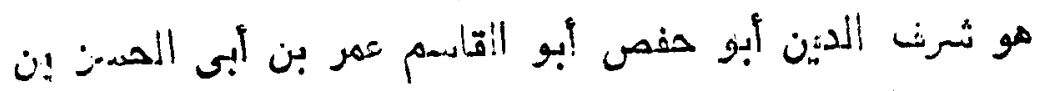

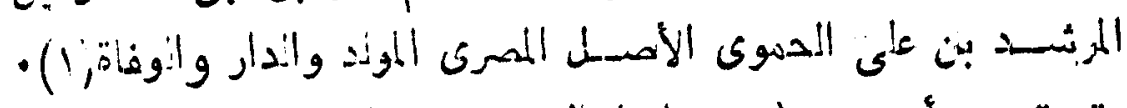

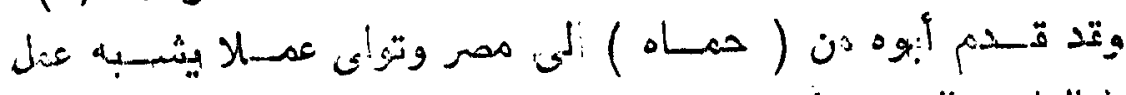

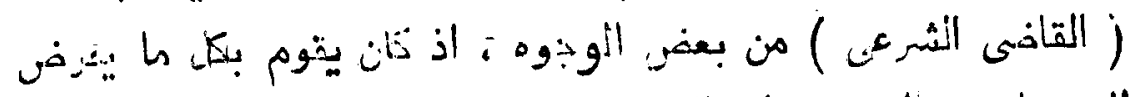

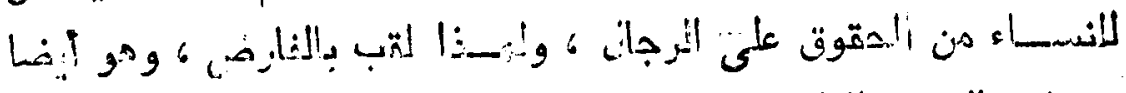

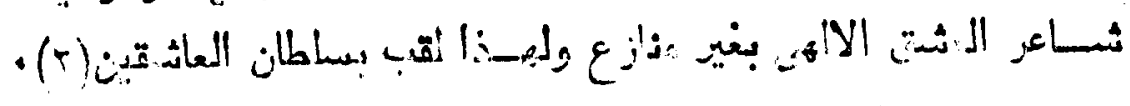

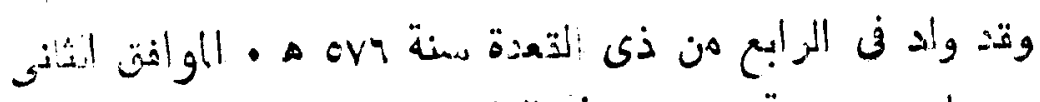

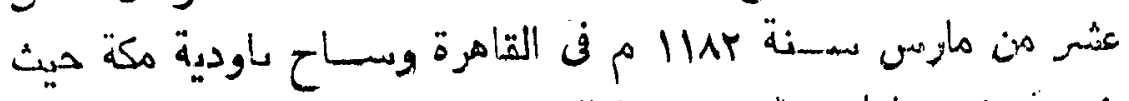

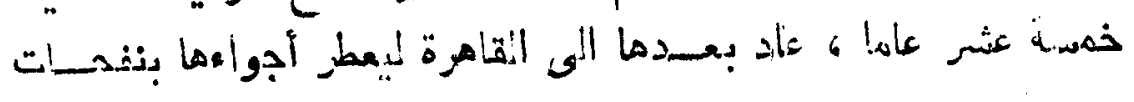

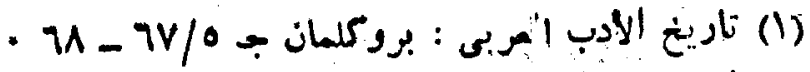

(T) 


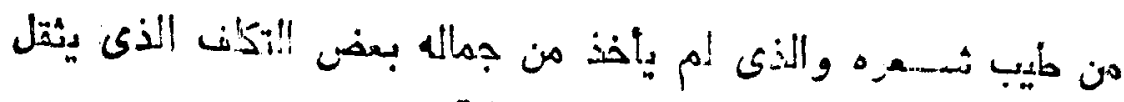

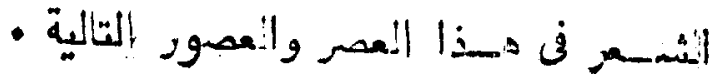

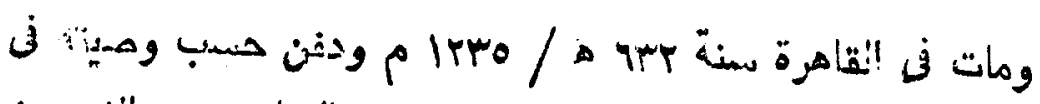

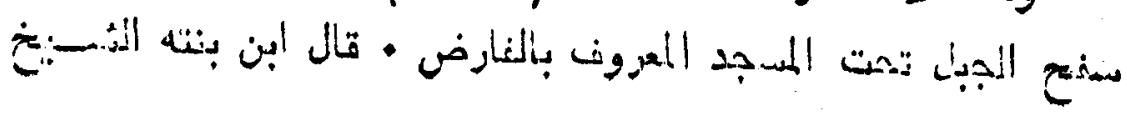

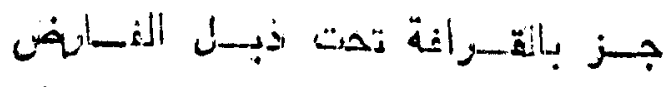

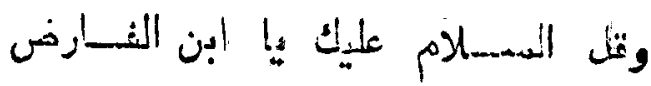

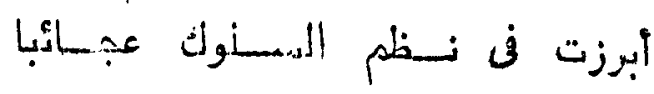

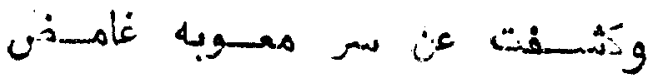

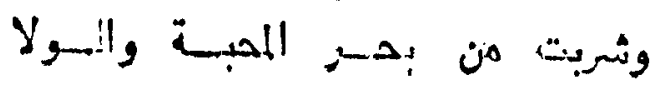

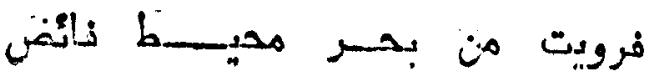

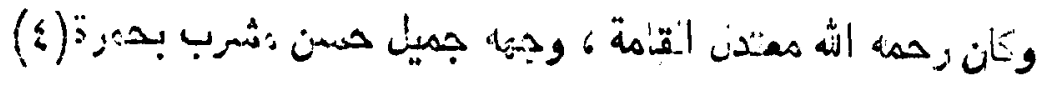

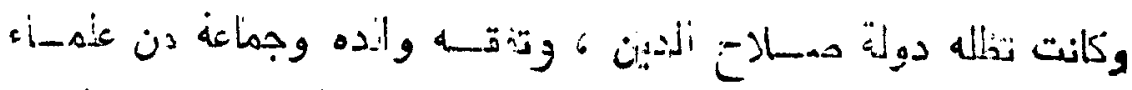

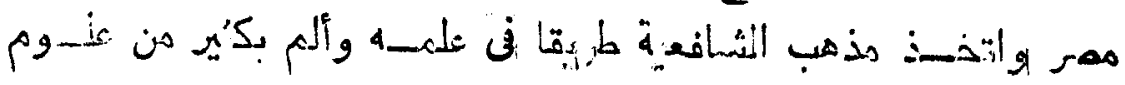

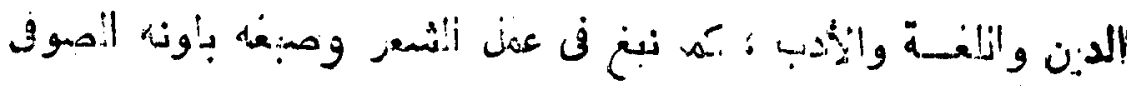

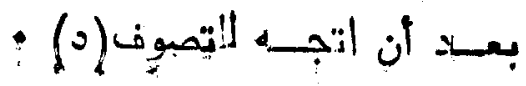

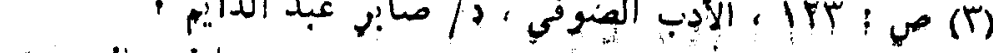

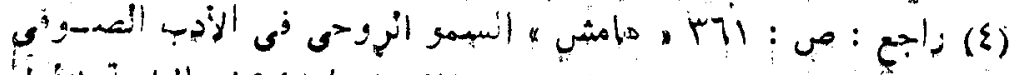

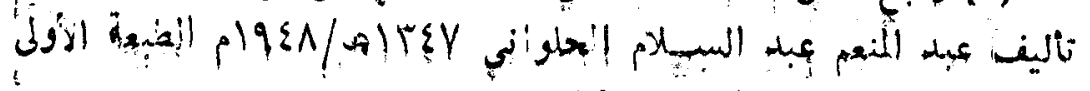

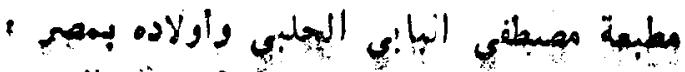

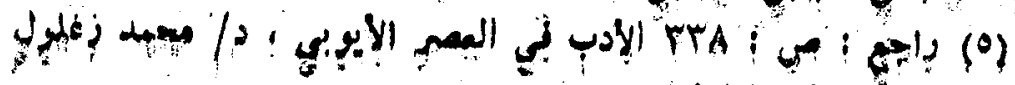




\section{ระด}

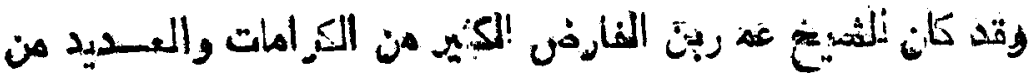

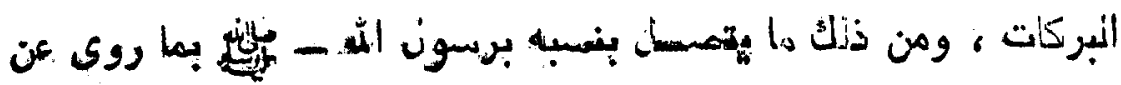

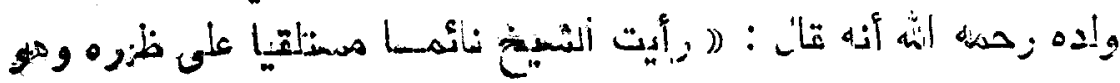

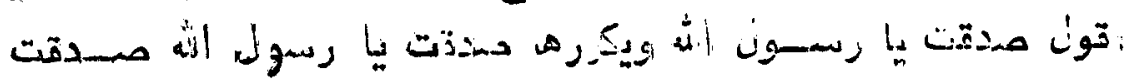

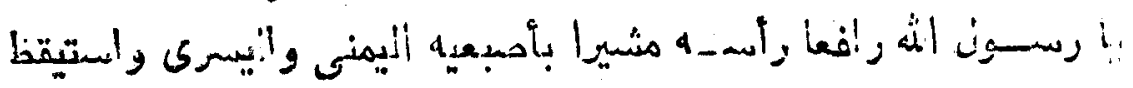

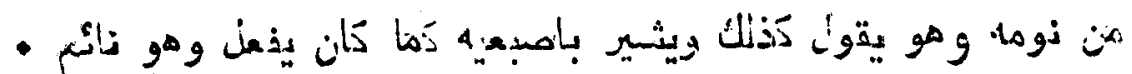

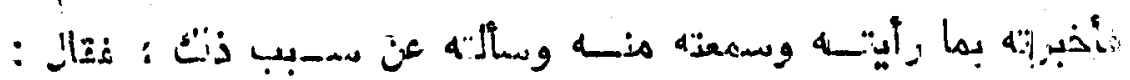

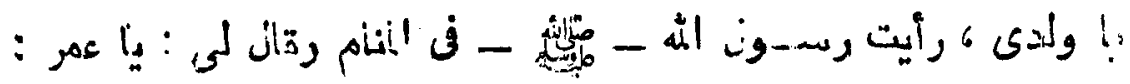

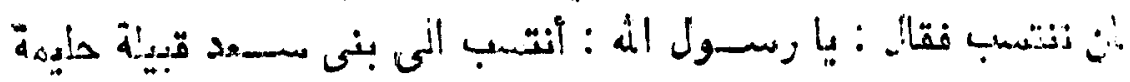

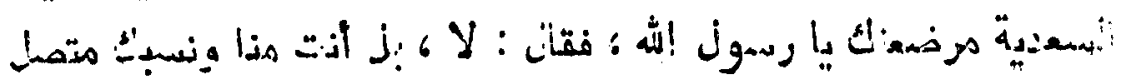

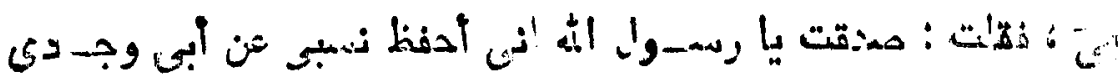

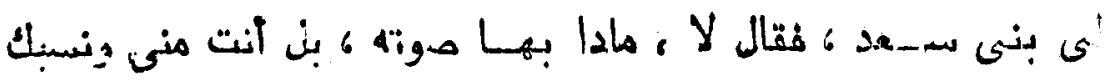

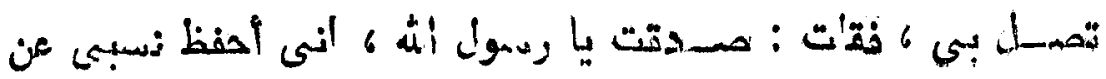

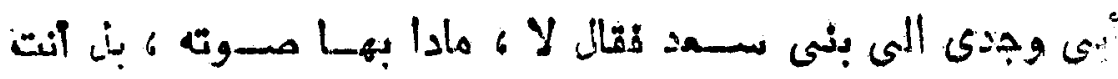

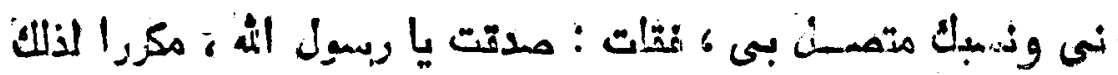

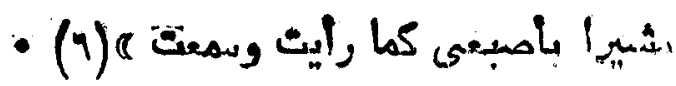

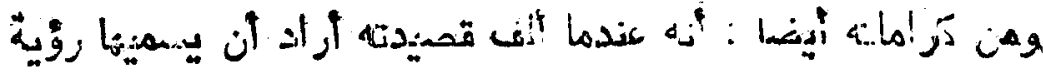

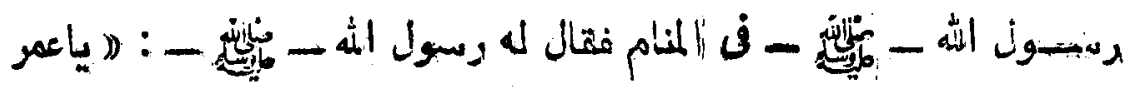

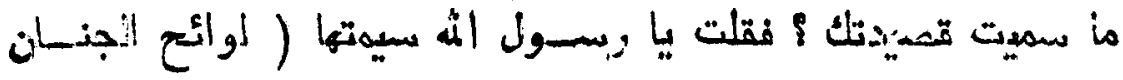

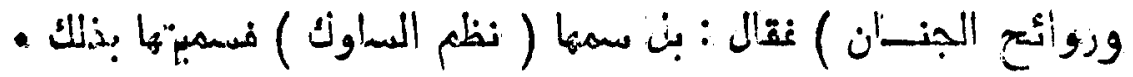

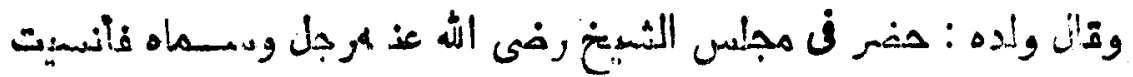

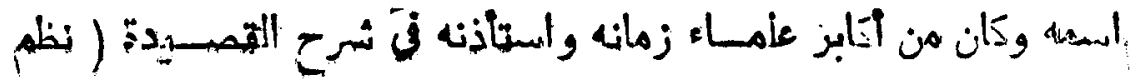

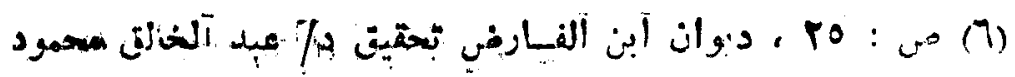

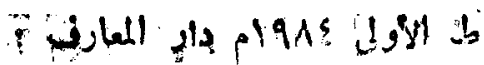
$+2+a$ 


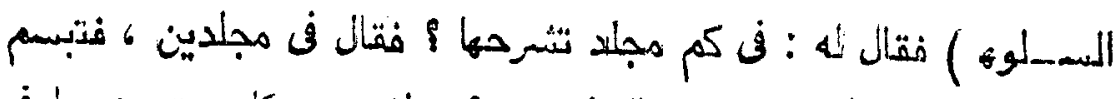

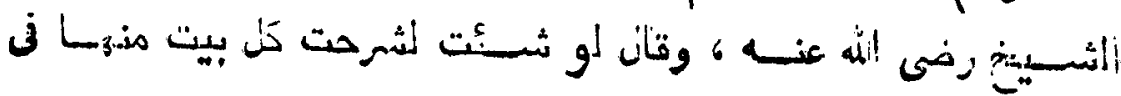

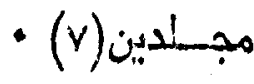

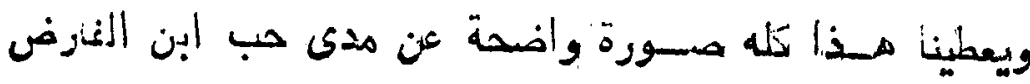

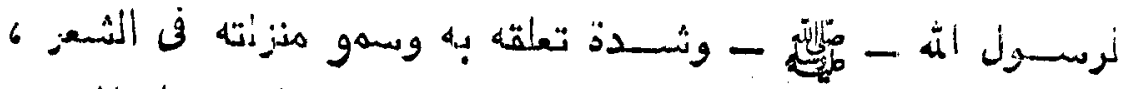

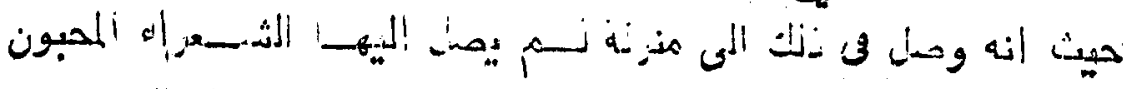

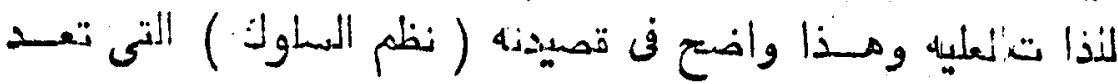

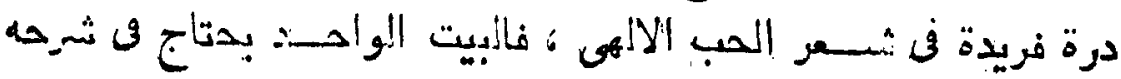

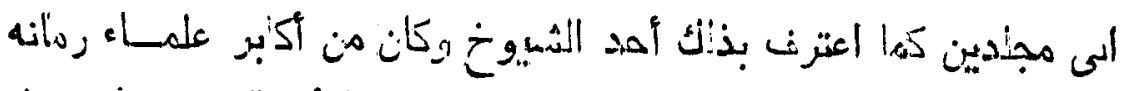

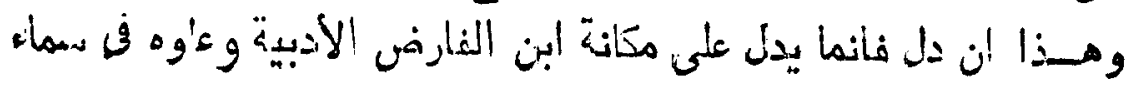

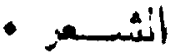

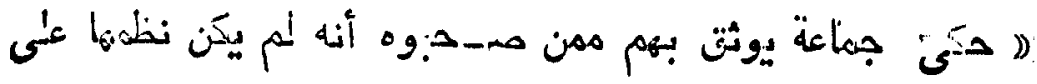

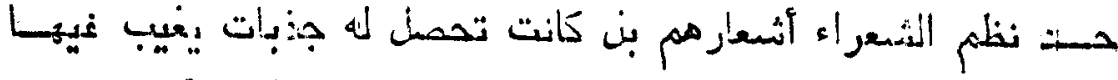

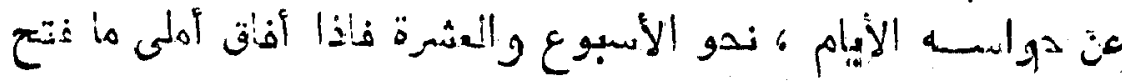

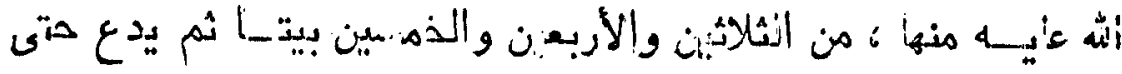

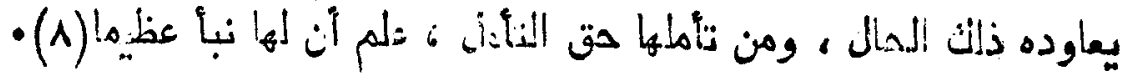

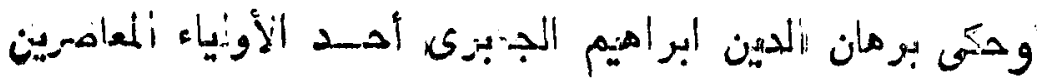

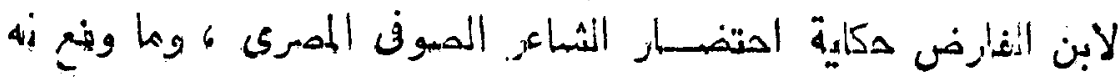

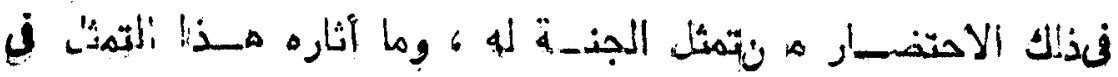

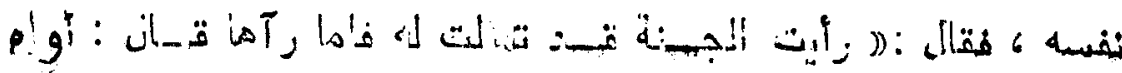

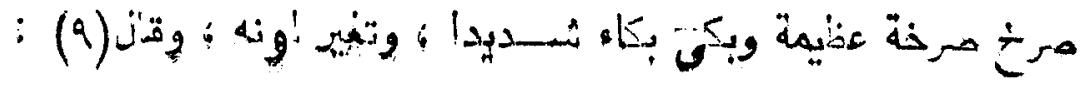

1 Po (V)

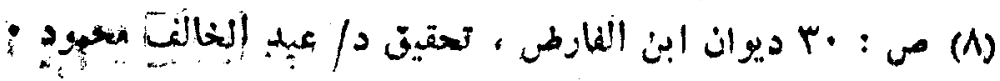

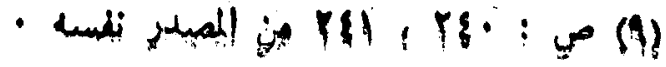


PTV

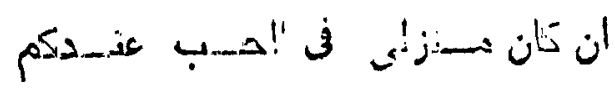

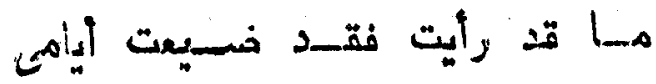

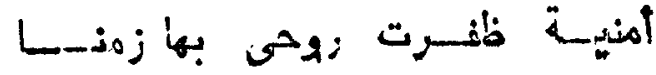

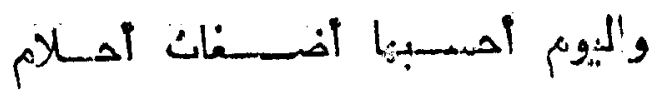

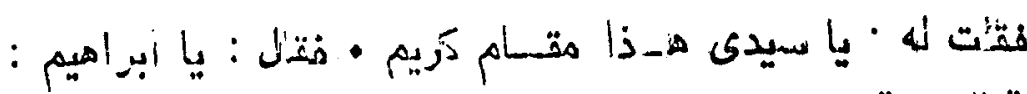

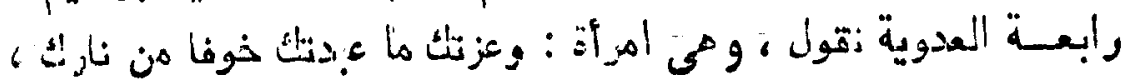

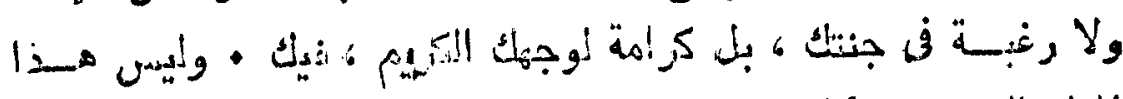

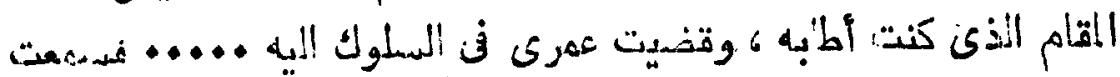

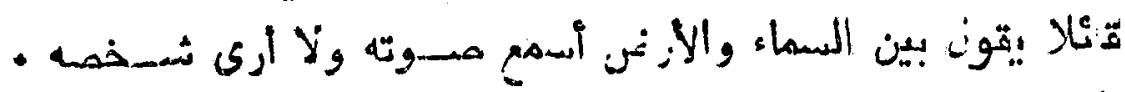

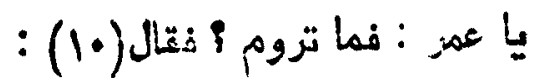

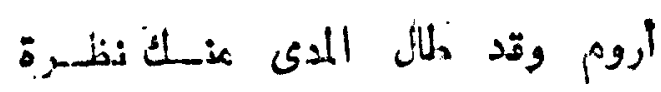

وكم ه il

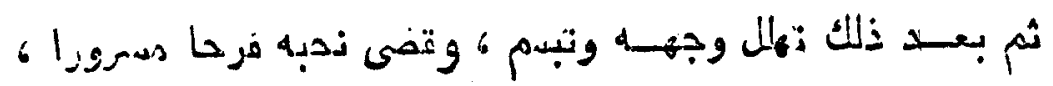

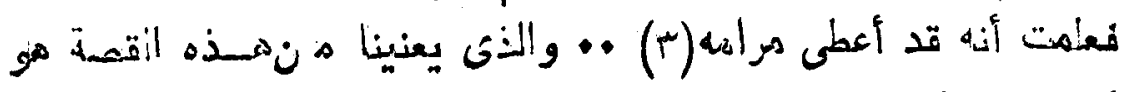

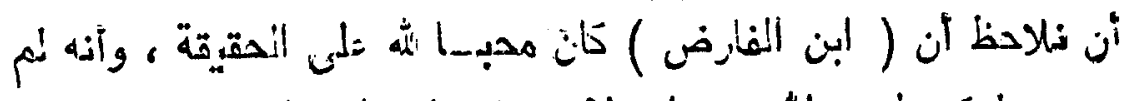

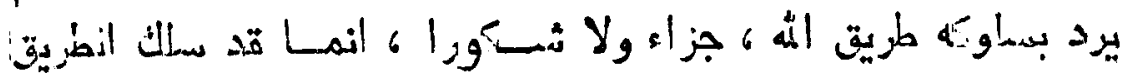

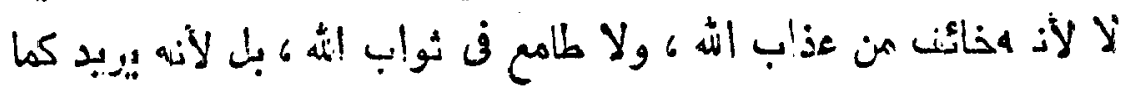

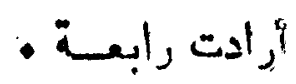

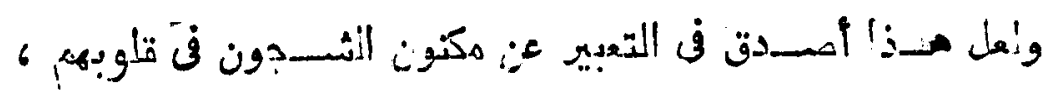

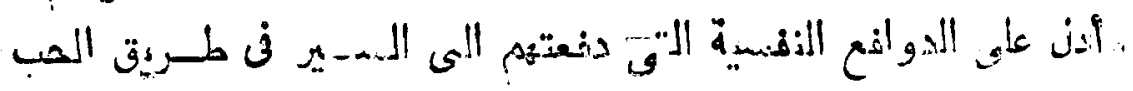

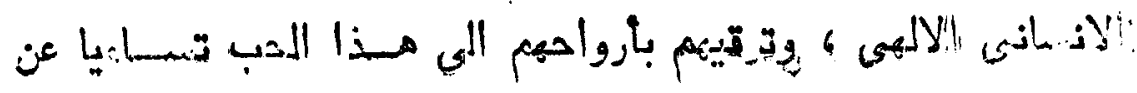




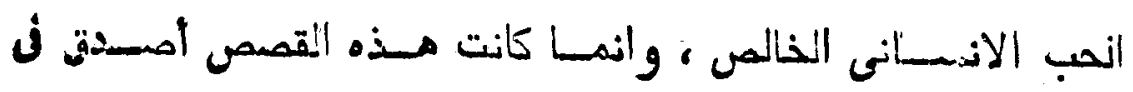

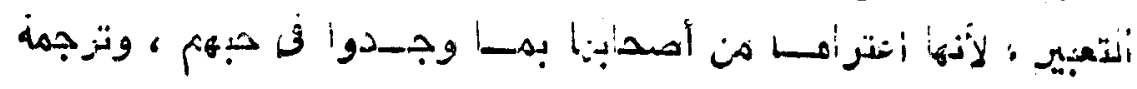

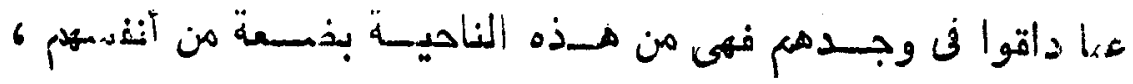

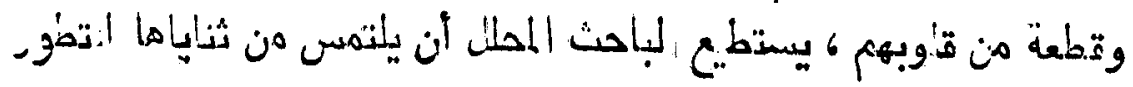

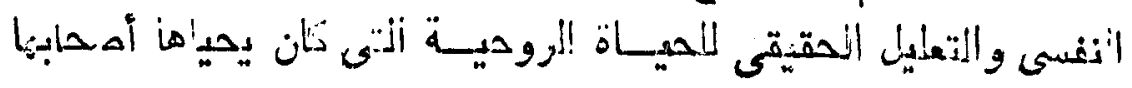

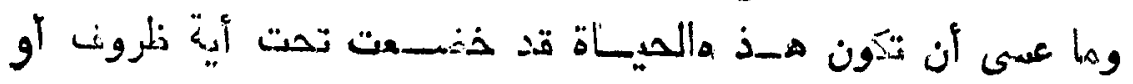
-

\section{اين الفـارض وضلكنـاد}

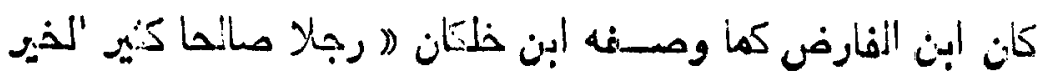

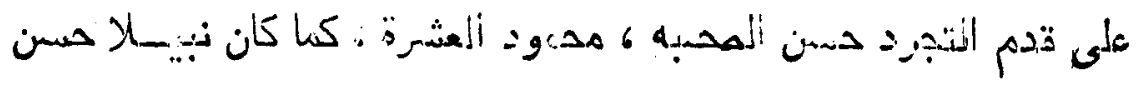

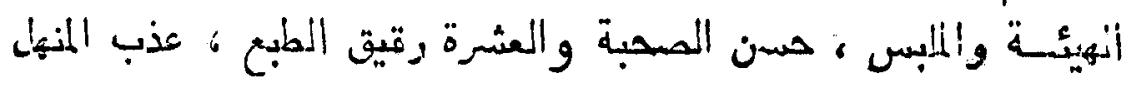

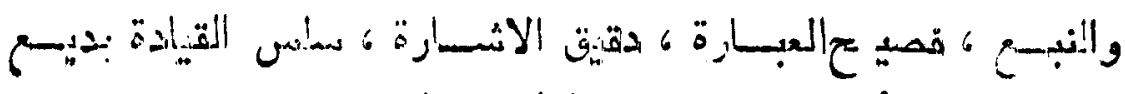

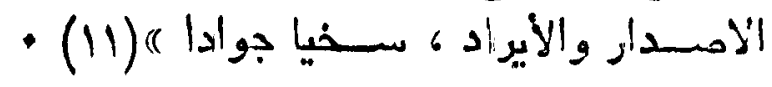

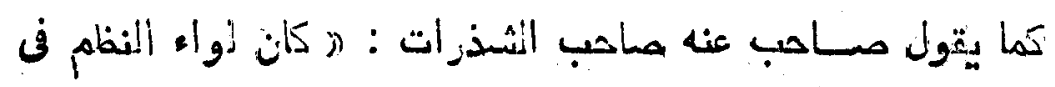

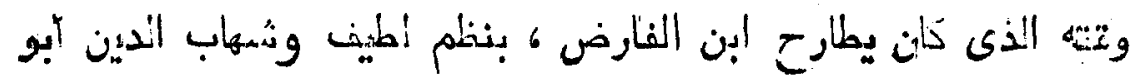

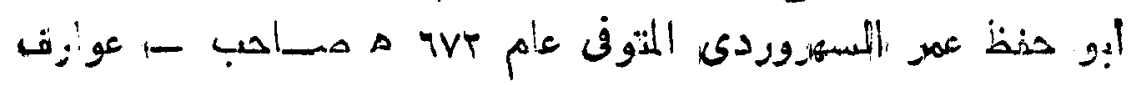

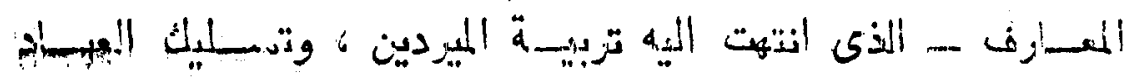

- ومشيخة المارق( Ir)

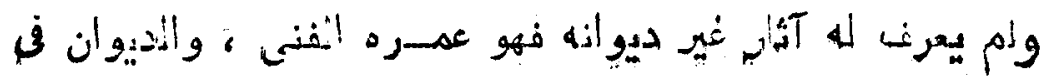

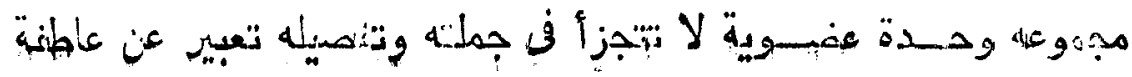

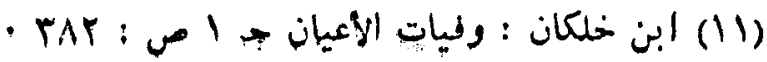

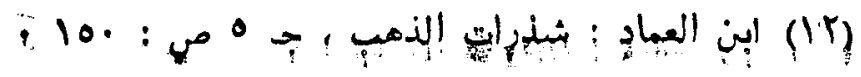




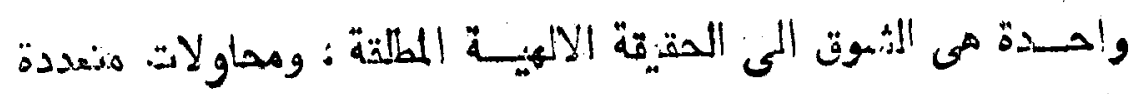

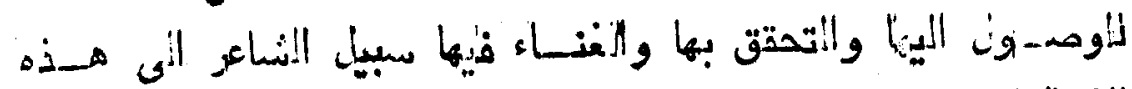

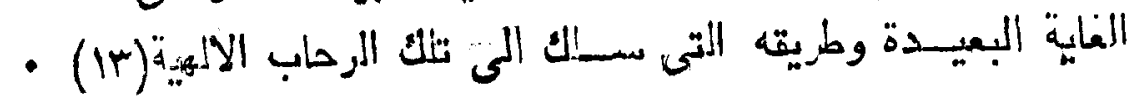
وما هو نأ ابن نبي حيلة يصن ديوان ابن الفهـارض بقــونه .

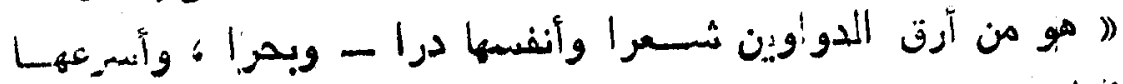

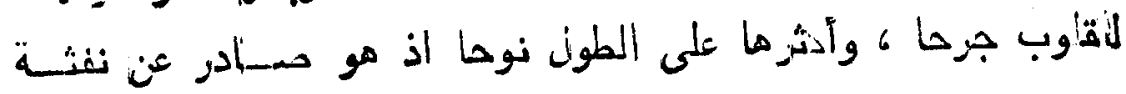

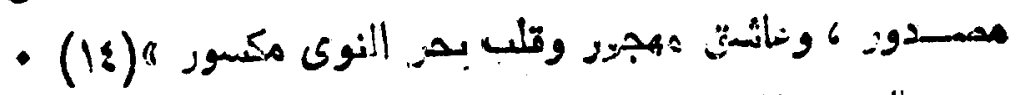

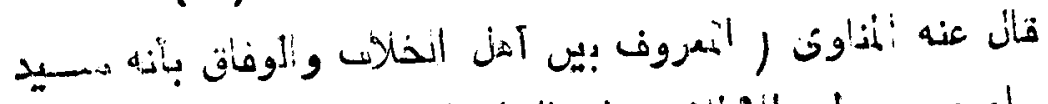

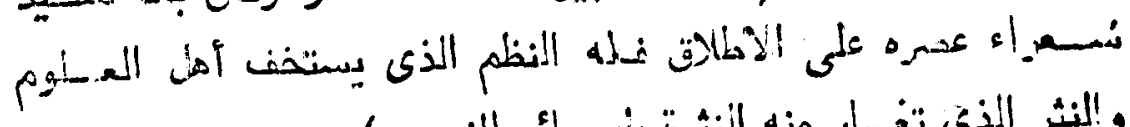

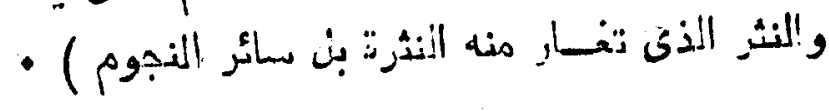

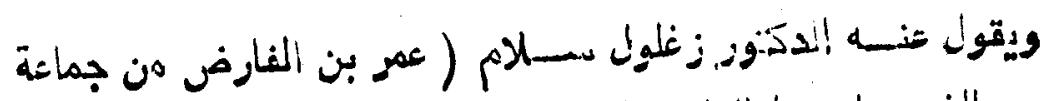

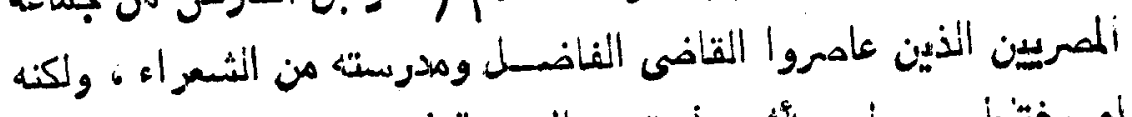

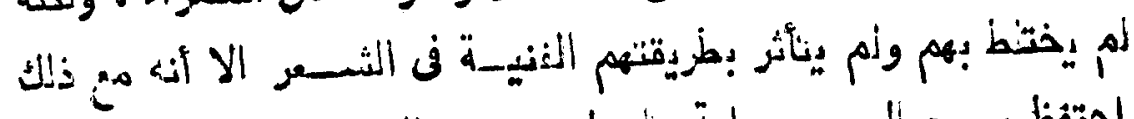

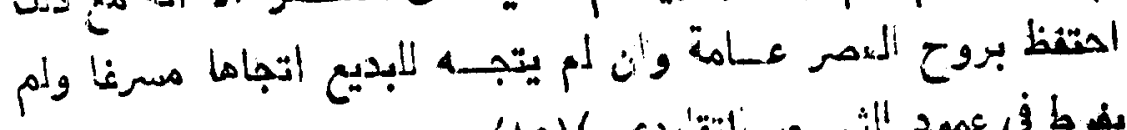

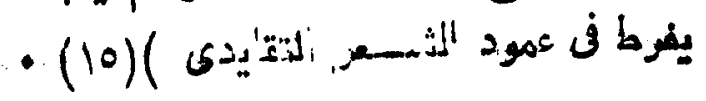

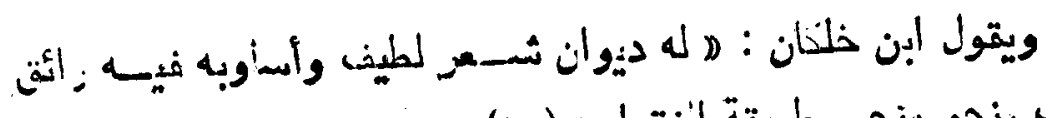

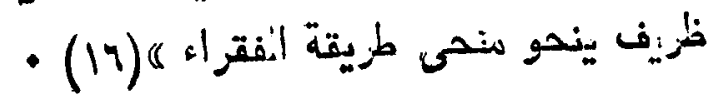

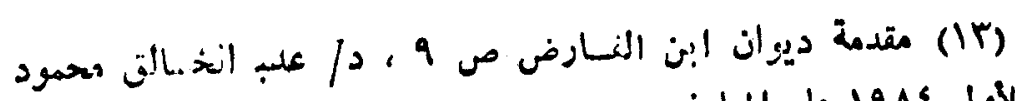

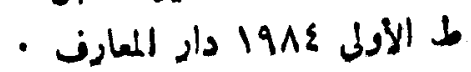

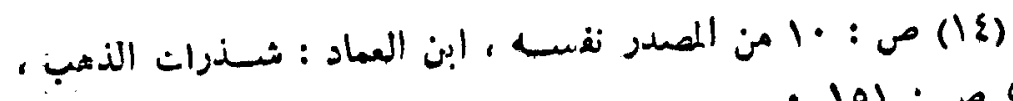
ب 0 ص :

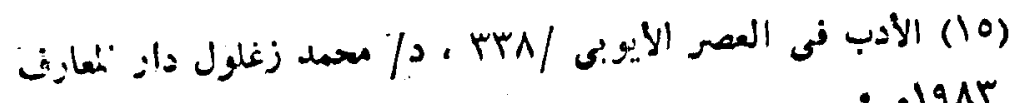
- منة

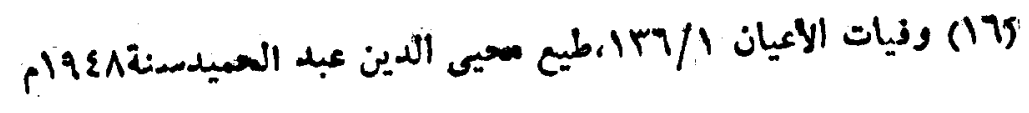


ويمَّن أن نعسد عمر بن انفــارض من جمــاعة الممريدين الذيز

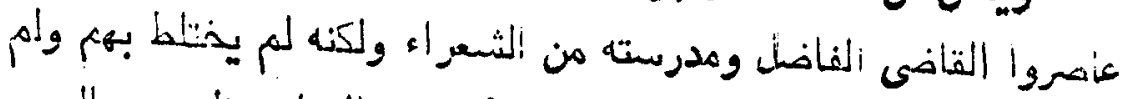

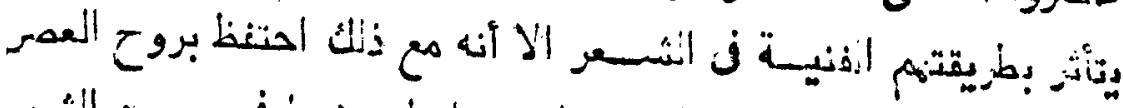

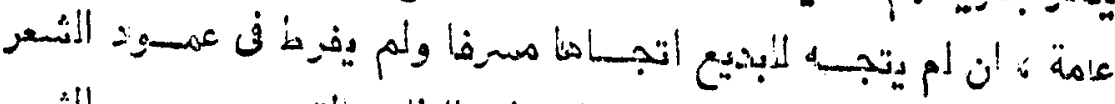

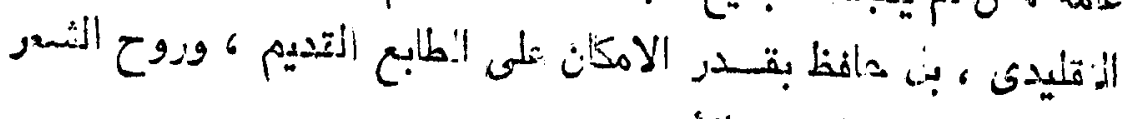

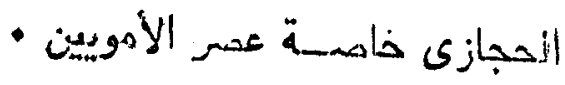

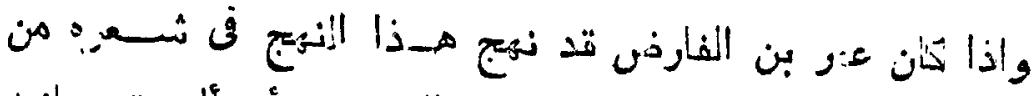

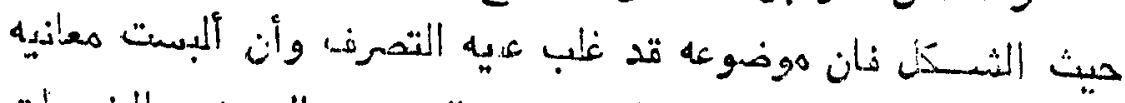

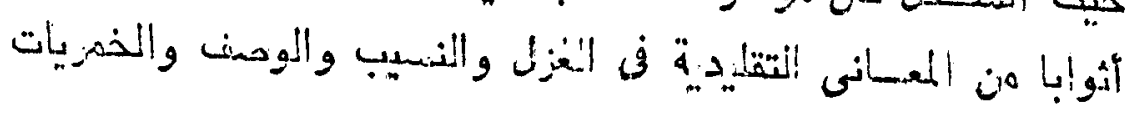

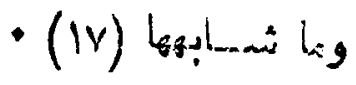

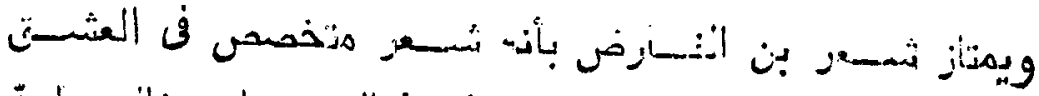

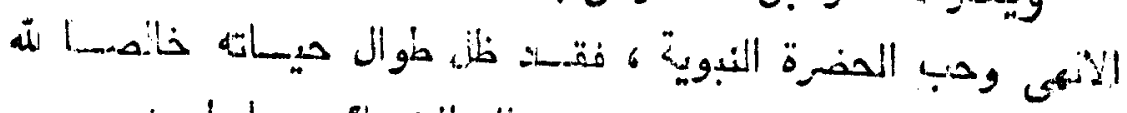

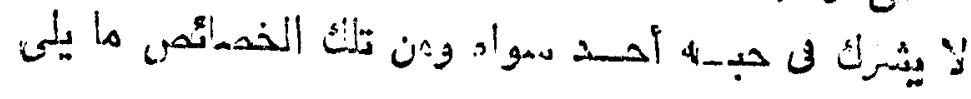

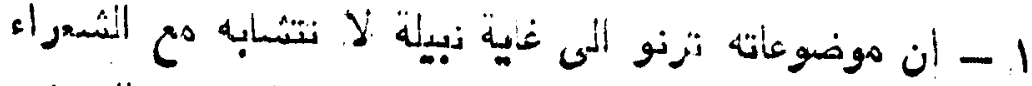

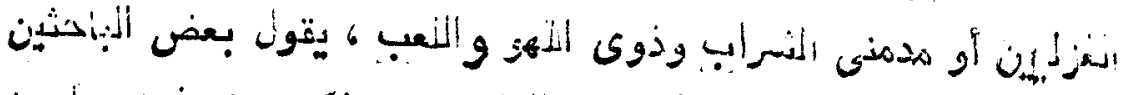

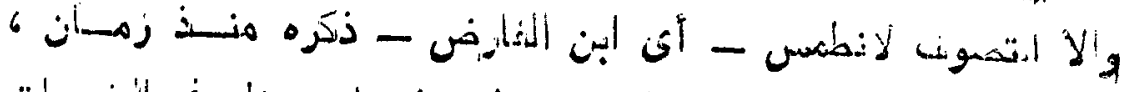

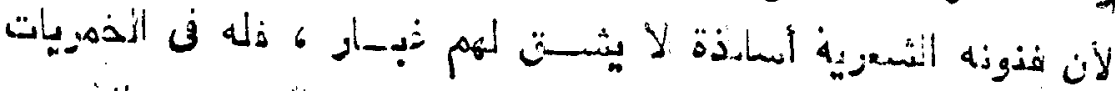

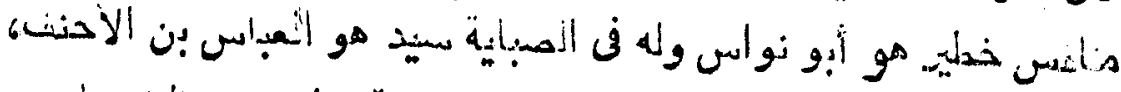

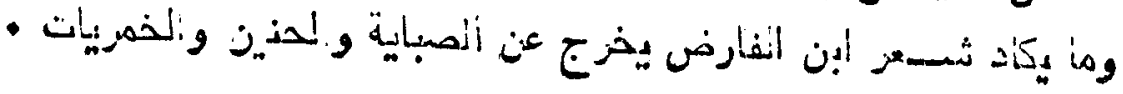

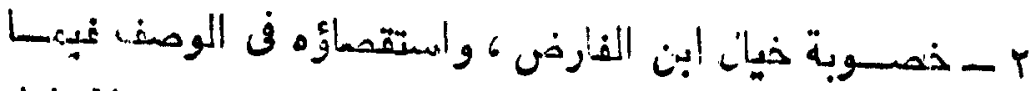

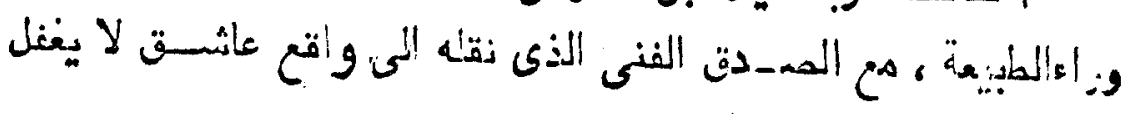

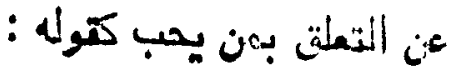

(IV) 
واسـتعرغ الآناقى لحوى بخطسرا

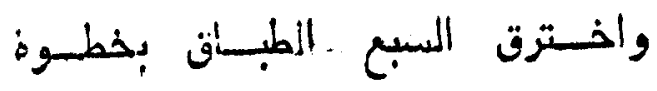

وأنه-باتح من إم انتق فيهم بقيهـة

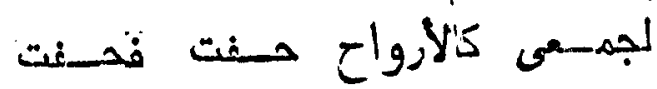

r - ومن ،لخصائص أتى امتساز بها ابن الفارض أنها جمع بين

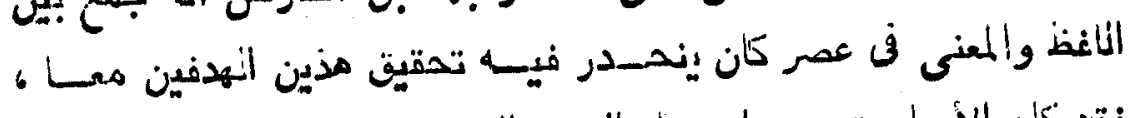

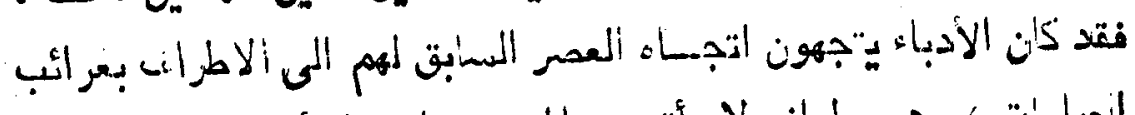

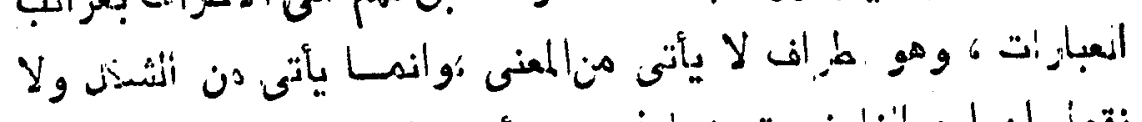

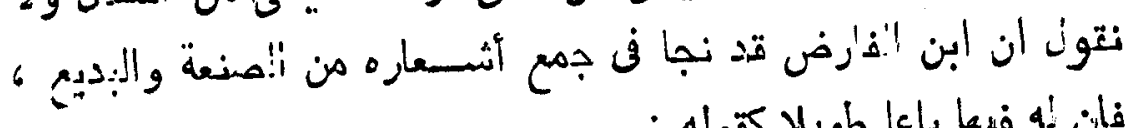

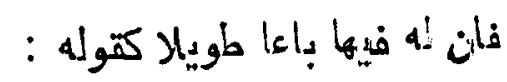

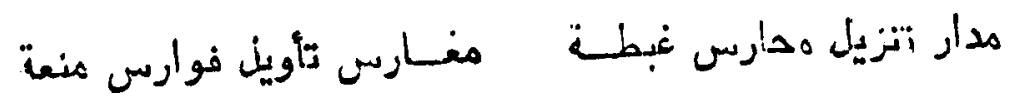

فالمسنعة البنديعية ظاهرة هنا ، ولكن المعنى الى جانبها تيوى لا

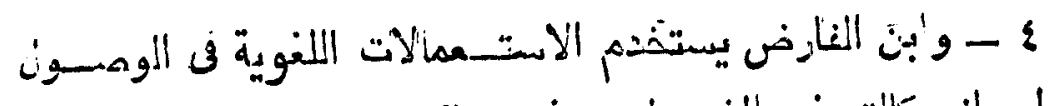

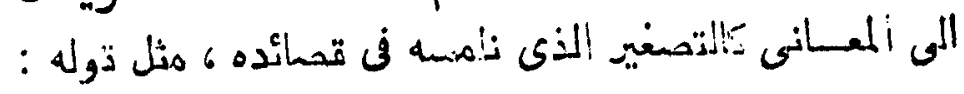

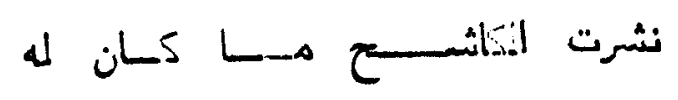

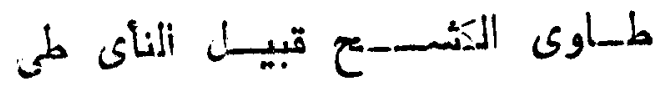

$$
\text { و3_ald }
$$

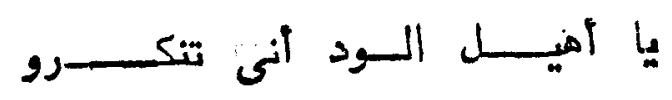

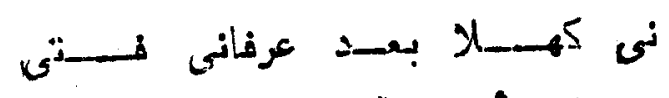

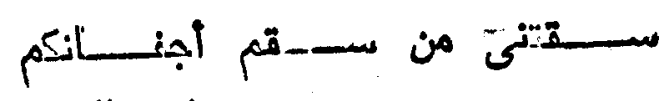

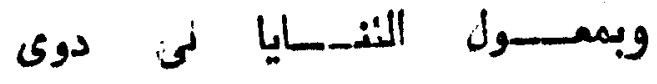




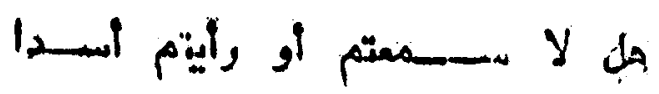

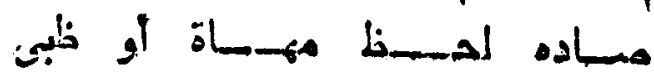

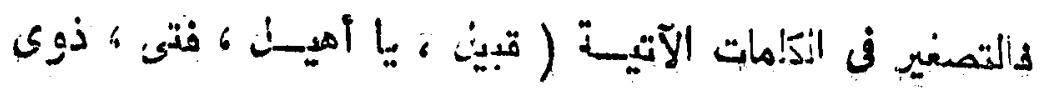
- $(-3)$

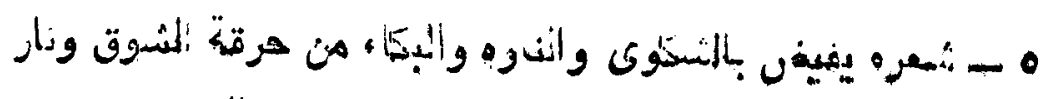

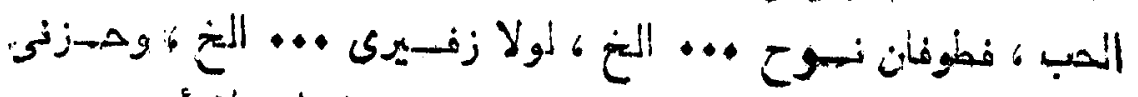

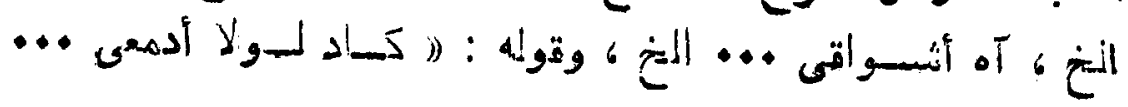
- (11) a $\dot{c} !$

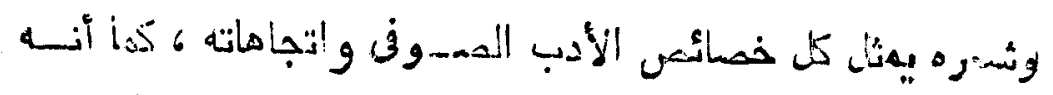

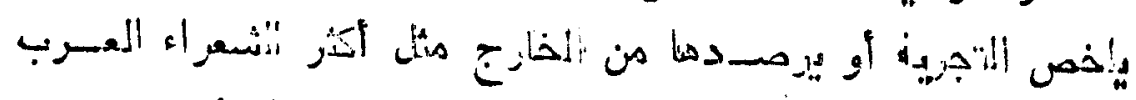

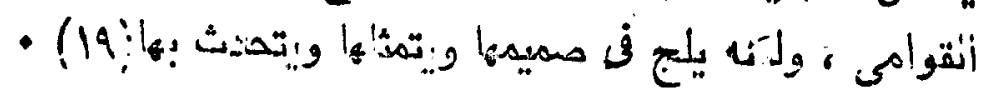

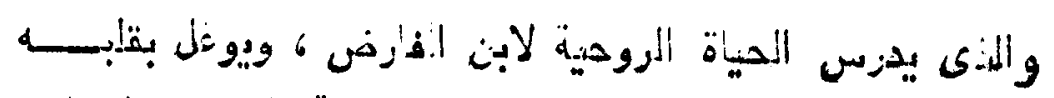

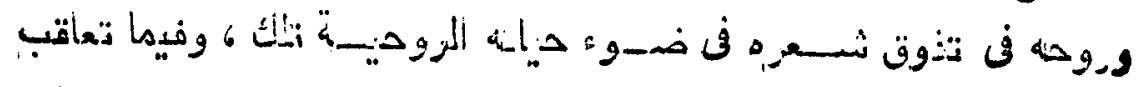

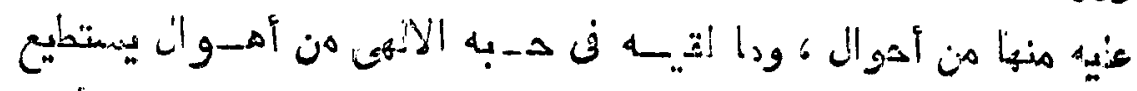

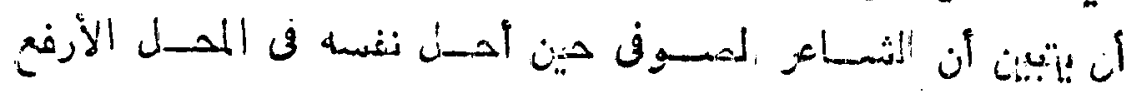

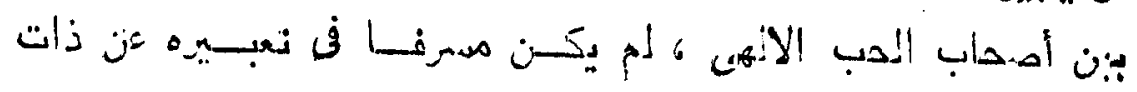

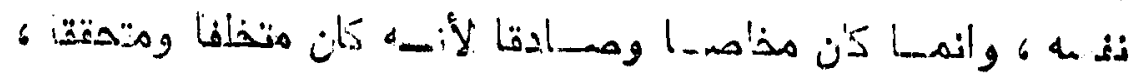

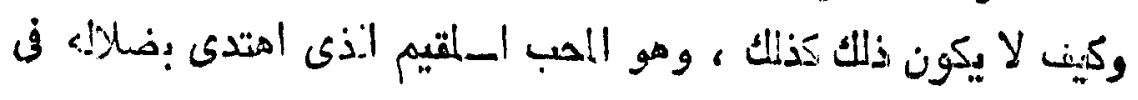

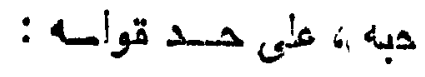

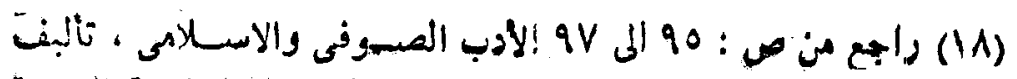

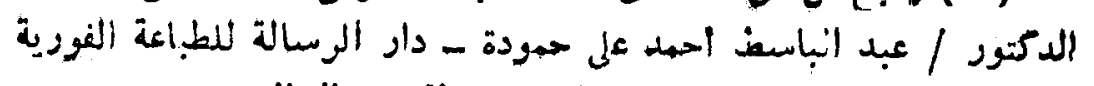

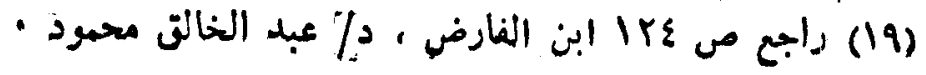




\section{IYY}

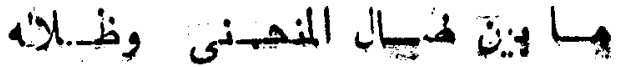

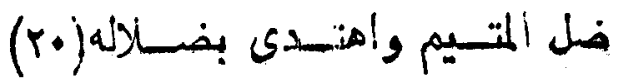

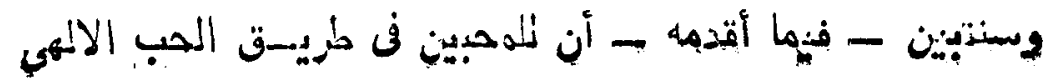

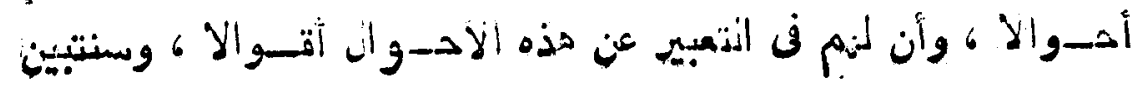

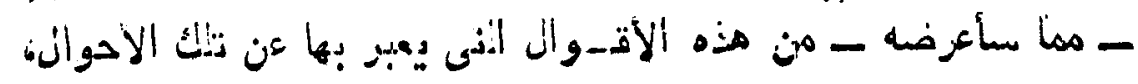

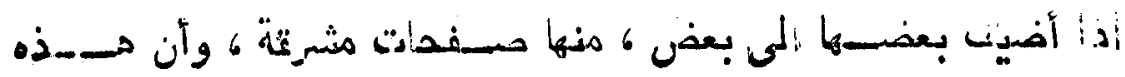

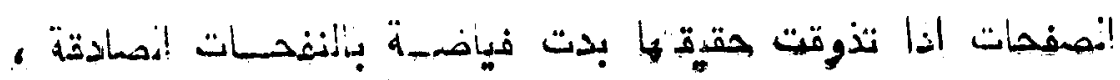

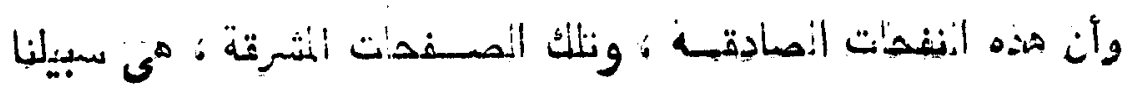

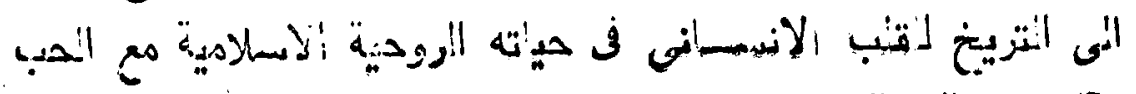

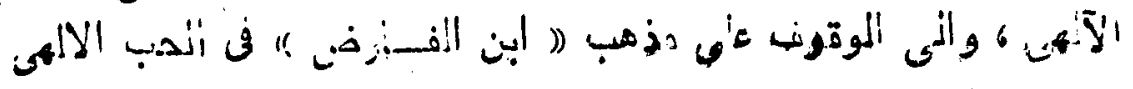

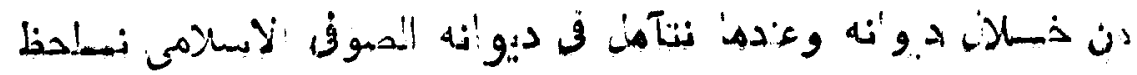

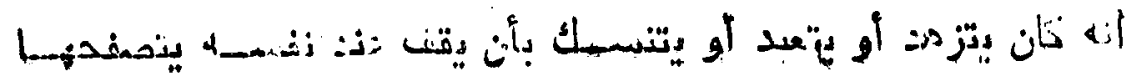

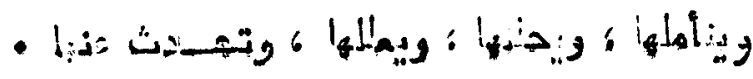

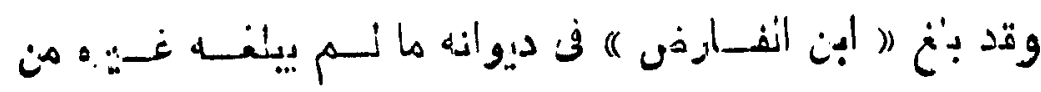

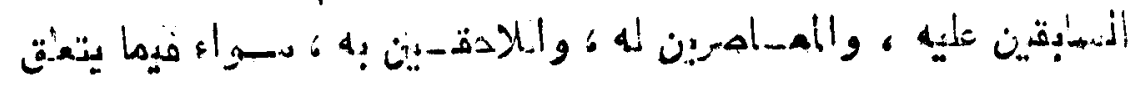

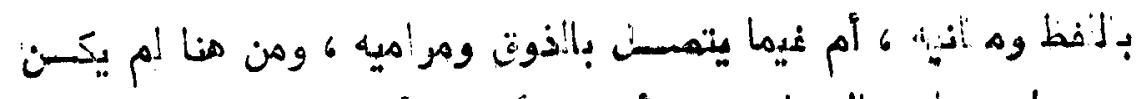

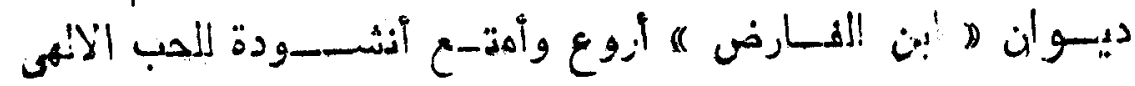

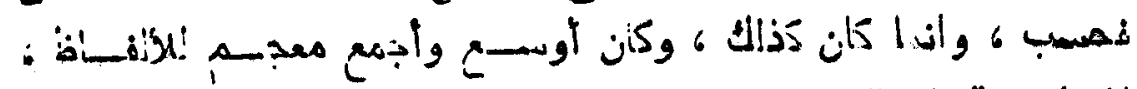

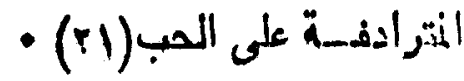

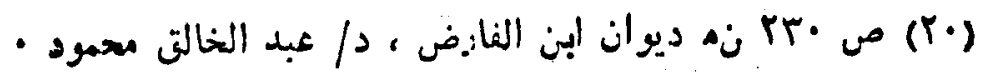

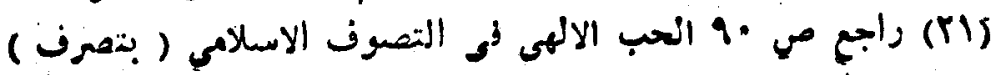




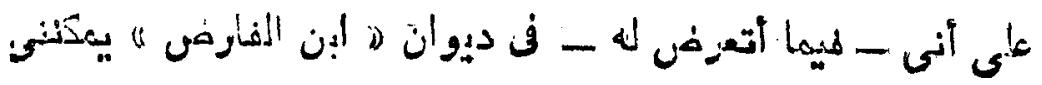

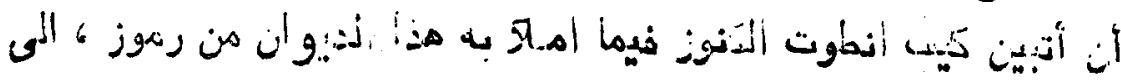

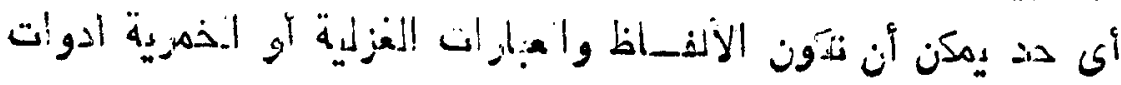

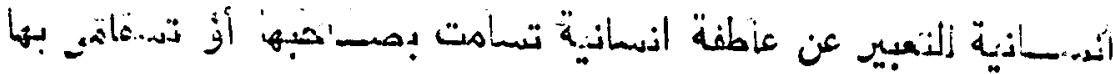

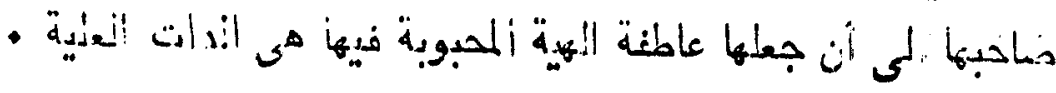

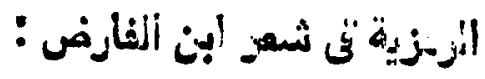

ان اشــعر ألدينى أقرب ألى الوحدان ألثع:ى من آى شسيع

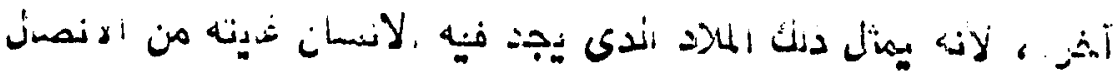

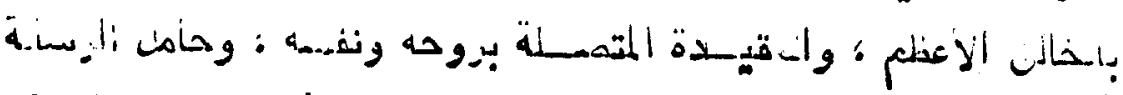

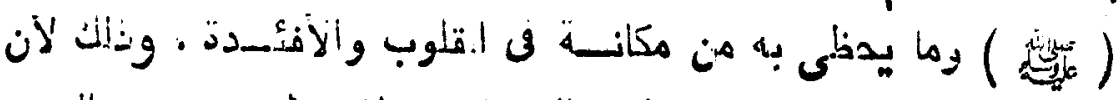

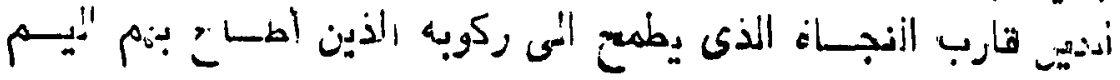

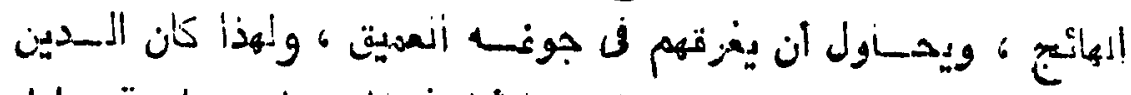

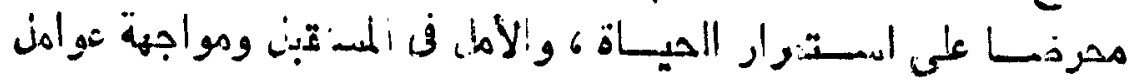

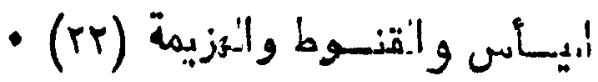

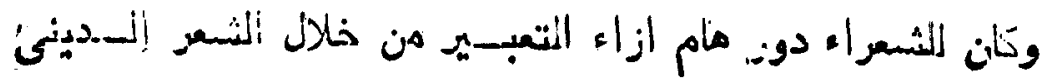

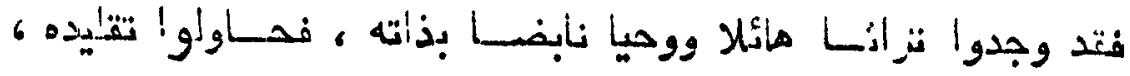

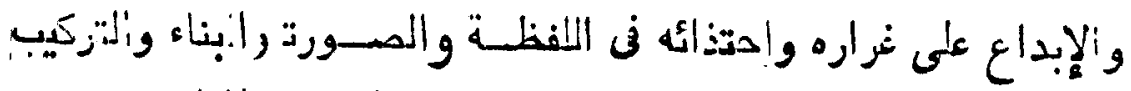

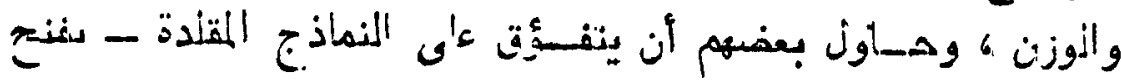

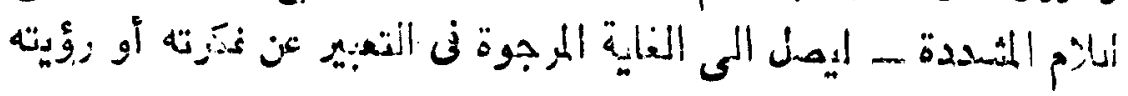

- (rT)

-

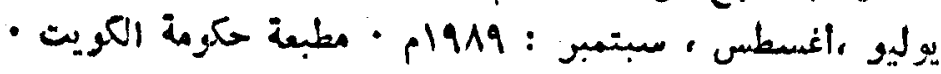

- 


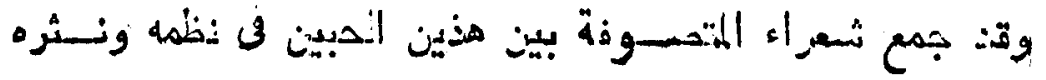

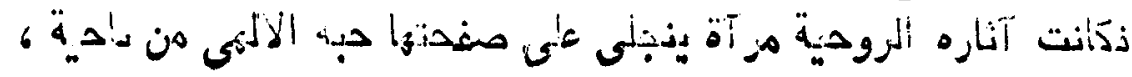

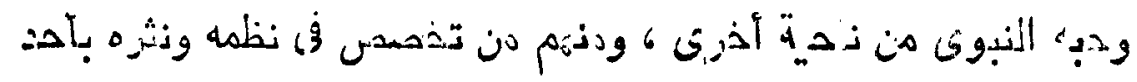

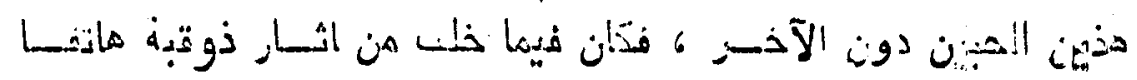

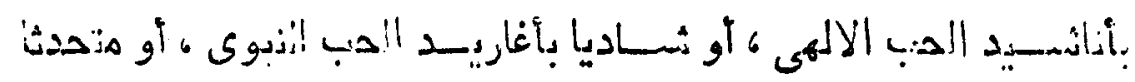

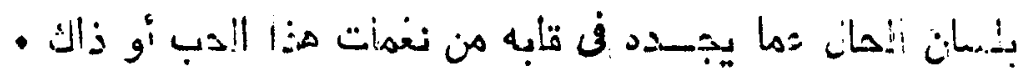

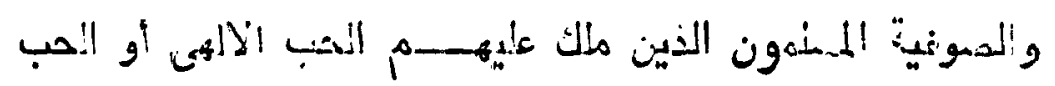

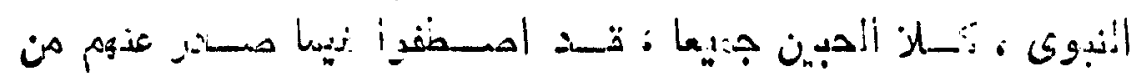

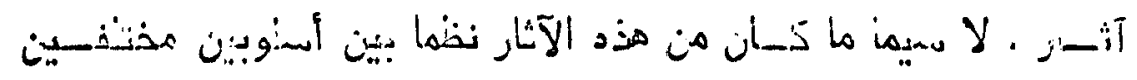

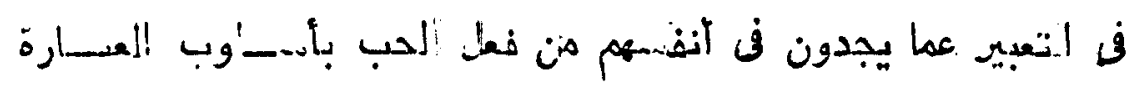

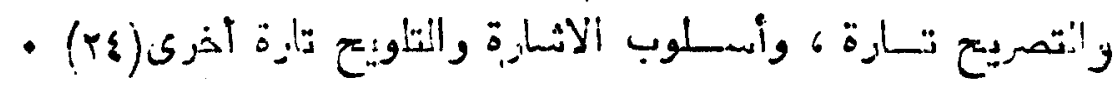

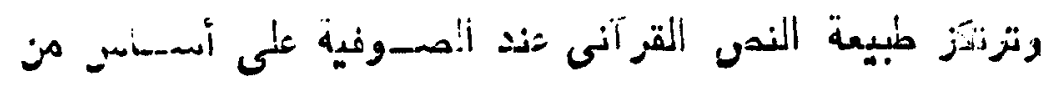

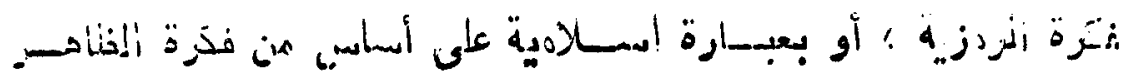

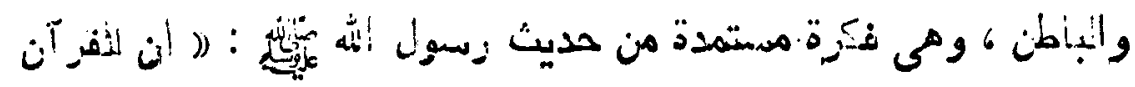

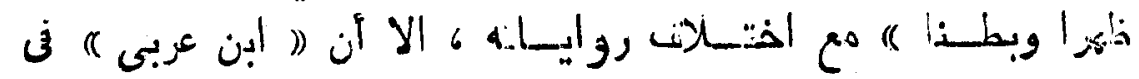

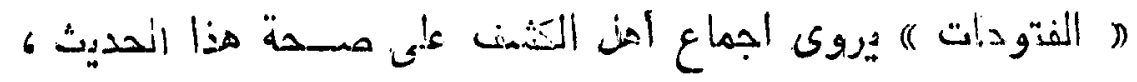

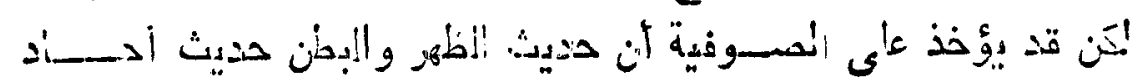

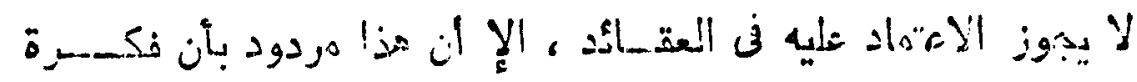

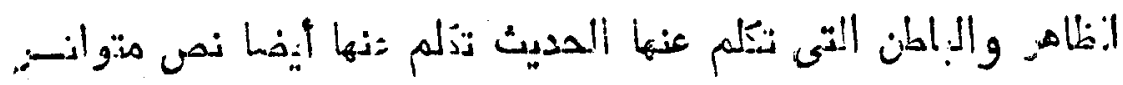

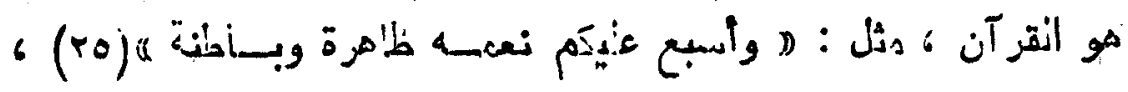

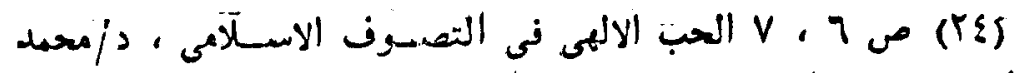

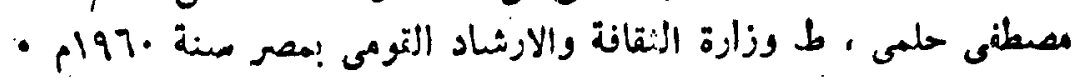

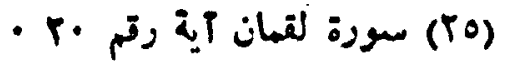




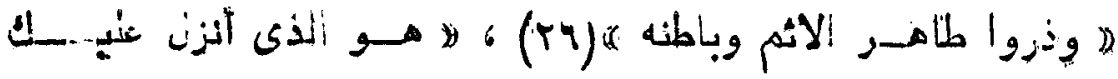

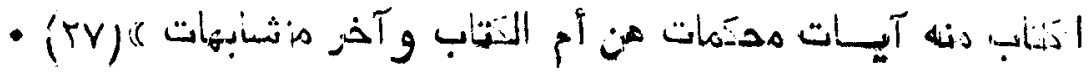

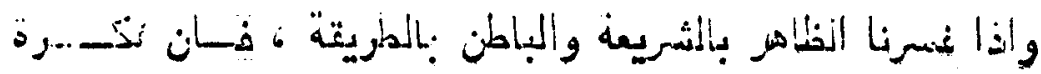

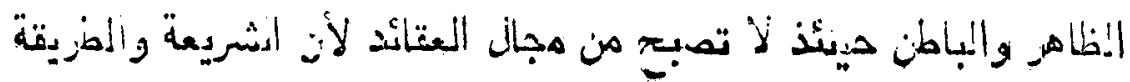

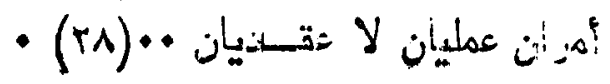

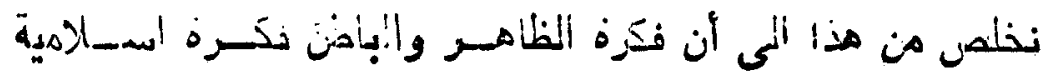

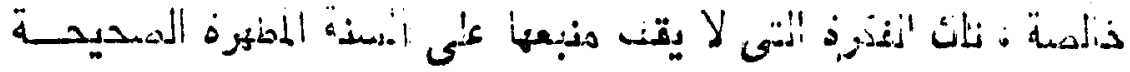

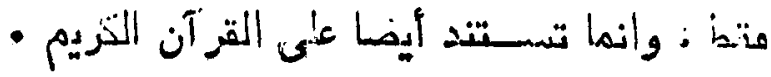

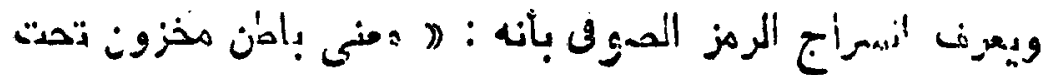

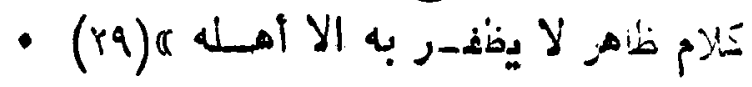

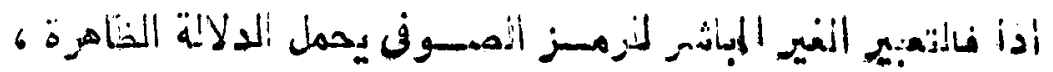

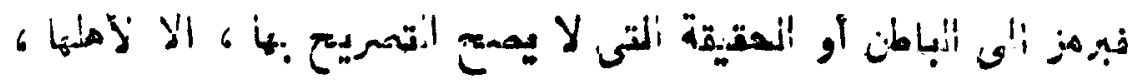

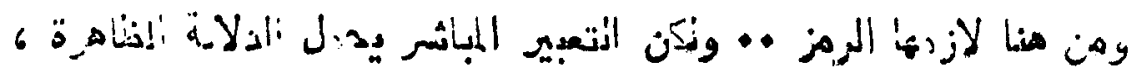

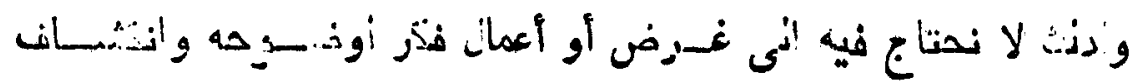

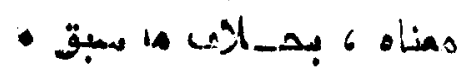

ومن هنا ذهب لهريق هن ألمتعبين على التصسـوف والصسيونية

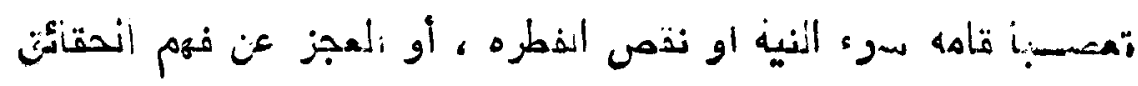

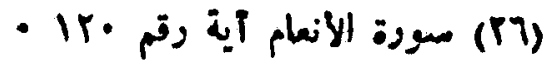

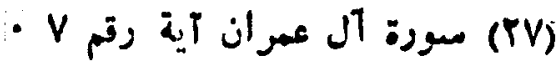

(PA)

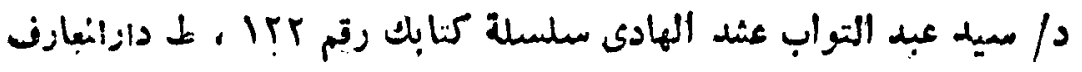




\section{rry}

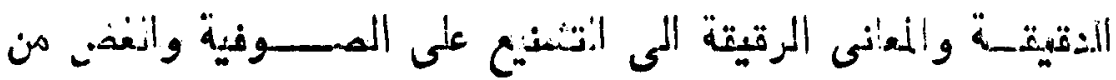

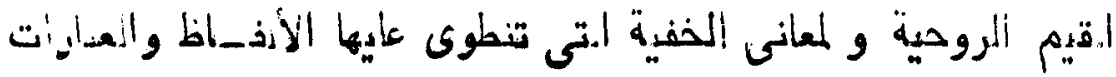

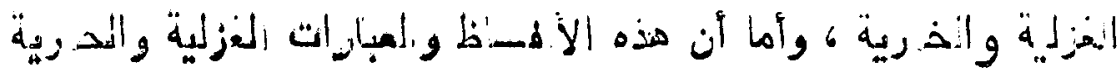

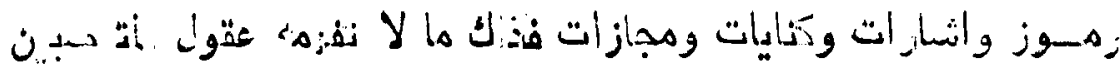

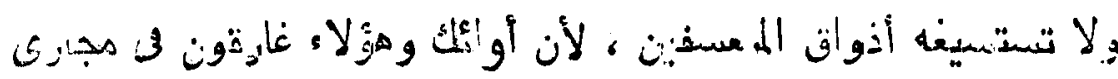

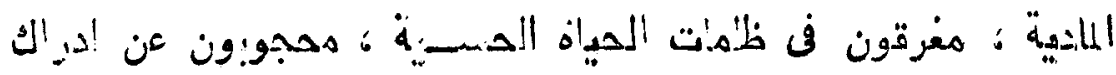

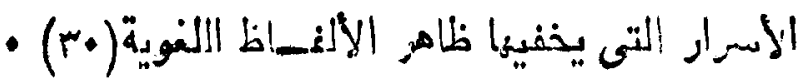

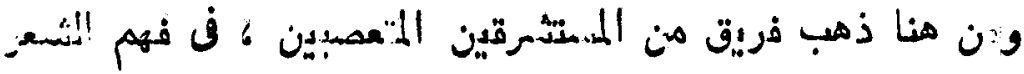

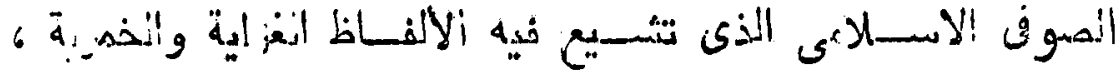

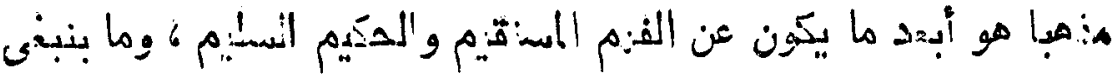

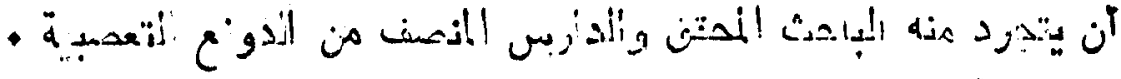

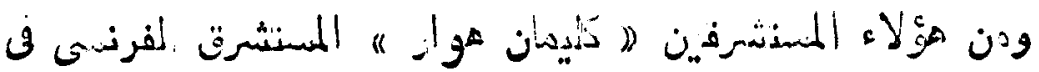

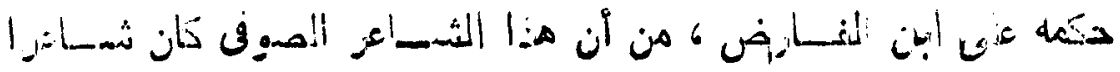

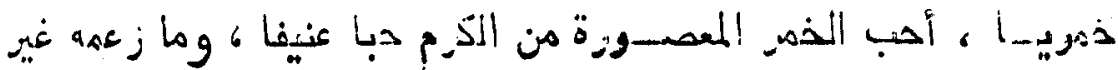

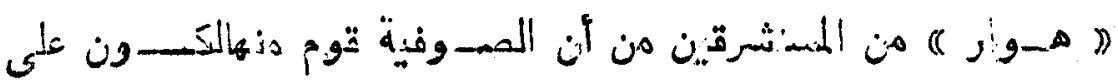

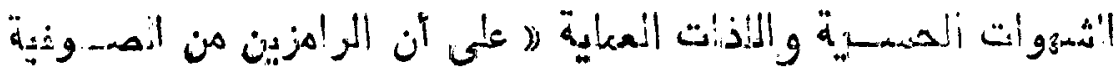

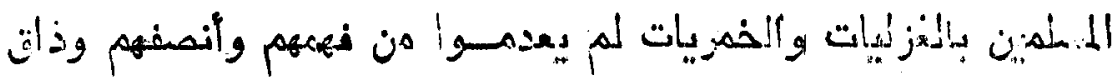

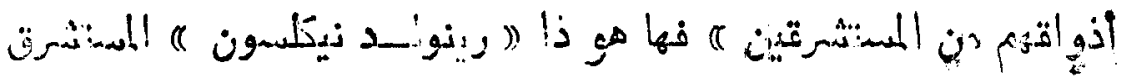

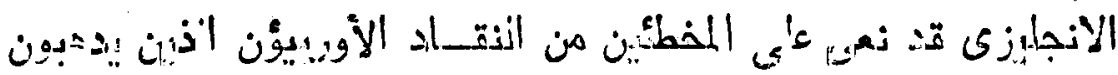

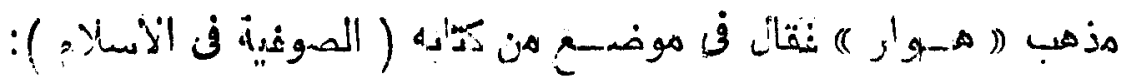

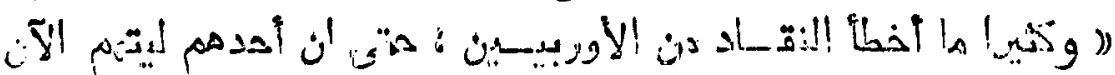

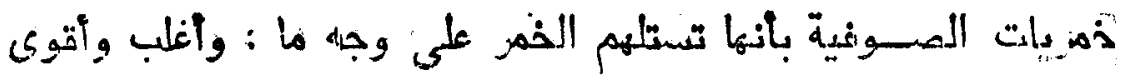

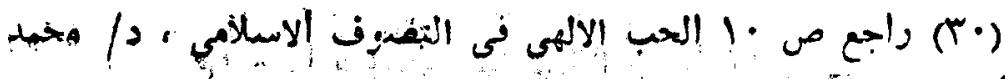

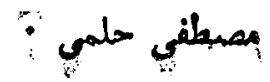


rra

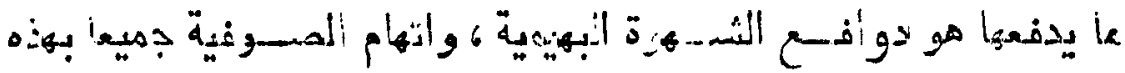

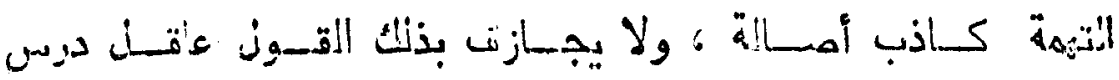

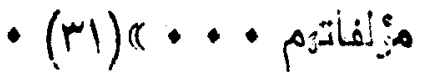

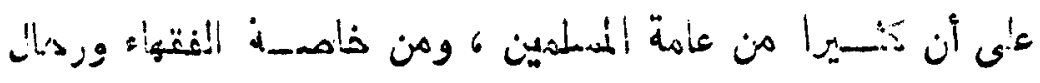

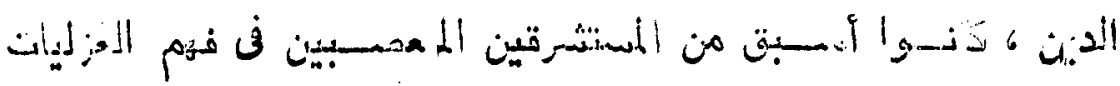

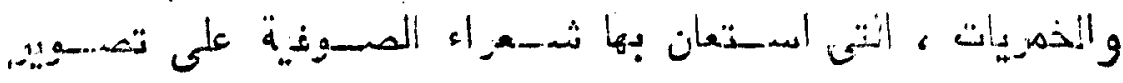

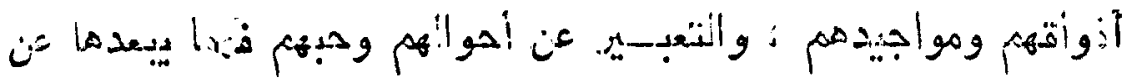

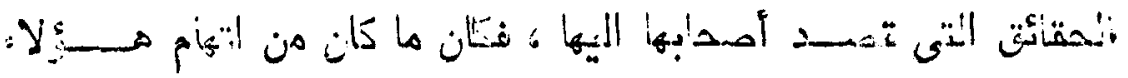

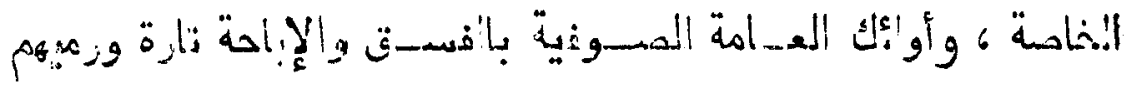

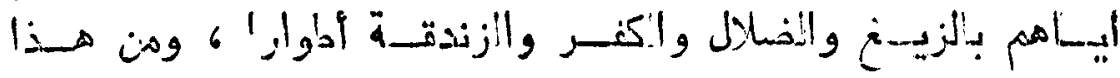

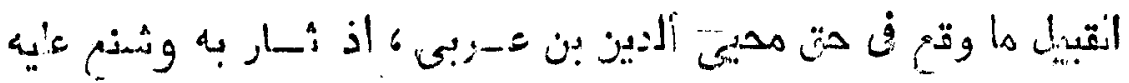

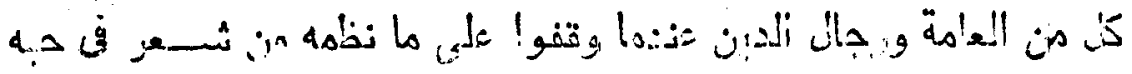

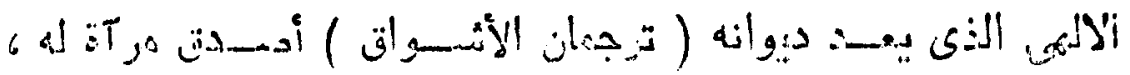

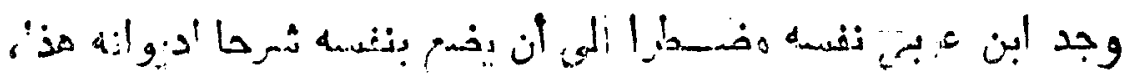

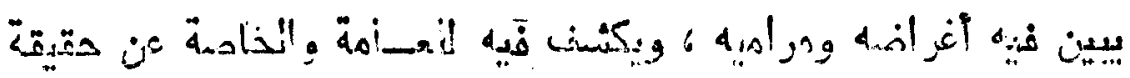

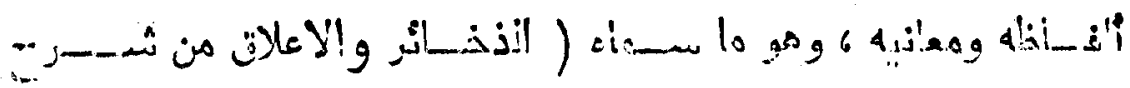
- تزجمان الأنموأقة (r) (r)

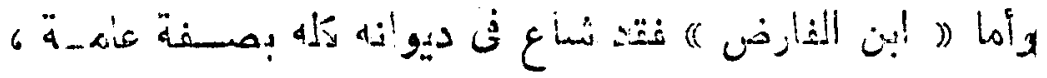

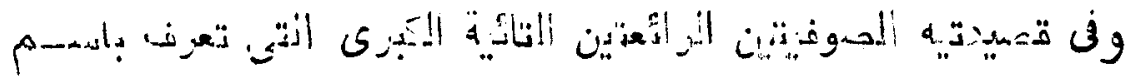

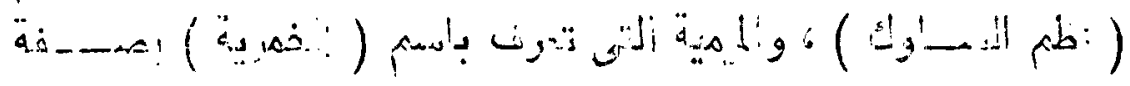

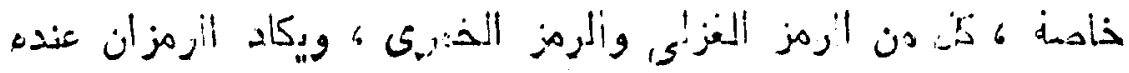

•

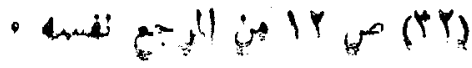


res

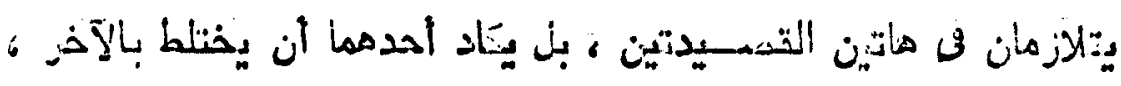

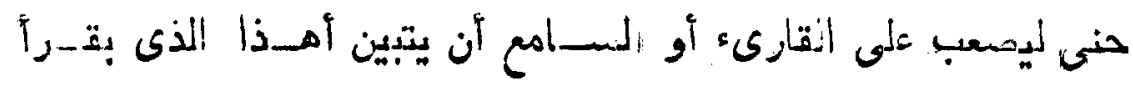

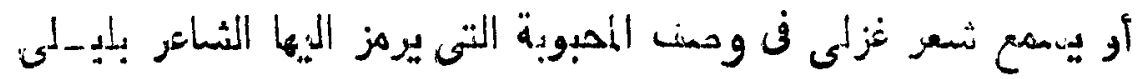

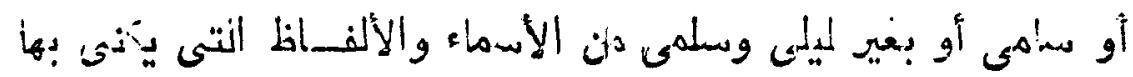

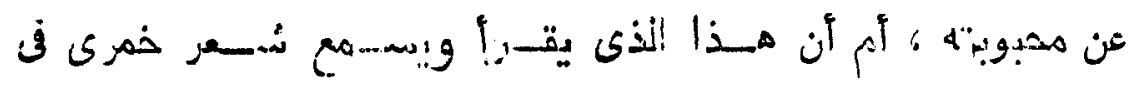

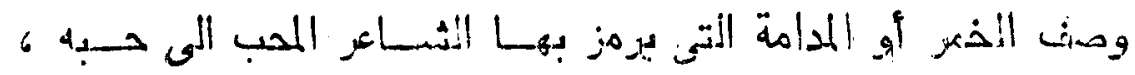

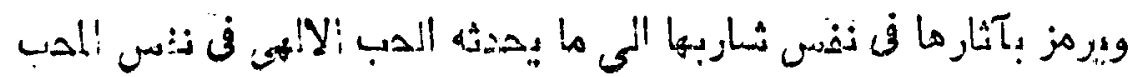

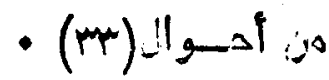
يقون اليتتتور / كحمد زغلول سلام : (أختلف إباحثزن فيما جاء في شعره من تشبيهات واستعسازات

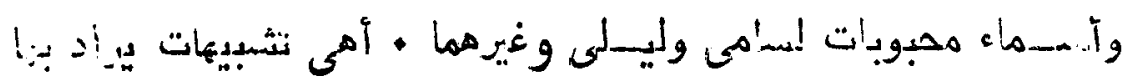

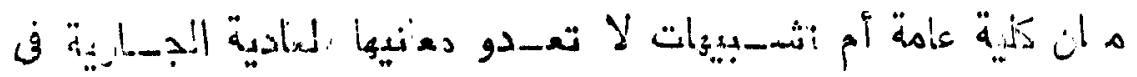

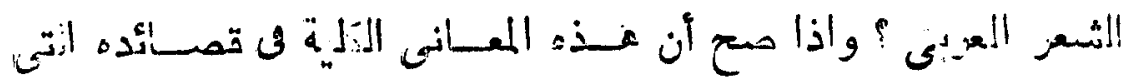

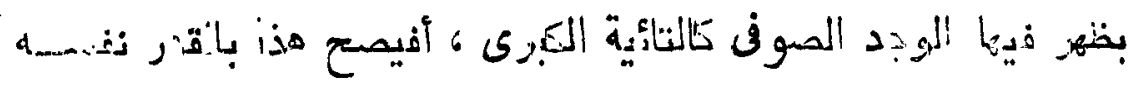

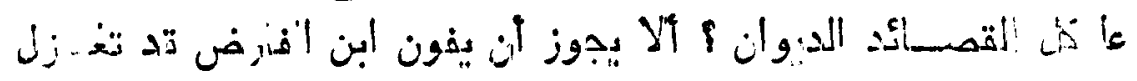

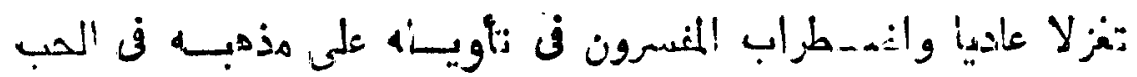

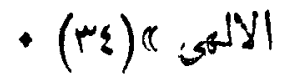

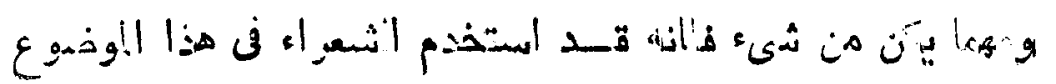

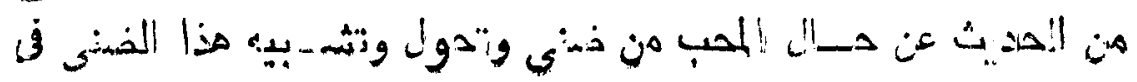

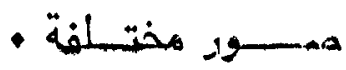

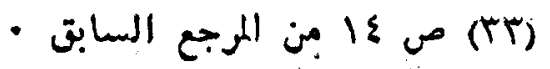

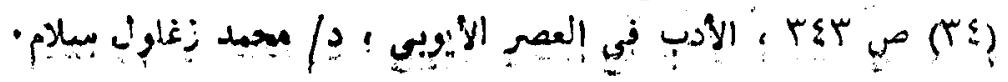




$$
1 \text { - سدّنتى حميل احب راح_ة دقلتى }
$$

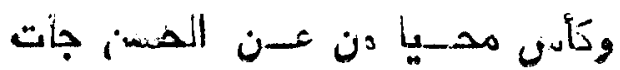

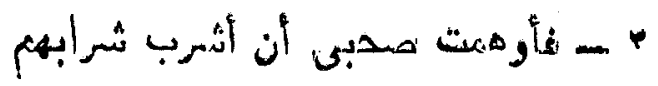

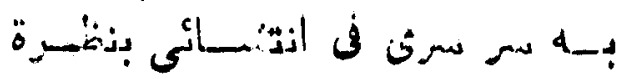

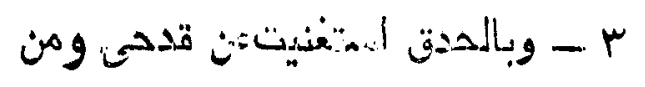

ثم

$$
\text { ? - فذه ح'ن سكرى ح'نشكزى لُفتية }
$$

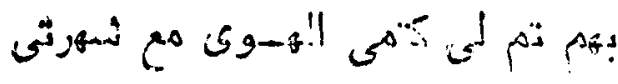

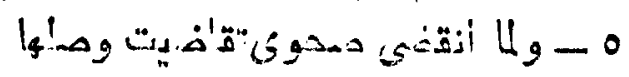

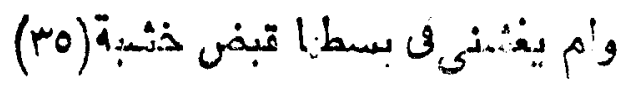

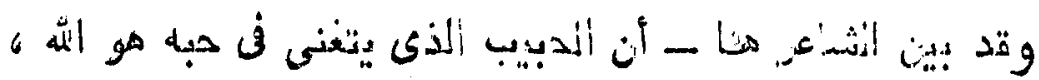

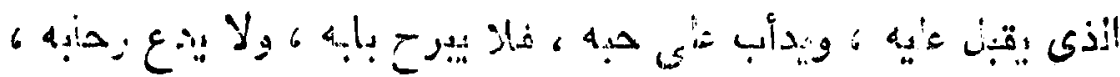

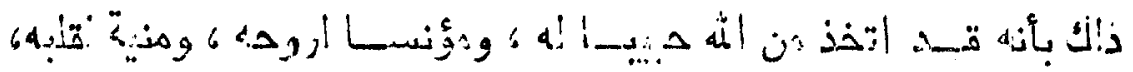

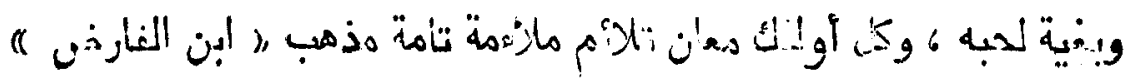

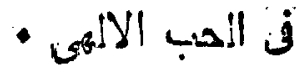

$$
\text { ومطلح قصسيدنته المهنهة } 6 \text { حيث دقواله : }
$$

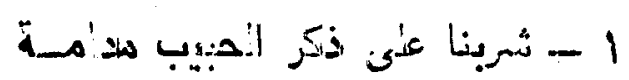

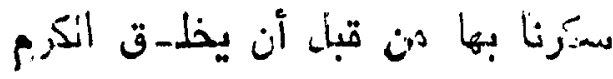

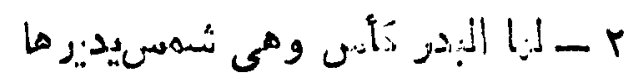

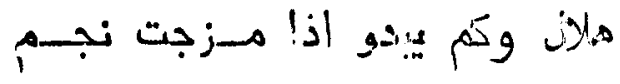

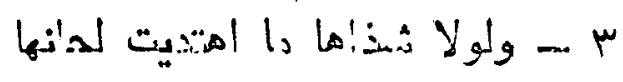

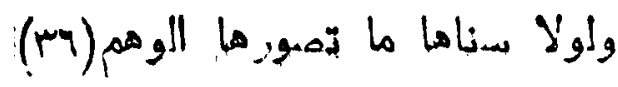

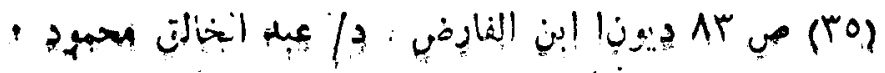

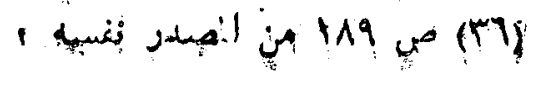




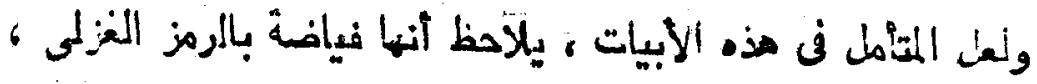

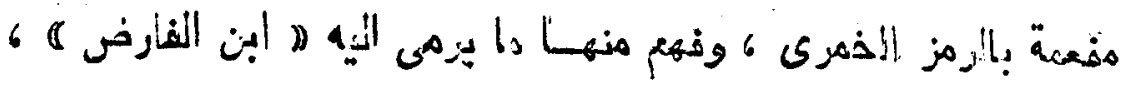

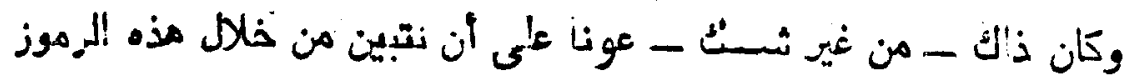

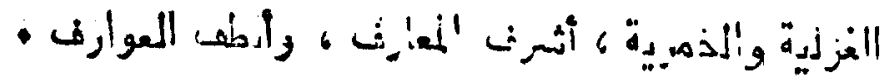

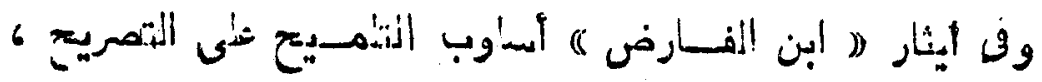

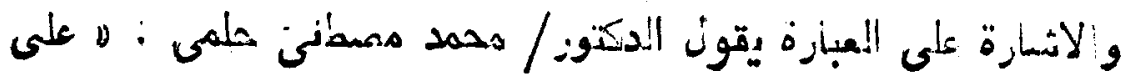

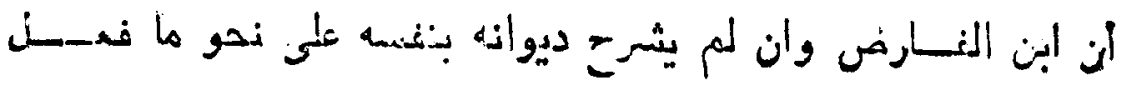

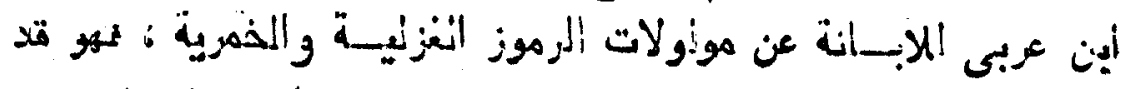

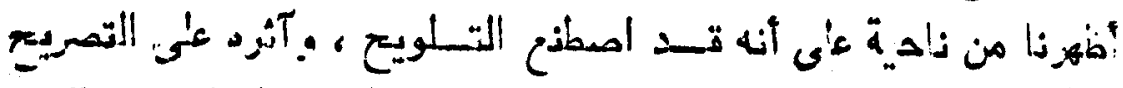

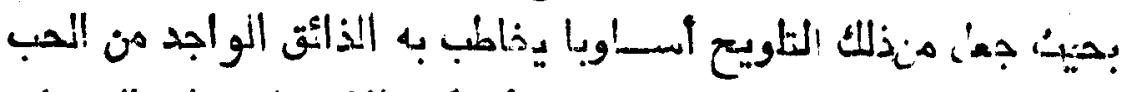

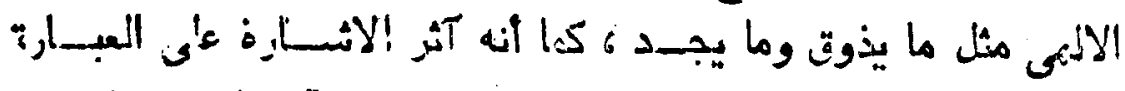

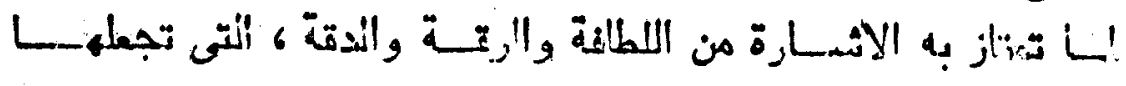

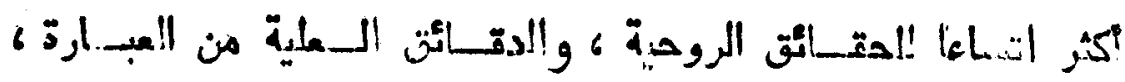

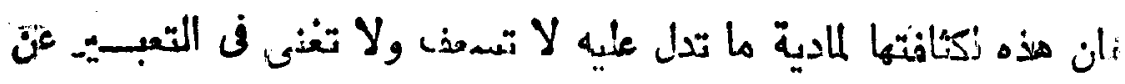

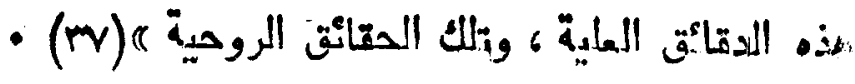

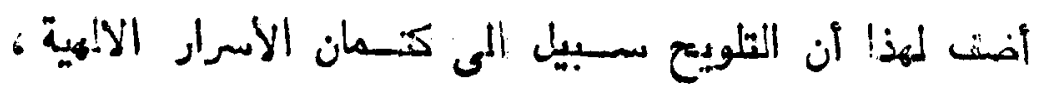

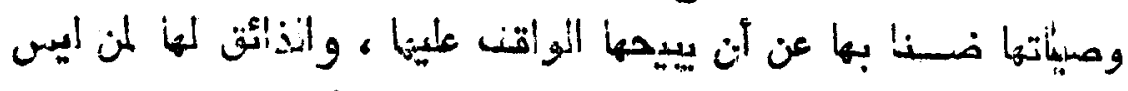

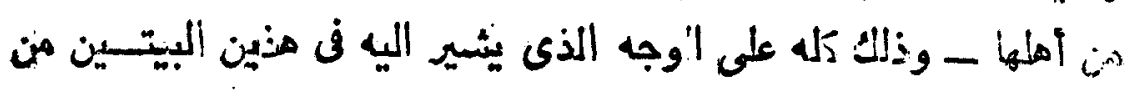
:

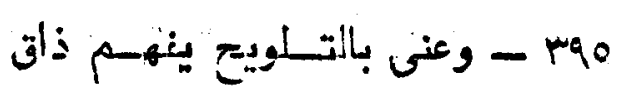

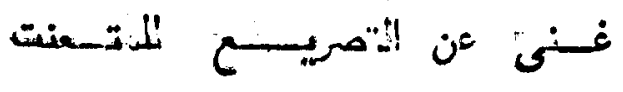

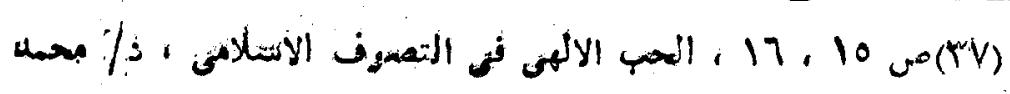
$1: 19-1)$

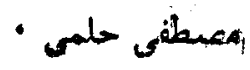




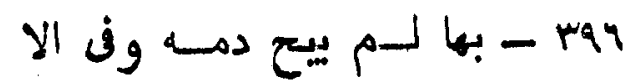

$$
\begin{aligned}
& \text { اثسـارة معسنى والعبارة حدث (rی) }
\end{aligned}
$$

والمرزز اللفوى يؤازر الرمز الموضدوعى فن تكَّيف التجربة الدموفية

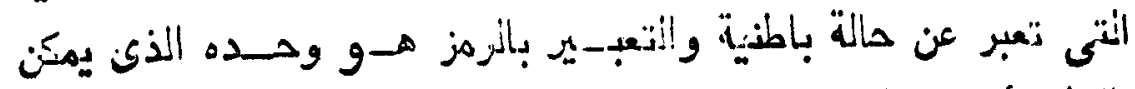

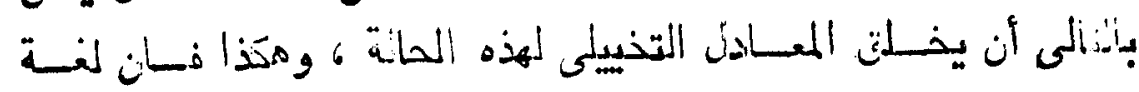

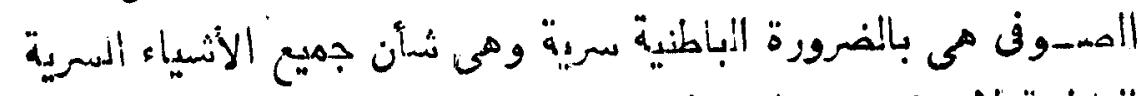

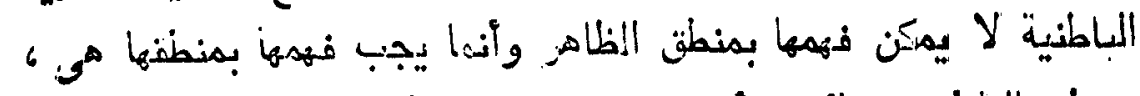

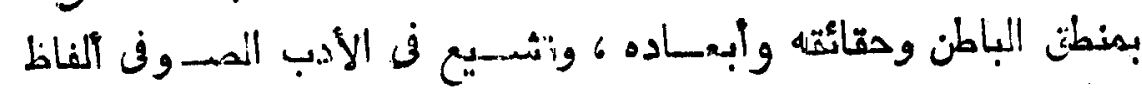

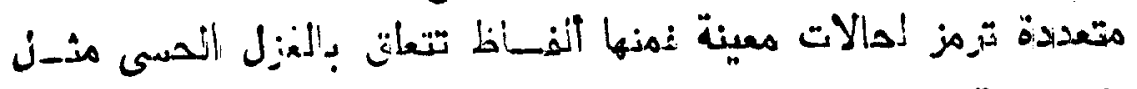

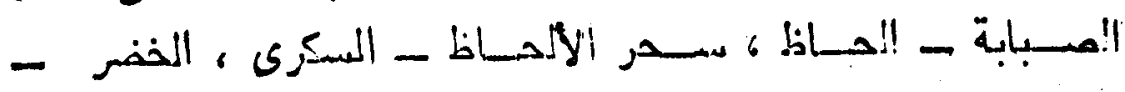

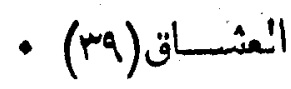

وابن الفارض يهف في قصيدة كاهـلة ( الخدسرذ ) وهى ليبست

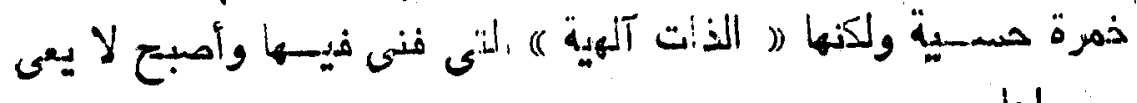
ســواهـا

$$
\text { ويقول ابن الفنسارض : }
$$

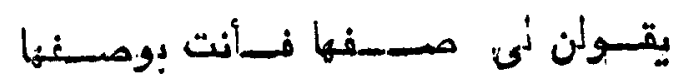

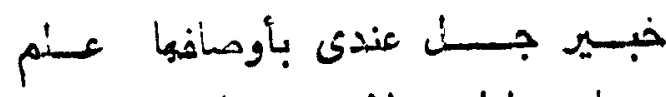

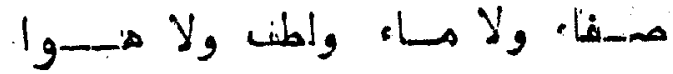

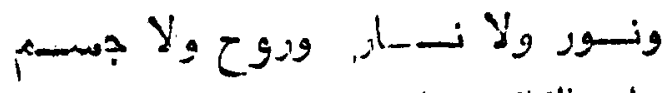

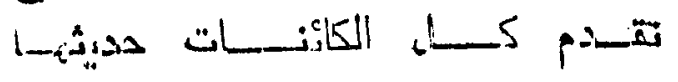

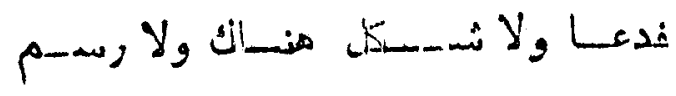

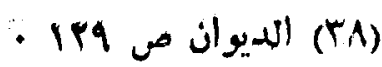

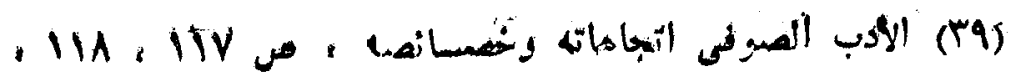


rer

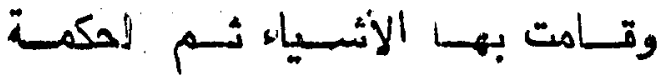

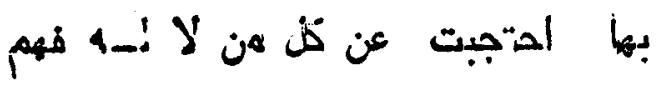

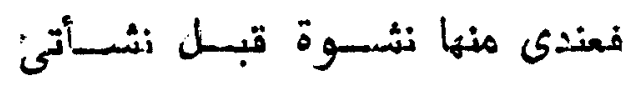

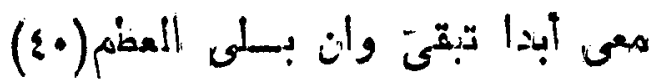

وهذه الألفساط التقى وزدت في هذ مالأبيات تنطبق على الـذات

-

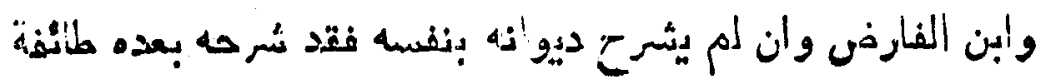

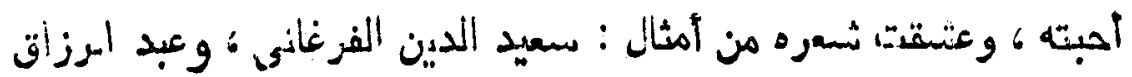

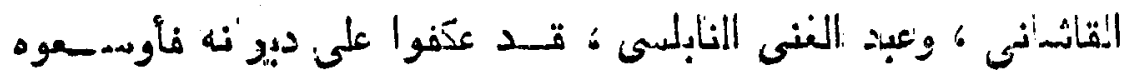

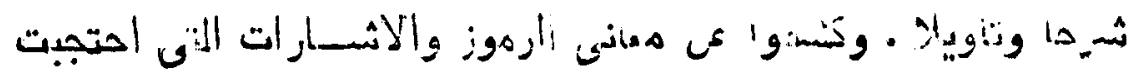

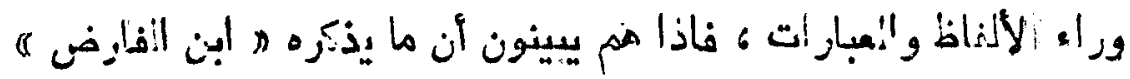

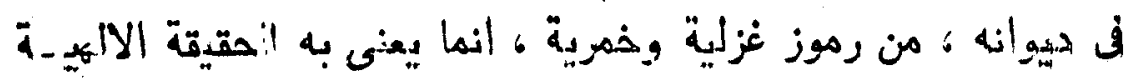

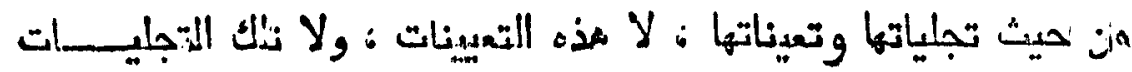
$\cdots$ L L ب

وتسد تدنث ابن الفارغي وهو المام المحبين ف الحب الأهي: 6

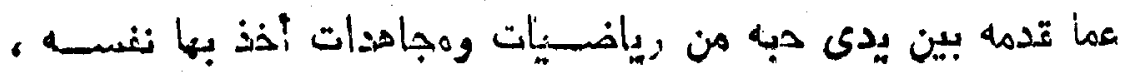
:

$$
\text { 隹 }
$$

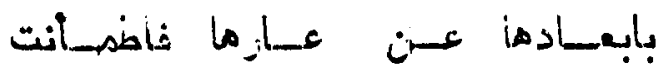

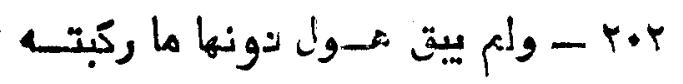

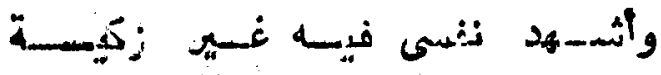




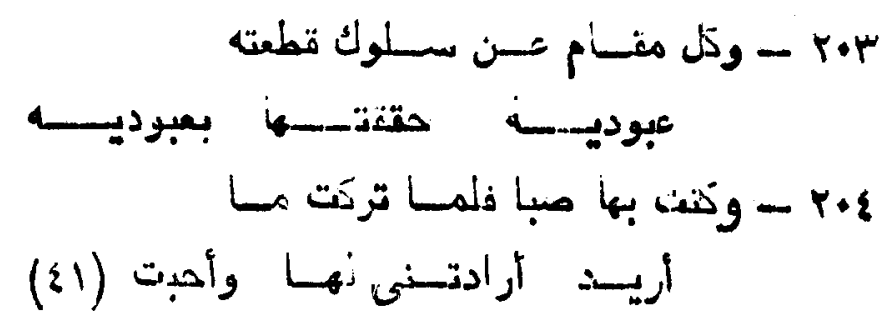

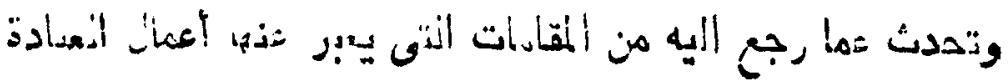

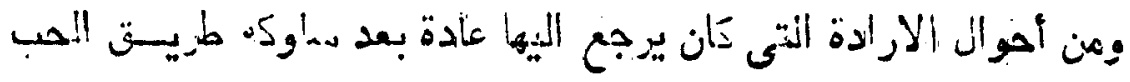

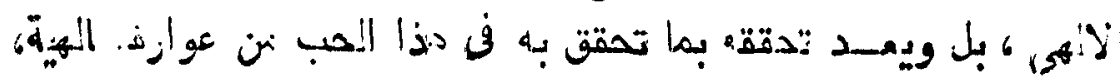

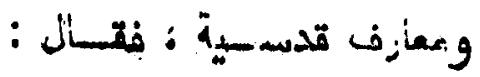

$$
\begin{aligned}
& \text { رجعت لأعمسال المعبســادة عـادة }
\end{aligned}
$$

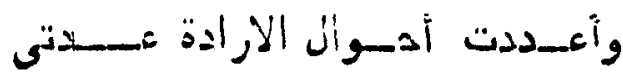

$$
\begin{aligned}
& \text { وع:ت. بنسنى بعد هتكى وعدت من }
\end{aligned}
$$

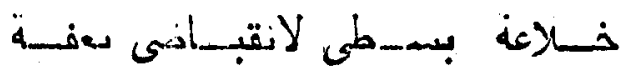

$$
\begin{aligned}
& \text { وصمت نهـارتى رغبسة في مثوبــة }
\end{aligned}
$$

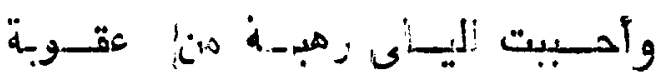

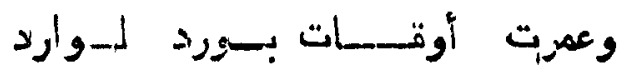

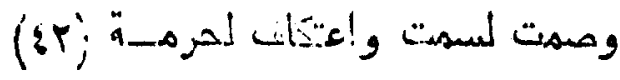

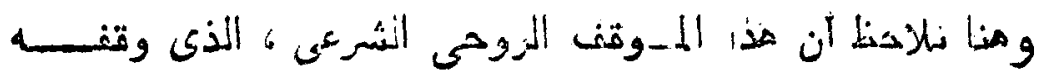

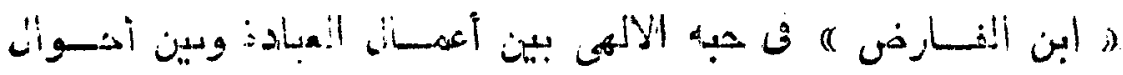

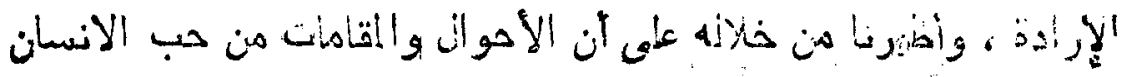

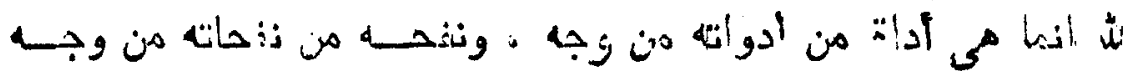

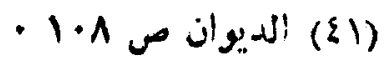

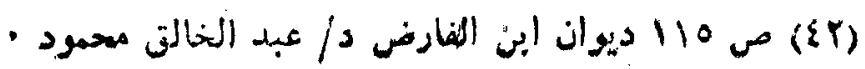




\section{res}

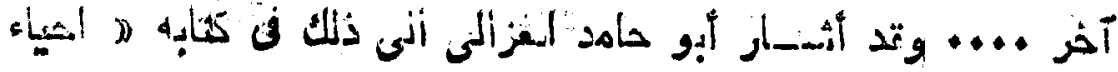

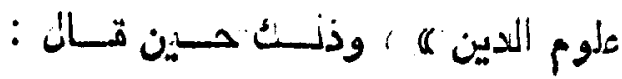

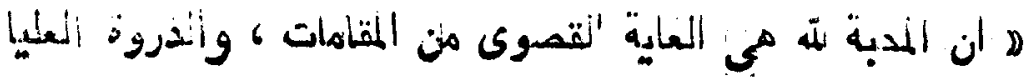

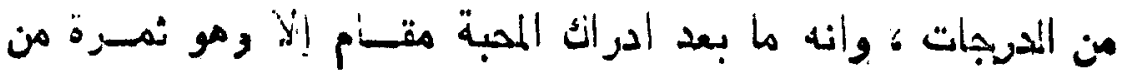

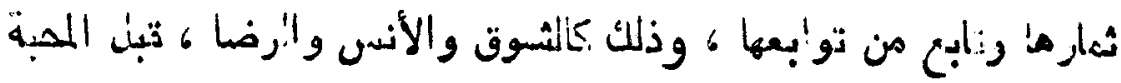

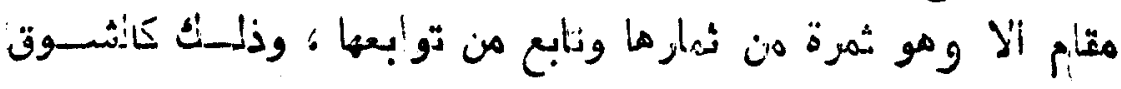

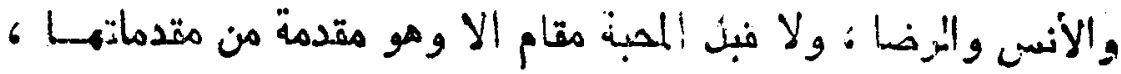

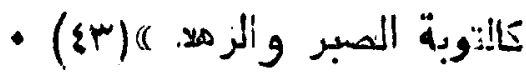

والموفيون إيسوا نتهاء يك بعن ألثعر ، لـتهم شسعراء يم:لكون

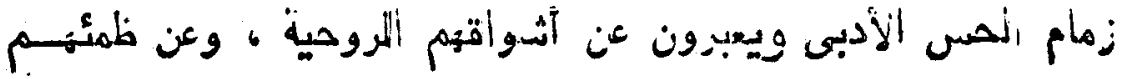

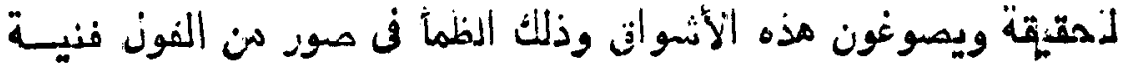

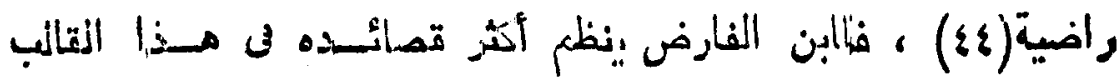

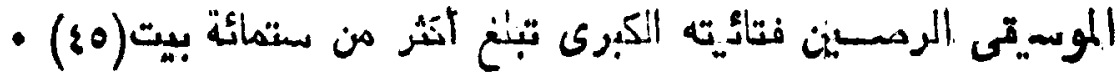

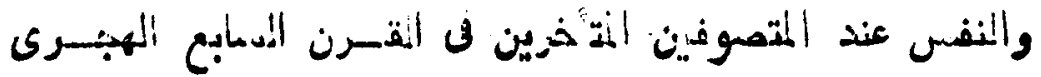

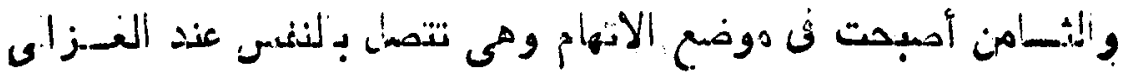

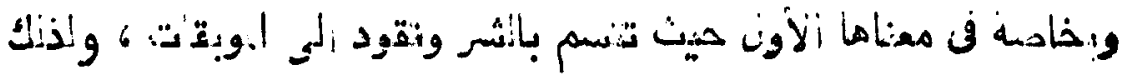

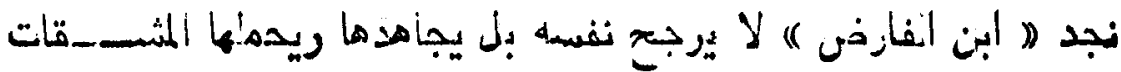

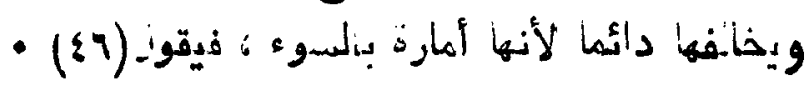

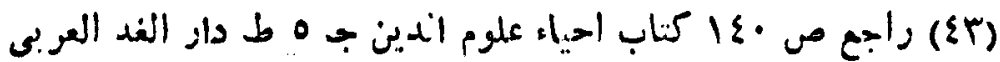

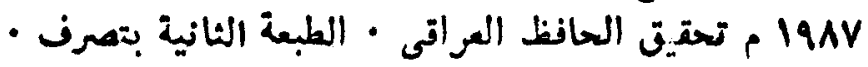

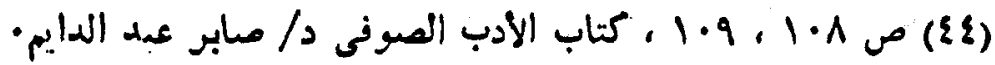

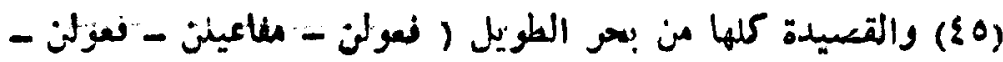

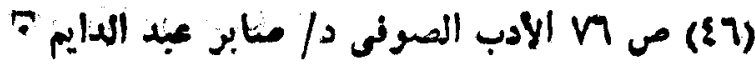




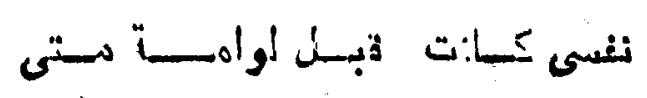

أطعرت ت عصت أو تعصى كـأنت، مطيعتى

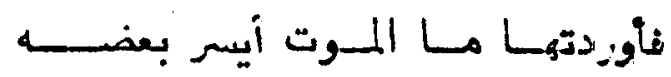

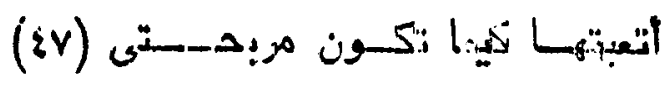

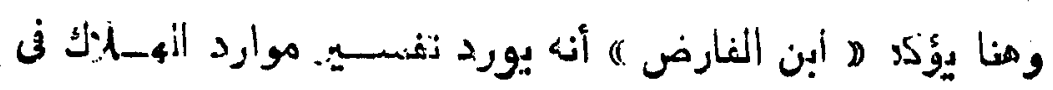

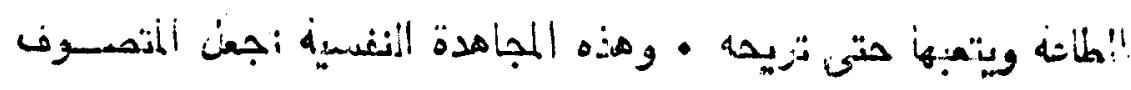

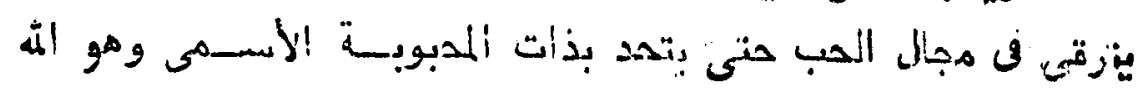

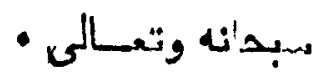

كما يصوز حبه واخلاصه نلمدبوب المقدس فن تجربة شعرية حارة

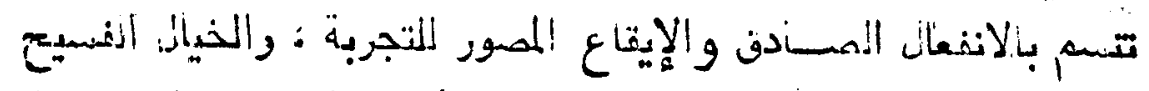

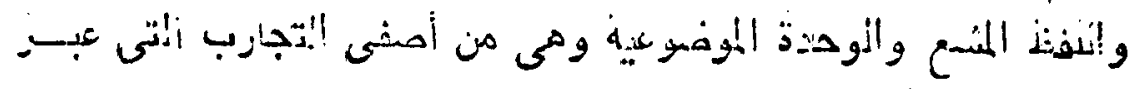

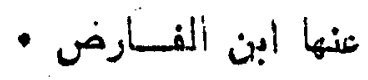

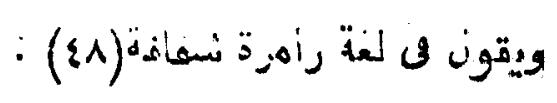

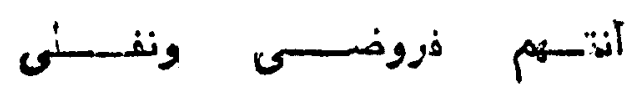

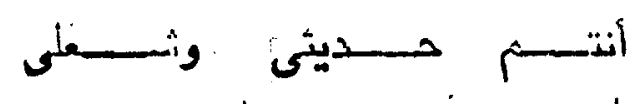

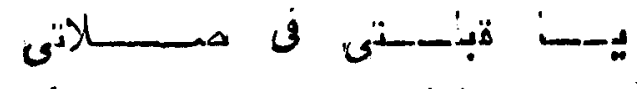

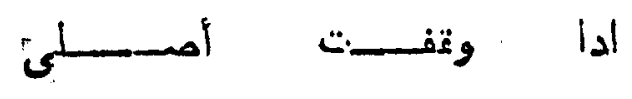

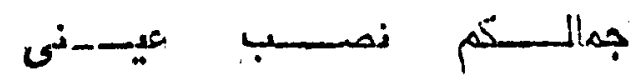

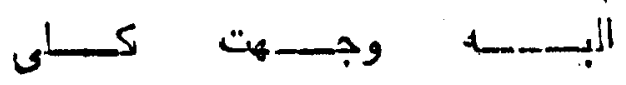

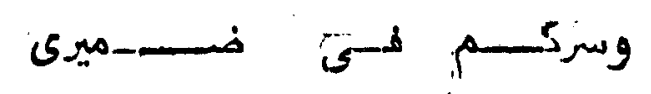

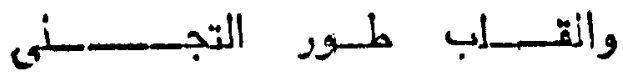

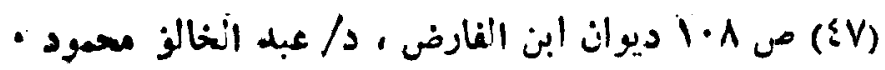

· (IA) 
rev

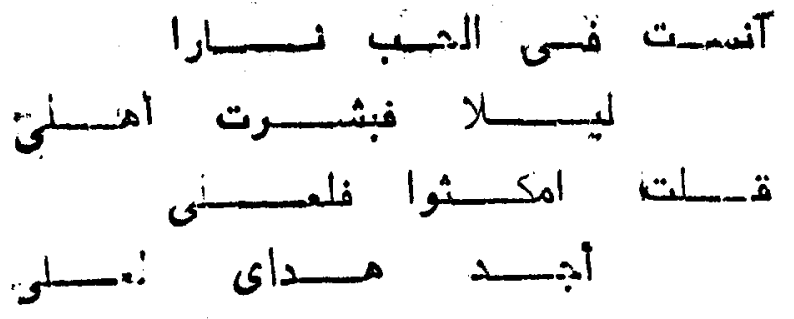

ملاهح ومؤونرات في ثنـاءريته :

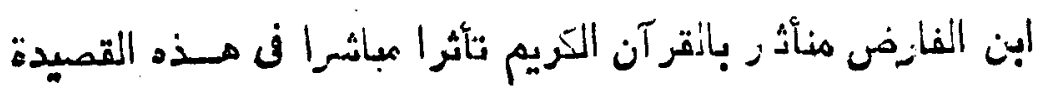

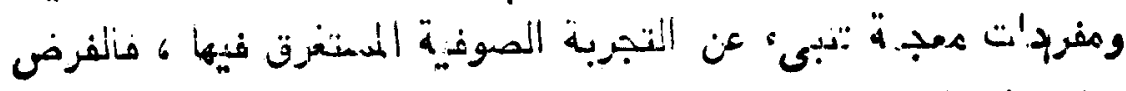

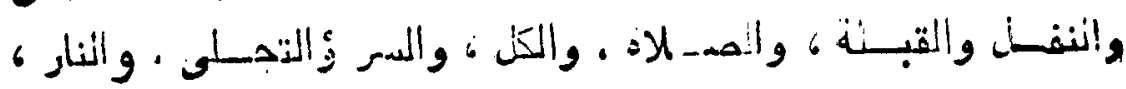

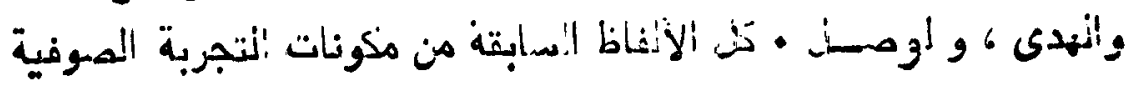

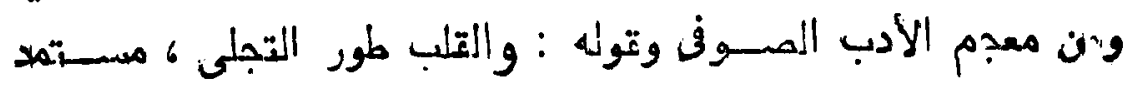

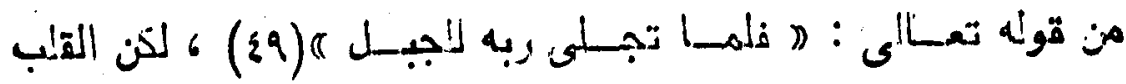

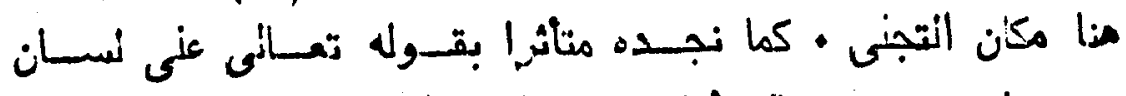

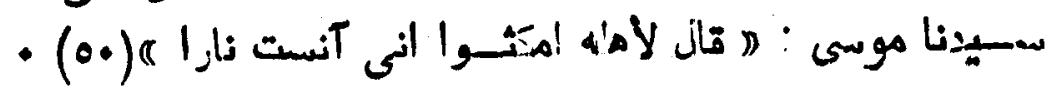

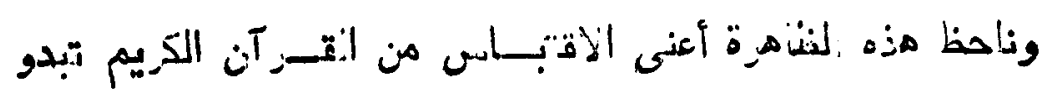

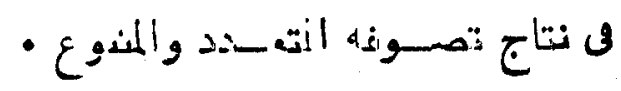

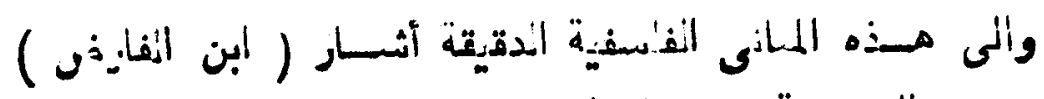

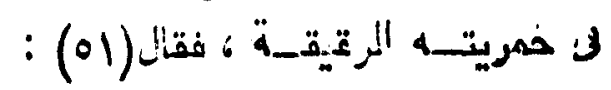

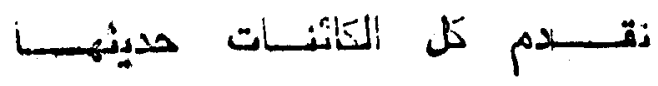
قديما ولا شــكل مناك ولا وبنس

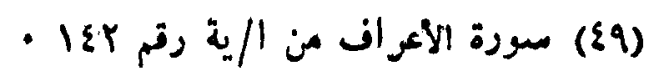

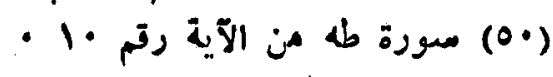

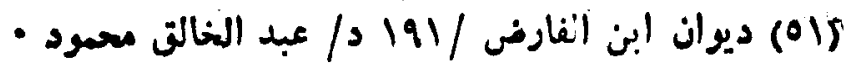




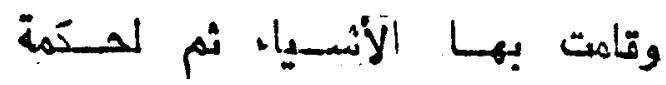

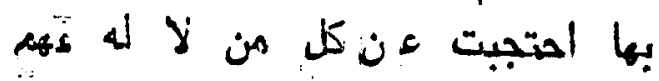

$$
\text { وتــان أيضدــ(or) }
$$

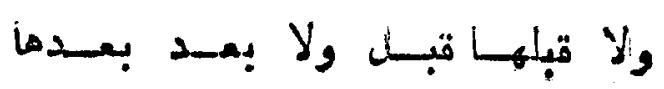

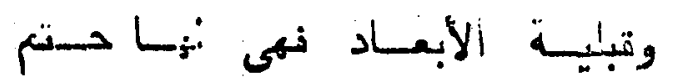

وعصر المدى من كائ قبله كان عصرهأ

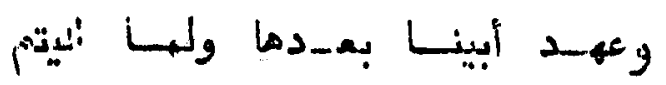

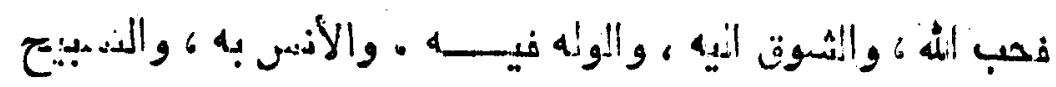

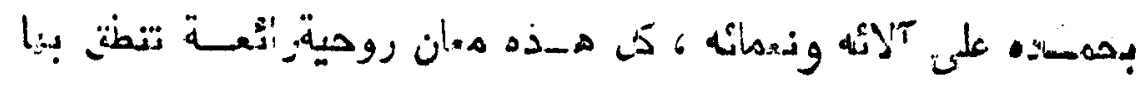

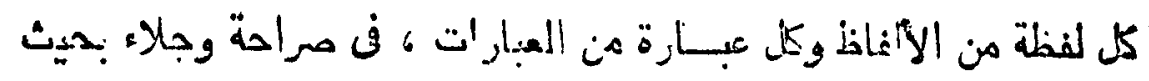

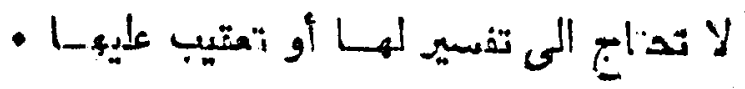

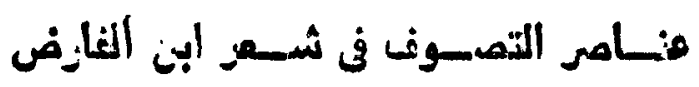

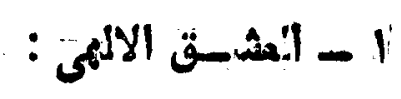

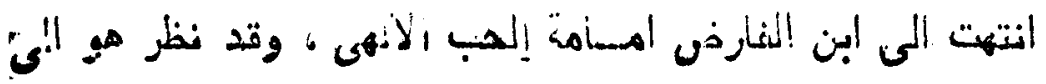

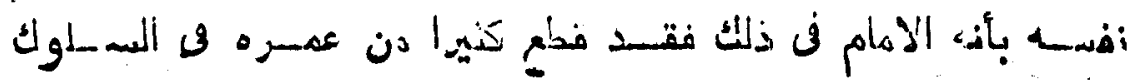

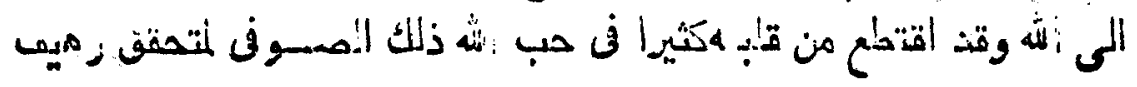

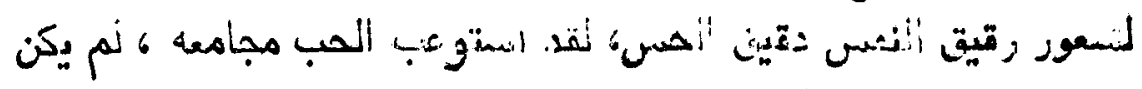

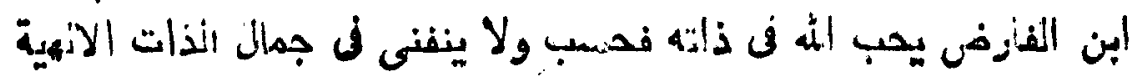

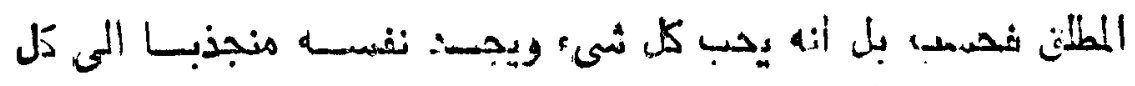

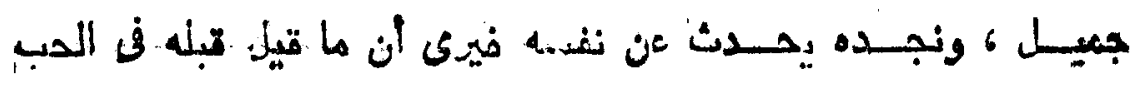

- 191\% السابت (or) 
$\$ 19$

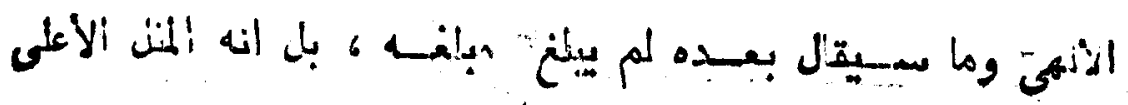

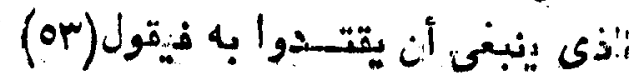

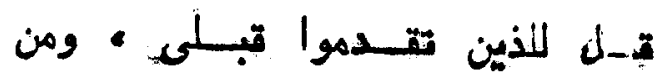

بعسدى ومن أضسحي لأثجانى يرى ومن

يثنى خذوا وبى أتتدوا ولى المهعوا

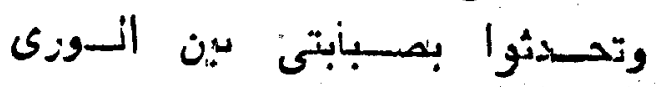

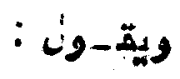

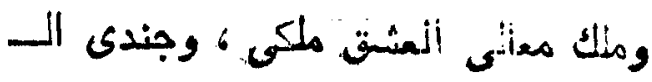

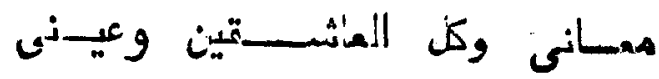

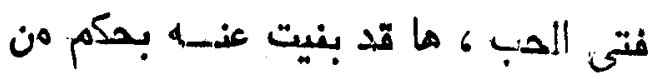

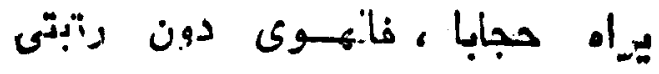

$$
\text { ويم-سول(00) : }
$$

ونيســت بحبى آية المثــق من تلنى

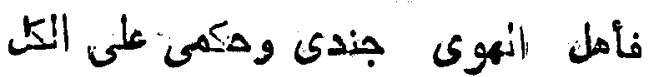

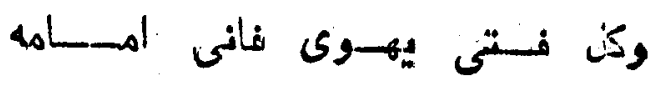

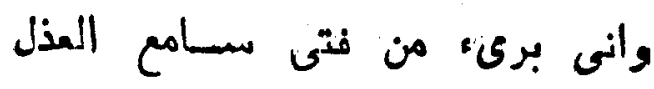

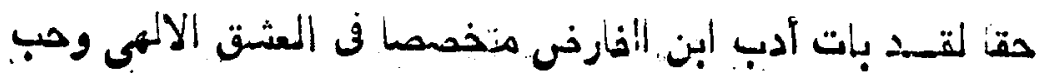

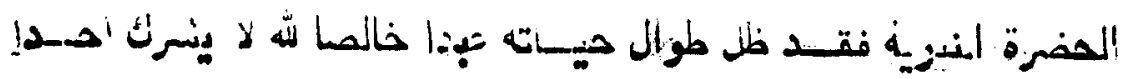

- (04)

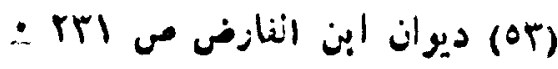

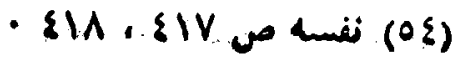

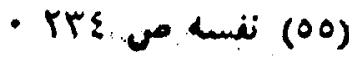

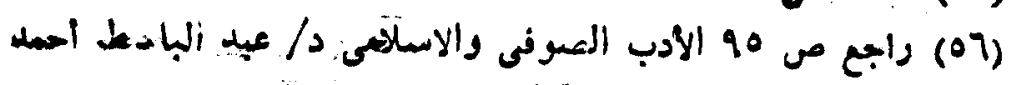

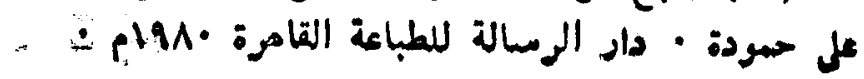




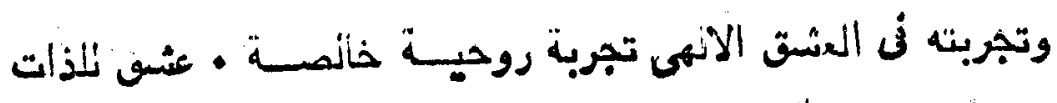

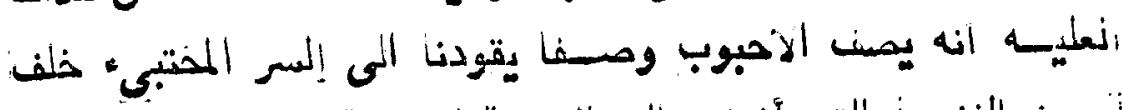

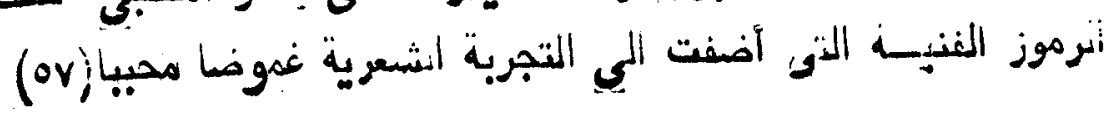

(ا كمات مهأسنه فلو أهدى إنســان.

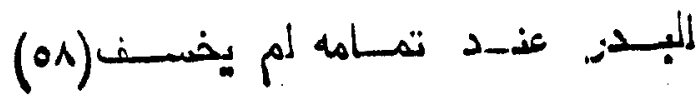

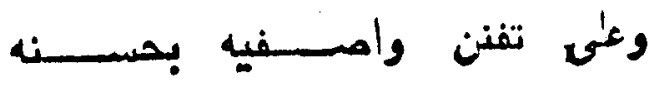

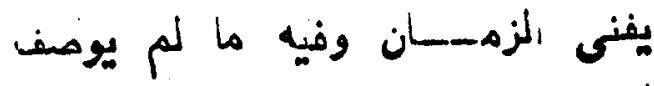

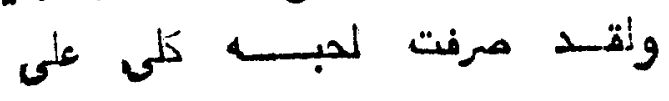

يـد حس_نه فحمسيت حسن تصرفى

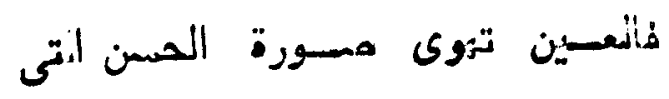

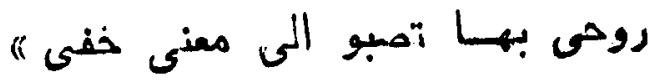

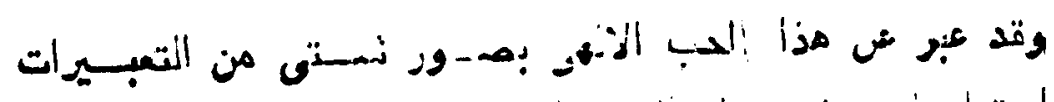

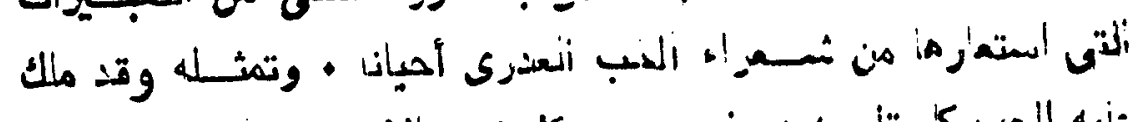

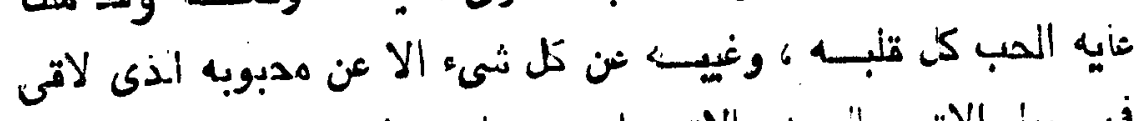

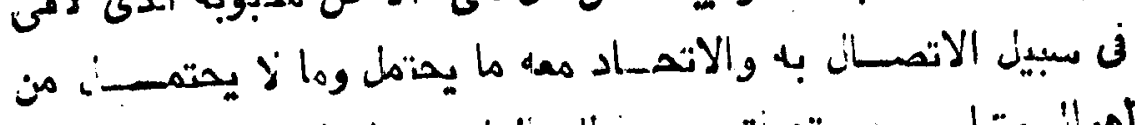

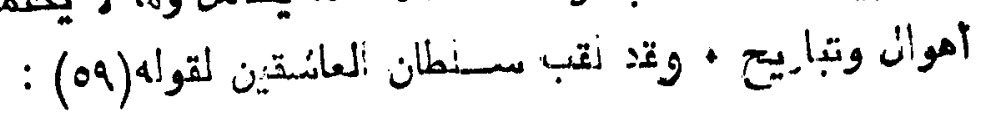

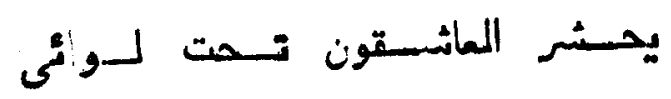

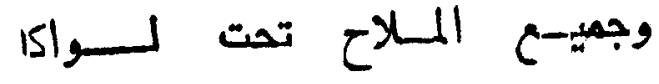

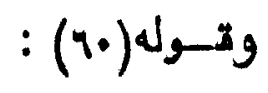

(OV)

(ON)

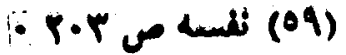

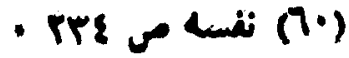




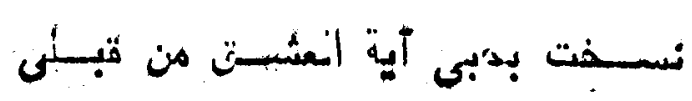

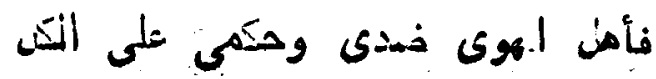

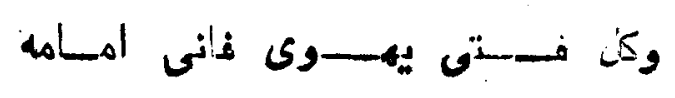

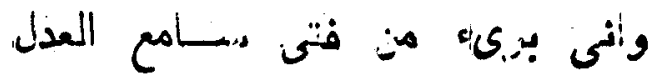

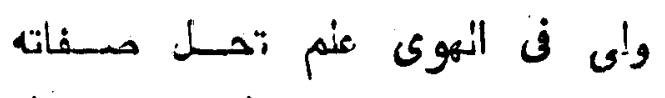

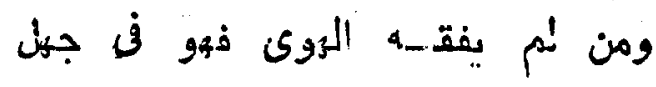

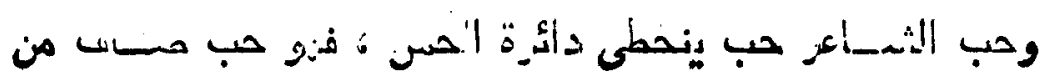

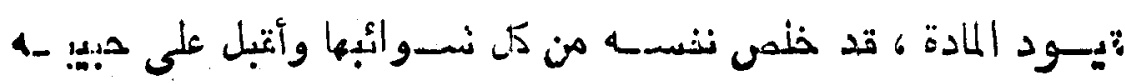

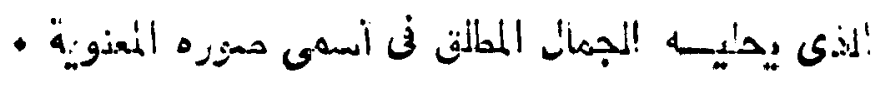

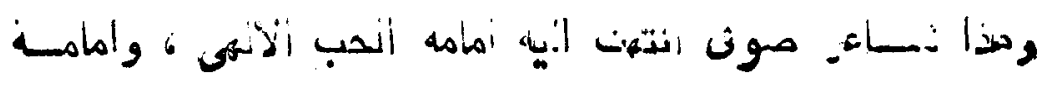

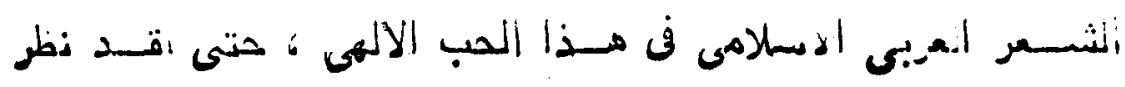

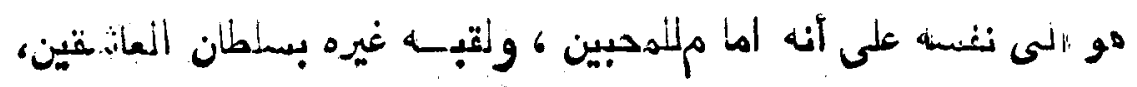

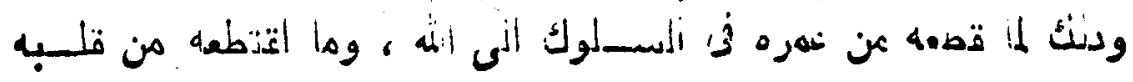

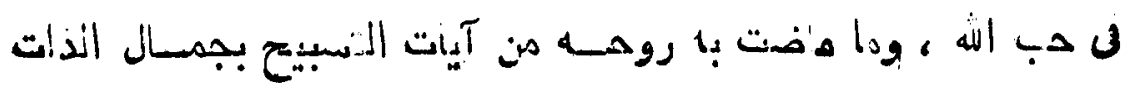

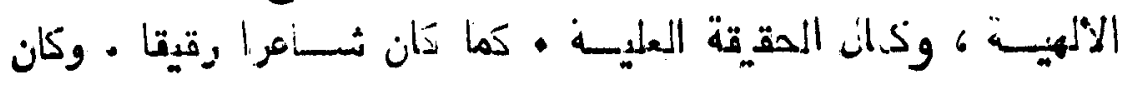

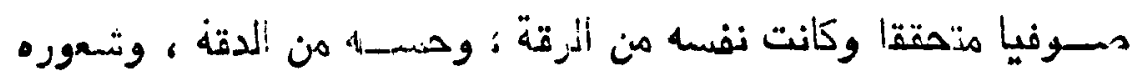

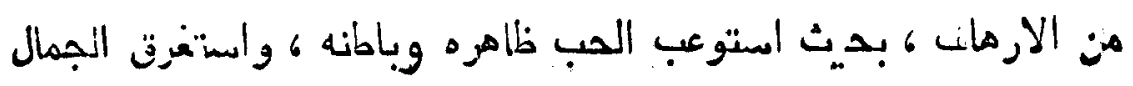

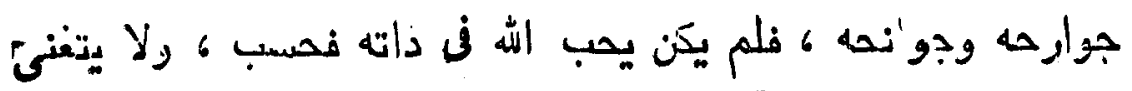

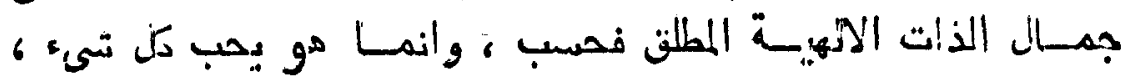

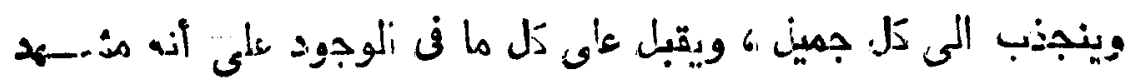

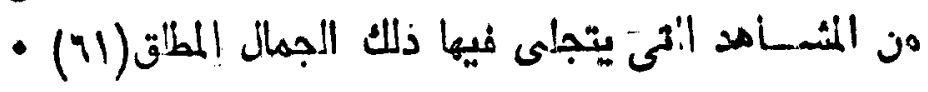

(71)

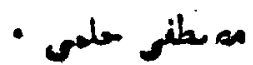




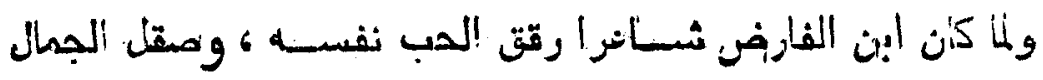

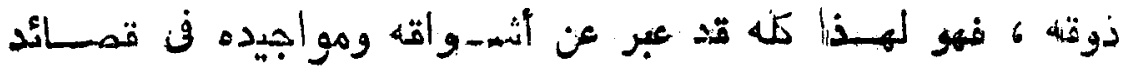

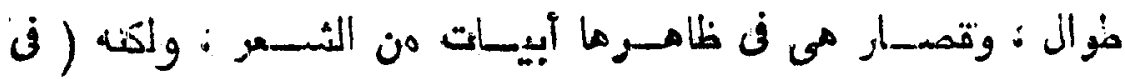

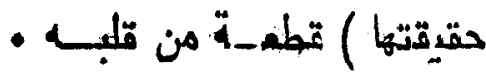

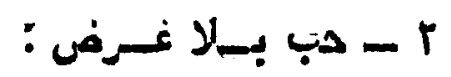

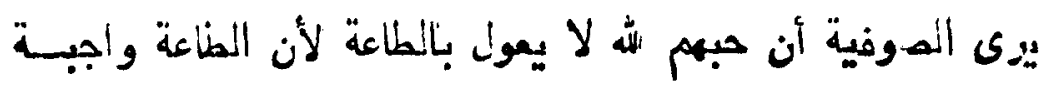

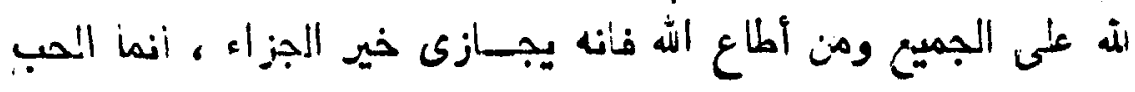

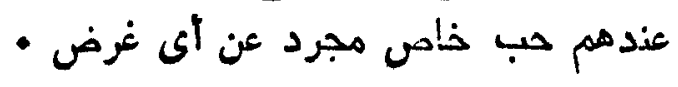

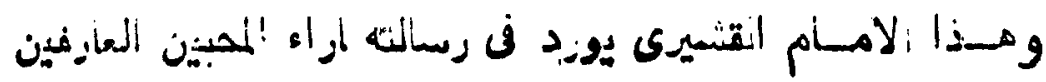

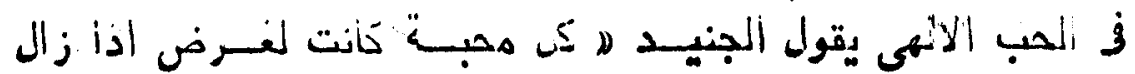

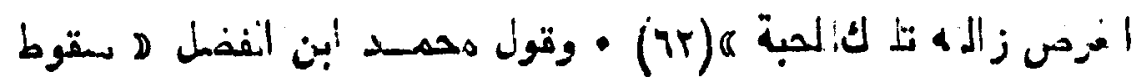

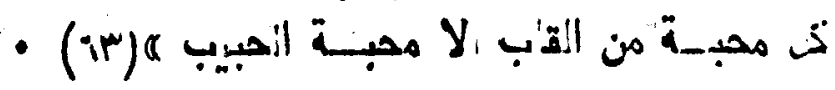

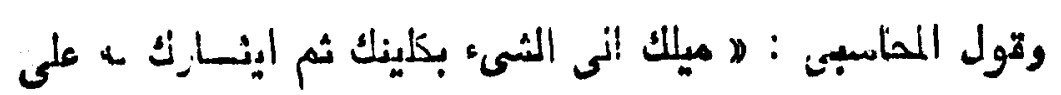

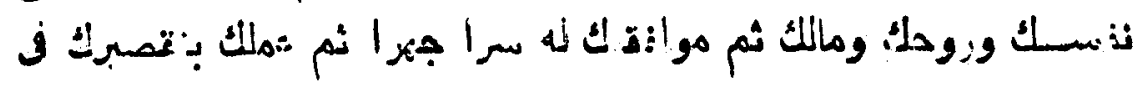

$$
\text { - (7ई) (2) }
$$

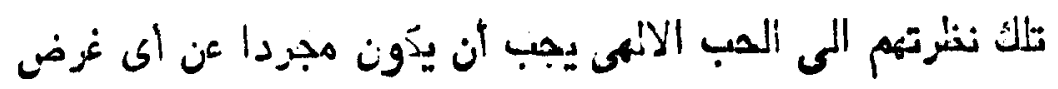

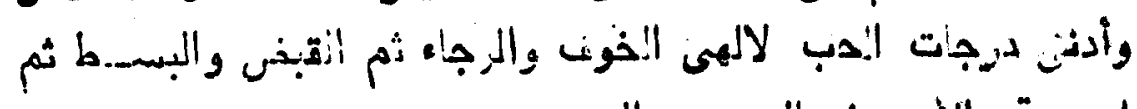

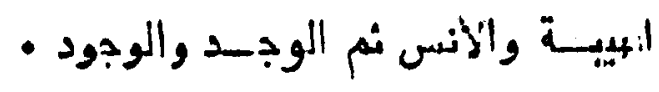

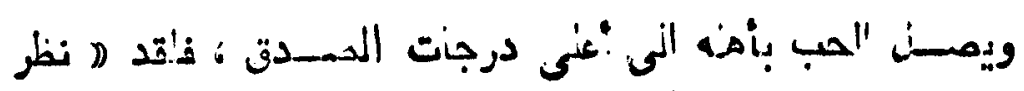

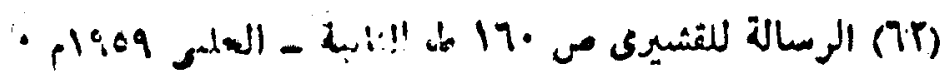

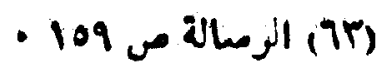

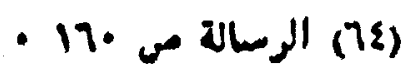




\section{ror}

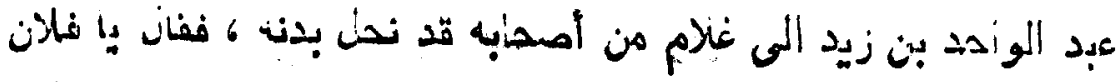

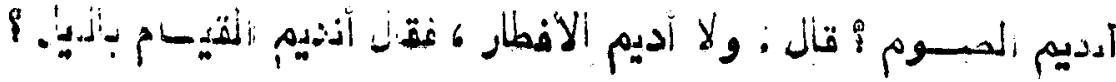

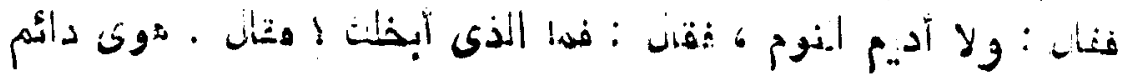

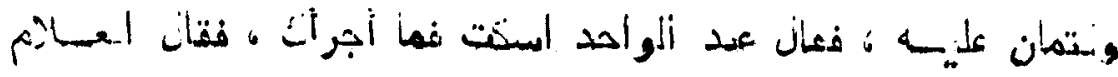

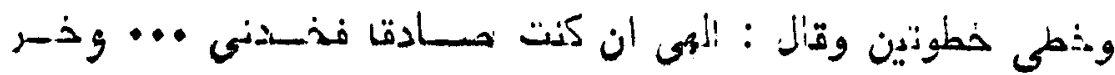
- (10) ( L L-i.s

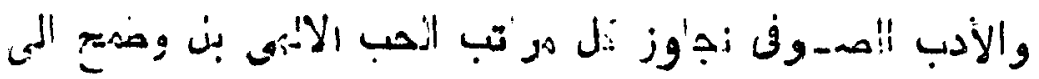

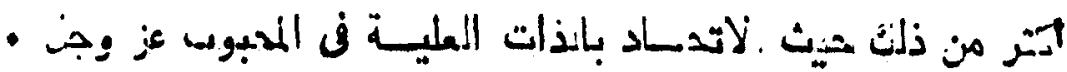

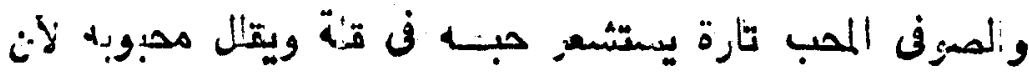

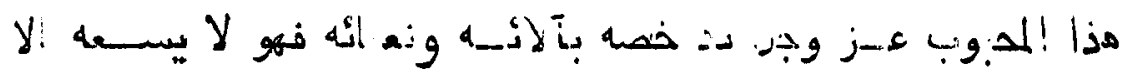

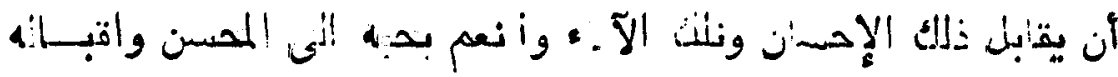
- أنسأس

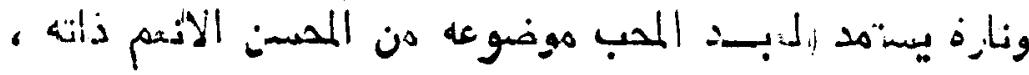

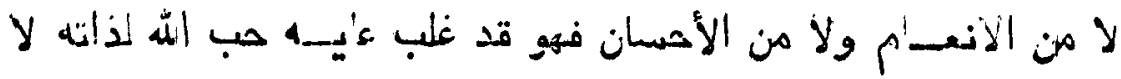

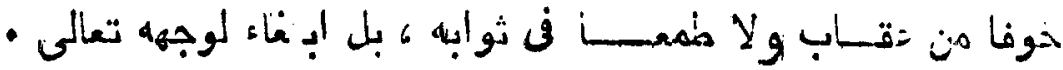

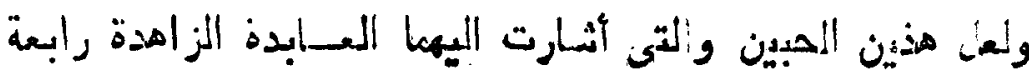
:

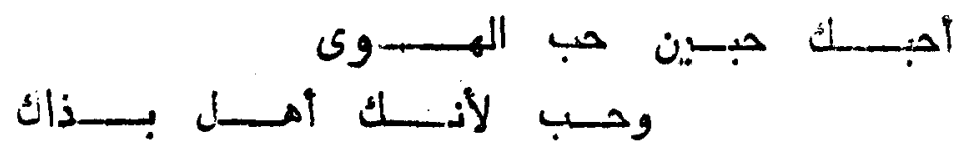

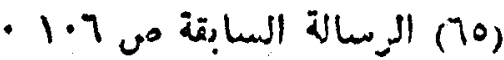

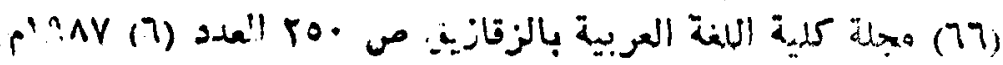

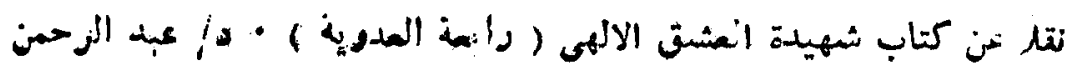




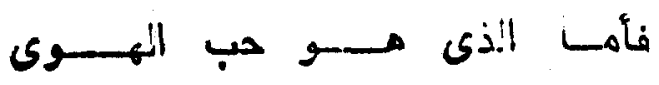

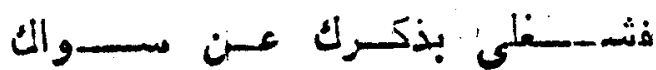

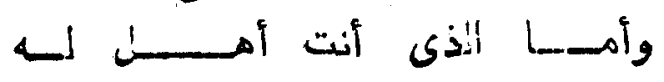

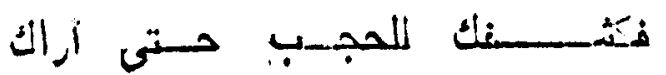

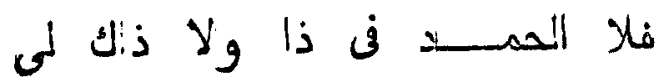

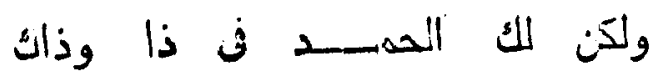

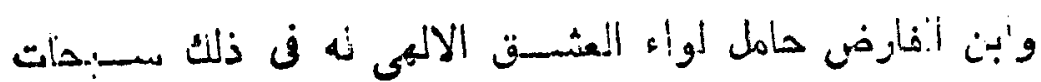

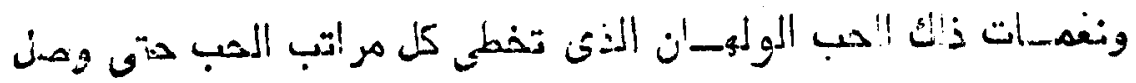

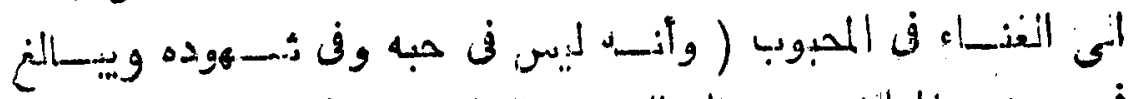

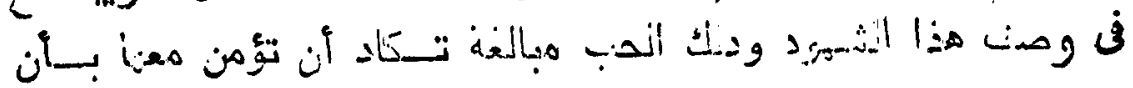

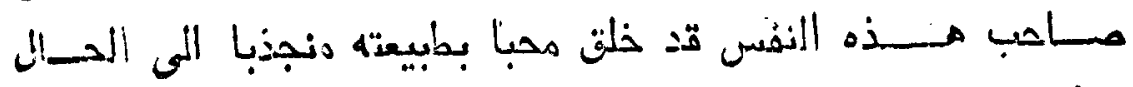

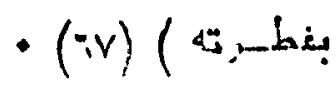

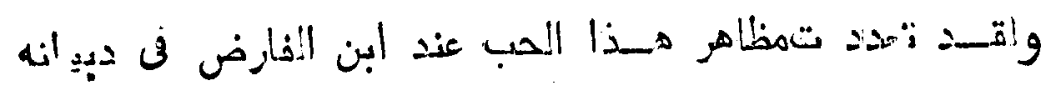

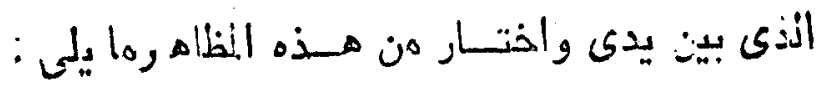

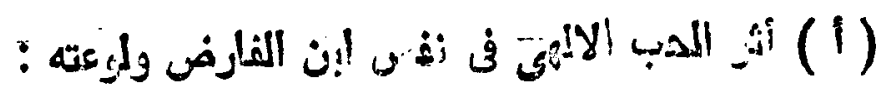

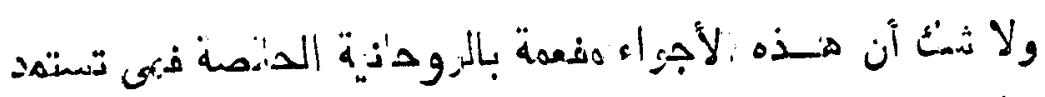

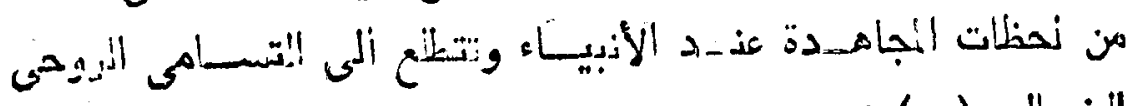

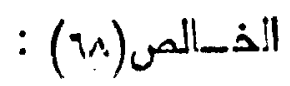

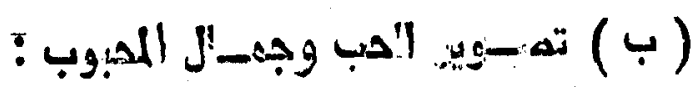

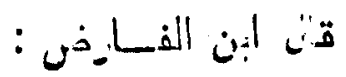


زدنى بفـرط الحب فِيــلك تحسيا

وارحم حشى بلــــى هولك تسمرا

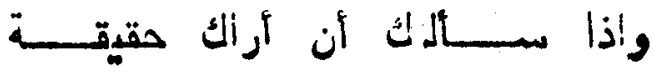

فأس-ديح ولا تجعل جوابى لمن ترى

يـا قــلب أنت وع_تنى فن هبهم

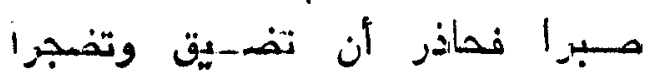

ان الغـــــام هو الحيـاة فمت بـانه

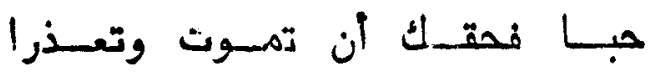

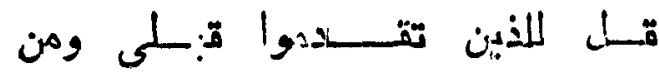

بعسدى ومن أضـهم، لالشجانى هيرى

عنى خـذوا وبى اقتدوا ولى اسمعوا

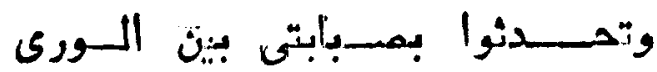

ولقــ خلوت هع الصيب وبيننـا

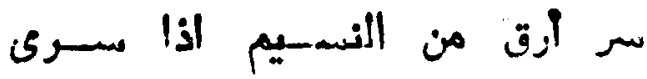

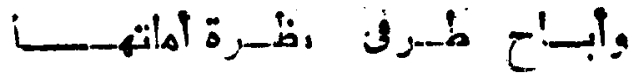

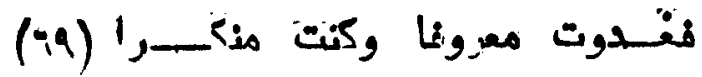

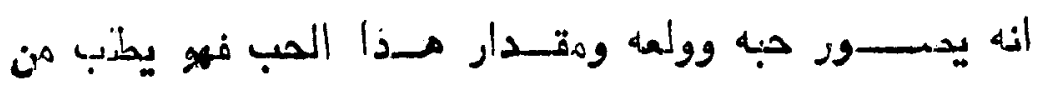

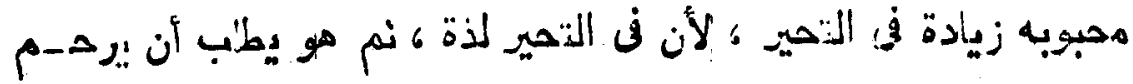

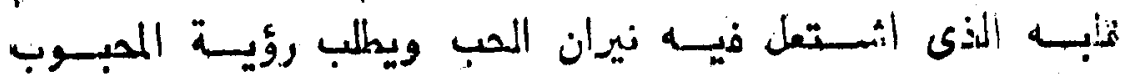

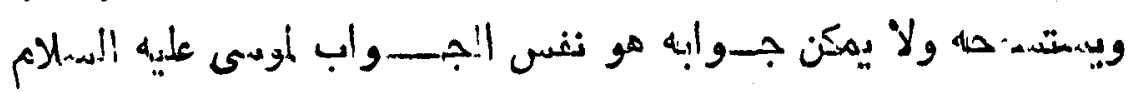

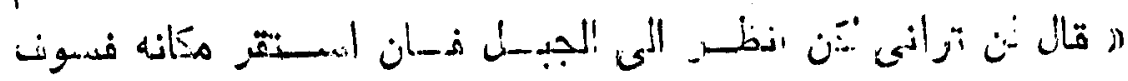

$$
\text { - تزانى }
$$

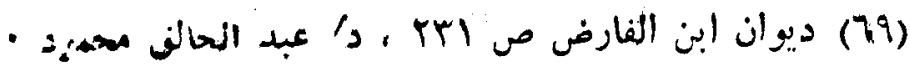

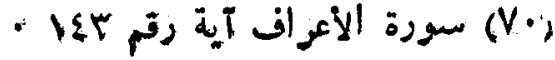




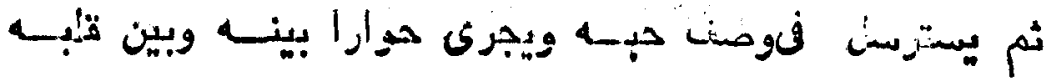

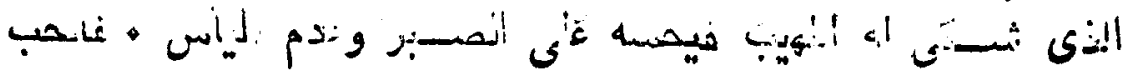

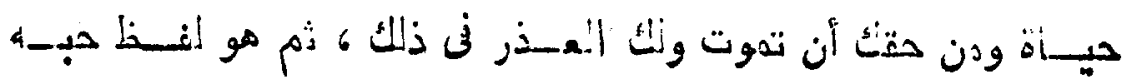

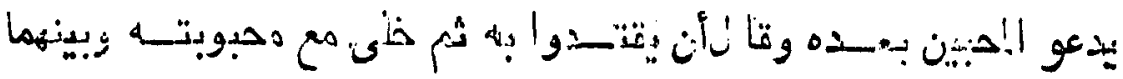

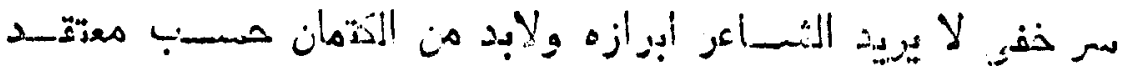

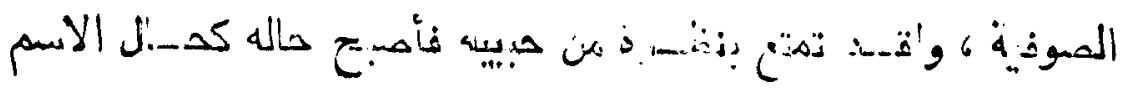

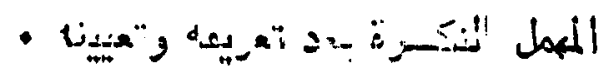

$$
\text { : (vi) (nم يقول }
$$

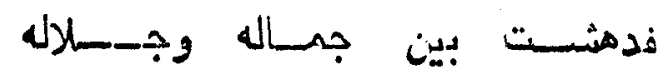

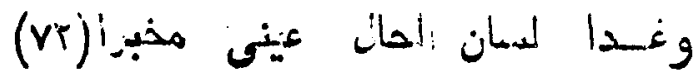

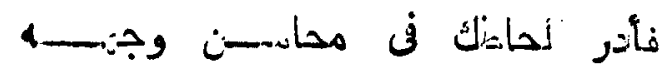

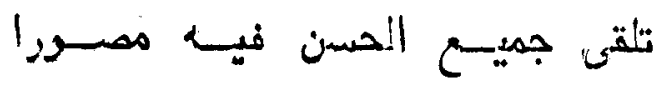

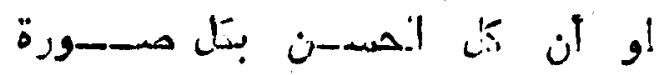

ورآه كان

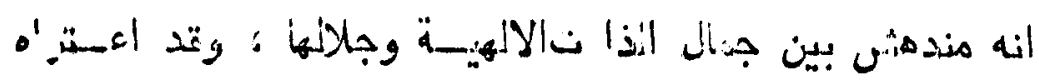

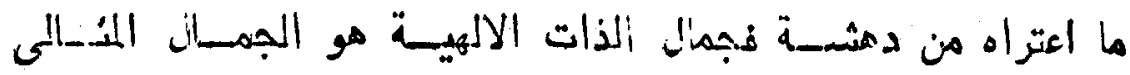

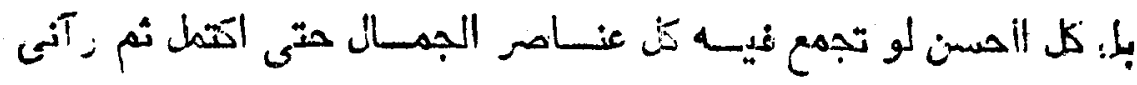

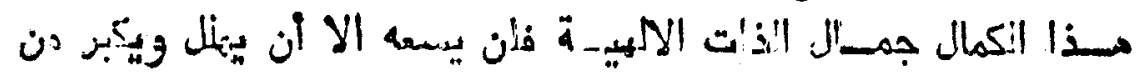

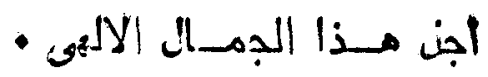

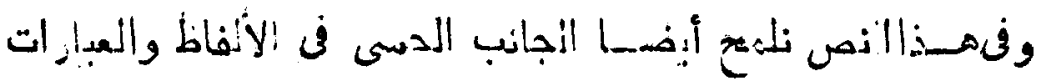

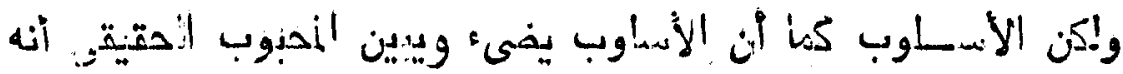

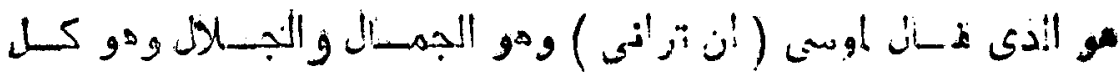

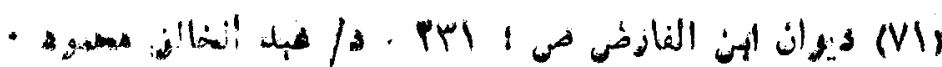




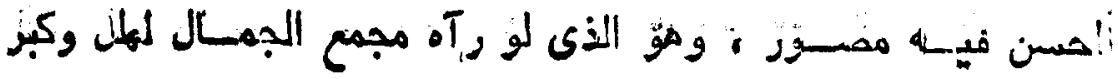

- أنه الله المطلى التهنديز مصنيز

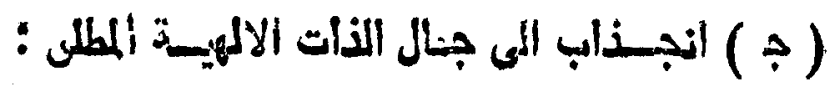

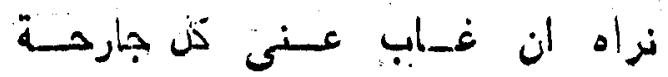

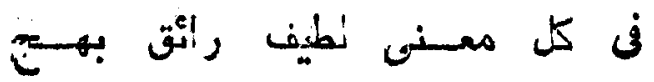

في نغهة العسود والناى الرخيم اذا فال

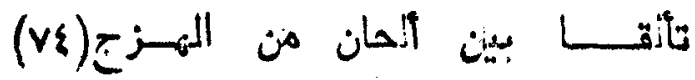

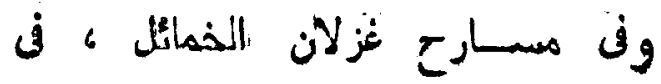

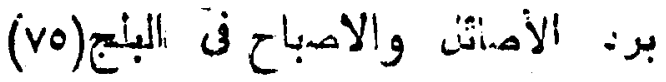

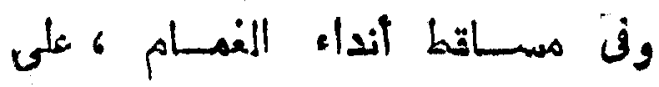

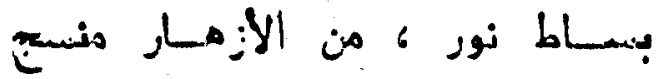

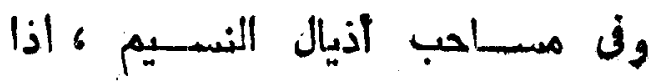

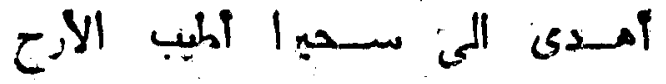

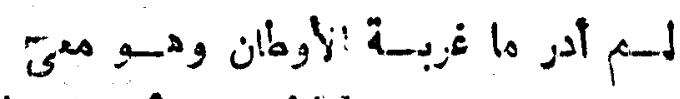

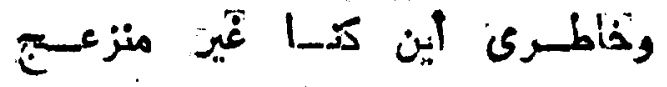

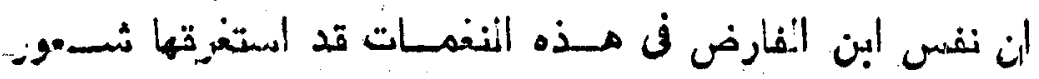

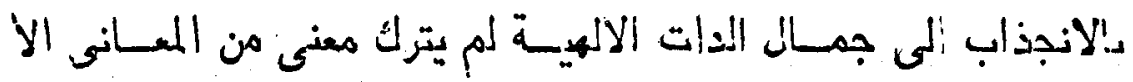

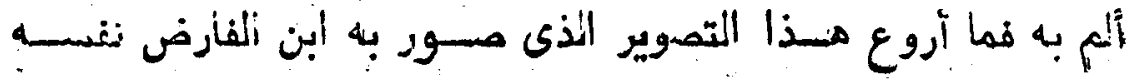

-

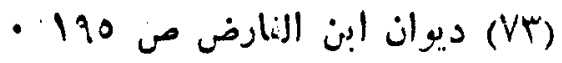

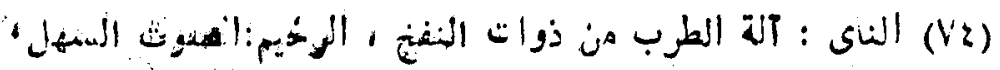

$$
\text { ' }
$$

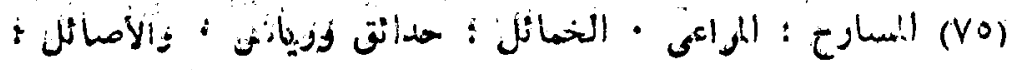

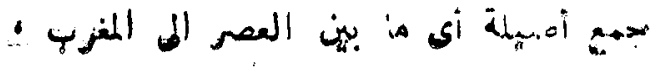

$1 ;(4,1)$ 
أنتى استغرتته: جمال الذذات ألالهيــة المطلق استغراقا جعله يئسهد

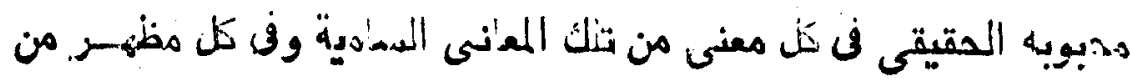

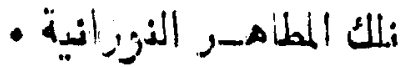

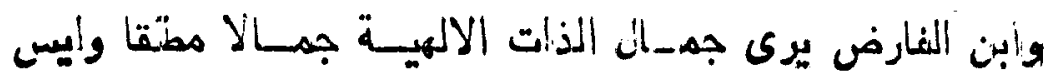

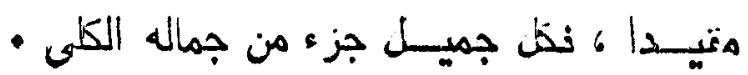

$$
\text { : يقــول(vq) }
$$

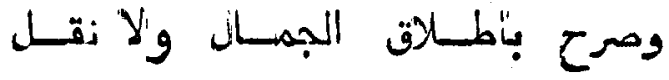

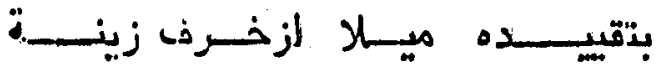

فكل مليــع حســنه من جمــــاله

معسـار له أو حسن كل مليحس

بهـا تيس لبنى هام بل كل عل عائق

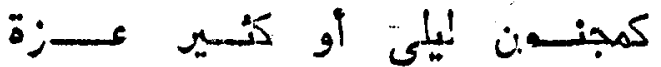

ففى الندئاة الاولى تـراءت لآده.

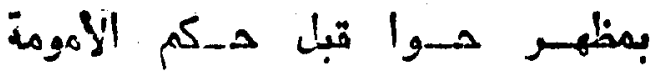

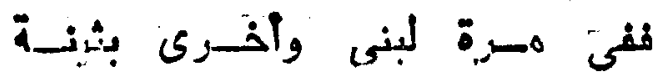

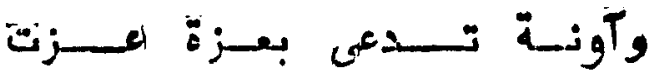

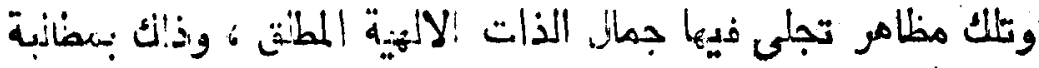

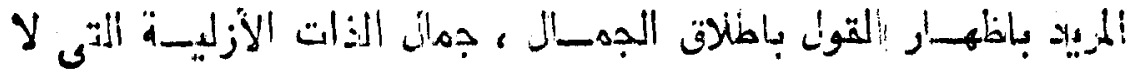

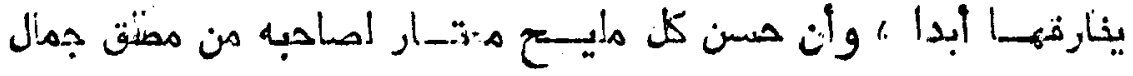

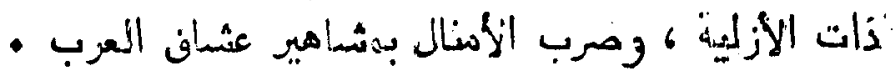

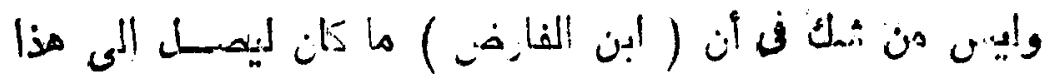

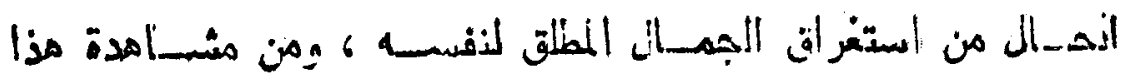

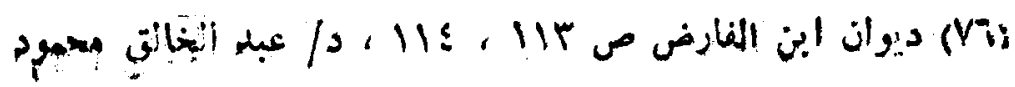




\section{res}

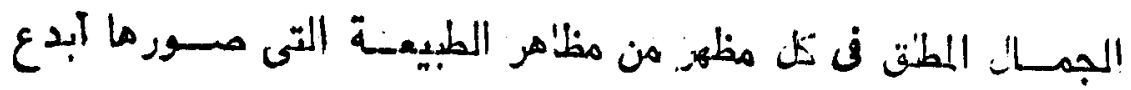

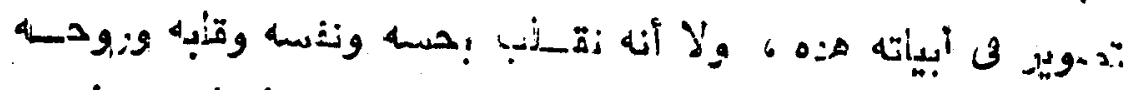

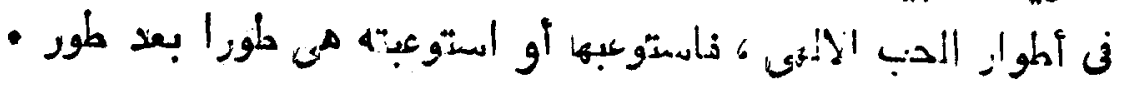

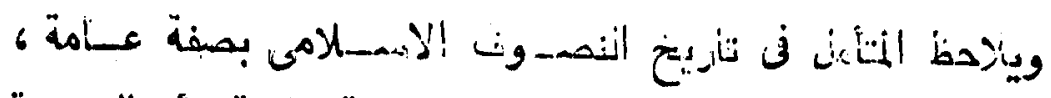

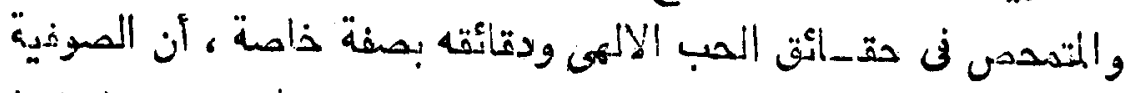

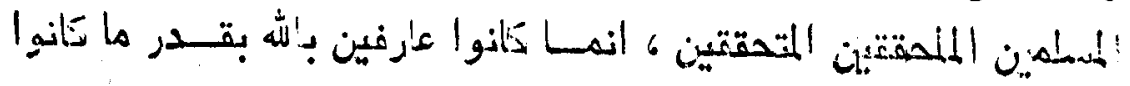

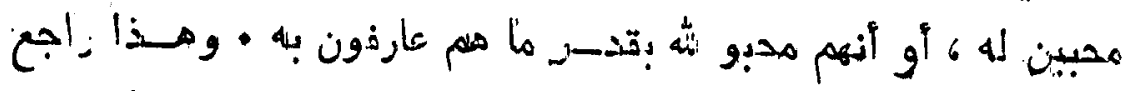

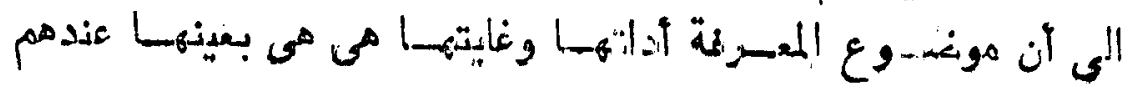

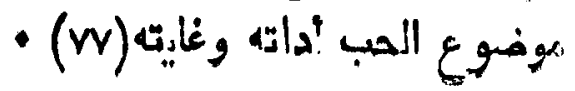

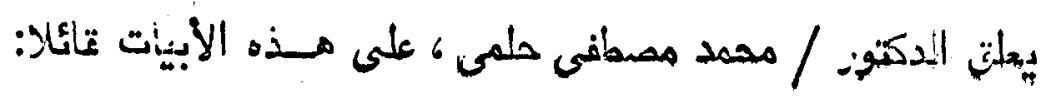

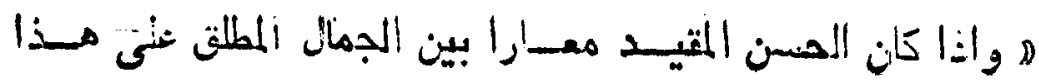

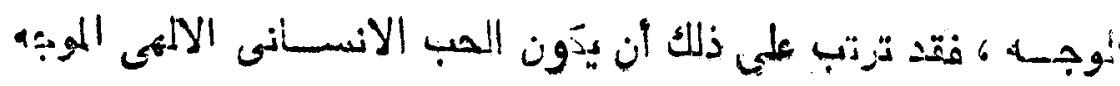

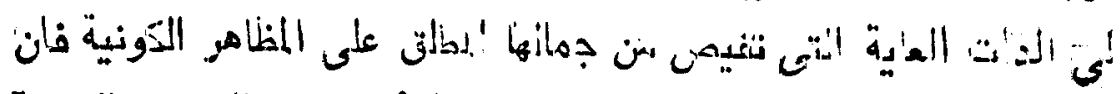

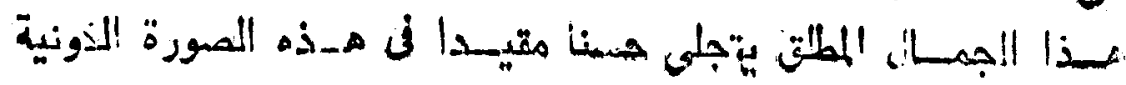

- (va) « sib

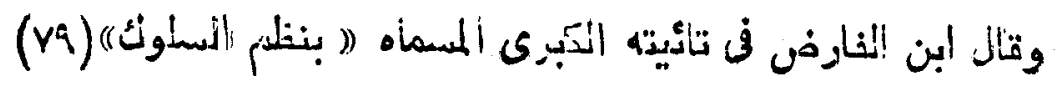

ولمـا انتضى صدوى نقاضت وملها

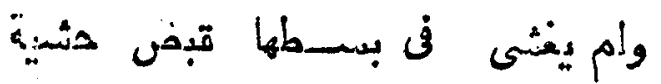

هله , (VV)

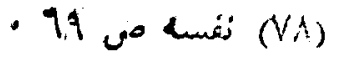

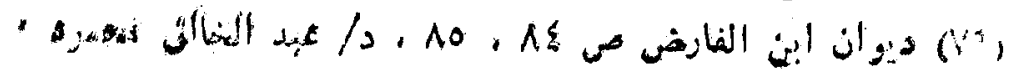


وأبثشتهـن مهـا بـى ولم يكُ هـاضرى

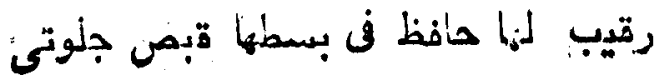

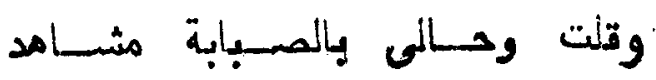

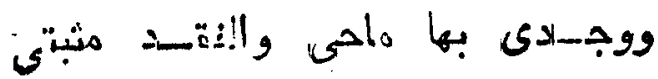

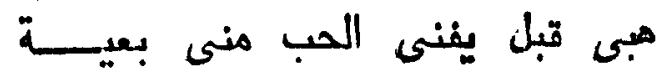

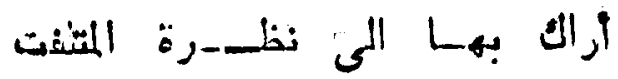

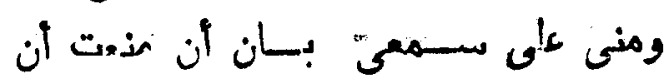

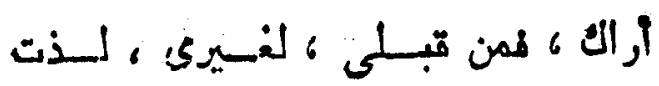

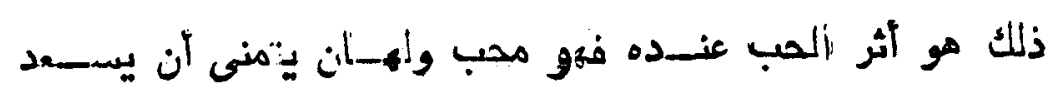

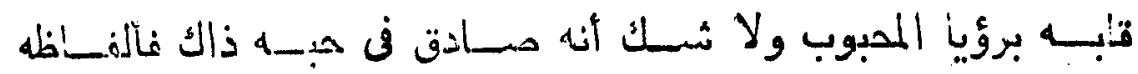

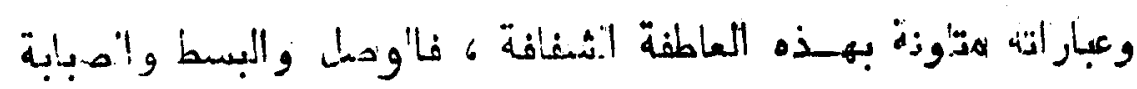

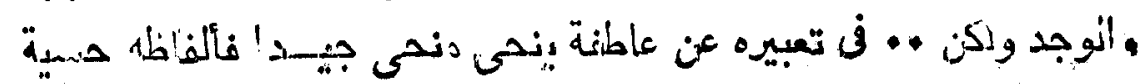

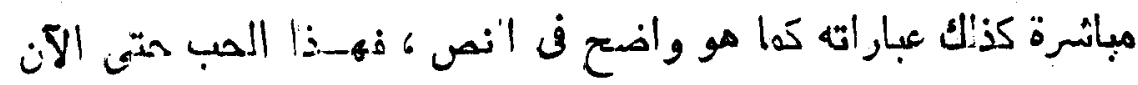

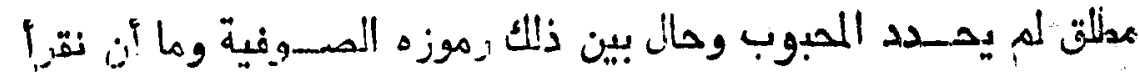

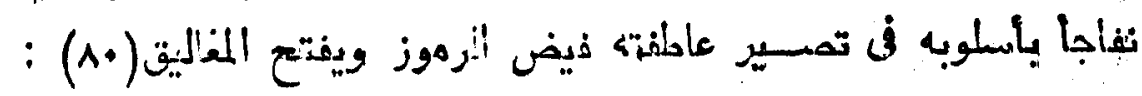

$$
\text { ولو أن هما بى بالجبال وكان طـور }
$$

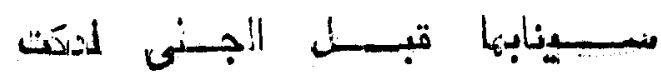

$$
\text { وطوفان نوح عند نوحى كأدمعى }
$$

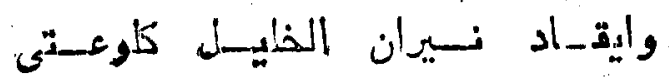

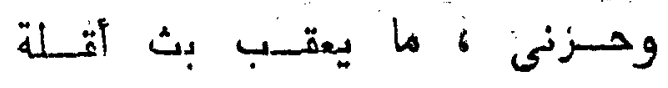

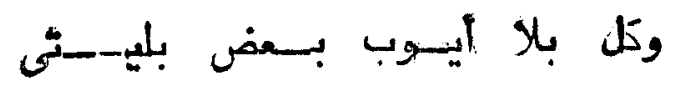


141

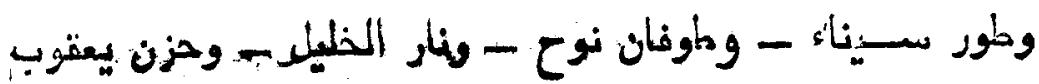

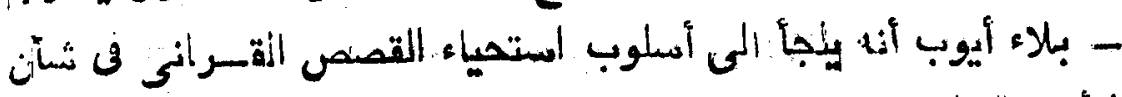

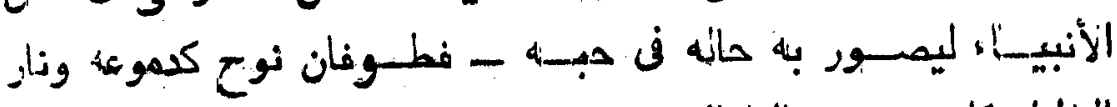

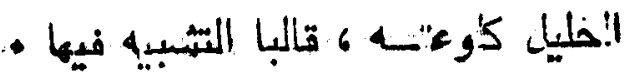

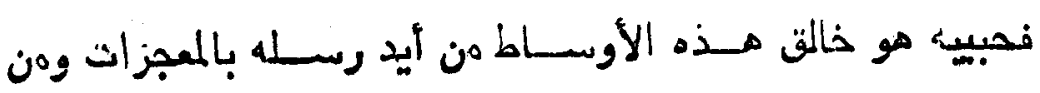

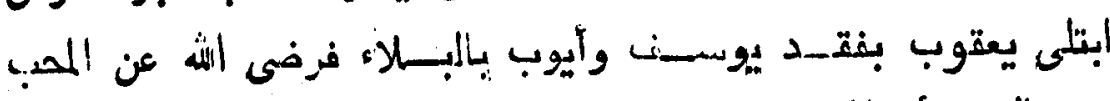

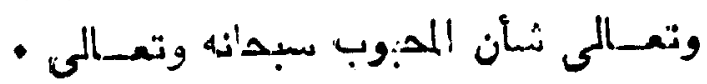

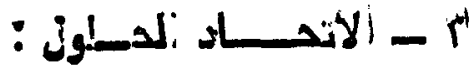

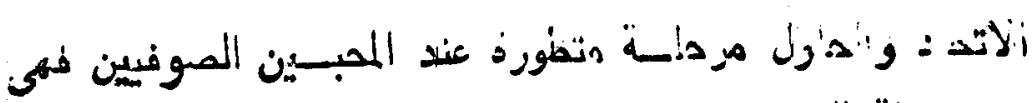

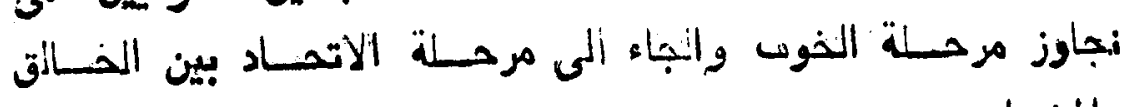
• إلخهلوق

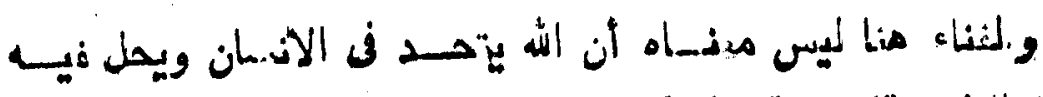

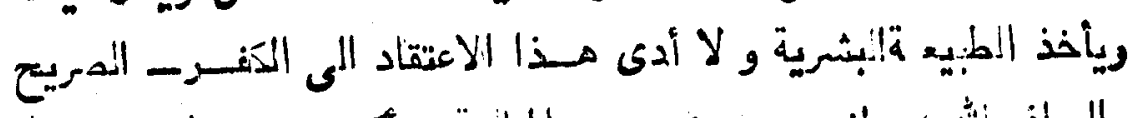

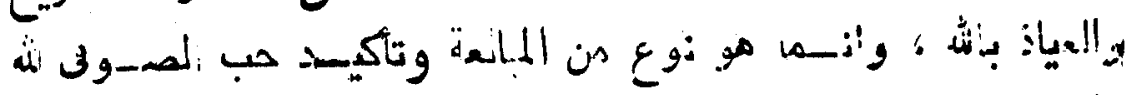

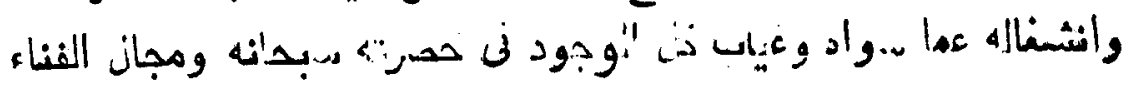

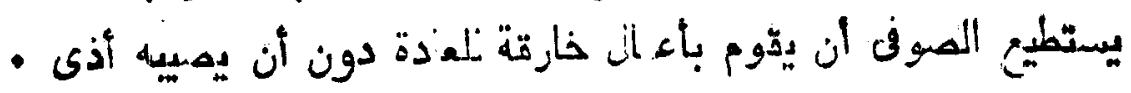

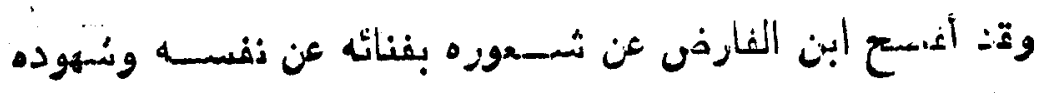

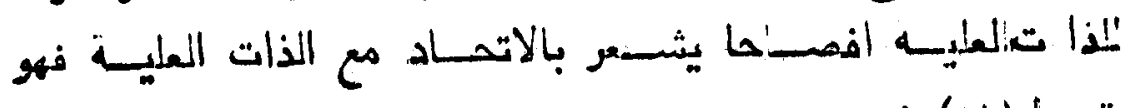
:

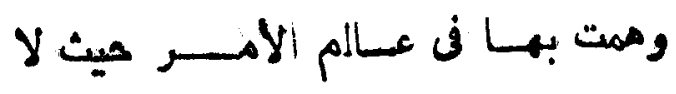

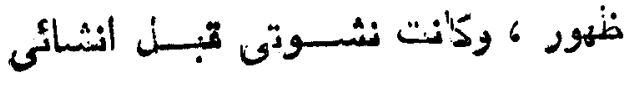




\section{PIf}

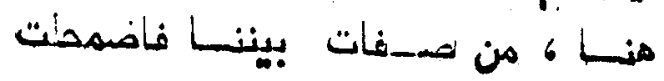

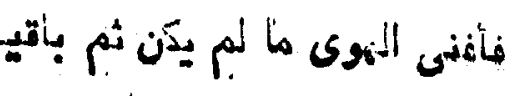

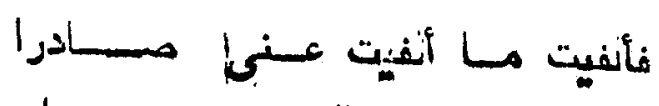

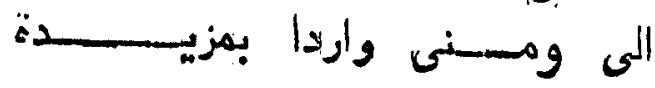

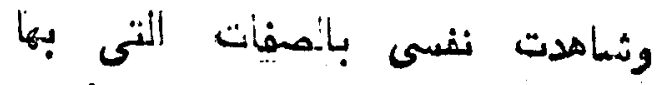

تحبيت عنى فن شئهودى وحجتى لهات

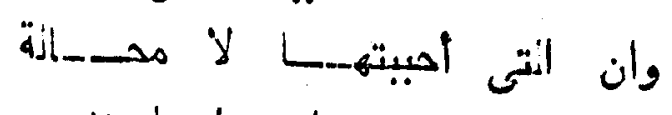

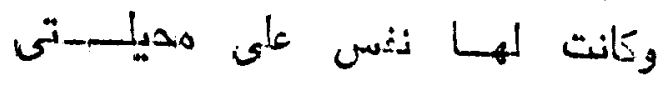

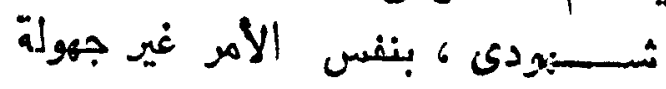

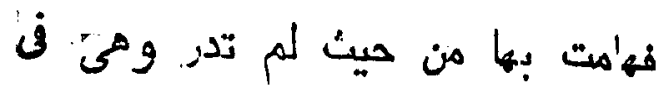

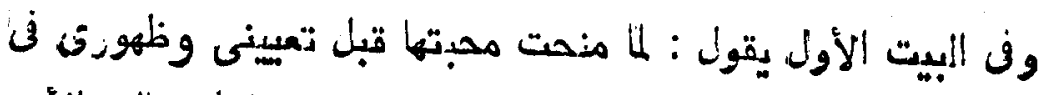

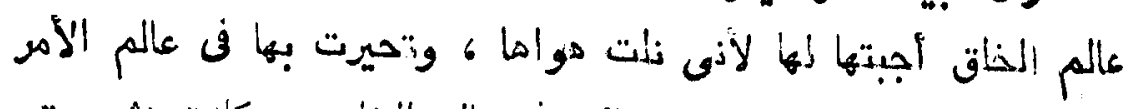

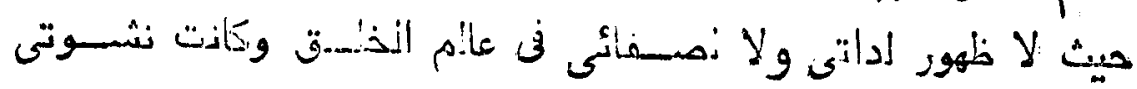

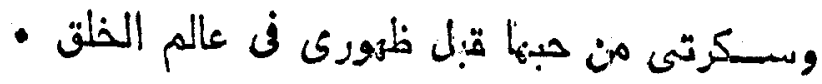

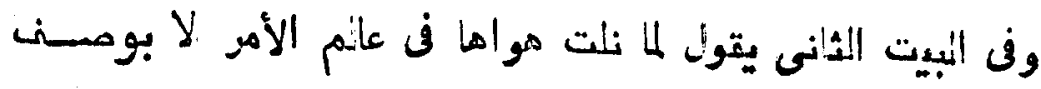

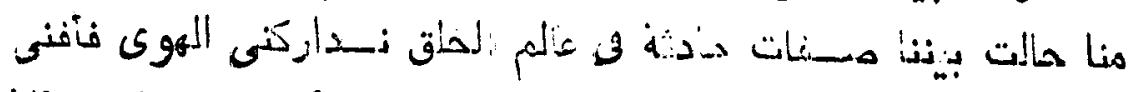

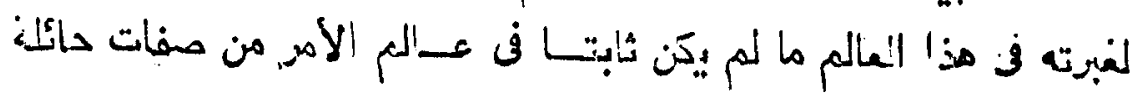

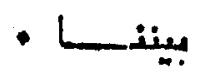

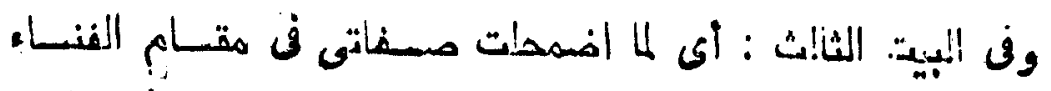

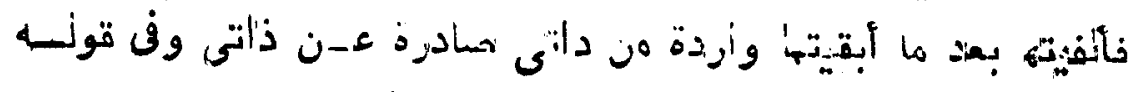

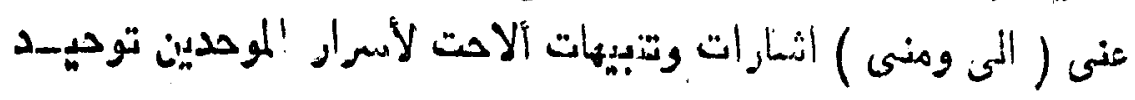

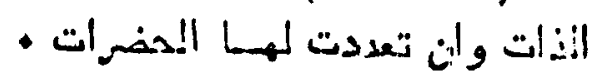

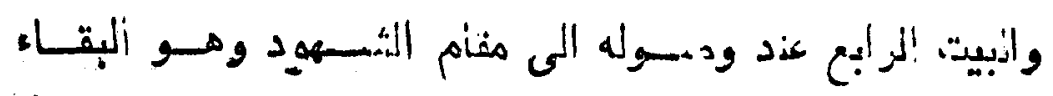

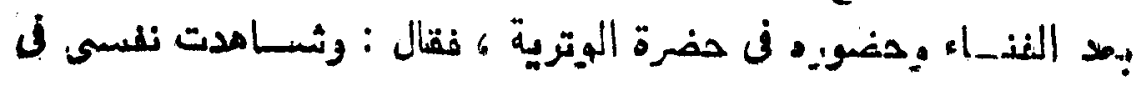




\section{pyp}

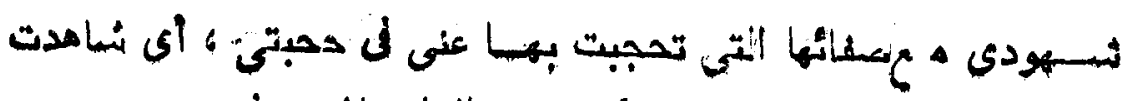

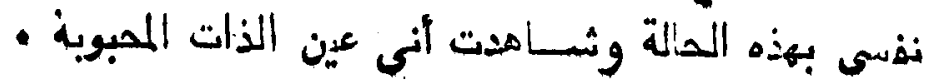

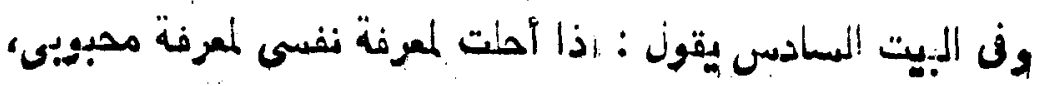

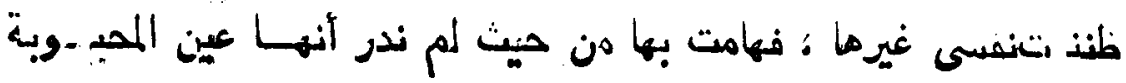

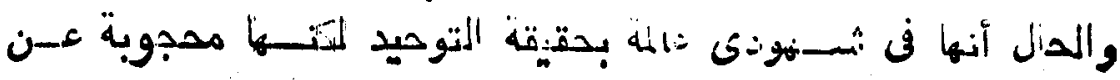

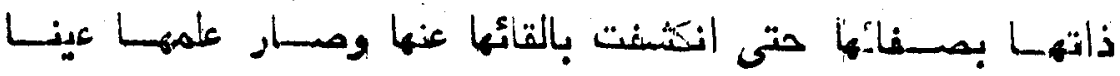

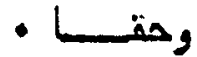

ويتلفت المنـــاعر فيذذا هو فاق فى محبــوبه عني نحو ما نراد فن تمسيدة بدايتهـا :

تملبى بحســـثنى بأنك متلفي ل....

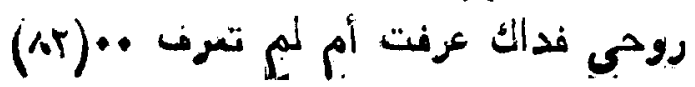

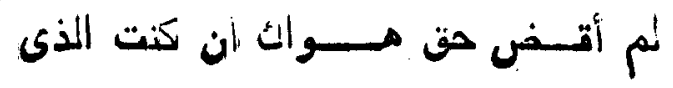

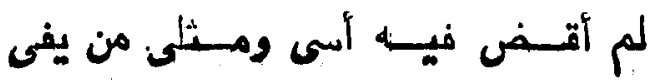

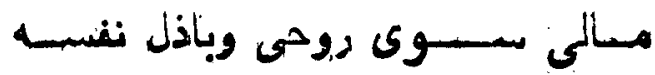

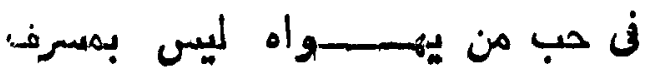

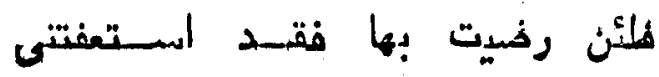

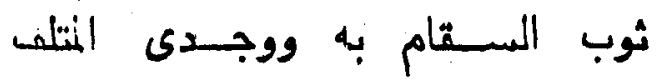

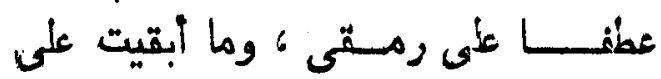

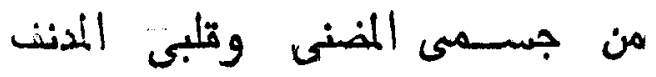

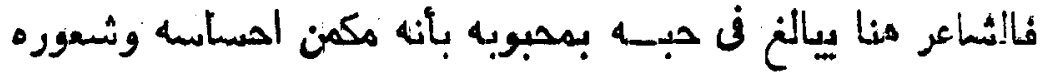

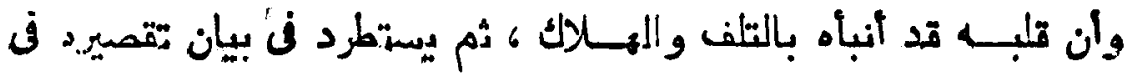

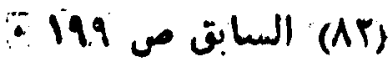




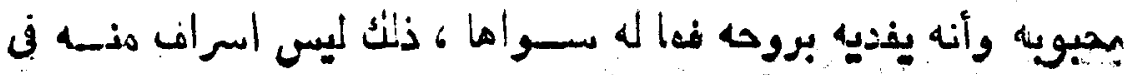

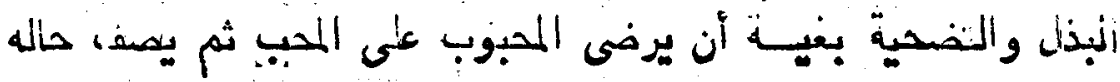

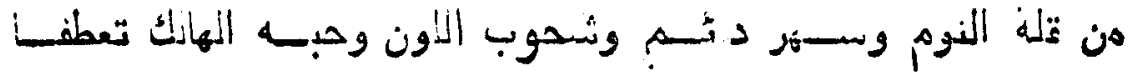

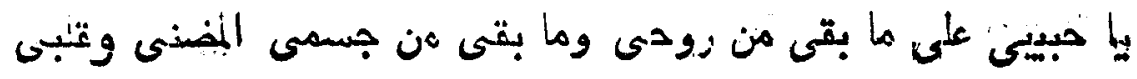
الذى جهـد الألى

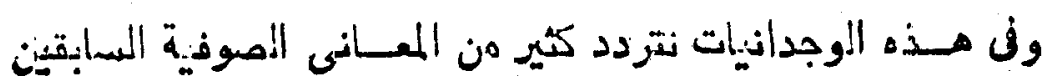

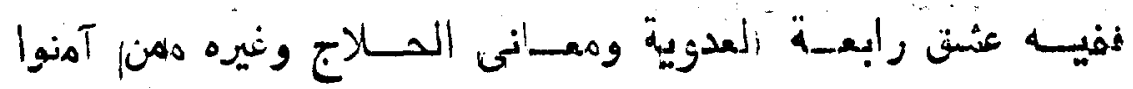

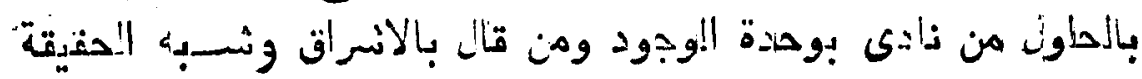

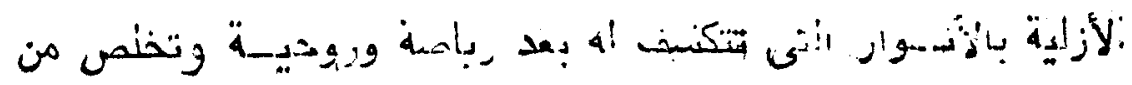

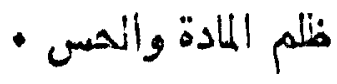

كذلنك نرى فن بعض معانيـه الوجدانية صــوزا فريبـة. من ظنوز

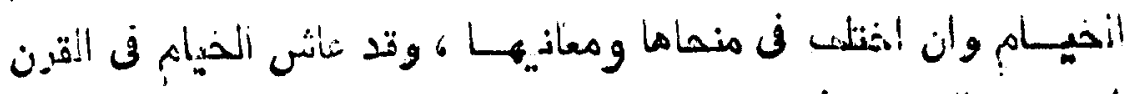

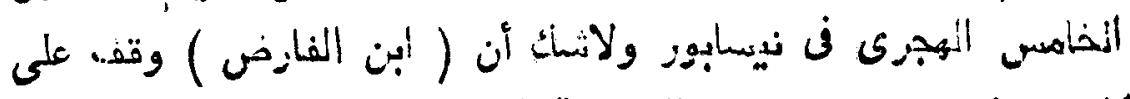

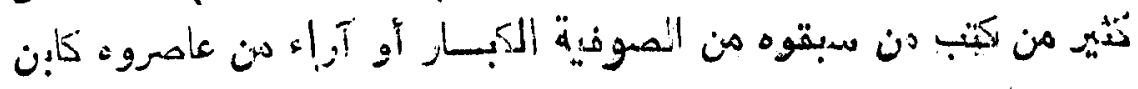

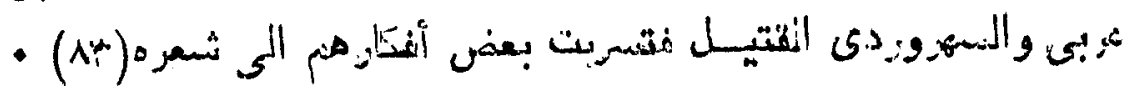

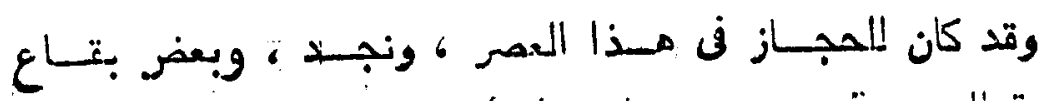

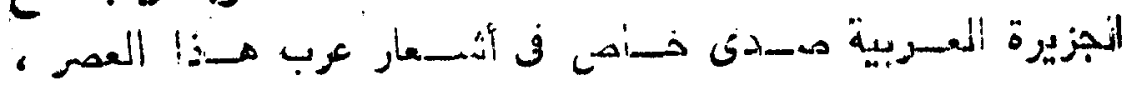

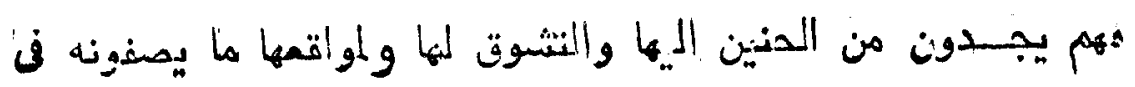

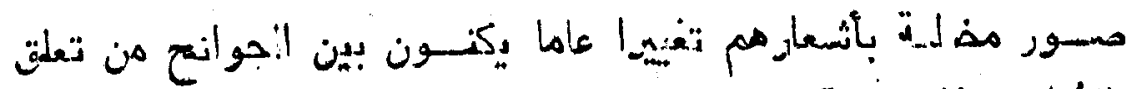

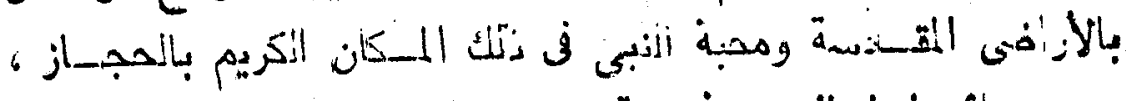

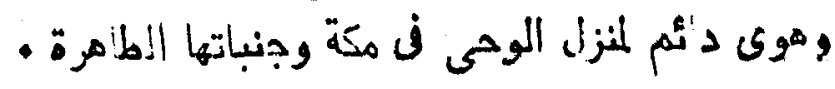

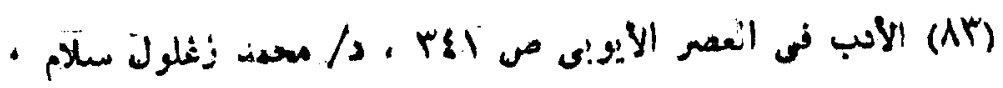




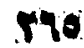

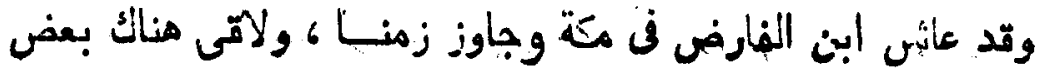

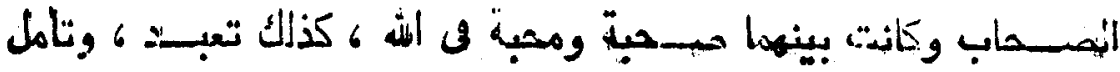

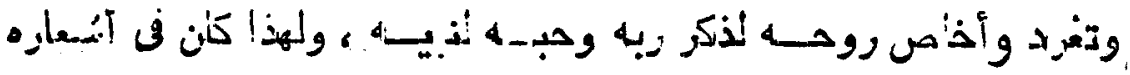

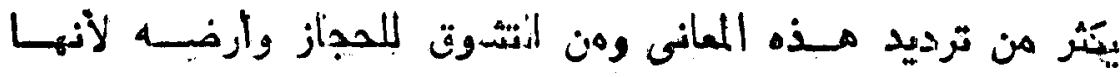

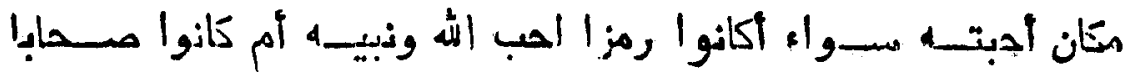

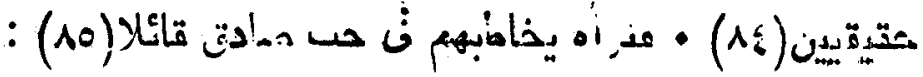

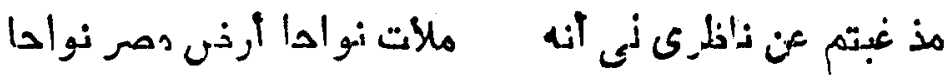

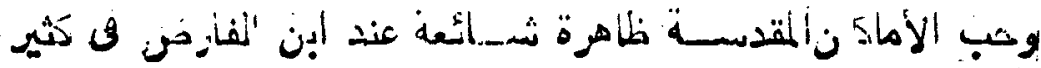

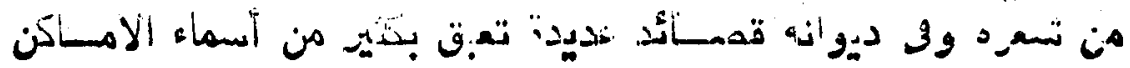

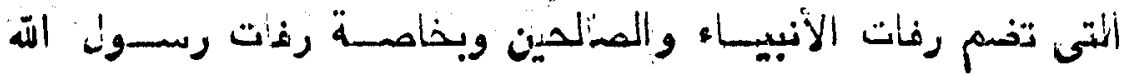

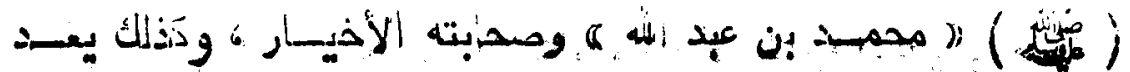

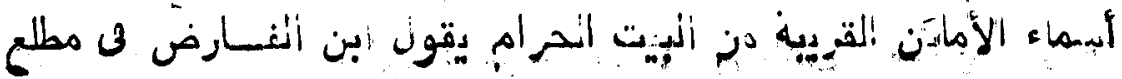

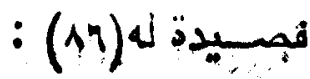

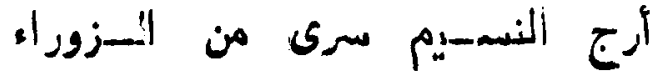

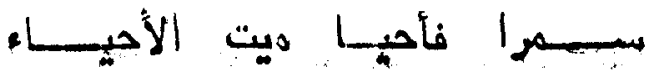

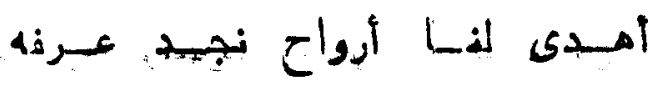

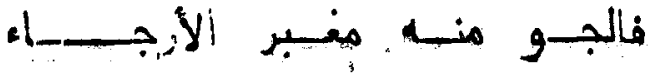

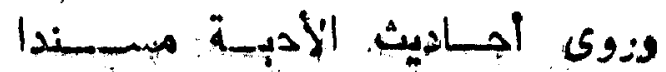

(Av) اذنة

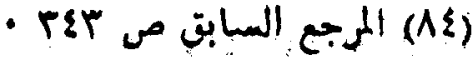

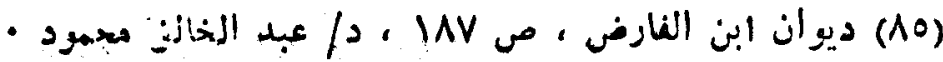

- IVr نف (AT)

المدرب (AV)

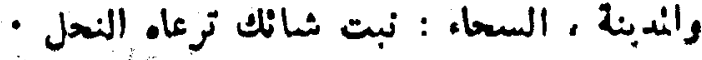




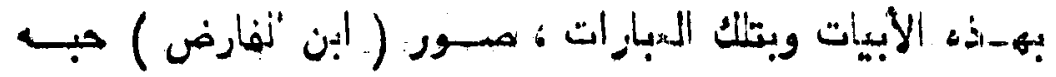

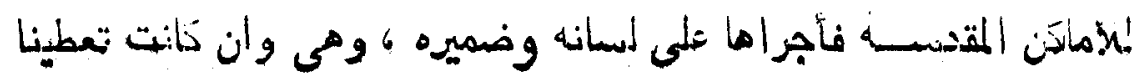

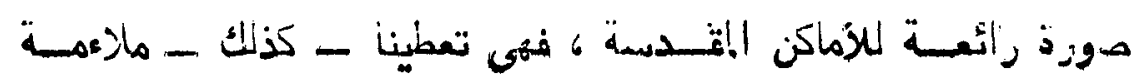

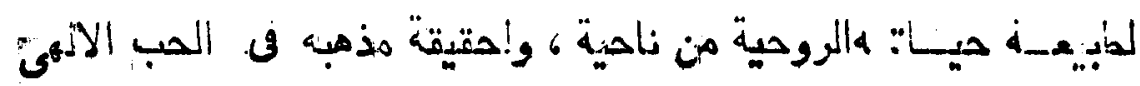

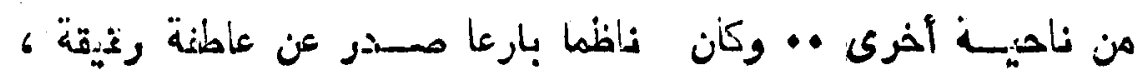

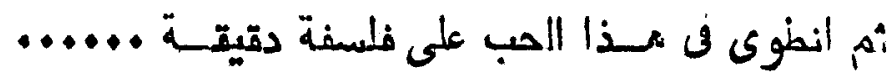

بعسد هـــذه الرحلة انخاطفة الثى تجولنسـا في ديوان عهز بن

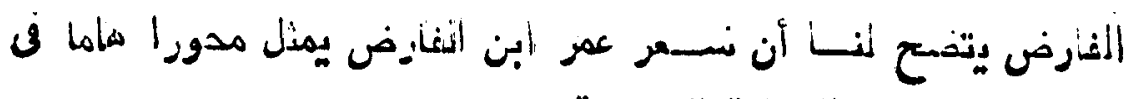

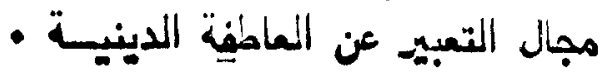

وها هي الا صفحات متواضعة تناولتها فن الحب الالهن ومعسانيه

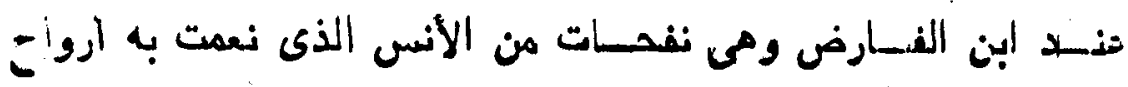

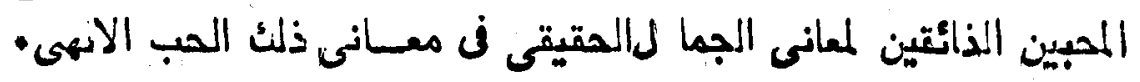

وخلاصسية القول أن ابن الفنارض كان من الذين زكت نفوسهم

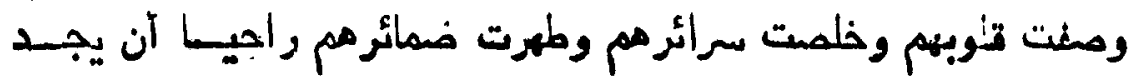

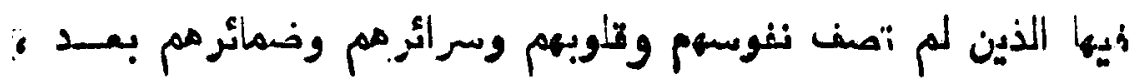

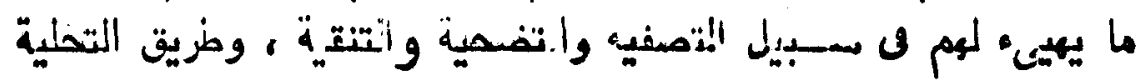

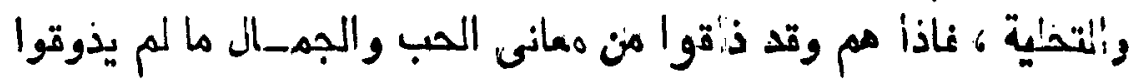

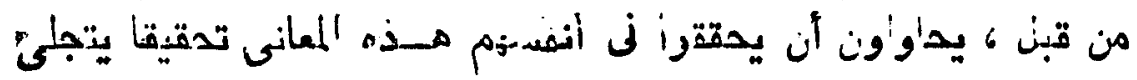

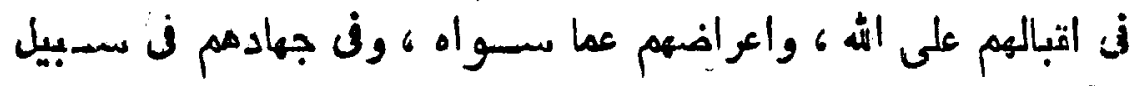

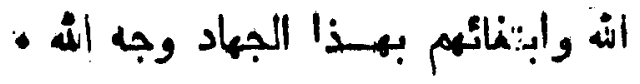

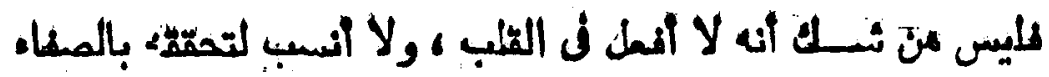

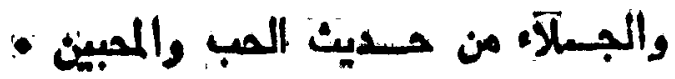


PบY.

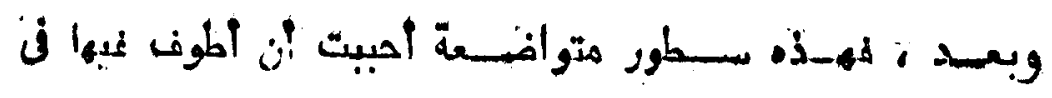

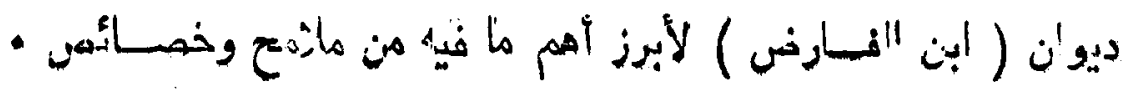

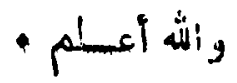

دكي-ور

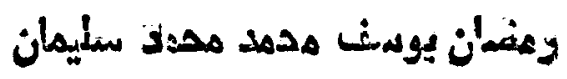

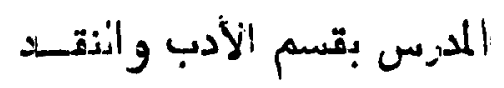

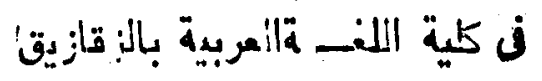




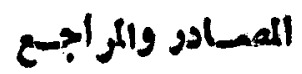

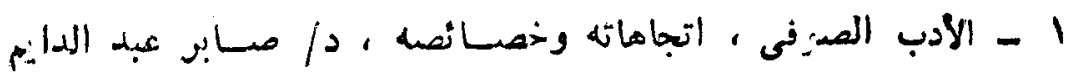

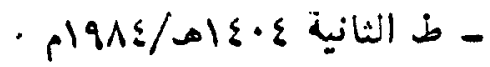

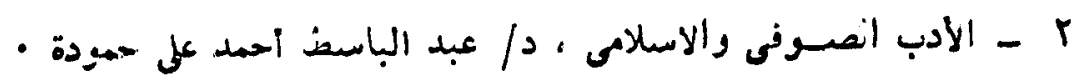

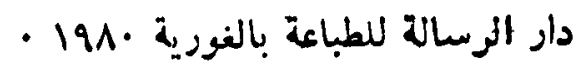

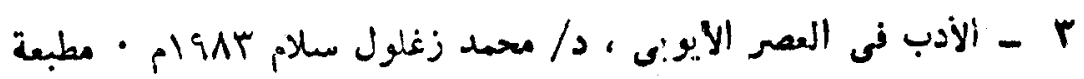
-

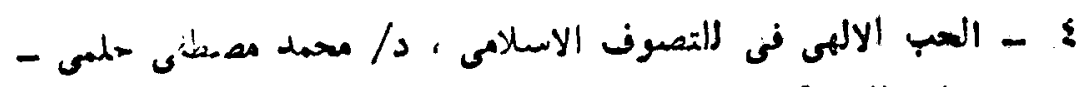

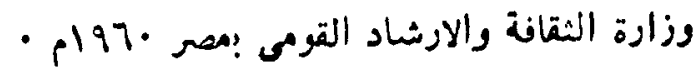

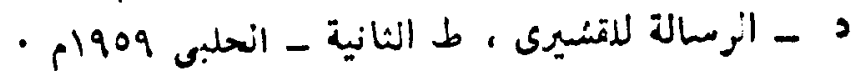

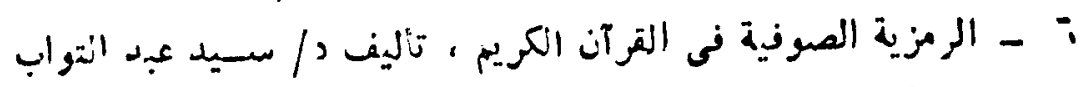

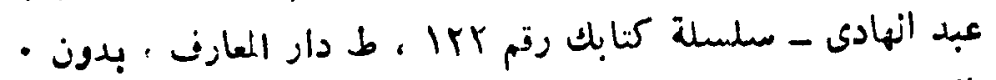
V - V

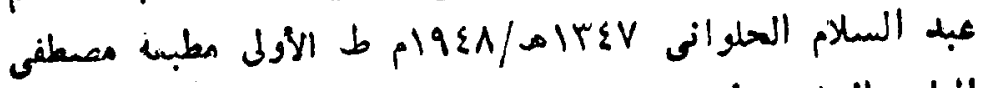

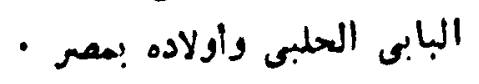

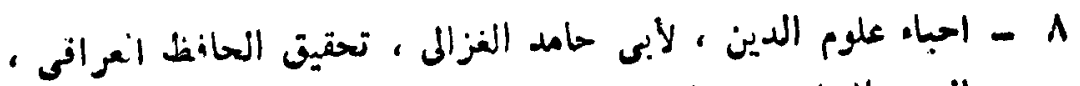

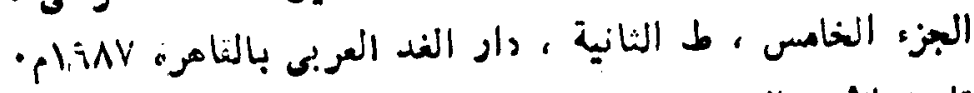
1 - 1

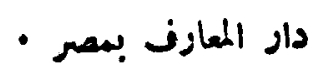

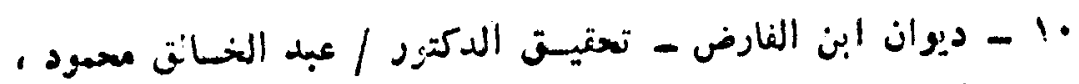

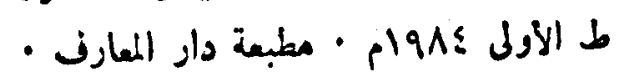

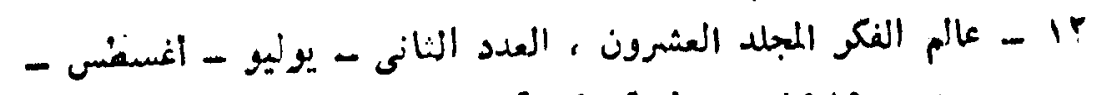

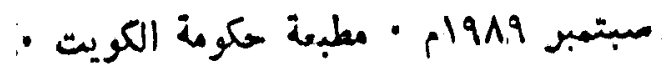

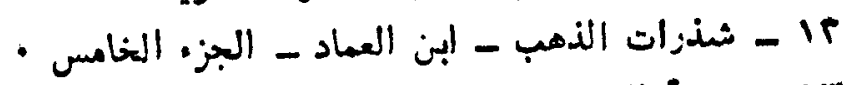

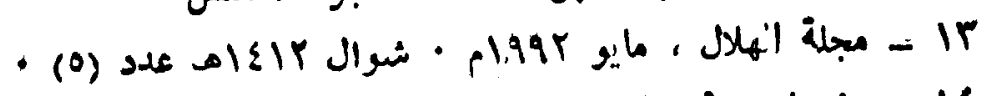

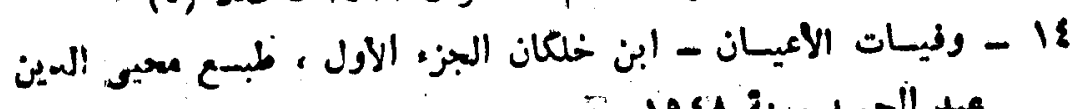

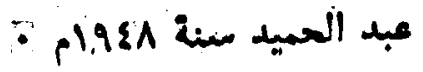




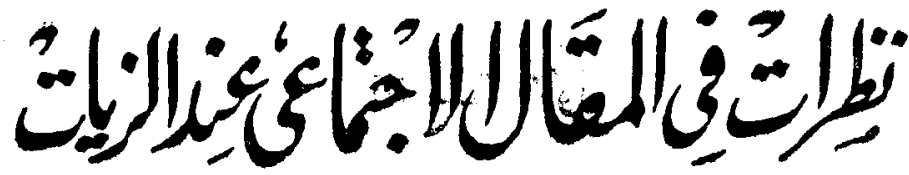

لالدكتور / عهم:ذ دهدان هده: بذيت"

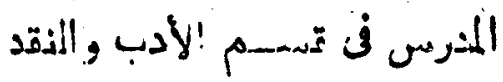

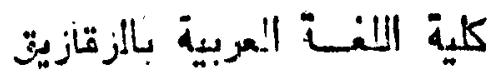

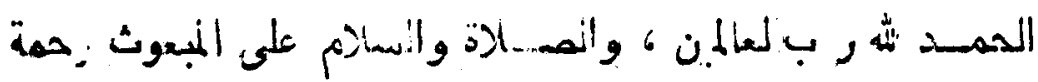

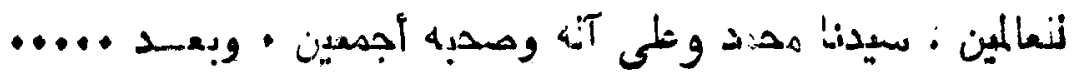

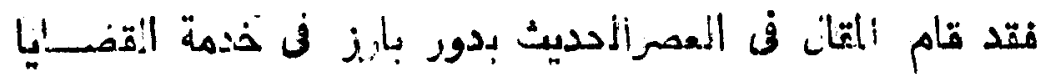

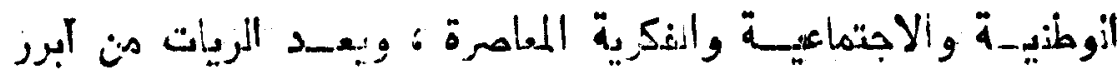

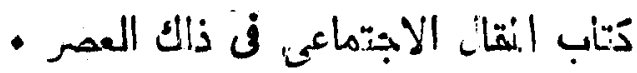

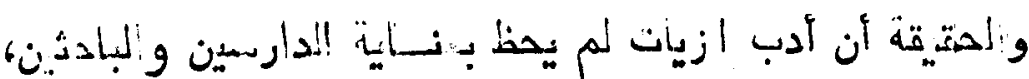

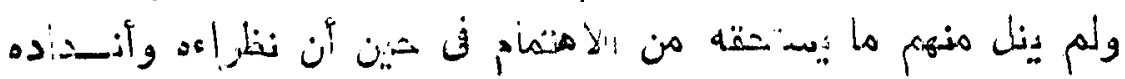

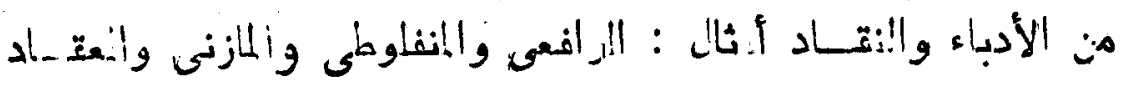

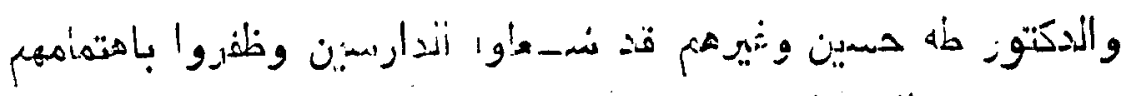

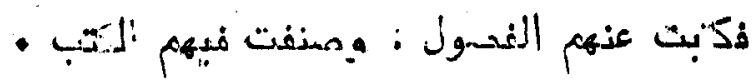

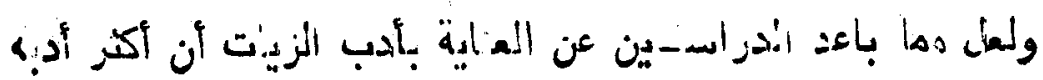

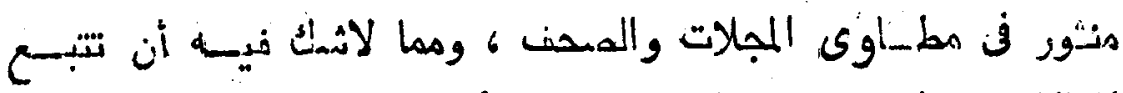

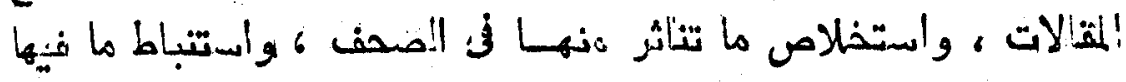

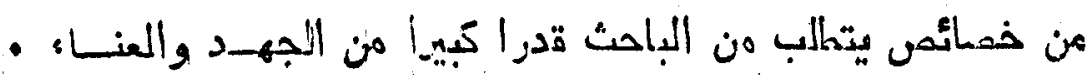

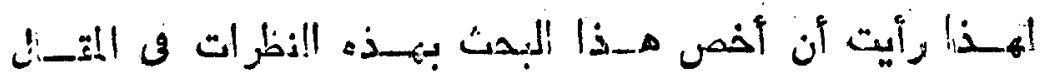

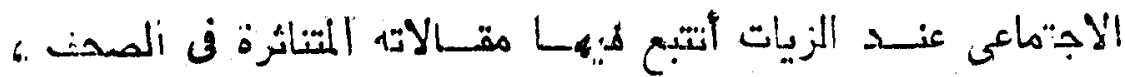

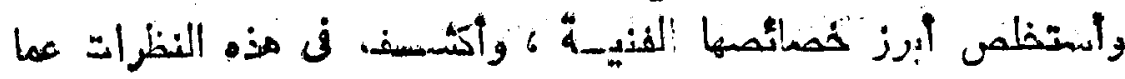

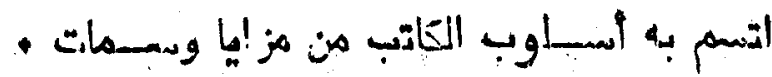

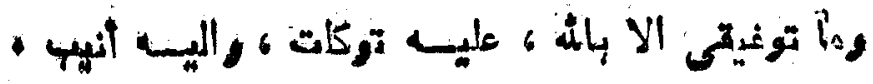




\section{ألفمسل الآول}

\section{تهب-سـد:}

عاثت مصر هنذ الاحتلال البريطسانى عام IMAT م تعنى مرارة

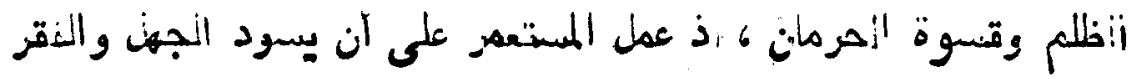

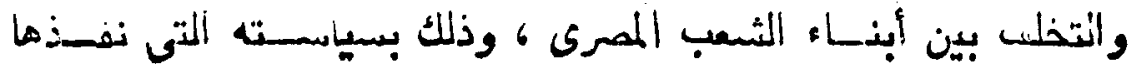

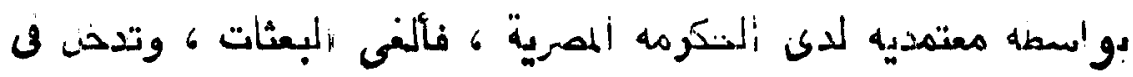

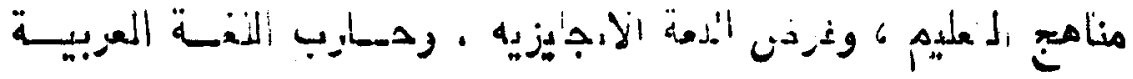

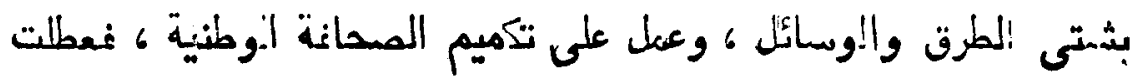

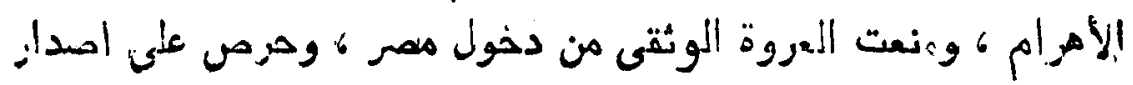

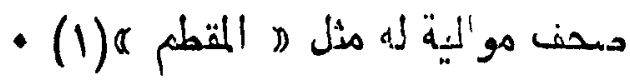

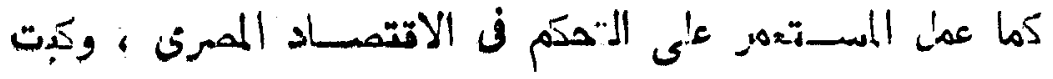

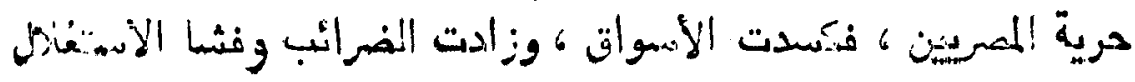
• والفستهاد

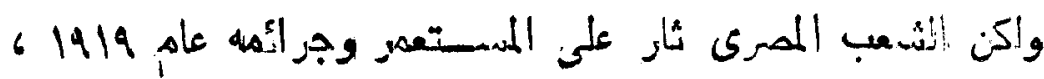

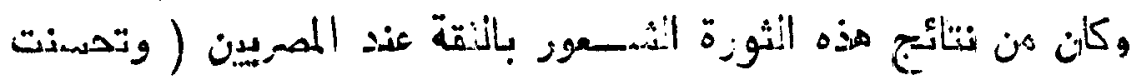

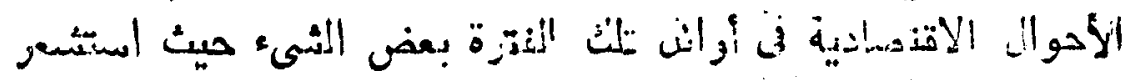

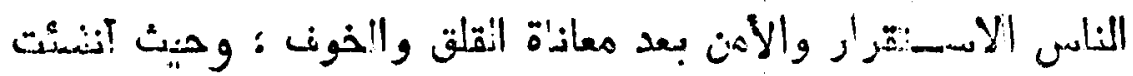

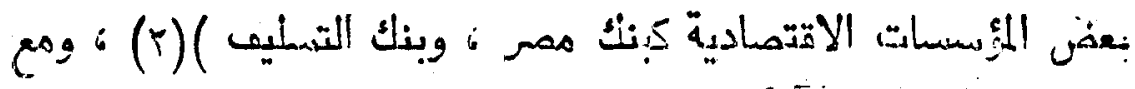

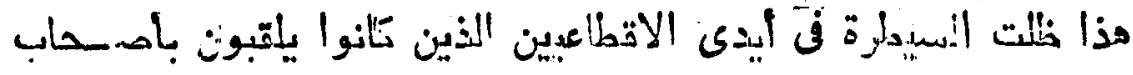

(ا) أدب المقانة الصحفية فى مصر. بـ ع للدكتور عبد النطينذ همزة - ru, rV ص

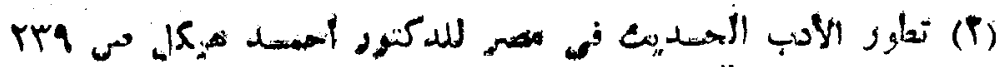
- 21 il 


\section{YVI}

الصسـالح الحقيقية ، وعاثى ألشسبع المصرى ذليلا على أرضه يعانى

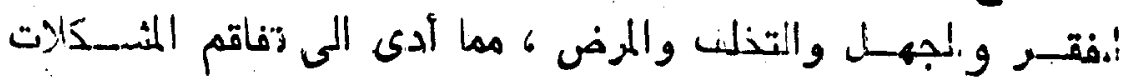

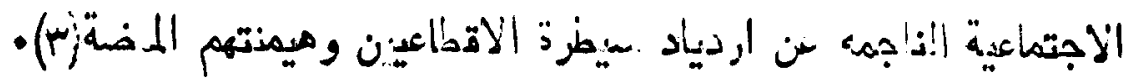

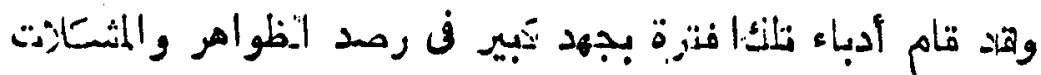

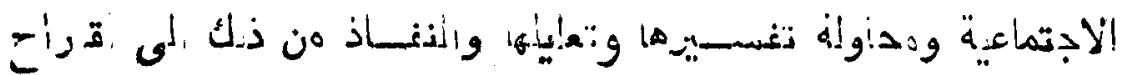

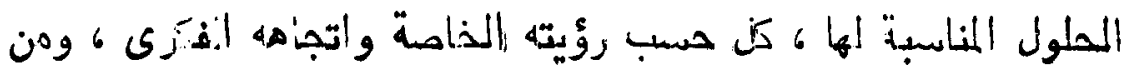

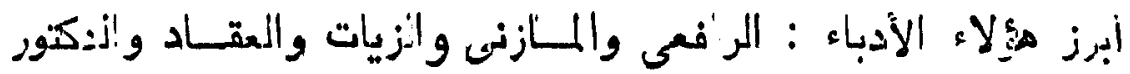

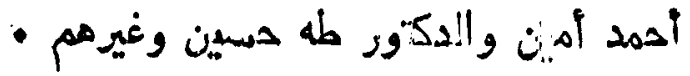

\section{هياة الزيات : - ديات}

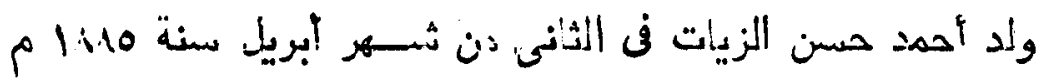

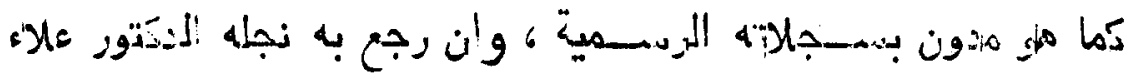

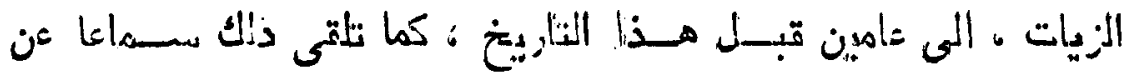

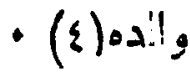

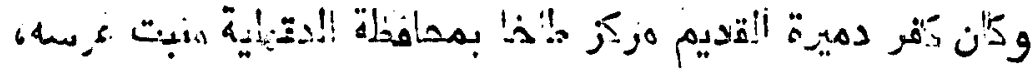

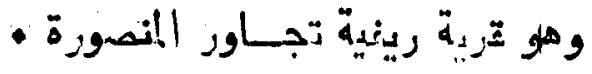

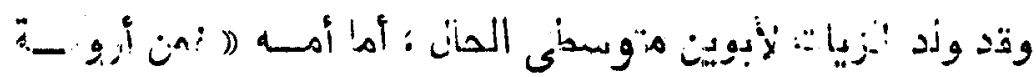

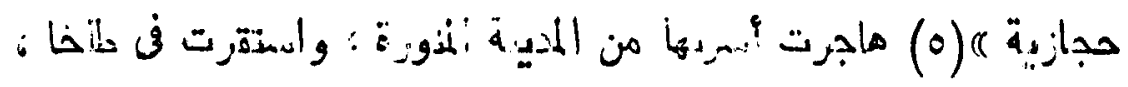

جا (r) راجع فى ذلك : فى أعقاب الثورة المصرية لعبد الرحمن الزأفعى

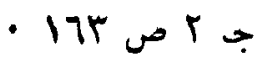

(ع) أحمد خسسن الزيات بين البلاغة والنقد الأد!ي للمتتور مهمد

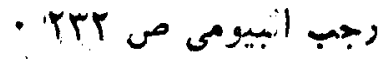

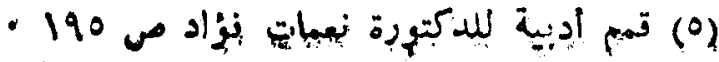




\section{rvi}

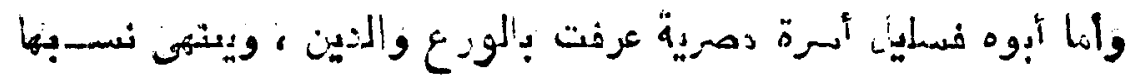

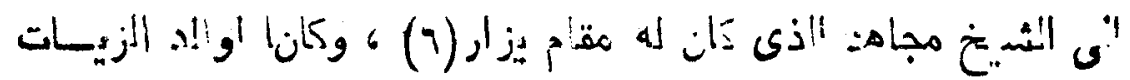

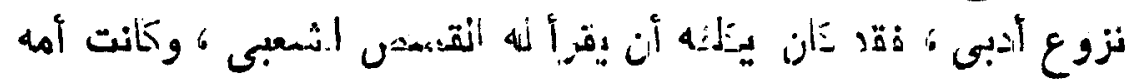

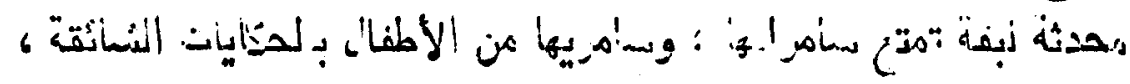

$$
\text { - (v) }
$$

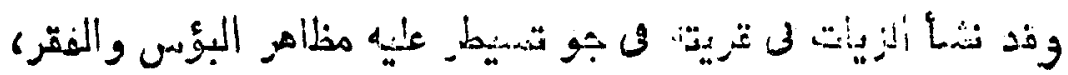

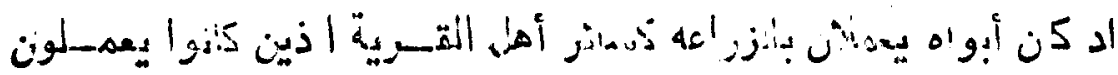

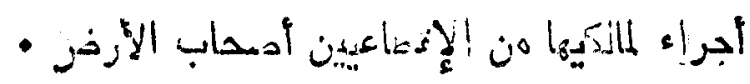

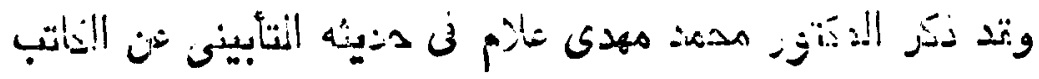

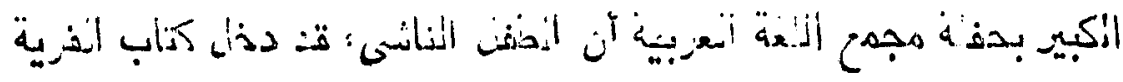

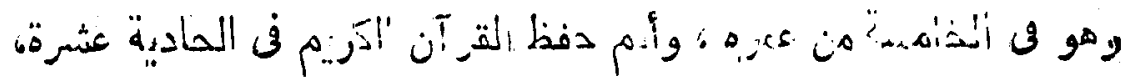

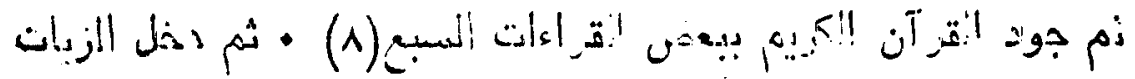

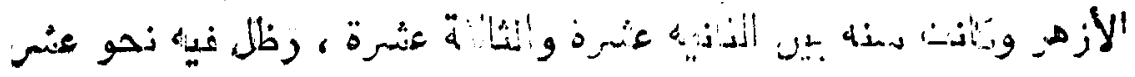

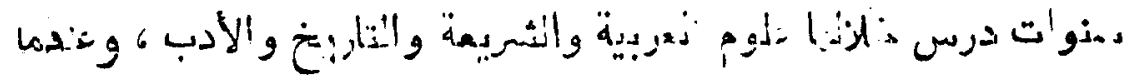

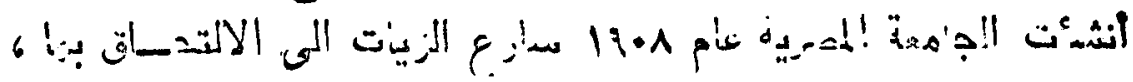

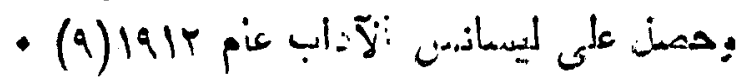

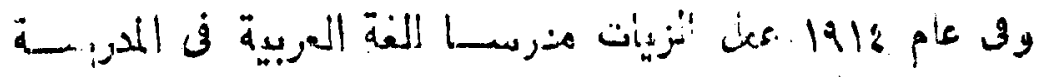

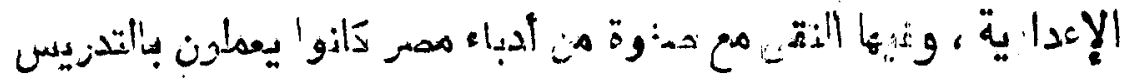

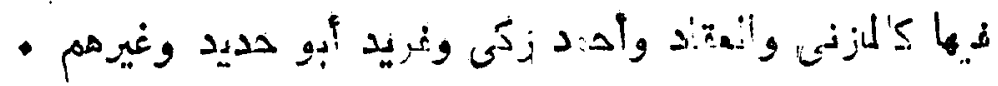

$$
\begin{aligned}
& \text { - (7) المرجع السابق }
\end{aligned}
$$

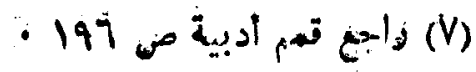

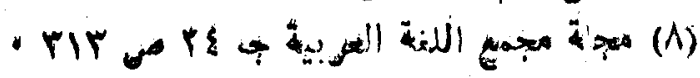

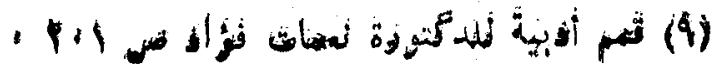


rne

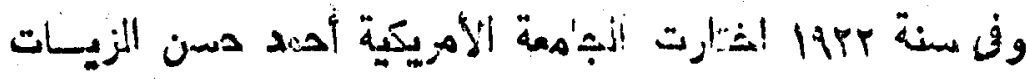

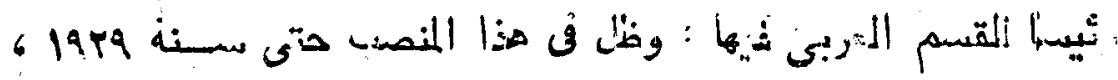

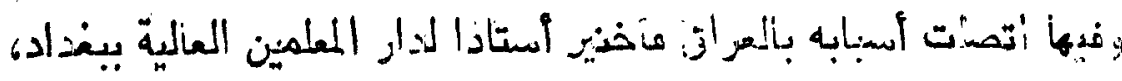

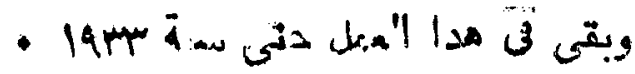

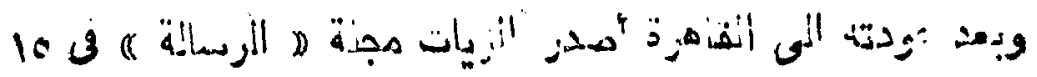

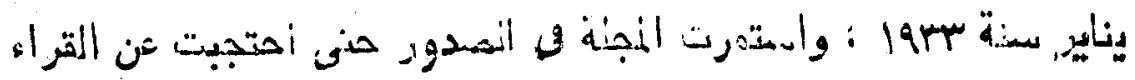

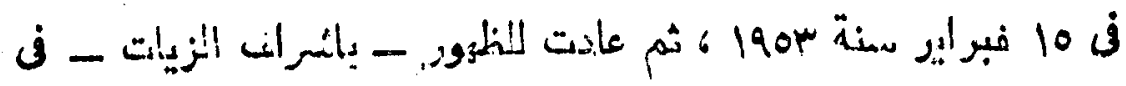

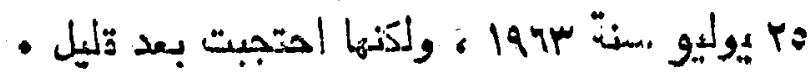

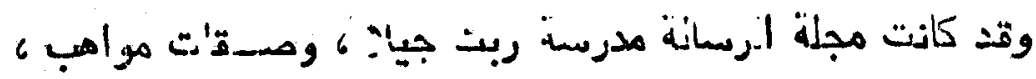

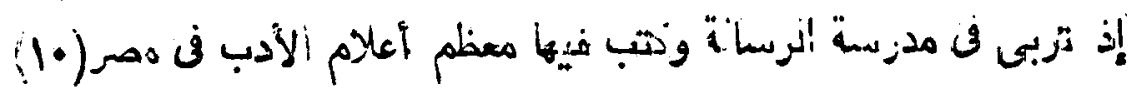

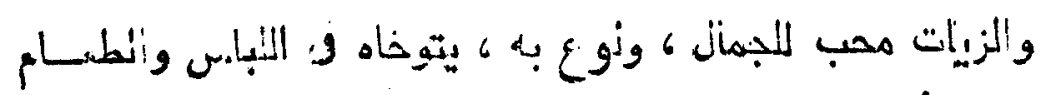

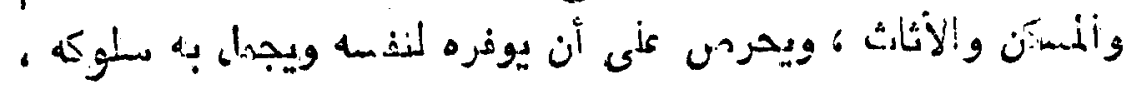

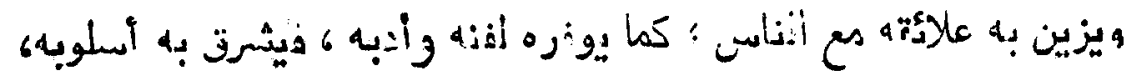

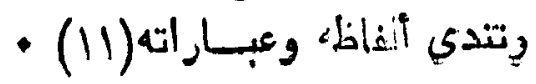

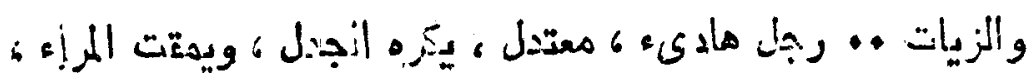

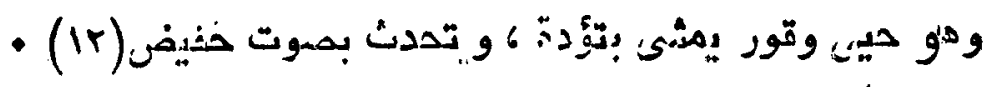

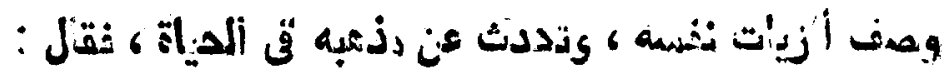

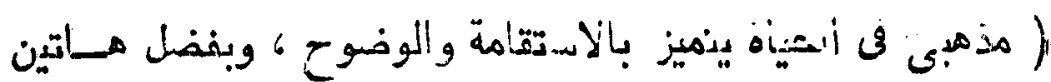

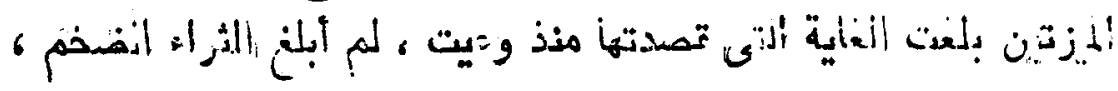

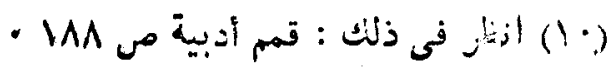

$$
\begin{aligned}
& \text { - (II) } \\
& \text { • (T) }
\end{aligned}
$$

(j) $11 . x p)$ 


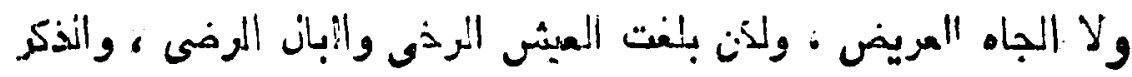

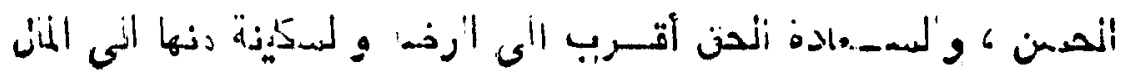

- المنصب )

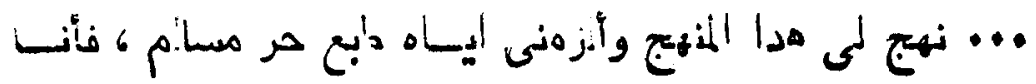

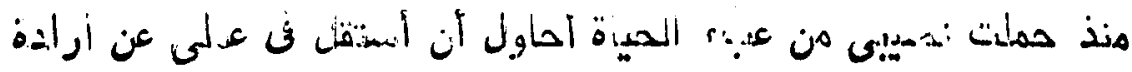

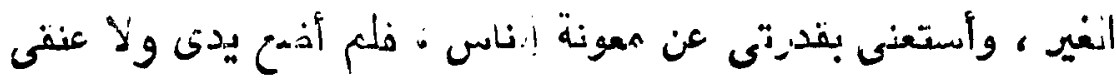

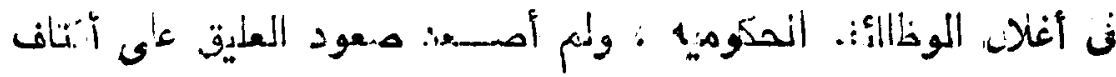

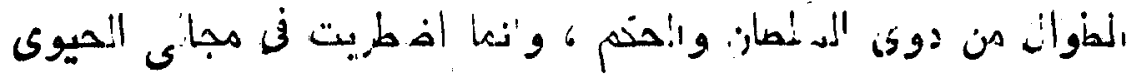

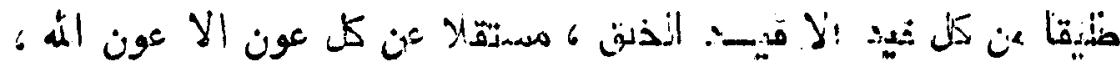

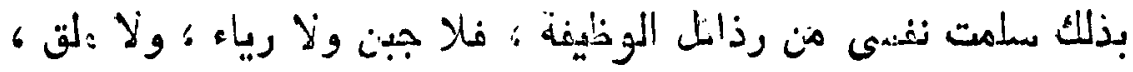

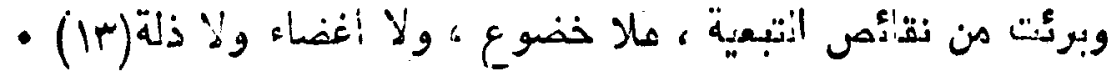

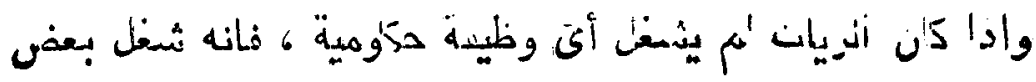

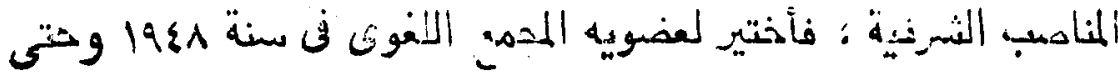

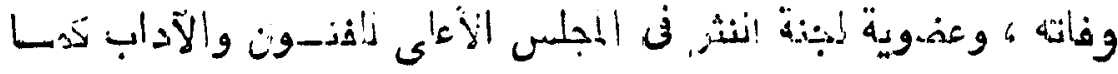

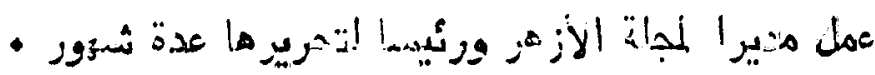

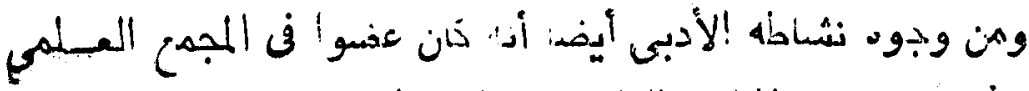

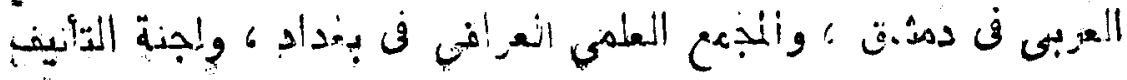

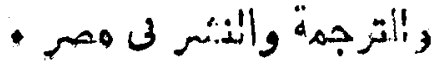

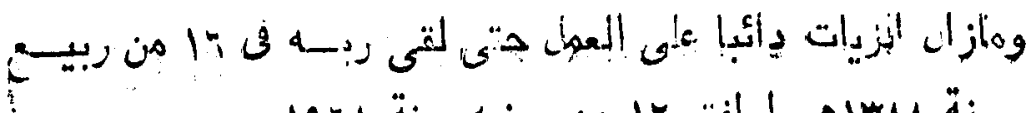

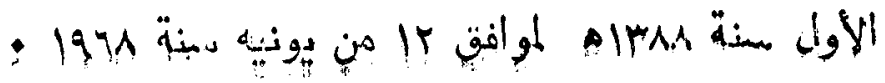

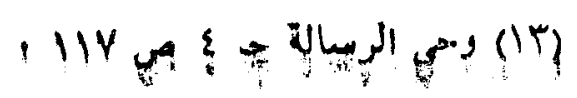


rvo

\section{الفهـــل الثـاني}

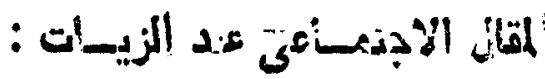

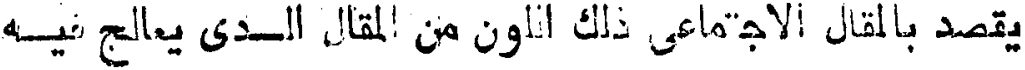

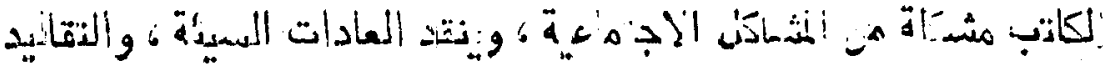

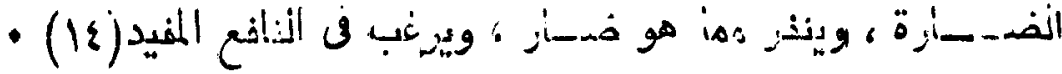

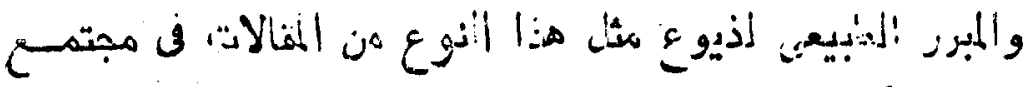

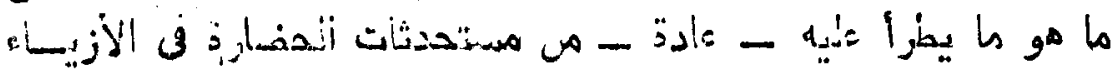

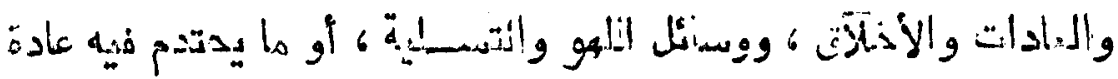

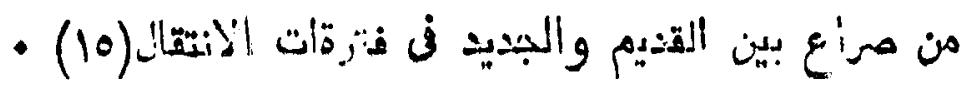

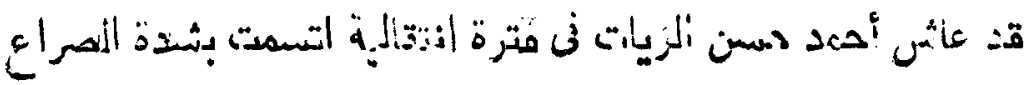

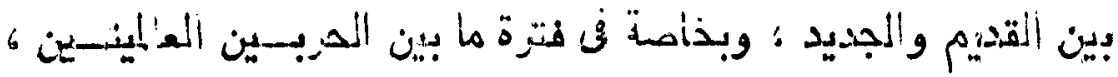

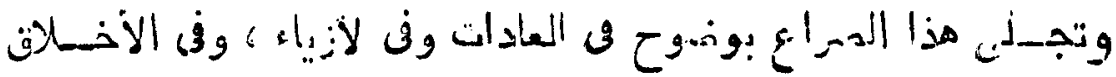

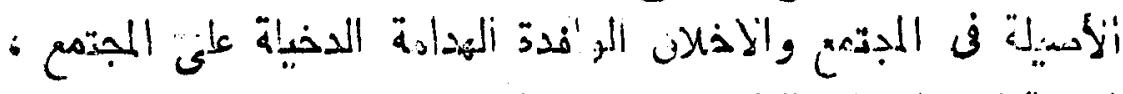

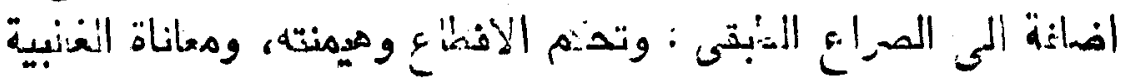

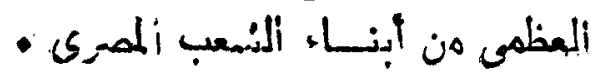

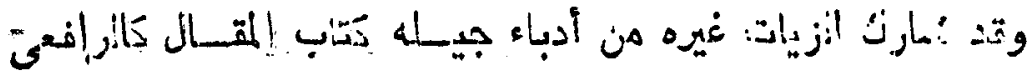

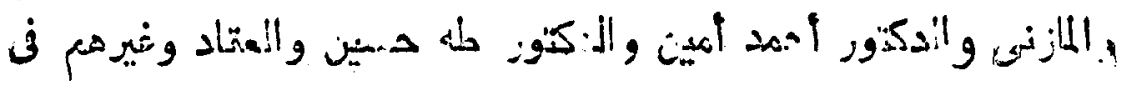

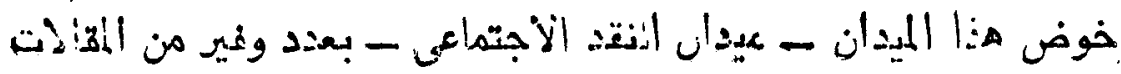

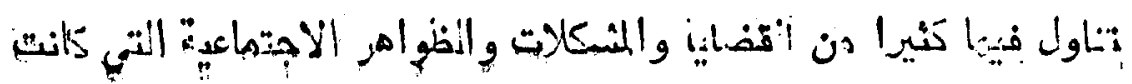

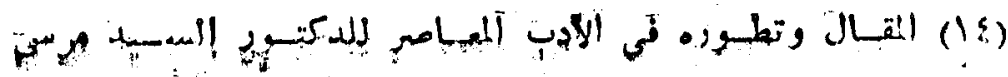

$$
\text { : Vद u }
$$

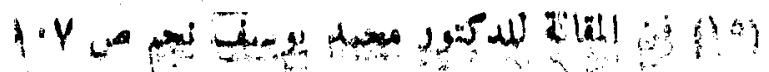


TVY

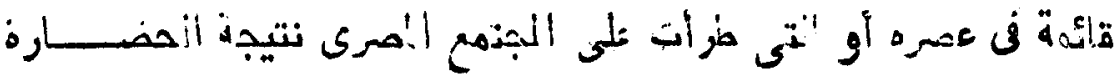

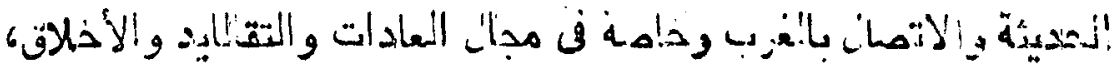

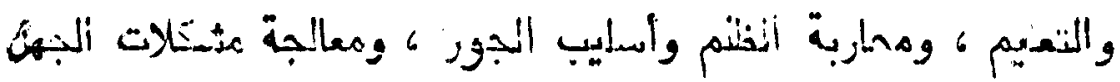

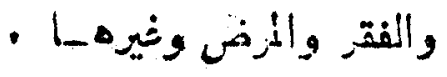

وأستطيع أن أهذد أهم ألموضوسات الذوي تناولها الزيات في مقاناته

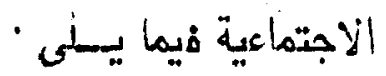

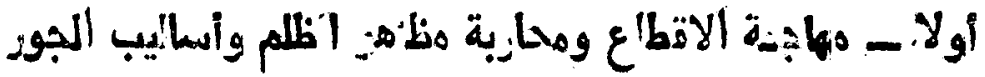

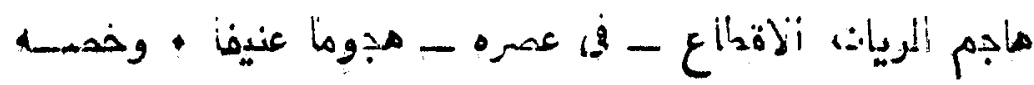

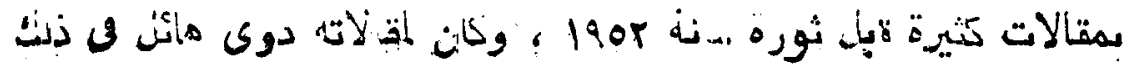

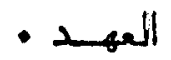

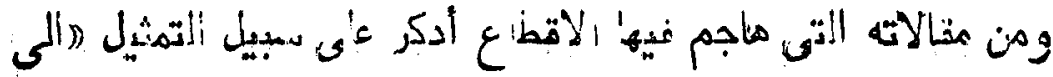

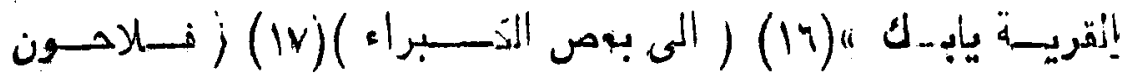

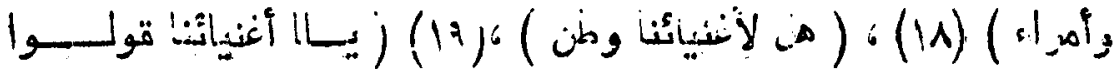

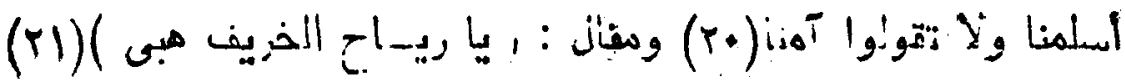

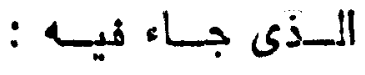

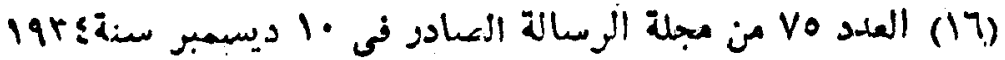

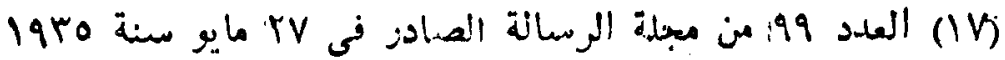

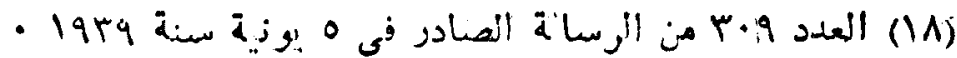

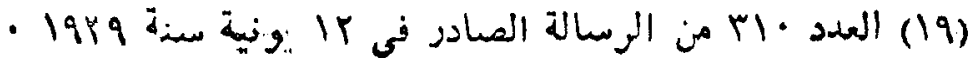
•

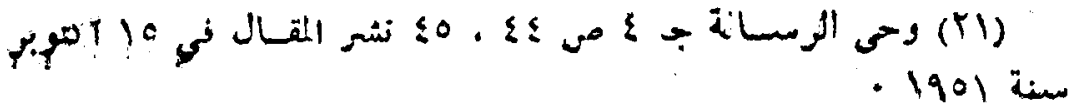




\section{PY}

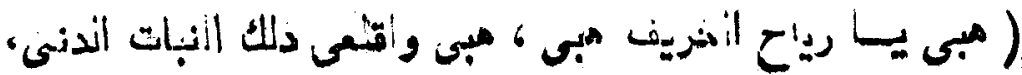

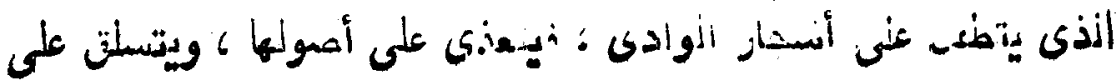

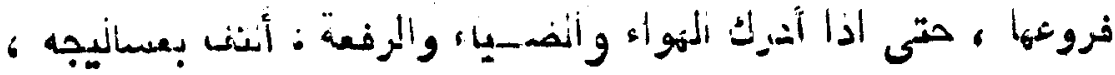

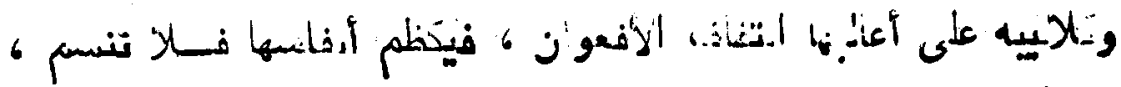

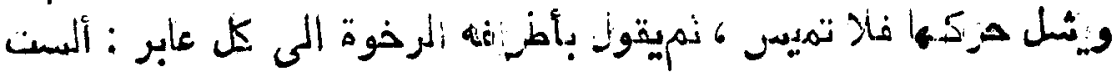

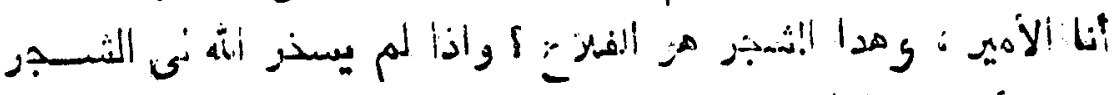

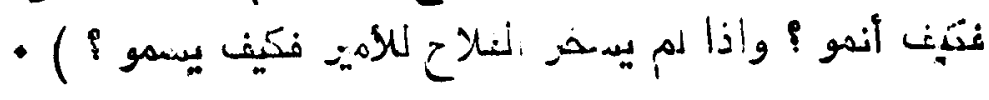

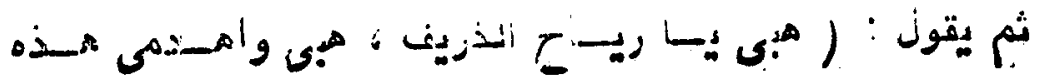

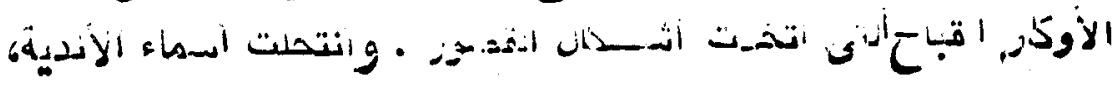

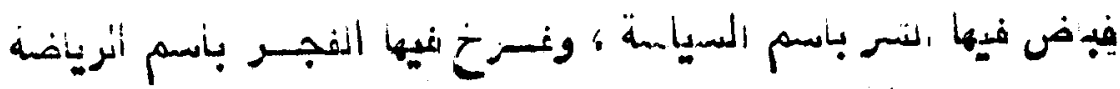

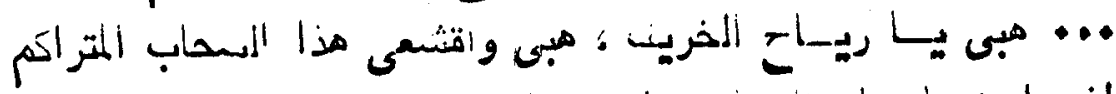

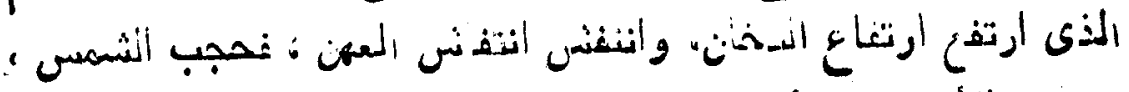

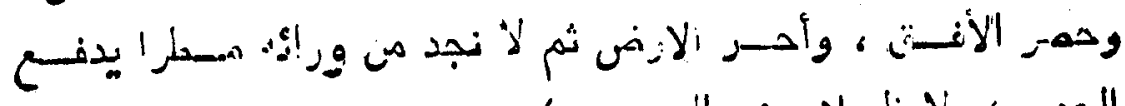

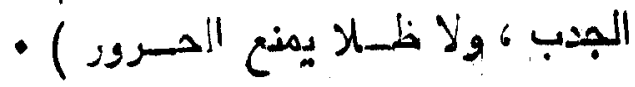

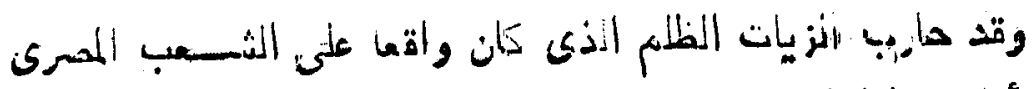

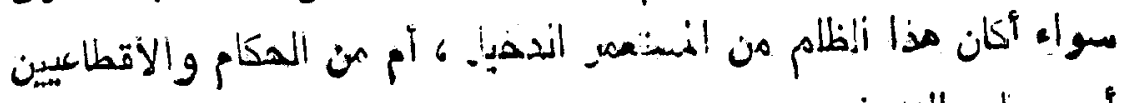
$\therefore$

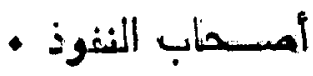

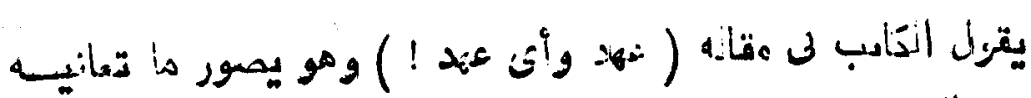

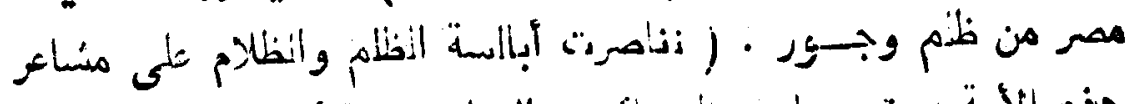

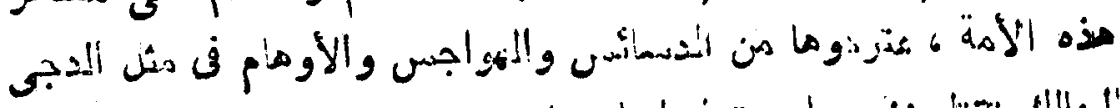

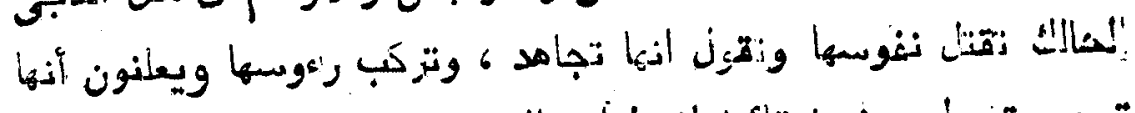

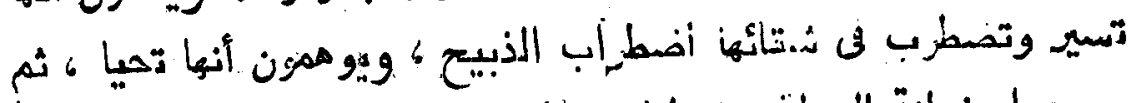

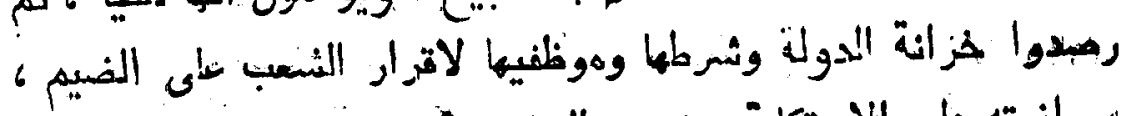

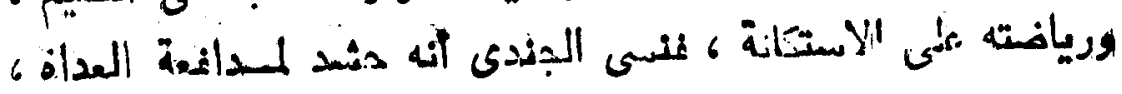




\section{PYA}

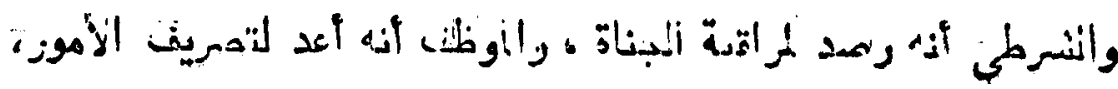

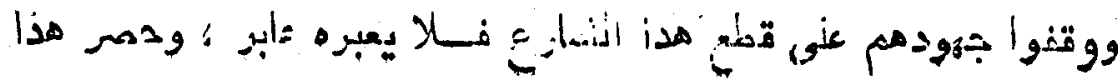

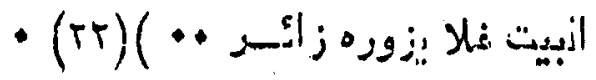

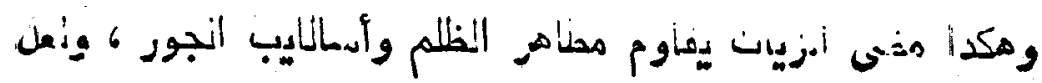

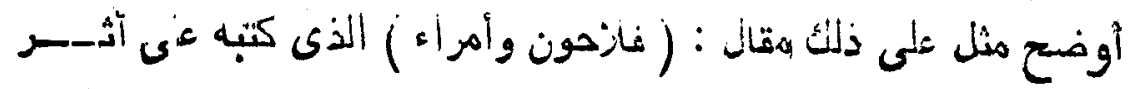

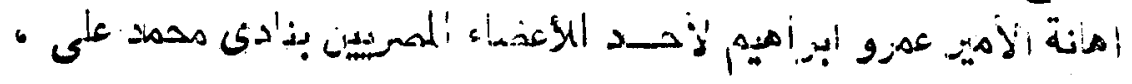

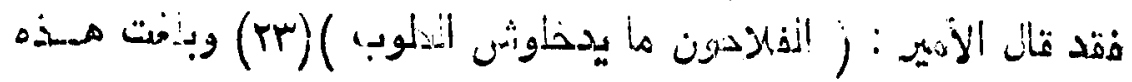

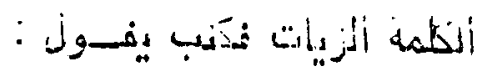

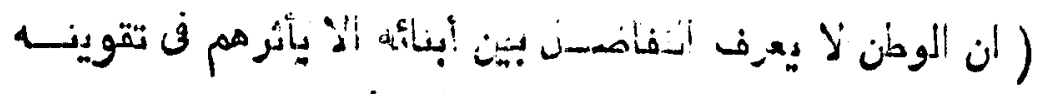

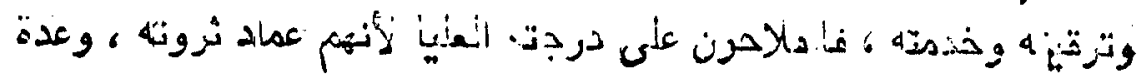

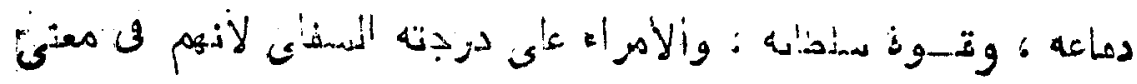

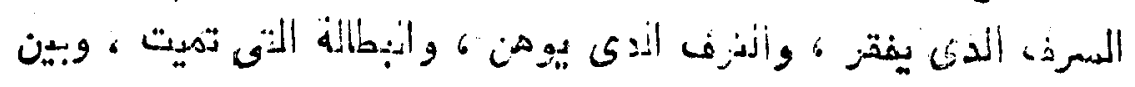

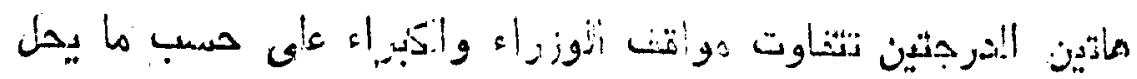

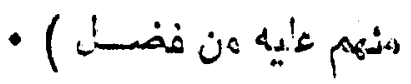

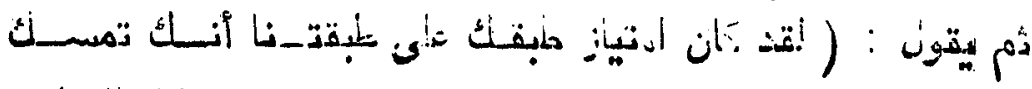

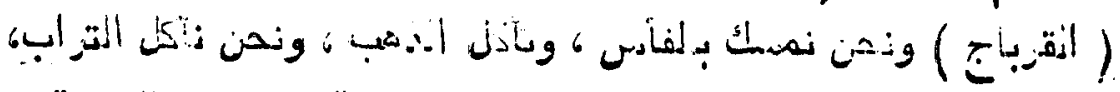

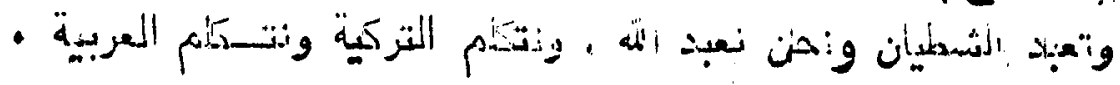

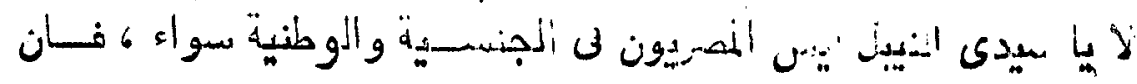

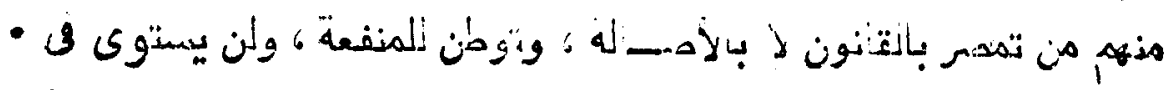

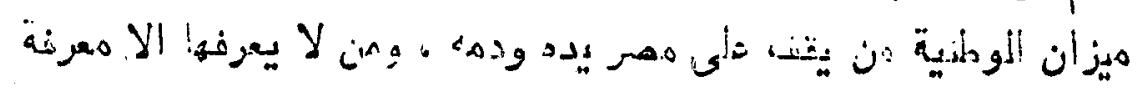

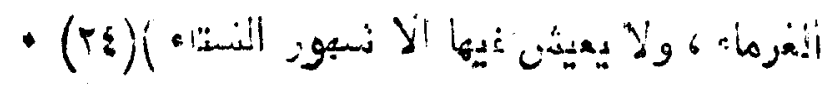

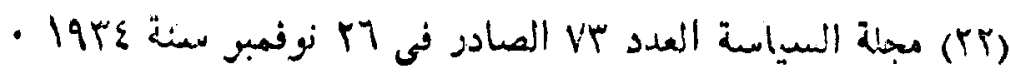

$$
\text { - }
$$

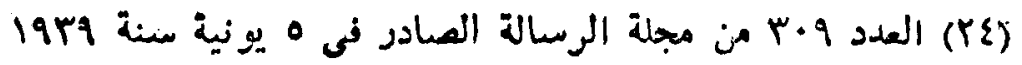

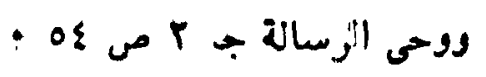


iv

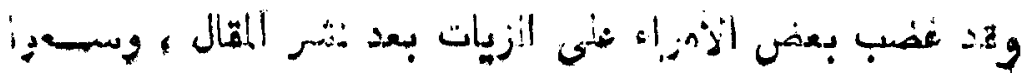

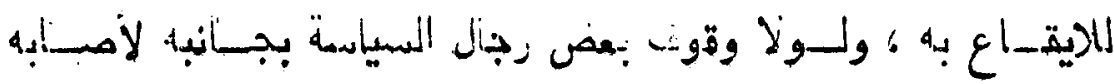

- شر محقـق

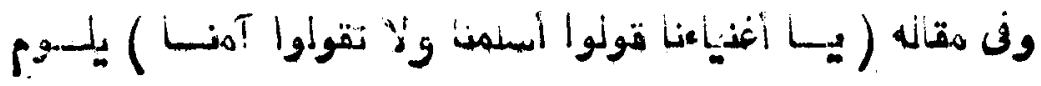

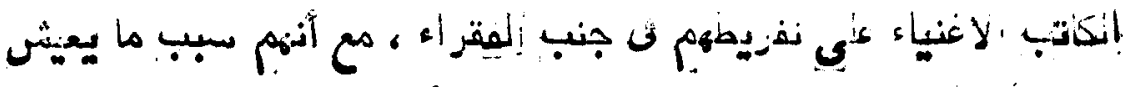

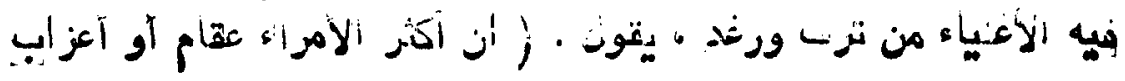

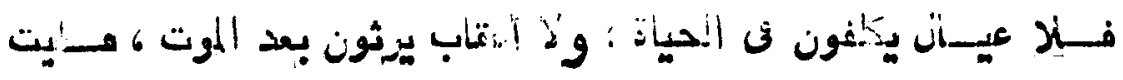

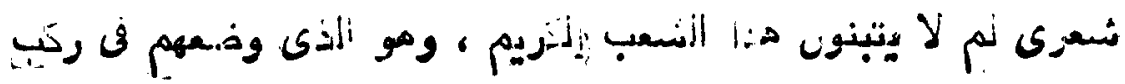

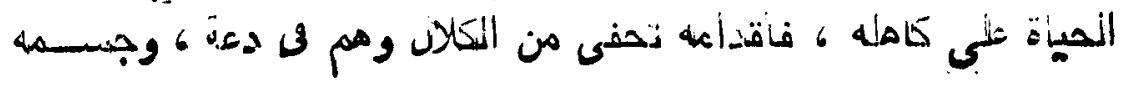

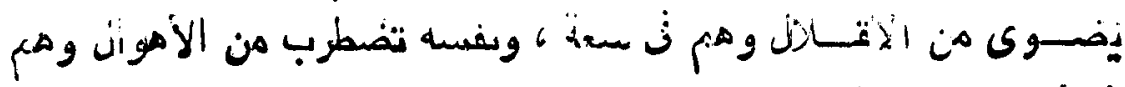

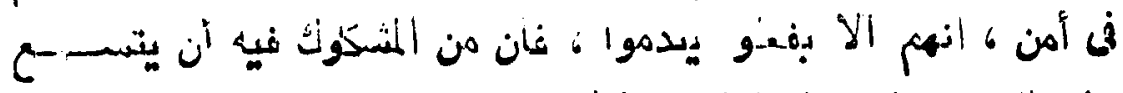

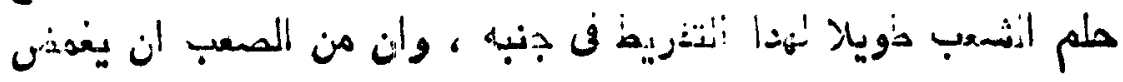

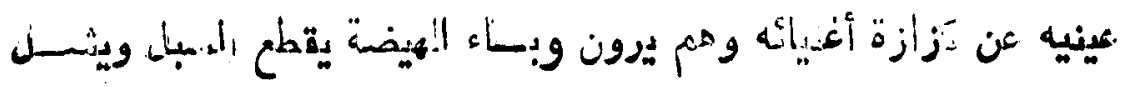

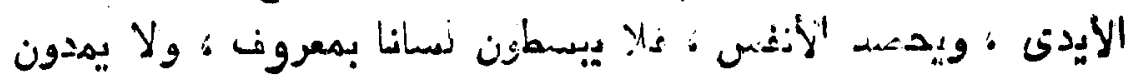

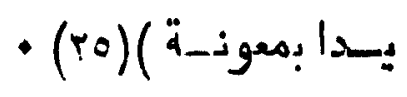

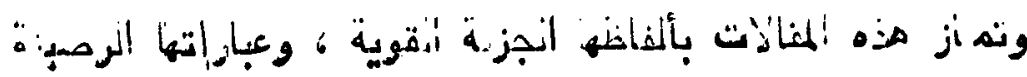

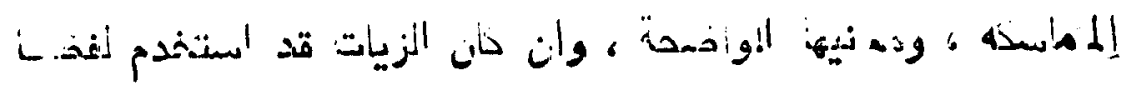

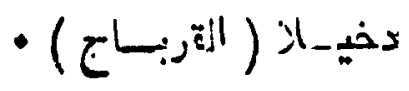

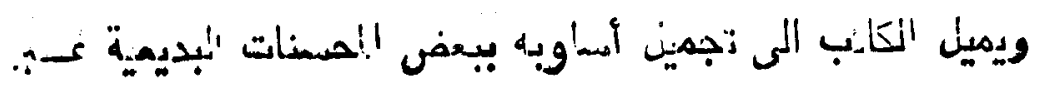

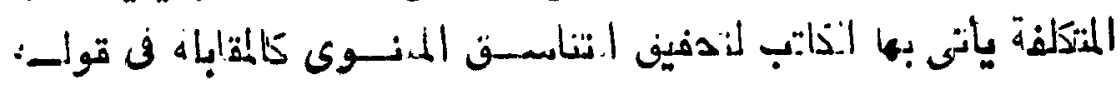

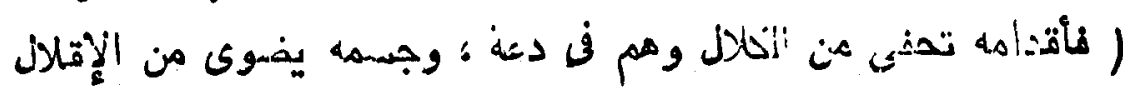

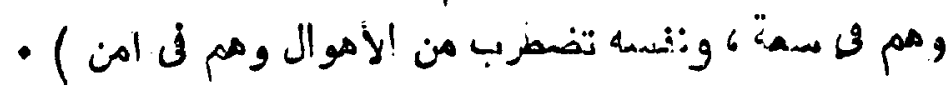

- rq1 


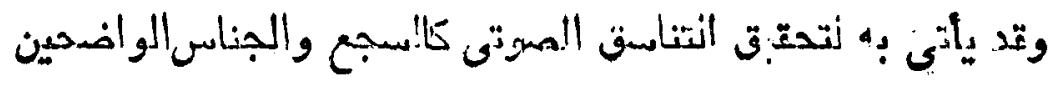

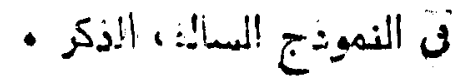

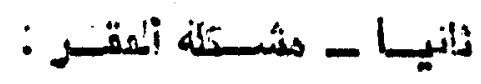

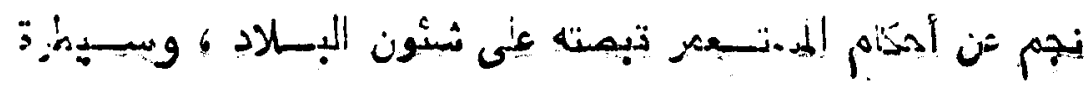

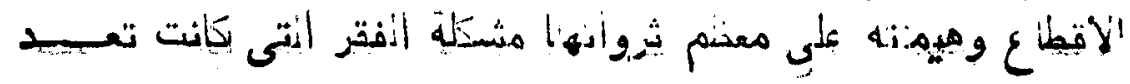

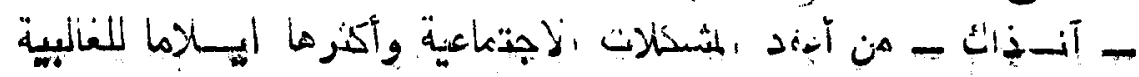

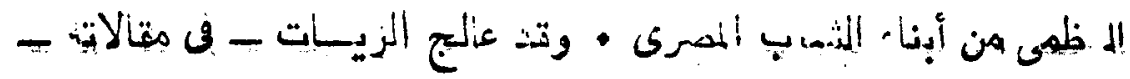

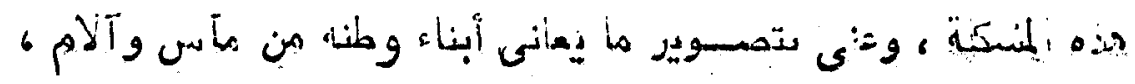

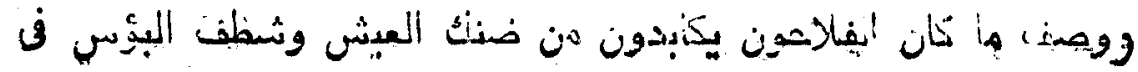

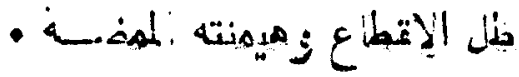

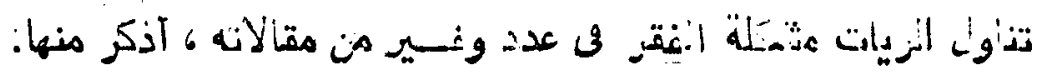

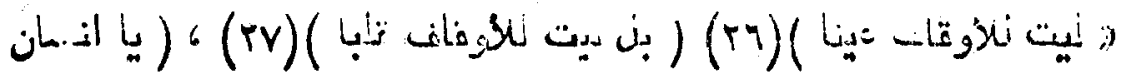

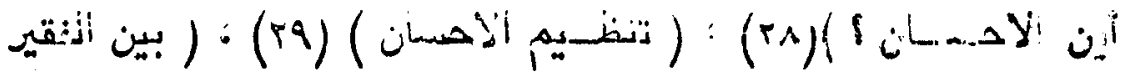

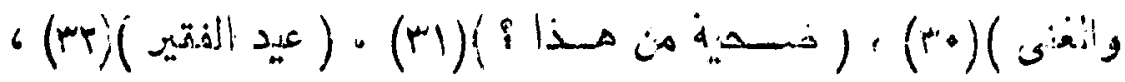

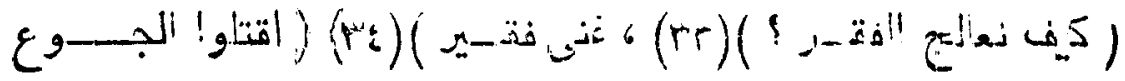

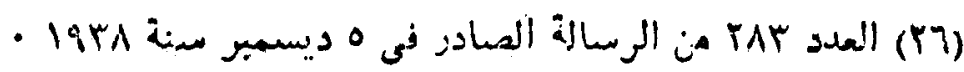

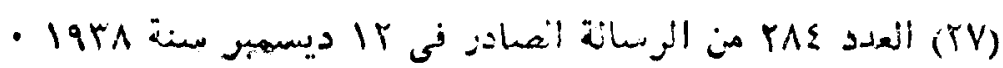

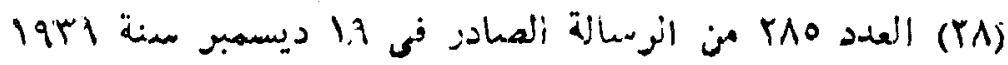

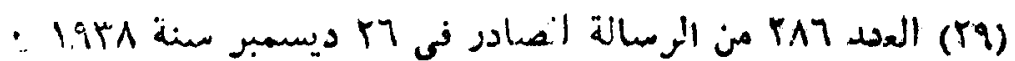

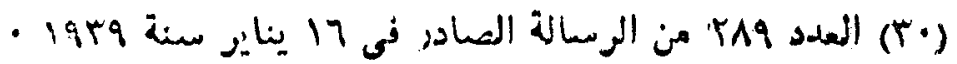

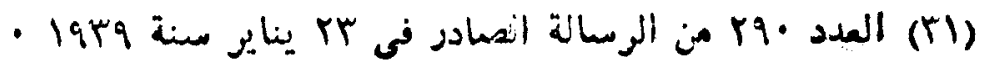

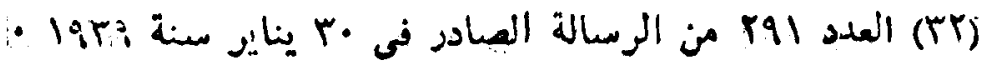

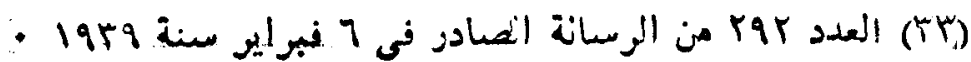

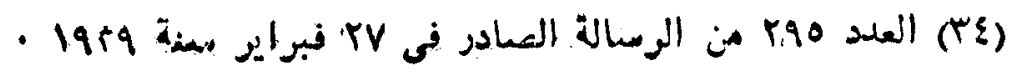


PAI

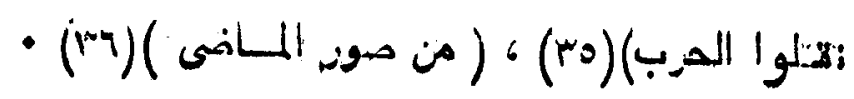

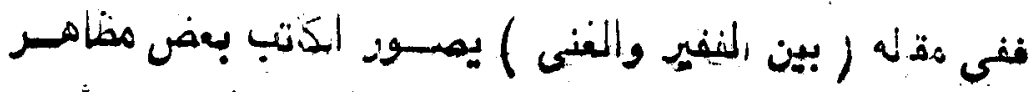

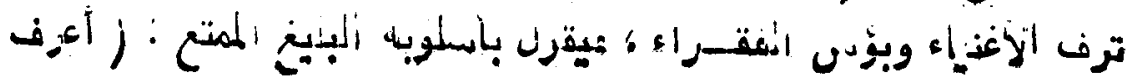

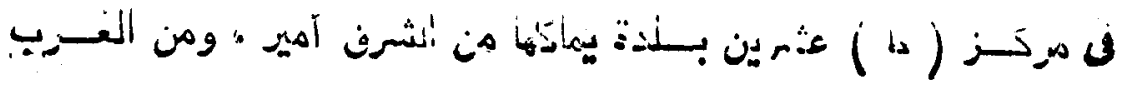

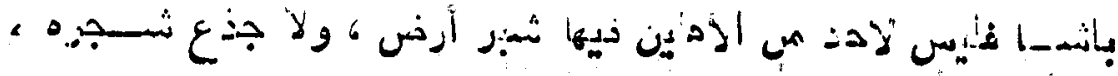

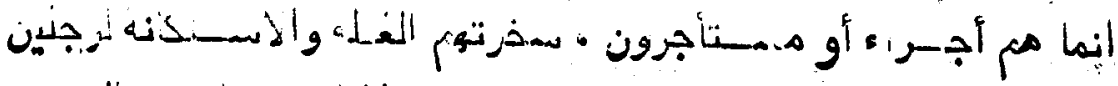

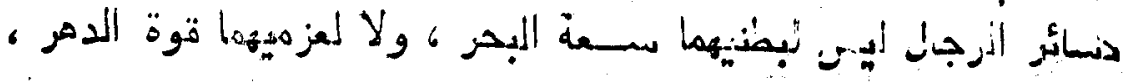

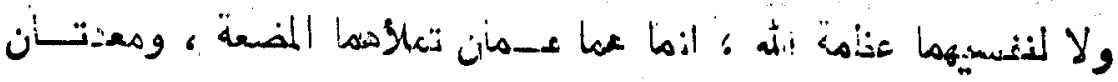

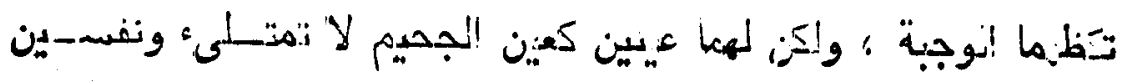

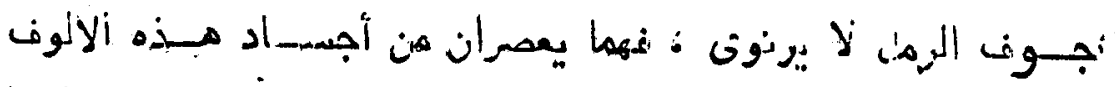

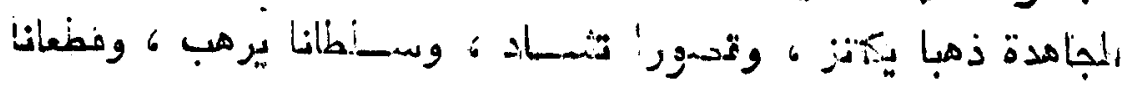

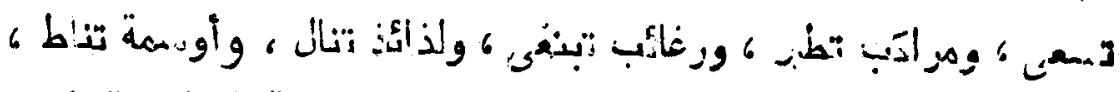

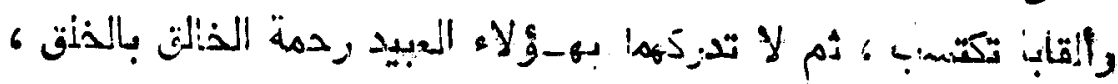

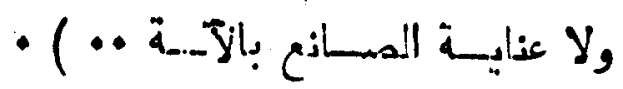

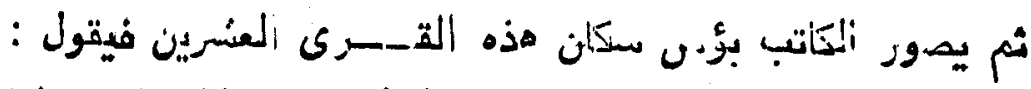

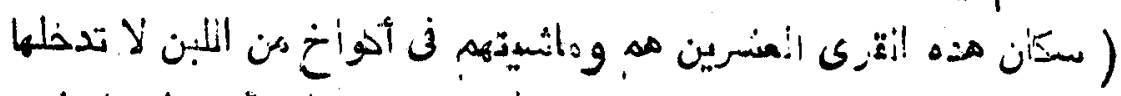

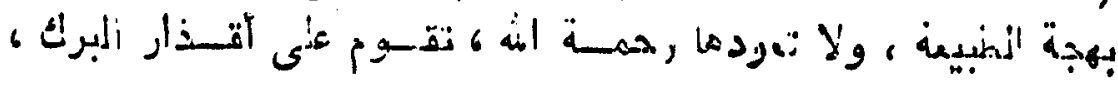

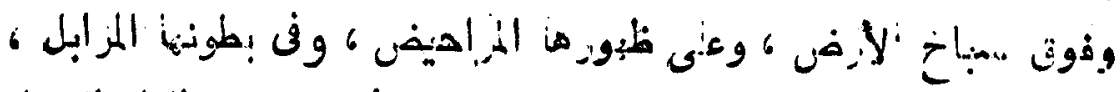

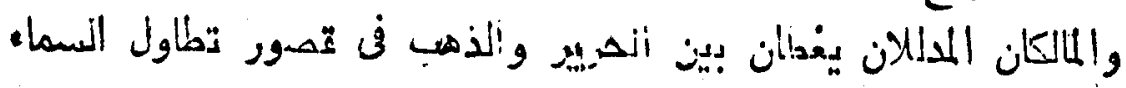

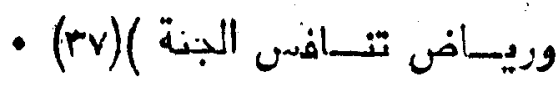

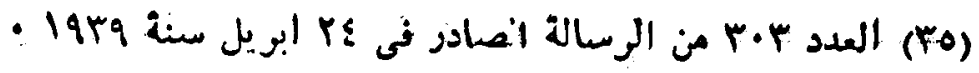

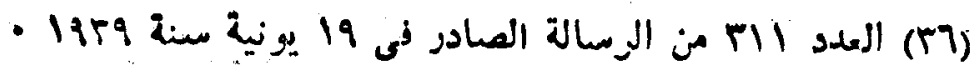

E 
والئن كيثن نع'لج معنسملة الفقر

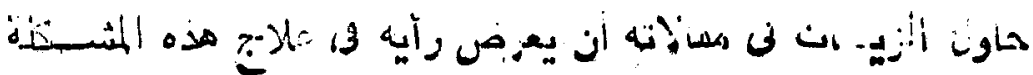

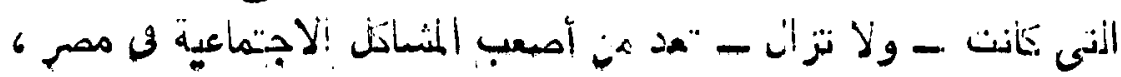

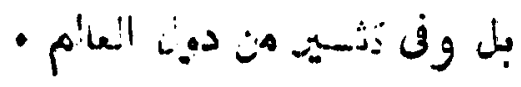

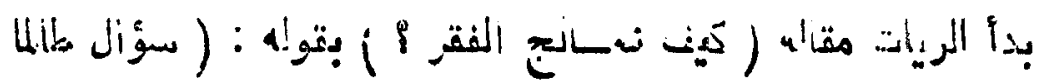

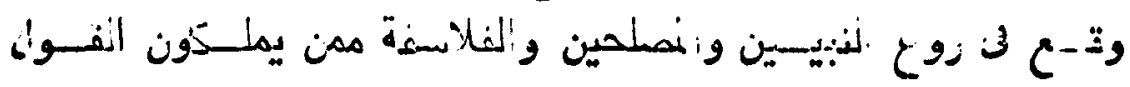

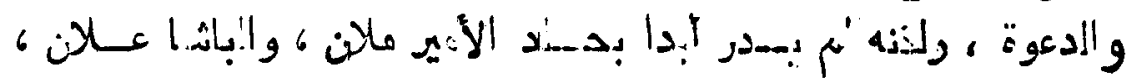

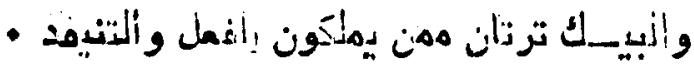

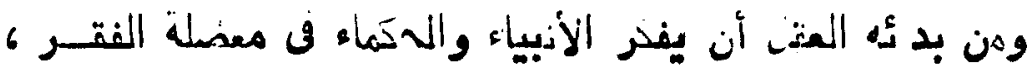

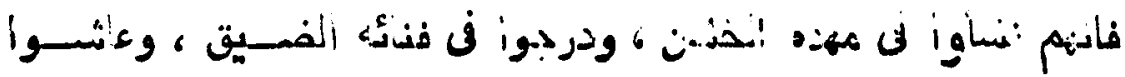

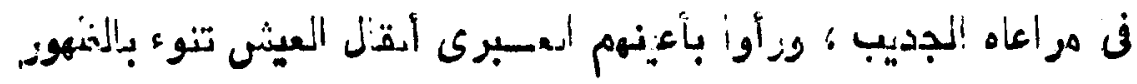

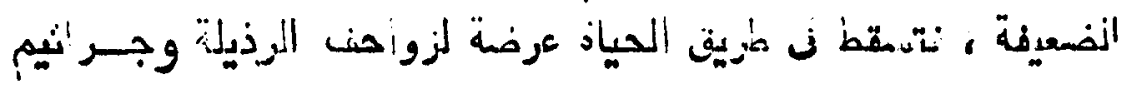

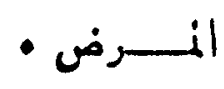

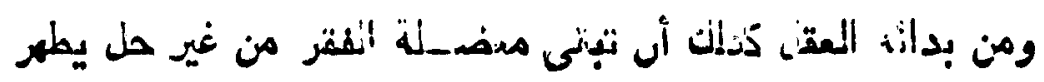

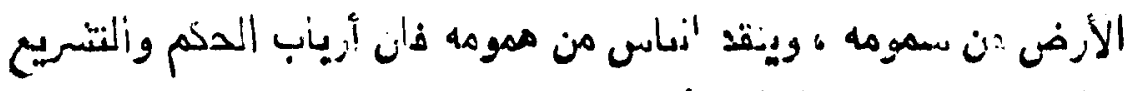

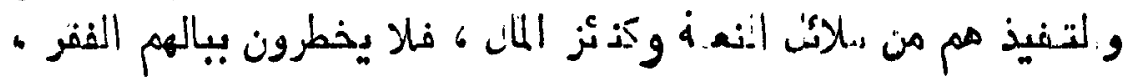

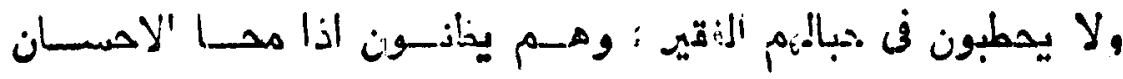

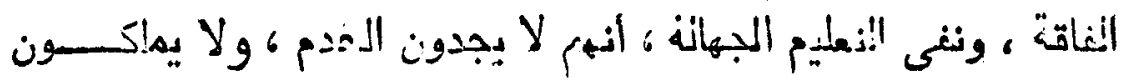

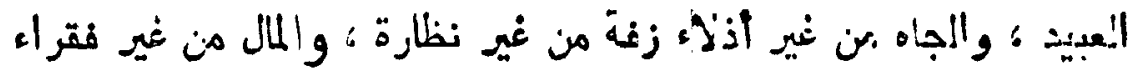

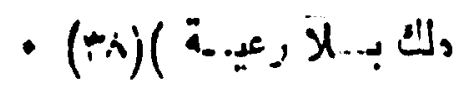

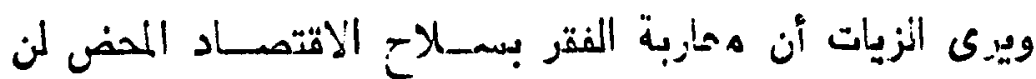

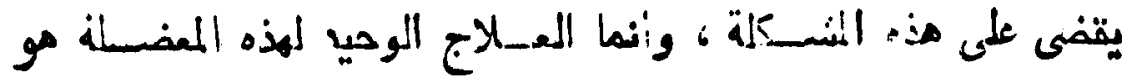

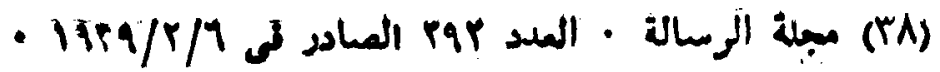


YAF

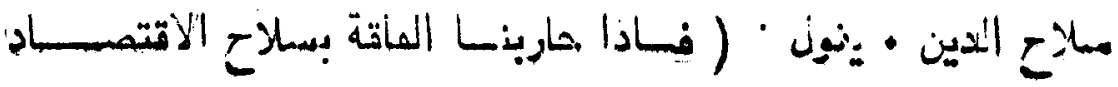

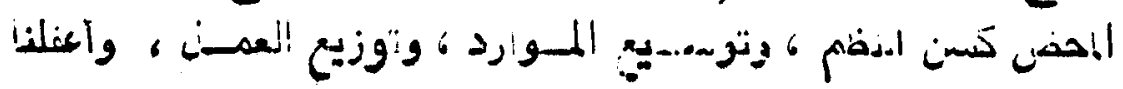

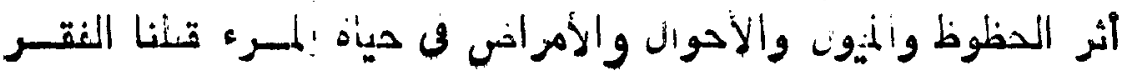

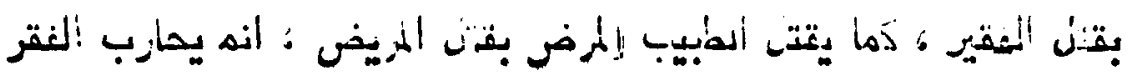

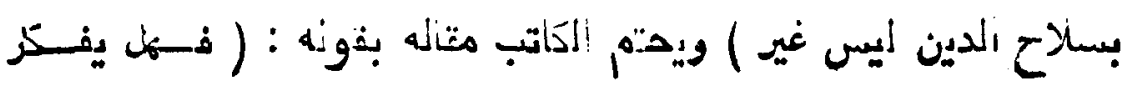

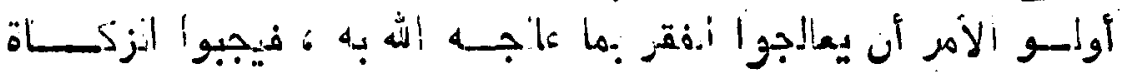

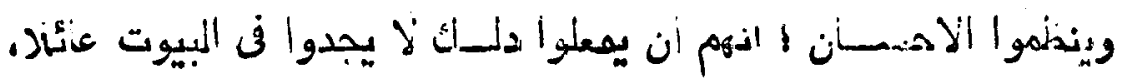

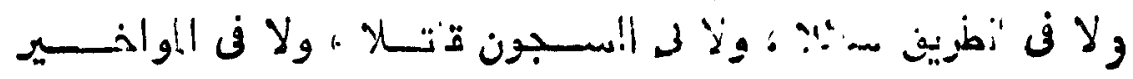
-

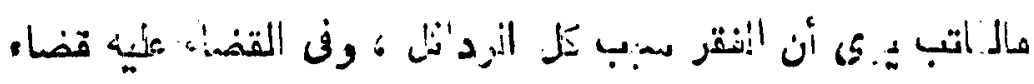

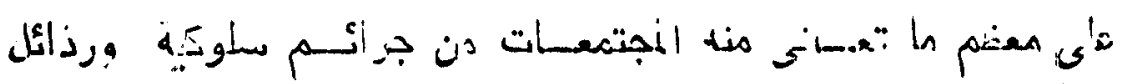

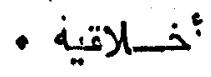

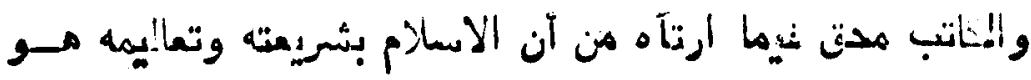

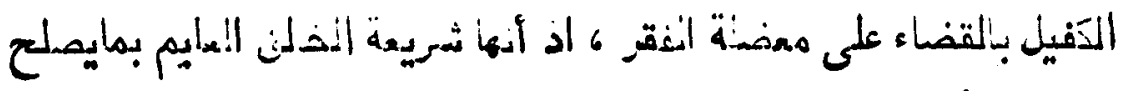

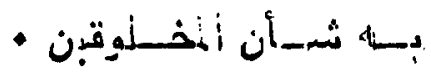

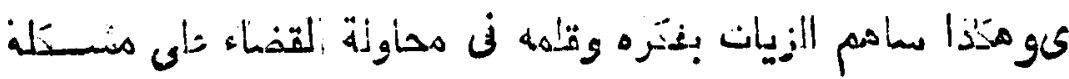

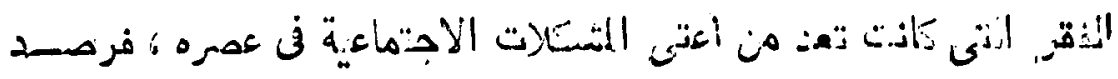

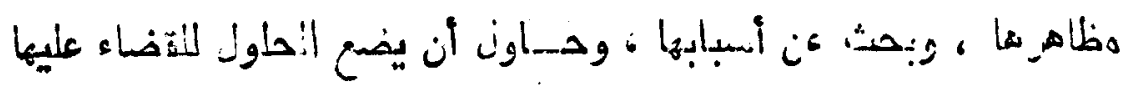

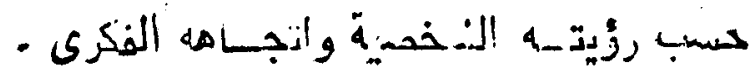

\section{وا.نال ل في هذه المقانات يالمظ أهر:ن الآول:}

أن ه:ه إلمقالات. نه.طبغ بالمسـبعة الإبلاميثة 6 فاتجاه كاتبهـا 


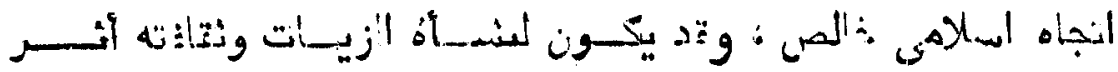

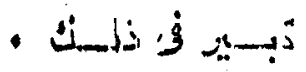

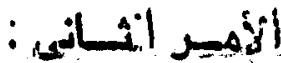

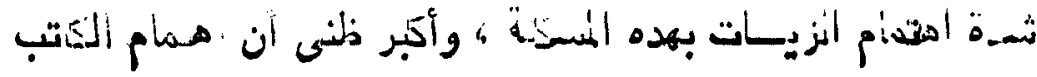

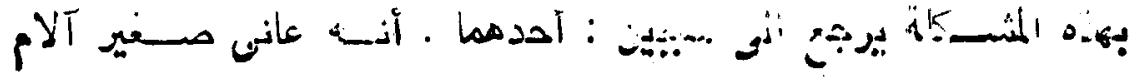

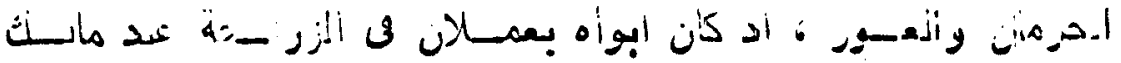

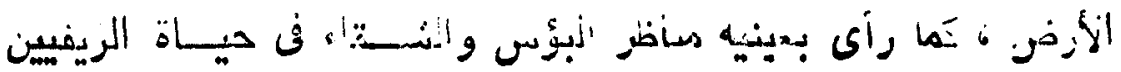

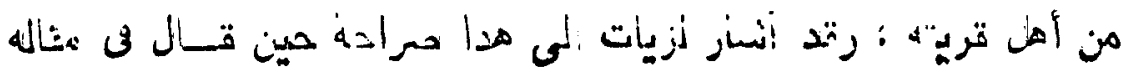

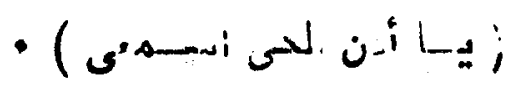

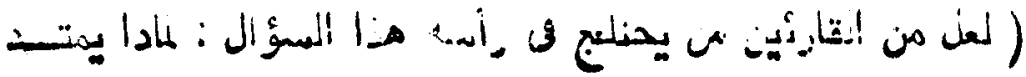

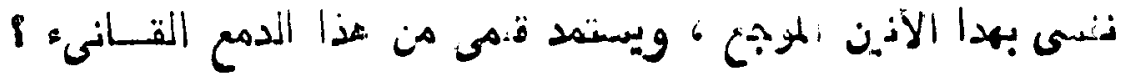

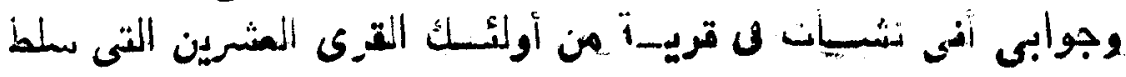

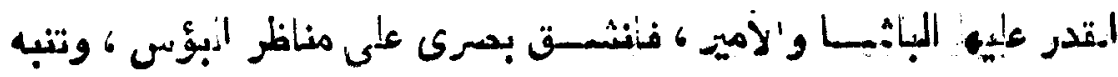

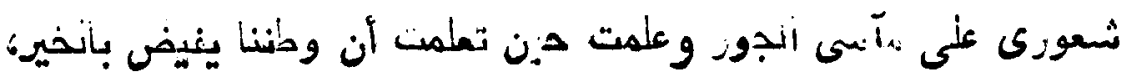

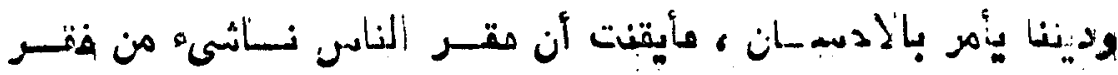

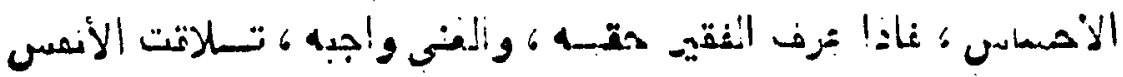

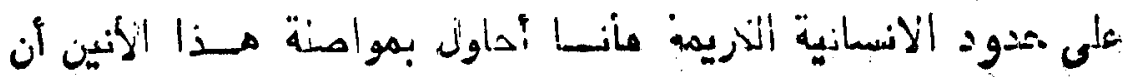

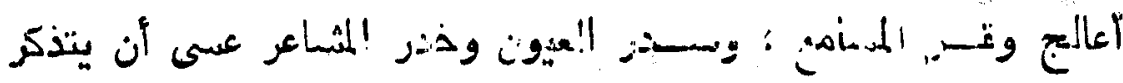

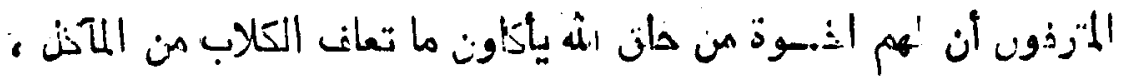

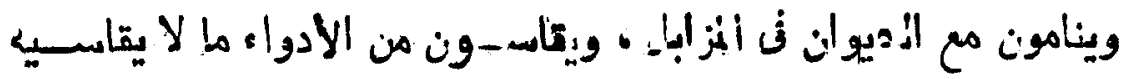

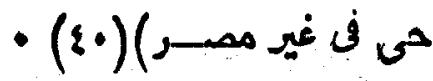

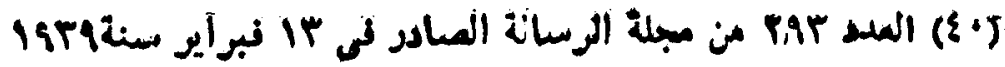




\section{YAO}

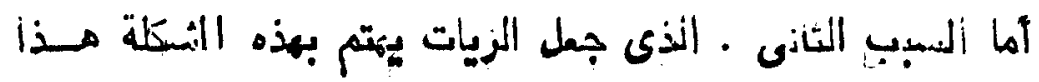

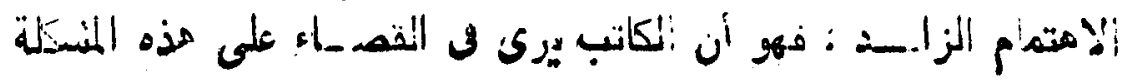

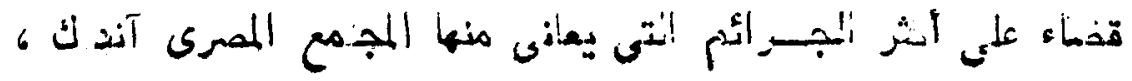

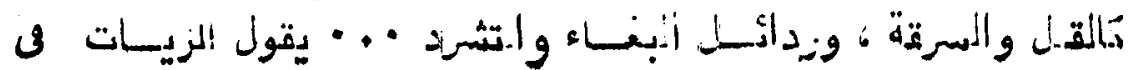

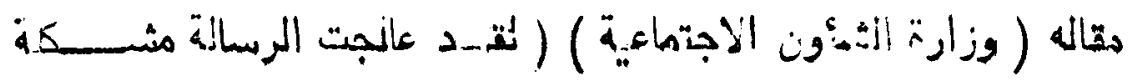

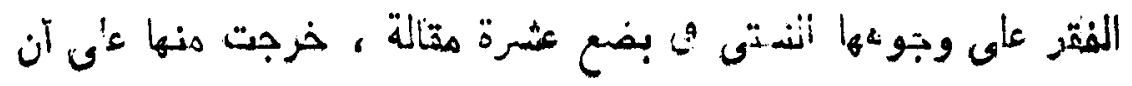

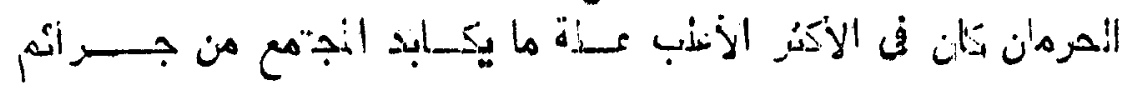

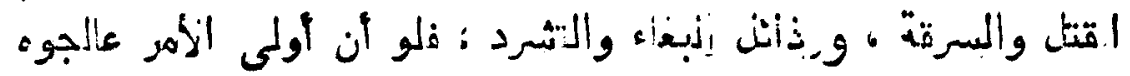

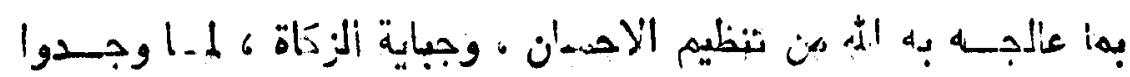

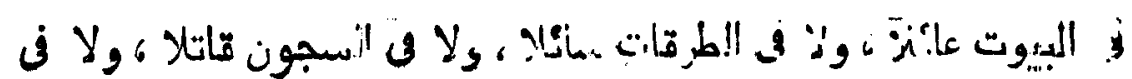

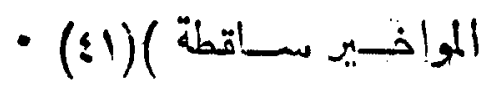

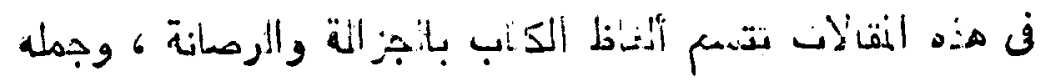

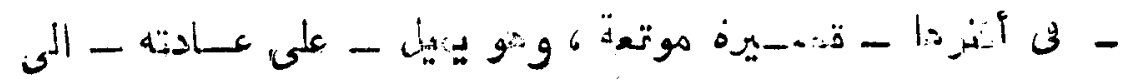

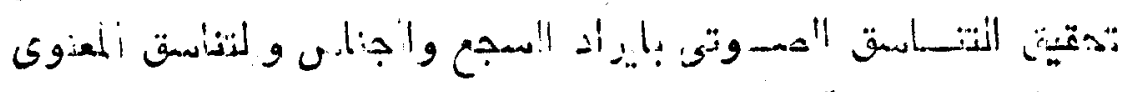

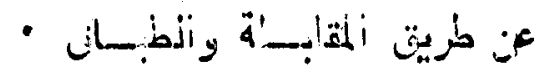

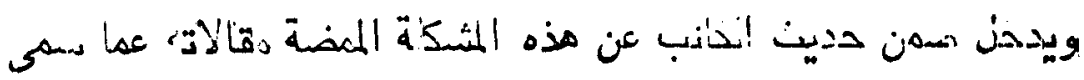

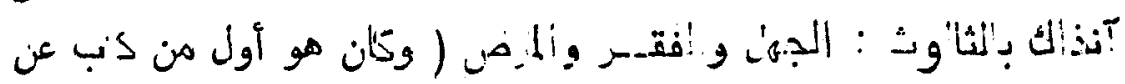

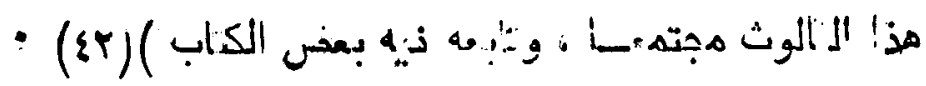

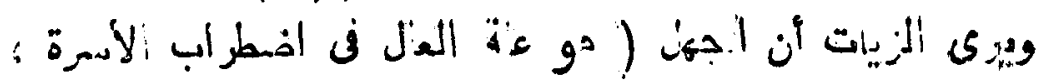

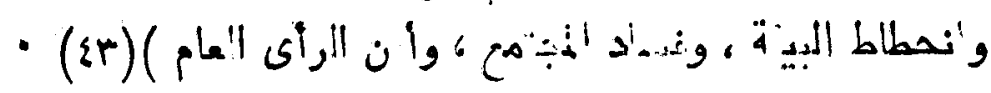

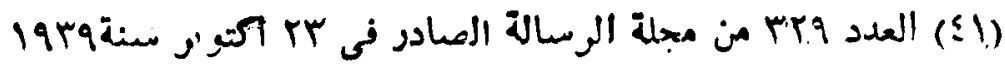

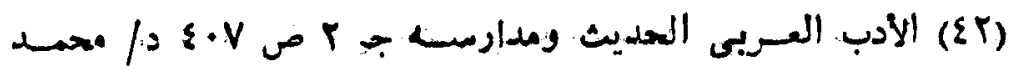

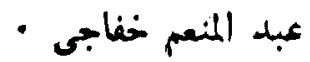

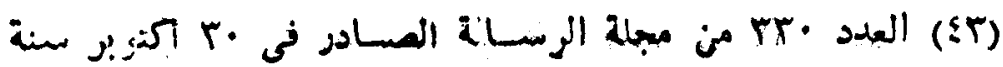

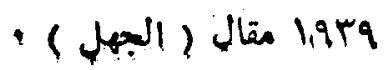




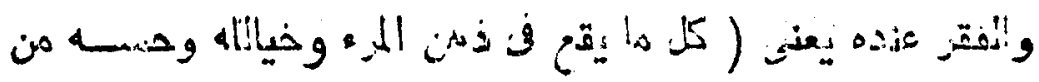

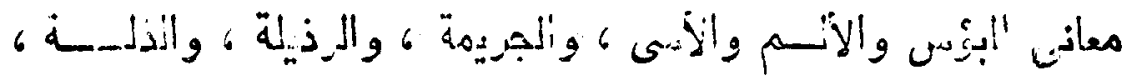

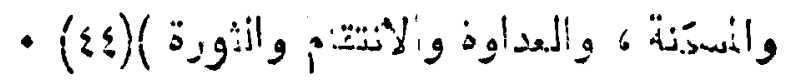

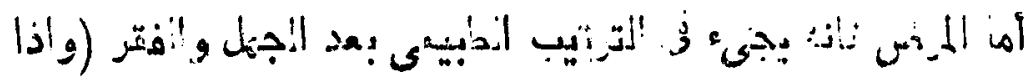

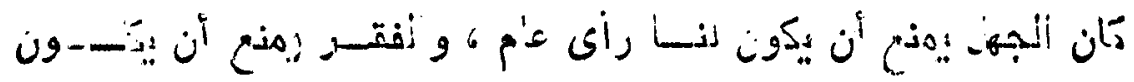

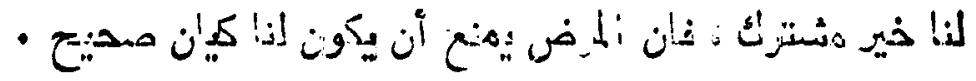

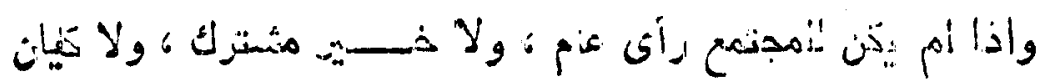

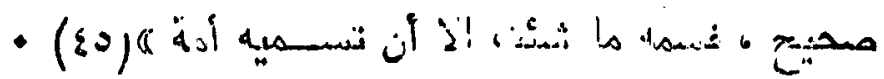

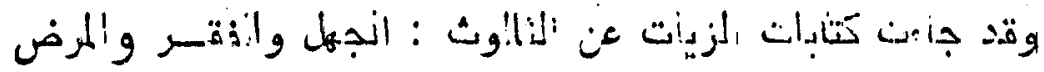

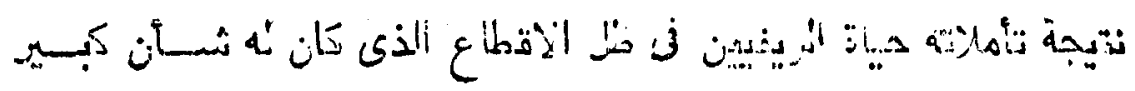

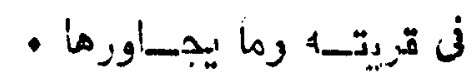

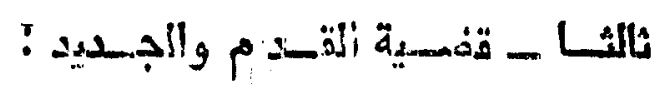

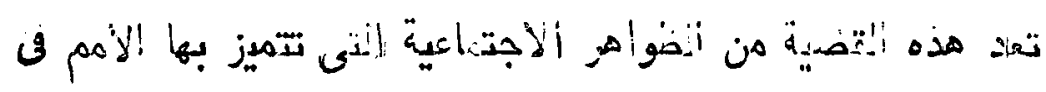

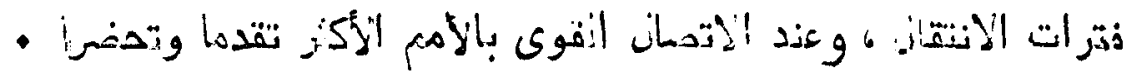

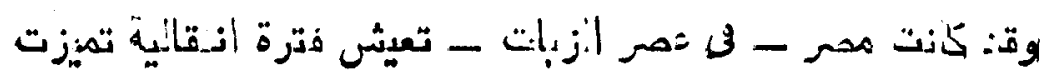

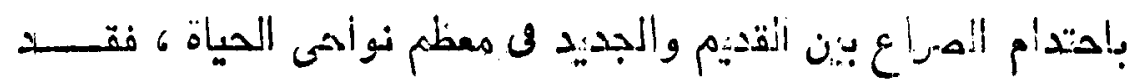

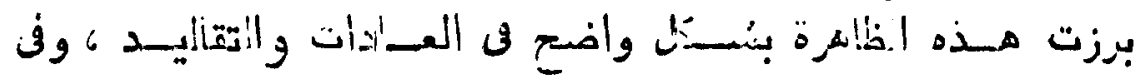

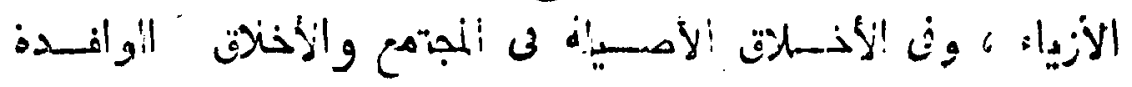
ألدذيــا'

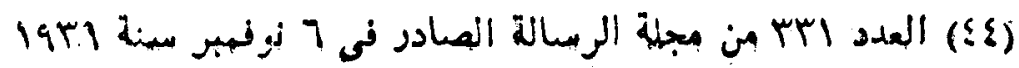

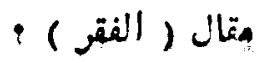

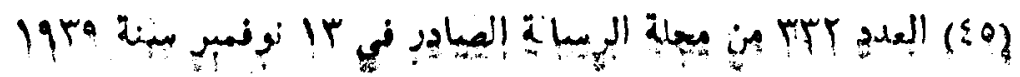

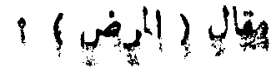




\section{YAY}

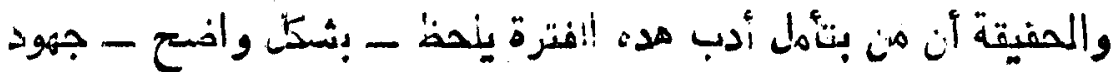

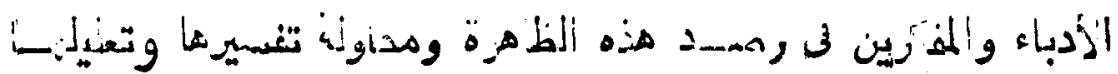

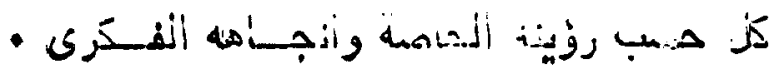

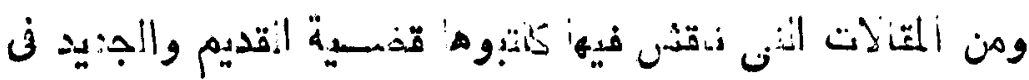

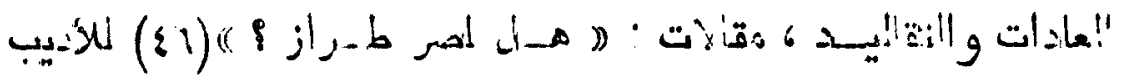

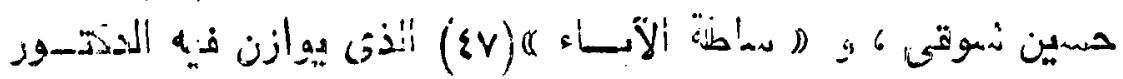

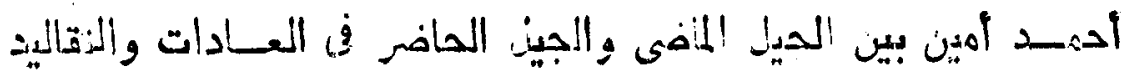

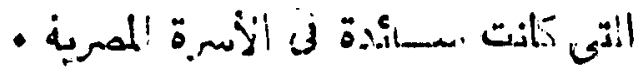

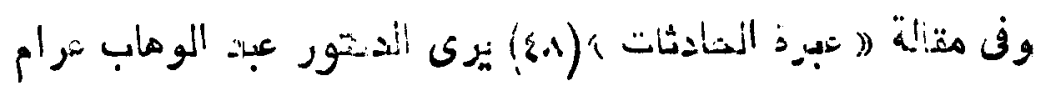

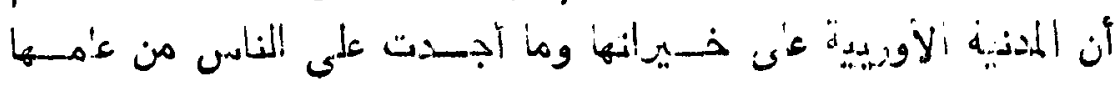

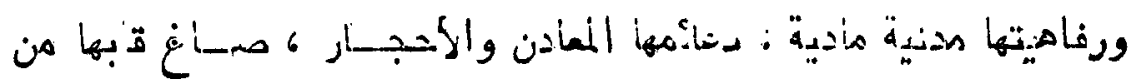

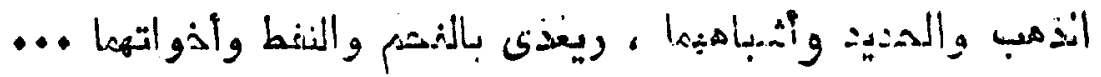

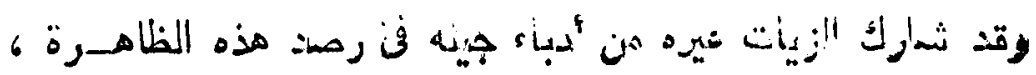

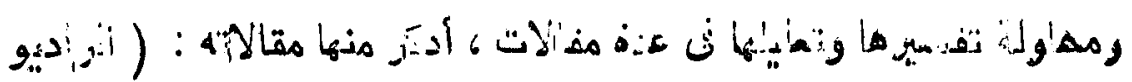

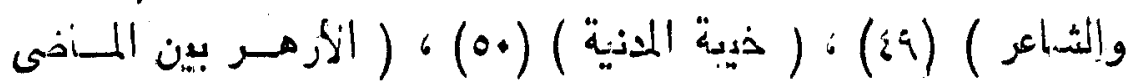

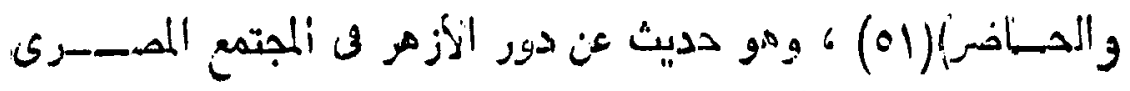
-

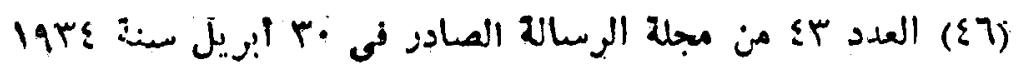
(IV) (IN) - 1.9ro

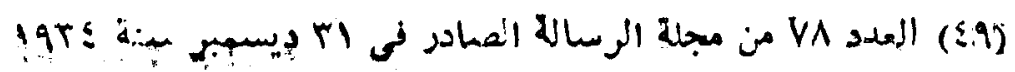

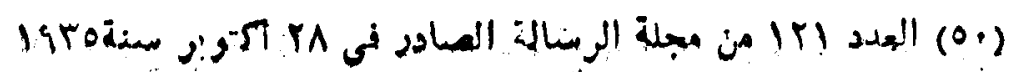

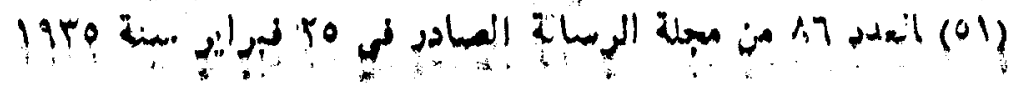


$Y M$

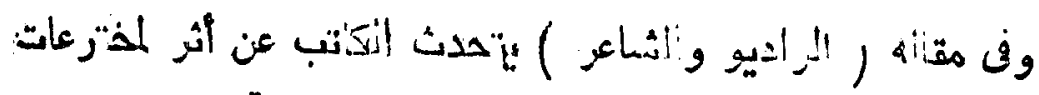

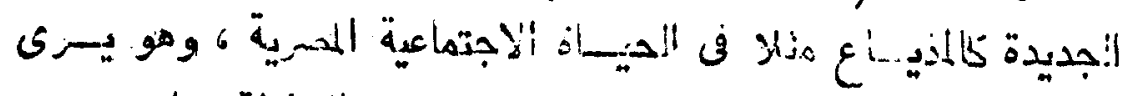

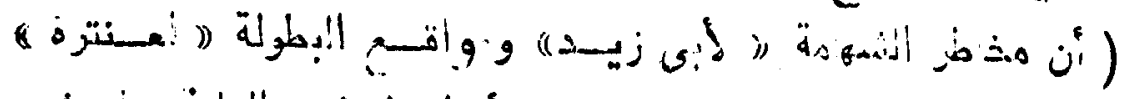

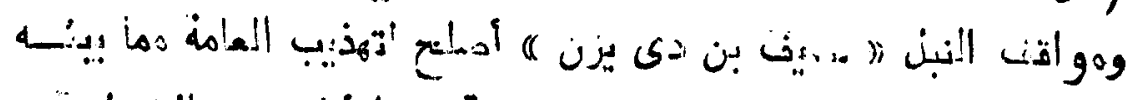

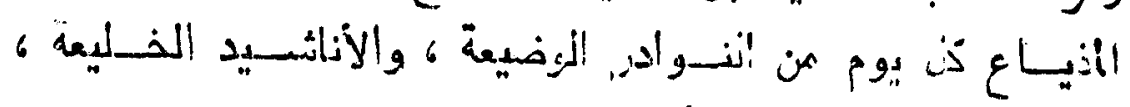

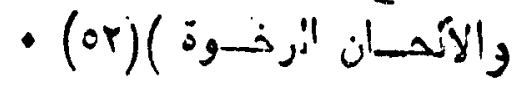

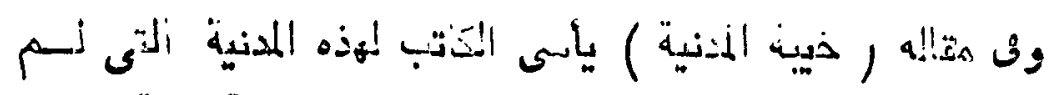

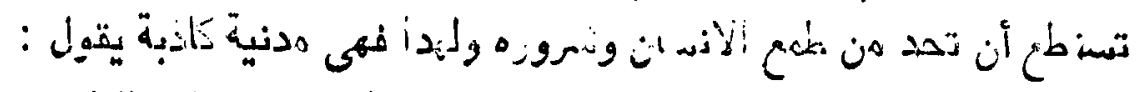

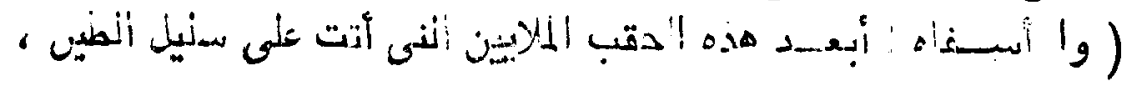

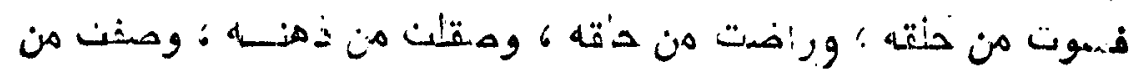

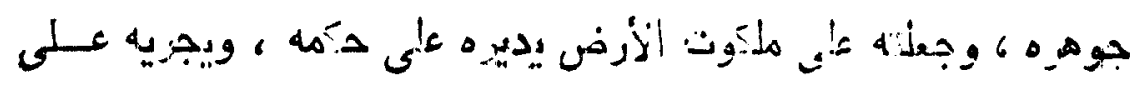

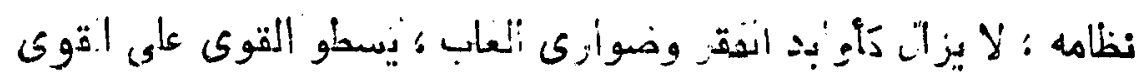

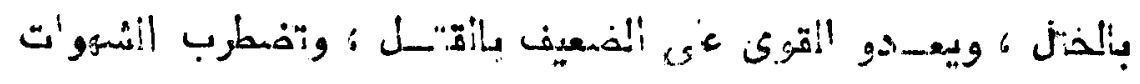

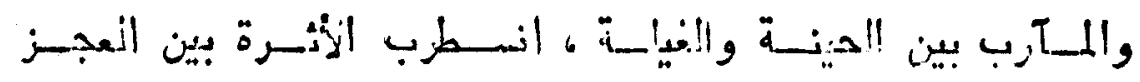

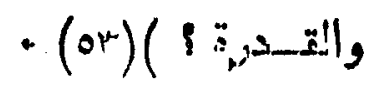

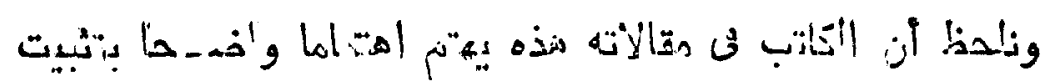

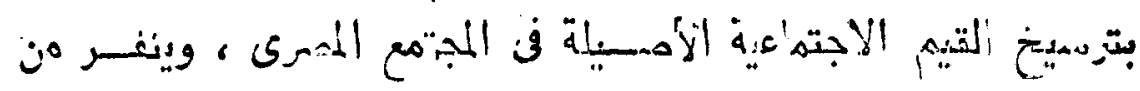

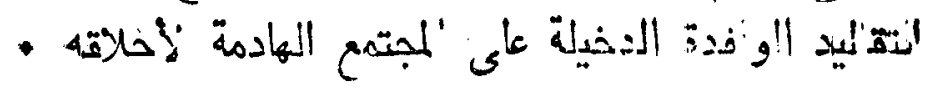

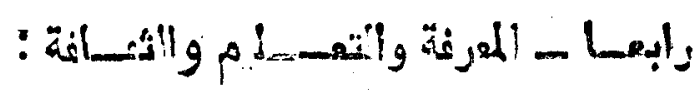

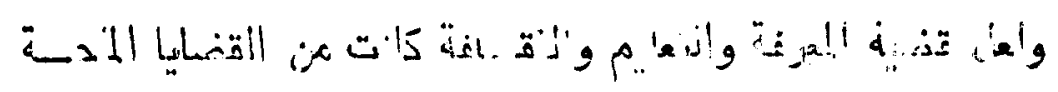

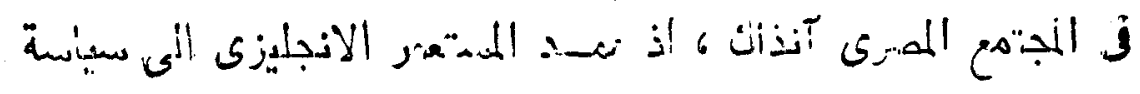

- 19r2/1r/ri في

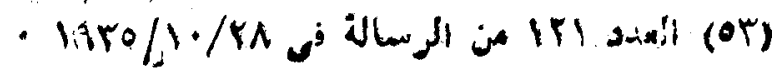




\section{YNA}

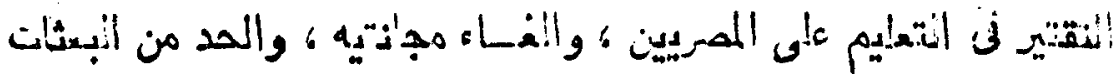

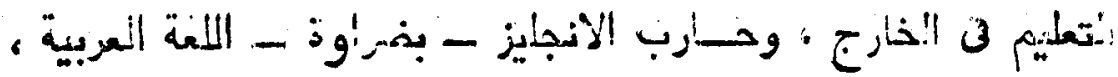

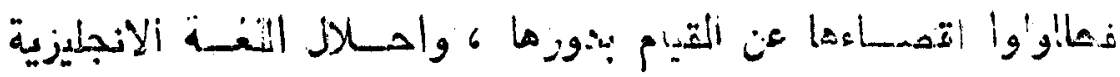
-

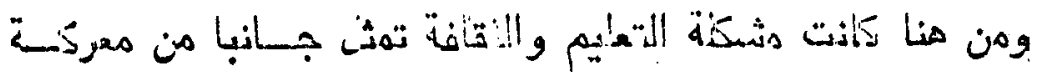

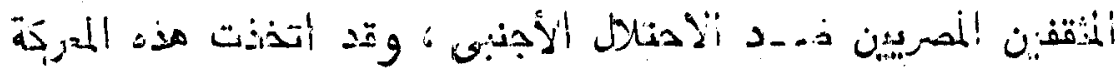

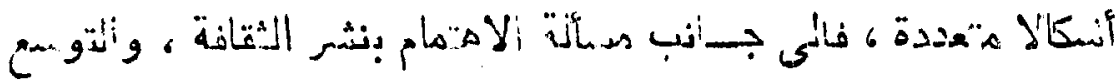

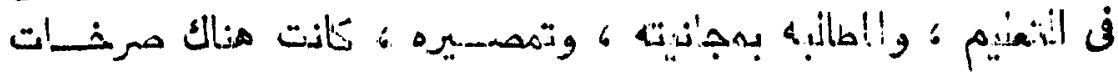

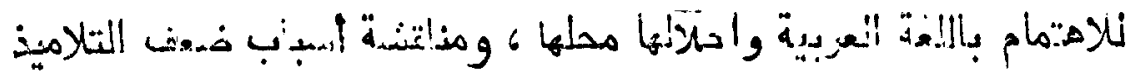

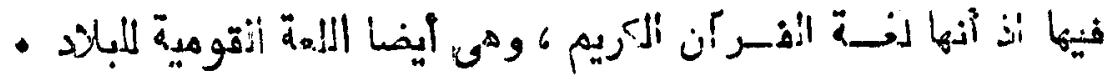

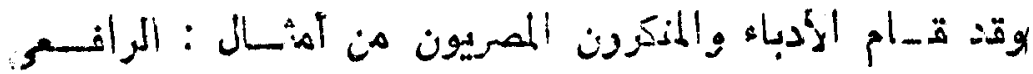

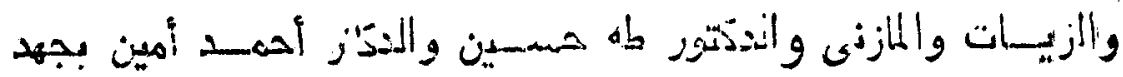

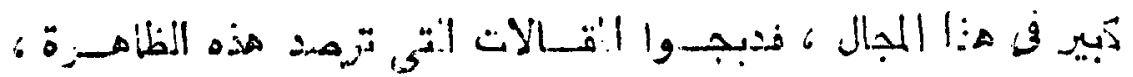

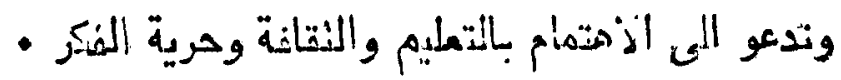

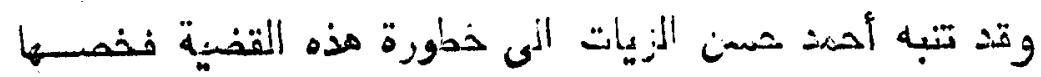

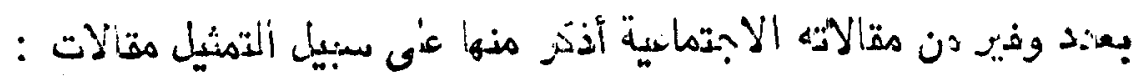

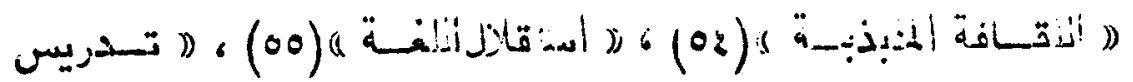

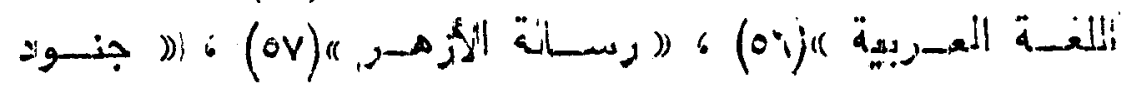
مجه-ولون ه (ON)

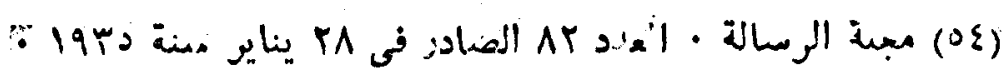

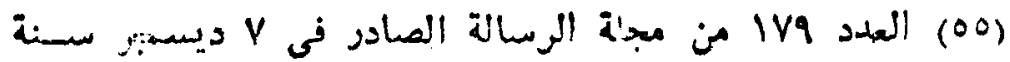
- lat?

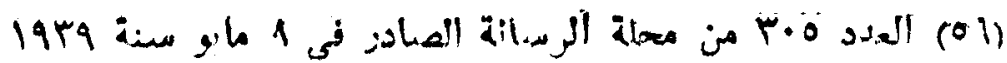

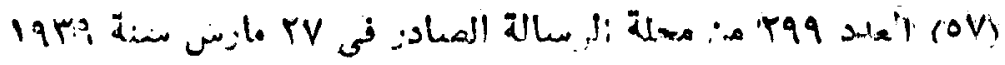

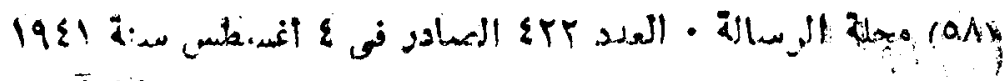

$$
(j 19-\rho)
$$


ra.

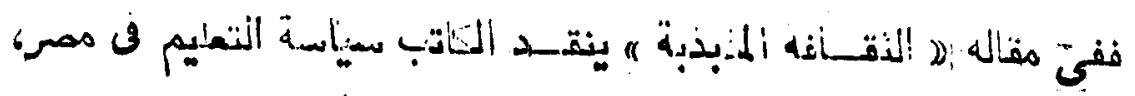

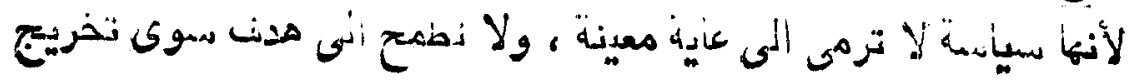

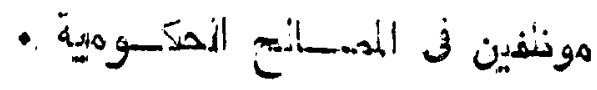

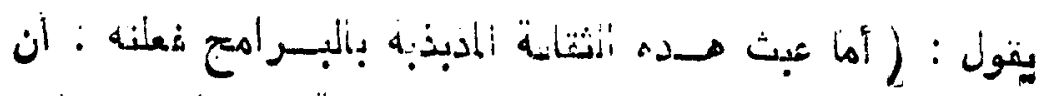

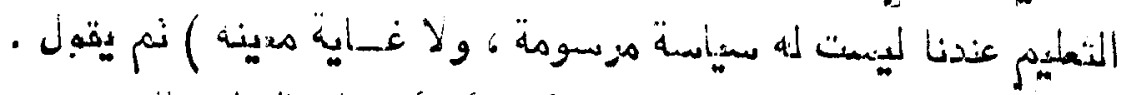

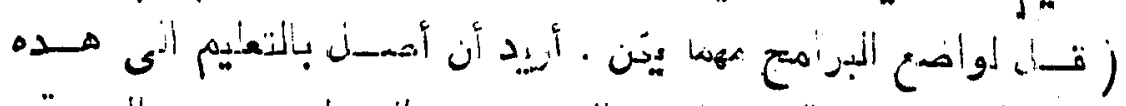

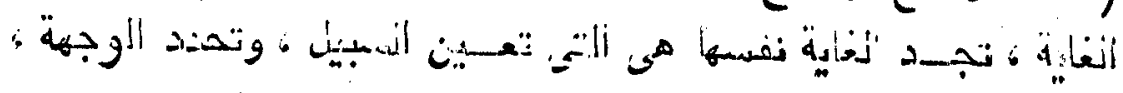

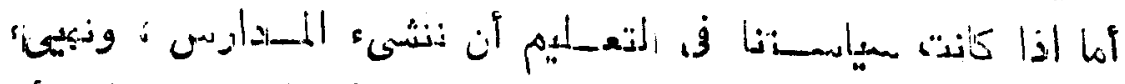

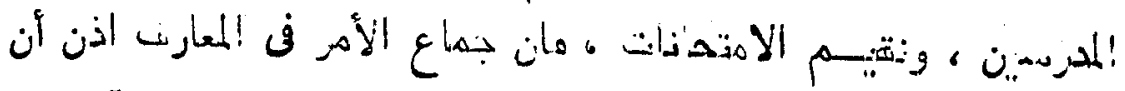

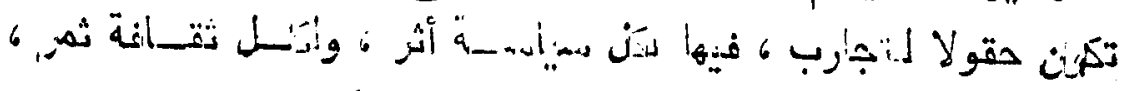

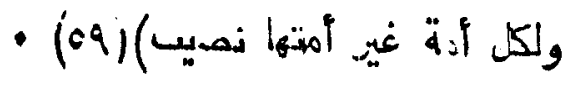

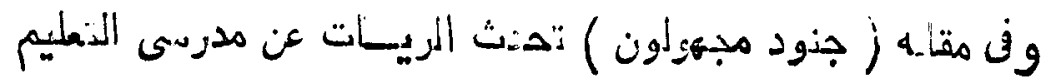

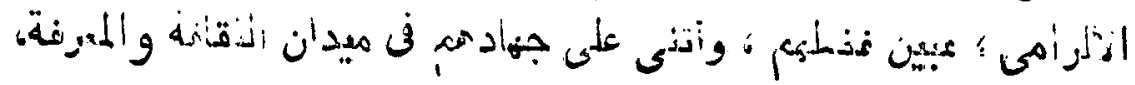

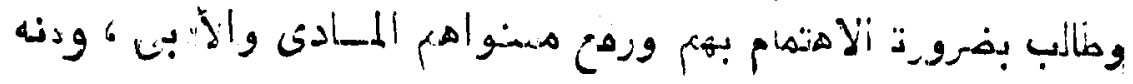

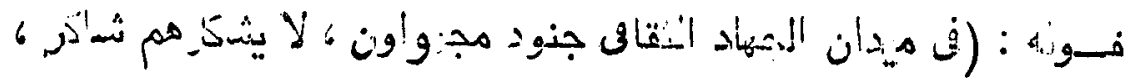

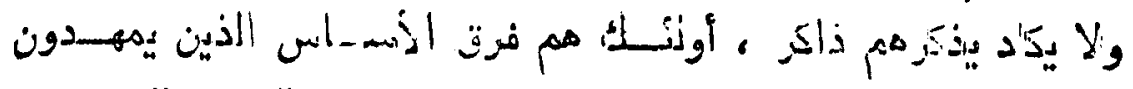

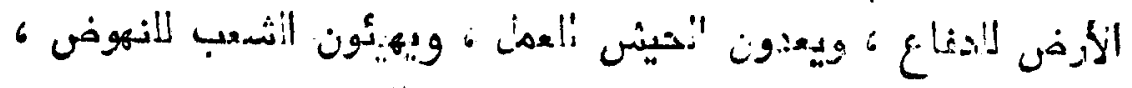

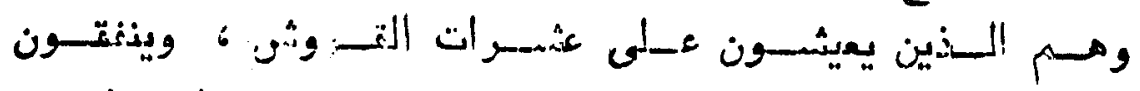

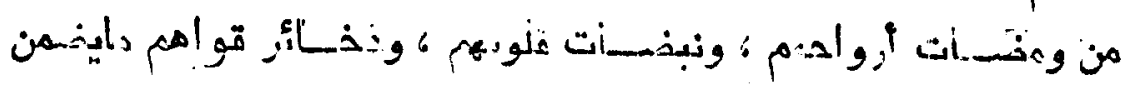

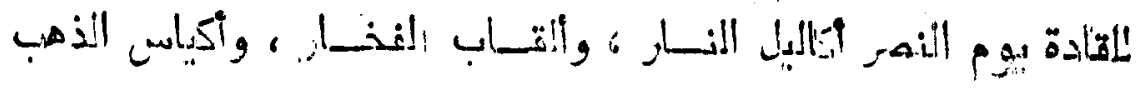

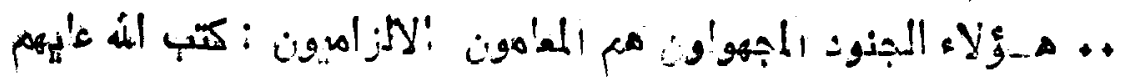

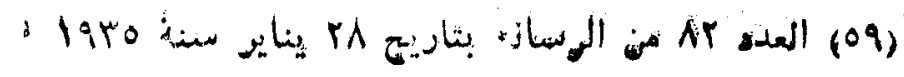




\section{ral}

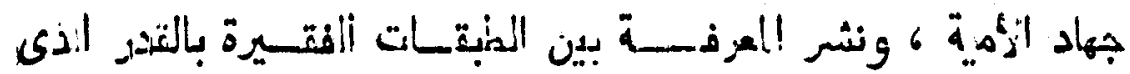

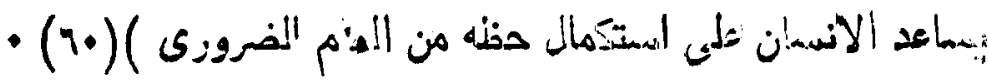

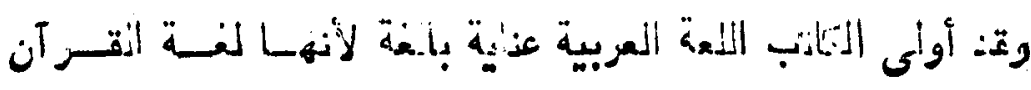

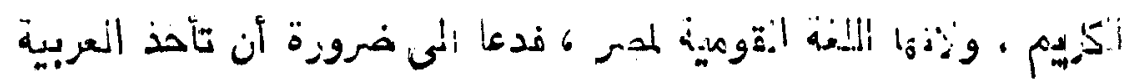

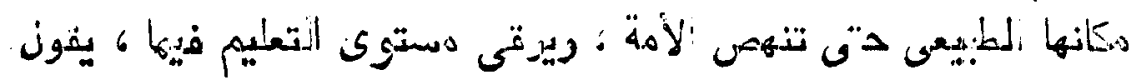

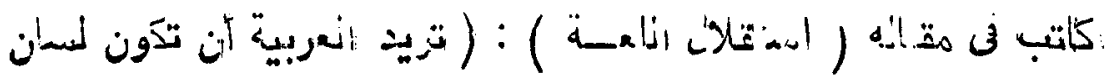

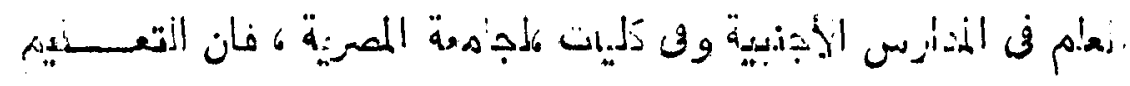

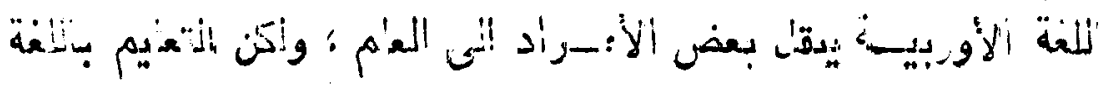

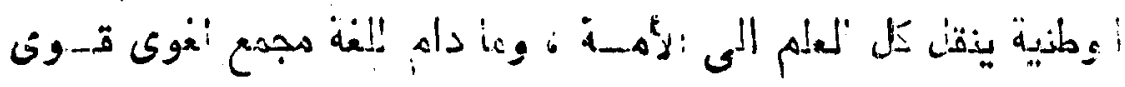

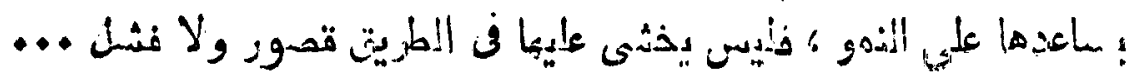

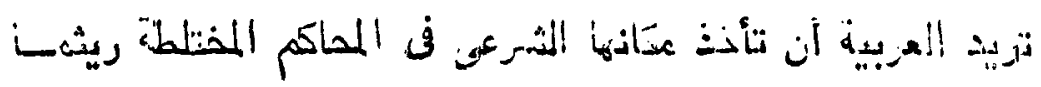

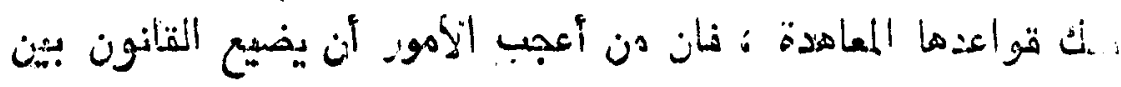

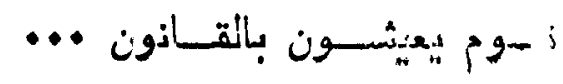

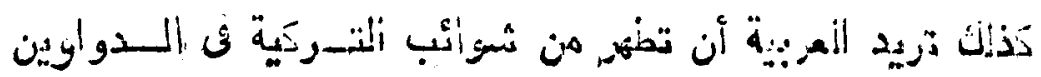

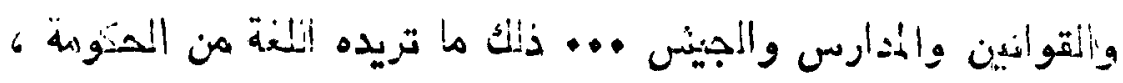

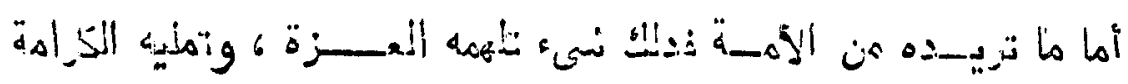

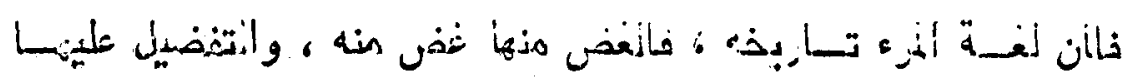

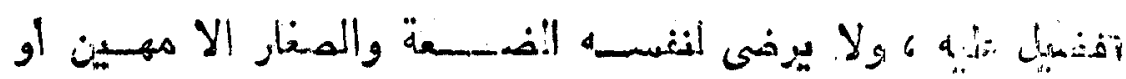
- (11)( : Invale

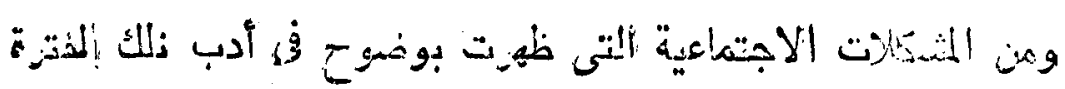

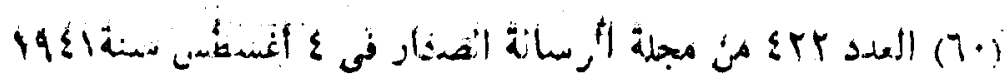

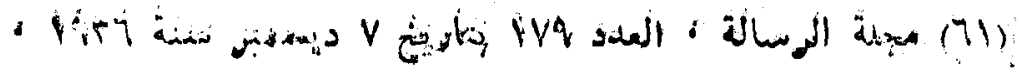




\section{rar.}

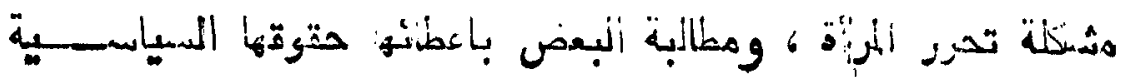

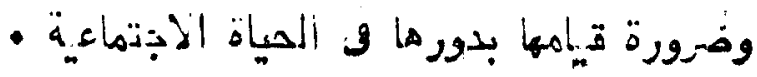

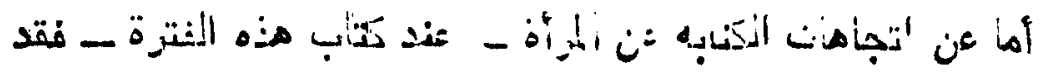

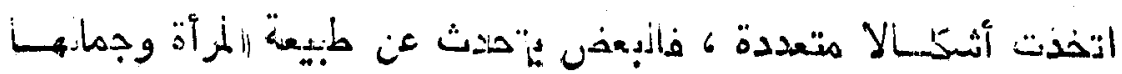

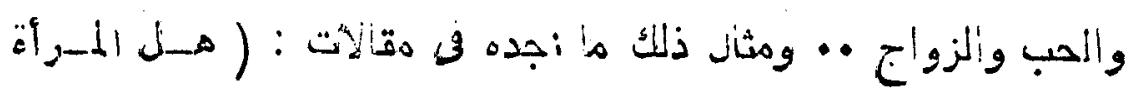

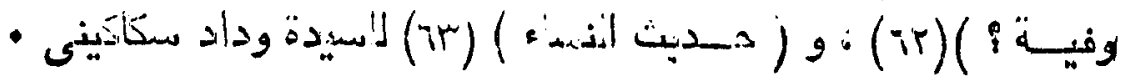

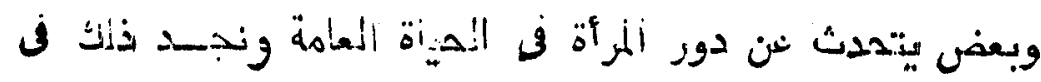

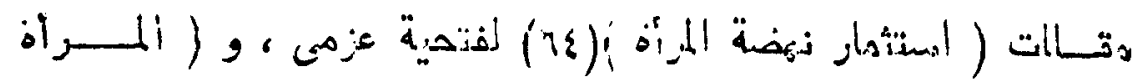

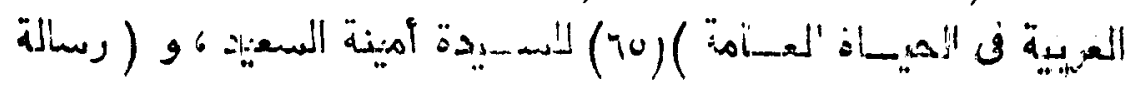

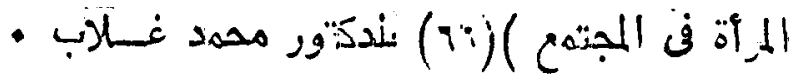

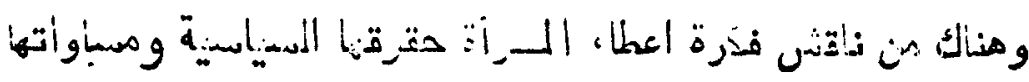

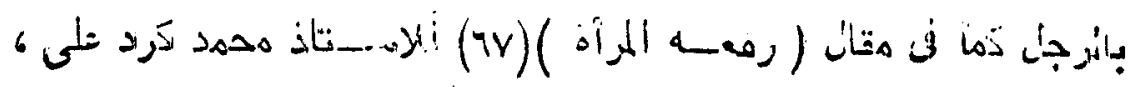

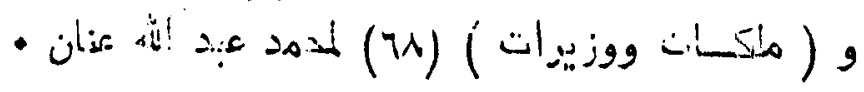

وقن عذى الزيـات بقصدية المرأف ؛ وتمنيهها 6 وأهمية مشاركتها

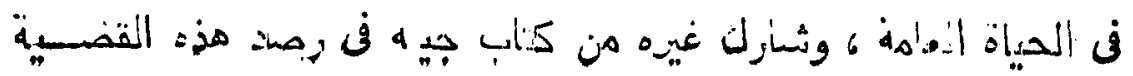

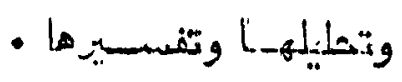

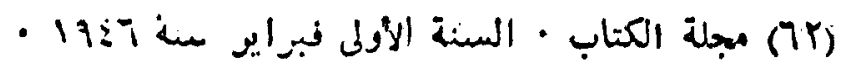

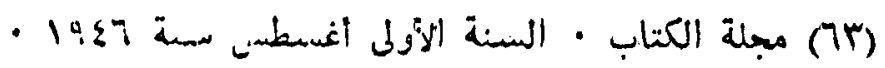

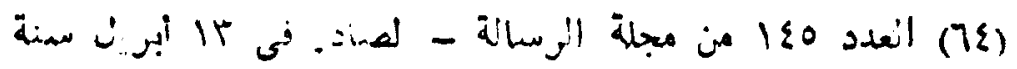

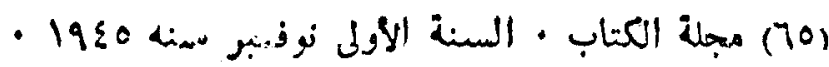

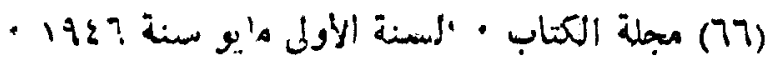

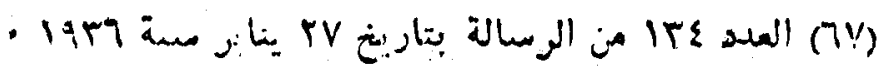

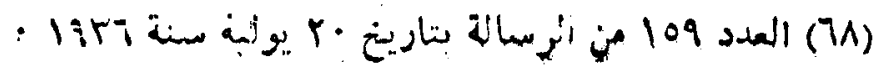




\section{rap}

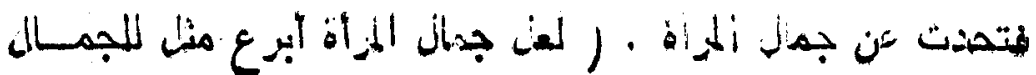

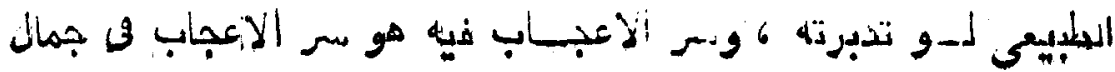

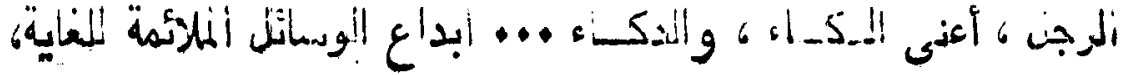

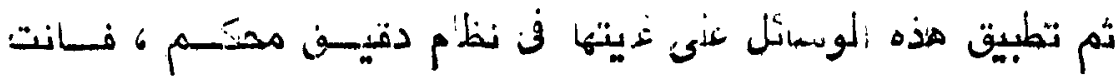

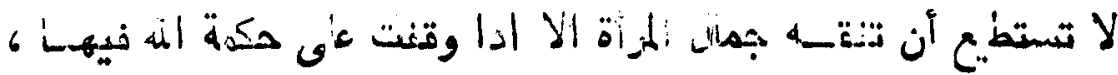

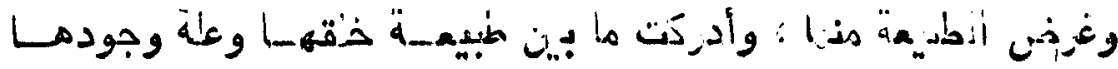

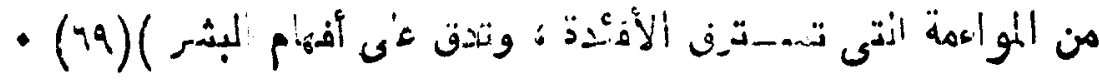

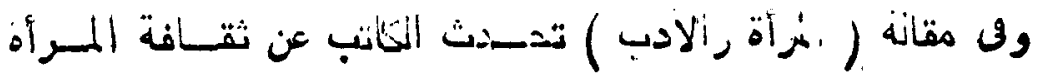

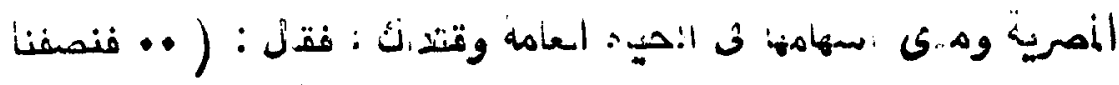

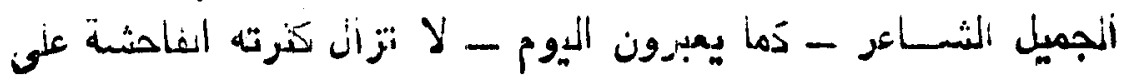

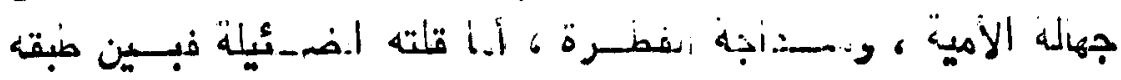

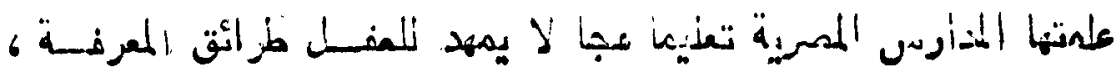

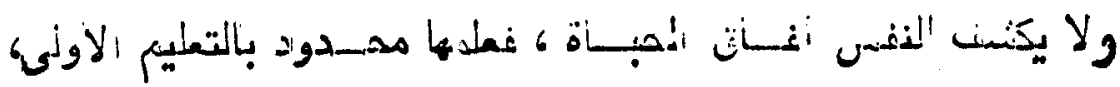

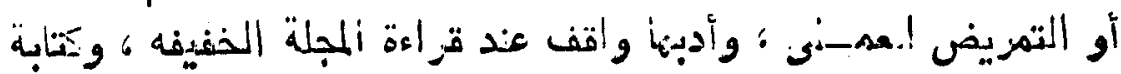

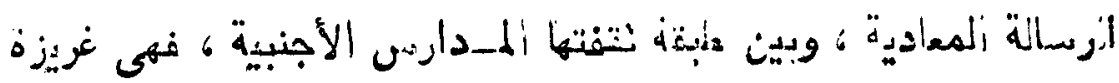

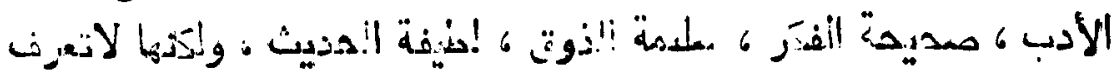

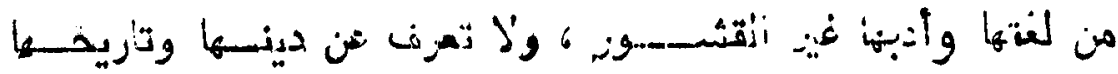

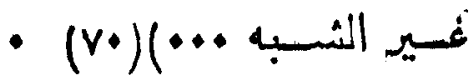

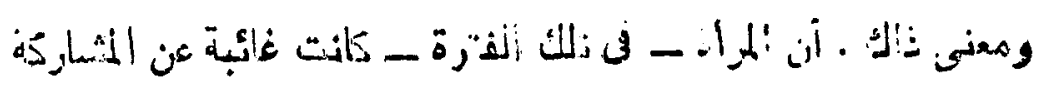

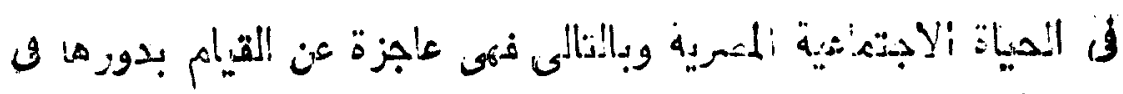

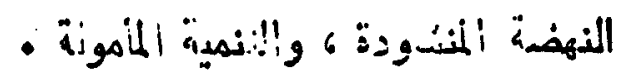

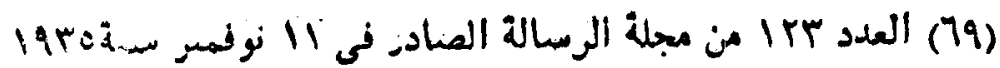
العدد • \& (V.) 


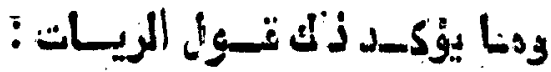

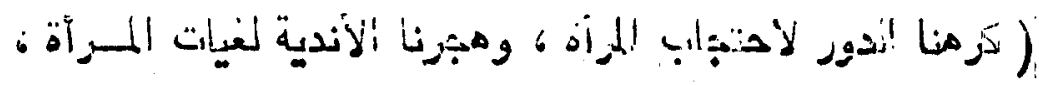

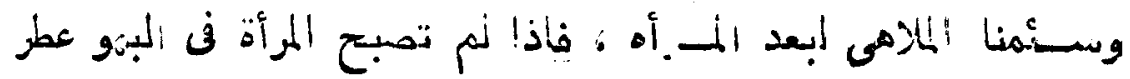

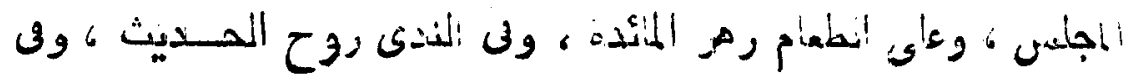

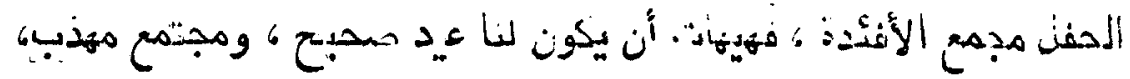

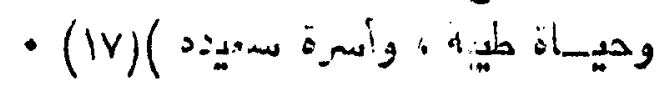

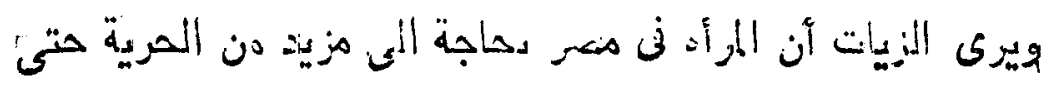

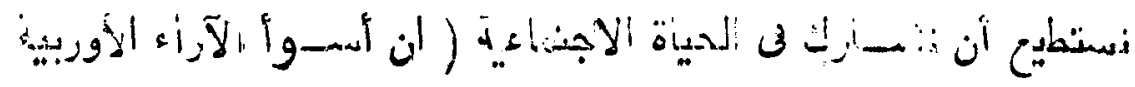

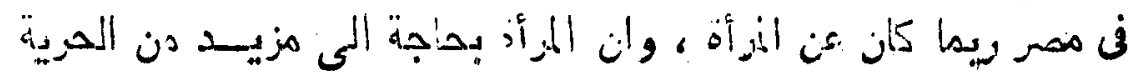

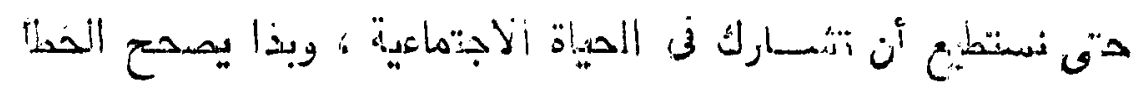

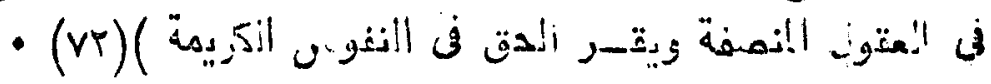

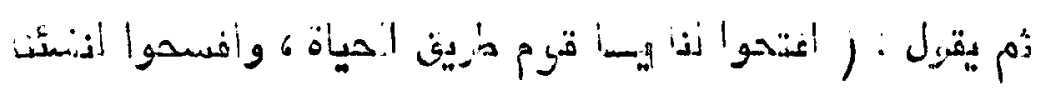

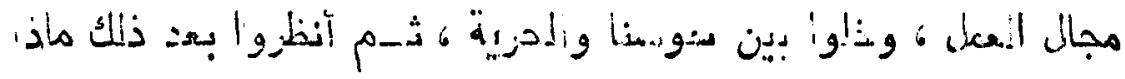

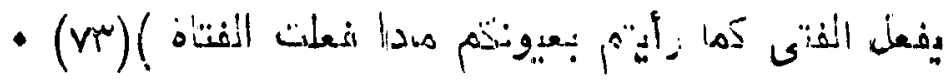

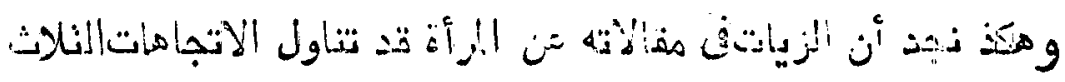

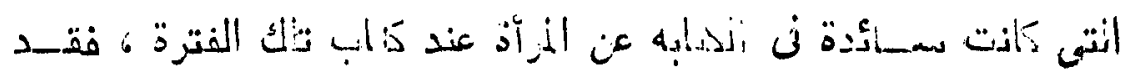

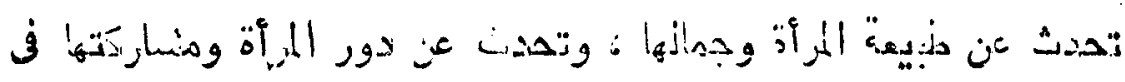

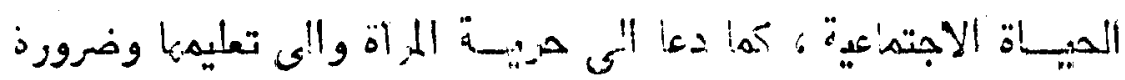

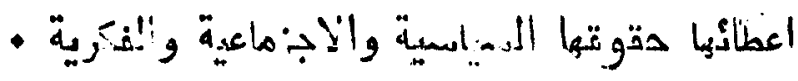

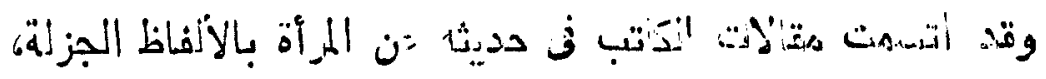

(V) (VT)

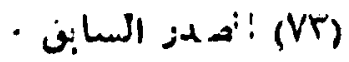




\section{0}

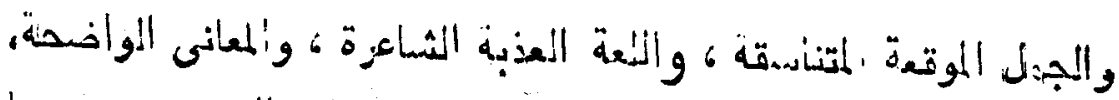

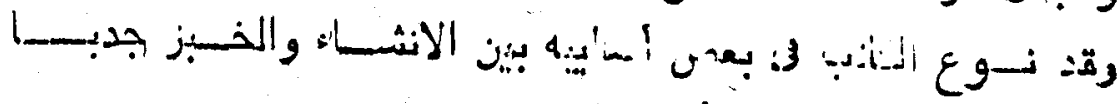

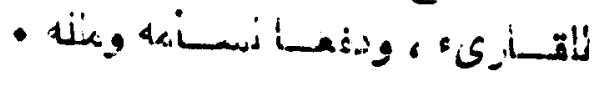

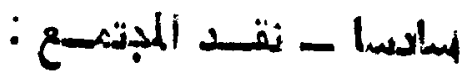

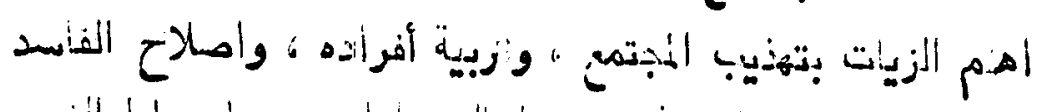

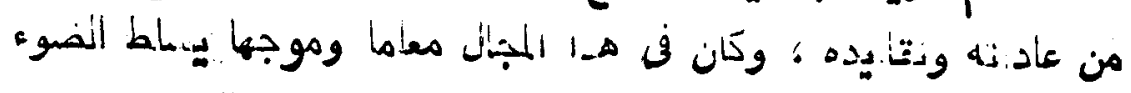

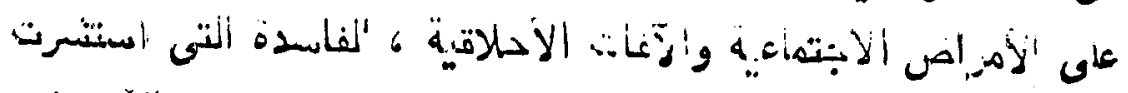

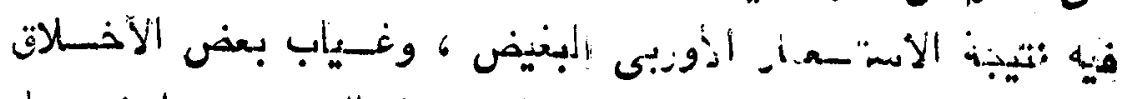

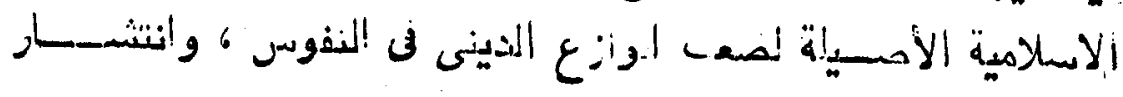

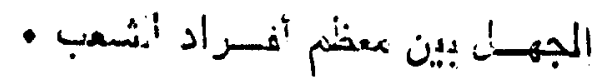

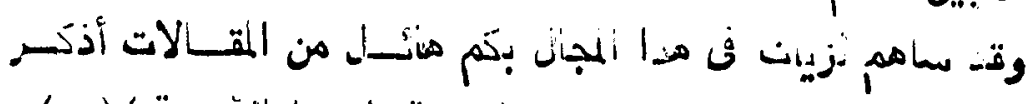

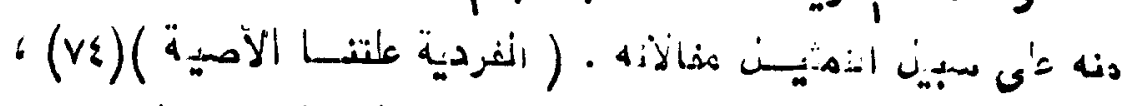

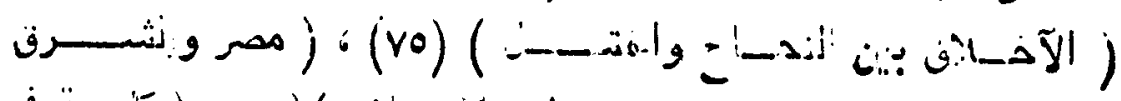

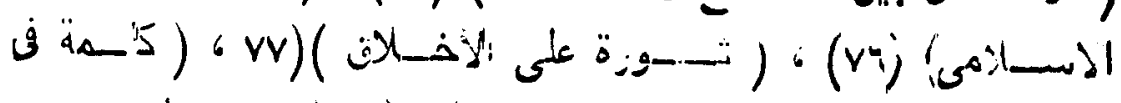

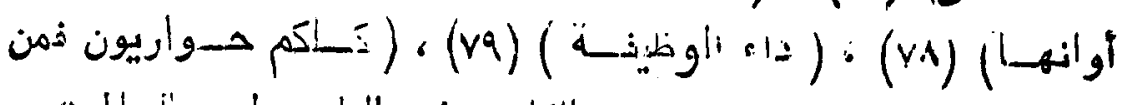

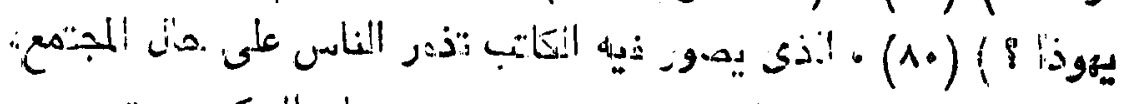

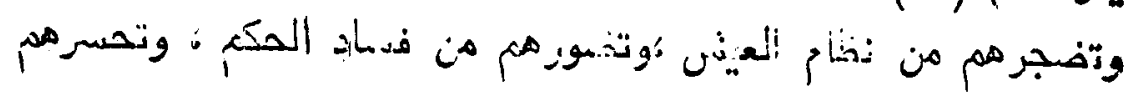

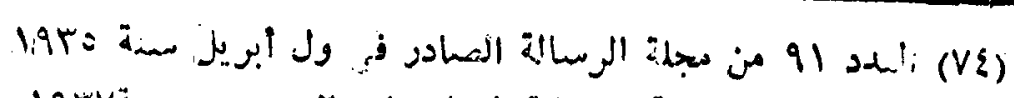

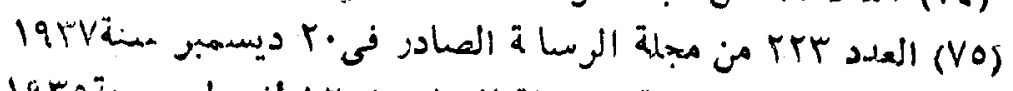

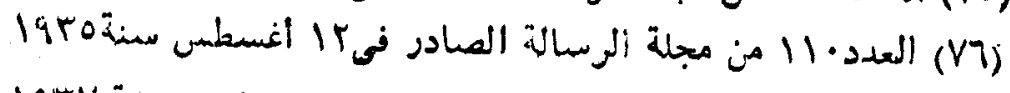

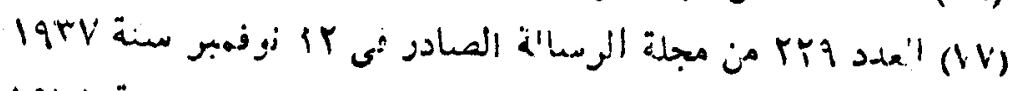

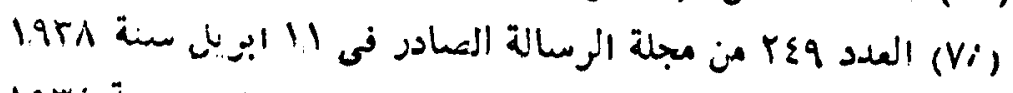

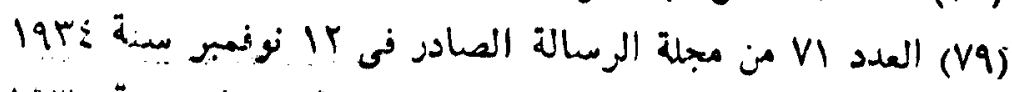

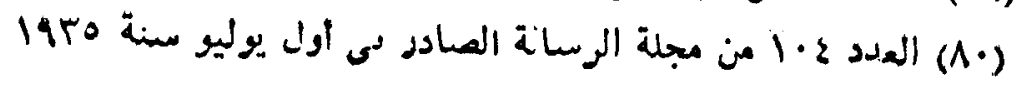




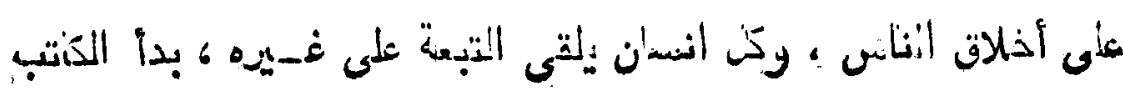

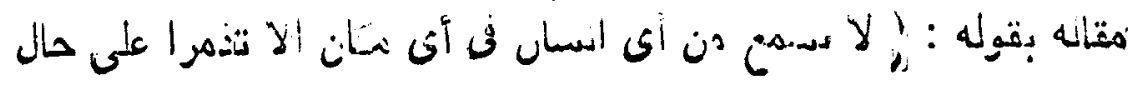

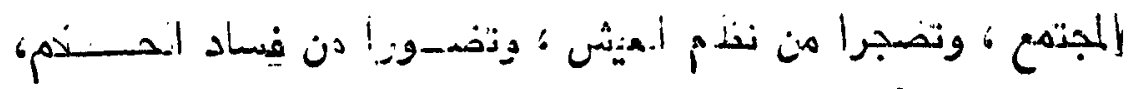

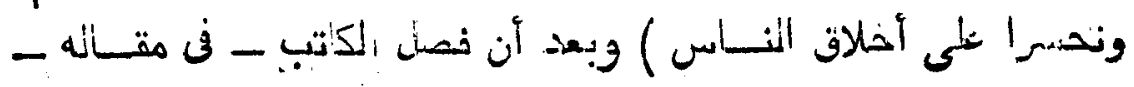

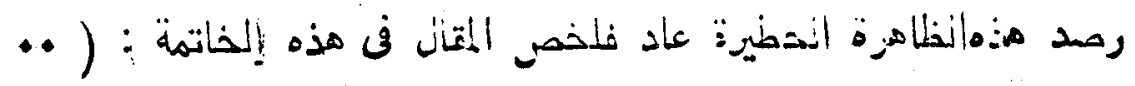

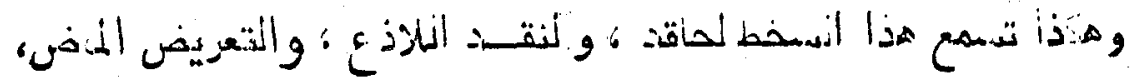

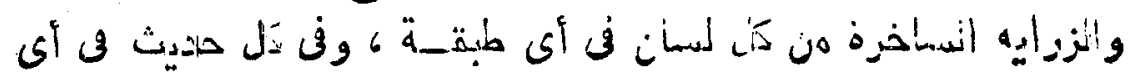

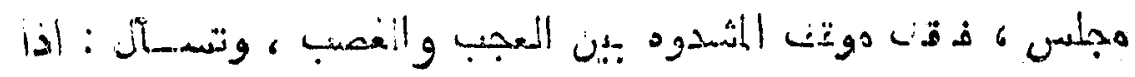

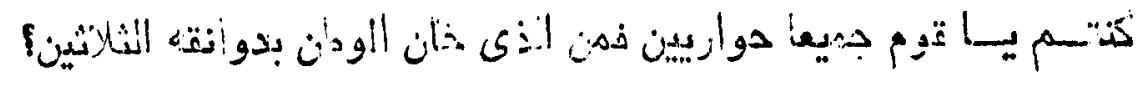

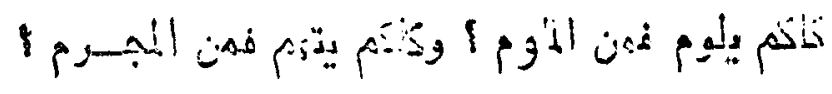

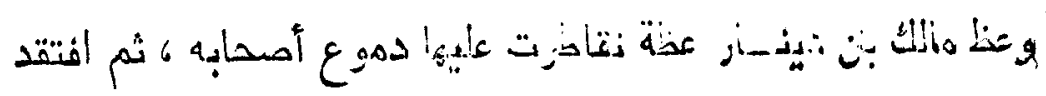

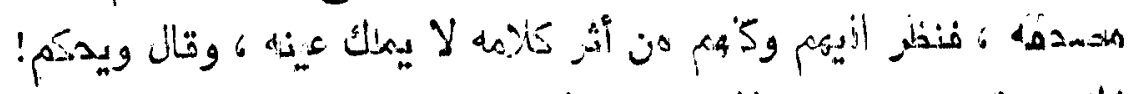

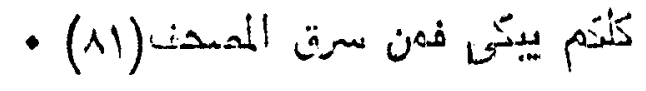

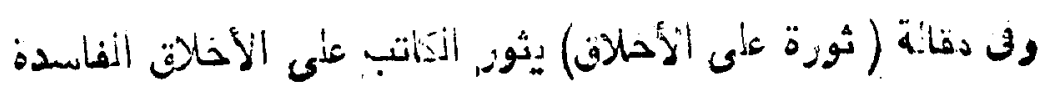

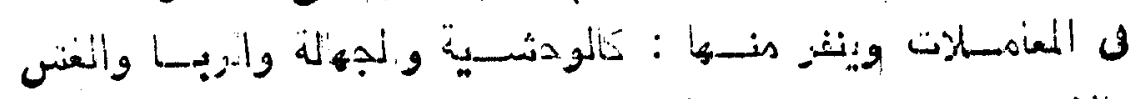

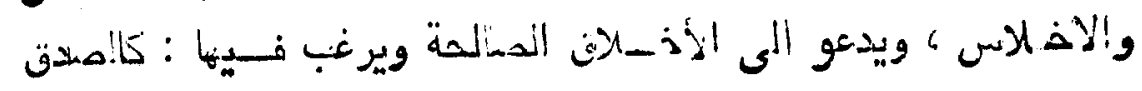

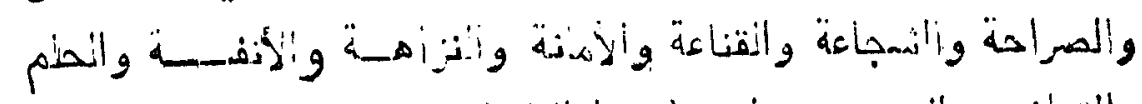

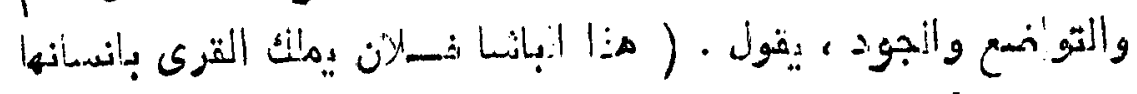

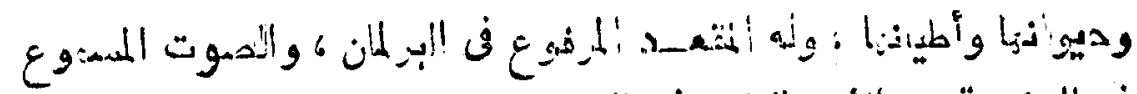

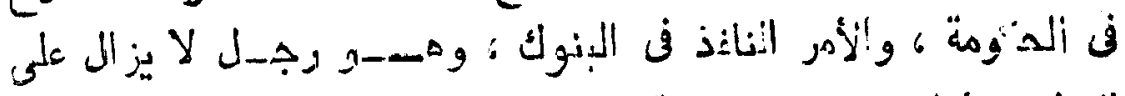

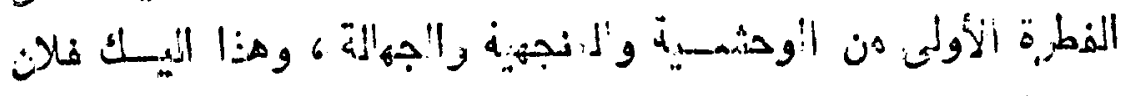

(11) 


\section{rav}

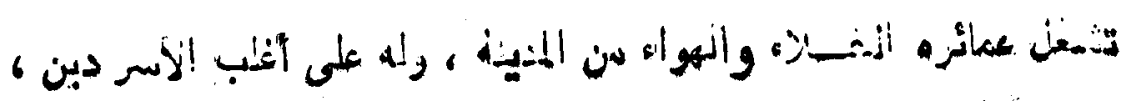

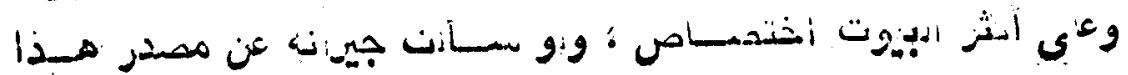

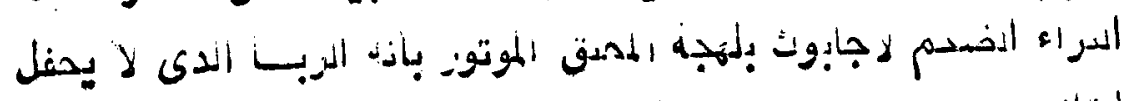

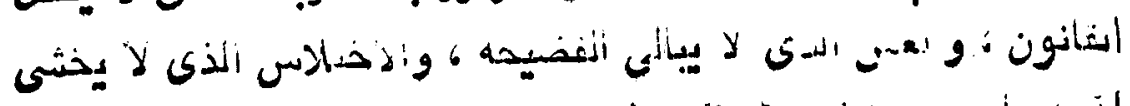

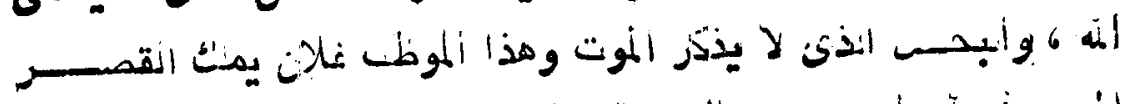

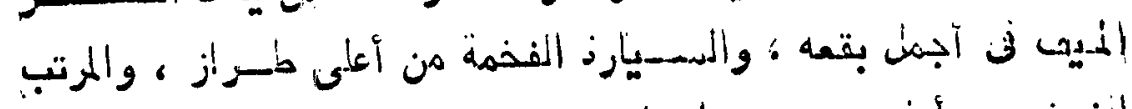

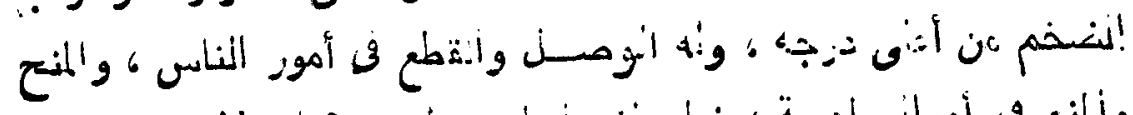

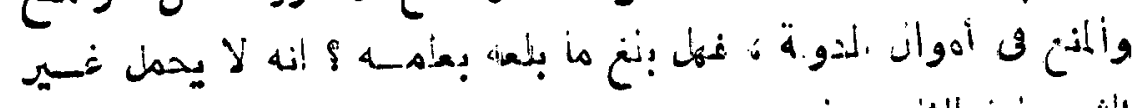

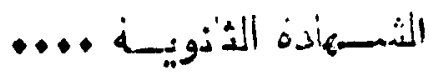

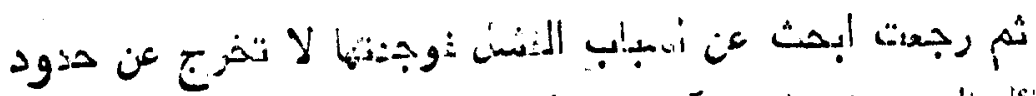

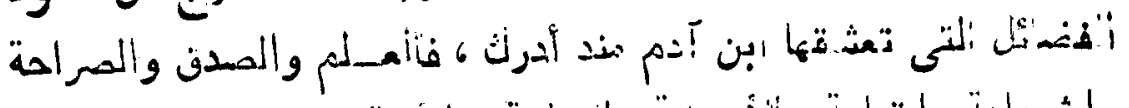

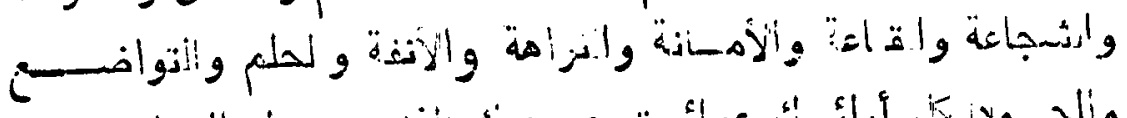

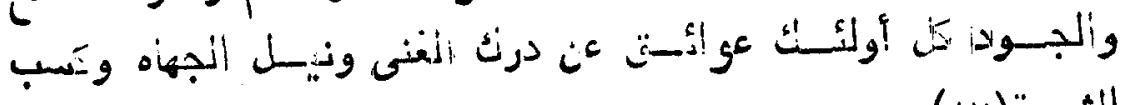
- الشهرة) والجـودان

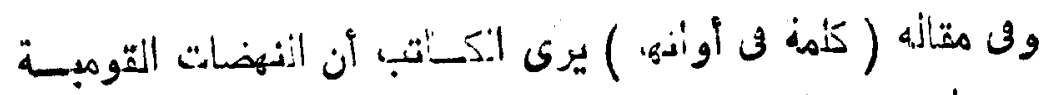

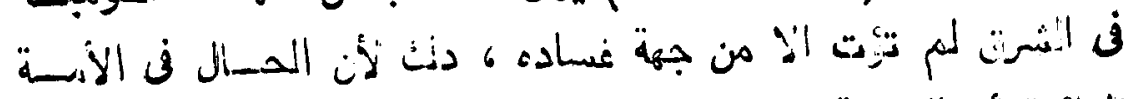

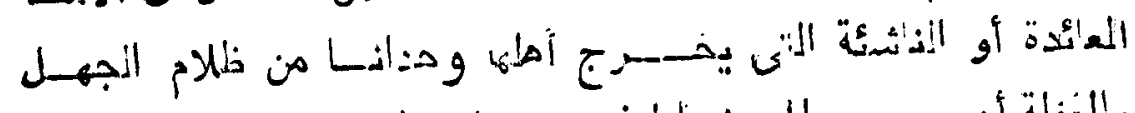

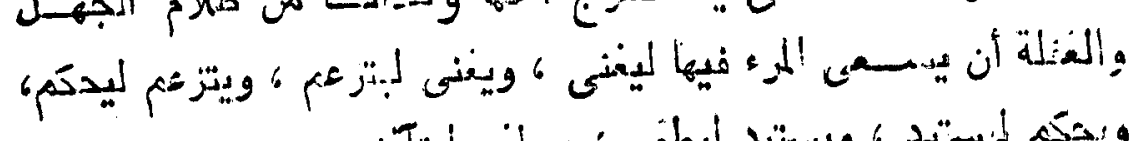

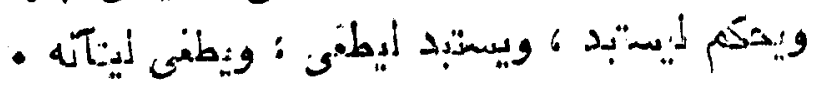

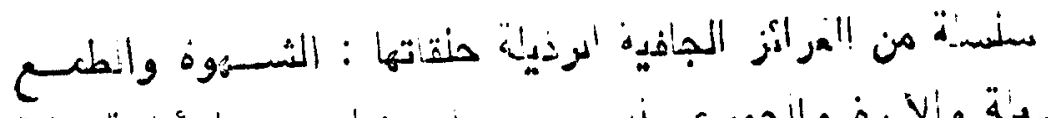

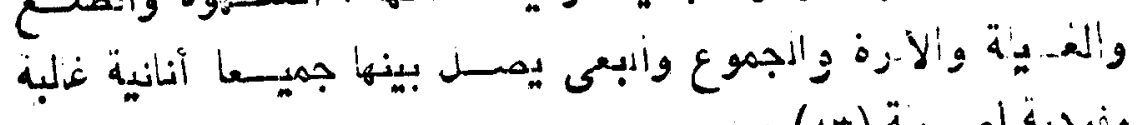

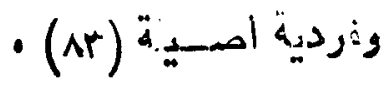

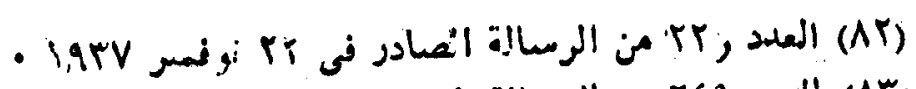

• ا 


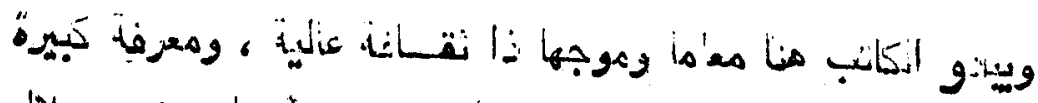

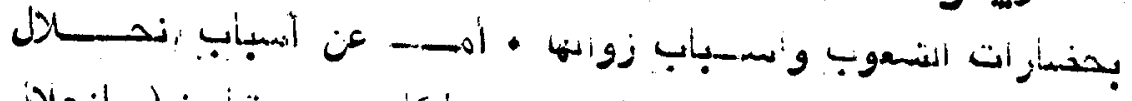

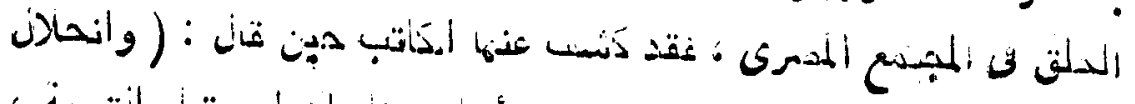

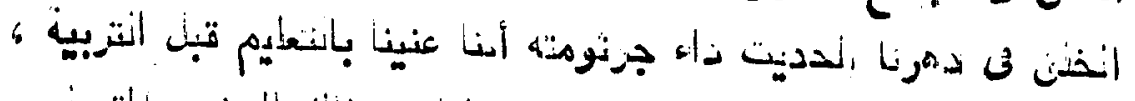

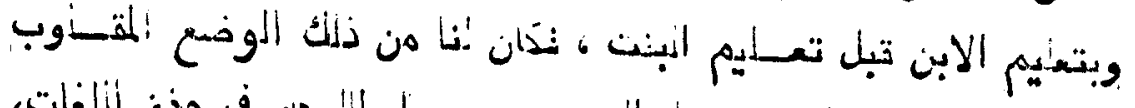

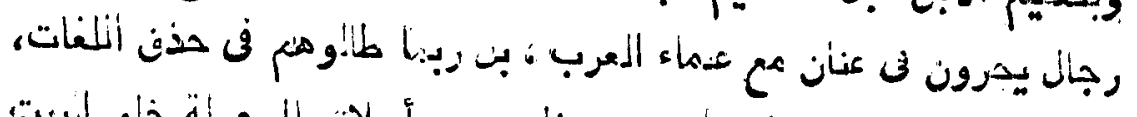

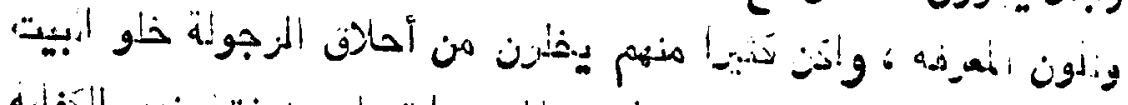

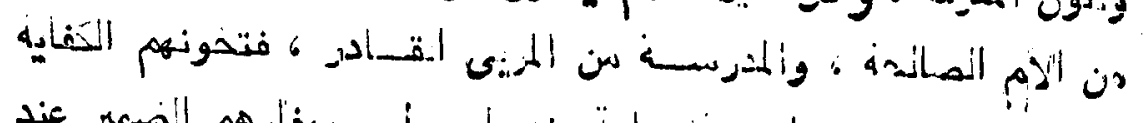

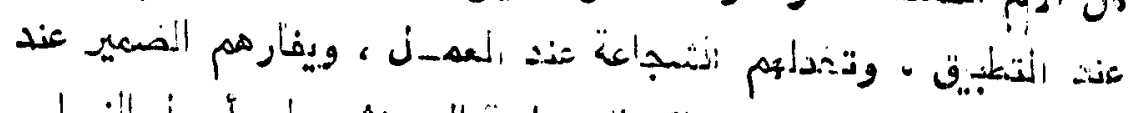

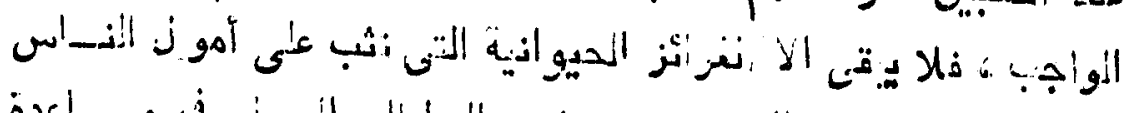

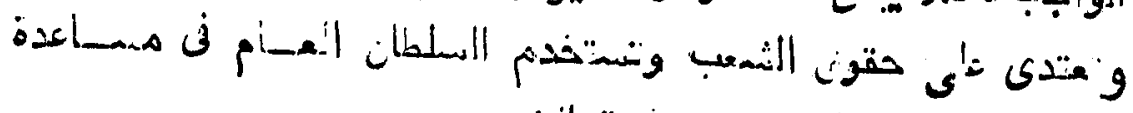

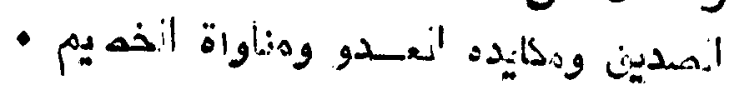

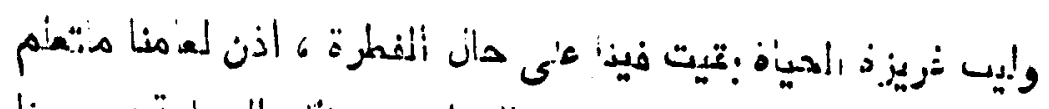

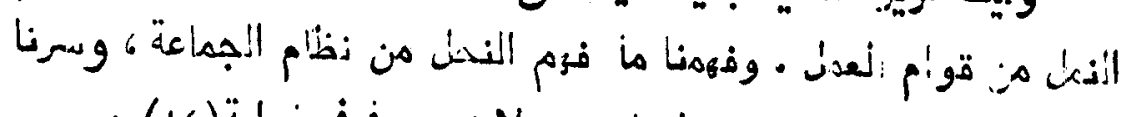

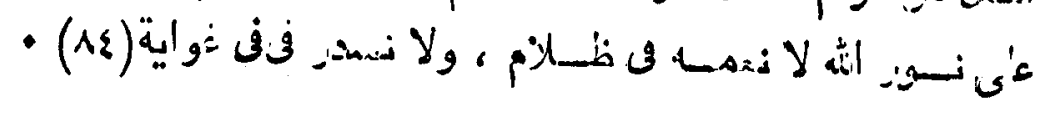

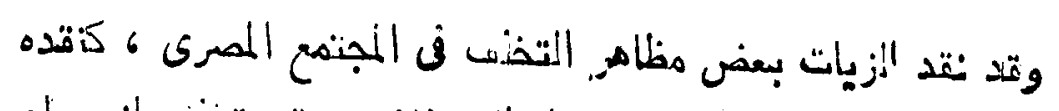

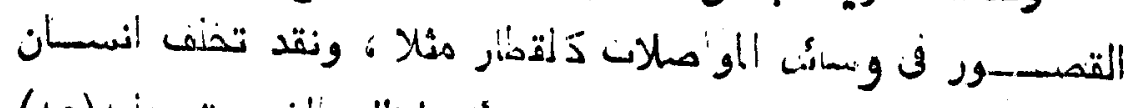

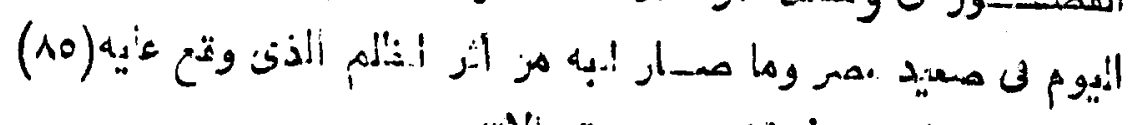

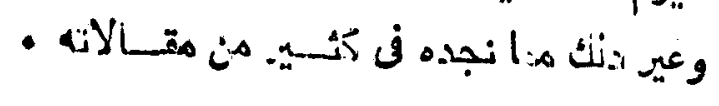

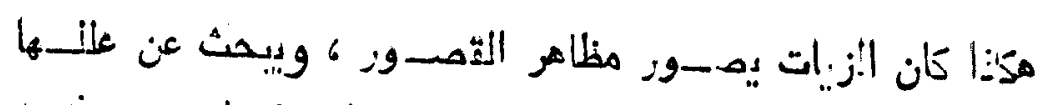

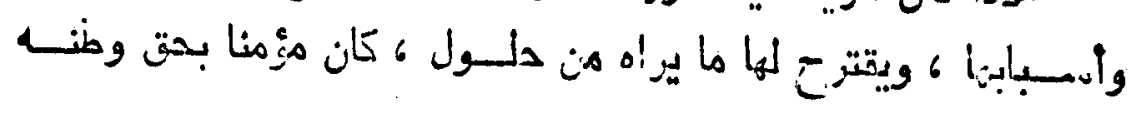

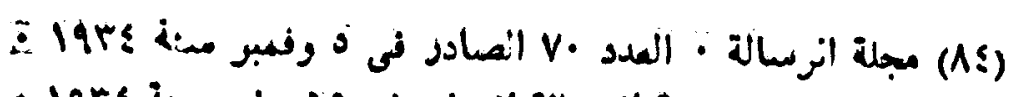

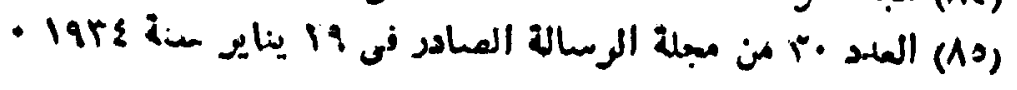




\section{$r 99$}

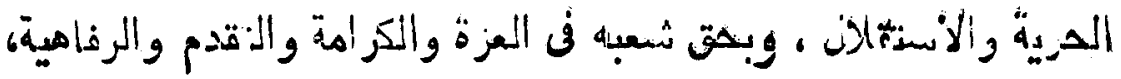

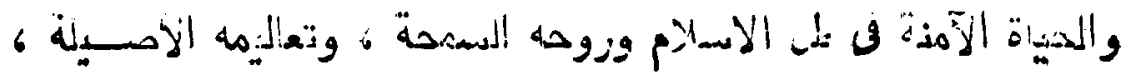

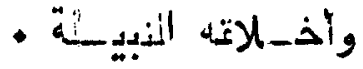

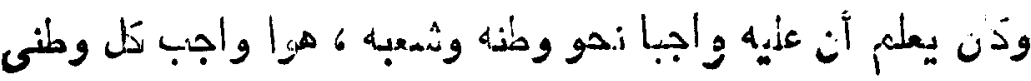

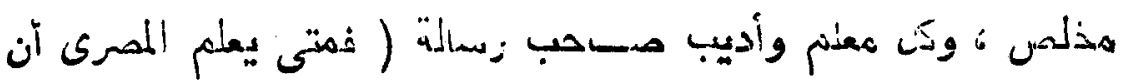

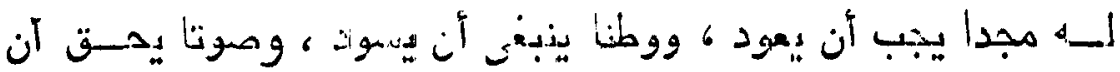

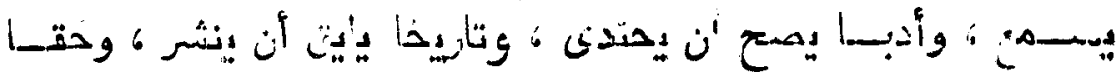

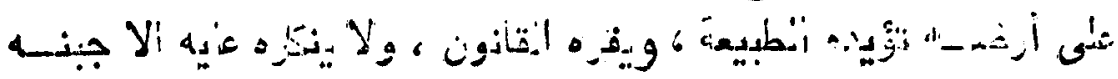

$$
\text { - }(\wedge T)(1+1 \text { ) }
$$

$$
\text { : }
$$

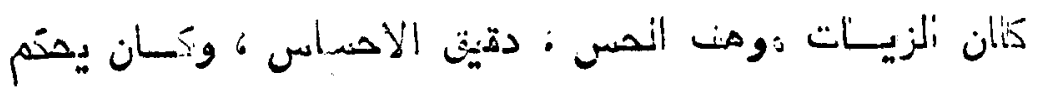

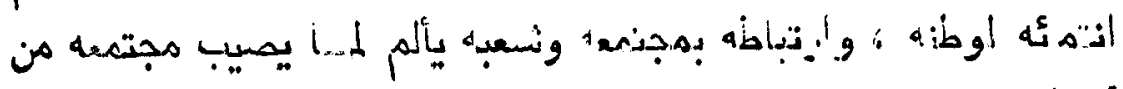

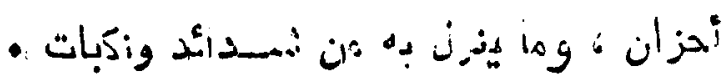

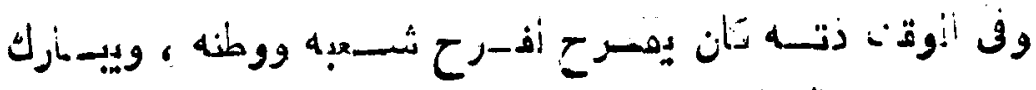
كل بادزة بنقسدم آو أنتصسئز

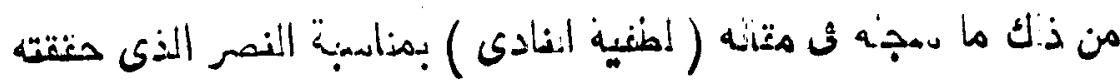

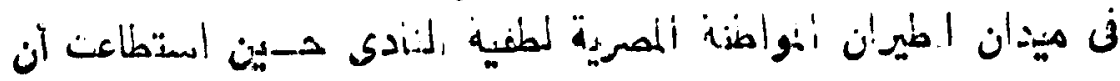

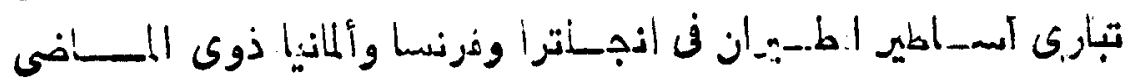

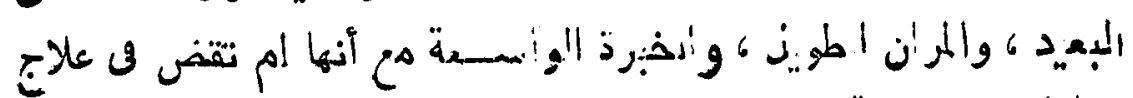

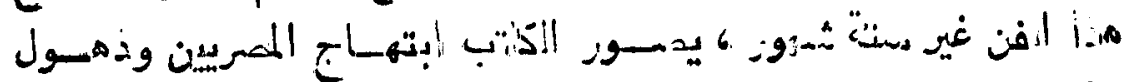

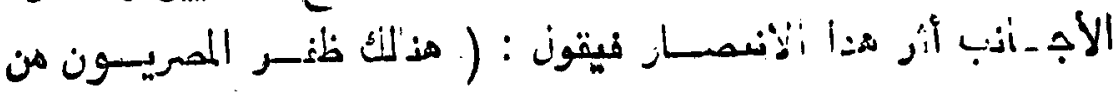

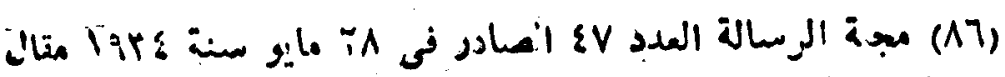

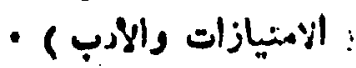




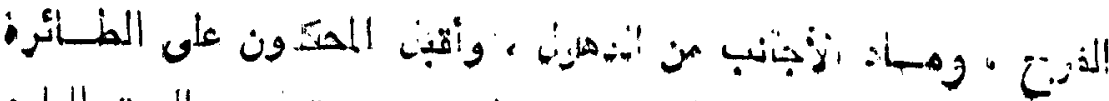

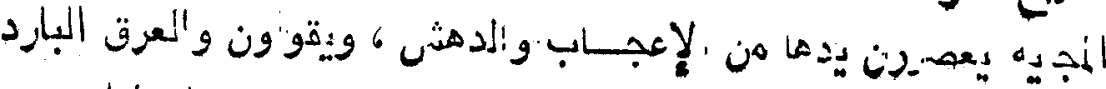

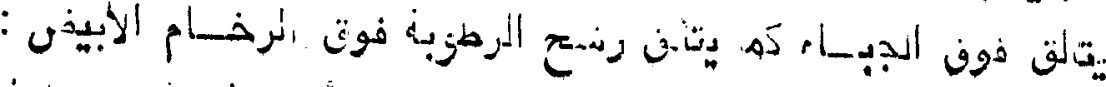

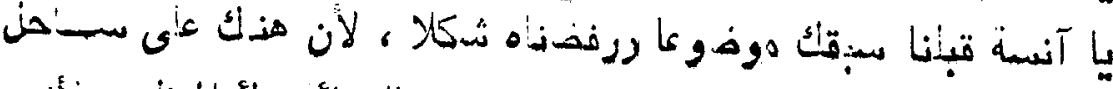

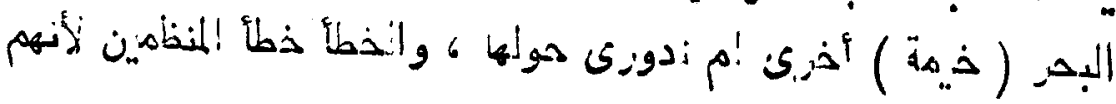

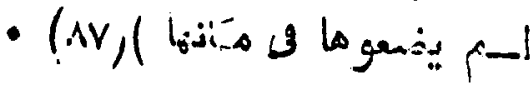

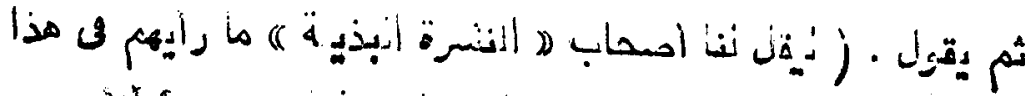

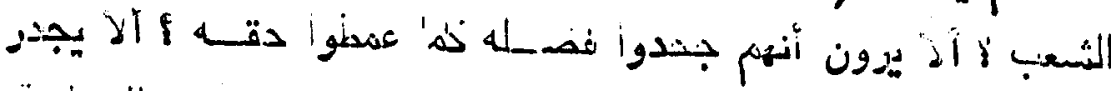

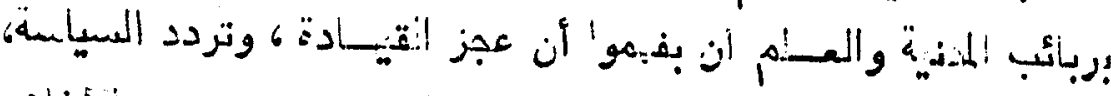

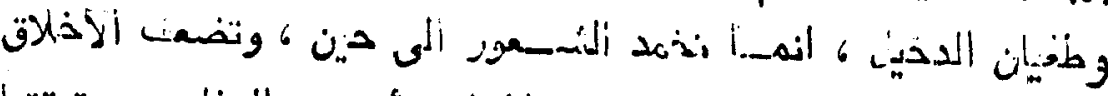

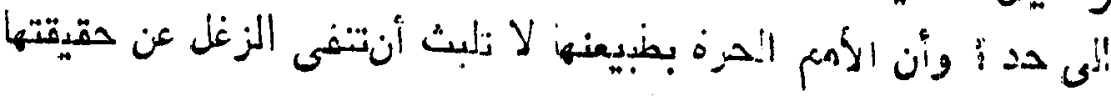

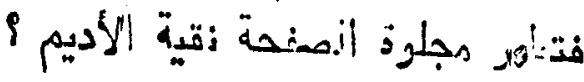

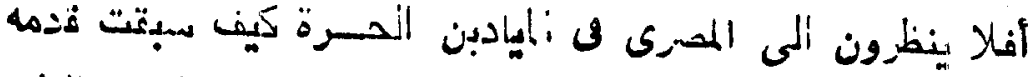

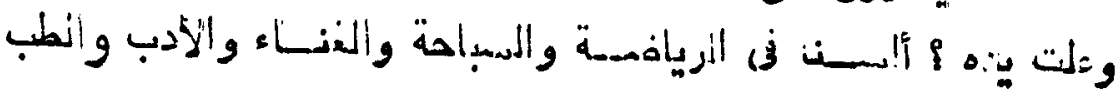

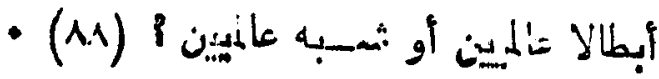

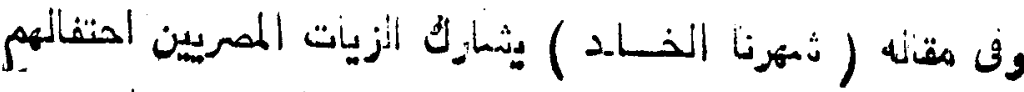

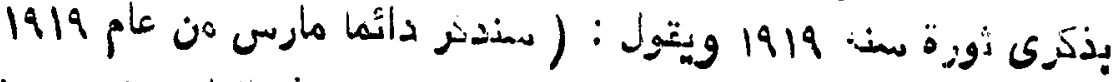

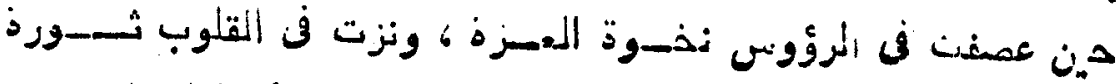

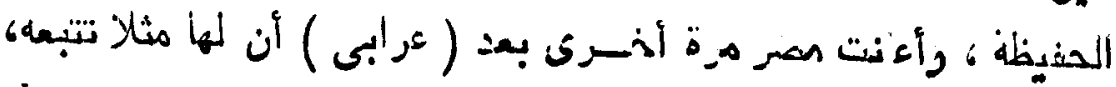

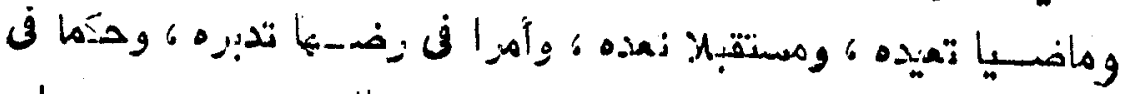

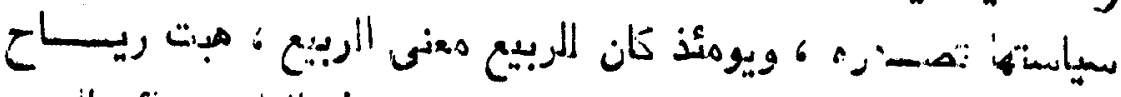

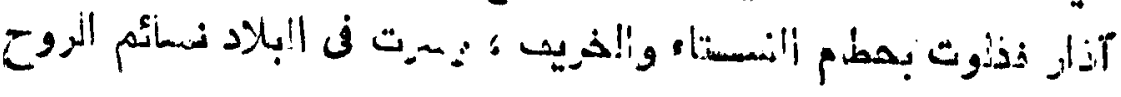

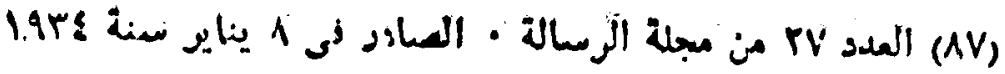
- 


\section{$M \cdot 1$}

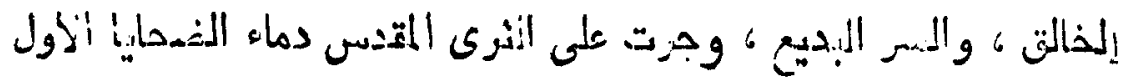

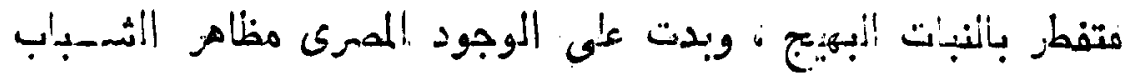

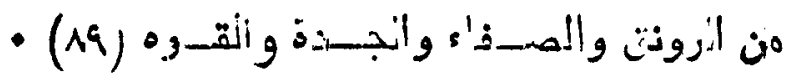

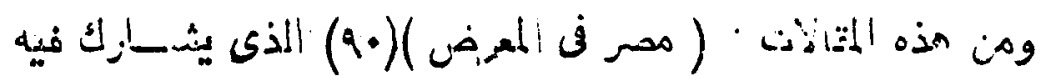

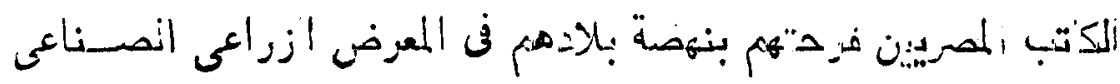

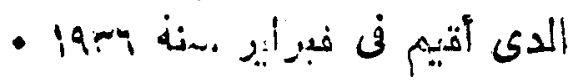

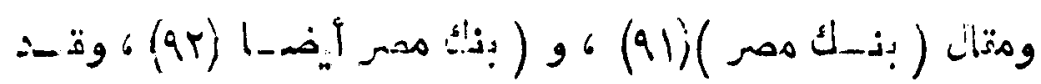

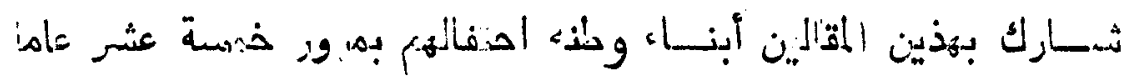

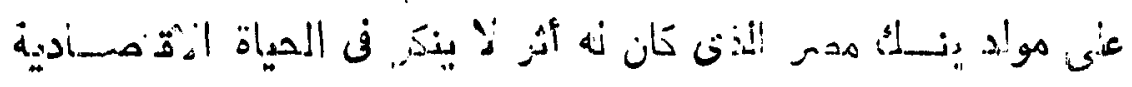

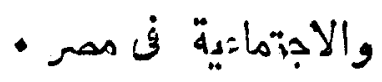

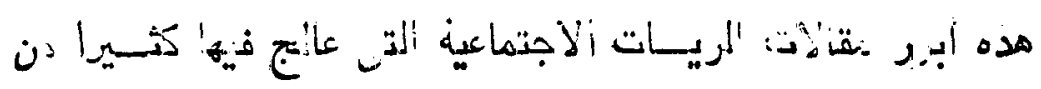

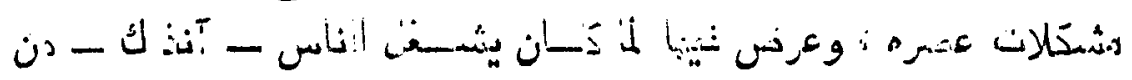

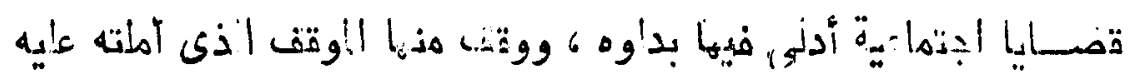

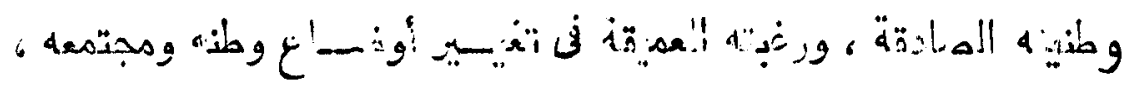

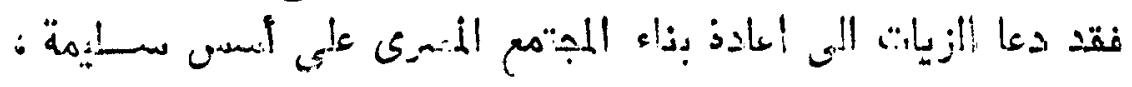

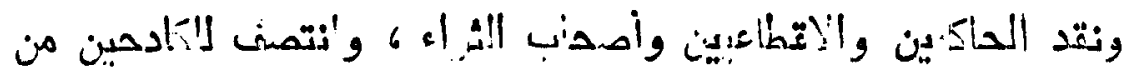

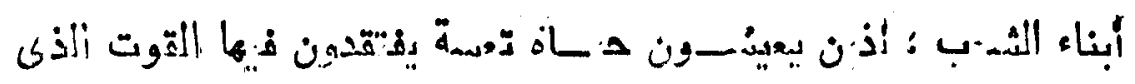

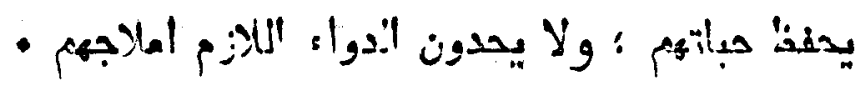

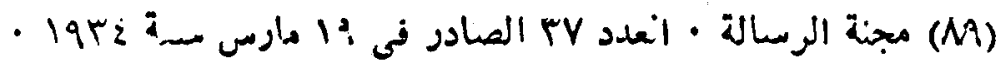

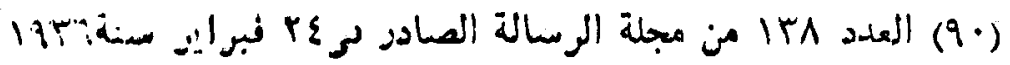

(91)

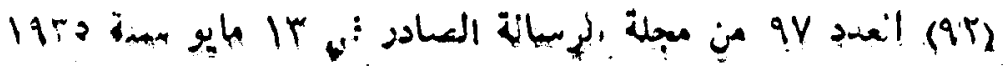




\section{$r \cdot r$}

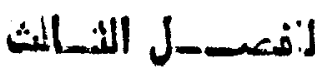

\section{الخصسائص إ:نيسة إقـالاته :}

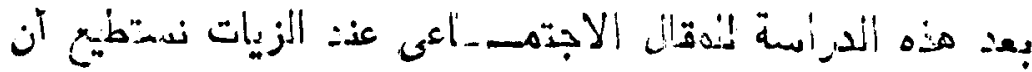

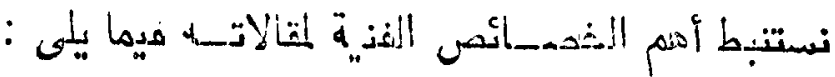

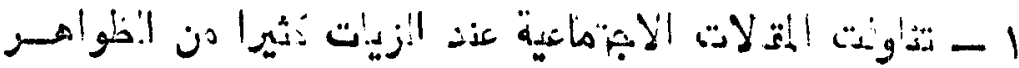

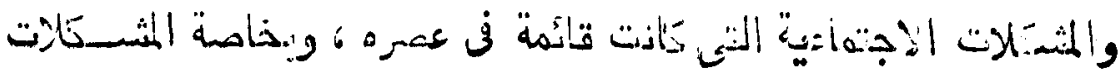

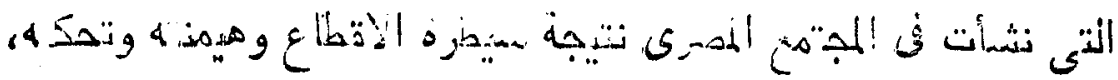

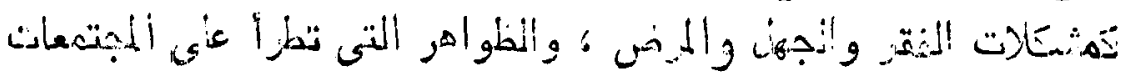

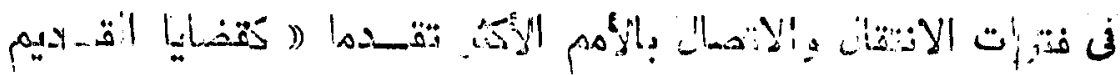

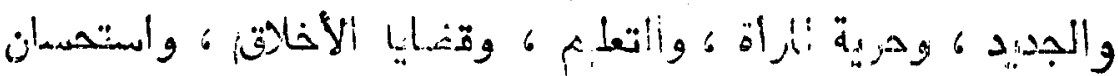

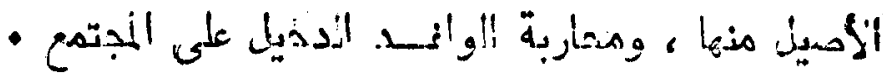

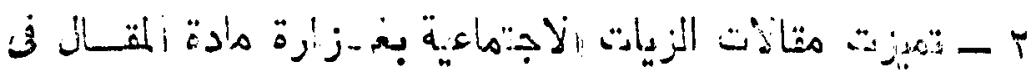

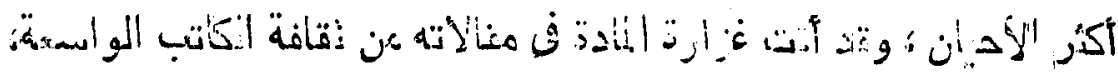

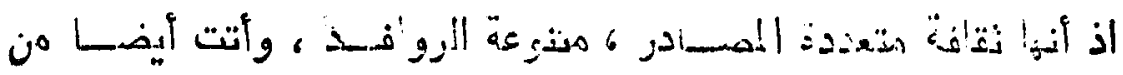

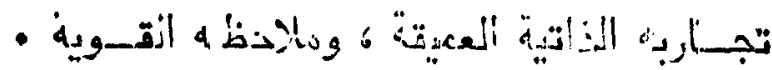

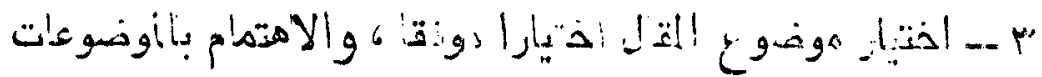

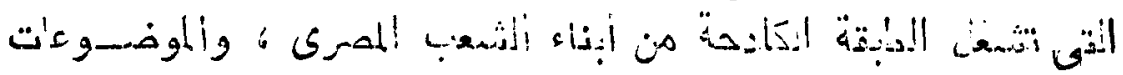

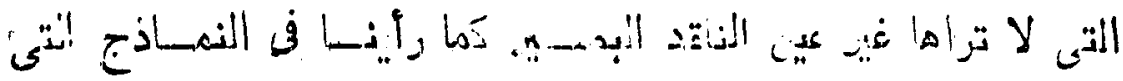

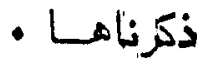

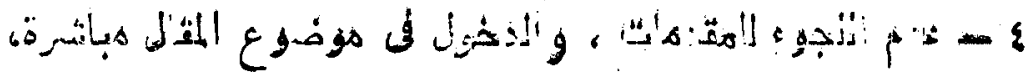

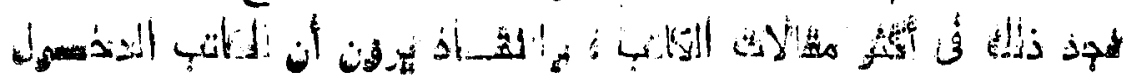




\section{$r \cdot r$}

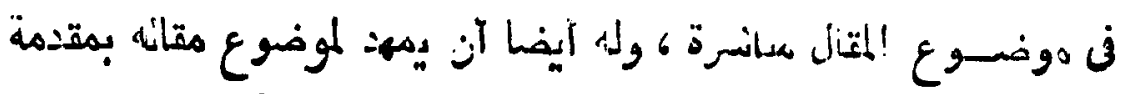

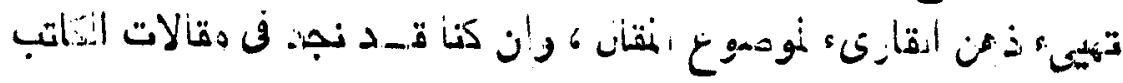

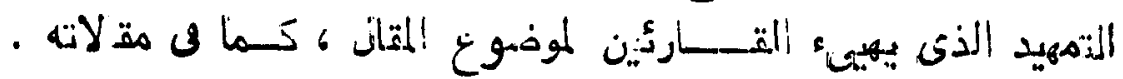

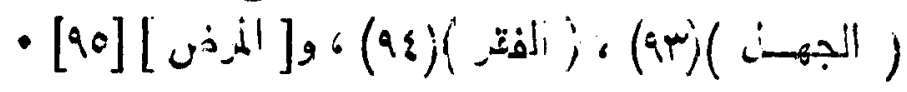

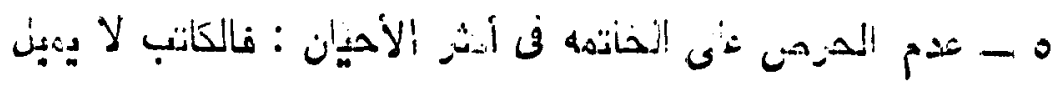

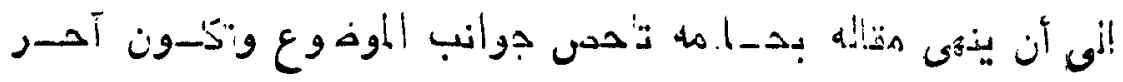

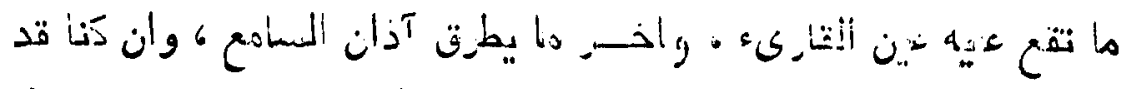

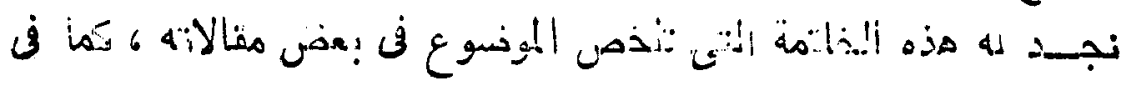

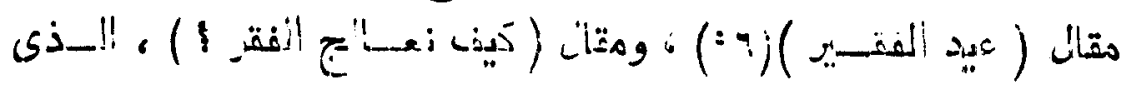

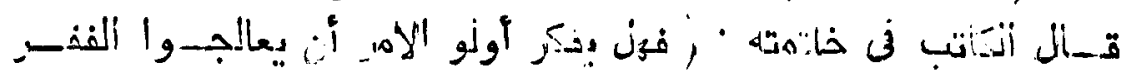

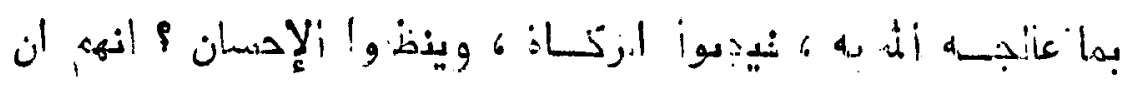

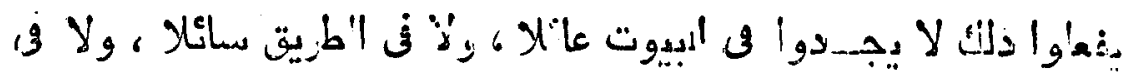

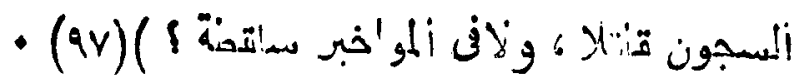

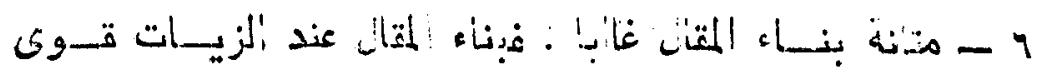

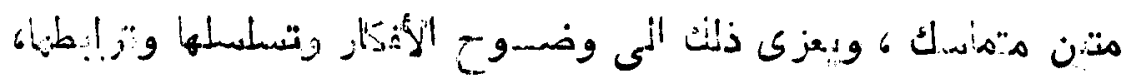

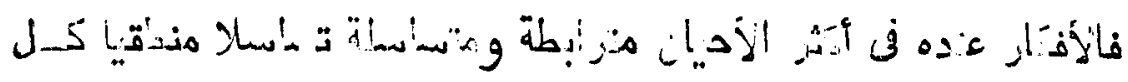

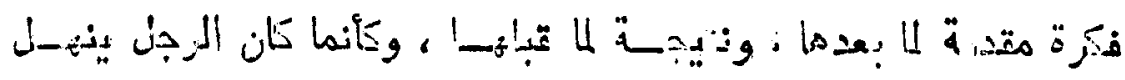

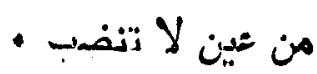

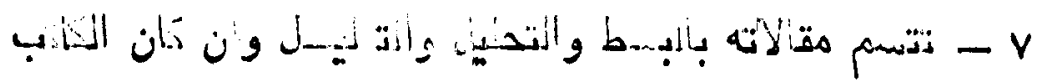

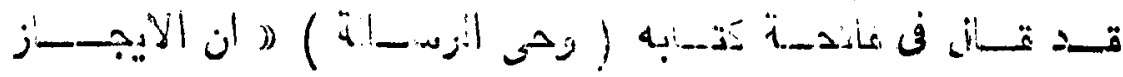

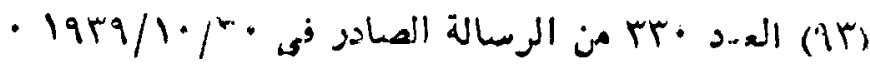

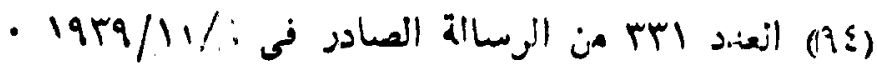

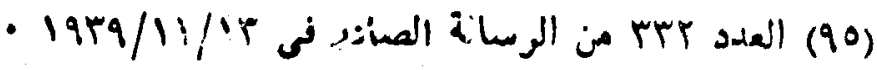

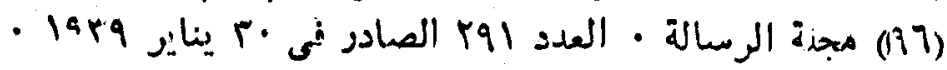

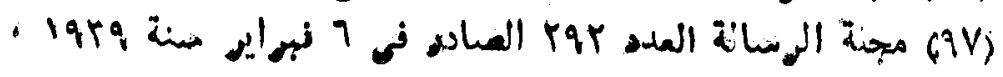




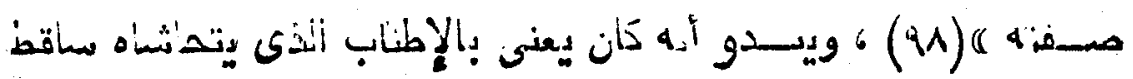

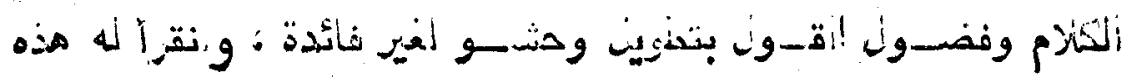

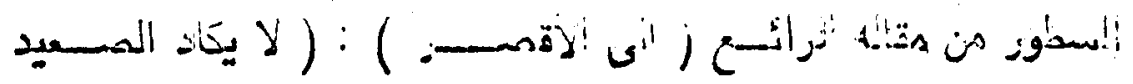

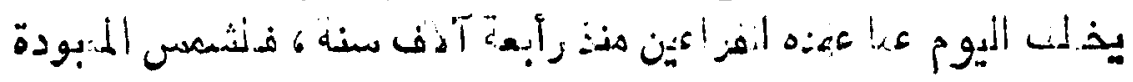

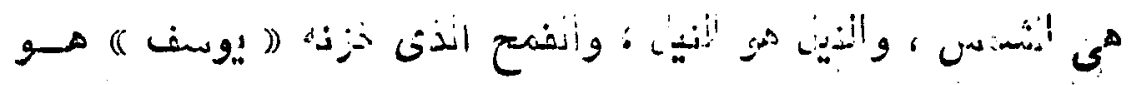

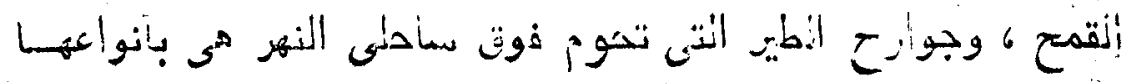

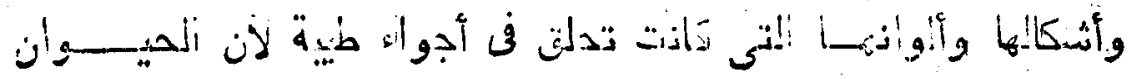

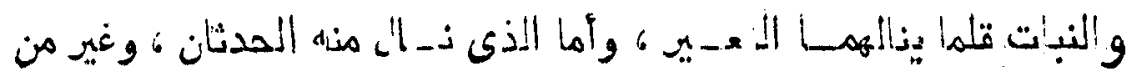

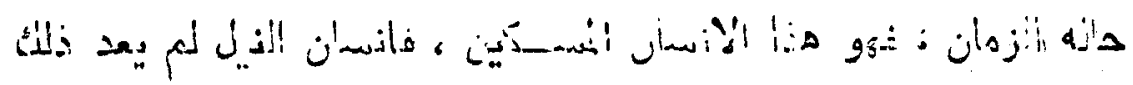

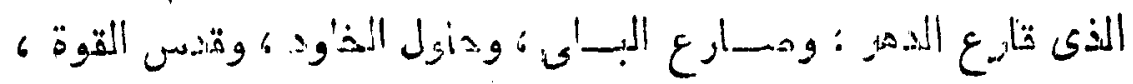

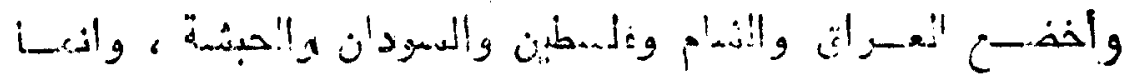

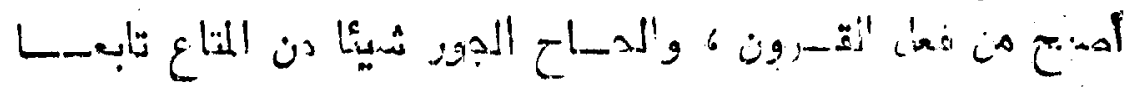

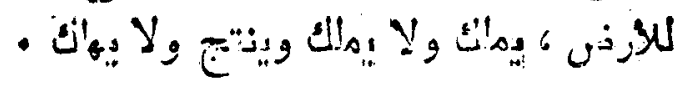

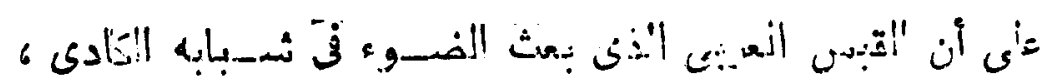

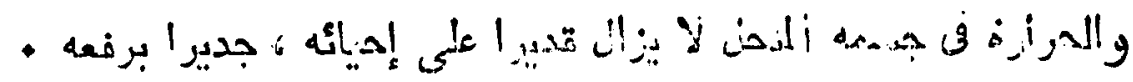

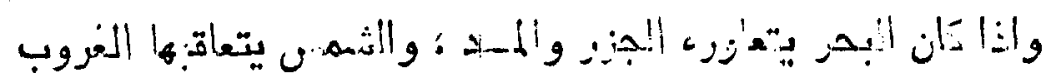

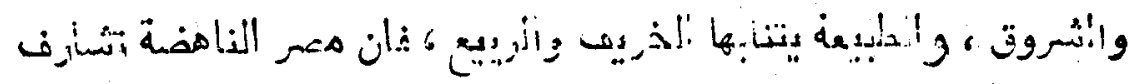

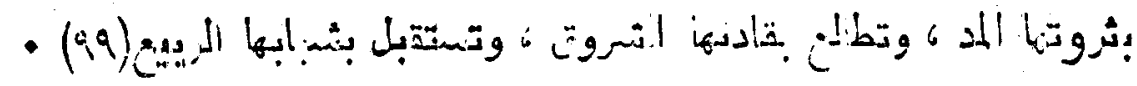

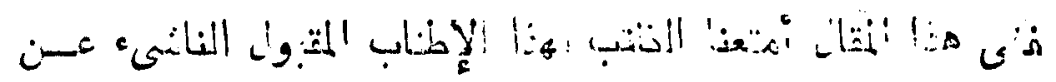

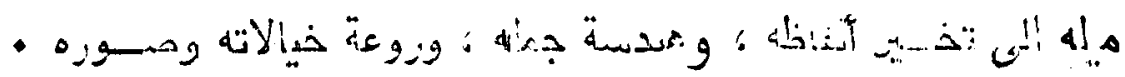

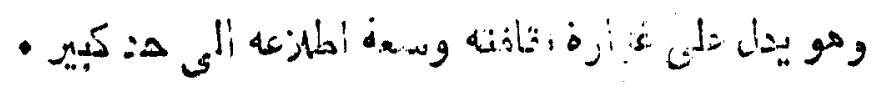

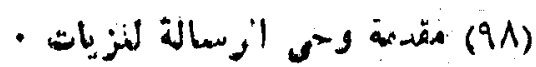

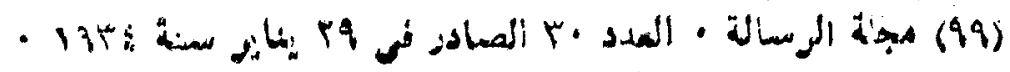




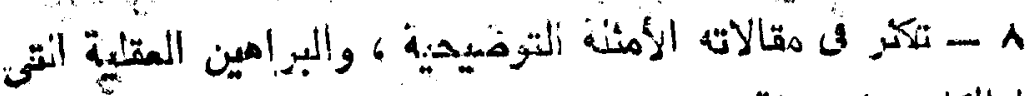

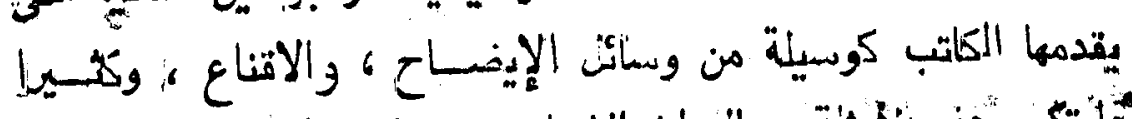

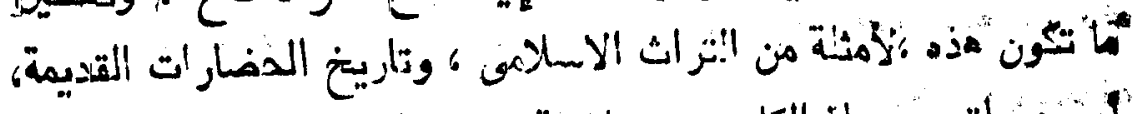

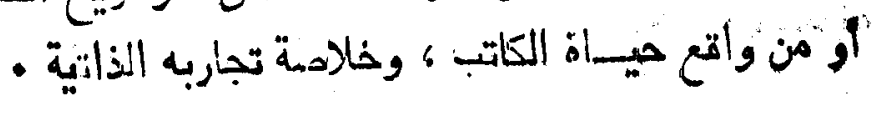

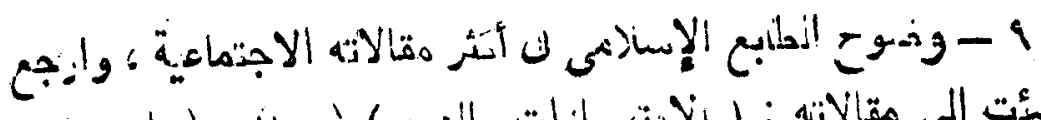

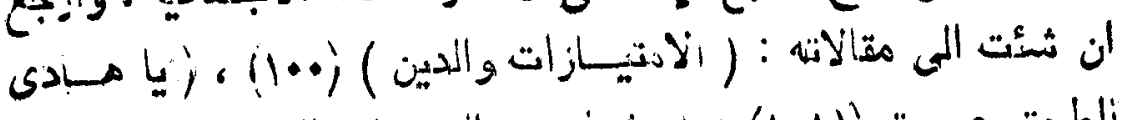

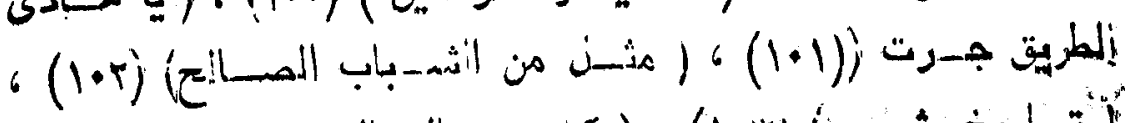

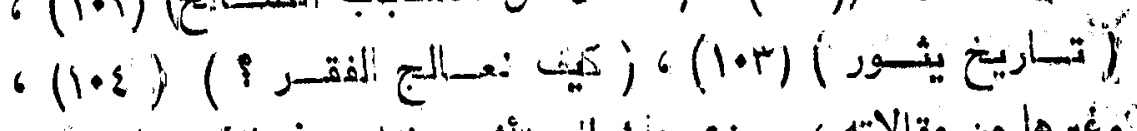

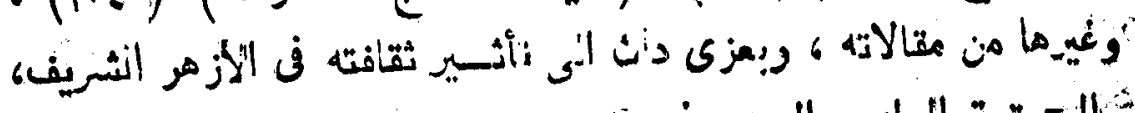

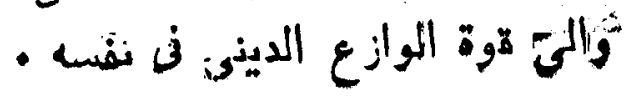

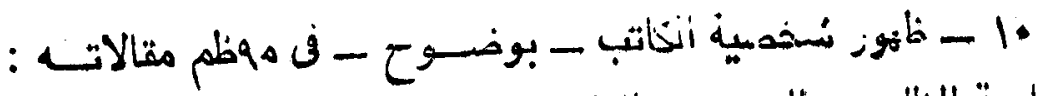

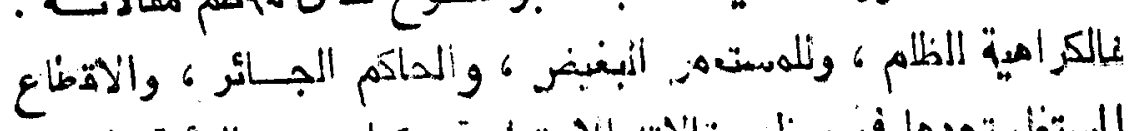

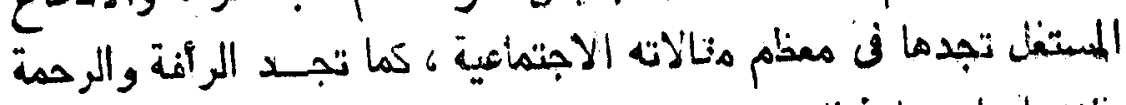

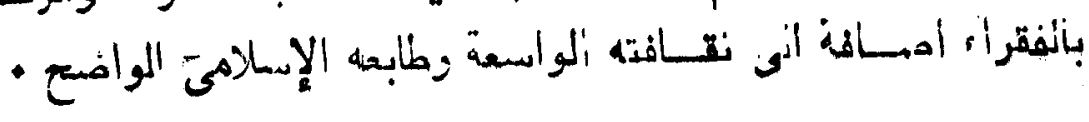

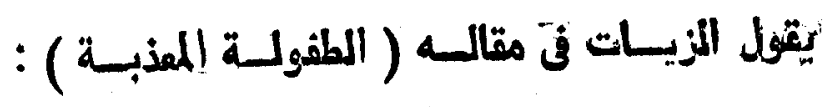

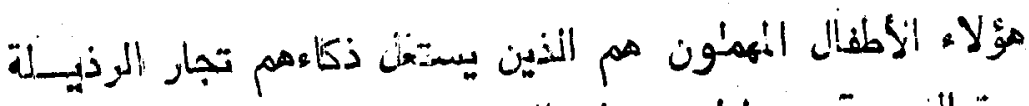

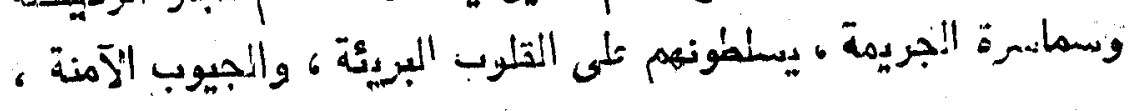

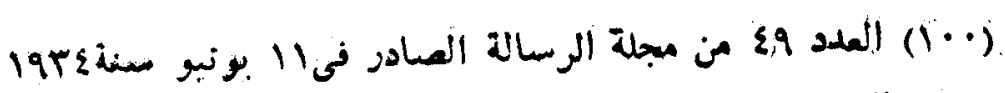

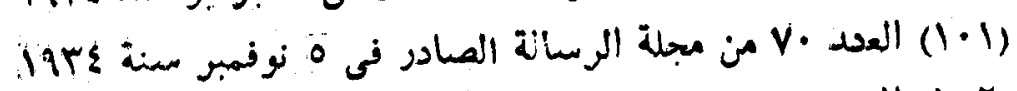

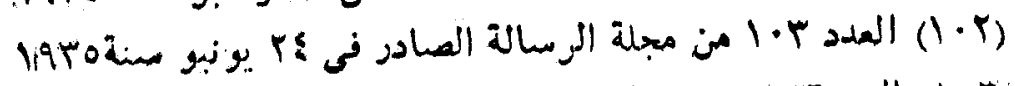

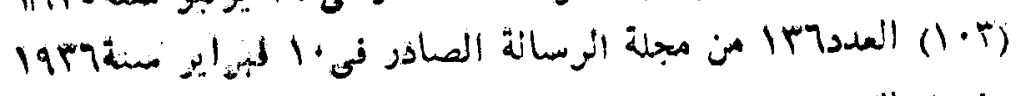

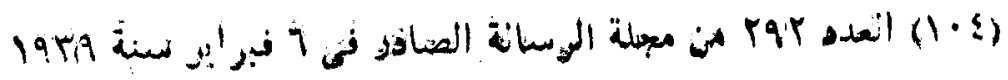
$(i t i p)$ 


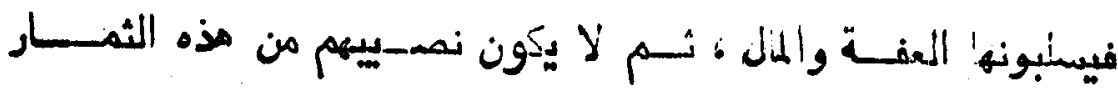

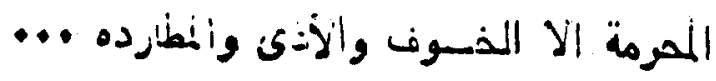

ان سادتنا المترفين ليأنفون أن تقع أعينهم على مذا انقبح ، وتدنوا

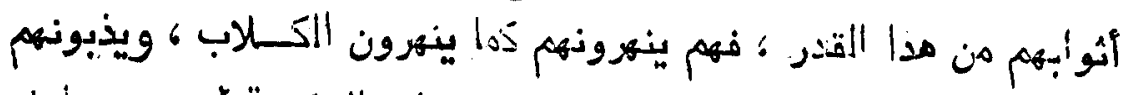

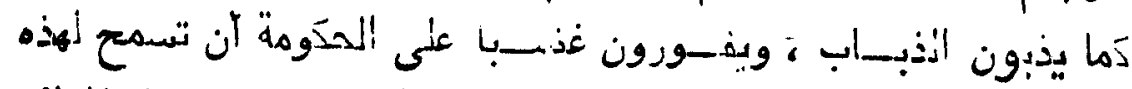

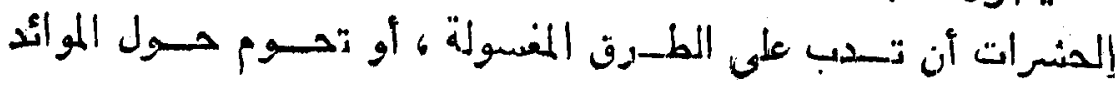

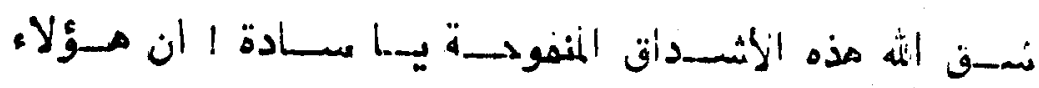

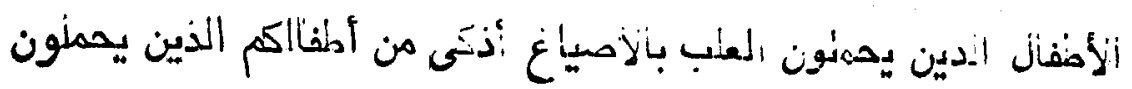

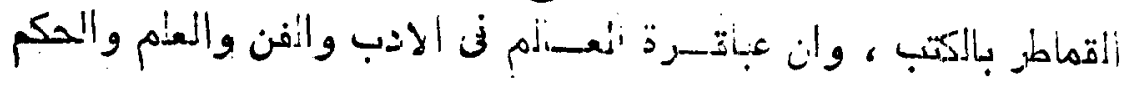

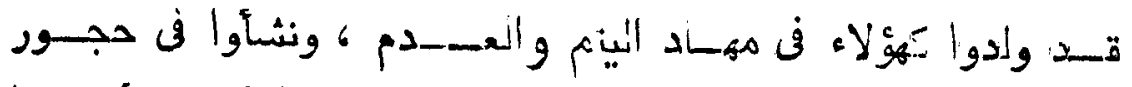

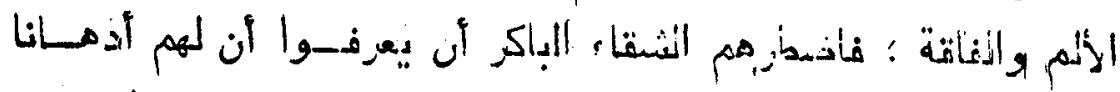

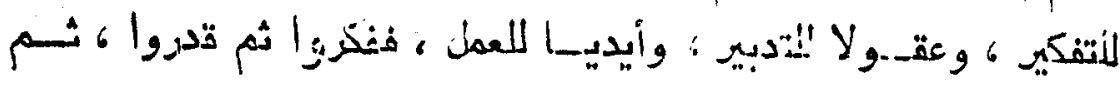

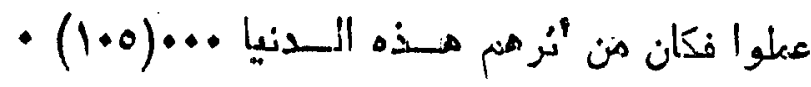

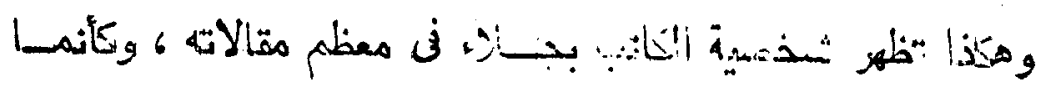

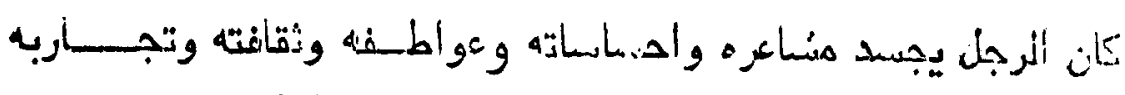

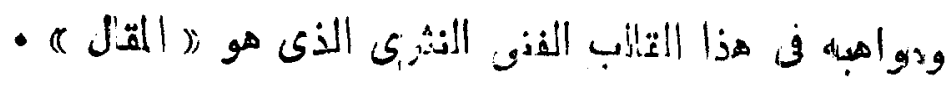

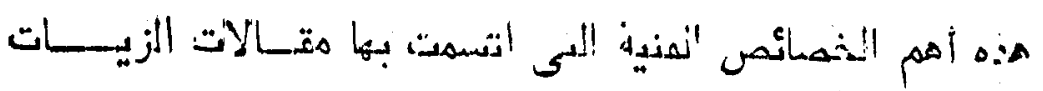

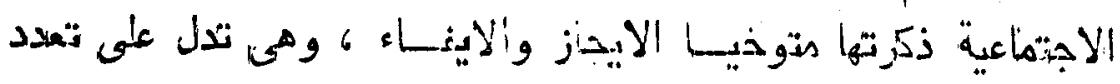

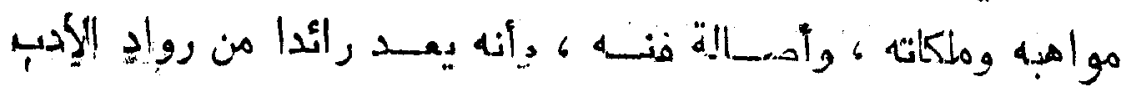
ألاجتماشق فى العدمر أنح-ديث

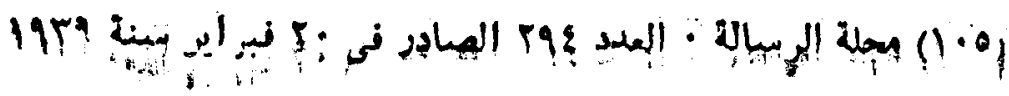




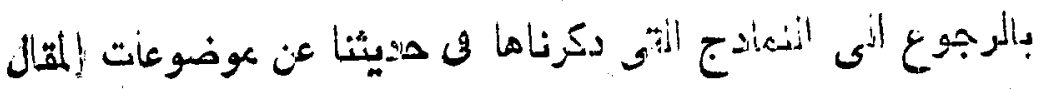

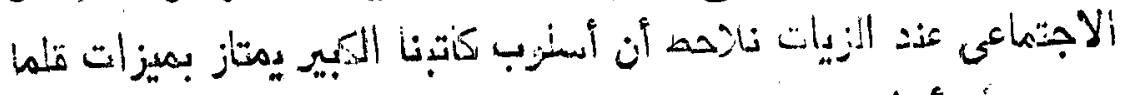

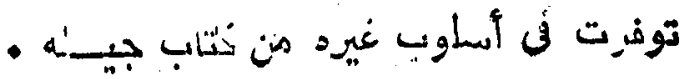

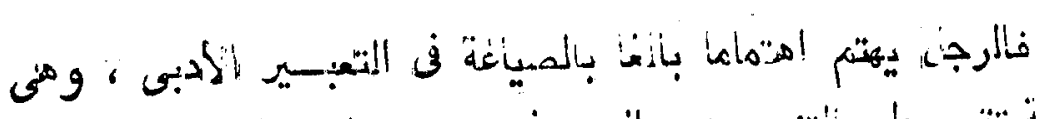

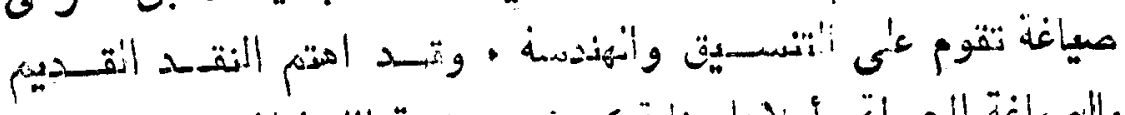

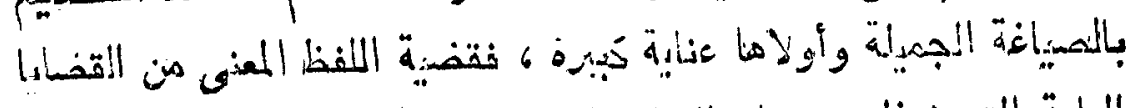

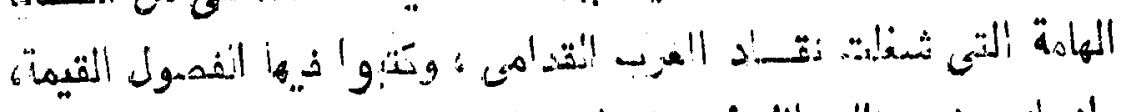

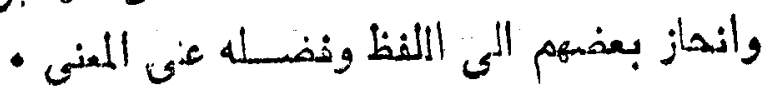

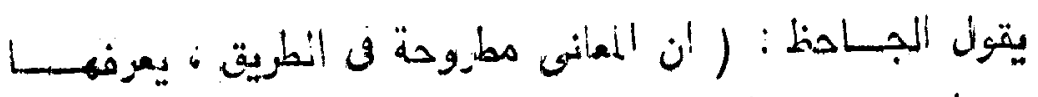

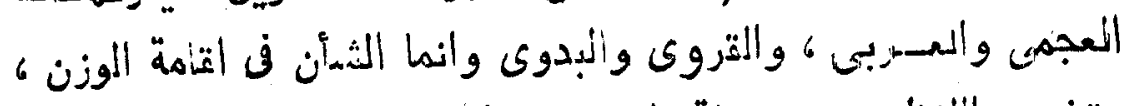

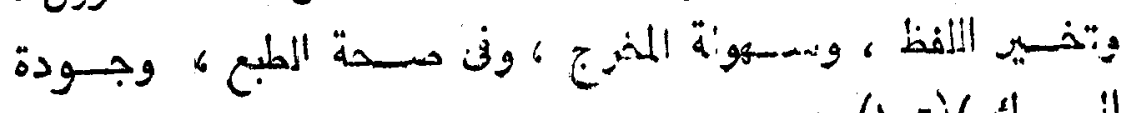
- $(1+7)($ )

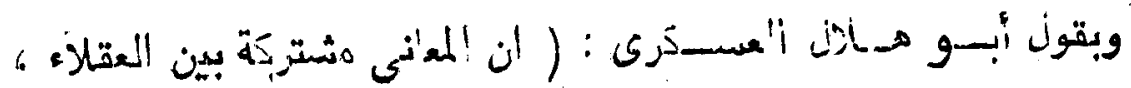

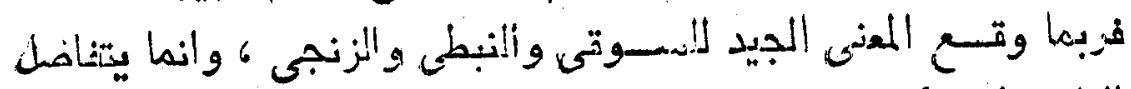

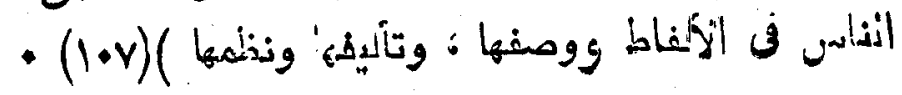

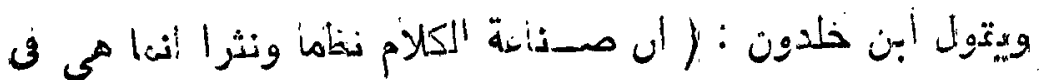

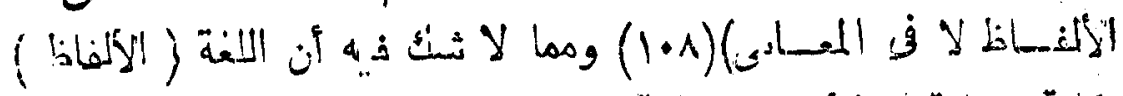

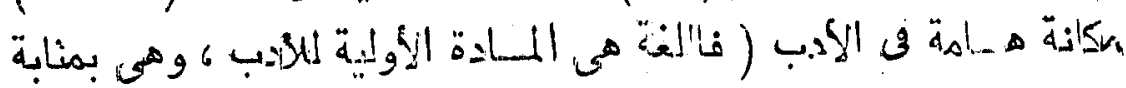

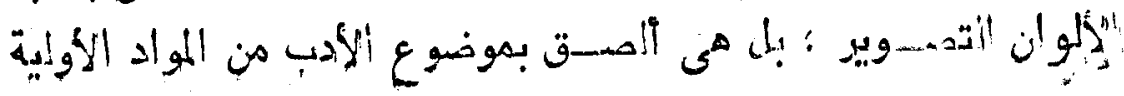

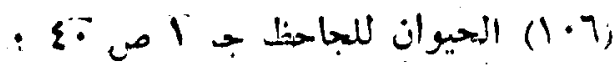

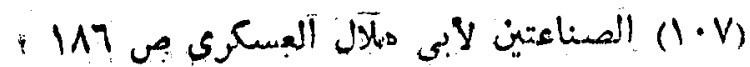

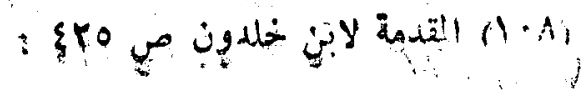




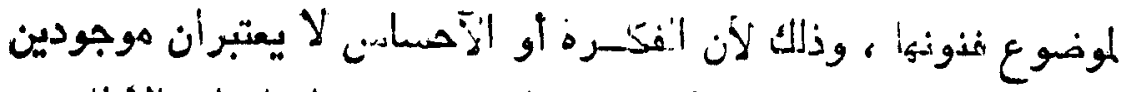

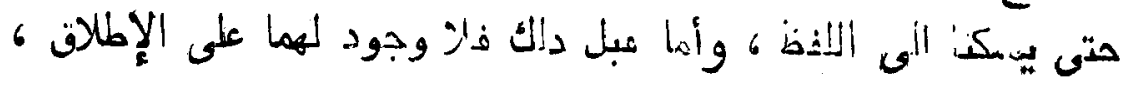

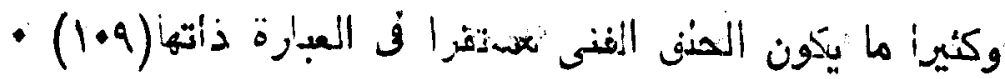

وتعتدد الصياغة عند الز إت على عذة هقوهات نم أهنها :

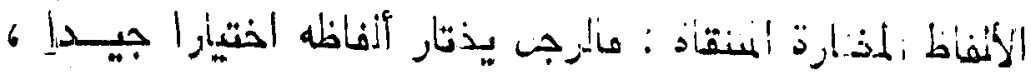

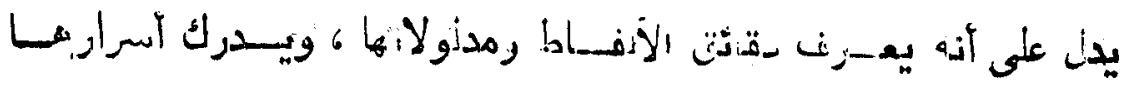

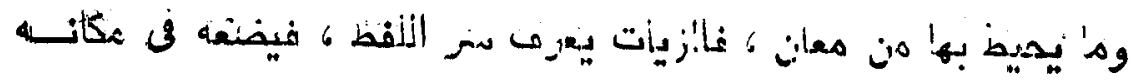

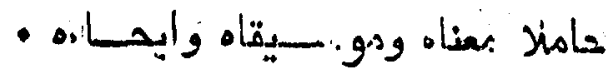

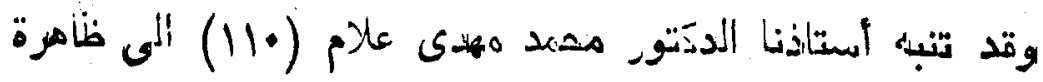

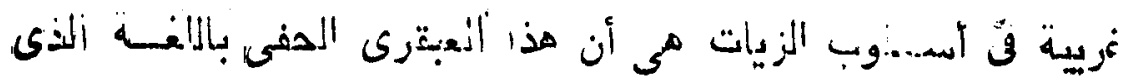

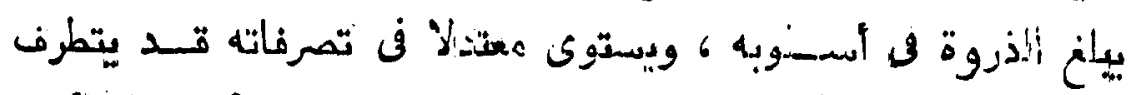

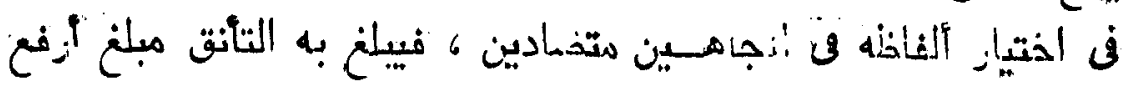

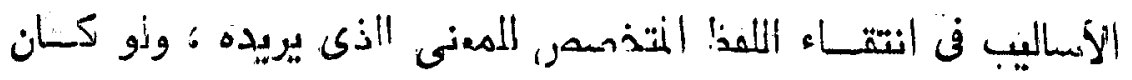

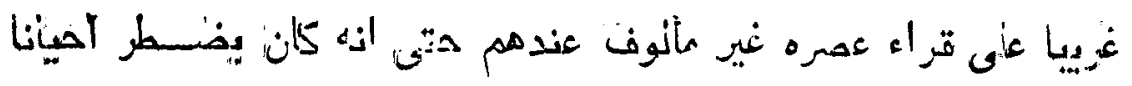

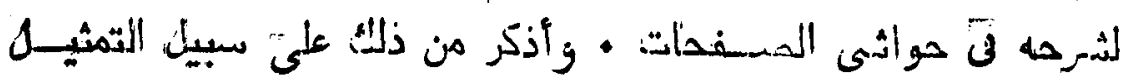

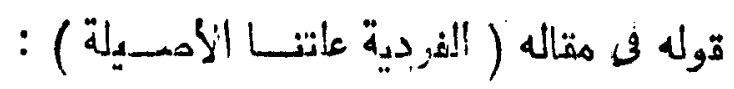

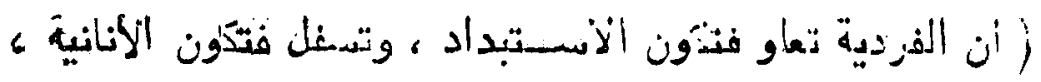

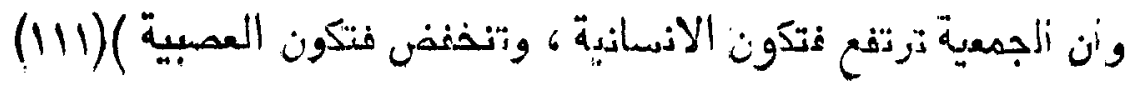

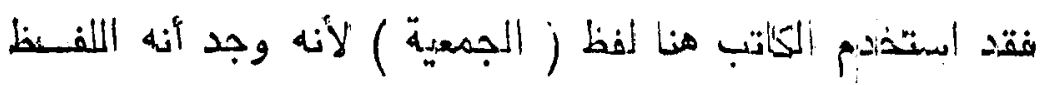

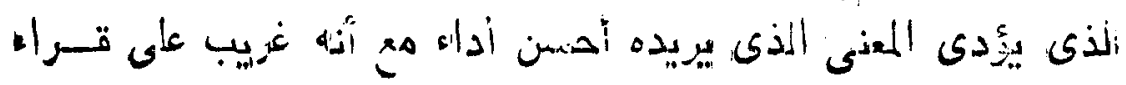

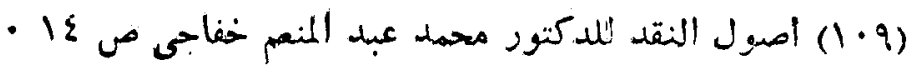

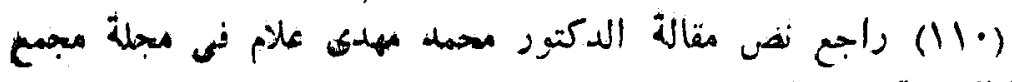

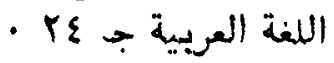

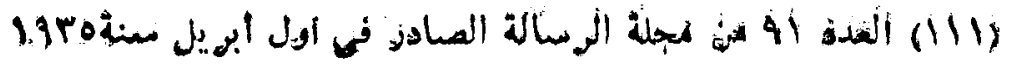




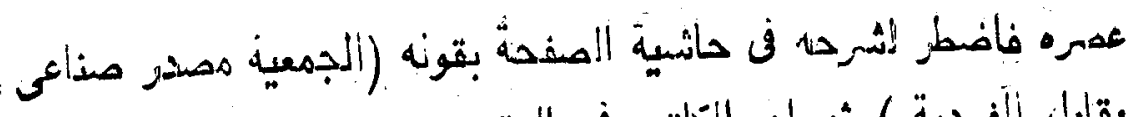

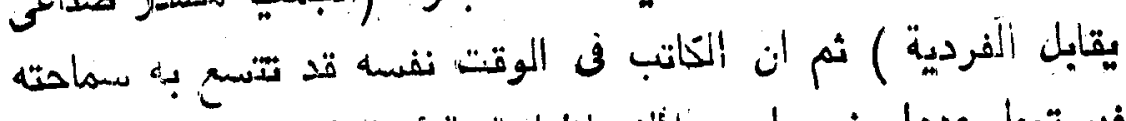

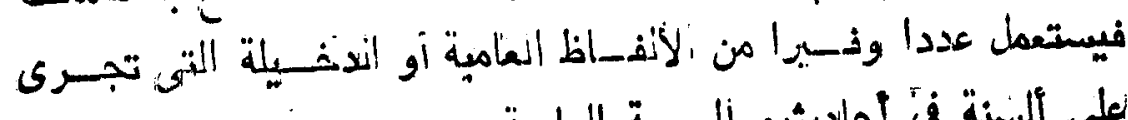

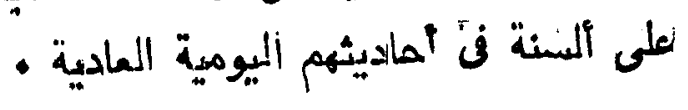

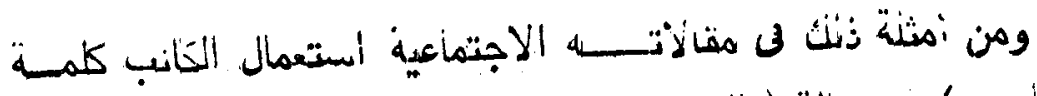

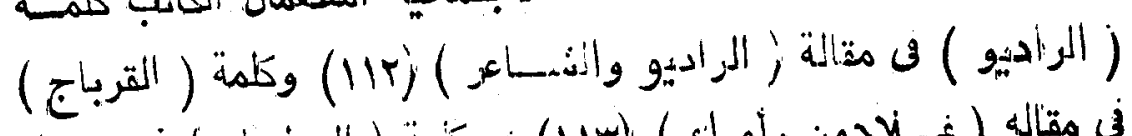

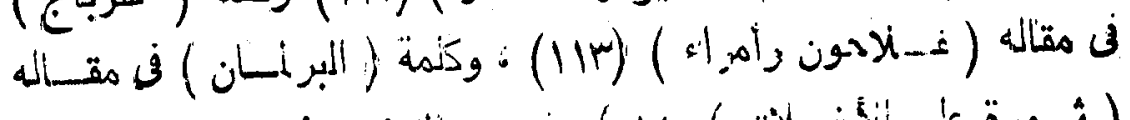

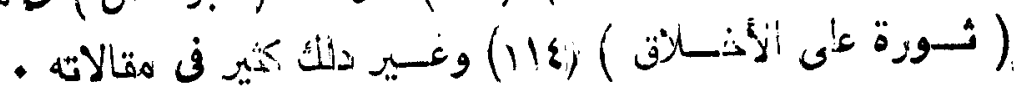

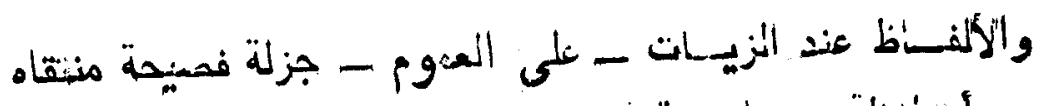

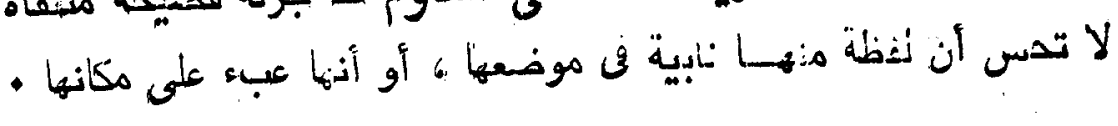

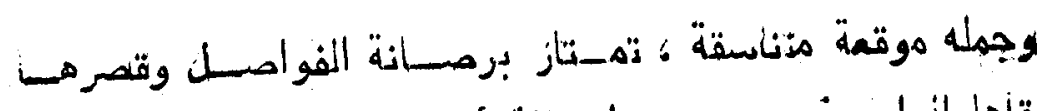

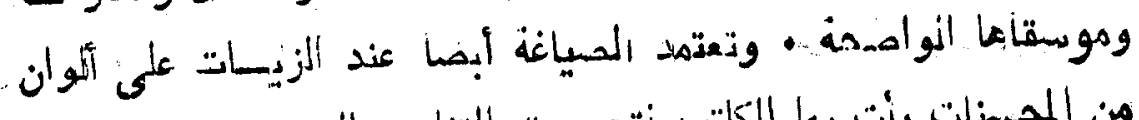

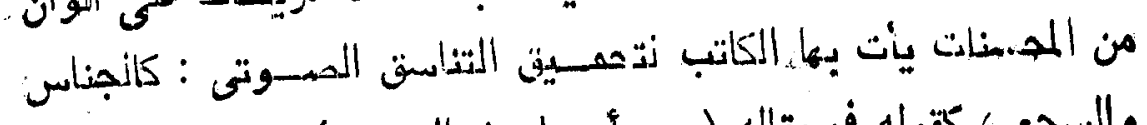

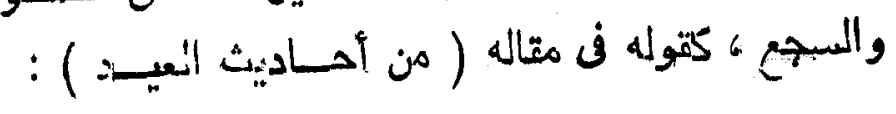

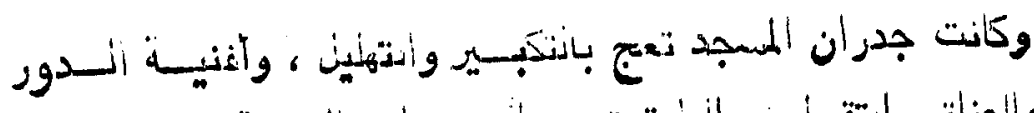

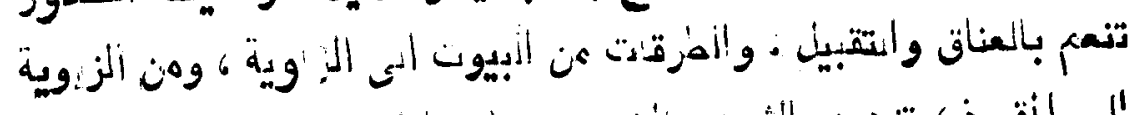

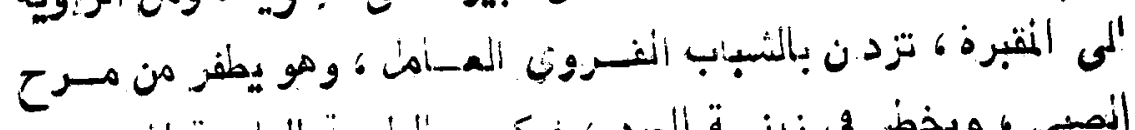

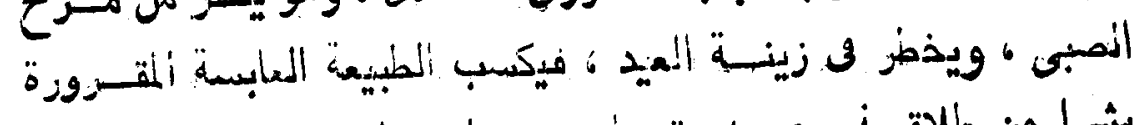

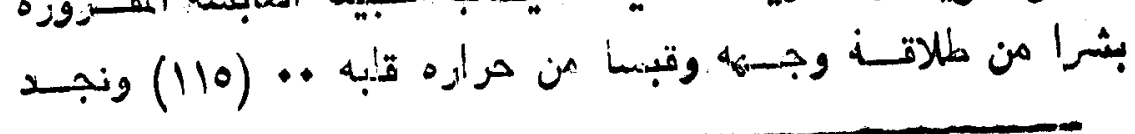

(IIT) سنة 19r8

19r9 194 (1) V

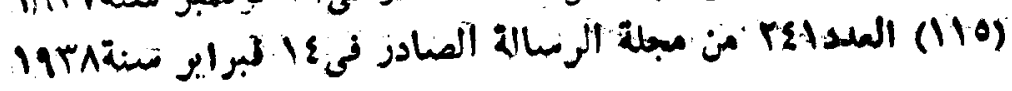




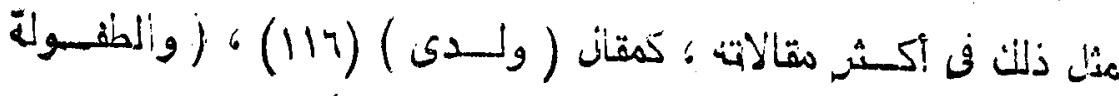

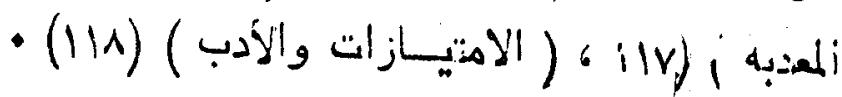

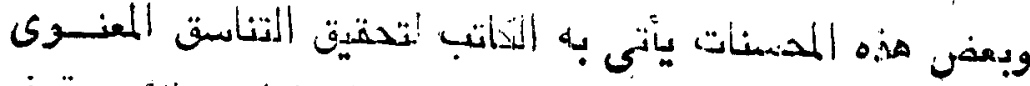

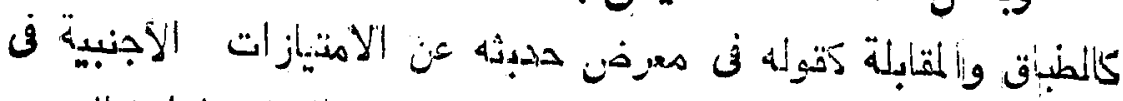

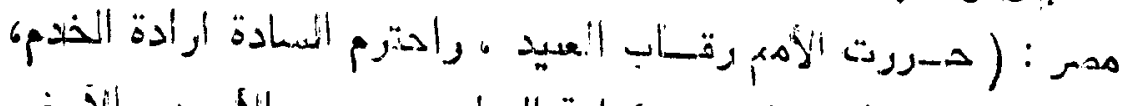

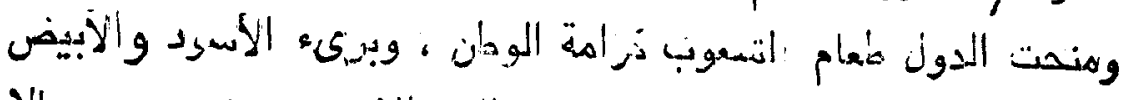

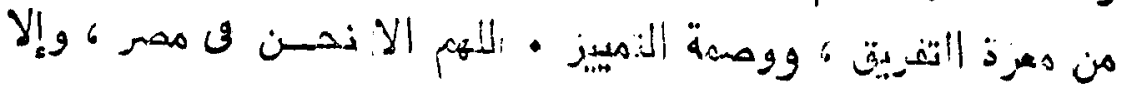

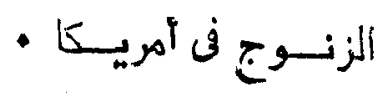

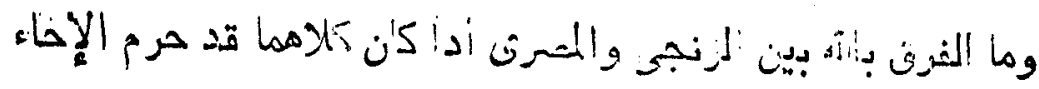

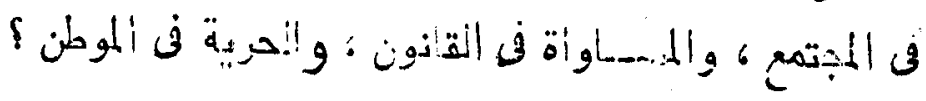

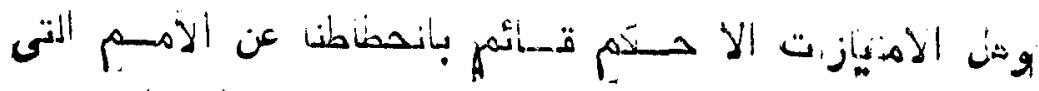

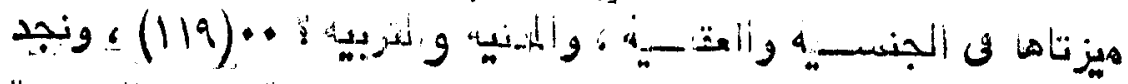

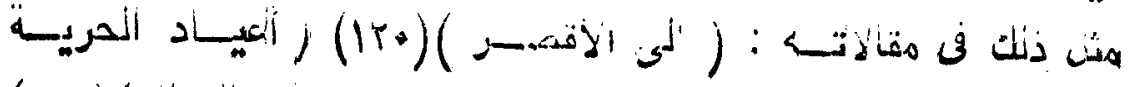

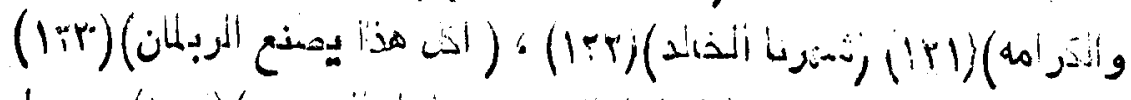

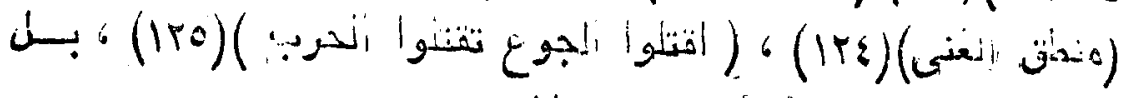

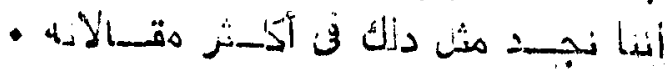

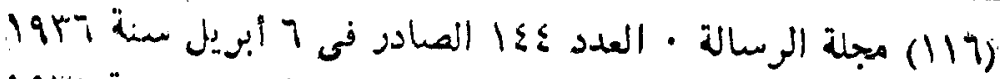
(IIV)

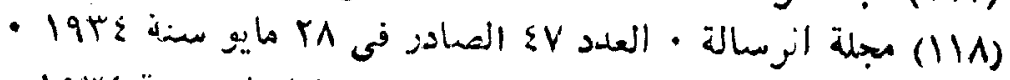

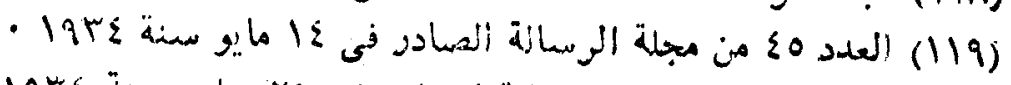

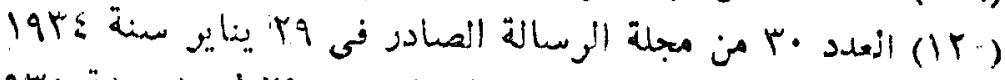
(IT)

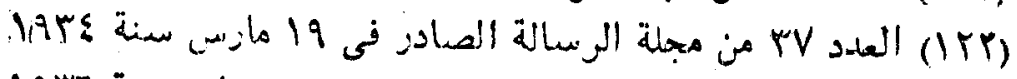

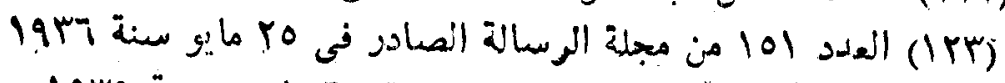

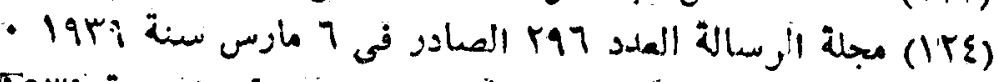

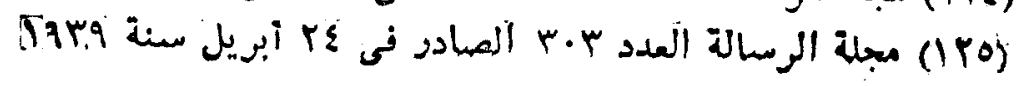




\section{MII}

واسلوب الزيات على جرجه عالية في البلانة ، ولعل من آهـسـم

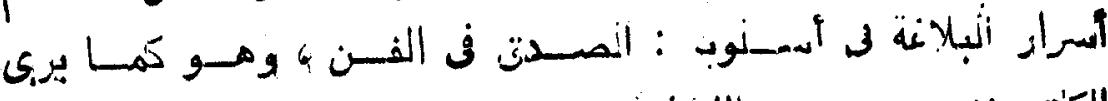

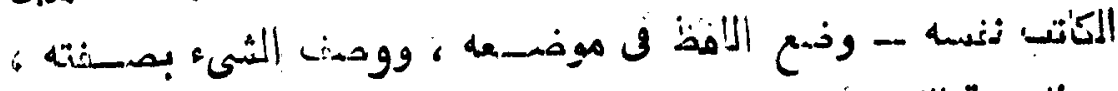

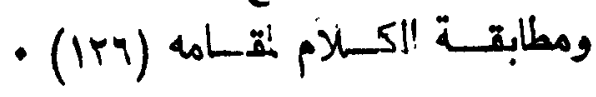

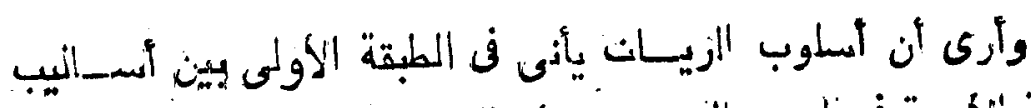

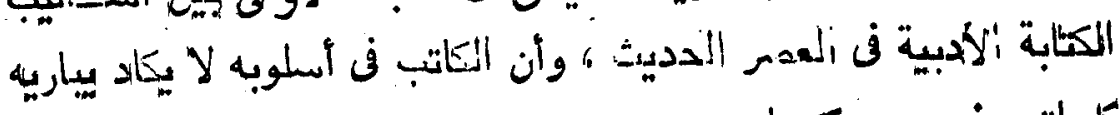

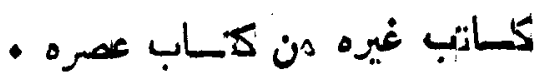

\section{آراء النقـــاد في أسـلوبه :}

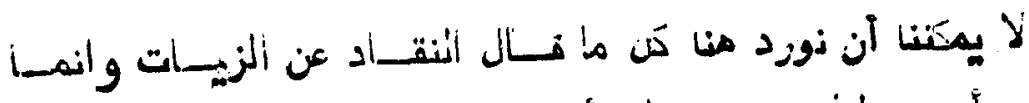

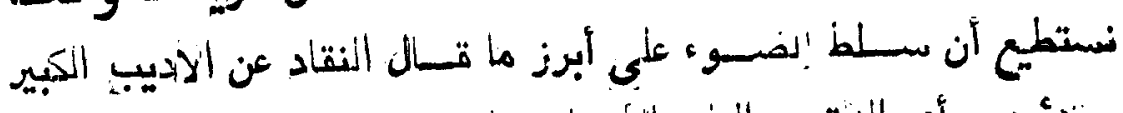

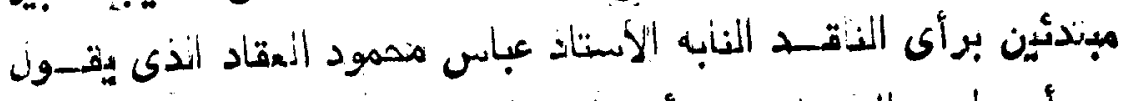

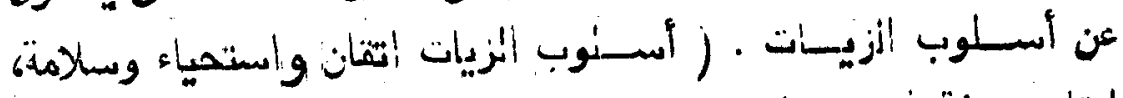

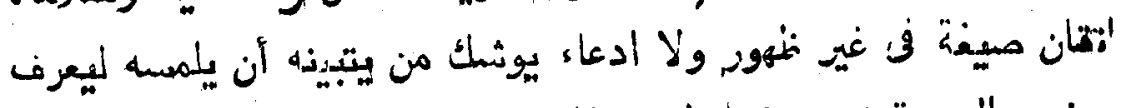

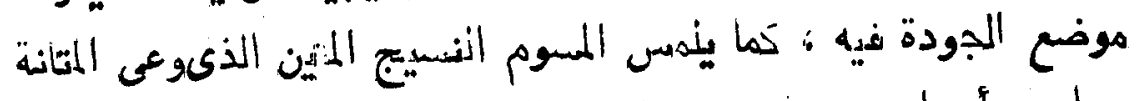

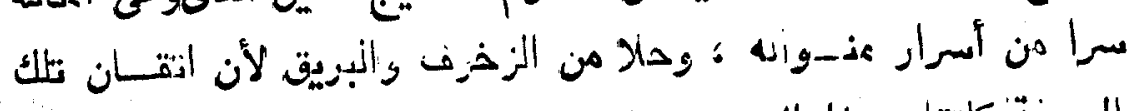

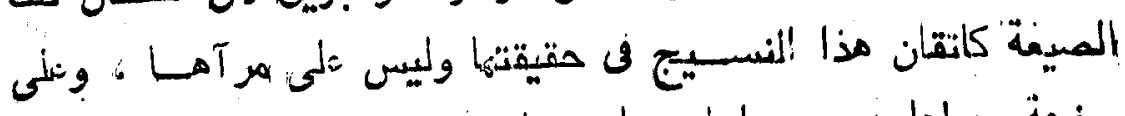

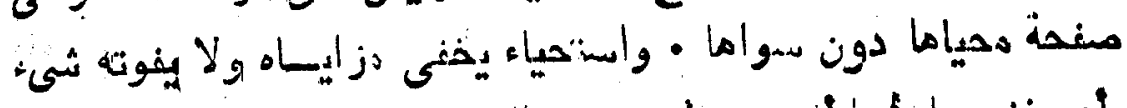

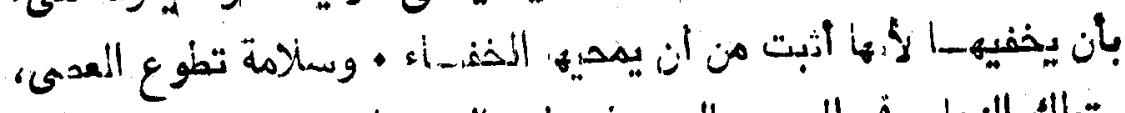

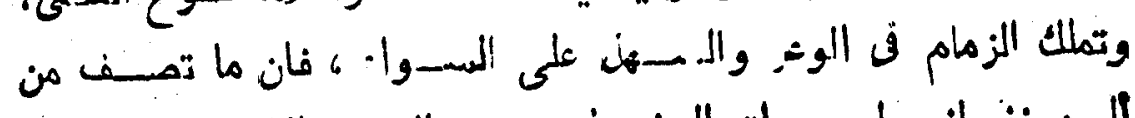

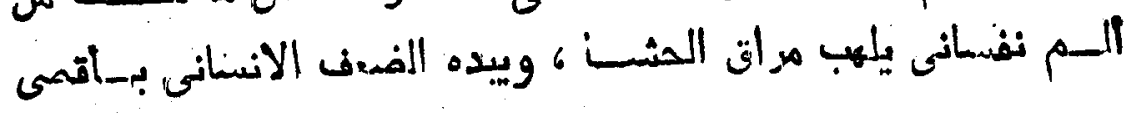

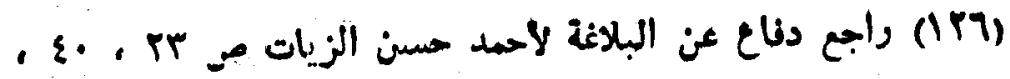




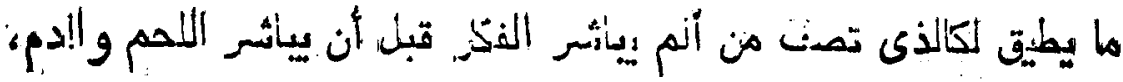

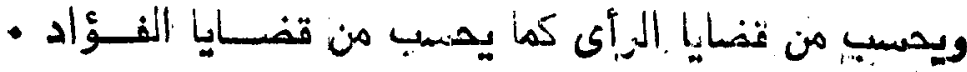

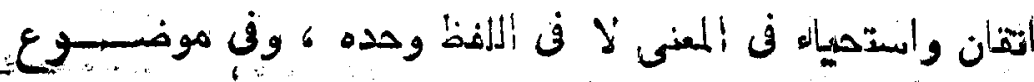

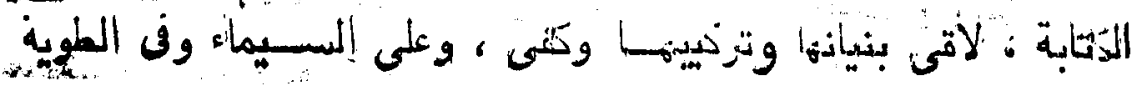
• سمواء (ITV)

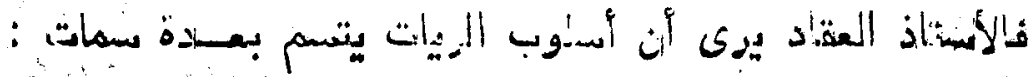

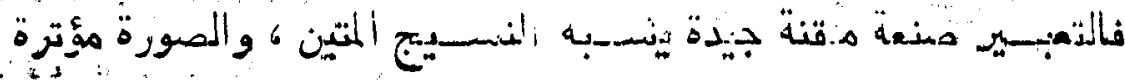

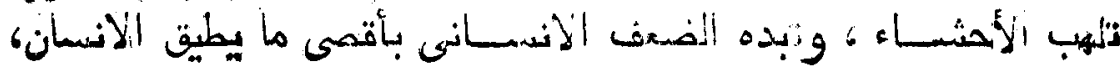

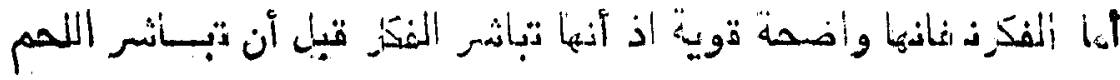

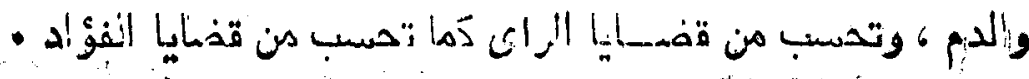
وعن. أسلوب الزيـات يتول أللاتتور بثر فـسارس :

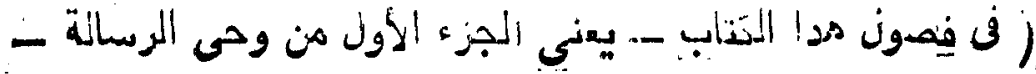

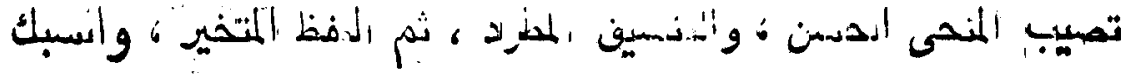

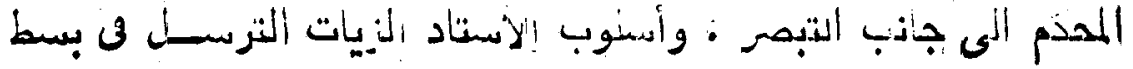

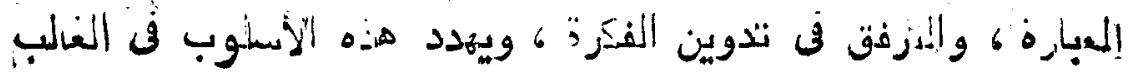

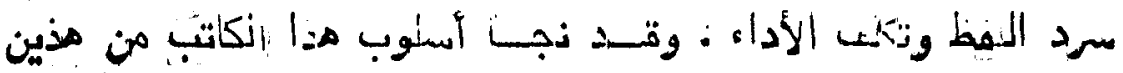

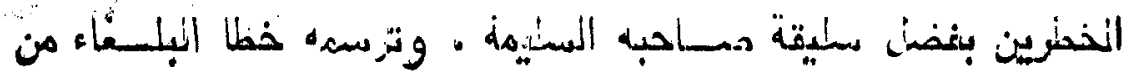

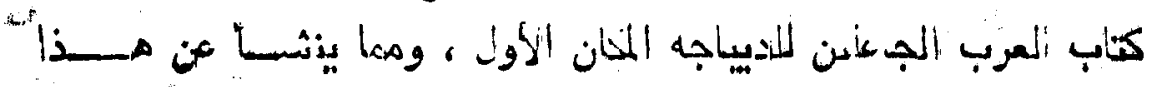

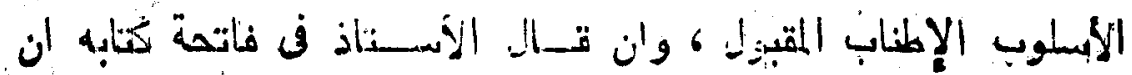

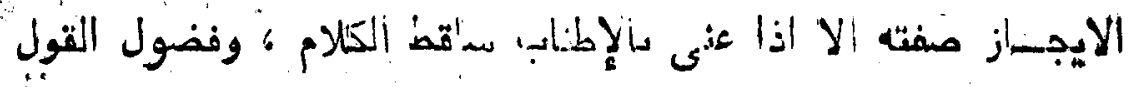

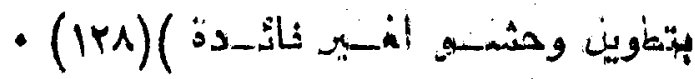

(IVV)

- 


\section{wir}

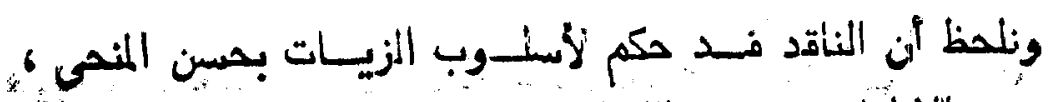

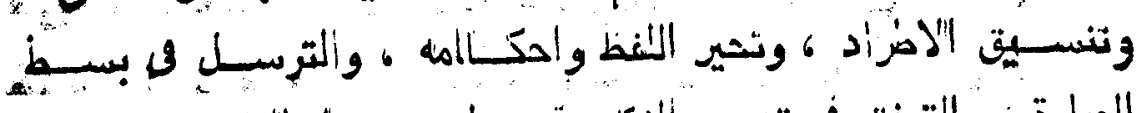

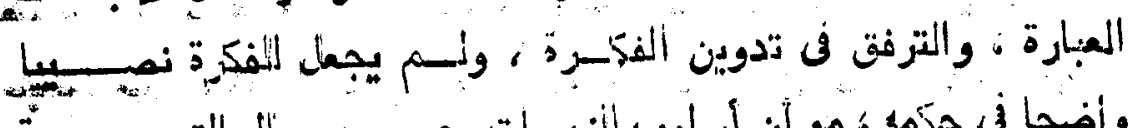

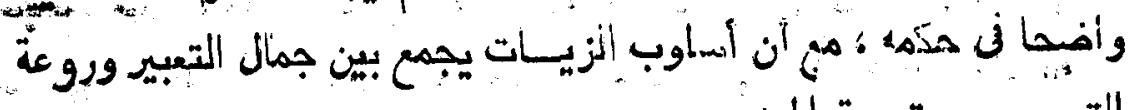

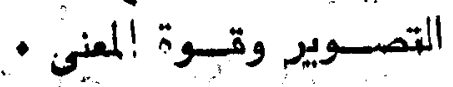

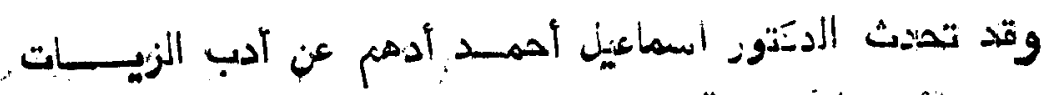

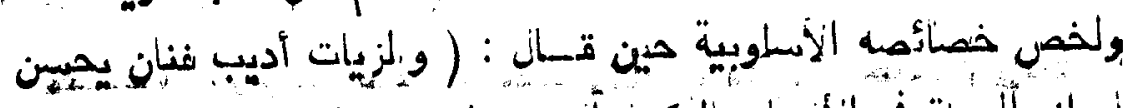

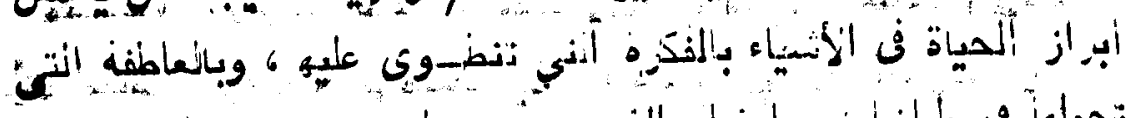

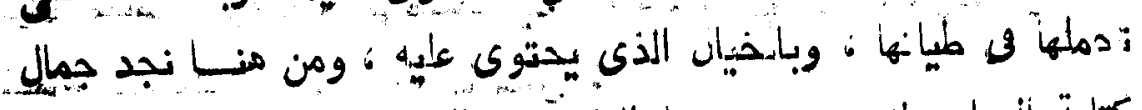

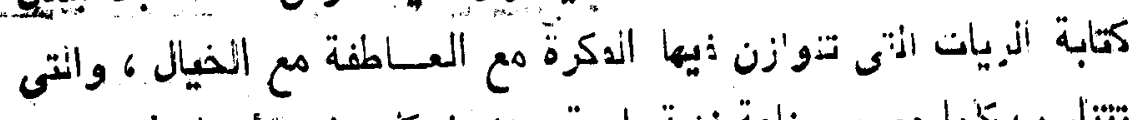

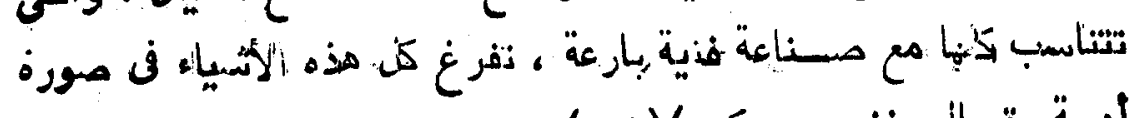

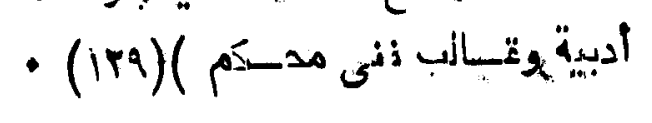

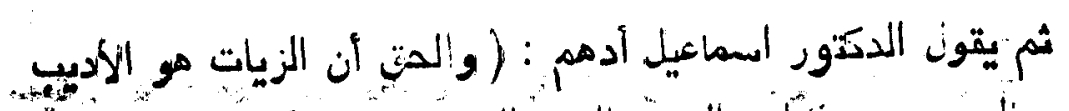

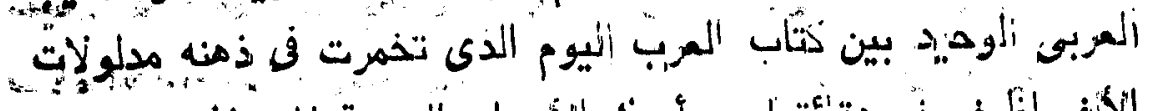

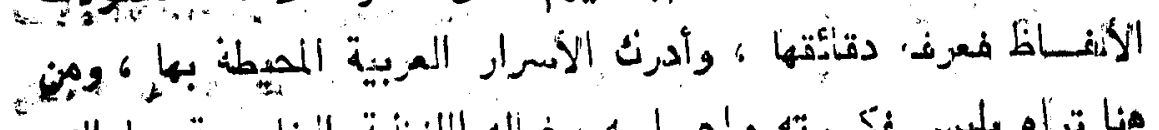

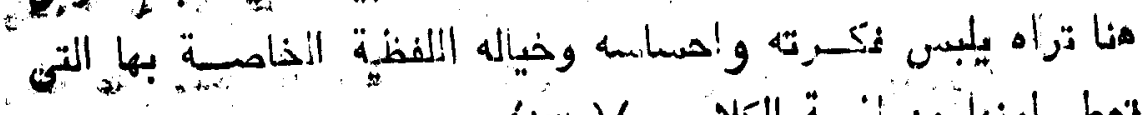

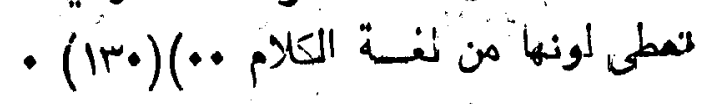

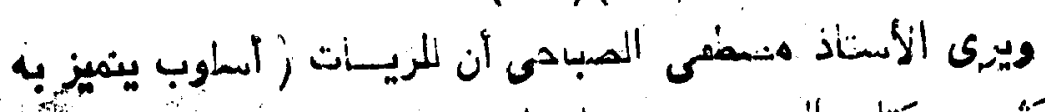

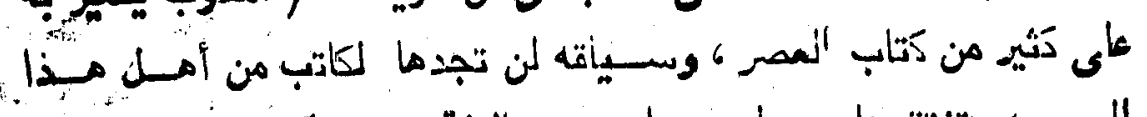

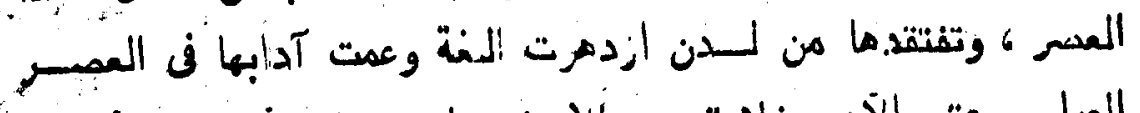

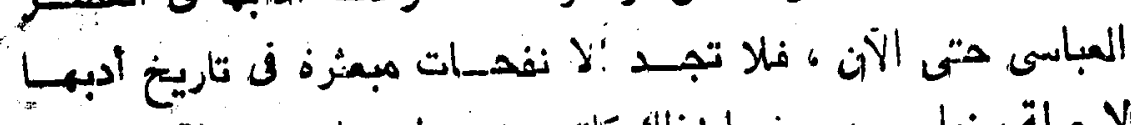

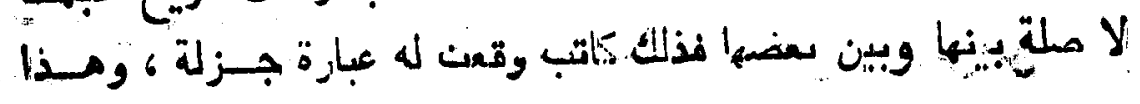

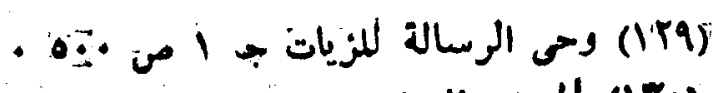




\section{ris}

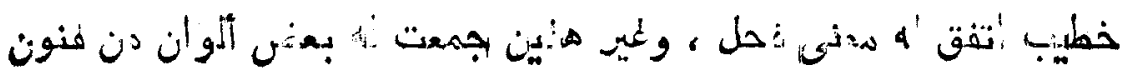

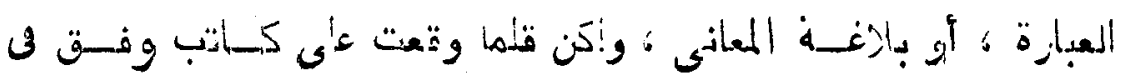

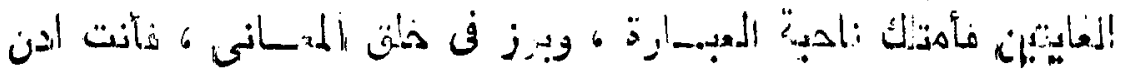

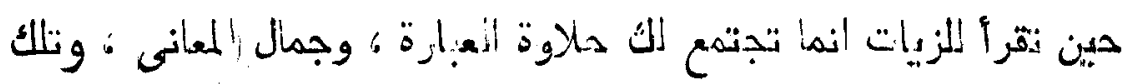

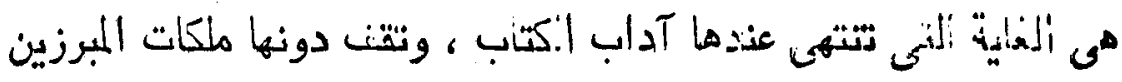

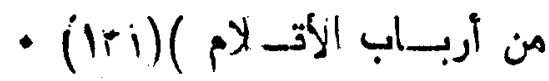

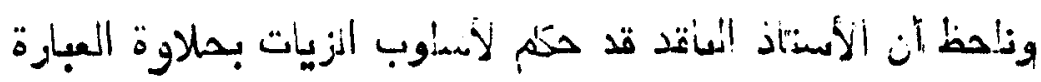

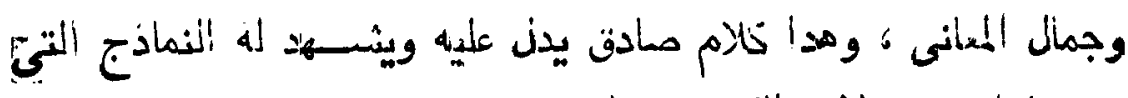

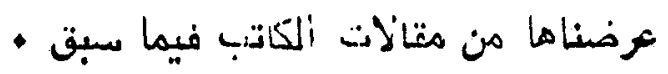

وعن أسطاب انزيات يتول النذكور زذى المهندس في افتتحية مهلة

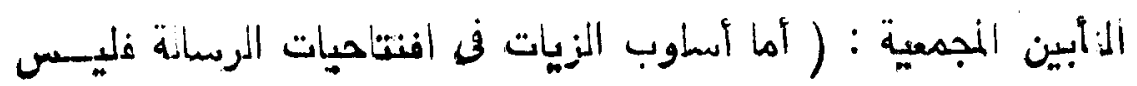

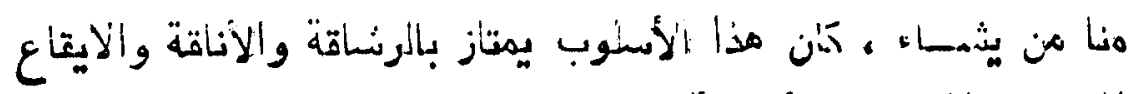

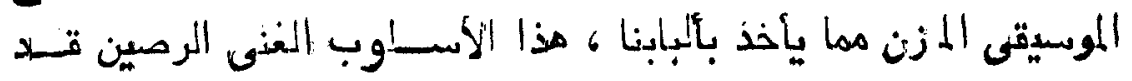

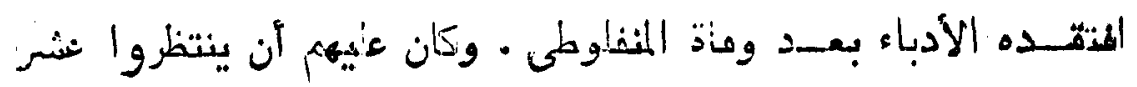

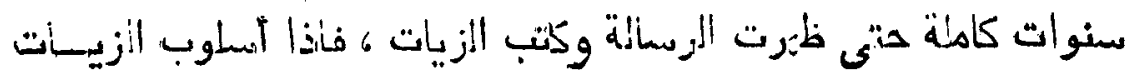

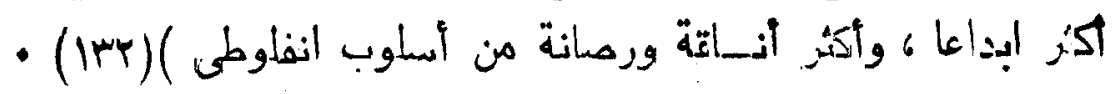

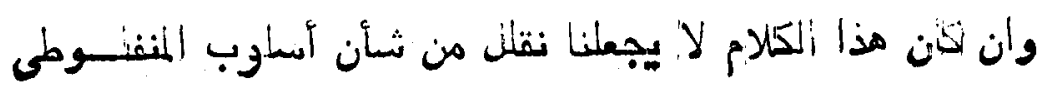

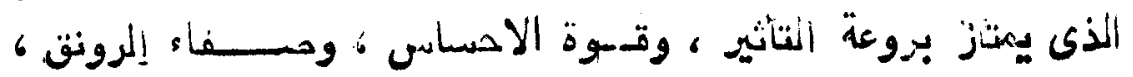

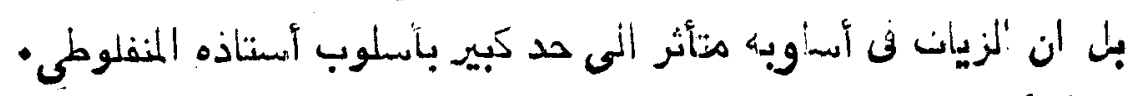

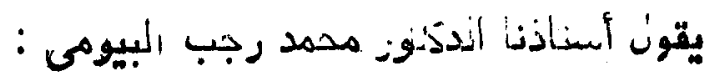

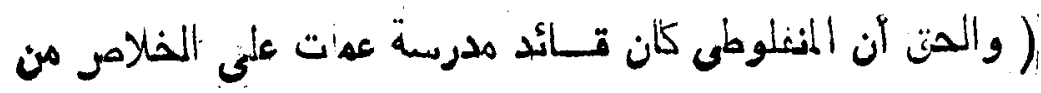

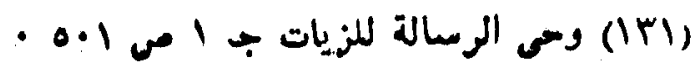

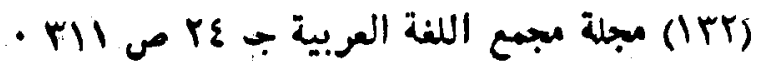




\section{mo}

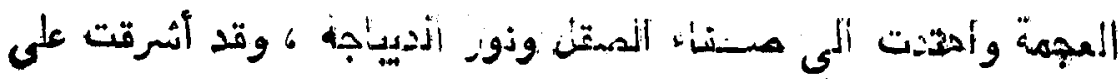

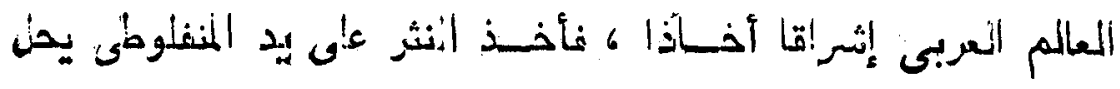

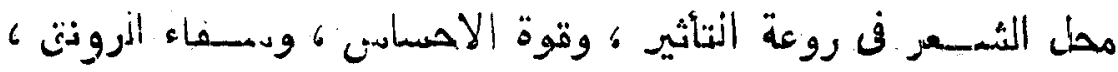

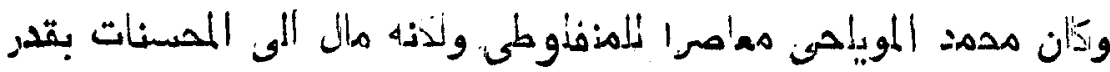

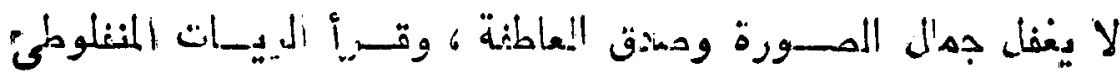

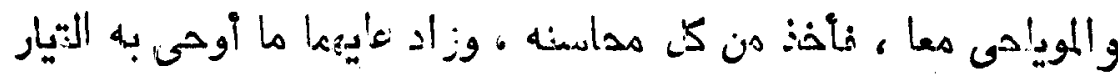

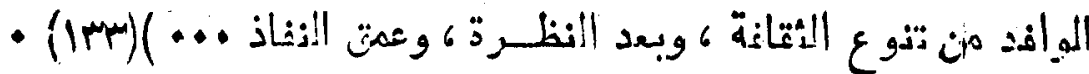
ويقول الذاقد النبير الأستاذ سـيد قطب زدمها الته : ( والأستاذ

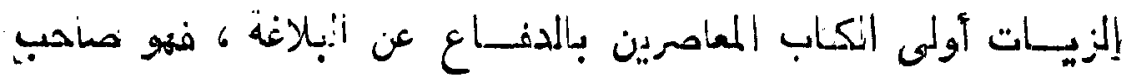

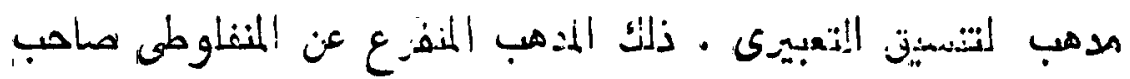

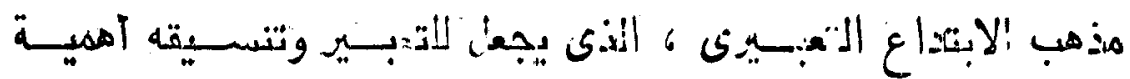

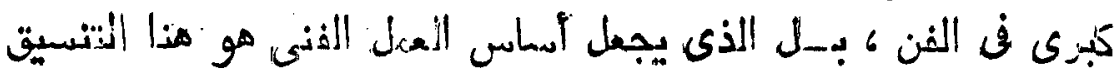

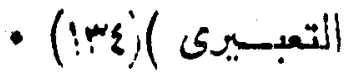

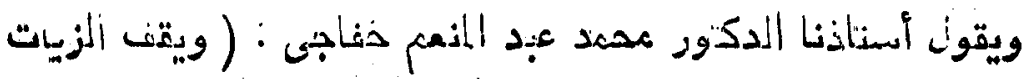

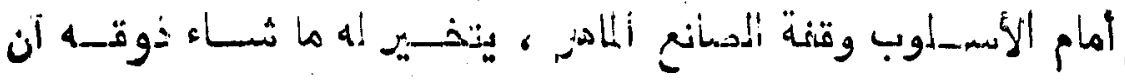

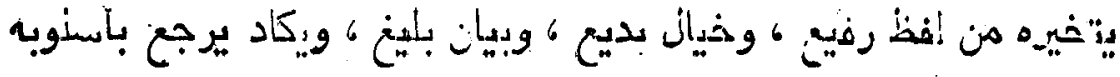

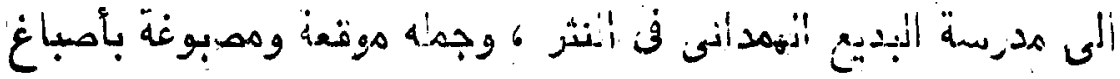

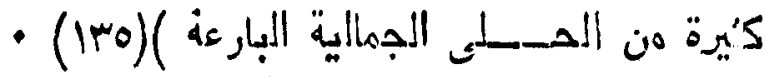
ويزفعه أسيتاذنا الدكوز ممدد رجب أبيومى مكانا عا!يا اذ يقدل:

(الحس (ITr) أحسد حسن الزيات بين البلاغة والنقد الأدبى للدكتوز محمد

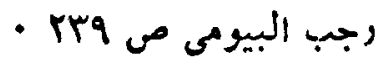

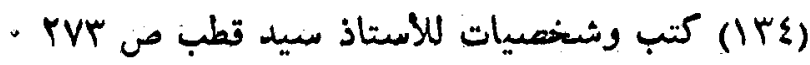

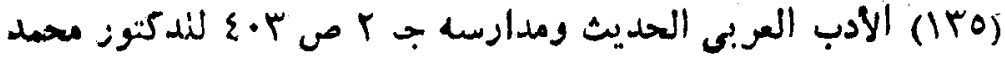

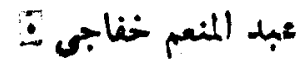




\section{mity}

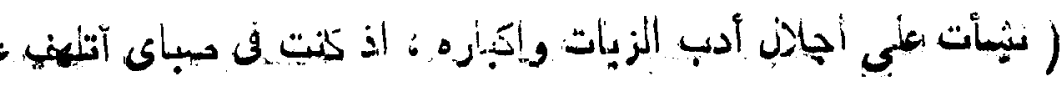

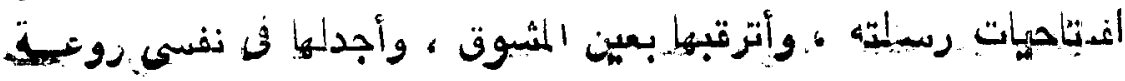

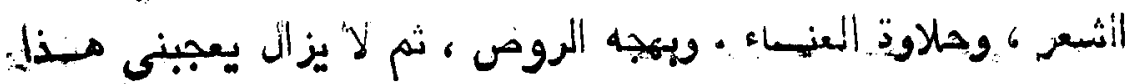

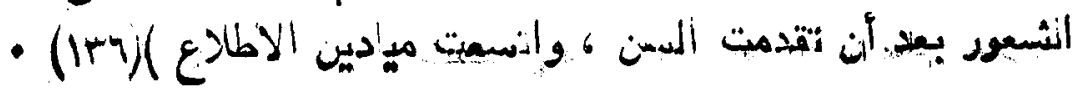

هذه أبرز آناء أسطاطين النقــد المربق فن أسلوب الزيات ، واني.

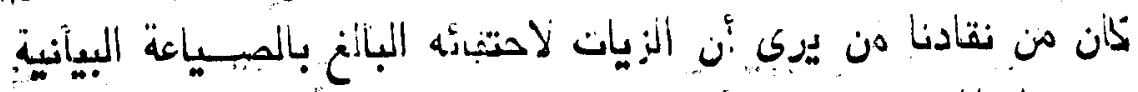

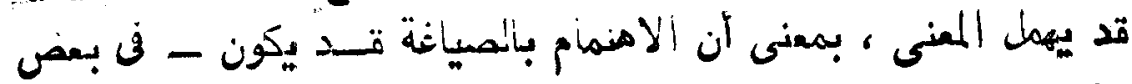

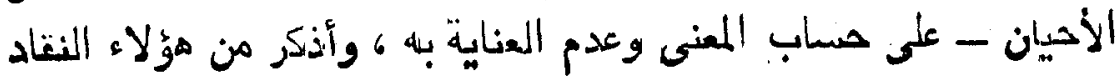

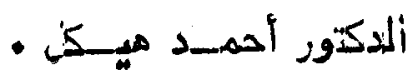

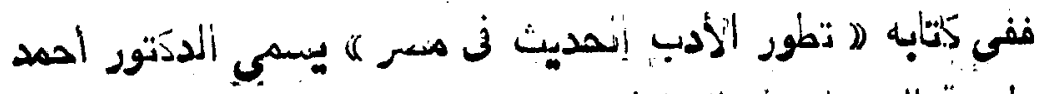

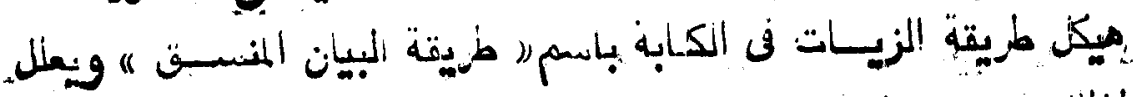

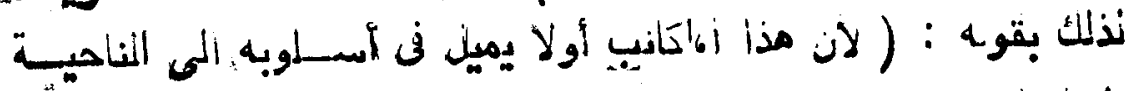

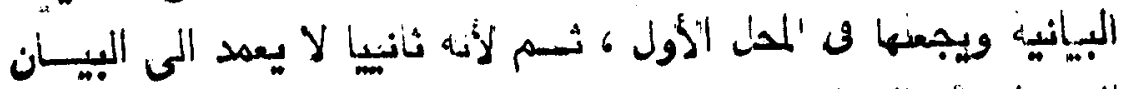

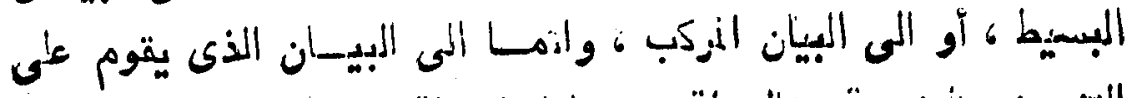

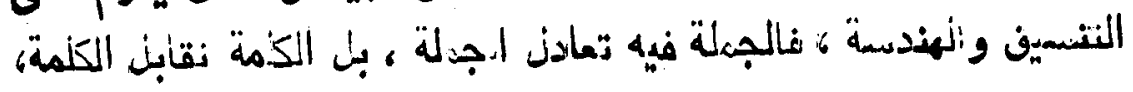

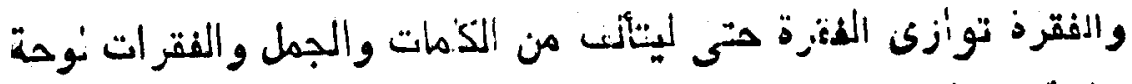

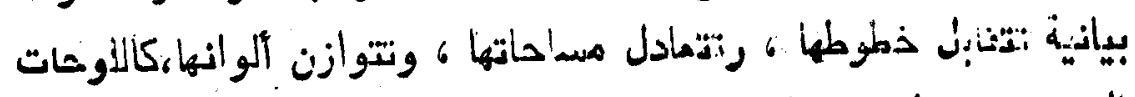

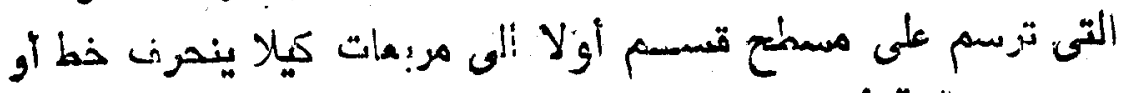

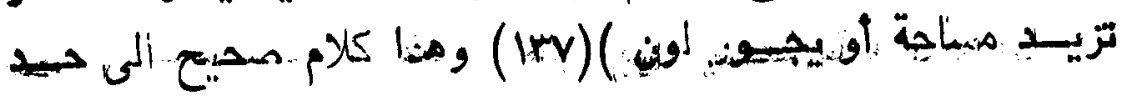

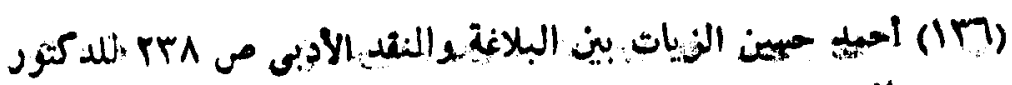

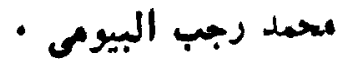

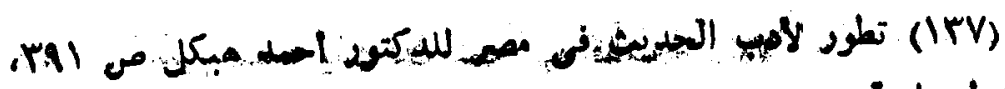




\section{riv}

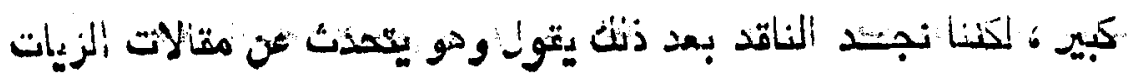

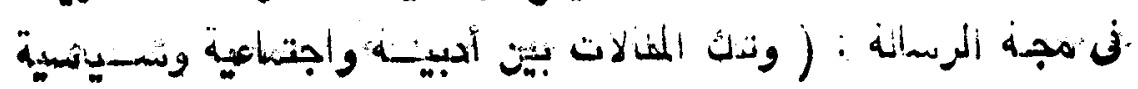

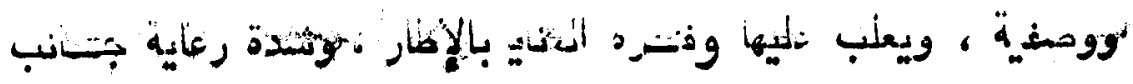

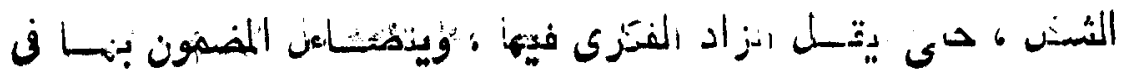

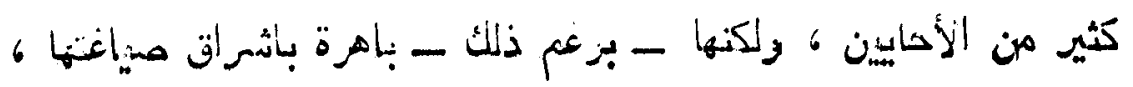

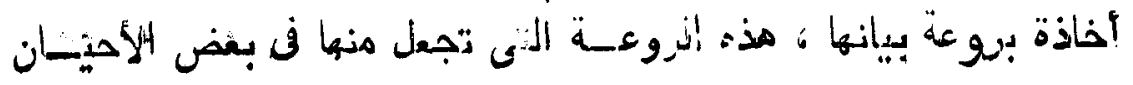

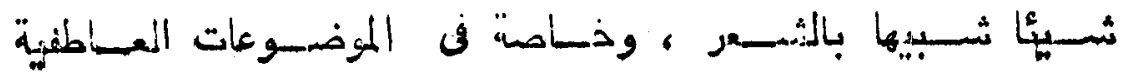

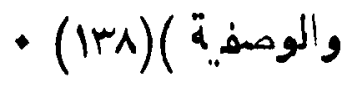

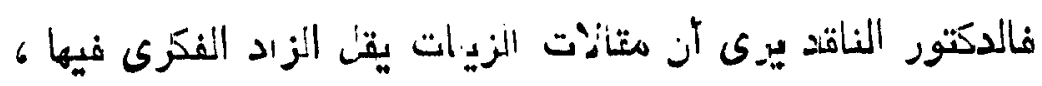

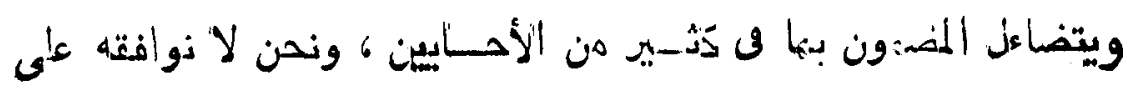

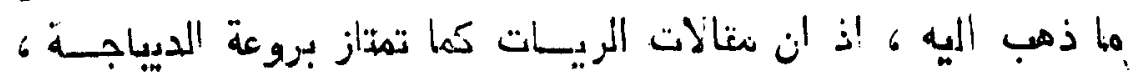

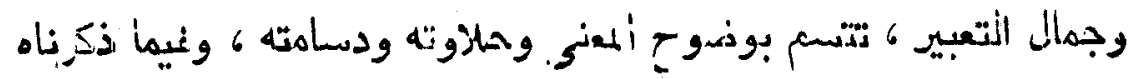

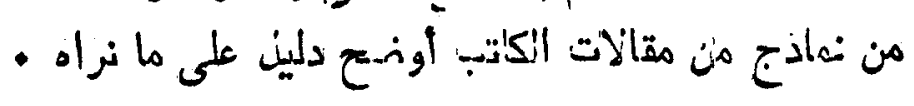

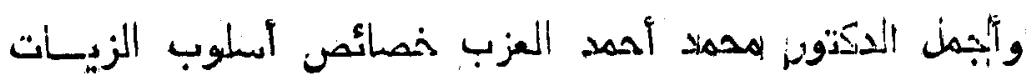

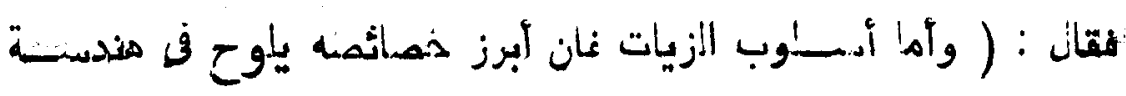

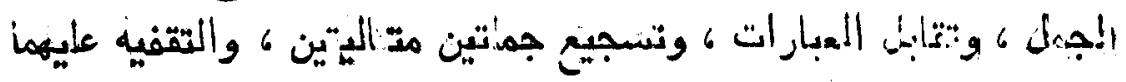

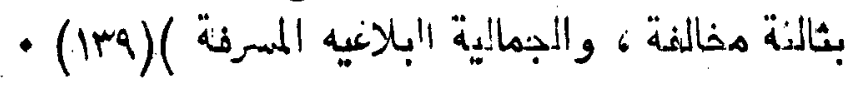

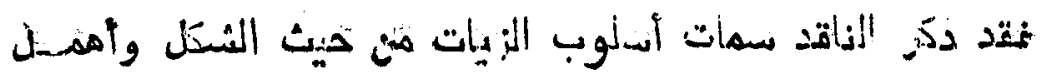

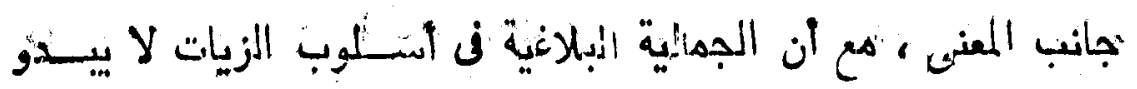

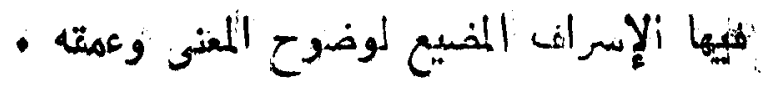

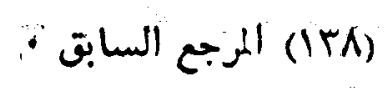

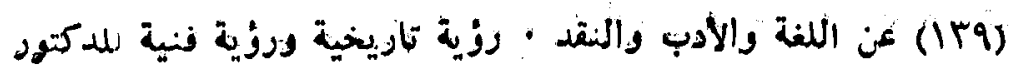




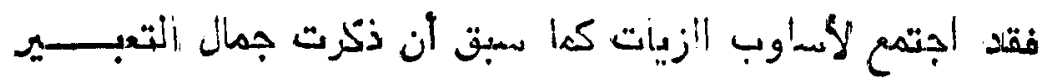

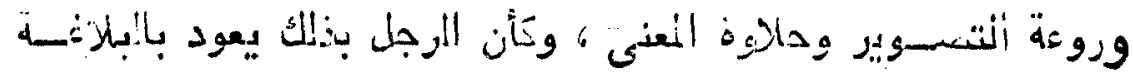

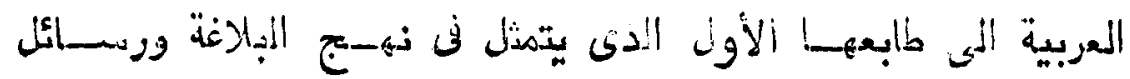

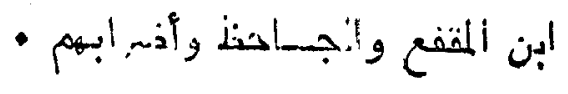

خاتمــــة :

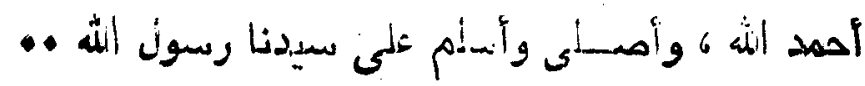

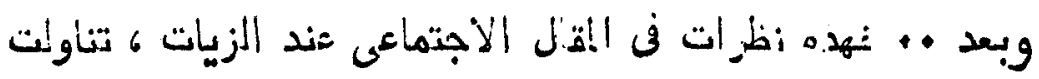

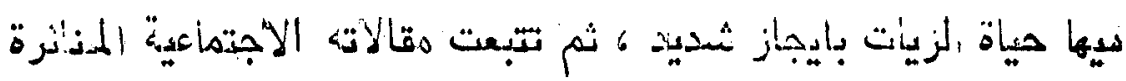

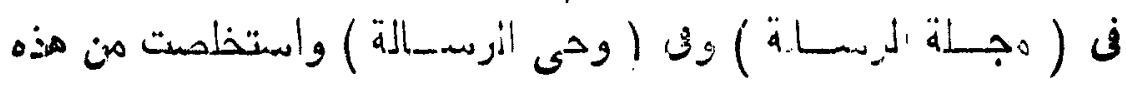

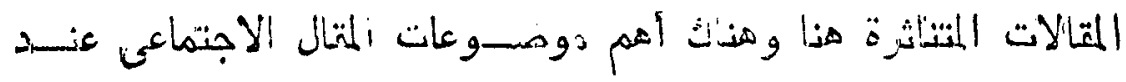

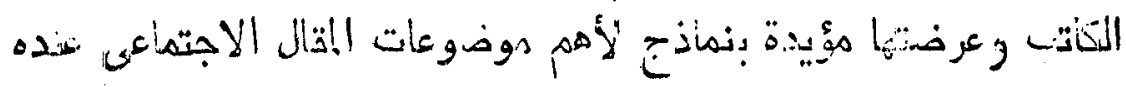

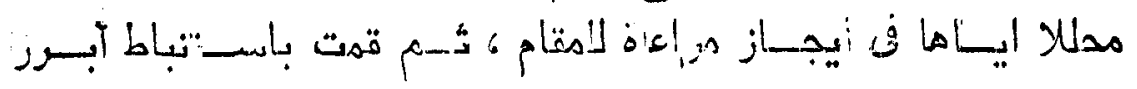

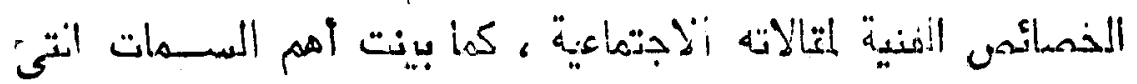

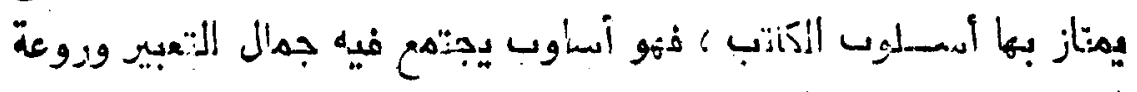

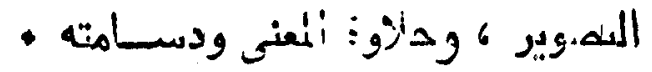

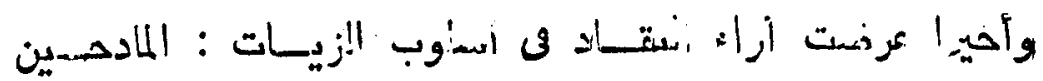

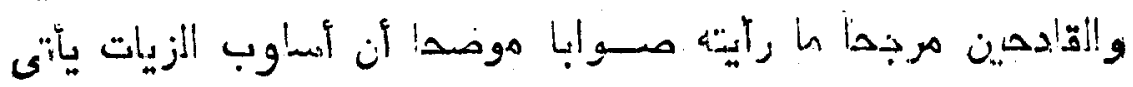

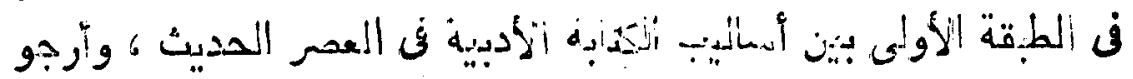

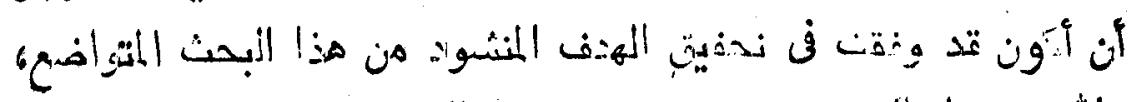

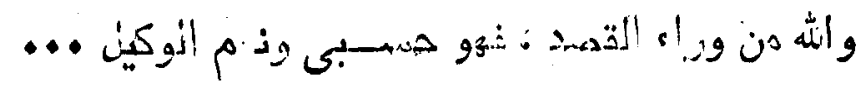

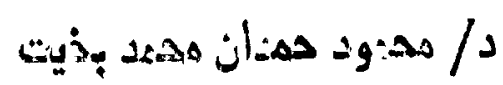

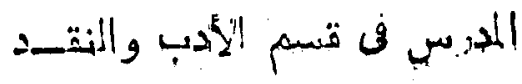

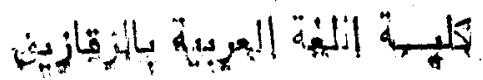




\section{مصـادر البعث ومراجعــ}

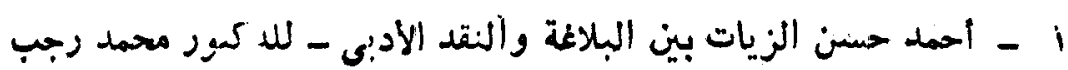

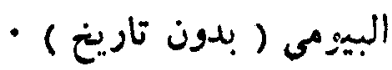

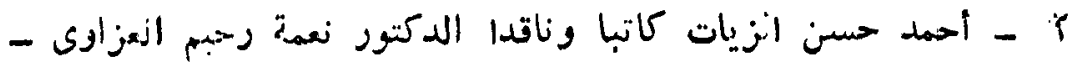

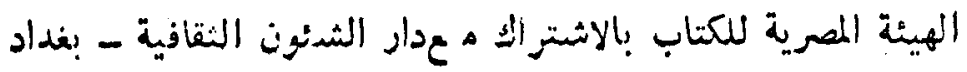

منة 1917

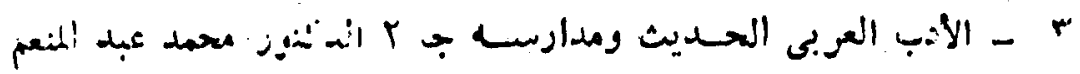

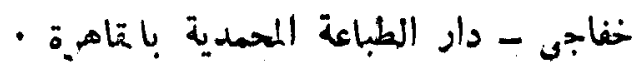

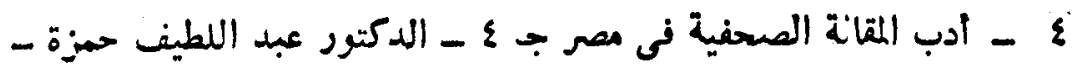

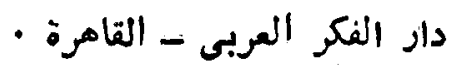

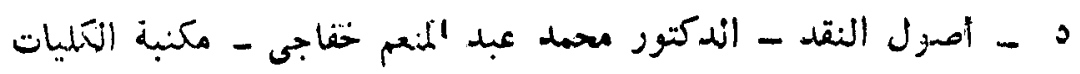

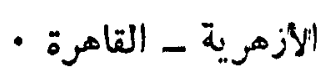

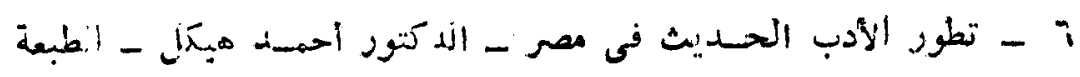

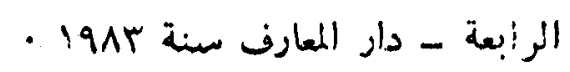

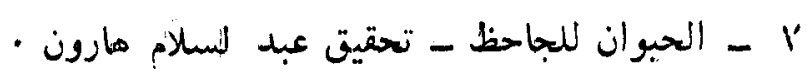

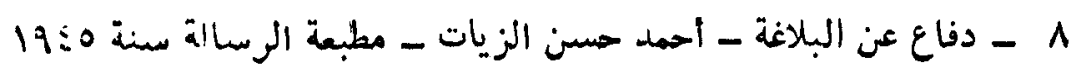

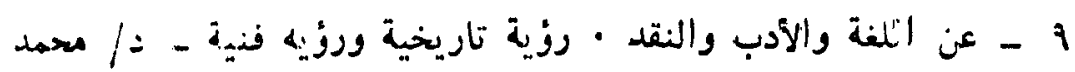

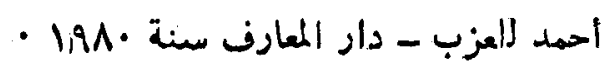

• 1 - فن المقالة ـ الدكثور محمد يوسف نجم - دار الثقافنة - بيروت

- 1974 لبنان المنان

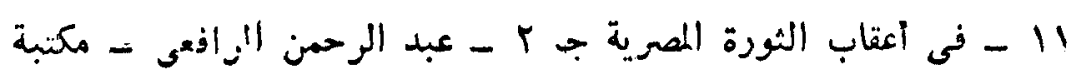

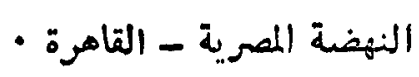

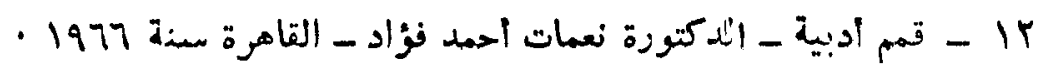

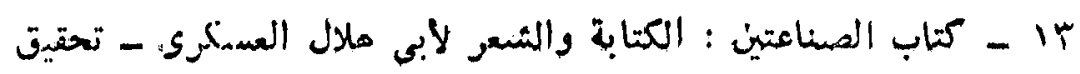

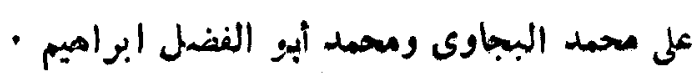

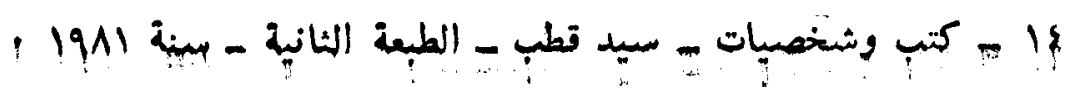


$r r$.

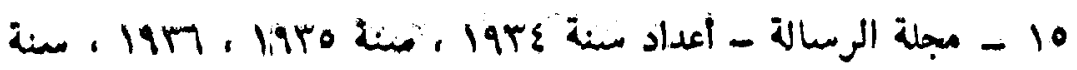

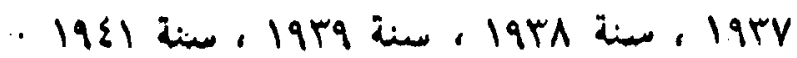

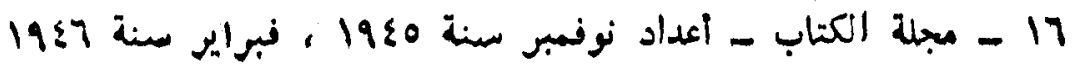

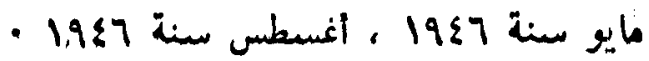

IV

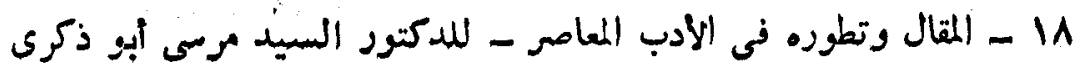

ـ دار المعارف - سنة

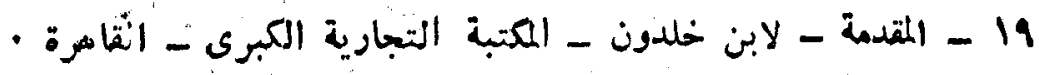

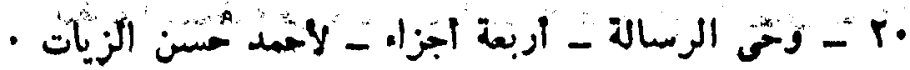




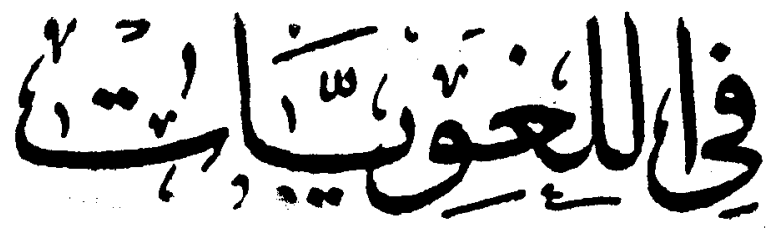

$$
(j-1)
$$


tiw

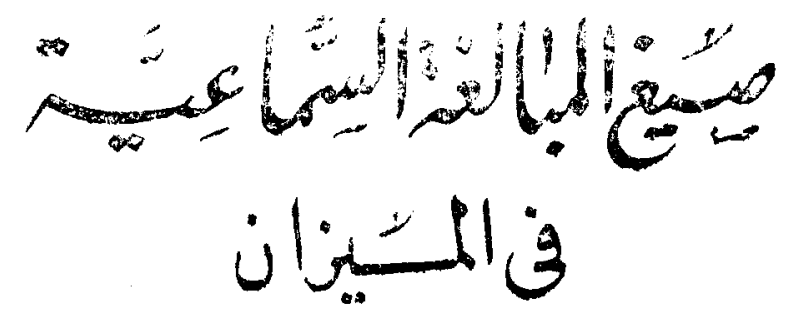

$$
\text { Cijjita, , is }
$$

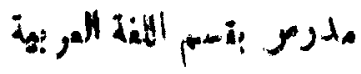

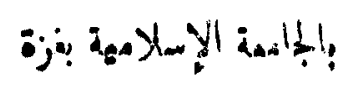

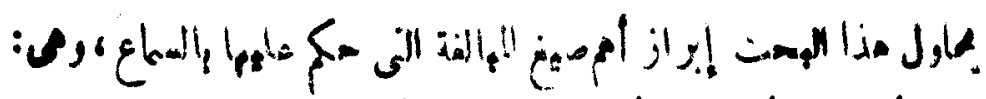

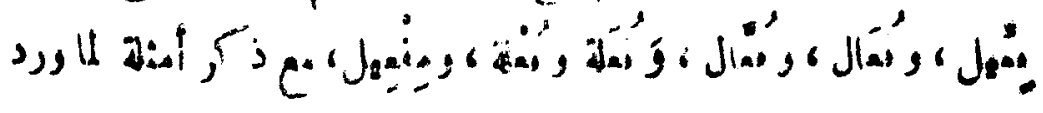

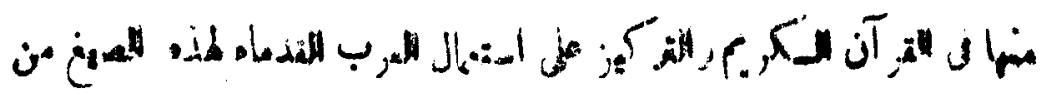

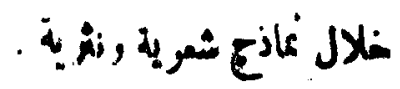

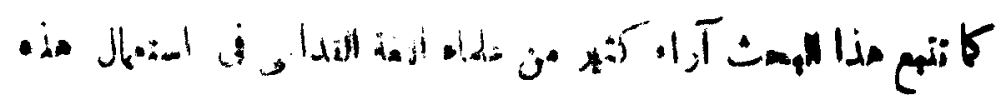

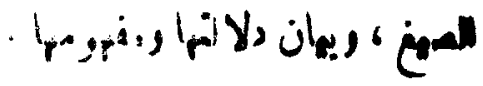

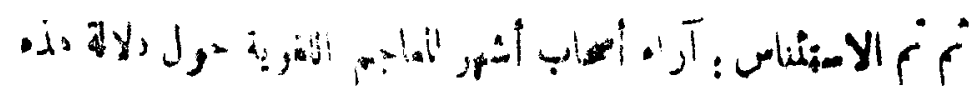
الأبنهة ، راستعمالامبا .

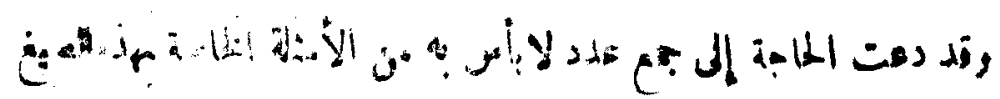

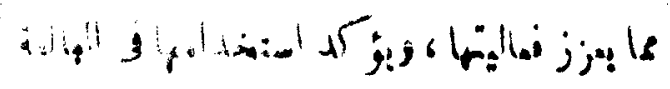

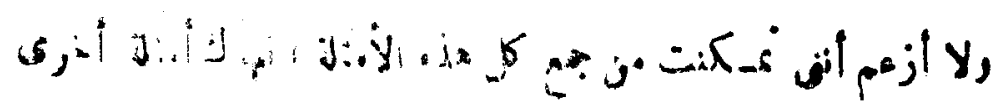


ص-

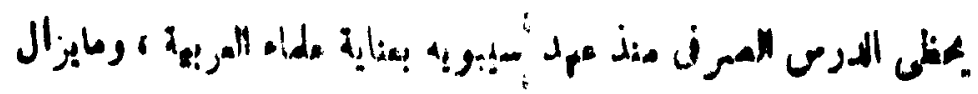

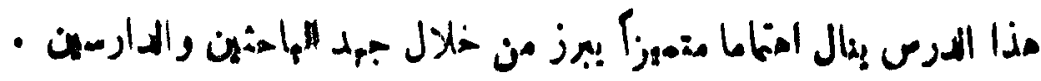

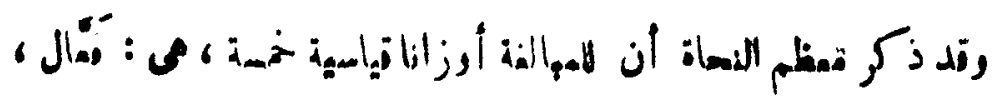
(1)

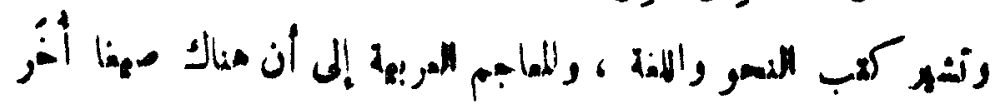

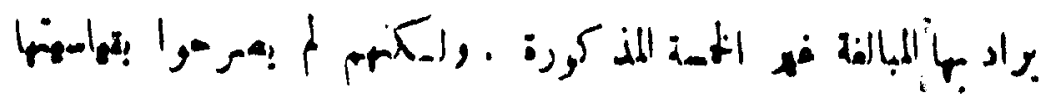
-

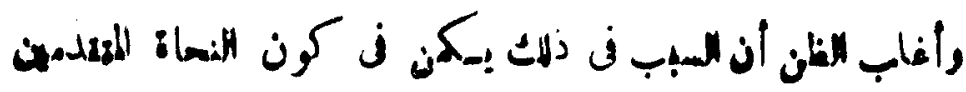

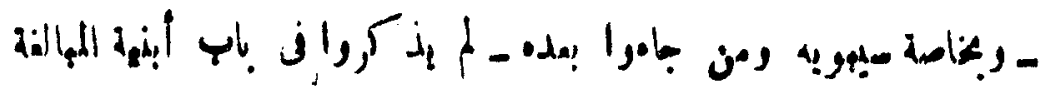

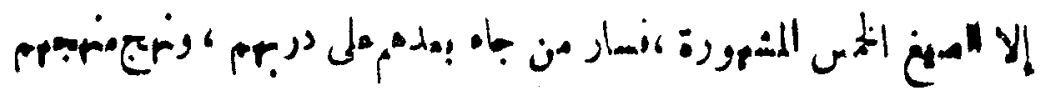

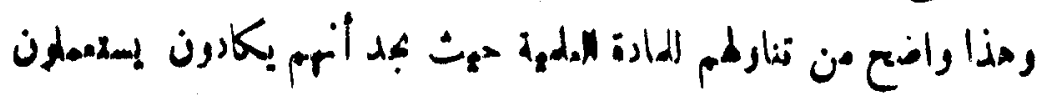

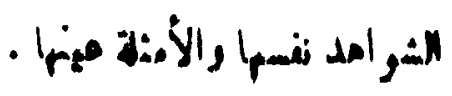

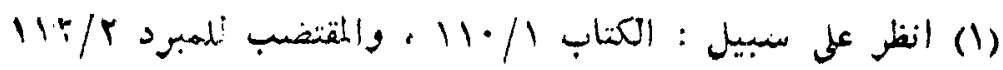

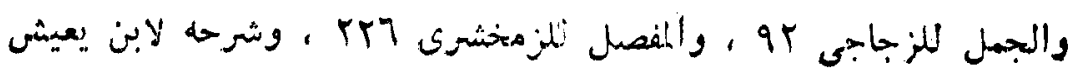

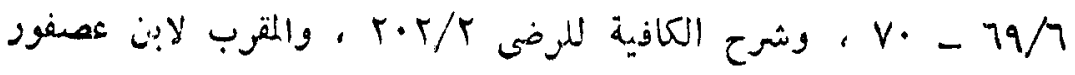

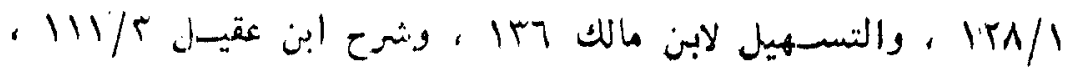

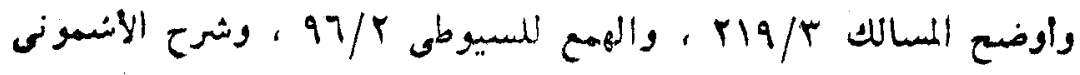

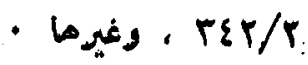




\section{rro}

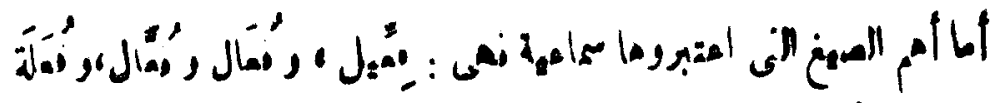

$$
\begin{aligned}
& \text { (1) }
\end{aligned}
$$

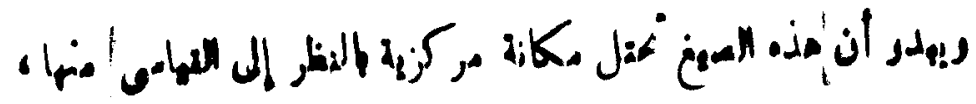

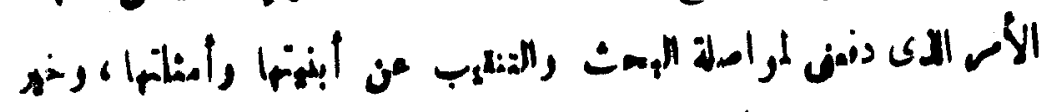

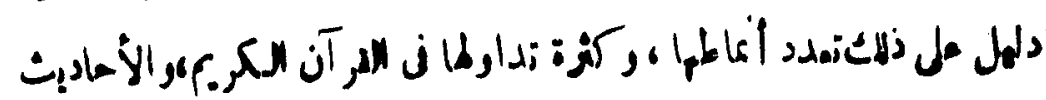

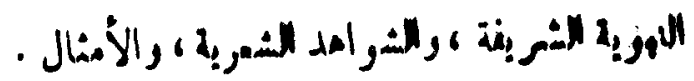

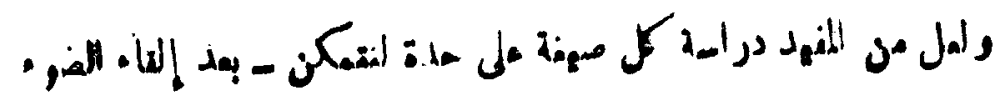

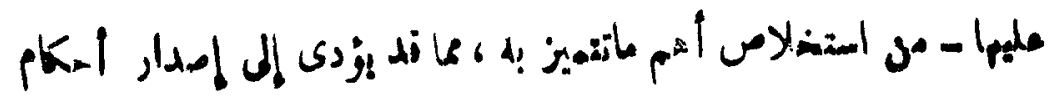
جديدة تتملت بها

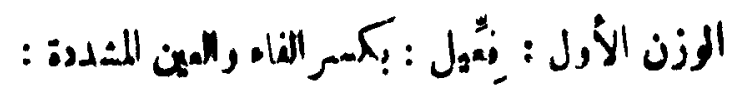

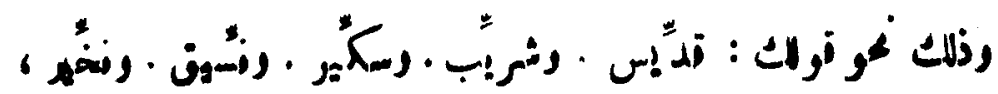

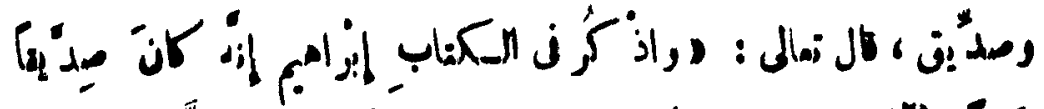

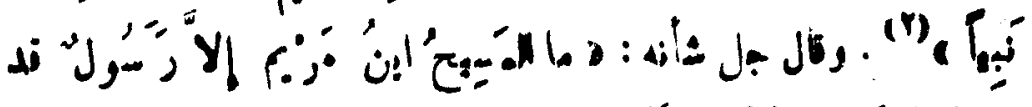

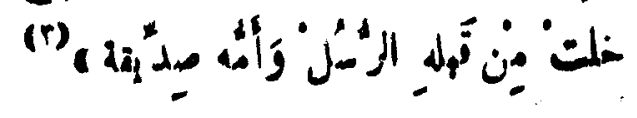

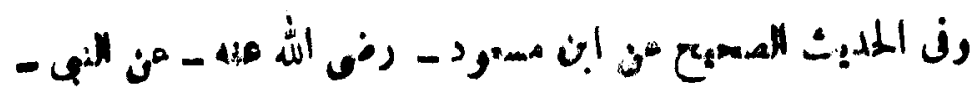

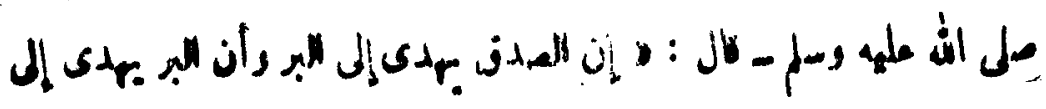

(1) هنال صيغ أخرى قد تبنى العرب المبالغة عليها ذكرها ابن

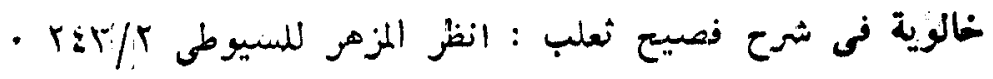

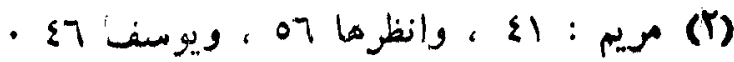




\section{rpq}

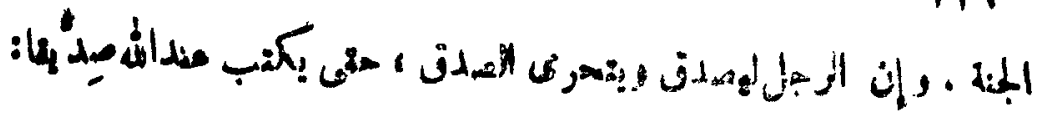

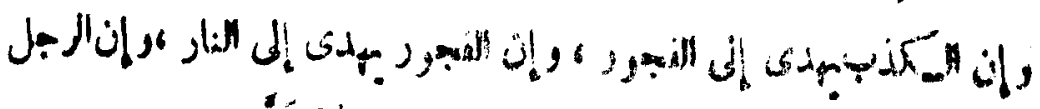

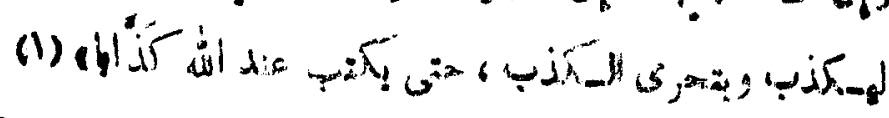

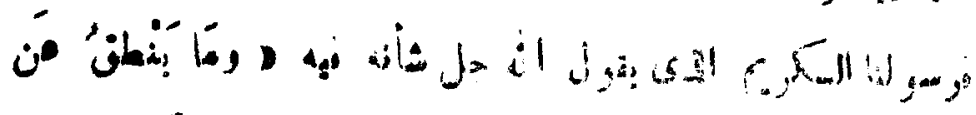

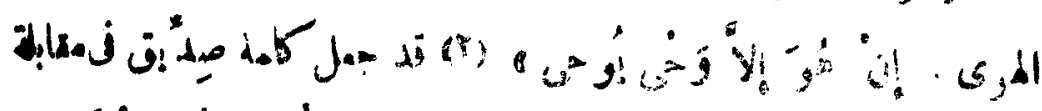

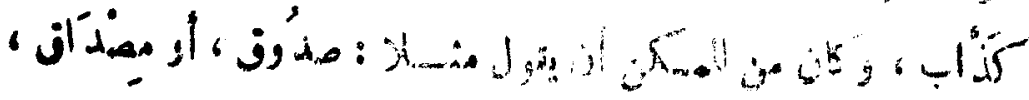

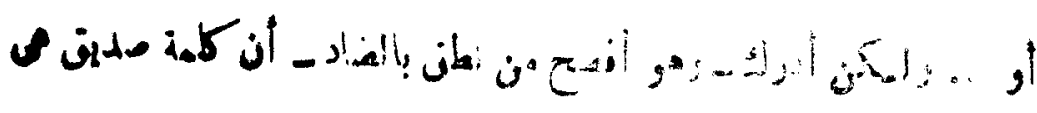

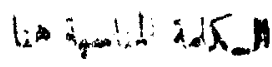

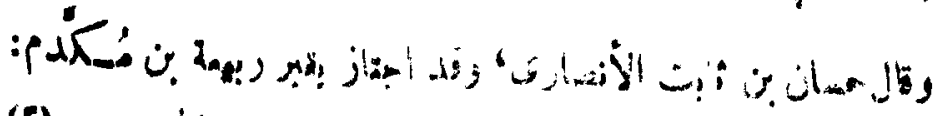

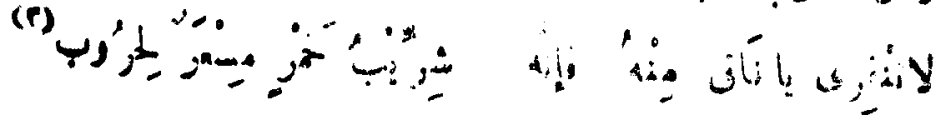
:

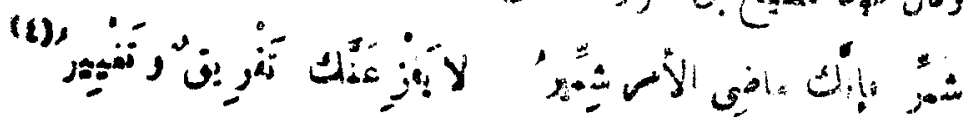
:

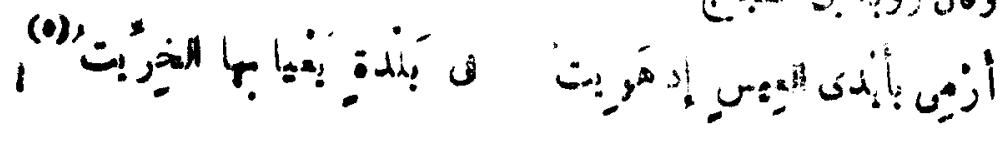
(1)

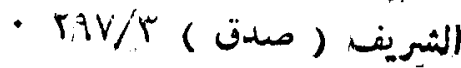

•

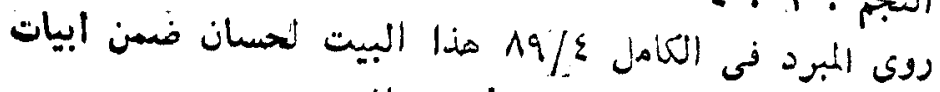

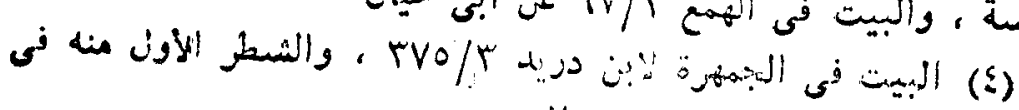

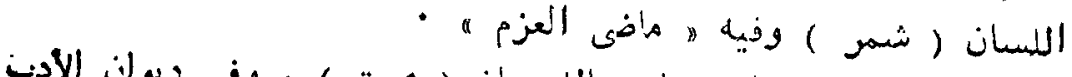
(o)

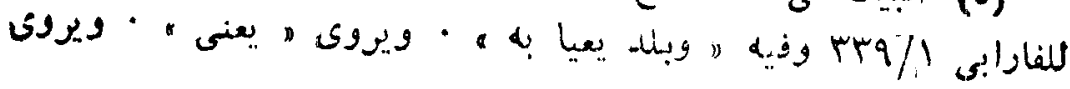




$$
: \text { s sill }
$$

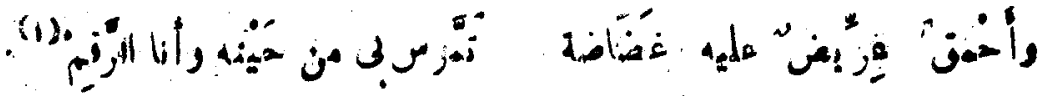

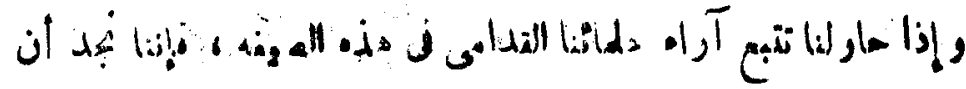

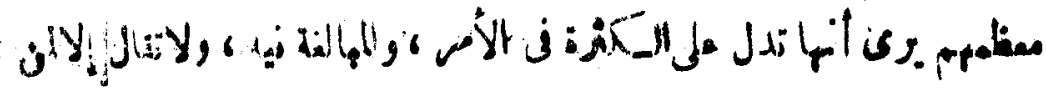

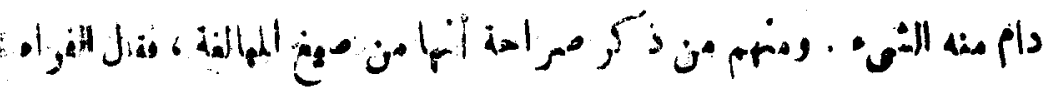

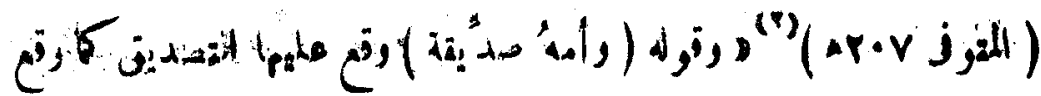

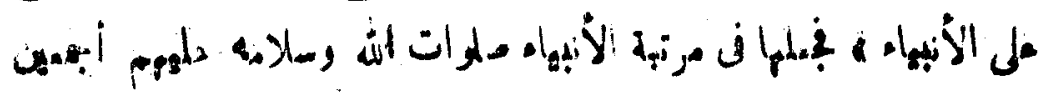

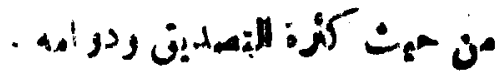

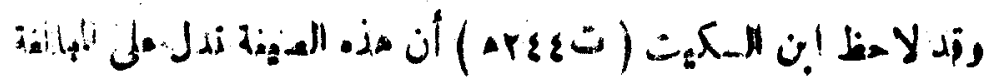

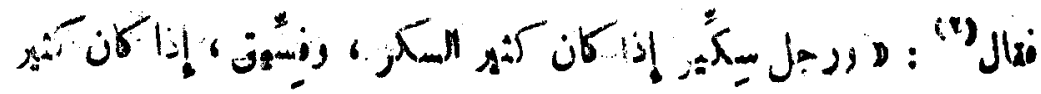

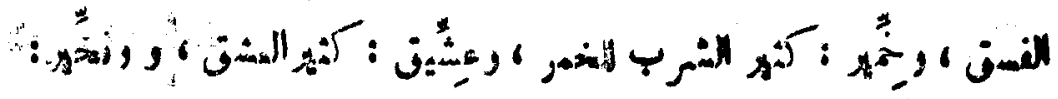

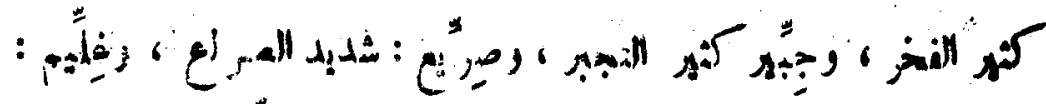

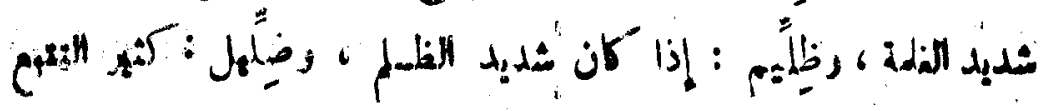

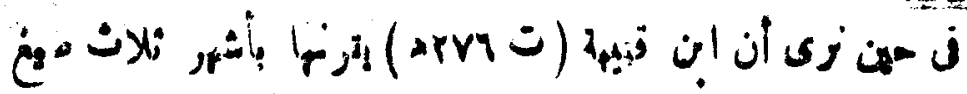
المغلال I I

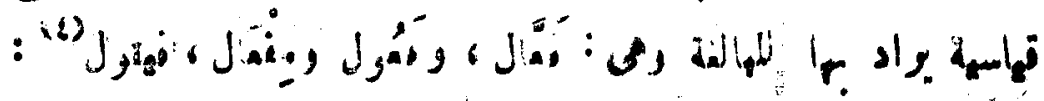

$$
\begin{aligned}
& \text { (1) البيت فى أساس البلانة ، واللسان ( عرض ) مان ) } \\
& \text { : } \\
& \text { - rliq ris }
\end{aligned}
$$

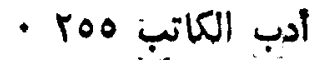


PYA

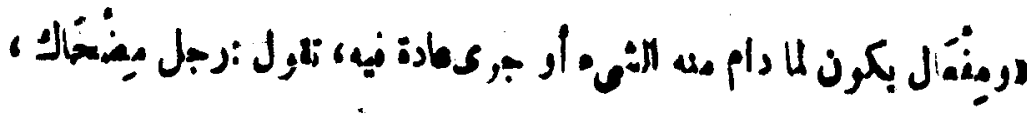

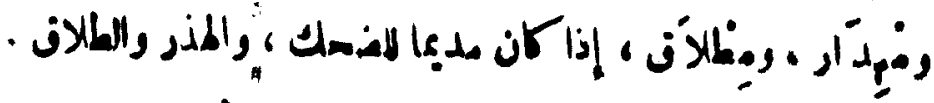

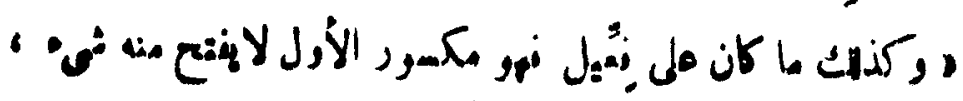

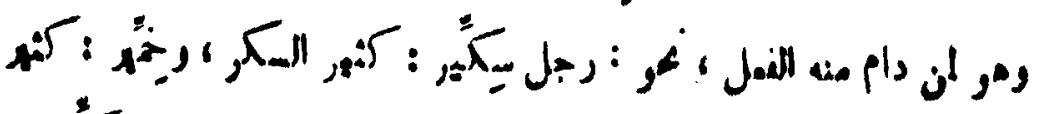

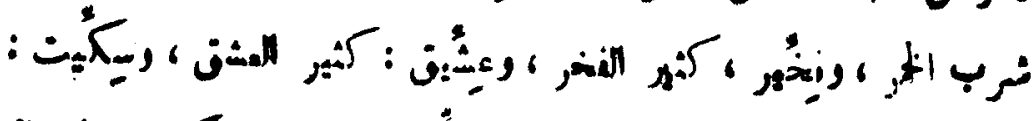

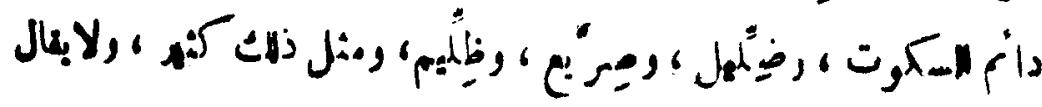

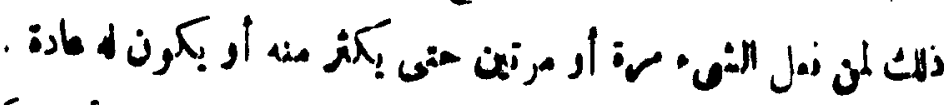

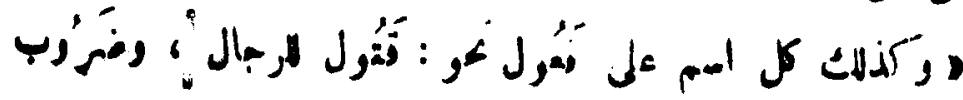

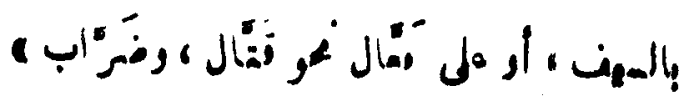

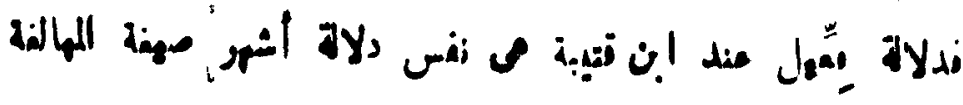

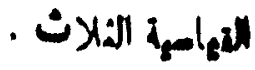

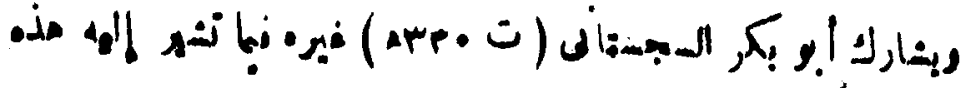

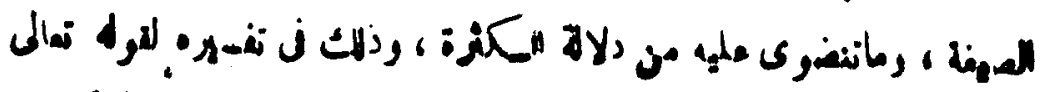

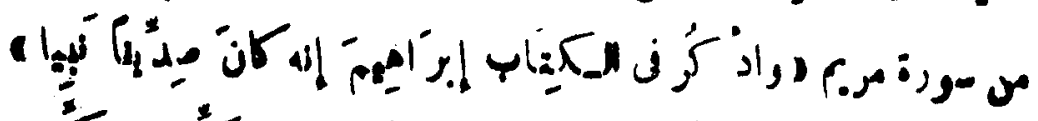

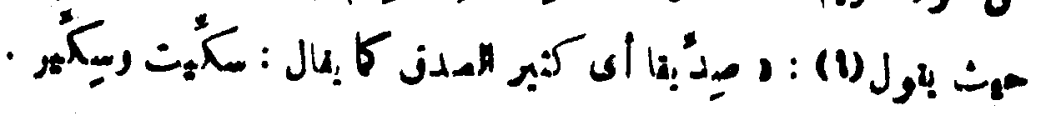

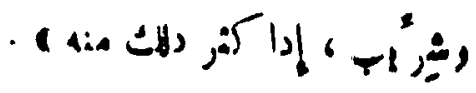

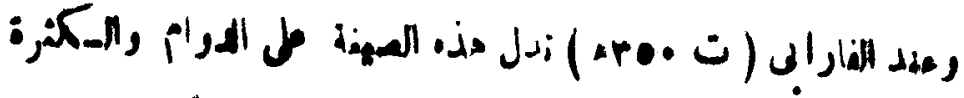
ر"

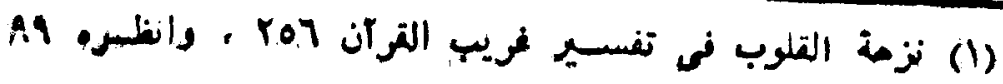




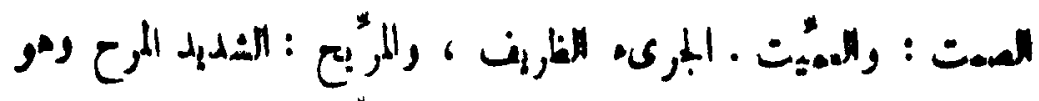

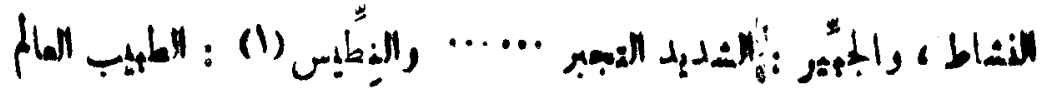

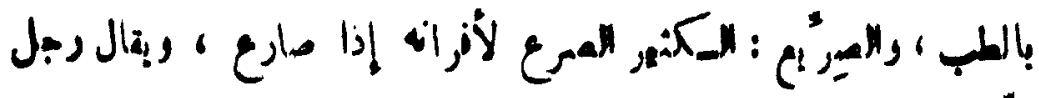

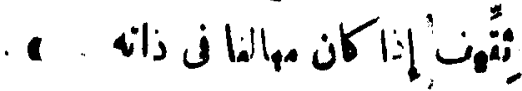

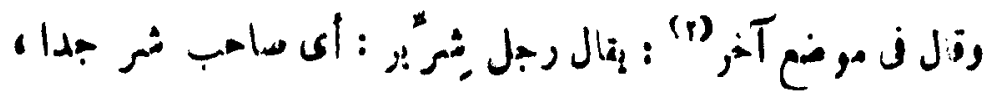

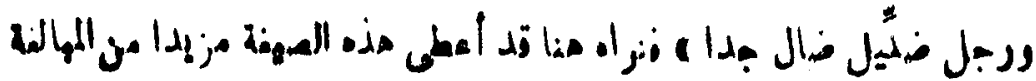

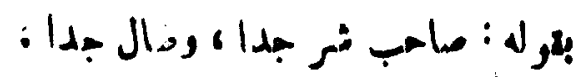

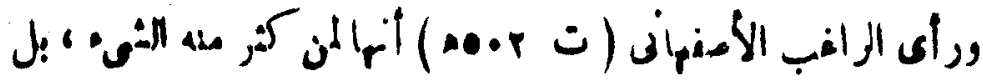

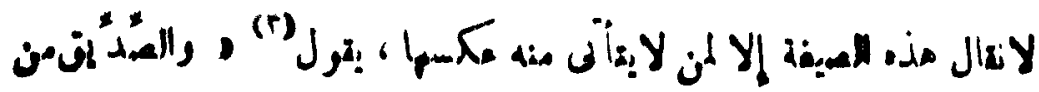

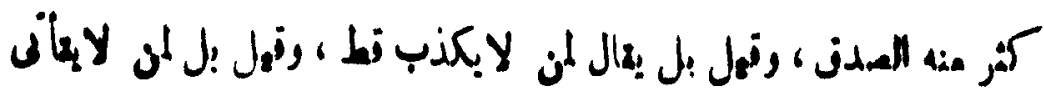

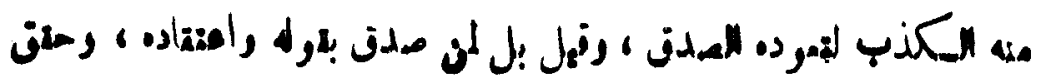
- atis vide

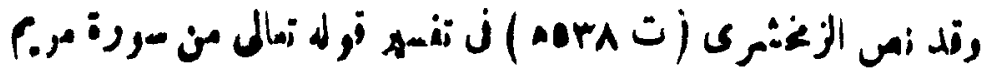

قال الزمخشرى فى اساس البلانة ز نطس ) : " والنطيس :

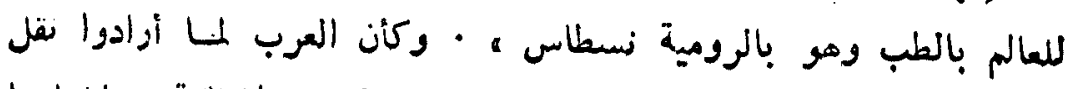

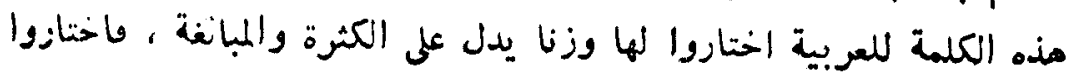

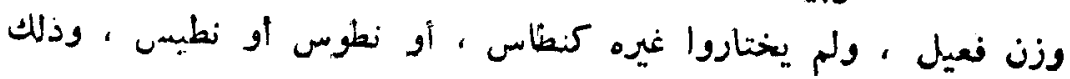

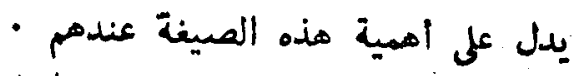
. 


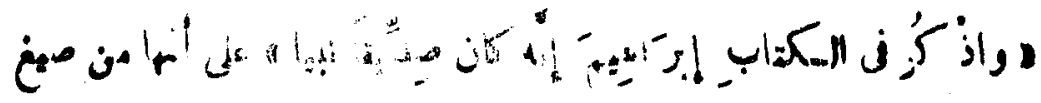

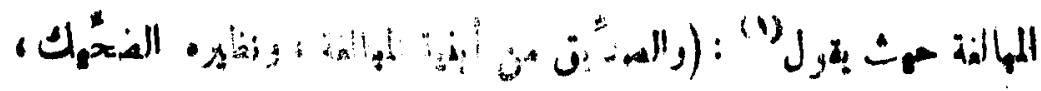

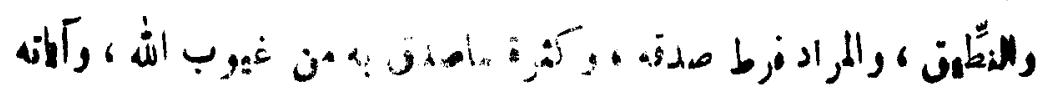

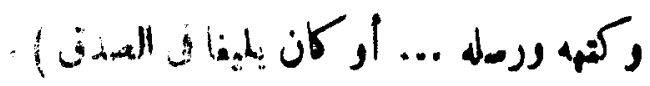

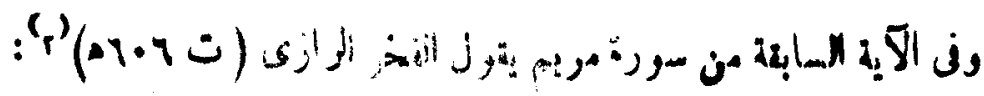

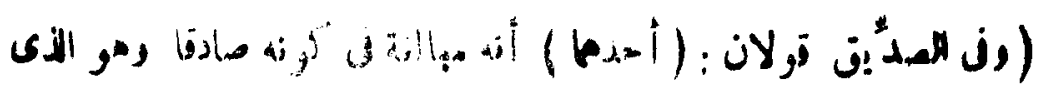

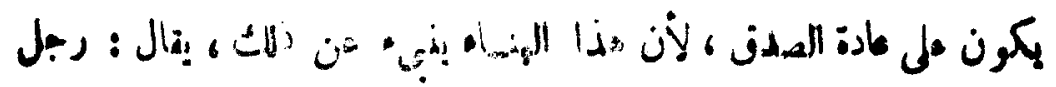

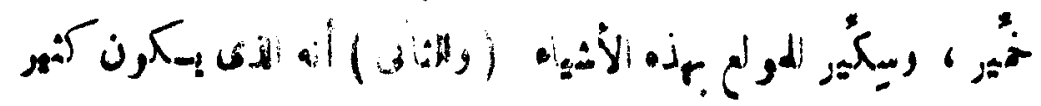

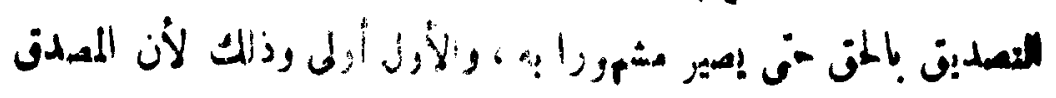

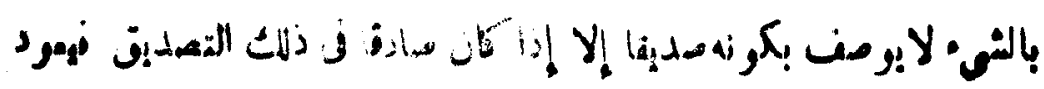

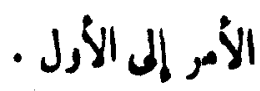

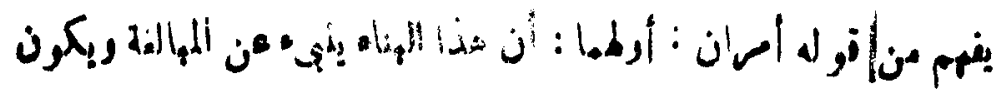

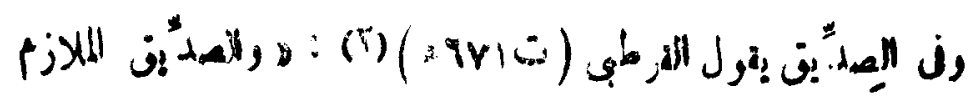

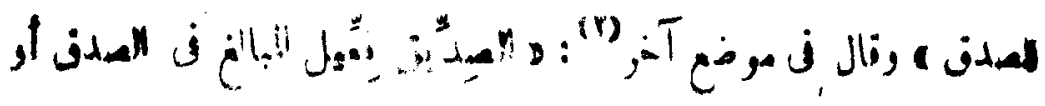

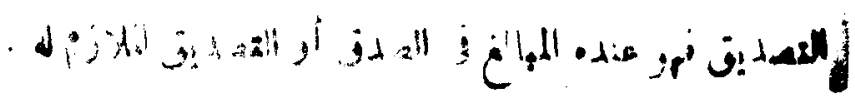

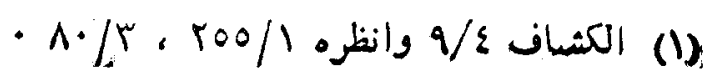

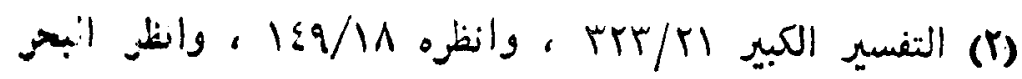
- المسبط

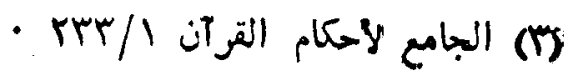
نفس : rVr/o 
Pr

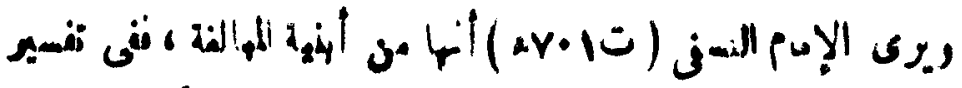

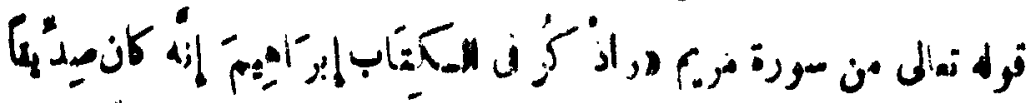

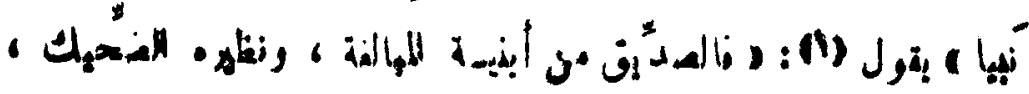

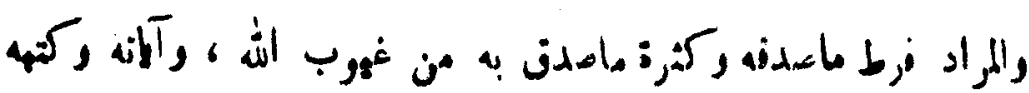
(

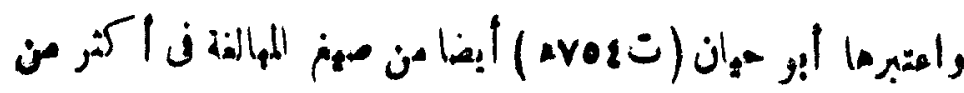

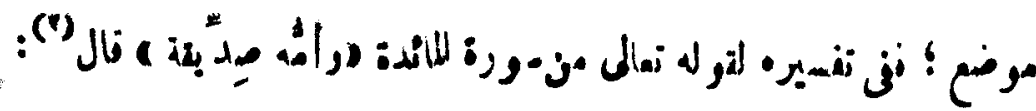

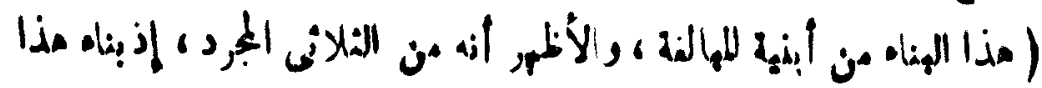

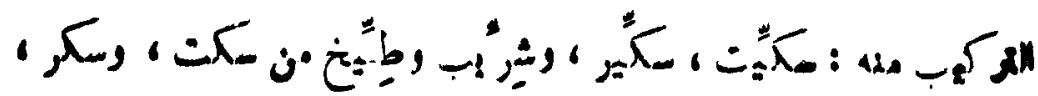

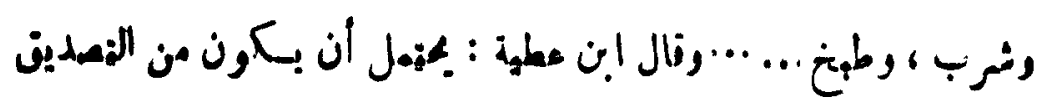

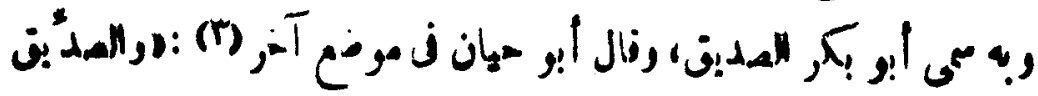

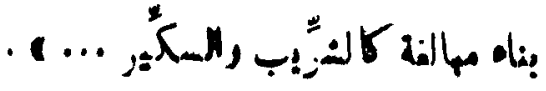

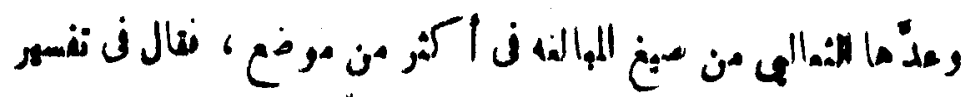

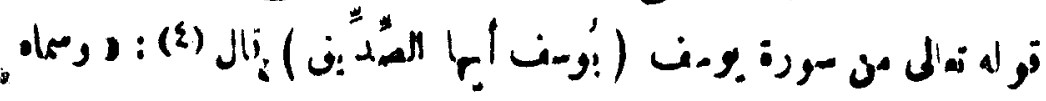

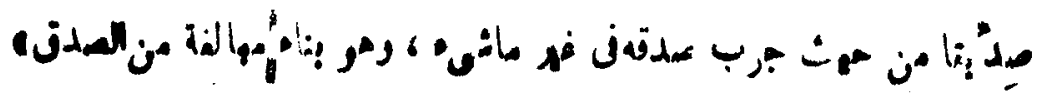

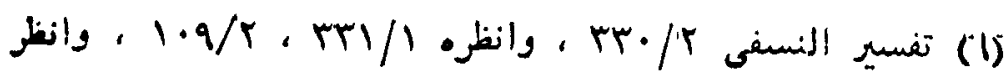

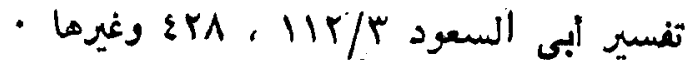

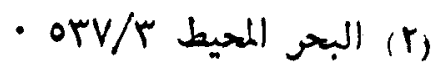

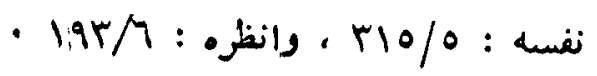

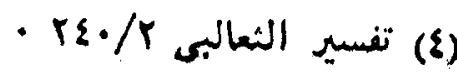




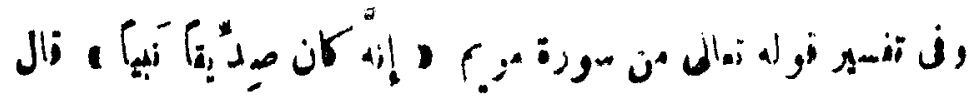

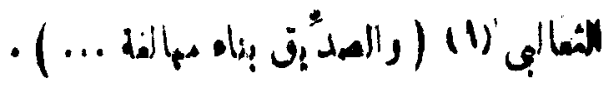

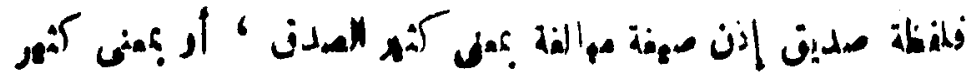

is dinill

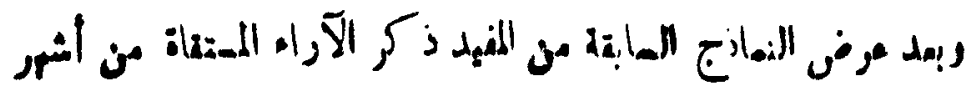

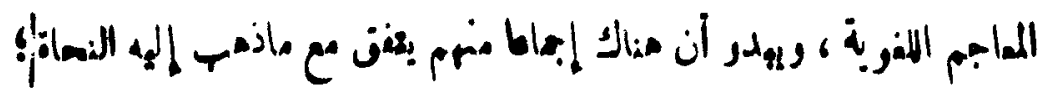

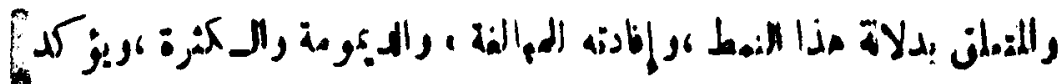

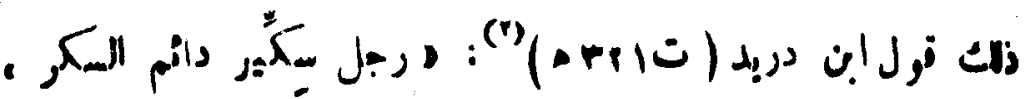

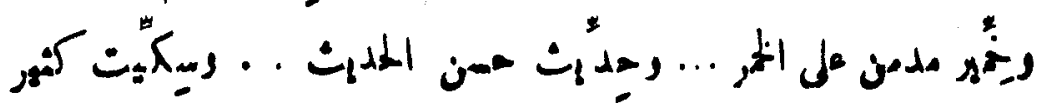

$$
\text { . .... . . }
$$

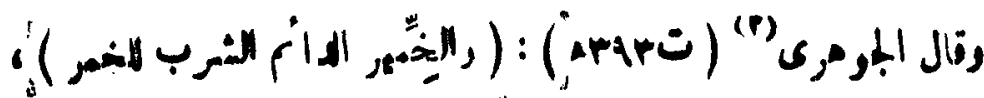

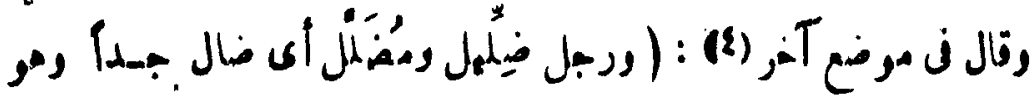

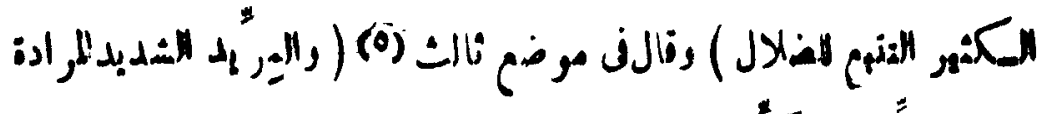

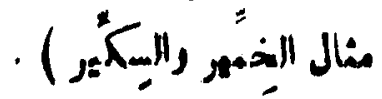

:

$\therefore \varepsilon V A, r A q / 1:$ : (1)

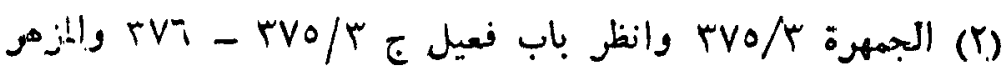

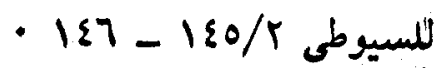

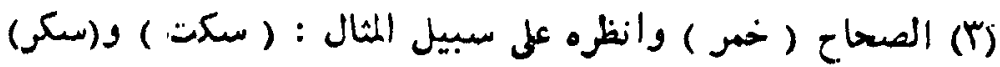

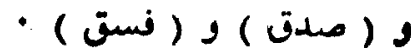

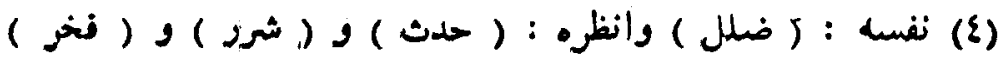

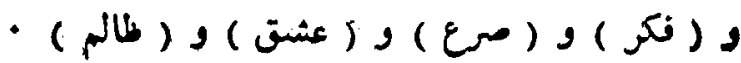

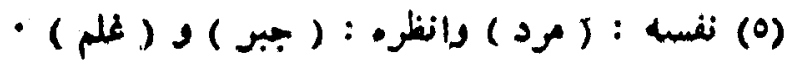




\section{prr}

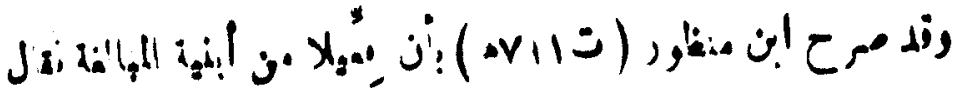

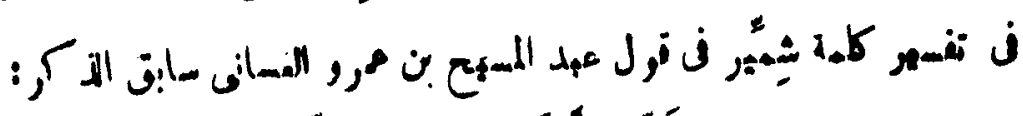

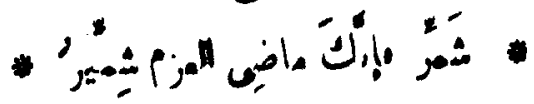

قال)

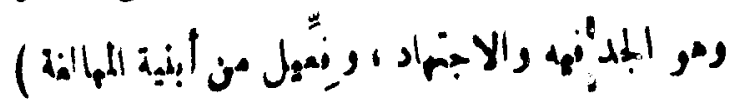

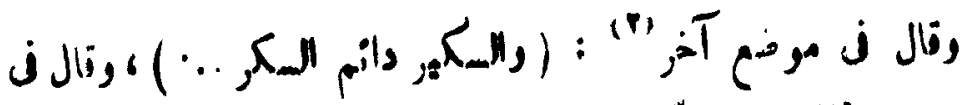

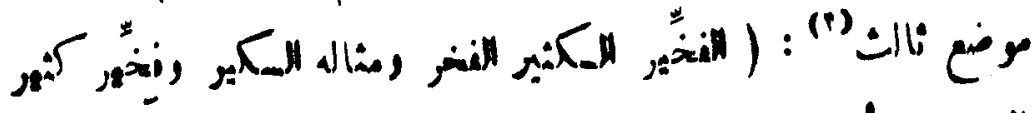

: الانجئl

\section{-}

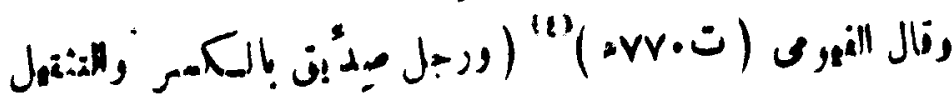

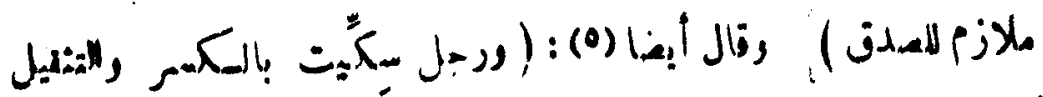

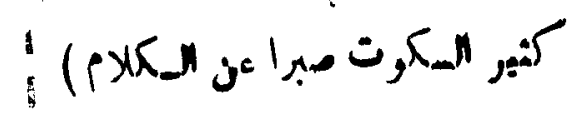

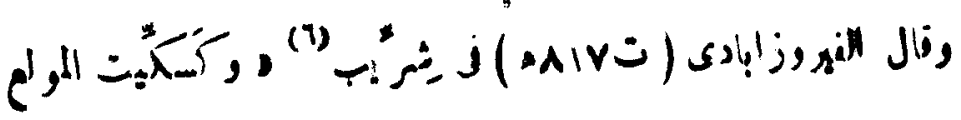

\section{(1) اللسان ( شهر )}

(r) نفسه : ( سكو ) ، وانظره على سبيل المثال ( خمر ) و ( ومدن)

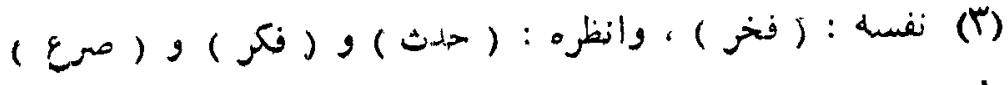

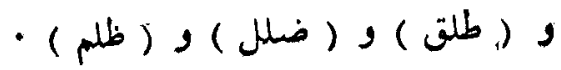

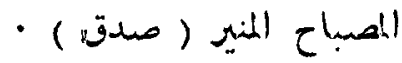

نفسه : ( سكت )

القاموس المحبط( شرب ) 


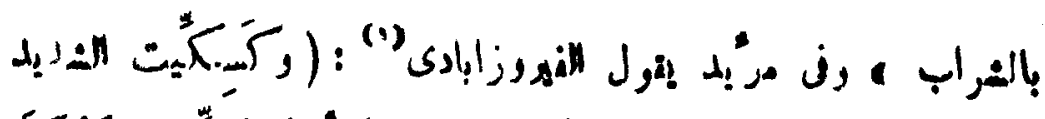

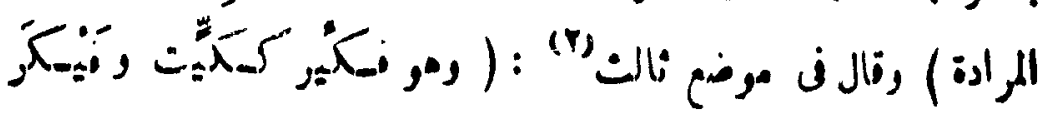
-

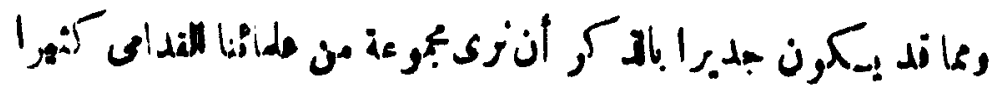

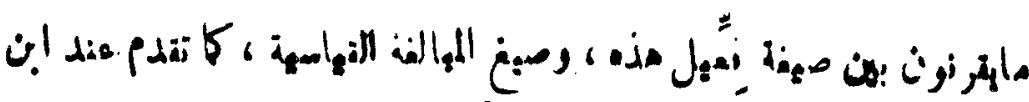

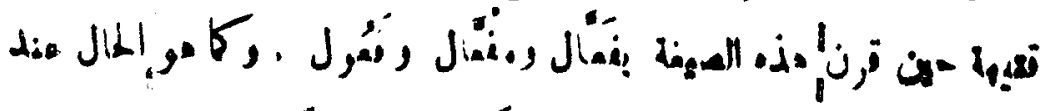

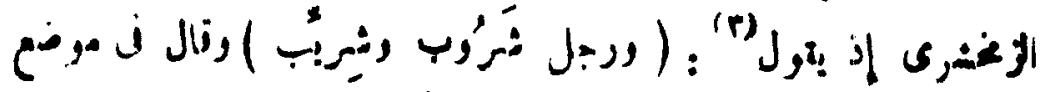

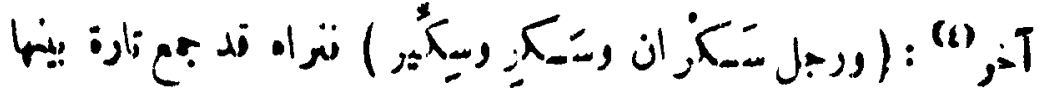

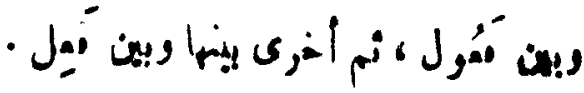

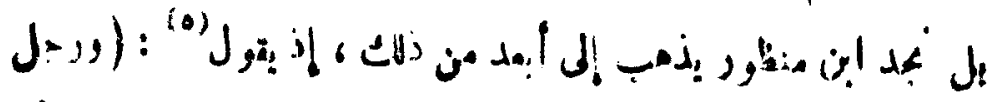

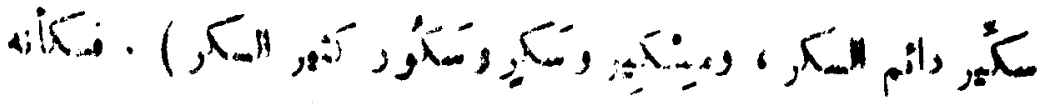

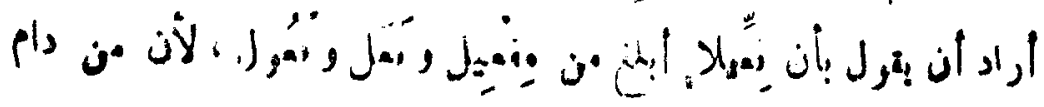

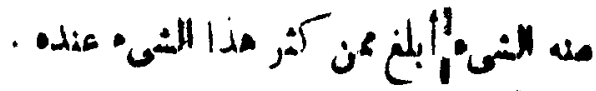

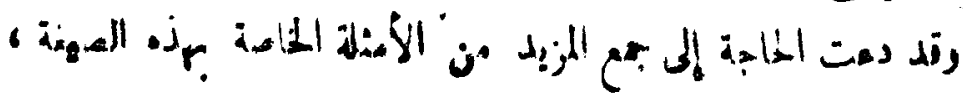

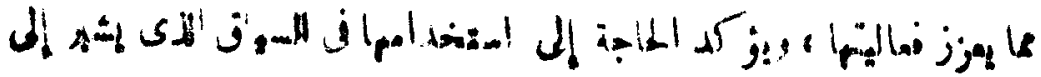

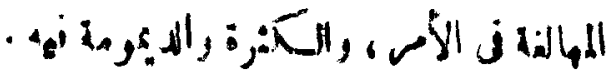

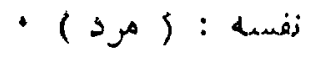

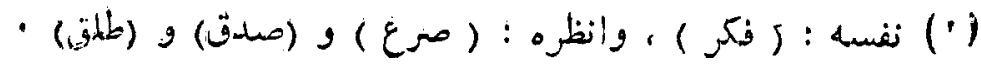

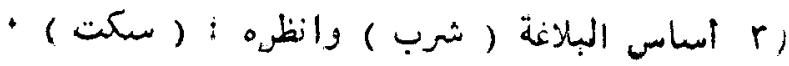

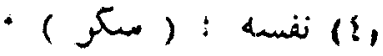

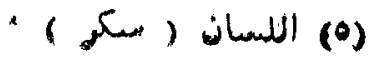




\section{rro}

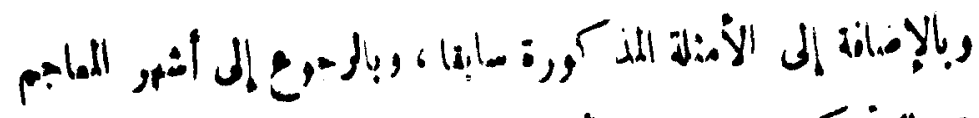

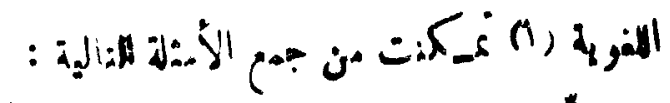

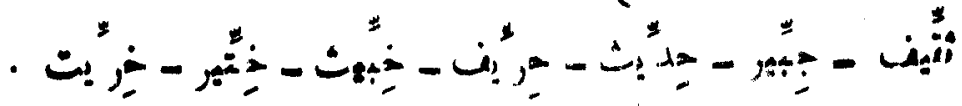

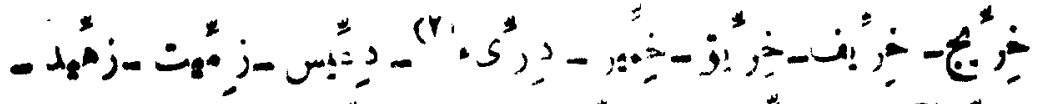

رسبهن

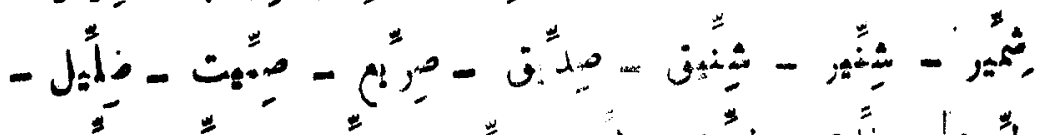

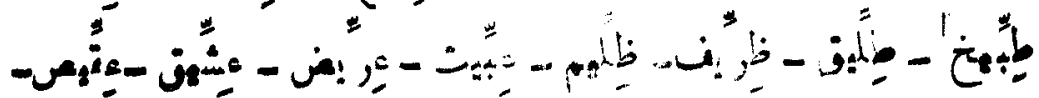

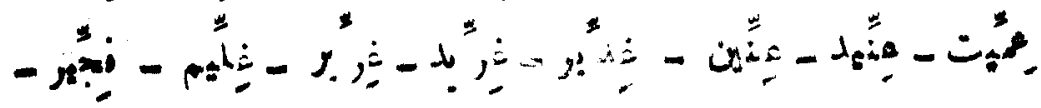

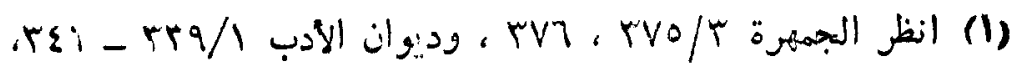

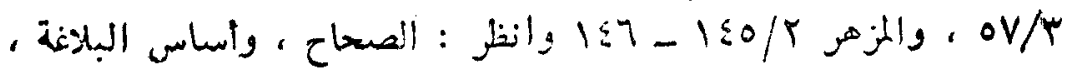

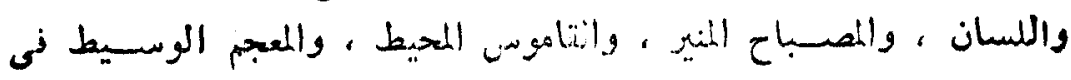

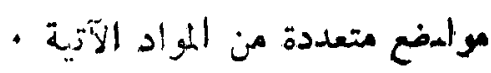

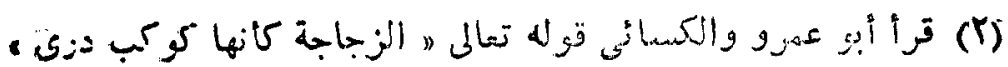

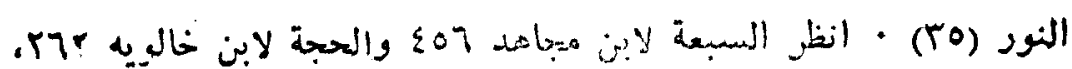

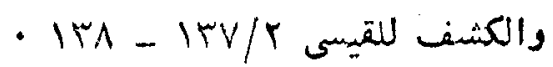
وقال ابن خانويه هنا ها فالحجة لمن كسر ومهز : أنه أخذه من ألدر

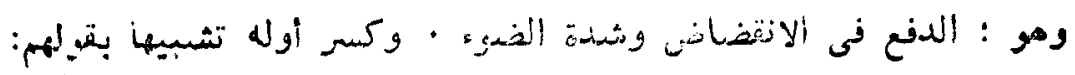

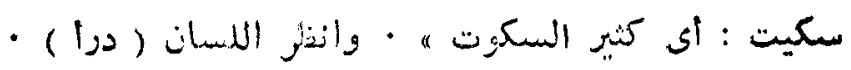

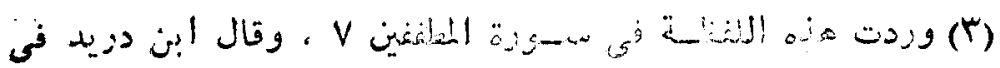

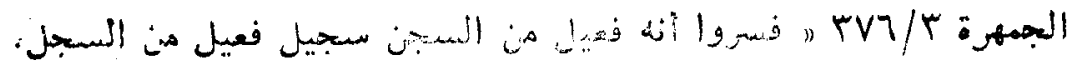

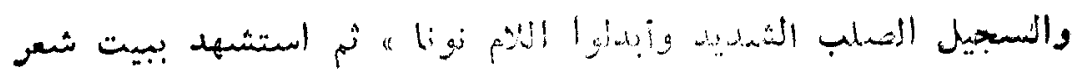

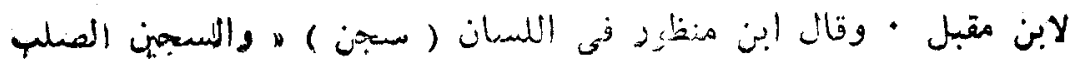

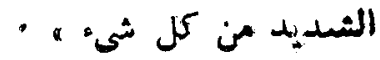




\section{Pry}

· ن

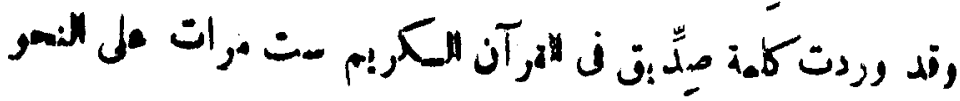

: ل)

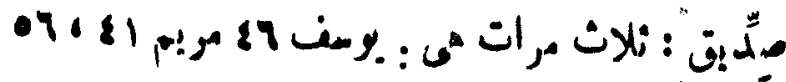

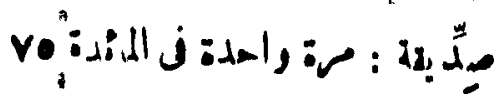

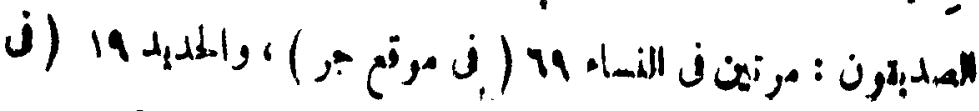

-

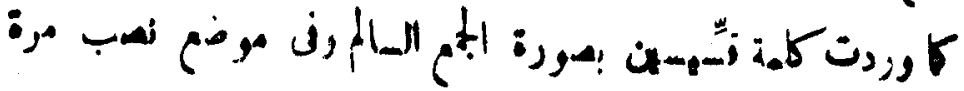

$$
\text { Ar ilili }
$$

وتد ذهب بهن

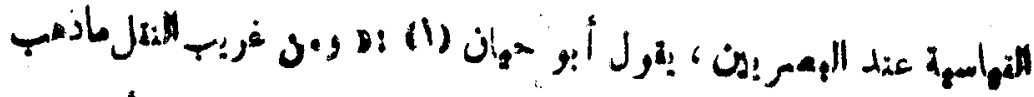

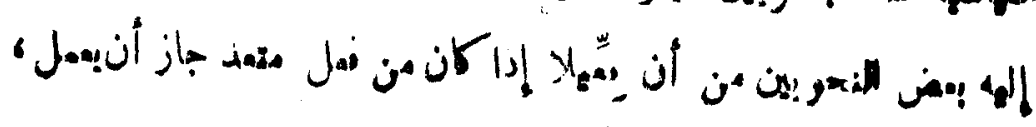

$$
\text { (r) }
$$

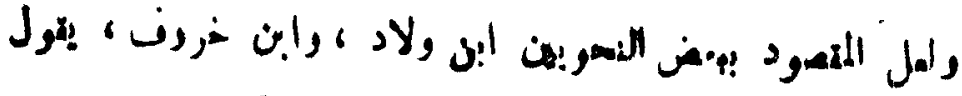

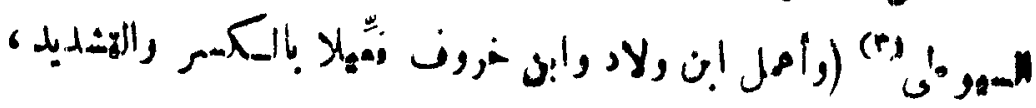

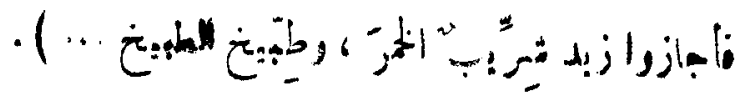

- rigr/7 (1) البحر المحيط (1)

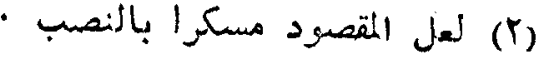

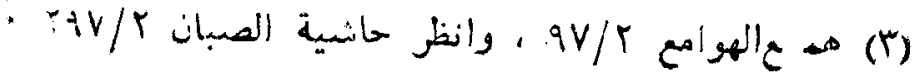




\section{Prt}

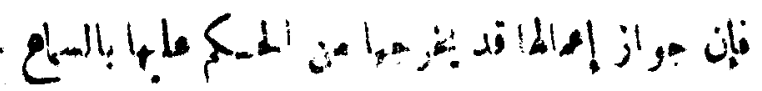

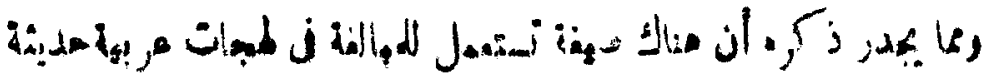

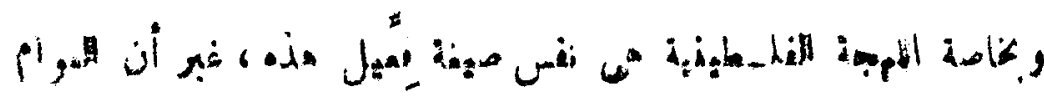

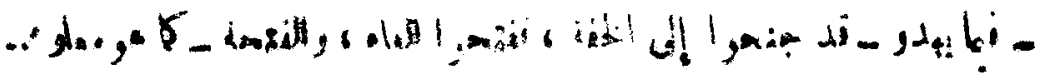

|

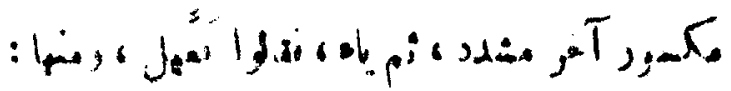

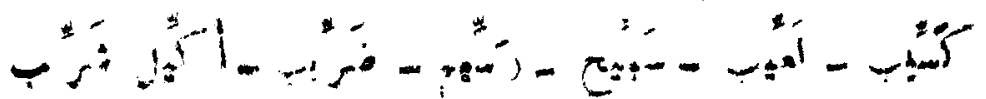

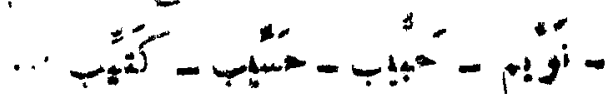

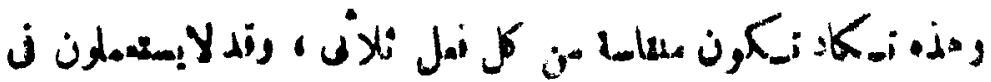

- المالة

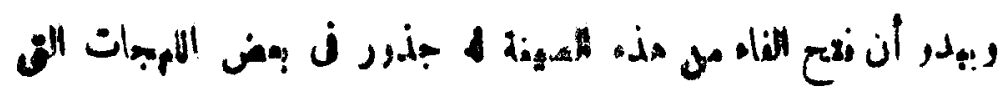

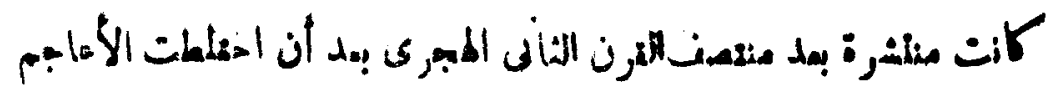

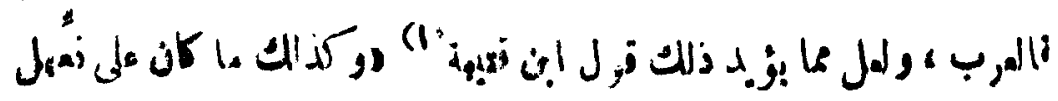

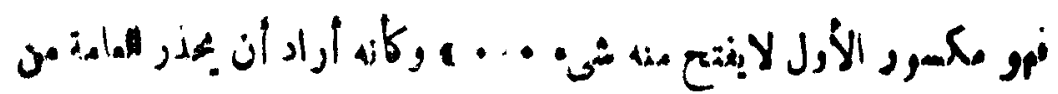

$$
\text { - di }
$$

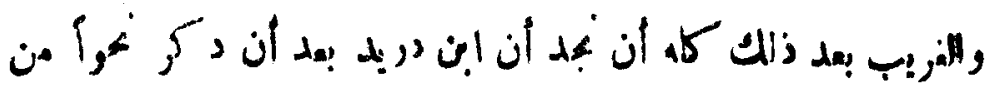

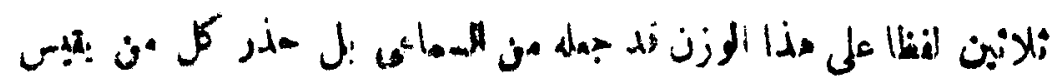

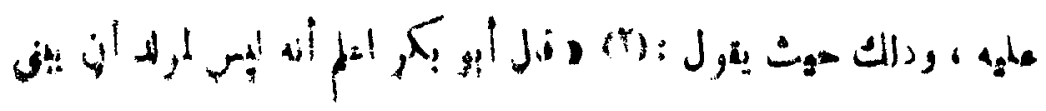

$$
\begin{aligned}
& \text { - (1) أدب الكاتب (1) } \\
& (j-r)
\end{aligned}
$$

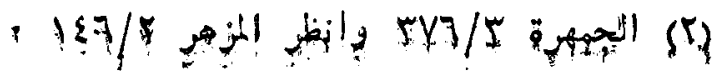




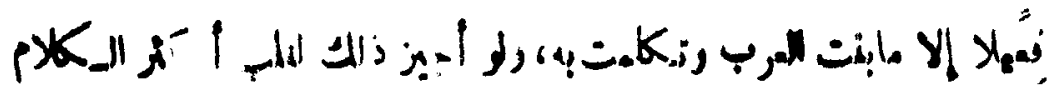

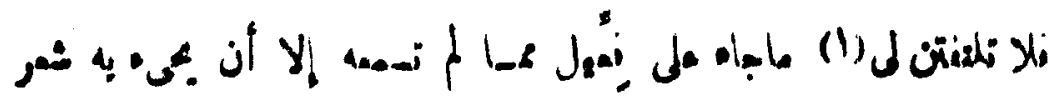

- crai

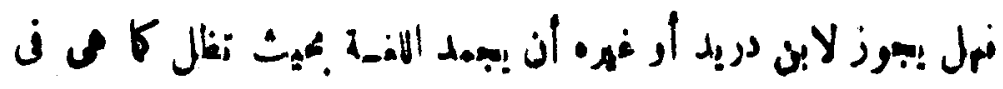

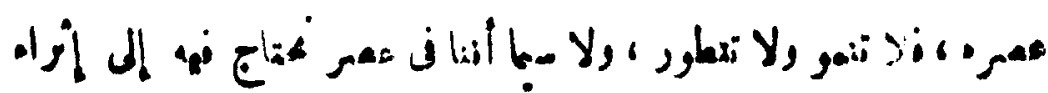

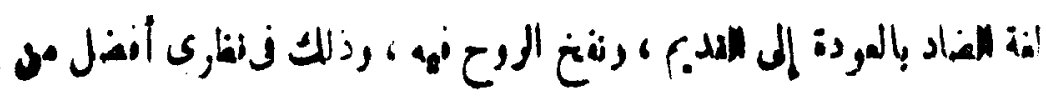

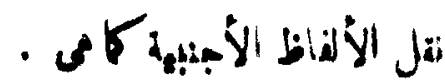

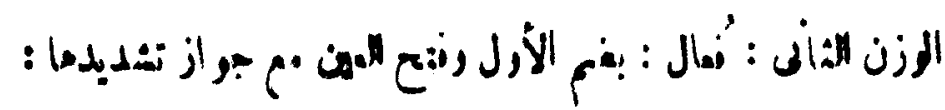

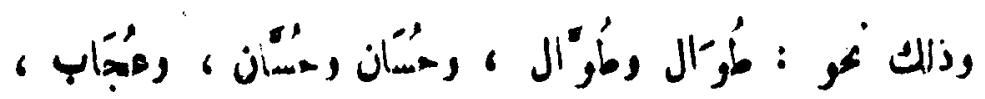

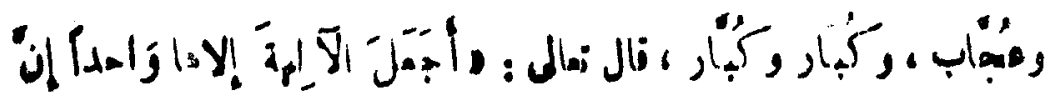

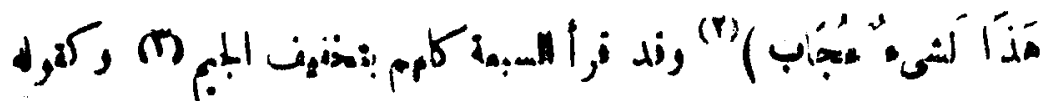

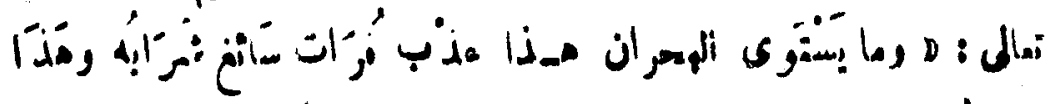

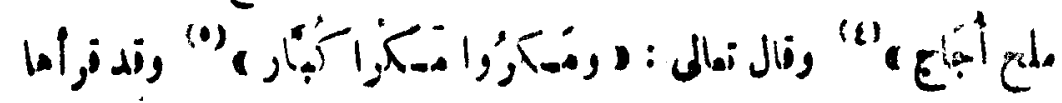

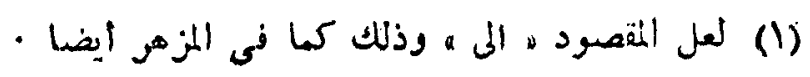

$$
0: 0(1)
$$

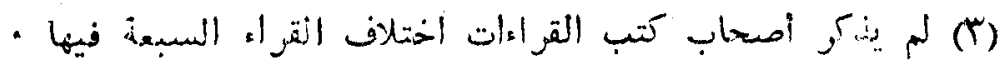

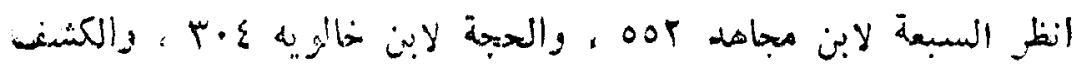

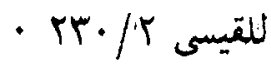

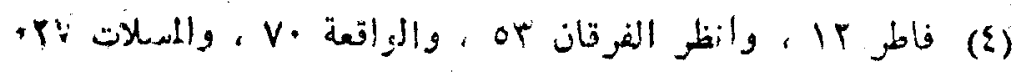


$+1$

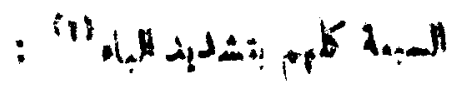$$
\text { : isis لylis }
$$

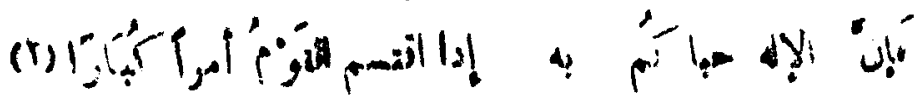

$$
\text { : }
$$

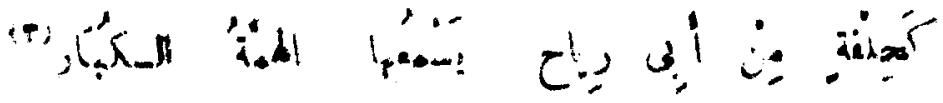

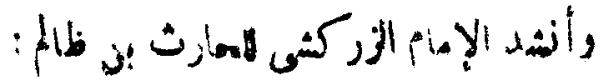

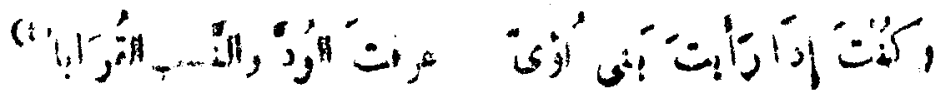

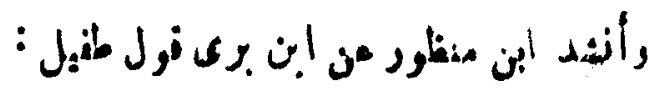

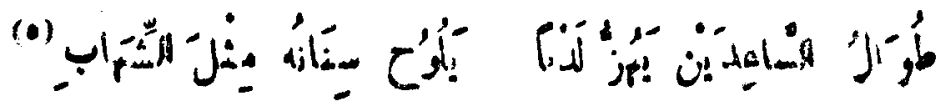

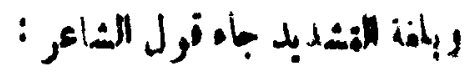

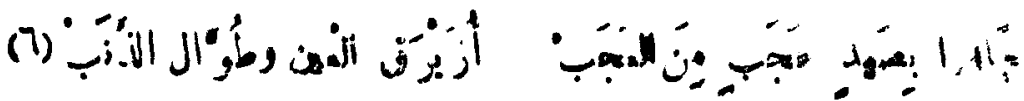
رنال ذو الأصبح الهدوأنا :

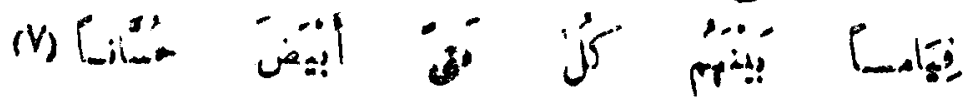

(1) 'م يذكر اصحاب كتب القراءات اختلاف السبعة فيها • انظز

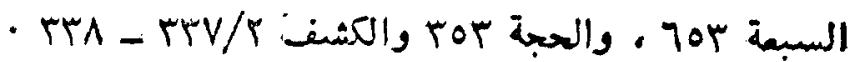

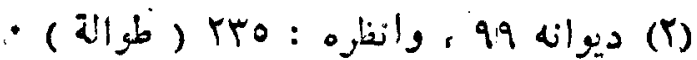

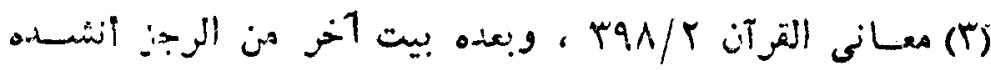

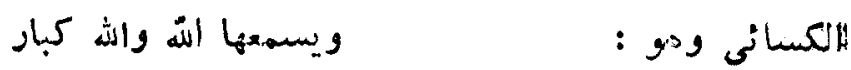

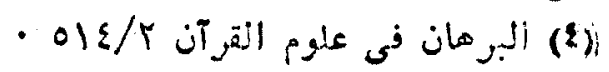

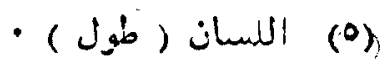

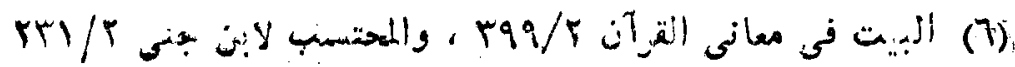

• (V) 
Y.

: isphall Jo,

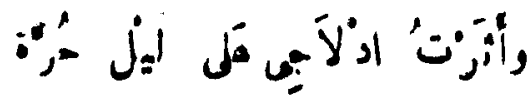

(1)

$$
\text { : }
$$

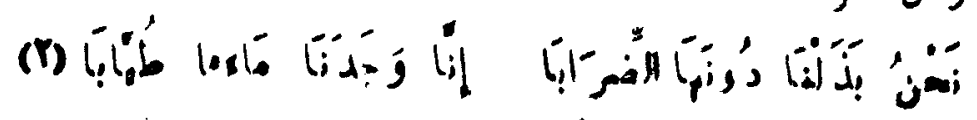

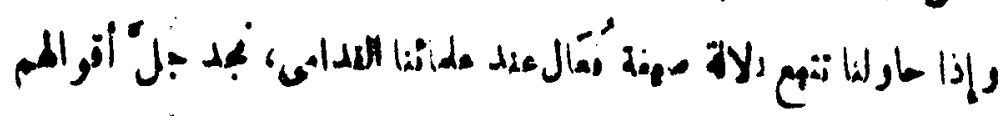

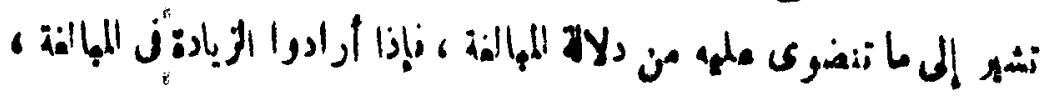

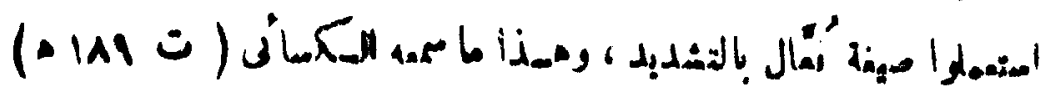

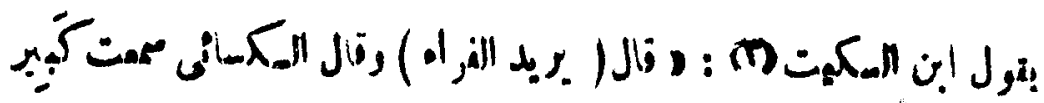

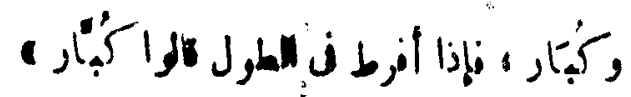

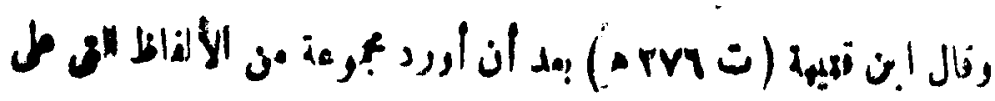

- Jlás' J Je;:

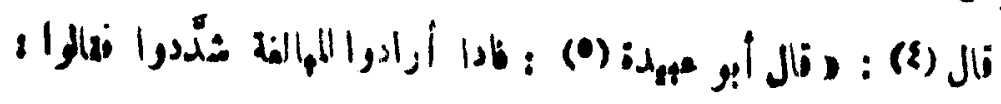

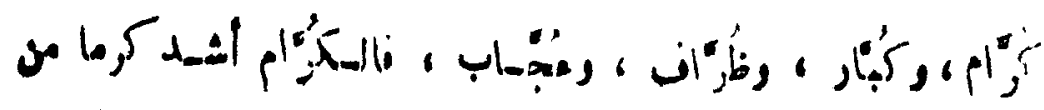

e

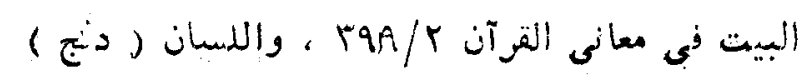

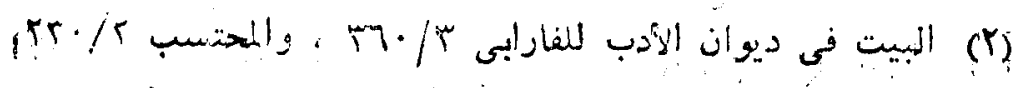

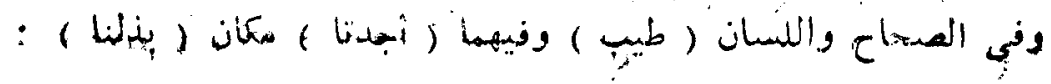

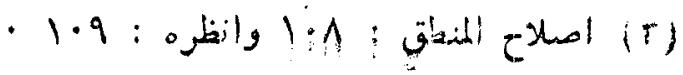

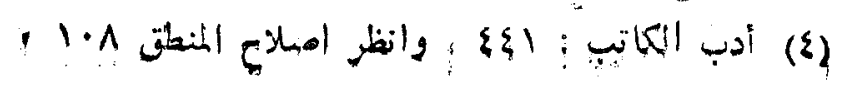

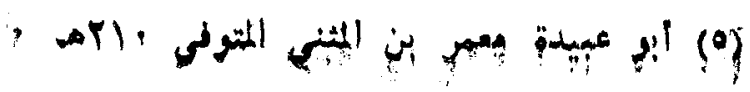


11

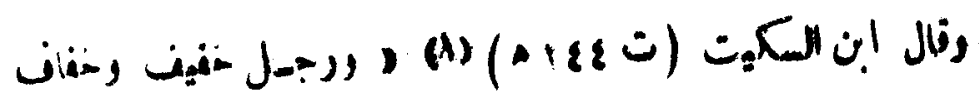

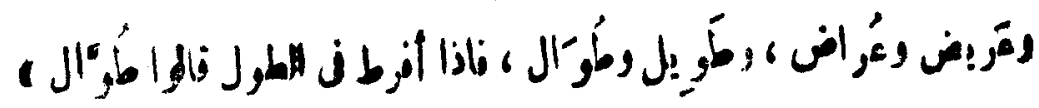

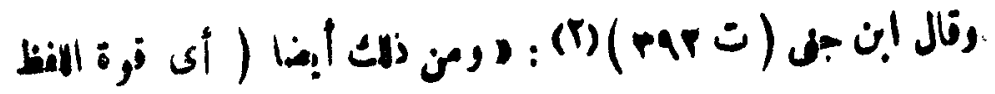

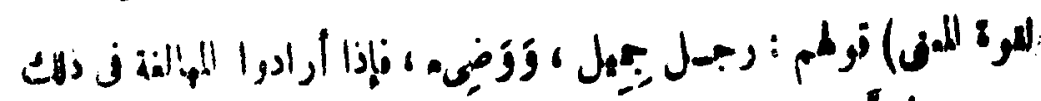

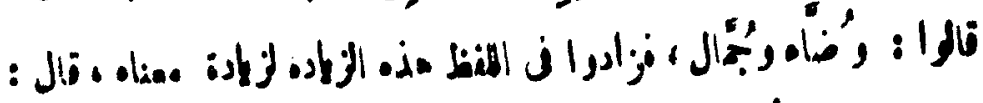

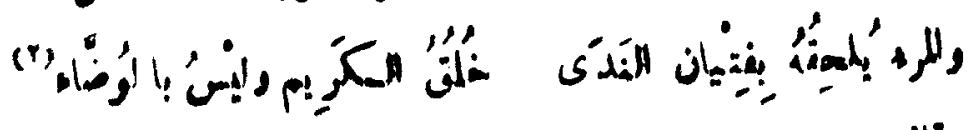
,

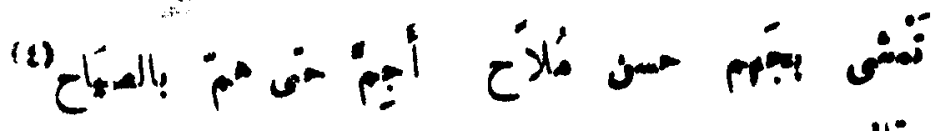
ر

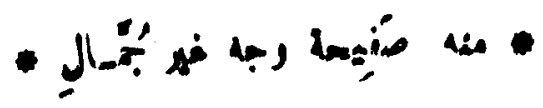

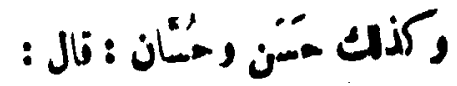

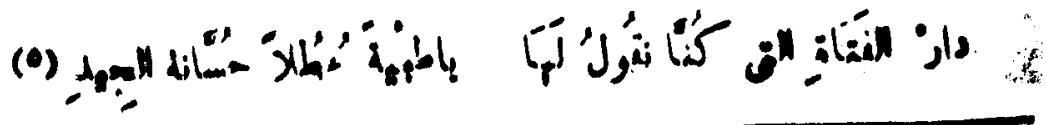

$$
\text { (1) }
$$

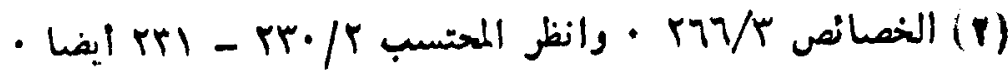

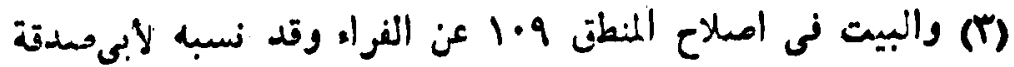

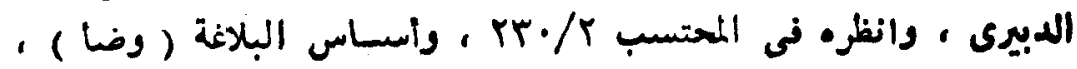

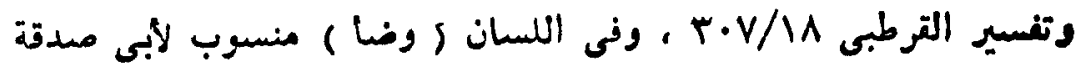

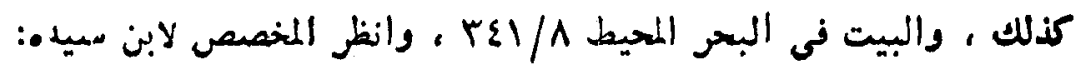
- $19 / 10$

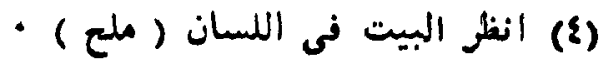

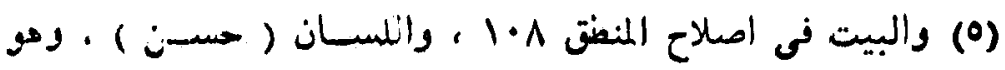

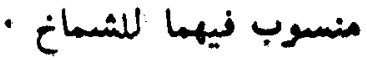




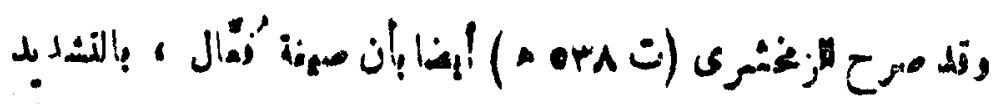

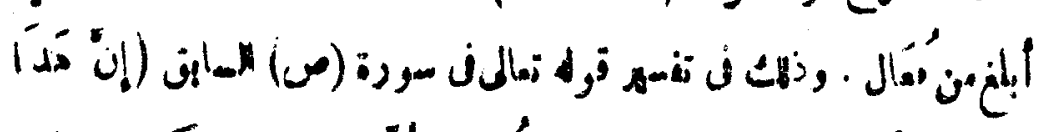

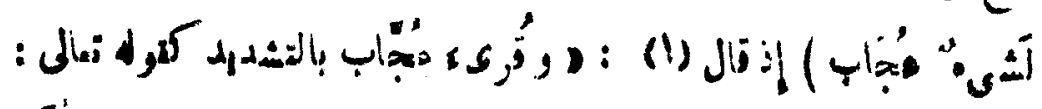

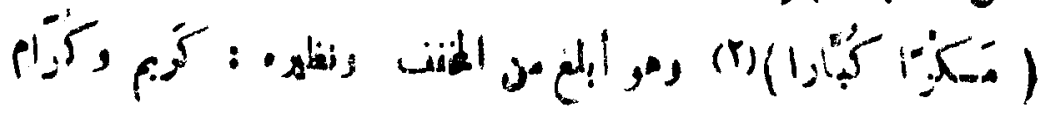
is:

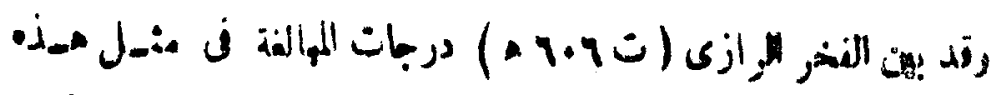

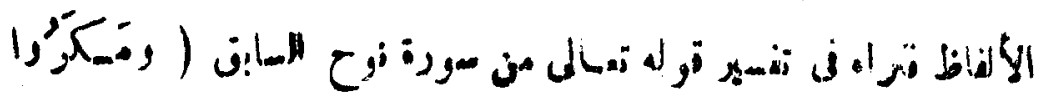

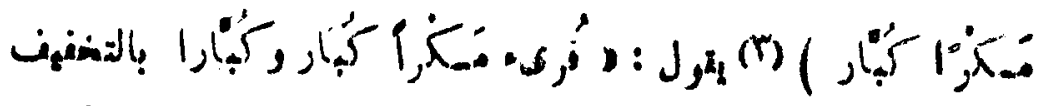

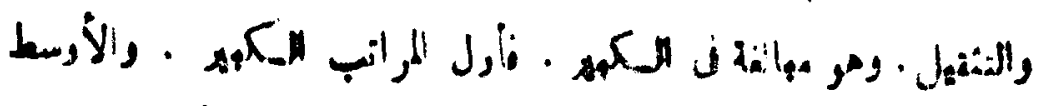

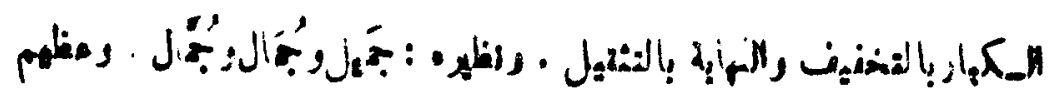

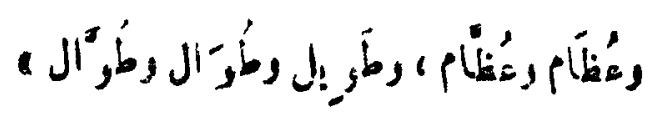

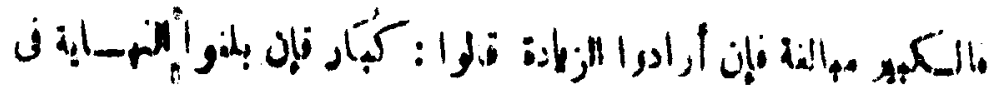

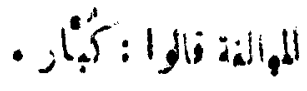

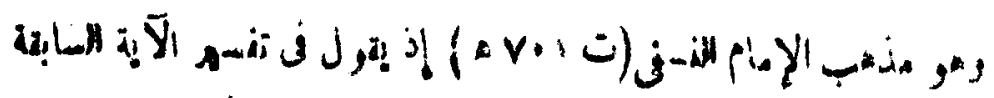
من

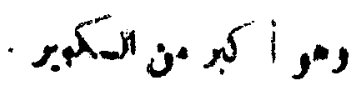

: Irr/0 (1) (1)

$$
\begin{aligned}
& \text { - rr: z g; (r) }
\end{aligned}
$$

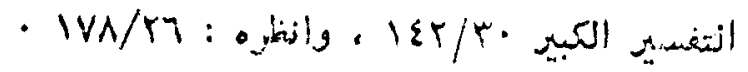

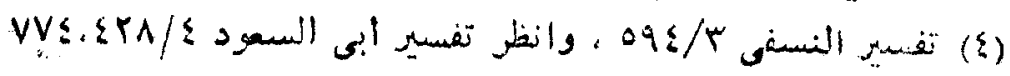




\section{rip}

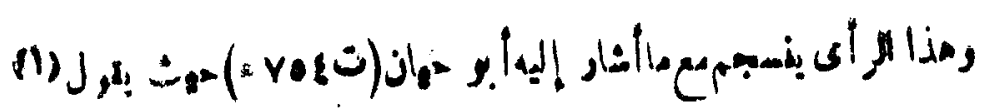

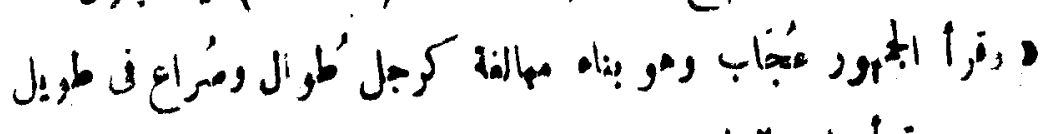

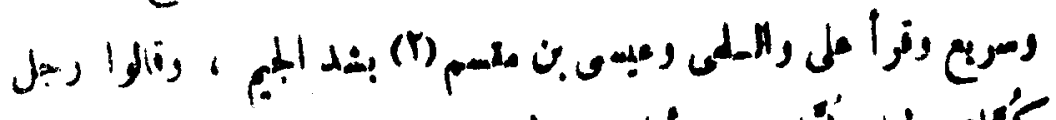

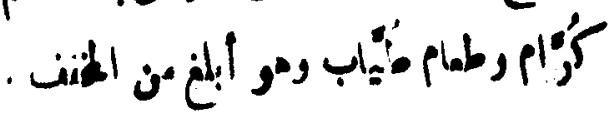

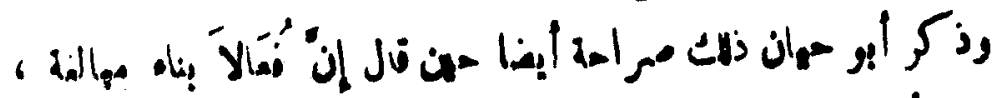

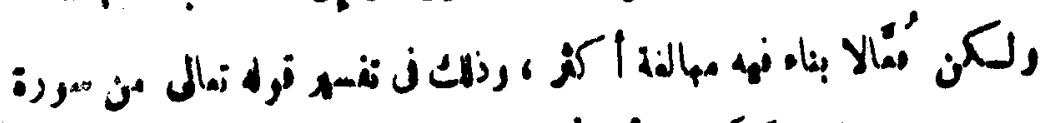

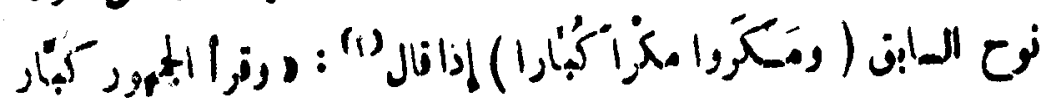

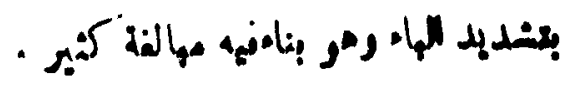

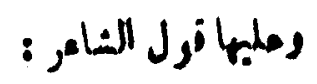

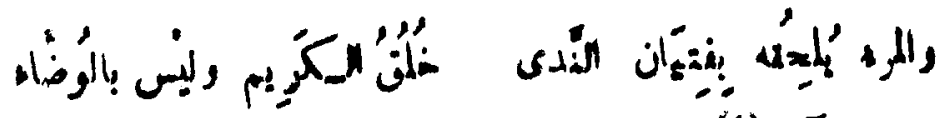
رقول الآخر

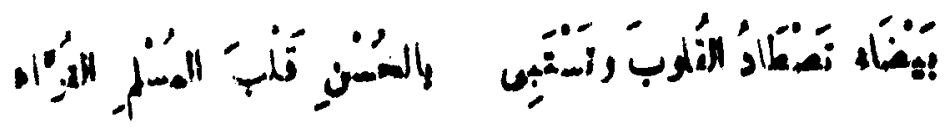

$$
\because r \wedge 0 \% \mathrm{~V} \text { (1) }
$$

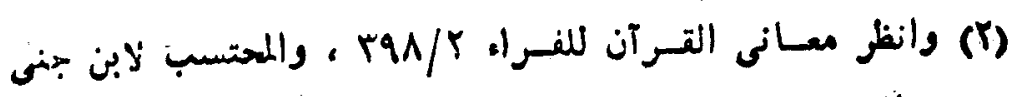

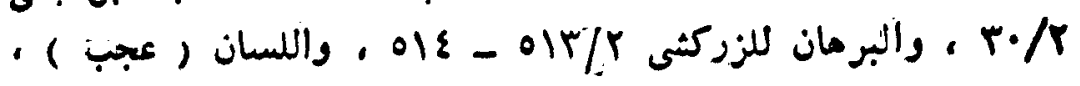

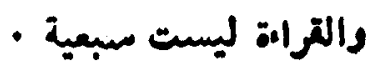

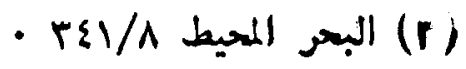

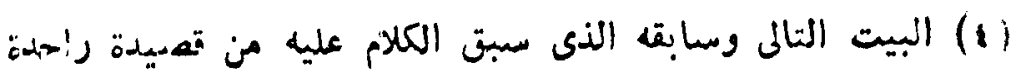

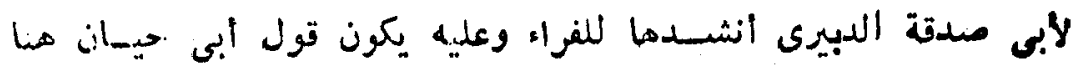

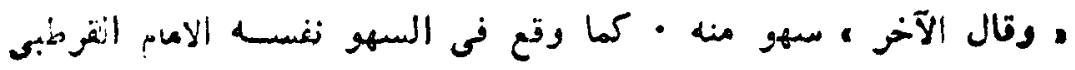

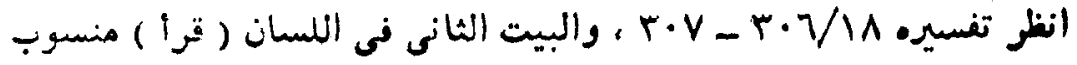


Pet

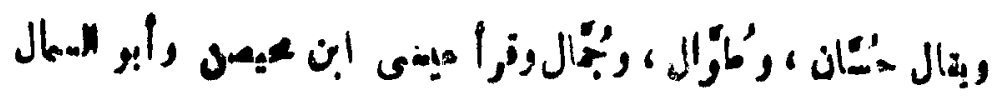

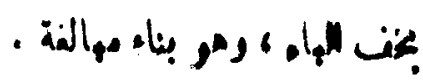

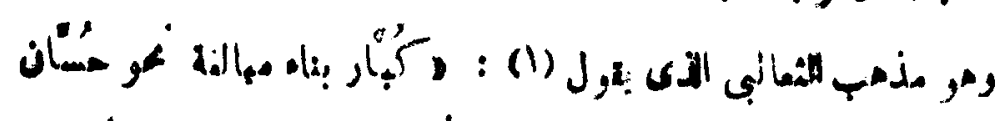

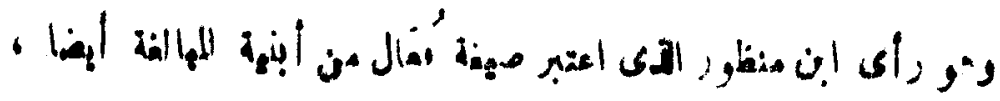

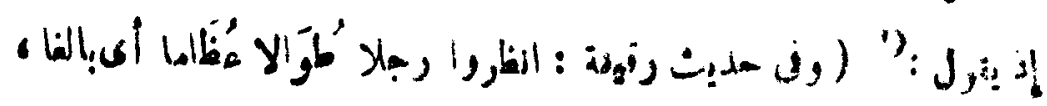

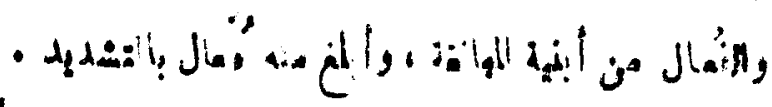

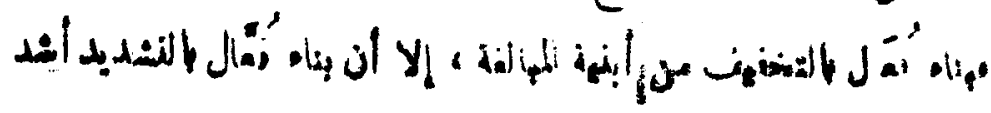
- Ain into

ja

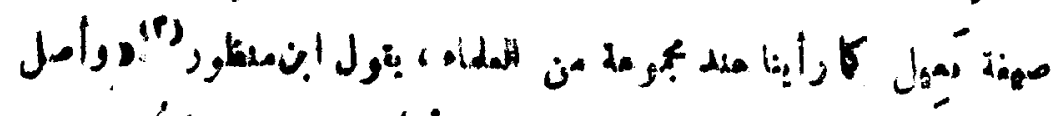
ز

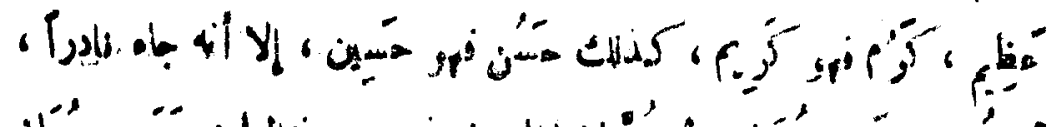

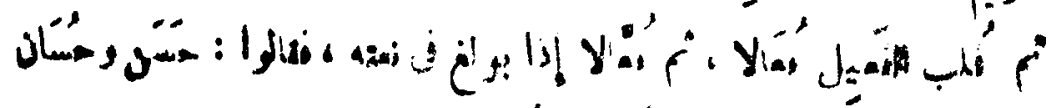

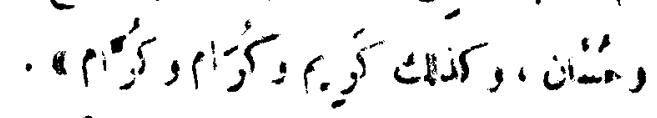

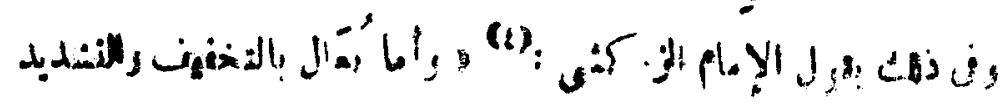

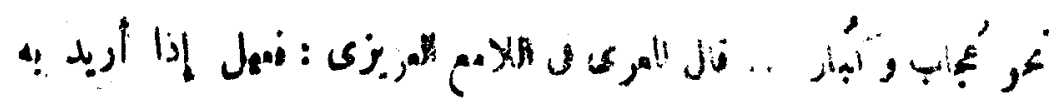

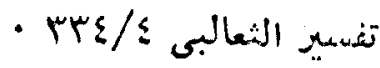

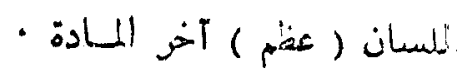

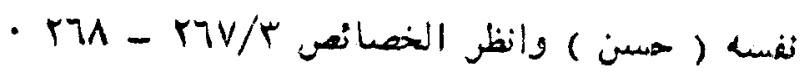

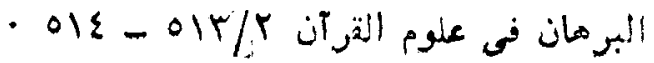




\section{rov}

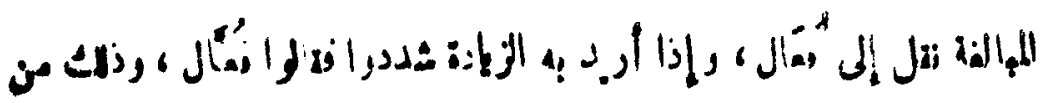

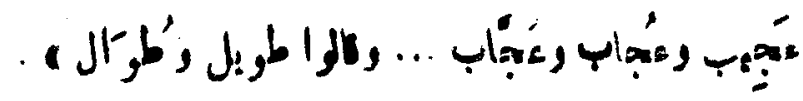

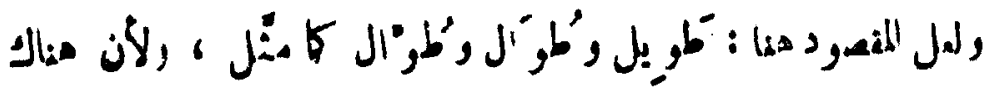

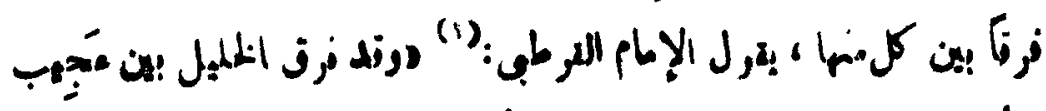

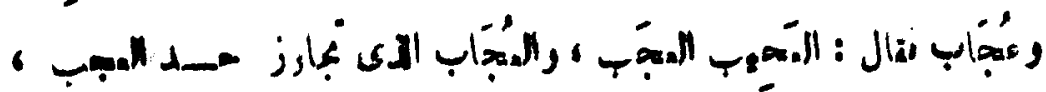

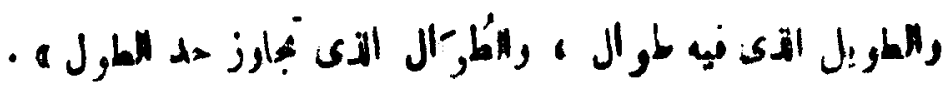

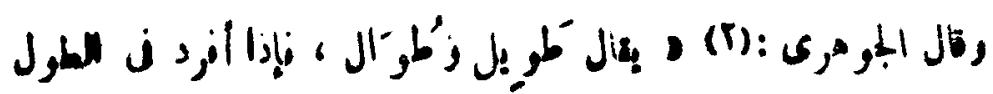

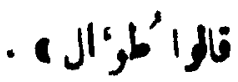

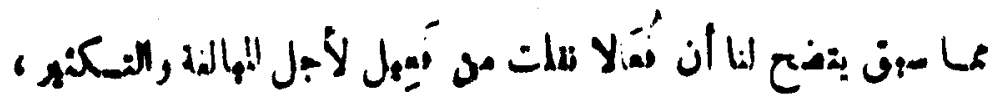

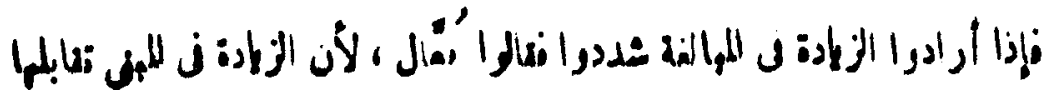

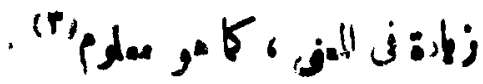

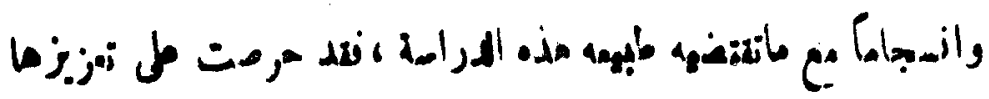

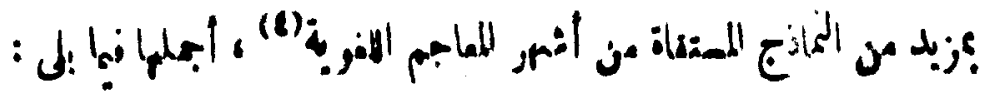

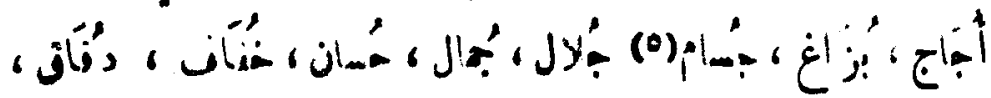

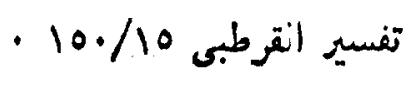

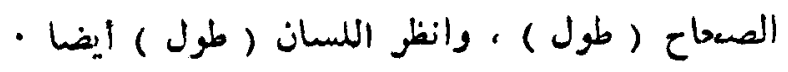

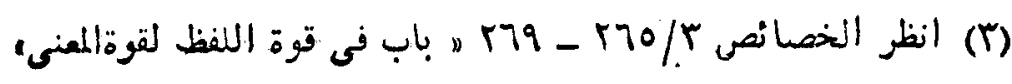

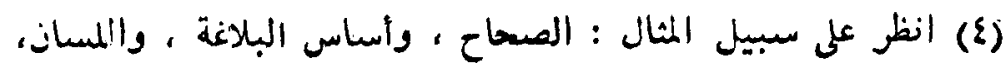

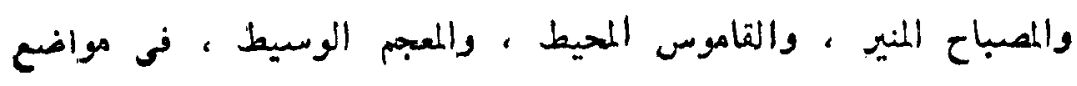

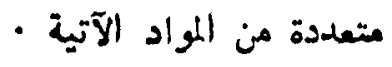

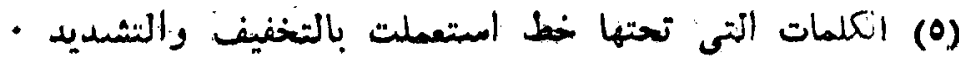




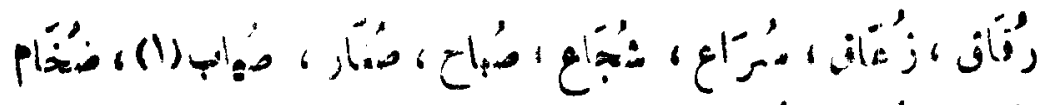

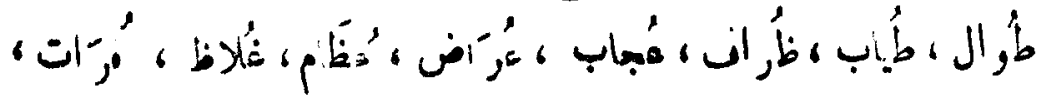

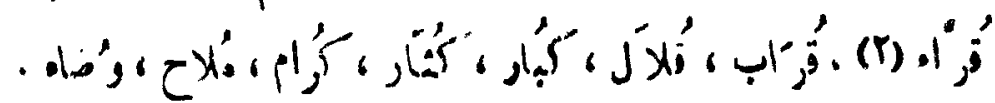

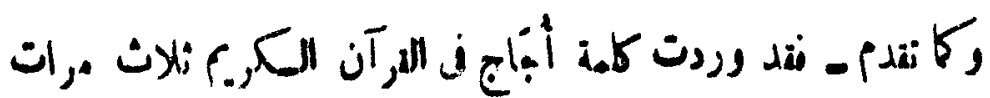

$$
\text { وذن }
$$

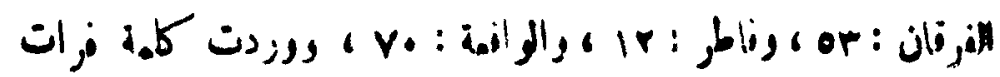

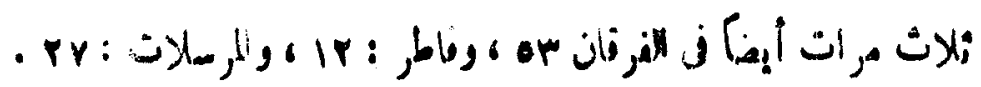

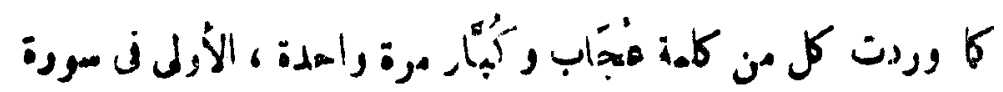

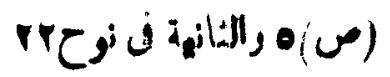

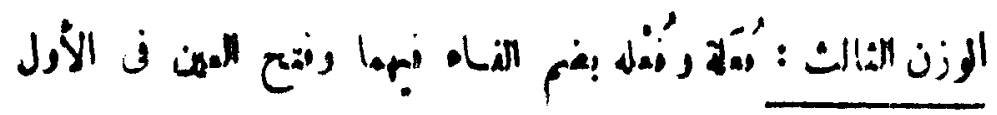

$$
\text { : }
$$

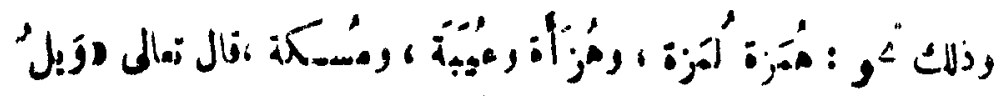

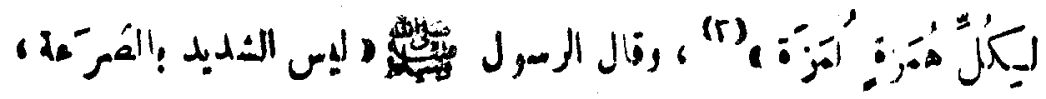

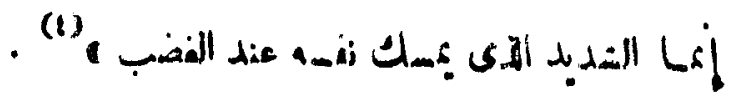

(1) الصياب والصيابة املل التوم وخيارمم ، وقد يقال مسوابة :

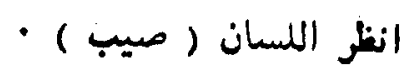

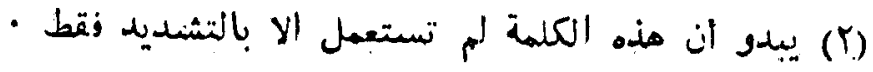

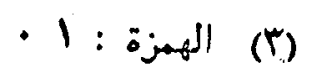

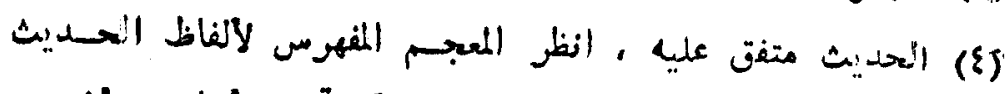

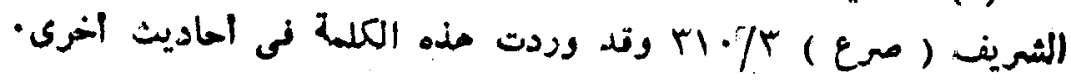




\section{rev}

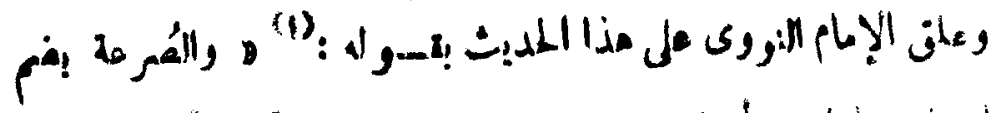

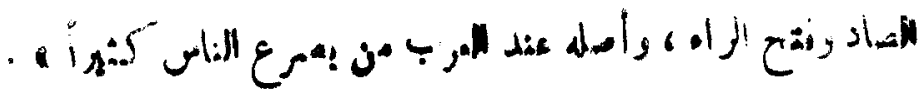

$$
\text { : المثأling }
$$

(r)

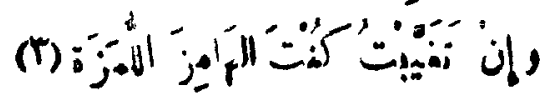

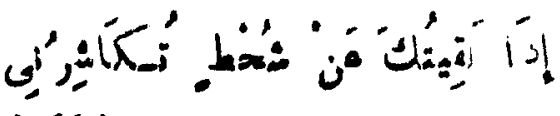

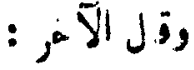

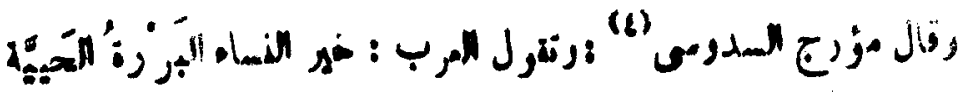

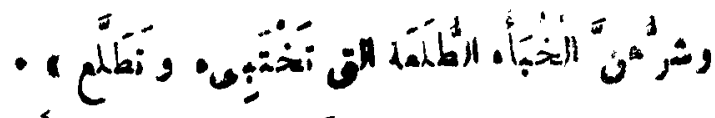

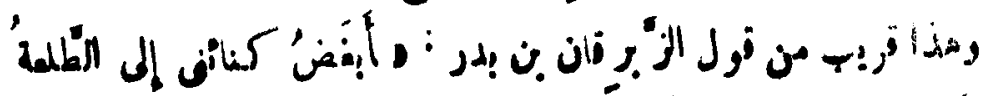

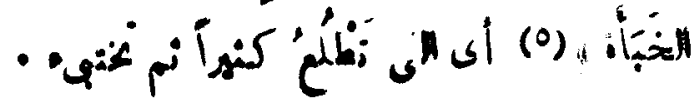

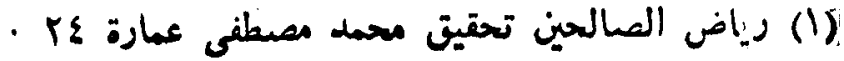

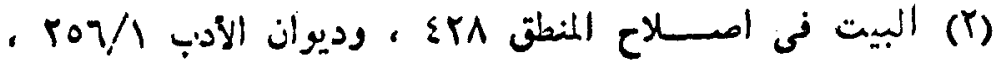

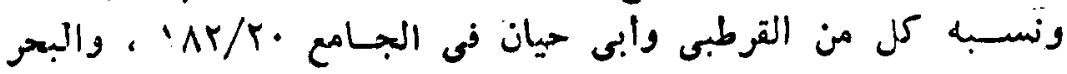

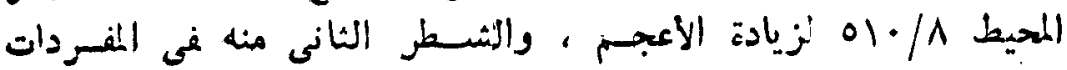

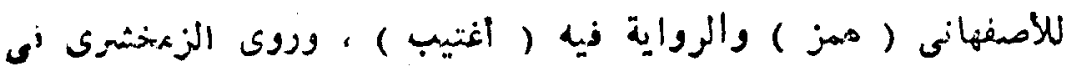

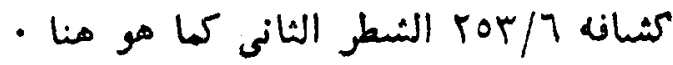

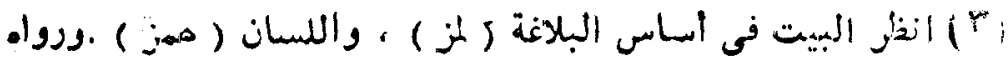

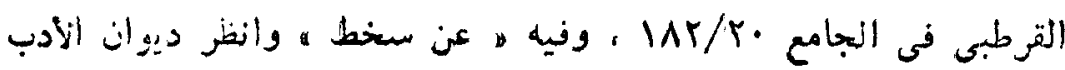
- rov/l

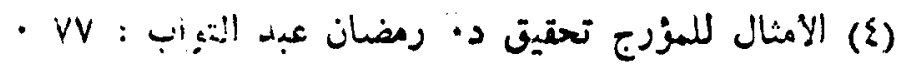

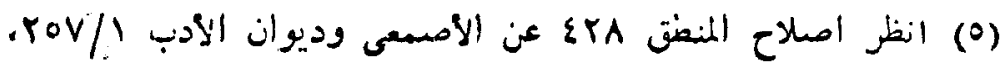




\section{Min}

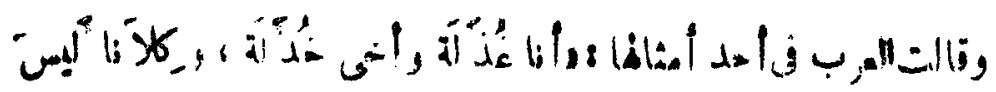

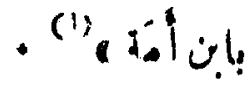

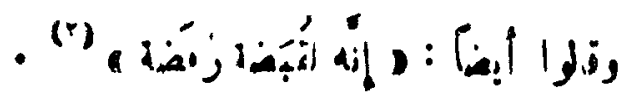

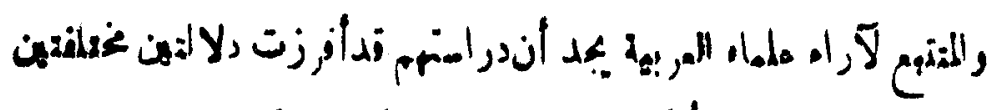

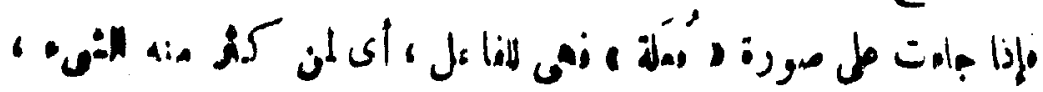

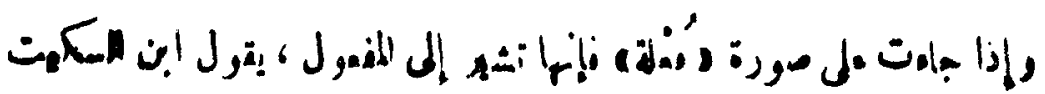

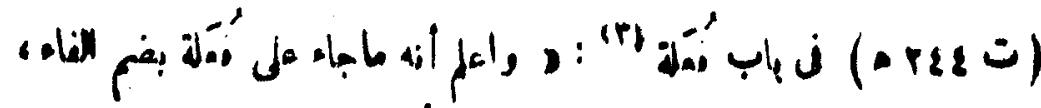

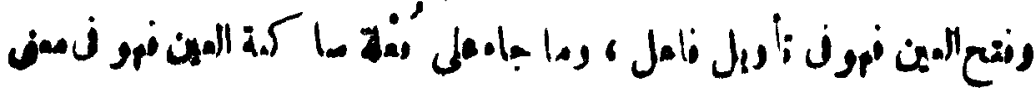
مغن ل

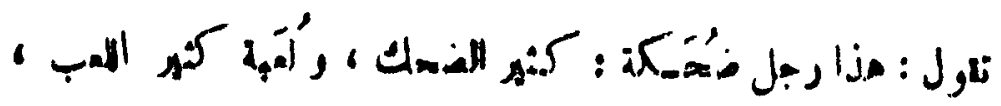

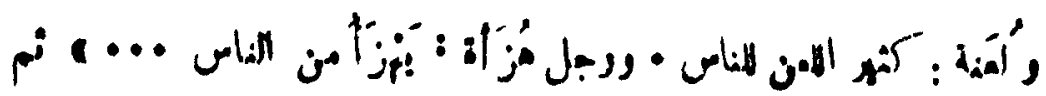

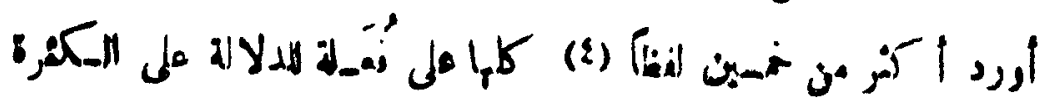

- jolit

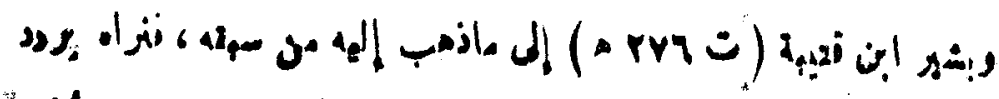

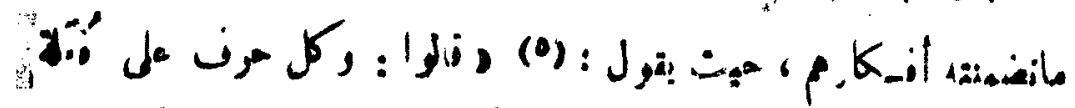

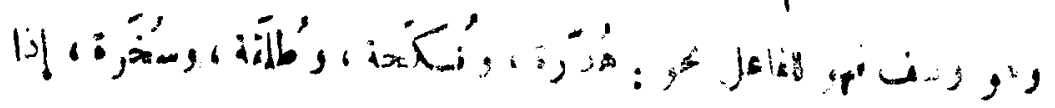

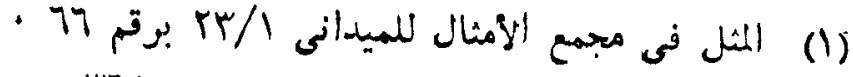

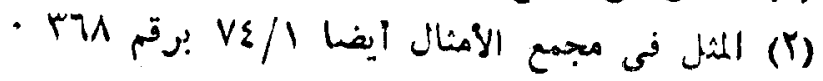

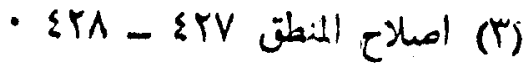

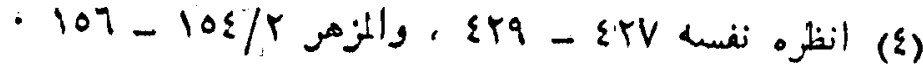

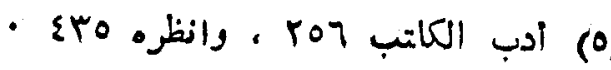




\section{ris}

sol

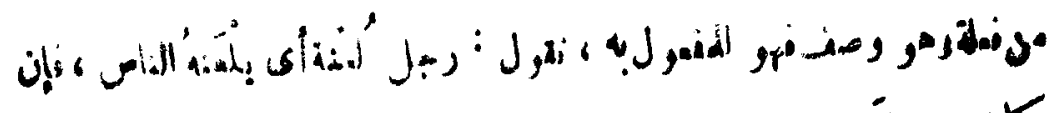
:

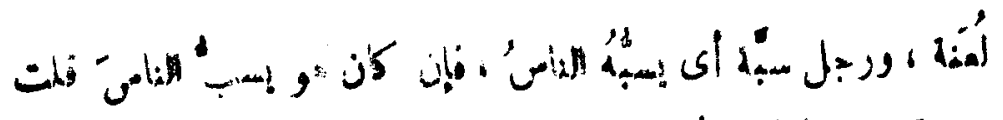

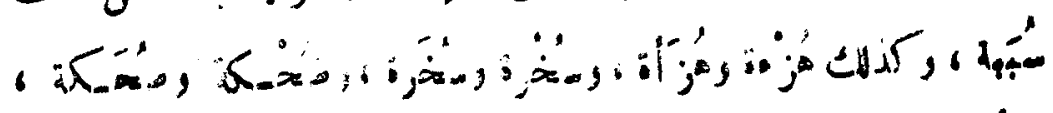

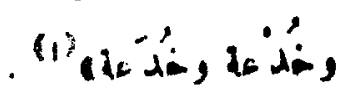

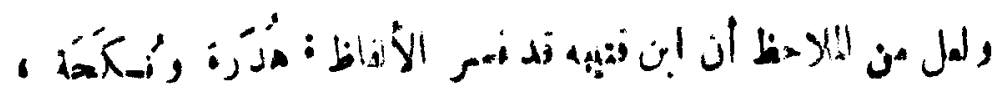

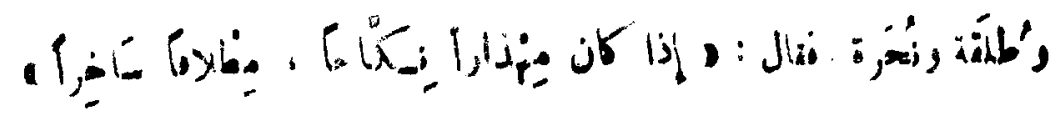

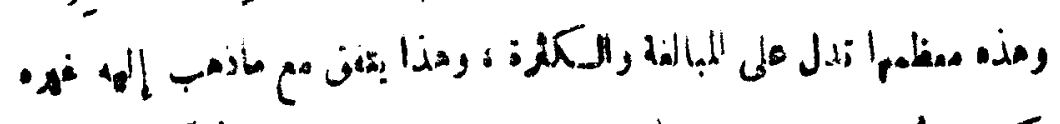

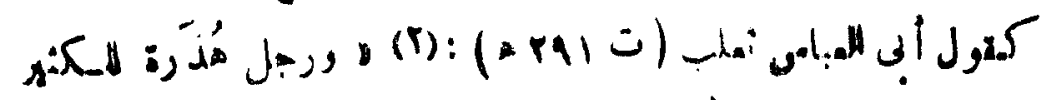

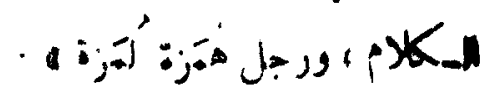

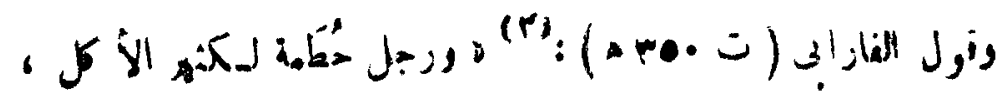

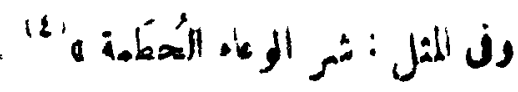

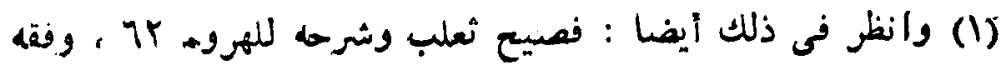

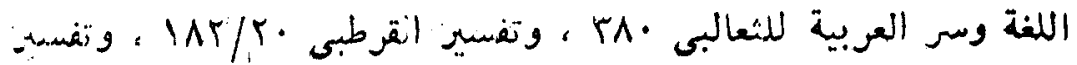

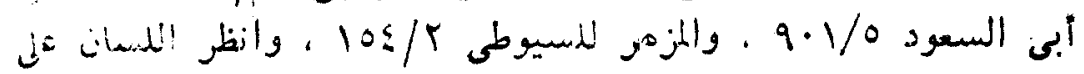

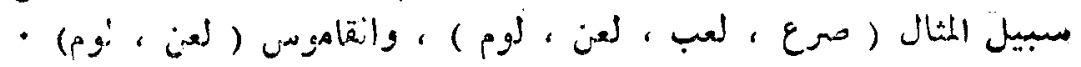

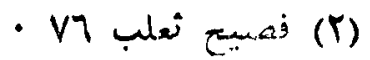

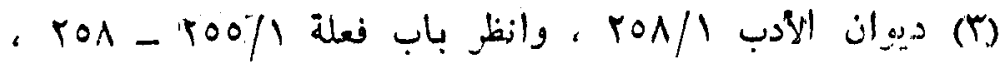
. $r \leqslant 0, r 19,57 / r$

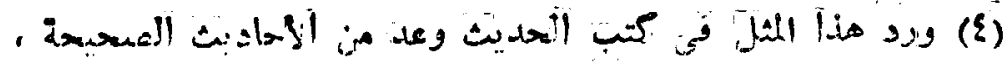

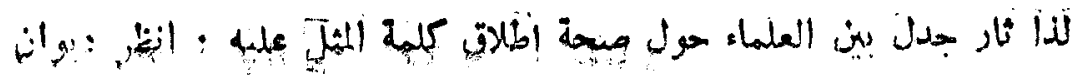


ف

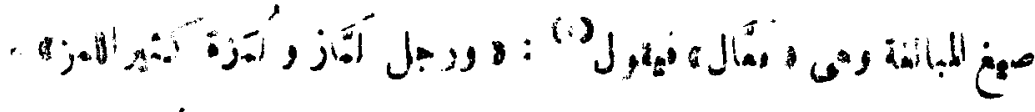
أ

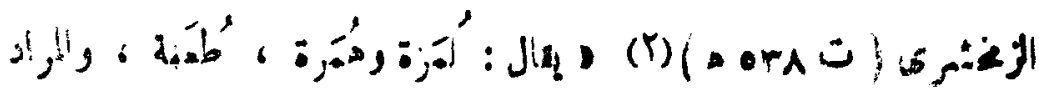

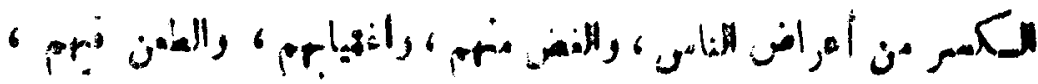

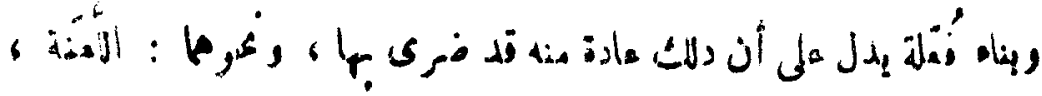

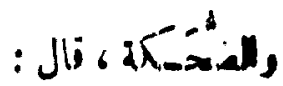

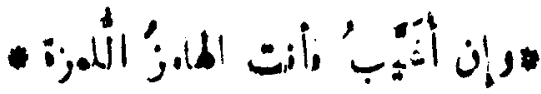

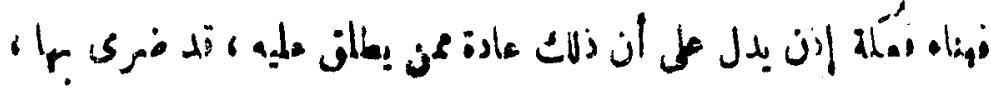

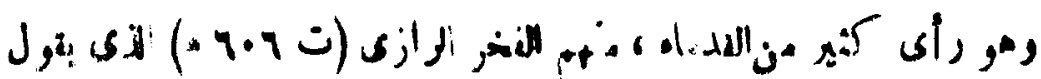

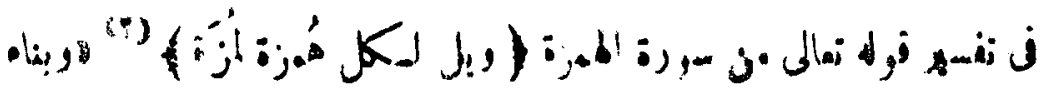

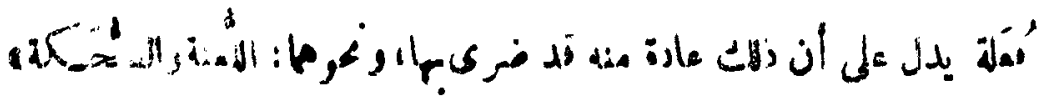

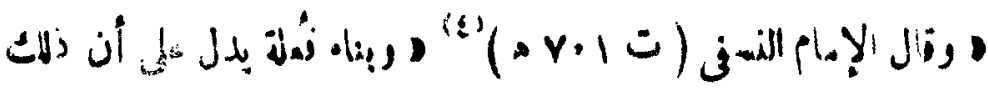
- a sis

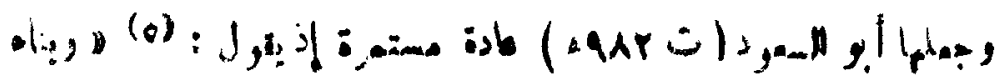

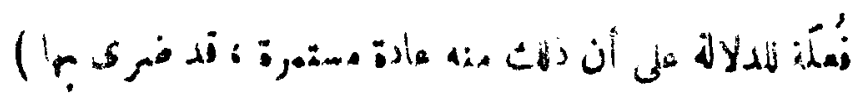

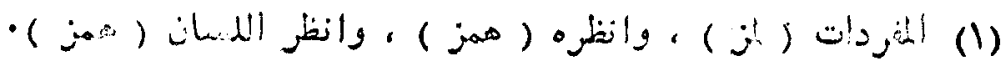
- ror/7 الكثياف

$$
\begin{aligned}
& \text { - } \\
& \text { - VTrjo }
\end{aligned}
$$

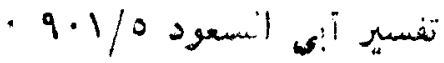


Yol

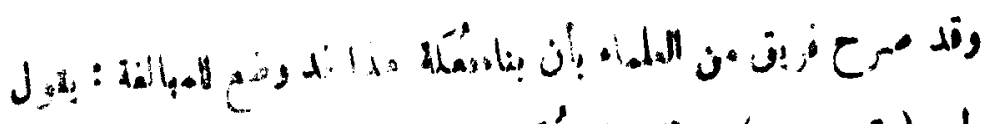

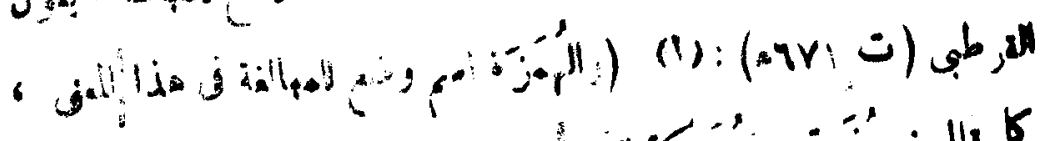

كالمال :

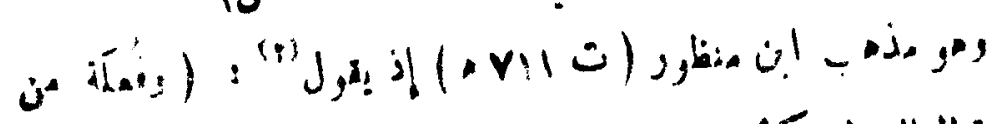

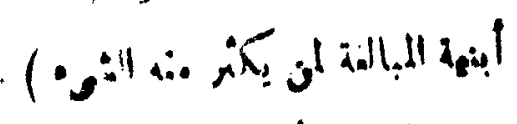

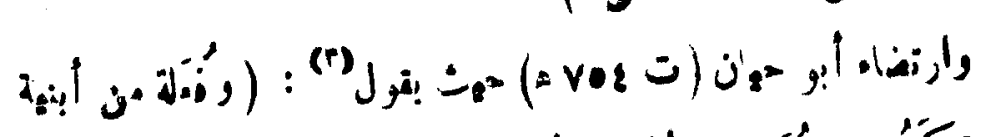

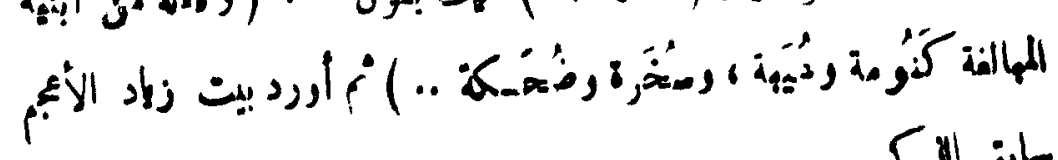

كابن الy

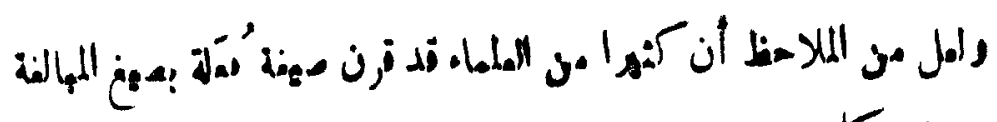

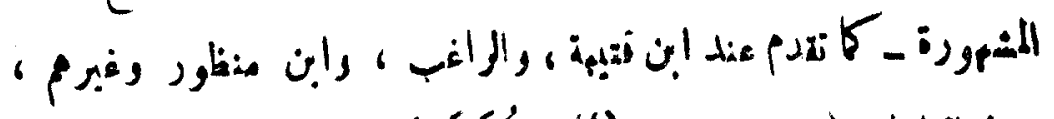

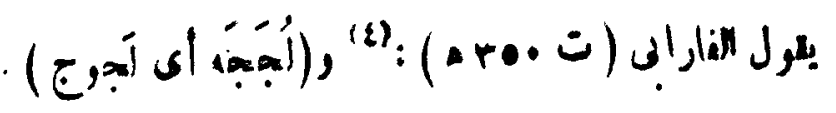

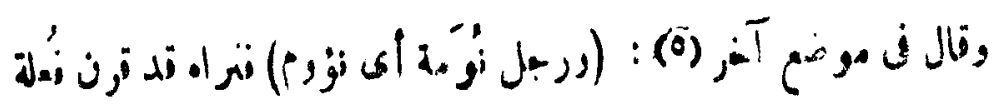

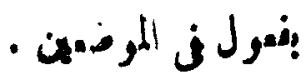

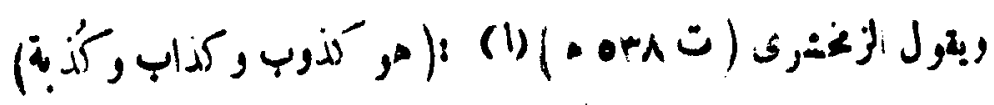

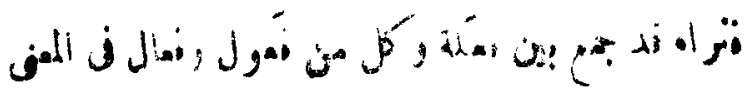

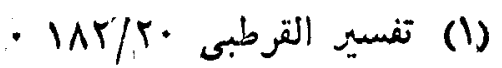

- ( نكم) : (T)

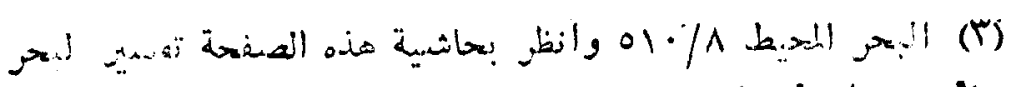

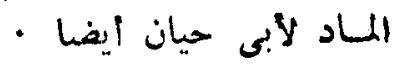

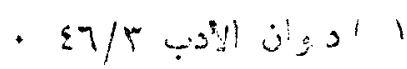

- ros/t d a is (0)

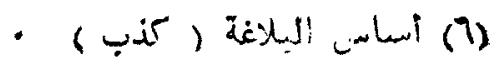




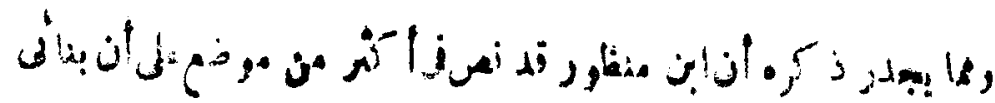

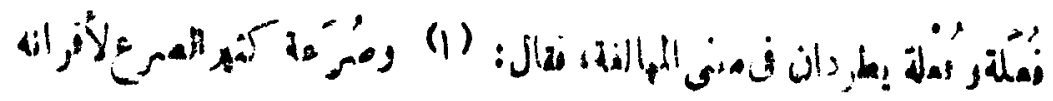

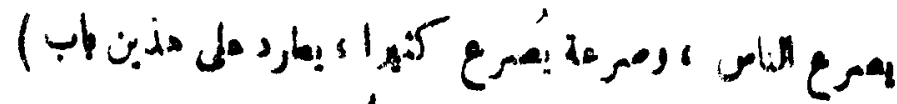

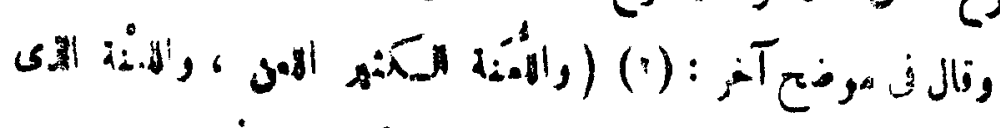

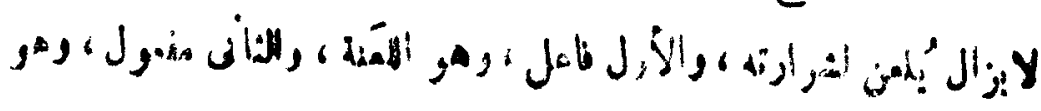

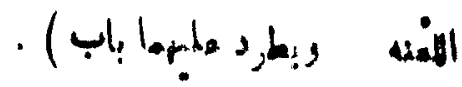

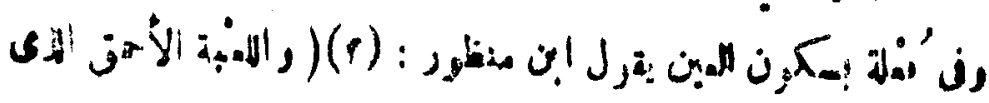

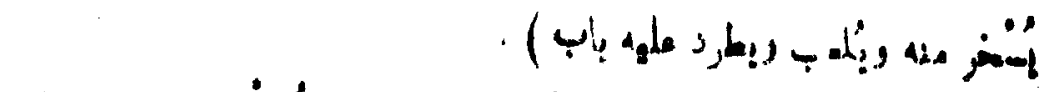

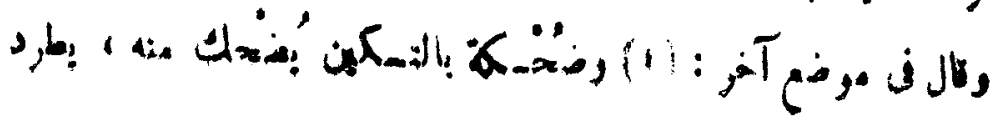
•

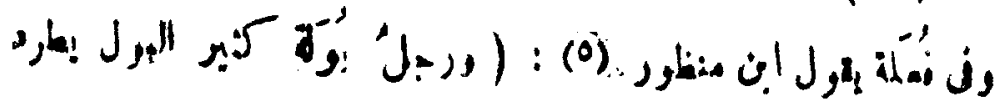
.

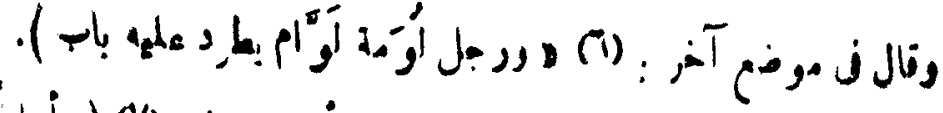

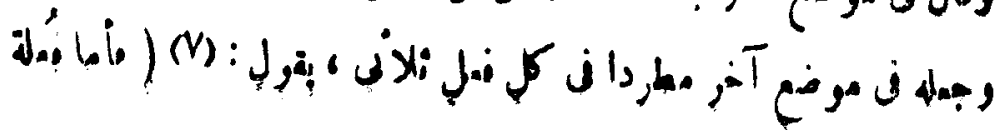

$$
\begin{aligned}
& \text { - المسان ( صرع ) }
\end{aligned}
$$

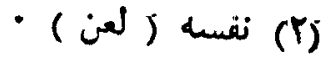

$$
\begin{aligned}
& \text { نقسه ( ضحكك ) م الك } \\
& \text { نفسه ( بول ) } \\
& \text { نفسه ( لوم ) }
\end{aligned}
$$

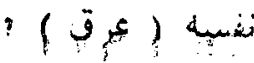

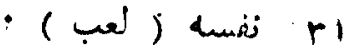




\section{rop}

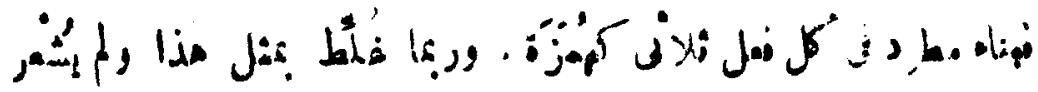
$(0.1)$ b uk?

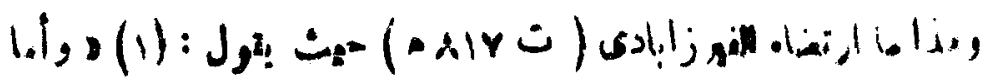
is

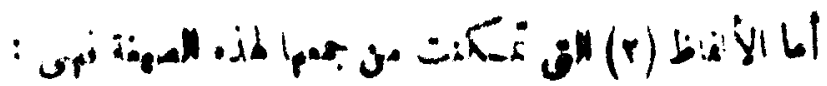

a

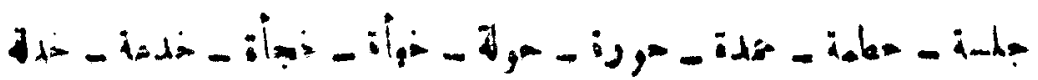

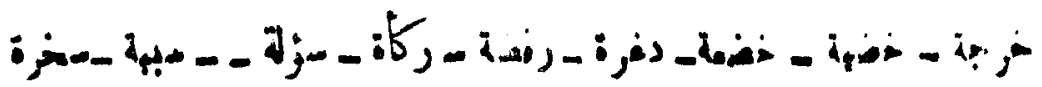

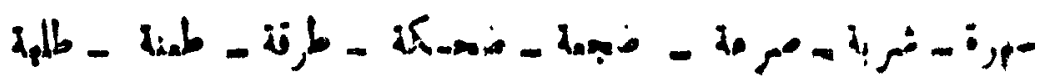

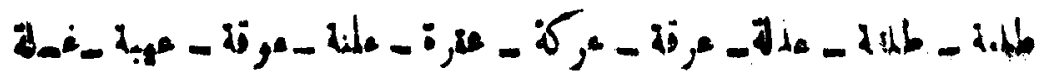

-

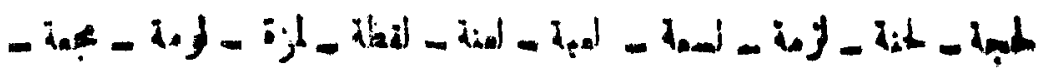

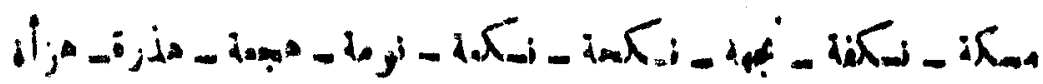

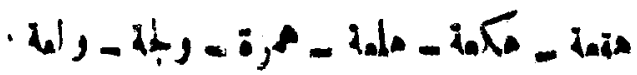

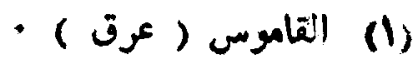

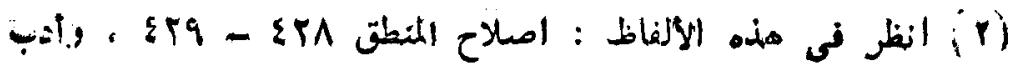

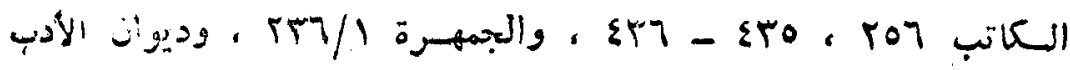

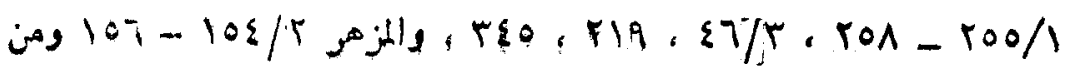

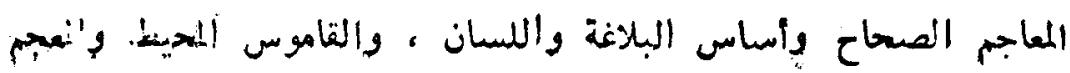

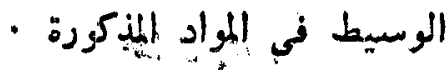

$(j+r)$ 


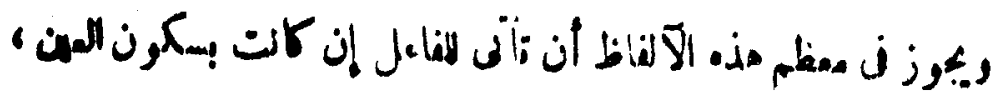

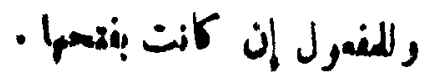

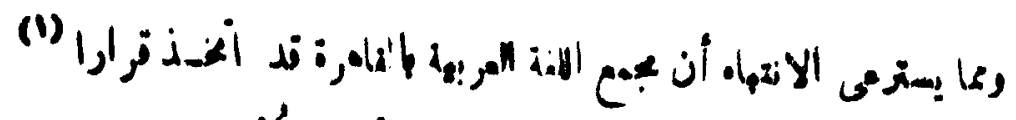

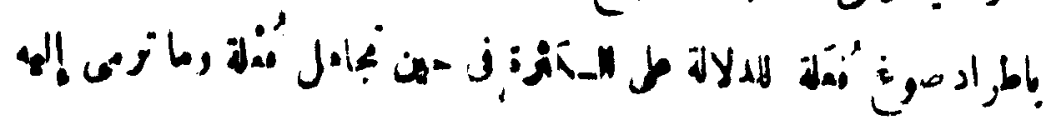

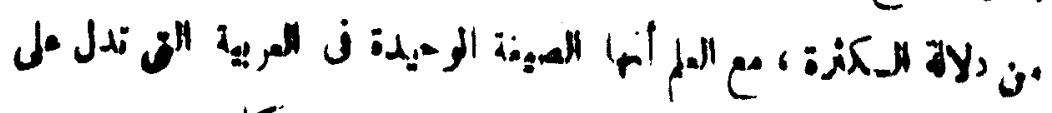

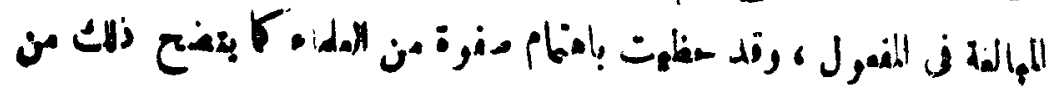

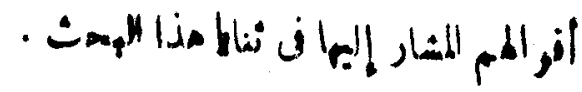

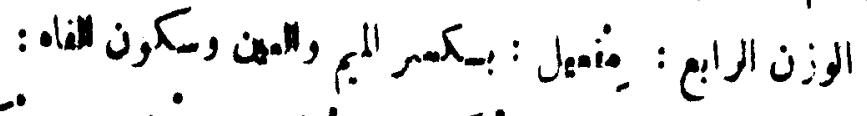

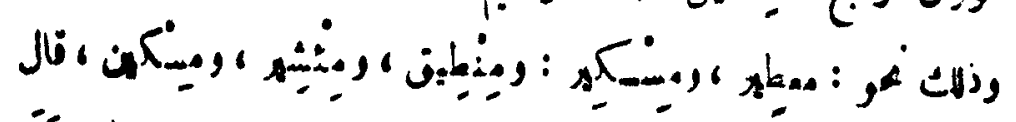

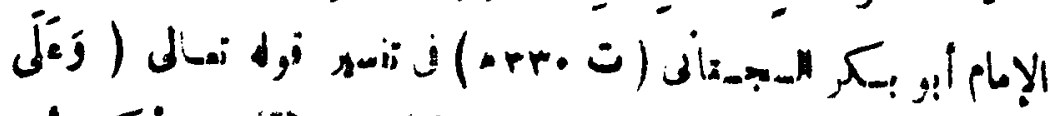

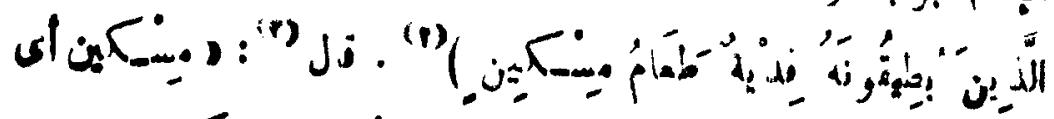

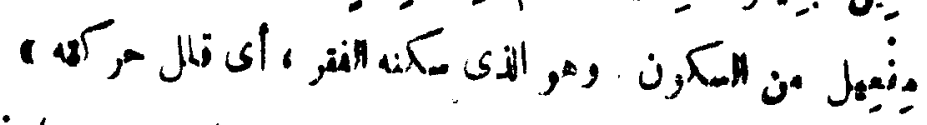

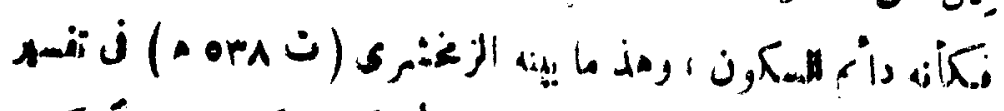

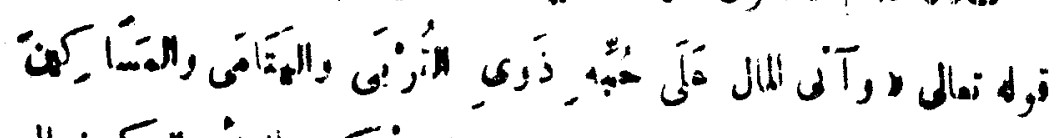

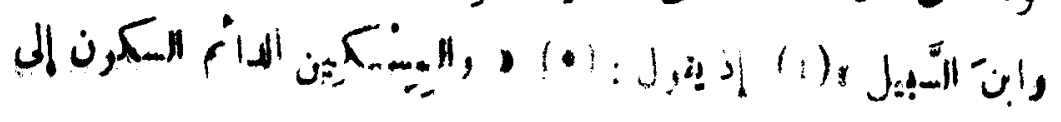

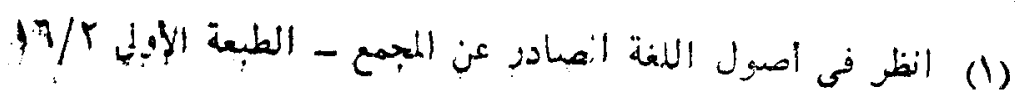

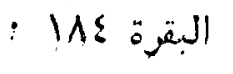

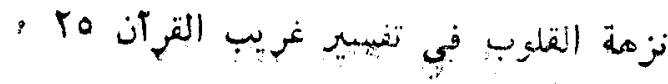

البقرة: IVV 


\section{$p$}

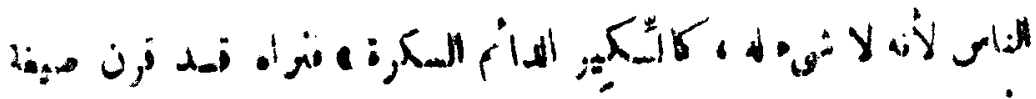
- Jonit J:ais

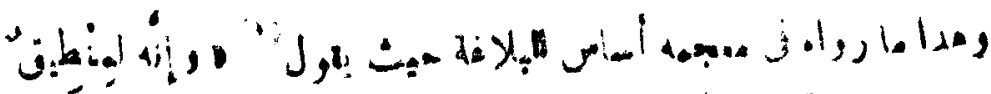

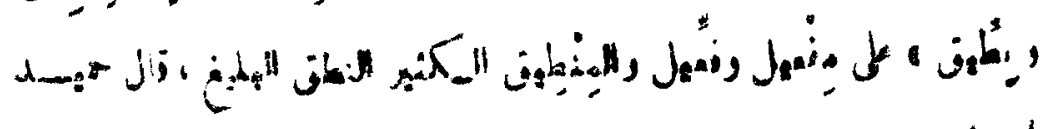
: رiv!

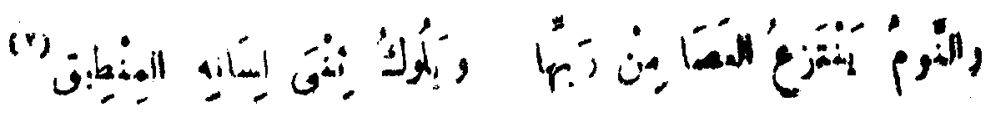

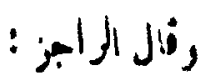

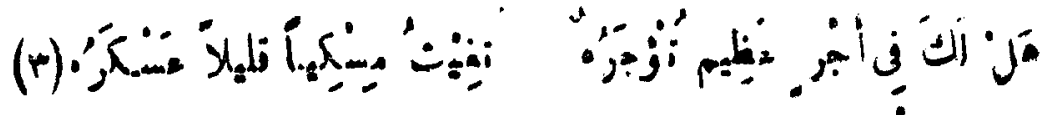

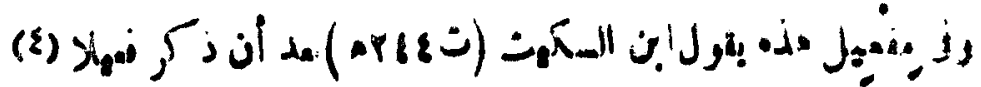

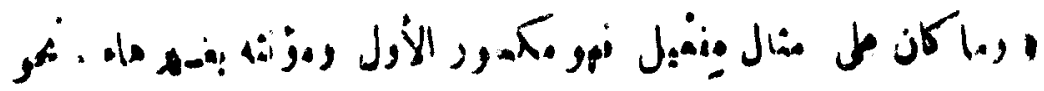

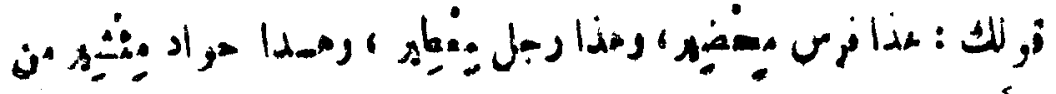
(الأَُّ (0) $;$ 小

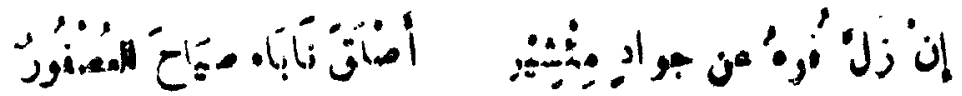

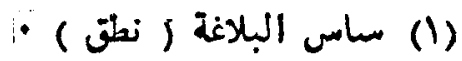

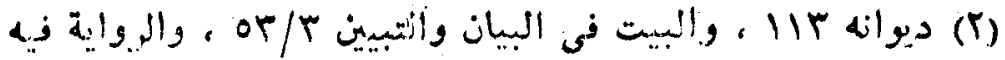

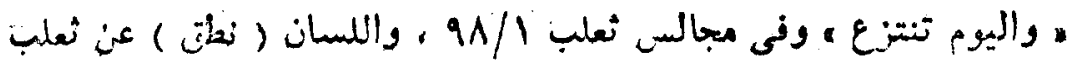

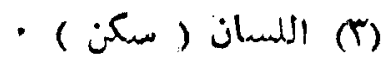

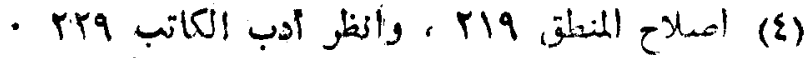

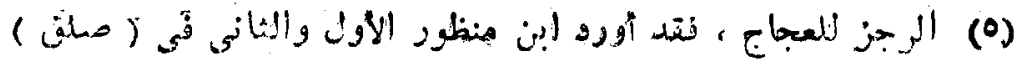

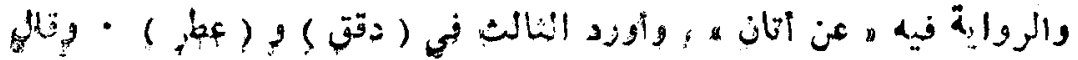

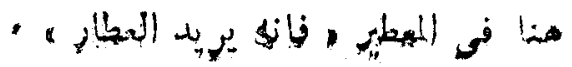




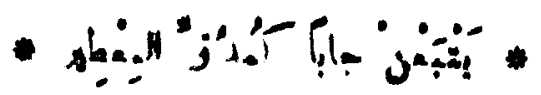

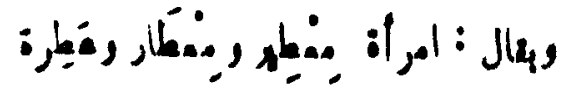

$$
\begin{aligned}
& \text { : }
\end{aligned}
$$

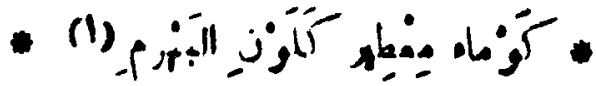

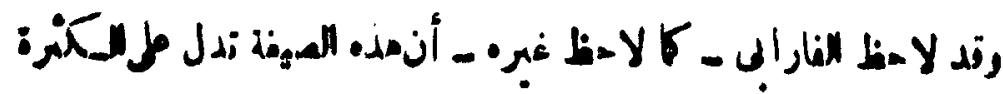

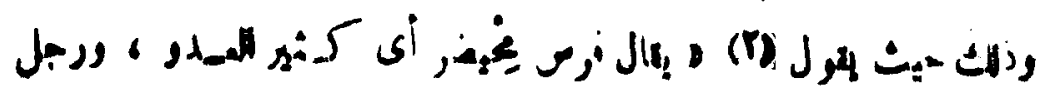

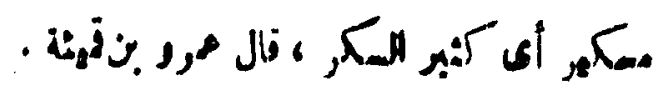

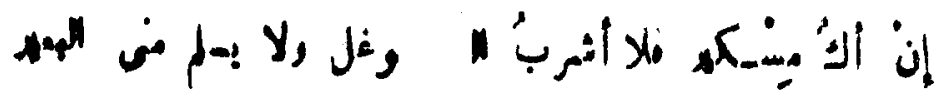
'

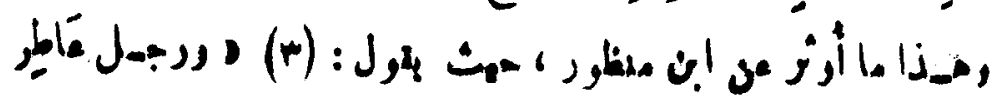

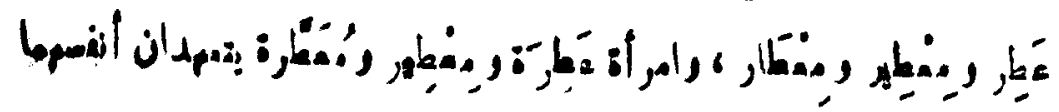

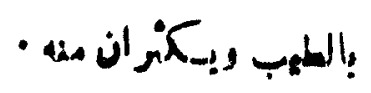

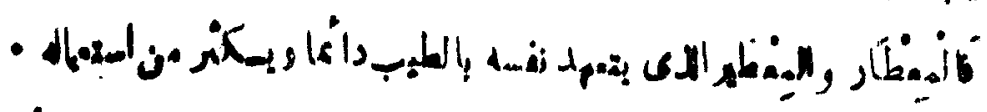

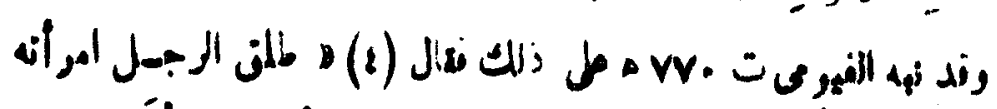

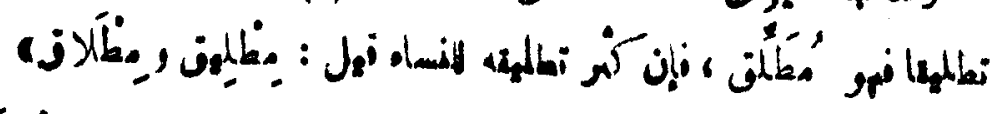

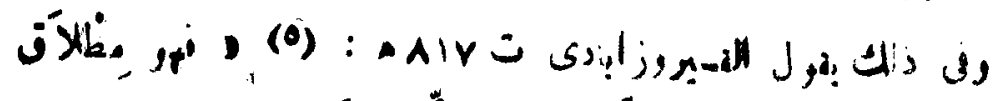

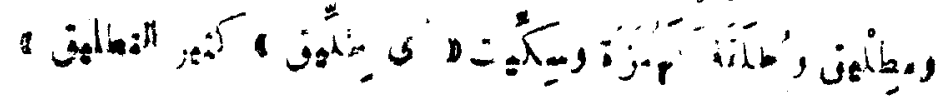

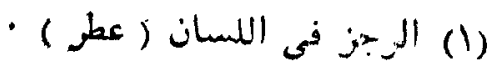

$$
\begin{aligned}
& \text { - Tाع/1 (1) }
\end{aligned}
$$

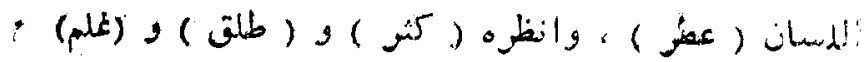

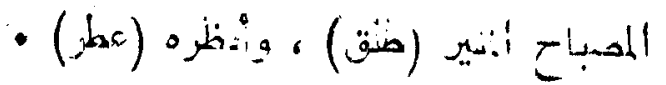

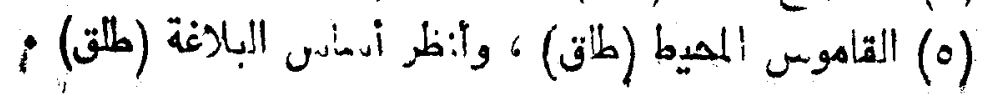




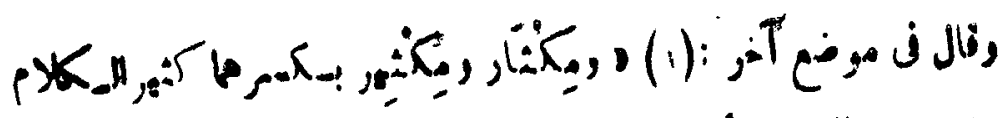

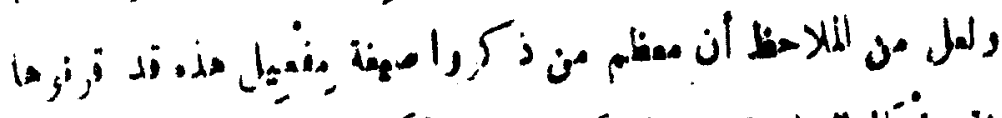

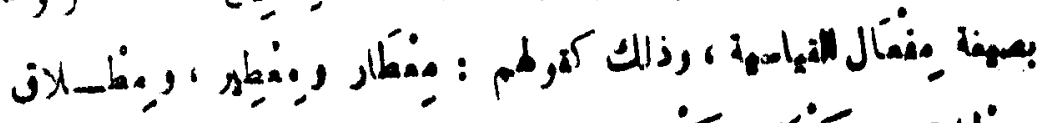

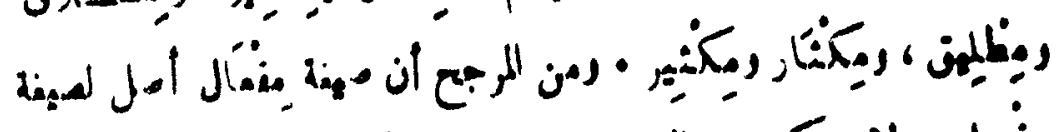

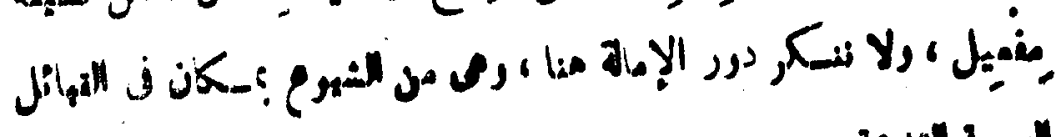

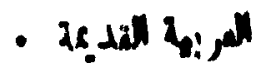

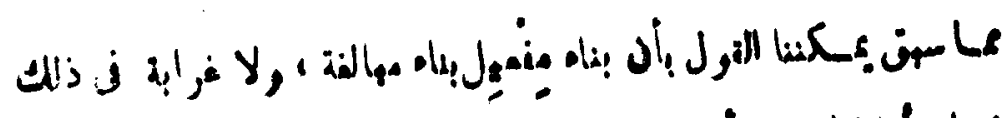

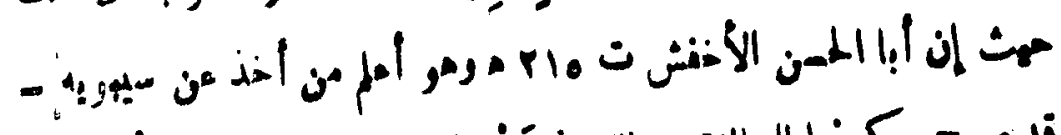

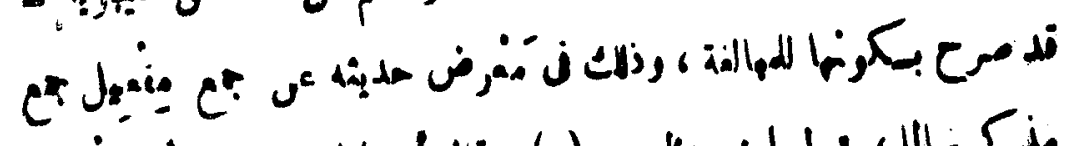

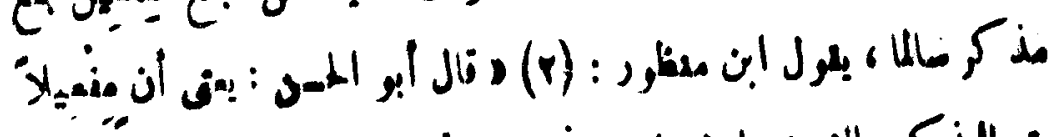

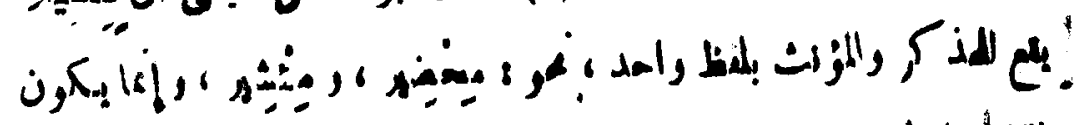

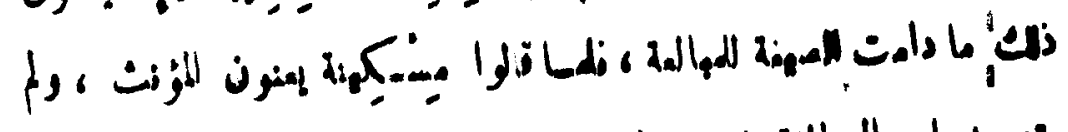

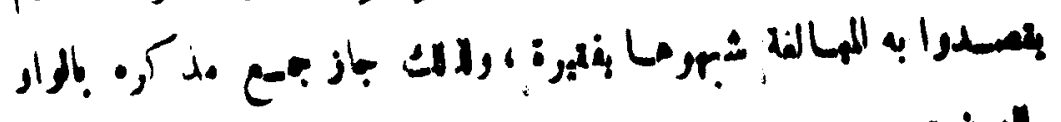
رلمثرن ا ـ .

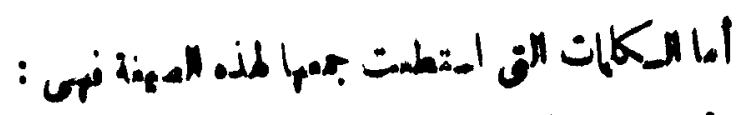

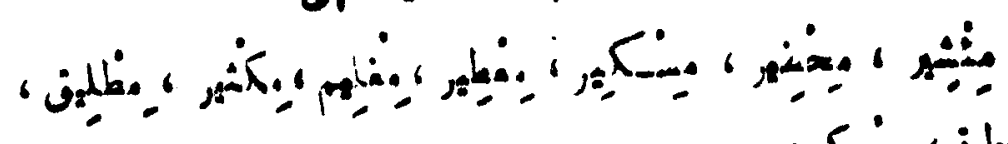

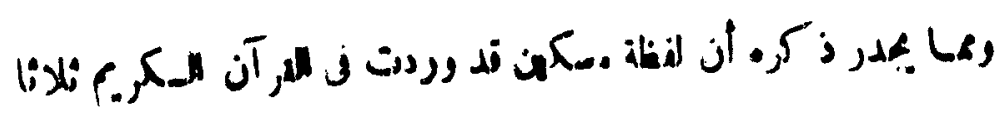

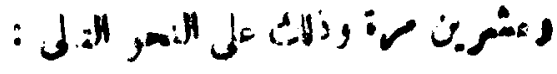

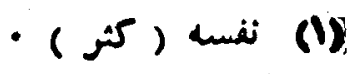

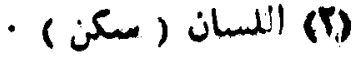




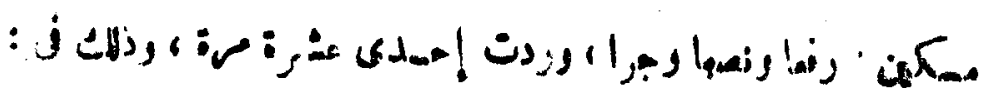

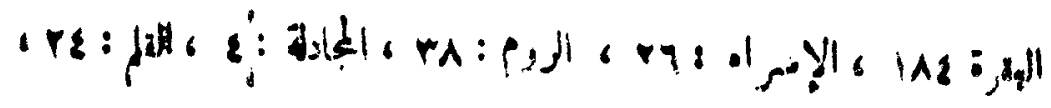

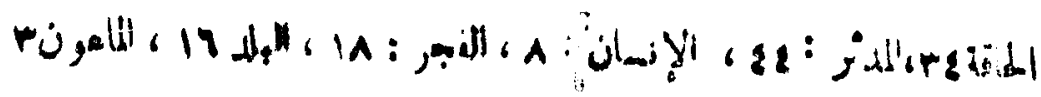

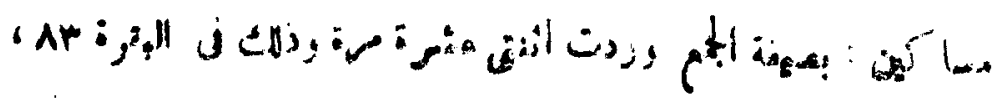

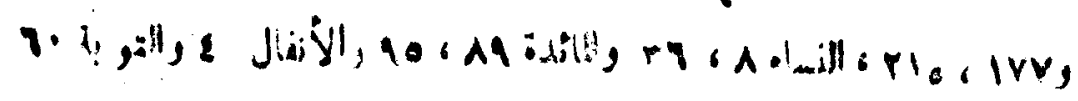

$$
\begin{aligned}
& r \text { inl, rr, , in, va ipsn, }
\end{aligned}
$$

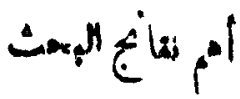

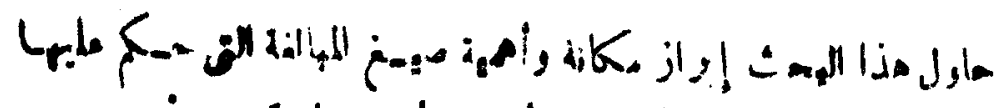
萑

:

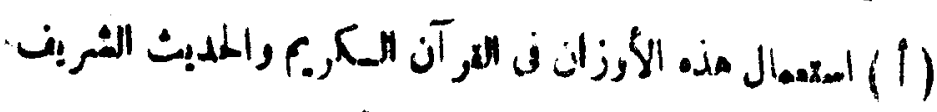

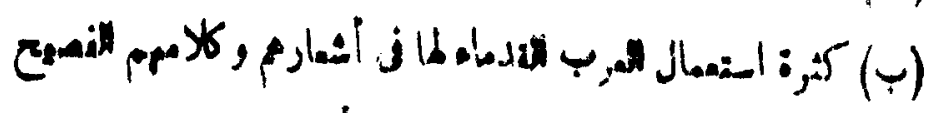

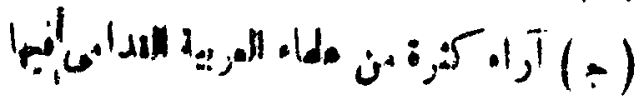

$$
\begin{aligned}
& \text { (د) }
\end{aligned}
$$

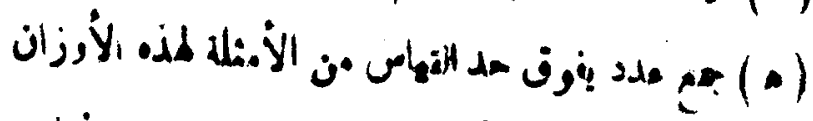

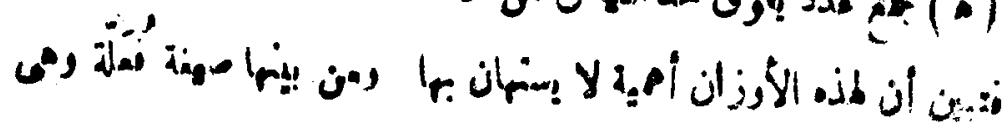

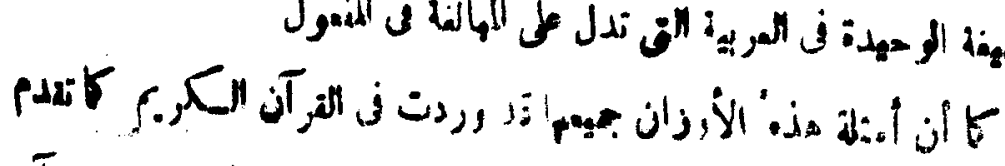

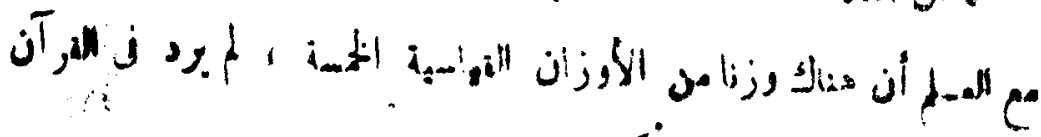

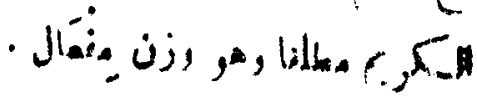




\section{ros}

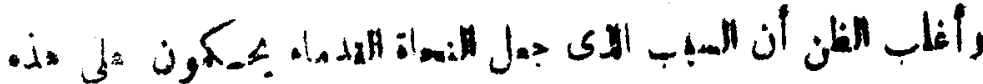

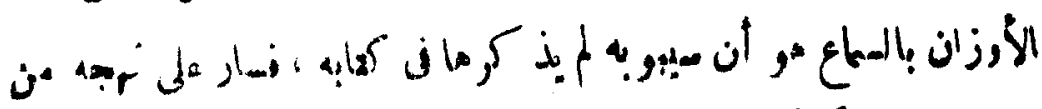

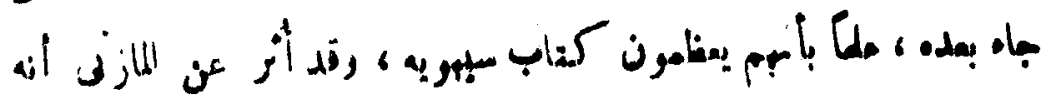

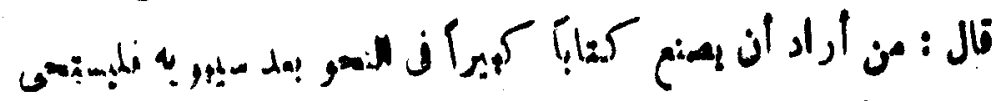

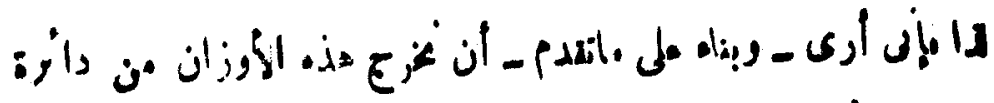

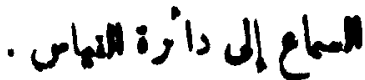




\section{اهم المصادر والمرابع}

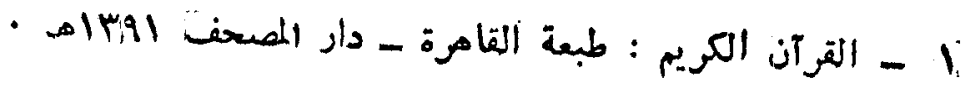

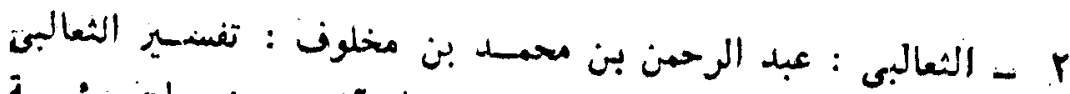

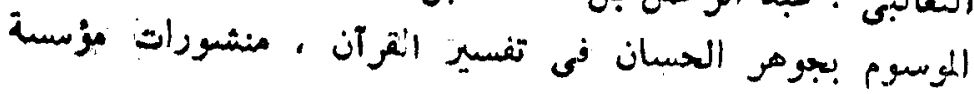

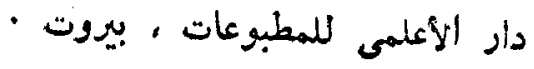

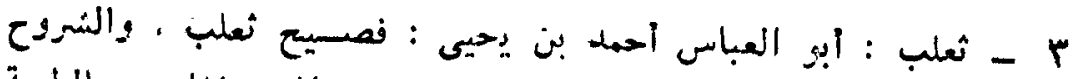

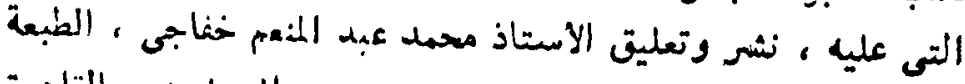

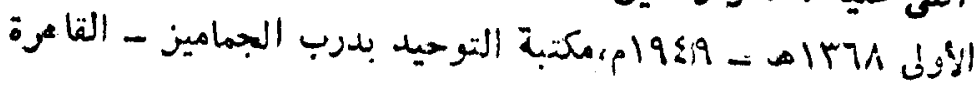

ع - ابن جنى : أبو الفتح عثمان : الخصائص ، تحقيق محمن على النجار.

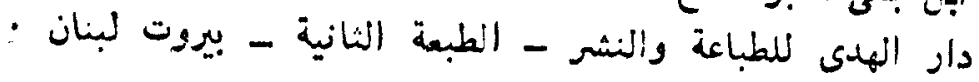

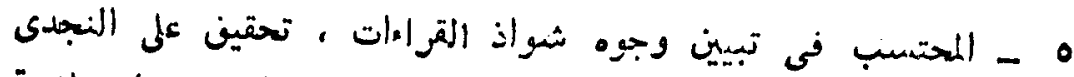

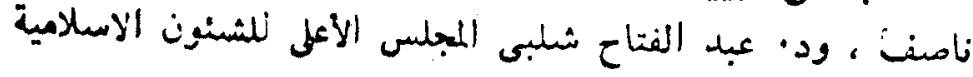

$$
\text { - }
$$

7 - الجوهرى : اسماءيل بن حمساد : الصسحاح ، تحفيق أحمسد

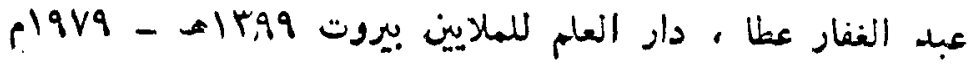
- V

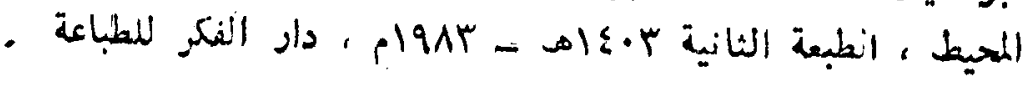

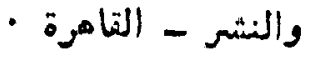

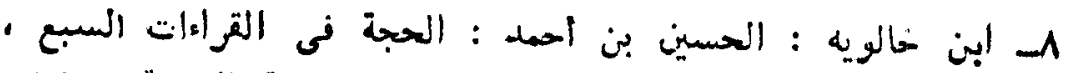

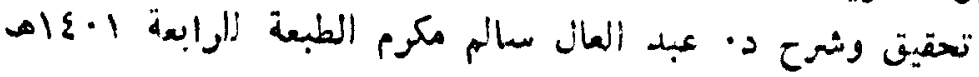

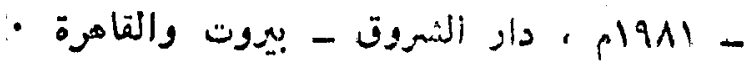

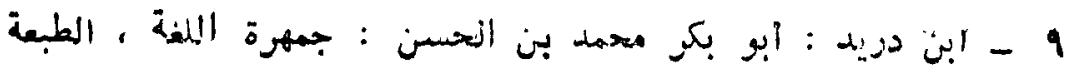

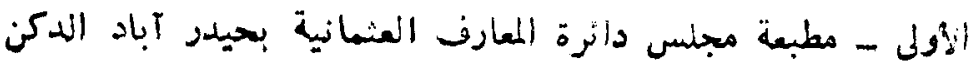




\section{1}

ها - الرازي : الفنز الرازى : التفسيـ الكبيز - الطبعة الثانية .

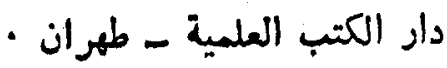

ال ـ الراغب الأصغهانى : أبو القاسم الحسين بن محمد : المفردأت

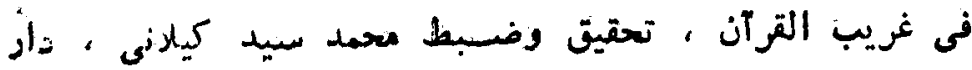

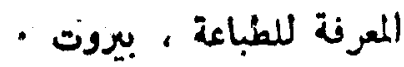

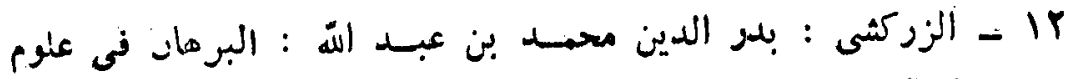

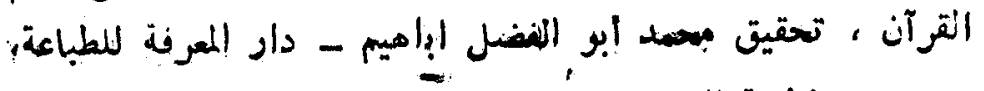

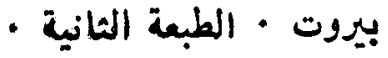

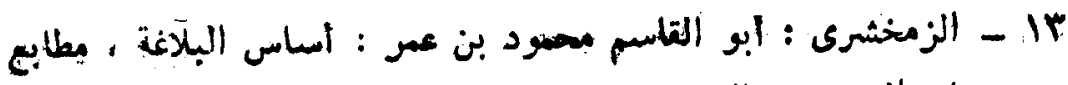

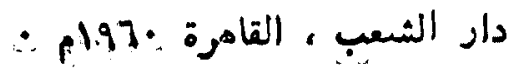

ع ا - تفسير الكشنف ، تحقيق محعد مربى عابر مراجيعة د. شعبان

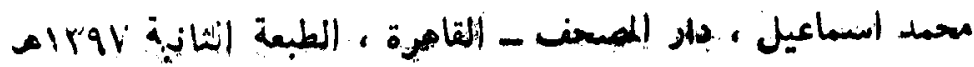

$$
\text { - plaVV - }
$$

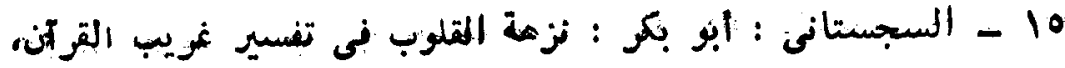

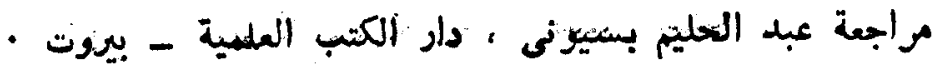

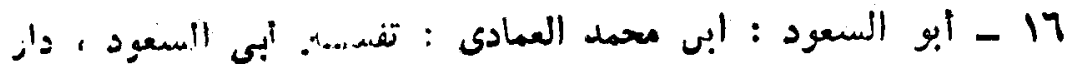

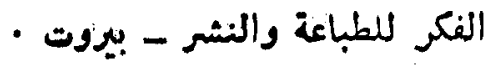

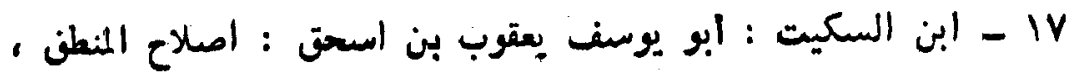

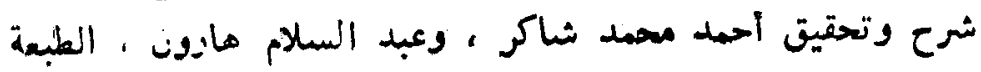

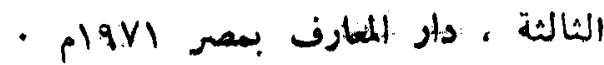

11 - السيوطى : جلال الدين عبد الرحمن : المزهر ، تحقيت معهد أحمد

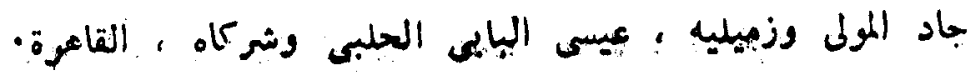

$$
19 \text { - همع الهوامع ، داد المعرنة للطباعة - بيزوت • }
$$




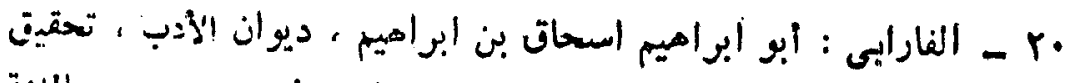

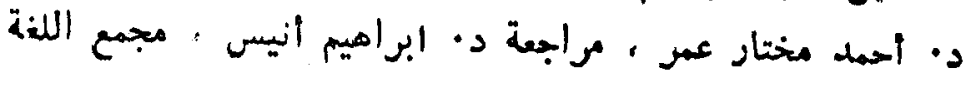

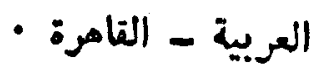

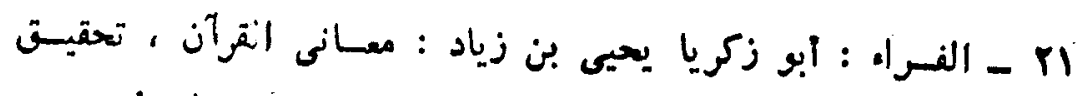

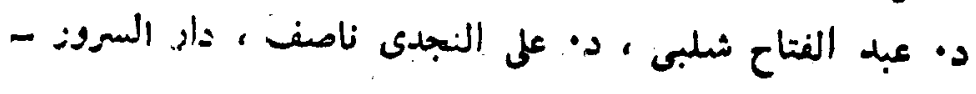

بِيروت

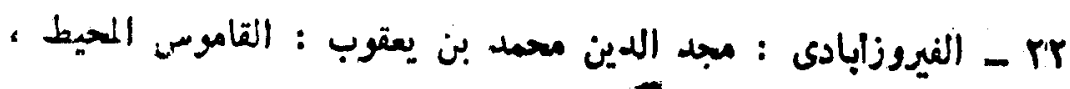

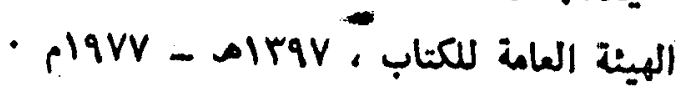

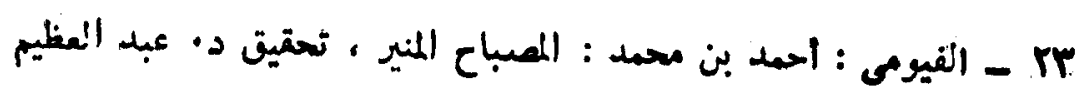

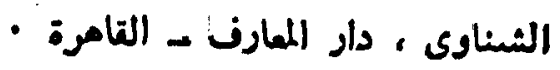

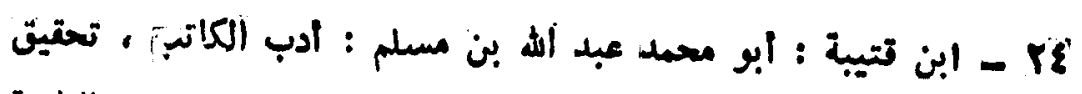

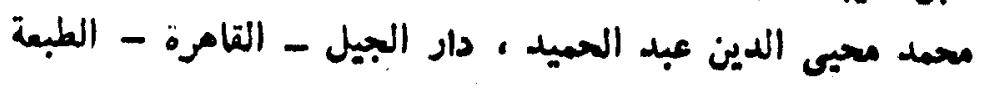

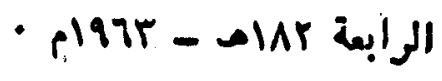

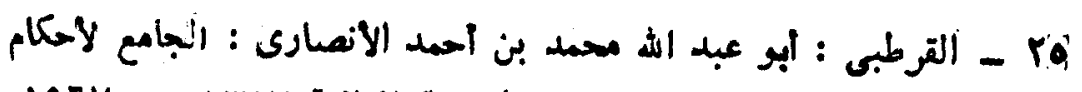

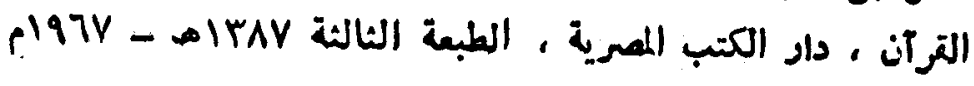

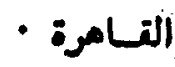

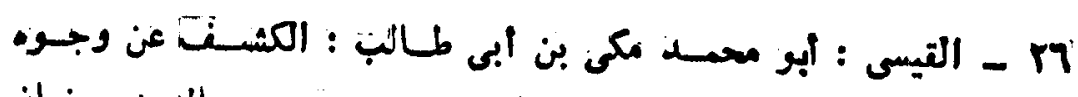

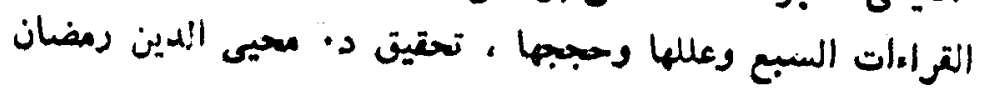

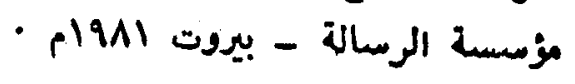

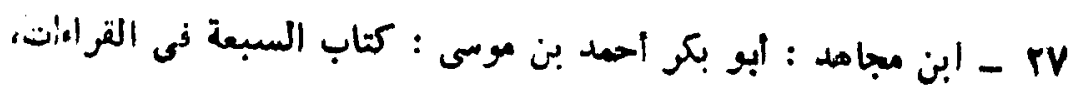

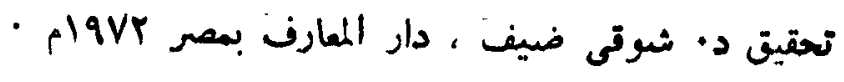

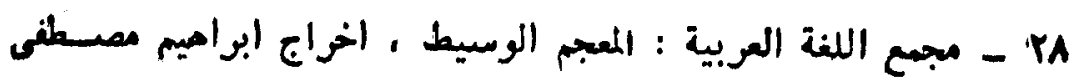

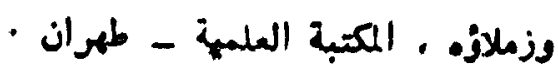




\section{rir}

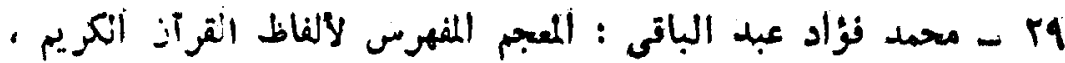

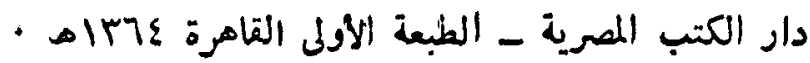

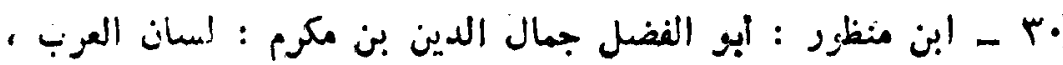

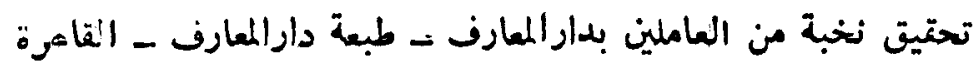

الr ـ النسفى : أبو البركات عبد الله بن احمد : تفسير النسفى ، ترتيب

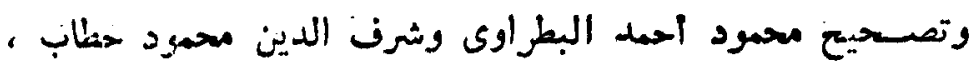

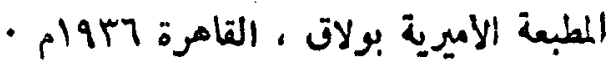




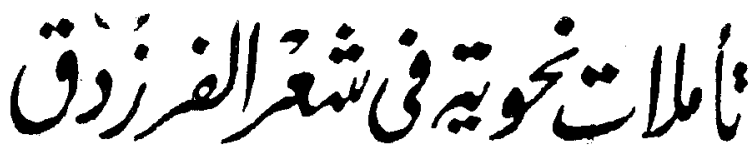

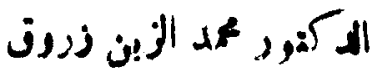

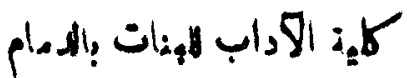

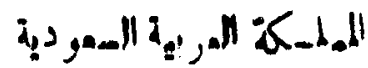

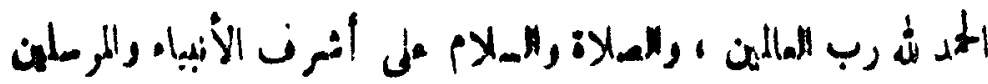
:

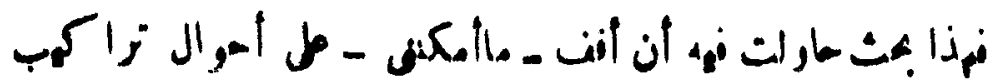

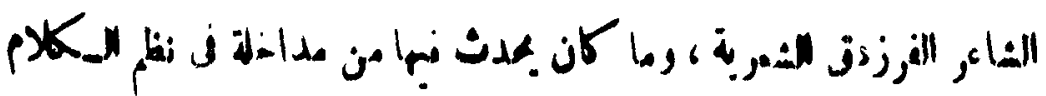

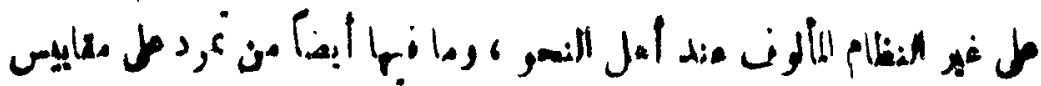

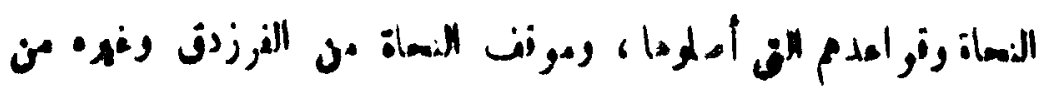

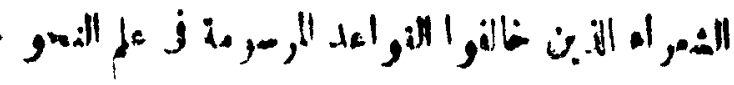

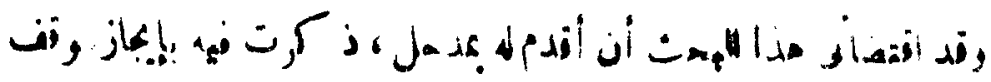

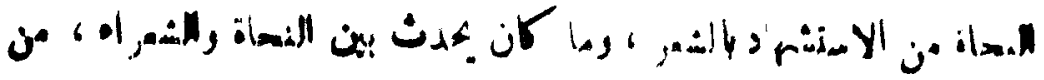

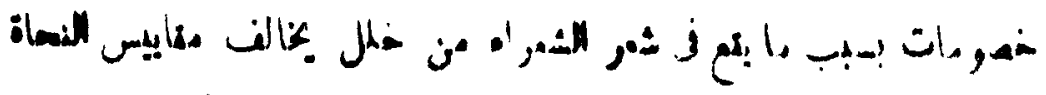

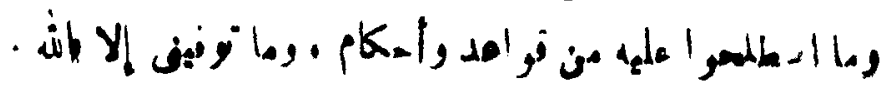


iv

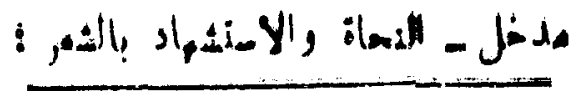

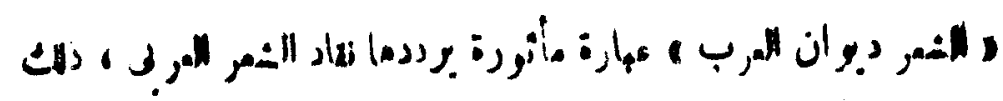

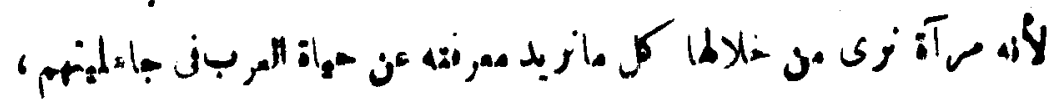

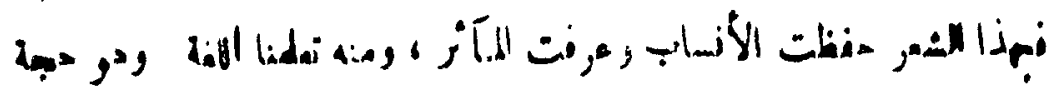

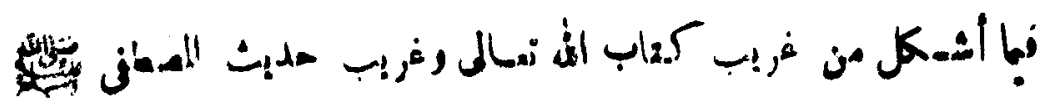

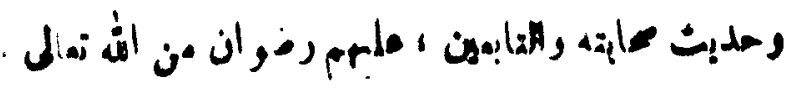

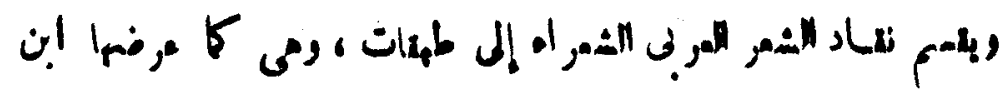

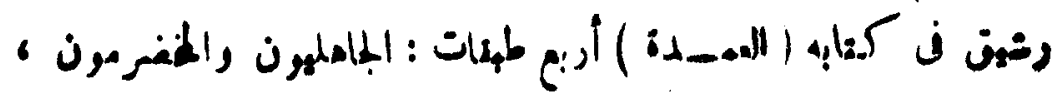

$$
\text { ماللعدمون وللاولدرن (1) }
$$

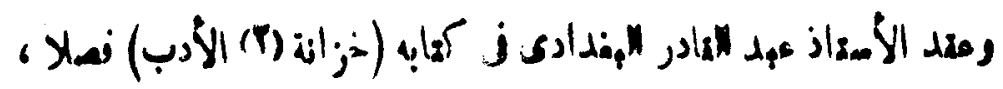

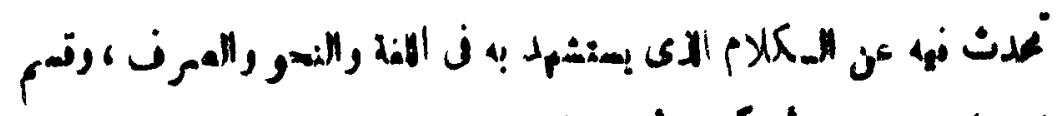

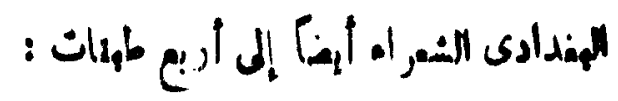

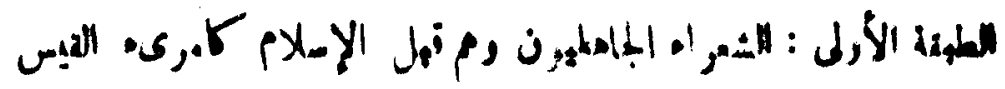
s.s.

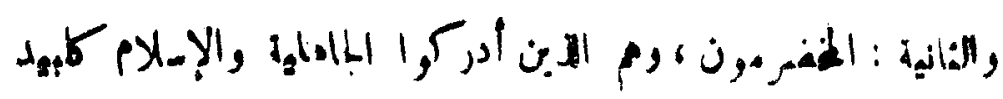
- نlmes

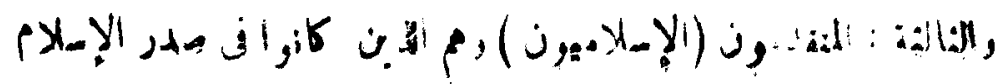
j;j,

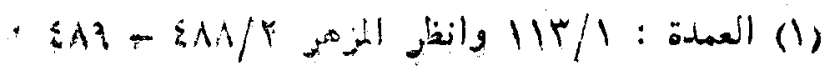

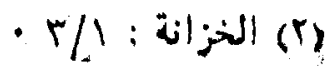




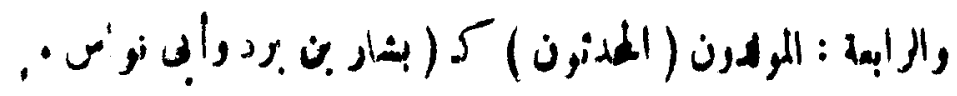

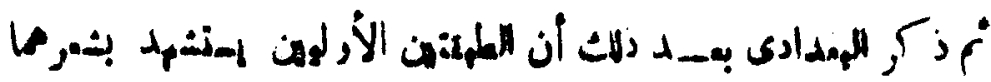

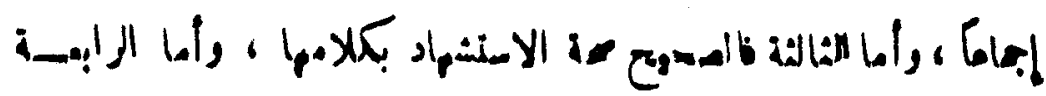

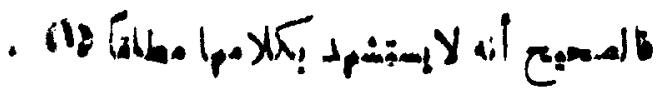

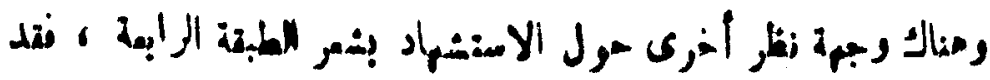

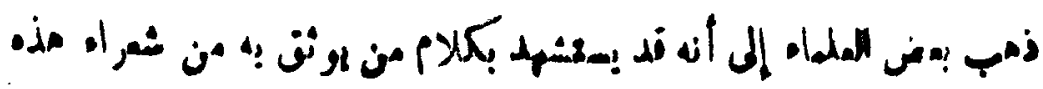

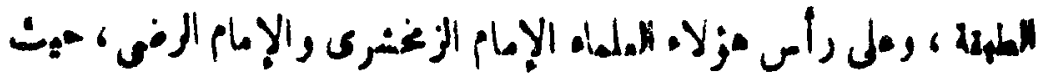

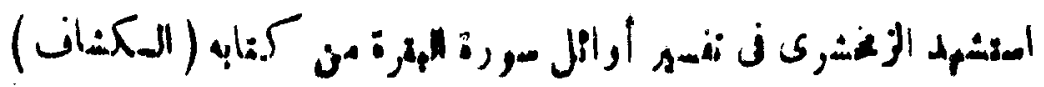

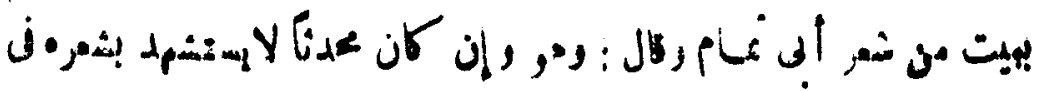

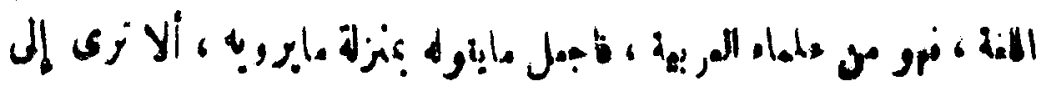
تول ب:مض لاملهاه :

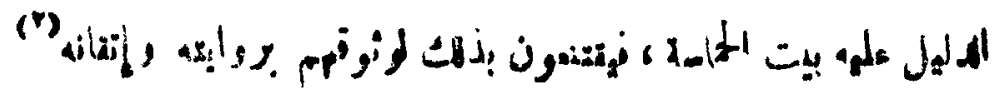

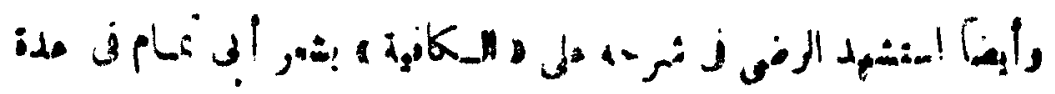

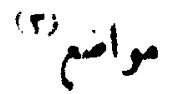

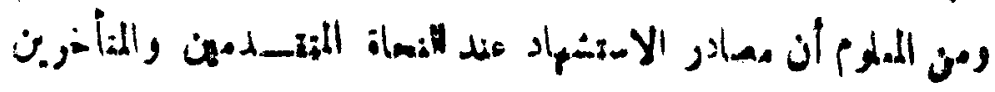

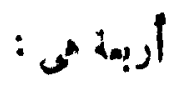

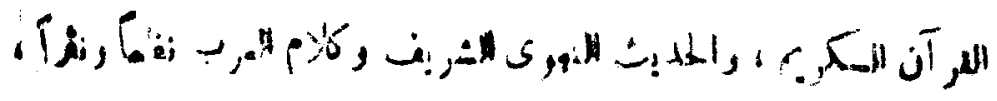

$$
\text { (1) الخزانة : }
$$

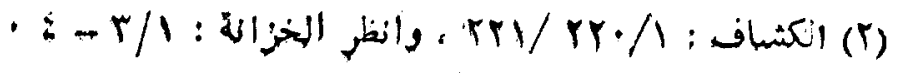

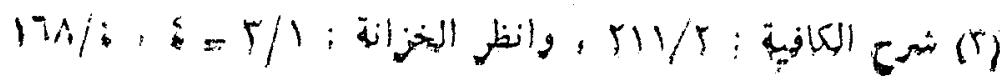




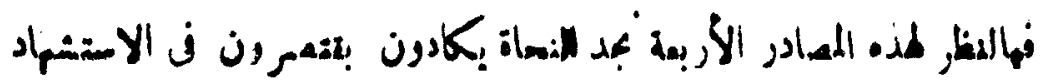

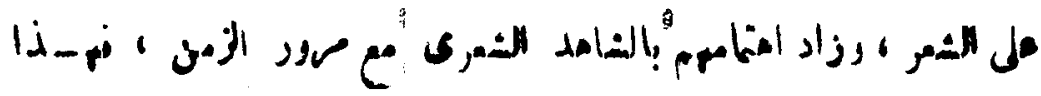

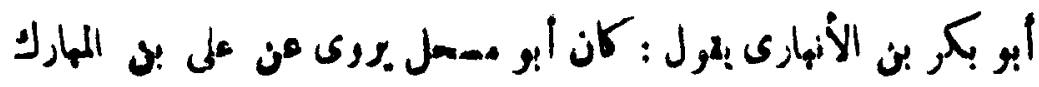

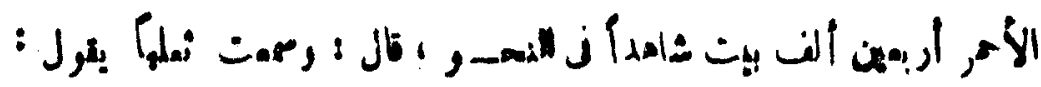

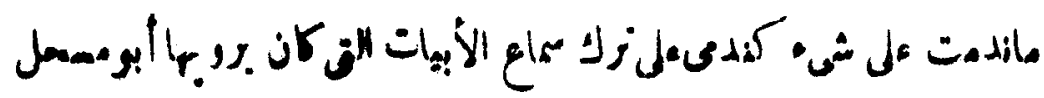
(1) عز مل بن المهارك

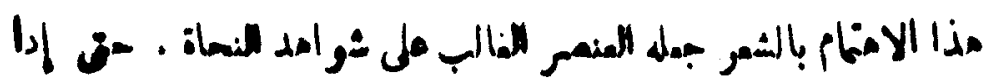

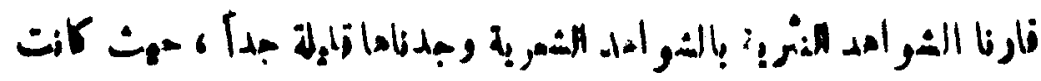

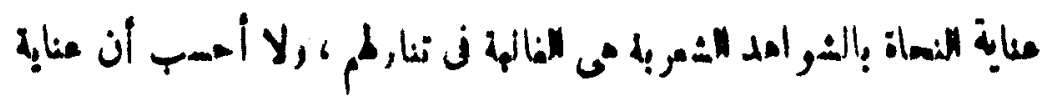

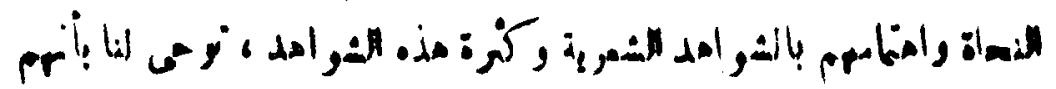

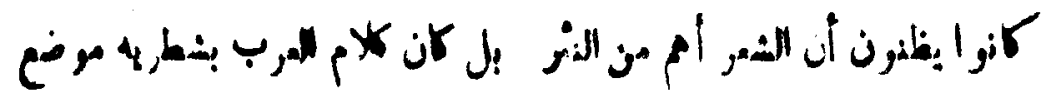
الاهنام والمنابة .

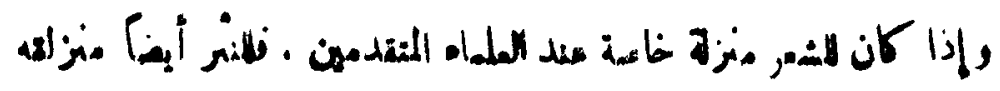

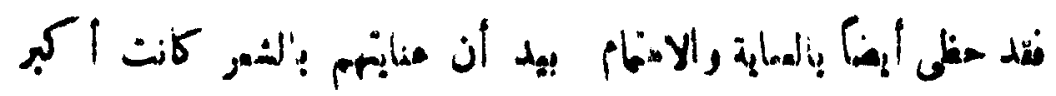

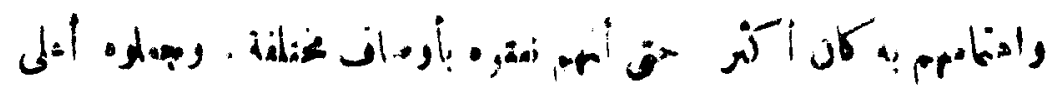

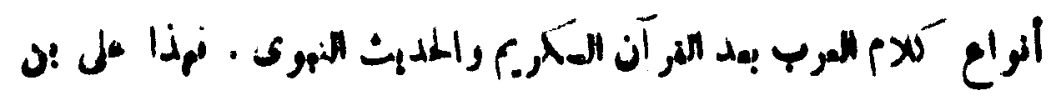

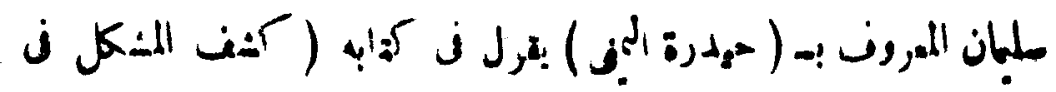
- : (1)

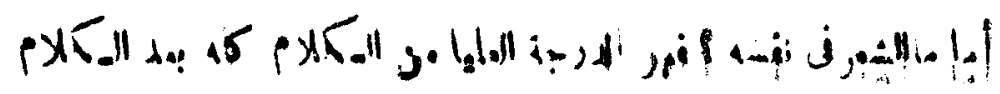

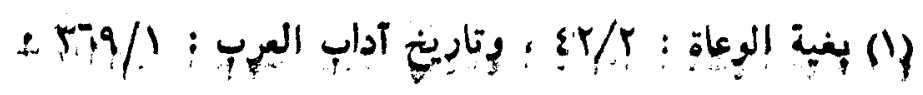


PIA

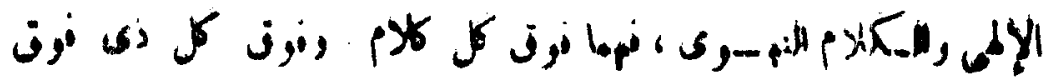

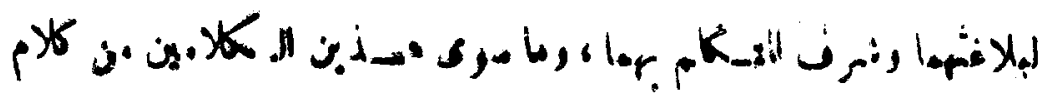

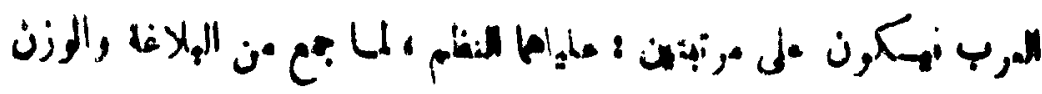

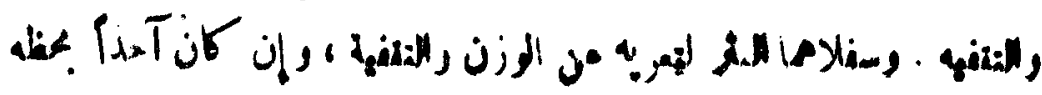

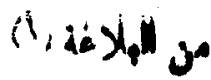

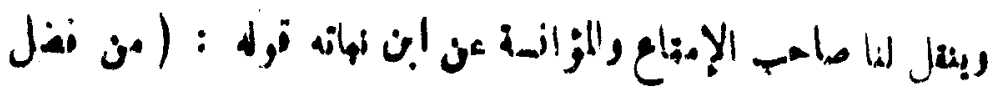

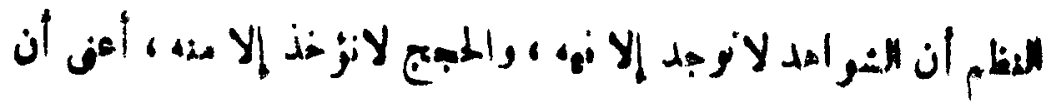

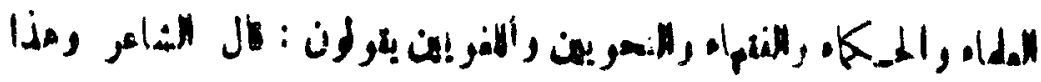

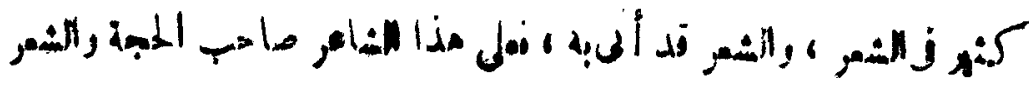

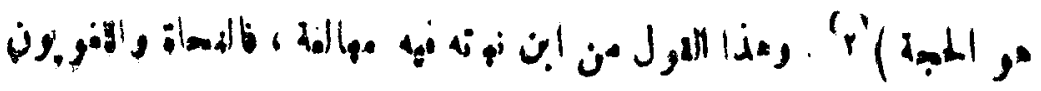

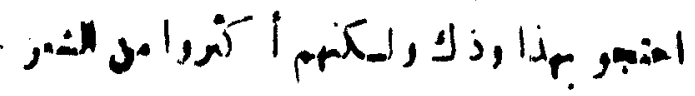

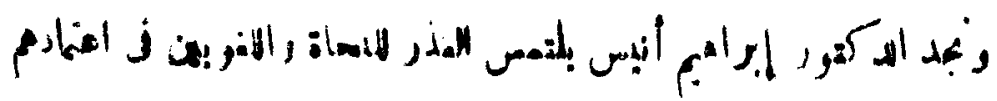

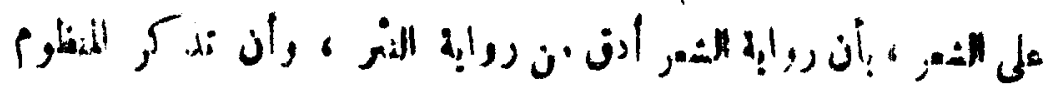

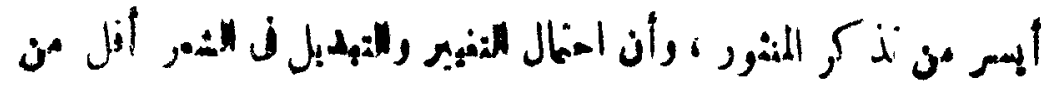
(i)

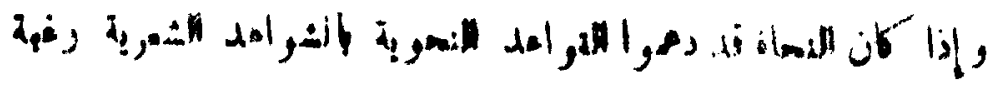

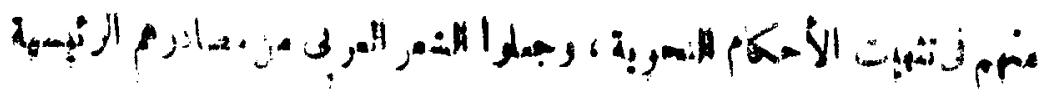

$$
\begin{aligned}
& \text { (1) كمفف المشكل فى النحو : }
\end{aligned}
$$

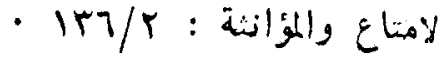

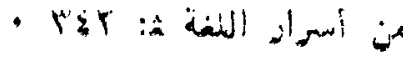




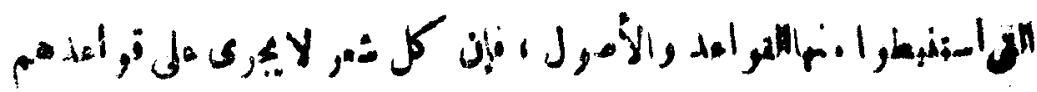

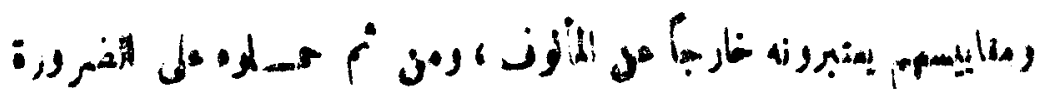
1

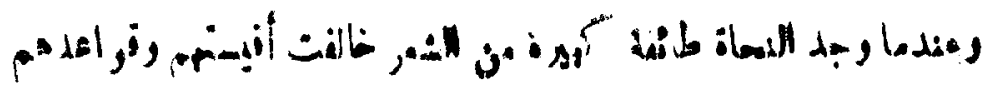

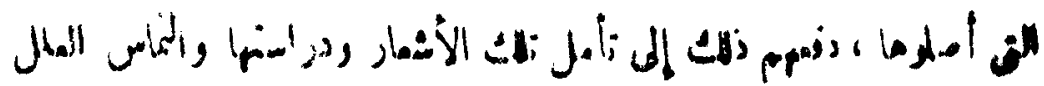

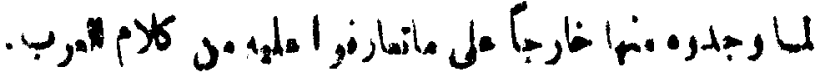

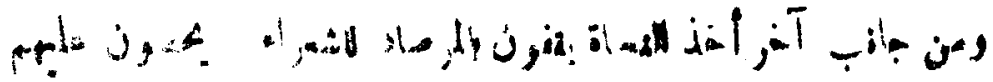

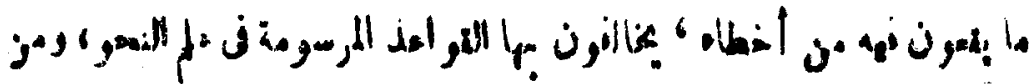

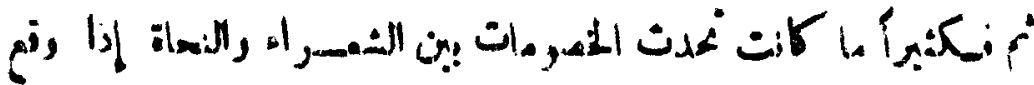

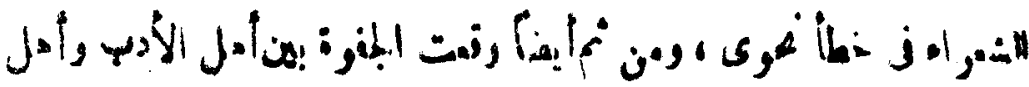

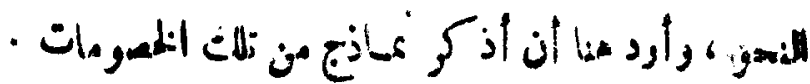

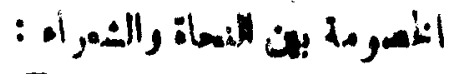

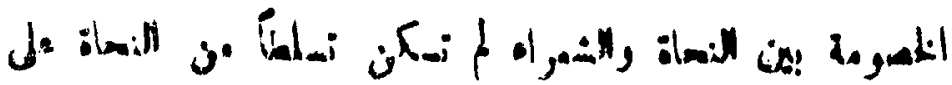

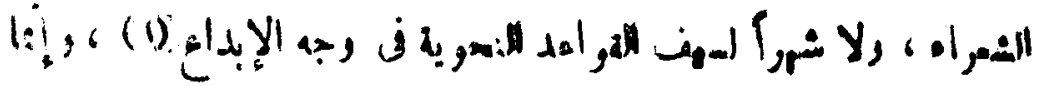

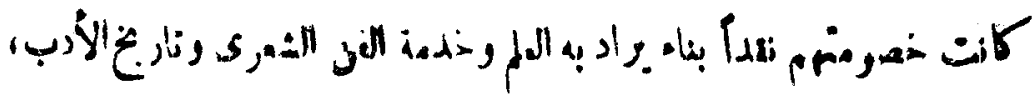
j

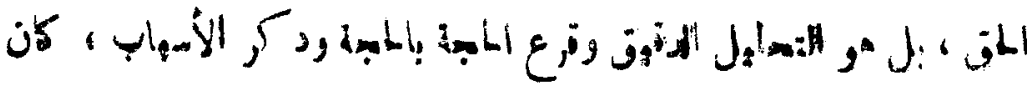

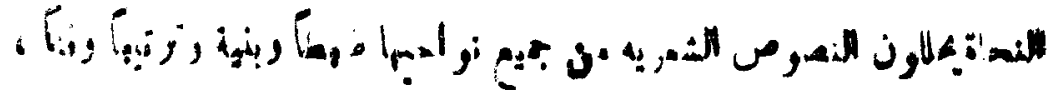

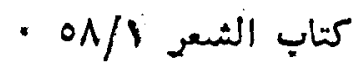

$(j-r q)$ 
riv

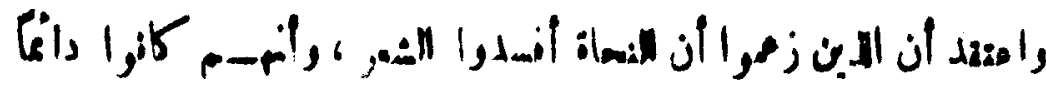

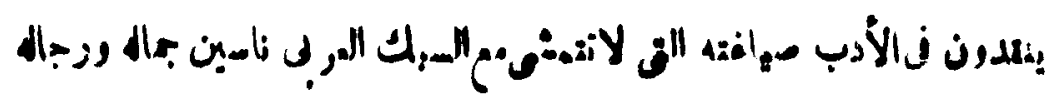

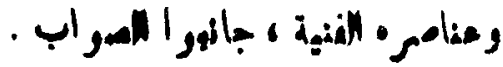

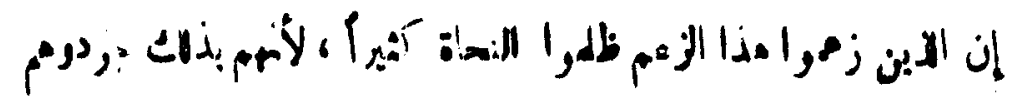

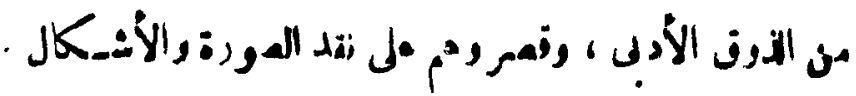

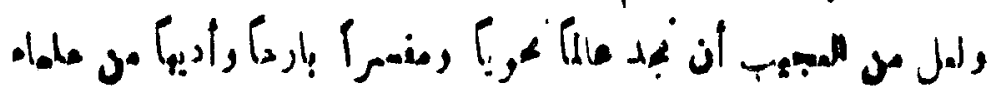

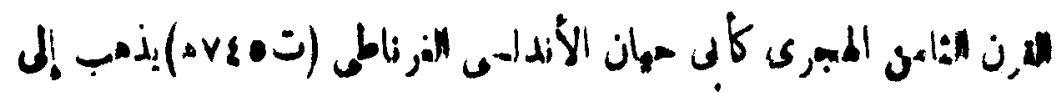

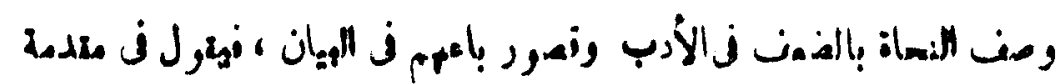

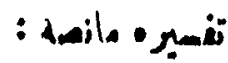

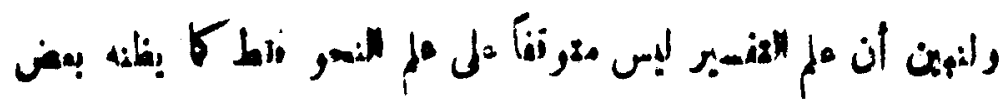

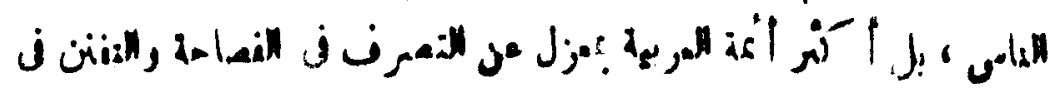

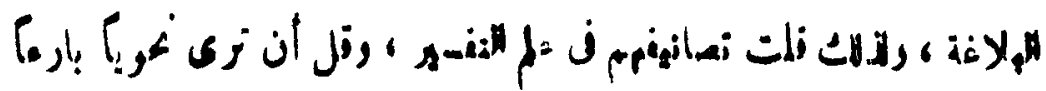

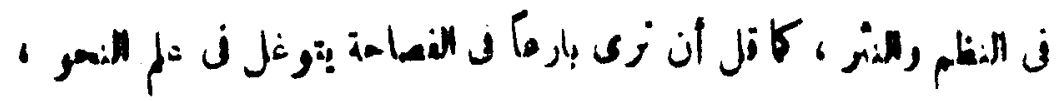

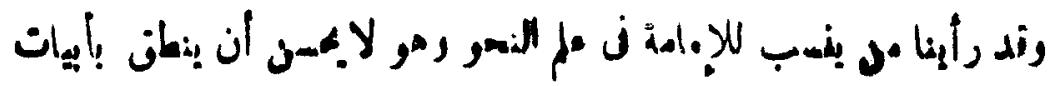

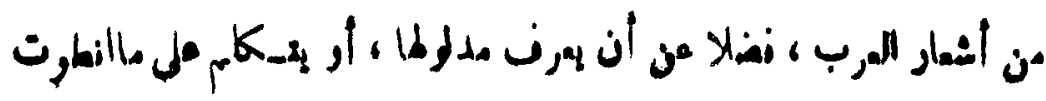
• (1)

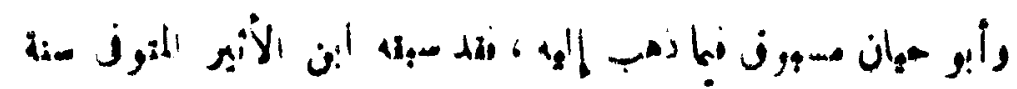

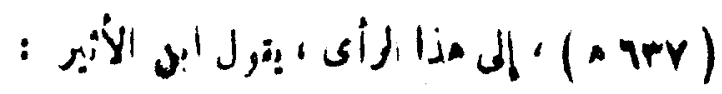

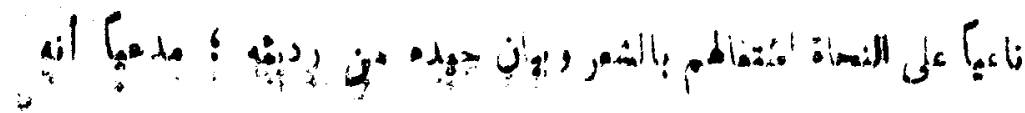

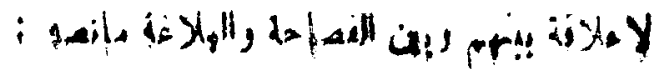

19/1 : 1) البحر إلمحيط 
PrI

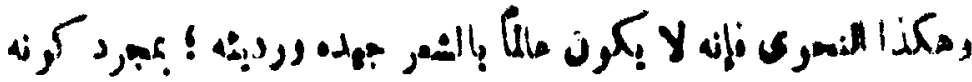

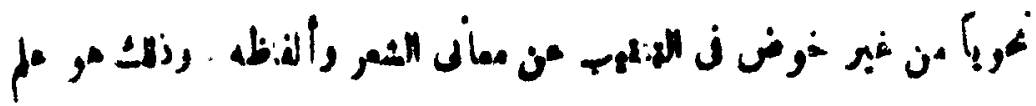

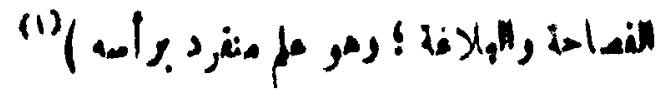

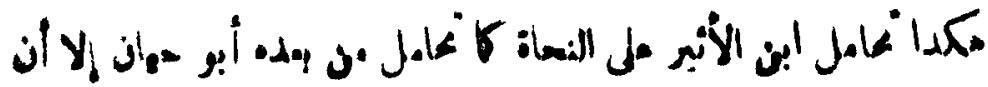

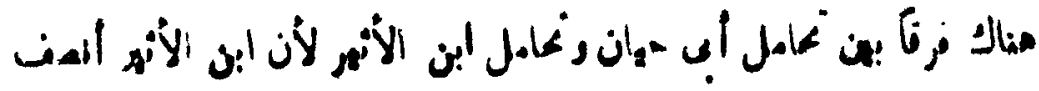

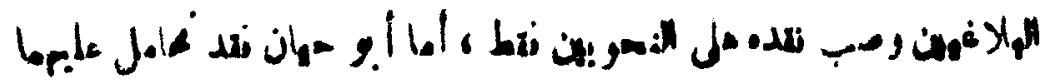

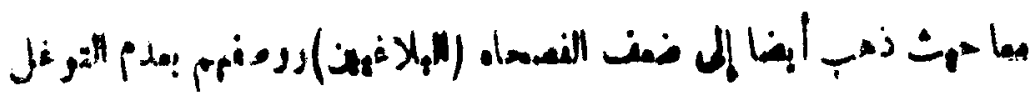
i

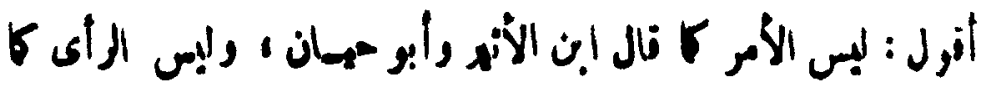

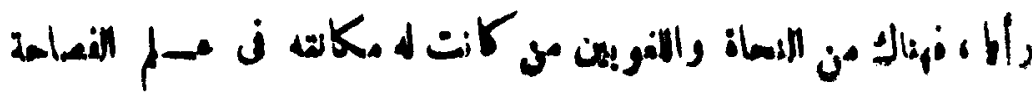

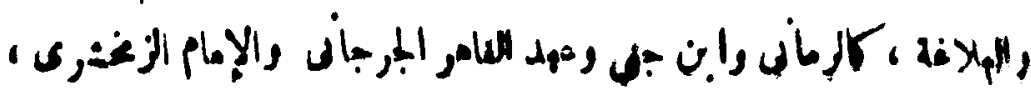

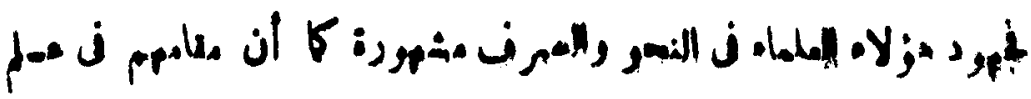

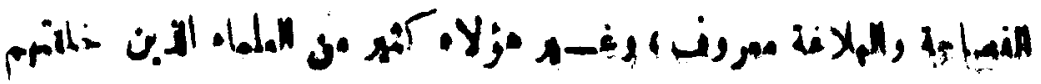

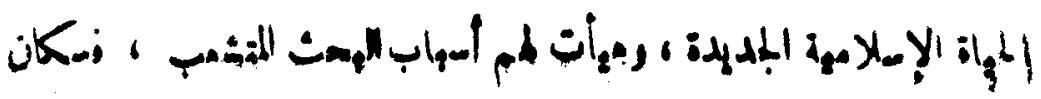

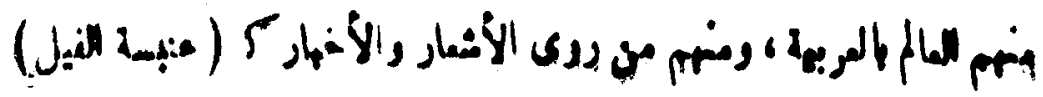

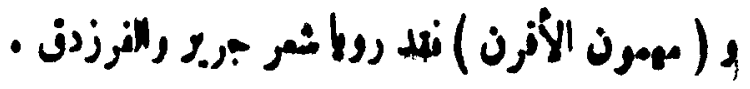

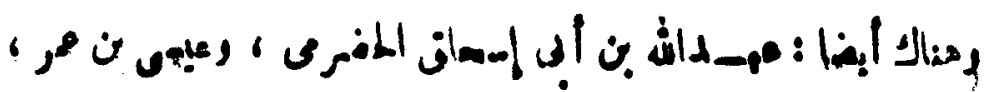

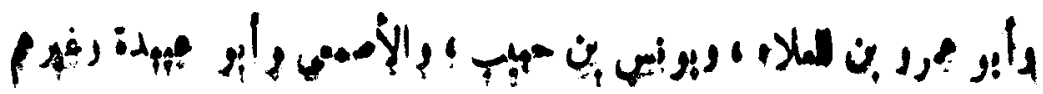

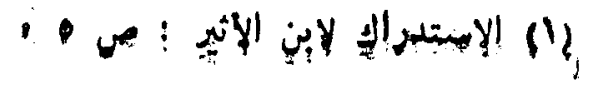




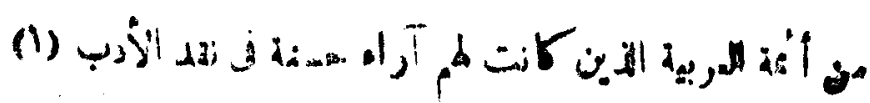

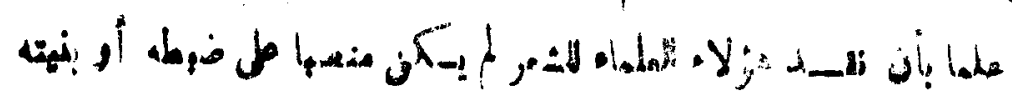

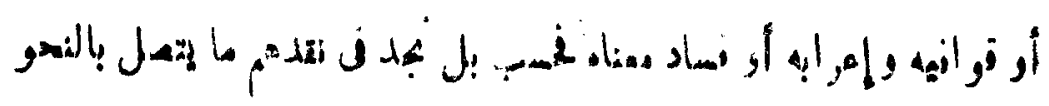

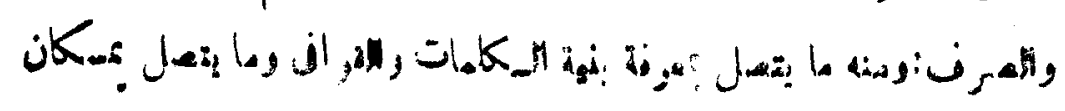
. Jitigatiog

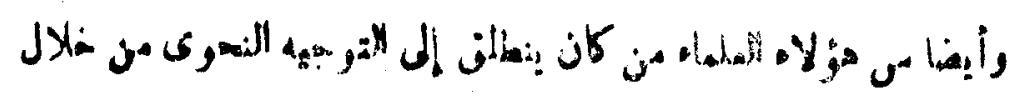

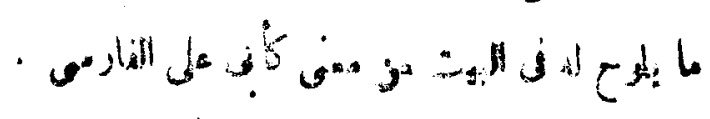

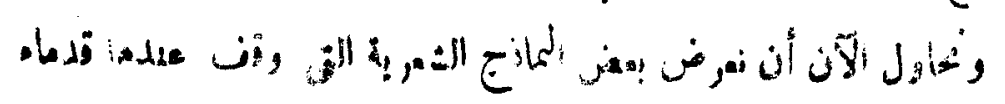

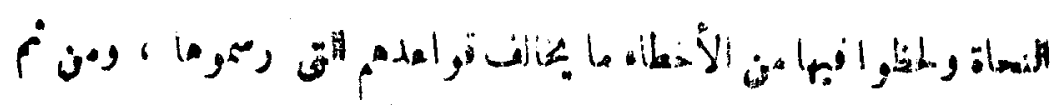

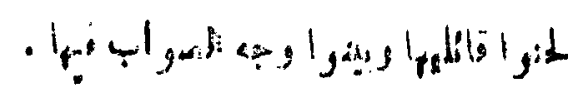

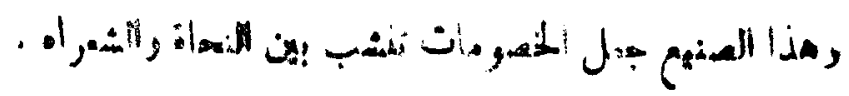
1

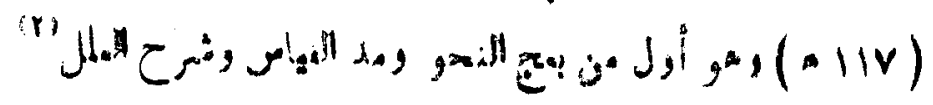

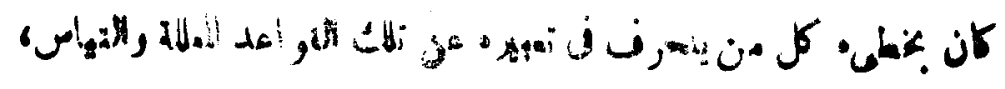

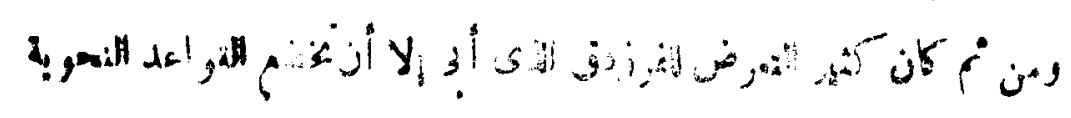

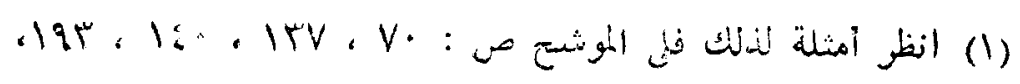
- TrV

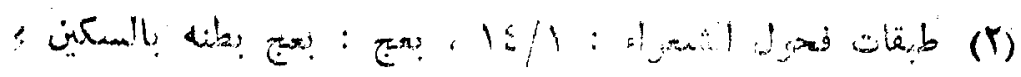

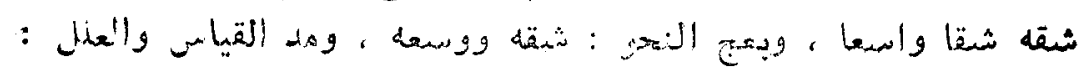

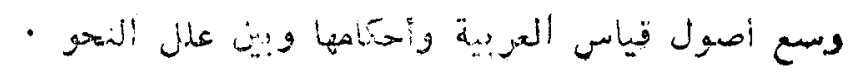




\section{YYY}

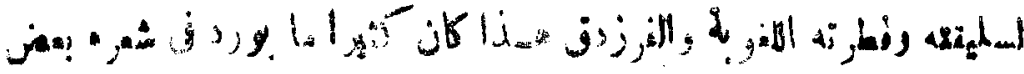

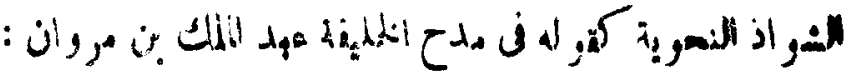

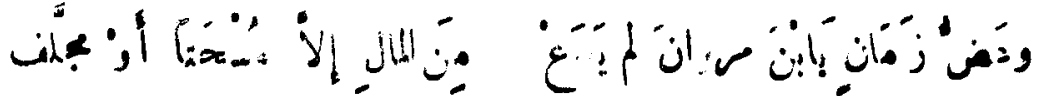

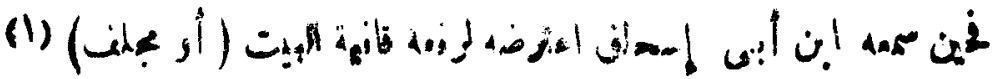

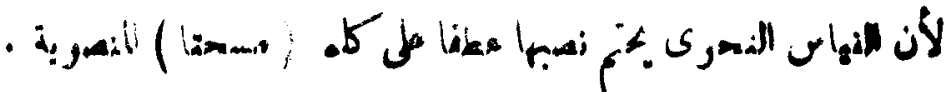

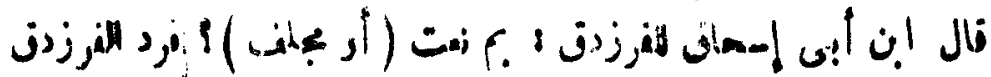

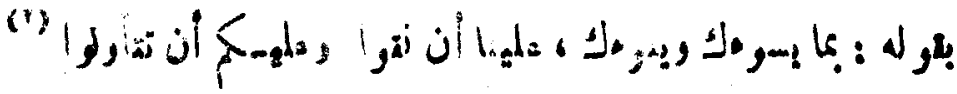

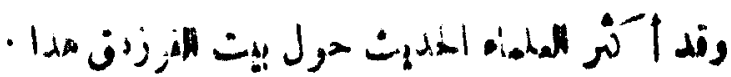

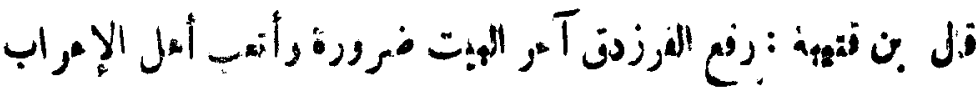

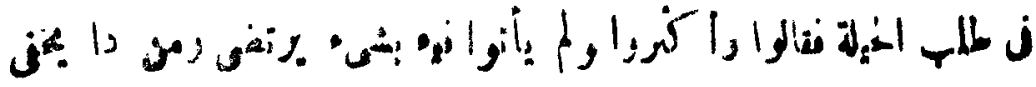

(1) فيمن رواه كذلك ، وعض زمان ، بالرفع عطفا على ( عموم المنم)

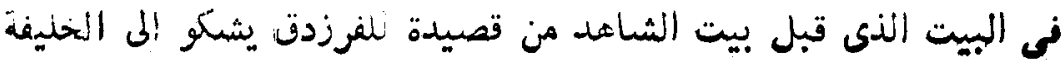

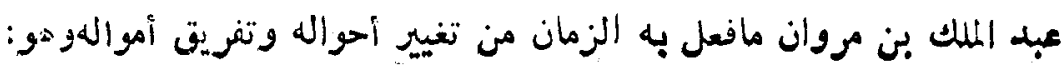

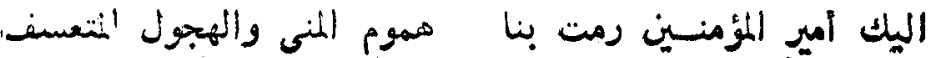

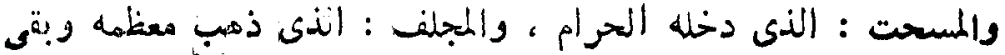

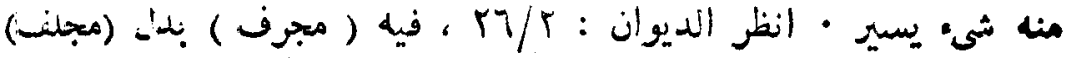

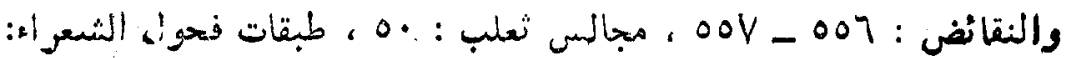

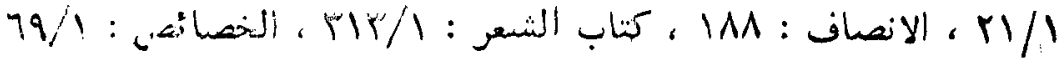

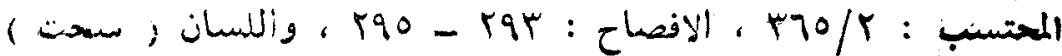
و ( ) ملف )

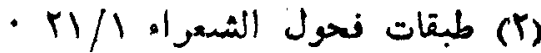




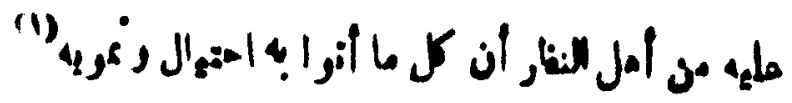

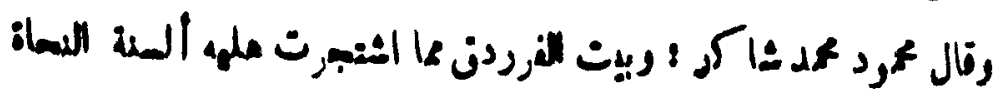
( (s) (s)

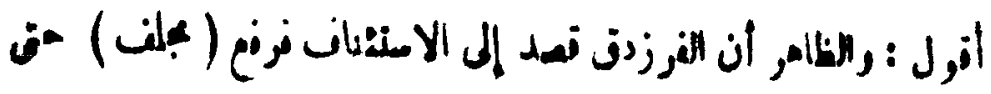

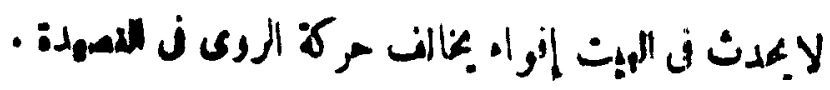

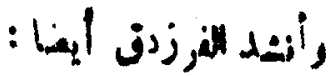

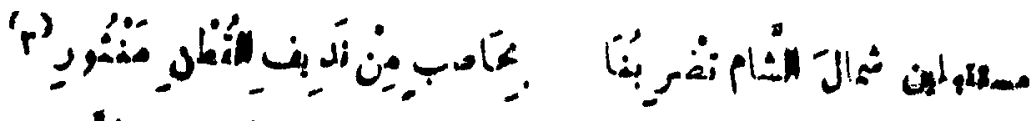

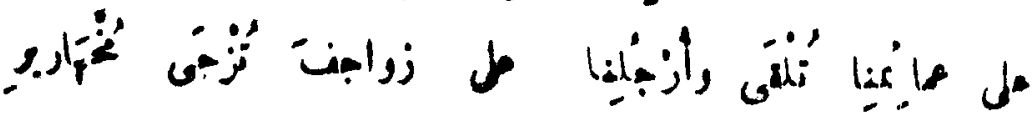

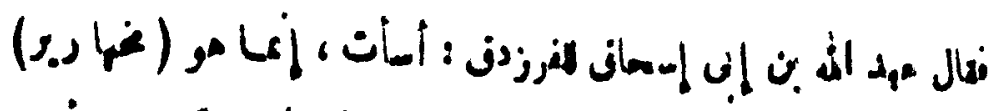

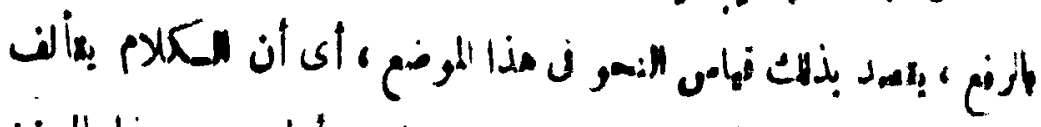

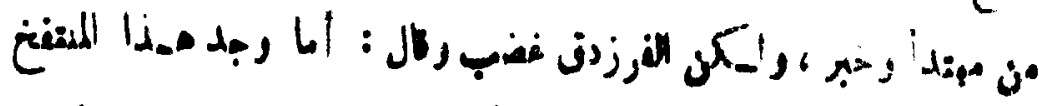

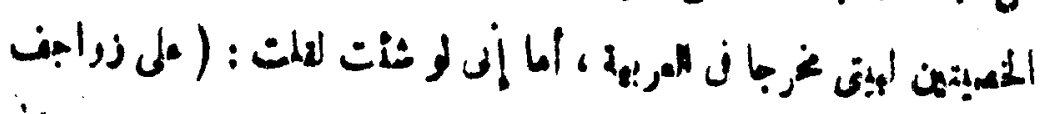

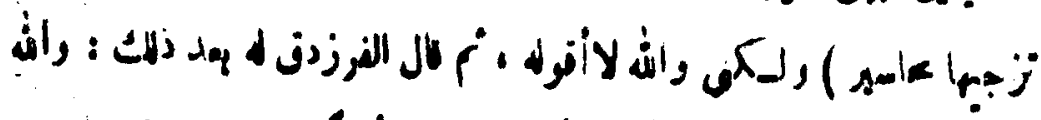

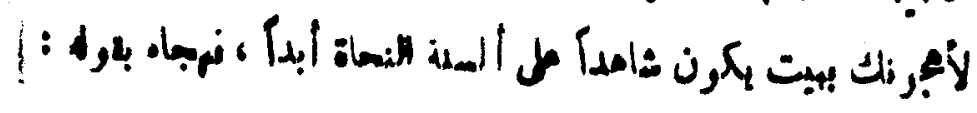

\section{$\longrightarrow$}

- $r \xi V / r: \alpha_{j \mid j} \mid$ (1)

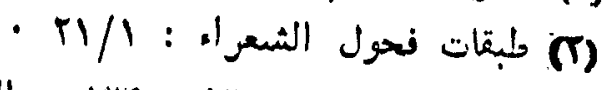

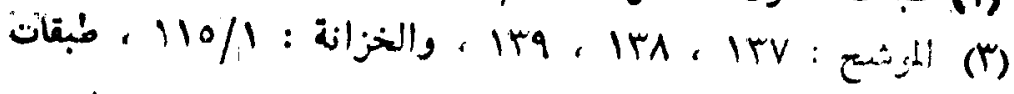

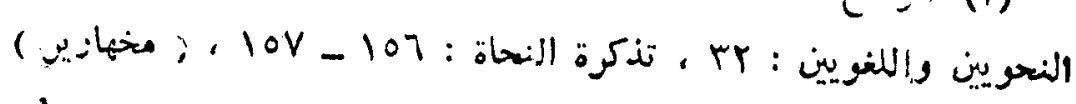

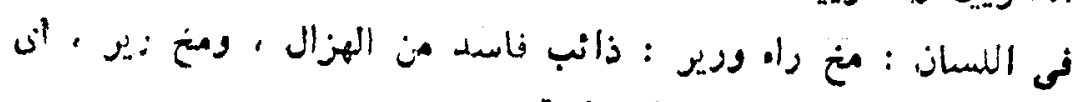

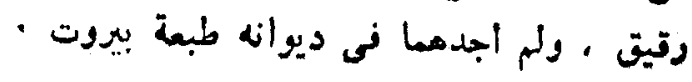


rvo

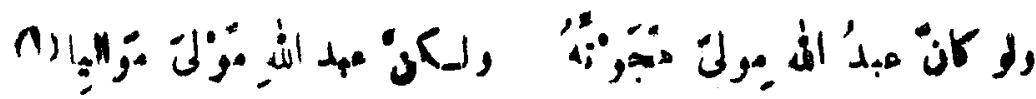

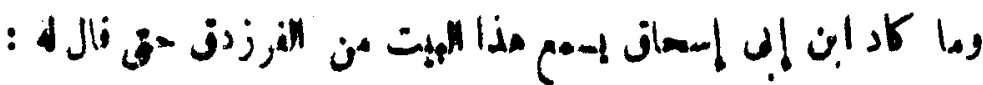

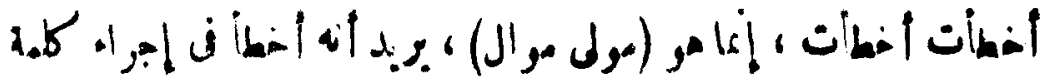

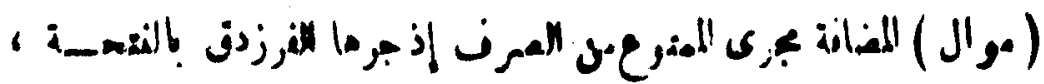

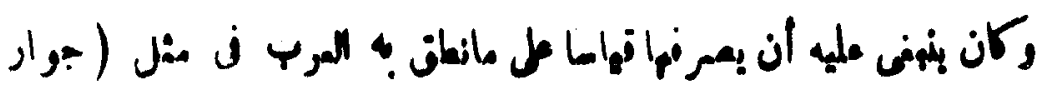

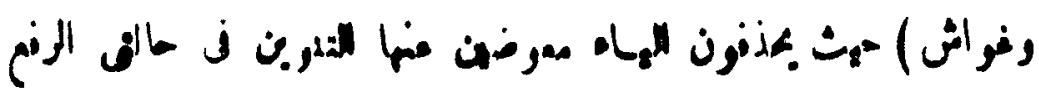

$$
\text { (الم) }
$$

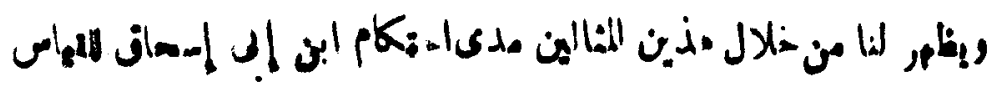

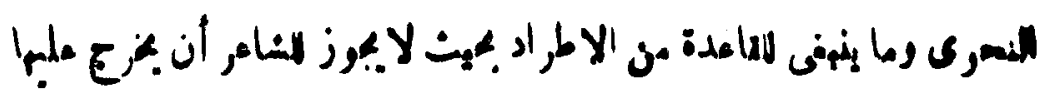

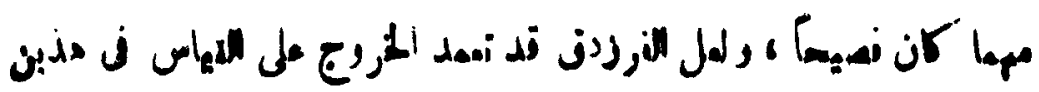

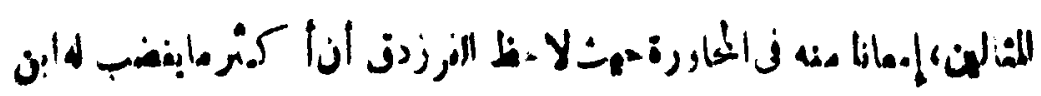

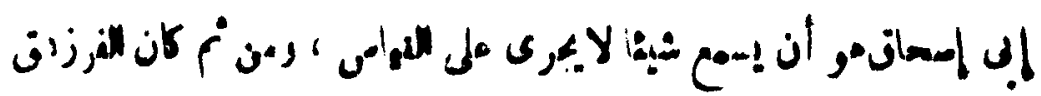

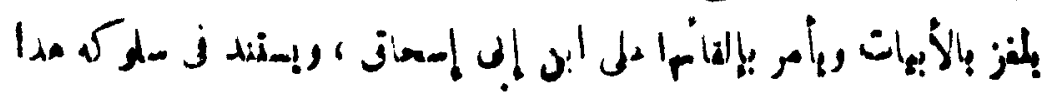

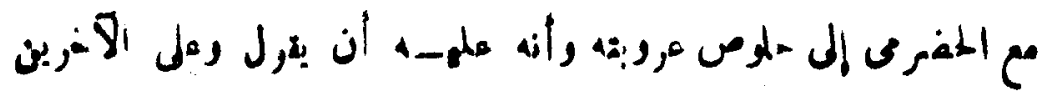
. أinasen

ال

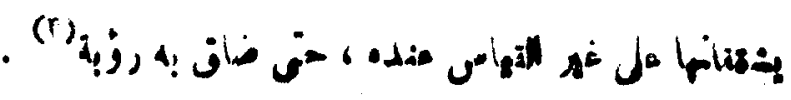

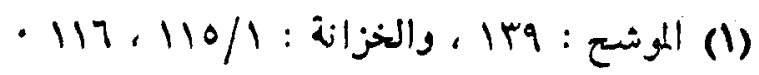

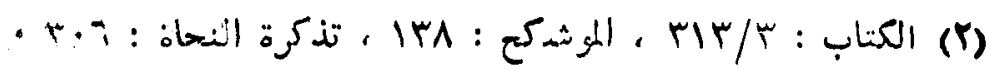

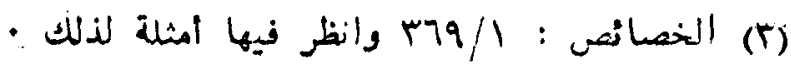




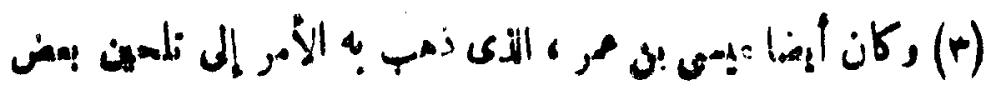

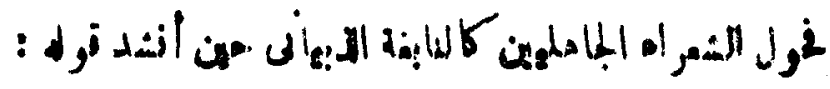

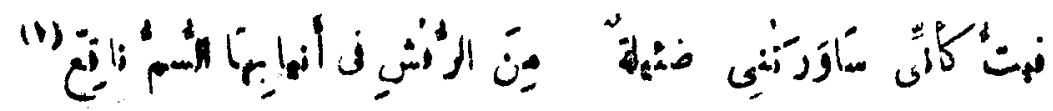

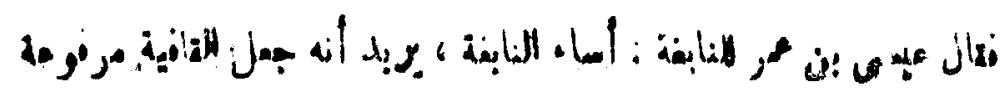

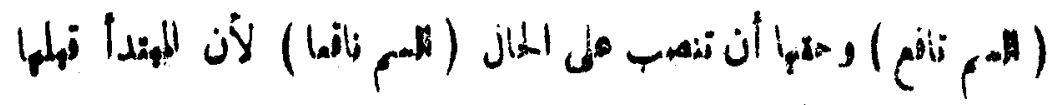

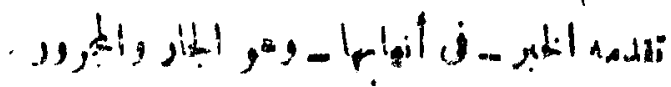

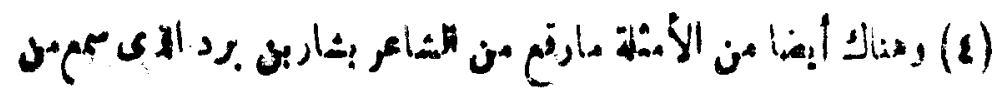

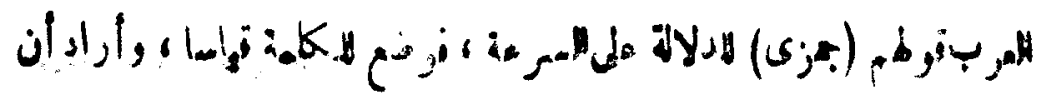

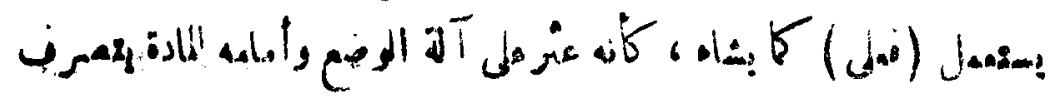

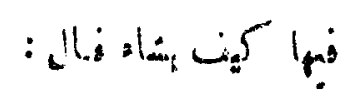

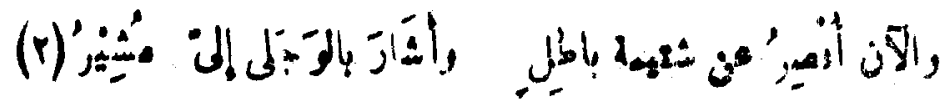
: ling

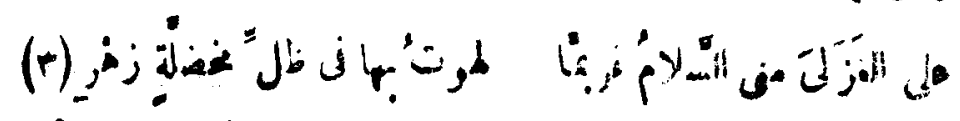

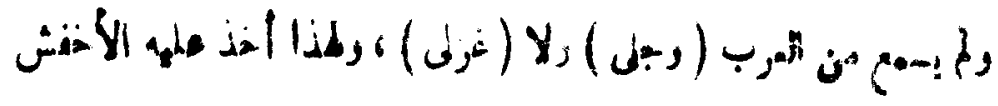

(1) ديوانه : ·1 ، ضئيلة : أفعى دقيقه اللحمر ، وساورننى : واثبتنى

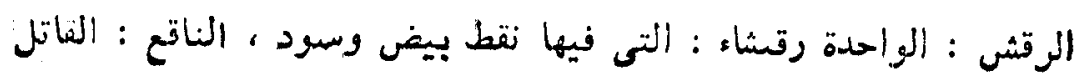

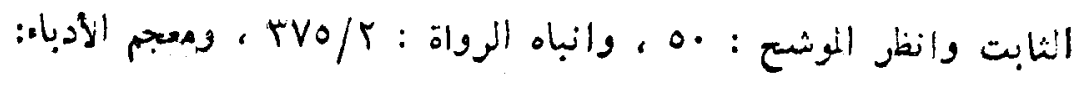
• 187/17

- rrv/r : : (r)

- rq9/5 : ه s 


\section{PYV}

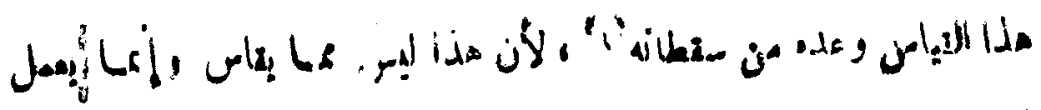
- 2 bath $40 ;$

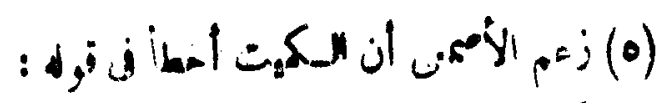

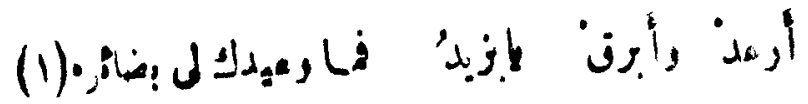

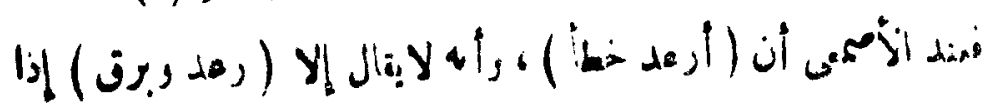

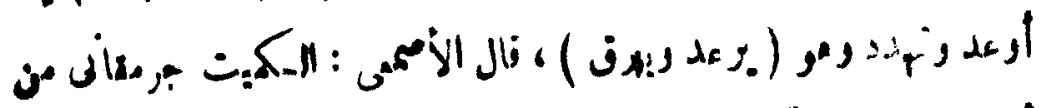

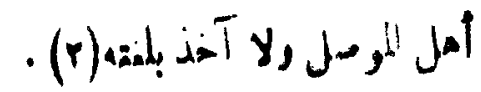

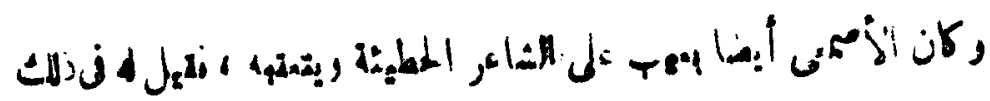

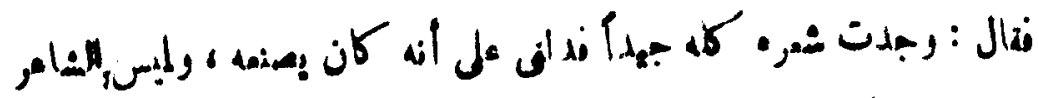

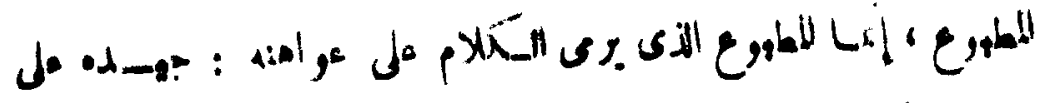
: (0) a 4ips

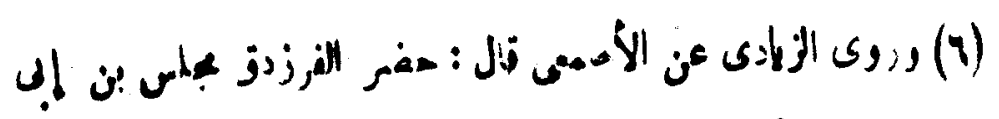

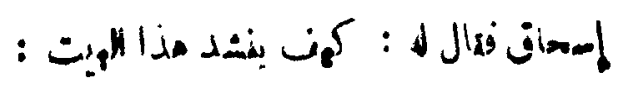

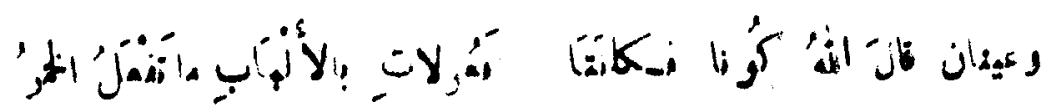

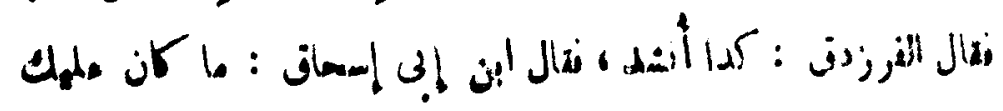

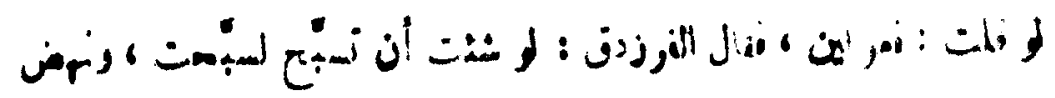

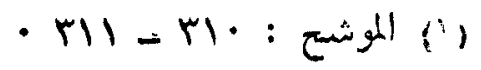

$$
\begin{aligned}
& \text { - roo - ros : الموشيح (r) }
\end{aligned}
$$

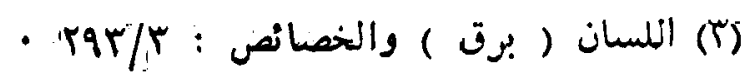

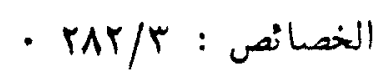


ry

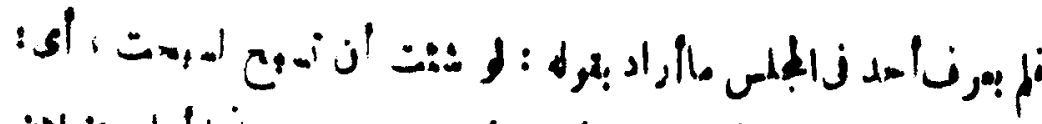

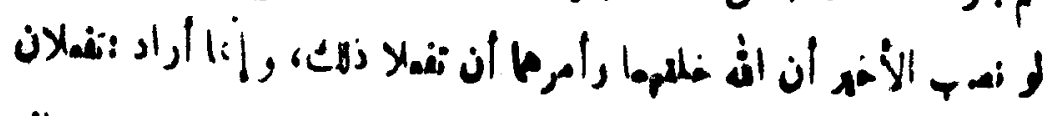

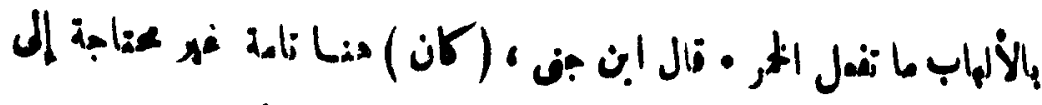

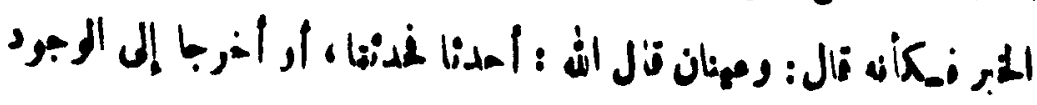

(1) ${ }^{6} \div$

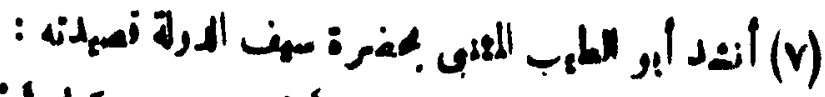

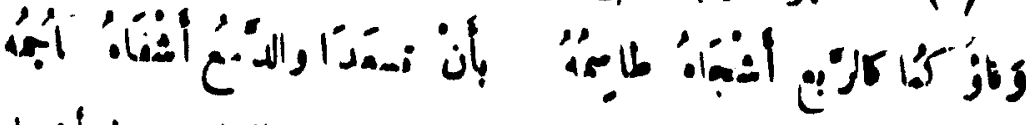

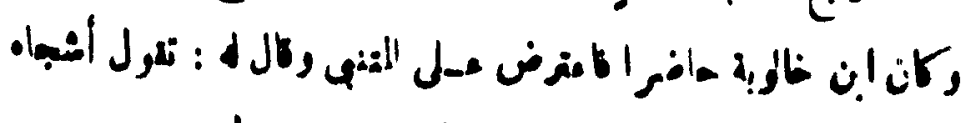

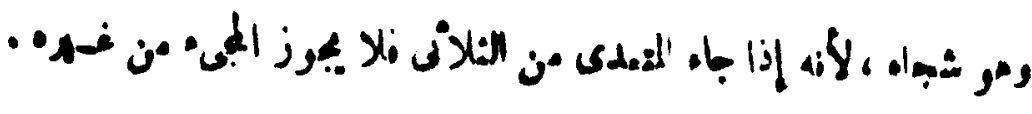

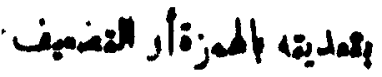

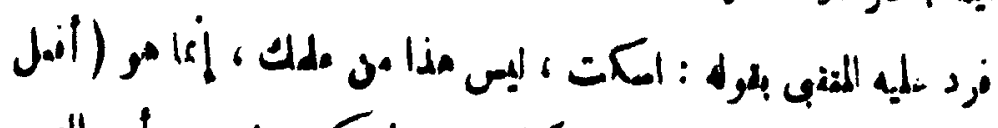
فئا

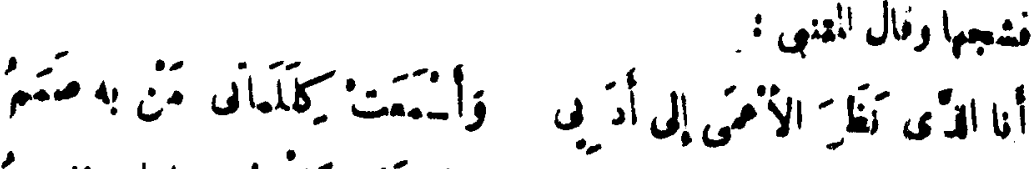

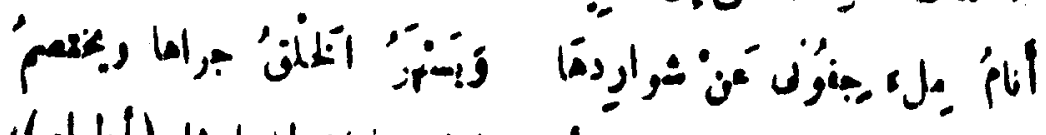

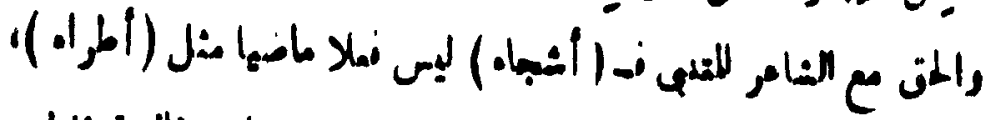

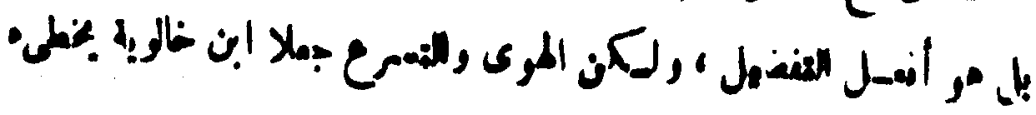

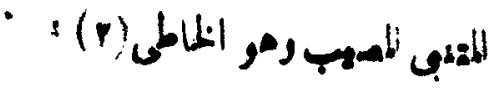

(1) البيت لذى الرمة فى ديوانه مى : rav والرواية فيه (نعولين)

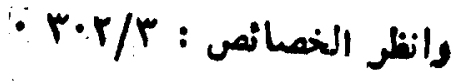

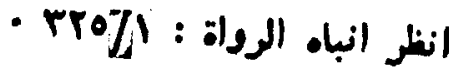


pra

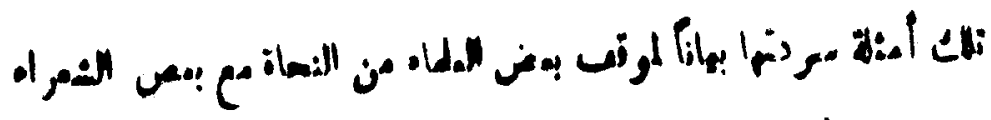

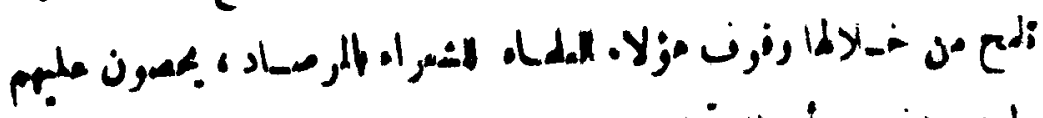

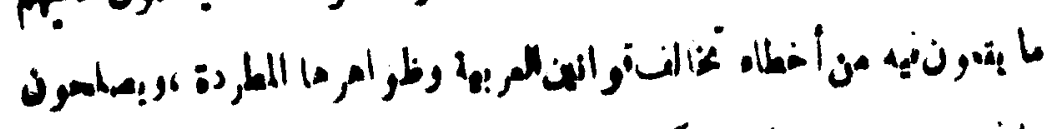

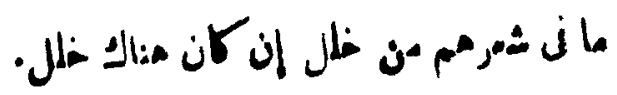

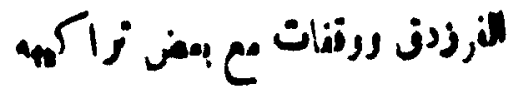

\section{مد م" المأرزنز}

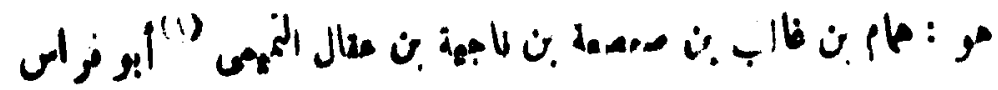

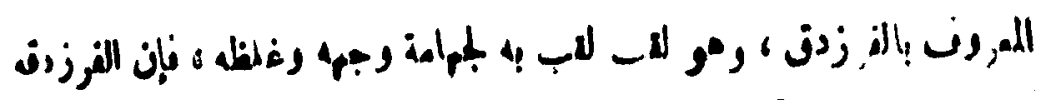
)

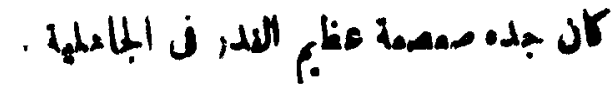

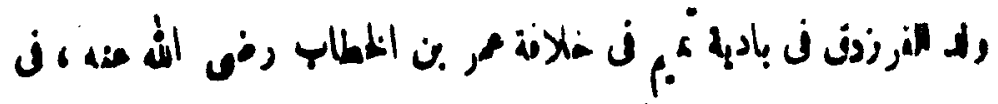

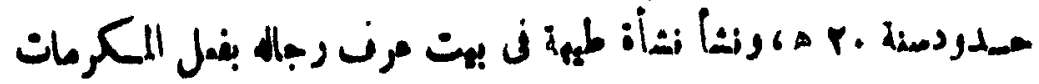

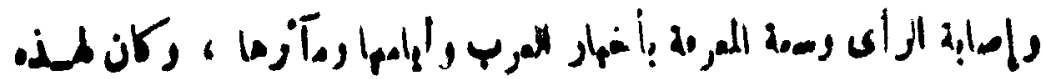

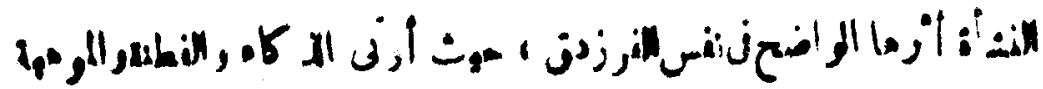
- نluli=ilas

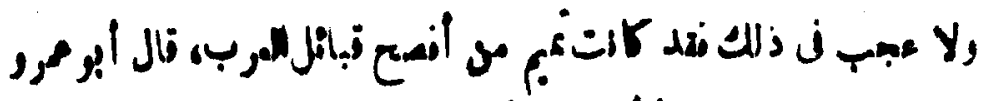

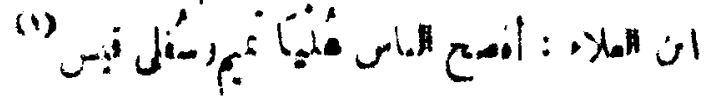

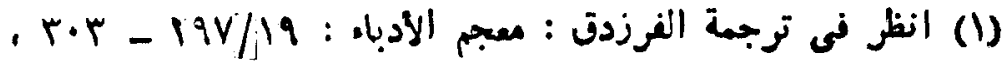
خزانة الادب : 1.0/1 وطبقات فحول الشعراه : - 


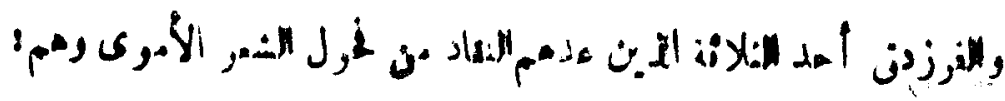

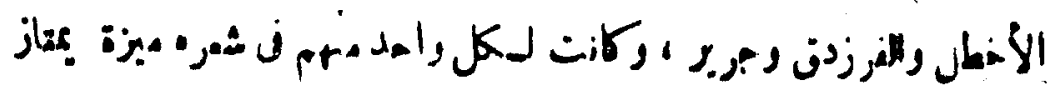

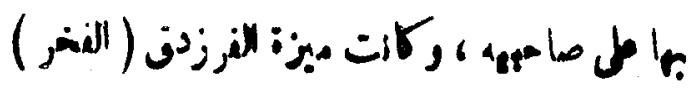

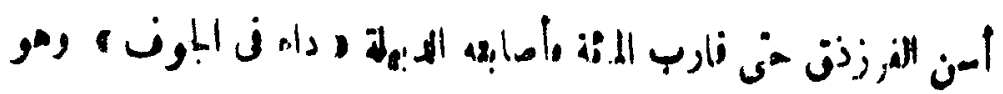

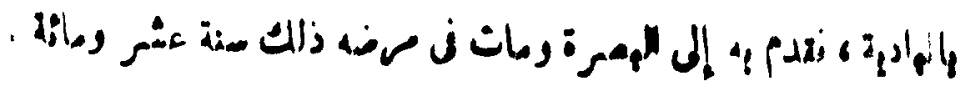

: asildit

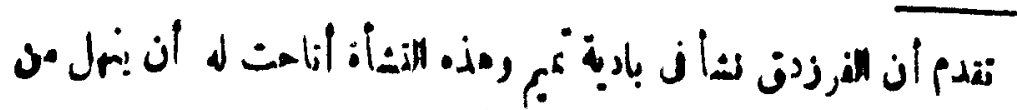

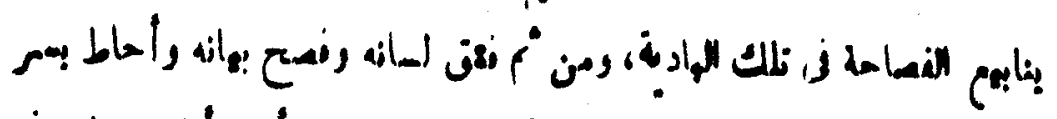

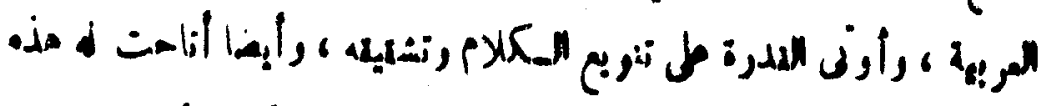

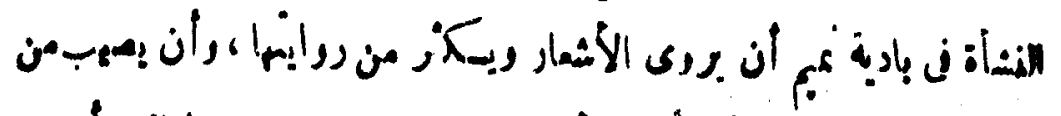

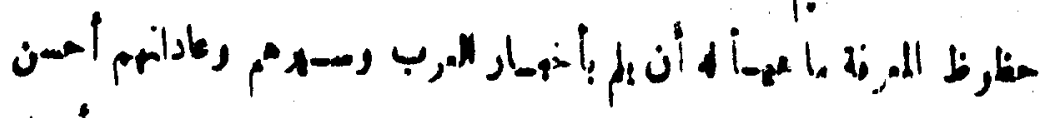

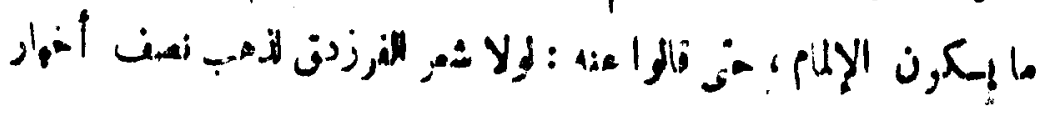
(1)

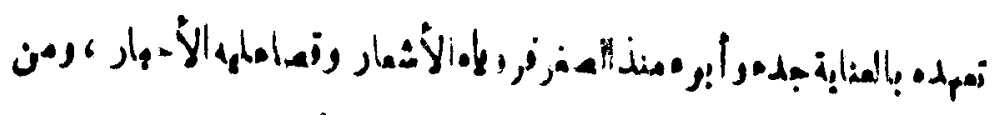

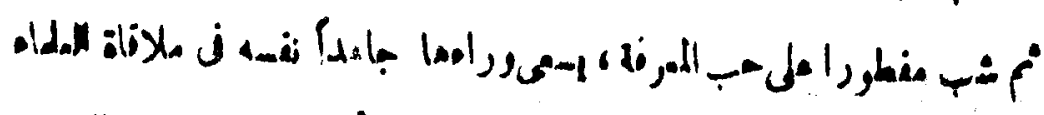

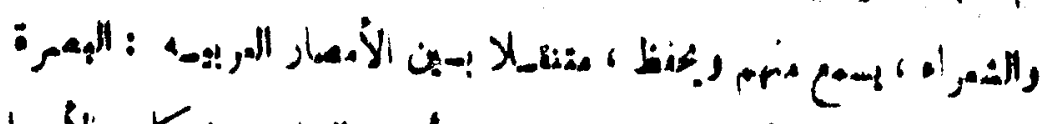

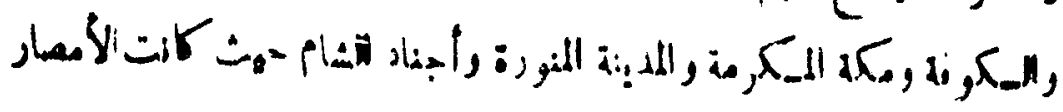

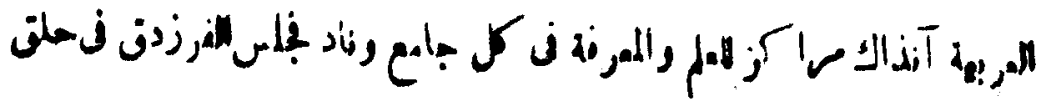

• rrI/I : البيان والتبيين 


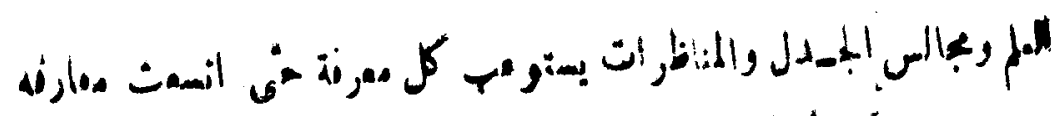

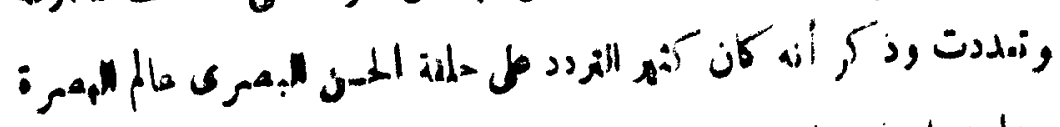

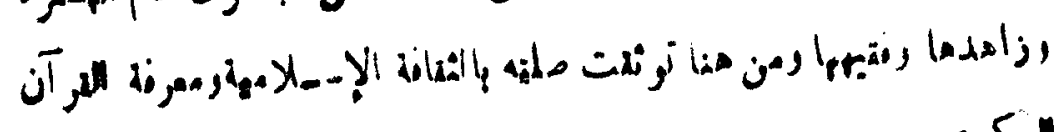
(.) $\Sigma-\lambda$

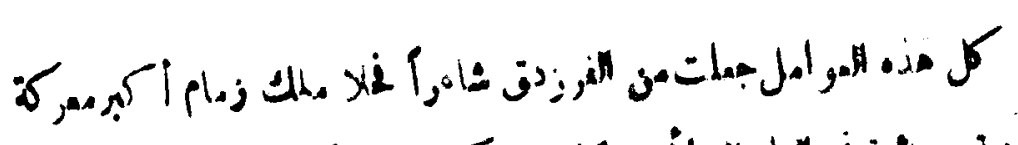

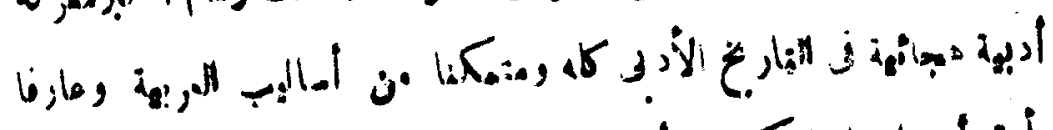

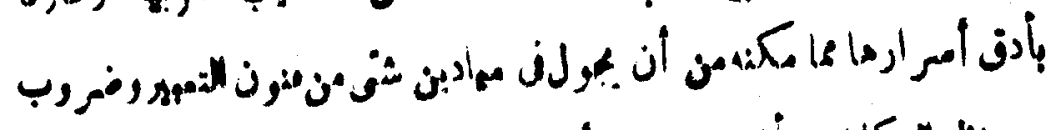

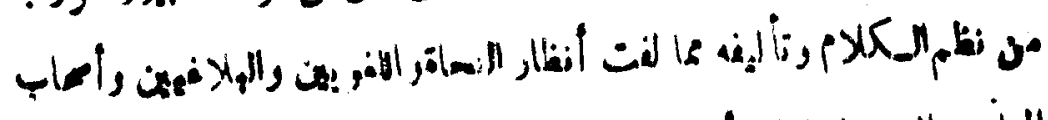

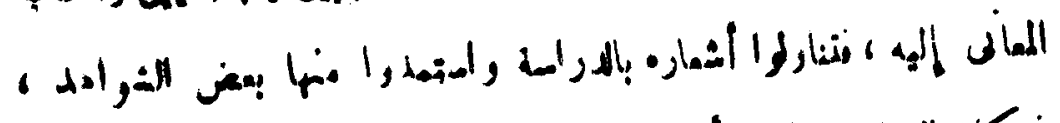

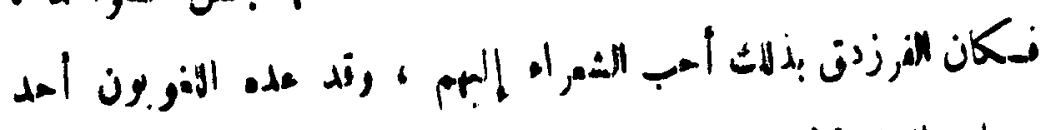

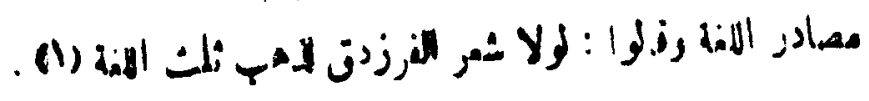

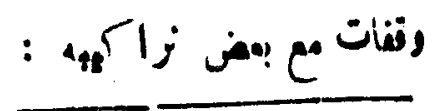

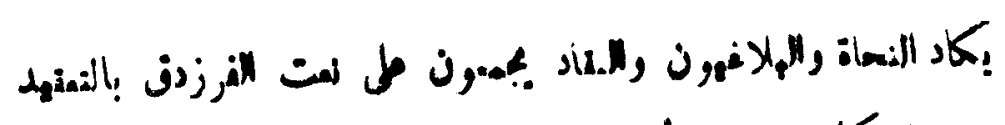

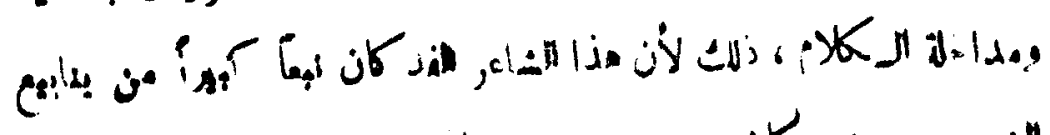

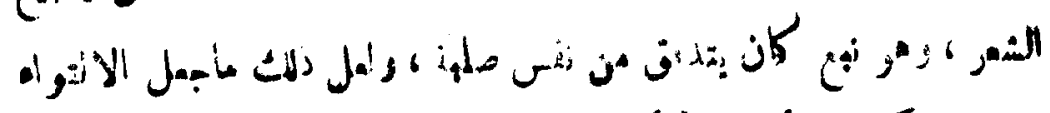

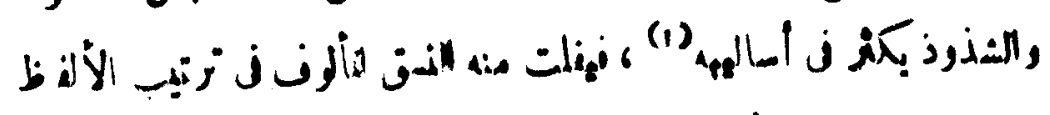

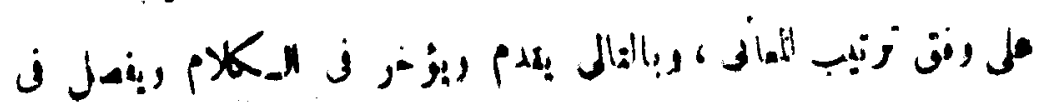

$$
\begin{aligned}
& \text { - }
\end{aligned}
$$

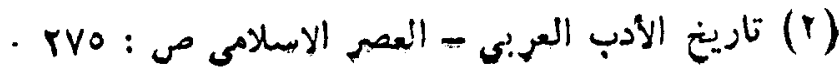




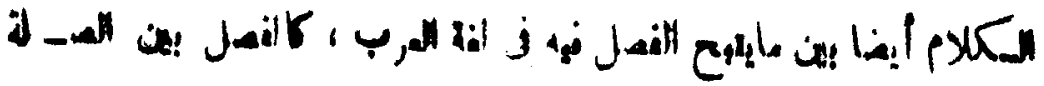

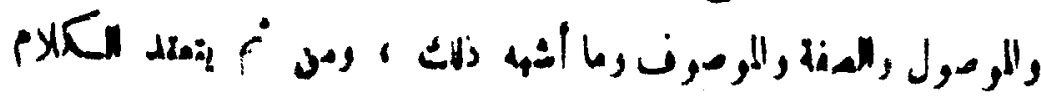

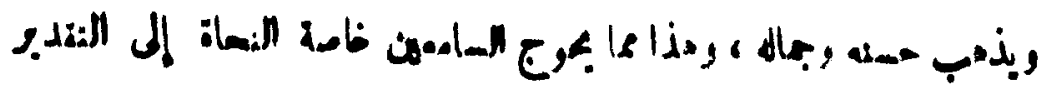

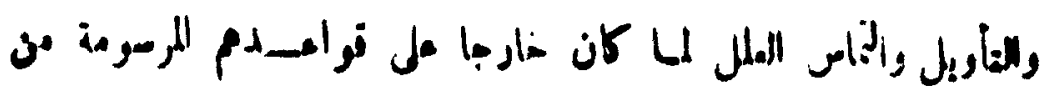

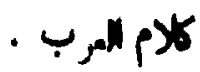

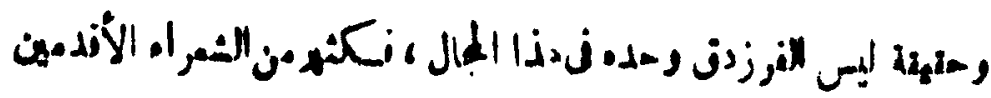

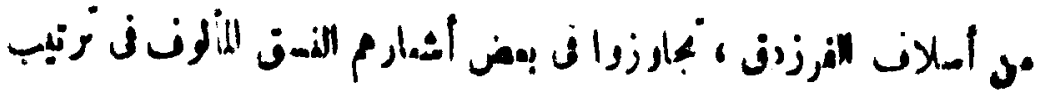

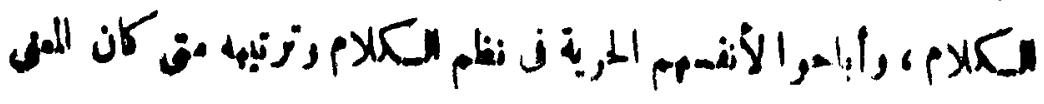
لار اد وافها بينا .

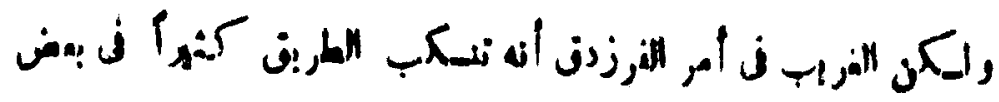

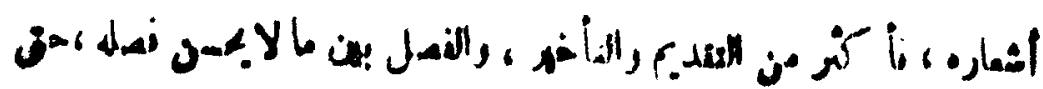

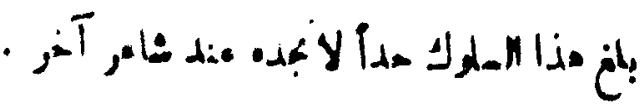

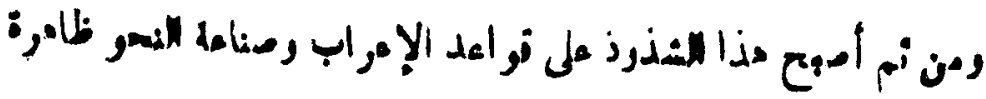

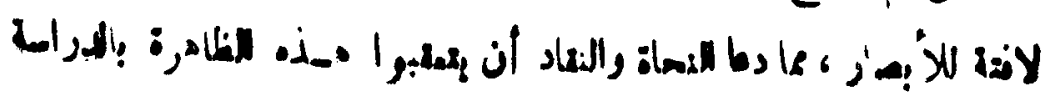

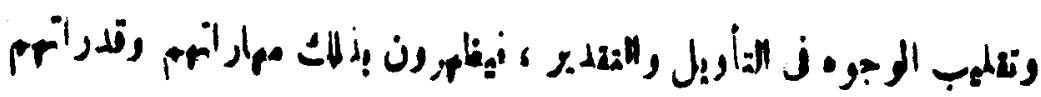

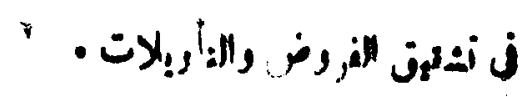

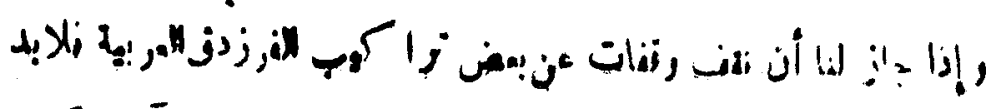

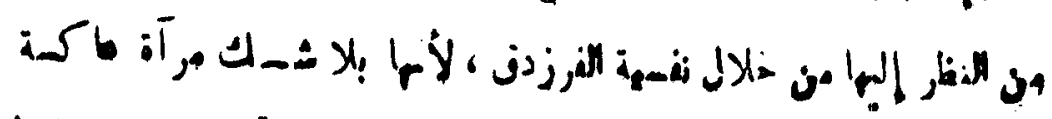

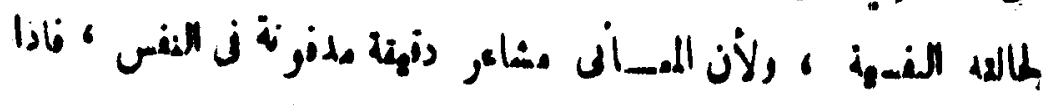

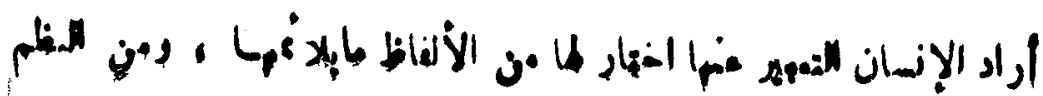

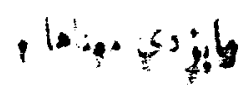


rar

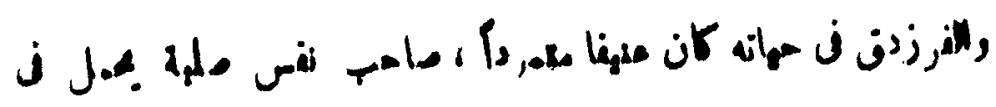

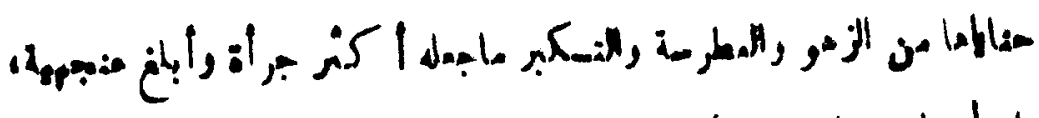

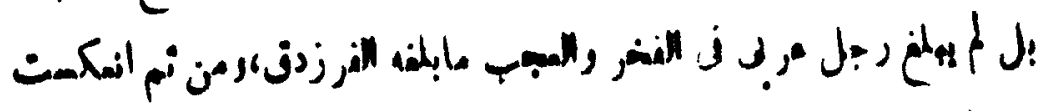

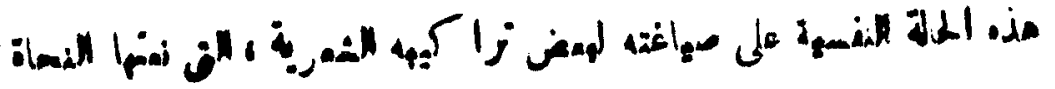

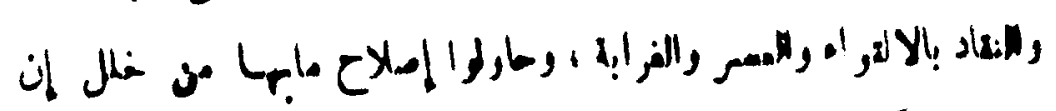

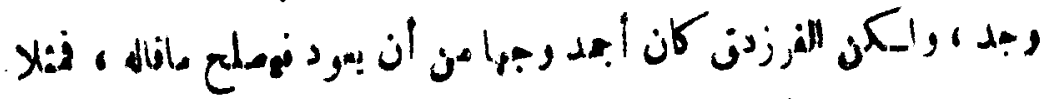

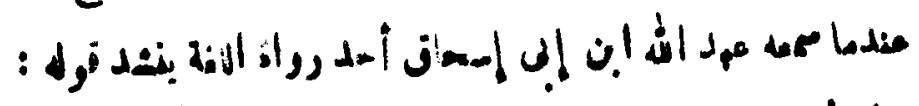
(1)

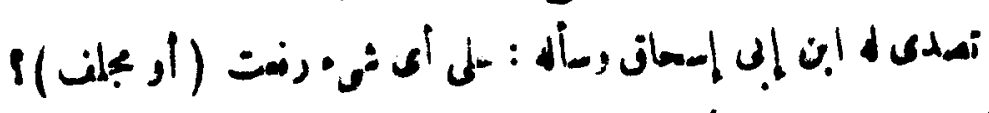

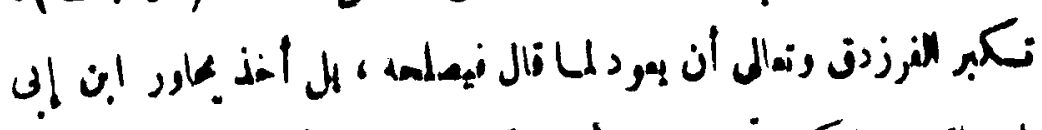

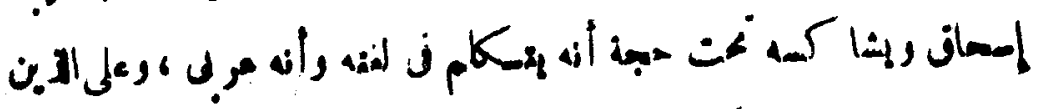

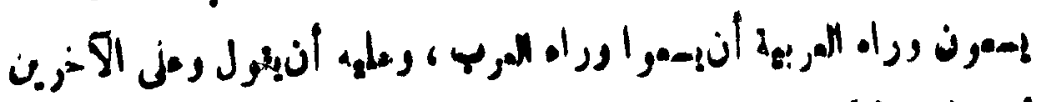
Crigit

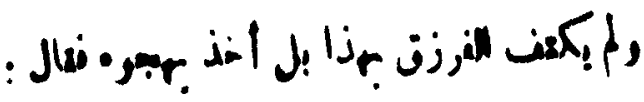

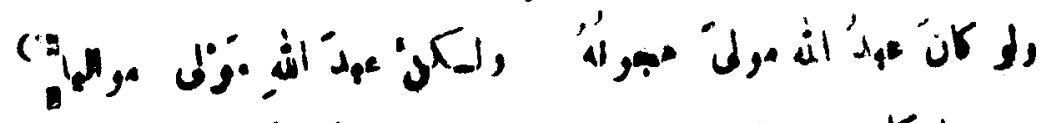

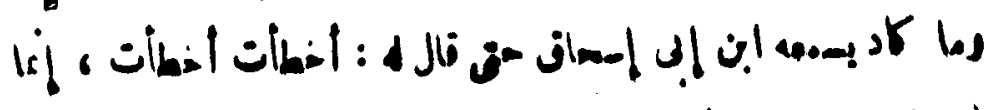

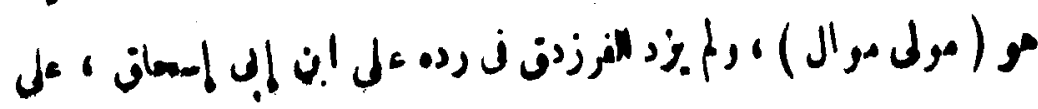

: (1) iril/ : : (r)

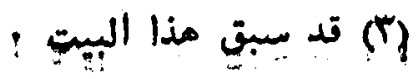


PAI

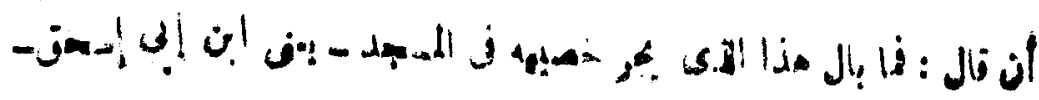

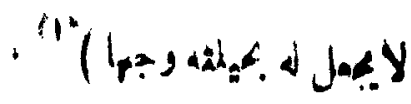

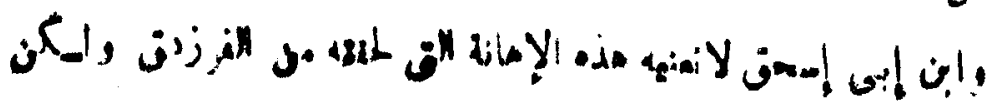

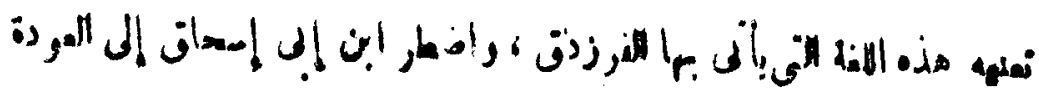

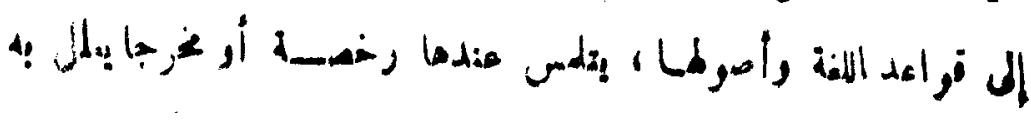

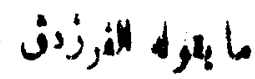

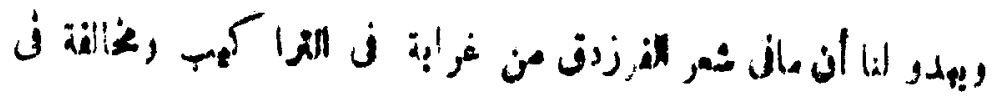

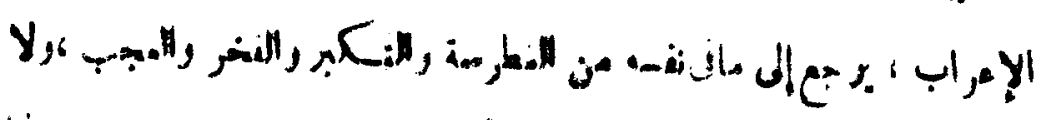

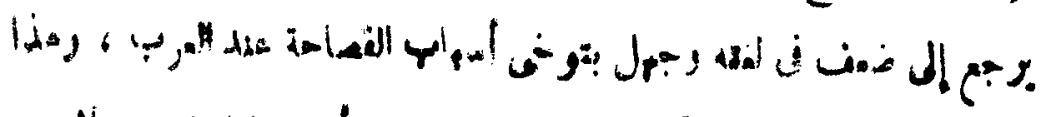

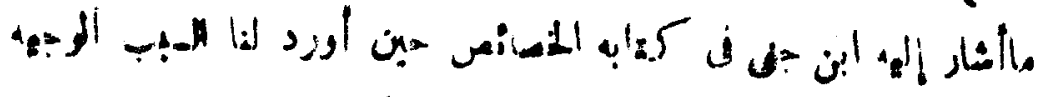

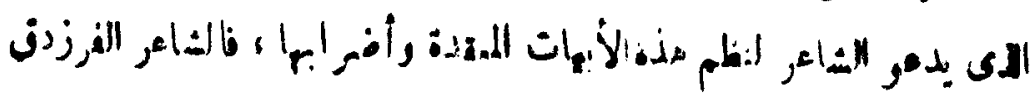

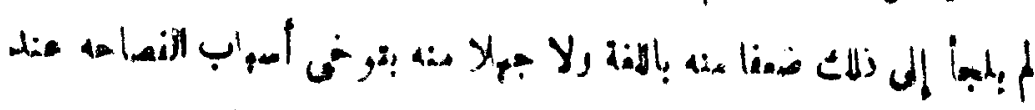

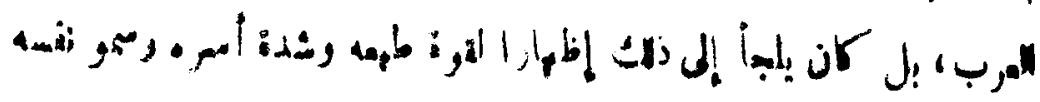

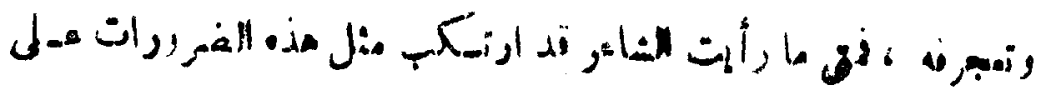

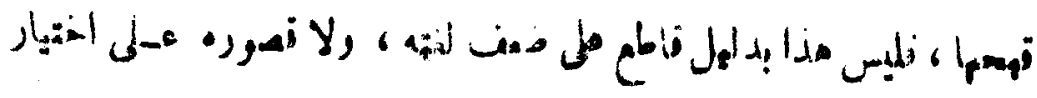

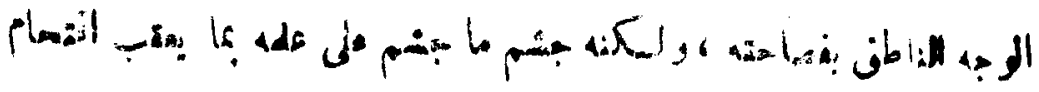

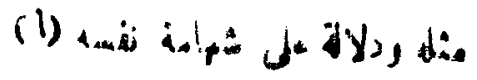

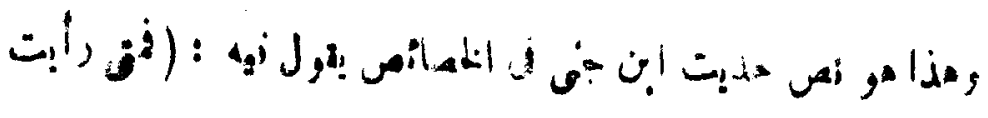

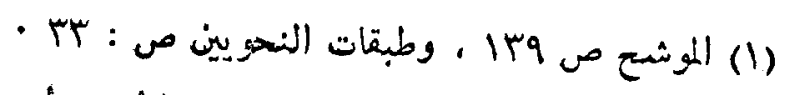

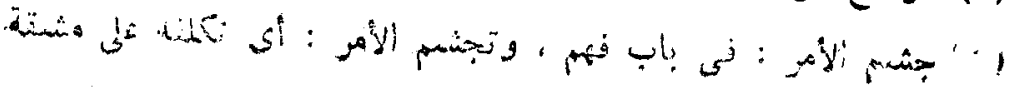




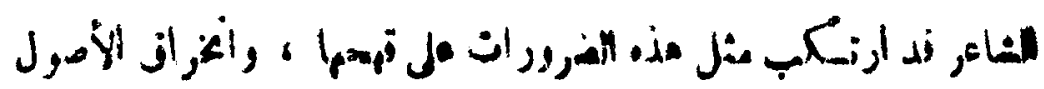

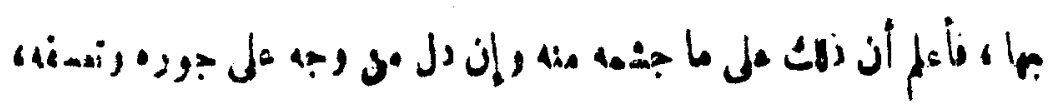

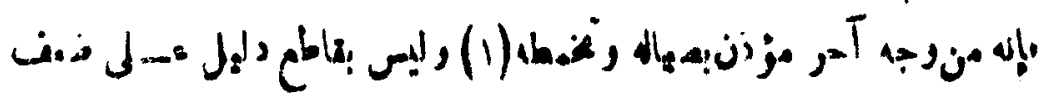

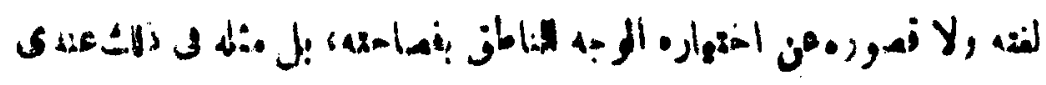

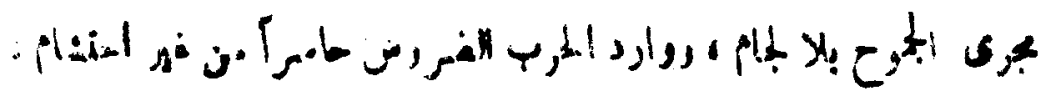

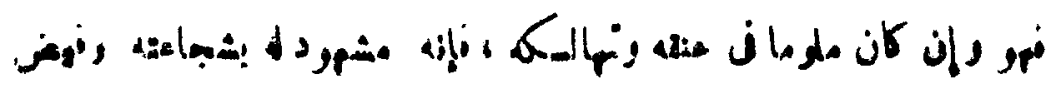

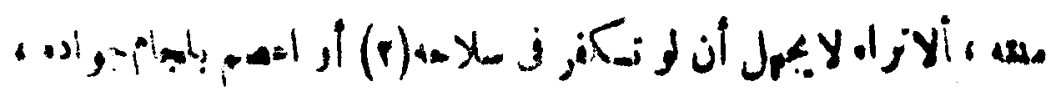

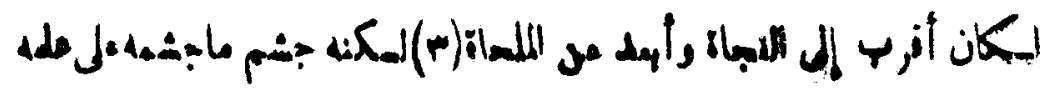
(1).

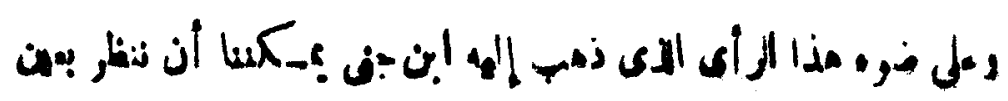

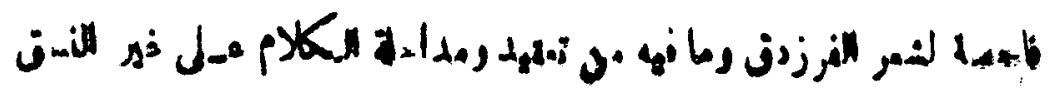
-

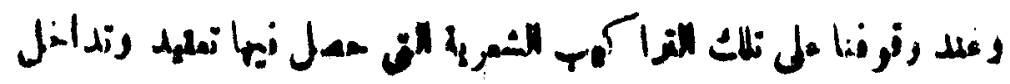

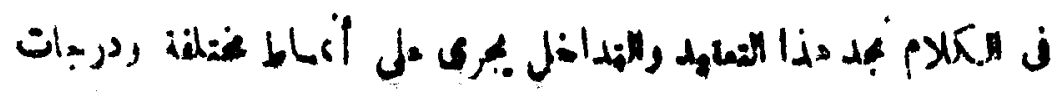

- iijas

(1) يقال : كخمط الفحلَ : هدر وثار ، وتخمط : تكبر -

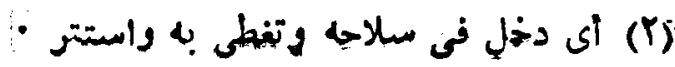

•

, rqr/r :

$(j-r 0)$ 


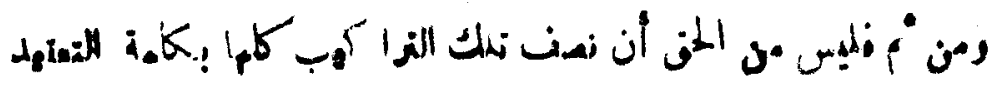

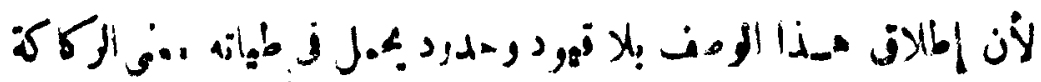

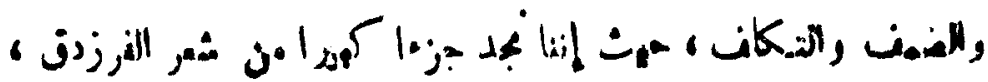

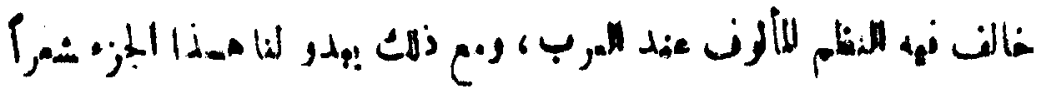

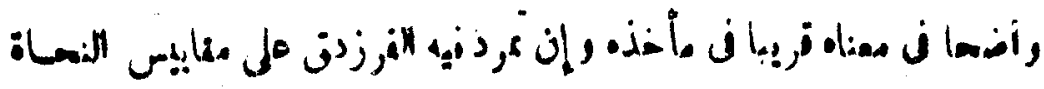

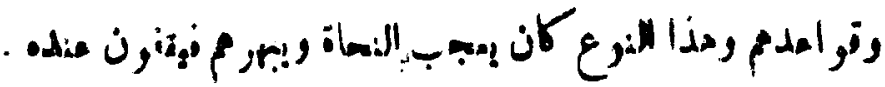

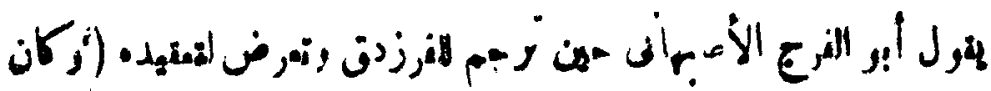

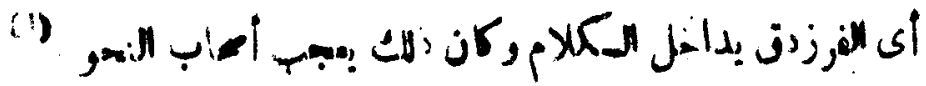

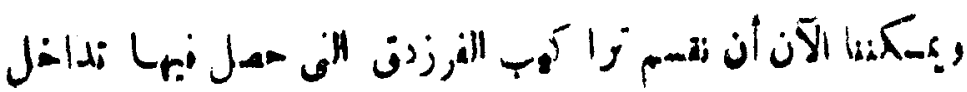

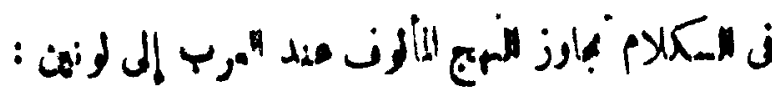

$$
\text { : } 1
$$

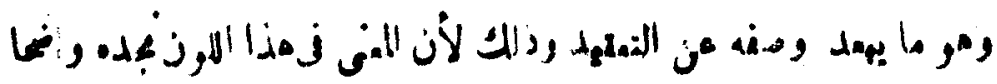

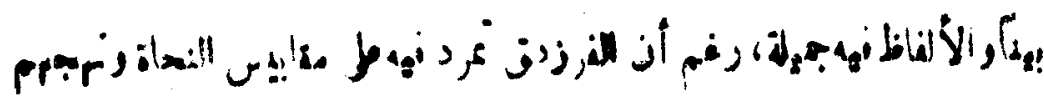

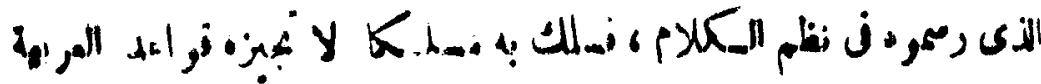

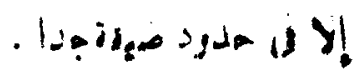
is, إن ك.

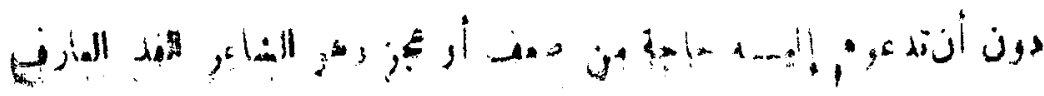
iall

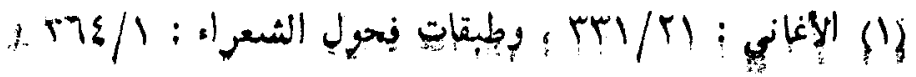


raY

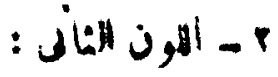

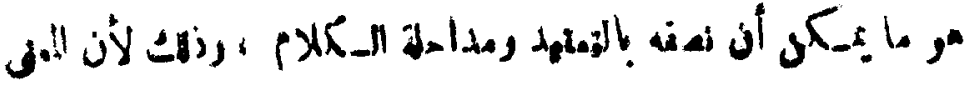

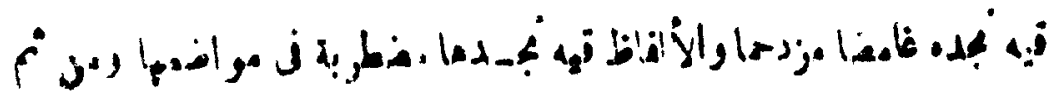
|l

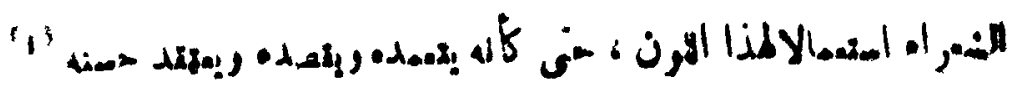

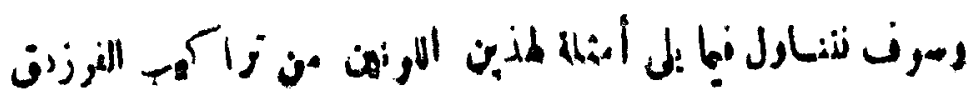

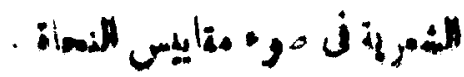

$$
\begin{aligned}
& \text { أله من اللون الأول : } \\
& : 4 ;
\end{aligned}
$$

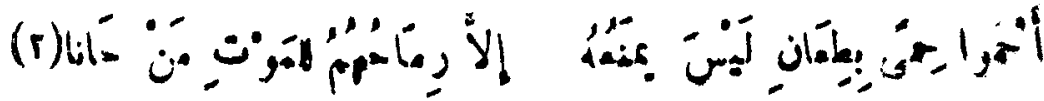

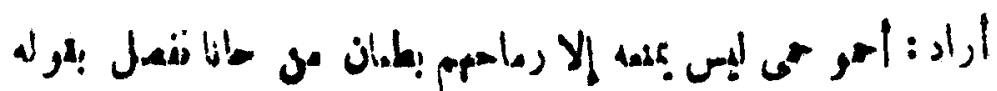

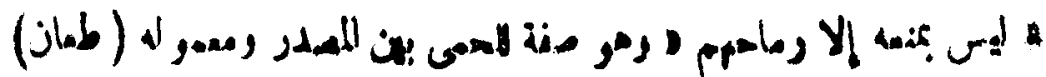

$$
\begin{aligned}
& \text {. } \\
& \checkmark j ;-1
\end{aligned}
$$

(P)

$$
\begin{aligned}
& \text { : 115 - 111 : (11) }
\end{aligned}
$$

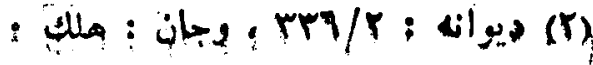

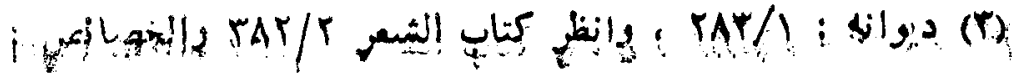




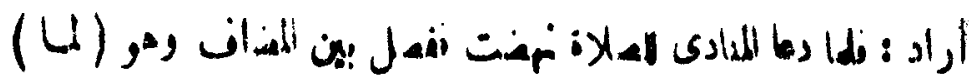

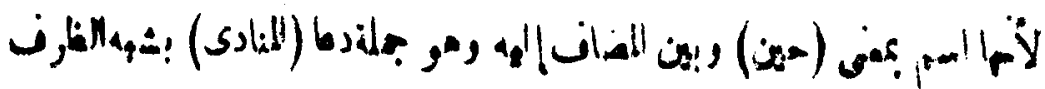

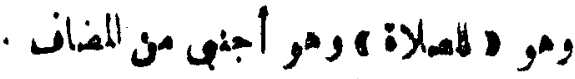

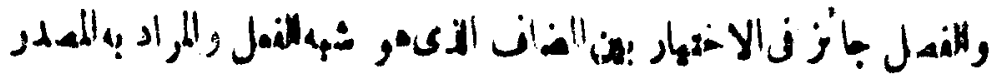

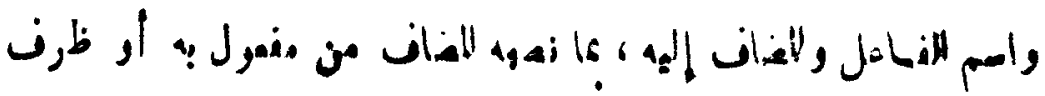

$$
\begin{aligned}
& \text { أو } \\
& \text { بـ آرله }
\end{aligned}
$$

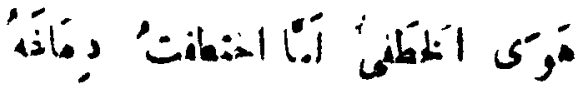

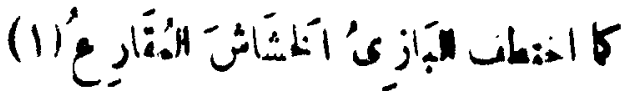

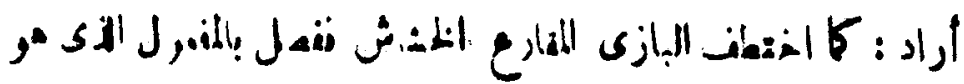

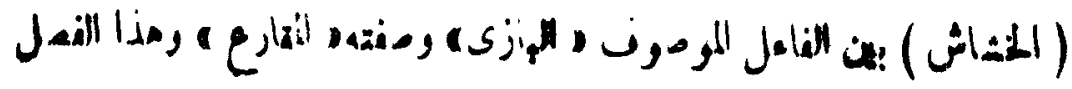

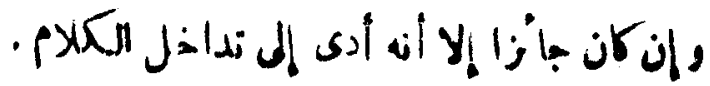
8

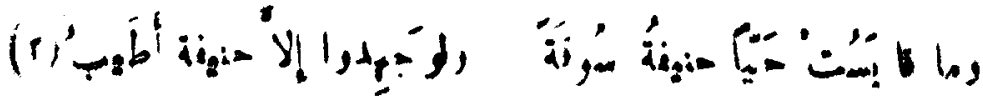

أراد : ومان

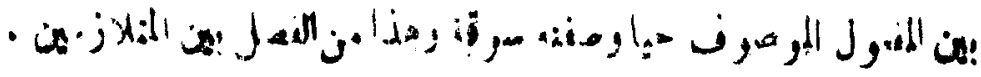

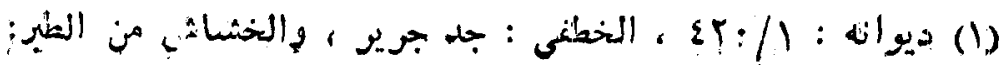

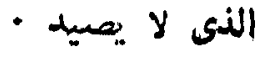

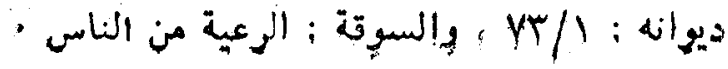




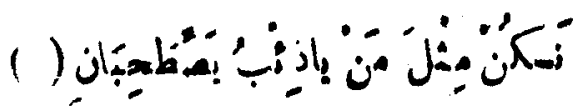

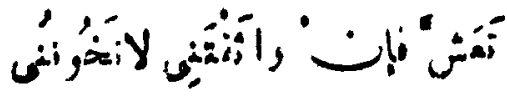

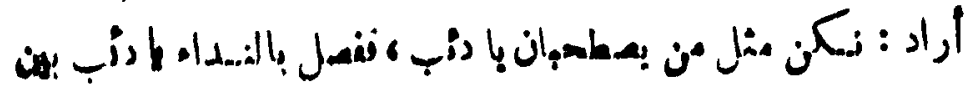

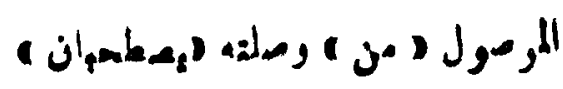

: 4 j (

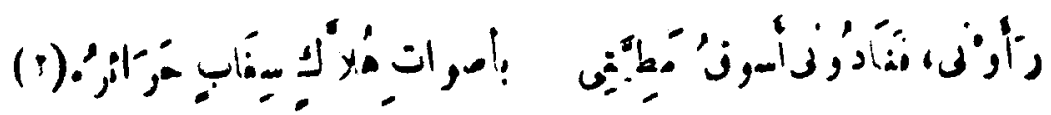

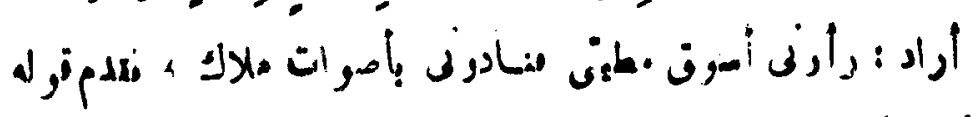

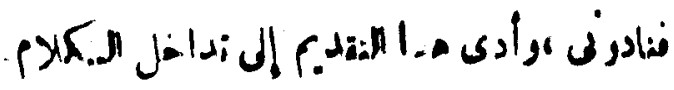

$\sqrt{ }, j(V)$

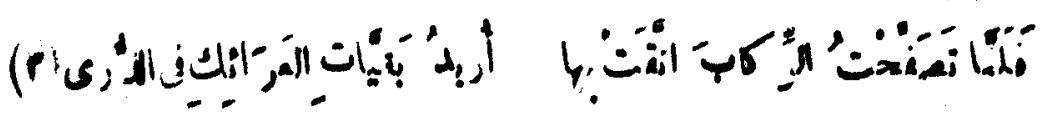

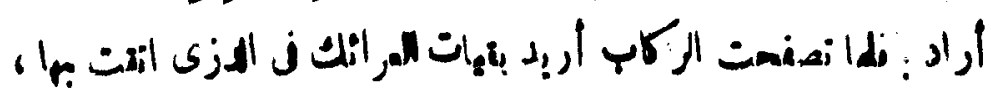

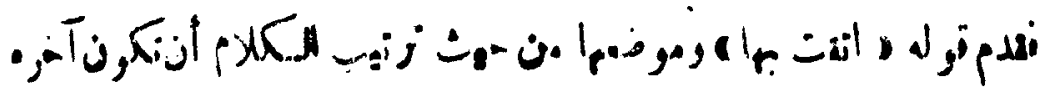

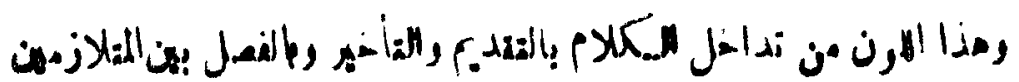

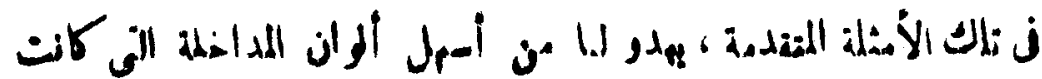

$$
\text { ديوانه : }
$$

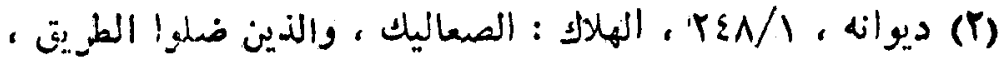

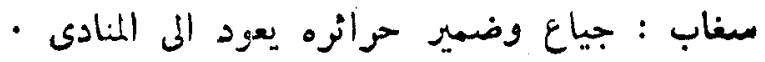

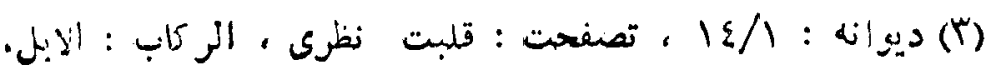

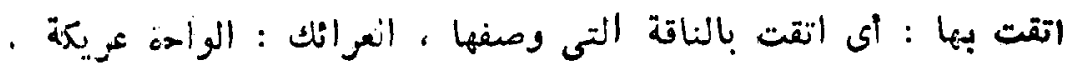




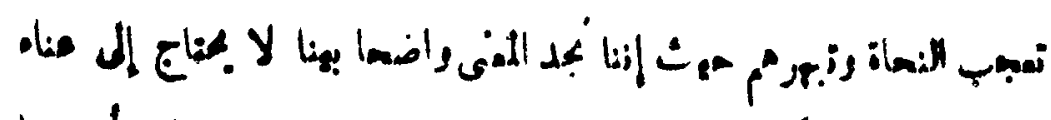

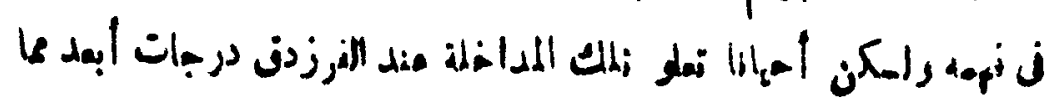

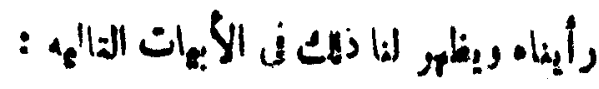

نِ

$$
\text { وأز }
$$

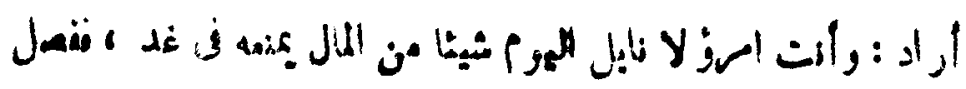

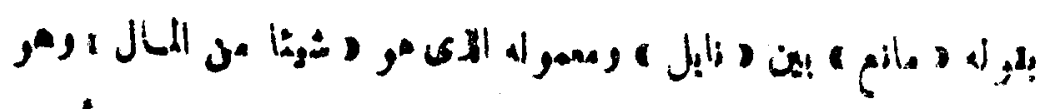

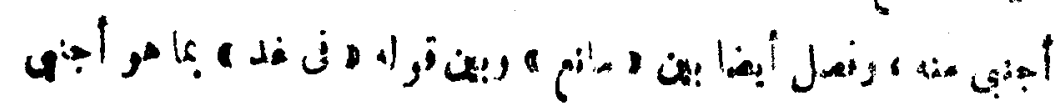

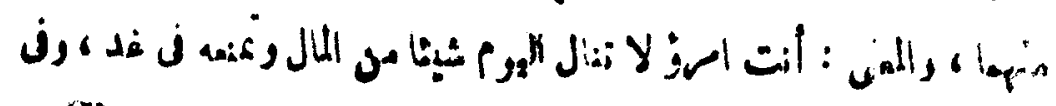

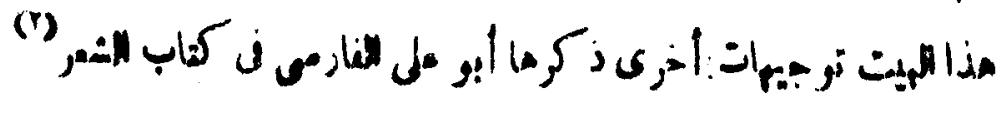

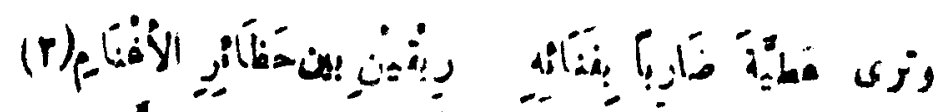

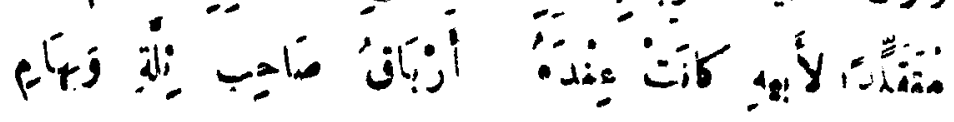

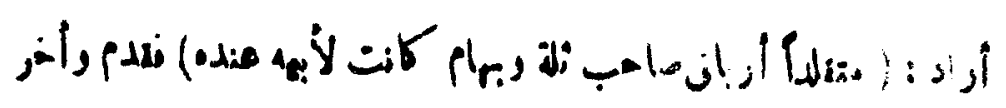

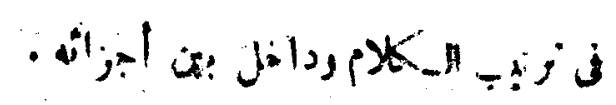

$$
\text { - } 0 \leqq / 1: \text { : (1) (1) }
$$$$
\text { • كتاب الشعر : : }
$$

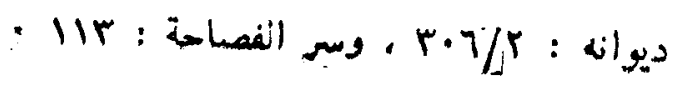


$: \Delta, i(1 \cdot)$

وَلث

(1)

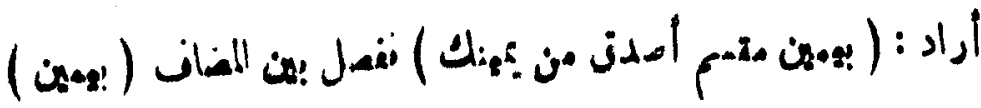

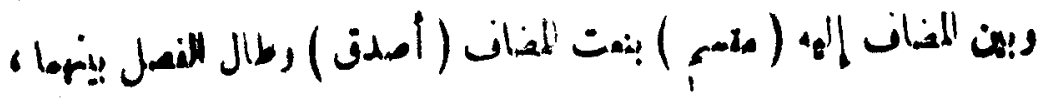

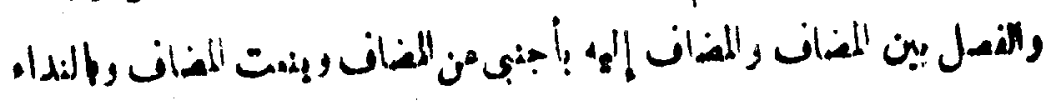

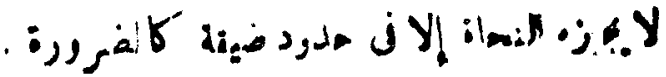

$$
\begin{aligned}
& \text { : } 4 \text {; (11) }
\end{aligned}
$$

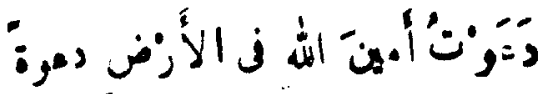

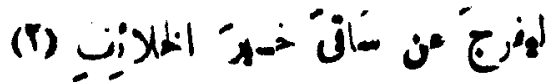

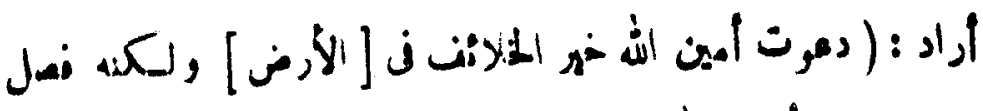

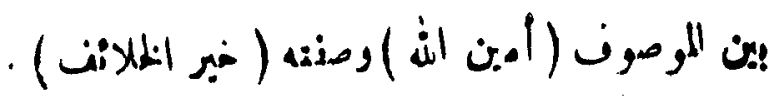

$: \Delta, j(17)$

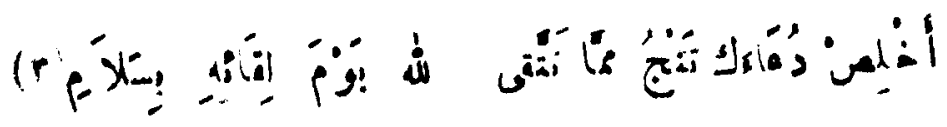

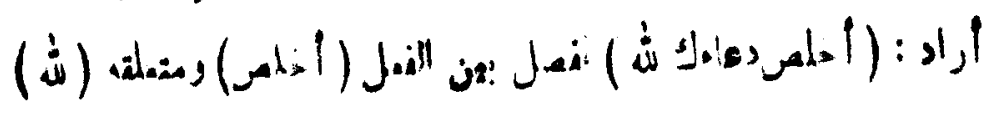

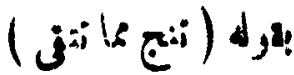

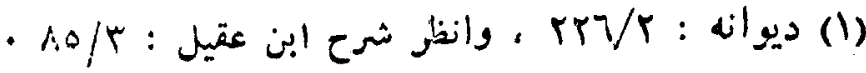

$$
\begin{aligned}
& \text { - } 9 / r \text { : 4اونه } \\
& \text { - } r \wedge \varepsilon / r: r \text { : ديوانه }
\end{aligned}
$$




\section{Pis}

$$
: \text { : } j(I r)
$$

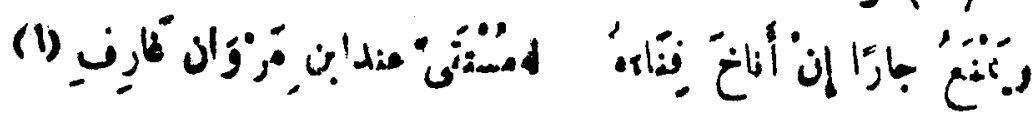

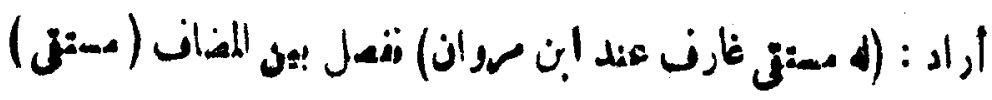

$$
\begin{aligned}
& \text { والمفان إلهه (غارن) . } \\
& \text { : } 4 \text {; (18) }
\end{aligned}
$$

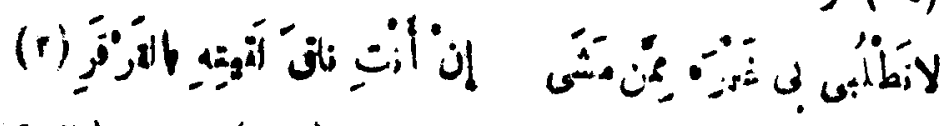

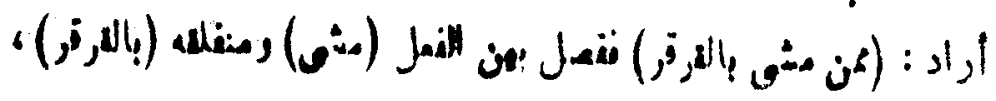

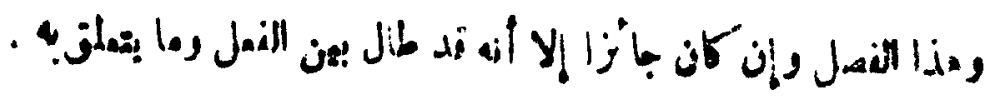

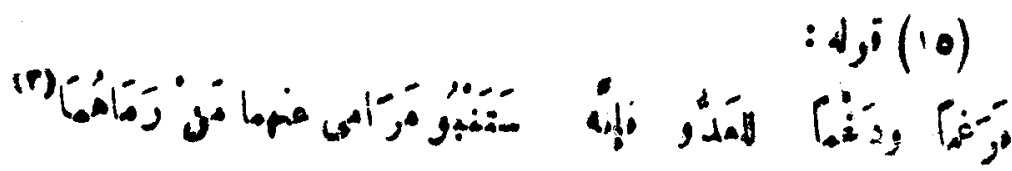

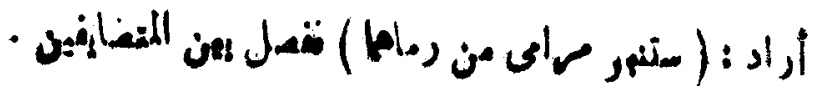

$$
8 d, j(17)
$$

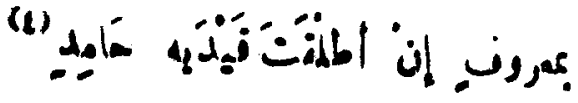

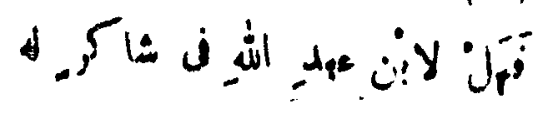

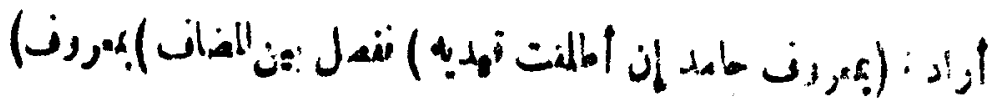

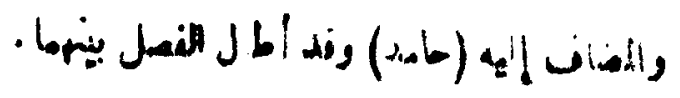

$$
\text { - 19/r: : (1) }
$$

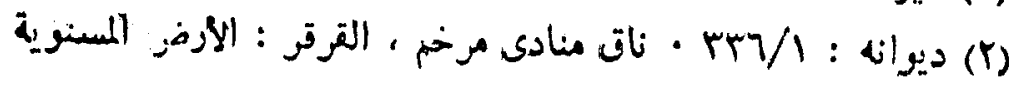
) 


\section{$: d, j(i v)$}

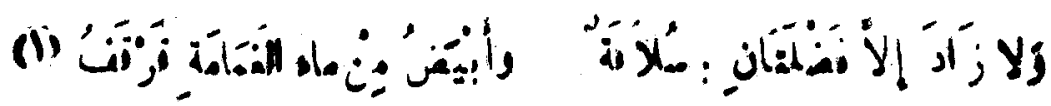

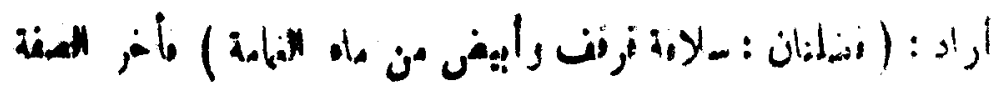

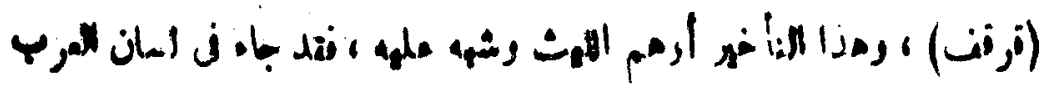

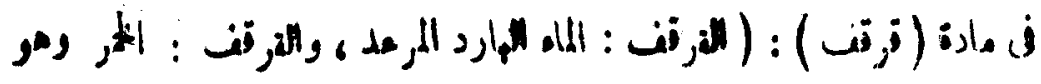

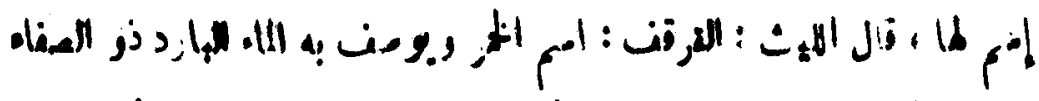

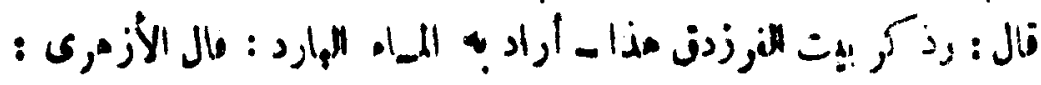

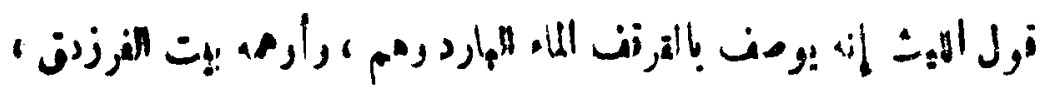

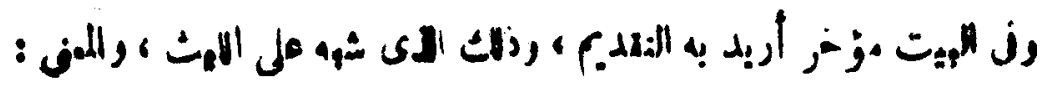

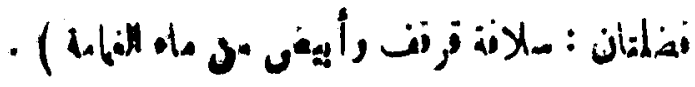
:

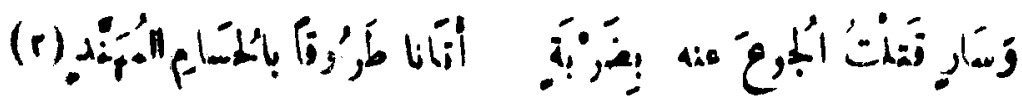

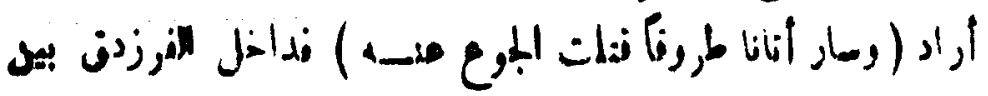

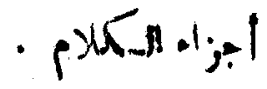

:

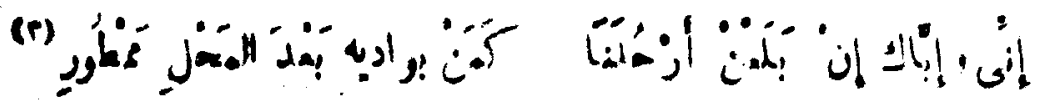

(1)

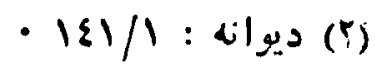

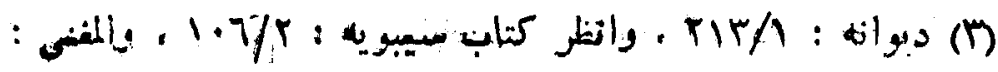




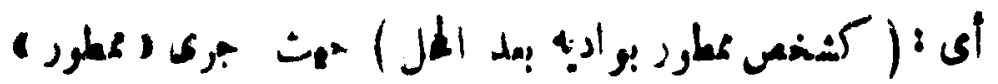

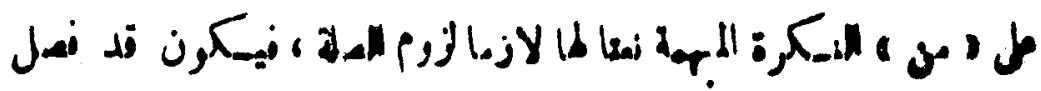

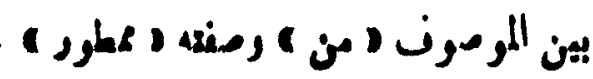
كاك (1)

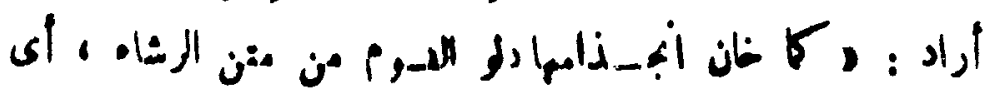

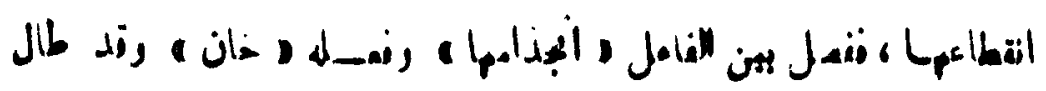
- lore! Jeill

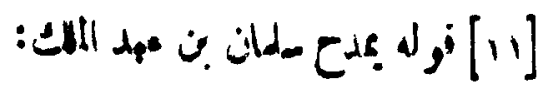

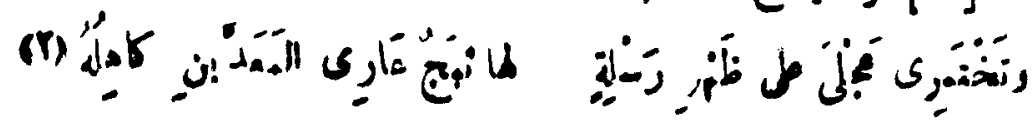

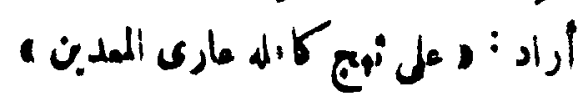
أمثلة مى المون المأن

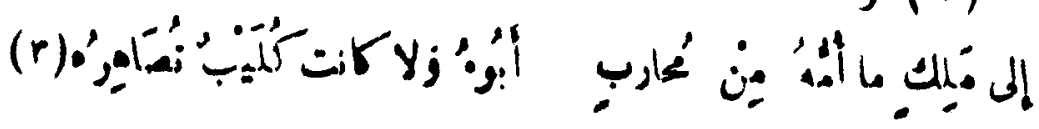

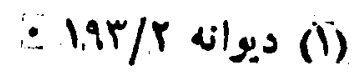

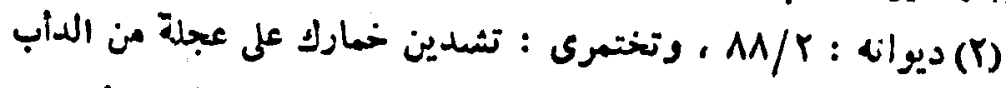

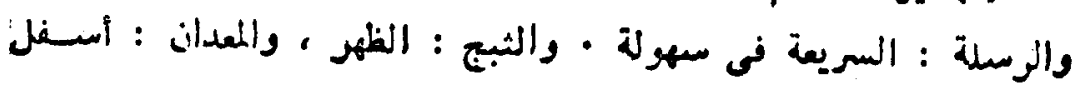

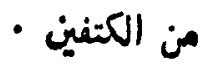

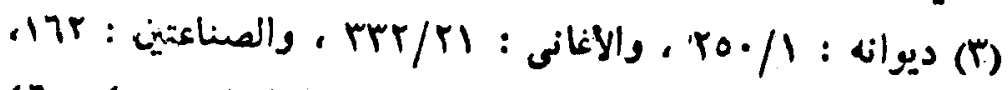

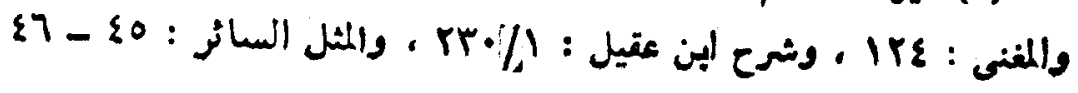


ra

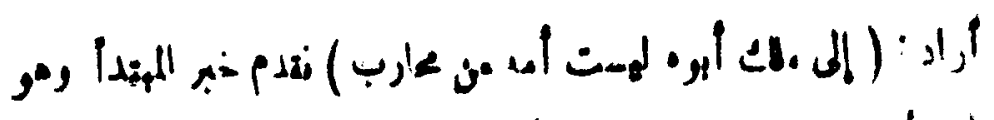

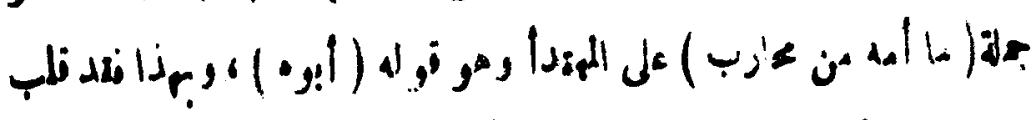

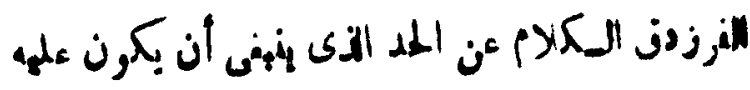

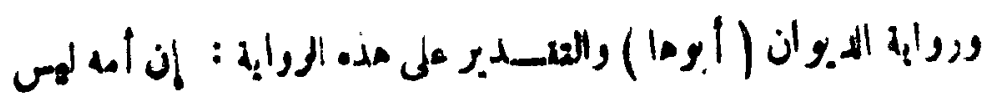

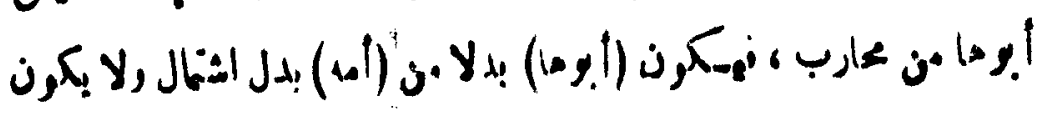

في

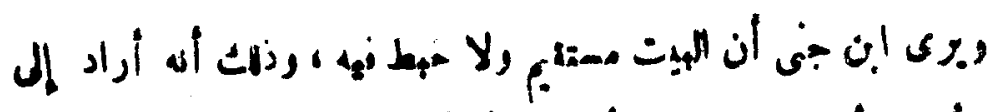

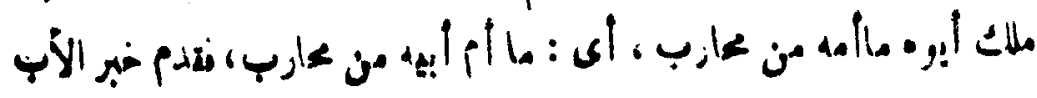

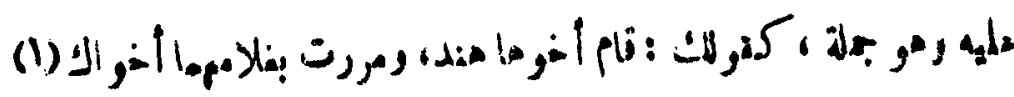

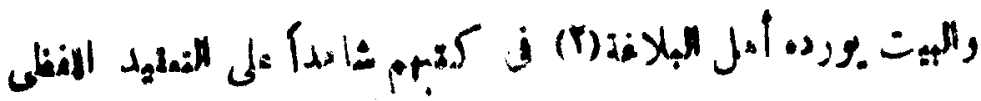

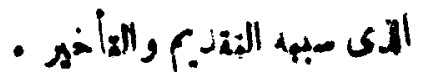

(r)

:

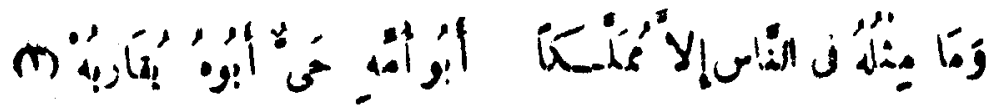

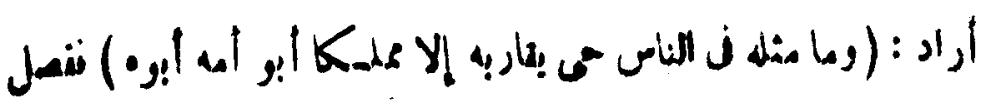

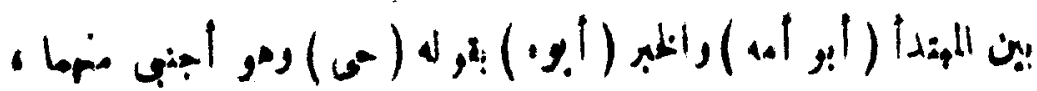

- rq\&/r : : (1)

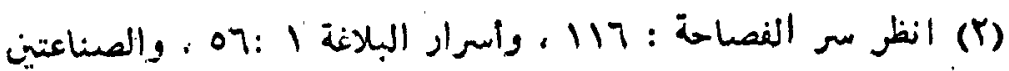

- $17 r$

(r) كتاب الشسر : IVV/

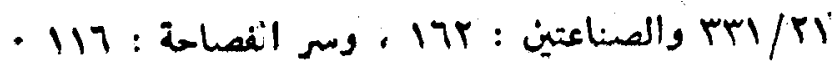




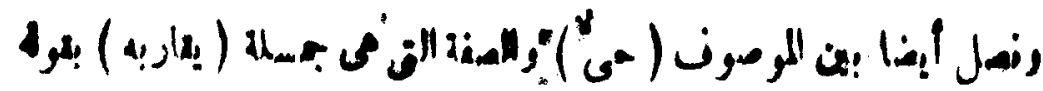

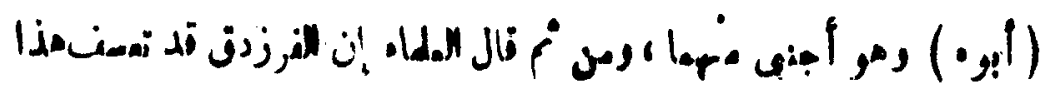

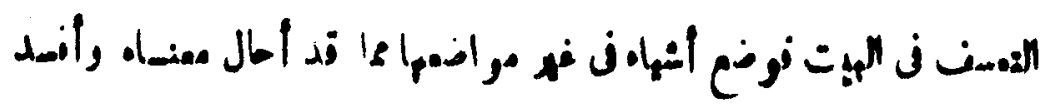
(1)

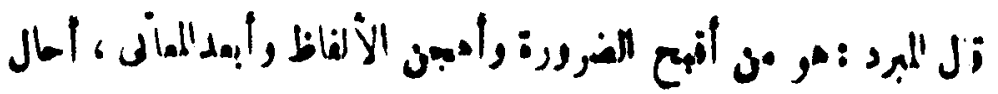

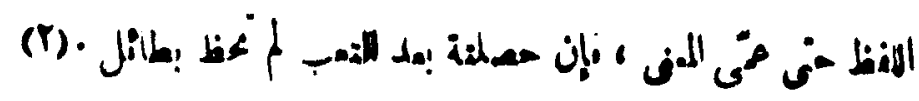

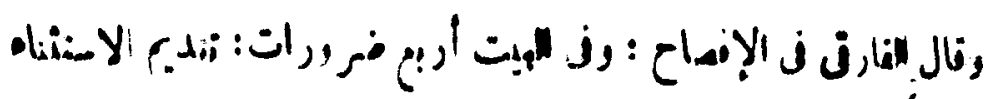

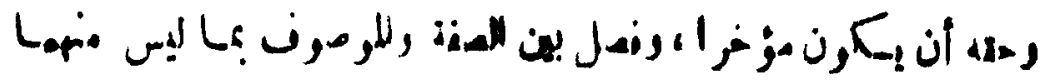

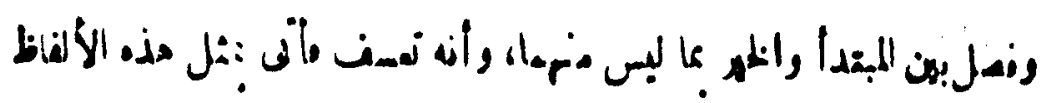

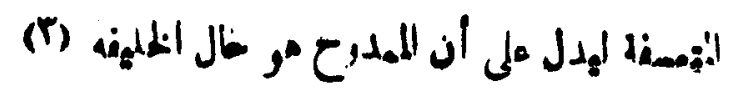

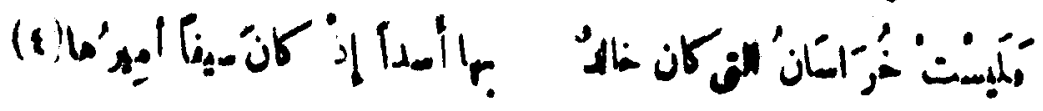

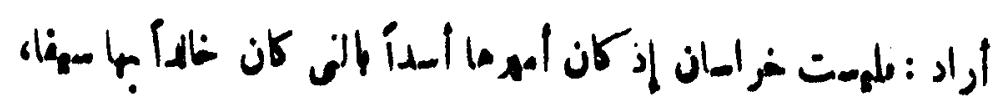

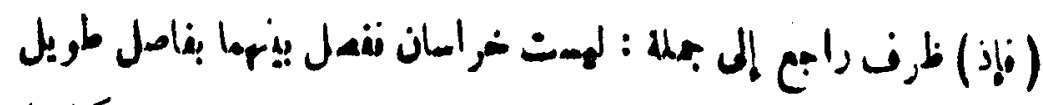

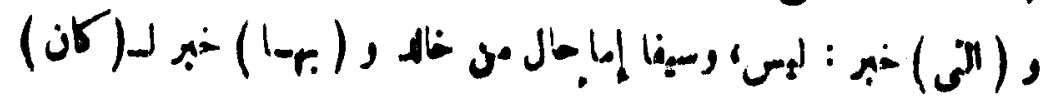

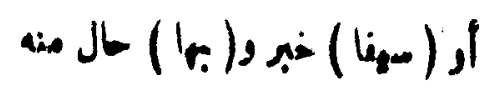

- 117 : (1) سمر الفصاه (1)

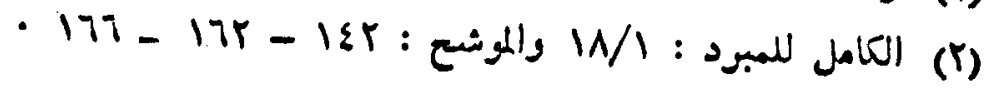

- AV : ح

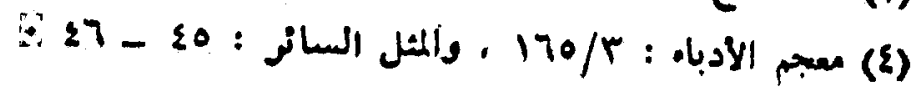




\section{Piv}

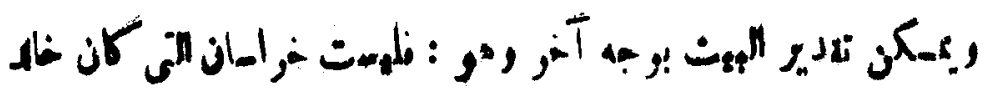

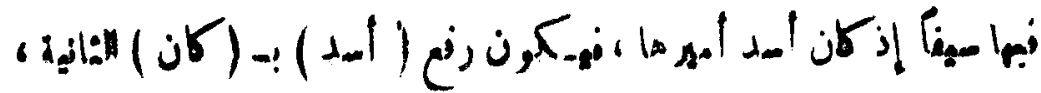

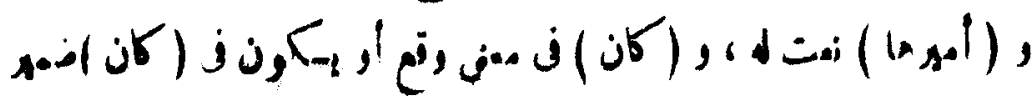

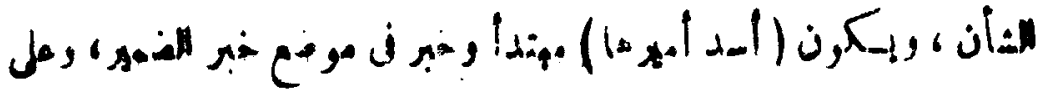

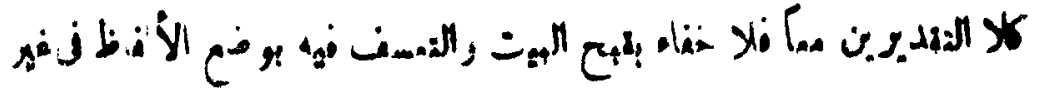

(1) مر اضمها

$$
: 4,8
$$

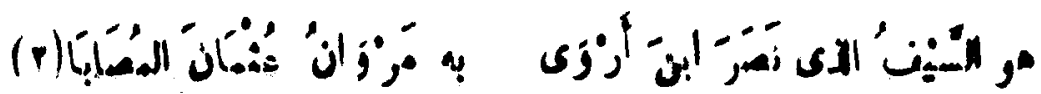

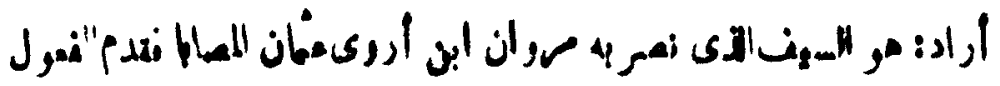

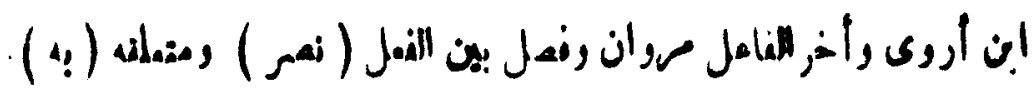

$$
: \Delta, 0
$$

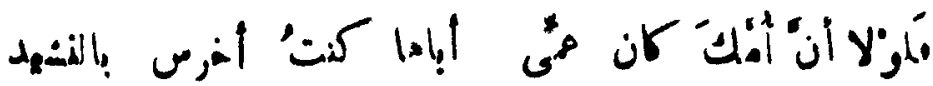

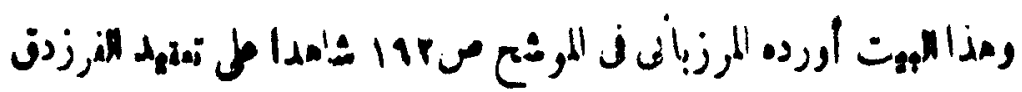

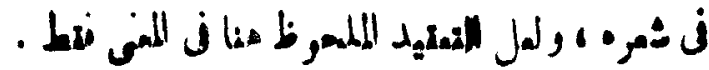

$$
: 4,-7
$$

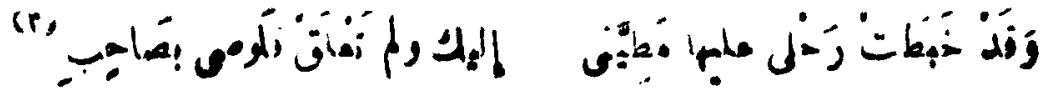

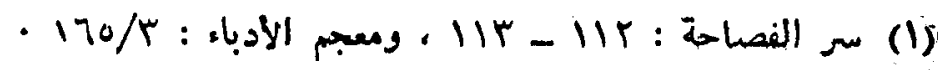

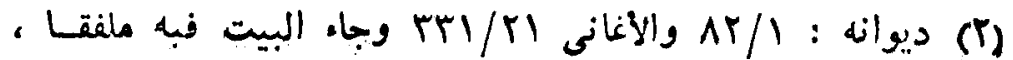

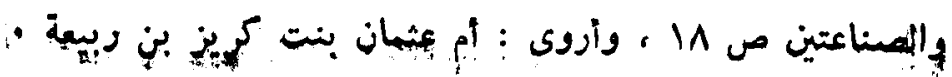

$$
\text { : 70/ }
$$




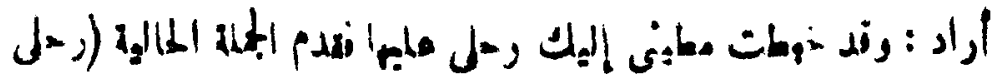

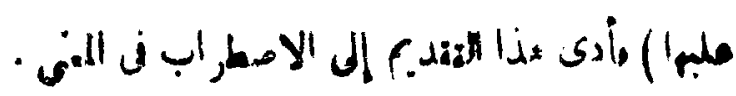

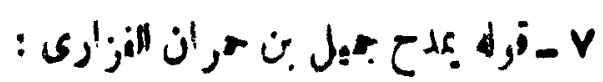

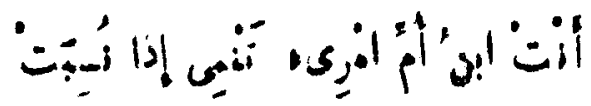

(1)

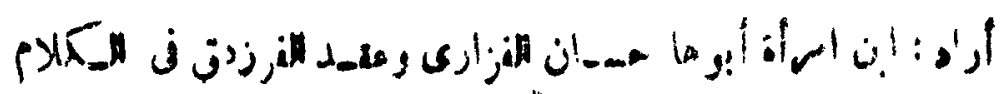
alilat

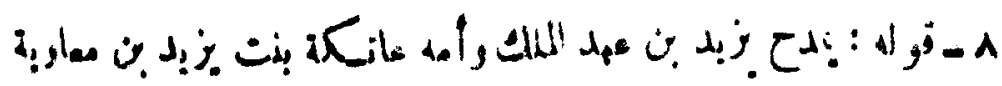

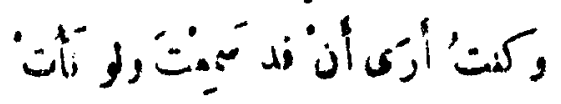

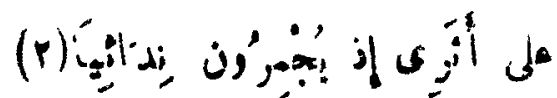

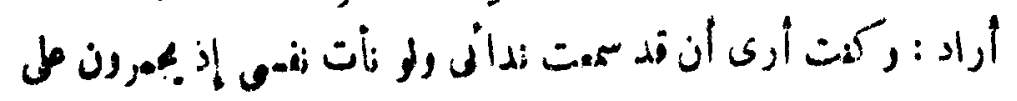

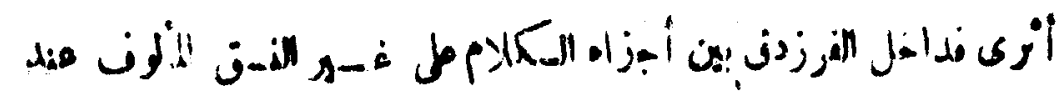

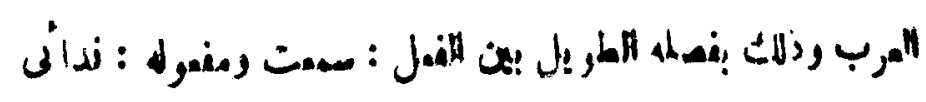

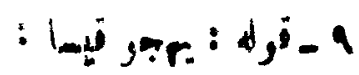

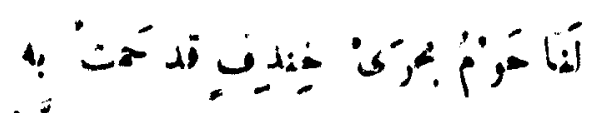

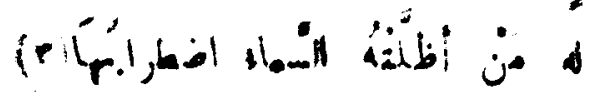

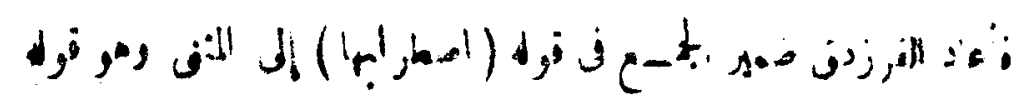

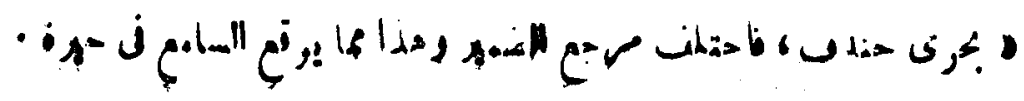

- rrar : 4iga (1)

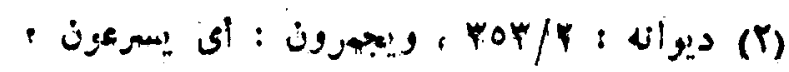

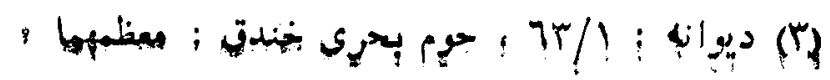




$$
\text { : } 1 \text { - } 1 \text { - }
$$

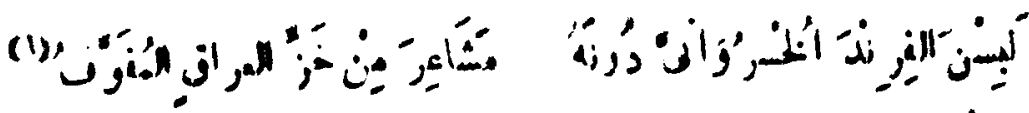

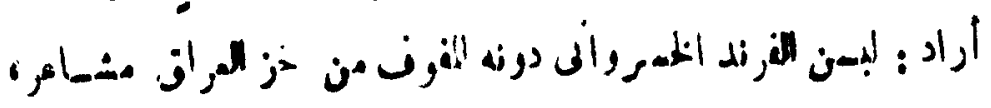

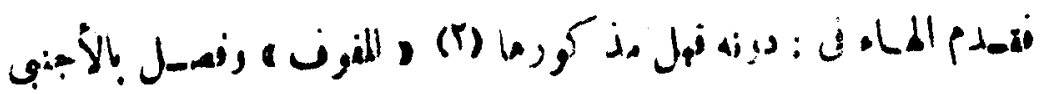

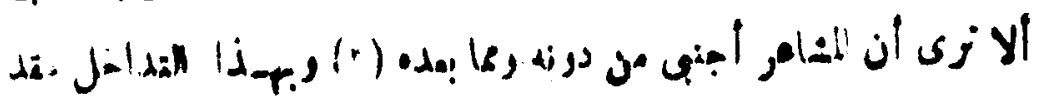

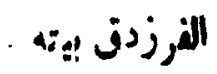

: 11

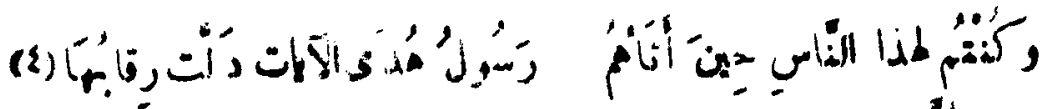

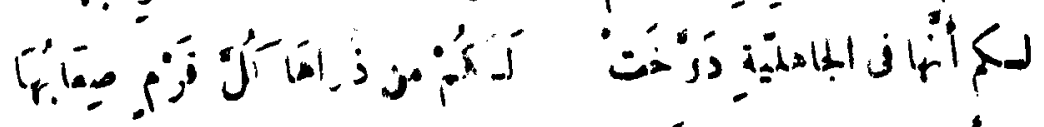

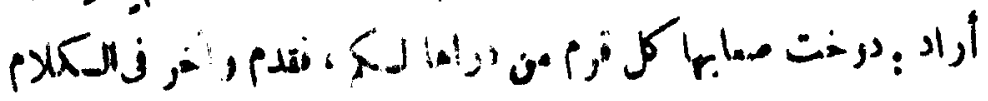

dise

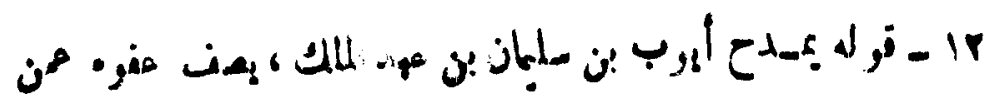

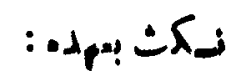

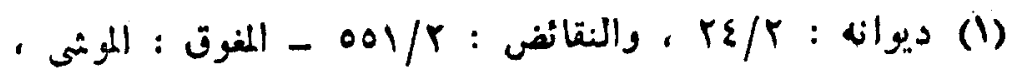

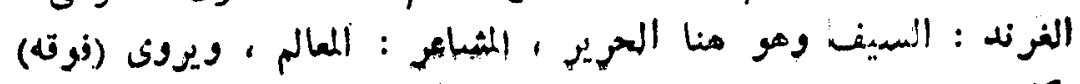

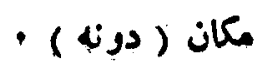

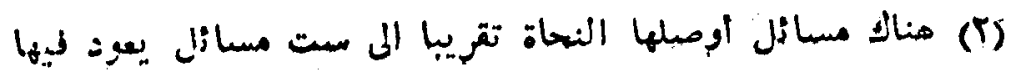

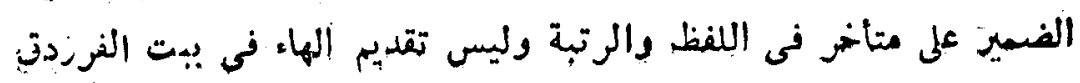

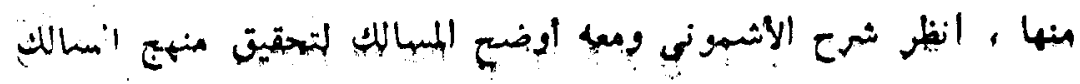

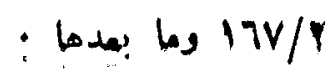

(r)

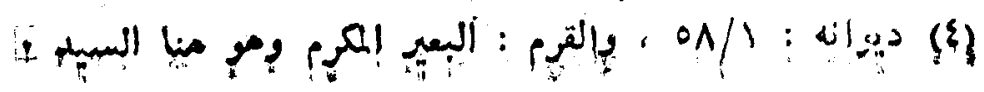




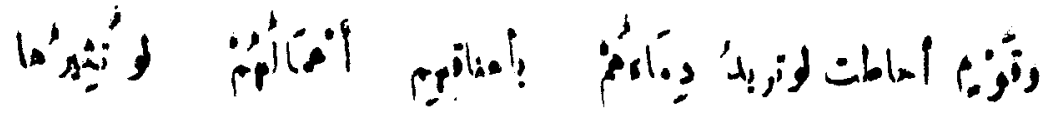

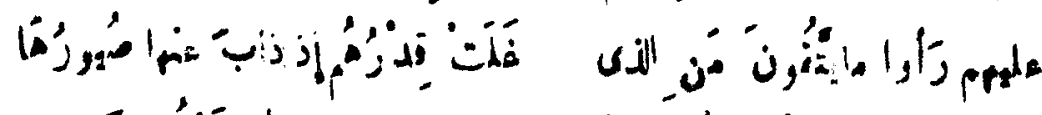

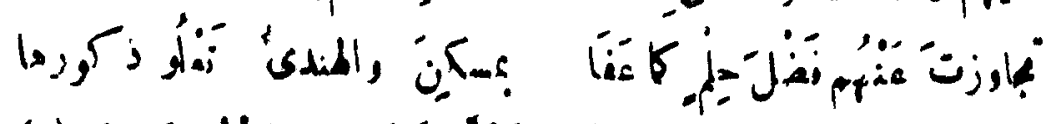

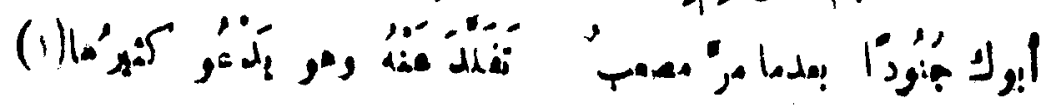

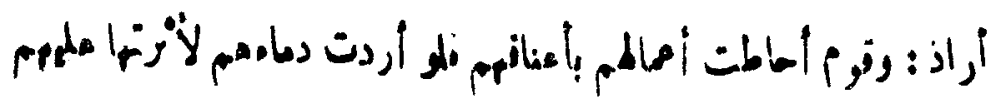

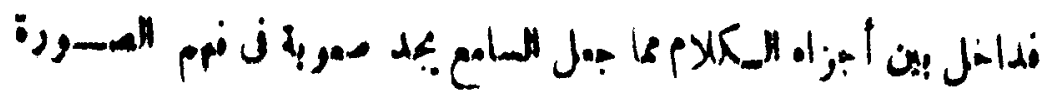

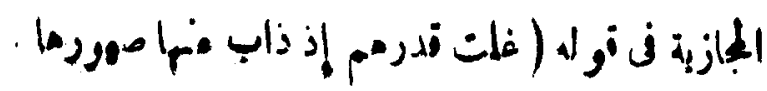
$: 4, j$ ir

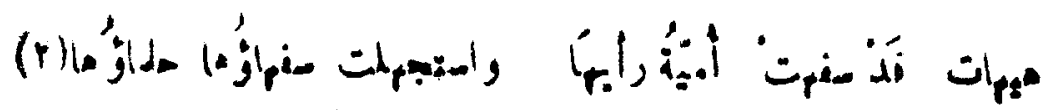

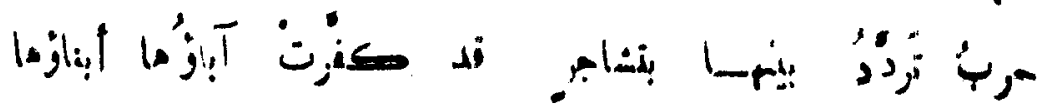

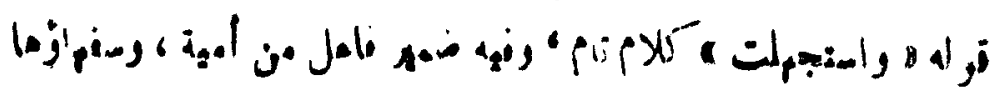

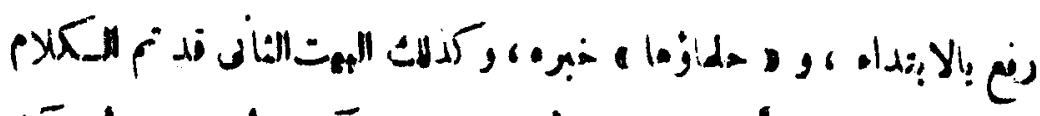

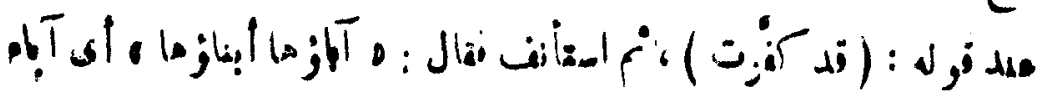

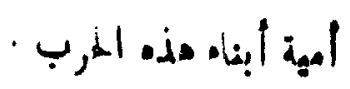

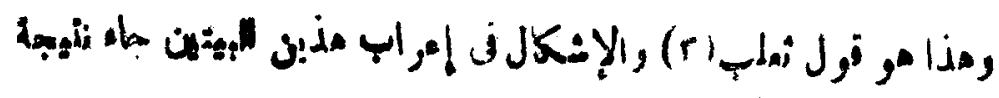
المداهلة ال. كلغام

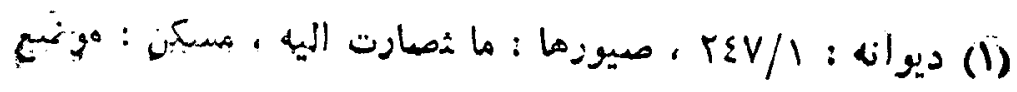

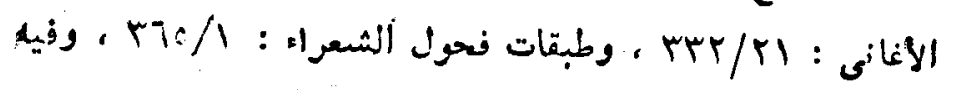

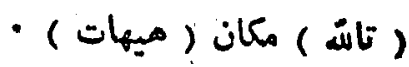

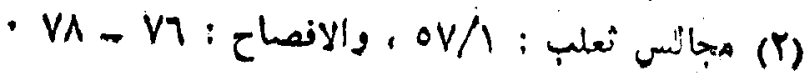


$(\cdot)$

$$
: 40
$$

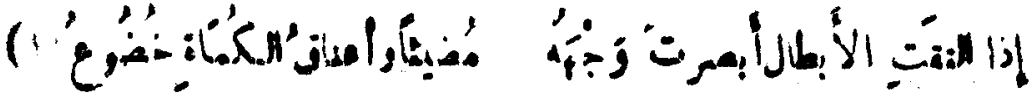

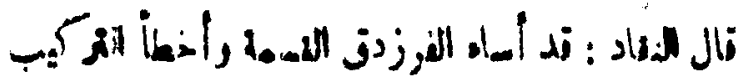

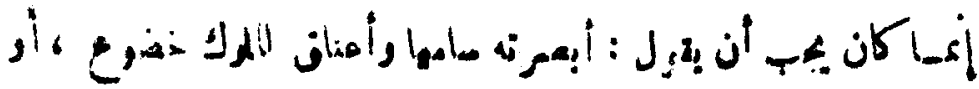

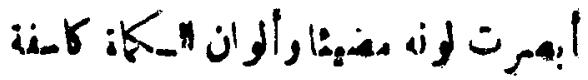

أل :

Iliki

$: \mathbf{s}^{j}-10$

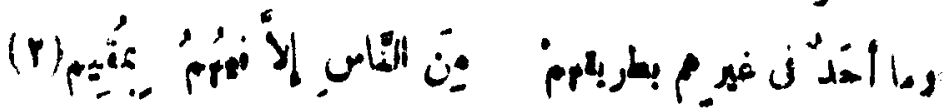

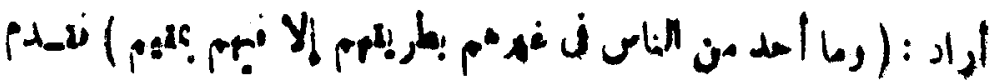

-

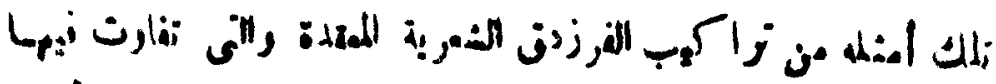

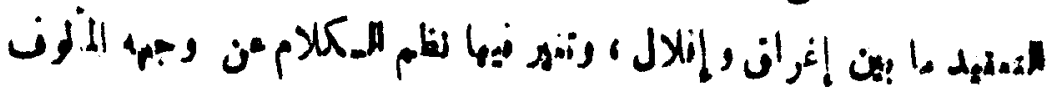

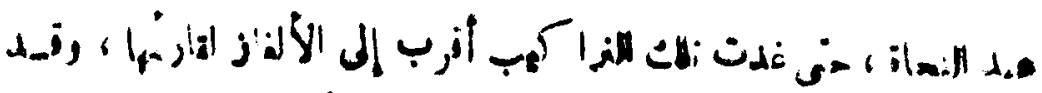

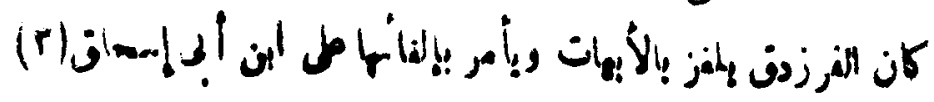

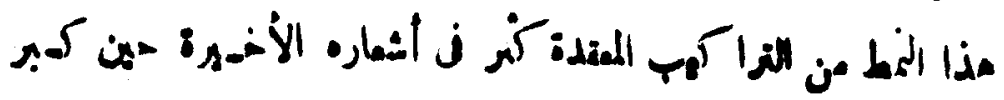

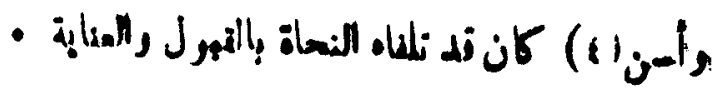

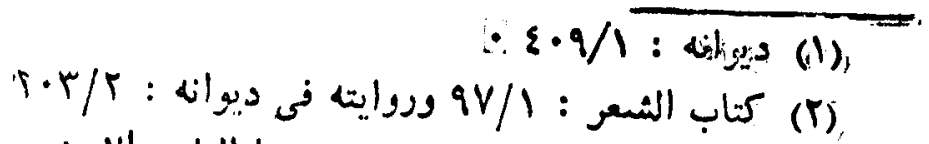

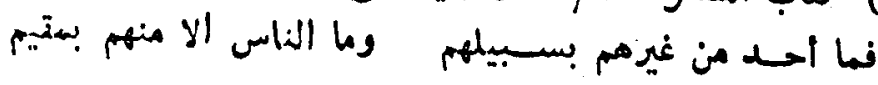

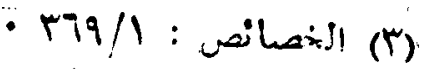

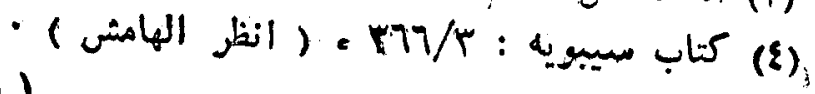
$(j-r)$ 


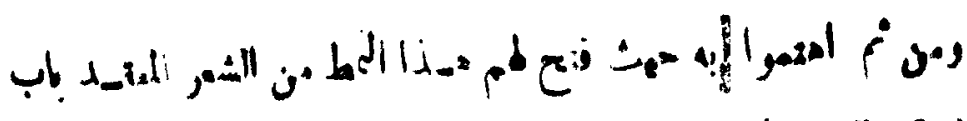

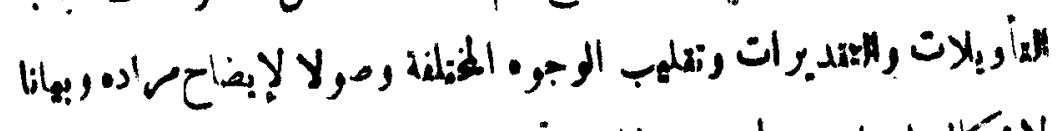

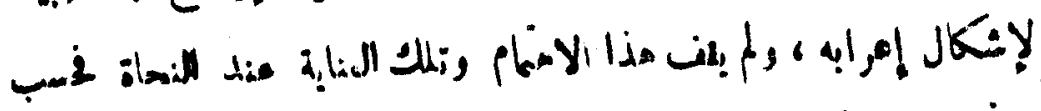

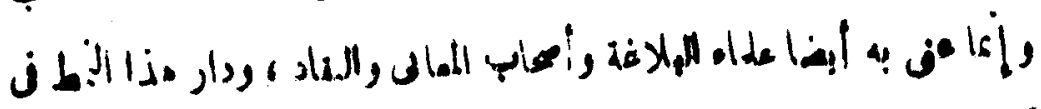

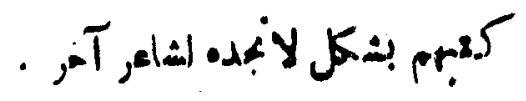

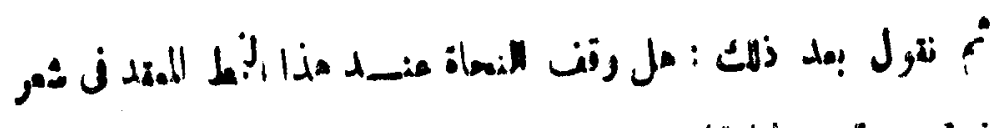

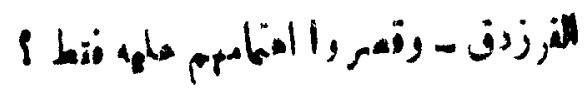

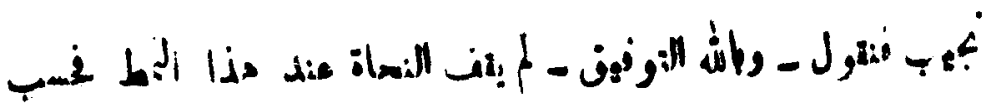

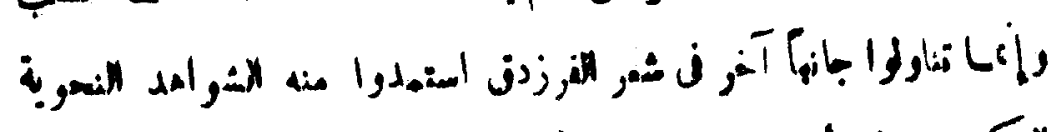

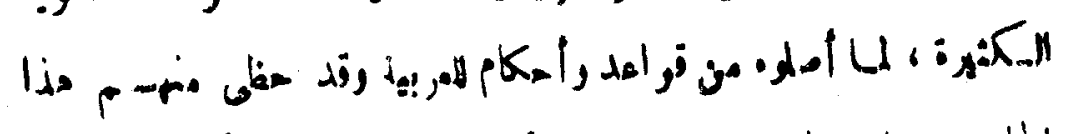

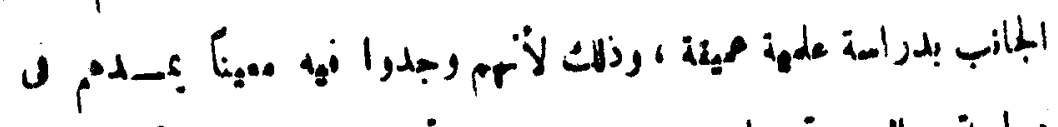

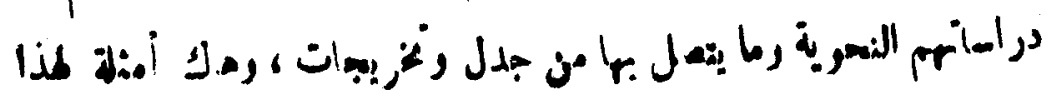
: البانه

$$
\text { : }
$$

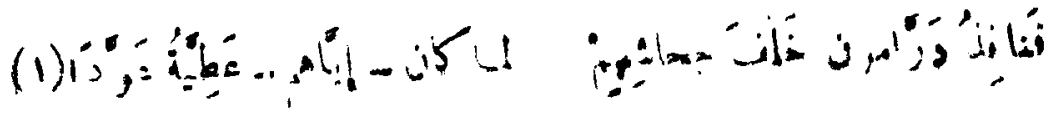
$e^{+}$

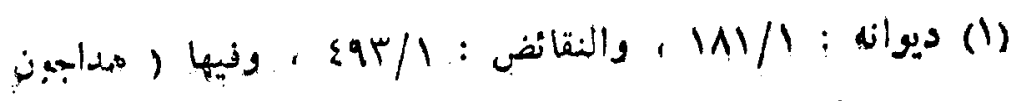

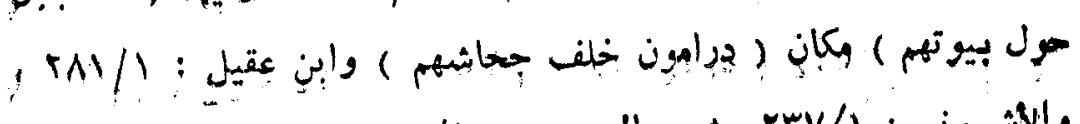

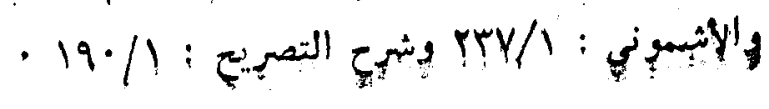




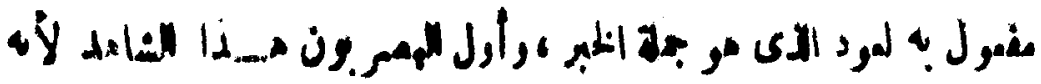
.

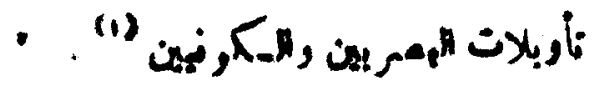

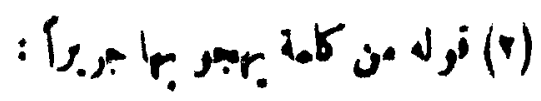

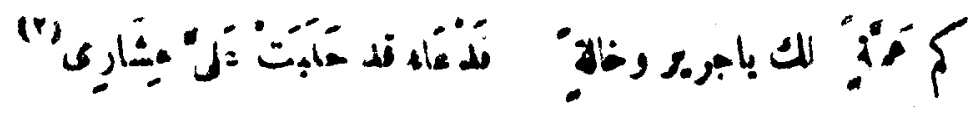

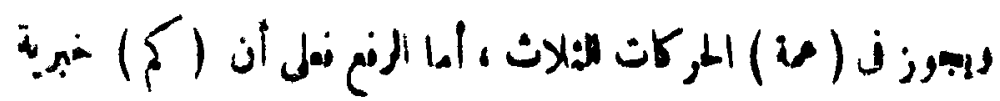

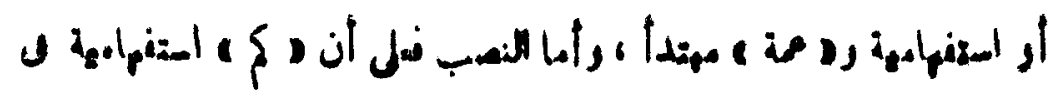

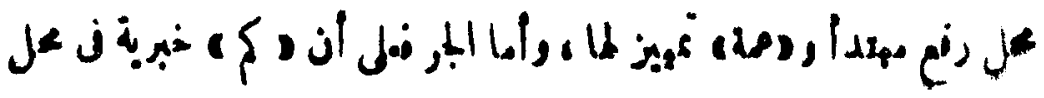

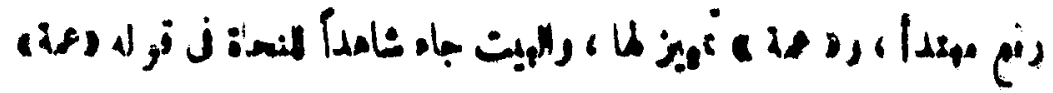

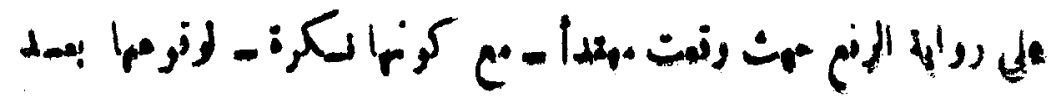
$\therefore 4$ $1, j(r)$

(r)

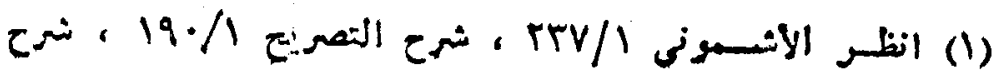
- ابن عقيل

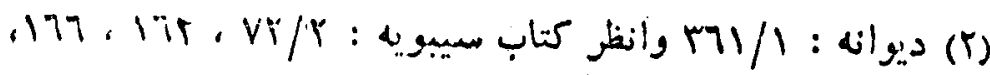

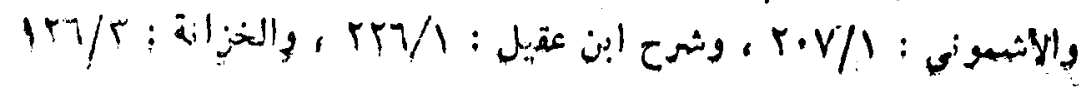

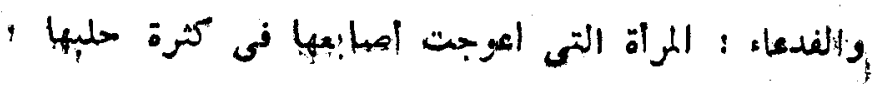

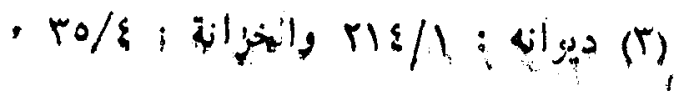




\section{8}

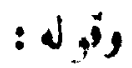

(1) : is

(r)

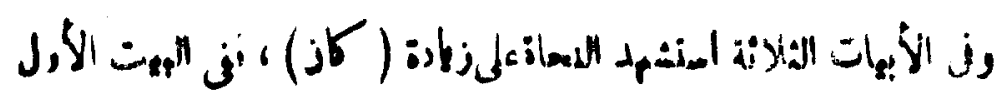

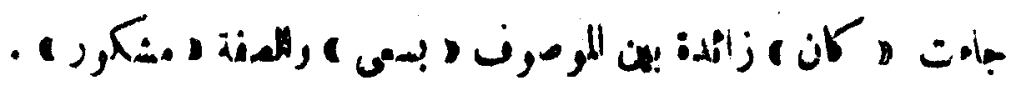

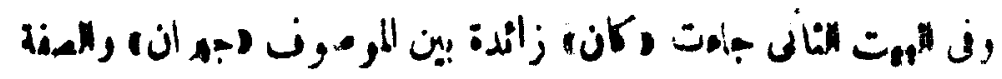

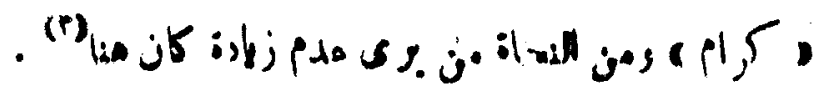

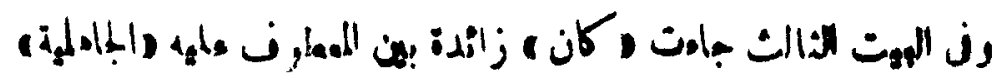

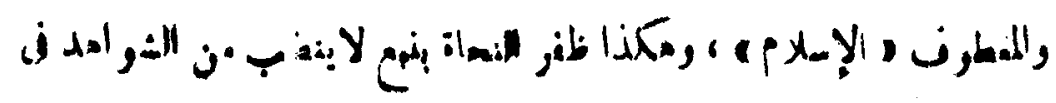

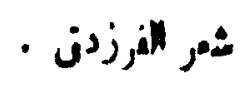

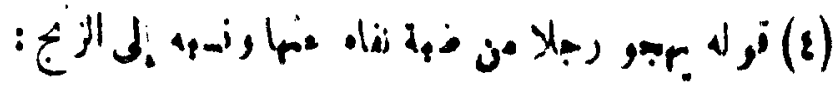

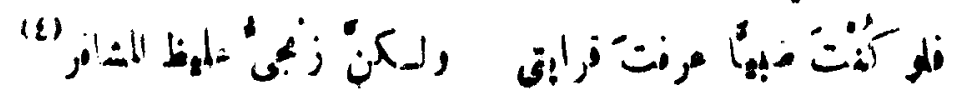

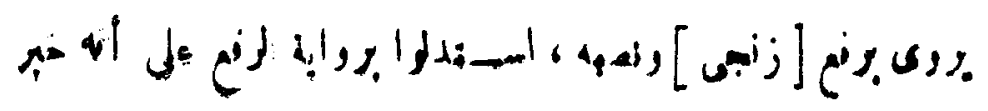

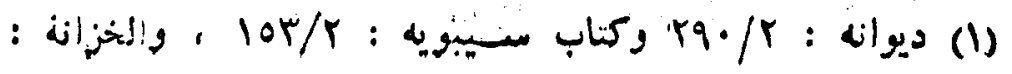
- $r v / \varepsilon$

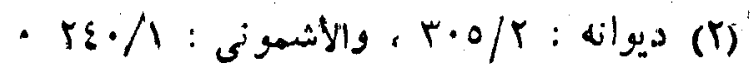

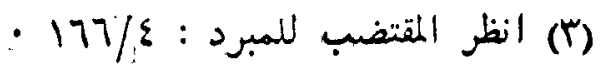

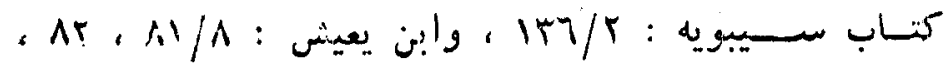

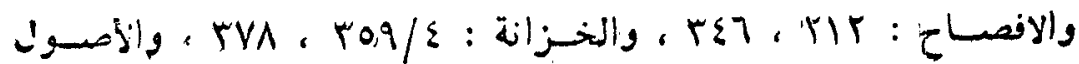


(1)

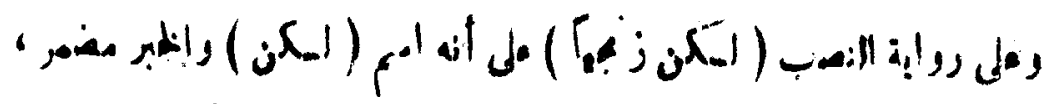

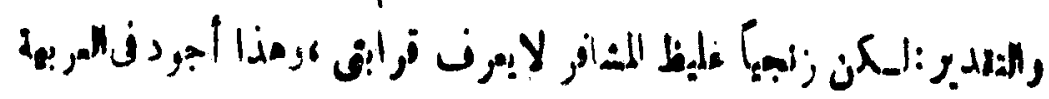

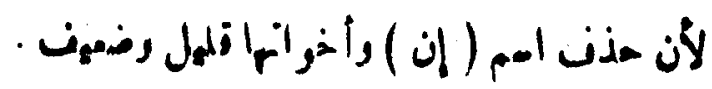

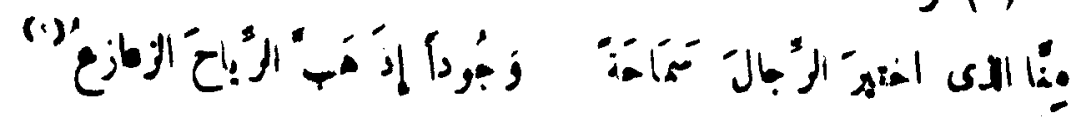

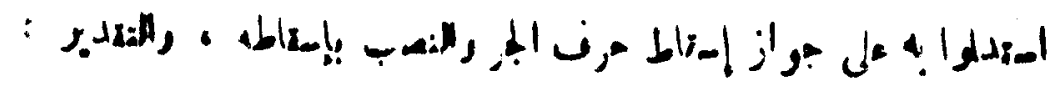
اختير من الرجال ركذلاك تر له:

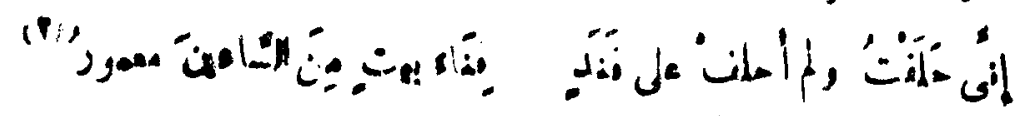

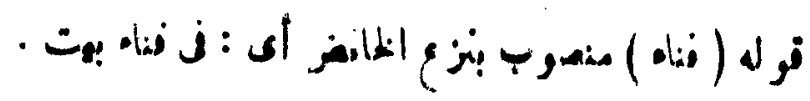

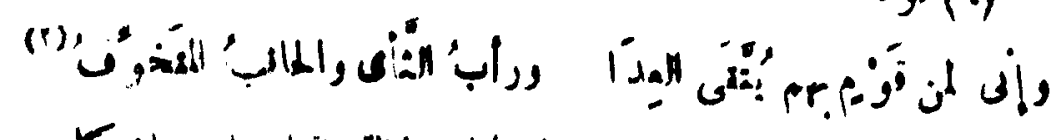

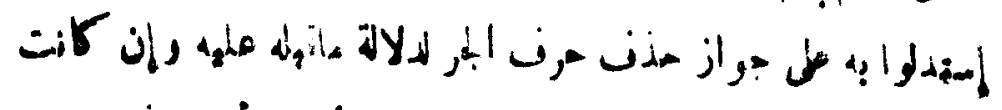

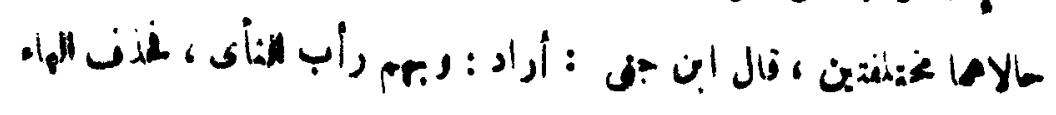

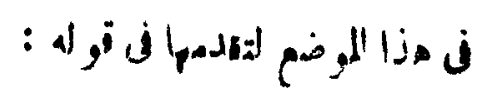

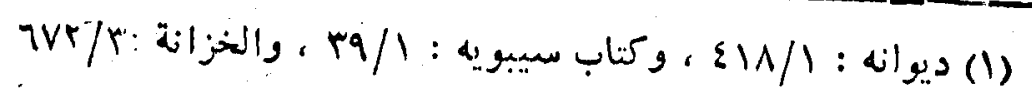

$$
\begin{aligned}
& \text { • } \\
& \text { (r) } \\
& \text { rvo/ }
\end{aligned}
$$

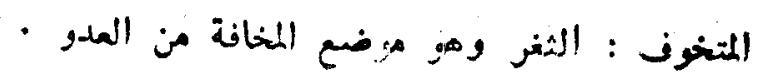




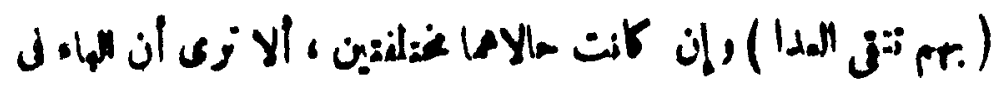

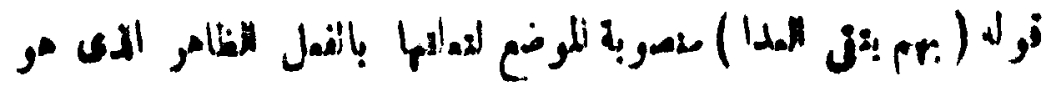

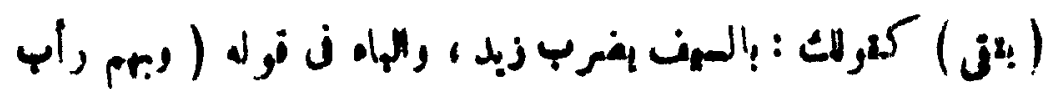

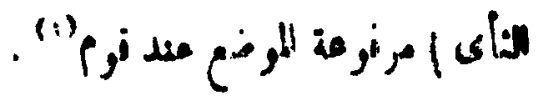

$$
\begin{aligned}
& \text { : توله }
\end{aligned}
$$

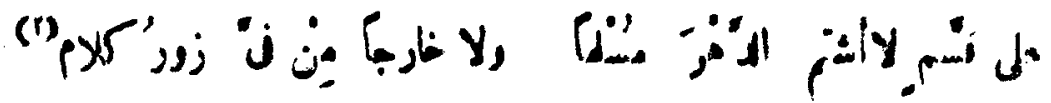

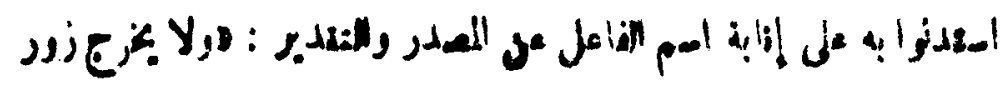

$$
\begin{aligned}
& \text { كلام } \\
& \therefore \text { a }
\end{aligned}
$$

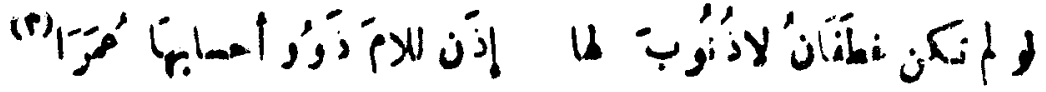

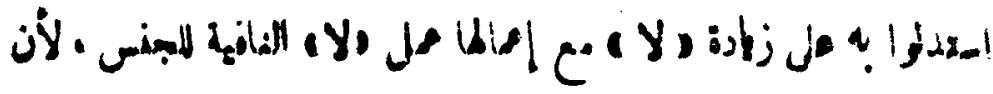

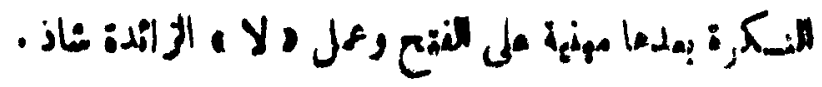

$$
\therefore \text { : } 19
$$

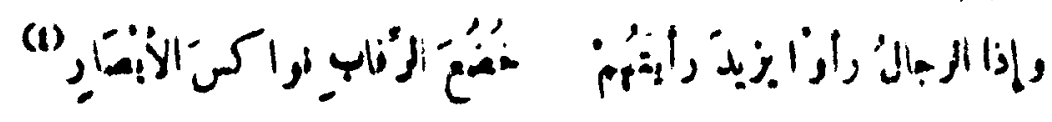

- TAT/1 :

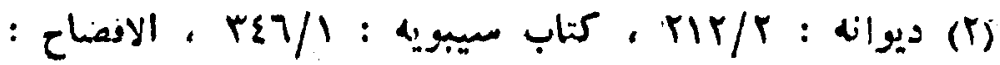

- rrt , rre , inT

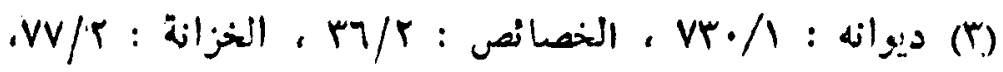

- rrT A AN

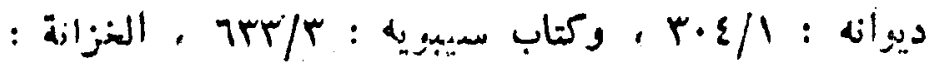




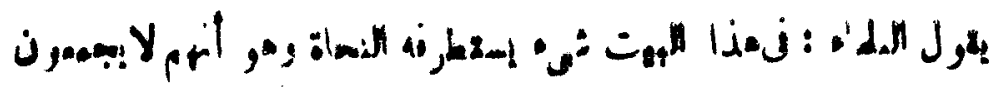

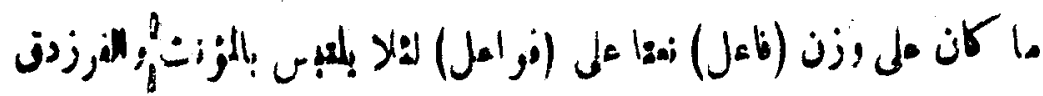

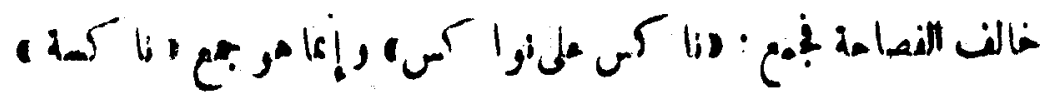
: $\mathbf{a},(1 \cdot)$

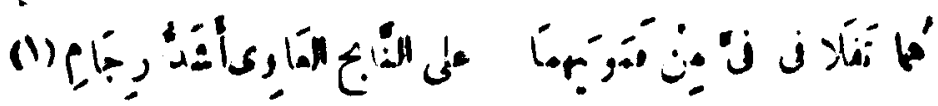

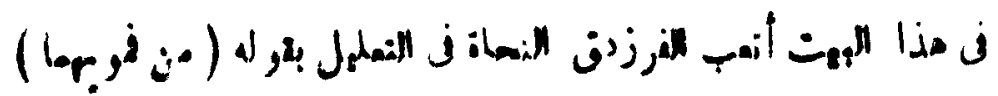

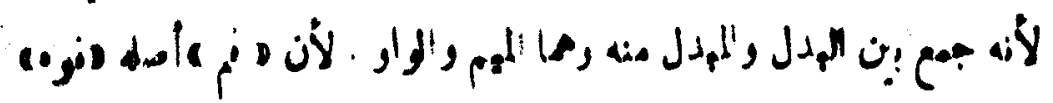

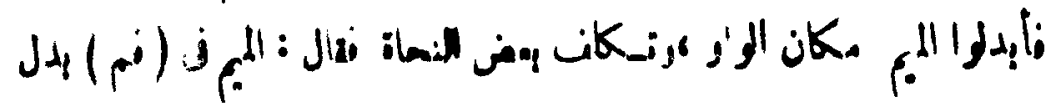

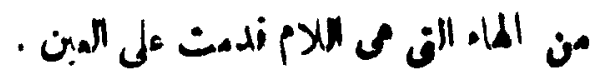
$: 4, j, 11)$

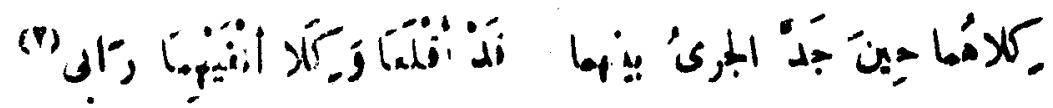

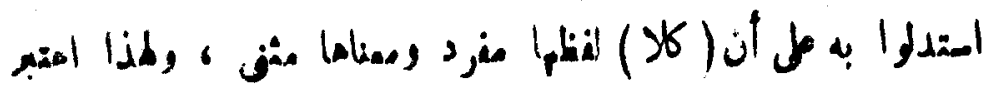

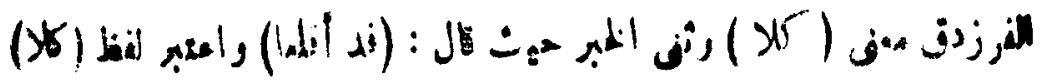

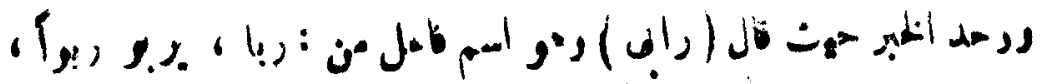

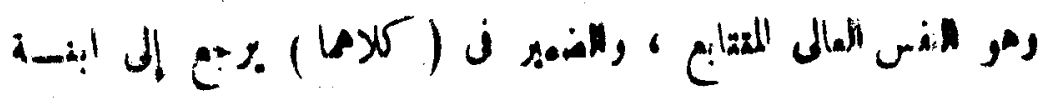

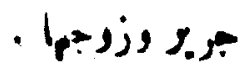

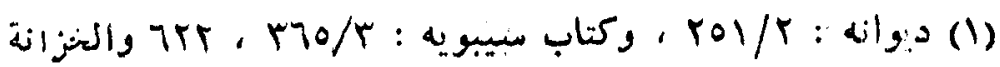
- $r \leqslant 7 / r$, rาq/r

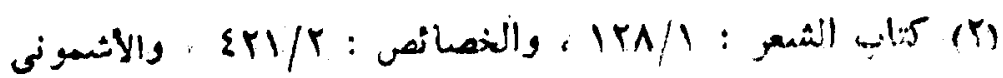




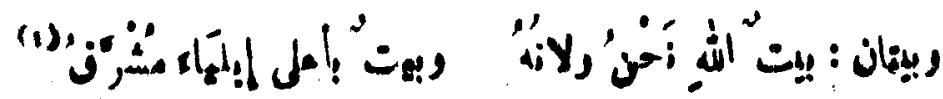

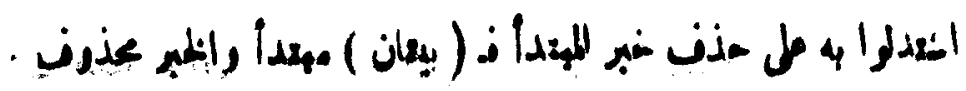

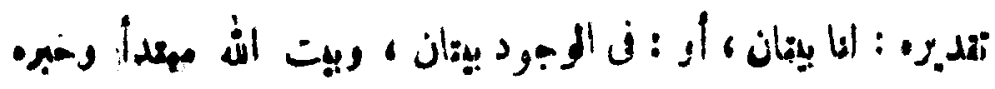
"

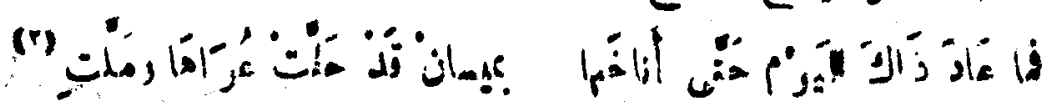

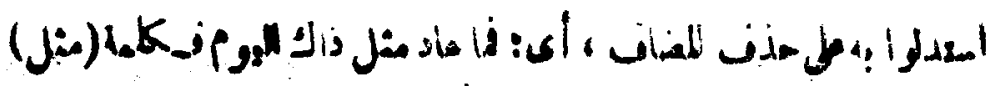

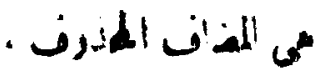

$$
\begin{aligned}
& : \text { ifie }
\end{aligned}
$$

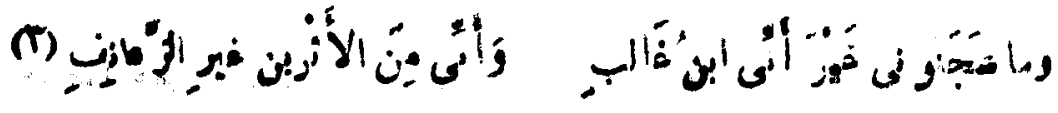

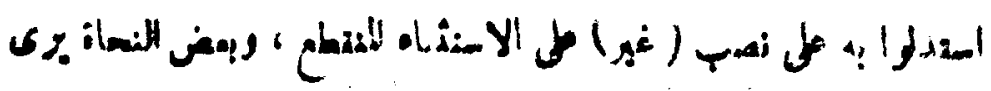

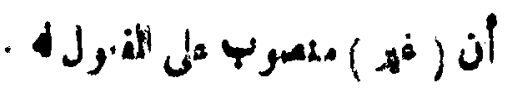

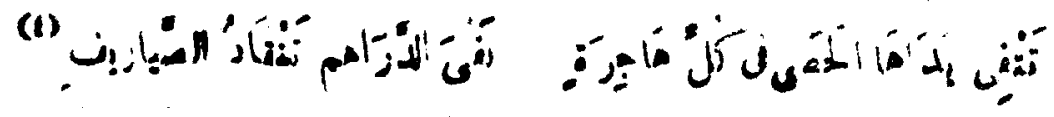

$$
\text { : dille }
$$




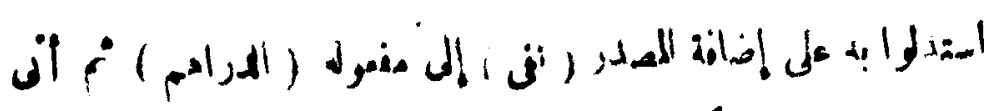

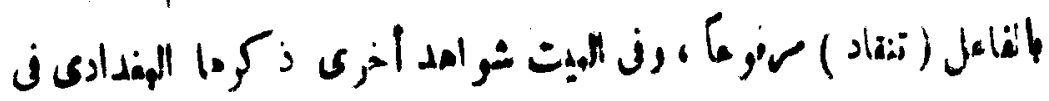
(1)

$$
: 4,0(17)
$$

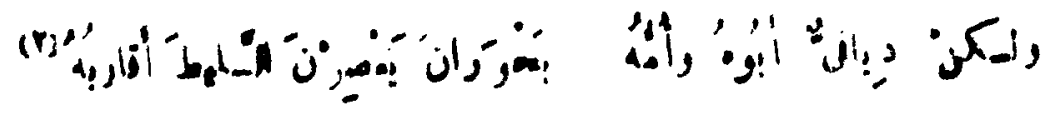

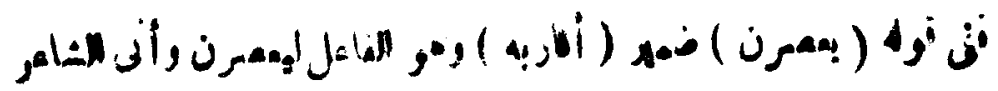

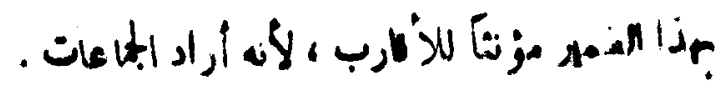
:

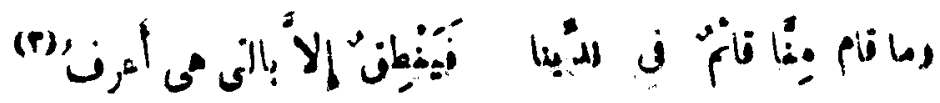

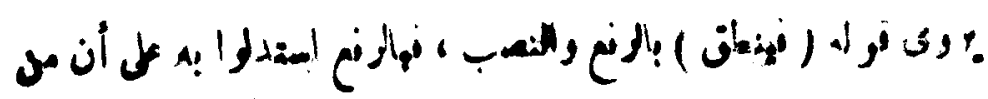

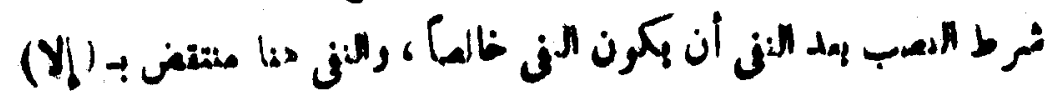

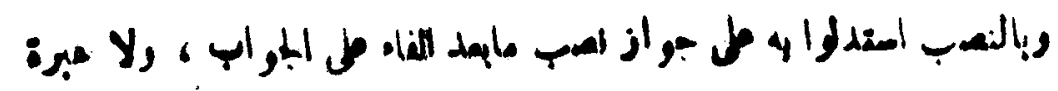
بد

(1) roo/r :

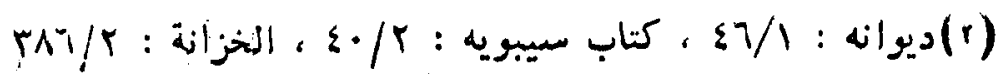

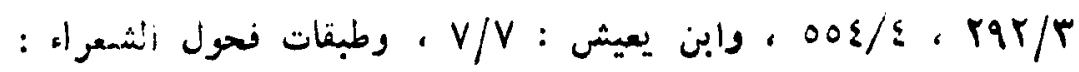

- rrg/1

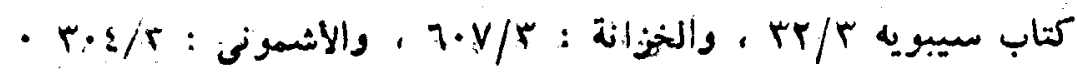

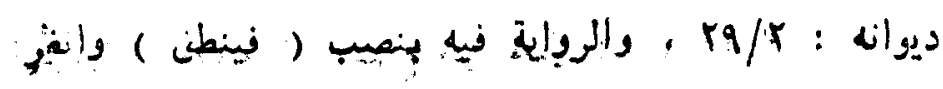




$$
\begin{aligned}
& 1
\end{aligned}
$$

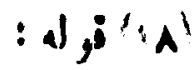

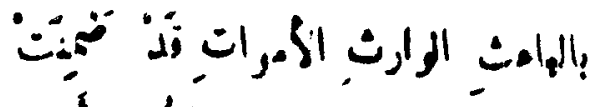

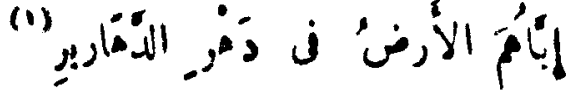

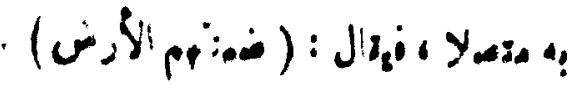

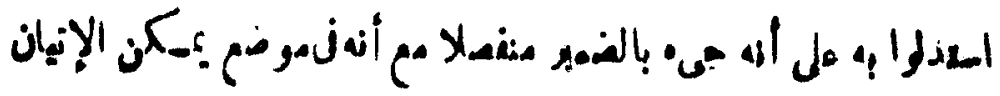

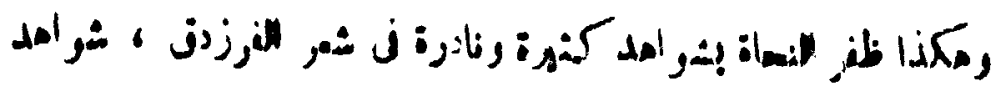

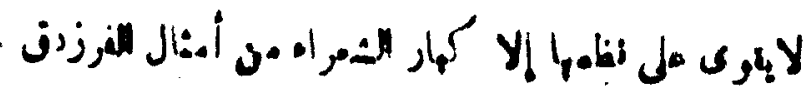

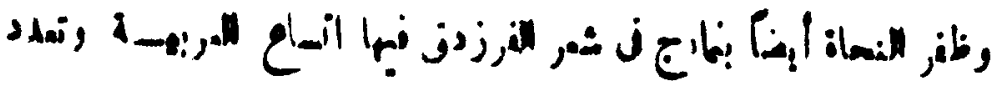

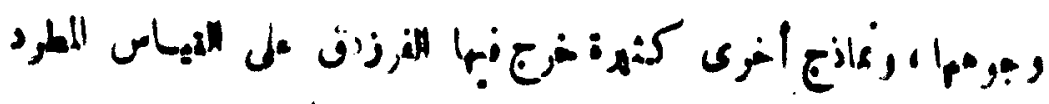

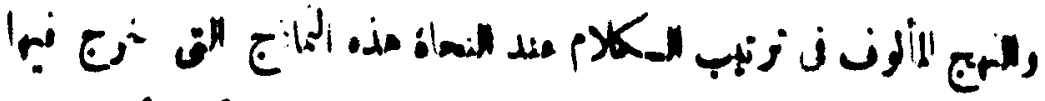

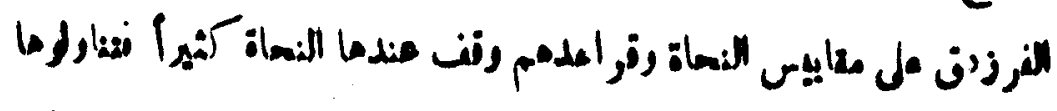

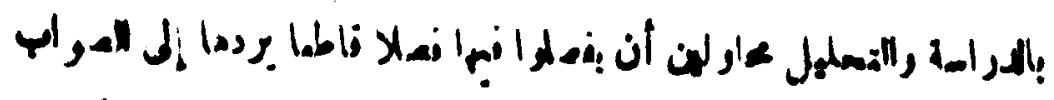

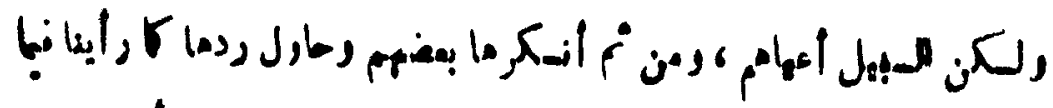

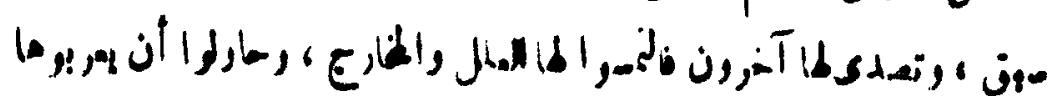

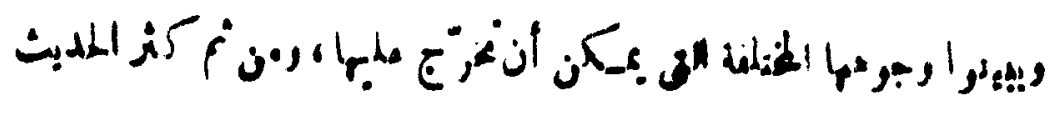

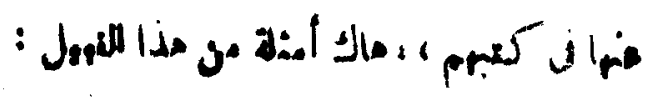

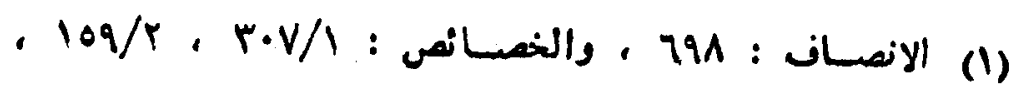

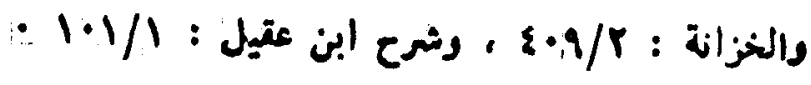


III

$$
: \$, ;(1)
$$

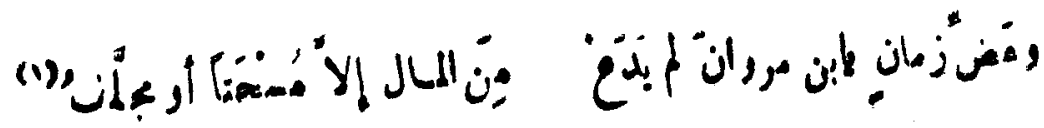

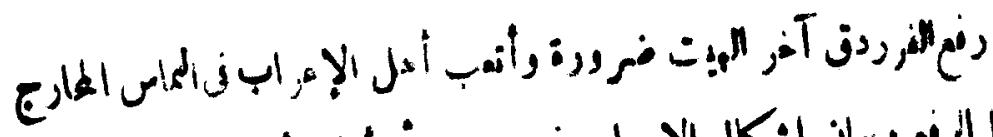

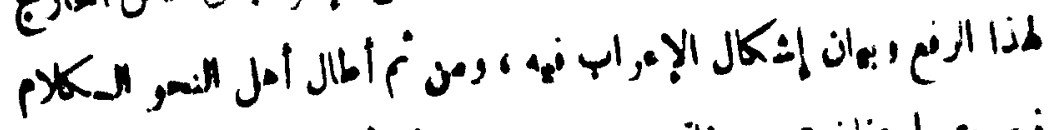

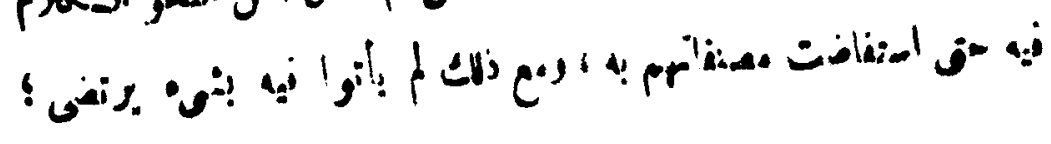

$$
\text { : }
$$

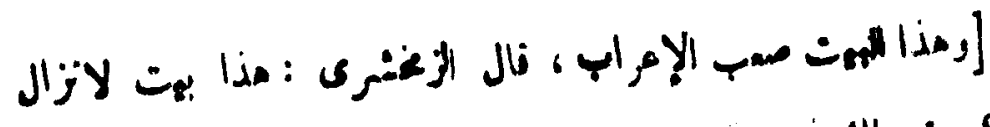

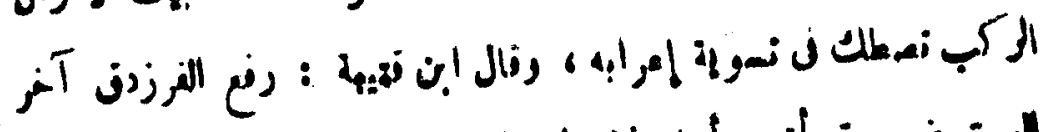

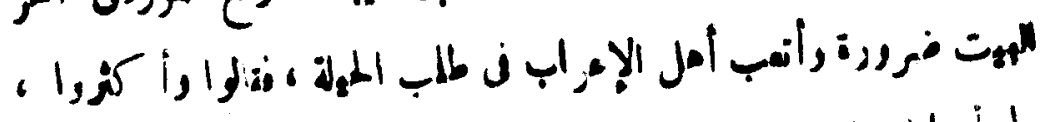

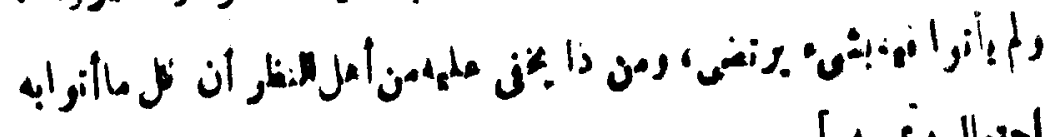

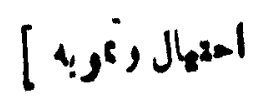

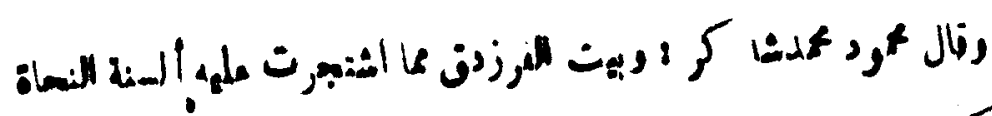

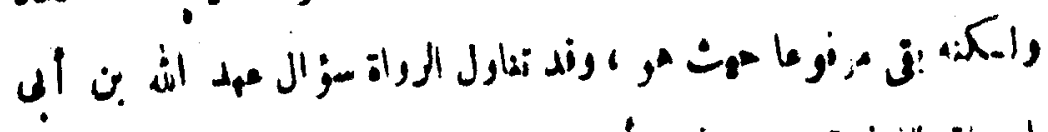

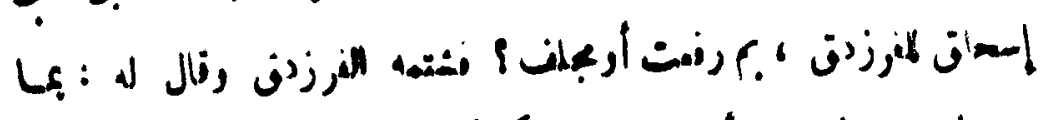

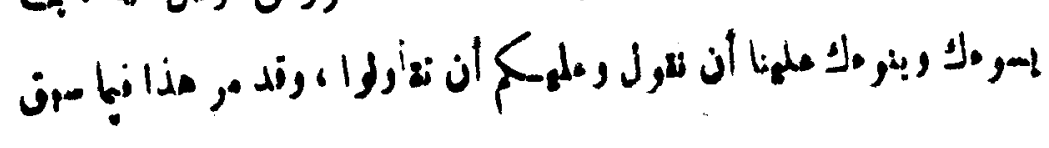

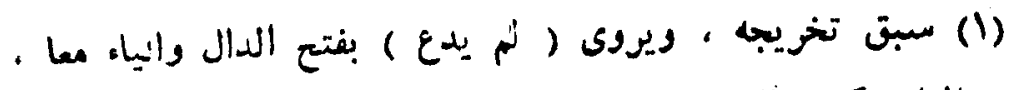

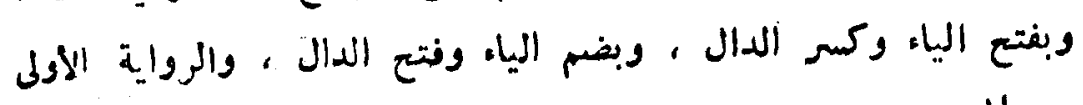

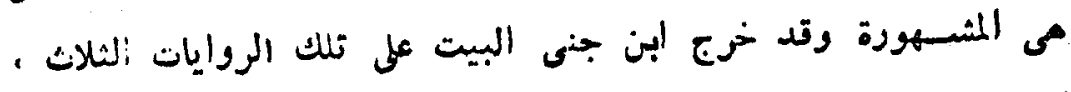

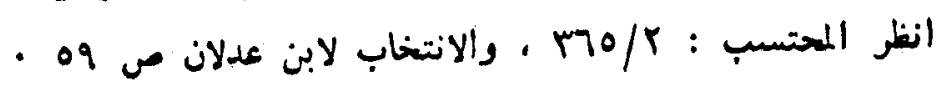




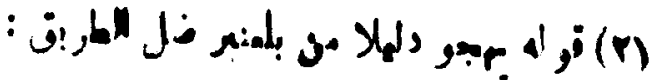

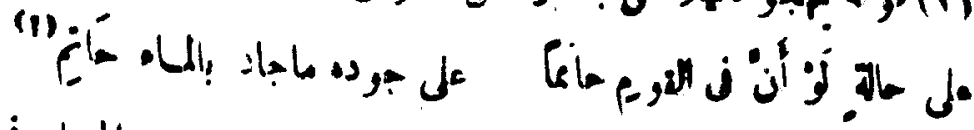

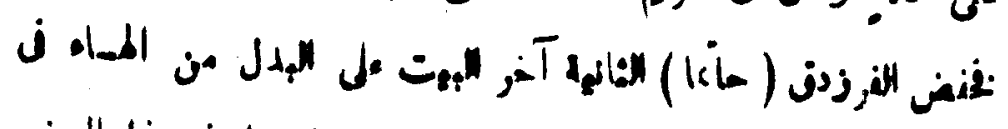

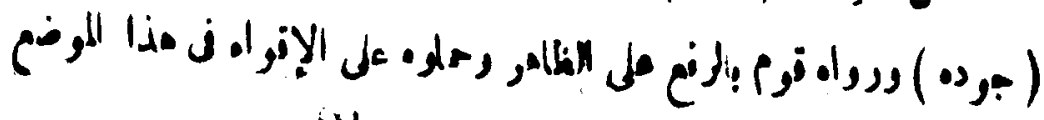

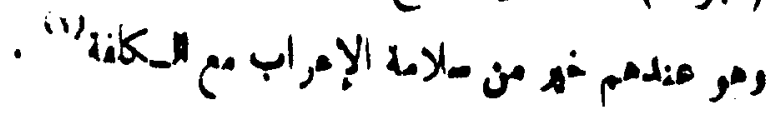

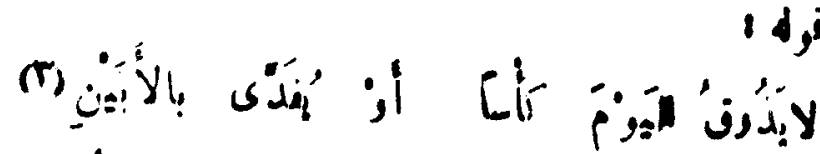

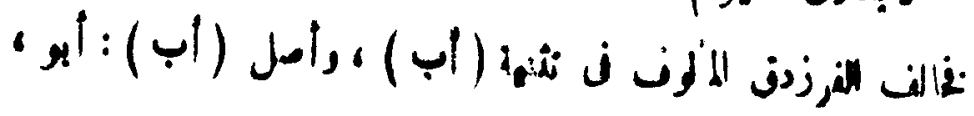

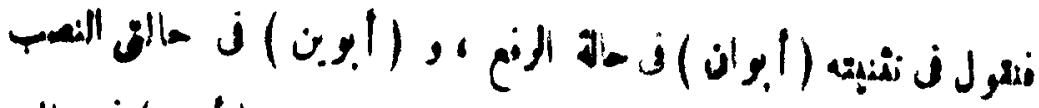

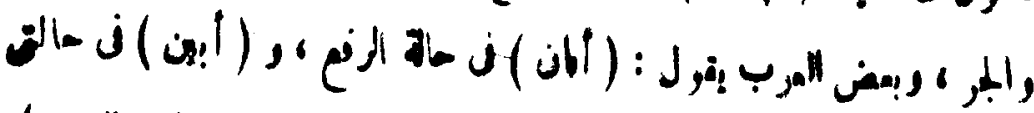

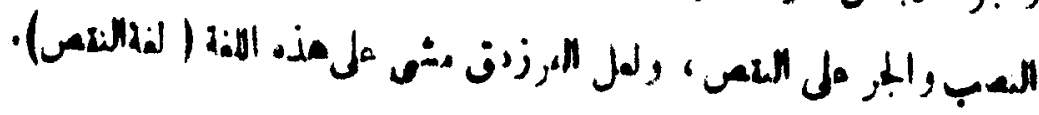

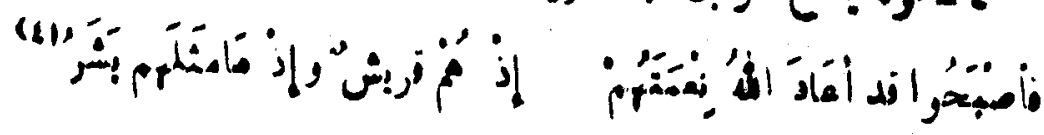

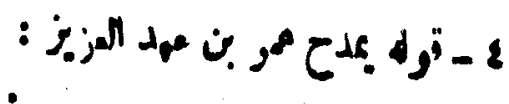

$$
\text { : rqv/r : والرواية فيه (1) }
$$

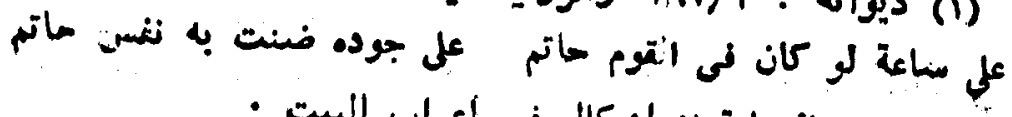

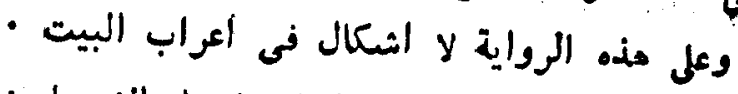

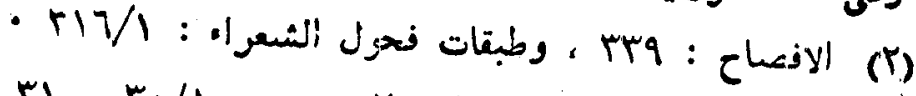

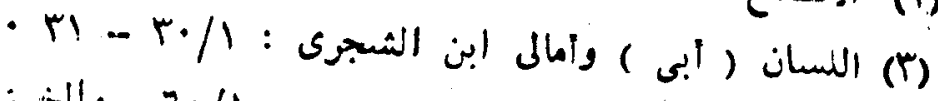

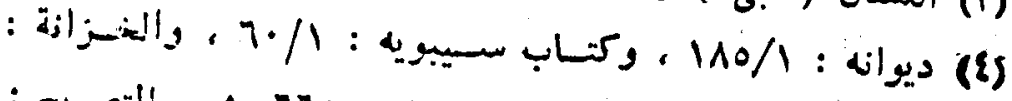

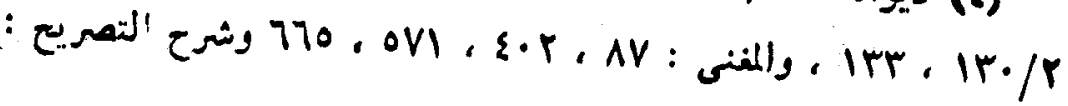

• 
if

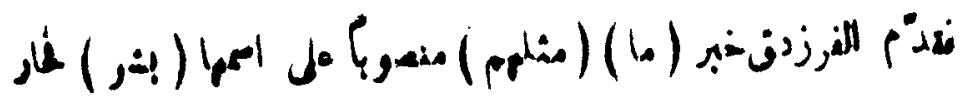

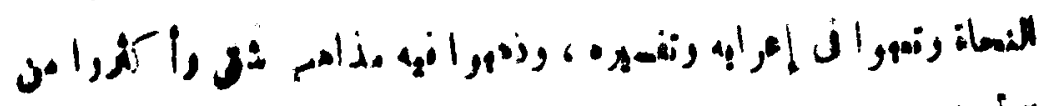

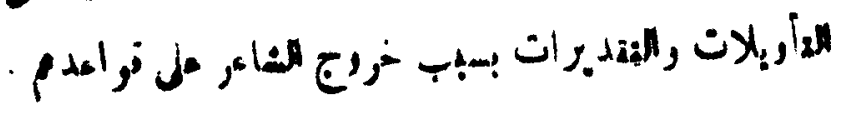

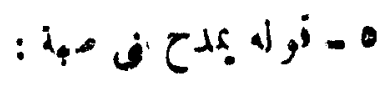

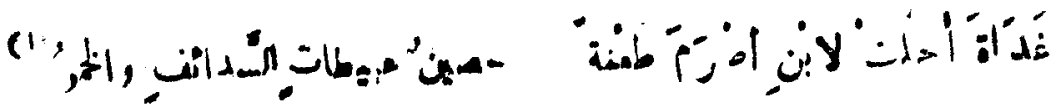

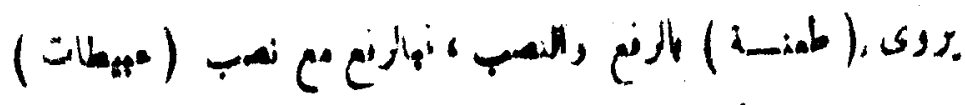

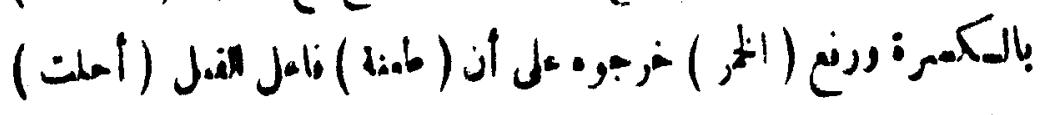
ر )

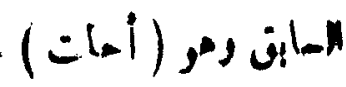

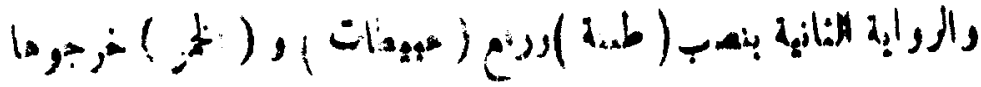

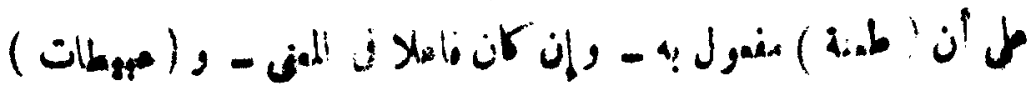

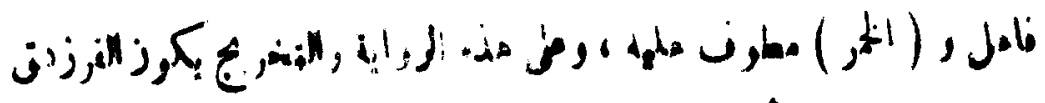

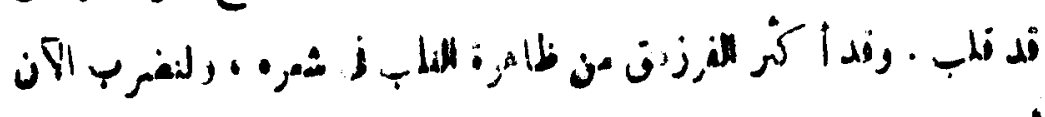

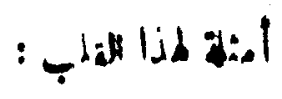

$$
\text { : isis : is }
$$

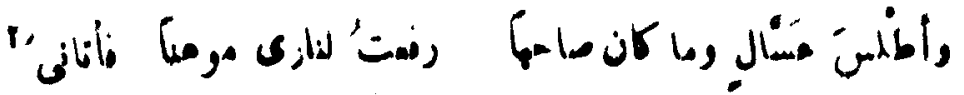

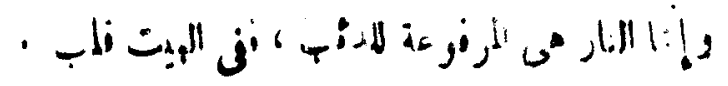

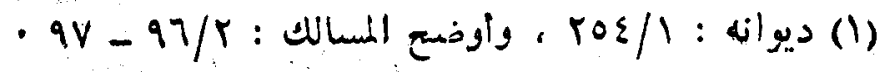

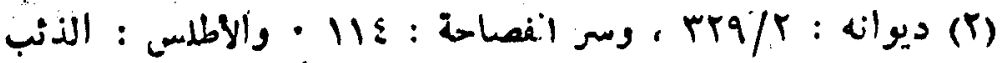

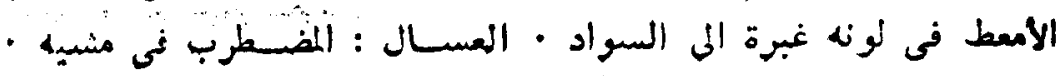




$$
: d, j-r
$$

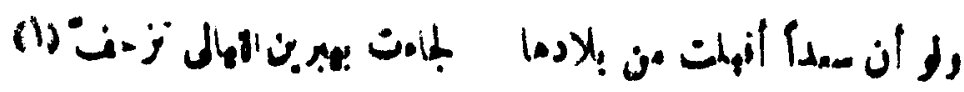

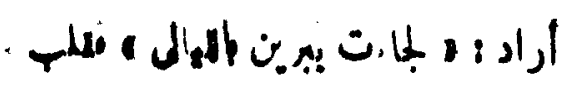

$$
: 4, i-r
$$

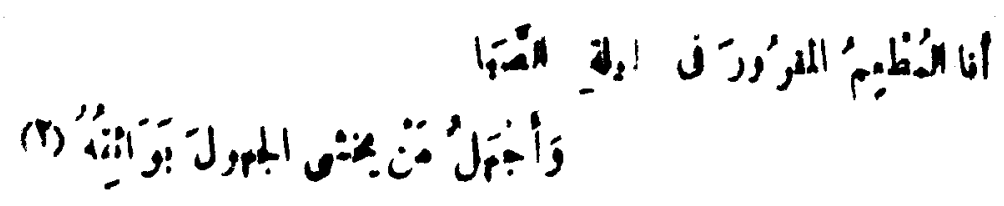

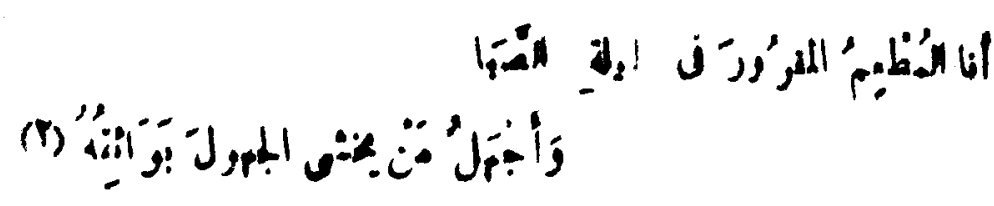

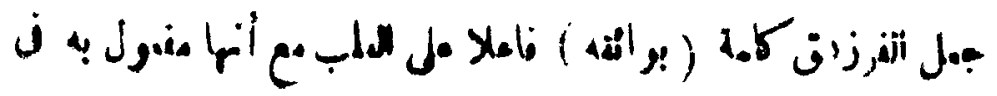

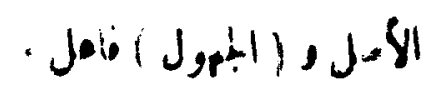

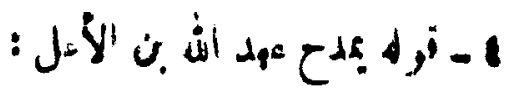

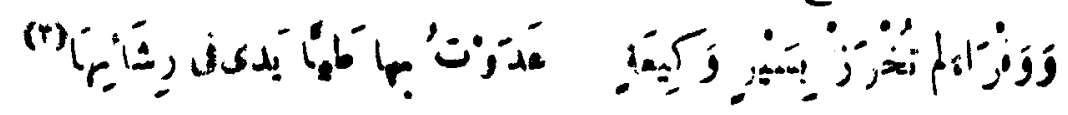

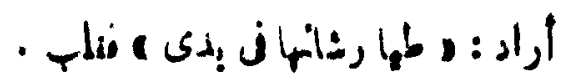

$$
\begin{aligned}
& x: 4,0
\end{aligned}
$$

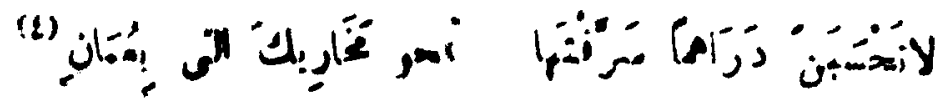

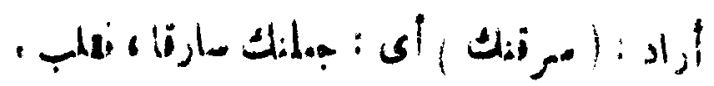

$$
\text { د. ديز انه : }
$$

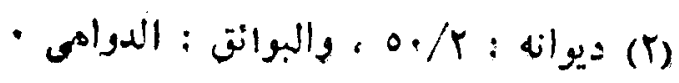

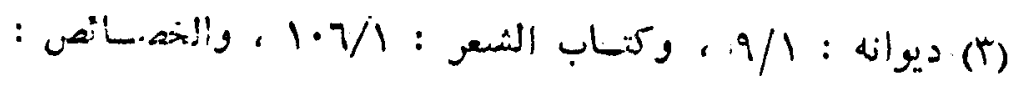

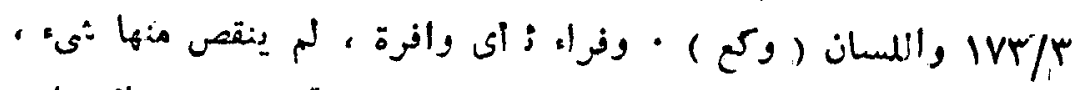

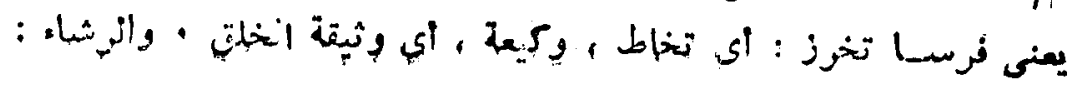

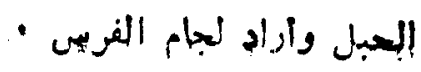

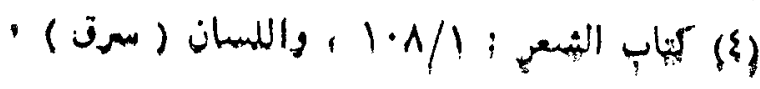




$$
\text { "ز }
$$

(1)

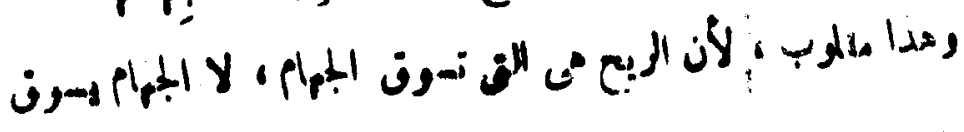

$$
\begin{aligned}
& \text { - الر } \\
& \text { : }
\end{aligned}
$$

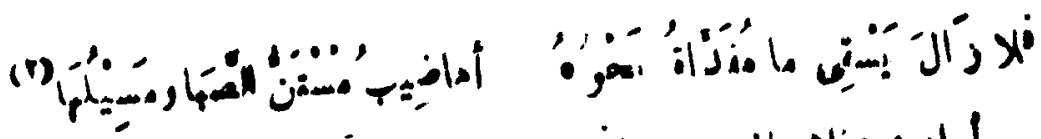

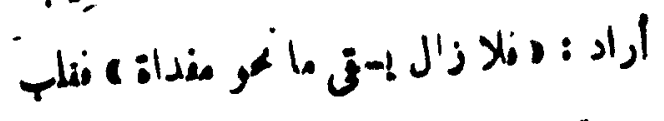

$$
\text { : } 4 \text {, }
$$

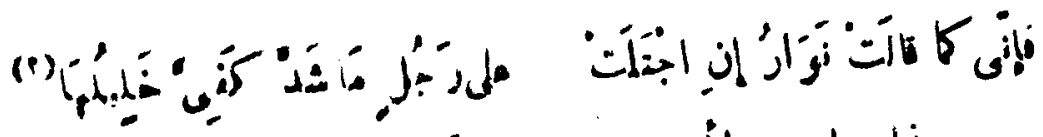

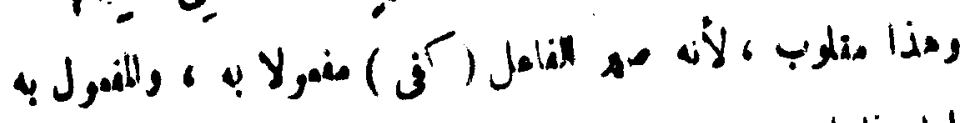

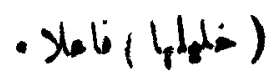

(1) ديوانه : 1.91/5 ، الثشول : الواحدة شائله : الناقة أذا جنت

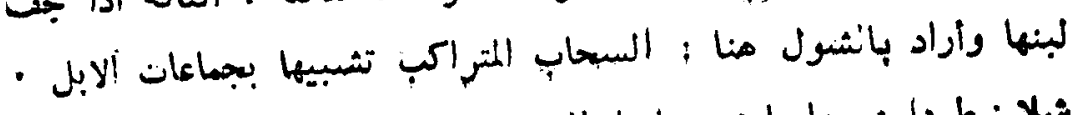

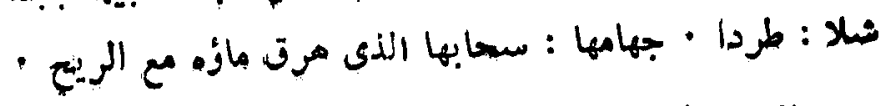

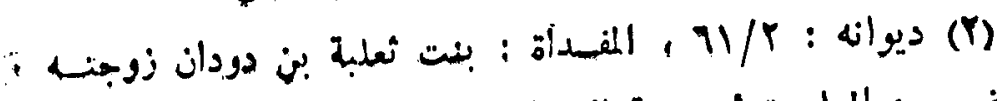

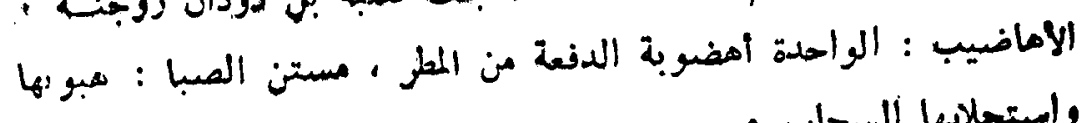

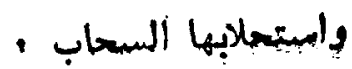

-

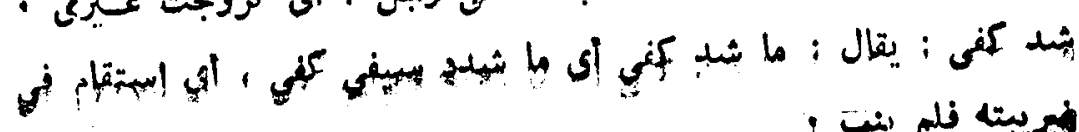


(1) 1 10 -

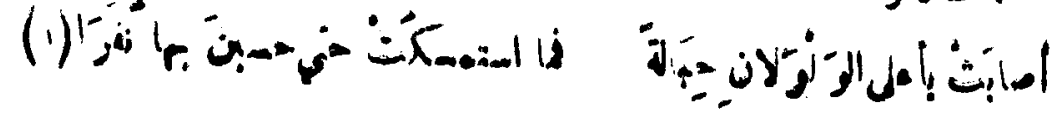

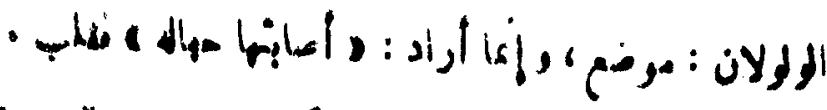

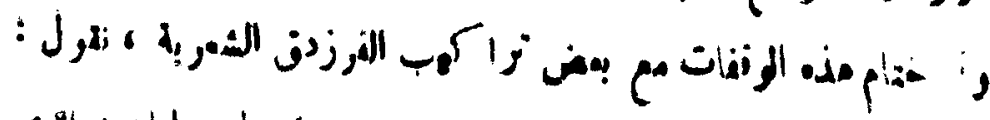

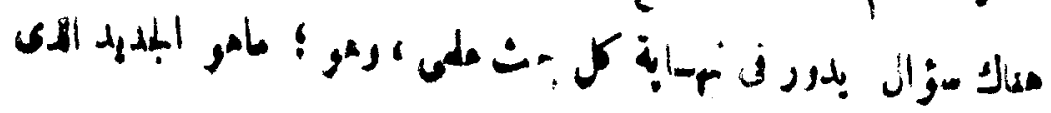

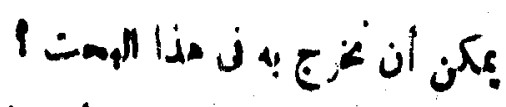

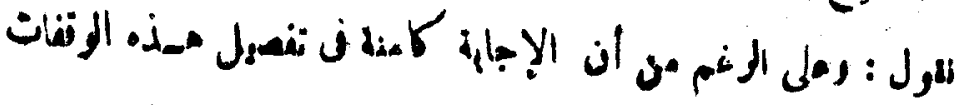

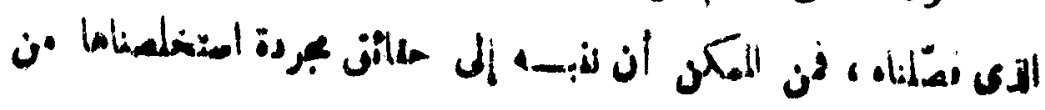

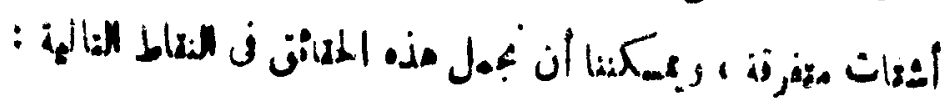

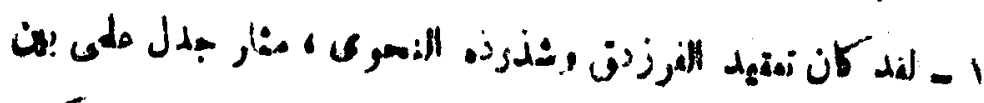

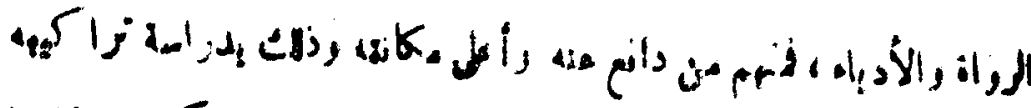

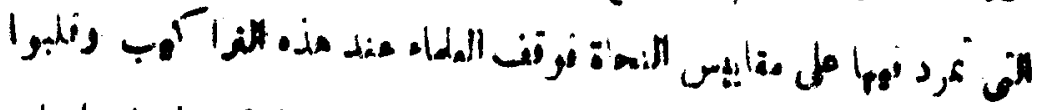

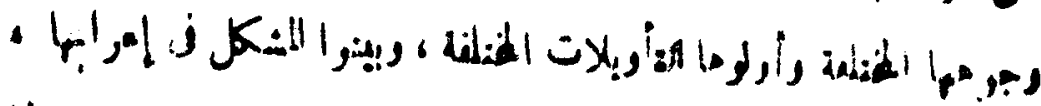

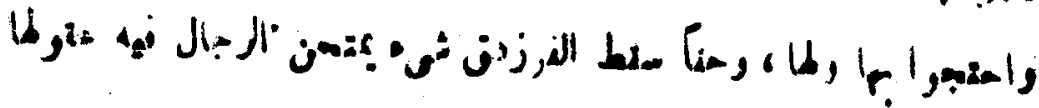

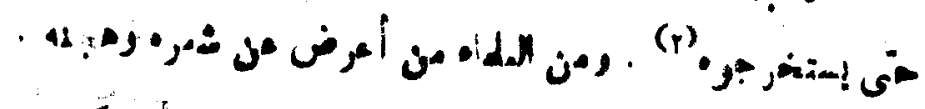

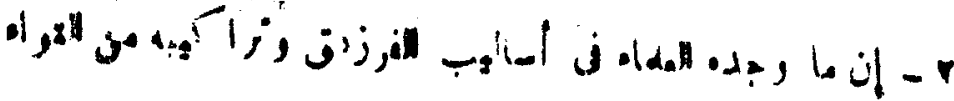

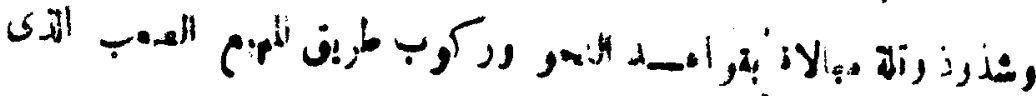

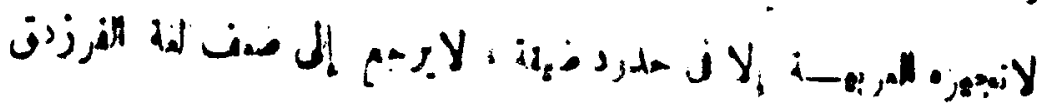

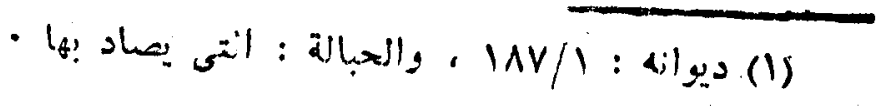

$$
\begin{aligned}
& \text { • 17r : الموشتح }
\end{aligned}
$$




\section{IIV}

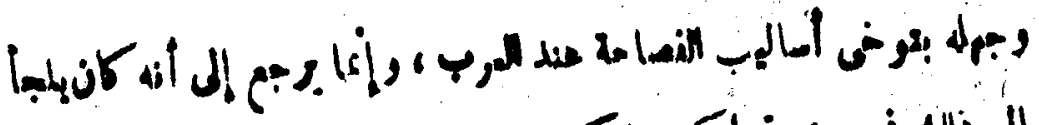

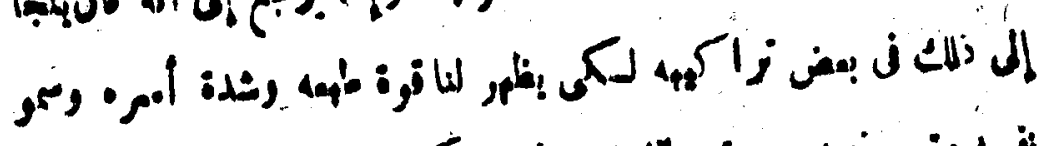

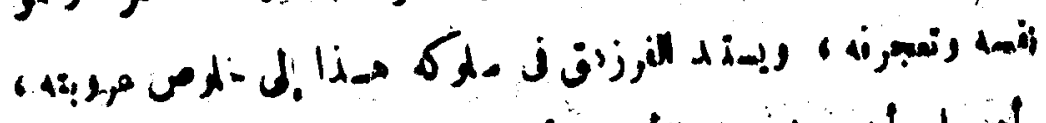

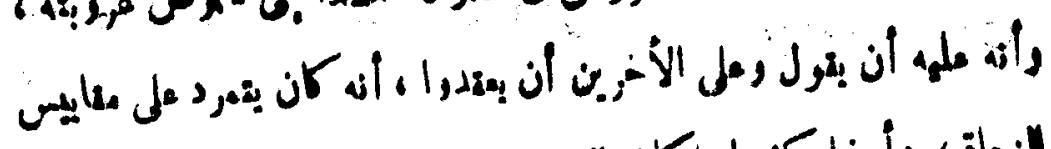

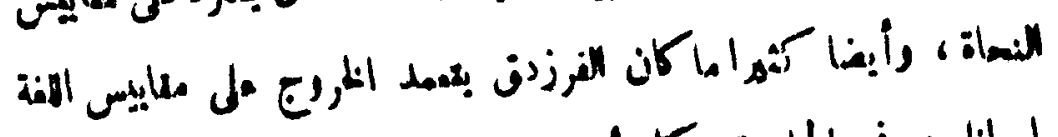

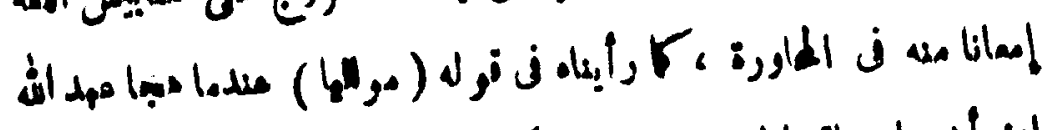

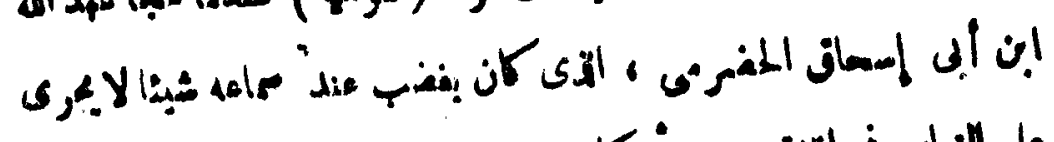

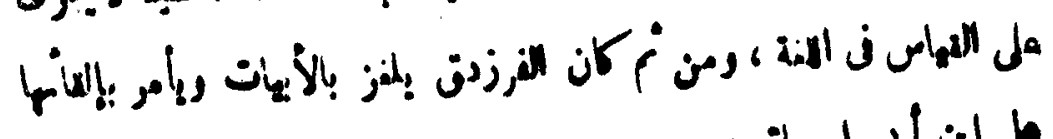

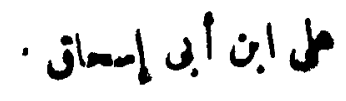

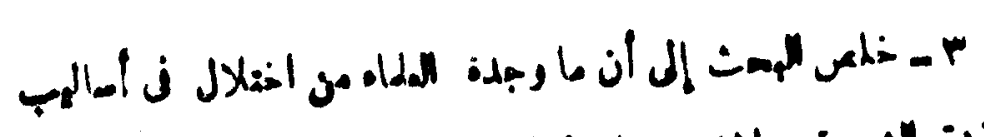

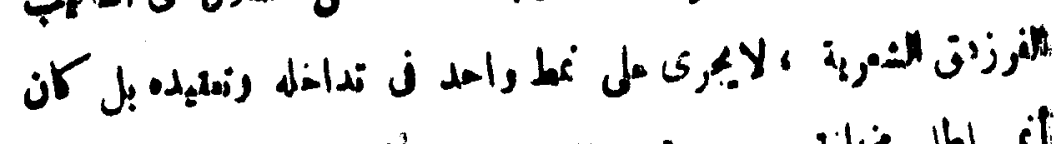

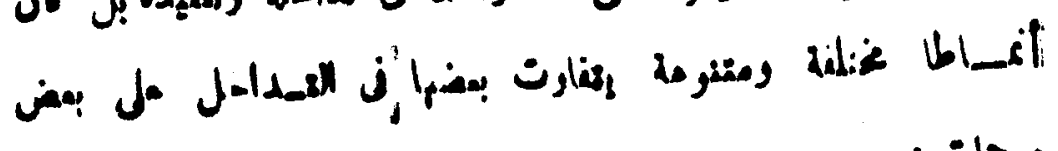
هر مات -

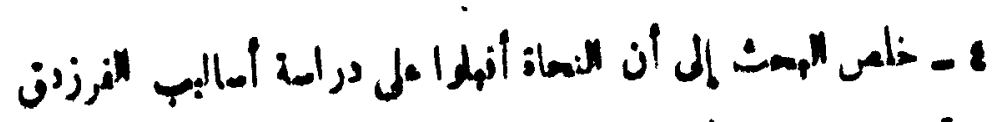

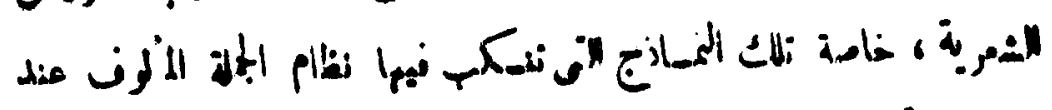

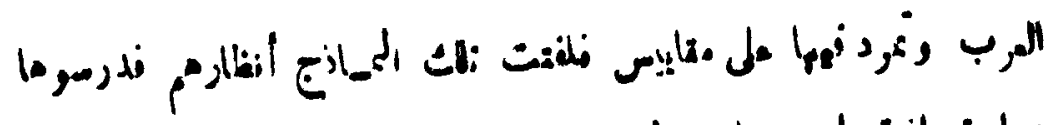

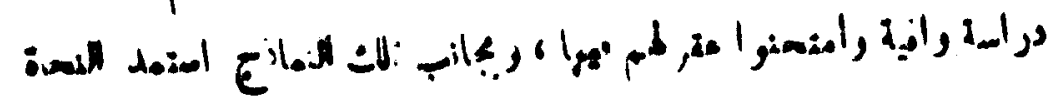

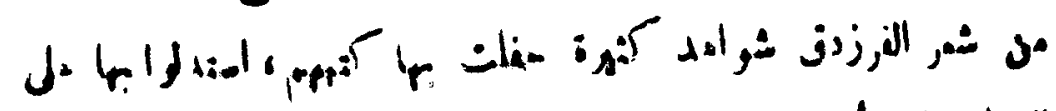

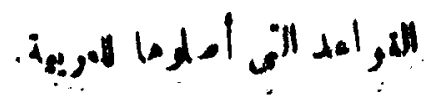




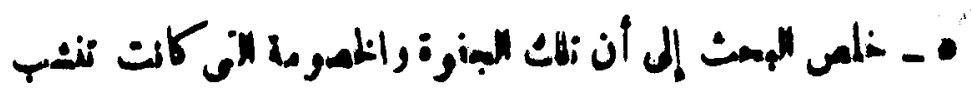

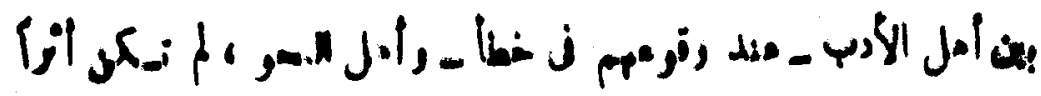

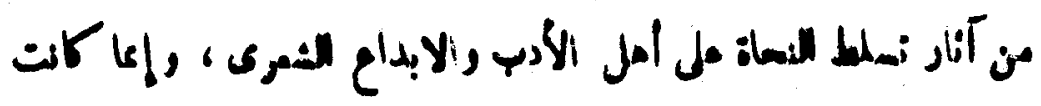

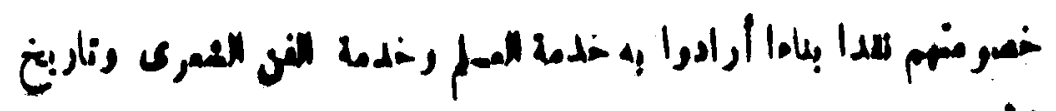
الأرب . 


\section{اهم المراجبع}

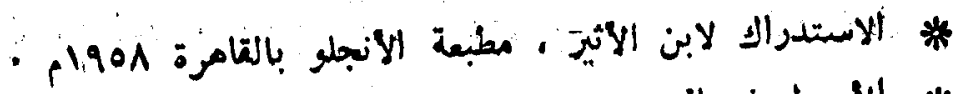

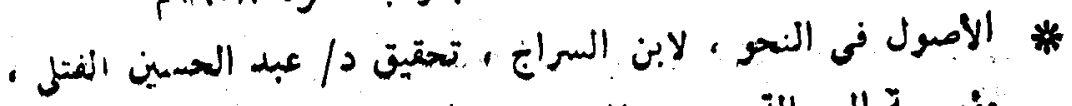

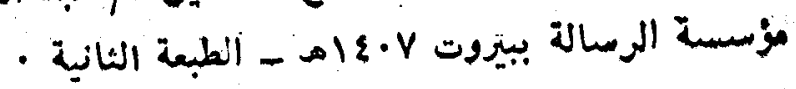

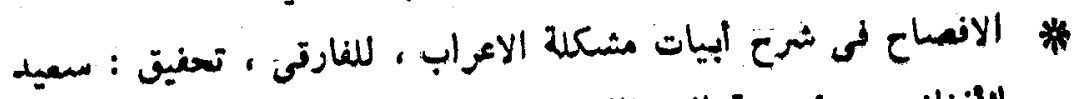

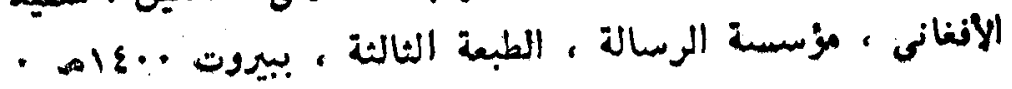

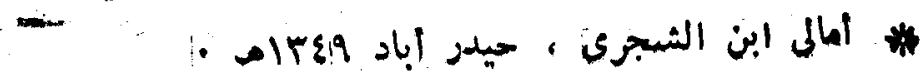

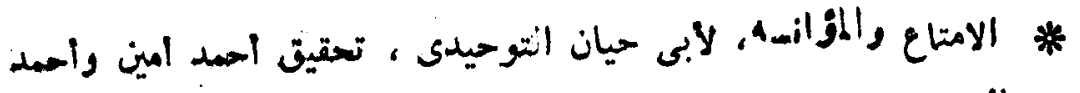

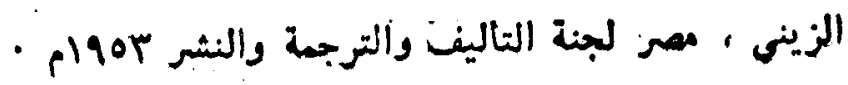

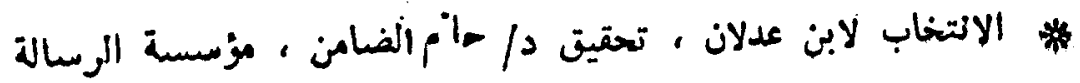

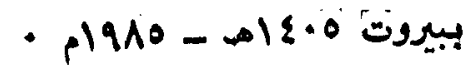

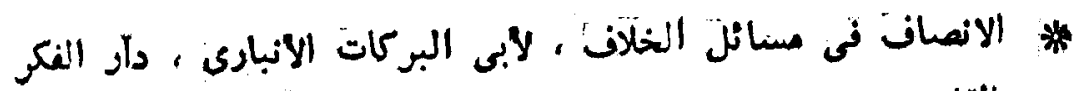

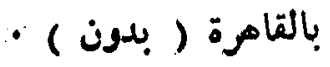

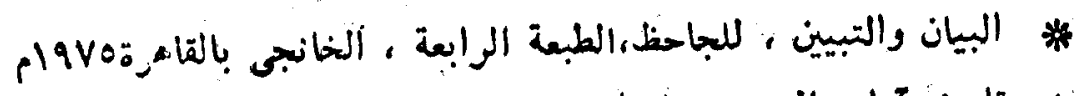

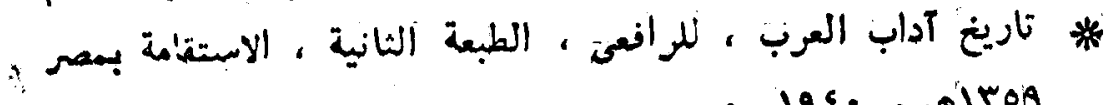

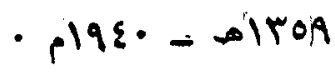

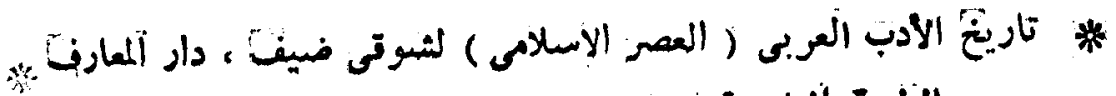

nx.

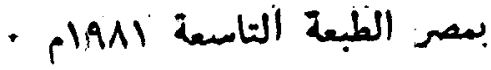

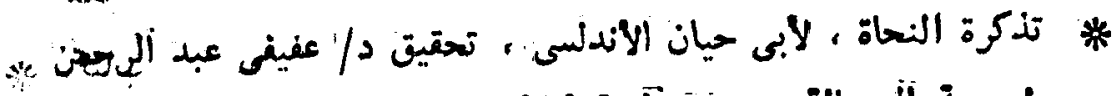

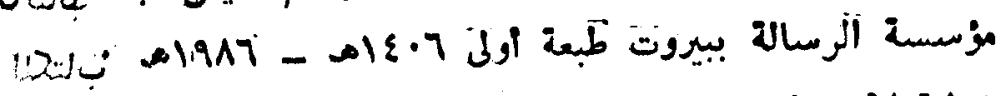

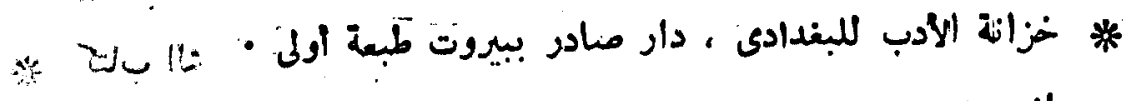

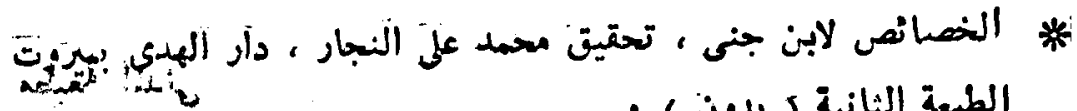
* Villaniz

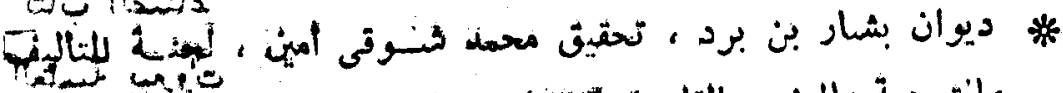

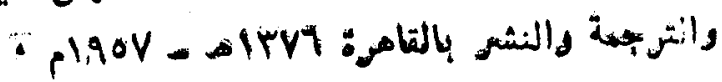




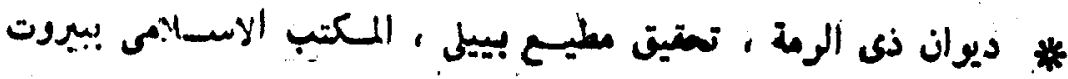
f. 1978 - - IrAE

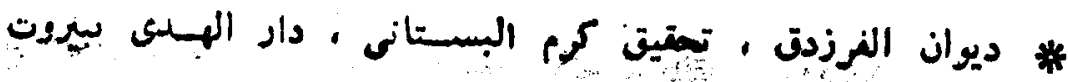

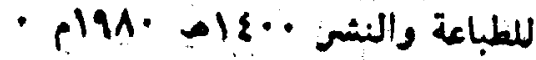

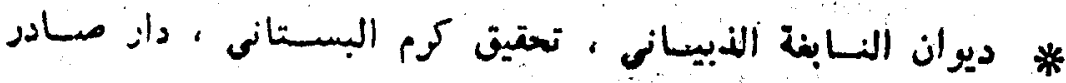
بيروت ( بلدون )

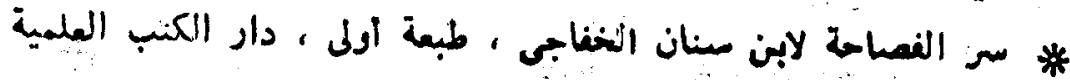
- بيروت

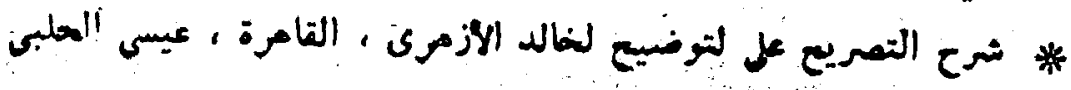
• (بدون )

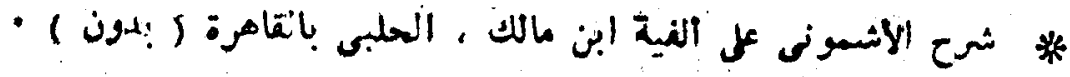

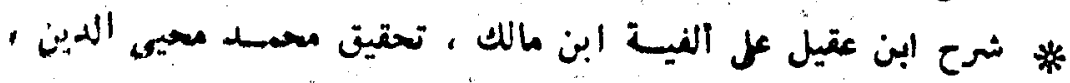

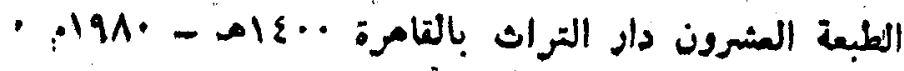

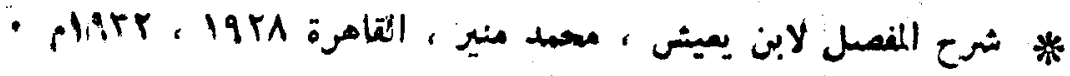

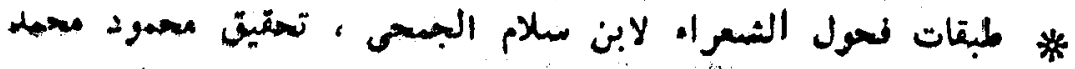

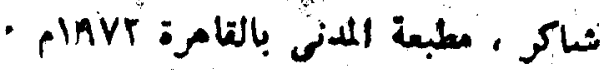

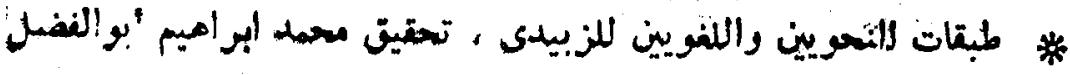

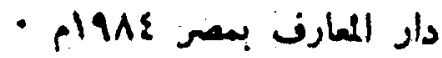

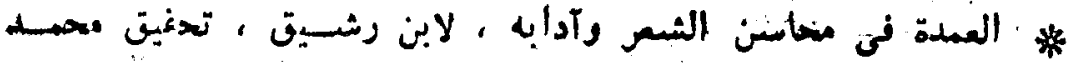

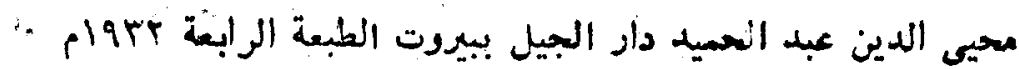

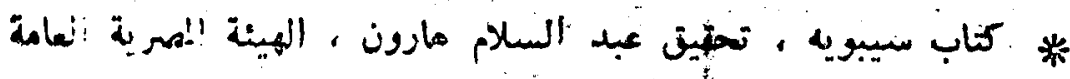
- للكتاب

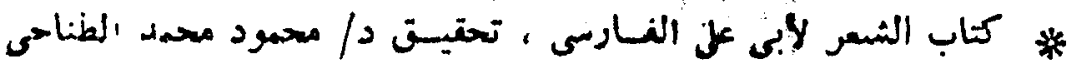

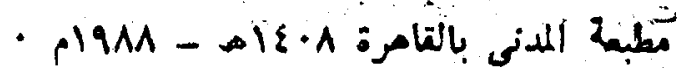

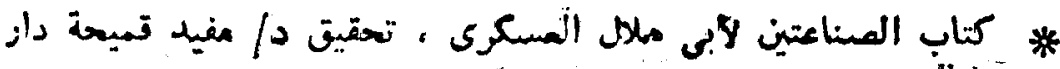

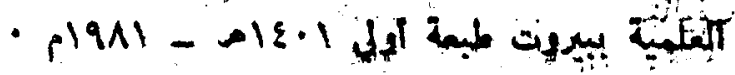




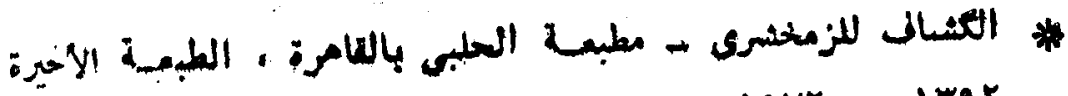
- elarr - - elrar

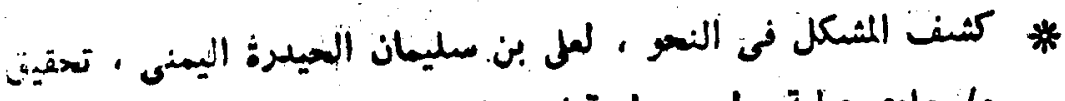

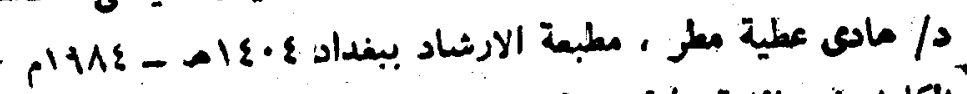

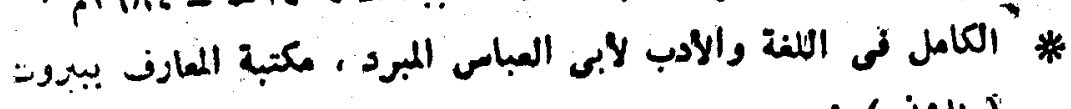
- ( بدون (1)

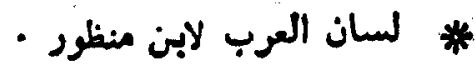

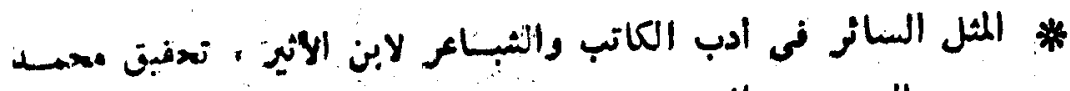

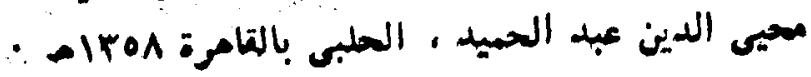

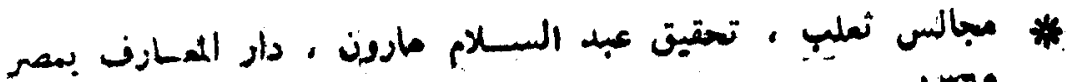
- - 1 1r79

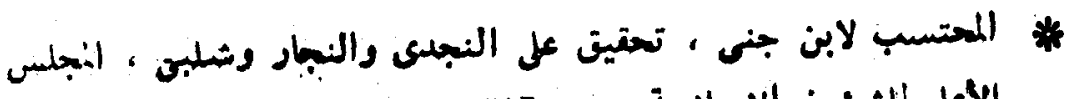

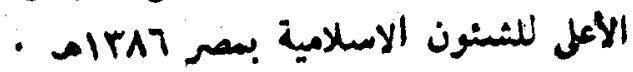

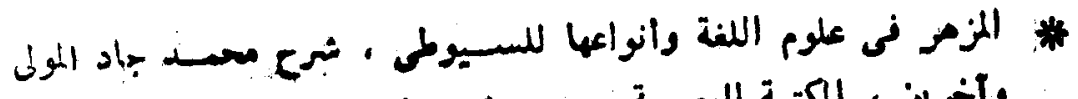

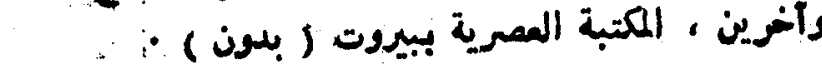

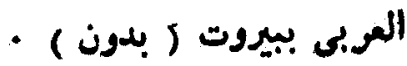

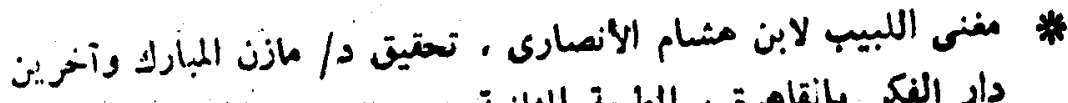

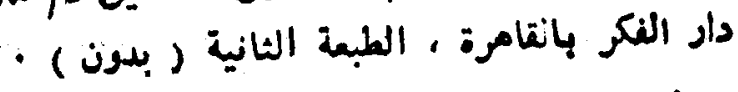

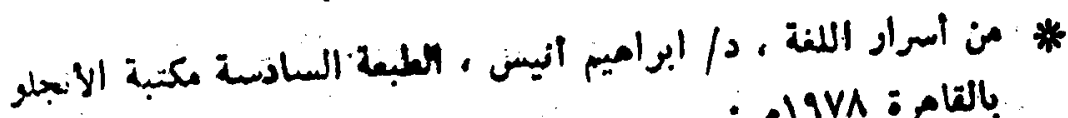

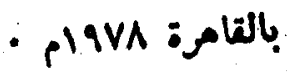

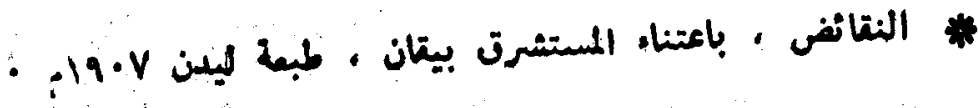




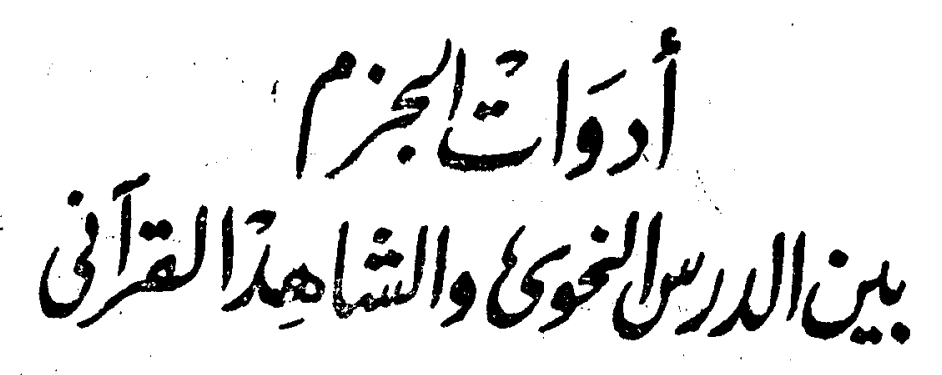

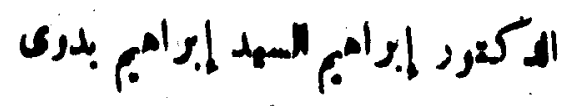

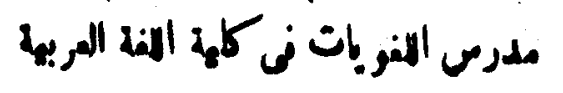

بازل ازئ

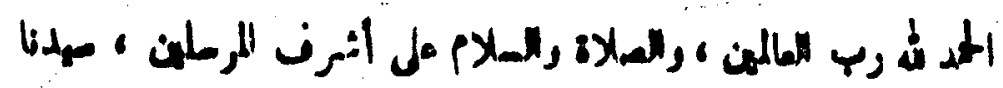

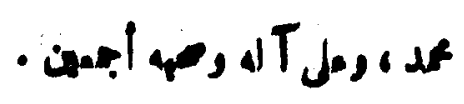

وبعسد :

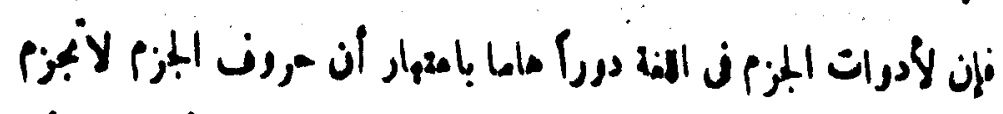

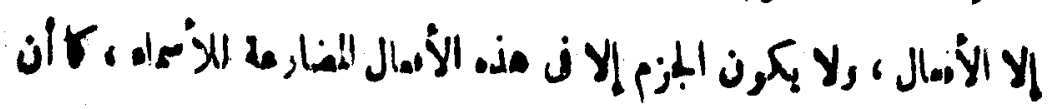

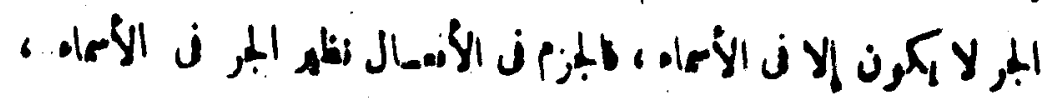

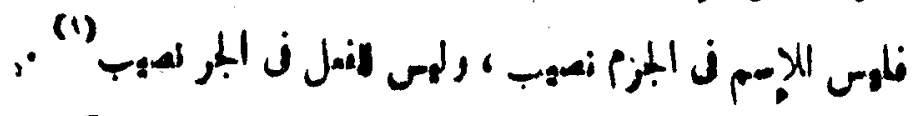

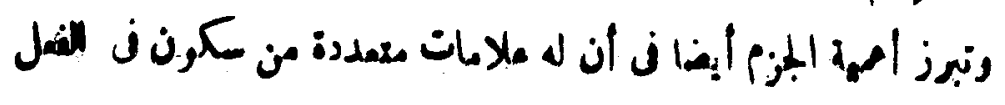

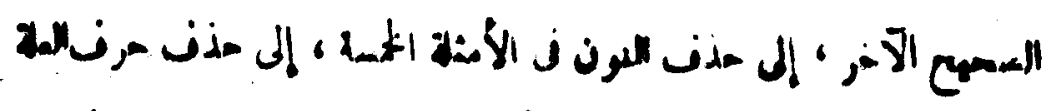

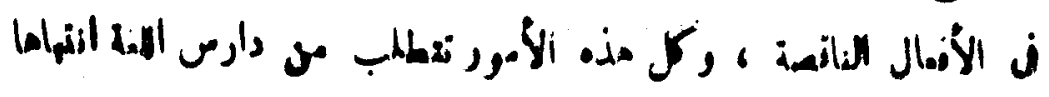
ikus 


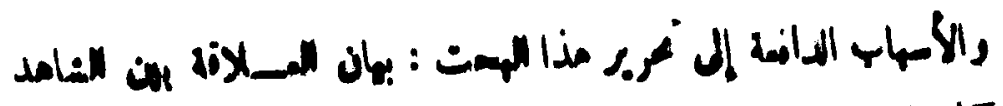

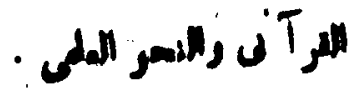

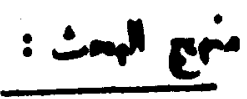

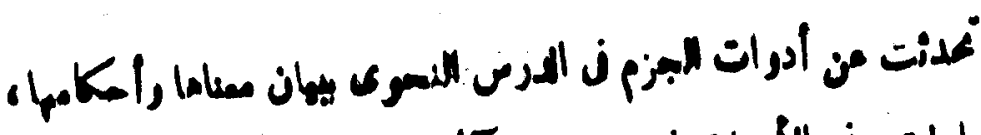

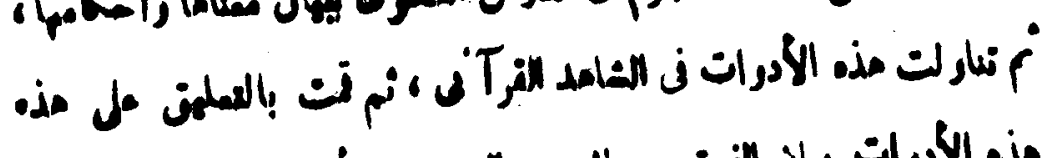

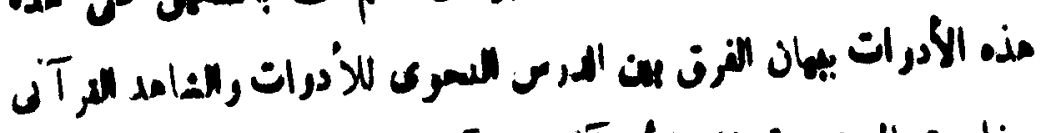

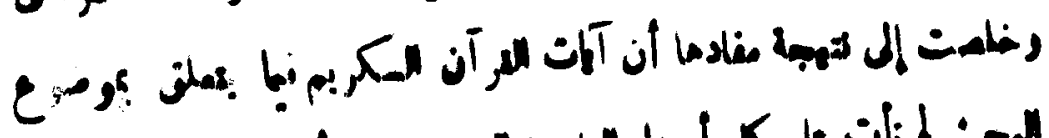

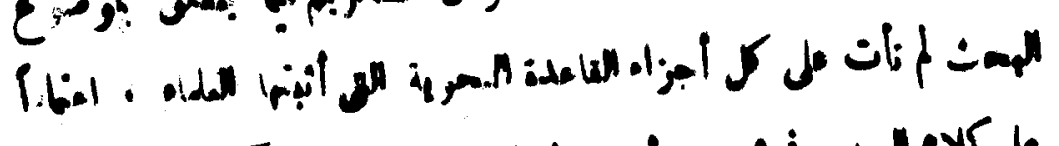

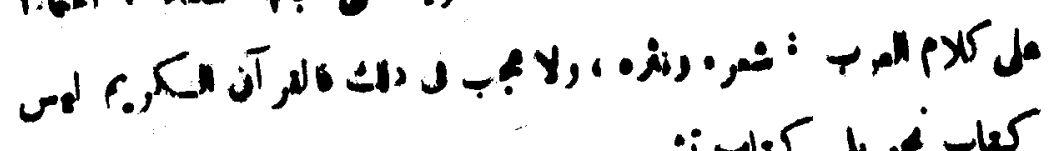

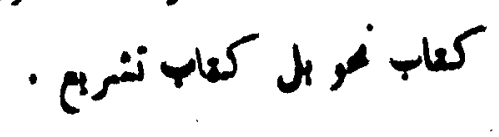

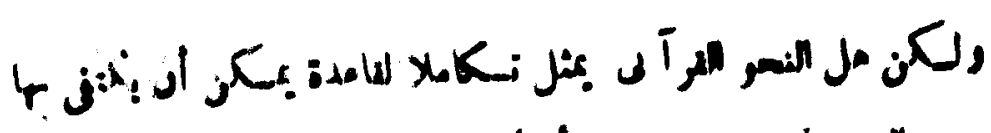

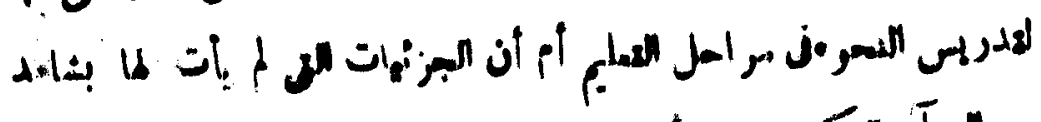

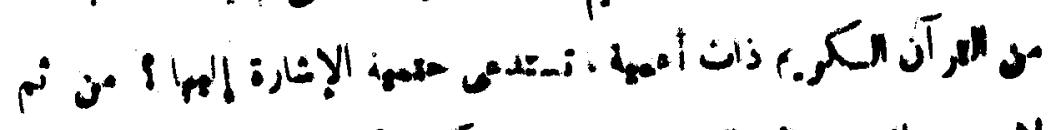

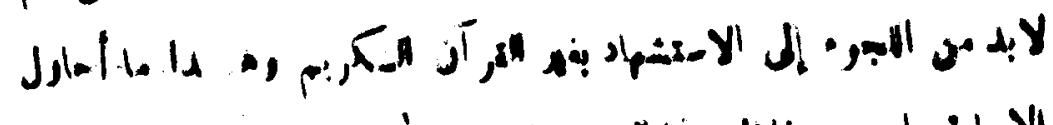

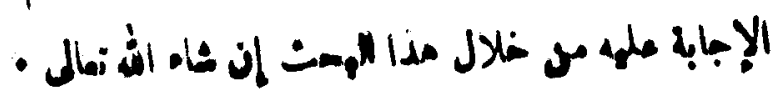

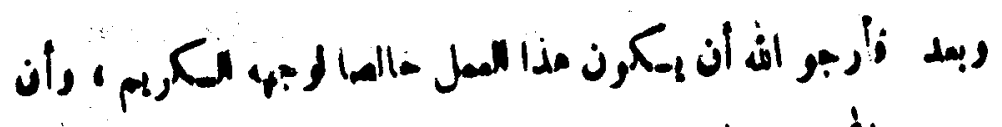

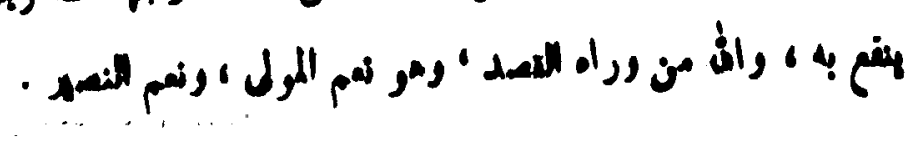




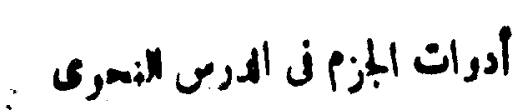

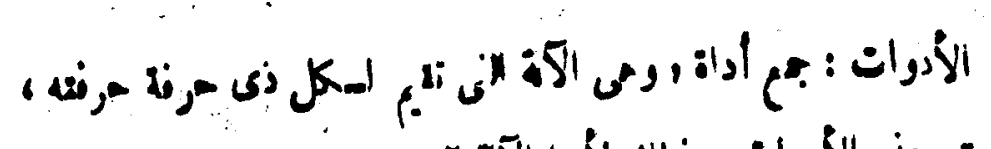

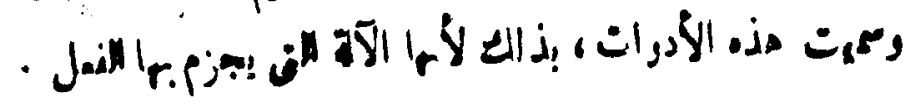

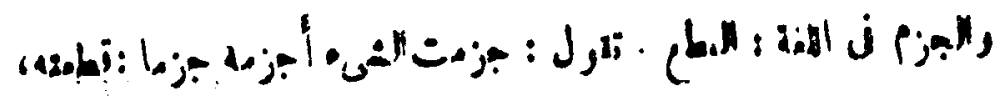

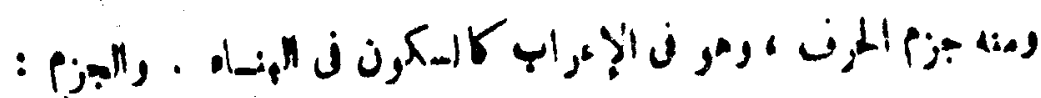

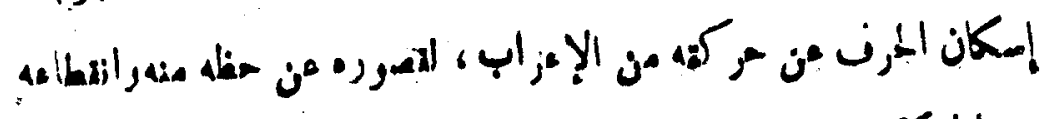

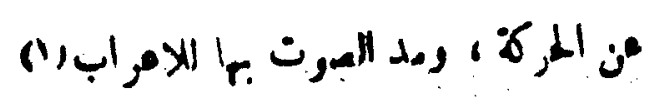

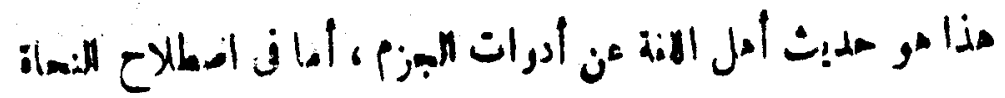

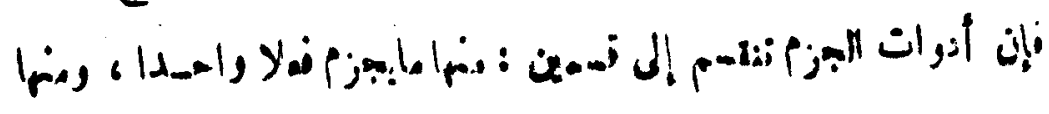

$$
\text { - intipionto }
$$

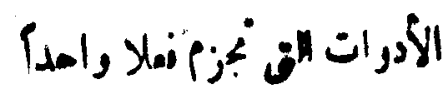

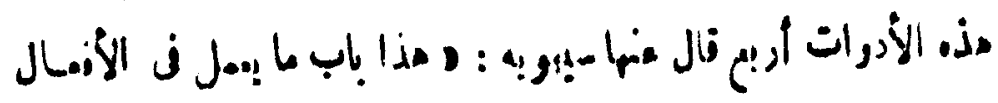

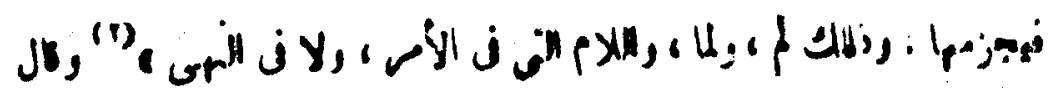

$$
\text { : sli. ن. }
$$

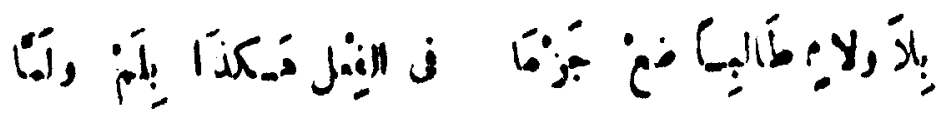

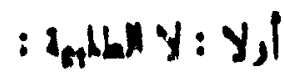

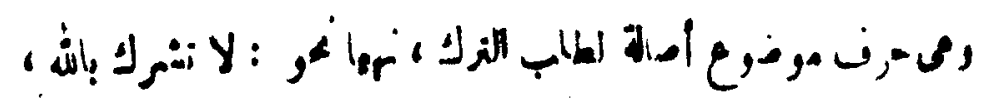

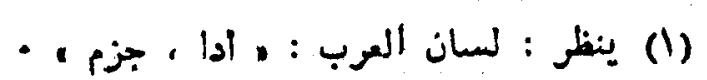

$$
\begin{aligned}
& \text { - }
\end{aligned}
$$




\section{0}

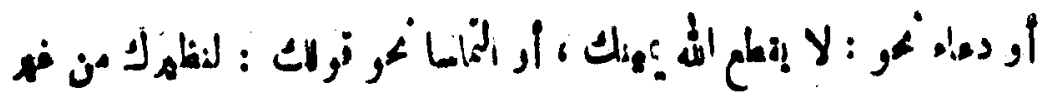

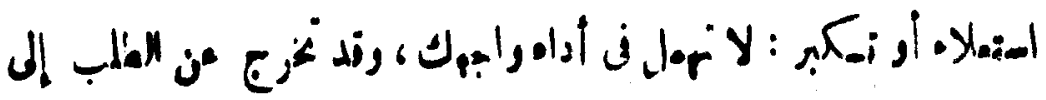

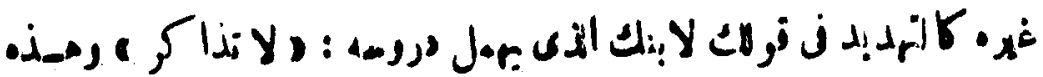

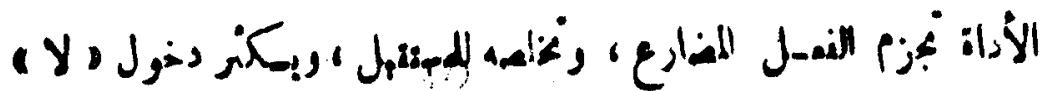

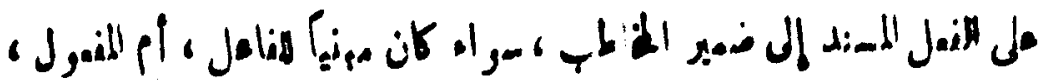

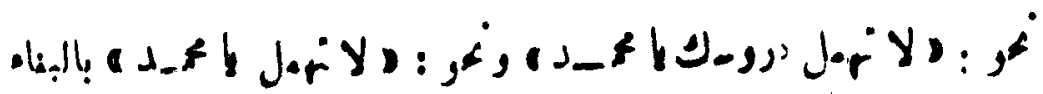

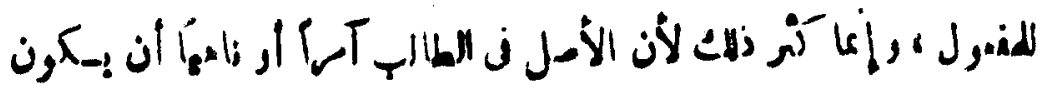

في المطلرب منه ه

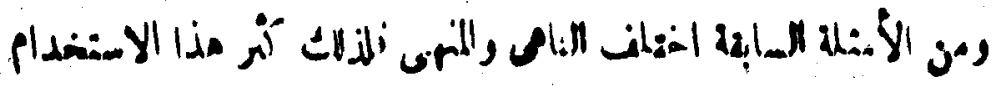

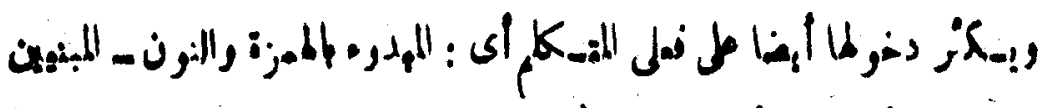

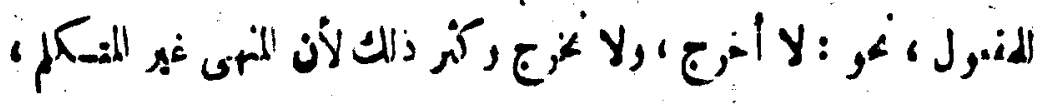

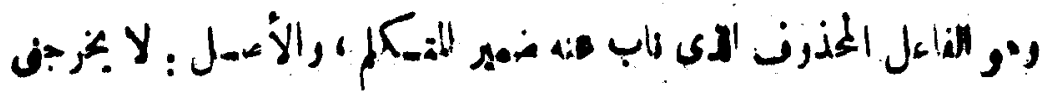

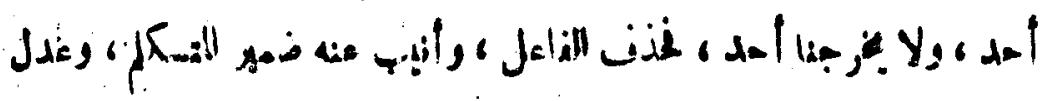

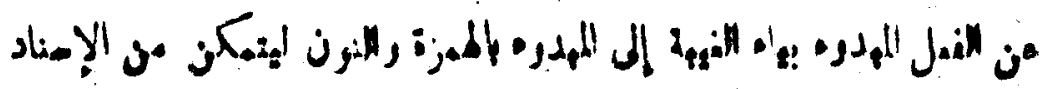

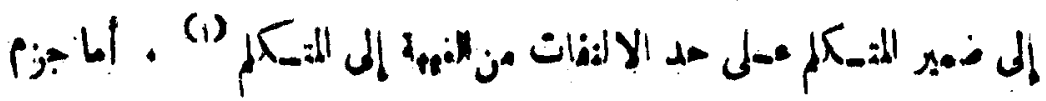

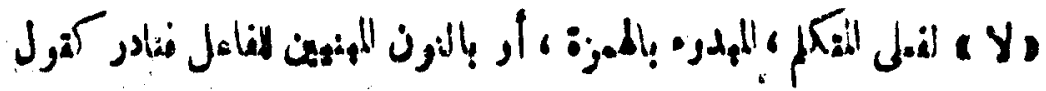

:

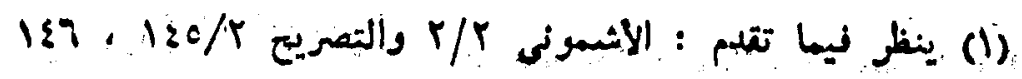




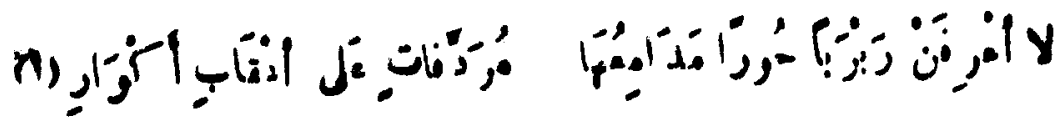

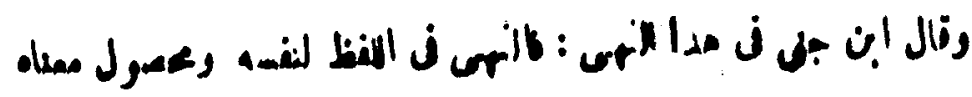

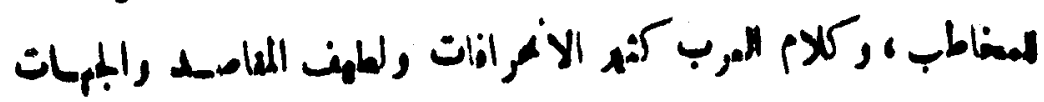

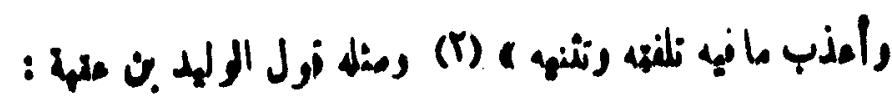

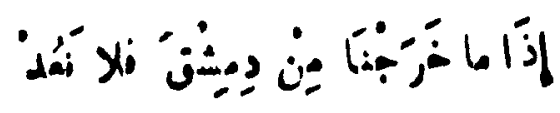

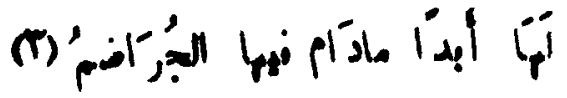

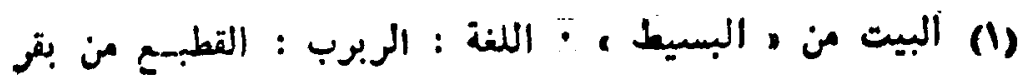

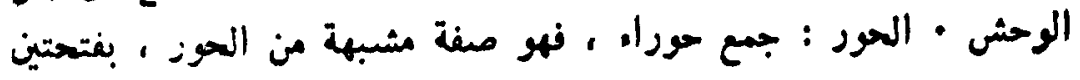

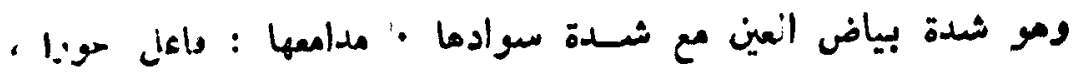

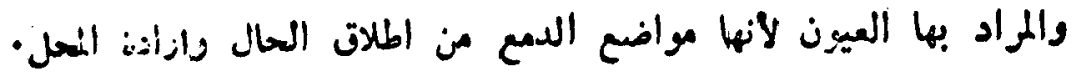

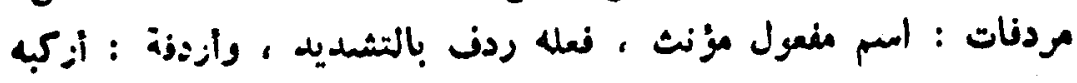

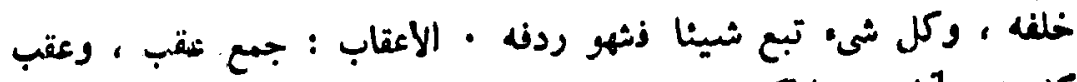

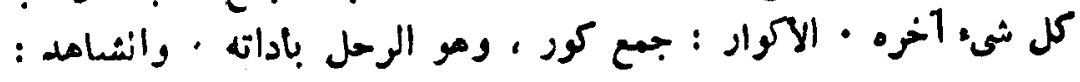

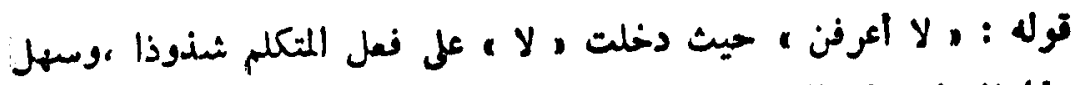

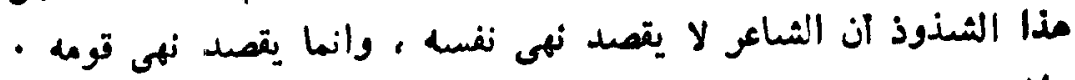

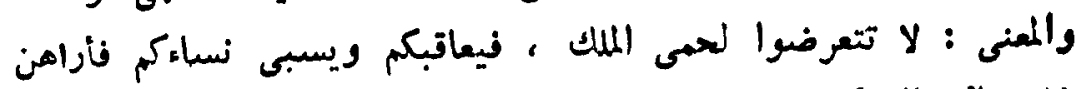

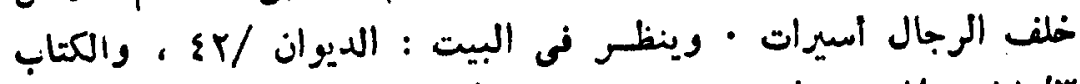
رارتشاف

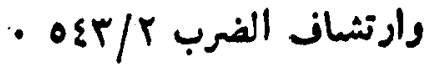

$$
\text { : } 17 / r \text { (Y) }
$$

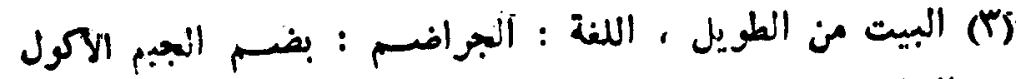
الواسع البطن

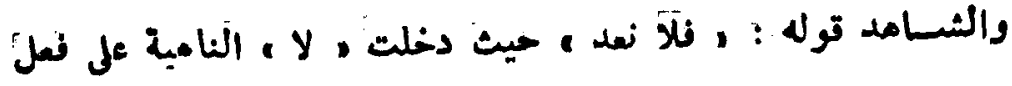




\section{erv}

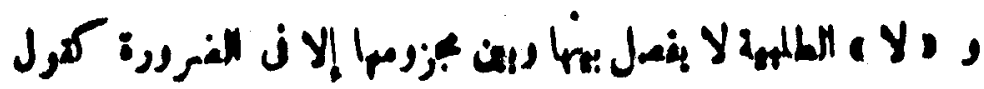
E.:

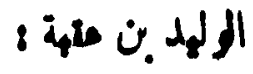

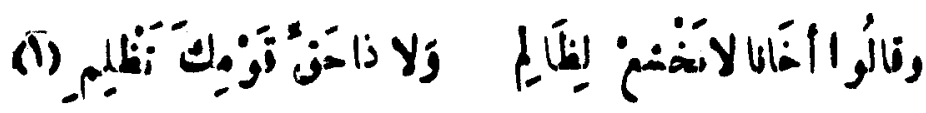

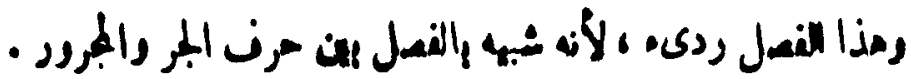

رجوز الآهدى مذفن مجزرم د لا ه المالمهيه إذا دل عله دلهل ، مُو:

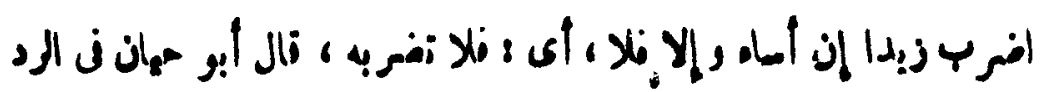

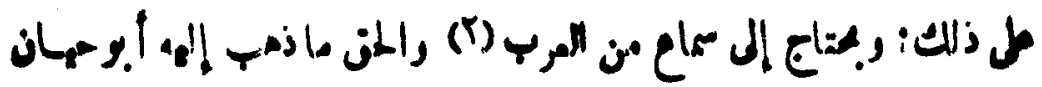

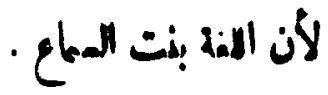

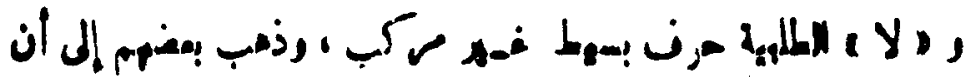

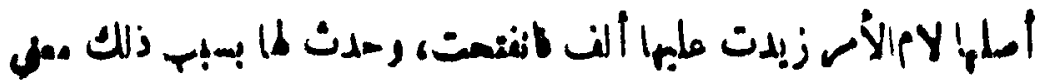

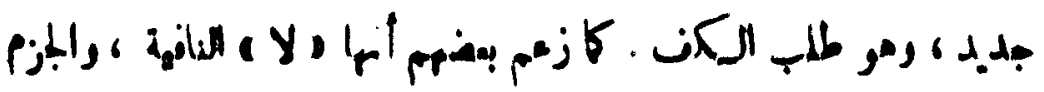

$=$

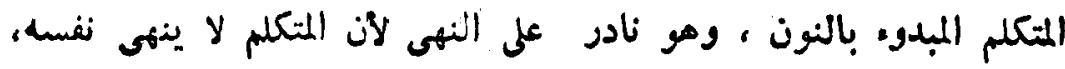

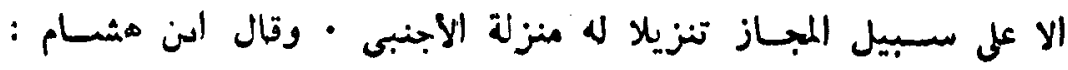

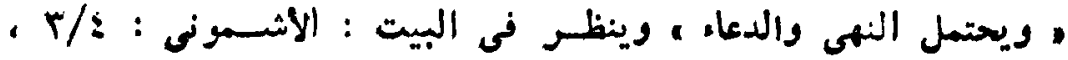

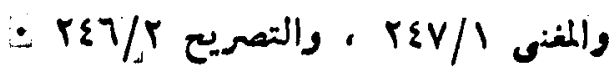

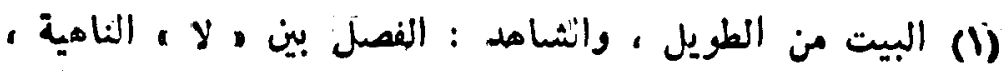

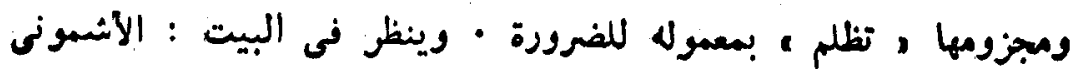

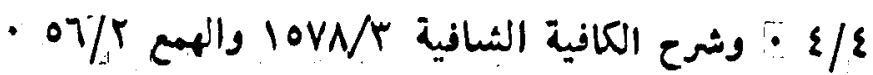

- ا 


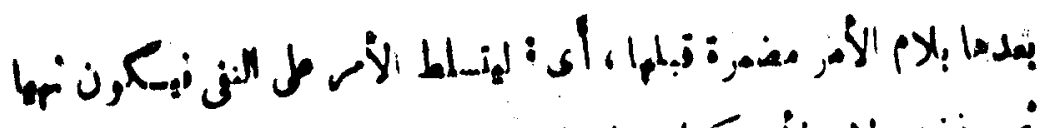

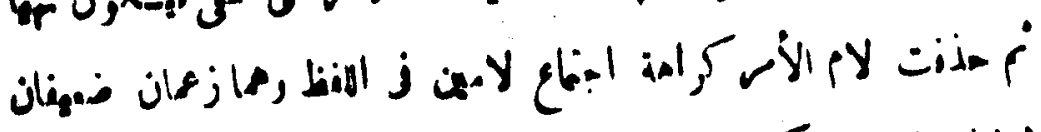

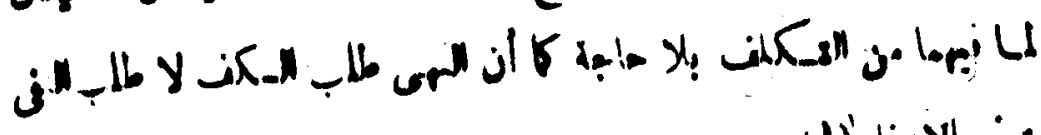

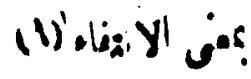

\section{:}

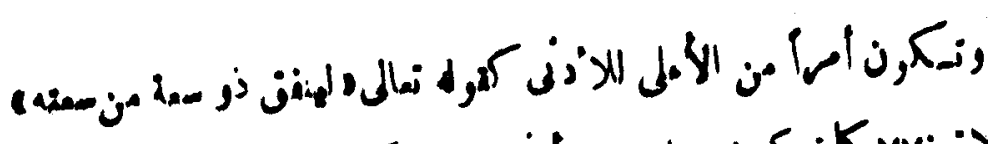

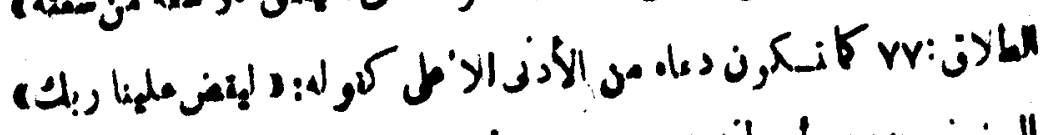

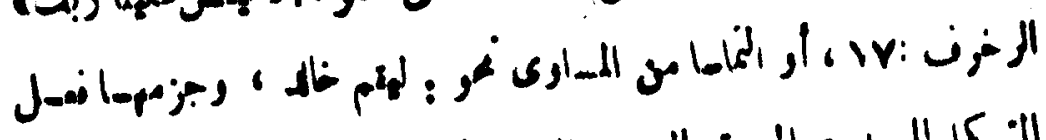

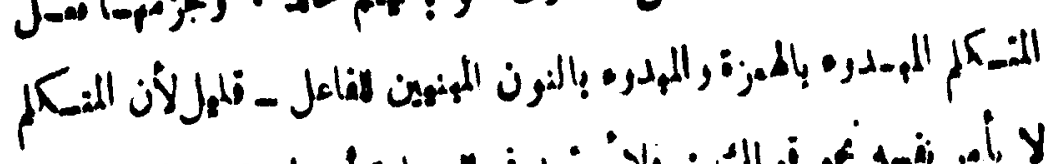

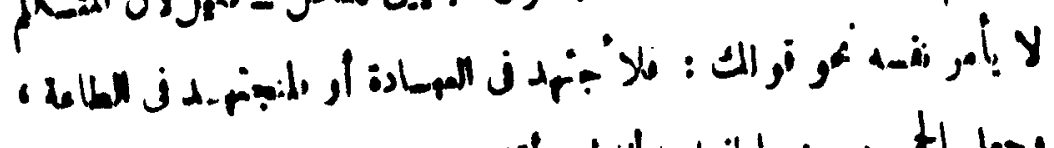

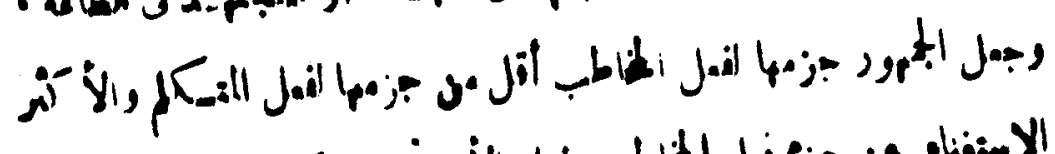

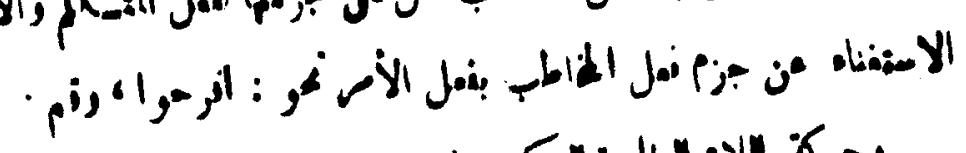

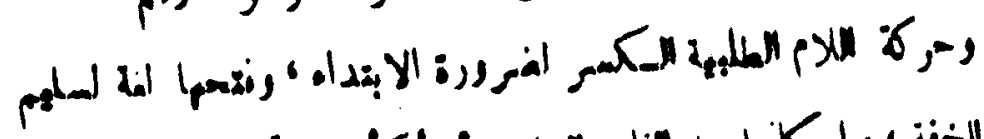

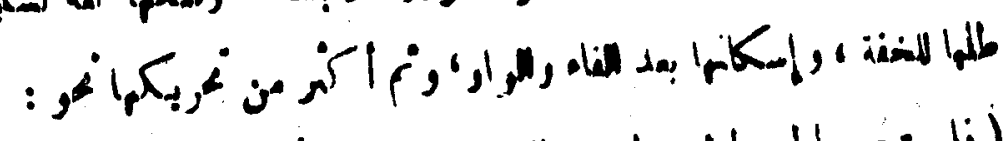

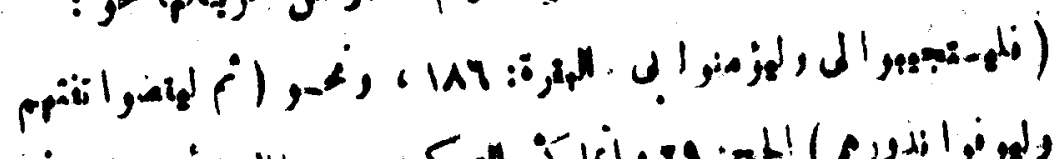

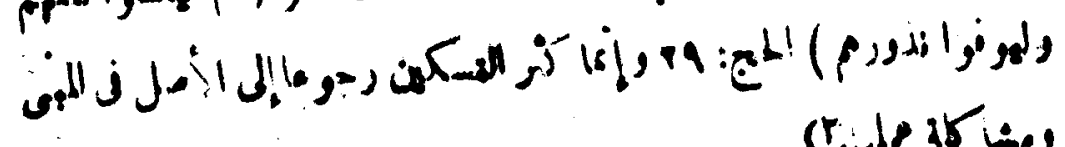
(r.jole abing

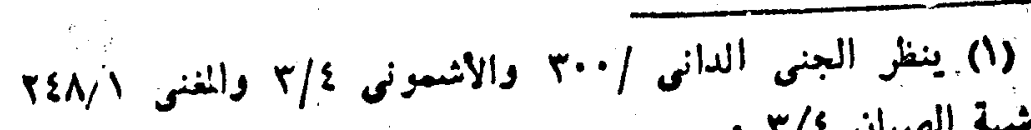

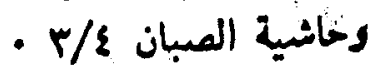

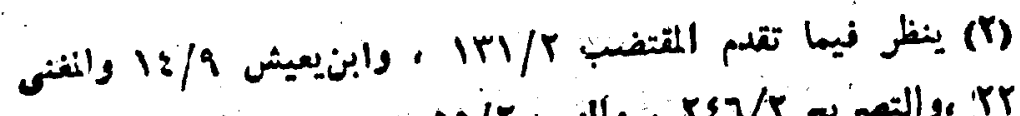

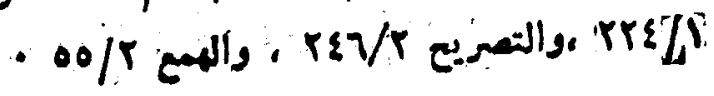




\section{IYI}

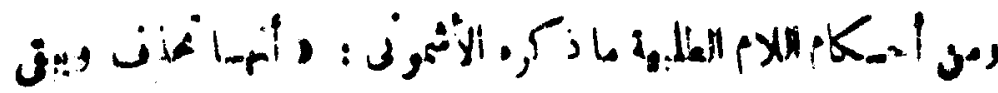

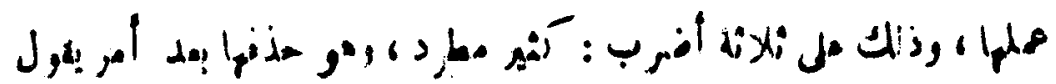

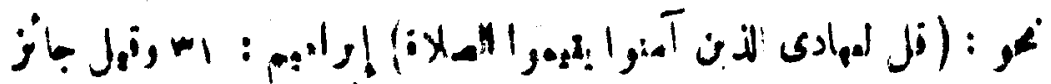

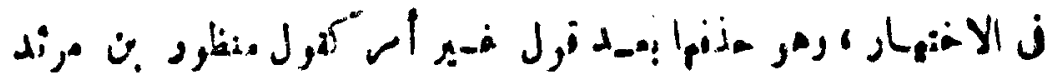
: الأ-مدى

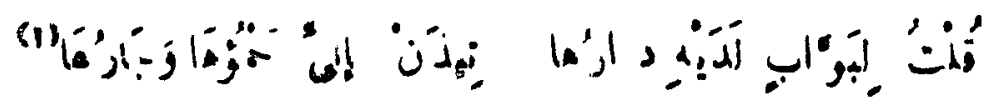

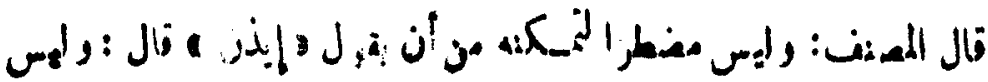

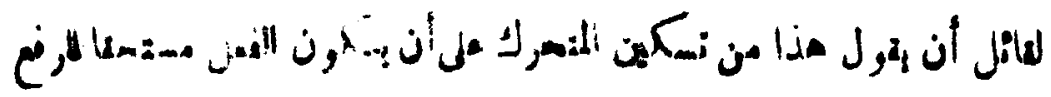

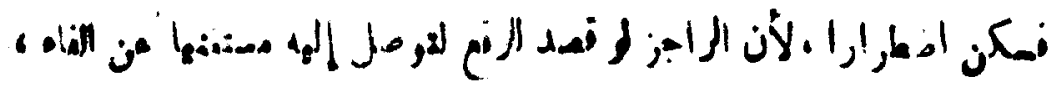

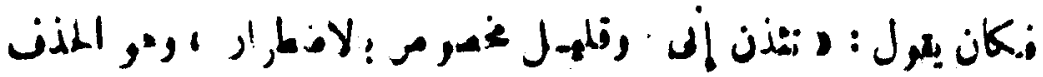

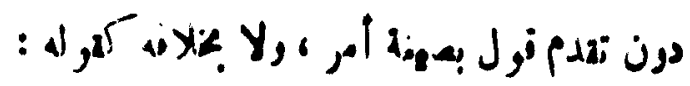

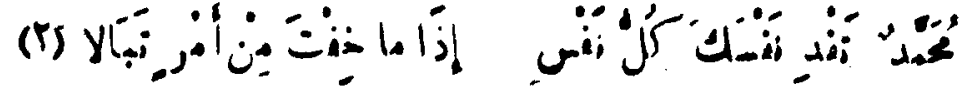

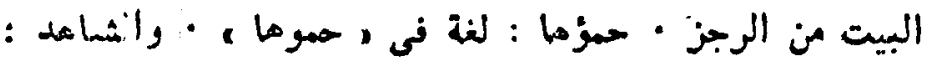

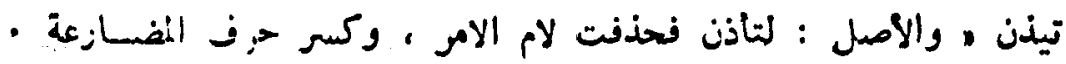

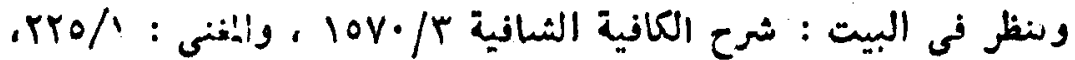

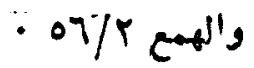

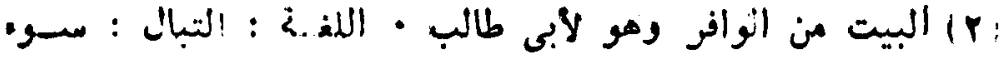

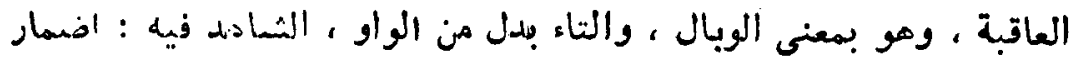

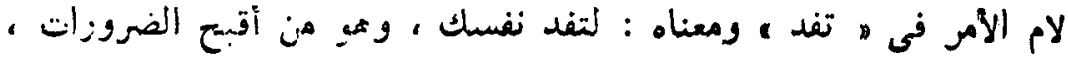

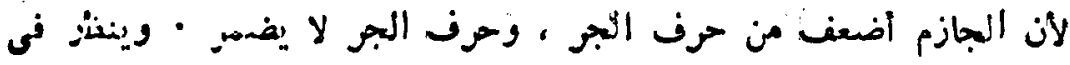

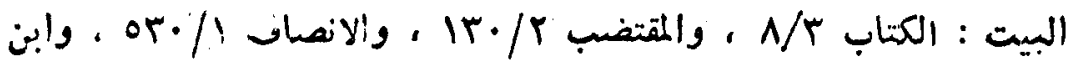

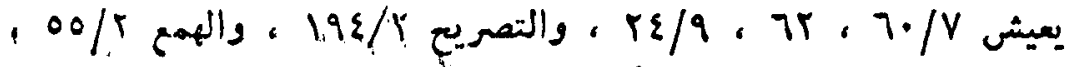

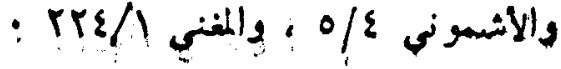




\section{(r.}

وزم 14

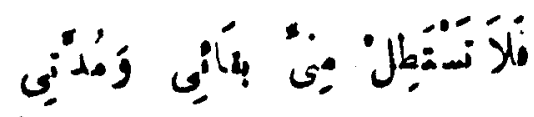

$$
\begin{aligned}
& \text { ور }
\end{aligned}
$$

(r) انزم

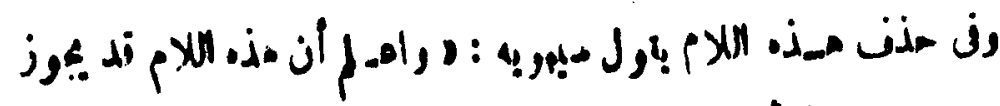

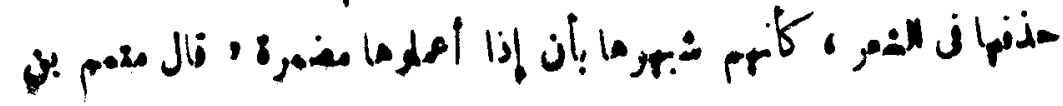

$$
\begin{aligned}
& \text { S }
\end{aligned}
$$

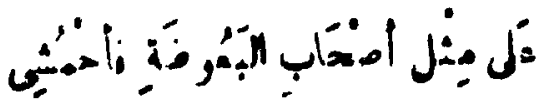

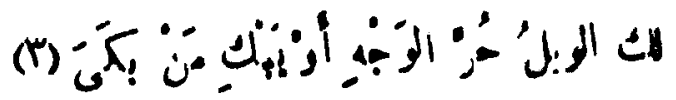

(1) البيت من الطويل ، ولم يعلم قائله ، يخاطب فيه الشاءئ ابنه

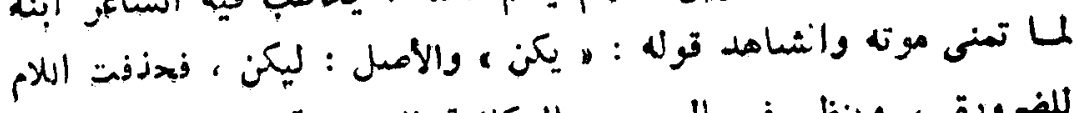

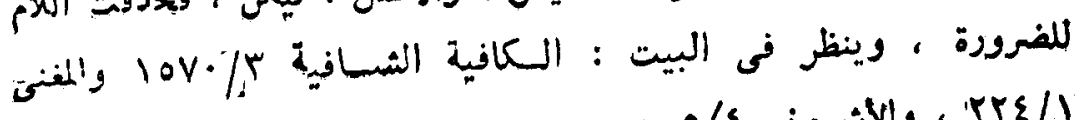

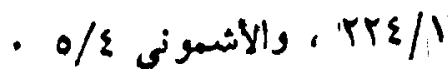

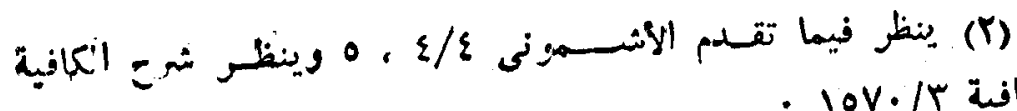

(r) البيت من ه الطويل ، النغة : البعوضة : ماءة معرو فة بالبادية

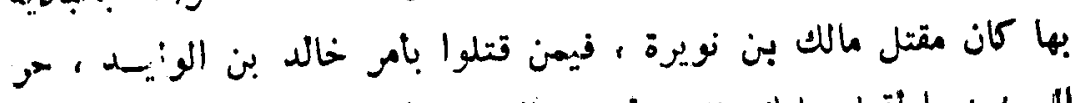

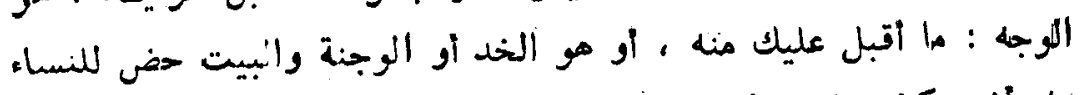

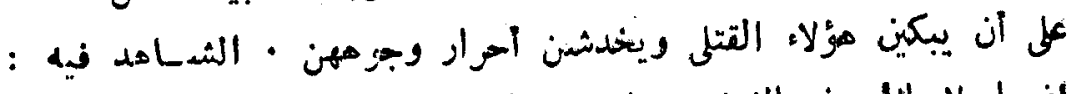

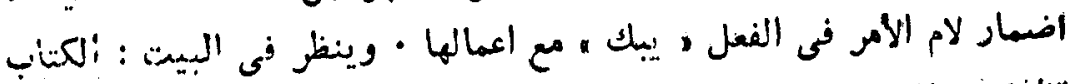

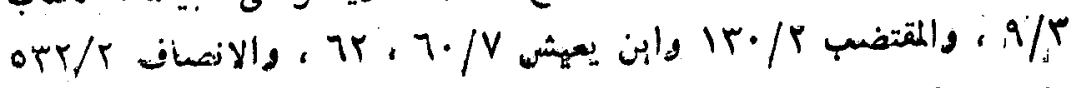




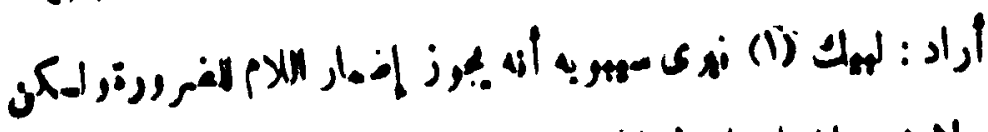

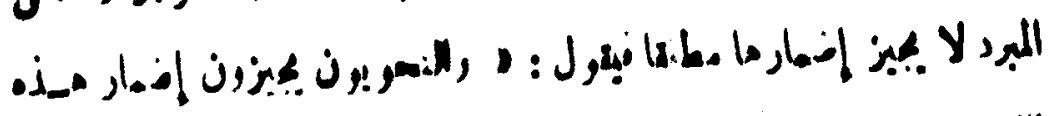

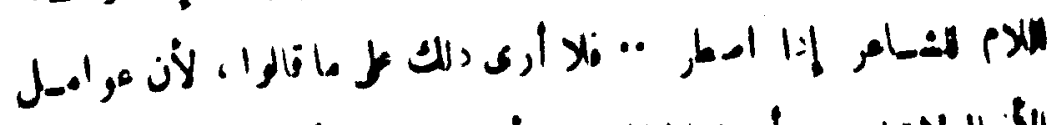

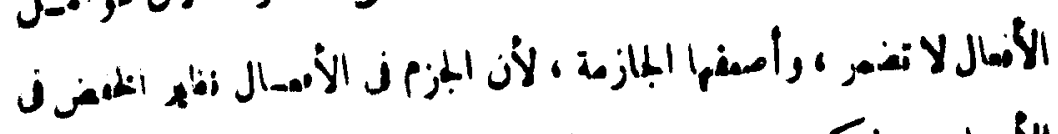

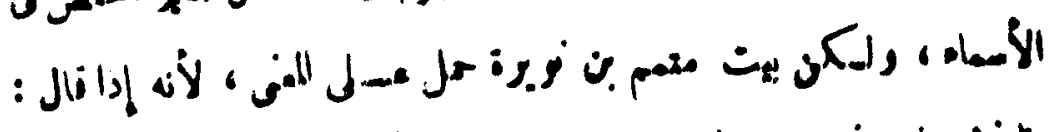

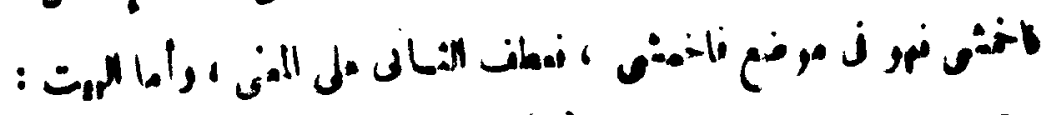

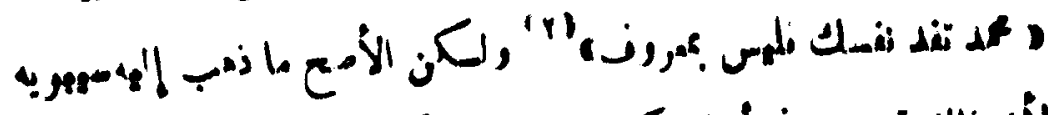

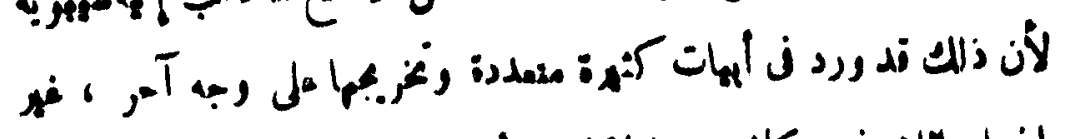

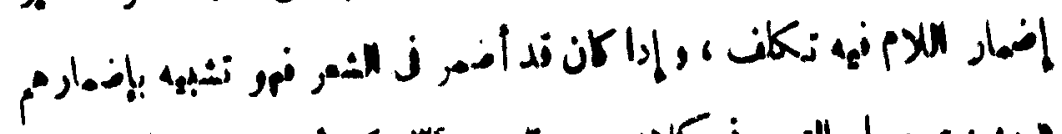

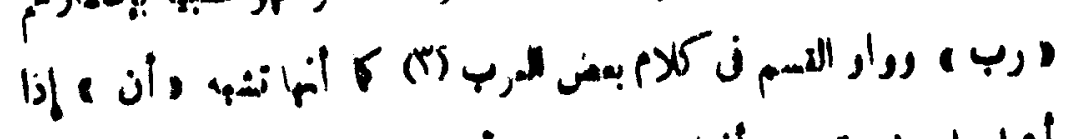

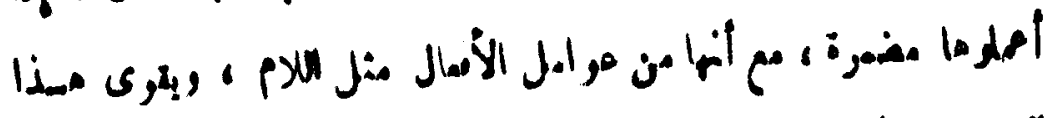

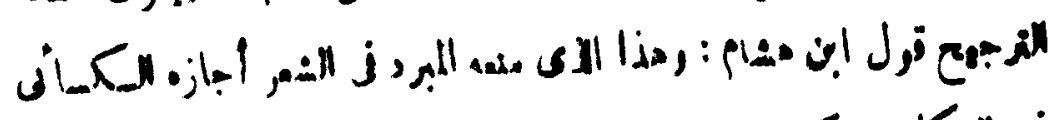

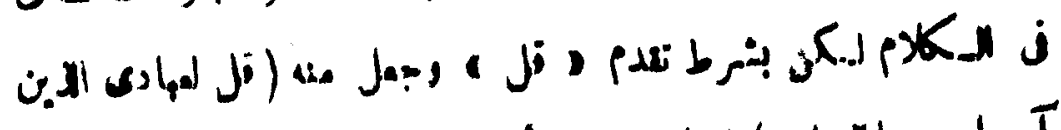

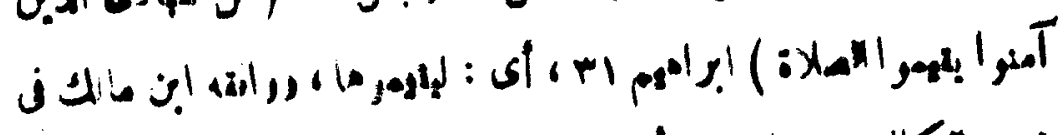

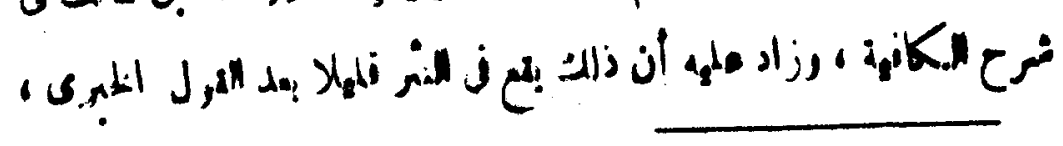

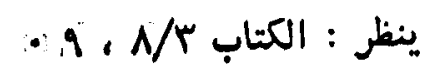

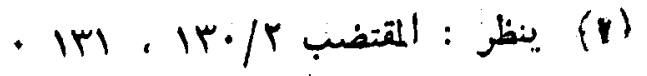

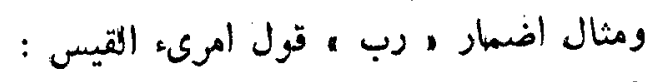

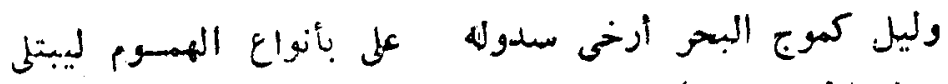

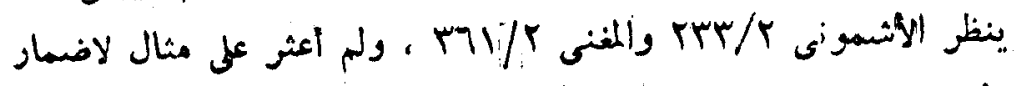

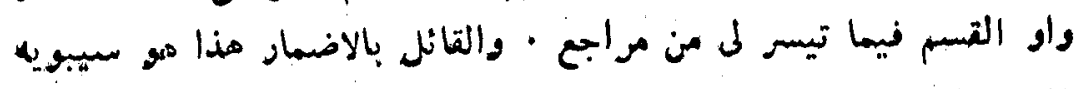




\section{EYY}

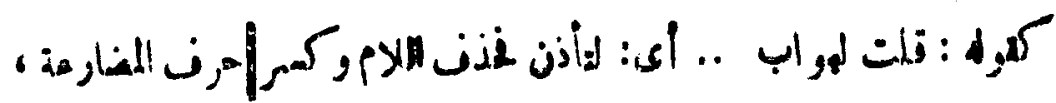

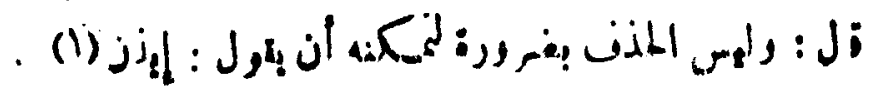

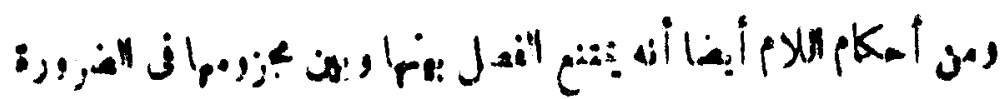

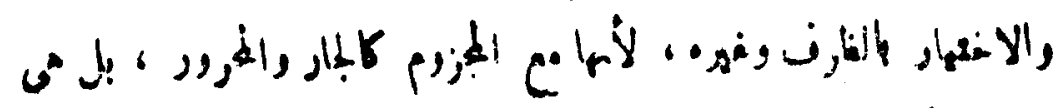

•

: 1)

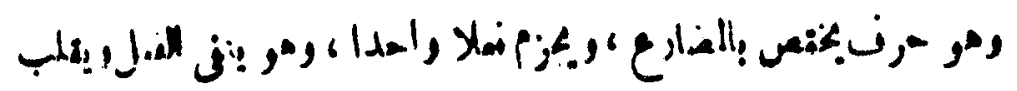

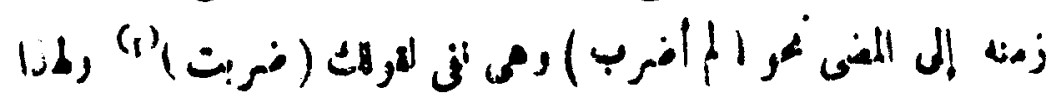

: الd

$\mid$

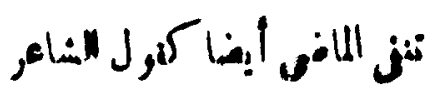

(r)

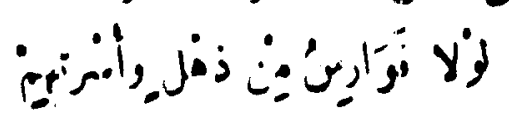

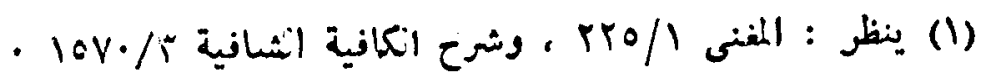

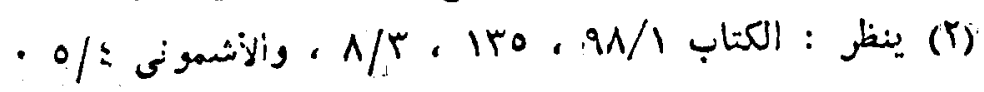

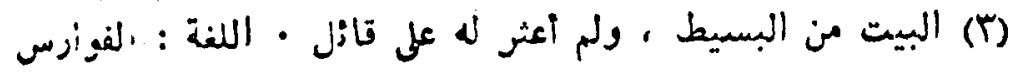

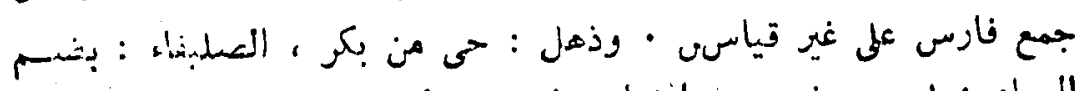

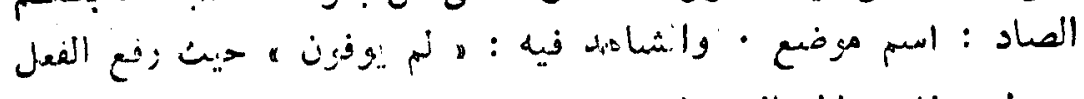

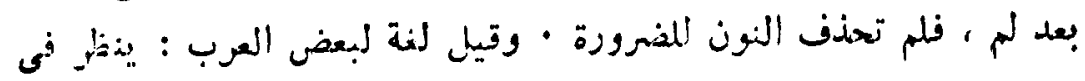

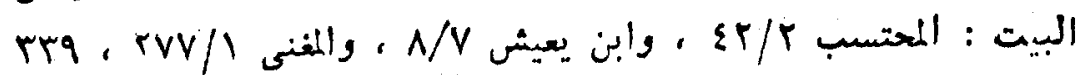

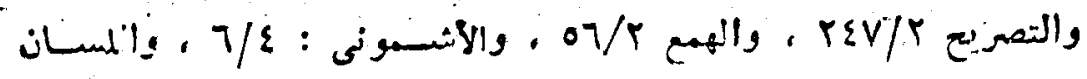

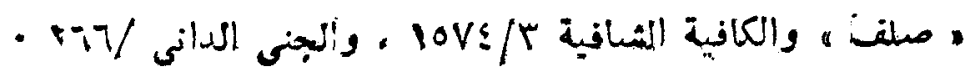




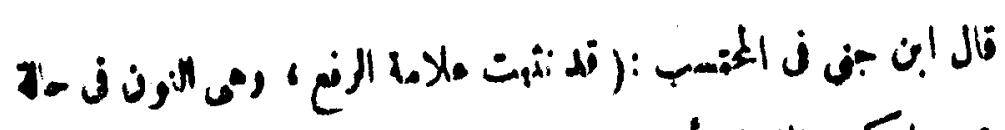

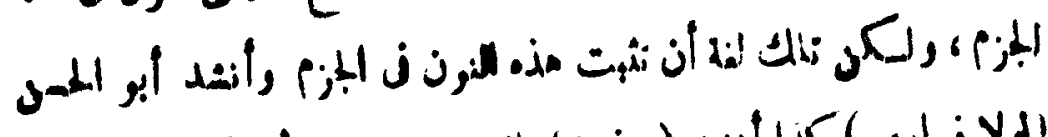

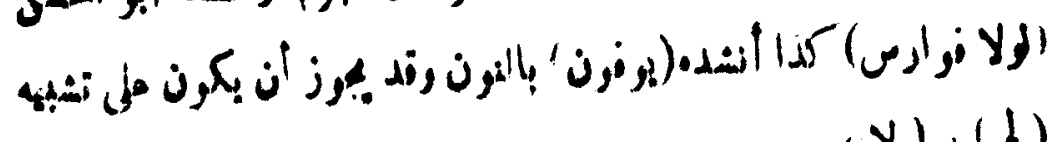
( ) ( ) ( )

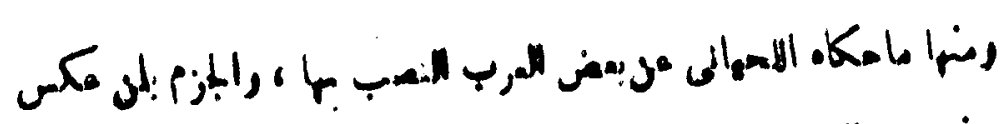

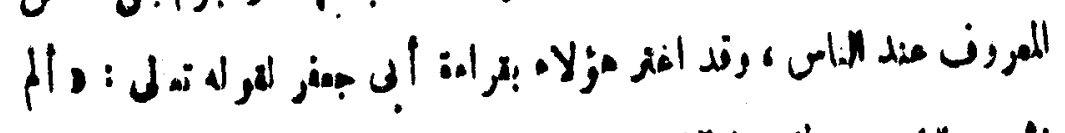

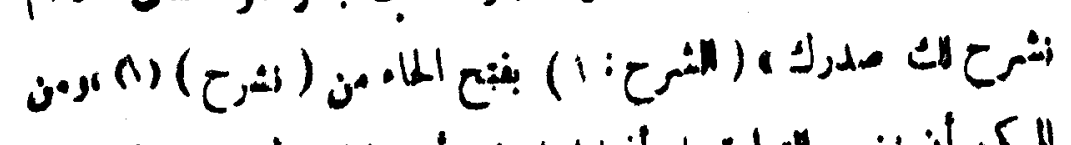

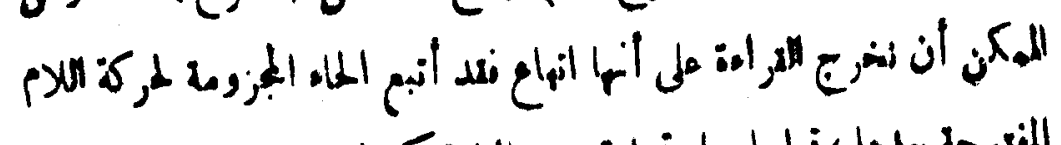

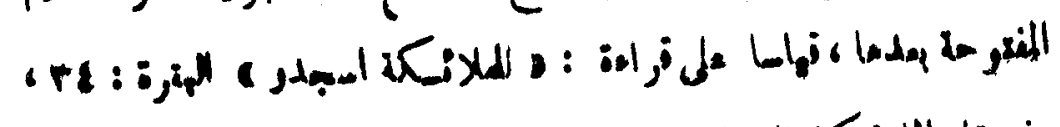

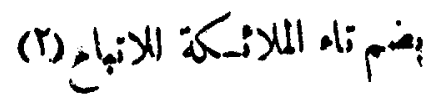

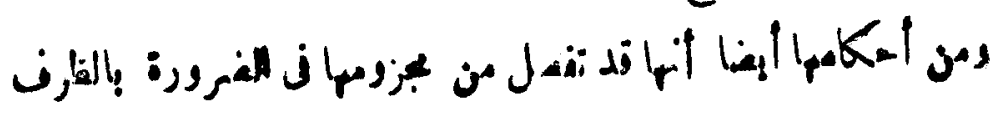

$$
\text { : }
$$

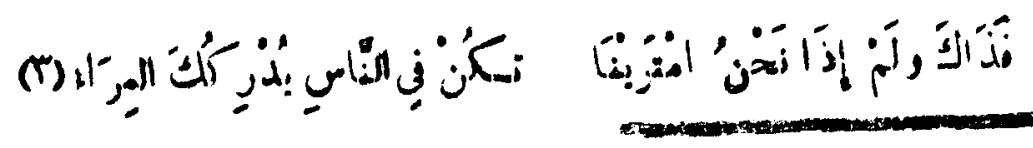

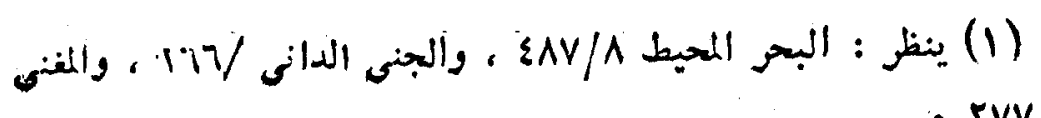

- rVv/

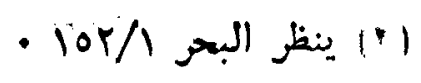

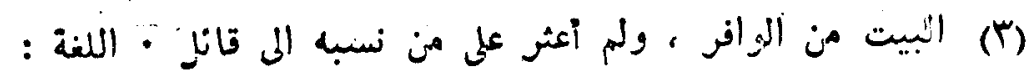

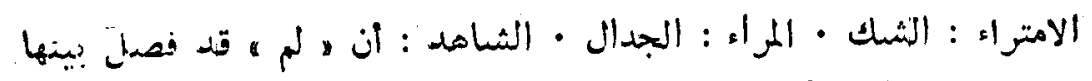

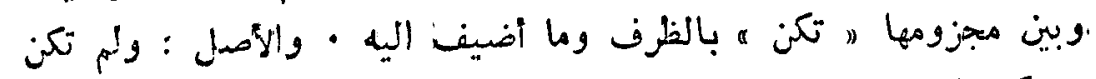

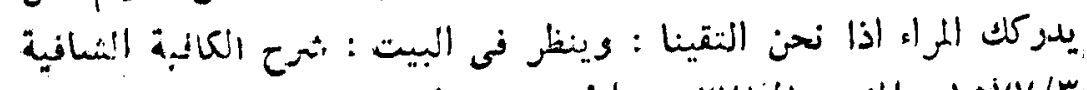

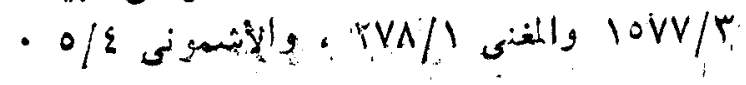

$$
(j-\gamma \wedge)
$$




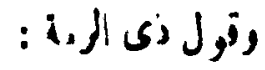

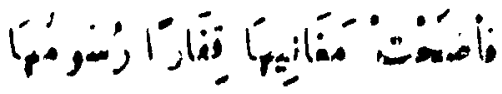

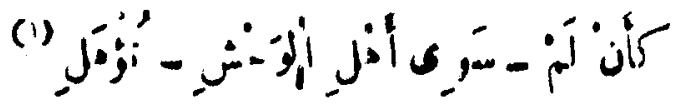

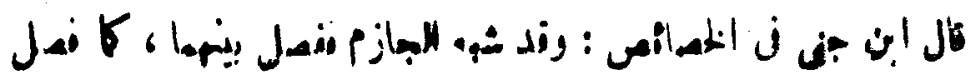

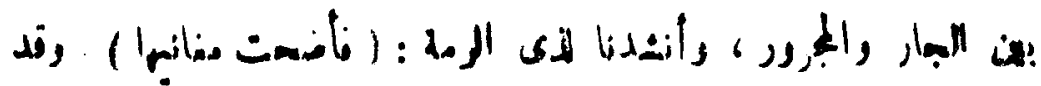

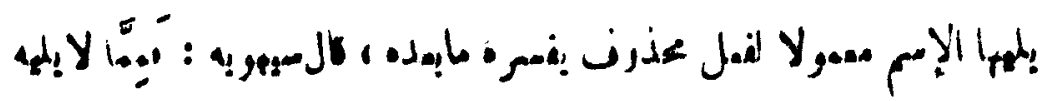

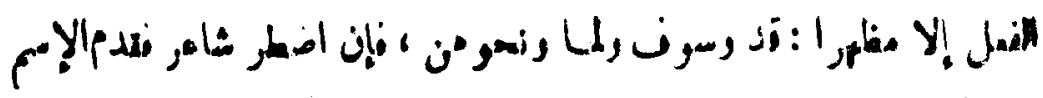

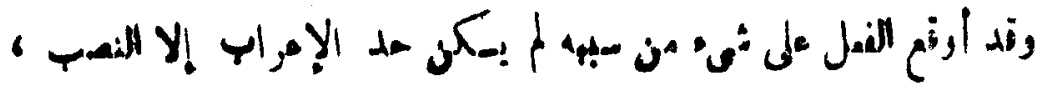

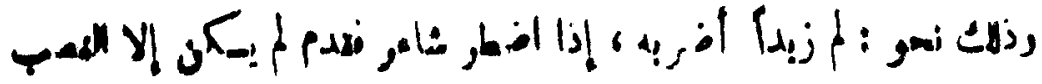

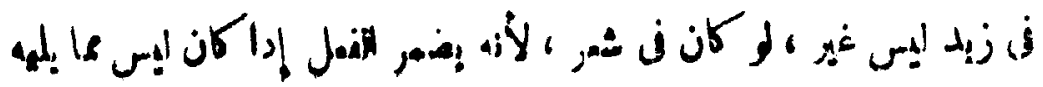

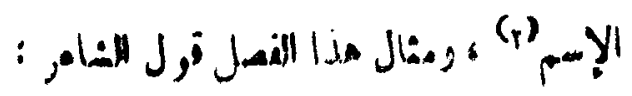

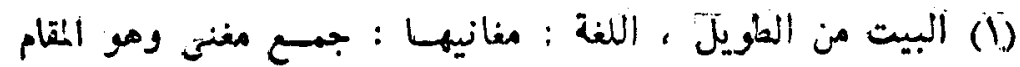

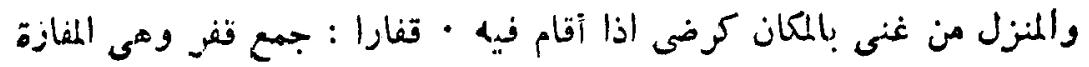

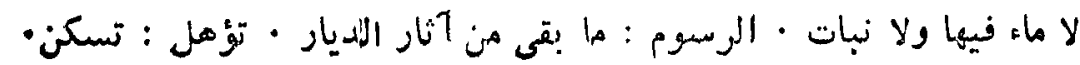

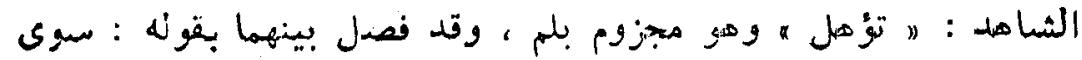

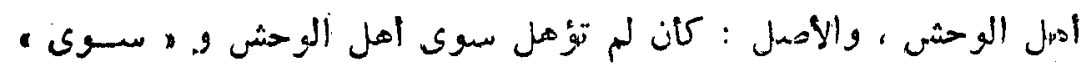

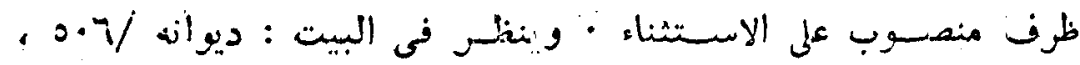

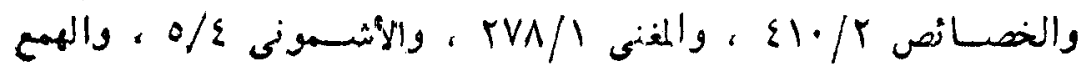

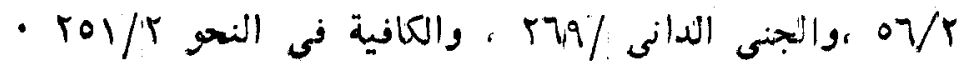


tro

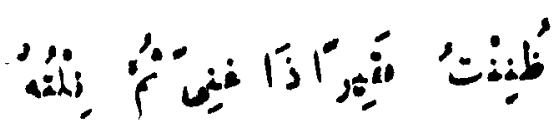

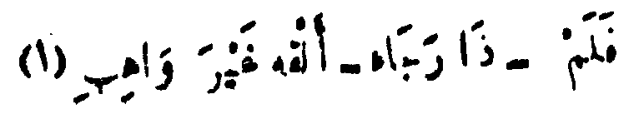

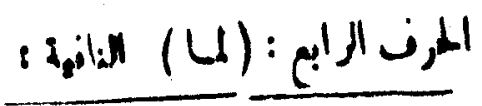

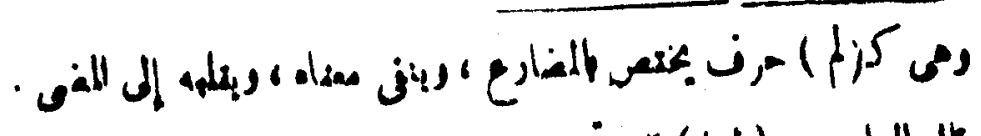

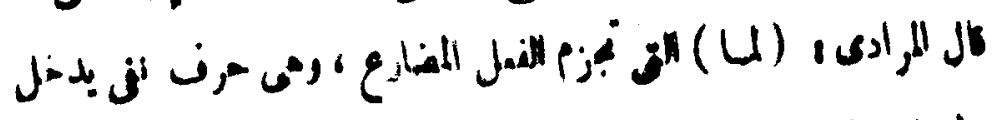

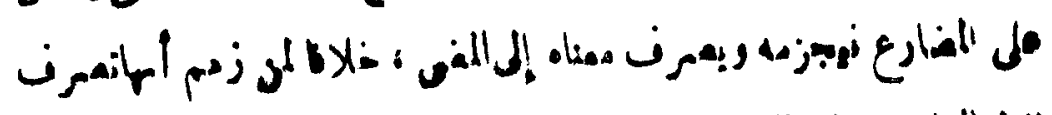

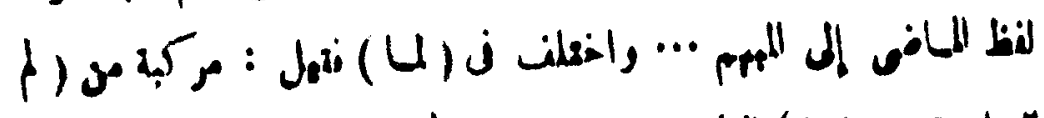

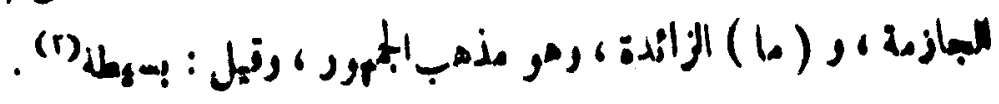

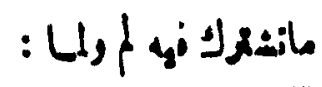

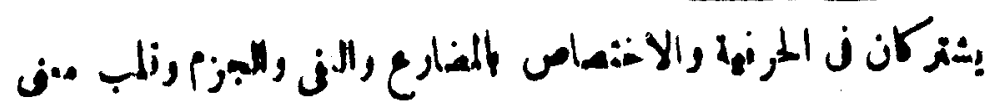

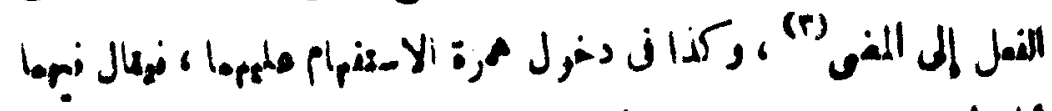

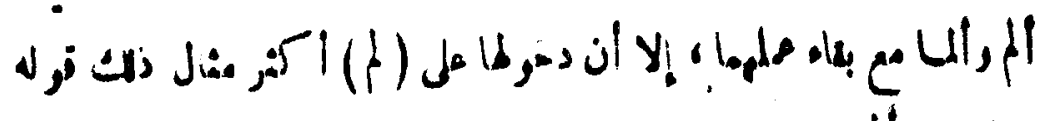

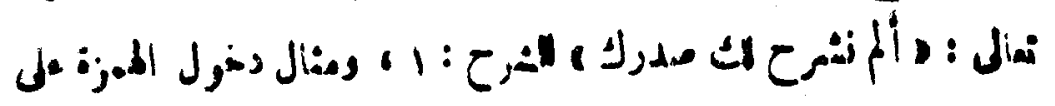

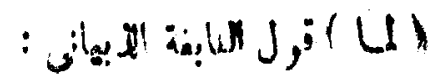

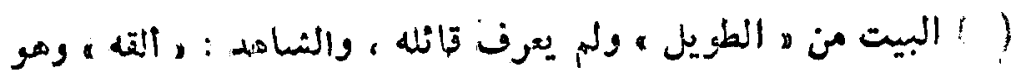

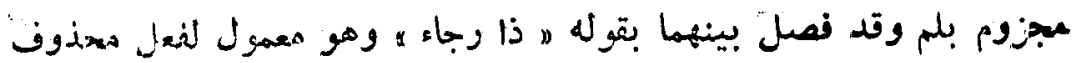

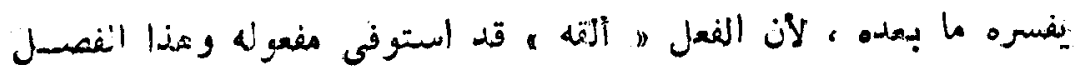

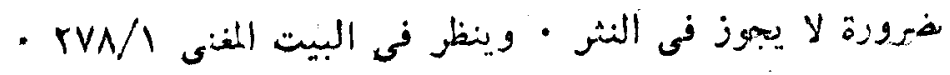

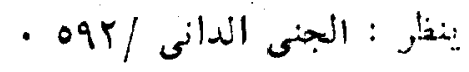
• / الأشهون 


$$
\text { عَلَّ }
$$

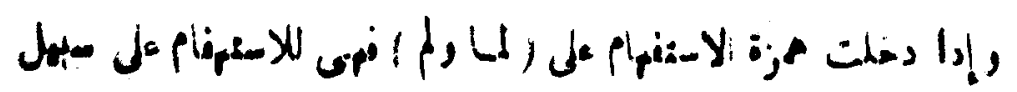

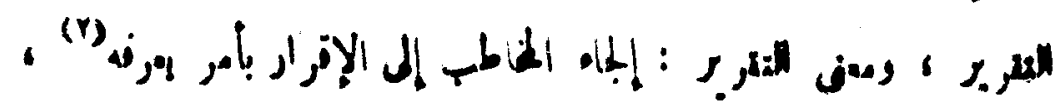

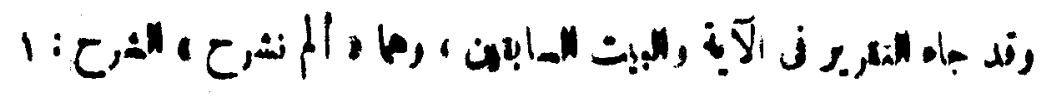

$$
\text { ) }
$$

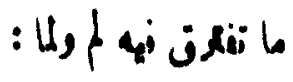

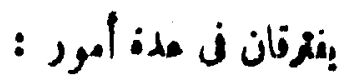

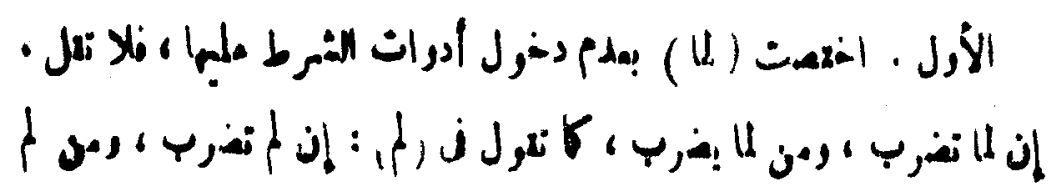

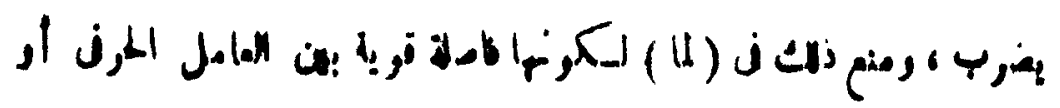

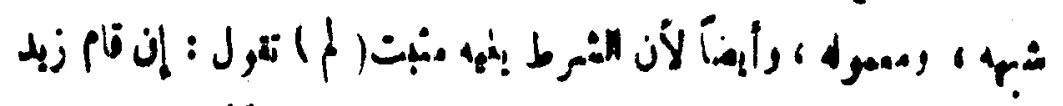

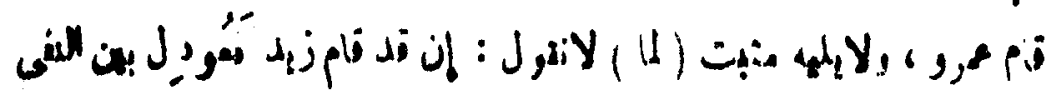

ل) (البيت من الطويل ، اللغة : الوازع : الناهى الزاجر ، واسناد

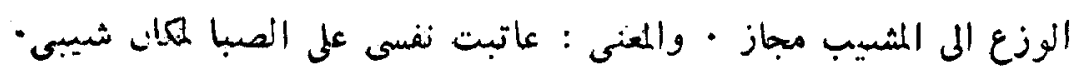

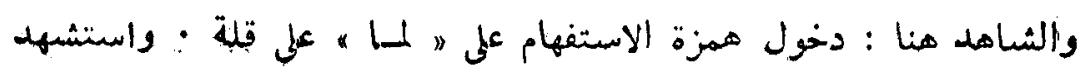

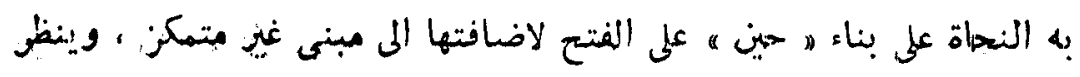

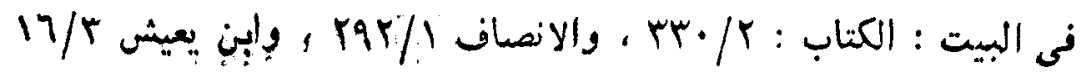
والهمع : - rol/r (r) 


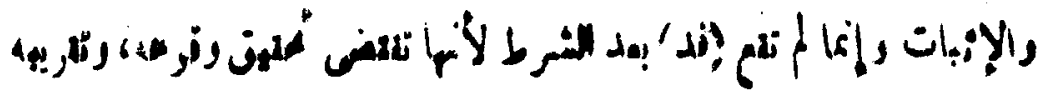

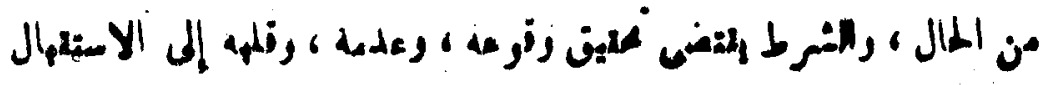

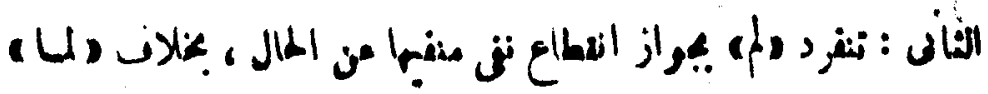

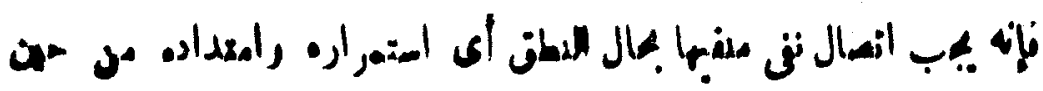

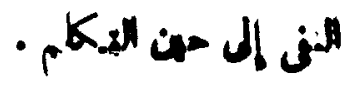

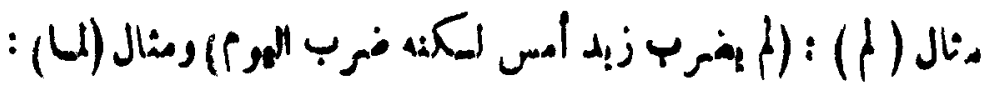

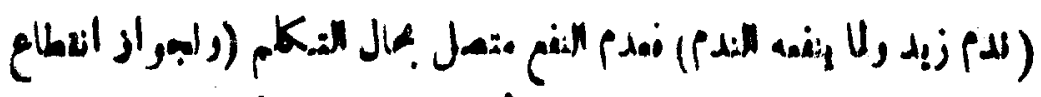

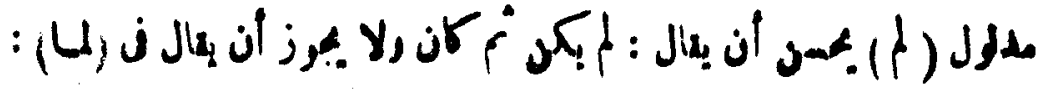

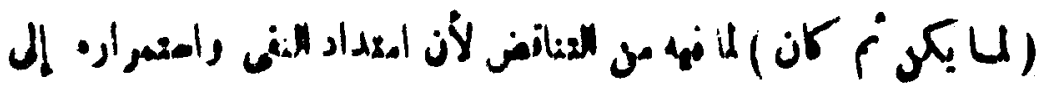

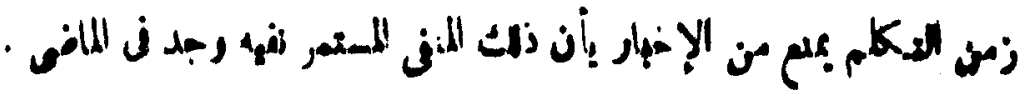

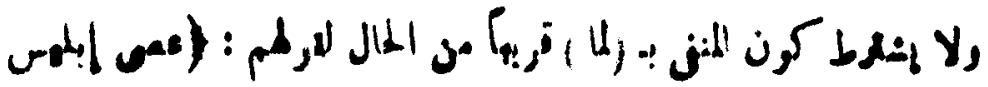

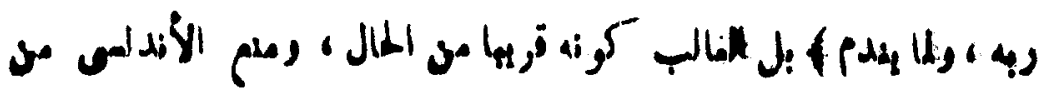

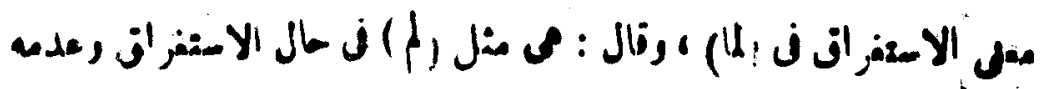

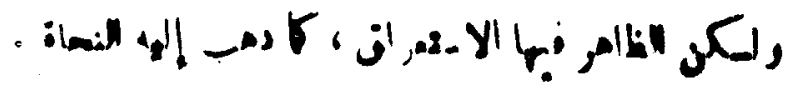
رمال

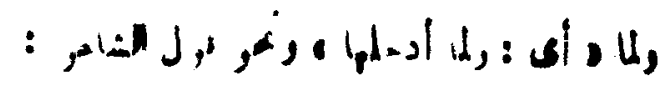

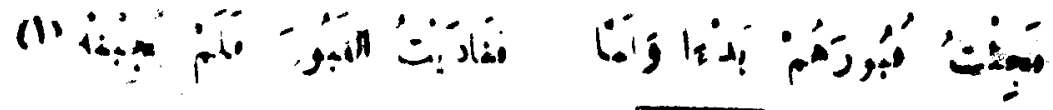

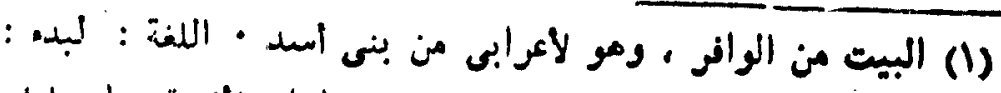

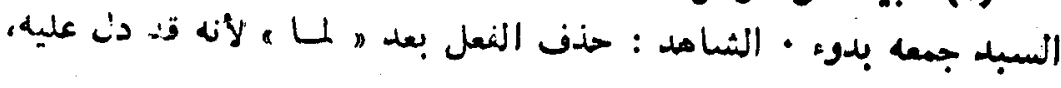

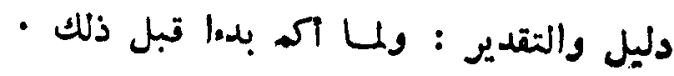

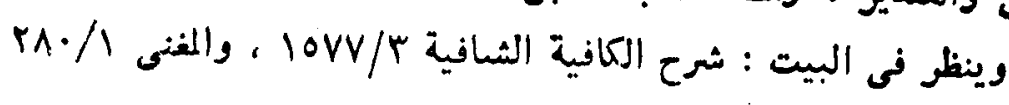

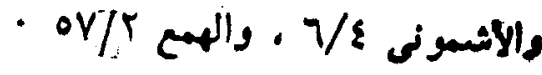




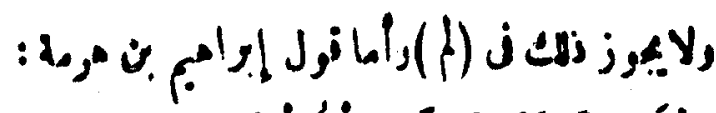

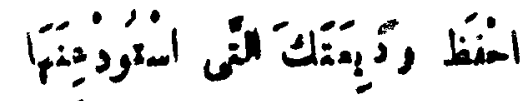

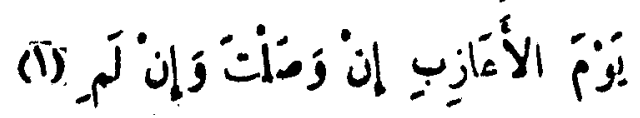

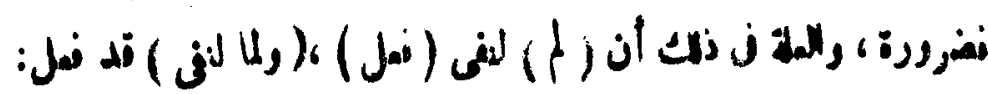

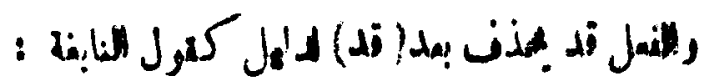

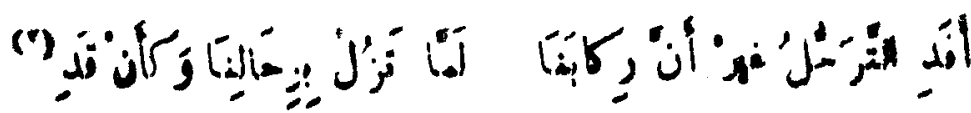

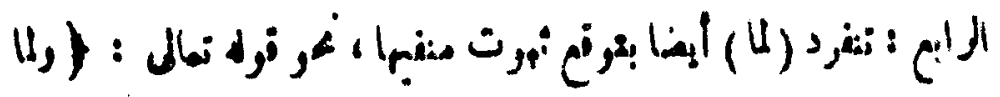

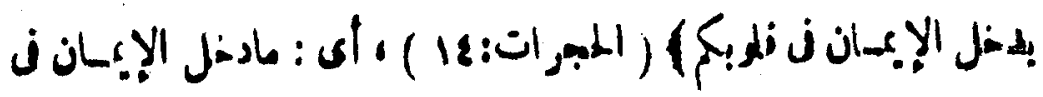

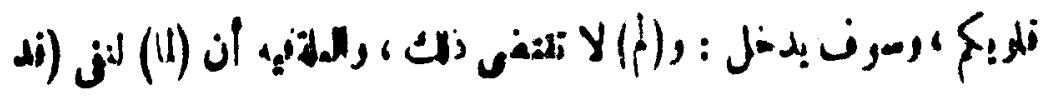

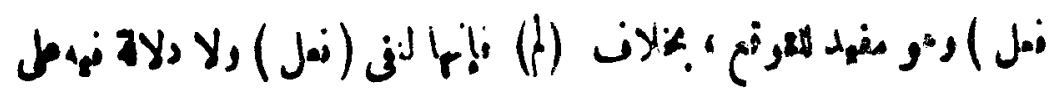

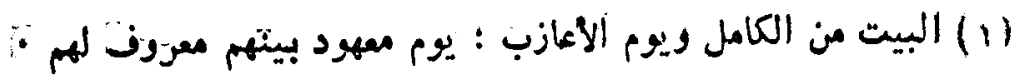

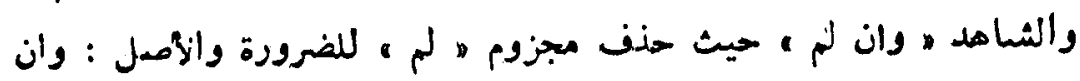

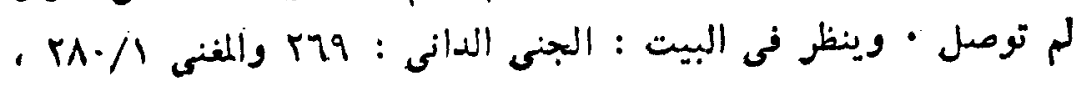

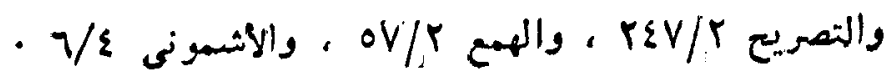

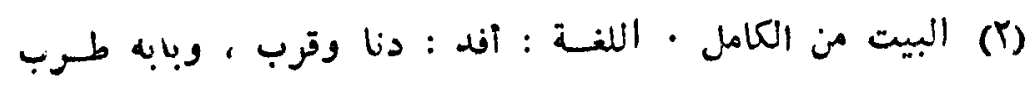

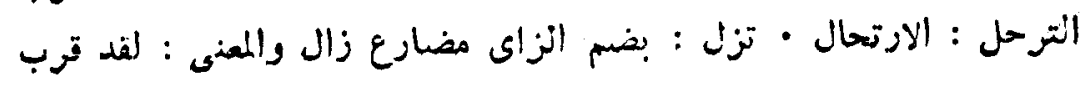

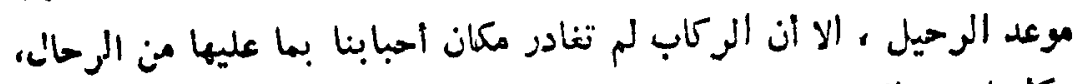

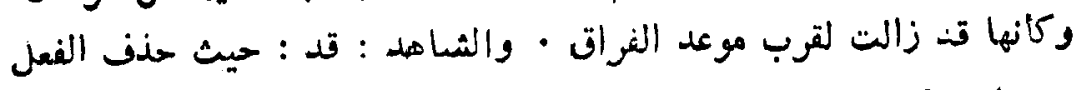

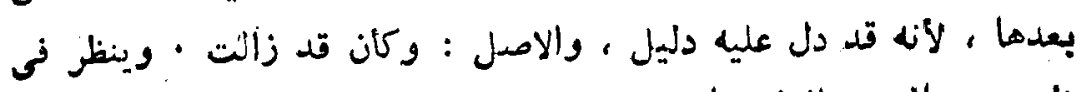

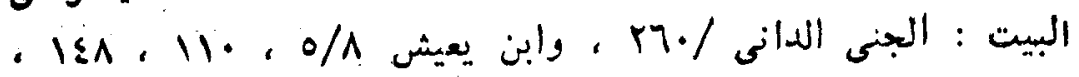
. • د 


\section{ip4}

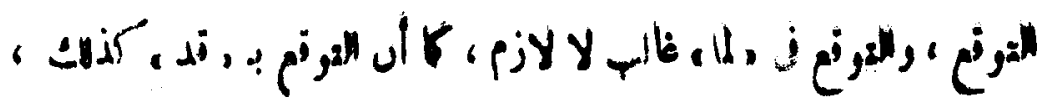

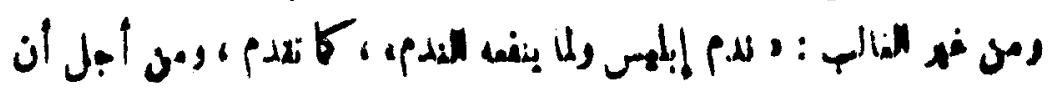

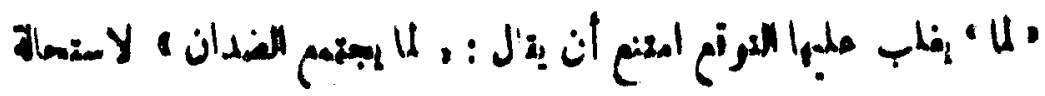

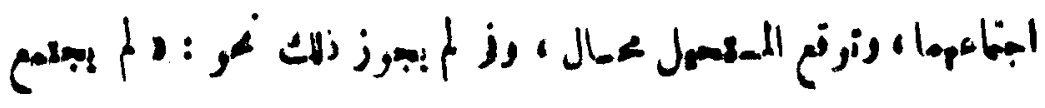
المندان ، المغان

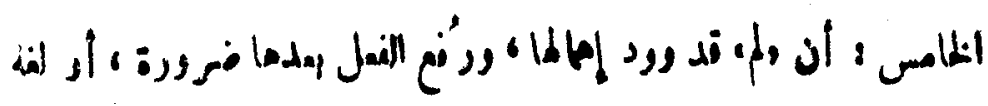

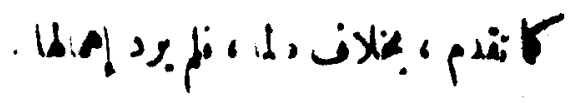

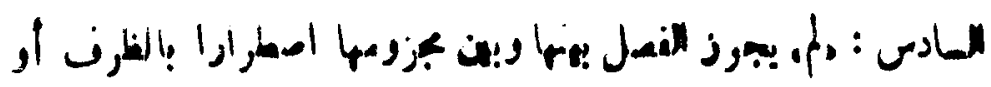

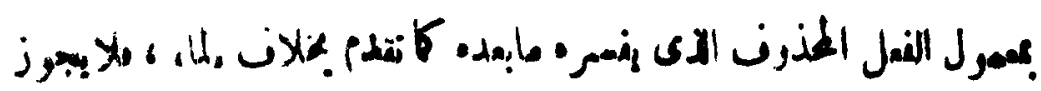

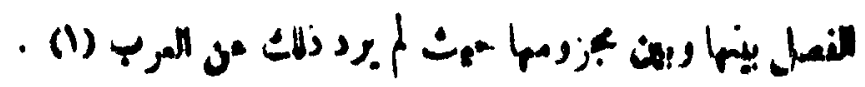

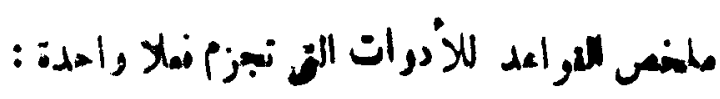

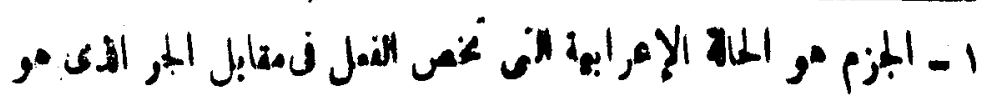

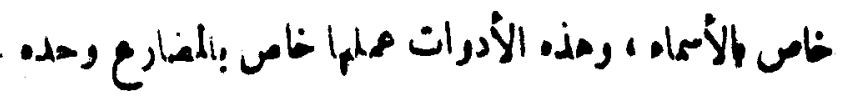

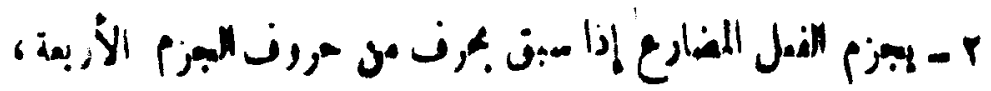

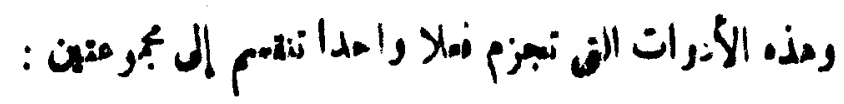

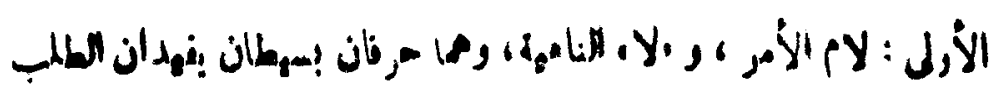

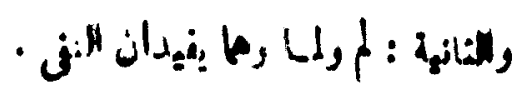

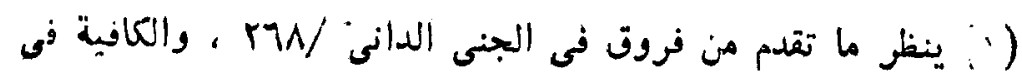

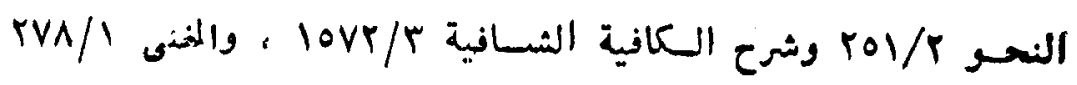

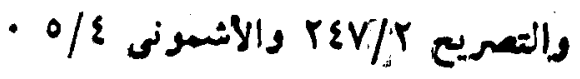




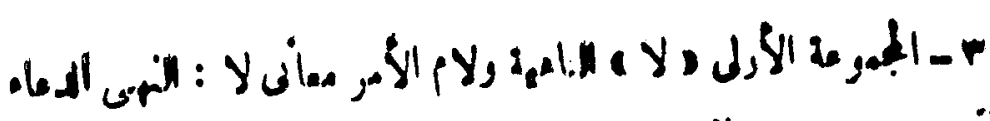

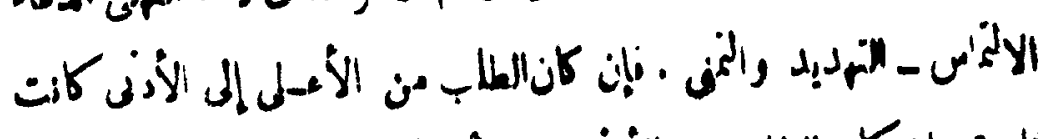

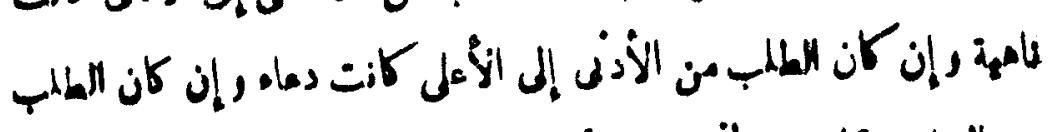

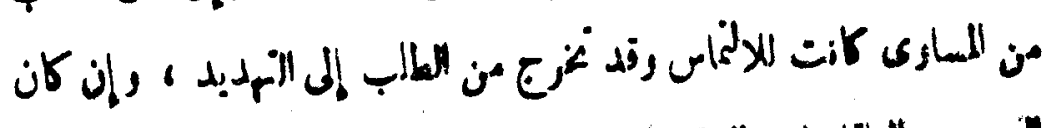
"

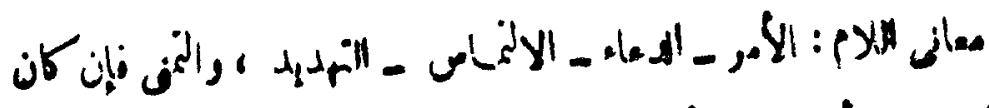

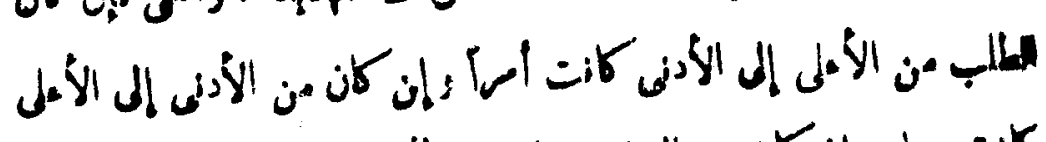

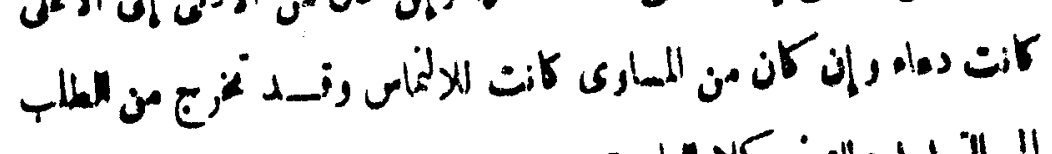

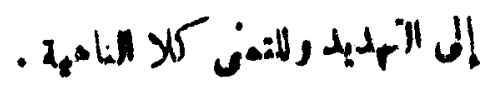

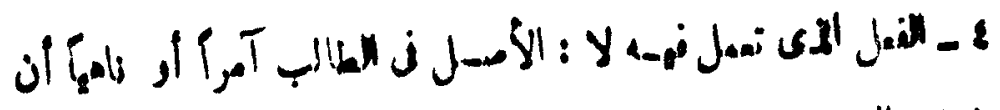

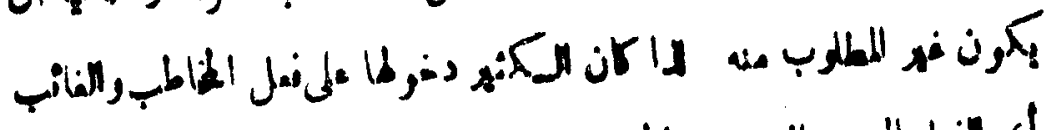

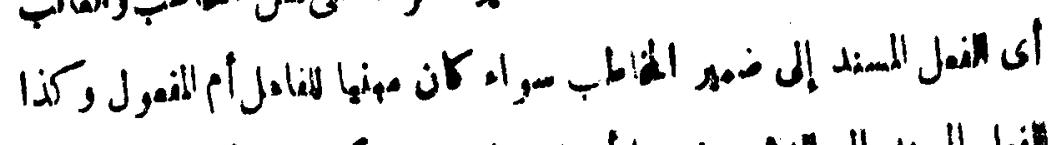

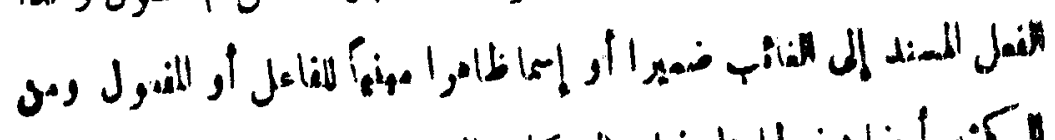

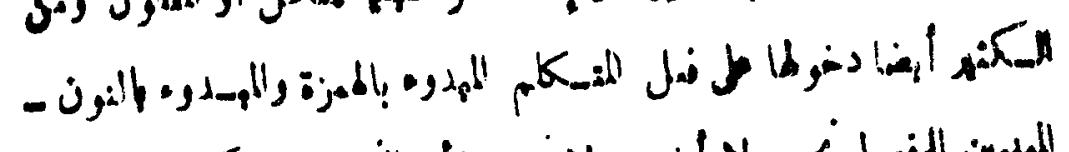

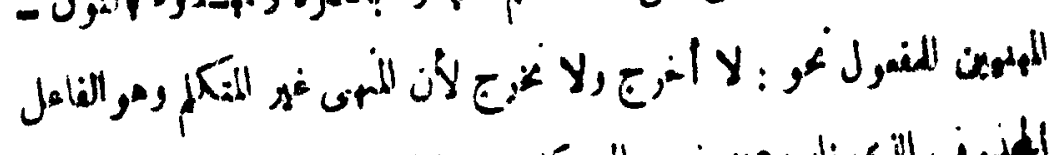

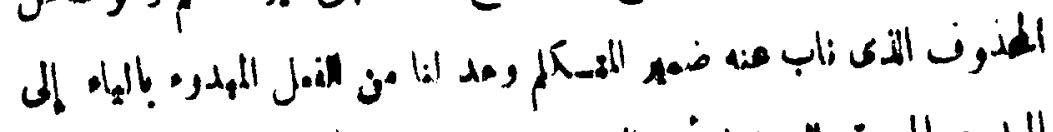

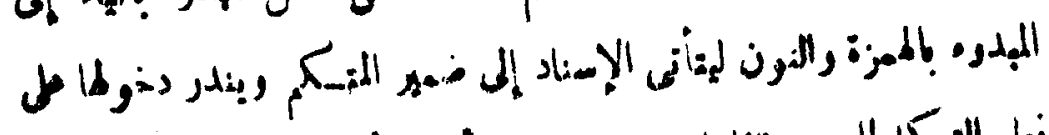

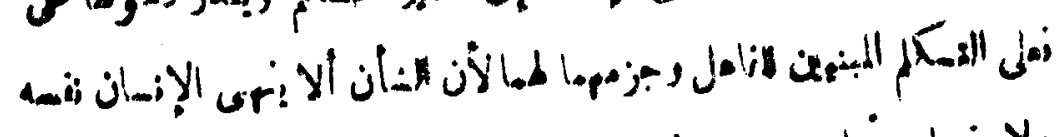

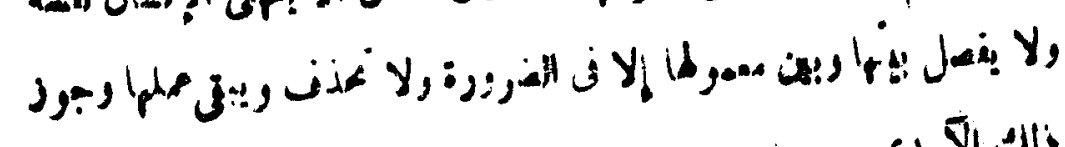
.

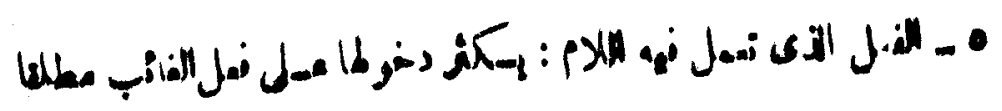




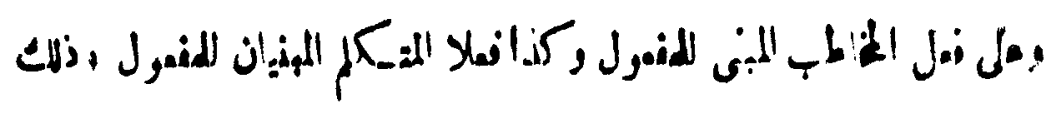

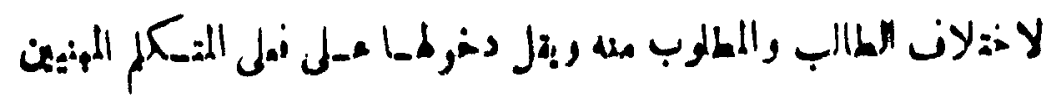

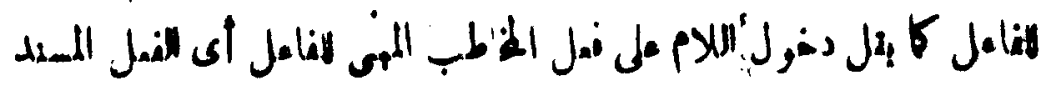

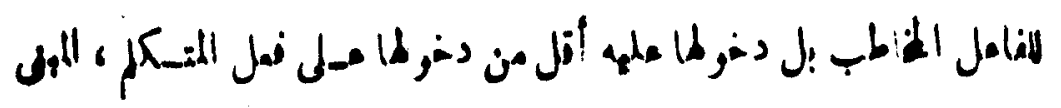

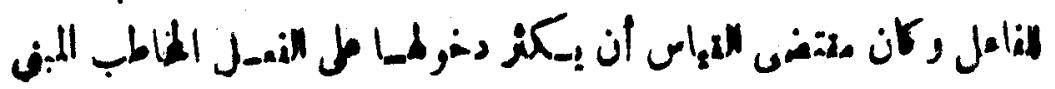

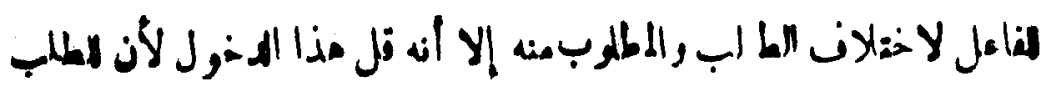

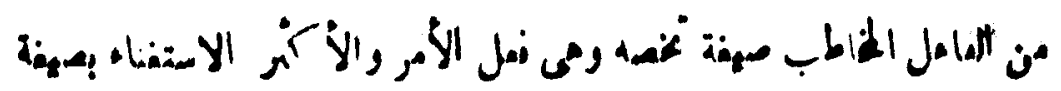

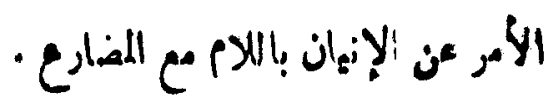

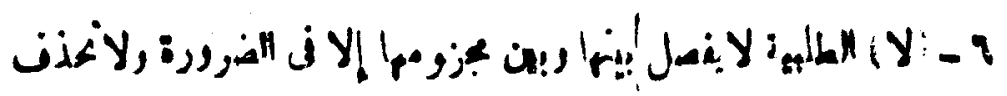

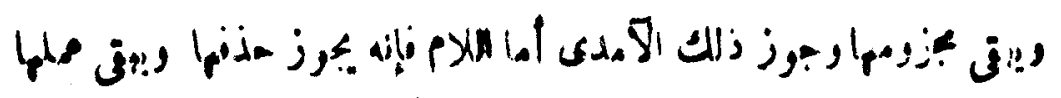

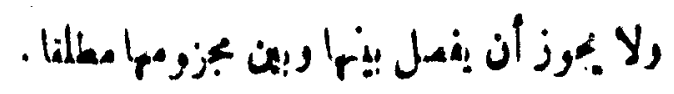

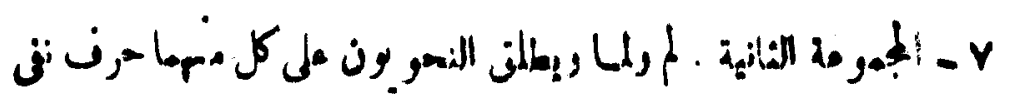

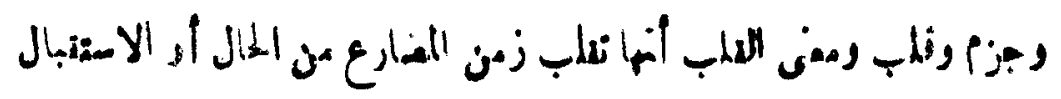

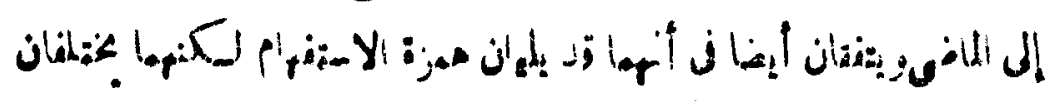

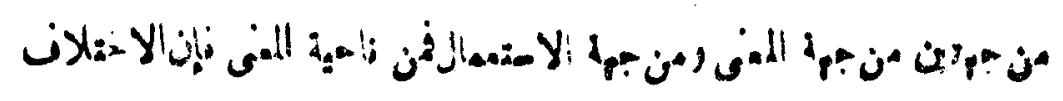

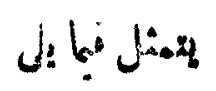

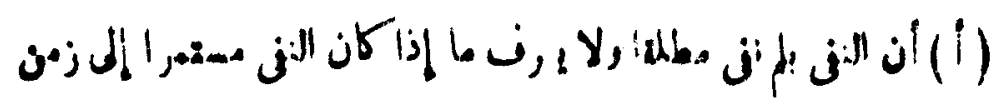

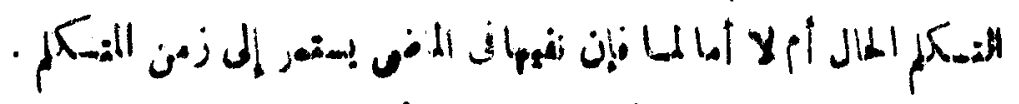

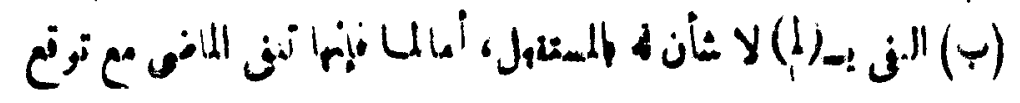

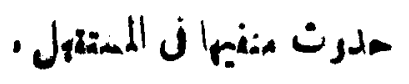




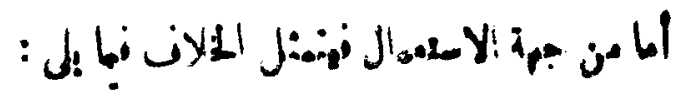

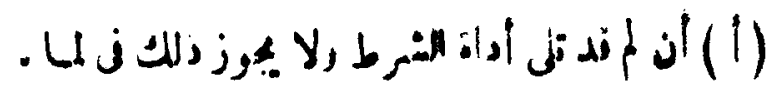

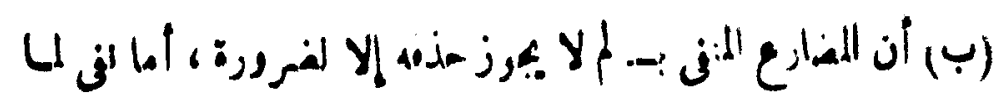

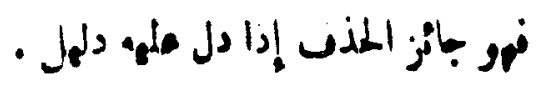

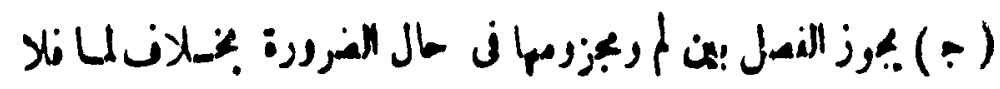

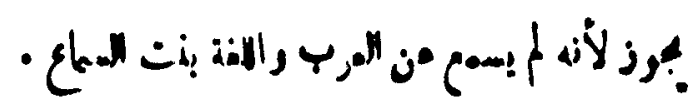

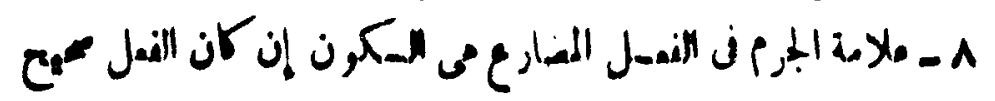

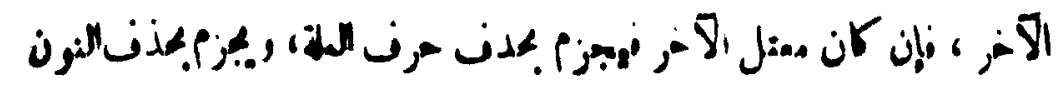

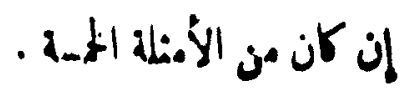

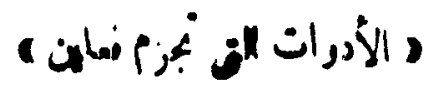

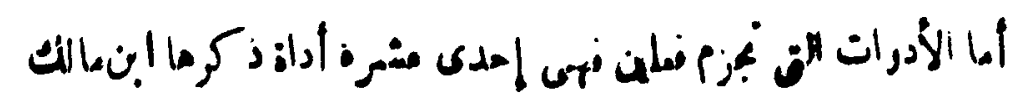
ز الألفه فنال .

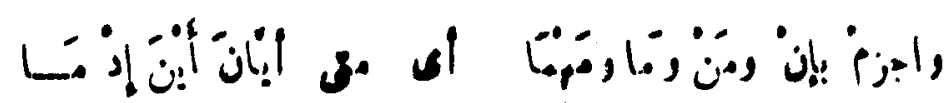

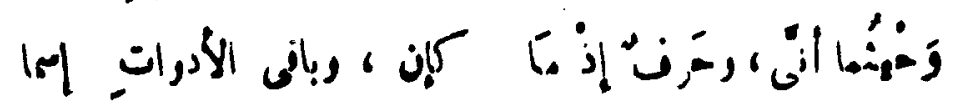

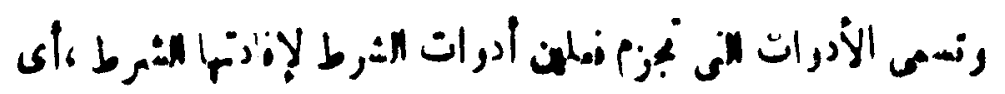

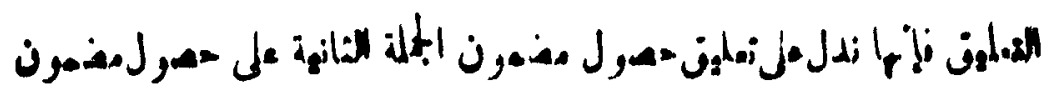
J)

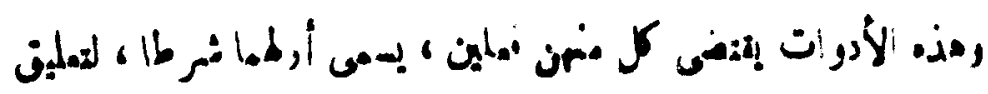

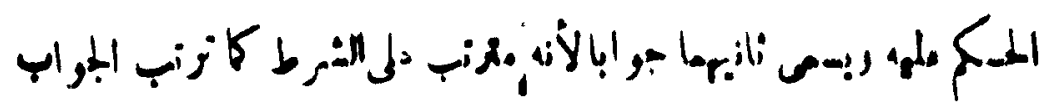

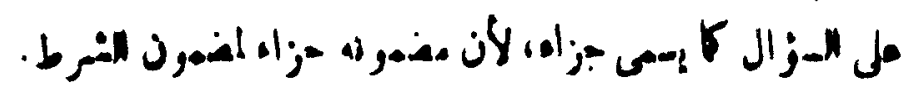

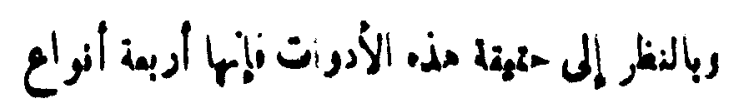


$18 \%$

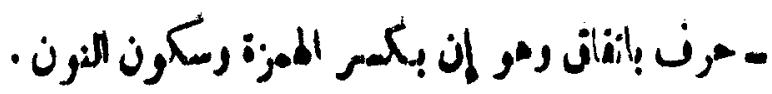

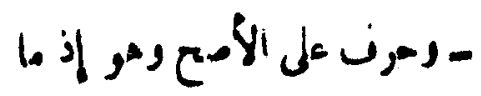

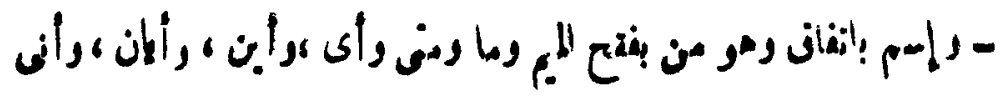

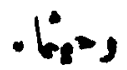

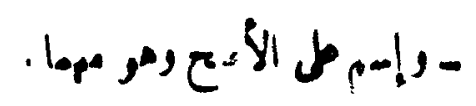

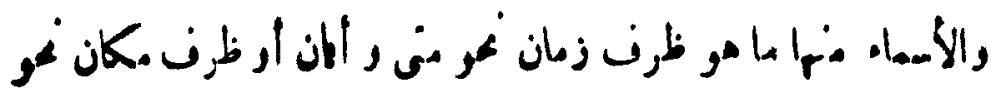

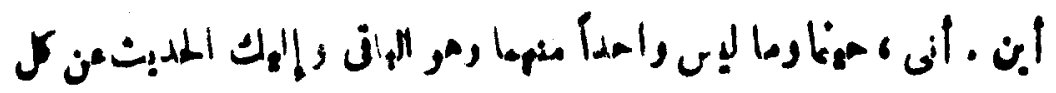

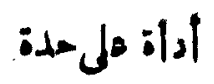

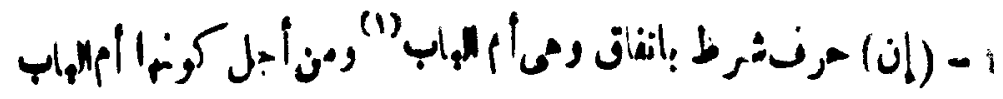

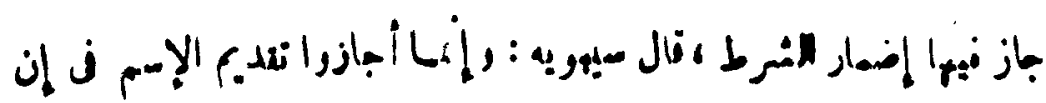

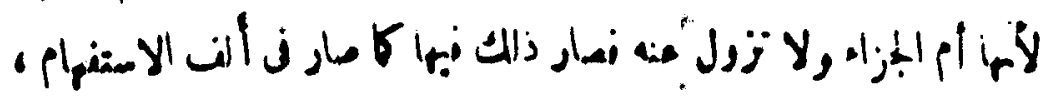

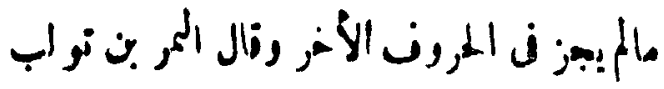

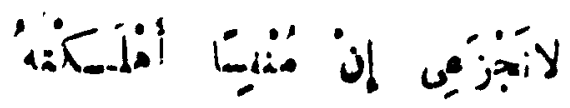

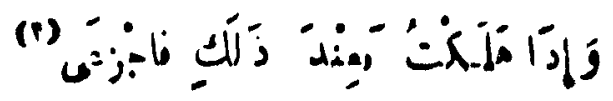

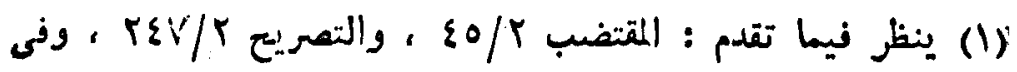

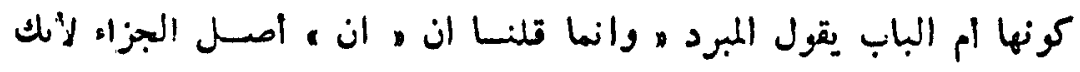

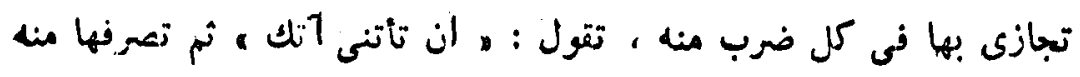

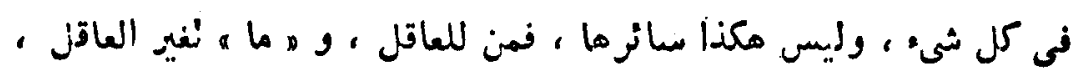

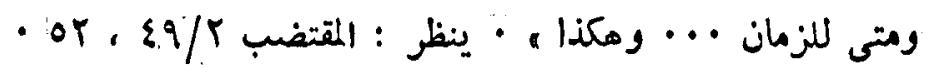

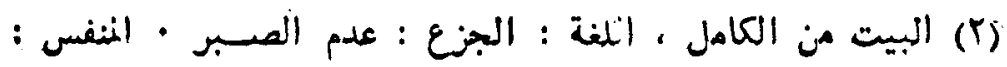




\section{1}

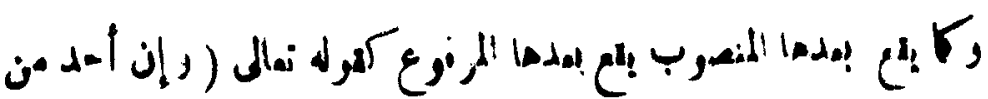

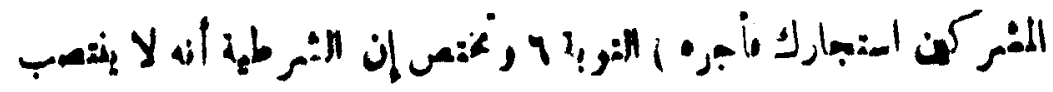

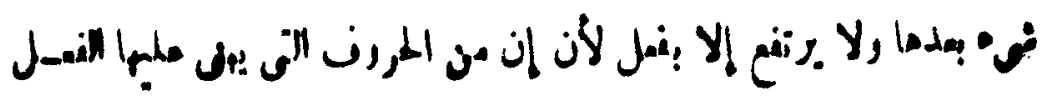

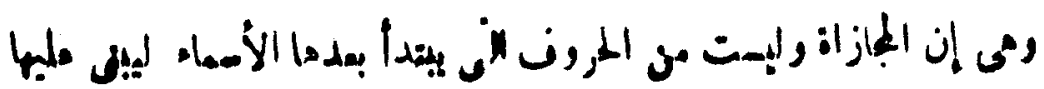

. الأسمان.

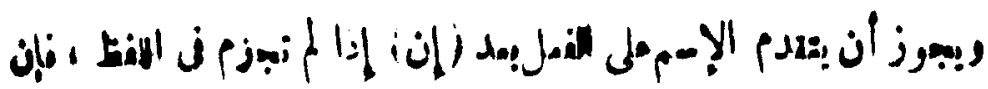

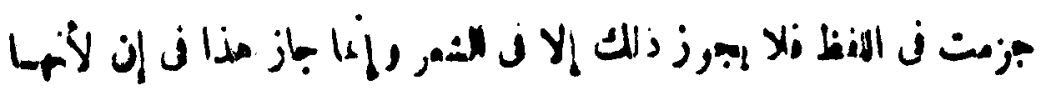

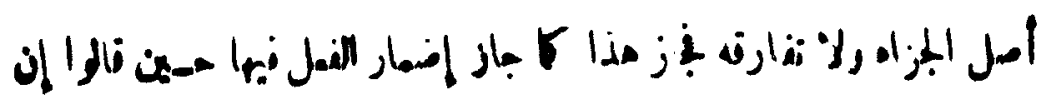

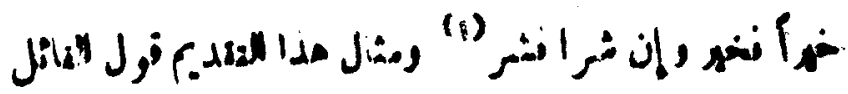

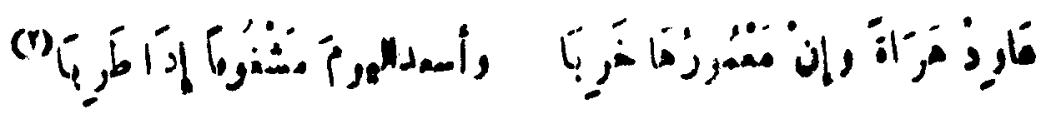

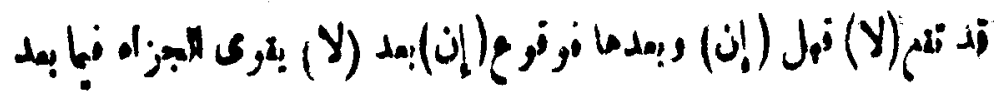

النفيس يتنافس فيه ويرغب · والمعنى ان زوجتسه لامته علي اتلاف ماله

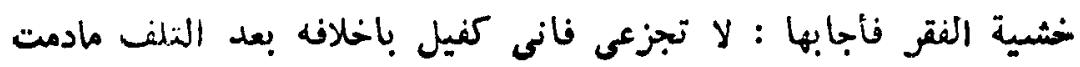

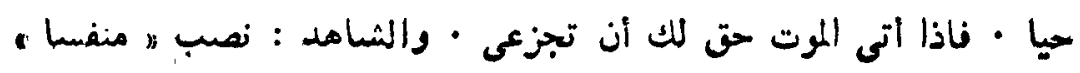

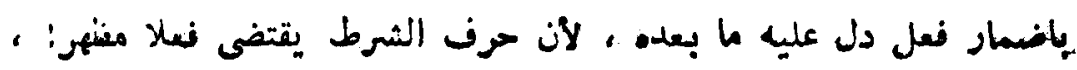

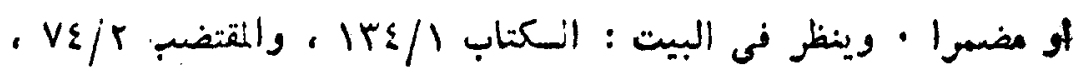

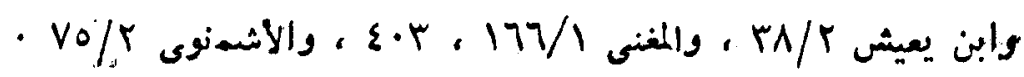

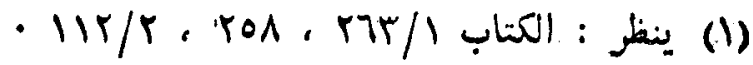

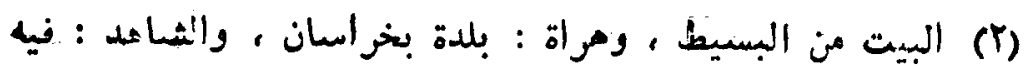

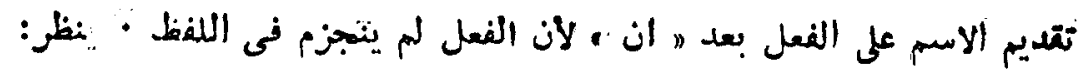

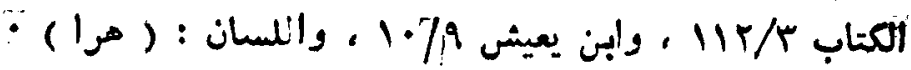




\section{\&o}

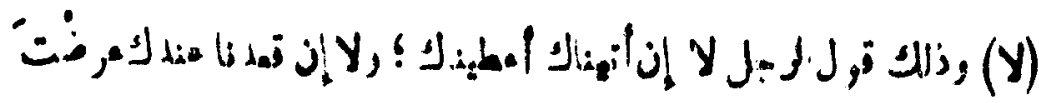

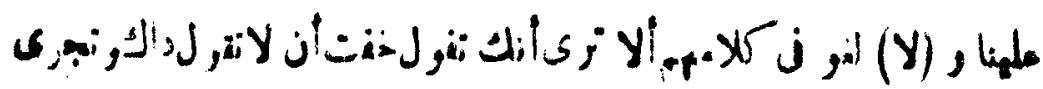

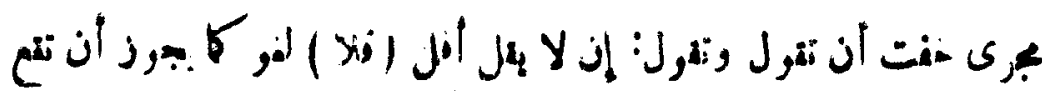

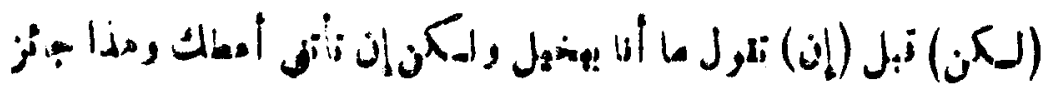
(1) :

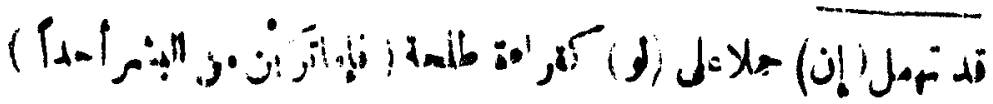

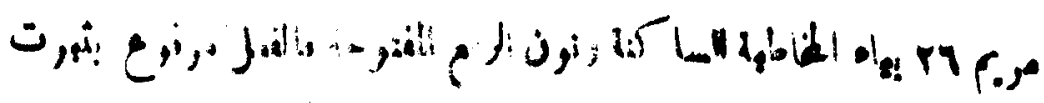

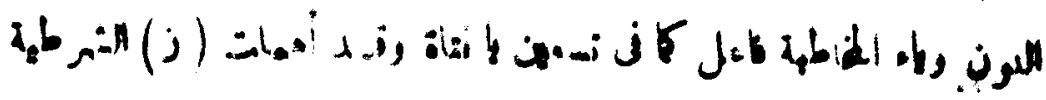

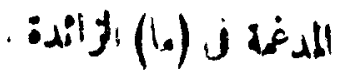

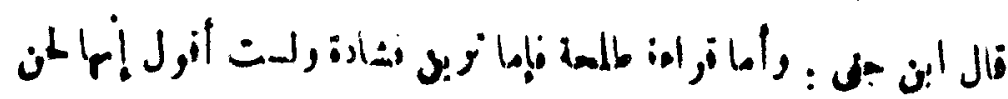

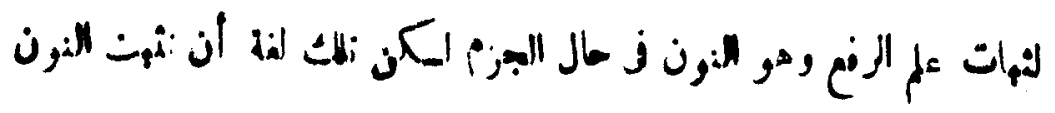

(I)

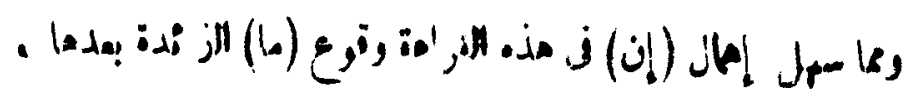

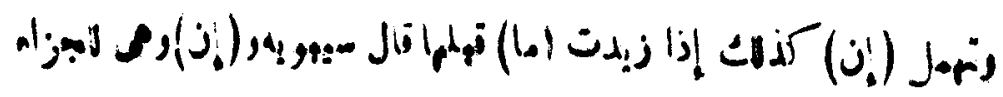

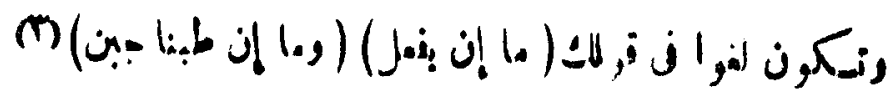

- VV/r ينظر الكتاب (1)

• $2 r / r:$ :

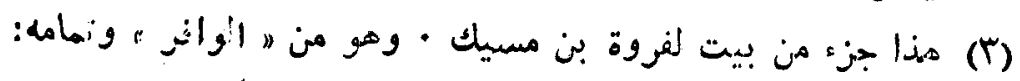

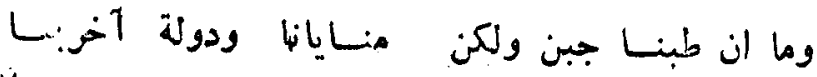

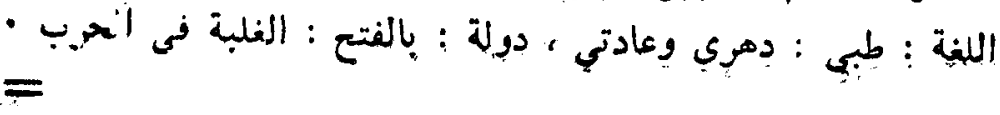




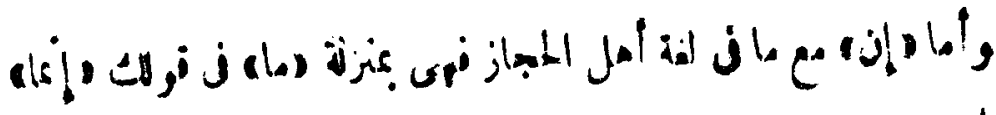

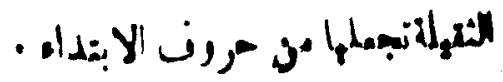

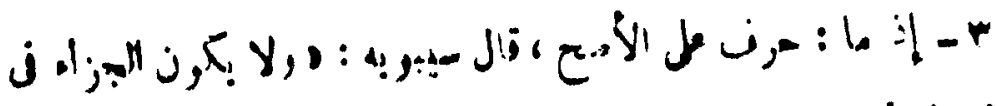

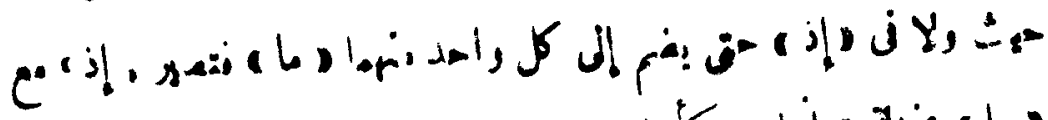

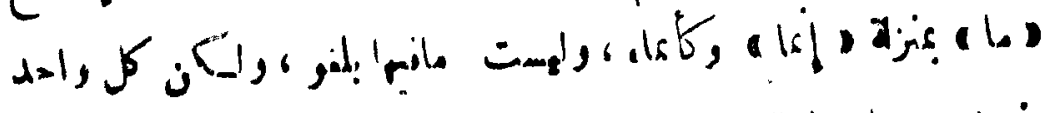

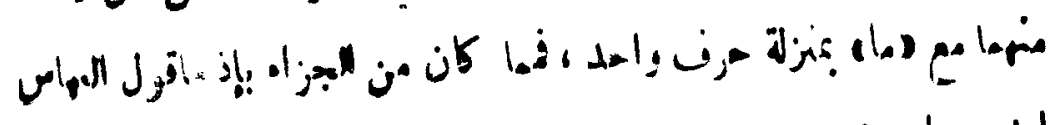

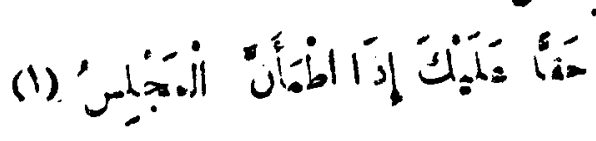

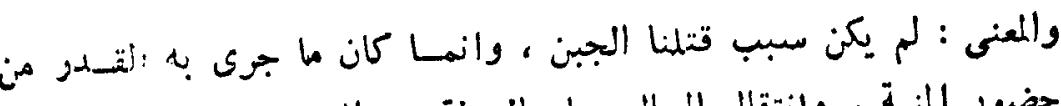

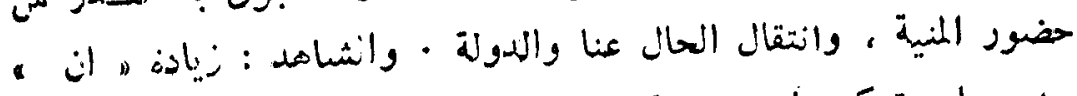

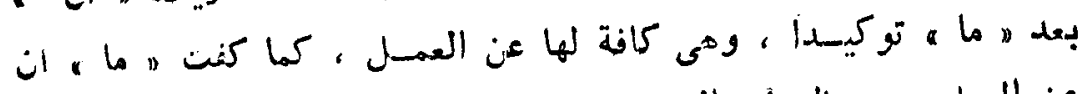

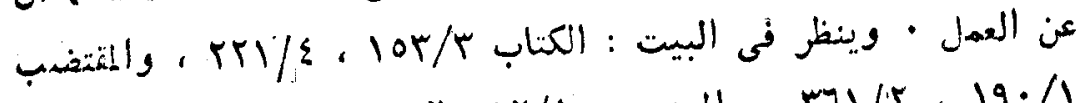

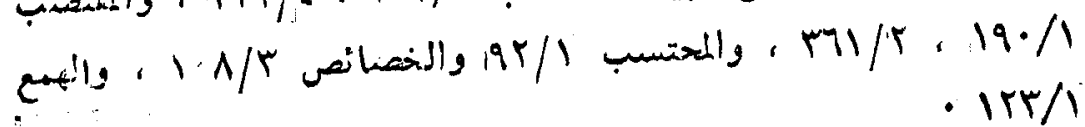
$i$

(1) البيت من الكامل ، والمجلس : ألناس ، او المراد أهل المجلس.

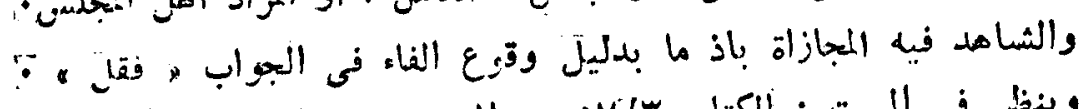

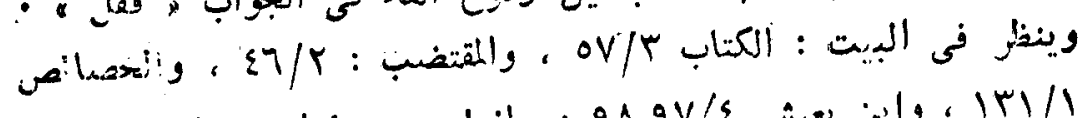

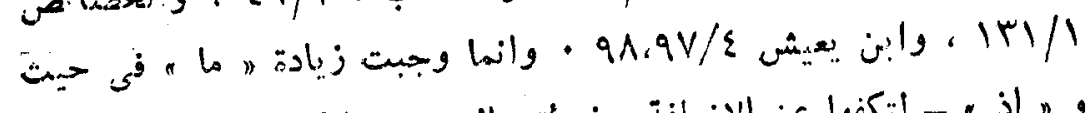

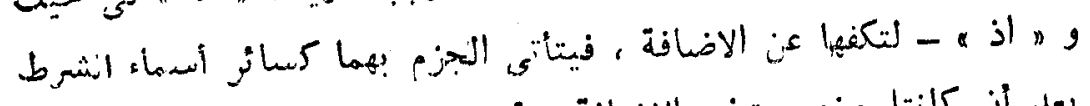

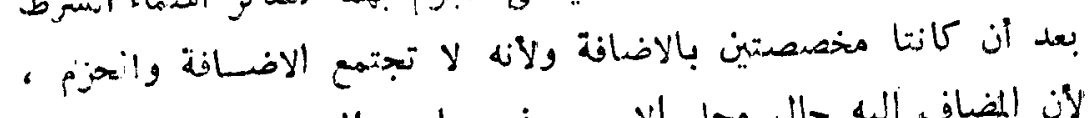

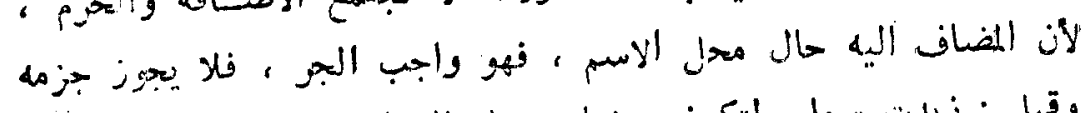

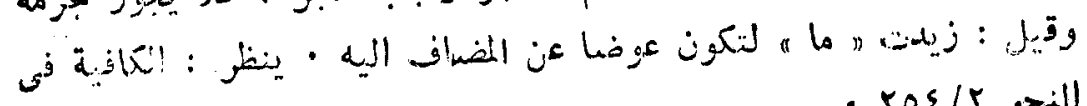




\section{(I)}

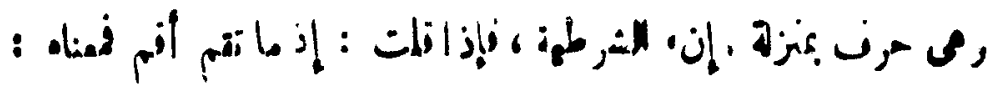

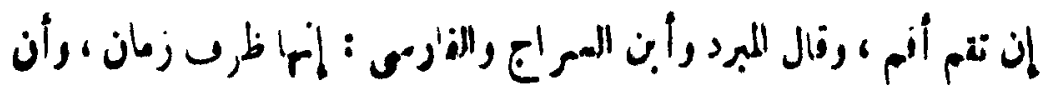

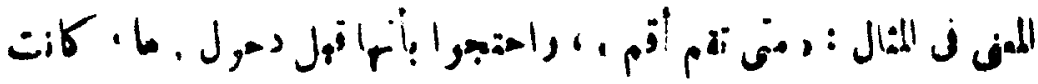

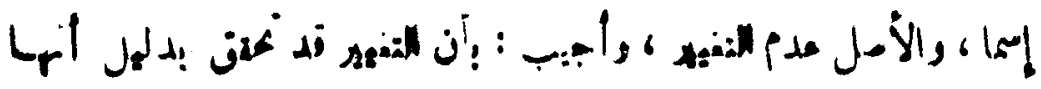

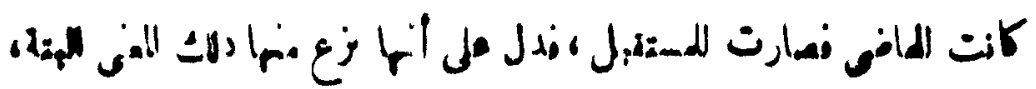

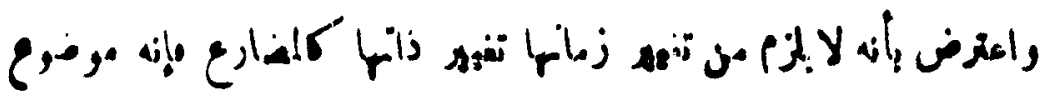

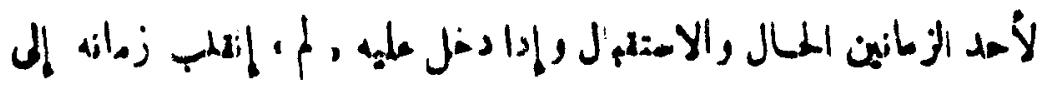

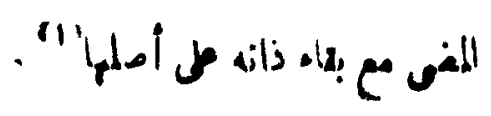

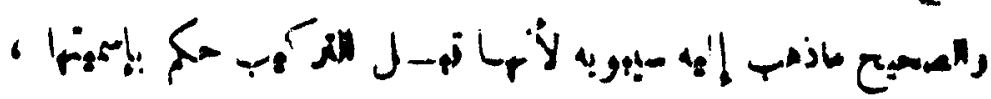

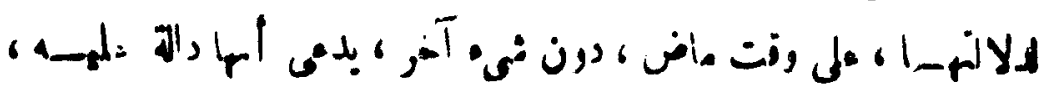

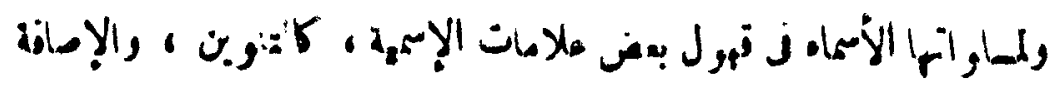

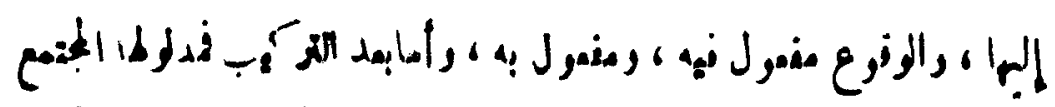

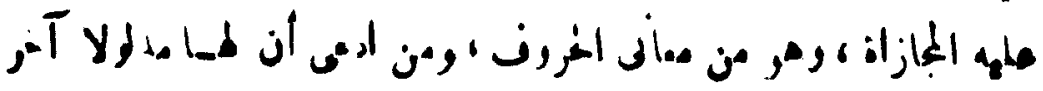

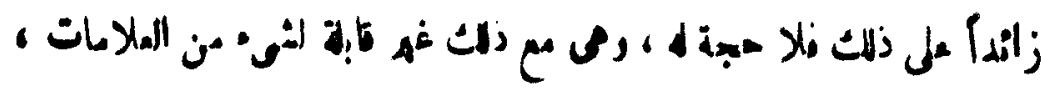

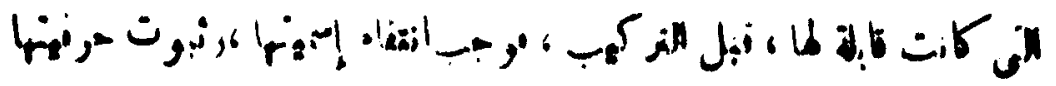

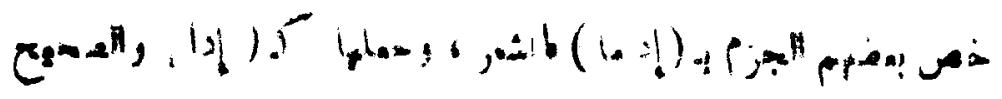

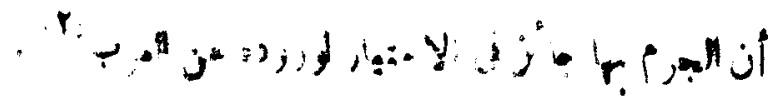

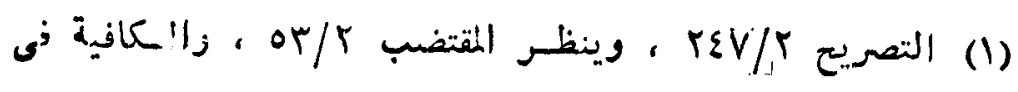
النحو ror/T ror

• 191/ (r) ينظر : الجنى الندانى 


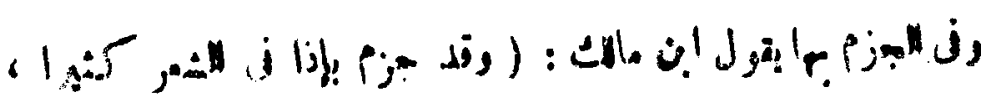

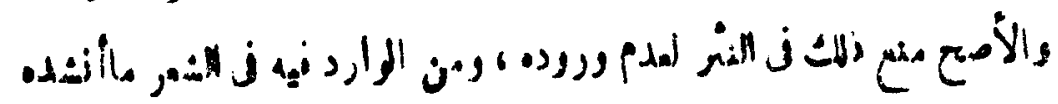

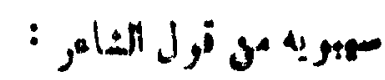

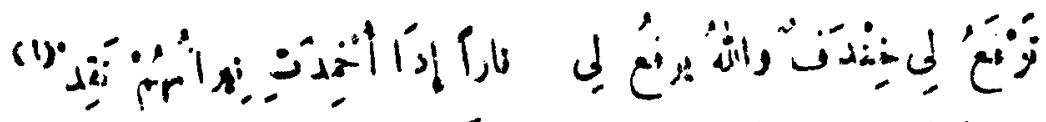

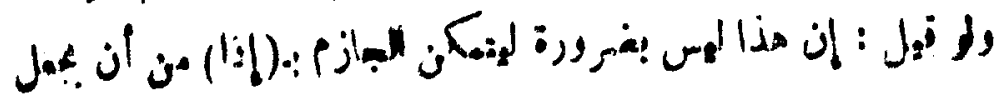

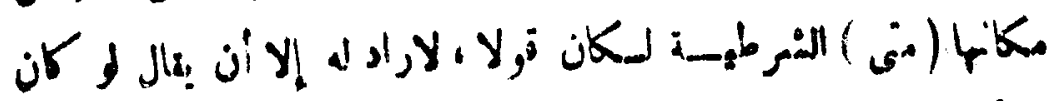

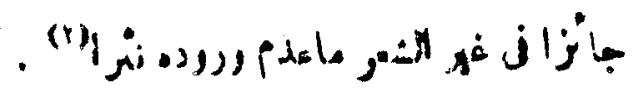

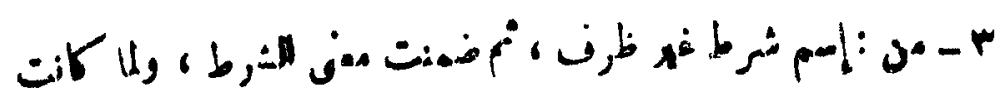

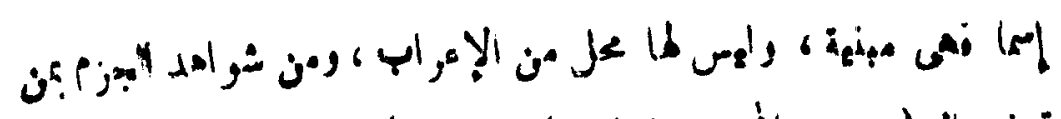

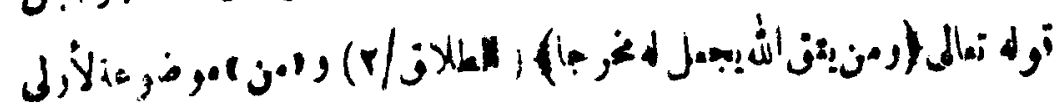

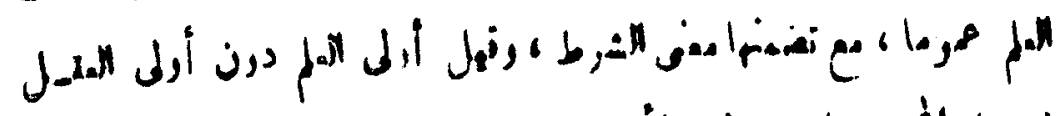

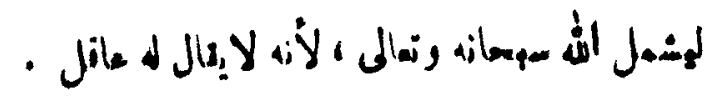

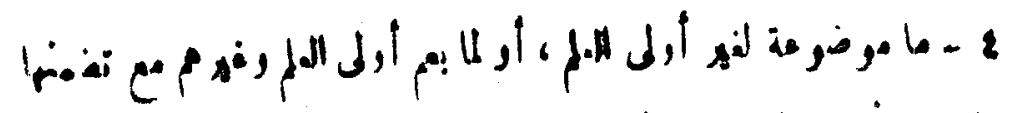

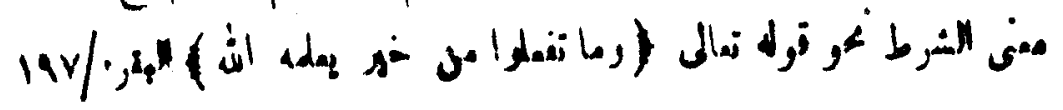

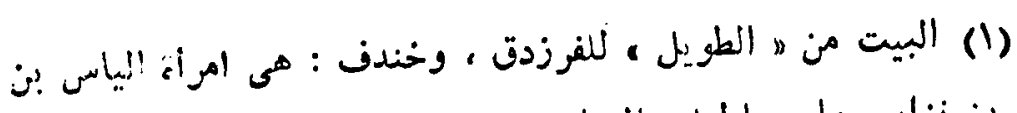

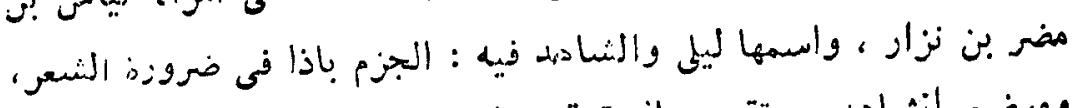

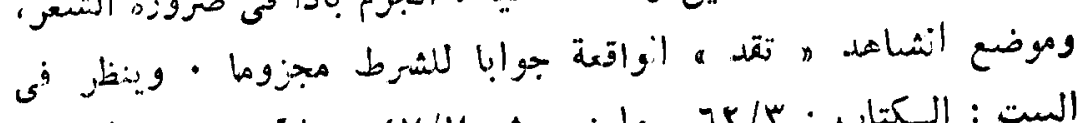

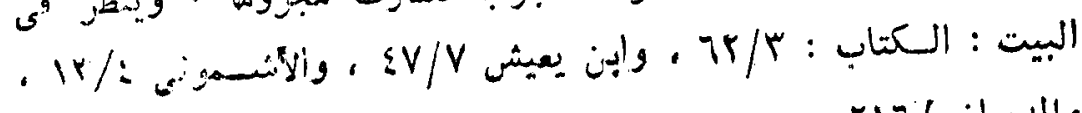

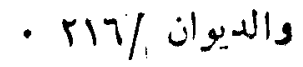

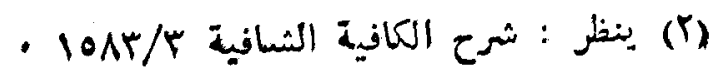




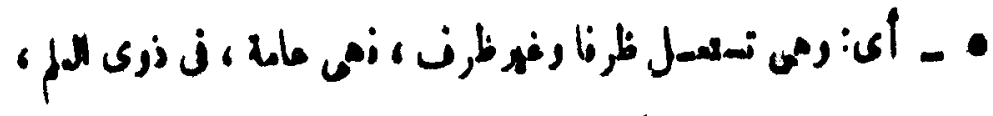

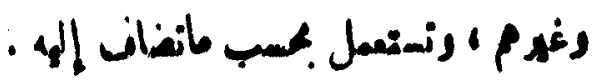

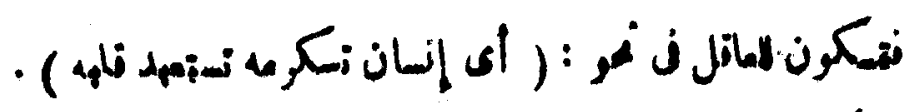

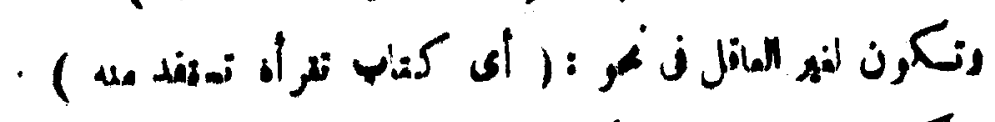
ون

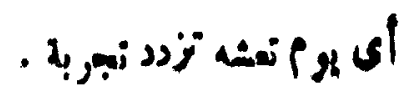

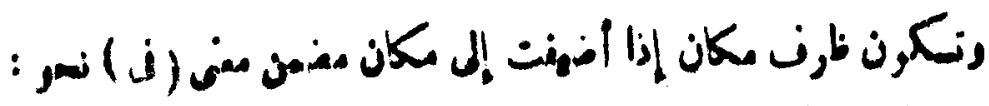

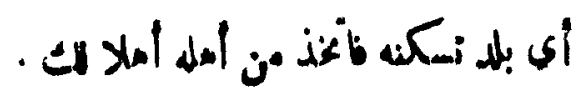

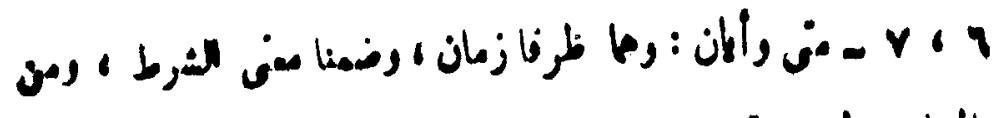

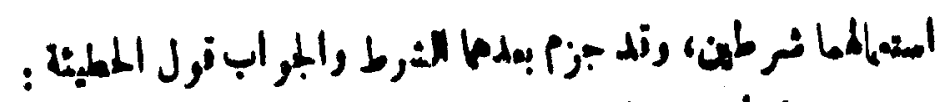

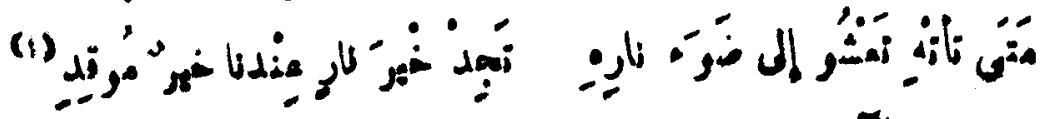

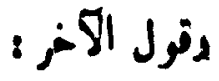

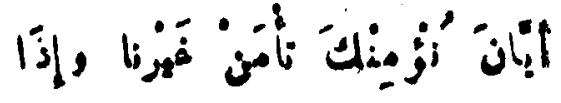

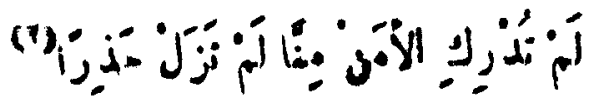

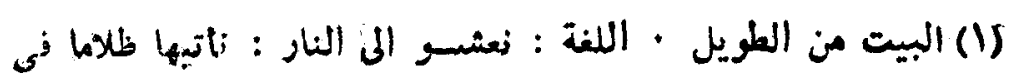

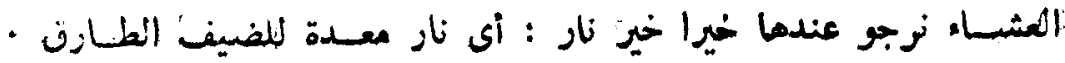

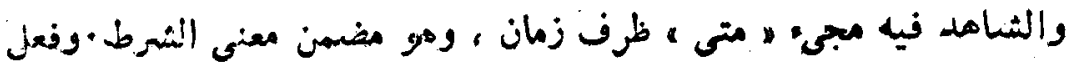

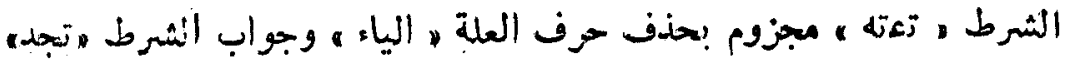

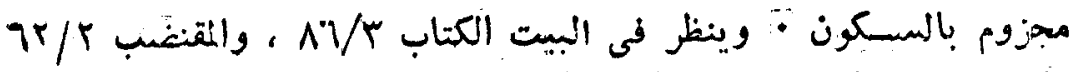

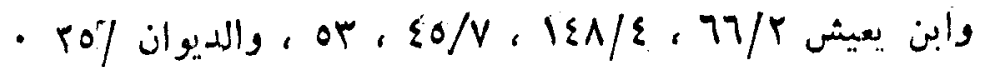
(r)

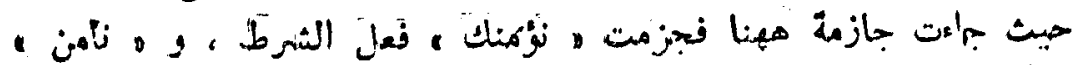

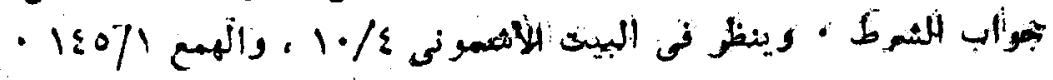
$(j-r q)$ 


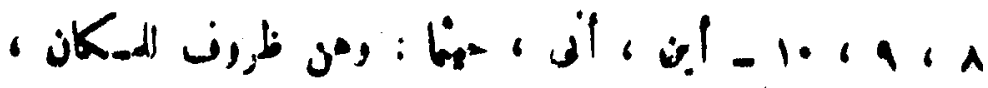

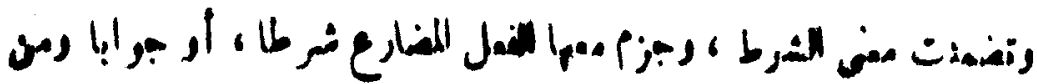

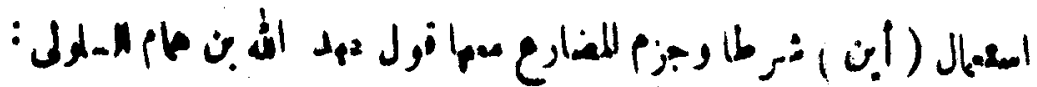

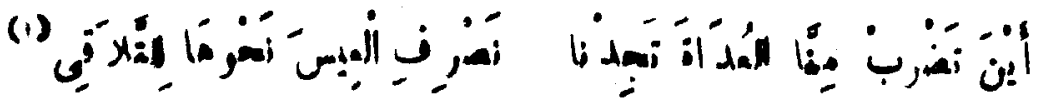

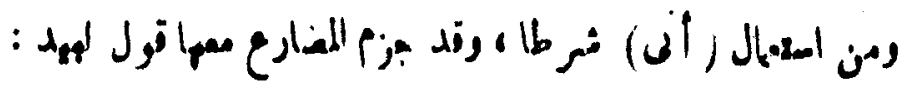

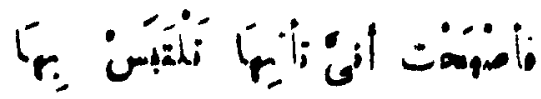
(V)

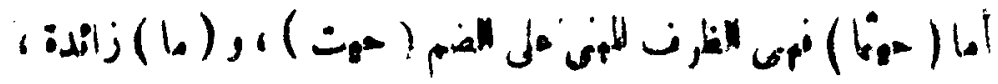

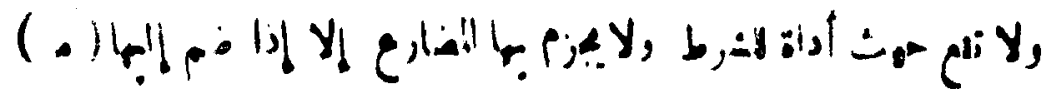

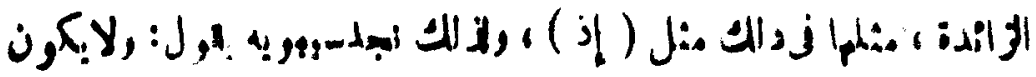

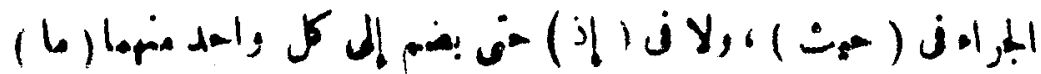

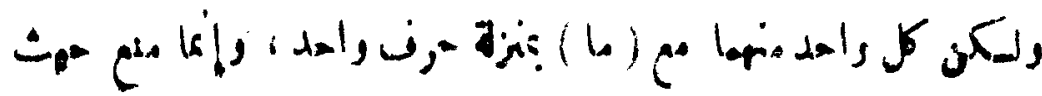

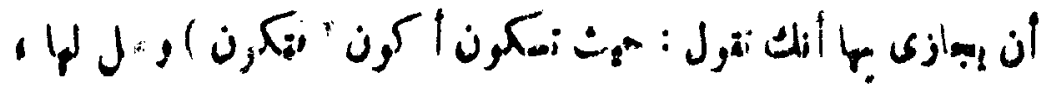

(1) البيت من الخفيف ، اللغة : العداة : بضم العين جهم عاد كقاض

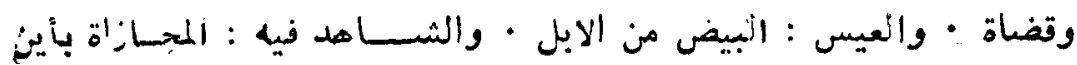

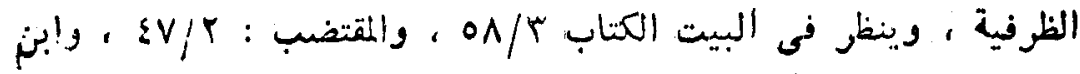

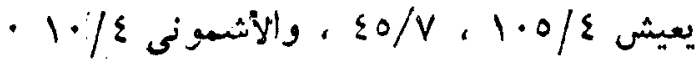

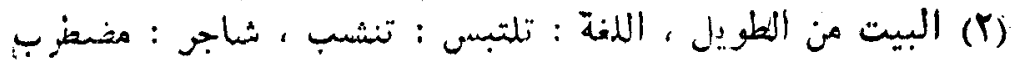

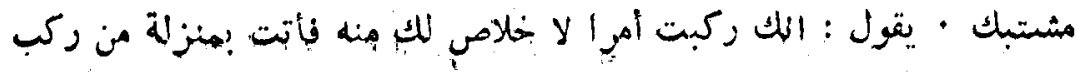

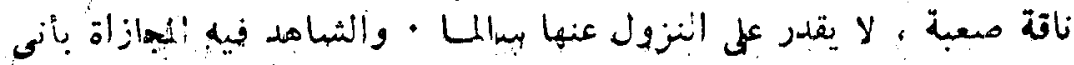

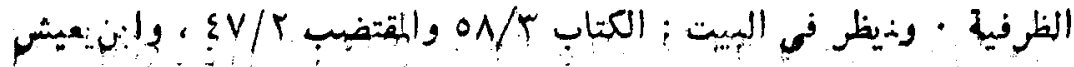
: $7 . \%$, w 


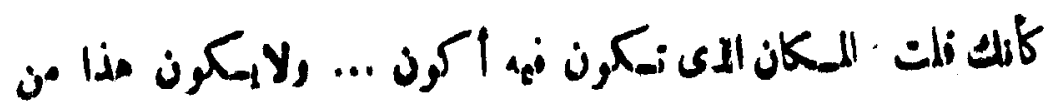

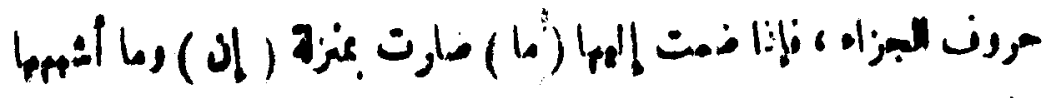

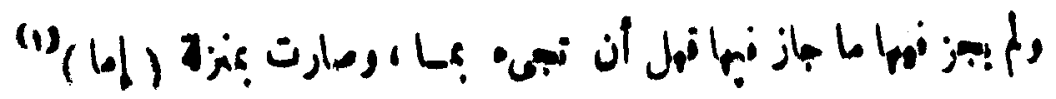

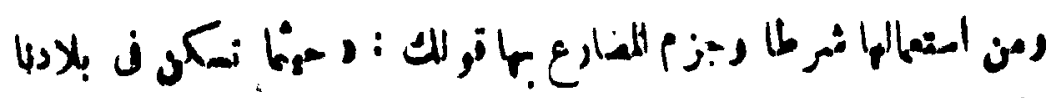

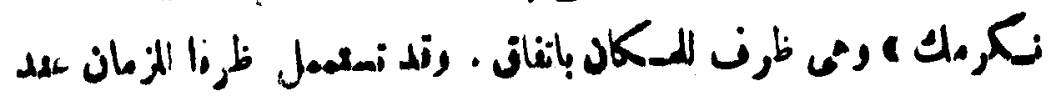

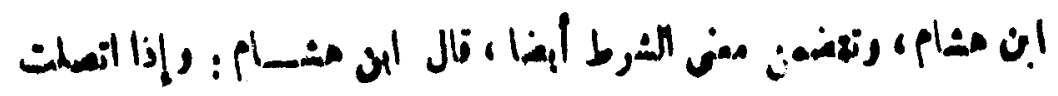

:

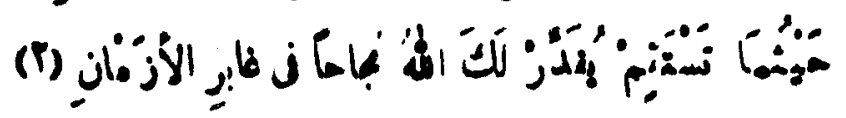

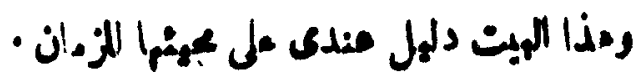

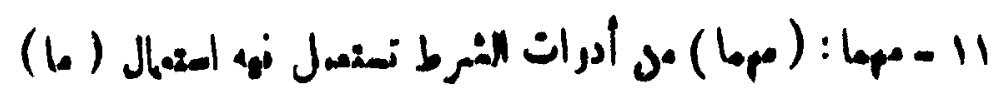

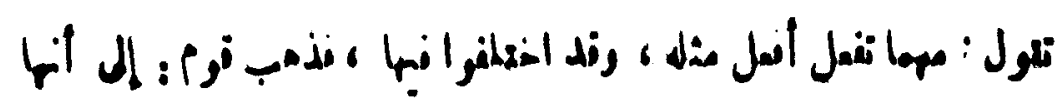

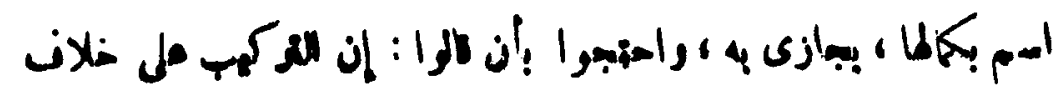

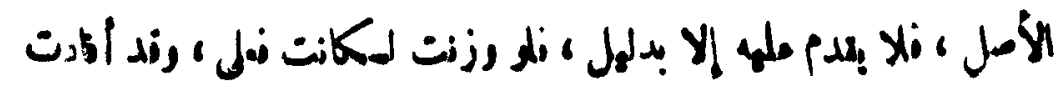

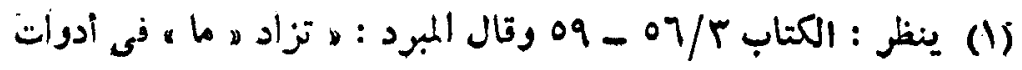

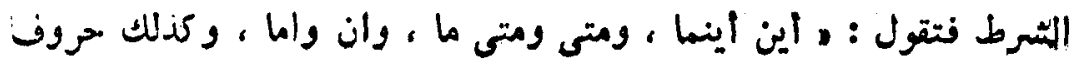

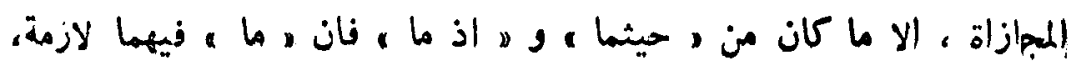

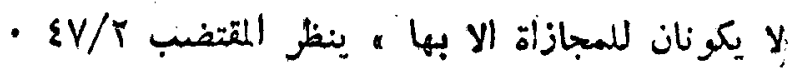

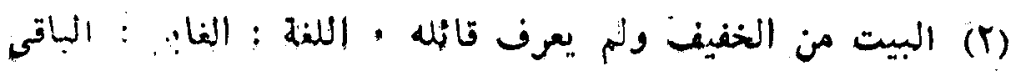

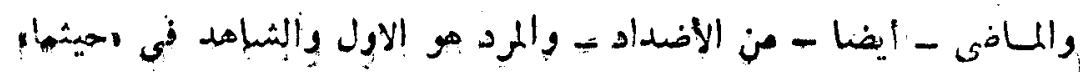

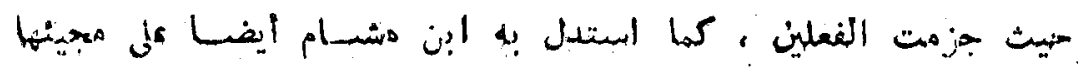

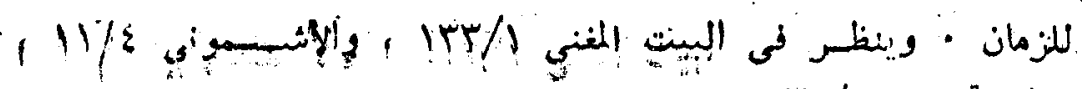

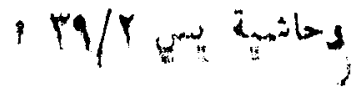




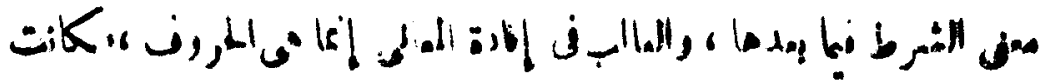

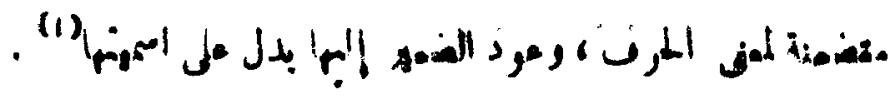

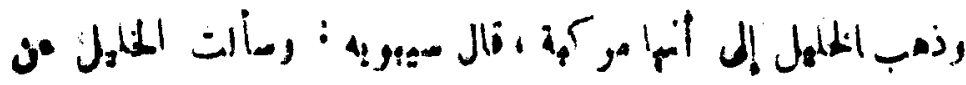

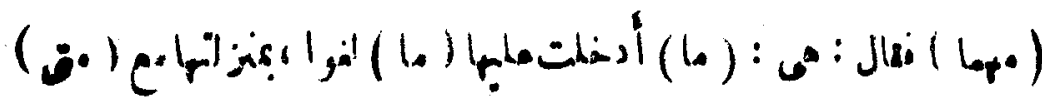

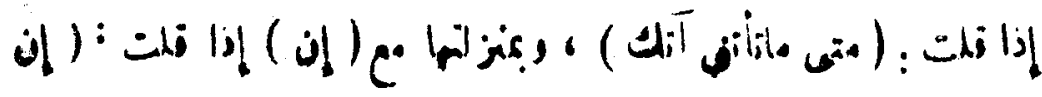

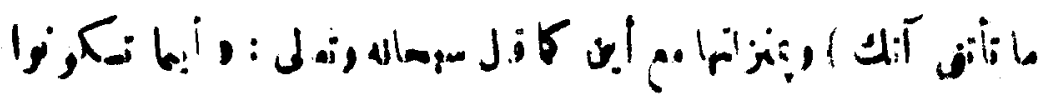

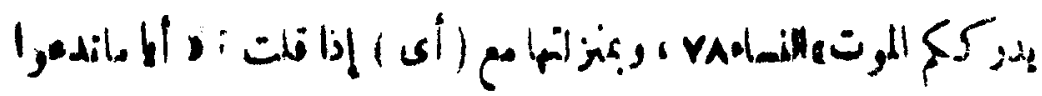

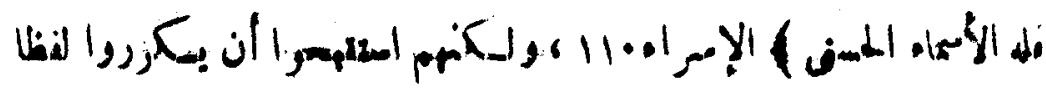

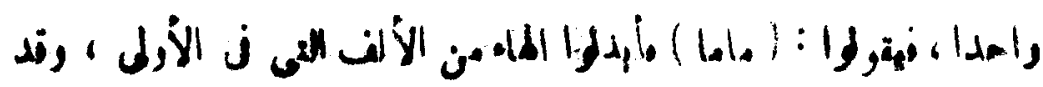

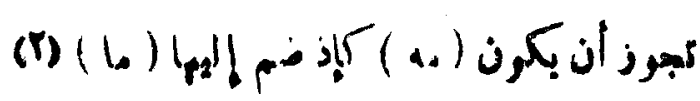

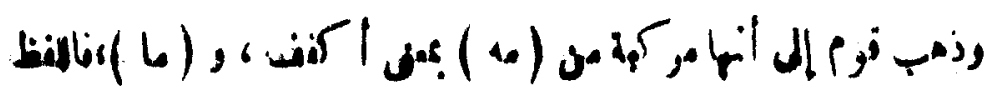

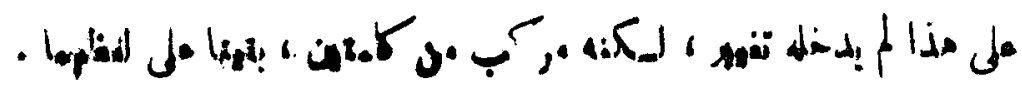

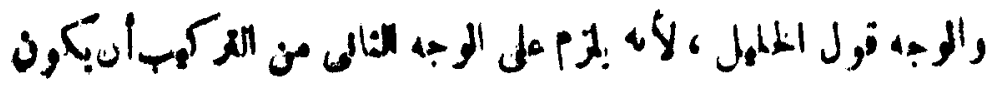

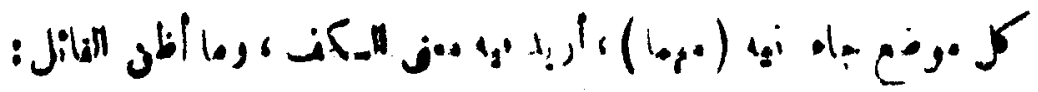

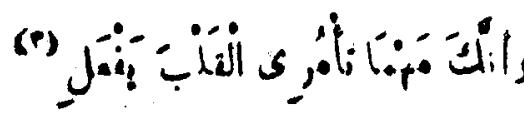

(1) ينظر ابن يعيش (I) •

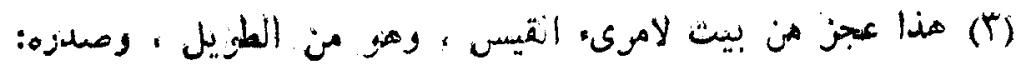

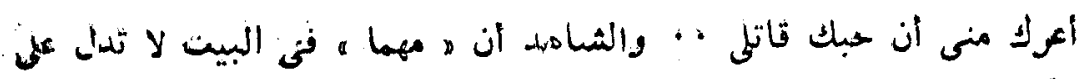

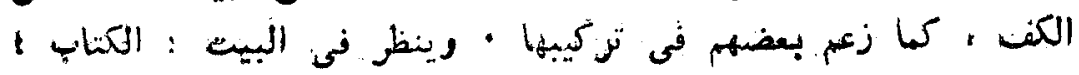
• rII/Y 


\section{Sor}

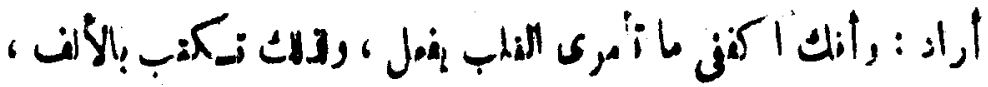

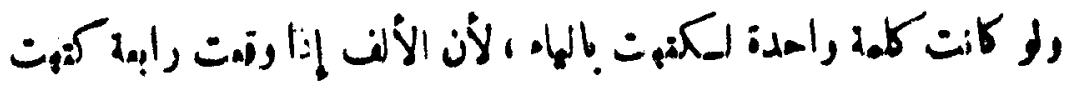

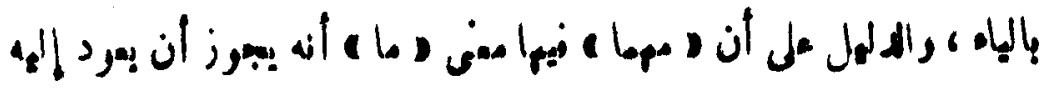

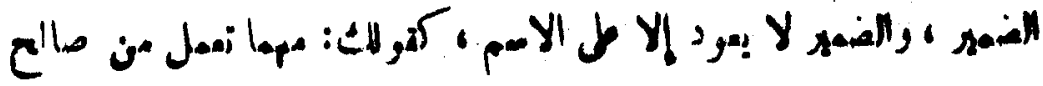

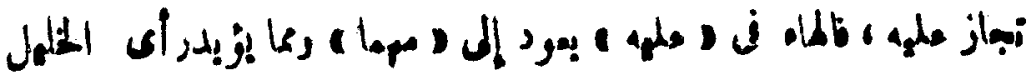

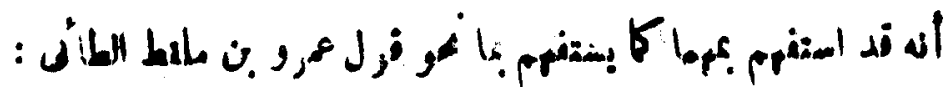

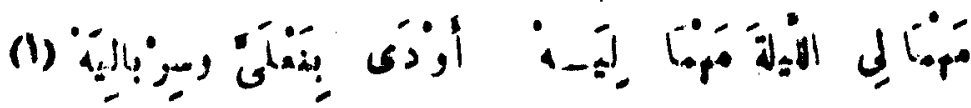

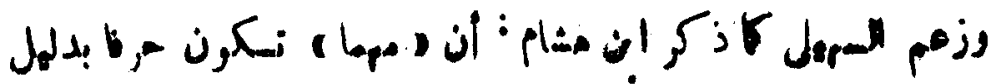

: ankoj $+j \mathrm{j}$

(v) أن

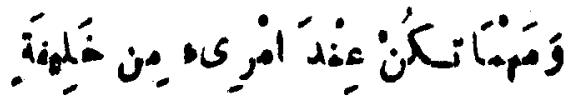

(البيت من : ألسريع " اللاغة : أودى : هلك ، وفعلى فاعلى وأبناء

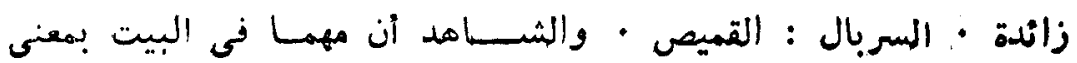
الاستفهام وينظل فى البيت ابن يسيش

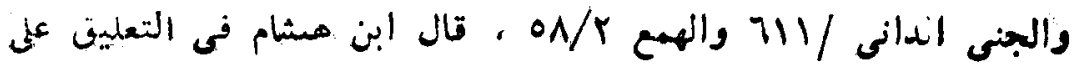

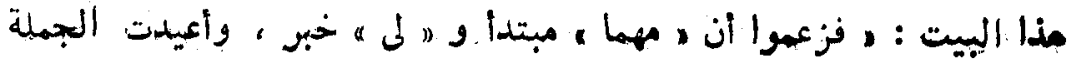
توكيدا ،ولا دليل فى البيت لاحتمال أن التقدير "ه مه ه اسم فعنز بجعنى اكفف ثم استأنف استفهاما بما وحلهها • المغنى

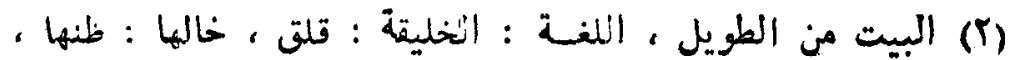

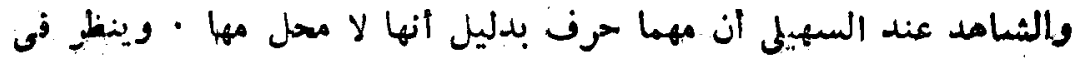

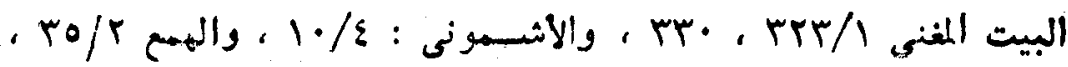

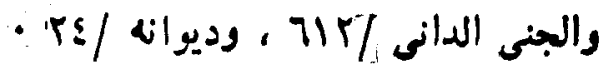




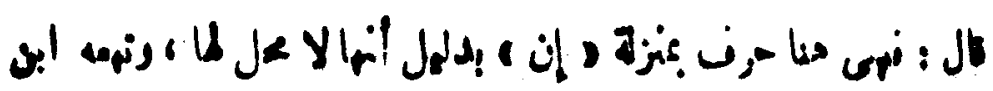

(1)

$$
\begin{aligned}
& \text { بعeرن ، راسعدل بعره : }
\end{aligned}
$$

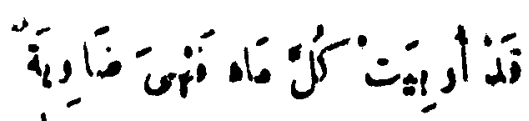

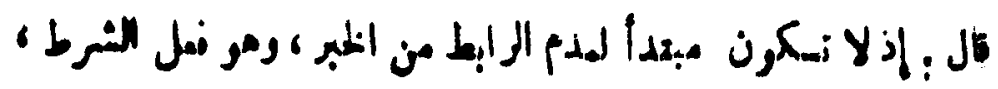

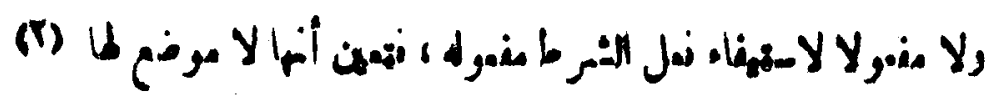

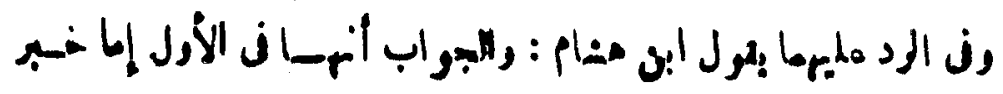

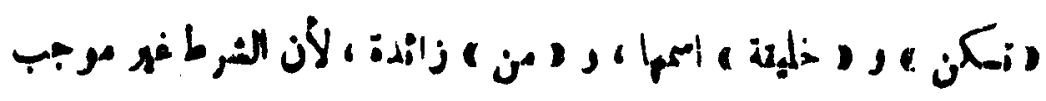

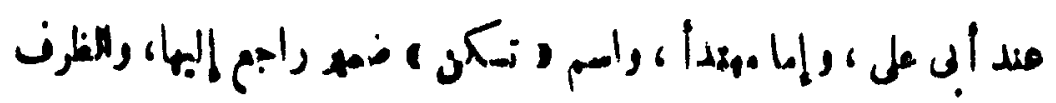

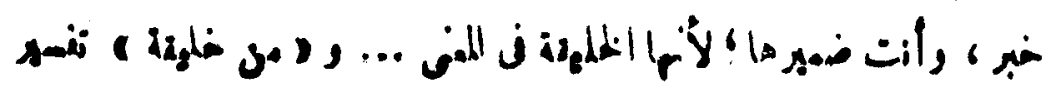

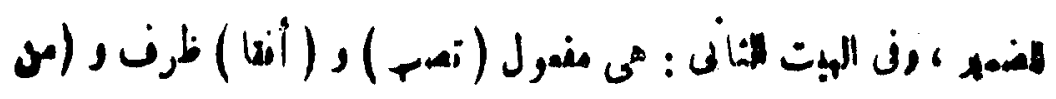

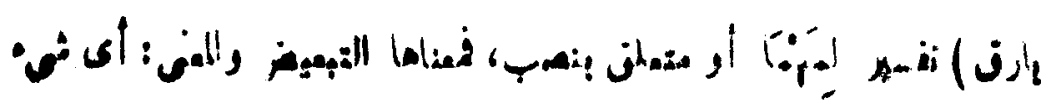

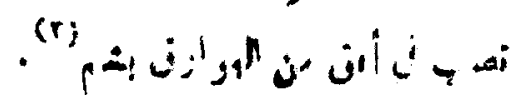

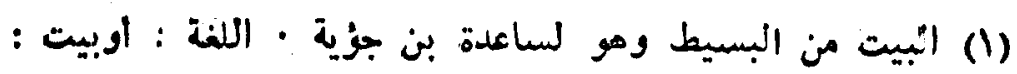

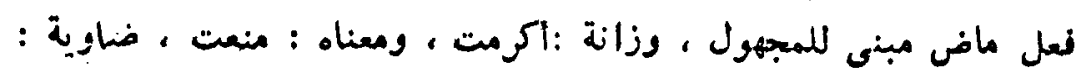

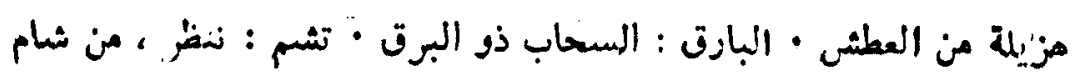

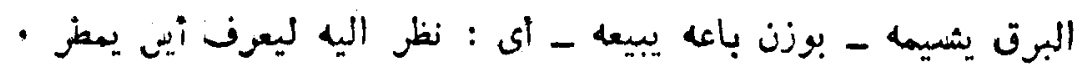

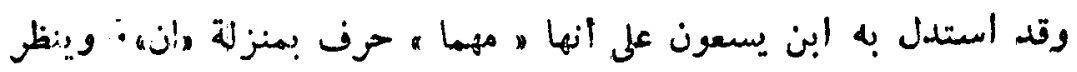

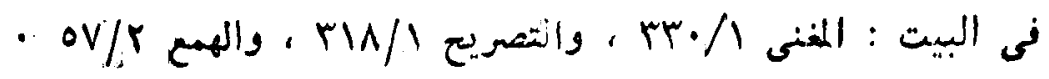

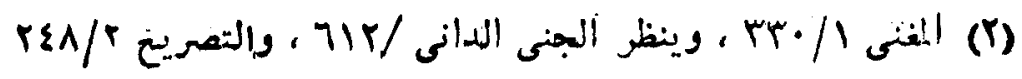

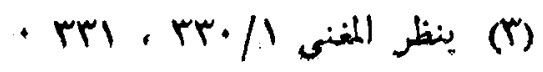


100

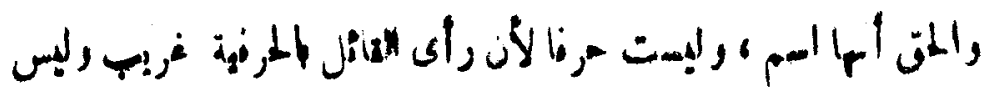

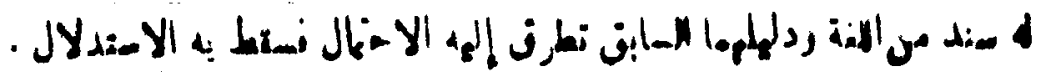

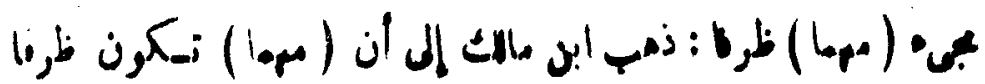

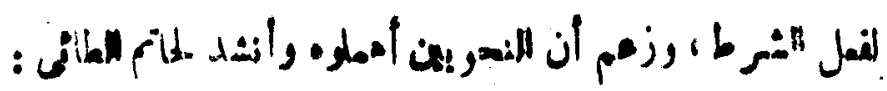

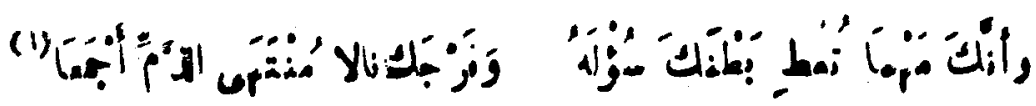

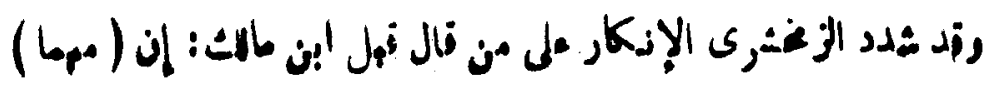

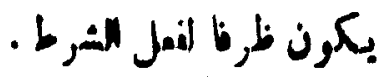

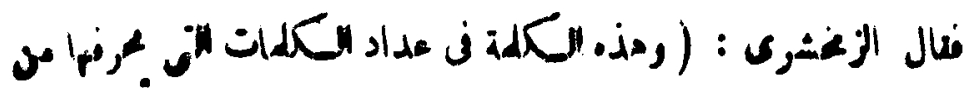

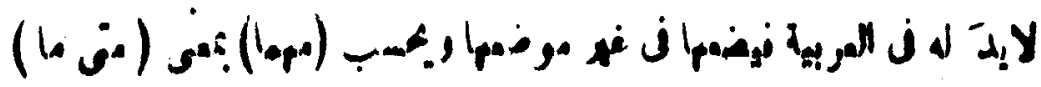

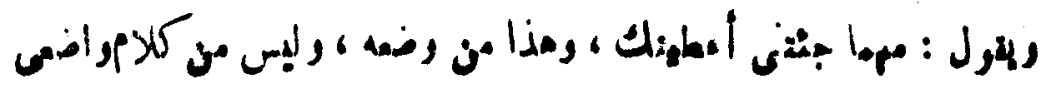

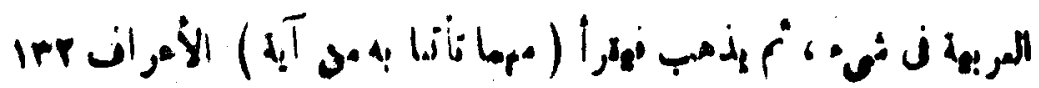

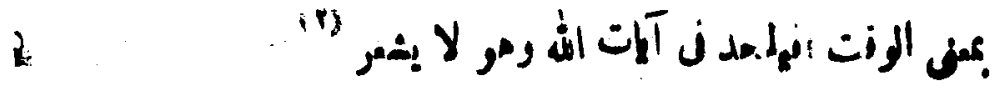

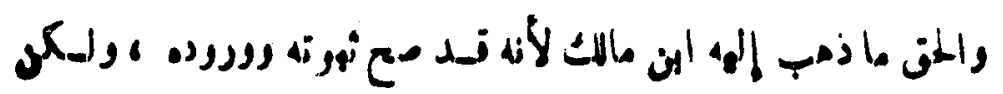

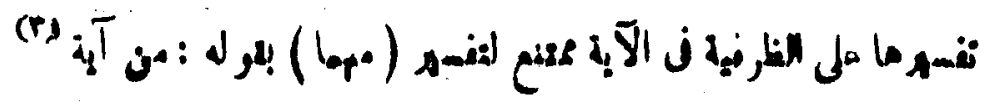

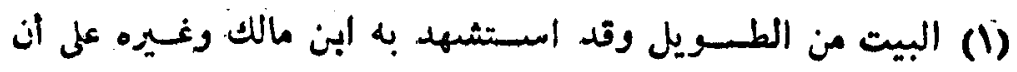

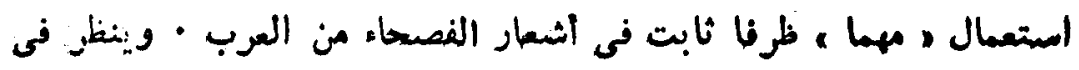

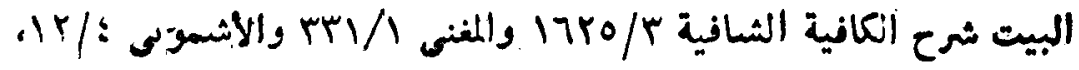

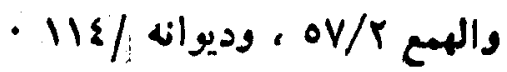

- 1.V/r

: rrr/l ينظر (I) 


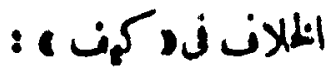

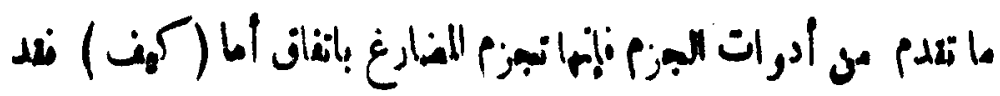

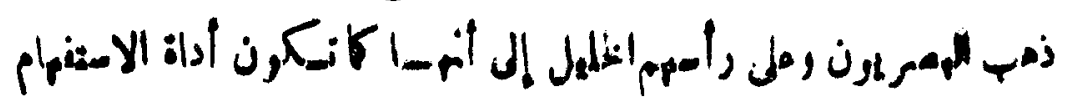

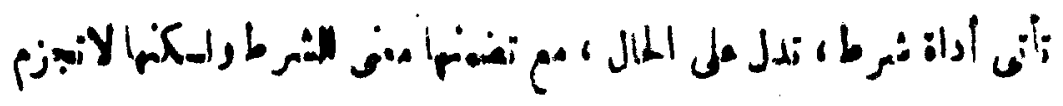

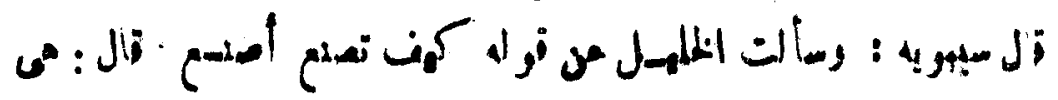

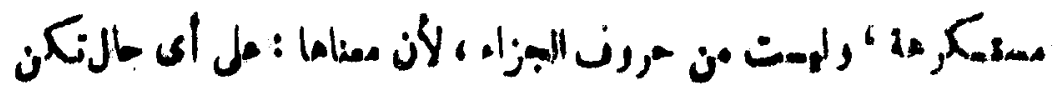
(1)

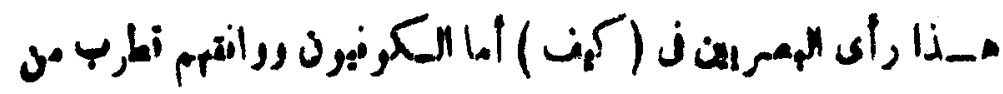

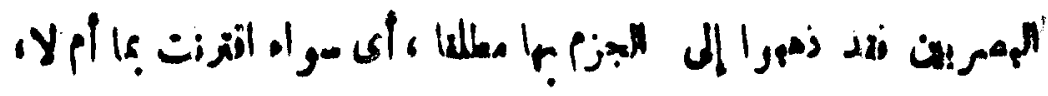

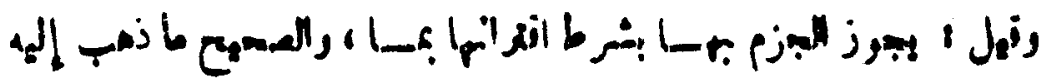

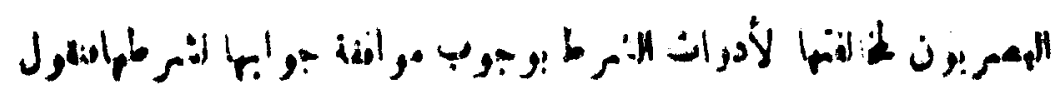

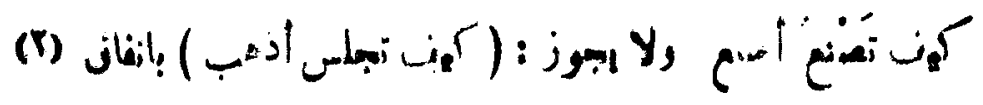

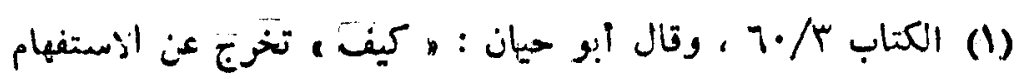

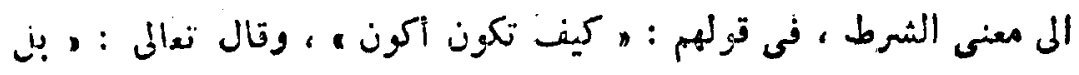

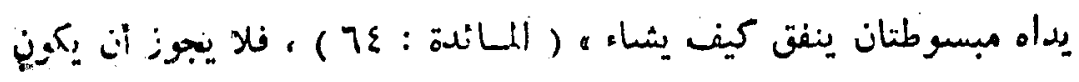

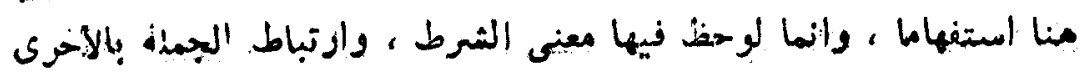

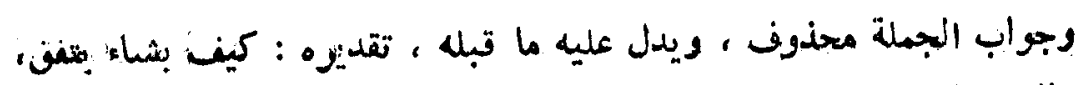

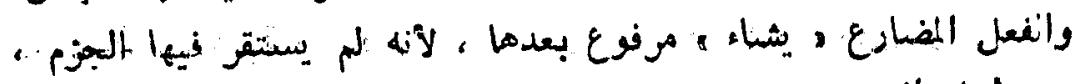

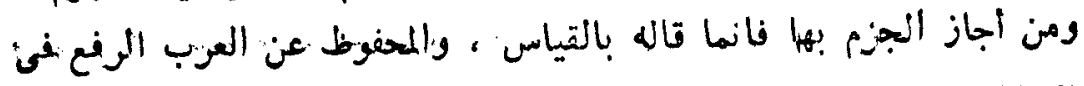

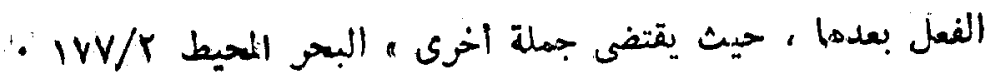

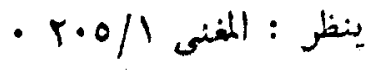




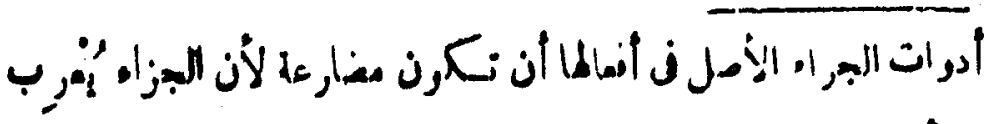

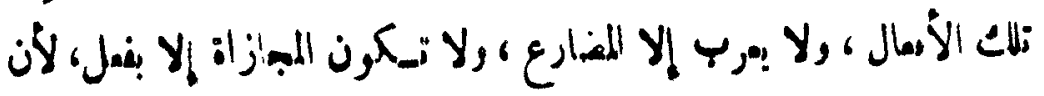

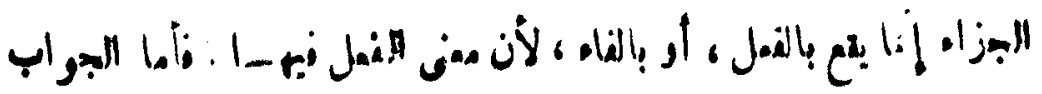

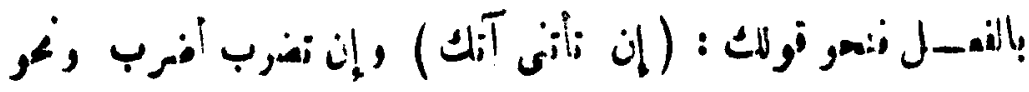

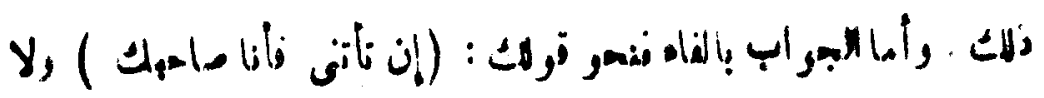

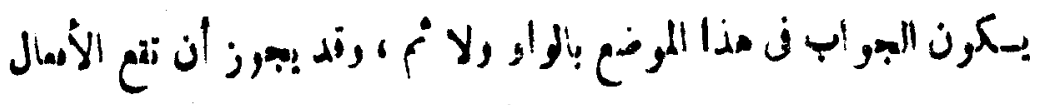

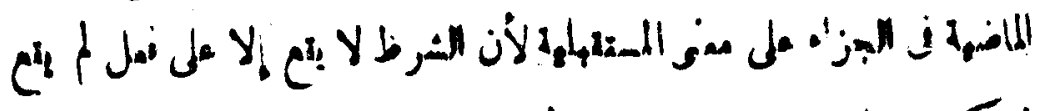

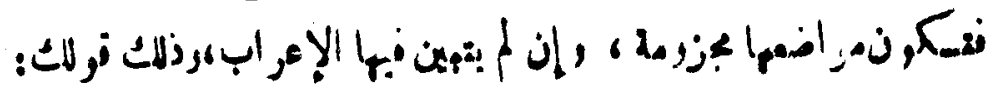

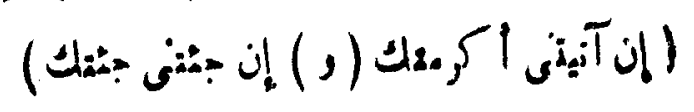

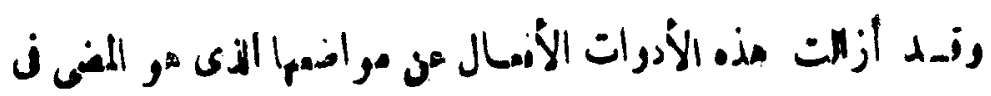

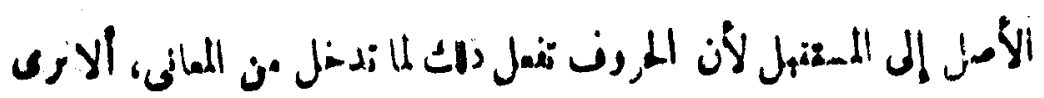

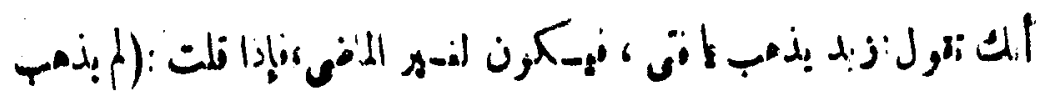

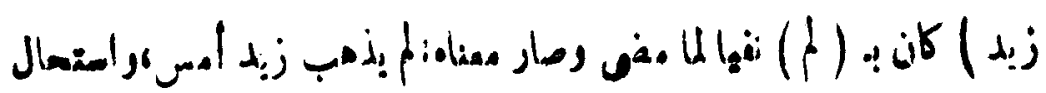

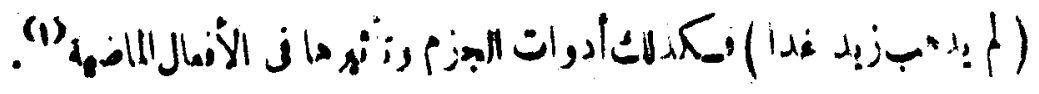

$$
\star \star
$$

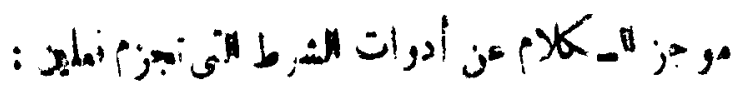

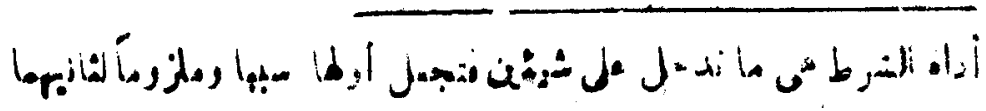

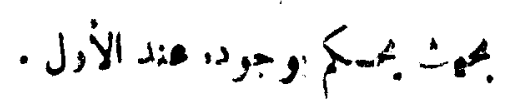

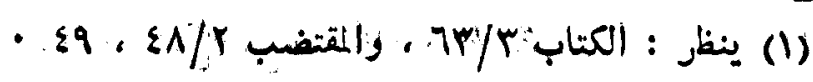




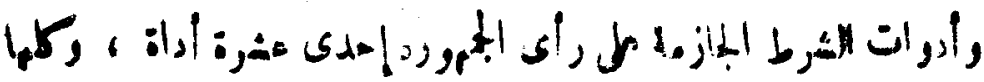

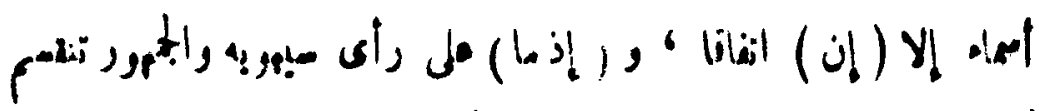

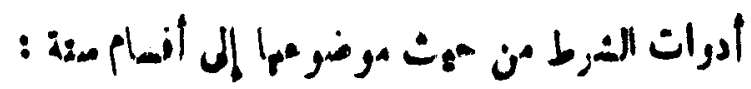

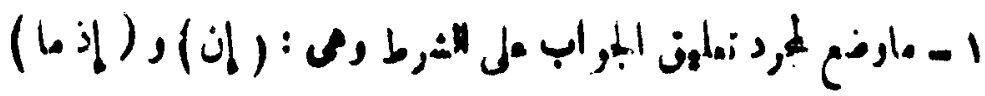

$$
\text { . }
$$

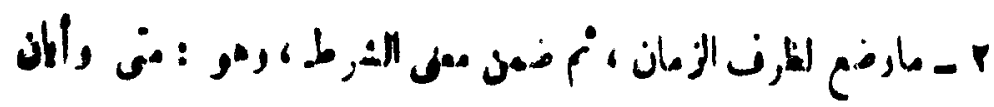

$$
\text { • }
$$

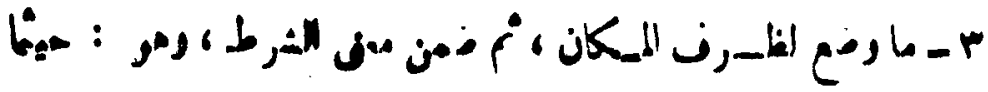

$$
\text { . ji, il, }
$$

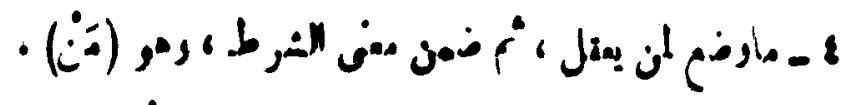

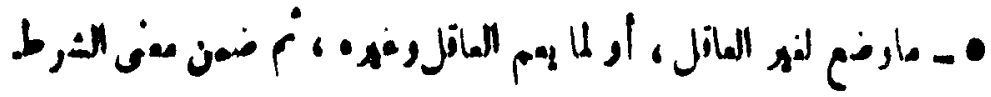

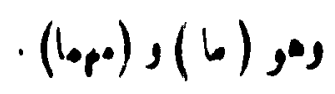

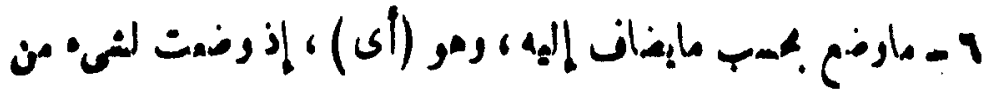

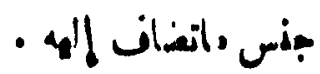

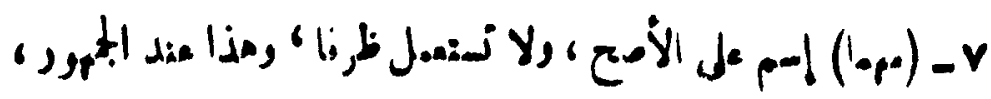

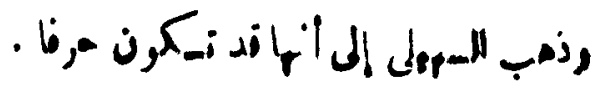

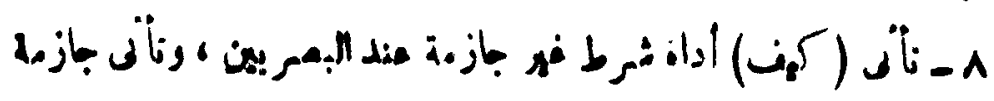

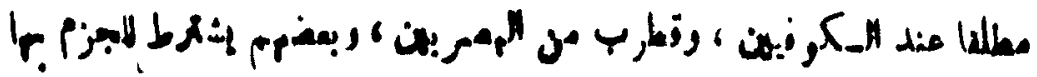
- If |blail

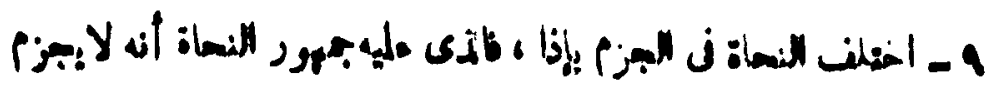




\section{4}

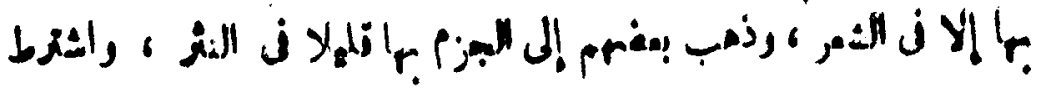
|

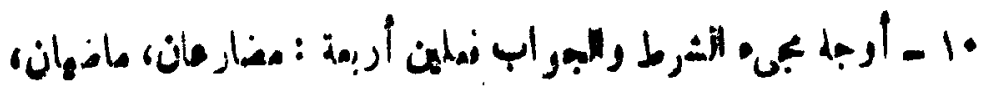

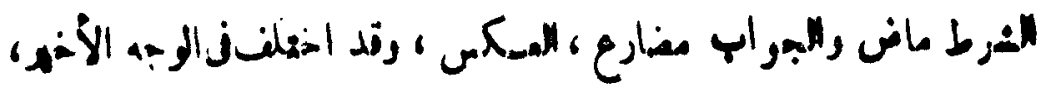
والصحتح جراز

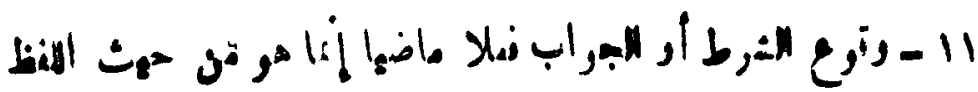

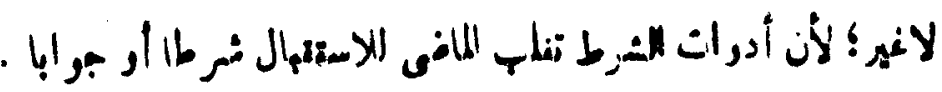

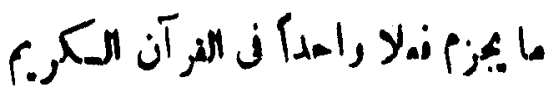

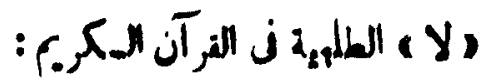

$$
\text { . (ل) }
$$

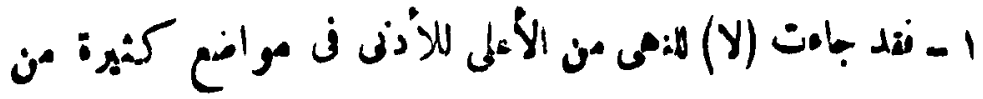

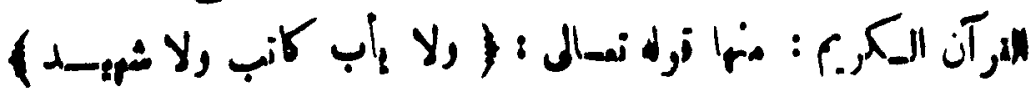

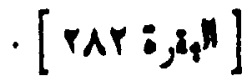

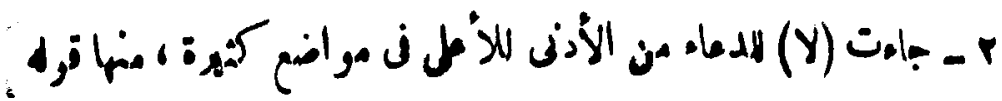

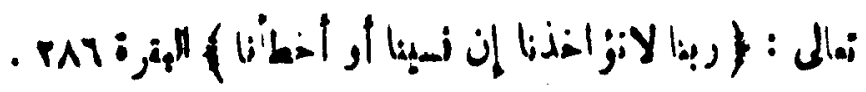

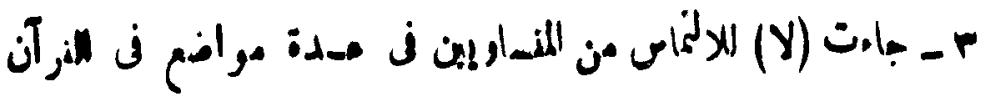

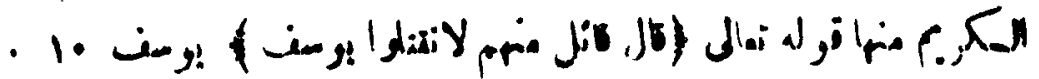

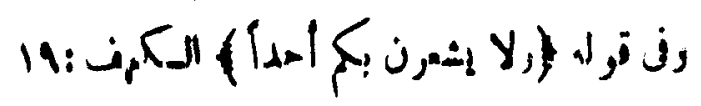

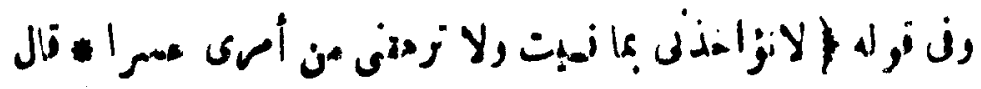

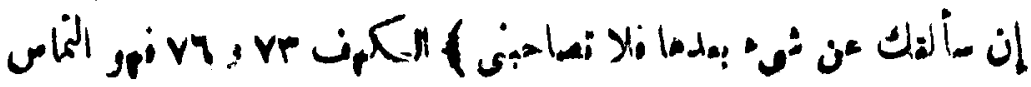


(1.

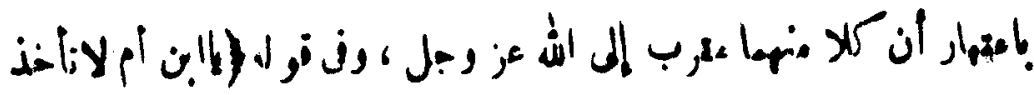

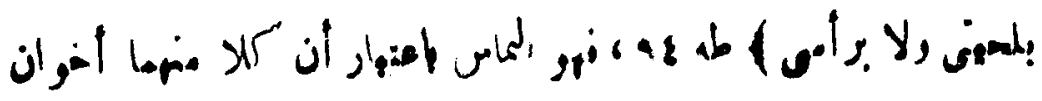

نيهان مهسلان

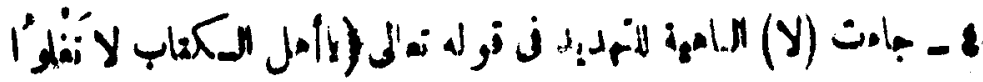

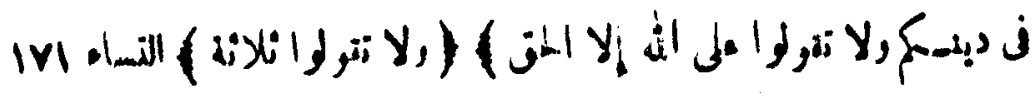

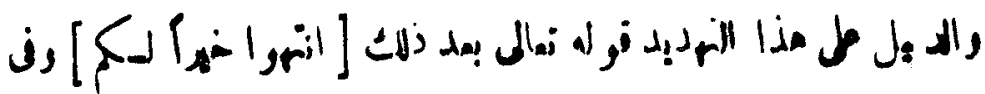

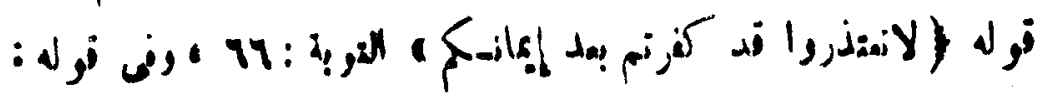

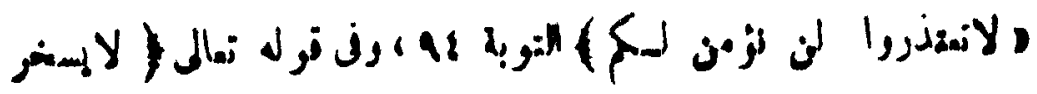

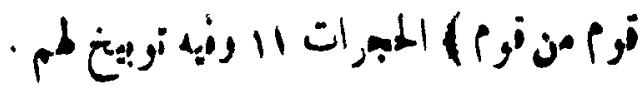

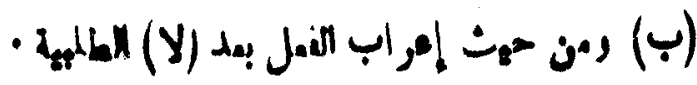

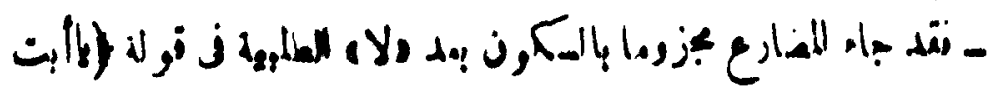

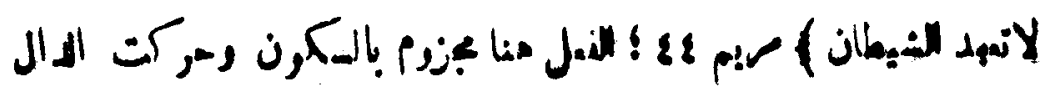

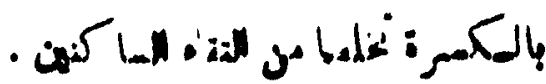

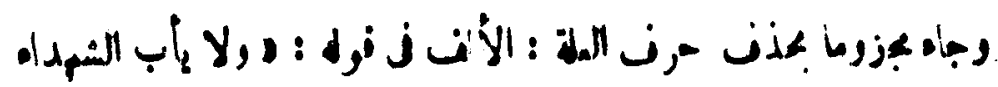

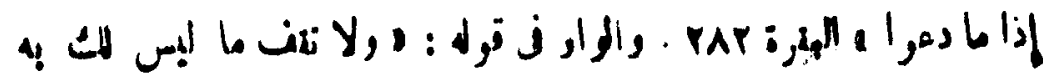

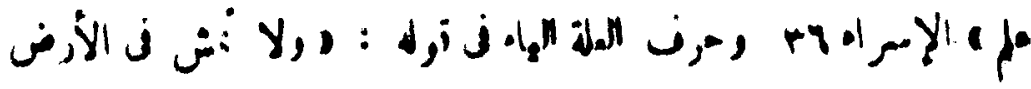

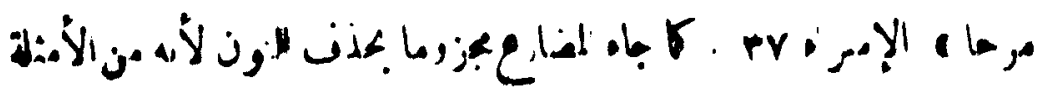

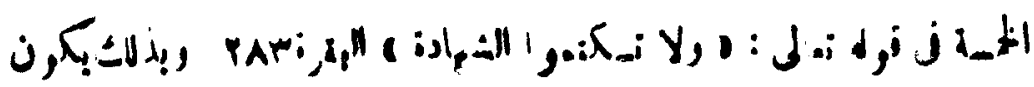

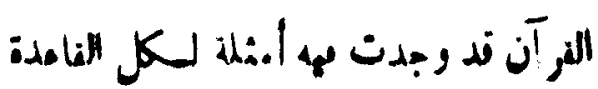

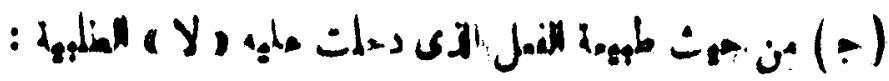

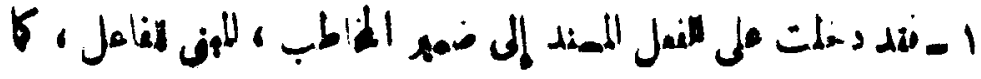


:

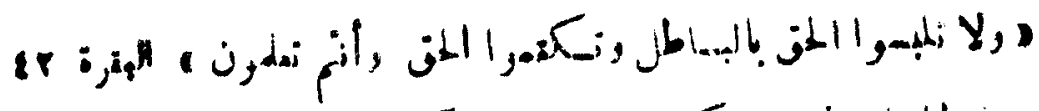

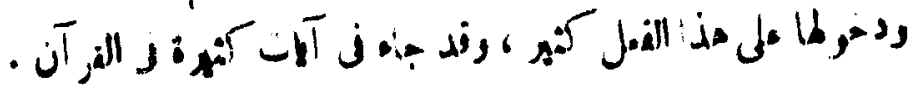
ولإ

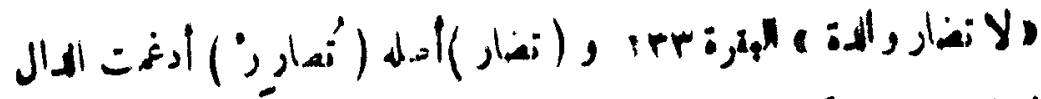

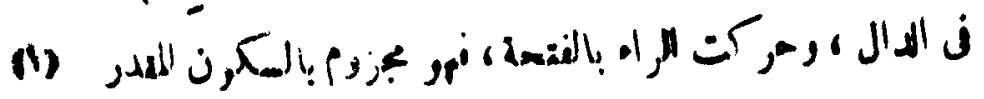

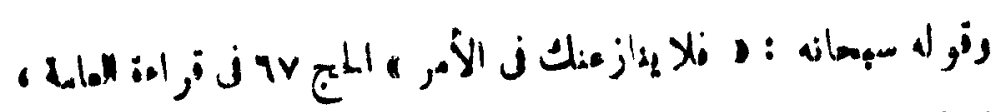

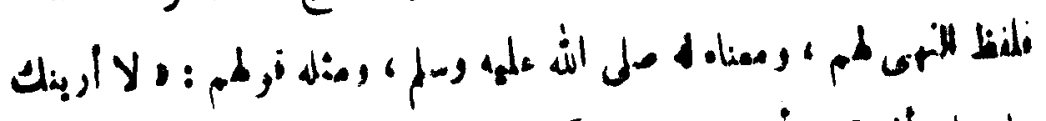

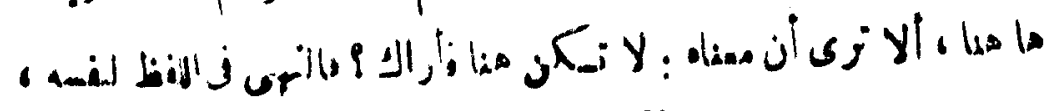

$$
\text { (') }
$$

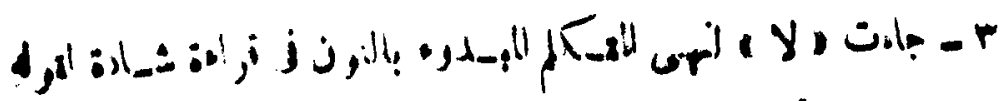

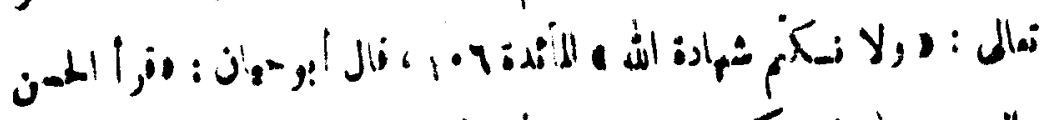

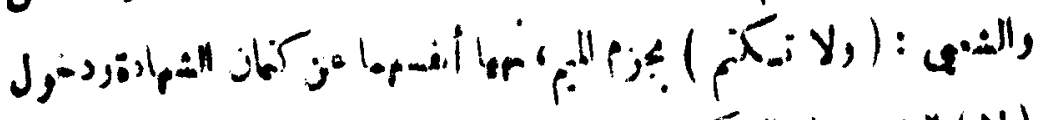
(i) : تملئن

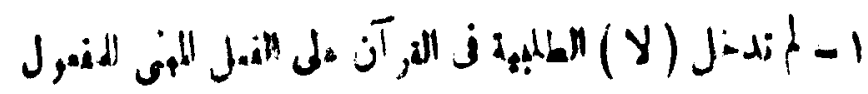
. " مأز

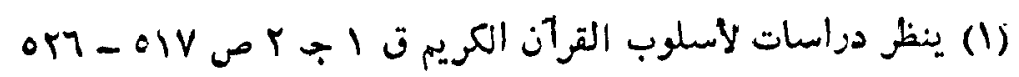

• $17 / r$ (r) إنظر المحتسن

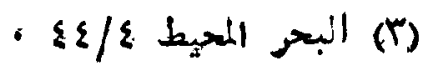




$$
\begin{aligned}
& \text { لام الlla } \\
& \text { : }
\end{aligned}
$$

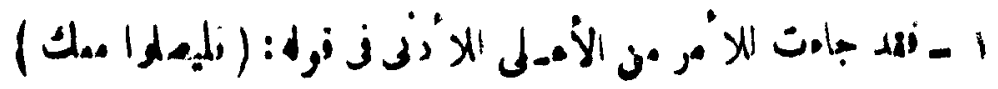

$1 \cdot r$ An

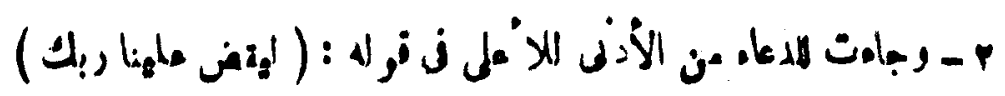

$$
\text { vr }
$$

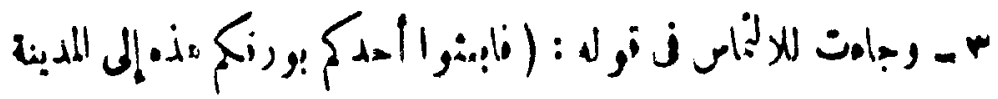

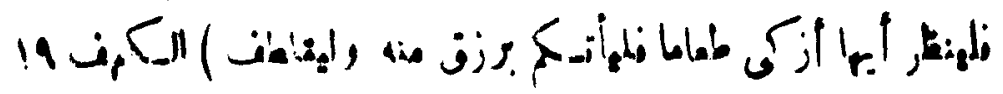

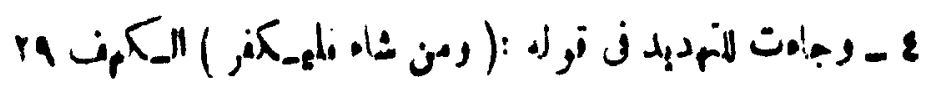

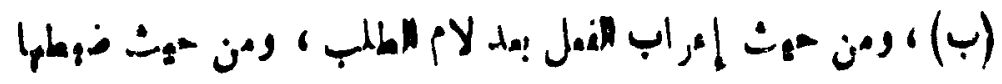

|

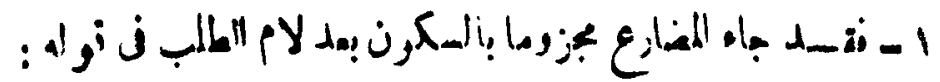

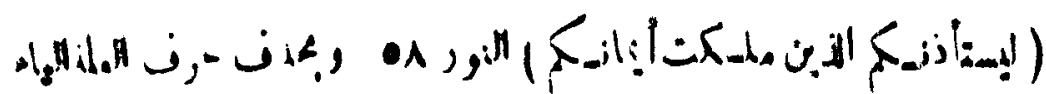

$$
\text { - in is (aie }
$$

ا

بإبـ

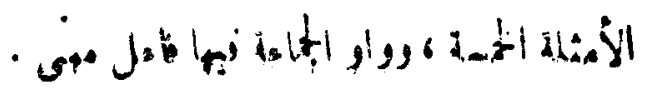

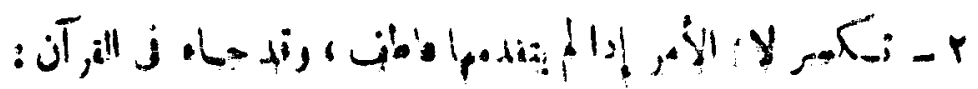

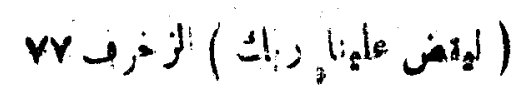

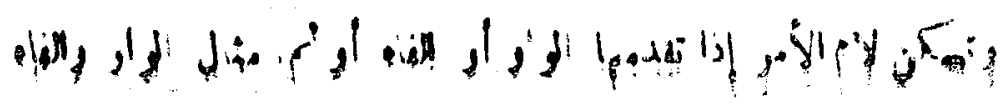




\section{7}

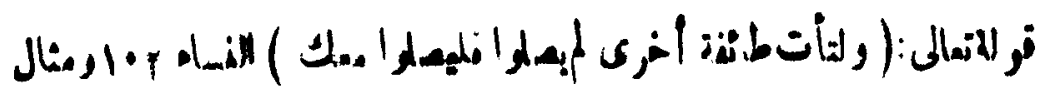

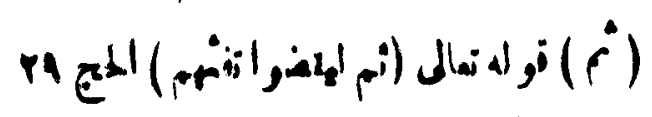

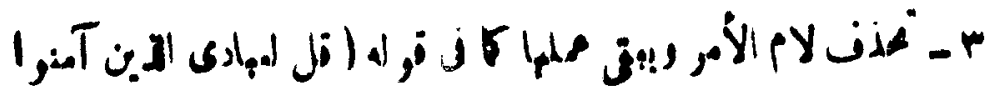

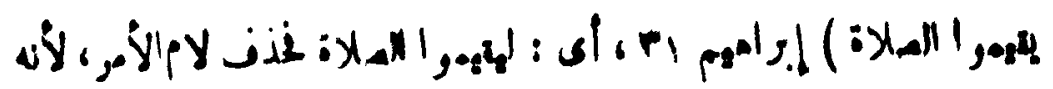

$$
\text { "li) (j) }
$$

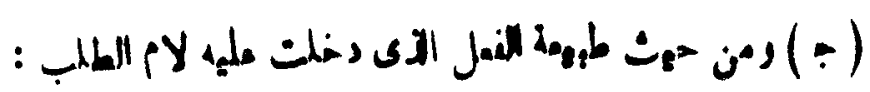

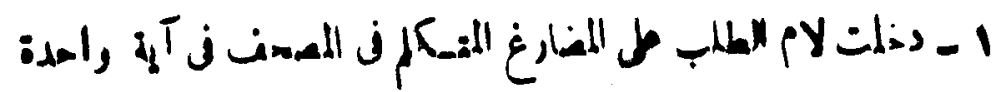

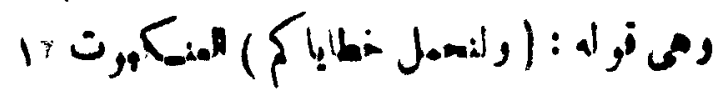

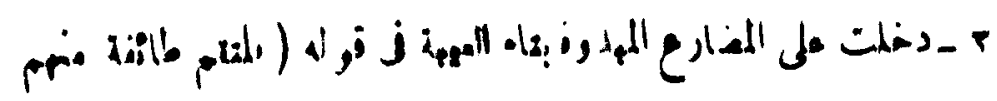

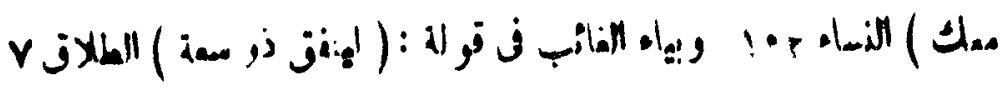

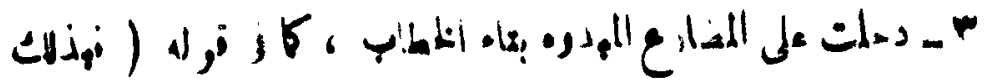

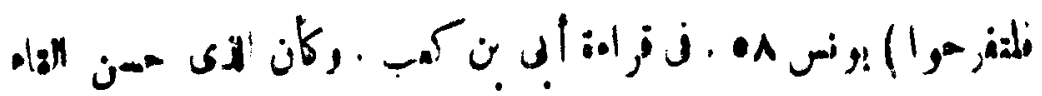

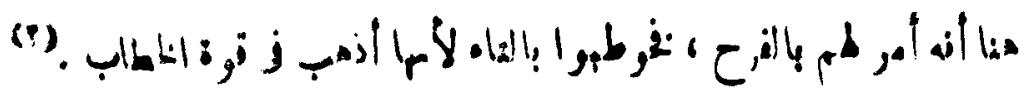

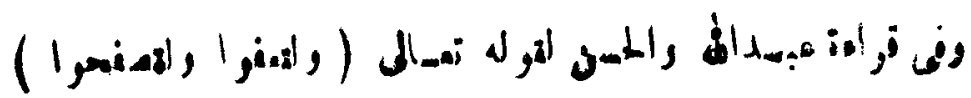

(i)

i is

1

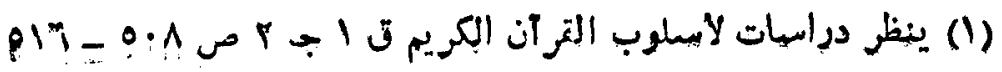

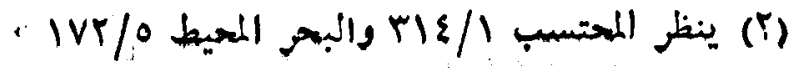

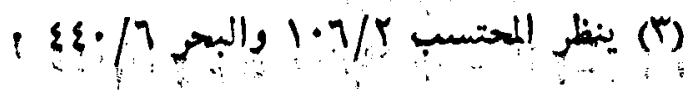




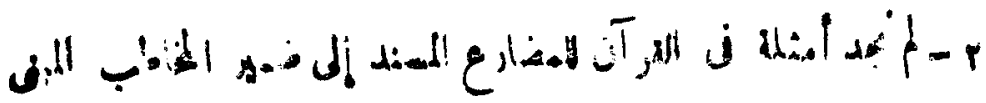

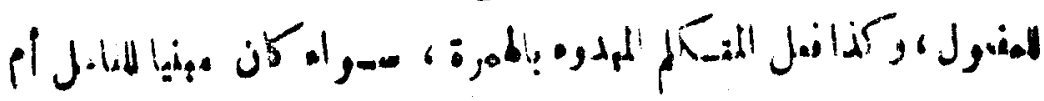

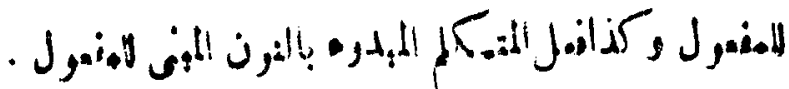

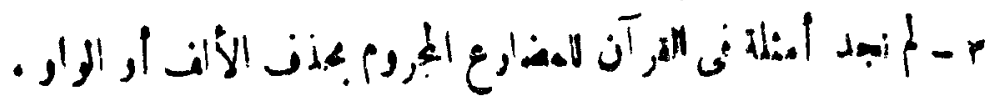

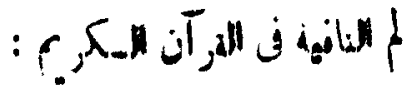

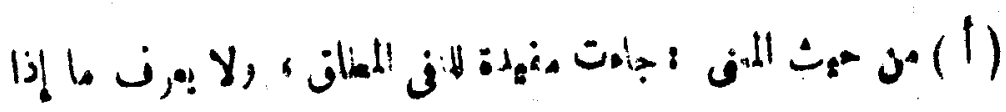

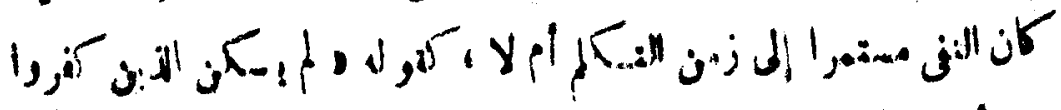

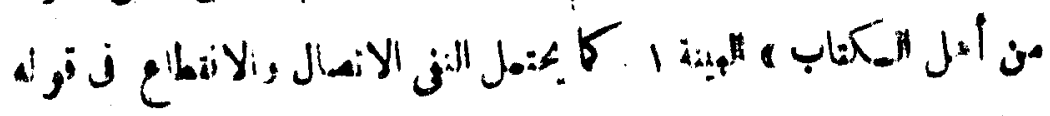

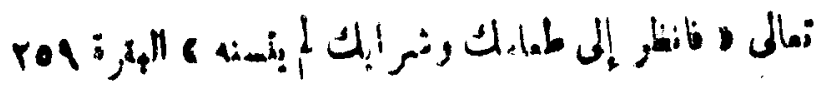

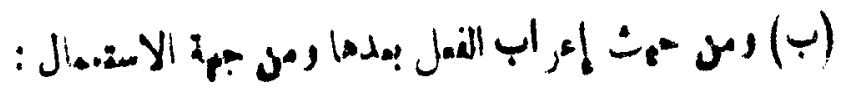

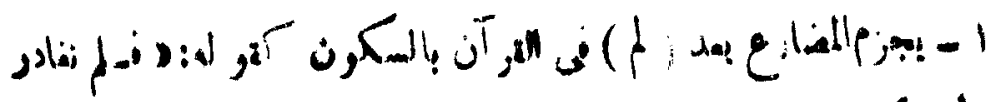

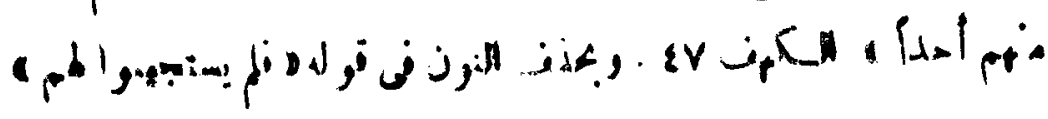

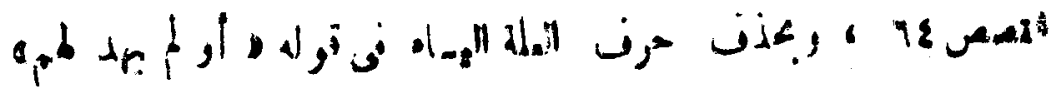
14

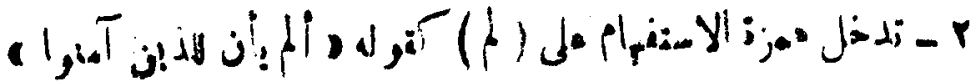

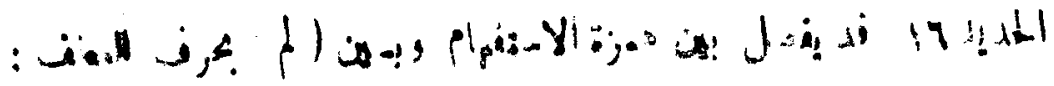

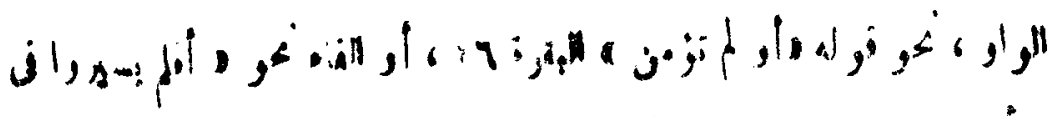
(1) الأرض ه ه 
170

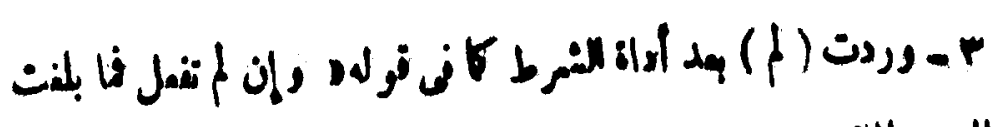

$$
\text { iv: : }
$$

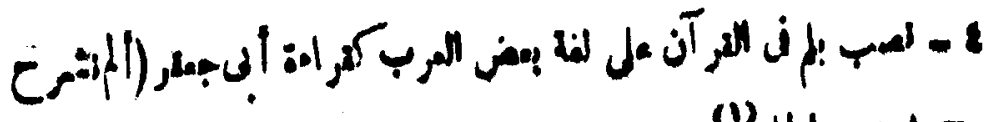

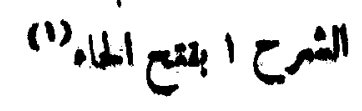

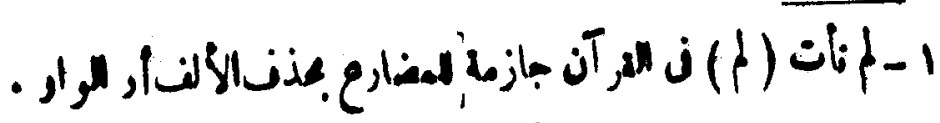

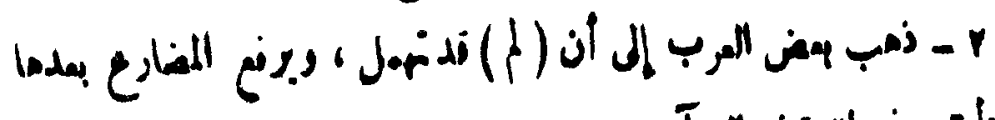

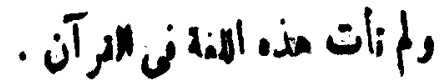

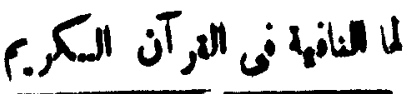

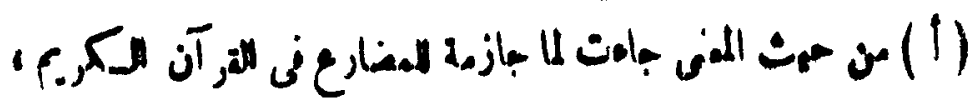

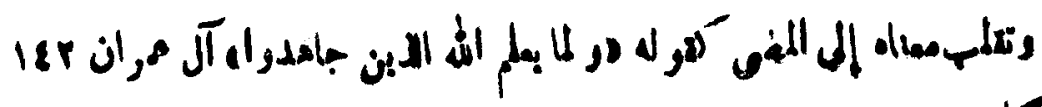

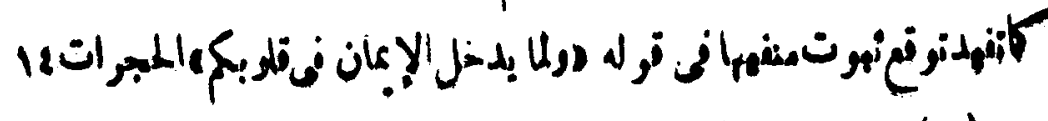

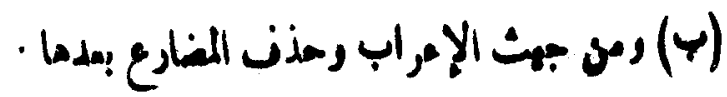

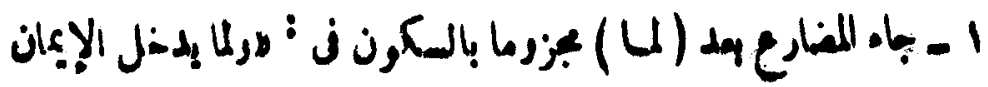

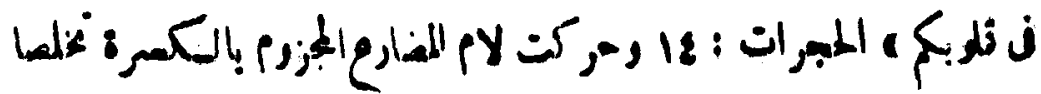

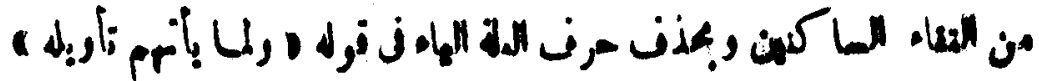

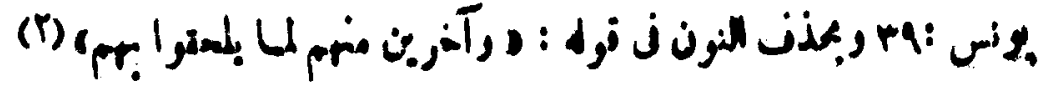
$r:$ : iatl

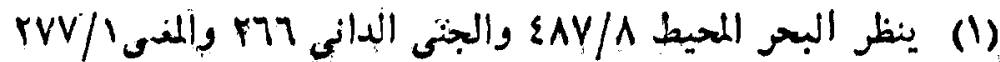

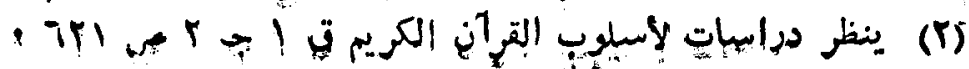
$(j-\infty)$ 


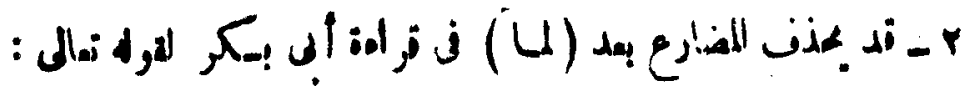

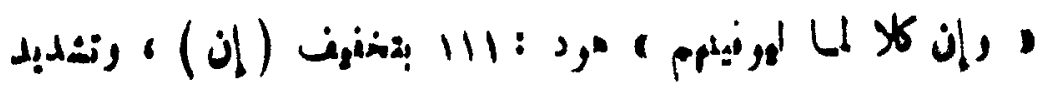

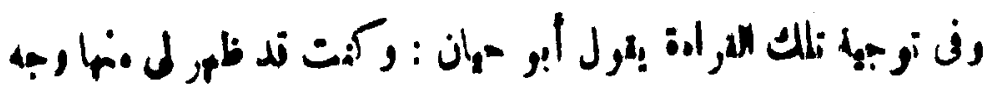

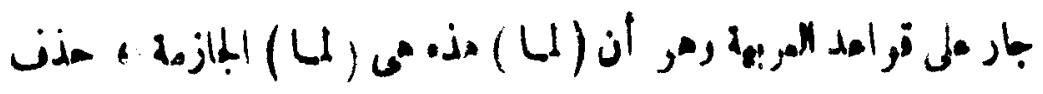

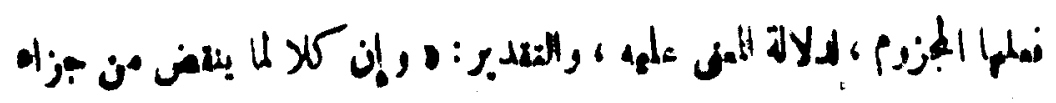

(1) 18

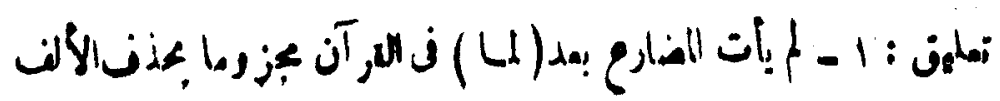
أر الرار .

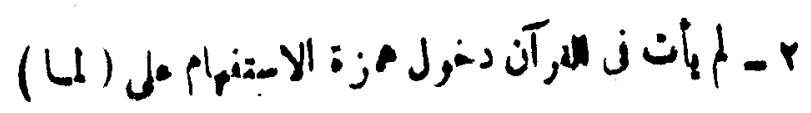

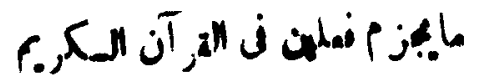

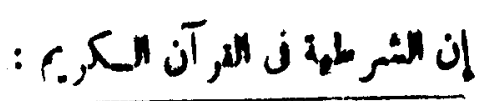

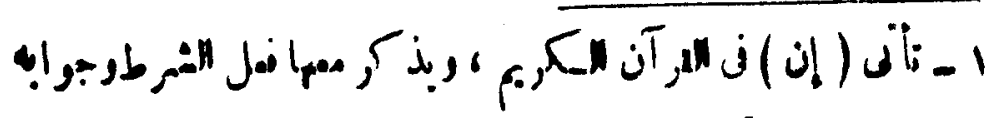

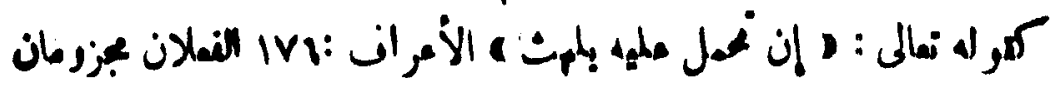

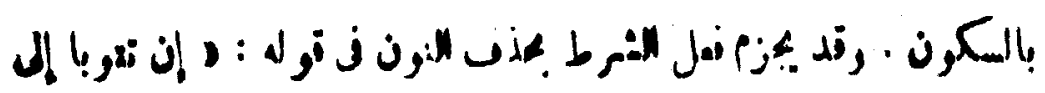

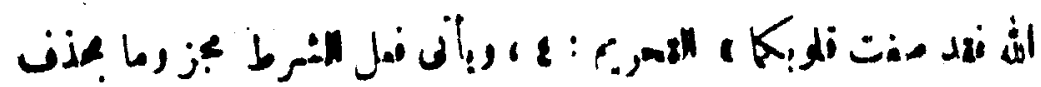

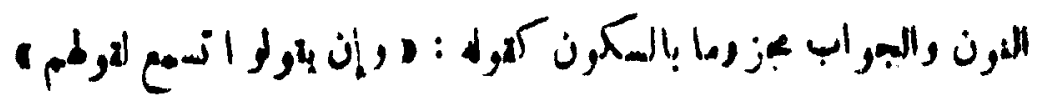

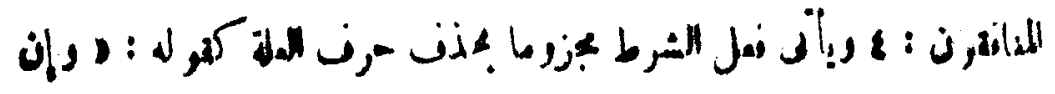

. (1) 


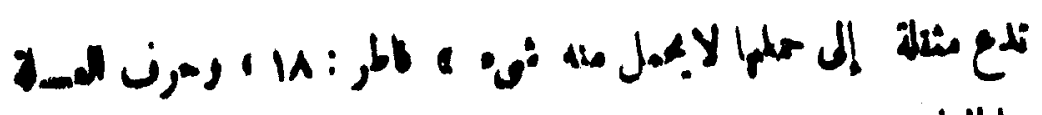
مثا الرار .

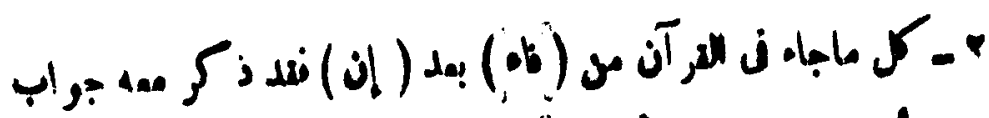

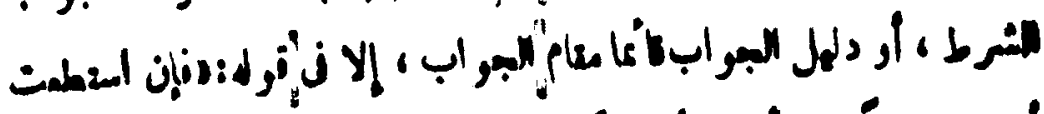

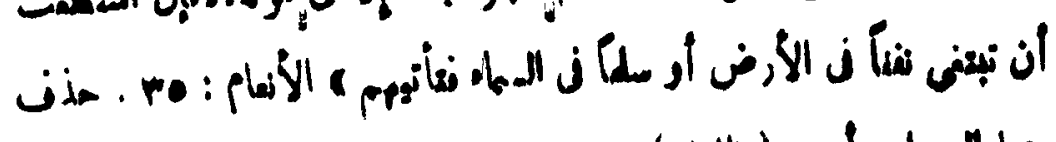

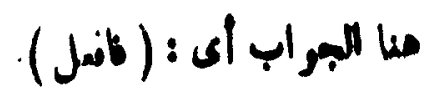

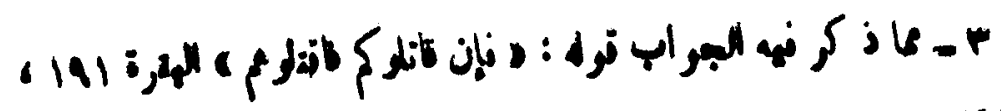

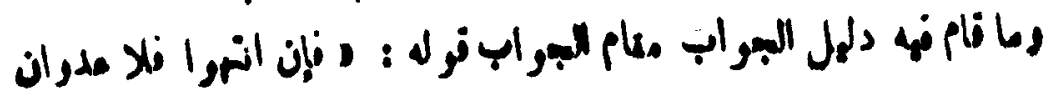

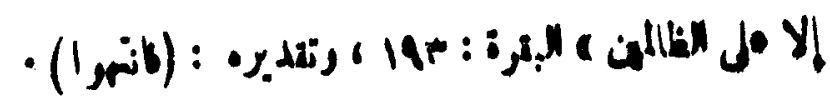

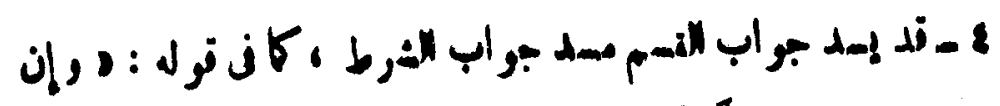

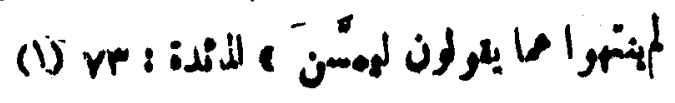

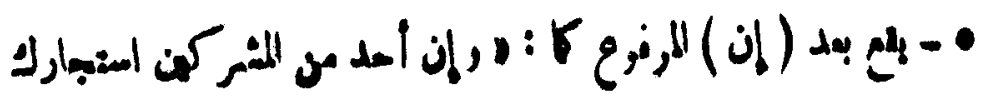

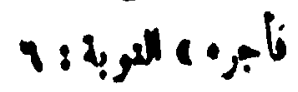

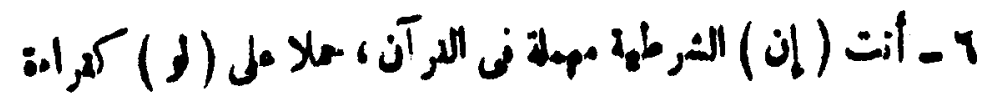

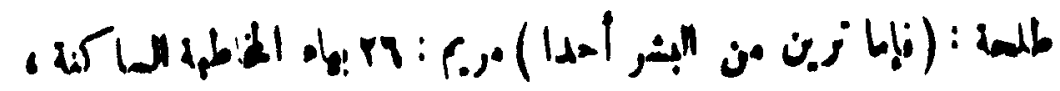

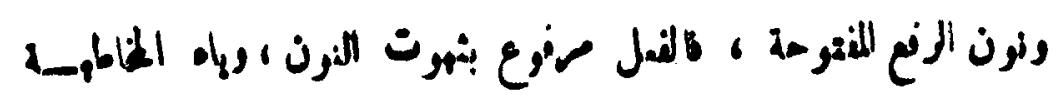
(I) (I)

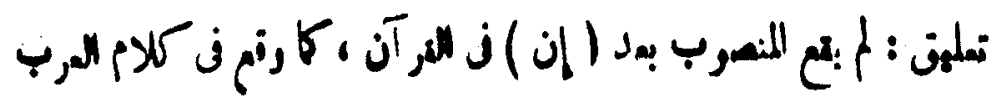

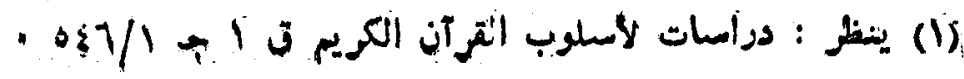

$$
\begin{aligned}
& \text { • }
\end{aligned}
$$




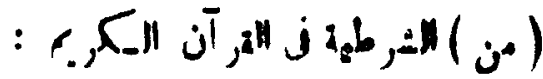

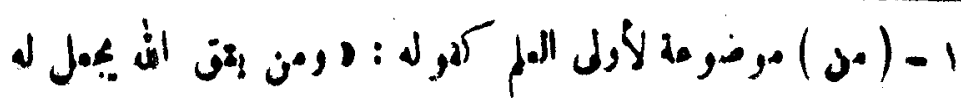

$$
\begin{aligned}
& \text { r: }
\end{aligned}
$$

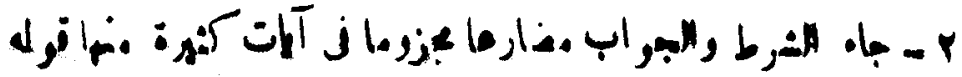

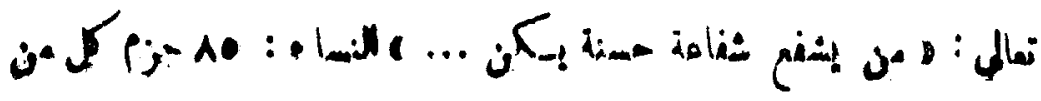

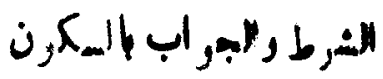

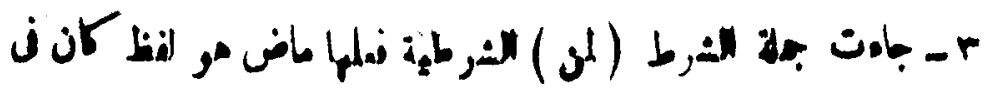

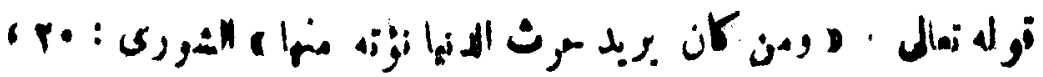

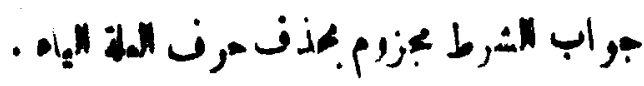

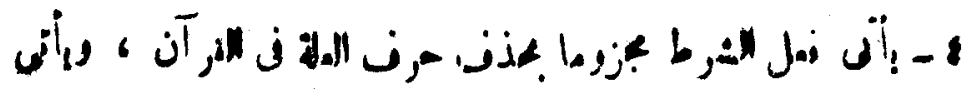

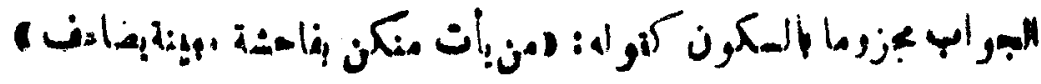

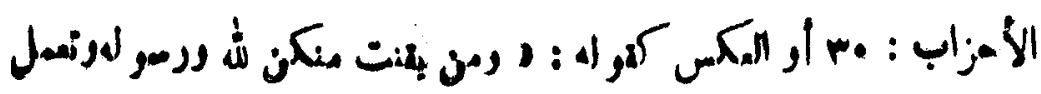

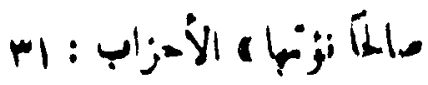

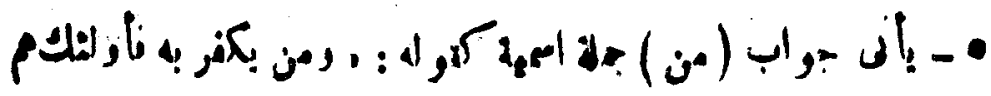

$$
\text { الذافرون }
$$

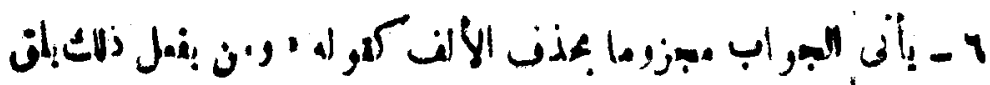

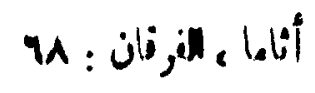

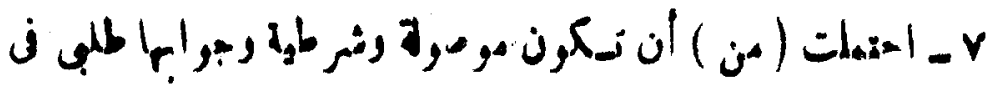

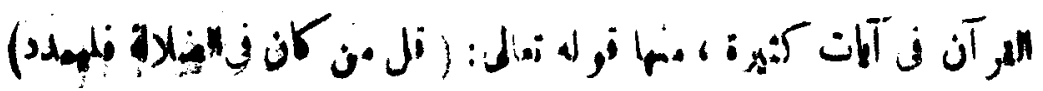

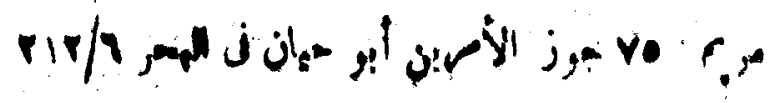


14

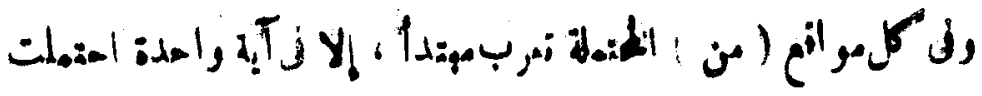

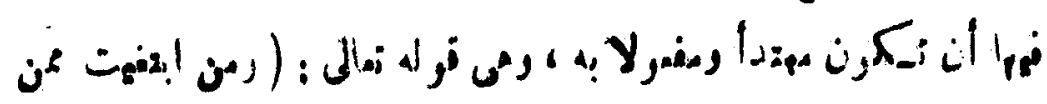

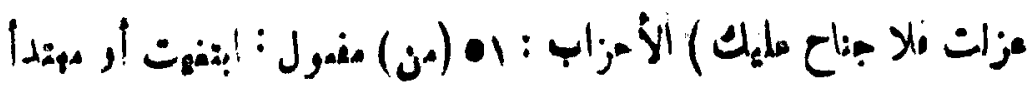

(1)

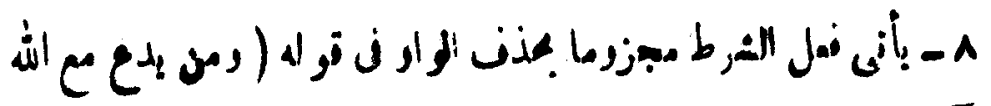

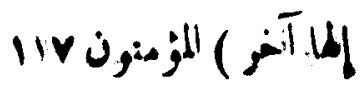

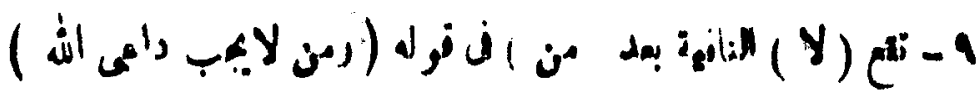

re : : is

ما lith

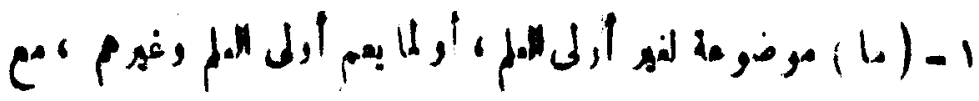

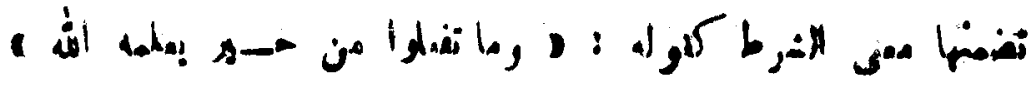

Iav : : : in

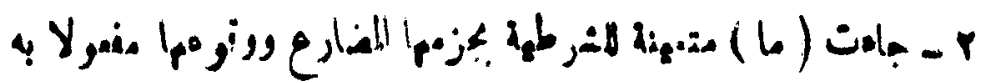

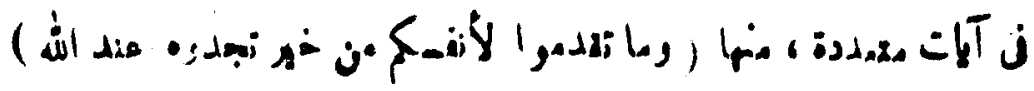

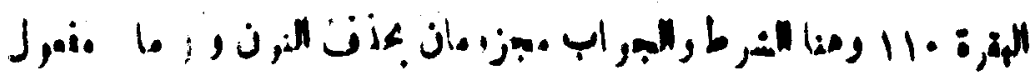

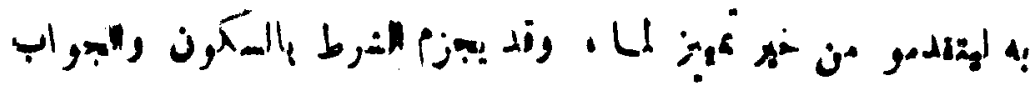

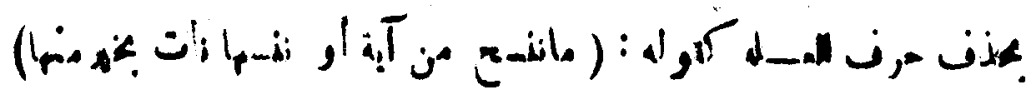

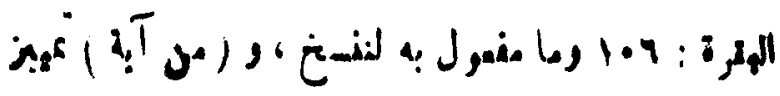

190 - IVV/r ينظر : دراسات لأسلوب القرآن الكرين ق 190 


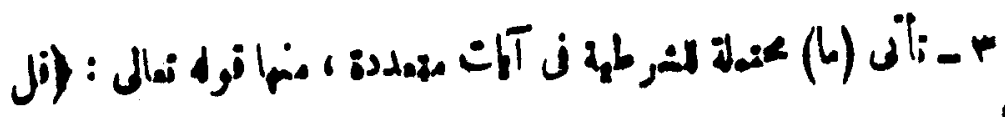

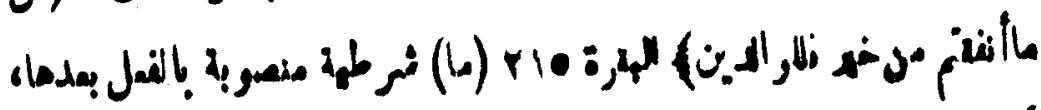

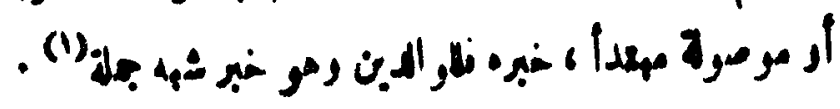

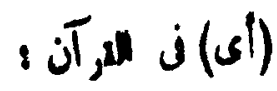

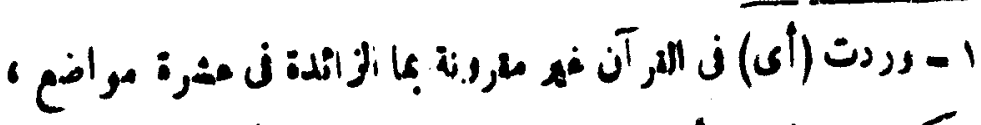

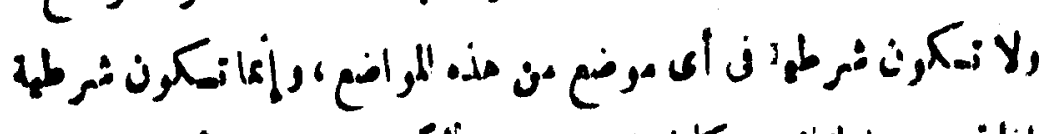

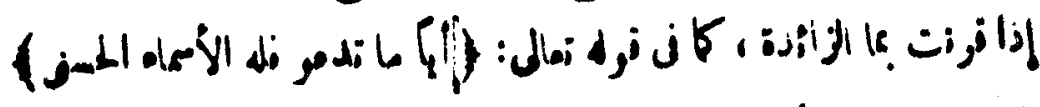

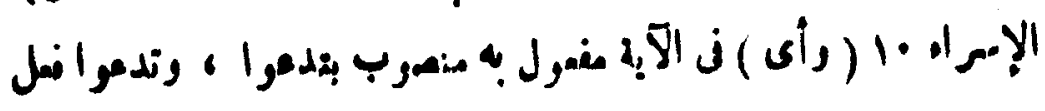

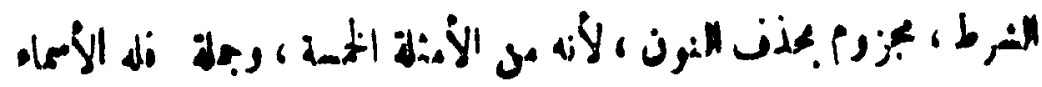

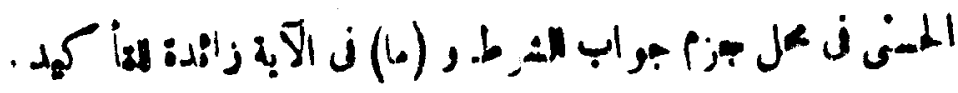

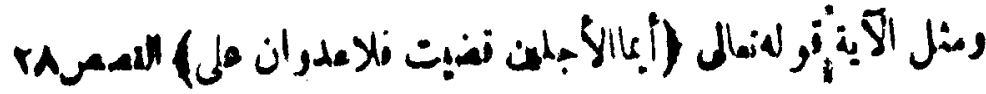

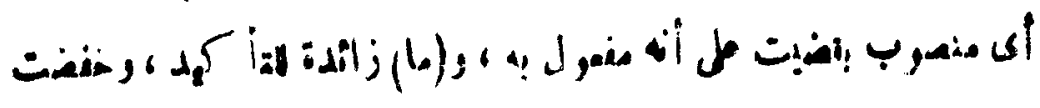

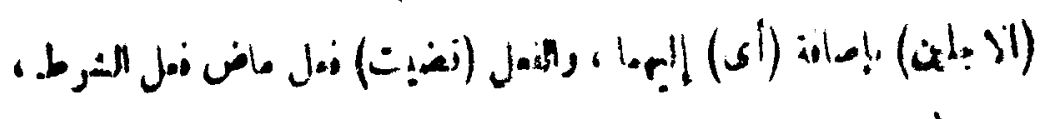

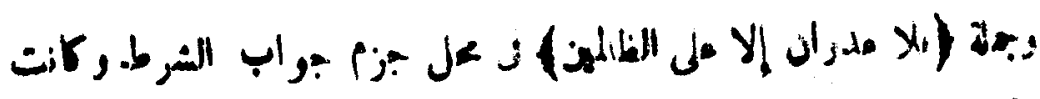

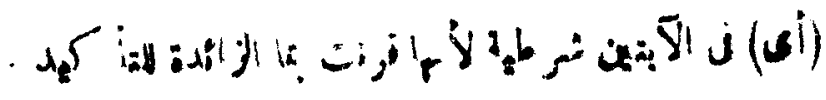

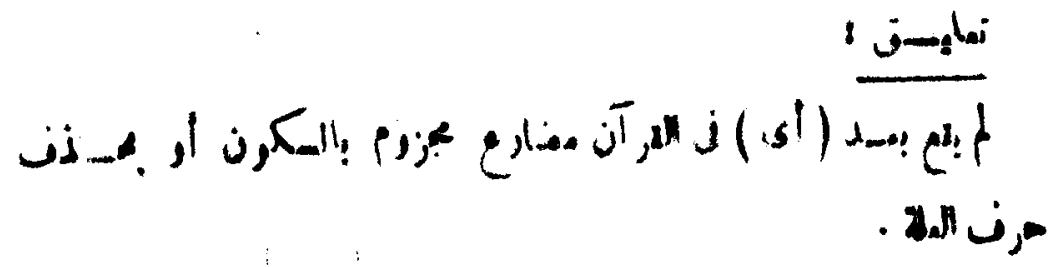
(1) المصدر السابق ص عه - 
$|\gamma|$

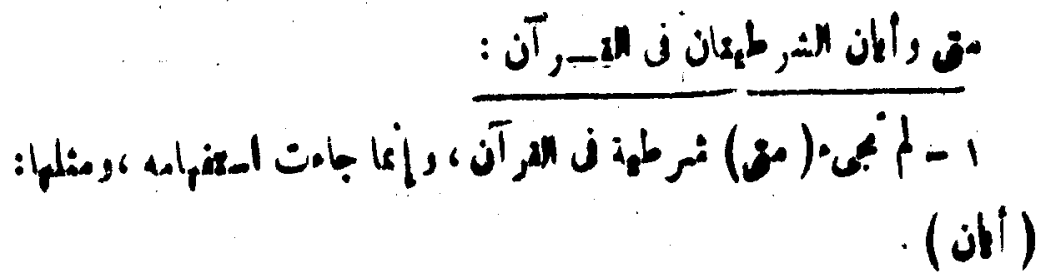

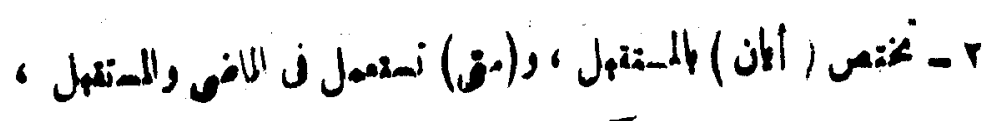

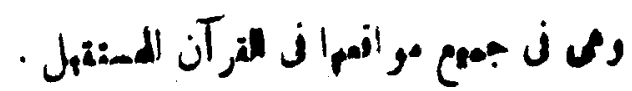

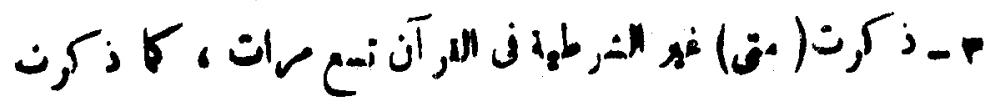

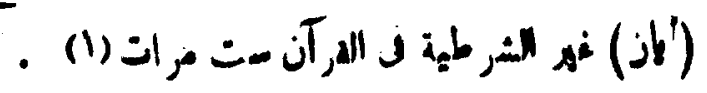

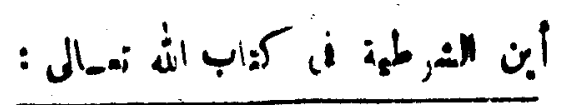

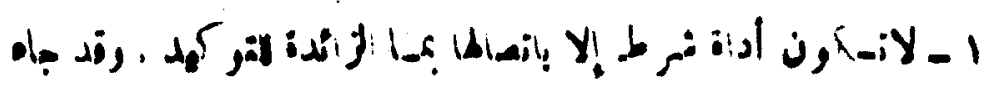

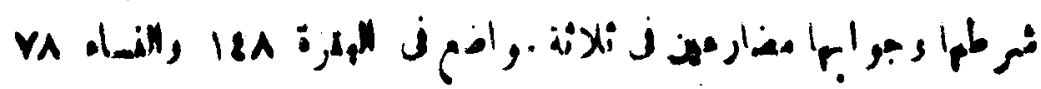

$$
\text { vi Jaill, }
$$

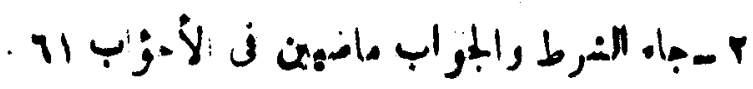

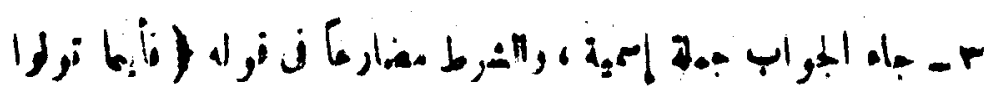

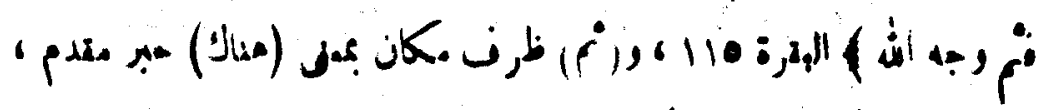

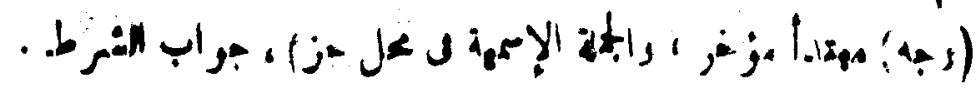

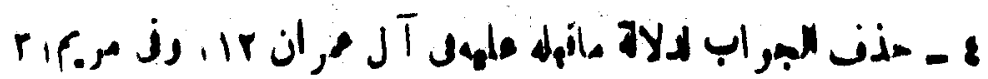

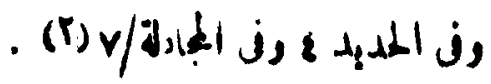

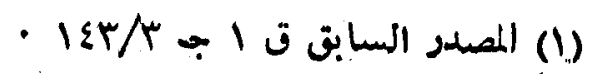

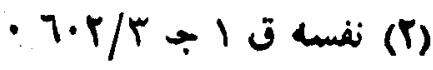




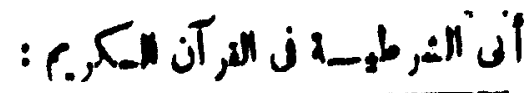

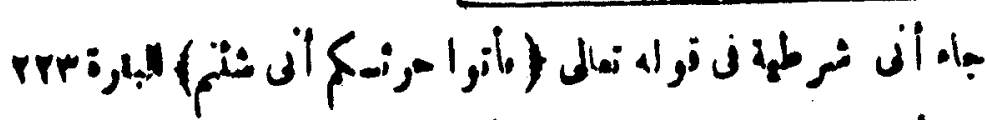

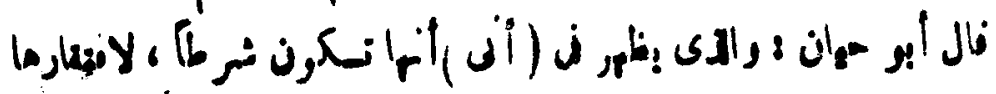

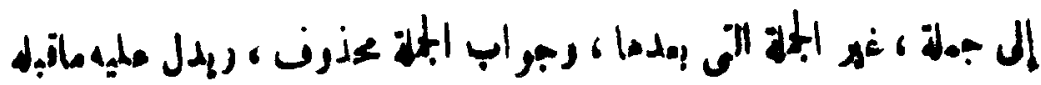

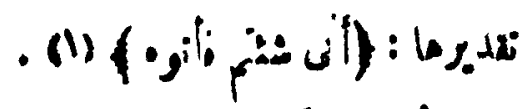

:

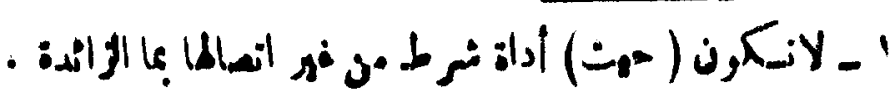

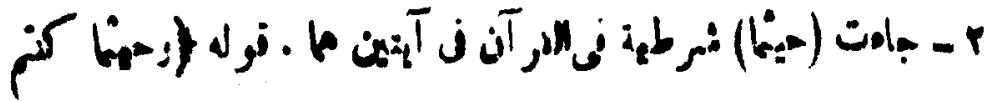

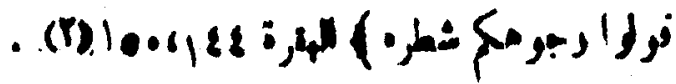

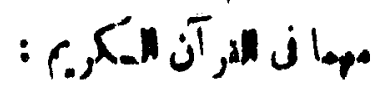

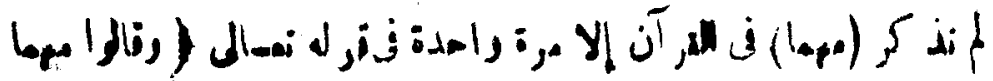

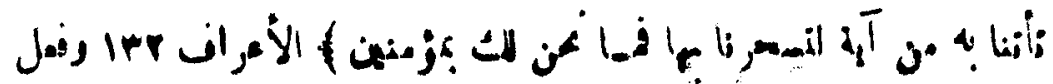

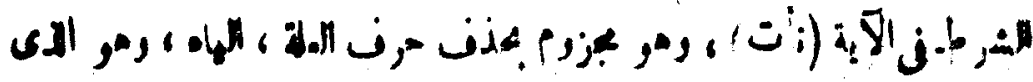

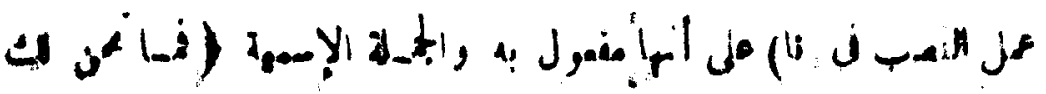

.

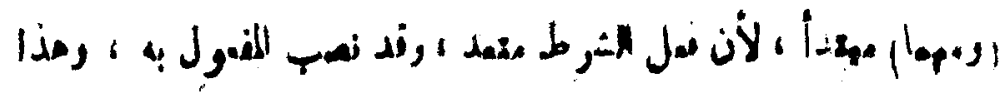

(1) ينظر : البحر المجيط r/ IVr/ ، ودراسات لاسلوب القرآن ق ا .071/1 ب

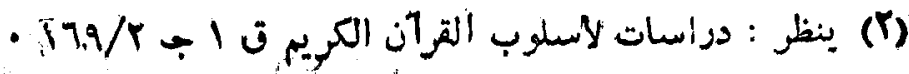




\section{Irr}

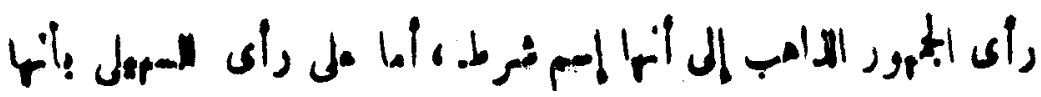

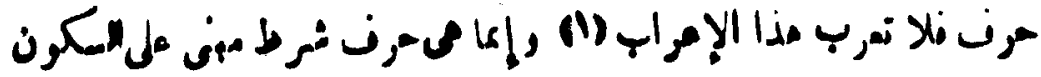
لاعل لا من الإمراب.

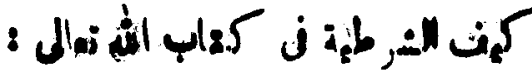

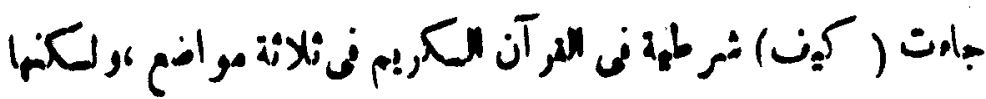

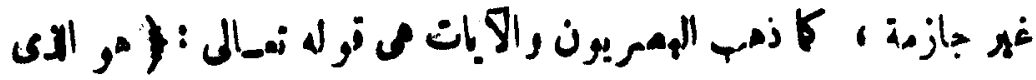

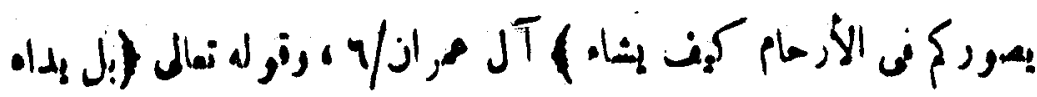

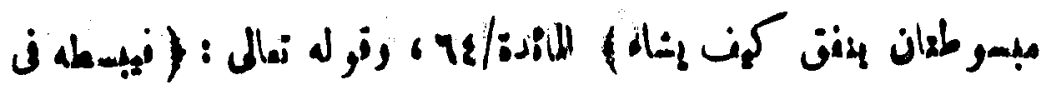

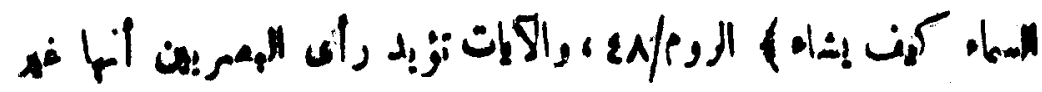

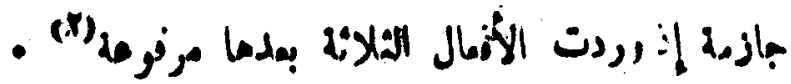

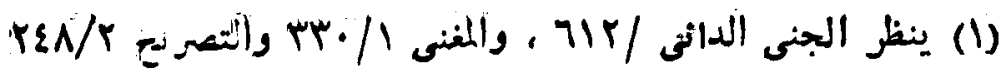

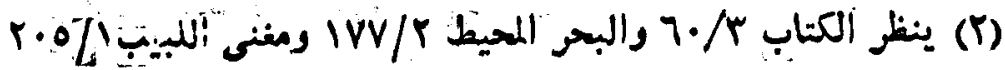




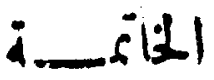

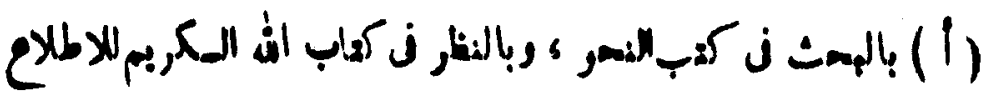

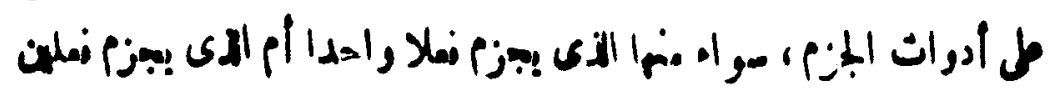

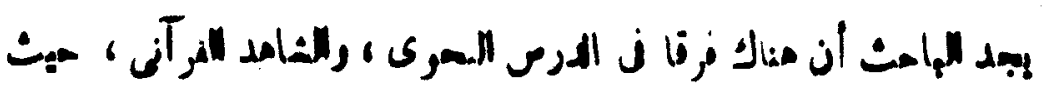

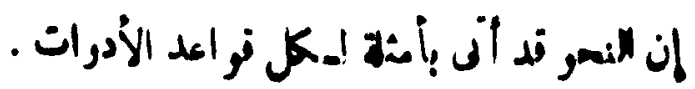

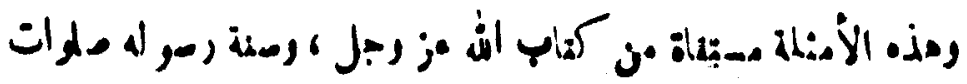

$$
\text { الثه وملامه مليه ، وأقر ال المرب رأثمار م . }
$$

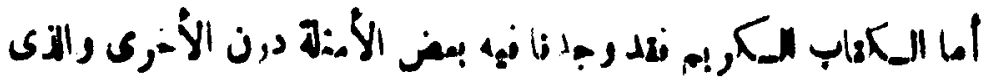

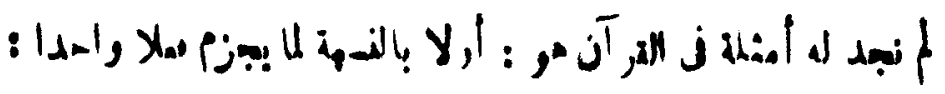
•

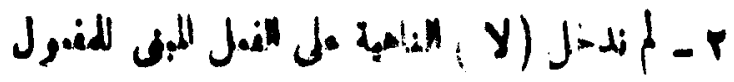

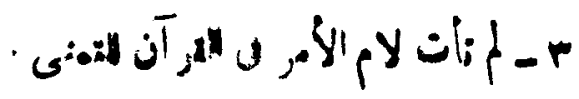

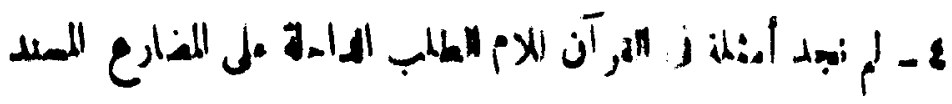

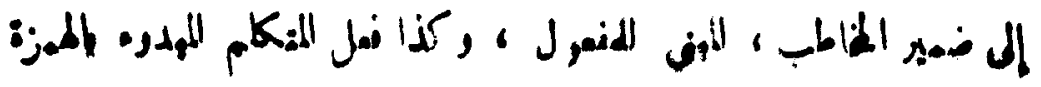

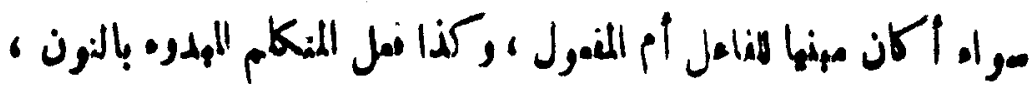

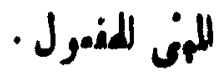

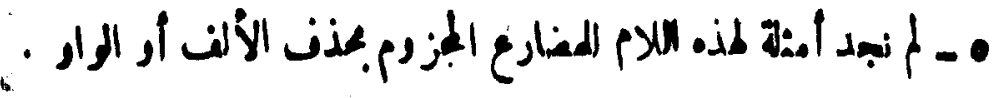

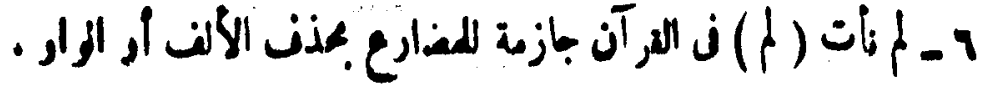

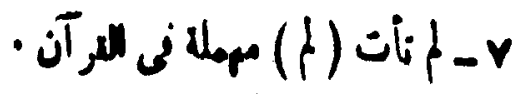


tro

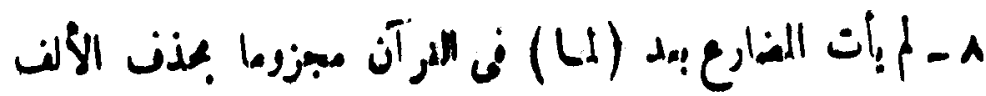

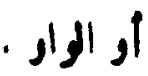

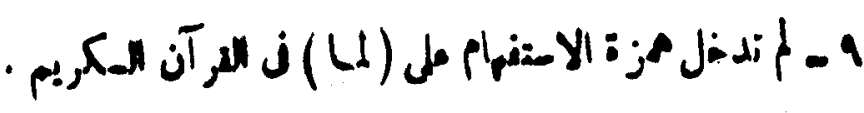

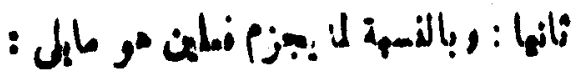

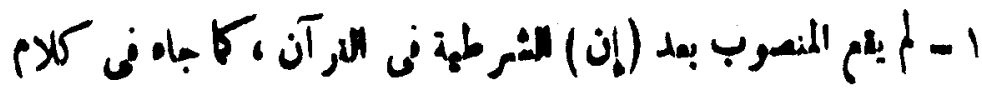

المرب.

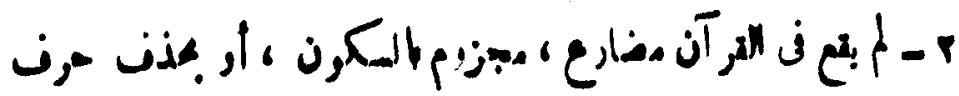

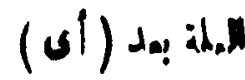

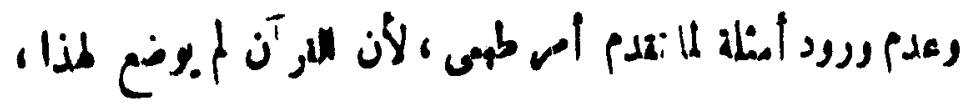

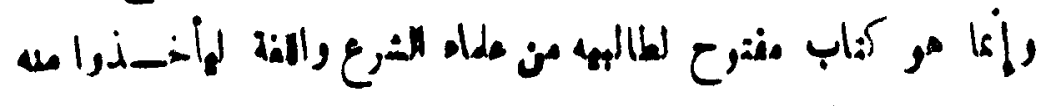

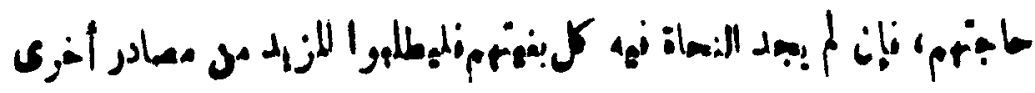

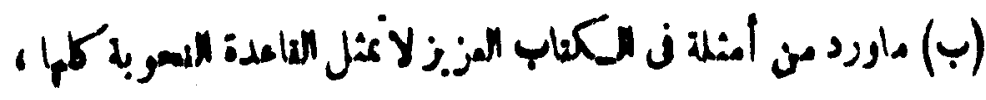

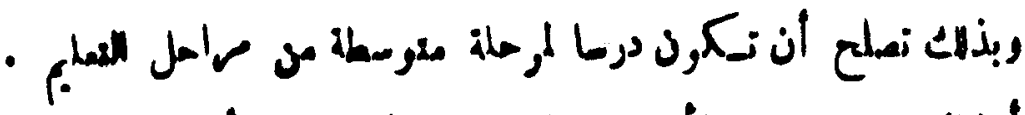

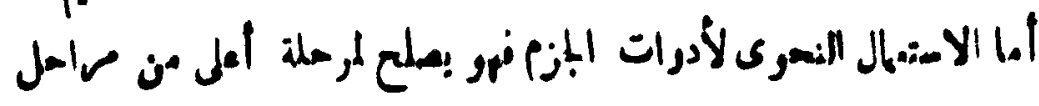

$\cdot \beta^{\text {dein }}$

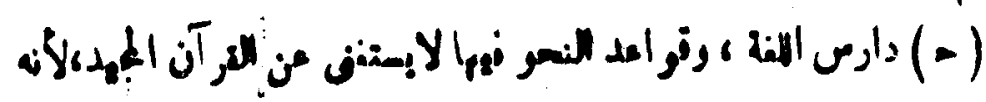

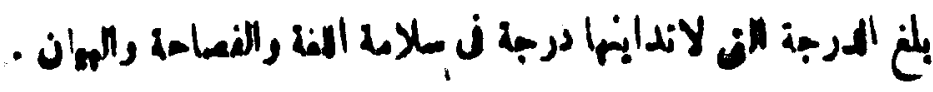

" ربعد (-

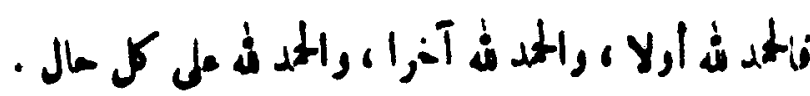


1

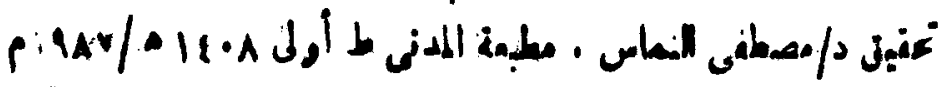

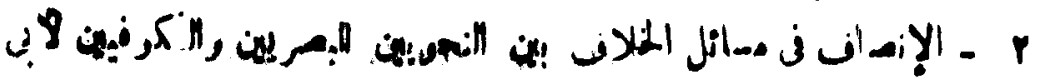

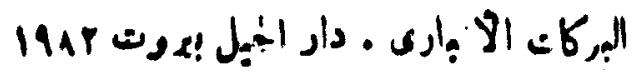

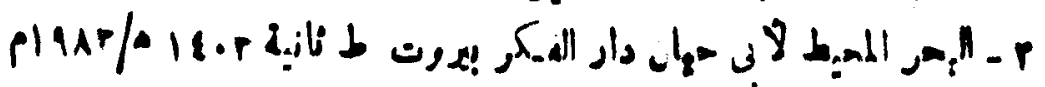

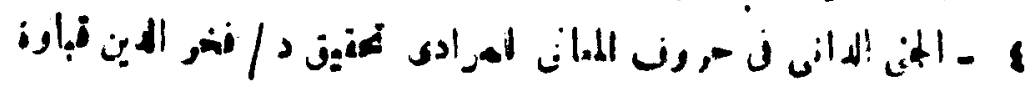

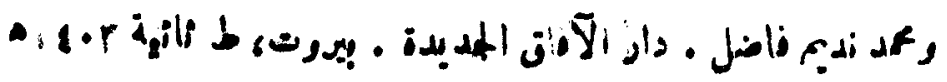

\section{platar}

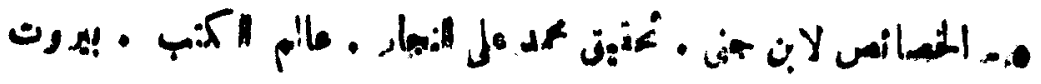

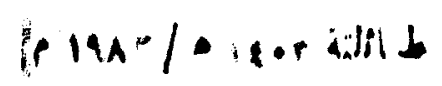

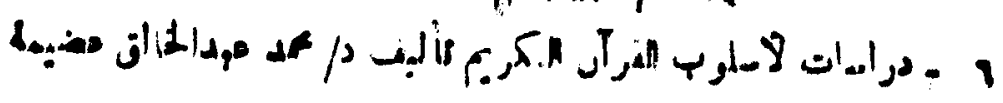

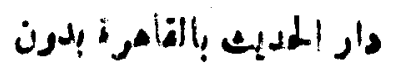

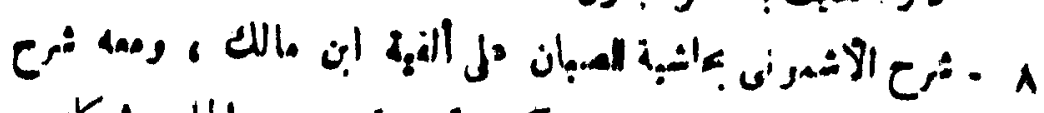

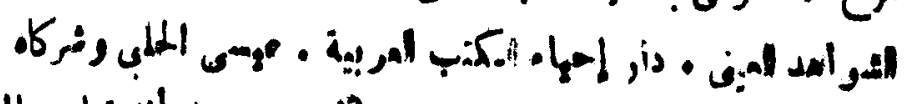

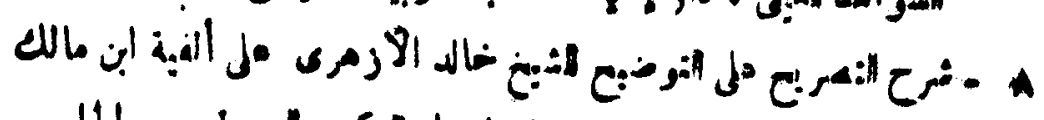

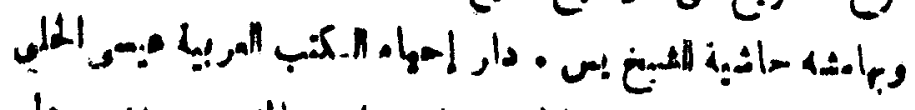

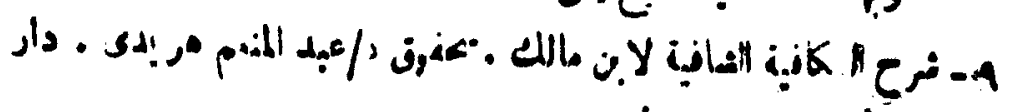

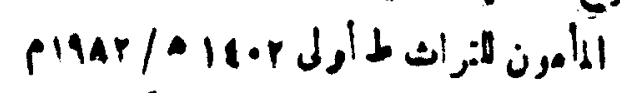

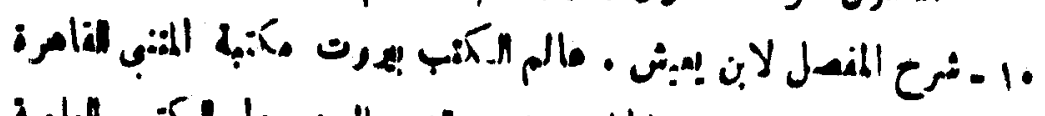

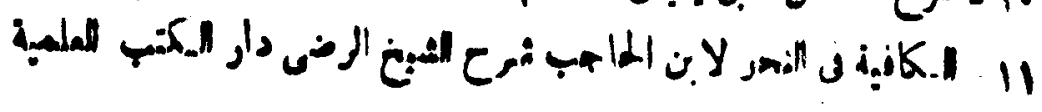

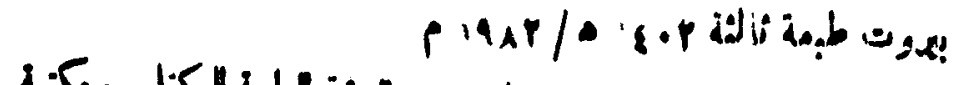

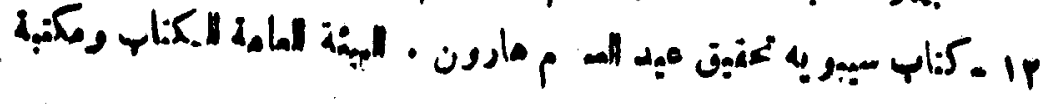
plar wit| 
IvV

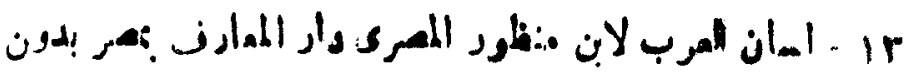

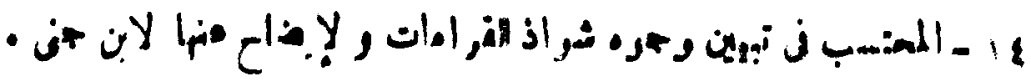

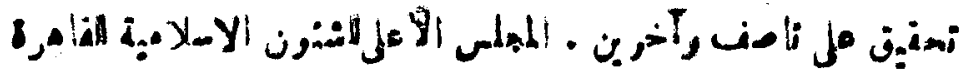

p1979/a |rat

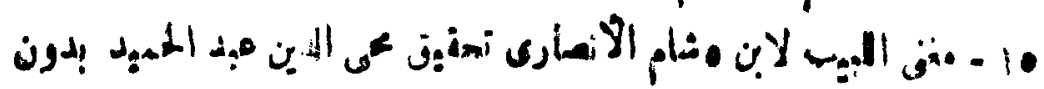

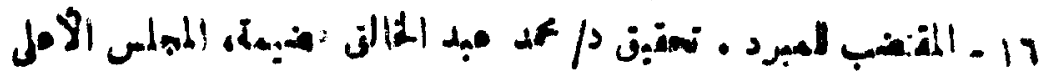

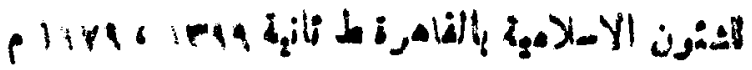

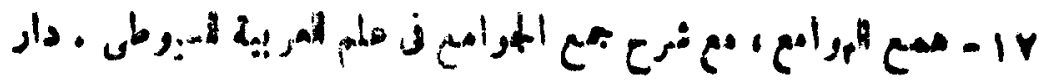

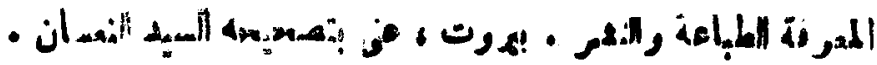

دا ابراهيم السيد أبراهيم بلوى

مدرس الننويات

في كلية اللفة العربية بالزتقازيق النيات

جامسة الزده 
وت البلاغتموالتنتح 


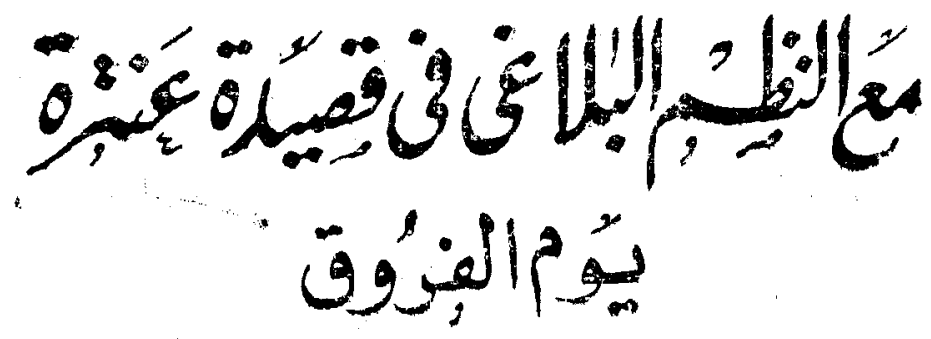

أ. أد/ عبد ألجواد مهمسيد همهد طبيق

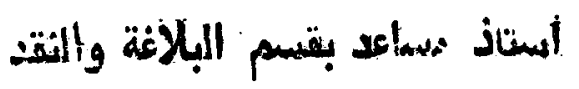

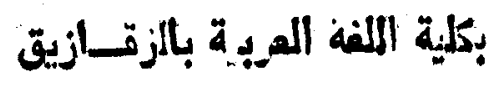

تمهستيد :

بسم الله نبدأ ؛ ومنه نستمد العون والتوفيق 6 ونصلى وينسيلم

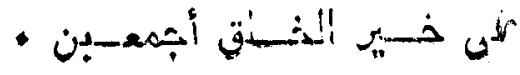

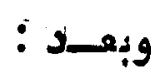

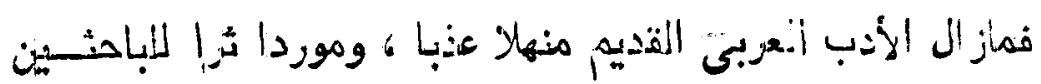

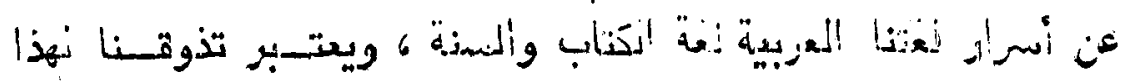

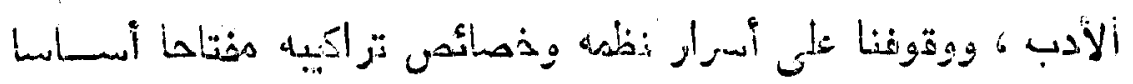

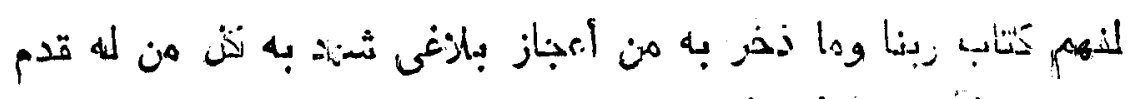

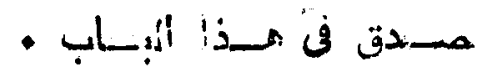

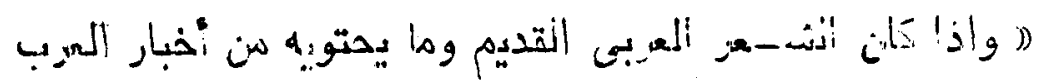

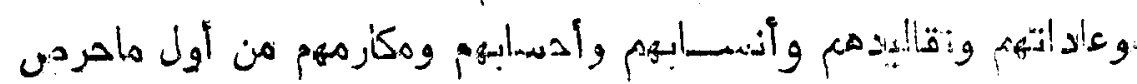

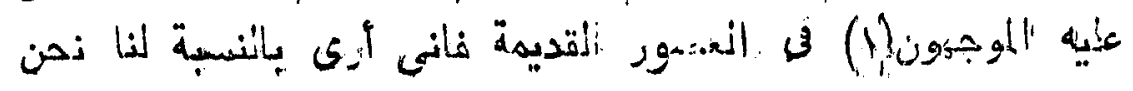

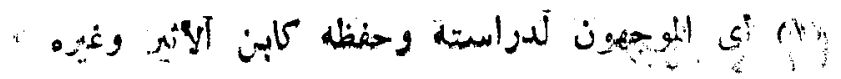




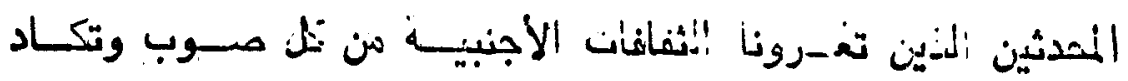

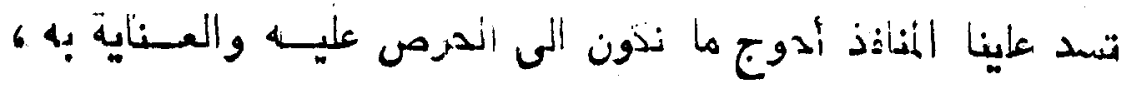

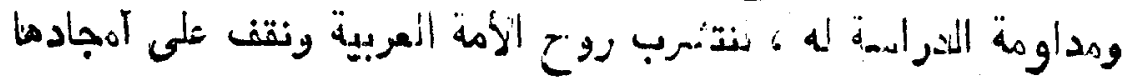

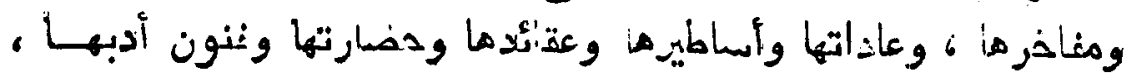

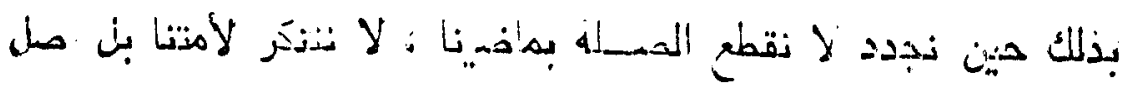

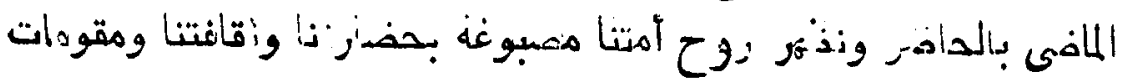

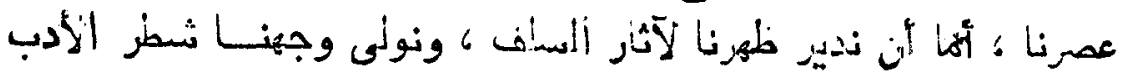

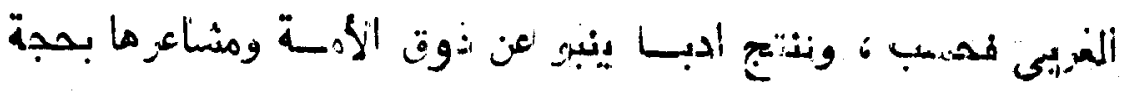

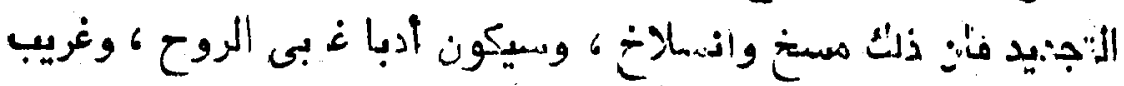

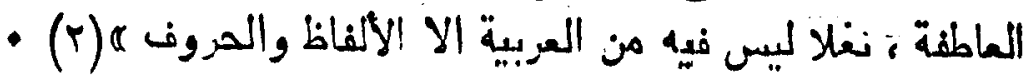
وتأتى هذه الليرابسة ـقصهية: ؤحدة هن أصحاب ألمعلقات في العصر

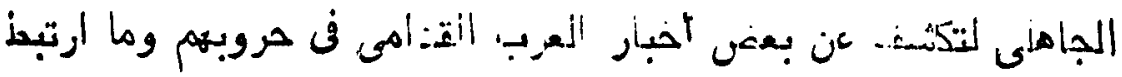

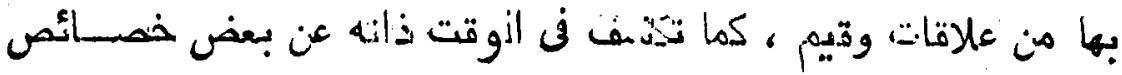

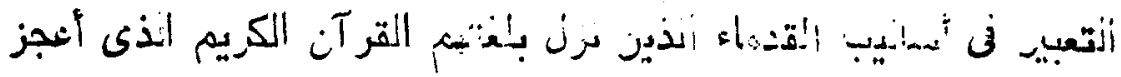

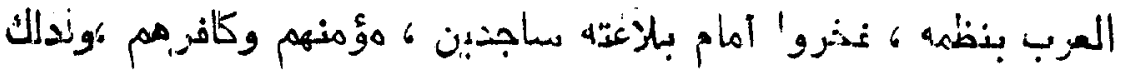

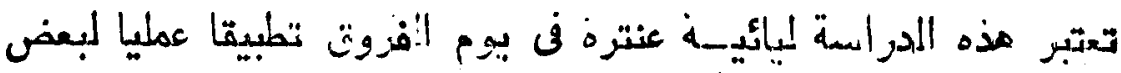

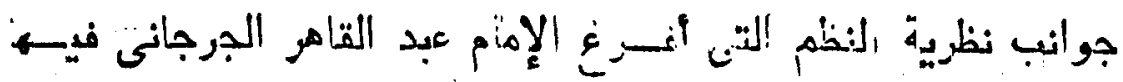

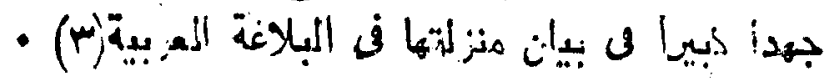

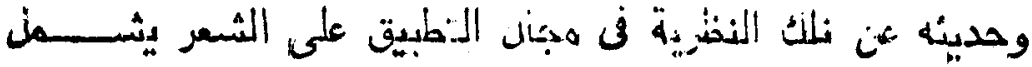

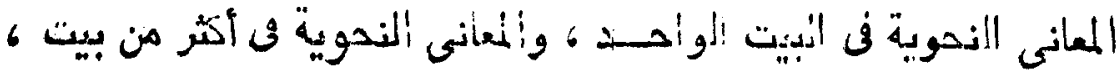

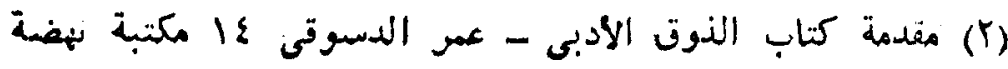

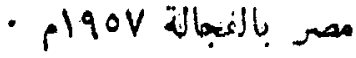

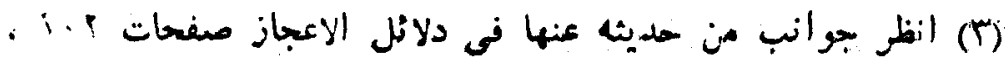
• 


\section{EAr}

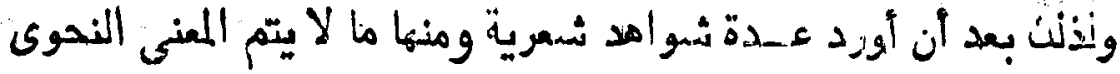

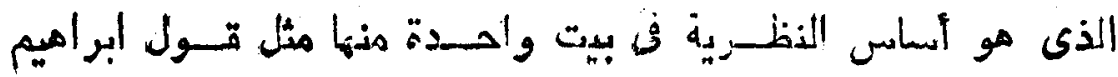

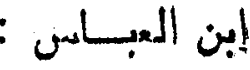

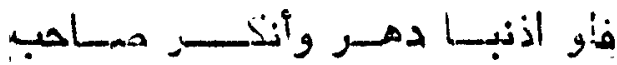

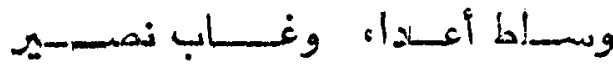

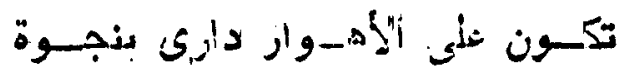

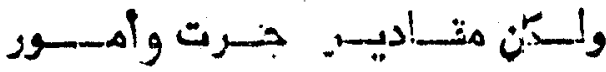

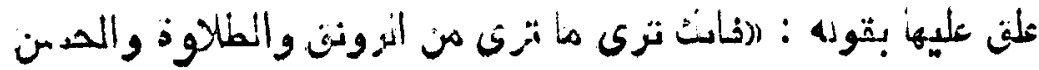

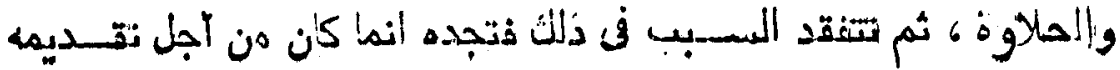

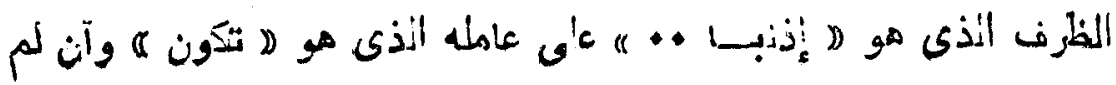

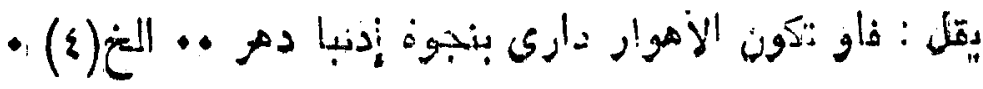

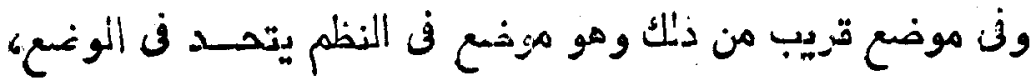

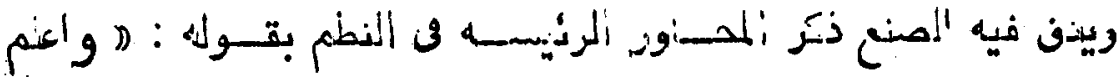

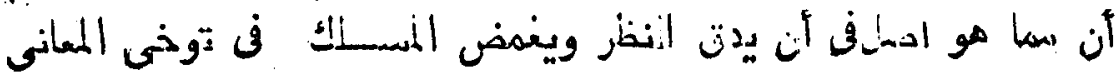

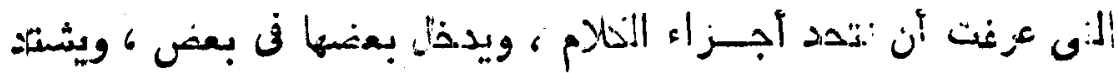

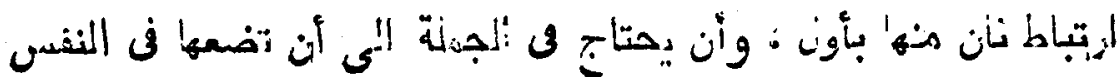

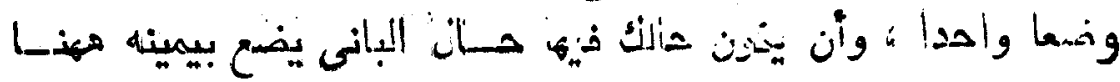

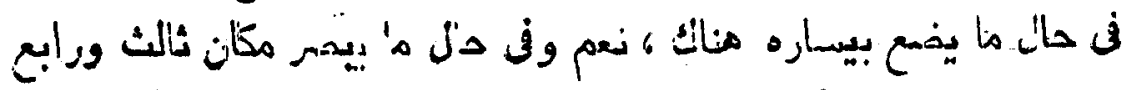

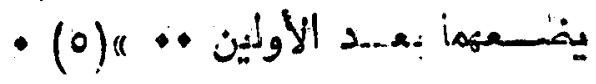

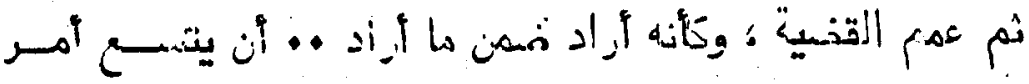

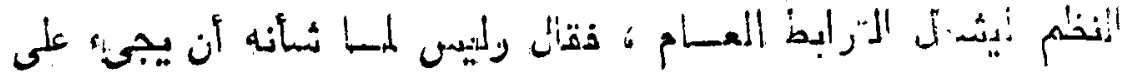




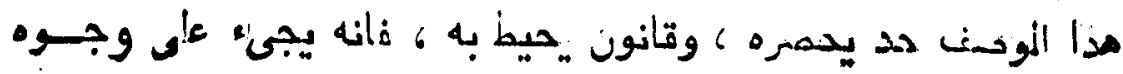

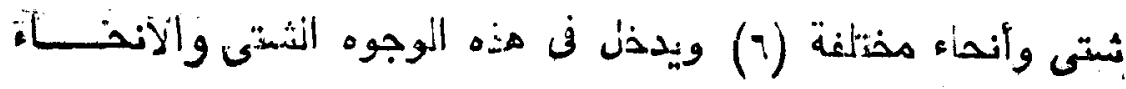

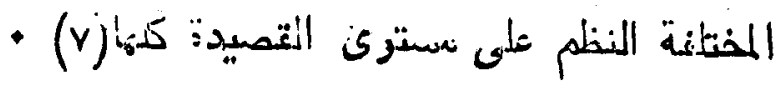

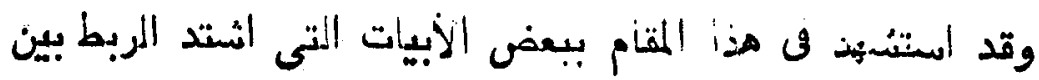

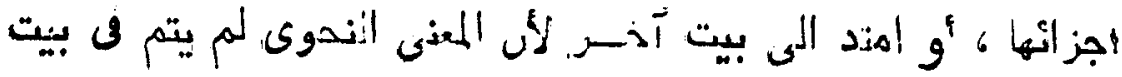

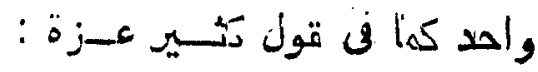

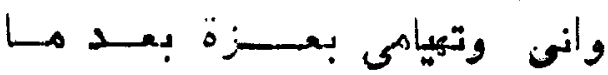

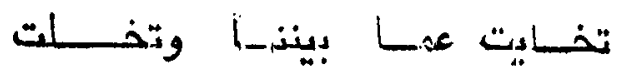

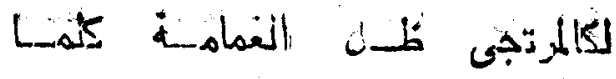

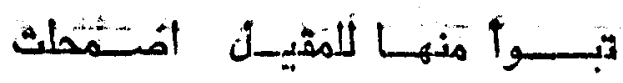

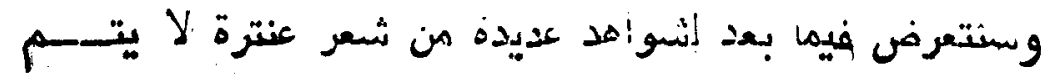

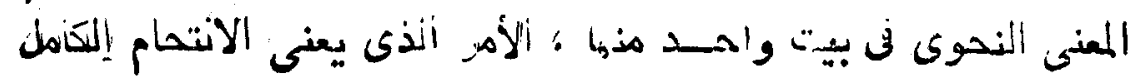

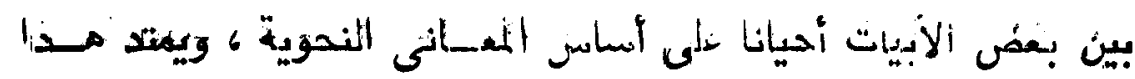

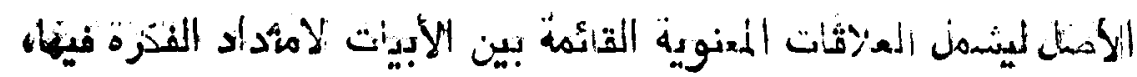

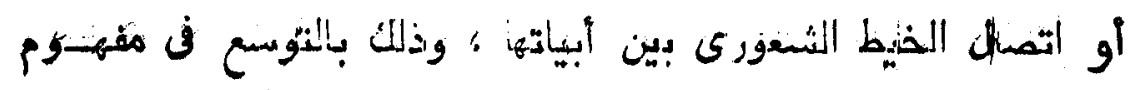

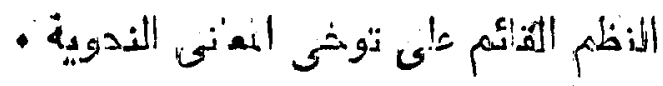

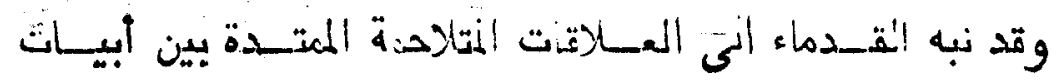

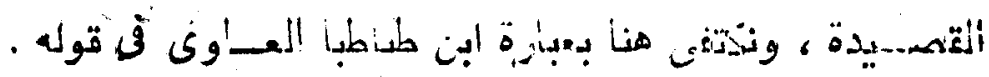

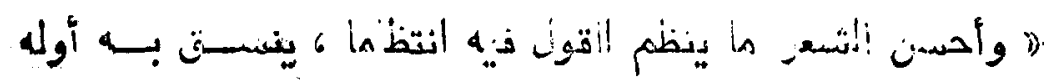

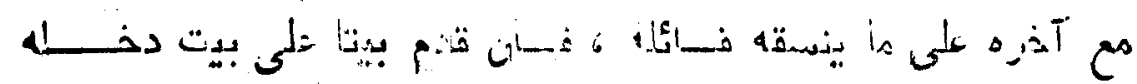

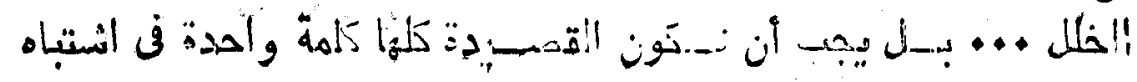

$$
\text { • (7) المرجع السابق }
$$

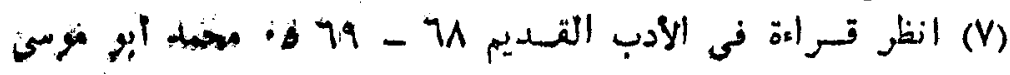
دار الفكر العربى - 


\section{(4)}

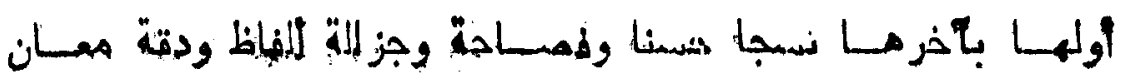

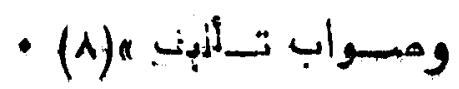

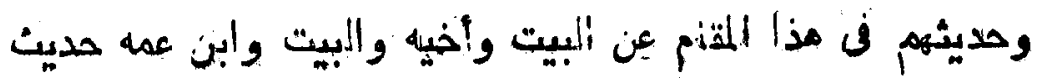

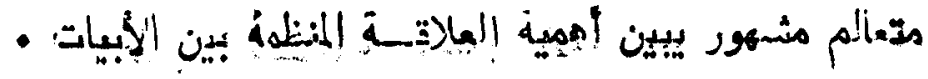

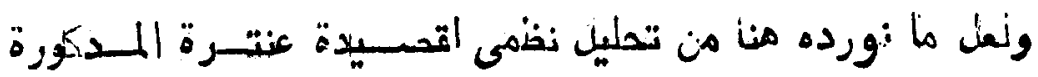

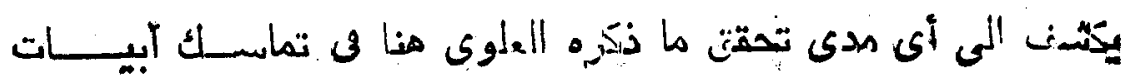

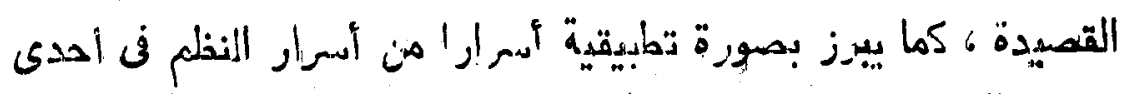

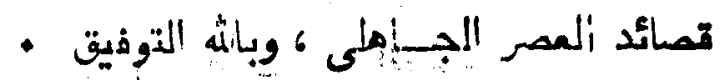

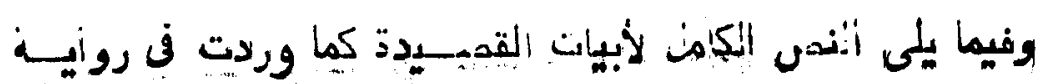

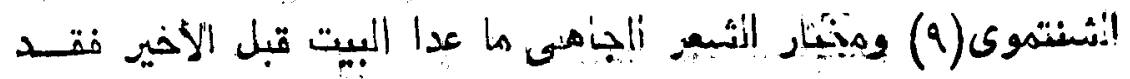

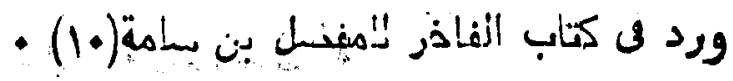

\section{في يســـوم الفـــــروق}

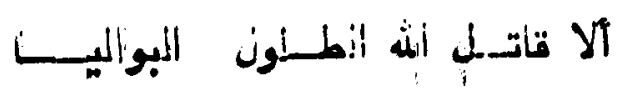

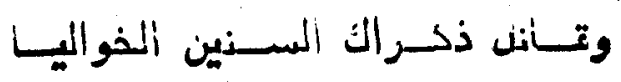

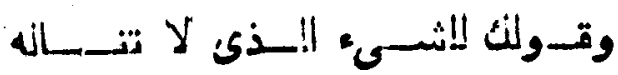

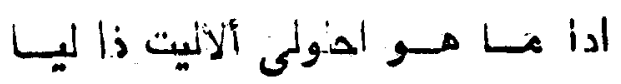

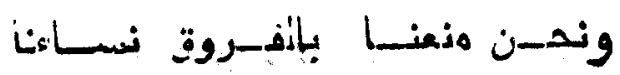

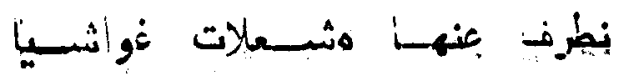

- ITV - IT7 عيار انشعر (A)

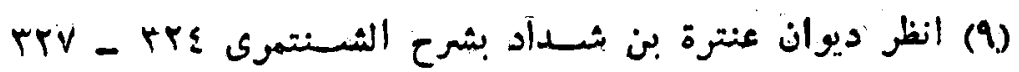

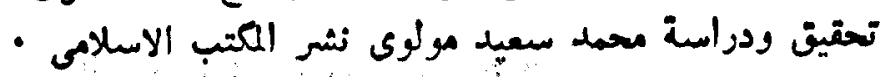

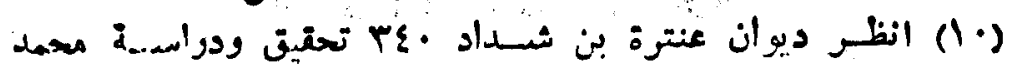


هلفنا لهـئم والتيـل تردى بذا مهيا

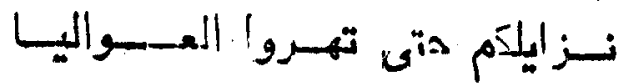

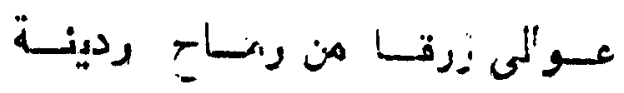

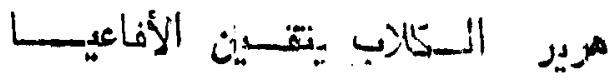

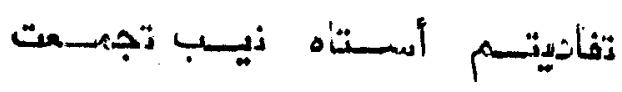

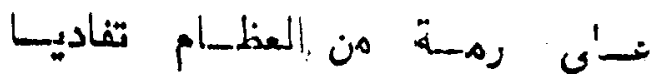

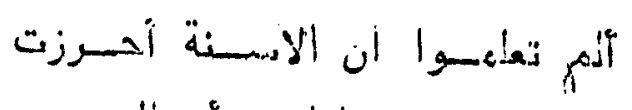

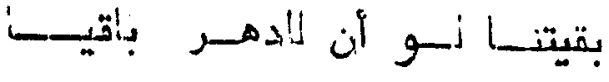

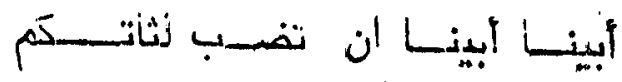

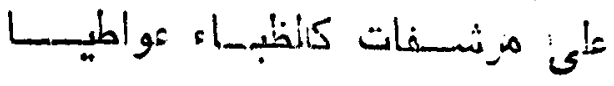

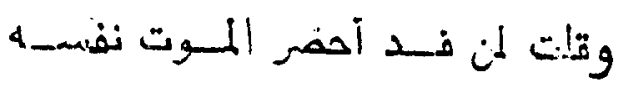

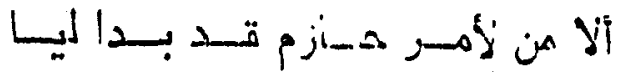

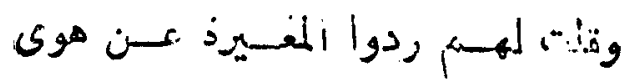

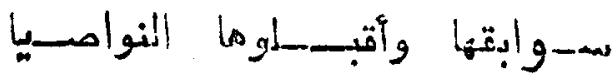

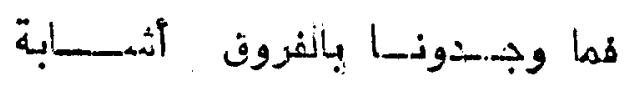

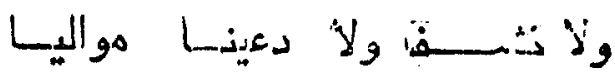

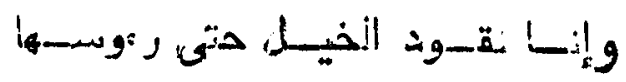

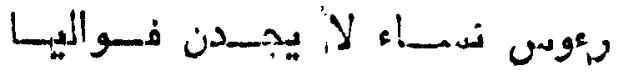

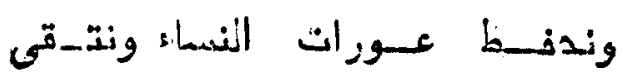

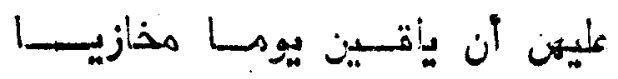

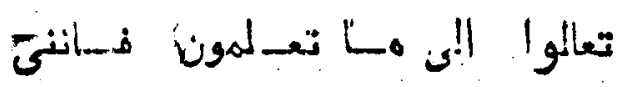

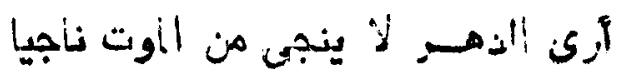


tAY

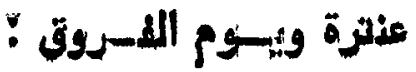

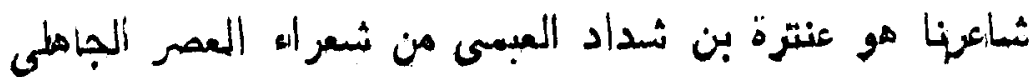

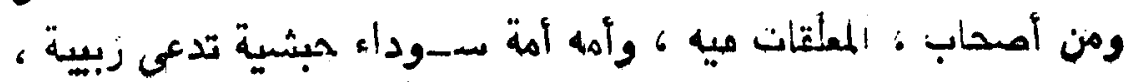

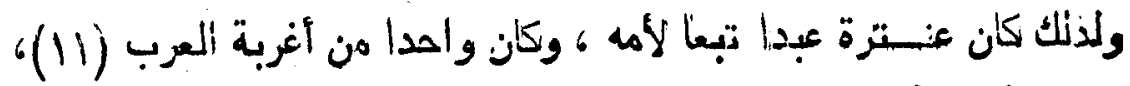

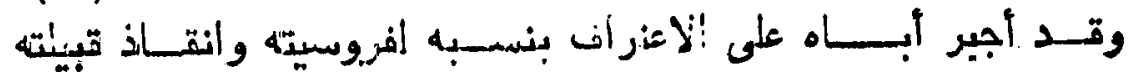
- من أعدائهـ

وكان لعبوديته واحساسه بأنذونية أثر كبـير فن شعره ك ولذلك دار حول

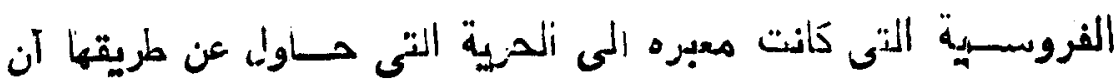
- بدل النى صساحبته عبستية

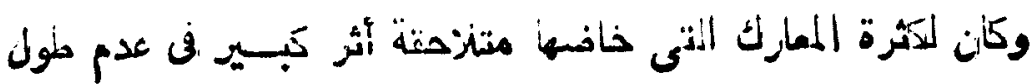

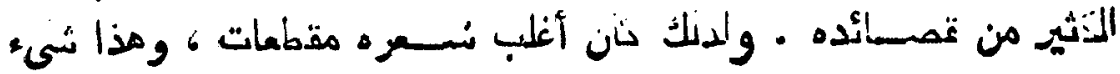

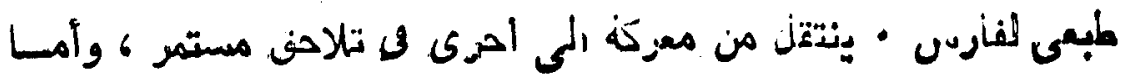

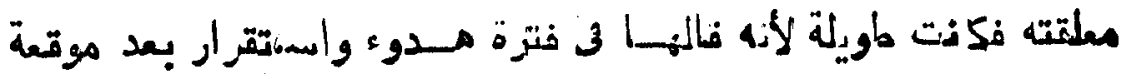

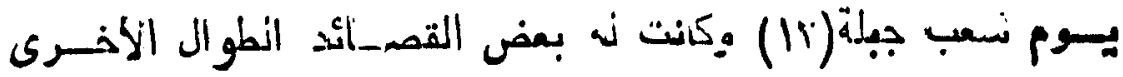

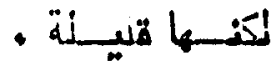

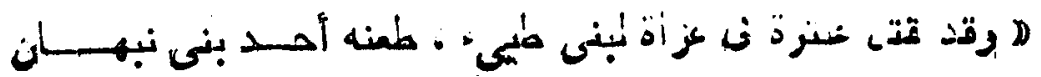

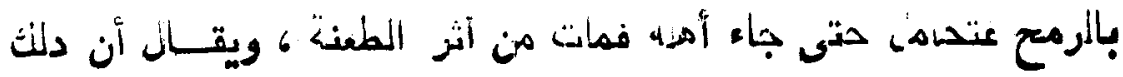

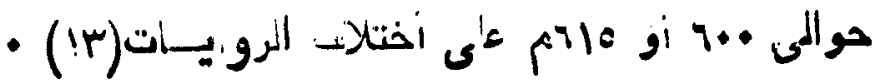

، يذكرون منهم ثلاثة ، مم عنترة ، وخفاف بن ندبة المسلمى (II)

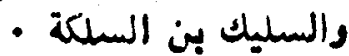

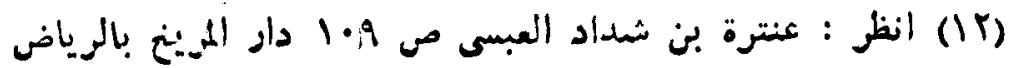

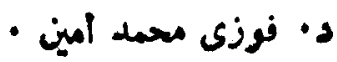

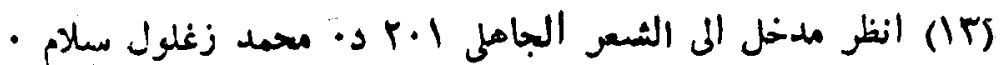

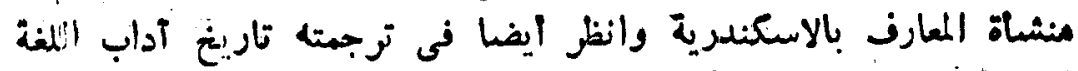

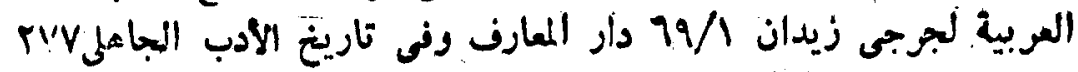

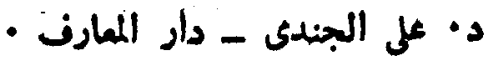




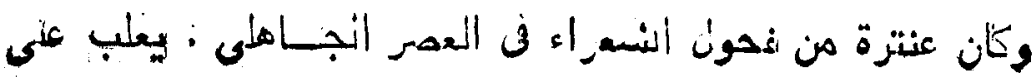

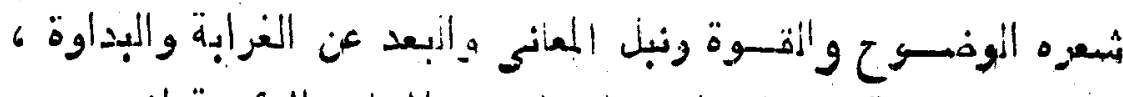

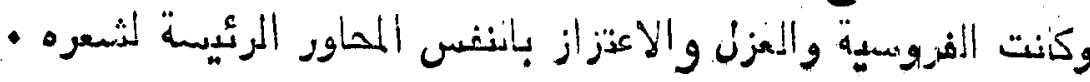

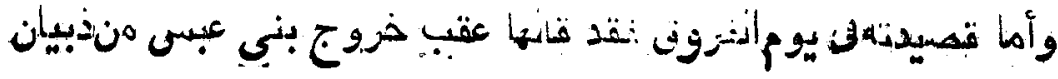

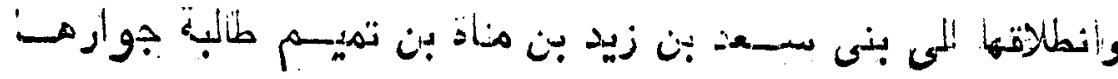

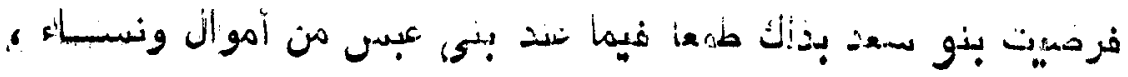

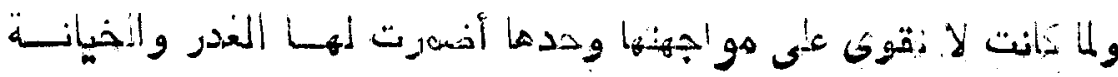

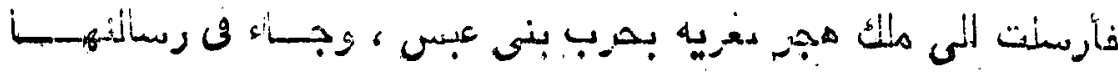

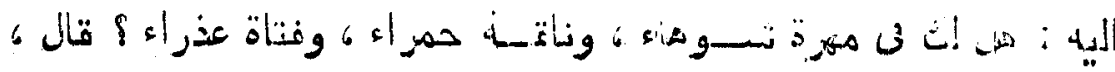

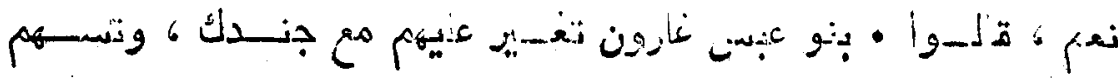

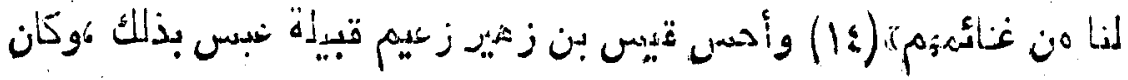

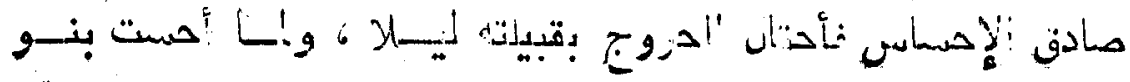

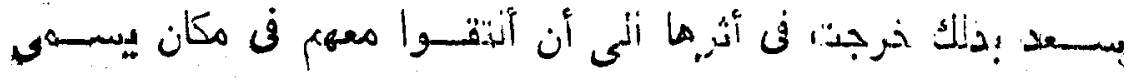

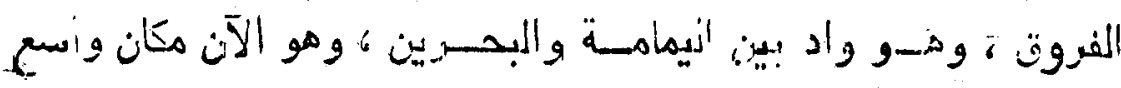

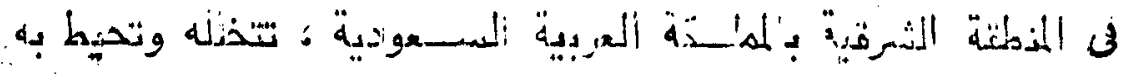

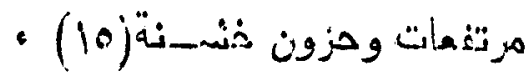

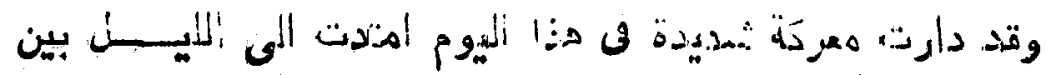

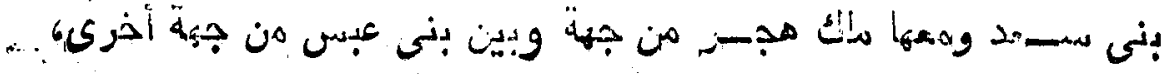

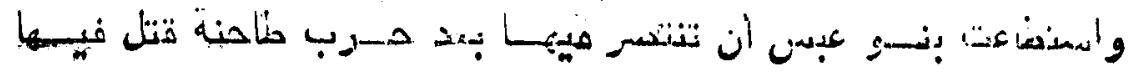

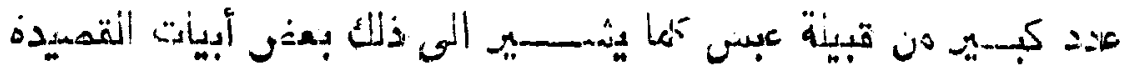
(6)

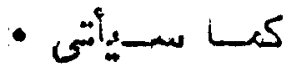

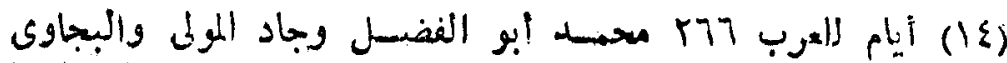

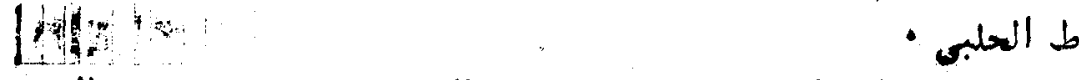

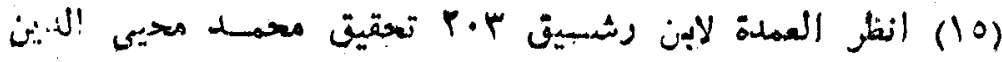

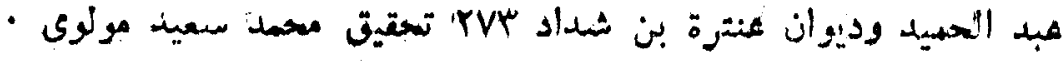




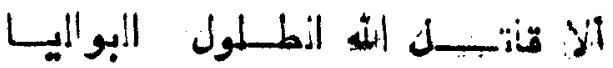

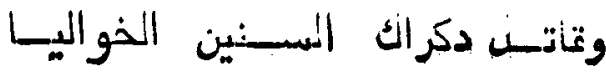

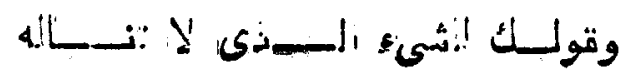

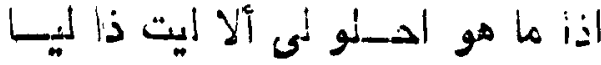

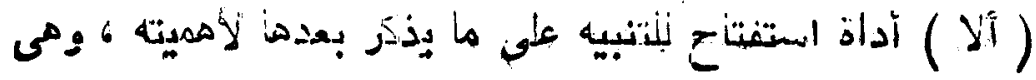

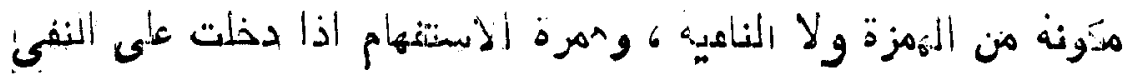

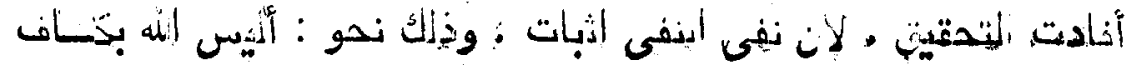

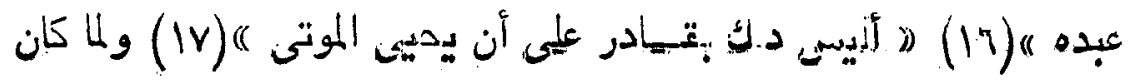

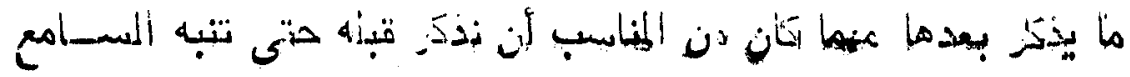

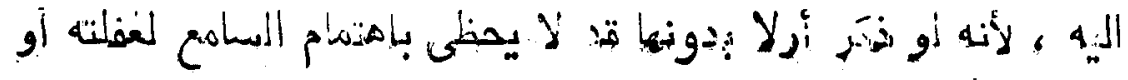

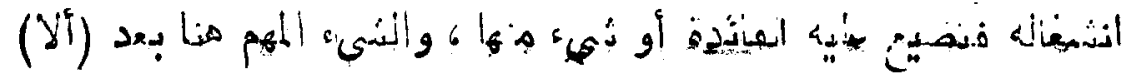

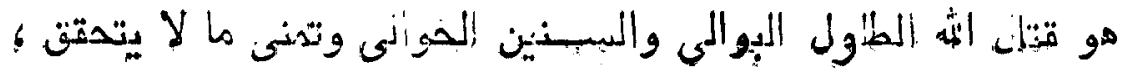

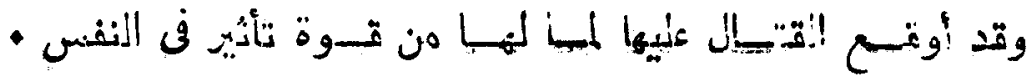

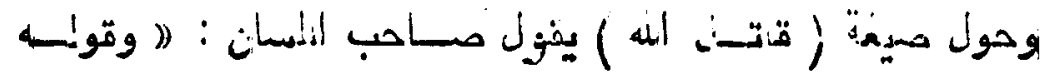

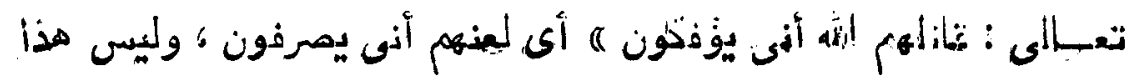

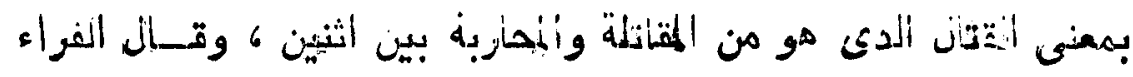

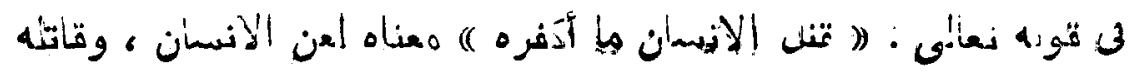

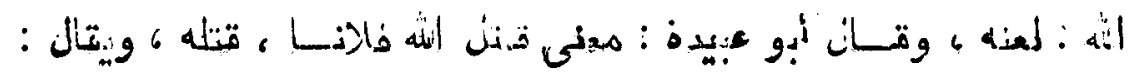

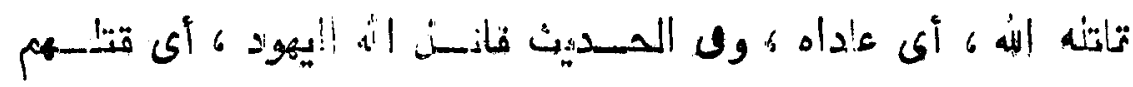

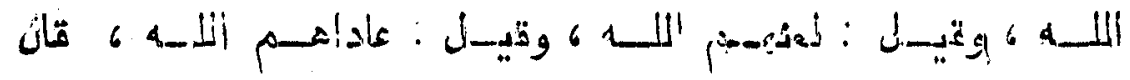

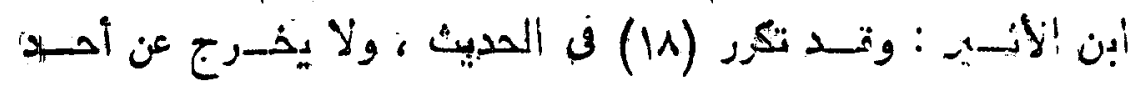

$$
\text { (17) }
$$

(IV)

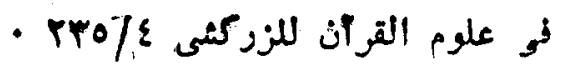
• 


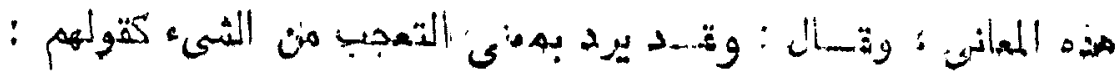

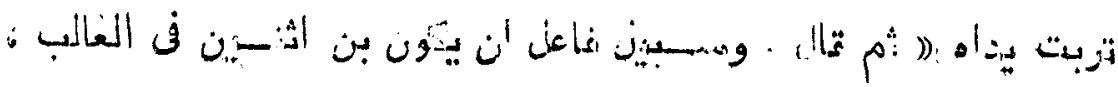

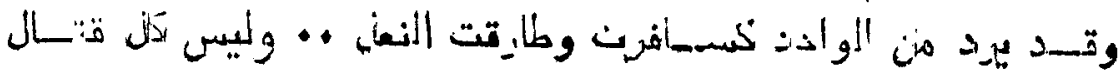
-

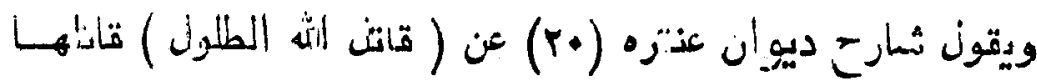

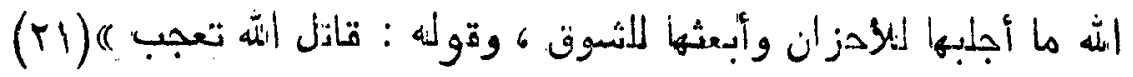

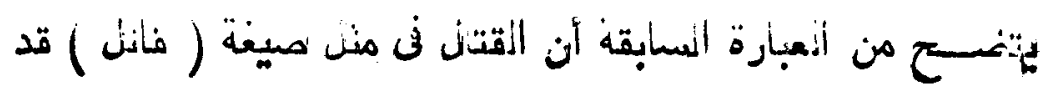

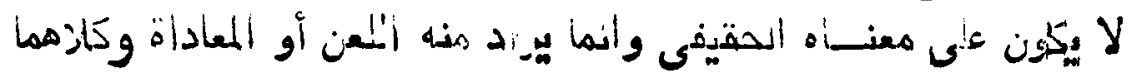

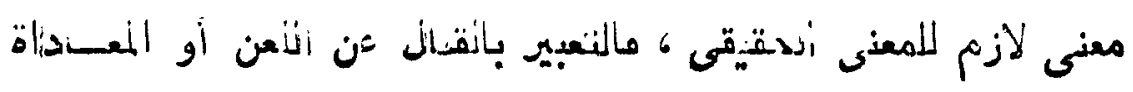

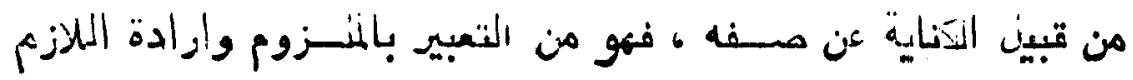

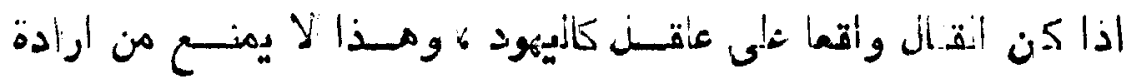

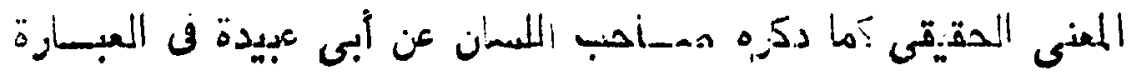

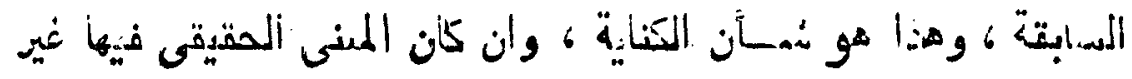

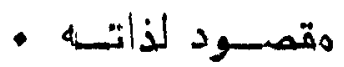

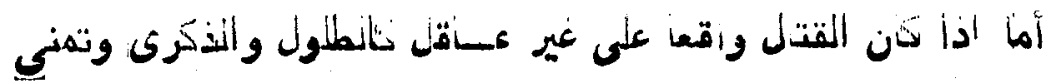

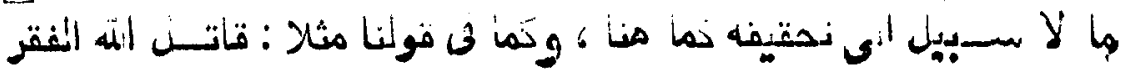

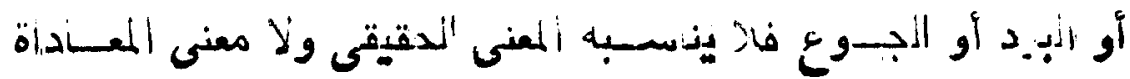

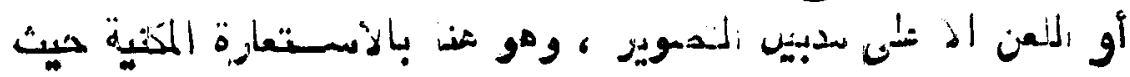

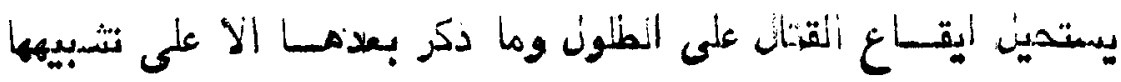

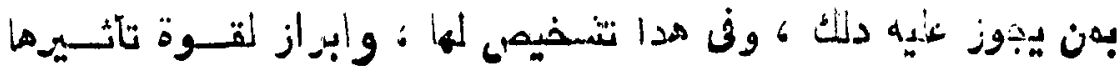

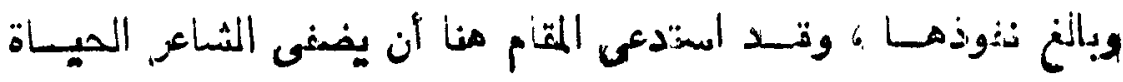

• (19) انظر لسان العرب مادة قتلز (19)

$$
\text { • (r) }
$$

(انظ (T) 


\section{(9)}

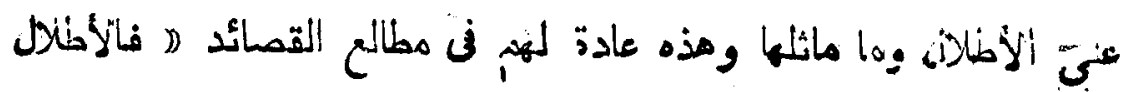

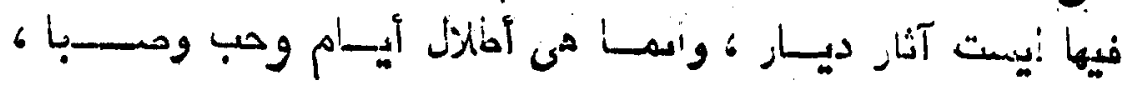

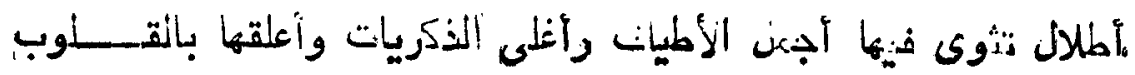

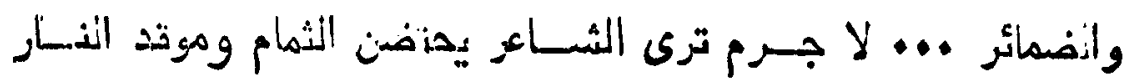

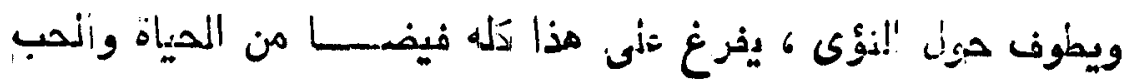

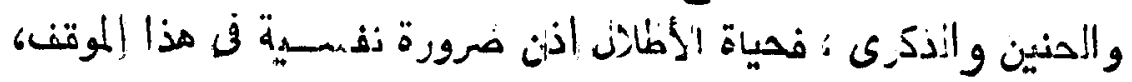

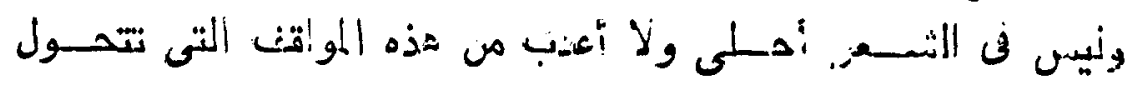

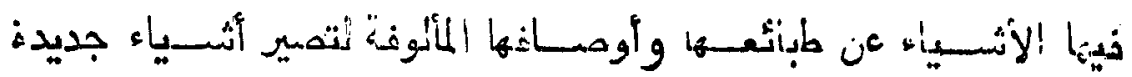

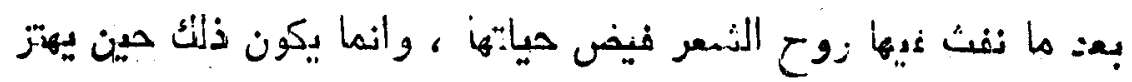

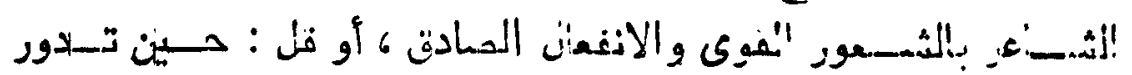

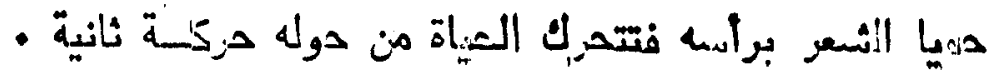

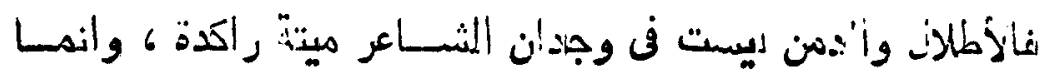

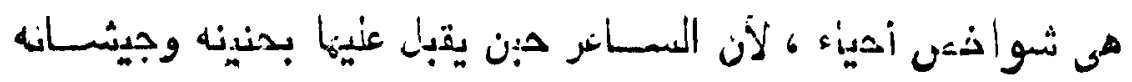

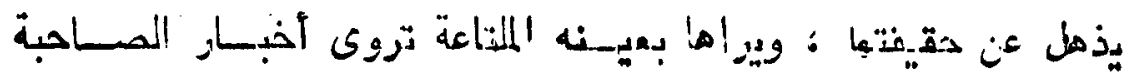

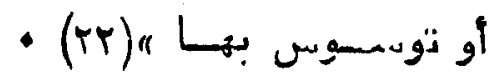

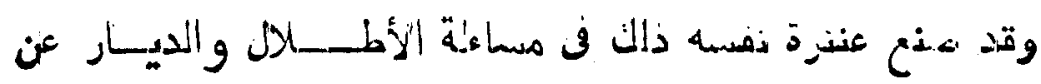

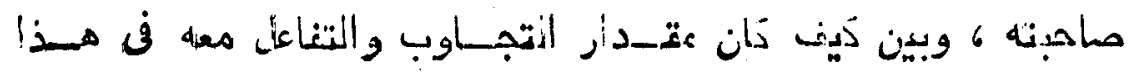

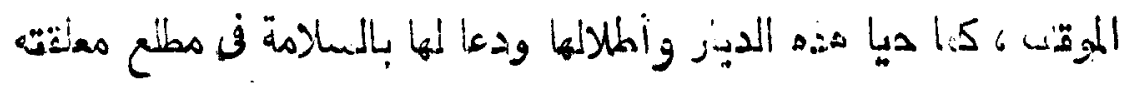

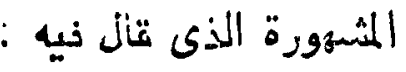

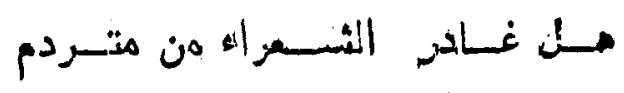

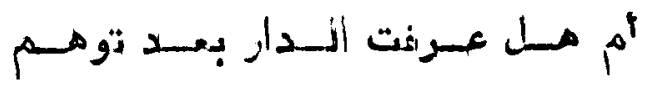

وم طr) 


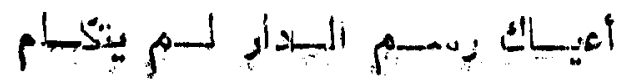

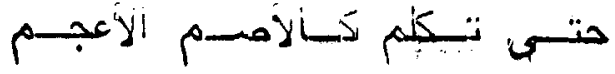

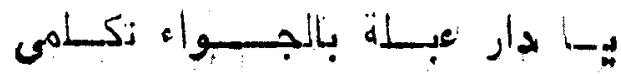

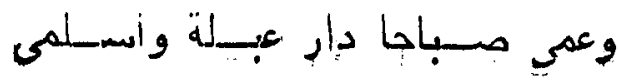

$$
\begin{aligned}
& \text { ديديت هن }
\end{aligned}
$$

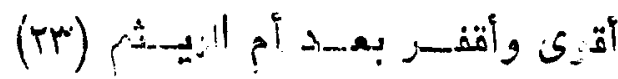

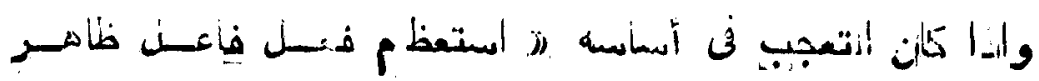

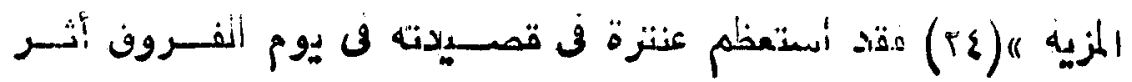

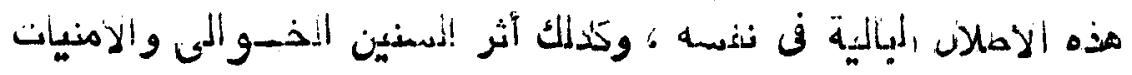

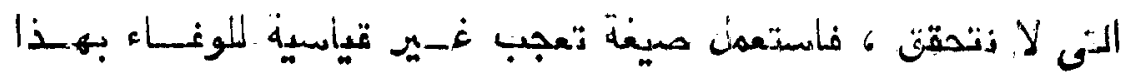

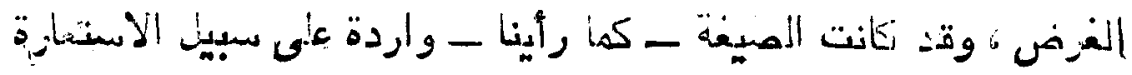

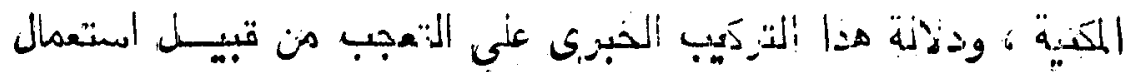

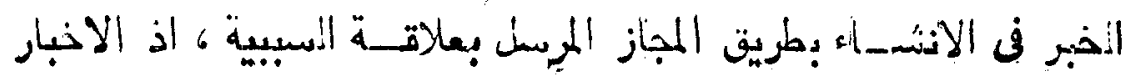

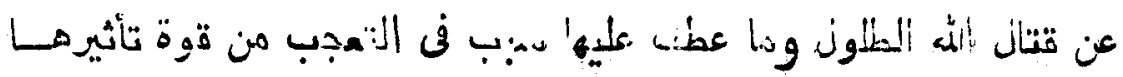

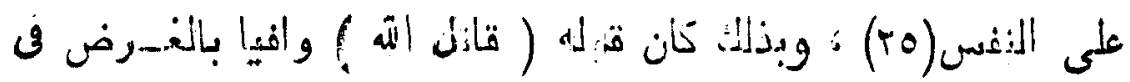

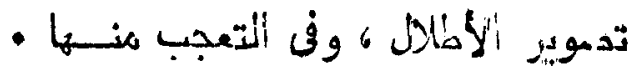

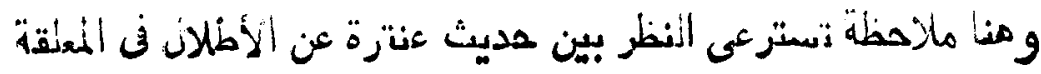

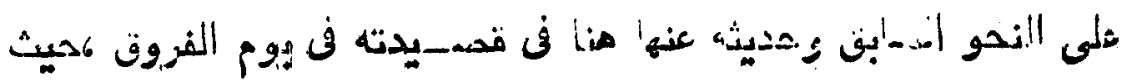

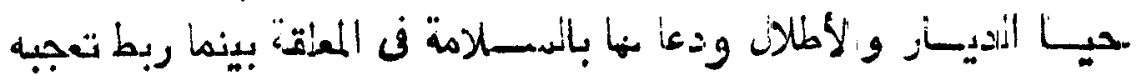

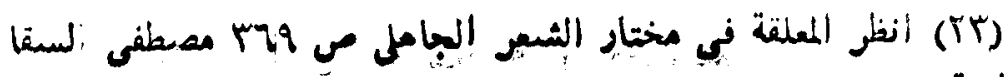

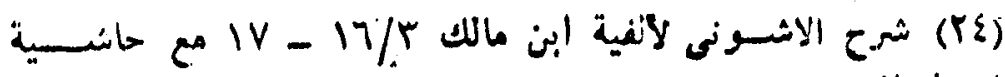

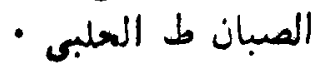

ا

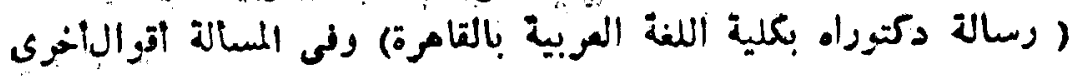




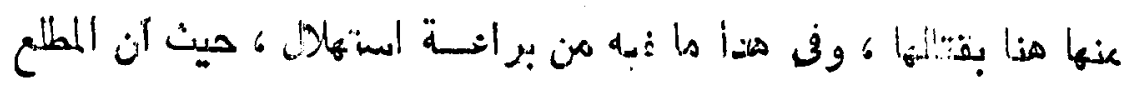

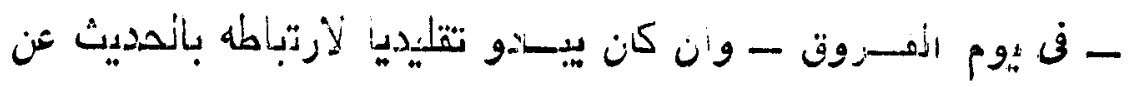

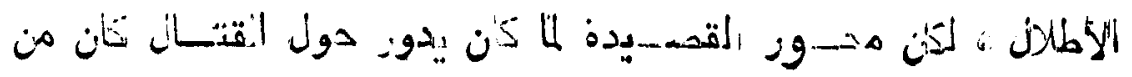

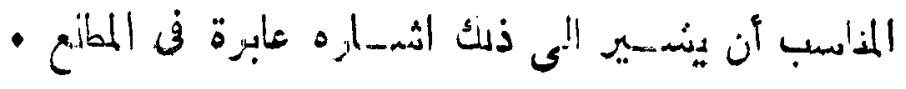

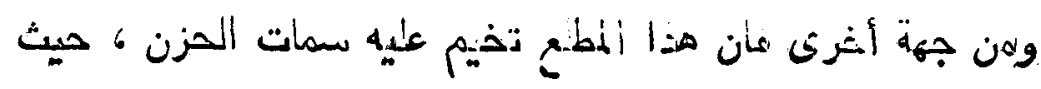

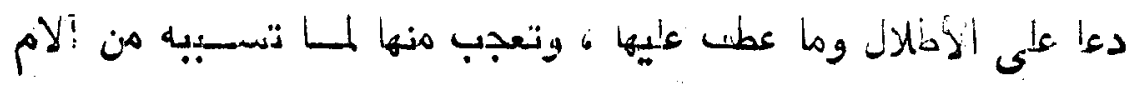

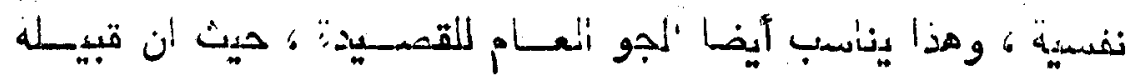

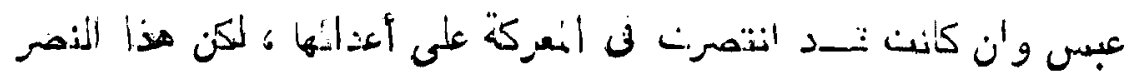

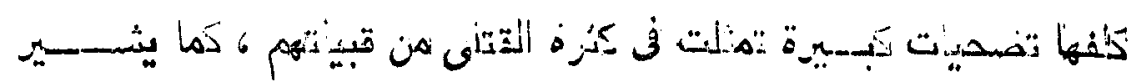

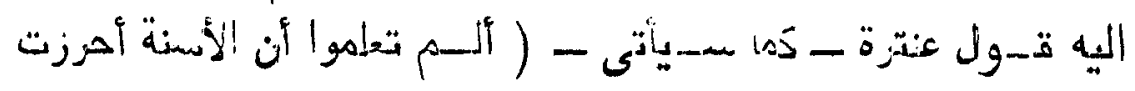

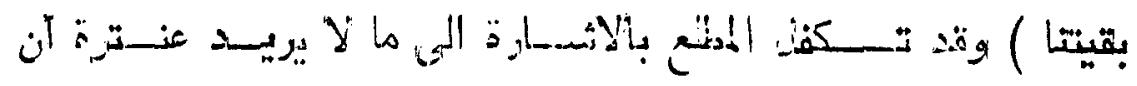

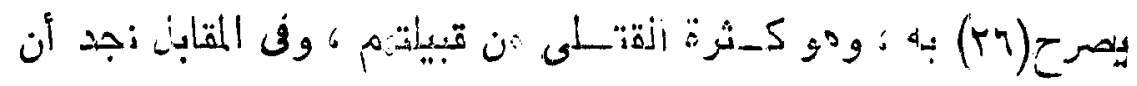

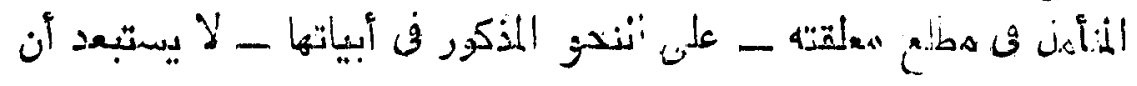

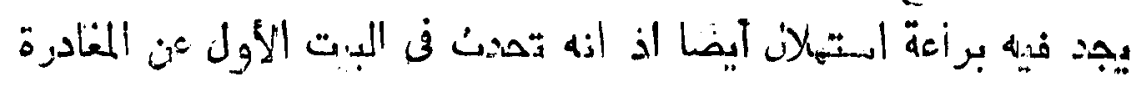

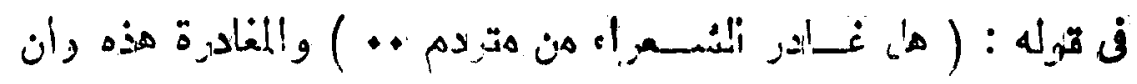

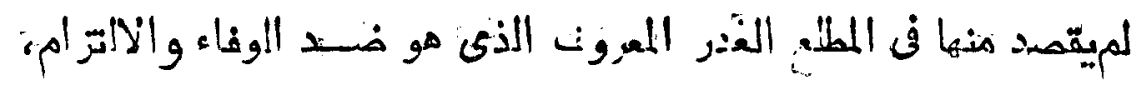

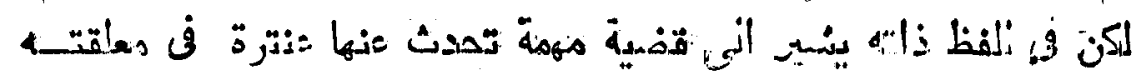

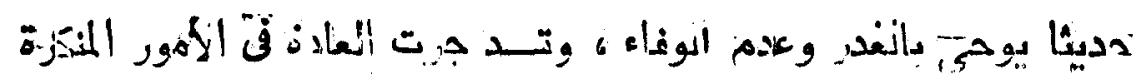

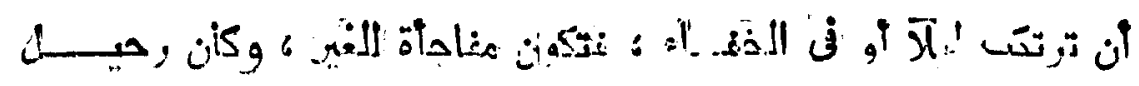

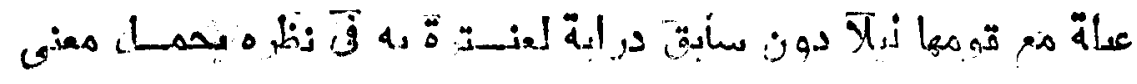

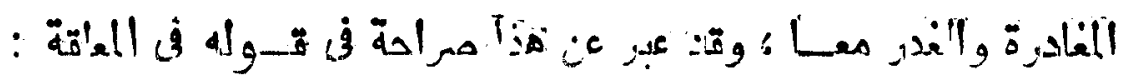

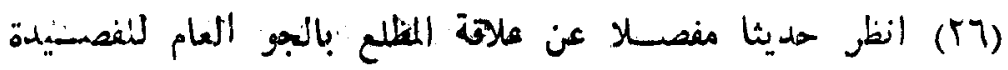

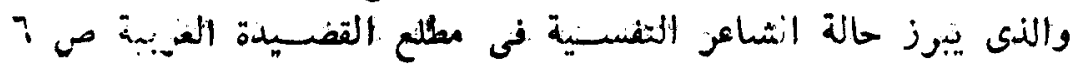

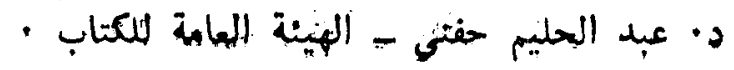




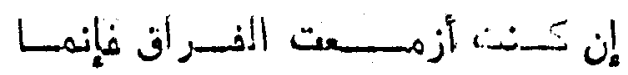

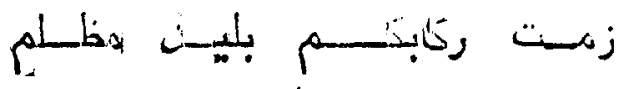

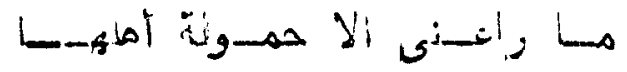

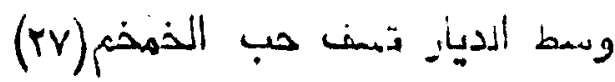

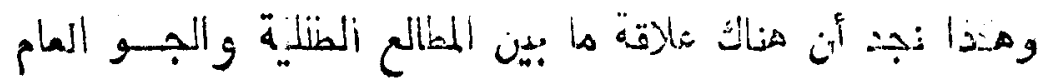

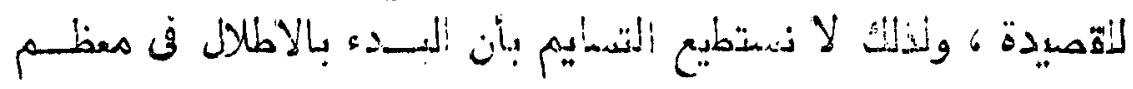

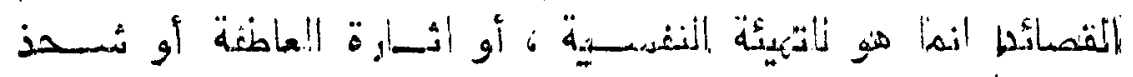

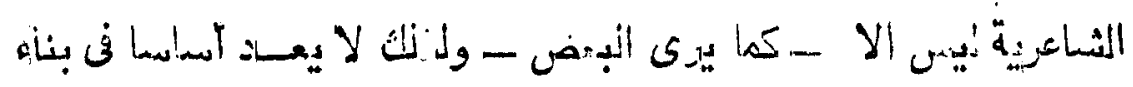

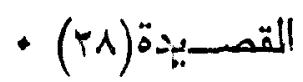

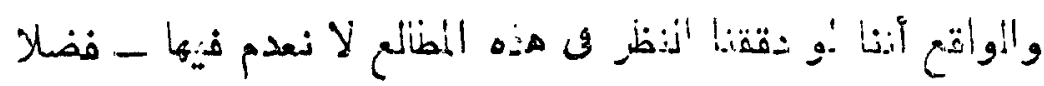

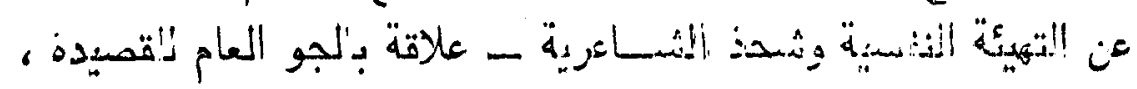

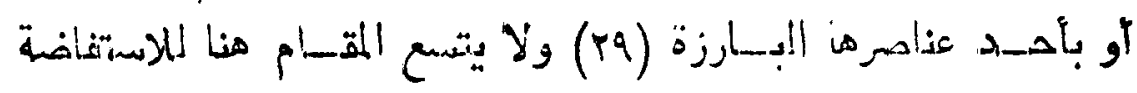

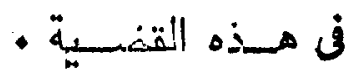

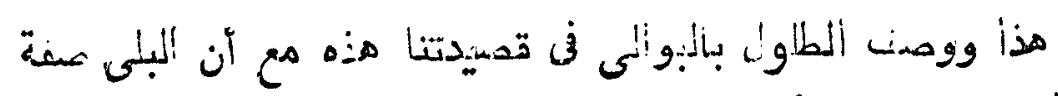

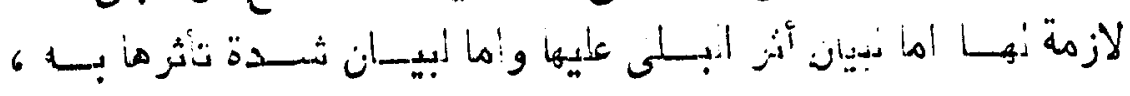

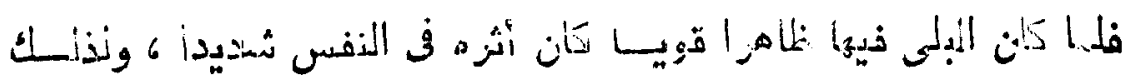

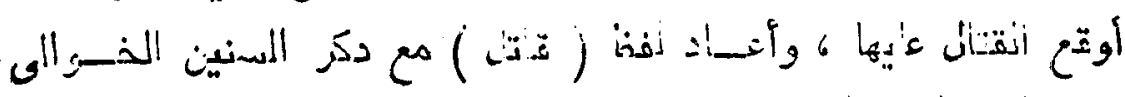

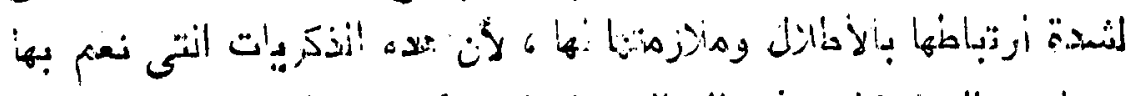

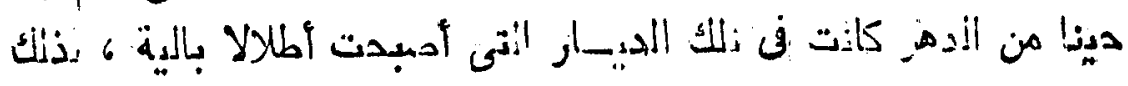

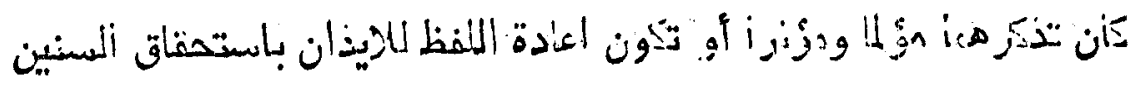

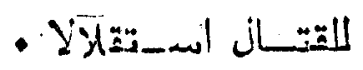

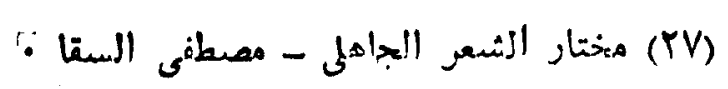

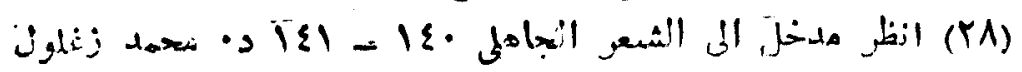

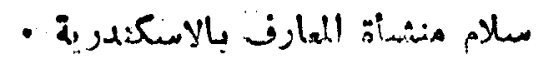

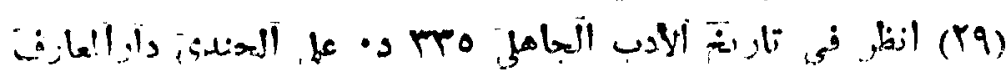

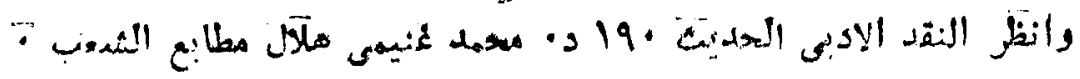




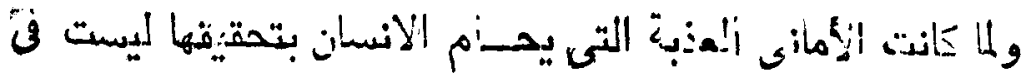

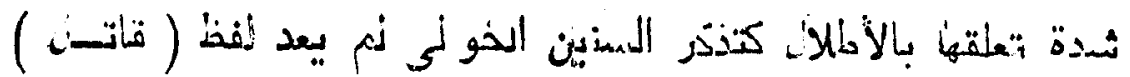

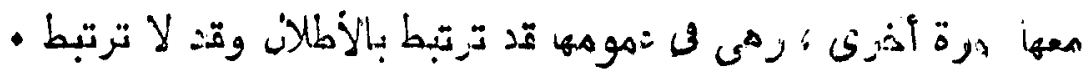

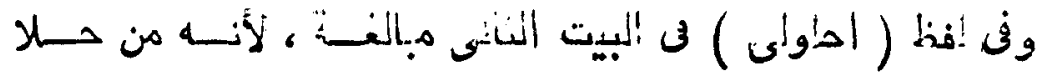

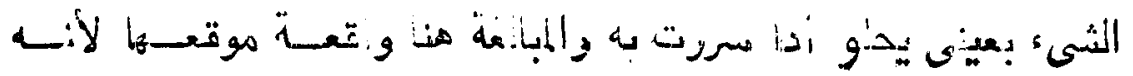

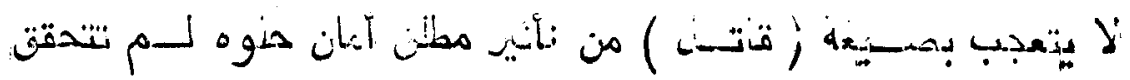

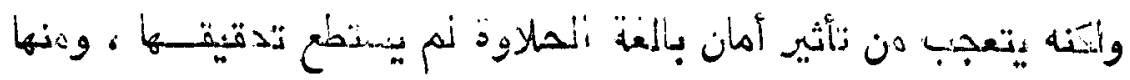

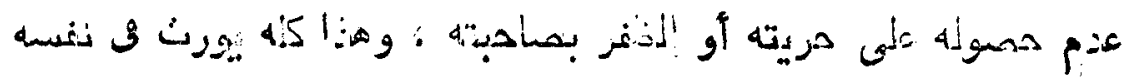

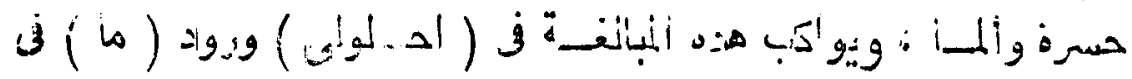

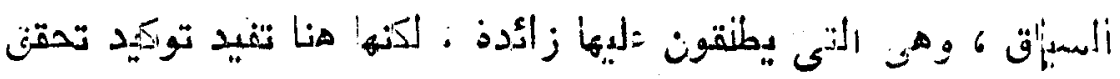

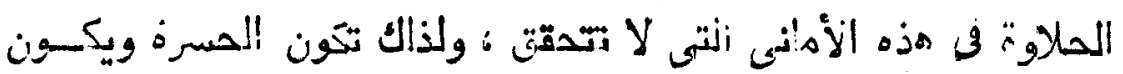

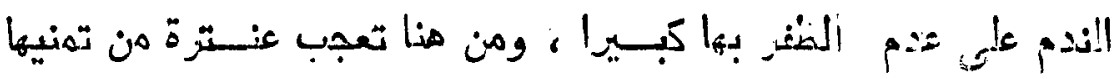

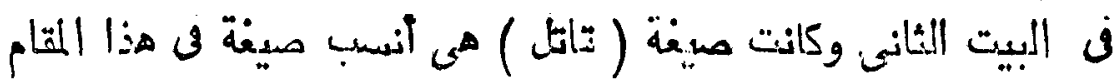

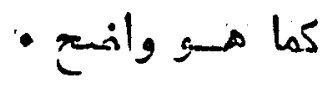

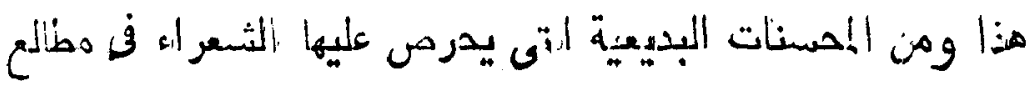

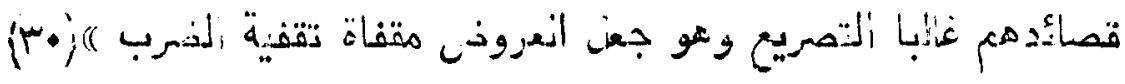

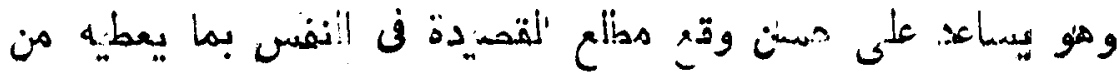

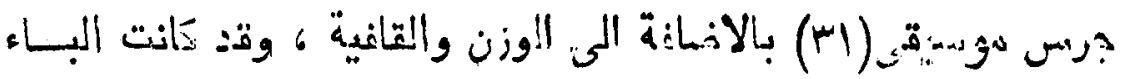

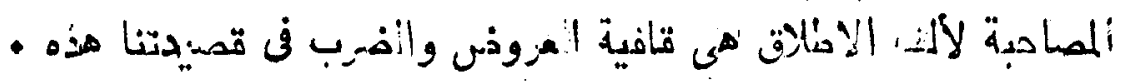

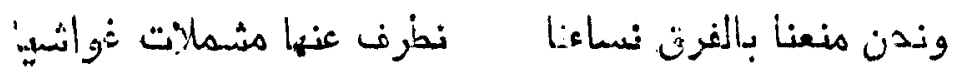

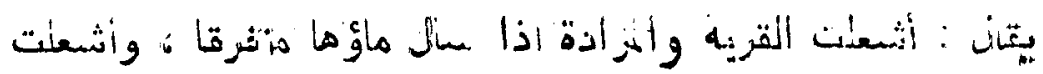

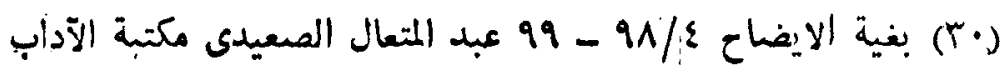

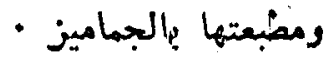

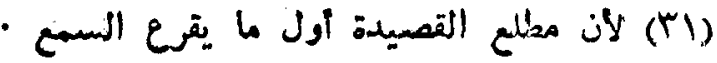




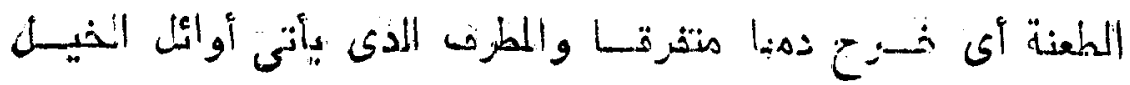

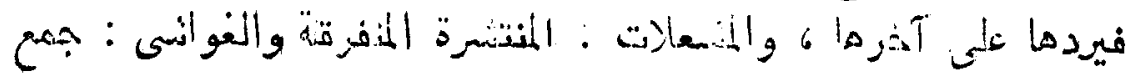

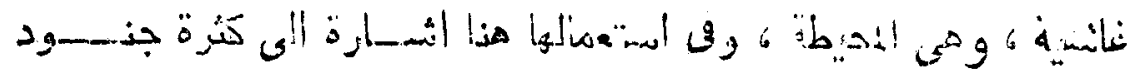

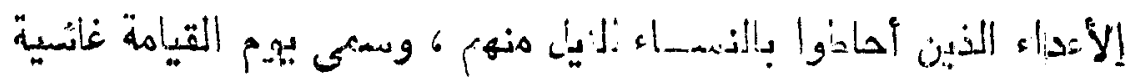

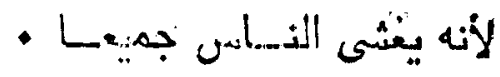

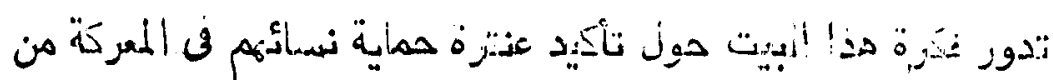

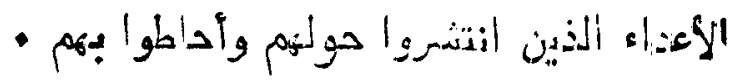

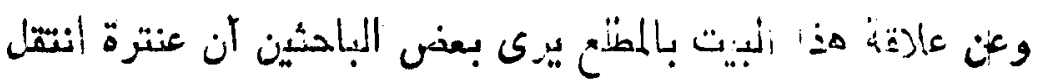

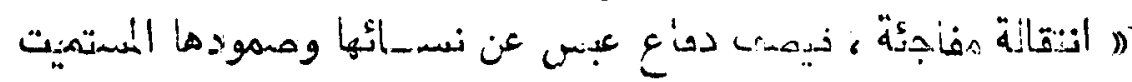

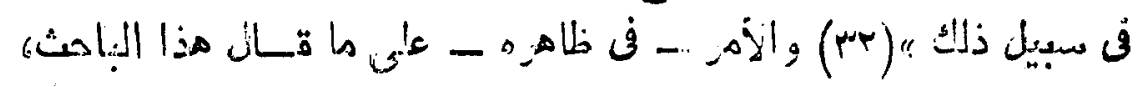

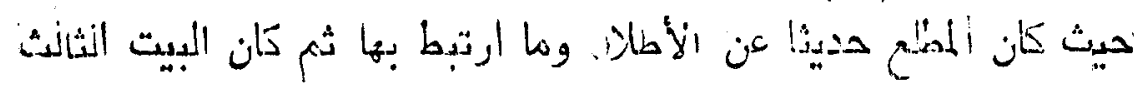

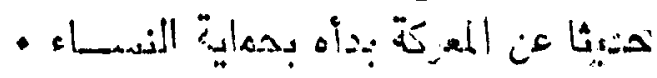

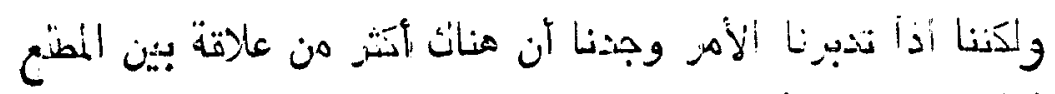

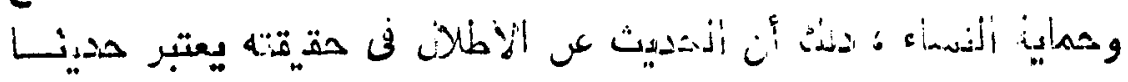

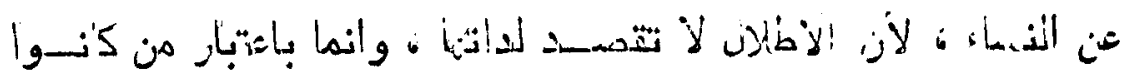

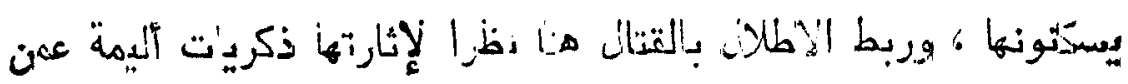

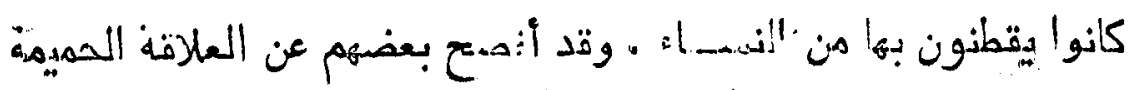

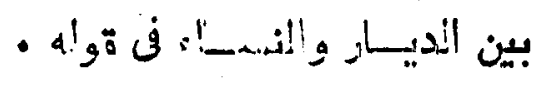

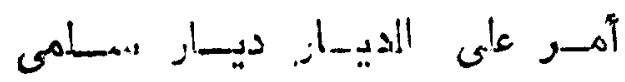

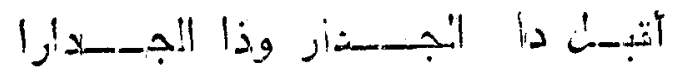

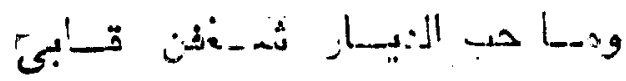

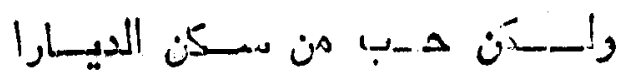

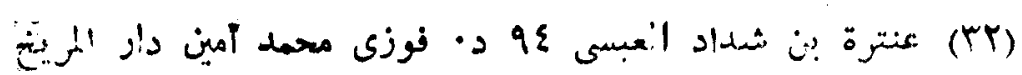




\section{$\varepsilon 9 V$}

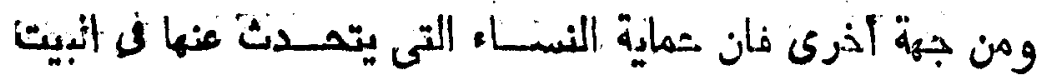

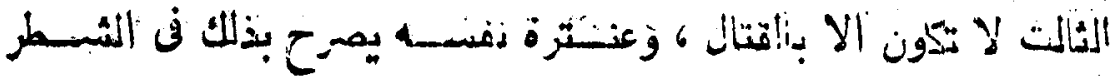

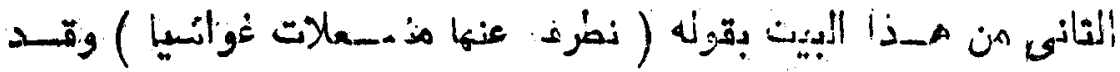

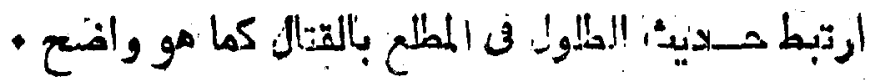

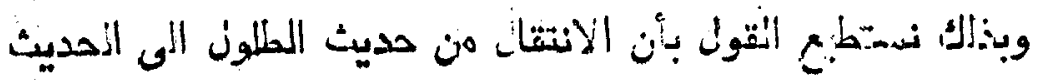

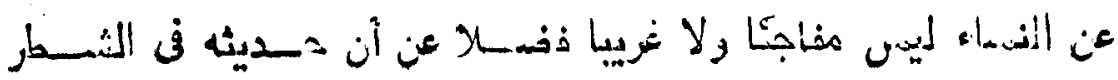

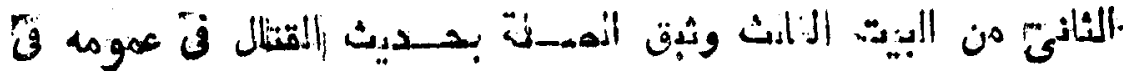
- i-

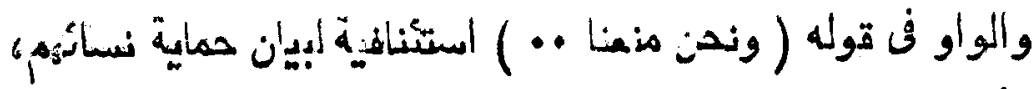

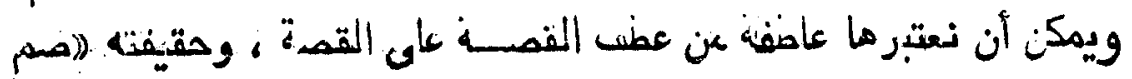

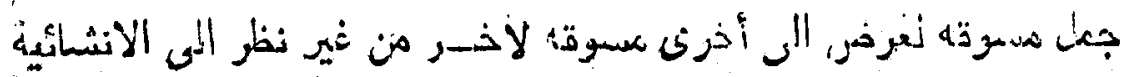

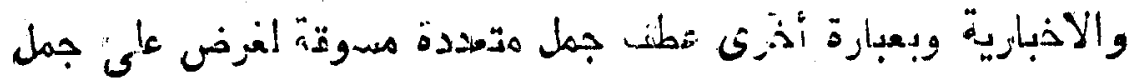

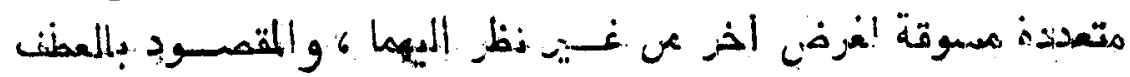

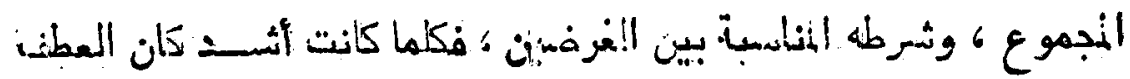

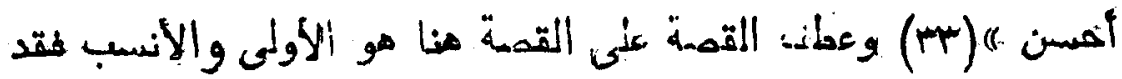

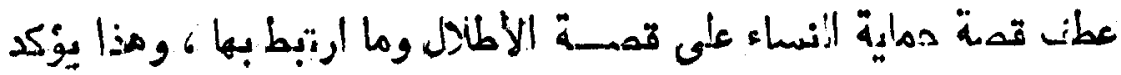

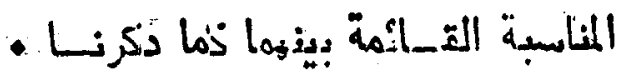

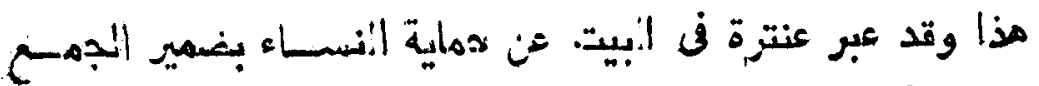

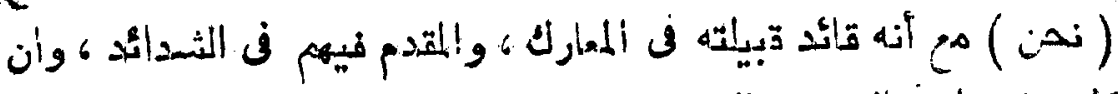

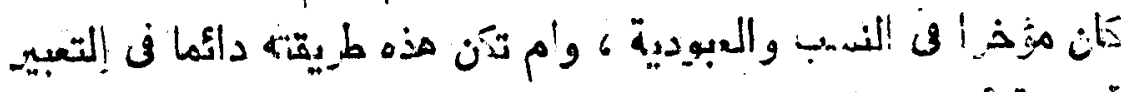

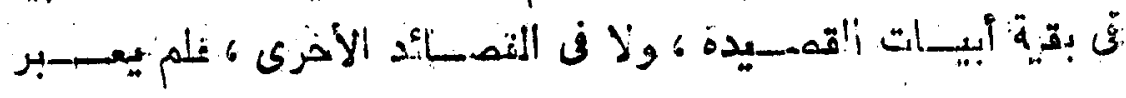

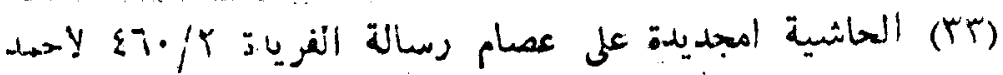

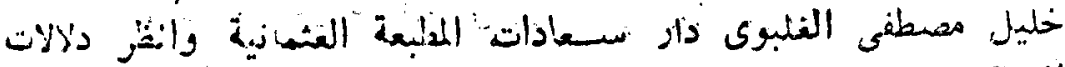
$(j-r)$

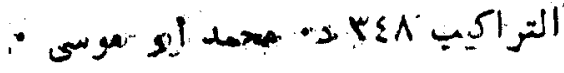




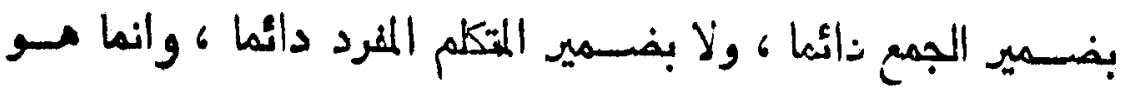

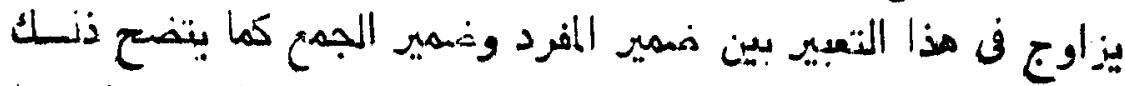

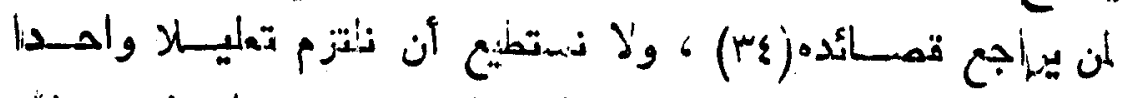

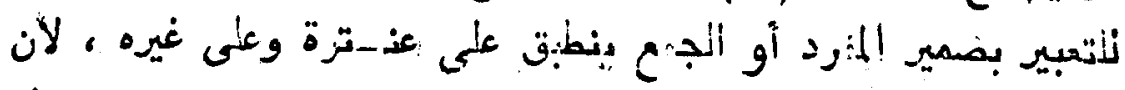

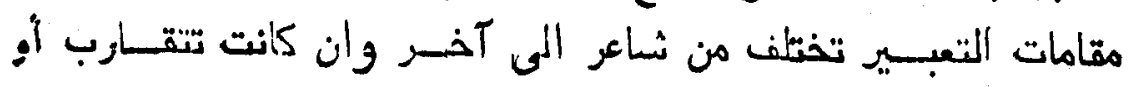

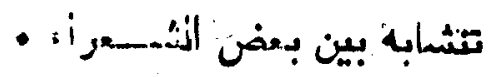

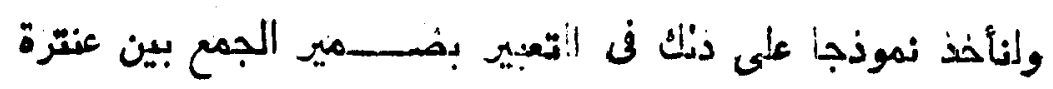

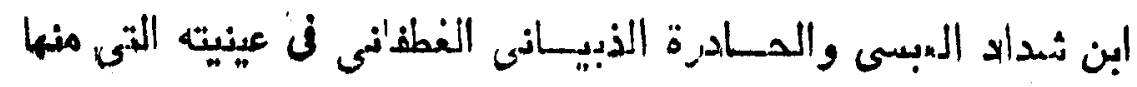
كسوله :

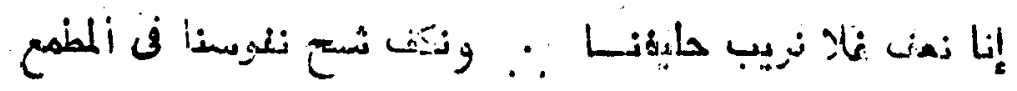

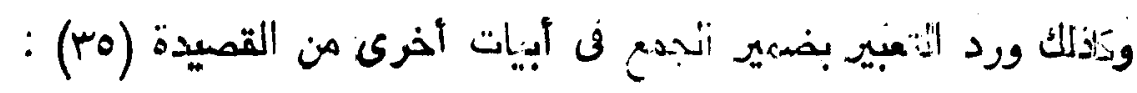

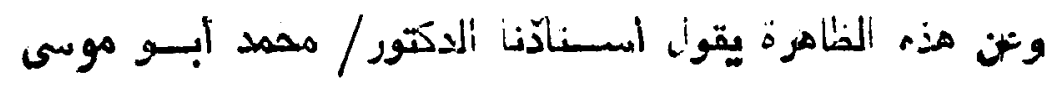

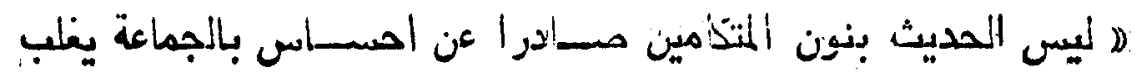

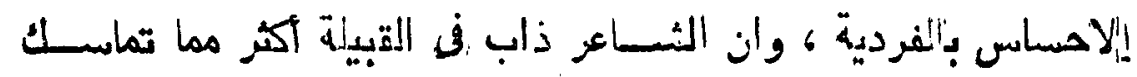

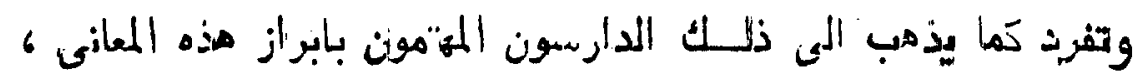

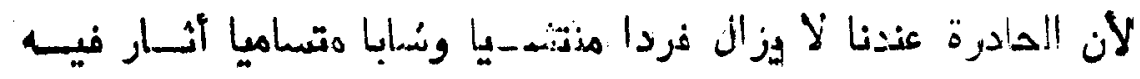

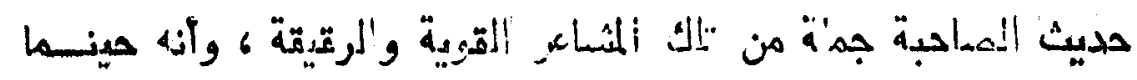

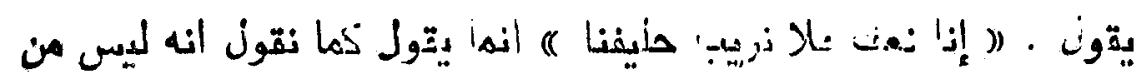

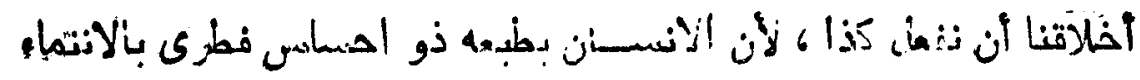

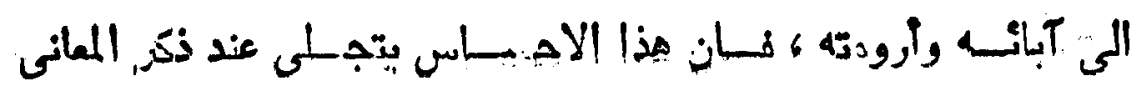

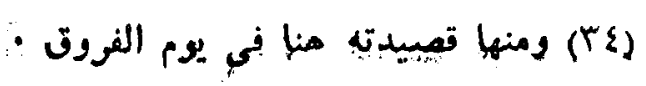

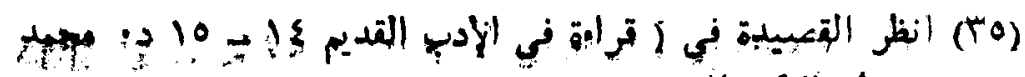

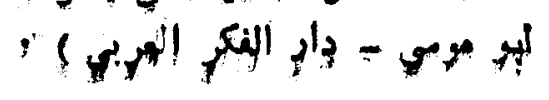




\section{$299^{\circ}$}

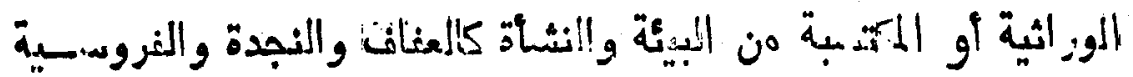

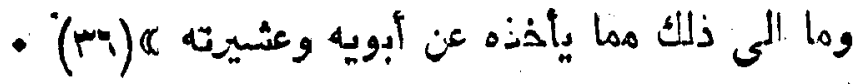

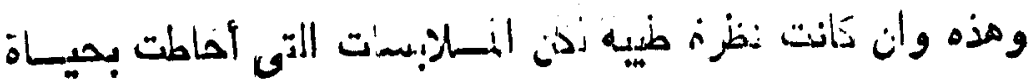

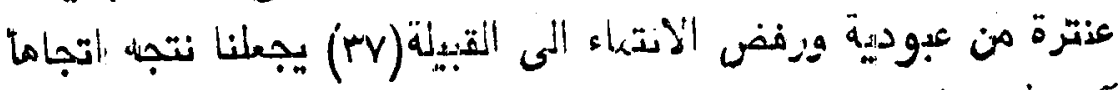

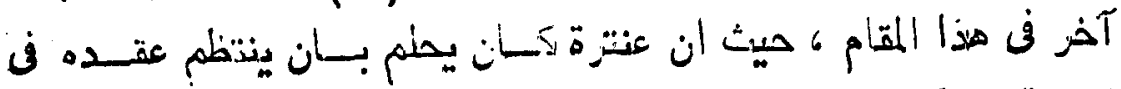

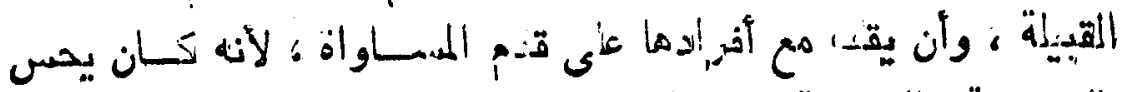

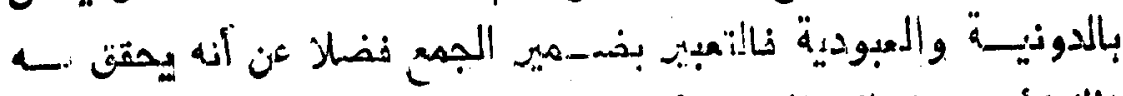

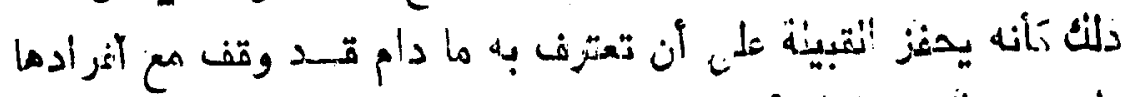

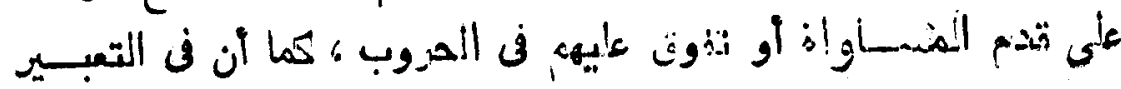

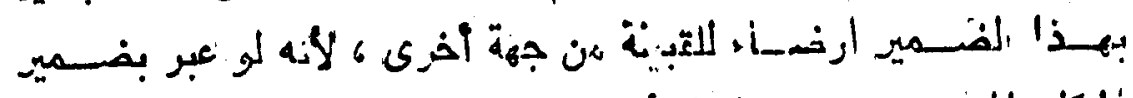

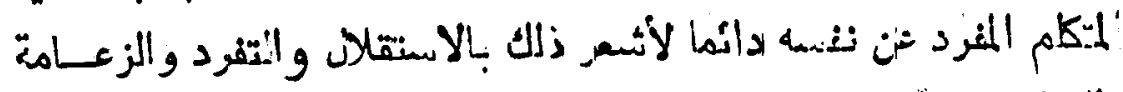

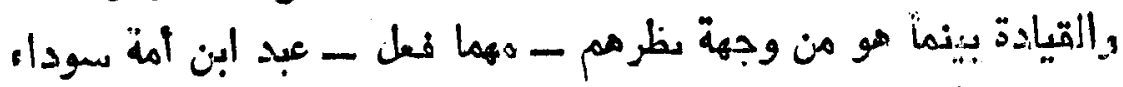

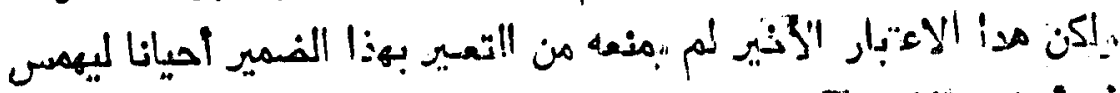

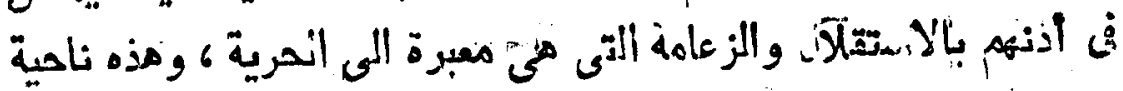

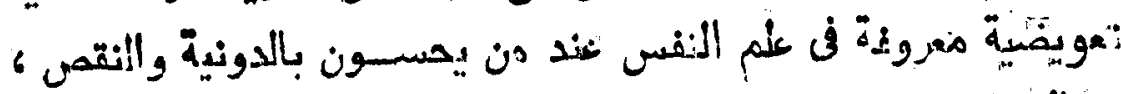

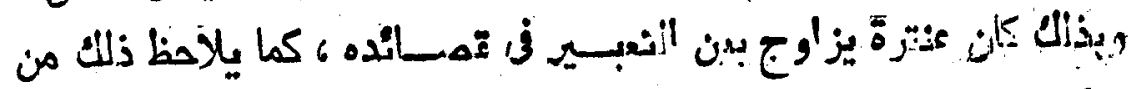

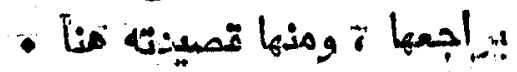

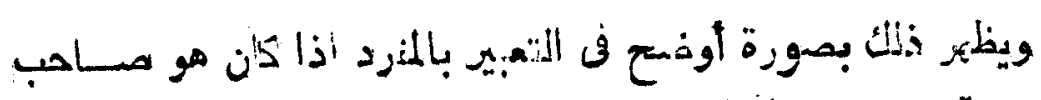

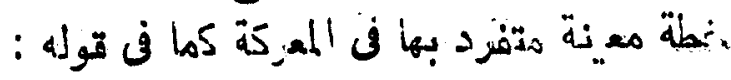

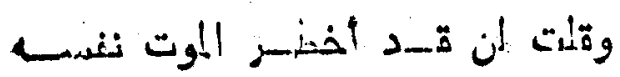

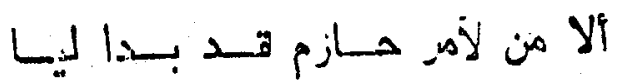

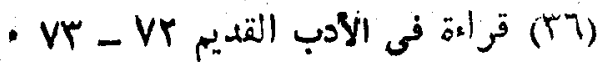

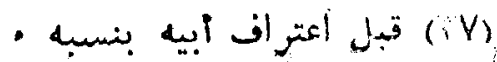


وتلت لهم ردو! المغسيرد ع-ن هـ-وى

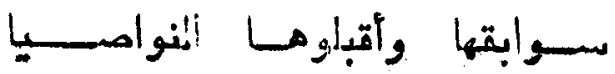

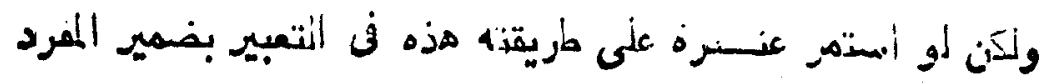

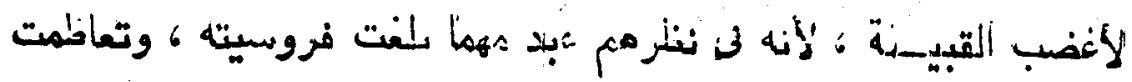

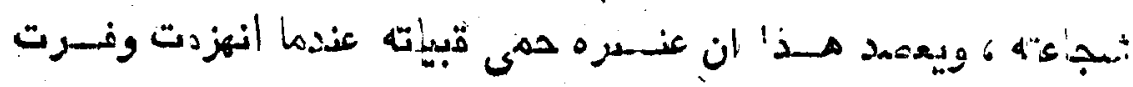

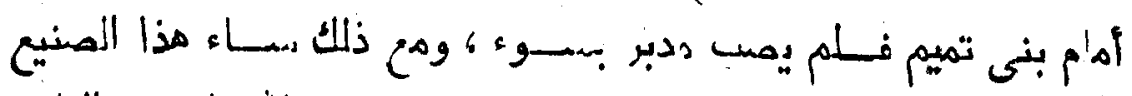

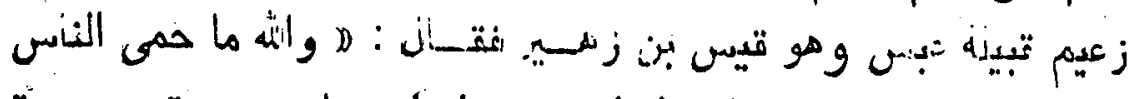

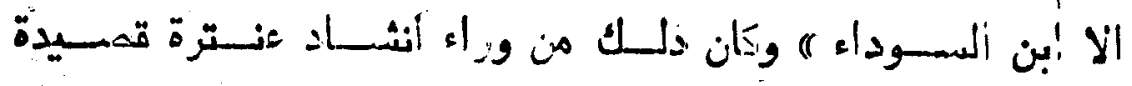

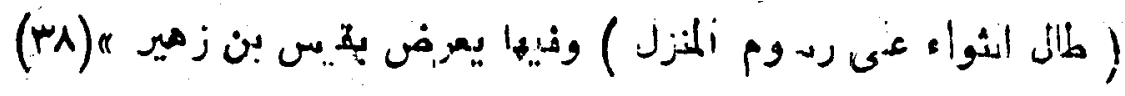
فلا عجب اذن أن يزاوج عنـترة بـن الته:يد بالضــميرين معا قى

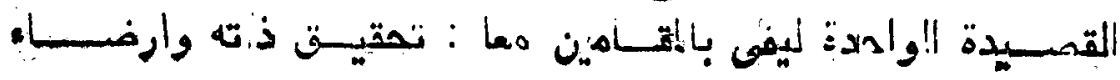

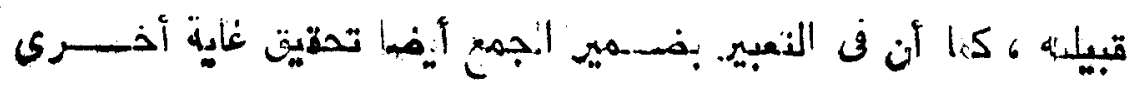

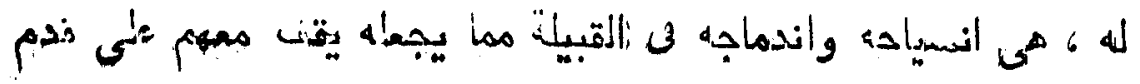

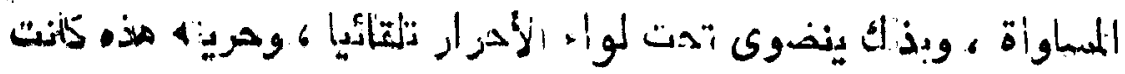

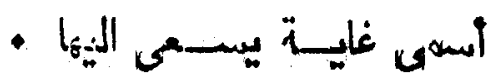

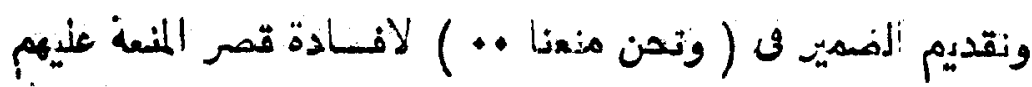

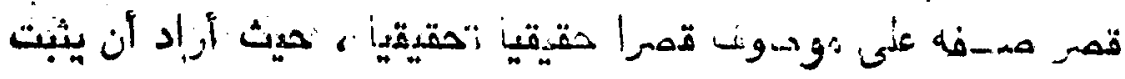

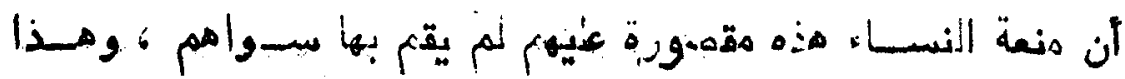

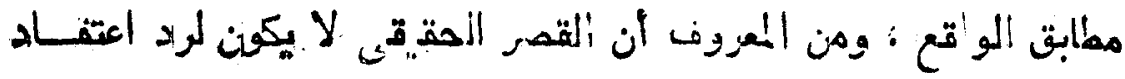

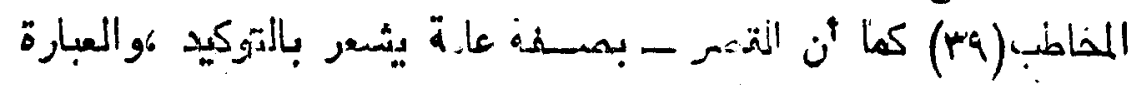

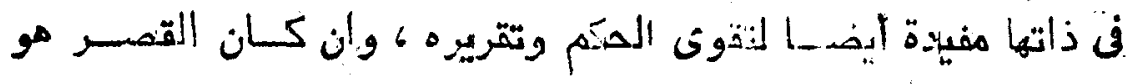

(r^)

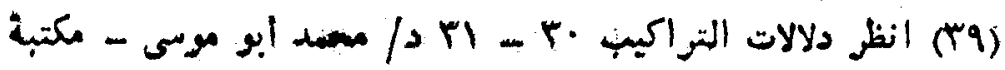




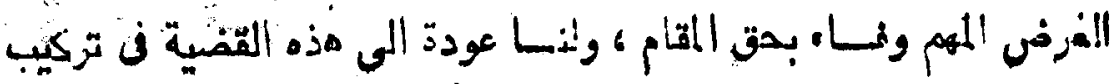

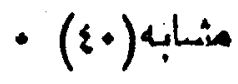

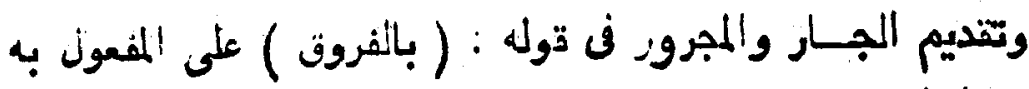

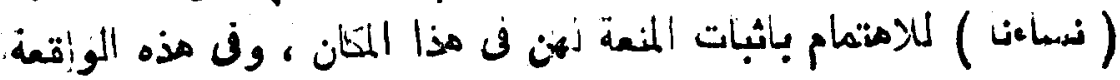

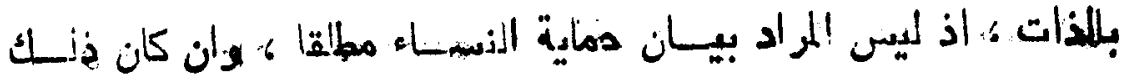

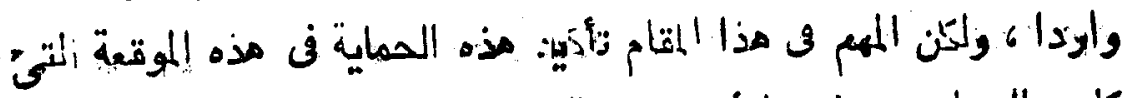

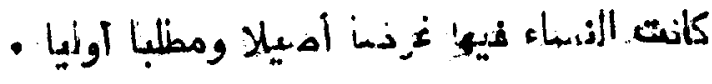

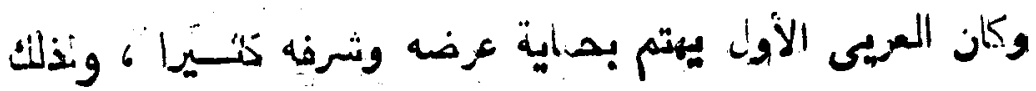

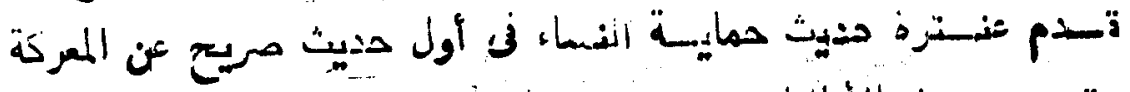

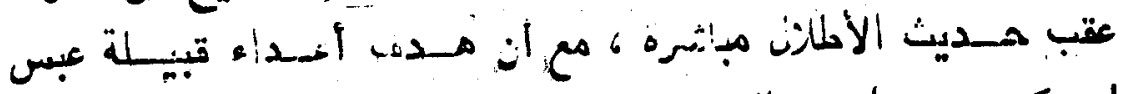

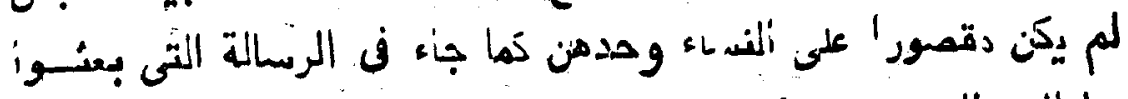

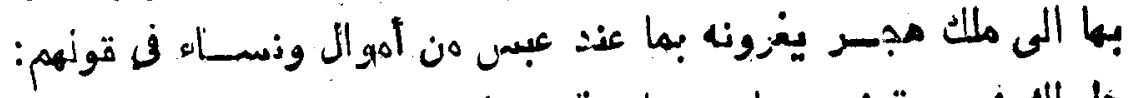

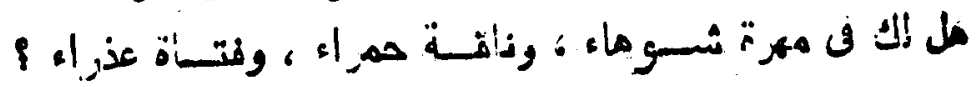

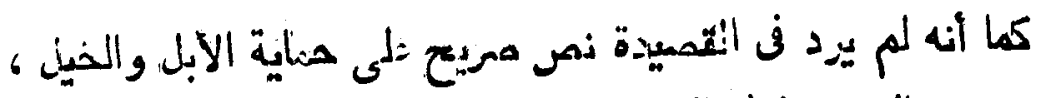

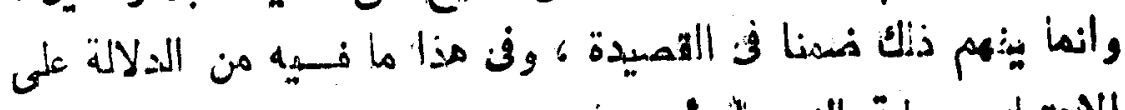

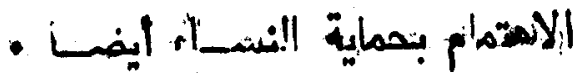

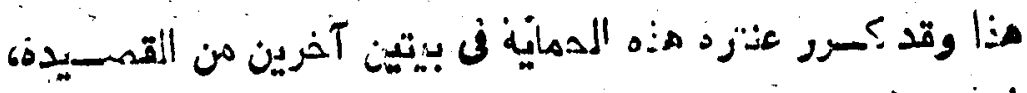

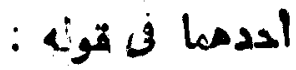

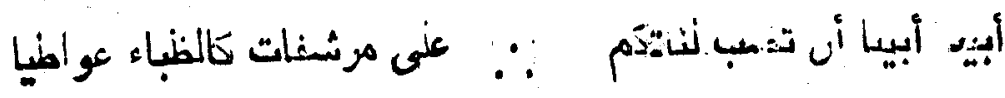

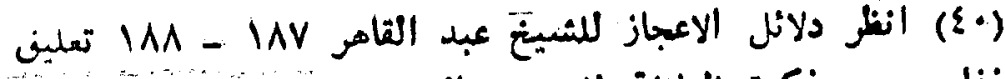

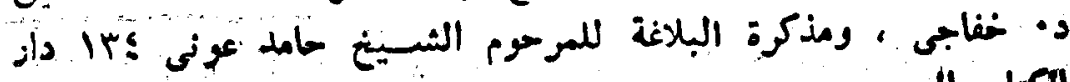

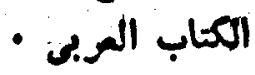




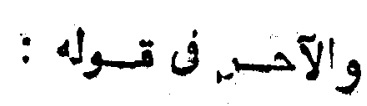

وندفيظ عورات النهباء ونتقى :

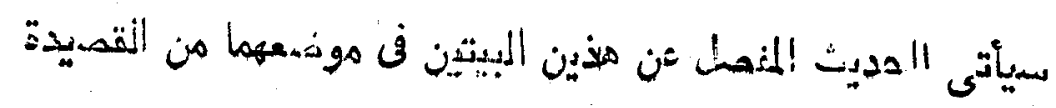

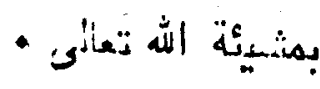

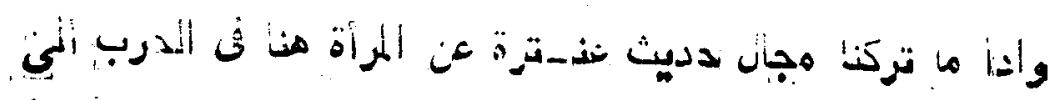

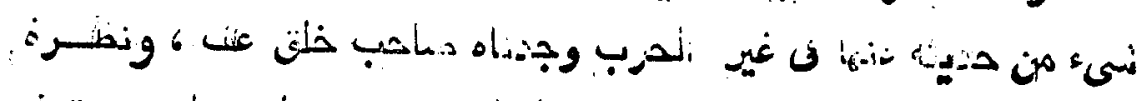

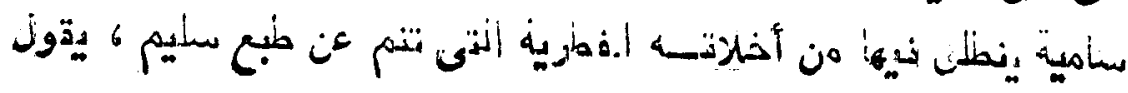

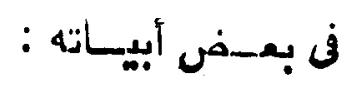

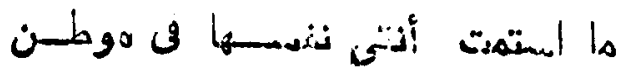

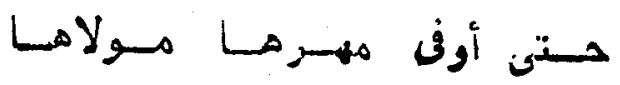

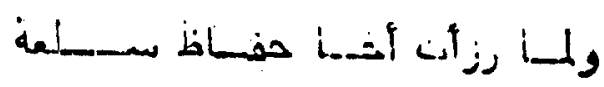

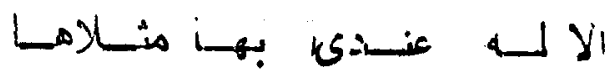

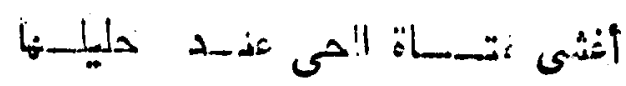

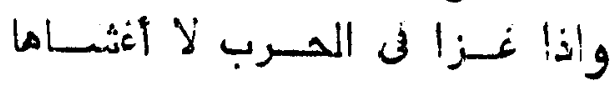

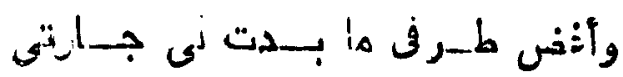

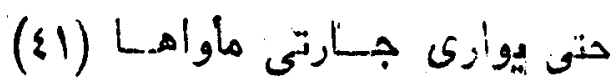

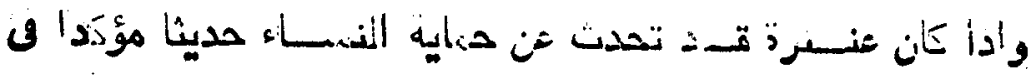

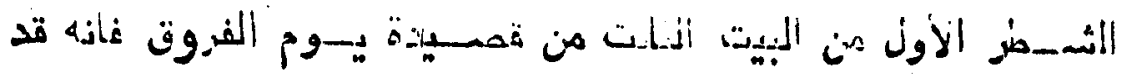

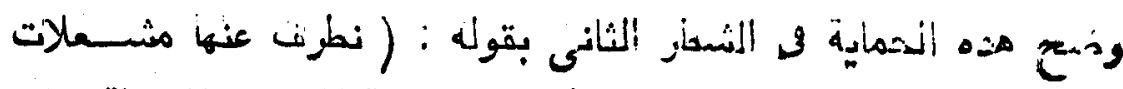

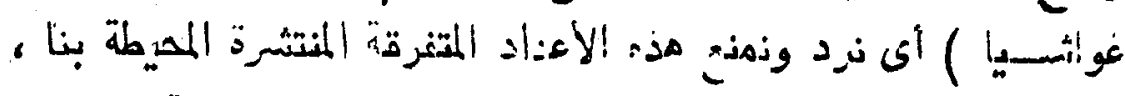

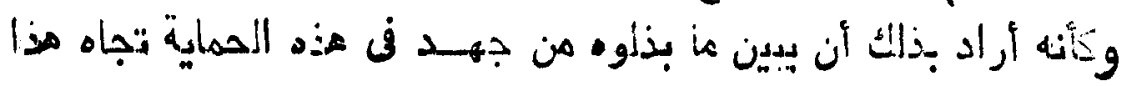

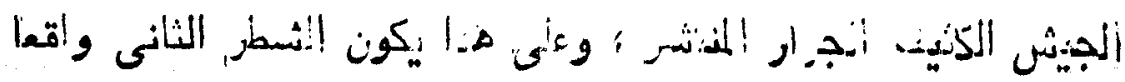

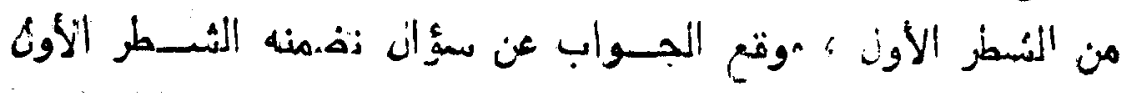

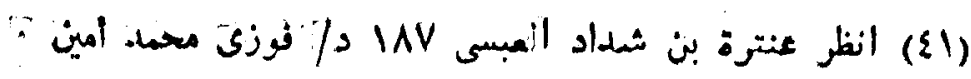




\section{$0 \%$}

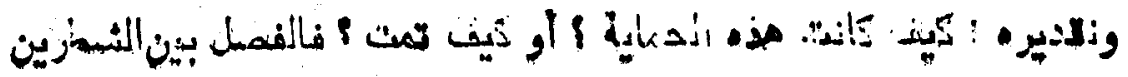

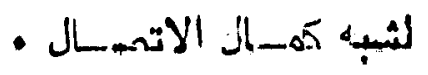

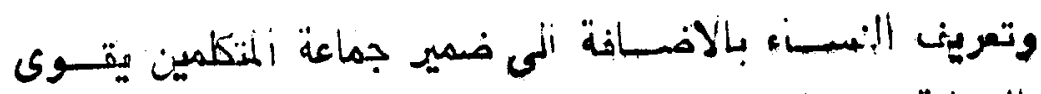

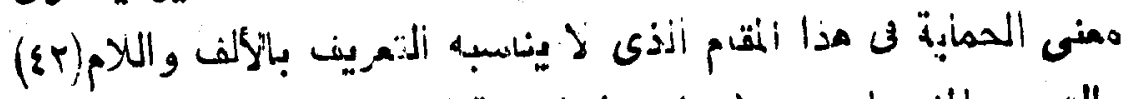

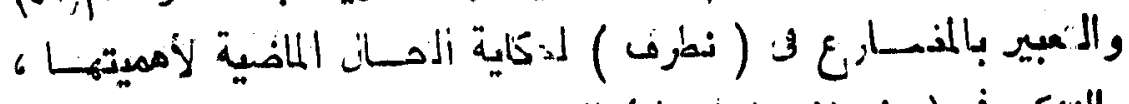

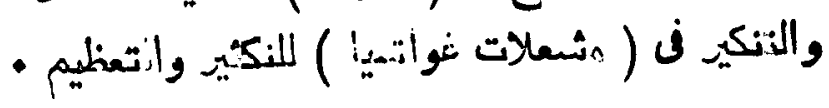

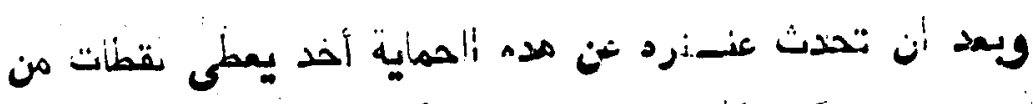

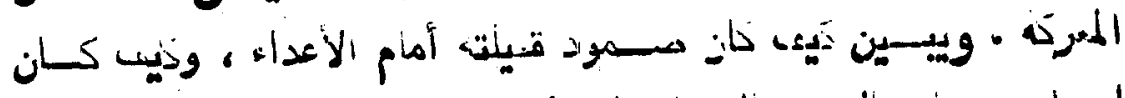

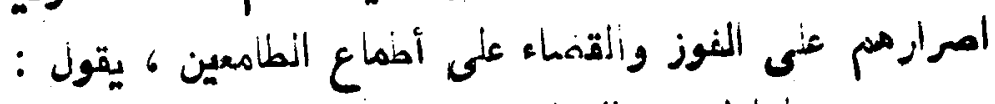

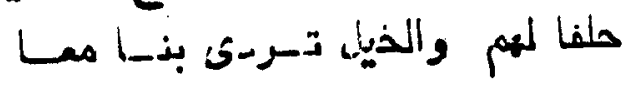

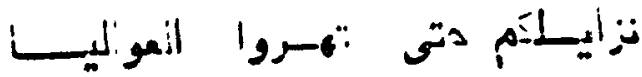

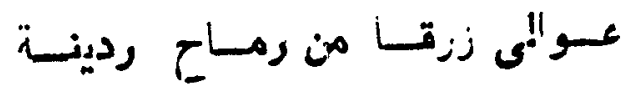

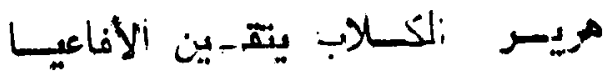

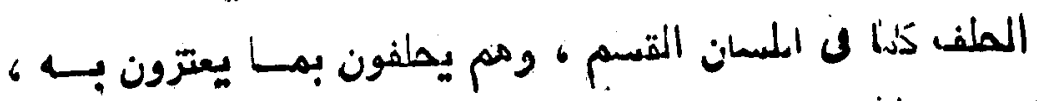

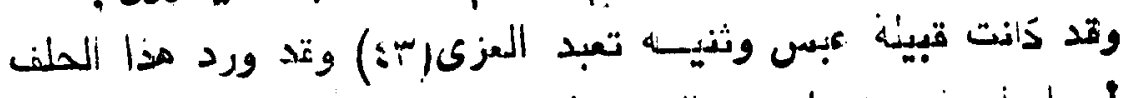

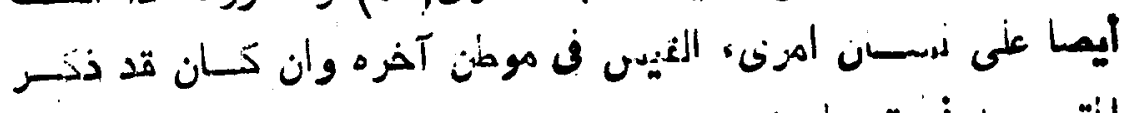

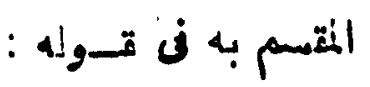

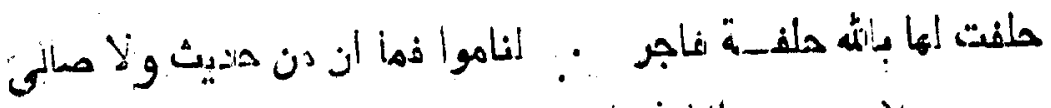

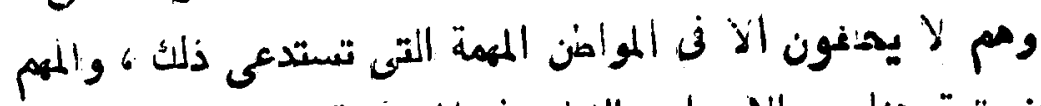

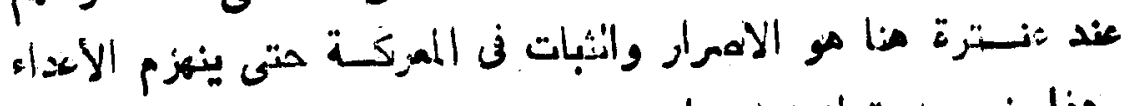

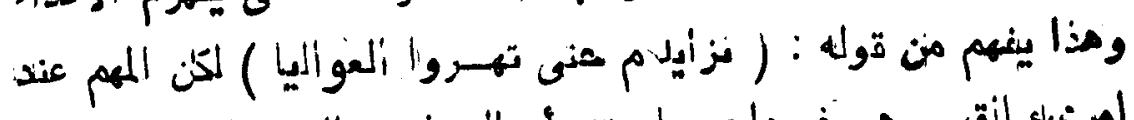

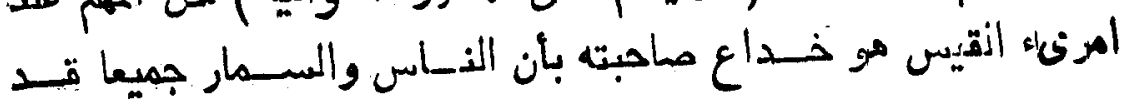

-

- 


\section{i.}

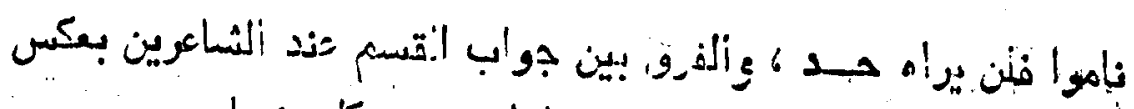

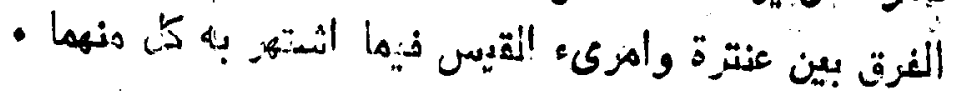

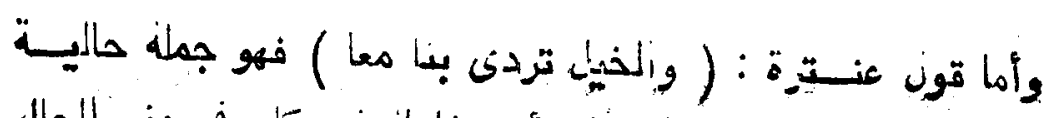

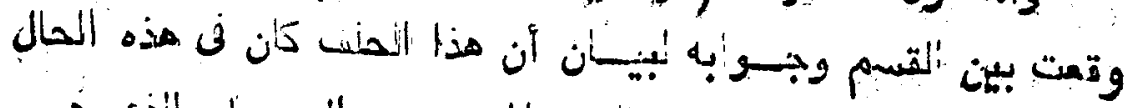

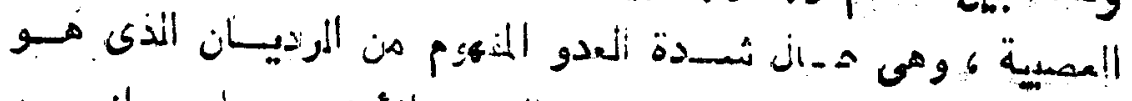

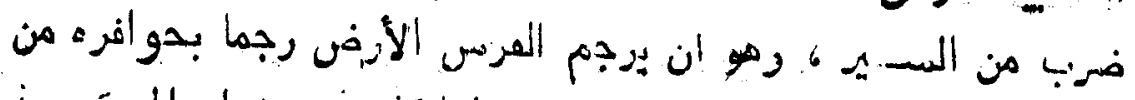

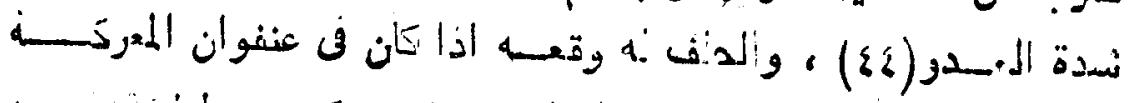

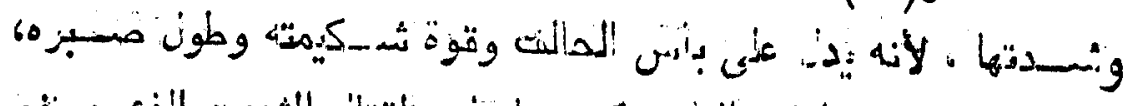

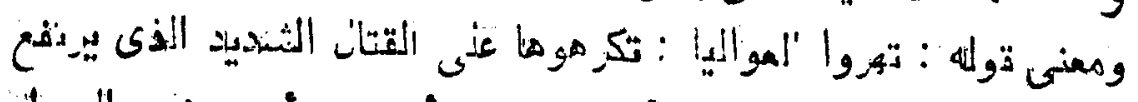

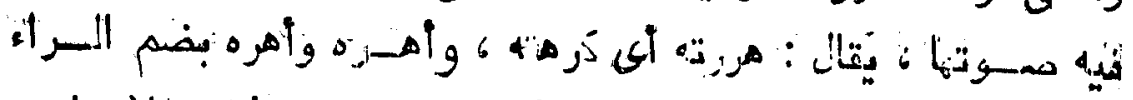

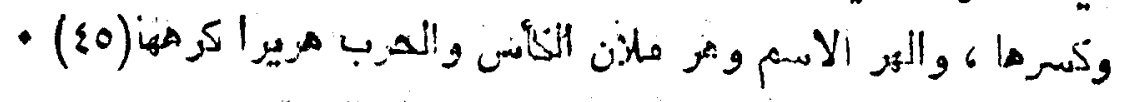

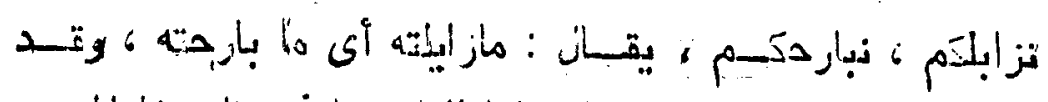

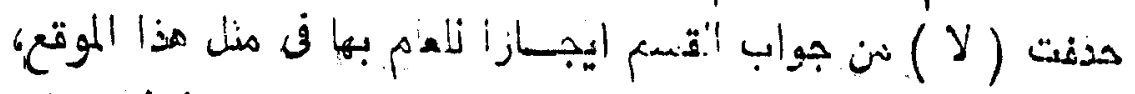

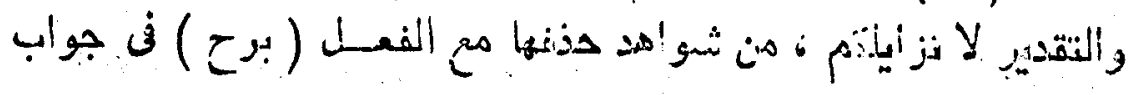

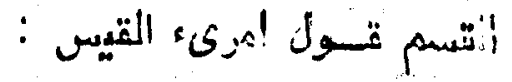

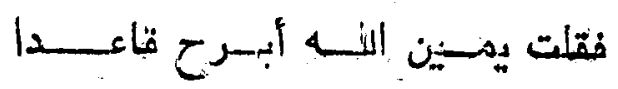

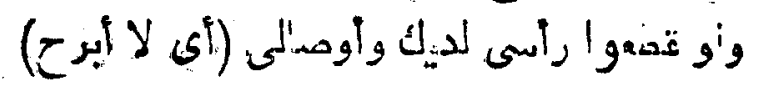

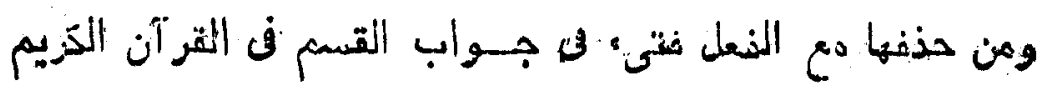

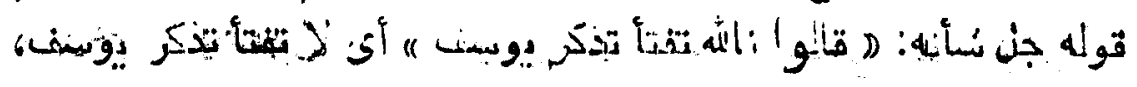

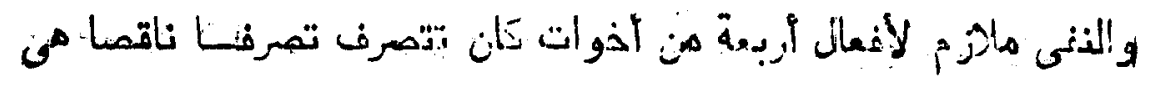

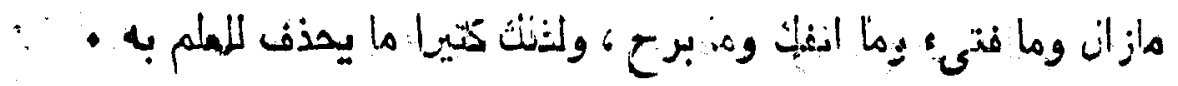

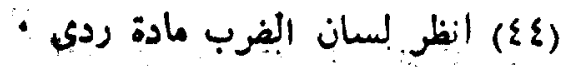

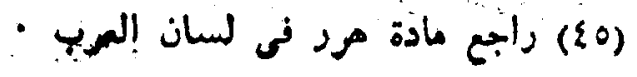




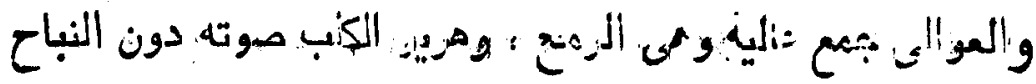

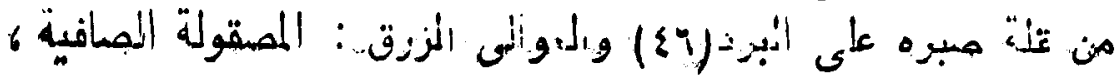

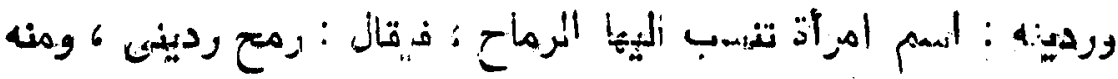

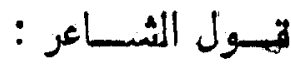

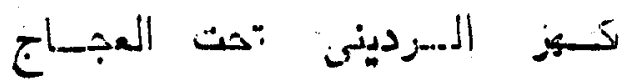

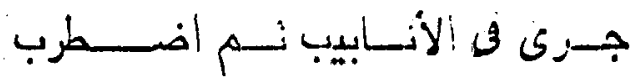

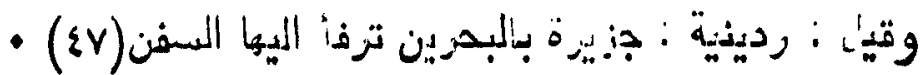

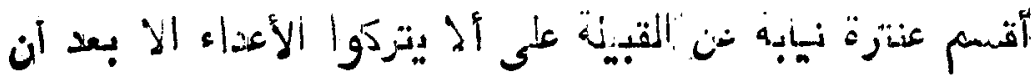

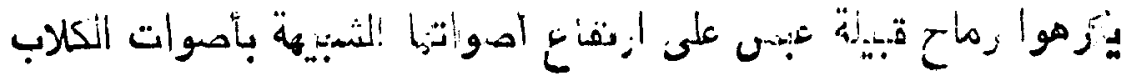

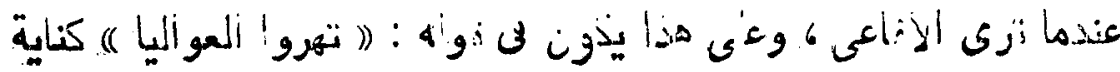

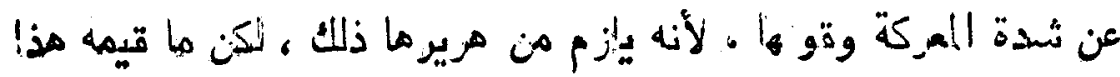

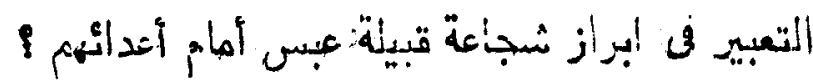

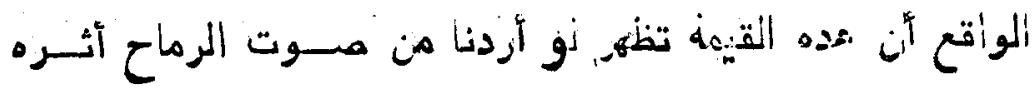

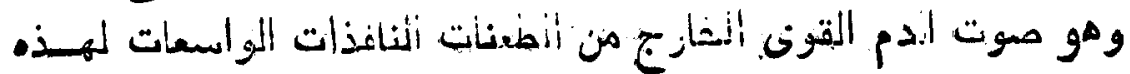

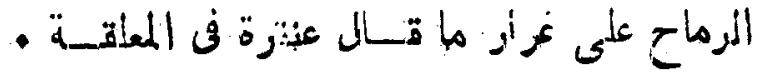

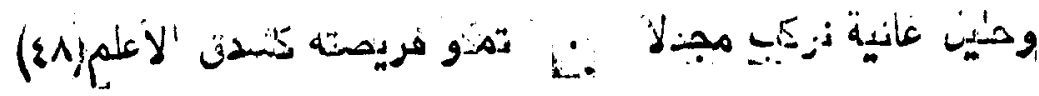
ومند. ألثطر الثاند ان فريمها ؛ وهى التحمة تمت الابط بحذاه

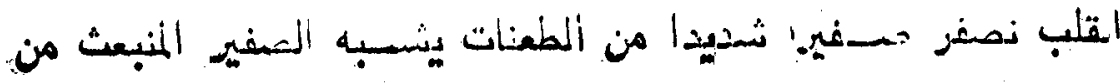

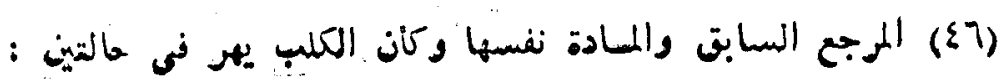

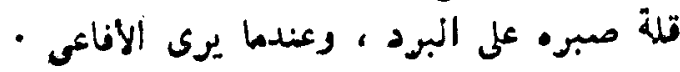
(\&V)

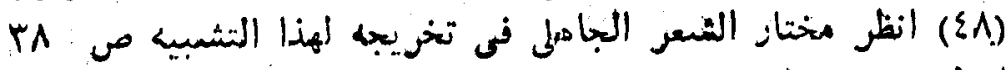

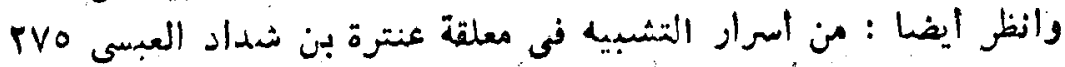

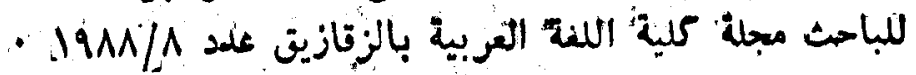


نسمتي الأعلم ، وهو البعيد ، وهميرها هو دموت المسدم ألفوار المنبعث

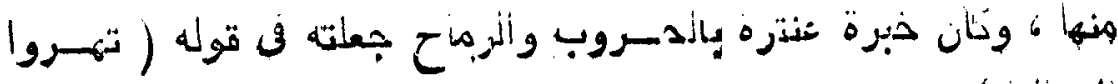

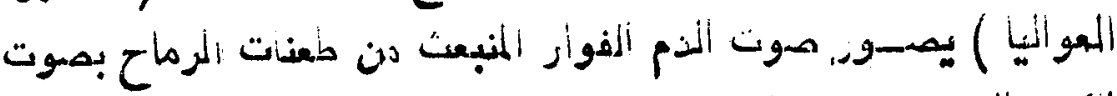

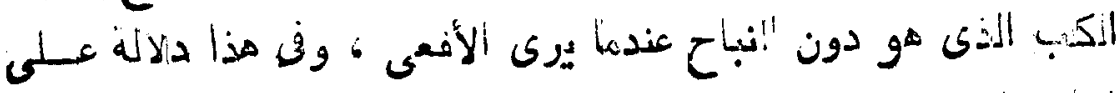

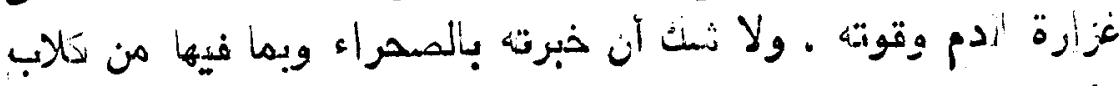

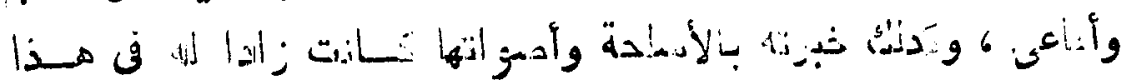

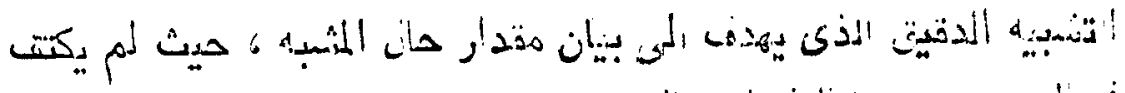

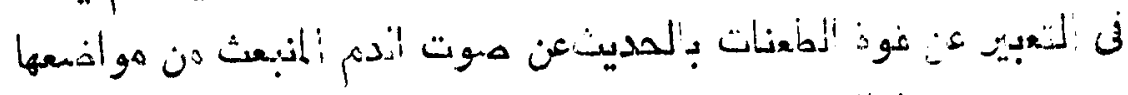

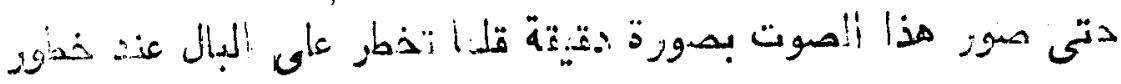

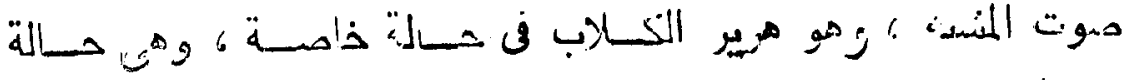

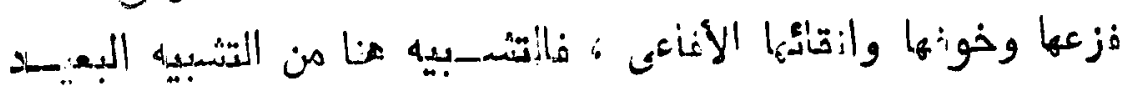

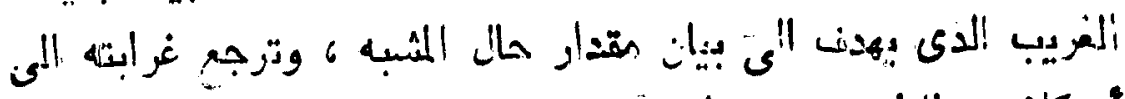

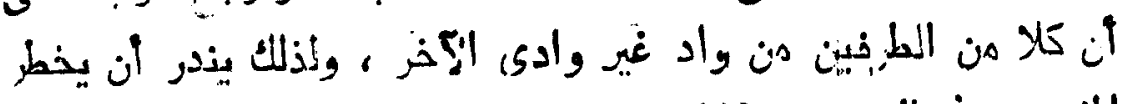

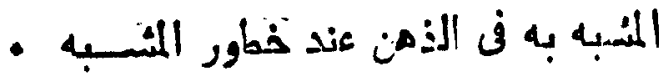

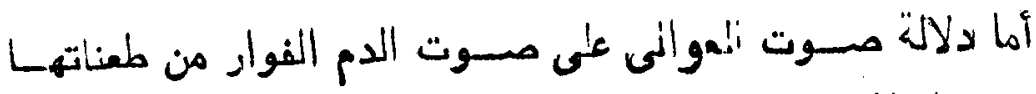

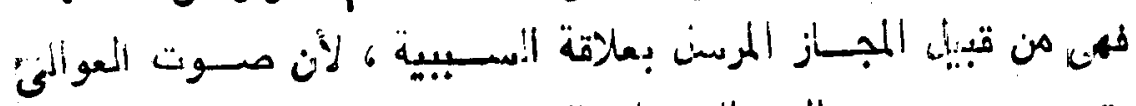

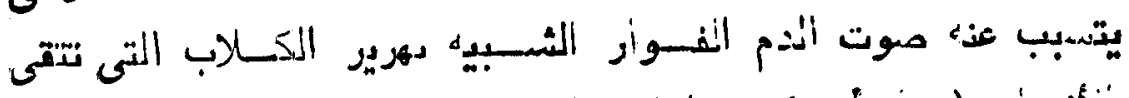

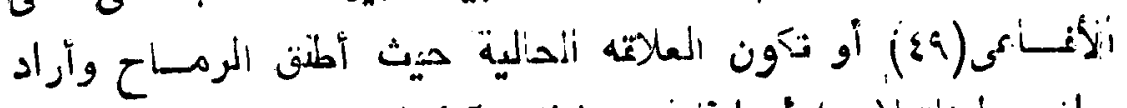

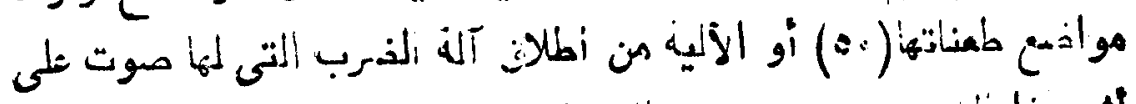

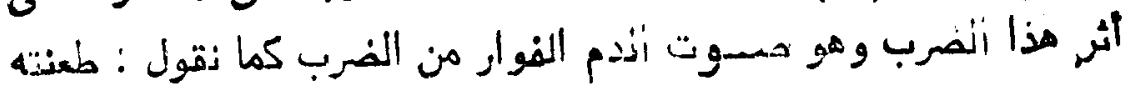

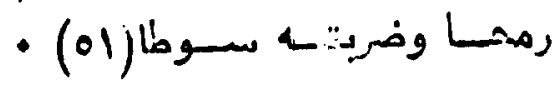

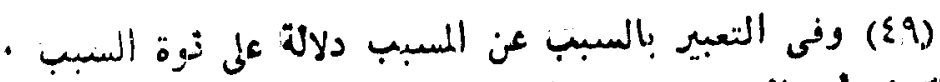

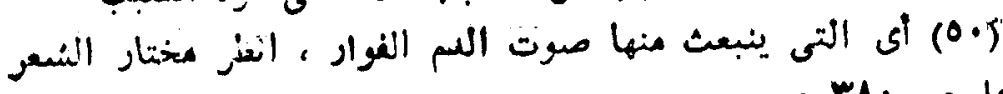

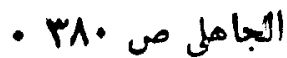

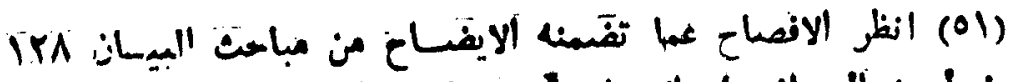

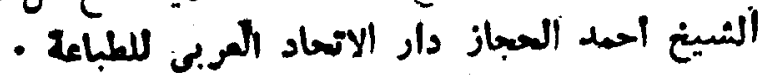


واحتمال، اتئريج المجازى لأكثر من علآتمة يدل على خهم-وبة

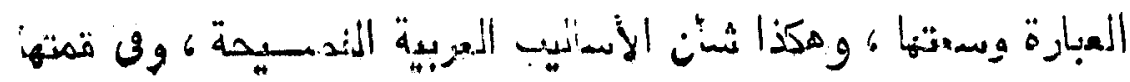

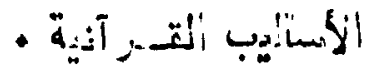

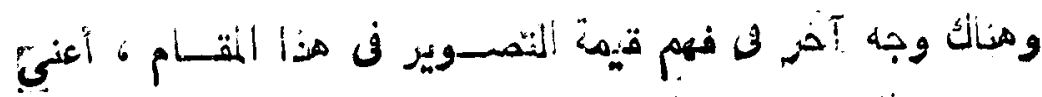

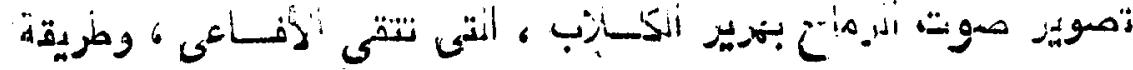

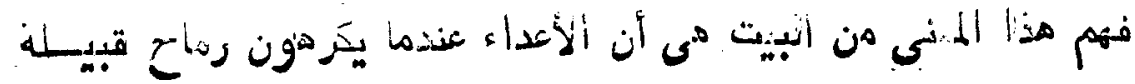

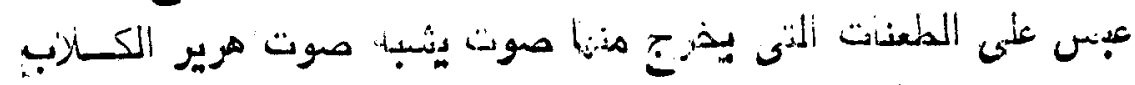

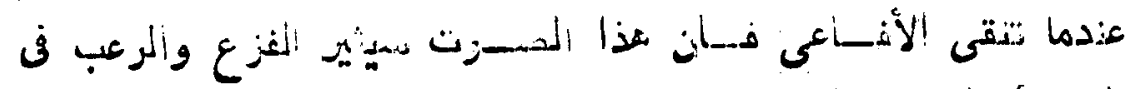

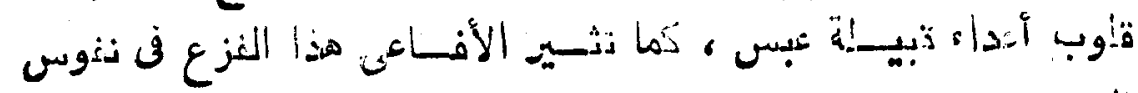

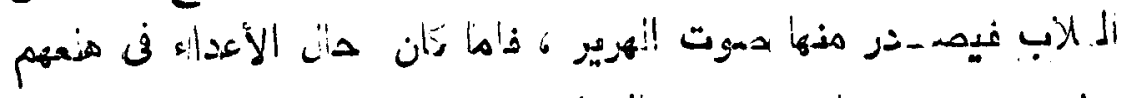

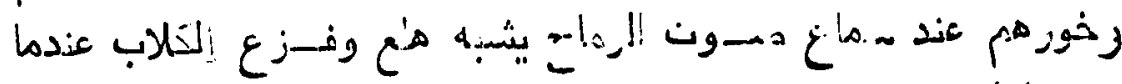

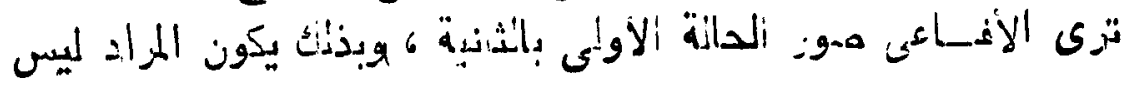

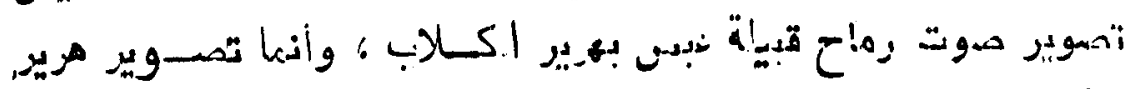

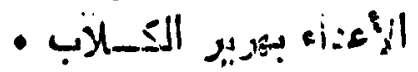

ويتئسمن هذا التنبيده التمنيلى تثبيه فبيلة عبس بالأناعى وتشبيه

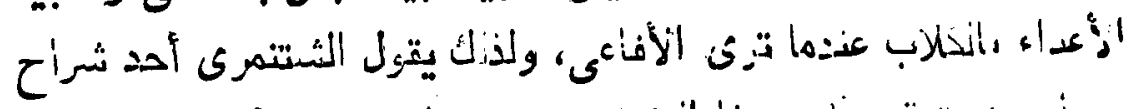

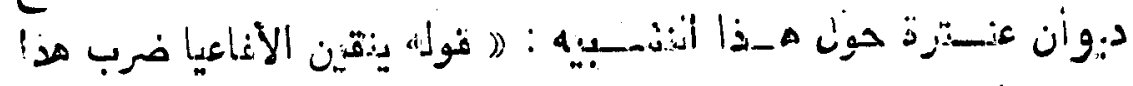

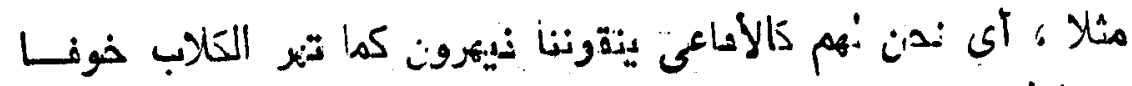

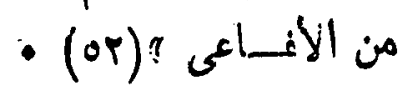

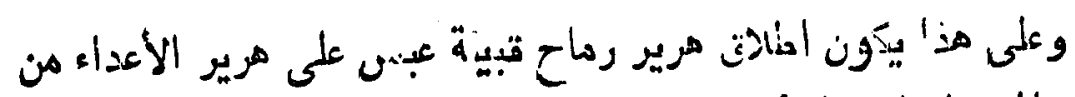

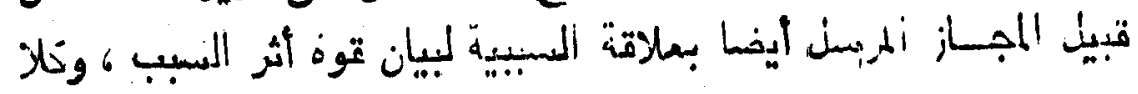

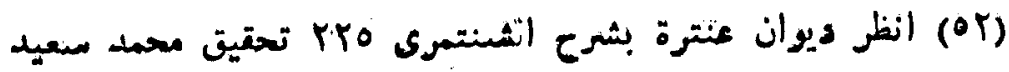




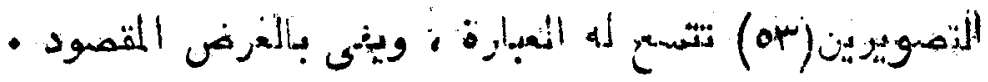

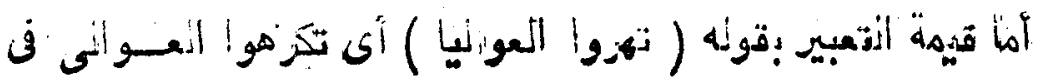

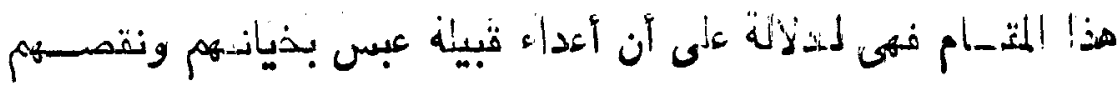

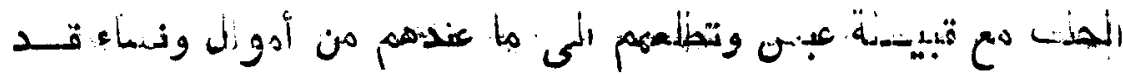

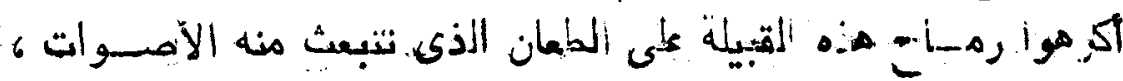

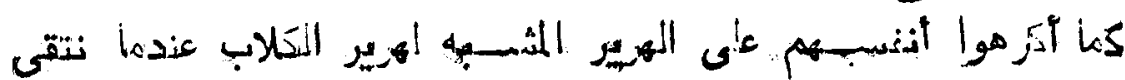

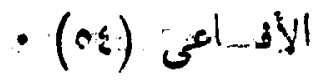

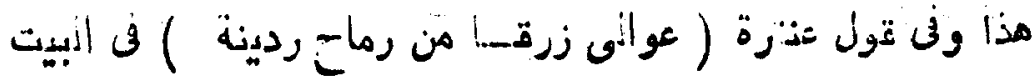

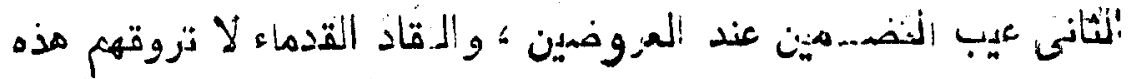

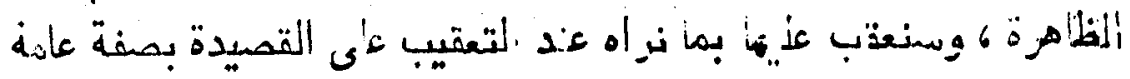

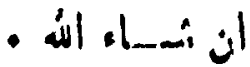

ولما صور عنــترة فزع ودنب ألآعداء أمام قبيلة عبس فن قونه :

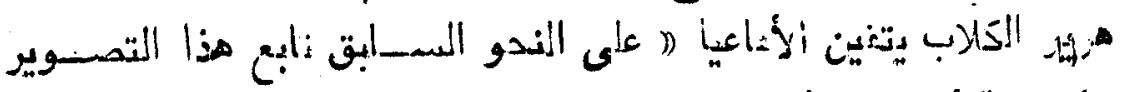

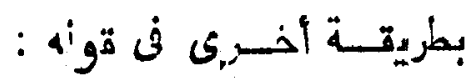

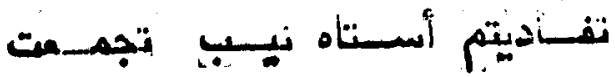

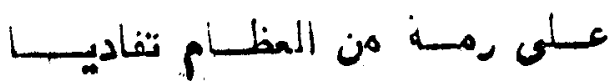

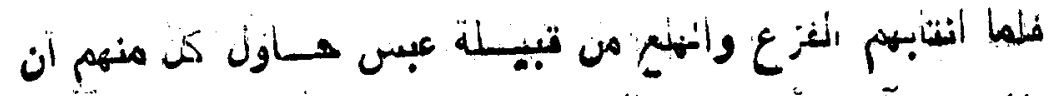

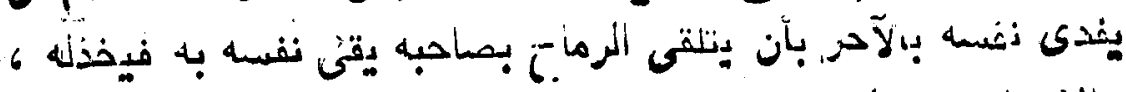

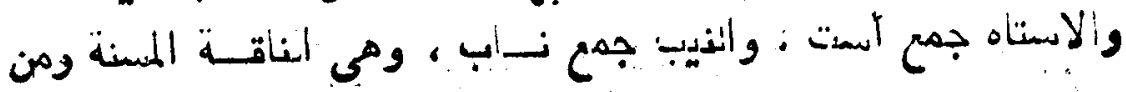

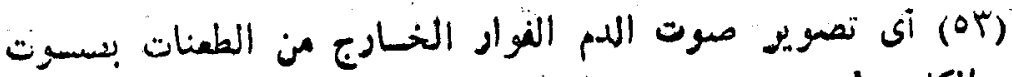

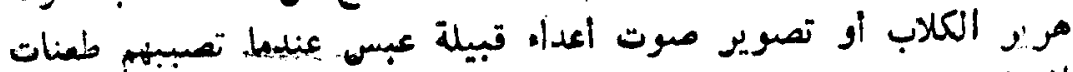

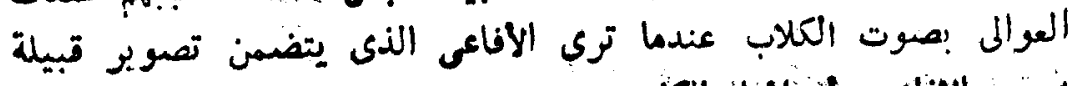

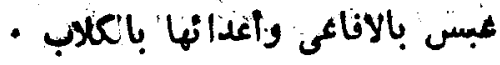

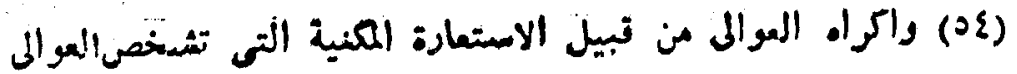




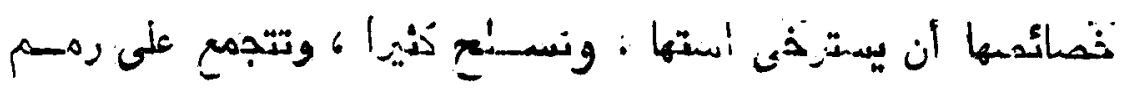

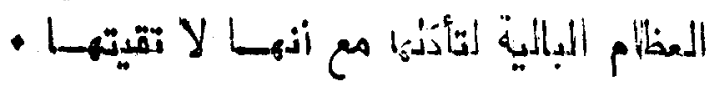

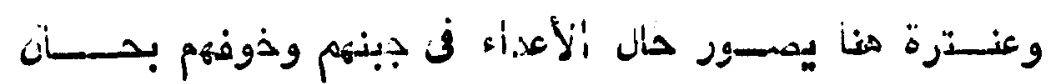

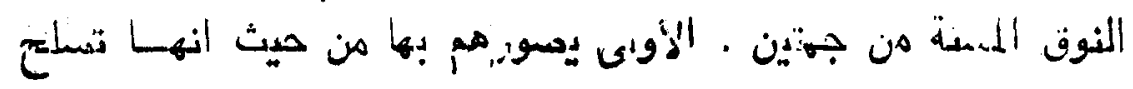

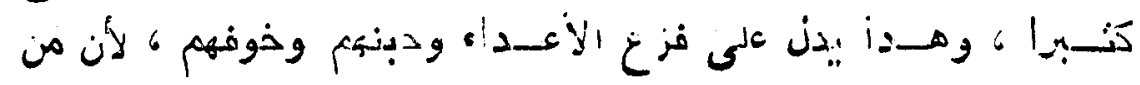

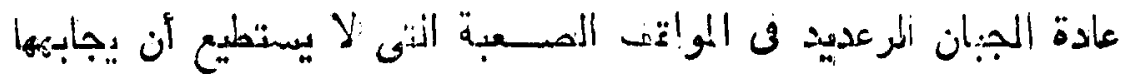

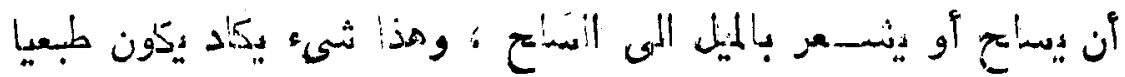

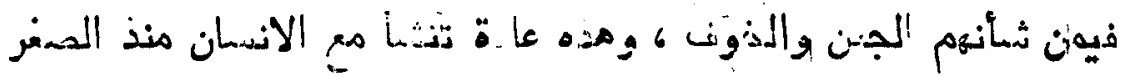

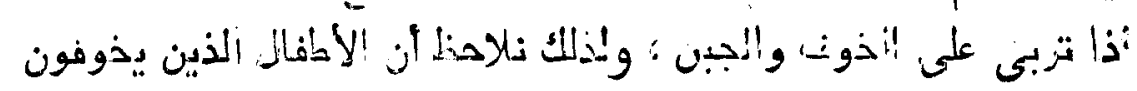

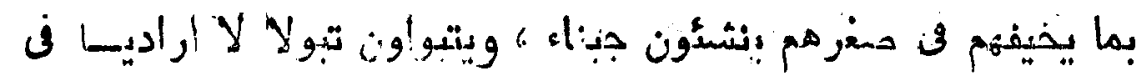

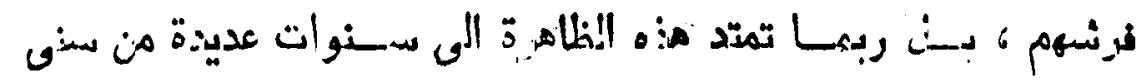
هيـاتهم

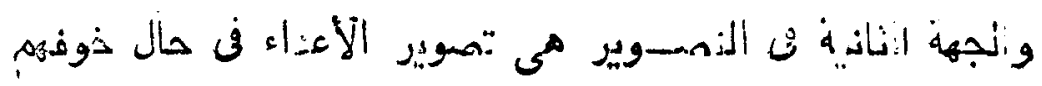

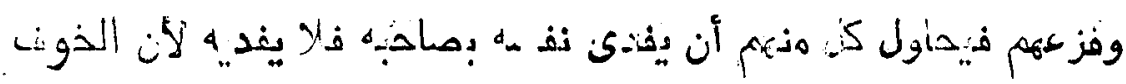

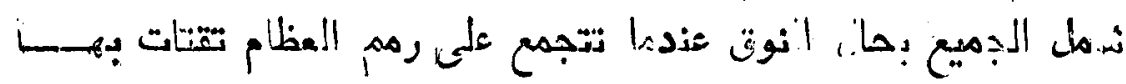

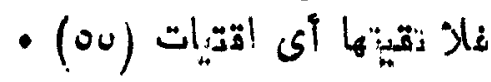

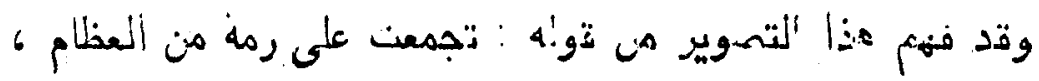

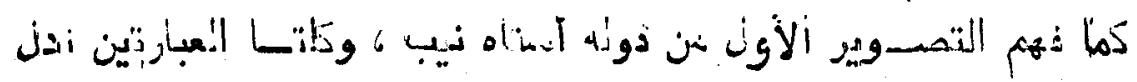

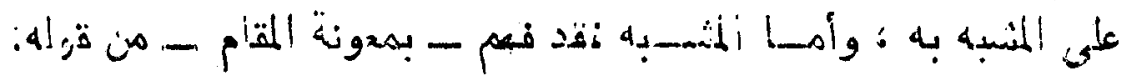

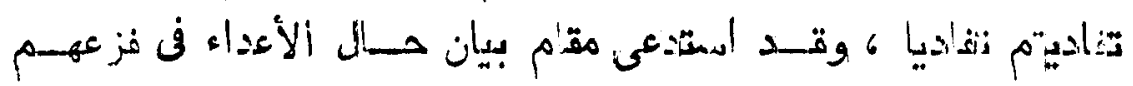

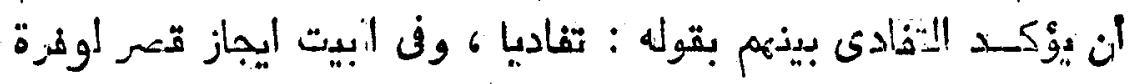

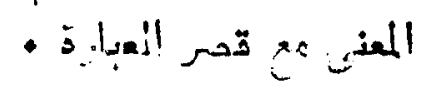

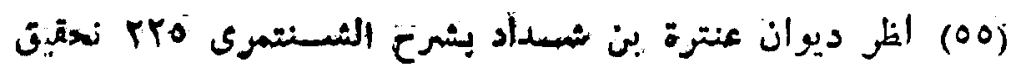

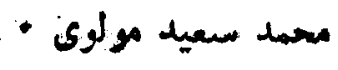




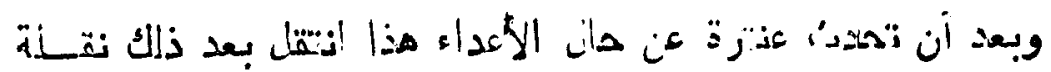

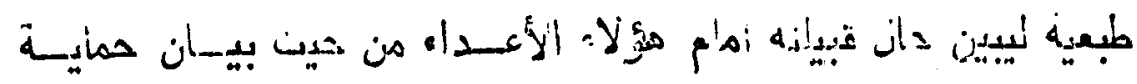

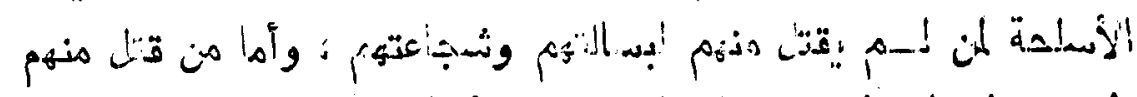

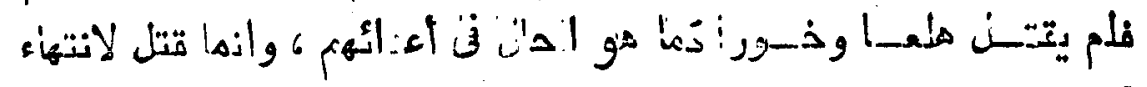

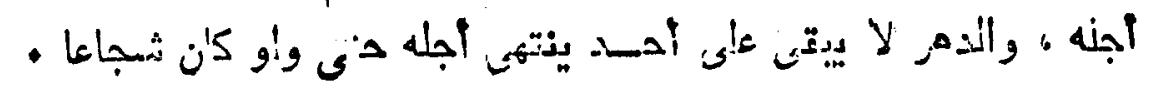

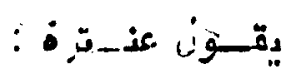

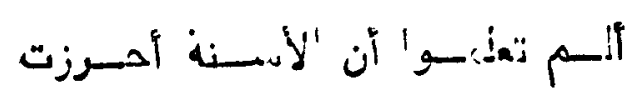

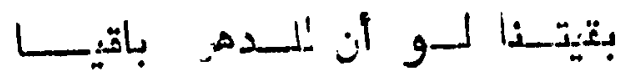

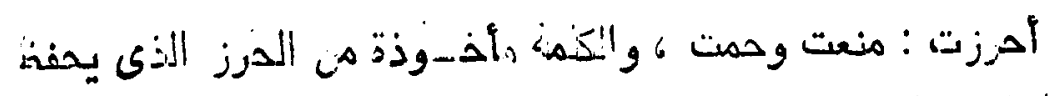

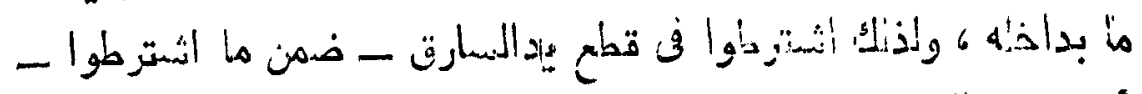

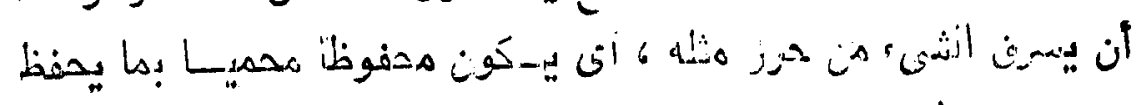

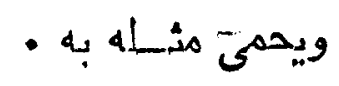

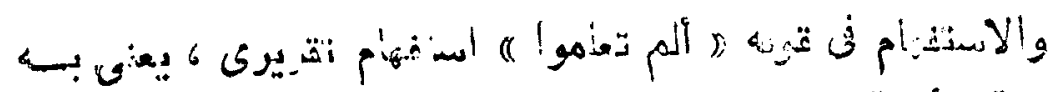

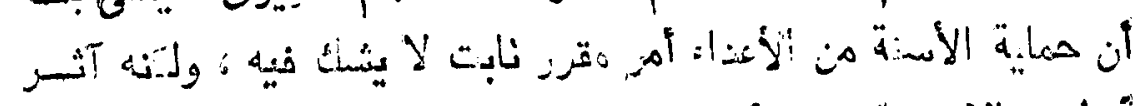

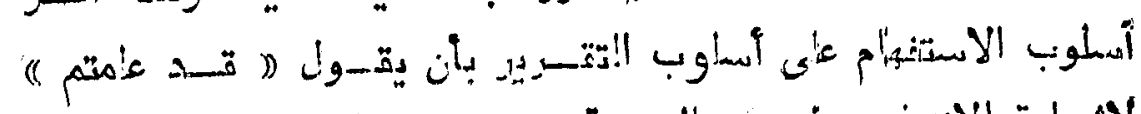

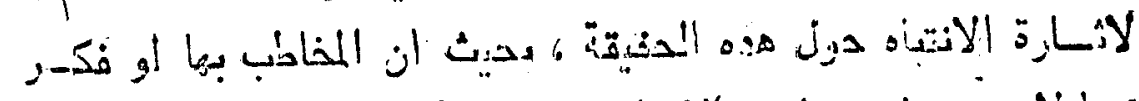

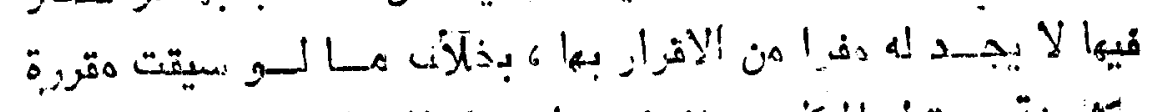

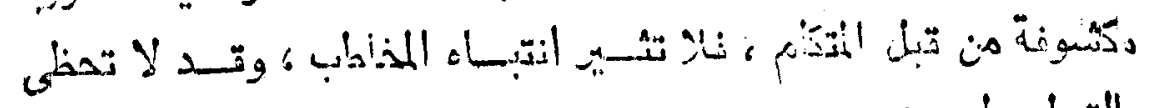

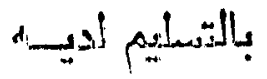

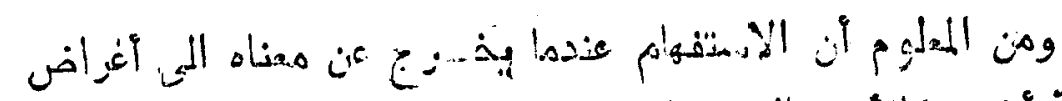

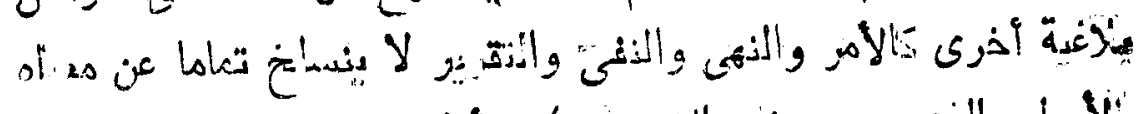

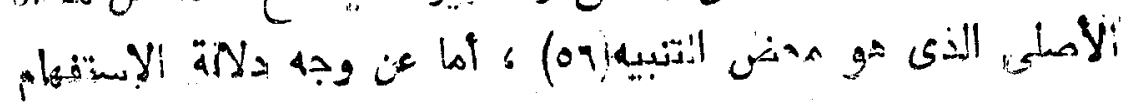

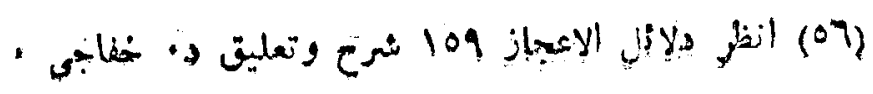




\section{oll}

على انتقرير وغيره هن الاغراض البلاغية التى يذرج اليها نقــد تعددت

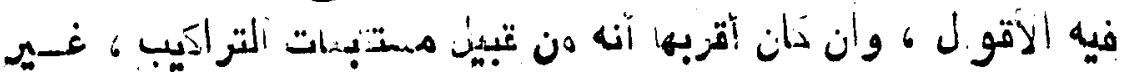

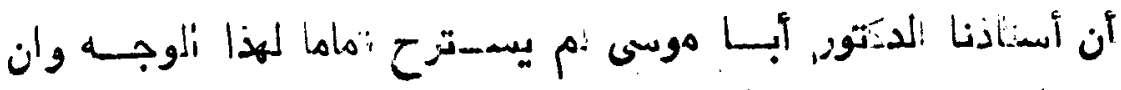

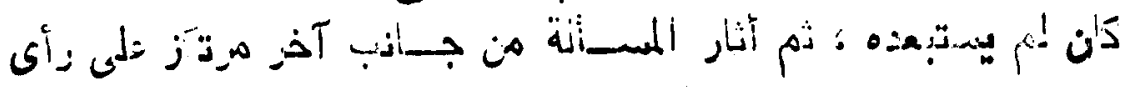

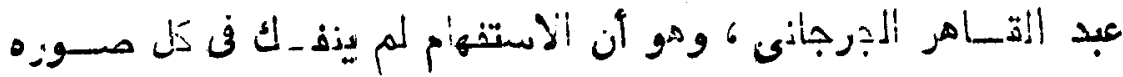

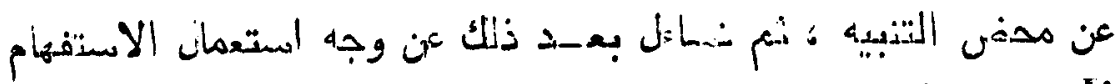

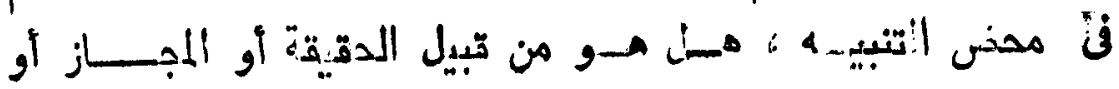
- (ov) \& i ألئis

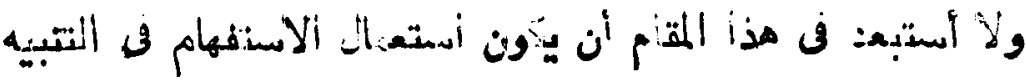

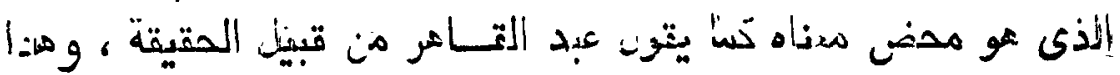

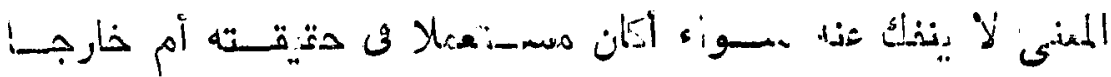

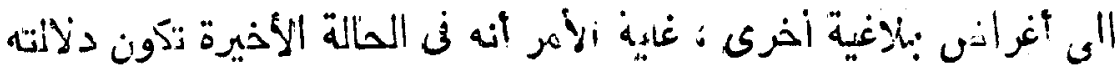

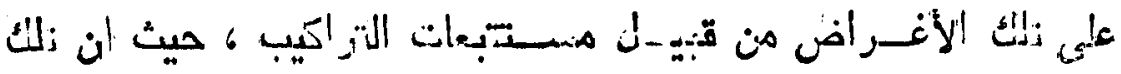

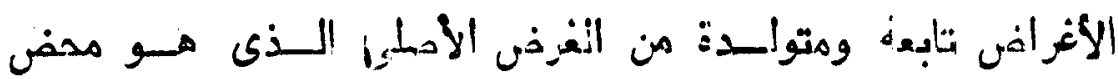

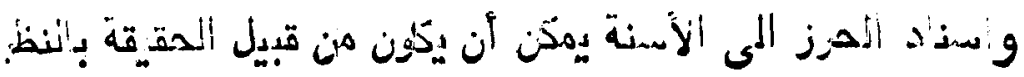

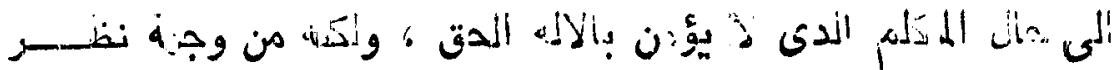

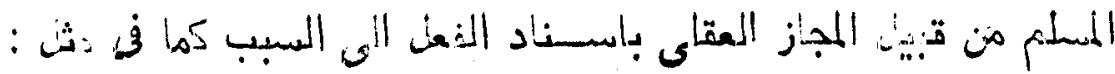

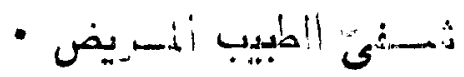

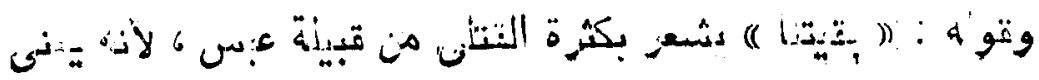

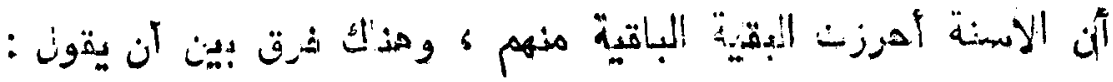

كومة (OV) 


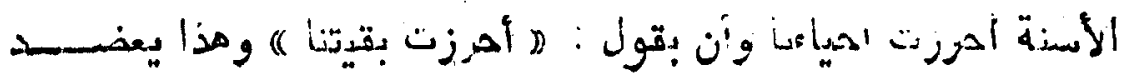

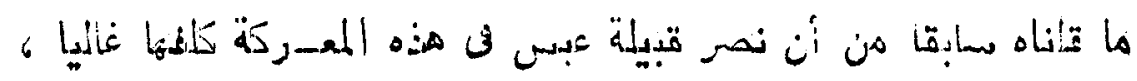

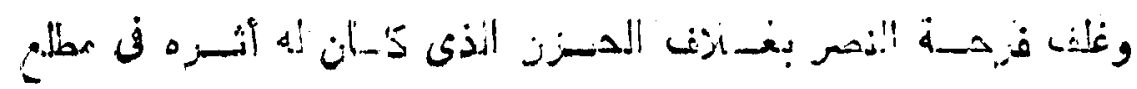

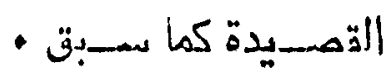

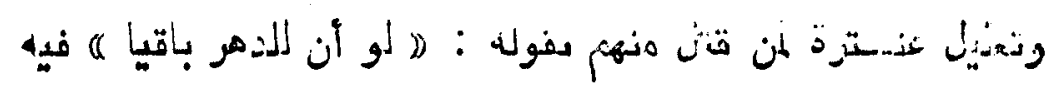

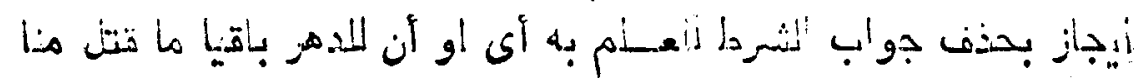

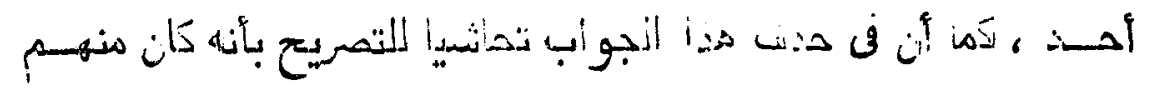

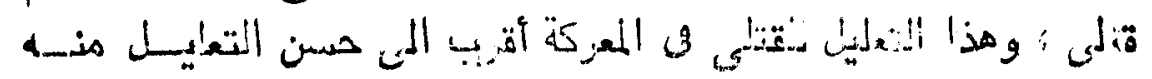

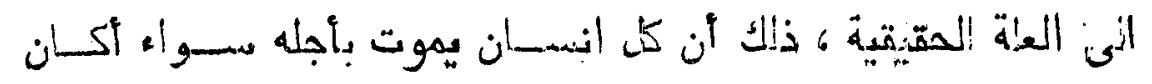

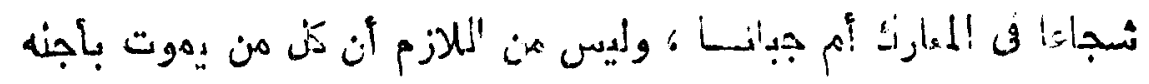

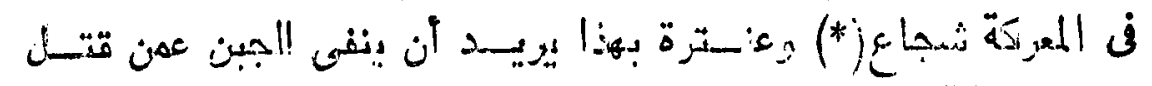

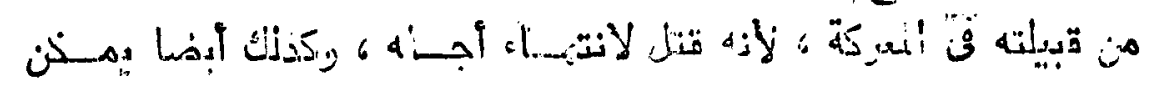

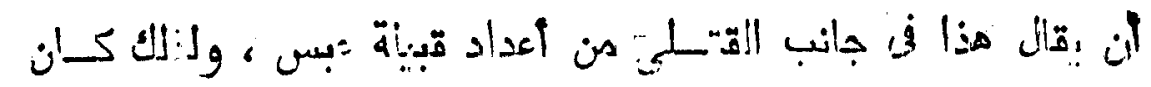

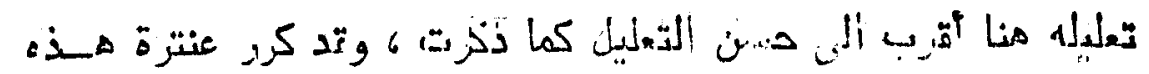

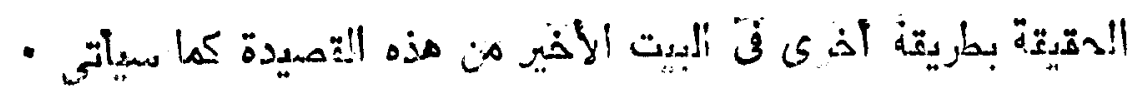

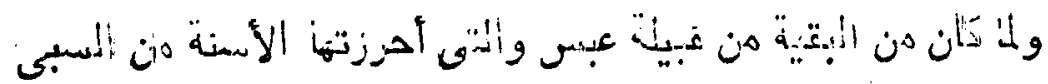

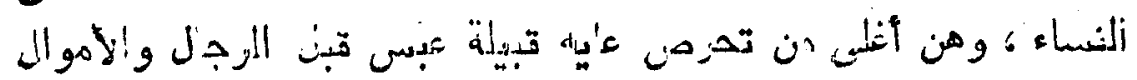

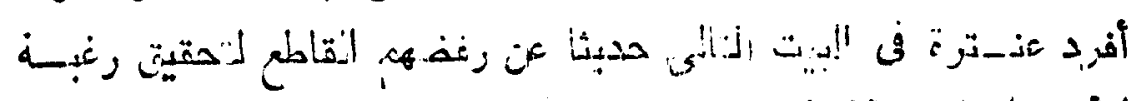

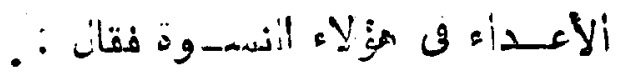

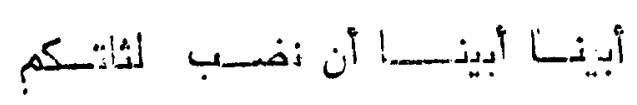

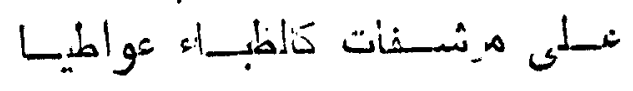

(潅)

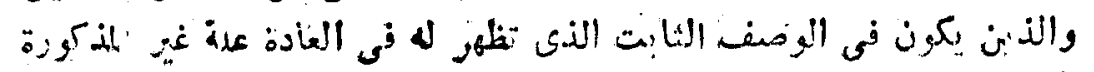

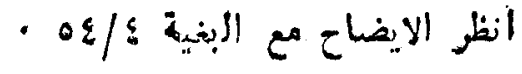




\section{oIr}

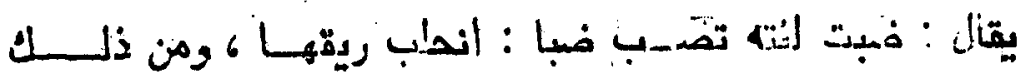

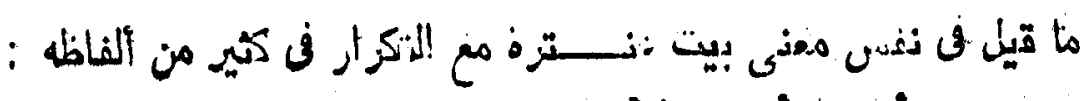

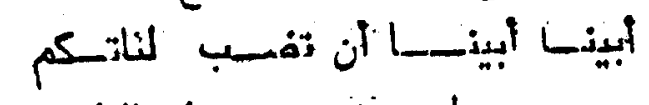

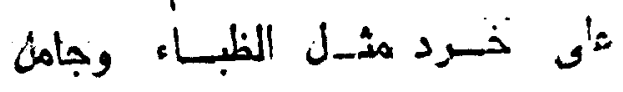

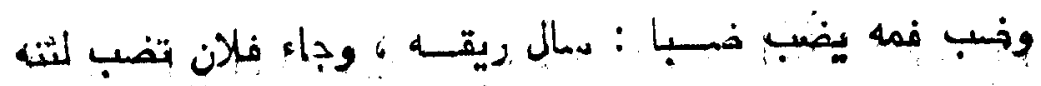

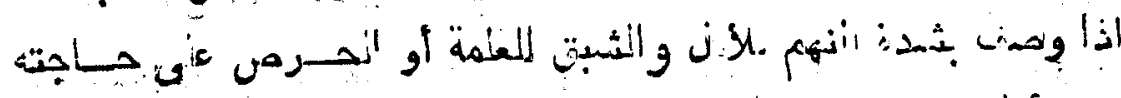

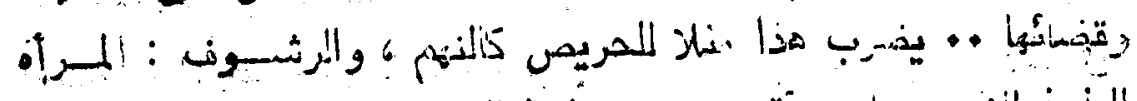

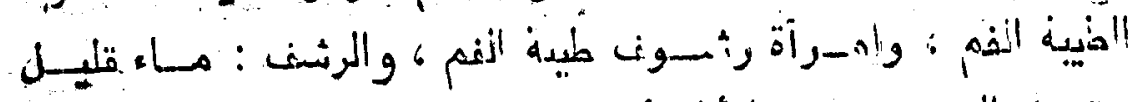

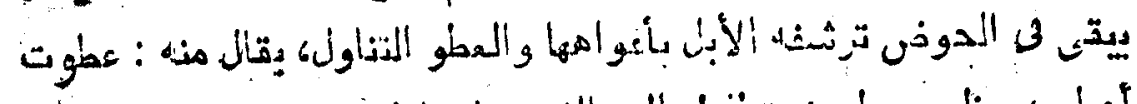

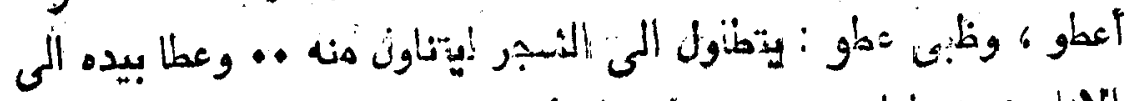

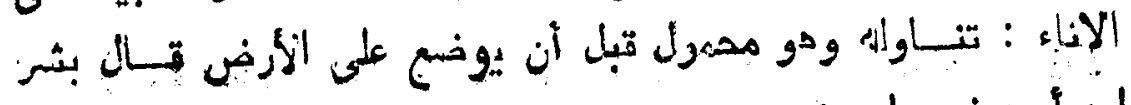

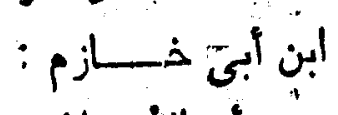

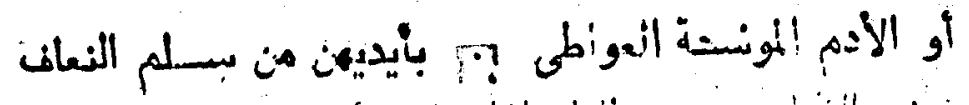

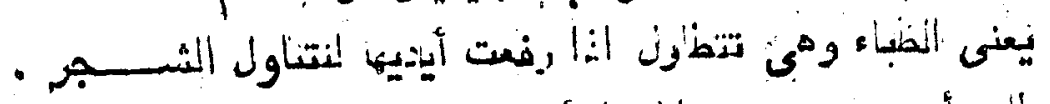

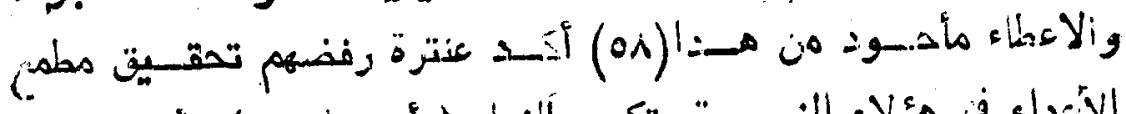

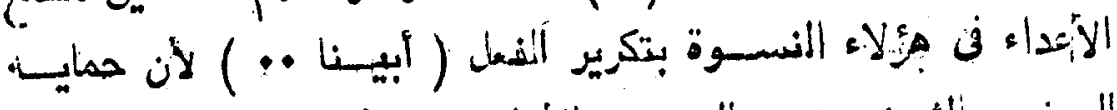

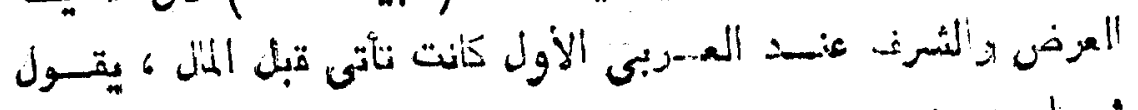

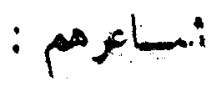

أنهم-ون عـرضى بدسالى لا أدنديس

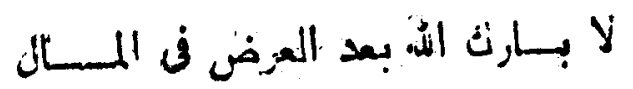

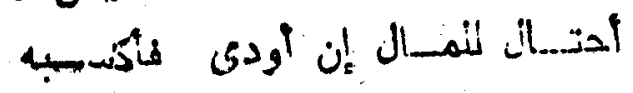

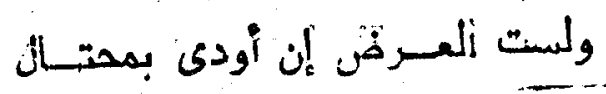

(01)

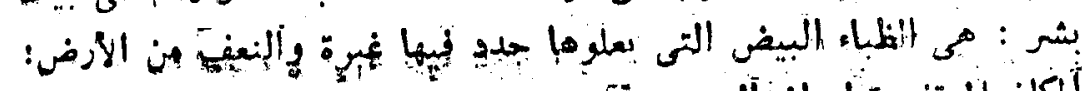

$$
(2+\infty)
$$

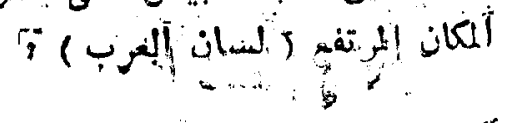




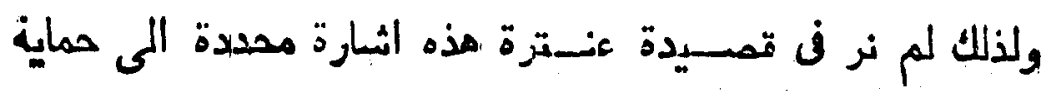

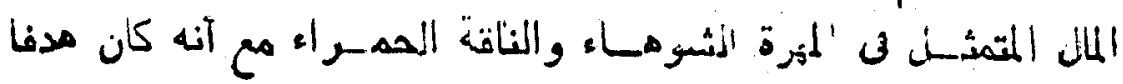

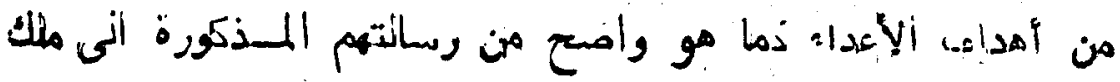

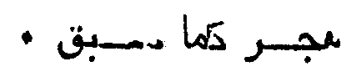

هذا وفن الوتتا الذى ذتر ميه عندترة هذا انلفظ ( آبي:ا ) مكردا

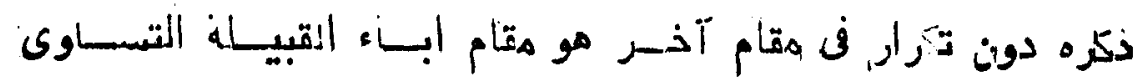

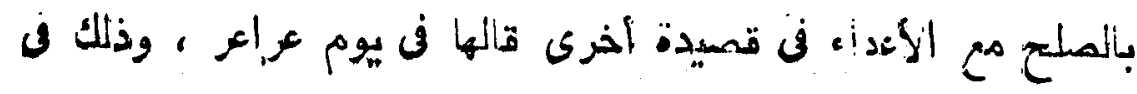
قولسه :

أبينا فلا نعطو السواء عدونا .. قياما بأعضاء السراء المعطت

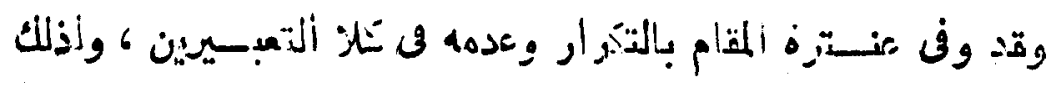

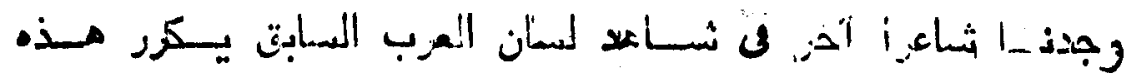

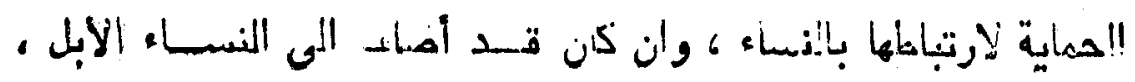

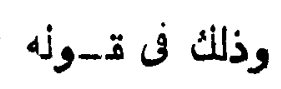

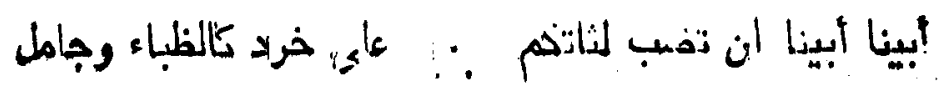

واذا كانت النساء المدهيات فن شهـاهد اللسان نوعا خاما وهن

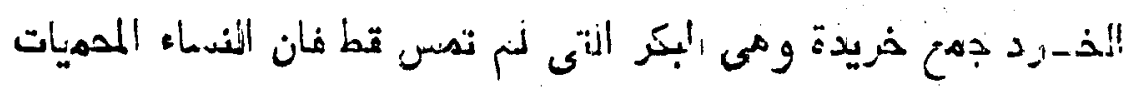

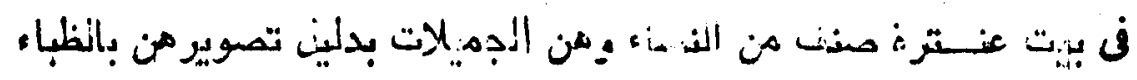

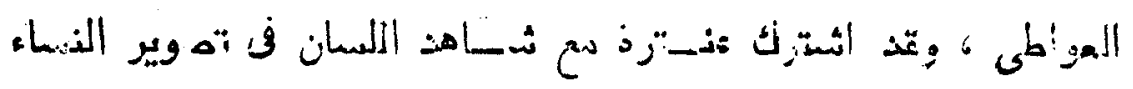

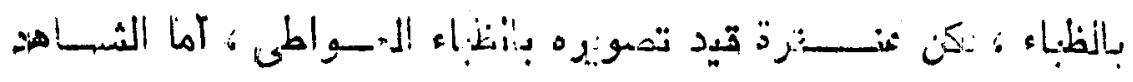

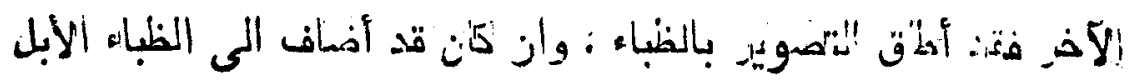

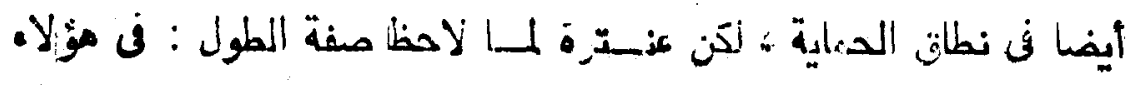

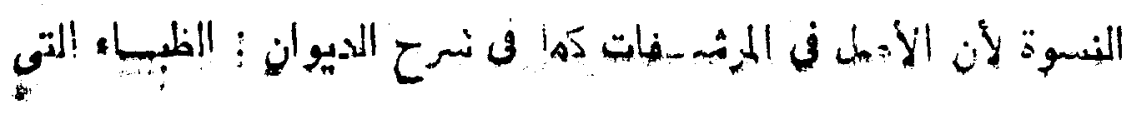




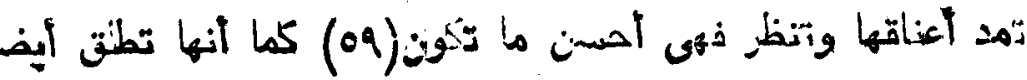

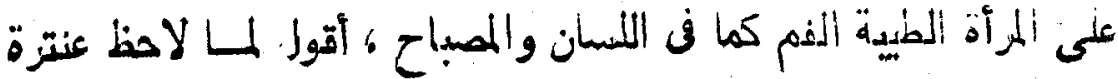

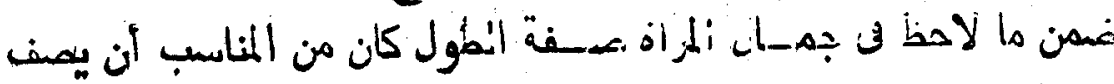

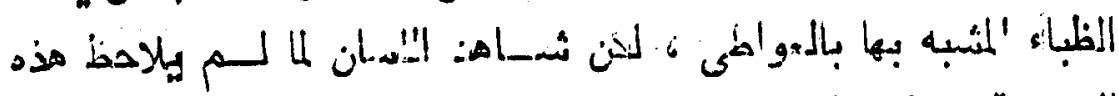

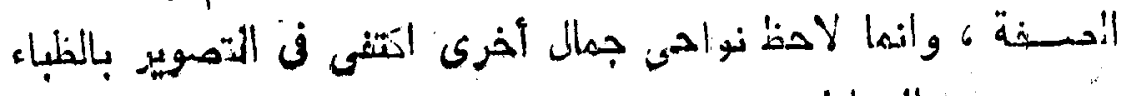

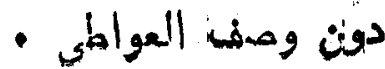

ولمن مسففات الجمان أنتى حظيت، بسها النساء في كال الشاهنين

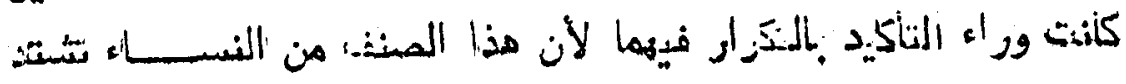

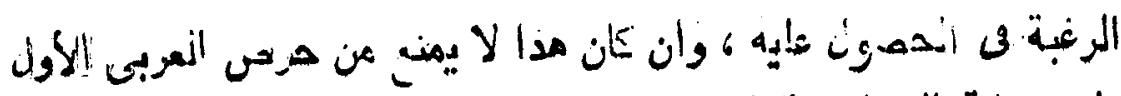

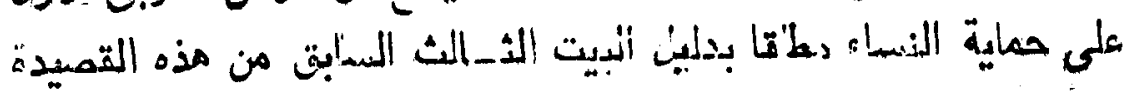

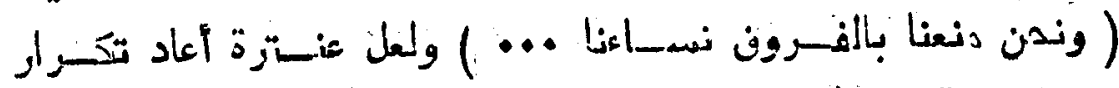

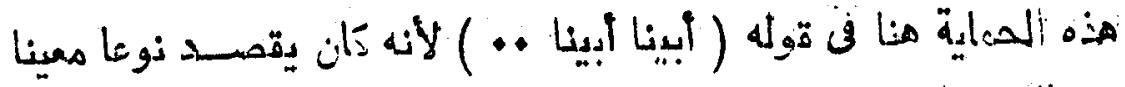

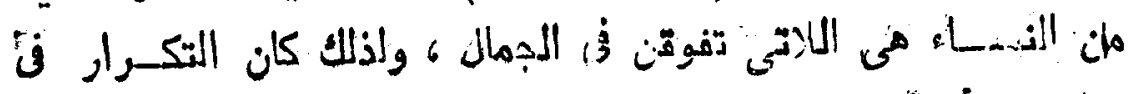

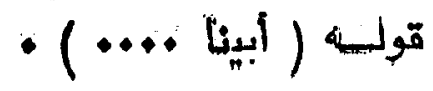

وفى توله : تضب لثاتذهم على مرشهـفات لا استعارة تمثئية جرت

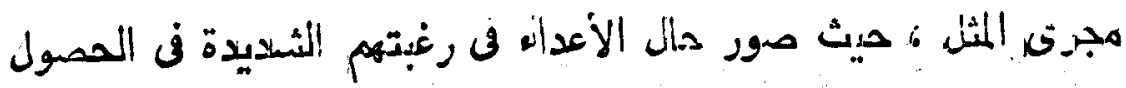

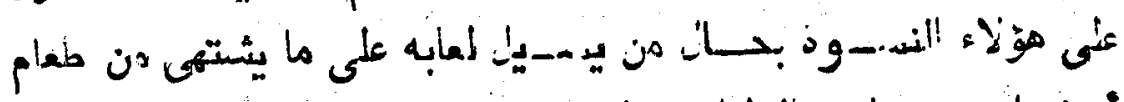

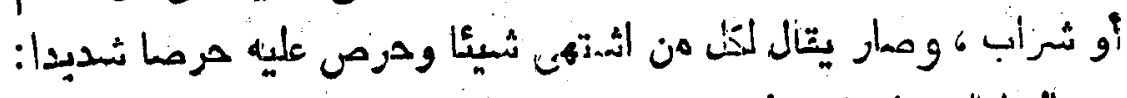

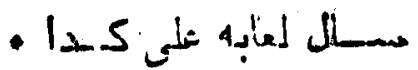

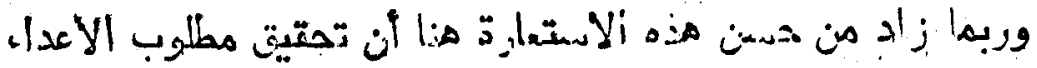

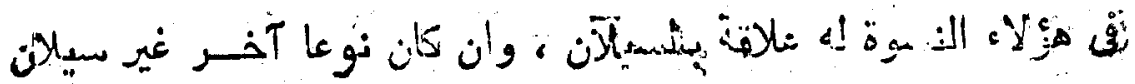

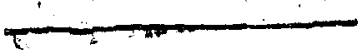

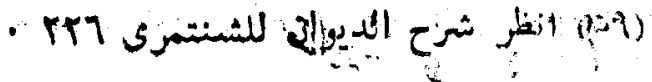




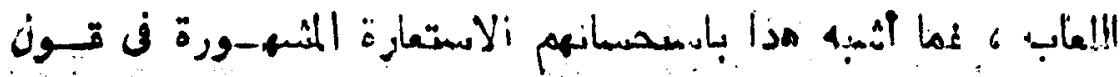
القائسلـل

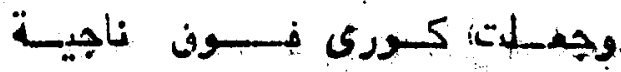

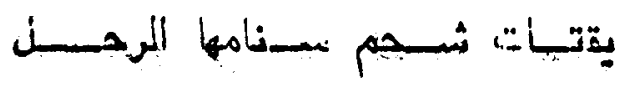

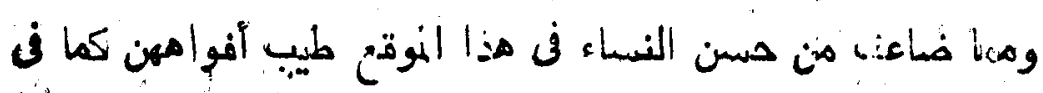

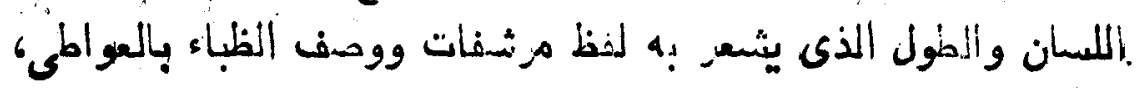

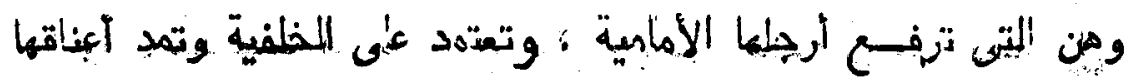

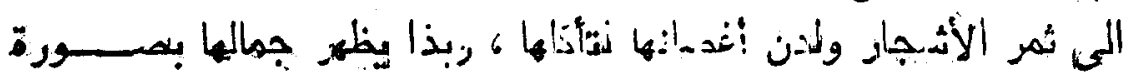

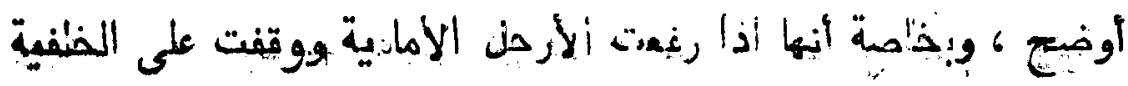

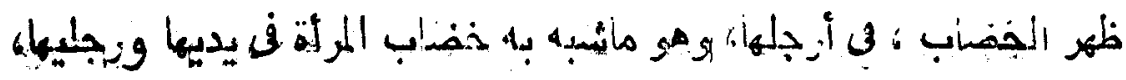

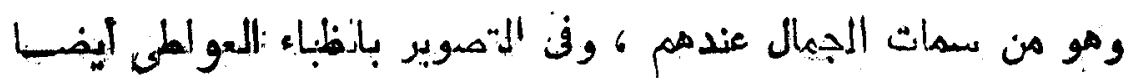

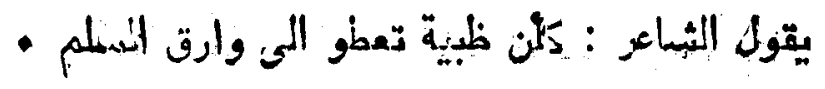

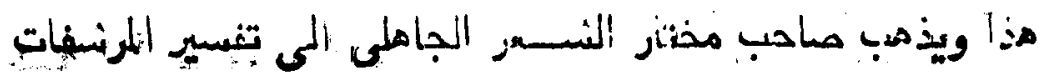

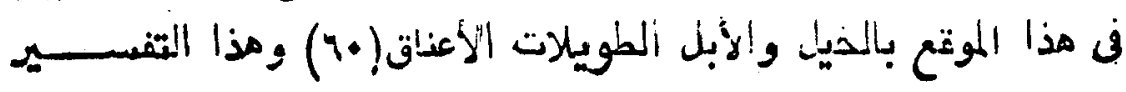

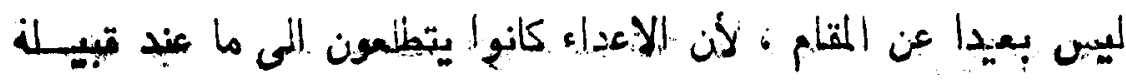

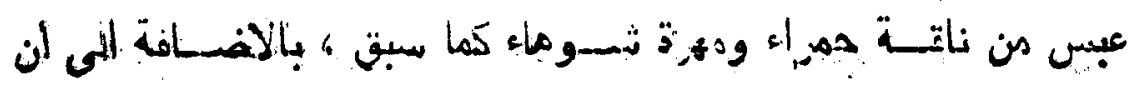

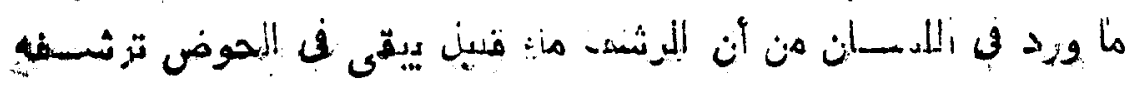

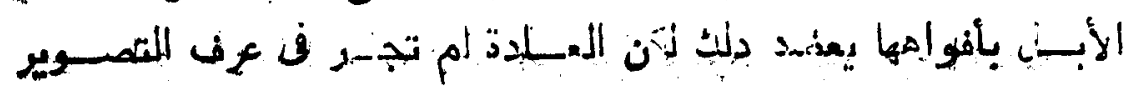

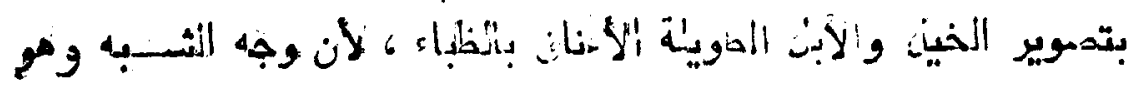

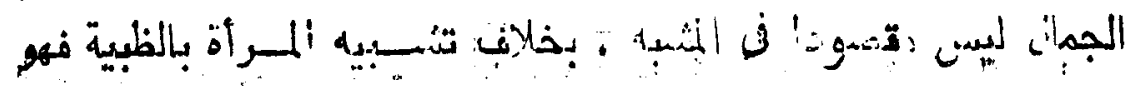

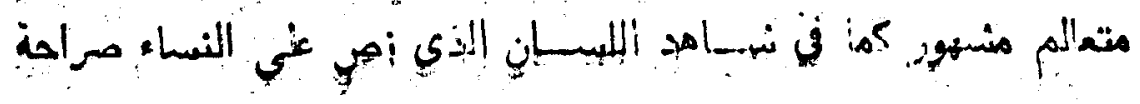

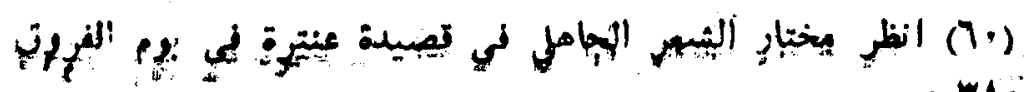
- ra. 
ofv

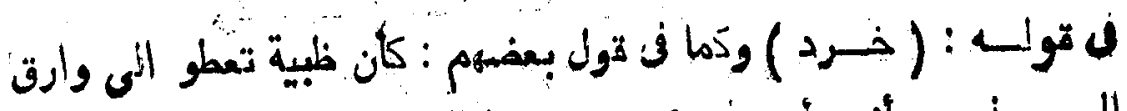

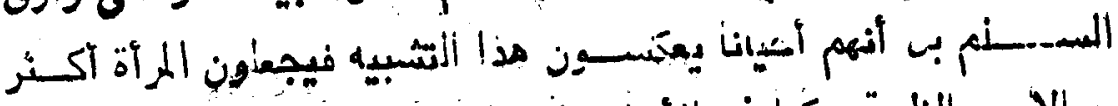
جمالا من الفلبية ، كما فن الأبيات النتانية :

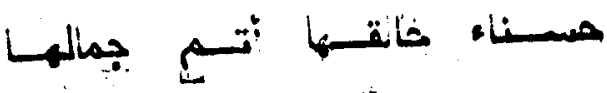

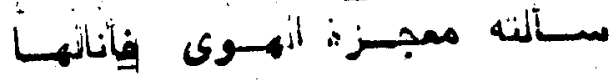

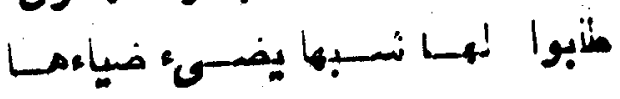

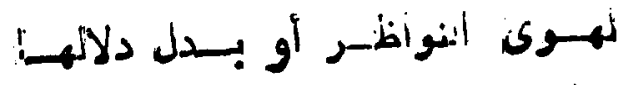

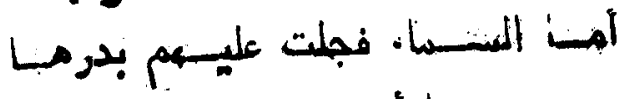

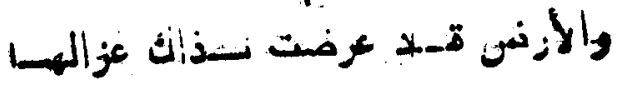

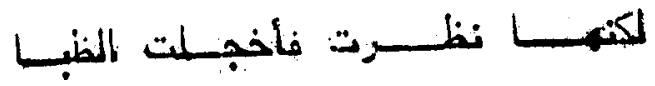

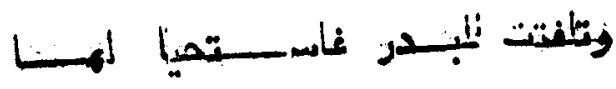

وأحيا يثبهون عينى المرأة فن جمالها بعينى الفززال ، من ذلك قول عنـــــترة ن المعاقة :

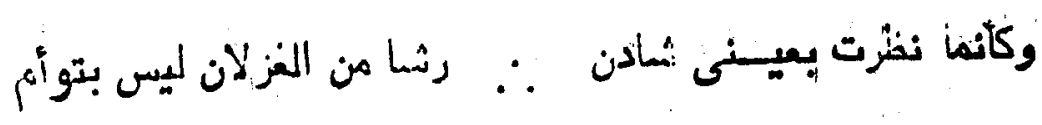

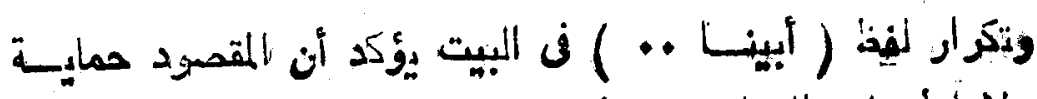

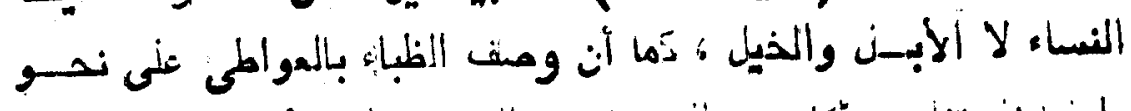

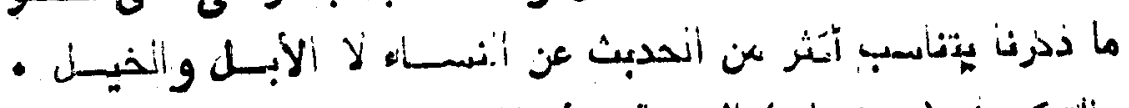

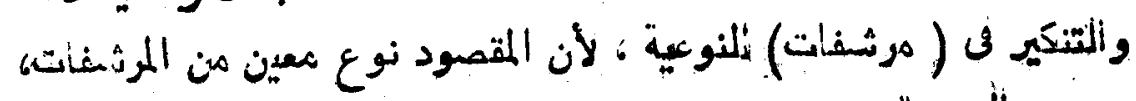

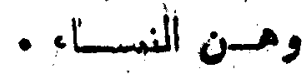

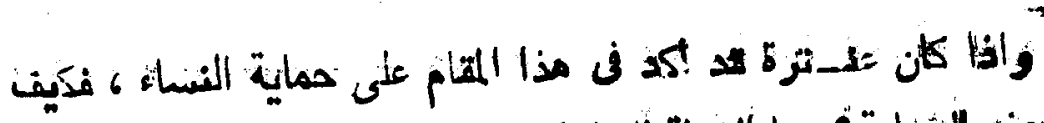

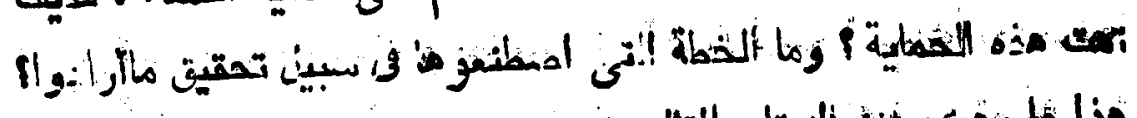

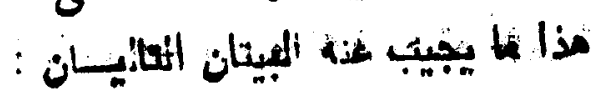


وتلت لمـن تسـد أخطـ ر إنوت نفسه

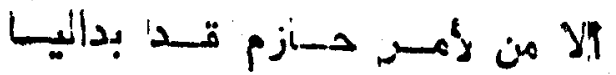

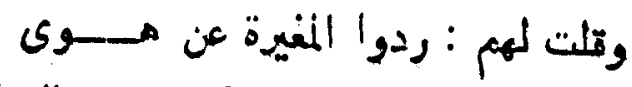

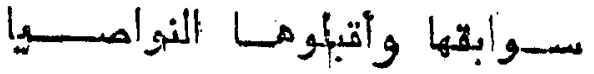

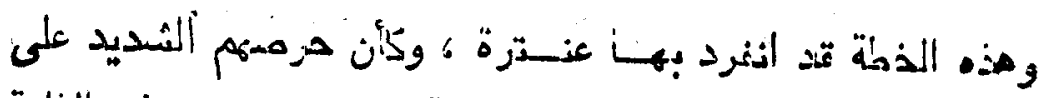

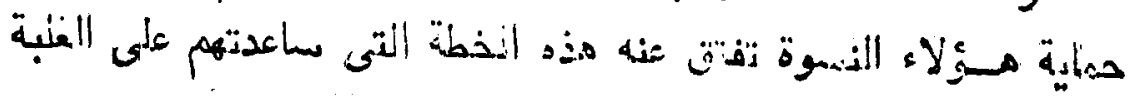
والظغــر

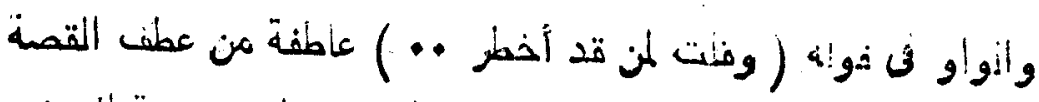

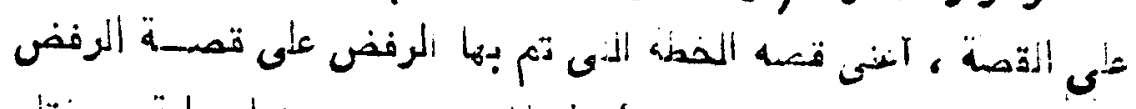

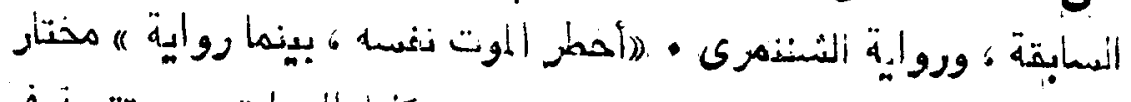

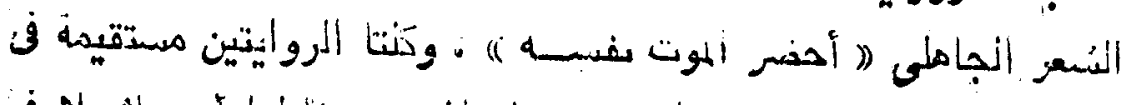

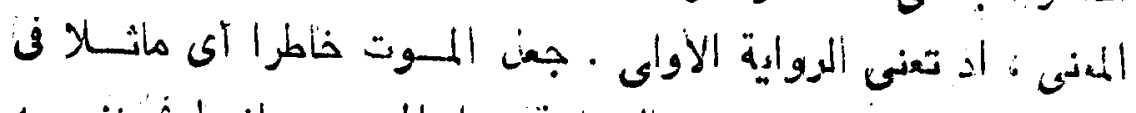

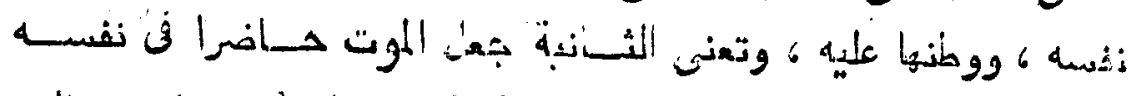

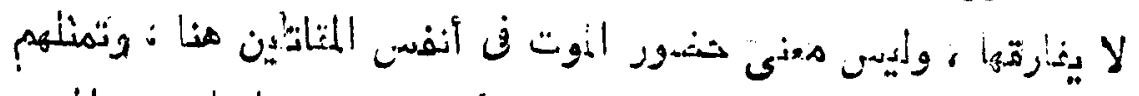

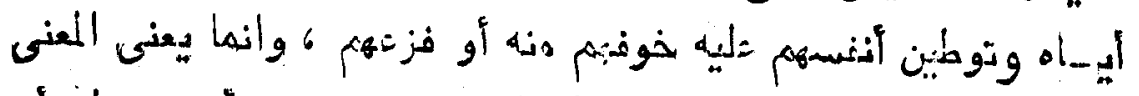

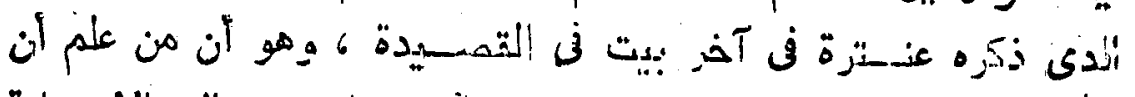

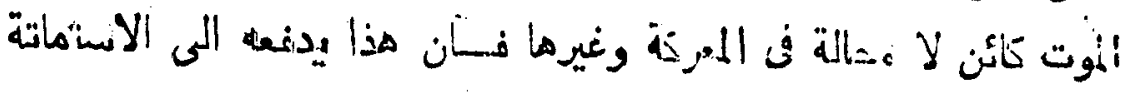

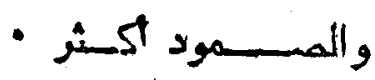

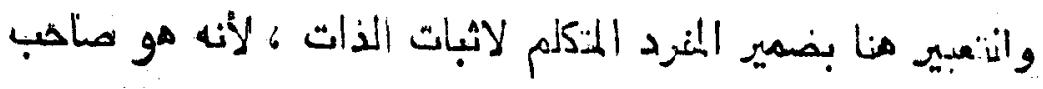

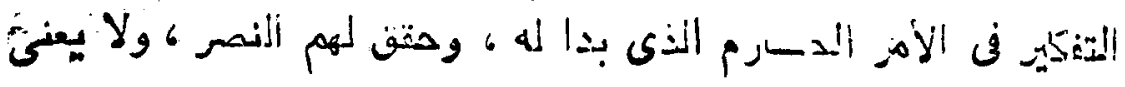

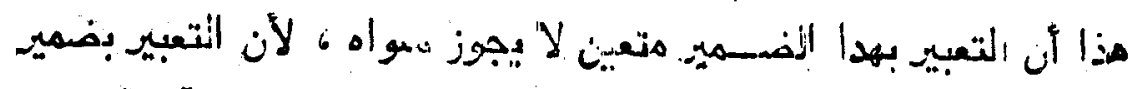

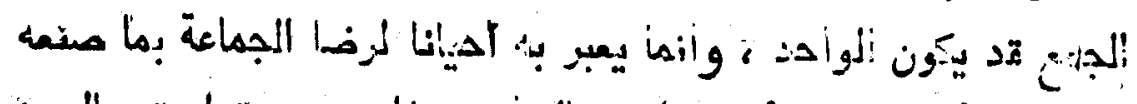

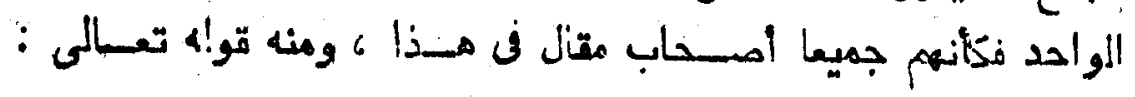




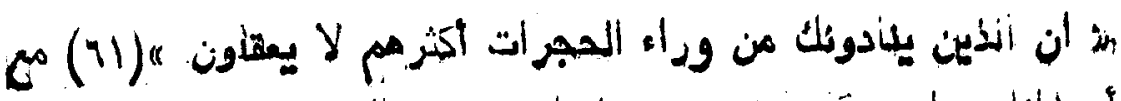

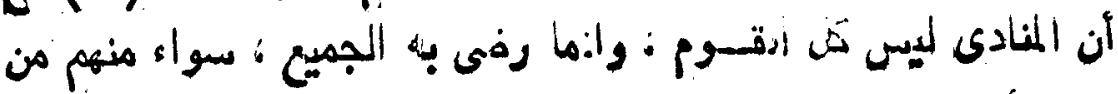

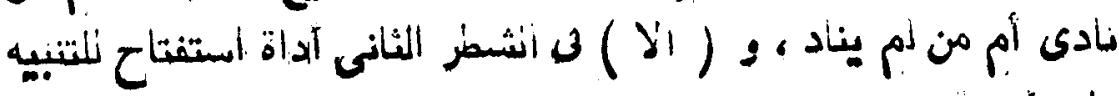

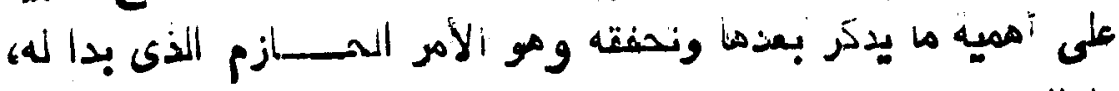

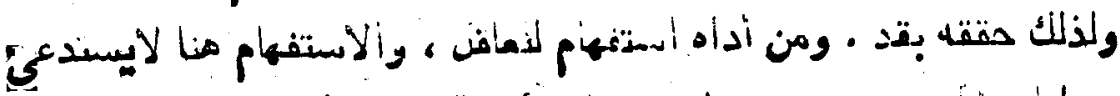

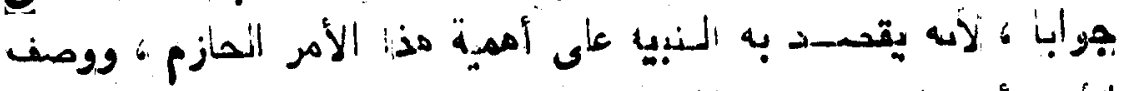

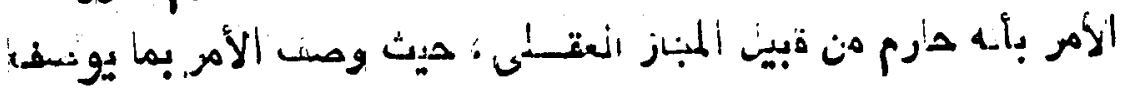

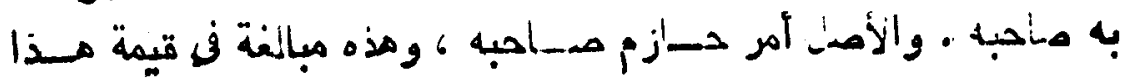

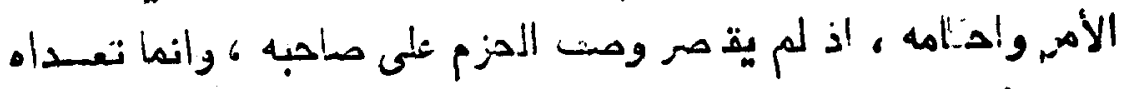

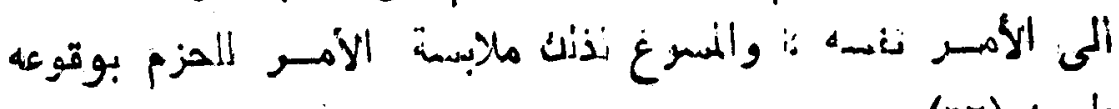
- (ir) (ليس

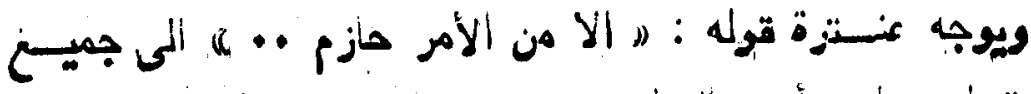

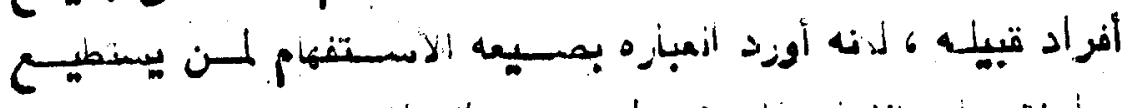

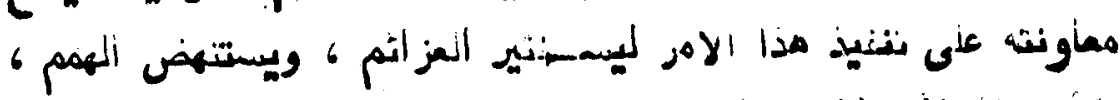

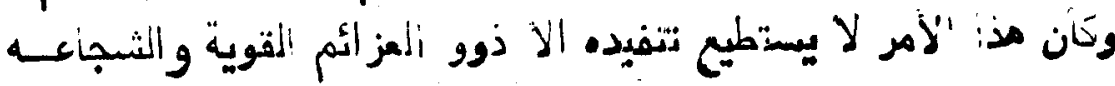

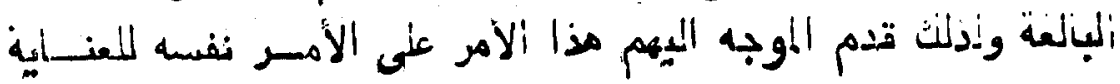

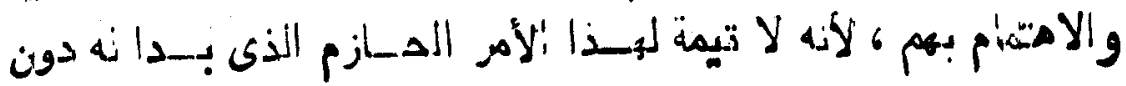

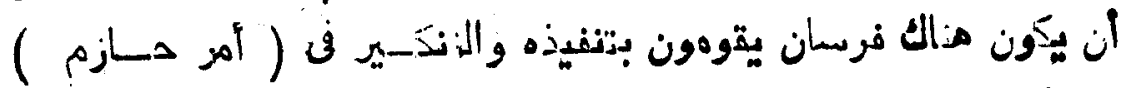

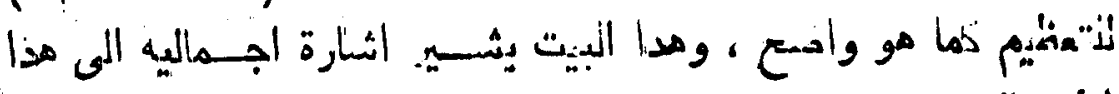

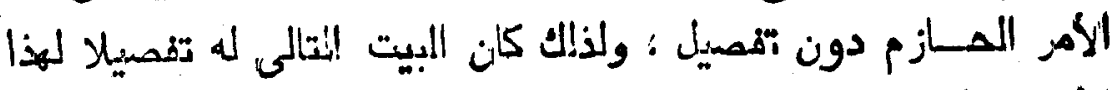

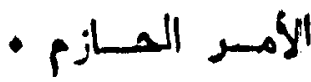

- 8 (

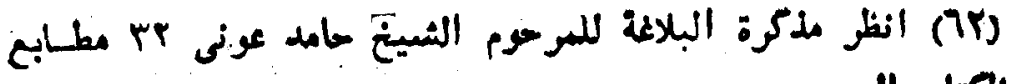
دار المتاب المربم بعصر مدكرة البلاع 


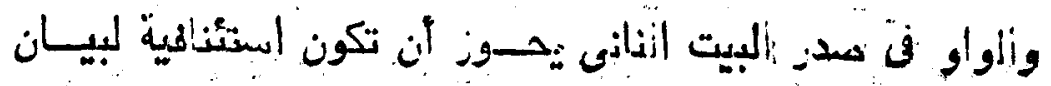

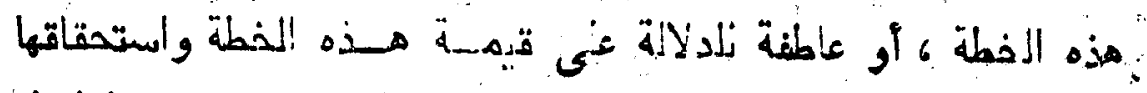

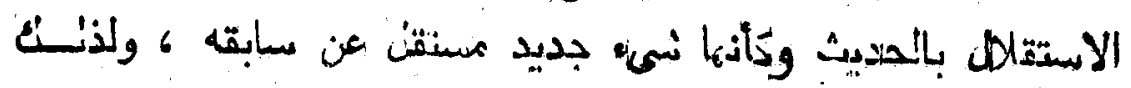

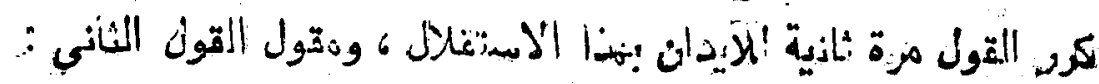

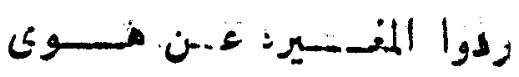

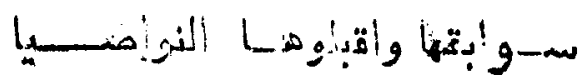

ويدنى بذلك أنه ينبنى علديهم في هذد الذطة أن يردوا الخيل المعبية

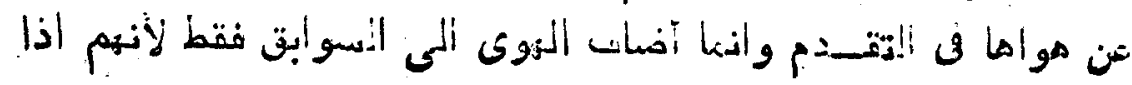

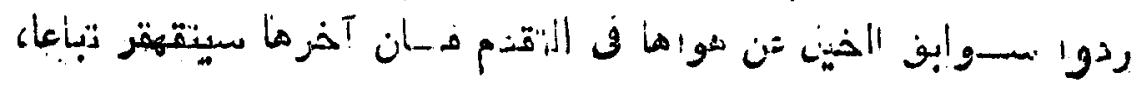

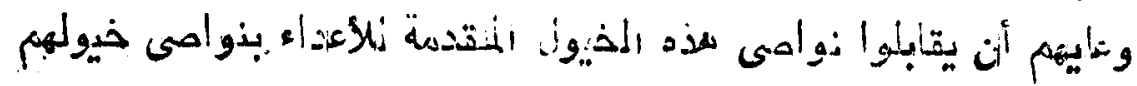

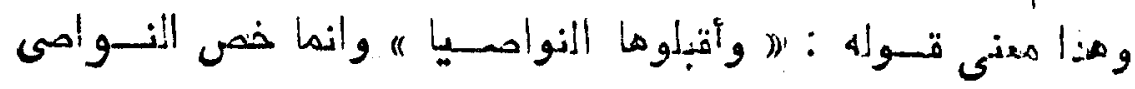

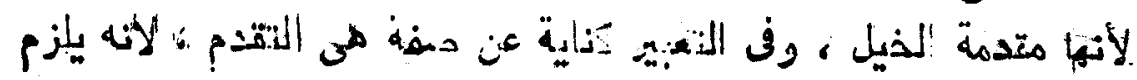

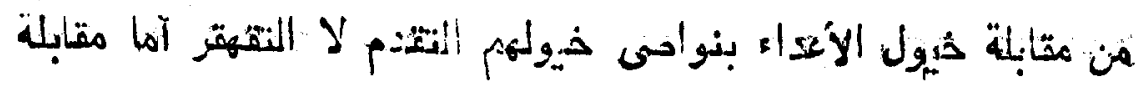

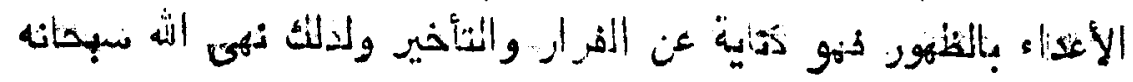

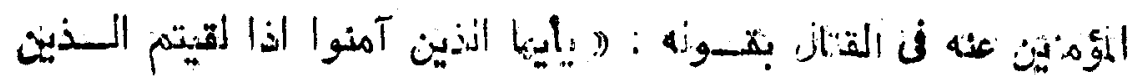

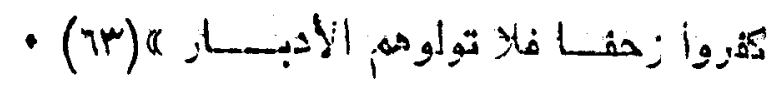

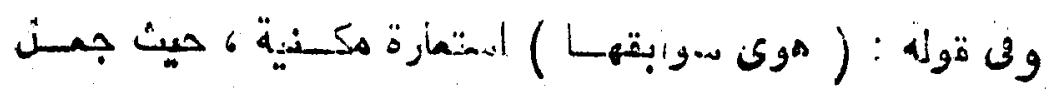

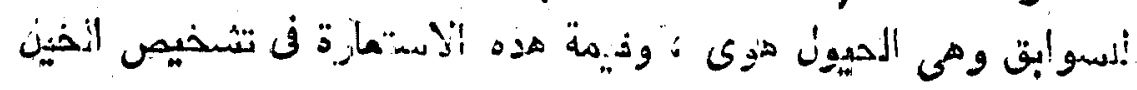

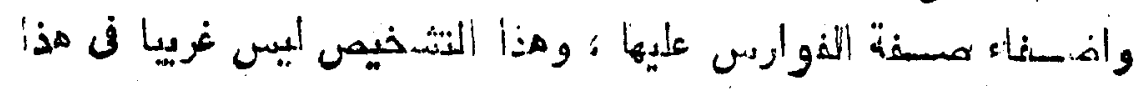

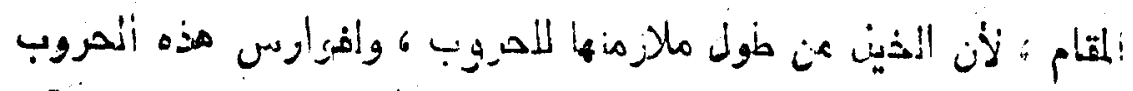

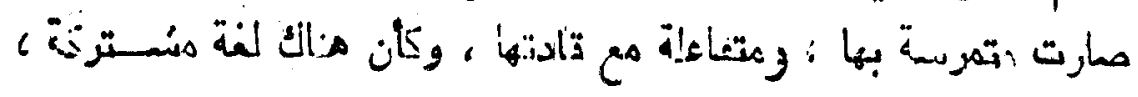




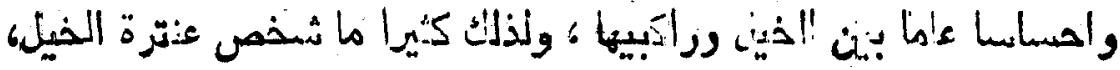

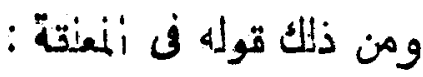

$$
\begin{aligned}
& \text { هلا دمــألت الخبل يـا ابنــة مــالك }
\end{aligned}
$$

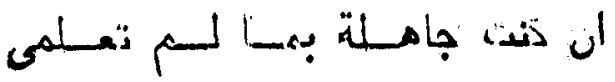

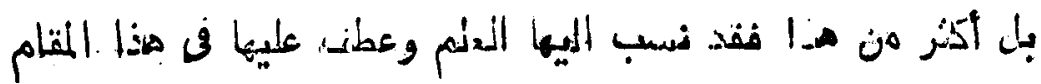

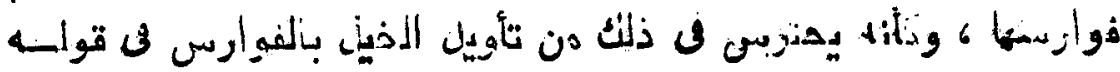

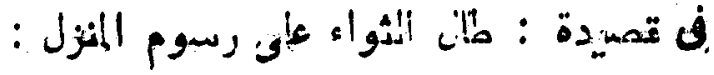

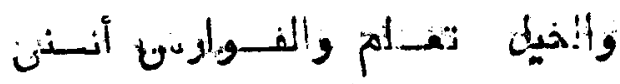

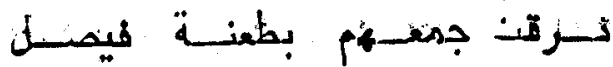

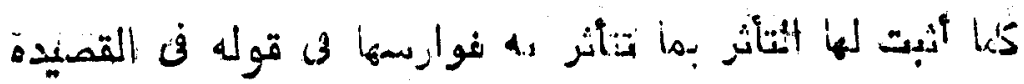

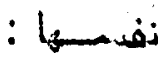

وابذيل ...ـاهمة أنوجهــره كأنمـا

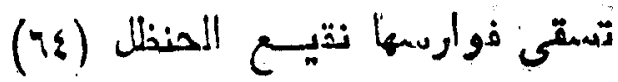

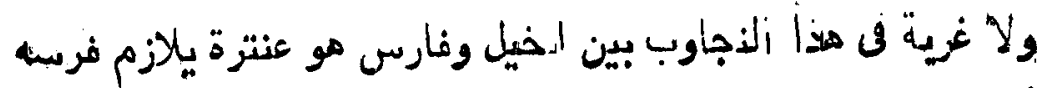

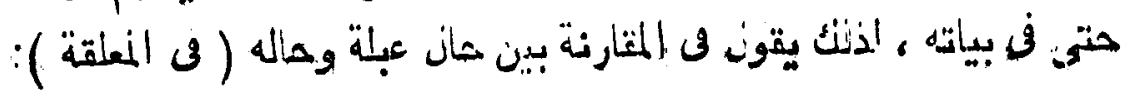

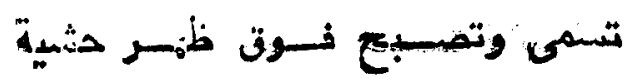

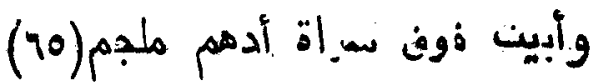

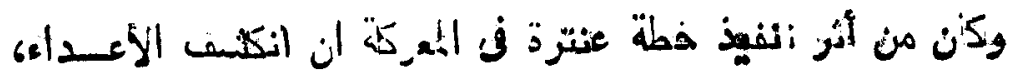

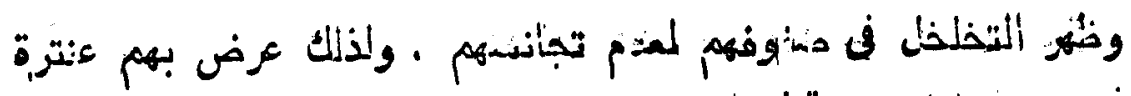

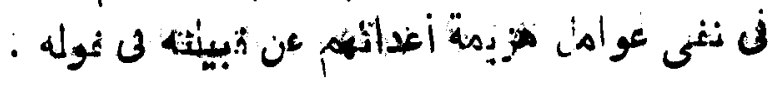

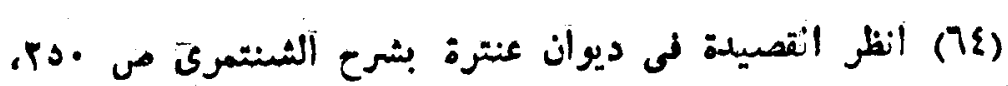

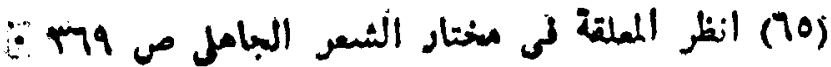




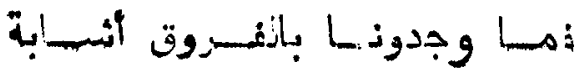

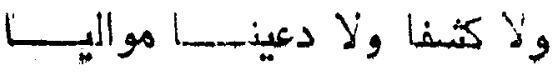

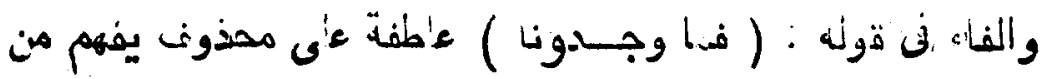

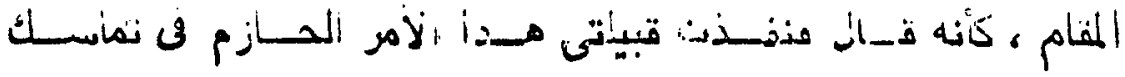

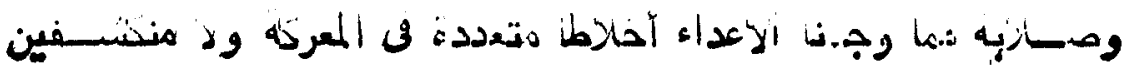

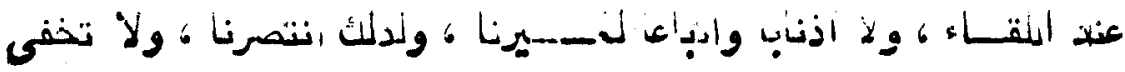

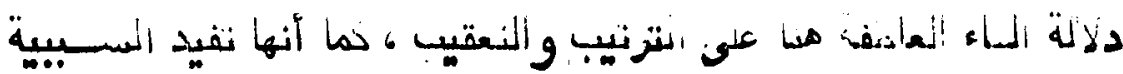

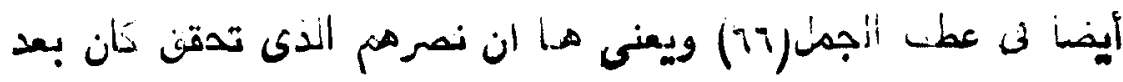

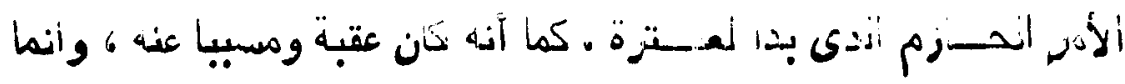

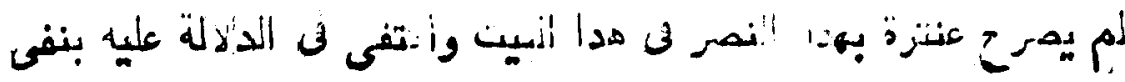

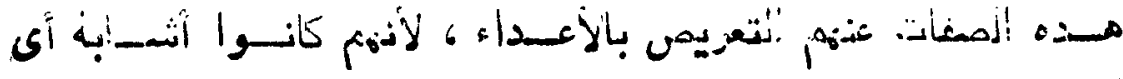

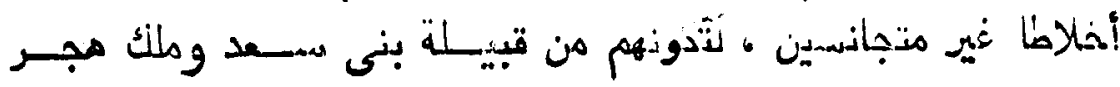

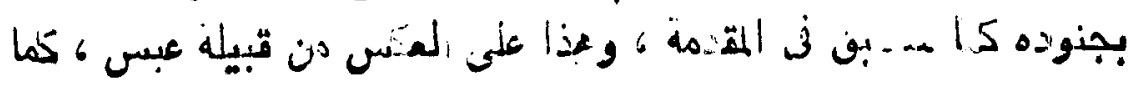

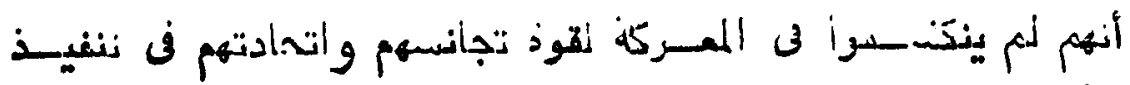

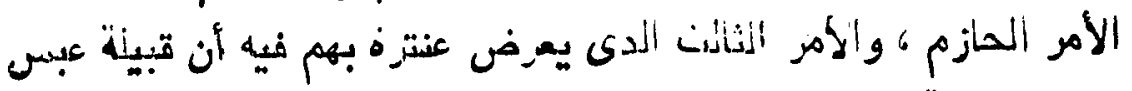

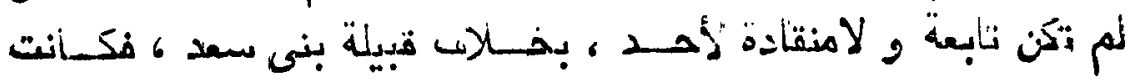

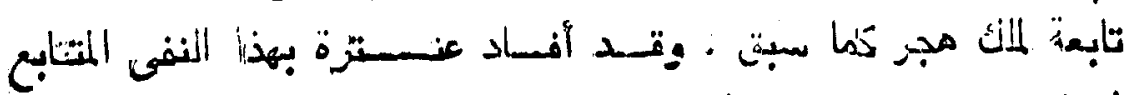

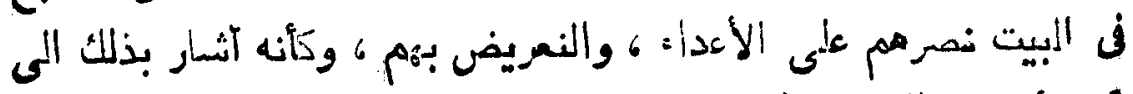

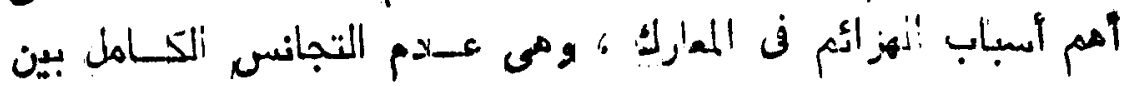

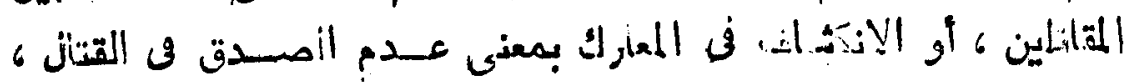

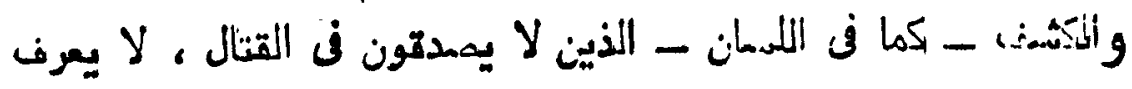

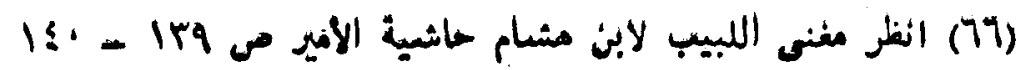




\section{orr}

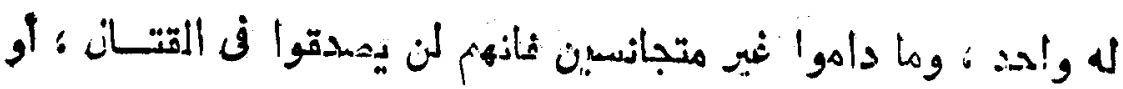

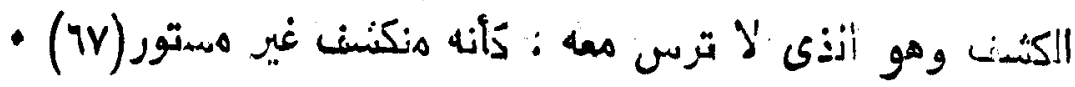

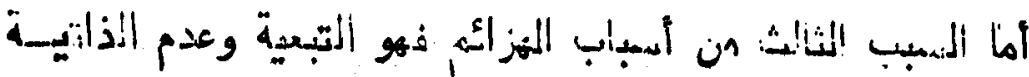

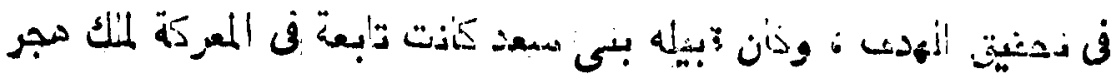

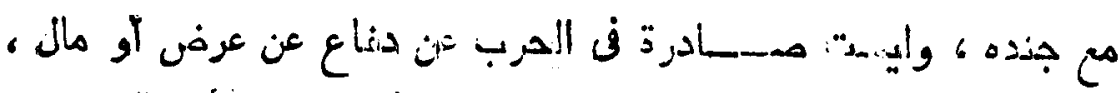

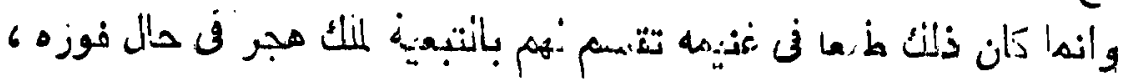

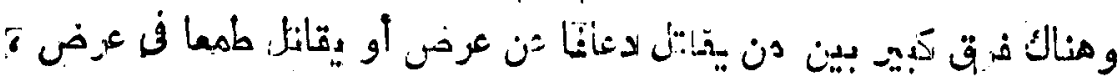

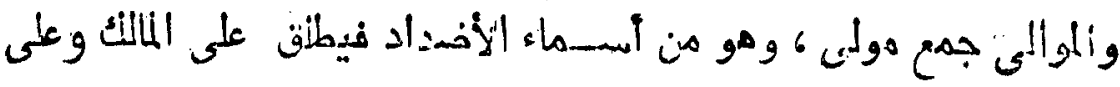

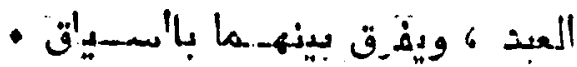

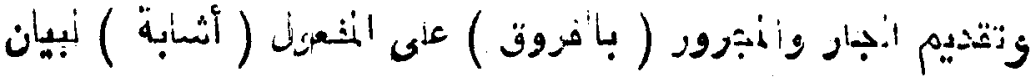

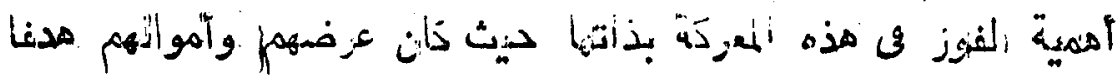

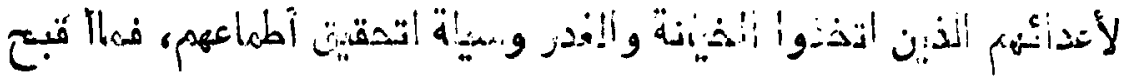

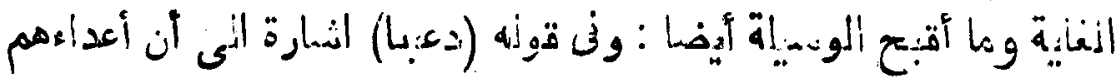

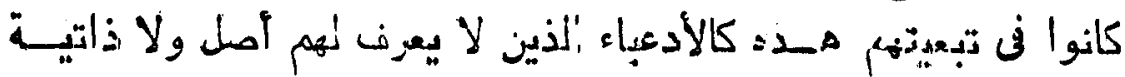

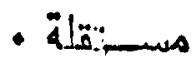

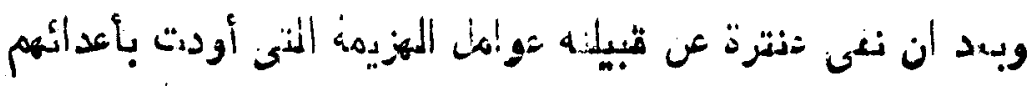

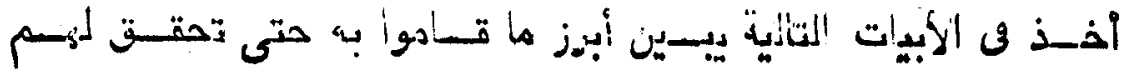

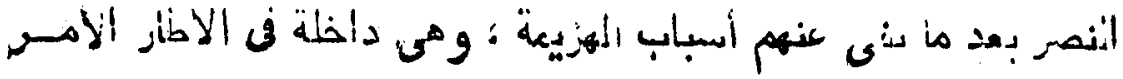

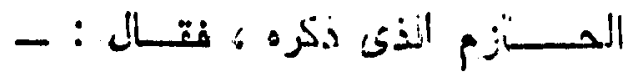

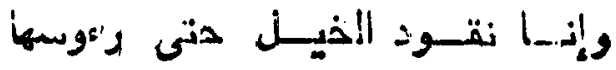

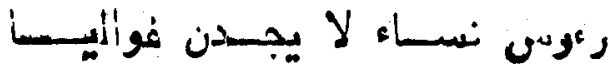

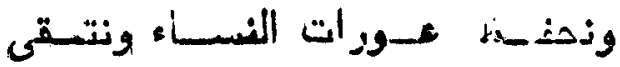

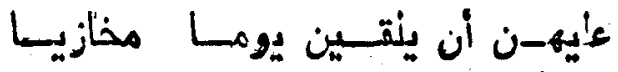

• النظر المسادة في لسان العرب (TV) 


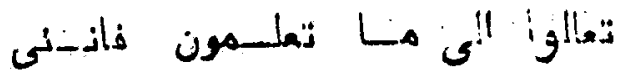

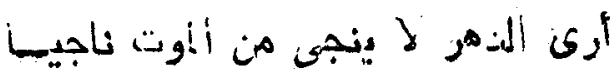

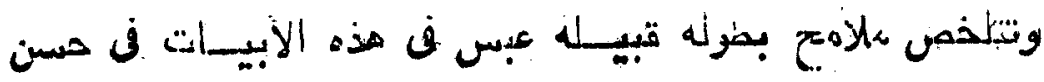

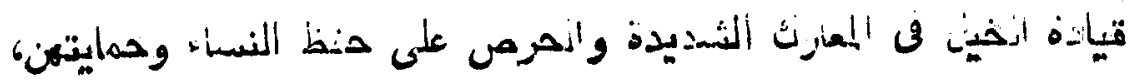

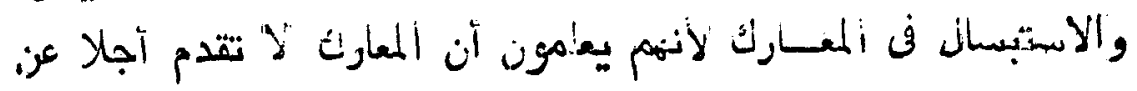

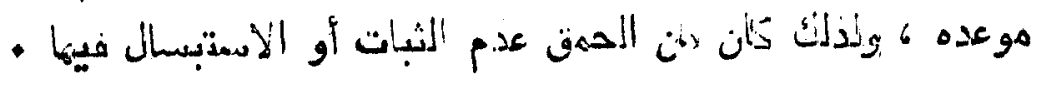

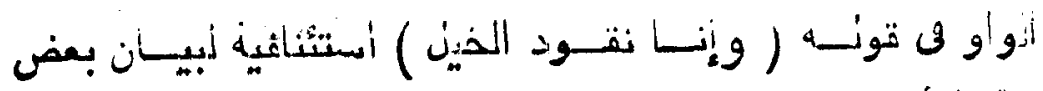

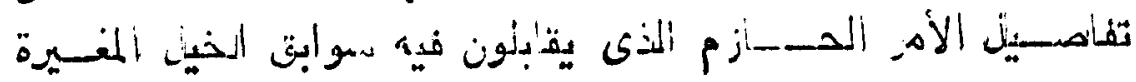

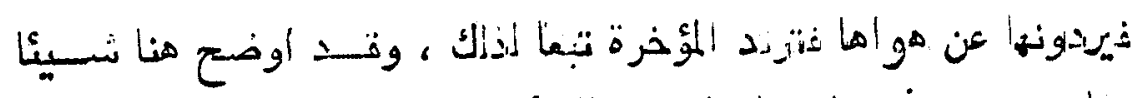

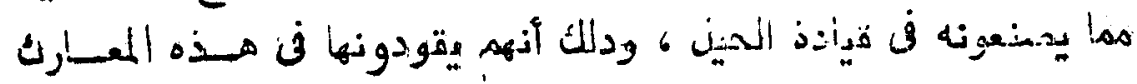

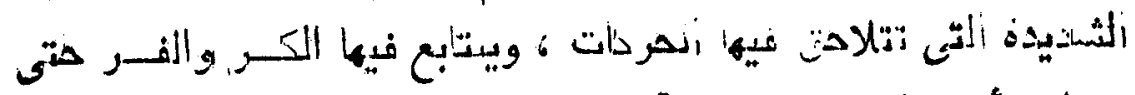

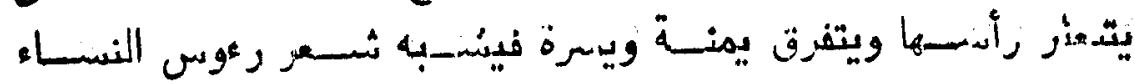

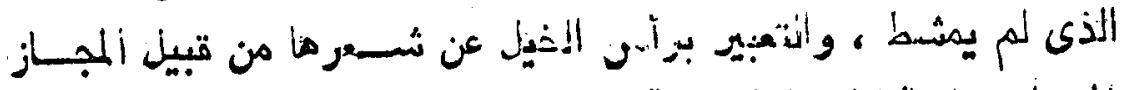

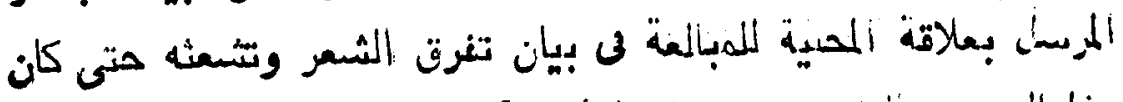

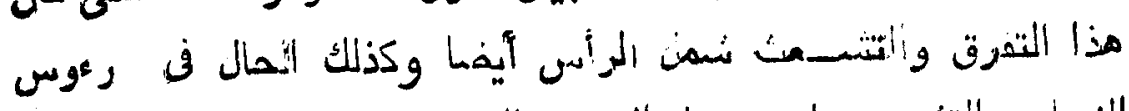

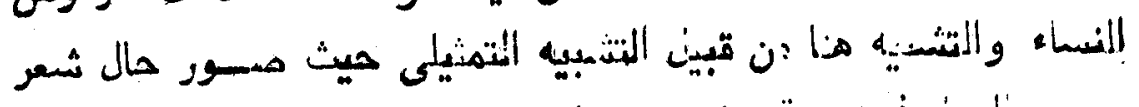

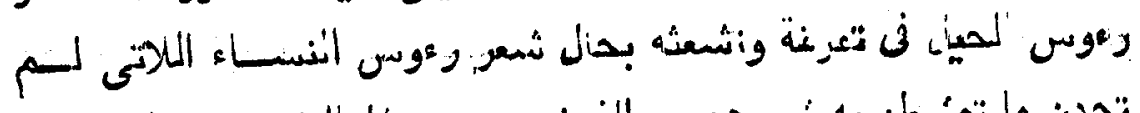

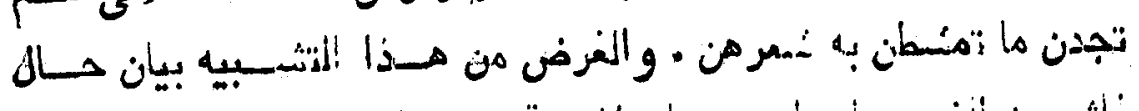

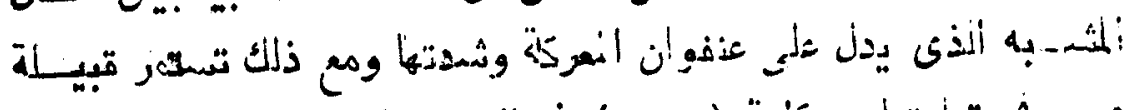

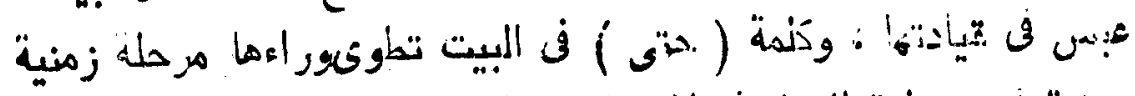

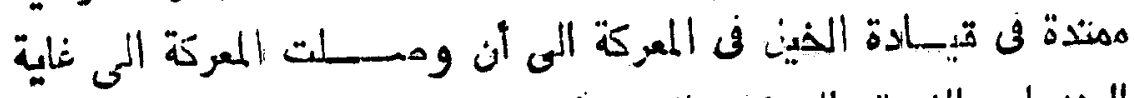

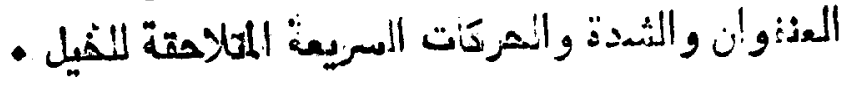

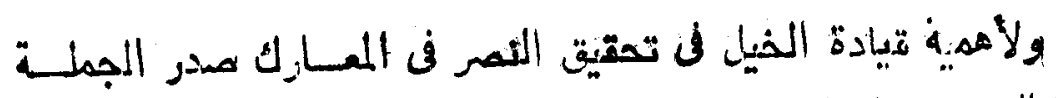

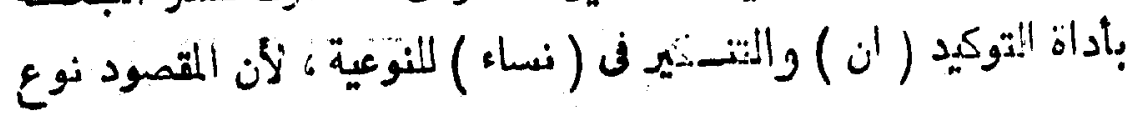




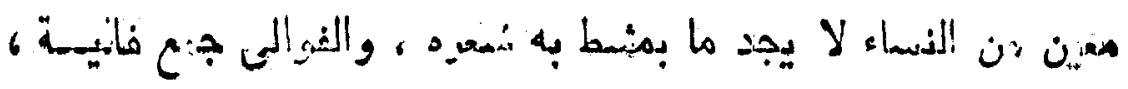

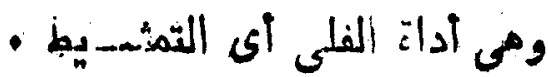

ومن آثار هذه القيادة المهديه للإيل أنهم المتطاعوا أن يدفظلوا

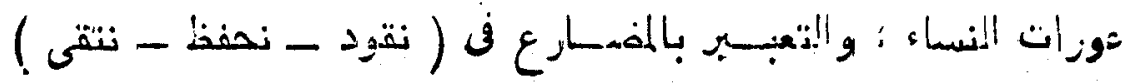

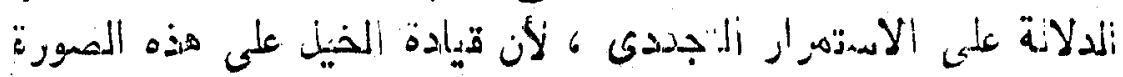

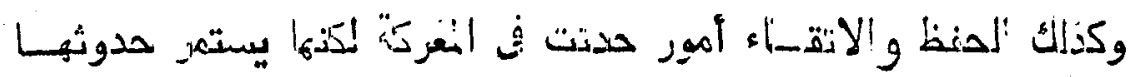

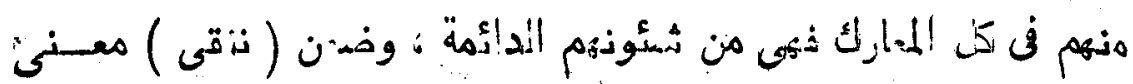

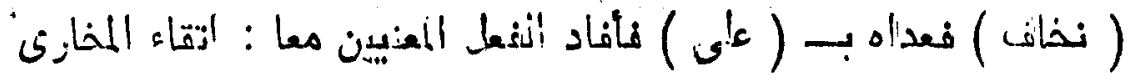

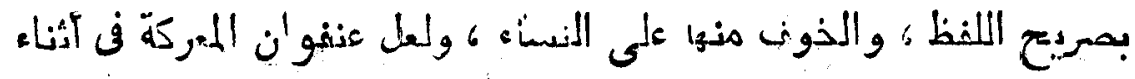

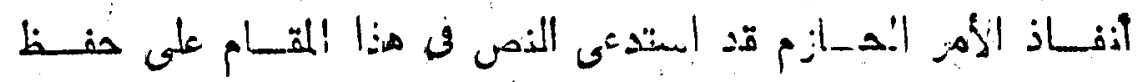

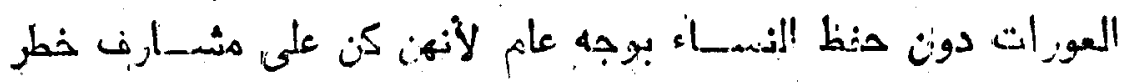

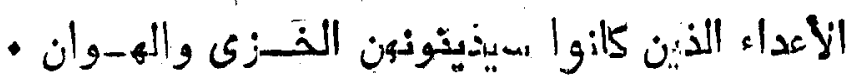

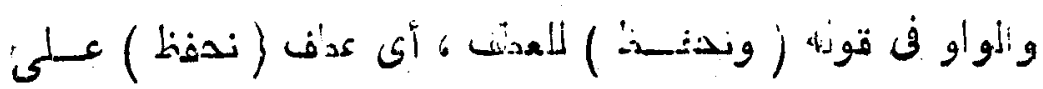

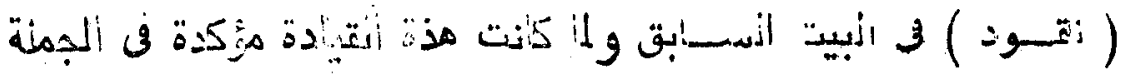

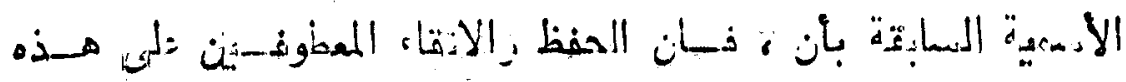

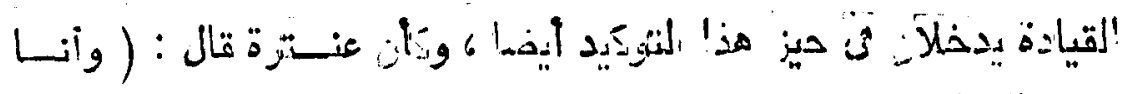

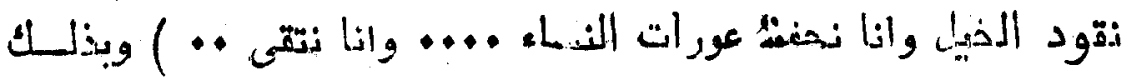

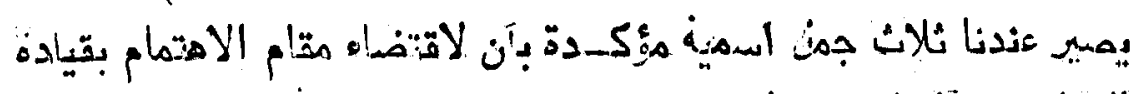

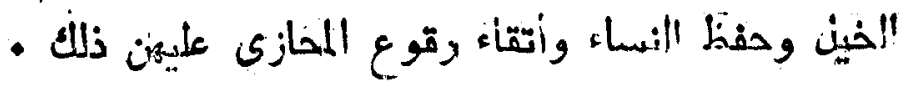

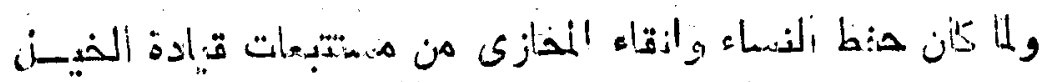

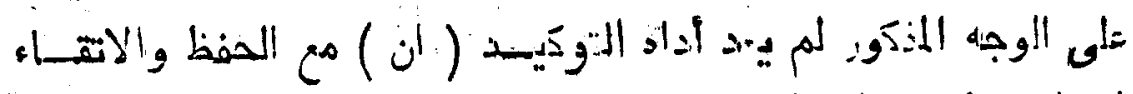

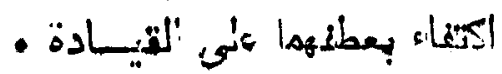

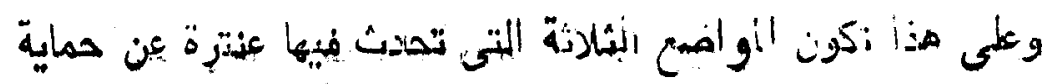

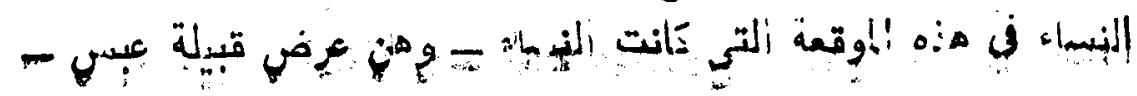




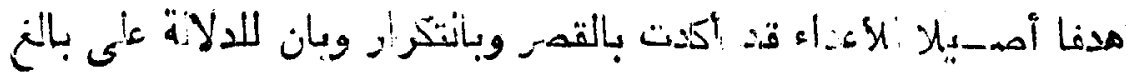

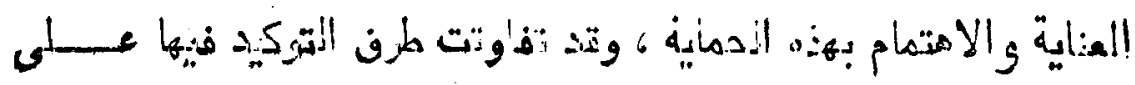

- النحسبو المبـابن

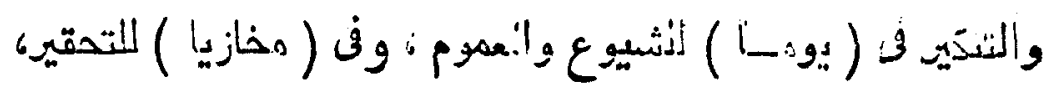

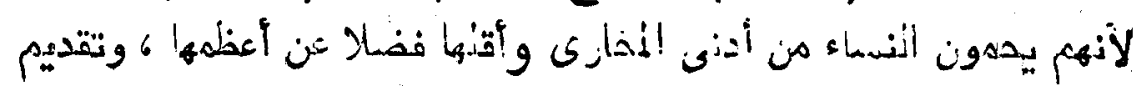

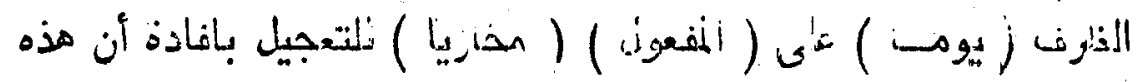

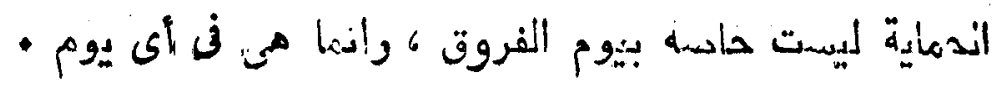

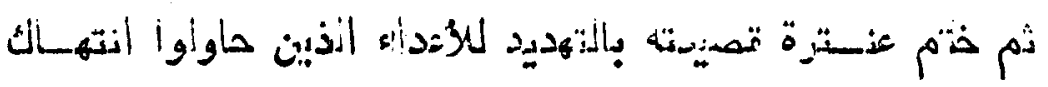

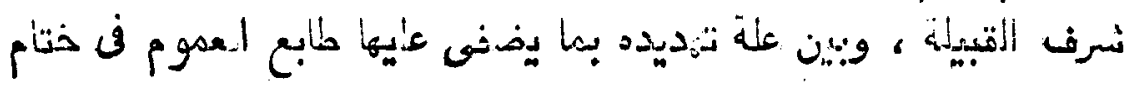

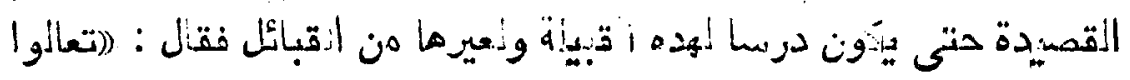

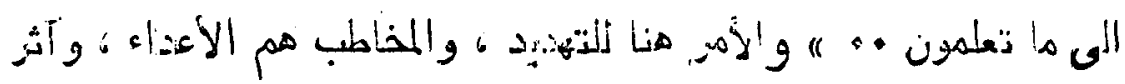

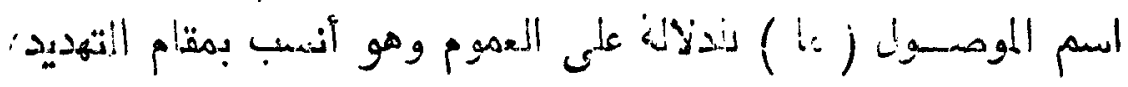

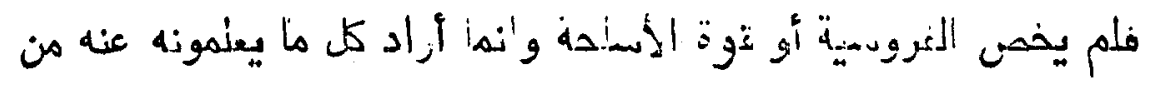

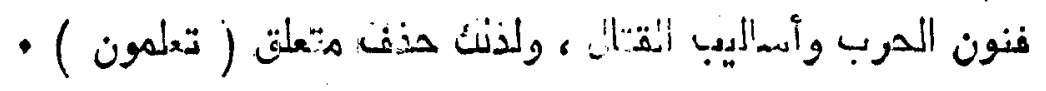

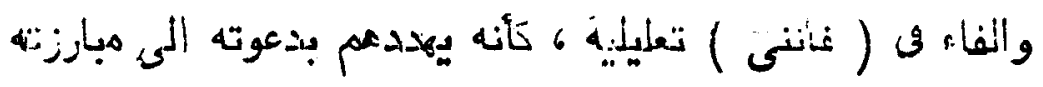

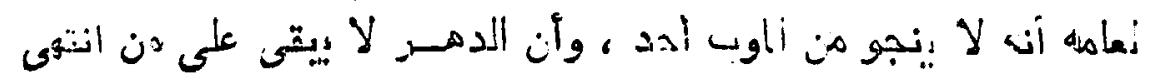

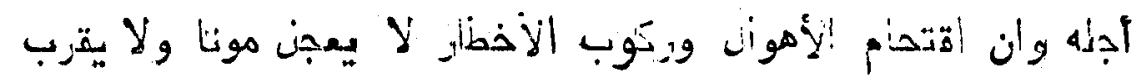

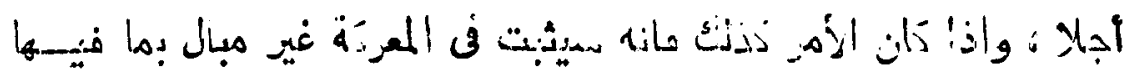

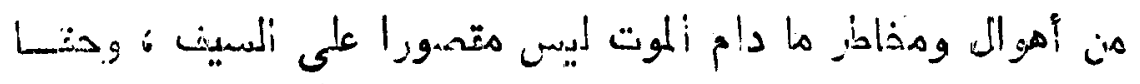

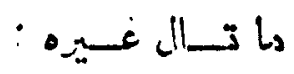

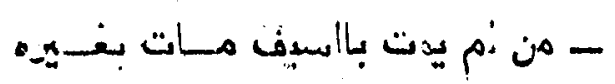

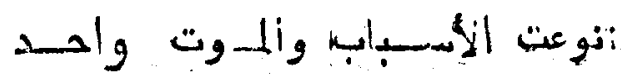


$0 \times \bar{V}$

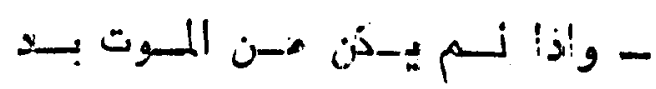

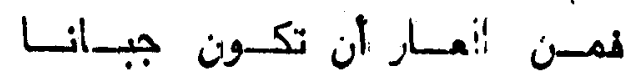

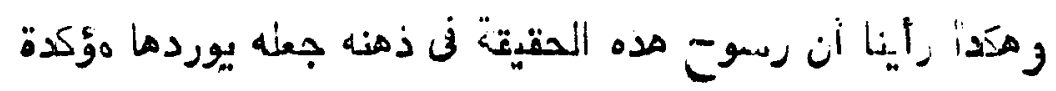

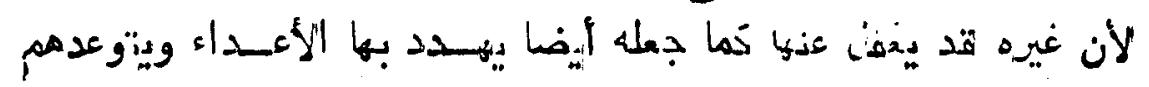

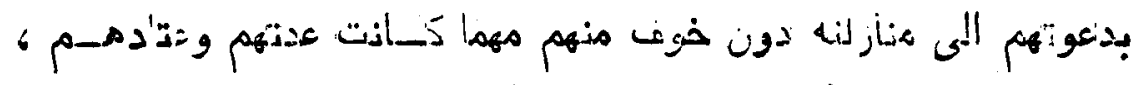

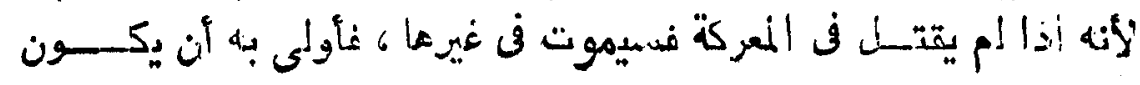

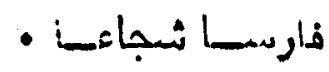

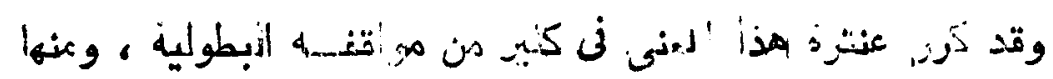

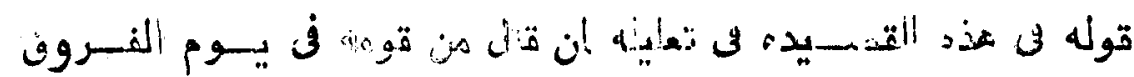

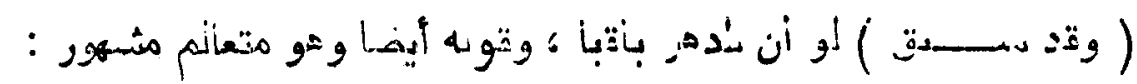

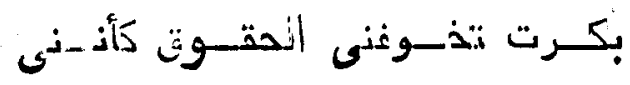

$$
\begin{aligned}
& \text { أصهبت عن نسرض الإقوف بمعسزل }
\end{aligned}
$$

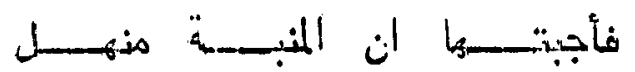

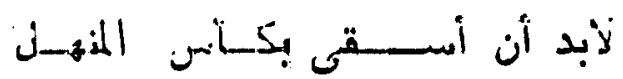

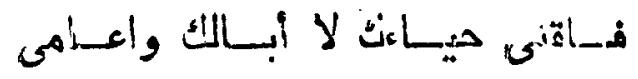

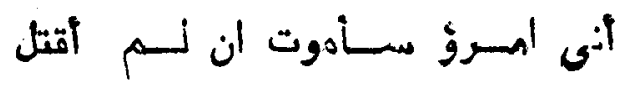

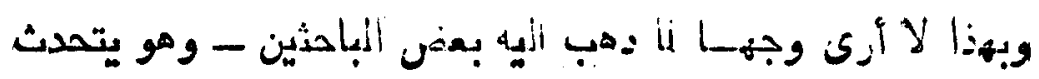

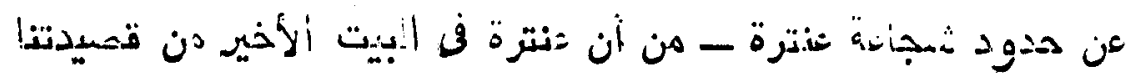

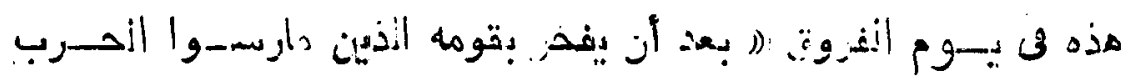

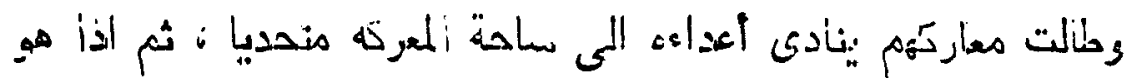

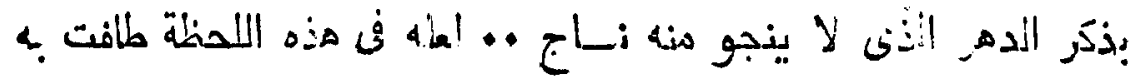

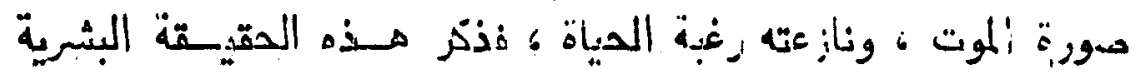

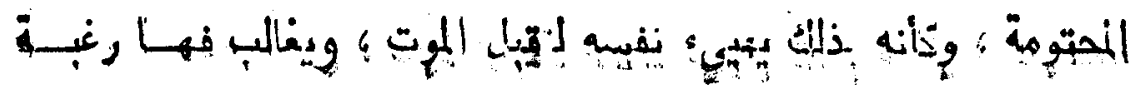




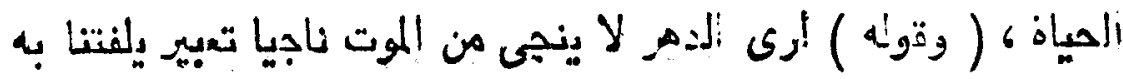

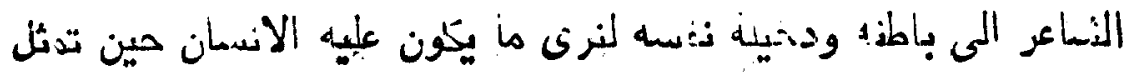

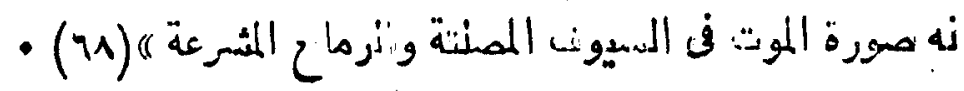

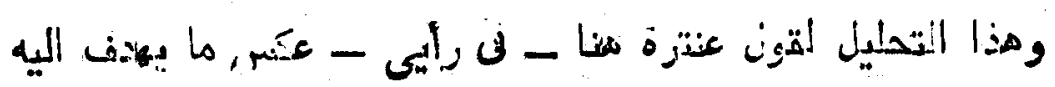

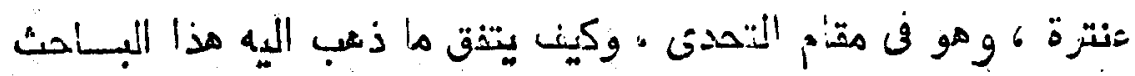

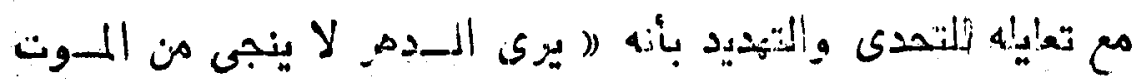

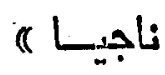

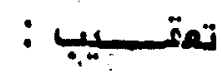
رأينا دين حنلت هذه القصيدة على قصرها بمباحث بلانية عديدة

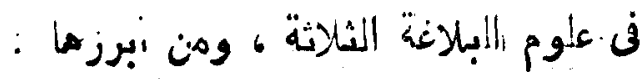

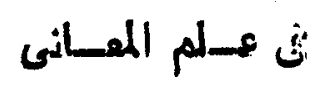

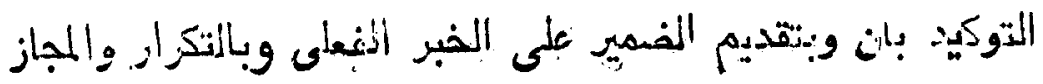

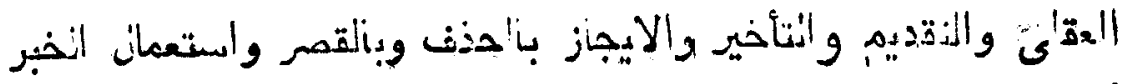

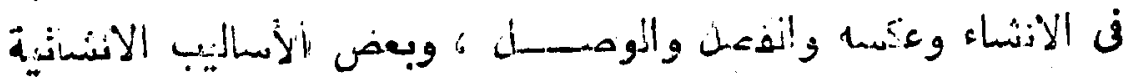

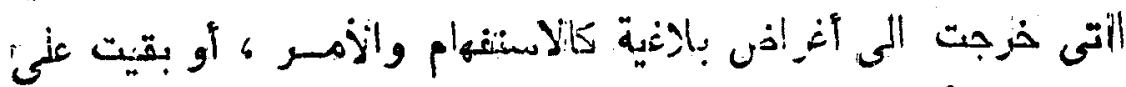

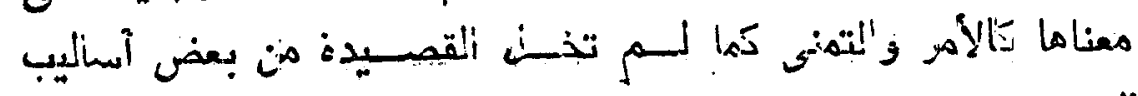
"لقصــــر

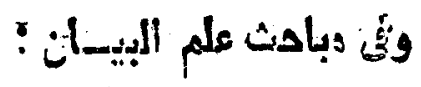

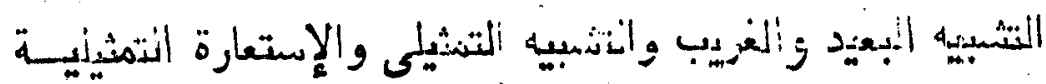

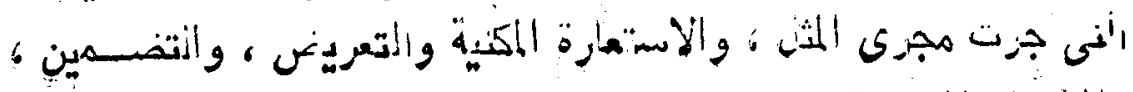

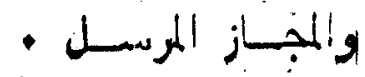

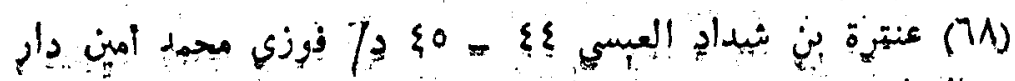

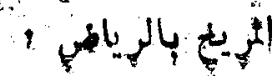




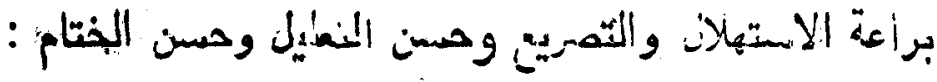

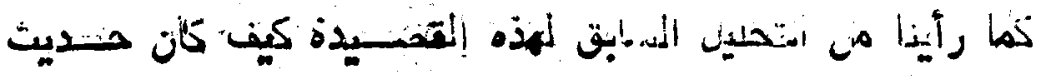

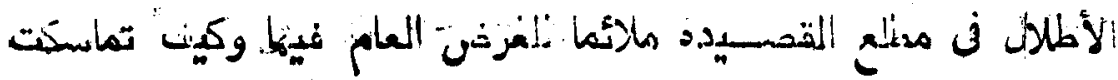

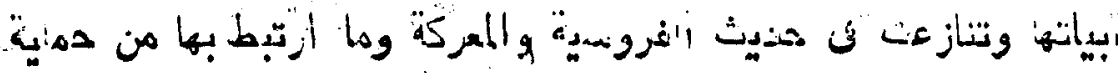

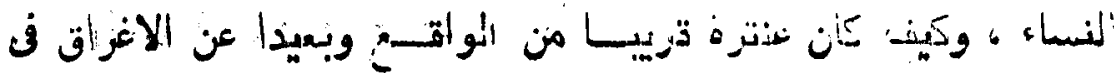

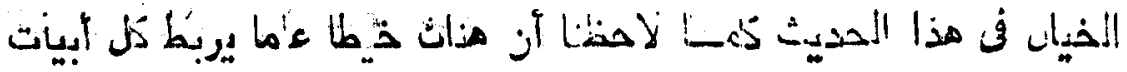

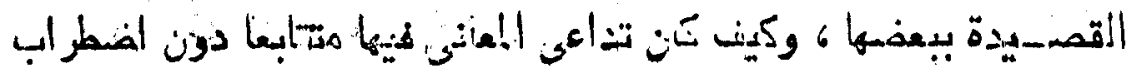

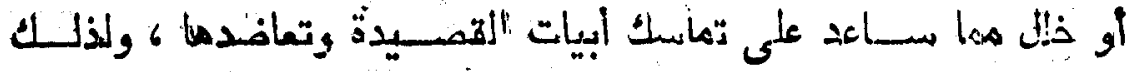

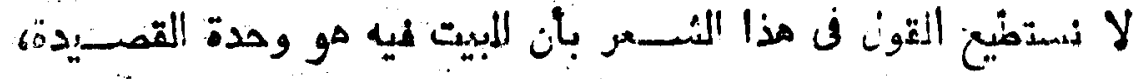

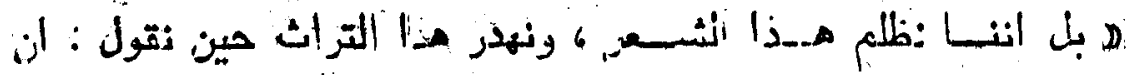

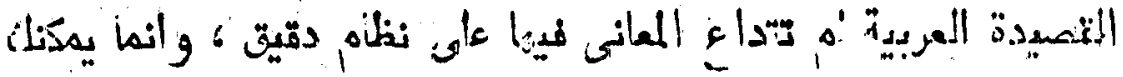

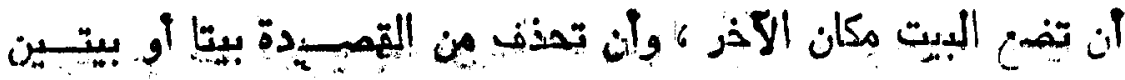

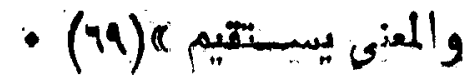

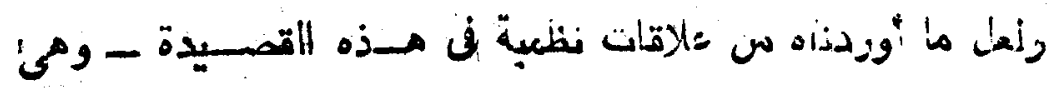

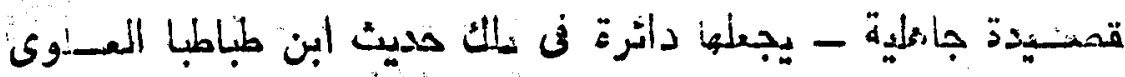

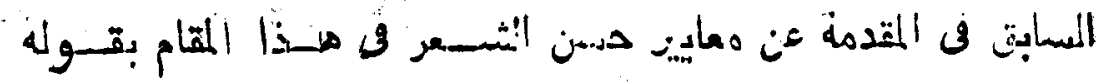

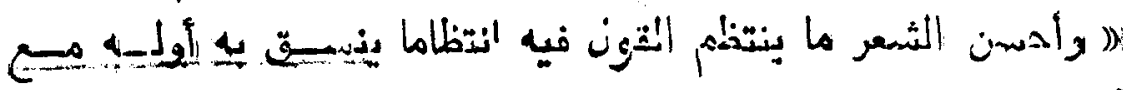

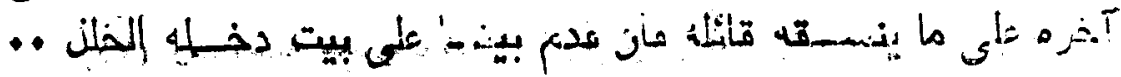

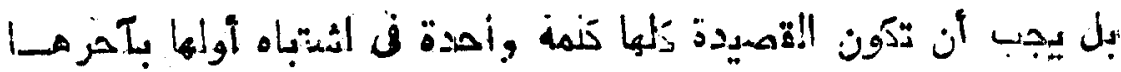

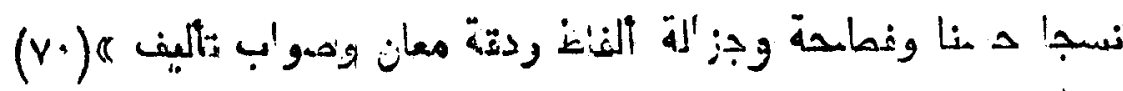

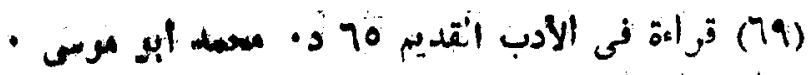

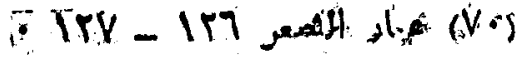


or.

كما أن حديثهم فن مذا ألمثام عن البيث وإخيه والبيت وابن عهه دشهود متواتر كا ذكرنسا

ومن هنا يهكن نهد إلذدبر إلمتانبي أن نصئر على العلاقة المناسبة بين

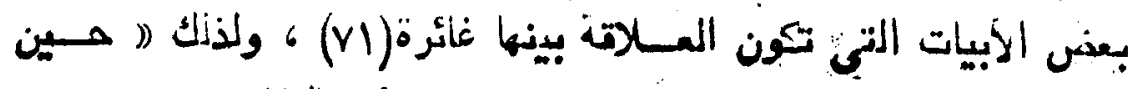

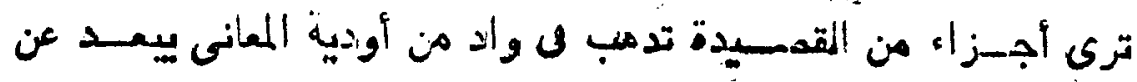

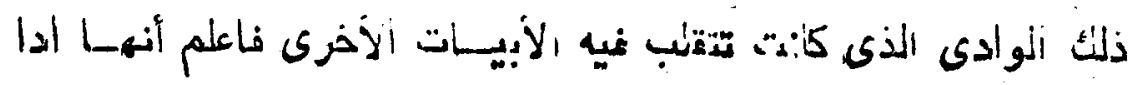

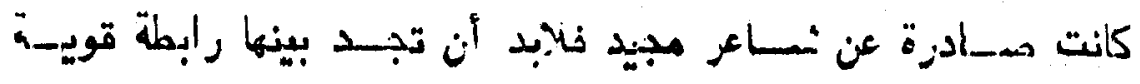

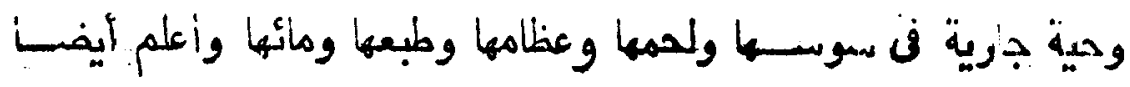

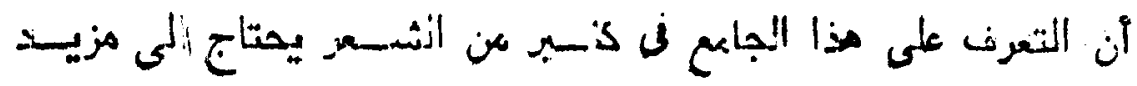

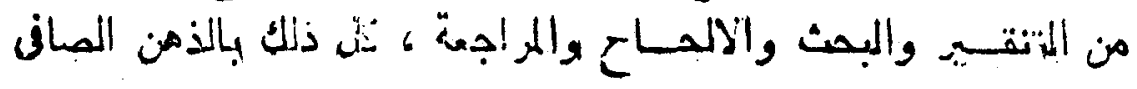

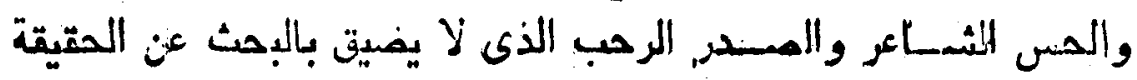

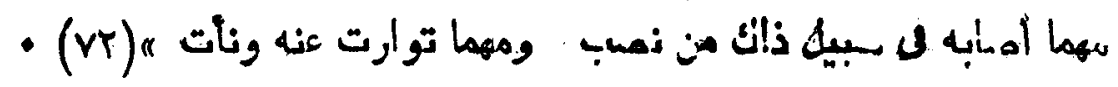

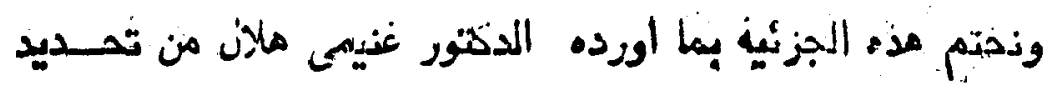

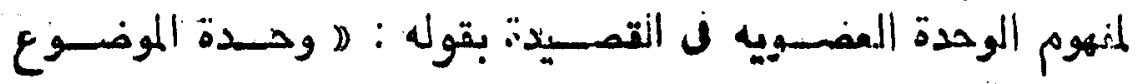

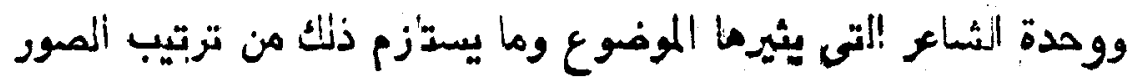

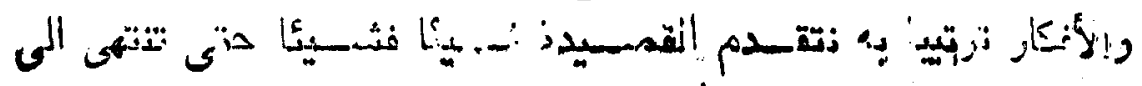

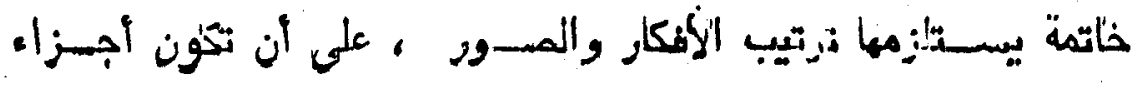

•

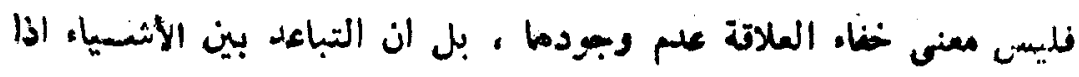

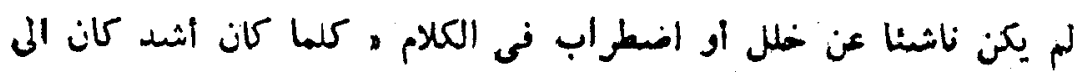

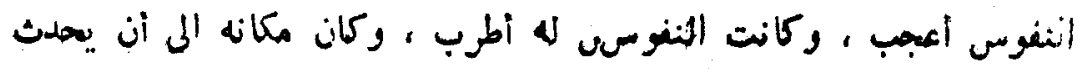

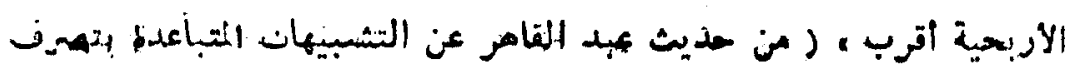

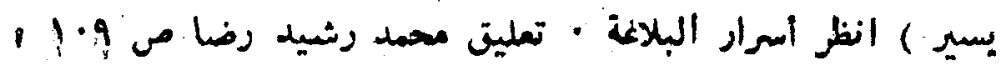
? 
ort

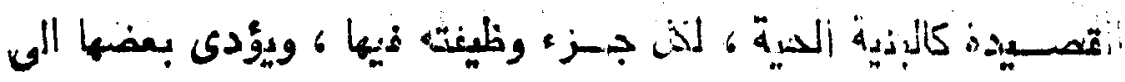

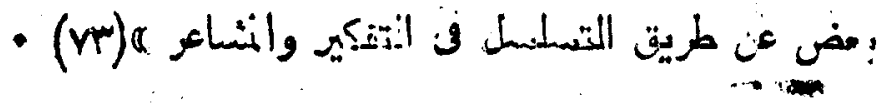

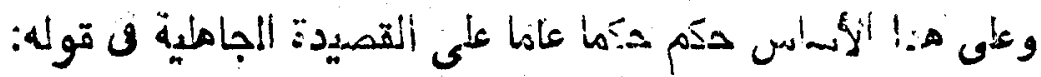

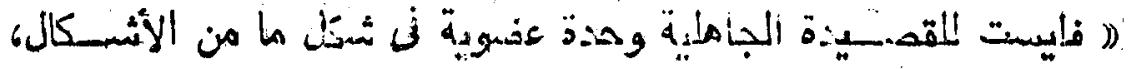

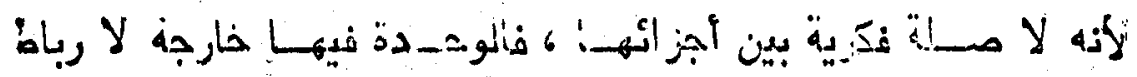

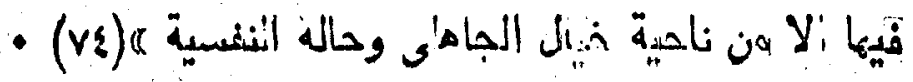

ذم قرر بعن ذلك أن النقاد القدأمى من الإمسبرب قسـد أخطئوا 3

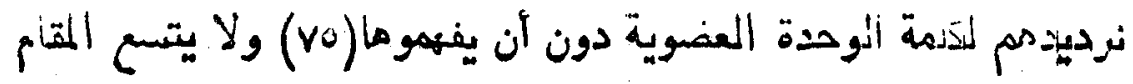

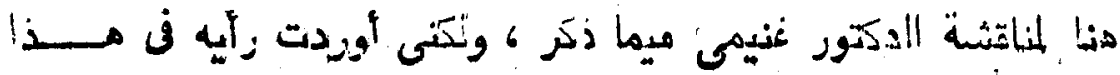

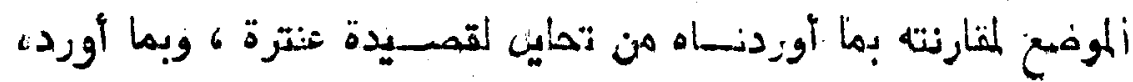

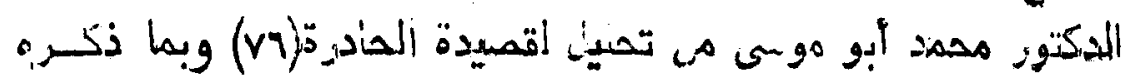

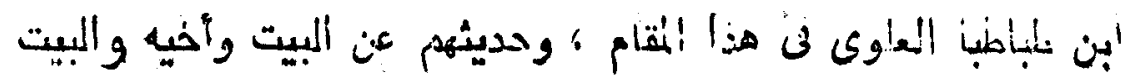

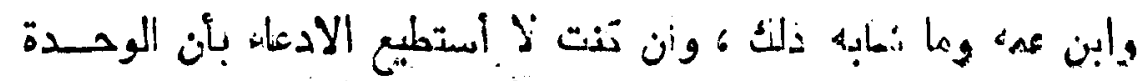

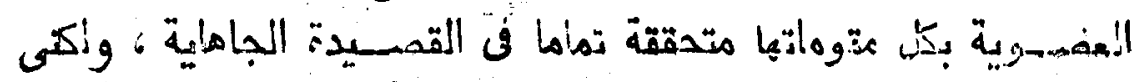

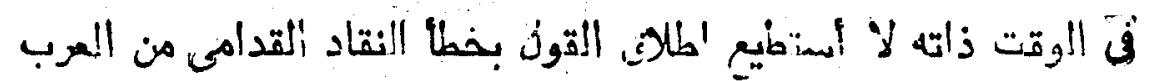

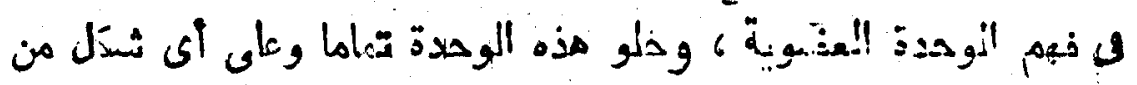

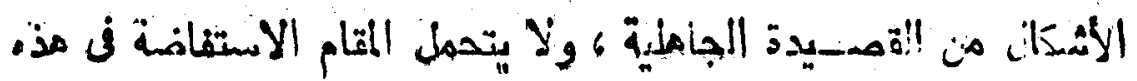

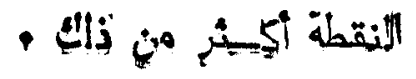

• النقد الادبى الحديث ا •ـع دار ومطابع الشعب (VR)

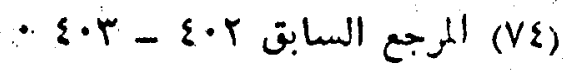

- Vo)

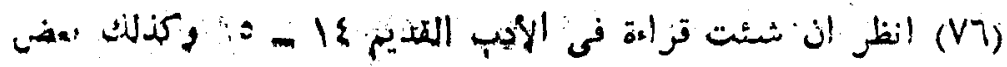
1 


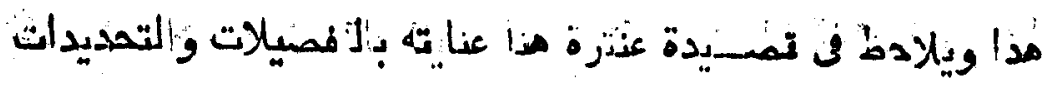

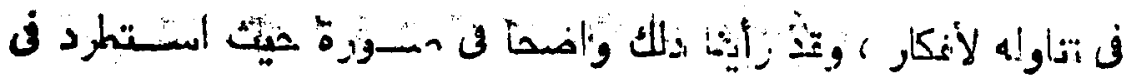

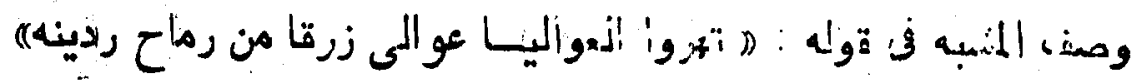

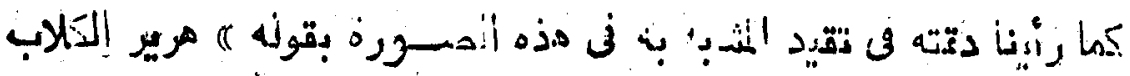

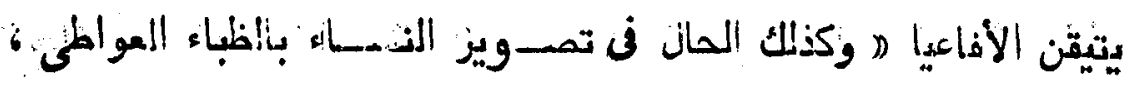

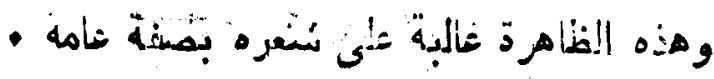

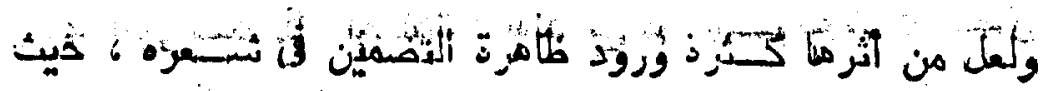

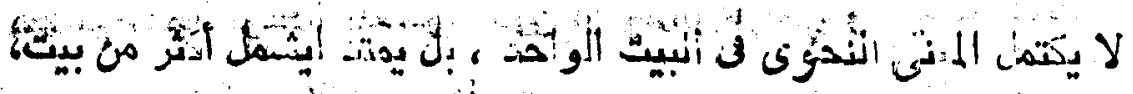

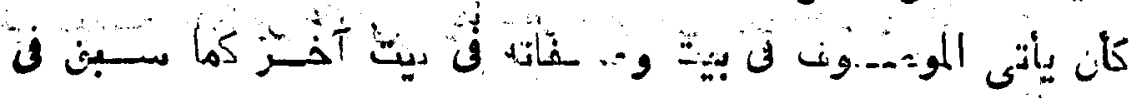
تــوله :

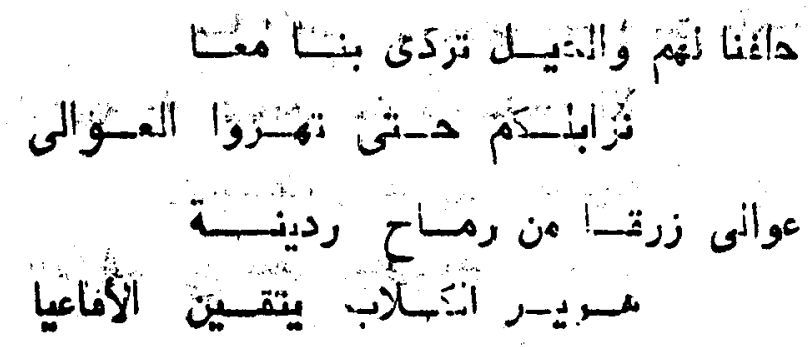

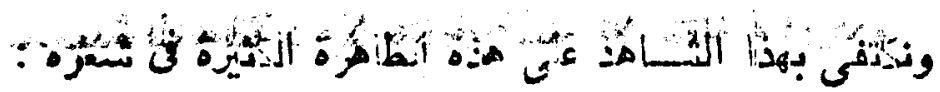

(ا واننقاند انتـدماء لا تروقهم هذه الطـاهرة ، ويرون آن القافية

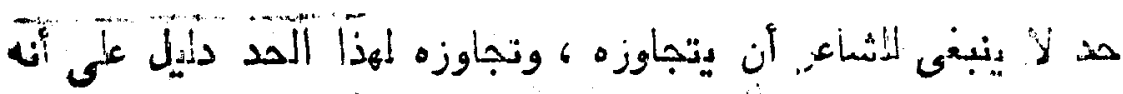

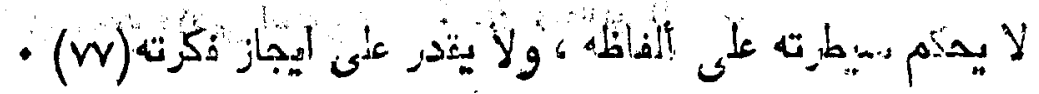

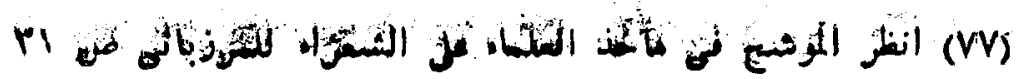

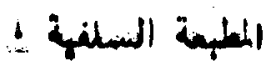


$\Delta+4$

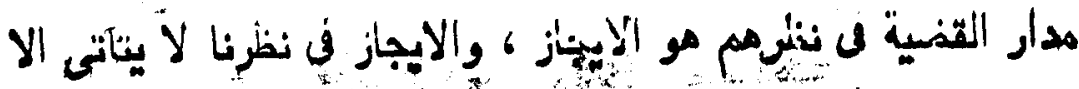

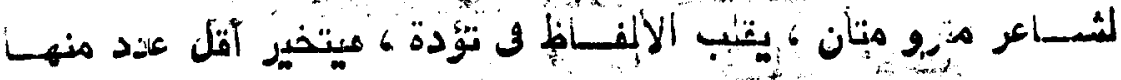

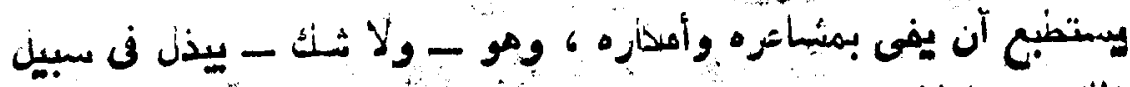

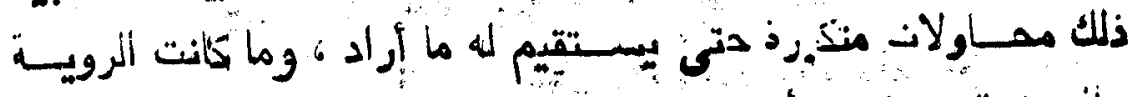

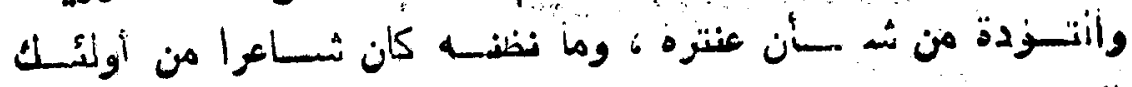

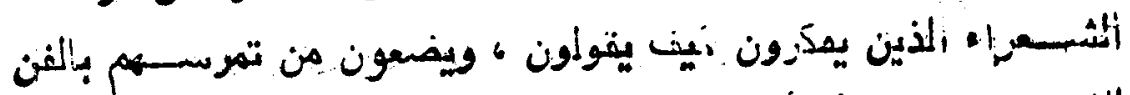

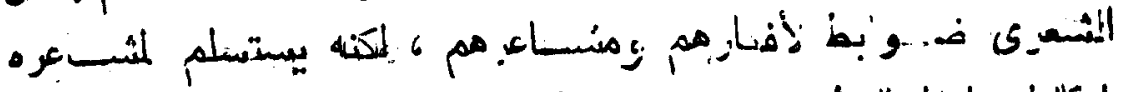

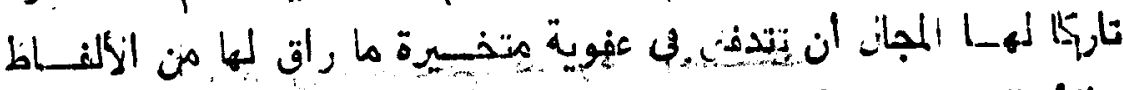

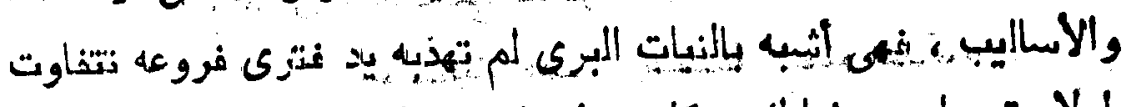

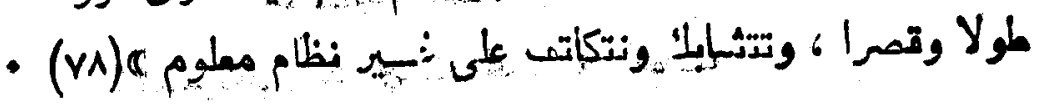
واذا كثت هذه إلذلاه د ترجع الى طبيعة المشاعر وملابسات هياته،

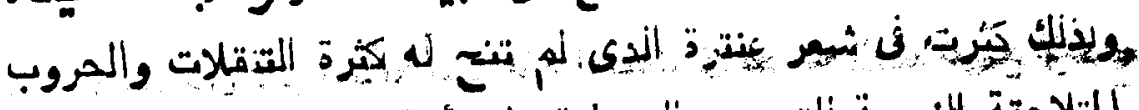

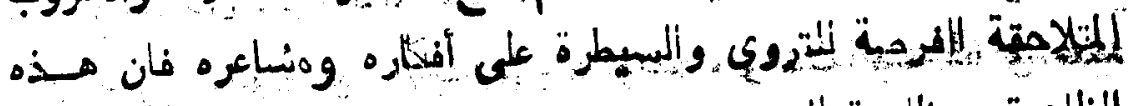

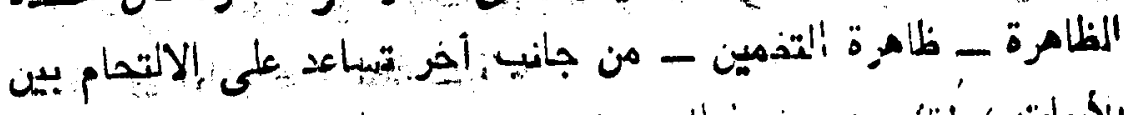

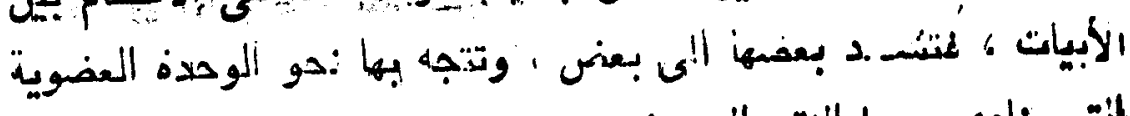

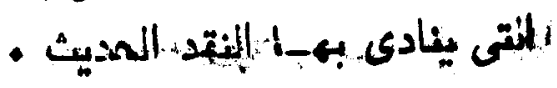

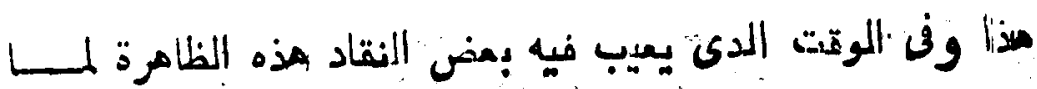

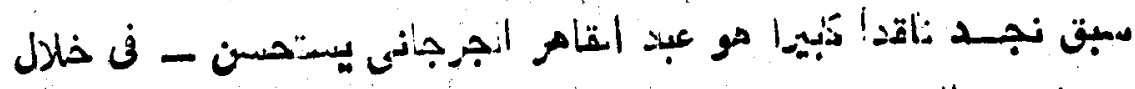

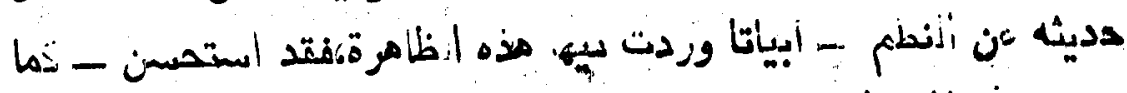

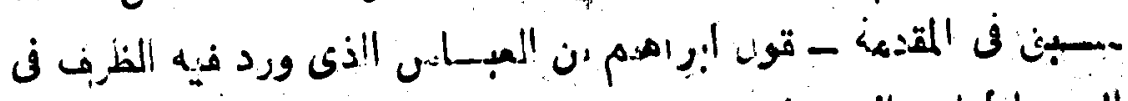

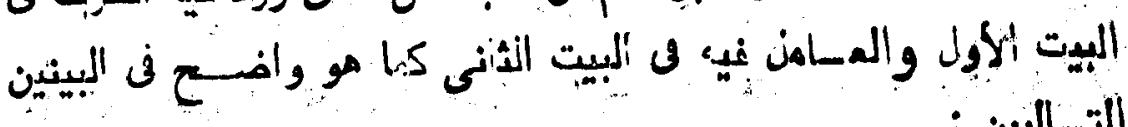
$-\%$

إلتـاليين : 


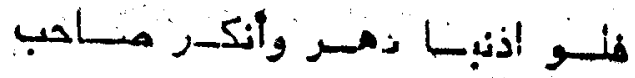

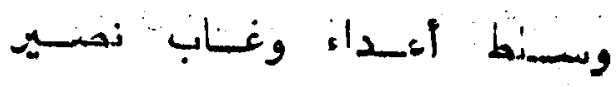

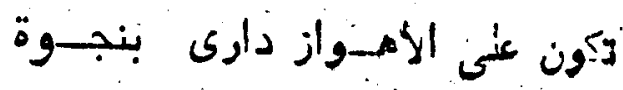

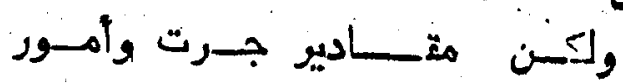

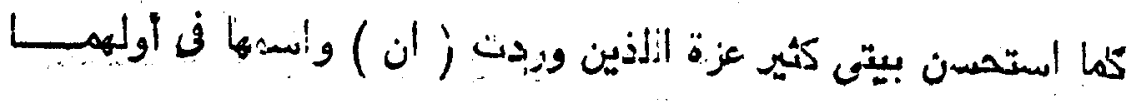

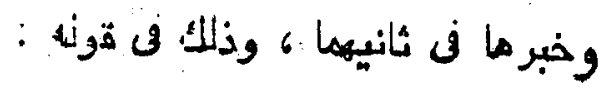

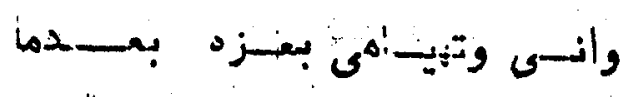

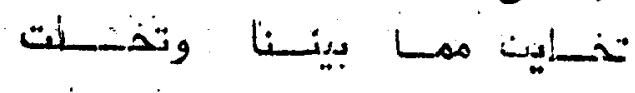

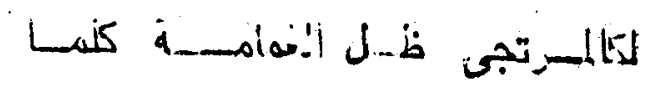

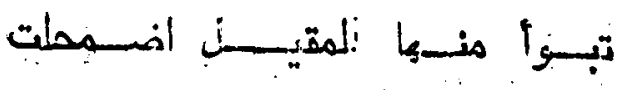

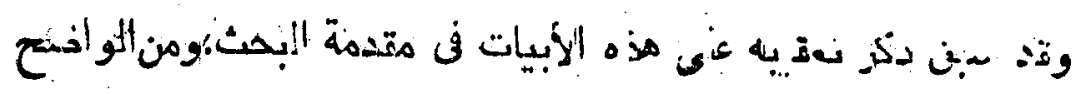

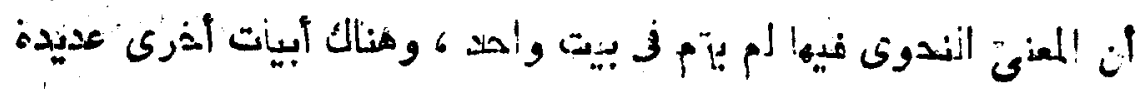

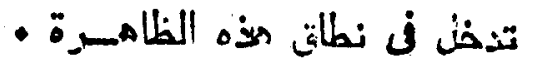

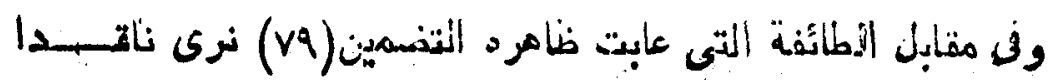

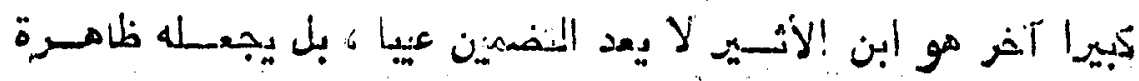

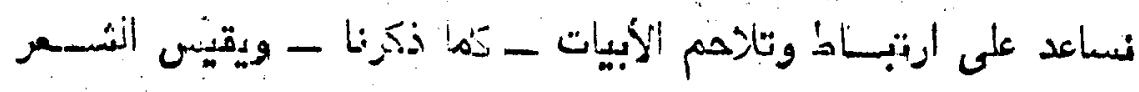

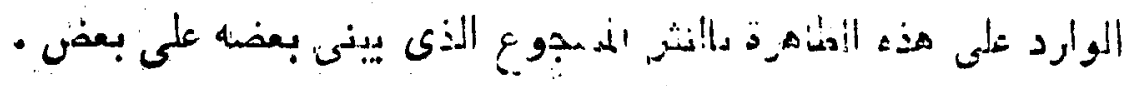

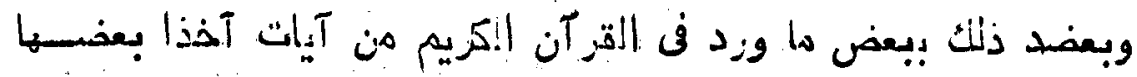

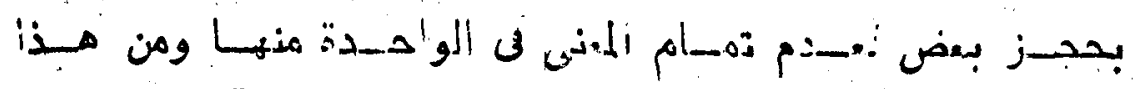

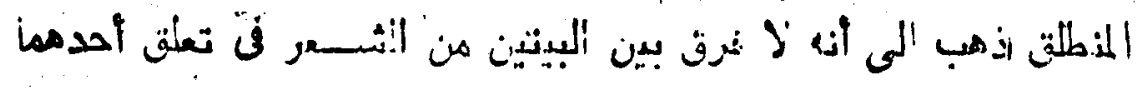

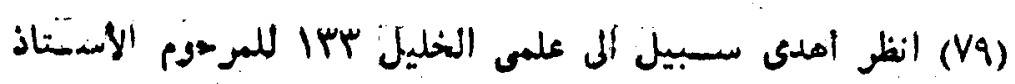

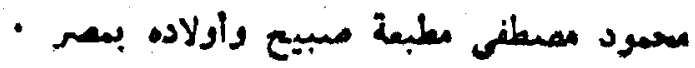




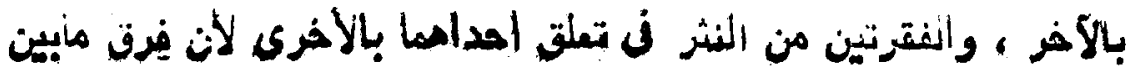

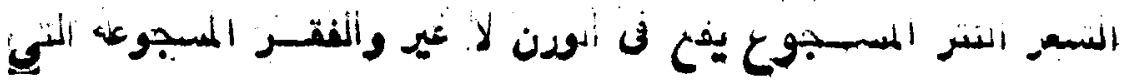

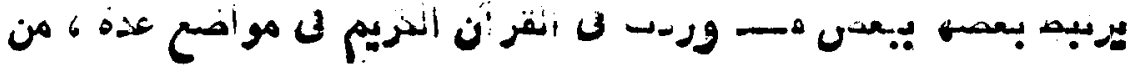

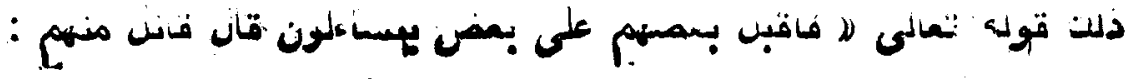

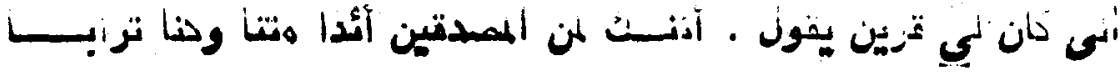

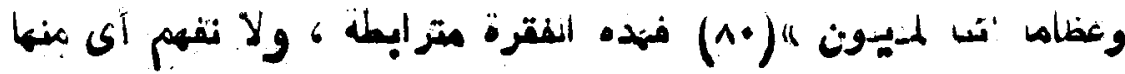

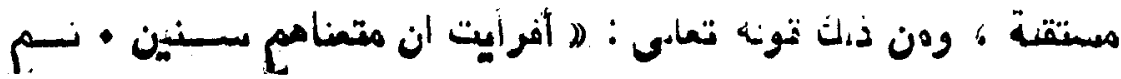

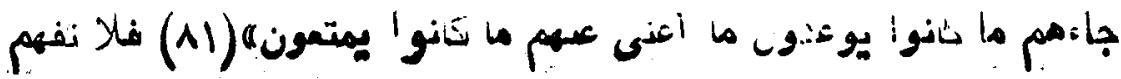

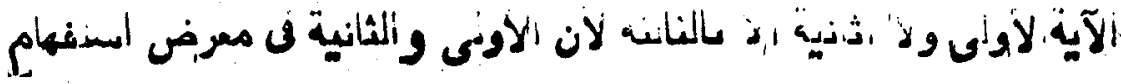

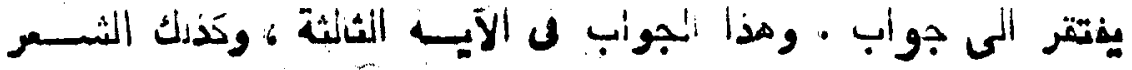

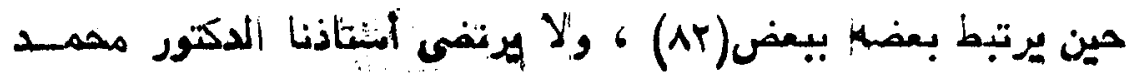

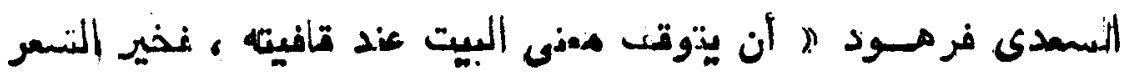

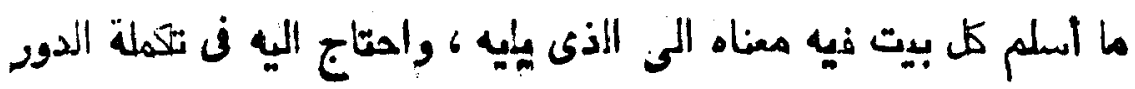

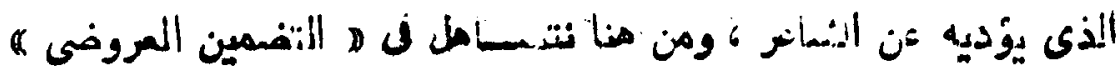

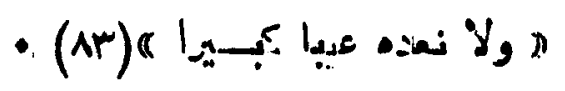

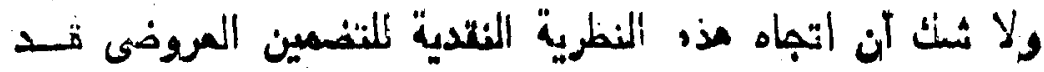

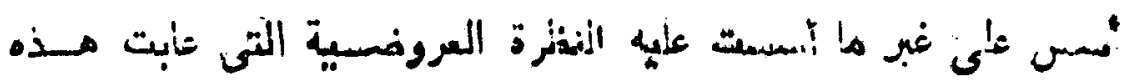

$$
\begin{aligned}
& \text { - or _ 0 - }
\end{aligned}
$$

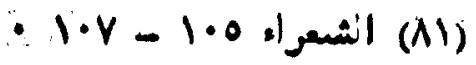

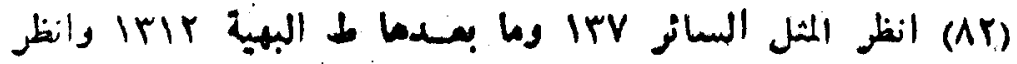

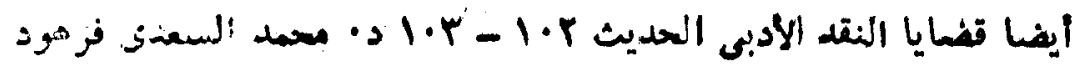

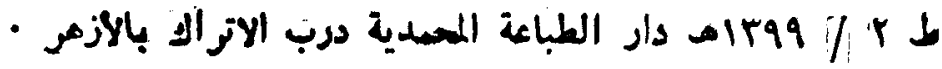

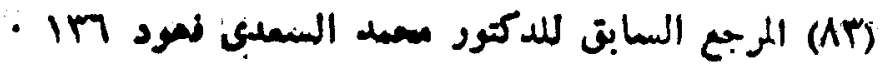


orf

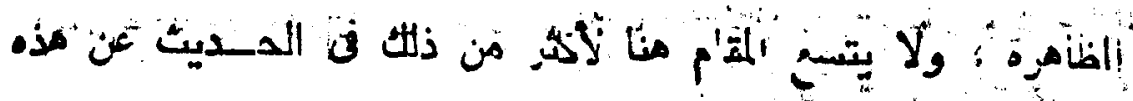

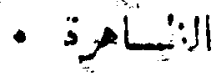

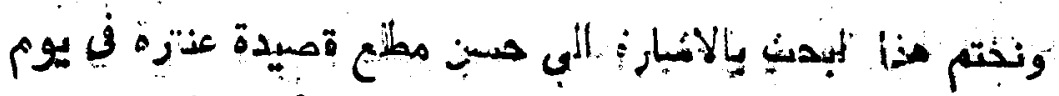

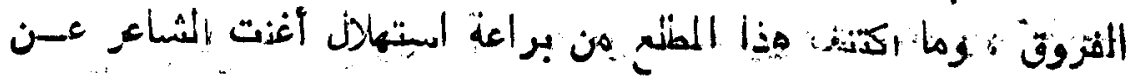

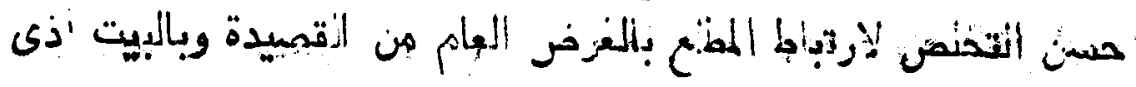

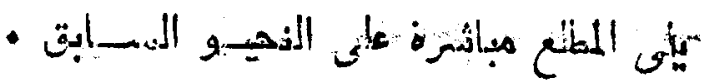

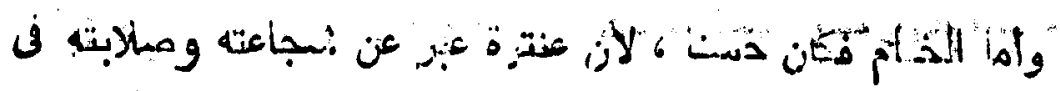

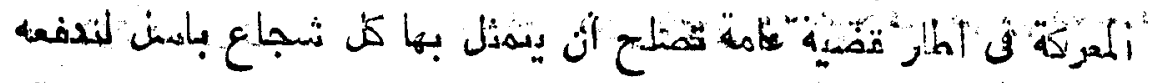

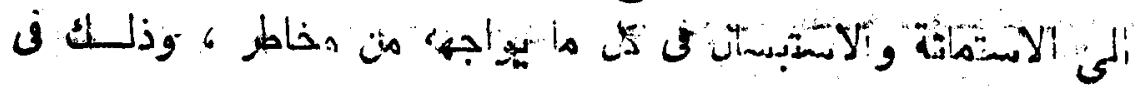
قوأق

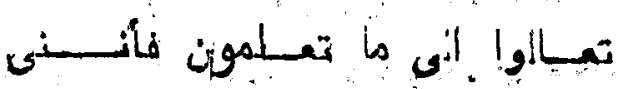

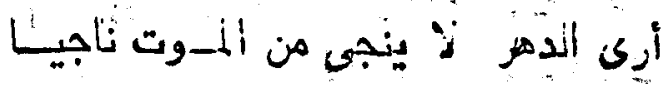

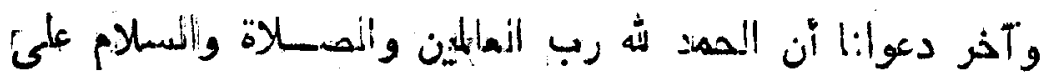

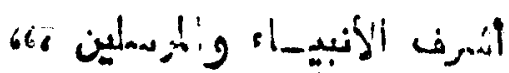

دم عبدا ألجواد مهمد هحمد طبستق

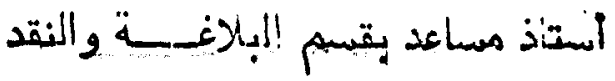

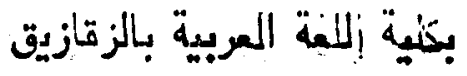

الزمازيق فى :

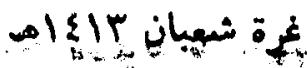

pl99 / 1/ is 
$64 y$

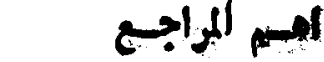

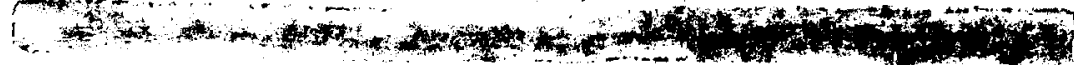

1

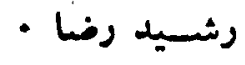

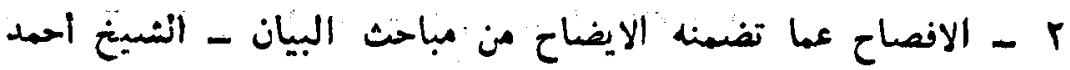

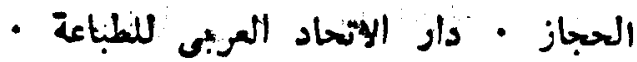

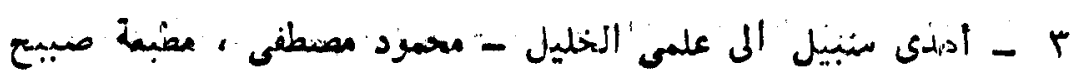

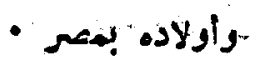

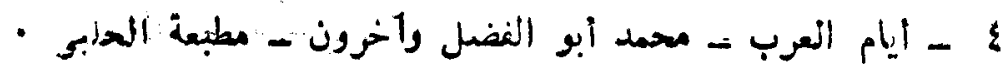
0 - بغية الايضراح - "عبد المتعال الصعيدى - مكتبة الآدابب ومطبعتها - بالجمناميز

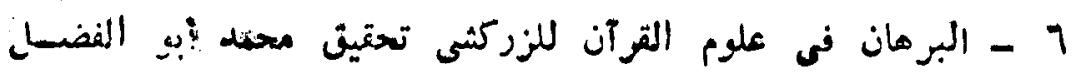
ابورأهـيم

- V

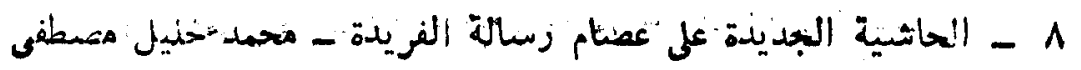

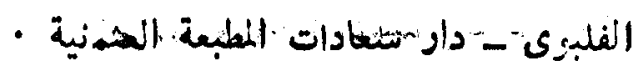

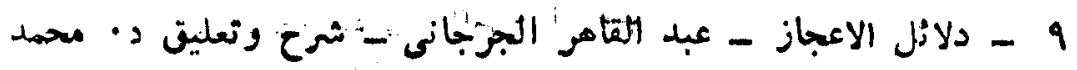
- عبد المنعم نغلغاجى

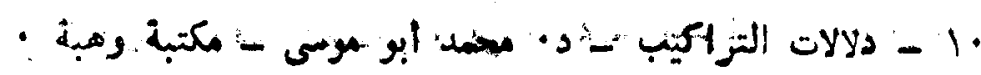
11 - ديوان عنترة بن شدّاد العبسى - تحقيق ودرلسة فحمد سندين

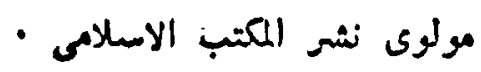

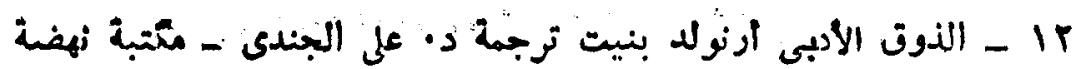

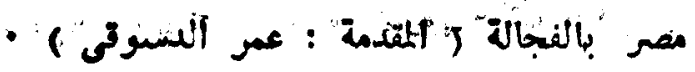

با - شرح الاثهمونى على ألفية ابن مالك ـ دار اهياء الكتبَ المربية 


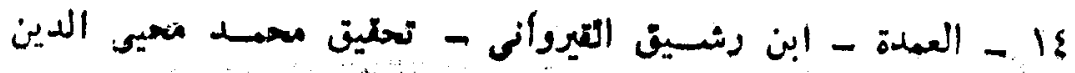

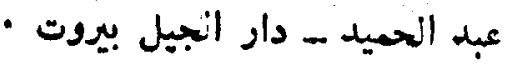

10 - 10 17 - 17

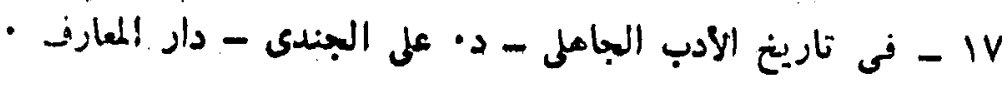

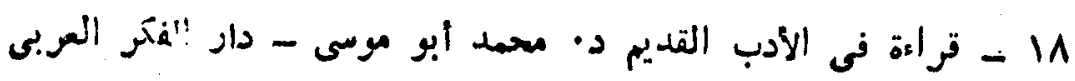

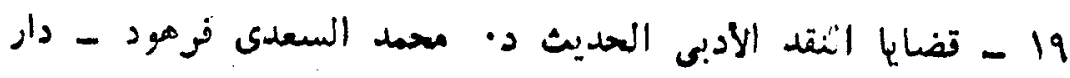

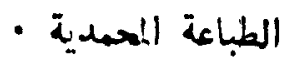

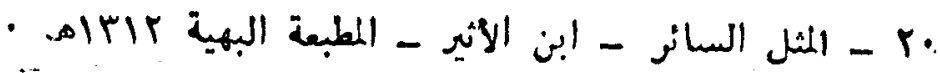

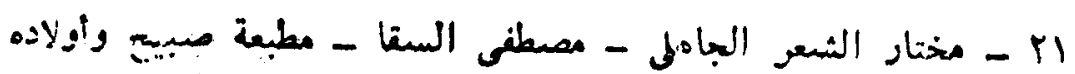

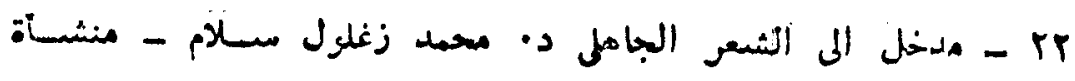
- المعارف بالاسكندرية

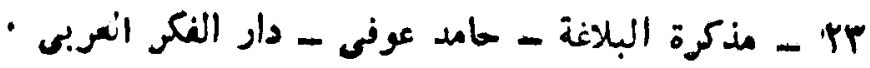

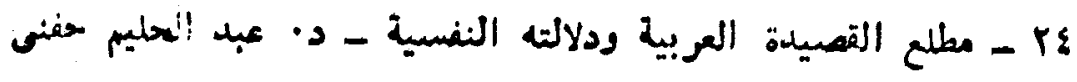

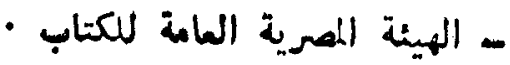

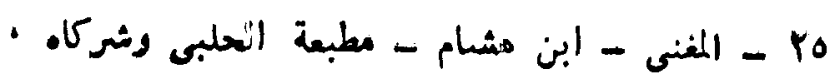

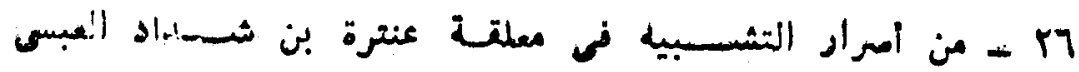
د. عبد الجواد محمد طبق مجـلة كلية اللغة العربية بالزقازبيز

- $1911 / 1$

- rV

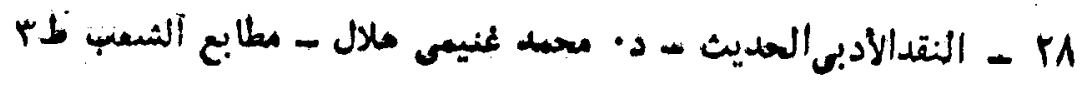




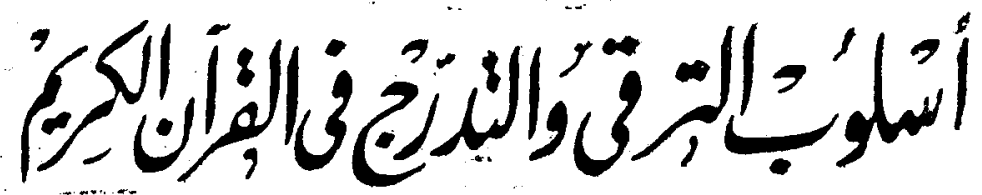

أ+د/ عبد ألله همعد سُيمان هذدأوى

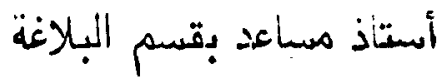

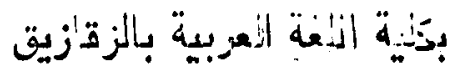

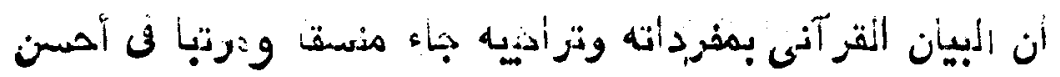

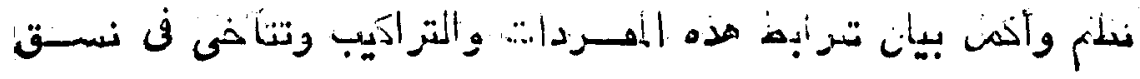

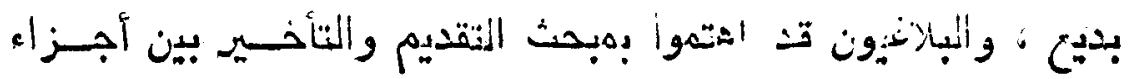

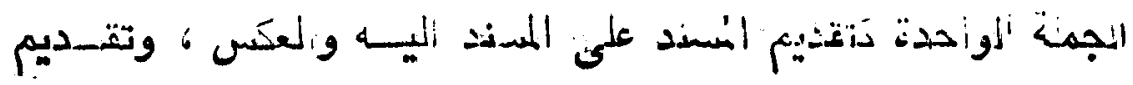

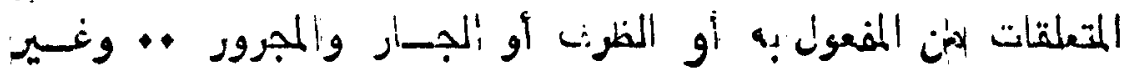

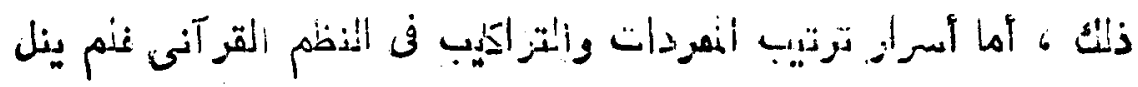

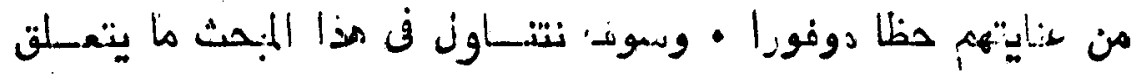

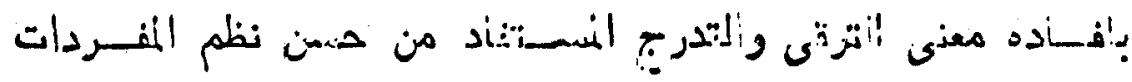

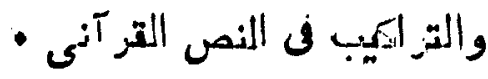

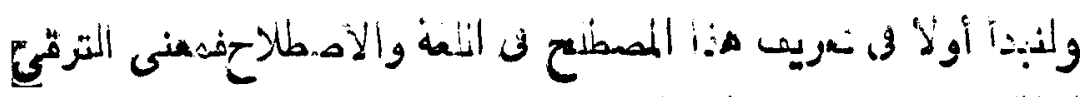

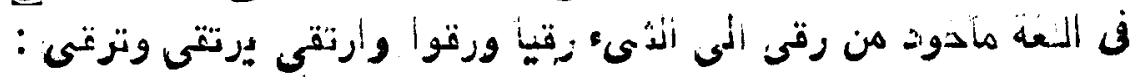

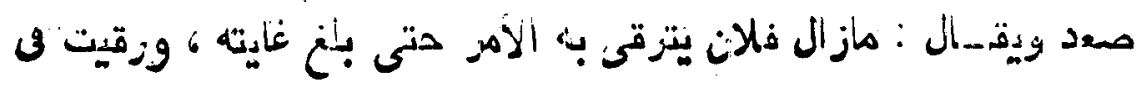

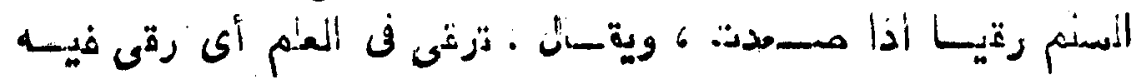

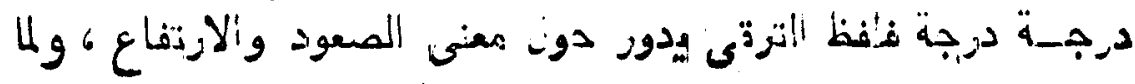

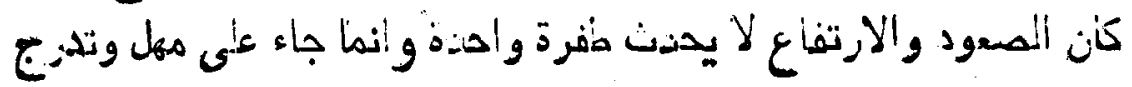

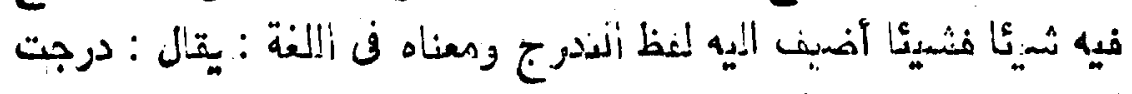

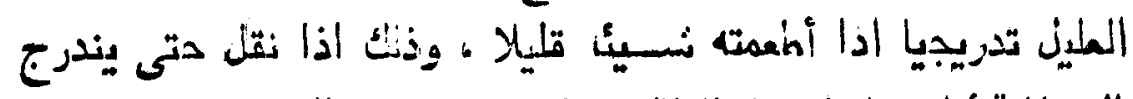

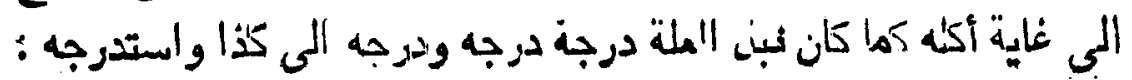




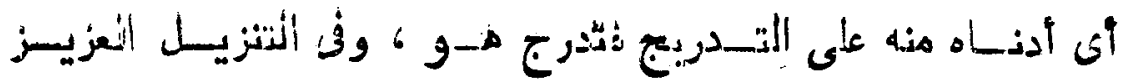

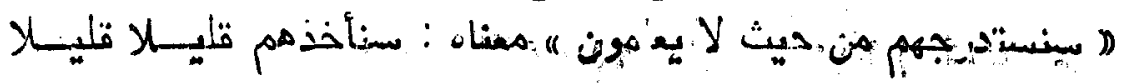

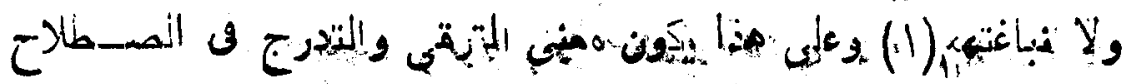

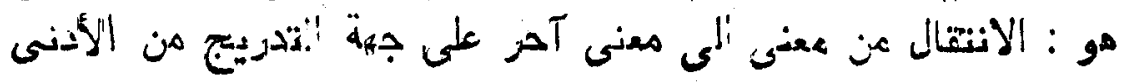

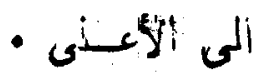

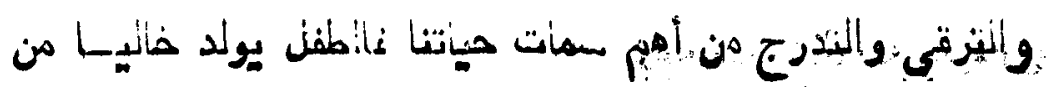

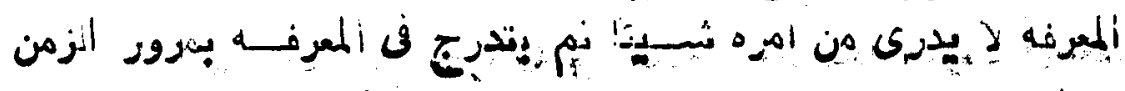

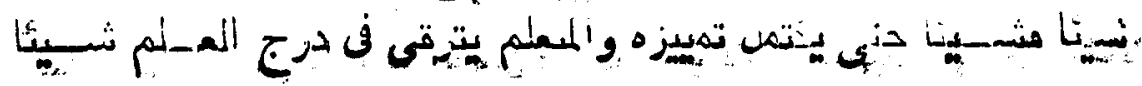

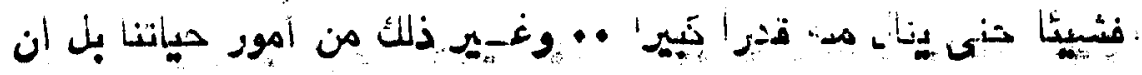

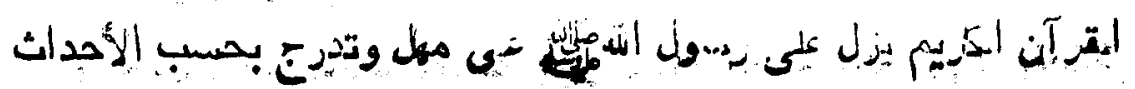

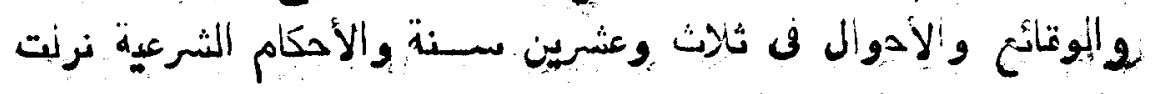

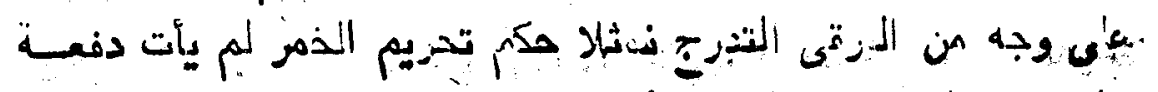

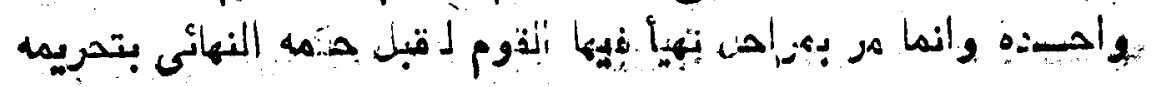

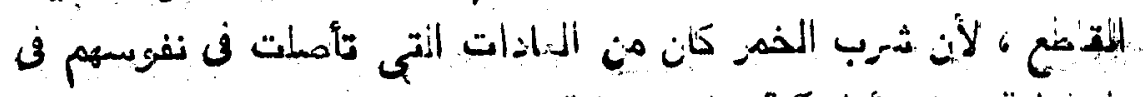

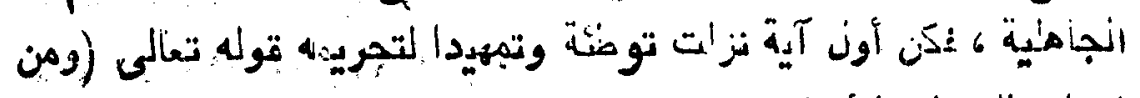

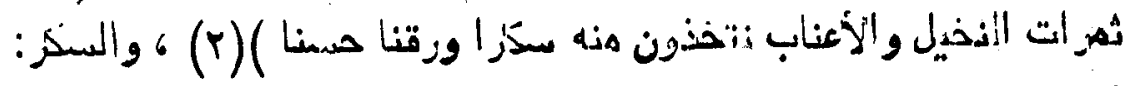

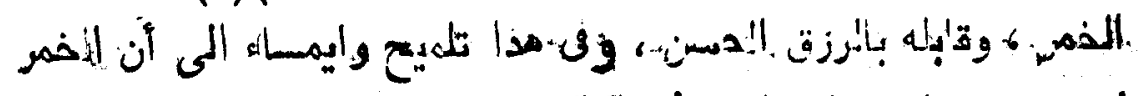

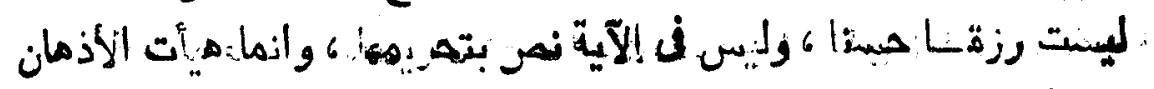

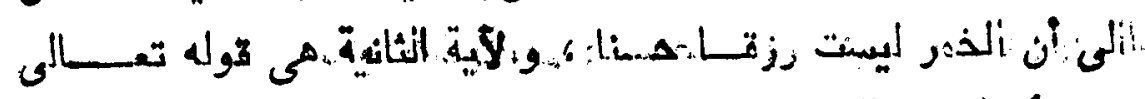

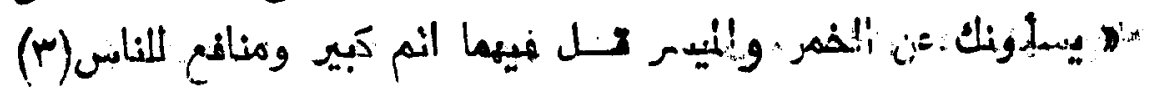

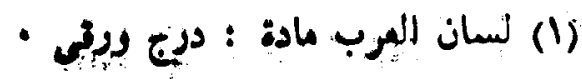

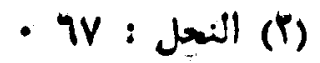

- rVq : البع (Y) 


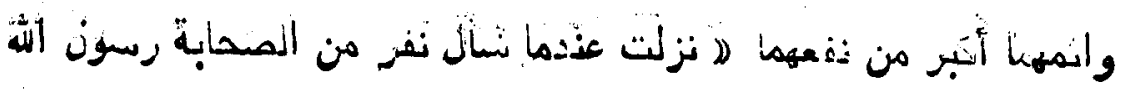

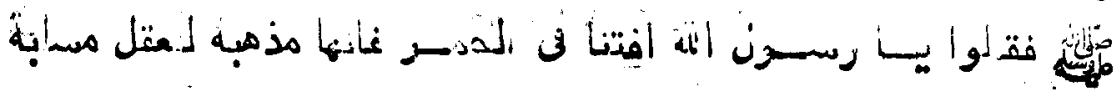

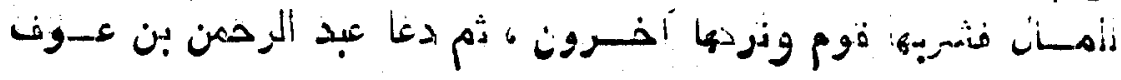

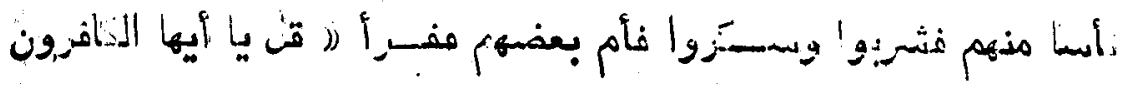

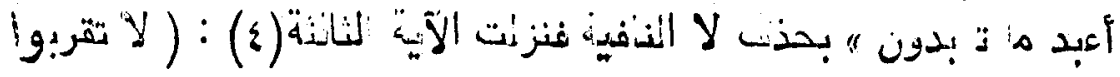

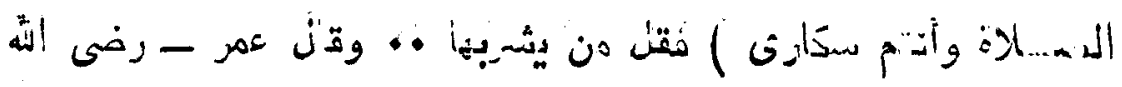

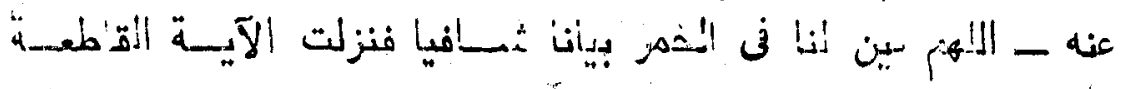

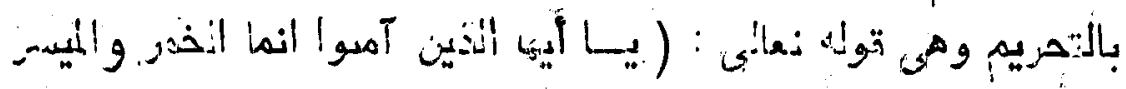

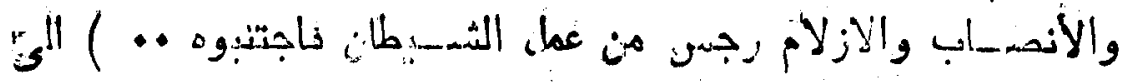

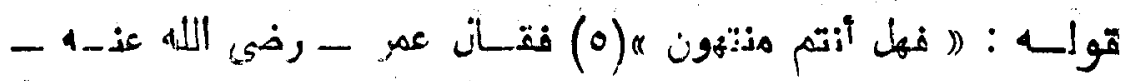

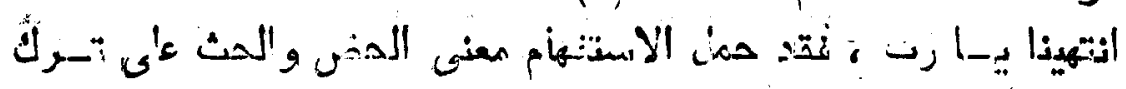

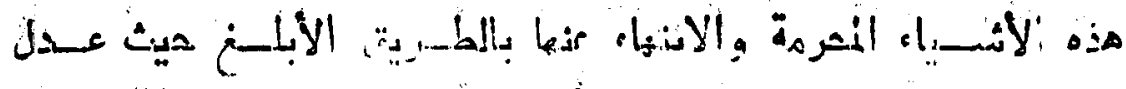

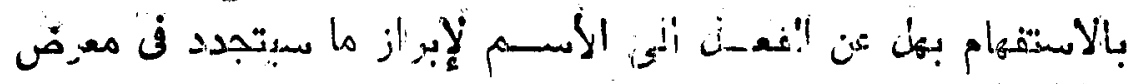

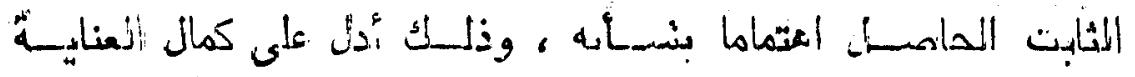

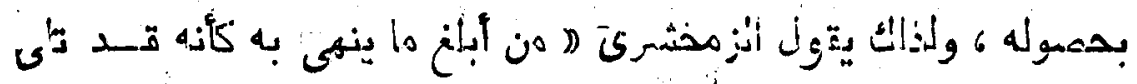

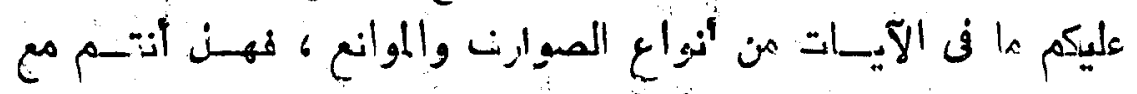

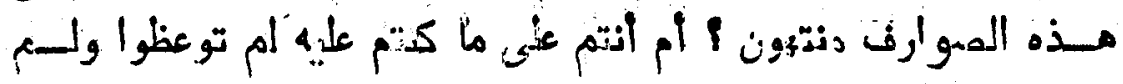

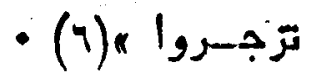

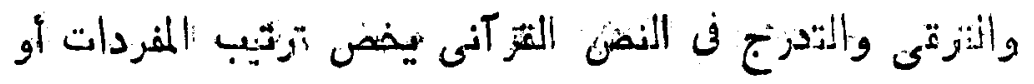

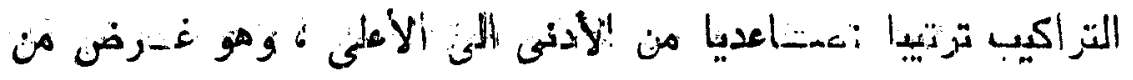

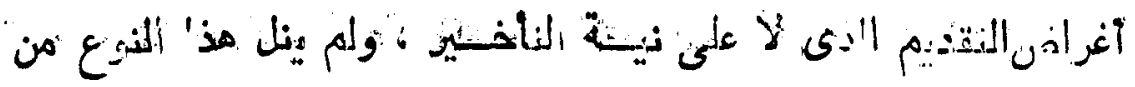

(8) 


\section{ogr}

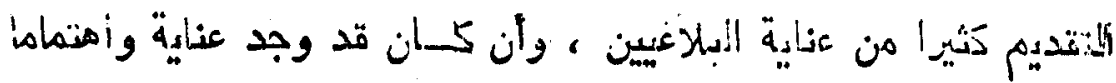

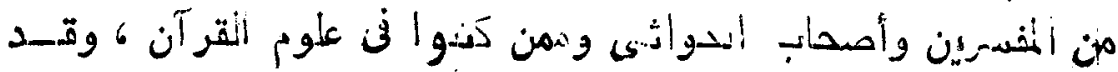

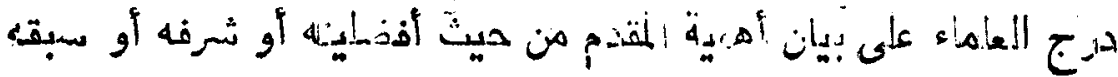

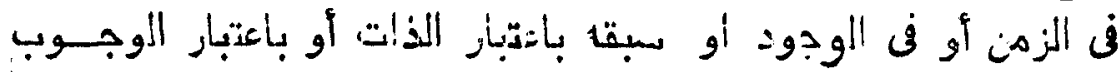

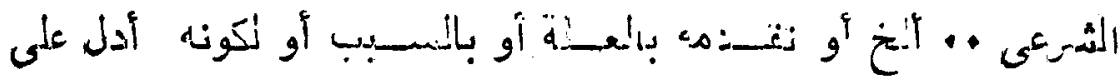

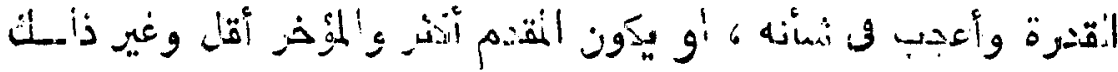

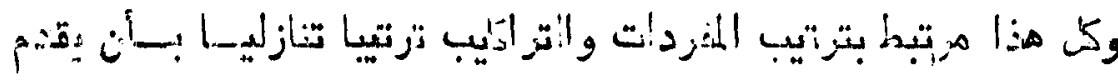

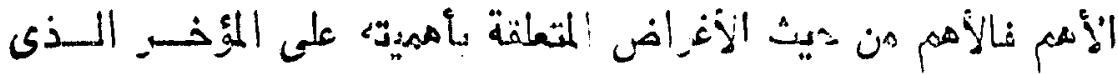

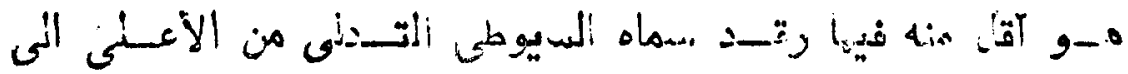

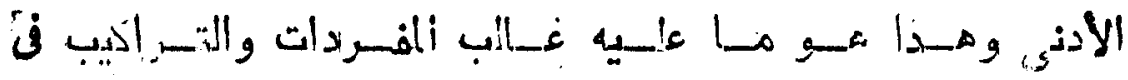

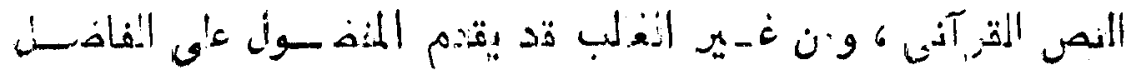

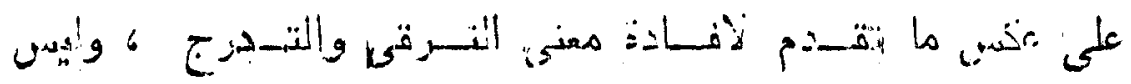

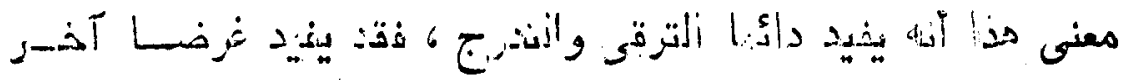

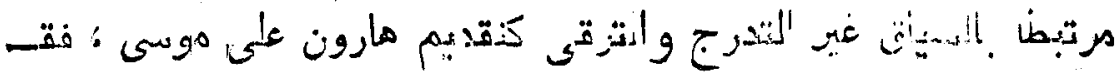

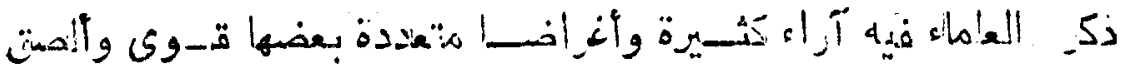

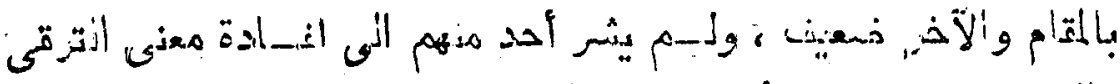

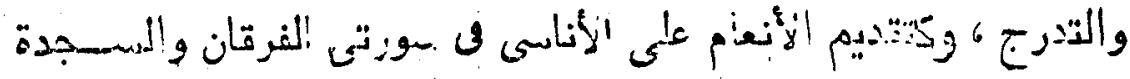

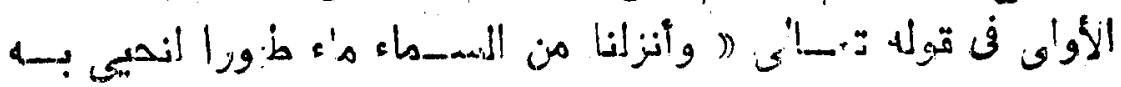

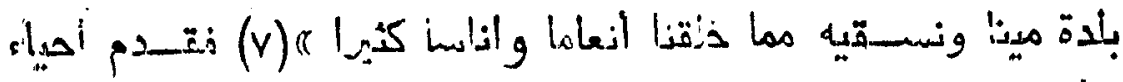

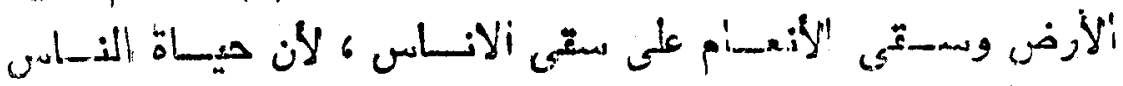

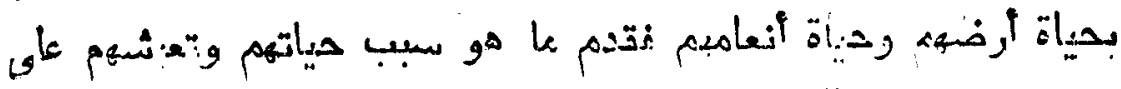

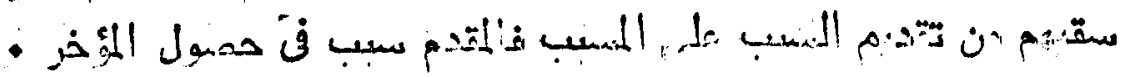

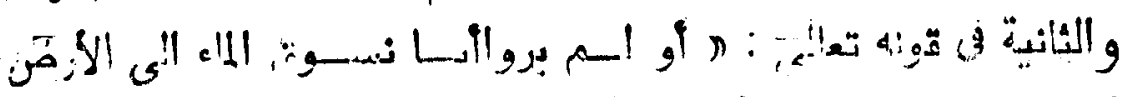

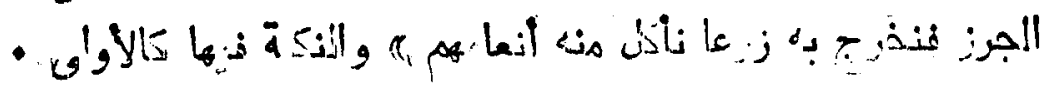




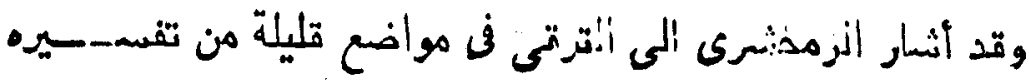

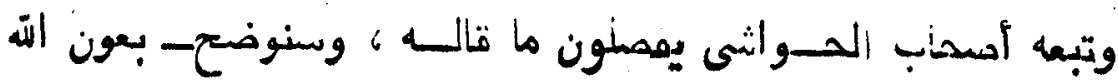

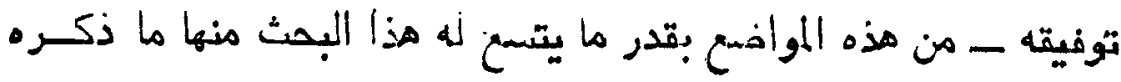

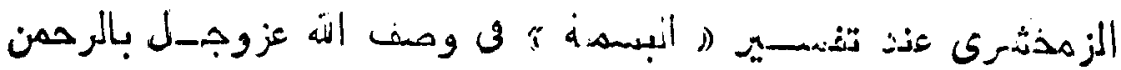

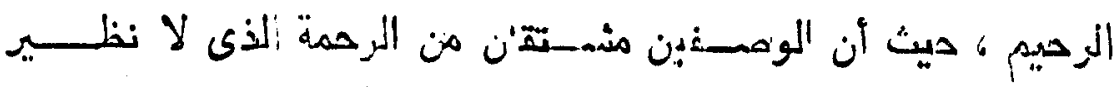

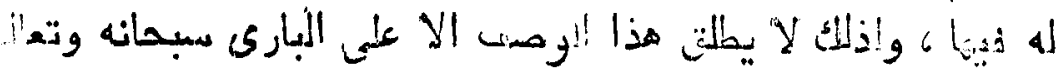

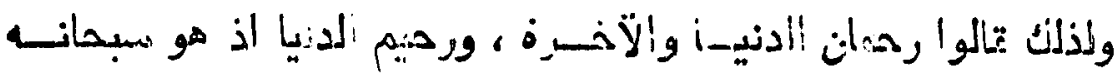

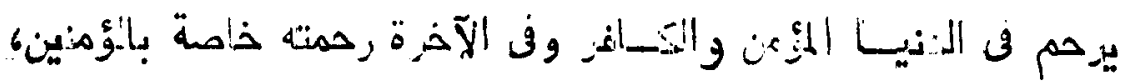

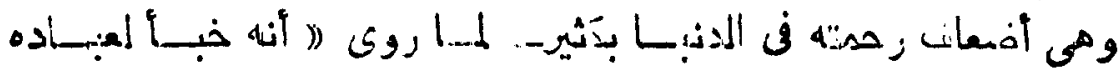

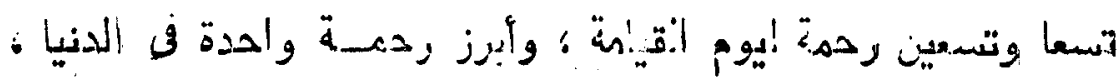

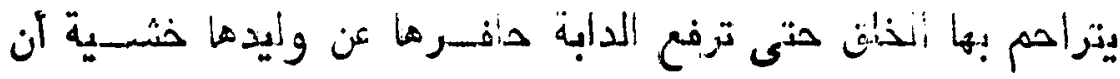

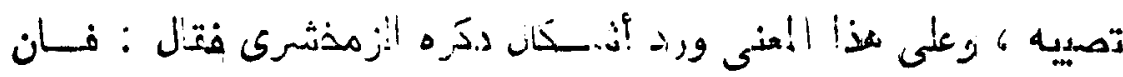

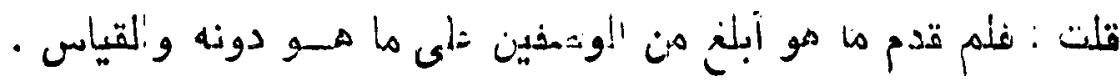

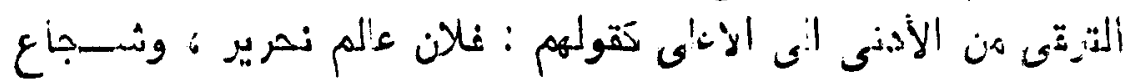

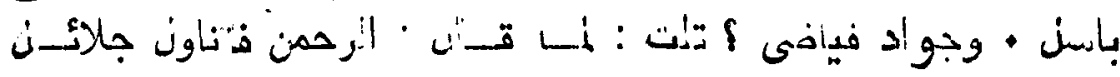

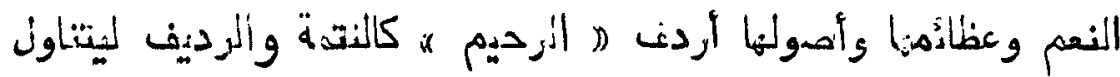

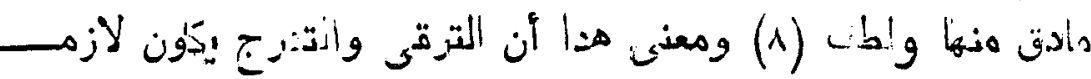

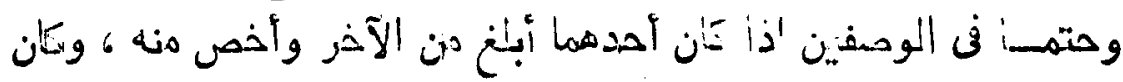

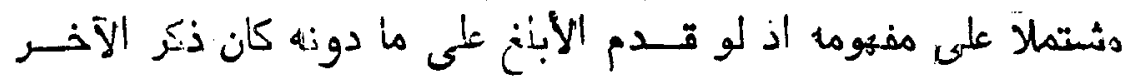

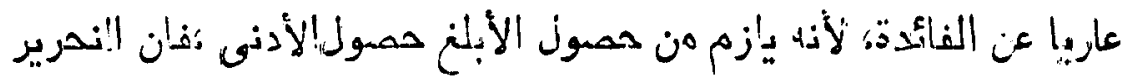

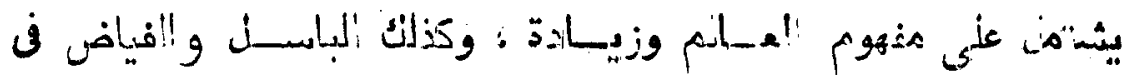

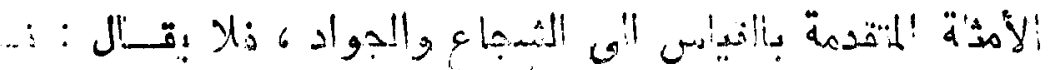

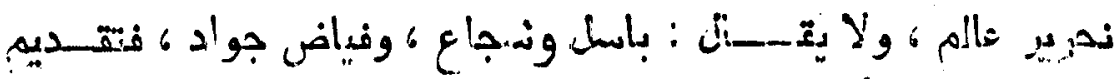

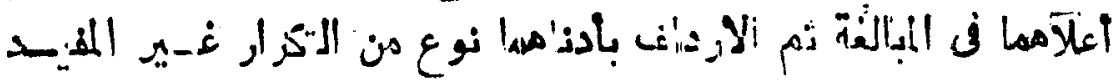




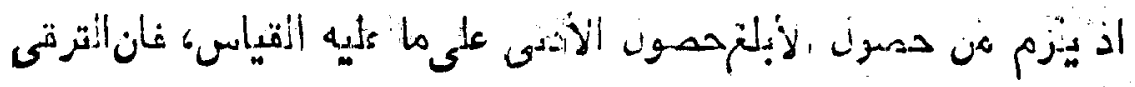

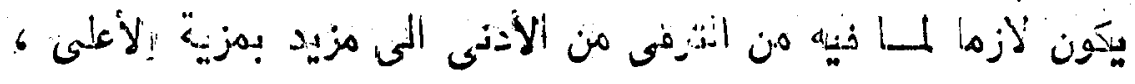

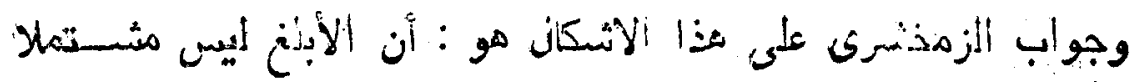

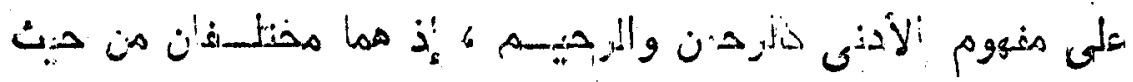

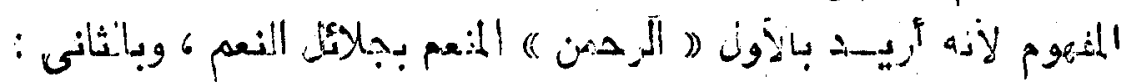

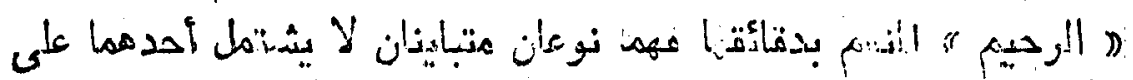

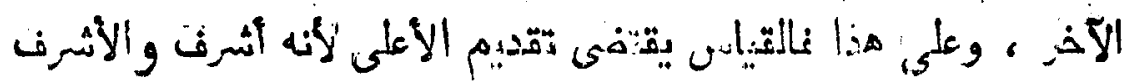

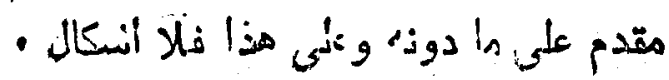

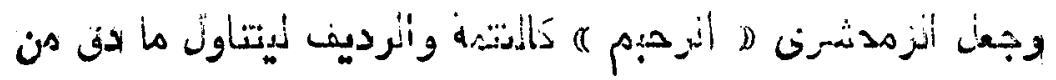

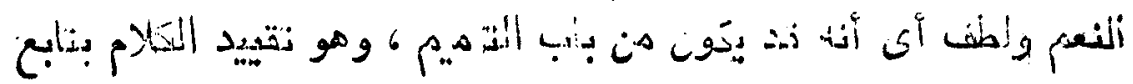

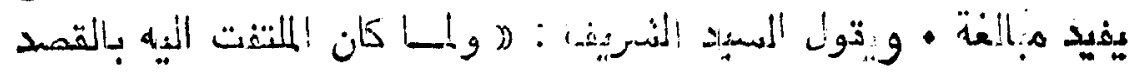

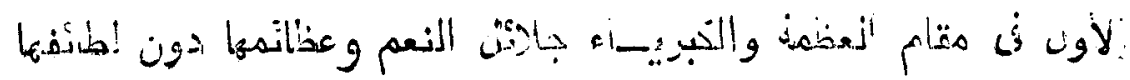

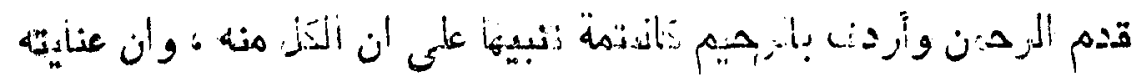

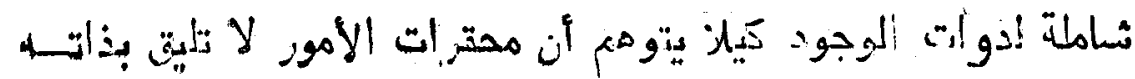

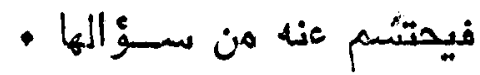

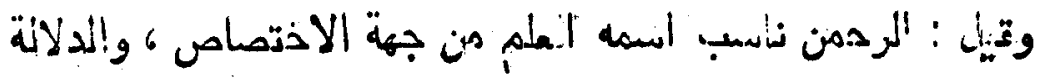

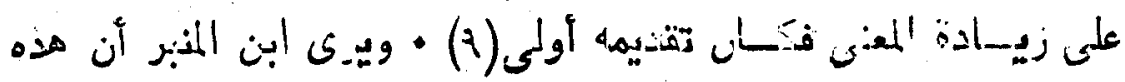

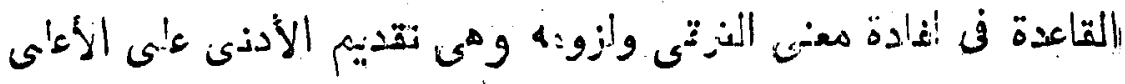

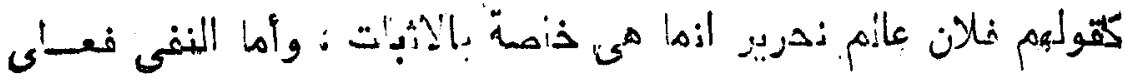

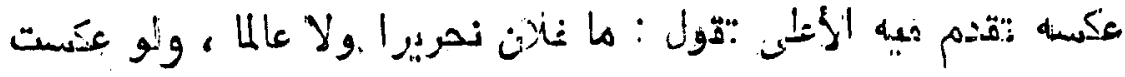

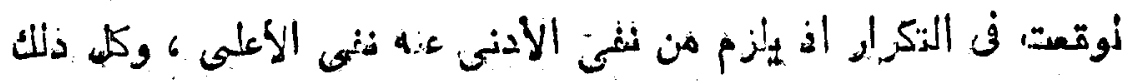

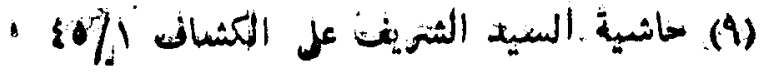


مستمدة فن عموم 'لأنمى وخصوص الأبلغ ، واثبات الأفص يستلزم

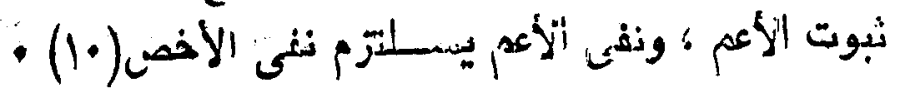

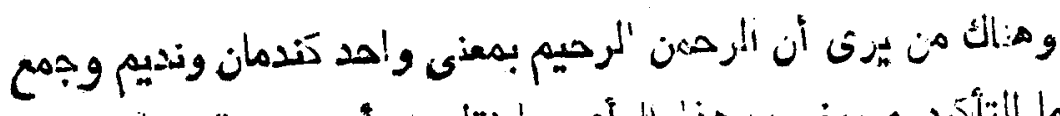

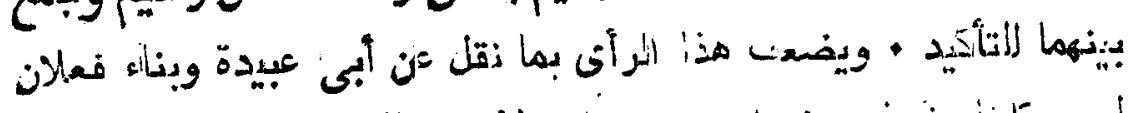

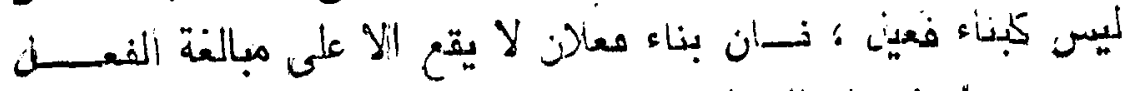

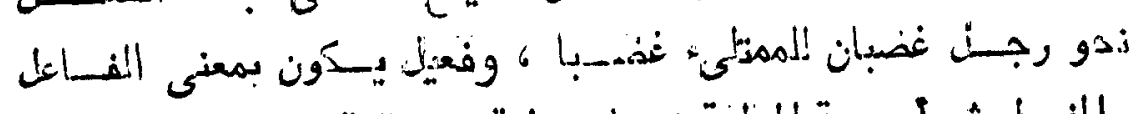

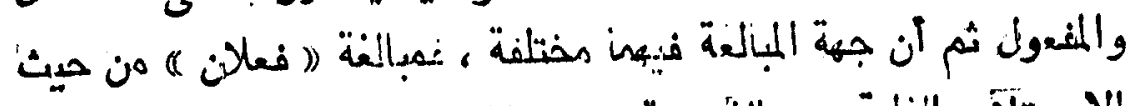

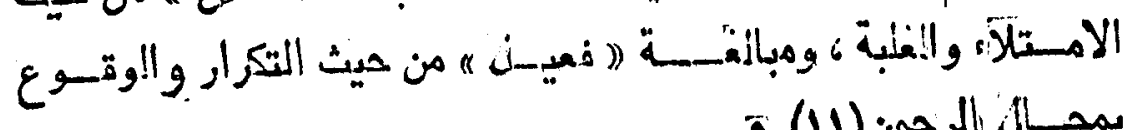

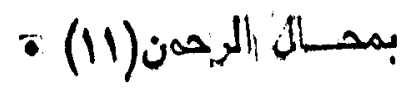

\section{الثيتي والتدرج قل الأثيسالم القزآيسمة:}

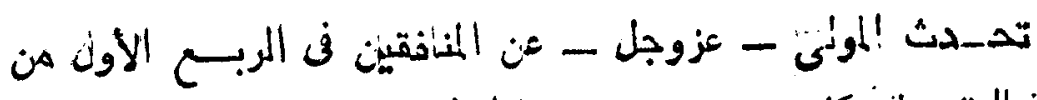

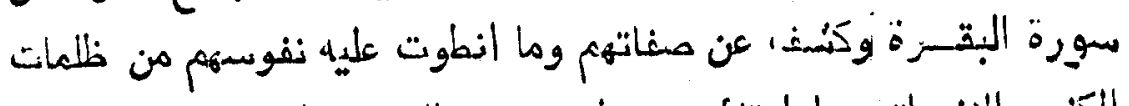

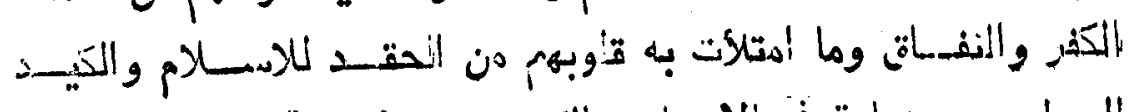

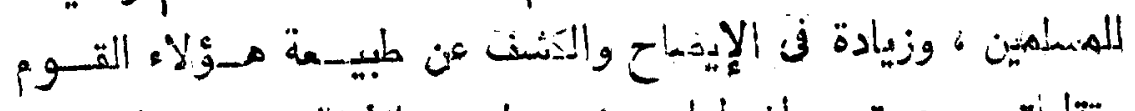

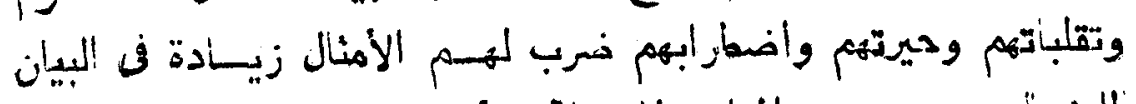

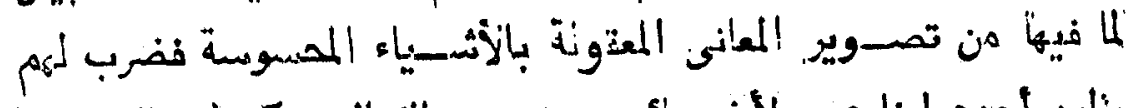

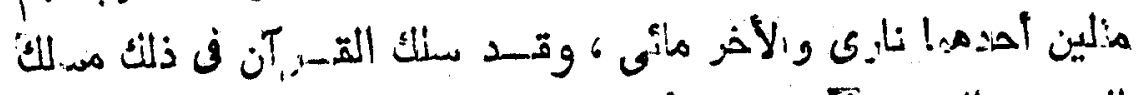

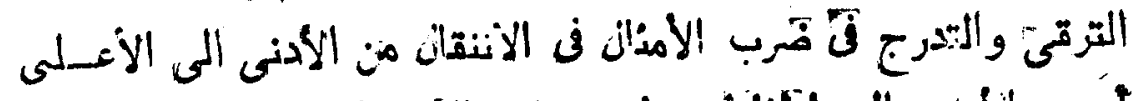

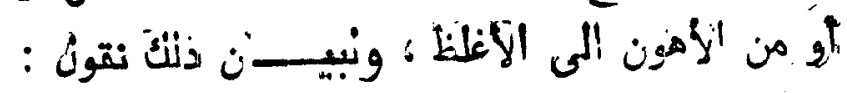

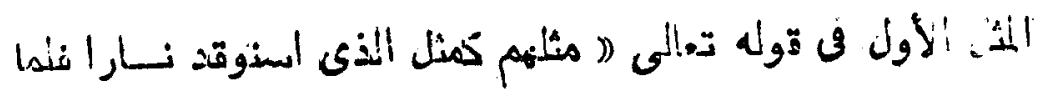

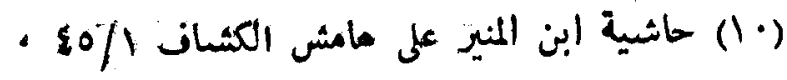
• (11) 


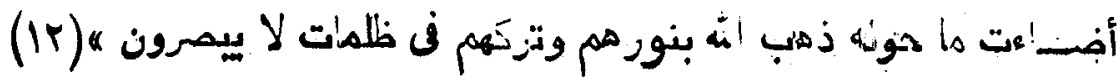

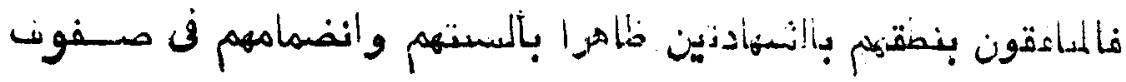

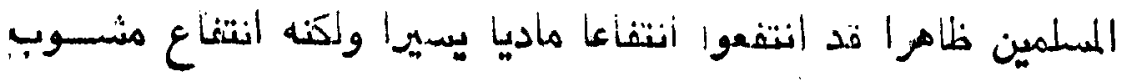

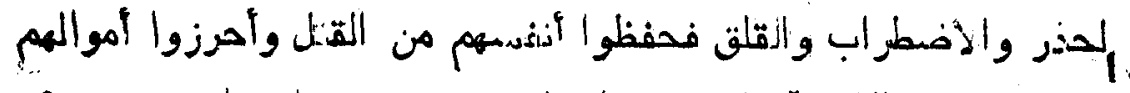

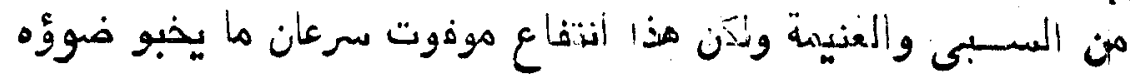

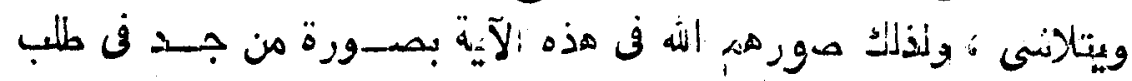

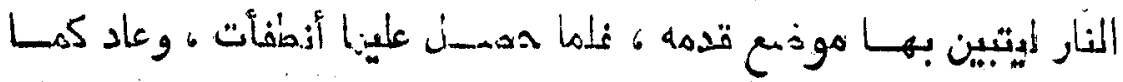

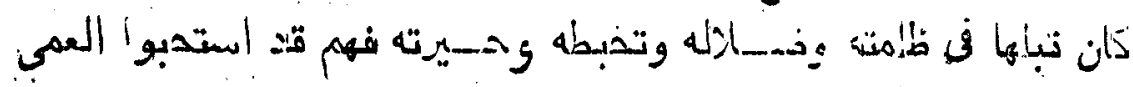

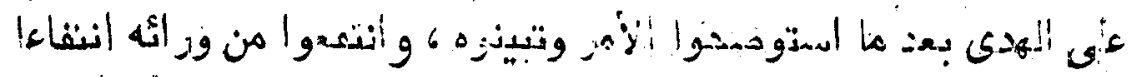

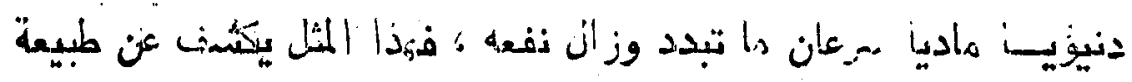

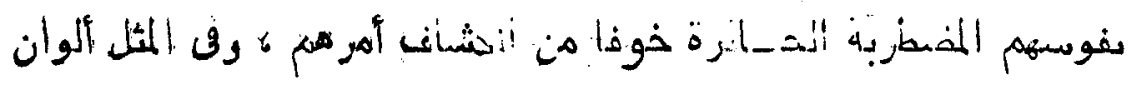

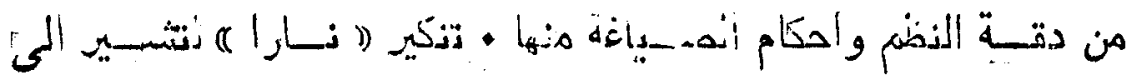

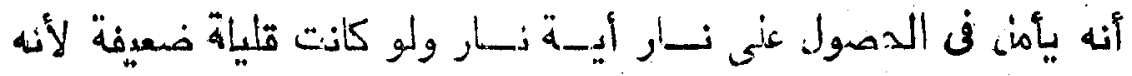

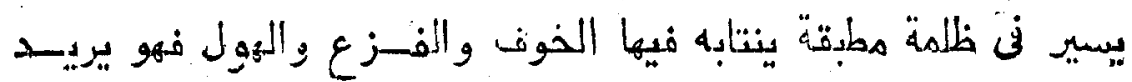

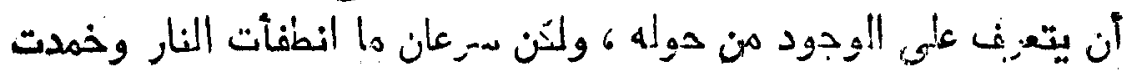

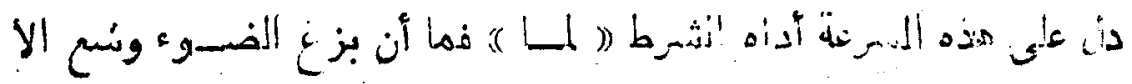

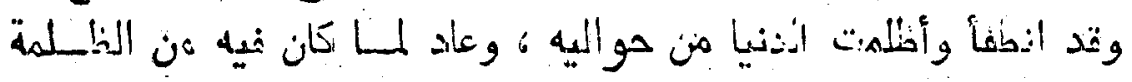

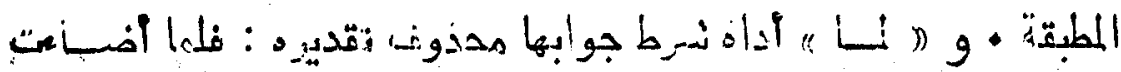

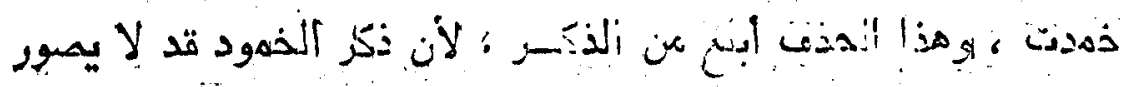

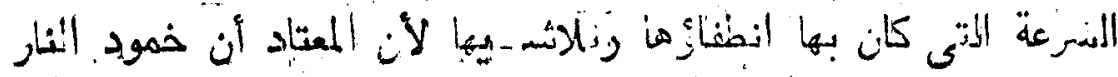

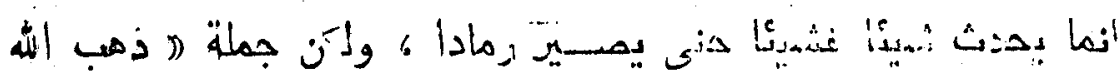

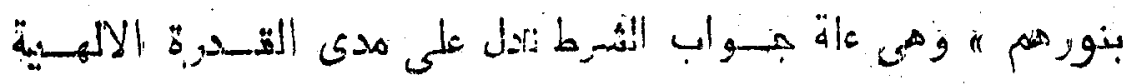

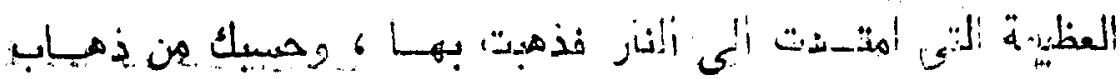

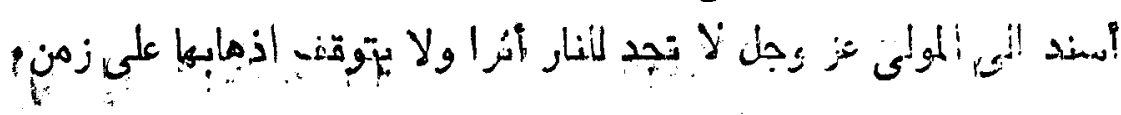

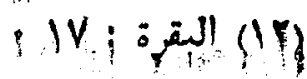




\section{EIV}

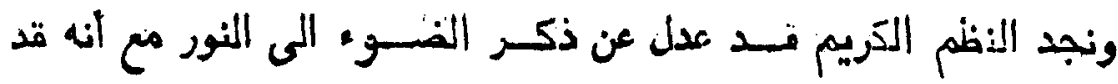

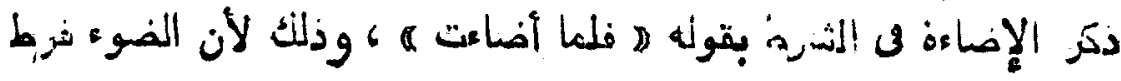

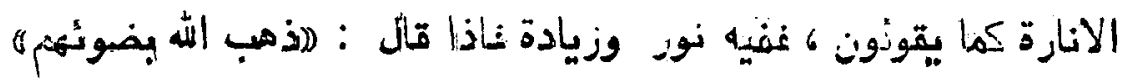

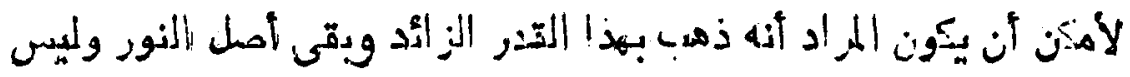

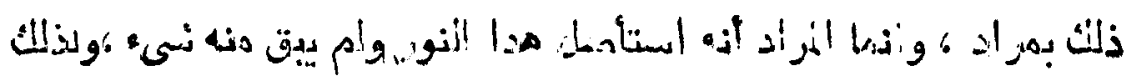

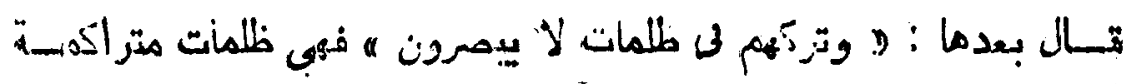

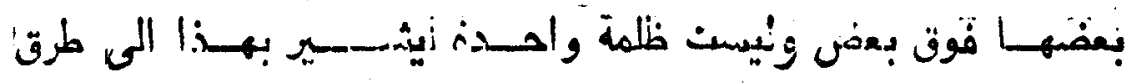

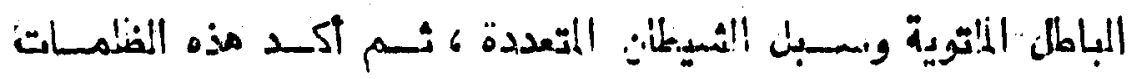

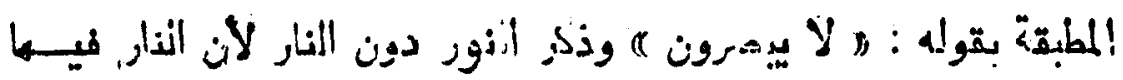

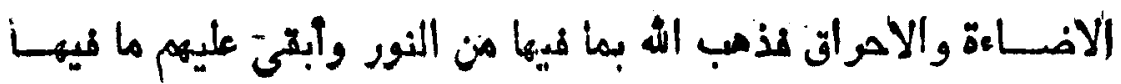

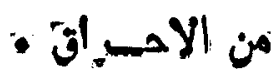

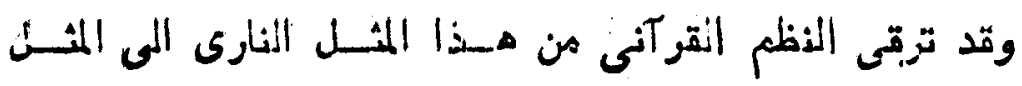

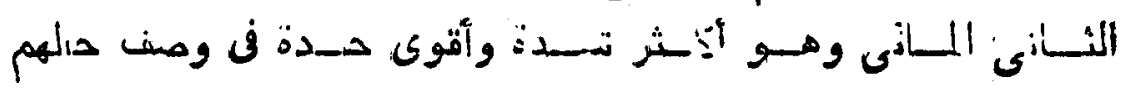

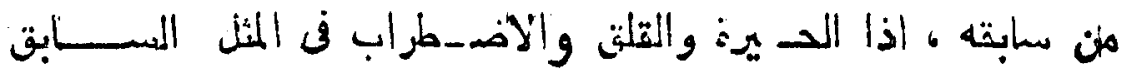

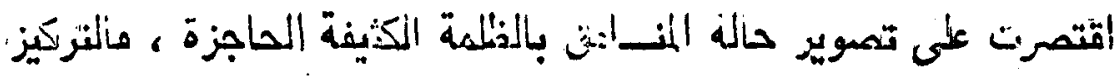

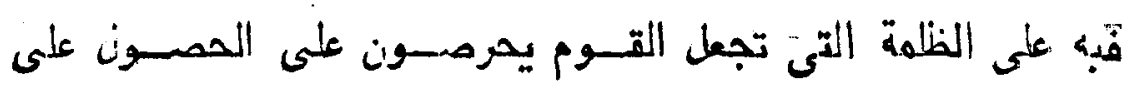

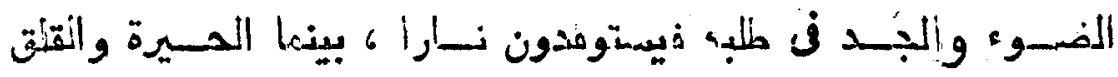

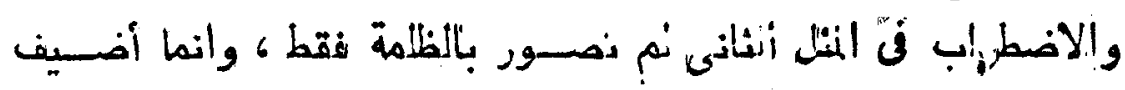

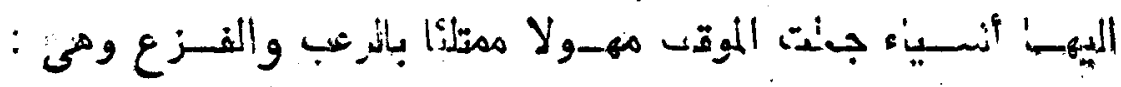

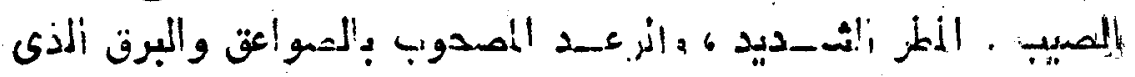

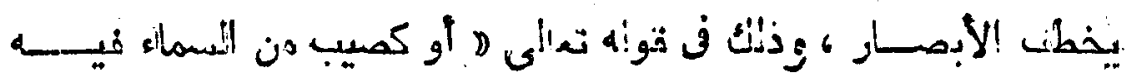

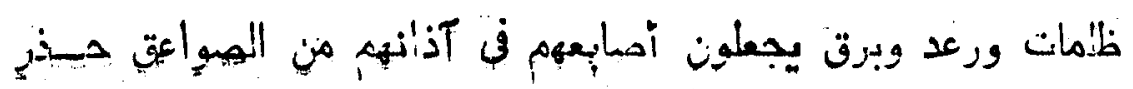
المـوت ه ه ه

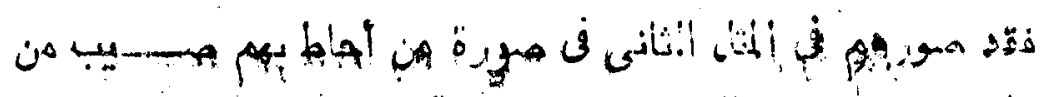

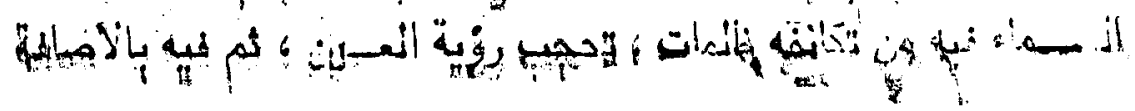




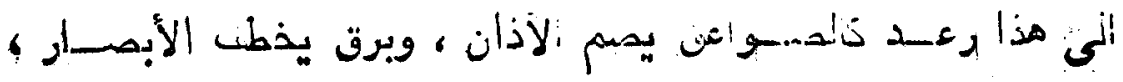

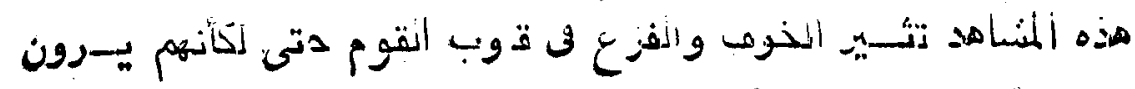

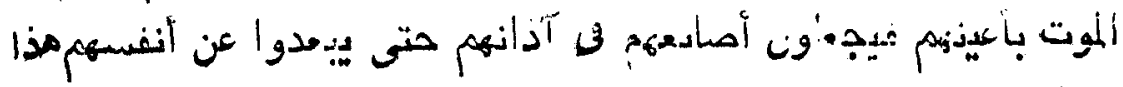

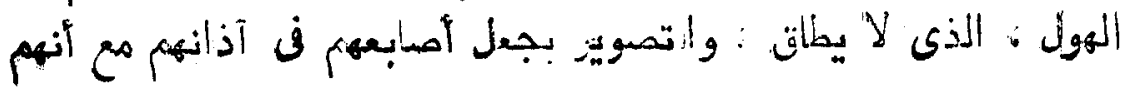

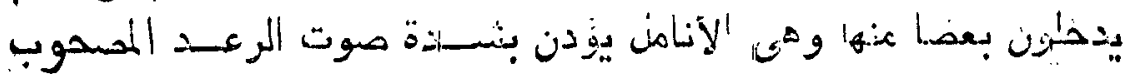

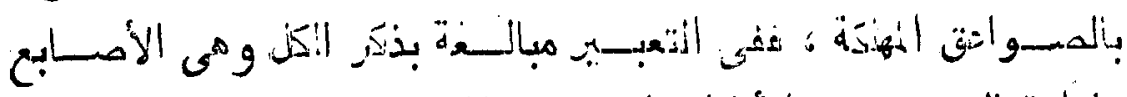

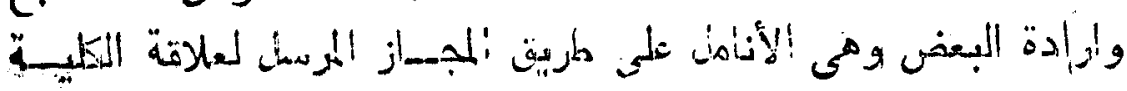

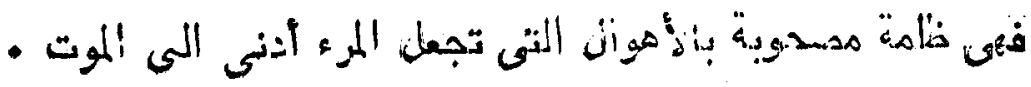

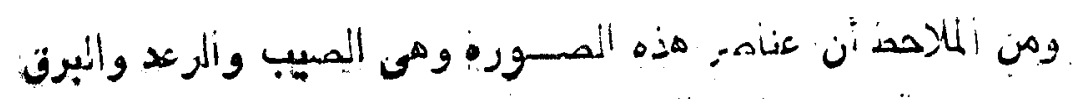

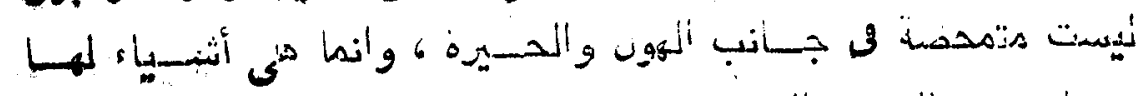

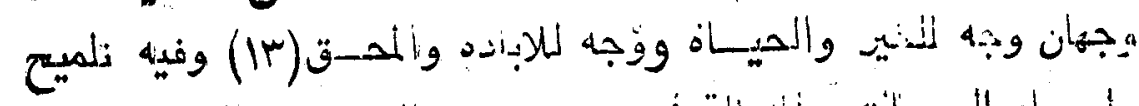

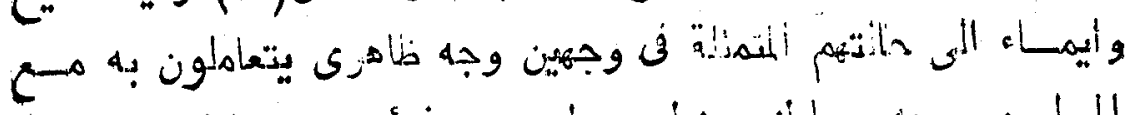

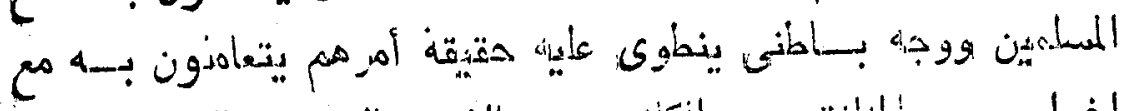

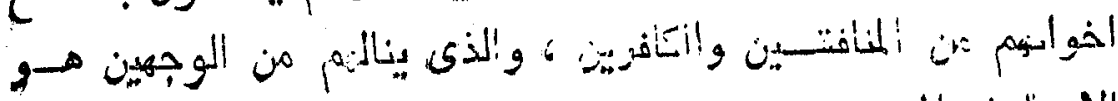

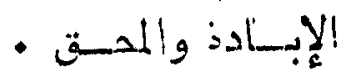

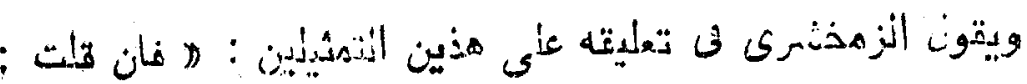

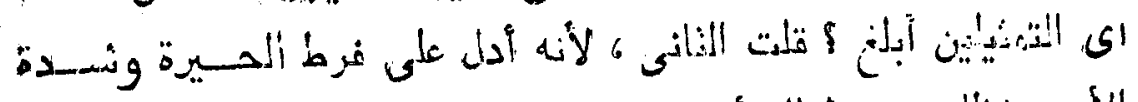

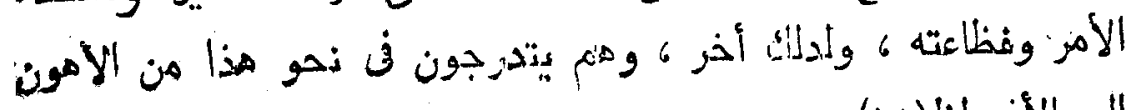

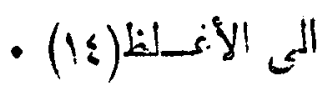

(IT) انظر : التصوير البيانى للدكتود مصمد أبو موسى ص ^A،A 


\section{os}

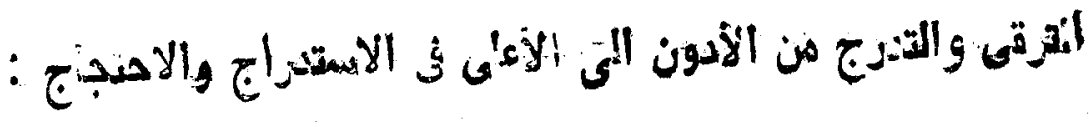

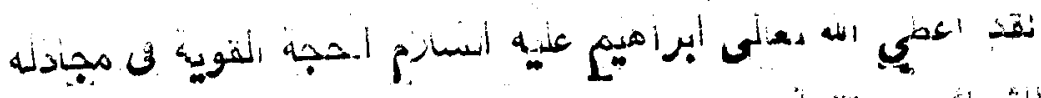

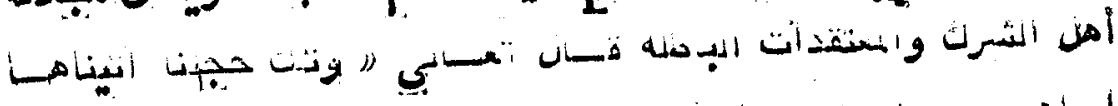

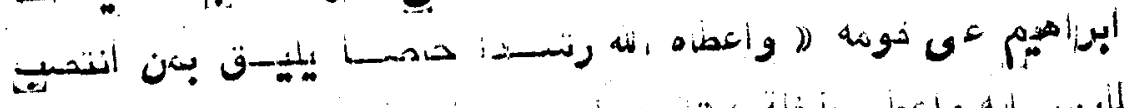

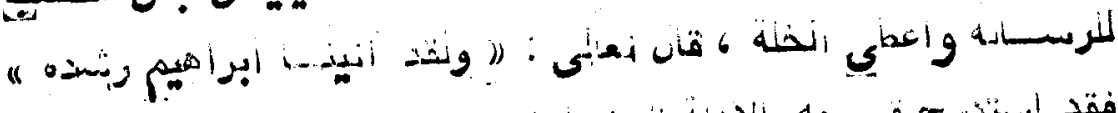

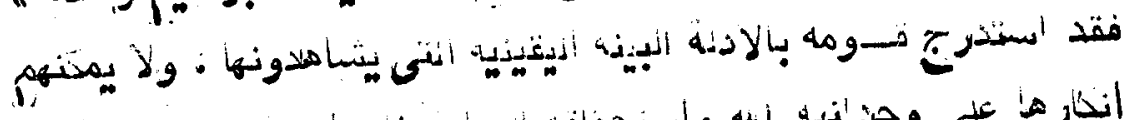

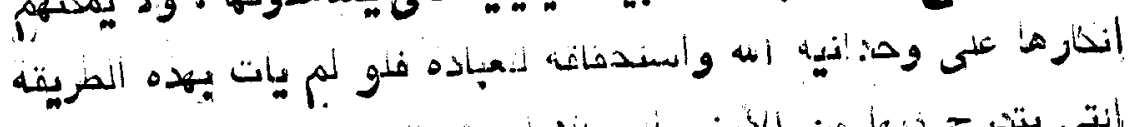

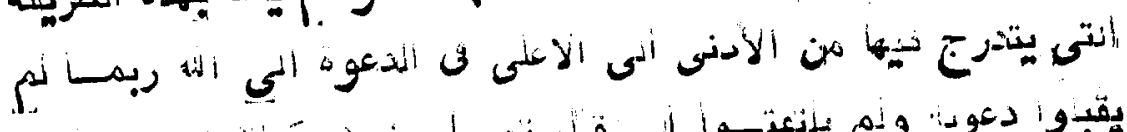

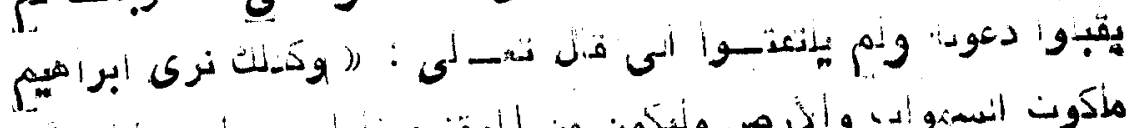

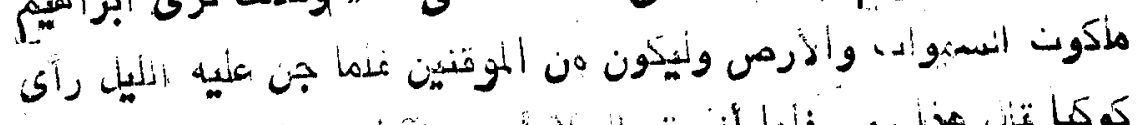

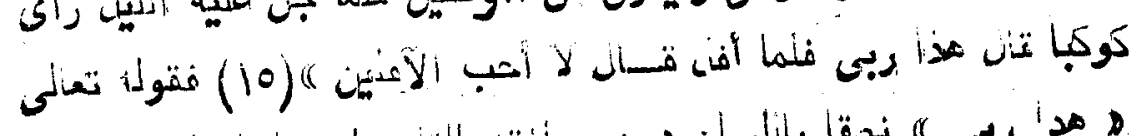

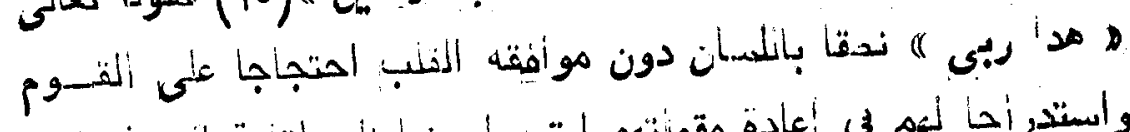

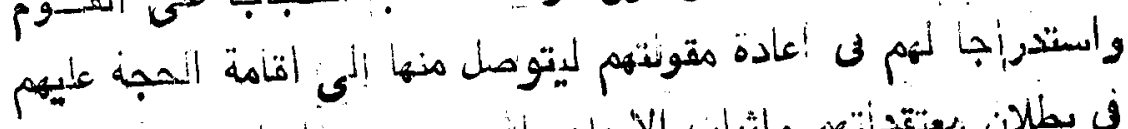

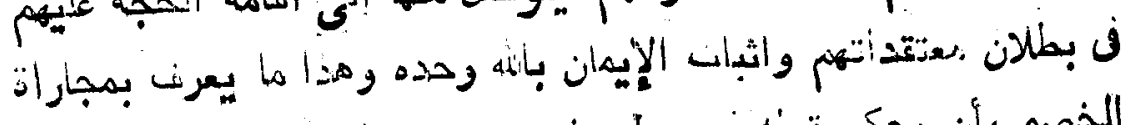

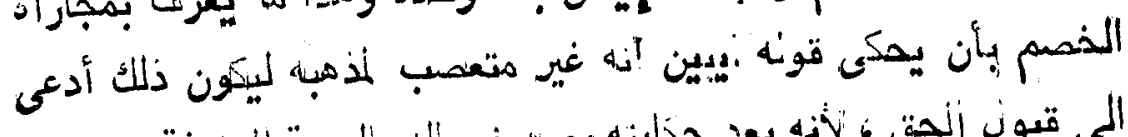

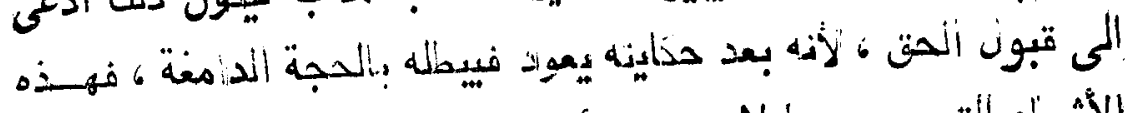

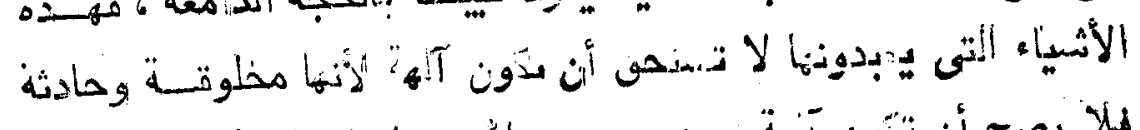

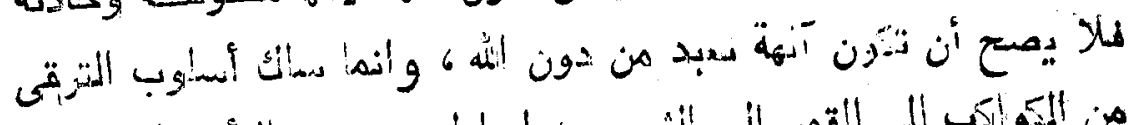

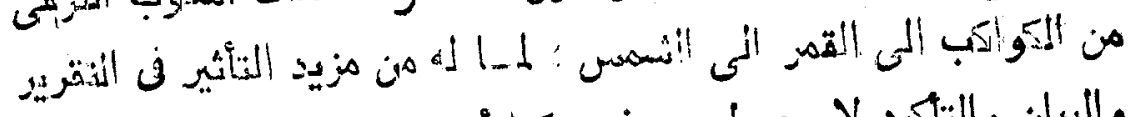

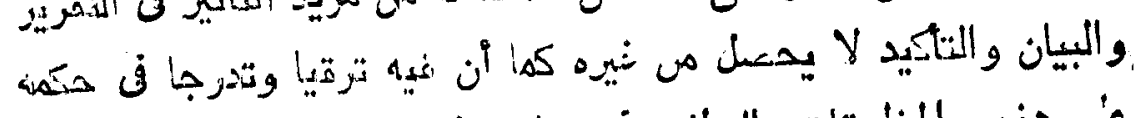

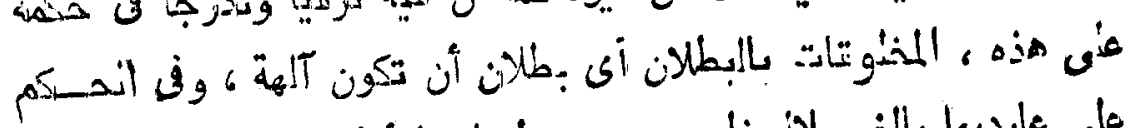

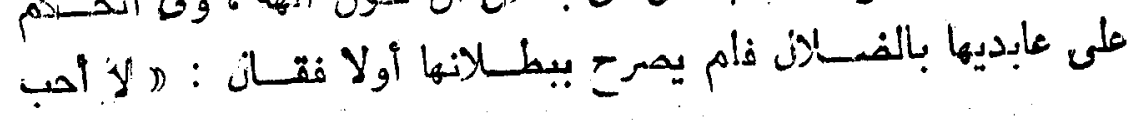


it.

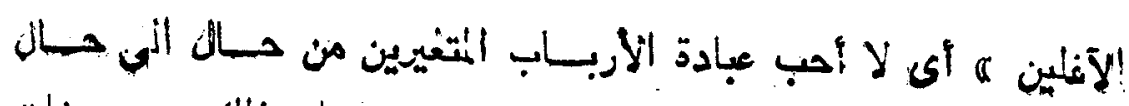

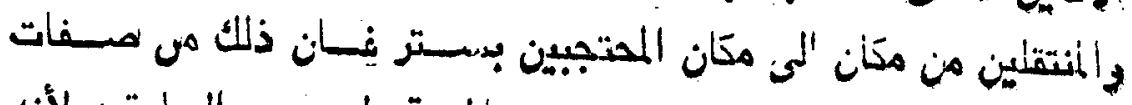

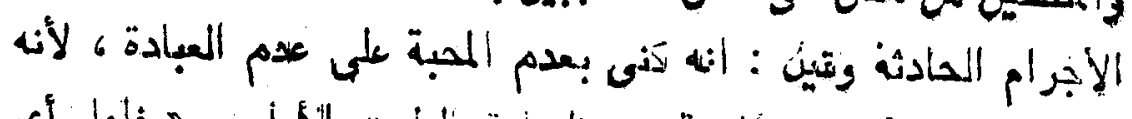

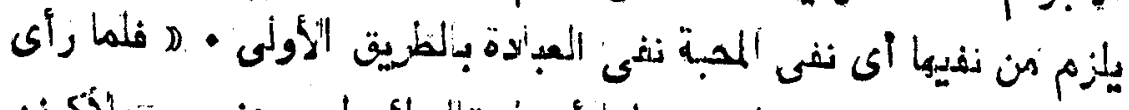

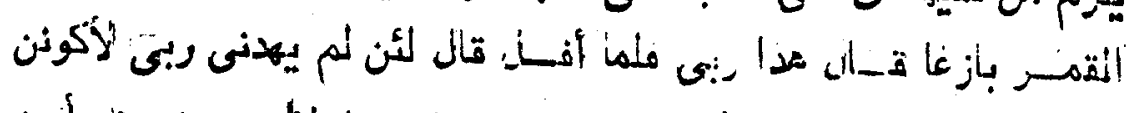

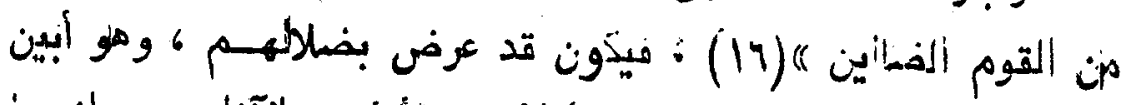

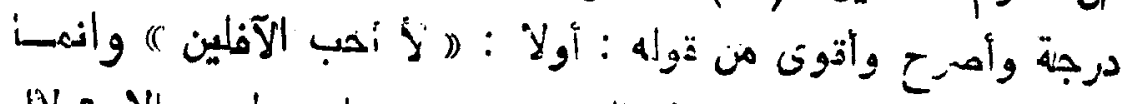

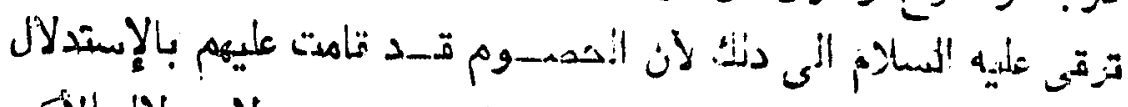

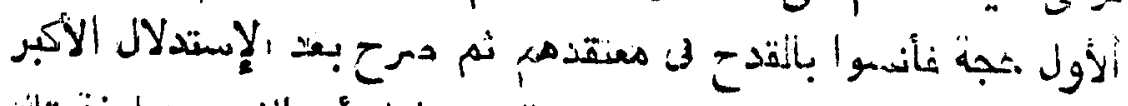

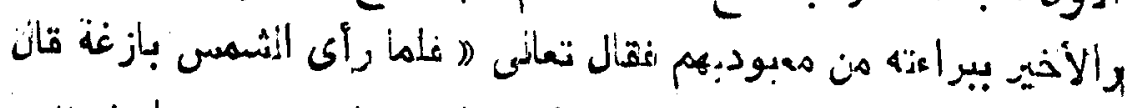

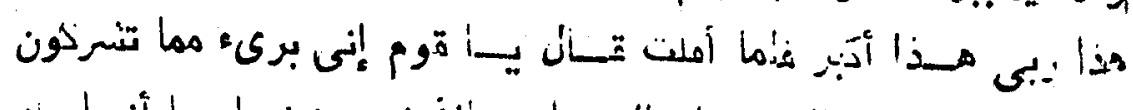

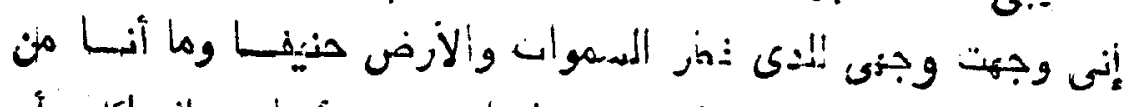

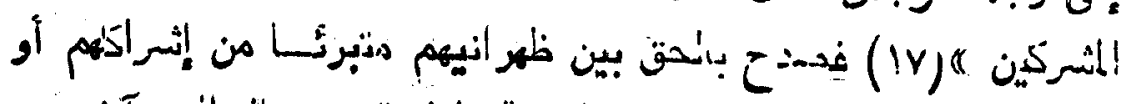

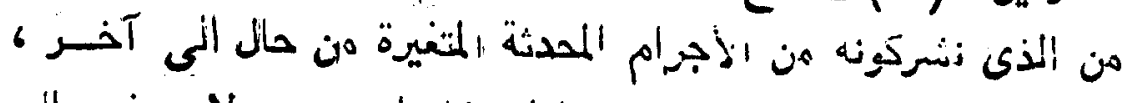

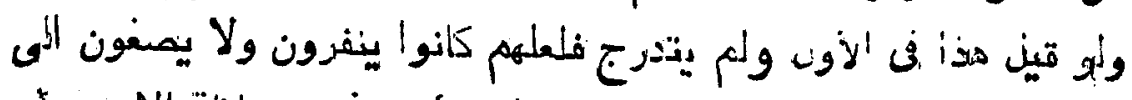

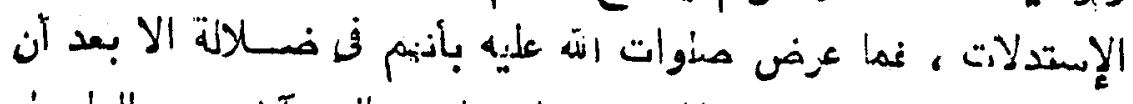

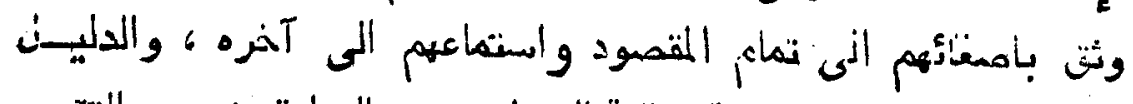

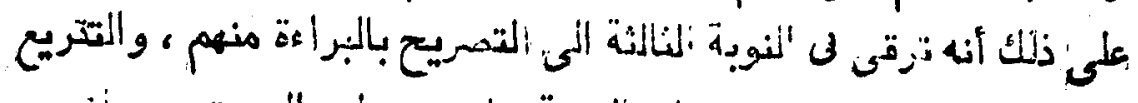

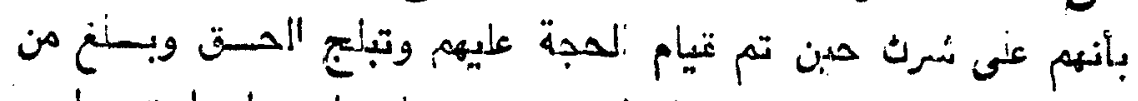

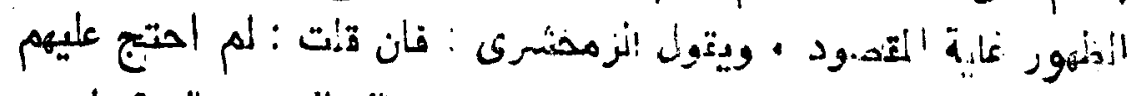

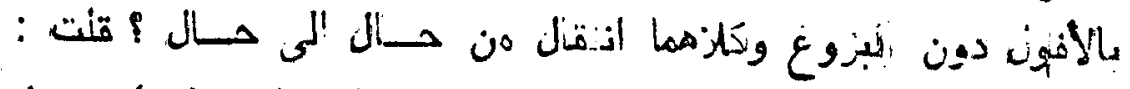

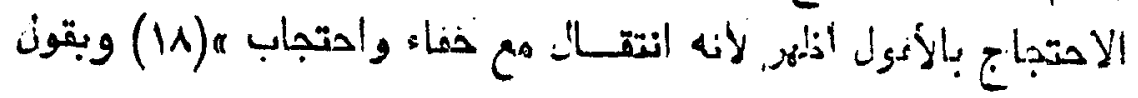

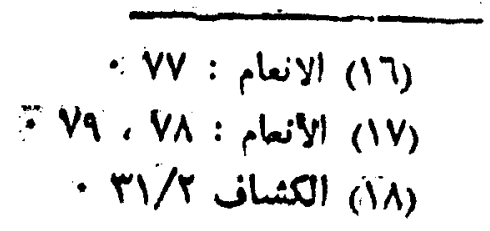




\section{1}

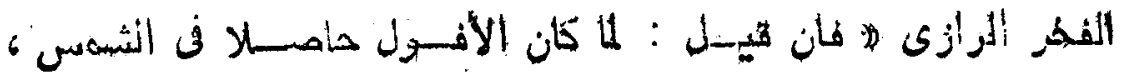

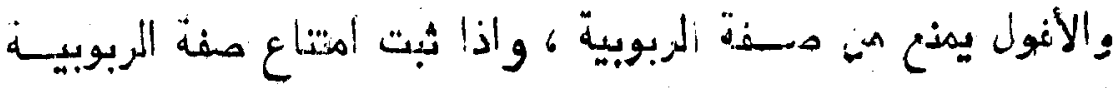

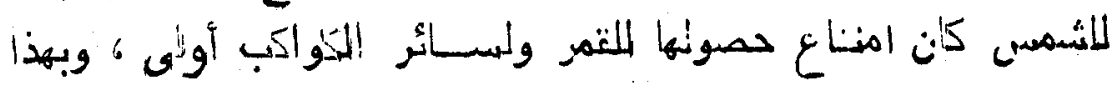

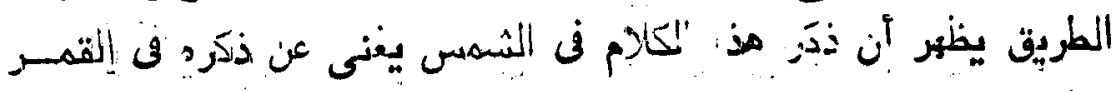

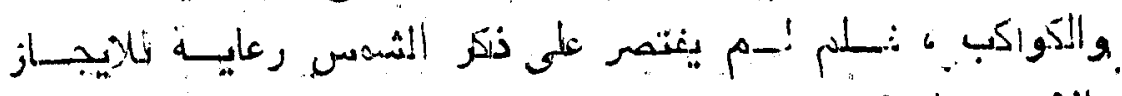
|الاذتتصــار

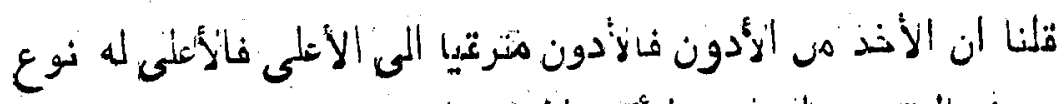

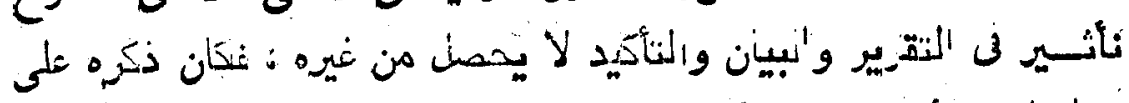

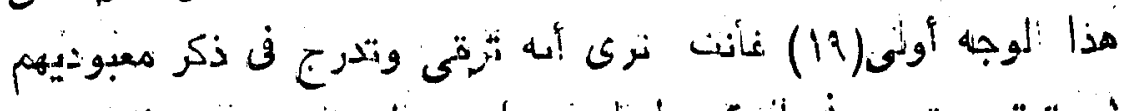

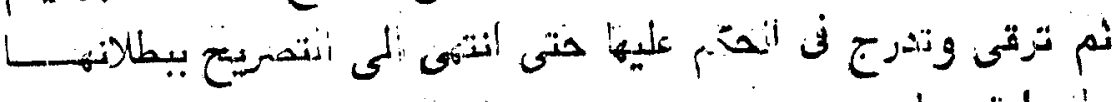

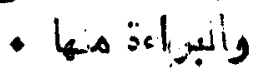

الثترقى والندرج عن الأخص المى الأعم وبالمكس :

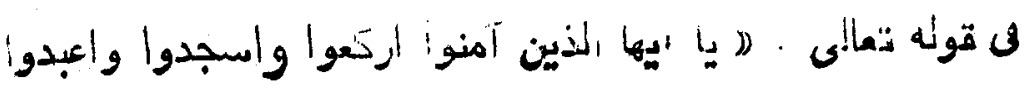

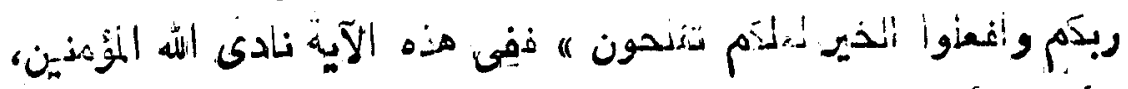

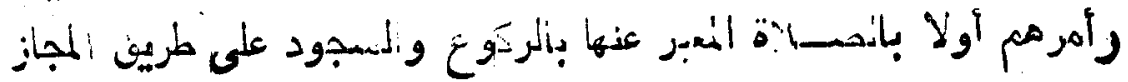

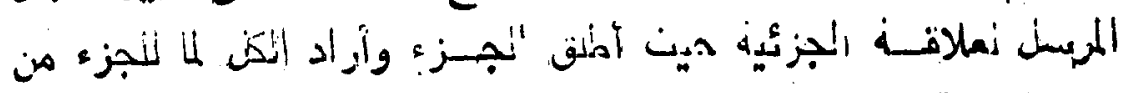

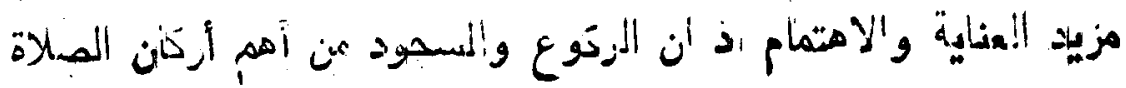

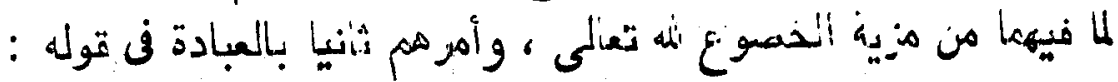

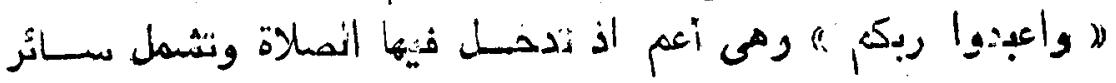

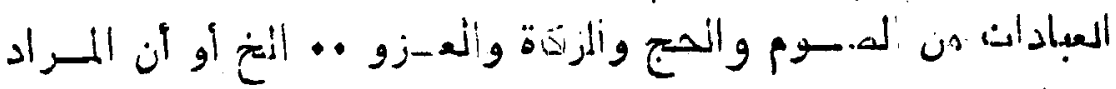

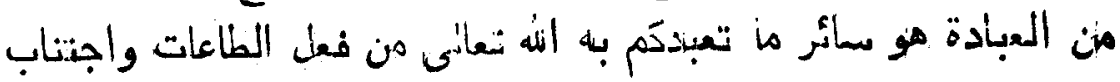




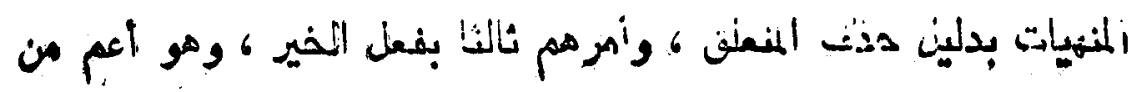

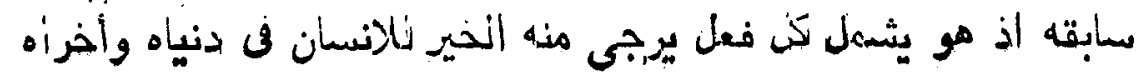

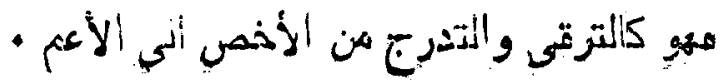

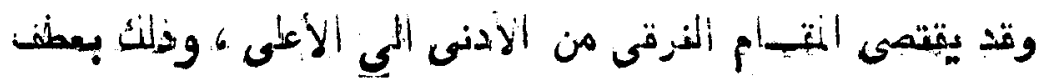

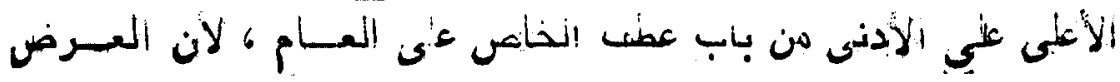

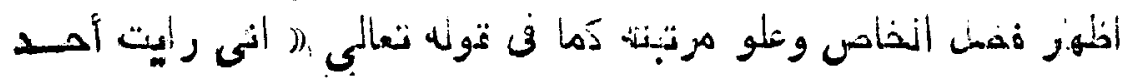

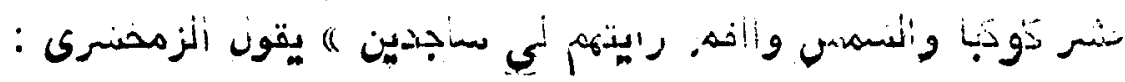

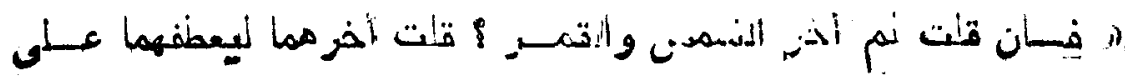

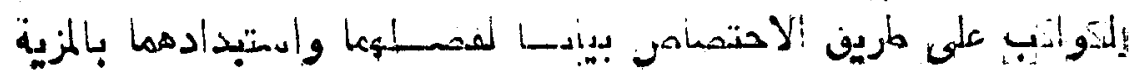

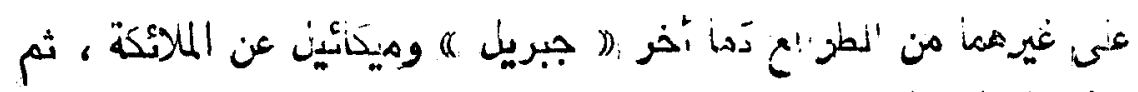

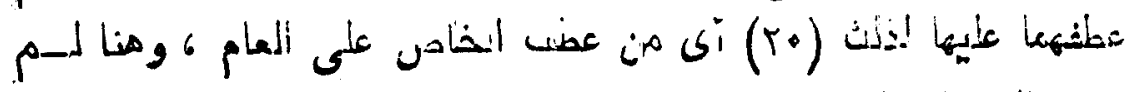

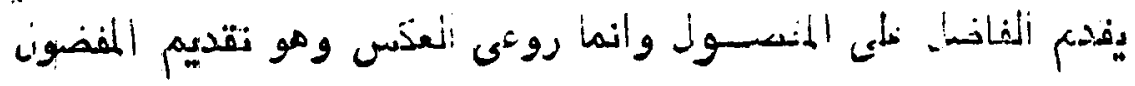

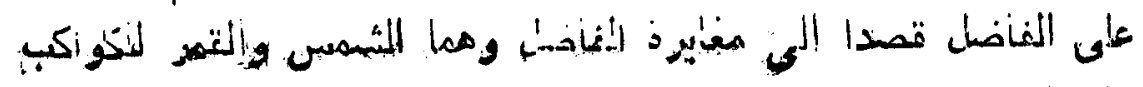

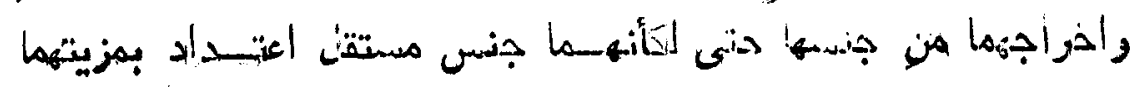

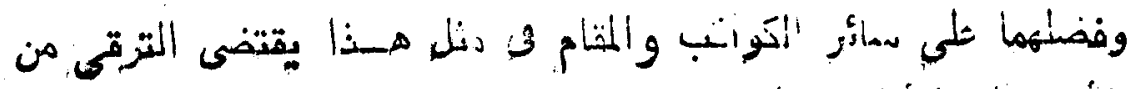

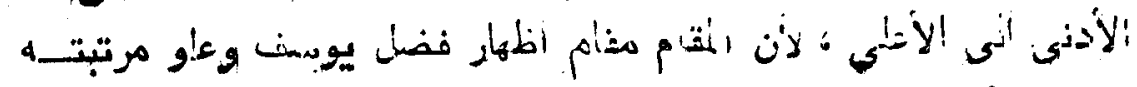

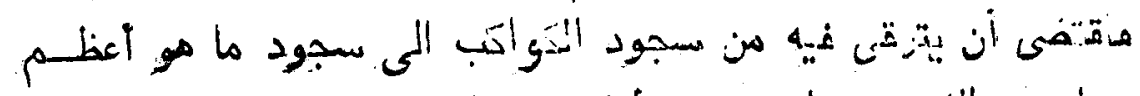

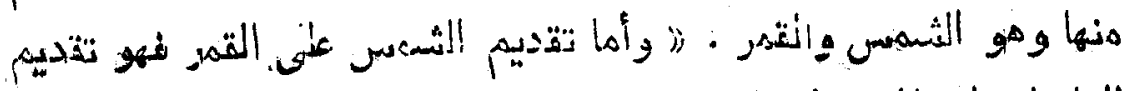

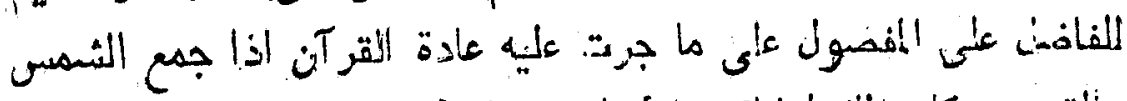

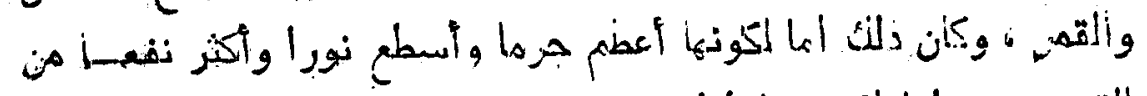

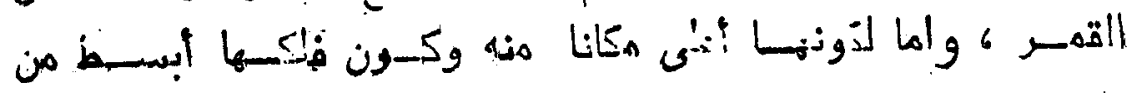
-

? r r

- IVq/\& 
Dor

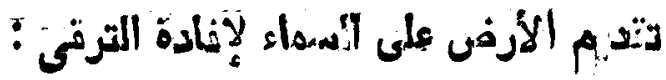

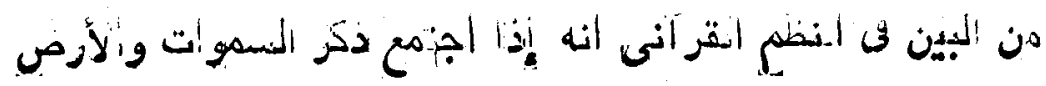

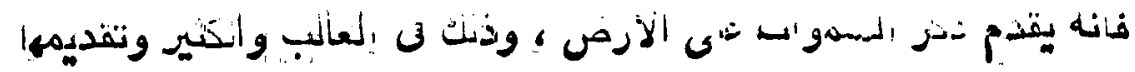

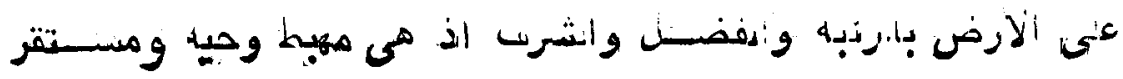

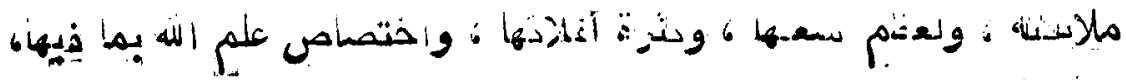

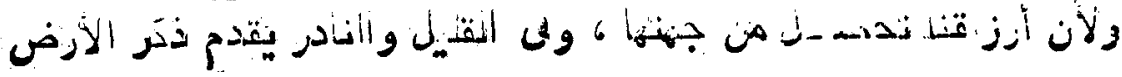

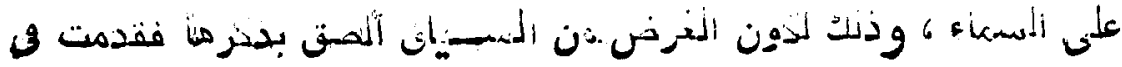

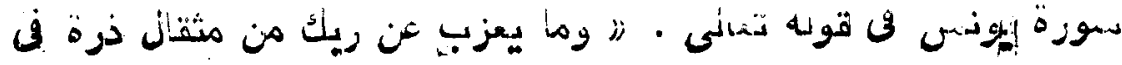

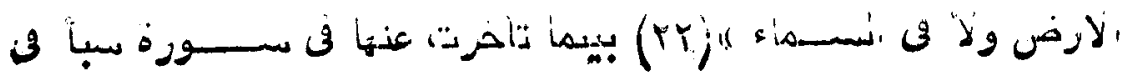

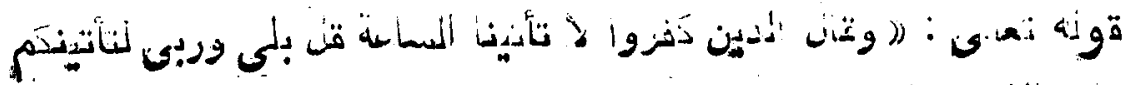

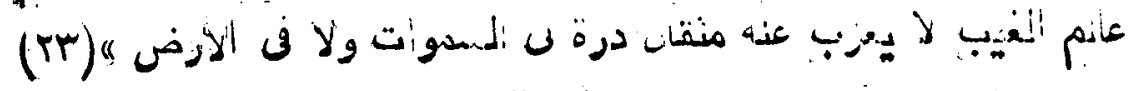

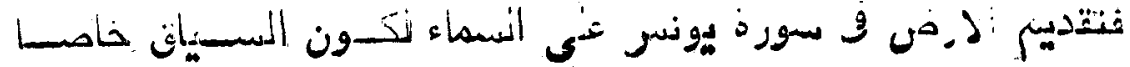

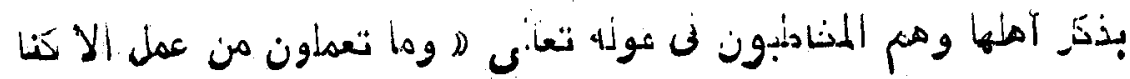

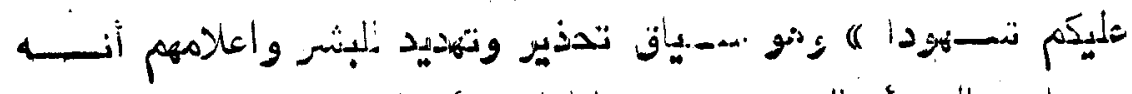

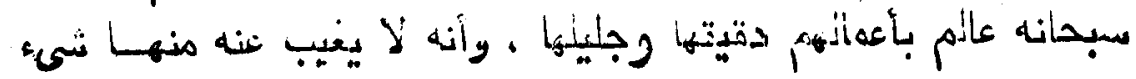

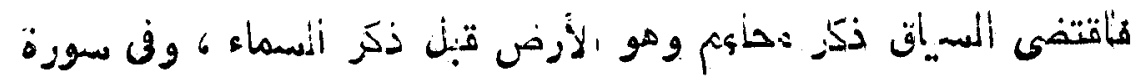

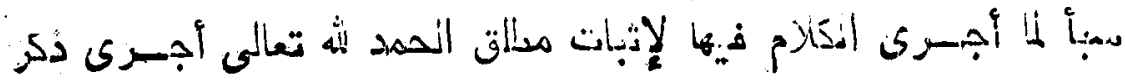

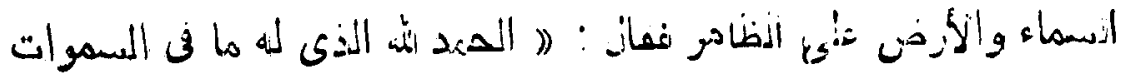

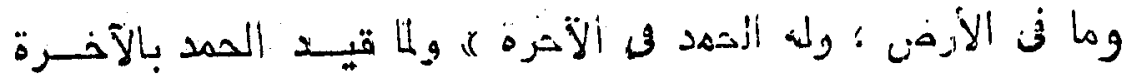

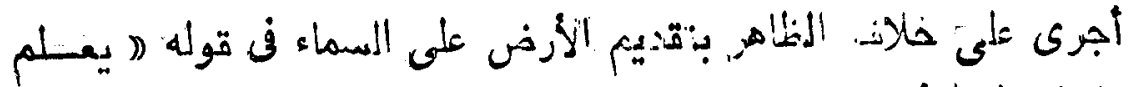

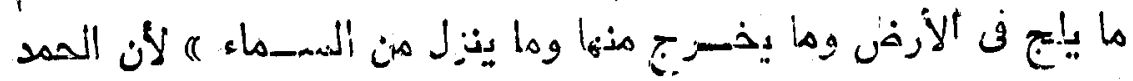

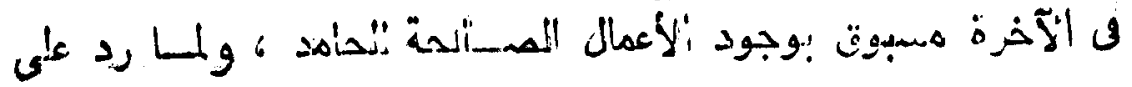

- 71 : مسورة يونس (TY)

$\therefore r: 21:$ : 


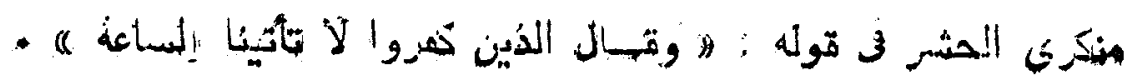

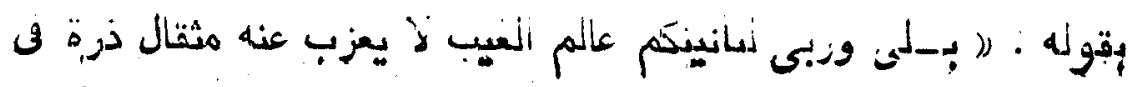

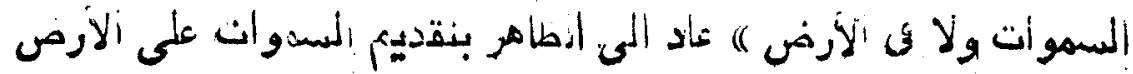

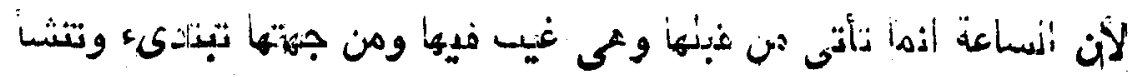

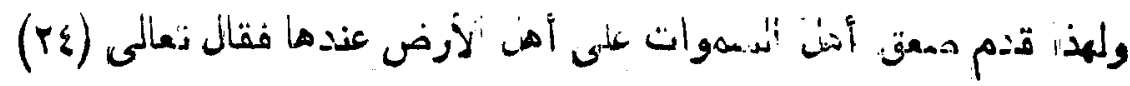

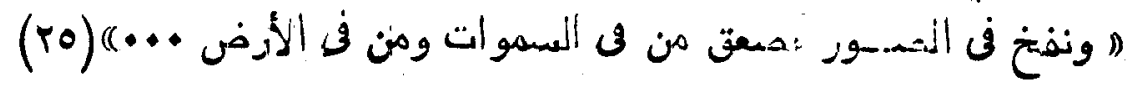

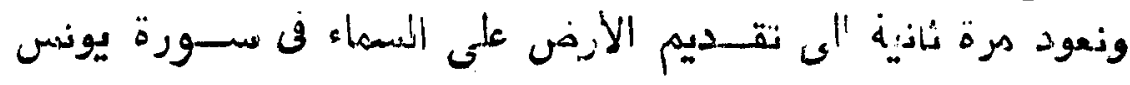

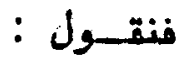

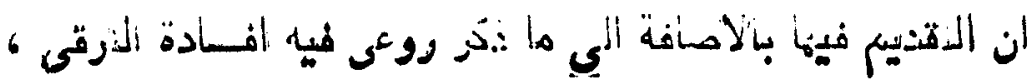

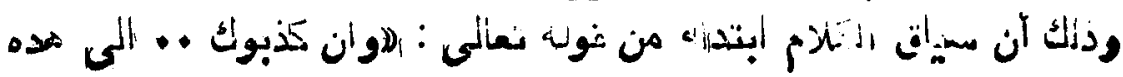

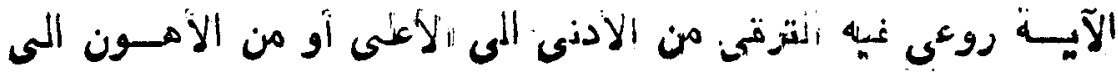

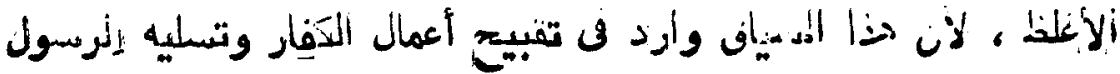

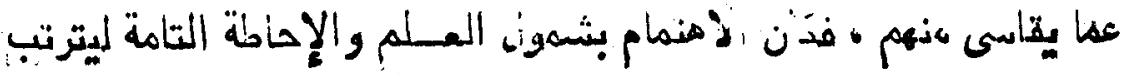

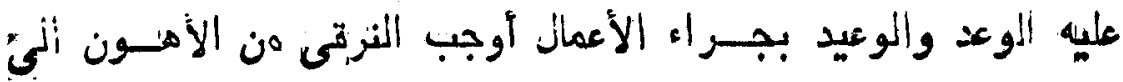

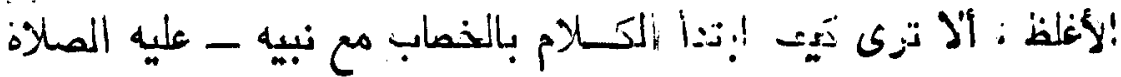

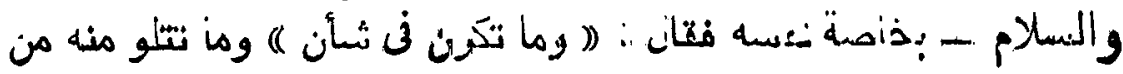

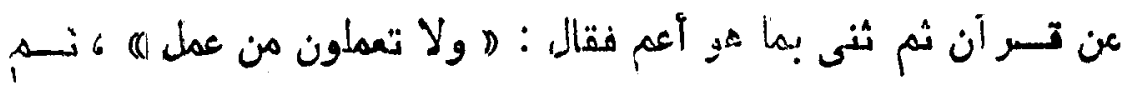

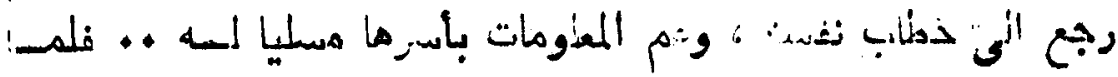

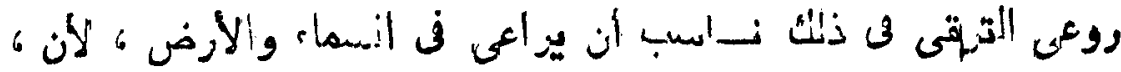

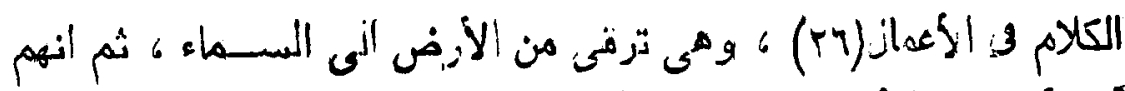

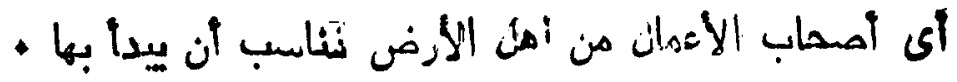

- $\mathrm{U}$

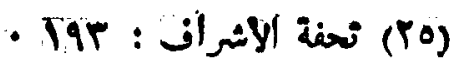

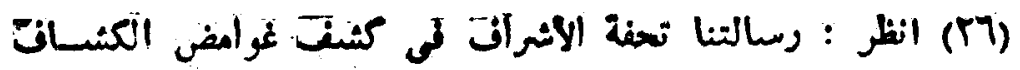

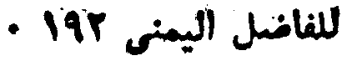




\section{eoe}

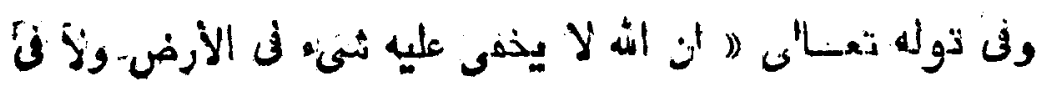

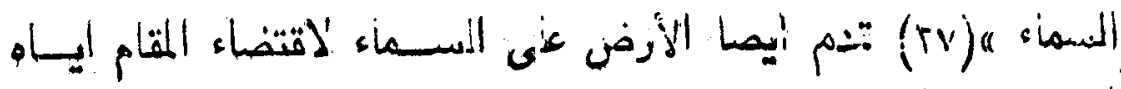

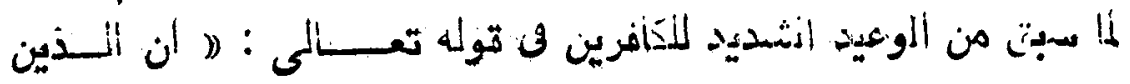

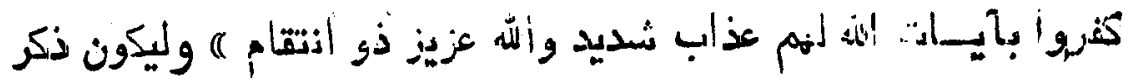

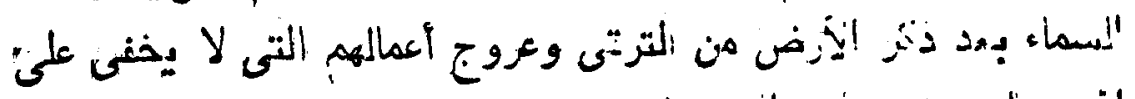

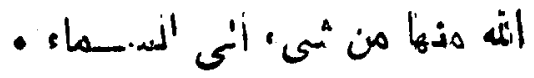

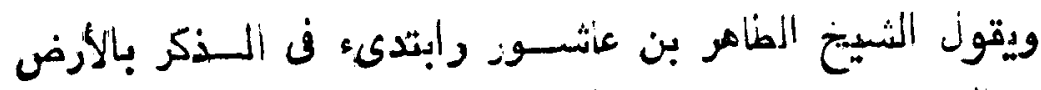

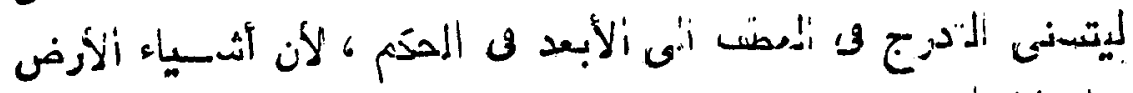

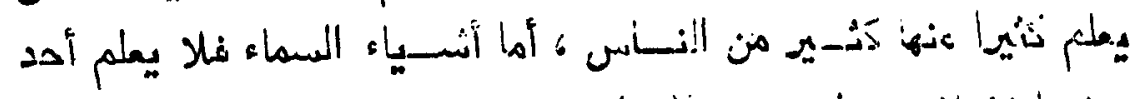

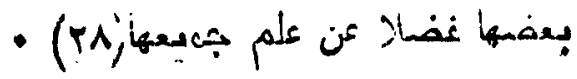

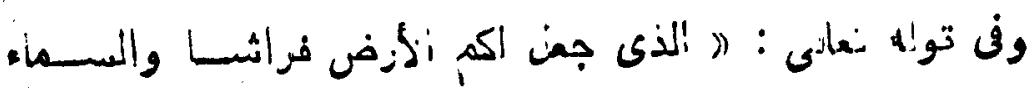

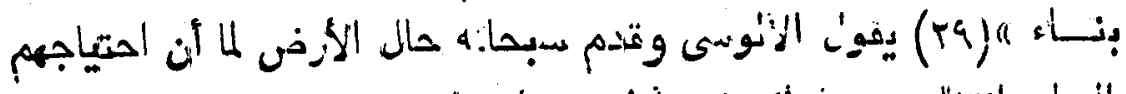

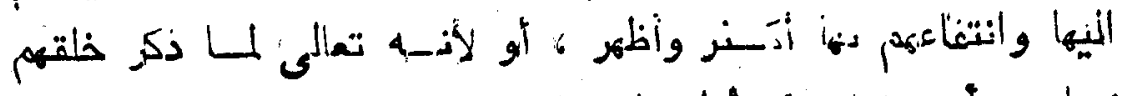

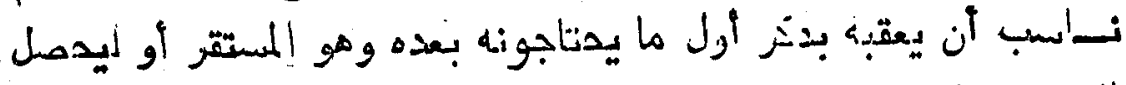

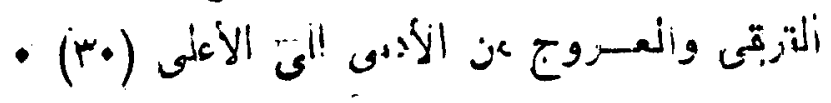

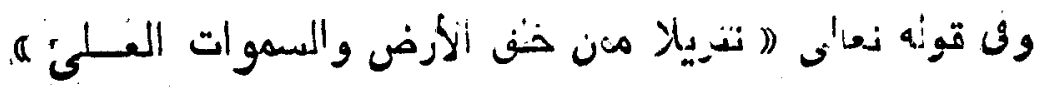

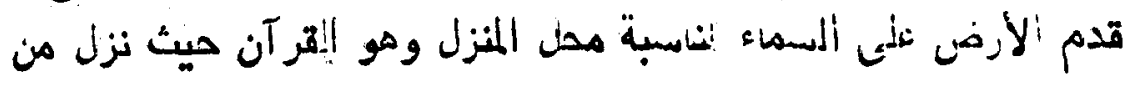

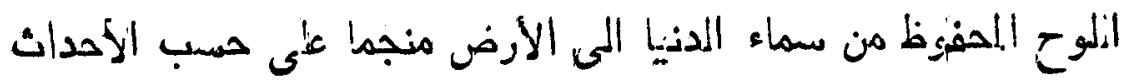

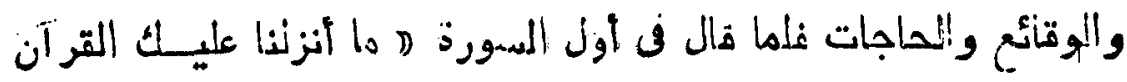

$$
\text { • } \quad \text { : }
$$

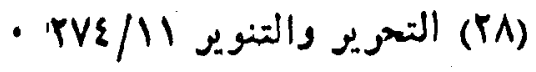$$
\text { ) }
$$$$
\text { - IMN/1 }
$$ 


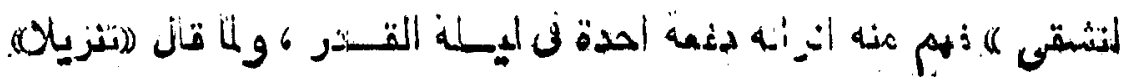

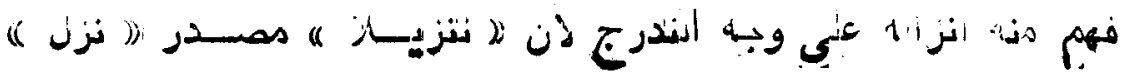

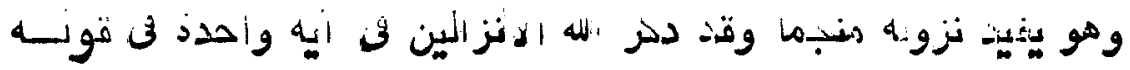

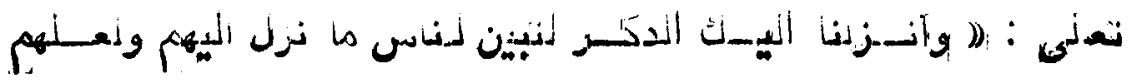

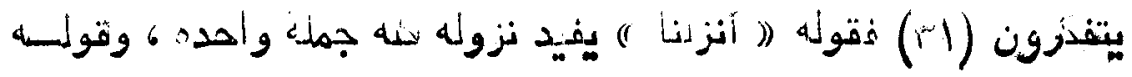

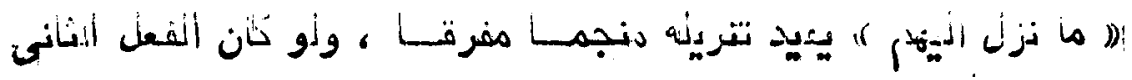

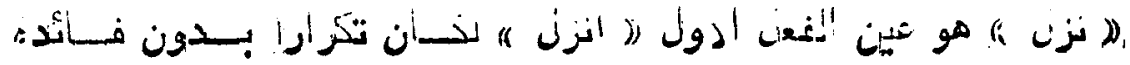

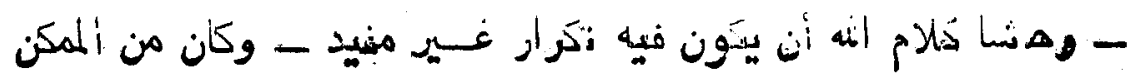

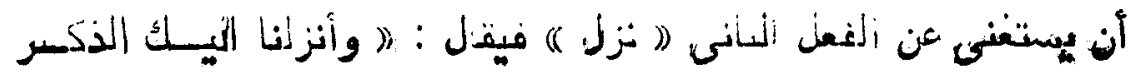

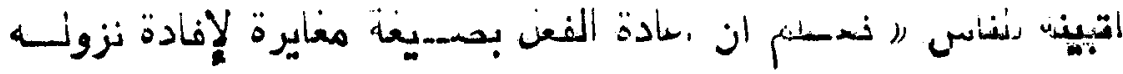

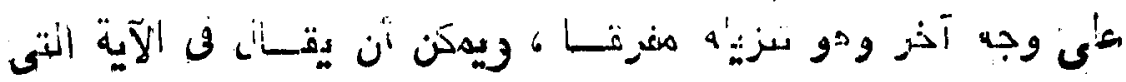

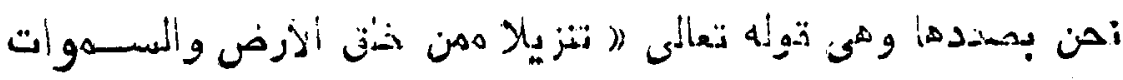

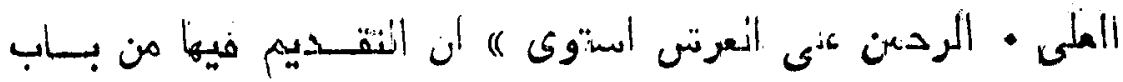

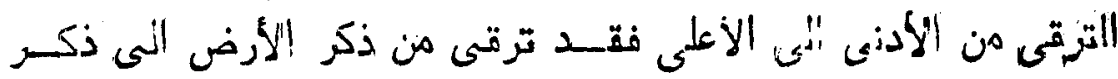

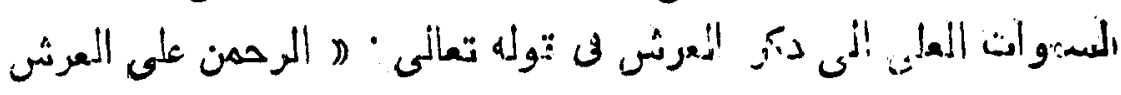
- المست-ون

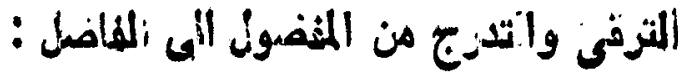

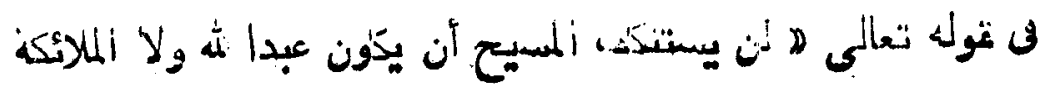

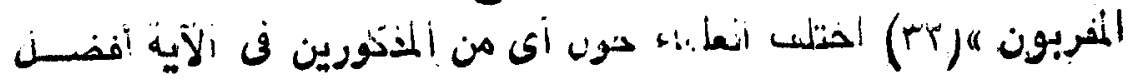

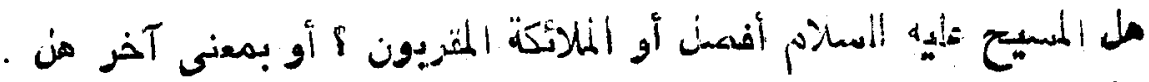

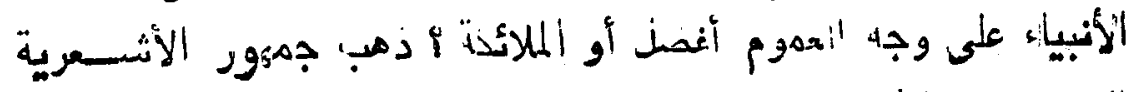

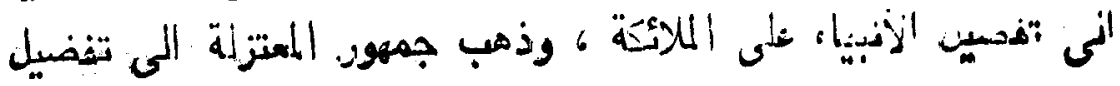

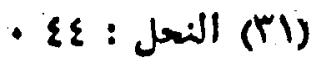

IVP : IVT : 


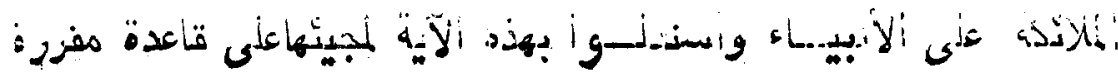

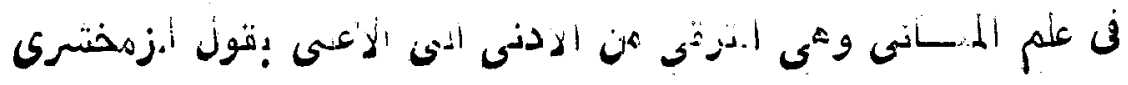

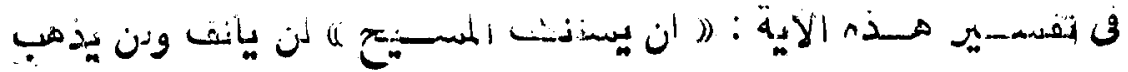

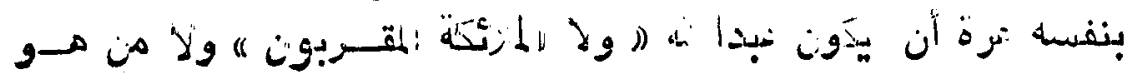

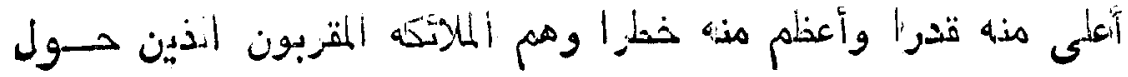

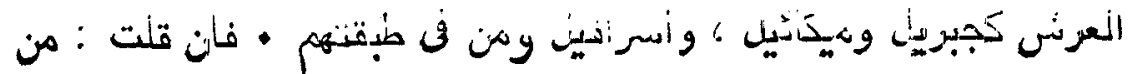

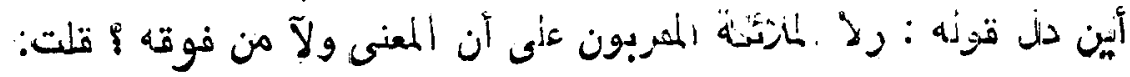

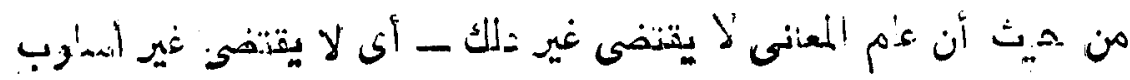

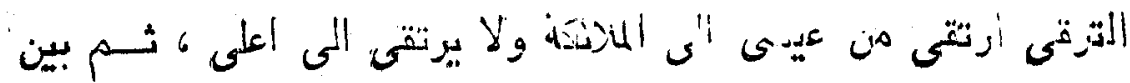

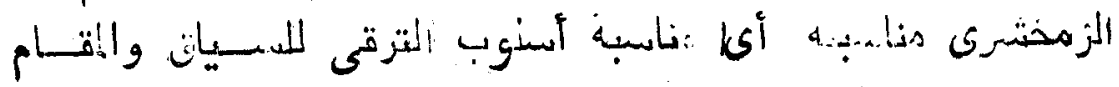

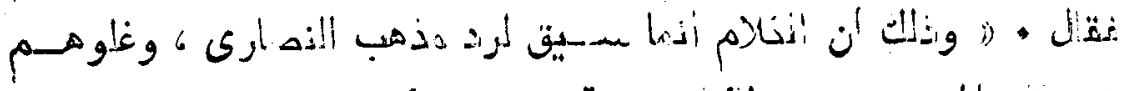

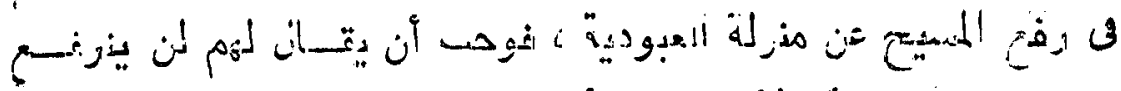

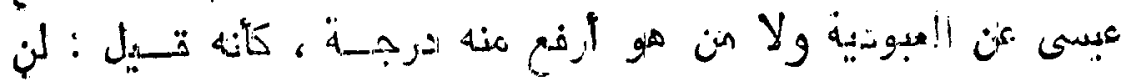

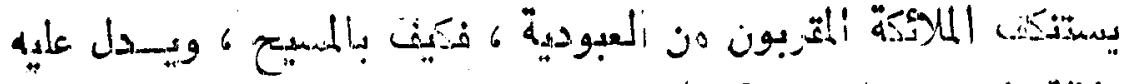

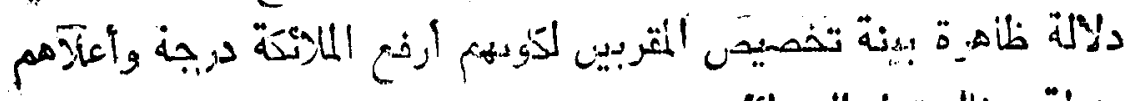

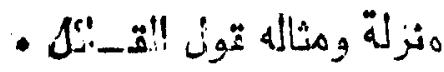

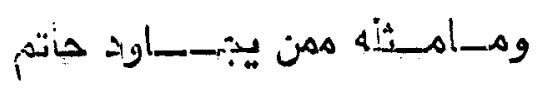

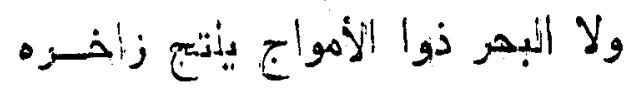

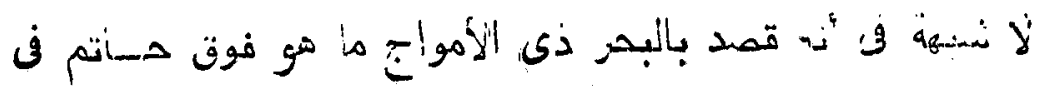

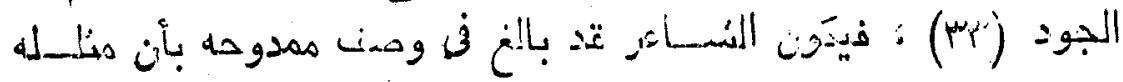

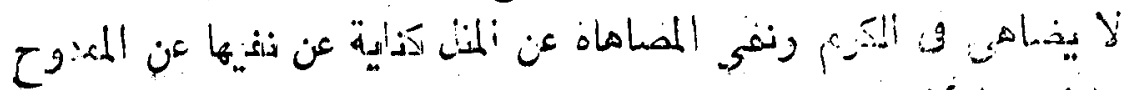

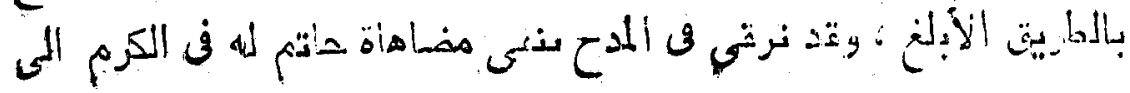


001

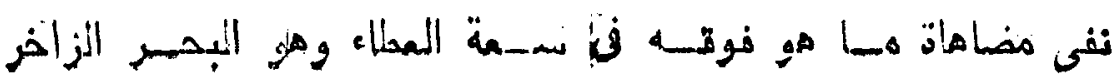

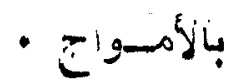

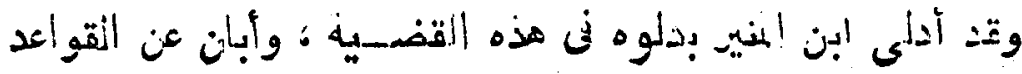

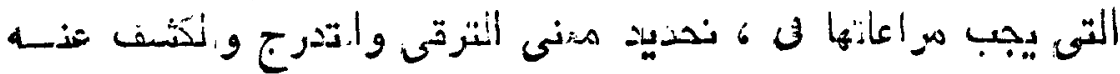

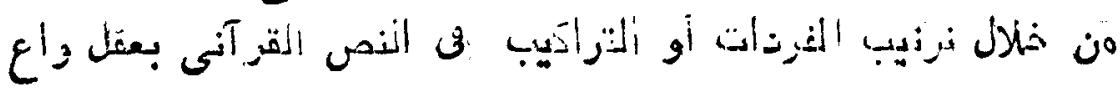

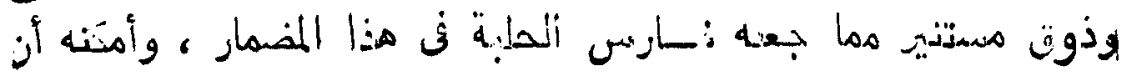

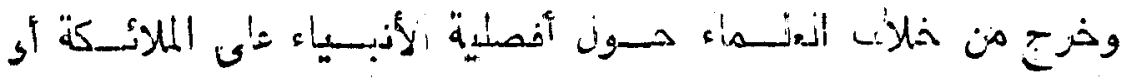

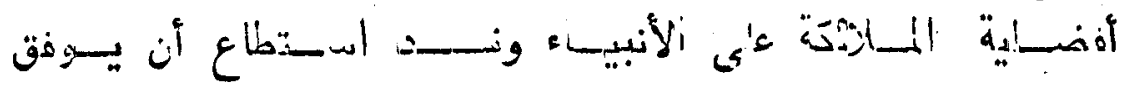

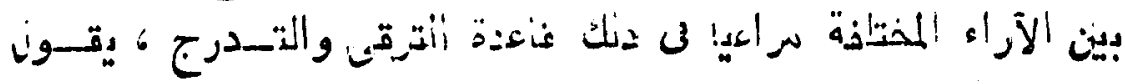

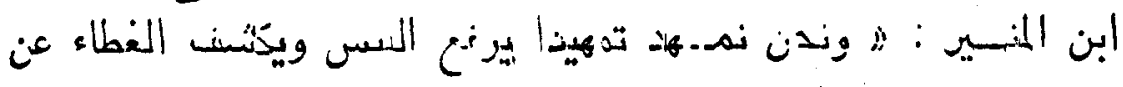

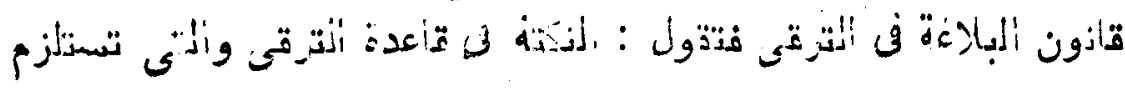

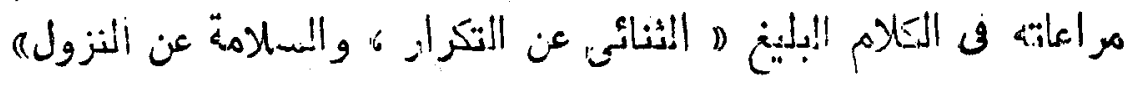

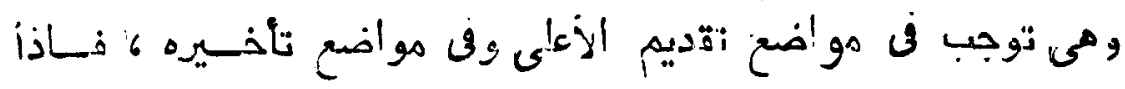

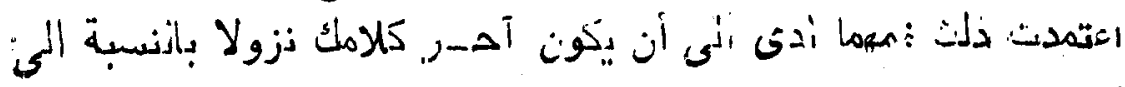

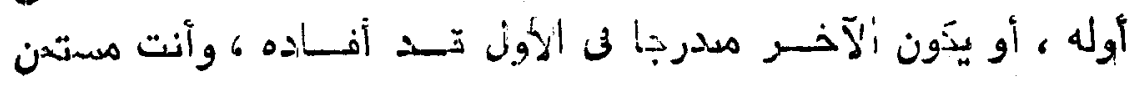

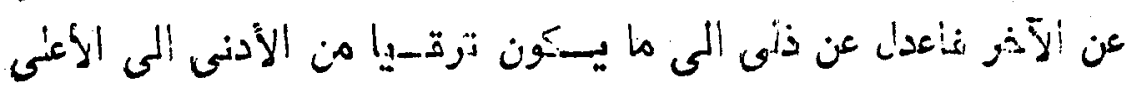

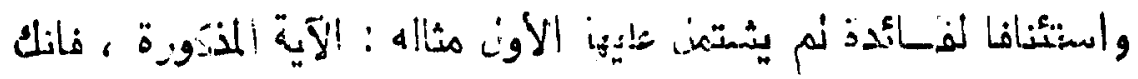

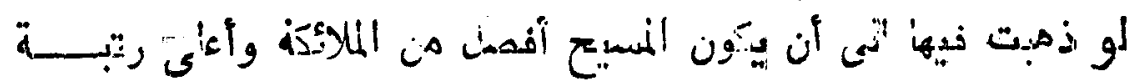

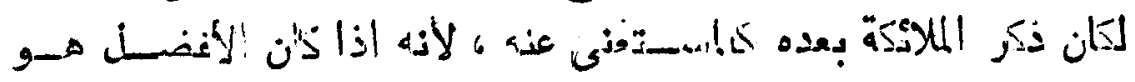

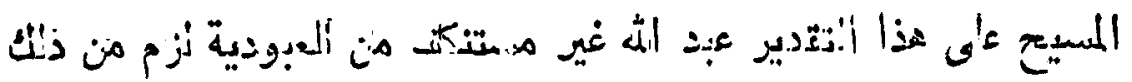

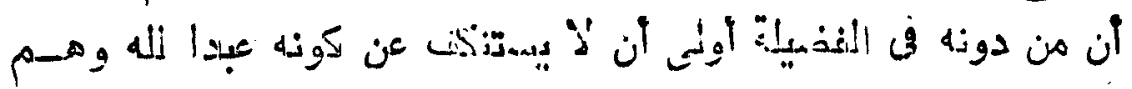

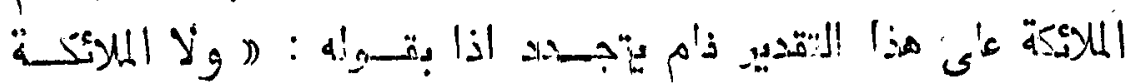

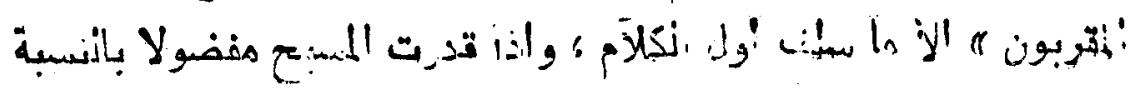

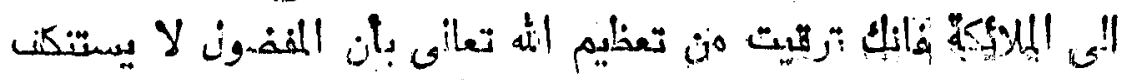

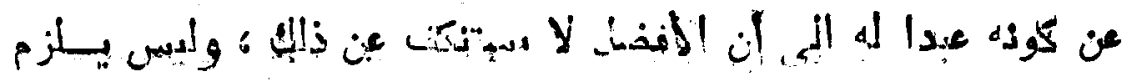

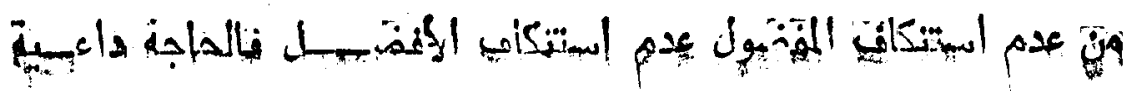




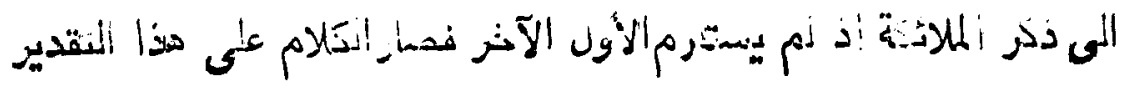

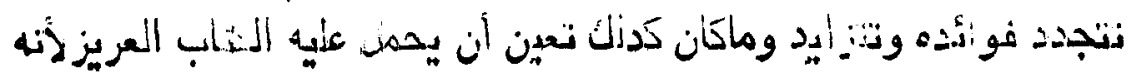

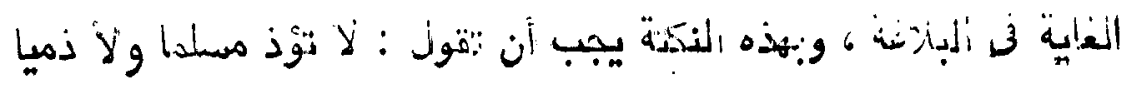

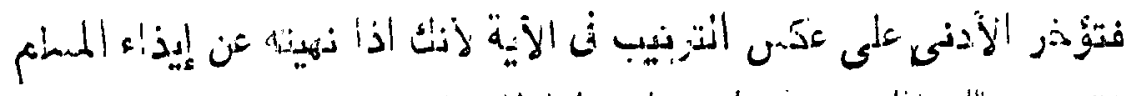

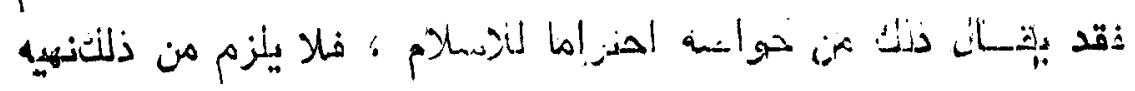

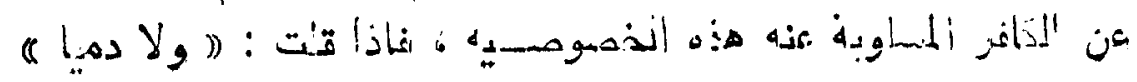

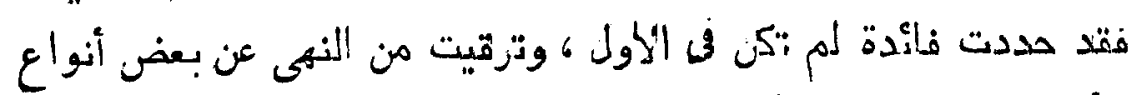

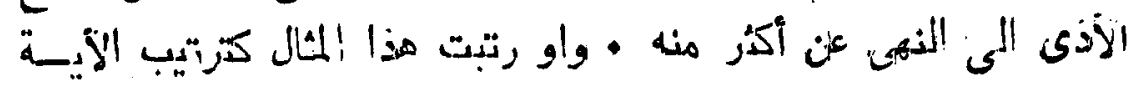

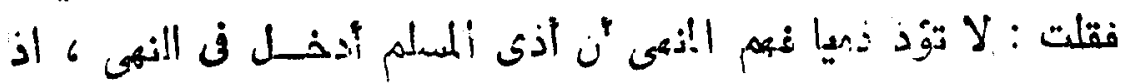

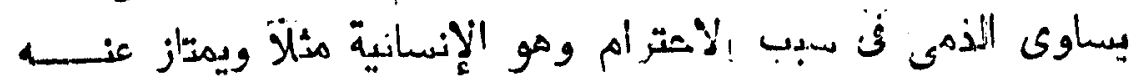

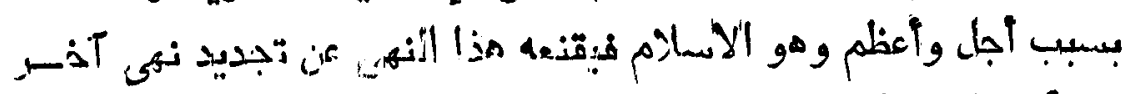

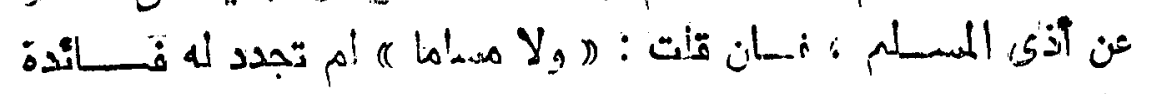

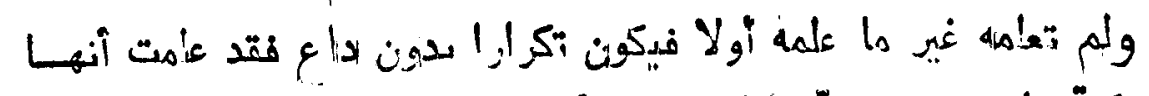

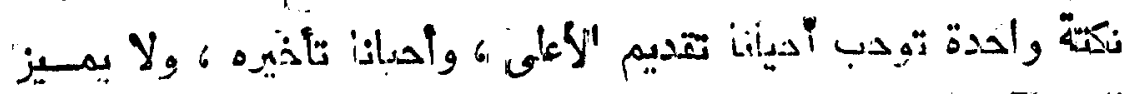

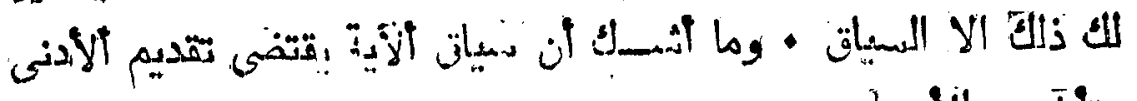

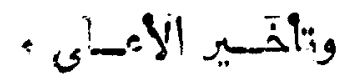

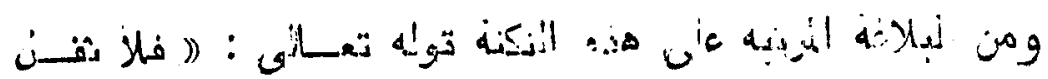

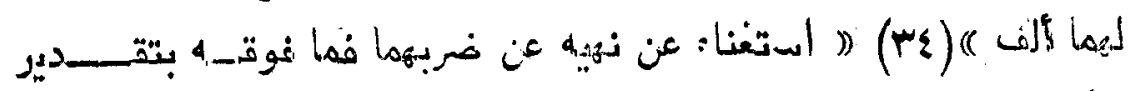

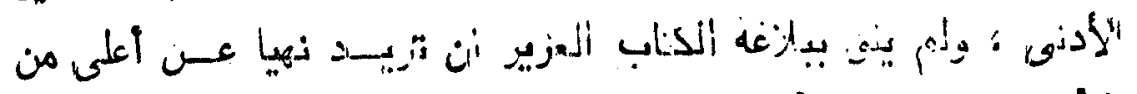

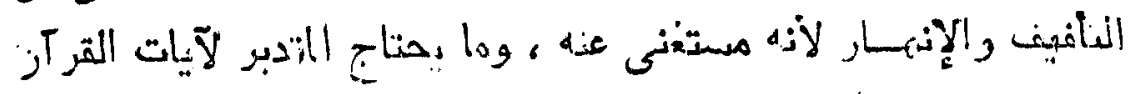

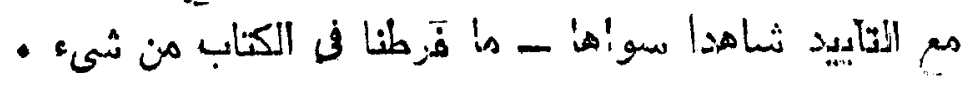

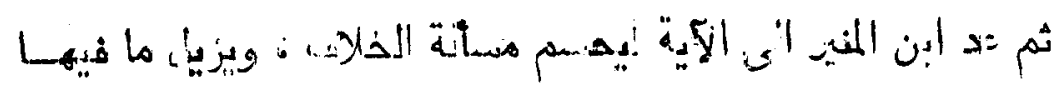

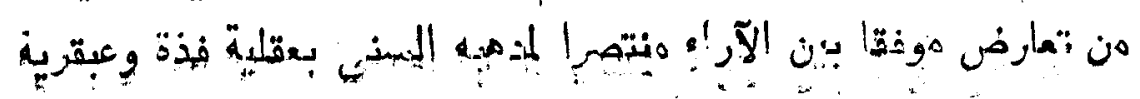




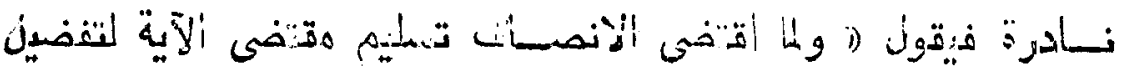

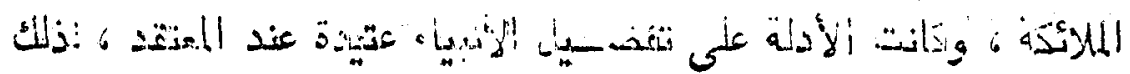

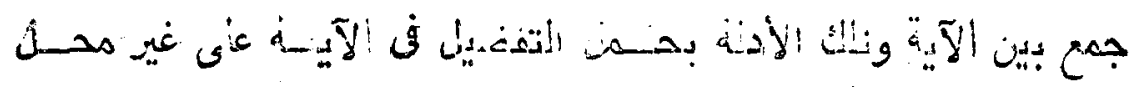

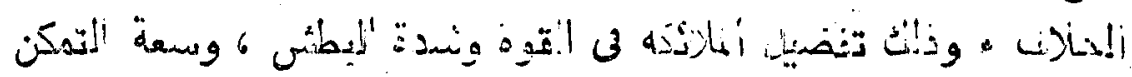

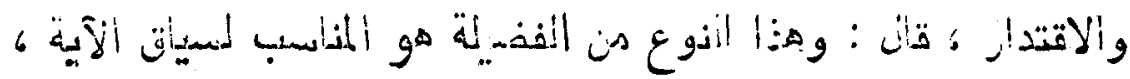

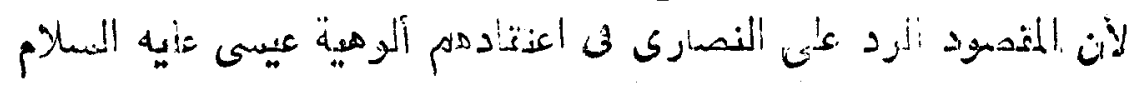

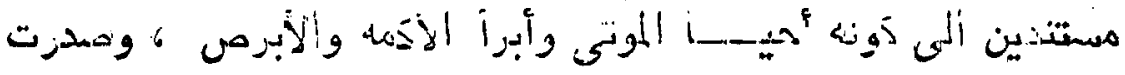

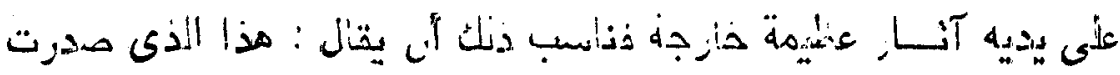

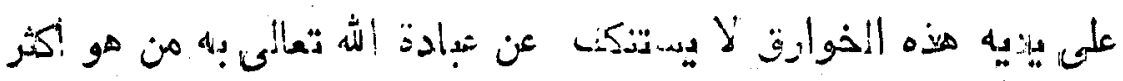

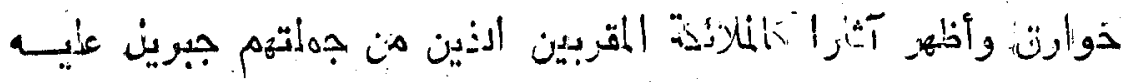

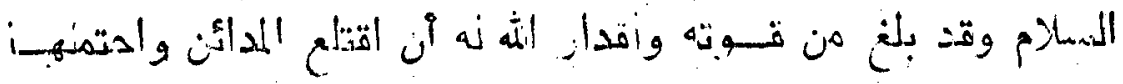

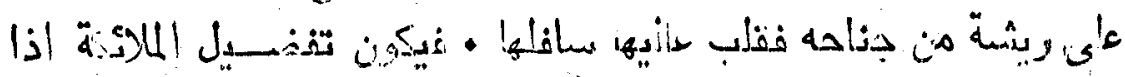

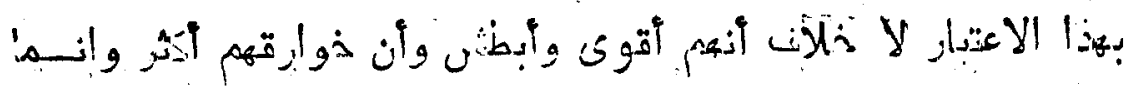

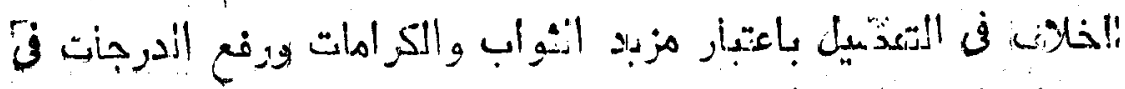

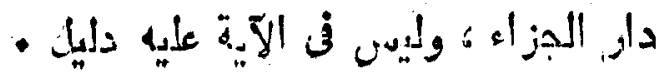

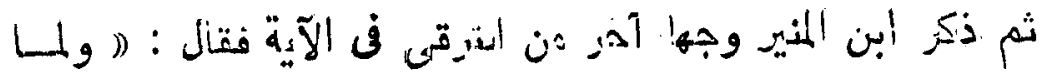

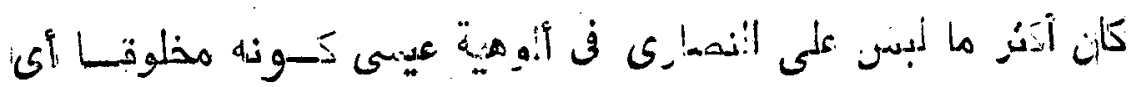

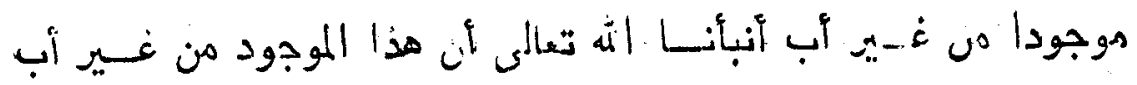

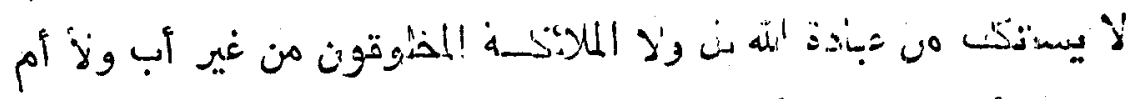

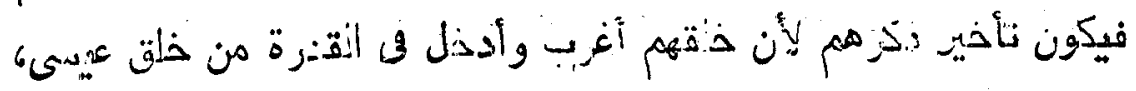

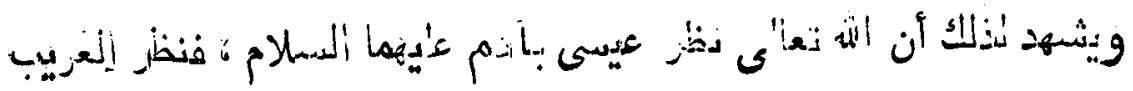

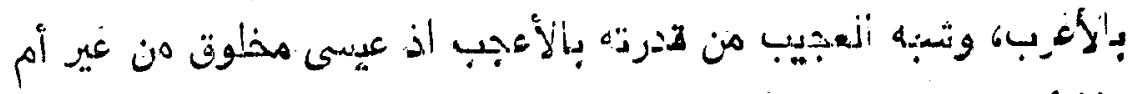

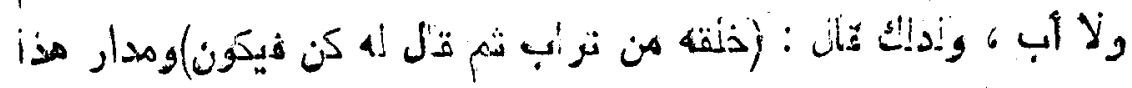

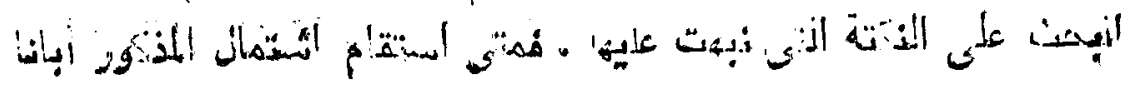


على نائدة لم يُّتهل عليها ألاون باى طزيق كان من تتضيل أو غير.

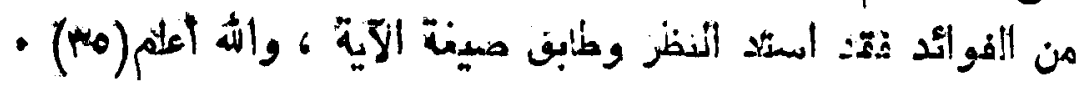
وانما ذكرت ند ابس المنير بطوله الأنه الأساس إلذى يعثمد عليه

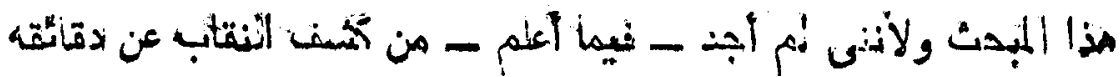

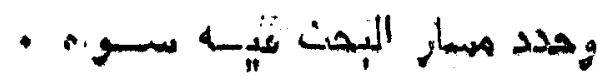

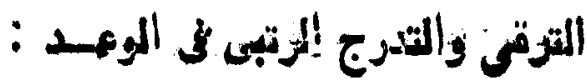

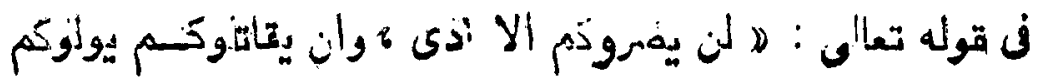

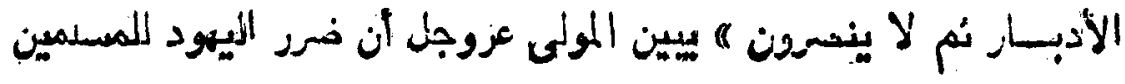

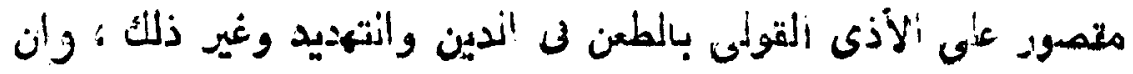

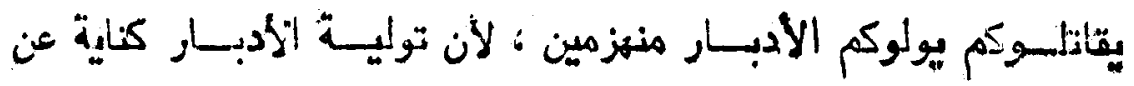

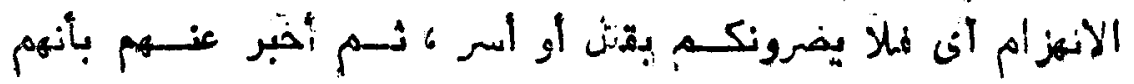

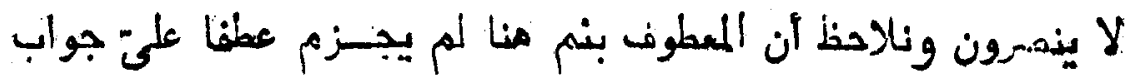

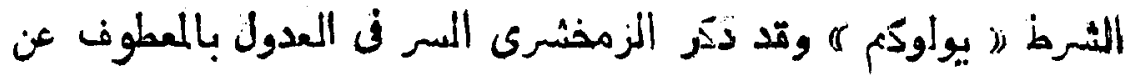

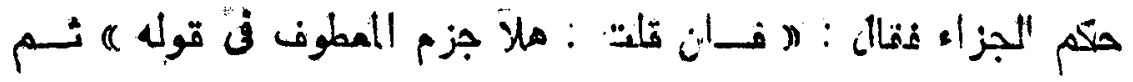

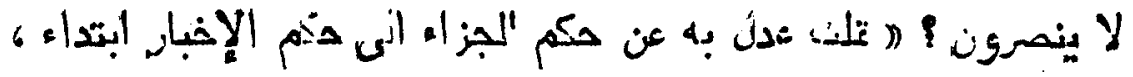

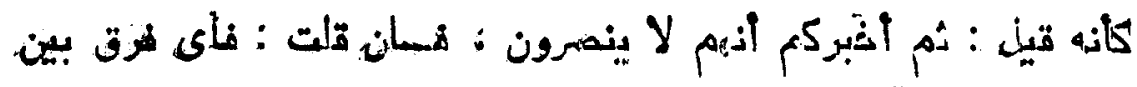

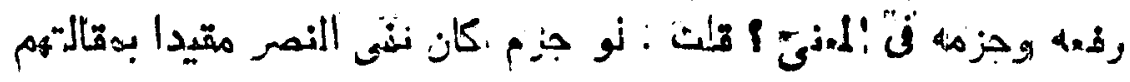

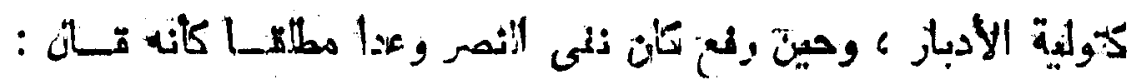

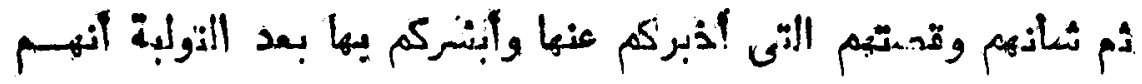

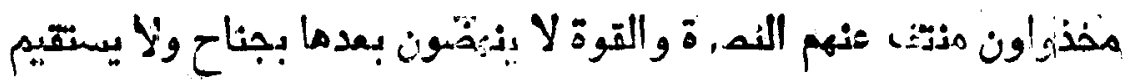

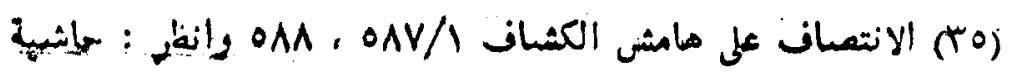

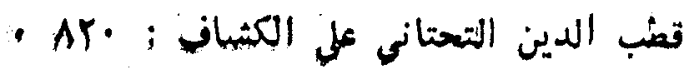
$1,-11$ 


\section{otr}

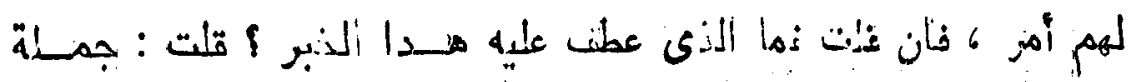

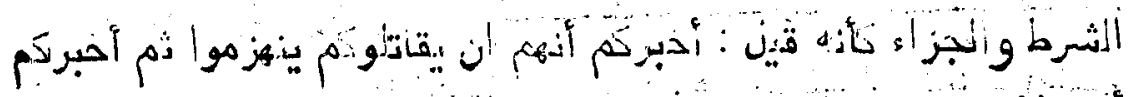

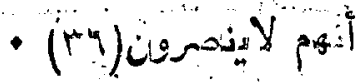

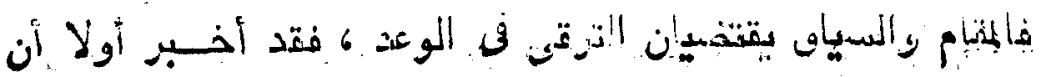

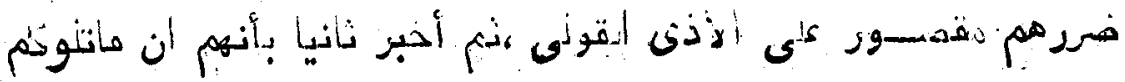

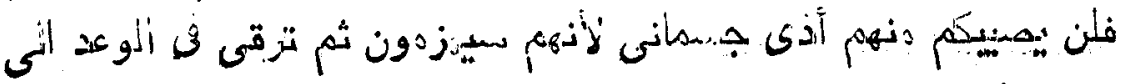

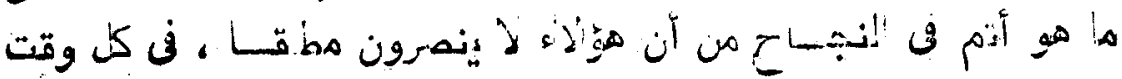

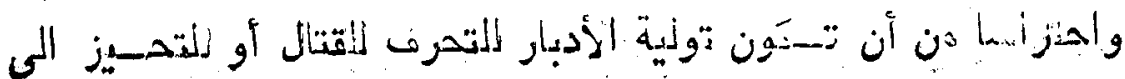

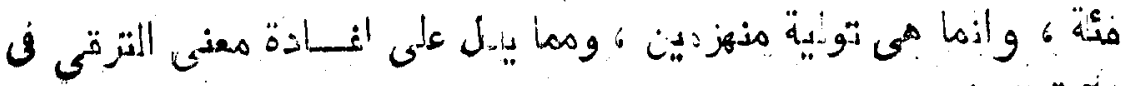

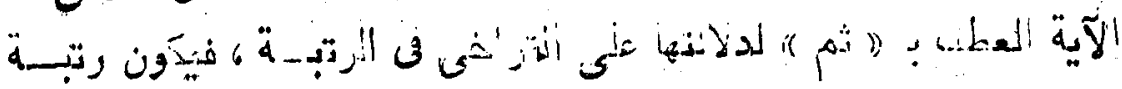

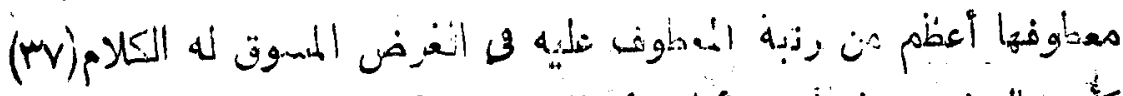

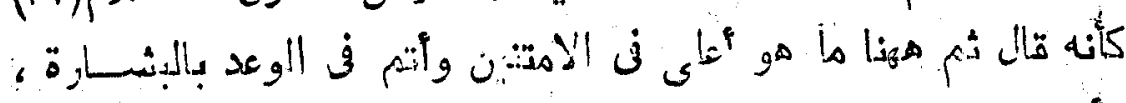

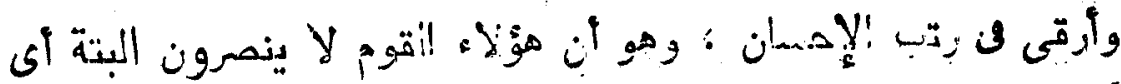

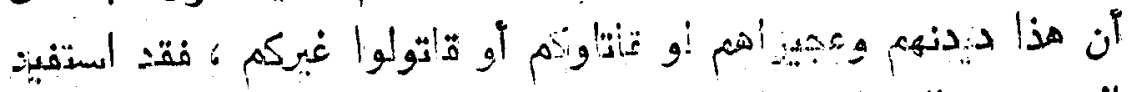

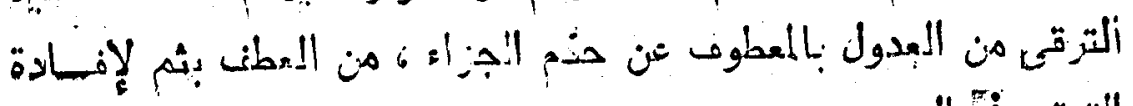

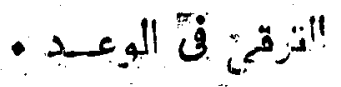

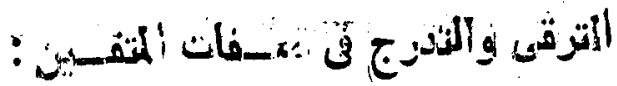

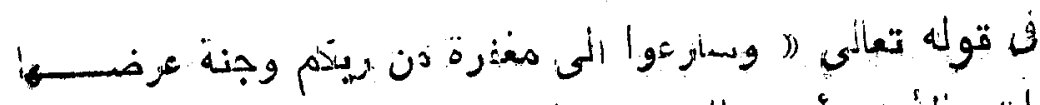

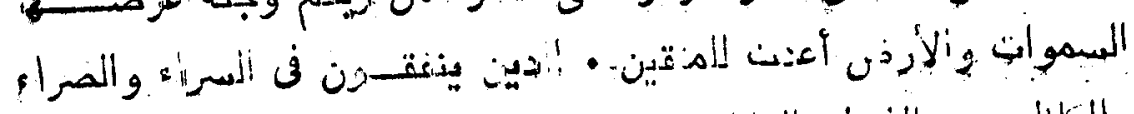

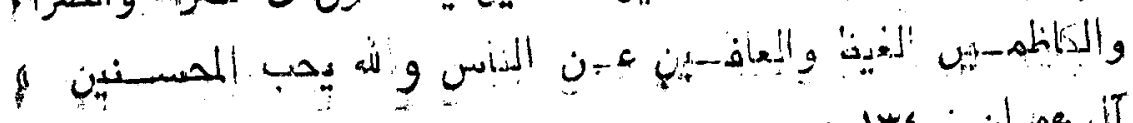

- Irq : ن it 
exp

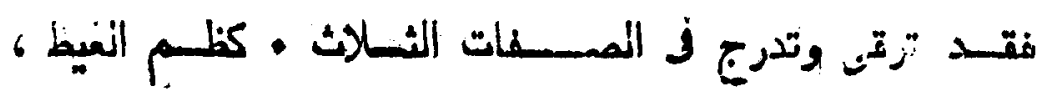

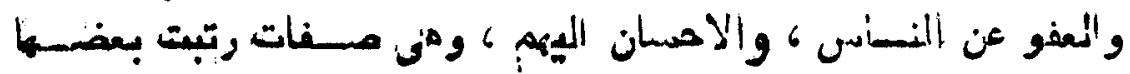

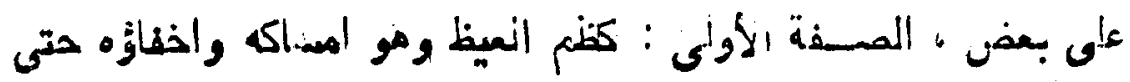

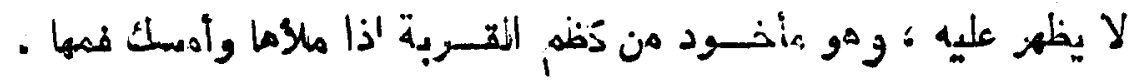

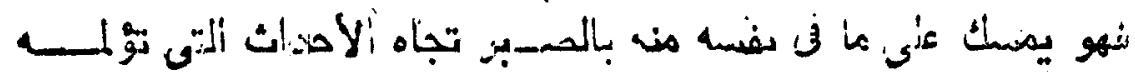

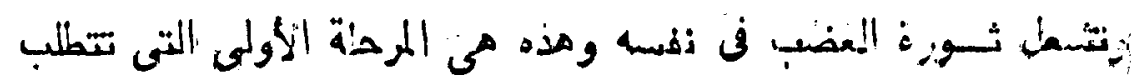

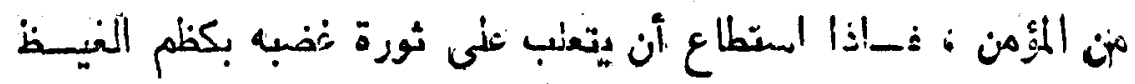

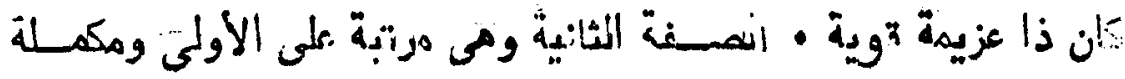

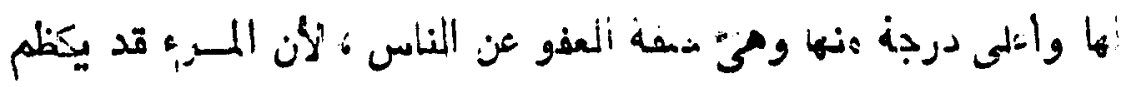

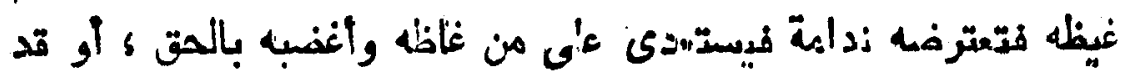

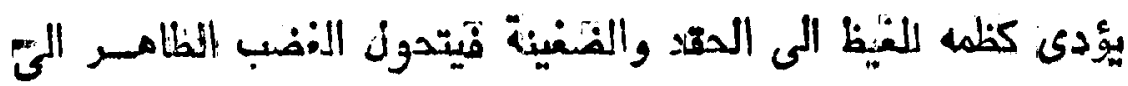

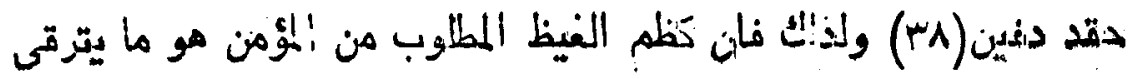

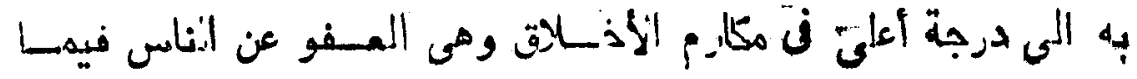

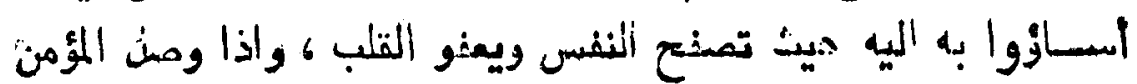

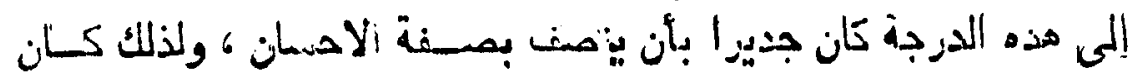

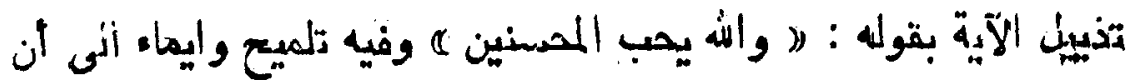

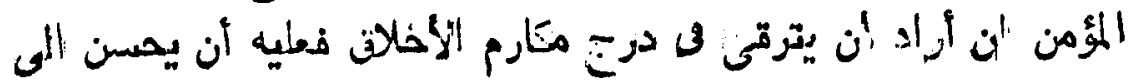

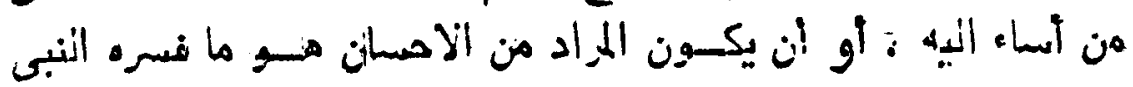

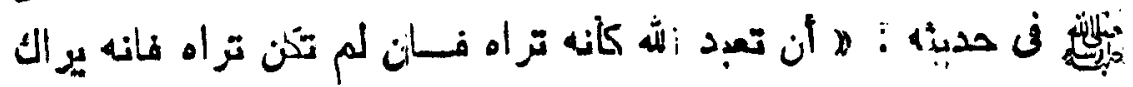

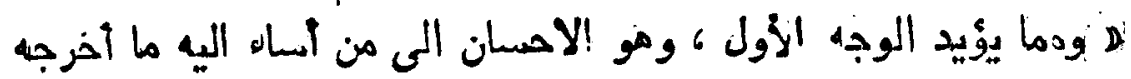

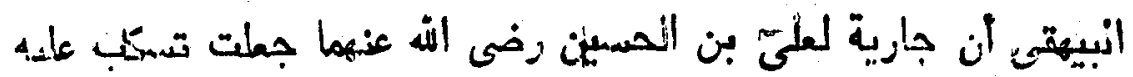

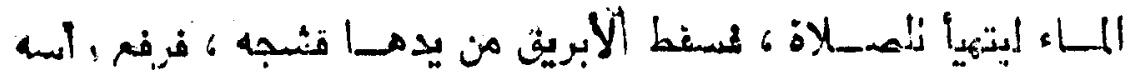

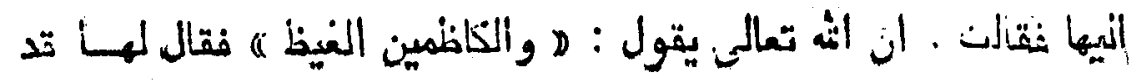

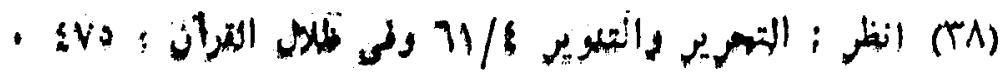




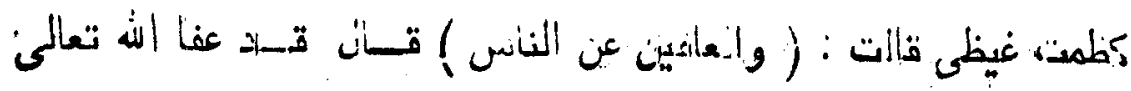

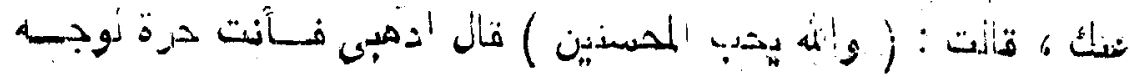
- (ri) (ril

وبمقتضن تانون ألبالاثة في ترتيب الصنسفات عندما يكون المقدم

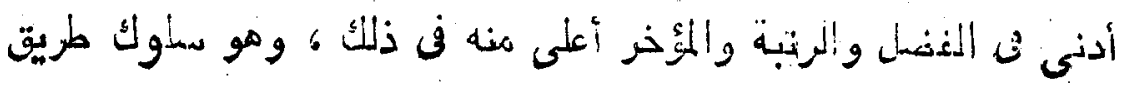

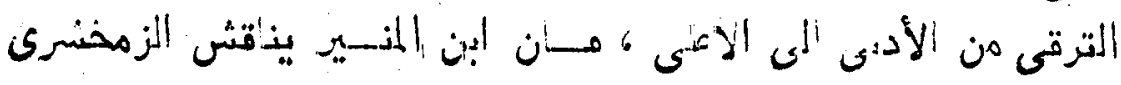

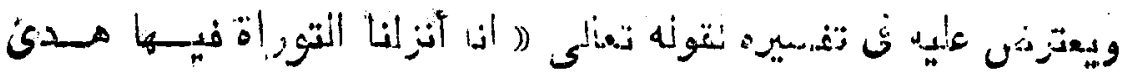

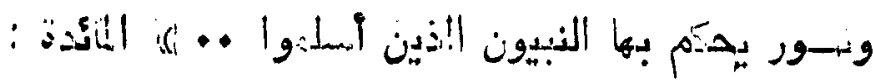

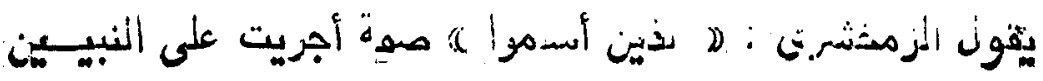

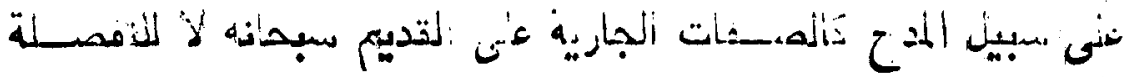

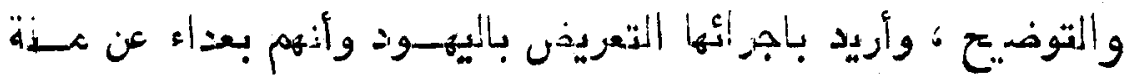

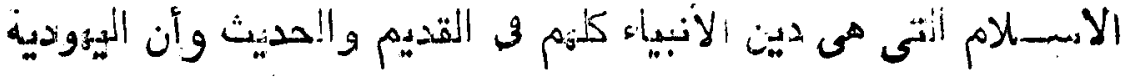

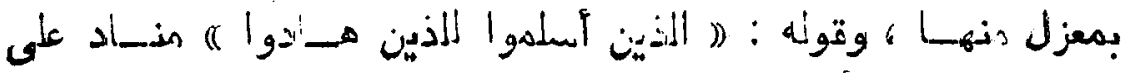

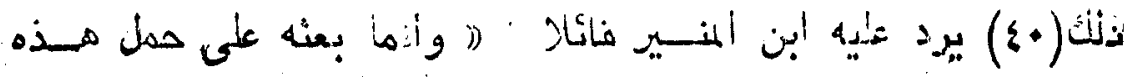

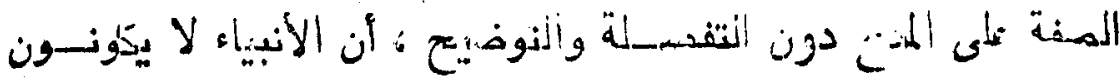

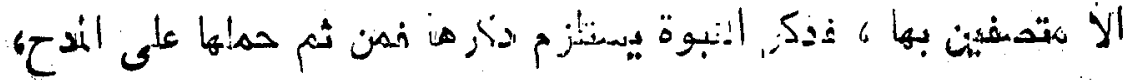

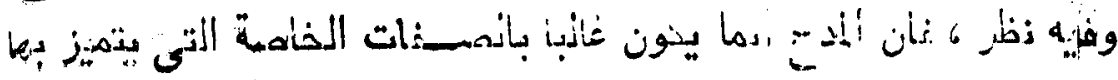

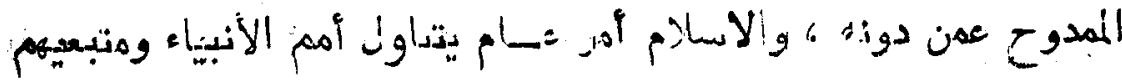

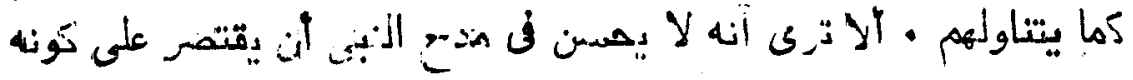

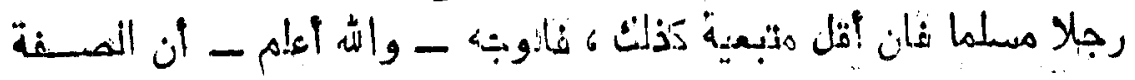

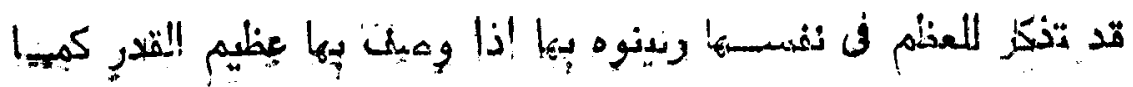


070

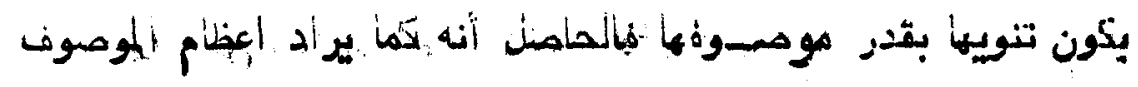

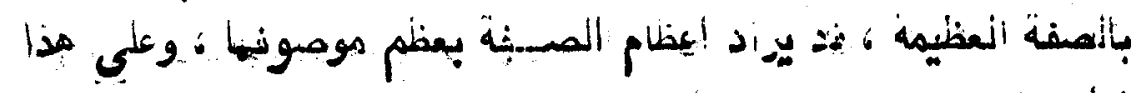

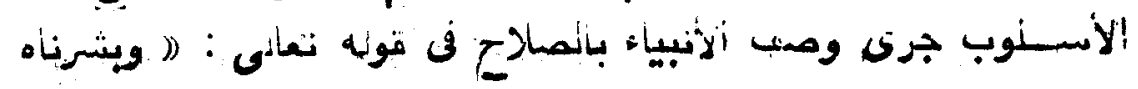

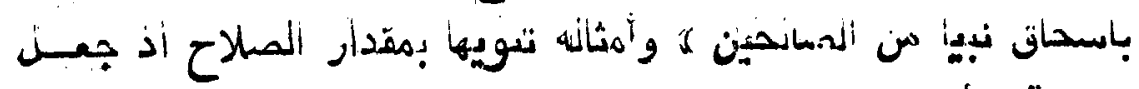

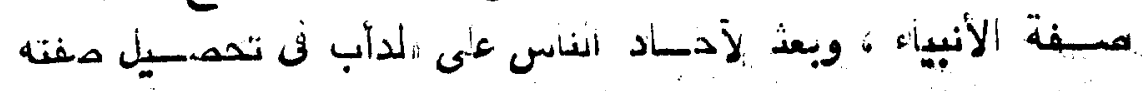

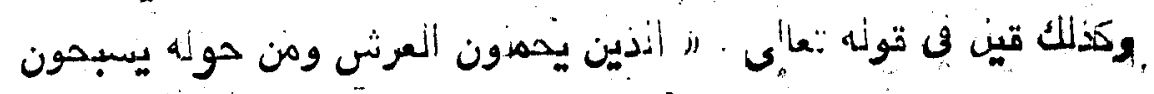

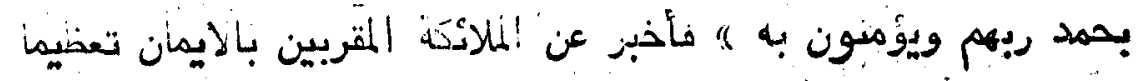

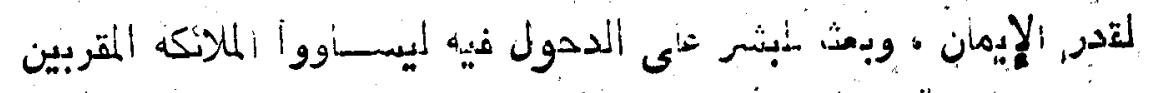

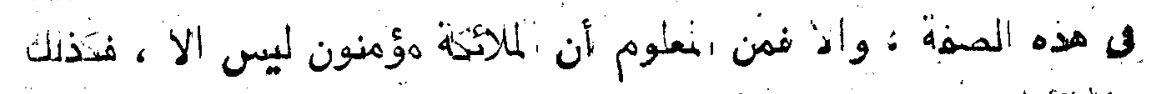

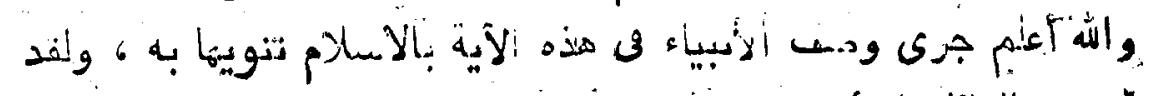

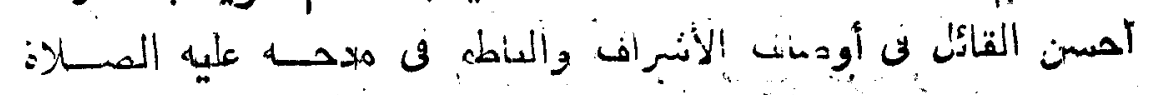

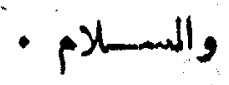

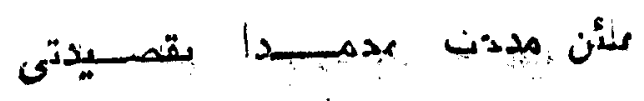

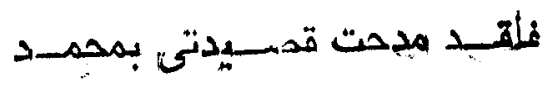

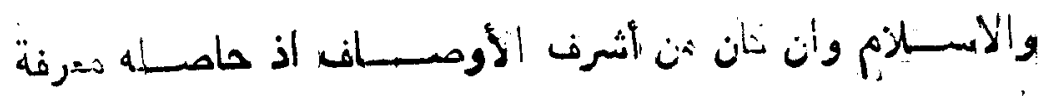

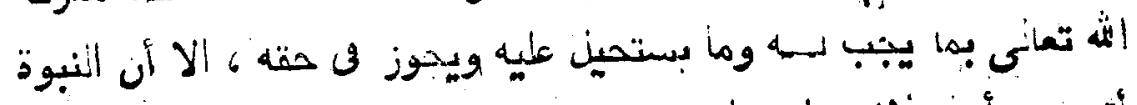

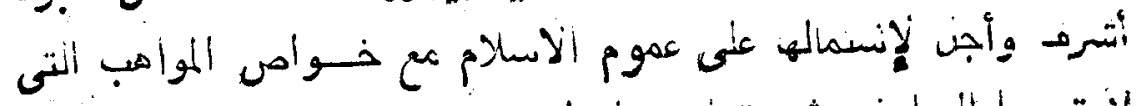

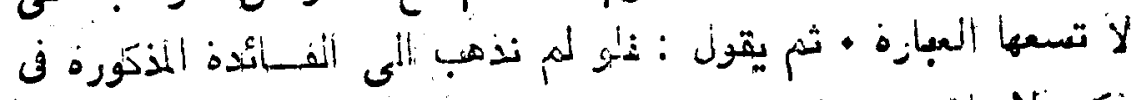

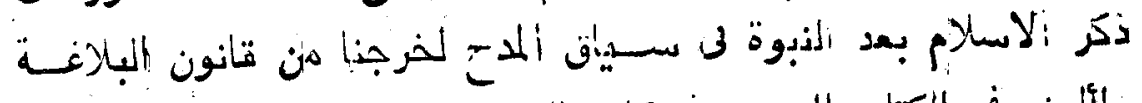

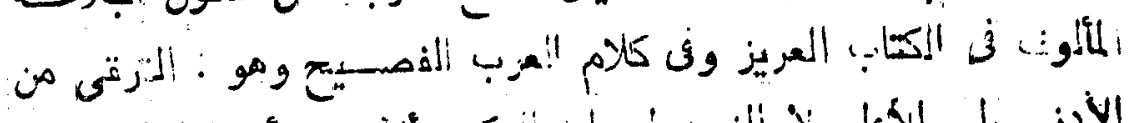

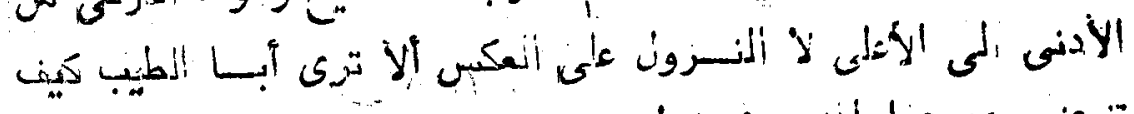

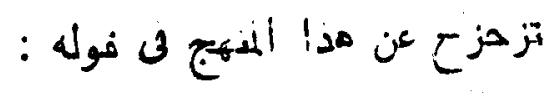

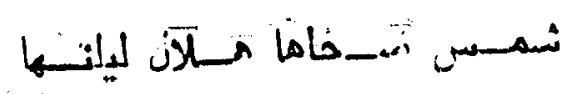

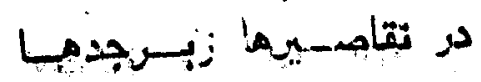




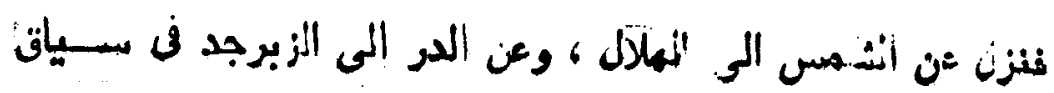

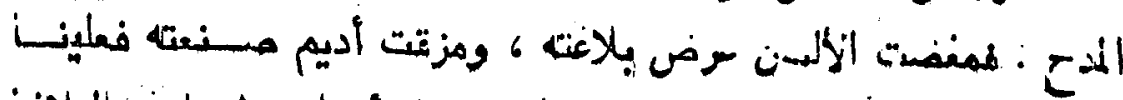

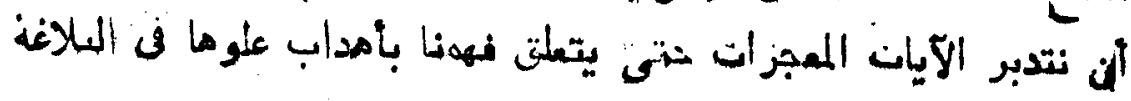

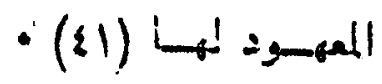

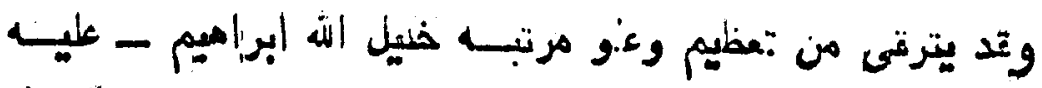

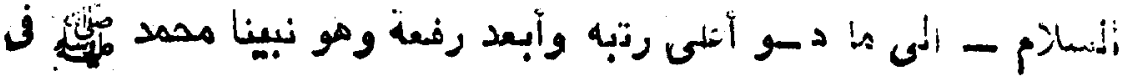

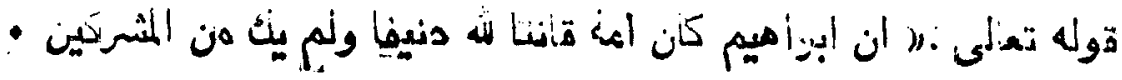

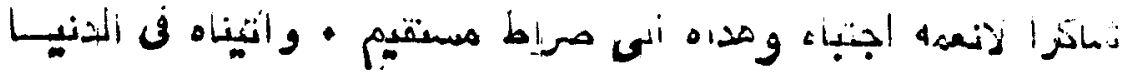

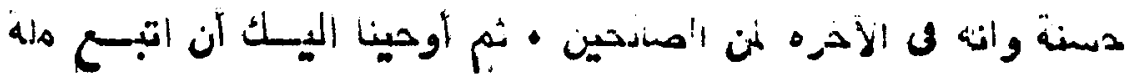

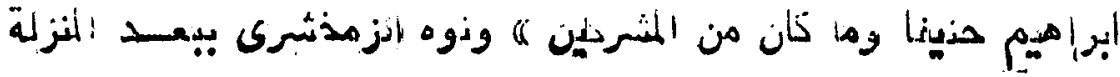

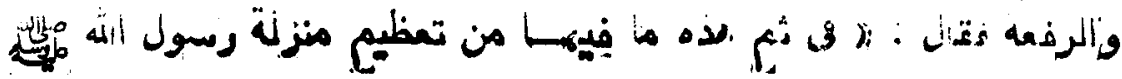

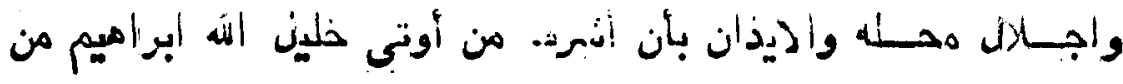

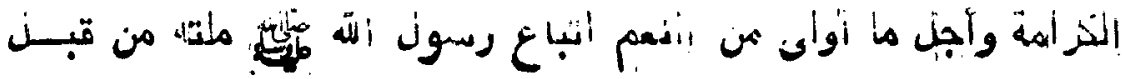

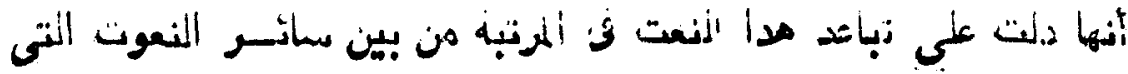

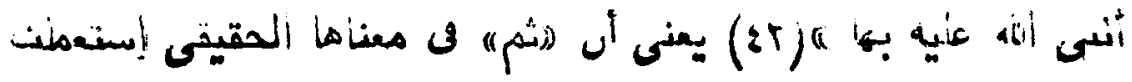

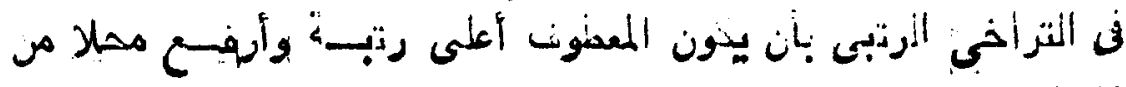

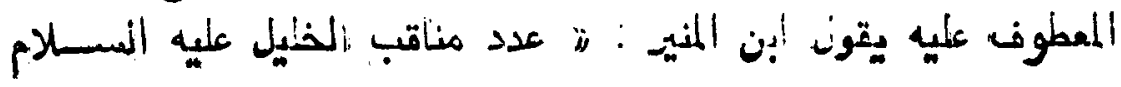

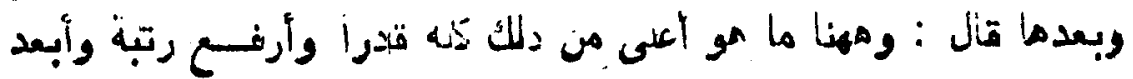

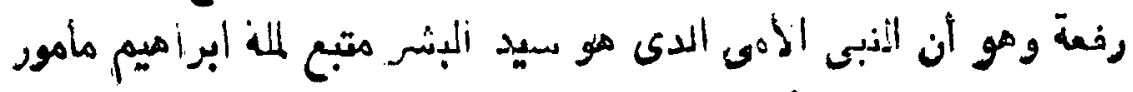

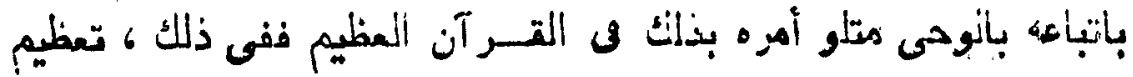

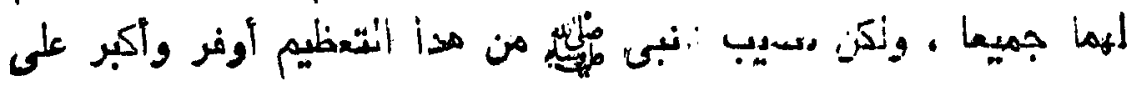

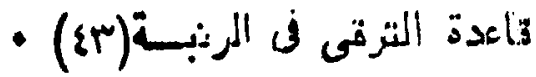

(8)

-

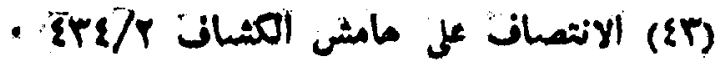


0.4

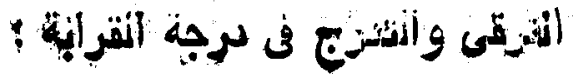

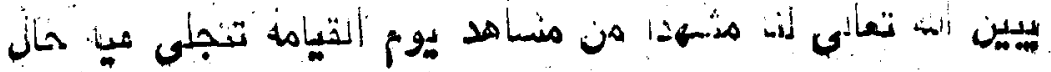

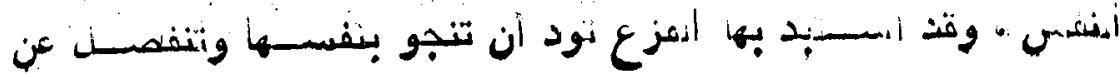

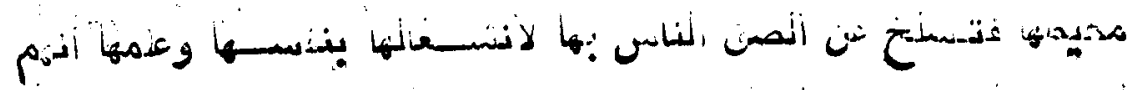

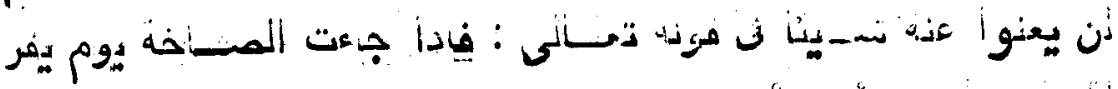

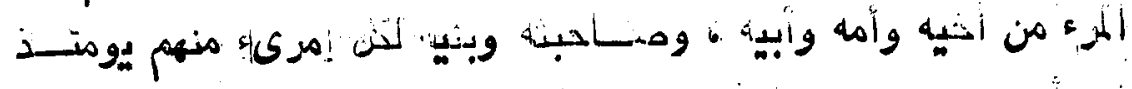

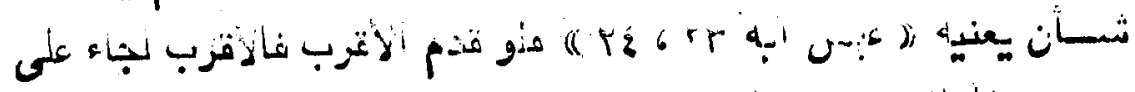

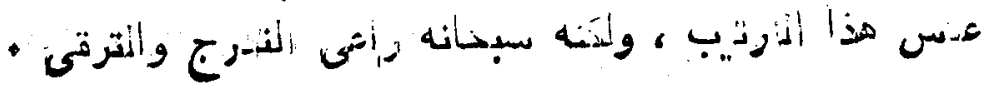

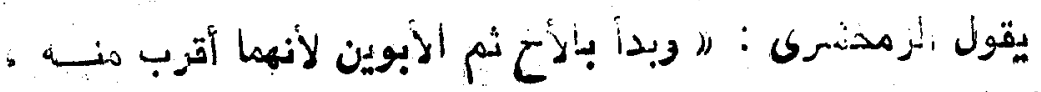

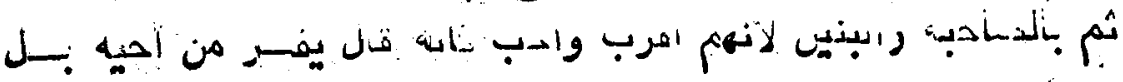

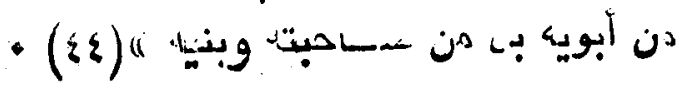

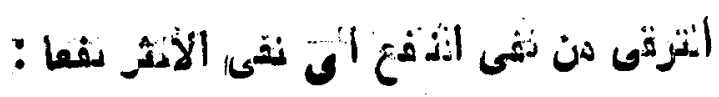

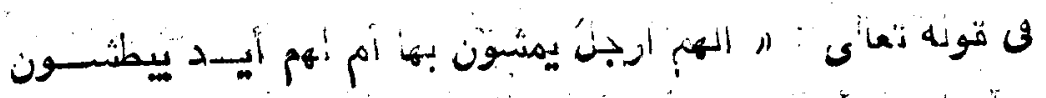

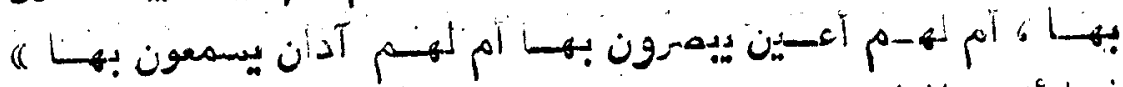

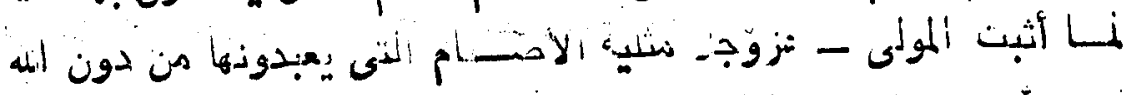

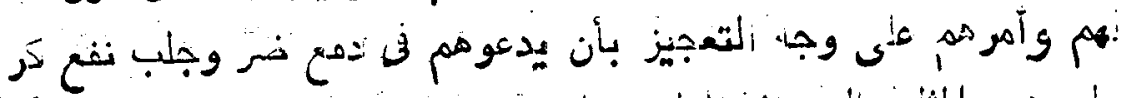

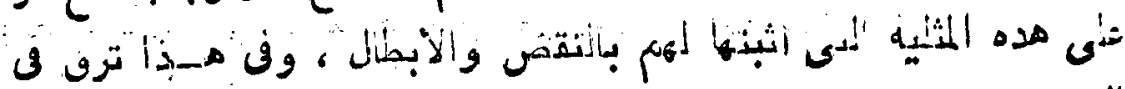

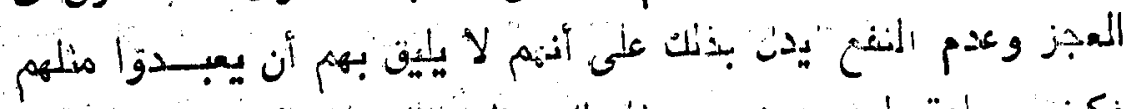

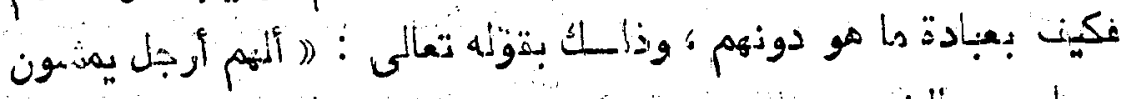

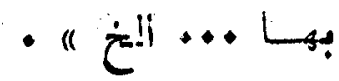

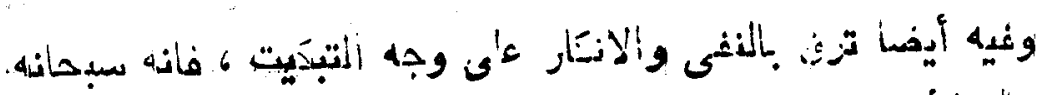

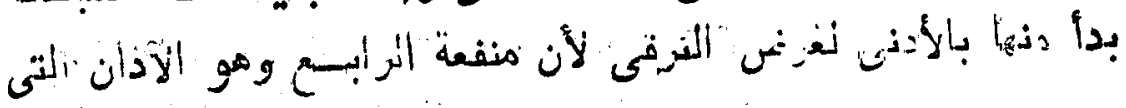




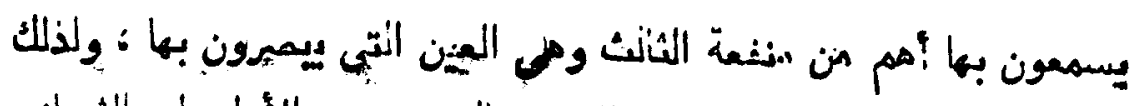

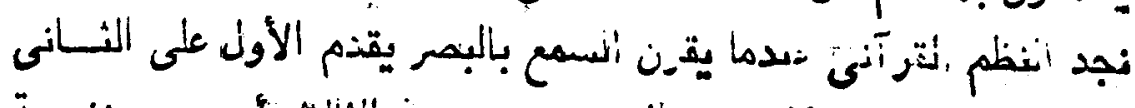

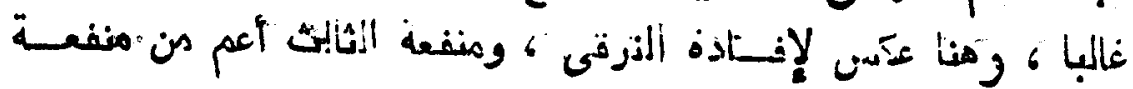

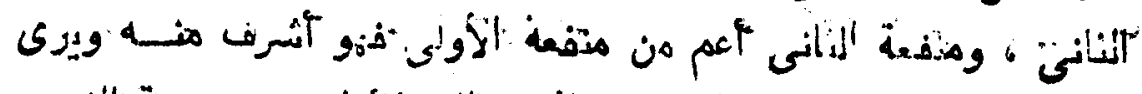

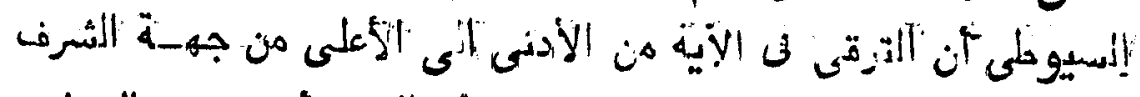

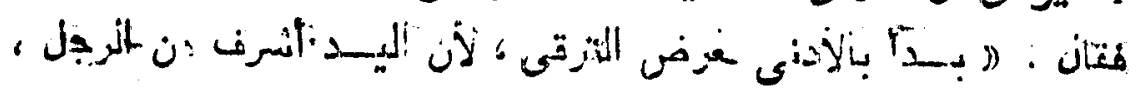

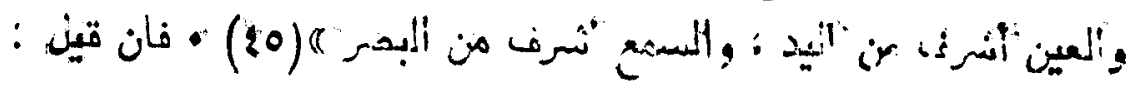

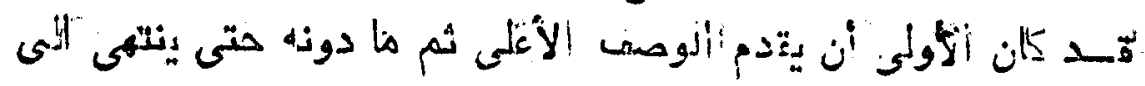

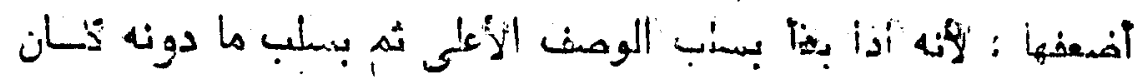

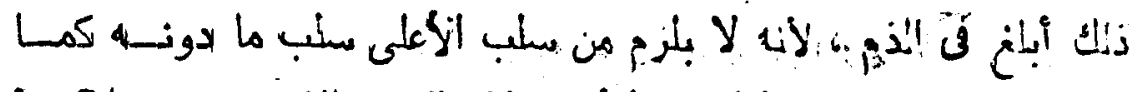

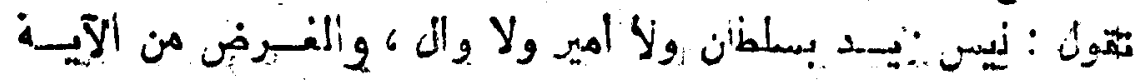

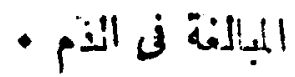

تلت : هذه ضريقت حسنه في علم ألمانى ، والمقدسود من الآية طريقة

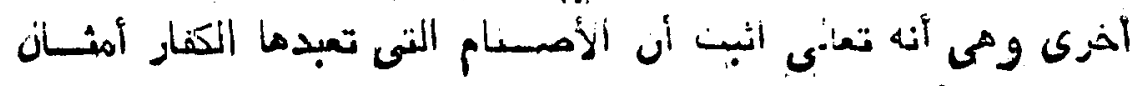

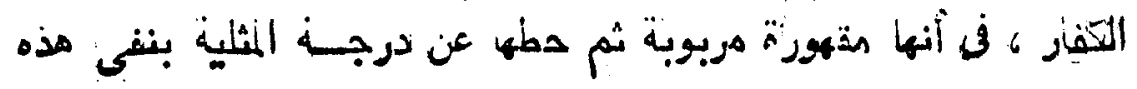

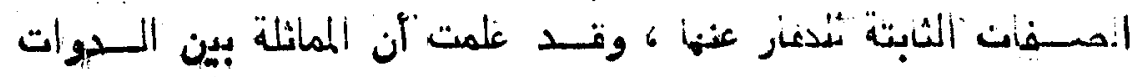

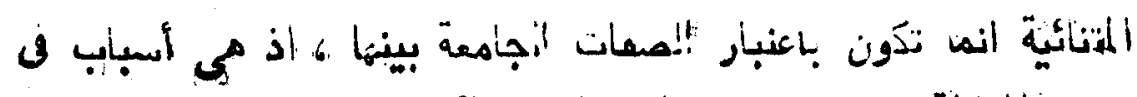

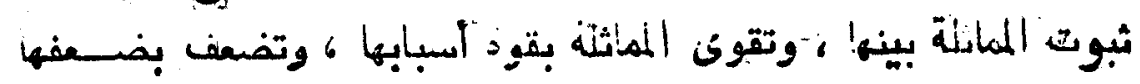

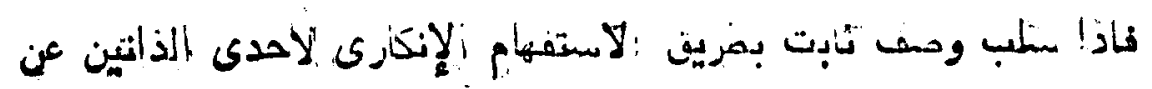

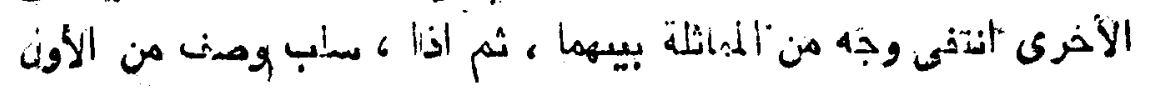

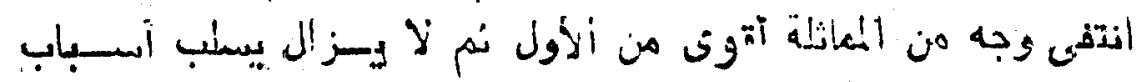

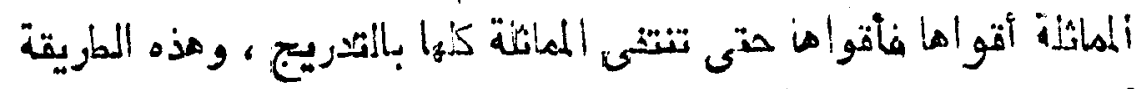

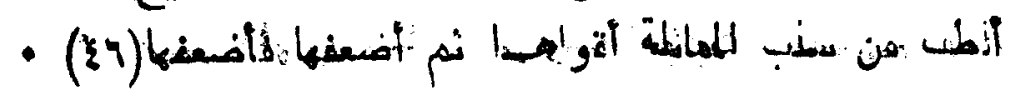

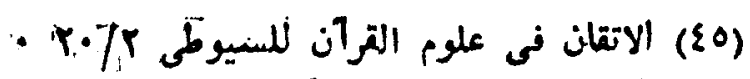

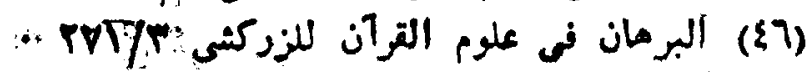




\section{9}

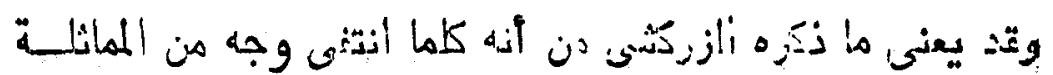

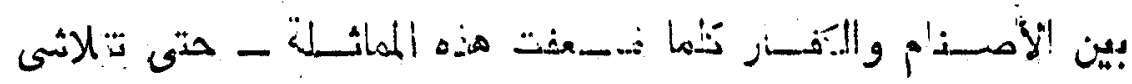

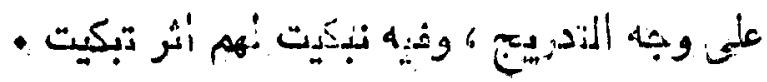

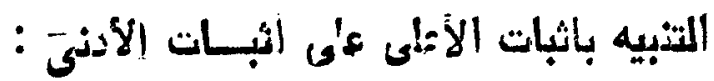

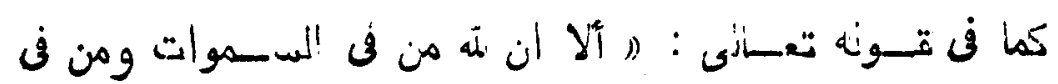

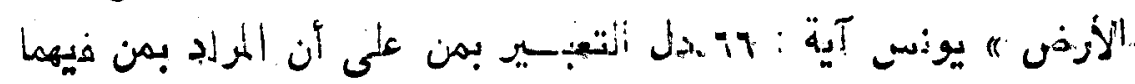

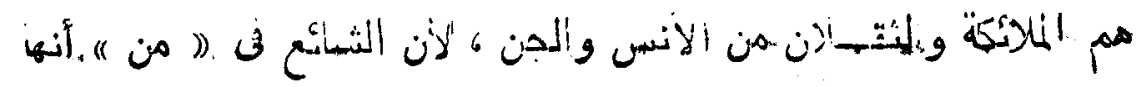

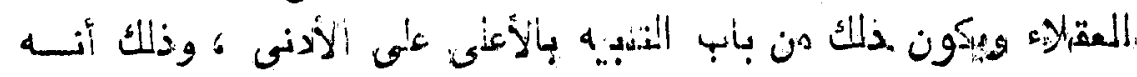

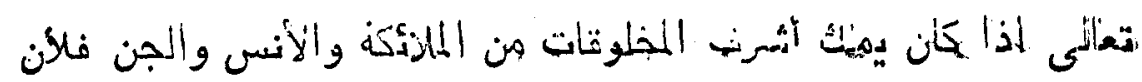

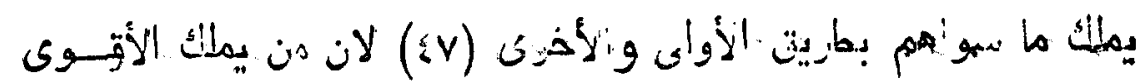

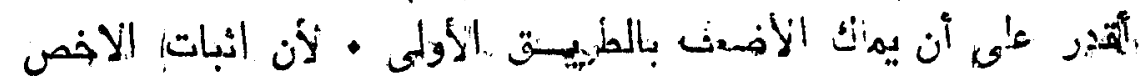

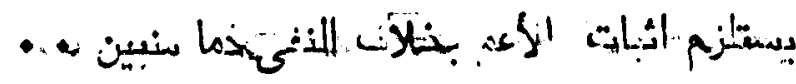
: النزييه بنفى الأدنى على نفي الأعلى :

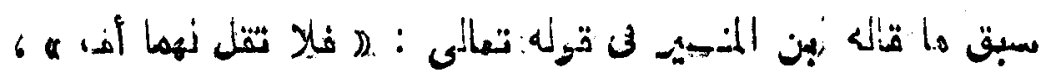

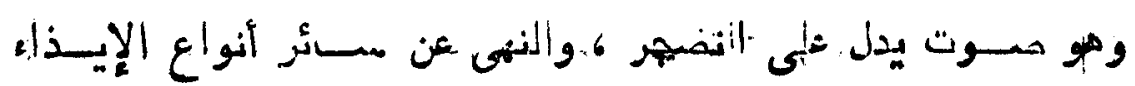

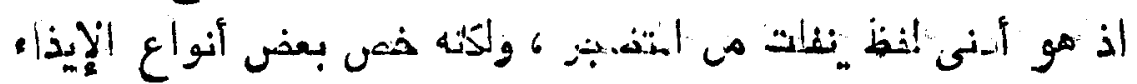

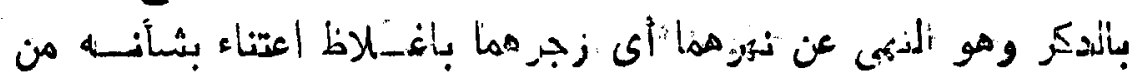

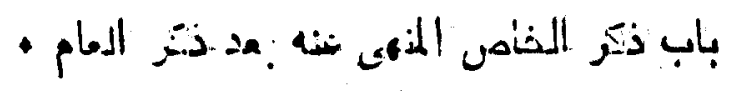

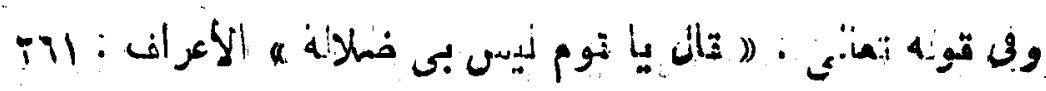

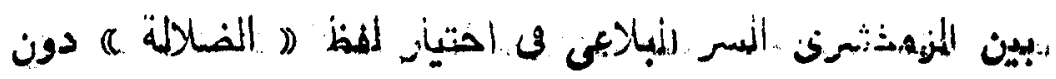

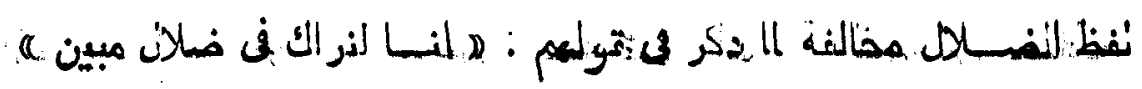

• انظز : الدور المصون للسمين الحلبي (£V) 


\section{ov.}

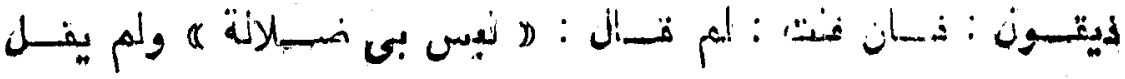

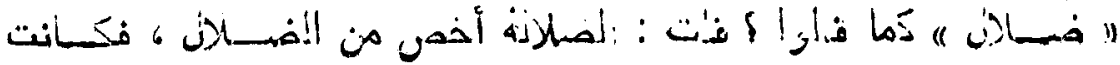

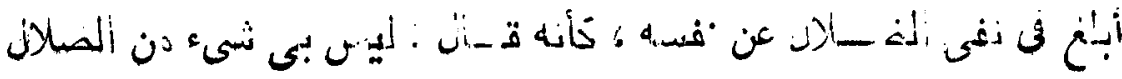

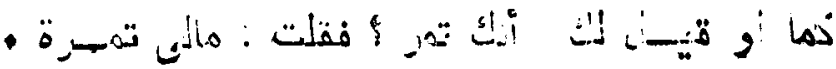

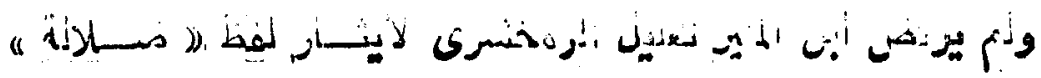

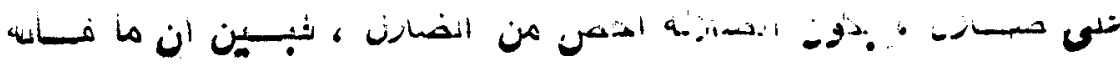

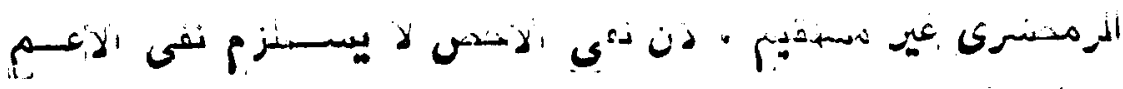

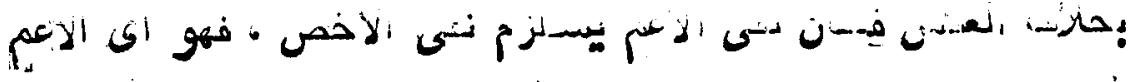

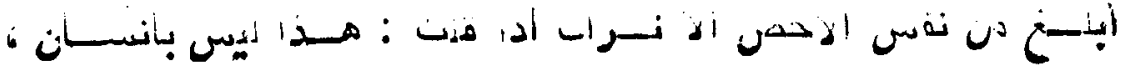

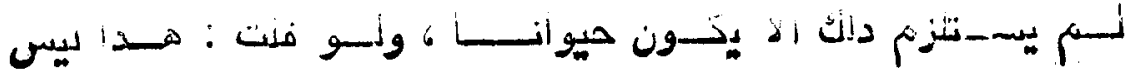

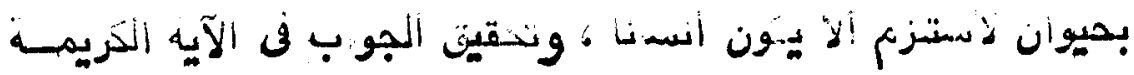

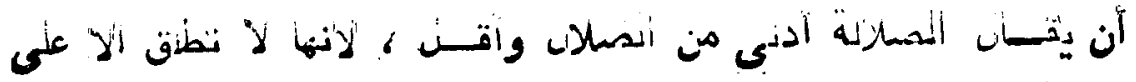

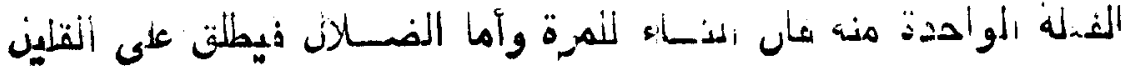

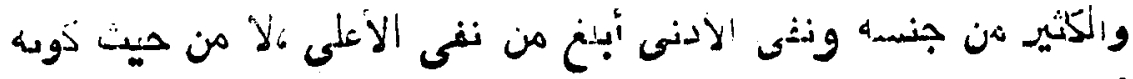

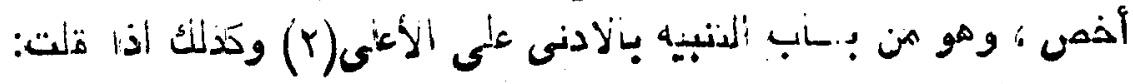

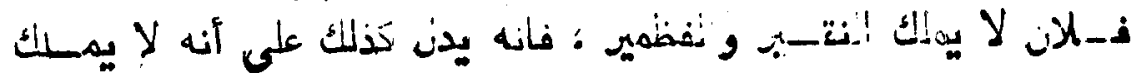

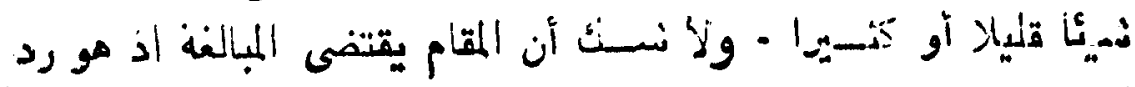

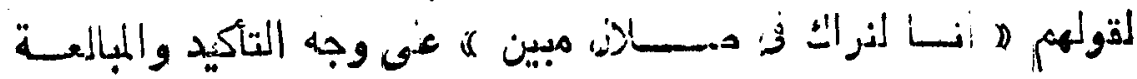

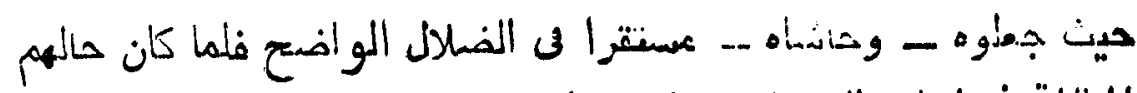

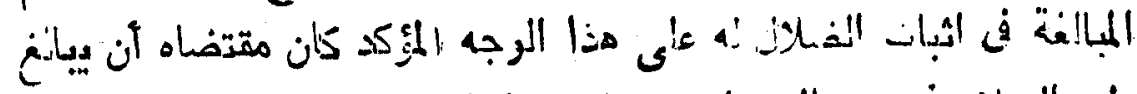

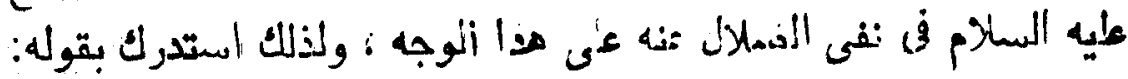

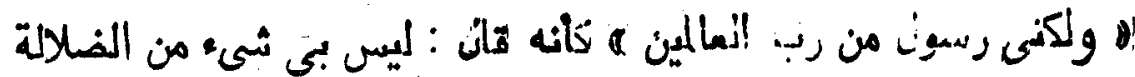

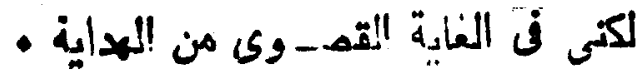


Tovi

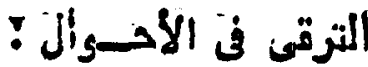

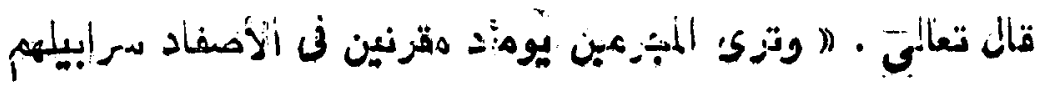

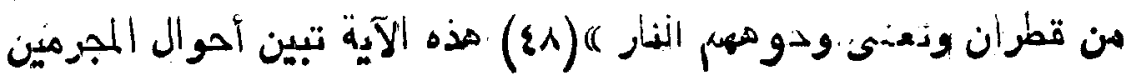

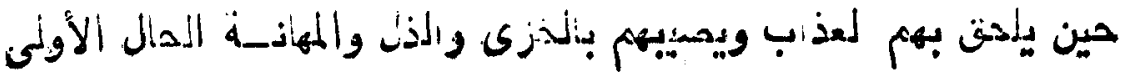

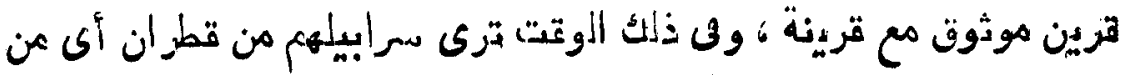

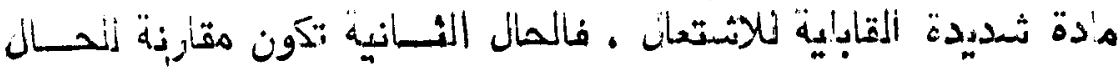

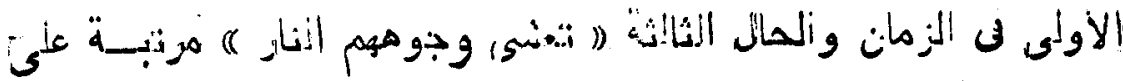

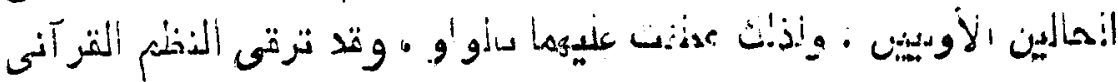

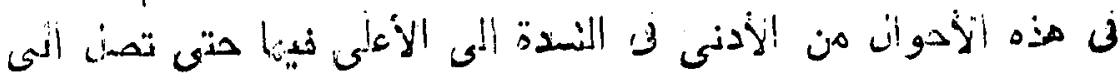

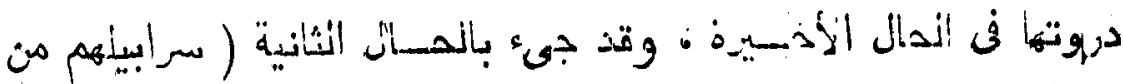

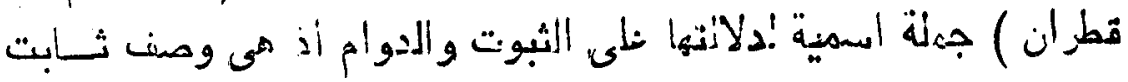

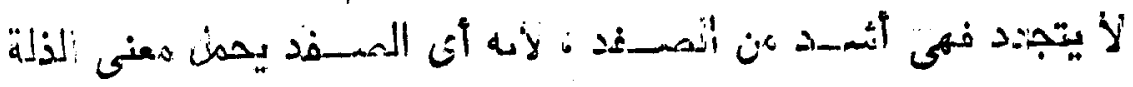

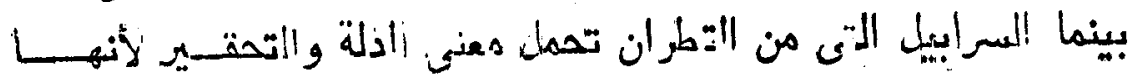

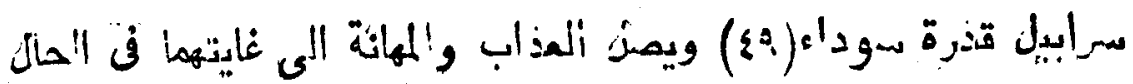

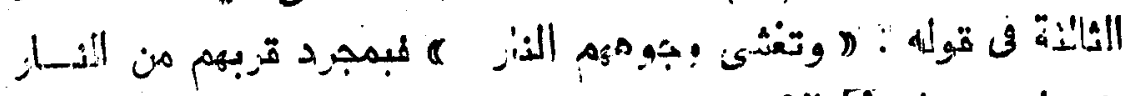

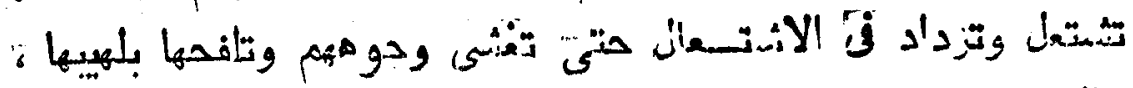

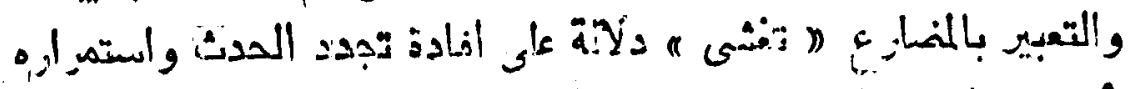

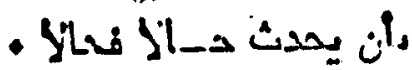

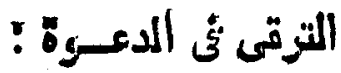

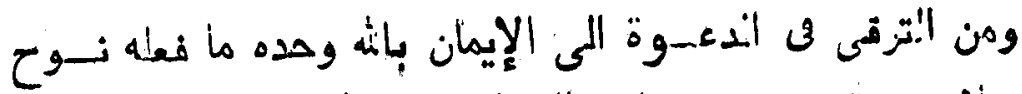

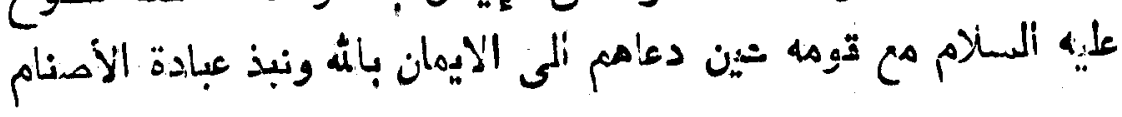

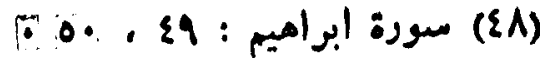

- riIr/\& \& 


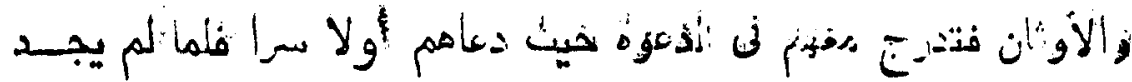

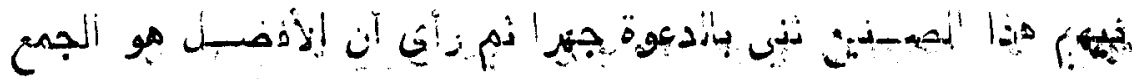

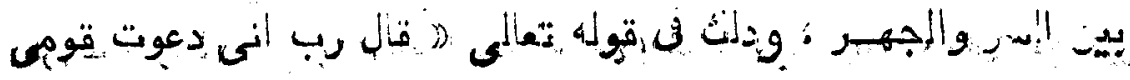

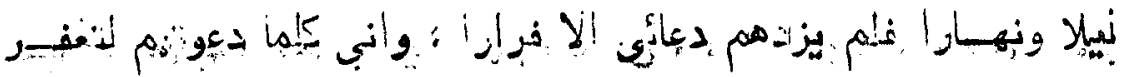

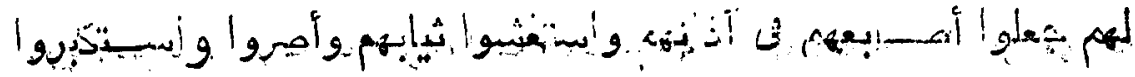

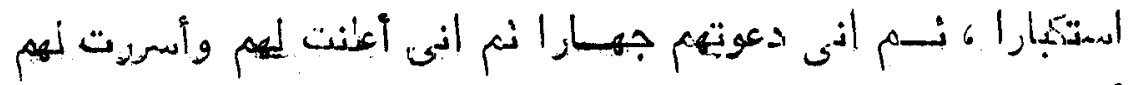

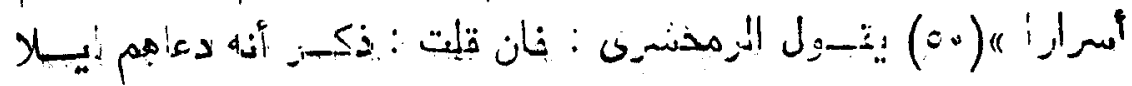

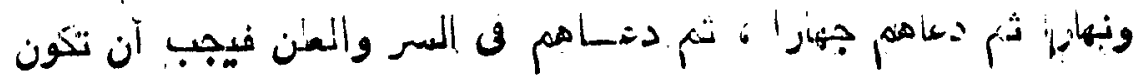

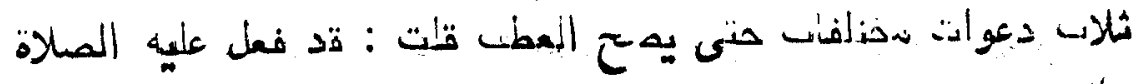

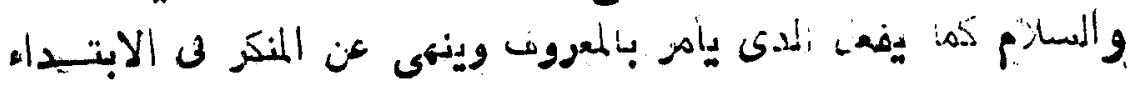

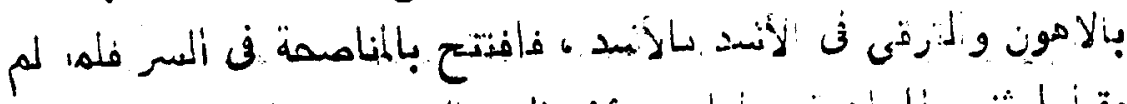

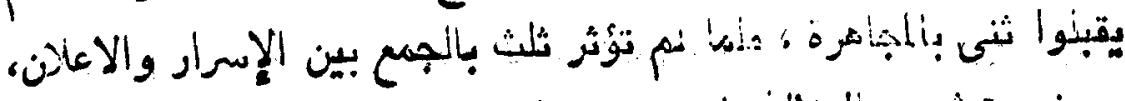

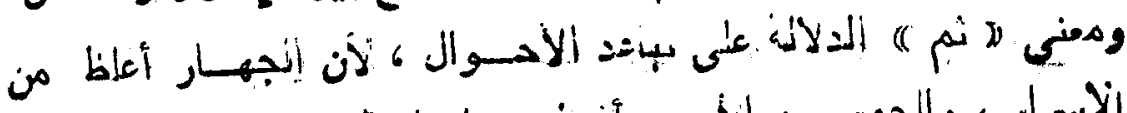

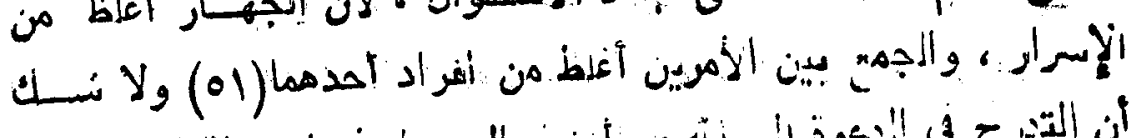

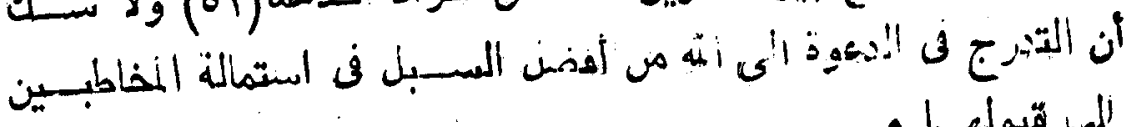

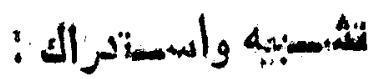

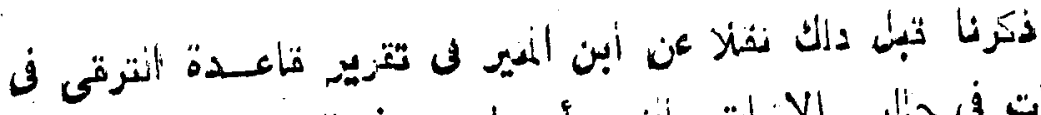

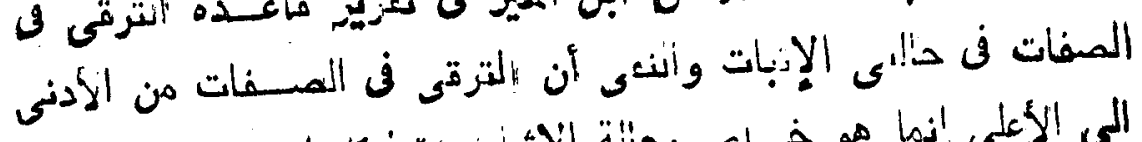

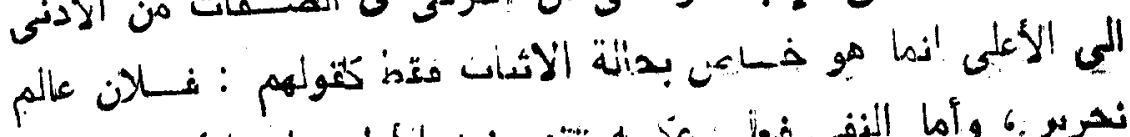

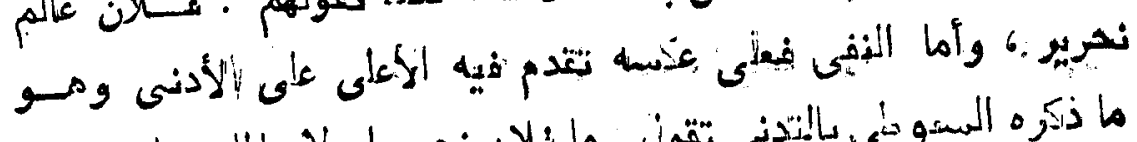

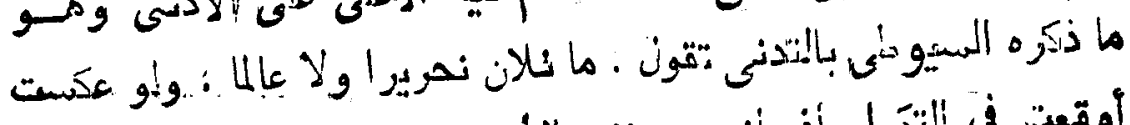

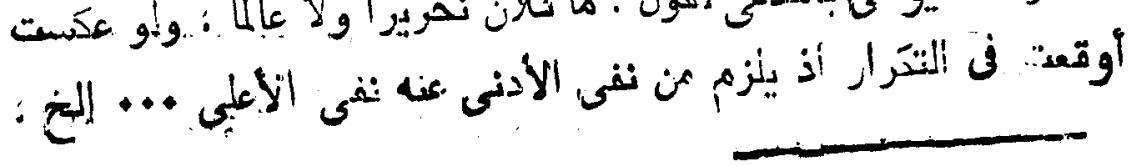

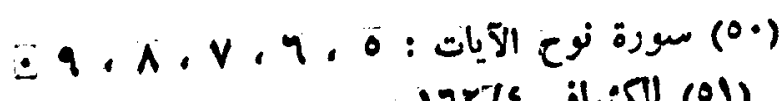

$$
\begin{aligned}
& \text { - } 17 r / \& \text { \& }
\end{aligned}
$$


ovr

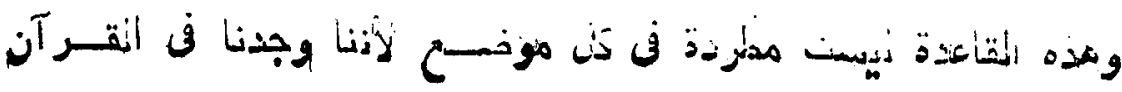

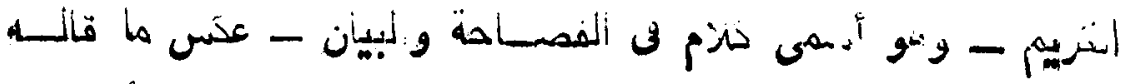

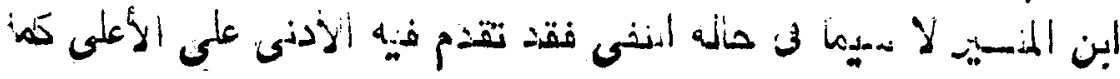

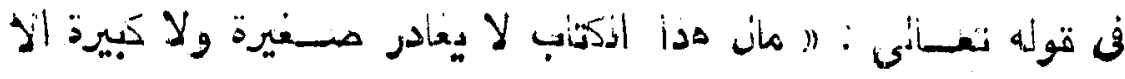

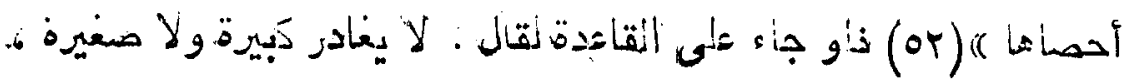

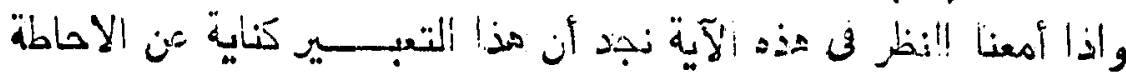

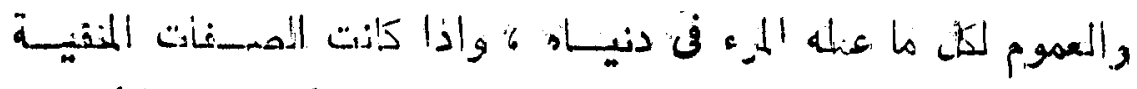

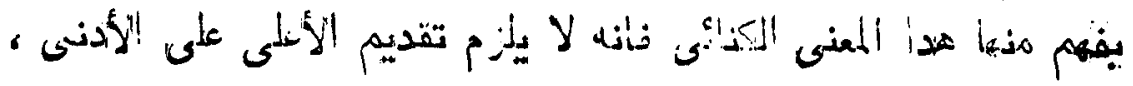

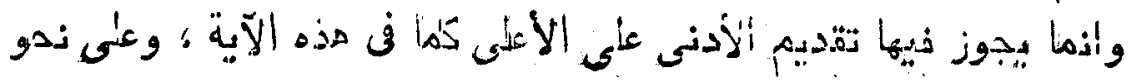

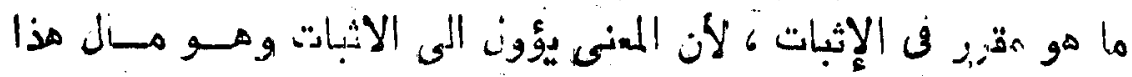

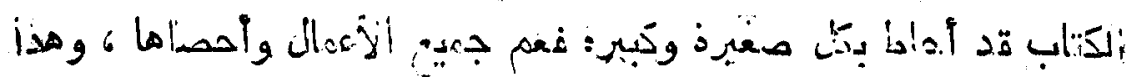

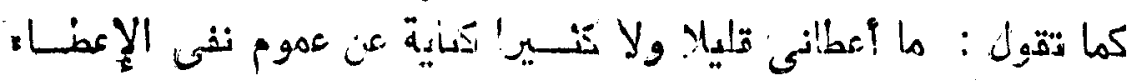

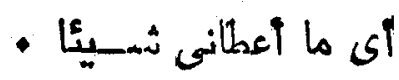

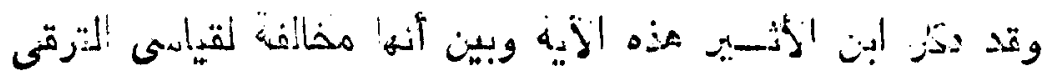

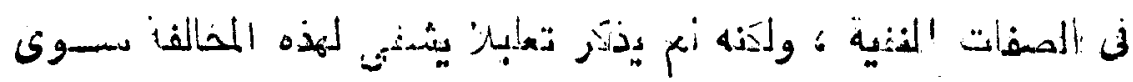

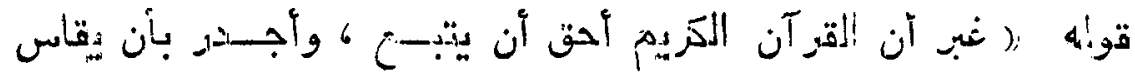

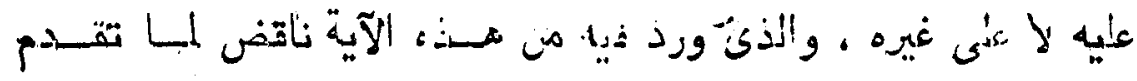

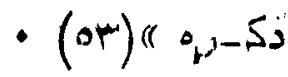

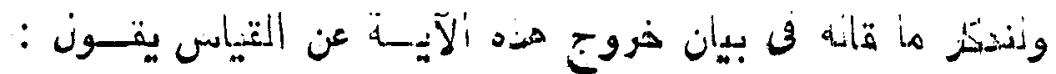

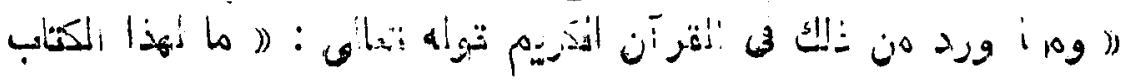

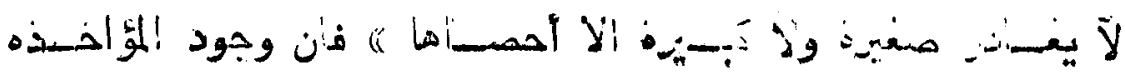

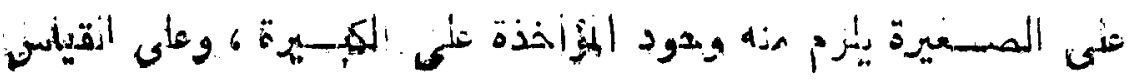




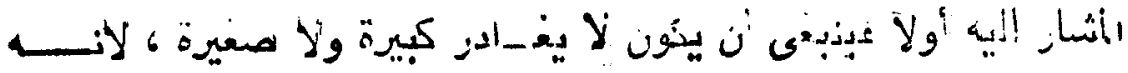

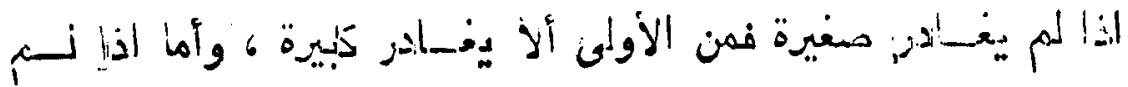

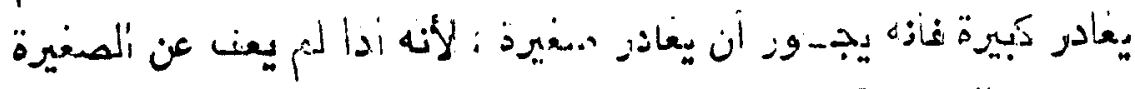

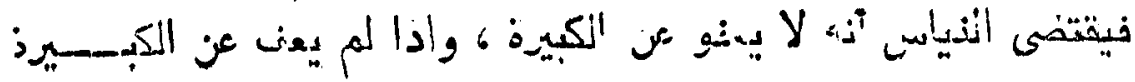

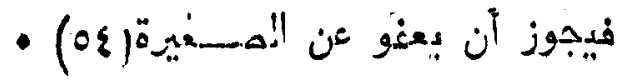

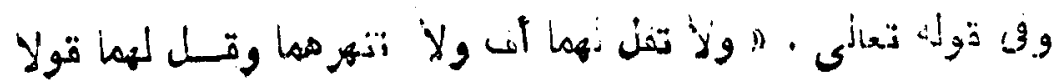
- (oc) \& 8 is

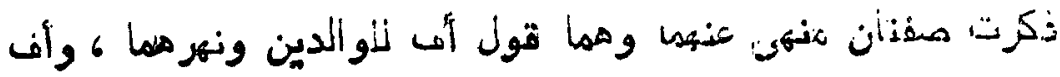

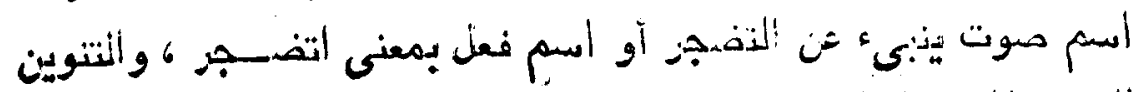

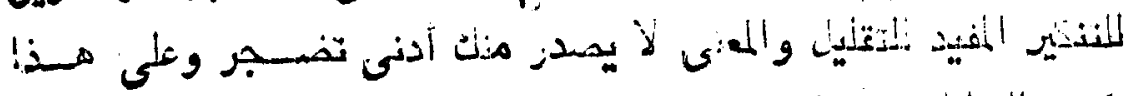

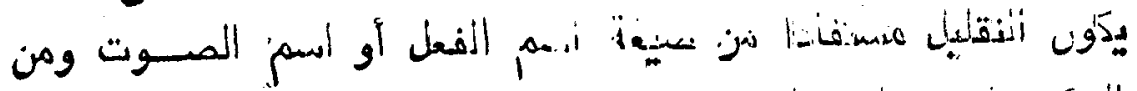

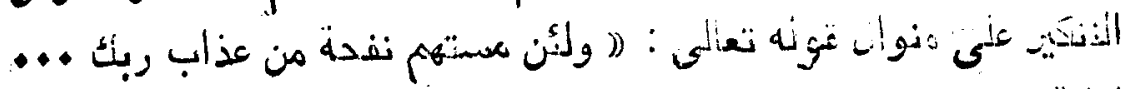

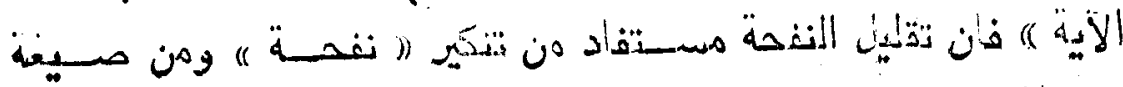

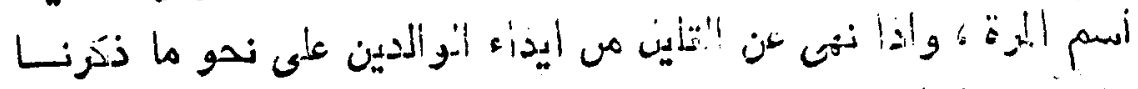

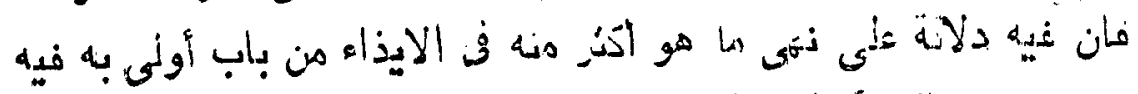

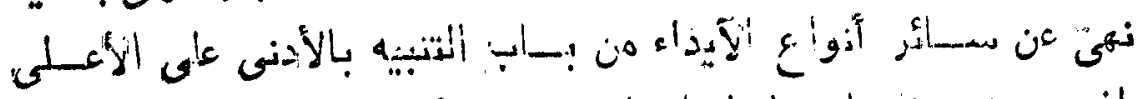

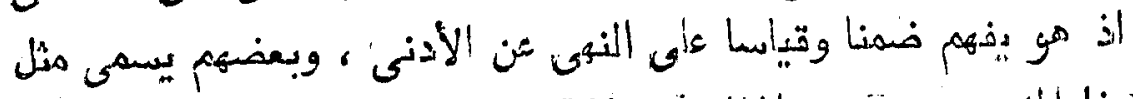

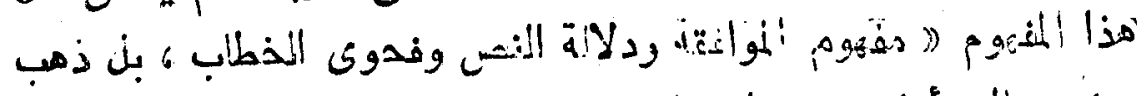

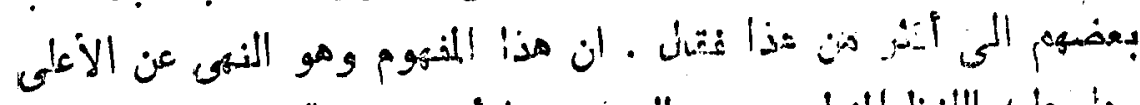

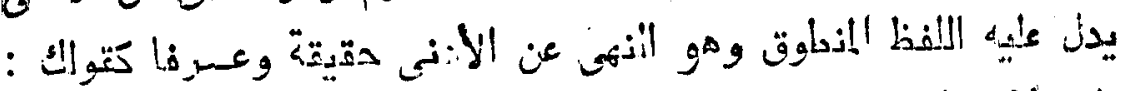

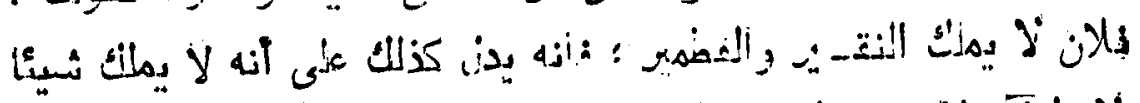

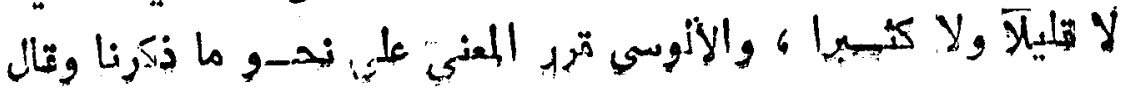


ovo

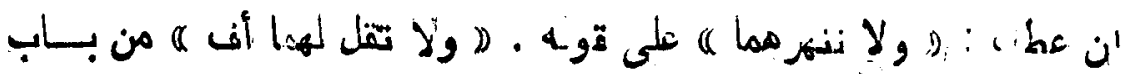

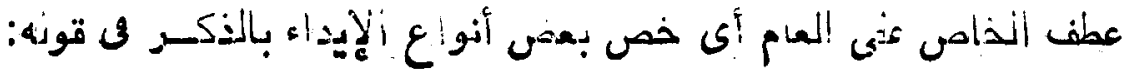

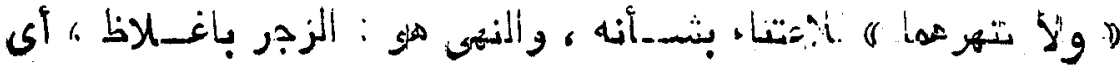

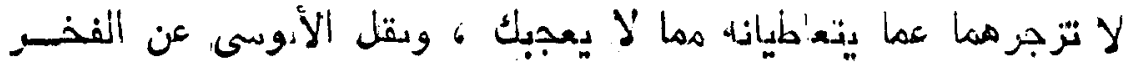

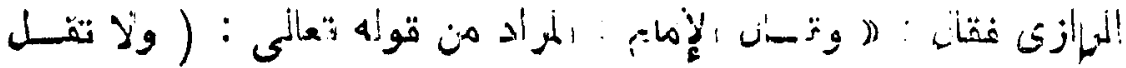

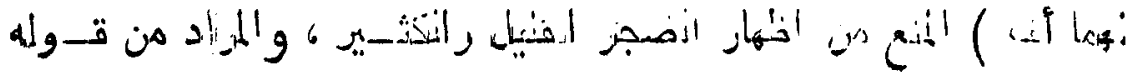

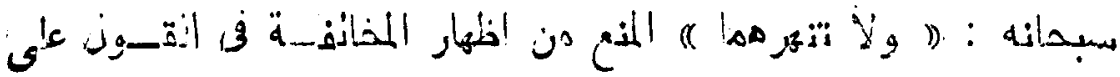

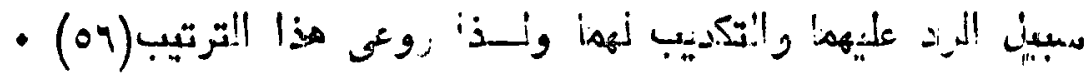

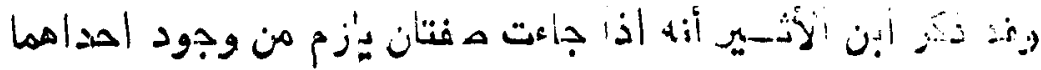

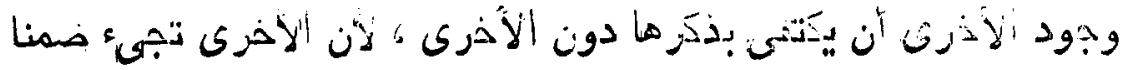

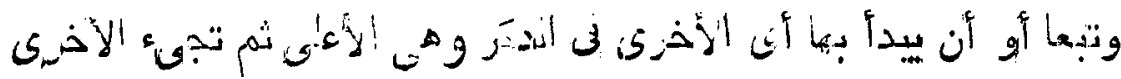

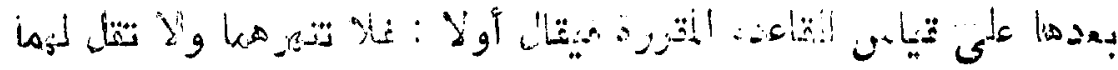

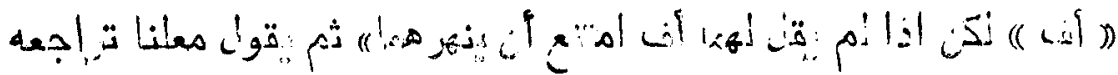

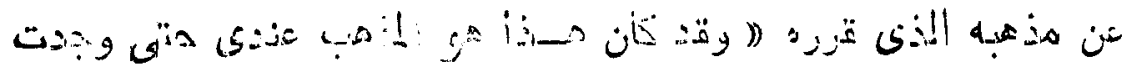

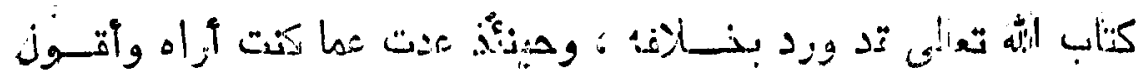
- (ov) \&

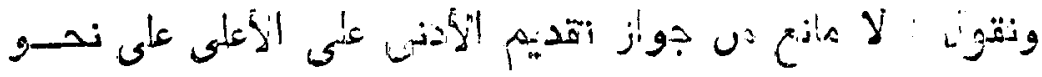

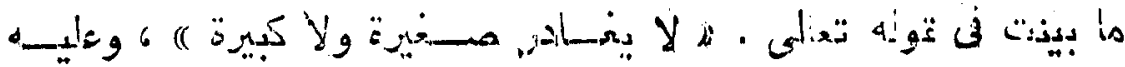

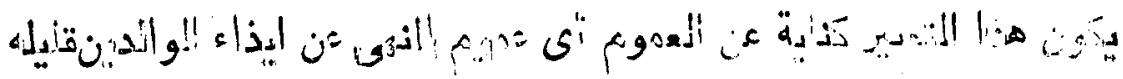

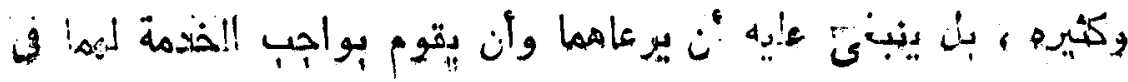

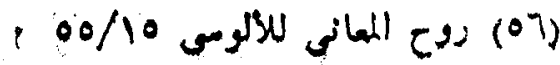

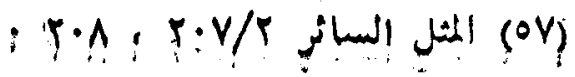




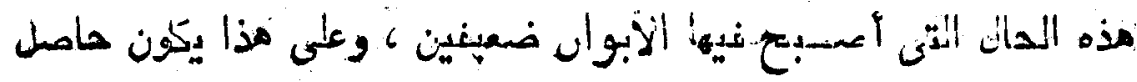

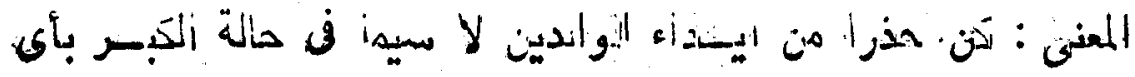

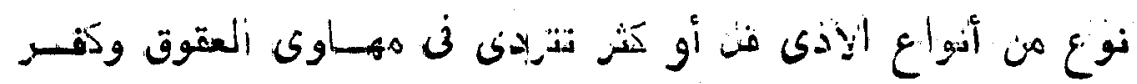

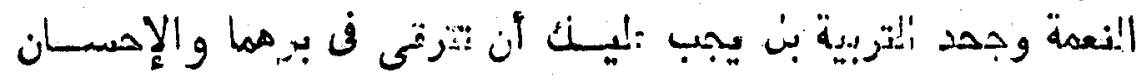

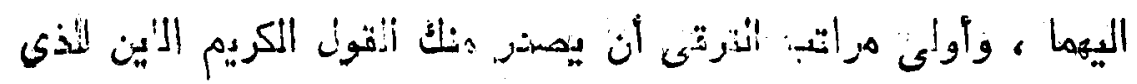

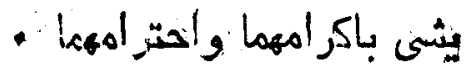

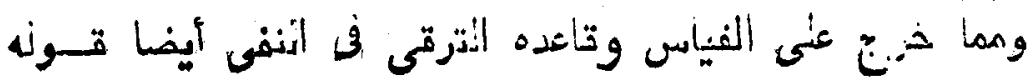

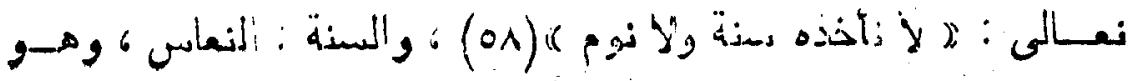

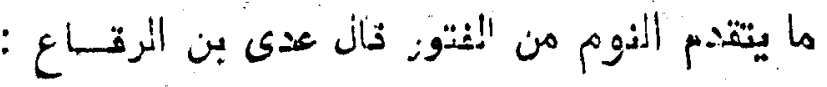

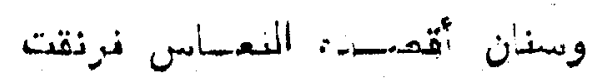

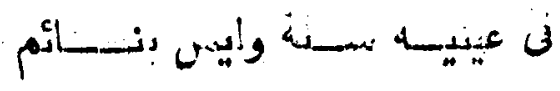

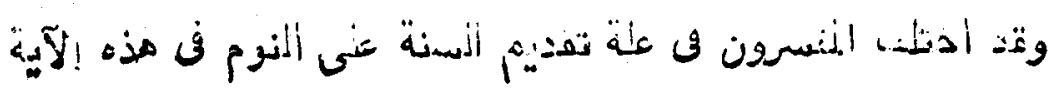

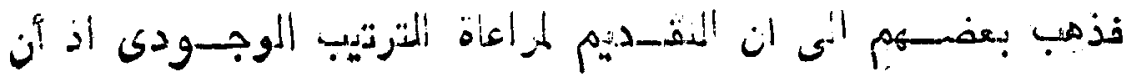

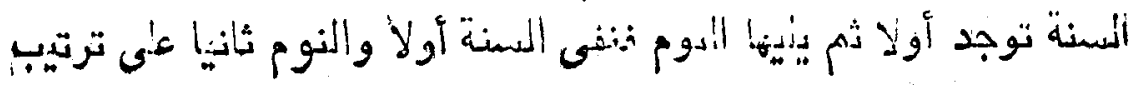

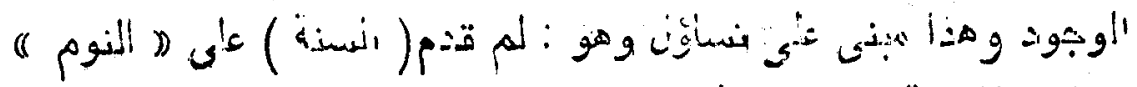

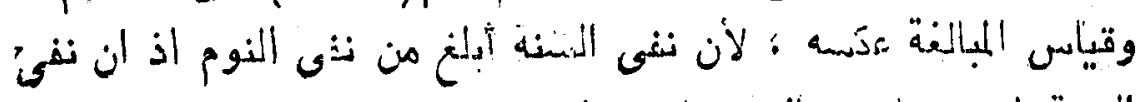

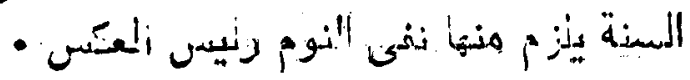

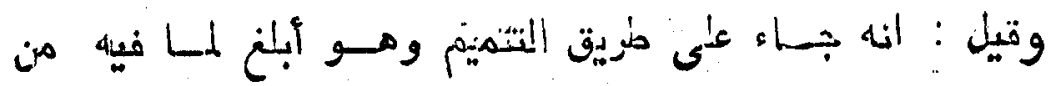

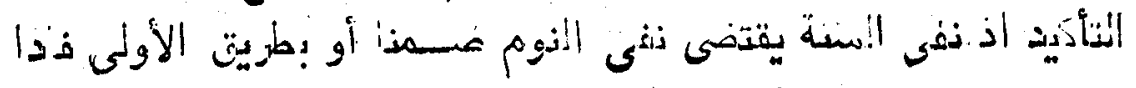
نذنى ثان.

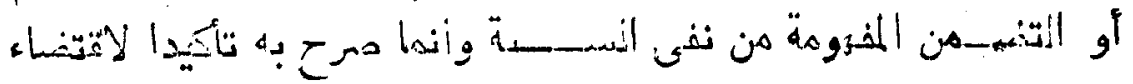

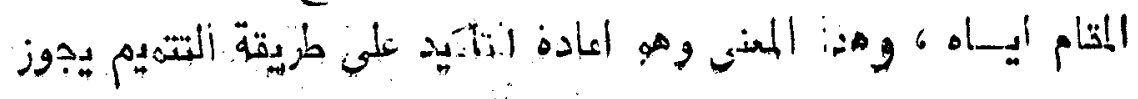

• roo : البقرة : آية الكرسي 


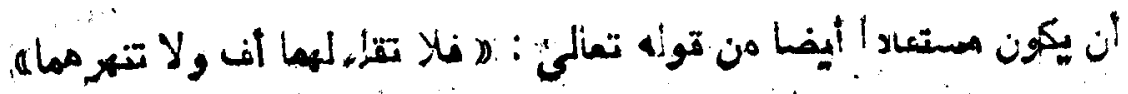

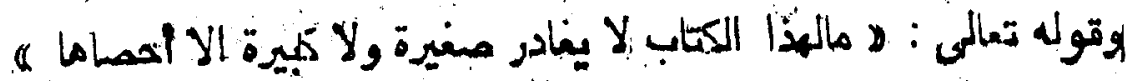

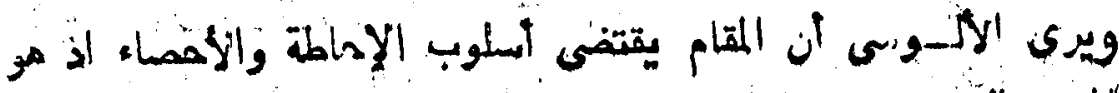

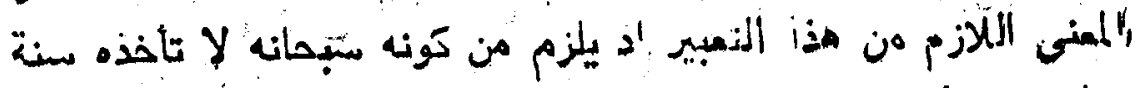

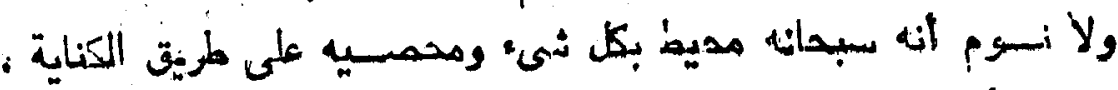

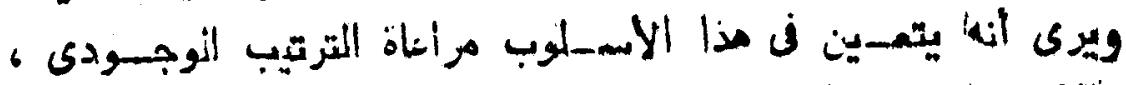

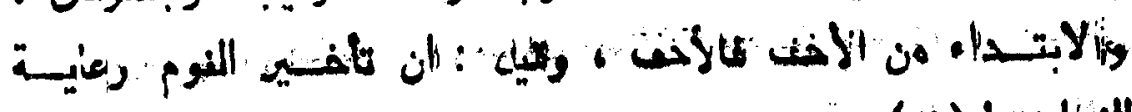

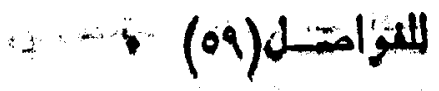

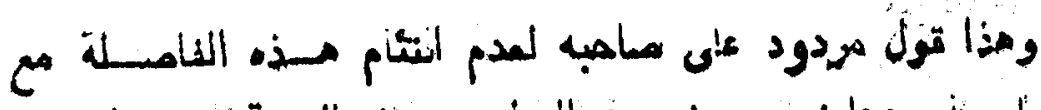

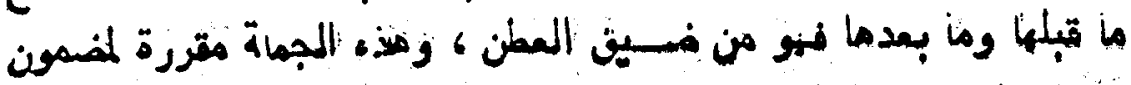

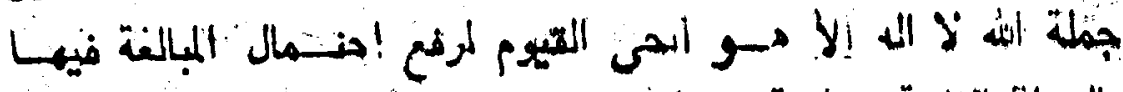

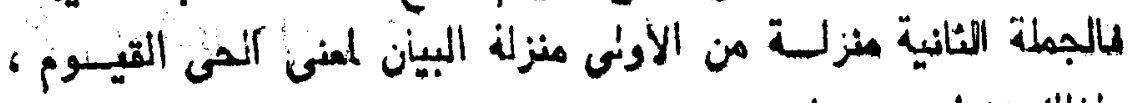

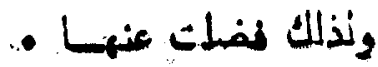

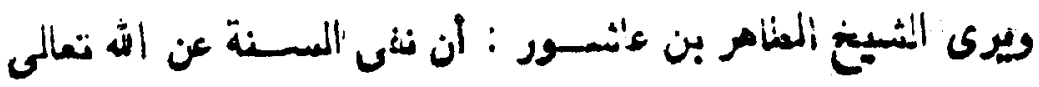

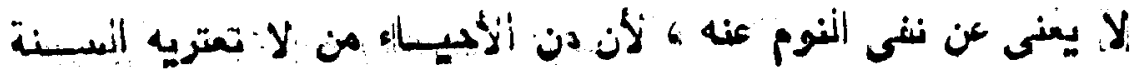

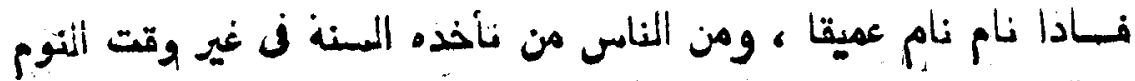

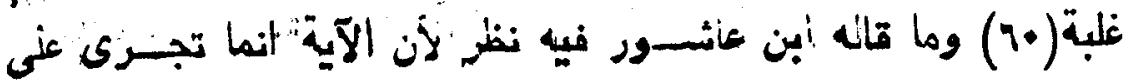

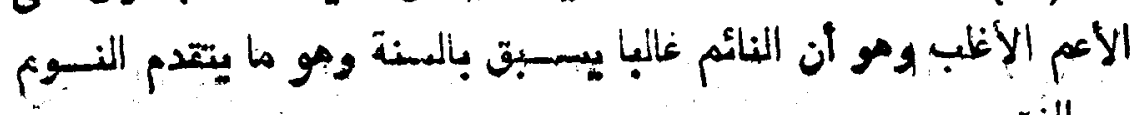

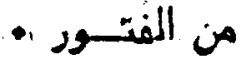

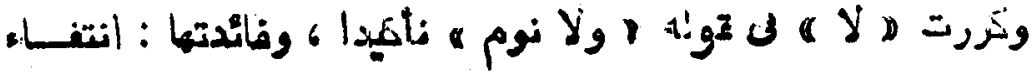
كل و!مذ منهما على وجه الاستقلان ؛ ولو لم تذكر لاحتمل نفيهما بقيد 


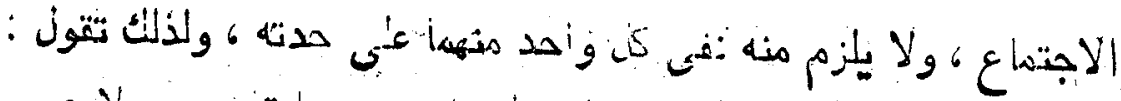

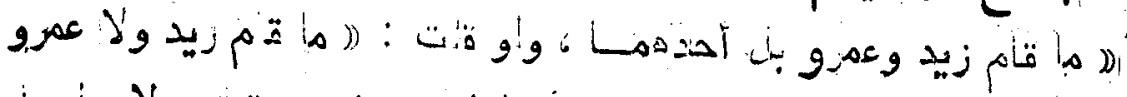

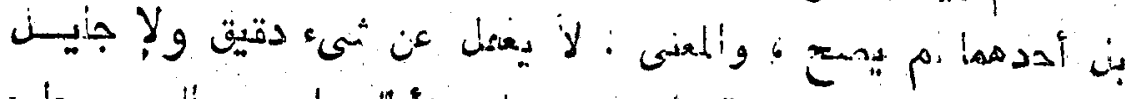

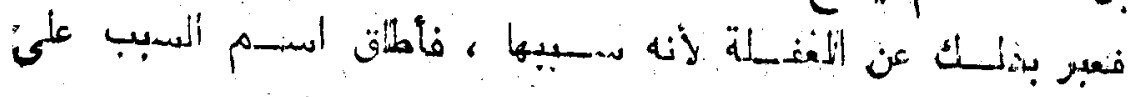

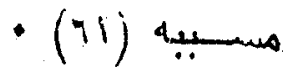

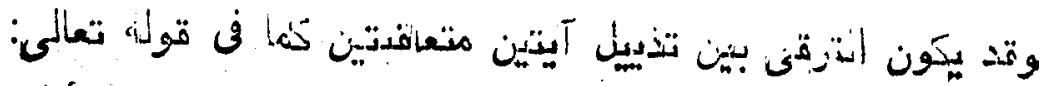

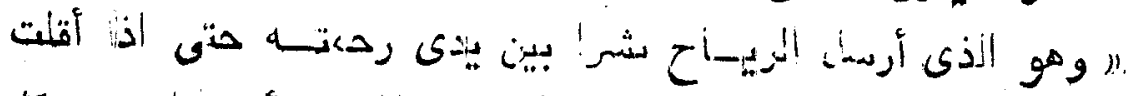

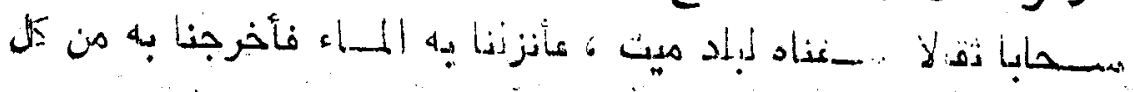

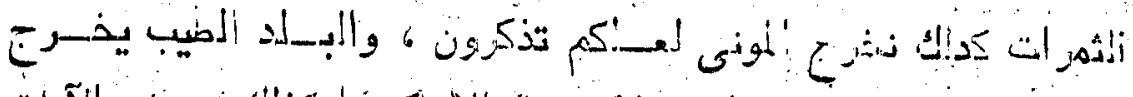

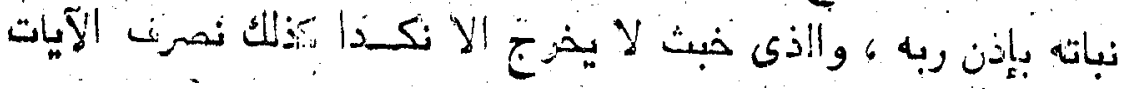

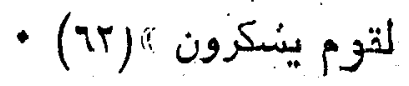

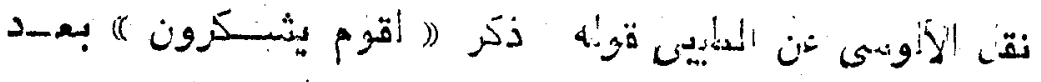

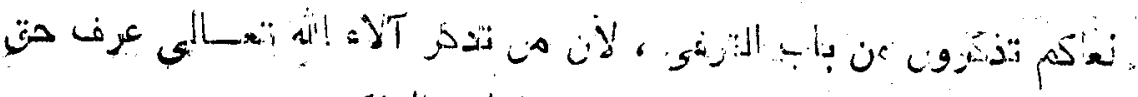

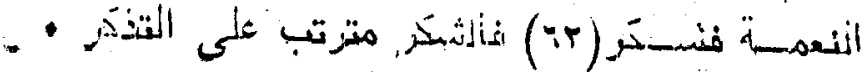

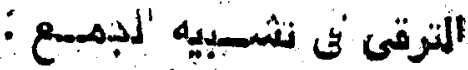

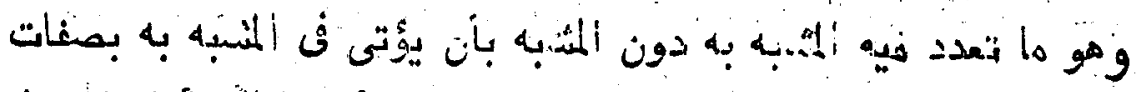

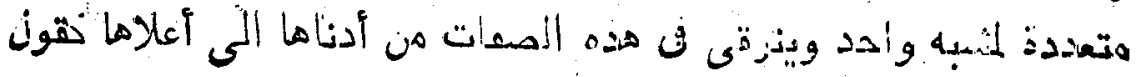

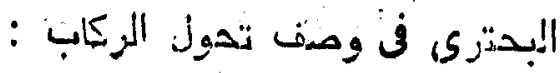

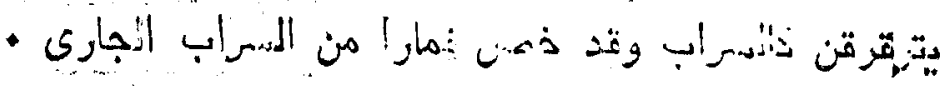

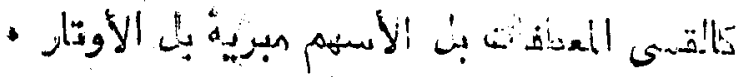


ألا ترى أنه رتى ن تثبيه ندولها من الأدنى الى الأعنى، فتبهها

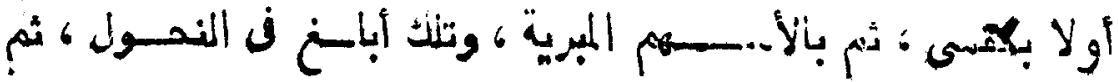

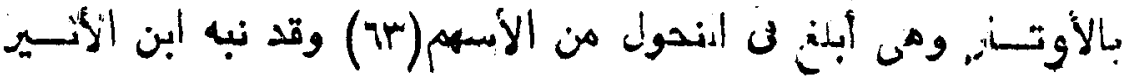

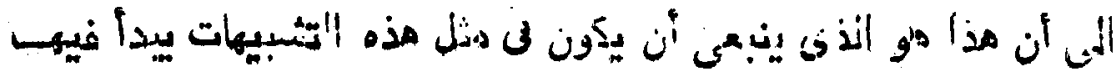

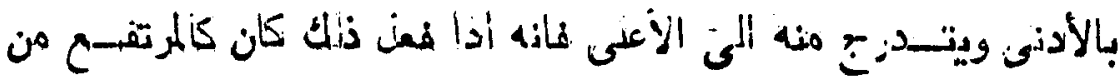

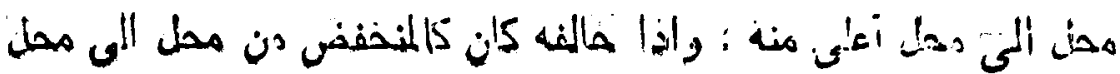

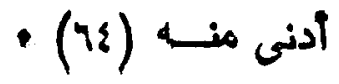

\section{التئقى في جه ألثبه بذكر صفات متعدة للمشبه به :}

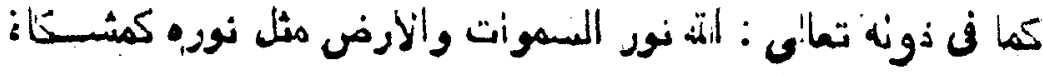

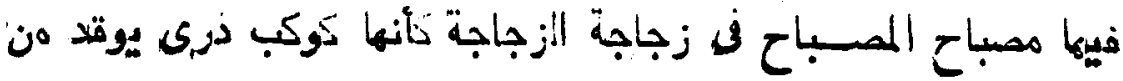

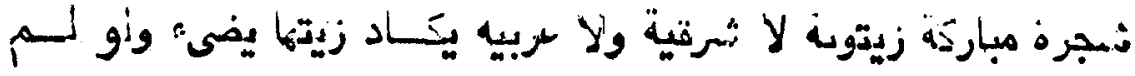

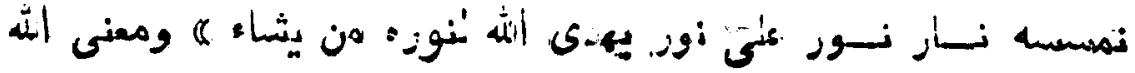

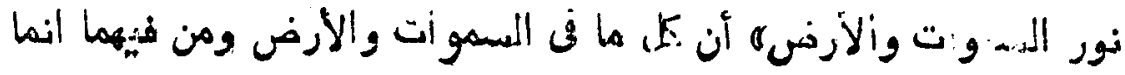

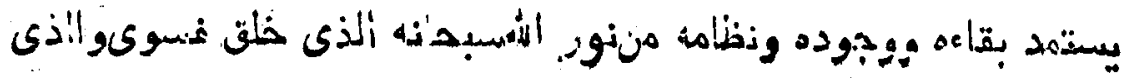

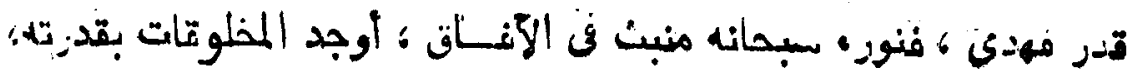

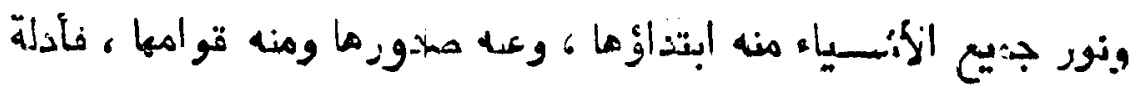

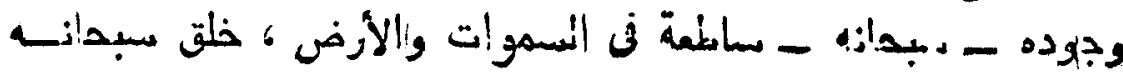

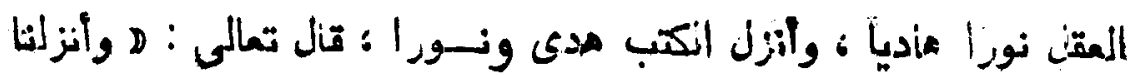

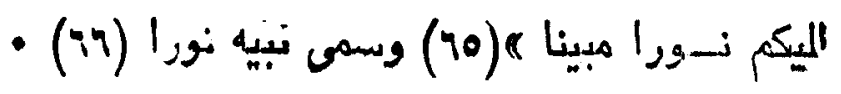

•

;

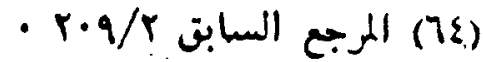

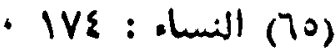

- \$1 \$ 


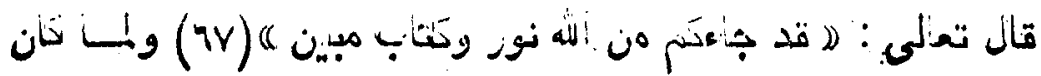

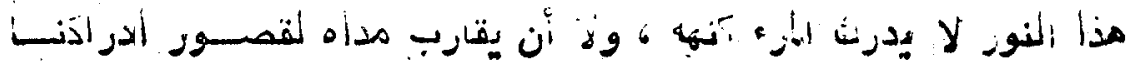

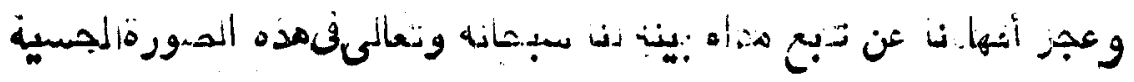

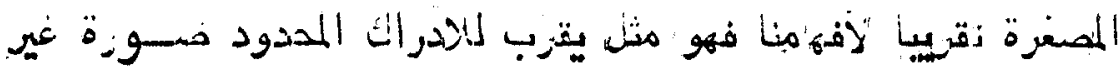

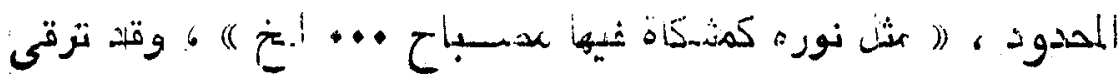

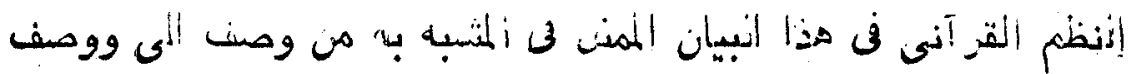

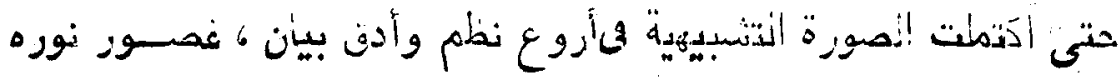

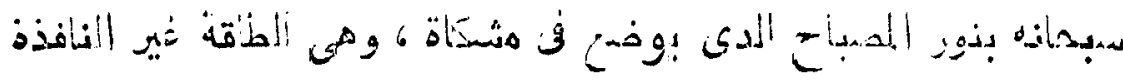

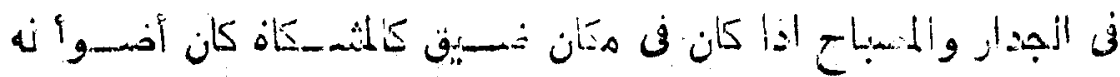

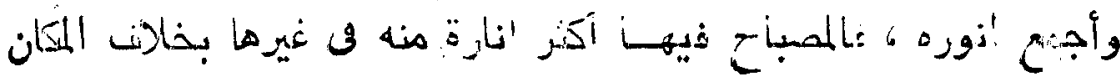

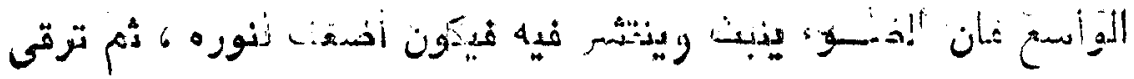

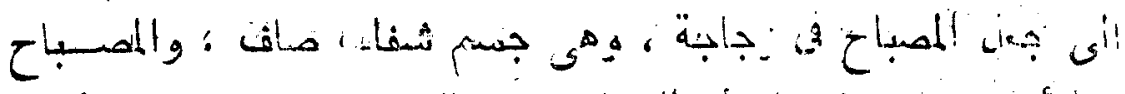

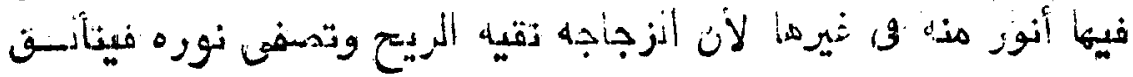

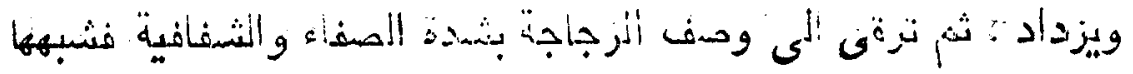

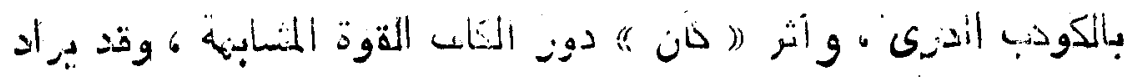

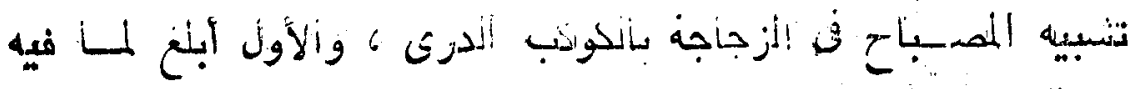

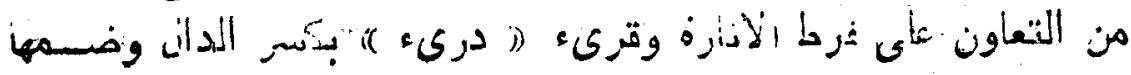

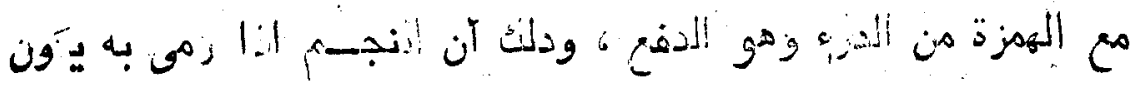

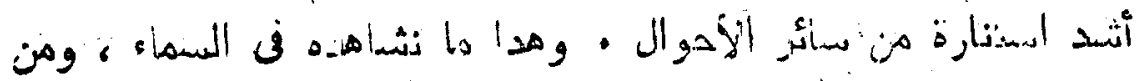

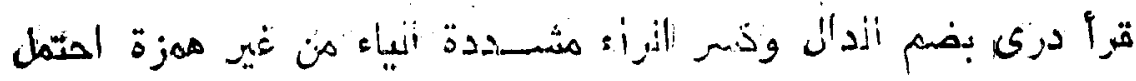

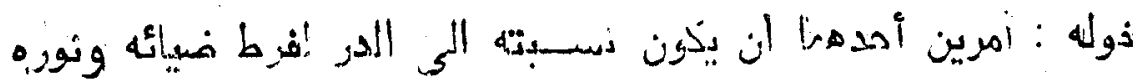

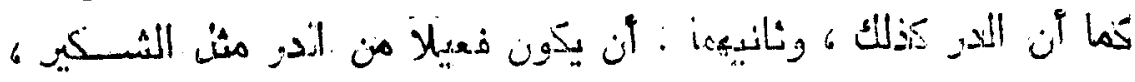

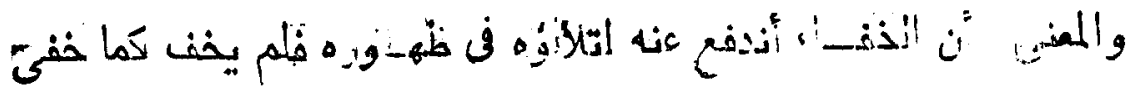




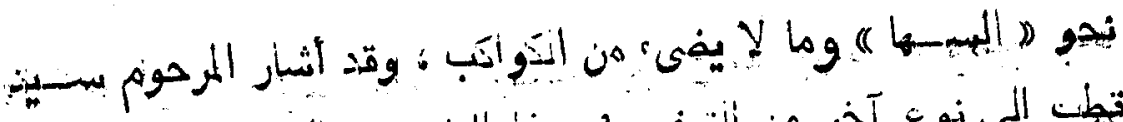

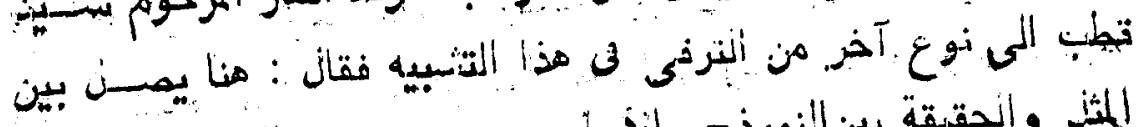

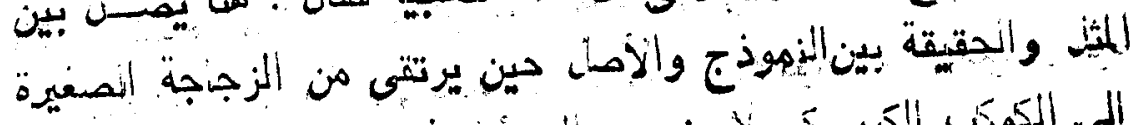

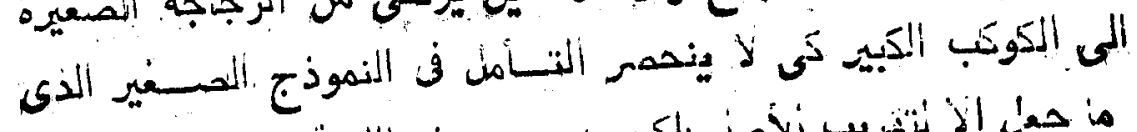

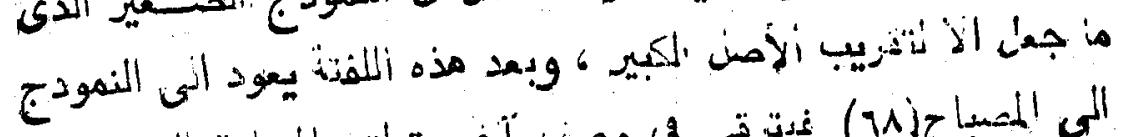

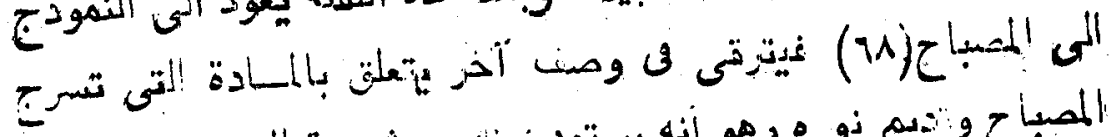

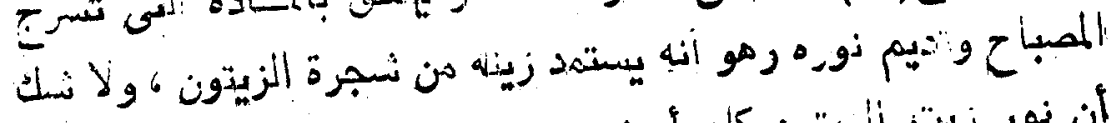

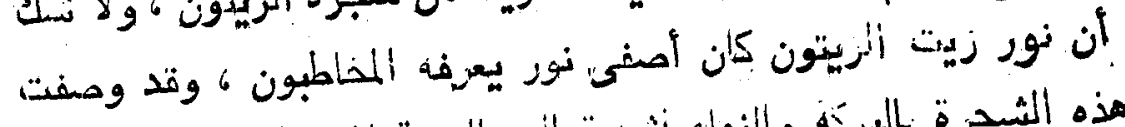

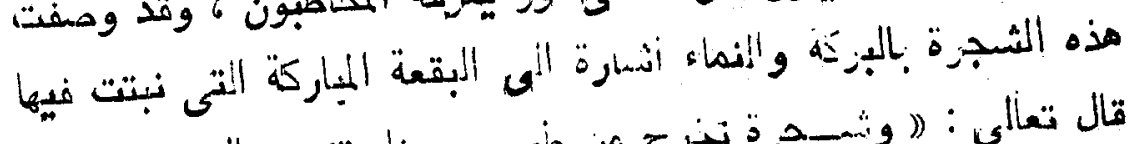

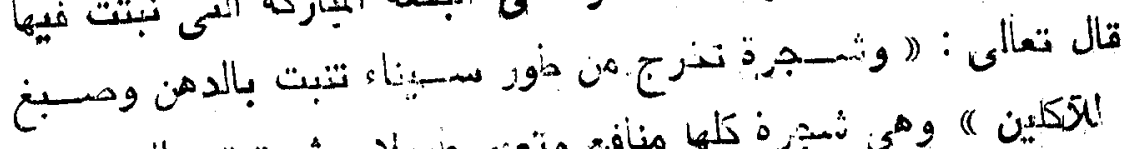

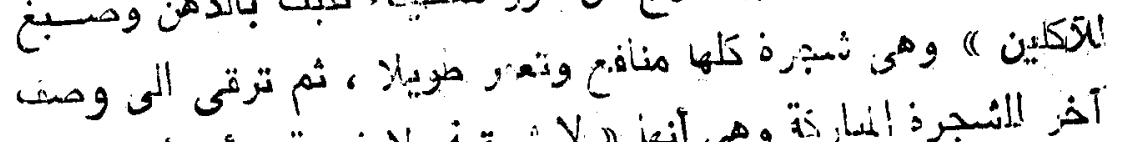

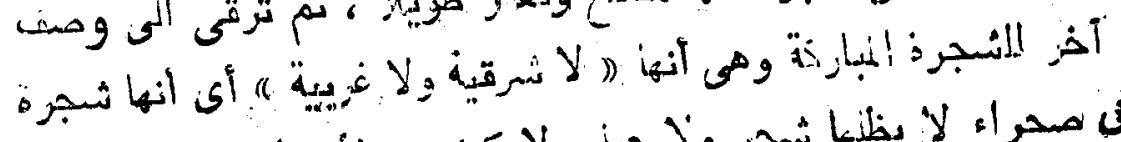

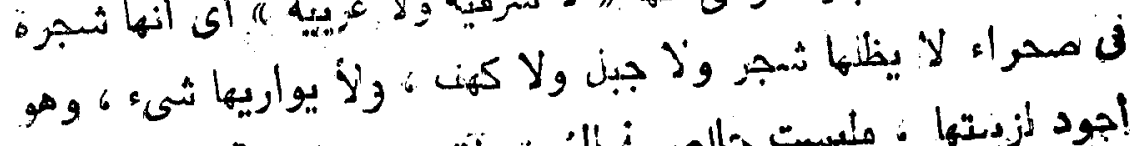

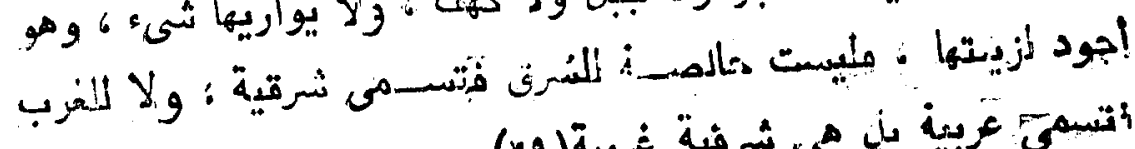

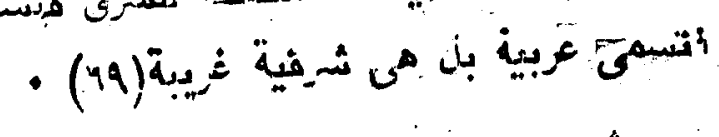

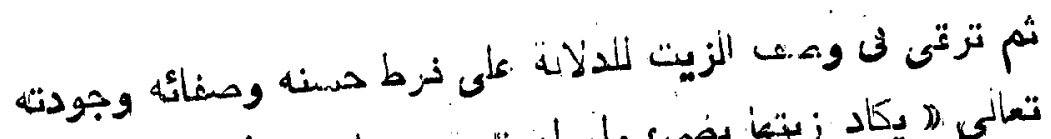

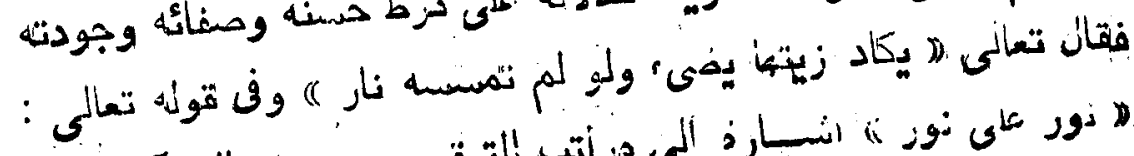

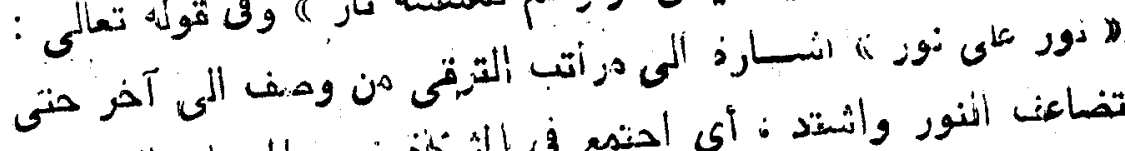

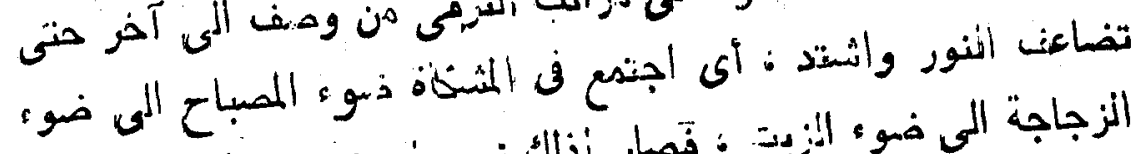

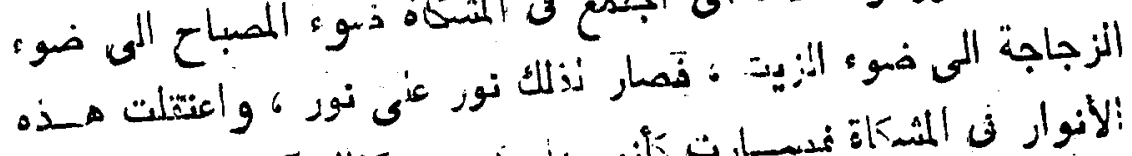

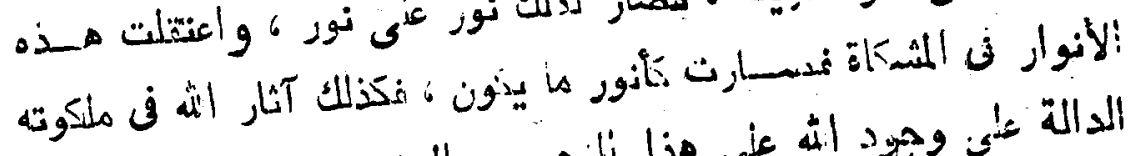

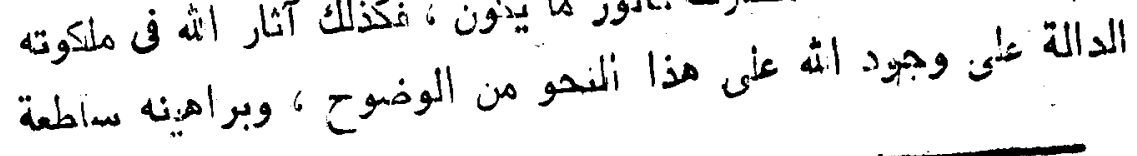


on

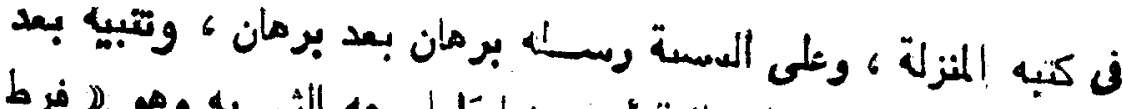

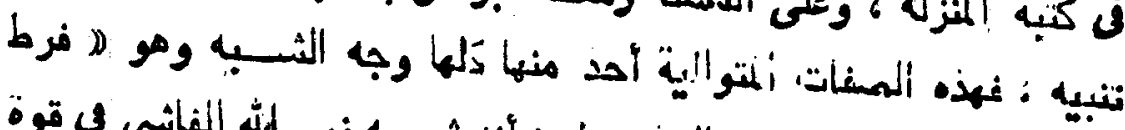

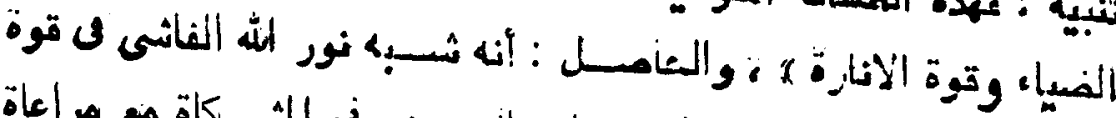

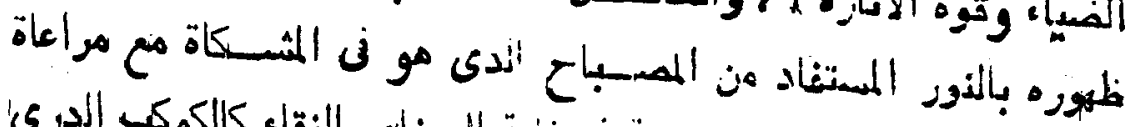

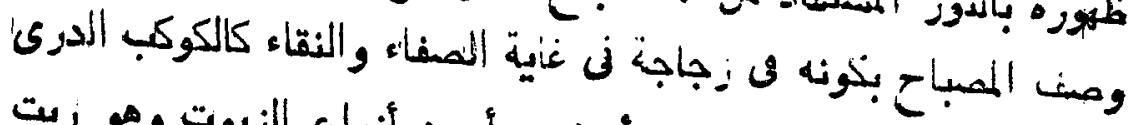

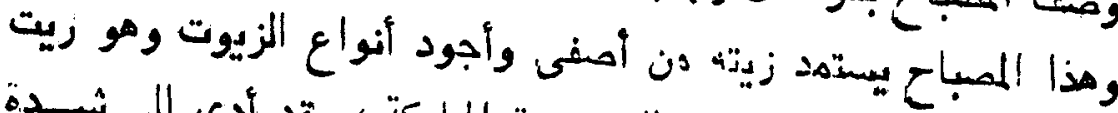

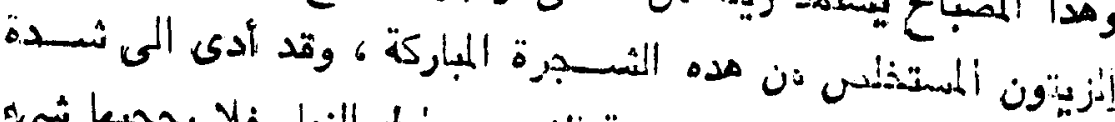

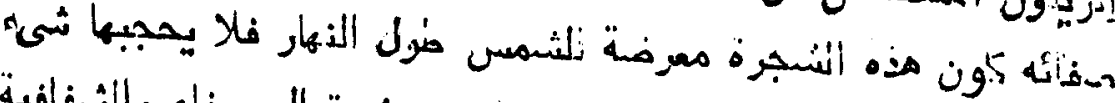

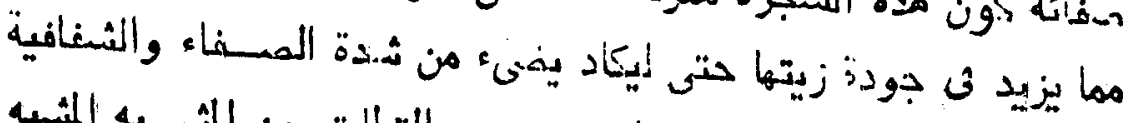

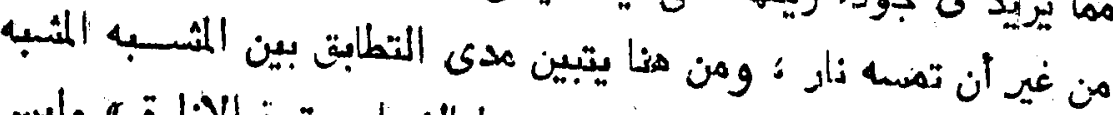

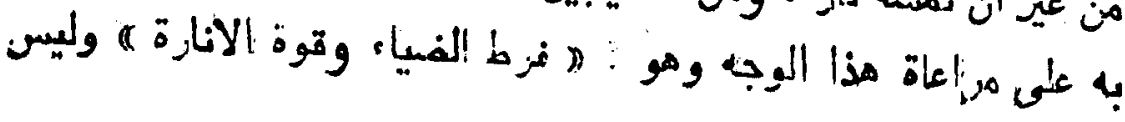

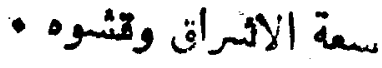

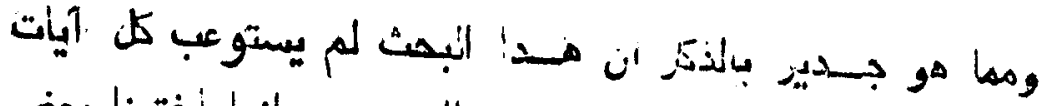

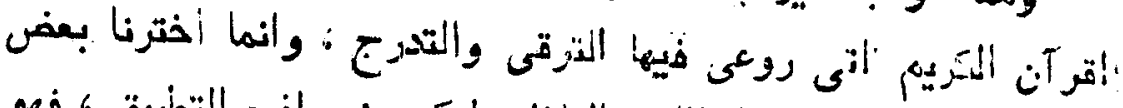

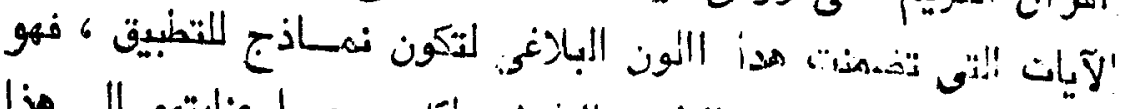

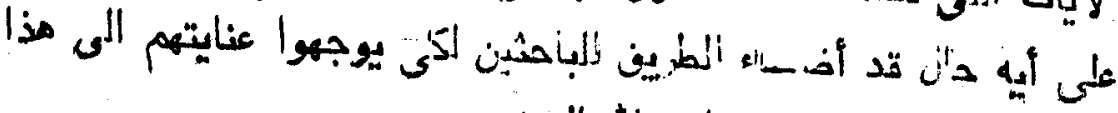

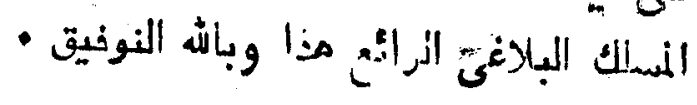

• وآخر دعوانا ان ألدمد الثه رب المالمين

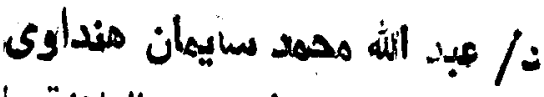

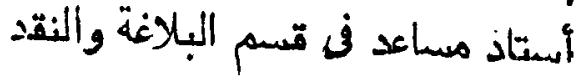
بكلية اللغة العربية بالزتازيق 
ont

\section{هصسادر ومراجع البتث}

1 - الاتقان في علوم القرآن للسيسيوطى ط الحلبى بهصر - الطبعـة

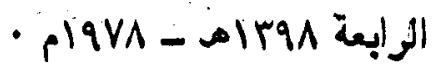

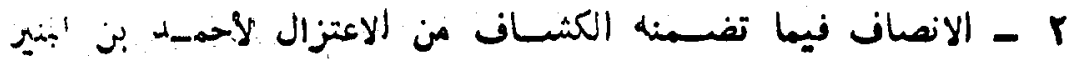

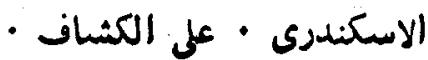

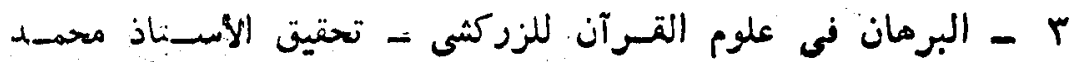

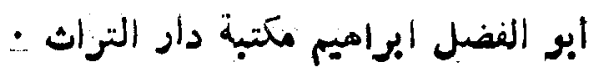

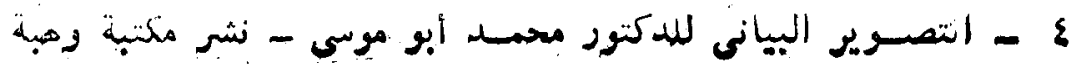

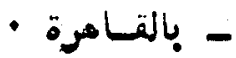

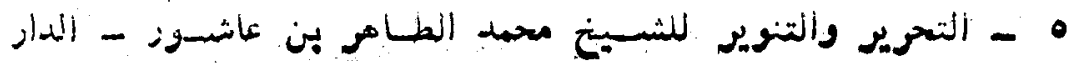

$$
\text { التونسية للنشير والتريو }
$$

1

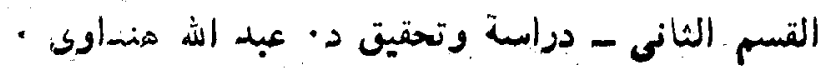

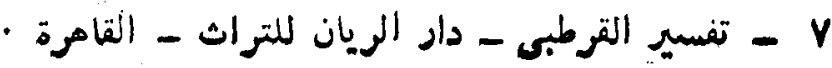

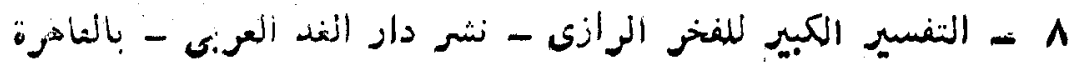

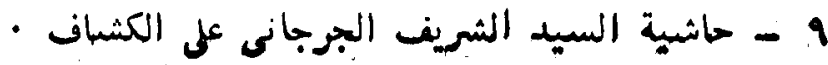

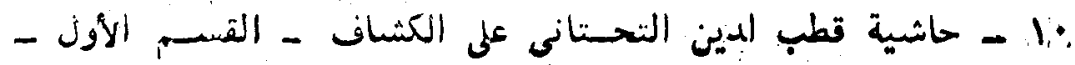

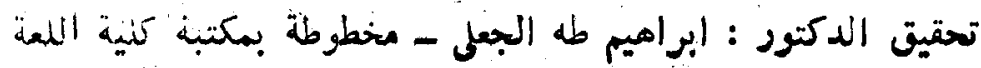

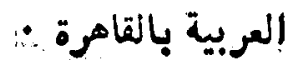

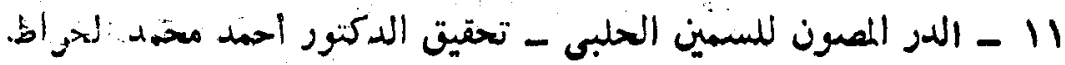

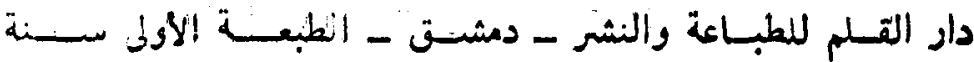

$$
\text { - } 1917-01 \varepsilon \cdot 7
$$

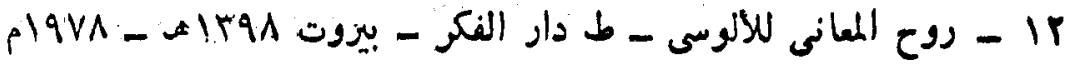

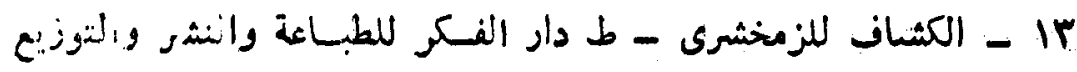

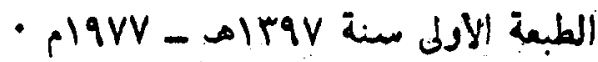

18 - المثل البسائر لاين الاثير - طبعة دار المعارف بالقاهرة - 
$\therefore$

... 
ون أصُول اللغنَة 
$\therefore \quad \therefore$ 


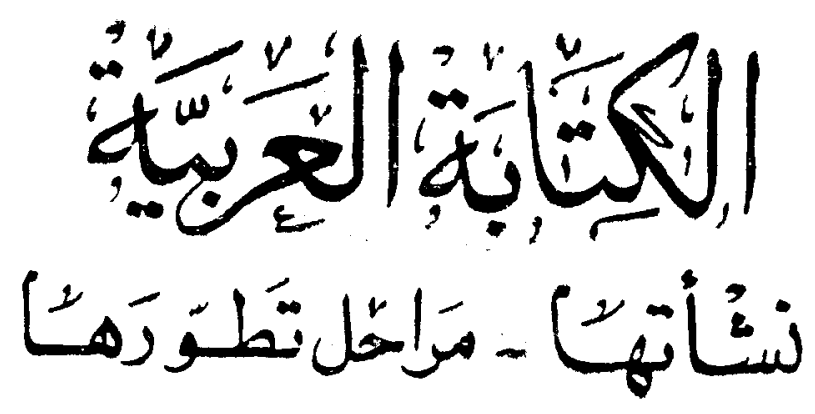

د/ مهنوت عبد الله محمد المظاهر

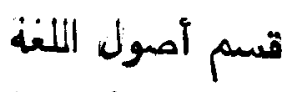

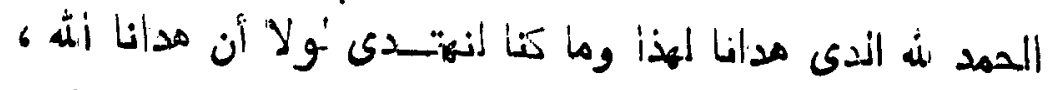

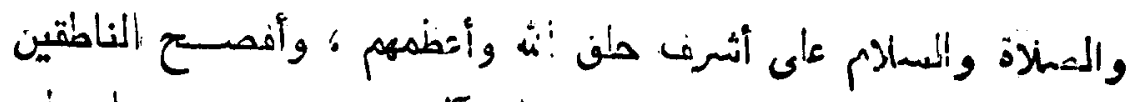

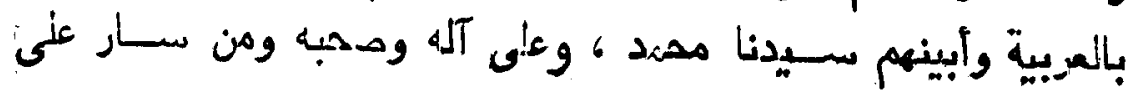

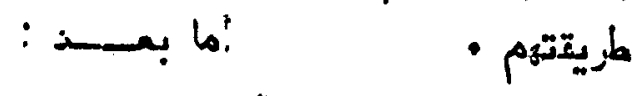

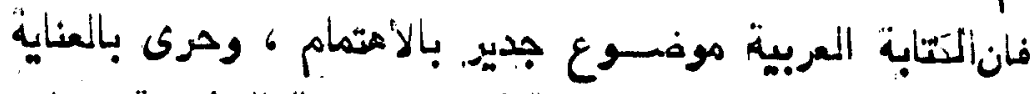

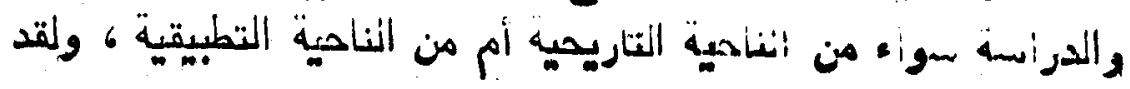

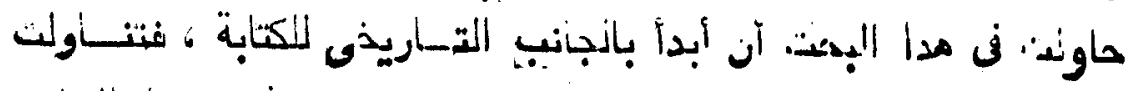

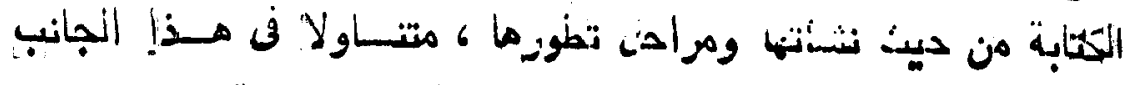

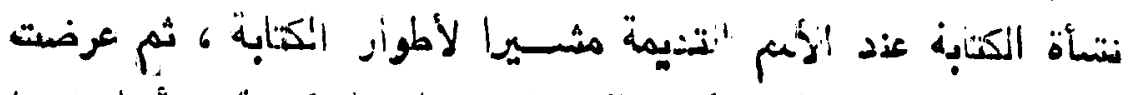

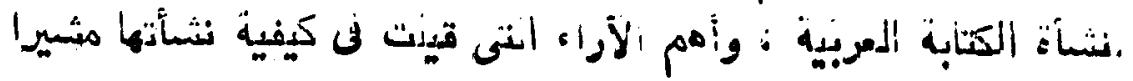

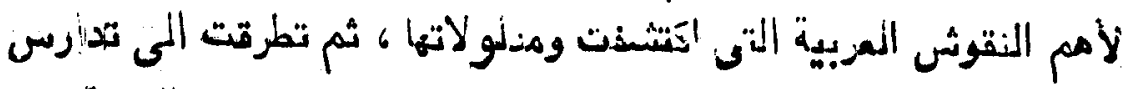

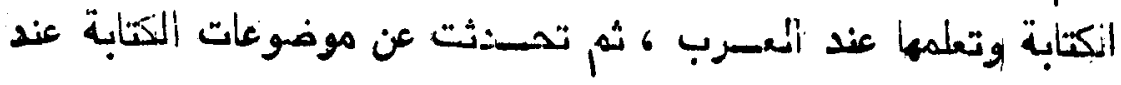

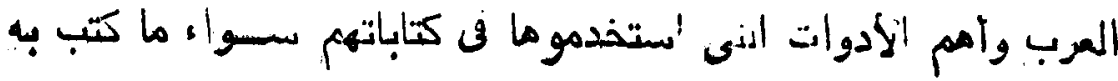

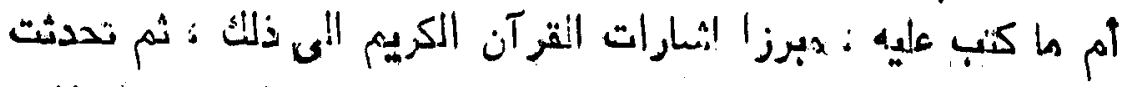

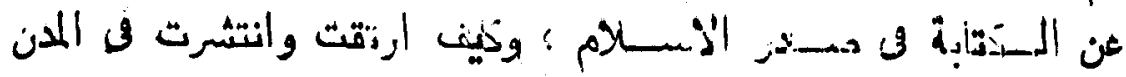

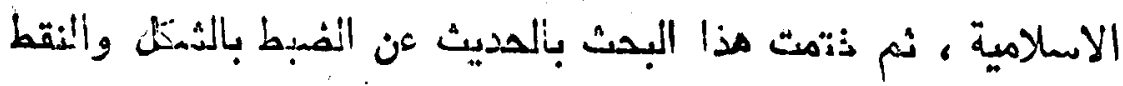

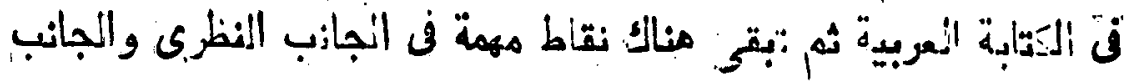

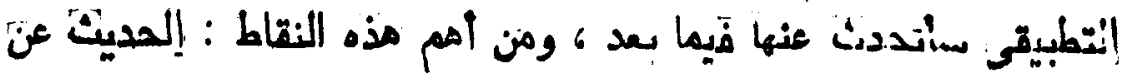


أنواع الخطوط العزبية ، والكتبة عند العزب فن وابداع + مواصفات

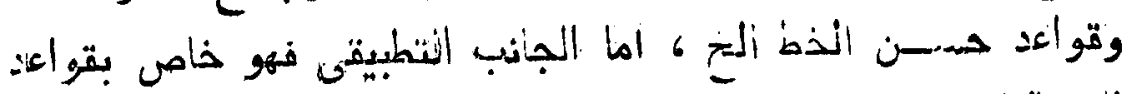

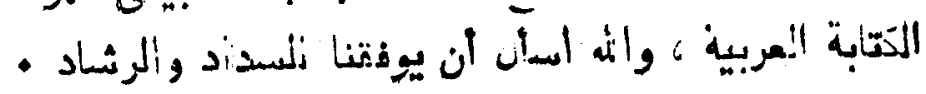
تهعيد : نثأة الكتابة عند الأمم التزيمة :

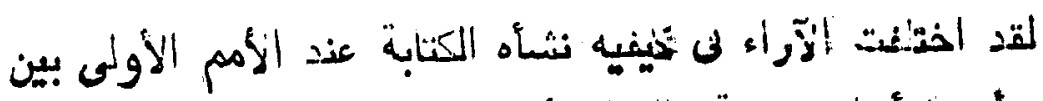

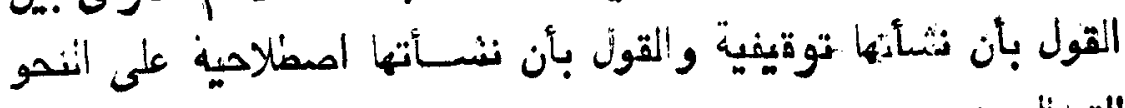
الة

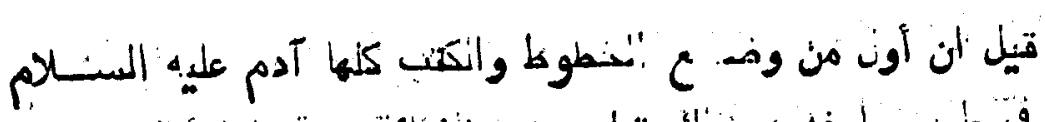

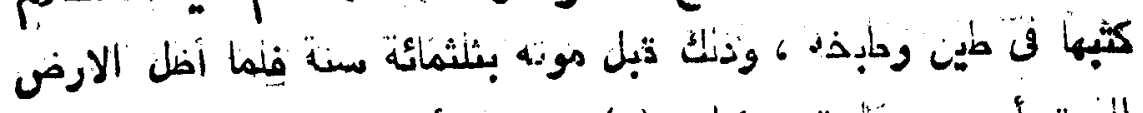

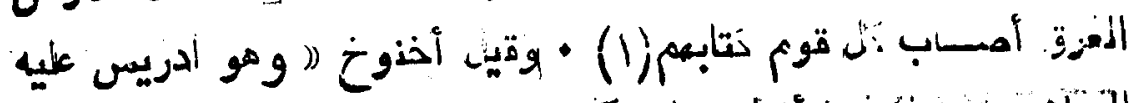

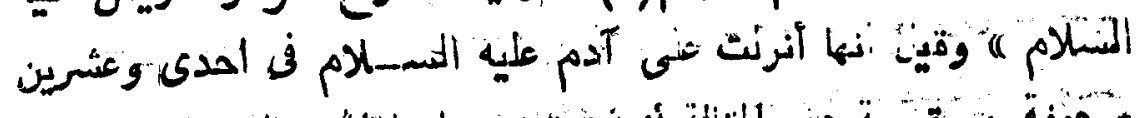

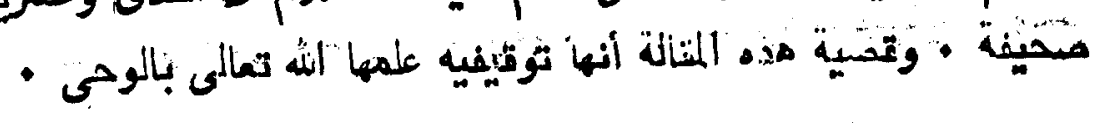

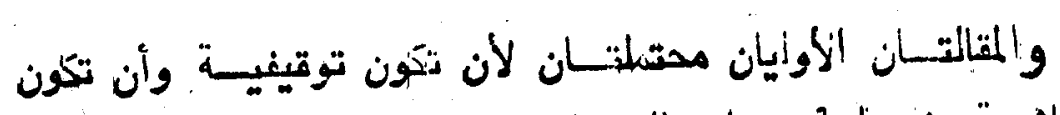

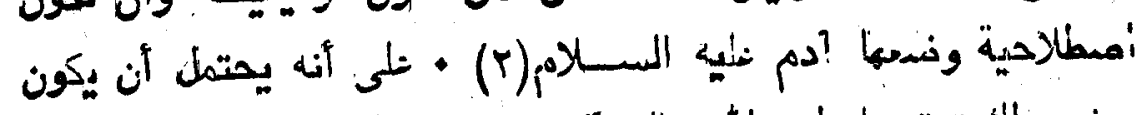

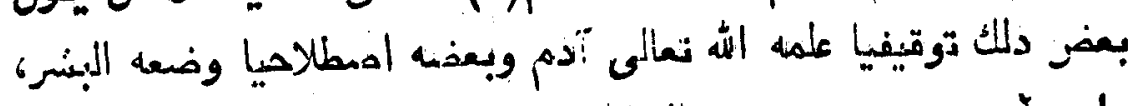

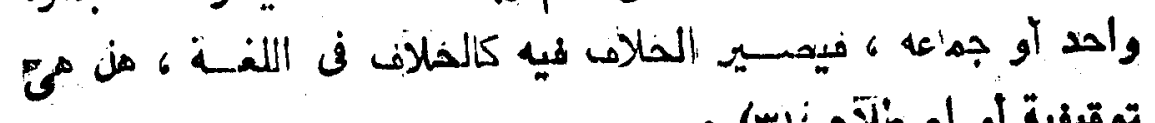

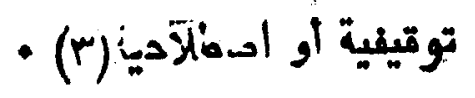

هزالهل تطور الكتابة :

لقد مرت الكابة بدر!فأه مختنية وأطوار متلدرجة عبر ألعصور

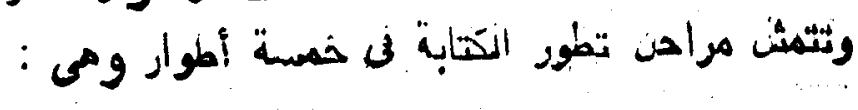

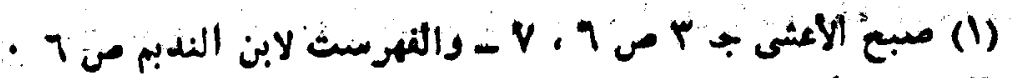

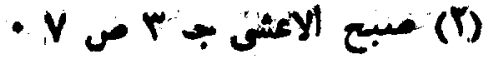




\section{'OA9}

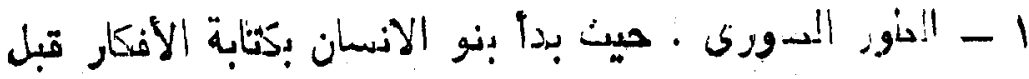

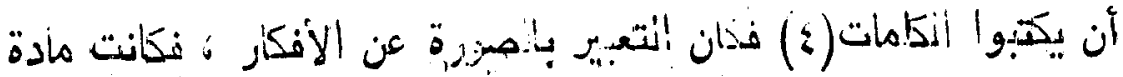

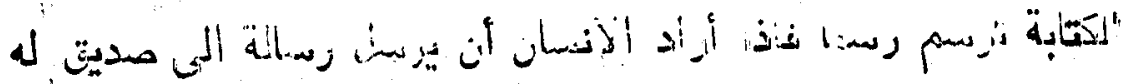

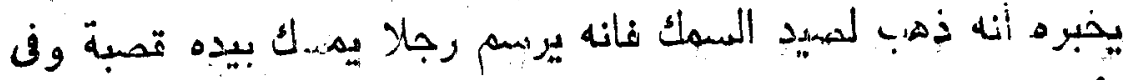

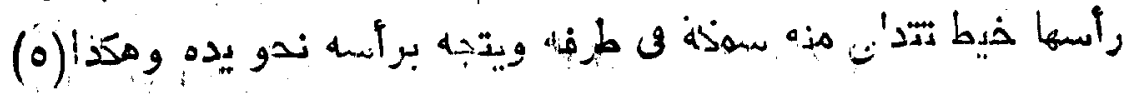

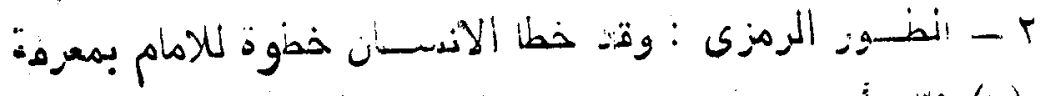

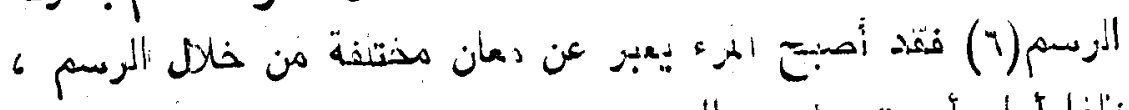

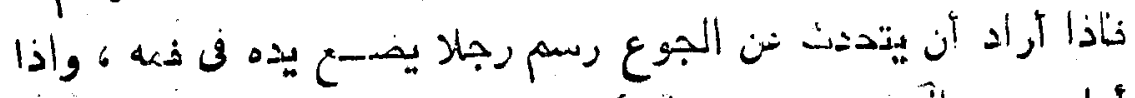

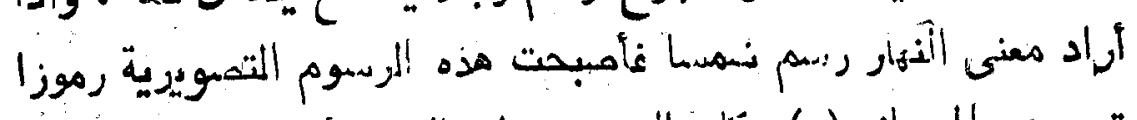

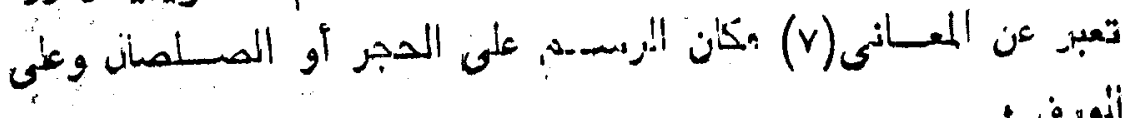
- (iأنورف

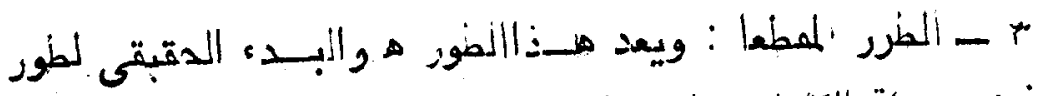

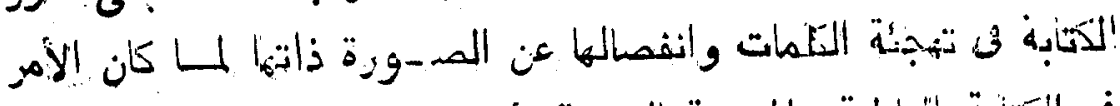

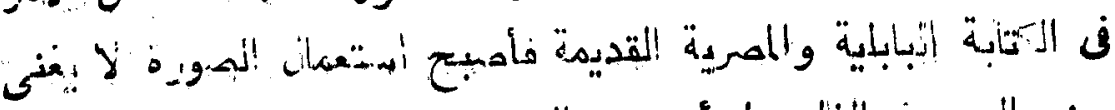

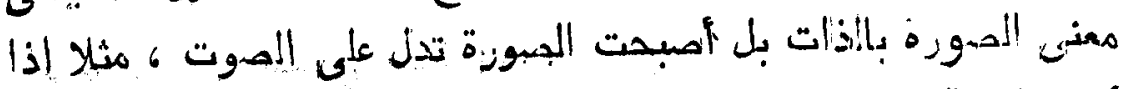

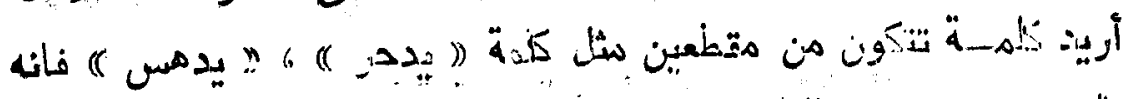

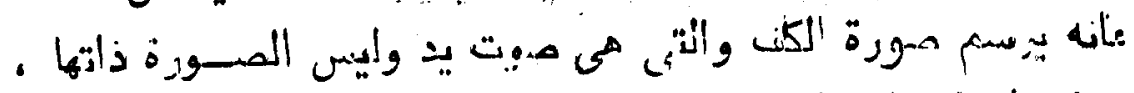

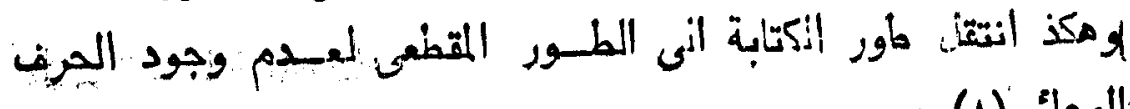
- الهحاتّى(1)

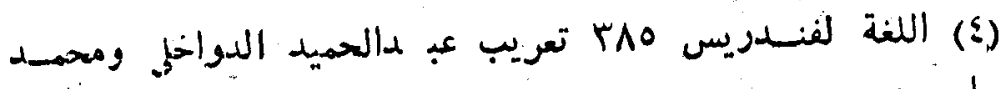

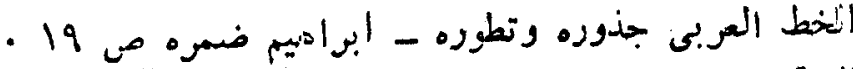

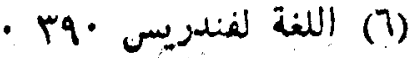

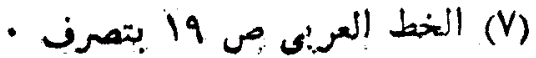

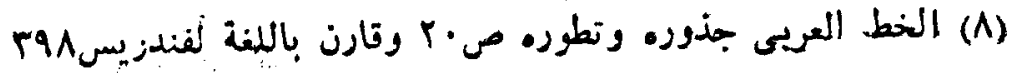




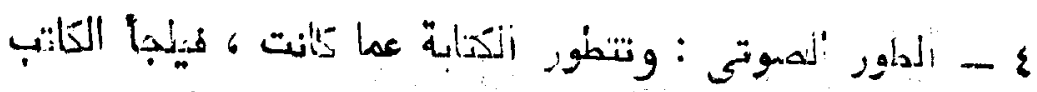

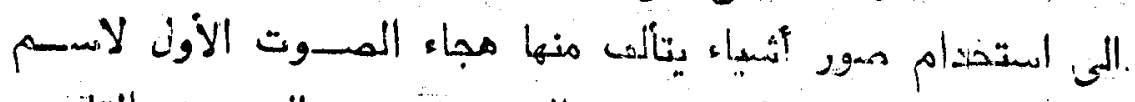

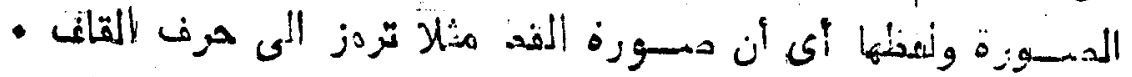

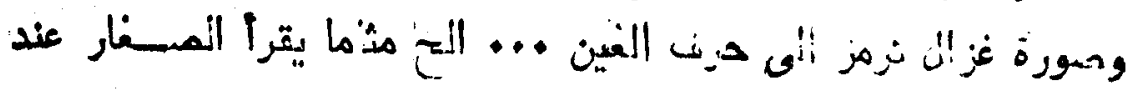

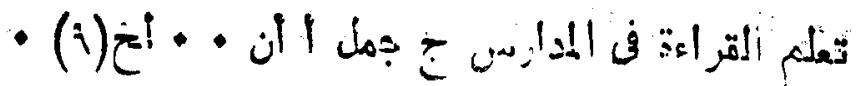

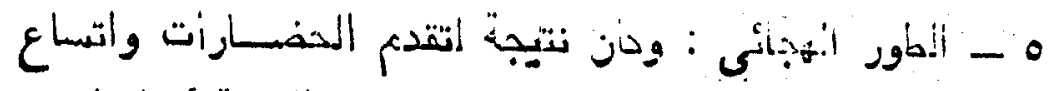

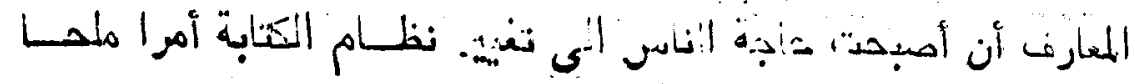

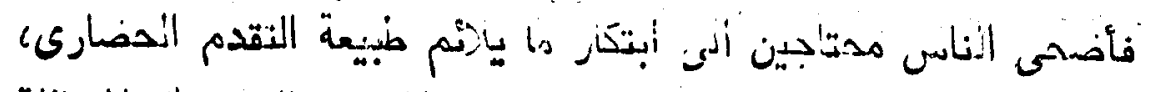

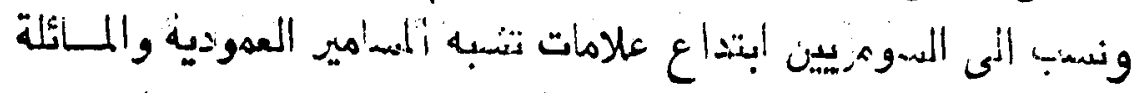

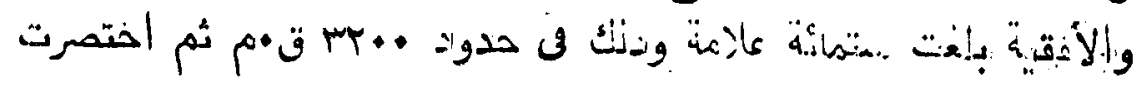

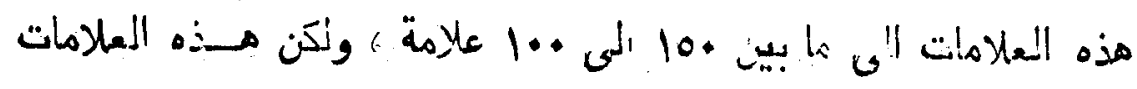

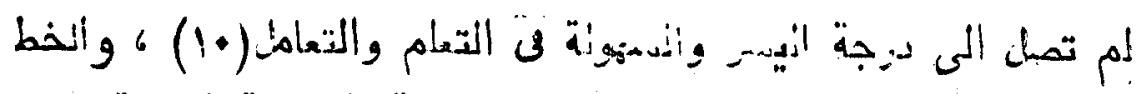

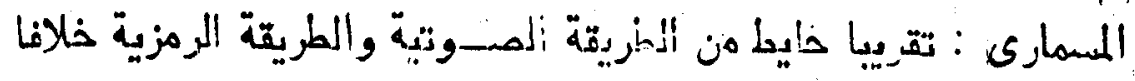

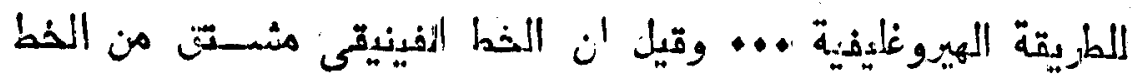
- المسمازي علو، أساس هجائي(11)

نشاة الآتوبة المزبية وتطورما ثبل الاسلام

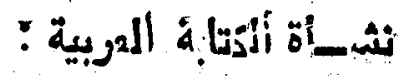

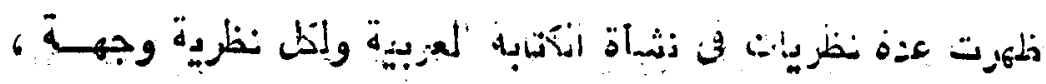

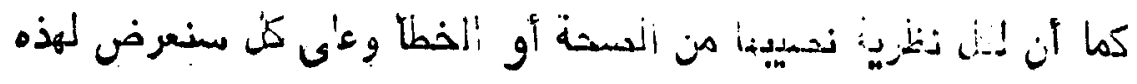

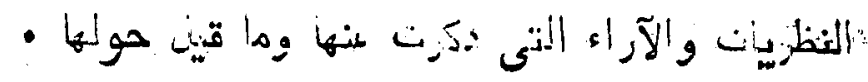

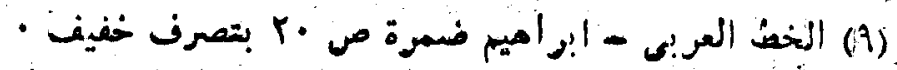

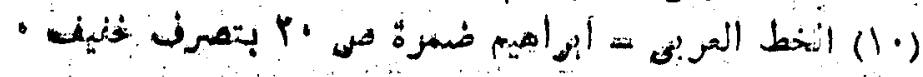




\section{1.}

1

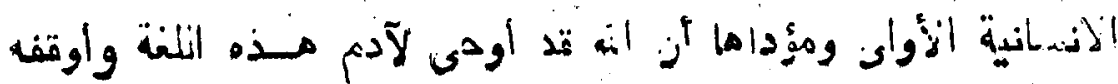
(Ir) عليها (ir)

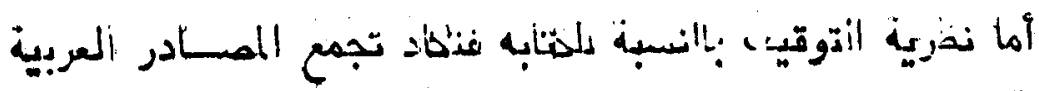

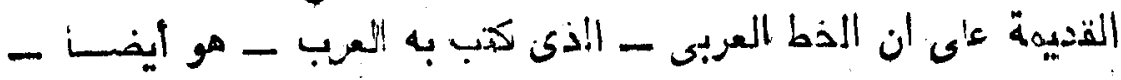

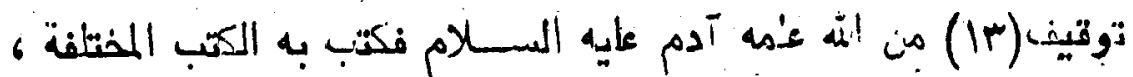

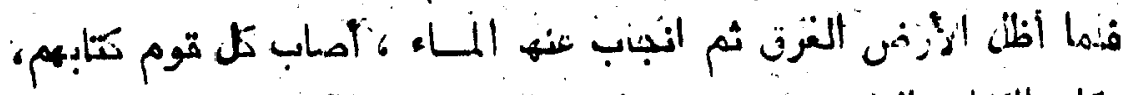

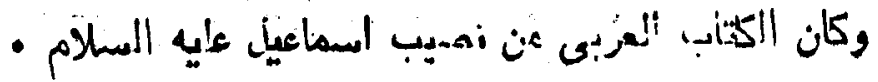

وتيله ان 'نعرب اثتتقوا حطهم من ألمسند المميرى ، ولكن ايس

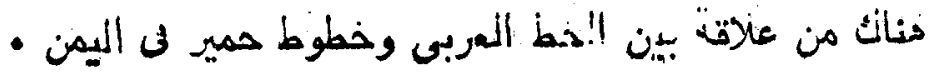

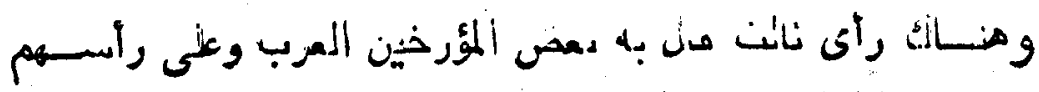

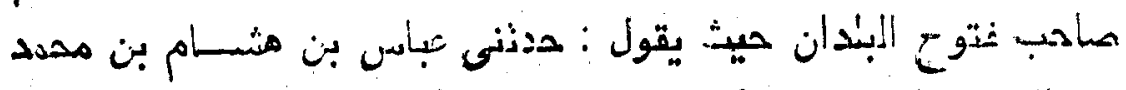

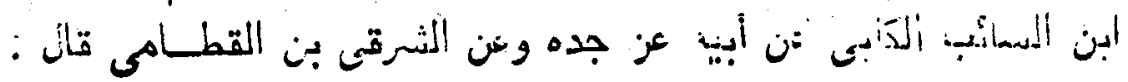

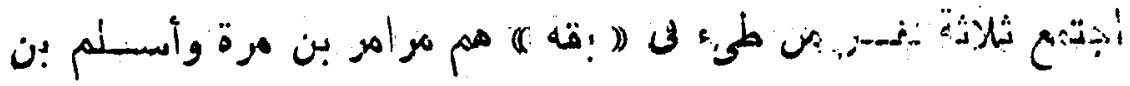

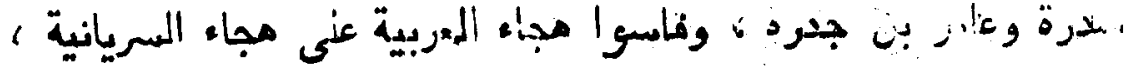

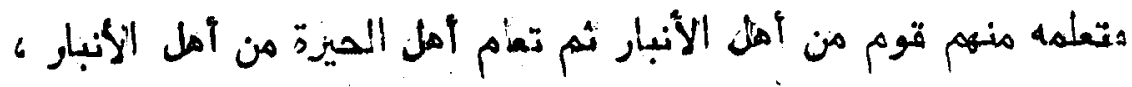

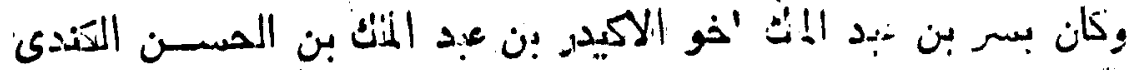

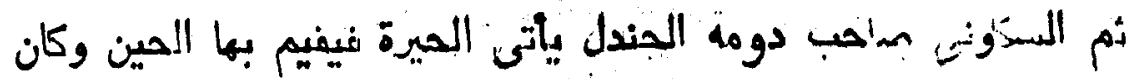

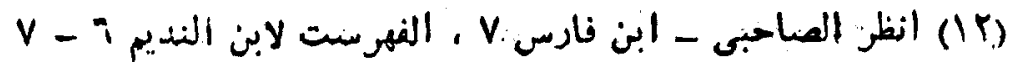

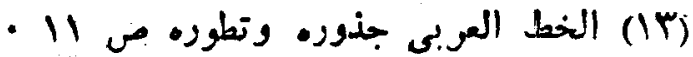

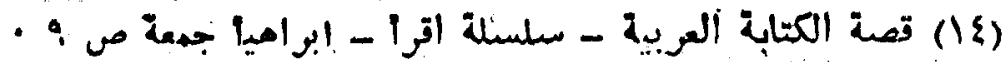

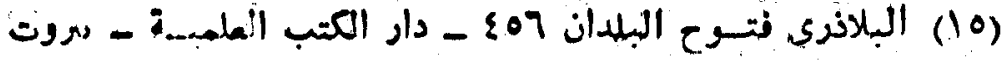

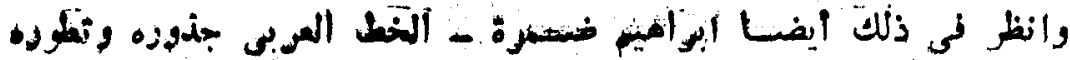




\section{oar}

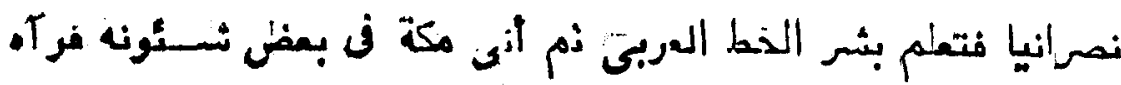

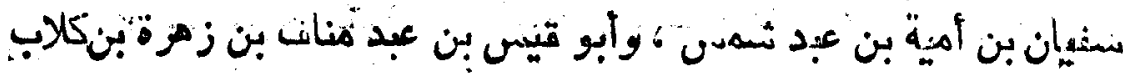

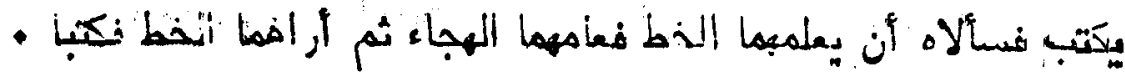

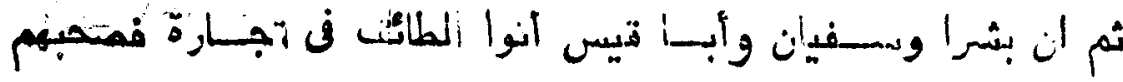

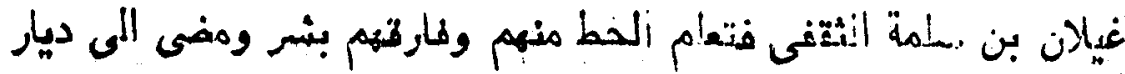

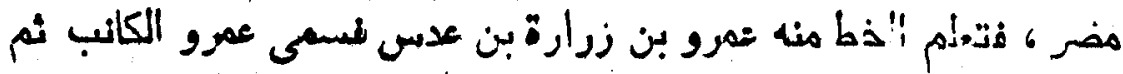

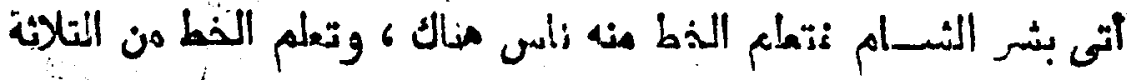

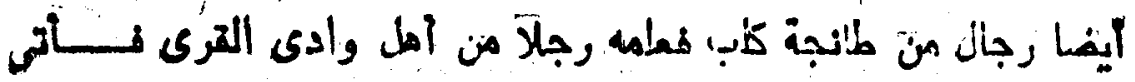

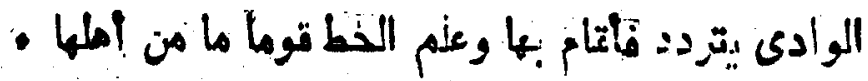

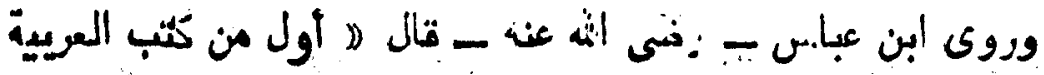

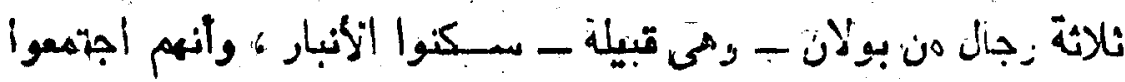

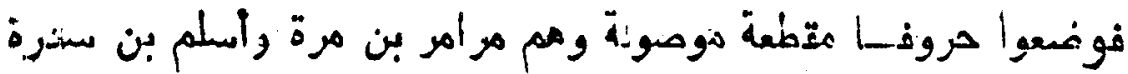

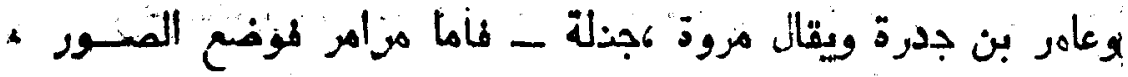

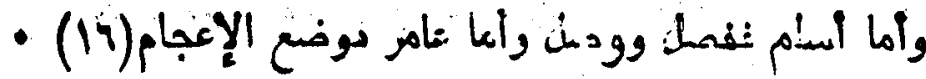

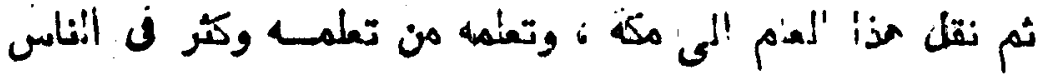
وتداولوه ونتل الجوعزن عن نسرقى المطامى : أن أول من وضسيسه رجال من طحى منهم ميمامر بن مرة وأنشديد عليه : -

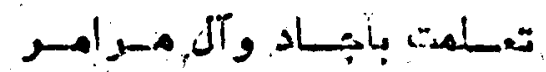

وستسودة: إثوابى ولمست بكاتب

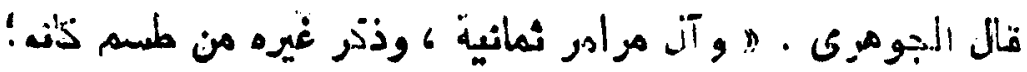

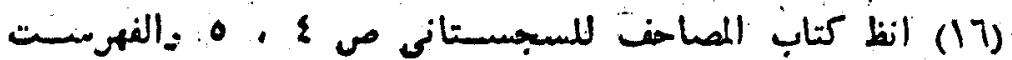

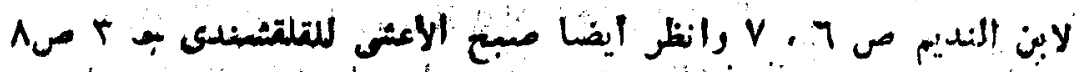

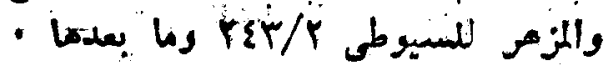




\section{pax}

نزولا عند عـدنان بن أدل وكانت اسمائهم : أيجــد ، وموز ، وحطي

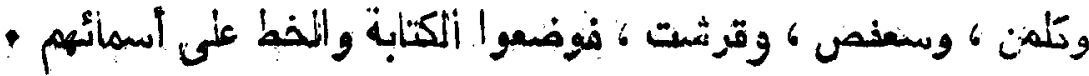

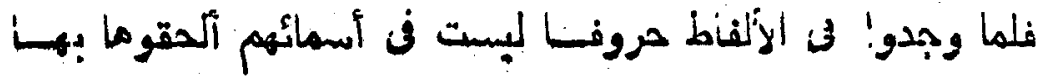

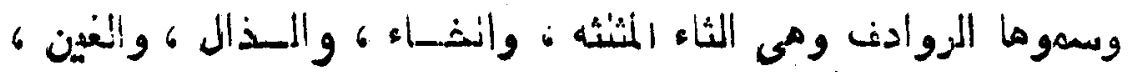

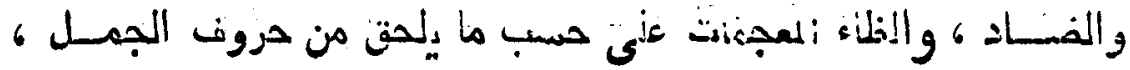

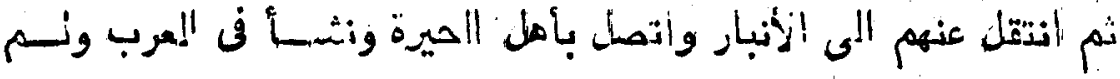

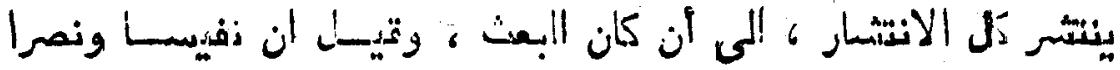

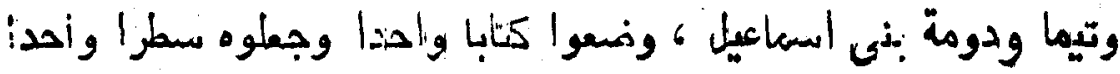

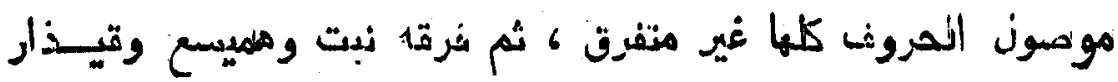

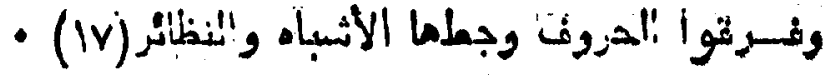

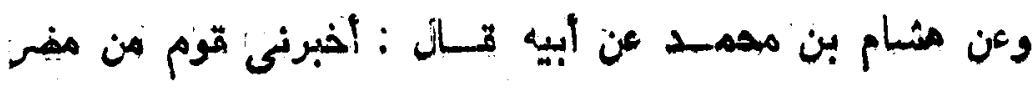

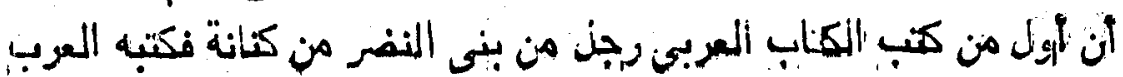
حينــــ

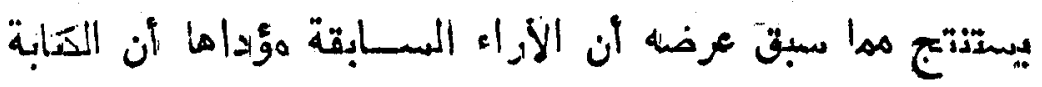

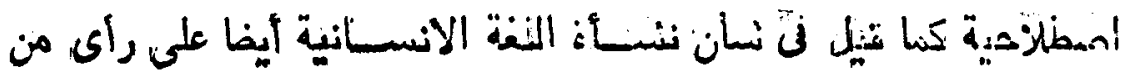

$$
\text { قـال بسذلة }
$$

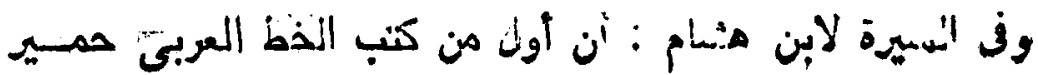

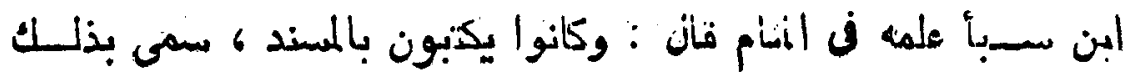

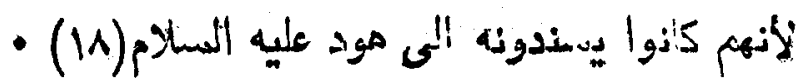

(IV) وتطوره ص Ir

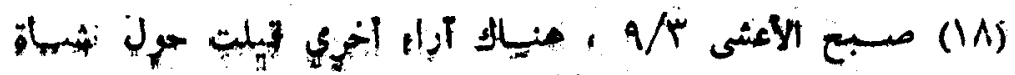

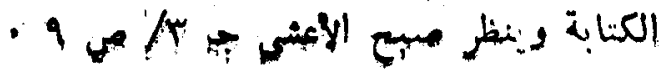




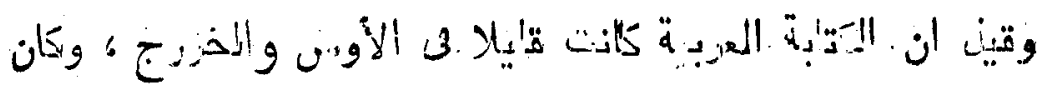

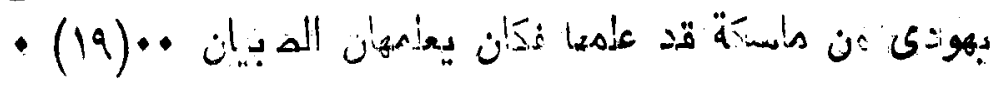

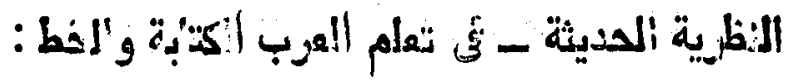

ومؤداها أن أعرب أخذوا "اذختانة عن النبط ندن هم ألنبط وتكيف

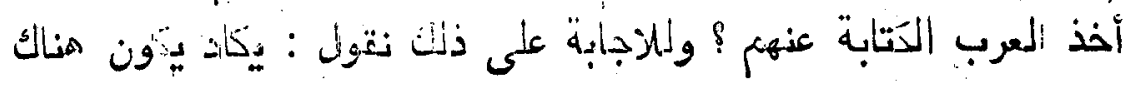

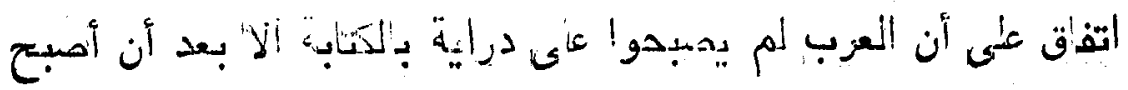

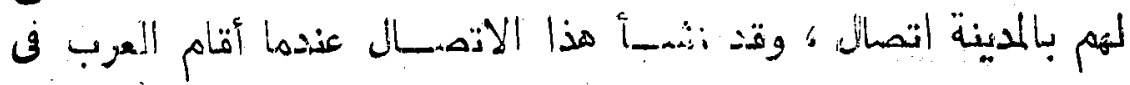

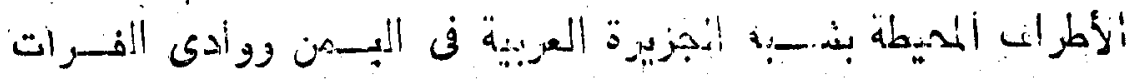

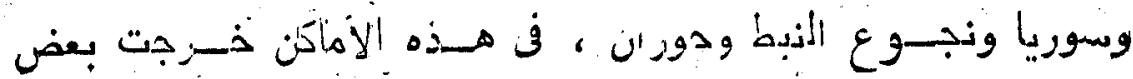

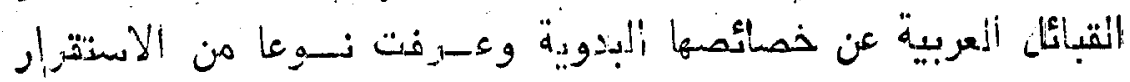

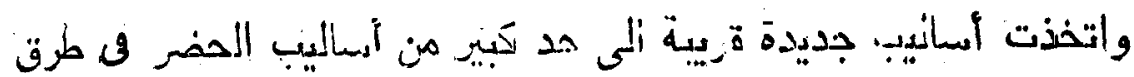

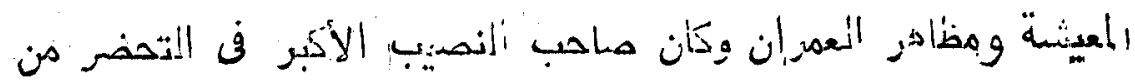

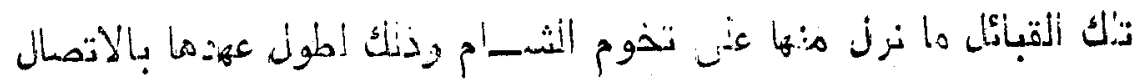

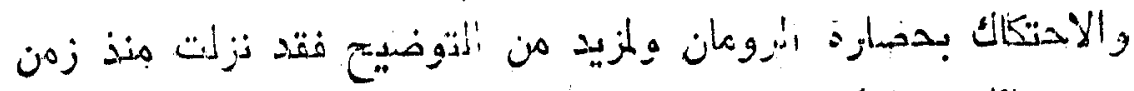

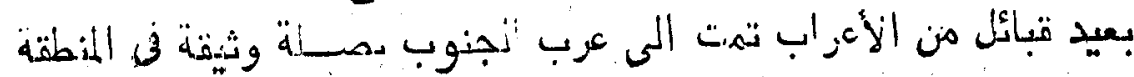

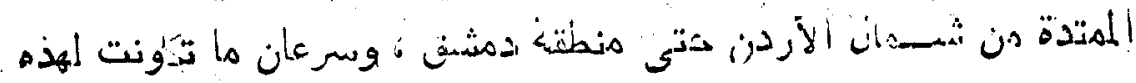

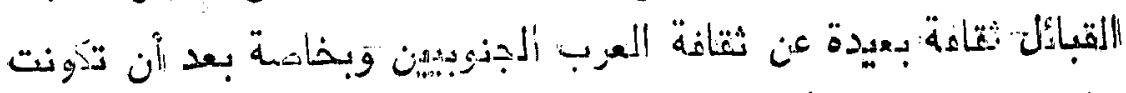

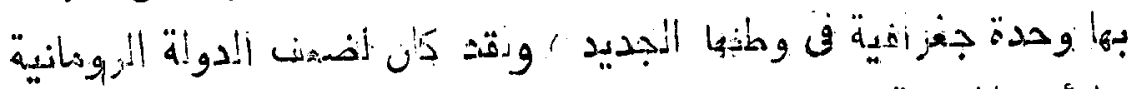

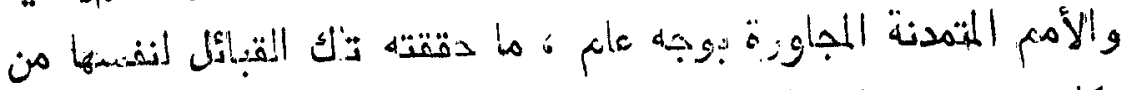

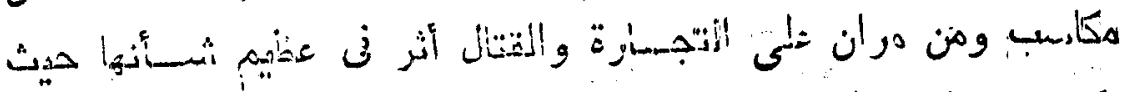

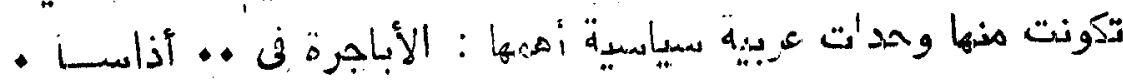

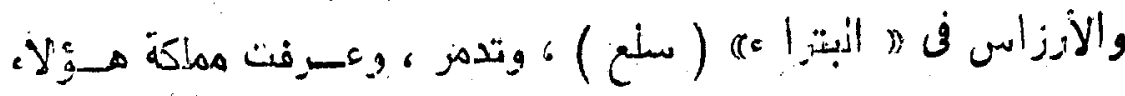

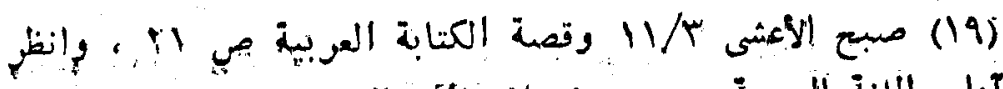

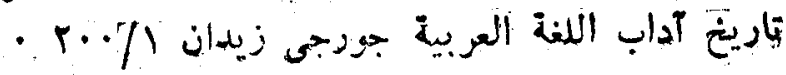


09

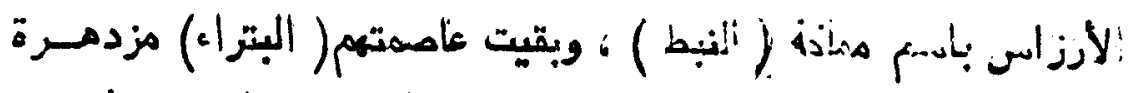

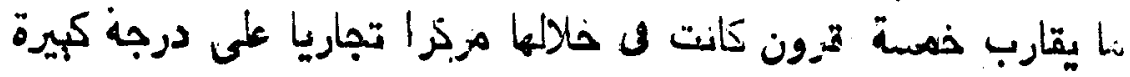

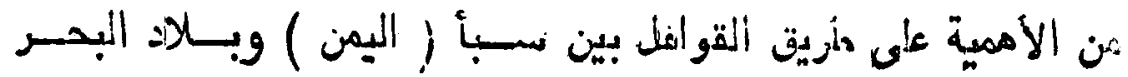

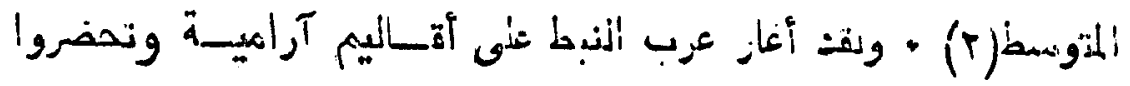

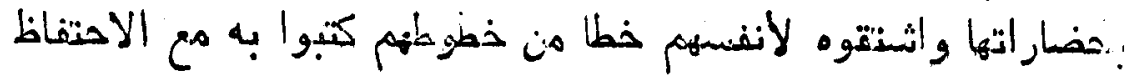

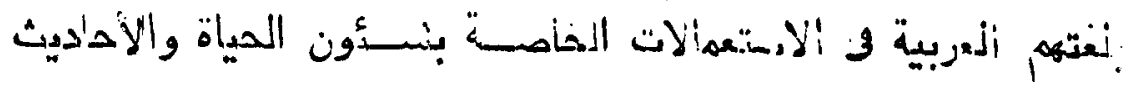

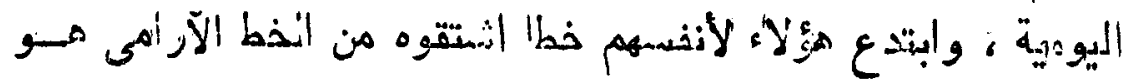

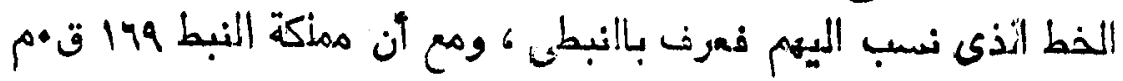

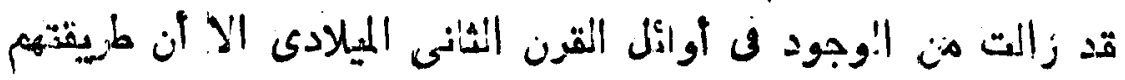

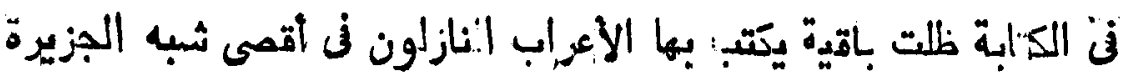

- زهـاء ثلاثة قرونزأباتهة

بولقد مرن هذه المئابتج بادوار مثلاثة :

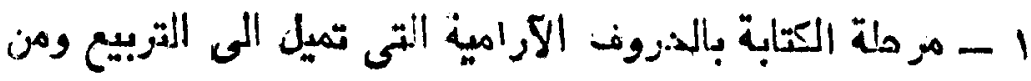

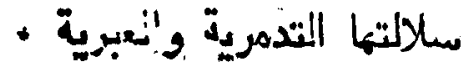

ץ .ـ عرحن انتتأل من الفط الآرامى المربع الى الخط النبطى

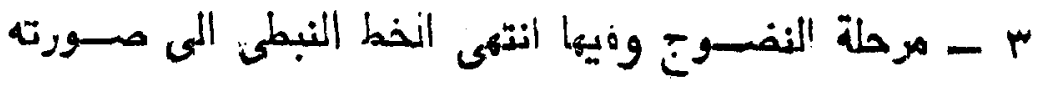

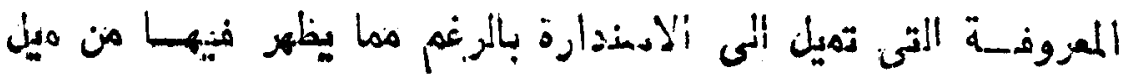

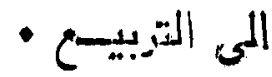

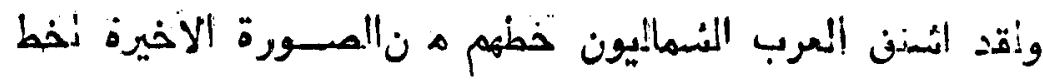

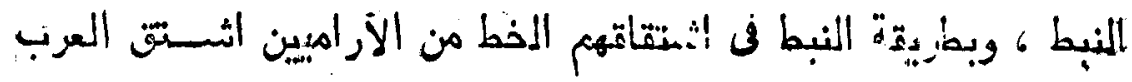

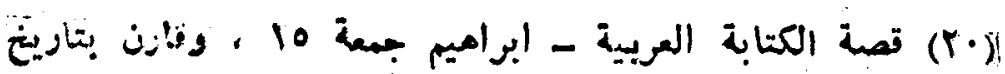

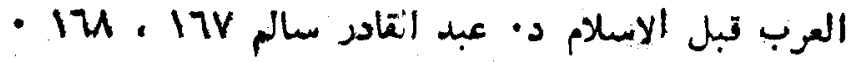

: IV ، 17 (F) 


\section{7}

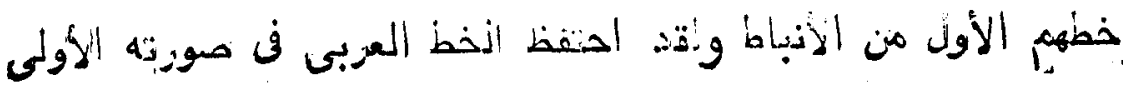

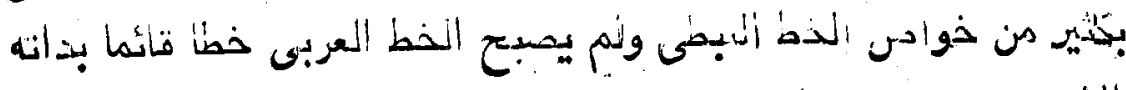

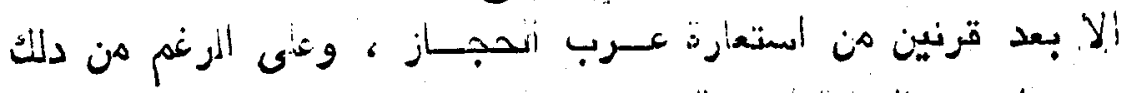

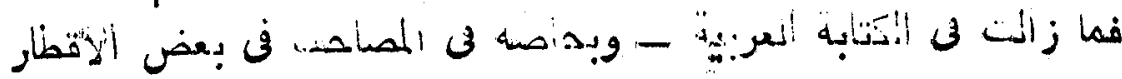

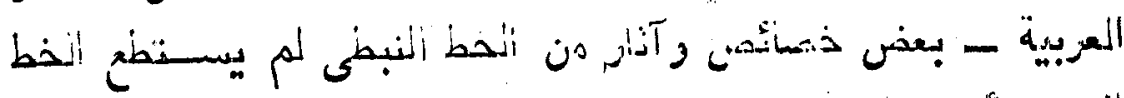

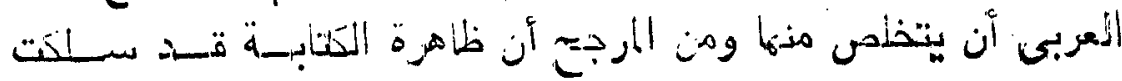

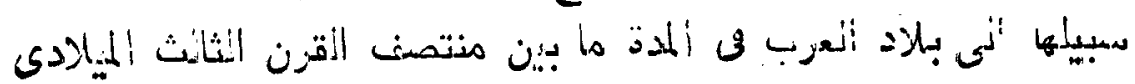

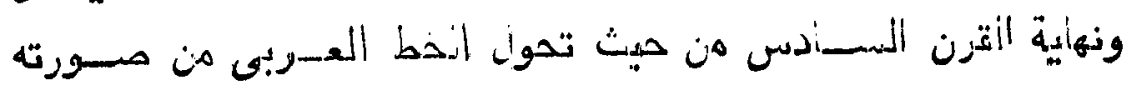

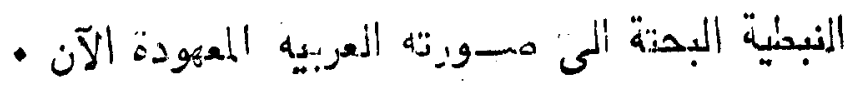

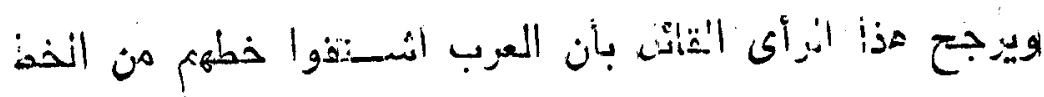

- النبطىى

\section{عسدة أهور هنها :}

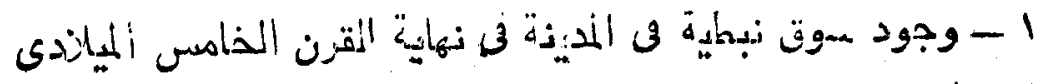

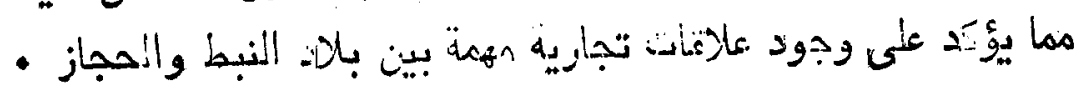

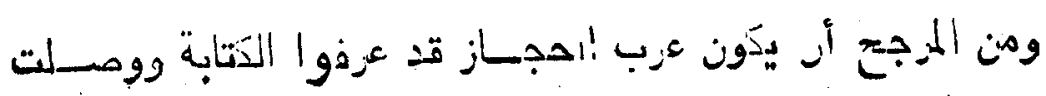

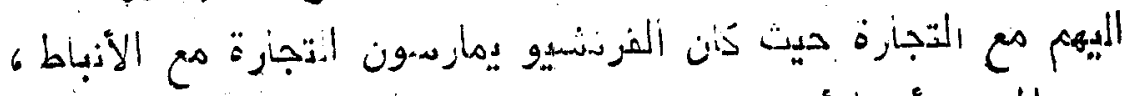

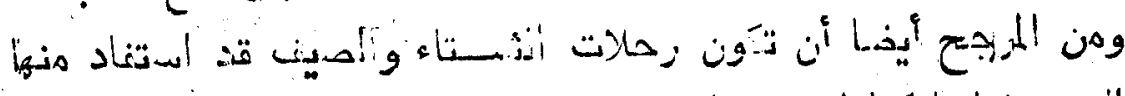

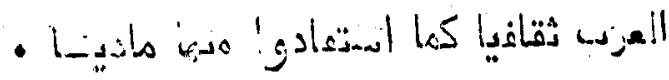

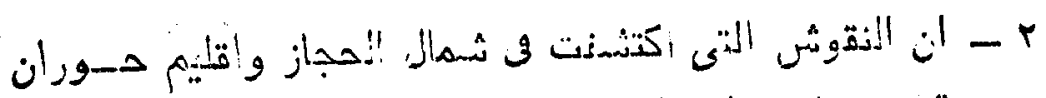

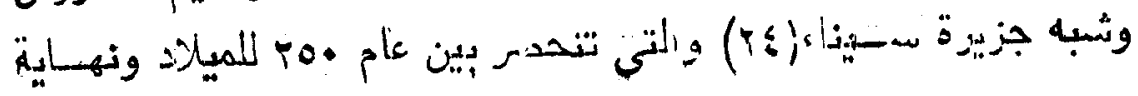

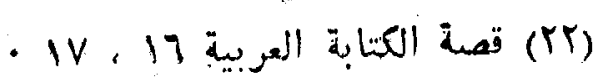$$
\text { - نفسيس }
$$

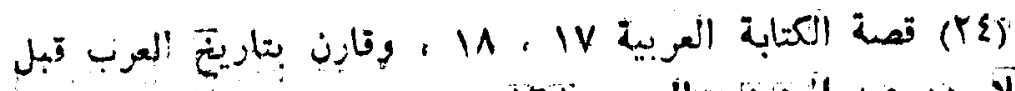

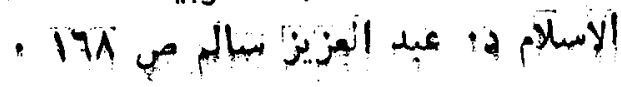




\section{-4V}

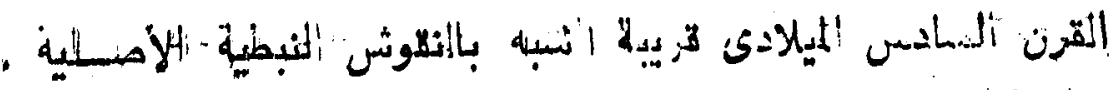

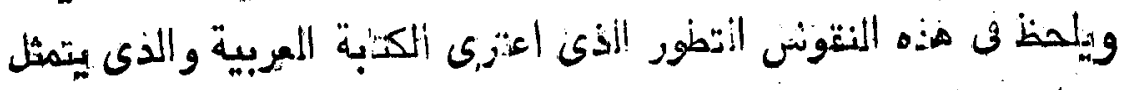

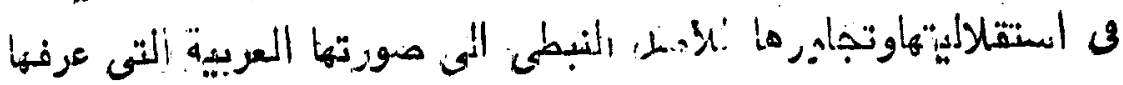

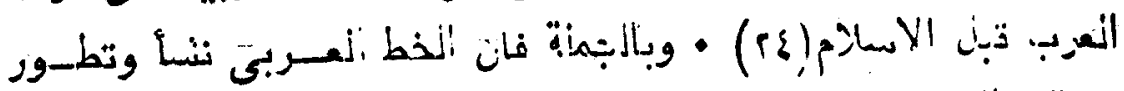

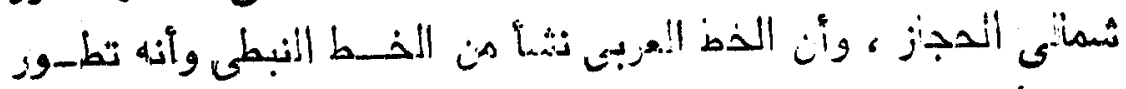

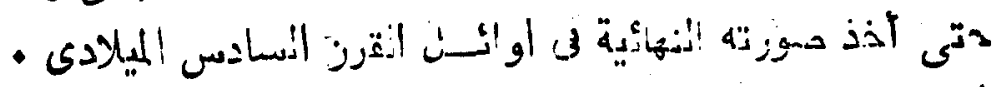

\section{انتقوش المسزبية ودلَّادم| :}

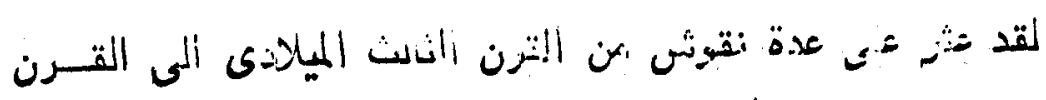

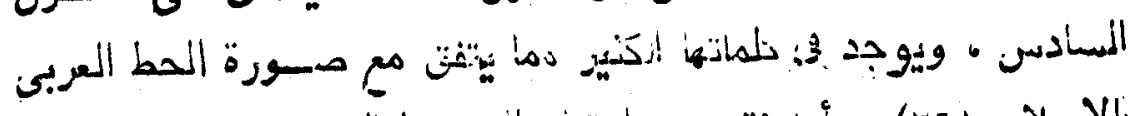

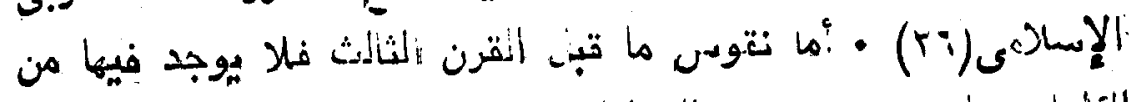

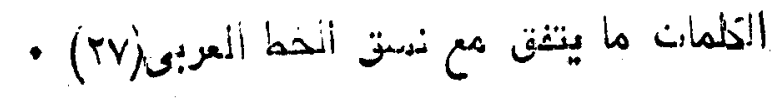

\section{وين أهسم هـدة أندقوثى :}

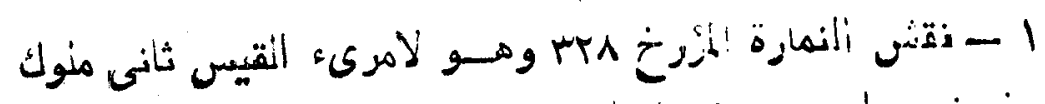

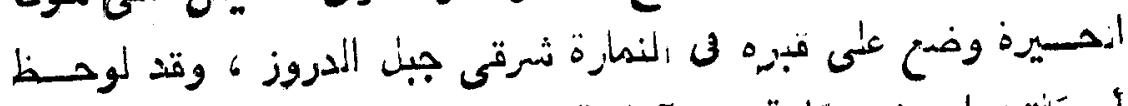

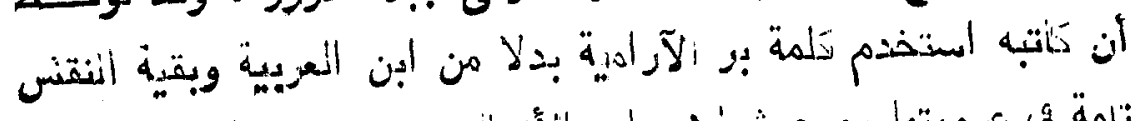

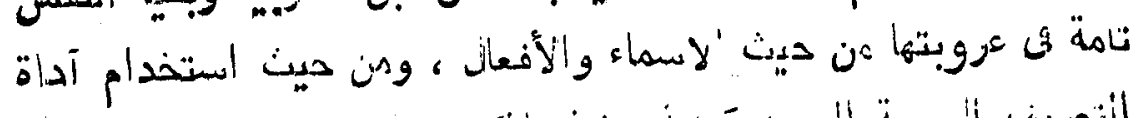

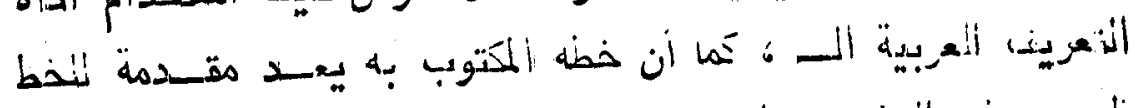

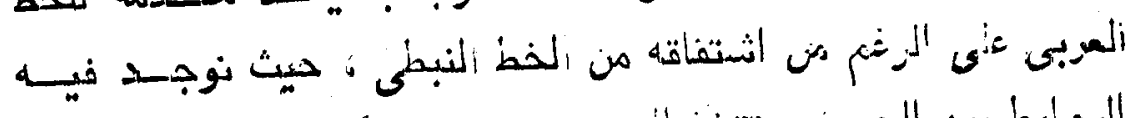

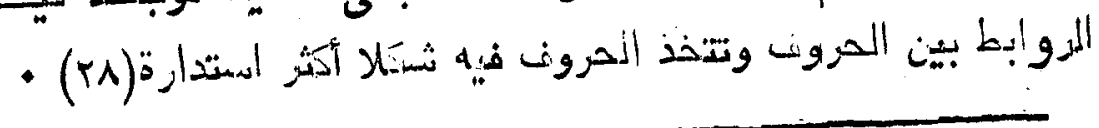

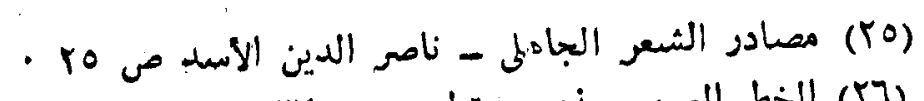

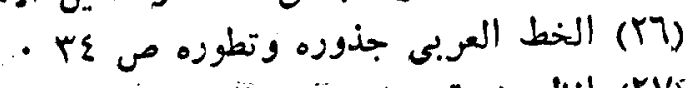

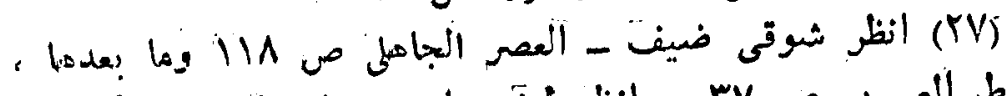

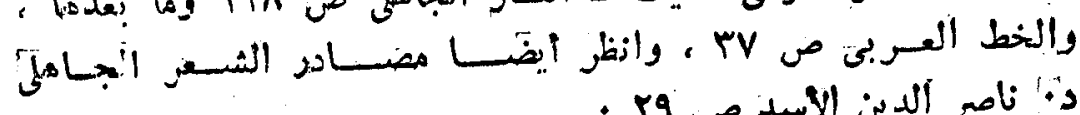

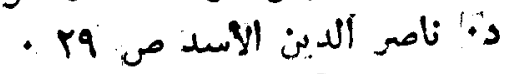

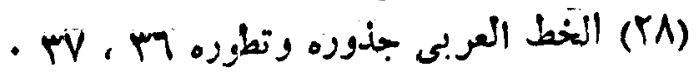




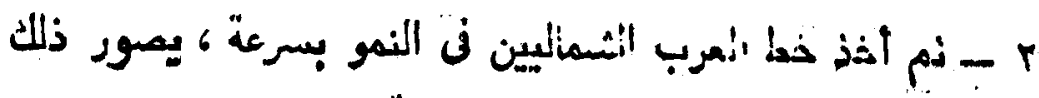

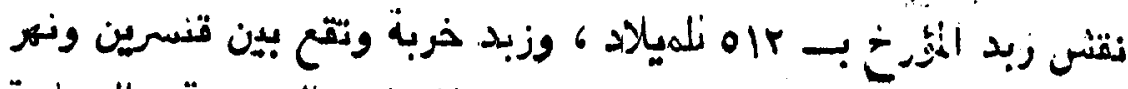

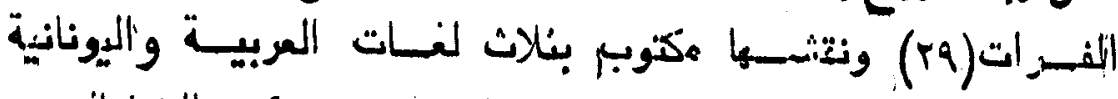

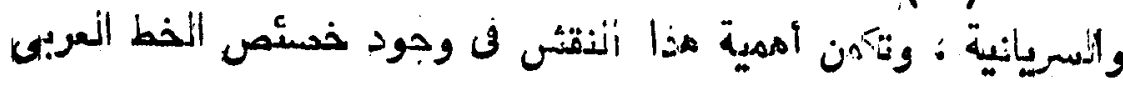

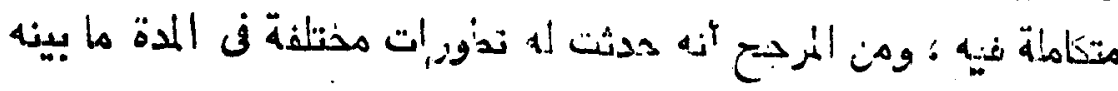

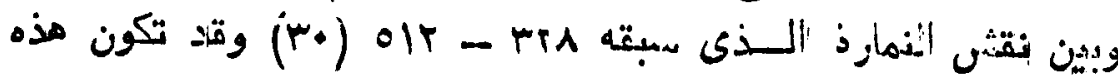

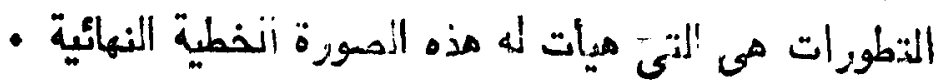

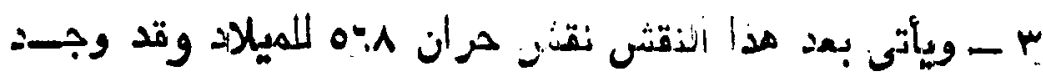

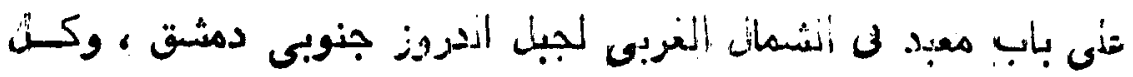

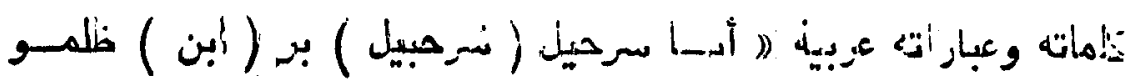

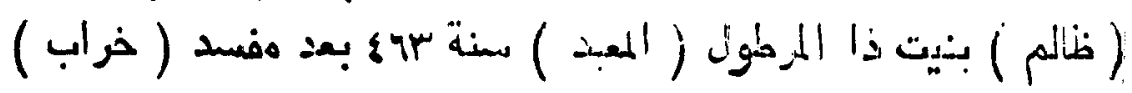

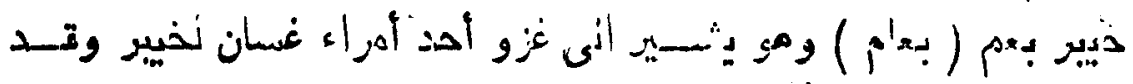

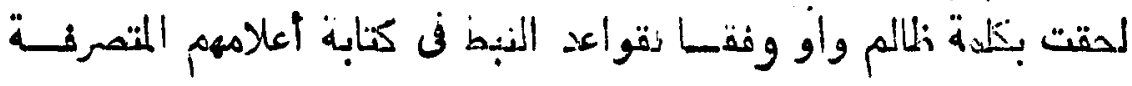

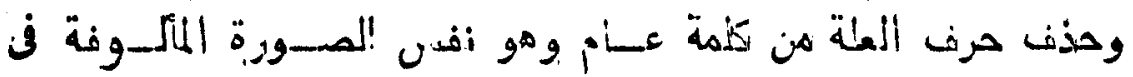

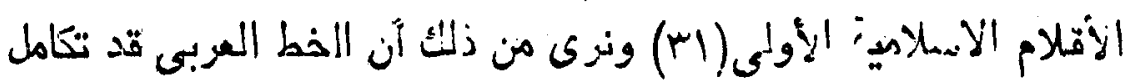

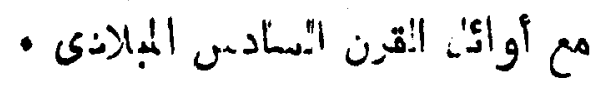

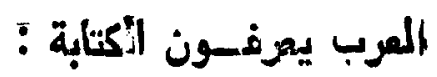

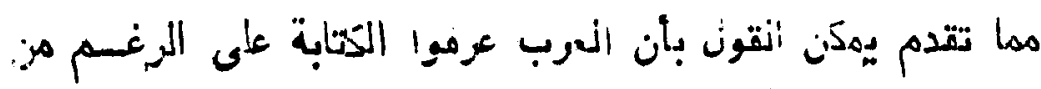

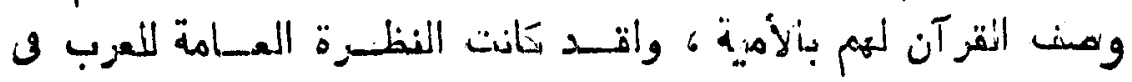

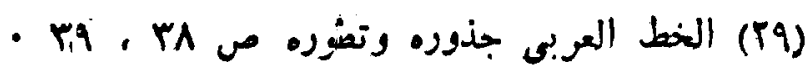

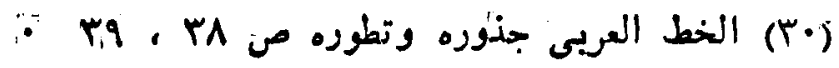

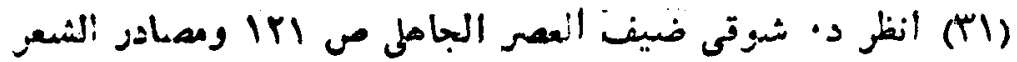

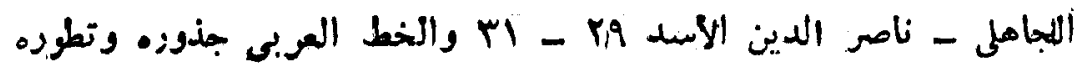




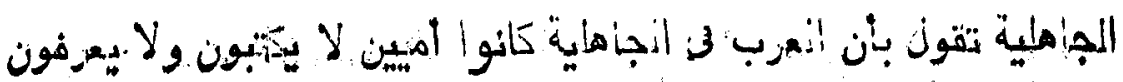

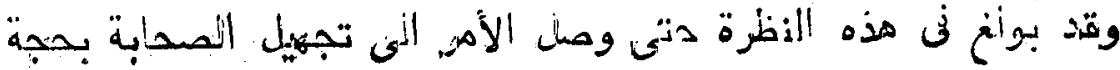

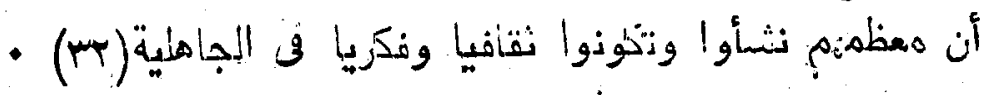

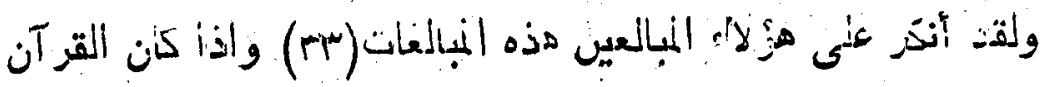

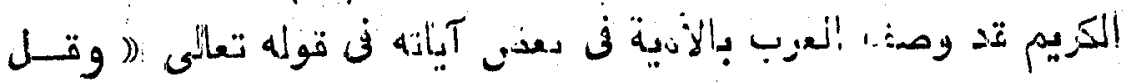

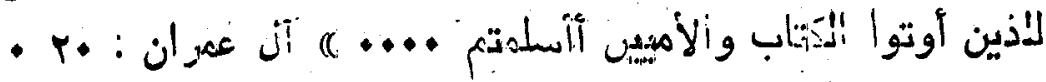

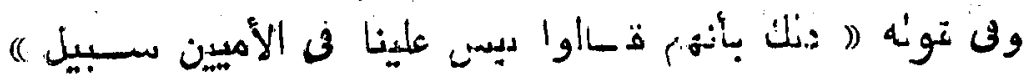
-vo : آل عمــران

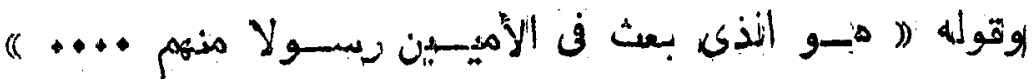

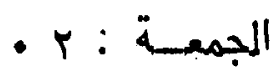

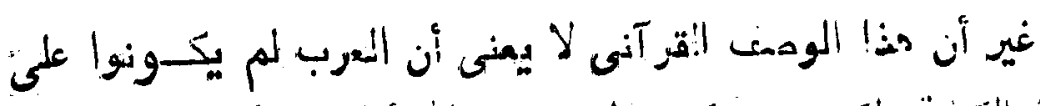

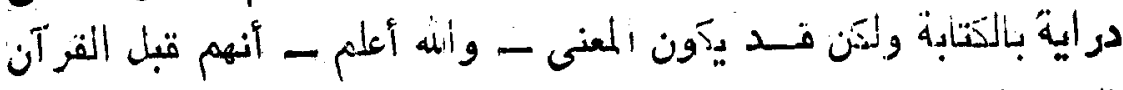

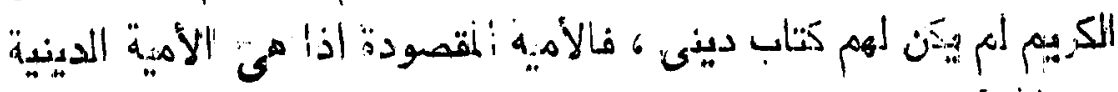
-

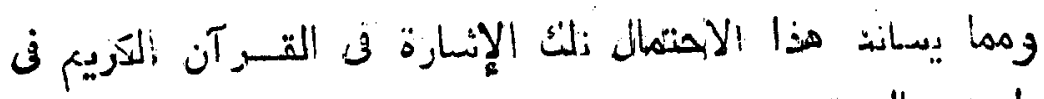

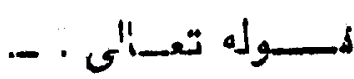

لا غويل للاذين يكتبون الكتاب بأيديهم ثم يتوأون هذا هن عند الثند

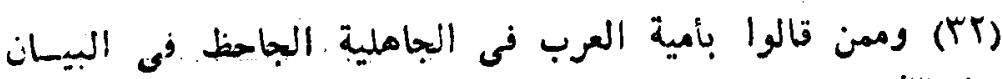

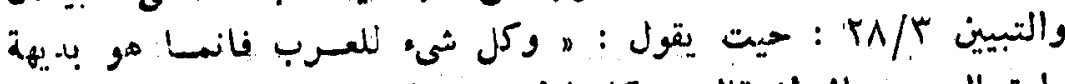

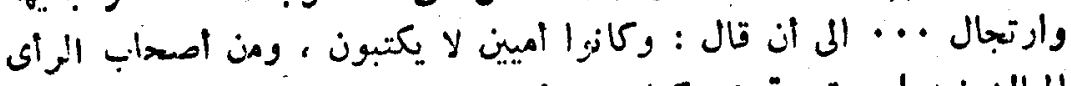

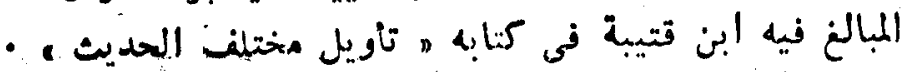

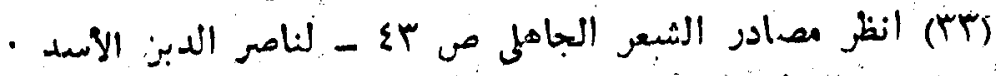

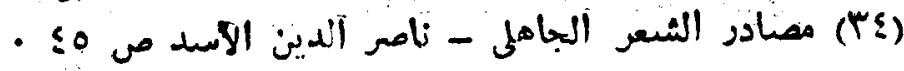




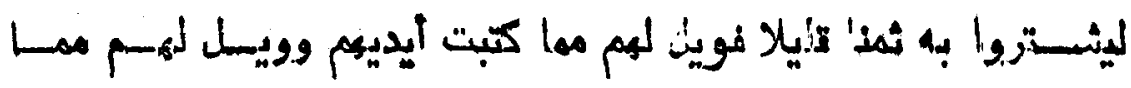

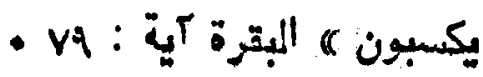

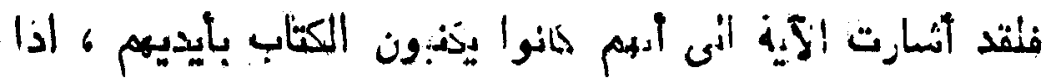

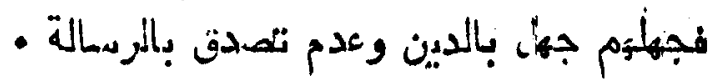

والقد ورلد ف الدديث: اننشريف ودمث لأمية العرب فن تول 'نزسول -

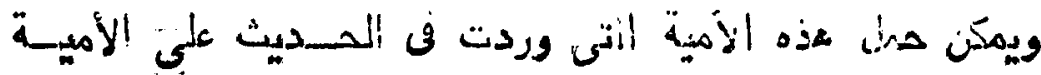

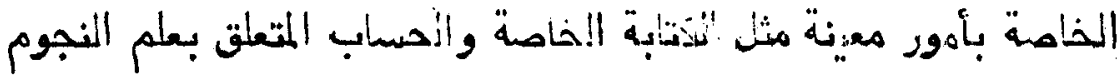

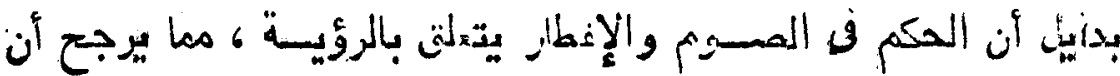

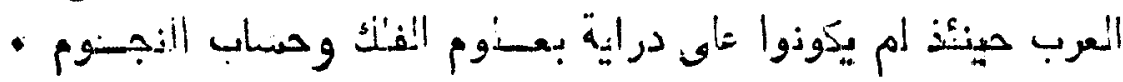

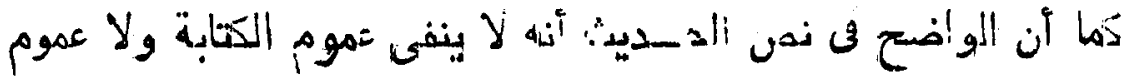

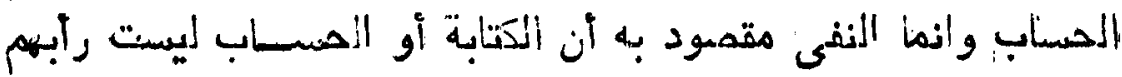

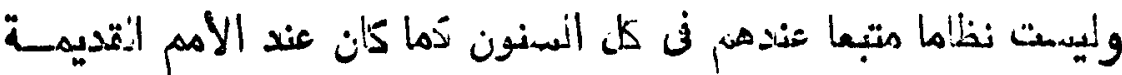

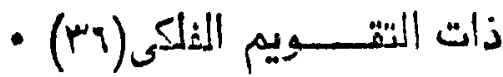

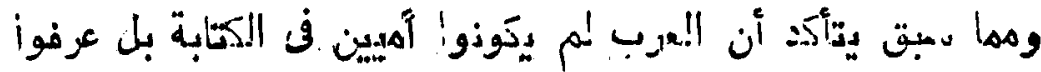

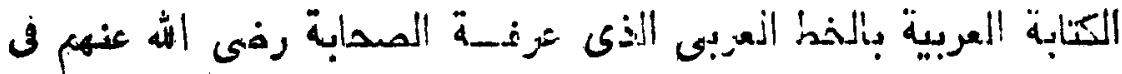

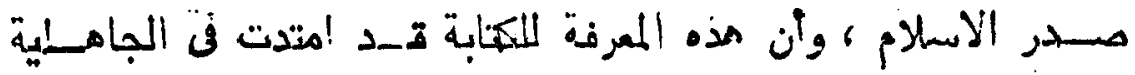

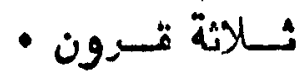

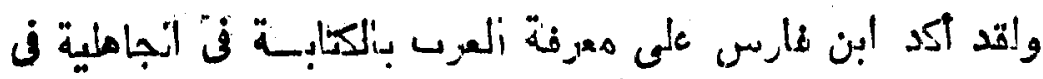

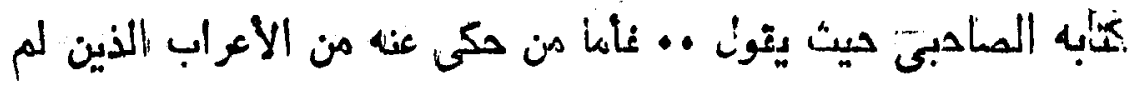

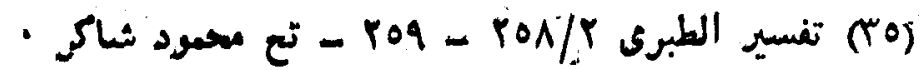

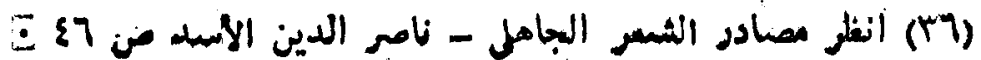




\section{T.1.}

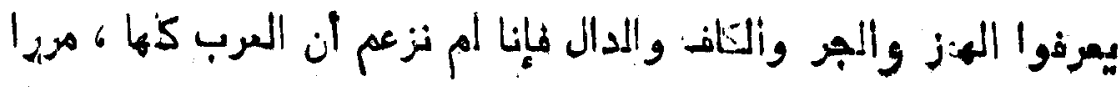

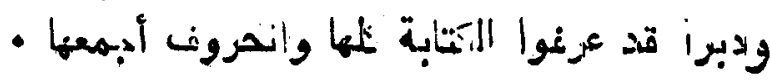

وما العرب من قديم الزهان الا كنهن اليوم ، نما كل يعرف إلكتابة

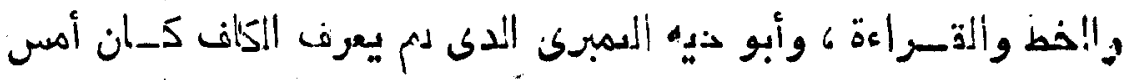

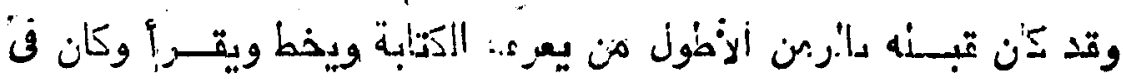

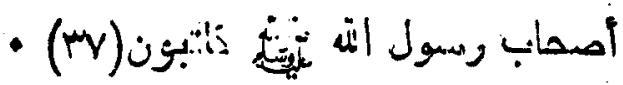

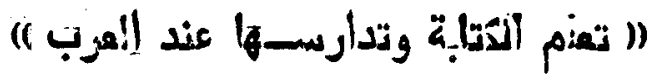

لقد تأكد عمرنة المعرب بالتتابه تبن الاسلالام وتأكد أيضا استعمال

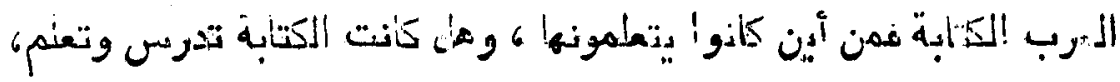

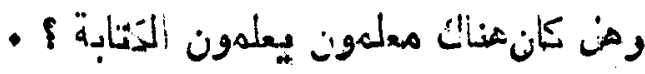

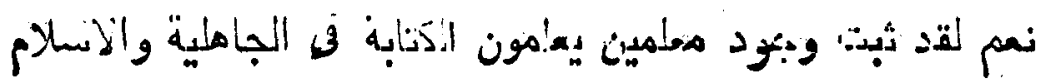

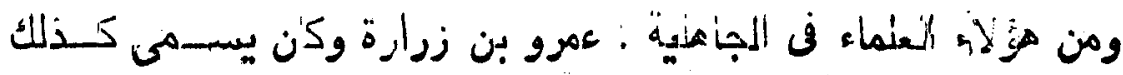

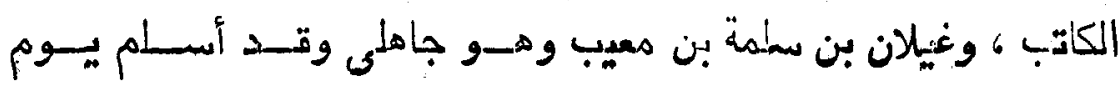

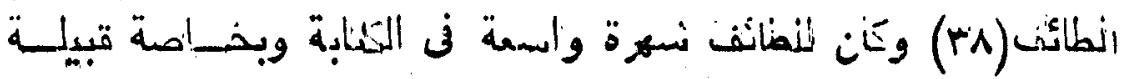

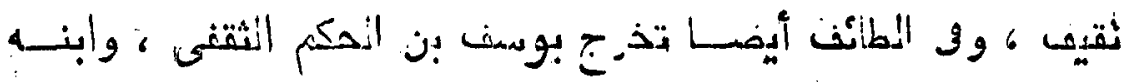

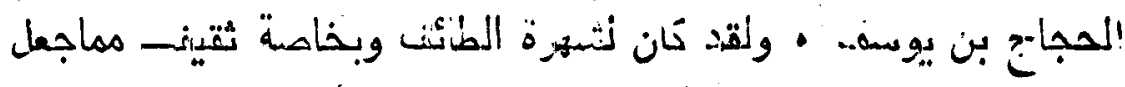

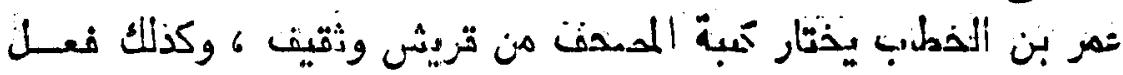

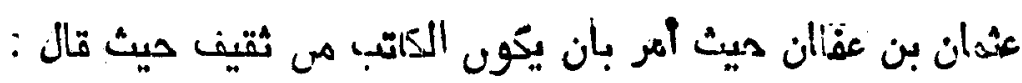

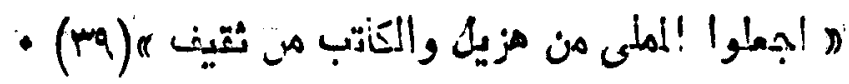

- 11 - 1 ( الصاحبى - ابن نارس (rV)

(YA) 


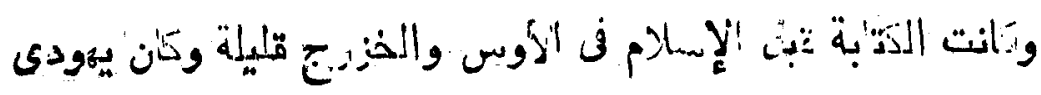

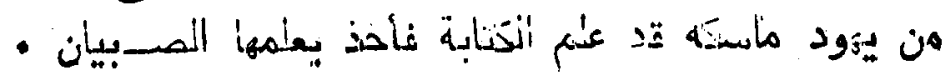

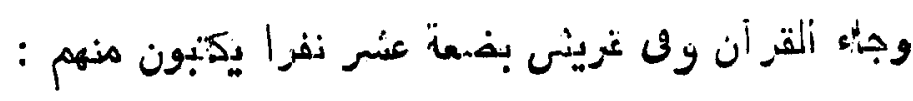

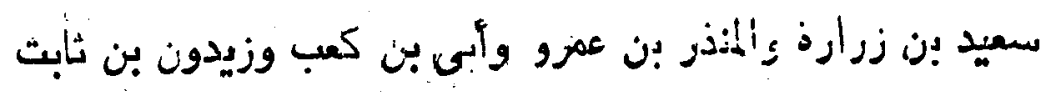

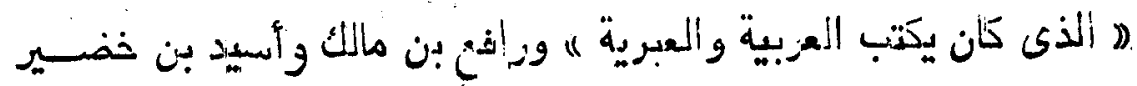

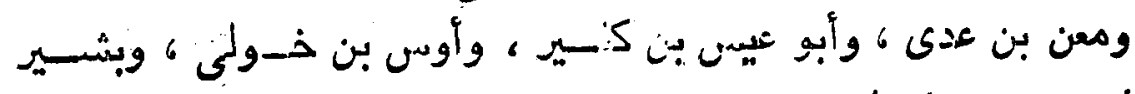

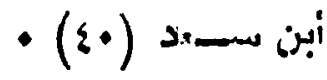

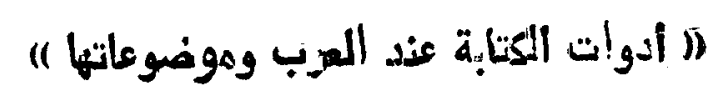

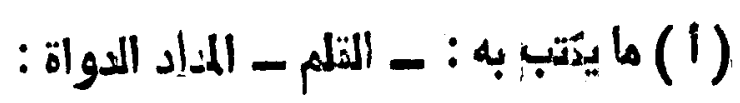

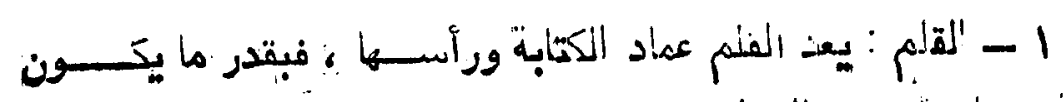

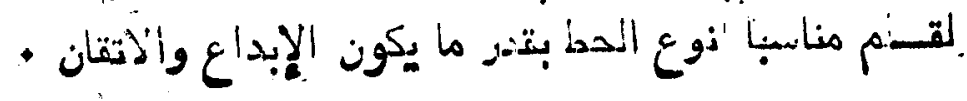

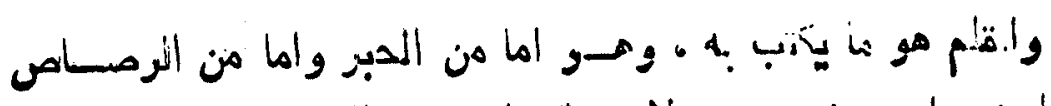

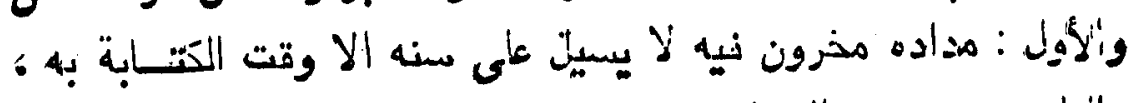

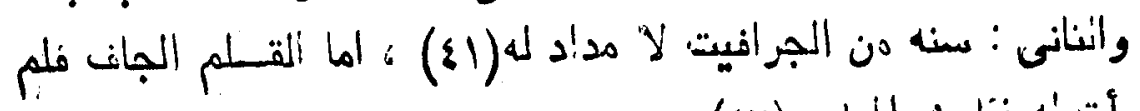

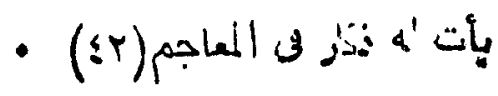

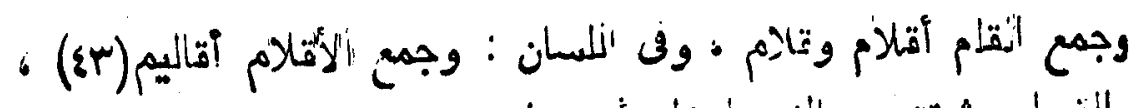

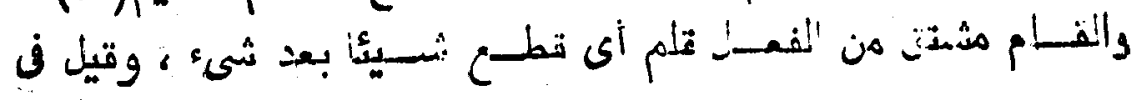

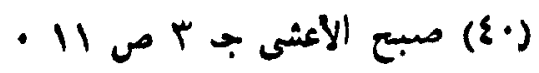

$$
\begin{aligned}
& \text { - (\&l) }
\end{aligned}
$$

هن

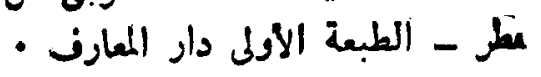
• 


\section{Iers?}

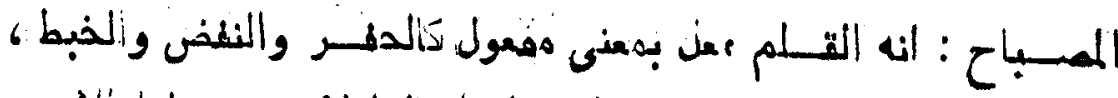

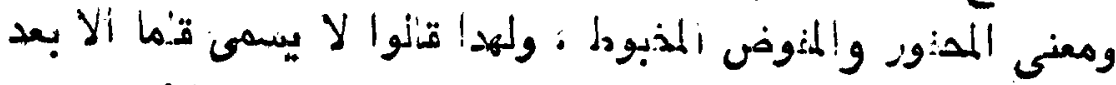

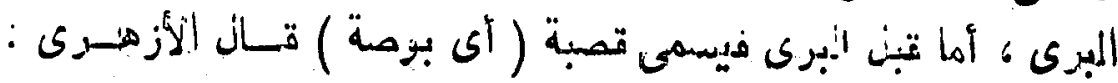

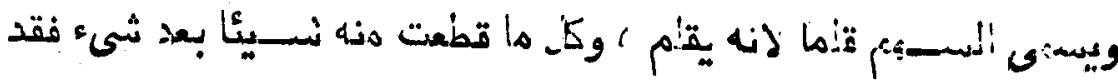

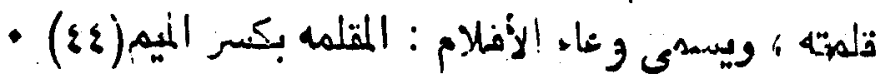

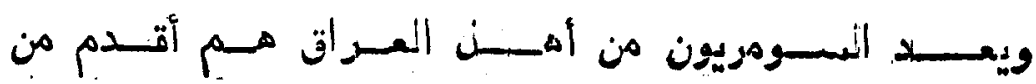

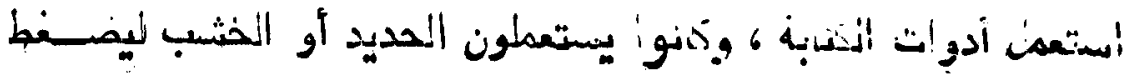

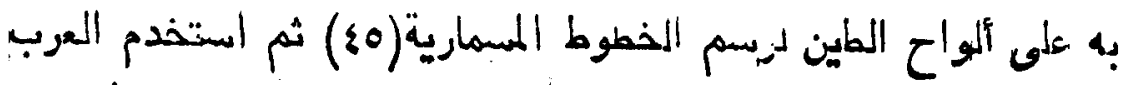

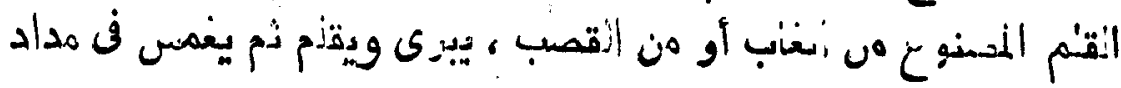

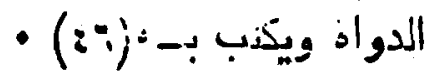

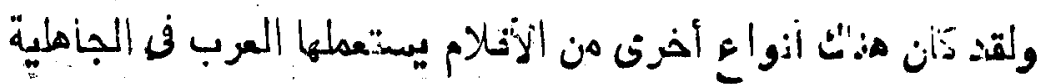

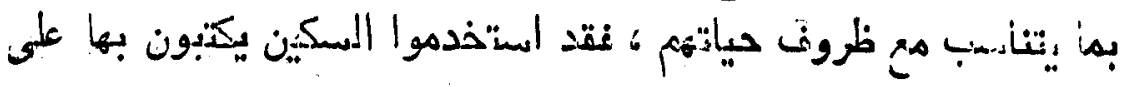

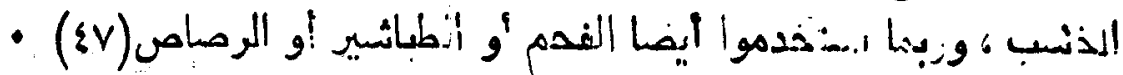

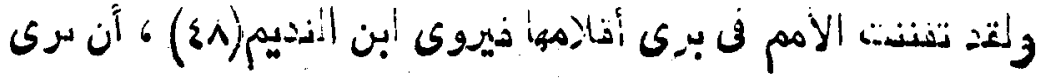

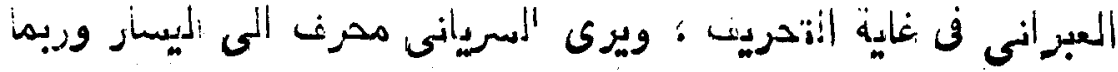

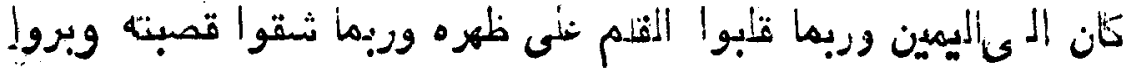

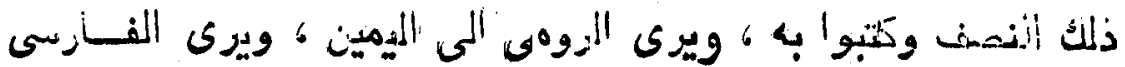

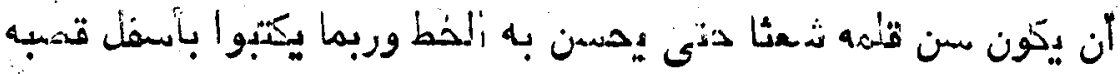

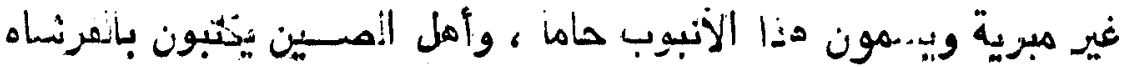

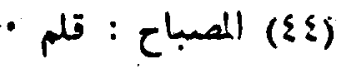

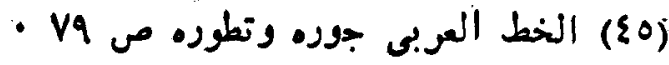

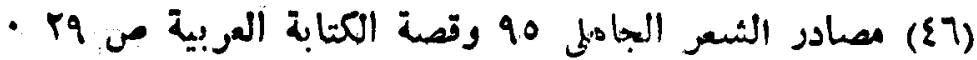

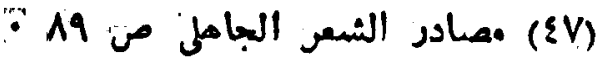

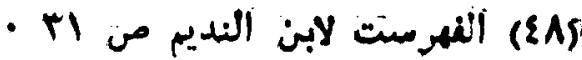




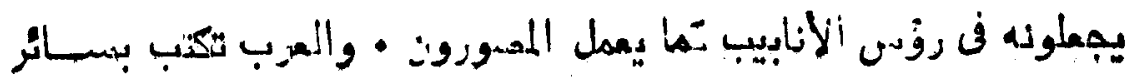

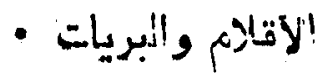

هذا ولقدم وزيد ذكر - لفط - القلم في القترآن الكريم نـلاث هـرات :

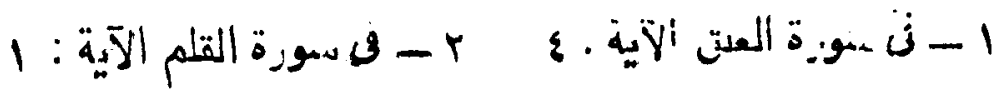

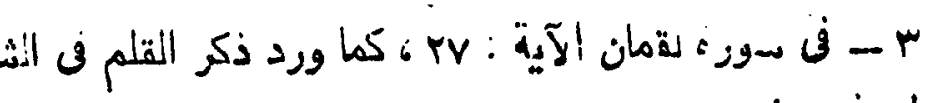

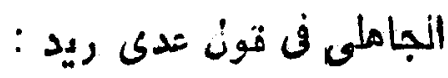

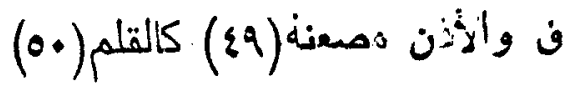

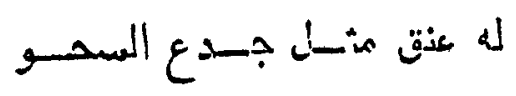

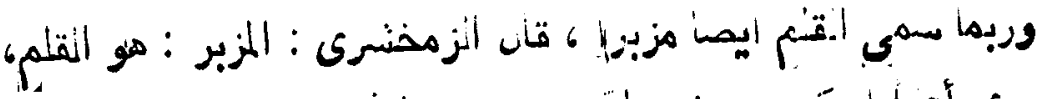

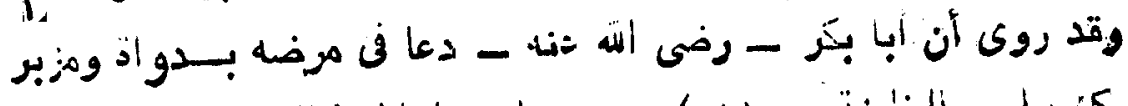

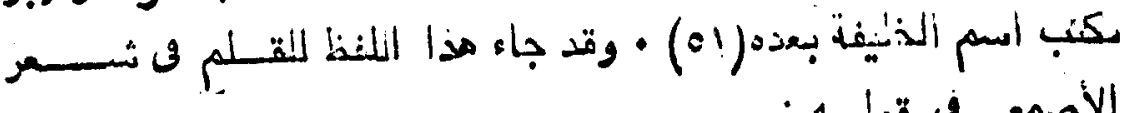

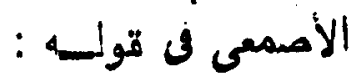

$$
\text { - قد قضى الأهر وجف المزبز(or) }
$$

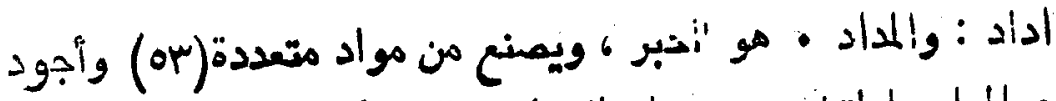

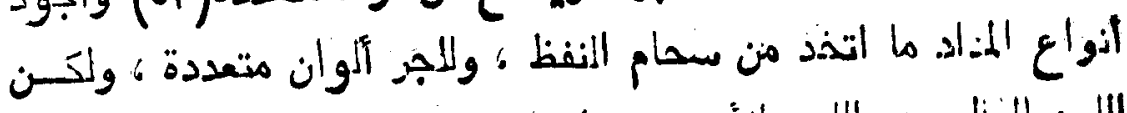

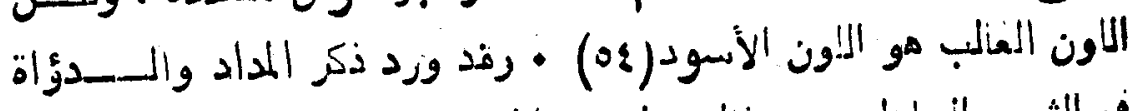

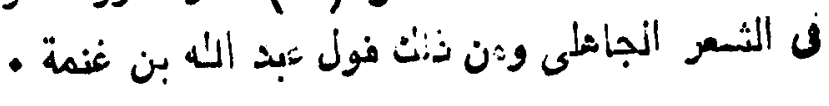

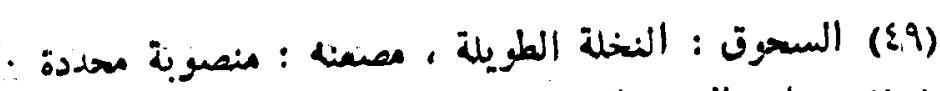

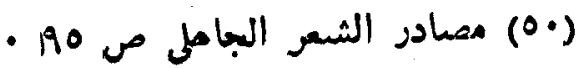

-

(OY)

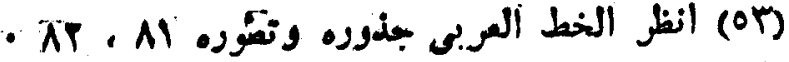




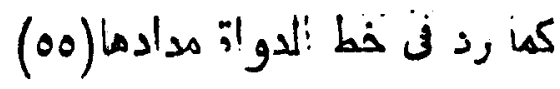

$$
\text { نلـم ديق الا دمنــة ومنازل }
$$

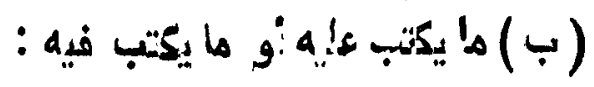

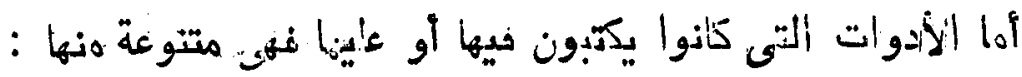

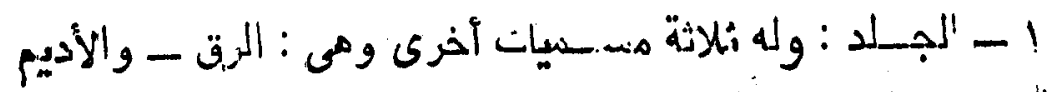

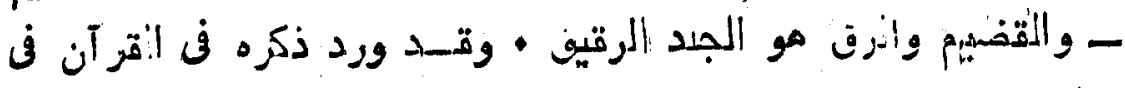

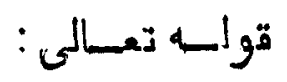

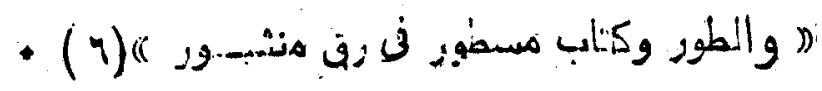

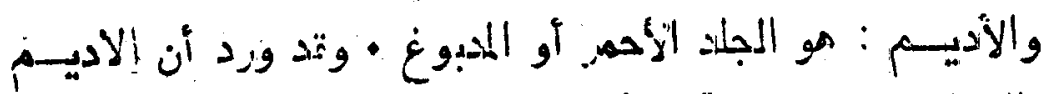

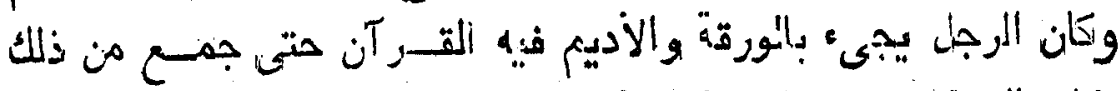

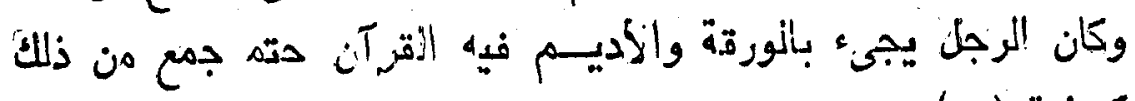

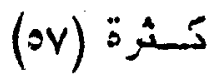

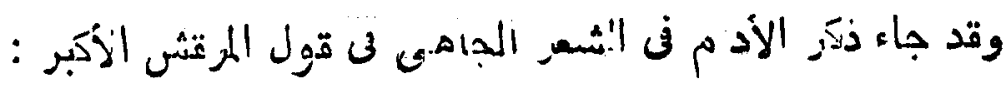

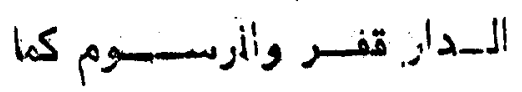

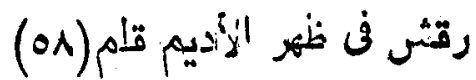

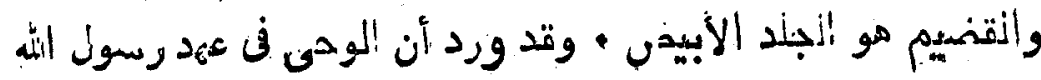

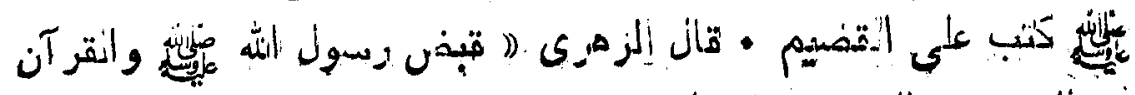

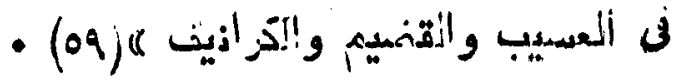

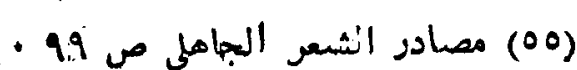

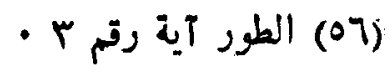

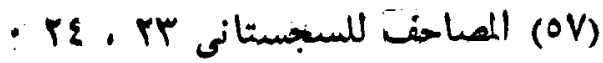

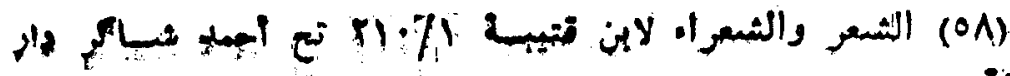

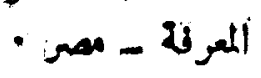

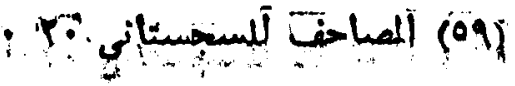




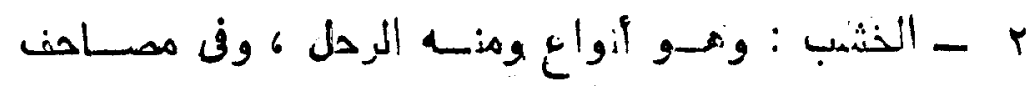

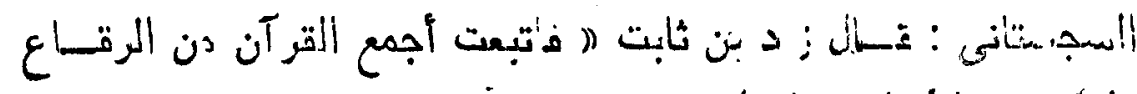

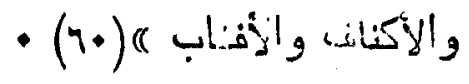

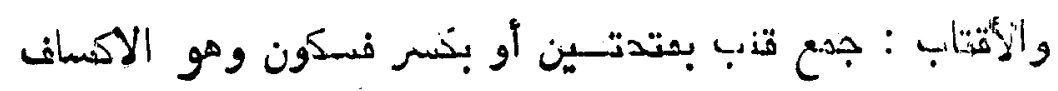

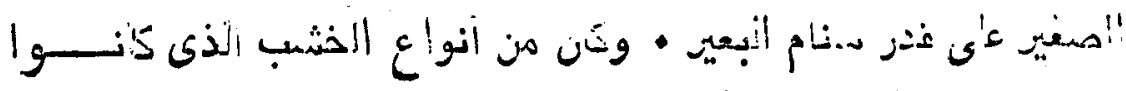

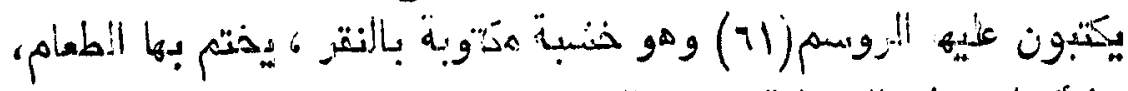

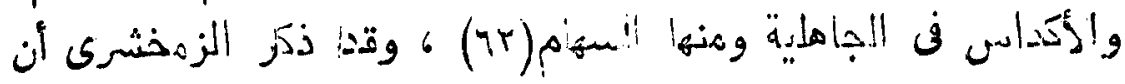

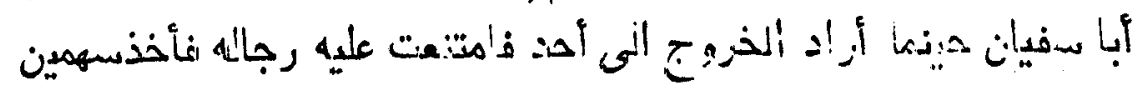

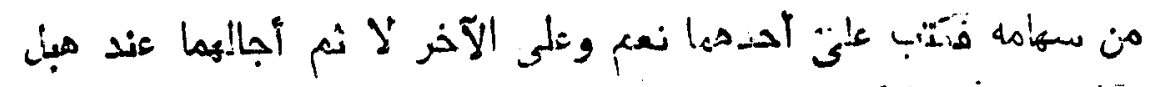
- نذّ-رج

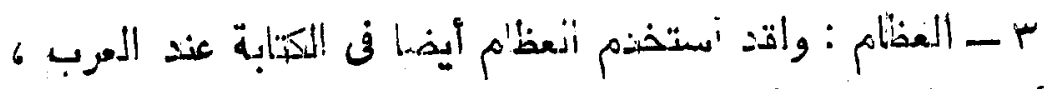

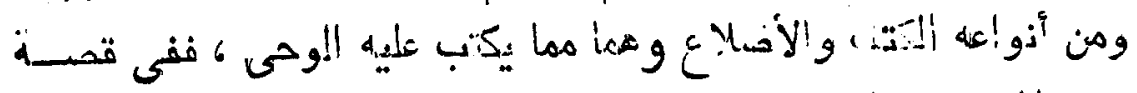

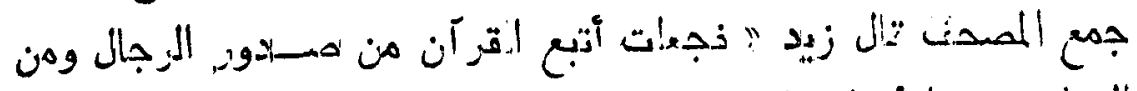

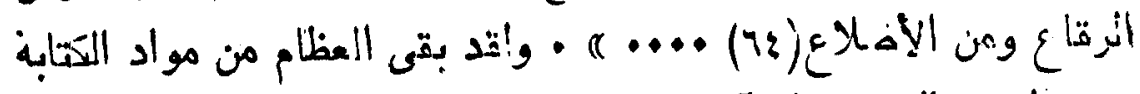

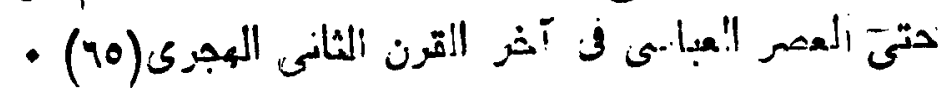

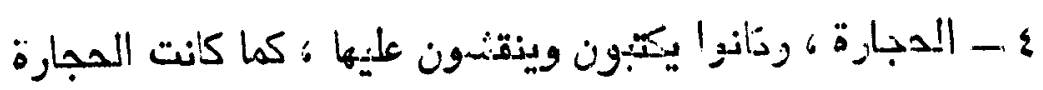

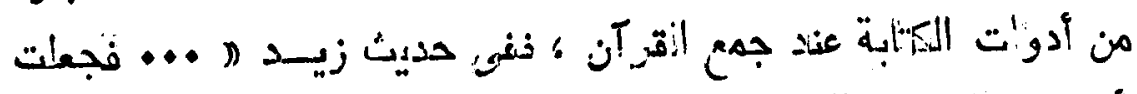

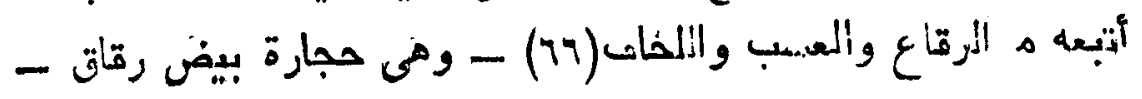

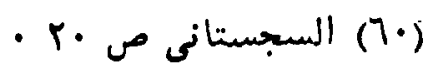

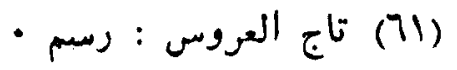

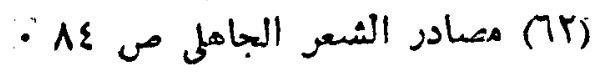

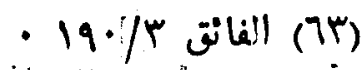

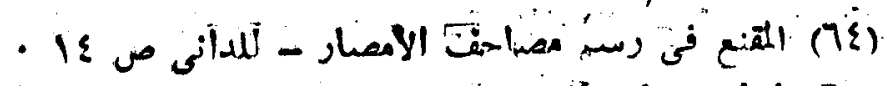

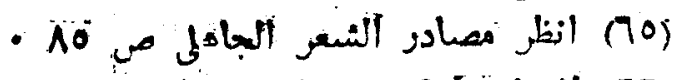

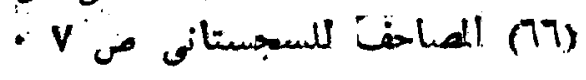




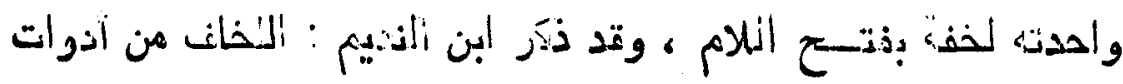

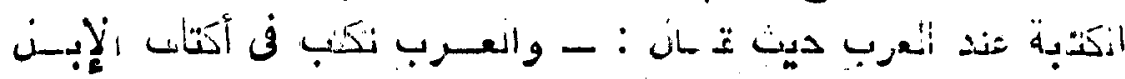

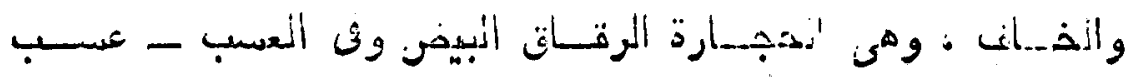

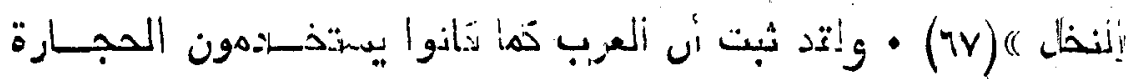

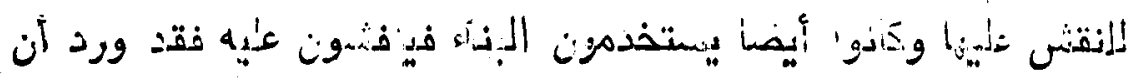

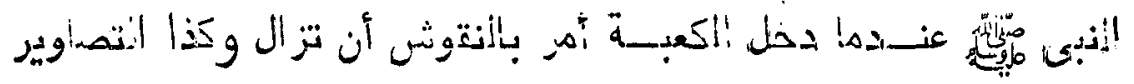

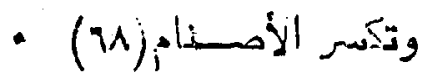

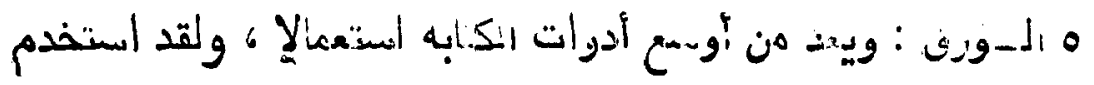

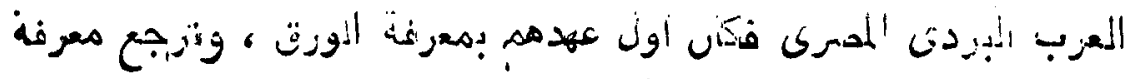

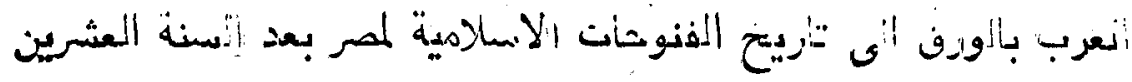

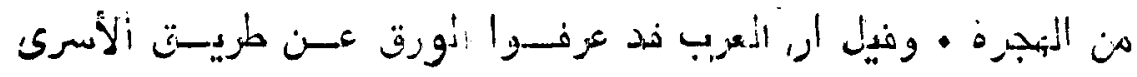

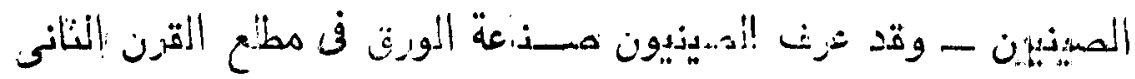

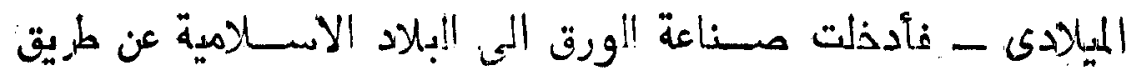

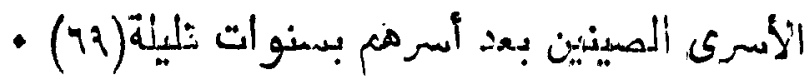

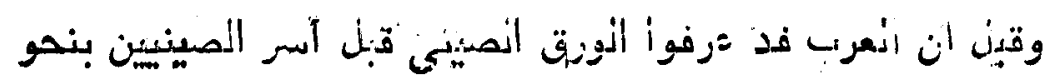

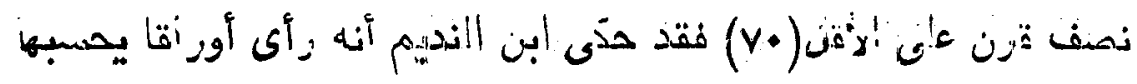

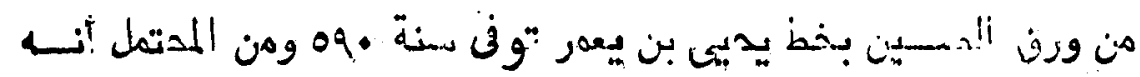

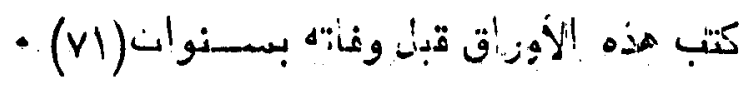

- r النهر (TV)

(79)

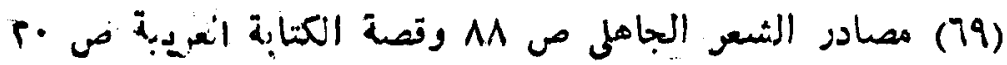

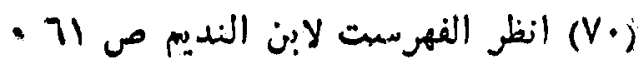

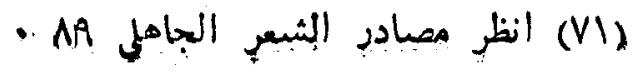




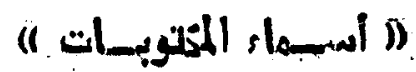

لقد ثبت أن المزيب تَّنوا بتتبون وكان لهه هن الأدوات، انتى كانوا

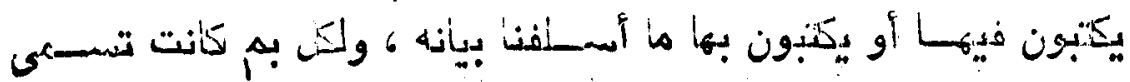

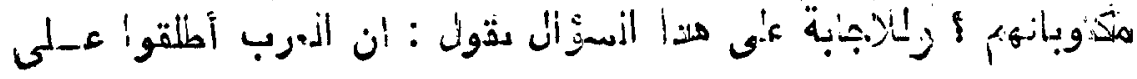

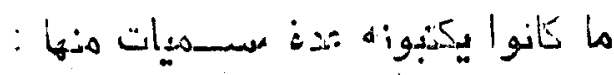

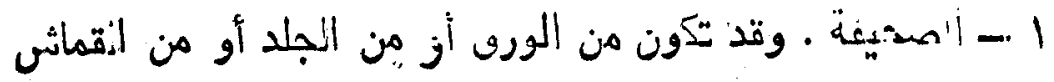

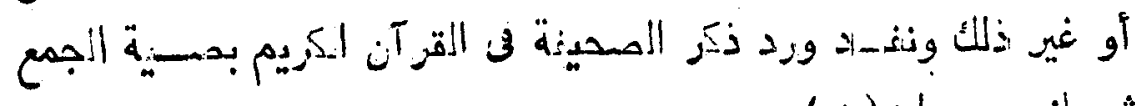
- ثمسانى" مسران

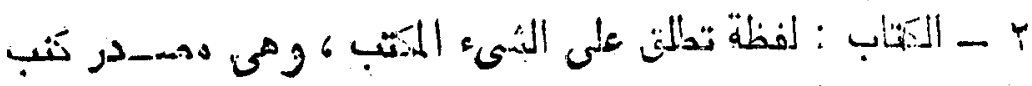

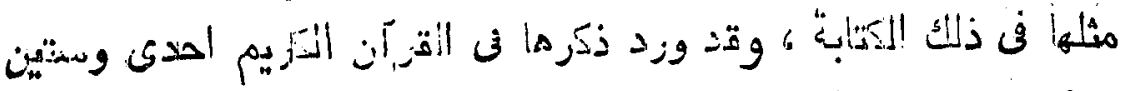

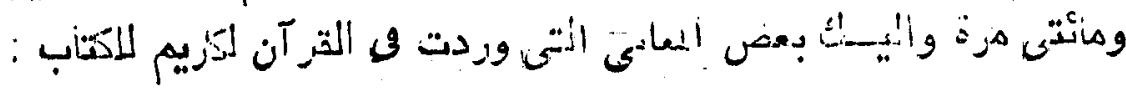

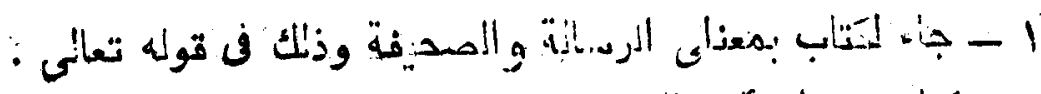

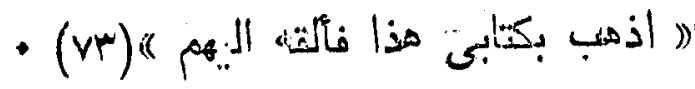

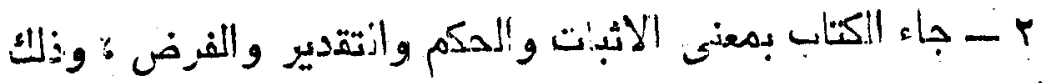

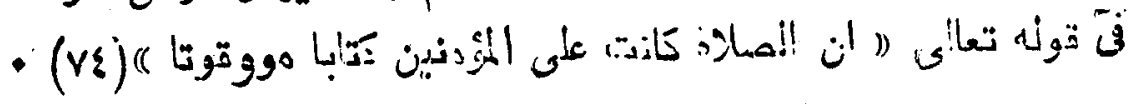

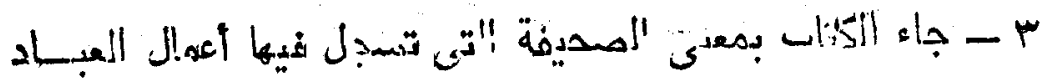

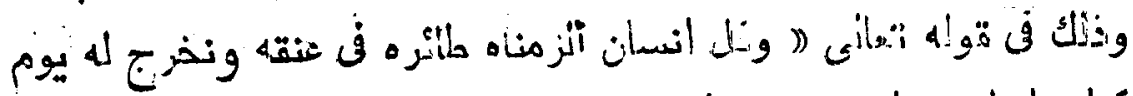

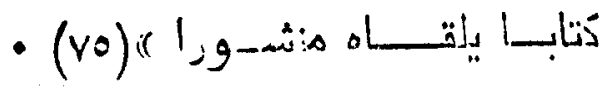

(IT) - F "

- H النساء آل

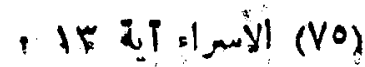




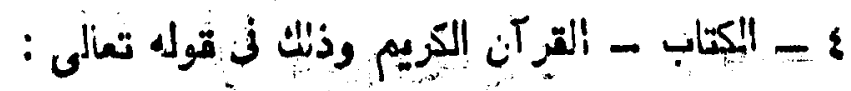

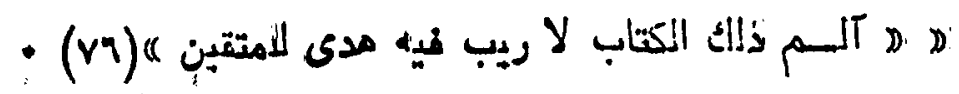

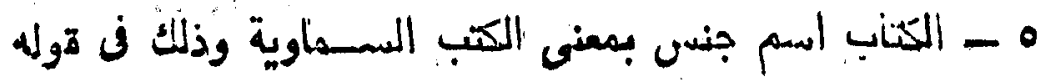

: تمسالى

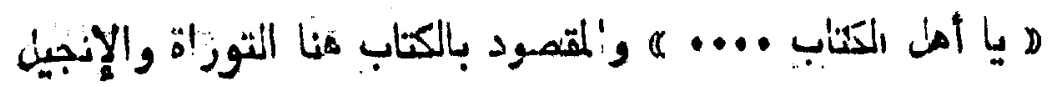

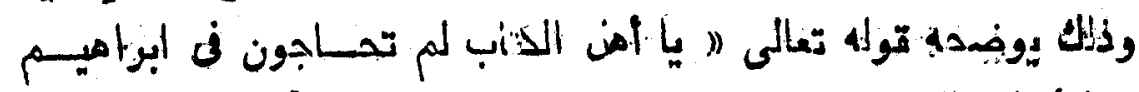

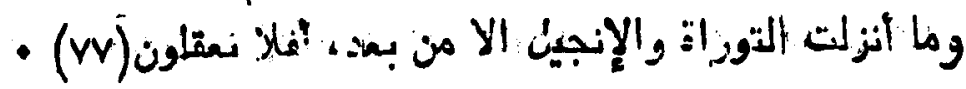

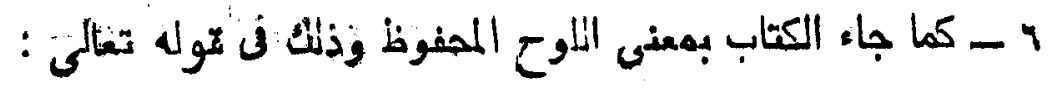

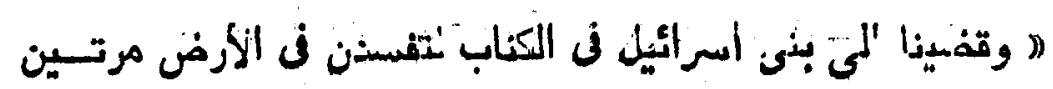

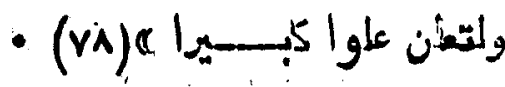

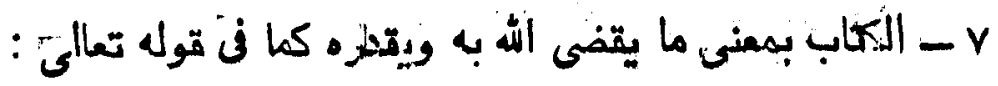

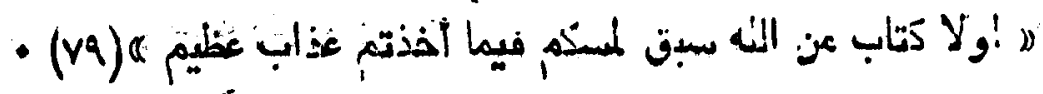

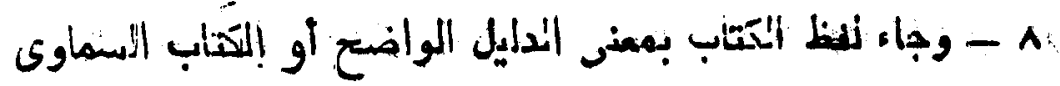

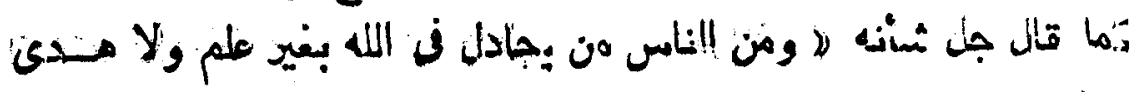

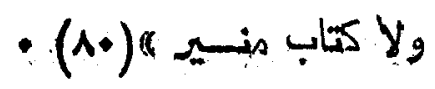

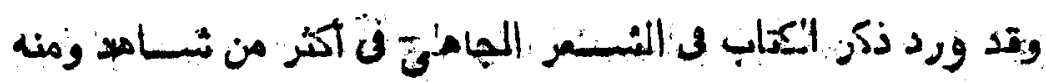

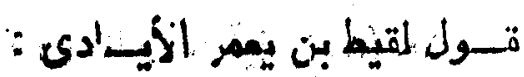

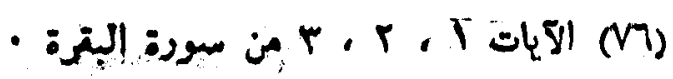

- 10 (TV)

- الاسراه 1لية ؟ الإن

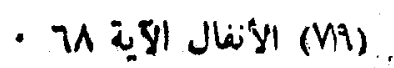

- 1 (الآلية

$(i+r)$ 


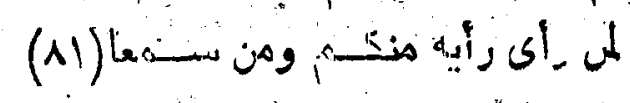

\section{$\therefore$}

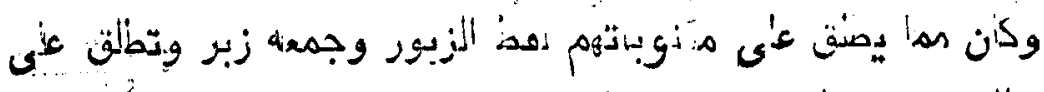

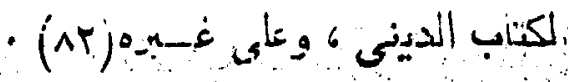

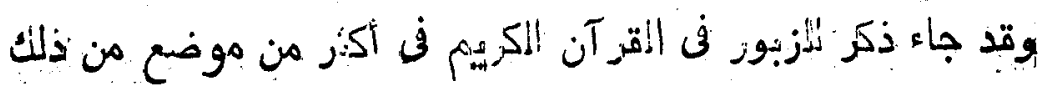

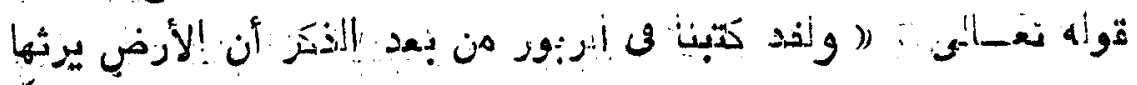

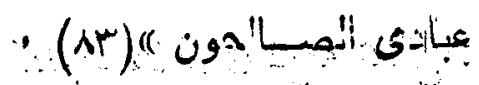

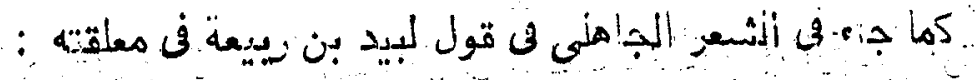

وجـلا الســيون على اiٔطسون ذأذنهـا

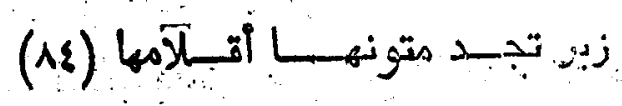

هوضـوءات الزتابسة :

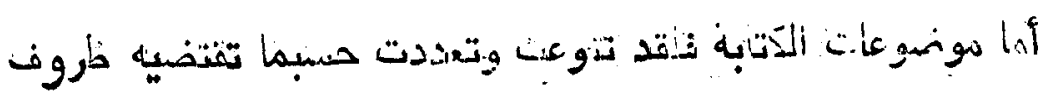

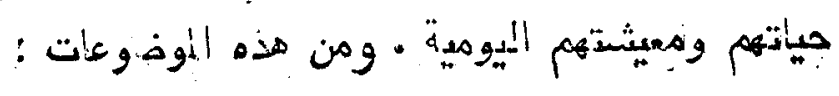

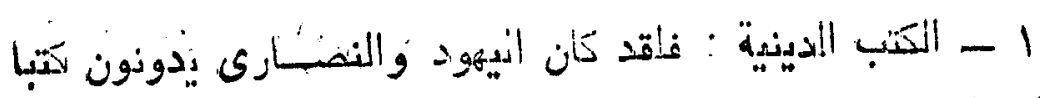

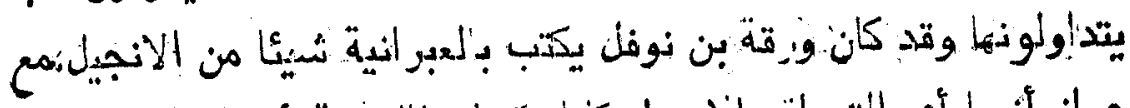

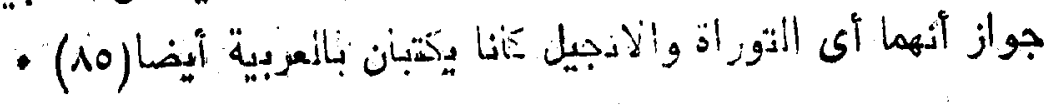

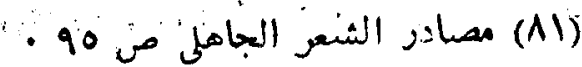

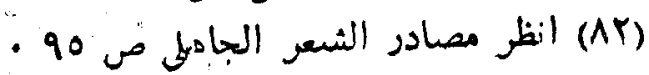

. 1 .

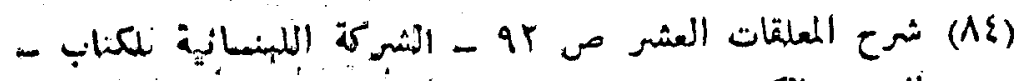

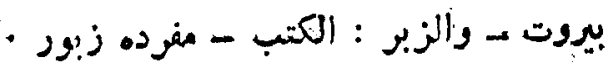

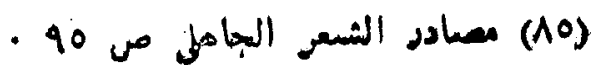


r - كتابة العهود والئواثيق وألأحلافت: ومن أثــهر تثلك المهود

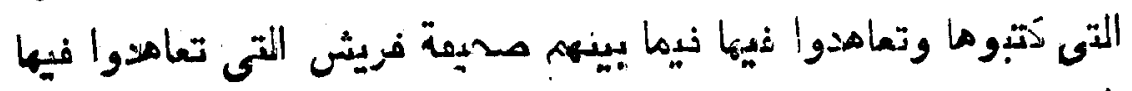

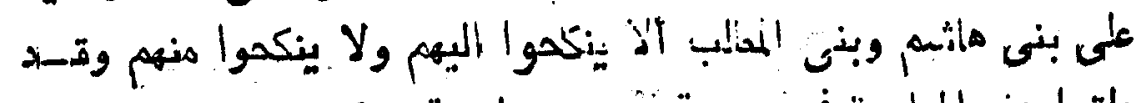

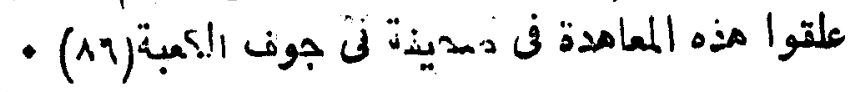

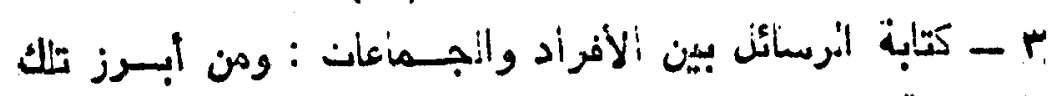

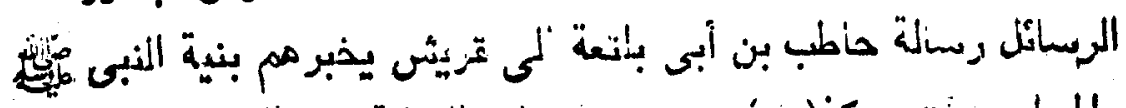

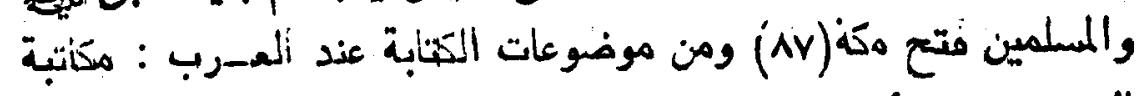

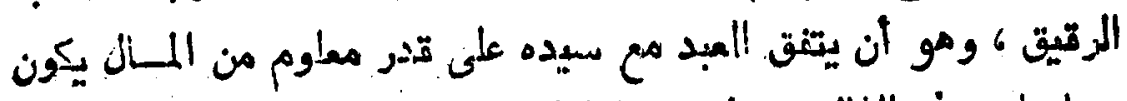

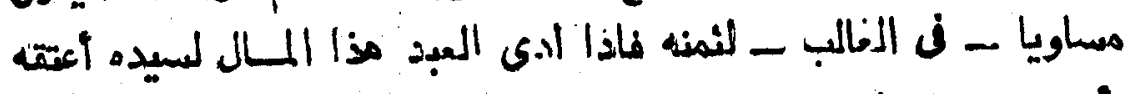
- i ومنانك موضوعات أفرى متنوعة منها :

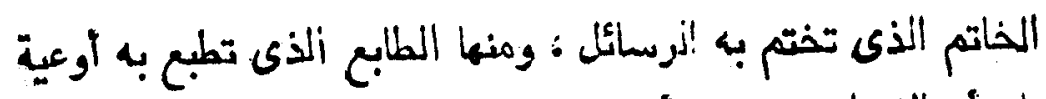

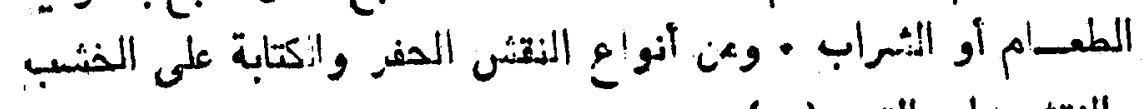

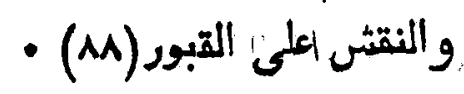

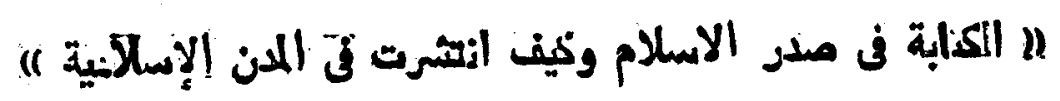

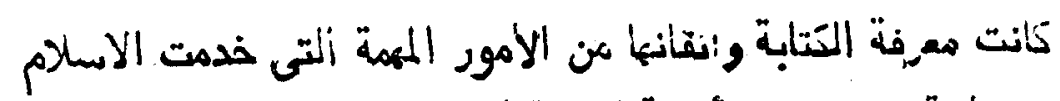

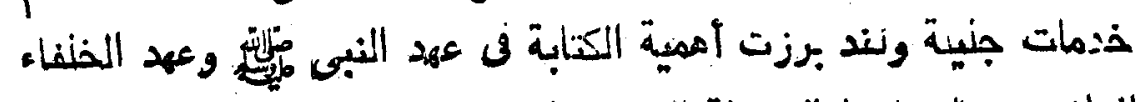

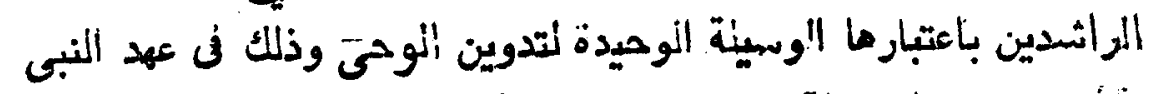

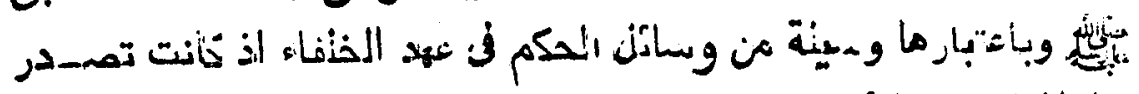

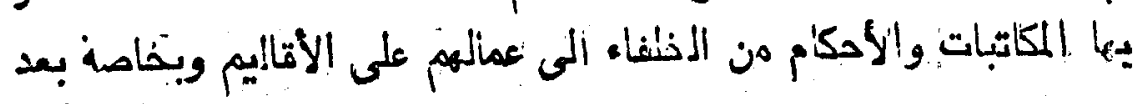

$$
\begin{aligned}
& \text { - rV7 - rVo مهاد (AT) } \\
& \text { (AV) }
\end{aligned}
$$

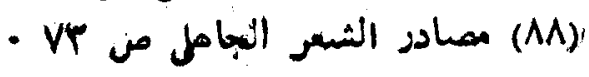




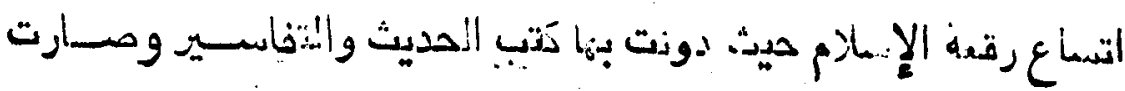

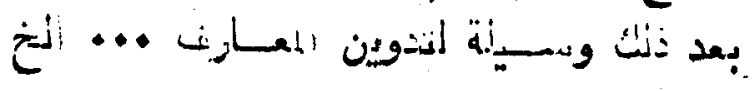

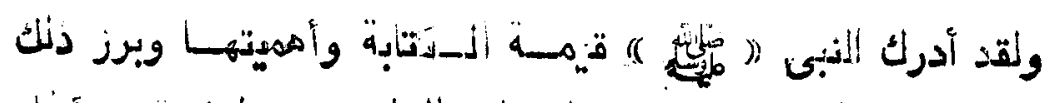

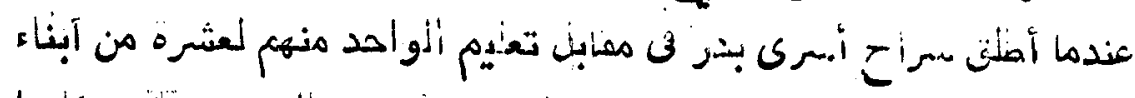

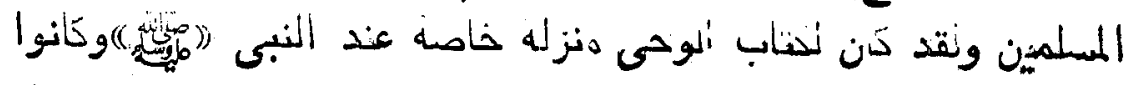

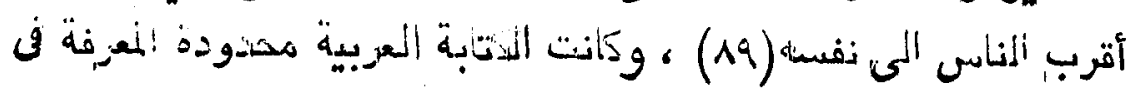

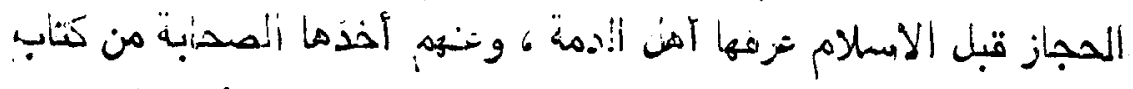

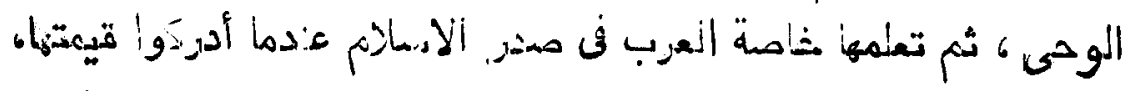

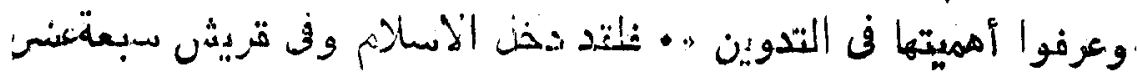

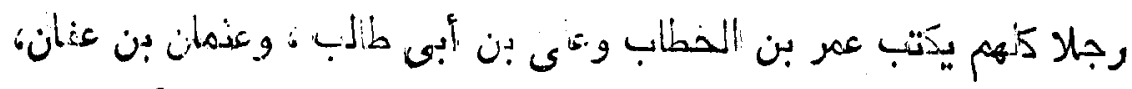

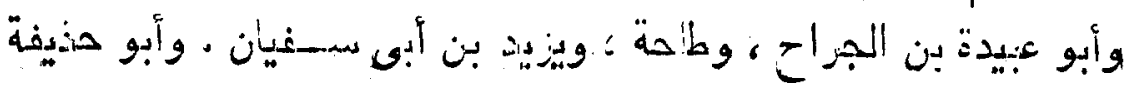

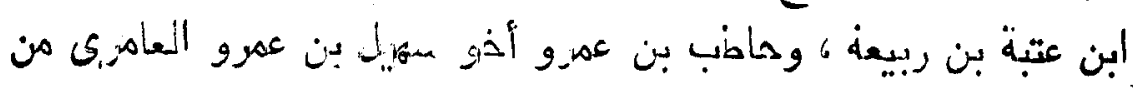

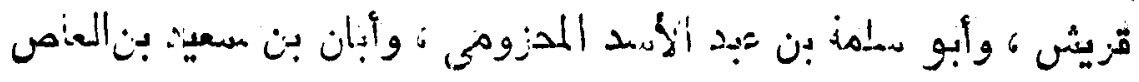

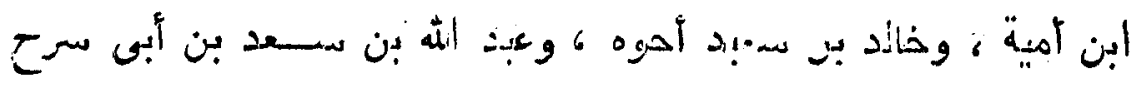

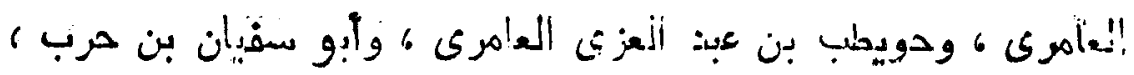

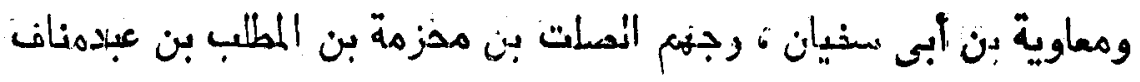

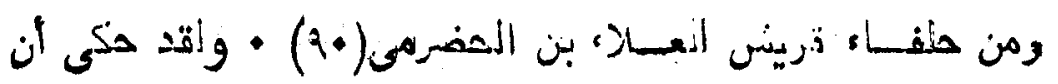

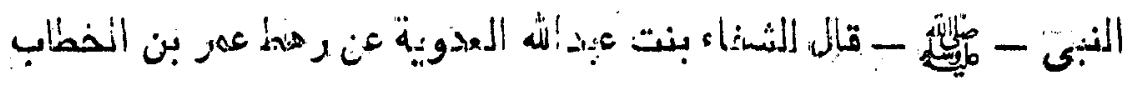

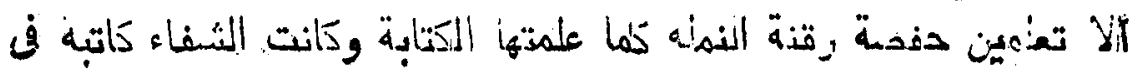

تو (19)

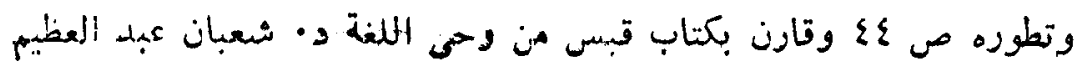
- 1,94r

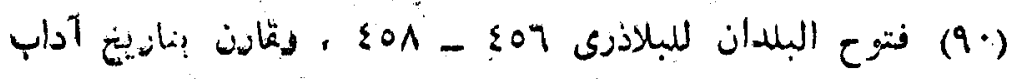

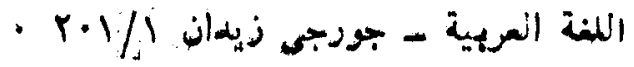


Vir

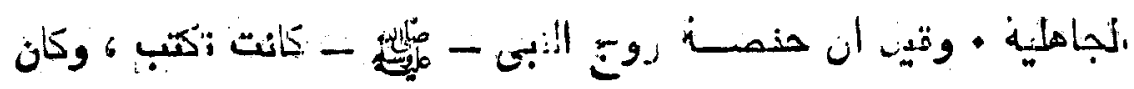

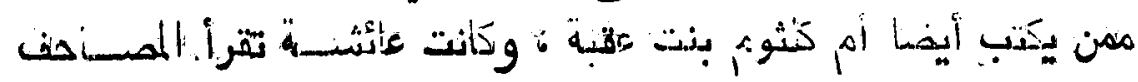

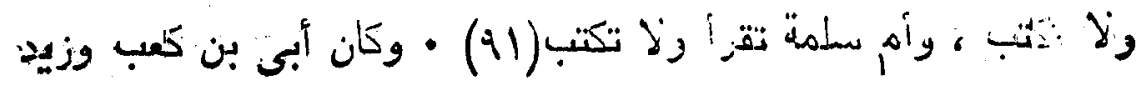

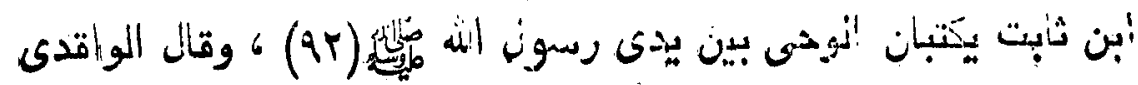

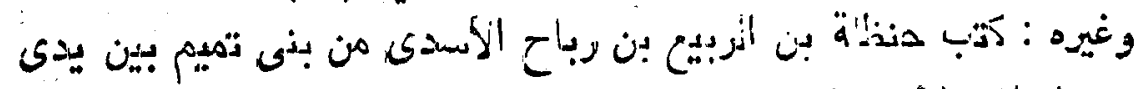

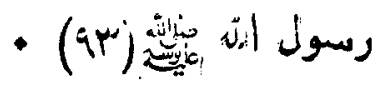

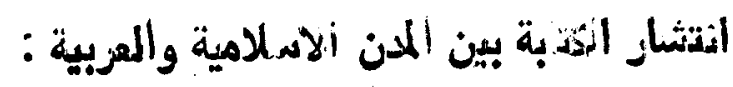

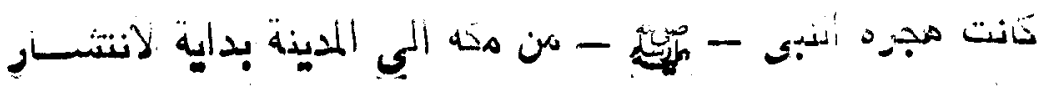

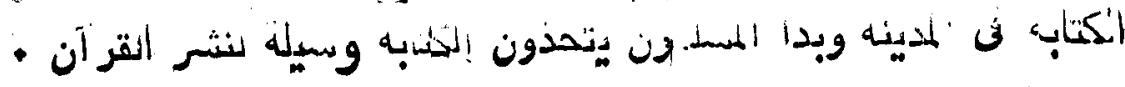

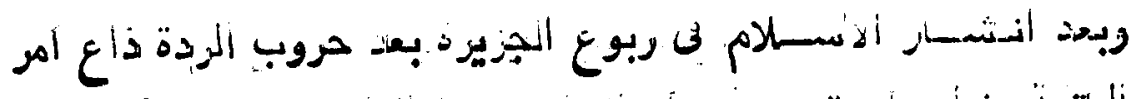

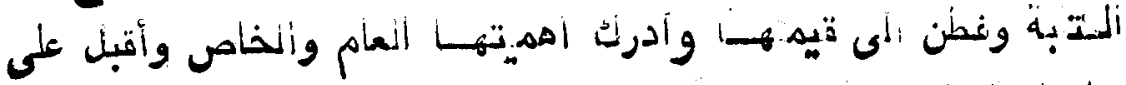

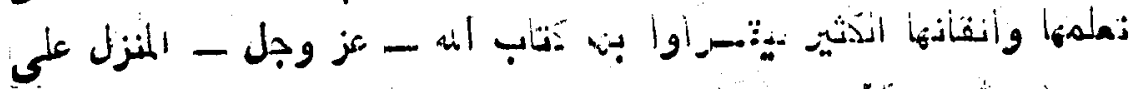

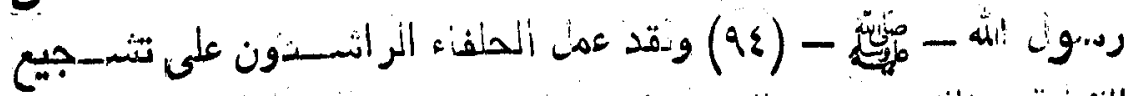

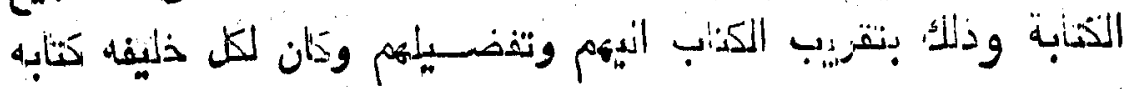

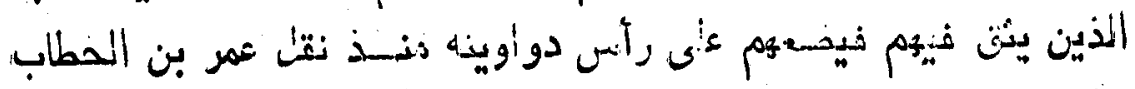

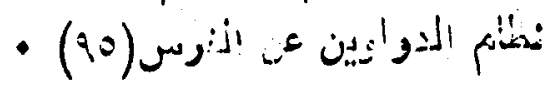

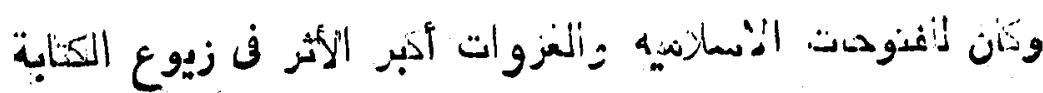

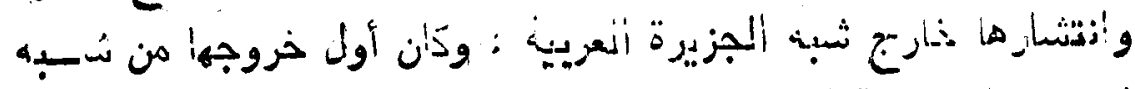

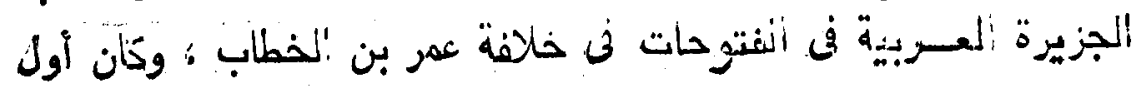

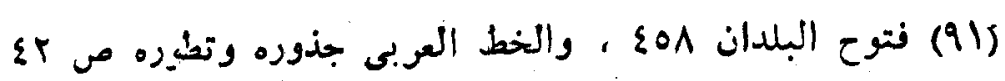

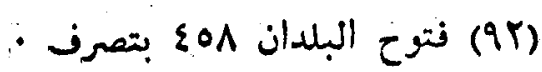

- نغس (98)

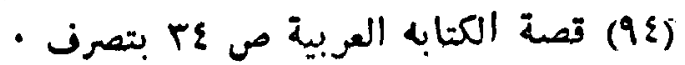




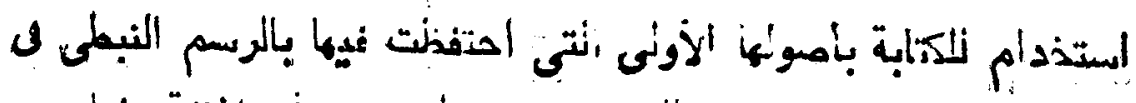

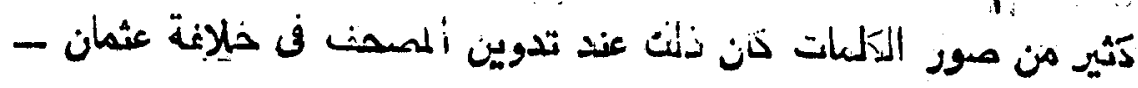

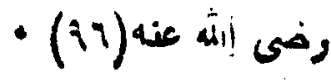

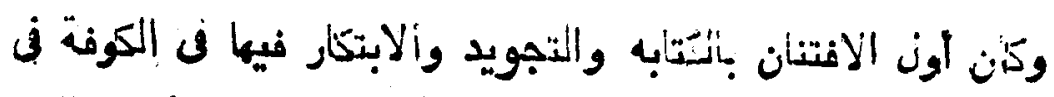

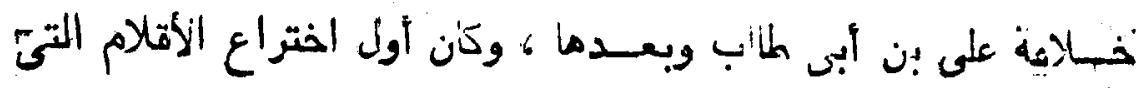

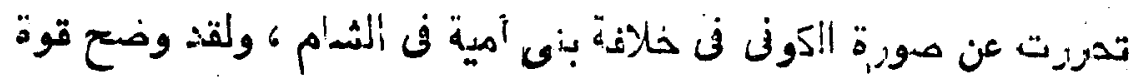

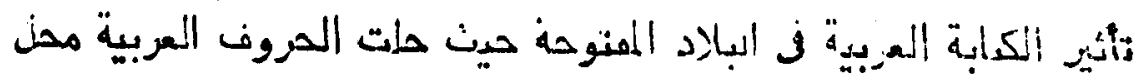

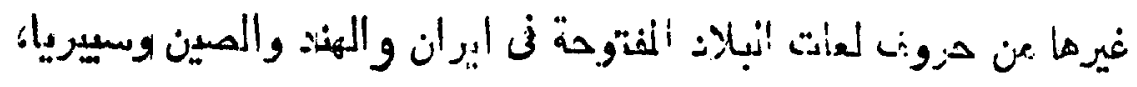

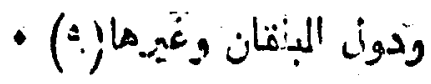

\section{" ضبط إلكتبة ألمربية بالنقط والثكل " "}

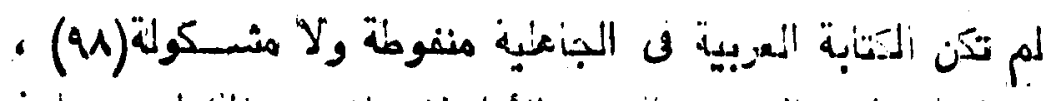

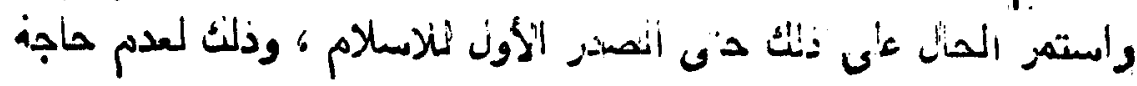

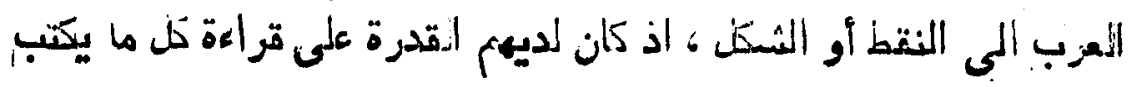

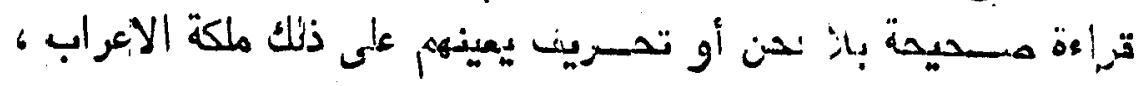

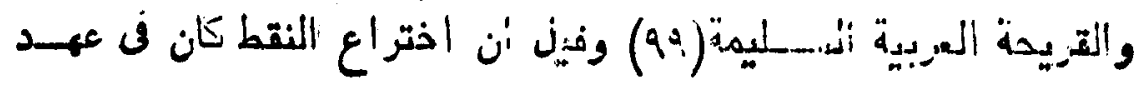

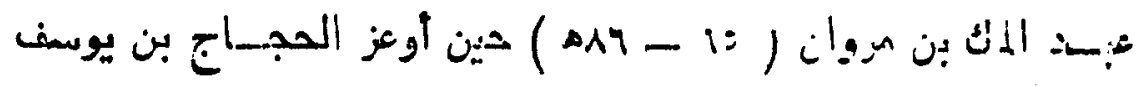

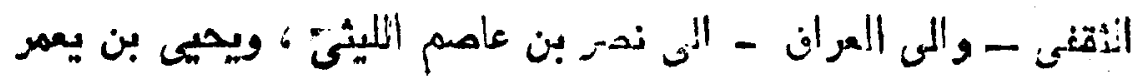

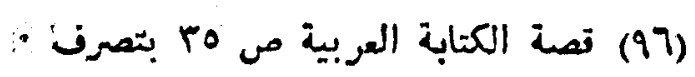

• (9V)

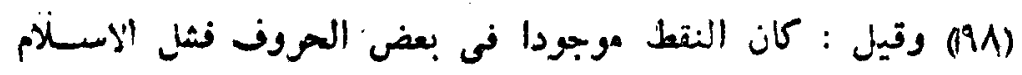

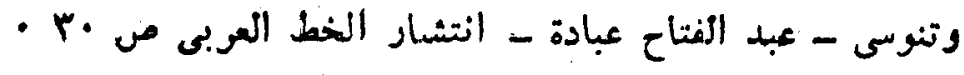

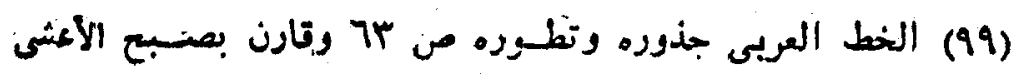

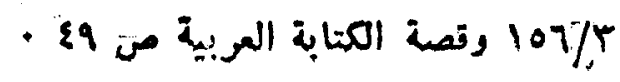




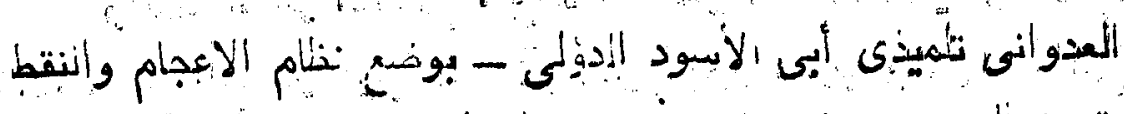

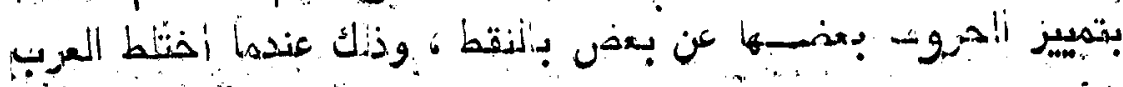

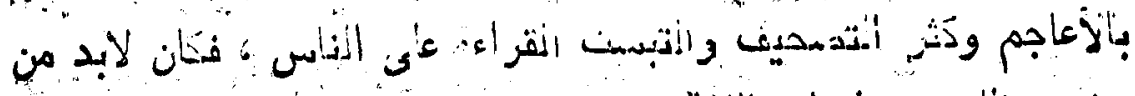

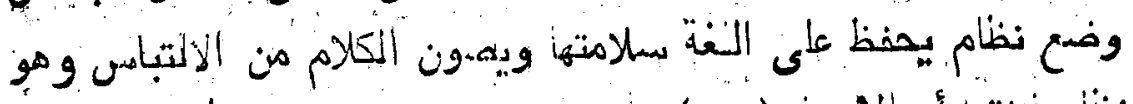

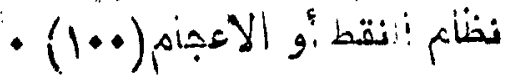

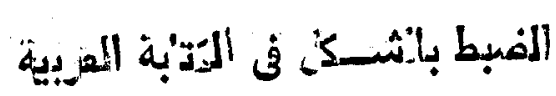

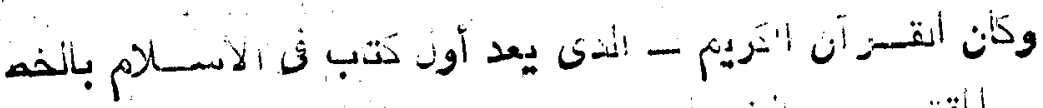

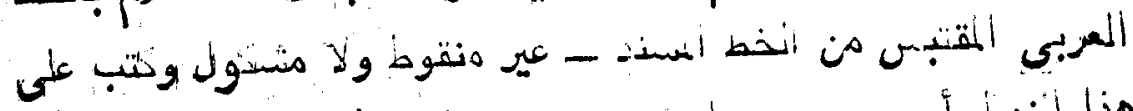

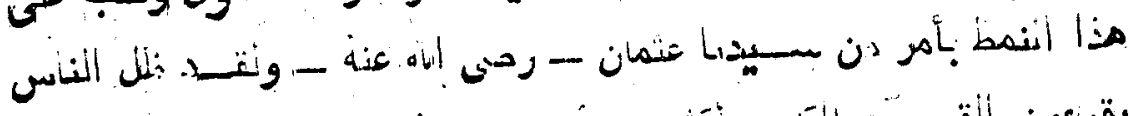

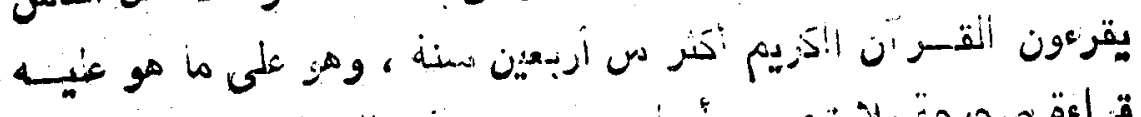

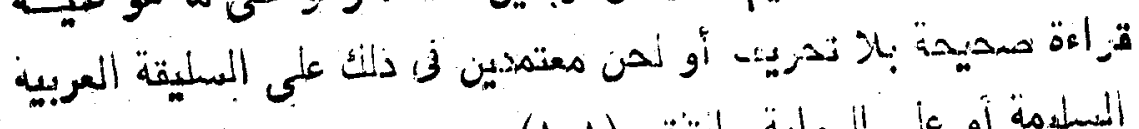

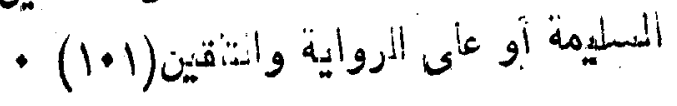

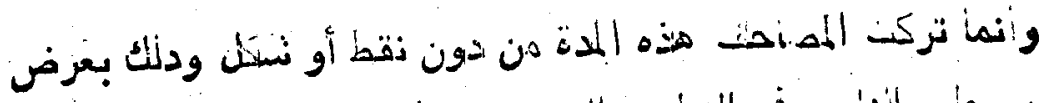

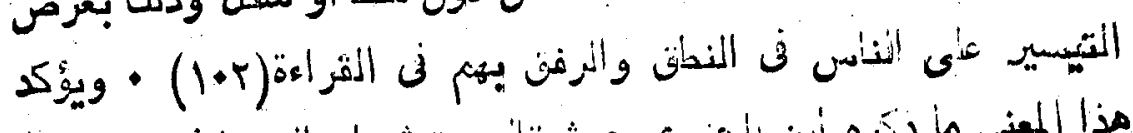

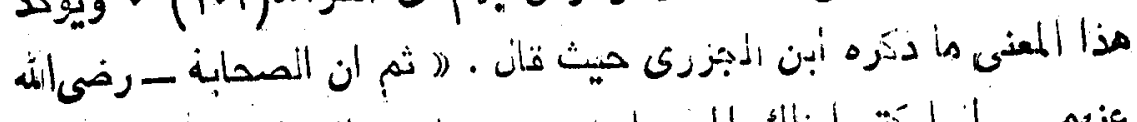

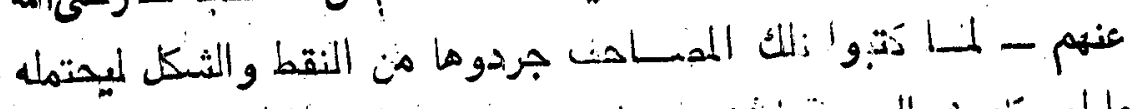

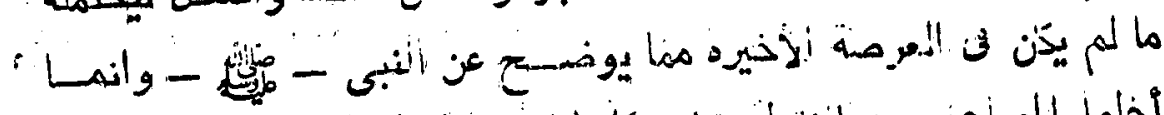

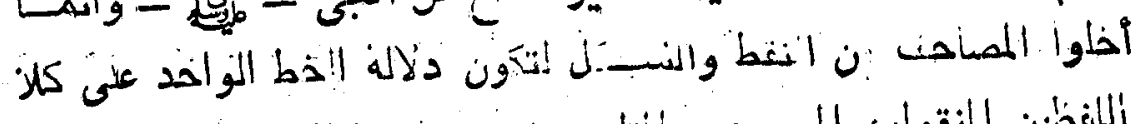

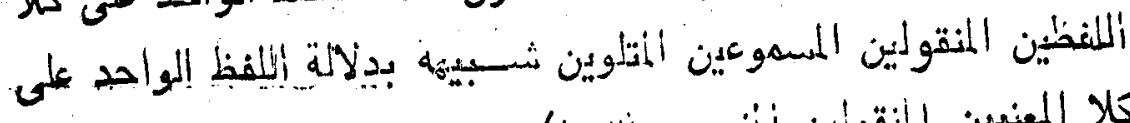

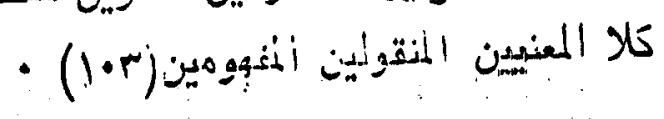

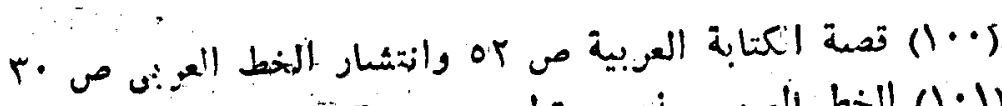

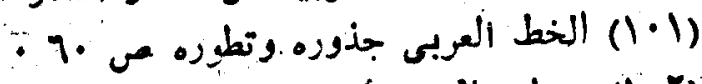

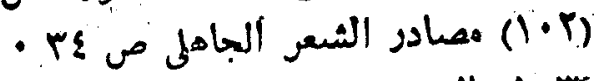

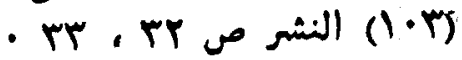




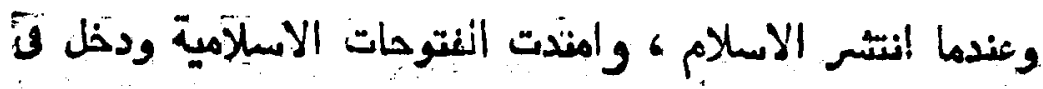

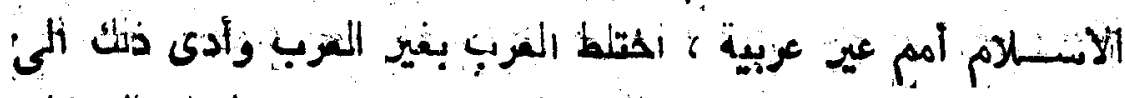

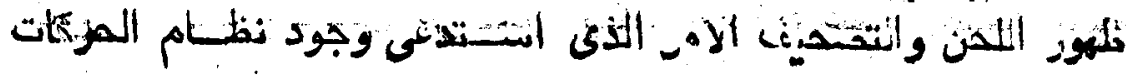

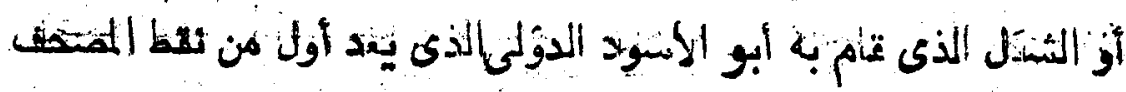

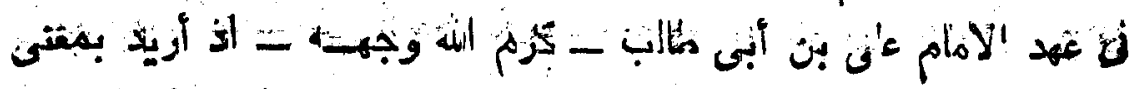

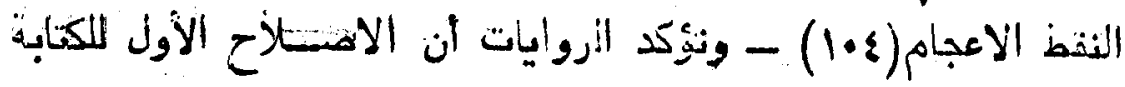

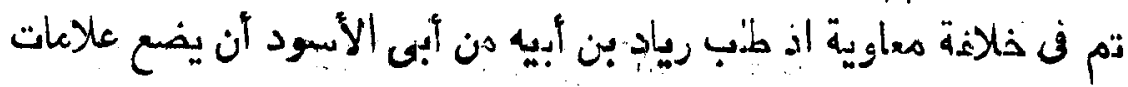

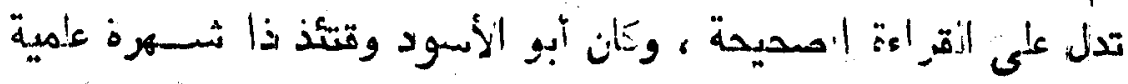

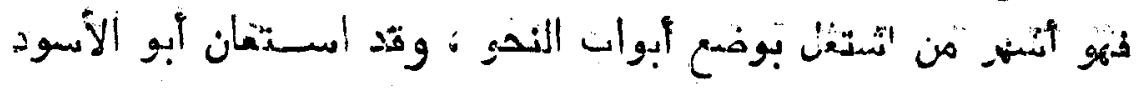

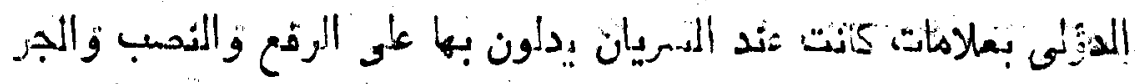

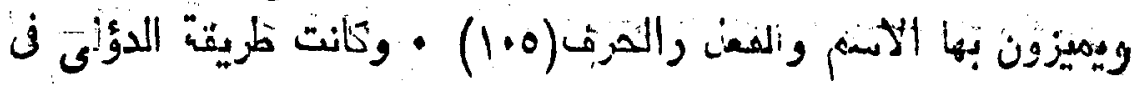

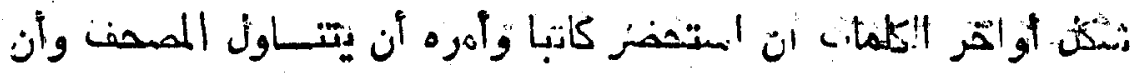

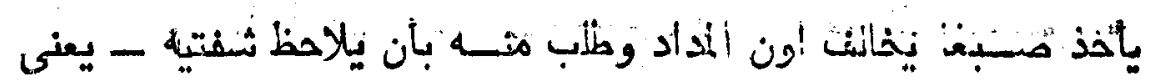

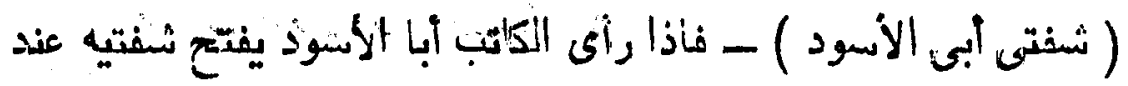

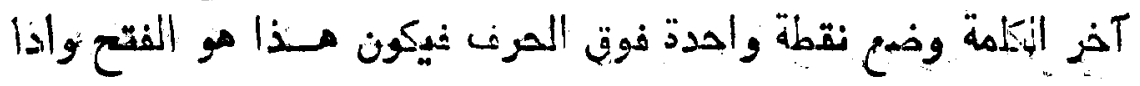

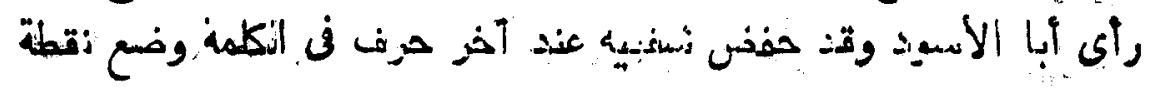

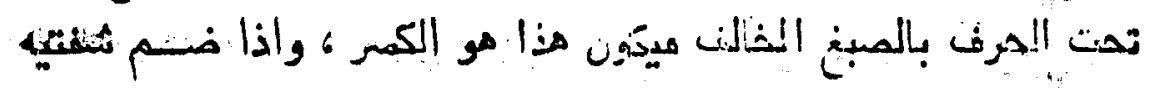

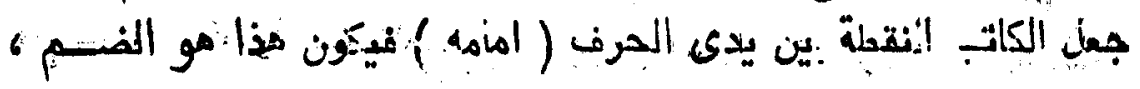

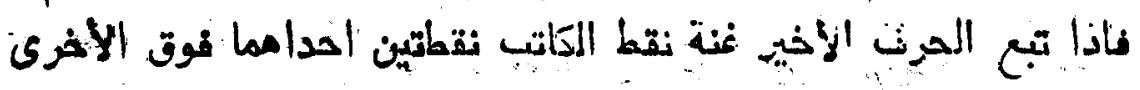

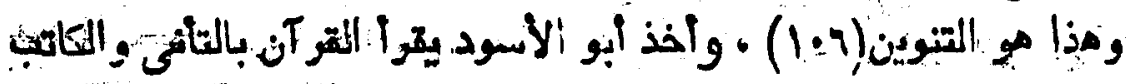

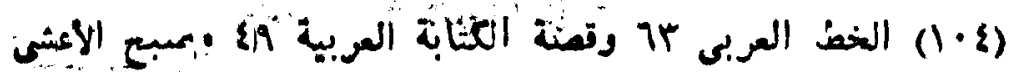
1107/5

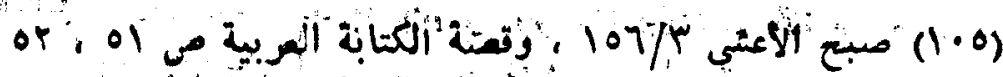

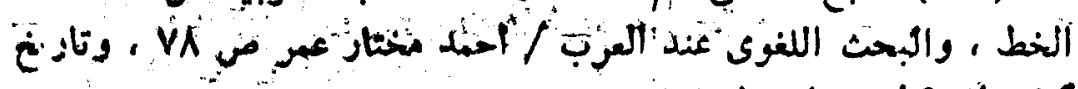

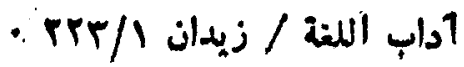




\section{Ixw}

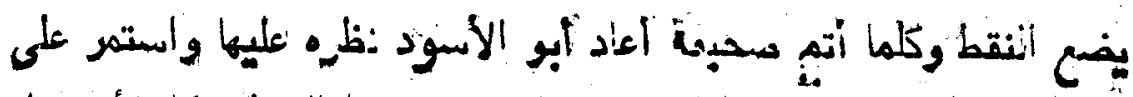

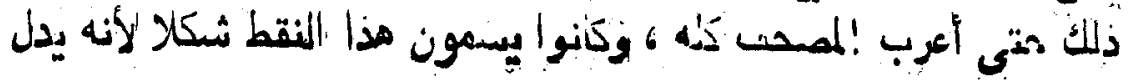

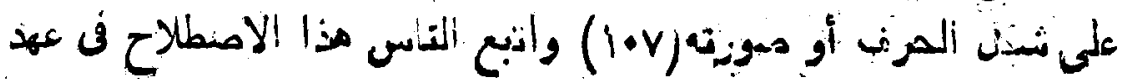

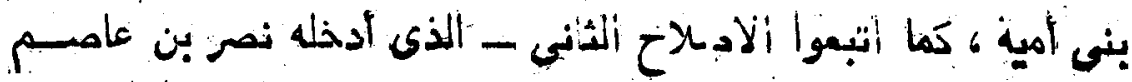

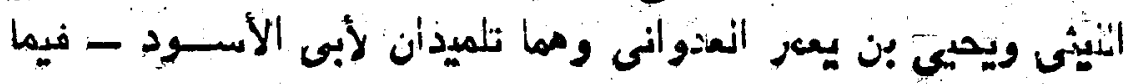

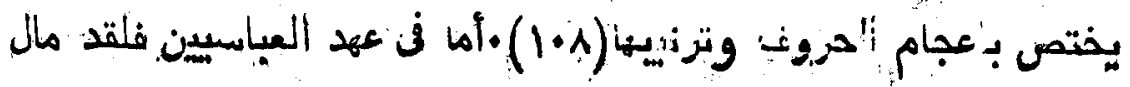

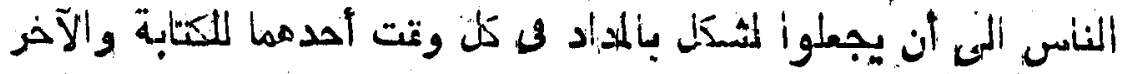

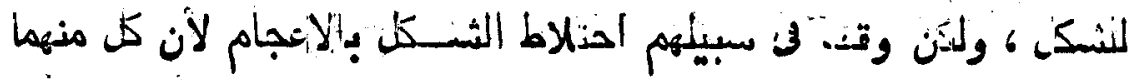

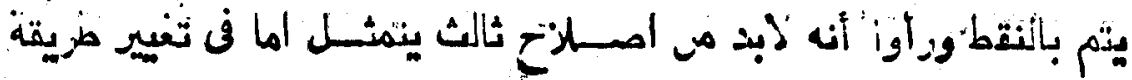

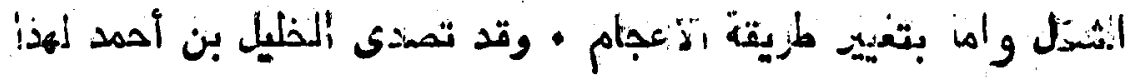

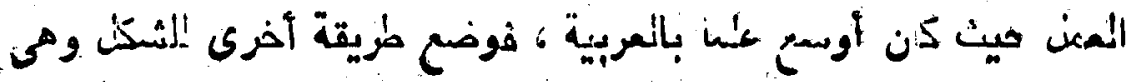

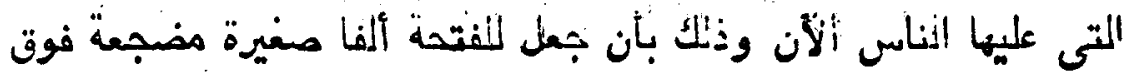

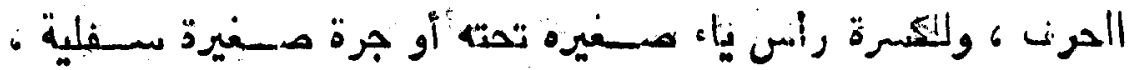

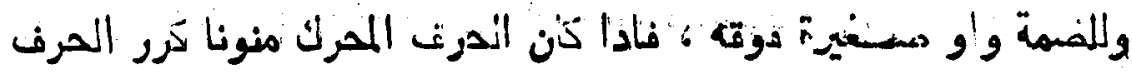

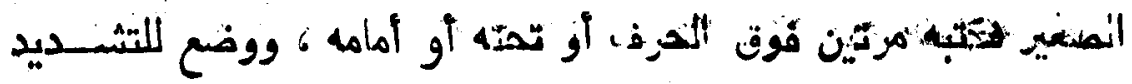

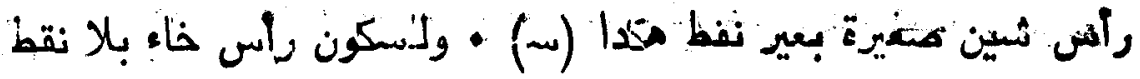

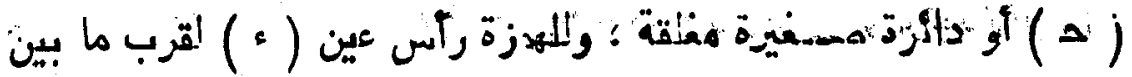

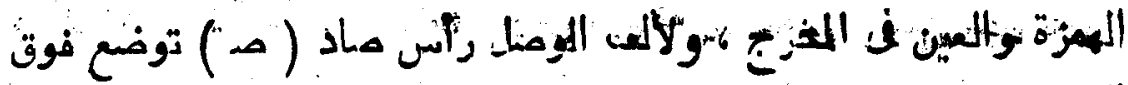

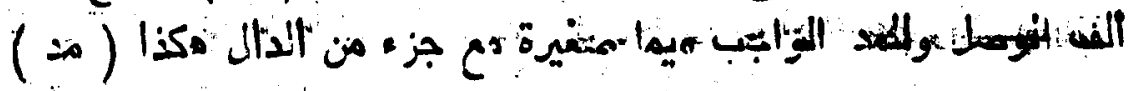

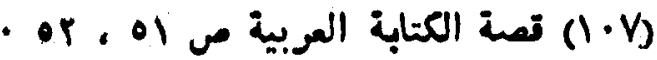

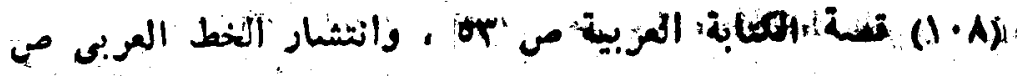

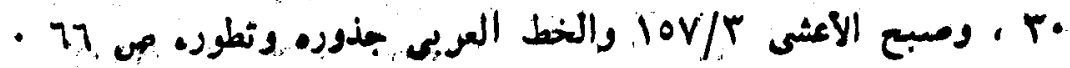

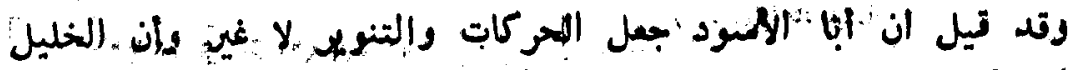

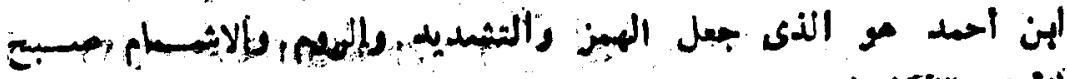




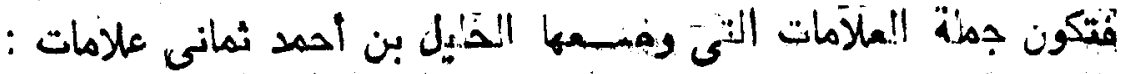

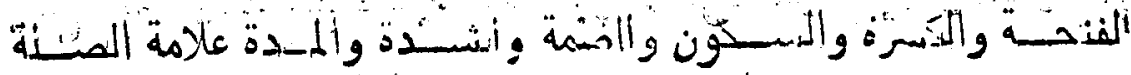

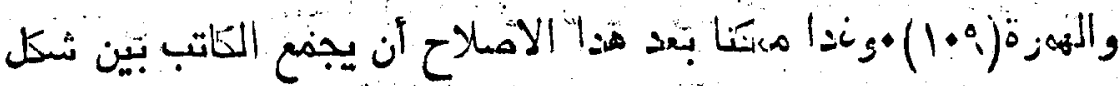

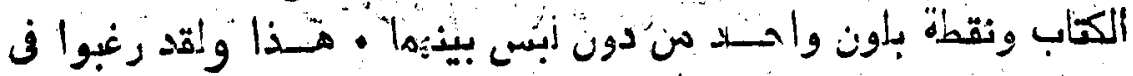

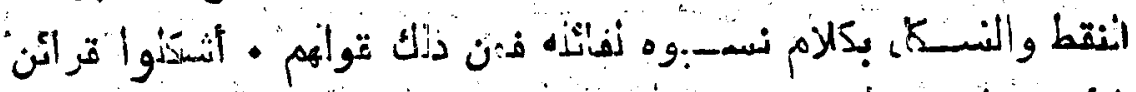

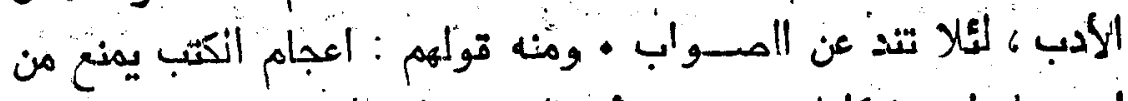

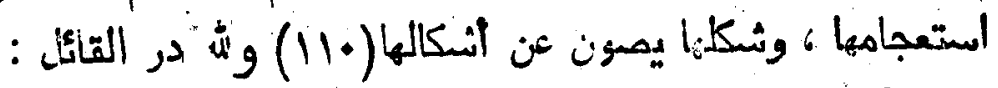

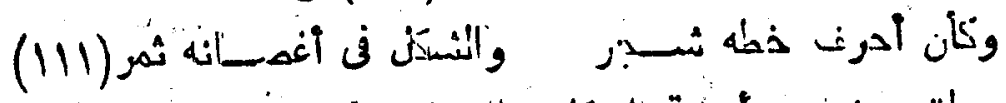

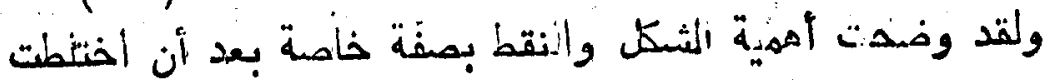

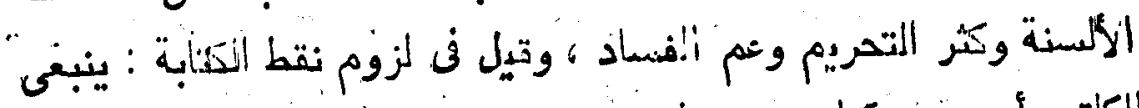

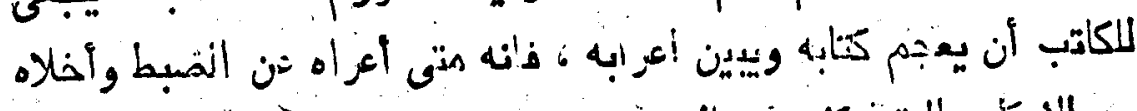

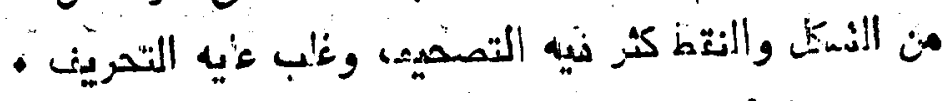

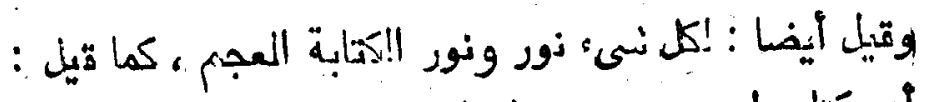

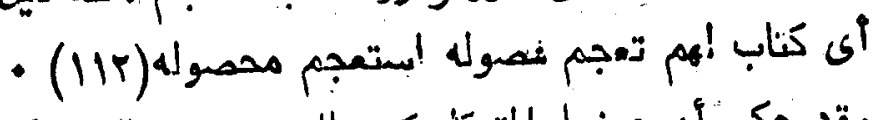

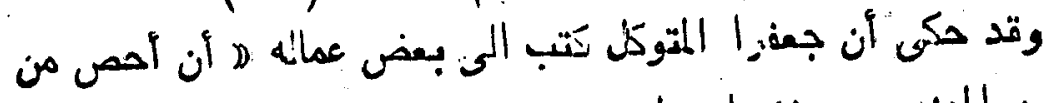

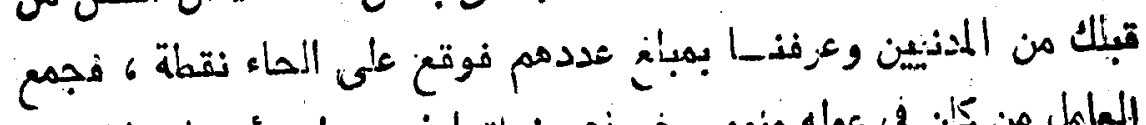

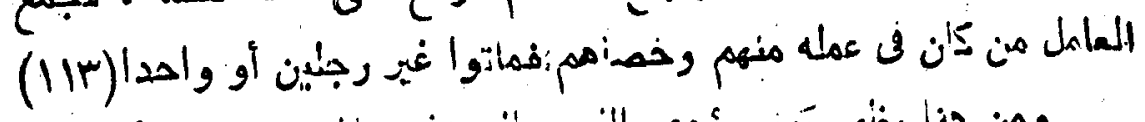

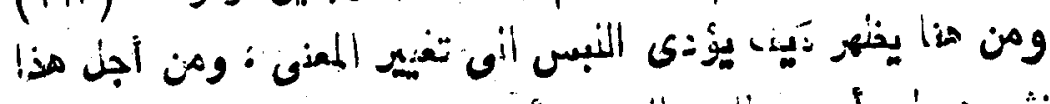

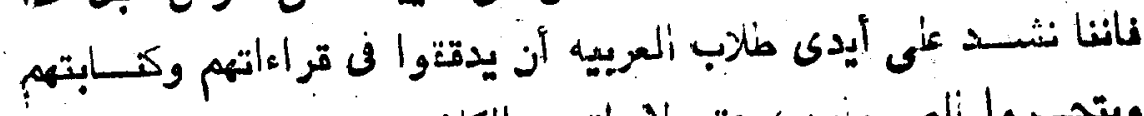

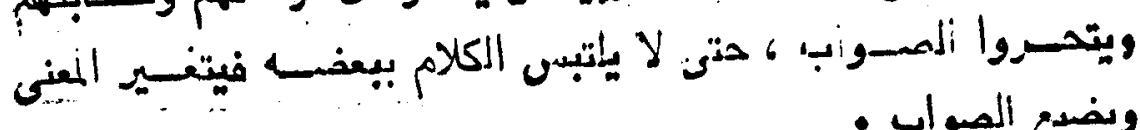

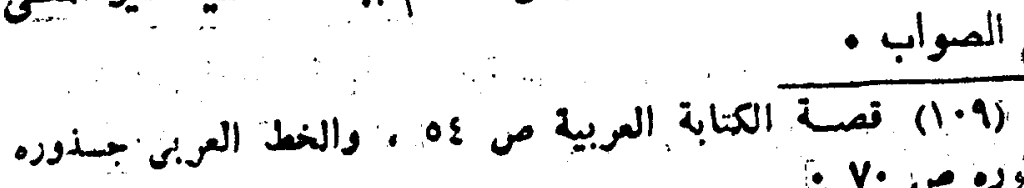

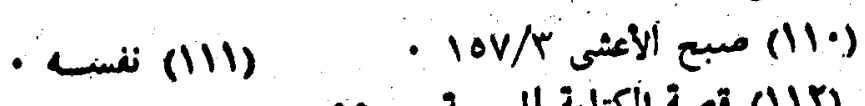

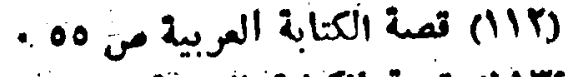

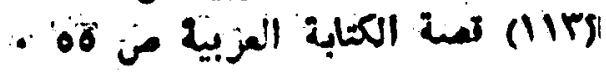


राष

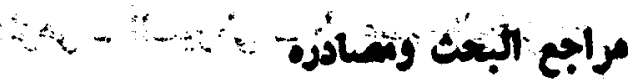

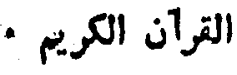

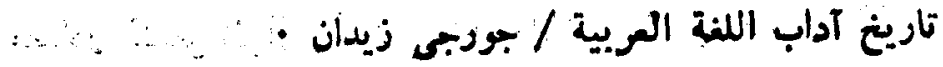

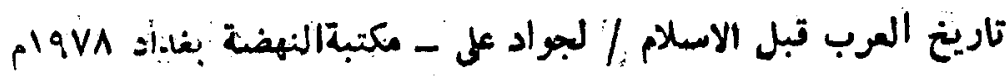

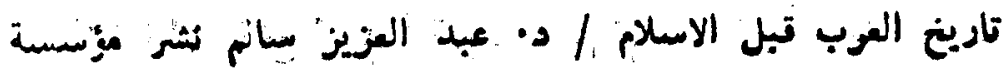

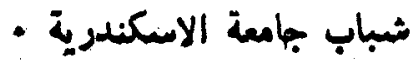

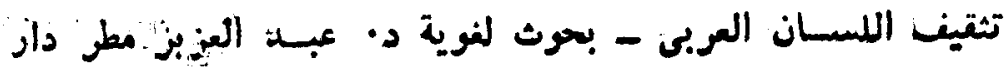

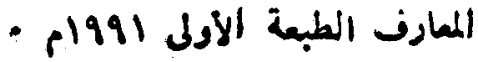

تنسير الطبرى - دار الفكر العربى I9VA -

النخط العريى بذوره وتطوره - ابراهيم ضمرة ـ مكتبة المنار الأردن

r. 19A4

ديوان الاعثى - ط دار الكتاب العربى - بيروت ·

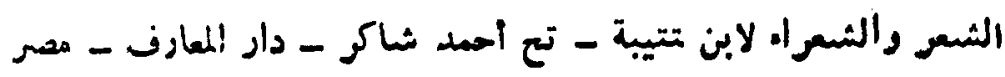

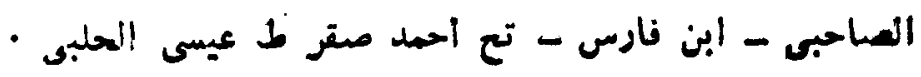

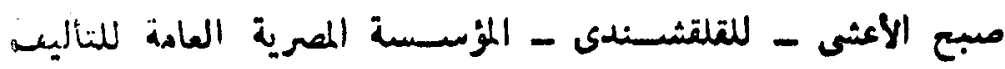

- وانترجة الاعثة

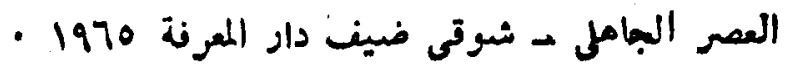

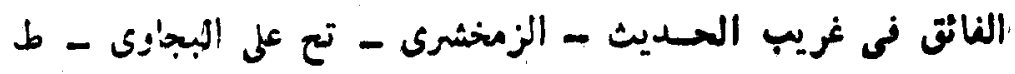

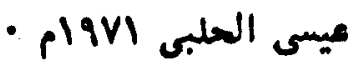

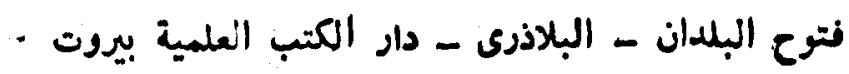

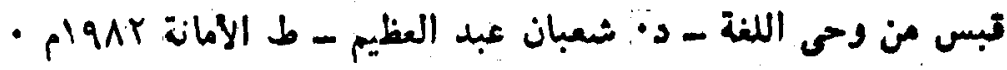

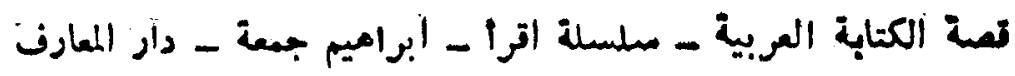

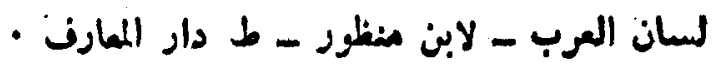

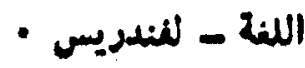




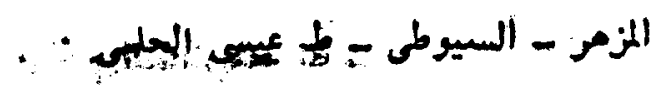

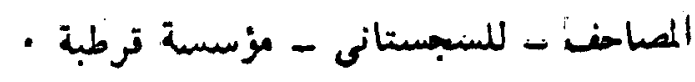

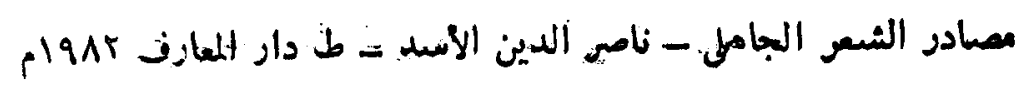

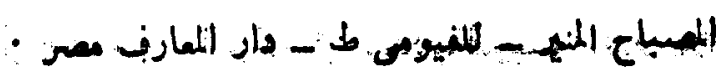

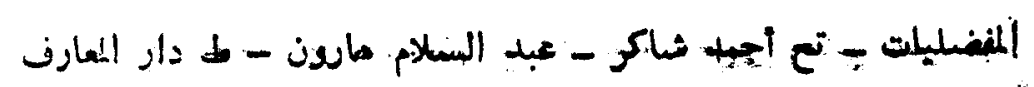

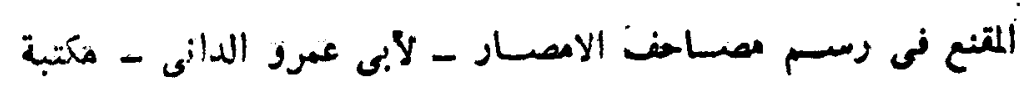

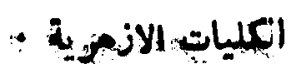

النشر فى القراءات العشر لابن الجزدى ـ ط دار اللفكر ل 
गิ

\section{st}

inat:

$r$

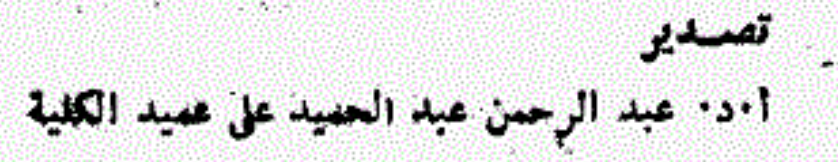

كה

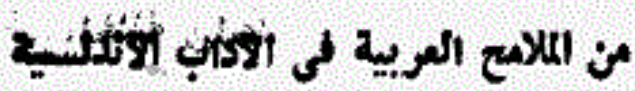

$v$

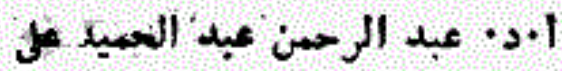

ملامح التشكيل الاسلوبى والايقأي

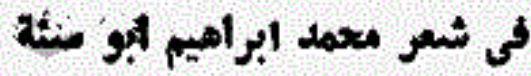

rA

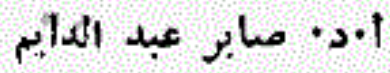

رؤية فح آكق الادب الامبلادى

or

أ.د. ميحمد بن مريسى الحارثى

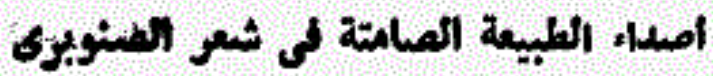

no

ا.

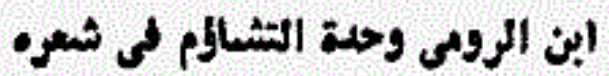

IEV

د. الحسينى محمد إبراهيم الفقى

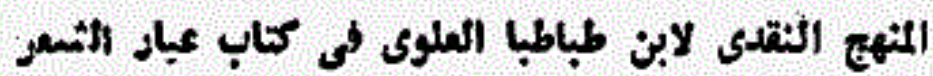

195

د. عاطفت عبد اللطيف الميد

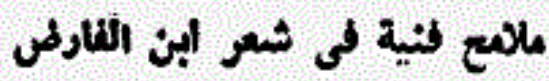

rrr

s.

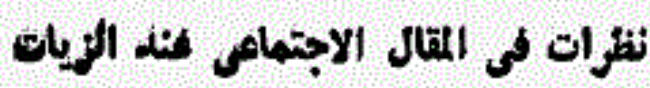

MII

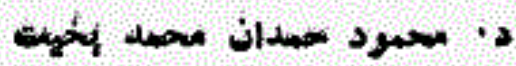




\section{TKK ,}

inin

rrr

فى اللغـويات

صيغ البالغة السماعية في الميزان

mะ

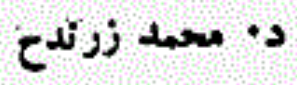

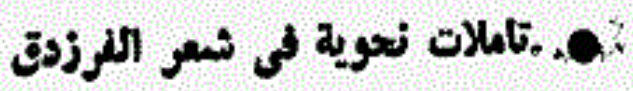
د' מصهد الزين زدوت

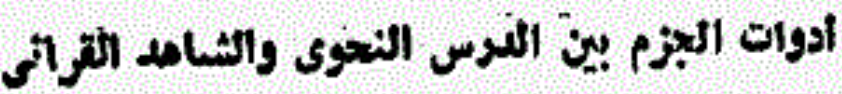
srr

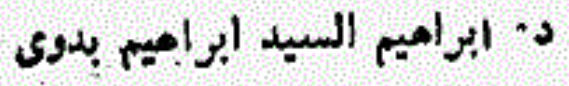

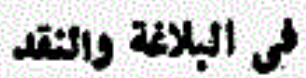

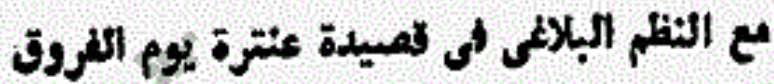

$\{A$

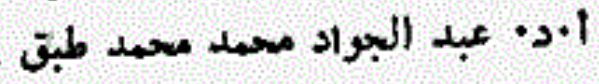

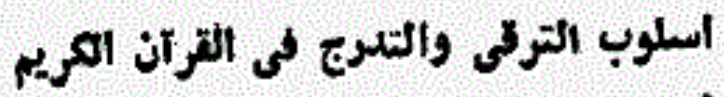
०ั9

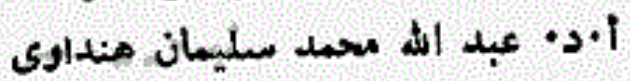

كي أمسول

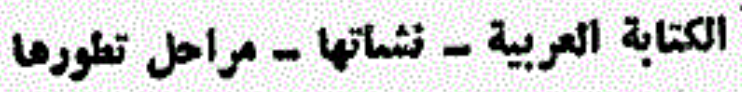

ANV

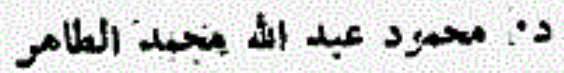


